W3

1)
ind

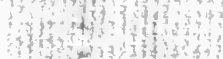

(1)

की

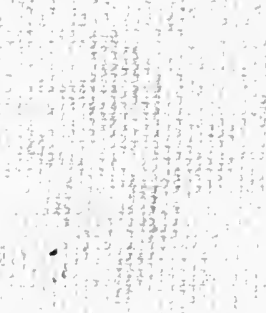

\title{
(a)
}

tis

$$
3^{b}
$$



$1 \longdiv { 8 6 }$ whes by Baster at 125
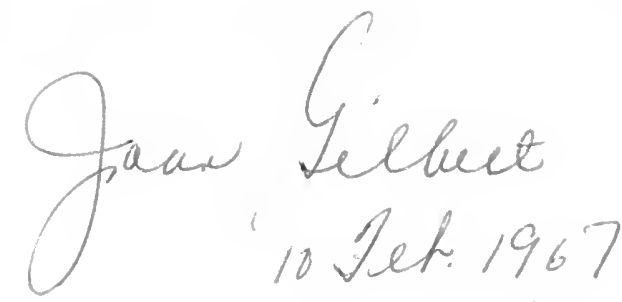

hrexel Unitciute

From the collection of the

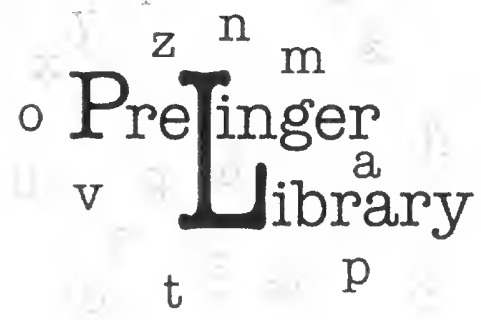

San Francisco, California

2006 


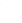




\section{A GUIDE TO THE STUDY OF}

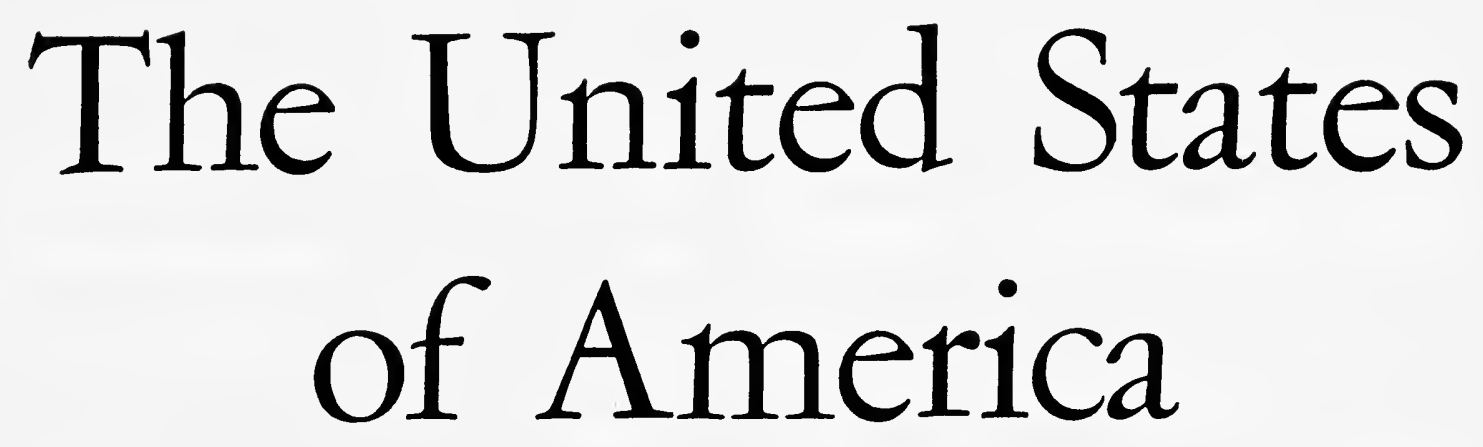

Representative Books Reflecting the Development of American Life and Thought

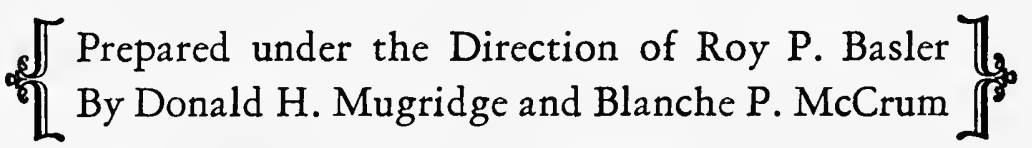

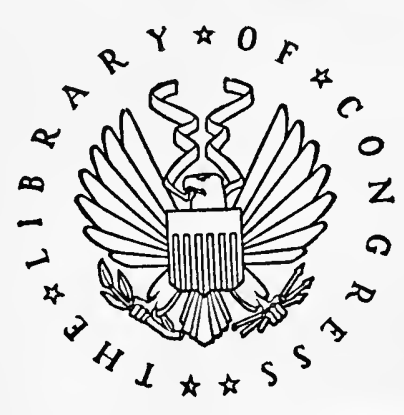

GENERAL REFERENCE AND BIBLIOGRAPHY DIVISION • REFERENCE DEPARTMENT LIBRARY OF CONGRESS - Washington: 1960 


\section{UNITED STATES \\ GOVERNMENT PRINTING OFFICE \\ WASHINGTON : 1960}

FOR SALE BY THE SUPERINTENDENT OF DOCUMENTS, WASHINGTON 25, D.C. PRICE \$7 


\section{Contents}

Introduction

Acknowledgments

Key to Symbols

Item Nos.

CHAPTER I

Literature (1607-1955)

A. The Thirteen Colonies (1607-1763)

B. The Revolution and the New Nation (1764-1819)

C. Nationalism, Sectionalism, and Schism (1820-1870)

D. The Gilded Age and After (1871rgi4)

E. The First World War and the Great Depression (1915-1939)

F. The Second World War and the Atomic Age (1940-1955)

$1-95$ 96-185 I86-682

$683-1152$ 1153-1906 1907-2235

CHAPTER II

Language

A. Dictionaries

B. Grammars and General Studies

C. Dialects, Regionalisms, and Foreign Languages in America

D. Miscellaneous

2236-224I

$2242-2252$

2253-2271

$2272-2275$

CHAPTER III

Literary History and Criticism
A. Anthologies and Series
B. History and Criticism
C. Periodicals

2276-2370

2371-2550

$255 \mathrm{I}-2577$
Item Nos.

CHAPTER IV

Biography and Autobiography 2578-2844

CHAPTER v

Periodicals and Journalism
A. Newspapers: General
B. Newspapers: Periods, Regions, and Topics
C. Individual Newspapers
D. Newspapermen
E. Foreign Language Periodicals
F. The Practice of Journalism
G. Magazines: General
$\mathrm{H}$. Individual Magazines
I. The Press and Society
$2845-2850$
2851-2865
2866-2876
2877-2894
2895-2899
2900-2912
2913-2919
2920-2926
2927-2932

CHAPTER VI

Geography
A. General and Physical Geography
B. Geology and Soil
C. Climate and Weather
D. Plants and Animals
E. Historical Geography and Atlases
F. Polar Exploration

2933-294I

2942-2947

2948-2953

2954-2966

$2967-2976$

2977-2981

CHAPTER VII

The American Indian
A. General Works
B. Archaeology and Prehistory
C. Tribes and Tribal Groups
D. Religion, Art, and Folklore
E. The White Advance
F. The Twentieth Century

2982-2989

2990-2997

2998-3014

3015-3021

3022-3037

3038-3043 
Item Nos.

Item Nos.

CHAPTER VIII

C. The Navy

\section{General History}

A. Historiography

3044-3069

B. General Works

$3070-3152$

C. The New World

3153-3175

D. The Thirteen Colonies

E. The American Revolution

F. Federal America (1783-1815)

$3176-3236$

3237-3272

3273-331 I

G. The "Middle Period" ( $1815-60$ )

$3312-335^{8}$

$H$. Slavery, the Civil War, and Reconstruction (to 1877 )

I. Grant to McKinley (1869-190I)

J. Theodore Roosevelt to Wilson (190I-2I)

K. Since 1920

3359-34I 7

$3418-3451$

$345^{2-3474}$

3475-350ob

CHAPTER IX

\section{Diplomatic History and Foreign Relations}

A. Diplomatic History

Ai. General Works

Aii. Period Studies

Aiii. Personal Records

Aiv. The British Empire

Av. Russia

Avi. Other European Nations

Avii. Latin America: General

Aviii. Latin America: Individual Nations

Aix. Asia

B. Foreign Relations

Bi. Administration

Bii. Democratic Control

Biii. Policies

Biv. Economic Policy
$3527-3542$

3543-3549

3550-3559

$3560-3568$

3569-3573

3574-3579

$3580-3587$

$35^{88-3597}$

$3598-3608$

$3609-3616$

$3617-3635$

$3^{6}{ }^{6} 6-3642$
$350 \mathrm{x}-3526$

CHAPTER $x$

\section{Military History and the Armed Forces}
A. General Works
B. The Army

$3643-3652$

$3653-3665$

D. Wars of the United States

Di. The Revolution

Dii. $\quad$ 1798-1848

Diii. The Civil War

Div. The Spanish-American War

Dv. World War I

Dvi. World War II

$3^{666-3677}$

$3678-3684$

$3685-3689$

$3690-3706$

$3707-3708$

$3709-37$ r 6

$3717-3727$

CHAPTER XI

\section{Intellectual History}
A. General Works
3728-3737
B. Periods
C. Topics
3738-3749
D. Localities
$375^{0}-3762$
E. International Influences: General
$3763-3767$
F. International Influences: By Country $3773-3780$
$3768-377^{2}$
$3773-3780$

CHAPTER XII

Local History: Regions, States, Cities
A. General Works, including series
$378 \mathrm{I}-4025$
B. New England: General
4026-4031
C. New England: Local
$4032-4042$
D. The Middle Atlantic States
$4043-4065$
E. The South: General
$4066-4084$
F. The South Atlantic States: Local
$4085-4096$
G. The Old Southwest: General
$4097-4098$
H. The Old Southwest: Local
4099-4108
I. The Old Northwest: General
$4109-4117$
J. The Old Northwest: Local
4 I I $8-4$ I 44
K. The Far West
L. The Great Plains: General
4 I $45-4 I 50$
$4 \mathrm{I} 5 \mathrm{I}-4 \mathrm{I} 64$
M. The Great Plains: Local
$4165-4171$
N. The Rocky Mountain Region:

\section{General}

$4172-4177$

O. The Rocky Mountain Region: Local 4I $78-4185$

P. The Far Southwest: General

4 186-4I9I

Q. The Far Southwest: Local

4 I $92-4$ I 99

R. California

S. The Pacific Northwest: General 

T. The Pacific Northwest: Local
U. Overseas Possessions

CHAPTER XIII

\section{Travel and Travelers}
A. General Works
B. Anthologies
C. 5o Selected Travelers, I743-I894 (chronologically arranged by the date of their travels)

CHAPTER XIV

Population, Immigration, and Minorities
A. Population
B. Immigration: General
C. Immigration: Policy
D. Minorities
E. Negroes
F. Jews
G. Orientals
H. North Americans
I. Germans
J. Scandinavians
I. Other Stocks

4223-4230

$4231-4235$

Item Nos.

4215-4217

$4218-4222$

$4^{236-4389}$
$4390-4403$

4404-4417

$4418-4425$

$4426-4435$

$443^{6}-445^{1}$

$4452-4462$

$4463-4469$

$4470-4476$

$4477-448$ I

$4482-4487$

$44^{88-4498}$

CHAPTER XV

Society

A. Some General Views

B. Social History: Periods

C. Social History: Topics

D. Social Thought

E. General Sociology; Social Psychology

F. The Family

G. Communities: General

H. Communities: Rural

I. Communities: Urban

J. City Planning; Housing

K. Social Problems; Social Work

L. Dependency; Social Security

M. Delinquency and Correction
4499-4513

$4514-4522$

$4523-4534$

$4535-4545$

$4546-455^{8}$

4559-4573

$4574-4578$

$4579-45^{8} 5$

$45^{86-4599}$

$4600-4613$

$4614-4627$

$4628-4638$

$4639-4660$
CHAPTER XVI

\section{Communications}

A. The Post Office; Express Companies 466I-467I

B. Telegraph, Cable, Telephone

$4672-468 \mathbf{r}$

C. Radio, Television: Broadcasting

$4682-4698$

D. Radio, Television: The Audience

$4699-4705$

E. Government Regulation

$4706-47$ I I

CHAPTER XVII

Science and Technology

A. General Works

$4712-4730$

B. Particular Sciences

C. Individual Scientists

D. Science and Government

E. Invention

F. Engineering

$473 \mathrm{I}-474 \mathrm{I}$

$4742-4760$

$476 \mathrm{r}-4779$

$4780-4792$

$4793-4803$

CHAPTER XVIII

Medicine and Public Health
A. Medicine in General
B. Physicians and Surgeons
C. Psychiatry
D. Other Specialties
E. Hospitals and Nursing
F. Medical Education
G. Public Health
H. Medical Economics

$4804-4817$

48 I $8-4832$

$4833-4840$

$484 \mathrm{I}-4844$

$4^{8} 45^{-4} 4^{8} 54$

$4855-486 \mathrm{I}$

$4862-4881$

$4882-4891$

\section{CHAPTER XIX \\ Entertainment}

A. General Works

B. The American Stage

$4892-4896$

Bi. History

4897-4906

Bii. Criticism

Biii. Particular Stage Groups, Theaters, Movements, etc. 49r3-4926

Biv. Biography: Actors and Actresses

4927-4939

Bv. Biography: Directors, Producers, etc.

4940-4943 
C. Motion Pictures

Ci. History

Cii. Special Aspects and Analyses 4947-495I

Ciii. Biography: Actors and

$$
\text { Actresses 4952-4956 }
$$

Civ. Biography: Directors,

$$
\text { Producers, etc. }
$$

D. Other Forms of Entertainment

Di. Radio and Television

Dii. The Dance in America

Diii. Vaudeville and Burlesque

Div. Showboats, Circuses, etc.
Item Nos. $4957-4963$ $4964-4966$ $4967-4972$ $4973-4976$ $4977-4982$
G. Contemporary Problems and Controversies

H. Periodicals and Yearbooks

$5232-5239$

$5240-5249$

CHAPTER XXII

\section{Philosophy and Psychology}
A. Philosophy: General Works
B. Representative Philosophers
C. Psychology

$5250-5264$

$5265-53^{8} 7$

5388-5393

\section{CHAPTER XXIII}

CHAPTER $\mathrm{XX}$

\section{Sports and Recreation}
A. General
4983-4996
B. Community and Scholastic Activities 4997-5000
C. Particular Sports and Recreations
Ci. Auto-Racing and Motoring 5001-5007
Cii. Baseball
Ciii. Boating
5008-5015
Civ. Boxing
5016-5022
Cv. Football
5023-5033
Cvi. Golf and Tennis
$5034-5045$
5046-5053
Cvii. Horse-Racing
$5054-5057$
Cviii. Miscellaneous
5058-5064
D. General Field Sports
5065-5097

\section{CHAPTER XXI}

\section{Education}

A. General Works

Ai. Historical and Descriptive 5098-5114

Aii. Philosophical and Theoretical 5115-5130

B. Primary and Secondary Schools

Bi. General and Historical Works 5131-5146

Bii. Preschool and Primary Grades 5147-5151

Biii. Secondary Schools

C. Colleges and Universities

$5152-5159$

Ci. General and Historical Works 5160-5190

Cii. Individual Institutions

$5191-5204$

D. Education of Special Groups

5205-5212

E. Teachers and Teaching

F. Methods and Techniques

5213-5223

$5224-5231$

Religion
A. General Works
B. Period Histories
C. Church and State
D. Religious Thought; Theology
E. Religious Bodies
F. Representative Leaders
G. Church and Society
H. The Negro's Church
5394-5404
5405-5417
$5418-5422$
$5423-5438$
5439-5473
$5474-5483$
$5484-5497$
$5498-5502$

CHAPTER XXIV

Folklore, Folk Music, Folk Art
A. Legends and Tales: General
B. Legends and Tales: Local
C. Folksongs and Ballads: General
D. Folksongs and Ballads: Local
E. Games and Dances
F. Folk Art and Crafts

5503-5519

$5520-554^{8}$

$5549-5564$

$5565-5584$

5585-5592

5593-5604

CHAPTER XXV

Music

A. General Histories and Reference Works

B. Contemporary Surveys and Special Topics

$5605-5614$

C. Localities

D. Religious Music

E. Popular Music
5615-5625 5626-5630 $5631-5634$ $5635-5640$ 

F. Jazz
G. Orchestras and Bands
H. Opera
I. Choirs
J. Music Education
K. Individual Musicians

\section{CHAPTER XXVI}

\section{Art and Architecture}
A. The Arts
B. Architecture: General
C. Architecture: Special
D. Interiors
E. Sculpture
F. Painting
G. Painting: Individual Artists
H. Prints and Photographs
I. Decorative Arts
J. Museums
K. Art and History

CHAPTER XXVII

\section{Land and Agriculture}
A. Land
B. Agriculture: History
C. Agriculture: Practice
D. Agriculture: Government Policies
E. Forests, National Parks
F. Animal Husbandry

CHAPTER XXVIII

Economic Life
A. General Works: Histories
B. Other General Works
C. Industry: General
D. Industry: Special
E. Transportation: General
F. Transportation: Special
G. Commerce: General
H. Commerce: Special

Item Nos. $5641-5646$ $5647-5654$ $5655-5663$ $5664-5667$ $5668-5672$ $5673-5687$

5688-5697 5698-5703 5704-5725 $5726-5732$ $5733-5740$ $5741-5759$ $5760-5776$ $5777-5783$ $5784-5793$ $5794-5800$ $5801-5807$
I. Finance: General

J. Finance: Special

K. Business: General

L. Business: Special

M. Labor: General

N. Labor: Special
Item Nos. 5965-5975 5976-6002 6003-6010 $6011-6030$ $6031-6042$ $6043-6058$

\section{CHAPTER XXIX}

\section{Constitution and Government}
A. Political Thought
B. Constitutional History
$6059-6072$
C. Constitutional Law
$6073-6089$
D. Civil Liberties and Rights
6090-6105
E. Government: General
6106-6r30
$6 \mathrm{r} 3 \mathrm{x}-6 \mathrm{r} 39$
F. The Presidency
6r40-6r49
G. Congress
H. Administration: General
$6150-6169$
6170-6180
I. Administration: Special
6 ז8 $1-6194$
J. State Government
6195-6206
K. Local Government
$6207-6218$

CHAPTER XXX

\section{Law and Justice}

$5^{808-5818}$

$5819-5838$

$5839-5850$

$5851-5861$

$5862-5866$

$5867-5874$
A. History: General

B. History: The Supreme Court

C. General Views

D. Digests of American Law

E. Courts and Judges

F. The Judicial Process

G. Administrative Law

H. Lawyers and the Legal Profession
$6219-6236$

$6237-6260$

$626 \mathrm{I}-6270$

$6271-6279$

6280-6293

$6294-6309$

$6310-6316$

$6317-6332$

\section{CHAPTER XXXI}

$5875-5883$ $5884-5900$ $5901-5906$ 5907-5919 5920-5925 5926-5943 5944-5950 $5951-5964$
Politics, Parties, Elections
A. Politics: General
B. Politics: Special
C. Political Parties
D. Local Studies
E. Machines and Bosses
F. Pressures

$6333-6340$
$6341-6346$

$6347-6373$

$6374-6383$

$6384-6391$

$6392-6399$ 
VIII / A GUIDE TO THE UNITED STATES

Item Nos.
G. Elections: Machinery
$6400-64$ I I
D. Book Selling and Collecting
H. Elections: Results
$6412-6423$
E. Libraries
I. Reform
$6424-6434$
F. Librarianship and Library Use

Item Nos.

$6460-6465$

$6466-6475$

$6476-6487$

CHAPTER XXXII

Books and Libraries

Page
A. Printing and Publishing: General
B. Individual Publishers
C. Book Production: Technology and
6435-6448 Appendix: Selected Readings
6449-6453 in American Studies
Art
6454-6459 Index

I08I

IO9I 


\section{Introduction}

FOR ALMOST a century and a half, since the purchase of Thomas Jefferson's library in 1815 , materials that reflect the development of the United States have been accumulating at an accelerating rate in the Library of Congress. By copyright deposit, by acquisition of special collections, and with the help of generous benefactors, the Library has become the home of the largest collection of Americana in the world. Even if it has not realized the dream of a former Librarian of Congress by assembling within its own walls "the complete product of the American mind in every department of science and literature," it nevertheless has reached such proportions that it justly may be called a mirror of the national culture. Generations of scholars, research workers, students, and readers have employed it, not only to see new facts and relationships that have extended their knowledge, but also to gain a clearer vision of the tradition, meaning, and character of civilization in these United States. To further such aims the Library has consistently bent its efforts through the years.

It was not, however, until the beginning of the decade just past that a marked increase was observed in the number and complexity of questions addressed to the Library about practically all phases of life in the United States. Numerically, of course, the largest number of requests for information came from individuals and institutions in this country; but the most comprehensive questions frequently were posed by national and public institutions located in the four corners of the world. The reply to one of the second class of inquiries involved assembling a bibliography composed of $\mathrm{r}, 800$ Library of Congress printed catalog cards. A comparable request led to the publication in $195^{\circ}$ of American History and Civilization: $A$ List of Guides and Annotated or Selective Bibliographies. The continuing interest in this bibliographical approach to American affairs, past and present, was made evident by demands that exhausted the first edition and required the publication, in $195 \mathrm{I}$, of a second and revised edition.

Many of the movements and events that inspired this growing interest are actively at work in the contemporary world. They include: the place as- sumed by the United States in the society of nations after World War II; the scientific achievements that have made communication relatively easy and breached international barriers resulting from distance; the increasing cultural maturity of the United States, made evident by growing self-examination and self-expression; the idea current among American educators that general education from childhood to maturity, in all phases of the American heritage, will help to increase national unity by basing it on a solid foundation of shared knowledge and understanding; the emergence in higher education, on both undergraduate and graduate levels, of programs in American studies developed through the interrelation of different disciplines; the establishment in countries as far apart as Germany and Japan of centers for American studies; the plan for exchange professorships put into effect through the Department of State in the interest of international education and mutual understanding between countries; and the work of the American Studies Association, the national society for the interdisciplinary study of American civilization.

With these and other influences operating in what is virtually a new international age, it has become more and more apparent that the Library of the Congress of the United States must anticipate even greater demands upon its reference and bibliographical services to mobilize American materials for increasing usefulness and use. This was the situation in the autumn of 1952, when the Library explored the feasibility of gathering together in one publication a series of bibliographical studies of civilization in the United States to which inquirers might refer. Clearly, if such a project could be carried through successfully it would enable the Library to accomplish two objectives at the same time: that of contributing to a wider diffusion of knowledge about this country throughout the world; and that of preventing wasteful duplication of work resulting from repeated attempts to give individual attention to questions that might be more satisfactorily answered within the compass of one carefully prepared reference book. The Guide contained in the following pages is the result.

The 6 years that then elapsed after the study was 
launched may be divided roughly into three periods: 1953-1954, the beginning stage, when members of the staff, while carrying on their regular assignments, studied the problems, planned the scope, put the work in train, and selected basic collections of books for various chapters; 1955-1956, when first two and later three persons devoted substantial but varying portions of their time to further selection of materials, as well as to their description and organization; and 1957-1958, when four or five bibliographers were working, as time could be spared from their other duties. During all these years the group at work suffered the usual dislocations from resignations, leaves of absence, new appointments, and transfers to other assignments. Thus it may be said that a skeleton staff produced the 32 chapters that compose the volume, which includes about 6,500 main entries and half again as many more references found in annotations and headnotes.

The work began and has continued under my general direction, and has been supervised by Henry J. Dubester, Chief of the General Reference and Bibliography Division. Under our instructions, Donald $\mathrm{H}$. Mugridge planned the general scope of the study, personally selected the references included in 24 chapters, and gave editorial revision to work done on them by other bibliographers. The annotations in Chapters VI, VII, X, XI, XIII, and XV, and in portions of several other chapters, also are his work. Blanche P. McCrum and Allan G. Anderson are responsible for the eight additional chapters, the most substantial of which is Chapter I, Literature. Other contributors and associates, and specialists in and outside the Library, who have generously helped us with their advice, are named in the section of Acknowledgments which follows this introduction. The paragraphs that follow immediately are designed to clarify a few points for the convenience of readers.

Selection of Material. References have been selected to meet the requirements of serious readers, students seeking orientation, and librarians engaged in developing collections of books about the United States. It is hoped, however, that the advanced specialist also may find the volume a useful desk reference book, particularly for subjects outside the range of his expert knowledge; and that, although no section on bibliographies as such is included, both he and the less advanced student will be served by the valuable bibliographies regularly noted when these appear in books for which main entries are provided.

The broad plan of selection has been to bring together between the covers of one volume materials relating to subjects as divergent as Art and Public Health, and thus to spread before readers a panorama of life in the United States, past and present.
The basis of selection throughout has been the value of each book as an expression of life in the United States, not necessarily because it has the reputation of being a classic, or because it is a learned monograph primarily of interest to the specialist. No book has been chosen for inclusion, however, unless it has seemed significant in the light of our purpose. By the very definition of that purpose many of the selections necessarily embody the thought and learning of the best minds found in this country from its beginning until today. Timeliness, too, has been considered as of the essence; therefore, except in the chapter on Literature, contemporary and revised editions, more readily available through publishers' lists and in libraries, have been preferred to the first publication of a text unless that has remained the best.

To arrive at any but a hypothetical date of publication, it was decided to set 1955 as the terminal date for selecting material and to prepare each section for the printer as it was completed. Parts of the work concluded in or shortly after 1955 conform to these rules. As the work progressed and was expanded, however, publication was necessarily delayed, and it was possible to include in various other chapters books published as late as 1958 . The timeliness of sections is therefore somewhat uneven, something particularly to be regretted in the chapters devoted to Literature, Intellectual History, Society, Education, Sports and Recreation, and Entertainment, all of which might have been enriched by a number of significant recent references if work on them could have been reopened.

A policy of extremely rigorous selection has been maintained. The Guide is an introduction to representative books that reflect the development of life and thought in the United States. In no sense is it a source of information about every conceivable facet of that life; nor has it any completeness as a catalog or compilation of Americana. Probably other bib. liographers would not have made identical choices; and specialists in the various subjects will doubtless regret omissions quite as keenly as do the bibliographers responsible for them. The fact remains that time and cost are hard masters that must be obeyed. It is equally true that a study of this kind can be elaborated to the point where it ceases to be selective and its complexity defeats its own purpose. We have endeavored to keep within limits properly imposed by all these considerations.

Main Entries and Bibliographical Style. The aim in preparing the entries has been to give references that may be readily identified in the Library of Congress catalogs and consequently in those of hundreds of other institutions where the same cards are used or where the Library's published catalogs are available. Call numbers have been included as addi- 
tional safeguards for exact identification. A small minority of entries record titles or editions that are not in the collections of the Library of Congress. In each case some other major library which does have the book is referred to by means of the appropriate symbol used in the National Union Catalog (see Key to Symbols).

Concerning the prevailing bibliographical style followed, it may be said in general that we have attempted to give an author's name in the form preferred by him, if that can be determined. When, however, he habitually uses the initial of his first name, we have spelled it out if possible for purposes of identification and have supplied a middle initial when known, even if that is regularly missing from his name on the title pages of his books. In the chapter concerned with Literature, on the contrary, the fullest known form of the names of principal authors has usually been preferred as a matter of literary history. Long titles, particularly of books published in the seventeenth and early eighteenth centuries, occasionally have been shortened by the omissions of repetitious endings and wordy subtitles. To conserve space, names of publishers have been shortened to the briefest form that can be readily identified. In these and other questions of bibliographical form we have striven for consistency throughout; but some differences inevitably appear in a work from various hands, and in which individuality is reflected from time to time in differences of concept and of style. When no confusion results from these human tendencies to be different, we have frequently preferred to spend time on matters of substance rather than on revisions to secure meticulous conformity of style.

Main entries in chapters are grouped according to classification schemes outlined in the introduction that precedes each chapter and explains its individual purpose and method. Subordinate arrangement of entries within the various schemes tends to be alphabetical by author's name, as in Literature, for which a period division is supplied by the plan of the classification itself. When arrangement of entries by date, place, or subject more effectively brings together related references, in part or all of a chapter, these variations have been made without hesitation.

Annotations and Headnotes. Annotations have been written primarily to aid the reader in judging what the book contributes to an understanding of the United States and in determining, more specifically, what bearing it has on the aspect of that subject in which he is particularly interested. These notes or annotations are not written as reviews, or literary essays, or dissertations on an author's thesis; quite simply they are meant to be aids which readers may use to eliminate materials irrelevant to their purpose and guideposts to lead them as quickly as possible to the heart of what concerns them. The length of an annotation must not be taken as evidence of the importance of the book annotated. The nature of a famous book may be nearly self-evident from the name of the author and the title, while a less conspicuous book may require more detailed description to place it properly in relation to the subject or subjects with which it deals. Upon occasions two or more books have been annotated together, with the annotation normally following the last entry in the group. For reasons of brevity and readability ellipses normally have not been used to mark the omission of initial or terminal connectives in quotations that appear in the annotations and headnotes, but of course no words and, we trust, no thoughts have been changed. Both annotations and headnotes have been freely used to provide additional documentation by means of brief references to books not described in main entries. Such additional citations are identified sometimes only by date of publication, if that suffices; but in general both imprint and number of pages are given.

The usual practice of annotating individual titles has been varied in some sections by the substitution of one headnote under the author's name, without additional annotations for his individual works unless the range of these was too great to be covered in a headnote. Interest has thus been focused on the total contribution of the writer, and reiteration of statements applicable to all or nearly all his books has been eliminated. Chapters that illustrate this method of approach are those on Literature and Biography and Autobiography, while the largest sections of the chapters on Travel and Travelers and Philosophy and Psychology have been treated in the same way. A similar device has been employed in some cases when the use of a headnote following the title of a long series of books has made it unnecessary to annotate the separate publications that make up the series, as in the cases of "Original Narratives of Early American History" and the readings selected by the Department of American Studies of Amherst College, "Problems in American Civilization."

Appendix: Selected Readings in American Studies. At a meeting of the Council at the American Studies Association held at the Library of Congress in June 1954, announcement was made that work on our bibliography was in progress and suggestions concerning it were solicited. A number of the members present favored the inclusion of a separate section containing those titles which have a synthetic approach, bridge the various academic and scholarly disciplines, and are therefore of special significance to teachers or students pursuing courses in American studies. As a result, a tentative list of 
Ioo such titles was submitted to various members of the Association, who examined it and made suggestions for additions and deletions. The Appendix contains a revision of this original list, enlarged somewhat by the inclusion of new titles located as our study progressed. Entries are in brief form, with reference numbers added to guide the user to the full description of each book in the main body of the bibliography. It remains a sample listing of references, which, if fully expanded, would constitute a new bibliographical enterprise outside our scope. 


\section{Acknowledgments}

MEMBERS or former members of the General Reference and Bibliography Division who have contributed one or more chapters of this book are Allan G. Anderson, Ann Duncan Brown, Helen F. Conover, Peter Draz, and Jane Kline. The following, who were attached to the Division for periods of varying length, lent valuable assistance to the work of the editors or the contributors: Nelson R. Burr, Edith H. Leeds, James S. Sweet, Burdette S. Wright, Jr., and Marko Zlatich.

Colleagues in various divisions of the Library of Congress have assisted us in a number of ways and greatly to the benefit of our study. The staff of the Music Division assumed responsibility for extending and annotating Chapter XXIV, Folklore, Folk Music, Folk Art and Chapter XXV, Music. Donald L. Leavitt took charge of the work on the first of these chapters and a similar labor of love for the chapter on Music was shared by Richard S. Hill, William J. Lichtenwanger, and Donald W. Krummel, in association with Frank C. Campbell, Darius Thieme, and Carroll Wade.

Reviews of chapters, criticisms, and suggestions for additions and deletions were sought and obtained from other members of the Library staff who have special knowledge of the subjects dealt with, as follows: David Baumgardt, former Consultant in Philosophy, now of Columbia University, Chapter XXII, Philosophy and Psychology; Edgar Breitenbach, Chief, Prints and Photographs Division, Chapter XXVI, Art and Architecture; Arch C. Gerlach, Chief, Map Division, Chapter VI, Geography; William H. Gilbert, Jr., Analyst, Indian Affairs, Legislative Reference Service (LRS), Chapter VII, The American Indian; Halford L. Hoskins, Senior Specialist, International Relations, LRS, Chapter IX, Diplomatic History and Foreign Relations; Helen A. Miller, Analyst, Education, LRS, Chapter XXI, Education; John K. Rose, Senior Specialist, Conservation, LRS, Chapter XXVII, Land and Agriculture; Willard Webb, Chief, Stack and Reader Division, Chapter X, Military History and the Armed Forces; Walter H. Zeydel, Assistant Chief, American-British Law Division, Law Library,
Chapter XXX, Law and Justice; and Raymund L. Zwemer, former Chief, Science and Technology Division, Chapter XVI, Communications, and Chapter XVII, Science and Technology.

From outside the Library's own walls we also received generous help from specialists in several subjects. Irene B. Taeuber, Research Associate, Office of Population Research, Princeton University, twice reviewed the section on Population, made suggestions, and permitted us to use her own bibliography; Dorothy M. Schullian, History of Medicine Division, National Library of Medicine, studied the chapter on Medicine and Public Health in detail and made comments and suggestions. Joy E. Morgan, in 1955 Director of the Publications Division, National Education Association, and Ruth C. Little, then Assistant Director, examined the chapter on Education, commented upon it, and suggested certain additions. Our debt to these specialists and those with whom we are associated in the Library is a very real one, which we acknowledge with pleasure and pride. It would ill requite them for their help, however, to lay any of our own bibliographical faults and failings at their doors. The working staff, not the specialists, are responsible for judgments implied or expressed and for the final form and content of the volume.

Finally, acknowledgment must be made of the contribution of two participants in the work who, although their names are not attached to any chapter, have nevertheless left their impress on most of the pages in the book. They are: Grace Hadley Fuller, Head of the Bibliography and Reference Correspondence Section of the General Reference and Bibliography Division, and Helen Dudenbostel Jones, Assistant Head, who reviewed and edited the whole manuscript with respect to its technical bibliographical details and supervised the preparation of the voluminous index which is a distinct feature of the work.

ROY P. BAsLer, Director, Reference Department. 



\section{Key to Symbols}

\begin{tabular}{|c|c|c|c|}
\hline CLU-C & $\begin{array}{l}\text { University of California at Los Angeles, } \\
\text { William Andrews Clark Memorial } \\
\text { Library. }\end{array}$ & $\begin{array}{l}\text { NNC } \\
\text { NNU }\end{array}$ & $\begin{array}{l}\text { Columbia University, New York. } \\
\text { New York University Libraries, New } \\
\text { York. }\end{array}$ \\
\hline $\mathrm{CSmH}$ & $\begin{array}{l}\text { Henry E. Huntington Library, San } \\
\text { Marino, Calif. }\end{array}$ & NRU & $\begin{array}{l}\text { University of Rochester, Rochester, } \\
\text { N.Y. }\end{array}$ \\
\hline CtMW & See CtW. & $\mathrm{NcD}$ & Duke University, Durham, N.C. \\
\hline $\mathrm{CtW}$ & $\begin{array}{l}\text { Wesleyan University, Middletown, } \\
\text { Conn. }\end{array}$ & $\begin{array}{l}\mathrm{NjP} \\
\mathrm{OCU}\end{array}$ & $\begin{array}{l}\text { Princeton University, Princeton, N.J. } \\
\text { University of Cincinnati, Cincinnati, }\end{array}$ \\
\hline $\mathrm{Ct} Y$ & Yale University, New Haven, Conn. & & Ohio. \\
\hline DA & $\begin{array}{l}\text { U.S. Department of Agriculture Li- } \\
\text { brary, Washington, D.C. }\end{array}$ & $\mathrm{OCl}$ & $\begin{array}{l}\text { Cleveland Public Library, Cleveland, } \\
\text { Ohio. }\end{array}$ \\
\hline DCU & $\begin{array}{l}\text { Catholic University of America Li- } \\
\text { brary, Washington, D.C. }\end{array}$ & $\begin{array}{l}\text { OO } \\
\text { OOxM }\end{array}$ & $\begin{array}{l}\text { Oberlin College, Oberlin, Ohio. } \\
\text { Miami University, Oxford, Ohio. }\end{array}$ \\
\hline $\begin{array}{l}\text { ICU } \\
\text { IU }\end{array}$ & $\begin{array}{l}\text { University of Chicago, Chicago, Ill. } \\
\text { University of Illinois, Urbana. }\end{array}$ & PHi & $\begin{array}{l}\text { Historical Society of Pennsylvania, } \\
\text { Philadelphia. }\end{array}$ \\
\hline & $\begin{array}{l}\text { State University of Iowa, Iowa City. } \\
\text { Boston Public Library, Boston, Mass. }\end{array}$ & PPD & $\begin{array}{l}\text { Drexel Institute of Technology, Phila- } \\
\text { delphia. }\end{array}$ \\
\hline MBAt & Boston Athenaeum, Boston. & PPLas & La Salle College, Philadelphia. \\
\hline MH & Harvard University, Cambridge, Mass. & PPT & Temple University, Philadelphia. \\
\hline MWiW-C & $\begin{array}{l}\text { Williams College, Chapin Library, } \\
\text { Williamstown, Mass. } \\
\text { Johns Hopkins University, Baltimore, }\end{array}$ & $\begin{array}{l}\text { PPTU } \\
\text { PSt }\end{array}$ & $\begin{array}{l}\text { See PPT. } \\
\text { Pennsylvania State University, Uni- } \\
\text { versity Park. }\end{array}$ \\
\hline $\mathrm{MeB}$ & $\begin{array}{l}\text { Md. } \\
\text { Bowdoin College, Brunswick, Maine. }\end{array}$ & PU & $\begin{array}{l}\text { University of Pennsylvania, Phila- } \\
\text { delphia. }\end{array}$ \\
\hline MeWC & Colby College, Waterville, Maine. & RPB & Brown University, Providence, R.I. \\
\hline $\begin{array}{l}\text { MiU } \\
\text { MiU-C }\end{array}$ & $\begin{array}{l}\text { University of Michigan, Ann Arbor. } \\
\text {-William L. Clements Library. }\end{array}$ & RPJCB & $\begin{array}{l}\text { John Carter Brown Library, Provi- } \\
\text { dence. }\end{array}$ \\
\hline $\mathrm{MnU}$ & University of Minnesota, Minneapolis. & ViHaI & Hampton Institute, Hampton, Va. \\
\hline NN & New York Public Library. & ViU & University of Virginia, Charlottesville. \\
\hline
\end{tabular}



 \\ Literature (I607-I955)}

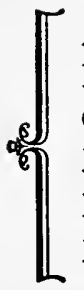

A. The Thirteen Colonies (1607-1763)

B. The Revolution and the New Nation (1764-1819)

C. Nationalism, Sectionalism, and Schism (1820-1870)

D. The Gilded Age and After (1871-1914)

E. The First World War and the Great Depression (1915-1939)

F. The Second World War and the Atomic Age (1940-1955)

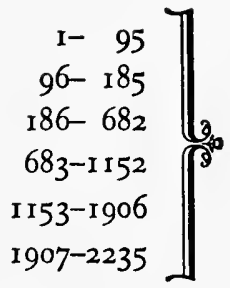

TIFE in America, from small beginnings in 1607 to vastness in 1955 , is the medium in which our writers have worked creatively. In the pages of the books that have resulted we relive the physical, intellectual, emotional, and spiritual experiences of the men and women who have shaped and been shaped by this nation. Through the processes of imagination and esthetic expression characters having "forms more real than living man" speak to us in the contemporary accents of each period. Personal narratives, journals, letters, and especially poems, plays, novels, short stories, and essays reveal the mind and spirit of America as it has developed during $35^{\circ}$ years. Writ large in this body of material, originally designed possibly for edification, information, persuasion, excitement, amusement, or even only for the sake of self-expression, are found firsthand impressions of our culture nowhere else preserved. The books so written supplement, even illumine, those substantial works of research and scholarship that have their place in other chapters of this bibliography. In these other chapters, notably those devoted to General History, Biography and Autobiography, and Philosophy, also will be found many references to books excellent for their literary quality, but too valuable on the score of content to be placed outside their subject category. Not "mere literature," however, but literature that preserves a record of American life is the specific concern of this chapter. A few paragraphs about the selection, description, and arrangement of the materials with which the chapter deals may serve to facilitate its use by the audience to which it is addressed.

Selection of Authors. Pre-eminence in the selection of authors inevitably has been given to acknowledged literary artists, because in general they not only write more powerfully but also about more important phases of American experience. Not every one of these, however, has found a place

within the limits of what is, after all, an introduction and a guide, not a catalog. Obviously, to include every example of a genre or a movement would confuse a landscape more clearly viewed if uncluttered by too many figures. On the other hand, popular and less distinguished writers have not been automatically excluded. While no author has been selected unless some genuine literary interest attaches to him, the relation may not always be as immediately apparent as in the case of writers that have deservedly received much greater critical acclaim. In some cases these minor writers have been selected because they have perceptibly influenced taste, or itlustrated manners and customs, or kept a region or a class from literary oblivion. Their importance derives from their historical and social significancepossibly also because they are good examples of "Americana"-and not from the unusual literary excellence of their accomplishment. Whether the selection that has been practiced has brought in major or minor figures, the touchstone of choice has been the relevance of the writer's work to the understanding of American civilization.

Description of Authors. In this chapter descriptive annotations generally are attached only to names of authors, rather than to titles of individual books, as in most other chapters. Such a variation in 
practice has been determined by a variety of considerations. Chief among these is the purpose to focus attention at once upon the total emphasis of the author's contribution, even if the scope of the chapter permits the inclusion of only a token representation of his complete work. It has seemed desirable also to facilitate the use of the guide by epitomizing the author's significance in a headnote, rather than by leaving that significance to be derived from the examination of numerous annotations of titles. Other reasons for using this device are: avoidance of boring repetitions resulting from annotations of numerous books by one author, all having similar characteristics; and economy of detail that makes it somewhat easier to see the literary forest in spite of its numerous bibliographical trees. In individual instances, however, when the headnote defies attempts to make it sufficiently explicit without becoming unduly wordy, supplementary annotations are incorporated with entries for titles of books.

To avoid repetition of information already fully supplied in standard histories and other studies of American literature, biographical and critical comments and citations usually have been omitted unless required for clarification or documentation. Guidance with respect to these aspects of a writer's work is provided in Chapter III, Literary History and Criticism, where entries will be found for such inclusive works as Literary History of the United States (no. 2460) and The Literature of the American People (no. 2496). References are given in the same chapter for numerous monographic studies of special aspects of American literature, and for anthologies that cover a wide range of topics dealing with writers and the books they have written.

Obviously, significant biographical and critical studies of authors have been published after the closing dates for inclusion of new material in the standard histories of literature. The bibliographical treatment given to a selection of these, in this study, is described in number 5 of the following paragraph. The reader is reminded, however, that for directions to the older, and in some cases the more important studies, he must turn to books of history and criticism such as those mentioned in the foregoing paragraph.

Arrangement under Author's Name. Sections A through $\mathrm{D}$, representing American literature from the beginning to 1914 , have identical arrangements. Following the headnote under the name of the author, full bibliographical entries are inserted for titles of books selected to represent his work. Ordinarily these entries are arranged chronologically by date of publication, and in the following sequence:

I. First or earliest identifiable edition of each title, chronologically arranged by date of publication.

2. (a) New editions and (b) reprints, entered under each title in the order indicated.

3. Collected works, followed first by new editions, and second by reprints.

4. Selected works, new editions, and reprints, in the sequence designated in (2) and (3).

5. Selected biographical and critical studies of the author, not already mentioned in the headnote, and not represented in standard texts because they appeared after the publication of such texts. In general these entries are for books issued between 1949 and the end of 1955 , with rare entries for works having 1956 imprints. They are arranged alphabetically by the name of the author of the biography or criticism.

Sections $E$ and $F$, concerned with modern and contemporary literature, have required two types of arrangement on account of the extremely large amount of material involved: (a) the plan used in sections $A-D$, when the author's work is represented by relatively few titles; and (b) a new scheme when representation involves a large number of titles. In the latter case, separate entries for individual titles are not supplied, if these titles are adequately covered in collections or selections for which entries are being given. Under this scheme, entries for collected, selected, and individual works are interfiled by date of publication. However, attention may be called to individual titles by mention either in the headnote or in annotations of the more comprehensive volumes.

In these two sections it has seemed unnecessary to cite reprints, either because the original edition is still available and is to be preferred, or because reprints may be anticipated after the publication of this bibliography. To keep abreast of such future reprints, reliance must be placed on standard guides to new books that appear periodically.

In the interest of clarity it may be well to amplify the foregoing statements. For instance, if a first edition perished in its entirety and is not at the present time susceptible of accurate bibliographical description, the next earliest edition usually has been selected for description. Another variation occasionally has resulted when the author himself has indicated that a later edition has replaced the first, or when a collected edition preserves the text of several first editions that have been scattered and lost.

It may also be in order to repeat the emphasis given earlier in connection with the selection of authors to be represented by saying that the same degree of selectivity has been applied to the choice of titles, editions, and reprints. The aim has been 
to show the author's value by citing those of his books that are most significant to the reader interested in American civilization. No effort has been made to give a complete panorama of the writer's achievements. Such a limitation of choice, necessitated by the purpose of this study, has forced the compilers to make many painful deletions, with which specialists understandably may disagree. Again, the reader is referred to Literary History of the United States, volume 3, "Bibliography" (no. 2460). Repetition of work already well and fully done would have been supererogation, even if it had been possible.

A final word of explanation must be given concerning the meaning of the words "edition" and "reprint" as used in this chapter. "Edition" implies one of the successive forms in which a text has been issued, either by the author or by an editor. "Reprint" has been taken to mean reproduction of material previously printed, but not necessarily by the use of the same type or plates. It is applied also to republications, perhaps in inexpensive format, and frequently with notes and comments designed to assist the reader.

Organization of the Chapter. The work of some $34^{\circ}$ authors, and its representation in 2,235 numbered items, make up the substance of this chapter. It has, therefore, been necessary to impose some sort of formal order on such a mass of material, not only for the convenience of readers but also to relate it as logically as possible to other chapters of the bibliography.
The method of organization finally selected has resulted in arrangement according to six periods of time between 1607 , when the first permanent colonists came to Jamestown, and 1955, the closing date assigned to the gathering of material. Authors are placed within each period alphabetically by their names, for ease of identification. There are certain objections to this division by periods; these are freely admitted. One difficulty is that authors are exceedingly unaccommodating about living and dying within the exact limits of designated periods. Moreover, arrangement by period, rather than by form, or style, or trend, brings together very strange literary bedfellows indeed. In spite of these diffculties, division of American literature into periods comparable to the large divisions of general American history has advantages for our purpose that outweigh objections. Such division has the merit of indicating the way in which literature marches with the political, social, religious, economic, and other developments of American civilization from the beginning of permanent colonization to the middle of the zoth century. The idea of this relation is basic to a correct understanding of literature itself; hence an arrangement that emphasizes the connection has been favored above others considered. For the same reason the six selected periods, named at the beginning of the chapter, have been characterized in historical rather than literary terms, to show the link between this chapter and other chapters of the bibliography.

\section{A. The Thirteen Colonies (1607-1763)}

The mixed company of adventurers, saints, sinners, and plain people who conquered the wilderness and made possible the settlement of 13 colonies in America were not given to thinking about writing as art for art's sake. Only two writers in the whole period, Anne Bradstreet and Edward Taylor, may be said to have carried on the tradition of belleslettres in any accepted meaning of the term. Colonial Americans, however, believed profoundly in using the written word to put themselves and their affairs on record. It is, therefore, to annals, diaries, histories, sermons, theological treatises, and personal narratives that we must look for the most significant literary beginnings in America.

Nineteen authors selected to represent the period in this bibliography reflect a wide range of interests and illustrate a variety of literary styles in their writings. John Smith, flamboyant chronicler of the settlement at Jamestown, shines through his own history as an embodiment of many qualities of courage and hardihood that animated English explorers in the 16th and 17th centuries. At the opposite extreme, the plain, even prosaic William Bradford undertook to justify the ways of God to man on the bleak New England coast, while faithfully setting down priceless details of the cold, hunger, hardships, troubles with the Indians, and loneliness that daily beset his Pilgrims. Cotton Mather, much later on the literary scene, gave evidence of the far-reaching interests of a Harvard graduate and early New England Brahmin by treating of the church, science, history, biography, and witchcraft in his voluminous writings. Jonathan Edwards, Yale-trained and a younger contemporary of Mather, is credited with one of the finest intellects that has left a mark on American civilization. 
Without his great theological-philosophical treatises, ideas of sin, salvation, destiny, and freedom of the will would not have sifted down, as they have done, with powerful effect on literary artists working in later periods.

Not all writers considered in the bibliography were, however, intellectuals, nor were all concerned with large questions related to this world and the next. At least two of the diaries described in the bibliography are replete with down-to-earth details of domestic manners and customs. A collection of Puritan love-letters is cited, and the narrative of a terrifying captivity among the Indians is used to illustrate a theme that has been developed in a variety of ways by an indefinite number of later writers. A fortunate life of wealth and security, lived on a fine Virginia plantation by a man of large affairs, is also given a place in the record to indicate the enrichment of culture that had taken place towards the end of the colonial period.

A part from the choicest books and parts of books written in this country before the Revolution, much of the literary heritage of the period is today of interest chiefly to the specialist. The Puritan cast of thought in the more substantial part of it, its prevailing sobriety, emphasis placed on beliefs and opinions long ago abandoned, and in some cases the use of crabbed, outmoded styles of writing, all impose barriers between certain colonial writers and 2oth-century readers. Nevertheless, the student of American civilization must turn back again and again to these authentic sources, from which have come ideas and influences formative in the country's destiny, and to which literature in the United States owes a continuing debt.

\section{WILLIAM BRADFORD, I590-1657}

Governor of the colony at Plymouth for 30 years between 1621 and 1656 , Bradford became the annalist of the beginning of New England. In his history he portrayed the piety of the Pilgrim Fathers who settled there, gave their English and European backgrounds in the Separatist movement, and told of their earlier wanderings for conscience's sake. The relations they established with the Indians and the courage they found for enduring hardships while making a home in the wilderness are also recorded with convincing contemporary detail. The vigor of the author's style when at its best and the quality of his thought have made the history highly influential in subsequent literary treatment of New England themes.

2. History of Plymouth Plantation. Now first printed from the original manuscript. Boston, Massachusetts Historical Society, I 856 . xix, 476 p.
(Massachusetts Historical Society. Collections, $4^{\text {th }}$ ser., v. 3) in 9-889 F6r.M4I, 4th ser., v. 3

Edited by Charles Deane.

3. Now reproduced in facsimile from the original manuscript, with an introd. by John A. Doyle. Iondon, Ward \& Downey; Boston, Houghton Mifflin, I8g6. I7 p., facsim. (535 p.)

No. I68. I $-\mathrm{I} 6539$ F68.B 78 RBD

4. —— Edited by William T. Davis. New York, Scribner, 1908. xv, 437 p. (Original natratives of early American history)

8-7375 F68.B802 $\mathrm{E}_{1} 87 . \mathrm{O}_{7} \mathrm{~B}_{7}$

Recently published by Barnes \& Noble, New York.

5. —— Edited by Worthington C. Ford. Boston, Published for the Massachusetts Historical Society by Houghton Mifflin, 1912. 2 v. illus.

12-29493 F68.B805

6. The complete text, with notes and introd. by Samuel Eliot Morison. New ed. New York, Knopf, 1952. xliii, 448 p.

5I-13222 F68.B8073

Modern text, under title, Of Plymouth Plantation, rearranged for easier reading, with documentation relegated to appendices.

\section{ANNE (DUDLEY) BRADSTREET, I6I2?- I672}

Mrs. Bradstreet, daughter of one governor of the Massachusetts Bay Colony and wife of another, had enjoyed a life of privilege and some leisure in England before she was subjected to pioneer conditions in the New World. The scope of her reading, her familiarity with the works of Edmund Spenser and Sir Philip Sidney, and particularly with translations of the poems of Guillaume du Bartas, influenced her style, which is characterized also by the typical metaphors and conceits of English poetry during her period. "Contemplations," her most famous piece, prose meditations, and various poems added to the edition of 1678 make use of themes drawn from admiration of the New England landscape, love of husband and children, and experiences of family life. These mitigate the sameness of her prevailing tone of Puritan piety. Mrs. Bradstreet is frequently called the first authentic poet writing in America.

$\sqrt{ } 8$. The tenth muse lately sprung up in America ... With divers other pleasant and serious: 
poems . . London, S. Bowtell, 1650. 207 p.

6-31257 PS7II.Ar I650 RBD

A second edition, revised by the author, was posthumously published under the title, Several Poems ... By a Gentlewoman of New England (1678).

9. Works in prose and verse. Edited by John Harvard Ellis. Charlestown, Mass., A. E. Cutter, I867. Ixxvi, 434 p. illus.

$$
\text { I 2-30892 PS7II.AI I867 }
$$

The Poems are reprinted from the second edition. Cf. p. $\left[7^{8}\right]$.

ro. —— New York, P. Smith, 1932. lxxvi, 432 p. illus. $32-2675$ I PS7II.AI 1932 A reprint of the edition of 1867 .

I I. Poems ... together with ... prose remains. With an introd. by Charles Eliot Norton. [New York] The Duodecimos, I897. xliv, 347 p. illus. $\quad 32-6990$ PS7I I.AI 1897

Editor's note signed: Frank E. Hopkins.

\section{WILLIAM BYRD, I674-I744}

The holder of various public offices of trust, Byrd traveled extensively over the outlying sections of Virginia, observing physical aspects for the benefit of his fellow members of the Royal Society in London, and looking at social conditions on an expanding frontier from the point of view of a man of large affairs. The commentaries and diaries which preserve his reflections on conditions in the colony when its age had passed the century-mark were written in a style typical of a gentleman educated in the English I 8th-century manner. For that reason, as well as for their contents, they have been useful literary sources for later writers on the place and the period.

13. The Westover manuscripts . . written from I 728 to 1736 , and now first published. Edited by Edmund Ruffin. Petersburg, Va., E. \& C. J. Ruffin, I84I. I43 p. $\quad \mathrm{Rc}-2772 \quad \mathrm{~F}_{229} \cdot \mathrm{Bg}_{3}$

Includes The History of the Dividing Line Betwixt Virginia and North Carolina; A Journey to the Land of Eden, A. D. 1733; and $A$ Progress to the Mines. Reprinted as A Journey to the Land of Eden and Other Papers, edited by Mark Van Doren (New York, Macy-Masius, 1928. 367 p. An American bookshelf, no. 4).

I4. Writings. Edited by John Spencer Bassett. New York, Doubleday, Page, rgor. Ixxxviii, 46I p. illus. One of an edition of 500 copies.

Includes also miscellaneous papers, e. g., letters and a catalog of some 4,000 volumes in Byrd's library at Westover.

15. The secret diary of William Byrd of Westover, I709-1712. Edited by Louis B. Wright and Marion Tinling. Richmond, Dietz Press, I94I. xxviii, $622 \mathrm{p}$. 4I-2I 807 F229.B97I5

A transcription from the original shorthand of the first part of Byrd's diary now in the Henry E. Huntington Library.

I6. Another Secret diary of William Byrd of Westover, 1739-1741, with letters \& literary exercises, 1696-1726. Edited by Maude H. Woodfin, translated and collated by Marion Tinling. Richmond, Dietz Press, 1942. xlv, 490 p.

43-1881 F229.B9717

Reproduced at the Henry E. Huntington Library from shorthand and holograph manuscripts owned by the University of North Carolina.

Bibliographical footnotes.

Both secret diaries supply details of daily life on a large plantation as lived by the ruling class in colonial Virginia. Louis B. Wright's The First Gentlemen of Virginia (San Marino, Calif., The Huntington Library, I940. 373 p.) throws light upon the intellectual qualities and activities of Byrd and his predecessors.

\section{JOHN COTTON, $1584-1652$}

John Cotton, once dean of Emmanuel College, Cambridge University, and a notable pulpit orator, incurred the wrath of Archbishop Laud on the score of his Puritanism. Fearing for his life and liberty, he chose to join his friends and fellow Puritans in Massachusetts Bay Colony, where he arrived in his 49th year. There his talents and his earnestness soon made him the leading clergyman of the infant colony. According to Puritan practice, this spiritual office carried with it civil influence as well, so much so that it has been said opinions uttered by Cotton in the pulpit soon were embodied in the laws of Massachusetts. In the remote outpost of civilization in which he found himself, the former university official continued his industry as a scholar and a voluminous writer. His catechism Milk for Babes ( 1646 ) became a standard text for the moral education of New England children. Among his other works are found books about prayer, collections of sermons, pamphlets on controversial subjects, and treatises on theological subjects, particularly in relation to the conduct of the Congregational Church in New England. They were written to warn, reprove, edify, and instruct his fellow Puritans, and to combat errors he found in ideas different from his own. Their value today to the student 
of American civilization is found chiefly in the light they throw on Puritanism and Calvinism as influences in the making of New England culture from which, some 200 years after Cotton's day, American literature flowered in the American Renaissance. No collected edition of Cotton's works has appeared.

18. God's promise to His plantation. London, J. Bellamy, 1630. $20 \mathrm{p}$.

49-56418 $\mathrm{F}_{67 .} \mathrm{C}_{3} \mathrm{RBD}$

Example of Puritan plain style used in sermons; preached for John Winthrop and his party immediately before their departure from England for the Bay Colony in Massachusetts. Reprinted in 1896 in Old South leaflets, general series, v. 3, no. 53 .

19. The way of the churches of Christ in New England. London, M. Simmons, I645. II6 p.

RBD

Treatise on the theory of government under which the New England church functioned; together with Cotton's The Keys of the Kingdom of Heaven (London, H. Overton, I644. 59 p.) it embodies the author's undemocratic and authoritarian philosophy of the relation of church and state.

20. The bloudy tenent washed and made white in the bloud of the Lambe .... Whereunto is added a reply to Mr. Williams' answer to Mr. Cotton's letter. London, H. Allen, I647. I94, I44 p. 49-38592 BV 741. W58c RBD

Polemic against religious toleration as advocated by Roger Williams in his The Bloudy Tenent, of Persecution, for Cause of Conscience (q. v.).

\section{JONATHAN EDWARDS, I703-1 $75^{8}$}

Edwards shared with Cotton Mather the experience of trying to uphold Puritan orthodoxy when it was declining in New England. Theologian and fiery preacher though he was, Edwards was not, however, concerned solely with the damnation of sinful men. Scientific, metaphysical, and mystical elements in existence, or "being," were reflected in important sections of his voluminous works. These legacies from his intellectual and spiritual life entered into the thought of America through his writings and bore fruit in succeeding generations of authors, particularly in New England. Emerson's theory of nature, in relation to his Transcendentalism, Hawthorne's preoccupation with the consequences of sin, and Melville's awareness of the powers of darkness in conflict with human souls-all these and many other ideas found ii American literature have been influenced by the fact that Edwards thought and wrote as the philos- opher he was. Substantial contributions to the understanding of Edwards' works and to an appreciation of his rightful place in American life and letters may be gained from Perry Miller's Jonathan Edwards (New York, Sloane, 1949. $34^{8}$ p. American men of letters series). See also Professor Miller's edition of Edwards' notes having the title Images or Shadows of Divine Things (New Haven, Yale University Press, 1948. I5 I p.), which emphasizes the empirical character of the writer's thought.

22. A faithful narrative of the surprising work of God in the conversion of many hundred souls in Northampton, and the neighbouring towns and villages of New Hampshire in New England. London, J. Oswald, 1737. I32 p.

$\mathrm{BR}_{520 . E_{4}}{ }_{1737} \mathrm{RBD}$

23. - $\quad 3$ d ed. Boston, D. Henchman, $173^{8}$. viii, 79 p. $21-18452$ BR520.E 4738 RBD

Fullest contemporary account of the revival launched by Edwards in 1735, a forerunner of the Great Awakening which began in 1740; an early work on phenomena observed in revival meetings.

24. Sinners in the hands of an angry God. Boston, S. Kneeland, 1741. 25 p. MBAt Sermon preached at Enfield, Massachusetts, July 8, 1741, during the Great Awakening; extreme example of Edwards' belief in appeal to the emotions to secure religious conversion.

25. A treatise concerning religious affections ... Boston, S. Kneeland \& T. Green, 1746. 343 p. I I-2602 BX7230. 4 I $746 \mathrm{RBD}$

Pioneer American contribution in the field of religious psychology.

26. A careful and strict enquiry into the modern prevailing notions of that freedom of will which is supposed to be essential to moral agency, virtue and vice, reward and punishment, praise and blame. Boston, S. Kneeland, 1754. 294 p.

28-7122 BT810.E25 I754 RBD

Written to clarify and establish Edwards' position concerning the Calvinistic doctrines of free will and determinism, the work is the cornerstone of the writer's famie as one of the foremost thinkers and philosophical theologians produced in America.

27. Works. Edited by Edward Williams and Edward Parsons. Leeds, Eng., Baines, 1806-11. $8 \mathrm{v}$.

$\mathrm{IaU}$

"Reprinted in 1817 , and again in 1847 , with two 'Supplementary Volumes'."-Literary History of the United States, v. 3, p. 482. 
28.

Jr., I 808 Worcester, Mass., Isaiah Thomas, Edited by Samuel Austin.

$$
\begin{array}{llll}
8-32280 & \mathrm{BX}_{7117 . E_{3}} \quad 1808
\end{array}
$$

A reprint of the edition, with additions, was issued as an 8th edition (New York, Leavitt \& Allen, I 85 I-52. 8 v.).

29. With a memoir of his life. New York, G. \& C. \& H. Carvill, 1830. Io v. illus. $\quad 25-2334 \mathrm{I} \quad \mathrm{BX}_{7117} \cdot \mathrm{E}_{3} \quad 1830$ Edited by Sereno E. Dwight.

30. Representative selections, with introd., bibliography, and notes by Clarence $\mathrm{H}$. Faust and Thomas H. Johnson. New York, American Book Co., 1935. cxlii, 434 p. (American writers series) 35-30040 $\quad \mathrm{BX}_{7117} \cdot \mathrm{E}_{33} \mathrm{~F}_{3} \quad$ 1935

Part of the introduction was issued as $\mathrm{C}$. $\mathrm{H}$. Faust's thesis (Ph. D.) University of Chicago, under the title: Jonathan Edwards's View of Human Nature. Brief selections are given in full; longer works are represented by excerpts. A bibliography, chiefly of critical works about Edwards and his writings, appears on p. cxix-cxlii.

3I. Puritan sage; collected writings of Jonathan Edwards. Edited by Virgilius Ferm. New York, Library Publishers, 1953. xxvii, 640 p. 53-3143 $\quad \mathrm{BX}_{7117} \cdot \mathrm{E}_{3} \quad 1953$

Anthology of partial or complete selections, drawn chiefly from the Works (1830) edited by Sereno E. Dwight.

\section{THOMAS HOOKER, I586-1647}

Hooker's background and experience before he came to America in 1633 closely paralleled those of his friend, John Cotton. Each was trained at Emmanuel College, Cambridge University, a stronghold of Puritanism in England. Both so persuasively preached doctrines unacceptable to the established Church of England that emigration was their refuge from prosecution on the charge of nonconformity. In Massachusetts Bay Colony, a destination they reached in the same boat, each began a career that was instrumental in promoting the influence of the Congregational church and Puritan ideologies in the developing life of the colony. (Their extant sermons and theological treatises preserved for posterity the beliefs that shaped the early culture of New England, and that were influential in all parts of the country where Calvinists were found. In 1636 Hooker and his congregation left Massachusetts to found a new colony at Hartford and surrounding points in Connecticut. There, it is said, Hooker's enunciation of the principle that "the foundation of authority is laid, firstly, in the free consent of the people" contributed to the adoption of the Connecticut Fundamental Orders of 1639 , an early and remarkable declaration of American democracy. Hooker's works have not been published in a collected edition; full reprints of separate works also are lacking.

33. The soules preparation for Christ ... London, R. Dowlman, 1632. 242 p. NN

Sermons widely known and discussed; influential in forming literary taste according to the Puritan plain style, without metaphysical complexities or ornate quotations, but characterized by pointed allusions and imagery drawn from homely situations.

34. A survey of the summe of church discipline. London, J. Bellamy, 1648. I8, [16], I39, 185296, 90, 46, 59 p. 22-6482 BX $7240 . \mathrm{H}_{7} \mathrm{RBD}$ Has been called the most important exposition of Congregational church polity; also includes discussion of philosophical theories affecting the development of New England law and politics.

35. The covenant of grace opened ... Being several sermons preached at Hartford in NewEngland. London, G. Dawson, 1649. 85 p.

$$
\text { 21-9106 } \mathrm{BX}_{7233} \cdot \mathrm{H}_{6 \mathrm{C}} \mathrm{RBD}
$$

Bases salvation on a contract between God and man, a legalistic concept also present in the Puritans' attitudes towards political and social relations.

\section{SARAH (KEMBLE) KNIGHT, 1666-1727}

Madam Knight, a lively, intelligent woman of substantial position in Boston, occupied herself by keeping a writing school, where, according to legend, Benjamin Franklin was a pupil. She also acted as an official recorder of public documents, a capacity in which she gained sufficient knowledge of court procedures to be employed from time to time in the settlement of estates. Having been called to New York to undertake such a piece of work, she made the unprecedented decision to go there on horseback without formal escort, except such as could be found on the way. The diary she kept during pauses on the hazardous journey to New York and back to Boston is marked by gusto, good humor, earthiness, and the evidence of keen observation. It is replete with apt, sometimes witty, comments on the manners of the people she encountered, the lack of suitable accommodations, and the physical aspects of the country traversed. Since the diary is neither pretentious nor self-conscious, it provides an unusually valuable picture of people and conditions along the New England shore at the beginning of the 18 th century. 
37. The private journal kept by Madam Knight on a journey from Boston to New York in the year 1704. In The journals of Madam Knight and Rev. Mr. Buckingham from the original manuscripts written in 1704 and I710. New York, Wilder \& Campbell, 1825. p. 9-70. I-I33I8 F7.K7I RBD

38. The journal of Madam Knight. With an introductory note by George Parker Winship. Boston, Small, Maynard, I920. xiv, $72 \mathrm{p}$.

$$
\text { 21-10698 F7.K } 723 \text { RBD }
$$

39. — New York, P. Smith, 1935. xiv, 72 p. 35-1287I F $7 . \mathrm{K}_{724} \mathrm{RBD}$

Facsimile reprint of the r 920 edition.

\section{4o. COTTON MATHER, $1663_{3}-1728$}

A member of the second generation of his family to be born and reared in America, Cotton Mather was descended on his maternal side from the apostolic John Cotton (q. v.). By paternal ancestry he belonged to the "Mather dynasty," composed of leaders in the church, in education, and in matters of state during the better part of a hundred years. He graduated from Harvard at the age of fifteen, then took his M. A., and became associated with his father in the Second Church of Boston. In ${ }^{6} 685$ he was ordained as one of its two ministers and served the same Congregational church for the remainder of his life. Mather was essentially a religious conservative in a time of transition to more liberal theology, and his lot was not always a happy one. Some of his many scientific interests also were viewed with suspicion by his contemporaries. For example, when popular opinion was inflamed against inoculation for smallpox, he was a persistent advocate of the new method. His various medical ideas and the progressiveness of his thought in this field recently have been analyzed by Otho T. Beall and Richard $\mathrm{H}$. Shyrock in their Cotton Mather, First Significant Figure in American Medicine (Baltimore, Johns Hopkins Press, 1954. 24I p.). Also akin to his interest in scientific observation was his continued investigation of alleged witches; but these activities may have contributed to the fanaticism that culminated in the Salem trials whose later odium Mather shared. His intellectual curiosity operated in many fields besides science. He made good use of a personal library, said to rival in size that of the second William Byrd at Westover. In the course of his busy life as a clergyman he found time to write some 450 books and pamphlets. In writing these he consciously experimented with various literary styles. However heavy and archaic some of his work may now appear, all of it is not in this vein. Moreover, it must be remembered that he formulated one of the first theories of literary composition enunciated in America. Although primarily a preacher and a Calvinist theologian, Mather has a place in the literature of America, as well as in its theology and religious history. However, no collected edition of his works has appeared.

4I. The wonders of the invisible world. Boston, S. Phillips, I693. I6, I, I5 I ( I), 8, I7-32 p.

NN

Concerning the witchcraft trials in Salem, Mass., in 1592 .

The text was republished in volume 1 of Samuel G. Drake's compilation entitled The Witchcraft Delusion in New England (Roxbury, Mass., E. Woodward, i 866. Woodward's historical series, no. 5), p. [ $\mathrm{I}_{1}-247$. Selections appear in Narratives of the Witchcraft Cases, $1648-1706$, edited by George L. Burr (New York, Scribner, 19r4. Original narratives of early American history [currently published by Barnes \& Noble, New York 1 ), p. 203-25I.

42. - On witcheraft, being The wonders of the invisible world. Mount Vernon, N. Y., Peter Pauper Press [1950?] $172 \mathrm{p}$.

$$
\text { 50-9778 BF } 1575 . M_{54} \quad 1950
$$

43. Magnalia Christi Americana; or, The ecclesiastical history of New-England. London, T.

Parkhurst, 1702 . 7 pts. in I v.

$$
\mathrm{I}-24698 \quad \mathrm{~F}_{7} \cdot \mathrm{M}_{4} \mathrm{I} \quad \mathrm{RBD}
$$

Covers the years $1620-98$ and includes numerous biographies of notable Puritans, stories of marvels, histories of Congregational churches, etc. Written in the author's "Massy" style, based on "fantastic" English prose of the 17 th century, and characterized by conceits and other artificialities.

44. With an introd. and occasional notes by the Rev. Thomas Robbins . . . To which is added a memoir of Cotton Mather by Samuel G. Drake. Hartford, Conn., S. Andrus, I 855, 1853 . $2 \mathrm{v}$. 3-4343 BR520.M

45. Bonifacius. Boston, S. Gerrish, I710. 206 p. $3^{8-12900} \mathrm{BV}_{4500 . M_{35}}$ i710 RBD

A guide for ordinary men, simply written in the "Plain" style congenial to Puritan taste, to be used in organizing charitable impulses so that they constitute a workable system which contributes to maximum benefits. Benjamin Franklin loved the book and ascribed to its influence his own interest in being useful as a citizen. Later editions were published as Essays To Do Good. 
46. The Christian philosopher ... London, E. Matthews, I72I. $304 \mathrm{p}$.

45-45057 BL180.M4 I721 RBD

Represents the author's interest in natural phenomena and science, in which he was a precursor of Benjamin Franklin and Thomas Jefferson.

47. Manuductio ad ministerium. Boston, T. Hancock, 1726. I49 p.

RBD

A manual for pastors, belonging to a well-developed I7th-century literary type; includes an important statement of the author's theory of literary style.

48. - Reproduced from the original edition ... with a bibliographical note by Thomas J. Holmes and Kenneth B. Murdock. New York, Published for the Facsimile Text Society by Columbia University, 1938. xix, 151 p. (Facsimile Text Society. Publication no. 42.)

$$
3^{8-843^{8}} \quad \mathrm{BV}_{4}{ }^{\circ 009 \cdot \mathrm{M}_{35}} \quad \mathrm{I7} 26 \mathrm{a}
$$

49. Diary, $\mathbf{1} 68 \mathrm{I}-\mathrm{I} 724$. Boston, Massachusetts Historical Society, IgII-I2. 2 v. (Massachusetts Historical Society. Collections, ser. 7 , v. $7-8$ )

$$
\text { II-I } 4733 \text { F6I.M. } 4 \text { I, ser. 7, v. 7-8 }
$$

50. Selections from Cotton Mather. Edited with an introd. and notes by Kenneth B. Murdock. New York, Harcourt, Brace, 1926. Ixiii, 377 p. (American authors series, general editor, S. T. Williams) 26-12606 BX7117.M25

"Selected reading list": p. lxi-lxiii.

\section{THOMAS MORTON, fl. $1622-1646$}

Attracted to New England by a desire to make money, the adventurer Morton traded guns and liquor to the Indians in order to secure furs for sale. He was twice expelled from the country by the Pilgrims of Plymouth for these offenses and also on account of the convivial life carried on at his trading post, Ma-re-Mount. In retaliation, he wrote and published a satire against the colonists which is unusual in the annals of early American literature for its expressions of enjoyment derived from the primitive environment, for the levity of its tone, and for its ridicule of fanaticism in the Pilgrims' way of life. For all these reasons the book has been used as a source of later literary treatment of the same themes, the best known of which is probably Hawthorne's sketch, "The May-Pole of Merrymount," in Twice-Told Tales (q. v.).

52. New English Canaan or New Canaan. Amsterdam, J. F. Stam, i637. I 88 p.
Reprint. With introductory matter and notes by Charles Francis Adams, Jr. Boston, Prince Society, 1883. vi, 38I p. (Prince Society, Boston. Publications [v. I4]) ${ }_{1-16032}$ EI86.P85, v. I4 F67.M875

\section{MARY (WHITE) ROWLANDSON, ca. 1635-ca. 1678}

Lancaster, Mass., experienced an Indian raid in February 1676, while King Philip's War was in progress. As a result, Mrs. Rowlandson and her three children were carried into captivity by the Indians. The youngest child soon died, a victim of the hardships and exposure to which the prisoners were subjected. Finally, however, the mother and her remaining children were ransomed and restored to their friends. Mrs. Rowlandson's account of their terrible experience, expressed in the tone of resignation and religious piety typical of Puritan writing at the time, was nevertheless a forthright and realistic portrayal of one of the grimmest aspects of colonization and frontier life in America. Personal narratives of Indian captivities, of which this is an outstanding example, created a body of literature that attained great popularity among readers. As such, it is responsible in part for the hatred of Indians that developed in the country, and also must be considered in connection with the romantic revolution from that hatred on the part of James Fenimore Cooper and other novelists who created idealized Indian characters.

54. The soveraignty \& goodness of God . . . being a narrative of the captivity and restoration of Mrs. Mary Rowlandson. 2d addition [!] corr. and amended. Cambridge, Mass., S. Green, I682. 6, $73 \mathrm{p}$.

MB

An earlier edition, supposed to have been published in the same year, is no longer extant.

55. — 2d ed. [i. e., 3d ed.?] Carefully corr. and purged from abundance of errors which escaped in the former impression. Boston, $S$. Phillips, I720. 80 p. 8-33637 E87.R862 RBD

Reprints having the title, The Narrative of the Captivity and Restoration of Mrs. Mary Rowlandson include the following: (a) a facsimile reprint edited by Henry S. Nourse and John E. Thayer (Lancaster, Mass. [Cambridge, Mass., J. Wilson] 1903. vii, $15^{8}$ p.); and (b) another reprint edited by Charles $\mathrm{H}$. Lincoln, in his Narratives of the Indian Wars, 1675-1699 (New York, Scribner, 1913. Original narratives of early American history [recently published by Barnes \& Noble, New York]), p. [107]-167. 


\section{SAMUEL SEWALL, I652-1730}

Sewall's success while a student at Harvard College led to his appointment as a resident fellow. Although he had considered entering the ministry, his final decision was in favor of a career in public life. Among prominent positions held by Sewall was that of chief justice of the Superior Court of Massachusetts. One of his unfortunate appointments was to membership in the special commission set up to hear the Salem witchcraft cases of 1692 . His part in the trial and condemnation of various defendants weighed so heavily upon him that he repudiated his judgment and announced his penitence in a public confession made in 1697 . His humanitarian sympathies were also manifest in The Selling of Joseph (1700); reprinted in the Diary, v. [2] p. 16-20. This pamphlet, one of the first documents against slavery written in America, contains the famous dictum: "It is most certain that all men, as they are sons of Adam, are coheirs; and have equal right to liberty, and all other outward comforts of life." With ample means, strong common sense, and considerable wit, this layman was qualified to portray in his diary and letters a view of colonial life in New England quite different from that presented in the prevailing clerical writings of the place and period.

57. Diary. 1674-1729. Boston, Massachusetts Historical Society, 1878-82. 3 v. (Massachusetts Historical Society. Collections, ser. 5, v. 5-7) 10-12994 F6r.M4I, ser. 5, v. 5-7

F67.S45

A Puritan Pepysian chronicle that includes trivia, financial records, intimate domestic details, shrewd comments on important men and events, and expressions of sincere religious belief.

Abridgment. Edited by Mark Van Doren. New York, Macy-Masius, 1927. 272 p. (An American bookshelf [I])

$$
27-23367 \quad F_{67 . S} 15
$$

58. Letter-book. [1685-1729] Boston, Massachusetts Historical Society, I886-88. 2 v. (Massachusetts Historical Society. Collections, ser. 6, v. I-2) I0-I 2993 F6r.M4I, ser. 6, v. I-2

\section{THOMAS SHEPARD, 1605-1649}

In 1635 Shepard followed John Cotton and Thomas Hooker to New England, there to constitute with them a triumvirate of highly educated Congregational clergymen who greatly influenced the cultural development of the young colony. In common with his two friends he had been driven out of
England by Archbishop Laud because of his nonconformity. Although he was a Puritan of the dissenting Calvinistic type, his sermons and theological writings included emotional and mystical elements that gave them unusually wide appeal, when delivered with the eloquence at his command. In spite of the fact that he was frequently unable to revise the rough drafts of his sermons and other writings before they were published, his works reached a large audience and attained the dignity of a collected edition in 1853. According to the biography by John Albro (Works, v. I, p. clxxxix) Jonathan Edwards' $A$ Treatise Concerning Religious Affections includes some 75 quotations from Shepard's The Parable of the Ten Virgins ( 1660 ). It has been suggested that Shepard's reputation for godliness and scholarship was influential in the choice of his parish at Cambridge, Massachusetts, for the location of Harvard College.

6o. The sincere convert. London, H. Blunden, I640. [27I] p.

NN

6r. The sound believer. London, R. Dawlman, I645. $352 \mathrm{p}$.

$$
\text { 52-46573 } \mathrm{BV}_{4914 . \mathrm{S}_{55} \quad 1645 \mathrm{RBD}}
$$

62. The clear sun-shine of the gospel breaking forth upon the Indians in New England. London, J. Bellamy, $1648 . \quad 3^{8} \mathrm{p}$.

$$
\text { 6-43056 } \mathrm{E}_{7} 8 . \mathrm{M}_{4} \mathrm{E}_{35}
$$

- Reprint. In Massachusetts Historical Society. Collections, ser. 3, v. 4. Cambridge, C. Folsom, 1832. p. 25-67.

$$
\text { 9-889 F6r.M4I, 3d ser., v. } 4
$$

63. Autobiography. With additional notices of his [Shepard's] life and character by Nehemiah Adams. Boston, Pierce \& Parker, 1832. 129 p.

$$
3^{6-16665} \mathrm{BX}_{7260 . \mathrm{S}_{53} \mathrm{~A}_{3}}
$$

64. Autobiography. In Colonial Society of Massachusetts, Boston. Publications [including] transactions, 1927-1930. v. 27; 1932. Boston. p. [343]-400. I-280 F6r.C71, v. 27

Based on a fresh study of the original manuscript first published in the edition by Nehemiah Adams described in the foregoing reference. A bibliography is supplied, p. 347-351.

65. Works. Boston, Doctrinal Tract and Book Society, 1853. 3 v. $39-1493 \quad \mathrm{BX}_{7117 . S_{5}}$ Contains a life of Shepard, by John A. Albro, v. I, p. [vii]-cxcii. Volume 3 is wanting in the Library of Congress set. 


\section{JOHN SMITH, 1579/80-1631}

Smith's right to be called one of the fathers of American literature may be defended on several counts and in spite of certain reservations that are in order. If he is thought of as a chronicler of his firsthand observations, it must be admitted that he was frequently hasty, careless, repetitious, boastful, and confused. His reputation for veracity, viewed more leniently by contemporary scholars than by those of an earlier time, must still sustain the charge that he told taller tales than the facts warranted. Nevertheless, interest in him as a man of letters has not suffered from the lack of exactitude in his writings. His Pocahontas story, whether true or apocryphal, soon became a legend. As such it inspired a literature of its own, which includes James Nelson Barker's drama, The Indian Princess (1808), and John Esten Cooke's novel, My Lady Pokahontas (1885). What Smith stood for in his own person has, perhaps, had the strongest literary influence. Coming to America as Elizabethan explorers went to strange places, he shared a heroic enterprise as a colonist, in the best tradition of an English gentleman adventurer. He was to succeeding generations of Americans the typically intrepid pioneer, frontiersman, and strong man whom they elevated into a national hero. His writings are, therefore, not only source materials for understanding early colonial life in Virginia, but also sources of inspiration for various themes that in different periods and with different emphasis have been used by writers in America. The most recent study of Smith's life, which favors the case for his reliability, is Bradford Smith's Captain John Smith, His Life \& Legend (Philadelphia, Lippincott, 1953. 373 p.).

67. A true relation of such occurrences .... as hath hapned in Virginia since the first planting of that collony ... London, J. Tappe, 1608 . 221.

NN

First account of the first permanent English colony established in America.

68. A map of Virginia. Oxford, Eng., J. Barnes, I612. 39, I I o p. fold. map.

$$
\text { Rc-2805 F229.S69 RBD }
$$

Includes a detailed account of the physical aspects of Virginia and of the Indian way of life observed there.

69. A description of New-England ... London, R. Clerke, 16r6. 61 p.

$$
7^{-15406} \quad \mathrm{~F}_{7} . \mathrm{S}_{3} \mathrm{RBD}
$$

Favorable description of the natural resources of New England, designed to attract settlers; part of Smith's campaign to promote colonization in that region, an enterprise in which he was interested for some 20 years after leaving Virginia in 1609.

70. The generall historie of Virginia, New-England, and the Summer Isles . . . London, M. Sparkes, r624. 248 p. illus.

Rc-2796 F229.S6I RBD

Repeats and enlarges upon various earlier writings; first appearance of the story of his rescue by Pocahontas.

71. Travels and works. Edited by Edward Arber. New ed., with a biographical and critical introd. by A. G. Bradley. Edinburgh, J. Grant, 1910. 2 v. ( 984 p.) illus. W 1 I-10 F229.S655

Bibliographies: v. I, p. xxvii-xxx, [cxxx]cxxxvi.

Reprints of Smith's shorter narratives about Virginia, and of Book IV of his General History of Virginia are contained in Narratives of Early Virginia, $1606-1625$ (1907), p. [25]-204; [289]-407, a collection edited by Lyon G. Tyler, for the Scribner series, Original narratives of early American history, recently published by Barnes \& Noble.

\section{EDWARD TAYLOR, 1642-1729}

Taylor was a devout Puritan clergyman who lived and wrote in Massachusetts during the late 17 th and early 18 th century. Nothing considerable was known of his poetical work until a representative selection of it was made from a manuscript belonging to Yale University. The result was published in 1939. His disinclination to permit his poetry to reach a contemporary audience may have stemmed from a fear that it revealed emotions too strong, in imagery too worldly, to be compatible with strict Puritan orthodoxy. Upon the appearance in print of the poetical works, a new name was therefore added to the short roster of colonial American poets, and a new light was cast on the deeper esthetic and emotional elements in Puritan religious thought. In structure, Taylor's verse belongs to the tradition of religious poetry represented by John Donne, George Herbert, and other English metaphysical poets of the $\mathrm{i} 7_{\text {th }}$ century. In content and style it combines, however, two personal departures from more typical Puritan poetry that give it unusual variety and interest: its piety is expressed by means of imagery derived from rich colors, sweet odors, and other delights perceived by the senses; and its reality is increased by contrasting imagery based on everyday experiences of ordinary Puritans, expressed in their own colloquial language. Taylor has been called "The greatest poet of New England before the nineteenth cen- 
tury" (Literary History of the United States, v. I, p. 65).

73. Poetical works. Edited with an introd. and notes by Thomas H. Johnson. New York, Rockland Editions, 1939. 231 p.

$$
\text { 39-34182 PS850.T2 r939 RBD }
$$

Notes to the edition are supplied on p. 189-199; Taylor's library is described and the contents listed, p. 201-220; the manuscript of Poctical Works is discussed, p. 22I-228; a bibliography of Taylor's manuscripts, printed works, and sources for the study of his life and achievements are found on $\mathrm{p}$. 229-23I.

74. Princeton, Princeton University Press, 1943. 231 p. A45-4662 DCU

\section{NATHANIEL WARD, ca. $157^{8-1652}$}

Another Cambridge University graduate driven out of England by Archbishop Laud, Ward in 1634 brought to New England his exceptional attainments in the law and in the Puritan ministry, his second profession. Wide experience of the world, not only in England but on the Continent, increased his stature. Although Ward was anything but a democrat in the modern understanding of the term, he was well-versed in the rights of the individual under British law. For that reason, his draft of the first code of laws for Massachusetts, adopted with some revisions in $16_{4} 1$, contained certain provisions for safeguarding such rights. Thus, even within the stronghold of authoritarian Puritanism, the heritage of British justice was preserved and its concepts made a part of American civilization. Ward's other contribution to early American letters (cited below) was a true r7th-century pamphleteering satire, directed against the sins of the times. In it the writer employed Puritan plain style mixed with other elements derived from Elizabethan and Jacobean literature, in which he was apparently steeped.

76. The simple cobler of Aggawam in America ... By Theodore de la Guard [pseud.] London, S. Bowtell, r647. 80 p.

MiU-C NN

77. —— Edited by Lawrence C. Wroth. New York, Scholars' Facsimiles \& Reprints, 1937. 8o p. $\quad 38-18217$ PS858. W2 5 1647a RBD

78. [The body of liberties] A coppie of The liberties of the Massachusetts Collonie in New

England. In Massachusetts Historical Society. Collections, ser. 3, v. 8. Boston, Little, Brown, 1843 . p. [216]-237. 9-889 F61.M41, ser. 3, v. 8 First printed edition of the document of 1641 . Cf. p. [rgr $]$.

79. MICHAEL WIGGLESWORTH, 1631-I705

A Puritan clergyman in Malden, Massachusetts, Wigglesworth apparently wrote his famous long poem, The Day of Doom, in ballad measures to attract unlearned readers and so to instruct them, for the salvation of their souls, in the dogmas of Calvinism. The poem immediately became a best seller, by virtue of its appeal to the emotions, beliefs, and literary taste prevailing at the time. Said to have been distributed not only as a book, but also in the form of broadsides, the work so far surpassed Mrs. Bradstreet's poems in public favor that the first edition was literally read to pieces and has entirely disappeared. The writer's potential poetic powers were also sacrificed to purposes of edification in two other poetical works: God's Controversy with New-England, written in 1662 but first printed in Proceedings, Jan. 1871-Mar. 1873, published by the Massachusetts Historical Society, v. 12, 1873, p. 83-93; and Meat Out of the Eater (1670).

8o. The day of doom; or, A description of the great and last judgment. London, J. Sims, 1673. $92 \mathrm{p}$.

RPJCB

The Literary History of the United States, v. 3, p. 773, and the Dictionary of American Biography, v. 20, p. 195, refer to an edition of 1662 . The foregoing reference is to the earliest edition currently described in the National Union Catalog at the Library of Congress; successive references illustrate the vitality of the work and the range of time represented in the publication of various editions.

81. Newcastle-upon-Tyne, Eng., J. White, 1711. 72 p. PS871.D3 17II RBD

82. With other poems. Also a memoir of the author, autobiography, and sketch of his funeral sermon by Rev. Cotton Mather ... From the 6th ed., 1715. New York, American News Co., 1867. $119 \mathrm{p}$.

$$
\text { 26-5364 PS87x.D3 I867 RBD }
$$

Edited by John W. Dean and William H. Burr.

83. With other poems. Edited with an introd. by Kenneth B. Murdock. New York, Spiral Press, r929. xi, 94 p. illus.

$$
\text { 30-1 } 1066 \text { PS87r. } \mathrm{D}_{3}
$$

1929

\section{ROGER WILLIAMS, ca. $1603-1683$}

When Williams became a Separatist and as an ordained clergyman emigrated to New England in 
1631 , he sought a country in which to live according to Christ's teachings, as he read them in the Bible. However, according to orthodox Puritanism, his interpretations, being wrong, led him into various heretical beliefs. These included his conviction that the individual had a right to freedom of conscience without interference from civil magistrates, and that it was necessary to make the church democratic. He also held that the appropriation of land from the Indians without paying for it was a violation of human rights and therefore a sin. By virtue of unceasing and vociferous efforts to implement these convictions until they became the basis of action in Massachusetts, he finally came to be considered a disturber of the peace and was banished from the colony into the outlying wilderness. Going south to a section still occupied by Indians, whose lifelong friend he was, Williams became the founder of the Rhode Island colony. The writings in which he expressed his ideas were theological for the most part, involved, and long-winded; for that reason they have been difficult to read and have become so rare as to have been sometimes forgotten. But the elevation of his thought, the realism of his language, and the spaciousness of his ideas concerning freedom and authority caused his pioneer testimony on behalf of liberalism to pass into the stream of American democratic thought, from which, more than a century after he died, emerged the principles embodied in the Constitution of the United States. The significance of Williams for the American tradition is discussed by Perry Miller in his Roger Williams (Indianapolis, Bobbs-Merrill, 1953. 273 p.), a work that includes numerous extracts from Williams' writings, provided in a modern text for ease of reading, particularly with respect to spelling, capitalization, punctuation, and abbreviations.

85. A key into the language of America ... London, G. Dexter, 1643. 197 p.

$\mathrm{RBD}$

Comments on various aspects of Indian life, accompanied by vocabularies suited to each aspect.

- Reprint. In Rhode Island Historical Society. Collections. v. I. Providence, 1827 . p. $17-163$.

Rc-2948 F76.R47, v. I

Reprint. 5th ed. Introd. by Howard M. Chapin. Providence, Rhode Island and Providence Plantation Tercentenary Committee, I936. 205 p. 37-5003 E99.Ni6W7 $\mathrm{PM}_{2003 . Z 5} \mathrm{~W}_{4} \quad 1936$

86. The bloudy tenent, of persecution, for cause of conscience . . . [London?] 1644. 247 p. I0-I2684 BV 74 I.W58 1644 RBD

This polemic was attacked by John Cotton in his The Bloudy Tenent Washed and Made White in the Bloud of the Lambe (q. v.), to which Williams replied in The Bloody Tenent Yet More Bloody (London, C. Calvert, 1652. 320 p.).

87. Experiments of spiritual life and health. London, I652. $59 \mathrm{p}$.

$\mathrm{OO}$

88. Edited with a historical introd. by Winthrop S. Hudson. Philadelphia, Westminster Press, 1951. 103 p.

51-7794 BV $4500 . W 6 \quad 195 \mathrm{I}$

Devotional book which is a directory of that spiritual life in which the Puritan "acquired a sturdiness of character and inner serenity ... [and] became the creator of a culture ... that was destined to place its stamp upon the Western world for three centuries to come." Introduction, p. 23-24.

89. Works. In Narrangansett Club, Providence. Publications. (First series) v. I-6. Providence [Providence Press Co., printers] r866-74. $6 \mathrm{v}$.

Subscribers' edition.

3-20323 $\mathrm{F}_{7} 6 . \mathrm{N}_{21}$

Chiefly reprints of the original editions of the works of Roger Williams.

No more published.

Contents.-v. I. Biographical Introduction, by R. A. Guild. A key into the language of America, edited by J. H. Trumbull. Letter of John Cotton and Roger Williams' reply, edited by R. A. Guild. I866.- -v. 2. John Cotton's answer to Roger Williams, edited by J. L. Diman. Queries, of highest consideration, edited by R. A. Guild. I 867.-v. 3 . The bloudy tenent of persecution, edited by S. L. Caldwell. 1867.- v. 4. The bloody tenent yet more bloody, edited by S. L. Caldwell. 1870.-v. 5 . George Fox digg'd out of his burrowes, edited by J. L. Diman. 1872.-v. 6. The letters of Roger Williams, I632-1682. Now first collected. Edited by J. R. Bartlett. I874.

\section{JOHN WINTHROP, 1588-1649}

Winthrop, many times governor of the Massachusetts Bay Colony, began his journal by chronicling the events of the voyage to America. Once the destination had been reached, the journal became a record of public and private affairs in the colony during the remainder of his life. As such, it added to American letters a contemporary view of the New England character and conscience under Puritan domination, twin themes treated ever since by some of the best writers produced in the United States. Winthrop's other individual pieces include $A$ Model of Christian Charity (In Massachusetts Historical Society. Collections, ser. 3, v. 7; 1838. Boston. p. 
$31-48$ ), written about 1630 as a guide to the colonists in their attempt to live together in a cooperative society according to Biblical principles. His speech to the General Court, made after he was vindicated of a charge against him, contains his famous definition of liberty under authority; it may be found in Hosmer's edition of the Journal, v. 2, p. 237-239. An extraordinary correspondence with Margaret Tyndal, his third wife, reflects a particularly happy marriage of two strong Puritan personalities. These letters have been collected in Some Old Puritan Love Letters, edited by Joseph H. Twichell (New York, Dodd, Mead, 1893, 1894. 187 p.). Various love letters, official documents, family correspondence, and business communications are available in two additional sources: Robert C. Winthrop's Life and Letters of John Winthrop, 2d ed. (Boston, Little, Brown, 1869. 2 v.); and the Winthrop Papers (Boston, Massachusetts Historical Society, 1929-47. $5 \mathrm{v}$.). The last is frequently called an unsurpassed collection of colonial papers.

91. [Journal] A history of New England from 1630 to 1649 . [Edited] by James Savage. New ed. with additions and corrections. Boston, Little, Brown, 1853. 2 v. I-12052 F67. W7 83

A first edition of part of the text appeared as $A$ Journal of the Transactions and Occurrences in the Settlement of Massachusetts and the Other New England Colonies .... (Hartford, Conn., E. Babcock, I79o. 364 p.). James K. Hosmer also edited the text, calling it Winthrop's Journal, "History of New England" (New York, Scribner, 1908. 2 v. Original narratives of early American history [recently distributed by Barnes \& Noble, New York]).

\section{JOHN WISE, I652-1725}

A Harvard graduate who served several parishes in Massachusetts as pastor, Wise opposed Increase and Cotton Mather's plan for a central church government with authority over individual Congregational churches in New England. The earlier of his two works described below is a biting satire directed against the Mather proposals; the second treatise is a more formal and systematic presentation of his belief that in church as in state good government must be grounded in natural law, reason, and virtuous democratic practices. These were early expressions of views that became more and more prominent in American political theory until they were finally embodied in the Declaration of Independence. The first full-length study of Wise was made by George A. Cook in his John Wise, Early American Democrat (New York, King's Crown Press, 1952. 246 p.). It includes a bibliography of the author's writings and of primary and secondary sources for the study of his life and thought, as well as extensive documentation in the form of notes. Modern reprints of Wise's works are not available at this time.

93. The churches quarrel espoused ... New York, W. Bradford, 17ı. I16 p. PHi

94. A vindication of the government of New England churches. Boston, N. Boone, 1717. I05, $12 \mathrm{p}$.

$\mathrm{MH}$

95. — Boston, J. Boyles, 1772. 271, [12] p. 23-5885 BX7136.W6 i772a RBD

Includes The Churches Quarrel Espoused (p. [75]-180).

\section{B. The Revolution and the New Nation (I764-1820)}

The many crises of the Revolutionary era in America had a strong impact on its literature. The conflicts of ideas and interests, which finally culminated in a long war, had a disruptive effect on society, of which literature is the voice. Neighbors disagreed with neighbors; the economic balance was disturbed; education suffered; and uncertainty about survival itself troubled the minds of the people. All this anxiety and confusion did not contribute to that state of "emotion recollected in tranquillity" which is most favorable to creative writing; nor was it to be expected that a large audience under such circumstances would support the publication of works having literary rather than political interest.

The prevailing mood of the colonists, however, inspired much of such literary effort as was made. Poets became ballad-makers in praise of feats of arms. Satires and political allegorics directed against the British were well received. The authorship of one war song might be a surer way to contemporary fame than the publication of several sustained but unexciting works from the same hand. At least one literary stylist and propagandist of genius produced political pamphlets that were avidly read. Much of the best writing of the period, 
indeed, was political in character. The remarkable men who were first the architects of the new $\mathrm{Na}$ tion and later its statesmen and diplomats left a whole library of official and personal papers to enrich American letters. In their various assignments they wrote innumerable documents, engaged in extensive correspondence, delivered addresses, and drafted declarations expressed in clear, sound English prose that sometimes rose to heights of genuine literary style. For descriptions of some of these important expressions of the American spirit, even if not in a strict sense part of its literature, the reader is referred to Chapter VIII, General History. However, a few of the shorter pieces from these hands are included in the references that follow, by virtue of having attained the status of American classics.

The spirit that had helped to create a new nation finally passed over also into its literature, there to develop a new trend: nationalism. Writers began to raise their voices in praise of themes drawn from American life and experience. The advancing frontier, destined to excite authors of belles-lettres for generations, began to emerge as the setting for a few novels. Americans were encouraged, at least upon one occasion, to look to their own people to produce writers of the future that would equal in greatness any that belonged to England's past. A battery of American "firsts" appeared: the first tragedy by an American acted on the professional stage in America; the first American professional novelist at work; and the first social comedy introducing a Yankee character written and staged. In the midst of these innovations, the use in America of the Addisonian essay, the novel of Gothic horror or picaresque design, the play with a classical locale, and poetry written in rhymed couplets and poetic diction still pointed to continued reliance upon English and European models. But the transition from imported to native themes, forms, and styles was at last beginning to be made. This was a seedtime for American literature; the abundant harvest was to come later.

\section{ABIGAIL (SMITH) ADAMS, $1744-1818$}

A notable letter-writer in her own or any generation, Mrs. Adams' life and fortunes placed her in a strategic position to observe and comment upon the social, political, and domestic scenes in America during the Revolutionary War and the early $\mathrm{Na}$ tional period. Her residence in France and in Britain during her husband's diplomatic service in those countries resulted in correspondence describing manners and customs abroad, a type of writing that became increasingly popular in later periods of American literature. When John Adams was elected the first Vice President, and later the second
President of the United States, Abigail was by his side, observing and recording in intimate letters her impressions of places, persons, and events. Her correspondence, therefore, provides an example of the art of letter-writing as practiced by an unusual 18th century New England woman; even more, it constitutes a documentary record of the civilization Mrs. Adams saw in the making during a fateful half-century of American life.

97. Letters. With an introductory memoir by her grandson, Charles Francis Adams [18071886] Boston, C. C. Little \& J. Brown, 1840. Ixiii, 447 p. $\quad 16-3756 \quad E_{322.1 . A 3}$ RBD

98. - $4^{\text {th }}$ ed., rev. and enl. Boston, Wilkins, Carter, 1848 . Ixi, $472 \mathrm{p}$.

$$
\text { 16-5357 } \mathrm{E}_{322.1 . A_{32}}
$$

Includes letters bearing dates from 1761 to 1816 .

99. Familiar letters of John Adams and his wife, Abigail Adams, during the Revolution. With a memoir of Mrs. Adams by Charles Francis Adams [1807-1886] New York, Hurd \& Houghton, 1876. xxxii, 424 p. 4-16982 $E_{322 . A 518}$

100. New letters, 1788-180r. Edited with an introd. by Stewart Mitchell. Boston, Houghton Miftin, 1947. xiii, 281 p. 47-11763 E322.1.A37 Letters to Mrs. Adams' sister, Mary (Smith) Cranch; reprinted with a revised introduction from the Proceedings of the American Antiquarian Society, Apr. 18, 1945-Oct. 17, 1945, new ser., v. 55, I947, p. [95]-232, [299]-444.

\section{ror. JOEL BARLOW, 1754-1812}

Born in rural Connecticut and educated at Yale, Barlow was to become a citizen of the world. His first important connection as a writer was with the Connecticut (or Hartford) Wits, or Yale Poets, as the informal group has been variously called. These men from the Hartford area were animated not only by a love of literature but also by their postRevolutionary patriotism to initiate a truly national literature that would reflect American principles and accomplishments. It was this stimulus that led to the composition of Barlow's American epic. His prose works, chiefly political in character, were written in praise of democratic institutions supporting the cause of human rights throughout the world. During a residence of 17 years abroad, chiefly in Europe, he engaged in diplomatic assignments from the United States and also amassed a fortune from his commercial transactions. Fortified by his wealth, he built near Washington his estate, Kalorama, where he provided a sort of salon for the dis- 
cussion of arts, letters, and the good of mankind. Included in the last of these categories was a cause that he promoted earnestly but unsuccessfully: that of an American national university, endowed by Congress, and dedicated to the discovery as well as the diffusion of knowledge. Important selections from Barlow's correspondence with his wife and others are found in Charles B. Todd's Life and Letters of Joel Barlow (New York, Putnam, I 886. 306 p.).

102. Hasty pudding: a poem. In three cantos. Written at Chambéry, in Savoy, January I793 ... [New Haven, Conn., 1796] i2 p. RPB

Whimsical mock-epic, spontaneously written in praise of a familiar American dish known as hasty pudding, or cornmeal mush.

103. Political writings. New ed. corr. New York, Mott \& Lyon, 1796 . xvi, $258 \mathrm{p}$.

$$
\text { 9-28922 JC21 } 2 \text {.B27 RBD }
$$

Contents.-Advice to the privileged orders in the several states of Europe [1792-1793].-A letter to the National Convention of France [ 1792$]$.-A letter addressed to the people of Piedmont, on the advantages of the French Revolution [1795].-The conspiracy of kings; a poem addressed to the inhabitants of Europe from another quarter of the world [1792].

I04. The Columbiad, a poem. Philadelphia, C. \& A. Conrad; Baltimore, Conrad Lucas, 1807. 454 p. 2-25640 E120.B255 RBD Epic in Miltonic style, based on the life of Christopher Columbus and portraying not only the future glories of America but also a vision of the coming together of nations into a league for the common good; an amplification of the author's The Vision of Columbus (Hartford, Conn., Hudson \& Goodwin, 1787,258 p.).

\section{I05. HUGH HENRY BRACKENRIDGE, $1748-1816$}

Brackenridge graduated from the College of New Jersey (afterwards Princeton University), when the American Revolution was brewing and a spirit of nationalism was beginning to develop. Two early dramas, The Battle of Bunkers-Hill (1776) and The Death of General Montgomery ( 1777 ), were patriotic in their inspiration. It was after he became a lawyer and a judge, with headquarters in Pittsburgh on the Western frontier, that lie wrote the novel for which he is best known. Avoiding the models provided by sentimental, didactic, and Gothic novels that were the fashion in fiction at that time, Brackenridge took Don
Quixote for his prototype. His long, picaresque narrative, arranged in episodes, portrays backwoods and frontier scenes and conditions with humor and irony. It was also used by the author to express his own anxieties and certain disillusionment concerning the trend of nationalism in the country. His satire was directed chiefly against excesses committed in the name of democracy, office-seekers unqualified to hold office, political incapacity, and social insecurity in a country so recently victorious in war. As a stylist, Brackenridge has been compared favorably with contemporary writers in England.

106. Modern chivalry: containing the adventures of Captain John Farrago and Teague O'Regan, his servant. Philadelphia, J. M'Culloch, I792. $2 \mathrm{v}$. in $\mathrm{I}$.

$\mathrm{NN}$

First edition of the first part of the novel. 107.

$$
\text { 6-15211 PS708.B5M6 I815 RBD }
$$

Final revised version of installments originally issued in 1792-93, 1797, 1804, 1805, and a fourth volume made up of new material.

108. —_ Edited with introd., chronology, and bibliography, by Claude M. Newlin. New York, American Book Co., 1937. xliv, 808 p. (American fiction series; general editor, Harry $\mathrm{H}$. Clark)

$$
\text { 37-27219 PS708.M5M6 }
$$

1937

\section{CHARLES BROCKDEN BROWN, I771- I8IO}

Brown was the first native-born author to make a profession of novel-writing in America. Because of his connections with the periodicals of the period, both editorially and as a contributor, he has been called also the father of literary criticism in the United States. His work is particularly significant in the history of national literary development because in it he applied his theory that American literature should profit by and develop springs of action and interest that differed essentially from those of Europe. Although the themes used to carry out this idea were chosen for their qualities of Gothic horror, they were developed realistically. Didactic elements were added for moral instruction, but each of the novels written in 1799-1800 was infused with essentially romantic intensity and emotional appeal. So designed, the books satisfied the taste of the age and were read with approval in England and on the Continent, although interest in American writing was not widespread abroad at that time. Selections from Brown's diaries, letters, and 
the "rarest of his printed works" are included in his Life, undertaken by Paul Allen and completed by William Dunlap (Philadelphia, J. P. Parke, I815. $2 \mathrm{v}$.). Recent biographical and critical studies are: The Sources and Influence of the Novels of Charles Brockden Brown, by Lulu R. Wiley (New York, Vantage Press, 1950. [387] p.); and David L. Clark's Charles Brockden Brown, Pioneer Voice of America (Durham, N. C., Duke University Press, 1952. 363 p.). For the latter book, unpublished papers of the Brown family constitute an important source.

I 10. Wieland; or, The transformation. New York, H. Caritat, 1798. $298 \mathrm{p}$.

9-2504 PZ3.B8 ${ }_{4} \mathrm{~W}$ RBD

Based in part on an actual murder committed by a New York farmer while under the influence of hallucinations.

II - Together with Memoirs of Carwin the Biloquist, a fragment. Edited with an introd. by Fred Lewis Pattee. New York, Harcourt, Brace, 1926. xlix, $35^{1}$ p. (American authors series; general editor, Stanley T. Williams) 26-3794 $\mathrm{PZ}_{3}$.B814 ${ }_{4}$

I 12. Ormond; or, The secret witness. New York, H. Caritat, I799. iv, $33^{8} \mathrm{p}$.

$$
\mathrm{A}_{31-1124} \mathrm{CSmH}
$$

113. —_ Edited with introd., chronology, and bibliography, by Ernest Marchand. New York, American Book Co., 1937. li, 242 p. (American fiction series; general editor, Harry H. Clark) 37-4089 $\mathrm{PZ}_{3} \cdot \mathrm{B}_{14} \mathrm{O}_{3}$

I 14. Edgar Huntley; or, Memoirs of a sleepwalker. Philadelphia, H. Maxwell, I799. 3 v. 5-4I074 PZ3.B814E RBD Illustrates an early use of material drawn from frontier life, with its dangers from savage Indians and wild animals.

115. —_ Edited with an introd. by David Lee Clark. New York, Macmillan, 1928. xxiii, 308 p. (Modern readers' series)

$$
\text { 28-13915 PZ3.B814 } \mathrm{E}_{12}
$$

116. Arthur Mervyn; or, Memoirs of the year 1793 . Philadelphia, H. Maxwell, I799. 2 v.

$$
\text { 6-18972 PZ3.B814A RBD }
$$

Volume 2 has imprint: New-York, Printed and sold by G. F. Hopkins, 1800 .

A novel describing Philadelphia during the yellow fever epidemic in 1793 .
117. Novels. Philadelphia, McKay, I887. $6 \mathrm{v}$.

$$
\text { 17-13039 to } \text { I7 }^{-13043} \mathrm{PZ}_{3 . \mathrm{B} 81_{4}}
$$

Contents.-v. I. Memoir. Wieland.-v. 2-3. Arthur Mervyn.-v. 4. Edgar Huntley.-v. 5. Jane Talbot.-v. 6. Ormond. Clara Howard.

\section{18. TIMOTHY DWIGHT, 1752-1817}

Dwight's interest in literature, first as a student and later a tutor at Yale College, led to a connection that encouraged his efforts to write. This association was with the Connecticut Wits, whose members tried to promote belletristic writing during the social and political upheavals of the Revolutionary period. Under that inspiration he eventually produced three poetical works: a very long epic showing the influences of Alexander Pope and John Milton, in which Biblical events and characters were presented with American characteristics; a laborious satire directed against the ideas of Voltaire, David Hume, and other skeptical thinkers of the 18 th century; and a meditative, descriptive poem praising life in his own parish of Greenfield. Dwight's eminence as a clergyman and his outstanding contributions to education as a teacher and as president of Yale College tend to outweigh his poetic work, which is now chiefly of historical interest. In the literature of his country he is best remembered, perhaps, by two somewhat less ambitious pieces of writing: "Columbia," a war song written while he was a chaplain in the American army; and Travels in New England and New York (1821-1822), described in the section treating of Travel and Travelers.

119. The conquest of Canäan; a poem, in eleven books. Hartford [Conn.] E. Babcock, I785. 304 p. $\quad 45-5294 \mathrm{I} \mathrm{PS}_{739} . \mathrm{C}_{7}$ I785 RBD Epic celebrating the Old Testament story of Joshua's conquest of Canaan.

120. The triumph of infidelity: a poem. Printed in the world [n. p.] I788. 40 p.

AC9or. $\mathrm{H}_{3}$, v. $56 \mathrm{RBD}$

Volume 56, no. 7 , of the Hazard pamphlet collection.

121. Greenfield Hill: a poem, in seven parts. I. The prospect. II. The flourishing village. III. The burning of Fairfield. IV. The destruction of the Pequods. V. The clergyman's advice to the villagers. VI. The farmer's advice to the villagers. VII. The vision; or, Prospect of the future happiness of America. New York, Childs \& Swaine, I794. $183 \mathrm{p}$. I 8-23749 ACgor.D8, v. 48 RBD ACgor.M5, v. 314, no. I RBD 
[Duane pamphlets, v. 48, no. I; Miscellaneous pamphlets, v. 314, no. I.]

\section{BENJAMIN FRANKLIN, 1706-1790}

Printer, publisher, scientist, diplomat as popular abroad as at home, and statesman, Franklin made his chief contributions to American letters outside the limits of literary art as an end in itself. For that reason his collected works are entered with those of his peers under General History, and reference is made to his educational and scientific writings under those topics. In this section devoted to literature are described only his Memoirs (now called his Autobiography), a collection of family letters, and certain witty pieces that indicate his place among humorists. The style of these less formal works preserves the flavor of the 18 th century English essayists-Addison and Steele among others-who were his masters in the art of writing. Taken in conjunction with Poor Richard's Almanack, with which Franklin was associated from 1732 to $175^{8}$, they reveal the author's clarity of thought and expression, his proverbial wisdom, and his ability ta record for posterity basic ideas influential in establishing American civilization as it was at the beginning of the National period. Recent studies of Franklin's relation to the American heritage include: Verner W. Crane's Benjamin Franklin and a Rising People (Boston, Little, Brown, 1954. 219 p.) and I. Bernard Cohen's Benjamin Franklin: His Contribution to the American Tradition (Indianapolis, Bobbs-Merrill, I953. 320 p.). The latter publication belongs to the Makers of the American tradition series and consists of a collection of pertinent selections from Franklin's writings, accompanied by Professor Cohen's commentaries and an extensive introduction.

123. [Autobiography] Mémoires de la vie privée de Benjamin Franklin, écrits par lui-même, et adressés á son fils . . . Paris, Buisson, I791. [207] p. 7-7839 E802.6.F $7 \mathrm{~F}_{1}$ RBD

First edition of the Autobiography, to the year I731, with additional material translated from [James Jones?] Wilmer's Memoirs of the Late Dr. Benjamin Franklin (London, A. Grant, I790. 94 p.). Cf. Paul L. Ford's Franklin Bibliography (Brooklyn, I889. 467 p.), no. 383 .

124. Memoirs of the life and writings of Benjamin Franklin .... written by himself to a late period, and continued to the time of his death, by his grandson, William Temple Franklin ... and a selection from his political, philosophical, and miscellaneous works. London, H. Colburn, I8I $8.3 \mathrm{v}$. 19-14887 $\mathrm{E}_{302 . \mathrm{F} 82}$ I818 RBD
The Autobiography, in incomplete form but with various additions by W. T. Franklin, appears in volume one.

125. —_ Edited from his manuscript, with notes and an introd., by John Bigelow. Philadelphia, Lippincott, 1868.409 p.

$\mathrm{I}_{4}{ }^{-14054} \mathrm{E}_{302.6 . F_{7} \mathrm{~A}_{2}}$ I $868 \mathrm{RBD}$

The first appearance of the work from Franklin's own copy, the first publication in English of the four parts, and the first publication of the "outline" prepared by Franklin as a guide to be used when writing his own life. See Ford's Franklin Bibliography, no. 423 .

126. - Memoirs. Parallel text ed., comprising the texts of Franklin's original manuscript, the French translation by Louis Guillaume le Veillard, the French translation published by Buisson, and the version edited by William Temple Franklin, his grandson. Edited with an introd. and explanatory notes, by Max Farrand. Published in cooperation with the Huntington Library. Berkeley, University of California Press, 1949. xxxix, $422 \mathrm{p}$. 49-86I6 E302.6.F7 $\mathrm{A}_{2}$ I949a

"Mr. Farrand's Introduction is a reprint, with a few minor revisions, of his article, 'Benjamin Franklin's Memoirs,' which appeared in the Huntington Library Bulletin, No. ro, October 1936." The essay includes a detailed statement of the difficulties surrounding the effort to establish a true text of Franklin's own composition, without changes and emendations by other hands. Column one of this edition is based on the manuscript in Franklin's own handwriting, now in the Huntington Library. Comparison with versions in the other three columns, and the faithfulness of the original manuscript to Franklin's style of writing, provide the student with the standard version as it exists today.

127. Now printed for the first time from the manuscript as Franklin wrote it, and including his preliminary outline; with an introd. by Carl Van Doren and drawings by William Sharp. New York, Heritage Press, I95I. xix, 233 p.

$$
5^{1-4833} \mathrm{E}_{302.6 . \mathrm{F}_{7} \mathrm{~A}_{2}}{ }_{1951}
$$

128. Satires \& bagatelles. [Compiled by Paul McPharlin.] Detroit, Fine Book Circle, 1937. I39 p. 37-16487 $\mathrm{PS}_{745 . \mathrm{A}_{3} \mathrm{M}_{25}}$

129. The letters of Benjamin Franklin \& Jane Mecom, edited with an introd. by Carl Van Doren. Princeton, Published for the American Philosophical Society by Princeton University Press, 
1950. xx, 380 p. (Memoirs of the American Philosophical Society, v. 27.)

$$
\begin{array}{ll}
\text { 50-10857 } & \text { E302.6.F75Ar85 }_{73} \\
& \text { Q11.P612, v. } 27
\end{array}
$$

130. Franklin's wit \& folly: The bagatelles. Richard E. Amacher [editor] New Brunswick, N. J., Rutgers University Press, 1953. xiv, I88 p. 53-11052 PS750.B3 1953

Bibliography: p. 177-184.

A collection based on a partial list of Franklin's imprints from his private press at Passy; includes several serious pieces but omits a few of the humorous pieces, or bagatelles, among them some of the best known. Important for critical and textual commentaries.

13I. Representative selections, with introd. bibliography, and notes, by Frank Luther Mott and Chester E. Jorgenson. New York, American Book Co., 1936. clxxxviii, 544 p. (American writers series) $\quad 36$-IoI $75 \mathrm{PS}_{745 . \mathrm{A}_{3} \mathrm{M}_{7}}$

Includes an exact facsimile of Poor Richard Improved, 1753 (p. 225-260), a volume of a serial later published as Poor Richard's Almanack, a title by which the whole set is commonly known. For selected bibliography of works by and about Franklin see p. cli-clxxxviii.

132. A Benjamin Franklin reader. Edited by Nathan G. Goodman. New York, Crowell, 1945. xxi, 8I 8 p. 45-ro550 PS $745 . A_{3} \mathrm{G}_{5}$ Contains the Autobiography in the John Bigelow text. Additional selections include: expressions of Franklin's religious beliefs; papers reflecting his interests as an editor and publisher; selections from Poor Richard's Almanack; essays and humorous pieces; family papers; and miscellaneous letters and documents.

133. Autobiographical writings; selected and edited by Carl Van Doren. New York, Viking Press, r945. xvi, 8 ro p.

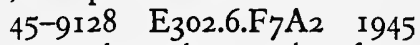

A selection in large part brought together from various existing collected editions of Franklin's works, but includes also: 50 letters and other papers omitted by the most recent collected edition known to Van Doren; and 50 pieces not previously printed in full. Notes accompanying the selections indicate the sources used in preparing the texts.

\section{PHILIP MORIN FRENEAU, I752-1832}

Journalist, editor, sea captain, farmer, and "poet of the American Revolution," Freneau was completely devoted to America and its way of life, an allegiance most significantly made manifest in his poetical works. These he wrote in two veins: lyrical, imaginative, and reflective poems concerned with nature and human destiny; and patriotic or political verses for the times, characterized by the vigor of their satire. In the first category the poems were early documents of the romantic movement in American literature, which reached its height in the next century. The second group was characterized by poems celebrating America and her struggle for independence and democracy, or castigating enemies of these ideals, whether in Britain or at home. "Literary Importations," a poem apparently written in 1786 , gives characteristic expression to his zeal for an American culture entirely divorced from English influence. Critics have said that Freneau had the finest poetic talent produced in America after Edward Taylor and before William Cullen Bryantan endowment sacrified in part to the making of propaganda verses. The poet's religious and philosophical speculations are considered in Nelson F. Adkins' Philip Freneau and the Cosmic Enigma (New York, New York University Press, 1949. 84 p.).

135. Poems written chiefly during the late war. Philadelphia, F. Bailey. I 786.407 p.

PS755.AI I786 RBD

136. Poems written and published during the American Revolutionary War, and now republished from the original manuscripts; interspersed with translations from the ancients, and other pieces not heretofore in print. $3 \mathrm{~d}$ ed. Philadelphia, L. R. Bailey, I809. 2 v.

$$
\text { 30-20889 PS755.A2 I809 RBD }
$$

137. A collection of poems on American affairs, and a variety of other subjects chiefly moral and political; written between the year 1797 and the present time. New York, D. Longworth, 1815 . $2 \mathrm{v}$.

$\mathrm{PS}_{755 . \mathrm{A} 2}{ }_{18 \mathrm{I}} \mathrm{RBD}$

138. The poems of Philip Freneau, poet of the American Revolution. Edited for the Princeton Historical Association by Fred Lewis Pattee. Princeton, N. J., The University Library, 1902-07. 3 v. $\quad 3-9603$ PS755.A2 1902

"Bibliography of the poetry of Philip Freneau": v. 3 , p. 407-417.

The editor explains (v. I, p. vi-vii) that the edition includes the most significant of Freneau's poems arranged in order of their first printing and in some cases, particularly those of the poetical pamphlets dealing with the American Revolution, in their original form, not as cut down later by Freneau. 
The editions of $1786,1788,1795,1809$, and 1815 constitute the chief sources used by the editor.

139. Poems. Edited with a critical introd. by Harry Hayden Clark. New York, Harcourt, Brace, I929. lxiii, 425 p. (American authors series; general editor, Stanley T. Williams)

“Selected reading list": p. 1xi-lxiii.

140. Miscellaneous works containing his essays, and additional poems. Philadelphia, F. Bailey, I788. xii, 429 p.

$$
\text { 32-I5552 PS755.AI I788 RBD }
$$

14I. Letters on various interesting and important subjects; many of which have appeared in the Aurora. Corr. and much enl. by Robert Slender, O. S. M. [pseud.] Philadelphia, Printed for the author, from the press of D. Hogan, I799. viii, I $42 \mathrm{p}$.

[Thorndike pamphlets, v. 7, no. 14 .]

$$
\begin{gathered}
\text { 19-2090 AC9or. T5, v. } 7 \text { RBD } \\
\text { PS757.L4 I799 RBD }
\end{gathered}
$$

142. — With an introd. and a bibliographical note by Harry Hayden Clark. New York, Scholars' Facsimiles \& Reprints, I943. vi p., facsim.: $142 \mathrm{p}$. $\quad 43-6720$ PS757.L4 I799a "Bibliographical note": p. vi.

143. Prose. Selected and edited by Philip M. Marsh. New Brunswick, N. J., Scarecrow Press, 1955. xii, $596 \mathrm{p}$.

$$
55^{-1} 435^{8} \quad \mathrm{PS}_{755} \cdot \mathrm{A}_{5} \mathrm{M}_{3}
$$

\section{THOMAS GODFREY, 1736-i 763}

Before the social and political upheavals of the Revolutionary period had begun to change a group of colonies into a nation, British models frequently were used by the few Americans writing in the belletristic tradition. Godfrey's literary output, small as it was, showed this influence. Debts to the Cavalier poets are apparent in his love songs, while The Court of Fancy (1762) was, according to his own statement, imitative of Chaucer and Pope. All the poems, however, showed a promise that might have been realized but for the writer's untimely death. His one play, a romantic drama located in Parthia at the beginning of the Christian era, is obviously in the Elizabethan manner, although its individual merits include sound construction and effective use of blank verse. It is interesting to note that his play was a genuine "first": the first tragedy written in America by an American that was acted on the professional stage in America.
Members of the Philadelphia group of creative artists who were Godfrey's friends and associates included Benjamin West, the painter, and Francis Hopkinson, the poet and composer. Together they took part in laying foundations for American art, music, and literature upon which later generations were able to build.

I45. Juvenile poems on various subjects. With The Prince of Parthia ... To which is prefixed Some account of the author and his writings. Philadelphia, Printed by $\mathrm{H}$. Miller, 1765 . xxvi, 223 p. $\quad 34-35375$ PS76r.Ar ${ }_{1765} \mathrm{RBD}$

Posthumously published through the efforts of the author's mentor and admirer, William Smith, provost of the College of Philadelphia, and of his friend, Nathaniel Evans. Reprints of The Prince of Parthia include the following: one edited with commentary by Archibald Henderson (Boston, Little, Brown, 1917. 189 p.) and a second in Montrose J. Moses' Representative Plays by American Dramatists (no. 2347).

\section{FRANCIS HOPKINSON, 1737-1791}

Pennsylvania and New Jersey were the scenes of Hopkinson's multiple activities as merchant, lawyer, citizen, musician, writer, and cultivated amateur of science and art. While he received assignments of such importance as membership in the Continental Congress, in which he voted for the Declaration of Independence and became one of its signers, he continued to write. Songs, poems, essays, and ballads constitute characteristic examples of the forms in which he expressed his artistic, literary, and political interests. Since only a partial collection of his writings has been made, George E. Hastings' The Life and Works of Francis Hopkinson (Chicago, University of Chicago Press, 1926. [517] p.) has value not only for its critical comments but also for numerous excerpts from the writings, and for the bibliography it provides. Hopkinson's ardent patriotism and his use of native themes are evidence of a growing national spirit as the country emerged from colonial status to independent power.

I47. A pretty story ... By Peter Grievous, esquire, A. B. C. D. E. [pseud.] Williamsburg, [Va.], J. Pinkney, r774. 16 p. 19-4I36 Ei87.C72, v. I2 RBD

[Colonial pamphlets, v. 12, no. 9.]

A political satire on the administration of the British colonies in North America, and the causes of the Revolution.

First and $2 \mathrm{~d}$ editions have imprint: Philadelphia, Printed and sold by John Dunlap, 1774 . 
Reprinted in 1857 and 1864 with title: The Old Farm and the New Farm: A Political Allegory.

148. Miscellaneous essays and occasional writings. Philadelphia, T. Dobson, r792. 3 v.

$$
\text { 5-30697 PS775.Ar I792 RBD }
$$

See v. 2, p. 146-160, for "A Letter on Whitewashing" $[1785]$ and v. 3, p. 169-173, for "The Battle of the Kegs" [1779]. 'The former is an Addisonian essay satirizing American methods of house cleaning; the latter is a ballad on the American attempt to use kegs of gunpowder as floating mines against the British.

\section{I49. THOMAS JEFFERSON, I743-1826}

Jefferson's rank with the foremost statesmen of the United States automatically places the main body of his writings in the section of this bibliography devoted to the general history of the $\mathrm{Na}$ tion. The one book described here consists of essays written in response to a series of questions that originated in an undertaking by the French Government to collect information about the several American states. The questions relating to $\mathrm{Vir}$ ginia were referred to Jefferson, and his answers constitute his Notes on the State of Virginia. The vigor and distinction of expression that characterized the book, its notable descriptions of the physical aspect of the state, the range and interest of its scientific observations, the views expressed on philosophy and morality, and the enlightenment evident in the writer's opinions about slavery and the Indians are among the elements that have established the book in its place with American literary classics.

150. Notes on the State of Virginia; written in the year 1781 , somewhat corr. and enl. in the winter of $I_{7} 82$, for the use of a foreigner of distinction, in answer to certain queries proposed by him ... I782. [Paris, 1785] 39I p.

$$
\text { I-2904 F230.J40 RBD }
$$

First edition: 200 copies printed for private distribution.

15I. Notes on the State of Virginia. Philadelphia, Prichard \& Hall, $1788.244 \mathrm{p}$.

$$
\text { Rc-2820 F230.J42 RBD }
$$

First American edition.

152. In The writings of Thomas Jefferson. Collected and edited by Paul Leicester Ford. v. 3. New York, Putnam, 1892-99. p. 68-295. 2-5666 E302.J466, v. 3

153. —_ Edited with an introd. and notes by William Peden. Chapel Hill, Published for the Institute of Early American History and Culture, Williamsburg, Va., by the University of North Carolina Press, I955 [ ${ }^{\mathrm{C}} \mathrm{1} 954$ ] xxv, 315 p. maps. 55-14659 F230.J5102 1955

\section{THOMAS PAINE, 1737-1809}

At heart a radical and a reformer, Paine had never been successful in earning a living in his native country, England. Having won an introduction from Benjamin Franklin, who was impressed by his abilities, he sought new opportunities in America. There he rapidly made connections that resulted in his becoming a journalist and a pamphleteer whose writings exerted a "prodigious" influence in the formation of public opinion favorable to the American Revolution. As an internationalist willing to participate always in the cause of human freedom from oppression, he was later associated with the moderate republicans in France, taking part with them in developing the French Revolution until it was taken over by violent elements and became the Terror. Returning to America, Paine found his earlier contributions frowned on by certain conservative leaders in the new republic. Since that time his character and his thought have been subjects of recurring, often uninformed, controversy. His reputation as a propagandist of genius is assured, however; and he takes his place among American men of letters on the basis of his accomplishments as a literary stylist. Thomas Jefferson, commenting on this aspect of Paine's work, wrote: "No writer has exceeded Paine in ease and familiarity of style, in perspicuity of expression, happiness of elucidation, and in simple and unassuming language."

155. Writings collected and edited by Moncure Conway. New York, Putnam, I 894-96. $4 \mathrm{v} . \quad 4$-r936 JCI77. $\mathrm{A}_{3} \mathrm{I}_{94}$ Partial Contents.-v. i, p. 67-r20, Common sense [1776]; p. I68-38o, The American crisis $\left[177^{6-8}\right]$ ]. -v. 2, p. $25^{8-389}$, The rights of man [179I]; p. 390-583, The rights of man, part second [1792].-v. 4, p. I-84, The age of reason [1794]; p. 85-195, The age of reason, part second [1795].

I56. The complete writings of Thomas Paine, collected and edited by Philip S. Foner, Ph. D., with a biographical essay, and notes and introductions presenting the historical background of Paine's writings. New York, Citadel Press, 1945. 2 v.

$$
\text { 45-2289 JCI77.A3 } 1945
$$

157. Selections. Edited with an introd. by Arthur Wallace Peach. New York, Harcourt, Brace, 
1928. liii, 378 p. (American authors series; general editor, Stanley T. Williams)

Reading list: p. li-liii.

$$
\text { 28-22448 JCI77.A5 } 1928
$$

158. Representative selections, with introd., bibliography, and notes, by Henry Hayden Clark.

New York, American Book Co., 1944. cli, 436 p. (American writers series)

$$
\text { "Selected bibliography": p. cxxv-cli. }
$$$$
\text { 44-3959 JCI77.A5 } 1944
$$

159. Selected work of Tom Paine. Edited by Howard Fast. New York, Duell, Sloan \& Pearce, 1945. xiii, $33^{8} \mathrm{p}$.

$$
45^{-2364} \mathrm{JC}_{177 \cdot A_{5}} 1945
$$

160. Common sense, and other political writings. Edited with an introd. by Nelson F. Adkins. New York, Liberal Arts Press, 1953. liii, I 84 p. (American heritage series, no. 5)

Bibliography: p. 1-liii.

$$
\text { 53-11326 JCI77.A5 } 1953
$$

\section{I. SUSANNA (HASWELL) ROWSON, $1762-1824$}

During the Revolutionary period, writing in America reached its greatest distinction in the works of its statesmen, rather than in the sphere of belleslettres. The art of fiction, particularly, lagged in its transit to the New World, where the battle for survival absorbed the energies of the people and where the Puritan tradition was against books that were not predominantly serious and edifying. As the 18th century wore on, however, an increasing appetite for imported fiction became apparent, with the result that sentimental and didactic novels began to be written in America for this waiting audience, composed chiefly of women. Among early books of this type, Mrs. Rowson's Charlotte Temple in its long history has achieved the status of one of the country's all-time best sellers. Born in England but permanently settled in America for the last 30 years of her life, the author produced a novel highly moral in tone, straightforward in narrative interest, and abundantly supplied with details of an exciting seduction. According to R. W. G. Vail's Susanna Haswell Rowson (Worcester, Mass., American Antiquarian Society, I933. I16 p.), the book has gone through more than 200 editions and has been read possibly by half a million individuals. The vogue of novel-reading was deplored by the Nation's intellectuals, while the books were being devoured by their wives and mothers and daughters. In the case of Mrs. Rowson's most characteristic works, light is cast on 18 th-century standards of morality for the two sexes, on the circumscribed lives and interests of average American women, and on the details of daily domestic life at the time.

162. Charlotte; a tale of truth. Philadelphia, M. Carey, 1794. 2 v. in I. $(87,83$ p. $)$

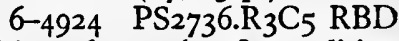

First American edition, from the first edition published in London, 1790 ; later editions have title: Charlotte Temple.

163. Charlotte Temple; a tale of truth ... With an historical and biographical introd., bibliography, etc., by Francis W. Halsey. New York, Funk \& Wagnalls, 1905. cix, 131, 150 p. illus.

\section{5-39587 $\mathrm{PZ}_{3 .} \mathrm{R}_{799 \mathrm{C}_{30} \mathrm{RBD}}$}

"The best of all editions, including a long and valuable historical introduction, a bibliographical checklist of editions which, however, contains many errors and duplications, numerous footnotes, and seventeen illustrations."-Vail, p. 8r.

164. Reuben and Rachel; or, Tales of old times. Boston, D. West, 1798. 2 v. in I (364 p.)

8-945 PZ3.R799Reu RBD

Historical and sentimental romance beginning with the life of Christopher Columbus and ending in 18 th century America. An early example of an American novel introducing idealized Indian characters.

\section{JOHN TRUMBULL, 1750-1831}

Trumbull has been called the most gifted of the Connecticut Wits, with whom he was associated in efforts to improve education provided by Yale College and to promote a taste for literature in America. Since his own taste was for satire, his style was greatly influenced by such English writers as Samuel Butler and Jonathan Swift; but the content of what he wrote was American throughout. Although he wrote two series of prose essays satirizing the errors he observed in Connecticut dignitaries and the culture they were attempting to create, his principal medium was poetry. At the Yale commencement of 1770 , he recited a poem attacking the existing curriculum and making a plea for replacing the heavy concentrations in mathematics, metaphysics, and logic by courses in the fine arts, particularly in "polite literature." In the section of the poem devoted to the future of American literature he prophesied that in his native land writers, born and nurtured there, would be the equals of England's Addison, Swift, and Shakespeare. The Progress of Dullness, a trilogy in verse, also satirized existing methods of education and emphasized the folly of contributing to the vanity and light-minded- 
ness of women by depriving them of higher education. Trumbull's principal literary achievement, however, was the mock-epic, M'Fingal, a political satire against the British and in praise of American Whigs in relation to the Revolution. This work was enormously popular, being hawked about, as the author said, by peddlers and petty chapmen. Not only did it delight contemporary audiences, but it was also preserved for later generations in various mediums such as school readers. Thus, over an extended period of time, it was a poem not often surpassed in favor until Longfellow's poems became household words.

166. An essay on the use and advantages of the fine arts. Delivered at the public commencement in New Haven, Sept. I2, I770. New Haven, Conn., T. \& S. Green [1770] 16 p.

AC9or.W8, v. 20 RBD

Wolcott pamphlets, v. 20, no. 5 .

167. Poetical works. Containing M'Fingal [1782], a modern epic poem, rev. and corr., with copious explanatory notes; The progress of dullness [1772-1773]; and a collection of poems on various subjects, written before and during the Revolutionary War. Hartford, Conn., S. G. Goodrich, I820. 2 v. 30-20909 PS852.AI I820 RBD

A Memoir of the Author, said to be Trumbull's own autobiography, appears in volume one.

- Reprint. In The Colonnade, v. I4, 1919-1922, pt. 2. New York, Andiron Club of New York City, 1922. p. [287]-538.

AP2.C662, v. 14

The reprint was edited by Arthur $\mathrm{H}$. Nason.

\section{ROYALL TYLER, I757-1826}

A lawyer who attained the dignity of becoming chief justice of the Supreme Court of Vermont, Tyler takes his place in the annals of American literature chiefly because he was the author of the first social comedy written and staged in the United States, for and about Americans. While it follows the design of Richard Brinsley Sheridan's The School for Scandal, seen by Tyler in its New York production, the prologue of his own play specifically states his purpose to provide a drama that Americans might call their own. The "contrast" from which the piece takes its title is between American character and society, portrayed as fundamentally simple and marked by "probity, virtue, and honor," and other characters and societies in which European polish is assumed to have produced a combination of sophistication, foppishness, and falseness. Born in Boston and educated at Harvard, Tyler was particularly well equipped to create his Yankee character, "Jonathan," whose combination of New England sturdiness and provincial simplicity was influential in establishing a "type" character portrayed in later popular "Yankee plays." The Contrast also has the merit of contributing to an understanding of the social history of New York towards the end of the r8th century, by detailed treatment of conversation, manners, dress, and atmosphere. Tyler was a prolific and witty contributor of essays and poems to the periodical press of the time. He has also to his credit several plays less important than The Contrast; a novel, The Algerine Captive (I797), based on the captivity of a member of his family enslaved by the Algerians; and Yankee in London (1809), a series of fictional letters accepted as authentic at the time.

169. The contrast, a comedy in five acts. Written by a citizen of the United States; performed with applause at the theatres in New-York, Philadelphia, and Maryland. Philadelphia, Prichard \& Hall, ז790. $79 \mathrm{p}$.

Produced in 1787 .

$$
7-27486 \quad \mathrm{PS} 8_{55} \cdot \mathrm{T}_{7} \mathrm{C} 6 \quad \text { I790 RBD }
$$

I70. $\begin{aligned} & \text { Bxxiii, } 120 \text { p. facsims. } \\ & \text { xxxving Mifflin, } 1920 .\end{aligned}$ 2I-824 PS855.T7C6 $1920 \mathrm{RBD}$

Reprints may be located in various collections described in the section on Anthologies, as follows: Montrose J. Moses' Representative Plays by American Dramatists (no. 2347); Allan G. Halline's American Plays (no. 2337); and Arthur H. Quinn's Representative American Plays, 7 th ed. (New York, Appleton-Century-Crofts, 1953).

\section{I71. MASON LOCKE WEEMS, 1759-I825}

One of the talents attributed to the eccentric "Parson" Weems is that of making facts perform antics according to his will. This gift was employed to the full in developing his fictionized biographies. While he wrote lives of William Penn and Benjamin Franklin, Weems exercised his imagination with particular expansiveness when dealing with the personalities and exploits of two Revolutionary generals: George Washington and Francis Marion. His "life" of Washington, issued as a small pamphlet the year after Washington's death, was later published in enlarged form and under several titles. It is said that the various editions of the work were represented by at least 84 printings within 30 years. The spread of these recurring publications throughout the United States contributed to creating in the public mind an idea of Washington the hero that became a mythical symbol of the greatness of America. Weems was an or- 
dained clergyman whose greatest passion was for reading "good and improving books," and for $3 \mathbf{r}$ years his principal occupation was that of an itinerant bookseller. Traveling up and down the Atlantic seaboard and westward towards Pennsylvania, he distributed books that helped to keep reading alive among the scattered farms and towns of a country devoid of adequate means of communication. The letters written during his wanderings, particularly those addressed to Mathew Carey, the Philadelphia publisher, are significant documents in the history of American literary taste and of the spread of culture in the United States.

172. A history, of the life and death, virtues, and exploits, of General George Washington; dedicated to Mrs. Washington ... George-Town [D. C.] Printed for the Rev. M. L. Weems by Green \& English [1800] $80 \mathrm{p}$.

NN

173. A history of the life and death, virtues, and exploits of General George Washington. Faithfully taken from authentic documents, and, now, in a $2 \mathrm{~d}$ ed. improved . . . Philadelphia, Reprinted by John Bioren, for the author [180o] $82 \mathrm{p}$. ${ }_{15-10673} \mathrm{E}_{312 . W_{347}} \mathrm{RBD}$

174. The life of Washington the Great, enriched with a number of very curious anecdotes ... $5^{\text {th }}$ ed. Augusta, Reprinted by Geo. F. Randolph, I 806 . $80 \mathrm{p}$.

NN

Text rewritten; the story of the hatchet and the cherry tree appears here for the first time.

175. The life of George Washington; with curious anecdotes, equally honorable to himself and exemplary to his young countrymen. Ioth ed., greatly improved. Philadelphia, M. Carey, I810. 228 p. illus.

$15-3829 \quad E_{312 .} W_{372}$

176. A history of the life and death, virtues \& exploits of General George Washington. [New York] Macy-Masius, 1927. 374 p. (An American bookshelf [2]) $27^{-27804} \quad \mathrm{E}_{312 .} \mathrm{W}_{3} 894$

"The present text is taken from one of the later editions . . ."-Editor's note signed: M. V.D. [i. e. Mark Van Doren].

177. Mason Locke Weems, his, works and ways. In three volumes. [I] A bibliography left unfinished by Paul Leicester Ford. [2-3. Letters 1784-1825] Edited by Emily E. F. Skeel. New York, 1829. 3 v. illus. 29-3631 Z8962.S62 Most of the letters are addressed to Mathew Carey. Sources consulted: v. I, p. $345-3^{85}$.

\section{I78. JOHN WOOLMAN, I720-1772}

Nearly 20 years before the signing of the Declaration of Independence, Woolman had already declared his belief that liberty was the natural right of all men equally. To the realization of that conviction he devoted his life, as a sort of itinerant apostle of a righteous social gospel for his country and the world. His was the strongest American voice raised in his time against Negro slavery; after he was dead his written words still spoke powerfully in support of the antislavery movement. The increase of greed leading to a materialistic philosophy of life, the employment of workers in dangerous trades, the conduct of schools-these and other problems in American society he sought to solve with wisdom in advance of his time. Written by this Quaker mystic who earned his bread by tailoring, the journal and essays he contributed to American literature give evidence of the impact of the Friends on the civilization of the country. Critics agree, moreover, that the journal is a classic of the inner life, as Franklin's almost contemporary autobiography is a classic record of a man at home in the r 8th century world. No mention of Woolman as a writer, however brief, would be complete without the often-repeated advice from Charles Lamb to the Reader: "Get the writings of John Woolman by heart."

179. Journal. With an introd. by John G. Whittier. Boston, J. R. Osgood, I87I. viii, 315 p. $\mathrm{BX}_{7795} \cdot \mathrm{W}_{7} \mathrm{~A}_{3}$ I87 $\mathrm{RBD}$

I80. - New century ed. London, Headley, rgoo. ix, $336 \mathrm{p}$.

$$
\text { I-25198 } \mathrm{BX}_{7795} . \mathrm{W}_{7} \mathrm{~A}_{3}
$$

Includes $A$ Word of Remembrance and Caution to the Rich, other addenda, and a bibliography (p. 301-325).

I8r. - New York, Dutton, 1922. xix, 250 p. (Everyman's library, edited by Ernest Rhys. Biography [no. 402])

\section{6-37445 ACr.E8, no. 402}

Text based on the edition by John Greenleaf Whittier, with a few omissions; includes several additional pieces by Woolman.

Introduction by Vida D. Scudder.

List of the works of John Woolman: p. xix.

182. —— Edited by Janet Whitney. Chicago, H. Regnery, 1950. [xv] 233 p. 50-10962 $\mathrm{BX}_{7795} \mathrm{~W}_{7} \mathrm{~A}_{3}$ 1950 
183. —_ Edited and with introd. by Thomas

S. Kepler. Cleveland, World Pub. Co., 1954.

$\mathrm{xx}, 235 \mathrm{p}$. (World devotional classics)

$$
\text { 54-5339 } \mathrm{BX}_{7795} \mathrm{~W}_{7} \mathrm{~A}_{3} \quad 1954
$$

184. Works. In two parts. Philadelphia, J. Crukshank, i774. xiv, $436 \mathrm{p}$.

36-21088 BX-617.W6 1774 RBD
The Journal constitutes part one; miscellaneous writings are contained in part two.

185. Journal and essays. Edited from the original manuscripts with a biographical introd. by Amelia Mott Gummere. New York, Macmillan, 1922. xxii, $643 \mathrm{p}$.

22-24II7 $\mathrm{BX}_{7795} \mathrm{~W}_{7} \mathrm{~A}_{3} \quad 1922$

\section{Nationalism, Sectionalism, and Schism (1820-1870)}

Literature in America between 1820 and 1870 was the mirror of a society in which tremendous energy was at work. A surge of migration westward pushed the frontier past the fertile Middle West to the grainlands of the Middle Border and beyond. In 1848 the discovery of gold in California caused a rush to the Pacific Coast. Immigrants from Britain and Europe, attracted by the vision of a land of opportunity, came to America in great numbers, frequently to find themselves forced to sell their labor cheaply. But the availability of western lands and the rapidly expanding economy of the Nation as a whole enabled them to prosper and to remain, thus adding rich new elements to the culture of the United States. In the expanding economy transportation became a prime necessity. Horses and vehicles, long the only means of conveyance even for great distances, were replaced. Steamboats that plied the natural waterways and great canals built to float them then became the preferred carriers, only to be superseded in their turn by railroads that began to reach farther and farther across the continent. New and old sections of the country were conscious of the importance of their regions and of their mission to prosper even at the expense of other sections.

Tensions grew between sections, particularly between the industrial North and the agrarian South, with its rich plantation economy based on slave labor. While jealousies and conflicts of interests increased, slavery and its expansion into new states and territories became an issue upon which the public mind was inflamed. In 1851-52 Harriet Beecher Stowe wrote her powerful antislavery novel, Uncle Tom's Cabin, thereby helping to "loose the fateful lightning" that led to the conflagration of the Civil War. By 1865 sectional differences had been settled by force of arms. The South was in ruins; but slavery was gone; and Abraham Lincoln's persuasive plea for "a new birth of freedom" was being answered, slowly and with suffering, while the reconstruction of the South progressed.
During and after the years that saw such cataclysmic forces at work in American civilization, literature emerged into a phase of growing nationalism. James Fenimore Cooper's historical novels of bygone days in America, and Washington Irving's familiar essays, sketches, and folk tales of old New York State attracted delighted attention abroad as well as at home. Another development that was popular outside as well as within the United States was the emergence in literature of humor native to America. Such writings were often associated with the frontier and with the oddly assorted characters who gravitated there, uttering homely philosophies of life in strange dialects. The Puritan heritage of solemnity was thus mitigated.

Another Puritan and Calvinistic concept, that of "sinners in the hands of an angry God," also was changed by the Unitarian doctrines convincingly enunciated by William Ellery Channing, in which were set forth man's innate innocence and goodness and the love of God for humanity. The same trend of thought led to the optimism, self-reliance, utopianism, democracy, and belief in the Over-Soul associated with Ralph Waldo Emerson and his circle of Transcendentalists. The group under these influences included Nathaniel Hawthorne, Henry D. Thoreau, Herman Melville, and Walt Whitman. Their novels, short stories, essays, poems, and miscellaneous prose were of such excellence as to win for the period of their publication the term "American Renaissance."

A gradually widening diffusion of education, ever the accompaniment of a renaissance of culture, enlarged the audience of readers to whom a native literature appealed. Literary periodicals therefore increased in number, bringing in their train editors, critics, and contributors who formed groups of "literati." While not always individually important, these circles by their work provided mediums of publication for better writers and thus contributed to raising the level of reading interest. In formal education, Harvard, oldest of the Nation's universi- 
ties, gathered into its faculties men of learning who were also writers of distinction. On the roster of such names Henry Wadsworth Longfellow, James Russell Lowell, and Oliver Wendell Holmes stand high.

Even if time and space availed to assess more developments in American literature during these 50 years, the record would always be incomplete without recognition of the romanticism, more easily felt than defined, that pervaded much of the writing of the period. Cooper's noble Red Man, Longfellow's idealization of themes drawn from American history, the Transcendentalism of Emerson, Edgar Allan Poe's mystery and other worldliness, Melville's exotic South Pacific islanders, Whitman's chants of democracy and individualism, John Greenleaf Whittier's celebration of simple people and natural beauty, and the doctrine of "progressive improvement" which suffused the thought and attitudes of so many minor, and not a few major, writers, all reflect the romantic impulse simultaneously at work in Britain, Europe, and America. Thus out of colonialism, provincialism, and small beginnings, American literature entered the stream of world literature to enrich it permanently.

\section{AMOS BRONSON ALCOTT, 1799-1888}

The enormous mass of Alcott's journals constitutes the best part of his literary lifework. Published selections from these document the thoughts expressed in his lectures and his ideas about educational reform, philosophy, religion, and communal living at Fruitlands. A member of the Concord group and an intimate associate of Emerson and Thoreau, he was a mystic and a Transcendentalist of the most idealistic type. His place in American life and thought is treated in his biography, Pedlar's Progress, by Odell Shepard (Boston, Little, Brown, 1937. 546 p.).

187. Journals. Selected and edited by Odell Shepard. Boston, Little, Brown, 1938. 559 p. 38-27766 PSior3.A4 $193^{8}$

\section{LOUISA MAY ALCOTT, 1832-1888}

Miss Alcott's books for children are the distillation of experiences shared by Amos Bronson Alcott's four daughters, of whom Louisa May was the second. The father's extrerne Transcendentalism resulted in economic hardships for his family. These are chronicled as part of life in New England during and after the Civil War. Told with sentiment, humor, pathos, and realism the stories have been dear to every generation of American children and parents since they were written. A recent study of this author is Madeleine B. Stern's Louisa May Alcott (Norman, University of Oklahoma Press, 1950. 424 p.), in which see particularly the bibliography of sources consulted, p. 361-407.

189. Little women; or, Meg, Jo, Beth and Amy. Boston, Roberts, 1868-69. 2 v. ViU

Frequently reprinted in modern editions, as in the Modern Library of the world's best books series (New York, Modern Library, I950. 596 p.).

\section{r9o. TIMOTHY SHAY ARTHUR, 1809-1885}

Full of the reforming spirit and devotion to good causes characteristic of the mid-nineteenth century in America, Arthur became a prolific writer of moralizing tales, particularly in support of the temperance movement. These were widely read and approved, as were the magazines he edited and published. Among the latter Arthur's Home Magazine and The Children's Hour were particularly successful.

191. Ten nights in a bar-room, and what I saw there. Philadelphia, J. W. Bradley, I 854 . $24^{\circ} \mathrm{p}$.

$\mathrm{MH}$

\section{GEORGE WILLIAM BAGBY, $1828-1883$}

Bagby's lectures, sketches, and familiar essays frequently appeared first as letters and editorials in newspapers and periodicals with which the writer was connected as a journalist or as an editor. His work was done between 1854 and 1882 and much of it appeared as ephemera that is now rare or lost. The residue, best seen in a modern collected edition, is of three types: idealized portrayals of plantation life in Bagby's native state, Virginia, before the Civil War; realistic and humorous sketches in "country" dialect represented by the type of misspelling considered amusing at the time; and humorous, affectionate representations of the psychology and speech of Negro slaves.

193. The Old Virginia gentleman, and other sketches. Edited and arr. by his daughter, Ellen M. Bagby. [5th ed.] Richmond, Dietz Press, 1948. xxvii, 318 p.

Bibliography: p. $[315]-318$.

$$
4^{8-I I 9 I 7} \text { F230.BI4 } 194^{8}
$$

\section{JOSEPH GLOVER BALDWIN, 1815-1864}

Baldwin's sketches preserve impressions of his life as a lawyer during a practice of some 18 years in Mississippi and Alabama when both states were on the old southwestern frontier. The back 
woods lawyers, wildcat speculators, gamblers, braggarts, and brave men who were typical of the time and place are treated with satiric humor and realism in what has been called a minor American classic.

195. The flush times of Alabama and Mississippi. New York, Appleton, I853. 330 p.

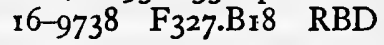

196. - 2d ed. New York, Appleton, 1854. $\mathrm{x}, 330 \mathrm{p} . \quad \mathrm{II}-32574 \quad \mathrm{~F}_{327 . \mathrm{Br} 82}$

197. — Americus, Ga., Americus Book Co., 1908. vii, 330 p. I6-1II35 F327. Br89

198. JAMES NELSON BARKER, 1784-1858

Barker's contribution to the development of American drama apparently was inspired by a belief in the art of theater as part of the cultural life of a nation. His was one of the first voices raised in praise of the use of national themes and against Americans remaining "mental colonists" of Great Britain. Applying his own theories, he wrote a play based on the Pocahontas story, a pioneer work in the long tradition of romanticizing that legend in particular and the Red Man in general. Barker's most substantial play, a tragedy in blank verse, also derived its plot from American colonial history, this time weaving together "superstitious" fears of witchcraft in Massachusetts and conflicts with Indians in the same area. The work illustrates an early treatment of themes derived from Puritan ideology that reappeared repeatedly in American literature. Tears and Smiles (produced 1807 , published 1808 ) used the technique of a comedy of manners to satirize social life and customs in Philadelphia. The text of the original edition, not previously reprinted, is included in James Nelson Barker, $1784-1858$ (Philadelphia, University of Pennsylvania Press, 1929) p. 138-207, a study by Paul H. Musser.

199. The Indian princess; or, La belle sauvage. Philadelphia, G. E. Blake, 1808. 74 p. I-2075 PSio65.B83I6 i808 RBD

A musical play called "an operatic melodrame." The music by John Bray is not included in this edition. For a reprint see Representative Plays by American Dramatists, edited by Montrose J. Moses (no. 2347).

200. The tragedy of Superstition. Carefully corrected from the prompt books of the Philadelphia theatre. By M. Lopez, prompter. [Philadelphia] A. R. Poole [1826] 68 p. (Lopez \& Wemyss' edition. Acting American theatre [no. 3]) 27-23186 PS1065.B83 $\mathrm{T}_{7} \quad 1826$
For reprints see American Plays, selected and edited by Allan G. Halline (no. 2337), and the seventh edition of Arthur H. Quinn's Representative American Plays.

\section{ROBERT MONTGOMERY BIRD, I806- 1854}

Author of blank verse dramas on classical themes, or inspired by Spanish colonial life in the New World, which were produced with marked success by Edwin Forrest, Bird is perhaps most frequently mentioned as a historical novelist of frontier life about the close of the Revolution. Written in the romantic tradition of good story telling, Nick of the Woods represents a deliberate effort to provide the correction of idealizations of "the noble savage" by giving realistic portrayals of uncivilized and cruel Indians and by emphasizing the contributions made by white pioneers to the westward transit of civilization in America. The book also records the exploits of a lawless frontiersman, "Roaring Ralph Stackpole."

202. Nick of the woods; or, The Jibbenainosay. A tale of Kentucky, by the author of Calavar. Philadelphia, Carey, Lea \& Blanchard, r837. 2 v. 6-13129 $\mathrm{PZ}_{3} \cdot \mathrm{B}_{532 \mathrm{~N}} \mathrm{RBD}$

203.

$$
\begin{aligned}
& \text { New ed., rev. by author. New } \\
& \text { York, Redfield, r853. xi, 39r p. } \\
& \text { 8-34324 } \mathrm{PZ}_{3} \cdot \mathrm{B}_{532} \mathrm{~N}_{4}
\end{aligned}
$$

204. — Edited, with an introd., chronology, and bibliography, by Cecil B. Williams. New York, American Book Co., 1939. 1xxv, 408 p. (American fiction series; general editor, $\mathrm{H}$. $\mathrm{H}$. Clark) 39-15203 PZ3.B532Ni5 "Selected bibliography": p. lxvi-lxxv.

The text is that of the edition of 1853 . Cf. Preface, p. v.

205. Dramatic works. In Foust, Clement E. The life and dramatic works of Robert Montgomery Bird. New York, Knickerbocker Press, 1919. p. 169-722. 21-733 PSrog9. B5Z72 Thesis (Ph. D.)-University of Pennsylvania.

Bibliography: p. 161-r67.

"Of the four plays in this volume, Pelopidas, The Gladiator, and Oralloossa appear in print for the first time. The Broker of Bogota was first published in Prof. A. H. Quinn's recent volume, Representative American Plays [1917] ..." Preface, p. vi. 


\section{GEORGE HENRY BOKER, 1823-1890}

Boker was an American dramatist who turned to the history and literature of England, Spain, and Italy for inspiration. His noteworthy Francesca da Rimini, first produced in 1855 , was revived with success as late as roor. As a poet he is remembered not only for his posthumous Sonnets (1929) edited by Sculley Bradley, but also for Poems of the War (1864) composed chiefly as patriotic verses for publication in newspapers during the Civil War. "Our Heroic Themes," a poem read before the Phi Beta Kappa Society of Harvard University on July 20, 1865, contains an eloquent tribute to Lincoln.

207. Plays and poems. Boston, Ticknor \& Fields, 1856.2 v. $\mathrm{CtY}$

Contents.-v. I. Plays: Calaynos; Anne Boleyn; Leonor de Guzman; Francesca da Rimini.-v. 2. Plays: The betrothal; The widow's marriage.Poems.

208. - 2d ed. Boston, Ticknor \& Fields, 1857. 2 v. 20-17126 PSiro5.A I 1857

Francesca da Rimini is included in American Plays, edited by Allan G. Halline (no. 2337), and in Representative American Plays, 7 th ed., edited by Arthur H. Quinn.

209. CHARLES FARRAR BROWNE ("ARTEMUS WARD"), $1834-1867$

The lectures, newspaper columns, and books produced by Browne under his pseudonym of "Artemus Ward" became enormously popular and helped to contribute to the establishment of a tradition of native American humor which came to full fruition in Mark Twain's writings. Browne, through the pages of $P$ unch, as well as on the lecture platform, also won sustained applause in England. His backwoods philosophers and Down East characters, whose sayings were enriched by absurd misspellings, were used by their creator to satirize sham and hypocrisy wherever discovered. Browne's humor was particularly admired by Abraham Lincoln.

210. Artemus Ward, his book. New York, Carleton, $1862 . x,[17-262] \mathrm{p}$.

$$
\text { 36-29489 PN6r6r.B735 1862 RBD }
$$

211. Artemus Ward; his travels. With comic illus. by Mullen. New York, Carleton, 1865. 231 p. 3-25798 PN616r.B737 1865 RBD

Contents.-pt. I. Miscellaneous.-pt. 2. Among the Mormans.

212. Complete works of Artemus Ward [pseud.] With a biographical sketch (by Melville D.
Landon, "Eli Perkins") [Complete ed.] New York, Carleton, 1879. 347 p. $\mathrm{CSmH}$

213. - Rev. ed. New York, G. W. Dillingham, 1898.449 p. illus. $98-564 \quad$ PN6r6r.B73 1898

214. Artemus Ward's best stories. Edited by Clifton Johnson; with an introd. by W. D. Howells. Illustrated by Frank A. Nankivell. New York, Harper, r912. xv, 274 p.

$$
\text { 12-22824 PN6r6r.B739 }
$$

215. Selected works of Artemus Ward [pseud.] Edited with an introd. by Albert Jay Nock. New York, Boni, 1924. 295 p.

$$
\text { 25-2376 PSII4I.N6 }
$$

\section{WILLIAM CULLEN BRYANT, I794-1 878}

During the early years of the igth century the poets widely read in the United States were predominantly British. Scott, Burns, and Byron particularly appealed to the current taste for romance, sentiment, minstrelsy, and adventure. Not until the r83o's, after the publication of poems by the New Englander, Bryant, did American critics concede the arrival of a major national poet. Bryant's work is preeminently that of a poet who thought abstractly and reflectively about nature and man in relation one to the other, and whose expression has a classical quality. Interwoven in his poems are the universal themes of human freedom, suffering, death, faith, and immortality. His Lectures on Poetry, delivered in 1825 , contains an eloquent and explicit statement of his poetic principles, which invites comparison with Poe's The Poetic Principle (1850). Bryant's influence on public opinion in America, literary and otherwise, was extended by his long career as a journalist, particularly during his editorship of the New York Evening Post, from r829 to 1878 . Throughout his life he was consistently a champion of the liberal position on national problems, such as slavery, free trade, and free speech.

217. Poems. Cambridge, Mass., Hilliard \& Metcalf, 1821. 44 p.

21-13044 PS1150.E21 RBD

Contents.-The ages.-To a waterfowl.-Translation of a fragment of Simonides.-Inscription for the entrance into a wood.-The yellow violet.Song.-Green river.-Thanatopsis.

218. New-York, E. Bliss, 1832. 240 p. 6-7137 PSI150.E 32 RBD 
Includes the eight poems published in 1821 , and $8 \mathrm{I}$ others, most of which had appeared in different periodicals.

219. - Edited by Washington Irving. London, J. Andrews, I832. xii, $235 \mathrm{p}$.

I6-4995 PSir50.E32a RBD

First London edition, dedicated to Samuel Rogers, by Irving, and containing the same poems as the New York edition of the same date.

220. Collected and arr. by the author. New York, Appleton [1876] 50I p. illus. 21-I3049 PSi $150 . E_{76}$

Last edition which passed through Bryant's hands; includes final text of poems.

221. - Selected and edited with a commentary by Louis Untermeyer, and illustrated with engravings by Thomas W. Nason. New York, Limited Editions Club, 1947. xix, 298 p.

$$
\text { 47-3186 PSII5I.U } \text { RBD }
$$

222. Letters of a traveller; or, Notes of things seen in Europe and America. New York, Putnam, I $850.442 \mathrm{p}$.

$$
\text { 26-2I283 G470.B8 I850 RBD }
$$

223. The life and works of William Cullen Bryant. New York, Appleton, 1883-84. 6 v.

Edited by Parke Godwin.

$$
\text { I7-16129 } \mathrm{PS}_{1150 . \mathrm{E} 83}
$$

Contents.-1-2. A biography of William Cullen Bryant, with extracts from his private correspondence.-3-4. The poetical works .. -5-6. Prose writings.

224. Poetical works. Roslyn ed.; with chronologies of Bryant's life and poems, and bibliography of his writings by Henry C. Sturges, and a memoir of his life by Richard Henry Stoddard. New York, Appleton, 1903. cxxx, 4I 8 p.

$$
\text { 3-22094 PSII50.Fo3 }
$$

225. Representative selections, with introd., bibliography, and notes, by Tremaine McDowell, New York, American Book Co., I935. 1xxxii, 426 p. (American writers series)

"Selected bibliography": p. Ixxiii-Ixxxii.

\section{WILLIAM ALEXANDER CARUTHERS, I 800 (ca.) -1846}

Caruthers was one of several Southern writers of the period who turned to local history for the sources of novels. Two romances celebrate the past history of his native state, Virginia, through the use of such famous episodes as Bacon's Rebellion ( 1676 ) and Governor Alexander Spotswood's exploration in 1716 of what was then the western wilderness, now the Shenandoah Valley of Virginia. His first novel, The Kentuckian in New York (1834) is an epistolary work of contemporary sentiment and manners in which interests of the North and South are mingled. A recent biographical and bibliographical study of Caruthers has been made by Curtis C. Davis in his Chronicler of the Cavaliers (Richmond, Dietz Press, 1953. $57^{\circ}$ p.).

227. The cavaliers of Virginia; or, The recluse of Jamestown. New York, Harper, 1834-35. 2 v. in I. $\left(228,246\right.$ p.) $4 \mathrm{I}-32194 \mathrm{PZ}_{3.253 \text { Cav2 }}$ 4I-32194 $\mathrm{PZ}_{3} \cdot \mathrm{C}_{253} \mathrm{Cav} 2$

228. The knights of the horseshoe. Wetumpka, Ala., C. Yancey, 1845.248 p.

PU

229. - New York, A. L. Burt [1928] 43I p. (Burt's library of the world's best books)

$$
{ }_{28-24158} \mathrm{PZ}_{3} \cdot \mathrm{C}_{253} \mathrm{Kn} 8
$$

\section{WILLIAM ELLERY CHANNING, 1780- 1842}

Channing's place in American literature is discussed at length by Robert E. Spiller in "A Case for W. E. Channing," The New England Quarterly, v. 3, Jan. 1930, p. 55-8r. Briefly, it may be said that Channing in his "The Importance and Means of a National Literature," The Christian Examiner, I 830, advocated intellectual self-reliance in America seven years before Emerson's The American Scholar ( 1837 ) gave classic expression to the same idea. In his discourses, sermons, and essays he expressed his revolt from Calvinism, his interest in but qualified rejection of idealism, and his firm conviction of the loving-kindness of God and the inherent nobility of man. Thus he was instrumental in preparing the way for the Transcendentalism of the Concord circle, with which he was affiliated. As a writer, Channing was one of the few Americans of his time to win enthusiastic recognition in England. To avoid lengthy descriptions of pamphlets on a wide variety of subjects, reference is made below to his collected works. In these the student of religion in America will find essential material. Robert L. Patterson's The Philosophy of William Ellery Channing (New York, Bookman Associates, I952. 298 p.) contributes to an understanding of his intellectual quality. David P. Edgell's William Ellery Channing (Boston, Beacon Press, 1955. 264 p.) has a twofold purpose: to reintroduce Channing as a man of his times in America; and to present an 
intellectual portrait of him which shows the nature of his thought and its significance, past and present. $\mathrm{He}$ has been called the apostle of Unitarianism in America.

231. Discourses, reviews, and miscellanies. Boston, Carter \& Hendee, $1830.603 \mathrm{p}$.

$$
\text { 32-6508 } \mathrm{BX}_{9815 . \mathrm{C}_{45} \mathrm{RBD}}
$$

Includes: "Remarks on the Character and Writings of John Milton," published in The Christian Examiner (1826); "Remarks on the Life and Character of Napoleon Bonaparte," pt. I-2, The Christian Examiner (1827, 1828); and "The Moral Argument Against Calvinism," from The Christian Disciple ( 1820 ).

232. Slavery. Boston, J. Munroe, 1835. I67 p. II $-6662 \mathrm{E}_{449 . \mathrm{C}_{454} \mathrm{RBD}}$

233. Self-culture. An address introductory to the Franklin lectures, delivered at Boston, September, 1838 . Boston, Dutton \& Wentworth, 1838 . 8 i p. 5-4280I $\mathrm{LC}_{3}$ r. $\mathrm{C}_{5} \mathrm{RBD}$

234. Lecture on war. Boston, Dutton \& Wentworth, 1839. ix, 50 p. ro-r9810 RBD Waterman pamphlets, v. 94, no. 13 .

235. Lectures on the elevation of the labouring portion of the community. Boston, Ticknor, 1840. vi, 81 p. E9-19ro HD696r.C 36

236. Works. Ist complete American ed. With an introd. [by the author] Boston, J. Munroe, I $84 \mathrm{I}-43$. $6 \mathrm{v}$. $\quad 33-1567 \quad \mathrm{BX}_{9} 8 \mathrm{I}_{5} \cdot \mathrm{C}_{4} \quad$ I $84 \mathrm{I}$

237. - Boston, American Unitarian Association, 1903. $6 \mathrm{v}$ MeWC

238. New and complete ed., rearranged, to which is added The perfect life. Boston, American Unitarian Association, 1903. I060 p. 4-10382 BX9815.C4 1903

\section{LYDIA MARIA (FRANCIS) CHILD, I802-I880}

Mrs. Child, who was born in Medford, Massachusetts, became part of a Boston and Cambridge group of Unitarians and Transcendentalists. Her novels, written at an early age, are didactic, sentimental tales emphasizing American patriotism in colonial and Revolutionary times; one of them celebrates the "noble savage" Hobomok. She wrote a variety of books designed for women and to explore their special interests. To various stories and books for children she added a periodical which she edited, The Juvenile Miscellany (1826-1834). For more than 30 years she was one of the most vocal champions of the abolition of slavery. As a reformer Mrs. Child designed her writings also as propaganda against social injustices and various evils she found in American society, notably capital punishment and unfair wage scales. A Biography of Lydia Maria Child by Bernice G. Lambert (College Park, Md., 1953) was submitted to the University of Maryland as a doctoral dissertation. It comprises a typescript of 182 leaves, of which leaves $173^{-182}$ are devoted to a bibliography of Mrs. Child's writings classified by type.

240. An appeal in favor of that class of Americans called Africans. Boston, Allen \& Ticknor, 1833. $232 \mathrm{p}$. I I-4047 $\mathrm{E}_{449 . \mathrm{C}_{53} \mathrm{RBD}}$

24I. Hobomok, a tale of early times. By an American. Boston, Cummings, Hilliard, 1824. I88 p. 6-20980 $\mathrm{PZ}_{3} \cdot \mathrm{C}_{437} \mathrm{H}$ RBD

242. Letters from New-York. New York, C. S. Francis, 1843. ix, 276 p.

$$
\text { I9-6724 Fi28.44. } 53
$$

243. Second series. New York, C. S. Francis, 1845. [ix]-xii, $287 \mathrm{p}$. 28-559 FI28.44.C534

First edition, published 1844 .

244. Letters. With a biographical introd. by John G. Whittier and an appendix by Wendell Phillips. Boston, Houghton Mifflin, 1883. xxv, 280 p. 2I-2II77 PSI293.Z8 ז883 Collected and arranged by Harriet Winslow Sewall.

Bibliography: p. 272-274.

\section{JOHN ESTEN COOKE, 1830-1886}

The plantation tradition in Virginia, the Civil War, and idealization of the South are themes that dominate the romantic historical novels of John Esten Cooke. He was also one of the biographers who contributed to the growth of the Robert E. Lee and "Stonewall" Jackson legends and was the author of various pieces of historical writing that glorified Virginia.

246. The Virginia comedians; or, Old day in the Old Dominion. New York, Appleton, 1854. $2 \mathrm{v}$. ${ }_{12-19565} \mathrm{PZ}_{3} . \mathrm{C}_{775} \mathrm{Vi} \mathrm{RBD}$

247. Surry of Eagle's-Nest; or, The memoirs of a staff-officer serving in Virginia. New York, Bunce \& Huntington, 1866 . viii, 484 p. 34-4938 $\mathrm{PS}_{13}{ }^{82 . S 8}$ I866 RBD Includes four illustrations by Winslow Homer. 
248. New York, M. A. Donohue [1937?] 484 p. $\quad 38-1585 \quad \mathrm{PZ}_{3} \cdot \mathrm{C}_{775} \mathrm{Su} 8$

249. Mohun; or, The last days of Lee and his paladins. New York, F. J. Huntington, 1869. $509 \mathrm{p}$. UCLi 8-3023 ViU

250. Charlottesville, Va., Historical Pub. Co., 1936. 376 p. $\quad$ 36-25555 $\quad \mathrm{PZ}_{3} . \mathrm{C}_{775 \mathrm{Mog}}$

251. My Lady Pokahontas. Boston, Houghton Mifflin, $1885.190 \mathrm{p}$.

$$
\text { 6-27178 } \mathrm{PS}_{1382 . \mathrm{M}_{9}} \mathrm{I}^{88} \mathrm{R} \text { RBD }
$$

\section{JAMES FENIMORE COOPER, I789-1851}

Cooper was one of the first professional literary men produced in the United States. With Irving and Channing he won enthusiastic acceptance in England and on the Continent, where his books were translated into numerous European languages. From his early home in Cooperstown, New York, he had observed the migration westward towards new frontiers. This firsthand knowledge enabled him to give historical realism to his otherwise romantic novels of hunters, trappers, woodsmen, Indians, frontier life, and the American Revolution. His service as a youth in a merchant ship and also in the United States Navy equipped him to write The History of the Navy of the United States of America (1839) and to impart to his numerous novels about life at sea an authentic feeling of ships and men in action. After he moved to New York and had experienced its club life and the more sophisticated atmosphere of the growing city, Cooper felt an urge to know England and the Continent of Europe also. During a residence of seven years abroad, he wrote and spoke as an interpreter of America. Upon his return to the United States he published several travel books which stimulated American interest in the Old World. Writing as he did at a time when the United States had suffciently come of age to begin some self-examination of its own culture, his penetrating, often critical books on social and political questions were and are significant in relation to the temper of his age. While Cooper has been best remembered for his contribution to the romantic tradition in historical fiction, of which Sir Walter Scott was the great English exponent at the time, critics now tend to emphasize the importance of the American writer's books that reflect conservative social and political opinions in his country at midpoint of the rgth century. The latter aspects of his work are most comprehensively treated in Robert E. Spiller's Fenimore Cooper, Critic of His Times (New York, Minton,
Balch, 193I. 337 p.). For a more recent critique of his writings and a general biographical study see James Grossman's James Fenimore Cooper (New York, Sloane, 1949. 273 p. American men of letters series).

253. The spy; a tale of the neutral ground. New York, Wiley \& Halstead, 1821. 2 v. CtY

Relations between Loyalists and patriots during the American Revolution provide the background for this, the author's second novel and first literary success.

254. - Rev., corr., and . . . with a new introd., notes, etc., by the author. London, $R$. Bentley, 1849. xi, $4^{\text {IO }}$ p. (Standard novels, 3 ) 6-32152 $\mathrm{PZ}_{3} \cdot \mathrm{C}_{7} 86 \mathrm{Sp}$ I I

255. With an introd. by Tremaine McDowell ... New York, Scribner, I931. xivii, 508 p. (Modern student's library)

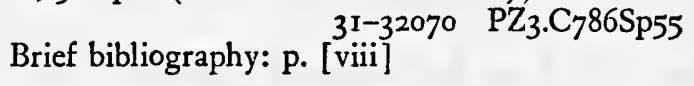

256. The pilot; a tale of the sea. New York, C. Wiley, $1823.2 \mathrm{v}$.

$$
\text { 6-29865 } \mathrm{PZ}_{3} \cdot \mathrm{C}_{7} 86 \mathrm{Pi} \mathrm{RBD}
$$

257. With the latest revision and corrections of the author. New York, Stringer \& Townsend, 1856. x, 486 p. (Choice works of Cooper. Revised and corrected series, v. 7)

$$
\text { 26-24687 } \mathrm{PZ}_{3} \text {.C786Pi9 }
$$

258. The pioneers; or, The sources of the Susquehanna. New York, C. Wiley, 1823. 2 v. $\mathrm{NN}$

First of the "Leatherstocking Tales." In order of composition followed by The Last of the Mohicans (1826); The Prairie (1827); The Pathfinder (1840); and The Deerslayer (1841). Frontier novels usually thought to contain the author's most unforgettable characters, whites and Indians. In reading sequence The Deerslayer should come first and be followed by The Last of the Mohicans.

259. - Rev., corr. and ... with a new introd., notes, etc. by the author. London, H. Colburn \& R. Bentley, 1832 . xi, 460 p. (Standard novels, no. 14) 6-29701 $\mathrm{PZ}_{3}$.C786Pio5

260. —— New York, Dutton, 1929. xv, 444 p. (Everyman's library, edited by Ernest Rhys. Fiction [no. 171]) 36-37033 ACr.E8, no. 17r First published in this edition, 1907; reprinted ... 1929. Bibliography: p. viii-ix. 
26r. Notions of the Americans: picked up by a travelling bachelor. Philadelphia, Carey, Lea \& Carey, 1828. 2 v.

$$
\text { I-26767 } \mathrm{E}_{16} 6 . \mathrm{C}_{77} \mathrm{RBD}
$$

262. A letter to his countrymen. New York, J. Wiley, I834. II6 p.

$$
{ }_{10}-876_{5} \quad \mathrm{E}_{3} 8 \text { r. } \mathrm{C}_{7} 6 \mathrm{RBD}
$$

263. Gleanings in Europe: England, by an American. Philadelphia, Carey, Lea \& Blanchard, 1837. 2 v. in I $(270,260$ p. $)$

$$
\text { 2-30337 DA625.C777 RBD }
$$

English edition issued the same year under title: England. With Sketches of Society in the Metropolis. Published, also in the same year, in Paris as Recollections of Europe.

264. Gleanings in Europe. Edited by Robert E. Spiller. New York, Oxford University Press, 1928-30. 2 v. 28-18308 D9r9.C8

Contents.-I. France.-2. England.

265. The American democrat; or, Hints on the social and civic relations of the United States of America. Cooperstown, N. Y., H. \& E. Phinney, 1838. I92 p. 9-21770 JK216.C 72 RBD

266. - Edited with an introd. by H. L. Mencken. New York, Knopf, I931. xx, I 84 p. (Americana deserta)

$$
\text { 3I-25625 JK216.C } 72 \text { I93I }
$$

267. — With an introd. by H. L. Mencken, and an introductory note by Robert E. Spiller. New York, Vintage Books, 1956. xxviii, 19o p. (A Vintage book, K26) 56-13687 JK216.C72 1956

268. Satanstoe; or, The Littlepage manuscripts. New York, Burgess, Stringer, 1845. 2 v. 6-29679 $\mathrm{PZ}_{3} \cdot \mathrm{C}_{7} 86 \mathrm{~S} \mathrm{RBD}$

First novel in the Littlepage manuscripts trilogy, continued in The Chainbearer (1845) and The Redskins ( 1846 ), works treating of the antirent troubles between wealthy landlords and tenants or squatters in New York; valuable also for its treatment of New York society and customs of the period.

269. —_ Edited, with introd., chronology, and bibliography, by Robert E. Spiller and Joseph D. Coppock ... New York, American Book Co., 1937. xli, 424 p. (American fiction series; general editor, H. H. Clark)

Selected bibliography: p. xxxiii-xli.
270. Correspondence. Edited by his grandson, James Fenimore Cooper . . . New Haven, Yale University Press, 1922. 2 v. ( 776 p.)

$$
\text { 22-21436 PSI } 43 \text { I.A3 }
$$

Partial collection of the author's letters, to which have been added numerous letters to him.

271. Cooper's novels. New York, W. A. Townsend, 1859-6r. 32 v. Volume I published I86r.

Illustrated from drawings by F. O. C. Darley.

Represents the first effort to make a definitive edition; influenced the preparation of various later editions and remains an important text; lacks only Ned Myers among the full-length novels, but omits certain other prose pieces and short stories. $C f$. Literary History of the United States (no. 2460).

272. Works. [Mohawk ed.] New York, Putnam, 1912. $32 \mathrm{v}$.

$$
\text { 12-31598 PSI400.FI2 }
$$

273. Representative selections, with introd., bibliography, and notes, by Robert E. Spiller. New York, American Book Co., 1936. cii, 350 p. (American writers series) $\quad 36-10603$ PS 1403.56 "Selected bibliography": p. Ixxxix-cii.

\section{RICHARD HENRY DANA, I8I5-I882}

Dana, while a Harvard undergraduate, had trouble with his eyes and was sent to sea on a merchant ship as part of his cure. Ten years after his return to his normal environment, he used the journal kept when he was "before the mast" to produce an American classic in which the hardships of a seaman's life in the I830's were recounted with such power that the book was influential in reforming some of the more brutal punishments to which sailors were subjected at the time. It may be read for a comparison to Herman Melville's WhiteJacket ( 1850$)$.

275. Two years before the mast. New York, Harper, I840. 483 p. (Harper's family library, no. Io6) 5-22627 G540.D2 I840 RBD

Frequently reprinted at popular prices, as in Everyman's library edition (New York, Dutton, I930. $33^{8}$ p.). Also published in conjunction with a biographical sketch of the author by his grandson, H. W. L. Dana (New York, Dodd, Mead, I948. $33^{8}$ p. Great illustrated classics series).

276. An autobiographical sketch (I8I5-I 842 ). Edited by Robert F. Metzdorf, with an introd. by Norman Holmes Pearson. Hamden, Conn., Shoe String Press, 1953. x, I 19 p. 
First publication in its entirety of a sketch written by Dana in 1842 .

"... the great mass of the material [Dana's papers] still lies fallow in the collections of the Massachusetts Historical Society. That the papers of Dana will someday be printed in extenso seems inevitable; he is the Boswell of Boston, in a sense, and his journal, letters, and speeches provide a key to the social, literary, and political history of Massachusetts in the mid-nineteenth century."-Preface, p. ix.

\section{JOHN WILLIAM DE FOREST, r 826-igo6}

The rise of realism in the American novel after the middle of the roth century, usually associated with the work of William Dean Howells, was anticipated in the novels of a Connecticut officer in the Union Army, J. W. De Forest. He wrote vigorously and factually of life in the South, without romantic overtones, and dealt honestly with the mistakes and miseries of the Civil War. Later his Honest John Vane (1875) and Playing the Mischief (1875) exposed the political corruption following the war. His personal reminiscences of life in the army, originally issued serially in the 1860's, have been republished by the Yale University Press as: $A$ Volunteer's Adventures (1946); and A Union Officer in the Reconstruction (1948).

278. Miss Ravenel's conversion from secession to loyalty. New York, Harper, 1867. 521 p. 42-43995 PSr525.D5M5 I867 RBD

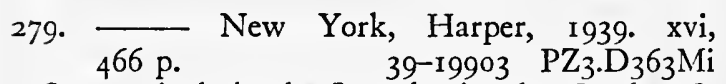
See particularly the Introduction by Gordon $S$. Haight (p. xvi) in which is quoted William D. Howell's opinion that De Forest deserves to be "lastingly recognized as one of the masters of American fiction."

\section{RALPH WALDO EMERSON, $1803-1882$}

Emerson reached maturity in the full tide of roth-century romanticism, material prosperity, and westward expansion in the United States. He came from New England roots planted in America about fourteen years after the first settlement in Massachusetts. His background derived from some ancestors who were Puritan clergymen and from others who were shrewd Yankees engaged in trade; his education was obtained at the Boston Latin School, Harvard College, and the Harvard Divinity School. Following his graduation from the last of these institutions he passed into the Unitarian ministry, but resigned in less than four years because of doc- trinal differences. Before he was 32 years of age he settled permanently in Concord. From that quiet village his intellectual interests ranged far. He became a philosopher in his own right, a Platonist with keen interests in the sacred books of the East, and in the literature of German idealism. Montaigne and Shakespeare were his lifelong enthusiasms. Poetic form and substance held his continued interest. During his travels in Europe he formed a lasting friendship with Carlyle and a not uncritical admiration for England. At home he was the center of the Transcendentalist circle in Concord. In that capacity he influenced writers as dissimilar as H. D. Thoreau, Jones Very, Nathaniel Hawthorne, and Walt Whitman. Although he avoided the extreme views of some of his circle and took no part in the communal settlements of Brook Farm and Fruitlands, he contributed to and edited the Transcendentalist organ, The Dial (1840-1844). Throughout his career he proclaimed to America and the world his philosophy of idealism, optimism, individualism, self-reliance, moral intuition, and the Over-Soul. His message was given by means of public lectures, in essays, and in poems. On the basis of all these he became a leading citizen and a formative force not only in American life but also in the creation of a national literature for the United States.

281. Nature. Boston, J. Munroe, i836. 95 p. 34-25488 PSi6r3. A r 836 RBD Published anonymously, this first of Emerson's books contained the essence of the Transcendental philosophy that he elaborated in later works.

282. — New ed. Boston, J. Munroe, 1849 . 74 p. $\quad 34^{-25487}$ PSi6r3.Ar $1849 \mathrm{RBD}$

283. [The American scholar] An oration delivered before the Phi Beta Kappa Society . . . [of Harvard College] Boston, J. Munroe, 1837 . $26 \mathrm{p}$. 24-24542 $\mathrm{PS}_{1} 623 . \mathrm{O}_{7}{ }_{1} 837 \mathrm{RBD}$

Frequently called the declaration of independence of American intellectual life.

284. An address delivered before the senior class in Divinity College, Cambridge, Sunday evening, 15 July, 1838 . Boston, J. Munroe, 1838 . 31 p. $4-36592 \quad \mathrm{BX}_{9} 8_{42} . E_{55}$ i 838 RBD
ACgor. W3, v. 4 RBD

Republished as The Divinity School Address and issued in its fifth printing by the American Unitarian Association in Boston, 1928.

285. Essays: [first series] Boston, J. Munroe, I84 I. $303 \mathrm{p}$.

$$
\text { 22-I 772I PSI608.A2 I84I RBD }
$$


Contents.-History.-Self-reliance.-Compensation.-Spiritual laws.-Love.-Friendship.-Prudence.-Heroism.-The Over-Soul.-Circles.-Intellect.-Art.

286. Essays: second series. Boston, J. Munroe, I844. 3I3 P.

Contents. - The $99^{-2780}$ PSi608.A 1844 RBD ter.-Manners.-Gifts.-Nature.-Politics.-Nominalist and realist.-New England reformers; lecture at Amory Hall.

287. Essays, first and second series; with introd. by Irwin Edman. New York, Crowell, 1951. $43^{8} \mathrm{p}$. 5I-7280 PSI608.AI I95I

288. Poems. Boston, J. Munroe, 1847. 251 p. I-582 PSI624.AI I 847 RBD

First American edition; first English edition published slightly earlier in the same year (London, Chapman, 1847. I99 p. PSi624.AI 1847a).

289. Household ed. Boston, Houghton Mifflin, r892. vi, 324 p. (Household edition of the poets) 48-43255 PSI624.AI 1892

"Contains nearly all the pieces included in the Poems and May-Day of former editions . . . Also, some pieces never before published are here given in an Appendix."

First published in 1883 as v. 9 of the Riverside edition of Emerson's Complete Works.

290. - Selected and edited with a commentary, by Louis Untermeyer; illustrated with water-colors by Richard \& Doris Beer. New York, Heritage Press, I945. xvi, 238 p. (American poets, edited by Louis Untermeyer)

$$
\text { 45-6422 PSI624.AI7 I945 RBD }
$$

291. English traits. Boston, Phillips, Sampson, 1856. $312 \mathrm{p}$.

3-2575 DA625.E54 1856 RBD

Shows the reaction to the character and quality of the English people, by an American living at the middle of the rgth century.

292. The conduct of life. Boston, Ticknor \& Fields, I86o. 288 p.

36-r5513 PSr6o6.Ar I860 RBD

Contents.-Fate.-Power.-Wealth.-Culture.Behavior.-Worship.-Considerations by the way.Beauty.-Illusions.

293. The conduct of life, Nature, and other essays. New York, Dutton, r927. xi, 308 p. (Every- man's library, edited by Ernest Rhys. Essays and belles lettres, no. 322)

$$
\text { 36-37199 ACI.E8, no. } 322
$$

294. Journals of Ralph Waldo Emerson, with annotations, edited by Edward Waldo Emerson and Waldo Emerson Forbes. Boston, Houghton Mifflin, I909-14. Io v.

$$
\text { 9-29980 PSi63I.A3 } 1909
$$

Contents. - I. I $820-1824 .-2.1824-1832 .-3$. 1833-1835.-4. I 836-1838.-5. I 838-1841.-6. I $841-$ 1844-7. I $845-1948 .-8$. $\quad 1849-1855$. -9. I856I863.- - I0. I864-1876.

295. The heart of Emerson's journals, edited by Bliss Perry. Boston, Houghton Mifflin, 1926. ix, 357 p. 26-15215 PSi63r.A3 1926

296. Letters; edited by Ralph L. Rusk. New York, Columbia University Press, r939. $6 \mathrm{v}$. 39-12289 PSi631.A3 1939

297. Complete works. Centenary ed. With a biographical introd. and notes by Edward Waldo Emerson, and a general index. Boston, Houghton Mifflin, I903. $12 \mathrm{v}$.

$\mathrm{NcD}$

The set in the Library of Congress has imprint dates 'I903-2I (33-21674 PSi6oo.FO3a).

298. English traits, Representative men \& other essays. New York, Dutton, 1932. ix, 374 p. (Everyman's library, edited by Ernest Rhys. Essays and belles lettres, no. 279)

$$
\text { 36-37246 ACr.E8, no. } 279
$$

299. Representative selections, with introd., bibliography, and notes, by Frederic I. Carpenter. New York, American Book Co., r934. 1vii, 456 F. (American writers series) $34-7266 \quad \mathrm{PSI}_{1} 602 . \mathrm{C}_{3}$ "The text of Emerson's prose and verse included in the present volume is that of the Centenary edition, which incorporates the author's final revisions."-Preface.

"Selected bibliography": p. xlix-lvi.

300. Complete essays and other writings, edited, with a biographical introd., by Brooks Atkinson. Foreword by Tremaine McDowell. New York, Modern Library, 1950. xxvii, 930 p. (Modern Library college editions, $\mathrm{T}_{14}$ )

Bibliography: p. xxvii.

$$
\text { 50-12215 PS160o.F5o }
$$

301. Basic selections from Emerson; essays, poems \& apothegms. Edited by Eduard C. Lindeman. New York, New American Library, 1954. 215 p. (A Mentor book, $M$ 102)

$$
\text { 54-6005 PSi603.L5 }
$$


Another recent collection in inexpensive format was edited by Robert E. Spiller and announced for publication in 1957, by Appleton-Century-Crofts in that firm's classics series.

Recent contributions to the voluminous critical studies of Emerson's life and thought include:

302. Carpenter, Frederic I. Emerson handbook. New York, Hendricks House, 1953. xiv, 268 p. (Handbooks of American literature)

$$
\text { 53-2274 PSi631.C34 }
$$

303. Hopkins, Vivian C. Spires of form; a study of Emerson's aesthetic theory. Cambridge, Harvard University Press, 195r. x, 276 p.

Bibliography: p. [252]-256. 5r-9713 $\mathrm{PS}_{1} 6_{42} \mathrm{~A}_{3} \mathrm{H} 6$

304. Paul, Sherman. Emerson's angle of vision; man and nature in American experience. Cambridge, Harvard University Press, I952. viii, $268 \mathrm{p}$.

52-5039 PSi638.P

Bibliographical references included in "Notes": p. $[233]-258$.

305. Rusk, Ralph L. The life of Ralph Waldo Emerson. New York, Scribner, 1949. ix, $592 \mathrm{p}$.

"Index and bibliography": p. 553-592.

306. Whicher, Stephen E. Freedom and fate; an inner life of Ralph Waldo Emerson. Philadelphia, University of Pennsylvania Press, 1953. 203 p.

Includes bibliography.

53-9552 PSi631. W5

\section{TIMOTHY FLINT, $1780-1840$}

Traveler, clergyman, editor, and novelist, Flint was born in Massachusetts and educated at Harvard. He brought to his missionary journeys and other expeditions, in the Mississippi Valley and beyond, the same intellectual enthusiasm for the wilderness and for advancing the frontier that inspired other men of his period to carry civilization westward. His Recollections make available a contemporary source for learning the reactions of an educated, idealistic man of the time to the rigors as well as excitements of pioneering, thus contributing to an understanding of an important phase in the social and economic development of the United States. His novels entitle him to be classed with the founders of Western fiction in America.

308. Recollections of the last ten years. Boston, Cummings, Hilliard, 1826.395 p.

$$
{ }_{1-8704}^{3} \mathrm{~F}_{353} \cdot \mathrm{F}_{3}
$$

309. —— Edited, with an introd., by C. Hartley Grattan. New York, Knopf, 1932. xix, $3^{80}$ p. (Americana deserta)

$$
3^{2-26991} \mathrm{~F}_{353} \cdot \mathrm{F} 632^{2}
$$

310. Biographical memoir of Daniel Boone, the first settler of Kentucky. Interspersed with incidents in the early annals of the country. Cincinnati, N. \& G. Guilford, r833. viii, 267 p. illus. 7-1044I $\mathrm{F}_{454 . \mathrm{B}_{744}}$

3II. Francis Berrian; or, The Mexican patriot. Boston, Cummings, Hilliard, 1826. 2 v. $\mathrm{CtY}$

Romance portraying a New Englander in Mexico during the revolutionary years of the 1820 's.

312. The Shoshonee Valley. Cincinnati, E. H. Flint, 1830. 2 v.

$$
\text { 6-39999 PZ3.F649S RBD }
$$

Novel introducing Rocky Mountain trappers and fur traders, or "mountain men."

\section{3. (SARAH) MARGARET FULLER (MAR- CHESA D'OSSOLI), 1810-1850}

A New England child prodigy, who later became a legend because of her melodramatic life, Margaret Fuller was an American pioneer of her period-a journalist, traveler in Europe and America, critic, lecturer, feminist, Transcendentalist, and social reformer-in whose work the awakening literary and social conscience of the time had a significant manifestation. During her brief editorship $(1840-42)$ of The Dial $(1840-44)$ she developed it as a liberal literary review and secured for it contributions from some of the best writers of the country. As part of her work with Horace Greeley on the New York Tribune she criticized the leading authors of England and America, not always kindly, but with ability. Her translations, particularly from the German, reached the small audience prepared for this material. Her "conversations," or informal lectures on ideas and events, were influential in developing opinions among the intelligentsia. Before her untimely death she became a citizen of the world, at home in foreign literary circles and an adherent of Mazzini in the Roman Revolution. Although severely bowdlerized by her distinguished editors, R. W. Emerson, W. H. Channing, and J. F. Clarke, her Memoirs (Boston, Phillips, Sampson, $1852,2 \mathrm{v}$.) still provide a useful source for the study of intellectual America in the mid-nineteenth century. 
314. Summer on the lakes, in 1843 . Boston, C. C. Little \& J. Brown, I844. 256 p.

$\mathrm{Rc}-\mathrm{I}_{71} \mathrm{~F}_{55 \mathrm{r} . \mathrm{O} 84 \mathrm{RBD}}$

Account of a trip through the Middle West and Great Lakes country and of the "unfolding, noble energies" anticipated by the writer in the United States, as migrations from the East to the West and back again were continued.

315. Woman in the nineteenth century. New York, Greeley \& McElrath, 1845. 201 p. 28-22266 HQi154.O8 I845 RBD

"A reproduction, modified and expanded, of an article published in The Dial, Boston, July I843, under the title of "The Great Lawsuit. Man versus Men: Woman versus Women'."-Preface.

A pioneer work, which reached an audience in England as well as in America, and -which was instrumental in forwarding the woman's movement.

316. - Edited by her brother, Arthur B. Fuller. New and complete ed., with introd. by Horace Greeley. Boston, Roberts, I874. $420 \mathrm{p}$. 7-36542 HQII54.O86

317. Papers on literature and art. New York, Wiley \& Putnam, 1846.2 v. in I. (Wiley and Putnam's library of American books. [no. 19-20]) 24-I $830 \quad \mathrm{PS}_{2504 . P_{3}}$

"American Literature: Its Position in the Present Time, and Prospects for the Future," appears in pt. 2, p. [122]-165.

318. Writings. Selected and edited by Mason Wade. New York, Viking Press, I94I. $608 \mathrm{p}$. $\quad 4 \mathrm{I}-6756 \mathrm{PS}_{2501}$. W 3 "Bibliography of published writings of Margaret Fuller": p. [593]-6oo.

\section{JAMES HALL, I793-1868}

Hall, a Philadelphian who migrated westward in 1820 , became active as a lawyer (later a judge), financier, editor, and writer in a region between the Ohio and Mississippi Rivers. His sketches, legends, stories, and historical miscellanies portray with realism colored by romance the Indians and whites, manners and customs, and daily events of life when that section of country was part of the American frontier. He was also coauthor with Thomas L. McKenney of the History of the Indian Tribes of North America (Philadelphia, E. C. Biddle, $1836-44.3$ v.).

320. Letters from the West. London, H. Colburn, I828. $385 \mathrm{p}$.
Includes descriptions of scenery, manners, and customs associated with life in the Mississippi Valley, and gives various anecdotes of frontier life in the same region.

321. Sketches of history, life, and manners in the West. Cincinnati, Hubbard \& Edmands, I834. 263 p. I-8652 F $_{35}$ I.HI7 RBD

Of this edition apparently only volume I was published. It was reissued in a 2-volume edition in I835. Deals with the valleys of the Mississippi and Ohio Rivers.

\section{Legends of the West. [Author's rev. ed.] New York, Putnam, 1853 . 435 p. \\ 35-3376r PSi779. Hr6L4 I853}

Chiefly a collection of short tales and sketches, of which the first edition was published in 1832 . Includes a novel, The Harpe's Head (1833), published also under the title, Kentucky.

\section{FITZ-GREENE HALLECK, I790-1867}

Halleck, a Connecticut minor poet long identified with New York literary circles, perpetuated in America the romantic tradition of which Byron, Campbell, and Scott were representative in Britain. In the 1830 's he was second only to Bryant in popular favor in the United States. His "Croacker Poems," written in collaboration with Joseph Rodman Drake, to satirize local writers, artists, scientists, and politicians, made him famous overnight. His shorter poems, some of which were written in enthusiasm for European affairs engendered by a trip abroad, are his most lasting achievements. Among these, "Burns" and "Marco Bozzaris" are typical. "On the Death Of Joseph Rodman Drake" is remembered as a poet's devoted tribute to another poet who was his friend. Halleck's poems on native American themes include "The Field of the Grounded Arms," celebrating the American victory at Saratoga during the Revolutionary War, and "Red Jacket," a eulogy of an Indian chief of the Tuscaroras.

324. Alnwick Castle, with other poems. New York, G. \& C. Carvill, r827. 64 p.

$$
\text { I7-11659 PS } \text { PS }_{72 . A_{5}} \text { I827 }_{27} \mathrm{RBD}
$$

325. - New-York, Harper, r 845 . 104 p. 26-854 PSI782.A51845 RBD

326. Poetical works. Now first collected. New York, Appleton, I847. 280 p. illus. 26-6565 PS $1780 . A_{2} \quad 1847$

327. — New York, Appleton, 1859. 238 p. 26-6570 PSi780.A2 1859 
328. The poetical writings of Fitz-Greene Halleck, with extracts from those of Joseph Rodman Drake. Edited by James Grant Wilson. New York, Appleton, 1869. xviii, $3^{89} \mathrm{p}$.

$$
\text { 15-18389 PS } 1780 . A_{2} \quad 1869
$$

329. Life and letters. By James Grant Wilson. New York, Appleton, i869. $607 \mathrm{p}$. 26-6572 $\mathrm{PS}_{17} 73 . \mathrm{W}_{5}$

\section{GEORGE WASHINGTON HARRIS}

("SUT LOVINGOOD"), 1814-1869

Harris' humorous sketches and tall tales celebrate the practical jokes and exploits of a hero, Sut Lovingood, from the mountains of East Tennessee. Written in the local dialect, they draw their inspiration from the manners and customs of the region in the middle of the igth century.

33r. Sut Lovingood. Yarns spun by a "nat'ral born durn'd fool." New York, Dick \& Fitzgerald, $1867 . \quad \mathrm{xv}, 299 \mathrm{p}$.

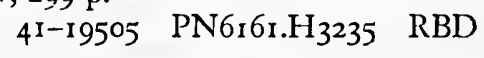

332. - Edited with an introd. by Brom Weber. New York, Grove Press, 1954. [xxxiv] 262 p. $\quad 54-10739$ PS I 799.H87S8

This edition comprises stories selected from the foregoing collection of 1867 and also the text of the author's "Sut Lovingood Travels with Old Abe Lincoln." The latter sketches were originally published in the Nashville Union and American, Feb. 28, Mar. 2 and 5, I86r.

\section{NATHANIEL HAWTHORNE, I804-r 864}

Hawthorne was a descendant of one of the stern judges of witchcraft in Salem, Massachusetts, in the 17 th century. In that same town Hawthorne was born, spent most of his youth, and developed as a writer. Later, he was associated particularly with Concord, where he was a cool and detached observer of the Transcendentalist group of which Emerson was the center. In fact he repented early of his own "Transcendental wild oats," an experience that led to the writing of The Blithedale Romance (1852). Revolting from what he felt to be the easy optimism and naive otherworldliness of the Transcendentalists, he turned for the themes of his novels and tales to early times in New England, when life was dominated by Puritanism and particularly by Calvinistic theology. These matters were dealt with by Hawthorne not as a historical novelist, but as a writer on timeless and universal themes having to do with the presence of evil in the world, the inevitable consequences of sin, the cruelty of dogmatism, and the necessity of morality. His work was accomplished under the stimulus of a powerful imagination, and in his longer books resulted in what he called romances, rather than novels. However, the adventures of which he wrote, frequently using symbolism and allegory, were primarily those of the human soul and were not in celebration of experiences necessarily particular to any given time or place. His reactions to a residence of more than five years in England, part of the time as consul at Liverpool, were given in his English notebooks. A shorter stay in Italy led to the choice of Rome as the setting for his romance, The Marble Faun (1860), in which the plot traces the aftereffects of a crime and the dawn of conscience in a child of nature. The author's own mind and life may be studied profitably in his posthumously published notebooks. His contemporary critics included Herman Melville, upon whom the impact of Hawthorne's masterpiece, The Scarlet Letter, was contributory to the writing of Moby Dick, and Edgar Allan Poe, whose review of the second series of Twice-Told Tales, published in Graham's Magazine, v. 20 , Apr.-May, 1842, p. $254,298-300$, not only discussed the technique of Hawthorne's short stories and sketches, but included also a formulation of Poe's own theories of the short story as a form of literary art.

334. Twice-told tales. Boston, American Stationers Co., $1837.334 \mathrm{p}$. 9-2689 PSi $870 . A I \quad I 837$ RBD

First edition of the first series.

335. - Boston, J. Munroe, 1842. 2 v. MH Second edition of the first series; first edition of the second series.

336. — A new ed. Boston, Ticknor, Reed, \& Fields, $185 \mathrm{r} .2 \mathrm{v}$.

$$
\text { 7-3872 PSr } 870 \text {.AI 185I RBD }
$$

337. - New-York, Dutton, 1932. xvi, 357 p. (Everyman's library, edited by Ernest Rhys. Fiction [no. 53I])

$$
\text { 36-37338 ACr.E8, no. 531 }
$$

338. Mosses from an old manse. New York, Wiley \& Putnam, 1846.2 v. in $1 . \quad(207$, $21 \mathrm{I}$ p.) (Wiley and Putnam's library of American books, no. 17-18)

$$
\text { 7-3870 PSr 863.AI } 1846 \text { RBD }
$$

339. New ed., carefully rev. by the author.
Boston, Ticknor \& Fields, 1854.
$\begin{array}{rlll}6-15467 & \text { PSI } 863 . A 1 & \text { 1854 } & \text { RBD }\end{array}$ 
340. Salem ed. With an introd. by George Parsons Lathrop. Boston, Houghton Miflin, 1893 [ ${ }^{\circ} \mathrm{r} 882$ ] $277 \mathrm{p}$.

54-50422 PSr863.AI 1893

A contemporary Houghton Mifflin edition is announced for publication in July 1956.

34r. The scarlet letter, a romance. Boston, Ticknor, Reed, \& Fields, 1850.322 p.

7-3785 PSr868.Ax r850 RBD

342. - Introd. by Austin Warren. New York, Rinehart, 1947. xiii, 251 p. (Rinehart editions, I)

$4^{8-1188} \quad \mathrm{PZ}_{3} \cdot \mathrm{H}_{3}{ }^{18 \mathrm{Sc}} 8_{2}$

343. With an introd. by Newton Arvin. New York, Harper, 1950. xiii, 278 p. (Harper's modern classics)

$$
\begin{array}{lll}
50-6269 & \mathrm{PZ}_{3} \cdot \mathrm{H}_{3} 18 \mathrm{Sc} \quad 86
\end{array}
$$

344. - Introd. by John C. Gerber. New York, Modern Library, 1950. xxxiv, 300 p. (Modern Library college editions, $\mathrm{T}_{2 \mathrm{I}}$ )

Bibliography: p. xxxiii-xxxiv.

50-12245 $\mathrm{PZ}_{3} \cdot \mathrm{H}_{3} 18 \mathrm{Sc} \quad 87$

345. The house of the seven gables, a romance. Boston, Ticknor, Reed, \& Fields, 1851. vi, 344 p. $\quad 7-3868$ PSi 86r.AI I85r RBD

For Hawthorne's distinction between a romance and a novel, see p. [iii]-iv.

346. - New York, Dutton, 1930. xv, 310 p. (Everyman's library, edited by Ernest Rhys [no. ${ }^{176]}$ ) $36-37232$ ACr.E8, no. 176

347. With illus. reproducing drawings for early editions ... [ [and] an introductory biographical sketch of the author and anecdotal captions by Basil Davenport. New York, Dodd, Mead, 1950. xiii, 335 P. (Great illustrated classics) 50-6979 $\mathrm{PZ}_{3} \cdot \mathrm{H}_{3} \mathbf{1} 8 \mathrm{Ho} \quad 68$

348. The heart of Hawthorne's journals. Edited by Newton Arvin. Boston, Houghton Mifflin, 1929. xiv, 345 p. 29-10491 PSr88r.A25

349. The American notebooks, based upon the original manuscripts in the Pierpont Morgan Library, and edited by Randall Stewart. New Haven, Yale University Press, 1932. xcvi, $350 \mathrm{p}$. 32-28143 PSI865.AI 1932

"Originally prepared as a doctoral dissertation at Yale University [1930]"-Preface, p. ix.

Includes the passages omitted in the edition edited by Mrs. Hawthorne and published under title: Passages from the American Note-Books of Nathaniel Hawthorne.
350. The English notebooks, based upon the original manuscripts in the Pierpont Morgan Library and edited by Randall Stewart. New York, Modern Language Association of America, r94I. xliv, $667 \mathrm{p}$. (The Modern Language Association of America. General series, 13 ) $41-21963$ PS1881.A43

Includes the passages omitted in the edition edited by Mrs. Hawthorne and published under title: Passages from the English Note-Books of Nathaniel Hawthorne.

"Continues the work which was begun with . . . [the editor's] edition of The American Notebooks (Yale University Press, 1932) and which will be completed with an edition of The Italian Notebooks, now being prepared by Mr. Norman Holmes Pearson."-Preface.

"Published with the cooperation of Brown University."

Bibliographical references included in "Notes" (p. [623]-654).

351. Complete works, with introductory notes by George Parsons Lathrop and illustrated with etchings by Blum, Church, Dielman, Gifford, Shirlaw, and Turner. [Riverside ed. Cambridge, Mass., Printed at the Riverside Press, I883] I2 v. illus.

PPTu

352. [Riverside ed. Boston, Houghton Mifflin, $1887-88] \quad 12$ v. illus. 42-26389 $\mathrm{PS}_{1} 850 . \mathrm{E} 87$

353. Complete writings. [Old Manse ed. Boston, Houghton Mifflin, rgoo] 22 v. illus. NcD

354. — Autographed ed. [Boston, Houghton Mifflin, 1900] $22 \mathrm{v}$. illus. $13-21420$ PS 1850 .Foo

355. Representative selections, with introd., bibliography, and notes, by Austin Warren. New York, American Book Co., 1934. xci, 368 p. (American writers series)

$$
\text { 34-ro889 PSr } 852 . \mathrm{W}_{3}
$$

"Selected bibliography": p. lxxv-lxxxix.

356. Complete novels and selected tales. Edited, with an introd. by Norman Holmes Pearson. New York, Modern Library, 1937. 1223 p. (Modern Library of the world's best books) 37-28752 $\mathrm{PZ}_{3} \cdot \mathrm{H}_{3}$ 18Com

357. The portable Hawthorne. Edited with an introd. and notes, by Malcolm Cowley. New York, Viking Press, 1948. vi, 634 p. (The Viking portable library, 38) $3_{48-7869}$ PS $_{1} 852 . \mathrm{C} 6$ "A very short bibliography": p. $633-634$. 
358. The best of Hawthorne. Edited with introd. and notes by Mark Van Doren. New York, Ronald Press, I95I. v. 436 p.

Bibliography: p. $435-436 .^{5 I-9259} \mathrm{PSI}^{182 . V_{3}}$

359. Selected tales and sketches. Introd. by Hyatt H. Waggoner. New York, Rinehart, 1950. Xxx, 410 p. (Rinehart editions, 33)

$$
\text { 50-14223 PSI } 852 \text {. W25 }
$$

"A bibliographical note": p. xxvii-xxviii.

During the past several years students of Havthorne have made available new light on his work. These studies include:

360. Davidson, Edward H. Hawthorne's last phase. New Haven, Yale University Press, r949. xiv, 174 p. (Yale studies in English, v. III) 49-1 858 PS $1882 . D_{37}$

Bibliography: p. $[163]-168$. PR I3. $Y_{3}$, v. III

36r. Fogle, Richard H. Hawthorne's fiction: the light \& the dark. Norman, University of Oklahoma Press, 1952. ix, 2 I9 p.

Bibliography: p. 207-214.

52-4268 PSI 888.F6

362. Stein, William B. Hawthorne's Faust, a study of the Devil archetype. Gainesville, University of Florida Press, 1953. vii, $172 \mathrm{p}$.

Bibliography: p. $167-168$.

$$
\text { 53-9337 } \mathrm{PS}_{1} 892 . \mathrm{D}_{4} \mathrm{~S}_{75}
$$

363. Van Doren, Mark. Nathaniel Hawthorne.

New York, Sloane, 1949. xiii, 285 p. (American men of letters series)

Bibliographical note: p. $269-273$.

$$
\text { 49-8394 } \mathrm{PS}_{1} 88 \mathrm{r} . \mathrm{V}_{3}
$$

364. Waggoner, Hyatt $H$. Hawthorne, a critical study. Cambridge, Mass., Belknap Press of Harvard University Press, 1955. 268 p.

$$
\text { 54-9778 PSI } 888 . W_{3}
$$

\section{CHARLES FENNO HOFFMAN, I806- I 884}

Hoffman, a New York editor, novelist, and writer of musical verses, whose personality Poe admired, was one of the cultivated easterners who traveled in what was then the far western part of the United States. By the publication of his observations and impressions of places, events, and characteristic types among the population, he contributed to a growing interest in the frontier. His novel Greyslaer (1840) celebrated the famous Beauchamp murder case, known also as the Kentucky Tragedy, and was successfully produced as a play in the year of its publication. Hoffman's Poems were collected and edited by his nephew, Edward Fenno Hoffman (Philadelphia, Porter \& Coates, 1873. 238 p.).

366. A winter in the West. By a New Yorker. New York, Harper, 1835 . 2 v.

$$
\text { I-I } 6856 \quad F_{4} 84 \cdot 3 . H 68 \text { RBD }
$$

Narrative of a journey through Pennsylvania, the Old Northwest, Missouri, Kentucky, Tennessee, and Virginia.

367. Wild scenes in the forest and prairie. London, R. Bentley, I839. 2 v.

$$
\text { 7-6. } \mathrm{I}_{47} \quad \mathrm{PZ}_{3} \cdot \mathrm{H}_{74} \mathrm{~W}
$$

368. OLIVER WENDELL HOLMES, 1809-1894

A Boston Brahmin who counted Mrs. Anne Bradstreet among his ancestors, Holmes found in his native city a satisfying hub of the universe. His familiar essays, full of revelations of the writer's life and personality, were a characteristic and popular feature of The Atlantic Monthly, for which Holmes supplied the name when the journal was founded. As a poet he dealt with historic and patriotic themes, as in "Old Ironsides," and with spiritual and imaginative ideas, characteristically expressed in "The Chambered Nautilus." $\mathrm{He}$ also exercised a talent for writing light verse, of which "The Deacon's Masterpiece" is an example. Characterized by humor interspersed with pathos, common sense, moral uprightness, and love of his country and his region, his literary work preserves the flavor of the time and place in which he lived. As a physician for many years on the medical faculty of Harvard University he attacked ignorance and prejudice in matters of health and became the author of medical essays and monographs which show that he made at least one important contribution to the improvement of medical science. His few novels deait with psychopathological themes, which anticipate later theories of psychoanalysis and psychiatry.

369. Poems. Boston, Otis, Broaders, 1836 . xiv, I63 p. 26-858 PSI955.Ar I836 RBD

370. Complete poetical works. Cambridge ed. [edited by Horace E. Scudder] Boston, Houghton Mifflin, I895. xxi, 352 p.

$$
\text { 4-13823 PSI955.AI } 1895
$$

371. The autocrat of the breakfast-table. Boston, Phillips, Sampson, r858. $373 \mathrm{p}$.

$$
\text { I7-4959 PSig64.AI } 185^{8} \text { RBD }
$$


372. - Boston, Houghton Mifflin, 1895 . xxiv, 321 p. (The Riverside literature series. [no. 8I ]) I7-4960 PSig64.AI I895 Has subtitle: Everyman his own Boswell; includes a biographical sketch.

373. - Edited with an introd. by Franklin T. Baker. New York, Macmillan, 1928. $\mathrm{xxv}, 369 \mathrm{p}$. (The modern readers' series) 28-26745 PSig64.AI 1928

374. - New York, Dutton, 1931. x, $300 \mathrm{p}$. (Everyman's library, edited by Ernest Rhys. Essays. [no.66]) 36-37070 ACr.E8, no. 66

375. Elsie Venner; a romance of destiny. Boston, Ticknor \& Fields, 186r. 2 v.

7-5180 PSig6o.Ai I86r RBD

First published under title The Professor's Story in The Atlantic Monthly, Jan. 1860-Apr. I86r, not December 1859 as stated in [publishers'] preface; the novel in which Holmes defined his concept of a Brahmin caste in New England.

In order to isolate the medical and psychiatric elements in Elsie Venner and Holmes' other novels, The Guardian Angel and A Mortal Antipathy, Clarence P. Oberndorf has brought together abridgments and annotations of each book under the title, The Psychiatric Novels of Oliver Wendell Holmes (New York, Columbia University Press, 1943. 268 p.).

Houghton Mifflin (Boston) has recently announced that the firm has in preparation a republication of Elsie Venner.

376. Writings. [Riverside ed. Boston, Houghton Mifflin, I89r-95] $13 \mathrm{v}$.

$$
\text { 4-16396 PSr950.E93 }
$$

377. Works. [Standard library ed.] Boston, Houghton Mifflin, 1892-96. 15 v. NjP

Contents of v. I-I 3 correspond to contents of Riverside edition. Life and Letters, by John $T$. Morse constitute v. 14-15. The student of Holmes' work will wish also to consult Thomas F. Currier's A Bibliography of Oliver Wendell Holmes (New York, New York University Press, 1953. 707 p.), which was edited for the Bibliographical Society of America by Eleanor M. Tilton.

378. Representative selections, with introduction, bibliography, and notes by S. I. Hayakawa and Howard Mumford Jones. New York, American Book Co., 1939. cxxix, 472 p. (American writers series) 39-2I 102 $\mathrm{PS}_{1953 . \mathrm{H}_{4}}$

"Selected bibliography": p. cxvii-cxxix.
379. JOHNSON JONES HOOPER, $1815-1862$

"Simon Suggs," a Southern frontier type of gambler and rogue, was created by Hooper for use in the Alabama newspapers with which he was connected as journalist and editor. The deeds and sayings of this fictitious sharper, through which the author expressed his own humor and irony, were widely popular. Some of the adventures were reprinted as far afield as New York, in the Spirit of the Times (1831-186r). The life and times of Hooper are discussed, and an extensive bibliography is supplied in William S. Hoole's Alias Simon Suggs (University, Ala., University of Alabama Press, 1952. xxii, 283 p.).

380. Some adventures of Captain Simon Suggs, late of the Tallapoosa Volunteers; together with "Taking the Census," and other Alabama sketches. By a country editor. With a portrait from life, and other illus., by Darley. Philadelphia, Carey \& Hart, 1846. $201 \mathrm{p}$.

$7-526_{3} \quad \mathrm{PZ}_{3} \cdot \mathrm{H}_{7} 66_{4} \mathrm{So}$

First edition published in 1845 . Cf. Hoole, p. 58 . Simon Suggs' Adventures is the title of a later edition (Philadelphia, T. B. Peterson, I88I. 217 p.).

\section{WASHINGTON IRVING, I783-1859}

Irving, a cosmopolitan and man of fashion, had his beginnings in New York when the city was developing as a financial and cultural center. His early work satirized New York society and history with a burlesque touch. As his style developed it was characterized by elegance and gentle humor which have endeared it to admirers of such English essayists as Addison, Steele, and Lamb. However, his taste for sentiment, legends, and landscape, all frequently infused with melancholy, brought him into the romantic tradition. Many years spent abroad as a businessman, traveler, and diplomat enlarged his circle of literary friends and admirers, which included Scott, Coleridge, and Byron, among others. The Europeanization of his outlook influenced him to bring into the bounds of American literature such contributions as his The Life and Voyages of Columbus (1828) and his book of romantic Spanish legends and sketches, The Alhambra ( 1832$)$. After one of his returns to the United States he contributed to the literature developing from the exploration of the western frontier $A$ Tour of the Prairies, included in The Crayon Miscellany (1835). His Life of George Washington in 5 volumes (1855-59) portrays his subject as the central figure in the beginning of the Nation. Irving has been called the first American literary man to win genuine recognition abroad and the 
writer who, in such pieces as "Rip Van Winkle" and "The Legend of Sleepy Hollow," fathered the American short story, which Hawthorne, Poe, and their successors developed.

382. A history of New York from the beginning of the world to the end of the Dutch dynasty. By Diedrich Knickerbocker [pseud.] New York, Inskeep \& Bradford, I809. 2 v.

$$
\text { 4-18970 Fi22.170 RBD }
$$

383. Diedrich Knickerbocker's $A$ history of New

York. Edited with a critical introd. by Stanley Williams and Tremaine McDowell. New York, Harcourt, Brace, 1927. lxxvii, 475 p. (American authors series; general editor, S. T. Williams) 27-2639 Fr22.I.I834

334. The sketch book of Geoffrey Crayon, gent. [pseud.]. New York, C. S. Van Winkle, I819-20. 7 pts.

$\mathrm{CtY}$

This is the work that includes his celebrated story, "Rip Van Winkle."

385. ${ }^{8}$ ed. New York, C. S. Van Winkle, 1819-20. 7 pts. in $2 \mathrm{v}$.

7-94.92 PS2066.AI I819a RBD

386. — New York, Dutton, 1936. x, 368 p. (Everyman's library, edited by Ernest Rhys [no. II7]) 36-37106 ACi.E8, no. II7 Bibliography: p. viii.

387. Introd. and descriptive captions by Harry Hansen. New York, Dodd, Mead, 1954. 39I p. illus. (Great illustrated classics) 54-3604 PS2066.AI 1954

388. Bracebridge Hall; or, The humourists. A medley, by Geoffrey Crayon, gent. [pseud.]

New York, C. S. Van Winkle, 1822. 2 v. 4-34448 PS2057.AI 1822 RBD

389. Handy volume ed. New York, Putnam, 1910. 2 v. in 1 .

IU

390. Tales of a traveller. London, J. Murray, I $824.2 \mathrm{v}$.

I-I258 PS2070.AI I824 RBD

First American edition published also in 1824 , by C. S. Van Winkle.

39I. Astoria; or, Anecdotes of an enterprise beyond the Rocky Mountains. Philadelphia, Carey, Lea \& Blanchard, 1836 . 2 v.

$$
\text { Rc-37I F880.I7I RBD }
$$

Belongs to the literature of overland journeys to the Northwest, the fur trade in Oregon, and the Pacific Fur Company.

Available (1954) from Binfords \& Mort, I24 N. W. $9^{\text {th }}$ Avenue, Portland, Oregon, publishers of books of interest in connection with the Pacific Northwest.

392. Letters to Henry Brevoort. Edited, with an introd., by George S. Hellman. New York, Putnam, I9I5. 2 v. I5-2226o PS2081.A4 I9I5 Republished in 1918 in one volume $(462$ p.).

393. The journals of Washington Irving (hitherto unpublished) Edited by William P. Trent and George S. Hellman. Boston, Bibliophile Society, I9I9. 3 v. 20-1680 PS2081.A3 1919

Covers the years from July 1815 to July 1842 .

Stanley T. Williams has edited the following volumes of journals:

Journal of Washington Irving, I823-1824. (Cambridge, Mass., Harvard University Press, 1931. 278 p.)

Journal, I803, by Washington Irving (London and New York, Oxford University Press, 1934. 48 p.)

Journal of Washington Irving, I828, and miscellaneous notes on Moorish legend and history. (New York, American Book Co., I937. 80 p.)

394. Works. New ed. rev. New York, Putnam, I848-5I. I5 v. I-I 239 PS2050.E49

Vols. I-I I, I4: "New edition revised"; v. I-I0, I5: "Author's revised edition."

395. Kinderhook ed. New York, Putnam [ $\left.{ }^{\mathrm{I}} \mathrm{1} 850-\mathrm{r} 880\right]$ Io $\mathrm{v}$. I6-I6979 PS2050.E50a

396. Hudson ed. New York, Putnam [cr856]-89. $27 \mathrm{v}$.

CtY

397. _ Author's rev. ed. New York, Putnam, 1863-66. 21 v. MH

398. Knickerbocker ed. New York, Putnam, I89I-97. $40 \mathrm{v}$.

OCU

Dates of publication found in the foregoing entries have been transcribed from cards in the $\mathrm{Na}$ tional Union Catalog and the Main Catalog of the Library of Congress and do not necessarily represent the first publication of each edition described. For original publication dates see Stanley T. Williams and Mary E. Edge's A Bibliography of the Writings of Washington Irving (New York, Oxford University Press, 1936. p. 2-4). 
399. Representative selections, with introductions, bibliography, and notes, by Henry A. Pochmann. New York, American Book Co., 1934. cxiv, $380 \mathrm{p}$. (American writers series)

$$
\text { “Selected bibliography": p. xciii-cx. }
$$

400. Selected writings. Edited, with an introd., by Saxe Commins. New York, Modern Library, 1945. xix, 669 p. (Modern Library of the world's best books [240])

$$
45-37863 \quad \text { PS2052.C6 }
$$

40r. Selected prose. Edited with an introd. by Stanley T. Williams. New York, Rinehart, 1950. xxiv, 423 p. (Rinehart editions, 4I) 50-10714 PS2052. W5 xxii.

"Biographical and bibliographical note": p. xxi-

\section{SYLVESTER JUDD, 1813-1853}

Lowell, in A Fable for Critics, called Judd's Margaret "the first Yankee book with the soul of Down East in it." This authentic local flavor was derived from the author's experiences when, removing from Massachusetts where he was reared, he settled in Augusta, Maine, as clergyman of a Unitarian church. His local interests were reflected not only in a few historical and genealogical works, but also particularly in his regional romances of rural New England. These he used to record descriptions of the landscapes he loved and as a medium for expressing his religious Transcendental, and social views. His writings also include Richard Edney (1850), a novel, and Philo, an Evangeliad $(1850)$, a didactic poem.

403. Margaret; a tale of the real and ideal. Boston, Jordan \& Wiley, I845. $460 \mathrm{p}$.

$$
\text { 7-3525 } \mathrm{PZ}_{3} \text {.J885 M RBD }
$$

404. Rev. ed. Boston, Phillips, Sampson, I 85 I. 2 v. $\quad 3-22366 \mathrm{PZ}_{3} . \mathrm{J}_{88} \mathrm{M}_{3}$

\section{JOHN PENDLETON KENNEDY, 1795- 1870}

Of combined Maryland and Virginia ancestry, Kennedy had a cosmopolitan circle of acquaintances in the North and in Europe, and took part in public life both locally and nationally. $\mathrm{He}$ was a pioneer writer about plantation life in Old Virginia, which he presented in Swallow Barn, a series of urbane sketches reminiscent of the writings of his friend, Washington Irving. His historical novels of frontier life in Maryland, Virginia, and the Caro- linas in the colonial and Revolutionary periods are factually true but thoroughly representative of the tide of romanticism rising in his time. It is said that he advised Thackeray, whom he met on his travels, concerning local color for The Virginians. He was also instrumental in securing recognition for Edgar Allan Poe.

406. Swallow Barn; or, A sojourn in the Old Dominion [by Mark Littleton, pseud.] Philadelphia, Carey \& Lea, 1832.2 v.

\section{$7-3061 \quad \mathrm{PZ}_{3} \cdot \mathrm{K}_{3} 8_{3} \mathrm{~S} \mathrm{RBD}$}

407. Rev. ed., with twenty illus. by Strother. New York, Putnam, 1851. 506 p. ${ }_{3-28} 1_{5} \quad \mathrm{PZ}_{3} \cdot \mathrm{K}_{3}{ }_{3} \mathrm{~S}_{2}$

408. —_ited with an introd. by Jay B. Hubbell. New York, Harcourt, Brace, 1929. xxxiv, 422 p. (American authors series; general editor, S. T. Williams) $\quad 29-9094 \quad \mathrm{PZ}_{3} \cdot \mathrm{K}_{3} 8{ }_{3} \mathrm{~S} 9$

"The text followed is that of the second edition, revised by Kennedy ... in $1851 . "-N o t e$ on text.

Selected reading list: p. xxxiii-xxxiv.

409. Horse-Shoe Robinson; a tale of the Tory ascendency, by ... [Mark Littleton, pseud.] Philadelphia, Carey, Lea, \& Blanchard, 1835. 2 v. 3-1607 $\mathrm{PZ}_{3} \cdot \mathrm{K}_{3} 83 \mathrm{H}$ RBD

4 10. Rev. ed. New York, Putnam, 1852. xiv, 598 p. 3-19517 $\mathrm{PZ}_{3} \cdot \mathrm{K}_{3}{ }_{3} \mathrm{H}_{3}$

4II. - Edited, with introd., chronology, and bibliography, by Ernest E. Leisy. New York, American Book Co., 1937. xxxii, 550 p. (American fiction series; general editor, $\mathrm{H}$. $\mathrm{H}$. Clark) $\quad 37-4088 \quad \mathrm{PZ}_{3} \cdot \mathrm{K}_{3} 8{ }_{3} \mathrm{H}_{2} 6$

Selected bibliography: p. xxix-xxxii.

412. Rob of the Bowl; a legend of St. Inigoe's. By the author of "Swallow barn." Philadelphia, Lea \& Blanchard, $1838.2 \mathrm{v}$.

$$
\text { 7-12839 PS2162.R6 1838 RBD }
$$

413. Rev. ed. Philadelphia, Lippincott, I860. 432 p. 7-10956 $\mathrm{PZ}_{3} \cdot \mathrm{K}_{3}{ }_{3}{ }_{3} \mathrm{R}_{2}$

414. At home and abroad; a series of essays: with a journal in Europe in $1867-8$. [New York] Putnam, I872. 4I5 P.

3-30553 PS2162.A7 I872

415. CAROLINE MATILDA (STANSBURY)
KIRKLAND, I80I-I 864

Edgar Allan Poe, in the section devoted to Mrs. Kirkland in his "The Literati of New York 
City" ( 1846 ) said: "Unquestionably she is one of our best writers, has a province of her own, and in that province has few equals." Her province was that of portraying community types, manners and customs, misfortunes, and virtues observed by a cultivated New York woman during three years spent in sharing with others the making of a frontier settlement at Pinckney, Michigan. Writing with candor and realism unusual at the time, with tartness, but with humanity, Mrs. Kirkland recorded a phase of American civilization which was soon to pass. Her fictional sketches are also an early landmark in the use of the small town as a recurring theme in the national literature.

416. A new home-who'll follow? or, Glimpses of western life. By Mrs. Mary Clavers [pseud.] New York, C. S. Francis, I839. 317 p. I3-9373 PZ3.K6 $35 \mathrm{~N}_{3} \mathrm{RBD}$

Reissued as Our New Home in the West (New York, Miller, 1872. 298 p.).

417. with an introd. by John Nerber. New York, Putnam, I953. 308 p. $53^{-12508} \quad \mathrm{PZ}_{3} \cdot \mathrm{K} 635 \mathrm{~N} 8$

"This editing of $A$ New Home, and those portions of Forest Life [1842] which by substance belong to the earlier narrative .... is designed only as an introduction for the modern reader to a delightful and nearly forgotten classic of another day."Introduction, p. 6 .

418. Forest life. By the author of $A$ new home. New York, C. S. Francis, 1844. $2 \mathrm{v}$. 7-13208 $\mathrm{PZ}_{3} \cdot \mathrm{K} 635 \mathrm{~F}$ RBD

First edition published 1842 .

\section{I9. ABRAHAM LINCOLN, I809-1865}

Lincoln's place in the American heritage is with the Nation's statesmen. His collected writings are therefore entered in the section of this bibliography devoted to references on General History, where they stand beside the works of Washington, Jefferson, Franklin, and their successors. In this section on Literature it has been considered sufficient to suggest only briefer collections, in which Lincoln, the literary artist, may be observed at work, varying his style from the homely and simple to the stately and rhetorical, and throughout clearly revealing the mind and heart of mid-nineteenth century America at its best.

420. Abraham Lincoln, his speeches and writings. Edited with critical and analytical notes by Roy P. Basler. Pref. by Carl Sandburg. New York, World Pub. Co., r946. xxx, 843 p.

$$
\text { 53-28573 } \mathrm{E}_{457.92} \quad \text { I946 }
$$

"Lincoln's Development as a Writer," p. I-49, contains the editor's analysis of Lincoln's literary craftsmanship and accomplishments.

Sources and bibliography: p. 807-822.

Generally the most accurate text available aside from the Collected Works (1953).

421. The life and writings of Abraham Lincoln. Edited, and with a biographical essay, by Philip Van D. Stern; with an introd., "Lincoln in his writings," by Allan Nevins. New York, Modern Library, 1942. xxvi, 863 p. (Modern Library of the world's best books. [Modern Library giants]) 43-16859 $\mathrm{E}_{457.92}$

A useful collection in spite of the fact that the text follows the sometimes unreliable Nicolay and Hay Complete Works.

\section{DAVID ROSS LOCKE ("PETROLEUM V. NASBY"), 1833-1888}

Locke, a humorist in the tradition of Charles Farrar Browne, wrote under the pseudonym of "Petroleum V. Nasby." Many of his pieces were issued individually in Ohio newspapers with which he was connected as a journalist or editor. Various collections were later published in book form. For some of his work Thomas Nast, the famous cartoonist, supplied illustrations. Locke's satires, marked by ridiculous spelling, gross distortions of grammar, puns, horseplay, and jokes of all kinds were useful war propaganda and political campaign literature in the North during and after the Civil War. They were eagerly read by a large audience, which included President Lincoln. His posthumous novel, The Demagogue (189r), castigated political corruption in Ohio.

423. The Nasby papers ... [by] Petroleum V. Nasby [pseud.] Indianapolis, C. O. Perrine, 1864. $64 \mathrm{p}$. 5-40609 E647.L75 RBD

424. "Swingin round the cirkle." By Petroleum V. Nasby [pseud.] Illustrated by Thomas Nast. Boston, Lea \& Shepard, 1867. 299 p. 8-1248 PN6r6r.L638 1867 RBD A briefer work having the same title was published by the American News Company, New York, I $866,3^{8} \mathrm{p}$.

425. The struggles (social, financial and political) of Petroleum V. Nasby [pseud.] ... With an introd. by Hon. Charles Sumner. Illustrated by Thomas Nast. Boston, I. N. Richardson, 1872 . 720 p. 12-6202 PN6161.L637 RBD

Sumner's introduction emphasizes Lincoln's enthusiasm for Locke's work. 
426. Nasby in exile. Toledo, Ohio, Locke Pub. Co., 1882. $\quad x v, 672$ p. 3-15519 D919.L8I

Comments shrewdly on manners and customs observed during six months of travel in the British Isles, France, Germany, Switzerland, and Belgium.

Originally published from week to week in the Toledo Blade.

\section{HENRY WADSWORTH LONGFEL- LOW, $1807-1882$}

New Englander of Pilgrim descent, student and traveler in Europe, Harvard professor of modern languages and belles-lettres, but most of all a poet, Longfellow in his work displayed technical skill in versification, ability to tell a story, simplicity, sweetness, and emphasis on morality. A romantic poet, he derived inspiration from America's historic past, particularly from Indian lore and colonial history, from European folklore, and from the quiet tenor of everyday life. His narrative poems, some of the longest in American literature, have a vigorous sweep; his ballads are stirring; and his sonnets are thought by some critics to be among his best achievements. Longfellow is a national poet because he gave America the poetry it was ready and able to appreciate, so that his poems entered into the minds of the people and became household words even to schoolchildren. Through his work, which was widely translated abroad, Europe became increasingly aware of American literature, while Americans profited by the influences of older cultures transmitted in his poems. A recent and highly favorable study of Longfellow's place in American literature is found in Edward C. Wagenknecht's Longfellow; a Full-Length Portrait (New York, Longmans, Green, 1955. 370 p.).

428. Ballads and other poems. Cambridge, Mass., J. Owen, I842. $132 \mathrm{p}$.

$$
\text { 8-26999 PS2255.AI I } 842 \text { RBD }
$$

First edition issued December $184 \mathrm{I}$.

429. Evangeline, a tale of Acadie. Boston, Ticknor, $1847 . \quad 163 \mathrm{p}$.

10-5566 PS2263.Ar I847 RBD

430. Kavanagh, a tale. Boston, Ticknor, Reed, \& Fields, 1849. 188 p.

$$
\text { 7-I } 4788 \text { PS2273. } \mathrm{K}_{3} \quad \text { I } 849 \mathrm{RBD}
$$

Includes (chapter 20) an expression of Longfellow's sense of the debt owed by American writers to their intellectual inheritance from Europe; also sets forth his belief in the importance of international and universal interests to a growing national literature; a short novel frequently autobiographical.
43I. The seaside and the fireside. Boston, Ticknor, Reed, \& Fields, I850. I4I p.

$$
\text { 6-4654I PS2266.AI I850 RBD }
$$

First edition published December 1849 .

432. The song of Hiawatha. Boston, Ticknor \& Fields, 1855 . 316 p.

$6-46545$ PS2267.AI $1855 \mathrm{RBD}$

433. The courtship of Miles Standish, and other poems. Boston, Ticknor \& Fields, I858.

215 p. 6-46552 PS2262.AI $1858 \mathrm{RBD}$

"Birds of Passage": p. [II7]-209.

434. Tales of a wayside inn. Boston, Ticknor \& Fields, 1863. 225 p.

$$
\text { 6-46546 PS2269.Ar I863 RBD }
$$

435. The masque of Pandora, and other poems. Boston, J. R. Osgood, 1875. I 46 p.

$$
\text { 6-46553 PS227I.M3 } 1875 \mathrm{RBD}
$$

436. Complete works. Rev. ed. Boston, Ticknor \& Fields, r866. $7 \mathrm{v}$.

$$
\text { 8-22190 PS2250.E66 RBD }
$$

437. Complete poetical and prose works. Riverside ed. [Boston, Houghton Mifflin, 1886-93.] II v.

\section{Contents:}

Prose works, with bibliographical and critical notes. [1886] 2 v.

$$
\text { 28-1405I PS2272.AI } 1886
$$

Poetical works, with bibliographical and critical notes. [1886] $6 \mathrm{v}$. 28-II440. PS2250.E86a

The Divine comedy of Dante Alighieri, translated by Henry Wadsworth Longfellow. [1892-93] $3 \mathrm{v}$.

Published originally in 1886 .

$$
\text { 30-3804 PQ4315.L7 I892 }
$$

438. Works, with bibliographical and critical notes and his life, with extracts from his journals and correspondence; edited by Samuel Longfellow. [Standard library ed.] Boston, Houghton Mifflin, r886-9r. $14 \mathrm{v}$.

$\mathrm{MdBJ}$

439. Complete writings. Craigie ed. Boston, Houghton Mifflin [1932?] I I v. 33-35334 PS2250.F $32 a$

Includes illustrations by J. S. Sargent, J. La Farge, E. W. Longfellow, and others. First published in 1904.

440. Complete poetical works. Boston, Houghton Mifflin [1893?] 689 p. (Cambridge edition of the poets; edited by H. E. Scudder) 
441. Cambridge ed. Boston, Houghton Mifflin [ ${ }^{\mathrm{C}} 1903$ ] xxi, 689 p. (Cambridge edition of the poets; edited by H. E. Scudder) 40-22245 $\mathrm{PS}_{2250 . \mathrm{FO}_{3} \mathrm{a}}$ "Biographical Sketch" signed: H. E. S. [i. e., Horace Elisha Scudder ].

442. Representative selections, with introd., bibliography, and notes, by Odell Shepard. New York, American Book Co., 1934. lxiv, $371 \mathrm{p}$. $\begin{array}{llll}\text { (American writers series) } & 34^{-1} 324^{\circ} & \text { PS2252.S } 37\end{array}$ "Selected bibliography": p. lvii-lxii.

443. The poems of Henry Wadsworth Longfellow, selected, and edited with a commentary, by Louis Untermeyer. New York, Heritage Press, 1943. xxiii, 444 p. illus. (The American poets; edited by Louis Untermeyer)

$$
\text { 43-12592 } \mathrm{PS}_{2252 . \mathrm{U}_{5}}
$$

444. Favorite poems; with an introd. by Henry Seidel Canby. Garden City, N. Y., Doubleday, 1947. xx, 395 p. illus.

$$
\text { 47-11080 PS2252. } \mathrm{C}_{3}
$$

\section{AUGUSTUS BALDWIN LONGSTREET, $1790-1870$}

Realism and humor are joined in Longstreet's robust newspaper sketches of country and backwoods life in Georgia while the state was still part of the frontier. They provide an early example of earthy humor, frequently expressed in local dialect, which appealed to American taste and set a fashion that culminated in the work of humorists of the West after the Civil War, notably in that of Mark Twain.

446. Georgia scenes, characters, incidents, \&c., in the first half century of the Republic. By a native Georgian. Augusta, Ga. Printed at the S. R. Sentinel Office, $1835.235 \mathrm{p}$.

$$
{ }_{17}-6124 \mathrm{PZ}_{3} \text {.L866G2 RBD }
$$

447. $2 \mathrm{~d}$ ed. With original illus. New York, Harper, 1850.214 p. 18-17312 PZ3.L866Gio RBD

448. New ed., from new plates, with the original illus. New York, Harper, 1897. $297 \mathrm{P}$. 8-26638 PZ3.L866G20

\section{JAMES RUSSELL LOWELL, I819-r891}

Lowell, one of the famous group of literary men in New England which included Holmes and Longfellow among others, was notable for his ver- satility. As a man of the world he was a traveler, at home in England and on the Continent, and as a diplomat at the Spanish and British courts. In these capacities he was noticeably successful in interpreting American democratic ideals to other countries and in bringing back to the United States reflections of the cultural heritage of older nations. He was erudite in humanistic disciplines, so that he was a logical choice to succeed Longfellow in the professorship of modern languages and belles-lettres at Harvard. When The Atlantic Monthly was founded in 1857 he was appointed editor, an office he held until $186 \mathrm{I}$, when the importance of that literary journal was already established. He was also for some years joint editor of The North American Review and was a voluminous contributor to the periodical press of the country. As a writer he was a poet skilled in the techniques of versification, a critic, a humorist, a master of letter-writing and the familiar essay. His ardent interest in public affairs was expressed in his work for the abolition of slavery. Because of his many-sided interests, he is regarded by some critics as the representative American writer of his period. A detailed study of Lowell's early literary career and his literary output, "within the human context of its origins," is found in Leon Howard's Victorian Knight-Errant (Berkeley, University of California Press, 1952. 388 p.).

450. Poems. Cambridge, Mass., J. Owen, 1844 [1843] 279 p. PS2305.AI 1844 RBD

451. —— Cambridge, Mass., J. Owen, I844. $279 \mathrm{P} . \quad 7-279^{\circ} \quad \mathrm{PS}_{2305}$.AI $1844^{\mathrm{a}} \mathrm{RBD}$ Reissue of first edition of the same date.

452. Second series. Cambridge, Mass., G. Nichols, 1848 [ 1847 ] viii, I 84 p. 6-18395 PS2305.AI 1847 RBD

453. Complete poetical works [edited by Horace E. Scudder] Cambridge ed. Boston, Houghton Miffin, 1896 . xvii, $492 \mathrm{p}$.

$$
4^{-1} 3^{8} 31 \quad \text { PS } 2305 \text {.AI } \quad 1896
$$

454. - Boston, Houghton Mifflin, 1917. xvii, 492 p. (Cambridge edition of the poets) $40-37872 \quad P_{2300 . F_{17}}$

455. The vision of Sir Launfal. Cambridge, Mass., G. Nichols, 1848.27 p. 24-I 7590 PS2312.AI 1848 RBD

Characterized by interpretations of nature observed in the New England countryside, by moral teachings concerning the brotherhood of man, and by some of Lowell's most skillful versification; the work that established his reputation as a poet. 
456. The Biglow papers [first series] ... by

Homer Wilbur, A. M., pastor of the First Church in Jaalam . . Cambridge, Mass., G. Nichols, 1848. xxxii, $163 \mathrm{p}$.

6-7135 PS2306.AI 1848 RBD

At head of title: Meliboeus-Hipponax.

Fields, r867. lxxx, $258 \mathrm{p}$.

$$
\text { 23-16620 PS2306.AI } 1867 \text { RBD }
$$

At head of title: Meliboeus-Hipponax.

Satiric pieces, predominantly in verse written in Yankee dialect, called forth by the writer's strong reactions to national problems such as the War with Mexico, the annexation of Texas, slavery, and the preservation of the Union.

458. [A fable for critics] Reader! walk up at once (it will soon be too late) and buy at a perfectly ruinous rate $A$ fable for critics . . . [New York] Putnam $[1848] 78 \mathrm{p}$.

8-26997 PS2309.AI I848 RBD

Rhymed criticisms of contemporary American authors, somewhat in the manner of Lord Byron's English Bards and Scotch Reviewers (1809).

459. Ode recited at the commemoration of the living and dead soldiers of Harvard University, July 2 I, I865. Cambridge, Mass., Priv. print., I865. $25 \mathrm{p} . \quad 50-53826 \quad \mathrm{PS}_{23} \mathrm{I}_{4} . \mathrm{O}_{3} \mathrm{RBD}$

"Fifty copies printed. No. 22."

Immediately after the poem was read Lowell added to it a tribute to Abraham Lincoln as a symbol of democracy and "the first American."

460. Democracy, and other addresses. Boston, Houghton Mifflin, 1887. 245 p. 23-r6635 $\mathrm{PS}_{2322 . D_{4}}$ I887 RBD

The address on democracy, delivered in Birming. ham, England, in 1884, is an example of the way in which Lowell became a spokesman for American life and institutions to other countries; also included is his "Harvard Anniversary" address ( 1886 ) which sets forth his views on the functions of education in a democracy.

46r. American ideas for English readers, with introd. by Henry Stone. Boston, J. G. Cupples, ${ }^{\mathrm{c}} \mathrm{I} 892 . \mathrm{xv}, 94 \mathrm{p}$.

33-37837 PS2322.A5 1892 RBD

Eleven addresses delivered in England from November 6, 1880, to December 23, 1888 .

462. Letters. Edited by Charles Eliot Norton. New York, Harper, I894. 2 v.

$4^{-17167} \mathrm{PS}_{233}$ I.A3N6
Norton later edited an enlarged collection of the Letters, which was included as volumes $14-16$ in both the Elmwood and the de luxe editions of Lowell's Complete Writings. More recently M. A. De Wolfe Howe edited New Letters of James Russell Lowell (New York, Harper, 1932. 364 p.).

463. Anti-slavery papers. Boston, Houghton Mifflin, 1902. $2 \mathrm{v}$. 2-27437 E449.L91

More than 50 articles published in newspapers between 1844 and 1850 ; edited from the manuscripts by W. B. Parker but not included in the collected works cited below.

464. Uncollected poems; edited by Thelma $M$. Smith. Philadelphia, University of Pennsylvania Press, 1950. xxv, $291 \mathrm{p}$.

Bibliography: p. $[28 \mathrm{r}]-283^{5}$.

50-10335 PS2305.S5

Poems rejected by Lowell from his early volumes are not included; but the editor has attempted to collect other printed poems omitted from the Elmwood edition, of which there were a substantial number. No claim is made that these are among the poet's best. It is believed by the editor, however, that the student of Lowell and of American life in the rgth century will find ideas of genuine interest in them. Cf. Preface, p. vii, and Introduction, p. ix.

465. Writings. [Large paper ed.] [Cambridge, Riverside Press, 1890-92] $12 \mathrm{v}$.

$$
\text { 23-16621 PS2300.E9o }
$$

Originally in ro vols., revised by author; v. [ I I12] not numbered, added later by C. E. Norton. Contents.-v. I-4. Literary essays.-v. 5. Political essays.- - v. 6. Literary and political addresses.v. 7-Io. Poems. - [v. II] Latest literary essays and addresses. 1891.- $[\mathrm{v} .12]$ The old English dramatists. 1892 .

466. Complete writings [Elmwood ed.] Boston, Houghton Miffin, r904. I6 v. OCI Includes Horace E. Scudder's Life of James Russell Lowell, 2 v., and Lowell's Letters, edited by C. E. Norton, 3 v.

467. — Ed. de luxe. [Cambridge, Printed at the Riverside Press, 1904] $16 \mathrm{v}$.

$$
\text { 4-22260 } \mathrm{PS}_{2300 \mathrm{FO}_{4}}
$$

Volumes 8, 14-16, edited by C. E. Norton.

Contents.-v. I. Fireside travels.-v. 2. My study windows.-v. 3-5. Among my books.-v. 6 . Political essays.-v. 7. Literary and political addresses. -v. 8. Latest literary essays. The old English dramatists. - v. 9-13. The poetical works.-v. I4-16. Letters, ed. by C. E. Norton. 
468. Representative selections, with introd., bibliography, and notes, by Harry Hayden Clark and Norman Foerster. New York, American Book Co., 1947. clxvi, 498 p. (American writers series)

Bibliography: p. cxliii-clxvi. 47-671 PS2302.C5

469. Essays, poems and letters. Selected and edited by William Smith Clark II. New York, Odyssey Press, 1948. liv, 424 p. (Odyssey series in literature)

Selected bibliography: p. 1-liv.

\section{HERMAN MELVILLE, 1819-1891}

When Melville was a young boy without financial prospects he went to sea to mend his fortunes, being in turn cabin boy, whaler, and enlisted man on a United States frigate. His experiences during this period constituted his higher education and gave him a wealth of material utilized during his career as a writer. The kindness and simplicity of native life in the South Pacific Islands impressed him greatly, as did the arrogance and cruelty of various Americans encountered in his seafaring years. Finally he became a democrat of the most thoroughgoing kind, a strong individualist, a passionate advocate of social justice, a hater of shams and of the evils inherent in slavery, imperialism, and the "divine rights" theory of property. The ferment of these ideas and the impact of his friendship with Hawthorne contributed to the writing of his masterpiece, Moby-Dick. This classic of adventures encountered in the pursuit of whales by New England whalemen is also a metaphysical and symbolic portrayal of the forces of evil that lie in wait for human souls. As such it reflects the climate of thought represented by the work of Emerson, Hawthorne, Thoreau, and Whitman.

471. Typee: a peep at Polynesian life. During a four months' residence in a valley of the Marquesas. New York, Wiley \& Putnam, I846. 2 pts. in I v. (325 p.) (Wiley \& Putnam's library of American books [no. 13])

Sequel: Omoo.

$$
\text { 3-27253 PS2384.T8 1846b RBD }
$$

Romantic fictional narrative of the simple, happy life enjoyed by the cannibal natives and of the hero's exotic adventures among them.

472. London, New York, H. Milford, 1924. xvi, $33^{8}$ p. (The World's classics, 274) $25-26583 \quad \mathrm{PZ}_{3} \cdot \mathrm{M}_{498 \mathrm{~T}_{24}}$

473. New York, Dutton, 1930. x, 286 p. (Everyman's library, edited by Ernest Rhys. Fiction, no. 180) $\quad 36-37236$ ACr.E8, no. 180
474. With an introd. by Raymond $M$ Weaver and illus. by Miguel Covarrubias. New York, Limited Editions Club, 1935. xxviii, 409 p. 35-16595 PS2384.T8 I935 RBD

475. Illustrated by Mead Schaeffer. New York, Dodd, Mead, 1951. viii, 289 p. 51-5640 PZ3.M498T 35 "Sequel containing The Story of Toby": p. 270283.

476. Omoo: a narrative of adventures in the South Seas. New York, Harper, 1847. xv, [I7]389 p. $\quad 42-33235 \mathrm{PS}_{23} 84 . \mathrm{O} 6$ I847a RBD Sequel to Typee.

477. - New York, Dutton, 1925. xiv, 328 p. (Everyman's library, edited by Ernest Rhys. Fiction [no. 297])

Bibliography: p. vii.

$$
\text { 36-37148 ACr.E8, no. } 297
$$

478. Mardi: and a voyage thither. New York, Harper, I849. 2 v.

$$
\text { 7-r7954 } \mathrm{PS}_{23} 8_{4} \cdot \mathrm{M}_{3} \quad \mathrm{r} 849 \mathrm{RBD}
$$

Allegorical romance located in an imaginary world somewhere in Polynesia, in which the writer gives expression to the social, religious, political, and philosophical questions with which he was concerned; these were later much more powerfully developed in Maby-Dick. It is the subject of Merrell R. Davis' monograph, Melville's Mardi, a Chartless Voyage (New Haven, Yale University Press, 1952. 240 p. Yale studies in English, v. II9).

479. White-jacket; or, The world in a man-of-war. New York, Harper, 1850. vii, [9]-465 p. 42-309 I PS2384. W5 RBD

Fictional account of the writer's service on the U. S. man-of-war, United States, and of the abuses, particularly flogging, to which the seamen were subjected; may be contrasted with R. H. Dana's Two Years Before the Mast (1840).

480. With an introd. by Carl Van Doren. London, Oxford University Press, 1929. xx, 380 p. (World's classics, 253)

$$
3_{33-2293^{8}} \mathrm{PZ}_{3} \mathrm{M}_{498} \mathrm{~W}_{36}
$$

481. Moby-Dick; or, The whale. New York, Harper, r851. xxiii, 634 p. 7-17953 PS2384.M6 I85I RBD

An annotated edition of the text of the American first edition has been prepared by Willard Thorp (New York, Oxford University Press, 1947. 532 p.); another edition has an introduction by Newton Arvin (New York, Rinehart, I948. 566 p.). 
Arvin is also the author of Melville's critical biography in the American men of letters series (New York, Sloane, 1950. 316 p.). The Trying-Out of Moby-Dick, by Howard P. Vincent, joint editor of the novel in the Complete Works of Melville, was published by Houghton Mifflin (I949. 400 p.); it "combines a study of the whaling sources of MobyDick, with an account of its composition, and suggestions concerning its interpretation and meaning." Milton O. Percival's A Reading of MobyDick (Chicago, University of Chicago Press, $195^{\circ}$. [136] p.) provides an analysis of the text as an allegory of the problem of good and evil.

Among convenient editions of the novel in reprint series may be mentioned the following:

482. Introd. by Leon Howard. New York, Modern Library, 1950. xxxi, 565 p. (Modern Library college editions, T20)

Bibliographical note: p. xxvii. 50-I I9I4 PZ3.M498Mo6r

483. Introd. by Sherman Paul. New York, Dutton, 1950. xxxv, 664 p. (Everyman's library, r79A. Fiction) 50-58247 $\mathrm{PZ}_{3} \cdot \mathrm{M}_{49} 8 \mathrm{Mo6}_{2}$

An introductory bibliography of Melville's works appears on p. [666-667].

484. The piazza tales. New York, Dix \& Edwards, $1856.431 \mathrm{p}$.

$$
\text { 7-17952 } \mathrm{PS}_{23} 84 . \mathrm{P}_{4} \text { I856 RBD }
$$

Contents. - The piazza.-Bartleby.-Benito Cereno.-The lightning-rod man.-The Encantadas; or, Enchanted islands. - The bell-tower.

For a new edition see entry under Complete Works.

485. The confidence-man: his masquerade. New York, Dix, Edwards, I857. vi, 394 p.

$$
\text { 7-17956 PS2384.C6 1857 RBD }
$$

For a new edition see entry under Complete Works.

486. Battle-pieces and aspects of the war. New York, Harper, $1866 . \quad \mathrm{x}, 272 \mathrm{p}$.

$\mathrm{Al}_{18-98} \mathrm{PS}_{23} 84 \cdot \mathrm{B}_{3} \quad 1866 \mathrm{RBD}$

Poems that commemorate events of the Civil War from Manassas to the victory of the Union forces; includes a supplement in prose dealing with the existing political situation.

487. Billy Budd, and other prose pieces. Edited by Raymond [M.] Weaver. London, Constable, 1924. 399 p. (The works of Herman Melville. Standard edition, v. 13)
First publication of the novel that was written shortly before the author's death; a story of valor and tragedy in the life of an American sailor. The complete text of the work, with variant readings based on Melville manuscripts, was edited by $\mathrm{F}$. Barron Freeman ([Cambridge, Mass.] Harvard University Press, 1948. $38 \mathrm{r}$ p.). An opera in four acts by Benjamin Britten was inspired by the novel, as was a play in three acts by Louis O. Coxe and Robert Chapman (Princeton, Princeton University Press, 195r. 56 p.).

The volume includes also Melville's long, enthusiastic essay on Hawthorne's work, entitled "Hawthorne and His Mosses," in which he compared Hawthorne to Shakespeare and made the famous statements: "Men, not very much inferior to Shakespeare, are this day being born on the banks of the Ohio... Let America, then, prize and cherish her writers; yea, let her glorify them. . . . And while she has good kith and kin of her own, to take to her bosom, let her not lavish her embraces upon the household of an alien."

488. Poems, containing Battle-pieces and aspects of the war, John Marr and other sailors, Timoleon, etc., and Miscellaneous poems. London, Constable, r924. xii, 434 p. (The works of Herman Melville. Standard edition, v. I6)

$$
\text { 25-16079 PS2380.F22, v. I6 RBD }
$$

For a new edition see entry under Complete Works.

489. Journal of a visit to Europe and the Levant, October II, 1856-May 6, I857. Edited by Howard C. Horsford. Princeton, N. J., Princeton University Press, 1955. xiv, 299 p. (Princeton studies in English, no. 35)

Bibliography: p. xiii-xiv.

$$
\text { 54-5005 D919.M58 } 1955
$$

An earlier and very limited edition of Melville's journal for this period is found in Journal $U_{p}$ the Straits, edited by Raymond M. Weaver (New York, The Colophon, 1935. 182 p.). The first publication of two original notebooks, edited by Eleanor $M$. Metcalf, appeared as Journal of a Visit to London and the Continent, 1849-1850 (Cambridge, Mass., Harvard University Press, 1948. I89 p.).

490. Works. Standard ed. London, Constable, 1922-24. $16 \mathrm{v}$.

$\mathrm{PS}_{23} 80 . \mathrm{F}_{22} \mathrm{RBD}$

49r. [Complete works] New York, Hendricks House, 1947.

Note changes of publisher in contents described below: 
Collected poems. Edited by Howard P. Vincent. Chicago, Packard, I947. 548 p. (Complete works, I4) 47-4470 PS2382. 5 Piazza tales. Edited by Egbert S. Oliver. New York, Hendricks House, 1948. 256 p. (Complete works, 9) $\quad 4^{8-9243} \mathrm{PS}_{23} 84 . \mathrm{P}_{4} \mathrm{I}_{948} 8$

Pierre; or, The ambiguities. Edited by Henry A. Murray. New York, Hendricks House, 1949. 514 p. (Complete works, 7) 49-3233 PZ3.M498P 13 Moby-Dick; or, The whale. Edited by Luther S. Mansfield and Howard P. Vincent. New York, Hendricks House, 1952. 851 p. (Complete works) 52-6994 PZ3.M498Mo64

Bibliographical references included in the "Index" (p. $833-85 \mathrm{I}$ ).

The confidence-man: his masquerade. Edited by Elizabeth S. Foster. New York, Hendricks House, 1954. xcv, 392 p. 55-188 $\quad \mathrm{PZ}_{3} \cdot \mathrm{M}_{49} 8 \mathrm{Cp} 3$

Includes an introduction with footnotes; explanatory notes (p. $287-367$ ) based chiefly on the editor's doctoral dissertation on the origin and meaning of the work (Yale, I942); textual notes (p. 367-371); and an Appendix (p. 372-392). Volume number, series note, and blue buckram binding, characteristic details usually found in volumes constituting Complete Works, are absent in the copy described above. It is, therefore, possibly designed to serve as a trade edition having minor variations from the more elaborate set of Complete Works.

492. Representative selections, with introd., bibliography, and notes, by Willard Thorp. New York, American Book Co., 1938. clxi, 437 p. (American writers series) $\quad 38-18635$ PS2382. T5 "Selected bibliography": p. cxxxiii-clxi.

493. Complete stories. Edited with an introd. and notes, by Jay Leyda. New York, Random House, 1949. xxxiv, 472 p. 49-89 I $\mathrm{PZ}_{3} \cdot \mathrm{M}_{498 \mathrm{Co}}$ Includes the short stories in The Piazza Tales and all Melville's known short fiction, the product of his writing in the mid-r85o's. Cf. Introduction, p. xxix.

494. Selected tales and poems. Edited with an introd. by Richard Chase. New York, Rinehart, I950. xxiv, 417 p. (Rinehart editions, 36) Bibliography: p. [xxi]. 5I-244 PS2382.C4

495. The portable Melville. Edited, and with an introd., by Jay Leyda. New York, Viking Press, 1952. xxii, 746 p. (The Viking portable library [58]) $\quad 5^{2-6308}$ PS2382.L4 $_{4}$ “... this collection has... strung the work selected along the thread of the life that produced it . . . Thus ordered, even the portion of his work included here shows unity of purpose and consistency of imagery, though these did not govern the selection."-Introduction, p. xiv.

496. Selected writings: complete short stories, Typee [and] Billy Budd, foretopman. New York, Modern Library, 1952. 903 p. (Modern Library of the world's best books)

5I-I4537 PS2382.M6

A voluminous literature has been inspired by Melville and his writings. Contributions made to these studies within recent years include the following:

497. Chase, Richard V. Herman Melville, a critical study. New York, Macmillan, I949. xiii, $305 \mathrm{p}$. 49-II34I PS2386. 5

Work addressed to scholars, having as its thesis Melville's use of myth and symbol; also emphasized his use of American folklore and background.

498. Gilman, William H. Melville's early life and Redburn. New York, New York University Press, I95I. ix, 378 p. 5I-I2I26 PS2386.G46 Bibliographical references included in "Notes" (p. $[289]-368)$.

499. Hillway, Tyrus, ed. Moby-Dick centennial essays. Edited for the Melville Society, with an introd. by Tyrus Hillway and Luther S. Mansfield. Dallas, Southern Methodist University Press, 1953. xiv, $182 \mathrm{p}$. 53-129I7 $\mathrm{PS}_{23} 8_{4} \cdot \mathrm{M}_{2} \mathrm{H}_{4}$

50o. Howard, Leon. Herman Melville, a biography. Berkeley, University of California Press, I95I. xi, 354 p. 51-62667 PS2386.H6

501. Leyda, Jay, ed. The Melville log; a documentary life of Herman Melville, I8I9-I89r. New York, Harcourt, Brace, 1951. 2 v. (xxxiv, 899 p.)

"The sources": v. 2, p. $84 \mathrm{I}-85^{8}$.

502. Metcalf, Eleanor M., ed. Herman Melville, cycle and epicycle. Cambridge, Harvard University Press, I953. xvii, 3 I I p.

$$
\text { 52-9393 } \mathrm{PS}_{23} 86 . \mathrm{M}_{4} 6
$$

"Letters by, to, and about Melville ... . with ... commentary by Melville's granddaughter."Dust jacket.

503. Rosenberry, Edward H. Melville and the comic spirit. Cambridge, Harvard University Press, r955. x, 21 I p. 55-10976 PS2387.R64 Bibliography: p. [20I]-205. 
504. Stone, Geoffrey. Melville. New York, Sheed \& Ward, r949. ix, 336 p. (Great writers of the world [4])

Bibliography: p. 320-326.

Presents the Roman Catholic point of view.

505. Wright, Nathalia. Melville's use of the Bible. Durham, N. C., Duke University Press, 1949. 203 p. (Duke University publications)

$$
\text { 49-9775 } \mathrm{PS}_{23} 88 . \mathrm{B}_{5} \mathrm{~W}_{7}
$$

506. DONALD GRANT MITCHELL ("IK MARVEL"), I822-1908

A frequent contributor to literary periodicals, a traveler, and a consul abroad, Mitchell conveyed his impressions of Europe and America to American readers in articles and books. He developed a type of fictional essay of sentiment and reflection that enjoyed marked popularity at the mid-century point and later. His most substantial literary work, however, resulted from his passion for nature, landscape gardening, and farming. His experiences in these connections resulted in several books about life at his country home.

507. Reveries of a bachelor; or, A book of the heart. By Ik Marvel [pseud.] New York, Baker \& Scribner, 1850. 298 p.

$$
\text { 4-8631 } \mathrm{PZ}_{3 \cdot \mathrm{M} 692} \mathrm{RBD}
$$

508. Illus. by C. B. Falls. New York, Holborn House, r931. 222 p.

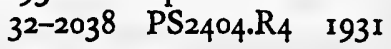

509. My farm of Edgewood: a country book. By the author of Reveries of a bachelor. New York, Scribner, 1863. x, 319 p.

$$
\text { 22- } 15237 \quad \mathrm{~S}_{521 . M 65} \mathrm{I}_{56}
$$

510. Works. [Edgewood ed.] New York, Scribner, 1907. I5 v. illus.

$$
\text { 7-31247 PS2400.A2 } 1907
$$

\section{JAMES KIRKE PAULDING, 1778-1860}

A collaborator of William and Washington Irving in writing Salmagundi (first series, r807-8), Paulding's favorite genre, like that of his contemporary, Cooper, was the historical novel of colonial, Revolutionary, and frontier life. Most successful as a novelist of the Dutch in New York, he was also an essayist, poet, dramatist, and humorist of the "tall-tale" school. Since his politics were those of a liberal democrat, and because he was a strong advocate of an agrarian civilization, he was naturally sympathetic toward the South. His position on the issue of slavery was moderate but without approval. An ardent patriot, whose family fortunes had been ruined in the Revolutionary War, he was engaged from time to time in writing sarcastic replies to criticisms by British travelers in the United States. He was an advocate of a "National Literature," true to nature and reality in America, not marred by the addition of "high-seasoned dishes of foreign cookery."

512. The United States and England. New York, A. H. Inskeep, I815. II 5 .

$$
\begin{array}{r}
9-24530 \quad \mathrm{E}_{16} \cdot \mathrm{I}_{4} 8 \mathrm{RBD} \\
\mathrm{AC} 90 \text { r. } 3 \text {, v. } 57 \mathrm{RBD}
\end{array}
$$

One of a series of controversial, sometimes satiric, works in which the author answers British critics of America; includes also material on politics, government, social life, and customs in the United States.

513. Letters from the South. New York, J. Eastburn, 18r7. 2 v.

$$
\text { Rc-2430 } \mathrm{F}_{230 . \mathrm{P}_{32} \mathrm{RBD}}
$$

514. The Dutchman's fireside. A tale. New York, Harper, 1831. 2 v. (Harper's stereotype ed.) 7-34069 $\mathrm{PZ}_{3} \cdot \mathrm{P}_{2} 82 \mathrm{Du} \mathrm{RBD}$

515. New York, University Pub. Co., [no. 44]) $0-5518 \quad \mathrm{PZ}_{3} \cdot \mathrm{P}_{282} \mathrm{Du} 12$

516. Westward Hol A tale. New-York, J. \& J. Harper, 1832. 2 v.

$$
\text { 7-33782 } \quad \mathrm{PZ}_{3} \cdot \mathrm{P}_{282} \mathrm{~W} \text { RBD }
$$

Novel on the theme of Virginians pioneering in Kentucky.

517. American comedies. By J. K. Paulding and William Irving Paulding. Philadelphia, Carey \& Hart, 1847. 295 p. 28-14875 PS2527.A5 1847 RBD

The first only is by J. K. Paulding.

Contents.-The Bucktails; or, Americans in England.-The noble exile.-Madmen all; or, The cure of love.-Antipathies; or, The enthusiasts by the ears.

518. The lion of the West. Edited and with an introd. by James N. Tidwell. Stanford, Calif., Stanford University Press, 1954. $64 \mathrm{p}$.

$$
\text { 54-12970 PS2527.L5 } 1954
$$

First publication of a play which won the prize offered by James $\mathrm{H}$. Hackett, an actor-producer, for "an original comedy whereof an American should be the leading character." First revised by John A. Stone, and later by William B. Bernard, who changed the title to The Kentuckian; or, $A$ Trip to New York, the play was acted successfully from 
time to time for some 20 years. The manuscript disappeared from view and only now, after nearly a hundred years, it has been located and reproduced from two texts identified as A and B. Said to be the first American comedy to use an uncouth frontiersman as its central character. Cf. Introduction, p. 7-Ir.

519. Works. [New York, Harper, $1834-37]$
14 v. in 7.

520. EDGAR ALLAN POE, I809-1849

In Poe's tragic life the center of interest was not political, social, or philosophical. His art of literary composition and the tales and poems he wrote brought into the mainstream of American romanticism his own love of beauty, mysticism, intensity, and preoccupation with death. In all these absorptions he was influenced by Byron, Shelley, and Coleridge. He is known for his major contribution to the development of the short story as a form of literary art. Modern mystery and horror stories, and often science fiction and even detective stories, owe much to his beginnings, though often unworthily. His lyric poetry is known throughout the civilized world and particularly in Europe, where his work has been repeatedly translated and where he has long been acclaimed a genius of the first order. As a frequent contributor to periodicals and himself the editor of several, he was instrumental in the rise of literary criticism in America, particularly by his "The Philosophy of Composition" ( 1846 ), "The Rationale of Verse" ( 1843 , 1848), "The Poetic Principle" (1850), and by miscellaneous reviews, essays, and studies, a number of which are gathered in his The Literati (1850). Not by any definition a writer concerned with purveying peculiarly "American" themes for a democratic American audience, he nevertheless attained a high position in the national literature by values in his work that are universal. Among the individuals and groups that bear his impress are Ambrose Bierce, Hart Crane, Robert Louis Stevenson, and many of the late Igth-and 2oth-century French poets, including Charles Baudelaire. Baudelaire on Poe, critical papers translated and edited by Lois and Francis E. Hyslop (State College, Pa., Bald Eagle Press, 1952. I75 p.), brings together in convenient form the essays which, together with Baudelaire's translations of Poe, contributed much to the latter's reputation abroad.

52I. Tamerlane and other poems, by a Bostonian. Boston, C. F. S. Thomas, 1827. 40 p. PU
522. - Reproduced in facsimile from the ed. of 1827 , with an introd. by Thomas Ollive Mabbott. New York, Published for The Facsimile Text Society by Columbia University Press, 194I. lxvi p., facsim.: 2 p. I., [iii]-iv, [5]-40 p. (The Facsimile Text Society. Publication no. $5 \mathrm{I}$ )

$$
\text { 4I-588I PS26ro.T3 г827b }
$$

523. Al Aaraaf, Tamerlane, and minor poems. Baltimore, Hatch \& Dunning, 1829. 71 p. 54-50784 PS2610.A6 I829 RBD

524. - Reproduced from the ed. of 1829 , with a bibliographical note by Thomas Ollive Mabbott. New York, Published for The Facsimile Text Society by Columbia University Press, 1933. facsim.: 7 I p. (The Facsimile Text Society, ser. I: Language and literature, v. 9)

$$
\text { 33-3804 PS26ro.A6 r82gb RBD }
$$

525. Poems. 2d ed. New York, E. Bliss, 1831 . I24 p. 55-46240 PS2605.AI I83I RBD Poe called this a second edition because he considered it a revision of Al Aaraaf (1829). The inclusion of new material, however, has caused critics to consider it the first edition of a separate work.

526. - Reproduced from the ed. of 1831 , with a bibliographical note by Killis Campbell. New York, Published for The Facsimile Text Society by Columbia University Press, 1936. facsim.: I24 p. (The Facsimile Text Society. Publication no. 35) 36-8568 PS2605.AI I83 Ia Reproduced from the copy in the Harvard College Library.

Contents.-Dedication.-Letter to $\mathrm{Mr}$. -Introduction.-To Helen.-Israfel.-The doomed city.-Fairyland.-Irene.-A pæan.-The valley Nis.-Al Aaraaf.-Tamerlane.

527. —_ Edited by Killis Campbell. Boston, Ginn, 1917. Ixvi, $332 \mathrm{p}$.

$$
\text { 17-24169 PS2605.AI I917a }
$$

528 Tales of the grotesque and arabesque. Philadelphia, Lea \& Blanchard, 1840. 2 v. 7-35802 PS2612.AI 1840 RBD

529 Tales. New York, Wiley \& Putnam, I845. 228 p. $45-41682$ PS2612.Ar 1845 Contents.-The gold-bug.-The black cat.Mesmeric revelation.-Lionizing.-The fall of the house of Usher.-A descent into the maelström.The colloquy of Monos and Una.-The conversation of Eiros and Charmion.-The murders in the Rue Morgue.-The mystery of Marie Rogét.-The purloined letter.-The man in the crowd. 
530. The raven and other poems. New York, Wiley \& Putnam, r845. 9I p. (Wiley and Putnam library of American books [no. 8]) I8-13432 PS2609. AI I845a RBD

"The Raven" was first published in the Evening Mirror (New York) v. I, no. 97, Jan. 29, 1845, p. [4]. The present collection contains nearly all of the poetry written by Poe up to this time.

531. Eureka: a prose poem. New York, Putnam, 1848. I $43 \mathrm{p}$.

I8-1 1047 PS2620.AI I848 RBD

Elaboration of his lecture on the "Cosmogony of the Universe," delivered in the New York Society Library, Feb. 3, 1848 .

532. Letters. Edited by John Ward Ostrom. Cambridge, Harvard University Press, 1948. 2 v. (xxviii, 664 p.) $\quad 4^{8}-9083 \quad \mathrm{PS}_{2} 6_{3}$ I.A374

"A continuation and an expansion of the editor's $A$ Check List of Letters to and from Poe, published as no. 4 in the Bibliographical series ... of the University of Virginia."

"Bibliography and list of manuscript collections": p. [547]-557.

533. Complete works. Edited by James A. Harrison. [Virginia ed.] New York, Crowell, 1902. $17 \mathrm{v}$ 2-20043 $\mathrm{PS}_{2} 601 . \mathrm{H}_{3} \mathrm{RBD}$

"Bibliography of the writings of Edgar A. Poe": v. 16, p. $[355]-379$.

Contents. - v. I. Biography [by James A. Harrison]-v. 2-6. Tales.-v. 7. Poems.-v. 8-13. Literary criticism.-v. I4. Essays and miscellanies.-v. 15. Literati. Autography.-v. I6. Marginalia. Eureka.-v. I7. Poe and his friends. Letters relating to Poe.

534. Representative selections, with introductions, bibliography, and notes; begun by Margaret Alterton and completed by Hardin Craig. New York, American Book Co., 1935. cxxxvi, 563 p. (American writers series) 35-I1900 PS2603.A6 "Selected bibliography": p. cxix-cxxxiii.

535. Edgar Allan Poe, selected and edited, with an introd. and notes, by Philip Van Doren Stern. New York, Viking Press, r945. xxxviii, 664 p. (The Viking portable library)

$$
45^{-8508} \quad \mathrm{PS}_{2} 602 . \mathrm{S}_{75}
$$

536. Complete poems and stories, with selections from his critical writings. With an introd. and explanatory notes by Arthur Hobson Quinn; texts established, with bibliographical notes, by Edward H. O'Neill. Illustrated by E. McKnight Kauffer. New York, Knopf, 1946. 2 v. (542,
543-I092 p.) $4^{6-7971} \mathrm{PS}_{2601 . Q 5}$

"Bibliographical and textual notes": v. 2, p. [1055]-r087. Bibliography: v. 2, p. [ro89]-rog2.

537. Selected prose and poetry. Edited, with an introd. by W. H. Auden. New York, Rinehart, 1950. xxvi, 528 p. (Rinehart editions, 42) 5I-2058 PS2602.A8

"Textual and bibliographical note": p. xxi-xxiii.

538. Selected poetry and prose. Edited with an introd. by T. O. Mabbott. New York, Modern Library, 195r. xix, 428 p. (Modern Library college editions, $\mathrm{T}_{5} 8$ )

Bibliography: p. xv-xvi.

51-5396 $\mathrm{PS}_{2} 602 . \mathrm{M}_{3}$

Text based chiefly on Harrison's Virginia edition of Poe's works. Includes among the prose pieces the following: Instinct vs Reason-A Black Cat [recently discovered]; The Philosophy of Composition [1846]; Tale-Writing-Twice-Told Tales [etc.] by Nathaniel Hawthorne [1842]; and The Poetic Principle, a lecture frequently delivered by Poe but not published until i 850 .

Among recent historical and critical studies that contribute to an understanding of Poe's place in American literature are the following:

539. Braddy, Haldeen. Glorious incense; the fulfillment of Edgar Allan Poe. Washington, Scarecrow Press, 1953. 234 p.

Includes bibliography.

$$
\text { 53-7181 } \mathrm{PS}_{26} 6_{3} \mathrm{~B}_{7}
$$

Designed as a survey of critical writing about Poe, ca. I850-1950, and an evaluation of the survival value of his work. For John Ostrom's criticism see American Literature, v. 25, Jan. 1954, p. 508-509.

540. Chivers, Thomas Holley. Life of Poe; edited with an introd. by Richard Beale Davis, from the mss. in the Henry E. Huntington Library, San Marino, Calif. New York, Dutton, 1952. 127 p. 52-5295 PS2631.C53

Bibliographical references included in "Explanatory notes" (p. IOI-I2I).

541. Fagin, Nathan B. The histrionic Mr. Poe. Baltimore, Johns Hopkins Press, I949. xiii, $289 \mathrm{p}$.

Bibliography: p. 24 I-254. 49-9270 $\mathrm{PS}_{26} 6_{31} \mathrm{~F}_{3}$

\section{HENRY WHEELER SHAW ("JOSH BIL- LINGS"), I 81 8-1885}

Shaw's aphorisms and stories, published under the pseudonym of "Josh Billings," were part of the 
humorous literature that rose in popularity in the mid-nineteenth century, to which Lincoln and other notables were devoted. Born in Massachusetts, Shaw traveled and worked as a steamboat captain in what was then the West, and finally settled in New York. These varied experiences gave him wide familiarity with the sayings, jokes, and folk speech of different regions. They formed the background from which his social satire developed, and for the dialects and outlandish spellings that gave delight to his readers. His popularity was such that for Io years he was able to maintain Josh Billings' Farmer's Allminax (1870-80) as a repository for his proverbial wit and wisdom. He was also much in demand as a lecturer, thus foreshadowing Mark Twain's later success with spoken humor.

543. Josh Billings, hiz sayings. With comic illus. New York, Carleton, $1866.232 \mathrm{p}$. 12-10995 PN6161.S535 RBD

Not the first publication of the sayings, but issued after his adoption of unusual spelling had increased the popularity of his work.

544. Complete works. With one hundred illus. by Thomas Nast and others, and a biographical introd. Rev. ed. Chicago, M. A. Donohue, 1919. xxxii, $504 \mathrm{p}$.

$$
\text { 36-34515 PN6r6r.S5317 } 1919
$$

545. Uncle Sam's Uncle Josh: or, Josh Billings on practically everything, distilled from Josh's rum-and-tansy New England wit by Donald Day. Boston, Little, Brown, 1953. 243 p.

$$
\text { 53-5263 } \mathrm{PS}_{2} 806 . \mathrm{D}_{3}
$$

\section{WILLIAM GILMORE SIMMS, $1806-1870$}

It has been suggested that Simms might be called the Cooper of the South, because he achieved recognition second only to Cooper's when writing in the same genre. Using Georgia, Mississippi, and Kentucky, but principally his native South Carolina, as the settings for his romantic novels, he treated three subjects derived from American history: the frontier; Indian warfare; and the Revolutionary War. Concerning the last subject his work is most fully sustained, although his frontier criminals are powerfully if sensationally portrayed, and his treatment of Indian character is informed and dramatic. His minor and comic characters, particularly the well-known Lieutenant Porgy, are counted among his best achievements. Simms' place in literature is that of a novelist; but in the additional capacities of editor, commentator on society and politics, biographer, and poet he became known to contemporary northern "literati." His theory of American writing emphasized the development of a literature culturally emancipated from that of England and devoted chiefly to themes native to the United States.

547. The partisan; a tale of the Revolution. New York, Harper, 1835. 2 v.

8-13055 PS2848.P2 1835 RBD

First of a trilogy on the South Carolina campaigns in the Revolutionary War; continued in Mellichampe (New York, Harper, 1836. 2 v.), which in turn was followed by Katharine Walton (Philadelphia, A. Hart, 185r. 2 v.).

548. The Yemassee. A romance of Carolina. New York, Harper, 1835.2 v.

$$
\begin{array}{llll}
8-8999 & \text { PS } 2848 . Y_{5} & \text { 1835 } & \text { RBD }
\end{array}
$$

549. - Edited, with introd., chronology, and bibliography, by Alexander Cowie. New York, American Book Co., 1937. xliv, 406 p. (American fiction series; general editor, $\mathrm{H}$. $\mathrm{H}$. Clark) $\quad 37-408_{3} \quad \mathrm{PZ}_{3} . \mathrm{S}_{592} \mathrm{Y}_{34}$

Indian warfare in South Carolina provides the theme. In Cowie's edition the text is that of the I 853 edition, which was slightly corrected by the author.

550. Beauchampe; or, The Kentucky tragedy. Philadelphia, Lea \& Blanchard, 1842. 2 v. 29-25298 $\mathrm{PZ}_{3} \cdot \mathrm{S}_{592} \mathrm{~B}_{2} \mathrm{RBD}$

Plot is based on the same murder case that was the inspiration of C. F. Hoffman's Greyslaer (1840); later Simms wrote Charlemont (New York, Redfield, 1856. 447 p.) for which Beauchampe serves as a sequel. Both are frontier or border novels.

551. Views and reviews in American literature, history and fiction. Ist [and 2d] series. New York, Wiley \& Putnam, 1845.2 v. in I. $(238$, 184 p.) (Wiley and Putnam's library of American books [no. 9]) 30-1722I PS2850.V5 I845 RBD

552. The forayers; or, The raid of the dog-days. New York, Redfield, I855. 560 p.

8-13063 PS2848.F6 1855 RBD

This book and its sequel Eutaw (New York, Redfield, 1856.582 p.) are novels of the American Revolution. The action takes place in South Carolina.

553. - New and rev. ed. New York, J. W. Lovell, $1885.560 \mathrm{p}$. (Lovell's library, v. 13, no. 697) I0-1290 PS2848.F6 I885 RBD

554. Letters; collected and edited by Mary C. Simms Oliphant, Alfred Taylor Odell [and] T. C. Duncan Eaves. Introd. by Donald Davidson. Biograpical sketch by Alexander S. Salley. Colum- 
bia, University of South Carolina Press, 1952-55. 4 v. $\quad$ 52-2352 PS2853.A 1952 Bibliographical footnotes.

ConTENTs.-V. I. 1830-1 844.-v. 2. 1845-1849.v. 3. $1850-1857$.- -v. 4. $1858-1866$.

To be completed with the publication of volume 5 .

555. Works. Uniform ed. Illustrated by Darley. New York, W. J. Widdleton, I853-66. $20 \mathrm{v}$. NRU

Volumes 8-13 have half title: Border novels and romances of the South, v. $1-6$.

Incomplete collection, omitting particularly biographical, historical, critical, and miscellaneous writings.

\section{CHARLES HENRY SMITH ("BILL ARP"), 1826-1903}

Smith, a Georgia lawyer, politician, and planter, was a Confederate officer in the Civil War, and was for many years a contributor to the Atlanta Constitution. He wrote partly in the illiterate dialect of a "Cracker," and partly in more literary style as a rustic philosopher and satirist whom he called "Bill Arp." His sketches and stories, however humorous, give an insight into Southern problems and attitudes during the war and Reconstruction and into the racial and agrarian questions that troubled his region. Tolerance, narrative skill, good feeling, and some clever delineations of character have contributed to the preservation of his reputation as a humorist of a type exemplified in the 2oth century by Will Rogers (1879-1935). Autobiographical elements are present in Smith's Bill Arp: From the Uncivil War to Date (1930). The Farm and the Fireside (1891) contains "sketches of domestic life in war and peace."

557. Bill Arp, so called. A side show of the southern side of the war. Illustrated by M. A. Sul-

livan. New York, Metropolitan Record Office, I 866. 204 P. I2-I 4838 PN6I6r.S653 RBD

Parts of the book are written in the form of letters addressed to Abraham Lincoln, "Artemus Ward," and others.

\section{SEBA SMITH ("MAJOR JACK DOWN- ING"), I 792-I 868}

A true Yankee from the state of Maine, Smith used his invention, a homely country character named Jack Downing, as the mouthpiece for his own humorous but shrewd judgments of faults in contemporary politics and life during the era of Jacksonian democracy. Characterized by portrayals of peculiarities in the speech and manners of rural
New England, Smith's work captured the attention of a large audience and was instrumental in establishing a genre used by his immediate successors as well as by such more recent humorists as Finley Peter Dunne and Will Rogers.

559. The life and writings of Major Jack Downing [pseud.] of Downingville, away Down East in the State of Maine. Boston, Lilly, Wait, Colman \& Holden, I833. xii, $260 \mathrm{p}$.

$$
\text { 12-5647 PS2876.L68 1833. RBD }
$$

Comprises material originally published in the Portland Daily Courier, a newspaper founded by Smith.

560. - 3d ed. Boston, Lilly, Wait, Colman \& Holden, 1834 . xvi, $288 \mathrm{p}$. 30-29693 PS2876.L68 1834 RBD

56r. Way Down East; or, Portraitures of Yankee life. By Seba Smith, the original Major Jack Downing. New York, J. C. Derby, I854. $3^{84}$ p. 3-24500 PS2876.W 3 I 854 RBD

Tales having New England local color interest. Smith had numerous imitators who even borrowed the name of Major Downing as their own pseudonym; hence the claim to original authorship in the foregoing entry.

\section{HARRIET (BEECHER) STOWE, I8II- 1896}

To the crusade for the abolition of slavery in America one of the most effective contributions was Mrs. Stowe's novel, Uncle Tom's Cabin. Melodramatic and sentimental, it nevertheless possessed the power to appeal to the conscience of the world and thus became a highly significant document of the controversy over slavery. The book has been many times dramatized and has had a phenomenal record as a best seller in England, on the Continent, and in the United States, long after the abuses it was written to uncover had ceased to exist. Mrs. Stowe was a tireless and voluminous writer of miscellaneous works. These include regional novels, sketches, and stories, sometimes expressed in New England dialect, and having as their local particularly Maine, Massachusetts, and Connecticut. Numerous autobiographical and biographical elements in them reflect Calvinistic influences in the writer's background. The books are also characterized by realism concerning village and seafaring life prevalent in New England in the 18th century, a period that the author believed to be seminal in the life of the region and America. Charles H. Foster in The Rungless Ladder: Harriet Beecher Stowe and New England Puritanism (Durham, N. C., Duke Uni- 
versity Press, I954. $27^{8}$ p.) concludes that Mrs. Stowe's most important achievement was her ability to give readers a clear sense of New England Puritanism, while arousing sympathy based on understanding of its causes and results.

563. Uncle Tom's cabin; or, Life among the lowly. Boston, J. P. Jewett, I 852.2 v. I2-15048 $\mathrm{PZ}_{3} . \mathrm{S} 89 \mathrm{Un} \mathrm{RBD}$

First published in the National Era at Washington from June 1851 to April 1852 .

564. Thirtieth thousand. Boston, J. P. Jewett, $1852.2 \mathrm{v}$. 18-16942 PS2954.U5 I852c RBD

565. - New ed. With an introductory account of the work by the author. Boston, Houghton Mifflin, 1887 [ ${ }^{\mathrm{C}} \mathrm{1} 879$ ] xlii, $500 \mathrm{p}$. 5 ${ }^{\mathrm{I}-4870 \mathrm{I}} \mathrm{PZ}_{3} . \mathrm{S} 89 \mathrm{Un}_{30}$

566. —_ With an introd. by Raymond [M.] Weaver. New York, Limited Editions Club, 1938. xv, $294 \mathrm{p}$.

39-14273 PS2954.U 51938 RBD

Illustrated by Miguel Covarrubias.

567. - With introductory remarks and captions by Langston Hughes. New York, Dodd, Mead, r952. 442 p. illus. (Great illustrated classics) 52-12396 $\mathrm{PZ}_{3} . \mathrm{S}_{9} \mathrm{Un}_{77}$

568. The minister's wooing. New York, Derby \& Jackson, 1859. 578 p.

8-16122 PS2954.M5 I859 RBD

569. - 24th ed. Boston, Houghton Mifflin, 1887. 578 p. $\quad 12-37862 \mathrm{PZ}_{3} .589 \mathrm{Mi} 8$

570. The pearl of Orr's Island: a story of the coast of Maine. Boston, Ticknor \& Fields, 1862. $437 \mathrm{p}$. 8-16118 $\quad \mathrm{PZ}_{3} . \mathrm{S} 89 \mathrm{P}$

571. 3oth ed. Boston, Houghton Mifflin, 189o. 437 p. $\quad$ 8-16117 $\mathrm{PZ}_{3 . S 89 P_{30}}$

572. Oldtown folks. Boston, Fields, Osgood, 1869. viii, 608 p. 8-16119 PZ3.S89o

573. $-25^{\text {th }}$ ed. Boston, Houghton Mifflin, 1883. viii, $608 \mathrm{p}$.

$$
\text { 42-27103 } \mathrm{PZ}_{3} \cdot \mathrm{S} 8903
$$

574. Sam Lawson's Oldtown fireside stories. Boston, J. R. Osgood, 1872.216 p.

$$
\text { 8-16II4 PZ3.S89s }
$$

575. $287 \mathrm{p}$. Boston, Houghton Miflin, 1899. o-70 I $\mathrm{PZ}_{3} . \mathrm{S}_{9} \mathrm{~S}_{4}$

Includes four additional pieces.

576. Poganuc people: their loves and lives. New York, Fords, Howard, \& Hulbert [1878] $375 \mathrm{p}$.

8-16115 $\mathrm{PZ}_{3 . S 89 \mathrm{Po}}$

577. Life of Harriet Beecher Stowe, compiled from her letters and journals by her son, Charles Edward Stowe. Boston, Houghton Mifflin, 1889. xii, 530 p. illus. $\quad 16-7887$ PS2956.A3 1889 See also Life and Letters of Harriet Beecher Stowe, edited by Annie Fields (Boston, Houghton Mifflin, 1897. 406 p. 4-I7386 PS2956.F5 1897).

578. Writings, with biographical introductions ... [Cambridge, Mass., Riverside Press, 1896] $16 \mathrm{v}$. illus. 28-5720 PS2950.E96a RBD

\section{DANIEL PIERCE THOMPSON, 1795- 1868}

A devoted citizen of Vermont, with strong antiquarian interests, Thompson wrote some half-dozen historical novels on themes such as frontier life in the state and on patriotism in Vermont during the American Revolution. His work belongs to the tradition inaugurated in America by Cooper and illustrates the spread of interest in historical "romances" concerned with different parts of the country.

580. The Green Mountain Boys. Montpelier, Vt. E. P. Walton, I839. 2 v.

$\mathrm{CtY}$

Ethan Allen's capture of Fort Ticonderoga is featured in the work, which is said to have gone through 50 editions before 1860 ; for many years it was considered a classic American historical novel for boys.

581. - New York, J. W. Lovell [1882] 2 v. in 1 ( 360 p.) (Lovell's library, v. I, no. 2I) CA10-1621 PZ3.T3725Gr7

582. — New York, T. Nelson, 1927. 485 p. illus. $\quad 27-277^{87} \quad \mathrm{PZ}_{3} \cdot \mathrm{T}_{3725} \mathrm{Gr20}$

583. Locke Amsden; or, The schoolmaster, a tale. Boston, B. B. Mussey, 1847. 231 p.

49-32096 PZ3.T3725Lo

Regional novel influenced by the author's early struggles to secure an education and by his boyhood experiences of life and labor on a remote Vermont farm under pioneer conditions.

584. Boston, Hall \& Whiting, I88I. 


\section{HENRY DAVID THOREAU, I8 $17-1862$}

Thoreau, a natural "solitary" and member of Emerson's Concord circle of Transcendentalists, in his own experience realized many of the ideals of his associates in the group. In view of that fact, the 39 notebooks containing his journal, which came to light after his death, constitute not only his own spiritual autobiography but also a highly individual record of literary thought in New England at the time of the American Renaissance. Fruitlands and Brook Farm failed as Transcendentalist experiments in communal living; but Thoreau's individual venture at $\mathrm{Walden}$ Pond enabled him to push the doctrine of simplification to its limits and to add a classic to the literature of his region. Nature, with which he was perhaps more intimate than with any human being, provided him, as Emerson thought it should, with the enjoyment of "an original relation to the universe." From that relation he derived the inspiration for his most sustained literary work. The results are preserved in several volumes of prose showing the discipline of wide reading, particularly in English literature of the 17 th century. As a political thinker and a social philosopher he expressed his belief in freedom and individualism, even when the search for these objectives of the good life involved civil disobedience. Like Emerson, Thoreau was a poet, whose poems, according to his own dictum, are "a piece of very private history, which unostentatiously lets us into the secret of a man's life." For his contributions to The Dial and other journals, and for his longer publications in their earlier appearances, Thoreau received qualified approval, chiefly from the Concord circle. Writing shortly after his death Lowell mixed praise with blame for his oddities, in almost equal proportions. But time has reversed the earlier verdicts. On the basis of his notable additions to an authentic American literary tradition his reputation has grown steadily among the reputations of world figures in literature.

586. [Civil disobedience] Resistance to civil government; a lecture delivered in 1847 . In Aesthetic papers, edited by Elizabeth P. Peabody. New York, Putnam, I849. p. 189-213.

$$
\text { 5-3424 } \mathrm{AP}_{2 . \mathrm{A}_{27} \mathrm{RBD}}
$$

For useful reprints of this essay, see the last entry under Walden below, and volumes of selections listed by Bode, Canby, Cargill, and Crawford.

587. A week on the Concord and Merrimack Rivers. Boston, J. Munroe; New York, Putnam, 1849. $4^{\mathrm{I}} 3 \mathrm{p}$. 8-14408 $\mathrm{F}_{72} \mathrm{C}_{5} \mathrm{~T}_{4} \mathrm{RBD}$

588. Edited with an introd. by Odell Shepard. New York, Scribner, I921. xxviii,
292 p. (Modern student's library [edited by W. D. Howe]) 2I-9999 $\mathrm{F}_{72 . \mathrm{C}_{5} \mathrm{~T}_{56}}$

589. Walden; or, Life in the woods. Boston, Ticknor \& Fields, 1854. 357 p.

$$
\text { 15-2573. PS } 3048 \text {.A1 } 1854 \text { RBD }
$$

$A$ Centennial Check-List of the Editions of Henry David Thoreau's Walden has been prepared by Walter R. Harding (Charlottesville, Va., University of Virginia Press, 1954. 32 p.).

590. With an introd. by Joseph Wood

Krutch. New York, Harper, r950. xii, 440 p. (Harper's modern classics)

50-6285 PS3048.AI I950a

59r. Walden and other writings. Edited with an introd. by Brooks Atkinson. New York, Modern Library, 1937. xx, 732 p. (Modern Library of the world's best books) $37-28676 \quad$ PS $_{3} 0_{42 .}$ A $_{7}$

Issued $195^{\circ}$ as $\mathrm{T}_{35}$ in Modern Library college editions.

592. Walden, and selected essays. Introd. by George F. Whicher. Chicago, Packard, 1947. xxii, $4^{8} 3$ p. (University classics)

$$
47-725^{8} \quad \mathrm{PS}_{3042 . \mathrm{W}_{5}}
$$

593. Walden; or, Life in the woods. On the duty of civil disobedience. Introd. by Norman

Holmes Pearson. New York, Rinehart, 1948. xii, 304 p. (Rinehart editions, 8)

$$
\text { 48-8445 PS3048.AI } 1948
$$

594. The Maine woods. Boston, Ticknor \& Fields, I 864. 328 p. I-8882 F27.P5 $T_{43}$ RBD Edited by Sophia Thoreau and William E. Channing.

The first of the papers was published in the Union Magazine, New York, in 1848; the second in The Atlantic Monthly in 1858; and the last is here first printed.

Contents.-Ktaadn.-Chesuncook.-The Allegash and east branch.

595. With an introd. by Annie Russell Marble. New York, Crowell, I906. xv, 359 p. (Handy volume classics) 6-23057 F24.T494

596. Cape Cod. Boston, Ticknor \& Fields, I 865 . $252 \mathrm{p}$ 3-21052 $\mathrm{F}_{72 . \mathrm{C}_{3} \mathrm{~T}_{37} \mathrm{RBD}}$

Ediied by Sophia Thoreau and William Ellery Channing; first four chapters published in Putnam's Magazine in 1855; the fifth and eighth chapters appeared in The Atlantic Monthly in October and December 1864 . 
597. With an introd. by Annie Russell Marble. New York, Crowell, 1907. xiii, 263 p. (Astor prose series) $7-37720 \quad \mathrm{~F}_{72} \cdot \mathrm{C}_{3} \mathrm{~T}_{42}$

598. Collected poems. Edited by Carl Bode. Chicago, Packard, 1943. xxi, $385 \mathrm{p}$.

First critical edition.

$$
\text { 43-1227 } \quad \mathrm{PS}_{3041 . B 6} \text { 1943a }
$$

599. Writings. With bibliographical introductions and full indexes. In ten volumes. [Riverside ed.] [Boston, Houghton Mifflin, I89495] 11 v. $\quad{ }^{4-13875} \quad \mathrm{PS}_{3040 . E 94}$ Volumes $5^{-8}$ edited by Harrison G. O. Blake. First collected edition; introductory notes by Horace E. Scudder. The Familiar Letters (1894) edited by Franklin B. Sanborn, were added as an I Ith volume. Cf. Francis $\mathrm{H}$. Allen, $A$ Bibliography of Henry David Thoreau (Boston, Houghton Mifflin, 1908).

600.

ton Mifflin, 1906. $20 \mathrm{v}$.

6-4618 PS $3040 . F 06$

Volume [6] includes Familiar Letters edited by Franklin B. Sanborn, enl. ed.; volumes [7-20] contain Thoreau's Journal, edited by Bradford Torrey.

6or. [Walden ed.] Boston, Houghton Mifflin, 1906. $20 \mathrm{v}$. $\mathrm{MH}$

The standard Walden edition was printed from the plates of the Manuscript edition. Cf. Literary History of the United States (no. 2460).

602. [New Riverside ed.] With bibliographical introd. and full indexes. Boston, Houghton Mifflin [1932?] II v.

$$
\text { 33-16767 } \mathrm{PS}_{3040 . \mathrm{F}_{32}}
$$

603. The heart of Thoreau's journals, edited by Odell Shepard. Boston, Houghton Mifflin, 1927. xiii, $34^{8}$ P. 27-23170 PS $_{3053 . A 25} 1927$

604. Henry David Thoreau; representative selections, with introd., bibliography, and notes, by Bartholow V. Crawford. New York, American Book Co., ${ }^{c}$ 1934. lxxii, 379 p. (American writers $\begin{array}{lll}\text { series) } & 34-23823 & \mathrm{PS}_{3042 . C_{7}}\end{array}$ "Selected bibliography": p. lix-lxix.

605. Works. Cambridge ed. Selected and edited by Henry S. Canby. Boston, Houghton Mifflin, 1937. xviii, $848 \mathrm{p}$.$$
\text { 37-28734 } \quad \mathrm{PS}_{3042 . \mathrm{C}_{3}} \quad 1937
$$

606. Works. With a biographical sketch by Ralph Waldo Emerson. New York, Crowell, 1940. 3I, [2], 440,319, [2], 492, $423 \mathrm{p}$.

$$
4^{0-27855} \mathrm{PS}_{3040 . F_{40}}
$$

Contents.-Biographical sketch, by R. W. Emerson.-Walden.-Cape Cod.-A week on the Concord and Merrimack Rivers.-The Maine woods.

607. The portable Thoreau. Edited, and with an introd., by Carl Bode. New York, Viking Press, 1947. viii, 696 p. (The Viking portable library)

Bibliography: p. $695-696$.

608. Selected writings on nature and liberty; edited with an introd., by Oscar Cargill. New York, Liberal Arts Press [1953, ${ }^{\circ} 1952$ ] xx, 163 p. (The American heritage series, no. 3 )

$$
\text { 53-942 } \mathrm{PS}_{3042 . \mathrm{C}_{34}}
$$

“A reader's vocabulary, edited by Dr. Fritz A. H. Leuchs" published as supplement (28 p.) and inserted at end.

Bibliography: p. xix-xx.

Recent studies that document contemporary critical opinion concerning Thoreau include:

609. Cook, Reginald L. Passage to Walden. Boston, Houghton Mifflin, 1949. xvi, $238 \mathrm{p}$. $49-8084 \quad \mathrm{PS}_{3057 . \mathrm{N}_{3} \mathrm{C} 6}$

Essays aiming to "penetrate the essential quality and evoke the richness of his correspondence with nature."

6ro. Harding, Walter R., ed. Thoreau: a century of criticism. Dallas, Southern Methodist

University Press, 1954. 205 p. 55-II $6 \mathrm{PS}_{3054} \cdot \mathrm{H}_{3}$

Twenty-four essays by such varied writers as J. $R$. Lowell, R. W. Emerson, R. L. Stevenson, Henry Miller, and Alfred Kazin.

6I I. Seybold, Ethel. Thoreau; the quest and the classics. New Haven, Yale University Press, 1951. $\mathrm{x}, 148$ p. (Yale studies in English, v. 116) $5^{1-1} 77^{x} P_{3057 . L 55 S_{4}}$ $\mathrm{PR}_{13}$. Y 3 , v. 116

Bibliographical footnotes.

Begun as a dissertation with the aim of investigating Thoreau's classicism, the work is also designed as an inquiry into the essential meaning of his life and thought. See also Appendixes as follows: "Classical Books Used by Thoreau," p. [91 ]102; "Classical Quotations in Thoreau," p. [103]123; and "Index of Classical Quotations, References, and Allusions," p. [124]-14I. 


\section{THOMAS BANGS THORPE, $1815-1878$}

Born and educated in Massachusetts, Thorpe for reasons of health spent nearly 20 years of his life in Louisiana. During that time he formed a deep affection for the South and for the whole southwestern frontier, over which he traveled widely. An artist and portrait painter patronized by distinguished people, an informed student of politics, a historian of sorts, and an editor and promoter of newspapers, Thorpe brought unusual powers of observation and understanding to bear on what he saw about him. The prairies, forests, animals, country people, speech, manners, and folklore of the region fascinated him. The stories and sketches that preserve his firsthand impressions are characterized by romance, realism, and robust humor.

6r3. The hive of "the bee-hunter," a repository of sketches, including peculiar American character, scenery, and rural sports. New York, Appleton, 1854 . 312 p. illus.

15-II538 F $_{396 . T_{5}}$ RBD

Includes "Tom Owen, the Bee-Hunter," p. [47]53; and Thorpe's most admired tale, "The Big Bear of Arkansas," p. [72]-93, which was first written for and published in the Spirit of the Times (New York, 183I-6I), v. 9, Mar. 27, I84I, p. 43-44.

\section{HENRY TIMROD, 1828-1867}

Timrod was a member of a literary group in Charleston, South Carolina, where he was associated with Simms and Hayne. His "Theory of Poetry" (1863-64), first published in The Atlantic Monthly, v. 96, Sept. 1905, p. 313-326, sets forth objections to Poe's definitions of poetry and indicates the serious interest in poetics felt by the southern group before the Civil War. Timrod's one volume of verse published in those years reveals his characteristically sensitive response to nature. Later, animated by intense love of the South, he became the poet of the Confederacy. His odes and other poems of the war years express the powerful emotions of the Southern people, in verse forms influenced by English romantic poetry of the roth century.

615. Poems. Boston, Ticknor \& Fields, I860. I30 p. 39-13915 PS3070.A2 I860 RBD

616. The poems of Henry Timrod. Edited, with a sketch of the poet's life, by Paul H. Hayne.

New York, E. J. Hale, 1873. 205 p.

$$
\text { 8-24837 PS3070.A2 } 1873 \text { RBD }
$$

617. - Memorial ed. With memoir and portrait. Boston, Houghton Mifflin, 1899. xxxviii, I93 p. 99-1766 PS3070.A2 1899

6r8. Essays. Edited with an introd. by Edd Winfield Parks. Athens, University of Georgia Press, 1942. vi, 184 p. $\quad 42-18682$ PS3071.P 3 Deals with literature in the South, and particularly with theories of poetical form and composition.

\section{WALT WHITMAN, 1819-1892}

English, Dutch, and Quaker strains converged in Whitman's heredity. The son of a New York farmer turned carpenter, he was formally educated only through the elementary grades. He was in turn office boy, printer, itinerant country school teacher, and journalist. At the age of thirtysix he put on sale the first edition of his poems, Leaves of Grass. In this and successive editions, it is clear that Whitman saw nature "with every leaf a miracle," and human beings, including the lowly and the common, as the very stuff of which poetry could be made "to define America, her athletic democracy." He took inspiration from the Concord circle and from the general, liberal romanticism of the first half of the Igth century; but by natural bent he became a forerunner of the realism that began to characterize American literature after 1870. The poetic technique he developed also had old derivations and new foreshadowings. A source of the cadences heard in his poetry is found in the majestic lines of the King James Bible; his loose rhythmic form was the fountainhead of the "free verse" of the 1920's. Language as used in America fascinated him, and the "barbaric yawp" of which he boasted included slang, oddly worded catalogs of things, strained invocations, mongrel words, and tags from foreign languages. At the other extreme, however, his diction often approaches classic purity. In a mixture of both modes, he chanted the glory of democracy, the beauty of love and comradeship, the life of the American people, and the infinite variety of the country. The result was shocking to most American readers of the period, who equated it with vulgarity. His pungent vocabulary, forceful style, bathos joined to beauty, egotism, license, and boisterous optimism for a long time offended the refined and elegant members of society. Some of his poems dealing with sex were so startlingly direct that to Thoreau they sounded "as if the beasts spoke." On the other hand, the middle classes, whose spokesman Whitman desired to be, were puzzled and put off by his mysticism and Transcendentalism. In spite of the contradictory elements in his work, time has accorded him a high place in American letters, as well as among the greatest spokesmen for democ- 
racy. His force was such that it has been felt around the world.

620. Leaves of grass. Brooklyn, $1855.95 \mathrm{p}$.

First edition.

$$
\text { 3-23679 PS } 3201 \text { I } 855 \text { RBD }
$$

Includes the famous first preface, omitted in the same form from later editions. In it Whitman glorifies the United States as being in themselves the greatest poem, extols the poet as a seer, and calls the highest poetic art that which is simplest and most natural.

From 1855 to $188 \mathrm{I}$ when the poet made the final revision of the text, Leaves of Grass grew in succeeding editions from its original slender dimensions to a work of 438 pages. For the history and significance of this evolution see Gay W. Allen's Walt Whitman Handbook (Chicago, Packard, 1946), p. 104-235, and Oscar L. Trigg's "The Growth of 'Leaves of Grass'," found in The Complete Writings of Walt Whitman, book-lover's Camden edition, "Prose Works," v. 7, i.e. v. [10] of The Complete Writings, p. 99-1 34 .

$62 \mathrm{I}$.

$$
\text { Brooklyn, } 1856 . \quad 384 \mathrm{p} \text {. }
$$

Second edition.

$$
\text { 3-23702 PS } 3201 \quad 1856 \mathrm{RBD}
$$

Published by Fowler and Wells, New York, without publisher's statement on the title page; sale was later abandoned by the firm on account of criticism.

Adds 20 new poems to 12 in the first edition and has lettered on the backstrip: "I greet you at the beginning of a great career, R. W. Emerson." This unauthorized quotation was taken from a letter written by Emerson to acknowledge a complimentary copy of the first edition.

622. Boston, Thayer \& Eldridge, Year 85 of the States. (1860-6I ), $456 \mathrm{p}$.

Third edition. 3-23678 PS $_{3201}$ I860 RBD

Includes 124 new poems, with revisions of those found in the two earlier editions.

623. - New York [W. E. Chapin] 1867. $33^{8}, 72,24,3^{6} \mathrm{p}$.

Fourth edition.

$$
\text { 3-23703 } \mathrm{PS}_{3201} 1867 \mathrm{RBD}
$$

Includes Drum-Taps (1865; Sequel to DrumTaps (1865-66); and Songs Before Parting. The Sequel to Drum-Taps contains the elegiacs on Lincoln, notably "When Lilacs Last in the Door-Yard Bloom'd" and "O Captain! My Captain!".

624. Washington [New York, J. S. Redfield] $1871.384 \mathrm{p}$.

Fifth edition.
Includes Drum-Taps; Marches Now the War Is Over; and Songs of Parting.

625. 382 p. $\quad 43-36897$ PS 3201 I $882 b$ RBD Issued from the plates of the "suppressed edition" (Boston, J. R. Osgood, I881-82). Edition which received the poet's last textual revisions and in which final titles and the order of arrangement were assigned to the poems.

626. Leaves of grass; including Sands at seventy, ist annex, Good-bye my fancy, 2nd annex. "A backward glance o'er travel'd roads" . . . Philadelphia, McKay, I89I-92. $438 \mathrm{p}$.

$$
\text { 3-15387 PS3201.I89I RBD }
$$

Last edition that received the author's personal supervision; known as the "Deathbed edition."

627. Leaves of grass. Edited by Emory Holloway, from the text of the ed. authorized and editorially supervised by his literary executors, Richard Maurice Bucke, Thomas B. Harned, and Horace L. Traubel. Inclusive ed. Garden City, N. Y., Doubleday, 1954 [ ${ }^{\circ} 1926$ ] xx, $682 \mathrm{p}$.

54-496x PS320I 1954a Includes Whitman's discarded poems, chiefly from the Putnam edition of The Complete Writings (1902), and his significant prefaces, i. e., those of I855, I872, 1876, and "A Backward Glance O'er Travel'd Roads" preface to November Boughs (1888).

628. Leaves of grass, and selected prose. Edited with an introd. by Sculley Bradley. New York, Rinehart, 1949. xxx, 568 p. (Rinehart editions, 28) 49-49650 $\mathrm{PS}_{3200 . \mathrm{F}_{49} \mathrm{a}}$

629. Leaves of grass. With an introd. by Oscar Cargill. New York, Harper, 1950. xxxi, 537 p. (Harper's modern classics) 50-6167 PS3201 1950

630. With an introd. by Sculley Bradley, New York, New American Library, 1954. 430 p. (A Mentor book, Ms II 7 )

$$
\text { 54-10986 } \mathrm{PS}_{3201} \mathrm{x} 954
$$

63r. Democratic vistas. Washington, I87r. $84 \mathrm{p}$. I2-I283I EI68.W6I RBD

At head of title: Memoranda.

On cover: New York, J. S. Redfield, publisher. Copyrighted I 870 , by Walt Whitman.

Prose work essential to an understanding of the poet's theories concerning literature, democracy, and "personalism," or individualism. 
632. With an introd. by John Valente. New York, Liberal Arts Press, 1949. xvii,

69 p. (Little library of liberal arts, no. 9)

"Selected bibliography": p. xvii.

$$
\text { 49-3309 } \mathrm{PS}_{3213} \cdot \mathrm{A}_{2} \mathrm{~V}_{3}
$$

Mr. Valente is Executive Secretary of the Walt Whitman Project of Brooklyn College.

633. Specimen days \& Collect. Philadelphia, R. Welsh, 1882-83. $374 \mathrm{p}$.

CA12-1030 PS3220.AI 1882 RBD

A revised edition published on London, I887, under title: Specimen Days in America. Cf. Carolyn Wells, $A$ Concise Bibliography of Walt Whitman (Boston, Houghton Mifflin, I922).

For the most part comprises four types of prose descriptions: (I) genealogical and autobiographical information; (2) realistic memoranda taken from notebooks kept by Whitman during his experiences in camps and hospitals during the Civil War (1862$65)$; (3) idyllic expressions of delight in nature observed on the banks of Timber Creek while recovering from a paralytic stroke suffered in 1873; and (4) recollections of people, places, and literary figures and friends, such as Carlyle, Poe, Longfellow, and Emerson.

634. Specimen days in America. London, H. Milford, Oxford University Press, 1932. xiv, 317

p. (The World's Classics, no. 37I) 32-28186 PS3220.AI 1932

635. Specimen days, Democratic vistas, and other prose, edited by Louise Pound. Garden City, N. Y., Doubleday, Doran, 1935. liii, 370 p. (Doubleday-Doran series in literature)

“Selected bibliography": $\begin{gathered}35-8359 \\ \text { p. xlvii-lii. }\end{gathered}$

636. Complete poems \& prose of Walt Whitman, I 855-1888; authenticated \& personal book (handled by W. W.) Portraits from life, autograph. [Philadelphia, Ferguson, I888] 382, 374, 140, 2 p. 43-36870 PS3200.E88 RBD

"Edition: Six hundred. Number one hundred forty."-Ms. note on verso of $2 \mathrm{~d}$ preliminary leaf.

637. The complete writings of Walt Whitman. Issued under the editorial supervision of his literary executors, Richard Maurice Bucke, Thomas B. Harned, and Horace L. Traubel; with additional bibliographical and critical material prepared by Oscar Lovell Triggs, Ph.D. New York, Putnam [1902] Io v. illus. 2-2550I PS 3200. Fo2 RBD "The book-lover's Camden edition."

Limited edition of 500 signed and numbered sets. This set not numbered.
Bibliography of Walt Whitman, compiled by O. L. Triggs: v. [1o], p. 135-233.

Contents. - v. [I-3] Leaves of grass. -v. [4-10] The complete prose works.

638. Complete prose works. Philadelphia, McKay, I892. viii, 522 p.

22-22228 PS3202 I 892 RBD

Contents.-Specimen d a y s.-Collect.-November boughs.-Good-bye, my fancy.-Some laggards yet.-Memoranda.

639. Complete poetry \& selected prose and letters, edited by Emory Holloway. London, Nonesuch Press, 1938. xxxix, I I 6 p.

$$
\text { 38-276r4 } \mathrm{PS}_{3200 . \mathrm{F}_{3} 8}
$$

"Biographical and bibliographical chronology": p. xxxi-xxxix. Published also in New York by Random House (1938).

640. Walt Whitman; representative selections, with introd. bibliography, and notes by Floyd Stovall. Rev. ed. New York, American Book Co., ' 1939. lxvi, 480 p. (American writers series)

"Selected bibliography": p. liii-lxiii.

641. Walt Whitman, selected and with notes by Mark Van Doren. New York, Viking Press, 1945. 698 p. (The Viking portable library) $45-6887 \mathrm{PS}_{3203} . \mathrm{V}_{3}$

642. The complete poetry and prose of Walt Whitman, as prepared by him for the Deathbed edition. With an introd. by Malcolm Cowley. New York, Pellegrini \& Cudahy, 1948. 2 v. (The American classics series. New York)

48-10006 PS3200.F 48 Reprint. Garden City, N. Y., Garden City Books, I954, "i948. 482, $53^{8}$ p. (World famous classics)

54-7937

643. Faint clews \& indirections; manuscripts of Walt Whitman and his family. Edited by Clarence Gohdes and Rollo G. Silver. Durham, Duke University Press, 1949. x, $25^{\circ} \mathrm{p}$.

49-10012 PS $3200 . F_{49}$

"Contains the previously unpublished manuscripts of Walt Whitman and a selection from the Whitman family letters now in the Trent Collection in the Library of Duke University."

644. The best of Whitman, edited with an introd. and notes by Harold W. Blodgett. New York, Ronald Press Co., 1953. x, $47^{8}$ p.

Bibliography: p. $467-471$.
52-12519 PS3203.B6 
645. Poems; selections with critical aids. Edited by Gay Wilson Allen and Charles T. Davis. New York, New York University Press, 1955. x, $280 \mathrm{p}$.

Bibliography: p. $273-276$.

55-8234 PS $3203 . A_{5}$

646. The Whitman reader. Edited, with an introd., by Maxwell Geismar. New York,

Pocket Books, 1955. 507 p. (Cardinal edition, GC-25)

Includes bibliography.

The centenary of the publication of Leaves of Grass in 1955, and the years immediately preceding that date, were marked by the appearance of a large number of critical and biographical studies of Whitman. Among these are found the following:

647. Allen, Gay W. The solitary singer; a critical biography of Walt Whitman. New York, Macmillan, 1955. xii, 616 p. illus.

55-II4 PS3231.A69

Bibliographical references included in "Notes" (p. 545-594).

648. Allen, Gay W., ed. Walt Whitman abroad; critical essays from Germany, France, Scandinavia, Russia, Italy, Spain, and Latin America, Israel, Japan, and India. Syracuse, N. Y., Syracuse University Press, 1955. xii, $290 \mathrm{p}$.

55-55I I PS $3238 . \mathrm{A} 75$

Essays are given in English translations; British essays are omitted, reference being made to Harold Blodgett's Walt Whitman in England (Ithaca, N. Y., Cornell University Press, 1934. 244 p.). Includes bibliographical references.

649. Beaver, Joseph. Walt Whitman, poet of science. New York, King's Crown Press, 195I. $x v, 178 \mathrm{p} . \quad 5 \mathrm{I}-288 \mathrm{PS}_{3242} \mathrm{PS}_{3} \mathrm{~B}_{4}$ Bibliography: p. [17I]-I74.

650. Briggs, Arthur E. Walt Whitman: thinker and artist. New York, Philosophical Library, I952. $489 \mathrm{p}$. 52-13025 $\mathrm{PS}_{3231 . \mathrm{B}_{7}}$

651. Chase, Richard V. Walt Whitman reconsidered. New York, Sloane, i955. I9I p. 55-6326 PS $3231 . \mathrm{C}_{47}$

652. Clark, Leadie M. Walt Whitman's concept of the American common man. New York, Philosophical Library, 1955. $178 \mathrm{p}$.

Thesis-University of Illinois.

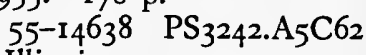

653. Eby, Edwin H. A concordance of Walt Whitman's Leaves of grass and selected prose writings. Seattle, University of Washington Press, 1949-54. 5 v. A50-9002rev PS3245.E2

654. Faner, Robert D. Walt Whitman \& opera. Philadelphia, University of Pennsylvania Press, I95I. xi, 249 p. $\quad$ 5I-7724 PS $3242 . \mathrm{MBF}_{3}$ Bibliography: p. $237^{-244}$.

655. Freedman, Florence B., ed. Walt Whitman looks at the schools. New York, King's Crown Press, 1950. xii, $278 \mathrm{p}$. 5I-9067 $\mathrm{PS}_{3204 . \mathrm{F}_{7}}$

The editor's thesis-Columbia University.

Includes articles on schools and the education of youth that appeared in the Brooklyn Evening Star and the Brooklyn Daily Eagle.

Bibliography: p. [26r ]-272.

656. Hindus, Milton, ed. Leaves of grass one hundred years after; new essays. Stanford, Calif., Stanford University Press, 1955. I49 p. 54-II783 PS 323 I. $\mathrm{H}_{5}$

Among the contributors are: William Carlos Williams, Richard Chase, Leslie Fiedler, Kenneth Burke, David Daiches, and J. Middleton Murry.

657. Rubin, Joseph J., and Charles H. Brown, eds. Walt Whitman of the New York Aurora, editor at twenty-two. A collection of recently discovered writings. State College, Pa., Bald Eagle Press, 1950. viii, I47 p. $\quad$ 50-14220 PS $3203 \cdot \mathrm{R} 8$

658. Traubel, Horace. With Walt Whitman in Camden. Boston, Small, Maynard, 1906-53. 4 v. illus. $\quad 8-5603 \quad \mathrm{PS}_{3232}$. $\mathrm{T}_{7}$ Volume 2 has imprint: New York, D. Appleton; volume 3, New York, M. Kennerley; volume 4, Philadelphia, University of Pennsylvania Press.

659. U. S. Library of Congress. Reference Dept. Walt Whitman; a catalog based upon the collections of the Library of Congress. With Notes on Whitman collections and collectors [by Charles E. Feinberg] Washington, 1955. xviii, I 47 p. 55-60006 Z8971.5.U62 $\mathrm{Z} 663.2 . \mathrm{W}_{3}$

660. U. S. Library of Congress. Reference Dept. Walt Whitman: man, poet, philosopher; three lectures presented under the auspices of the Gertrude Clarke Whittall Poetry and Literature Fund. Washington, 1955. $53 \mathrm{p}$.

$$
\begin{array}{ll}
55-60021 & P_{3231} U_{52} \\
& Z_{663} \cdot 2 . W_{32}
\end{array}
$$

Contents.-The man, by G. W. Allen.-The poet, by M. Van Doren.-The philosopher, by D. Daiches. 
66r. Willard, Charles B. Whitman's American fame, the growth of his reputation in America after 1892 . Providence, Brown University, 1950. 269 p. (Brown University studies, v. 12. Americana series, no. 3) 50-5345rev PS $_{323} 8$. W $_{55}$

Thesis-Brown University.

Bibliography: p. [253]-257.

\section{JOHN GREENLEAF WHITTIER, I807- 1892}

Whittier, in the poems for which he is valued today, preserved in the medium of his simple style the natural beauties peculiar to New England landscapes and the idyllic elements he found to be characteristic of simple lives in the same countryside. The historic past of his native state, Massachusetts, where his family had lived continuously since 1638 , also provided themes congenial to him. A Quaker, he produced some of America's best religious poetry. A few of the choicest hymns in use today are by him. His early romantic inspiration came in part from his admiration of Robert Burns' poems, an influence that persisted, since The Cotter's Saturday Night finds a sort of American analogue in Whittier's narrative poem, Snow-Bound (1866). During his long life Whittier wrote in many forms. He contributed to newspapers and periodicals, became an editor, wrote miscellaneous prose, and to the detriment of his own literary career became for a time a propagandist in verse and prose for the abolition of slavery. His literary work, however, which again predominated from the I860's forward, brought him various honors and attracted to him numerous visitors and friends. A carefully documented study of Whittier's life and accomplishments is provided by John A. Pollard's John Greenleaf Whittier, Friend of Man (Boston, Houghton Miffin, 1949. 615 p.).

663. Justice and expediency; or, Slavery considered with a view to its rightful and effectual remedy, abolition. Haverhill, Mass., C. P. Thayer, 1833. $23 \mathrm{p}$. 7-2288I E449.W61 RBD

A pamphlet in prose.

664. Voices of freedom. 7 th and complete ed. Philadelphia, T. S. Cavender; Boston, Waite, Pierce, 1846 . vi, $192 \mathrm{p}$.

$$
\text { 40-r46o PS3269.V6 I846 RBD }
$$

665. Leaves from Margaret Smith's journal. Boston, Ticknor, Reed, \& Fields, 1849. 224 p.

$$
\text { 7-22150 PS3272.L4 I849 RBD }
$$

Early history of Massachusetts woven into a fictitious diary of an English visitor purporting to spend part of two years in the Colony.
666. In war time, and other poems. Boston, Ticknor \& Fields, 1864 . vi, $152 \mathrm{p}$.

$$
\text { 7-21853 PS } 3259 . I_{5} \text { I } 864 \text { RBD }
$$

First edition published in November 1863 .

667. Snow-bound. A winter idyl. Boston, Ticknor \& Fields, r866. 5 I p.

$$
\text { 7-21855 PS } 3266 . A 1 \quad 1866 \mathrm{RBD}
$$

668. The tent on the beach, and other poems. Boston, Ticknor \& Fields, 1867. 172 p.

$$
\text { 7-21865 } \mathrm{PS}_{3268 . \mathrm{AI}} \text { I }^{267} \mathrm{RBD}
$$

669. Among the hills, and other poems. Boston, Fields, Osgood, r869. 100 p.

$$
\text { 7-21844 PS } 3255 . A_{4} \text { I869 RBD }
$$

670. Writings. Riverside ed. [Boston, Houghton Mifflin, 1888-89] $7 \mathrm{v}$.

$$
\text { 7-22147 PS3250.E88 }
$$

“. . . the later ( 1894 ) issue is the standard library edition . . ." Literary History of the United States (no. 2460).

671. Complete poetical works. Cambridge ed. Boston, Houghton Miflin, 1894. xxii, 542 p. (Cambridge edition of the poets)

$$
\text { 47-39698 } \mathrm{PS}_{3250 . E_{94 a}}
$$

Edited with biographical sketch, by Horace E. Scudder.

672. Life and letters, by Samuel T. Pickard. Boston, Houghton Mifflin, r894. 2 v. (802 p.) $4^{-17396} \mathrm{PS}_{3281 . P_{5}}$ I894a

Bibliography: v. 2, p. 787-790.

Based on material assembled by Whittier for the use of a possible biographer; includes a large collection of letters, representing nearly every year of the poet's life. Cf. Preface, p. [iii]. Other collections of Whittier's letters have also been made; among the more substantial of these are Whittier's Correspondence from the Oak Knoll Collection, edited by John Albree (Salem, Mass., Essex Book and Print Club, 19ı I. 295 p.); and Whittier's Unknown Romance; Letters to Elizabeth Lloyd, with an introduction by Marie V. Denervaud (Boston, Houghton Miffin, 1922. 72 p.).

673. Poems. Selected and edited with a commentary by Louis Untermeyer, and illustrated with pencil drawings by R. J. Holden. New York, Limited Editions Club, 1945. xx, 333 p. 46-1204 PS $3252 . U_{5}$ 
674. NATHANIEL PARKER WILLIS, 18061867

Willis was a prolific writer. As journalist, editor, and professional man of letters he worked in such varied literary forms as poetry, sketches, short stories, familiar essays, novels, and dramas. He was in turn romantic, sentimental, chatty, urbane, discursive, and extravagant in his writing. His long residence abroad as a foreign correspondent for American journals and his cordial reception in fashionable and literary circles in England and on the Continent enabled him to become an unofficial cultural representative from the New World to the Old, and vice versa. It has been said that after the works of Irving and Cooper his most nearly responded to the taste of American readers in the 1830 's and 1840 's.

675. À l'abri; or, The tent pitch'd. New York, S. Colman, 1839. 172 p.

$$
\text { 14-3402 FI27.T6W7 RBD }
$$

Written in the form of a series of letters from the Valley of the Susquehannah River, New York, to embody impressions of that region where the writer's home, Glenmary, was located. Later republished in a volume of prose and poetry entitled Letters from Under a Bridge (London, G. Virtue, 1840. 333 p.).

676. Tortesa, the usurer. New York, S. Colman, 1839. I 49 p. (Colman's dramatic library) $\mathrm{PS}_{3324 . T 6} 1839$

Play dealing with medieval Florence; romantic comedy in blank verse successfully produced in the United States and in England.
677. Pencillings by the way. rst complete ed. New York, Morris \& Willis, 1844. 216 p. (The mirror library, no. 27)

$$
\text { 5-6529 AP2.N65I RBD }
$$

Originally published in The New-York Mirror, Feb. 13, 1832-Jan. 14, 1836, as a series of reports on residence and travel abroad, in Europe, England, and Asia Minor.

678. London, T. W. Laurie, 1942. $522 \mathrm{p}$. (Live books resurrected, edited by L. S. Jast) 43-16544 D919. W738 1942

679. Poems of early and after years. Illus. by $\mathrm{E}$. Leutze. Philadelphia, Carey \& Hart, 1848 . $410 \mathrm{p}$. 49-35203 $\mathrm{PS}_{3324 . \mathrm{P}_{4}} \quad 1848$

Revised and corrected by the author. Cf. Preface, p. i.

68o. Poems, sacred, passionate, and humorous. Complete ed. New York, Clark \& Maynard, 1869. xvi, 380 p. 12-40407 PS3324.P6 1869 Biographical sketch: p. [iii]-xii.

68I. Poems. London and New York, G. Routledge, 1891. xvi, $304 \mathrm{p}$.

2-8744 $\mathrm{PS}_{3324} \mathrm{P}_{3} \quad \mathrm{I} 891$

Includes a brief memoir of the author and poems grouped under the following headings: "Scriptual," "Religious," "College Poems," "City Poems," and "Miscellaneous Poems."

682. Prose writings. Selected by Henry A. Beers. New York, Scribner, $1885 . \quad x v i, 365 \mathrm{p}$.

$$
{ }_{12-40465} \mathrm{PS}_{3322 . B_{4}}
$$

\section{The Gilded Age and After (I87I-I9I4)}

The boom times that came after the Civil War, marked by vulgarity and moral laxity, formed an era named and satirized by Samuel Langhorne Clemens and Charles Dudley Warner in their book, The Gilded Age (1873). A "war to waste" ended and was followed by "a peace to corrupt." In these years and many that came after them politics reeked of scandals resulting from graft and the spoils system. Speculation, particularly in connection with railroad building, was wild and ruthless. With the extension of railroads and the increased business made possible by the new means of transportation cities grew greatly in size. In the large industrial centers that resulted the mansions of the rich looked down on slums in which were housed the poor, whose labor made possible the wealth of their employers. A new aristocracy of money arose in the land, having "robber barons" of industry for its nobility. Even the passage of time and the improvement in public morals after the Gilded Age did not bring about thoroughgoing reforms. Soon after the turn of the century "muckrakers" uncovered so much corruption in great corporations and in all levels of government that they launched a movement to better conditions by creating a literature of articles and books exposing what they had found.

Industrial expansion and commercial development were only two of the forces operating to change American civilization after the Civil War. 
Among other powerful influences that played upon the United States at this time must be counted the long-continued migration westward, to which attention was called in the preceding section. In the period currently considered this movement of the people brought about, more and more completely, the settlement of the Far West and the Southwest, until no farther frontier was left to beckon. The courage and endurance that conquered mountains and deserts were reflected in the character of the culture developed in the western regions. The United States, so long oriented to Britain and Europe by virtue of being centered on the Atlantic seaboard, now encompassed within its own borders an area and a variety of conditions-climatic, geographic, economic, social-with which the Nation as a whole, willy-nilly, found it necessary to reckon. The old order had burst at the seams; a new order, larger, cruder, more heterogeneous, richer, more promising, was being put together.

Henry Adams, whose intellectual autobiography is one of the important documents of the period, complained bitterly of the disunity and confusion he found in his time, attributing these faults to the multiplicity of stresses under which American civilization labored. He thought his centenary might come (in 1938) before one might hope to "find a world that sensitive and timid natures could regard without a shudder." Iustifiable as Mr. Adams' shudders may have been, American literature in his period reached a new level of productivity. Many more people became professional writers; more aspects of life in the United States were represented in literature; a few new literary forms were exploited; and several new trends were originated which have been influential ever since.

With respect to literary forms, the short story now came into new prominence. Developed earlier chiefly by Irving, Hawthorne, and Poe, it was now a favored medium used by nearly half of the writers selected to represent the period. One of the striking innovations in these stories was the increased emphasis on portrayal of characteristics peculiar to a number of different places and regions. Local color was provided through details of dress, food, manners, customs, and dialects of various sections. Cowboys on the trial with their herds, housewives in hamlets on the Maine coast, mountaineers in their backwoods isolation, Creole folk on the bayous of Louisiana, and miners in western camps were only a few of the many American groups allowed to speak in their own idiom through these stories. Likewise, poets and versemakers turned to dialect and vernacular writing to sing of unlettered dwellers on the frontier, of simple country people, oldfashioned Negroes on plantations "before the war," and smalltown life in general.
Humorous writing and lecturing, so much in vogue around the time of the Civil War, were still popular and were also identified with the school of local color and vernacular writing. This trend was sustained in part by journalists who were forerunners of today's columnists. By means of newspaper articles and miscellanies, which were collected later and published as books, the journalists told tall tales, made jokes, and commented on the passing scene after the manner of crackerbox philosophers who spoke colloquially or in dialect. Some of these pieces were designed chiefly to amuse; some, while retaining their humorous character, were used to convey penetrating criticisms of human nature, society, national problems, and foreign relations. Prominent among the best works of the period are the voluminous writings of Mark Twain, humorist, novelist, and exponent of the American spirit to the world.

In even the briefest comment on literature produced in America between 1871 and 1914, it is essential to notice one trend so marked that it is mentioned frequently as characterizing the whole period: the trend toward realism. As the term is used, however, realism is a semantic house of many mansions. Its first enthusiastic proponent, William Dean Howells, thought that conditions of American life at the time invited the artist (including the writer) to the study and appreciation of what was common rather than exclusive. The arts, he contended, must become democratic, and the artist must continually ask himself, "Is it true?" when evaluating his material. Novels (excluding Hawthorne's) that were primarily romantic, or those having a strong sentimental cast, he would eliminate from categories of importance, on the score that they were good reading only when the reader was sick or when he was silly. Fiction as an art, Howells believed, must be concerned with what is actual, observable, and true to facts, though not necessarily, or even properly perhaps, grim or unpleasant facts. Grimness, however, crept into the work of one of Howell' disciples, Hamlin Garland, who called his literary theory "veritism." Henry James, by confining his search for realism to the minds and spirits of expatriated Americans and members of good society in the Eastern United States, was able to handle, on the level of psychological realism, a number of themes which were beyond the pale of either the realism of Howells or the veritism of Garland. Various other novelists of the time looked about them-at city life, at industry, at poverty, at a competitive society-and found in these and other elements of American life much that was ugly, shocking, and violent. Such conditions they exploited in their novels and stories, sometimes realistically, sometimes with Zolaesque exaggeration. From 
this type of realism, fed by a growing consciousness of social problems, it was only a step to the deterministic naturalism of Theodore Dreiser and other writers belonging to the next period.

\section{ANDY ADAMS, 1859-1935}

Adams' semi-autobiographical fiction deals chiefly with what he calls "the Old Trail days," of the I880's, when hundreds of herds of cattle were driven on trails extending from Texas as far north as Montana. The heroes of these migrations were cowboys whom Adams knew at firsthand because he was one of them. The still undeveloped country through which their way often led, the speech and manner of the special breed of men attracted to the life of a cowboy, the attitude of these men to the horses they rode and the cattle they drove, and the stories they told each other when the day's work ended are portrayed by the author less as a literary expression than as an authentic record of personal experience. Sympathy, affection, and humorous realism characterize his books, which derive their chief value from the fact that they retain the flavor of a bygone phase of American life, changed forever by the extension of railroads and the social and economic development of what had long been western frontier country.

684. The $\log$ of a cowboy. Boston, Houghton Mifflin, 1903. 387 p. $3^{-12817} \quad \mathrm{PZ}_{3}$.A2IL

685. — Boston, Houghton Mifflin, 1927. 324 p. (Riverside bookshelf)

27-2025I PZ3.A2IL5

"In preparing this classic of frontier literature for The Riverside Bookshelf the number of chapters has been reduced by three."-Publisher's note, preceding table of contents.

686. The outlet. Boston, Houghton Mifflin, I905. $\mathrm{x}, 371 \mathrm{p}$. 5-8678 $\mathrm{PZ}_{3} \cdot \mathrm{A}_{21} \mathrm{O}$

A work that complements The Log of a Cowboy by introducing the same kinds of characters and events, with the addition of elements connected with sharp practices of railway promoters and builders.

687. Cattle brands; a collection of western campfire stories. Boston, Houghton Mifflin, Igo6. $316 \mathrm{p}$. 6-9625 $\mathrm{PZ}_{3} \cdot \mathrm{A} 2 \mathrm{IC}$

Includes "The Story of a Poker Steer," considered a classic by J. Frank Dobie, writing on Adams in the Southwest Review, v. II, Jan. 1926, p. 92-101, 96.

\section{HENRY ADAMS, 1838 -1918}

Henry Adams came of distinguished Massachusetts ancestry, which included a grandfather and a great-grandfather who were Presidents of the United States, and a father, Charles Francis Adams, whose secretary Henry was while the father served as minister to Great Britain during the Civil War. A traveler, scholar, editor of the North American Review, historian of the United States, teacher at Harvard, and associate of many notable contemporaries, Adams contributed to the literature of his country by means of novels, essays, a book of travel, familiar letters, and particularly through $T$ he $E d u$ cation of Henry Adams. An appreciative evaluation of Adams and his writings, accompanied by quotations from and summaries of most of his works, has been addressed to the general reader by Robert A. Hume in his Runaway Star (Ithaca, N. Y., Cornell University Press, 1951. 270 p.). The most recent and extensive biography is Elizabeth Stevenson's Henry Adams; a Biography (New York, Macmillan, 1955. 425 p.).

689. Democracy, an American novel. New York, Holt, 1880. 374 P. (Leisure-hour series, no.

I12) 7-12165 PS I004. ${ }_{4} \mathrm{D}_{4}$ I880 RBD Variously attributed by different authorities to Henry Adams, John Hay, and Clarence King. Cf. William R. Thayer, Life and Letters of John Hay (Boston, Houghton Mifflin [1915]) v. 2, p. 58-59. The authorship of Adams is affirmed by the publisher Henry Holt in the Unpartizan Review, no. 29, Jan.-Mar., 1921, p. 156; and Literary Review, Dec. 24, 1920.

An anonymous satiric novel on political corruption in Washington and on the state of society there after the Civil War.

69o. - New York, Farrar, Straus \& Young, 1952. 246 p. 52-321 I PZ3.A2137 D12 "An attractive new edition; without editorial apparatus."-American Literature, v. 24, Jan. 1953, p. 575 .

69r. Esther, a novel, by Frances Snow Compton [pseud.] New York, Holt, 1884. 302 p. (American novel series, no. 3)

6-30382 PSIO04.A4E8 I 884 RBD

New York society, the influences of art, and of religion in the contemporary life of the period are themes developed in this novel.

692. W With an introd. by Robert E. Spiller. New York, Scholars' Facsimiles \& Reprints, 1938. xxv p., facsim.: $302 \mathrm{p}$.

$$
3^{8-18393} \quad \mathrm{PZ}_{3} \cdot \mathrm{A}_{2137} \mathrm{E} 8
$$


Facsimile of the original ( 1884 ) edition.

Bibliographical note: p. xxiii-xxv.

693. Mont Saint Michel and Chartres. Washington, 1904. vi, $355 \mathrm{p}$.

5-1469 DC20.A2 RBD

First result of the author's plan to study forces operating in history and to relate them at two periods of time. The hundred years from 1150 to 1250 and the achievements of this century are presented as an epoch when "man held the highest idea of himself as a unit in a unified universe" and when faith in the Virgin Mary operated as the greatest force felt in the Western world.

694. With an introd. by Ralph Adams Cram. Boston, Houghton Mifflin, 1936. xiv, 397 p. illus. $\quad 36-27246$ DC20.A2 1936 A popular edition is described in Houghton Mifflin's A Complete Catalog of Publications (Cambridge, Mass., I955. p. [I]).

695. The education of Henry Adams. Washington, 1907. 453 p. EI75.5.Aiz RBD

Correlative study to Mont Saint Michel and Chartres. In it Adams' philosophy of history is developed through the device of writing an autobiography that is a commentary on the multiplicity of forces operating in the late igth century to bring disunity and confusion, instead of unity, in intellectual, political, social, and general cultural aspects of American life. The work shows the influence on Adams of Darwin's theory of evolution and reflects his pessimism in the face of increased materialism that followed the rapid spread of industrialism in the United States.

696. Boston, Houghton Mifflin, I9I8. x, 519 p. $\quad$ I8-18517 EI75.5.Ai72

"This volume, written in 1905 . . was privately printed .... in $1906 \ldots$ The Massachusetts Historical Society now publishes the 'Education' as it was printed in 1907, with only such marginal corrections as the author made."-Editor's preface, signed: Henry Cabot Lodge.

697. — Boston, Houghton Mifflin, 1930. 517 p. (The Riverside library)

$$
\text { 32-23054 EI75.5.AI7423 }
$$

698. Introd. by James Truslow Adams. New York, Modern Library, 1931. x, 517 p. (Modern Library of the world's best books)

$$
\text { 3I-30066 EI75.5.AI7424 }
$$

699. Letters. Edited by Worthington Chauncey Ford. Boston, Houghton Mifflin, 1930-38. $2 \mathrm{v}$. 30-25080 EI75.5.AI743 70o. Selected letters. Edited with an introd. by Newton Arvin. New York, Farrar, Straus \& Young, I95I. xxxiv, 279 p. (Great letters series) 51-7883 $\quad$ Er75.5.Ar7433

\section{GEORGE ADE, 1866-r944}

Reared in rural Indiana and later a columnist on the Chicago Record, Ade brought to his career as a writer an intimate knowledge of country life, small towns, plain citizens, and city magnates of the Middle West. His humorous fables, essays, and stories "of the streets and of the town" preserve his shrewd, realistic judgments of midwestern life at the turn of the igth century. The use of slang and local vernacular in his writing imparts a special flavor to the social scene depicted in his work. Ade's book for the comic opera, The Sultan of Sulu, produced in I 902 and published in I903, and a play, The College Widow, first acted in 1904 and published in 1924, were among his most successful contributions to the stage.

702. Fables in slang. Chicago, H. S. Stone, Igoo. 201 p. illus.

$$
\text { 45-26353 PSioo6.A6F27 Ig00 RBD }
$$

703. More fables. Chicago, H. S. Stone, Igoo. 218 p. illus. 0-6497 PZ3.A228M RBD

704. Stories of the streets and of the town, from the Chicago Record, r893-rgoo. Edited with an introd. by Franklin J. Meine. Chicago, Caxton Club, 194I. xxx, 278 p. illus.

Bibliography: p. $277-278$.

$$
\text { 4I-24958 PSi oo6.A6S7 I94I }
$$

705. The permanent Ade; the living writings of George Ade. Edited by Fred C. Kelly. Indianapolis, Bobbs-Merrill, I947. 347 p.

47-3039I PSioo6.A6A6 I947

Includes selections from the author's fables, stories, and essays, together with Marse Covington ( ${ }^{\circ}{ }_{1918)}$, a one-act play, and The Sultan of Sulu.

\section{THOMAS BAILEY ALDRICH, I836-1907}

Aldrich wrote a classic account of New England boyhood in The Story of a Bad Boy, a humorous, fictional autobiography of his own youth in Portsmouth, New Hampshire. In his maturity he found an ideally congenial environment when he settled in Boston, where be became a protégé of the literary group of which Longfellow was the center. There, in I88I, he succeeded William Dean Howells as editor of The Atlantic Monthly. Although Aldrich wrote polished verse as well as several novels and plays, his best medium was the short story. 
707. The story of a bad boy. Boston, Fields, Osgood, 1870. 261 p. illus. 48-32255 $\mathrm{PZ}_{7} . \mathrm{A}_{37} \mathrm{Sto}_{3} \mathrm{RBD}$

708. - Boston, Houghton Mifflin, 1923. 279 p. (Riverside bookshelf) ${ }_{23}-15255 \mathrm{PZ}_{3} \cdot \mathrm{A}_{3} 6{ }_{5} \mathrm{Stor}_{4}$

709. With an introd. by V[ictor] L. O. Chittick. New York, Macmillan, 1930. xxii, $23^{8}$ p. (Modern readers' series)

$$
3^{0-I_{4} 665} \quad \mathrm{PZ}_{7} \cdot \mathrm{A}_{37} \mathrm{Sto}_{4}
$$

710. - New York, Pantheon Books, 195I. 232 p. illus. 5I-I3435 $\mathrm{PZ}_{7} \cdot \mathrm{A}_{37} \mathrm{Sto}_{40}$

7II. Marjorie Daw, and other people. Boston, J. R. Osgood, 1873.272 p.

$$
\text { 6-499 } \quad \mathrm{PZ}_{3} \cdot \mathrm{A}_{3} 65 \mathrm{Ma} 3
$$

Contents.-Marjorie Daw.-A Rivermouth romance.-Quite so.-A young desperado.-Miss Mehetabel's son.-A struggle for life.-The friend of my youth.-Mademoiselle Olympe Zabriski.Père Antoine's date-palm.

712. Marjorie Daw. Boston, Houghton Mifflin, 1908. 123 P. 8-29734 $\mathrm{PZ}_{3} \cdot \mathrm{A}_{3} 65 \mathrm{Ma10}$

713. From Ponkapog to Pesth. Boston, Houghton Mifflin, $1883.267 \mathrm{p}$.

$$
\text { 3-15938 D9r9. A36 }
$$

A contribution to the literature of European travel that responded to America's growing interest in its European origins.

714. A book of songs and sonnets selected from the poems of Thomas Bailey Aldrich. [Cambridge] Riverside Press, 1906. II3 P.

$$
\text { 6-1 } 786_{3} \text { PS 1022.R5 } 1906 \mathrm{RBD}
$$

The writer's final selection of what he considered his best poems.

715. Writings. [Ponkapog ed.] Boston, Houghton Mifflin, 1907.9 v. illus.

$$
\text { 7-41488 PSio20.Fo7 }
$$

\section{JAMES LANE ALLEN, I849-1925}

Allen's works ranged from romantic sketches, short stories, and sentimental fiction to problem novels dealing with religious fundamentalism, the impact of Darwin's theory of evolution, farm life, and the confusion in social conventions and standards after the Civil War. The author's belief in the intimacy of man's relation with nature pervades his writing, for which Kentucky provides the setting.
His place in American literature is fully discussed in Grant C. Knight's James Lane Allen and the Genteel Tradition (Chapel Hill, University of North Carolina Press, 1935. 313 p.).

717. The blue-grass region of Kentucky, and other Kentucky articles. New York, Harper, 1892. $322 \mathrm{p}$. IRc-2635 $\mathrm{F}_{457 . \mathrm{B}^{2} \mathrm{~A}_{4} \mathrm{RBD}}$

718. The reign of law; a tale of the Kentucky hemp illus. fields. New York, Macmillan, 19oo. $385 \mathrm{p}$. o-33II $\mathrm{PZ}_{3} \cdot \mathrm{A}_{427} \mathrm{R}$

719. The mettle of the pasture. New York, Macmillan, 1903. $448 \mathrm{p}$.

$$
\text { 3-1544I PS } \text { PO34.M }_{4} \text { I903 RBD }
$$

720. - New York, Grosset \& Dunlap, I912. 448 p. (Macmillan's standard library)

38-35068 $\mathrm{PZ}_{3} \cdot \mathrm{A}_{4}$

\section{GERTRUDE FRANKLIN (HORN) ATHERTON, $1857-1948$}

The history of California, including the Spanish influence on its culture, inspired Mrs. Atherton's most enduring work. Her popular novels of American life in other localities and periods were frequently sensational but also contained elements of the realism that began to develop as a trend in the fiction of the early 19oo's. Adventures of a Novelist (1932) is her autobiography.

722. Senator North. New York, J. Lane, Igoo. 367 p. $\quad 6-4520$ PSro42.S 4 1900 RBD

A novel of political life in Washington and of tensions in relations between Negroes and whites.

723. The conqueror. New York, Macmillan, 1902. xiv, $546 \mathrm{p}$. 2-8II7 PZ3.A869Co

Biographical novel of which Alexander Hamilton is the hero. Currently published by J. P. Lippincott, East Washington Square, Philadelphia, Pa.

724. The conqueror; a dramatized biography of Alexander Hamilton. New York, Stokes [ ${ }^{\circ}$ Igr6] xii, 536 p. I8-13115 PZ3.869Co5 "Twenty-fourth edition (from new plates with revisions)."

725. The splendid idle forties; stories of old California. New York, Macmillan, 1902. $389 \mathrm{p}$. 2-24242 $\mathrm{PZ}_{3}$. A869Sp

A revised and enlarged edition of a volume issued in I 894 under the title: Before the Gringo Came. 


\section{EDWARD BELLAMY, $1850-1898$}

Bellamy began his career as a writer when the United States was feeling the full impact of increasing industrialization after the Civil War. The social and economic conflicts of the period stimulated the thinking reflected in his novels and finally led him to imagine a remedy for inequalities among the people by postulating a state of society in which all citizens would be as free and equal in their material and cultural lives as in the political sphere where their rights were protected by the American form of government. He gave literary expression to these ideas in his Utopian romance, Looking Backward. This novel, purporting to portray a cooperative economic and social life enjoyed in Boston, Massachusetts, in the year 2000, A. D., is said to have sold nearly a million copies in the ten years following its publication. It contributed to the temporary spread of a socialist doctrine advocating the nationalization of all industry. In support of his ideas Bellamy became a publicist and a propagandist. He was also the founder and editor of a reforming journal, The New Nation (1891-94). His Selected Writings on Religion and Society has been announced as published by the Liberal Arts Press, 153 West $72 d$ Street, New York, N. Y., in its American heritage series.

727. Dr. Heidenhoff's process. New York, Appleton, I880. I 40 p. (Appleton's new handyvolume series, 54) 6-II697 $\mathrm{PZ}_{3}$. $\mathrm{B}_{417} \mathrm{Do}$

Early novel of the psychiatric type in which Bellamy introduced a fantasy that foreshadowed modern "shock" therapy currently used in some psychological disorders.

728. Looking backward, 2000-1887. Boston, Ticknor, r888. $470 \mathrm{p}$.

6-II7 10 HX811 I887.B2

The sequel, Equality (1897), is considered more of a tract than a novel.

729. Boston, Houghton Mifflin [1931?] xxi, 337 p. (Riverside library) 34-10625 HX81 1 1887.B32

Introduction by Heywood Broun.

730. - Introd. by Frederic R. White. Chicago, Packard, 1946. xxxviii, 233 p. (University classics) 46-4182 H-8 I I $1887 . \mathrm{B}_{327}$ Selected bibliography: p. xxxvii-xxxviii.

731. — With an introd. by Robert L. Shurter. New York, Modern Library, i95 I. xxvi, 276 p. (Modern Library college editions, $\mathrm{T}_{42}$ ) $5 \mathrm{I}-2252$ HX81 I $1887 . \mathrm{B}_{33}$ Bibliography: p. xxii-xxiii.
732. AMBROSE (GWINNETT) BIERCE, 18421914 ?

After the Civil War, in which Bierce served with distinction, he settled in California. There, as a journalist writing for various weeklies, he achieved a reputation as arbiter of literary fashion on the Pacific Coast. Later, as a contributor to the San Francisco Sunday Examiner, his witty, satirical column justified the title, "Bitter Bierce." He was a devotee of the bohemian life and an apostle of a pessimism verging on nihilism. Bierce's most enduring work is found in his realistic short stories about war and in his tales of the supernatural and the horrible. These show certain kinship with the stories of Poe and Bret Harte. Paul Fatout's Ambrose Bierce, the Devil's Lexicographer (Norman, University of Oklahoma Press, 195I. 349 p.) supplies new details for an understanding of the author. These were derived from study of manuscripts and other source materials. Fatout maintains the thesis that Bierce's social satires and criticisms constitute his most important work. These were collected and published in book form in The Cynic's Word Book (1906) and republished in I9 1 1 as The Devil's Dictionary.

733. Can such things be? New York, Cassell [ [ $\left.{ }^{\mathrm{I}} \mathrm{8} 893\right] \quad 320 \mathrm{p}$.

6-13ro3 $\mathrm{PZ}_{3} \cdot \mathrm{B}_{479} \mathrm{C} \mathrm{RBD}$

Short stories chiefly of the Civil War and the California frontier.

734. - Washington, Neale Pub. Co., I 903. $320 \mathrm{pl} \quad 3-933 \mathrm{I} \quad \mathrm{PZ}_{3} \cdot \mathrm{B}_{479 \mathrm{C}_{2}}$

735. In the midst of life; tales of soldiers and civilians. New York, Putnam, I898. vi, 362 p. 6-13102 PZ3.B479I

First published under title: Tales of Soldiers and Civilians (1891).

736. — New York, Boni \& Liveright, I918. 403 p. $\quad 35-33432 \quad \mathrm{PZ}_{3} . \mathrm{B}_{479} \mathrm{I6}$

737. — Introd. by George Sterling. New York, Modern Library [ ${ }^{\mathrm{C}}{ }_{1927]}$ xvi, $403 \mathrm{p}$. (Modern Library of the world's best books)

$$
\text { 27-19196 PZ3. B479I io }
$$

738. Letters. Edited by Bertha Clark Popc. With a memoir by George Sterling. San Francisco, Book Club of California, 1922. xlvii, 204 p.

23-7856 PS $1097 . Z_{5} A_{3}$ i $922 a$

739. Collected writings. With an introd. by Clifton Fadiman. New York, Citadel Press, 1946. xix, 8 1 0 p. 47-30068 PSro97.Ar r 1946 
Contents.-Ambrose Bierce: portrait of a misanthrope, by Clifton Fadiman.-In the midst of life, tales of soldiers and civilians.-The devil's dictionary.-Can such things be?-Fantastic fables.-The monk and the hangman's daughter.-Negligible tales.-The parenticide club.

\section{JOHN BURROUGHS, 1837-1921}

Burroughs, a student of Emerson, Thoreau, and Whitman, derived from these writers ideas that influenced his own interest in the natural world. Surrounded by the beauties of the Catskill region in New York, where he lived for many years, he cultivated the habit of close observation of out-ofdoor life, recording his impressions in literary essays on natural history. These had a decided vogue in the United States for a number of years. Literary Values (I902) is Burroughs' contribution to critical theory respecting literature in America. It includes his essay, "Democracy in Literature." His life and achievements may be further explored through works described in the section on Biography.

74I. Locusts and wild honey. Boston, Houghton, Osgood, r879. 253 p.

$$
\text { 5-2474 QH8r.B94 I879 }
$$

Contents.-The pastoral bees.-Sharp eyes.Strawberries.-Is it going to rain?-Speckled trout.-Birds and birds.-A bed of boughs. - Birds'nesting.- The halcyon in Canada.

742.

_- Boston, Houghton Mifflin [ $\left.{ }^{\mathrm{C}} \mathrm{1907}\right]$
7-1956 QH8I.B94

743. Writings. [Riverby ed.] Boston, Houghton Mifflin [ $\left.{ }^{\mathrm{C}} 190_{4}\right]-22.23$ v. NNU

744. John Burroughs' America; selections from the writings of the Hudson River naturalist. Edited with an introd. by Farida A. Wiley. Foreword by Julian Burroughs. New York, Devin-Adair, 1951. 304 p. illus. 5 $5^{1-1} 3^{897}$ QH81.B963 I95I

\section{GEORGE WASHINGTON CABLE, I844- I925}

Cable's antiquarian knowledge of his native New Orleans supplied the source upon which he drew when in $1879-80$ he brought into the literature of the South a new romantic regional element in his portrayal of Creoles in Louisiana before the Civil War. A special flavor is imparted to his early work by the use of Creole dialect. Among his less successful later writings were novels such as $D r$. Sevier (I885), a story of hardships and struggles experienced in New Orleans during and after the Civil
War, and Bonaventure (1888), which introduces descendants of the Acadians. The tragic deportation of these unfortunate people from Nova Scotia to Louisiana and elsewhere previously had been celebrated by Longfellow in his Evangeline. A recent work, Twins of Genius, by Guy A. Cardwell (East Lansing, Michigan State College Press, 1953. I34 p.), compares the literary influence of Cable and Clemens, discusses their joint lecturing tour in the r880's and reviews the association of the two writers. Letters of Mark Twain, Cable, and others are found on p. [79]-Ir2.

746. Old Creole days. New York, Scribner, I879. $229 \mathrm{p}$.

6-2227I PZ3.C.

747. — With an introd. by Lucy Leffingwell Cable Biklé. New York, Scribner, 1937. xv,

303 p. 37-10499 PZ3.CIIOI8

Madame Delphine ( 1880 ), added to the collection of stories in an edition of $\mathrm{r} 883$, is found also in this new edition which followed eight earlier editions. Cf. Introduction, p. v.

748. - Together with The scenes of Cable's romances, by Lafcadio Hearn; a prologue by Edward Larocque Tinker and illus. in color by John O'Hara Cosgrave II. New York, Limited Editions Club, 1943. xxxi, 224 p. 43-17083 PSI244.O6 I943 RBD Contents.-Jean-ah Poquelin.-'Tite Poulette."Posson Jone'."-Père Raphaël.-Madame Delphine.-Belles Demoiselles plantation.-Madame Délicieuse.-Café des exilés.-'Sieur George.

749. The Grandissimes, a story of Creole life. New York, Scribner, I880. 448 p. 43-I7083 PS I 244.06 I943 RBD

One section of the novel is entitled "The Story of Bras-Coupé," which is a revision of an earlier story of that title. It has been called a stronger indictment of slavery than can be found in Uncle Tom's Cabin.

750.

New York, Scribner, I916. ix, 448 p. I6-16158 PZ3.CirGrio

751. George W. Cable; his life and letters, by his daughter, Lucy Leffingwell Cable Biklé. New York, Scribner, 1928. xvi, 306 p. illus.

Bibliography: p. 303-306. 28-24845 PS $1246 . B_{5}$

752. Turner, Arlin. George W. Cable, a biography. Durham, N. C., Duke University Press, 1956. 391 p. $\quad 4^{6-9165}$ PSi246.T8 


\section{WILL CARLETON, $1845-1912$}

Carleton began writing for the periodical press when there was a vogue for sentimental versifying about plain people, particularly those living on farms or in rural communities. His pieces, written in language designed to be thought colloquial, were addressed to an audience interested in folk ballads. "Over the Hills to the Poor House" is a typical example of his style. Ten or more collections of his work, issued between 1871 and 1908, won for him the reputation of being the "people's laureate" of his region in the Middle West. These volumes, including Farm Legends (1875) and City Ballads ( 1885 ), sold on a wave of popularity that lasted into the 2oth century.

754. Farm ballads. New York, Harper, 1873 . 108 p. $13-15969$ PS $1257 . F_{3} \quad 1873$ RBD

755. New ed. from new plates. New York, Harper, I9or. viii, I47 p. I-30460 PSI257.F 3 I901

\section{CHARLES WADDELL CHESNUTT, $1858-1932$}

A Negro writer best known for his short stories in dialect about his race in America before and after the Civil War, Chesnutt was also the author of several novels, among them The House Behind the Cedars (1900) and The Marrow of Tradition (1901), works that sought to deal frankly and fairly with the problems of Negroes in contemporary society in the United States. An intimate view of the author's struggles and achievements, interspersed with his correspondence, has been supplied by his daughter, Helen M. Chesnutt, in her Charles Waddell Chesnutt, Pioneer of the Color Line (Chapel Hill, University of North Carolina Press, 1952. 324 p.).

757. The conjure woman. Boston, Houghton Mifflin, 1899. $229 \mathrm{p}$.

“، 'The Co-15426 $\mathrm{PZ}_{3} \cdot \mathrm{C}_{4253} \mathrm{C}$ " 'The Conjurer's Revenge' is reprinted from the Overland Monthly."

Contents.-The goophered grapevine.-Po' Sandy.-Mars Jeems's nightmare.-The conjurer's revenge.-Sis' Becky's pickaninny.-The gray wolf's ha'nt.-Hot-foot Hannibal.

758. The wife of his youth, and other stories of the color line. Boston, Houghton Mifflin, 1899. 323 p. illus. 0-113 $\mathrm{PZ}_{3} \cdot \mathrm{C}_{4253 \mathrm{~W}}$

\section{KATE (O'FLAHERTY) CHOPIN, 1851- 1904}

Mrs. Chopin belonged to the local color school. Her themes were drawn from dramatic events resulting from the relations of Creoles, Negroes, and Cajuns (the last reputed to be of Acadian French descent) in remote sections of Louisiana. From long residence among these people, she knew the cadence of their speech, the landscape through which they moved, and the humor, pathos, and tragedy implicit in their daily lives. Much of Mrs. Chopin's work is said to remain uncollected, but the two volumes of short stories that exist are enough to establish her quality. A biographical, critical, and bibliographical study of the author is provided by Daniel $\mathrm{S}$. Rankin in his Kate Chopin and Her Creole Stories (Philadelphia, University of Pennsylvania Press, 1932. 313 p.). This book was issued also as a doctoral dissertation submitted at the University of Pennsylvania. It includes reprints of selected short stories and numerous excerpts from Mrs. Chopin's miscellaneous writings.

760. Bayou folk. Boston, Houghton Mifflin, 1894 . 313 P. 4-15082 PZ3.C456B

Twenty-three short stories, including "Désirée's Baby"; "Madame Célestin's Divorce"; and "A Gentleman of Bayou Têche."

76r. A night in Acadie. Chicago, Way \& Williams, $1897.416 \mathrm{p}$.

Short stories.

$$
\text { 6-20969 PSi294.C63A7 RBD }
$$

\section{WINSTON CHURCHILL, $187 \mathrm{I}-1947$}

Written at a time when the rise of realism was a dominant mood in American literature, Churchill's romantic historical novels glorifying the Nation's past illustrated a countercurrent to the prevailing trend. In his later work, however, Churchill chose contemporary political, industrial, and religious themes for his novels, as in The Inside of the Cup (1913) and The Dwelling Place of Light (1917). These failed to win the popular success achieved by his earlier books.

763. The crisis. New York, Macmillan, 1gor. 522 p. illus. ${ }_{1-31838} \mathrm{PS}_{1297} \mathrm{C}_{7}$ Igor RBD Concerns results of the conflict of Northern and Southern sympathies in St. Louis, Missouri, during the Civil War, and the final outcome of the struggle in the whole country. Abraham Lincoln, one of the historical characters introduced, is effectively portrayed. 
764. - New York, Macmillan, 1914. ix, 522 p. illus. 16-6481 $\mathrm{PZ}_{3} . \mathrm{C}_{474} \mathrm{Cr} 6$

765. Edited by Walter Barnes; rev. by H[arold] Y. Moffett. New York, Macmillan, 1930. xxii, 750 p. illus. (New pocket classics) 30-13104 PZ3. $4474 \mathrm{Cr}_{15}$

A dramatization of the novel was published earlier (New York, French, ${ }^{\circ} 1927.96$ p.).

766. The crossing. New York, Macmillan, 1904 . 598 p. illus. $\quad 4-\mathrm{II}_{335} \quad \mathrm{PZ}_{3} \cdot \mathrm{C}_{474} \mathrm{Cs}$

Deals with pioneer life on the frontier in Kentucky and the significance of that section in relation to the Revolutionary War.

767. New York, Macmillan, 1912. vii, 598 p. illus. $\quad{ }_{16} 6-6482 \quad \mathrm{PZ}_{3} \cdot \mathrm{C}_{474} \mathrm{Cs} 6$

\section{SAMUEL LANGHORNE CLEMENS ("MARK TWAIN"), I835-1910}

Mark Twain, without formal education after his $13^{\text {th }}$ year, was first a frontier boy on the banks of the Mississippi River, then a printer's apprentice, and later a journeyman printer in the Middle West, New York, and Philadelphia. Next he became an expert pilot of steamboats plying the Mississippi. Then came an unsuccessful interlude as a prospector and speculator in Nevada, an impasse from which he escaped by becoming a journalist, first in Nevada and later in California. From these beginnings he ernerged as a public lecturer of immense popularity at home and abroad, a commentator from firsthand knowledge on life in Europe and the Orient, a humorist on the grand scale, and one of the most important of the country's novelists. He lived an American saga in which provincialism and sophistication, poverty and riches, failure and success were mingled. From the experiences gained in such a life he drew the substance of books that have been read scarcely less avidly in Europe and Latin America than in the United States. He used a literary style compounded of simple words, vigorous expressions, and colloquial language having the rhythm of speech used in what was then the American West; and he frequently employed many localcolor details, particularly those of life along the Mississippi. There was also in his work an element of sentimental romanticism, a quality which found probably its most open expression in the fictional biography, Personal Recollections of Joan of $\operatorname{Arc}(1896)$. In his more characteristic writing wit, irony, fun, and satire were used consciously for purposes of entertainment, and may from time to time have obscured his serious reflections on the civilization of which he was a part. He hated hypocrisy and meanness; suffering inflicted on the bodies or minds of helpless people enraged him; and the sorrowful and tragic aspects of life overwhelmed him. In the end the man usually considered the greatest exponent of the comic spirit in American literature finished his career in a mood of pessimistic naturalism.

769. The innocents abroad. Hartford, Conn., American Pub. Co., I869. xviii, 65I p. illus. 4-28129 PSI312.Ar 1869 RBD

A mock-serious autobiographical account of a pilgrimage to Europe and the Holy Land; frequently satirizes the Old World, while proclaiming the superiority of America. A work that belongs to the author's beginning period as a writer of humorous books.

770. - New York, Harper, ${ }^{c}$ IgII. 2 v. in I. (377, 446 p.) 15-22628 PSI312.AI I9II

Biographical criticism by Brander Matthews, p. v-xxxiii.

771. With an introd. by Albert Bigelow Paine. New York, Macmillan, 1927. xvi, 537 p. (Modern readers' series)

$$
\text { 27-12406 PSi312.AI } 1927
$$

772. Roughing it. Hartford, Conn., American Pub. Co.; Chicago, F. G. Gilman, 1872. xviii, 59 r p. illus.

6-21353 PS 1318 .AI 1872 RBD

Saga of boom towns, silver rushes, land-grabbing, and boisterous living on the Western frontier in the early I $860^{\prime}$ 's.

773. - New York, Harper, 1913. 2 v. in I. $([287,330]$ p.) 28-1234 PSI318.AI 1913

774. — Introd. by Rodman W. Paul. New York, Rinehart, 1953. xviii, 333 p. (Rinehart editions, 61) $52-13058$ PS I318.AI 1953

"This text is a verbatim reprint of the first sixtyone chapters of the first edition, as originally published at Hartford in $1872 \ldots$ the present edition thus breaks off at the end of Mark Twain's western adventures ...." Introduction, p. xvi, xvii.

775. The gilded age; a tale of to-day, by Mark Twain (Samuel L. Clemens) and Charles Dudley Warner. Hartford, Conn., American Pub. Co., 1873. 574 p. illus.

NN

Satiric novel which gave the title to the period after the Civil War when political corruption and economic exploitation were recurring elements in American experience. 
776. Hartford, Conn., American Pub. Co., 1874. 574 p. illus.

I7-6I I I $\mathrm{PZ}_{3} \cdot \mathrm{C}_{59} \mathrm{G}_{2} \mathrm{RBD}$

777. — New York, Harper, 1915. 2 v. in I. ([320, 337] p.) $\quad 28-1683 \quad \mathrm{PZ}_{3} \cdot \mathrm{C}_{59} \mathrm{Gi} 6$

778. The adventures of Tom Sawyer. Hartford, Conn., American Pub. Co.; San Francisco, A. Roman, 1876. xvi, 274 p.

34-25476 PSI306.AI I876 RBD

Classic representation of youth in the Mississippi

River country during the mid-nineteenth century; the first work of the author's second and major period.

779. $\frac{}{328 \text { p. }}$ New York, Harper, I903. xiii,

780. With an introd. by Dr. Percy Boynton. New York, Harper, I920. xxiv, 290 p. (Harper's modern classics) 20-3262 PZ3.C 59 Adr6

781. The text edited and with an introd. by Bernard De Voto, with a prologue, "Boy's manuscript," printed for the first time. Illustrated with drawings by Thomas Hart Benton. Cambridge, Mass., Printed for members of the Limited Editions Club at the University Press, I939. xxx, $340 \mathrm{p}$. 40-5879 PS $1306 . A_{1}$ I939 RBD

782. The adventures of Tom Sawyer and The adventures of Huckleberry Finn. New York, Modern Library, I940. x, 59I p. (Modern Library of the world's best books) $4^{\mathrm{I}-5 \mathrm{IO}} \mathrm{PZ}_{3} \cdot \mathrm{C}_{59} \mathrm{Adv}$

783. The adventures of Tom Sawyer and Adventures of Huckleberry Finn. Introd. by William Donahey. Chicago, Spencer Press, r953. I9I, 254 p. illus. $\quad 53^{-1} 325 \quad \mathrm{PZ}_{3} \cdot \mathrm{C}_{59 \mathrm{Ad} 63}$

Said to be an exact reprint of the first edition of each work.

784. Life on the Mississippi. Boston, J. R. Osgood, 1883. 624 p. illus.

3-2550I $\mathrm{F}_{353 . \mathrm{C} 63 \mathrm{RBD}}$

Reminiscences and descriptions, realistic, ironic, and romantic, of the author's experiences as a river pilot.

785. - New York, Harper, 1899. Biographical ed. xii, 465 p. $\quad 99-538$ I $\quad F_{353 .}$ C636 $_{36}$
786. With an introd. by Dixon Wecter. New York, Harper, I950. xvi, 526 p. (Harper's modern classics)

$$
\text { 50-626I } \mathrm{F}_{353} \cdot \mathrm{C}_{456} \quad 1950
$$

787. The adventures of Huckleberry Finn (Tom Sawyer's comrade) London, Chatto \& Windus, r884. xvi, $43^{8}$ p. illus.

35-20965 PSI305.AI I 884 RBD

Sequel to The Adventures of Tom Sawyer; picaresque story of boy life in the Mississippi River region; also reflects the author's revolt from the injustice and abuse of human rights evident in race relations and class distinctions at the time. Frequently cited as Mark Twain's most notable book.

788. - New York, C. L. Webster, I885. 366 p. illus. $\quad 3^{1-35230} \mathrm{PZ}_{3} \cdot \mathrm{C}_{59} \mathrm{~A}$ RBD

789. New ed. from new plates. New York, Harper, i 896. xi, 338 p.

$$
\text { 3-19534 } \mathrm{PZ}_{3} \cdot \mathrm{C}_{59} \mathrm{~A}_{4}
$$

790. —— Edited, with an introd, by Bernard De Voto. Illustrated by Thomas Hart Benton. New York, Limited Editions Club, 1942. lxxvi, 396 p. $\quad 4^{2-17247} \mathrm{PS}_{1305}$.AI I942 RBD

79I. —_ With introductions by Brander Matthews and Dixon Wecter. New York, Harper, 1948. xxv, 404 p. (Harper's modern classics) 48-20I9 $\mathrm{PZ}_{3}$. $\mathrm{C}_{59} \mathrm{~A}_{5 \mathrm{I}}$

792. — Introd. by Lionel Trilling. New York, Rinehart, 1948. xxii, 293 p. (Rinehart editions, II) $4^{8-8523} \mathrm{PZ}_{3} \cdot \mathrm{C}_{59} \mathrm{~A}_{52}$

793. - Descriptive captions and introductory remarks by Stanley T. Williams. New York, Dodd, Mead, I953. vi, 3 I2 p. illus. (Great illustrated classics) 53-9538 $\mathrm{PZ}_{3} \cdot \mathrm{C}_{59} \mathrm{~A}_{57}$

794. A Connecticut Yankee in King Arthur's court. New York, C. L. Webster, i 889. xv, 575 p. illus. 3-1953I PSI308.AI I889 RBD The feudal society of King Arthur's Britain provides the setting for the writer's portrayal of the knightly virtues of the age contrasted with its miseries. In spite of constant humorous overtones, the book embodies a serious social satire designed to show the merits of a democratic society and the defects of one based on outmoded ideas of rank and privilege in a country where class differences are emphasized.

795. - New York, Harper [1925?] ix, 449 p. $\quad 25-27463 \quad \mathrm{PZ}_{3} \cdot \mathrm{C}_{59} \mathrm{Co} 8$

Carried in Harper's current list. 
796. __ _ With an introd. by Carl Van Doren. Illustrated by Honoré Guilbeau. New York, Heritage Press, 1948. vii, 269 p. 49-I558 PS ${ }_{13}$ 08.AI 1948

797.

- New York, Modern Library [1949, ${ }^{1}$ 1917] vi, 450 p. (Modern Library of the world's best books) 49-9037 $\mathrm{PZ}_{3} \cdot \mathrm{C}_{59} \mathrm{Cor}_{7}$

798. The man that corrupted Hadleyburg, and other stories and essays. New York, Harper [1900] $398 \mathrm{p}$.

13-9365 PSI322.M25 $1900 \mathrm{RBD}$

Contents.-The man that corrupted Hadleyburg.-My début as a literary person.-From the "London Times" of 1904.-At the appetite-cure.My first lie, and how I got out of it.-Is he living or is he dead?-The Esquimau maiden's romance.How to tell a story.-About play-acting.-Concerning the Jews.--Stirring them in Austria.-The Austrian Edison keeping school again.-Travelling with a reformer.-Private history of the "Jumping frog" story.-My boyhood dreams.

The story that gives the name to the collection is a typical expression of the author's last, or naturalistic, period.

799. —— New York, Harper, 1917. 364 p. 28-1680 PZ3. $\mathrm{C}_{59} \mathrm{Mg}$

8oo. Mark Twain's letters, arr. with comment, by Albert Bigelow Paine. New York, Harper, 1917. 2 v. ([856] p.) illus.

$$
\text { 17-30756 PS } 133 \text { I.A3 } 1917
$$

8or. The love letters of Mark Twain. Edited and with an introd. by Dixon Wecter. New York,

Harper, 1949. 374 p. 49-II7II PS 133 1.A3C6

Letters to Olivia Langdon Clemens, written between 1868 and 1904 .

802. Mark Twain to Mrs. Fairbanks. Edited by Dixon Wecter. San Marino, Calif., Huntington Library, 1949. xxx, 286 p. (Huntington Library publications) $49-9860 \quad \mathrm{PS}_{133} \mathrm{~A}_{3} \mathrm{~A}_{3} \mathrm{~F}_{3}$

Bibliographical footnotes are supplied with the letters.

803. Writings. Author's national ed. New York, Harper, I869-1909. 25 v. A $10-453$ OCI

804. —- Autograph ed. Hartford, Conn., American Pub. Co. [1899-1900] 22 v. 0-2689 PSI 300. E99 $_{9}$

805. - [Author's national ed.] New York, Harper, I899-1910. $25 \mathrm{v}$.
806.

American Pub. Co. [190I-07] 25 v.

8-20712 $\mathrm{PZ}_{3} \cdot \mathrm{C}_{592}$

807. - [Author's national ed. New York, Harper, I907-18] $25 \mathrm{v}$.

$$
\text { 20-1932I } \quad \mathrm{PZ}_{3} \cdot \mathrm{C}_{596}
$$

808. —— New York, G. Wells, 1922-25. $37 \mathrm{v}$.

Definitive edition.

Introductions signed: Albert Bigelow Paine.

809. Mark Twain's works. New York, Harper, 1933. $29 \mathrm{v}$. in 23.

$\mathrm{MiU}$

810. Representative selections, with introd. and bibliography by Fred Lewis Pattee. New York, American Book Co., 1935. lxiii, 459 p. (American writers series) 35-9143 PS $1303 . P_{35}$ Selected bibliography: p. liii-lxi.

8I I. The favorite works of Mark Twain. De luxe ed. [rev.] New York, Garden City Pub. Co., 1939. xxiv, II78 p. 39-27117 PS $1302 . G_{3}$ Includes complete texts of Life on the Mississippi, The Adventures of Tom Sawyer, The Adventures of Huckleberry Finn, and A Connecticut Yankee at King Arthur's Court. Various excerpts are added from other works. The text is specially edited from The Family Mark Twain, published by Harper.

812. The portable Mark Twain. Edited by Bernard De Voto. New York, Viking Press. 1946. vii, 786 p. (Viking portable library) 46-6686 $\mathrm{PS}_{3302 . \mathrm{D}_{4}}$

Continuing interest in Mark Twain's contribution to American literature has been made evident in recent years by studies that include the following:

8r3. Allen, Jerry. The adventures of Mark Twain. Boston, Little, Brown, 1954. 359 p. illus. 54-6873 PSi33r.A7 1954

Designed as a biographical introduction for the general reader; includes some fictional treatment of factual material.

814. Andrews, Kenneth R. Nook Farm, Mark Twain's Hartford circle. Cambridge, Harvard University Press, 1950. xii, 288 p. illus.

Bibliography: p. [271 ]-28o.
50-975I PS $1334 . A 6$ 
815. Bellamy, Gladys C. Mark Twain as a literary artist. Norman, University of Oklahoma Press, 1950. xiii, 396 p. illus.

Bibliography: p. $377-3^{82}$.

$$
\text { 50-4775 PSI } 338 . \mathrm{B}_{4}
$$

8r6. Branch, Edgar M. The literary apprenticeship of Mark Twain, with selections from his apprentice writing. Urbana, University of Illinois Press, 1950. xiv, 325 p. $\quad 50-7851$ PS 332. B $_{7}$

Bibliographical references included in "Notes" (p. 271-302).

817. Canby, Henry Seidel. Turn west, turn east: Mark Twain and Henry James. Boston, Houghton Mifflin, 1951. xii, 318 p.

Bibliography: p. 3or-303.

$$
\text { 51-I } 4000 \text { PSi } 33^{1 . C_{25}}
$$

818. De Voto, Bernard. Mark Twain's America. Cambridge, Houghton Mifflin, I951 [ ${ }^{\circ} 1932$ ] xvi, $35^{1}$ p. illus. $\quad 5 \mathrm{I}-6 \mathrm{I} 60 \mathrm{PS}_{33} \mathrm{I}^{\mathrm{I}} \mathrm{D}_{4}$ I95I Bibliography: p. [323]-339.

Republication of a work that, in treating of Mark Twain's environment before he came East, also provides a view of the frontier as a primary element in American cultural history.

8rg. Scott, Arthur L., ed. Mark Twain, selected criticism. Edited with an introd. Dallas, Southern Methodist University Press [1955] xii, 289 p. 55-12080 PS 133 I.S 3

"Guide to Mark Twain bibliographies": p. 286289. Bibliographical footnotes.

Includes thirty-four critical articles published in English between 1867 and 1951. For articles in foreign languages the reader is referred to Roger Asselineau's The Literary Reputation of Mark Twain from 1910 to 1950 (Paris, Librairie Marcel Didier, 1954. 242 p.).

820. Wecter, Dixon. Sam Clemens of Hannibal. Boston, Houghton Mifflin, 1952. ix, 335 p.

Bibliography: p. 317-322.

$$
\text { 52-5258 } \mathrm{PS}_{3332 . \mathrm{W}_{4}}
$$

Posthumous publication of the completed portion of a biography planned to be definitive; written by the third editor of the Mark Twain Estate. Covers ancestry, early family life, and youth up to age eighteen in Hannibal, Missouri; hence deals with the places and the period from which Clemens later drew the inspiration for his best work.

\section{STEPHEN CRANE, I87I-1900}

In a period when gentility and the happy ending were particularly popular among American readers, Crane was decidedly an innovator when he wrote a short novel having a prostitute as the heroine. However, not until the publication of his Civil War novel, The Red Badge of Courage, which portrayed the realities of the battlefield as faithfully in words as Míathew B. Brady did in photographs, was his reputation established as an initiator of realism in American literature. He was a prolific and uneven writer of short stories as well as novels and of poems that in the absence of conventional rhymes may be called free verse. Irony and naturalism were present in his best work, and his themes frequently dealt with suffering, mutilation, terror, and death. Various writers in America whom he is said to have influenced include Willa Cather, Ernest Hemingway, Theodore Dreiser, and F. Scott Fitzgerald. A recent biographical and critical study of Crane is provided by John Berryman's Stephen Crane (New York, Sloane, I950, xv, 347 p. American men of letters series).

822. Maggie, a girl of the streets, by Johnston Smith [pseud.] [New York, Priv. print., 1893] $163 \mathrm{p}$.

823. - New York, Appleton, 1896. vi, ${ }_{5} 8 \mathrm{p}$. $\quad 6-30866 \mathrm{PZ}_{3}$.C $8_{52 \mathrm{M}} \mathrm{RBD}$ Second edition revised by the author.

824. Together with George's mother [1896] and "The blue hotel" [1899] With an introd. by Henry Hazlitt. New York, Knopf, r93I. xi, 218 p. $\quad 3$ I-28r40 PZ3.C852Mag

825. The red badge of courage; an episode of the American Civil War. New York, Appleton, I895 [ $\left.{ }^{\circ} \mathrm{I} 894\right] 233 \mathrm{p}$.

$49-366_{15} \mathrm{PS}_{1449 .} \mathrm{C}_{5} \mathrm{R}_{3}$ I $895 \mathrm{RBD}$

826. New ed., with port. and pref. New York, Appleton, igoo. x, 233 p.

Preface contains biographical notice. $\begin{array}{lll}0-3652 & \mathrm{PZ}_{3} \cdot \mathrm{C}_{5} \mathrm{R}_{2}\end{array}$

827. - Illustrated by John Steuart Curry, with an introd. by Carl Van Doren. New York, Heritage Press, 1944. xiii, $170 \mathrm{p}$. 44-62 I6 PSI $449 . \mathrm{C}_{5} \mathrm{R}_{3}$

828. Introd. by Robert Wooster Stallman. New York, Modern Library, 1951. xlv, 266 p. (Modern Library college editions, $\mathrm{T}_{45}$ )

Bibliography: p. xlii-xlv. $5^{\mathrm{I}-227^{8}} \quad \mathrm{PZ}_{3} \cdot \mathrm{C}_{52} \mathrm{R}_{12}$

829. Edited and introduced by John $\mathrm{T}$. Winterich. With Civil War photographs 
[taken by Mathew B. Brady] London, Folio Society [I95I] $159 \mathrm{p}$. $\quad 52-2542 \quad \mathrm{PZ}_{3} . \mathrm{C}_{52} \mathrm{RI}_{4}$

"The present edition of The Red Badge of Courage contains material from the original manuscript which has never appeared in print before."-"A Note on this Edition," p. 21.

83o. The open boat, and other tales of adventure. New York, Doubleday \& McClure, r88g. $336 \mathrm{p}$. 6-30865 $\mathrm{PZ}_{3} \cdot \mathrm{C}_{520} \mathrm{RBD}$

83I. War is kind. Drawings by W. Bradley. New York, Stokes, I899. 96 p.

Poems. 99-1667 PS ${ }^{4} 449 . C 85$

832. Works. Edited by Wilson Follett. New York, Knopf [ ${ }^{\mathrm{c}} 1925^{-26}$ ] i2 v. 25-25565 PSI449.C85 I925 RBD Introductions by Amy Lowell, Willa Cather, Henry L. Mencken, Sherwood Anderson, and others.

833. Collected poems. Edited by Wilson Follett. New York, Knopf, I930. I32 p.

$$
\text { 30-9605 PSi } 449 . \mathrm{C}_{5} \mathrm{AI}_{7} \quad 1930
$$

834. Twenty stories. Selected, with an introd., by Carl Van Doren. New York, Knopf, 1940. xvii, $507 \mathrm{p}$.

Notes: p. 50I-507.

835. Selected prose and poetry. Edited with an introd. by William M. Gibson. New York, Rinehart, 1950. xix, 230 p. (Rinehart editions, 47) 50-107II PSi449.C85A6 $195^{\circ}$

"Textual and bibliographical note": p. xvii.

Includes among other selections Maggie, "The Bride Comes to Yellow Sky" (I898), "The Monster" (1899), and poems from The Black Riders (1895), War ls Kind (1899), and "Three Poems" from Collected Poems (1930).

Another Rinehart collection is announced for future publication: The Red Badge of Courage and Selected Prose and Poetry.

836. Stephen Crane: an omnibus. Edited, with introd. and notes, by Robert Wooster Stallman. New York, Knopf, 1952. xlv, 703 p.

Bibliography: p. 697-703.

$$
\text { 52-6416 PS } 1449 . C_{5} \text { A } 61952
$$

Brings together texts of the novels, Maggie, George's Mother, and The Red Badge of Courage; ten short stories; sixteen poems; and fifty-seven new letters accompanied by reprints of various letters previously published. Crane's contribution to journalism is represented by four articles. Cf. Editor's Foreword, p. vii.
837. Stories and tales. Edited by Robert Wooster Stallman. New York, Vintage Books, 1955. xxxii, $35^{\circ}$ p. (A Vintage book, $\mathrm{K}-10$ )

Bibliography: p. 347-350. 55-159 $\mathrm{PZ}_{3} \cdot \mathrm{C}_{52} \mathrm{St}$

Includes Maggie and George's Mother in addition to selected short stories.

\section{EMILY DICKINSON, I830-1886}

Emily Dickinson lived out her 56 years of life in the college town of Amherst, Massachusetts, where she grew to maturity under the domination of a father who came from a New England family of Calvinistic convictions. By the age of 36 Miss Dickinson had achieved a withdrawal from the world that culminated in a life of complete retirement within the family home and grounds. In this seclusion of her physical person her mind and imagination were extremely active, with the result that hundreds of brief lyrics on love, death, nature, and God, as well as many letters, poured from her pen. These reveal an intense inner life that continues to challenge interest and arouse speculation on the part of numerous critics. Her poems are highly original, often cryptic, sometimes gay, and frequently witty. In them economy in the use of words is carried to the point of frugality. They are characterized by a strong metaphysical interest, daring metaphors, imagery, conceits, and by much irregularity in meter and rhyme. Hers was a poetic voice as new when her poems began to be published posthumously as Whitman's had been when Leaves of Grass appeared in 1855 .

839. Poems [first series] Edited by two of her friends, Mabel Loomis Todd and T. W. Higginson. Boston, Roberts, 1890. xii. 152 p. 3-18785 PSI54I.P6 I8go RBD

840. Poems, second series. Edited by two of her friends, T. W. Higginson and Mabel Loomis Todd. Boston, Roberts, I8g1. $230 \mathrm{p}$.

$$
\text { 3-18788 PS I54I.P62 I891 RBD }
$$

841. Poems, third series. Edited by Mabel Loomis Todd. Boston, Roberts, I8g6. vii, 200 p.

$$
3^{-18787} \mathrm{PS}_{54}{ }^{1 . P 6}{ }_{3} \quad 1896 \mathrm{RBD}
$$

842. Poems. Edited by Martha Dickinson Bianchi and Alfred Leete Hampson; introd. by Alfred Leete Hampson. Boston, Little, Brown, 1937. xi, $484 \mathrm{p}$.

37-2949 PSr54I.AI 1937

"In the present edition all the poems of the preceding collections of poems are included in a single volume."-Introduction, p. $x$. 
843. Bolts of melody; new poems. Edited by Mabel Loomis Todd and Millicent Todd Bingham. New York, Harper, 1945. xxix, $35^{2}$ p. 45-35045 PSI54I.AI37

844. Selected poems. With an introd. by Conrad Aiken. New York, Modern Library, 1948. xvi, 23 I p. (Modern Library of the world's best books [25]) 48-9350 PSi54r.A6 r948a Selected Poems, edited by Conrad Aiken, was published in London by J. Cape, 1924, in $272 \mathrm{p}$.

845. Poems. Selected and edited with a commentary by Louis Untermeyer. Illustrated by Helen Sewell. New York, Heritage Press, 1952. xxviii, 284 p. (American poets) 53-1806 PSi541.A6 I952a

Based on the Limited Editions Club edition of the same year.

846. Poems; including variant readings critically compared with all known manuscripts. Edited by Thomas H. Johnson. Cambridge, Belknap Press of Harvard University Press, 1955. $3 \mathrm{v}$. (lxviii, x266 p.) facsims.

54-863 I PSi541.Ax I955

Inclusive scholars' edition of the poet's complete poetical work. In an extensive introduction the editor discusses historical and stylistic developments found in the poems.

Editions of the poems before Bolts of Melody failed to set accuracy of the text as a primary consideration.

847. Letters. Edited by Mabel Loomis Todd. Boston, Roberts, I894. 2 v. illus. 24-2210I PSi54r.Z $\mathrm{A}_{3}$

Includes ro2 additional poems or parts of poems.

848. — New and enl. ed. Edited by Mabel Loomis Todd. New York, Harper, I931. xxxi, 457 p. illus. 3I-32229 PSI541.Z5 $\mathrm{A}_{3} \mathrm{I}_{93} \mathrm{I}$

849. —— Edited by Mabel Loomis Todd, with an introd. by Mark Van Doren. Cleveland, World Pub. Co., I95x. xxiv, 389 p. illus. 5 ${ }^{\mathrm{I}-9898} \quad \mathrm{PSr}_{54} \mathrm{x} . \mathrm{Z}_{5} \mathrm{~A}_{3} \quad$ 195 $\mathrm{x}$

850. Letters to Dr. and Mrs. Josiah Gilbert Holland. Edited by their granddaughter, Theodora Van Wagenen Ward. Cambridge, Harvard University Press, r951. vii, 252 p. illus. 5I-10236 PSr $541 . Z_{5} \mathrm{~A}_{36}$

Understanding of Emily Dickinson's life and art has been greatly broadened in the past ten years by the availability of various new critical and biographical studies, which include the following:

85x. Bingham, Millicent (Todd). Ancestors' brocades; the literary debut of Emily Dickinson.

New York, Harper, 1945. xiii, 464 p. illus. 45-35042 PSi $541 . Z_{5} B_{53}$

"Early Reviews of Books by Emily Dickinson, I890-1896": p. 406-4r I. "Books by Emily Dickinson, a Partial List of Editions of Books Brought Out by Mabel Loomis Todd and Thomas Wentworth Higginson": p. 412-415. Includes an important analysis of difficulties to be faced in preparing a definitive edition of the poems.

852. Bingham, Millicent (Todd). Emily Dickinson, a revelation. New York, Harper, I954. rog p. illus. 54-I2227 PSi54r.Z5 Includes some unpublished letters, and some late poems by Emily Dickinson. On the basis of this material, supplemented by extensive research, the writer identifies the last great love of Emily's life as her father's friend, Otis Phillips Lord, a prominent judge in Massachusetts.

853. Bingham, Millicent (Todd). Emily Dickinson's home; letters of Edward Dickinson [Emily's father] and his family. With documentation and comment by Millicent Todd Bingham. New York, Harper, I955. xvii, 600 p. illus. Includes bibliographies. $55^{-6} 673$ PS $1541 . Z_{5} B_{543}$

854. Chase, Richard V. Emily Dickinson. New York, Sloane, I951. xii, 328 p. (The American men of letters series)

$$
5^{\mathrm{x}-\mathrm{I}} 4929 \quad \mathrm{PS}_{154} \mathrm{I}_{2} \mathrm{Z}_{5} \mathrm{C}_{5}
$$$$
\text { "Bibliographical note": p. 313-317. }
$$

855. Johnson, Thomas H. Emily Dickinson: an interpretive biography. Cambridge, Belknap Press of Harvard University Press, 1955. $276 \mathrm{p}$. illus.

55-9439 PSi54ז.Z5J6

\section{PAUL LAURENCE DUNBAR, 1872-1906}

Dunbar, born in Ohio to parents who had formerly been slaves, owes his significance in American literature chiefly to his poems and short stories in Negro dialect. In the majority of these he memorialized the humor and also the pathos of the old-fashioned plantation Negro, giving his themes the idealization used by various other writers, and particularly by Thomas Nelson Page. Dunbar also wrote traditional romantic poems in conventional English and novels, such as The Sport of the Gods (rg02). 
857. Lyrics of lowly life. With an introd. by W. D. Howells. New York, Dodd, Mead, I 896. $\mathrm{xx}, 208 \mathrm{p}$. 4-13820 PS $1556 . \mathrm{L6} \quad 1896$

858. Lyrics of the hearthside. New York, Dodd, Mead, 1899. $x, 227 \mathrm{p}$.

$$
\text { 99-1025 PSI556.L7 I } 899
$$

859. Life and works; containing his complete poetical works, his best short stories, numerous anecdotes, and a complete biography of the famous poet. By Lida Keck Wiggins, and an introd. by William Dean Howells. Naperville, Ill., Memphis, Tenn., J. L. Nichols [ ${ }^{\mathrm{I}}$ 1907] 430 p. illus. $7^{-1} 34^{14}$ PSI $_{557 .}$ W $_{5}$

860. Best stories. Selected and edited with an introd. by Benjamin Brawley. New York, Dodd, Mead, r938. xvii, 258 p.

$3^{8-5603} \quad \mathrm{PZ}_{3}$.D9irBe

Selections are taken from the following collections of short stories: Folks from Dixie (1898); The Strength of Gideon (1900); In Old Plantation Days (1903); and The Heart of Happy Hollow (1904).

861. Complete poems. With the introd. to Lyrics of lowly life by W. D. Howells. New York, Dodd, Mead, 1940. xxxii, 289 p.

Previously issued in I913.

$$
4^{0-34708} \text { PSi556.AI I940 }
$$

\section{FINLEY PETER DUNNE ("MR. DOOLEY"), 1867-1936}

Dunne, a Chicago newspaper reporter and later an editor, created a crackerbox philosopher, "Mr. Dooley," who, speaking in the brogue of Irish immigrants, became the author's medium for expressing his own serious views on social, political, and foreign affairs. The essays were enormously popular, first as newspaper columns and later in the form of books. "Josh Billings," "Artemus Ward," and Will Rogers are representative figures in the tradition of American writing to which Dunne belonged.

863. Mr. Dooley in peace and in war. Boston, Small, Maynard, 1898 . xviii, $260 \mathrm{p}$. 98-1501 PN6r61.D82 1898

864. Mr. Dooley in the hearts of his countrymen. Boston, Small, Maynard, I 899 . xi, 285 p. 99-5065 PN6r6i.D825

865. Mr. Dooley at his best. Edited by Elmer Ellis; with foreword by Franklin P. Adams. New York, Scrfibner, 1938. xxvi, 291 p. 38-27991 PN6r6r.D818
866. Mr. Dooley: now and forever, created by Finley Peter Dunne. Selected, with commentary and introd. by Louis Filler. Stanford, Calif., Academic Reprints, 1954. xv, 298 p. (American culture and economics series, no. 4)

$$
\text { 54-12399 PN6r6r.D817 }
$$

Includes material from the 1898,1899 publications cited above, and also from What Dooley Says (1898); Mr. Dooley's Philosophy (1900); Mr. Dooley's Opinions (1901); Observations by $\mathrm{Mr}$. Dooley (1902); Dissertations by Mr. Dooley (I906); and Mr. Dooley Says (rgro).

\section{EDWARD EGGLESTON, 1837-1902}

Eggleston, largely a self-educated man, was a Methodist clergyman, an editor, and a historian as well as a novelist. He was inspired to apply to the writing of fiction the idea that a good artist paints subjects chosen from his own environment. His birth and early years in the Middle West had made him familiar with Southern Ohio, Indiana, and Illinois, and with the "Hoosier" dialect used there in the early part of the Igth century; consequently it was to this part of the country that he turned for his material. His novels and stories, once popular, suffer from melodramatic plots, poor characterization, forced humor, and sentimentality. Historically, however, they give early evidence of the trends in American literature after the Civil War towards increasing interest in the speech and social conditions of common men, in realistic rather than romantic themes, and in the local color of regions remote from the older centers of culture in the East.

868. The Hoosier schoolmaster. New York, Orange Judd [ ${ }^{\mathrm{c}} \mathrm{I} 8 \mathrm{7}$ ] ${ }^{226} \mathrm{p}$.

$$
\text { 3-19544 PS } 1582 . \mathrm{H}_{2} \text { 1871 RBD }
$$

Title varies: The Hoosier Schoolmaster; a Novel; The Hoosier Schoolmaster; a Story of Backwoods Life in Indiana.

869. - New and rev. ed. New York, Orange Judd, 1893.218 p. illus.

$$
\text { 3-19546 } \mathrm{PZ}_{3} . \mathrm{E}_{29} \mathrm{H} 8
$$

870. — Rev. with an introd. and notes ... by the author. New York, Grosset \& Dunlap ['1913] 281 p. $\quad 40-\mathrm{r}_{52} \quad \mathrm{PZ}_{3} \cdot \mathrm{E}_{29} \mathrm{H} 8$ 87r. With an introd. by Emory Holloway. New York, Macmillan, 1928. xxviii, 203 p. (Modern readers' series) 28-2535I $\mathrm{PZ}_{3}$.E29Hi5 
872. The circuit rider. New York, J. B. Ford, 1874. 332 p. 6-37566 $\mathrm{PZ}_{3}$. $\mathrm{E}_{29} \mathrm{C}$

873. - New York, Scribner, 1902. 332 p. 2-III34 $\mathrm{PZ}_{3} \cdot \mathrm{E}_{29} \mathrm{C}_{7}$

874. Roxy. New York, Scribner, I878. viii, 432 p. $\quad 4^{-22067} \quad \mathrm{PZ}_{3}$.E2gR

875. - New York, Scribner, 1906. viii, 432 p. $\quad 6-277 I_{4} \quad \mathrm{PZ}_{3} \cdot \mathrm{E}_{29} \mathrm{R}_{2}$

876. The Graysons; a story of Illinois. New York, Century [1888] 362 p. illus. 4-15098 PSi582.G7 1888 RBD

Includes a courtroom scene in which Abraham Lincoln, as counsel for the defense, plays a leading part.

877. The Graysons; a story of Abraham Lincoln. New York, Century, 1918 [ ${ }^{\circ}$ 1915] 362 p. illus. $\quad 53-49456$ PSI582.G7 I9I8 RBD

Published also under title: The Graysons; a Story of Illinois.

\section{EUGENE FIELD, 1850-1895}

From 1883 to 1895 Field pioneered in a new type of newspaper column, which he called "Sharps and Flats." It appeared regularly in the Chicago Morning News (afterwards called the Chicago Record). Sometimes written in real or manufactured dialect and slang, the column was a mélange of jokes, gossip about persons or events, idealistic short stories, lullabies, parodies, familiar verses particularly for or about children, political sarcasm, and miscellaneous humorous pieces. It is said that most of what he published in book form, as for example $A$ Little Book of Western Verse (1889) and A Little Book of Profitable Tales (1889), had appeared first in his column. He is remembered particularly for his innovations in journalistic literature and for the appeal his verses had to the taste of his period, a time when James Whitcomb Riley also attracted a large audience.

879. Poems. Complete ed. New York, Scribner, 1915. xii, $553 \mathrm{p}$.

16-6502 PSI665.A2 1915

880. Writings in prose and verse. New York, Scribner, 1898-rgor. I2 v. illus.

32-2826 PS I665.Ai 1898

"Eugene Field; a Memory," by Roswell Martin

Field, v. I, p. ix-xlvii.

Vols. I-IO, I898; V. II-I2, Igor.
Introductions by Joel Chandler Harris, Edward Everett Hale, and others.

Reissued by Scribner in rgrr.

88r. MARY E. (WILKINS) FREEMAN, I852$193^{\circ}$

The name of Mrs. Freeman, a writer whose early and most successful short stories are set in rural New England, is frequently linked with the names of Harriet Beecher Stowe and Sarah Orne Jewett as belonging to the school of local color writing about that region. However, her own objectivity, economy, and force applied to the delineation of her characters, their environment, and the society of which they were a part constitute her individual contribution to the realistic American dialect story of the late 1gth century. Mrs. Freeman's stories, concerned chiefly with frustration and repression in provincial Massachusetts circles, forcefully convey her own view of life as essentially tragic.

882. A humble romance, and other stories. New York, Harper, i 887 . iv, $436 \mathrm{p}$. $\mathrm{I}-247^{8} \quad \mathrm{PZ}_{3} . \mathrm{F} 88 \mathrm{Hu}$

Twenty-eight short stories.

883. A New England nun, and other stories. New York, Harper, r891. iv, 468 p.

Twenty-four short stories. $4^{-15} \mathrm{I}^{108} \mathrm{PZ}_{3} \cdot \mathrm{F} 88 \mathrm{~N}$

884. W With an introd. by Professor Fred Lewis Pattee. New York, Harper [ ${ }^{\mathrm{C}} \mathrm{I}$ 200] xxvi, 468 p. (Harper's modern classics) 20-18608 $\quad \mathrm{PZ}_{3} \cdot \mathrm{F} 88 \mathrm{~N} 6$

885. Edgewater people. New York, Harper ['1918] 314 P. $18-21528 \quad \mathrm{PZ}_{3}$.F88Ed

Includes twelve short stories.

$\mathrm{PS}_{1712 . \mathrm{E}_{4}}$

886. Best stories. Selected and with an introd. by Henry Wysham Lanier. New York, Harper, 1927. xi, 465 p. $27-5840 \quad \mathrm{PZ}_{3} . \mathrm{F} 88 \mathrm{Be}$

887. HENRY BLAKE FULLER, I857-1929

A Chicago banker, journalist, and novelist, Fuller wrote at a time when Chicago was going through a period of rapid social change, marked by expansion, material wealth, social ambition, and municipal corruption. Fuller knew this life so intimately that it naturally provided the material for his novels and short stories. These were written in the tradition of realism associated with the work of William Dean Howells, lacking as they did the 
naturalistic view of American society later developed by Theodore Dreiser. In another and different mood Fuller reacted to a number of trips abroad by writing various volumes that record his enjoyment of Europe, among them The Chevalier of Pensieri-Vani (189o), a gently humorous book, half fact, half fancy, about experiences in Italy.

888. The cliff-dwellers, a novel. New York, Harper, 1893. 324 p. illus.

$$
\text { 6-44578 } \mathrm{PZ}_{3} \cdot \mathrm{F}_{957} \mathrm{Cl}
$$

889. With the procession, a novel. New York, Harper, $1895 \cdot 336 \mathrm{p}$.

$$
\text { 6-44576 } \mathrm{PZ}_{3} \cdot \mathrm{F}_{957} \mathrm{Wi}
$$

\section{HAMLIN GARLAND, 1860-1940}

After a boyhood devoted to a man's labor on family farms in Wisconsin, Iowa, and Dakota Territory, Garland went as a young man to Boston. There he came under the influence of William Dean Howells and imbibed the latter's theories of literary realism. Garland, however, soon went beyond his preceptor's position by evolving his own literary theory. This he called "veritism." Its principal tenets included: a national American literature purged of imitations of older literatures; realism faithful not merely to facts but to the writer's impressions of truth underlying the facts; themes drawn from the author's own experiences, whether agreeable or not; and local color dependent upon intimate knowledge of the place or region depicted. In the best of Garland's work he remained true to these principles. His short stories of farm life in the Middle West, often grim but also powerful, contributed to the marked success of the short story as a literary form at the end of the rgth century. A series of autobiographical works, dealing with the Middle Border in relation to his own family, chronicles the influence of the frontier on three generations of middle-class Americans.

891. Main-traveled roads; six Mississippi Valley stories. Boston, Arena Pub. Co., I891. 260 p. I7-26999 PSi732.M3 I89I RBD

892. - New ed., with additional stories. New York, Macmillan, 1899. ix, 299 p. 99-4062 $\mathrm{PZ}_{3} \cdot \mathrm{GI}_{1} 8 \mathrm{M}_{4}$

893. - Sunset ed. New York, Harper [I909?] 299 p. I9-5047 PZ3.Gi8M5

Contents.-Introduction by W. D. Howells.-A branch road.-Up the coolly.-Among the cornrows. - The return of a private.-Under the lion's paw.-The creamery man.-A day's pleasure.Mrs. Ripley's trip.-Uncle Ethan Ripley.
894. With illus. by Constance Garland. New York, Harper, 1930. $406 \mathrm{p}$.

Includes six additional stories. 30-28187 PZ3.Gi $8 \mathrm{M}$ 10

895. Edited with an introd. by Thomas A. Bledsoe. New York, Rinehart, 1954. 185 p. (Rinehart editions, 66) $\quad 54-5867 \quad \mathrm{PZ}_{3} . \mathrm{GI}_{8} 8 \mathrm{MI}_{3}$

896. Crumbling idols; twelve essays on art, dealing chiefly with literature, painting and the drama. Chicago, Stone \& Kimball, 1894. ix, I92 p. 27-20780 PSI732.C7 1894

Contents.-Provincialism.-New fields.-The question of success.-Literary prophecy.-Local color in art.-The local novel.-The drift of the drama.-The influence of Ibsen.-Impressionism.Literary centres.-Literary masters.-A recapitulatory afterword.

897. — With an introd. by Robert E. Spiller. Gainesville, Fla., Scholars' Facsimiles \& Reprints, 1952. viii, I92 p.

$$
\text { 52-9716 PSi732. } 7 \text { I952 }
$$

898. A son of the Middle Border. New York, Macmillan, 1917. 467 p. illus.

I7-22272 PS1733.A4

Second in a series, in point of chronology, the first being The Trail-Makers of the Middle Border (1926); the third, A Daughter of the Middle Border (1921, Pulitzer Prize, 1922); and the fourth BackTrailers from the Middle Border (1928).

Currently reprinted by the same publisher.

899. - New York, Grosset \& Dunlap, 1928, ${ }^{\mathrm{c}}$ 1917. v, $466 \mathrm{p}$.

$$
{ }_{48-35778} \operatorname{PS}_{7333 . A 47} \quad 1928
$$

900. EDWARD EVERETT HALE, 1822-1909

Hale was a Unitarian clergyman of distinguished New England ancestry and connections, whose long life was spent in or near Boston. His voluminous writings, which included essays, addresses, short stories, novels, sermons, books of travel, and other literary forms, reveal his catholic interest in miscellaneous fields-literature, history, antiquities, government, the opening of the Middle West, European culture, and practical ethics, among others. His works are now significant chiefly as records of the mind and character of a man widely known and appreciated in his time and place.

901. The man without a country. Boston, Ticknor \& Fields, $1865.23 \mathrm{p}$.

I5-3I74 PSI772.M3 $1865 \mathrm{RBD}$ 
Published first in The Atlantic Monthly, Dec. I863, to combat Northern or "Copperhead" sympathy with the Confederacy during the Civil War and to inspire patriotism in a united nation, the story has been republished frequently, both separately and in short story collections.

902. - [Limited ed.] Boston, J. S. Smith

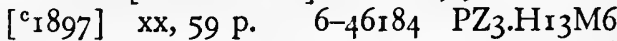

Includes author's account of the background and circumstances of the writing and publication of the story, and of its subsequent history.

903. - New ed. With an introd. in the year of the war with Spain. Boston, Little, Brown, ז898. xxxii, 59 p. $9^{8-23^{8}} \mathrm{PZ}_{3} \cdot \mathrm{H}_{3} \mathrm{M}_{7}$

904. — New ed., with an introd. in the year of the war with Spain. Boston, Little,

Brown, 1923. xxxii, 59 p. 27-7343 $\mathrm{PZ}_{3} . \mathrm{Hr}_{3} \mathrm{M}_{30}$

905. — With an introd. by Carl Van Doren and illus. by Edward A. Wilson. New York, Limited Editions Club, 1936. x, 55 p. $3^{6-18845} \mathrm{PS}_{1772 . \mathrm{M}_{3}} 1936 \mathrm{RBD}$

906. A New England boyhood. New York, Cassell [1893] xxv, 267 p. illus.

4-1696r F73.44.Hi5

Describes a Boston boyhood before the middle of the rgth century, giving details of a happy home life, social and religious experiences, the reading of the New England children at the time, and student life at Harvard.

907. — A new ed. With foreword by Edwin D. Mead. Boston, Little, Brown, 1927. xxxii, 208 p. illus. 27-19168 PSI773.A2 1927

908. Works. Library ed. [Boston, Little, Brown, r898-rgor] ro v. 99-5408 PSI770.A2 1898

909. The man without a country, and other stories. Edited with introd. and notes by Samuel Marion Tucker. New York, Macmillan, 19ro. xxviii, 200 p. ([Macmillan's pocket American and English classics])

$$
\text { 10-22723 } \mathrm{PZ}_{3} \cdot \mathrm{H}_{13} \mathrm{M}_{25}
$$

\section{JOEL CHANDLER HARRIS, r848-rgo8}

Harris' position as an author derives from his contribution to Negro folk literature in America, typified by the Uncle Remus stories and rhymes first published in the Atlanta Constitution, a newspaper with which Harris was associated from 1876 to 1900. The first collected edition was received enthusiastically, not only in the South but also in the North, where it gave evidence of the vitality of Southern literature after limitations imposed on it by the Civil War. This and successive collections made their appeal through their modern treatment of animal mythology as well as through their gentle humor, plantation Negro dialect, and popular philosophy. The stories Harris wrote about mountaineers, freed Negroes, and poor whites in his native Georgia, while less well-known than the Uncle Remus stories, have an authentic local color and a democratic realism that differ sharply and with salutary effect from Thomas Nelson Page and George William Bagby's romantic glorification of Southern plantation life before the Civil War. For useful data on Harris' life and contributions see Stella Brewer Brooke's Joel Chandler Harris, Folklorist (Athens, University of Georgia Press, 1950. 182 p.).

911. Uncle Remus, his songs and his sayings. New York, Appleton, r88r. 231 p. illus.

$$
\text { 7-2896 } \mathrm{PZ}_{3} \cdot \mathrm{H}_{24} \mathrm{Un}_{3}
$$

Described as "the folk-lore of the old plantation."

First published in 1880 .

Contents.-Legends of the old plantation.Plantation proverbs.- - His songs.-A story of the war.-His sayings.

912. — New and rev. ed., with one hundred and twelve illust. by A. B. Frost. New York, Appleton, I895. xxi, 265 p.

$$
\text { 7-2897 } \mathrm{PZ}_{3} \cdot \mathrm{H}_{242} \mathrm{Un}_{3}
$$

913. — New and rev. ed., with 112 illus. by A. B. Frost. New York, Appleton-Century, 1947. xxi, 270 p. $\quad 47-5732 \quad \mathrm{PZ}_{7} \cdot \mathrm{H}_{242} \mathrm{Un}_{4} \mathrm{O}$ Based on the author's revision of 1895 .

914. Nights with Uncle Remus. Boston, J. R. Osgood, 1883 . xxxvi, 416 p. illus.

$$
\text { 8-2392 I PZ3. } \mathrm{H}_{242 \mathrm{~N}}
$$

Subtitle: Myths and legends of the old plantation.

915. $22 \mathrm{~d}$ ed. Boston, Houghton Mifflin [ ${ }^{\mathrm{c}} \mathrm{88} 3$ ] xxxvi, $4 \mathrm{I} 6 \mathrm{p}$. illus.

$$
\text { 42-26420 } \mathrm{PZ}_{3} \cdot \mathrm{H}_{24} \mathrm{~N}_{2}
$$

9r6. W With illus. by Milo Winter. Boston, Houghton Mifflin, 1917. viii, $33^{8} \mathrm{p}$.

$$
{ }_{17-25512} \mathrm{PZ}_{3} \cdot \mathrm{H}_{242} \mathrm{~N}_{4}
$$

917. Mingo, and other sketches in black and white. Boston, J. R. Osgood, 1884. 273 p.

$$
\text { I 2-32982 } \mathrm{PZ}_{3} \cdot \mathrm{H}_{242 \mathrm{Mi}}
$$

Contents.-Mingo: a sketch of life in middle Georgia.-At Teague Poteet's: a sketch of the Hog Mountain range.-Blue Dave.-A piece of land. 


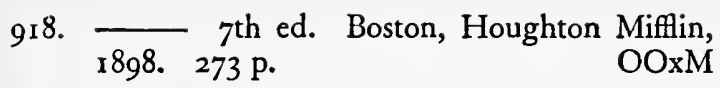

919. - New York, Mckinlay, Stone \& Mackenzie ['1912] $273 \mathrm{P}$. (The booklovers ed.)

$\mathrm{ViU}$

920. Free Joe, and other Georgia sketches. New York, Scribner, $1887.236 \mathrm{p}$.

$$
{ }_{7-3663} \quad \mathrm{PZ}_{3} \cdot \mathrm{H}_{24} \mathrm{~F}
$$

Contents.-Free Joe.-Little Compton.-Aunt Fountain's prisoner.-Trouble on Lost Mountain.Azalia.

921. New York, Scribner, 1906. 236 p. $\mathrm{NN}$

922. Uncle Remus and his friends; old plantation stories, songs, and ballads, with sketches of Negro character. Illustrated by A. B. Frost. Boston, Houghton Miffin, I892. xv, $357 \mathrm{p}$.

$$
\text { 7-2895 } \mathrm{PZ}_{7} . \mathrm{H}_{24} \mathrm{Unh}_{3}
$$

923. Joel Chandler Harris: editor and essayist. Edited by Julia Collier Harris. Chapel Hill, University of North Carolina Press, 1931. 429 p. 3I-3I655 PSi 80 I. $\mathrm{H}_{3}$

Comprises miscellaneous literary, political, and social writings.

924. The favorite Uncle Remus. Illustrated by A. B. Frost. Selected, arr. \& edited by George Van Santvoord and Archibald C. Coolidge. Boston, Houghton Mifflin, 1948. viii, 3ro p. 48-1944 PZ7. $\mathrm{H}_{242} \mathrm{Fav}$

Published in celebration of the centenary of the author's birth. This is one of many reprints of selections made available from time to time.

925. The complete tales of Uncle Remus. Compiled by Richard Chase. With illus. by Arthur Burdette Frost [and others] Boston, Houghton Mifflin, 1955. xxxii, $875 \mathrm{p}$.

$$
\text { 54-I2233 } \mathrm{PZ} 7 . \mathrm{H}_{24} \mathrm{Co}
$$

"The tales in this edition have been left as Mr. Harris wrote them. Our concern has been with the folktales only, and not with the songs, rhymed versions of the tales, proverbs, and character sketches ..." Foreword, p. xiii.

\section{6. (FRANCIS) BRET HARTE, 1836-1902}

Journalist, parodist, poet, literary critic, and finally literary hack, Harte has been called the father of the local color movement in American literature and the originator of a new genre in short story writing, whose influence may be traced in the work of such dissimilar writers as Mark Twain, Ambrose Bierce, and O. Henry. Departing from the genteel tradition so long dominant in the literature produced in New England, he took as his province the rough life of the frontier after it had advanced to California under the impetus provided by the discovery of gold in that region in 1848 . His characters were for the most part miners, gamblers, rascals, and adventurers of all kinds. These men and women he brought to life with a certain romantic, sentimental glow for sophisticated audiences in the East and abroad, who immediately made his work the literary fashion of the 1870 's. While he remained a good craftsman, his repeated use of his original themes dulled the appetite for the work he continued to turn out until he died.

927. The Luck of Roaring Camp, and other sketches. Boston, Houghton Mifflin [1869] 256 p. (The Riverside library) NcD

928. — Boston, Fields, Osgood, ז870. 239 p. PSI827.AI 1870 RBD

929. — Boston, J. R. Osgood, 1871. 256 p. 25-28034 PS1827.AI I87I RBD

930. The Luck of Roaring Camp, and other stories. [3d ed.] Boston, Houghton Mifflin, 1886. 279 p. (The Riverside Aldine series)

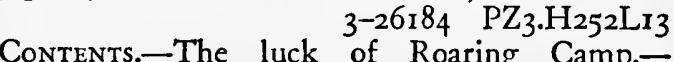
M'liss.-The outcasts of Poker Flat.-Miggles.Tennessee's partner.-The idyll of Red Gulch.How Santa Claus came to Simpson's Bar.-The fool of Five Forks.-The romance of Madroño Hollow.-The Princess Bob and her friends.

931. The Luck of Roaring Camp, and selected stories and poems. Edited with an introd. by George R. Stewart, Jr. New York, Macmillan, 1928. $\mathrm{xx}, 188 \mathrm{p}$. (The modern readers' series) 28-7034 PZ3. $\mathrm{H}_{252 \mathrm{~L}} 25$

932. The Luck of Roaring Camp, and other sketches. Chicago, Fountain Press, 1949. viii, 309 p. illus. (World's greatest literature) 50-5573 $\mathrm{PZ}_{3} \cdot \mathrm{H}_{25} \mathrm{~L}_{4} \mathrm{O}$

933. Poems. Boston, Fields, Osgood, 187I. vi, 152 p. 24-6284 PSI 830 1871 RBD

Includes a group of dialect poems (p. 49-88). Among them is "Plain Language from Truthful James," which became the rage after its initial publication in the Overland Monthly, Sept. 1870; republished at times under the title, "The Heathen Chinee," it has been called "the most spectacular 
poem in the Pike language." See annotation under the name of John (Milton) Hay for comment on this form of vernacular verse.

934. Household ed. Boston, Houghton 3-463 PSI $830 \quad 1902$

935. Works. Riverside ed. Collected and rev. by the author. [Boston, Houghton Mifflin, 1894-1900] $6 \mathrm{v}$.

PPLas

936. The writings of Bret Harte. Standard library ed. Boston, Houghton Mifflin [ ${ }^{\circ} 1896-$ 1903] I9 v. illus. Ar3-1720 PSi820.E96a

A Riverside edition was published by Houghton Mifflin in 20 v., ${ }^{\circ} 1896{ }^{c} 1914$, of which v. 20 has the title: Stories and Prose and Other Uncollected Writings.

937. Bret Harte's stories of the old West. Selected by Wilhelmina Harper and Aimée M. Peters; illus. by Paul Brown. Boston, Houghton Mifflin, 1940. 322 p. 40-34192 $\mathrm{PZ}_{3} . \mathrm{H}_{242}$ Stc

Contents.-The Luck of Roaring Camp.-The outcasts of Poker Flat.-Tennessee's partner.-How Santa Claus came to Simpson's Bar.-Highwater mark.-M'liss.-An ingenue of the Sierras.-A ward of Colonel Starbottle's.-Miggles.-A knighterrant of the foothills.-Dick Boyle's business card.-Plain language from truthful James.

938. Bret Harte; representative selections, with introd., bibliography, and notes, by Joseph B. Harrison. New York, American Book Co., 1941. cxxviii, 416 p. (American writers series)

$$
\text { 4I-II710 PSi } 822 . \mathrm{H}_{3}
$$

"Selected bibliography": p. cxiii-cxxviii.

939. Selected stories of Bret Harte: The Luck of Roaring Camp, The outcasts of Poker Flat, Tennessee's partner, M'liss, and other tales. New York, Caxton House, 1946. ix, 306 p. (Caxton library of the world's greatest literature)

$$
\text { 46-1319 } \mathrm{PZ}_{3} \cdot \mathrm{H}_{252} \mathrm{Se}
$$

940. Best short stories. Edited, and with an introd. by Robert N. Linscott. New York, Modern Library, 1947. x, 517 p. (Modern Library of the world's best books [250])

$$
47-30278 \quad \mathrm{PZ}_{3} \cdot \mathrm{H}_{252} \mathrm{Bg}
$$

\section{JOHN (MILTON) HAY, 1838-1905}

Hay and Bret Harte were pioneers in writing humorous or sentimental vernacular poetry glorifying people or events on the frontier. In these verses their aim was to reproduce the speech and sketch the characteristics of unlettered residents of the Middle West, identified during the California Gold Rush as "Pikes" or "Pikers" because so many of them migrated from the counties of Pike in Illinois, Missouri, Arkansas, and other states. Hay, who was eventually Secretary of State, a cosmopolitan, and a member of Henry Adams' circle in Washington, later discounted the importance of his few ballads in Pike dialect. However, they were so constantly read and recited that they attained the status of folk poems. As such they contributed to setting a pattern in verse that was used over and over again, notably by James Whitcomb Riley. Hay also wrote numerous conventional poems on romantic themes. His prose works included: Castilian Days (I87I), travel sketches of European experiences written for Americans interested in the Old World; The Bread-Winners (1884), a novel reflecting conservative upper-class ideas concerning labor unions and private enterprise; and Abraham Lin$\operatorname{coln}$ (189o), a monumental biographical work written jointly with John G. Nicolay.

942. Pike County ballads and other pieces. Boston, J. R. Osgood, 1871. 167 p.

$$
\text { 25-15310 PSig02.P } 5 \text { 1871 RBD }
$$

Includes "Jim Bludso" and "Little Breeches," both publistied originally in the New York Tribune, a newspaper with which Hay was connected for some years in an editorial capacity.

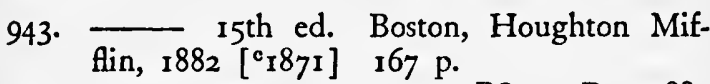
50-4709I PSIg02.P5 1882

944. Complete poetical works, including many poems now first collected, with an introd. by Clarence L. Hay. Boston, Houghton Mifflin, I9I6. xiii, 271 p. 16-22653 PSrgoo.A2 I916 Large-paper edition.

"The Pike County Ballads": p. 3-[25].

\section{LAFCADIO HEARN, I850-1904}

Hearn was born on the Greek island of Leukas and died in Japan a naturalized citizen of that country. The middle period of his life, however, was spent as a journalist in the United States. There he was set apart from the more conventional writers of the period by his prevailing interest in perfecting a polished but ornate literary style and in developing an impressionistic method of treating themes that were often exotic. His sketches, essays, stories, and novels of life and society in New Orleans and the West Indies are contributions to the local color literature of these places. 
Numerous other volumes record his observations of Japanese manners and customs. These were designed to interpret his adopted country to the Western world.

946. Chita; a memory of Last Island. New York, Harper, 1889. 204 p.

$$
\text { 7-5049 } \quad \mathrm{PZ}_{3} \cdot \mathrm{H}_{35} \mathrm{IC} \mathrm{RBD}
$$

Short novel centering around the story of a Creole child carried away by a tidal wave that overwhelmed one of the coastal islands south of Louisiana.

947. — New York, Harper [ ${ }^{\mathrm{c}}{ }^{1917]}{ }_{\mathrm{ViU}}^{204 \mathrm{p} .}$

948. — New York, Harper [1938] MH

949. Youma; the story of a West-Indian slave. New York, Harper, 1890. 193 p. 7-5043 PZ3.H35IY RBD

The heroism and death of a Negro slave, for the sake of the white Creole child in her care, provide the plot of the novel; said to be based on an actual occurrence in the slave insurrection of 1848 on the island of Martinique.

950. - New York, Harper [1915] $\mathrm{MH}$

951. W ritings. Large-paper ed. [Boston, Houghton Mifflin, I922] $16 \mathrm{v}$. illus. 23-7259 PSr9r5.A2 I922 RBD

Introduction by Ferris Greenslet: v. I, p. xiii[xxx].

Partial Contents. - $r$. Leaves from the diary of an impressionist, Creole sketches and Some Chinese ghosts.-2. Stray leaves from strange literature and Fantastics and other fancies.-3. Two years in the French West Indies, v. I. Appendix: Some Creole melodies.-4. Two years in the French West Indies, v. 2. Chita and Youma.-5-6. Glimpses of unfamiliar Japan.-9. Exotics and retrospectives and In ghostly Japan.-II. Kotto and Kwaidan.-I2. Japan, an attempt at interpretation.

952. - [Koizumi ed. Boston, Houghton Mifflin, I923] 16 v. illus. NN

Contents comparable to those of the large-paper edition, with slight variations in statements of a few titles.

953. The life and letters of Lafcadio Hearn, by Elizabeth (Bisland) [Wetmore] Boston, Houghton Mifflin, r9o6. 2 v. illus.

$$
\text { 6-44374 PSigr8. W4 }
$$

The work is made up chielly of Hearn's letters, preceded by a brief biography. His letters are found also in v. 13-16 of his Writings. Japanese
Letters, also edited by Elizabeth Bisland Wetmore, comprises v. 16 .

954. Creole sketches. Edited by Charles Woodward Hutson, with illus. by the author. Boston, Houghton Mifflin, 1924. xxv, $201 \mathrm{p}$.

$$
\text { 24-10002 } \mathrm{F}_{3} 80 . \mathrm{C}_{9} \mathrm{H}_{3}
$$

955. Selected writings. Edited by Henry Goodman, with an introd. by Malcolm Cowley. New York, Citadel Press, r949. viii, 566 p.

49-1 i635 PSigr6.G6

Contents.-Lafcadio Hearn, by Malcolm Cowley.-Editor's introduction.-Kwaidan.-Some Chinese ghosts.-Chita.-American sketches [from Cincinnati, New Orleans, and the Caribbean].-Japan: Stories of Japanese life; Travel; Folk culture; Essays; Weird tales.-Sources.-Bibliography [books and articles about Hearn] p. 564-566.

\section{ROBERT HERRICK, I 868-1938}

Herrick, for 30 years a professor of English at the University of Chicago, observed around him the advent of increased industrialization, expanding business, and accelerated economic competition. Results of the operation of these forces, found in the ethical and social character of middle class life in the capital city of the Middle West, were the themes he developed in a succession of realistic novels. His novel Together (1908) reflects his reaction to the changing relations of men and women in such a society. Sometimes (1933), a satirical Utopian novel, postulates a remote future in which the characters, freed from acquisitiveness, might develop creative personalities and a good life. Herrick was a humanist and an intellectual, rather than a self-conscious reformer. That fact perhaps accounts for the analytical, sometimes undramatic, quality of his work and for its neglect by general readers.

957. The memoirs of an American citizen. New York, Macmillan, 1905. xi, 351 p.

$$
5^{-23023} \mathrm{PZ}_{3} . \mathrm{H}_{435} \mathrm{Me}
$$

First published in The Saturday Evening Pcst (1905), the novel provides a realistic portrait of a self-made capitalist, antedating Dreiser's The Financier by seven years.

958. Clark's field. Boston, Houghton Mifflin, 1914. $477 \mathrm{p}$. 14-1 I043 $\mathrm{PZ}_{3} \cdot \mathrm{H}_{435} \mathrm{Cl}$

959. EDGAR WATSON HOWE, 1853-1937

Owner and editor of the Daily Globe of Atchison, Kansas, from 1877 to 1911 , and afterwards of 
E. W. Howve's Monthly, Howe enjoyed a national reputation on account of the brief paragraphs and aphorisms contributed by him in his editorial capacity. He was also the author of a novel in which the treatment of smalltown life constituted a pioneer work of unrelieved realism. It forecast the trend towards naturalistic writing on the same theme culminating in Sherwood Anderson's Winesburg, Ohio (I919) and its successors in the I920's. Howe's autobiography, Plain People (New York, Dodd, Mead, I929. 317 p.), also is a contribution to the realistic regional literature of the Middle West.

960. The story of a country town. Atchison, Kans., Howe, 1883 . 226 p.

45-45006 $\mathrm{PZ} \mathrm{Z}_{3} \cdot \mathrm{H}_{3} 6_{4} \mathrm{~S}$

Privately printed by the author after being rejected by several publishers.

96r. With an appreciation by William Dean Howells. New York, Harper [1917] 4I3 p. illus. $\mathrm{MB}$

962. - New York, A. \& C. Boni, 1926. 413 p. (The American library)

$$
\text { 26-26999 } \mathrm{PZ}_{3} \cdot \mathrm{H}_{3}{ }_{3} \mathrm{SS}_{4}
$$

963. … New York, Dodd, Mead, r 927. xiii, 36r p. illus. 28-224I $\mathrm{PZ}_{3} \cdot \mathrm{H}_{3}{ }_{3} \mathrm{SS}_{9}$

Includes a Foreword which gives a history of the original and subsequent publications of the book, its reception by critics, and the author's comments about the background of his novel.

\section{WILLIAM DEAN HOWELLS, I837-1920}

Formal education ended for Howvells when he left elementary school to set type for his father's smalltown newspaper in Hamilton, Ohio. Before his death at the age of eighty-three he had refused professorships at Johns Hopkins and Harvard, had received honorary degrees from Columbia, Yale, Oxford, and Princeton, and was familiarly known as the "Dean" of American writers. A partial list of the many experiences by which his education was extended includes: journalism in Ohio; a United States consulship in Venice, where he became an unofficial reporter on European life for newspapers and periodicals at home; a ten-year term as editorin-chief of The Atlantic Monthly; and a long connection with Harper's Magazine, as an editorial writer and critic. For many of these years he was the friend of the leading writers of his period, as well as the mentor of those who showed promise in his chosen field. Having formulated what was probably the first well-defined theory of literary realism enunciated in the United States, he applied it in a variety of literary forms. These included autobiographical works having Ohio and New Eng. land regional interest, critical essays, travel sketches addressed to the contemporary American interest in European culture, and many novels. Naturalistic elements were excluded from the realism of his fiction, which emphasized the commonplace and avoided sordid incidents or a pessimistic philosophy of life. The novels tended, rather, to be decorous if shrewd expressions of the author's reactions to the middle-class life he knew at first hand. Different themes were conspicuous in his novels at different stages in his development. These included courtship and marriage, the impress of Italian civilization on Americans visiting or living in that country, the impact of different social classes on each other in a city such as Boston, and the need of social change in the United States along socialistic lines. Howells' books have been called documents of the cultural and social history of his time.

965. A modern instance. Boston, J. R. Osgood, 1882. 514 p. 4-8624 $\mathrm{PZ}_{3}$. $\mathrm{H}_{24} \mathrm{Mo}$

A study of married life, and the result of degeneration of the husband's character.

966. 26 th ed. Boston, Houghton Mifflin [189-?] 514 p. 4-I5I24 PZ3.H84Mo26 Fourteenth edition published 1887 .

Currently published by Houghton Miflin in the Riverside college classics series.

967. The rise of Silas Lapham. Boston, Houghton Mifflin [ $\left.{ }^{\mathrm{I}} \mathrm{1} 88_{4}\right] 515 \mathrm{p}$.

47-35488 PS2025.R5 1885 RBD

Concerned with Boston society and the relation of a group of the nouveaux riches to certain impoverished aristocrats; popularly considered Howells' best social novel.

968. Centenary ed. With introd. by Booth Tarkington. Boston, Houghton Mifflin, 1937. xiv, 380 p. $\quad 37-9254 \quad \mathrm{PZ}_{3} . \mathrm{H}_{4}{ }_{4} \mathrm{Ri}_{29}$

969. Introd. by George [Warren] Arms. New York, Rinehart, 1949. xviii, 394 p. $\begin{array}{lll}\text { (Rinehart editions, 19) } & 49-487 \text { I } & \mathrm{PZ}_{3} . \mathrm{H}_{4}{ }_{4} \mathrm{Ri} 35\end{array}$

970. Introd. by Harry Hayden Clark. New York, Modern Library, I95I. xxii, 324 p. (Modern Library college editions, $T_{56}$ ) ${ }^{\mathrm{I}-5402} \mathrm{PZ}_{3} . \mathrm{H}_{4}{ }_{4} \mathrm{Ri} 37$

971. Indian summer. Boston, Ticknor, I 886. 395 p. $\quad 7-577^{1} \quad \mathrm{PZ}_{3} \cdot \mathrm{H} 84 \mathrm{In}$

An international novel portraying American char- 
acters living abroad, a theme used also in many of the novels by Henry James. James L. Woodress in his Howells \& Italy (Durham, N. C., Duke University Press, 1952. 223 p.) studies the influence on Howells of his life in Italy.

972. New introd. by William M. Gibson. New York, Dutton, 195I. xxii, 317 p. (Everyman's library $654 \mathrm{~A}$. Fiction)

Bibliography: p. xxi-xxii. $5^{\mathrm{I}-7375} \mathrm{PZ}_{3} \cdot \mathrm{H}_{4} \mathrm{InI}_{5}$

973. A hazard of new fortunes. New York, Harper [ 1889$] 2 \mathrm{v}$.

$\mathrm{MH}$

An economic novel that introduces the clash in New York between capitalistic interests of industrialists and the interests of workers on various levels; illustrates the author's growing belief in socialism, a development influenced by his study of Tolstoy and other Russian writers.

974. — Edinburgh, D. Douglas, 1889. 2 v. 42-32100 $\mathrm{PZ}_{3} . \mathrm{H}_{4}{ }_{4} \mathrm{HaIc}$

975. — Introd. by Alexander Harvey. New York, Boni \& Liveright, 1917. 2 v. in I. (Modern Library of the world's best books) I9-9539 $\mathrm{PZ}_{3} \cdot \mathrm{H}_{4}{ }_{4} \mathrm{Ha} 6$

976. —. New introd. by George Warren Arms. New York, Dutton, 1952. 552 p. (Everyman's library, 646A. Fiction)

$$
\text { 52-5309 } \mathrm{PZ}_{3} \cdot \mathrm{H}_{4} \mathrm{Haro}
$$

977. Criticism and fiction. New York, Harper, 1891. 188 p. I8-1642 PN81.H6

Gives Howells' defense of realism in imaginative writing. Everett Carter's Howells and the Age of Realism (Philadelphia, Lippincott, 1954. 307 p.) is a current estimate of realism in the author's work.

978. A traveler from Altruria. New York, Harper, I894. 318 p. $7-5756 \quad \mathrm{PZ} 3 . \mathrm{H} 84 \mathrm{Tr}$

With its sequel, Through the Eye of the Needle (1907), this "romance" illustrates the author's concern over paradoxes in American society produced by inequalities of wealth and opportunity. Possible solutions are indicated by comparison with the fictitious Utopian republic of Altruria.

979. Literary friends and acquaintance; a personal retrospect of American authorship. New York, Harper, rgoo. viii, $287 \mathrm{p}$.

$$
\text { 0-6798 PS2033.A6 1900 }
$$

Contents.-My first visit to New England.First impressions of literary New York.-Roundabout to Boston.-Literary Boston as I knew it.-
Oliver Wendell Holmes.-The white Mr. Longfellow.-Studies of Lowell.-Cambridge neighbors.

980. The Leatherwood god. New York, Century, I9r6. $236 \mathrm{p}$. illus.

$$
\text { I6-2240I } \mathrm{PZ} 3 . \mathrm{H} 84 \mathrm{Le}
$$

Regional novel of Ohio before the middle of the rgth century, and the impact on a pioneer community of a man who proclaims himself a god; based on a historical incident.

98 I. Life in letters. Edited by Mildred Howells. Garden City, N. Y., Doubleday, Doran, 1928. 2 v. illus. $\quad 28-28879$ PS2033.A67 1928

A bibliography of the works of William Dean Howells: v. 2, p. 403-409.

982. Selected writings. Edited, with an introd. by Henry Steele Commager. New York, Random House, r95o. xvii, $946 \mathrm{p}$.

$$
\text { 50-9450 PS2022.C6 } 1950
$$

Contents.-The rise of Silas Lapham (1885).- A modern instance (1882).-A boy's town (1890).-My Mark Twain (rgro).

983. Representative selections. Introd, bibliography, and notes, by Clara Marburg Kirk and Rudolf Kirk. New York, American Book Co., 1950. ccv, 394 p. (American writers series). 50-13680 PS2022. $\mathrm{K}_{5}$

Includes a particularly detailed introduction, a bibliography of biographical and critical writings about Howells, and a chronological table of his life and works.

\section{HELEN MARIA (FISKE) HUNT JACK- SON ("H. H."), I83I-I885}

Mrs. Jackson, one of the numerous "literary ladies" active in the I870's and I 880's, wrote books for children and contributed her "bits" as she called them to the growing literature of travel in Europe and the Far West that was greatly in demand during this period. Her poetry also was admired by her contemporaries, among whom Emerson must be included. She is best remembered now, however, for the writing she did under the impetus of her moral indignation caused by injustices in the treatment of Indians by the United States Government. Some literary interest and curiosity also attach to her connection with Emily Dickinson, and the locale of Amherst, Massachusetts, where both of them were reared and where Mrs. Jackson placed the setting of her novel, Mercy Philbrick's Choice (1876). A short story, "Esther Wynn's LoveLetters," published in the first series of a collection called Saxe Holm's Stories (1874-1878) includes in 
its plot various incidents that resemble characteristic features of Miss Dickinson's experience.

985. Ramona; a story. Boston, Roberts, I 884. $490 \mathrm{p}$. I $\rightarrow 1275 \quad \mathrm{PZ} 3 . J 1_{43} \mathrm{R}$

Romance that reveals the conflicts of interest between old Spanish and new American elements in California as a result of westward migrations during the middle decades of the 19th century; also eloquently champions California Indians mistreated by Americans. The latter theme was factually developed in the author's historical study, $A$ Century of Dishonor (1881, 1885).

\section{HENRY JAMES, 1843-1916}

The senior Henry James' "progressive" ideas of education made the son a cosmopolitan in his boyhood, with the result that the younger Henry settled permanently in England while still in his early thirties. By expatriating himself in this way he found an environment more favorable for perfecting his art of writing. The theories he developed and the techniques of writing that he evolved are described in his critical works. These include the early essay, The Art of Fiction (1884), and the prefaces he wrote in 1907-8 for the New York edition of his novels and stories. At one stage of his career he believed drama should be his chosen form of expression. His plays, however, were not successful "theatre," consequently fiction remained his chief medium. The "international" novels and short stories, his most distinctive contribution to American literature, portray Americans of James' own class exposed to tensions resulting from alien standards encountered when they seek for a higher level of social and cultural life in the Old World than that provided by their own country. The author's analysis of motives and actions observed under these conditions was that of an artist who was also profoundly concerned with the ethical and moral issues involved in human relationships. As his friend, William Dean Howells, is called a realist of the commonplace, so James is frequently described as a psychological realist. He also repeatedly treated American characters on their native ground. The latter novels and storles open vistas for viewing the social, intellectual, and ethical qualities he found in life on the eastern seaboard of the United States, notably in New York, Boston, and Newport. In spite of his American origins and interests, James' roots in English life had grown deep during his long residence in England. In 1915, less than a year before his death, he made an act of devotion to the Allied cause in the First World War and to his adopted country by becoming a naturalized British subject.
987. The American. Boston, J. R. Osgood, 1877 . 473 p. 7-7560 PS2г16.A6 i877 RBD International novel in which an American's wealth does not enable him to overcome the opposition of a conventional French family to his marriage to a daughter of the house.

988. — Introd. by Joseph Warren Beach. New York, Rinehart, 1949. 360 p. (Rinehart editions, I6) 49-1037I PZ3.J234Ame3

989. The portrait of a lady. London, Macmillan, 1881. 3 v. 23-319 PS2116.P6 1881 RBD Appeared originally in Macmillan's Magazine, Oct. 1880-Nov. 1881, and in The Atlantic Monthly, Nov. I880-Dec. I88r.

Considered the chief novel in James' earlier and more direct manner, the book provides an intellectual and moral representation of an American woman unhappily married to an American expatriate in Europe. While the action takes place abroad, the character of the "lady," rather than the international aspect of the setting, is central in the plot.

990. I I th ed. Boston, Houghton Mifflin, 1897. $529 \mathrm{p}$. 5-15127 PZ3.J234 $\mathrm{Po5}_{5}$

Leon Edel is the editor of a new edition (1956) designed for inclusion in Houghton Miflin's Riverside classics series.

991. — Introd. by Fred B. Millett. New York, Modern Library, 1951. 2 v. in 1. (Modern Library college editions, $\mathrm{T}_{47}$ )

Bibliography: p. xxxvi-xxxvii.

$$
\text { 5I-226I PZ3.J234Po35 }
$$

992. The Bostonians. London, Macmillan, I 886 . 3v. 23-165 PS2116.B6 I886 RBD Originally appeared in the Century Magazine from Feb. 1885 to Feb. I886; satirical representation of the American passion for good causes, in this case that of women's rights, and the hysterical infatuation of a grown woman for a young girl under her influence; a realistic novel of Boston life in the 1880 's, and the author's longest narrative in which the locale and characters are uniformly American.

993. London and New York, Macmillan, I 886. $449 \mathrm{p}$. 4-15126 PS2116.B6 1886a RBD

994. - [Introd. by Philip Rahv] New York, Dial Press, 1945. ix, $37^{8} \mathrm{p}$.

45-9737 PZ3.J234Boro

Included also in American Novels and Stories, edited by F. O. Matthiessen (no. 1008). 
995. Introd. by Irving Howe. New York, Modern Library, 1956. xxviii, 464 p. (Modern Library of the world's best books [16]) 56-5414 PZ3.J234Bor5

996. The wings of the dove. New York, Scribner, 1902. 2 v.

$$
\text { 2-20827 PS2116. W5 } 1902 \text { RBD }
$$

International novel in which the designs of an English couple are made of no effect by the nobility of the mortally ill American heroine; frequently called the author's greatest book; written in his noted final style characterized by intricate ideas, delicate perceptions, and implied impressions conveyed through an arrangement of words and sentences that calls for attentive participation from the reader.

997. New York, Scribner, 1945. xxx, 329, 439 p. $\quad 45-9835$ PZ3.J234Wiro

Published also as number 244 in the Modern Library of the world's best books.

998. The ambassadors. New York, Harper, i 903. 431 p. $\quad 3-28287$ PS2ri6. $A_{5}$ I903 RBD A novel that was originally published in the North American Review, Jan.-Dec. 1903. The "ambassadors" are portrayed as emissaries of a wealthy woman in Massachusetts, who prevails upon them to undertake a mission to Europe in the hope of persuading a young American to break the ties he has formed with a fascinating French woman, in order to return to manage the family business in America. With The Wings of the Dove and The Golden Bowl this novel forms what has been called a spiritual trilogy in James' last phase.

999. — With an introd. by Martin W. Sampson. New York, Harper ['I930] xv, 431 p. (Harper's modern classics)

30-344II $\mathrm{PZ}_{3}$.J234 $\mathrm{Amb}_{4}$ tion.

Currently published also in Harper's college edi-

rooo. The golden bowl. New York, Scribner, I904. 2 v. 4-3232I PZ3.J234Go

James' last long novel, in which an international marriage between a fabulously rich American girl and an impoverished Italian nobleman resulted in grievous suffering for all the principal characters.

I001. Introd. by R. P. Blackmur. New York, Grove Press, I952 [' 1932 ] xxi, 4I2, $377 \mathrm{p}$. 52-933I PZ3.J234Go6

1002. The American scene. New York, Harper, 1907. vi, $44^{2}$ p. 7-5704 Fio6.J27 RBD Contents.-New England: an autumn impres-
sion.-New York revisited.-New York and the Hudson: a spring impression.-New York: social notes.-The Bowery and thereabouts.-The sense of Newport.-Boston.-Concord and Salem.-Philadelphia.-Baltimore.-Washington.-Richmond.Charleston.-Florida.

1003. - Edited, with an introd,, by W. H. Auden. New York, Scribner, 1946. xxx, 50r p. illus. 46-25289 Fro6.J273 "Saratoga," "Newport," and "Niagara," taken from Portraits of Places, are added to the contents of this edition.

1004. Novels and tales. New York ed. [New York, Scribner, 1907-17] $26 \mathrm{v}$.

$$
\text { 7-41582 PS2110.Fo7 }
$$

Includes numerous revisions of texts and provides a series of prefaces to volumes 1-24. These contain important critical material concerning the structural technique of fiction. The prefaces were afterwards republished in a group, with an introduction by Richard P. Blackmur, as The Art of the Novel (New York, Scribner, 1934. xli, 348 p.). Volume 25, The Ivory Tower, and volume 26 , The Sense of the Past, were left unfinished when the author died. They were edited for publication by Percy Lubbock. Volume 26 is lacking in the Library of Congress.

1005. Letters. Selected and edited by Percy Lubbock. New York, Scribner, 1920. 2 v. illus. $\quad 20-6773 \quad \mathrm{PS}_{2123 . A_{5}} 1920$

1006. Selected letters. Edited with an introd. by Leon Edel. New York, Farrar, Straus \& Cudahy [ I955] xxxiv, 235 p. (Great letters series) 55-11183 PS2123.A43

1007. Great short novels. Edited with an introd. \& comments by Philip Rahv. New York, Dial Press, r944. xiii, 799 p.

44-47807 PZ3.J234Gr

Contents.-Madame de Mauves.-Daisy Miller. -An international episode.-The siege of London.-Lady Barberina.- The author of Beltraffio.The Aspern papers.-The pupil.-The turn of the screw.-The beast in the jungle.

1008. American novels and stories. Edited, and with an introd., by F. O. Matthiessen. New York, Knopf, r947. xxvi, 993 p.

$$
\text { 47-1392 PZ3.J234An }
$$

Contents.-The story of a year.-The Europeans.-Washington Square.-The point of view.A New England winter.-Pandora.-The Bostonians.-_Europe."-Julia Bride.-The jolly cor- 
ner.-Crapy Cornelia.-A round of visits.-The ivory tower.

1009. Notebooks. Edited by F. O. Matthiessen and Kenneth B. Murdock. New York, Oxford University Press, 1947. xxviii, 425 p.

47-I 1461 PS $2123 . A_{4}$

Contents.-Chronological list of James' chief publications.-Notebook I-9.-The 'B. B.' case and 'Mrs. Max.'-Preliminary sketch for The sense of the past.-Project for The ambassadors.

roro. The art of fiction, and other essays; with an introd. by Morris Roberts. New York, Oxford University Press, 1948. xxiv, $240 \mathrm{p}$.

${ }_{48-6}{ }^{8} 6 \mathrm{PN}_{3499 . J} \mathrm{~J}_{25}$

Partial Contents.-The art of fiction.-The new novel.-Criticism.-Emerson.

roxx. Short stories. Selected and edited, with an introd. by Clifton Fadiman. New York, Modern Library, 1948. xx, 644 p. (Modern Library of the world's best books. Modern Library giants)

${ }_{48-935}{ }^{8} \quad \mathrm{PZ}_{3}$.J234 $\mathrm{Sh}_{4}$

Ior 2. Ghostly tales. Edited with an introd. by Leon Edel. New Brunswick, Rutgers University Press, 1948 [i. e. 1949] xxxiv, 765 p.

49-7759 PZ3.J234Gh

Contents.-The romance of certain old clothes.De Grey: a romance.-The last of the Valerii.-The ghostly rental.-Sir Edmund Orme.-Nona Vincent.- The private life.-Sir Dominick Ferrand.Owen Wingrave.-The altar of the dead.-The friends of the friends. - The turn of the screw.The real right thing.- The great good place.Maud-Evelyn.- The third person.-The beast in the jungle.-The jolly corner.

ror3. Complete plays. Edited by Leon Edel. Philadelphia, Lippincott, 1949. 846 p. illus. 49-10769 $\mathrm{PS}_{211 \mathrm{r} . \mathrm{E}_{4}}$

First collected edition of the complete plays, together with an unfinished scenario and various notes and prefaces. Cf. Foreword, p. 9.

ror 4. Selected fiction. Edited with an introd. and notes by Leon Edel. New York, Dutton, 1953. xxiv, 6o9 p. (Everyman's library, 649A. Fiction)

Bibliography: p. xxi-xxiv. 53-8253 PZ3.J234Sb

Includes Daisy Miller, Washington Square, The Aspern Papers, The Pupil, The Beast in the Jungle, The Jolly Corner, and The Art of Fiction, as well as prefaces and additional commentary by James.
1015. Autobiography. Edited with an introd. by Frederick W. Dupee. New York, Criterion Books, 1956. 622 p. illus. 56-6211 PS2123.A3

Brings together James' three autobiographical works: A Small Boy and Others (1913); Notes of a Son and Brother (1914); and The Middle Years, edited by Percy Lubbock (1917)-a collection which greatly enriches the student's understanding of the author, his American beginnings, and the rgth century civilization he portrayed in his novels and other prose writings.

Recent critical works that continue to indicate the important place occupied by James in American literature include the following:

ıox6. Beach, Joseph Warren. The method of Henry James. [Enl. ed., with corrections] Philadelphia, A. Saifer, 1954. 299 p. 55-1809 PS2124.B4 1954

Consists of the original text of the first edition (1918) but adds a lengthy introduction that reviews recent critical discussions of James' work by Ezra Pound, Van Wyck Brooks, Edmund Wilson, Leon Edel, and others.

1017. Canby, Henry Seidel. Turn west, turn east: Mark Twain and Henry James. Boston, Houghton Mifflin, 1951. xii, 318 p.

Bibliography: p. 301-303.

$$
5^{1-14000} P_{1331 . C_{25}}
$$

1018. Dupee, Frederick W. Henry James. New York, Sloane, 1951. xiii, 301 p. (The American men of letters series)

$$
\text { 51-20I2 PS2123.D8 }
$$

rorg. - $2 \mathrm{~d}$ ed., rev, and enl. Garden City, N. Y., Doubleday, 1956. 265 p. (Doubleday anchor books, A68)

$$
\text { 56-5971 PS2123.D8 } 1956
$$

1020. Edel, Leon J. Henry James. [v. I] The untried years, $1843-1870$. Philadelphia, Lippincott [1953] 350 p. 53-5421 PS2123.E33

Bibliographical references included in "Notes": [v. I] p. 345-35I.

This is the first part of a study planned for completion in three volumes.

1021. Le Clair, Robert C. Young Henry James, 1843-1870. New York, Bookman Associates, 1955. 469 p. $55-3467$ PS2123.L 4

1022. Stevenson, Elizabeth. The crooked corridor; a study of Henry James. New York, Macmillan, 1949. I72 p. $\quad 49-11903$ PS2123.S8 "Bibliographical note": p. 164-166.

Deals with James' fiction. 


\section{SARAH ORNE JEWETT, 1849-1909}

Mrs. Stowe in her local color sketches and stories of New England sought to preserve the qualities of the region that she believed constituted its greatness and justified its influence in America and "on the civilized world." Writing in the same genre a generation later, Miss Jewett found her inspiration in the coastal countryside of Maine and in the courage, even nobility, of the people living there after the great shipping trade was dead and industries in the towns, or westward migrations, had drawn off many of the most vigorous young people. Miss Jewett's art included the ability to use the beauty of the landscape as a background for the underlying drama in apparently commonplace lives. This effect she achieved with classic economy and restraint.

Clara C. Weber and Carl J. Weber have compiled A Bibliography of the Published Writings of Sarah Orne Jewett (Waterville, Me., Colby College Press, I949. xi, ro5 p. Colby College monographs, no. 18).

1024. Deephaven. Boston, J. R. Osgood, I877. 255 p. 34-25494 PS2132.D 4877 RBD

A collection of local color stories published earlier in The Atlantic Monthly.

1025. - 14th ed. Boston, Houghton Mifflin, 1885. 255 p. 44-10710 PZ3.J55De2

I026. - Boston, Houghton Mifflin [I905] 255 p. 5-1185 PZ3.J55 De7

1027. The country of the pointed firs. Boston, Houghton Mifflin, 1896. $213 \mathrm{p}$.

7-993I $\mathrm{PZ}_{3} \cdot \mathrm{J}_{55} \mathrm{Co}$

I028. Boston, Houghton Mifflin [ ${ }^{ } \mathrm{I} 9 \mathrm{I}$ ] 269 p. $\quad$ 10-23633 PZ3.J55Co5

1029. The country of the pointed firs, and other stories. Selected and arr. with a pref. by

Willa Cather. Garden City, N. Y., Doubleday, 1954. 320 p. (Doubleday anchor books, A26)

54-3594 $\mathrm{PZ}_{3}$. $\mathrm{J}_{55} \mathrm{Co} 7$

Reprinted in full by arrangement with Houghton Mifflin from The Best Stories of Sarah Orne Jewett (q. v.).

1030. Stories and tales. Boston, Houghton Mifflin [1910] $7 \mathrm{v}$ AII-I493 PU

1031. The best stories of Sarah Orne Jewett. Selected and arr. with a pref. by Willa Cather.

Boston, Houghton Mifflin, 1925. 2 v. 25-13439 PS2130.A2 1925

At head of title: The Mayflower edition.
1032. GRACE ELIZABETH KING, I85I or $1852-1932$

The complex culture of New Orleans and its surrounding plantations, in which American, French, and Negro elements and dialects were mingled, provided the local color of Miss King's short stories, novels, and histories. These exploited the same material used earlier by G. W. Cable and ministered to the appreciation of Southern regional writing that developed after the Reconstruction period, following the Civil War.

1033. Tales of a time and place. New York, Harper, I892. $303 \mathrm{p}$.

$4^{-1} 5^{133} \quad \mathrm{PZ}_{3} \cdot \mathrm{K}_{5} 8_{3} \mathrm{~T}$

Contents.-Bayou l'Ombre.-Bonne Maman.Madrilène; or The festival of the dead.-The Christmas story of a little church.

1034. Balcony stories. New York, Century, I 893. 245 p. illus. $\quad 7-12167 \quad \mathrm{PZ}_{3} \cdot \mathrm{K}_{5} 8_{3} \mathrm{~B}$

1035. New York, Macmillan, I925. 296 p. illus. 25-19107 $\mathrm{PZ}_{3} \cdot \mathrm{K}_{5} 8_{3} \mathrm{~B} 6$

New edition with new stories.

Contents. - The balcony.-A drama of three.La grande demoiselle.-Mimi's marriage.-The miracle chapel.-The story of a day.-Anne Marie and Jeanne Marie.-A crippled hope.-"One of us."-The little convent girl.-Grandmother's grandmother.-The old lady's restoration.-A delicate affair.-Pupasse.-Grandmamma.-Joe.

1036. New Orleans; the place and the people. New York, Macmillan, 1895. xxi, 404 p.

illus. I $-8773 \quad \mathrm{~F}_{379} \mathrm{~N}_{5} \mathrm{~K}_{5}$

1037. Memories of a southern woman of letters. New York, Macmillan, 1932, 398 p.

$$
\text { 32-29668 } \mathrm{PS}_{2178 . \mathrm{A}_{4}} 1932
$$

\section{SIDNEY LANIER, I842-1881}

Lanier was a musician as well as a poet. Since he believed that the laws governing the two arts were in effect identical, he constantly experimented when writing poetry in an effort to substantiate his thesis. While he is known best for "The Marshes of Glynn," "The Song of the Chattahoochee," and other regional poems celebrating the landscape of his native state, Georgia, his writing also reveals his strong social consciousness. Poems having the latter interest include "Corn," in part a tribute to the dignity of work on the land, and "The Symphony," a protest against over-commercialism in America, with its attendant economic and social evils. In collaboration with his brother he also 
pioneered in the field of folk poetry written in Negro dialect and in the "Cracker" dialect used by poor whites in Georgia. Although Lanier was a Confederate veteran, who ardently loved the South and whose untimely death may be attributed to hardships suffered during the Civil War and the Reconstruction period, his ultimate loyalty was to the nation as a whole. He did not glorify the old plantation tradition of his native region, but rather, as in his essay "The New South" (1880), he acclaimed the rise of the independent small farmer.

1039. Poems. Philadelphia, Lippincott, 1877. 94 p. 4-31102 PS2205.E77

Made up for the most part of poems previously published in Lippincott's Magazine.

1040. — Edited by his wife [Mary (Day) Lanier] with a memorial by William Hayes Ward. New York, Scribner, 1884. 252 p. CtY

1041. New ed. New York, Scribner, I891. xli, 260 p. $4^{-13827}$ PS2205.EgI

1042. New ed. New York, Scribner, 1916. xli, 262 p. 17-1199 PS2205.Fr6

1043. - New ed. New York, Scribner, 1920. xlii, 262 p. 35-33093 PS2205.F20

Bibliography: p. [xlii].

1044. The science of English verse. New York, Scribner, r88o. xxii, $315 \mathrm{p}$.

6-24737 PEi505.L2 i88o

Exposition of Lanier's theory of prosody and an expression of the Igth century interest in the interrelation of the arts.

$$
\begin{aligned}
& \begin{array}{l}
\text { 1045. New York, Scribner [ }{ }^{\mathrm{C}} \text { I922] xxii, } \\
\text { 315 p. illus. (music) }
\end{array} \\
& \text { 40-23579 PEI505.L2 } 1922
\end{aligned}
$$

1046. The centennial edition of the works of Sidney Lanier. [Baltimore, Johns Hopkins Press, 1945] 10 v. illus. (incl. music), facsims. (incl. music) A46-2793 PS220.F 45 General editor: Charles R. Anderson.

Bibliography, compiled by Philip Graham and Frieda C. Thies: v. 6, p. [377]-412.

Partial Contents.- r. Poems and Pcem outlines, edited by C. R. Anderson.-2. The science of English verse and Essays on music, edited by P. F. Baum.-4. The English novel and Essays on literature, edited by Clarence Gohdes and Kemp Malone.-5. Tiger-lilies and Southern prose, edited by Garland Greever, assisted by Cecil Abernethy.6. Florida and miscellaneous prose, edited by Philip
Graham.-7-10. Letters, edited by Charles R. Anderson and Aubrey $\mathrm{H}$. Starke.

First uniform collection of Lanier's poetry and prose; a scholar's edition that includes much previously unpublished or uncollected material.

1047. Selected poems. With a pref. by Stark Young. New York, Scribner, 1947. xvii, 146 p. $\quad 47-11957$ PS2205.F 47

\section{JACK (JOHN GRIFFITH) LONDON, $1876-1916$}

Jack London read widely, if uncritically, in the works of Karl Marx, Herbert Spencer, and Friedrich Nietzsche. From his reading he derived and reconciled various conflicting doctrines concerning social revolution, biological determinism, and the superman. His Marxist ideas he preached as radical remedies for the social and economic injustice of the time, which the Progressive Movement of the same general period was seeking to remedy by legislation. London's varied experiences in California and elsewhere-among other activities were those of an oyster pirate in San Francisco Bay, a sailor, a mill worker, a seeker for gold in the Klondike, a hobo, and a war correspondent-gave him rich sources for the plots and subjects of some 50 books written in I6 years. The Alaskan frontier in particular provided the locale for some of his most successful short stories. The spectacular success of his fiction resulted from the taste of the time, which demanded romantic adventure stories that he was admirably equipped to write. Naturalism, however, was also an element in his work. It is found in the violence and brutality of his supermen, the struggles of Alaskan Indians and white adventurers to conquer the Northern wilderness, and the grim details which abound in a number of his books. His socialistic tracts, among them War of the Classes (1905) and Revolution and Other Essays (1910) explain his conversion to socialism and illustrate his contribution to it as a cause. These polemical works, as well as his novels and short stories, have been translated into numerous foreign languages and widely read outside the United States.

1049. The son of the wolf. Boston, Houghton Mifflin, 1900. $25 \mathrm{I}$.

0-2266. $\mathrm{PZ}_{3} \cdot \mathrm{L} 8_{4} 6 \mathrm{So}_{\text {o }}$

Tales of courage, hardship, and brutality in the Far North, which won recognition for the author.

1050. Boston, Houghton Mifflin, 1930. 25I p. $\quad$ 3I-26I94 $\mathrm{PZ}_{3}$.L846So4

Currently published by Houghton Miflin in the Riverside library series. 
1051. The call of the wild. New York, Macmillan, 1903. 231 p. illus. 3-16822 PZ3.L846C2

Story of a dog's return to the joys of freedom and wildness as leader of a wolf pack, recounted with poetic intensity. It is estimated that a million and a half copies were sold before 1945, something that puts the book fairly high among American bestsellers. Currently available from Macmillan, and from Pocket Books, Rockefeller Center, New York, as Pocket Book 593 .

1052. The call of the wild and other stories. With an introd. by Frank Luther Mott. New York, Macmillan, 1935. xxxv p., 268 p. illus. (Modern readers' series) $35^{-2} 7^{14} 3 \quad \mathrm{PZ}_{3} . \mathrm{L} 846 \mathrm{C}_{33}$

Contents. - The call of the wild.-To build a fire.-The heathen.-The strength of the strong.

1053. The people of the abyss. New York, Macmillan, 1903. xiii, $319 \mathrm{p}$. illus.

$$
\text { 3-26516 HV4088.L8L8 1903a }
$$

Issued by the same publisher in 1903 without illustrations.

A brief visit to England gave London the material for attacking the evils of poverty suffered by underprivileged residents of the city of London; a book of propaganda for social betterment.

1054. The sea-wolf. New York, Macmillan, 1904. vii, 366 p. $\quad 4-30593 \quad \mathrm{PZ}_{3} . \mathrm{L}_{4} 6 \mathrm{Se}_{2}$

The life, brutalities, and miserable end of a sea captain who represents London's interest in primitive "supermen" are mingled in this book with adventure and romance.

Macmillan announces a contemporary edition in the company's catalog for 1954; available also as number 325 from Pocket Books, Rockefeller Center, New York.

1055. The iron heel. New York, Macmillan, 1907. xiv, $354 \mathrm{p}$.

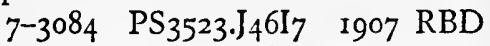

Novel describing a hypothetical future organization of capitalistic monopolies in the United States into a fascistic government, its final overthrow by the socialists, and the halcyon period of collectivism that would result.

1056. Martin Eden. New York, Macmillan, 1909. 4II p. 9-22752 PZ3.L846M

Autobiographical novel revealing the torments and struggles experienced by a writer in conflict with conventional social and political standards, particularly with reference to money as the criterion of success. The ultimate suicide of the hero intensifies the effect of grimness and tragedy in the book.
1057. New York, Penguin Books, 1946. 346 p. (Penguin books, 587) 46-86 I I PZ3.L846Mar4

1058. Lost Face. New York, Macmillan, igıo. vii, 240 p. $\quad$ 10-6488 PZ3.L846Lo

Contents.-Lost Face.-Trust.-To build a fire.-That Spot.-Flush of Gold.-The passing of Marcus O'Brien.-The wit of Porportuk.

1059. [Novels and tales] New York, Macmillan, I 925-29. $21 \mathrm{v}$.

On cover: Sonoma edition.

106o. Best short stories. Garden City, N. Y., Sun Dial Press, 1945. 3II p.

45-3930 PZ3.L846Be

1061. EDWIN MARKHAM, I852-1940

A California shepherd and farm laborer who acquired sufficient education to become a school teacher, Markham awoke to find himself famous upon the publication of his "The Man with the Hoe," a poem in blank verse inspired by Jean François Millet's painting "L'Homme à la Houe." As a protest against the exploitation of the landless laborer, the poem became a sort of focus for humanitarian impulses and the stirrings of social unrest felt in the United States at the turn of the Igth century. It was also widely distributed abroad. The title poem of Markham's Lincoln and Other Poems (New York, McClure, Phillips, 1901. I25 p.) eulogizes Abraham Lincoln as the common man cast in heroic mold.

1062. The man with the hoe, and other poems. New York, Doubleday \& McClure, 1899.

I34 p. 99-2566 $\mathrm{PS}_{2362 . \mathrm{M}_{3}} 1899$

1063. Poems, selected and arr. by Charles L. Wallis. New York, Harper, 1950. xviii, $198 \mathrm{p}$. 50-7489 $\mathrm{PS}_{2360 . \mathrm{A}_{5} \mathrm{~W}_{3}}$

\section{JOAQUIN MILLER (CINCINNATUS} HINER MILLER), I839? or 184 I ?-1913

Miller, a flamboyant American with a flair for the spectacular, went to the Far West in his teens and therefore knew, more intimately than most of his contemporaries, the life of the Pacific Coast in the heyday of its development after 1849. For nearly 40 years he was a prolific miscellaneous writer; but poetry was his chosen form of expression. Songs of the Sierras (I 871) includes many of his best poems. His significance comes less from the quality of his writing than because he pioneered as a 
poet in giving literary expression to the characteristic landscape of a region and to the life of the people who had pioneered in its development. A readable narrative that presents Miller's unusual personality effectively is M. Marion Marberry's biography of the writer, entitled Splendid Poseur (New York, Crowell, 1953. 3ro p.).

1065. Life amongst the Modocs: unwritten history. London, R. Bentley, I873. viii, 400 p. A22-655 E99.M7M59

Also published under titles: Unwritten History: Life Amongst the Modocs, Hartford, 1874; Paquita, the Indian Heroine, Hartford, I881; My Own Story, Chicago, 1890; My Life Among the Indians, Chicago, 1892; and Joaquin Miller's Romantic Life Amongst the Red Indians, London, 1898.

I066. Joaquin Miller's poems. [Bear ed.] San Francisco, Whitaker \& Ray, 1909-10. 6 v. 9-9533 PS2395.A2 1909

Contents.-v. I. An introduction, etc.-v. 2. Songs of the Sierras.-v. 3. Songs of the sunlands.v. 4. Songs of Italy and others.-v. 5. Songs of the American seas.-v. 6. Poetic plays.

r067. Poetical works. Edited with an introd. and notes by Stuart P. Sherman. New York, Putnam, 1923. xii, $5^{87} \mathrm{p}$.

\section{Selections.}

$$
\text { 23-7262 PS2395.A2 } 1923
$$

1068. Overland in a covered wagon; an autobiography. Edited by Sidney G. Firman, illus. by Esther M. Mattson. New York, Appleton, 1930. I29 p. 30-31468 PS2398.A2 1930 Appeared originally as the introduction to the Bear edition of his poems (q. v.). Has been called the most accurate record he left of his life and work; has also been called "useful but untrustworthy."

\section{WILLIAM VAUGHN MOODY, I869-
I910}

A humanist and a university teacher of English, Moody in some of his poems reacted against social, economic, and political faults in American life to which his patriotism made him particularly sensitive. Among these poems "An Ode in Time of Hesitation" and "On a Soldier Fallen in the Philippines" reveal his opposition to imperialism in foreign policy. Two prose plays, The Great Divide (1909) and The Faith Healer (1909) are essentially dramas of revolt against the Puritan cast of thought surviving in America and the subservience of the people to what he considered worn-out social laws and customs. In the first play the West is made the symbol of freedom and happiness, the East that of repression. An unfinished trilogy of symbolic plays in verse, of which The Fire-Bringer (1904) was designed as the first part, and The Masque of Judgment (1900) as the second, explores the relation of the soul to God and the ultimate meaning of human life.

ro7o. Poems and plays. With an introd. by John M. Manly. Boston, Houghton Mifflin, I9I2.

2 v. $\quad$ 12-26319 PS2425.A2 1912

Contents.-I. Poems and poetic dramas. -2 . Prose plays.

For reprints of selected poems see the entry that follows immediately. The Great Divide is reprinted in Thomas H. Dickinson's Chief Contemporary Dramatists, Ist ser. (Boston, Houghton Mifflin, I9I5, 1922), p. 283-315. The Faith Healer appears in Arthur H. Quinn's Representative American Plays, 7 th ed.

1071. Selected poems. Edited by Robert Morss Lovett. Boston, Houghton Mifflin, ' 1931 . xcii, 243 p. (Riverside college classics)

$$
\text { 31-8586 PS } 2426 . L 6
$$

\section{I072. JOHN MUIR, 1838-1914}

Muir, who was born in Scotland, became a naturalist, whose predominant interests centered about the geology and botany of America. As a child he was brought to Wisconsin, where he spent a laborious youth on his father's farm. Poverty and hardship, however, did not stifle his increasing joy in nature. This joy developed into the passion that inspired his lifework-that of studying and describing the beauties and wonders of the visible world, particularly the glaciers, mountains, and forests of the Far West. It has been said that, like Robinson Jeffers at a later time, Muir looked at California and knew he had come home. However, he traversed other great areas of the United States on foot, gaining firsthand experiences that he transmitted through books that became popular among substantial sections of the American people. His writings concerning the goodly natural heritage of the country thus became a factor in the growth of a movement for the conservation of forests and the development of national parks. In this movement Muir played a formative part.

1073. The mountains of California. New York, Century, 1894. xiii, $3^{81}$ p. illus. Rc-874 F866.M95 
1074. Illustrated by preliminary sketches and photographs furnished by the author. New and enl. ed. New York, Century, 191 I. xiv, $389 \mathrm{p}$. I I-12846 F866.Mg6

1075. Our national parks. Boston, Houghton Mifflin, rgor. $37^{\circ}$ p. illus.

$$
\text { I-26282 EI 60.M95 }
$$

1076. - New and enl. ed. Boston, Houghton Mifflin, 1909 . $\mathrm{x}, 3^{82} \mathrm{p}$. illus.

$$
\text { 9-284II Ei6o.M954 }
$$

1077. The Yosemite. New York, Century, I9I2. $\mathrm{x}, 284$ p. illus. I2-11005 F868.Y6M9

1078. The story of my boyhood and youth. With illus. from sketches by the author. Boston, Houghton Mifflin, 1913. 293 p.

$$
\text { I3-5573 QH31.M9A35 }
$$

Deals with the writer's experience of frontier and pioneer life in Wisconsin.

ro79. A thousand-mile walk to the Gulf. Largepaper ed. Boston, Houghton Mifflin, I916. xxvi, 2 I9 p. illus. 16-23580 F215.M95

Posthumously published journal kept while making a tour on foot from Indiana to the Gulf of Mexico; includes details of flora, forests, physical geography, and inhabitants of the sections through wlich he passed. Edited by William F. Badè.

1080. John of the mountains; the unpublished journals of John Muir. Edited by Linnie Marsh Wolfe. Boston, Houghton Miflin, 1938. xxii, 459 p. illus. $\quad 3^{8-27397}$ QHro5.C2M8

1081. Writings. Sierra ed. [Boston, Houghton, Mifflin, '1915-24] ro v. illus. CtY

Edited by William Frederic Badè, whose Life and Letters of John Muir comprise v. 9-1o of this edition and also of the Manuscript edition.

1082. - Manuscript ed. Boston, Houghton Mifflin, rgr6-24. ro v. illus. NcD

Edited by William Frederic Badè.

1083. The wilderness world of John Muir. With an introd. and interpretive comments by Edwin Way Teale; illustrated by Henry B. Kane. Boston, Houghton Mifflin, 1954. xx, $332 \mathrm{p}$.

Selections from Muir's writings.
1084. MARY NOAILLES MURFREE.

("CHARLES EGBERT CRADDOCK"), I850-1922

Originally published in Lippincott's Magazine and The Atlantic Monthly, Miss Murfree's early local color stories of life in the Cumberland and Great Smoky Mountains of Tennessee won an enthusiastic audience on the score of their originality. These and other stories, subsequently made available in collections, are characterized by meticulous details of dress, food, and manners, by elaborate descriptions of scenery, and by complicated spelling used to reproduce the sound of local dialect. The hardships and loneliness of the segment of the American people known as mountaineers are emphasized.

1085. In the Tennessee mountains, by Charles Egbert Craddock [pseud.] Boston, Houghton Mifflin, 1884. 322 p. 7-4450 PZ3.M943It

1086. I I $^{\text {th }}$ ed. Boston, Houghton Mifflin, I886. $322 \mathrm{p}$.

$$
\text { 34-3779I PZ3.M943Itr3 }
$$

1087. The prophet of the Great Smoky Mountains, by Charles Egbert Craddock [pseud.] Boston, Houghton Mifflin, $1885 . \quad 308 \mathrm{p}$.

$$
\text { 4-I5142 } \mathrm{PZ} 3 . \mathrm{M} 943 \mathrm{Pr}
$$

1088.

$$
\begin{aligned}
& \text { 308 p. Boston, Houghton Miffin }\left[{ }^{\mathrm{c}}{ }_{1913}{ }_{16-25045} \mathrm{PZ}_{3} \cdot \mathrm{M}_{943} \operatorname{Pr}_{4}\right. \\
& { }_{16}
\end{aligned}
$$

1089. (BENJAMIN) FRANK(LIN) NORRIS I870-1902

One of the younger novelists encouraged by Howells, Norris was influenced by reading Zola and turned away from realism according to Howells' definitions to evolve his own theories, which led him to pioneer in naturalistic writing. He insisted, however, that only by what he called "romantic" imagination and insight could the novelist penetrate to depths below surface appearances, with which realism, he believed, was concerned. Since the depths included many violent, sordid, and unlovely elements, he asserted that these also were fit subjects for "romantic" writing-a doctrine followed in his own principal works perhaps with undue fidelity. The author's favorite locale was California and his favorite period was the contemporary. Historically it is interesting to note that Norris' endorsement of Dreiser's Sister Carrie won a publisher for that novel some 12 years before the demand for gentility in fiction declined sufficiently to make the book acceptable. 
rogo. McTeague. New York, Doubleday \& McClure, 1899. $442 \mathrm{p}$.

99-1053 $\mathrm{PZ}_{3} \cdot \mathrm{N}_{792} \mathrm{Ma} \mathrm{RBD}$

Called by the author "a story of San Francisco." The novel portrays the disintegration of character under influence of financial greed.

1091. Introd. by Henry S. Pancoast. New York, Boni \& Liveright, 1918. xiv, 442 p. (Modern Library of the world's best books) 23-7733 $\mathrm{PZ}_{3}$.N792Ma3

1092. —_ Edited with an introd. by Carvel Collins. New York, Rinehart, 1950. xix, 324 p. (Rinehart editions, 40)

Bibliography: p. xix. 50-12507 $\mathrm{PZ}_{3} \cdot \mathrm{N}_{792 \mathrm{Ma}}$

1093. The octopus. New York, Doubleday, Page, [1]) I901. $652 \mathrm{p}$. (His The epic of the wheat Deals with the war between the wheat grower in California and the railroad trust; shows man at the mercy of forces in society beyond his control; continued in The Pit. Latest reissue by Doubleday and Company, 1947.

1094. The pit. New York, Doubleday, Page, 1903. 421 p. (His The epic of the wheat [2]) $3-1580 \quad \mathrm{PZ}_{3} \cdot \mathrm{N}_{792} \mathrm{P}$ Special presentation edition.

Has as its theme the financial ruin of a Chicago speculator when the natural law of growth operates to produce a surplus of wheat. The Wolf, planned as a third volume in the trilogy but never written, was to have centered in the export of wheat for food in famine areas abroad.

1095. —- New York, Modern Library, 1934. 403 p. (Modern Library of the world's best books) 34-28425 $\mathrm{PZ}_{3}$.N792Pro

1096. The responsibilities of the novelist, and other literary essays. New York, Doubleday, Page, 1903. 3II p. 3-234II PN3324.N6

Includes expositions of Norris' theories of novel writing.

1097. Complete works. New York, Doubleday, Page, 1903. 7 v.

Golden Gate edition.

$15-22323$ PS2470.A2 I903 RBD

1098. The Argonaut manuscript limited ed. of Frank Norris's works. [Garden City, N. Y., Doubleday, Doran, 1928] 10 v. illus.

29-5199 PS 2470.A2 I928 RBD
1099. THOMAS NELSON PAGE, 1853-1922

A phenomenon in American life at the close of the Reconstruction period following the Civil War was the shift from an attitude of condemnation of the South, represented in writings by abolitionists, to sentimentality concerning Southern life and its typical institutions. Thomas Nelson Page, American ambassador to Italy and biographer of Robert $\mathrm{E}$. Lee, in his novels, short stories, and essays, romanticized plantation life and the contentment of Negro slaves under the old regime in Virginia. His artistic ability made his works popular in the North as well as in the South, even though his purpose evidently was to leave on record a favorable portrayal of the economic and social order permanently destroyed by the war and its aftermath.

1100. In Ole Virginia. New York, Scribner, 1887. 230 p. 7-35797 PZ3.P154In

Subtitle: Marse Chan and other stories.

Contents.--Marse Chan.--"Unc' Edinburg's drowndin'."-Meh Lady.-Ole 'stracted._- No haid pawn."-Polly.

I ror. - Illustrated by W. T. Smedley, B.W. Clinedinst, C. S. Reinhart, A. B. Frost, Howard Pyle, and A. Castaigne. New York, Scribner, 1896. $\mathrm{xi}, 275$ p. 4-15145 PZ3.PI45In3

II02. New York, Scribner, 1910. $230 \mathrm{p}$. 12-31300 PZ3.P145In6

r 103. The Old South; essays social and political. New York, Scribner, 1892. ix, 344 p.

3-31223 F206.P13

Contents.-The Old South.-Authorship in the South before the war.-Glimpse of life in colonial Virginia.-Social life in old Virginia before the war.-Two old colonial places.-The old Virginia lawyer.-The want of a history of the southern people.-The Negro question.

1104. With a new pref., by [the author] Chautauqua, N. Y., Chautauqua Press, 1919. viii, 344 p. (Chautauqua home reading series) I9-13150 F206.P135

I105. Red Rock; a chronicle of Reconstruction. New York, Scribner, 1898. xv, 584 p. 98-1252 $\mathrm{PZ}_{3} \cdot \mathrm{P}_{45} \mathrm{Re}$

I 106 . Novels, stories, sketches and poems. [Plantation ed.] New York, Scribner, 1906-18. $18 \mathrm{v}$. illus. 


\section{DAVID GRAHAM PHILLIPS, I867-191 I}

For more than a decade Phillips had been a successful journalist, first with the New York Sun, then with the New York World, when free-lance work placed him among the "muckrakers." This term was applied to various writers who were seeking to arouse the country to economic, political, and social abuses that had crept into American life with the spread of industrialism and the growing power of financial tycoons. Between I9OI and I9II, Phillips wrote more than 20 novels. The Deluge (1905) dealt with the manipulation of the stock market by Wall Street magnates; The Plum Tree (1905) had as its theme the machinations of politicians; and Susan Lennox: Her Fall and Rise, posthumously published in I9I7, revealed the author's concern about marital problems and the relations of the sexes in American society. Since all of his novels were written to expose and reform wrongs, rather than as literature, they are significant chiefly because they are documents of the social movements of his period.

I 108. The great god Success, a novel by J. Graham [pseud.] New York, Stokes, Igor, 299 p. I-24902 PZ3.P543Gre

Has as its theme the gradual corruption of an honest and able journalist by ambition for power and money.

rrog. The second generation. New York, Appleton, 1907. 334 p. $\quad$ 7-416o PZ3.P543Se

Advances the idea that a rich man's children degenerate under the expectation of their inheritance, but may be restored if forced to earn their own living.

IIIO.

New York, Appleton, 1919. 334 p. 20-1646r PZ3.P543Seg

\section{WILLIAM SYDNEY PORTER ("O. HENRY"), 1862-rgro}

An author said to have written as many as 65 short stories in one year, $O$. Henry's mild irony, sentiment, pathos, and humor were expressed in simple vernacular language, frequently interlarded with the slang of the day. He achieved the effects for which he is best known by applying a few formulas to produce unexpected, or trick, endings of human-interest stories dealing with characters as diverse as adventurers in Latin America, Texas ranches, and (preferably) clerks occupying back bedrooms in New York lodging houses. As a raconteur might tell a story in passing, he wrote of comic or tragic episodes in the lives of these other- wise ordinary people. At a time when enthusiasm for the short story was at its height in America, his work was enormously popular. Afterwards, the estimates of his characterizations and thought declined under the rigorous methods of criticism developed in the contemporary period. A recent study of his life and work is E. Hudson Long's $O$. Henry (Philadelphia, University of Pennsylvania Press, 1949. $15^{8}$ p.).

I I12. Cabbages and kings, by O. Henry [pseud.] New York, McClure, Phillips, I904. 344 P. 4-32750 PZ3.P835C

First published collection of the author's stories. These are concerned with Latin America.

III3. New York, Penguin Books, 1946. I84 p. (Penguin books, 595)

$$
\text { 47-18969 } \mathrm{PZ}_{3} \cdot \mathrm{P}_{35} \mathrm{Cr}_{5}
$$

II14. The four million. New York, McClure, Phillips, 1906. 26r p.

6-12856 $\quad \mathrm{PZ}_{3} \cdot \mathrm{P} 835 \mathrm{~F}$

A collection of the New York stories that includes two of the best known of all the author's stories: "The Gift of the Magi"; and "The Furnished Room."

I115. W With a note by Burges Johnson. Garden City, N. Y., Doubleday, Page, 1925. xix, $215 \mathrm{p}$. 25-21919 $\mathrm{PZ}_{3} \cdot \mathrm{P}_{35} \mathrm{FI}_{4}$

At head of title: O. Henry biographical edition.

III6. The voice of the city; further stories of the four million. New York, McClure, 1908. 243 p. $\quad 8-17555 \quad \mathrm{PZ}_{3} \cdot \mathrm{P} 835 \mathrm{~V}$ Republished from the New York World and Ainslee's Magazine.

II 7. - With a note by Archibald Sessions. Garden City, N. Y., Doubleday, Page, 1925. xii, 222 p.

25-21593 PZ3.P835 VII

At head of title: O. Henry biographical edition.

III8. The voice of the city and other stories. A selection, with an introd., by Clifton Fadiman; with illus. by George Grosz. New York, Limited Editions Club, I935. xi, 220 p.

35-11910 PS2649.P5V6 1935 RBD

1119. Options. New York, Harper, 1909. 323 p. 9-27747 $\mathrm{PZ}_{3} \cdot \mathrm{P} 735 \mathrm{Op}$

I 120. With a note by Maximilian Foster. Garden City, N. Y., Doubleday, Page, I925. ix, $259 \mathrm{p}$. 25-23723 PZ3.P835Opro

At head of title: O. Henry biographical edition. 


\section{6 / A GUIDE TO THE UNITED STATES}

I121. Complete writings. Garden City, N. Y., Doubleday, Page, 1917. 14 v. illus.

Edition de luxe.

$$
17-31460 \quad \mathrm{PS}_{2649 . P_{5}}{ }_{1917}
$$

I 122. Complete works. Foreword by Harry Hansen. Garden City, N. Y., Doubleday, 1953. 2 v. (xiii, I692 p.) 53-6098 $\mathrm{PS}_{26} 69 . \mathrm{P}_{5} 1953$

1123. Selected stories. Edited by C. Alphonso Smith. Garden City, N. Y., Doubleday, Page, 1922. xvi, 225 p. 22-II5I5 PZ3.P835Sel

I124. Best short stories. Selected, and with an introd., by Bennett A. Cerf and Van $\mathrm{H}$. Cartmell. New York, Modern Library, 1945. x, $33^{8}$ p. (Modern Library of the world's best books) 45-35 $106 \quad \mathrm{PZ}_{3} . \mathrm{P} 835 \mathrm{Be} 2$

1 125. The pocket book of O. Henry [pseud.] thirty short stories, edited and with an introd. by Harry Hansen. New York, Pocket Books [1948] xii, 291 p. (Pocket book 5 I0)

$$
{ }_{48-98}^{8}{ }_{5} \quad \mathrm{PZ}_{3} \cdot \mathrm{P} 835 \mathrm{Po}
$$

\section{JAMES WHITCOMB RILEY, 1849-1916}

After "Pike" speech was reproduced effectively by John Hay and Bret Harte in their folk ballads, dialect verses attained a distinct vogue in the United States. The most popular writer in this genre was Riley, whose The Old Swimmin'-Hole and 'Leven More Poems ( 1883 ) included pieces first published in the Indianapolis Journal while the writer was on the staff of that newspaper. Not all of his poems were written in dialect, but the most distinctive ones are expressed in an accurate reproduction of the Hoosier speech of his native Indiana. They are poems of sentiment, humor, and pathos that celebrate simple themes drawn from childhood, nature, farm life, and neighborliness among plain people in the Middle West. "When the Frost is on the Punkin," "Little Orphant Annie," and "The Old Man and Jim" are typical of individual poems immediately beloved by a large public, for whom they had the appeal of folk ballads. Riley's reputation was enhanced by his frequent appearance as a reader of his own poems with the humorous lecturer, "Bill" Nye. During the latcer part of the 19th century sophisticated as well as less critical audiences delighted in this form of entertainment, which Mark Twain elevated to an art.

I 127. Poems and prose sketches. [Homestead ed.] New York, Scribner, 1897-1914. I6 v. (The works of James Whitcomb Riley) $4^{-13835}$ PS2700.E97
Among the volumes reissued in this edition those most popular since their first publication include the following: Afterwhiles (1887); Rhymes of Childhood (1890); and Poems Here at Home (I893).

I 128. Complete works, in which the poems, including a number heretofore unpublished, are arr. in the order in which they were written, together with photographs, bibliographic notes and a life sketch of the author. Collected and edited by Edmund Henry Eitel. Biographical ed. Indianapolis, Bobbs-Merrill, 1913. $6 \mathrm{v}$.

Bibliography: v. 6, p. [409]-466.

$$
13-26127 \text { PS270r. } E_{5}
$$

I129. Complete works, including poems and prose sketches, many of which have not heretofore been published ... [Memorial ed.] Indianapolis, Bobbs-Merrill, I9I6. Io v. (280I p.) illus. 16-25215 PS2700.FI6

I 3 o. Complete poetical works. Pref. by Donald Culross Peattie. Indianapolis, Bobbs-Merrill, 1937. xxix, 886 p. $\quad 38-8805 \quad P_{2700 . F} 77$ Reprint of a reissue of the Biographical edition.

II31. De luxe ed. New York, Garden City Pub. Co., 1941. xxix, 886 p.

Music: p. 656-657.

$$
4 \mathrm{I}-5 \mathrm{I} 66 \mathrm{I} \mathrm{PS}_{2700 . F_{41}}
$$

A contemporary survey of Riley's place in American literature is provided in the reference that follows.

1132. Nolan, Jeannette (Covert), Horace Gregory, and James T. Farrell. Poet of the people; an evaluation of James Whitcomb Riley. Bloomington, Indiana University Press, 195 I. 106 p.

$$
\text { 5 I-3048 PS2706.N6 }
$$

Contents.-Riley as a children's poet, by J. C. Nolan.-James Whitcomb Riley, a Victorian American, by H. Gregory.-The frontier and James Whitcomb Riley, by J. T. Farrell.

Essays presented originally as a symposium at Indiana University, in 1949, during the centennial celebration of Riley's birth. Without forgetting the significance in the American scene of ballads and folk poetry and Riley's place in that connection, the essayists were asked to separate the traditions and sentiments surrounding the man from the merits of his work as a poet.

\section{IRWIN RUSSELL, 1853-1879}

A minor but authentic poet born in Mississippi, Russell is known for his early use for literary 
purposes of Negro themes and dialect, through which he showed a sympathetic awareness of Negro character and speech.

1134. Poems. New-York, Century [ ${ }^{\mathrm{c}} 1888$ ] xi, 109 p. II-18675 PS2740.A2 1888

Introduction by Joel Chandler Harris.

Lacks some nine poems included in the collection described in the following entry.

I135. Christmas-night in the quarters, and other poems. With an introd. by Joel Chandler Harris, and an historical sketch by Maurice Garland Fulton. New York, Century, I9I7. xxxiv, I82 p. illus. $\quad$ I7-2925I PS2740.A2 1917

\section{CHARLES DUDLEY WARNER, I829- I900}

Warner has been called a transitional figure in American literature. When he wrote of his boyhood, or about his travels in Europe, the Orient, and the United States, or described in familiar essays the joys of nature and a garden, his style was reminiscent of Washington Irving's mellowness and grace. Over the years, however, as the hard-working editor of the Hartford Courant, he developed for other types of writing a vigorous, natural journalistic style suited to the spirit of the late Igth century. His literary criticism, advocating a distinctly American approach, was collected in such volumes as The Relation of Literature to Life (1896) and Fashions in Literature (1902). He expressed a conservative Northern view; nevertheless he used his connection with Harper's Magazine to find a medium of publication for minor Southern authors, such as Grace King. Social criticism in his work is confined chiefly to his novels. One of these, The Gilded Age (1873), was written in collaboration with S. L. Clemens (q. v.). Warner made a genuine contribution to the history of American literature through his general editorship of the first series entitled "American Men of Letters," for which he wrote the volume on Washington Irving, and to literary appreciation in general through his editorial work on the first edition of the Library of the World's Best Literature (New York, Peale \& Hill [ ${ }^{\mathrm{c}} 1896^{-{ }^{c}} 97$ ] $30 \mathrm{v.})$.

I137. My summer in a garden. Boston, Fields, Osgood, 1871 . xii, $183 \mathrm{p}$. 22-10088 PS3152.M6 I871

Includes an introductory letter by Henry Ward Beecher.

I138. With illus. by F. O. C. Darley. Boston, Houghton Mifflin, I898. 212 p. 98-1695 PS3152.M6 1898
I139. Being a boy. Boston, J. R. Osgood, 1878 . vi, 244p. illus.

$\begin{array}{lll}\mathrm{CAI}_{12-1071} & \mathrm{PS}_{3152 . \mathrm{B}_{4}} & 1878\end{array}$

I 140. Boston, Houghton Miflin [ ${ }^{\mathrm{c}} 1905$ ] vi, 244 p. illus. 5-33.975 $\mathrm{PS}_{3152 . \mathrm{B}_{4} \quad 1905}$

I I4I. Boston, Houghton Mifflin [ ${ }^{\mathrm{C}}$ I9I9] 186 p. (The Riverside literature series) 38-29713 $\mathrm{PS}_{3152 . B_{4}} 1919$

This edition is without the illustrations by Clifton Johnson.

1142. A little journey in the world. New York, Harper, r889. 396 p.

8-337'5 PZ3. W243L Originally published in Harper's Monthly, as a serial, in 1888; first of a trilogy of novels that includes also The Golden House (1895) and That Fortune (1899), all of which deal with the temptations and difficulties attendant upon the acquisition, possession, and loss of wealth.

I143. - New York, Harper, 1894. 396 p. (Harper's Franklin Square library, no. 747) I3-12913 PZ3. W243L2

1144. Complete writings. [Backlog ed. Edited by Thomas R. Lounsbury] Hartford, Conn., American Pub. Co., 1904. 15 v. illus.

$$
4-32205 P_{3}{ }^{150 . A 2} \quad 1904
$$

\section{I145. OWEN WISTER, 1860-1938}

A Pennsylvania-born graduate of Harvard University, Wister utilized several trips West in search of health to provide him with material for his stories of cowpunchers, combined in Lin McLean (1898), and also used for his later successful novel, The Virginian. Both books illustrated the repeated return of American writers to themes drawn from pioneer or rugged life in the West, and also capitalized on an interest in the strenuous life that was abroad in the land during the presidency of Theodore Roosevelt. Mr. Wister's strong, plain heroes and their refined brides of the I870's and I880's, surrounded by dangers and inevitable adventures in the great open spaces of the Wyoming cattle country of that time, appealed to the American taste of the period for novels of action that were at the same time highly romantic. A survival of this interest may be seen in the contemporary popularity of the "western." Lady Baltimore (I906), a novel of society in Charleston, South Carolina, about the turn of the igth century, is treated with a light touch and sympathetic delicacy. 
1146. The Virginian; a horseman of the plains. New York, Macmillan, 1902. xiii, 504 p. 2-I $443 \mathrm{I} \quad \mathrm{PZ}_{3} \cdot \mathrm{W}_{7} 68 \mathrm{~V}$

1147. — New ed. With ... drawings from western scenes by Frederic Remington. New York, Macmillan, I9II. xv, 506 p.

$$
\text { II-26412 PZ3.W768Vio }
$$

I 4 8. With an introd. by Struthers Burt and illus. by William Meyers. Los Angeles, Printed for members of the Limited Editions Club by the Plantin Press, 195I. xix, $437 \mathrm{p}$.

$$
\text { 51-37493 } \mathrm{PS}_{3345 .} \mathrm{V}_{5} \text { 1951 RBD }
$$

For a current publication of The Virginian see the New pocket classics series, issued by Macmillan.

\section{II49. CONSTANCE FENIMORE WOOLSON, I $84^{-}-1894$}

Following the pattern set by her great-uncle, James Fenimore Cooper, Miss Woolson called her shorter pieces "sketches." They are, in fact, early and exceptionally realistic local color stories, chiefly about life around the Great Lakes (in Ohio and Michigan) and in the South, where the writer became familiar with characteristic localities in Florida, the Carolinas, and Virginia. Her work was welcomed by editors of the best periodicals at the time that Bret Harte's stories were in vogue. It won sufficient recognition to be republished later in collections and has given her a secure place among regional writers of the 1870 's and I880's. Several novels, written after she left the United
States to live in Italy, are increasingly concerned with psychological problems resulting from the interplay of character and circumstance, an interest that Miss Woolson may have developed from her mentor, Henry James.

II50. Castle Nowhere: lake-country sketches. Boston, J. R. Osgood, I875. 386 p.

8-37232 $\mathrm{PZ}_{3}$.W888C

I15I. Rodman the keeper: southern sketches. New York, Appleton, I88o. 339 p.

8-37226 ${ }^{3} Z_{3}$.W888R

Originally published in The Atlantic Monthly, Appletons' Journal, and other periodicals; stories of the South under Reconstruction. Written with sympathy but also objectivity by a Northerner, they are said to have influenced the development in the North of interest in Southern literature.

1152. Constance Fenimore Woolson; arr. and edited by Clare Benedict. London, Ellis, 1932. xvi, 560 p. illus $32-22803 \quad \mathrm{PS}_{33} 60$. $\mathrm{A}_{5} \mathrm{~B}_{4}$

Bibliography begun by the author and completed by the editor: p. 550-553.

A reprint of volume 2 of Clare Benedict's larger work, Five Generations (London, Ellis [1930?] 3 v.). Includes part of an article dealing with Miss Woolson, taken from Henry James' Partial Portraits ( 1888 ), together with extracts from her correspondence, articles, and miscellaneous writings. In Appendix A, p. 4I3-549, is found a selection of her poems and stories.

\section{E. The First World War and the Great Depression (1915-1939)}

Between April 1917 and November 1918, some two million soldiers went to Europe to take their country's part in a world war. The aftermath of that war was a decade of inflated prosperity leading to an orgy of speculation on the stock market, which in turn was followed by a depression so severe as to create an army of unemployed that numbered, according to various estimates, between 12 and 15 million former workers. It is not surprising that war and financial collapse, twin peaks of disaster, should mark the period as one in which frustration, disillusionment, pessimism, and cynicism colored American attitudes. No more surprising is the fact that each crisis colored the period in its own way, so that, except for purposes of convenience, it might be regarded logitimately as two periods. First, with the rapidly accelerating tempo of life in the twenties, a decade became an age, the "Jazz Age," filled with speed, excitement, and self-expression. These characteristic manifestations of the spirit of the time inevitably were reflected in literature. But later when the depression struck, American writing took on an increasingly serious tone and many writers accepted the theory that all literature should have a message for a world that was in sore trouble. Seriousness and social reform became the watchwords.

Although the messages to be found in much of the best writing done in the 19th century in the United States were still applicable, and were in fact rediscovered and reiterated by the not always original moderns, the "genteel" book was vigorously 
rejected on the score of prudery and hypocrisy. A generation, in which emotions of fear and uncertainty engendered by war had been fostered by economic misfortune, found little that was congenial in the Puritan heritage of respectability and gentility founded on solid prosperity. Observation of crass materialism and injustices to minority or underprivileged groups gave rise to strong social indignation. A climate of liberal opinion arose that was favorable to social and economic reforms instituted within the period.

During the same span of time the country also felt an impact from the acceleration of other forces already operating to change its way of life. Science and invention had replaced horses with horsepower, and registered automobiles in the United States rose to a number nearly equal to one for every five Americans. The populace, so far as it was able, took to the roads. These roads in turn were extended and improved to carry the constantly increasing volume of traffic to which the restlessness of the "Jazz Age" contributed. When distances were too great to make motoring feasible, communication across state and national boundaries was made possible by a growing system of telephones. Radio programs broadcast identical information and entertainment over wide areas. The powerful motion picture industry, offering its wares in local theaters from one end of the country to another, created a kind of mass sophistication that had its own effects on manners, morals, and customs, as did the inexpensive magazines sold across the land. By the end of the period, travel by airplane had become as common as travel by automobile had been at its beginning. All these facilities for mobility and easy communication of ideas contributed greatly to a modification of the sectionalism that had up to this time been present in American culture. Provincialism also decreased with the emergence of the United States as a great power among the nations of the world. Reciprocity of esthetic and philosophical ideas between Europe and America increased, with notable effects on American literature.

The growing complexity of American life at this time had its counterpart in the literature produced in the years between the coming of the First World War and the end of the country's worst depression. The ever-present struggle of man with his environment and his dissatisfaction with the state of being "a stranger and afraid, in a world I never made" found their most complete expression in fiction. Realism, so characteristic of novels and stories written in the preceding period, continued as a prevailing trend, which, however, tended to shade into pessimistic, behavioristic naturalism, exemplified by the work of Theodore Dreiser and James T. Farrell, or the more complex, "Freudian" naturalism of Sherwood Anderson or William Faulkner. Social criticism as a factor in literature became a prime force in the thirties, when almost all literature was for a while judged in terms of its message and social value. All this is not to say, however, that writing according to an older and more conventional pattern did not win wide approval during the period. Regionalism, with new social and spiritual overtones, was present in the novels of Ellen Glasgow and Willa Cather. Historical novels portraying America's past continued to attract enthusiastic audiences and became, with the trend toward more and more realism, frequently the product of research as careful as that traditionally lavished only on definitive history.

Among the most startling literary developments of a period in which so many men were ill at ease was the rebirth of interest in the art of poetry, despite its decline in market sales. Here again, as in the case of fiction, experimentation and to some extent realism were at the heart of the revival; but experimentation as well as realism took many forms and progressed through various degrees: Edwin Arlington Robinson and Robert Frost, using conservative poetic forms for freshly realistic and occasionally hardbitten portraits and utterances, which assumed, particularly in the work of Frost, symbolic dimensions; Carl Sandburg, Vachel Lindsay, and Edgar Lee Masters, each with a new rhythm and a different slant on "the American Dream"; Ezra Pound, T. S. Eliot, Wallace Stevens, E. E. Cummings, and William Carlos Williams, in each of whom experimentalism reached a highly personal poetic style in an effort to express the individual human condition in its universal proportions and significance. This experimental movement, with its numerous cross-currents of schools, fostered by a succession of "little magazines" which frequently represented also new philosophical, social, and economic views, developed a surprising number of poets. These joined the novelists in making themselves felt as social critics no less than as creative artists. Whatever value time may place eventually on the work of poets writing in this era, the fact remains that it constitutes a second renaissance of poetry in the development of American literature.

Emphasis inevitably has been placed on prose fiction and poetry, in which much of the best work of the period was done. However, Eugene O'Neill, America's leading playwright, wrote all but a very few of his plays during these years, and a number of other playwrights produced works of literary as well as theatrical distinction. Outstanding work in other forms also was produced, notably in humor, the general essay, and criticism, which now entered the field as literature in its own right. Criticism has not been represented in this section, except when 
the author has been included for his other work, but critical writings have received detailed treatment in the chapter devoted to Literary History and Criticism.

\section{LÉONIE ADAMS, I899-}

As a lyric poet Miss Adams has won immediate and continuing recognition from critics for her mastery of technical poetic forms, new and old; for her sensitive response to nature; and for the mystical quality in her perceptions.

1154. Poems: a selection. New York, Funk \& Wagnalls, 1954. $128 \mathrm{p}$. 54-6356 PS35or.D285A6 1954

Part II of this volume (p. 52-124) includes poems previously published in the poet's earlier works: Those Not Elect (1925) and High Falcon (1929).

\section{SAMUEL HOPKINS ADAMS, I 871-}

Adams is probably best known for his fiction, much of which depicts I th-century life in the Erie Canal area of New York State. Conservative and "victorian" in approach, as in the novel Siege (1924), he has often tried to infuse a degree of modernism in his work, as in Plunder (1948), a fictionalpolitical commentary which is a satirical account, in a highly conversational style, about a crude, starspangled-American demagogue who almost becomes dictator. He has also written short stories, as in From a Bench in Our Square (1922), which deals with New York City, where he was for some time a journalist. He has also published a number of biographies, works of history, commentary, and juvenile books. He was early associated with the muckraking movement and wrote The Great American Fraud (1906, I905), an influential revelation of medical quackery at the turn of the century. His later work tends to be pervaded by a gentle humor.

I 156. Revelry. New York, Boni \& Liveright, 1926. 318 p. 26-21303 PZ3.A217Re2

A novel about the political corruption in Washington during the Harding administration.

1157. Canal town. New York, Random House, 1944. 465 p. 44-40112 PZ3.A217Can A novel evoking Palmyra, N. Y., in 1820 .

I 158. Banner by the wayside. New York, Random House, 1947. $442 \mathrm{p}$.

$$
\text { 47-1795 PZ3.A217Ban }
$$

A novel centering about a group of entertainers touring the Erie Canal area in the mid-nineteenth century.

II59. Sunrise to sunset. New York, Random House, 1950. 373 p.

$$
\text { 50-7919 } \mathrm{PZ}_{3} \cdot \mathrm{A}_{217} \mathrm{~Sv}
$$

A novel using a setting in and around the cotton mills of Troy, New York, in the 1830 's.

I16o. Grandfather stories. New York, Random House, 1955. 312 p.

55-6657. $\mathrm{PZ}_{3} \cdot \mathrm{A}_{21} \mathrm{Gr}$

A retelling of memories of the Erie Canal country as told to the author by his grandfathers; depicts early igth-century New York State.

\section{II6r. CONRAD POTTER AIKEN, r889-}

Poet, novelist, short story writer, and critic, Conrad Aiken's work has been influenced by Freudian concepts, the writings of James Joyce, and the stream-of-consciousness technique in general. His novels in particular illustrate these influences. His poetry is characterized by a melodic quality indicative of his interest in the relation between poetry and music. In 1930 he received the Pulitzer prize for poetry for his Selected Poems (1929).

I162. Blue voyage. New York, Scribner, 1927. $318 \mathrm{p}$.

27-15974 PZ3.A2912Bl

Using the stream-of-consciousness technique, Aiken has in this novel produced a study of life as presented to the mind of a writer on a transatlantic liner.

1163. Great circle. New York, Scribner, I933. $335 \mathrm{p}$.

33-12047 PZ3.A2912Gr

A psychological novel centering about a man whose wife has been having a love affair with his friend. Meetings with a psychoanalyst are introduced to trace the origin of the main character's present situation.

ir64. Short stories. New York, Duell, Sloan \& Pearce, I950. $416 \mathrm{p}$.

$$
\text { 50-9750 PZ3.A2912Sh }
$$

i165. Ushant, an essay. New York, Duell, Sloan \& Pearce, 1952. $365 \mathrm{p}$.

$$
\text { 52-9071 PS } 3501 . I_{5} Z_{53}
$$

A psychoanalytic autobiography of the poet, reconstructed in a series of flashbacks.

i 66. Collected poems. New York, Oxford University Press, 1953. $895 \mathrm{p}$. 53-9180 PS $4501 . I_{5} A_{7} 1953$ 
This collection contains those poems which Aiken wished to preserve. They are arranged approximately in order of composition, rather than of publication. The poems selected are from previous volumes such as Turns and Movies (19r6), Punch: The Immortal Liar (I92I), John Deth, a Metaphysical Legend (1930), The Coming Forth by Day of Osiris Jones (193I), Preludes for Memnon (1931), Landscape West of Eden (1934), Time in the Rock (1936), And in the Human Heart (1940), Brownstone Eclogues (1942), The Soldier (1944), The Kid (1947), and The Divine Pilgrim (1949).

\section{HERVEY ALLEN, 1889-1949}

Diarist and fiction writer of World War I, and a leader among those who fostered a rebirth of interest in the art of poetry in the South, Mr. Allen was also the author of the scholarly biography, Israfel; the Life and Times of Edgar Allan Poe (1926). He is better known, however, for his influence in advancing the vogue of the historical novel in America.

1168. Carolina chansons; legends of the low country, by Du Bose Heyward and Hervey Allen. New York, Macmillan, 1922. I3I p.

$$
\text { 22-24847 } \mathrm{PS}_{35}{ }^{15} \cdot \mathrm{E}_{98} \mathrm{C}_{3} \quad 1922
$$

I169. Anthony Adverse; decorations by Alla McNab. New York, Farrar \& Rinehart, 1933. I224 p. 33-27189 PZ3.A4264An

Picaresque novel which spans the life of the hero in Europe, Africa, and America, from 1775 to I825; some two million copies have been sold.

I 170. Toward the flame; a war diary. New York, Farrar \& Rinehart, I934. 282 p.

$$
\text { 34-4704 D570.9.A53 }
$$

II7I. The forest and the fort. New York, Farrar \& Rinehart, 1943. 344 p.

43-4731 $\mathrm{PZ}_{3} \cdot \mathrm{A}_{42}{ }_{4} \mathrm{Fo}_{\mathrm{O}}$

First of three parts of a historical novel planned in five parts. The series, left incomplete by the author's death, was, with a fragment of the fourth part, edited by Julie Eidesheim and published as The City in the Dawn (1950). Its theme is 18thcentury pioneer life on the American frontier.

\section{MAXWELL ANDERSON, I888-}

This dramatist's interests vary from satirizing political corruption in the United States, as in Both Your Houses (1933), which won the Pulitzer prize, to recreating for American audiences episodes in their British and European heritage, as in
Elizabeth the Queen (1930), Mary of Scotland (1933), and Joan of Lorraine (1946; rev. ed. 1947). One of the more important influences of some thirty-odd plays he has written in as many years is the interest they have created in the use of poetry as a dramatic medium on the stage.

I 73. Winterset; a play in three acts. Washington, Anderson House, 1935. 134 p.

$$
\text { 35-2743I PS } 3501 . N_{25} 6 \mathrm{~W}_{5} \text { 1935a }
$$

Deals with the problem of justice and reflects a more universal aspect of his earlier interest in the Sacco-Vanzetti case, which inspired his Gods of the Lightning (1928).

I174. Eleven verse plays, 1929-1939. [New York] Harcourt, Brace, 1940. [1321] p. 40-27679 PS3501.N256 I940

Contents.-Elizabeth the queen.-Night over Taos.-Mary of Scotland.-Valley Forge.-Winterset.-The Wingless victory.-High Tor.-The masque of kings.-The feast of ortolans.-Second overture.-Key Largo.

1175. Off Broadway. New York, Sloane, 1947. 9 I p.

47-30369 PN2021.A54

Collection of critical essays and lectures; see particularly "Poetry in the Theater," p. 47-54, and "The Uses of Poetry," p. 87-91, for Mr. Anderson's theories concerning the place of poetry in the contemporary theater.

II76. Barefoot in Athens. New York, Sloane, I95I. Ior p. 5I-13750 PS $3501 . N_{256 B} \mathrm{~B}_{27}$

Freedom of opinion in relation to democracy, the theme of the play, gives timeliness to this dramatic presentation of the life and death of Socrates at the end of the fifth century, B. C., in Athens.

II77. Bad seed; a play in two acts. The dramatization of William March's novel, The bad seed. New York, Dodd, Mead, 1955. 96 p. $55-7822 \quad \mathrm{PS}_{35}$ 05. $\mathrm{A}_{53}{ }_{57} \mathrm{~B}_{36} 6$

William March is the pseudonym of William Edward March Campbell (1893-1954), an Alabama author of short stories and novels.

\section{78. SHERWOOD ANDERSON, 1876-1941}

Short stories, novels, and autobiographical works, most successful when dealing with smalltown life in Ohio, ca. 1880-1910, were used by the author to express his pessimism concerning the fate of simple people, adjusted to primitive conditions derived from the pioneer period in rural America, who are defeated or frustrated by forces at work in a society rapidly becoming industrialized. Ander- 
son's work is characterized by frankness of expression in advance of his time, by a mystical faith in the life force in man, and by introspection almost psychoanalytical in quality.

I179. Winesburg, Ohio. New York, Huebsch, 1919. 303 p. 19-17477 $\mathrm{PZ}_{3}$. A55 Win Short stories.

I 180. Poor white; a novel. New York, Huebsch, I920. $371 \mathrm{p}$. 20-2747 I PZ3.A55 Po $\mathrm{PS}_{35}$ or.N4P6

1181. The triumph of the egg; a book of impressions from American life in tales and poems. New York, Huebsch, r921. 269 p.

$$
\text { 21-21097 } \mathrm{PZ}_{3} \cdot \mathrm{A}_{55} \mathrm{Tr}
$$

II82. A story teller's story; the tale of an American writer's journey through his own imaginative world and through the world of facts, with many of his experiences and impressions among other writers--told in many notes-in four booksand an epilogue. New York, Huebsch, r924. $442 \mathrm{p}$. 24-27699 $\mathrm{PS}_{3501 . \mathrm{N}_{4} \mathrm{Z}_{5}}$

1183. Dark laughter. New York, Boni \& Liveright, 1925. 319 p. 25-20829 PZ3.A55 Da

The title refers to the vital laughter of the unrepressed Negroes in the background of this novel about sterility and frustration in the machine age. This story of the Midwest is written with a streamof-consciousness technique.

1184. Tar, a Midwest childhood. New York, Boni \& Liveright, 1926. 346 p. 26-22222 $\mathrm{PS}_{35}$ or. $\mathrm{N}_{4} \mathrm{Z}_{52}$

1185. The portable Sherwood Anderson, edited, and with an introd., by Horace Gregory.

New York, Viking Press, 1949. 631 p. (The Viking portable library)

$$
\text { 49-856 PS } 3501 . \mathrm{N}_{4} \mathrm{A6} \text { г949 }
$$

Includes among numerous selections Death in the Woods (1933), p. 532-548, considered by the editor of this collection the masterpiece among Anderson's short stories.

1186. Sherwood Anderson's memoirs. [New York] Harcourt, Brace, 1942. 507 p.

$$
\text { 42-1 } 1377 \text { PS } 35 \text { or. N } 4 Z_{49}
$$

1187. Letters; selected and edited with an introd. and notes by Howard Mumford Jones, in association with Walter B. Rideout. Boston, Little, Brown, I953. 479 p. 52-12649 PS $3501 . N_{4} Z_{54}$
1 188. Howe, Irving. Sherwood Anderson. New York, Sloane, 1951. xiii, 27 I p. (The American men of letters series)

“Bibliography": p. 257-260. 51-9927 $\mathrm{PS}_{35}$ or. $\mathrm{N}_{4} \mathrm{Z6}$

1 189. Schevill, James Erwin. Sherwood Anderson, his life and work. [Denver] University of Denver Press, 195 I, xvi, 360 p. illus.

Bibliography: p. $35^{6}-357$.

$$
\text { 5I-10225 } \mathrm{PS}_{3501 . \mathrm{N}_{4} \mathrm{Z8}}
$$

\section{IIgo. SHALOM ASCH, I880-}

Asch is a Polish-born commentator on Jewish life and problems. His cycle of novels on Biblical themes-The Nazarene (1939), The Apostle (1943), Mary (1949), and The Prophet (1955)has enjoyed wide circulation in the United States, where the author, although long a naturalized citizen, continues to write in Yiddish and to have his books translated for the American audience. One of his recurring themes, illustrated by the titles below, is the adjustment of Jewish immigrants to the new environment encountered in the United States, usually in an urban setting such as New York City. The author has also dealt with problems of Jewish life abroad, as in Three Cities (1933), a trilogy dealing with Jews in Russia.

II9I. The mother; authorized translations by Elsa Krauch. New York, Putnam, 1937. 295 p. 37-28739 PZ3.A798Mo6

An earlier version was published in 1930 in a translation by Nathan Ausübel.

1192. Three novels: Uncle Moses, Chaim Lederer's return, Judge not-; translation by Elsa Krauch. New York, Putnam, 1938. 176, 116, $127 \mathrm{p}$. $\quad 38-29527 \quad \mathrm{PZ}_{3}$.A798Thr

Written originally between 1916 and 1923 .

1193. East River, a novel. Translation by A. H. Gross. New York, Putnam, 1946. $43^{8}$ p. 46-7365 PZ3.A798Eas

1194. A passage in the night. New York, Putnam, 1953. 367 p. 53-8146 PZ3.A798Pas

1195. Lieberman, Herman. The Christianity of Sholem Asch, an appraisal from the Jewish viewpoint. [From the Yiddish, by Abraham Burstein] New York, Philosophical Library, 1953. $276 \mathrm{p}$. 
rig6. MARY (HUNTER) AUSTIN, I868-I934

A writer with a strong local interest in the Indian culture of the Southwest, particularly in California and New Mexico, Mrs. Austin left an autobiographical record of her varied literary career in Earth Horizon (1932). The American Rhythm (1923, enl. ed., r930) expounds her idea that the American environment and way of life determine the verse forms suited to poems written in the United States. It includes also an anthology of her "re-expressions" of native Indian verse.

1197. The land of little rain. Boston, Houghton Mifflin, 1903. 280 p. $\quad 3-26358$ F786.A93 Short stories.

I I98. One-smoke stories. Boston, Houghton Mifflin, 1934. 294 p.

$$
\text { 34-2707 } \mathrm{PZ}_{3} \cdot \mathrm{A}_{9373} \mathrm{On}
$$

\section{PHILIP BARRY, 1896-1949}

While Barry's recognized genre was that of the social comedy, in which he had numerous successes on the stage, his plays also provide penetrating studies of marriage as an institution, the relation of parents to children, and other important aspects of American family life. Hotel Universe (1930), a symbolic play on the mystic power of goodness in a man considered by the world to be insane, is one of his most serious dramatic works.

1200. Holiday, a comedy in three acts. New York, S. French, 1929. 205 p. 29-788r $\mathrm{PS}_{3503 . A 6} 8 \mathrm{H} 6 \quad 1929$

1201. The animal kingdom, a comedy. New York, S. French, 1932. $198 \mathrm{p}$.

$$
3^{2-17483} \mathrm{PS}_{3503 . A 648 \mathrm{~A} 8} 193^{2}
$$

1202. The Philadelphia story; a comedy in three acts. New York, Coward-McCann, 1939. 206 p. 40-III46 PS $3503 .{\mathrm{A} 648 P_{5}}$ 1939a

1203. Second threshold; with revisions and a pref. by Robert E. Sherwood. New York, Harper,

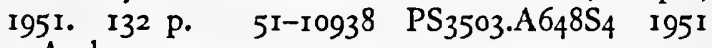
A play.

\section{SAMUEL NATHANIEL BEHRMAN, I893-}

Behrman began by writing "pure" comedy. Faced by the turmoil of the thirties, he began in his plays to explore the possibility of comedy in our time and produced comedies reflecting the more serious issues of the period. In recent years he has adapted a number of foreign plays, written reminiscences of his childhood in Worcester, Massachusetts, and he has also published a humorous, perceptive biography of an art dealer: Duveen (i952).

1205. Biography, a comedy. New York, Farrar \& Rinehart, 1933. $24 \mathrm{I} \mathrm{p}$.

$33-4065 \mathrm{PS}_{3503 .} \mathrm{E}_{37} \mathrm{~B}_{5} 1933$

1206. Three plays: Serena Blandish, Meteor, The second man. New York, Farrar \& Rinehart,

1934. 355 p. $\quad 34-6070 \quad \mathrm{PS}_{3503 .} \mathrm{E}_{37} \mathrm{~T}_{5} \quad 1934$

1207. Rain from heaven, a play in three acts. New York, Random House, 1935. 250 p. 35-2998 $\mathrm{PS}_{3503 .} \mathrm{E}_{37} \mathrm{R}_{3} \quad{ }_{1935}$

1208. End of summer. New York, Random House, r936. $256 \mathrm{p}$.

$$
3_{36-7652} \mathrm{PS}_{3503 . \mathrm{E}_{37} \mathrm{E} 6} \quad \mathrm{I936}
$$

1209. No time for comedy. New York, Random House, 1939. $216 \mathrm{p}$.

$$
\text { 39-14726 PS } 3503 . E_{37} \mathrm{~N} 6 \quad 1939
$$

1210. The Talley method, a play in three acts. New York, Random House, 1941. 197 p. $4_{4}{ }^{\mathrm{I}-855^{\circ}} \quad \mathrm{PS}_{3503} \cdot \mathrm{E}_{37} \mathrm{~T}_{3} \mathrm{I}_{194 \mathrm{I}}$

I211. The pirate. New York, Random House, 1943. xii, 209 p. plate.

A play.

$$
\text { 43-5III4 } \mathrm{PS}_{3503} \cdot \mathrm{E}_{37} \mathrm{P}_{5}
$$

1212. Jane. New York, Random House, I952. 195 p. 52-8279 $\mathrm{PS}_{3503 . \mathrm{E}_{373}}$

1213. The Worcester account. New York, Random House, 1954. $239 \mathrm{p}$.

Reminiscences.

53-5014 $\mathrm{PS}_{3503 . \mathrm{E}_{37} \mathrm{Z}_{53}}$

\section{ROBERT CHARLES BENCHLEY, I889- 1945}

A successful journalist and drama critic, Benchley achieved his greatest prominence as a comedian working through short films and radio appearances, as well as through his numerous humorous articles, which were originally written mainly for periodicals, and later collected in volumes such as Of All Things (1921), Love Conquers All (1922), Pluck and Luck (1925), The Early Worm (1927), The Treasurer's Report, and Other Aspects of Community Singing (1930), and From Bed to Worse; or, Comforting Thoughts about the 
Bison (1934). The titles themselves reflect the literate, verbal nonsense which was his specialty. His gentle satire (of which he himself was the main target) encompassed a broad range of topics, chiefly concerned with everyday affairs such as pigeon persecution, music interpretation, and the menace of buttered toast. Selections from earlier volumes appeared in Inside Benchley (1942), Benchley-Or Else! (1947), and The Benchley Roundup (1954). An additional element of humor was given the Benchley books by the many illustrations supplied by Gluyas Williams.

1215. 20,000 leagues under the sea; or, David Copperfield. New York, Holt, I928. 233 p.

illus. 28-31116 PS3503.E49T8 1928

1216. No poems; or, Around the world backwards and sideways. New York, Harper, 1932. 330 p. illus. $\quad 32-34924 \mathrm{PS}_{3503} . \mathrm{E}_{49} \mathrm{~N} 6{ }_{1932}$

1217. My ten years in a quandary, and how they grew. New York, Harper, 1936. 36r p.

illus. $\quad 36-9634 \mathrm{PS}_{3503 . \mathrm{E}_{49} \mathrm{M}_{9}} 1936$

1218. After 1903-what? New York, Harper, 1938. $271 \mathrm{p}$. illus.

$$
3^{8-2530} \quad \mathrm{PS}_{3503 . E_{49} \mathrm{~A}_{7} \quad 1938}
$$

1219. Benchley beside himself. New York, Harper, 1943. 304 p. illus.

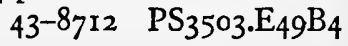

1220. Chips off the old Benchley. New York, Harper, r949. 273 p. illus.

$$
\text { 49-10872 } \mathrm{PS}_{3503} \mathrm{E}_{49} \mathrm{C}_{5}
$$

1221. Benchley, Nathaniel. Robert Benchley, a biography. New York, McGraw-Hill, 1955. $25^{8}$ p. illus. 55-10402 $\mathrm{PS}_{3503 . E_{49} \mathrm{Z6}}$

\section{STEPHEN VINCENT BENÉT, , 898-r943}

As a poet, novelist, and short story writer, Benét made use of themes drawn from American history and folklore. In his poetry he often adapted forms from folk ballads, a device he used also in the varying metrics of his Civil War epic, John Brown's Body (r928), which was awarded a Pulitzer prize and which has been called the most popular long poem of the century. His posthumous Western Star (1943), celebrating the English settlements at Jamestown and Plymouth, constitutes book one of an incomplete narrative poem about the western migration of peoples. As a short-story writer Benét is probably best known for The Devil and Daniel Webster (1937), which has practically become a part of New Hampshire folklore, and which was made into a successful movie and also used to produce a libretto for an opera by Douglas Moore (b. 1893). Benét's first two novels, The Beginning of Wisdom (I92I) and Young People's Pride (1922), were stories of developing young authors, and they showed the influence of F. Scott Fitzgerald. The third novel of his youthful period was Jean Huguenot (1923), which dealt with the problem of a woman's values in life. Spanish Bayonet (1926), which is probably his best-known novel, is a story of the development of Florida, with the Revolutionary War period for temporal background. In America (I944) Benét produced a short, popular history of this country from its founding to Pearl Harbor. Also published posthumously was The Last Circle (1946), in which his wife, Rosemary Carr Benét (b. 190o), collected stories and poems not appearing in previous volumes and for the most part written in the last few years of the author's life.

1223. James Shore's daughter. Garden City, N. Y., Doubleday, Doran, r934. 277 p.

34-15494 $\mathrm{PZ}_{3} \cdot \mathrm{B}_{4292 \mathrm{Jam}}$

A novel in which the main attempt is to recreate the spirit of the times of the late 19 th and the opening decades of the 2oth centuries in America.

1224. Selected works. New York, Farrar \& Rinehart, 1942. 2 v.

$$
\text { 42-15523 } \mathrm{PS}_{3503 .} \mathrm{E}_{5325} \mathrm{~A} 6 \quad 1942
$$

The first volume is devoted to Benét's poetry. In addition to the epic poem John Brown's Body (1928), it includes material from the author's earlier volumes, Young Adventure (1918), Heavens and Earth (1920), Tiger Joy (1925), Ballads and Poems, 1915-1930 (1931), and Burning City (1936). The second volume is devoted to his prose; in addition to the complete novel, Spanish Bayonet (1926), it includes short stories under the three headings of "Stories of American History," "Tales of Our Time," and "Fantasies and Prophecies." Benét's earlier collections of short stories were Thirteen O'Clock (1937) and Tales Before Midnight (1939).

\section{JOHN PEALE BISHOP, I892-1944}

Bishop's poetry, criticism, general essays, reviews of poetry, and miscellaneous articles, published posthumously in collected editions, contribute to an understanding of forces that impinged upon American society between two world wars and that were reflected in the literature of the period. He wrote in a style formed by his taste for classic restraint, substantial values, decorum, and elegance. William Butler Yeats and T. S. Eliot were formative influences in the development of his poetical 
work. Bishop also produced some distinguished fiction: notably, Many Thousands Gone (New York, Scribner, 1931. 282 p.), a volume of short stories dealing with the South during the Civil War period, and Act of Darkness (New York, Scribner, 1935. 368 p.), a novel which reflects life in a West Virginia town early in the 2oth century.

1226. Collected essays. Edited with an introd. by Edmund Wilson. New York, Scribner, 1948. 508 p. $\quad 48-8528 \quad$ PS $3503 . I 79$ Ar6 1948

This volume is divided into ten sections: "Essays," "Painters," "Moving Pictures," "Novelists of the Twenties," "Novelists of the South," "Poetry Reviews," "Miscellaneous Articles," "Aphorisms and Notes," "Portraits of Places," and "Stories." The last section does not constitute a collection of his short stories, for none of those in Many Thousands Gone (vide supra) are included.

1227. Collected poems. Edited with a pref. and a personal memoir by Allen Tate. New York, Scribner, 1948. 277 p.

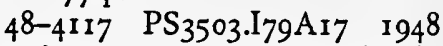

This volume contains many poems previously unpublished or published only outside the earlier volumes of the author's poetry, as well as reprinting the contents of Green Fruit (1917), Now with His Love (1933), Minute Particulars (1935), and the new material in Selected Poems (194I).

\section{RICHARD PALMER BLACKMUR, 1904-}

By his own experience as a poet Blackmur is exceptionally well-qualified to analyze, interpret, and criticize the language and accomplishments of poets such as Emily Dickinson, Ezra Pound, T. S. Eliot, Wallace Stevens, Marianne Moore, and E. E. Cummings. An insight into his critical methods and purposes may be gained from "A Critic's Job of Work," an essay found in The Double Agent and also in Language as Gesture.

1229. The double agent; essays in craft and elucidation. New York, Arrow Editions, 1935. $302 \mathrm{p}$. 35-31958 PS $324 . \mathrm{B} 6$

1230. From Jordan's delight [poems] New York, Arrow Editions, 1937. I05 p.

$$
\text { 37-4180 } \mathrm{PS}_{35} \text { o3.L.266F7 }_{1937}
$$

123I. The expense of greatness. New York, Arrow Editions, 1940. $305 \mathrm{p}$.

40-34I48 PR $473 \cdot \mathrm{B}_{56}$

Partial Contents.-The craft of Herman Melville: a putative statement.-A note of Yvor Winters.-The composition in nine poets: $1937 .-$ Nine poets: 1939.-The letters of Marian Adams. The expense of greatness: three emphases on Henry Adams.

1232. The second world [poems] Cummington, Mass., Cummington Press, 1942. 29 p.

$$
42-17666 \mathrm{PS}_{3505} \cdot \mathrm{L}_{2} 66 \mathrm{~S}_{4}
$$

1233. Language as gesture; essays in poetry. New York, Harcourt, Brace, 1952. 440 p.

$$
\text { 52-6451 PNio55.B55 }
$$

1234. The lion and the honeycomb; essays in solicitude and critique. New York, Harcourt,

Brace, 1955. 309 p. $55-5638$ PSi2r.B59

1235. Anni mirabiles, 1921-1925: reason in the madness of letters; four lectures presented under the auspices of the Gertrude Clarke Whittall Poetry and Literature Fund. Washington, Reference Dept., Library of Congress, x956. 55 p. 56-60048 PN77I.B56

A discussion of European and American literature of the twenties.

1236. LOUISE BOGAN, I897-

Throughout Louise Bogan's career critics have ascribed to her poetry excellence of form, traditional lyric quality, originality, and sustained power. Her scholarship in literary criticism, particularly with reference to poetry, is evidenced in frequent contributions to journals and in her Achievement in American Poetry, 1900-1950 ( 195 I).

1237. Collected poems, 1923-1953. New York, Noonday Press, 1954. $126 \mathrm{p}$. 54-9946 PS 3503 .Or95AI7 1954

The material in this volume is mostly derived from the author's earlier books of poetry: Body of This Death (1923), Dark Summer (1929), The Sleeping Fury (1937), and Poems and New Poems (I94I).

1238. Selected criticism: prose, poetry. New York, Noonday Press, 1955. $404 \mathrm{p}$.

55-8230 PN5II.B54

A selection of critical articles and reviews (mostly of new poetry) which Louise Bogan prepared for various periodicals over a period of thirty years.

\section{JAMES BOYD, I888-1944}

James Boyd first gained prominence by novels with a Southern setting dealing with the Revolutionary and Civil Wars. These were followed 
by Long Hunt (1930), which dealt with the opening of the frontier from North Carolina to the Mississippi, and Bitter Creek (1939), which reflected life in the high plains country of the Rocky Mountains during the second half of the Igth century. Roll River (1935) was a story of four generations of a Pennsylvania family. A posthumous volume, Old Pines, and Other Stories (1952) was a selection of stories set in his home state of North Carolina.

1240. Drums. New York, Scribner, 1925. $490 \mathrm{p}$. 25-8792 $\mathrm{PZ}_{3.69375 \mathrm{Dr}}$

A Revolutionary War novel that has become a "high school classic."

1241. Marching on. New York, Scribner, 1927. 426 p. 27-II031 ${\text { PS } 3503.0885 M_{3}} 1927$

$\mathrm{PZ}_{3}$.B69375 Ma

This book, whose story centers about a Confederate soldier during the Civil War, presents characters who are descendants of those in Drums.

\section{KAY BOYLE, rgo3-}

Kay Boyle has passed much of her life as an expatriate, a fact which is reflected in her fiction dealing with one or two Americans in Europe, often in France. As a result her theme often becomes one of contrasting individuals or cultures. Occasionally she has drifted from portraying "normal" conflicts to portraying sexual perversions and writing moral "horror" stories, such as Gentlemen, I Address You Privately (1933) and Monday Night (1938). An experimentalist who has been praised for her style and for her evocation of places and things more than for her character presentation, her objectivity or noninvolvement in her stories lends an appearance of realism, despite linguistically mannered prose. Her work is usually more sustained in her short stories and novelettes than in her longer works, and many have regarded her as one of the best of modern short-story writers.

1243. Plagued by the nightingale. New York, Cape \& Smith, 1931. 334 p.

$$
\text { 31-6593 PZ3.B69796Pl }
$$

An American girl and her French husband face the problem of the need to have a child in order to obtain money from his relatives, and the conflicting desire to avoid passing on a hereditary ailment.

r244. Year before last. New York, H. Smith, 1932. 373 p. 32-175I4 PZ3.B69796Ye A young man on the Riviera struggles between love of a woman and love of a magazine (financed, conditionally, by his aunt).
1245. Death of a man. New York, Harcourt, Brace, 1936. $321 \mathrm{p}$.

36-22179 PZ3.B69796De

A Nazi sympathizer, an American woman, and her English husband meet in the Austrian mountains. The book ends with Dollfuss' assassination.

1246. The crazy hunter; three short novels. New York, Harcourt, Brace, 1940. 295 p. 40-6737 PZ3.B69796Cr

Contents.-The crazy hunter.-The bridegroom's body.-Big Fiddle.

1247. Primer for combat. [New York] Simon \& Schuster, 1942. $320 \mathrm{p}$.

42-36354 PZ3.B69796Pr

Centering about an American woman, her husband, and their three children, this diary-form novel reflects life in a German-controlled French village during the summer of 1940 .

1248. Thirty stories. New York, Simon \& Schuster, 1946. $362 \mathrm{p}$.

46-I I845 PZ3.B69796Th

A selection from stories published in the preceding twenty years.

1249. His human majesty. New York, Whittlesey House, 1949. $295 \mathrm{p}$.

49-8270 $\quad \mathrm{PZ}_{3} . \mathrm{B} 69796 \mathrm{Hi}$

A novel about ski troops training in the Colorado mountains in the winter of 1944. They are made up of emigrés representing all countries overrun by the Nazis.

1250. The smoking mountain; stories of post war Germany. New York, McGraw-Hill, r95I.

$273 \mathrm{p}$.

5I-10197 PZ3.B69796Sm

1251. The seagull on the step. New York, Knopf, 1955. 247 p. 55-5604 PZ3.B69796Se

A concern over Franco-American relations is revealed in this novel about an American girl who comes to understand a French village.

\section{PEARL (SYDENSTRICKER) BUCK, I 892-}

As the daughter of American missionaries in China, Pearl Buck acquired the deep appreciation of the Chinese people which motivates her best-known works of fiction. Her portrayal of American missionaries in China and the blending of Chinese and Western humanism in her own philosophy of life are of particular significance to the student of American civilization. She has furthered her role of interpreter of the East to the West through her 
translations and nonfictional writings. In 1932 she was awarded a Pulitzer prize and in 1938 a Nobel prize. In $195^{8} \mathrm{Mrs}$. Buck revealed that she had published novels with an American setting under the pen name of "John Sedges."

1253. The good earth. New York, John Day, I93I. 375 p. 3I-26625 PZ3.B8555Go

1254. Sons. New York, John Day, 1932. 467 p. 32-27061 PZ3.B8555 So

1255. The mother. New York, John Day, I934. $302 \mathrm{p}$.

$\mathrm{PZ}_{3} \cdot \mathrm{B} 8555 \mathrm{Mo}$

34-807 PS $3503 . P_{198 \mathrm{M} 6}$

1256. A house divided. New York, Reynal \& Hitchcock, 1935. 353 p.

35-159I $\quad \mathrm{PZ}_{3} . \mathrm{B}_{5555 \mathrm{Ho}}$

1257. The exile. New York, Reynal \& Hitchcock, 1936. 315 p. 36-35 II BV 3427.S852B8

1258. Fighting angel; portrait of a soul. New York, Reynal \& Hitchcock, 1936. 302 p. $37^{-27009} \mathrm{BV}_{3427 . S 8} \mathrm{~B} 8 \quad 1936$

Fighting Angel, the biography of the author's father, is a companion volume to The Exile, which is a biography of her mother. Together they form a work to be entitled The Spirit and the Flesh. Cf. Ist preliminary leaf.

1259. Dragon seed. New York, John Day, 1942. $37^{8} \mathrm{p}$. $4^{\mathrm{I}-273 \mathrm{I} 8} \quad \mathrm{PZ}_{3} \cdot \mathrm{B} 8555 \mathrm{Dr}$

1260. My several worlds, a personal record. New York, John Day, I954. 407 p. 54-10460 PS3503.UI98Z5

126r. JAMES BRANCH CABELL, 1897-

Cabell expressed his ironic-satirical comments on mankind in general and Virginians in particular in a highly mannered but distinguished prose. Books such as The Crean of the Jest (1917) and Something About Eve (1927) were among those that stood out in his disconnected series of novels which had his mythical, somewhat medieval kingdom of Poictesme for setting. His most famous book, Jurgen (1919), aroused considerable publicity and controversy upon being banned at the time of its publication. Cabell writes symbolically in a style and context that tends to restrict his audience to those with a taste for preciosity. Always concerned with the esthetics of literature, he has continued over the years to produce his own rather special type of book, and has over fifty volumes to his credit.
I262. Works. [Storisende ed.] New York, McBride, 1927-30. $\quad$ I8 v.

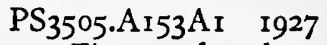

Contents.-I. Beyond life.-2. Figures of earth.3. The silver stallion.-4. Domnei. The music from behind the moon.-5. Chivalry.-6. Jurgen.7. The line of love.-8. The high place.-9. Gallantry.-Io. Something about Eve.-I I. The certain hour.-12. The cords of vanity.-13. From the hidden way. The jewel merchants.-I4. The rivet in grandfather's neck.-I5. The eagle's shadow.16. The cream of the jest. The lineage of Lichfield.-17. Straws and prayer-books.-18. Townsend of Lichfield.

1263. Ladies and gentlemen: a parcel of reconsiderations. New York, McBride, I934. 304 p.

$$
\text { 34-34569 PS 3505.Ar53L } 1934
$$

Twenty letters addressed to famous personalities, real and fictitious, reassessing their reputations and characters.

1264. Smirt; an urbane nightmare. New York, McBride, 1934. xxi, 309 p. [The nightmare has triplets, v. I] $\quad 34-6047 \quad \mathrm{PZ}_{3} \cdot \mathrm{C}_{107} \mathrm{Sm}$

1265. Smith; a sylvan interlude. New York, McBride, 1935. ix, 313 p. [The nightmare has triplets, v. 2] 35-22390 $\mathrm{PZ}_{3} \cdot \mathrm{C}_{107} \mathrm{Smi}$

1266. Smire; an acceptance in the third person. Garden City, N. Y., Doubleday, Doran, 1937. 3II p. [The nightmare has triplets, v. 3] 37-6125 $\mathrm{PZ}_{3}$.Cro7SI

1267. Let me lie, being in the main an ethnological account of the remarkable Commonwealth of Virginia and the making of its history. New York, Farrar, Straus, 1947. 286 p.

47-30215 F227.C213

Contents.-Quiet along the Potomac.-The first Virginian.- Myths of the Old Dominion.Colonel Esmond of Virginia.-Concerns heirs and assigns.-Mr. Ritchie's Richmond.-Almost touching the Confederacy.-General Lee of Virginia.Is of Southern ladies.- "Published in Richmond, Virginia."-Miss Glasgow of Virginia.-As to our life and letters.

1268. Quiet, please. Gainesville, University of Florida Press, 1952. ro5 p.

$$
\text { 52-7061 PS3505.A153Q5 }
$$

Autobiographical notes and commentary.

1269. As I remember it; some epilogues in recollection. New York, McBride, 1955. 243 p. 55-11765 PS3505.A153Z52 


\section{ERSKINE CALDWELL, 1903-}

Caldwell's regional novels and short stories deal chiefly with Georgian poor whites. Although relieved by humor and concern, depravity and degeneracy are characteristic aspects of the people and situations with which his books are concerned. He has been variously regarded as an extreme realist and as an extreme romanticist of the horrible.

1271. Tobacco road. New York, Scribner, I932. $241 \mathrm{p}$. 32-5023 PZ3.Cr2734To

Dramatized by Jack Kirkland in 1933, the play had a phenomenal continuous Broadway run of over 3,000 performances.

1272. God's little acre. New York, Viking Press, 1933. $303 \mathrm{p}$. 33-329I PZ 3 .C12734Go

1273. Trouble in July. New York, Duell, Sloan \& Pearce, 1940. 24I p. 40-27204 $\mathrm{PZ}_{3} \cdot \mathrm{Cr}_{2734} \mathrm{Tr}$

1274. Tragic ground. New York, Duell, Sloan \& Pearce, 1944. 237 p. 45-1137 PZ3. $12734 \mathrm{Tq}$

1275. Complete stories. New York, Duell, Sloan \& Pearce, 1953. 664 p. 53-10243 $\mathrm{PZ}_{3} \cdot \mathrm{C}_{12734 \mathrm{Cn}}$

\section{WILLA SIBERT CATHER, 1873-1947}

Willa Cather studied in her novels the struggle between the spirit and the world. Her strong point was probably the stylistic purity of her depiction of her native Nebraska and the Southwest. The sympathy she was able to feel for these regions dominates $O$ Pioneers! (1913), The Song of the Lark (1915), My Antonia (1918, rev. 1926), $A$ Lost Lady (1923), and Death Comes for the Archbishop (1927). Her novels, to a large extent either directly or symbolically autobiographical, tend more to chronicle form than to plot structure.

1277. The novels and stories. Library ed. [Bosillus. ton, Houghton Miffin] I937-4I. I3 v.

Each volume has special t. p. A43-1040 DCU

Contents.- -1 . O Pioneers!-2. The song of the lark.-3. Alexander's bridge \& April twilights.4. My Ántonia.-5. One of ours.-6. Youth and the bright Medusa.-7. A lost lady.-8. The professor's house. -9. Death comes for the archbishop.-Io. Shadows on the rock.-ri. Lucy Gayheart \& My mortal enemy.-r2. Obscure destinies \& Literary encounters.- 3 . Sapphira and the slave girl.
1278. On writing; critical studies on writing as an art, with a foreword by Stephen Tennant. New York, Knopf, 1949. 126 p. 49-10534 PS $3505 . A 87048 \quad 1949$

Contents.-Four letters: On Death comes for the Archbishop. On Shadows on the rock. Escapism. On The professor's house.-The novel démeublé.Four prefaces: The best stories of Sarah Orne Jewett. Gertrude Hall's The Wagnerian romances. Stephen Crane's Wounds in the rain and other impressions of war. Defoe's The fortunate mistress.My first novels (there were two).-On the art of fiction.-Katherine Mansfield.-Light on adobe walls (an unpublished fragment).

1279. Bennett, Mildred R. The world of Willa Cather. New York, Dodd, Mead, r95I. xviii, 226 p. illus. $\quad 5^{\mathrm{I}-9633} \mathrm{PS}_{3505 . A 8} 7_{Z_{5}} 8$

1280. Brown, Edward Killoran. Willa Cather, a critical biography [by] E. K. Brown; completed by Leon Edel. New York, Knopf, 1953. $351 \mathrm{p}$. 52-I2204 PS3505.A87 2584 "Bibliographical note": p. [346]-351.

1281. Daiches, David. Willa Cather, a critical introduction. Ithaca, Cornell University Press,

195I. I93 p.

51-9710 PS $3505 . \mathrm{A}_{7} \mathrm{Z6}_{2}$

1282. Lewis, Edith. Willa Cather living; a personal record. New York, Knopf, r953. 197 p. 52-12190 PS $3505 \cdot \mathrm{A}_{7} \mathrm{Z}_{72}$

1283. Sergeant, Elizabeth Shepley. Willa Cather, a memoir. Philadelphia, Lippincott, 1953. 288 p. illus. 52-13732 PS $3505 . \mathrm{A}_{7} \mathrm{ZZ}_{3}$

\section{MARY ELLEN CHASE, r887-}

Mary Ellen Chase writes primarily of Maine coast characters and the sea in her novels and novelettes. She has also written a number of autobiographical works: $A$ Goodly Heritage (1932) and $A$ Goodly Fellowship (1939) reflect her Maine background and her life as an English teacher, chiefly at Smith College. The White Gate; Adventures in the Imagination of a Child (1954) portrays three years of her Maine childhood.

1285. Mary Peters. New York, Macmillan, I934. $377 \mathrm{p}$. 34-27262 $\mathrm{PZ}_{3}$.C9orMar

The heroine passes her youth on her father's ship, but later returns to settle in the Maine coastal village of her ancestors.

1286. Silas Crockett. New York, Macmillan, 1935. $404 \mathrm{p}$. 35-25387 $\mathrm{PZ}_{3}$.C 39 orSi 
A novel which depicts maritime life along the coast for one hundred years through the story of four generations of a New England family.

1287. Dawn in Lyonesse. New York, Macmillan, 1938. II5 p. 38-27053 PZ3.C390rDaw The Tristan and Isolde story reworked in a modern tale of Cornwall.

I288. Windswept. New York, Macmillan, I94 I. $440 \mathrm{p}$ 4 4I-2I397 PZ3.C390IWi

Story of a Maine coastal family and their friends, from the I 880 's to 1939 .

1289. The plum tree. New York, Macmillan, 1949. 98 p. 49-II252 PZ3.C390IPl

A novelette of a day in a home for aged women.

\section{I290. ROBERT PETER TRISTRAM COFFIN, I 892-I 955}

Coffin is a Maine poet best known for his realistic, pastoral lyrics, verses which express a degree of sentimentality and a rural "wholesomeness" in a retrained, conventional manner; he was awarded the Pulitzer prize for poetry for Strange Holiness (1935). A prolific author, he has written in a number of forms besides poetry, though usually and best about his native Maine. He has written novels, such as Red Sky In the Morning (1935) and John Dawn (1936); biography, represented by Captain Abby and Captain John (1939), the story of two Maine sea captains; and history as in Kennebec, Cradle of Americans (1937), the first volume in the Rivers of America series (q. v.). The recurring theme of Maine life, manners, and history may be found in these and most of his other works, including books such as Yankee Coast (I947) and Maine Doings (r950). In these works he pictures a part of rural America, past and present, at times using characterizations that verge on folklore in their presentation of basic aspects of American character, personality, and dreams.

I291. Portrait of an American. New York, Macmillan, I93I. I $82 \mathrm{p}$. illus.

$$
\text { 3I-3I494 PS } 3505.0_{234} \mathrm{P} 6 \text { I93 }
$$

Biography of the author's father.

1292. Lost paradise; a boyhood on a Maine coast farm. New York, Macmillan, I934. 284 p. Autobiography.

$$
\text { 34-35147 PS } 3505.0_{234} Z_{5} \quad 1934
$$

I293. Thomas-Thomas-Ancil-Th om as. New York, Macmillan, I94I. $342 \mathrm{p}$.
A novel in poetic prose on the theme of the continuity of life from father to son through the generations; the contemporary heir is a Maine farmer.

1294. Book of uncles. New York, Macmillan, I942. I5I p. 42-22252 PS $3505 . \mathrm{O}_{234 \mathrm{~B} 6}$

Fifteen sketches, each about a different uncle.

I295. Collected poems. New and enl. ed. New York, Macmillan, r948. $446 \mathrm{p}$.

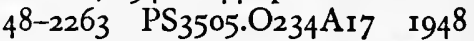

Much of Coffin's poetry had previously appeared in such volumes as his Christchurch (1924), Dew and Bronze (1927), Golden Falcon (1929), The Yoke of Thunder (1932), Ballads of Square-Toed Americans (1933), Saltwater Farm (1937), Maine Ballads (1938), There Will Be Bread and Love (1942), Primer for America (1943), Poems for a Son with Wings (1945), and People Behave like Ballads (1946).

I296. Apples by ocean. [Poems] New York, Macmillan, 1950. $128 \mathrm{p}$.

$$
\text { 50-10425 PS3505. } \mathrm{O}_{234} \mathrm{~A}_{7}
$$

1297. Selected poems. New York, Macmillan, I955. I I 2 p.

$$
\text { 55-I4775 PS } 3505 . \mathrm{O}_{234} \mathrm{A6} \text { I955 }
$$

\section{I298. JAMES GOULD COZZENS, I903-}

Cozzens is a realistic novelist who writes about a variety of topics. Employing a carefully practiced style within traditional limits, he presents objective, rounded pictures of individuals and situations.

1299. The last Adam. New York, Harcourt, Brace, 1933. 301 p.

33-r $357 \quad \mathrm{PZ}_{3} \cdot \mathrm{C} 8{ }_{39}{ }_{3} \mathrm{~L} \mathrm{Las}$

London edition (Longmans, Green \& Co.) has title: $A$ Cure of Flesh.

A smalltown doctor's story which presents life in a Connecticut community.

1300. Men and brethren. New York, Harcourt, Brace, 1936. $282 \mathrm{p}$.

36-755 $\mathrm{PZ}_{3} \cdot \mathrm{C}_{39} 8_{3} \mathrm{Me}$

A study of a clergyman in contemporary New York City.

130r. The just and the unjust. New York, Harcourt, Brace, 1942. $434 \mathrm{p}$.

$$
\text { 42-I } 7992 \quad \mathrm{PZ}_{3} \cdot \mathrm{C}_{398}{ }_{3} \mathrm{Ju}
$$

Presents life in a small Connecticut village during a murder trial. 
1302. Guard of honor. New York, Harcourt, Brace, 1948. $631 \mathrm{p}$.

$4^{8-8544} \quad \mathrm{PZ}_{3} \cdot \mathrm{C}_{398}{ }_{3} \mathrm{Gu}$

Story of three days at an air training base in Florida in 1943; it reflects the problems of civilians adjusting to military life.

\section{HART CRANE, 1899-1932}

Hart Crane experienced many literary influences, such as the Elizabethans, some late rgthcentury French poets, and Dante; he also highly admired and drew inspiration from Whitman, but his work was closer in spirit and technique to Poe. Although Crane published only two books during his life, he is generally considered one of the foremost poets of his era. Through his belief in the "logic of metaphor," applying to it his emotional and intellectual force, and employing tonal adroitness, he created a poetry of eloquence and sonorous, compelling rhetoric. When on occasion his work fails to be the integrated entity he desired, it succeeds as fragments, verbally intense and sensitive. His most ambitious work was The Bridge, an attempt to create a meaningful, affirmative integration of modern American life.

1304. The collected poems; edited with an introd. by Waldo Frank. New York, Liveright, 1933. I79 p. front. (port.)

33-27III PS3505.R272 1933

This collection includes the poems from White Buildings (1926) and The Bridge (1930). It also contains a section entitled Key West: An Island Sheaf, a group of publications which Crane had prepared for separate volume publication. In addition there is a group of "Uncollected Poems" and an essay on "Modern Poetry."

1305. Letters, 1916-1932; edited by Brom Weber. New York, Hermitage House, 1952. 426 p. 52-12760 PS $3505 . R_{272} Z_{54}$

1306. Weber, Brom. Hart Crane, a biographical and critical study. New York, Bodley Press,

1948. $45^{2}$ p. ports., facsims. 48-608r PS3505.R272Z8

Includes an appendix of Hart Crane's uncollected poetry and prose and the worksheets of Atlantis.

"Selected bibliography": p. 441-443.

\section{COUNTEE CULLEN, 1903-1946}

Cullen was a Negro poet who wrote conservative, formal lyrics. Although he expressed little of the racial consciousness or Negro rhythms found in the verse of men such as Langston Hughes and James Weldon Johnson, his greater verbal and metrical fluency gained him more popularity.

1308. On these I stand; an anthology of the best poems of Countee Cullen. Selected by himself and including six new poems never before published. New York, Harper, 1947. 197 p.

$$
\text { 47-30109 PS3505.U287A6 } 1947
$$

\section{EDWARD ESTLIN CUMMINGS, I894-}

Since his first book of poetry, Tulips and Chimneys, the poetry of E. E. Cummings has been romantic and typographically unusual. Although he occasionally employs other moods, his most characteristic poems are romantic lyrics with a surrealistic touch, marked by considerable verbal experimentation. Far less known for his prose, he has nevertheless produced several distinguished volumes in that medium.

1310. The enormous room. New York, Boni \& Liveright, 1922. $271 \mathrm{p}$.

22-9403 D570.9.C82

An account of his imprisonment by mistake in a French military prison during the First World War.

1311. Eimi. New York, Covici, Friede, 1933. 432 p. 33-88I9 PS $3505 . \mathrm{U}_{334} \mathrm{E}_{5}$ 1933a

The record of a trip through Soviet Russia, with an account of the author's protests against conditions there.

1312. I; six nonlectures. Cambridge, Harvard University Press, 1953. 118 p. (The Charles Eliot Norton lectures, 1952-1953)

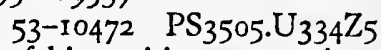

Contains a statement of his position as a writer; some autobiographical material is included.

1313. Poems, 1923-1954. New York, Harcourt, Brace, 1954. $468 \mathrm{p}$.

$$
\text { 54-9724 } \quad \mathrm{PS}_{3505 . U_{334}} \mathrm{I} 954
$$

Contents.-Tulips and chimneys (1923). - \& (1925).-XLI poems (1925).-Is 5 (1926).-W (1931).-No thanks (1935).--New poems [from Collected poems] (1938).-50 poems (1940).-I X I (1944).-XAIPE (1950).

\section{HAROLD LENOIR DAVIS, I896-}

H. L. Davis is an Oregon author who regularly writes about his home area. Best known for his fiction, which includes Beulah Land (1949), a story of the frontier, and Winds of Morning (1952), a novel of the Columbia River Valley country that 
has been called an "intellectual western," Davis has also produced a volume of regional poetry, Proud Riders (1942).

1315. Honey in the horn. New York, Harper, 1935. 380 p. $35-16787 \quad \mathrm{PZ}_{3}$.D29355 Ho

A novel about homesteading in Oregon early in the 2oth century; the book was awarded a Pulitzer prize in 1936.

1316. Team bells woke me, and other stories. New York, Morrow, 1953. $300 \mathrm{p}$.

$$
\text { 53-5338 } \mathrm{PZ}_{3} . \mathrm{D}_{29355} \mathrm{Te}
$$

\section{CLARENCE DAY, 1874-1935}

Day was a humorous essayist who was best known for his autobiographical works portraying family life, the most popular of which was Life with Father (1935), which in play form (by Howard Lindsay and Russel Crouse, 1940) was a great Broadway success. Some critics consider Day's somewhat cynical, satirical This Simian World (I920) his best work.

1318. The best of Clarence Day, including God and $m y$ father, Life with father, Life with mother, This simian world, and selections from Thoughts without words. New York, Knopf, 1948. 45 I p. illus. $48-6580 \quad \mathrm{PS}_{3507 . \mathrm{A}_{5}{ }_{5} \mathrm{~B}_{4}}$

\section{HILDA DOOLITTLE, 1886-}

H. D., as she preferred to sign herself, was in a sense the main poet of the Imagist group, for she was the one who abided most consistently by its doctrines. Her work, which has often been called "classic," does not attempt either to interpret or to present the problems of modern life; rather, it is a frugal, evocative presentation of something seen in nature.

1320. Collected poems of H. D. New York, Boni \& Liveright, $1925.306 \mathrm{p}$. 25-9543 PS $3501 . L_{373 A I 7} 1925$

This volume was reissued in 1940. Earlier books of poetry by Hilda Doolittle include Sea Garden (1916), Hymen (1921), and Heliodora, and Other Poems (1924).

1321. Red roses for bronze, by H. D. Boston, Houghton Mifflin, 1931. $147 \mathrm{p}$.

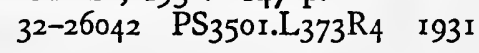

1322. The walls do not fall, by H. D. London, New York, Oxford University Press, I944. $4^{8} \mathrm{p}$. 44-7016 PS350r.L373W
1323. Tribute to the angels, by $H$. D. London, New York, Oxford University Press, I945. $42 \mathrm{p}$. 45-10399 PS 35 or.L.L373 $\mathrm{T}_{7}$

1324. The flowering of the rod, by H. D. London, New York, Cumberlege, Oxford University Press, 1946. $50 \mathrm{p}$. 47-59I $\mathrm{PS}_{3501 . L_{3}}{ }_{373} \mathrm{~F}_{5}$

\section{JOHN RODERIGO DOS PASSOS, 1896-}

John Dos Passos started as a leftist novelist. He is probably best known for his triology entitled U. S. A., originally published as $42 n d$ Parallel (1930), r1919 (1932), and The Big Money (1936), a work of realistic fiction with many stylistic innovations; a heavy emphasis on fact and a detailing of the background give the work value as a commentary on a period in this country's history. As Dos Passos later turned from his leftist views, he turned increasingly to nonfiction: observational books of fiction, biographical works, etc. Part of his work now appears dated because of its journalistic nature; much survives, however, as fiction or reportage of more than momentary interest.

1326. Three soldiers. New York, G. H. Doran, 1921. $433 \mathrm{p} . \quad 2 \mathrm{I}-26886 \quad \mathrm{PZ}_{3} \cdot \mathrm{D}_{74} \mathrm{Th}$ Depicts the effects of World War I on three "typical" American privates.

1327. Manhattan transfer. New York, Harper, 1925. 404 p. $25-23116 \quad \mathrm{PZ}_{3}$. $\mathrm{D}_{74} \mathrm{Ma}$

The lives of more than a dozen individuals are presented in numerous fictional episodes meant to mirror the complex pattern of life in modern New York City.

1328. U.S. A. I. The 42nd parallel. 2. Nineteen nineteen. 3. The big money. New York, Harcourt, Brace, 1937. [ [ 47 I ] p.

Various pagings. $3^{8-27019} \quad \mathrm{PZ}_{3} \cdot \mathrm{D}_{74} \mathrm{Us}$

1329. The ground we stand on; some examples from the history of a political creed. New York, Harcourt, Brace, 194 I. 420 p.

$$
\text { 4I-16286 EI } 83 . D_{7}
$$

The development of the American creed of liberty is traced through biographical studies of individuals who influenced the conception.

1330. State of the Nation. Boston, Houghton Mifflin, 1944. 333 p. plates.

$$
\text { 44-6169 EI69.D68 }
$$

An account of a trip through the United States during the Second World War. 
1331. Chosen country. Boston, Houghton Mifflin, I95I. 485 p. $\quad 51-7856 \quad \mathrm{PZ}_{3} \cdot \mathrm{D}_{74} \mathrm{Ch}$ $184^{8-1930}$ in America reflected through numerous episodic sections, after the manner of the author's U.S.A.

1332. District of Columbia. Boston, Houghton Miflin, 1952. $342,248,446 \mathrm{p}$.

${ }_{52-7617}^{2} \quad \mathrm{PZ}_{3} \cdot \mathrm{D}_{74} \mathrm{Di}$

Also published as three separate volumes: Adventures of a Young Man; Number One; and The Grand Design.

Reflects American life in the twenties, thirties, and early forties.

\section{THEODORE DREISER, $1871-1945$}

Dreiser's works played a major role in the breakdown of the "genteel" tradition in American literature and in the development of fiction as a medium for serious treatment of social and economic abuses. His novels are, in general, deterministic, portraying as they do human beings acted upon by their biological drives and by external forces in society and their environment. However unworthy Dreiser's characters may be, he presents them with sympathy, pity, and without condemnation. Important sources for a study of Dreiser's increasing disillusionment and pessimism, induced by life in Chicago, New York, and Philadelphia, are found in his numerous autobiographical works.

1334. Sister Carrie. New York, Doubleday, Page, I900. 557 p. I-29034 PZ3.D8 I4S

This edition was said to have been withheld from circulation because of the book's supposed "immorality." A new edition was given general release in 1912. The story, set mainly in Chicago and New York, is about a smalltown girl who rises from mistress to successful actress, while her erstwhile beloved sinks from successful businessman to beggardom and suicide.

1335. Jennie Gerhardt, a novel. New York, Harper, IgIr. $432 \mathrm{p}$.

I I-26603 $\mathrm{PZ}_{3} . \mathrm{D} 8$ I $_{4} \mathrm{~J}$

Set largely in Cleveland and New York, this is the story of a woman who gives up a man, whose mistress she has become, in order that he may inherit a legacy and assume a less controversial position in society.

1336. The financier. New York, Harper, Igiz. 779 p. (A trilogy of desire, v. I) $\mathrm{I}_{2}-24487 \quad \mathrm{PZ}_{3}$.D8 I $_{4} \mathrm{Fi}$

A character study of a rising big businessman in Philadelphia during the I860's and early I87o's. A revised version appeared in 1927 .
1337. The Titan. New York, John Lane, 1914. 55I p. (A trilogy of desire, v. 2)

$$
{ }_{4}-9767 \quad \mathrm{PZ}_{3} . \mathrm{D} 8 \mathbf{1}_{4} \mathrm{~T}
$$

The great capitalist of The Financier has established himself in Chicago and prospers even more. Commercial and public utilities financial deals are shown against a background of the period's social standards and cultural views.

In The Stoic (r947) the hero's further career was traced to London, where he undertook the building of that city's subway system.

1338. An American tragedy. New York, Boni \& Liveright, 1925. $2 \mathrm{v}$.

26-r $4 \mathrm{I}_{\mathrm{PZ}} \mathrm{PZ}$.D8 $\mathrm{I}_{4} \mathrm{Am}$

Based on an actual New York State murder case, this book presents the author's naturalistic and essentially tragic view of life in America. Contrasting standards and manners of various social strata are portrayed.

1339. The "genius." New York, John Lane, 1915. $73^{6} \mathrm{p}$.

$$
{ }_{15-20 I 43} \mathrm{PZ}_{3} . \mathrm{D}_{14} \mathrm{IG}_{3} \mathrm{RBD}
$$

The story of a small-town Illinois artist's adjustment to society as his life develops in Chicago and New York and he finds his true vocation as a realistic painter.

1340. A Hoosier holiday. New York, John Lane, I916. 513 p. illus. I6-23068 EI69.D77 EI68.D77

An automobile trip from New York City to Indiana.

1341. Free, and other stories. New York, Boni \& Liveright, I9I8. 369 p.

$$
\text { I8-26757 PZ3.D814 Fr }
$$

1342. Twelve men. New York, Boni \& Liveright, I919. $3^{60} \mathrm{p}$.

Short stories.

$$
\text { 19-6139 } \mathrm{PS}_{350 \dot{7}} \cdot \mathrm{R}_{55} \mathrm{~T}_{9} \text { I919 }
$$

1343. The bulwark. Garden City, N. Y., Doubleday, 1946. $337 \mathrm{p}$.

$$
{ }_{46-25076} \mathrm{PZ}_{3} . \mathrm{D} 8{ }_{14} \mathrm{Bu}
$$

A book of religious probing, it presents the life of a Quaker in a Quaker community near Philadelphia.

1344. A book about myself. New York, Boni \& Liveright, 1922. $502 \mathrm{p}$.

22-25344 PS $3507 \cdot R_{55} Z_{5} \quad 1922$

Republished in 1931 in two volumes bearing the titles: Dawn and Newspaper Days. 
1345. The best short stories of Theodore Dreiser, edited with an introd. by Howard Fast. Cleveland, World Pub. Co., 1947. 349 p. $47-3829 \quad \mathrm{PZ}_{3} \cdot \mathrm{D} 8{ }_{14} \mathrm{Be}$

1346. Dreiser, Helen (Patges) My life with Dreiser. Cleveland, World Pub. Co., I951. 328 p. illus. $\quad 51-10332 P_{3507} \cdot R_{55} Z_{5} 8$

1347. Elias, Robert H. Theodore Dreiser, apostle of nature. New York, Knopf, 1949. xii, 354, xxi p. illus. 49-7227 $\mathrm{PS}_{3507 \cdot \mathrm{R}_{55} \mathrm{Z}_{3}}$

1348. Kazin, Alfred, and Charles Shapiro, eds. The stature of Theodore Dreiser; a critical survey of the man and his work. With an introd. by Alfred Kazin. Bloomington, Indiana University Press, 1955. 303 p. $\quad 55-8446 \quad$ PS $_{3507 . R_{55} Z 64}$

1349. Matthiessen, Francis Otto. Theodore Dreiser. New York, Sloane, 1951. 267 p. (The American men of letters series)

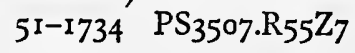

\section{RICHARD EBERHAR'T, 1904-}

Although he apparently writes in large part by inspiration, Eberhart's poetry is known for its intellectual and philosophical aspects. His search is for the nature of man, and the position of man in time (and the meaning of time) and the universe.

1351. Selected poems. London, Chatto \& Windus, 195I. $86 \mathrm{p}$.

$$
\text { 5I-3I53 PS3509.B } 456 \text { A6 I95I }
$$

Eberhart's earlier volumes of poetry are $A$ Bravery of Earth (1930), Reading the Spirit (1936), Song and Idea (1940), Poems, New and Selected (1944), and Burr Oaks (1947).

1352. Undercliff: poems, 1946-1953. New York, Oxford University Press, 1953. 127 p. 53-13069 PS $3509 . B_{456} 6$

\section{WALTER DUMAUX EDMONDS, 1903-}

Edmonds is a popular historical novelist who concerns himself mainly with the New York State area, his best-known works being set in the Mohawk Valley and along the Erie Canal.

1354. Rome haul. Boston, Little, Brown, 1929. 347 p. 29-5703 PZ3.E242Ro

Portrays Erie Canal life in the 1850 's.

1355. Drums along the Mohawk. Boston, Little, Brown, 1936. 592 p.

$$
3^{6-16924} \quad \mathrm{PZ}_{3} \cdot \mathrm{E}_{242 \mathrm{Dr}}
$$

A story of the Revolutionary War and its influence on the farmers of the Mohawk Valley.

1356. Erie water. Boston, Little, Brown, 1933. $506 \mathrm{p}$.

33-3217 $\mathrm{PZ}_{3}$.E242Er

A story of the building of the Erie Canal and life along the route from 1817 to 1825 .

\section{THOMAS STEARNS ELIOT, $1888-$}

T. S. Eliot, an American who became a British subject, wrote early poetry of frustration, disillusion, and despair expressive of the spiritual aridity and insecurity of a generation. His The Waste Land (1922) came to epitomize the feelings of the West's, and to some extent of the world's, cultured youth after the First World War. A subsequent turning to a highly religious poetry, as in Ash Wednesday (1930), reflected his acceptance of Anglican Catholic dogma and conservatism in political and social views. Hence his essays have come to show an authoritarian assessment of literature and society. In recent years he has concentrated on verse drama, continuing experiments in verse forms, and leaning towards social satire and comedy. All his work has evidenced an extensive assimilation of modern psychological theories. Eliot has been one of the most influential of modern poets, his poetry having transcended national and linguistic boundaries, and having provoked a formidable mass of critical and exegetical studies, not to mention innumerable imitations. His receipt in 1948 of the Nobel prize for literature is partial indication of the entrenchment of his work in modern literature.

1358. Selected essays. New York, Harcourt, Brace, 1950. $460 \mathrm{p}$.

$$
\text { 50-10103 PN511.E443 } 1950
$$

1359. Complete poems and plays. New York, Harcourt, Brace, 1952. 392 p.

$$
\text { 52-11345 PS } 3509 . L_{43} 1952
$$

This volume contains the poetry published in earlier volumes, such as Prufrock (Igr7), Poems (1920), The Waste Land (1922), The Hollow Men (1925), and Ash Wednesday (1930), as well as the "Ariel Poems," the "Minor Poems," and other verse as originally brought together in the author's Collected Poems, 1909-1935 (1936). It also contains the subsequent poems from Four Quartets (1943), Old Possum's Book of Practical Cats (1939), and the plays Murder in the Cathedral (1935), The Family Reunion (1939), and The Cocktail Party (1950).

1360. The confidential clerk, a play. New York, Harcourt, Brace, 1954. 159 p.

54-5253 PS $3509 . L_{43}$ C69 
1361. Drew, Elizabeth A. T. S. Eliot, the design of his poetry. New York, Scribner, 1949. $216 \mathrm{p}$. 49-1640 PS $3509 . L_{43} Z_{7}$

1362. Gallup, Donald Clifford. T. S. Eliot; a bibliography, including contributions to periodicals and foreign translations. New York, Harcourt, Brace, 1953. 177 p.

53-5644 Z8260.5.Gi6 1953

$A$ revision and extension of the author's $A B i b$ liographical Checklist of the Writings of T.S. Eliot, published in 1947 .

1363. Gardner, Helen Louise. The art of T. S. Eliot. New York, Dutton, 1950. 185 p. 50-9034 PS $3509 . L_{43} Z_{75}$ 1950

1364. March, Richard, and M. J. Tambimuttu, eds. T.S. Eliot; a symposium from Conrad Aiken [and others] Compiled by Richard March and Tambimuttu. Chicago, Regnery, 1949. 259 p. illus. 49-48864 PS350g.L43Z73 I949

"A tribute to T. S. Eliot, on his sixtieth birthday, from his friends."

1365. Maxwell, Desmond Ernest Stewart. The poetry of T. S. Eliot. London, Routledge \& Paul [1952] 223 p.

$$
\text { 52-4500 } \mathrm{PS}_{3509 \cdot \mathrm{L}_{43} \mathrm{Z}_{7} 8} 1952
$$

1366. On the Four quartets of T. S. Eliot. Anon. With a foreword by Roy Campbell. London, Stuart, I953. $64 \mathrm{p}$.

\section{4-3457 PS 3509.L43F668}

1367. Rajan, Balachandra, ed. T. S. Eliot; a study of his writings by several hands. New York, Funk \& Wagnalls, 1948. 153 p. 49-7235 PS $3509 . L_{43} Z_{22} \quad 1948$

Contents.-The waste land: an analysis, by Cleanth Brooks.-Ash Wednesday, by E. E. Duncan Jones.-Four quartets: a commentary, by $\mathrm{H}$. L. Gardner.-The unity of the quartets, by B. Rajan.Eliot's philosophical themes, by Philip Wheelwright.-A question of speech, by Anne Ridler.Eliot's critical method, by M. C. Bradbrook.Notes on 'Gerontion,' by Wolf Mankowitz.-A check of T. S. Eliot's published writings (p. 139153).

1368. Robbins, Rossell Hope. The T. S. Eliot myth. New York, Schuman, 1951. 226 p. 5I-14190 PS $3509 . L_{43} Z_{28}$

1369. Smidt, Kristian. Poetry and belief in the work of T. S. Eliot. Oslo, Dybwad, I949.
228 p. (Skrifter utg. av det Norske videnskapsakademi i Oslo. II. Hist.-filos. klasse, I949, no. I) 52-17717 PS $3509 . L_{43} Z 866$

1370. Unger, Leonard, ed. T. S. Eliot: a selected critique. New York, Rinehart, 1948. xix, $478 \mathrm{p}$.

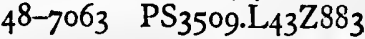

1371. Williamson, George. A reader's guide to T. S. Eliot; a poem-by-poem analysis. New York, Noonday Press, 1953. 248 p.

53-7584 $\mathrm{PS}_{3509 . \mathrm{L}_{43} \mathrm{Z} 898}$

\section{JAMES THOMAS FARRELL, 1904-}

James Farrell is best known for his novels, although he has also written short stories and nonfiction, the latter largely literary commentary. The locale for much of his fiction is that part of Chicago in which he grew up, a declining middle- and lowerclass area whose inhabitants were for the most part Irish Catholics. Farrell, a liberal, wrote in the tradition of naturalistic realism, with as many sociological as philosophic or poetic overtones, so that his work is an indictment of a section of society and its frequently despiritualizing effects. The dual moral standards of this group result in the ruin of Studs Lonigan (the hero of the early trilogy which is usually considered Farrell's most forceful work), while Danny O'Neill (the hero of a second, contrasting series) survives and rises to a mature view of life. A somewhat comparable series tells the story of Bernard Clare (renamed Bernard Carr after the first volume); Clare (Carr) is presented as a Chicago-born writer whose career centers in New York, where much of his attention focuses on the problem of the leftist political position in the thirties.

1373. Studs Lonigan. New York, Vanguard Press, 1935. 20r, 412, $465 \mathrm{p}$.

$$
\begin{array}{ll}
36-214 & \mathrm{PZ}_{3 .} \cdot \mathrm{F}_{24} 6_{5} \mathrm{St} \\
\mathrm{PS}_{3511 . \mathrm{A}_{73} 8 \mathrm{~S}_{7}} \mathrm{I} 935
\end{array}
$$

Contents.-Young Lonigan.-The young manhood of Studs Lonigan.-Judgment day.

1374. A world I never made. New York, Vanguard Press, 1936. 508 p.

$$
\text { 36-24944 PZ3. } \mathrm{F}_{24} 6_{5} \mathrm{Wo}
$$

The story of Danny O'Neill is continued in No Star Is Lost (1938. 38-17566 $\mathrm{PZ}_{3} \cdot \mathrm{F}_{24} 65 \mathrm{No}$ ); Father and Son (1940. 40-32291 PZ3.F2465Fat); My Days of Anger (1943. 43-16086 $\mathrm{PZ}_{3} . \mathrm{F}_{24} 65$ My); and The Face of Time (1953. 53-10805 $\mathrm{PZ}_{3} \cdot \mathrm{F}_{24}{ }_{5} \mathrm{Fac}$ ). 
1375. The league of frightened Philistines, and other papers. New York, Vanguard Press, 1945. xiv, 2 1o p.

45-35125 PS351r.A738A16 1945 "Selected from .... [the author's] critical and non-fictional writing of the past fifteen years."Preface.

1376. Bernard Clare. New York, Vanguard Press, 1946. $367 \mathrm{P}$. $\quad 46-3585 \quad \mathrm{PZ}_{3} \cdot \mathrm{F}_{24} 65 \mathrm{Be}$ Continued in: The Road Between (1949. 49${ }_{444} \mathrm{PZ}_{3} \cdot \mathrm{F}_{24} 65 \mathrm{Ro}$ ) and Yet Other Waters (1952. 52-i1116 PZ3.F2465Yg).

1377. Literature and morality. [New York] Vanguard Press, 1947. xv, 304 p.

$$
47-4577 \quad \mathrm{PN}_{49} \cdot \mathrm{F}_{3}
$$

1373. Reflections at fifty, and other essays. New York, Vanguard Press, 1954. 223 p.

$$
54^{-11517} \quad \mathrm{PS}_{35} \text { II.A }_{73} 8 \mathrm{R}_{4}
$$

\section{WILLIAM FAULKNER, 1897-}

Faulkner, who was awarded the Nobel prize for literature in 1950 , has been considered by some critics, in this country as well as abroad, to be the greatest of living novelists. Much of his writing has been experimental, utilizing techniques of stream-of-consciousness, interior monologues, and multiple personal narratives to portray events with psychological realism. Patterns of symbolic myth woven on the universal theme of human fate have been discovered by critics in many of his stories. The paradox of passion and compassion, violence and beatitude, pathos and comedy, realism and idealism, mammonism and mysticism are seldom separated very far in any of his work. Seeking moral purpose, he presents the past alive in the present-a historic deep South pervading a modern South. His stories usually take place in a fictional Mississippi county, a counterpart to his own home area, where morality and immorality take a large battlefield in a rural locale. While each volume is an individual unit, no character can take curtain bows with full assurance he will not be called upon to play a part in some subsequent drama. In this way Faulkner has presented a "human comedy" of a Southern community. Although he most characteristically presents a vision of life, rather than a concept of it, he allows philosophy to dominate in his latest novel $A$ Fable, which was awarded the Pulitzer prize in 1955. Faulkner has also been one of the most influential of modern short-story writers, with volumes such as These 13 (1931) and Go Down, Moses (1942), which form an integral part of his work. He has also published some poetry:
The Marble Faun (1924) and A Green Bough (1933). He has on occasion spelled his name as "Falkner."

1380. Soldiers' pay. New York, Boni \& Liveright, 1926. $319 \mathrm{P} . \quad 26-6911 \quad \mathrm{PZ}_{3} \cdot \mathrm{F}_{272} \mathrm{So}$

Story of an American in the British air force during World War I who is seriously wounded and returns to his home in Georgia to die.

138I. Mosquitoes. New York, Boni \& Liveright, 1927. $349 \mathrm{p} . \quad 27-10732 \quad \mathrm{PZ}_{3} \cdot \mathrm{F}_{272 \mathrm{Mo}}$

A satire with a New Orleans locale.

1382. Sartoris. New York, Harcourt, Brace, 1929. $380 \mathrm{p}$. 29-3496 $\mathrm{PZ}_{3}$.F $272 \mathrm{Sar}$

Faulkner's first novel, portraying life in the South, traces the degeneracy of a prominent family in the course of three generations, from the Civil War to World War I.

1383. The sound and the fury. New York, Cape \& Smith, 1929. $401 \mathrm{p}$.

$$
\text { 29-20977 } \mathrm{PZ}_{3} \text {.F } 272 \mathrm{Sou}
$$

An experimental novel about a degenerate Southern family, written, for most of the book, from the narrative point of view of the family's idiot boy.

1384. As I lay dying. New York, Cape \& Smith, 1930. $254 \mathrm{P}$. 30-27682 $\mathrm{PZ}_{3} \cdot \mathrm{F}_{272} \mathrm{As}$

A somewhat acridly humorous portrait of the irrational behavior of human beings as seen by various individual characters in the story.

1385. Sanctuary. New York, Cape \& Smith, 1931. $380 \mathrm{p}$. $\quad 3 \mathrm{I}-41^{182} \quad \mathrm{PZ}_{3} \cdot \mathrm{F}_{272}$ San

This, "the most horrific tale" of sex, cruelty, and violence which the author could imagine was successfully aimed at the popular market which his more serious works had failed to attain.

1386. Light in August. [New York] Smith \& Haas, 1932. $480 \mathrm{p}$.

32-25588 $\quad \mathrm{PZ}_{3} \cdot \mathrm{F}_{272 \mathrm{Li}}$

The story of a pregnant girl's search for her lover.

1387. Pylon. New York, Smith \& Haas, 1935. $315 \mathrm{p} . \quad 35-4415 \quad \mathrm{PZ}_{3}$. F $_{272 \mathrm{Py}}$

A story of airplane racing contestants during a carnival in a Southern city, this book, reflecting Faulkner's dislike of cities, is outside the main current of his studies of a Southern community.

1388. Absalom, Absalom! New York, Random House, 1936. $384 \mathrm{P}$.

${ }_{36-24678} \quad \mathrm{PZ}_{3} \cdot \mathrm{F}_{272} \mathrm{Ab}_{3}$

A tour de force of technical dexterity which traces 
the story of a Southern planter's family in the rgth century, as it has become known to a young college student in the 2 oth century. The several threads of narrative, each limited to that version of events which filters through the mind and personality of the character who narrates it, evoke a sense of the relativity of human history and an awareness of the symbolic significance of human character and human motives in the past, as they are known in the present.

1389. The unvanquished. New York, Random House, 1938. 293 p.

$$
3^{8-7091} \quad \mathrm{PS}_{35 \mathrm{II} . \mathrm{A} 86 \mathrm{U}_{5} \quad 1938}
$$

Seven short stories forming a continuous novel which traces the life of the Sartoris family during the Civil War and the Reconstruction period.

1390. The wild palms. New York, Random House, 1939. 339 p.

$$
\text { 39- } 75^{\circ} \quad \mathrm{PZ}_{3} \cdot \mathrm{F}_{27}{ }_{2} \mathrm{Wi}
$$

Two interwoven novelettes which develop contrapuntal treatments of the theme of escape. One is the story of a New Orleans doctor who seeks with his beloved to escape from society but winds up in prison after the woman's death from an abortion. The other is the story (Old Man) of a convict who escapes from a chain gang during a flood on the Mississippi, and in the unavoidable performance of an act of heroism in saving the lives of a woman and her newborn baby becomes so trammeled in responsibility that he welcomes his return to prison.

139I. The hamlet. New York, Random House, I940. 42I p.

$$
\text { 40-7215 } \mathrm{PS}_{35} \text { II.A86H } 3 \text { 1940 }
$$

A large family of lower-class whites batten upon a Southern community through cunning exploitation of Southern honor and integrity.

1392. Intruder in the dust. New York, Random House, 1948. $247 \mathrm{p}$.

$$
\text { 48-85I9 } \mathrm{PZ}_{3} \cdot \mathrm{F}_{272} \mathrm{In}
$$

Two boys, one Negro and one white, and an aristocratic old maid accumulate the evidence to prove the innocence and prevent the lynching of a Negro accused of murder.

1393. Knight's gambit. New York, Random House, 1949. $246 \mathrm{p}$.

49-I I $472 \quad \mathrm{PZ}_{3} \cdot \mathrm{F}_{272} \mathrm{Kn}$

Six stories centering about a county attorney.

1394. Collected stories. New York, Random House, 1950. $900 \mathrm{p}$.
1395. Requiem for a nun. New York, Random House, 1951. $286 \mathrm{p}$.

5I-I 273I PS 35 II.A86R4 I95I later.

The story of the "heroine" of Sanctuary eight years

1396. A fable. [New York] Random House, 1954. 437 p. 54-6651 PZ3.F272Fab

Set against the battlegrounds of Europe in World War I, this is the story of Christ in modern guise.

1397. Campbell, Harry M., and Ruel E. Foster. William Faulkner, a critical appraisal. Norman, University of Oklahoma Press, I95I. 183 p. 51-12064 PS 35 I1.A86Z75

1398. Coughlan, Robert. The private world of William Faulkner. New York, Harper,

1954. I5I p. illus. 54-8943 PS $_{35 \text { I I.A } 86 Z_{7} 6}$

1399. Hoffman, Frederick J., and Olga W. Vickery, eds. William Faulkner: two decades of criticism. [East Lansing] Michigan State College Press, 1951. vii, 280 p. 5I-13066 PS 3511.A86Z8

1400. Howe, Irving. William Faulkner, a critical study. New York, Random House, 1952. xiii, 203 p. 52-5147 PS3511.A86Z84

1401. Miner, Ward L. The world of William Faulkner. Durham, N. C., Duke University Press, 1952. I70 p. 52-14931 PS 35 I1.A86Z9

I402. O'Connor, William Van. The tangled fire of William Faulkner. Minneapolis, University of Minnesota Press, 1954. I82 p.

54-5657 PS 35 I.A86Z93

\section{EDNA FERBER, I887-}

Edna Ferber has been successively a new'spaper reporter, a writer of short stories, a novelist, and a playwright collaborating chiefly with George S. Kaufman. Her sympathies, reflected in her choice of themes, are as wide as the variations in the American scene she portrays. She has written now of the trials and triumphs of a middle-class businesswoman or a farm wife, now of pioneering in Oklahoma, or again of life on a floating rgth-century theater set up in a showboat on the Mississippi River. Humor, rapid-paced narrative, love of life, and devotion to the United States infuse her books with qualities that have given them an extensive popular appeal. Her autobiography, A Peculiar Treasure (1939), is a document of the American experiment that touches the life of the Nation at many points. 
1404. So-Big. Garden City, N. Y., Doubleday, Page, I924. 360 p. 24-26I $88 \quad \mathrm{PZ}_{3} \cdot \mathrm{F}_{3} 80 \mathrm{So}$ Story of a farm wife's work for her son. Awarded the Pulitzer prize in 1925.

1405. Show boat. Garden City, N. Y., Doubleday, Page, 1926. 398 p.

26-15187 $\mathrm{PZ}_{3} \cdot \mathrm{F}_{3} 8 \mathrm{oSh}$

1406. Cimarron. Garden City, N. Y., Doubleday, Doran, 1930. $388 \mathrm{p}$.

30-8609 $\quad \mathrm{PZ}_{3} \cdot \mathrm{F}_{3} 80 \mathrm{Ci}$

Depicts the 1889 land rush in Oklahoma and the later development of the area.

1407. Saratoga trunk. Garden City, N. Y., Doubleday, Doran, I941. $35^{2} \mathrm{p}$.

$4 \mathrm{I}-24504 \mathrm{PS}_{35} \mathrm{II} \mathrm{E}_{4} 6 \mathrm{~S}_{3}$ 194I

A Creole adventuress and a cowboy gambler at a 19th-century New York spa became involved in a struggle for control of a train trunk line.

1408. One basket; thirty-one short stories. New York, Simon \& Schuster, 1947. $58 \mathrm{r}$ p.

47-30149 $\mathrm{PZ}_{3} \cdot \mathrm{F}_{3} 8 \mathrm{On}$

A collection that throws light on the development of the author's style.

\section{THOMAS HORNSBY FERRIL, 1896-}

Ferril, who lives in Denver, is a regional poet. However, in terms of his own region he is concerned with all time and all places. He watches mountains wearing away, cities coming and going, the passing of nations and the generations of man. In I Hate Thursday (1946), a collection of articles most of which were written for a weekly newspaper, the Rocky Mountain Herald, he comments, with a less regional emphasis than in his poetry, on a great variety of specific topics.

1410. New and selected poems. New York, Harper, 1952. $169 \mathrm{p}$.

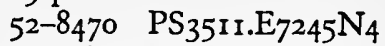

Ferril's earlier volumes of poetry were High Passage (1926), Westering (1934), and Trial by Time (1944).

\section{I4II. DOROTHEA FRANCES (CANFIELD) FISHER, I879-}

Dorothy Canfield Fisher, whose New England regional novels and stories of American domestic life reveal the author's insight into the drama of lives that on the surface seem uneventful, published many of her early works under the name Dorothy Canfield. Her great love for France and French life is woven into her books as a theme second only to that of the devotion she feels for her permanent locale in rural Vermont. She writes in what has come to be called the conventional manner: that is, she designs a plot, develops her characters, tells a story, and tends to resolve conflicts idealistically.

1412. The bent twig. New York, Holt, I9I5. 480 p. $\quad 15-26659 \quad \mathrm{PZ}_{3} \cdot \mathrm{F}_{53} \mathrm{~B}$

The development and maturing of a Middle West university professor's daughter.

1413. Home fires in France. New York, Holt, r918. $306 \mathrm{pl} \quad \mathrm{I} 8-26756 \quad \mathrm{PZ}_{3} . \mathrm{F}_{53} \mathrm{Ho}$

Short stories based on the author's experiences in France during World War I.

1414. The brimming cup. New York, Harcourt, Brace, I92I. 409 p. 2I-4I68 $\mathrm{PZ}_{3} \cdot \mathrm{F}_{53} \mathrm{Br}$

Problems of modern life studied in terms of Vermont characters.

1415. Rough-hewn. New York, Harcourt, Brace, 1922. 504 p. 22-19057 PZ $3 . F_{53}$ Ro May be regarded as a "preface" to The Brimming Cup. It presents the childhood and youth of two of the main characters, taking them to the point where the earlier published book begins.

1416. The deepening stream. New York, Harcourt, Brace, I930. $393 \mathrm{p}$.

30-28175 $\quad \mathrm{PZ}_{3} \cdot \mathrm{F}_{33} \mathrm{De}$

Childhood through early married life of a woman born in the Middle West and spending some time in France.

1417. Seasoned timber. New York, Harcourt, Brace, I939. 485 p. $39-27079 \quad \mathrm{PZ}_{3} \cdot \mathrm{F}_{53} \mathrm{Se}$

A Vermont study which centers about a poor, rural academy and a problem of democratic principles.

I418. Four-square. [Short stories] New York, Harcourt, Brace, 1949. $236 \mathrm{p}$.

49-1 I $288 \quad \mathrm{PZ}_{3} \cdot \mathrm{F}_{53} \mathrm{Fo}$

1419. Vermont tradition; the biography of an outlook on life. Boston, Little, Brown, 1953. 488 p. 53-10226 F $_{49} \cdot F_{57}$

A "spiritual" history of the author's adopted State.

\section{VARDIS ALVERO FISHER, I895-}

Vardis Fisher is a prolific novelist whose early novels, in part autobiographical, realistically emphasize the hardships of life and the primitive conditions encountered on farms and in frontier 
locations in Idaho, Utah, and adjacent regions in the Far West. In various historical novels Mr. Fisher has developed additional themes drawn from the literature of westward migrations in America. Among these are the discovery and final decline of the fabulous Comstock Lode, at Virginia City, Nevada, and the tragic suffering of the Donner Party during their trek from Illinois to California in $1846-47$. In I952 The Island of the Innocent appeared, being the seventh novel in a twelve-volume series entitled The Testament of Man, designed to trace the history of mankind from prehistoric to modern times. This constitutes the author's most ambitious effort to portray man's struggle and attainments under different civilizations.

1421. Toilers of the hills. Boston, Houghton Mifflin, 1928. 361 p. 28-23667 PZ3.F539'To

Deals with life on a dry farm in Idaho.

1422. Dark Bridwell. Boston, Houghton Miffin, 1931. 376 p. 31-I4419 PZ3.T539Dar Elemental passions in the lives of a family on a remote mountain farm in Idaho comprise the materials of the plot which this novel develops.

1423. In tragic life. Caldwell, Idaho, Caxton Printers, 1932. $464 \mathrm{p}$.

$$
32-35789 \quad \mathrm{PZ}_{3} \cdot \mathrm{F}_{539 \mathrm{In}}
$$

Tetralogy concerned with the long search of the Western hero, Vridar Hunter, for the meaning of life. Succeeding volumes in their order of publication are: Passions Spin the Plot (1934); We Are Betrayed (1935); and No Villain Need Be (1936).

1424. Children of God. New York, Harper, 1939. 769 p. 39-27649 PZ3.F539Ch

A historical novel that treats as an American epic the beginnings of Mormonism, the persecution of the Mormons, and their long migration from the Middle West to Utah.

\section{I425. FRANCIS SCOT'T KEY FITZGERALD, I 896-1940}

F. Scott Fitzgerald was one of the leading recorders of the "jazz-age" or "frivolous twenties." His most successful novel, The Great Gatsby, like most of his work, dealt with millionaires, parvenus, and the general stridency of the period, this time mainly with a Long Island, New York, setting. Fitzgerald's later career as a Hollywood writer is the basis for Budd Schulberg's novel, The Disenchanted (New York, Random House, r950. $33^{8}$ p.).

1426. This side of paradise. New York, Scribner, 1920. 305 p. 20-6430 PZ3.F5754Th
1427. The beautiful and damned. New York, Scribner, 1922. 449 p.

$$
\text { 22-4437 } \mathrm{PZ}_{3} \cdot \mathrm{C}_{5754} \mathrm{Be}
$$

1428. The great Gatsby. New York, Scribner, 1925. 218 p. 25-10468 $\mathrm{PZ}_{3} \cdot \mathrm{F}_{5754} \mathrm{Gr}$

1429. The portable F. Scott Fitzgeraid, selected by Dorothy Parker. Introd. by John O'Hara. New York, Viking Press, 1945. 835 p. (The Viking portable library) $\quad 45-8464 \quad \mathrm{PZ}_{3} . \mathrm{F}_{5754} \mathrm{Po}$

Contents.-Novels: The great Gatsby. Tender is the night.-Stories: Absolution. The baby party. The rich boy. May day. The cut-glass bowl. The offshore pirate. The freshest boy. Crazy Sunday. Babylon revisited.

1430. Kazin, Alfred, ed. F. Scott Fitzgerald: the man and his work. Cleveland, World Pub. Co., 195I. 219 p. 51-10640 PS3511.I9Z67

I431. Mizener, Arthur. The far side of paradise; a biography of F. Scott Fitzgerald. Boston, Houghton Miffin, 195I. xx, 362 p. ports.

51-9185 PS 35 I1.IgZ7

"Fitzgerald's published work": p. 350-356.

\section{JOHN GOULD FLETCHER, I 886-r950}

Living as an expatriated American in England, Fletcher early wrote poetry associated with the Imagist movement of 1907-17. In company with Amy Lowell he also experimented with the use of polyphonic prose. When he returned to live in his native State, Arkansas, he wrote of that region and on other themes native to the United States in a vein of mysticism colored by romance. His autobiography, Life Is My Song (1937), indicates his intimate association with the course of American poetry throughout a period of significant development.

1433. Selected poems. New York, Farrar \& Rinehart, 1938. $237 \mathrm{p}$.

38-14768 PS 35 rr.L457A6 I938

On the basis of this volume Fletcher was awarded the Pulitzer prize for poetry in 1939. The selections are from his earlier volumes: Irradiations, Sand and Spray (1915), Goblins and Pagodas (1916), The Tree of Life (1918), Breakers and Granite (1921), The Black Rock (1928), and XXIV Elegies (1935). Preludes and Symphonies (1922) was a reissue of Irradiations, Sand and Spray, and Goblins and Pagodas:

1434. South star. New York, Macmillan, 1941. I17 p. 4I-6401 PS35II.L457S6 I94I 
Includes a long poem in four parts, "The Story of Arkansas," accompanied by lyrics on various Southern themes.

1435. The burning mountain [poems] New York, Dutton, 1946. $96 \mathrm{p}$.

$$
4^{6-4558} \quad \mathrm{PS}_{35} \text { II.L } 457 \mathrm{~B} 8
$$

1436. Simon, Charlie May (Hogue) Johnswood. New York, Dutton, 1953. 249 p.

$53-6090 \quad P_{3537.16} Z_{5}$

Mrs. Fletcher's reminiscences of the home in Arkansas and the life she shared with her husband.

\section{ESTHER FORBES, 1894?-}

Esther Forbes is known for the accuracy of her evocative historical novels depicting New England. She conveys not only local color, but also character. She has also written some nonfiction, such as Paul Revere \& the World He Lived In (1942), which was awarded a Pulitzer prize for history, and The Boston Book (1947), a book of photographs by Arthur Griffin for which she wrote the text.

1438. O genteel lady! Boston, Houghton Mifflin, 1926. $296 \mathrm{p} . \quad 26-9023 \quad \mathrm{PZ}_{3} \cdot \mathrm{F}_{74} \mathrm{I} 8 \mathrm{O}$

The Massachusetts-bred heroine confronts the conventions and the intellectual life of the Victorian period.

1439. A mirror for witches in which is reflected the life, machinations, and death of famous

Doll Bilby, who, with a more than feminine perversity, preferred a demon to a mortal lover. Here is also told how and why a righteous and most awful judgment befell her, destroying both corporeal body and immortal soul. Boston, Houghton Mifflin, 1928. 213 p. illus.

$$
\text { 28-12074 } \mathrm{PZ}_{3} \cdot \mathrm{F}_{741} 8 \mathrm{Mi}
$$

The story of a witch in 17 th-century Salem, Massachusetts.

1440. Miss Marvel. Boston, Houghton Mifflin, 1935. 304 p. $\quad 35^{-1} 4885 \quad \mathrm{PZ}_{3} \cdot \mathrm{F}_{4}$ I $8 \mathrm{Mis}$

A New England mill manager's daughter achieves spinsterhood in the hope of romantic love.

1441. Paradise. New York, Harcourt, Brace, 1937. 556 p. 37-27104 PZ3.F 7418Par

A story of colonial pioneering in early $\mathrm{I} 7$ th-century New England, through the beginning of King Phillip's War.

1442. The general's lady. New York, Harcourt, Brace, 1938. 394 p.
Love and life, with the last years of the American Revolution for setting.

1443. The running of the tide. Boston, Houghton Mifflin, $1948.632 \mathrm{p}$.

$$
4^{8-4573} \quad \mathrm{PZ}_{3} \cdot \mathrm{F}_{74} \mathrm{I} 8 \mathrm{Ru}
$$

Life in later 18 th- and early 19 th-century Salem, then at its height as a shipping city.

1444. Rainbow on the road. Boston, Houghton Mifflin, 1954. 343 p.

53-9248 $\quad \mathrm{PZ}_{3} \cdot \mathrm{F}_{74}$ I8Rai

A picaresque novel about an itinerant portrait painter in New England in the 1830's.

\section{WALDO DAVID FRANK, r889-}

Waldo Frank is the author of numerous works, both fiction and nonfiction. His greatest reputation has been in Latin America, where, through his lectures and writings, he has helped gain an audience for other American authors. This interest has been a reciprocal affair, reflected in books such as his biography of Bolivar, Birth of a World (195I), and South American Journey (1943). $\mathrm{He}$ has also written on Spanish culture in Virgin Spain, rev. ed. (1942). In The Jew in Our Day (1944) he discussed some of the problems of his fellow Jews. He has also written books on more general aspects of American society and development, such as Our America (1919), The Re-discovery of America (1929), and In the American lungle [19251936] (1937), a collection of essays on industrial America. His better-known novels, often dealing with life in America, tend to portray social groups or areas. They have been criticized for lack of "character" development, which is probably in part a result of his belief that the individual is a product of environment. In his early work Frank was a leftist, but he turned against the Communists in the thirties. There remains in his writings something of a mystical, prophetic quality which either permeates or dominates his realistic work.

1446. Rahab. New York, Boni \& Liveright, 1922. 250 p. 22-4977 PZ3.F8498Ra

Set in New York, this is the story of a girl who, in purity of spirit, discovers God, while socially lapsing into prostitution.

1447. The death and birth of David Markand, an American story. New York, Scribner, I934. $542 \mathrm{p}$. 34-33666 PZ3.F8498De

A New York businessman leaves home and family in search of life, and finds a new (radical) faith after four years of wandering about America. 
1448. The bridegroom cometh. New York, Doubleday, Doran, 1939. 628 p. 39-13360 $\quad \mathrm{PZ}_{3} \cdot \mathrm{F} 8498 \mathrm{Br} 2$

A novel that reflects American life between 1914 and r924. The story is that of an inhibited girl, raised puritanically, who finds herself in social work and communism.

1449. Island in the Atlantic, a novel. New York, Duell, Sloan \& Pearce, r946. 503 p. 46-6710 PZ3.F8498Is

A novel that reflects social changes in America, as three generations on Manhattan Island are traced from the Civil War to 1912.

1450. Not heaven; a novel in the form of prelude, variations, and theme. New York, Hermitage House, 1953. 287 p. $53-8718 \quad \mathrm{PZ} 3 . \mathrm{F} 8498 \mathrm{No}$

This is an attempt to extend the limits of the novel; separate incidents are united by theme rather than traditional unities of time, place, or action. The theme might be said to be the situation of the modern human being.

\section{ROBERT FROST, I874-}

A pastoral poet, Frost has been called a modern Theocritus. His poems are descriptive of rural New England, mainly Vermont and New Hampshire, but they take incident and environment at a crucial, symbolic moment, which projects his idylls into the realm of the metaphysical lyric. His poetry has increasingly passed from an earlier relative emphasis on environment and setting to a more recent elaboration of philosophical speculation. His verse has been cast primarily in the form of lyrics or dramatic monologues, or dialogues-with all forms having a prominent dramatic element. This is even further reflected in his language, which is an adaptation of conversational style to poetic form. Although in the main stream of modern thought, Frost has held aloof from the urban currents and eddies of "modern" literary convention, and remains authentically representative of the indigenous culture which absorbs but does not succumb to the machine age.

1452. Complete poems of Robert Frost, 1949. New York, Holt, r949. 642 p. 49-9497 PS 35r.R94 1949

This is the most recent, generally available edition of Frost's collected writings, although there have been many editions of his collected and selected poetry. His earlier volumes include $A$ Boy's Will (1913), North of Boston (1914), Mountain Interval (1916), New Hampshire (1923), West-Running Brook (1928), A Further Range (1936), A Witness
Tree (1942), A Masque of Reason (1945), A Masque of Mercy (1947), and Steeple Bush (1947). Frost's many other volumes are mainly single poems published in individual booklets.

\section{ZONA GALE, I874-1938}

Zona Gale wrote mainly novels and short stories which, whatever the name used, had her home town, Portage, Wisconsin, for setting. Her early books were sentimental, regional works, such as the popular Friendship Village (1909); however, she soon turned from sentimental tales to realistic works, and then, increasingly, a strain of mysticism and a concern for social conditions infused her work.

1454. Birth. New York, Macmillan, 1918. 402 p. I8-20940 PZ3.Gr3I9B

1455. Miss Lulu Bett. New York, Appleton, 1920. $264 \mathrm{p}$.

20-4218 PZ3.Gr319Mi

1456. Faint perfume. New York, Appleton, I923. $217 \mathrm{p}$.

23-6r39 PZ3.Gi3rigFa

1457. Preface to life. New York, Appleton, 1926. 345 p. 26-r8625 PZ3.GI3I9Pr

1458. Yellow gentians and blue. New York, Appleton, 1927. $\quad$ r $88 \mathrm{p}$.

$$
\text { 27-2043I PZ3.Gi3igYe }
$$

1459. Papa La Fleur. New York, Appleton, 1933. 154 p. $\quad 33-5483 \quad \mathrm{PZ}_{3} \cdot \mathrm{GI}_{319} \mathrm{Pap}$

1460. ELLEN ANDERSON GHOLSON GLASGOW, 1874-1945

Ellen Glasgow was a Virginian who depicted her State in realistic novels that may to some extent be regarded as social histories. Her idealism, her belief in the triumph of morality over futility, always restrains and directs her literary craftsmanship. The worldly cause may at times be lost or obscure, but there is always a spiritual victory. She attempts to deal truthfully with a post-Civil War South, presenting settings and situations that are often grim, but relieved by her humor and affection. Although many of her numerous books have been acclaimed, Barren Ground (1925), Vein of Iron (1935), and The Romantic Comedians (1926) seem generally to be the most highly regarded.

146r. [Works] Virginia ed. New York, Scribner, 1938. I2 v. fronts.

$$
3^{8-24704} \quad \mathrm{PS}_{35} \mathrm{I}_{3} \cdot \mathrm{L}_{34}{ }_{1938}
$$

Contents.-I. Barren ground.-2. The miller of Old Church.-3. Vein of iron.-4. The sheltered 
life. -5 . The romantic comedians. -6 . They stooped to folly.-7. The battle ground.-8. The deliverance.-9. Virginia.-10. The voice of the people.II. Romance of a plain man.-I2. Life and Gabriella.

1462. In this our life. New York, Harcourt, Brace, 1941. $467 \mathrm{p}$.

$$
41-51629 \quad \mathrm{PZ}_{3} \cdot \mathrm{G}_{4} 6_{4} \mathrm{In}
$$

1463. The woman within. New York, Harcourt, Brace, 1954. 307 p. illus.

Autobiography.

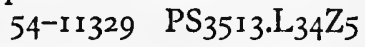

"The works of Ellen Glasgow": p. 302.

\section{CAROLINE GORDON, I895-}

Caroline Gordon, wife of Allen Tate, writes novels and short stories dealing with the South, especially the Kentucky-Tennessee region, and reflecting the philosophy of the agrarians.

1465. Penhally. New York, Scribner, I93I. 282 p. $\quad 31-25046 \quad \mathrm{PZ}_{3} \cdot \mathrm{C}_{525} \mathrm{Pe}$

A story of a Kentucky family and their estate, Penhally, from 1826 into the 20 th century.

1466. Aleck Maury, sportsman. New York, Scribner, 1934. $287 \mathrm{p}$.

$34-3708_{3} \quad \mathrm{PZ}_{3} \cdot \mathrm{G}_{525} \mathrm{AI}$

A character novel that takes the form of an autobiography of a Virginia hunting and fishing enthusiast.

1467. The garden of Adonis. New York, Scribner, 1937. $299 \mathrm{p}$.

37-33903 PZ3.G6525 Gar

Conflicts of various social groups are presented in this novel set against a background of present-day plantation life in the South.

I 468. None shall look back. New York, Scribner, 1937. $37^{8}$ p. $\quad 37^{-27189} \quad \mathrm{PZ}_{3} . \mathrm{G}_{525} \mathrm{No}$

Civil War story centering on the exploits of Confederate Major General Nathan Forrest and the part played in the war by a Kentucky-Tennessee border family.

1469. Green centuries. New York, Scribner, I941. $469 \mathrm{p}$.

41-22068 PZ3.G6525Gr

A novel of the westward movement from Virginia into Kentucky in the years before the Revolution.

1470. The women on the porch. New York, Scribner, I944. $316 \mathrm{p}$.
A psychological novel in which a woman leaves her New York husband and returns to her family home in Tennessee, where most of the story takes place.

1471. The forest of the South. New York, Scribner, 1945. 245 p. $45-9169$ PZ3.G6525Fo Short stories.

1472. The strange children. New York, Scribner, I95I. 303 p. 5I-12447 PZ3.G6525St

A novel about a group of restless, rootless intellectuals in Tennessee.

\section{PAUL ELIOT GREEN, I894-}

Paul Green is known primarily for his plays. He has been called a folk dramatist, and most of his work, including his novels and short stories, depicts life in the South, especially in North Carolina. In 1927 his In Abraham's Bosom was awarded the Pulitzer prize for drama.

1474. This body the earth. New York, Harper, 1935. 422 p. $35^{-19876} \quad \mathrm{PZ}_{3} . \mathrm{G} 824^{\circ} 8^{\prime} \mathrm{Th}$

A story which reflects the folkways and social conditions of the poor tenant-farmer class of North Carolina.

1475. Out of the South, the life of a people in dramatic form. New York, Harper, I939.

577 p. $\quad 39-27317 \quad \mathrm{PS}_{3513} \cdot \mathrm{R}_{452 \mathrm{O}} \mathrm{I} 939$

Contents.-The house of Connelly.-The no 'count boy.-Saturday night.-The field god.Quare medicine.-The hot iron.-In Abraham's bosom.-Unto such glory.-Supper for the dead.Potter's field.-The man who died at twelve o'clock.-White dresses.-Johnny Johnson.-Hymn to the rising sun.-The lost colony.

1476. Salvation on a string, and other tales of the South. New York, I946. 278 p.

46-6956 PZ3.G8248Sal

Short stories about the people of a small North Carolina farm town.

1477. The common glory, a symphonic drama of American history, with music, commentary, English folksong and dance. Chapel Hill, University of North Carolina Press, 1948. 273 p.

$$
4^{8-11307} \mathrm{PS}_{35} \mathrm{I}_{3} \cdot \mathrm{R}_{452} \mathrm{C} 6
$$

A spectacle drama about Virginia's contribution to the establishment of a democratic government in America; with Thomas Jefferson as the main character. 
1478. Dog on the sun, a volume of stories. Chapel Hill, University of North Carolina Press, 1949. $178 \mathrm{p}$. 49-II774 PZ3.G8248Do $\mathrm{PS}_{3513 . \mathrm{R}_{452} \mathrm{D} 6}$

I479. Adams, Agatha B. Paul Green of Chapel Hill; edited by Richard Walser. Chapel Hill, University of North Carolina Library, I95I. vii, 116 p. (The University of North Carolina. Library extension publication, v. 16, no. 2)

$$
{ }_{51-62187} \mathrm{PS}_{35} \mathrm{I}_{3} \cdot \mathrm{R}_{452} \mathrm{Z}_{5} 8
$$

\section{SAMUEL BERNARD GREENBERG, I893-1917}

Samuel Greenberg was a Viennese Jewish immigrant who lived in poverty in New York. He left school at seventh grade to work. He early became ill with tuberculosis, and it was while in hospitals that he found time to do almost all of his writing. Untrained formally, and in isolation, he wrote a highly modernistic, mystic verse which has since come to be recognized as an extraordinary precursor of the modern school. Drawing much of his inspiration from Emerson and Thoreau, Greenberg himself was to have a profound influence on Hart Crane, who read his work in manuscript.

I481. Poems. A selection from the manuscripts, edited with an introd. by Harold Holden and Jack McManis; pref. by Allen Tate. New York, Holt, 1947. II7 P. $\quad 47-47$ I5 $\quad \mathrm{PS}_{35}$ I3.R $_{4582} \mathrm{P} 6$ Includes autobiographical sketch.

\section{HORACE VICTOR GREGORY, I898-}

Horace Gregory writes urbane poetry in a dramatic tone. In addition to his poetry and some critical work, he is known for his translation of poems by Catullus (1931) and a History of American Poetry, 1900-1940 (1946), which he wrote with his wife, Marya Zaturenska (q. v.).

1483. Selected poems. New York, Viking Press, 195I. $143 \mathrm{p}$.

$$
\text { 5I-II788 PS } 3513 \cdot R_{55} 8 \mathrm{A6} \text { I95I }
$$

Earlier volumes of poetry by Gregory include Chelsea Rooming House (1930), No Retreat (1933), Chorus for Survival (1935), and Poems, 1930-1940 (194I).

\section{ZANE GREY, 1872-1939}

Zane Grey was an Eastern dentist who became a highly successful author of westerns. However, critics considered his writing stilted, his characters wooden, his situations unrealistic, and his plots melodramatic. Despite this, he has probably been the prime factor in crystallizing the European, and to some extent even the American, "conception" of early Western life. After becoming rich on the income from his novels, Grey passed much of his time in outdoor activities, especially fishing. This resulted in a number of autobiographical books (discussed in the Sports and Recreation section of this bibliography), which were more favorably received by many critics, although less well received by the general public. His books are still popular in cheap editions.

1485. Riders of the purple sage. New York, Harper, I9r 2. $334 \mathrm{p}$.

I2-1131 $\mathrm{PZ}_{3} \cdot \mathrm{G} 87 \mathrm{Ri}$

This has probably been the most popular of the more than fifty novels by Zane Grey. Because his plots were almost all constructed on one basic formula, this book may be used to exemplify that aspect of his work which has had such a wide nonliterary influence.

1486. The Zane Grey omnibus, edited by Ruth G. Gentles. New York, Harper, 1943. xvii,

409 p. $\quad 43-43 I_{4}$ PZ3.G87Zan Contents.-Zane Grey: a biographical sketch.Zane Grey: an interpretation.-"The ringer."Wild Horse mesa, a novel.-Don, the story of a lion dog.-Tales of fishes.-Down an unknown jungle river.--Exercises.

1487. Karr, Jean. Zane Grey, man of the West. New York, Greenberg, I949. 229 p. 49-II953 PS 35 I3.R6545Z 7949

"The books of Zane Grey": p. 21 5-229.

\section{I488. ALFRED BERTRAM GUTHRIE, I90I-}

Guthrie's novels of American migrations in the middle of the igth century recreate for the reader the opening of the wilderness on the now vanished western frontier. He writes in a poetic prose of the pioneers' love of the new land and the open sky.

1489. The big sky [by] A. B. Guthrie, Jr. New York, Sloane, I947. $386 \mathrm{p}$.

$$
47-3316 \quad \mathrm{PZ}_{3} \cdot \mathrm{G}_{95} 876 \mathrm{Bi}
$$

1490. The way west. New York, Sloane, I949. $340 \mathrm{p}$.

$$
\text { 49-1II98 } \mathrm{PZ}_{3} . \mathrm{G}_{95} 876 \mathrm{Way}
$$

\section{MOSS HART, 1904-}

Moss Hart, a New York dramatist, did much of his ear!ier work in collaboration with George S. Kaufman (q. v.), including such comedies as You 
Can't Take It With You (1937) and The Man Who Came To Dinner (1939). In addition to collaborating on such plays, he acted in the capacity of librettist for some musical comedies. Subsequently he has, in addition to adaptations, undertaken some more ambitious work in dramas which reflect on contemporary life, such as Winged Victory (1943), a World War II play about the air force.

1492. Light up the sky, a play. New York, Random House, 1949. $120 \mathrm{p}$.

49-8200 PS $351_{5}$. A7943L5

1493. The climate of Eden, a play; based on Edgar Mittelholzer's novel, Shadou's move among them. New York, Random House, 1953. 177 p. 53-5528 PS 35 I5.A7943C6

\section{ERNEST HEMINGWAY, r898-}

Hemingway as a novelist and short-story writer evolved the journalistic style to its artistic ultimate; from this has developed one of the most prolific schools of modern fiction. A novelist of pain and suffering, whose characters lose much and gain little (though some would claim an occasional spiritual victory, it is usually won in a lost cause), he emphasizes conversational realism and objective presentation, but frequently achieves the effect of symbolic fable. His stories are usually of Americans, but seldom of America, since they often have a foreign setting. He was awarded the Nobel prize for literature in 1954 .

1495. The sun also rises. New York, Scribner, 1926. $259 \mathrm{p}$. 26-19ro6 $\mathrm{PZ}_{3} \cdot \mathrm{H}_{3736 \mathrm{Su}}$

Members of the British and American element in European society wander about the continent (largely France and Spain) indulging in drinking, loving, and general aimless merriment-all realistically indicative of the ineffectuality of their lives.

1496. A farewell to arms. New York, Scribner, 1929. 355 p. 29-20658 $\mathrm{PZ}_{3} \cdot \mathrm{H}_{3736 \mathrm{Fa}}$

A story of an American in the Italian ambulance service and his love affair with an English nurse in Italy during World War I.

1497. For whom the bell tolls. New York, Scribner, 1940. $471 \mathrm{p}$.

40-27732 $\mathrm{PZ}_{3} \cdot \mathrm{H}_{3736 \mathrm{Fo}}$

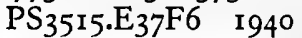

A novel about an American in the Loyalist army during the Spanish Civil War.

1498. The short stories: the first forty-nine stories and the play The fifth column. New York,
Modern Library, 1942. 597 p. (The Modern Library of the world's best books)

$$
\text { 42-36273 PS3515.E37Ar5 } 1942
$$

1499. Across the river and into the trees. New York, Scribner, 1950. $308 \mathrm{p}$.

50-9370 $\mathrm{PZ}_{3} \cdot \mathrm{H}_{3736 \mathrm{Ac}}$

A novel about an American Army officer's return visit to Italy, after having been there during World Wars I and II.

1500. The old man and the sea. New York, Scribner, 1952. $140 \mathrm{p}$.

52-11935 $\quad \mathrm{PZ}_{3} \cdot \mathrm{H}_{3736 \mathrm{Ol}}$

A philosophic and symbolic novelette with the moral that man is not meant for defeat (though he may be destroyed), this is the story of an old man from a Cuban fishing village and his protracted struggle with a giant fish.

150r. Atkins, John A. The art of Ernest Hemingway; his work and personality. London, Nevill, 1952. 245 p. $\quad 53-26230 \quad P_{35}{ }_{15} \cdot E_{37} Z_{57}$

1502. Baker, Carlos H. Hemingway; the writer as artist. Princeton, Princeton University Press, 1952. xix, $322 \mathrm{p}$.

52-8759 PS $3515 . E_{37} Z_{5} 8$

Bibliographical footnotes. "A working check-list of Hemingway's prose, poetry, and journalism": $p$. [299]-310.

1503. Fenton, Charles A. The apprenticeship of Ernest Hemingway: the early years. New York, Farrar, Straus \& Young, I954. xi, 302 p. 54-7968 $\mathrm{PS}_{35} \mathrm{I}_{5} . \mathrm{E}_{37} \mathrm{Z}_{59}$

1504. McCaffery, John K. M., ed. Ernest Hemingway, the man and his work. Cleveland, World Pub. Co., 1950. 351 p.

$$
\text { 50-10036 PS } 3515 . \mathrm{E}_{37} \mathrm{Z}_{7}
$$

1505. Young, Philip. Ernest Hemingway. New York, Rinehart, 1952. 244 p. (Rinehart critical studies) ${ }_{52-5603} \mathrm{PS}_{35}$ I5. $\mathrm{E}_{37} \mathrm{Z} 6$

\section{JOSEPH HERGESHEIMER, I880-1954}

Hergesheimer's earlier, more widely acclaimed work was mainly in the form of novels with realistic historical backgrounds. Based on much research, these depicted aspects of the American past, analyzed character, and presented the "atmosphere" of his settings. Into such evocations of places in the past he projected his imaginative stories. 
1507. The three black Pennys. New York, Knopf, 1917. $408 \mathrm{p} . \quad{ }_{17}-25287 \quad \mathrm{PZ}_{3} \cdot \mathrm{H}_{422} \mathrm{Th}$ Against a background of the Pennsylvania iron fields, this novel depicts the rise and decline of a family through the story of three alternate generations, starting from the late colonial period.

1508. Java Head. New York, Knopf, Igrg. $255 \mathrm{p} . \quad \quad$ 19-579 $\quad \mathrm{PZ}_{3} \cdot \mathrm{H}_{422} \mathrm{Ja}_{\mathrm{a}}$

The story of a New England merchant vessel captain who married a Chinese wife and brought her home to Salem, Massachusetts, when that port was experiencing its most flourishing period.

1509. Linda Condon. New York, Knopf, 19rg. $304 \mathrm{p}$.

19-27595 $\mathrm{PZ}_{3} . \mathrm{H}_{422 \mathrm{Li}}$

A character study of a woman who in social terms is emotionally unresponsive. She lives for beauty, in the form of personal adornment, until she perceives a beauty that transcends mortality in the work of a sculptor who has been inspired by her.

1510. Quiet cities. New York, Knopf, 1928. $354 \mathrm{p} . \quad 28-1391 \mathrm{I} \quad \mathrm{PZ}_{3} \cdot \mathrm{H}_{422} \mathrm{Qu}$

Nine short stories depicting different American cities at various points in the past, from colonial times to the pre-Civil War period.

15II. The limestone tree. New York, Knopf, 1931. $386 \mathrm{p}$. 3I-2676 PZ3. $\mathrm{H}_{422 \mathrm{Le}}$ A novel with I8th- and Igth-century Kentucky for background.

\section{DU BOSE HEYWARD, I885-1940}

Heyward first gained attention as a poet, notably with Carolina Chansons (1922), which he wrote with Hervey Allen (q. v.). However, his most prominent book was Porgy, a novel depicting Negroes in Charleston, S. C., a work which was the source of George Gershwin's opera Porgy and Bess. Another novel on the Southern Negro was Mamba's Daughters (1929).

1513. Porgy. New York, Doran, I925. 196 p. 25-17940 PZ3.H1586Po

1514. Durham, Frank. Du Bose Heyward, the man who wrote Porgy. Columbia, University of South Carolina Press, I954. 552 p. illus. 54-IOIII PS 35 I5.E98Z6

"An informal version of a dissertation ... for the Ph. D. degree at Columbia University."

\section{ROBERT SILLIMAN HILLYER, I 895-}

Robert Hillyer writes polished, conventional poetry in the Igth-century tradition, but with a modern temper. In his lyrics his themes tend to be general and unlocalized; he has also written poems for specific occasions, such as the Phi Beta Kappa poems, two of which are included in $A$ Letter to Robert Frost and Others (1937), and another, "In Time of Mistrust," is included in Pattern of a Day (1940). Hillyer has also published two novels: Riverhead (1932) and My Heart for Hostage (1942).

1516. Poems for music, 1917-1947. New York, Knopf, 1947. 83 p.

47-5283 PS $3515.169 \mathrm{P} 6$

The author's selection of his seventy best lyrics. An earlier selection of the author's poetry is his $\mathrm{Col}$ lected Verse (1933), which brings together material from Sonnets and Other Lyrics (1917), The Five Books of Youth (1920), The Hills Give Promise (1922), The Halt in the Garden (1925), The Seventh Hill (r928) and The Gates of the Compass (1930). Hillyer was awarded a Pulitzer prize for poetry for this earlier collection.

1517. The suburb by the sea, new poems. New York, Knopf, 1952. 71 p.

$52-573^{8} \quad \mathrm{PS}_{35} 15.169 \mathrm{~S}_{9}$

\section{SIDNEY COE HOWARD, I891-1939}

Sidney Howard was a dramatist whose plays bear, or were borne by, a "message," so that much of his work has been dated by the passing of time and the specific cause which motivates them, although a few survive as examples of the "newer" realism. He was awarded the Pulitzer prize for drama for They Knew What They Wanted, a marital comedy set in California.

1519. The silver cord; a comedy in three acts. New York, Scribner, 1927. 204 p. (The Theatre guild library)

$$
\text { 27-5629 } \mathrm{PS}_{35} 15.0847 \mathrm{~S}_{5} \quad 1927
$$

A drama of a widowed mother's pathological love for her two sons.

1520. Yellow jack, a history by Sidney Howard, in collaboration with Paul De Kruif. New

York, Harcourt, Brace, 1934. 152 p. plates.

$$
\text { 34-18182 } \quad \mathrm{PS}_{3515} \cdot \mathrm{O}_{47} \mathrm{Y}_{4} \quad 1934
$$

"Based on the dramatic 'Walter Reed' chapter of Paul de Kruif's 'Microbe hunters' . . . this play deals with man's struggle against and final victory over the dread yellow fever."-Publisher's announcement. 
1521. LANGSTON HUGHES, I902-

Hughes is a Negro writer who first gained attention for his verse in such books as The Weary Blues (1926) and Fine Clothing to the lew (1927); these were in part derived in form and mood from Negro blues and jazz. More recently his prose has received greater attention, in part because of its presentation of Harlem Negroes. A leftist and somewhat anti-white in the thirties, he has in recent years written with less bias and a sense of humor.

1522. The big sea, an autobiography. New York, Knopf, I940. $335 \mathrm{p}$.

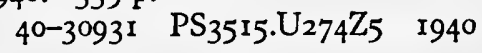

1523. Simple speaks his mind. [New York] Simon \& Schuster, 1950. 23I p.

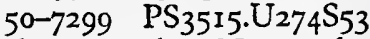

Short stories centering about Simple, a Negro who expresses opinions on a variety of subjects.

1524. Laughing to keep from crying. New York, Holt, 1952. $206 \mathrm{p}$.

$$
\text { 52-7952 PZ3.H87313Lau }
$$

Twenty-four short stories about Negroes.

1525. Simple takes a wife. [New York] Simon \& Schuster, 1953. $24^{\circ} \mathrm{p}$.

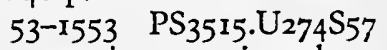

Further humorous short stories centering about Simple; occasionally there are still bitter undertones.

\section{ZORA NEALE HURSTON, 1903-}

Zora Neale Hurston is a Negro who usually writes of Negro people in Florida. She has been commended for her recording of the folklore and dialect of the area.

1527. Jonah's gourd vine. Philadelphia, Lippincott, 1934. $33^{16}$ p. 34-76II PZ3.H9457Jo

1528. Their eyes were watching God; a novel. Philadelphia, Lippincott, I937. $286 \mathrm{p}$. 37-18658 $\quad \mathrm{PZ}_{3} \cdot \mathrm{H}_{9457} \mathrm{Th}$

1529. Seraph on the Suwanee, a novel. New York, Scribner, 1948. 3II p.

$$
\text { 48-8745 } \quad \mathrm{PZ}_{3} \cdot \mathrm{H}_{9457} \mathrm{Se}
$$

\section{FEDERICO SCHARMEL IRIS, I889-}

Scharmel Iris was born in Italy; as a youth he came to America and settled in Chicago, where he began to write poetry in English. His short, taut lyrics are little known, despite the fact that they have been brilliantly praised by a number of prominent authors, including William Butler Yeats, who wrote: "Of poets writing today there is no greater!" Iris' first volume, Lyrics of a Lad, appeared in 1914; there followed a period of disappearing manuscripts, so that it was not until $x 953$ that a second volume appeared, reprinting some of the work in the earlier book. Much of his work has been published in periodicals under various pseudonyms.

1531. Bread out of stone. [Poems] Chicago, Regnery, 1953. $62 \mathrm{p}$.

$$
53-8795 \quad \mathrm{PS}_{3517 \cdot \mathrm{R}_{5} \mathrm{~B}_{7}}
$$

\section{ROBINSON JEFFERS, i 887-}

Isolated in his "inevitable place" on the spectacular California coast near Carmel, Jeffers has looked at America and the world, where he has seen evil, decadence, and tragedy as inevitable accompaniments of human, particularly of family, relations. So extreme is his vision of sin that it attains some of the characteristics of romanticism, although of an inverted kind. His long narrative poems deal with murder, incest, and horrors equal to them; his short poems also express what he calls a philosophic mood of "Inhumanness." These startling, if unconvincing, revelations of total depravity are set forth powerfully in poems marked by technical proficiency and imaginative use of themes drawn in part from classical and Biblical sources, and from the folklore of California. In recent years Jeffers has increasingly devoted his talents to making free adaptations of classical Greek tragedy. His most recent work of this kind is The Cretan Woman, first performed in 1954 .

1533. The women at Point Sur. New York, Boni \& Liveright [ ${ }^{\mathrm{C}}{ }^{927}$ ] ${ }^{\mathrm{I}} 75 \mathrm{p}$. 44-35263 PS 35 19. E27W6 1927a

1534. Selected poetry. New York, Random House, 1938. $622 \mathrm{p}$.

$$
3^{8-28958} \quad \mathrm{PS}_{3519 . \mathrm{E}_{27} \mathrm{~A} 6} \quad \mathrm{I}_{938}
$$

Presents some new poems and about one half of the poet's previously published work; includes selections from Tamar and Other Poems (1924), Roan Stallion (1925), Cawdor (1928), Dear Judas (1929), Thurso's Landing (1932), Give Your Heart to the Hawks (1933), Solstice (1935), and Such Counsels You Gave to Me (1937).

1535. Medea, freely adapted from the Medea of Euripides by Robinson Jeffers. New York, Random House, 1946. $107 \mathrm{p}$.

$$
\text { 46-25I59 } \mathrm{PA}_{3975 . \mathrm{M}_{4} \mathrm{~J}_{4}}
$$


1536. Hungerfield, and other poems. New York, Random House, 1954. II5 P.

Includes The Cretan Woman. 53-9714 $\mathrm{PS}_{35} \mathrm{I}_{9} . \mathrm{E}_{27} \mathrm{H} \mathrm{H}_{9}$

\section{JAMES WELDON JOHNSON, 1871-1938}

Johnson was a Negro author of diversified interests who was probably best known for some of his poetry. His versified Negro sermons are imaginative interpretations, in the idiom of primitive religion, of the character and quality of his race. Although he strove for objectivity on the matter, race consciousness is a strong element in his work.

1538. God's trombones; seven Negro sermons in verse. New York, Viking Press, 1927. $56 \mathrm{p}$. 27-12269 PS3519.O2625G6 I927

1539. Along this way; the autobiography of James Weldon Johnson. New York, Viking Press, 1933. $418 \mathrm{p}$. 33-29189 Er 85.97.J69

1540. Saint Peter relates an incident, selected poems. New York, Viking Press, 1935. 105 p. 35-22368 PS 3519.O2625A6 1935

\section{MACKINLAY KANTOR, 1904-}

Kantor is a Midwestern author whose many works cover a wide range. In The Voice of Bugle Ann (1935) and its sequel The Daughter of Bugle $A n n$ (1952) he presented two widely read foxhound stories which represent the rural-life animal-story genre in popular American fiction. Typical of the patriotic and sentimental strains in much of his work is God and My Country (1954), a novelette in praise of the Boy Scouts. Author's Choice (1944) is a selection of forty of his short stories. While he has written in such forms as adventure and mystery stories, and poetry, much of his more serious work has gone into historical fiction dealing with the Civil War.

1542. Long remember. New York, Coward-McCann, 1934. 4II p.

34-27082 $\quad \mathrm{PZ}_{3} \cdot \mathrm{K}_{42}$ Lo A novel dealing with the Battle of Gettysburg.

1543. But look, the morn. New York, CowardMcCann, 1947. $308 \mathrm{p}$.

$$
47-30121 \quad \mathrm{PS}_{3521 . \mathrm{A}_{47} \mathrm{Z}_{5}}
$$

The story of the author's childhood in a small Iowa town.

1544. Andersonville. Cleveland, World Pub. Co., 1955. 767 p. 55-8257 $\mathrm{PZ}_{3}$. Kr $42 \mathrm{An}$
A novel, presenting by implication the entire Civil War, but dealing specifically with a notorious prisoner-of-war camp in Georgia.

\section{GEORGE SIMON KAUFMAN, 1889-}

George S. Kaufman is a New Yorker who has been a journalist and director as well as a playwright. He has worked on many popular, humorous plays. For most of these he acted as a collaborator, commonly with authors such as Moss Hart, Marc Connelly, Edna Ferber, Morris Ryskind, and Ring Lardner. His work, much of which takes the form of satire on aspects of American life, is noted for its "wise-crack" element.

1546. Merton of the movies, in four acts, a dramatization of Harry Leon Wilson's story of the same name, by George S. Kaufman and Marc Connelly. New York, French, 1925. II2 p. illus. (French's standard library edition)

$$
\text { 25-9428 } \mathrm{PS}_{3521 . A_{727} \mathrm{M}_{4} \quad 1925}
$$

1547. Stage door, a play in three acts, by Edna Ferber and George S. Kaufman. New York, Dramatists Play Service, I938. I65 p. illus. 38-25234 PS35ir.E46S8 1938

1548. Six plays by Kaufman and Hart, with an introd. by Brooks Atkinson. New York, Modern Library [ ${ }^{\mathrm{C}}$ 1942] xxxii, $586 \mathrm{p}$. (The Modern Library of the world's best books)

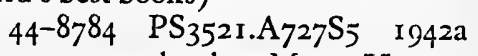

Contents.-Men at work, by Moss Hart.Forked lightning, by G. S. Kaufman.-Once in a lifetime.-Merrily we roll along.-You can't take it with you.-The American way.-The man who came to dinner.-George Washington slept here.

1549. The late George Apley, a play by John P. Marquand and George S. Kaufman, based on Mr. Marquand's novel. [New York] Dramatists Play Service, $1946.72 \mathrm{p}$.

$$
46-20312 \mathrm{PS}_{3525} \cdot \mathrm{A}_{6695} \mathrm{~L}_{3} \quad 1946
$$

1550. The solid gold Cadillac; a comedy, by Howard Teichmann and George S. Kaufman. New York, Random House, r954. I5I p. illus. $\quad 54-8795$ PS3539.E24S6

\section{OLIVER LA FARGE, I901-}

La Farge is an anthropologist, ethnologist, and archaeologist whose writings deal in large part with American Indians; his main interest is in the Navajos. His first novel, Laughing Boy, was awarded the Pulitzer prize for fiction and remains, 
in the opinion of many, his most successful work. He dealt with the Navajos again in The Enemy Gods (1937), a thesis novel which depicts the Indian's inability to adapt to the white man's way of life. Less directly concerned with Indians were books such as the autobiography Raw Material (1945), and Eagle In the Egg (1949), the official history of the Air Transport Command.

1552. Laughing Boy. Boston, Houghton Mifflin, 1929. 302 p. 29-23247 PZ3.Lr29Lau

1553. All the young men; stories. Boston, Houghton Miftin, 1935. $272 \mathrm{p}$.

$$
\text { 35-13561 PZ3.Li29Al }
$$

Contents.-Hard winter.-All the young men.Haunted ground.-A family matter.-North is black.-Higher education.-The goddess was mortal.-Dangerous man.-Love charm.-Women at Yellow wells.-Camping on my trail.-No more Bohemia.

\section{RING WILMER LARDNER, I885-I933}

In a slangy, conversational style Ring Lardner wrote mordant, humorous stories, most popularly and prominently about baseball figures. His own most acclaimed collections were How To Write Short Stories (1924) and The Love Nest, and Other Stories (1926).

1555. The portable Ring Lardner. Edited, and with an introd. by Gilbert Seldes. New York, Viking Press, 1946. 756 p. (The Viking portable library) $\quad 46-7398 \mathrm{PS}_{3523 . A 7 A 6} 1946$

\section{WILLIAM ELLERY CHANNING LEONARD, 1876-1944}

Leonard, for many years a professor in the English Department at the University of Wisconsin, wrote imaginatively on psychological aspects of his personal experience; his scholarly work was done largely in the field of translations of epical works in different languages. The personal works range through the autobiographical poetry of Two Lives (r923) and his psychoanalytic autobiography to his posthumously published volume of sonnets, $A$ Man Against Time, an Heroic Dream (1945). His intense poetic feeling, expressed in academic and traditional form, is thought by some critics to have found more enduring expression in his metrical translations of Beowulf, Gilgamesh, the De Rerum Natura of Lucretius, and the fragments of Empedocles. He also made a notable contribution to regional drama with Red Bird (1923), a play based on a story of Wisconsin pioneer days.
1557. The locomotive-god. New York, Century, 1927. 434 p. 27-20232 PS3523.E62Z

The author's autobiography in which, by psychoanalysis, he traces the origin of certain mental maladies.

1558. A son of earth, collected poems. New York, Viking Press, 1928. $x, 235 \mathrm{p}$.

$$
\text { 28-23943 } \mathrm{PS}_{3523 . E 62 S_{5}} \mathrm{I}_{928}
$$

\section{SINCLAIR LEWIS, I885-195 I}

Lewis rose to prominence through his romantically realistic novels of middle class life in the Midwest. Most of his work is satiric; his characters are usually types (businessman, preacher, social worker, etc.) rather than individuals; and his novels verge on being (and sometimes openly are) social tracts. As the first American to be awarded the Nobel prize for literature (1930), his reputation and influence have been extensive. The novels with which he first gained fame are usually considered his best.

1560. Main Street, the story of Carol Kennicott. New York, Harcourt, Brace \& Howe, 1920. $45 I$ p. $\quad 20-18934 \quad \mathrm{PZ}_{3} \cdot \mathrm{L}_{5} 884 \mathrm{Ma}$

The story of a well-educated but limited young woman who tries to introduce culture and taste into a small, unimaginative, Minnesota town.

1561. Babbitt. New York, Harcourt, Brace, 1922. 40I p. 22-14419 $\quad \mathrm{PZ}_{3}$. L $588_{4} \mathrm{Ba}$

Babbitt is the stereotyped businessman hero in this satirical novel of a Midwestern urban society with generally restricted views and values.

1562. Arrowsmith. New York, Harcourt, Brace, 1925. $44^{8} \mathrm{p}$. 25-6078 $\mathrm{PZ}_{3} \cdot \mathrm{L}_{5} 88_{4} \mathrm{Ar}$

The story of a doctor's career, this novel was awarded a Pulitzer prize for literature in 1926, but Lewis declined it.

1563. Elmer Gantry. New York, Harcourt, Brace, 1927. 432 p. 27-4761 PZ3.L5884 $\mathrm{EI}_{1}$

A novel satirizing religious hypocrisy.

1564. Dodsworth, a novel. New York, Harcourt, Brace, 1929. 337 p.

29-26270 $\mathrm{PZ}_{3} \cdot \mathrm{L}_{5} 88_{4} \mathrm{Do}$

The story of an American businessman from a Midwestern city who, after retirement, travels to Europe in search of culture. Dodsworth is Babbitt's alterego. 
1565. Ann Vickers. Garden City, N. Y., Doubleday, Doran, 1933. $562 \mathrm{p}$.

$$
\begin{array}{r}
\text { 33-27006 } \mathrm{PZ}_{3} \cdot \mathrm{L}_{5} \mathrm{S8}_{4} \mathrm{An} \\
\mathrm{PS}_{3523} \text {.E94 } \mathrm{A} 67
\end{array}
$$

A study of a woman social worker and the question of a woman's place in American society.

1566. It can't happen here; a novel. Garden City, N. Y., Doubleday, Doran, 1935. $45^{8}$ p.

$$
\text { 35-19689 PZ3.L5884It }
$$

An imaginary story of the establishment of a dictatorial, fascistic government in America.

1567. Gideon Planish, a novel. New York, Random House, 1943. 438 p.

$$
\text { 43-5 I122 } \mathrm{PZ}_{3} \cdot \mathrm{L}_{5} 88_{4} \mathrm{Gi}
$$

A satire exposing the racket of organized philanthropy.

1568. Cass Timberlane, a novel of husbands and wives. New York, Random House, 1945. $390 \mathrm{p}$. 45-49 $18 \quad \mathrm{PZ}_{3} \cdot \mathrm{L} 5884 \mathrm{Cas}$

A novel about a respected, middle-aged judge in a Minnesota town who takes a young, second wife; the book presents many standard American sentimental and cynical observations on marriage.

1569. Kingsblood royal. New York, Random House, 1947. $348 \mathrm{p}$.

47-2064 $\mathrm{PZ} 3 . \mathrm{L}_{5} 88_{4} \mathrm{Ki}$

A social document novel on the Negro problem.

1570. From Main Street to Stockholm; letters of Sinclair Lewis, 1919-1930. New York, Harcourt, Brace, $1952.307 \mathrm{p}$.

$$
\text { 52-6449 } \mathrm{PS}_{3523} \cdot \mathrm{E}_{94} \mathrm{Z}_{53}
$$

\section{LUDWIG LEWISOHN, I882-}

Lewisohn is probably best known for his novels, which are largely propagandistic works giving his views on recurrent subjects such as sex, marriage, divorce, and the positions of Jews in society. Rivaling the best of these in popularity, and by some the most esteemed of his productions, have been his autobiographical works. He has also gained prominence through other forms, such as his book on the American spirit revealed in literature, Expression in America (1932; a postscript was added to the 1939 edition, which bore the later title: The Story of American Literature); his dramatic articles from The Nation, reprinted in The Drama and the Stage (I922); his lay philosophical work, such as The Permanent Horizon; A New Search for Old Truths (1934); and, among his nonfiction books dealing specifically with Jews, The American lew,
Character and Destiny (1950). It has been claimed that Lewisohn's work is usually too largely polemical or pamphleteering to be literature; but most critics have admired his lucid, expressive style, his penetration; his realistic post-Freudian presentations, and the spirit with which he works in behalf of his beliefs, have also won praise.

1572. Up stream; an American chronicle. New York, Boni \& Liveright, 1922.248 p. 22-5315 PS 3523 .Eg6Z 1922

Autobiography.

Continued in Mid-Channel.

1573. The case of Mr. Crump. Paris, E. W. Titus, 1926. $435 \mathrm{p}$.

NN

Story of a young musician from South Carolina who goes to New York, where he is seduced by an older woman. The bulk of the book is a bitter exposé of 12 years of miserable marriage, acridly presenting one of the most unpleasant women in world literature.

The book was for some time banned from the mails.

A paperback edition appeared in 1947 under the title The Tyranny of Sex.

1574. The island within. New York, Harper, 1928. 350 p. 28-6770 PZ3.L59IIs

The story of a Jewish Polish family that immigrates to America, but maintains its essential Jewishness.

1575. Mid-channel; an American chronicle. New York, Harper, 1929. 310 p. 29-9655 $\mathrm{PS}_{3523} \cdot \mathrm{E}_{96 \mathrm{Z}_{55}}$

Autobiography: a continuation of the author's $U_{P}$ Stream.

1576. Stephen Escott. New York, Harper, I930. $315 \mathrm{p}$. 30-71 10 PZ3.L59ISt

A sociological novel discussing the problem of sex and marriage.

1577. The golden vase. New York, Harper, 193I. I41 p. 31-28151 PZ3.L591Go

A philosophical novelette on the theme of love renounced because of age and lack of courage.

1578. Renegade. New York, Dial Press, 1942. $333 \mathrm{p}$. $42-6285 \quad P Z_{3}$.L59IRe

A historical novel set in France at the time of Louis XIV, this is the story of a wealthy Jew who leaves his religion for love, but after a period of adversity discovers how deep is his religious connection. 
1579. Anniversary. [New York] Farrar, Straus, 1948, ${ }^{\circ}$ 1946. 304 p. 48-5114 PZ3.L59IAn A stream-of-consciousness novel set in a small New England city, and with sex, love, marriage, divorce, and middle-class morality for themes.

\section{NICHOLAS VACHEL LINDSAY, I879- 1931}

Vachel Lindsay, a regional poet intimately associated with the Middle West, was one of the "new" poets who came into prominence during the First World War. His chief claims to being an innovator lie in the derivation of his verse forms from ballads and folk songs, and in his use of American themes, frequently unconventional, originating in his own experiences of camp meetings and revivals, in his friendship with hobos and laborers, and from tales of folk heroes, real and imaginary. He conceived of poetry as an oral art, comparable to a "higher vaudeville" in which the arts of music and poetry were to be blended in a result that was to be chanted rather than read. Devotion to his own idealized and romanticized dream of democracy in America was a dominant influence in his work.

1581. Collected poems. Rev. and illustrated ed. New York, Macmillan, 1925. 464 p. $25-10046 \quad \mathrm{PS}_{3523} 3.158 \mathrm{~A} 17 \quad 1925$

Lindsay's early poetry was first printed in pamphlets meant to be traded for food and shelter during his wanderings about the country; perhaps the most famous of these early works is Rhymes to $B e$ Traded for Bread (1912?). As he emerged from his formative period, he produced a series of books on which his fame mainly rests: General William Booth Enters into Heaven, and Other Poems (1913), The Congo, and Other Poems (1914), and The Chinese Nightingale, and Other Poems (1917). Thereafter Lindsay continued to be prolific, but the quality of his work declined. The later volumes include The Daniel Jazz, and Other Poems (1920), Going-to-the-Sun (1923), Going-to-the-Stars (1926), The Candle in the Cabin (1926), and Every Soul Is a Circus (1929). A volume of Selected Poems was published in 1931 .

1582. Harris, Mark. City of discontent; an interpretative biography of Vachel Lindsay, being also the story of Springfield, Illinois, USA, and of the love of the poet for that city, that State and that Nation. Indianapolis, Bobbs-Merrill, 1952. $403 \mathrm{p}$. 52-5806 PS $3523.158 \mathrm{Z} 6$

\section{AMY LOWELL, 1874-1925}

Amy Lowell was a New Englander of great strength and will who resolved to be a poet. With her second book, Sword Blades and Poppy Seed, she started the experimentation which in large measure was to make her name. Using a technique of free verse in "polyphonic prose," she practiced her theory of imagism,--meanwhile largely taking over the Imagist movement and shaping it to her own ends. Mainly a poet of the visual, she at times projected moods and emotional overtones into her imagery, thus reflecting her personality. In her later work the influence of Chinese poetry, particularly its imagery, reinforced the already established emphasis on the visual in her work. Vitality and experimentation applied to the Imagist theory were the factors by which this determined woman achieved for herself a position as a poet. These qualities were well represented in Men, Women, and Ghosts, which some have considered her best book, in Legends, and in What's O'Clock, a posthumous volume which was awarded the Pulitzer prize.

1584. Complete poetical works. With an introd. by Louis Untermeyer. Boston, Houghton Mifllin, 1955. xxix, $607 \mathrm{p}$.

$\begin{array}{lll}55-6949, & P_{3523 . O 88} 1955\end{array}$ In addition to some "new" poems, this volume contains the work previously published in $A$ Dome of Many-Coloured Glass (1912), Sword Blades and Poppy Seed (1914), Men, Women, and Ghosts (1916), Can Grande's Castle (1918), Pictures of the Floating World (1919), Legends (1921), Fir-Flower Tablets (1922), A Critical Fable (1922), What's O'Clock (1925), East Wind (1926), and Ballads for Sale (1927).

\section{ARCHIBALD MACLEISH, 1892-}

Although influenced by many poets, MacLeish has evolved his own individual poetic style and statement. His great skill in handling poetic forms has been employed in a large body of work. Increasingly over the years he had tended to conceive of the poet as social force, a role in which he has expounded views on national and international questions of much moment, using prose as well as poetry as a medium for this purpose, e. g., in his selected addresses, $A$ Time to Act (1943). At his best in the short lyric, MacLeish nevertheless achieved a tour de force, which some have regarded as his masterpiece, in Conquistador (1932), a story of the conquest of Mexico, written in terza rima. $\mathrm{He}$ has also gone far in developing some outstanding radio scripts in dramatic-narrative verse.

1586. Collected poems, 1917-1952. Boston, Houghton Mifflin, 1952. $407 \mathrm{p}$.

$$
\text { 52-6083 } \mathrm{PS}_{3525} \mathrm{~A}_{27} \mathrm{Al}_{7} 1952
$$

In addition to a group of new poems, this volume 
contains material from earlier books and booklets such as The Happy Marriage (1924), The Pot of Earth (1925), Streets in the Moon (1926), The Hamlet of A. MacLeish (1928), Einstein (1929), New Found Land (1930), Conquistador, Frescoes for Mr. Rockefeller's City (1933), Poems, 19241933 (1933), Public Speech (1936), America Was Promises (1939), and Actfive, and Other Poems (I948).

1587. This music crept by me upon the waters. [A play] Cambridge, Harvard University Press, I953. $\quad 3^{8}$ p. (The Poets' theatre series, I)

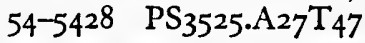

1588. Songs for Eve. Boston, Houghton Mifflin, 1954. $5^{8}$ p. $\quad 54-9118$ PS $3525 . \mathrm{A}_{27} \mathrm{~S}_{72}$

1589. JOHN PHILLIPS MARQUAND, 1893-

John P. Marquand writes popularly successful novels which usually depict society in New England, frequently in Massachusetts. Often his characters are from the upper classes and are trying to live in accord with values which are no longer valid or are at least debatable. A strain of humor, frequently satire, runs through a large part of his work.

1590. The late George Apley; a novel in the form of a memoir. Boston, Little, Brown, 1937. $354 \mathrm{p}$. 37-646 $\mathrm{PZ}_{3} \cdot \mathrm{M}_{344} 66 \mathrm{Lat2}$

1591. Wickford Point. Boston, Little, Brown, 1939. $45^{8}$ p. $\quad 39-27145 \quad \mathrm{PZ}_{3} \cdot \mathrm{M}_{34466 \mathrm{Wi}}$

1592. H. M. Pulham, Esquire. Boston, Little, Brown, I94I. $431 \mathrm{p}$.

$$
4 \mathrm{I}-5 \mathrm{I}_{574} \mathrm{PZ}_{3} \cdot \mathrm{M}_{34466 \mathrm{H}_{2}}
$$

A serial version of this story appeared in McCall's under the title of "Gone Tomorrow."

1593. So little time. Boston, Little, Brown, 1943. 594 p. $\quad 43^{-I_{2} I_{44}}$ PZ3.M $_{34466}$

1594. Repent in haste. Boston, Little, Brown, 1945. 152 p. 45-9462 PZ3.M34466Re

I595. Melville Goodwin, USA. Boston, Little, Brown, 1951. $596 \mathrm{p}$.

$$
\text { 5I-12737 PZ3.M34466Me }
$$

1596. Point of no return. Boston, Little, Brown, 1949. 559 p. $\quad 49-7556 \mathrm{PZ}_{3} \cdot \mathrm{M}_{34466 \mathrm{Po}}$

1597. Sincerely, Willis Wayde. Boston, Little, Brown, 1955. 511 p.
1598. Hamburger, Philip P. J. P. Marquand, Esquire, a portrait in the form of a novel. Boston, Houghton Miffin, I952. II4 p. ${ }_{52-9587} \mathrm{PS}_{3525} \mathrm{~A}_{6695} \mathrm{Z}_{7}$

A biographical study written in a style imitating Marquand's novels.

\section{EDGAR LEE MASTERS, I868-1950}

Masters' one great popular success was the Spoon River Anthology, a collection of free verse poems inspired by the Greek Anthology and meant to represent truthful epitaphs spoken in death by residents of the Spoon River cemetery. In this way a small Midwestern community is "brought to life." Most of Masters' other work was imitation of better known Igth-century poets. Across Spoon River (1936) is his autobiography.

I60o. Spoon River anthology. New York, Macmillan, 1915. $248 \mathrm{p}$.

$$
{ }_{15}-8027 \quad \mathrm{PS}_{3525} \cdot \mathrm{A}_{3} \mathrm{~S}_{5} \quad{ }_{1915}
$$

I601. Selected poems. New York, Macmillan, I925. 4I I P.

25-18498 PS $3525 . A 83 A 6 \quad 1925$

This volume contains selections from Spoon River Anthology (1915), Songs and Satires (1916), The Great Valley (1917), Toward the Gulf (1918), Starved Rock (1919), Domesday Book (1020), The Open Sea (1921), and The New Spoon River (1924). Because the selection was made to represent all his work, less than a tenth of his major volume has been included.

1602. HENRY LOUIS MENCKEN, I880-1956

In his period of greatest activity and fame H. L. Mencken was primarily a journalist with a flair for attacking "established nonsense" (some liked to call him an iconoclast); his views found expression through periodicals such as The Smart Set, The American Mercury, and the Baltimore Sun. Since most of his work dealt with matters of current interest, it now seems in large part to be dated. His studies of the American language and the autobiographical "Days," which reflected life in Baltimore, are of more significance to the student of American civilization.

1603. The American language; an inquiry into the development of English in the United States. [4th ed., corr., enl., and rewritten] New York, Knopf, 1936. 769 p.

Includes bibliographies. 36-27236 $\mathrm{PE}_{2} 808 . \mathrm{M}_{4} \quad 1936$ Supplements I and II appeared in 1945 and 1948. 
1604. The days of H. L. Mencken: Happy days, Newspaper days, Heathen days. New York, Knopf, 1947. [958] p.

$$
\text { 47-I 1231 } \mathrm{PS}_{3525} \cdot \mathrm{E}_{43} \mathrm{D}_{34}
$$

Each part has special t. p. and is paged separately.

1605. A Mencken chrestomathy, edited and annotated by the author. New York, Knopf,

1949. 627 p. $\quad 49-3^{8} 94 \quad \mathrm{PS}_{3525}$. E34A6 1949

r606. Kemler, Edgar. The irreverent Mr. Mencken. Boston, Little, Brown, 1950. x, $317 \mathrm{p}$. illus. $\quad 5^{0-7313} \mathrm{PS}_{3525}$.. $\mathrm{E}_{43} Z_{59}{ }_{1950}$

Bibliographical references included in "Notes" (p. [295]-303). "Chronology of ... [H. L. Mencken's] books": p. [304]-306.

r607. Manchester, William R. Disturber of the peace; the life of $H$. L. Mencken. New York, Harper, 1951. xiv, $33^{6}$ p. ports.

$$
{ }_{51-9028} \mathrm{PS}_{3525} \cdot \mathrm{E}_{43} \mathrm{Z67}
$$

"Bibliographical note": p. 317-322.

\section{EDNA ST. VINCENT MILLAY, 1892- I950}

Miss Millay was a very popular poet who was most renowned for her highly romantic lyrics, especially some of her sonnets expressing passionate love of life and beauty. Although her main achievement was in shorter works, her one-act play Aria da Capo (1921) successfully satirized war and warmakers. This play was included with Two Slatterns and $a$ King (1921) and The Lamp and the Bell (1921) in the volume Three Plays (1926). Perhaps her best-known play is The King's Henchman (1927), which with slight modifications was used as the libretto for an opera by Deems Taylor (b. 1885). In the thirties Miss Millay cultivated, without great poetic success, the "social consciousness" required by the period; this culminated in The Murder of Lidice (1942), a narrative poem about one of the atrocities of the early years of World War II. Her posthumous Letters (1952) reflect aspects of her life and personality not always clear in her poetry itself.

1609. Collected poems. New York, Harper, I956. $73^{8}$ p. $\quad 5^{6-8756}$ PS $3525 . I_{495} \mathrm{AI}_{7} \quad{ }_{1956}$

Other volumes of poetry by Millay include Renascence (1917), A Few Figs from Thistles (I92I), Second April (1921), The Buck in the Snow (1928), Fatal Interview (1931), Wine from These Grapes (1934), Conversation at Midnight (1937), Huntsman, What Quarry? (1939), and Make Bright the Arrows (1940). Mine the Harvest (1954) was a posthumous collection of her poems which had not previously appeared in volume form. Collected Sonnets (194I) and Collected Lyrics (1943) present most of her poetry arranged by type; this same division is to some extent retained in the Collected Poens.

1610. Sheean, Vincent. The indigo bunting; a memoir of Edna St. Vincent Millay. New York, Harper, 195I. I3I p.

$$
\text { 5I-13495 PS } 3525 . I_{495} Z 8
$$

\section{I6ri. HENRY MILLER, I8gr-}

Miller has striven to express imaginatively in his fiction and books of travel his concepts of reality. He has on occasion treated the theme of the American expatriate in Europe between 1928 and 1939. The frankness with which details of physical experience are presented in some of his novels aroused official disapproval in America and made it impossible to publish in this country books such as his Tropic of Cancer (1935), which is an autobiographical story of an American expatriate in Paris, and Black Spring (1936), which pictures bums, café habitués, etc., in Paris. The esthetic merits and/or social justification or desirability of Miller's works, which are largely autobiographical and inclined to be radical, have brought forth sharply conflicting views from the critics, some of whom consider him a major author to be praised for his extraordinary vigor and realism, while others deliver an equally strong denunciation.

16r2. Tropic of Capricorn. Paris, Obelisk Press [1939] $367 \mathrm{p}$.

$$
\text { 39-I3888 PS } 3525 . I_{5454} \text { T8 } 1939 \text { RBD }
$$

A vivid, if revolting, account of the life of an absolute dissident who despises, or pretends to despise, megalopolitan humanity as represented by life in New York City during the first quarter of the 2oth century, but who relishes every detail of his personal existence, particularly the physiological ones.

16r3. The air-conditioned nightmare. New York, New Directions, 1945-47. 2 v.

$$
\text { 45-11390 Er69.M6 }
$$

Based on his travels about the United States, this book reflects the author's critical reaction to, and emotional rejection of the country. His antipathy is intense, and he finds himself most comfortable with people in Indian rescrvations or the distinctively foreign (especially if poorer) sections of the cities. The second volume bore the title Remember to Remember. 


\section{I6I4. MARY BRITTON MILLER ("ISABEL BOLTON"), I $88_{3}$ -}

Mary Miller's career as an author started with poetry, but she first gained general acclaim with the publication in 1943 of her first novel, In the Days of Youth, a story set in New England in the late igth century. In the forties she began to write under the pseudonym "Isabel Bolton." The short novels with New York City settings which she published under this name have been highly regarded for their style and a lyric quality in precise phrasing and in situation.

I6I5. Do I wake or sleep, by Isabel Bolton [pseud.] New York, Scribner, I946.

202 p. 47-I265 PZ3.M6I573Do

I6I6. The Christmas tree, by Isabel Bolton [pseud.] New York, Scribner, I949.

$212 \mathrm{p}$. 49-7858 $\mathrm{PZ}_{3} \cdot \mathrm{M6}_{1573} \mathrm{Ch}$

I6r7. Many mansions [by] Isabel Bolton [pseud.] New York, Scribner, 1952. 215 p. 52-12830 PZ3.M6I573Man

1618. MARGARET MITCHELL, 1900-1949

Margaret Mitchell's one book was a historical novel of Georgia during the Civil War and the Reconstruction. In publication terms it is said to have been the most successful publication of the century, having sold unprecedented numbers of copies on an international scale; it is still selling well. It was also the source of a highly popular motion picture.

16rg. Gone with the wind. New York, Macmillan, 1936. $1037 \mathrm{p}$.

$$
3^{6-27334} \mathrm{PZ} 3 \cdot \mathrm{M} 6948_{4} \mathrm{Go}
$$

\section{MARIANNE MOORE, I $887-$}

Marianne Moore's poetry, based on mathematical syllabic patterns, is precise in word usage, at times exotic in either its subject matter or its attitudes, and often of abstract philosophical background. She is an objectivist who devotes much attention to fauna such as the jerboa. She believes poems should be ". . . imaginary gardens with real toads in them."

162I. Collected poems. New York, Macmillan, I95I. $180 \mathrm{p}$.

$$
\text { 5I-I4374 PS } 3525.056 \text { I6A6 I951a }
$$

This collection includes poems from the author's earlier volumes Selected Poems (1935), What Are Years (I94I), and Nevertheless (1944), as well as a group of poems which had not previously been brought together in book form.

1622. Predilections. New York, Viking Press, 1955. 171 p. $55-7376$ PS $3525 . \mathrm{O}_{5} 6 \mathrm{I} 6 \mathrm{P} 7$

A volume of literary criticism made up of articles. essays, and reviews.

\section{MERRILL MOORE, Igo3-}

It has been estimated that Dr. Moore has already written some roo,000 sonnets. While he writes in a nominally traditional form, he is modernistic in his free treatment of it, and often also in his subject matter. Many of his sonnets are autobiographical, often reflecting his Southern background or his experiences as a psychiatrist.

1624. $M$; one thousand autobiographical sonnets. New York, Harcourt, Brace, 1938. 1000 p. 39-537 $\mathrm{PS}_{3525 . \mathrm{O}_{5} 6_{3} \mathrm{M} 2}{ }_{1938}$

1625. Clinical sonnets. New York, Twayne, 1949. 72 p. [The Twayne library of modern poetry, 6] 49-501 $8 \mathrm{PS}_{3525 . \mathrm{O}_{5} 6_{3} \mathrm{C} 6}$

1626. Illegitimate sonnets. New York, Twayne, I950. I25 p. 5I-225 $\mathrm{PS}_{3525 . \mathrm{O}_{5} 6_{3} \mathrm{I}_{4}}$

1627. More clinical sonnets. New York, Twayne, 1953. 72 p. 53-II72 $\mathrm{PS}_{3525 . \mathrm{O}_{5} 63 \mathrm{M} 6}$

I628. Wells, Henry W. Poet and psychiatrist: Merrill Moore, M. D.; a critical portrait with an appraisal of two hundred of his poems. New York, Twayne, I955. $325 \mathrm{p}$.

$$
55-3466 \mathrm{PS}_{3525} \mathrm{O}_{56} \mathrm{Z}_{94}
$$

1629. OGDEN NASH, 1902-

Nash, who is noted for the tortured rhymes and irregular rhythms of his light verse, in which he expresses gently ironic commentaries on life, is commonly considered America's best modern humorous poet.

I630. I'm a stranger here myself. Boston, Little, Brown, 1938. $283 \mathrm{p}$.

$$
3^{8-27468} \quad \mathrm{PS}_{3527 \cdot \mathrm{A}_{37} \mathrm{I}_{5} \quad 1938}
$$

I631. Good intentions. Boston, Little, Brown, 1942. I8o p. 42-25547 PS $3527 . A 637 \mathrm{G} 6$

1632. Many long years ago. Boston, Little, Brown, 1945. xvii, $333 \mathrm{p}$.

$$
45^{-\delta} 449 \quad \mathrm{PS}_{3527 . \mathrm{A}_{37} \mathrm{M}_{3}}
$$


1633. Versus. Boston, Little, Brown, 1949 . $\begin{array}{lll}\text { r69 p. } & 49-7579 & \mathrm{PS}_{3527} \cdot \mathrm{A}_{37} \mathrm{VV}_{4}\end{array}$

1634. The private dining room, and other new verses. Boston, Little, Brown, 1953. 169 p. ${ }_{52-12647} \mathrm{PS}_{3527} \cdot \mathrm{A}_{37} \mathrm{P}_{73}$

\section{ROBERT GRUNTAL NATHAN, 1894-}

Robert Nathan's first critical acclaim came for his book Autumn (1921), a Vermont pastoral characteristic of most of his work. His books are usually very short imaginative novelettes of fantasy written in a style that has often been called poetic and delicate, and which are pervaded by a tenderness that eliminates almost any astringent effects from the irony and satire of his humor. His books range from The Puppet Master (1923), wherein dolls converse, through Journey of Tapiola (1938), the adventures of a terrier in New York, to Road of Ages (1935), the story of a caravan of Jews wending their way to a new home, and But Gently Day (1943), a tale of a young airman, killed in the war, who in the moment before dying joins his ancestors of the Civil War period and has a love affair with his grandmother. Children, animals, toys, and dreams recur in Nathan's stories, but he considers them to be as real as famine, floods, share-croppers, production lines, and slums, and so defends himself from charges of irreality and irrelevance. Nathan has also written several volumes of formal, conservative verse; The Green Leaf (1950) was a volume of collected poems.

1636. One more spring. New York, Knopf, 1933. $212 \mathrm{p}$.

33-3086 PZ3.Nr95On

A novelette in which some characters take refuge, during a depression winter, in a shed in New York's Central Park.

1637. The Barly fields, a collection of five novels. New York, Knopf, 1938. xiv, 523 p. 38-27469 $\mathrm{PZ}_{3}$.Nr95 $\mathrm{Bar}$

Contents.-The fidler in Barly.-The woodcutter's house.-The bishop's wife.-The orchid.There is another heaven.

1638. Winter in April. New York, Knopf, 1938. $228 \mathrm{p}$.

38-27028 PZ3.N195Wi

A novel, without much of the usual fantasy, in which youth and age fall in love.

1639. Portrait of Jennie. New York, Knopf, r940. $212 \mathrm{p}$. 40-270 1 I PZ3.Ni95Po

A fantasy in time which seems to imply a mystical belief in the immortality of the soul.
1640. Journal for Josephine. New York, Knopf, 1943. I42 p. 43-2244 $\mathrm{PS}_{3527 . \mathrm{A}_{74} \mathrm{~J} 6}$ A picture of Cape Cod during the summer of 1942; to some extent it may be generalized to a picture of the home front during World War II.

1641. The married look. New York, Knopf, 1950. $195 \mathrm{P} . \quad 5^{0-13123} \quad \mathrm{PZ} 3 . \mathrm{N}$ 195Mar

Another romantic fantasy in time.

1642. The innocent Eve. New York, Knopf, 1951. I84 p. 51-10299 PZ3.Nig5In

Lucifer visits New York with his secretary.

1643. Sir Henry. New York, Knopf, 1955, '1954. $187 \mathrm{p}$.

A satirical fantasy. $54^{-12039} \mathrm{PZ7} \cdot \mathrm{Nr} 95 \mathrm{Si}$

1644. JOHN GNEISENAU NEIHARDT, r88 I-

Neihardt's major undertaking was a series of epics depicting the trans-Missouri country in the rgth century, particularly the $1880^{\circ}$ 's. In iambic pentameter rhymed couplets he wrote of the pioneers and the Indians. His prose, dealing with much the same theme and setting, is linguistically less artificial.

1645. A cycle of the West: The song of three friends [1919], The song of Hugh Glass [1915], The song of Jed Smith [194r], The song of the Indian Wars [1925], The song of the Messiah [1935]. New York, Macmillan, 1949. 254, I13, r79, r1 p. $\quad 49-857^{8} \quad \mathrm{PS}_{3527} . \mathrm{E}_{35} \mathrm{C} 8$

r646. When the tree flowered; an authentic tale of the old Sioux world. New York, Macmillan, 1951. 248 p. $\quad 5$ I-6974 $\quad \mathrm{PZ}_{3} \cdot \mathrm{N}_{3}$ I6Wh

1647. EUGENE GLADSTONE O'NEILL, r8881953

Eugene O'Neill emerged, through the experimentalist little theater movement in general and the Provincetown Playhouse in particular, as America's first major dramatist; in doing this he set aside a dramatic tradition of theater as craft alone, and established one of theater as art. O'Neill's plays are a search for the nature of tragedy in modern times. Life must be meaningfully expressed in a relationship between the individual (frequently seen through Freudian theories) and forces, internal or external, which are beyond his control, rather than one between man and God. This concept may be clearly seen in Mourning Becomes Electra, a Trilogy, wherein the ancient Greek tragedy, or tragedies, of Agamemnon, Orestes, Electra, et al., is transformed and transferred to New England of the period fol- 
lowing the Civil War. Also regularly recurrent is the character's struggle to find his place in the world and with regard to himself: either finding it, as in Lazarus Laughed; or losing himself successfully in a world of fantasy, as in the philosophical The Iceman Cometh; or losing himself unsuccessfully in despair, as in The Hairy Ape. While normally a romantic realist, seeking a rational ideal, he turned occasionally to a more visionary type of drama, which reached its peak in the affirmative vision of Lazarus Laughed, which some consider his greatest play. Others prefer the psychological-sociological probing in plays such as the mammoth Strange Interlude. A few prefer his early, less ambitious sea plays, e. g., The Moon of the Caribbees, and Six Other Plays of the Sea. Meanwhile the lyrical, nostalgic comedy $A h, W i l d e r n e s s !$ remains one of his most popular full-length works, particularly with small theater groups. In 1936 O'Neill was awarded the Nobel prize for literature.

1648. Plays. New York, Random House, 195I. 3 v. (The Random House lifetime library) $5^{1-9684} \mathrm{PS}_{3529 . N_{5}} \mathrm{I}_{951}$

Contents.-I. Strange interlude (1928). Desire under the elms (1925). Lazarus laughed (1927). The fountain (1926). The moon of the Caribbees (1919). Bound east for Cardiff (1916). The long voyage home (1919). In the zone (1919). Ile (1919). Where the cross is made (1919). The rope (I9I9). The dreamy kid (I922). Before breakfast (I9I6).-2. Mourning becomes Electra (1931). Ah, wilderness! (1933). All God's chillun got wings (r924). Marco millions (1927). Welded (1924). Diff'rent (1921). The first man (1922). Gold (1920).-3. "Anna Christie" (1922). Beyond the horizon (1920). The Emperor Jones (I921). The hairy ape (1922). The great god Brown (I922). The straw (I921). Dynamo (1929). Days without end (I934). The iceman cometh (1946).

1649. A moon for the misbegotten. New York, Random House, 1952. $177 \mathrm{p}$. 52-6668 PS $3529 . N_{5}$ M68 1952

1650. Engel, Edwin A. The haunted heroes of Eugene O'Neill. Cambridge, Harvard University Press, 1953. 310 p.

$$
\text { 53-5068 } \mathrm{PS}_{352 \mathrm{~g} \cdot \mathrm{N}_{5} \mathrm{Z}_{3}}
$$

\section{DOROTHY (ROTHSCHILD) PARKER, I893-}

Dorothy Parker is a New York wit who gained fame for her light (and often barbed) verse and her satirical short stories. Her collected poems ap- peared in Not So Deep as a Well (1936), and her collected stories in Here Lies (1939). She has also written for stage and film.

1652. Dorothy Parker, with an introd. by W. Somerset Maugham. New York, Viking Press,

1944. $544 \mathrm{p}$. (The Viking portable library)

A collection of pocms and stories.

\section{JULIA MOOD PETERKIN, I880-}

Julia Peterkin described in her fiction the life of isolated plantation Negroes in South Carolina. Her local color stories were characterized not only by an evocation of the setting, but also by an attempt to reproduce the dialect. The novels have been considered among the best about Negroes. In Roll, Jordan, Roll (1933) she undertook a nonfictional presentation of the Negroes in her tales; the book was extensively illustrated with photographs by Doris Ulmann.

1654. Black April. Indianapolis, Bobbs-Merrill, 1927. 315 p. 27-5080 PZ3.P436BI

1655. Scarlet sister Mary. Indianapolis, BobbsMerrill, r928. 345 p.

28-24477 PZ3.P $436 \mathrm{Sc}$

Awarded the Pulitzer prize for literature in 1929.

\section{ERNEST POOLE, I880-1950.}

Ernest Poole was a novelist concerned with social problems. He commonly wrote with the point of view of a socialist of the early part of the century. His first novel, The Voice of the Street (I906), which depicts poverty in New York's East Side, in a way set the pace for his works, which often deal with American problems, frequently with a New York particularization. However, there are exceptions, such as With Western Eyes (1926), in which a Russian scientist views America; The Nancy Flyer, a Stagecoach Epic (1949), a reconstruction of stagecoach history in Poole's adopted state of New Hampshire; and Blind: A Story Of These Times (1920), which in part portrays tenement life in New York, but also deals with Europe and the Russian Revolution. The Bridge, an autobiography, was published in $194^{\circ}$.

1657. The harbor. New York, Macmillan, I915. $387 \mathrm{p}$. $\quad 1_{5-2844} \quad \mathrm{PZ}_{3} . \mathrm{P}_{7} 85 \mathrm{H}$

Usually considered Poole's best book, this has been called the outstanding American proletarian novel.

1658. His family. New York, Macmillan, r9I7: $320 \mathrm{p}$. ${ }_{17}-1_{3623} \mathrm{PZ}_{3} \cdot \mathrm{P}_{7} 85 \mathrm{Hi}$ 
A New York family as typifying changes in modern life; the book was awarded a Pulitzer prize in 1918 .

\section{KATHERINE ANNE PORTER, I894-}

Katherine Anne Porter, who writes short stories on a wide range of topics, has been generally acclaimed for her perfection on a small scale, the precision of her English, her restraint, and the poetic element in her style. Born and reared in Texas and Louisiana, her experience has also included several years in Mexico and Europe; from each of these areas she has drawn settings for her stories. Although her work is small in bulk, and in some respects in scope, almost all of it has been highly praised. Outside the short-story form her work includes the writing of Mae Franking's anonymously published My Chinese Marriage (1921), which Miss Porter disclaims on the grounds that she was merely setting down another person's story, and The Days Before (1952), a collection of essays and articles, most of which were written to meet specific editorial demand at various times throughout her career.

I66o. Flowering Judas. New York, Harcourt, Brace, 1930. $145 \mathrm{p}$.

$$
\begin{array}{r}
\text { 30-25819 } \mathrm{PS}_{3531 . \mathrm{O}_{752} \mathrm{~F}_{55} \text { 1930 }} \mathrm{PZ}_{3 . \mathrm{P} 83 \mathrm{I}} \mathrm{Fl}
\end{array}
$$

Contents. - Maria Concepción. - Magic. Rope.-He.-The jilting of Granny Weatherall.Flowering Judas. Theft, That Tree, The cracked looking-glass, and Hacienda were added in the 1935 edition.

166r. Pale horse, pale rider; three short novels. New York, Harcourt, Brace, 1939. 264 p.

$$
\begin{array}{r}
\text { 39-27273 } \mathrm{PZ}_{3} \cdot \mathrm{P}_{3}{ }_{15} \mathrm{Pal} \\
\mathrm{PS}_{353} \mathrm{O}_{752} \mathrm{Pe}
\end{array}
$$

Contents.-Old morality.-Noon wine.-Pale horse, pale rider.

1662. The leaning tower, and other stories. New York, Harcourt, Brace, I944. 246 p.

$$
\text { 44-7946 PZ3.P8315Le }
$$

1663. Schwartz, Edward. Katherine Anne Porter; a critical bibliography. New York,

New York Public Library, I953. 42 p.

Reprinted from the Bulletin-2504 Z87057.S 35 Public Library of May 1953.

\section{EZRA LOOMIS POUND, I885-}

In his early literary essays, poetry, and translations, as well as personally, Pound exerted a considerable effect on American literature, influencing and "discovering" poets such as Hart Crane, William Carlos Williams, Robert Frost, T. S. Eliot, Archibald MacLeish, Carl Sandburg, Amy Lowell, and others. The supreme greatness or hopelessly obfuscated cacophony of his later work is still being debated: partly in nonliterary terms, for Pound rests in political disrepute, largely based on the economic and political views which led him to side with Mussolini during World War II. Always concerned with literary theory and technique (when not obsessed by economic matters), even his Letters, 19071941 (1950) as edited by D. D. Paige are presentations of literary views, rather than reflections of a personal life. Pound's translations and adaptations of poems from Chinese and Provençal, among others, have not only done much to make such literature known to Americans, but the creativeness applied to some of them has given the work the seminal effect of forceful original poetry. Considered by some an outstanding achievement in modern verse drama is his translation of Sophocles' Women of Trachis, which appeared in 1954 in the winter issue of The Hudson Review.

1665. The cantos. [New York] New Directions, 1948. 149, $56,46,167,118 \mathrm{p}$. $48-4633 \mathrm{PS}_{353} \mathrm{I}_{\mathrm{O}} \mathrm{O} 8 \mathrm{C}_{2} 8$

Contents.-A draft of XXX cantos.-Eleven new cantos, XXXI-XLI.-The fifth decade of cantos.Cantos LII-LXXI.-The Pisan cantos.

1666. Personae; the collected poems. [New York] New Directions [1950? " I926] 273 p. 50-1 3308 PS $3531.082 P_{4} 1950$

Personae was first used by Pound as a title for a rgog volume of poetry; the title was used again for a collection of poetry published in 1926 . This collection also included material from Exultations (1909), Ripostes (1912), Lustra (1916), Hugh Selwyn Mauberley (1920), and Homage to Sextus Propertius, which was first published independently in 1934, although it dates from 1917. The present edition of the Personae is meant to include all Pound's poems other than the Cantos. Pound's other independent volumes of poetry have included Canzoni (1911), Cathay (1915), Quia Pauper Amavi (r919), Umbra (1920), Poems, 1918-2I (1921), Indiscretions (1923), and Alfred Venison's Poems (1935).

r667. The translations of Ezra Pound. [New York] New Directions [1953?] 408 p. 53-11965 PN6020.P6

1668. Literary essays. Edited with an introd. by T. S. Eliot. [Norfolk, Conn.] New Directions, 1954. $\mathrm{xv}, 464 \mathrm{p}$.
54-7905 PN511.P625 
1669. Edwards, John H. A preliminary checklist of the writings of Ezra Pound, especially his contributions to periodicals. New Haven, KirgoBooks, 1953. viii, 73 p. $\quad 5^{2-12855}$ Z8709.3. E3

1670. Espey, John J. Ezra Pound's Mauberley; a study in composition. Berkeley, University of California Press, I955. I 39 p.

$$
\text { 54-6474 PS } 3531.082 \mathrm{H}_{42} \quad 1955
$$

167r. Kenner, Hugh. The poetry of Ezra Pound. Norfolk, Conn., New Directions, I951. 342 p. $\quad 5^{\mathrm{I}-12356} \mathrm{PS}_{353 \mathrm{r} .082 Z 7}$

1672. Leary, Lewis G., ed. Motive and method in The cantos of Ezra Pound. New York, Columbia University Press, 1954. viii, 135 p. (English Institute. Essays, 1953)

$$
\text { 54-11609 PEroro.E5 } 1953
$$

1673. Russell, Peter, ed. An examination of Ezra Pound; a collection of essays. [Norfolk, Conn.] New Directions, 1950. 268 p. 50-10415 PS 353 1.082Z8 r950a

London ed. (P. Nevill) has title: Ezra Pound.

1674. Watts, Harold H. Ezra Pound and The cantos. Chicago, Regnery, 1952. 132 p.

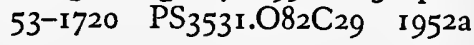

\section{JOHN CROWE RANSOM, I888-}

Ransom's poetry is distinguished by verbal elegance and precision, and permeated by gentle, intellectual irony. His first book, Poems About God (I9I9), bore the promise that has been fulfilled in the small quantity of verse he has since published. Not only an accomplished poet, Ransom is also prominent as a literary critic and as editor of the literary quarterly. The Kenyon Review (v. I + winter r939+ Gambier, Ohio, Kenyon College).

1676. Chills and fever, poems. New York, Knopf, 1924. $95 \mathrm{p}$.

$$
\text { 24-21606 } \mathrm{PS}_{3535 . \mathrm{A}_{35} \mathrm{C}_{5} \quad 1924}
$$

1677. Two gentlemen in bonds. New York, Knopf, 1927. 87 p.

Verse.

$$
\text { 27-2199 PS } 3535 . A 635 \text { T8 } 1927
$$

1678. The world's body. New York, Scribner, 1938. 350 p. 38-2747I PNII36.R

Contents.-A poem nearly anonymous.-Forms and citizens.-Poets without laurels.-The poet as woman.-Poetry: a note in ontology.-A psychologist looks at poetry.-A cathedralist looks at mur-
der.-The cathartic principle.-The mimetic principle.-Sentimental exercise.-The tense of poetry.Contemporaneous not contemporary.-Shakespeare at sonnets.-Art and Mr. Santayana.-Criticism, inc.

1679. Poems and essays. New York, Vintage Books, 1955. 185 p. (A Vintage book, K-24） 55-3813 PS3535.A635A6 1955

The poems in this volume are, with two additions, the same as those which appeared in Ransom's Selected Poems (1945). The essays are from periodicals, and had not previously had publication in volume form.

\section{I680. MARJORIE (KINNAN) RAWLINGS, 1896-1954}

Mrs. Rawlings' books have dealt with the isolated and somewhat primitive hammock district of Florida, with the exception of The Sojourner (1952), which was set in New York State. Best known for her novels, she has also published a volume of short stories and an autobiographical book describing her Florida neighbors as much as her own life. Her work, which has much local color detail and description, is realistic in manner, at times inclined to be sentimental, and with a frank love of the country and its people. An impression of their dialect is conveyed more in wording than spelling.

168I. South moon under. New York, Scribner, I933. 334 p. 33-5485 PZ3.Rig6gSo

A novel depicting the life of a hunter in the Florida backwoods.

1682. Golden apples. New York, Scribner, I935. 352 p. 35-r8688 PZ3.Rrg69Go

A story, with some culture conflict, of farming in the Florida back country.

1683. The yearling. New York, Scribner, 1938. $428 \mathrm{p}$. 38-27280 PZ3.Rig69Ye

The author was awarded a Pulitzer prize for this novel about an adolescent in the Florida back country and his love for a pet fawn.

1684. When the whippoorwill- New York, Scribner, 1940. $275 \mathrm{p}$.

$$
\text { 40-27409 PZ3.RI969Wh }
$$

Contents.-A crop of beans.-Benny and the bird dogs.-Jacob's ladder.-The pardon.-Varmints.-The enemy.-Gal young 'un.-Alligators.-A plumb clare conscience.-A mother in Mannville.-Cocks must crow. 
1685. Cross Creek. New York, Scribner, 1942. 368 p. $\quad 42-36118 \quad \mathrm{PS}_{3535 . A 8}{ }_{45} \mathrm{C}_{7}$

Autobiographical work descriptive of the author's home area in Florida.

\section{EUGENE MANLOVE RHODES, I869- 1934}

A cowboy and a writer in New Mexico, Rhodes wrote regional novels and short stories which are considered among the most literary of westerns. He truthfully depicted the background and social attitudes (which he shared) of the cowboy society of the late Igth century on the cattle ranges. One of his most esteemed novels, Paso por Aqui (1927) was widely distributed as the movie Four Faces West. May Davison Rhodes, his wife, shortly after his death wrote a biography of him: The Hired Man on Horseback (Boston, Houghton Mifflin, 1938. 263 p.).

1687. Best novels and stories. Boston, Houghton Mifflin, 1949. xxii, 551 p.

$$
\text { 49-I I703 PZ3.R } 3443 \mathrm{Bd}
$$

Novels and novelettes included: Pasó por aqui.Good men and true.-Bransford of Rainbow Range.-The trusty knaves.-The desire of the moth.-Hit the line hard.

\section{I688. ELMER L. RICE, I892-}

Elmer Rice, born Elmer Reizenstein, is a New York dramatist who first attracted attention with realistic plays which commonly carried some leftist moral. A withdrawal from his leftist position was effected in his later work. Probably his most famous play is Street Scene, which reflects life in a New York slum tenement block. He tried to give the same treatment to New York as a whole in his novel, Imperial City (1937). His earlier novel, A Voyage to Purilia (1930) was a satire on the movie industry; his later novel, The Show Must Go On (1949) was a more serious study of theater life.

1689. Seven plays. New York, Viking Press, 1950. $\mathrm{x}, 524 \mathrm{p}$.

$$
\text { 50-10796 } \mathrm{PS}_{3535 . \mathrm{I}_{22} \mathrm{~S}_{45}}
$$

Contents.-On trial (1914).- The adding machine (1923).- Street scene (1929).-Counsellor-atlaw (I93I).-Judgment day (I934).-Two on an island (1940).-Dream girl (1946).

169o. The winner, a play in four scenes. New York, Dramatists Play Service, 1954. 127 p. 54-II654 PS $3535 . I_{224} \mathrm{~W}_{5}$
I69I. CONRAD MICHAEL RICHTER, I890-

Conrad Richter writes historical novels and short stories which give his impressions of life in America. His setting is often the American Southwest, to which he himself moved, or the region about Ohio and Pennsylvania, where he was born. His lucid style, depiction of local color, and recording of historical details are characteristics of his work. He has also written nonfiction, such as The Mountain on the Desert (1955), which expresses his philosophic and mystic view of life.

1692. Early Americana and other stories. New York, Knopf, 1936. 322 p.

$$
\text { 36-2I0II } \mathrm{PZ}_{3} \cdot \mathrm{R}_{417} \mathrm{Ear}
$$

Contents.-Early Americana.-Smoke over the prairie.-New home.-Long drouth.-Frontier woman.-As it was in the beginning.-Buckskin vacation.-The square piano.-Early marriage.

1693. The sea of grass. New York, Knopf, I937. I $49 \mathrm{p}$.

37-27107 $\mathrm{PZ}_{3} \cdot \mathrm{R}_{417} \mathrm{Se}_{2}$

A refined heroine leaves her husband and children and their large cattle ranch to return to the city; after 20 years she returns and is accepted back by her husband.

1694. The trees. New York, Knopf, 1940. 302 p. 40-27179 $\mathrm{PZ}_{3} \cdot \mathrm{R}_{4} \mathrm{I}_{7} \mathrm{Tr}$

The first volume of a trilogy, this is the story of a Pennsylvania pioneer family's immigration to Ohio near the end of the i8th century. It was followed in 1946 by The Fields $\left(\mathrm{PZ}_{3} \cdot \mathrm{R}_{4}{ }_{7} \mathrm{Fi}{ }_{46} 6-\right.$ 2155), which is the story of the next generation opening up the frontier community. In $195^{\circ}$ appeared The Town ( $\mathrm{PZ}_{3} \cdot \mathrm{R}_{41}{ }^{7} \mathrm{To}$ 50-633 $^{\mathrm{I}}$ ), in which the family moves from a cabin to a mansion, and the community becomes a town, while the frontier has moved further West.

1695. The free man. New York, Knopf, 1943. I47 P. 43-II545 PZ3.R4I7Fr

The story of a German who arrives in America as an indentured servant; fights in the Revolutionary War against the British; and lives with the Pennsylvania Dutch as a free man.

1696. The light in the forest. New York, Knopf, 1953. I79 p. 52-12207 PZ3.R417Li

A story of the conflict of white and Indian views of life. It centers about the rescue of a boy after I I years with the Delaware Indians who had captured him, of the boy's attempt to rejoin the Indians, and the results. 
1697. ELIZABETH MADOX ROBERTS, I886-

Elizabeth Madox Roberts wrote novels and short stories of life in rural Kentucky at various social levels and at different periods, among which the 2oth century predominates. Artistry of style and lyricism are characteristics of her best work. In the field of poetry the author wrote first for children and later for adults, introducing certain aspects of the folk song into this portion of her work. Her last volume of poems was Song in the Meadow (1940). In almost all of her writing she made some use of the English spoken in the Kentucky hills. The dialect added freshness and vitality to her work, except when the form was extreme or when its presence constituted an impediment for readers unfamiliar with the speech of the locality.

1698. The time of man. New York, Viking Press, 1926. $382 \mathrm{p}$. 26-1540 $\mathrm{PZ}_{3} \cdot \mathrm{R}_{54} \mathrm{I}_{45} \mathrm{Ti}$

The author's first novel and the one most frequently read and reprinted. It is a story of poor whites in rural Kentucky.

1699. My heart and my flesh . . . a novel. New York, Viking Press, r927. 300 p. 27-22999 PZ3.R54145My

Against a Kentucky setting this book unfolds a psychological story of a young woman, of aristocratic family, who survives near-insanity and protracted illness to find happiness.

1700. Jingling in the wind. New York, Viking Press, 1928. $256 \mathrm{p}$.

28-22353 PZ3.R54145Ji

A humorous fantasy about a rural rainmaker and his trip to the metropolis to attend a convention of rainmakers.

r7or. The great meadow. New York, Viking Press, 1930. $33^{8} \mathrm{p}$.

$3^{0-7676} \quad \mathrm{PZ}_{3} \cdot \mathrm{R}_{54145 \mathrm{Gr}}$

A story of pioneer life in Kentucky and conflict with the Indians.

1702. A buried treasure. New York, Viking Press, r931. $296 \mathrm{p}$.

31-28312 PZ3.R5414Bur

A humorous narrative about a farmer and his wife who discover a buried treasure, and the celebration party they hold.

1703. The haunted mirror. New York, Viking Press, 1932. 288 p.

A volume of short stories.
1704. He sent forth a raven. New York, Viking Press, 1935. $255 \mathrm{p}$.

35-27098 $\mathrm{PZ}_{3} \cdot \mathrm{R}_{54}{ }_{45} \mathrm{He}^{\mathrm{He}}$

A poetic and somewhat mystic story about a farmer who, after his wife's death, vowed not to set foot on earth again, and then spent the rest of his life directing the farm work from his porch.

1705. Black is my truelove's hair. New York, Viking Press, 1938. 28r p.

\section{$3^{8-27966} \quad \mathrm{PZ}_{3} \cdot \mathrm{R}_{54145} \mathrm{Bl}$}

A lyrical novel of a Kentucky village girl who eventually finds true love; the story is written in a simple prose reflecting the native speech of the region.

I 706. Not by strange gods; stories. New York, Viking Press, I94I. 244 p.

$$
\text { 4I-5II4 PZ3.R54145No }
$$

Contents.-The haunted palace.-I love my bonny bride.-Swing low, sweet chariot.-Holy morning.- The betrothed.-Love by the highway.

\section{KENNETH LEWIS ROBERTS, r885-}

Kenneth Roberts is a historical novelist who usually sets his stories in early America (from the pre-Revolutionary period through the War of 1812 ). Maine, the state in which he lives, or characters from Maine, are often prominent in his books.

1708. Arundel, being the recollections of Steven Nason of Arundel, in the province of Maine, attached to the secret expedition led by Colonel Benedict Arnold against Quebec and later a captain in the Continental Army serving at Valcour Island, Bemis Heights, and Yorktown. Garden City, N.Y., Doubleday, Doran, 1930. 618 p.

$$
30-3872 \quad \mathrm{PZ}_{3} \cdot \mathrm{R}_{5426} \mathrm{Ar}
$$

Sequels: Rabble in Arms and Captain Caution.

1709. Rabble in arms; a chronicle of Arundel and the Burgoyne invasion. Garden City, N. Y., Doubleday, Doran, 1933. $870 \mathrm{p}$.

Sequel: Captain Caution (1934).

$$
33-3326_{3} \quad \mathrm{PZ}_{3} \cdot \mathrm{R}_{54}{ }_{2} 6_{3} \mathrm{Rab}
$$

Preceded by: Arundel.

1710. Northwest passage. Garden City, N. Y., Doubleday, Doran, 1937. $2 \mathrm{v}$.

$$
\text { 37-2740r PS } 3535 . \text { Or7@6 } 1937
$$

The first part recounts the campaigns of Robert Rogers and Rogers' Rangers against the Indians; the second part is largely the story of Rogers' search for a northwest passage. 
1711. Oliver Wiswell. New York, Doubleday, Doran, 1940. $2 \mathrm{v}$.

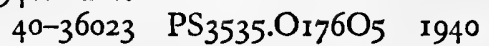

A novel of the American Revolution as seen by a colonial loyalist.

1712. Boon Island. Garden City, N. Y., Doubleday, $1956,{ }^{\mathrm{c}}$ 1955. $275 \mathrm{p}$.

56-5443 $\mathrm{PZ}_{3} \cdot \mathrm{R}_{5426} \mathrm{Bo}$

The story of a shipwreck, which occurred in the winter of $\mathrm{i} 7 \mathrm{I}$ o on a rocky island off the New Hampshire ccast, and of the endurance of the survivors who underwent extreme hardships.

\section{I713. EDWIN ARLINGTON ROBINSON, I869-1935}

Robinson's poetry is basically a searching for ultimate moral values. This quest is often presented through dramatic sketches of individuals, many of whom are associated with Tilbury, the fictitious name he assigned to Gardiner, Maine, the town in which he was reared. Although his content was novel, he employed conservative verse forms. He started writing near the beginning - and was himself part-of the revolt against the effete sunsets-and-nightingales poetry that quantitatively dominated late igth-century poetic production. At his best in his dramatic sketches and lyrics, Robinson also wrote a number of long narrative poems which attracted considerable attention when they were first published. Initially he struggled in isolation for recognition, so that he became a somewhat embittered author; but his subsequently acknowledged position as an important poet and his transitional modernity have led various schools to claim him as a member, or at least as a precursor. The struggle for achievement, recognition, and even survival is reflected more directly in his letters than in his poetry.

1714. Collected poems. New York, Macmillan, 1937. xii, $1498 \mathrm{p}$. 37-27280 PS $3535 . O_{25} \mathrm{AI}_{7} \quad 1937$ "Complete edition with additional poems. Published April r937."

Contenrs. - The man against the sky (1916).The children of the night (1890-1897). - Captain Craig, etc. (I902).-Merlin (I9I7).-The town down the river (1910).-Lancelot (1920).-The three taverns (I920).-Avon's harvest, etc. (192I) Tristram (1927).--Roman Bartholow (r923).Dionysus in doubt (1925).- The man who died twice (1924).-Cavender's house (1929).-The glory of the nightingales (1930).-Matthias at the door (193r). - Nicodemus (1932). - Talifer (1933).-Amaranth (1934).-King Jasper (1935).
1715. Selected letters. New York, Macmillan, 1940. $x$, I9I p. 40-27180 PS $3535 . \mathrm{O}_{25} \mathrm{Z}_{53}$

1716. Untriangulated stars; letters of Edwin Arlington Robinson to Harry de Forest Smith, I890-1905. Edited by Denham Sutcliffe. Cambridge, Harvard University Press, 1947. xxvii, $34^{8} \mathrm{p}$.

47-11410 PS $3535 . \mathrm{O}_{25} \mathrm{Z}_{54}$

r717. Barnard, Ellsworth. Edwin Arlington Robinson, a critical study. New York, Macmillan, 1952. xii, $318 \mathrm{p}$.

$$
\text { 52-7104 PS } 3535 . \mathrm{O}_{25} \mathrm{Z}_{555}
$$

I718. Fussell, Edwin S. Edwin Arlington Robinson; the literary background of a traditional poet. Berkeley, University of California Press, I954. 21 p. 54-80I7 PS3535. $\mathrm{O}_{25} \mathrm{Z66}$

1719. Neff, Emery E. Edwin Arlington Robinson. [New York] Sloane, 1948. xviii, $286 \mathrm{p}$. (The American men of letters series)

$$
4^{8-8640} \quad \mathrm{PS}_{3535 . \mathrm{O}_{25} \mathrm{Z}_{74}}
$$

1720. OLE EDVART RØLVAAG, 1876-1931 Rølvaag came to America from Norway in 1896. He attended St. Olaf College in Minnesota, where from 1907 to 193 I he was professor of Norwegian; in that language all his books were originally written. The first novel of the trilogy which was his major work is usually regarded as his best; in it he realistically depicts the life of Norwegian emigrants in South Dakota when it was part of the Northwestern frontier. The two subsequent novels follow the family history after the initial pioneer period had passed.

1721. Giants in the earth; a saga of the prairie. New York, Harper, 1927. 465 p.

$$
\text { 27-125I3 PZ3.R6275Gi }
$$

Translated by the author from I De Dage, published by Aschehoug, 1924-25.

1722. Peder Victorious, a novel. Translated from the Norwegian, English text by Nora $O$.

Solum .... and the author. New York, Harper, I929. $350 \mathrm{p}$.

Translation of Peder Seier.

1723. Their fathers' God, a novel. Translated from the Norwegian by Trygve M. Ager. New York, Harper, 1931. $33^{8}$ p.

$$
\text { 31-29967 PZ } 3 \cdot \mathrm{R}_{275} \mathrm{Th}
$$

Translation of Den Signede Dag. 


\section{ARCHIBALD HAMILTON RUTLEDGE, I883-}

Archibald Rutledge comes from a low country area, formerly a rice plantation, in South Carolina; this he usually uses as a setting for his writings. Some of his best work is that of a nature-lover and hunter describing his hunting experiences and the woods and swamplands, with much attention given to the animals inhabiting them; such books include Children of Swamp and Wood (1927), An American Hunter (1937), and Hunter's Choice (1946). Further aspects of life on his plantation are treated in the short stories of Old Plantation Days (1921) and the somewhat sentimental Peace in the Heart (1930). In addition to the short stories and the nature and hunting sketches, Rutledge has also written much conservative poetry, a recent volume of selections being Brimming Tide and Other Poems (1954).

1725. Wild life of the South. New York, Stokes, r935. 253 p. illus.

$$
\text { 35-1719r QH8r.R9783 }
$$

1726. Home by the river. Indianapolis, New York, Bobbs-Merrill, 1941. 167 p. plates, ports. $\quad 4 \mathrm{I}-4 \mathrm{r} 27 \quad \mathrm{~F}_{279} \cdot \mathrm{H}_{25} \mathrm{R} 8$

A book of Rutledge's experiences and observations at, as well as some historical background of, the family plantation at Hampton, S. C.

\section{CARL SANDBURG, 1878 -}

Sandburg first gained prominence as a realistic poet of America in general and of Chicago and the Midwest in particular. $\mathrm{He}$ has adapted Whitman's form and idiom with much success to evoke urban industrial America, the small town, and rural America. Although a $195^{\circ}$ volume of his collected poetry was awarded a Pulitzer prize for poetry, his free verse has tended in recent years to be overshadowed by his prose: his biographical work on Lincoln, his autobiography, and the long historical novel, Remembrance Rock.

1728. Abraham Lincoln, the prairie years. With ro5 illus. from photographs, and many cartoons, sketches, maps, and letters. New York, Harcourt, Brace, 1926. 2 v. $26-38885-E_{457 \cdot 3 . S_{22}}$

1729. Abraham Lincoln, the war years. With 414 half-tones of photographs and 249 cuts of cartoons, letters, documents. New York, Harcourt, Brace, 1939. $4 \mathrm{v}$. 39-27998 $\mathrm{E}_{457 \cdot 4 . \mathrm{S}_{3} 6}$
1730. Remembrance Rock. New York, Harcourt, Brace, 1948. 1067 p.

48-8509 $\mathrm{PZ}_{3} . \mathrm{S}_{21} \mathrm{Re}$ A patriotic novel attempting to convey the "American Dream." The book attempts this through picturing the people and times at three critical stages: the Puritan period, the time of the Revolutionary War, and the pre-Civil War and Civil War period.

1731. Complete poems. New York, Harcourt, Brace, $195^{\circ} .676 \mathrm{p}$.

50-11502 PS $3537 . A 618 \quad 1950$

Among earlier volumes of Sandburg's poetry are In Reckless Ecstasy (1904), Chicago Poems (1916), Cornhuskers (1918), Smoke and Steel (1920), Slabs of the Sunburnt West (1922), Good Morning, America (1928), and The People, Yes (1936).

1732. Always the young strangers. New York, Harcourt, Brace, 1952. 5271.

Autobiographical.

$$
53-9843 \text { PS } 3537 \cdot A 618 Z_{5} \quad 1952
$$

\section{GEORGE SANTAYANA, I863-r952}

Santayana was born in Spain of a Spanish father and a New England mother; he came to America as a child, but after some forty years returned to Europe, where he passed the rest of his life. He has been praised for his poetry, despite its limited bulk; his one novel achieved considerable renown; and he wrote an outstanding autobiog. raphy. However, it is as a philosopher of literary merit that he is best known, and his philosophical works are treated under the Philosophy section of this bibliography. In all his work Santayana has been a stylist of conservative tendencies and with a consciousness of word connotations.

1734. Poems. New York, Scribner, 1923. I 40 p. 23-5779 PS2770.A4 1923

I735. The genteel tradition at bay. New York, Scribner, I931. 74 p. 31-26894 B82I.SI7 Three essays on the old and the new humanism.

1736. The last Puritan; a memoir in the form of a novel. London, Constable, 1935. 721 p. 35-31979 $\mathrm{PZ}_{3} . \mathrm{S}_{22} 84 \mathrm{Las}$

A study of the New England character, bleakly bowed beneath the weight of moral duty.

1737. Persons and places. New York, Scribner, 1944-53. 3 v. $43-5{ }^{13} 6_{3} \quad \mathrm{~B}_{945 . \mathrm{S}_{24} \mathrm{~A}_{3}}$

Autobiography.

Contents.-[v. I] The background of my life.v. 2. The middle span.-v. 3. My host the world. 
1738. Dialogues in limbo, with 3 new dialogues. New York, Scribner, 1948. 248 p.

First issued in 1925 .

$$
4^{8-10294} \text { B945.S23 D5 } 1948
$$

1739. Dominations and powers; reflections on liberty, society, and government. New York, Scribner, 1951. $481 \mathrm{p}$. $5^{1-10642} \mathrm{JC}_{25} \mathrm{I}_{\mathrm{S}} \mathrm{S}_{33}$

1740. The poet's testament: poems and two plays. New York, Scribner, 1953. 216 p.

53-II773 PS2772.P6

The two plays are The Marriage of Venus and Philosophers at Court.

174I. Letters. Edited, with an introd. and commentary, by Daniel Cory. New York, Scribner, 1955. xxxi, 45I p.

$$
\text { 55-9677 B945.S24 } \mathrm{A}_{4}
$$

1742. Duron, Jacques. La pensée de George Santayana; Santayana en Amérique. Paris, Nizet [1950] viii, $55^{6}$ p. 51-22923 B945.S24D8

\section{EVELYN SCOTT, 1893-}

Evelyn Scott is a novelist who has been concerned with establishing basic motivations and attitudes behind human actions. Her exposure of hypocrisies and shams, expressed with seriousness of purpose and resultant common lack of humor, have resulted in subjects and views to which conservatives have objected. Her usually long, fictional accounts of life in America are written in a realistic, neo-naturalistic style and with a wealth of accurately ohserved detail expressive of her impressionistic rather than interpretational approach. Some of her books are episodic in character, rather than adhering to rigid plot structure. This may be seen in works such as Breathe Upon These Slain (1934), a novel which recreates the lives of former inhabitants of a rented English farmhouse, evolving the story from the evidence of what they have left behind: At the same time she shared with Waldo Frank a milder (i. e., less communistic) liberalism and a tendency to see characters as part of a group or setting, rather than as individuals; early influenced by the writings of Karl Marx, in the thirties she turned from what she considered a perversion of his principles, and started to evolve her own course of liberalism. In addition to her fiction, she has written some poetry and two volumes of autobiography: Escapade (1923) and Background In Tennessee (1937), which is as much a study of her background as of any part of her life.
1744. The narrow house. New York, Boni \& Liveright, 1921. 221 p.

$$
\text { 21-5273 } \mathrm{PZ}_{3} \cdot \mathrm{S}_{245} \mathrm{Na}
$$

A novel of drab lives pressed together in a narrow house.

1745. The wave. New York, Cape \& Smith, 1929. 624 p. 29-14106 $\mathrm{PZ}_{3} . \mathrm{S}_{4245} \mathrm{Wav}$

A loosely structured novel of narratives of the Civil War.

1746. A calendar of sin, American melodramas. New York, Cape \& Smith, 193I. 2 v.

$$
\text { 3I-28I34 } \mathrm{PZ}_{3} . \mathrm{S}_{4245} \mathrm{Cal}
$$

A novel evolving from the stories of five generations of a family.

1747. Eva Gay, a romantic novel. New York, Smith \& Haas, 1933. $799 \mathrm{p}$.

$$
\text { 33-27102 } \mathrm{PZ}_{3} . \mathrm{S}_{4245} \mathrm{Ev}
$$

A story with the world for stage; on the plot level it is concerned with a woman and her two loves.

1748. The shadow of the hawk. New York, Scribner, 1941. 494 p. $\quad 41-7659 \quad \mathrm{PZ}_{3} . \mathrm{S}_{4245} \mathrm{Sh}$

The story of a boy who grows up with the knowledge that his father, convicted of murder, was innocent.

\section{ROBERT EMMET SHERWOOD, ז896- 1955}

Robert Sherwood distinguished himself in several fields, but is probably best known for his dramatic work. His early plays, such as The Road to Rome (1927) and Reunion in Vienna (1932), tended to be comedies displaying Shavian influence. With The Petrified Forest he began to show a more personal style in serious drama. After this his work was predominantly serious. Related to his work in drama is his writing for films. Sherwood was also the author of Roosevelt and Hopkins, an Intimate History (1948, rev. 1950), for which he was awarded the Pulitzer prize for biography. He also three times received the Pulitzer award for drama.

1750. The petrified forest. New York, Scribner, 1935. $176 \mathrm{p}$.

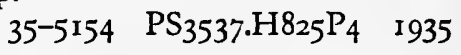

175I. Idiot's delight. [A play] New York, Scribner, 1936. $190 \mathrm{p}$.

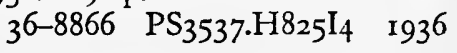

1752. Abe Lincoln in Illinois, a play in twelve scenes. New York, Scribner, 1939. $25^{\circ}$ p. 39-27098 PS $3537 . \mathrm{H}_{25} \mathrm{~A}_{3} \quad 1939$ 
1753. There shall be no night. New York, Scribner, r940. $178 \mathrm{p}$.

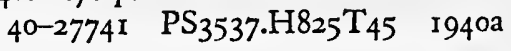

\section{UPTON BEALL SINCLAIR, I878-}

Upton Sinclair is an extremely prolific author with a gift for presenting action in a journalistic manner. His usually realistic work has been largely propagandistic and, in his early years, almost entirely "proletarian" in emphasis. The Jungle, his first successful publication, was an exposé of conditions in the meat industry in Chicago; it was influential in starting a crusade for pure food in the Theodore Roosevelt era, and has been called the most powerful novel of the muckraking movement. Later he turned to writing pamphlets, from The Profits of Religion (1918) through Mammonart (1925) and Money Writes (1927); in this series he produced one of the most thorough, if unbalanced, Marxian interpretations of American culture. After a few years he again turned from proletarian novels in order to write in aid of his campaign for the governorship of California, to which he was nearly elected in 1934. In $194^{\circ}$ he started publication of a series of novels centering about Lanny Budd, a hero whose mobility enabled the author to comment about numerous contemporary affairs. The series depicts the situation, national and international, from the beginning of World War I through the period following World War II. In 1943 the third volume, Dragon's Teeth, was awarded a Pulitzer prize. The series was announced as complete with the publication in 1949 of volume ten; however, it was resumed in 1953. Although Sinclair has also produced a few dramatic works, it is his novels which are well known. It has been claimed that in some foreign countries he is the most widely read of American authors and that he has been translated more often into more foreign languages than any other modern author. In 1925 he was officially declared a Soviet classic, an act which evidenced his great popularity in Russia.

I755. The jungle. New York, Doubleday, Page, 1906. 413 p. 6-6264 $\mathrm{PZ}_{3}$.S616J

1756. Oil! A novel. New York, Boni, 1927. 527 p. $\quad 27-7669^{\circ} \quad \mathrm{PZ}_{3} .5616 \mathrm{Oi}$

A story derived from scandals during President Harding's administration, especially the Teapot Dome scandal.

1757. American outpost; a book of reminiscences. New York, Farrar \& Rinehart, 1932. 280 p. 32-26373 PS $3537.185 Z_{5} \quad 1932$
1758. Lanny Budd series. New York, Viking Press, 1940-53. II v.

Contents.-v. I. World's end (PZ3.S616Wo 40-7472).--v. 2. Between two worlds ( $P Z_{3} . S_{1} 6_{16 e}$

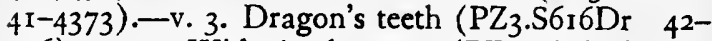
106).- -v. 4. Wide is the gate (PZ3.S6r6Wi 43162).--v. 5. Presidential agent ( $\mathrm{PZ}_{3} . \mathrm{S}_{616 \mathrm{Pl}} 4^{-}$ 4916).-v. 6. Dragon harvest (PZ3.S6r6Dp 45$35107)$.-v. 7. A world to win ( $\mathrm{PZ}_{3} . \mathrm{S}_{16} 6 \mathrm{Wn}$ 46-3965).-v. 8. Presidential mission ( $\mathrm{PZ}_{3}$.Só I6Po 47-30286).-v. 9. One clear call ( $\mathrm{PZ}_{3} .56160 \mathrm{~m}$ 48-8056).--v. 1o. O shepherd, speak! (PZ3.S616O $49-9981) .-v$. Ir. The return of Lanny Budd (PZ3.S6r6Re 53-5202).

\section{LILLIAN EUGENIA SMITH, I897-}

Born and reared in the South and coeditor from 1936 to 1945 of South Today, Miss Smith's novel, Strange Fruit, was the expression of a Southerner's soul searching on account of evils resulting from racial discrimination in her native section. The purpose of the novel to expose the ultimate of these evils necessitates tragedy and violence in the action of the book; but these are expressed with literary artistry as well as power. The author's position with regard to a love affair between members of different races, and her fidelity to language natural to uneducated characters but not in ordinary use, made the book a controversial one. Partly for that reason it reached a large audience. It has also been translated into French, Italian, Spanish, and other languages.

176o. Strange fruit, a novel. New York, Reynal \& Hitchcock, I944. 37 r p. 44-40028 $\quad \mathrm{PZ}_{3} . \mathrm{S}_{5}{ }_{3} 6 \mathrm{St}$

r76r. The journey. Cleveland, World Pub. Co., 1954. 256 p. 53-6643 PZ3.S6536Jo

Spiritual autobiography of the author's journey thus far through life.

\section{WILBUR DANIEL STEELE, I886-}

Although he has written several novels, Steele is best known for his short stories; these are frequently set in places such as New England, South Carolina, and Arizona. Ingenuity of plot presentation and sustained action have led some reviewers to regard him as the best of conventional short-story writers. He has also done some dramatic work, such as Terrible Woman, and Other One Act Plays (1925); these were written for the Provincetown Players. In some cases he has collaborated with other authors in the writing of plays. 
1763. That girl from Memphis. Garden City, N. Y., Doubleday, Doran, r945. 470 p. 45-5456 PZ3.S8I 49 Th

A novel of the early West, in which a young man falls in love with a prostitute.

1764. The best stories of Wilbur Daniel Steele. Garden City, N. Y., Doubleday, 1946. 469 p. ${ }_{4}^{6-5578} \quad \mathrm{PZ}_{3} . \mathrm{S} 8{ }_{149 \mathrm{Be}}$

1765. Full cargo; more stories. Garden City, N. Y., Doubleday, 1951. 369 p.

$$
\text { 51-145I6 } \mathrm{PZ}_{3} . \mathrm{S}_{1} \text { I }_{49} \mathrm{Fu}
$$

\section{GERTRUDE STEIN, 1874-1946}

Gertrude Stein lived most of her life in France, where she created her experimental writings on essentially American subjects, based on her memories of her native land or on encounters with Americans abroad. Much of her work was constructed on a principle of verbal repetition with slight modification, so as to arrive at and establish with precision some nuance of meaning. Thus in her attempts for clarity she evolved in her prose not only a tendency to occasionally complex syntax, but also to a frequent heavy abstraction, characterized in part by an emphasis on verbs and a deemphasis on nouns (a procedure reversed in much of her poetry),-with the result that most readers find her more experimental books "difficult." Nevertheless, her works have been highly admired by a few and influential on a number of prominent writers, such as Hemingway, Sherwood Anderson, and Louis Bromfield. Her reputation for difficulty has to some extent kept from her a wide audience such as might seem consonant with her wide influence; consequently a number of authors, who have derived stylistic elements from her works, have themselves been far more popular. In her more conservative books the speech rhythms on which she based the bulk of her work become obvious, and a few might be viewed as largely lucid conversational reportage-a factor which draws her considerably closer to some of the authors who have found her writings seminal.

1767. Three lives; stories of the good Anna, Melanctha, and the gentle Lena. New York,

Grafton Press, I909. 279 p.

$$
\text { 9-20912 PS } 3537 \cdot \mathrm{T}_{323} \mathrm{~T}_{5} 1909
$$

1768. The making of Americans, being a history of a family's progress, written ... I906-1908.

[Paris, Contact Editions] 1925. 925 p.

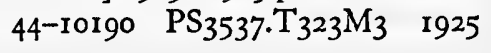

1769. Wars I have seen. New York, Random House, 1945. 259 p.

$$
45^{-2075} \mathrm{PS}_{3537 \cdot \mathrm{T}_{323} \mathrm{~W}_{3}}
$$

1770. Brewsie and Willie. New York, Random House, 1946. II 4 p.

$46-5457 \quad \mathrm{PS}_{3537} \cdot \mathrm{T}_{323} \mathrm{~B}_{7}$

A conversational-styled book reflecting the personal problems of American soldiers in France during World War II.

1771. Selected writings. Edited, with an introd. and notes, by Carl Van Vechten. New York, Random House, 1946. 622 p.

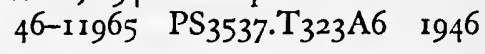

In addition to selections from the books listed above, this volume contains material from Geography and Plays (1922), and some miscellaneous pieces, as well as the complete texts of Tender Buttons (1914), Miss Stein's autobiographical The Autobiography of Alice B. Toklas (1933), and Four Saints in Three Acts (1934), which was used by Virgil Thomson as the libretto for his opera of the same name. Miss Stein's fiction is represented by short stories, rather than by selections from her novels Lucy Church Amiably (1930) and Ida (I94I).

1772. The Yale edition of the unpublished writings of Gertrude Stein. New Haven, Yale University Press, 1951. 51-6628 PS3537.T323A6

1773. Rogers, William Garland. When this you see remember me; Gertrude Stein in person. New York, Rinehart, 1948. 247 p.

$$
4^{8-7376} \mathrm{PS}_{3537 . \mathrm{T}_{323} \mathrm{Z8}}
$$

1774. Sutherland, Donald. Gertrude Stein, a biography of her work. New Haven, Yale University Press, 195I. $218 \mathrm{p}$.

$$
5^{\mathrm{I}-12323} \quad \mathrm{PS}_{3537 \cdot \mathrm{T}_{323} \mathrm{Z}_{3}}
$$

\section{JOHN STEINBECK, 1902-}

Steinbeck is a realistic and naturalistic novelist from California who commonly uses his home area as a setting for his fiction. His sympathy is with the inarticulate masses who are unable to speak for themselves. He pictures with understanding the lowest classes, the brute, the animalistic, the moronic, and the less intelligent social outcasts. Grapes of Wrath, a social document of the problems and life of the migratory farmers of the Southwest during the dustbowl period of the depression years, has probably been his most influential and widely read novel of social criticism. 


\section{I44 / A GUIDE TO THE UNITED STATES}

1776. The long valley. New York, Viking Press, 1938. $303 \mathrm{p}$. $\quad 3^{8-27754} \mathrm{PZ}_{3} . \mathrm{S}_{1}{ }_{195 L 02}$

Short stories.

1777. The grapes of wrath. New York, Viking Press, 1940. 619 p.

$$
\text { 40-6r33 PZ3.S8195Gri }
$$

"First published in April 1939 ... eleventh printing February 1940."

1778. The wayward bus. New York, Viking Press, 1947. $312 \mathrm{p}$.

$$
\begin{array}{r}
47-30085 \text { PZ3.S8r95 Way } \\
\mathrm{PS}_{3537 . \mathrm{T}_{32} 34 \mathrm{~W}_{3}}
\end{array}
$$

1779. East of Eden. New York, Viking Press, I952. 602 p. 52-4118 PZ3.S8195Eas

1780. Short novels: Tortilla Flat [1935]; The red pony [1937]; Of mice and men [1937]; The moon is down [1942]; Cannery Row [1945]; The pearl [1947]. With an introd. by Joseph Henry Jackson. New York, Viking Press, 1953. xiii, $407 \mathrm{p}$.

53-9ig6 PZ3.S8r95Sh

$\mathrm{PS}_{3537 . \mathrm{T}_{3234} \mathrm{~A} 6} \mathrm{I} 953$

1781. Sweet Thursday. New York, Viking Press, 1954. 273 p. $54-7983 \quad \mathrm{PZ}_{3} . \mathrm{S} 8 \mathrm{r}_{95} \mathrm{Sw}$

1782. WALLACE STEVENS, I879-1955

The name of Stevens has been ranked with that of T. S. Eliot as first in impressiveness among poets belonging to the modern movement of poetry in English. However, he worked in relative solitude and constituted his own school for studying the mind and its perceptions. His first published book, Harmonium (1923), appeared when he was 44 years of age and at once revealed the eloquence and elegance for which this Connecticut poet was to become known. On the other hand a heavy richness, which might be called "gaudiness," also characterized the part of his work that has verbal and metrical flamboyance. Using a style and selecting subjects frequently exotic, his universal theme is the role of the human imagination. The philasophical bent informing his technical virtuosity resulted in an impressive body of constantly maturing poetry.

1783. The necessary angel; essays on reality and the imagination. New York, Knopf, 1951. $176 \mathrm{p}$. 5I-I2072 PNio55.S68

A collection of essays, lectures, etc., which expresses the author's theory of poetry.
1784. Collected poems. New York, Knopf, 1954. 534 p. 54-11750 PS $3537 . T_{4753} \quad 1954$ This collection, which was awarded a Pulitzer prize, includes the poems of earlier volumes such as Harmonium (1923), Ideas of Order (1935), The Man with the Blue Guitar (1937), Parts of a World (1942), Transport to Summer (1947), and The Auroras of Autumn (1950).

1785. O'Connor, William Van. The shaping spirit, a study of Wallace Stevens. Chicago, Regnery, 1950. ix, $146 \mathrm{p}$.

\section{$5^{0}-7455 \quad P_{3537 .} \mathrm{T}_{4753 Z_{7}}$}

\section{JAMES HOWELL STREET, 1903-1954}

James Street's career included professional specialization as a Baptist clergyman, a journalist, a novelist, and a writer of short stories. Born in Mississippi, he imparted to the majority of his books a strong regional interest in the South, although the time and place represented may vary from I8thcentury wars with the Indians on the frontier of the Old Southwest to essentially contemporary conditions on a cotton farm in Mississippi. However, he was at home also in the Middle West, the locale of his sequel novels about a clergyman's life in a small town. His sympathetic and perceptive short stories about children and adolescents, their animals, games, and adventures appeared in The Saturday Evening Post and other popular periodicals before a representative collection appeared in 1945. Whether in stirring historical romances or in novels written about the lives and in the colloquial speech of plain people, Mr. Street expressed his consciousness of the epic story of America's development, and his faith in its future.

1787. Oh, promised land. New York, Dial Press, 1940. 816 p. 40-27414 $\mathrm{PZ}_{3} . \mathrm{S}_{91557 \mathrm{Oh}}$

I788. In my father's house. New York, Dial Press, 1941. 348 p.

$4{ }_{4}^{1-5679} \quad \mathrm{PZ}_{3} \cdot \mathrm{S}_{91557 \mathrm{In}}$

1789. The gauntlet. Garden City, N. Y., Doubleday, Doran, 1945. 3i 1 p.

Sequel: High Calling (1951).

$$
\text { 45-9403 } \mathrm{PZ}_{3} \cdot \mathrm{S}_{91557 \mathrm{Gau}}
$$

I790. Short stories. New York, Dial Press, 1945. 3I4 p.

45-5601 PZ3.S91557Sh

Contents.-The golden key.-In full glory reflected.-The old Gordon place.-Weep no more, my lady.-Please come home, my lady.-Buck and fo' bits.-The crusaders.-Pud'n and Tayme.-They know how.-The road to Gettysburg.-All out with 
Sherman.-Set the wild echoes flying.-The biscuit eater.--The house.

1791. James Street's South. Edited by James Street, Jr. Garden City, N. Y., Doubleday, $\begin{array}{lll}1955 . & 282 & \text { p. }\end{array}$ "Essays on the South and its cities."

\section{r792. THOMAS SIGISMUND STRIBLING, I88I-}

T. S. Stribling's better-known novels usually reflect the Tennessee and Alabama districts with which he was familiar. Although not distinguished by stylistic merits, his works display a gift for narrative and a recording of colloquial conversation. This aptitude was probably developed in the popular and pulp fiction which he wrote in his early years. While the characteristic embedding of realistic details in his presentation of Southern life appeared in early work such as Birthright (1922), his narrative abilities came to the fore with such novels as Fombombo (1923) and Red Sand (1924), which depict American "businessmen" in Venezuela, and derive from Stribling's stay in that country. These elements were brought together in his later work, for which he returned to the rural South as a setting. In 1933 he was awarded a Pulitzer prize for the second volume of a trilogy which has been considered by some to be his main work. Another transition was made with The Sound Wagon (1935), in which his satirical tendencies became dominant. With These Bars of Flesh (1938), he continued in this vein, satirizing contemporary politics and education; the setting in this work was "Megapolis" in the North.

1793. The forge. Garden City, N. Y., Doubleday, Doran, 1931. $525 \mathrm{p}$.

Volume one of a trilogy.

$$
\text { 31-6082 } \mathrm{PZ}_{3} \cdot \mathrm{Sg}_{9} \text { 66For }
$$

1794. The store. Garden City, N. Y., Doubleday, Doran, 1932. $571 \mathrm{p}$.

Volume two of the same trilogy.

$$
\text { 32-2667I } \mathrm{PZ}_{3} \cdot \mathrm{S}_{9166 \mathrm{Sr} 2}
$$

1795. Unfinished cathedral. Garden City, N. Y., Doubleday, Doran, I934. $3^{83} \mathrm{p}$.

Volume three of the trilogy.

$$
34^{-2} 7^{1} 37 \mathrm{PZ}_{3} . \mathrm{S}_{9} \text { r66Un }
$$

\section{RUTH SUCKOW, r892-}

Ruth Suckow's first novel, Country People (1924), dealt with three generations of a GermanAmerican family from the time of their arrival in
Iowa in the middle of the 19th century. Since then she has quite consistently used Iowa as the locale for her fiction. Probably best known for her novels, she has also been praised for her short stories, of which a number of collections have been published, such as Children and Older People (193I). In both forms her merit has consisted of a "homey" but psychologically and physically accurate depiction of common people in everyday circumstances. It has been commented that this results in her work being basically character sketches rather than stories.

1797. Iowa interiors. New York, Knopf, 1926. $283 \mathrm{p}$. 26-27442 $\mathrm{PZ}_{3}$.S942Io

Contents.-A start in life.-A home-coming.The daughter.-The top of the ladder.-Mame.Uprooted.--Renters.-Retired.-A pilgrim and a stranger.-A rural community.-Just him and her.The resurrection.-Wanderers.-An investment for the future.-Four generations.-Golden wedding.

1798. The Bonney family. New York, Knopf, 1928. $296 \mathrm{p}$ 28-3333 $\mathrm{PZ}_{3} \cdot \mathrm{S}_{942 \mathrm{Bo}}$

1799. The folks. New York, Farrar \& Rinehart, 1934. 727 p. 34-32214 PZ3.S942Fo

I 800 . New Hope. New York, Farrar \& Rinehart, 1942. 342 p. 42-3175 PZ3.S942Ne

I $80 \mathrm{r}$. Some others and myself; seven stories and a memoir. New York, Rinehart, 1952. 28r p. 51-14899 $\mathrm{PZ}_{3} . \mathrm{S}_{942}$ So

1802. NEWTON BOOTH TARKINGTON, r869-r946.

Booth Tarkington was a highly prolific Midwestern novelist who achieved prominence in two fields of fiction. He is probably best known for his humorous stories of childhood and adolescence, such as Penrod and Sam (1916). He also wrote a number of serious novels, usually studies of Middle Western life; these include The Gentleman from Indiana (1899), The Conquest of Canaan (1905), and The Heritage of Hatcher Ide (194I). He was twice awarded a Pulitzer prize: for The Magnificent Ambersons (1918), the first volume of a trilogy, and in 1922 for Alice Adams, which has often been adjudged his best book. He attained a mastery of novel technique and an easy style, through which he expressed his often humorous and at times sentimental, "realist-romantic" tales. While he maintained a wide popular following, many of his works have been criticized for lack of psychological penetration and perception of sociological situations. Much of his work, particularly that of the first quarter of the century, remains generally popular. 
1803. Penrod. Garden City, N. Y., Doubleday, Page, 19r4. 345 p. 14-5820 PZ3.Tr75Pe

1804. Seventeen; a tale of youth and summer time and the Baxter family, especially William. New York, Harper, 1916. 328 p. I6-6604 PZ3.Tr75 Se

1805. Alice Adams. Garden City, N. Y., Doubleday, Page, I921. 434 p.

$$
\text { 21-26561 PZ3.Ti75Al }
$$

I 806. Growth. Garden City, N. Y., Doubleday, Page, 1927. $887 \mathrm{p}$.

$$
\text { 27-27696 } \quad \mathrm{PZ}_{3} . \mathrm{T}_{175} \mathrm{Gr}
$$

Contents.-The magnificent Ambersons.-The turmoil.-National avenue.

1807. Russo, Dorothy Ritter, and Thelma L. Sullivan. A bibliography of Booth Tarkington, 1869-1946. Indianapolis, Indiana Historical Society, 1949. xix, 303 p. illus.

$$
\text { 49-50289 Z8858.9.R8 }
$$

1808. Woodress, James L. Booth Tarkington, gentleman from Indiana. Philadelphia, Lippincott, I955. $35^{\circ} \mathrm{p}$. 55-6307 PS2973.W6

\section{ALLEN TATE, 1899-}

Tate was an early and leading member of the Nashville, Tennessee, group of authors known as Fugitives, because of their periodical The Fugitive (1922-25); this group developed, with changes in membership, into the Agrarians and the general movement known as Regionalism, which remained basically a Southern movement opposing the industrialization of the South. The Fugitives also included Robert Penn Warren, John Crowe Ransom, and Merrill Moore (qq. v.); the Agrarian-Regionalists added such names as Cleanth Brooks and John Gould Fletcher (qq. v.), with such authors as William Faulkner, Eudora Welty, and the more northerly Ruth Suckow (qq. v.) loosely associated with the Regionalist movement. The Regionalists voiced themselves through such prominent periodicals as the Southern Review (1935-42), The Kenyon Review (1939+), and The Sewanee Review (1892 +), of which Tate assumed the editorship from 1944 to 1946 . However, Tate's work, and that of many fellow Regionalists, is beyond narrow Regionalism. Tate is known for his intellectuality, concern with form, and restraint of emotion, both as a critic and as a poet. He has also written biographies of Stonewall Jackson (1928) and Jefferson Davis (1929).
1810. On the limits of poetry, selected essays: 19281948. New York, Swallow Press, 1948. 379 p. $\quad 48-8822$ PNio3r.T3

Selected from the author's previously published works: Reactionary Essays on Poetry and Ideas (1936), Reason in Madness (1941), and The Hovering Fly (1949).

181 1. Poems, 1922-1947. New York, Scribner, 1948. 208 p. $\quad 4^{8-5674} \mathrm{PS}_{3539 . \mathrm{A}_{74} \mathrm{P}_{5}^{8}}$

Earlier books of poetry by Allen Tate include Mr. Pope, and Other Poems (1928), Ode to the Confederate Dead .... (1930), Poems, 1928-193I (1932), Selected Poems (1937), and The Winter Sea (1945).

1812. Arnold, Willard B. The social ideas of Allen Tate. Boston, Bruce Humphries,

I955. $64 \mathrm{p}$. 54-9591 PS3539.A74Z6

\section{SARA TEASDALE, I884-1933}

Sara Teasdale's better poems, mainly lyrics of love and muted emotions, are handled with delicate control, and infused with quiet sincerity and simplicity. In subject and style her work is reminiscent of the later Igth century, although a few elements reveal the influence of the free verse and Imagist movements.

1814. The collected poems. New York, Macmillan, 1937. $311 \mathrm{p}$.

$$
\text { 37-28625 PS } 3539 . E_{15} 1937
$$

Contents.-Sonnets to Duse and other poems (1907).--Helen of Troy and other poems (IgII).Rivers to the sea (1915).-Love songs (1917).Flame and shadow (I920).-Dark of the moon (1926).- Stars to-night (1930).-Strange victory (1933).

\section{JAMES GROVER THURBER, 1894-}

James Thurber is a humorist in love with life and fantasy. His whimsical realism sometimes conceals a mordant satire, but his tone is usually gentle, for he finds more folly than depravity in the world. The illustrations he produces for his own work complement his prose, and are thought by some to be masterpieces of line drawing. Though a realistic appearance usually dominates, his work is occasionally somewhat eerie, and nightmares run loose in midday streets or Victorian drawing-rooms.

I816. Is sex necessary? or, Why you feel the way you do, by James Thurber and E. B. White. New York, Harper, 1929. $197 \mathrm{p}$. 
1817. Cream of Thurber, skimmed from the following writings and drawings of James Thurber: My life and hard times, The owl in the attic, The middle-aged man on the flying trapeze, Let your mind alone! London, Hamilton [1939] 250 p. illus. $\quad 40-6648 \mathrm{PS}_{3539} \cdot \mathrm{H}_{94} \mathrm{A6} \quad 1939$

1818. The Thurber carnival. New York, Harper, 1945. $3^{69}$ p. illus.

$$
\text { 45-1366 PS } 3539 . \mathrm{H}_{94} \mathrm{~T}_{5}
$$

1819. The Thurber album; a new collection of pieces about people. New York, Simon \& Schuster, 1952. 346 p. illus.

$$
\text { 52-10216 } \mathrm{PS}_{3539 \cdot \mathrm{H}_{94} \mathrm{~T}_{4} 6}
$$

1820. Thurber country; a new collection of pieces about males and females, mainly of our own species. New York, Simon \& Schuster, 1953. 276 p. illus.

53-9700 $\mathrm{PS}_{3539 . \mathrm{H}_{94} \mathrm{~T}_{53}}$

\section{I821. FREDERIC RIDGELY TORRENCE, $1875-195^{\circ}$}

Ridgely Torrence produced a restrained, conservative type of poetry. Although the volume of his work is very slim, he wrote what has been called flawless verse. His lyricism reached maturity in Hesperides ( 1925 ). $\mathrm{He}$ also experimented with Negro drama, preparing the way for others. As a poetry editor of The New Republic during the twenties, he gave encouragement to a number of younger poets.

1822. Poems. New ed., with new poems. New York, Macmillan, 1952. I27 p.

$$
\text { 52-3721 PS } 3539.063 \text { P6 } 1952
$$

\section{MARK ALBERT VAN DOREN, I894-}

Poet, editor, critic, lecturer, and professor of English at Columbia University, Van Doren for a number of years has been instrumental in the development of literary interest and taste in the United States. He is an exceedingly prolific poet, whose work expresses, sometimes symbolically, his sensitive response to life in America and to nature seen and enjoyed in rural areas. In 1940 his Collected Poems, 1922-1938 (1939) won the Pulitzer prize. He has written prose that is also poetical, as in a novel, Windless Cabins (1940), and much distinctive criticism.

1824. Jonathan Gentry. New York, Boni, I93I. 205 p. illus.

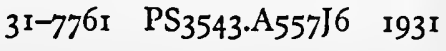

An epic poem of America, in three parts: "Ohio River (1800)"; "Civil War"; and "Foreclosure."

1825. The Mayfield deer. New York, Holt, i94I. $27 \mathrm{I}$ p. illus.

$$
\text { 4I-I2993 PS 3543.A557M3 I94I }
$$

Narrative poem based on an incident re-recorded in an Illinois county history, but told also as an episode of the Wisconsin frontier.

1826. Mortal summer. Iowa City, Prairie Press, Poem. 1953. 63 p. $54^{-18137} \mathrm{PS}_{3543 \cdot A_{557 M 6}}$

1827. Selected poems. New York, Holt, r954. ix, 238 p. $\quad 54-9660$ PS 3543 .A557 AI7 1954 This selection includes poems from the author's Spring Thunder, and Other Poems (1924), 7 P. M., and Other Poems (1926), Now the Sky, and Other Poems (1928), A Winter Diary, and Other Poems (1935), The Last Look, and Other Poems (1937), Collected Poems (1939), The Seven Sleepers, and Other Poems (1944), New Poems (1948), and Spring Birth, and Other Poems (1953). It does not include the long works: Jonathan Gentry, The Mayfield Deer, and Mortal Summer, which are entered above.

\section{I828. CARL VAN VECHTEN, I880-}

Van Vechten has been noted as an interpreter of jazz society life in New York City during the I920's. His first prominence came as a music critic, from which he branched off to essays in other fields. Essays from his early volumes were selected for Red: Papers on Musical Subjects (1925) and Excavations: $A$ Book of Advocacies (1926). The "earlier" Tiger in the House (1920) was a book on cats in history, folklore, and the arts. With Peter Whiffle (1922) Van Vechten turned to fiction, the form in which he became most famous; this was a humorous, "sparkling," "civilized" book about Bohemian life in New York before World War I. His last novel, Parties (1930) brought the record of frivolous life in New York City up to the depression. In 1932 he published a series of autobiographical essays in Sacred and Profane Memories. As the mode of life with which he is associated became a thing of the past, Van Vechten ceased to write extended works. Since then he has appeared primarily as an editor or as the author of introductions; much of his time has been devoted to photography.

I829. The blind bow-boy. New York, Knopf, I923. 261 p. 23-11805 PZ3.V368BI

A novel about fashionable life in New York in the I920's. 
1830. The tattooed countess; a romantic novel with a happy ending. New York, Knopf, r924.

286 p. $\quad 24-21077 \quad \mathrm{PZ}_{3} . \mathrm{V}_{3} 68 \mathrm{Ta}$

A commentary on the culture of a small Iowa town, to which the heroine returns on a visit to her sister. The time is the late igth century.

183x. Firecrackers; a realistic novel. New York, Knopf, 1925. 246 p.

$$
\text { 25-16657 } \mathrm{PZ}_{3} \cdot \mathrm{V}_{3} 68 \mathrm{Fi}
$$

A story of New York in the mid 1920's.

1832. Nigger heaven. New York, Knopf, 1926. 286 p. 26-15403 $\mathrm{PZ}_{3} . \mathrm{V}_{3} 68 \mathrm{Ni}$

A novel depicting Negro life and customs in Harlem.

1833. Spider boy; a scenario for a moving picture. New York, Knopf, 1928. 297 p.

A humorous novel on Hollywood.

$$
\text { 28-19963 } \mathrm{PZ}_{3} \cdot \mathrm{V}_{3} 68 \mathrm{Sp}
$$

1834. Jonas, Klaus W. Carl Van Vechten, a bibliography. New York, Knopf, 1955. xii, 82 p. 55-79 I I Z8926.J6

1835. Lueders, Edward G. Carl Van Vechten and the twenties. [Albuquerque] University of New Mexico Press, 1955. $150 \mathrm{p}$.

$$
\text { 55-545I } \mathrm{PS}_{3543 \cdot \mathrm{A} 653 \mathrm{Z8}}
$$

\section{HOWELL HUBERT VINES, 1899-}

The local-color novels of Howell Vines reflect the Warrior rivers country of northern Alabama. Although they do not have a strong plot line, and are not outstanding as works of characterization (with the region itself contending for the position of main character), they do have a position among works of regional literature. The author's style shows a sensitivity to the English spoken in the area, though more in its cadences and vocabulary than in the use of phonetic spellings of pronunciational variations, and his total effect is nearer to the experience of those who know the South at first hand than that of better-known writers.

1837. A river goes with heaven. Boston, Little, Brown, 1930. $290 \mathrm{p}$.

$$
\text { 30-29555 PZ3.V749Ri }
$$

1838. This green thicket world. Boston, Little, Brown, 1934. 375 p.
1839. GLENWAY WESCOTT, 1901-

With the publication of his first novel, The Apple of the Eye (1924), Wescott began to use regional themes drawn from aspects of life observed in his native state, Wisconsin. These include: the influence on a boy's developing instincts of life in a rural district of the state; a young man's nostalgic rediscovery of his ancestors, all the way back to pioneer days, from stories suggested by pictures in an old family album; and short stories descriptive of landscapes and localities, with overtones of social criticism. Before writing his later books the author was almost continually abroad for 9 years, on the Riveria and in Paris. From these expatriate years came influences that doubtless contributed to the writing of his short novel, The Pilgrim Hawk (1940), which introduces international elements, and to that of his war novel, Apartment in Athens (1945), concerned with the effects of the German occupation of Greece during World War II on a native family.

I 840. The grandmothers; a family portrait. New York, Harper, 1927. $338 \mathrm{p}$.

27 -26866 $\quad \mathrm{PZ}_{3} . \mathrm{W}_{512 \mathrm{Gr}}$

The story of a pioneer family in the Middle West.

I841. Good-bye Wisconsin. New York, Harper, 1938. 362 p. 28-21484 $\mathrm{PZ}_{3}$. W512Go

Short stories.

\section{NATHANAEL WEST, 1902-1940}

West wrote bitter satiric-comedy novels in a somewhat surrealistic manner. His stories range from that of a man who is editor of a New York newspaper advice-to-the-lovelorn column to a report on Hollywood as he saw it while he was a film writer there.

1843. Miss Lonelyhearts. New York, Liveright, 1933. 213 p. $\quad 33^{-14139} \quad \mathrm{PZ}_{3}$. W51952Mi

1844. The day of the locust. New York, Random House, 1939. $238 \mathrm{p}$.

$$
\text { 39-12578 } \mathrm{PZ}_{3} . \mathrm{W}_{51952 \mathrm{Day}}
$$

\section{EDITH NEWBOLD (JONES) WHARTON, 1862-1937}

Edith Wharton in her novels chronicled New York's decaying aristocracy of the late igth century. Her writings involve a degree of satire and irony directed at the faults of this small group, of which she herself was a part. A careful craftsman who had little direct influence on serious literature, she probably contributed much to raising the standards 
of popular fiction. Artistically she survives as a careful author of manners and as a regionalist. She depicted one segment of society without implying or perceiving aspects of the nature and direction of American society as a whole. One of her more deliberate attempts to depict the group she knew so well was her series entitled Old New York, which appeared in 1924 in four volumes which may be read as separate works; the individual titles under which they appeared were False Dawn (The 'Forties), The Old Maid (The 'Fifties), The Spark (The 'Sixties), and New Year's Day (The 'Seventies). In a few instances Edith. Wharton departed from portraying New York society by employing a New England or Middle West background, or by handling the theme of Americans in Europe.

1846. The valley of decision. New York, Scribner, 1902. 2 v. 2-6076 $\mathrm{PZ}_{3} . \mathrm{W}_{555} \mathrm{~V}$

1847. The house of mirth. London, New York, Macmillan, 1905. $5^{16} \mathrm{p}$.

44-44937 $\mathrm{PZ}_{3} . \mathrm{W}_{555} \mathrm{Ho2}_{2}$

1848. Ethan Frome. New York, Scribner, I9Ir. I95 p. II $-25015 \quad \mathrm{PZ}_{3}$. W555Et

1849. The reef. New York, Appleton, 1912. 366 p. $\quad 12-25996 \mathrm{PZ}_{3}$. W555 Re

1850. The custom of the country. New York, Scribner, I9I3. 594 p.

$$
\begin{array}{r}
\text { I3-22207 }^{\mathrm{PZ}_{3} . \mathrm{W}_{555} \mathrm{Cu}} \\
\mathrm{PS}_{3545 . \mathrm{H}_{6} 6 \mathrm{C} 8}
\end{array}
$$

1851. Xingu, and other stories. New York, Scribner, I9I6. $43^{6}$ p. I6-2I972 $\mathrm{PZ}_{3}$. W555X Contents.-Xingu.-C o m ing home.-Autre temps ...-Kerfol.-The long run.-The triumph of night.-The choice.-Bunner sisters.

1852. The age of innocence. New York, Appleton, I920. 364 p. 20-I86I5 PZ3. W 555 Ag

1853. The mother's recompense. New York, Appleton, 1925. $34 \mathrm{I} \mathrm{p}$.

$$
\text { 25-8793 } \mathrm{PZ}_{3} . \mathrm{W}_{555} \mathrm{Mo}
$$

1854. Hudson River bracketed. New York, Appleton, I929. $559 \mathrm{p}$.

$$
\text { 29-24077 PZ3. W555 Hu }
$$

Sequel: The Gods Arrive (New York, Appleton, 1932. 43 I p.).

1855. An Edith Wharton treasury; edited and with an introd. by Arthur Hobson Quinn. New York, Appleton-Century-Crofts, 1950. xxxi, $5^{81} \mathrm{p}$. 50-2775 $\quad \mathrm{PZ}_{3} . \mathrm{W}_{555} \mathrm{Ed}$
Contents.-The age of innocence.-The old maid.-After Holbein.-A bottle of Perrier.-The lady's maid's bell.- Roman fever.-The other two.Madame De Treymes.-The moving finger.Xingu.-Autre temps.-Bunner sisters.

1856. Nevius, Blake. Edith Wharton, a study of her fiction. Berkeley, University of California Press, I953. xi, $271 \mathrm{p}$.

$$
\text { 53-10439 PS } 3545 \cdot \mathrm{Hr}_{75}
$$

"The writings of Edith Wharton": p. 260-263. Bibliography: p. 264-265.

\section{JOHN HALL WHEELOCK, I886-}

Wheelock is a poet who began with rather exuberant poems, but before long turned to philosophic lyrics of moderated tone. Writing always in a traditional manner (in large part derived from Henley, Whitman, and the Romantics), his early verse at times reflected, as a background to his themes, life in New York; his later verse has usually been generalized insofar as any "setting" is concerned, but deals with love, loneliness, longing, and an awareness that "That too has passed away."

1858. Poems old and new. New York, Scribner, 1956. $203 \mathrm{p}$.

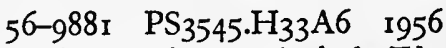

Wheelock's earlier volumes of poetry include The Human Fantasy (IgII), The Belovéd Adventure (1912), Love and Liberation (1913), Dust and Light (1919), The Black Panther (1922), The Bright Doom (1927), and Poems, 1911-1936 (1936).

\section{ELWYN BROOKS WHITE, I899-}

Long associated editorially with The New Yorker, E. B. White writes familiar essays with touches of sophisticated humor which have been called the best now being written in English. Commonly commenting on and reflecting life in urban (and suburban) America, usually in articles first written for The New Yorker, he also has a taste for rural life, as evinced in the essays he wrote for Harper's during the years in which he lived on a Maine farm. The serious undercurrent in his work has come to the fore in productions such as The Wild Flag (1946), which argued the cause for federal world government, and the booklet essay, Here Is New York (1949), which some have adjudged the best such literary description of the city that has been written. In addition to his prose, he has written light verse, as in The Lady Is Cold (1929) and The Fox of Peapack, and Other Poems (1938). 
1860. Everyday is Saturday. New York, Harper, 1934. $242 \mathrm{p}$.

$34-33063 \quad \mathrm{PS}_{3545 . \mathrm{H}_{5} \mathrm{I}_{7} \mathrm{E} 8} 1934$

"The paragraphs that make this book appeared first in the New Yorker."

1861. Quo vadimus? or, The case for the bicycle. New York, Harper, 1939. 219 p. 39-4681 PS $3545 . \mathrm{H}_{5187 Q 6} 1939$

1862. One man's meat. New York, Harper, 1942. $346 \mathrm{p}$. $\quad 42-16753 \quad \mathrm{PS}_{3545 . \mathrm{H}_{5} 187 \mathrm{O}_{5}}$

All but three of the essays are from the monthly department "One man's meat" in Harper's Magazine.

1863. The second tree from the corner. New York, Harper, 1954. 253 p.

Prose and poetry.

$$
{ }_{53-11864} \mathrm{PS}_{3545 . \mathrm{H}_{5} \mathrm{I}_{7} \mathrm{~S}_{4}}
$$

\section{THORNTON NIVEN WILDER, I897-}

As an author Thornton Wilder cannot readily be regarded as being in the main currents of modern fiction. He tends to write in a concise, expressive, and almost classical manner. In this he reveals his scholarly background, as also at times in his subject matter. Thus, The Woman of Andros (1930) is a novel based on Terence's Andria. Wilder started as a novelist with The Cabala (1926); however, in 1928 appeared his third book, a collection of short plays entitled The Angel that Troubled the Waters, and Other Plays, and since then he has gained considerable stature as a dramatist. In both fields his work has been experimental and lyrical; these aspects, combined with his frequent subtlety, his sparseness of detail, and a humor tending to gentle satire or irony, have at times perhaps obscured the omnipresent philosophical attitude: the concern with the nature of man and the problems of idealism, which are illumined by the mystical impulse which impregnates his writing.

1865. Our town, a play in three acts. New York, McCann, 1938. $128 \mathrm{p}$.

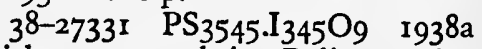

This play, which was awarded a Pulitzer prize for drama, is meant to depict life in the early 2oth century in a New Hampshire town, intended to typify American communities of the period.

1866. Heaven's my destination. New York, Longmans, Green, 1934. 244 p.

$$
\text { 35-4227 } \mathrm{PZ}_{3} . \mathrm{W}_{4} 68 \mathrm{He}
$$

An overtly realistic novel about a salesman who has undergone a religious conversion; though with tragic implications, the book is a comedy in which some Midwestern and Southern beliefs are examined.

1867. The bridge of San Luis Rey. New York, Boni, 1927. 235 p.

27-23452 $\mathrm{PS}_{3545 \cdot \mathrm{I}_{345} \mathrm{~B}}{ }_{1927}$

This novel, which received a Pulitzer prize, is about a group of people who were killed as the result of the collapse of a bridge in Peru. The stories are presented as derived from a book written by a Franciscan who had set out to establish that the deaths were the result of divine providence.

1868. The skin of our teeth, play in three acts. New York, Harper, 1942. I 42 p. $42-3642$ I PS $3545 \cdot \mathrm{I}_{345} \mathrm{~S}_{5}$

This unconventional comedy, which was awarded a Pulitzer prize for drama, attempts to present the history of civilized man through the story of a family living in Excelsior, New Jersey.

1869. The ides of March. New York, Harper, 1948. 246 p. $\quad 4^{8-647} \quad \mathrm{PZ}_{3}$.W6468Id

An epistolary novel, or "fantasia," centering about the life of Julius Caesar.

\section{I870. OSCAR WILLIAMS, 1900-}

Williams had an early start as a poet, but soon turned to the lucrative world of advertising. Then, after a fairly long period, he returned to poetry, and soon established a reputation as a poet of the city, expressed in an obviously "modern" verse that is heavily studded with figures of speech. An even greater reputation was established by Williams as anthologist of poetry. His anthologies, which have been widely praised for their receptivity to new and little-known poets, include $A$ Little Treasury of Modern Poetry, English and American (1946; rev. ed., 1950), A Little Treasury of Great Poetry, English and American (1947), A Little Treasury of American Poetry (1948), and The New Pocket Anthology of American Verse (I955).

1871. Selected poems. New York, Scribner, 1947.

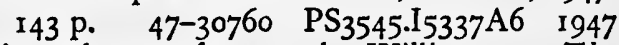
Earlier volumes of poetry by Williams are The Golden Darkness (192I), Adam \& Eve \& the City (1936), The Man Coming Toward You (1940), and That's All That Matters (1945).

1872. WILLIAM CARLOS WILLIAMS, 1883-

Williams was early a member of, but soon broke with, the Imagist school; however, he has always been a visual poet concerned with form and sound patterns as organic reinforcement of what 
he has to say. His poems reveal a humanitarian poet of social mores, ethics, and environment, who strives to establish a unique personal form and idiom. The cadences of speech pervade both his poetry and his prose. In both prose and poetry Williams is concerned with the question of what is "American," especially the localistic aspects as seen. in terms of his home area in New Jersey. This may be seen in the short stories of volumes such as The Knife of the Times, and Other Stories (1932) and Life Along the Passaic River (1938). A Voyage to Pagany (1928) is a novel about a smalltown doctor who goes to Europe with some ambition to write.

1873. In the American grain. New York, Boni, 1925. $235 \mathrm{p}$. 25-23403 E169.1. W52

Contents.-Red Eric.-The discovery of the Indies; Christopher Columbus.-The destruction of Tenochtitlan; Cortez and Montezuma.-The fountain of eternal youth; Juan Ponce de Leon.-De Soto and the New world.-Sir Walter Raleigh.--Voyage of the "Mayflower."-The founding of Quebec; Samuel de Champlain.-The Maypole at Merrymount; Thomas Morton.--Cotton Mather's Wonders of the invisible world: I. Enchantments encountered. 2. The trial of Bridget Bishop at Salem, The trial of Susanna Martin. 3. Curiosities.-Père Sebastian Rasles.-The discovery of Kentucky; Daniel Boone.-George Washington.-Poor Richard; Benjamin Franklin.-Battle between the Bon Homme Richard and the Serapis; John Paul Jones.-Jacataqua.-The virtue of history; Aaron Burr.-Advent of the slaves.-Edgar Allan Poe.Abraham Lincoln.

1874. White mule. Norfolk, Conn., New Directions, 1937. $293 \mathrm{p}$.

$$
\begin{array}{rr}
37^{-1} \text { I } 249 & \mathrm{PZ}_{3} . \mathrm{W} 67667 \mathrm{Wh} \\
\mathrm{PS}_{3545} \mathrm{I}_{544} \mathrm{~W}_{5}
\end{array}
$$

This novel was designed as the first part of a trilogy reflecting American manners; however, all three volumes can stand as individual works. The subsequent volumes were entitled In the Money and The Build-Up (vide infra).

1875. In the money. Norfolk, Conn., New Directions, 1940. $382 \mathrm{p}$.

$$
\text { 40-35170 } \mathrm{PZ}_{3} . \mathrm{W}_{67667} \mathrm{In}
$$

The second volume of a trilogy which began with White Mule (q.v.).

1876. Paterson. New York, New Directions,

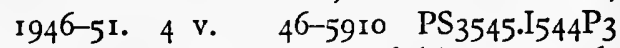

A fifth and concluding volume of this verse work was scheduled for publication in 1958 .
1877. A dream of love; a play in three acts and eight scenes. [New York, New Directions] 1948. 107 p. (Direction, 6)

$$
4^{8-8451} \quad \mathrm{AP}_{2 .} \mathrm{D}_{5} 8_{3}, \text { no. } 6
$$

1878. Collected later poems. [New York, New Directions $_{1}$ 1950. $240 \mathrm{p}$.

$$
\text { 50-11028 PS3545.I544A17 } 1950
$$

This is a collection of the poems Williams wrote during the 1940's, with the exception of the long poem on the author's New Jersey home town, Paterson (vide supra). Individual volumes of poetry which appeared in the period covered include The Broken Span (1941), The Wedge (1944), The Clouds, Aigeltinger, Russia, \&c. (1948), and The Pink Church (1949). During this period there also appeared in the New classics series of New Directions a volume of the Selected Poems (1949) of Williams.

1879. Make light of it; collected stories. New York, Random House, 1950. $342 \mathrm{p}$.

$$
\begin{array}{r}
\text { 50-10847 PZ3. W67667 Mak } \\
\text { PS } 3545 \text {.I544A6 } 1950
\end{array}
$$

1880. Autobiography. New York, Random House, I95I. $402 \mathrm{p}$.

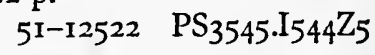

188I. Collected earlier poems. [New York, New Directions] 1951. $482 \mathrm{p}$.

$$
\text { 5I-8849 PS } 3545.1544 \mathrm{AI} 7 \text { I95I }
$$

Earlier volumes of poetry by Williams include Poems (1909), The Tempers (1913), A Book of Poems, Al Que Quierel (1917), Kora in Hell (1920), Sour Grapes (1921), Spring and All (1923), and An Early Martyr, and Other Poems (1935). An inclusive collection covering most of this period is The Complete Collected Poems ... 1906-1938 (1938).

I882. The build-up, a novel. New York, Random House, 1952. $335 \mathrm{p}$.

$$
\text { 52-5166 } \quad \mathrm{PZ}_{3} . \mathrm{W} 67_{7} 66_{7} \mathrm{Bu}
$$

The final volume of a trilogy which began with White Mule and In the Money (qq. v.).

I883. The desert music, and other poems. New York, Random House, 1954. 9o p.

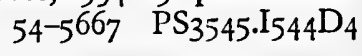

1884. Selected essays. New York, Random House, 1954. $34^{2} \mathrm{p}$.

$$
54-7815 \quad \mathrm{PS}_{3545} \text {.I544AI6 } 1954
$$

1885. Journey to love. New York, Random House, 1955. $87 \mathrm{p}$.

Poems. 55-8173 PS $3545.1544 J 6$ 


\section{2

1886. Koch, Vivienne. William Carlos Williams. Norfolk, Conn., New Directions, 1950. x, $27^{8}$ p. (The Makers of modern literature)

Bibliography: p. $267-273$. 50-697 PS $3545 \cdot \mathrm{I}_{544 \mathrm{Z}}$

\section{THOMAS WOLFE, 1900-1938}

Thomas Wolfe, the son of a stonecutter and his wife who kept a boarding-house, was born in Asheville, North Carolina, a hill city in a state proud of its mountains and the people who live among them. Educated at the University of North Carolina and at Harvard, he became a teacher in New York. Later, he was able to extend his experience by travel and observation of European civilization at first hand. The impact of these changing environments, and the combination of rags and riches about him before and during the great depression that began in 1929, influenced the development of ideas he poured forth in a spate, through the medium of his four massive novels. Sometimes mystically rhapsodic, at other times as naturalistic as those of Theodore Dreiser, these books are intensely autobiographical, as well as full of details of his family's experiences. Using an adaptation of the stream-of-consciousness technique, probably derived from his study of James Joyce, they reveal the author's unsuccessful search for permanent solutions for intellectual, philosophical, social, and economic problems observed in a world in flux. Because of their form as well as their meaning these novels are examples of a new direction still to be observed in American fiction.

1888. Look homeward, angel, a story of the buried life. New York, Scribner, 1929. 626 p. 29-22336 PZ3.W8314Lo

A biographical novel of Wolfe's youth, it traces the hero's youth through his attendance at the State University.

1889. Of time and the river; a legend of man's hunger in his youth. New York, Scribner, 1935. $912 \mathrm{p}$. 35-27095 PZ3.W8314 Of

A sequel to Look Homeward, Angel, this volume traces the hero's career through graduate work in playwriting at Harvard, teaching in New York City, and a European tour.

1890. The web and the rock. New York, Harper, 1939. 695 p. 39-27574 PZ3.W8314 We2

In some ways a sequel to Of Time and the River; however, the hero's name has been changed, and there is a recapitulation of his youth. The story then continues with his writing novels in New York, and having a love affair with a rich stage-designer. The book concludes with a trip to Germany.

189r. You can't go home again. New York, Harper, 1940. $743 \mathrm{p}$.

40-27633 PZ3.W8314Yo

A sequel to The Web and the Rock. The hero discovers that the home town he knew is lost in the past, and that the Germany he loved has been destroyed by Naziism. Much of the book reflects the pre-depression optimism and financial speculation in the twenties.

1892. The hills beyond. New York, Harper, i941. $386 \mathrm{p}$. 4I-21548 $\mathrm{PZ}_{3}$. W8314 $\mathrm{Hi}$

Contents.-The lost boy.-No cure for it.-Gentlemen of the press.-A kinsman of his blood.Chickamauga.-The return of the prodigal.- On leprechauns.-Portrait of a literary critic.-The lion at morning.-God's lonely man.-The hills beyond.-A note on Thomas Wolfe, by E. C. Aswell.

1893. Thomas Wolfe's letters to his mother, Julia Elizabeth Wolfe. Edited with an introd. by John Skally Terry. New York, Scribner, 1943. xxxv, $368 \mathrm{p}$. 43-6520 PS $3545 . \mathrm{O}_{337} \mathrm{Z}_{55}$

1894. Letters. Collected and edited, with an introd. and explanatory text, by Elizabeth Nowell. New York, Scribner, I956. xviii, 797 p. $5^{6-9880}$ PS $_{3545 . O_{337}} \mathrm{Z}_{4}$

1895. Adams, Agatha B. Thomas Wolfe, Carolina student; a brief biography. Chapel Hill, University of North Carolina Library, 1950. 91 p. (The University of North Carolina. Library extension publication, v. 15 , no. 2)

$$
\text { 50-63I83 } \mathrm{PS}_{3545 . \mathrm{O}_{337} \mathrm{Z6}}
$$

1896. Johnson, Pamela H. Hungry Gulliver; an English critical appraisal of Thomas Wolfe. New York, Scribner, 1948. $170 \mathrm{p}$.

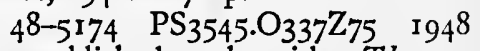

London edition published under title: Thomas Wolfe.

1897. Muller, Herbert J. Thomas Wolfe. Norfolk, Conn., New Directions Books, 1947. 196 p. (The Makers of modern literature)

$$
\text { 47-11790 PS } 3545 . O_{33778}
$$

1898. Pollock, Thomas C., and Oscar Cargill, eds. Thomas Wolfe at Washington Square. New York, New York University Press, 1954. xiii, I63 p. illus.

$54-5275 \quad \mathrm{PS}_{3545 . \mathrm{O}_{337} \mathrm{Z}_{3}}$

Contents.-Thomas Wolfe at Washington Square, by O. Cargill.-Memorabilia. His students 
remember: Drunk with words, by A. G. Doyle. Overloaded black briefcase, by B. W. Kofsky. Thomas Wolfe, a reminiscence, by J. Mandel. His colleagues remember: and gladly teche ... by $R$. Dow. Tom Wolfe: penance no more, by $H$. T. Volkening. My experiences with Thomas Wolfe, by V. Fisher. Replacing Tom Wolfe, by R. Krauss.-Bibliography (p. 153-163).

1899. Rubin, Louis D. Thomas Wolfe; the weather of his youth. Baton Rouge, Louisiana State University Press, 1955. I 83 p. illus.

$$
55-7364 \quad \mathrm{PS}_{3545 . O_{337} \mathrm{Z}_{5}}
$$

1900. Walser, Richard G., ed. The enigma of Thomas Wolfe; biographical and critical selections. Cambridge, Harvard University Press,

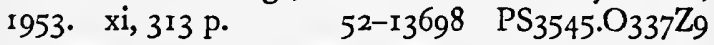

rgor. Watkins, Floyd C. Thomas Wolfe's characters, portraits from life. Norman, University of Oklahoma Press, 1957. $194 \mathrm{p}$.

$$
\text { 57-7335 PS } 3545 . \mathrm{O}_{337} \mathrm{Z}_{94}
$$

\section{ELINOR (HOYT) WYLIE, r887-1928}

Although she wrote several novels, Elinor Wylie is better known for her poetry, which has been praised for clarity, brilliancy, delicateness, brittleness, and a mastery of technique. Influenced by Donne and the metaphysicals, she was not of them. Her verse is limited in range, but displays great artistic integrity.

1903. Collected poems. [Edited by William Rose Benét] New York, Knopf, I932. 31 I p. 32-26577 $\mathrm{PS}_{3545 . Y_{45}}{ }_{1932}$

"The contents of this book embody the contents of Elinor Wylie's four books of poems, Nets to
Catch the Wind (1921), Black Armour (1923), Trivial Breath (1928), and Angels and Earthly Creatures (1929), in the exact sequence and order in which they were originally published. Added to these is a section of poems hitherto uncollected in book form, some of which have been previously published in periodicals."-Foreword.

1904. Collected prose. New York, Knopf, 1933. 879 p. $\quad 33-27444$ PS $3545 . Y_{45}$ Ar6 1933 Contents.-Jennifer Lorn, with a preface by C. Van Vechten.-The Venetian glass nephew, with a preface by C. Van Doren.-The orphan angel, with a preface by S. V. Benét.-Mr. Hodge and Mr. Hazard, with a preface by Isabel Paterson.-Fugitive prose, with a preface by W. R. Benét.

\section{MARYA ZATURENSKA, 1902-}

Although Marya Zaturenska was born in Russia, whence she came to America as a child, she has written distinguished poetry in English, and has found for herself a place in modern American poetry. Her subtle, lyrical verse won for her a Pulitzer prize for poetry, for her volume Cold Morning Sky. In addition to poetry she has, with her husband Horace Gregory (q. v.), produced a history of modern American poetry; by herself she has written a biography of Christina Rossetti (1949), whom she in some ways resembles.

1906. Selected poems. [New York ${ }_{1}$ Grove Press, 1954. $130 \mathrm{p}$.

54-8I I I PS 3549.A77A6 I954

In addition to new poems, this volume contains selections from the earlier books Threshold and Hearth (1934), Cold Morning Sky (1937), The Listening Landscape (194I), and The Golden Mirror (1944).

\section{F. The Second World War and the Atomic Age (1940-1955)}

It should be candidly admitted that this final section of "Literature" was split off from the preceding one largely as a matter of convenience. Hence, the logic of listing a dozen or more writers in this, rather than in the preceding, section is tenuous at best and cannot be completely sustained by argument. The more important writers belong to both periods and have contributed to most of the trends observable in both. That a new period is in the making, however, seems clear.

The years 1940-1955 were among the most mo- mentous in recorded history. In them the atomic bomb was brought into production and used as a means for winning the most destructive war the world has seen. Within the decade after the first bomb was dropped in 1945 tensions accompanying the progress of the atomic age spread over countries and continents until the whole world was, and is, affected. During these years American authors and their readers began living in a new international age. This era of international preoccupations was brought into being, not by a common language of 


\section{I54 / A GUIDE TO THE UNITED STATES}

scholarship and a common form of religion, as in the Middle Ages, but by an uneasy peace and a shared uncertainty concerning the future of human beings in a world brought together, for good or ill, by scientific discoveries which have annihilated distances that formerly contributed to a sense of safety within national boundaries.

The final effects of these forces with which modern man is at grips are hidden in the future. So far as their impact on American literature is concerned only a much longer historical perspective than that now available can contribute to a reliable verdict. It is, however, already a matter of literary history that William Faulkner, Eugene O'Neill, T. S. Eliot, and other contemporary writers whose works have been described in the preceding section have contributed to a second American renaissance, occurring roughly between 1920 and 1940. They have established their reputations, their places at the bar of contemporary criticism, and given to the "one world" of the atomic age an expression of American culture at its present state of maturity. For the purposes of this final section devoted to literature, attention is therefore focused on younger authors writing at mid-century, from whose work must be derived such evidence as exists of the new literary directions currently being taken.

One obvious point of departure for assessing trends in current literature is provided by writers' use of war as a theme. It will be remembered that the First World War was reflected in literature produced by a "lost generation" of disillusioned authors. Their pessimism after the failure of America's crusade to "make the world safe for democracy" contributed to the philosophy of deterministic natural. ism that pervaded much of their writing. The writers who participated in or observed the Second World War never hoped that their struggle would end war or bring peace all over the earth. They had fewer illusions to lose than had their seniors; hence, the trend of their writing about the last war is away from the deterministic "closed system" variety of naturalism and toward an "open ended" relativistic naturalism, with symbolic overtones, but occasionally owing much to the reportorial style developed by numerous correspondents whose work, it has been said, made this the most fully reported war in history.

Another characteristic of contemporary creative writing, including poetry, is its frequent use of language formerly considered, in general, too crude or unpleasant to be used in "polite society" and hence seldom or never embodied in literary expression. This uncommon "language of common men" is sometimes employed with such fidelity as to shock the segment of the reading public that has been educated in classic American literature characterized by decorous, even elegant, language, as so much of the best 19th-century writing was. Some critics feel that this shock treatment, used deliberately, not only achieves realism for characters to whom the language used would be natural, but also awakens complacent readers to awareness of conditions about which they may prefer to remain ignorant. It is doubtless true, also, that contemporary writing reflects one of the recurring changes in taste and manners that literature has mirrored down the ages.

Not merely the language used but also the subjects popularly treated by contem porary writers have undergone further change. Uncovering hidden abnormalities and compulsions in the lives of deviate individuals, or even in lives that on the surface appear commonplace, if not normal, has also had a part in this further break with the genteel tradition after its disruption by Theodore Dreiser and others in preceding periods. Not all the novels, short stories, and plays that feature this interest are grim. Irony, humor, fantasy, symbolism, Gothic horror, and the use of native American themes drawn from the historical past all lend variety and interest to much of this type of work. Even the bitterness, satire, and cynicism with which the darker aspects of contemporary life are frequently portrayed by young writers are, according to some critics, an indirect revelation of the moral indignation of the authors against private and public indifference to such conditions, as well as society's backwardness in coping with them. These authors are not reformers on a national scale, however, as were many earlier American writers who concerned themselves with large social and economic problems in the United States. It appears that literary artists today think of the spiritual and social problems of man in the contemporary world primarily in clinical and secondarily in sociological or anthropological frames of reference, rather than in the religious, political. socioeconomic frames of the past.

Literary criticism continues to flourish. It has been justly said that the creative-writer-critic and particularly the poet-critic constitute one of the most striking phenomena present in American literature today. It is also interesting to note that at a time when the United States is called the strongest defender of Western civilization such a volume of critical exposition is available for the understanding of America's own civilization, so far as it is reflected in literature. Long before literary historians could possibly complete their work of review and synthesis current studies by highly competent critics have been carried to interested national and international audiences by means of journals of literary opinion pub. 
lished both by university and commercial presses. Whether or not contemporary writing and the criticism of that writing reveal the American mind and spirit "in the round," the revelation that has been made is known far beyond the bounds of the United States. Writers, therefore, assume an increasing responsibility as representatives of their country in the world.

With respect to developments in American poetry, the critics emphasize: a departure from the use of experimental forms developed by the poets' forerunners; a return to lyricism; and a trend toward neo-classicism. Some commentators have undertaken to defend poets from charges of wilful complexity and obscurity leveled against them, sometimes by their peers. The champions of the "difficult" poets point out that the times reflected in poetry also are complex, hence not susceptible to treatment in simple, obvious terms; and that, moreover, good poetry has never been easy poetry. The reader's intelligence has its own part to play in reaching the poet's true meaning.

Finally, two striking and related aspects of literature during this fifteen-year fragment of a period are its extent and its accessibility. Men of letters, who constituted such a small fraction of American professional society in the early years of the country's history, now play a role enhanced in importance by their growing numbers and by their productivity. New avenues also tend to open out more widely to accommodate the distribution of their work. One of these is provided by the great increase in numbers of students receiving education at the college level. While stringent critics of education have been heard to deny that college education implies more than a minimum literacy for the student, the fact remains that the general effects of a national literary tradition are much more widespread than ever before. Even without formal higher education the citizen of today is constantly besieged by claims on his attention of ideas gleaned from his radio, his television, the motion picture theater he attends, and the reprints of books purchased cheaply at his local drugstore. The heterogeneous audience created by this interplay of education, entertainment, and information is not universally discriminating; consequently much of the writing designed to attract it is commercially inspired to win popular approval and to increase profits. However, one of the hopeful signs of the literary times is the dissemination of serious literary work by modern mass media of communication. At home and abroad the opportunities-and responsibilitiesof American writers are greater than in any earlier period.

\section{JAMES AGEE, rg09-1955}

Agee's serious and fastidious writing is marked by moral indignation at the faults of contemporary society and by his power to express his judgments with poetic intensity, in a highly individualistic vocabulary. His prose works include Let Us Now Praise Famous Men (I94I), a documentary text to photographs by Walker Evans, a book which is a biting arraignment of the system of farm tenantry in Alabama cotton production; and The Morning Watch (195I), a long short story of a twelve-year-old boy's inner conflicts and adjustments.

1908. Permit me voyage [poems] With a foreward by Archibald MacLeish. New Haven,

Yale University Press, 1934. 59 p. (The Yale series of younger poets, edited by $\mathrm{S}$. V. Benét)

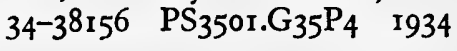

\section{LOUIS AUCHINCLOSS, I9I7-}

Auchincloss is a novelist of manners dealing with well-to-do elements of New York City society, somewhat in the tradition of Edith Wharton and Henry James (qq. v.). His first book, The Indifferent Children (1947) was published under the pseudonym of Andrew Lee.

19ro. The injustice collectors. Boston, Houghton Miflin, r950. $24^{8} \mathrm{p}$.

Short stories.

$$
\text { 50-14014 PZ3.A898IP }
$$

I9I I. Sybil. Boston, Houghton Mifflin, I952 [i. e. 195I] 284 p. 5I-8774 PZ3.A898Sy

1912. A law for the lion. [Cambridge, Mass.] Houghton Mifflin, 1953. $279 \mathrm{p}$.

$$
\text { 53-5728 } \mathrm{PZ}_{3 . \mathrm{A} 898 \mathrm{Law}}
$$

1913. The romantic egoists. Boston, Houghton Mifflin, 1954. 2 ro p.

Short stories.

$$
\text { 54-5984 PZ3.A898Ro }
$$

\section{JAMES BALDWIN, 1924-}

Baldwin in his first novel tells the story of a young Harlem Negro's spiritual problems and orthodox "salvation." The flashback technique is used to present the family background and to give the work wider scope for its oblique comment on morality and mores.

1915. Go tell it on the mountain. New York, Knopf, r953. 303 p.

52-12199 PZ4.Br8Go 


\section{SHIRLEY FRANCES BARKER, I9r I-}

Shirley Barker first appeared before the public as a poetess. Her The Dark Hills Under (1933) was published in The Yale series of younger poets. This volume presaged her interest in New England in general and her native New Hampshire in particular. To this setting she has regularly returned, most notably as a historical novelist dealing with the colonial period. However, in Fire and the Hammer (I953) she deals with Pennsylvania and New Jersey at the time of the Revolutionary War.

1917. Peace, my daughters. New York, Crown, 1949. 248 p. $49-1164 \quad \mathrm{PZ}_{3} \cdot \mathrm{B}_{2457} \mathrm{Pe}$

A novel about the Salem witchcraft trials.

I918. Rivers parting. New York, Crown, r950. 3II p. 50-r4406 PZ3.B2457 Ri

A novel set in 17 th century England and New Hampshire.

1919. A land and a people; a book of poems. New York, Crown, 1952. $78 \mathrm{p}$.

$$
{ }_{52-5683} \mathrm{PS}_{3503} \cdot \mathrm{A}_{5} 68_{4} \mathrm{~L}_{3}
$$

1920. Tomorrow the new moon. Indianapolis, Bobbs-Merrill, r955. 354 p.

$$
\text { 55-6820 PZ3.B2457 To }
$$

A novel reflecting life in New England during the period of Cotton Mather.

\section{SAUL BELLOW, 1915-}

With his third novel, The Adventures of Augie March, Bellow received wide, though not unanimous literary acclaim. A picaresque styled narrative about a Chicago Jew, it is a somewhat humorous, but not highly introspective fictional statement of the view that life is worth living.

1922. The adventures of Augie March. New York, Viking Press, 1953. $536 \mathrm{p}$.

$$
\text { 53-7953 PZ3.B4r937Ad }
$$

\section{JOHN BERRYMAN, 1914-}

Berryman practices a highly crafted verse somewhat in the tradition of Wallace Stevens. His quiet, philosophic poems have been appearing in leading literary periodicals since the early thirties. Prominent mainly as an example of the modern trend in poetry, Berryman has also written an important study of Stephen Crane, and has done much critical work.

1924. The dispossessed. [Poems] New York, Sloane, 1948. ro3 p.

$$
4^{8-6929} \mathrm{PS}_{3503 . E_{744} \mathrm{D}_{5}}
$$

\section{ELIZABETH BISHOP, 19II-}

Elizabeth Bishop's New England birth and rearing set against her visits to Key West have in part resulted in a poetry fusing a northern conservatism and a tropical luxuriance. Her work has been commended for metrical skill, ironic humor, incisive imagery, and keen powers of observation. Like most modern American poets, her work tends to appear first in periodicals. The first volume of this not very prolific poetess was North \& South (1946).

1926. Poems: North \& south. A cold spring. Boston, Houghton Mifflin, 1955. 95 p. 55-7003 $\mathrm{PS}_{35}{ }^{03} . \mathrm{I}_{7} 85 \mathrm{P} 6$

\section{PAUL FREDERIC BOWLES, rgro-}

Bowles has been regarded by some critics as one of the most forceful of the younger writers of fiction. His work is usually a picture of the modern sterility of spirit followed by a disintegration of personality; the stories are commonly evolved in terms of the civilized in contact with the primitive, frequently with an African setting. Thus Bowles projects and personifies some of the more strident overtones of modern life; this results in what might be called horror stories, but the horror is derived more from the psychological implications than from the gruesome physical facts. These qualities have placed him to the fore among authors of the modern Gothic tale. It could be said that Bowles presents a pessimistic waste land in prose fiction. He has also acquired a considerable reputation as a composer.

1928. The sheltering sky. [New York] New Directions, $1949.318 \mathrm{p}$. 49-1 1888 $\quad \mathrm{PZ}_{3} \cdot \mathrm{B} 682 \mathrm{Sh}$

I929. The delicate prey, and other stories. [New York Random House, 1950. 307 p.

$$
\text { 50-10899 } \mathrm{PZ}_{3} . \mathrm{B} 6826 \mathrm{De}
$$

Contents.-At Paso Rojo.-Pastor Dowe at Tacaté.-Call at Corazon.--Under the sky.-Señor Ong and Señor Ha.-The circular valley.-The echo.-The scorpion.- The fourth day out from Santa Cruz.-Pages from Cold Point.-You are not I.-How many midnights?-A thousand days to Mokhtar.-Tea on the mountain.-By the water.The delicate prey. $-A$ distance episode.

1930. Let it come down. New York, Random House, 1952. 3 II p. 
1931. The spider's house. New York, Random House, 1955. $406 \mathrm{p}$.

$$
\text { 55-8169 } \quad \mathrm{PZ}_{3} \cdot \mathrm{B} 6826 \mathrm{Sp}
$$

\section{RAY BRADBURY, 1920-}

Bradbury, one of the more popular sciencefiction authors, represents a rapidly growing field of American writing. Although the field has usually been dismissed as pulp fiction, the quality of Bradbury's work has attracted the attention of many literary critics. His tales, often touched with humor, are usually works of fantasy or horror. Although commonly set in the future, they often indirectly comment on present-day society; so much so that his novel, Fahrenheit 45I (1953), becomes in part a social tract in its portrayal of a regimented society in which books are banned.

1933. Dark carnival. Sauk City, Wis., Arkham House, 1947. 313 p.

Short stories.

$$
47^{-24598} \quad \mathrm{PZ}_{3} \cdot \mathrm{B}_{72453} \mathrm{Dar}
$$

1934. The Martian chronicles. Garden City, N. Y., Doubleday, 1950. $222 \mathrm{p}$.

$$
\text { 50-7660 } \mathrm{PZ}_{3} \cdot \mathrm{B}_{72453} \mathrm{Mar}
$$

1935. The illustrated man. Garden City, N. Y., Doubleday, 195I. 25I p.

Short stories.

$$
\text { 5I-I I } 40 \quad \mathrm{PZ}_{3} \cdot \mathrm{B}_{72453} \mathrm{II}
$$

1936. The golden apples of the sun. Garden City, N. Y., Doubleday, 1953. $25^{\circ}$ p. illus.

Short stories. $5^{2-1} 3569 \quad \mathrm{PZ}_{3} \cdot \mathrm{B}_{72453} \mathrm{Go}$

\section{GWENDOLYN BROOKS, I9I7-}

Gwendolyn Brooks is a Negro author who was born in Kansas and later moved to Chicago, which is reflected in much of her writing. Her first volume of poetry, A Street in Bronzeville (1945), was generally well received as expressing Negro urban life; in 1950 for her second book she was awarded a Pulitzer prize for poetry.

1938. Annie Allen. New York, Harper, 1949. 6o p. $\quad 49^{-10072} \quad \mathrm{PS}_{3503} \cdot \mathrm{R}_{7244} \mathrm{~A}_{7}$

1939. Maud Martha. New York, Harper, 1953. $180 \mathrm{p}$. 53-7726 $\quad \mathrm{PZ}_{4} \cdot \mathrm{B}_{72} \mathrm{Mau}$

A novelette, with a Chicago setting, about a young Negro woman and her love.

\section{JOHN HORNE BURNS, I9r6-}

The first book by Burns was a war novel, The Gallery, which depicted the great sympathy, and with what some have thought sentimentality, the Italians during the American occupation. His second book, Lucifer With a Book, was an attack on aspects of the private school system in America. $A$ Cry of Children is the story of an unsatisfactory love affair which crosses social lines, but includes vignettes of the modern American city and presents on several levels the conflicts of a changing morality. Burns' books are written in a realistic, "non-literary" manner, and they have been said to evidence an "inverted puritanism."

194I. The gallery. New York, Harper, 1947. 342 p. $\quad 47-4090 \quad \mathrm{PZ}_{3}$. B93702Gal

1942. Lucifer with a book, a novel. New York, Harper, 1949. $34^{\circ} \mathrm{p}$.

$$
\text { 49-8269 PZ3.B93702Lu }
$$

1943. A cry of children. New York, Harper, 1952. 276 p. $\quad$ 52-9547 $\mathrm{PZ}_{3} \cdot \mathrm{B} 93702 \mathrm{Cr}$

\section{TRUMAN CAPOTE, 1924-}

Mr. Capote's style has been characterized as rich, eloquent, and simple, with a remarkable suggestive power. Others say that he is precocious and exotic, or even decadent. Some say his stories with Southern settings have a folktale quality which bespeaks the humor and tenderness with which he approaches his characters and presents life as essentially sad, but redeemed by humor and tenderness. Others find his subject matter reprehensible. He is sympathetic toward and understanding of children and deviate individuals.

1945. Other voices, other rooms. New York, Random House, r948. $23 \mathrm{I}$ p.

$48-5135 \quad \mathrm{PZ}_{3} \cdot \mathrm{C}_{1724} \mathrm{Ot}$

A novel in which a lonely youth confronts abnormality and eccentricity in a relatively isolated and rundown Louisiana mansion.

1946. A tree of night, and other stories. New York, Random House, 1949. 209 p. 49-7722 PZ3.Ci724 Tr

Modern Gothic stories with psychological or supernatural settings wherein abnormal individuals abound.

1947. The grass harp. [New York ${ }_{\text {] }}$ Random House, I95I. I8I p.

$$
\text { 5I-r3ror } \mathrm{PZ}_{3} \cdot \mathrm{C}_{1724} \mathrm{Gr}
$$

A symbolistic book of fantasy and the grotesque, in which the unimaginative life of conformity is 
attacked. Three leading characters take up residence in a tree to provide the central episode about which the story revolves. The work also appeared as a stage play.

\section{JOHN CIARDI, 1916-}

Ciardi is a poet who has often used World War II as theme, or as a source of imagery for his nonwar poems. Besides the war, his themes are commonly America, love, and death. He has written both descriptive and symbolic poetry, usually with a highly concrete form of presentation. In addition to writing poetry, he has produced an anthology of the work of young American poets: MidCentury American Poets (1950).

1949. Homeward to America. New York, Holt, 1940. 62 p. 40-3997 $\mathrm{PS}_{3505 . I 27 H 6} 1940$

1950. Other skies. [Poems] Boston, Little, Brown, 1947. 83 p.

$$
\text { 47-31468 } \mathrm{PS}_{3505 \cdot \mathrm{I} 27 \mathrm{O} 8}
$$

1951. Live another day; poems. New York, Twayne, 1949. $88 \mathrm{p}$.

$$
\text { 49-10624 } \mathrm{PS}_{3505 . \mathrm{I}_{2}} \mathrm{~L}_{5}
$$

1952. From time to time. [Poems] New York, Twayne, 1951. 84 p. (The Twayne library

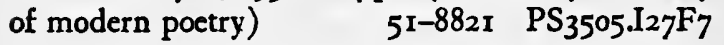

1953. As if; poems new and selected. New Brunswick, N. J., Rutgers University Press, 1955. $143 \mathrm{p}$. 55-9956 PS 3505.I27A75

1954. WALTER VAN TILBURG CLARK, 1909-

Clark is a novelist who depicts the West and, more particularly, Nevada. His first book revolved about an erroneous lynching; his second portrayed a Reno youth who wished to be a composer; and his third was the story of a hunt for a mountain lion. His works demonstrate a psychological awareness and a tendency to infuse symbolic overtones into his realistic presentations.

1955. The Ox-Bow incident. New York, Random House, 1940. 309 p.

$$
4^{0-33213} \mathrm{PZ}_{3} \cdot \mathrm{C}_{54} 8_{3} \mathrm{Ox}
$$

1956. The city of trembling leaves. New York, Random House, 1945. $690 \mathrm{p}$.
1957. The track of the cat, a novel. New York, Random House, 1949. 404 p.

49-903I $\mathrm{PZ}_{3} \cdot \mathrm{C}_{5483} \mathrm{Tr}$

1958. The watchful gods, and other stories. New York, Random House, 1950. 306 p. 50-9687 PS $3505 . \mathrm{L}_{37} 6 \mathrm{~W}_{3}$

Contents.-Hook.-The wind and the snow of winter.-The rapids. - The anonymous. - The buck in the hills.-Why don't you look where you're going?-The Indian well.-The fish who could close his eyes.-The portable phonograph.-The watchful gods.

\section{AUGUST WILLIAM DERLETH, r909-}

August Derleth is a prolific author of books on Wisconsin. His most prominent works, his historical novels, are sometimes criticized for their slow pacing. Selected Poems (1944) contained a representative group of his largely regional poems. Wisconsin Earth, A Sac Prairie Sampler (1948) republished in one volume Shadow of Night, Place of Hawks, and Village Year: A Sac Prairie Journal. In addition he has written a number of mystery stories and edited anthologies in that field. He has also edited a number of science-fiction anthologies, such as Strange Ports of Call (1948), Beachheads in Space (1952), Time to Come (1954), and Portals of Tomorrow (1954).

1960. Wind over Wisconsin. New York, Scribner, 1938. $391 \mathrm{p}$.

38-27410 $\mathrm{PZ}_{3} \cdot \mathrm{D}_{445 \mathrm{Wi}}$

This second volume of the Sac Prairie Saga takes place in the 1830's, the last years of the Indian wars.

1961. Restless is the river. New York, Scribner, 1939. 514 p. 39-27856 PZ $3 . D_{445} R e$

Pioneer life from 1839 to 1850 in the Sac Prairie country.

1962. Bright journey. New York, Scribner, 1940. $424 \mathrm{p}$. 40-33102 $\mathrm{PZ}_{3} \cdot \mathrm{D}_{445} \mathrm{Br}$

Frontier Wisconsin from 1812 to 1840 is reflected in this novel about fur trade in the Northwest Territory.

1963. Country growth. New York, Scribner, 1940. $322 \mathrm{p} . \quad 4^{0-1174^{8}} \quad \mathrm{PZ}_{3} \cdot \mathrm{D}_{4447} \mathrm{Co}$

Short stories.

1964. Evening in spring. Sauk City, Wis., Stanton \& Lee, $1945.308 \mathrm{p}$.

$$
4^{6-781} \quad \mathrm{PZ}_{3} \cdot \mathrm{D}_{445} \mathrm{Ev} 2
$$

A novel of adolescence in a Wisconsin village. 
1965. Village daybook: a Sac Prairie journal. Chicago, Pellegrini \& Cudahy, 1947. $306 \mathrm{p}$. illus. $47-3074 \quad \mathrm{PS}_{3507 . \mathrm{E}_{6} \mathrm{~V}_{4}}$

\section{RALPH ELLISON, 1914-}

The first novel of this Negro novelist traces the life of a Negro from his adolescence in the South to maturity in New York. The prose is at times surrealistic.

1967. Invisible man. New York, Random House, 1952. $439 \mathrm{p}$. 52-5159 PZ4.E47In

1968. PAUL HAMILTON ENGLE, 1908-

Paul Engle is an Iowa poet and teacher who has incorporated much of his knowledge of the land and his love of America in his verses. These in their usual affirmativeness have been accredited to the Whitman tradition, although echoes of MacLeish and other modern authors may be heard in Engle's writings. Also, his poetic craftsmanship has in recent years become both more formal and more accomplished. His first book of poems was Worn Earth (1932), which was included in The Yale series of younger poets. This was followed by American Song (1934) and Break the Heart's Anger (1936), which contain poems reflecting his life abroad as a Rhodes scholar, and also his increasing awareness of the social issues and attitudes of the period. Corn (1939) is something of a transition book, for it reflects his return to America and his taking as theme the Iowan farmer and the dominating virtues of America. His work since then has reflected his position as an Iowan, a professor, a father, and a native citizen of America. His position as a scholar is indicated by Reading Modern Poetry (1955), an anthology with commentary which he produced with Warren Carrier.

1969. Always the land. New York, Random House, I94I. 326 p.

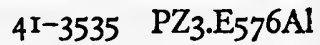

A poetic novel of Iowan farm life.

1970. West of midnight. New York, Random House, 1941. $96 \mathrm{p}$.

Poems.

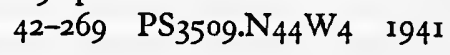

1971. The word of love. [Poems] New York, Random House, 1951. 39 P.
1972. American child; sonnets for my daughters, with thirty-six new poems. New York, Dial Press, 1956. 102 p.

56-9509 PS $3509 . N_{44} \mathrm{~A} 68 \quad 1956$

The first part of this was first collected in book form under the title American Child, a Sonnet Sequence (1945).

\section{HOWARD MELVIN FAST, 1914-}

Mr. Fast is a leftist novelist of much technical skill. Most of his work is in the form of the historical novel. In the main, these read extremely well. However, he slants his material obviously to influence readers rather than to render a comprehensive, objective view of his subject. Fast's most recent book, Silas Timberman (1954), the story of a quiet, conservative professor who ends up in jail because of his opposition to views of educationalists and members of Congress, who regard him as a Communist, is obvious propaganda.

1974. Conceived in liberty; a novel of Valley Forge. New York, Simon \& Schuster, 1939. $389 \mathrm{p}$. 39-27589 $\mathrm{PZ}_{3} . \mathrm{F}_{2} 65 \mathrm{Co}$

A novel based on the experiences of the American Army during the winter months at Valley Forge during the American Revolutionary War.

1975. The last frontier. New York, Duell, Sloan \& Pearce, 194I. 307 p.

$4^{\mathrm{I}-\mathrm{I} 3229 \quad \mathrm{PZ}_{3} \cdot \mathrm{F}_{2} 65 \mathrm{Las}}$

A story of Cheyenne Indians leaving an Oklahoma reservation in 1878 in a last striving for dignified survival.

1976. The unvanquished. New York, Duell, Sloan \& Pearce, 1942. $3^{16} \mathrm{p}$. 42-16612 $\quad \mathrm{PZ}_{3} \cdot \mathrm{F}_{26} 6 \mathrm{Un}_{\mathrm{n}}$

A novel based on the life of George Washington during the Revolution.

:1977. Citizen Tom Paine. New York, Duell, Sloan \& Pearce, 1943. 34r p.

$$
43-5 \mathrm{II}_{39} \quad \mathrm{PZ}_{3} \cdot \mathrm{F}_{2} 65 \mathrm{Ci}
$$

A fictionalized account of Tom Paine's life in both Europe and America, with some emphasis on the Revolutionary period.

1978. The American, a Middle Western legend. New York, Duell, Sloan \& Pearce, 1946. 337 p. $\quad 46-25220 \quad \mathrm{PZ}_{3}$.F $265 \mathrm{Am}$ A novel based on the life of John Peter Altgeld, a liberal Illinois politician and Governor of that State in the late igth century. 
1979. My glorious brothers. Boston, Little, Brown, 1948. 280 p. 48-8762 $\quad \mathrm{PZ}_{3} . \mathrm{F}_{2} 65 \mathrm{My}$

The story of the freeing of Israel from SyrianGreek rulers r oo years before Christ.

1980. The passion of Sacco and Vanzetti, a New England legend. New York, Blue Heron Press, 1953. 254 p. 53-3420 PZ3.F265Pas $A$ view of the events behind the execution of Nicola Sacco and Bartolomeo Vanzetti in 1927.

1981. JEAN GARRIGUE, 1912-

Jean Garrigue is a subjective poetess of minor scope who presents her emotions in a word-conscious verse that is reminiscent of Wallace Stevens.

1982. The ego and the centaur. [Poems. New York, New Directions] 1947. 126 p. 47-30700 $\mathrm{PS}_{35} \mathrm{I}_{3} \cdot \mathrm{A}_{7217} \mathrm{E}_{4}$

1983. The monument rose, poems. New York, Noonday Press, 1953. $5^{8} \mathrm{p}$. 53-10701 PS3513.A7217M6

\section{WILLIAM GOYEN, I9I5-}

Goyen is a young Texas author who writes a highly "literary," poetic prose which he has so far used more for a lyric evocation of a time and place than as a means of telling a story.

1985. The house of breath. New York, Random House, r950. I8r p.

50-9448 $\mathrm{PZ}_{3} \cdot \mathrm{G}_{74}{ }_{4} \mathrm{Ho}$

An emotional mood picture of Charity, Texas, apparently based largely on childhood recollections.

1986. Ghost and flesh; stories and tales. New York, Random House, 1952. 183 p.

$$
\text { 52-5I43 PZ3.G } 748_{4} \mathrm{Gh}
$$

1987. In a farther country; a romance. New York, Random House, 1955. $182 \mathrm{p}$.

$$
55-8 \text { I }_{43} \quad \mathrm{PZ}_{3} \cdot \mathrm{G}_{74} 84 \mathrm{In}
$$

A surrealistic novel about a Texas girl inhabiting a New York City "castle in Spain," where she is queen.

\section{LILLIAN FLORENCE HELLMAN, 1905-}

Lillian Hellman, possibly the most successful of modern American women dramatists, writes plays with a "message" - often related to current events.
1989. Four plays: The children's hour; Days to come; The little foxes; Watch on the Rhine.

New York, Random House, 1942. 330 p.

$$
\text { 42-7559 } \mathrm{PS}_{35} 15 \cdot \mathrm{E}_{343} \mathrm{~F} 6
$$

1990. Another part of the forest, a play in three acts. New York, Viking Press, 1947. I 34 P. 47-30238 PS $3515 . E_{343 A 8}$

1991. The autumn garden; a play in three acts. Boston, Little, Brown, 195I. 139 p.

$$
\text { 51-10951 PS } 3515 . E_{343 A 8}
$$

\section{JOHN RICHARD HERSEY, 1914-}

John Hersey is known mainly for his reportorial work on World War II. His first book, Men on Bataan (1942), told the story of General MacArthur and the fall of the Philippines. In 1946 an entire issue of The New Yorker was devoted to Hiroshima, Hersey's account of the effects of the atomic bomb on that city; it was issued the same year as a book. His second novel, The Wall (1950), told of the Polish Jews under the Nazi occupation. His most recent novel, The Marmot Drive (1953), is a symbolic story which ostensibly reports a small New England town's attempts to overcome an invasion of woodchucks. Except for the last novel, he has regularly presented his material in a simple, realistic manner, as a reporter.

1993. Into the valley; a skirmish of the marines. New York, Knopf, 1943. 138 p. illus. 43-1318 $\mathrm{D}_{767.98 . \mathrm{H}_{4}}$

1994. A bell for Adano. New York, Knopf, I944. $269 \mathrm{p}$. $\quad 44-\mathrm{I} 64 \quad \mathrm{PZ}_{3} \cdot \mathrm{H}_{43}{ }_{55} \mathrm{Be}$

A novel about the American occupation of a Sicilian village during World War II.

\section{WILLIAM MOTTER INGE, I9I3-}

William Inge, who was born in Kansas, is representative of some of the newer dramatists. His work, which is in the realist tradition, has met with considerable popular and critical acclaim both on the stage and in film.

1996. Come back, little Sheba. New York, Random House, I95०. II9 p.

50-837I PS $3517 \cdot \mathrm{N}_{26} \mathrm{C} 6 \quad 195^{\circ}$

An alcoholic, middle-aged chiropractor and his wife experience an unromantic family life.

1997. Picnic, a summer romance in three acts. New York, Random House, 1953. I68 p. (A Random House play) 
Set in a small Kansas town, this is a play about the effect of a good-looking vagrant on the women of the community.

1998. Bus stop. New York, Random House, 1955. I54 p. (A Random House play) 55-9043 PS $3517 . \mathrm{N}_{26}{ }_{5} \mathrm{~B} 8$

A group of characters are brought together in a roadside restaurant when the bus is snowbound.

\section{RANDALL JARRELL, 1914-}

Jarrell has developed a reputation as an occasionally coruscating critic of profound insight, as well as a sympathetic poet of musical and technical virtuosity. Many of his poems have been products of the war; these have appeared in volumes such as Little Friend, Little Friend (1945), Losses (1948), and The Seven-League Crutches (195I).

2000. Poetry and the age. New York, Knopf, 1953. 271 p. 52-12173 PNi271.J3

2001. Pictures from an institution, a comedy. New York, Knopf, 1954. 277 p. 54-5973 $\mathrm{PZ} 4 \cdot \mathrm{J}_{37} \mathrm{Pi}$

A satirical novel about life at a small college.

2002. Selected poems. New York, Knopf, 1955. 205 p. 55-5613 PS3519.A86A6 1955

2003. JAMES JONES, I921-

Jones' first novel was a realistic story of Army life in Hawaii, starting a few months before the Pearl Harbor attack and concluding shortly after it. A highly popular book, it was the source of an equally popular screen adaptation.

2004. From here to eternity. New York, Scribner, 1951. 861 p. $\quad$ 51-9228 $\quad \mathrm{PZ}_{4} \cdot \mathrm{J}_{77} \mathrm{Fr}$

\section{ROSS FRANKLIN LOCKRIDGE, 1914- 1948}

Lockridge wrote only one book, a somewhat prolix novel which dealt with the day of July 4, r892, in a small Indiana town, but which used the flashback technique to cover half a century of American life. The book rapidly became a bestseller and was widely acclaimed by critics, although a few clergymen objected to some passages. The author committed suicide about three months after publication of his book.

2006. Raintree County .. . which had no boundaries in time and space, where lurked musical and strange names and mythical and lost peoples, and which was itself only a name musical and strange. Boston, Houghton Mifflin, 1948. 1066 p. maps.

48-245 PZ3.L81146Rai

\section{ROBERT LOWELL, 1917-}

Robert Lowell has been one of the most widely acclaimed of the younger poets. He has considerable linguistic and technical skill at his command as he sets out to explain the moral polarity of the world. His poetry, which often uses New England as a setting, is subtle, sincere, intense, and at times involved; it is also representative of the return to "classical" forms, or formalism, though with a very modern astringency. In 1947 he was awarded a Pulitzer prize for Lord Weary's Castle.

2008. Land of unlikeness; introd. by Allen Tate. Cummington [Mass.] Cummington Press, 1944. [43] p. 45-237 $\mathrm{PS}_{3523.089 \mathrm{~L}_{3}}$

2009. Lord Weary's castle. New York, Harcourt, Brace, r946. $69 \mathrm{p}$.

$4^{6-795^{8}} \quad \mathrm{PS}_{3523.08 g \mathrm{~L} 6}$

2010. The mills of the Kavanaughs. [Poems] New York, Harcourt, Brace, 1951. 55 p. 5I-10214 $\mathrm{PS}_{3523.089 \mathrm{M}_{5}}$

\section{II. ROBERT JAMES COLLAS LOWRY, I9I9-}

Robert Lowry is the author of realistic novels and short stories, most of which derive in subject matter from World War II. These antimilitaristic and sometimes bitter works have been deplored by some for their "manner" and lack of restraint; the author has also been accused of sentimentality. However, his careful writing and the impression of truthfulness in his writings have won him many adherents. His most recent novel, The Violent Wedding (I953), is about a love affair between a white girl and a Negro prizefighter.

2012. Casualty. [New York ${ }_{\text {] New Directions, }}$ 1946. I53 p. 46-727 I PZ3.L9564Cas

2013. Find me in fire. Garden City, N. Y., Doubleday, 1948. $280 \mathrm{p}$.

$$
4^{8-7932} \quad \mathrm{PZ}_{3} \cdot \mathrm{L}_{95} 6{ }_{4} \mathrm{Fi}
$$

2014. The big cage. Garden City, N. Y., Doubleday, I949. 342 p. $\quad 49$-II $454 \quad \mathrm{PZ}_{3} \cdot \mathrm{L}_{95}{ }_{4} \mathrm{Bi}$

2015. The wolf that fed us. Garden City, N. Y., Doubleday, 1949. $220 \mathrm{p}$.

49-7962 PZ3.L9564Wo 
Contents. - The toy balloon.-The church.Layover in El Paso.-The war poet.-The wolf that fed us.-Visitors to the castle.-The terror in the streets. - The gold button.

2016. Happy New Year, kamerades! II stories. Garden City, N. Y., Doubleday, 1954. 256 p. 54-6783 PZ3.L9564Hap

\section{MARY THERESE MCCARTHY, 1912-}

Mary McCarthy started her literary career as a book reviewer and as a columnist dealing with New York stage productions; this latter aspect of her work may be seen in the essays selected for Sights and Spectacles, 1937-1956 (1956), which, partly because of the freedom allowed her by The Partisan Review, for which she wrote, is far from a full picture of the stage productions of the period. In recent years she has become famous as a novelist of biting satires. Her technique, however, is more one of close dissection of a neurotic character viewed narrowly than it is a caricaturing on a broad scale. Her characters are usually drawn from the literary and academic world in which she moves.

2018. The company she keeps. [New York Simon \& Schuster, 1942. 304 p.

$$
\text { 42-13269 } \mathrm{PZ}_{3} \cdot \mathrm{Mr}_{272} \mathrm{Co}
$$

A portrait of a neurotic, pseudo-intellectual, liberal girl as a product of the thirties.

2019. The oasis. New York, Random House, 1949. 181 p. 49-10152 $\mathrm{PZ}_{3} \cdot \mathrm{MI}_{272} \mathrm{Oas}$

The story of a group of intellectuals who attempt to establish a Utopia on a New England mountain.

2020. Cast a cold eye. New York, Harcourt, Brace, 1950. $212 \mathrm{p}$.

$$
\text { 50-9761 PZ3.Mr272Cas }
$$

A group of short stories distinguished by the author's famous stylistic abilities.

2021. The groves of Academe. New York, Harcourt, Brace, 1952. $302 \mathrm{p}$.

$$
\text { 52-7255 } \quad \mathrm{PZ}_{3} \cdot \mathrm{Mr}_{272} \mathrm{Gr}
$$

A novel, with a small Pennsylvania college setting, against which a neurotic-intellectual professor of literature is closely pictured with all his unpleasantnesses.

2022. A charmed life. New York, Harcourt, Brace, 1955. 313 p.

55-10153 $\mathrm{PZ}_{3} \cdot \mathrm{Mr} 272 \mathrm{Ch}$

A novel picturing life in a colony set up to encourage the creativity of writers and artists.
2023. CARSON (SMITH) McCULLERS, 1917-

Carson McCullers is a Southern novelist who usually writes subtle and original works set in her home area. She commonly presents understanding, sympathetic accounts of her characters' inner compulsions; this aspect is heightened by her emphasis on the factors of personality motivation and the differences in even the "well-adjusted" characters. She is a realist and tends to be symbolistic, with results that have been called metaphysical. Her Reflections in a Golden Eye (I94I) is a bizarre but brilliant story of a group of abnormal individuals whose fates intertwine at a prewar Southern Army post. The Member of the Wedding (1946) is an evocative novel which depicts the yearning of a young girl to escape her environment; it appeared also in both stage and screen adaptations.

2024. The ballad of the sad café; the novels and stories of Carson McCullers. Boston, Houghton Mifflin, 1951. $791 \mathrm{p}$.

$$
\text { 51-10969 } \mathrm{PZ}_{3} \cdot \mathrm{Mr}_{3} 88_{4} \mathrm{Bal}
$$

Contents. - The ballad of the sad café.-Wunderkind.-The jockey.-Madame Zilensky and the King of Finland.-The sojourner.-A domestic dilemma.-A tree, a rock, a cloud.-The heart is a lonely hunter.-Reflections in a golden eye.-The member of the wedding.

2025. NORMAN MAILER, 1923-

Mailer's first novel was a best seller that dealt with the war in the Pacific; it was noted for its realism and its accurate recording of the speech of the soldiers, as well as for passages of poetic intensity. His second book, a thesis novel which dealt with political ideologies and was set in postwar New York, and also his third, which portrays the denizens of the motion picture and entertainment world in California, were not so highly regarded by many reviewers.

2026. The naked and the dead. New York, Rinehart, 1948. $721 \mathrm{p}$.

$$
\text { 48-6633 } \mathrm{PZ}_{3} \cdot \mathrm{M}_{28} \text { I5 }_{5} \mathrm{Nak}
$$

2027. Barbary shore. New York, Rinehart, 1951. $312 \mathrm{p}$. 5I-10764 $\mathrm{PZ}_{3} \cdot \mathrm{M}_{28}{ }_{15} \mathrm{Bar}$

2028. The deer park. New York, Putnam, 1955. $375 \mathrm{p}$. 55-10093 PZ3.M2815De

2029. WILLIAM KEEPERS MAXWELL, I908William Maxwell was born in Illinois, and his life there is a source for much of the background in his writings. He was for a time an editor of The New Yorker. 
2030. Bright center of heaven. New York, Harper, 1934. $315 \mathrm{p}$.

Events of a day on a Wisconsin farm.

$$
\text { 34-28619 } \mathrm{PZ}_{3} \cdot \mathrm{M}_{45} \mathrm{18} \mathrm{Br}
$$

2031. They came like swallows. New York, Harper, 1937. $267 \mathrm{p}$.

$37-6382 \quad \mathrm{PZ}_{3} \cdot \mathrm{M}_{45} \mathrm{r} 8 \mathrm{Th}$

A story of commonplace events in the lives of members of an American family in 1918.

2032. The folded leaf. New York, Harper, 1945. $310 \mathrm{P}$.

45-3288 PZ3.M $4518 \mathrm{Fo}$

A story of the friendship of two boys, one an introvert and the other an extrovert.

2033. Time will darken it. New York, Harper, I948. $302 \mathrm{p} . \quad 48-8331 \quad \mathrm{PZ}_{3} \cdot \mathrm{M}_{45} 18 \mathrm{Ti}$

Set in a small Illinois town in 1912, this story mirrors life in America at that period.

\section{THOMAS MERTON, I915-}

Thomas Merton is a Catholic convert who became a Trappist monk. This story he tells in his popular autobiographical book, The Seven Storey Mountain. He initially received most attention as a Catholic poet writing in a surrealistic style. Of late he has been writing religious prose; meditations, biographical works, etc.

2035. A man in the divided sea. [Norfolk, Conn., New Directions] 1946 . 155 p. $46-7485 \quad \mathrm{PS}_{3525} \cdot \mathrm{E}_{71} \mathrm{~T}_{74} \mathrm{M}_{3}$

A collection of poems including those which appeared in Thirty Poems (1944).

2036. The seven storey mountain. New York, Harcourt, Brace, I $948.429 \mathrm{p}$.

Autobiography.

$4^{8-8645} \quad \mathrm{BX}_{4705} \cdot \mathrm{M}_{542} \mathrm{~A}_{3}$

2037. Figures for an apocalypse. [Poems] Norfolk, Conn., New Directions [1948] ${ }^{\circ} 1947$.

III p. $\quad 48-2906 \quad \mathrm{PS}_{3525}$.E7174 $\mathrm{F} 5$

2038. Seeds of contemplation. [Norfolk, Conn.] New Directions, 1949. 20I p.

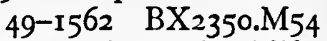

A mystic work of meditation on the spiritual life.

2039. The tears of the blind lions. [Poems. New York] New Directions, 1949. $32 \mathrm{p}$. 49-49074 $\mathrm{PS}_{3525} \cdot \mathrm{E}_{71} \mathrm{1}_{74} \mathrm{~T}_{4}$

2040. The waters of Siloe. New York, Harcourt, Brace, 1949. 377 p. illus.
This volume is something of a philosophy of monasticism and a history of the Cistercians, with an emphasis on Cistercian activities in the United States.

204I. The sign of Jonas. New York, Harcourt, Brace, 1953. $362 \mathrm{p}$.

$$
52-9857 \quad \mathrm{BX}_{4705 . \mathrm{M}_{542} \mathrm{~A}_{32}}
$$

"A collection of personal notes and meditations set down during about five years ... in the monastery of Gethsemani."

2042. No man is an island. New York, Harcourt, Brace, 1955. $264 \mathrm{P}$.

55-7420 BX2350.M535

This volume of reflections on the inner life serves as a sequei to Seeds of Contemplation (q. v.).

\section{ARTHUR MILLER, 1915-}

With his third book, the play All My Sons, Miller rose to prominence as an author, and started the work that was to establish him as one of the leading dramatists of his generation. His style is one of flat realism, so that it is from what he says and the way he organizes his material, rather than from any purely literary expression, that he achieves his effect.

2044. Situation normal. New York, Reynal \& Hitchcock, 1944. 179 p.

$$
\text { 44-47726 U766.M } 48
$$

An account, in the form of notes to a film producer, of civilians training to be soldiers as the author had observed them during a special tour.

2045. Focus. New York, Reynal \& Hitchcock, 1945. 217 p. $\quad 45-9586 \quad \mathrm{PZ}_{3}$.M61224Fo

A novel on the theme of anti-Semitism.

2046. All my sons, a play in three acts. New York, Reynal \& Hitchcock, 1947. 83 p.

47-30156 PS $3525 . \mathrm{I}_{5} 156 \mathrm{~A}_{7}$

A tragedy dealing with the social effects of an industrial war crime.

2047. Death of a salesman; certain private conversations in two acts and a requiem. New York, Viking Press, 1949. I 39 p.

$49-88 \mathrm{I}_{7} \quad \mathrm{PS}_{3525} \cdot \mathrm{I}_{5} 156 \mathrm{D}_{4}$

A tragedy reflecting the life of a salesman, and presenting the problem of values in modern society. This book was awarded a Pulitzer prize for drama, and it was the first play to be distributed by the Book-of-the-Month Club. 
2048. The crucible, a play in four acts. New York, Viking Press, 1953. 145 p. 53-6724 PS $3525 . I_{5156 C 7} 1953$

A play dealing with the Salem witchcraft trials.

2049. A view from the bridge; two one-act plays. New York, Viking Press, I955. I6o p. 55-10474 PS $3525 . \mathrm{I}_{5} \mathrm{I}_{5} 6 \mathrm{~V}_{5}$

$A$ View from the Bridge is the story of two Italians who illegally entered the United States, and who are seeking jobs as longshoremen. The second play, A Memory of Two Mondays, presents a view of life in a New York warehouse as reflecting the outside world.

\section{BUCKLIN MOON, I9I I-}

Moon is a Southern Negro author who in his works has attempted to present his view of race prejudice and relationships between whites and Negroes, especially as they exist in the South.

2051. Without magnolias. Garden City, N. Y., Doubleday, 1949. 274 p.

$$
\text { 49-8390 } \quad \mathrm{PZ}_{3} \cdot \mathrm{M}_{777}{ }^{2} \mathrm{Wi}
$$

A tract novel depicting a Negro community in Florida.

\section{WRIGHT MORRIS, I9IO-}

Morris' novels, which often use a Midwest setting, are written in the plain prose characteristic of much modern fiction. A professional photographer, Morris reflects an aptitude for recording visual details of commonplace things and acts as indirect indexes of character and personal relationships. This is further emphasized in some of his work by the joint use of photographs and text, as in The Home Place (1948), the story of a New York family on a visit to a Nebraska farm, which he continued, without pictures, in The World in the Attic (1949). His first book, My Uncle Dudley (1942), captured much of this photographic sense in a picaresque novel about the trip of some "bums" from Los Angeles to Chicago, basically humorous but with serious overtones. In The Man Who Was There (1945), a novel about the effects on others of a man missing in war action, Morris started to explore the geography of personality, the mystery of private human feelings, the interinfluence of characters, and the sorrow of individual loneliness and non-communication which have become dominant ingredients in his latest books. Throughout his work there is an attempt to find out and understand what an "American" is.
2053. Man and boy. New York, Knopf, I95I. $212 \mathrm{p}$. $5^{1-226} 3 \mathrm{PZ}_{3} \cdot \mathrm{M} 8346 \mathrm{Mam}$

A satire on a selfish mother about to christen a boat in honor of her hero-son who was killed at Guadalcanal.

2054. The works of love. New York, Knopf, I952, "I95I. 269 p.

5I-I1978 PZ3.M8346Wn

A study of the personality of a Midwesterner from his isolated boyhood in a rural community, through his successful career in the poultry business, to his isolated old age in Chicago, where he suddenly dies while employed as a store Santa Claus.

2055. The deep sleep. New York, Scribner, 1953. 3I 2 p.

53-II783 PZ3.M8346De

A novel told through the minds of five people brought together in a Philadelphia suburb by the death of a judge who had deeply influenced each of them.

2056. The huge season. New York, Viking Press, I954. 306 p. $\quad 54-1085^{8} \quad \mathrm{PZ}_{3} \cdot \mathrm{M} 8346 \mathrm{Hu}$

The main character visualizes the present-day (1952) situation in terms of the influences on him and his friends during their youth in the Jazz Age.

\section{EDWARD NEWHOUSE, I9II-}

Newhouse, because of the frequent appearance of his short stories in that periodical, is sometimes known as a New Yorker author. His work deals mainly with the New York scene, including the suburbs; however, most of the stories in The Iron Chain (1946) are concerned with World War II.

2058. Many are called; forty-two short stories. New York, Sloane, r95 I. 384 p.

$$
\text { 5I-I2I59 } \mathrm{PZ}_{3} \cdot \mathrm{N}_{45} 8 \mathrm{Man}
$$

2059. The temptation of Roger Heriott. Boston, Houghton Mifflin, 1954. 24I p.

54-IoI98 $\mathrm{PZ}_{3} \cdot \mathrm{N}_{458 \mathrm{Te}}$

A novel about the demands of integrity in a moderately well-to-do suburbanite who works in New York for a private foundation that awards fellowships to young musicians.

\section{JOHN FREDERICK NIMS, I913-}

Nims writes a polished poetry which usually employs urban themes, often those of the small city. While his work thus reflects aspects of modern American life, it also reflects his own life as a scholar. 
2061. The iron pastoral. New York, Sloane, 1947. $86 \mathrm{p}$. 47-4500 $\mathrm{PS}_{3527.1863 \mathrm{I}_{7}}$

Poems.

2062. A fountain in Kentucky, and other poems. New York, Sloane, 1950. 72 p. 50-6org $\mathrm{PS}_{3527 . \mathrm{I} 86_{3} \mathrm{~F} 6} 1950$

2063. CLIFFORD ODETS, rgo6-

Odets rose to prominence as a playwright concerned with conveying a meaningful view of life, especially the life of urban middle-class society. Raised in New York in a middle-class family, he portrays this background in many of his plays. Realism and forceful dialogue have been characteristic of much of his work. An experimentalist in subject matter and attitude, he rapidly became one of the leaders of the "new" drama of the thirties.

2064. Six plays. With a pref. by the author. New York, Modern Library, 1939. 433 p. (The Modern Library of the word's best books)

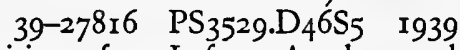

Contents.-Waiting for Lefty.-Awake and sing!-Till the day I die.-Paradise lost.--Golden boy.-Rocket to the moon.

2065. Night music; a comedy in twelve scenes. New York, Random House, I940. 237 p. $40-7217 \mathrm{PS}_{3529 . D_{4} 6 \mathrm{~N}_{5} \text { I940 }}$

2066. Clash by night. New York, Random House, 1942. $242 \mathrm{p}$.

$$
42-7560 \quad P_{3529 . D_{4} 6 C_{5}}
$$

2067. The big knife. New York, Random House, 1949. $147 \mathrm{p}$.

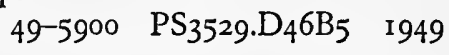

2068 The country girl, a play in three acts. New York, Viking Press, I95I. I24 p.

$$
\text { 5I-I860 PS } 3529 . D_{46} 66
$$

2069. JOHN HENRY O'HARA, I905-

John O'Hara, whose first novel is still considered by some to be his best work, writes often of common (in the pejorative sense) people. He is realistic in style and, to many, shockingly frank. His settings vary widely, though Hollywood, New York, and rural Pennsylvania do recur; a large percentage of his characters are modern urbanites.

2070. Appointment in Samarra, a novel. New York, Harcourt, Brace, 1934. $301 \mathrm{p}$. 34-25527 $\mathrm{PZ}_{3} \cdot \mathrm{O}_{3} 677 \mathrm{Ap}$
Three days of sex, alcohol, and gangsters in a Pennsylvania town in $193^{\circ}$ climax in the hero's suicide.

2071. The doctor's son and other stories. New Yerk, Harcourt, Brace, 1935. 294 p. 35-3041 $\mathrm{PZ}_{3} \cdot \mathrm{O}_{3} 677$ Do

2072. Files on parade. New York, Harcourt, Brace, 1939. 277 p.

Short stories.

$$
\text { 39-23749 } \mathrm{PZ}_{3} \cdot \mathrm{O}_{3} 677 \mathrm{Fi}
$$

2073. Pipe night. New York, Duell, Sloan \& Pearce, 1945. 205 p.

Short stories.

45-3002 $\mathrm{PZ}_{3} \cdot \mathrm{O}_{3} 677 \mathrm{Pi}$

2074. Here's O'Hara; three novels and twenty short stories. New York, Duell, Sloan \& Pearce, 1946. 440 p. $46-4951 \quad \mathrm{PZ}_{3} \cdot \mathrm{O}_{3} 677 \mathrm{He}$

The novels are Butterfield 8 (1935), which is based on a New York murder case, and which involves mainly the fringe elements of nightclub life; Hope of Heaven (1938), which presents the unhappy love affair of a Hollywood scenario writer and a bookstore clerk; and Pal Joey (1940), which takes the form of letters of a nightclub entertainer.

2075. Hellbox. New York, Random House, 1947. $210 \mathrm{p}$.

Short stories. 47-30414 $\mathrm{PZ}_{3} \cdot \mathrm{O}_{3} 677 \mathrm{Hc}$

2076. A rage to live. New York, Random House, 1949. 590 p. $\quad 49-10363 \quad \mathrm{PZ}_{3} \mathrm{O}_{3} 677 \mathrm{Rag}$ A somewhat panoramic novel of social and sexual life in a Pennsylvania community, starting a few years before World War I.

2077. The Farmers Hotel, a novel. New York, Random House, I95I. 153 p.

$$
\text { 5I-I4I2I } \mathrm{PZ}_{3} . \mathrm{O}_{3} 677 \mathrm{Far}
$$

The story of people snowbound in a Pennsylvania hotel.

2078. Ten North Frederick. New York, Random House, 1955. 408 p.

55-8167 $\mathrm{PZ}_{3} . \mathrm{O}_{3} 677 \mathrm{Te}$

A novel of manners set in O'Hara's home area in Pennsylvania.

\section{KENNETH PATCHEN, I9I I-}

Patchen's poetry is often sentimental in content, but normally modernistic in form. His themes have been: protest against social and economic injustices and follies, love of humanity and the uni- 
verse, hatred of mankind and the world, sex, and religion. His poetry has been extremely uneven, and the range of its critical laudation and denunciation has been equally great. He has also written several volumes of prose, which were largely surrealistic and with many of the qualities and much of the subject matter of his poetry. His most recent venture, Glory Never Guesses (1955), is a limited edition, silk-screen process volume worked originally by hand, in an attempt to produce a book as an integral work of art, somewhat in the tradition of some of Blake's work.

2080. First will \& testament. Norfolk, Conn., New Directions, 1939. I8I p.

Poems.

$$
\text { 40-1II4 PS } 353 \text { I.A76 }_{4} \mathrm{~F}_{5} 1939
$$

2081. The journal of Albion Moonlight. [Mount Vernon, N. Y., Walpole Printing Office] I94I. 313 p. 41-I9I28 PS3531.A764J6 I94I

A novel in surrealistic and often poetic prose; the work, written in the form of a journal, relies strongly on symbolism to convey its author's commentaries about life, society, and the individual.

2082. The memoirs of a shy pornographer. [New York, New Directions] 1945. 242 p. $45-8438 \quad \mathrm{PZ}_{3} \cdot \mathrm{P}_{27}{ }^{14} \mathrm{Me}$

An experimental, satirical novel about a naive young man whose novel becomes a pornographic best-seller as a result of the publisher's large-scale substitution of asterisks for otherwise innocuous words.

2083. The selected poems. [Norfolk, Conn.] New Directions, 1946. 86 p. (The New classics series) A48-781I PS3531.A764A6 1946

2084. Sleepers awake. [New York, Padell] 1946. $389 \mathrm{p}$. 46-21856 PS 353 I.A $76_{4} \mathrm{~S}_{5}$

A surrealistic novel attacking many of the follies of contemporary man; man's inhumanity to man is the basic theme for excoriation. The book incorporates an unusual amount of typographical experimentation.

2085. See you in the morning. New York, Padell, 1948, ${ }^{c}$ r947. $256 \mathrm{p}$.

48-17796 $\mathrm{PZ}_{3} \cdot \mathrm{P}_{27}{ }_{4} \mathrm{Se}$

In a sense Patchen's first novel, this is a short, conventional, poetic story about a young couple who accept life and love in the face of imminent death.

2086. Red wine \& yellow hair. [Poems] New York, New Directions, 1949. 64 p. $49-7607 \mathrm{PS}_{353} \mathrm{I}_{4} \mathrm{~A}_{76} \mathrm{R}_{4}$
2087. FREDERIC PROKOSCH, 1908-

Prokosch has spent much of his life abroad, a fact which is revealed in his poetry and novels. His settings and most of his characters are usually foreign, although some, if not all, of the central characters tend to be American. $\mathrm{He}$ is a careful, lyric writer who presents, often in a poetic prose of philosophic detachment, meditative reveries on the problems of the modern world. However, in $A$ Tale for Midnight (1955) he goes back several centuries for the story of the Cenci. Prokosch has also translated poetry from several languages.

2088. The Asiatics. New York, Harper, 1935. 423 p. 35-19872 PZ3.P9424As Travels of an American through Asia.

2089. The seven who Aled. New York, Harper, 1937. 479 p. 37-1825I PZ3.P9424Se

Seven Russian exiles have terrifying experiences wandering through Central Asia.

209o. Night of the poor. New York, Harper, r939. 359 p. 39-24223 $\mathrm{PZ}_{3} \cdot \mathrm{P}_{9424 \mathrm{Ni}}$

A novel that reflects aspects of America, especially the poor whites of the South, as seen by a boy hitchhiking from Wisconsin to Texas.

2091. The skies of Europe. New York, Harper, I94I. 500 p. 4I-I4057 PZ3.P9424Sk

A novel about Europe in the two years prior to World War II, as seen through the eyes of an American reporter who travels about the continent.

2092. The conspirators. New York, Harper, 1943. $33^{8}$ p. 43-II42 $\mathrm{PZ}_{3} . \mathrm{P}_{9424} \mathrm{Co}$

Refugees and espionage agents against a Lisbon setting during World War II.

2093. Age of thunder. New York, Harper, 1945. 3II p. $\quad 45^{-2642} \quad \mathrm{PZ}_{3} . \mathrm{P}_{9424} \mathrm{Ag}$

A philosophically inclined narrative of a search along the French-Swiss border for traitors.

2094. The idols of the cave. Garden City, N. Y., Doubleday, I946. $373 \mathrm{p}$.

$$
\text { 46-7545 PZ3.P9424Id }
$$

A novel that presents, in an almost disinterested manner, unusual, sideline characters in New York during the war.

2095. Chosen poems. Garden City, N. Y., Doubleday, I947. $81 \mathrm{p}$.

47-2987 $\mathrm{PS}_{3531 . \mathrm{R}_{7} 8 \mathrm{C}_{45} \quad 1947}$ 
2096. Storm and echo. Garden City, N. Y., Doubleday, 1948. $274 \mathrm{p}$.

$$
\begin{array}{r}
4^{8-8302} \mathrm{PZ}_{3} \cdot \mathrm{P}_{9424 \mathrm{St}} \\
\mathrm{PS}_{353} \mathrm{r} \cdot \mathrm{R} 78 \mathrm{~S} 7
\end{array}
$$

A novel which presents the fearfulness and impenetrability of man's inner life as discovered by a journey into the African jungle.

2097. Nine days to Mukalla. New York, Viking Press, 1953. $249 \mathrm{p}$.

$$
{ }_{52-14033} \mathrm{PZ}_{3} \cdot \mathrm{P}_{9424} \mathrm{Nk}
$$

A group of westerners, including some Americans, experience a plane crash on an isolated Arabic island in the Indian Ocean, and thereafter undergo unpleasant and exhausting adventures in their attempt to return to civilization.

\section{KENNETH REXROTH, 1905-}

Rexroth is a California poet who has by some critics been adjudged best in his nature and descriptive poetry, but who himself seems to place greater value on the philosophic parts of his work. His direct philosophic impulse led him to abandon the syntactical experimentation found in his early poems, In What Hour (1940), for a neoclassic syllabic verse form which would allow him more readily to communicate his message. The earlier experimentalism reappeared in another volume, The Art of Worldly Wisdom (1953), a collection of early work which had not previously been published in book form. While in many aspects his work is derived from modern French, American, and English poetry, Rexroth's work also shows classical influences, both East and West. Detectable in his lyrics, they become decisive in the lyric plays published in Beyond the Mountains.

2099. The phoenix and the tortoise. Norfolk, Conn., New Directions, 1944. $100 \mathrm{p}$.

Poems. 44-9924 $\mathrm{PS}_{3535}$.E923 $\mathrm{P}_{5}$

2100. The signature of all things; poems, songs, elegies, translations, and epigrams. New York, New Directions, 1950. $89 \mathrm{p}$.

$$
{ }_{50-5683} \mathrm{PS}_{3535} \cdot \mathrm{E}_{923} \mathrm{~S}_{5}
$$

2101. Beyond the mountains. [Plays. New York, New Directions] 195x. 190 p. (Direction, 20) ${ }_{51-963 \mathrm{I}} \mathrm{PS}_{3535} \cdot \mathrm{E}_{923} \mathrm{~B}_{4}$

Contents.-Phaedra.-Iphigenia.-Hermaios.Berenike.

2102. The dragon and the unicorn. Norfolk, Conn., New Directions, 1952. I7I p. 52-I 4902 PS $3535 . E_{923} \mathrm{D}_{7}$
"Large parts of ... [ [this poem] were previously published ... in the New Directions annuals for 1950 and 195r."

\section{THEODORE ROETHKE, 1908-}

Roethke is a poet of quiet tone and a modest though well-controlled range. A large percentage of his themes stems from his childhood experiences in a greenhouse. He is one of the younger poets to have achieved recognition. In 1954 he received the Pulitzer prize for The Waking, a selection which adequately represents his production to date.

2104. The waking; poems, 1933-1953. Garden City, N. Y., Doubleday, I953. I20 p.

$53-9125 \mathrm{PS}_{3535} \cdot \mathrm{O}_{39} \mathrm{~W}_{3}$

\section{MURIEL RUKEYSER, 1913-}

Born and bred in New York City, Rukeyser became an urban poet in the neo-metaphysical mould. Her leftist tendencies have repeatedly led in her work to a probing of social problems and injustices. Miss Rukeyser has occasionally ventured into other fields of writing, as in The Life of Poetry (1949), a study of the role of poetry in life, and in Willard Gibbs (1942), a scientist discussed at length under no. 475I.

2106. Selected poems. ${ }_{[}$New York, New Directions] 1951. III p. (The New classics series) $\quad 5 \mathrm{I}-\mathrm{I} 2264 \quad \mathrm{PS}_{3535} \cdot \mathrm{U}_{4} \mathrm{A6}$ I95I

Earlier volumes of poetry by Rukeyser include Theory of Flight (1935), U.S. I (1938), A Turning Wind (1939), Wake Island (1942), The Beast in View (1944), The Green Wave (1948), and Elegies (1949).

\section{JEROME DAVID SALINGER, 1919-}

Salinger rose to prominence in 195 I with a novel about a neurotic adolescent who is expelled from preparatory school and wanders about New York for a few days before going home. The story is told in the form of an interior monologue written in nonliterary conversational prose.

2108. The catcher in the rye. Boston, Little, Brown, 1951. $277 \mathrm{p}$.

$$
\text { 51-4713 PZ4.S165Cat }
$$

2109. Nine stories. Boston, Little, Brown, 1953 . $302 \mathrm{p}$.
52-12626 PZ4.S165 Ni 


\section{WILLIAM SAROYAN, I908-}

Saroyan is a highly prolific Armenian-American Californian who usually writes in somewhat amorphous form about California, although occasionally dealing with New York or some other place. His work is often highly imaginative reporting of the world as he sees it. Personality, fantasy, and humor inform his world of sweetness and light wherein wander all (and almost only) the beautiful people. However, a few of his later books have accepted the possibility of unpleasantness in life. Saroyan's first book was The Daring Young Man on the Flying Trapeze, and Other Stories (1934), which almost immediately established his popularity. While his numerous short stories and sketches continue to maintain for him a reputation as a short-story writer, he has also received considerable attention as a dramatist. My Heart's in the Highlands (1939) is usually considered his best play, but it was The Time of Your Life (1939), which was awarded the I940 Pulitzer prize for drama, which the author refused. $\mathrm{He}$ has also written a number of novels and autobiographical works. The latter is in some respects a formal distinction, for it has been claimed that he writes some fictional autobiography, and that the rest of his work is highly autobiographical fiction.

2111. My name is Aram. New York, Harcourt, Brace, 1940. $220 \mathrm{p}$.

$$
\text { 40-34075 } \mathrm{PZ}_{3} . \mathrm{S}_{24} 6 \mathrm{My}
$$

2112. Three plays: My heart's in the Highlands, The time of your life, Love's old sweet song. New York, Harcourt, Brace, I940. 121, 200, 146 p. 40-30799 $\mathrm{PS}_{3537 . A 826 \mathrm{~T}_{47}}$ 1940

2113. Three plays by William Saroyan: The beautiful people, Sweeney in the trees, and Across the board on Tomorrow Morning. New York, Harcourt, Brace, 1941. 275 p.

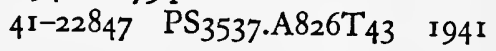

2114. Razzle dazzle. New York, Harcourt, Brace, 1942. $505 \mathrm{p}$.

$$
\text { 42-12443 PS } 3537 . \mathrm{A}_{226 \mathrm{R}_{35}}
$$

"Frontispiece" (added t. p. on two leaves, illustrated in color): Razzle-dazzle; or, The human ballet, opera and circus; or, There's something I got to tell you: being many kinds of short plays as well as the story of the writing of them.

2115. The human comedy. New York, Harcourt, Brace, 1943. 29I p. 2ri6. The Saroyan special, selected short stories. New York, Harcourt, Brace, 1948. 368 p. $4^{8-9565} \quad \mathrm{PZ}_{3} \cdot \mathrm{S}_{24} 6 \mathrm{Sar}$

2117. Don't go away mad, and two other plays: Sam Ego's house [and] A decent birth, a happy funeral. New York, Harcourt, Brace, I949. $23^{8} \mathrm{p}$. 49-II92I PS 3537.A826D6

2118. The Assyrian, and other stories. New York, Harcourt, Brace, I950. 276 p. 50-5197 $\mathrm{PZ}_{3} . \mathrm{S}_{24} 6 \mathrm{As}$

2119. The twin adventures: The adventures of William Saroyan, a diary. The adventures of Wesley Jackson, a novel. New York, Harcourt, Brace, 1950. 225, 285 p. 50-6550 $\mathrm{PZ}_{3} . \mathrm{S}_{24} 6 \mathrm{Tw}$ "An hour-to-hour chronicle of a writer at work on the writing of a novel, and the novel itself."

The novel was published separately in 1946 .

2120. Tracy's tiger. Garden City, N. Y., Doubleday, 195I. I43 p. 5I-13965 PZ3.S246Tp

2121. The bicycle rider in Beverly Hills. New York, Scribner, 1952. 178 p.

Autobiographical.

$$
\text { 52-12748 PS } 3537 \cdot \mathrm{A}_{2} 6 \mathrm{Z}_{52}
$$

2122. The laughing matter, a novel. Garden City, N. Y., Doubleday, 1953. 254 p. 52-13557 $\mathrm{PZ}_{3} . \mathrm{S}_{24} 6 \mathrm{Lau}$

\section{MAY SARTON, rgr2-}

May Sarton was born in Belgium, but came to America within a few years, after her family fled the country because of the German invasion. In her early years she had expected to make the theater her career; one of the products of this interest is the play, The Underground River (1947). She soon turned, however, from the theater to a career as a poet and novelist. As a poet she established a considerable reputation as a formal lyricist through works published in periodicals and in her small early collections, Encounter in April (1937) and Inner Landscape (1939). Her novels have reflected her European background and interests, for they have usually had European characters and settings. Thus works such as The Single Hound (1938), The Bridge of Years (1946), and Shadow of a Man (1950) have served to present Americans with pictures of life in Europe.

2124. The lion and the rose, poems. New York, Rinehart, 1948. $104 \mathrm{p}$. 
2125. A shower of summer days. New York, Rinehart, 1952. 244 p.

$$
\text { 52-9599 } \mathrm{PZ}_{3} . \mathrm{S}_{249} \mathrm{Shc}
$$

A novel in which an American girl matures in the course of a summer visit to the estate of relatives in Ireland.

2126. The land of silence, and other poems. New York, Rinehart, 1953. $99 \mathrm{p}$.

$$
53-77^{21} \quad \mathrm{PS}_{3537 \cdot \mathrm{A}_{32} \mathrm{~L}_{3}}
$$

2127. Faithful are the wounds. New York, Rinehart, 1955. 28I p. 55-5304 PZ3.S249Fai

This is May Sarton's first novel with an American setting. Its story is that of a Harvard professor who commits suicide. It has been claimed that the story is based on the life and death of F. O. Matthiessen (q. v.).

\section{MARK SCHORER, 1908-}

Mark Schorer has written a number of realistic novels and short stories which have been praised for their psychological insight as well as for their style and structure. In 1946 he published William Blake; the Politics of Vision, which is more an attempt to explain the poet's system of thought than it is a critical or historical work.

2129. A house too old, a novel. New York, Reynal \& Hitchcock, 1935. 305 p.

35-15150 $\mathrm{PZ}_{3} . \mathrm{S}_{375} \mathrm{Ho}$

A novel about settlers in a Wisconsin town, with the story of the growth of the community over the subsequent century.

2130. The hermit place, a novel. New York, Random House, I94I. 313 p.

$$
{ }_{41-7658} \quad \mathrm{PZ}_{3} \cdot \mathrm{S}_{375} \mathrm{He}
$$

A psychological novel about two sisters who were in love with a man who died a year before the time of the story.

213r. The state of mind, thirty-two stories. Boston, Houghton Mifflin, 1947. $346 \mathrm{p}$.

$$
{ }_{47-2350} \mathrm{PZ}_{3} \cdot \mathrm{S}_{375} \mathrm{St}
$$

2132. The wars of love, a novel. New York, McGraw-Hill, 1954. 174 p.

$$
53-7878 \quad \mathrm{PZ}_{3} . \mathrm{S}_{375} \mathrm{War}
$$

A story of some children together at an upstate New York resort, and how that summer works out when they come together as adults in New York City.

\section{DELMORE SCHWARTZ, I913-}

Delmore Schwartz is a New York poet whose work commonly reflects his native city and is usually philosophical in tenor. He has also published some short stories and dramatic work, as well as a number of distinguished critical reviews. His critical work has appeared in periodicals such as Partisan Review, of which he was editor, from 1943 to 1946 , and subsequently associate editor.

2134. In dreams begin responsibilities. Norfolk, Conn., New Directions, 1938. I7 1 .

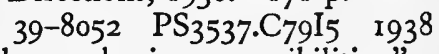

Contents.- "In dreams begin responsibilities," a story.-Coriolanus and his mother: the dream of one performance, a narrative poem.-Poems of experiment and imitation.-Dr. Bergen's belief, a play in prose and verse.

2135. Shenandoah. Norfolk, Conn., New Direc[8]) tions, 1941. $28 \mathrm{p}$. (The Poet of the month Poetic drama.

2136. Genesis ... [New York, New Directions] 1943+ 43-8710 PS3537. P $_{79} \mathrm{G}_{4}$

A story, in prose and poetry, of the making of an American.

2137. The world is a wedding. [Short stories. Norfolk, Conn.] New Directions, 1948 196 p. $\quad 4^{8-7957} \quad \mathrm{PZ}_{3} . \mathrm{S}_{4} 0_{5} \mathrm{Wo}$ Contents. - The world is a wedding.-New Year's Eve.-A bitter farce.-America!-The statues.-The child is the meaning of this life.-In dreams begin responsibilities.

2138. Vaudeville for a princess, and other poems. [New York] New Directions, 1950. 106 p. 50-9969 $\mathrm{PS}_{3537 \cdot \mathrm{C}_{79} \mathrm{~V}_{3}}$

2139. KARL JAY SHAPIRO, I913-

Although Karl Shapiro was a soldier when his first volumes appeared during the Second World War, he has developed into more than a war poet. His poetry usually deals with the implications of the poet's position, or evolves out of his immediate environment. His relatively formal verse thus reflects his life in America and in the Pacific. He edited Poetry: A Magazine of Verse from 1950 to I955.

2I40. Person, place and thing. [New York] Reynal \& Hitchcock, I942. $88 \mathrm{p}$.

$4^{2-51003} \mathrm{PS}_{3537 \cdot \mathrm{H}_{27}} \mathrm{P}_{4}$ 
2141. V-letter, and other poems. New York, Reynal \& Hitchcock, 1944. 63 p.

44-6977 $\mathrm{PS}_{3537 \cdot \mathrm{H}_{27} \mathrm{VI} 8}$

2142. Essay on rime. New York, Reynal \& HitchVerse. cock, 1945. 72 p. $45-9654 \quad \mathrm{PS}_{3537 \cdot \mathrm{H}_{27} \mathrm{E} 8}$

2143. Trial of a poet, and other poems. New York, Reynal \& Hitchcock, 1947. 81 p. 47-11585 ${ }^{-1} 3537 . \mathrm{H}_{27} \mathrm{~T}_{7}$

2144. Poems, 1940-1953. New York, Random House, 1953. 161 p.

53-6928 PS $3537 . \mathrm{H}_{27} \mathrm{Al}_{7} 1953$

A short selection from the author's earlier volumes, with a few new poems added.

\section{IRWIN SHAW, 1913-}

Shaw, who has written for films and radio, first attracted general public attention as a dramatist; among his plays are Bury the Dead (1936) and Sons and Soldiers (1944). Shortly after being acclaimed as a dramatist, he emerged as a prominent short-story writer. Here, as in all his writings, a clarity of expression and a driving moral purpose were evident. Writing usually of Americans in general, and often of New Yorkers in particular, Shaw has almost always directly or indirectly presented some social issue.

2146. The young lions. New York, Random House, 1948. $689 \mathrm{p}$.

$4^{8-8508} \quad \mathrm{PZ}_{3} . \mathrm{S}_{5357} \mathrm{Yo}$

Starting in a Bavarian forest in 1938 , this novel traces the story of three men and their part in World War II through 1945.

2147. Mixed company; collected short stories. [New York, Random House] 1950. 480 p. 50-10065 $\mathrm{PZ}_{3} . \mathrm{S}_{5357} \mathrm{Mi}$

2148. The troubled air. New York, Random House, 1951. 418 p.

$$
\text { 51-11045 } \mathrm{PZ}_{3} . \mathrm{S}_{5357} \mathrm{Tr}
$$

The story of an attempt to clear some people in the radio industry after they are subjected to unsubstantiated charges of communism. This is a political novel dealing with the problem of communism in America in the late forties; the emphasis is on the then prevalent attitude. Since it is a book with a message, few have reacted to it on any purely esthetic level, with the result that it has received mixed reviews.

\section{HARRY ALLEN SMITH, 1907-}

In loosely autobiographical narratives and novels $H$. Allen. Smith offers his humorous commentary on American life and customs. Coming from the Midwest to New York City, Smith began his writing career as a journalist; much of his early work reflects interview assignments with unusual people. In time he settled in Mt. Kisco, a New York suburb which he uses as a point of departure for a number of his writings.

2150. 3 Smiths in the wind: Low man on a totem pole. Life in a putty knife factory. Lost in the horse latitudes. Garden City, N. Y., Doubleday, 1946. 205, 218, 223 p. 46-7219 $\mathrm{PN}_{4} 874 . \mathrm{S}_{56} \mathrm{~A}_{35}$

2151. Lo, the former Egyptian! Garden City, N. Y., Doubleday, 1947. 212 p.

47-1 $53^{8}$ PN6r61.S6574

Autobiographical reminiscences pertaining to his youth in that part of Illinois known as Egypt.

2152. Larks in the popcorn. Garden City, N. Y., Doubleday, 1948. $256 \mathrm{p}$.

$$
\text { 48-9385 PN616r.S65734 }
$$

An account of life in the New York suburbs.

2153. We went thataway. Garden City, N. Y., Doubleday, 1949. $256 \mathrm{p}$.

$$
49^{-1} I_{5} I_{3} \quad \mathrm{PZ}_{3} . \mathrm{S}_{4} 80_{3} \mathrm{We}
$$

An account of a trip through the West to report to Mt. Kisco on the "western menace."

2154. Mister Zip. Garden City, N. Y., Doubleday, 1952. 252 p. 52-5112 $\mathrm{PZ}_{3} \cdot \mathrm{S6}_{4} 803 \mathrm{Mk}$

A satire, in novel form, on Hollywood westerns.

2155. The world, the flesh, and H. Allen Smith. Garden City, N. Y., Hanover House, 1954.

301 p. $\quad 54-8923 \quad \mathrm{PN}_{4} 874 . \mathrm{S}_{5} 6 \mathrm{~A}_{3} 8$

Selections made largely from Smith's London Journal (1952) and Low Man on a Totem Pole (I94I).

\section{JEAN STAFFORD, 1915-}

Jean Stafford is a New England novelist who has been much praised for her stylistic virtuosity as well as for psychological penetration. Her ambitious stories are more than well-written plots, for they attempt to comment on life and life values and on the position of good and evil in the world. Much of her work derives in mood and setting from her native New England. 
2157. Boston adventure. New York, Harcourt, Brace, 1944. 496 p.

$$
44-40{ }_{76} \quad \mathrm{PZ}_{3} . \mathrm{S}_{77} 8_{3} \mathrm{Bo}
$$

2158. The mountain lion. New York, Harcourt, Brace, r947. 23r p.

$$
{ }_{47}-\mathrm{r}_{9} 6_{3} \quad \mathrm{PZ}_{3} \cdot \mathrm{S}_{77} 8_{3} \mathrm{Mo}
$$

2159. The Catherine wheel, a novel. New York, Harcourt, Brace, 1952. 281 p.

$$
{ }_{52-6161} \mathrm{PZ}_{3} \cdot \mathrm{S}_{77}{ }_{3} \mathrm{Cat}
$$

2160. Children are bored on Sunday. New York, Harcourt, Brace, 1953. 252 p.

Short stories.

$$
{ }_{52-1}^{2} 3766 \mathrm{PZ}_{3} \cdot \mathrm{S}_{77} 8_{3} \mathrm{Ch}
$$

\section{6r. WALLACE EARLE STEGNER, 1909-}

Wallace Stegner regularly uses a setting in the Northwest and northern Midwest. In addition to his fiction, which began with short stories and his novelette Remembering Laughter (1937) about life on an Iowa farm, Stegner has written Mormon Country (1942), which is a history of the Mormons and, to a large extent, of Utah; One Nation (1945; with the editors of $($ ook), a report on foreign population elements in the United States; and $B e$ yond the Hundredth Meridian: John Wesley Powell and the Second Opening of the West (1954), a distinguished biographical-historical study.

2162. The Big Rock Candy mountain. New York, Duell, Sloan \& Pearce, 1943. 5 I5 p. 43-5128I PZ3.S8I8Bi

Life of a wandering family in the far West, Alaska, and Canada.

2163. Second growth. Boston, Houghton Mifflin, 1947. 240 p. $\quad 47-4398 \quad \mathrm{PZ}_{3} . \mathrm{S} 8 \mathrm{r} 8 \mathrm{Se}$

A story with a small New Hampshire town setting, reflecting the conflict of views between the regular inhabitants and the summer residents, who were largely educators.

2164. The preacher and the slave. Boston, Houghton Mifflin, r95o. 403 p.

$$
\text { 50-8708 } \mathrm{PZ}_{3} . \mathrm{S} 8 \mathrm{I} 8 \mathrm{Pr}
$$

A biographical novel about the last decade of the life of Joseph Hillstrom (1882-19r4), a leader of the I. W. W.

2165. The women on the wall. [Short stories] Boston, Houghton Mifflin, I950. 277 p.
2166. JESSE STUART, 1907-

Stuart first achieved recognition with his poems in Man With a Bull-Tongue Plow (1934), which depicted life in his native Kentucky hills. This folk-tale, local-color aspect dominates his rustic, regional works, which are written in a language reflecting the local dialect. His direct relationship to this area is unsophisticatedly present in his autobiographical works: Beyond Dark Hills (1938) and The Thread That Runs So True (1949), the latter covering his life through the time he left teaching to become a farmer so that he could afford to get married. It is not his nature to labor his work artistically, with the result that his plots are at times unconvincing, passing only as excuses for regionalistic prose emphasizing setting and character. While Stuart has been criticized for his excessive "cult of the primitive" and limited range, many enjoy his direct, down-to-earth stories.

2167. Head o' W-Hollow. New York, Dutton, 1936. 342 p. 36-8773 $\mathrm{PZ}_{3} . \mathrm{S}_{93} 06 \mathrm{He}$

Short stories.

2168. Men of the mountains. New York, Dutton, r94I. 349 p. $4 \mathrm{I}-4022 \quad \mathrm{PZ}_{3}$.S9306Men Short stories.

2169. Taps for Private Tussie. New York, Books, Inc., Distributed by E. P. Dutton, 1943. 303 p. illus. $\quad 43-17838 \quad \mathrm{PZ}_{3}$.S9306Tap2

2170. Tales from the Plum Grove hills. New York, Dutton, 1946. $256 \mathrm{p}$.

$4^{6}-7$ ror $\mathrm{PZ}_{3} . \mathrm{S}_{93} 06 \mathrm{Tal}$

2I7I. Clearing in the sky, \& other stories. New York, McGraw-Hill, 1950. $262 \mathrm{p}$. 50-1049I $\mathrm{PZ}_{3} . \mathrm{S}_{93} 06 \mathrm{Cl}$

2172. Kentucky is my land. [Poems] New York, Dutton, 1952. $95 \mathrm{p}$.

$$
\text { 52-I146r } \mathrm{PS}_{3537 . \mathrm{T}_{925} \mathrm{I}_{6 \mathrm{~K}}}
$$

2173. The good spirit of Laurel Ridge. New York, McGraw-Hill, 1953. 263 p. 53-10630 PZ3.S9306Go

\section{WILLIAM STYRON, 1925-}

Styron is a young author who has assimilated the influences of stream-of-consciousness novelists such as Faulkner and Joyce. His first novel dealt with the degeneracy of a Southern family.

2175. Lie down in darkness, a novel. Indianapolis, Bobbs-Merrill, r95I. 400 p.

$$
{ }_{5}^{\mathrm{I}-\mathrm{I} 2286} \mathrm{PZ}_{4} \cdot \mathrm{S}_{93} 8 \mathrm{Li}
$$




\section{PETER HILLSMAN TAYLOR, I9I7-}

Taylor is a Tennessee-born author whose stories reflect life in the upper South. He has been praised for his prose style, in which he quietly and simply presents complex psychological situations and character relationships and evokes the Southern setting. The continuing influence of the past in the present is a recurring factor in his work.

2177. A long Fourth, and other stories. New York, Harcourt, Brace, 1948. I66 p.

$$
4^{8-1781} \mathrm{PZ}_{3} \cdot \mathrm{T}_{21}{ }_{767} \mathrm{Lo}
$$

2178. A woman of means. New York, Harcourt, Brace, 1950 . $160 \mathrm{p}$.

$$
\text { 50-7597 } \mathrm{PZ}_{3} \text {. T21767 Wo }
$$

2179. The widows of Thornton. [Short stories] New York, Harcourt, Brace, 1954. 310 p. 53-7839 $\mathrm{PZ}_{3} . \mathrm{T}_{21767 \mathrm{Wi}}$

2180. GORE VIDAL, 1925-

Vidal is a skilled story-teller who in recent books has shown a tendency toward satire and irony. In one book, The City and the Pillar, he became almost a social tractarian, writing in a somewhat journalistic style on the problem of homo sexuality.

2181. Williwaw. New York, Dutton, 1946. 222 p. 46-4254 PZ3.V6668Wi

An "obscure corner of the war" novel which shows the experiences of three days on a freighter in the Aleutian waters while a williwaw is in progress.

2182. In a yellow wood. New York, Dutton, 1947. $216 \mathrm{p}$.

47-1967 PZ3.V6668In

A young veteran in a brokerage office roams through routine urban life confronted with the problem of possible alternative ways of life, but decides against a change.

2183. The city and the pillar. New York, Dutton, 1948. 314 p. 47-12503 PZ3.V6668Ci

2184. The season of comfort. New York, Dutton, I949. $253 \mathrm{p}$ 49-7028-PZ3.V6668Se

A young artist reaches spiritual and social maturity against a (Washington and national) background of a political family in the period between two world wars; the theme of the domineering mother is prominent.

2185. Dark green, bright red. New York, Dutton, 1950. $307 \mathrm{p}$. 50-9879 $\quad \mathrm{PZ}_{3}$.V6668Dar
A story of a Central American revolution, with an American for leading character.

2186. A search for the King, a 12th-century legend. New York, Dutton, I950. 255 p.

$$
\text { 49-50412 } \mathrm{PZ}_{3} \text {.V67 } \mathrm{Se}
$$

Based on the story of Blondel de Nesle's search for Richard Coeur de Lion.

2187. The judgment of Paris. New York, Dutton, 1952. $375 \mathrm{p}$.

52-5296 PZ3.V6668Ju

A young American goes to Europe to find himself, and finds self-discovery in love for his solution. The characters belong mainly to the international set or, at least, the international wanderers.

2188. Messiah. New York, Dutton, 1954. 254 p. 54-5053 PZ3.V6668Me

Somewhat in the tendency of science fiction, this is a story of the establishment, through modern advertising techniques and media, of a new messiah.

\section{I89. PETER ROBERT EDWIN VIERECK, IgI6-}

Peter Viereck is a satiric lyric poet who strives, in poetry that tends to be formal, for clarity and a conformity with what he considers the basic ethical implications of our civilization. He has also written several historico-philosophical works, such as Conservatism Revisited: The Revolt Against Revolt, 1815-1949 (1949) and Shame and Glory of the Intellectuals (1953), which more directly express the views and values with which he concerns himself.

2190. Terror and decorum; poems, 1940-1948. New York, Scribner, 1948. 1 10 p. 48-8754 $\quad \mathrm{PS}_{3543 . \mathrm{I}_{3} 25 \mathrm{~T}_{4}}$

219I. Strike through the mask! New lyrical poems. New York, Scribner, 1950. $70 \mathrm{p}$. 50-6348 PS $3543 . \mathrm{I}_{325} \mathrm{~S} 8$

"The essay in the appendix, "The poet in the machine age,' appeared in the Journal of the history of ideas, N. Y., I949."

2192. The first morning, new poems. New York, Scribner, 1952. $120 \mathrm{p}$.

$$
\text { 52-I2815 } \quad \mathrm{PS}_{3543 \cdot \mathrm{I}_{325} \mathrm{~F}_{5}}
$$

\section{ROBERT PENN WARREN, 1905-}

Warren is distinguished both as a poet and as a novelist, with an increasing mastery of form and technique. His early poetry was marked by its intellectualism and the influence of the metaphys- 
ical poets; his later work shows an assimilation of influences and a tendency to greater simplicity, along with the use of narrative and regional themes. While his work is not regional in the narrow sense of the word, he does use Southern material, with an emphasis on his native State, Kentucky.

2194. Night rider. Boston, Houghton Mifflin, 1939. 460 p. $\quad 39-5848 \quad \mathrm{PZ}_{3}$. W2549Ni

A novel of the tobacco war between growers and manufacturers in Kentucky in the early Igoo's.

2195. At heaven's gate. New York, Harcourt, Brace, 1943. 39I p.

$$
\text { 43-I3163 PZ3. W2549At }
$$

A modern "horror" novel in which sympathy aroused by a Southern girl's suicide saves her unscrupulous financier father.

2196. Selected poems, 1923-1943. New York, Harcourt, Brace, r944. Io2 p.

$$
\text { 44-3743 } \mathrm{PS}_{3545 \cdot \mathrm{A}_{74} 8 \mathrm{~S}_{4}}
$$

2197. All the king's men. New York, Harcourt, Brace, 1946. $464 \mathrm{p}$.

${ }_{4}^{6-6 I_{44}} \mathrm{PZ}_{3}$. W2549Al

Reflecting to some extent the career of Huey Long in Louisiana, this is a story of a Southern demagogue who attains political control of his State.

2198. The circus in the attic, and other stories. New York, Harcourt, Brace, r947. 276 p. 48-5I23 PZ3.W2549Ci

2199. World enough and time, a romantic novel. New York, Random House, 1950. 512 p.

$$
\text { 50-7242 } \mathrm{PZ}_{3} \text {. W2549Wo }
$$$$
\mathrm{PS}_{3545 . \mathrm{A}_{748} \mathrm{~W} 6} \text { I950 }^{\circ}
$$

Presenting a reconstruction of a Igth-century Kentucky murder case, the book mirrors the place and period of the story, as well as presenting some aspects of the author's search for the meaning of life and an assessment of man's values.

2200. Brother to dragons, a tale in verse and voices. [New York] Random House, I953. $230 \mathrm{p}$. 53-5009 $\mathrm{PS}_{3545 . \mathrm{A}_{748} 8 \mathrm{~B} 7}$

The story of an $18 \mathrm{x}$ I Kentucky frontier murder of a slave by the two sons of a sister of Thomas Jefferson.

2201. Band of angels. New York, Random House, 1955. $375 \mathrm{p}$.

55-58 I4 $\mathrm{PZ}_{3}$.W2549Ban

A somewhat melodramatic novel of the Civil War era, slavery, and miscegenation.

\section{EUDORA WELTY, 1909-}

Eudora Welty has been acclaimed as one of the best modern American short-story writers, with frequent mention made of her sensitivity, subtlety, and technical skill. She is a Southern writer who depicts much the same locale as does Faulkner. Her range of tone is considerable: nostalgic, fanciful, grotesque, humorous, etc. However, each book tends to be dominated by one tone. Her style and descriptions are the important elements, for she offers relatively little plot.

2203. A curtain of green. Garden City, N. Y., Doubleday, Doran, 1941. 285 p. $4 \mathrm{I}-52028 \quad \mathrm{PZ}_{3} \cdot \mathrm{W}_{4} 696 \mathrm{Cu}$

2204. The robber bridgegroom. Garden City, N. Y., Doubleday, Doran, I942. 185 p. 42-23596 $\mathrm{PZ}_{3}$. W4696Ro

2205. The wide net, and other stories. New York, Harcourt, Brace, r943. 214 p.

$$
\text { 44-I666 } \mathrm{PZ}_{3} . \mathrm{W}_{4} 696 \mathrm{Wi}
$$

2206. Delta wedding, a novel. New York, Harcourt, Brace, 1946. $247 \mathrm{p}$.

$$
{ }_{46-3217} \mathrm{PZ}_{3} . \mathrm{W}_{4} 696 \mathrm{De}
$$

2207. The golden apples. New York, Harcourt, Brace, 1949. 244 p.

$$
\text { 49-10054 } \mathrm{PZ}_{3} . \mathrm{W}_{4} 696 \mathrm{Go}
$$

2208. The Ponder heart. New York, Harcourt, Brace, $1954.156 \mathrm{p}$. illus.

A novelette.

54-5248 $\mathrm{PZ}_{3} \cdot \mathrm{W}_{4} 6{ }_{6} 6 \mathrm{Po}$

2209. The bride of the Innisfallen, and other stories. New York, Harcourt, Brace, I955.

207 p. $\quad 55-5248 \quad \mathrm{PZ}_{3} . \mathrm{W}_{4} 696 \mathrm{Br}$

\section{JESSAMYN WEST}

Jessamyn West is a novelist and short-story writer whose work ranges from realistic pictures of Indiana farm life through stories in the modern Gothic manner. She received notice also for her opera libretto $A$ Mirror for the Sky (1948), which presents the life of John Audubon (q. v.).

22II. The friendly persuasion. New York, Harcourt, Brace, I945. 2 I4 p.

45-3522I $\mathrm{PZ}_{3} . \mathrm{W}_{51903} \mathrm{Fr}$

Sketches of the life of Quakers in Indiana during the second half of the I gth century. 
2212. The witch diggers. New York, Harcourt, Brace, 195I. $44^{\mathrm{I}} \mathrm{p}$.

$$
\text { 5I-9108 } \mathrm{PZ}_{3} . \mathrm{W}_{51903} \mathrm{Wi}
$$

A symbolic and somewhat Gothic novel depicting life on a poor farm in Southern Indiana in 1899.

2213. Cress Delahanty. New York, Harcourt, Brace, 1953. 3II p.

$53-5654 \quad \mathrm{PZ}_{3} \cdot \mathrm{W}_{51903} \mathrm{Cr}$

An adult's somewhat humorous view of the life of an adolescent girl on a California ranch.

2214. Love, death, and the ladies' drill team. New York, Harcourt, Brace, 1955. 248 p.

Short stớries.

$$
\text { 55-10809 } \mathrm{PZ}_{3} \text {. W5 } 5 \text { 1903Lo }
$$

\section{RICHARD PURDY WILBUR, 1921-}

Richard Wilbur's poetry is a leading example of the modern neo-classic formal verse that has become prominent in the work of the younger poets. Lyrical and precise in observation, with life imaginatively perceived, some of his work is humorous, but normally far from the category of "light verse."

2216. The beautiful changes, and other poems. New York, Reynal \& Hitchcock, 1947. 55 p. 47-11597 $\mathrm{PS}_{3545.1}$ I2165 $_{4}$

2217. Ceremony, and other poems. New York, Harcourt, Brace, I950. 55 p.

$$
\text { 50-I0749 } \mathrm{PS}_{3545 . \mathrm{I}_{32165} \mathrm{C}_{4}}
$$

\section{TENNESSEE WILLIAMS, 1914-}

The plays of Tennessee Williams (whose original name was Thomas Lanier Williams) frequently draw on the Mississippi Delta region for setting and characters. With sympathy and understanding he presents, in a poetic and sometimes symbolistic style, characters so weighed down by the past that their incorrect adaptation to current life leads them to frustration and breakup.

2219. The glass menagerie. New York, Random House, 1945. I $24 \mathrm{p}$.

$$
45-7913 \quad \mathrm{PS}_{3545 . \mathrm{I}_{53} 65 \mathrm{G}_{5}}
$$

This work, which was successful as a play and in its motion-picture adaptation, is the story of the remnants of a Southern family with pretensions to gentility; the plot centers about the crippled daughter who lives in her dream world with a symbolic collection of fragile glass pieces, which stands in contrast with the family's St. Louis slum apartment.
2220. 27 wagons full of cotton, and other one-act plays. Norfolk, Conn., New Directions, 1946. 207 p. $\quad 46-2373 \quad \mathrm{PS}_{3545 . \mathrm{I}_{53} 6_{5} \mathrm{~T} 9}$ The motion picture Baby Doll (1956) is based on a film script which Williams produced by reworking the story of the title play in this collection. A small part of the film's plot was also drawn from the one-act play, The Long Stay Cut Short (1946). The two source plays are included in the version of the screen play published by New Directions.

222r. A streetcar named Desire. New York, New Directions, 1947. I71 p.

$$
4^{8-5556} \quad \mathrm{PS}_{3545 \cdot \mathrm{I}} 5365 \mathrm{~S} 8
$$

This play, which was awarded a Pulitzer prize for drama, and which was widely acclaimed both as a play and then as a movie, presents against a New Orlcans background the story of a neurotic, scxually frustrated woman, a descendant of a once prominent family, who is in conflict with the "vulgar" society of the slums, and unable to resolve for herself the problems of modern life.

2222. One arm, and other stories. [New York] New Directions, 1948. 2 10 p.

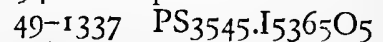

Contents.-One arm.-The malediction.-The poet.-Chronicle of a demise.-Desire and the black masseur.-Portrait of a girl in glass.-The important thing.- The angel in the alcove.-The field of blue children.-The night of the iguana.-The yellow bird.

2223. Summer and smoke. New York, New Directions, 1948. I $30 \mathrm{p}$.

$$
4^{8-1}{ }_{1} 6_{97} \quad \mathrm{PS}_{35} 45 \cdot \mathrm{I}_{53} 6_{5} \mathrm{~S}_{5}
$$

Set in a small Mississippi town, this play presents the story of a young woman who is unable to resolve satisfactorily the problems of her emotional life.

2224. The Roman spring of Mrs. Stone. [New York] New Directions, 1950. 148 p.

$$
\text { 50-9067 PZ3.W67655 Ro }
$$

This tautly wrought novelette is the story of a widowed actress who has retired to Rome, where she is confronted with the problem of trying to achieve a satisfactory love life.

2225. The rose tattoo. New York [New Directions] I95I. $144 \mathrm{p}$.

$$
\text { 5I-I I } 004 \text { PS } 3545.15365 R 6 \text { I95I }
$$

This play, which also had a successful screen adap tation, is unusual among Williams' usually sombre works in that with a touch of humor it relates the story of a widow finding love in a Gulf-coast community. 
2226. Camino Real. [Norfolk, Conn.] New Directions, 1953. I6I $\mathrm{p}$.

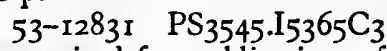

This text is a version, revised for publication, of a symbolistic and surrealistic play which in its technique was a new departure for Williams.

2227. Hard candy, a book of stories. [New York] New Directions, 1954. 220 p. 54-4797 $\mathrm{PZ}_{3} \cdot \mathrm{W}_{7} 6_{55} \mathrm{Har}$

2228. Cat on a hot tin roof. [Play. New York] New Directions, 1955. $197 \mathrm{p}$.

55-3093 PS $3545 . \mathrm{I}_{5365} \mathrm{C}_{37}$

This play, which received a Pulitzer prize for drama, is set on a Mississippi Delta plantation; its story is in large part that of a wife trying to reestablish sexual relations with her husband, who is suspected of being a homosexual.

\section{HERMAN WOUK, 1915-}

The setting of Wouk's writings has been New York City, in which he was raised, and the Navy, in which he served during World War II. His first book, Aurora Dawn (I947), is a satirical novel about the New York business world. His next work, The City Boy (1948), was a best-selling novel about an urban childhood. After that he turned briefly to drama with The Traitor (1949), a play about an American Communist. His work since then has grown in complexity and bulk, so that it appears at infrequent intervals. Through all his writings he has remained in the realist tradition, presenting life as it may be seen. With the best-selling status and impressiveness of his recent work, and the reissuance of his earlier novels, some now regard him as one of the more promising of the younger novelists.

2230. The Caine mutiny, a novel of World War II. Garden City, N. Y., Doubleday, 1951. 494 p. 51-9977 $\mathrm{PZ}_{3}$.W923 Cai

A novel about a Navy mutiny during World War II. It is a fictional incident in a historical setting, and it reflects Navy life of the period. The work was used as the source for a successful stage play and for a much praised movie.
2231. Marjorie Morningstar. Garden City, N. Y., Doubleday, r955. $565 \mathrm{p}$.

$\begin{array}{lll}55^{-6} 8_{5} & \mathrm{PZ}_{3} . \mathrm{W}_{923} \mathrm{Mar}\end{array}$

A novel reflecting life in a Jewish family in New York City.

\section{RICHARD NATHANIEL WRIGHT, rgo8-}

Richard Wright has been considered America's foremost Negro novelist, although his most recent novel, The Outsider, was generally reviewed unfavorably. He was raised among lower-class Southern Negroes and later moved to Chicago; it is this background that is reflected in his stories, especially in the autobiographical Black Boy (1945). Although his work inclines to the melodramatic, it is stylistically in the tradition of realism. In the thirties Wright became interested in communism and some of his work exhibits an awareness of leftist doctrines and attitudes.

2233. Native son. New York, Harper, 1940. $359 \mathrm{p}$. $\quad 40-4862 \quad \mathrm{PZ}_{3}$. W9352Nat

A somewhat melodramatic tale of the life and criminal acts of a Negro youth in the Chicago slums.

2234. Uncle Tom's children, five long stories. New York, Harper, [1940] xxx, 384 p. 40-29877 PZ3. W9352Un2

First published 1938 without the autobiographical introduction and without the fifth story.

Contents.-The ethics of living Jim Crow; an autobiographical sketch.-I. Big boy leaves home.2. Down by the riverside.-3. Long black son.-4. Fire and cloud.-5. Bright and morning star.

2235. The outsider. New York, Harper, 1953. 405 p. $\quad 53-5383 \quad \mathrm{PZ}_{3}$. W9352Ou

A melodramatic thesis novel with first a Chicago and then a New York setting. The story is that of a Negro whose mentality leads him to ruin through problems of alcohol, women, money, and communism. The book is meant to be a commentary on the emotional strains of life in our times. 


\section{II \\ Language}

$\left.\llbracket \begin{array}{ll}\text { A. Dictionaries } & 2236-224 \mathrm{I} \\ \text { B. Grammars and General Studies } & 224^{2-2252} \\ \text { C. Dialects, Regionalisms, and Foreign Languages in America } & 2253^{-2271} \\ \text { D. Miscellaneous } & 227^{2-2275}\end{array}\right]$

T HAS frequently been said that there is no American language, but that each individual 1 speaks his own language. To some extent this is true of any language, but that is more a problem for semantics (discussed under Philosophy, q. v.) than it is for linguistics. For there is obviously a basic language and a central core of usage. It is this central core of usage in the United States that is our main concern here, with some attention paid to aspects that are peripheral to it.

At the same time there is no intention at this point to enter into the question of a separate American language. It is simply noted that American English diverges from British English at a number of points, and to these differences attention is directed. As a result of this approach, some major works such as Otto Jespersen's A Modern English Grammar on Historical Principles; Completed ... . by Niels Haislund (Copenhagen, Munksgaard, 1949. 7 v.) have been omitted; for while they are highly useful for determining the language's historical background, they are mainly oriented towards British English. We have, however, considered for inclusion general works which were oriented towards American English, or which specifically studied the divergences that have developed between the two forms of the language.

Since dialects have played a role in the development of the language, and since they are a part of the general language picture in this country, a few books on dialect have been selected for their com-

prehensive coverage, or because they deal with major dialect groups. No attempt was made to cover all dialects and their variations; the compromise being the usual one of presenting representative titles.

The same is largely true for the few books on foreign languages in America, which were selected to represent some of the historically more important language groups of the many that have played so large a part in the life and in the developing English of an amalgamating people.

Since a certain amount of slang enters the more formal language with the passage of time, and since so much American literature has used slang in dialogue passages, a few guides to slang terms have been included.

New information on the changing language, as well as much on aspects of its past development, may be obtained from periodicals such as Language, the Linguistic Society of America's journal, and in American Speech; a Quarterly of Linguistic Usage.

\section{A. Dictionaries}

2236. Craigie, Sir William A., and James H. Hulbert, eds. A dictionary of American English on historical principles, compiled at the University 176 of Chicago. Chicago, University of Chicago Press [1938-44] 4 v. 39-8203 $\mathrm{PE}_{28}$ 35.C $72^{2}$ Paged continuously; bibliography: p. 2529-2552. 
This book attempts to present words that are either clearly or seemingly of American origin, as well as those more used in or associated with America. The terminal date for admission was I900, although some illustrations have been chosen from later writing; also, slang words were included only if of early origin or of special prominence. With these limitations, the dictionary is not one for the language written or spoken in America, but rather one for those elements which have originated or developed in America, adding to or modifying the English-language stock. A broader, though less detailed, coverage of the language may be found in works such as Webster's New International Dictionary of the English Language, $2 \mathrm{~d}$ ed., unabridged (Springfield, Mass., Merriam, 1945. cxii, 3210 p.), which has developed out of the original efforts of Noah Webster, whose biography is included in the Education section of this bibliography. Another long-established American dictionary which covers the language on a very broad basis is Funk \& Wagnalls New "Standard" Dictionary of the English Language . . . (New York, Funk \& Wagnalls, 1952. $1 \mathrm{xx}, 28 \mathrm{I} 5$ p.).

2237. Horwill, Herbert W. A dictionary of modern American usage. 2d ed. Oxford, Clarendon Press, 1944. xxxi, $360 \mathrm{p}$. A46-686 PE2835.H6 1946

First published in 1935, this work presents in a dictionary arrangement a discussion of American word usage as it differs from traditional British usage. The work does not cover slang, and it is nol designed to serve as a complete dictionary of "Americanisms."

2238. Kenyon, John Samuel, and Thomas Albert Knott, eds. A pronouncing dictionary of American English. Springfield, Mass., Merriam, 1953. 484 p. 53-14I6 PEIr37. 37

A record of the colloquial speech forms of educated Americans throughout the country; there is no attempt to provide for dialectal variations. The work covers the words in common usage in America, with special attention given to proper names. The work differs from, and so supplements, other dictionaries such as Webster's New International Dictionary, $2 \mathrm{~d}$ ed., in that the latter records the pronunciation of formal platform speech. The Kenyon and Knott book contains no definitions. Dr. Knott was general editor of the New International Dic- tionary, and Dr. Kenyon served as consulting editor in pronunciation.

2239. Mathews, Mitford M., ed. A dictionary of Americanisms on historical principles. Chicago, University of Chicago Press, I95I. 2 v. (xvi, 1946 p.)

Bibliography: p. 19r3-1946. 51-1957 $\mathrm{PE}_{28} 85 . \mathrm{D}_{5}$

This work is devoted exclusively to words which either originated in America or took on a new meaning here. In this respect it is more limited than Craigie's Dictionary of American English, above. However, within its limitations it is more complete, partly in inclusiveness, but mainly because it is more up-to-date. A discussion of the history and relative merits of leading types of dictionaries of the language may be found in James Root Hulbert's Dictionaries, British and American (London, A. Deutsch, 1955. 107 p.).

2240. Thornton, Richard H. An American glossary, being an attempt to illustrate certain Americanisms upon historical principles. Philadelphia, Lippincott, 1912. $2 \mathrm{v}$.

$$
\text { 30-25356 PE2835.T6 I912a }
$$

Volume III, edited by Louise Hanley. Madison, Wis., American Dialect Society, 1939. xiv, 452 p. (In Dialect notes ... New Haven, Conn., 1931-39. v. 6, pt. 3-18)

$$
\text { 30-25356 PE280r.D5, v. } 6
$$

"A biographical sketch of Richard Hopwood Thornton, LL. D., by the Reverend E. H. Clark": p. v-viii.

The first two volumes of the glossary constitute an historically important contribution to the subject, although they have in large part been superseded by Craigie's and Mathews' volumes cited above. However, the third volume, which was published in parts in the periodical Dialect Notes, has not been superseded, and it remains one of the most important reference works on the vocabulary of American dialects.

224I. Wentworth, Harold. American dialect dictionary. New York, Crowell, 1944. 747 p.

$$
\text { 44-6209 } \mathrm{PE}_{2} 835 . \mathrm{W}_{4}
$$

This is a dictionary which presents American local and regional terms, and those which verge on being colloquial. It supplies examples of early usage. 


\section{B. Grammars and General Studies}

2242. Curme, George O. Parts of speech and accidence. Boston, Heath, 1935. 370 p. (A Grammar of the English language .... v. 2) 35-17513 PErio5.G7, v. 2

2243. Curme, George O. Syntax. Boston, Heath, 1931. 616 p. (A Grammar of the English language...v. 3) $3 \mathrm{I}$-I9900 PEIro5.G7, v.3 The two volumes of $A$ Grammar of the English Language which have so far appeared approach the problem as that of one language; however, whereever necessary the differences between American and British English are discussed in detail. The first volume, History of the English Language, Sounds and Spellings, Word-Formation, by Hans Kurath, has not yet appeared, although it is still listed in the publisher's 1956 catalog.

2244. Fries, Charles C. American English grammar; the grammatical structure of presentday American English with especial reference to social differences or class dialects. The report of an investigation financed by the National Council of Teachers of English and supported by the Modern Language Association and the Linguistic Society of America. New York, Appleton-Century, 1940. 313 p. (National Council of Teachers of English. English monographs, no. 1o) 41-347 PE28 Ir.Fy

A report on the grammar of "standard" American English. The author recognizes that there may be a number of acceptable forms, rather than one "correct" form. Most of the distinctions made in the book are between "standard" and "vulgar" American English, with an attempt to record their frequency, extent, and divergencies.

2245. Galinsky, Hans. Die Sprache des Amerikaners; eine Einführung in die Hauptunterschiede zwischen amerikanischem und britischem Englisch der Gegenwart. Heidelberg, F. H. Kerle, 1951-52. $2 \mathrm{v}$.

52-37439 $\mathrm{PE}_{28}$ 13. $_{3}$

A detailed study and analysis of the American language as contrasted with British English. The emphasis is on the present-day situation, and not on the historical development, nor is it on dialectical variations. The first volume is divided into two sections on "Das Klangbild" and "Die Schreibung"; the second volume covers "Wortschatz und Wortbildung" and "Syntax und Flexion." Both volumes contain an extensive selective bibliography.
2246. Krapp, George P. The English language in America. New York, Century, for the Modern Language Association of America, 1925. 2 v.

Bibliography: v. 2, p. 273-284.

25-19533 $\mathrm{PE}_{2} 808 . \mathrm{K}_{7}$

Krapp (1872-1934) was a professor of English at Columbia University, and a leading student of the language of America. The first volume of his major work in this field has seven essays on "The Mother Tongue," "Vocabulary," "Proper Names," "Literary Dialects," "Style," "American Spelling," and "American Dictionaries." The second volume is devoted to pronunciation. Another work by him on the latter aspect is The Pronunciation of Standard English in America (New York, Oxford University Press, American Branch, 1919. 235 p.).

2247. Mathews, Mitford M., ed. The beginnings of American English; essays and comments. Chicago, University of Chicago Press, I931. I8I p. $3^{\mathrm{I}-28 \mathrm{I}_{4}} \mathrm{PE} 2805 . \mathrm{M}_{3}$

A useful collection of material made up mainly of quotations from I8th- and early Igth-century writers on the English language in America. A word index is supplied.

2248. Mencken, Henry L. The American language; an inquiry into the development of English in the United States. $4^{\text {th }}$ ed., cor., enl., and rewritten. New York, Knopf, r936. 769 p. 36-27236 PE2808.M4 1936

"Proper names in America": p. 474-554.

- Supplement I-II . . . New York, Knopf, 1945-48. 2 v. PE2808.M4 1936 Suppl. Includes bibliographies.

Mencken, who is included in the Literature section (q. v.), was a journalist rather than a linguist; nevertheless, he compiled one of the outstanding works on the history and nature of the American language. In addition to the Americana of "good" American English and place-names, he studied extensively American slang and dialects. The work does not attempt to rival the dictionaries in the field (compiled well after the first edition of his work in 1919), but is largely in the form of discursive text and essays. However, an excensive index in the main volume and its supplements does enable it to serve also as a lexicon of much linguistic esoterica. The supplements are aligned chapter by chapter with the main work. 
2249. Myers, Louis M. Guide to American English. New York, Prentice-Hall, 1955. 433 p. 55-8367 PE111.M954

A grammar aimed at students, this work presents American English without emphasizing British differences or using traditional approaches and terminology which the author regards as obsolete. The interest is in written English, rather than in the spoken language. Parts of the book have been drawn from the author's earlier American English; a Twentieth-Century Guide (New York, PrenticeHall, 1952. 237 p.).

2250. Pyles, Thomas. Words and ways of American English. New York, Random House, 1952. $310 \mathrm{p}$. 52-5156 PE:2808.P9

"The present book ... is an attempt to provide for the lay reader a brief yet adequate treatment of the English language as it has been and is spoken and written by Americans."-Preface.

A general introductory book to the topic is Richard D. Mallery's Our American Language (Garden City, N. Y., Halcyon House, 1947. 276 p.).
2251. Robertson, Stuart. The development of modern English. 2d ed., rev. by Frederic G. Cassidy. New York, Prentice-Hall, 1954. 469 p. 53-1301 I PEro75.R57 1954

A study of the history and nature of English, with the emphasis placed on picturing modern American English in its context within the English language as an entity. Individual chapters are followed by references for further reading. The original version of the work first appeared in 1934 .

2252. Schele de Vere, Maximilian. Americanisms; the English of the New World. New York, Scribner, 1872. 685 p. 10-26369 $\mathrm{PE}_{28} 85 . \mathrm{S}_{4}$

A work which in individual chapters studies special sources of Americanisms. There are chapters on the American Indian, immigrants, the West, politics, etc. The work is not meant to be exhaustive, but rather to track down the unusual Americanisms that at the period were to be found in good American English.

\section{Dialects, Regionalisms, and Foreign Languages in America}

2253. Adams, Ramon F. Western words; a dictionary of the range, cow camp and trail. Norman, University of Oklahoma Press, I944. I82 p. 44-40294 $\mathrm{PE}_{3727 . C 6 A_{4}}$

The concern in this dictionary is with the terminology of the range country of the West, not with pronunciation or local dialect variations. Bruce Grant's The Cowboy Encyclopedia (Chicago, Rand McNally, I951. I60 p.) has a smaller, if occasionally different, selection of words; but it also provides fairly extensive sketch illustrations.

2254. American Dialect Society. Publication. v. I 1944 + Gainesville, Fla.

The Publications were preceded by a similar series, Dialect notes, published by the Society from 1890 to 1939. Issues of the present series now appear twice a year; some representative titles from this series follow:

2255. Nixon, Phyllis J. A glossary of Virginia words. The secretary's report. 1946. 46 p. (no. 5) 46-8431 $\mathrm{PE}_{3}$ Ior.V8N5

2256. Woodard, Clement M. A word-list from (no. 6)

Virginia and North Carolina. I946. $46 \mathrm{p}$. 47-23449 PE3ror.V8W6
"Words from A glossary of Virginia words [by Phyllis J. Nixon] current in Maine, by B. J. Whiting": p. 44-46.

2257. Figh, Margaret Gillis. A word-list from "Bill Arp" [pseud.] and "Rufus Sanders" [pseud.] Comments on word-lists in PADS, by James Nathan Tidwell. A word-list from southern Kentucky, by A. P. Dalton. The secretary's report. 1950. 27 p. (no. 13) 5I-842I PE2926.Fs

2258. Bradley, Francis W. A word-list from South Carolina. Expressions from rural Florida, by Lucille Ayers and others. Minorcan dialect words in St. Augustine, Florida, by Lillian Friedman. 1950. 81 p. (no. I4)

$$
\text { 5I-8422 } \mathrm{PE}_{2927 . S 6 \mathrm{~B} 7}
$$

2259. Maurer, David W. The argot of the racetrack. I95I. 70 p. (no. 16) 52-8820 $\mathrm{SF}_{333} \cdot \mathrm{M}_{34}$

2260. Reed, David W. Eastern dialect words in California. Supplementary list of South Carolina words and phrases, by F. W. Bradley. The secretary's report. I954. 49 p. (no. 21) 54-3363 $\mathrm{PE}_{3}$ ror. $\mathrm{C}_{3} \mathrm{R}_{4}$ 
226r. Ives, Sumner. The phonology of the Uncle Remus stories. 1954. 59 p. (no. 22) 55-99 PSI818.185

2262. Maurer, David W. Whiz mob; a correlation of the technical argot of pickpockets, with their behavior pattern. I955. 199 p. (no. 24) 56-1443 $\mathrm{PE}_{3726 . \mathrm{M}_{3}}$

2263. Atwood, E. Bagby. A survey of verb forms in the eastern United States. [Ann Arbor] University of Michigan Press, 1953. viii, 53 p. 31 maps. (Studies in American English, 2)

53-7458 PEI273.A89

A study, with map illustrations, of the distribution along the Atlantic seaboard of American regional variants in verbal inflections and verb vocabulary. A leading result is the demonstration that the "vulgate" is not one, but many, and largely regional.

2264. Bentley, Harold W. A dictionary of Spanish terms in English, with special reference to the American Southwest. New York, Columbia University Press, 1932. 243 p. (Columbia University studies in English and comparative literature) 33-2210 PE1582.S7B4 1932a

A study of the influence of Spanish on English, especially in the American Southwest, where the two languages early came into contact. More than half the book is devoted to a dictionary presentation of Spanish terms and phrases used in English; there is also an appendix of American proper names which have their source in Spanish.

2265. Broussard, James F. Louisiana Creole dialect. Baton Rouge, Louisiana State University Press, 1942. $134 \mathrm{p}$.

\section{3-52792 PM7854.L6B7}

Contents. - Preface.-Phonetics.-Grammar.Idioms.-Folklore: Proverbs and dit-ons. Medical prescriptions. Superstitions. Poetry. Tales.-La Fontaine's fables in translation.-Glossary.-Bibliography (p. 130-r34).

A presentation of the dialect of French which started with the Negro slaves of white French owners. While fairly widely used in Louisiana, this is neither the Acadian French dialect found among many French groups in the state, nor is it the more urban French found among the descendants of the aristocracy. Both of these are much closer to the language as spoken in France.

2266. Buffington, Albert F, and Preston A. Barba. A Pennsylvania German grammar. Allentown, Pa., Schlechter, 1954. $167 \mathrm{p}$.
Pennsylvania German (also known as Pennsylvania Dutch) is a dialect of German that is represented by several hundred thousand native speakers, most of whom live in Pennsylvania, although a scattering of others may be located in New Jersey, Delaware, Maryland, North Carolina, and elsewhere. A fairly complete early phonetic dictionary of the dialect's distinctive words may be found in A. R. Horne's Pennsylvania German Manual, $3 \mathrm{~d}$ ed. (Allentown, Pa., T. K. Horne, 1905. 146 p.). Edwin R. Danner's Pennsylvania Dutch Dictionary (York, Pa., Dispatch Pub. Co., 1951. 178 p.) approaches the language through English. This dialect has accumulated a sizable literature. It is discussed in Earl F. Robacker's Pennsylvania German Literature: Changing Trends from 1683 to 1942 (Philadelphia, University of Pennsylvania Press, 1943. 217 p.), which includes an extensive bibliography on p. 189-202.

2267. Haugen, Einar. The Norwegian language in America; a study in bilingual behavior. Philadelphia, University of Pennsylvania Press, 1953. 2 v. (xiv, 695 p.) maps, diagrs., tables. (Publications of the American Institute, University of Oslo in coöperation with the Department of American Civilization, Graduate School of Arts and Sciences, University of Pennsylvania)

53-11316 $\mathrm{PD}_{26}{ }_{5} 5 . \mathrm{H}_{3}$

Contents.-v. I. The bilingual community.v. 2. The American dialects of Norwegian.

The Norwegian immigrants settled predominantly in Minnesota, North and South Dakota, Wisconsin, Montana, Iowa, Idaho, Illinois, Washington, and Oregon. The first volume of this work studies the historical and sociological aspects behind the linguistic problems of the Norwegian-American communities. The second volume studies the more purely linguistic problems, such as the inter-influence of Norwegian and English.

2268. Kurath, Hans, ed. Linguistic atlas of New England, by Hans Kurath, director and editor [with the collaboration of] Miles L. Hanley, associate director; Bernard Bloch, assistant editor, Guy S. Lowman, Jr., principal field investigator, Marcus L. Hansen, historian . . . sponsored by the American Council of Learned Societies and assisted by universities and colleges in New England. Providence, R. I., Brown University, 1939-43. 3 v. in 6. double maps. and handbook: xii, 240 p. maps. (Linguistic atlas of the United States and Canada) 39-3245I $\mathrm{PE}_{2} 845 \cdot \mathrm{L}_{5} \mathrm{~K} 8$ The Handbook has also special t. p.: Handbook of the linguistic geography of New England, by Hans Kurath, with the collaboration of Marcus L. Hansen, Julia Bloch [and] Bernard Bloch. 
"Bibliography of linguistic geography": Handbook, p. 54-61; "Bibliography of New England history": Handbook, p. 105-121.

The six very large volumes of the main part of this work present a linguistic analysis of the New England area mainly through the medium of folded maps marked to indicate the different areas of usage of a given form. The smaller handbook, which appeared in a larger edition, to some extent summarizes the material and presents an analysis of the historical background. The set was designed as the first part of a linguistic atlas of the United States and Canada, but no subsequent parts have yet appeared.

2269. Kurath, Hans. A word geography of the Eastern United States. [Ann Arbor] University of Michigan Press, I949. x, 88 p. I6 3 (i.e. 164) maps. (Studies in American English, I)

49-50233 PE2970.E2K87

Based on material collected for a linguistic atlas for the Eastern States, begun in I93I under the auspices of the American Council of Learned Societies.

Considers the dissemination of localized words, and provides historical interpretation for such dis- tribution, as well as for the development and subdivision of speech areas. The text is followed by diagrammatic maps illustrating the distribution of the words discussed and outlining the speech areas.

2270. Randolph, Vance, and George P. Wilson. Down in the holler; a gallery of Ozark folk speech. Norman, University of Oklahoma Press, 1953. $320 \mathrm{p}$.

Bibliography: p. 303-314.

A study, based largely on many years of personal observation, of the Ozark dialect. In addition to a dictionary approach to unusual words and word usage, there are chapters on other matters, such as general pronunciation, old English words which have survived in the dialect, folk sayings, figures of speech, etc.

227x. Turner, Lorenzo Dow. Africanisms in the Gullah dialect. Chicago, University of Chicago Press, 1949. 3 I7 p.

Bibliography: p. 293-299.

49-10175 $\mathrm{PM}_{7} 875 . \mathrm{G} 8 \mathrm{~T} 8$

A study of the Gullah dialect (which is spoken by Negroes of the South Carolina and Georgia coastal area) with emphasis on the African influence.

\section{Miscellaneous}

2272. Berrey, Lester V., and Melvin Van den Bark.

The American thesaurus of slang; a complete reference book of colloquial speech. $2 \mathrm{~d}$ ed. New York, Crowell, 1953. xxxv, 1272 p.

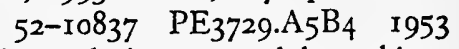

The bulk of this work is arranged by subject, with a complete index provided at the end. A shorter work is Joseph A. Weingarten's An American Dictionary of Slang and Colloquial Speech (New York, 1954. 390 p.), which arranges the words themselves alphabetically; the attempt was to include all general American slang and colloquialisms, and to indicate the earliest known usage for any given meaning. A much larger work also on historical principles is Eric Partridge's A Dictionary of Slang and Unconventional English (New York, Macmillan, 1951. I230 p.); however, the emphasis in this work is upon Britishisms.

2273. Kenyon, John S. American pronunciation. roth ed. Ann Arbor, Mich., Wahr Pub. Co., 1950. 265 p. $\quad$ 51-5688 PEII35.K $4195^{\circ}$
This book is designed primarily as an advanced textbook of the pronunciation of American English.

2274. Partridge, Eric. A dictionary of the underworld, British \& American, being the vocabularies of crooks, criminals, racketeers, beggars and tramps, convicts, the commercial underworld, the drug traffic, the white slave traffic, spivs. New York, Macmillan, I950. 804 p.

$$
\text { 50-8598 } \mathrm{PE}_{3726 . \mathrm{P}_{3}}
$$

Since this is a dictionary compiled on historical principles, and supplied with numerous examples and indications of period and milieu, there has been little attempt to be up to date. However, as the author points out, the conservatism of underworld slang leaves much of it still current. A less scholarly and non-historical work that may be used for supplementary purposes is the Dictionary of American Underworld Lingo (New York, Twayne Publishers, I950. 327 p.), edited by Hyman E. Goldin, Frank O'Leary, and Morris Lipsius; this work was compiled in prisons by prisoners and reflects the current situation, but without indication of either the origin or the evolution of the terms. A similar work 
by an amateur linguist is Criminal Slang; the Vernacular of the Underworld Lingo (Boston, Christopher Pub. House, 1949. 292 p.), by Vincent J. Monteleone, who compiled it through his experiences as a law enforcement officer.

2275. Pike, Kenneth L. The intonation of American English. Ann Arbor, University of
Michigan Press, 1945. 200 p. (University of Michigan publications. Linguistics. v. I)

Bibliography: p. I9I-200.

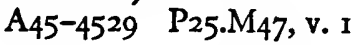

"This present study is . . . a statement of the structure of the English intonation system as such, in relation to the structural systems of stress, pause and rhythm ..."-Preface. 


\section{Literary History and Criticism}

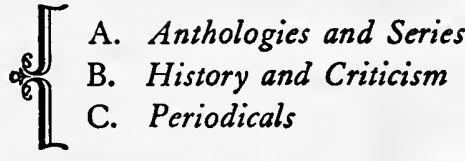

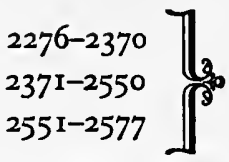

\section{$T$}

HIS section seeks to provide material for an approach to, and a clarification of, many views of American literature: as a general field, an d as a field for more specialized study in terms of genre, period, area, sociological implications, historical backgrounu, etc. It also provides for the study of criticism as a field in itself, and it opens up some paths of literature not explored within the Literature section (such as the detective story), and it presents, through prominent placing in critical works and in series, authors not included elsewhere. Thus this section not only seeks to serve for the analysis and clarification of literary materials presented el sewhere, but to lead to materials not otherwise presented.

An alphabetic arrangement has been adopted in each subsection in preference to a subject arrangement for several reasons. One is that the subject matter of many of the works listed is so various as to justify inclusion of each particular work under any one of several topics. Another is that a number of the iiterary critics and historians are of interest in their own right, so that it was deemed unadvisable to scatter their works on a subject basis. Not only would the placing of a book in one of several possible subject subdivisions be disputable, but on any level the titles so assembled would be incomplete, for much of the material on the same subject is elsewhere in the bibliography: e. g., all works of literary history and criticism, by writers having author entries under Literature, have been discussed along with the other works by those authors. This means that much important historical and critical work (by Blackmur, Eliot, Poe, Pound, Tate, etc.) is not to be found here, but under Literature. Also, much material on drama is to be found under Entertainment. Accordingly, the index must be rather extensively used to locate all relevant items.

Because of the large mass of material suitable for consideration for inclusion in this section, many works have had to be excluded by arbitrary limitations. Except in the case of works in a series, which as a whole might be regarded as general studies or anthologies, no work has been included here which deals with a single author. Highly specialized studies along other lines have also been excluded. For the rest, works were excluded if they were seriously out of date or if they too closely overlapped the material of other volumes; a few exceptions were made for works important in the history of criticism or as examples of literature in their own right. Most cases of special pleading, such as Calverton's Marxist approach to literature, have also been eliminated. Much of the excluded material may readily be identified through the bibliography volume of the Spiller, Thorp, Johnson, and Canby Literary History of the United States, which is

This listing of anthologies and series has been highly selective, except for the rather liberal representation given to textbook anthologies designed for use on the college level. If justification is sought for this exception, it may be found in the fact that these general anthologies of American literature present on the whole a uniformly high quality of editorial apparatus together with selections carefully chosen for the purpose at hand. It may be noted further that they present all too frequently the most available text, in part or in whole, of works listed individually in the literature section. An obvious additional factor is that they are excellent introductions to a large field. The main limitalisted below. 
tions imposed on selection of such anthologies is that no out-of-print works, however excellent, have been included.

Since the entire field of literary history and criticism, along with literature itself, is constantly and rapidly expanding, and since so much in both categories is often long available only in periodicals, there has been included a group of periodicals which are important for their role in the propagation of serious literature, literary history, and criticism.

\section{A. Anthologies and Series}

2276. American literature: a period anthology. Oscar-Cargill, general editor. [Rev. ed.] New York, Macmillan, 1949. 4 v.

\section{$49-48760 \quad \mathrm{PS}_{504} \cdot \mathrm{A}_{62}$}

Contents.- $[\mathrm{v} . \mathrm{I}$.$] The roots of national culture,$ American literature to 1830 , edited by Robert $E$. Spiller and Harold W. Blodgett (49-9906).--[v. 2] The romantic triumph; American literature from 1830 to 1860 , edited by Tremaine McDowell (49r 1990).--[v. 3] The rise of realism; American literature from 1860 to 1900 , edited by Louis Wann (49-41 19).- - [v. 4] Contemporary trends; American literature since 1900 , edited by John $\mathrm{H}$. Nelson and Oscar Cargill (49-11262).

Edited by scholars in American literature, these generous selections illuminate the life and thought of the country as expressed in its literature. Critical comments concerning authors and bibliographical notes also are supplied.

2277. American men of letters. Boston, Houghton Mifllin, $1881-1909.22 \mathrm{v}$.

This series, issued under the general editorship of Charles Dudley Warner (q. v.), comprises biographical and critical studies of a selected group of American writers, written by leading critics. Authors represented in this series who are discussed at length elsewhere in this bibliography are Bryant, Whittier, Holmes, J. R. Lowell, Aldrich, Longfellow, Emerson, Cooper, Franklin, Lanier, Prescott, Whitman, Thoreau, N. Webster, N. P. Willis, Simms, Irving, and Poe (qq. v.). Other books in the series are:

2278. Cary, Edward. George William Curtis. 1894. 343 p. I-205 PSi $493 . \mathrm{C}_{3}$

Curtis ( $1824-1892)$ was in his own day one of the most influential and esteemed of American authors. As a young man he spent some time at Brook Farm, and was closely associated with members of the Concord group. He first attained public notice with several Near East travel books. These were followed by Lotus Eating; a Summer Book (New York, Harper, 1852.206 p.), a collection of articles on various resorts, mostly American. Then came his famous fictional works: Potiphar Papers (New York, Putnam, r853. 25I p.) and Prue and I (New York, Dix, Edwards, 1856. 214 p.); these are largely periodical essays with a vague story thread. Trumps (New York, Harper, 186r. 502 p.) is a novel of Washington politics and New York social life. With these the first main phase of his literary career came to an end. In 1854 he began to write the essays for the Easy Chair editor's section of Harper's Magazine; these increasingly occupied his time until his death in 1892 . In his editorial work he became more concerned with political and social affairs, and his editorial essays give a valuable picture of American life at that period; a large selection of them was published in From the Easy Chair (New York, Harper, 1892-94. 3 v.). A recent study of Curtis is Gordon Milne's George William Curtis \& the Genteel Tradition (Bloomington, Indiana University Press, 1956. 204 p.).

2279. Frothingham, Octavius Brooks. George Ripley. 1882. 321 p. 7-8 PS2713.F6

Ripley (1802-1880), a practicing Unitarian minister from 1826 to 1841 , was a prominent religious writer and editor of periodicals and a number of influential foreign books, in which capacities he had an important influence on the Transcendentalist movement, of which he was a leader. He helped found The Dial (q. v.) and to organize Brook Farm (q. v.). His biographer, Frothingham (r8221895), was also a Unitarian minister and a Transcendentalist. Among his other books are Theodore Parker (Boston, Osgood, 1874. 588 p.), a leading abolitionist, Unitarian clergyman, and Transcendentalist; a history of Transcendentalism in New England (q. v.); a life of the philanthropist, statesman, abolitionist, reformer, Gerrit Smith (New York, Putnam, i878. 381 p.); a Memoir of William Henry Channing (New York, Houghton Mifflin, r886. 49 I p.), a Unitarian clergyman, Transcendentalist, and editor, and the nephew of W. E. Channing (q. v.); and the autobiographical Recollections and Impressions, 1822-1890 (New York, Putnam, i891. 305 p.). 
2280. Higginson, Thomas Wentworth. Margaret Fuller Ossoli. 1884.323 p.

$$
4^{-1} 7996 \mathrm{PS}_{2506 . \mathrm{H}_{5}}
$$

Margaret Fuller was a leader in the Transcendentalist movement; the literature section of this bibliography contains a discussion of her work. Higginson, her biographer, was one of the most esteemed men of letters of his day. Autobiographical works such as Old Cambridge (New York, Macmillan, I899. 203 p.) and Part of a Man's Life (Boston, Houghton Miftlin, I905. 3 II p.) constitute a valuable source for studying prominent contemporaries, especially those of the literary world and the Transcendentalist movement. Valuable both as literature and as a historical record is Army Life in a Black Regiment (Boston, Fields, Osgood, 1870. 296 p.), which recounts his experiences during the Civil War as the leader of the first Negro unit in the Army. Higginson also wrote biographies of Longfellow and Whittier, and a series of biographical sketches in Contemporaries (Boston, Houghton Mifflin, I899. 379 p.), which discusses people such as Emerson, A. B. Alcott, T. Parker, Whittier, Whitman, Lanier, L. M. Child, John Holmes, Thaddeus W. Harris, W. L. Garrison, Wendell Phillips, C. Sumner, and U. S. Grant.

2281. Sedgwick, Henry Dwight. Francis Parkman. 1904. 345 p. $4^{-1} 33$ I8 $\quad$ EI $_{75.5} \mathrm{P}_{24}$ Parkman (1823-1893) is one of America's leading I gth-century historians who also attained a position in literature; his works are discussed in the General History section of this bibliography. A recent volume of selections for the general reader is The Parkman Reader (Boston, Little, Brown, 1955. 533 p.). His biographer, Sedgwick (b. I\$6I), distinguished himself in this literary form, but mostly on non-American subjects such as in his Dante (1918), Marcus Aurelius (I921), Ignatius Loyola (1923), Henry of Navarre (1930), Marie Recamier (1940), Horace (1947), and others; his autobiography, Memoirs of an Epicurean, appeared in 1942.

2282. Smyth, Albert H. Bayard Taylor. 1896 . $320 \mathrm{p}$. 4-I7I9I PS2993.S5 I 896 Taylor $(1825-1878)$ was one of the foremost authors in his generation. He achieved a large part of his initial fame through his travel books, of which the most famous is probably Eldorado (q. v.). Most of his travel writings were about foreign lands (Asia, Africa, and Europe). Almost all his work was exotic, and at the same time endowed with the "polish" that was so essential an ingredient for the successful, refined literary production of the period. This was also true of his poetry, which advanced his purely literary reputation, although he is now usually classed as merely a good minor poet with the ambiguously kind title of "laureate of the gilded age." His posthumous Poetical Works (Boston, Houghton, Osgood, I880. 34I p.) remained in print well into the 20 th century. He was also a minor dramatist of some contemporary note; his Dramatic Works (Boston, Houghton Mifflin, I88o. 345 p.) includes "The Prophet," "The Masque of the Gods," and "Prince Deukalion." Taylor also wrote a number of fictional works. His first novel was Hannah Thurston: A Story of American Life (New York, Putnam, I863. 464 p.), which utilized a conventional love story plot as a framework for picturing American life and opinions in upstate New York. John Godfrey's Fortunes (New York, Putnam, I864. 5II p.) pictured literary activities in New York. Both The Story of Kennett (New York, Putnam; Hurd and Houghton, I866. 418 p.) and Joseph and His Friend (New York, Putnam, 1870. 36I p.) portrayed rural life in Pennsylvania. However, it was at the end of his life that Taylor undertook the work that brought him a degree of lasting fame; this was his translation of Goethe's Faust (Boston, Fields, Osgood, 1870-71. 2 v.), which has since gone through innumerable editions, and is still in print in several standard collections. Apart from this, his interest and importance nowadays are largely historical.

2283. The American men of letters series. New York, Sloane, 1948+

Second series issued under this title; in general designed to carry on in the contemporary period biographical and critical studies of authors not covered by Houghton Mifflin's earlier series (v. supra) of the same name. Since all the authors so far included in this new series are presented in the Literature section of the bibliography, reference to the most recent volumes is made there under the names of the individual authors treated. Earlier volumes include:

2284. Arvin, Newton. Herman Méville. 1950. 316 p. $\quad 50-7584 \quad \mathrm{PS}_{2386 . A 7} 1950$

2285. Beiryman, John. Stephen Crane. I950. 347 p. 50-10964 PSI $499 . \mathrm{C}_{5} \mathrm{Z}_{56}$

2286. Grossman, James. James Fenimore Cooper. 1949. $286 \mathrm{p}$.

$$
\text { 49-50106 PSI } 43 \text { I.G77 } 19.49
$$

2287. Krutch, Joseph Wood. Henry David Tho-

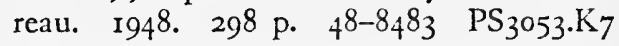

2288. Miller, Perry. Jonathan Edwards. I949.

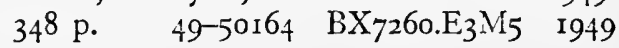


2289. Neff, Emery Edward. Edwin Arlington Robinson. 1948. 286 p.

$$
\text { 48-8640 } \mathrm{PS}_{3535 . \mathrm{O}_{25} \mathrm{Z}_{74}}
$$

2290. American writers series. New York, American Book Co., I934 †

The American writers series provides in each volume a representative selection from the writings of some author or group; in addition there is regularly an extensive and scholarly introduction, a chronological table, and an annotated bibliography. The series, most of whose parts have been kept in print, has appeared under the general editorship of Harry H. Clark. Authors represented in the series include Emerson, Hawthorne, Irving, Longfellow, Thoreau, Whitman, Bryant, Jonathan Edwards, Mark Twain, Poe, Cooper, Franklin, Melville, Holmes, Parkman, Harte, Henry James, Paine, J. R. Lowell, and Howells (qq. v.). Many of the volumes in this series have been cited elsewhere in this bibliography under the individual authors. Other volumes are:

2291. Alexander Hamilton and Thomas Jefferson; representative selections, with introd., bibliography, and notes by Frederick G. Prescott. 1934 . Ixxxi, $422 \mathrm{p}$. 34-21830 $\mathrm{E}_{302 . \mathrm{H}_{257}}$

Both Hamilton and Jefferson were prominent leaders in the early years of the Republic, and they both possessed a writing ability and cogency of thought which place their documents among the more important literary works of the period. Both these men are treated extensively under the General History section of this bibliography; Jefferson is also included in the section on the literature of the Revolutionary and Federal periods. This selection from the writings of the two men assumes that the reader has ready access to one of the many editions of The Federalist (q. v.).

2292. Southern poets; representative selections, with introd., bibliography, and notes by Edd Winfield Parks. 1936. cxlviii, 419 p.

36-7131 PS551.P27

A companion volume to the Southern Prose Writers below, this work has a wider range in that it also includes work readily available elsewhere. The object of the work is "to present the best poems by Southerners ... regardless of subject."

2293. John Lothrop Motley; representative selections, with introd., bibliography, and notes by Chester Penn Higby and B. T. Schantz. 1939. clxi, $482 \mathrm{p}$.

$$
\text { 40-1040 } \mathrm{PS}_{2435} \cdot \mathrm{A}_{4} \mathrm{H}_{5} \quad \mathrm{I} 939
$$

Motley $(1814-1877)$ is one of those historians whose work has achieved a position in belles-lettres. His three major works are The Rise of the Dutch
Republic (1856); History of the United Netherlands, from the Death of William the Silent, to the Twelve Years' Truce, 1609 (1860-67); and The Life and Death of John Barneveld (1874). He also wrote two novels: the autobiographical Morton's Hope; or, The Memoirs of a Provincial (1839), and Merry-Mount: A Romance of the Massachusetts Colony (1849).

2294. William Hickling Prescott; representative selections, with introd., bibliography, and notes by William Charvat and Michael Kraus. 1943. cxlii, 466 p. $43-1590 \quad P_{2} 656 . A_{4} 1943$ Prescott (1796-1859) is another of America's "literary" historians. His masterpiece is History of the Conquest of Mexico (1843). That and the History of the Conquest of Peru (1847) are his most frequently reprinted works. His other main histories are History of Ferdinand and Isabella $(1838)$ and History of the Reign of Philip the Second $\left(1855^{-58)}\right.$, of which the latter work was left incomplete at the time of his death. A 22-volume edition of his works (including the standard biography by Ticknor) was published in Philadelphia by Lippincott in 1904. In addition to his historical work, Prescott also had a considerable interest in literature, as may be seen in his Biographical and Critical Miscellanies ( 1845 ) which, except for the opening biographical study of Charles Brockton Brown (q. v.), was a collection of articles which first appeared in the North American Review. Some of these articles, as well as others which Prescott published only in periodicals, are included in the present selection, giving the volume the added merit of showing him as a literary critic as well as a historian. It is true that Prescott's subject matter is largely foreign, but, as stated on p. cxxviii of the introduction to this work, ". . . a true evaluation of American culture of the past must embrace writers like Prescott who, in getting out of their age, carried American ideals and traditions with them. His work adds to the mounting evidence that the main line of American thought has been anything but narrowly nationalistic . .."

2295. Minor Knickerbockers; representative selections, with introd., bibliography, and notes, by Kendall B. Taft. 1947. cxlviii, 4 IO $\mathrm{p}$. 47-2234 PS $549 \cdot \mathrm{N}_{5} \mathrm{~T}_{2}$ "Selected bibliography": p. cxi-cxlviii.

"Knickerbockers" is a term loosely applied to a group of early Igth-century New York City writers. The name came from Washington Irving's Diedrich Knickerbocker's History of New York (q. v.), and Irving himself is usually regarded as the leader of this cosmopolitan group. The Knickerbockers gained temporary dominance of the nation's litera- 
ture, and in doing so became increasingly nationalistic. Authors represented in the present selection include James Kirke Paulding, Samuel Woodworth, Fitz-Greene Halleck, John Howard Payne, Joseph Rodman Drake, Robert Charles Sands, William Leggett, George Pope Morris, William Cox, Nathaniel Willis, Charles Fenno Hoffman, Theodore Sedgwick Fay, Lewis Gaylord Clark, Park Benjamin, and Cornelius Matthews; a number of these are discussed elsewhere in the bibliography, especially in the Literature section for this period.

2296. Southern prose writers; representative selections, with introd., bibliography, and notes by Gregory Paine. 1947. cxiv, 392 p.

$$
\text { 47-679 } \mathrm{PS}_{55} \text { r.P23 }
$$

"The purpose . . . has been to make available to students of American literature southern literary materials not readily available in convenient form elsewhere and to present these materials in units sufficiently large to be genuinely representative of the authors chosen."-Preface. The authors included are: William Byrd, Jefferson, W. Wirt, John Taylor, Calhoun, H. S. Legaré, J. P. Kennedy, J. G. Bald. win, Longstreet, Crockett, Simms, J. E. Cooke, G. W. Cable, G. E. King, M. N. Murfree, J. C. Harris, S. Bonner, Lanier, 'T. N. Page, W. H. Page, J. L. Allen, W. S. Porter, and Woodrow Wilson. Most of these authors are represented more fully elsewhere in this bibliography.

2297. America's lost plays. Princeton, Princeton University Press, 1940-42. $20 \mathrm{v}$.

PS623.ArA6

A series presenting generally forgotten and unavailable plays which were once popular, and which remain an integral part of the historical picture of the development of the American drama. Almost all of them date from the rgth century. A few of the authors represented have been included in the Literature section of the bibliography.

2298. Vol. I. Forbidden fruit \& other plays, by Dion Boucicault. I940. viii, 313 p.

$$
\text { 40-31677 PR4I6r.B2A13 }
$$

Contents.-Forbidden fruit.-Louis XI.-Dot.Flying scud.-Mercy Dodd.-Robert Emmet.

2299. Vol. 2. False shame and Thirty years, two plays by William Dunlap. 1940. xiv, $106 \mathrm{p}$. $40-31678$ PSi $560 . F_{2} \quad 1940$ Translation and adaptation of Falsche Scham by August von Kotzebue and Trente ans, ou La vie d'un joueur, by Victor Ducange and Prosper Goubaux.
2300. Vol. 3. Glaucus, \& other plays, by George Henry Boker. xiv, 228 p. 1940.

$$
\text { 40-32028 PSiro5.G6 }
$$

Contents.-The world a mask.-The bankrupt.-Glaucus.

2301. Vol. 4. Davy Crockett, \& other plays, by Leonard Grover, Frank Murdock [!] Lester Wallack, G. H. Jessop, J. J. McCloskey. I940. xxv, $231 \mathrm{p}$. 40-35497 PS625.G6

Contents.-Rosedale; or, The rifle ball, by Lester Wallack.-Across the continent; or, Scenes from New York life and the Pacific railroad, by J. J. McCloskey.-Davy Crockett; or, Be sure you're right, then go ahead, by Frank Murdock [!]-Sam'l of Posen; or, The commercial drummer, by G. H. Jessop.-Our boarding house, by Leonard Grover.

2302. Vol. 5. Trial without jury, \& other plays, by John Howard Payne. r 940 . xvii, 264 p. $40-32715$ PS2530. $\mathrm{A}_{5} \mathrm{H}_{5}$

Contents.-Trial without jury; or, The magpic and the maid.-Mount Savage.-The boarding schools; or, Life among the little folks.-The two sons-in-law.-Mazeppa; or, The wild horse of Tartary.-The Spanish husband; or, First and last love.

2303. Vol. 6. The last duel in Spain, \& other plays by John Howard Payne. 1940. 265 p. 40-35574 PS2530. $\mathrm{A}_{5} \mathrm{H}_{4} 6$

Contents.-The last duel in Spain.-Woman's revenge.-The Italian bride.-Romulus, the shepherd king.-The black man; or, The spleen.

2304. Vol. 7. The early plays of James A. Herne, with act IV of Griffith Davenport. I940. $\mathrm{x}, \mathrm{I} 60 \mathrm{p}$. 4I-3201 PS r9I9. $\mathrm{H}_{75} \mathrm{Ar}_{3}$

Contents.-Introduction.-Within an inch of his life.-."The minute men" of I774-1775.-Drifting apart.-The Reverend Griffith Davenport.-Bibliography (p. [16I]).

2305. Vol. 8. The great diamond robbery, \& other recent melodramas, by Edward M. Alfriend \& A. C. Wheeler, Clarence Bennett [and others] ... I940. xv, $255 \mathrm{p}$.

41-3202 PS625.L4

Contents. - A royal slave, by Clarence Bennett.The great diamond robbery, by Edward M. Alfriend and A. C. Wheeler.-From rags to riches, by Charles A. Taylor.-No mother to guide her, by Lillian Mortimer.-Billy the kid, by Walter Woods.

2306. Vol. 9. Five plays by Charles H. Hoyt. 1941. $\mathrm{xv}, 240 \mathrm{p}$.

4I-3203 PS2039. $\mathrm{H}_{47} \mathrm{Al}_{2}$ Contents.-A bunch of keys. $-A$ midnight bell.-A trip to Chinatown.-A temperance town.A milk white flag. 
2307. Vol. Io. The banker's daughter, \& other plays, by Bronson Howard. 1941. xiv, $306 \mathrm{p}$. $4{ }^{\mathrm{I}-6275} \mathrm{PS}_{20 \mathrm{I}_{4}}$. $\mathrm{H}_{12} \mathrm{~B}_{3}$ I94I Contents.-Bronson Crocker Howard.-Survey of Howard's plays.-Hurricanes.-Old love letters.-The banker's daughter.-Baron Rudolph.Knave and queen.-One of our girls.-Bibliography (p. 299-306).

2308. Vol. I1. An arrant knave, \& other plays, by Steele MacKaye. I94I. xvii, 234 p. $4 \mathrm{I}-\mathrm{I} 0637$ PS2359.M42A8 $194 \mathrm{I}$

Contents.-Rose Michel.-Won at last.-In spite of all.-An arrant knave.

2309. Vol. I2. The cowled lover, \& other plays, by Robert Montgomery Bird. I94I. x, 22 I p. 41-10638 PS I 099. B5 C6 1941

Contents.-The cowled lover--Caridorf; or, The avenger.-News of the night; or A trip to Niagara.-'Twas all for the best; or, 'Tis all a notion.

2310. Vol. 13. The sentinels, \& other plays, by Richard Penn Smith. I94I. x, I7I p. 4I-10639 PS2869.S7S 4 I94I Contents.-Checklist of the plays of Richard Penn Smith (p. [ix]-x).-The sentinels; or, The two sergeants. - The bombardment of Algiers.William Penn.-Shakespeare in love.-A wife at a venture.-The last man; or, the cock of the village.

23II. Vol. 14. Metamora, \& other plays, by John Augustus Stone [and others] 194I. vi, 399 p. $4 \mathrm{I}-\mathrm{I} 8466 \mathrm{PS}_{32} . \mathrm{P}_{3}$

Contents.-Metamora; or, 'The last of the Wampanoags, by J. A. Stone.-Tancred, king of Sicily; or, The archives of Palermo, by J. A. Stone.-The spy, a tale of the neutral ground, by C. B. Clinch.The battle of Stillwater; or, The maniac, by $\mathrm{H}$. J. Conway (?)-The usurper; or, Americans in Tripoli, by J. S. Jones.-The crock of gold; or, The toiler's trials, by S. S. Steele.-Job and his children, by J. M. Field.--Signor Marc, by J. H. Wilkins.The duke's motto; or, I am here! By John Brougham.

2312. Vol. 15. Four plays by Royall Tyler. I941. viii, $120 \mathrm{p}$.

4I-28ro5 PS855.T7AI3

Contents. -The island of Barrataria.-The origin of the feast of Purim; or, The destinies of Haman \& Mordecai.-Joseph and his brethren.The judgment of Solomon.

2313. Vol. 16. Monte Cristo, by Charles Fechter, as played by James O'Neill, \& other plays by
Julia Ward Howe, George C. Hazelton, Langdon Mitchell [and] William C. De Mille. 1941. $360 \mathrm{p}$. $4^{1-24720}$ PS625.R8

Contents.-Monte Cristo, by Charles Fechter.Hippolytus, by J. W. Howe-Mistress Nell, by G. C. Hazelton.-Becky Sharp, by Langdon Mitchell.The Warrens of Virginia, by W. C. De Mille.

2314. Vol. 17. The plays of Henry C. De Mille, written in collaboration with David Belasco. r94It xxv, 342 p. $\quad 4^{\mathrm{I}-24493} \mathrm{PS}_{1534 . D 2 A r 2}$

Contenrs.- Introductory essay.-A complete list of the plays by $\mathrm{H}$. C. De Mille ( $\mathrm{I}$ p. following p. xxv).-The main line, by H. C. De Mille and Charles Barnard.-The wife, by David Belasco and H. C. De Mille.-Lord Chumley, by H. C. De Mille and David Belasco.- The charity ball, by David Belasco and H. C. De Mille.-Men and women, by H. C. De Mille and David Belasco.

2315. Vol. 18. The heart of Maryland, \& other plays, by David Belasco. 1941. xii, 319 p. 4I-28I06 PSro85. $\mathrm{B}_{23} \mathrm{H}_{4}$ I94I

Contents.-La Belle Russe.-The stranglers of Paris.-The girl I left behind me, by David Belasco and Franklin Fyles.-The heart of Maryland.Naughty Anthony.

23i6. Vol. 19. The white slave, \& other plays, by Bartley Campbell. 194I. Ixxxi, 248 p. 42-4434 PSr252.C25A19 194I

Contents.-Biographical sketch.-Alphabetical list of the plays of Bartley Campbell (p. [xv]Ixxxi).-The Virginian.-My partner.-The galley slave.-Fairfax.-The white slave.

2317. Vol. 20. Man and wife, \& other plays, by Augustin Daly. 1942. xxi, $407 \mathrm{p}$.

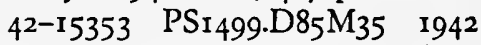

Contents. - List of Daly's plays (p. [xi]-xxi).Man and wife.-Divorce.-The big bonanza.Pique.-Needles and pins.

2318. Anthology of best original short-shorts. I953+ Ocean City, N. J., Oberfirst Publications, I954+ annual. Oberfirst's short-short fiction library) $\quad 54-33676 \quad \mathrm{PZI}_{1} . \mathrm{A6}_{3}$

Editor: $1954+$ R. Oberfirst.

The "short-short" is a refinement of the short story, and portrays a single action in one to five pages. Usually it poses a surprise or twist ending, in the tradition of O. Henry (q. v.). The 1953 volume above is not the first collection by Oberfirst, but it is apparently the first of a series, of which three have so far appeared. 
2319. Badger, Kingsbury M. American literature for colleges. Harrisburg, Pa., Stackpole Co. [1952-54] 2 v. $\quad 5^{2-2996}$ PS507.B 32 A college textbook anthology of American literature which is meant to trace the development of the American heritage. The result is a chronological development in terms of subject matter (pre-colonials, colonials, early nationalists, etc.), but not of material presented. In each section, the selections include not only work by people taking part in the period, movement, and activities discussed, but also subsequent people who wrote about it. The result also includes a far different representation of authors than is usual: the Amerindians receive considerable attention, and so do non-English colonists; also, many nonfiction authors infrequently regarded as part of "Literature" have been included, and, as an aspect of this, the usual authors included in literary anthologies have tended to have more than a usual proportion of space given over to their non-fictional writings. The second volume carries the work through the late rgth century and "Romanticism, Realism, and the Frontier."

2320. Beatty, Richmond Croom, Floyd C. Watkins, and Thomas Daniel Young, eds. The literature of the South. Randall Stewart, general editor. Chicago, Scott, Foresman, 1952. 1106 p. 52-2548 PS261.B43

An anthology reflecting the Southern experience in its many aspects through its more literary writers. The contemporary flourishing of belles-lettres in the South is reflected in some $4^{\circ}$ percent of the book being devoted to the 2oth century.

\section{Benét, William Rose, and Norman Holmes}

Pearson, eds. The Oxford anthology of American literature. New York, Oxford University Press, 1938. xxx, I705 p. $38-3436$ I PS507.O9

Unlike most anthologies of American literature, this work is not aimed primarily at the textbook market; also, it approaches the selecting problem as a purely literary one. While the editors claim no attempt to be all-inclusive, some 150 writers are represented by selections. Because of the emphasis on literary merit, major writers regularly receive far more space than do minor authors. The relative importance of modern literature is recognized by devoting about half the volume to this period. Commentary is not provided with the selections, but biographical sketches of the authors are found on p. 1577-1683, with short author bibliographies. A "background" bibliography is presented on p. $1685-$ I688.
2322. The Best American short stories ... and the Yearbook of the American short story ... 1915 + Boston, Houghton Mifflin, 1916+ 16-11387 PZI.B446235 Title varies: 1915-41, The Best Short Stories. 1942. The Best American Short Stories.

Editor: 1915-4I, E. J. O'Brien.-1942+ Martha Foley.

Imprint varies: $1915-25$, Boston, Small, Maynard \& Company.-r 1926-32, New York, Dodd, Mead and Company.-r $1933+$ Boston, Houghton Mifflin Company.

An annual survey of and selection from the short stories published in America during the preceding year. The present editor, Martha Foley, has also produced a number of more selective anthologies, including The Best of the Best American Short Stories, $1915-1950$ (Boston, Houghton Miflin, 1952. 369 p.) and, with Abraham Rothberg, U. S. Stories; Regional Stories from the Forty-Eight States (New York, Hendricks House-Farrar Straus, 1949. xix, 683 p.).

2323. Blair, Walter, Theodore Hornberger, and Randall Stewart, eds. The literature of the United States, an anthology and a history. Rev. ed. Chicago, Scott, Foresman, 1953. 2 v.

$53-2382 \quad P_{507 .} B_{527}$

Although the emphasis is on the more important authors, this anthology presents a fair range of selections from lesser authors. Arranged along historical lines, the literary selections also reflect the development of ideas. Each section has an extensive introduction on the period, and individual authors and selections are commented upon. As with most such college texts, guides to further reading are supplied.

2324. Bradley, E. Sculley, and others, eds. The American tradition in literature. Edited by Sculley Bradley, Richmond Croom Beatty [and] E. Hudson Long. New York, Norton, 1956. 2 v. 56-1312 PS507. 374

A college textbook anthology which has an emphasis on major writers, whom it attempts to present in their full variety and stature. The final criterion for all selections has been literary, but the critical apparatus has been designed to relate them to America's history and intellectual development.

2325. Burrell, John Angus, and Bennett A. Cerf, eds. An anthology of famous American stories. Edited by Angus Burrell and Bennett Cerf. New York, Modern Library, 1953. 1340 p. (The Modern Library of the world's best books. [A Modern Library giant, $\left.\mathrm{G}_{77}\right]$ )

53-9916 PZr.B94An 
A chronologically arranged collection of 73 short stories which the editors consider outstanding. This book is a revision of a work originally published in 1936 under the title The Bedside Book of Famous American Stories. As in the original work, the primary intent is still to provide stories for pleasurable reading, and only secondarily to provide a survey, so that nothing is included purely for historical purposes.

2326. Cady, Edwin Harrison, Frederick J. Hoffman, and Roy Harvey Pearce, eds. The growth of American literature; a critical and historical survey. New York, American Book Co., 1956. 2 v. (American literature series)

$$
\text { 56-1720 PS507.C19 }
$$

A college textbook for the study of American literature as it reflects the country's cultural development. Major writers are given a liberal representation among approximately one hundred authors presented. Introductions, chronologies, and highly selective bibliographies are supplied to guide the student.

2327. Cerf, Bennett A., and Van H. Cartmell, eds. Sixteen famous American plays. New York, Garden City Pub. Co., 1941. I049 p.

$$
{ }_{41-51686} \mathrm{PS}_{34} \cdot \mathrm{C}_{42}
$$

Contents.-They knew what they wanted, by Sidney Howard.-The front page, by Ben Hecht and Charles MacArthur.-The green pastures, by Marc Connelly.-Biography, by S. N. Behrman.Ah, wilderness! by Eugene O'Neill.-The petrified forest, by Robert Sherwood.-Waiting for Lefty, by Clifford Odets.-Dead end, by Sidney Kingsley.Boy meets girl, by Bella and Samuel Spewack.The women, by Claire Boothe.--"Having wonderful time," by Arthur Kober.-Our town, by Thornton Wilder.-The little foxes, by Lillian Hellman.-The man who came to dinner, by Moss Hart and George S. Kaufman.-The time of your life, by William Saroyan.-Life with father, by Howard Lindsay and Russel Crouse.

This work, which has also been published by Random House in a Modern Library reprint, offers a selection of plays produced between 1924 and 1939 . Because of its terminal date, the work might be supplemented by Jack Gaver's Critics' Choice . . . (no. 2336), which covers the 1935-55 period.

2328. Cooke, George Willis, ed. The poets of Transcendentalism, an anthology. With introductory essay and biographical notes. Boston, Houghton Miffin, 1903. xvi, 34I p.

$3-6145$ PS607.C7

An anthology of poetry influenced by the Transcendental movement in New England. Since the aim is "to give specimens of the poetical output of that movement," much of the book is devoted to work by minor and usually neglected poets.

2329. Davis, Joe Lee, John T. Frederick, and Frank Luther Mott, eds. American literature, an anthology and critical survey. New York, Scribner, 1948-49. 2 v.

$4^{8-9} 41 \quad \mathrm{PS}_{507 . D_{3}}$

A college textbook anthology that aims to provide a comprehensive collection of basic writings; essays on the periods and on the major authors are included, while the lesser authors are covered by headnotes. The work has been arranged chronologically, with the intention of presenting the American experience. The same work has been reissued under the title $A$ Treasury of American Literature (Chicago, Spencer Press, 955 [i. e., 1956]).

2330. Ellis, Harold Milton, and others, eds... A college book of American literature. Edited by Milton Ellis, Louise Pound [and] George Weida Spohn. New York, American Book Co., I939-40. 2 v. (American literature series; H. H. Clark, general editor) 39-22474 PS507.E65

"General bibliography": v. I, p. 1003-1012; v. 2, p. $1077-1082$.

A voluminous anthology, arranged chronologically. While most attention is given to major authors, many lesser ones are included, with nearly two hundred represented. The editorial intention is to present the significant statements of each period's spokesmen; the quantitative emphasis is on post-colonial writings. There are biographical sketches and bibliographies for each author. With the additional editorial assistance of Frederick J. Hoffman, there has appeared a one-volume abridged version of the work, intended for one-semester courses: A College Book of American Literature; Briefer Course, $2 \mathrm{~d}$ ed. (New York, American Book Co., 1954. I 107 p.).

2331. Foerster, Norman, ed. American poetry and prose. $3 \mathrm{~d}$ ed. Boston, Houghton Mifflin, 1947. 16 ro p. 47-4469 PS507.F6 1947 "Under the general editorship of Robert Morss Lovett."

"American civilization: a reading list": p. 1595I604.

A college textbook anthology of American writing from 1612 to the present. The emphasis is on major writers, with some minor authors represented. The purpose of the work is to register the progress of the United States in literature, and to present the growth of literature as a principal feature of American civilization. Brief biographical, bibliographical, and critical comments accompany the selections. For shorter courses William Charvat has prepared 
an abridged version (Boston, Houghton, Miffin, 1952. 924 p.) of this work.

2332. Gassner, John, ed. 'Twenty-five best plays of the modern American theatre. Early series. New York, Crown, 1949. xxviii, 756 p.

$$
\text { 49-957I PS634.G32 }
$$

Contents.- "The hairy ape," by Eugene O'Neill.-Desire under the elms, by Eugene O'Neill.-What price glory? By Laurence Stallings and Maxwell Anderson.-They knew what they wanted, by Sidney Howard.-Beggar on horseback, by George S. Kaufman and Marc Connelly.Craig's wife, by George Kelly.-Broadway, by Philip Dunning and George Abbott.-Paris bound, by Philip Barry.-The road to Rome, by Robert E. Sherwood.-The second man, by S. N. Behrman.Saturday's children, by Maxwell Anderson.-Porgy, by Dorothy and Du Bose Heyward.-The front page, by Ben Hecht and Charles MacArthur.Machinal, by Sophie Treadwell.-Gods of the lightning, by Maxwell Anderson and Harold Hickerson.-Street scene, by Elmer Rice.-Strictly dishonorable, by Preston Sturges.-Berkeley Square, by J. L. Balderston.-The clod, by Lewis Beach.Trifles, by Susan Glaspell.-Ile, by Eugene O'Neill.-Aria da capo, by Edna St. Vincent Millay.-Poor Aubrey, by George Kelly.-White dresses, by Paul Green.-Minnie Field, by E. P. Conkle.-Supplementary list of plays (p. 754755).-Bibliography (p. 756).

A ". . . record of the period between 1919 and r929, when our theatre arrived at maturity, and of the stirrings in the direction of modernity a few years earlier, as expressed by the Little Theatre movement ..." This work is a "belated effort" to cover the integral first period for the series that follows. Gassner has done much writing and anthologizing in the field of the drama, both foreign and domestic. His The Theatre in Our Times; a Survey of the Men, Materials, and Movements in the Modern Theatre (New York, Crown Publishers, 1954. 609 p.) discusses world drama, but from the vantage point of the New York theatergoer, so that the work may be used as a commentary on modern drama in America. With Dudley Nichols he edited Twenty Best Film Plays (New York, Crown, 1943. xl, 11 I2 p.).

2333. Gassner, John, ed. Twenty best plays of the modern American theatre. New York, Crown, 1939. xxii, 874 p. 39-32159 PS634.G3 Contents. - Winterset, by Maxwell Anderson.High Tor, by Maxwell Anderson.-Idiot's delight, by Robert E. Sherwood.-Johnny Johnson, by Paul Green.-Green pastures, by Marc Connelly.-You can't take it with you, by George S. Kaufman and
Moss Hart.-End of summer, by S. N. Behrman.The animal kingdom, by Philip Barry.-Boy meets girl, by Bella and Samuel Spewack.-The women, by Clare Boothe.-Yes, my darling daughter, by Mark Reed.-Three men on a horse, by George Abbott and John Cecil Holm.-The children's hour, by Lillian Hellman.-Tobacco road, by Jack Kirkland and Erskine Caldwell.-Of mice and men, by John Steinbeck.-Dead end, by Sidney Kingsley.Bury the dead, by Irwin Shaw. - The fall of the city, by Archibald MacLeish.-Golden boy, by Clifford Odets.-Stage door, by Edna Ferber and George S. Kaufman.-Plays by authors represented (p. 869871).-Plays by other authors, 1930-1940 (p. 87I872).-Bibliography (p. 873-874).

This is the first of an indefinite series of collections of modern American plays; volumes are issued to represent newly elapsed periods. Each volume, in addition to the texts of leading plays, contains a concise introduction on the theater situation during the years covered.

2334. Gassner, John, ed. Best plays of the modern American theatre, second series. New York, Crown, 1947. xxx, 776 p. 47-30270 PS634.G28

Contents. - The glass menagerie, by Tennessee Williams.-The time of your life, by William Saroyan.-I remember mama, by John Van Druten.Life with father, by Howard Lindsay and Russel Crouse.-Born yesterday, by Garson Kanin.-The voice of the turtle, by John Van Druten.-The male animal, by James Thurber and Elliott $\mathrm{Nu}$ gent.-The man who came to dinner, by George S. Kaufman and Moss Hart.-Dream girl, by Elmer Rice.-The Philadelphia story, by Philip Barry.Arsenic and old lace, by Joseph Kesselring.-The hasty heart, by John Patrick.-Home of the brave, by Arthur Laurents.-Tomorrow the world, by James Gow and Arnaud d'Usseau.-Watch on the Rhine, by Lillian Hellman.-The patriots, by Sidney Kingsley.-Abe Lincoln in Illinois, by Robert E. Sherwood.-Bibliography (p. 775-776).

2335. Gassner, John, ed. Best American plays; third series, I945-195I. New York, Crown, 1952. xxviii, 707 p. 52-5690 PS634.G277

Contents.-Introduction: The mid-century theatre, a reprise with variations, by John Gassner.Death of a salesman, by Arthur Miller.-A streetcar named desire, by Tennessee Williams.-The iceman cometh, by Eugene O'Neill.-The member of the wedding, by Carson McCullers.-The autumn garden, by Lillian Hellman.-Corne back, little Sheba, by William Inge.-All my sons, by Arthur Miller.Detective story, by Sidney Kingsley.-Billy Budd, by Louis O. Coxe and Robert Chapman.-Medea, by Robinson Jeffers.-Mister Roberts, by Thomas Hef- 
fen and Joshua Logan.-State of the Union, by Howard Lindsay and Russel Crouse.-Darkness at noon, by Sidney Kingsley.-Anne of the thousand days, by Maxwell Anderson.-Bell, book, and candle, by John Van Druten.-The moon is blue, by F. Hugh Herbert.-Summer and smoke, by Tennessee Williams.-Supplementary list of American nonmusical plays (p. 703-705).-American musical plays of the period (p. 705).-Bibliography (p. 706707).

2336. Gaver, Jack, ed. Critics' choice; New York Drama Critics' Circle prize plays, 1935-55. New York, Hawthorn Books, 1955. 661 p.

55-10113 PS634.G 35

A collection of the plays which since the $1935-36$ season have received the New York Drama Critics' Circle awards for best play of the season. With Cerf and Cartmell's Sixteen Famous American Plays (q. v.) this work anthologizes the modern theater movement in America. The award plays are: Maxwell Anderson's "Winterset" and "High Tor"; John Steinbeck's "Of Mice and Men"; William Saroyan's "The Time of Your Life"; Lillian Hellman's "Watch on the Rhine"; Sidney Kingsley's "The Patriots" and "Darkness at Noon"; Tennessee Williams' "The Glass Menagerie," "A Streetcar Named Desire," and "Cat on a Hot Tin Roof"; Arthur Miller's "All My Sons" and "Death of a Salesman"; Carson McCullers' "The Member of the Wedding"; John Van Druten's "I Am a Camera"; William Inge's "Picnic"; and John Patrick's "The Teahouse of the August Moon."

2337. Halline, Allan Gates, ed. American plays, selected and edited, with critical introductions and bibliographies. New York, American Book Co., r935. 787 p. (American literature series; H. H. Clark, general editor) $35-5220 \quad \mathrm{PS}_{23} . \mathrm{H}_{3}$ "Bibliographies": p. $75^{1-776 .}$

Contents.-The contrast, by Royall Tyler.André, by William Dunlap.-The bucktails; or, Americans in England, by James Kirke Paulding.Superstition, by James Nelson Barker.-The gladiator, by Robert Montgomery Bird.-Bianca Visconti, by Nathaniel Parker Willis.-Fashion, by Anna Cora Mowatt.-Francesca da Rimini, by George Henry Boker.-Horizon, by Augustin Daly.-The Danites in the Sierras, by Joaquin Miller.-The Henrietta, by Bronson Howard.-The New York idea, by Langdon Mitchell.-Madame Sand, by Philip Moeller.-You and I, by Philip Barry.-Icebound, by Owen Davis.-The great god Brown, by Eugene O'Neill.-The field god, by Paul Green.

This book aims to present a picture of the chronological development of the American drama. Each play is introduced by a discussion of the play itself and its philosophical and literary relationships, as well as the dramatist's other work. A longer work with the same purpose, but with the emphasis on the pre-modern period, is Arthur H. Quinn's Representative American Plays, from 1767 to the Present Day, $7^{\text {th }}$ ed., rev. and enl. (New York, AppletonCentury-Crofts, 1953. 1248 p.), which includes the following: Thomas Godfrey's "The Prince of Parthia" (1767); Royall Tyler's "The Contrast" (1787); William Dunlap's “André” (1798); James Nelson Barker's "Superstition" (1824); John Howard Payne and Washington Irving's "Charles the Second" (r824); George Washington Parke Custis' "Pocahontas, or The Settlers of Virginia" (1830); Robert Montgomery Bird's “The Broker of Bogota" (1834); Nathaniel Parker Willis' "Tortesa the Usurer" (1839); Anna Cora Mowatt Ritchie's "Fashion" (1845); George Henry Boker's "Francesca da Rimini" (1855); Dion Boucicault's "The Octoroon, or Life in Louisiana" (1859); Joseph Jefferson's "Rip Van Winkle" (1865); Steele MacKaye's "Hazel Kirke" (1880); Bronson Howard's "Shenandoah" (1889); James A. Herne's "Margaret Fleming" (1890); William Gillette's "Secret Service" (1896); David Belasco and John Luther Long's "Madame Butterfly" (rgoo); Clyde Fitch's "The Girl With the Green Eyes" (1902); Langdon Mitchell's "The New York Idea" (1906); Augustus Thomas' "The Witching Hour" (rgo7); William Vaughn Moody's "The Faith Healer" (r g09); Percy MacKaye's "The Scarecrow" (rgro); Edward Sheldon's "The Boss" (rgrr); Rachel Crothers' "He and She" (IgII); Eugene O'Neill's "Beyond the Horizon" (1920); Lula Vollmer's "Sun-Up" (1923); Sidney Howard's "The Silver Cord" (1926); Philip Barry's "Paris Bound" (r927); Maxwell Anderson's "Winterset" (r935); William Wister Haines" "Command Decision" (1947); and Richard Rodgers, Oscar Hammerstein II, and Joshua Logan's "South Pacific" (1949).

2338. Hart, James D., and Clarence Gohdes, eds. America's literature. New York, Dryden

Press, 1955. $95^{8}$ p. 55-14399 PS507.H24

An anthology designed for a first-year college course in American literature. Some 250 selections from the writings of 46 authors have been included. Long introductions relating literature to general culture have been provided for the four major editorial sections of the volume; also, each author has his own introduction.

2339. Howard, Leon, Louis B. Wright, and Carl Bode, eds. American heritage; an anthology and interpretive survey of our literature. Boston, Heath, 1955, 2 v. 54-9510 PS507.H6 
A college textbook which seeks to present the "American heritage of ideas, emotions, and points of view which are revealed in literature and which reveal the nature of America today." There are brief introductions to the nearly 200 authors from whose writings selections have been made.

2340. Hubbell, Jay B., ed. American life in literature. Rev. ed. New York, Harper, 1949. $2 \mathrm{v}$ 49-2372 PS507.H8 1949

Bibliography: v. 1, p. $955-967$; repeated in v. 2 , p. 931-943.

A college textbook anthology in which the emphasis is on American literature as an expression of American life and thought. Major writers are well represented, and selections included from a fairly large number of lesser figures; a total of about 140 authors being represented. In addition, about two dozen British writers are included for passages reflecting their view of America. Extensive historical interchapters and individual author biographies, with special detail for major authors, are designed to relate the work to American history and life in more than its literary aspects. An abridged edition prepared for a one-semester course appeared in one volume under the same title; the most recent revision was in 1951 .

2341. Jones, Howard Mumford, Ernest E. Leisy, and Richard M. Ludwig, eds. Major American writers. New York, Harcourt, Brace, 1952. $1930 \mathrm{p}$. 52-406 $\mathrm{PS}_{507 . J 6} 195^{2}$

An anthology textbook designed for college introductory courses in American literature. Major authors of the 18 th and 19 th centuries are presented, along with representative authors of the 17 th and 2oth centuries. Scholarly apparatus has been provided for the selections, but there are no period or movement survey essays. On the theory that too much is covered in most such anthologies and the courses for which they are designed, the editors have limited their selections, and only 42 authors are represented.

2342. Kreymborg, Alfred, ed. An anthology of American poetry; lyric America, I630-1941. New York, Tudor Pub. Co., I94I. xl, 675 p.

$$
4 \text { I-IO130 PS } 586 . \mathrm{K}_{7} \text { I } 94 \text { I }
$$

Originally published under title: Lyric America, an Anthology of American Poetry (1630-1930).

The main interest in this work is its representation of nearly three hundred major and minor poets. The anthology was designed as a companion volume, which could be used independently, for the author's historical-critical work: Our Singing Strength, an Outline of American Poetry (1620-1930) (New
York, Coward-McCann, 1929. 643 p.). Kreymborg (b. 1883) is a playwright, novelist, and anthologist; but his favorite medium is poetry, of which he has been a prolific writer. His publications since Selected Poems, 1912-1944 (New York, Dutton, 1945. 3 I9 p.) include Man and Shadow, an Allegory (New York, Dutton, 1946. 256 p.), a long poem on modern man as seen through his representatives on a visit to Central Park in New York City, and No More War, and Other Poems (New York, Bookman Associates, 1950. 127 p.). Throughout his career Kreymborg has been active in the cause of advancing "modern" American poetry, serving the cause both as editor and as anthologist.

2343. McDowell, Tremaine, ed. America in literature. New York, Crofts, 1944. 540 p. $44-5256$ PS $509 . \mathrm{U}_{5} \mathrm{M}_{2}$

A college textbook anthology, "collected both for individual readers and for students of composition, of American literature, and of our national life," this volume is not a survey of the development of American literature, but rather of the regions of America and the ideas which have influenced American life, as they have been presented by writers of varying literary stature. It is particularly adaptable for use as background reading for general courses in American civilization.

2344. Matthiessen, Francis O,, ed. The Oxford book of American verse. New York, Oxford University Press, 1950. Ivi, I1 32 p.

Bibliography: p. I107-III5.

$$
50-9826 \quad \mathrm{PS}_{5} 83 . \mathrm{O} 82
$$

A purely literary anthology on historical principles, this work emphasizes the work of the more important poets. Nothing is included for purely historical reasons; also, many of the quite minor poets are not represented, as they are in many anthologies (e. g., cf. Kreymborg supra). Other readily available anthologies of American poetry include $A$ Comprehensive Anthology of American Poetry (New York, Modern Library, 1944. 490 p.), edited by Conrad Aiken (q. v.), and The New Pocket Anthology of American Verse (Cleveland, World Pub. Co., I955. 670 p.), edited by Oscar Williams (q. v.). The latter work is arranged alphabetically and places an unusually heavy emphasis on modern poetry, so that it might almost be regarded as a 2oth-century poetry anthology. Williams has done a number of other popular poetry anthologies, such as $A$ Little Treasury of American Poetry (New York, Scribner, 1948. xxxvi, 876 p.). 
2345. Miller, Perry, and Thomas H. Johnson, eds. The Puritans. New York, American Book Co., 1938. 846 p. (American literature series; H. H. Clark, general editor) $3^{8-34986}{\text { PS } 530 . M_{5}}^{8}$ Bibliographies: p. 785-834.

An extensive anthology of colonial Puritan writings; the lengthy general introduction includes sections on "The Puritan Way of Life" and "The Puritans as Literary Artists." A recent but shorter anthology of the period which Miller has edited is The American Puritans, Their Prose and Poetry, which appeared in an Anchor books paperback edition in 1956. Another good and current paperback anthology in this field is Colonial American Writing (New York, Rinehart, 1950. 58I p.), edited by Roy H. Pearce. An older work in the field is Colonial Prose and Poetry (New York, Crowell, 1901), edited by William P. Trent and Benjamin W. Wells, and published in three very small, compact volumes. Another book of interest here is America Begins (New York, Pantheon, I950. $43^{8}$ p.), edited by Richard M. Dorson, who presents selections from I 7 th century writings depicting the Atlantic coastal communities.

2346. Miller, Perry, ed. The Transcendentalists, an anthology. Cambridge, Harvard University Press, 1950. xvii, $521 \mathrm{p}$.

Bibliography: p. [503]-510.

$$
\text { 50-7360 B905.M5 }
$$

"This book exists primarily on the level of what the Transcendentalists called the understanding .... It aims to make available articles and books that by now can be found only in a few special libraries. I have endeavored to arrange the selections so that they tell the story of themselves ... this volume . . . [omits Emerson and Thoreau, since their works] are readily accessible, at least in anthologies. ... Considering both the spatial limits and modern impatience, I have assumed the right to throw out irrelevancies and arid passages. I have tried to preserve only the hard core and the basic themes.... in order that this anthology might represent the group as they actually figured in history, I have limited the selection to what appeared at the time as public record ..."Introduction.

2347. Moses, Montrose J., ed. Representative plays by American dramatists; edited, with an introd. to each play, by Montrose J. Moses. New York, Dutton, I918-[25] 3 v. illus.

$$
\text { I 8-5466 PS623.M7 }
$$

Bibliographies: v. I, p. [II]-18; v. 2, p. 3-8; v. 3, p. $[4]-14$.

Contents.-I. 1765-1819. The Prince of Parthia, by Thomas Godfrey, Jr. 1765.-Ponteach; or,
The savages of America, by Robert Rogers. 1766.The group; a farce, by Mrs. Mercy Warren. I775.The Battle of Bunkers-Hill, by Hugh Henry Brackenridge. 1776.-The fall of British tyranny; or, American liberty, by John Leacock. I776.-The politician out-witted, by Samuel Low. 1789.-The contrast, by Royall Tyler. 1790.-André, by William Dunlap. 1798.- The Indian princess; or, La belle sauvage, by James Nelson Barker. 1808.- She would be a soldier; or, The Plains of Chippewa, by Mordecai Manuel Noah. 1819.-II. 1815-1858. Fashionable follies, by Joseph Hutton. 1815.Brutus; or, The fall of Tarquin, by John Howard Payne. 1818.- Sertorius; or, The Roman patriot, by David Paul Brown. I830.-Tortesa, the usurer, by Nathaniel Parker Willis. 1839.-The people's lawyer, by Joseph Stevens Jones. I839.-Jack Cade, by Robert T. Conrad. I841.-Fashion, by Mrs. Anna Cora Mowatt. 1850.-Uncle Tom's cabin, dramatized by George L. Aiken. 1852.- Self, by Mrs. Sidney F. Bateman, 1856.-Horseshoe Robinson, by Clifton W. Tayleure. I858.-III. I856I9II. Rip Van Winkle: a legend of the Catskills; a comparative arrangement with the Kerr version, by Charles Burke. 1850 .-Francesca da Rimini, by George Henry Boker. 1855.-Love in ' 76 ; an incident of the revolution, by Oliver Bell Bunce. 1857.-Paul Kauvar; or, Anarchy, by Steele Mackaye. 1887.- Shenandoah, by Bronson Howard. 1888.--In Mizzoura, by Augustus Thomas. 1893.The moth and the flame, by Clyde Fitch. 1898.The New York idea, by Langdon Mitchell. I 1906.The easiest way, by Eugene Walter. 1909.-The return of Peter Grimm, by David Belasco. I9II.

2348. Moses, Montrose J., ed. Representative American dramas, national and local; edited, with introductions, by Montrose J. Moses, rev. and brought up to date by Joseph Wood Krutch. Student's ed. Boston, Little, Brown, 1941. xvi; 104 I p. 4I-26062 PS634.M6 I94I

Contents.-1894. A Texas steer, by Charles $\mathrm{H}$. Hoyte.-1905. The girl of the golden West, by David Belasco.-1907. The witching hour, by Augustus Thomas.-igro. The city, by Clyde Fitch.-19ro. The scarecrow, by Percy MacKaye.-1910. The piper, by Josephine Preston Peabody.-I9II. Mrs. Bumpstead-Leigh, by Harry James Smith.-I9I4. It pays to advertise, by Roi Cooper Megrue and Walter Hackett.-1919. The famous Mrs. Fair, by James Forbes.-1920. The Emperor Jones, by Eugene O'Neill.-1921. Nice people, by Rachel Crothers.-I921. The detour, by Owen Davis.-1921. Dulcy, by George S. Kaufman and Marc Connelly.-1923. The adding machine, by Elmer L. Rice.-1925. The show-off, by George Kelly.-r925. Lucky Sam McCarver, by 
Sidney Howard.-I927. The second man, by S. N. Behrman.-1928. Holiday, by Philip Barry.1930. The green pastures, by Marc Connelly.1935. Awake and sing, by Clifford Odets.-1936. The petrified forest, by Robert Emmet Sherwood.1937. The masque of kings, by Maxwell Anderson.-Bibliographies, General references (p. ror3I014).

2349. Pochmann, Henry A., and Gay Wilson Allen, eds. Masters of American literature. New York, Macmillan, I949. 2 v. $\quad 49-6433$ PS507.P6

A college textbook anthology which aims at presenting major authors and their outstanding works, as an introduction to American literature. The work accordingly presents copious selections from about $30^{-}$authors. Introductory essays, bibliographies, and footnotes are included to assist the student.

2350. Poets of today. New York, Scribner, r $954+$ 54-10439 PS6r4.P64

Contents. - [ I] Poems and translations, by Harry Duncan. Samurai and serpent poems, by Murray Noss. Another animal, poems by May Swenson.2. The hatch, poems, by Norma Farber. The irony of joy, poems by Robert Pack. Good news of death and other poems by Louis Simpson.-3. The floating world and other poems, by Lee Anderson. My father's business and other poems, by Spenser Brown. The green town: poems, by John Langland.

A series which, for purposes of publishing economies, incorporates in each volume the poems for a first volume by each of several young poets. The series is edited by John Hall Wheelock, who has written discriminating introductory essays for the volumes.

2351. Prize stories. The $O$. Henry awards. IgI9+ Garden City, N. Y., Doubleday.

21-9372 PZI.OII

Title varies: 1919-46, O. Henry Memorial Award Prize Stories.

Stories for 1919-27 were "chosen by the Society of Arts and Sciences."

Editors: 1919-32, B. C. Williams.-I933-40, Harry Hansen.-I94I- Herschel Brickell (with Muriel Fuller, $19-46$ ).

An annual selection of leading American short stories of the preceding year. The 1956 volume was the 36 th in the series. The series was interrupted in 1952 and 1953 as a result of the editor's death. Although this series and The Best American Short Stories... annuals (q. v.) both attempt to pick the best short stories published in American periodicals, there is little duplication in the stories included. Also, this series tends toward shorter volumes, partly because it does not offer an annual survey and bibliography of short stories. Both collections, however, maintain high standards of merit.

2352. Richardson, Lyon, N., George H. Orians, and Herbert R. Brown, eds. The heritage of American literature. Boston, Ginn, 195I. 2 v. 5I-3922 PS $507 \cdot \mathrm{R}_{5}$

A college textbook which emphasizes major authors but gives some attention to minor figures; about one hundred and forty authors are represented. Sections, authors, and selections receive introductions designed to prepare students for classroom lectures; each author has a relatively extensive bibliography supplied.

2353. Short, Raymond W., and Wilbur S. Scott, eds. The main lines of American literature. New York, Holt, 1954. 648 p.

$\begin{array}{lll}54-6620 & P_{507 . S_{49}}\end{array}$ This college textbook anthology provides section and author introductions with some bibliographical information. The selections are designed to supplement full volume assignments of nine major authors who are not represented in this work. Available reprints of works by these omitted authors are listed in a pamphlet available to teachers from the publisher; the pamphlet also includes course syllabi.

2354. Tate, Allen, and John Peale Bishop, eds. American harvest; twenty years of creative writing in the United States. Garden City, N. Y., Garden City Pub. Co., I943. 544 p.

$$
\text { 45-2164 PS } 536 . \mathrm{T}_{3} \quad 1943
$$

An anthology of literary works (mainly short stories and poems) produced in the United States during the twenties and thirties.

2355. Thorp, Willard, Merle Curti, and Carlos Baker, eds. American issues. Rev, and enl. Philadelphia, Lippincott, I 954-55 [v. I, I 955] 2 v. $\quad 55-5334 \mathrm{PS}_{507 . \mathrm{T}_{53}}$ Contents.-v. I. The social record.-v. 2. The literary record.

A college textbook anthology (in reality two anthologies), this is obviously more than a literary guide. The second volume, meant to be purely literary in the material presented, includes work from about seventy-five authors. The work of major authors is emphasized, while that of minor authors is included for representation of a type of writing. The first volume, on the other hand, is designed to present the records of the issues at work in American society during its history; nearly 200 authors (many of whom are included in volume two for other work) have selections presented in a manner designed to augment the purely belletristic ap- 
proach to American literature. The usual scholarly apparatus is provided.

2356. Twentieth-century literature in America. Chicago, Regnery, I951-52. 6 v.

2357. Bogan, Louise. Achievement in American poetry, 1900-1950. I95I. I57 p.

$$
5^{\mathrm{I}-83^{8} 4} \text { PS221.B } 56
$$

2358. Brodbeck, May, James Gray, and Walter Metzger. American non-fiction, 1900-1950. 1952. $198 \mathrm{p}$. 52-12468 $\mathrm{PS}_{379 . \mathrm{B}_{7}}$

2359. Downer, Alan S. Fifty years of American drama, 1900-1950. 1951. $15^{8} \mathrm{p}$. $5^{1-13185}$ PS 35 1.D6

2360. Hoffman, Frederick John. The modern novel in America, 1900-1950. 195 I. 216 p. 51-13723 PS $379 . \mathrm{H} 6$

236r. O'Connor, William Van. An age of criticism: 1900-1950. 1952. $182 \mathrm{p}$.

$$
5^{2-12476} \mathrm{PN}_{99 .} \mathrm{U}_{52} \mathrm{O}_{3}
$$

2362. West, Ray Benedict. The short story in America, 1900-1950. 1952. $147 \mathrm{p}$.

$$
\text { 52-3551 } \mathrm{PS}_{374 . \mathrm{S}_{5} \mathrm{M}_{4}}
$$

2363. Untermeyer, Louis, ed. Modern American poetry. Mid-century [i. e. $7^{\text {th }}$ ] ed. New York, Harcourt, Brace, 1950. xxii, 709 p.

$$
\text { 50-5229 PS6ri.U6 I950 }
$$

A distinguished anthology of modern American poetry; the first edition appeared in 1919. Since then poets have been dropped and new ones added with each succeeding edition. The work attempts to represent the leading modern poets through a moderately large selection of their work; each poet's work is introduced by a concise half-page to eight pages of biographical information and critical discussion. Whitman and Dickinson (qq. v.) are included as precursors, and the cited 1950 edition includes recent work such as the poetry of Randall Jarrell, Peter Viereck, and Robert Lowell (qq. v.). The work has frequently been published with Untermeyer's comparable anthology of nıodern British poetry. The 1955 edition, Modern American \& Modern British Poetry (New York, Harcourt, Brace, 1955. 697 p.), which was edited with the assistance of Karl Shapiro and Richard Wilbur (qq. v.), is a much shorter work, and stripped of the biographical and critical introductions; however, it is still a good, if more restricted, work, and of value for its representation of very recent poets. With the many edi- tions of this work, and with many other anthologies, such as An Anthology of the New England Poets from Colonial Times to the Present Day (New York, Random House, 1948. xx, 636 p.), Untermeyer (b. 1885 ) has come to be one of the best-known of American anthologists. His Early American Poets (New York, Library Publishers, 1952. 334 p.) covers American poetry to the point where his Modern American Poetry begins, but lacks similar individual introductions. Untermeyer also has a literary reputation in other fields, most notably in poetry. His Selected Poems and Parodies was published in 1935.

2364. Uppsala. Universitet. Amerikanska Seminariet. Essays and studies on American language and literature. Upsala, Lundequistska Bokhandeln; Cambridge, Harvard University Press, 1945+

"The present series of Essays and Studies will be devoted to American philology in the wider sense. Occasionally, other subjects connected with American Humanities will be included. The series is intended to treat specialized as well as more comprehensive problems."-Publisher's statement on cover of number five.

Most of the volumes in the series to date have been published in both Sweden and the United States. In addition to the titles cited in full below, other works which have appeared in the series, or are said to be in preparation, include: R. C. Barton's The Change in Race Consciousness in American Negro Literature after 1930; F. Böök's Romantic Elements in Henry Thoreau; E. Ekwall's American and British Pronunciation; H. Elovson's The U.S. A. As a Symbol of Liberty in Swedish Literature in the Middle of the 1gth Century; R. Engländer's Edward McDowell and Scandinavian Musical Tradition; G. Fridén's James Fenimore Cooper and Ossian; N. M. Holmer's The Character of the Iroquoian Languages and Indian Place Names in North America; S. Liljeblad's The Northern Shoshoni Indians; S. B. Liljegren's The Quality and Function of AntiIntellectualism in American Romanticism and The Subject-Matter of American Literary Realism; and K. E. Lindblad's Noah Webster's Pronunciation and Modern New England Speech, a Comparison.

2365. Annebrink, Lars. The beginnings of naturalism in American fiction; a study of the works of Hamlin Garland, Stephen Crane, and Frank Norris, with special reference to some European influences, I89I-I903. I950. 505 p. ([no.] 9)

Includes bibliographies.

$$
\text { 50-8924 PS } 371 . A_{2}
$$


2366. Ekström, Kjell. George Washington Cable, a study of his early life and work. 1950 . 197 p. ([no.] 10)

Bibliography: p. [185]-193.

2367. Liljegren, Sten B. The revolt against romanticism in American literature as evidenced in the works of S. L. Clemens. 1945. $60 \mathrm{p}$. ([no.] I) 47-24I97 PSi342.R6L5 Bibliographical references included in "Notes" (p. 53-6o).

2368. Lundblad, Jane. Nathaniel Hawthorne and European literary tradition. 1947. $196 \mathrm{p}$. ([no.] 6) 48-3460 PS $1886 . \mathrm{L} 8$

"Hawthorne and the Tradition of Gothic Romance" (p. [8r]-149) issued also separately, with slight variations, under title: Nathaniel Hawthorne and the Tradition of Gothic Romance (no. 4 in this series).

Bibliography: p. [191]-196.

2369. Warfel, Harry R., and George Harrison Orians, eds. American local-color stories. New York, American Book Co., 1941. xxiv, 846 p. 41-17552 PZi.W23Am

A survey through short-story selections of the local color literary movement that flourished in the United States in the r th $^{\text {th }}$ century. This school placed primary emphasis on a local area, rather than on telling a story (although there usually was one), analyzing a person or situation, or presenting a thesis. The school relied heavily on dialect, landscape description, character types, etc. Most of the stories in this anthology were written after 1870 , and the most recent in 1907 . An attempt has been made to represent the various sections of the country in the 63 stories by $3^{8}$ authors.

2370. White, Elwyn B., and Katharine S. White, eds. A subtreasury of American humor. New York, Coward-McCann, I94I. xxxii, 8I4 p. 4I-52004 PN6I6r.W5223

This is a personal rather than a historical anthology of American humor. Within that limitation, its large quantity offers much variety, although mainly from modern authors. The work is available in a Modern Library reprint. Another such selection, but which shows a greater tendency to excise passages from longer works, is An Encyclopedia of Modern American Humor (Garden City, N. Y., Hanover House, Doubleday, I954. 688 p.), edited by Bennett Cerf. A highly personal anthology with a tendency to rather long selections is H. Allen Smith's Desert Island Decameron (Garden City, N. Y., Doubleday, Doran, 1945. 406 p.). A humor anthology intended to serve historical purposes as well as general reading pleasures is Edwin Seaver's Pageant of American Humor (Cleveland, World Pub. Co., 1948. 607 p.), which was compiled by means of responses to a questionnaire sent to several hundred writers. A collection that is more one of "jokes" than of the more general, and usually more literate, "humor" is Leewin B. Williams' Encyclopedia of Wit, Humor, and Wisdom (Nashville, Tenn., Abingdon-Cokesbury Press, 1949. 576 p.), which is an extensive, double-columned work arranged on a subject basis.

\section{B. History and Criticism}

237x. Aldridge, John W. After the lost generation; a critical study of the writers of two wars. New York, McGraw-Hill, 195I. xv, 263 p. 5I-10588 PS 379 . A5

The author attempts to trace the change that has occurred between the novelists produced in the atmosphere of the First World War and those who developed in the shadow of World War II. In the first third of the book he discusses those authors (Hemingway, Fitzgerald, and Dos Passos) whom he considers to be "most illustrative of the artistic preoccupations of their age and whose work has had the most lasting influence on the young writers of today." The rest of the book is devoted to a study of the novelists who appeared in the forties: Vance Bourjaily, Norman Mailer, John Horne
Burns, Irwin Shaw, Merle Miller, Gore Vidal, Paul Bowles, Truman Capote, Frederick Buechner, and others.

2372. Aldridge, John W., ed. Critiques and essays on modern fiction, 1920-1951, representing the achievement of modern American and British critics. New York, Ronald Press, 1952. xx, 6ro p. 52-6180 PN3355.A8

"This book has been designed for use as a primary text in courses in the criticism of modern fiction, and as a collateral text in courses in the survey of modern fiction. . . . the governing intention of the book is that it should meet the needs ... of serious students who are interested in fiction as an art rather than as a model, and who may be expected 
to be concerned with the element which most clearly distinguishes it as an art, its technique or form." Introduction.

A considerable portion of the book is either criticism by Americans, or criticism about Americans. Authors discussed at some length include Faulkner, R. P. Warren, K. A. Porter, S. Crane, F. S. Fitzgerald, S. Anderson, T. Wolfe, T. Dreiser, J. T. Farrell, E. Hemingway, and E. Welty. There is added on p. 553-610 a sizable selective bibliography of criticism of modern fiction.

2373. Aldridge, John W. In search of heresy; American literature in an age of conformity. New York, McGraw-Hill, r956. 208 p. 56-8166 PS22ז.A64

A discussion of American literature (fiction) after World War II. A heavy emphasis is laid on what the author regards as the pernicious influence of the universities-leading to conformity, camaraderie, and a limited, bland production.

2374. Arms, George W. The fields were green: a new view of Bryant, Whittier, Holmes, Lowell, and Longfellow; with a selection of their poems. Stanford, Stanford University Press, 1953. $246 \mathrm{p}$.

Bibliography: p. 238-24I.

53-6445 PS541.A8

Each poet is discussed in terms of his value for the present-day reader. The selections included are usually not the standard anthology poems.

2375. Babbitt, Irving. Rousseau and romanticism. Boston, Houghton Mifflin, r919. xxiii, $426 \mathrm{p}$. 19-26569 $\mathrm{PN}_{603 . \mathrm{B}_{3}}$

Bibliography: p. [399]-419.

Babbitt (1865-1933) was one of the leaders of the neo-humanist movement. While his work was largely in comparative literature, his theories had influence in general American literary criticism. In this respect Rousseau and Romanticism was probably at once his most influential and his most important book. His other work includes Literature and the American College; Essays in Defense of the Humanities (Boston, Houghton Mifflin, 1908. 262 p.); The New Laokoon; an Essay on the Confusion of the Arts (Boston, Houghton Mifflin, 19ro. 258 p.); Democracy and Leadership (Boston, Houghton Mifflin, 1924. 349 p.); and On Being Creative, and Other Essays (Boston, Houghton Mifflin, 1932. 265 p.). Irving Babbitt, Man and Teacher (New York, Putnam, r94I. 337 p.), edited by Frederick Manchester and Odell Shepard, is a collection of reminiscences about Babbitt by some 30 people who knew him. Louis J. A. Mercier's The Challenge of Humanism (New York, Oxford University Press, 1933. 288 p.) has much on the neo-humanist move- ment in general, and on both Babbitt and Paul Elmer More (q. v.) in particular. Of similar scope is Folke Leander's Humanism and Naturalism; a Comparative Study of Ernest Seillière, Irving Babbitt and Paul Elmer More (Göteborg, Elanders Boktryckeri Aktiebolag, 1937. 227 p.). The Critique of Humanism, a Symposium (New York, Brewer \& Warren, 1930. 359 p.), edited by C. Hartley Grattan, is a collection of articles which demonstrate the position of humanism and the influence on American critics of both Babbitt and More. A general study is G. R. Elliott's Humanism and Imagination (Chapel Hill, University of North Carolina Press, 1938. 253 p.), the first section of which focuses on Babbitt and More, and the second on Emerson, with the two types of humanism shown in contrast.

2376. Beach, Joseph Warren. American fiction, 1920-1940. New York, Macmillan, 1941.

$371 \mathrm{p} . \quad 4^{\mathrm{I}-6464} \quad \mathrm{PS}_{379 . \mathrm{B}_{3} 8}$

Critical essays on John Dos Passos, Ernest Hemingway, William Faulkner, Thomas Wolfe, Erskine Caldwell, James T. Farrell, John P. Marquand, and John Steinbeck.

Beach (b. 1880 ) is best known as a critic; in addition to material in periodicals and the work cited above, he has published a study of Henry James (q. v.) and The Twentieth Century Novel; Studies in Technique (New York, Century, 1932. 569 p.), which devotes much space to American fiction. He is also known for his poetry; in this field his most recent volume is Involuntary Witness (New York, Macmillan, 1950. 97 p.). In 1930 he published a novel, Glass Mountain (Philadelphia, Macrae Smith Co. 330 p.) about American expatriates in France. Forms of Modern Fiction (Minneapolis, University of Minnesota Press, I948. 305 p.), edited by William Van O'Connor, is a collection of essays in honor of Beach.

2377. Bretnor, Reginald, ed. Modern science fiction, its meaning and its future [by] John W. Campbell, Jr. [and others] New York, CowardMcCann, 1953. 294 p. $\quad$ 52-1I7I4 $\mathrm{PN}_{33} 8_{3} . \mathrm{S}_{4} \mathrm{~B}_{7}$

A group of essays on the causes, meanings, and position of science fiction in the field of literature. A history of this form, which has in recent years undergone a phenomenal growth, may be found in James O. Bailey's Pilgrims through Space and Time; Trends and Patterns in Scientific and Utopian Fiction (New York, Argus Books, 1947. 34 I p.). A book dealing with the audience for and the production of science fiction is Sam Moskowitz' The Immortal Storm; a History of Science Fiction Fandom (Atlanta, Atlanta Science Fiction Organization Press, 1954. 269 p.). 
2378. Brooks, Cleanth. Modern poetry and the tradition. Chapel Hill, University of North Carolina Press, 1939. 253 p.

39-22007 PNir36.B75

Contents.-Metaphor and the tradition.-Wit and high seriousness.-Metaphysical poetry and propaganda art.-Symbolist poetry and the ivory tower.-The modern poet and the tradition.-Frost, MacLeish, and Auden.-The waste land: critique of the myth.-Yeats: the poet as myth-maker.-A note on the death of Elizabethan tragedy.-Notes for a revised history of English poetry.

Brooks (b. 1906) has been one of the leaders in the "New Criticism" movement. His work, primarily in the field of poetry, is characterized by careful textual explication and structural analysis. In addition to his importance as a critic, he has had considerable influence on the teaching of literature through his college texts, such as Understanding Poetry (1938), Understanding Fiction (1943), and Modern Rhetoric (1949), works which he wrote in collaboration with Robert Penn Warren, and Understanding Drama (1945, 1948), which he co-authored with Robert B. Heilman.

2379. Brooks, Cleanth. The well wrought urn; studies in the structure of poetry. New York, Reynal \& Hitchcock, 1947. $270 \mathrm{p}$.

47-3I43 $\mathrm{PR}_{502 .} \mathrm{B}_{7}$

Reissued in 1956 in the Harvest books paperback series by Harcourt, Brace and Co.

2380. Brooks, Van Wyck. America's coming-ofage. New York, B. W. Huebsch, 1915. $183 \mathrm{p}$. 15-27963 Er68.B8835

Contents.-"Highbrow" and "lowbrow."-"Our poets."-The precipitant.-Apotheosis of the "lowbrow."-The Sargasso sea.

Brooks (b. I886) has been one of the most widely read literary critics of the first half of the 2oth century, outsicie the formal schools. He has done much work as a translator (from French) and as an editor, but is best known for the many books he has written, which include: Emerson and Others (New York, Dutton, I927. 250 p.), the first half of which is on Emerson, the rest a series of essays on R. Bourne, A. Bierce, H. Melville, U. Sinclair, etc.; The Life of Emerson (New York, Dutton, 1932. 215 p.); Sketches in Criticism (New York, Dutton, I932. 306 p.); The Ordeal of Mark Twain (New and rev. ed. New York, Dutton, 1933. 325 p.); Three Essays on America (New York, Dutton, 1934. 216 p.), the essays being "America's Coming of Age," "Letters and Leadership," and "The Literary Life in America"; Opinions of Oliver Allston (New York, Dutton, I94I. 309 p.), which indirectly expresses Brook's views on criticism; $A$
Chilmark Miscellany (New York, Dutton, 1948. 315 p.), a selection from the author's other books; Scenes and Portraits; Memories of Childhood and Youth (New York, Dutton, 1954. 243 p.); and John Sloan, a Painter's Life (New York, Dutton, 1955. 246 p.).

238r. Brooks, Van Wyck. Makers and finders; a history of the writer in America, 18001915. New York, Dutton, 1936-52 [v. I, 1944] $5 \mathrm{v}$.

Contents. - v. I. The world of Washington Irving [1800-1840] (PS208.B7 44-7345).-v. 2. The flowering of New England, 1815-1865 (PS243.B7 1936 36-27376).-v. 3. The times of Melville and Whitman [ca. 1847-1885] (PS20r.B7 47-11390).-v. 4. New England: Indian summer, 1865-r915 (PS243.B72 1940 40-30493).-v. 5. The confident years: $1885-1915$ (PS214.B7 5II4833).

The volumes in this series have been republished in Everyman's library.

2382. Brooks, Van Wyck. The writer in America. New York, Dutton, 1953. 203 p.

$$
\text { 52-12957 } \mathrm{PS}_{3 \mathrm{r}} \mathrm{B} 83
$$

2383. Brown, Clarence A., comp. The achievement of American criticism; representative selections from three hundred years of American criticism. New York, Ronald Press, 1954. 724 p. 54-6962 PN99.U5B

The selections, many in full, are assembled in categories such as the origins of American critical theory; neoclassicism, transition to romanticism; and realism and æstheticism. An anthology which attempts to present a cross section of the critical ideas and methods of various prominent and representative critics in the 2oth century is Charles I. Glicksberg's American Literary Criticism, 19001950 (New York, Hendricks House, 1952. 574 p.). Another book undertaking "to make accessible the contemporary achievement in criticism," both American and British, is Robert Wooster Stallman's anthology: Critiques and Essays in Criticism, 19201948 (New York, Ronald Press, 1949. xxii, 57 I p.).

2384. Brown, Herbert R. The sentimental novel in America, I789-1860. Durham, N. C., Duke University Press, 1940. 407 p. (Duke University publications) $\quad 4^{\mathrm{I}-\mathrm{I}} 35 \quad \mathrm{PS}_{377} \cdot \mathrm{B}_{7}$

Issued also as thesis ( $\mathrm{Ph}$. D.) Columbia University.

Bibliography: p. 37I-38o.

A study of the popular novel in America up to the Civil War, showing the role it played in American life. 
2385. Brownell, William Crary. American prose masters: Cooper-Hawthorne-EmersonPoe-Lowell-Henry James. New York, Scribner, 1909. $400 \mathrm{p}$. 9-28257 $\mathrm{PS}_{3} 62 . \mathrm{B}_{7}$

W. C. Brownell (185i-1928) was, with Woodberry and Stedman (qq. v.), considered one of the leading literary critics within the Genteel Tradition. However, he has also been viewed as a precursor of the New Humanism.

2386. Brownell, William Crary. William Crary Brownell, an anthology of his writings together with biographical notes and impressions of the later years, by Gertrude Hall Brownell. New York, Scribner, I933. 383 p.

$$
\text { 33-30961 PSir45.B6A6 }
$$

1933

2387. Burke, Kenneth. Counter-statement. New York, Harcourt, Brace, I93I. 268 p. 3x-29768 PN5ir.B79

A group of statements of principles of literary aesthetics which counter prevailing views.

Works such as The White Oxen, and Other Stories (New York, Boni, r924. 298 p.), Towards a Better Life (New York, Harcourt, Brace, 1932. 219 p.), an experimental "novel," and Book of Moments; Poems, 1915-1954 (Los Altos, Calif., Hermes Publications, r955. 96 p.) have given Kenneth Duva Burke (b. 1897) something of a reputation as an author of fiction and poetry. However, he is probably best known for his work as a literary critic. This has been heavily influenced by his interest in the modern semantics movement, as have been his probably less well known philosophical works such as Permanence and Change, an Anatomy of Purpose (New York, New Republic, I935. 35I p.) and Attitudes Toward History (New York, New Republic, 1937. 2 v.).

2388. Burke, Kenneth. The philosophy of literary form; studies in symbolic action. Baton Rouge, Louisiana State University Press, r941. $455 \mathrm{p}$. 4I-I I084. PN5II.B795

A collection of articles, all of which have been previously published, except the first: "The Philosophy of Literary Form" (p. I-r37). Cf. Foreword. The problem of semantics is given considerable attention in this volume.

2389. Burke, Kenneth. A grammar of motives. New York, Prentice-Hall, I945. xxiii, $\begin{array}{ll}530 \mathrm{p} . & 45-10249 \\ \text { B } 945 . \mathrm{B} 773 \mathrm{G} 7\end{array}$

This book is important for literary criticism, but its philosophical overtones and linguistic analyses render it important in other fields as well. It is the first volume of a trilogy on "motives" (vide infra).
2390. Burke, Kenneth. A rhetoric of motives. New York, Prentice-Hall, 1950. xv, 340 p. 50-5208 B840.B8

This, the second volume of an as yet uncompleted trilogy, analyzes literature and the human situation in terms of general semantics. Volume three is to have the title $A$ Symbolic of Motives.

2391. Burke, William J., and Will D. Howe. American authors and books, I640-1940. New York, Gramercy Pub. Co., x 943.858 p.

$$
\text { 43-1255 Z×224.B87 } 1943
$$

"Facts about the writing, illustrating, editing, publishing, reviewing, collecting, selling, and preservation of American books ... The material has been arranged in dictionary form, with cross-reference to related subjects. Bibliographical references for further study are given throughout the handbook."-Preface.

2392. Cady, Edwin H. 'The gentleman in America; a literary study in American culture. Syracuse, N. Y., Syracuse University Press, 1949. $232 \mathrm{p}$.

49-10671 BJi6or.C2

"What is attempted here is a study of the fate in America of the cluster of concepts, values, attitudes, and cultural forms implied by the word 'gentleman' as it is reflected in American literature. With that goes the effort to show how accurate criticism of certain interesting American authors depends upon a full reading of books which cannot be understood without a clear grasp of the gentlemanly configuration. Finally, it is hoped that something is here contributed toward a better understanding of the working relations among ideas, culture, and literature in America."-Introduction.

2393. The Cambridge history of American literature, edited by William Peterfield Trent, John Erskine, Stuart P. Sherman [and] Carl Van Doren. New York, Macmillan, I93I. 4 v. $3^{8-36} 65^{6}$ PS88.C 3 I931

A pioneer comprehensive history of the subject. Special features are: The inclusive scale, expanded to cover subjects frequently neglected; monographic chapters contributed by scholars specializing in the topic being presented; the extensive bibliographies supplied (arranged by chapters, at the end of volumes 1,2 , and 4 ); and the emphasis on a relation between the life of the American people and their literature.

2394. Canby, Henry Seidel. Definitions; essays in contemporary criticism. New York, Harcourt, Brace, I922. $303 \mathrm{p}$.

22-169o I PS78.C 3 , Ist ser.

In his long career as English professor and editor, 
Canby (b. 1878 ) has produced much literary criticism with a wide popularity. Like Van Wyck Brooks (q. v.), he flourished before the New Criticism became dominant, and has remained outside that movement. His many works include biographies of Whitman and Thoreau; a history of the Brandywine in the Rivers of America series (q. v.); and his autobiographical American Memoir (Boston, Houghton Mifflin, 1947. 433 p.) the first two parts of which, previously published independently as "The Age of Confidence," deal with his childhood in Wilmington, Delaware, while the third part, "Alma Mater," is a commentary on college life.

2395. Canby, Henry Seidel. Definitions; essays in contemporary criticism. (Second series) New York, Harcourt, Brace, 1924. 308 p.

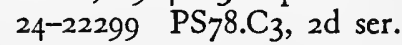

2396. Canby, Henry Seidel. American estimates. New York, Harcourt, Brace, 1929. 287 p. 29-7862 PN5II.C 34

An informal continuation of the "definitions" series above.

2397. Canby, Henry Seidel. Classic Americans; a study of eminent American writers from Irving to Whitman, with an introductory survey of the colonial background of our national literature. New York, Harcourt, Brace, 1931. 371 p.

"A selective bibliography": p. $353-360$. $3^{1-25290}$ PS88. 35

Contents.-The colonial background.-Washington Irving.--James Fenimore Cooper.-Ralph Waldo Emerson.-Henry David Thoreau.-Hawthorne and Melville.-Edgar Allan Poe.-Walt Whitman.

2398. Canby, Henry Seidel. Seven years' harvest; notes on contemporary literature. New York, Farrar \& Rinehart, 1936. 310 p.

$$
3^{6-28} 73 \text { I } \mathrm{PN}_{77} \mathrm{r}_{3} \mathrm{C}_{3}
$$

All but one of these essays were published originally in the Saturday Review of Literature, a weekly periodical which Canby edited from 1924 to 1936 .

2399. Cargill, Oscar. Intellectual America; ideas on the march. New York, Macmillan, 194I. $\mathrm{xxi}, 777 \mathrm{p}$. $41-21084$ PS88.C 37

Critical survey that undertakes to trace the effect of various European ideas on writers in America; concentrates chiefly on the period in American literature between I890-1940.

2400. Carpenter, Frederic Ives. American literature and the dream. New York, Philosophical Library, 1955. 220 p. 56-193 PS88.C 38
"This book began as a series of essays in interpretation of the major American authors. But in the process of writing, an idea crystallized: American literature has differed from English because of the constant and omnipresent influence of the American dream upon it. But this influence has usually been indirect and unconscious, because the dream has remained vague and undefined. ... But the vague idea has influenced the plotting of our fiction and the imagining of our poetry. Almost by inadvertence our literature has accomplished a symbolic and experimental projection of it."-Introduction.

2401. Clark, Harry Hayden, ed. Transitions in American literary history; edited ... f for the American Literature Group of the Modern Language Association. Durham, N. C., Duke University Press, 1953 [i. e. I954] 479 p.

53-8269 PS88.C6

Contents.-Introduction, by Harry Hayden Clark.-The decline of Puritanism, by Clarence $\mathrm{H}$. Faust.-The late eighteenth century: an age of contradictions, by Leon Howard.--The decline of neoclassicism, $1801-1848$, by M. F. Heiser.-The rise of romanticism, $1805^{-1855}$, by G. H. Orians.-The rise of Transcendentalism, 1815-1860, by Alexander Kern.-The decline of romantic idealism, I $855^{-1} 871$, by Floyd Stovall.-The rise of realism, r871-189r, by Robert Falk.

2402. Coan, Otis W., and Richard G. Lillard. America in fiction, an annotated list of novels that interpret aspects of life in the United States. $4^{\text {th }}$ ed. Stanford, Stanford University Press, 1956. $200 \mathrm{p}$. $\quad 56-7269$ Z136r.C6C6 1956

Includes best sellers as well as standard works. It is useful for its subject approach to aspects of American life as treated in novels. The emphasis is largely on realism rather than on literary merit.

2403. Coffman, Stanley K. Imagism, a chapter for the history of modern poetry. Norman, University of Oklahoma Press, I951. xi, $235 \mathrm{p}$.

$$
\text { 5i-9592 PS } 3 \text { I } 0 . I_{5} \mathrm{C} 6
$$

Following a chronology of the Imagist movement in England and the United States, the book sketches the contributions of various important figures in the movement and also provides material on the sources of modern poetic forms.

2404. Conner, Frederick W. Cosmic optimism; a study of the interpretation of evolution by American poets from Emerson to Robinson. Gainesville, University of Florida Press, 1949. xiv, $45^{8} \mathrm{p}$. 49-986r PS3 $10 . E 8 C 6$

Bibliography: p. 433-442. 
2405. Cowie, Alexander. The rise of the American novel. New York, American Book Co., 1951. xii, 877 p. (American literature series)

Bibliography: p. $861-862$.

$$
\text { 51-2714 PS371.C } 73 \text { 195I }
$$

Critical history of the novel from the beginning through the work of Henry James, with a final chapter on "new directions," 1890-1940.

2406. Cowley, Malcolm, ed. After the genteel tradition; American writers since 1910. New York, Norton, 1937. 270 p.

$$
\text { 37-27387 PS221.C645 }
$$

Contents.-Foreword: The revolt against gentility.-Theodore Dreiser, by John Chamberlain.Upton Sinclair, by Robert Cantwell.-Willa Cather, by Lionel Trilling.--Van Wyck Brooks, by Bernard Smith.-Carl Sandburg, by Newton Arvin.-Sherwood Anderson, by R. M. Lovett.-H. L. Mencken, by Louis Kronenberger.-Sinclair Lewis, by Robert Cantwell.--Eugene O'Neill, by Lionel Trilling.The James Branch Cabell period, by P. M. Jack.Two poets: Jeffers and Millay, by Hildegarde Flanner.-Dos Passos: poet against the world, by Malcolm Cowley.-Homage to Hemingway, by J. P. Bishop.-Thomas Wolfe, by Hamilton Basso.Postscript: Twenty years of American literature.A literary calendar: $1911-1930 .-B i o g r a p h i e s$ in brief.-Index of names.

Cowley (b. 1898) is in his own right a creative writer, but he is best known as a critic closely associated with the expatriate writers of the "lost generation." He has also done considerable work as an editor, including the volumes of writings by Faulkner, Hawthorne, and Hemingway in the Viking portable library series and The Complete Poetry and Prose of Walt Whitman for the American classics series.

2407. Cowley, Malcolm, ed. Books that changed our minds; edited by Malcolm Cowley \& Bernard Smith. New York, Doubleday, Doran, 1939. $285 \mathrm{p}$. 39-29439 Zroo3.C87

Contents.-A foreword on the books that changed our minds.-Freud and "The interpretation of dreams," by George Soule.- "The education of Henry Adams," by Louis Kronenberger.-Turner's "The frontier in American history," by C. A. Beard.-Sumner's "Folkways," by John Chamberlain.-Veblen and "Business enterprise," by R. G. Tugwell.-Dewey and his "Studies in logical theory," by C. E. Ayres.-Boas and "The mind of primitive man," by Paul Radin.-Beard's "Economic interpretation of the Constitution," by Max Lerner.--Richard's "The principles of literary criticism," by David Daiches.-Parrington's "Main currents in American thought," by Bernard Smith.-
Lenin's "The state and revolution," by Max Lerner.-Spengler's "The decline of the West," by Lewis Mumford.-An afterword on the modern mind.

2408. Cowley, Malcolm. Exile's return; a literary odyssey of the I920's. New York, Viking Press, 1951. 322 p. 51-4022 PS221.C65 1951

$A$ revised and enlarged version of a book that first appeared in 1934. The book deals with members of the "lost generation," particularly the expatriate authors.

2409. Cowley, Malcolm. The literary situation. New York, Viking Press, 1954. 259 p.

54-7984 PS221.C67

A discussion of the present-day situation of authors in America, and of the "new" fiction.

2410. Crane, Ronald S., ed. Critics and criticism, ancie: $1 i$ and modern, by R. S. Crane [and others] Chica ¿, University of Chicago Press, 1952. 647 p. $\quad 52-7330$ PN8r.C8

A collection of essays on critics which expresses the neo-Aristotelian views of the "Chicago school" of criticism.

2411. Criticism in America, its functions and status; essays by Irving Babbitt, Van Wyck Brooks, W. C. Brownell, Ernest Boyd, T. S. Eliot, H. L. Mencken, Stuart P. Sherman, J. E. Spingarn, and George E. Woodberry. New York, Harcourt, Brace, I924. 330 p. 24-3993 PS78.C7

"The first essay dates from Igro, the last from r923, and virtually every critical point of view is given a hearing."-Prefatory note.

2412. Denny, Margaret, and William H. Gilman, eds. The American writer and the European tradition. Minneapolis, Published for the University of Rochester by the University of Minnesota Press, 1950. $192 \mathrm{p}$.

50-13091 PSi57.D4

Contents.-The Renaissance tradition in America, by Louis B. Wright.-The Enlightenment and the American dream, by Theodore Hornberger.Benjamin Franklin, promoter of useful knowledge, by Robert E. Spiller.-Cosmopolitanism in American literature before $\mathrm{r} 880$, by Stanley T. Williams.Origins of a native American literary tradition, by Henry Nash Smith.-Americanization of the European heritage, by Leon Howard.-American writers as critics of nineteenth-century society, by Willard Thorp.-The reception of some nineteenth-century American authors in Europe, by Clarence Gohdes. American naturalism; reflections from another era, by Alfred Kazin.-Contemporary American literature in its relation to ideas, by Lionel Trilling.- 
The American poet in relation to science, by Norman Holmes Pearson.-Some European views of contemporary American literature, by Harry Levin.

2413. Deutsch, Babette. This modern poetry. New York, Norton, 1935. 284 p.

35-18099 PR6or.D 4

Babette Deutsch (b. 1895) has done much critical work on modern poetry, with articles appearing in a number of periodicals, and is the author of $W$ alt Whitman, Builder for America (New York, Messner, 1941. 278 p.). In addition she has distinguished herself as a poet with volumes such as Banners (New York, Doran, 19r9. I04 p.), Honey Out of the Rock (New York, Appleton, I925. I29 p.), Fire for the Night (New York, Cape \& Smith, 1930. 77 p.), Epistle to Prometheus (New York, Cape \& Smith, 1931. 95 p.), One Part Love (New York, Oxford University Press, 1939. 86 p.), Take Them, Stranger (New York, Holt, 1944. 72 p.), and Animal, Vegetable, Mineral (New York, Dutton, 1954. 59 p.). Another aspect of her work in poetry is the large number of translations she has made from foreign poetry, principally from German and Russian and usually in collaboration with her husband, Avrahm Yarmolinsky. She has also published four novels: A Brittle Heaven (New York, Greenberg, r926. 326 p.), which pictures a young woman's life in America, and in the character of Mark Gideon presents a view of Randolph Bourne (q. v.); In Such a Night (New York, Day, 1927. 260 p.), which depicts the guests at a housewarming party; Mask of Silenus, a Novel about Socrates (New York, Simon \& Schuster, 1933. 249 p.); and Rogue's Legacy, a Novel about François Villon (New York, Coward-McCann, I942. 392 p.).

24I4. Deutsch, Babette. Poetry in our time. New York, Holt, 1952. 4II p.

52-6624 PR6or.D43

A discussion of modern American and British poetry.

2415. De Voto, Bernard A. Forays and rebuttals. Boston, Little, Brown, I936. 403 p. 36-28727 PS $3507 . E 867 \mathrm{~F} 6 \quad 1936$

A collection of magazine articles, some of which are literary criticism, but many of which reveal De Voto's more general journalistic activities. Similar in nature are Minority Report (Boston, Little, Brown, I940. 346 p.) and The Easy Chair (Boston, Houghton Mifflin, I955. 356 p.).

De Voto (1897-1956) is probably best known for his historical works (discussed elsewhere in this bibliography), but his widest audience was for his articles in periodicals, principally Harper's Magazine and, earlier, The Saturday Review of Litera- ture. His first prominent literary role was that of a novelist, starting with The Crooked Mile (New York, Minton, Balch, I924. 432 p.), which pictures life in a small western city. His next novel was The Chariot of Fire, an American Novel (New York, Macmillan, 1926. 356 p.), which presents a view of frenzied religion in a pioneering frontier community. His other novels include The House of Sun-Goes-Down (New York, Macmillan, I928. 408 p.), which has for setting the opening of the West, but without the usual melodramatics and staging of "westerns"; We Accept With Pleasure (Boston, Little, Brown, 1934. 47I p.), which is about a group of Bostonian intellectuals in the post World War I period; and Mountain Time (Boston, Little, Brown, 1947. 357 p.), a psychological novel about a New York surgeon and an author's wife who find happiness and escape from neuroses in a city in the mountain west. In addition De Voto wrote mystery and espionage novels under the pseudonym of John August. The Hour (Boston, Houghton Mifflin, I95I. 84 p.) discusses, with a touch of humor, alcoholic beverages and the American tradition.

2416. De Voto, Bernard A. Mark Twain's America. Boston, Little, Brown, 1932. 353 p. 32-26989 PSi33i.D 4

Bibliography: p. [323]-334; "Newspaper humor of the Southwestern frontier": p. [335]-339.

A study of the contribution of frontier America to Mark Twain's writings. The work is by implication a discussion of a major series of factors in American literature. More specifically concerned with Mark Twain as creative artist is Mark Twain at Work (Cambridge, Harvard University Press, I942. I44 p.).

2417. De Voto, Bernard A. The literary fallacy. Boston, Little, Brown, I944. I75 p. 44-3169 PS221.D4

A discussion of an aspect of the literature of the "lost generation" and the twenties; in particular, it is an attack on some of the criticism of Van Wyck Brooks (q. v.) and its influence on some of the leading writers of the period.

2418. De Voto, Bernard A. The world of fiction. Boston, Houghton Mifflin, 1950. 299 p. 50-6694 $\mathrm{PN}_{333} \mathrm{I} \cdot \mathrm{D}_{4}$

A book on the production of fiction and the relationship between works of fiction and the reader.

2419. Duffey, Bernard I. The Chicago renaissance in American letters; a critical history. [East Lansing] Michigan State College Press, 1954. $285 \mathrm{p}$. 54-I 1828 PS285.C47D8 
Deals principally with such authors as Henry Fuller, Hamlin Garland, Joseph Kirkland, Robert Herrick, Edgar Lee Masters, Sherwood Anderson, Carl Sandburg, and Vachel Lindsay. "By an inevitable if inexact usage, the continuous wave of literary activity in Chicago, beginning in the last decade of the nineteenth century and continuing through the first two decades of the twentieth, has come to be known as the Chicago renaissance. It was, of course, not a re-birth but the working out within the city of creative forces common to the nation at that time."-p. 6.

2420. Feidelson, Charles N. Symbolism and American literature. Chicago, University of Chicagó Press, 1953. 355 p. $\quad$ 53-6890 PS201.F 4 Bibliography: p. 220-227.

Discusses the theory and use of symbolism in American literature from the 17 th century to the end of the Igth; emphasizes the works of Hawthorne, Whitman, Melville, and Poe, whom the author assesses as leading American symbolists.

2421. Fishman, Solomon. The disinherited of art; writer and background. Berkeley, University of California Press, 1953. xii, 178 p. (Perspectives in criticism, 2) 53-5797 PN85.F5

Written in the form of a series of related essays, the work is concerned with the ideas of American critics about the influence on American literature of the culture that produced it; considers major critical movements and conflicts in the United States since the time of the First World War; topics dealt with include literary nationalism, Marxism, agrarianism, and the "New Criticism." Wayne Shumaker's Elements of Critical Theory (Berkeley, University of California Press, 1952. I3I p.), the first volume in the Perspectives in criticism series, is a more general book dealing with the theory of criticism.

2422. Foerster, Norman. Nature in American literature; studies in the modern view of nature. New York, Macmillan, 1923. 324 p.

$$
\text { 23-5206 PSi63.F6 }
$$

A study of the observations of nature reflected in the work of writers during the Igth and early 20 th centuries. It includes material on Bryant, Whittier, Emerson, Thoreau, Lowell, Whitman, Lanier, Muir, and Burroughs.

Foerster (b. 1887) is one of the leading neohumanists. He has done much original and editorial work in the fields of literature and education in the humanities.

2423. Foerster, Norman. American criticism; a study in literary theory from Poe to the present. Boston, Houghton Mifflin, I928. xvi, $273 \mathrm{p}$. 28-13812 PS62.F6

Contents. - Poe.-Emerson.-Lowell.-Whitman.-The twentieth century: conclusion.

2424. Foerster, Norman, ed. The reinterpretation of American literature; some contributions toward the understanding of its historical development, edited ... for the American Literature Group of the Modern Language Association. New York, Harcourt, Brace, 1928. 271 p.

28-25395 PS88.F6

Contents.-A call for a literary historian, by Fred Lewis Pattee.-Factors in American literary history, by Norman Foerster.-The frontier, by Jay B. Hubbell.-The European background, by Howard Mumford Jones.-The Puritan tradition, by Kenneth B. Murdock.-The romantic movement, by Paul Kaufman.-The development of realism, by Vernon Louis Parrington.-American history and American literary history, by A. M. Schlesinger.-American literary history and American literature, by Harry Hayden Clark.-Appendix A. Select bibliography, by Gregory Paine (p. 217236).-Appendix B. List of dissertations and articles, and of Americana in libraries, by Ernest E. Leisy (p. 237-27I).

2425. Foerster, Norman, ed. Humanism and America; essays on the outlook of modern civilisation. New York, Farrar \& Rinehart, 1930. xvii, 294 p.

"A list of books": p. 29r-294.

Contents.-Preface, by Norman Foerster.-The pretensions of science, by Louis Trenchard More.Humanism: an essay at definition, by Irving Babbitt.-The humility of common sense, by Paul Elmer More.-The pride of modernity, by G. R. Elliott.Religion without humanism, by T. S. Eliot.-The plight of our arts, by Frank Jewett Mather, Jr.The dilemma of modern tragedy, by Alan Reynolds Thompson.-An American tragedy, by Robert Shafer.-Pandora's box in American fiction, by Harry Hayden Clark.-Dionysus in dismay, by Stanley P. Chase.-Our critical spokesmen, by Gorham B. Munson.-Behaviour and continuity, by Bernard Bandler II.-The well of discipline, by Sherlock B. Gass.-Courage and education, by Richard Lindley Brown.

2426. Frankenberg, Lloyd. Pleasure dome: on reading modern poetry. Boston, Houghton

Mifflin, 1949. $372 \mathrm{p}$. 49-50103 PS $324 . \mathrm{F} 7$

The author's purpose is "to give clues to the relationships between sound and meaning in the poems of living poets," with major attention to T. S. Eliot, Marianne Moore, E. E. Cummings, and Wallace 
Stevens to illustrate the variety of modern poetry, and with short statements on Ezra Pound, W. C. Williams, Ogden Nash, W. H. Auden, Robert Lowell, and Elizabeth Bishop.

2427. Frohock, Wilbur M. The novel of violence in America, 1920-1950. Dallas, Southern Methodist University, 1950. $216 \mathrm{p}$.

$$
5^{0-8028} \quad \mathrm{PS}_{379 . \mathrm{F}_{7}}
$$

The thesis is that during the period under discussion the stream of American fiction bifurcated into two major streams, one carrying the theme of the passing of time, and the other that of violence. From this point of view the author discusses Dos Passos, T. Wolfe, Farrell, Cain, Faulkner, Caldwell, Steinbeck, and Hemingway.

2428. Geismar, Maxwell D. Writers in crisis; the American novel between two wars. Boston, Houghton Mifflin, 1942. 299 p. [His The novel in America ] $\quad 4^{2-15988} \mathrm{PS}_{379 . G_{4}}$ Contents.-Ring Lardner.-Ernest Hemingway.-John Dos Passos.-William Faulkner.Thomas Wolfe.-John Steinbeck.

This is the first volume of a series entitled The novel in America.

2429. Geismar, Maxwell D. The last of the provincials; the American novel, I915-1925. H. L. Mencken, Sinclair Lewis, Willa Cather, Sherwood Anderson, F. Scott Fitzgerald. Boston, Houghton Mifflin, 1947. 404 p. [His The novel in America ] $47-$ I 1777 PS $379 . G_{36}$

2430. Geismar, Maxwell D. Rebels and ancestors; the American novel, I890-1915: Frank Norris, Stephen Crane, Jack London, Ellen Glasgow [and] Theodore Dreiser. Boston, Houghton Mifflin, 1953. 435 p. [His The novel in America]

$$
\text { 53-5730 } \mathrm{PS}_{379} \cdot \mathrm{G}_{3} 8
$$

2431. Gelfant, Blanche $H$. The American city novel. Norman, University of Oklahoma Press, 1954. 289 p. 54-5936 PS $_{374 . C_{5} G_{4}}$

A study of the metropolis in 2oth-century American fiction.

2432. Gohdes, Clarence L. F. American literature in nineteenth-century England. New York, Columbia University Press, 1944. I9I p.

$$
\text { A44-1777 PS2or.G6 }
$$

Using illustrations from the post-1832 period, the author has written with the purpose of demonstrating that the English people displayed a wide interest in American literature during the Igth century. The author has also written The Periodicals of American Transcendentalism (Durham, N. C., Duke University Press, 1931. 264 p.).
2433. Hart, James D. The Oxford companion to American literature. 3d ed. [rev. and enl.] New York, Oxford University Press, 1956. 890 p. 56-6557 $\mathrm{PS}_{21}$. $_{3} \quad$ I956

A reference work in dictionary form. It contains entries on all types of matters pertaining to the written word in America. Entries may be found for authors, titles, movements, magazines, awards, groups, and individuals mentioned in literature, etc.

2434. Hart, James D. The popular book; a history of America's literary taste. New York, Oxford University Press, 1950. 35 I p.

50-94I7 $\mathrm{Z}_{1003 . \mathrm{H}_{328}}$

"This study . . . examines the tastes that have guided Americans in selecting their popular reading over the past three centuries. Dealing with taste in relation to social compulsions, this inquiry is concerned with the connection between popular books read for pleasure by adult Americans and the times in which those books were read."-Postscript.

2435. Haycraft, Howard, ed. The art of the mystery story; a collection of critical essays, edited, and with a commentary, by Howard Haycraft. New York, Simon \& Schuster, 1946. 545 p. 47-30017 $\mathrm{PN}_{3448 . \mathrm{D}_{4} \mathrm{H}_{2} 8}$

"Putting crime on the shelf; for bibliophiles, bibliographers, and-readers": p. [45I]-507.

2436. Haycraft, Howard. Murder for pleasure; the life and times of the detective story. New York, Appleton-Century, I94r. 409 p.

$$
4 \mathrm{I}-\mathrm{I} 6907 \mathrm{PN}_{344} 8 . \mathrm{D}_{4} \mathrm{H}_{3}
$$

"Who's who in detection": p. $340-386$.

"Some reading about the detective story": p. 279297. "A detective story bookshelf": p. 298-3II.

A history of the detective story, starting with Edgar Allan Poe. This form of popular fiction originated and flourished in America, whence it spread to many other parts of the world. A history in the form of a bibliography with commentary is Queen's Quorum; a History of the DetectiveCrime Short Story as Revealed by the 106 Most Important Books Published in This Field since 1845 (Boston, Little, Brown, 1951. I32 p.) by "Ellery Queen," the pseudonym of a pair of mystery writers who have published much of the highly popular work in this field. An analysis of the form and content basic to this type of fiction may be found in Marie F. Rodell's Mystery Fiction: Theory and Technique (New York, Hermitage House, $195^{2}$. 230 p.), which was written as a handbook for writers in this field. 
2437. Hazard, Lucy Lockwood. The frontier in American literature. New York, Crowell, 1927. $\mathrm{xx}, 308 \mathrm{p}$. 27-2200 $\mathrm{PS}_{169} \mathrm{~F}_{7} \mathrm{H}_{3}$ "General bibliography": p. 301-304; bibliography at end of each chapter.

Based on F. J. Turner's thesis in The Significance of the Frontier in American History (q. v.), this work undertakes to trace the influence on American literature as conceived in a very broad sense. The first chapter is "The Puritan Frontier," and the last is "The Coming Age of Spiritual Pioneering."

2438. Herron, Ima Honaker. The small town in American literature. Durham, N. C., Duke University Press, I939. 477 p.

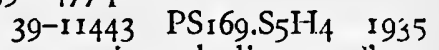

"Check-list for the town in early literature": p. [433]-434. "Selected bibliography": p. [439] -468.

2439. Hicks, Granville. The great tradition; an interpretation of American literature since the Civil War. Rev. ed. New York, Macmillan, 1935. xv, 34I p. 36-27042 PS214. H5 1935 Bibliography: p. 331-336.

Marxian standards applied to Igth- and 2oth-century literature in America. The first edition (1933) was later enlarged by a chapter on new proletarian writers. Since then the author has modified his extreme views. The work retains historical importance, however, both because of its influence and because it reflects the views of a once sizable trend in literary study.

2440. Hoffman, Frederick J. The twenties; American writing in the postwar decade. New York, Viking Press, 1955. 466 p.

Bibliography: p. 431-434.

$$
\text { 55-7379 PS2.21. } \mathrm{H}_{5} \delta
$$

Preoccupations, modes of thought, and attitudes in the United States, viewed from the perspective provided by American literature, roughly from 1918 to 1932 , for the purpose of realizing the major issues of the times. Hoffman is also the author of Freudianism and the Literary Mind (Baton Rouge, Louisiana State University Press, 1945. 346 p.), which does not limit its scope to American authors, but which does discuss a movement of major importance for contemporary American literature.

244I. Horton, Rod W., and Herbert W. Edwards. Backgrounds of American literary thought. New York, Appleton-Century-Crofts, 1952. 425 p. (Appleton-Century handbooks of literature)

$$
\text { 52-12730 PS88.H6 }
$$

A book which discusses American literature in terms of the milieu in which it was produced. The authors attempt to show that "Idealism and Opportunity have constantly been the principal dynamics of American civilization." Because of its condensed nature, few authors are discussed in detail; the organization is in terms of movements, such as Puritanism, Expansionism, Freudianism, Marxism, etc.

2442. Hubbell, Jay Broadus. The South in American literature, 1607-1900. Durham, N. C., Duke University Press, 1954. xix, $987 \mathrm{p}$.

54-9434 PS26r.I 778

In scope and detail by far the most comprehensive work on the subject, being based on nearly 20 years of research. In his Foreword the author emphasizes the following objectives of the work: It aims to integrate the literature of the Southern states with that of the rest of the Nation; discusses Southern life as it is represented by writers from other sections; suggests the pattern of literary culture in the South and the books read by Southerners; devotes proportionately more space to narrative and exposition, particularly in connection with biographical information, than to criticism. A special feature is the critical bibliographical essay (p. 88I974 ), which also includes bibliographical references to facilitate the study of individual authors. A symposium of 29 essays dealing with modern Southern literature is Southern Renaissance: The Literature of the Modern South (Baltimore, Johns Hopkins Press, 1953. $45^{\circ}$ p.), edited by Louis D. Rubin and Robert D. Jacobs; most of the essays appeared originally in The Hopkins Review.

2443. Hyman, Stanley Edgar. The armed vision; a study in the methods of modern literary criticism. New York, Knopf, 1948. 417 p.

$$
\text { 48-6970 } \mathrm{PN}_{94 . \mathrm{H}_{9}}
$$

A study of modern critical methods as exemplified by a selected group of literary critics. The sources of the techniques are also studied, and possibilities for an integrative system of the best aspects examined. Critics studied include Edmund Wilson, Yvor Winters, T. S. Eliot, Van Wyck Brooks, Constance Rourke, R. P. Blackmur, and Kenneth Burke.

2444. Johannsen, Albert. The House of Beadle and Adams and its dime and nickel novels; the story of a vanished literature. With a foreword by John T. McIntyre. Norman, University of Oklahoma Press, 1950. 2 v. illus.

Bibliography: v. 2, p. 328-338.

$$
5^{0-815^{8}} \quad \mathrm{Z}_{1231} \cdot \mathrm{F}_{4} \mathrm{~J} 68
$$

Contents.-v. I. A history of the firm. Numerical lists of the various series of Beadle novels.v. 2. The authors and their novels. Appendix. 
2445. Jones, Howard Mumford. Ideas in America. Cambridge, Mass., Harvard University Press, 1944. 304 p. A44-1981 PSi21.J6 A study of the historical role of ideas in America, particularly in the field of literature. Prof. Jones (b. I892) is a leading scholar in the field of American intellectual history and literature. He has written and edited a number of books in these fields, notably his America and French Culture, 1750-1848 (q. v.).

2446. Jones, Howard Mumford. The theory of American literature. Ithaca, Cornell University Press, 1948. 208 p. (Cornell University. Messenger lectures on the evolution of civilization, 1947) 48-11948 PS3r.J6

A survey of historical and critical attitudes toward American literature in the rgth and 2oth centuries.

2447. Jones, Howard Mumford. Guide to American literature and its backgrounds since I890. Cambridge, Harvard University Press, 1953. I5I p. 53-9039 Zi225.J65

Part I comprises a list of monographic studies and of critical journals, designed to enable the student better to understand the social and economic backgrounds of literature. Part II includes a classified guide to works in American literature that are thought to have contributed to shaping the American mind.

2448. Kazin, Alfred. On native grounds, an interpretation of modern American prose literature. New York, Reynal \& Hitchcock, I942. 54I p. 42-248I I $\mathrm{PS}_{379 . \mathrm{K}_{3}}$

Believing that "Our modern literature in America is at bottom only the expression of our modern life in America," the author seeks to establish that relationship historically in three periods: 1890-1917, 1918-1929, and 1930-1940. In 1956 a somewhat abridged version with an appendix covering postI940 writing was published in the Doubleday Anchor books series.

2449. Kazin, Alfred. The inmost leaf; a selection of essays. New York, Harcourt, Brace, 1955.

$273 \mathrm{p}$. 55-10810 PN511.K25

A group of 28 essays on literary figures and subjects. While there is a wide range of European and American topics, the emphasis is on the rgth century.

2450. Knight, Grant C. The critical period in American literature. Chapel Hill, University of North Carolina Press, I951. xi, 208 p.

Bibliography: p. 177-194.
245I. Knight, Grant C. The strenuous age in American literature. Chapel Hill, University of North Carolina Press, 1954. xi, $270 \mathrm{p}$.

Bibliography: p. [23I]-253.

54-13124 PS221.K6

The first of the books described in the two foregoing references covers 1890 to 1900 ; the second, its sequel, continues the examination through the years 1900-1910. The same approach is used in each, by giving literature a position in the social panorama and attempting to integrate literature with the social history of the time, in order that glimpses may be caught of other art forms, of politics, of philosophy, and of science. Cf. Foreword of The Strenuous Age, p. viii.

2452. Krieger, Murray. The new apologists for poetry. Minneapolis, University of Minnesota Press, 1956. 225 p. 56-78 i I PNro3r.K7

A discussion of some of the new critics as they throw light on some of the problems of poetry. The three main sections of the book are "The Creative Process," "The Aesthetic Object," and "The Function of Poetry."

2453. Krutch, Joseph Wood. Experience and art; some aspects of the aesthetics of literature. New York, Smith \& Haas, I932. 222 p.

32-32159 $\mathrm{PN}_{45} \cdot \mathrm{K}_{7}$

Krutch (b. 1893) has become prominent as a writer in a number of fields. His books on American literature include Edgar Allan Poe, a Study in Genius (New York, Knopf, 1926. 244 p.) and Henry L'avid Thoreau (New York, Sloane, 1948. 298 p.). In a more philosophical vein are The Modern Temper; a Study and a Confession (New York, Harcourt, Brace, 1929. 249 p.) and The Measure of Man: On Freedom, Human Values, Survival, and the Modern Temper (Indianapolis, Bobbs-Merrill, 1954. 26r p.). Krutch has also distinguished himself in the field of nature writing: The Best of Two Worlds (New York, Sloane, I953. I7 I p.) is an autobiographical work on his life as an urbanite who can spend most of his time in the country; The Desert Year (New York, Sloane, 1952. 270 p.) and The Voice of the Desert, a Naturalist's Interpretation (New York, Sloane, 1955. 223 p.) both record his observations of life in the Sonoran desert. In the same general field he has edited an anthology, Great American Nature Writing (New York, Sloane, r950. 444 p.).

2454. Kunitz, Stanley J., and Howard Haycraft, eds. American authors, 1600-1900; a biographical dictionary of American literature ... I300 biographies and 400 portraits. New York, Wilson, r938. $84^{6}$ p. $\quad 3^{8-2793^{8}}$ PS2r.K8 
Each biographical sketch, which emphasizes the individual's literary life, is followed by a brief bibliography. The work is especially useful for information about minor authors, although major authors are also discussed.

2455. Kunitz, Stanley J., and Howard Haycraft, eds. Twentieth century authors, a biographical dictionary of modern literature. With $185^{\circ}$ biographies and 1700 ports. New York, Wilson, 1942. 1577 p. (The Authors series)

$$
\text { “Supersedes } 43^{1003} \mathrm{PN}_{771 . K 86}
$$
"Supersedes ... Living Authors (I93I) and Authors Today and Yesterday (1933)."

- First supplement. Assistant ed.: Vineta Colby. New York, Wilson, 1955. 1 I 23 p. ports. (The Authors series) PN77r.K86s

These volumes are organized on the same principles as the above American Authors, 1600-1900. However, in these the scope is international. Nevertheless, the emphasis is very heavily on American authors, for the writers have been selected for inclusion on the basis of the influence or popularity of their books in America.

2456. Lawrence, David Herbert. Studies in classic American literature. New York, Seltzer, 1923. $26_{4} \mathrm{p}$. 23-12810 PSizr.L3

Contents.-Foreword.-The spirit of place.Benjamin Franklin.-Hector St. John de Crèvecoeur.-Fenimore Cooper's white novels.-Fenimore Cooper's Leatherstocking novels.-Edgar Allan Poe.-Nathaniel Hawthorne and "The scarlet letter."-Hawthorne's "Blithedale romance."-Dana's "Two years before the mast."-Herman Melville's "Typee" and "Omoo."-Herman Melville's "Moby Dick."-Whitman.

D. H. Lawrence (1885-1930) is best-known as a British novelist. His temporary residence in America led him to examine its "classical" literature in an attempt to reveal the American spirit. His resultant book presented ideas which are highly controversial and have been rejected in large part by most critics of American culture. Nevertheless, the book has been widely read and discussed, so that it has taken a historically important position in the criticism of this country's literature.

2457. Leary, Lewis G. Articles on American literature, 1900-1950. Durham, N. C., Duke University Press, I954. 437 p.

$$
\text { 54-5025 Z1225.L49 }
$$

A selective rather than an exhaustive bibliography, this is composed primarily of references to articles listed in "Articles on American Literature Appearing in Current Periodicals" in American Literature and "American Bibliography" in PMLA (qq. v.). Also, separate bibliographies of authors have been consulted when available. The main body of the work is arranged alphabetically by names of authors, followed by references to critical articles and reviews; there is also a subject bibliography of writings on American literature under topics such as "Diaries and Letters," "Literary History," and "Regionalism." The book is an extension and revision of a similarly titled book which was published in 1947 and covered the period 1920-1945.

2458. Leisy, Ernest E. The American historical novel. Norman, University of Oklahoma

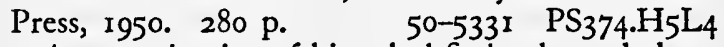
An examination of historical fiction by and about Americans. The arrangement is basically by subject. On p. 219-259 there is an appendix listing additional historical novels not discussed in the text of the book.

2459. Lewis, Richard W. B. The American Adam; innocence, tragedy, and tradition in the nineteenth century. Chicago, University of Chicago Press, 1955. 204 p. 55-5133 PS20r.L4

"This book has to do with the beginnings and the first tentative outlines of a native American mythology. The period I cover runs from about 1820 to 1860 ; the scene, for the most part, is New England and the Atlantic seaboard. ... I am interested . . . in the history of ideas and, especially, in the representative imagery and anecdote that crystallized whole clusters of ideas; my interest is therefore limited to articulate thinkers and conscious artists. A century ago, the image contrived to embody the most fruitful contemporary ideas was that of the authentic American as a figure of heroic innocence and vast potential-it is, poised at the start of a new history. This image is the title of the book."-Prologue.

2460. Literary history of the United States. Editors: Robert E. Spiller, Willard Thorp, Thomas H. Johnson [and] Henry Seidel Canby; associates: Howard Mumford Jones, Dixon Wecter [and] Stanley Williams. New York, Macmillan, I948. $3 \mathrm{v}$. $4^{8-11370}$ PS88.L5

A comprehensive, standard history of American literature from the colonial period to I948. The third volume is a collection of bibliographies, with sections on "Literature and Culture," "Movements and Influences," and "Individual Authors." The role this work has played in limiting entries in the Literature section of the bibliography is explained in the introduction to that section (q. v.). 
2461. - Rev. ed. New York, Macmillan, 1953. $\mathrm{xxii}, \mathrm{I} 456 \mathrm{p}$.

$$
\text { 53-13350 PS88.L5 } 1953
$$

The text is much the same as in the earlier edition, except that a "Postscript at Mid-Century" has been added. On the other hand, in this edition the bibliography is greatly abridged for the lay reader rather than for the scholar.

2462. Long, Orie William. Literary pioneers; early American explorers of European culture. Cambridge, Harvard University Press, 1935. $267 \mathrm{p}$. 35-18097 PS201.L6

This book studies specifically George Ticknor (179I-187I), Edward Everett (I794-I865), Joseph Green Cogswell (I 786-1871), George Bancroft (1800-1891), Henry Wadsworth Longfellow ( $1807-$ I882), and John Lothrop Motley (1814-1877). "The purpose of this volume is to record the many interesting relationships which these internationally minded men experienced in Europe, especially in Germany, and to show the part which they played afterwards in the advancement of American life. The revelation is found principally in their journals and correspondence, which furnish many parallels of impressions."

2463. Loshe, Lillie Deming. The early American novel. New York, I907. I3I p.

$$
\text { 8-34695 PS375.L6 } 1907
$$

Thesis (Ph. D.) -Columbia University, 1907.

Published also as Columbia University studies in English, ser. 2, v. 2, no. 2.

The bibliography (p. 106-124) presents chronologically American novels that appeared through I83o.

2464. Lynn, Kenneth S. The dream of success; a study of the modern American imagination. Boston, Little, Brown, 1955. 269 p.

$$
\text { 55-7459 PS } 379 . \mathrm{L} 9
$$

A study of the impact of the success myth on five American novelists: Theodore Dreiser, Jack London, David Graham Phillips, Frank Norris, and Robert Herrick.

2465. Marble, Annie (Russell) Heralds of American literature; a group of patriot writers of the revolutionary and national periods. Chicago, University of Chicago Press, 1907. $383 \mathrm{p}$.

$$
\text { 7-39037 PS } 186 . \mathrm{M}_{3}
$$

Contents.-I. Introductory: Signs of the dawn. The impulse of Franklin.-2. Francis Hopkinson.3. Philip Freneau: America's first poet.-4. John Trumbull: satirist and scholar.-5. A group of Hartford wits.-6. Joseph Dennie: "the lay preacher."-
7. William Dunlap: the beginnings of drama.-8. Charles Brockden Brown.-Bibliography (p. [319]353).-Index.

2466. Matthews, Brander. Aspects of fiction and other ventures in criticism. 3 d ed., enl. New York, Scribner, 1902. $297 \mathrm{p}$.

$$
\text { 2-21574 } \mathrm{PN}_{3335} \cdot \mathrm{M}_{3} \quad 1902
$$

Partial Contents.-American literature.-Two studies of the South.-The penalty of humor.-On pleasing the taste of the public.-On certain parallelisms between the ancient drama and the modern.The importance of the folk-theatre.-Aspects of fiction: The prose tales of M. François Coppée; . . . Mr. Charles Dudley Warner as a writer of fiction. In the late 19th and early 2oth centuries James Brander Matthews (1852-1929) was not only a professor of drama at Columbia University, but one of the foremost students and critics of the subject. His outstanding study, Molière (Igro), exemplifies his international interests. His interest in linguistics is revealed in works such as Americanisms and Briticisms (New York, Harper, 1892. 19o p.), Parts of Speech; Essays on English (New York, Scribner, I9or. 350 p.), and Essays on English (New York, Scribner, 1921. 284 p.). In his own lifetime he had a measure of fame as a short-story writer and as a novelist, but now receives attention as an author of fiction only for his depiction of New York life in sketches such as Vistas of New York (New York, Harper, 1912. 242 p.) and Vignettes of Manhattan: Outlines in Local Color (New York, Scribner, I921. 376 p.). He is remembered mainly for his work in the field of the drama.

2467. Matthews, Brander. Recreations of an anthologist. New York, Dodd, Mead, I904. $228 \mathrm{p}$. 4-2226I PS2372.R $\mathrm{R}_{4} \mathrm{I} 904$

Contents. - By way of introduction.-A theme, with variations.-Unwritten books.-Seed-corn for stories.-American satires in verse.-American epigrams.-A note on the quatrain.-Carols of cookery.-Recipes in rhyme.-The uncollected poems of H. C. Bunner.-The strangest feat of modern magic.

2468. Matthews, Brander. Inquiries and opinions. New York, Scribner, 1907. $305 \mathrm{p}$.

$$
\text { 7-29534 PS2372.I5 } 1907
$$

Partial Contents. - Literature in the new century.-The supreme leaders.-An apology for technic.-Old friends with new faces.-Invention and imagination.-Poe and the detective-story.-Mark Twain. The modern novel and the modern play.The literary merit of our latter-day drama.-The art of the stage-manager. 
2469. Matthews, Brander. The American of the future, and other essays. New York, Scribner, r909. $\quad 355$ p. $\quad 9-26987 \quad P_{2372 . A 4} 1909$

Contents. - The American of the future.-American character.-The Americans and the British."Blood is thicker than water."-The scream of the spread-eagle.-American manners.-American humor.-The speech of the people.-English as a world-language.-Simplified spelling and "fonetic reform."-The question of the theater.-Persuasion and controversy.-Reform and reformers.- "Those literary fellows."-Standards of success.

2470. Matthews, Brander. A study of the drama. Boston, Houghton Miffin, 1910. 320 p. illus. 10-7803 PNi66r.M3

2471. Matthews, Brander. Gateways to literature, and other essays. New York, Scribner, 1912. 296 p. 12-21990 PR99.M33

Contents.-Gateways to literature.-The economic interpretation of literary history.-In behalf of the general reader.-The duty of imitation.-The Devil's advocate.-Literary criticism and bookreviewing.-Familiar verse.-French poets and English readers.-A note on Anatole France.-Poe's cosmopolitan fame.-Fenimore Cooper.-Bronson Howard.

2472. Matthews, Brander. A book about the theater. New York, Scribner, igi6. 334 p. illus. 16-21742 PN2037.M 35

Contents.-The show business.-The limitations of the stage.-A moral from a toy theater.-Why five acts? - Dramatic collaboration.-The dramatization of novels and the novelization of plays.Woman dramatists.-The evolution of scene-painting.-The book of the opera.-The poetry of the dance.-The principles of pantomime.-The ideal of the acrobat.-The decline and fall of the Negrominstrelsy.-The utility of the variety-show.-The method of modern magic.-The lamentable tragedy of Punch and Judy.-The puppet-play, past and present.-Shadow-pantomime, with all the modern improvements.-The problem of dramatic criticism.

2473. Matthews, Brander. These many years, recollections of a New Yorker. New York, Scribner, 1917. $46_{3} \mathrm{p}$.

I7-25853 PS $2373 . A_{45}$ I9I7

An autobiographical work that reveals much of the literary world of the period, particularly drama. It is also useful for its picture of the life of a cultured, urban American.

2474. Matthews, Brander. The tocsin of revolt, and other essays. New York, Scribner,

1922. 295 p. 22-18653 PS2372.T6 1922
Contents.-The tocsin of revolt.-The duty of the intellectuals.-The dwelling of a day-dream.What is American literature?-The centenary of a question.-American aphorisms.-A plea for the platitude.-On the length of Cleopatra's nose.Concerning conversation.-The gentle art of repartee.-Cosmopolitan cookery.-On working too much and working too fast.-The modernity of Molière.-Theodore Roosevelt as a man of letters.Memories of Mark Twain.

2475. Matthews, Brander. Rip Van Winkle goes to the play, and other essays on plays and players. New York, Scribner, 1926. 256 p. 26-16526 PNi655.M25

Contents.-Rip Van Winkle goes to the play.Uncle Sam, exporter of plays.-What is a "wellmade" play? - The question of the soliloquy.-On the right of an author to repeat himself.-Secondhand situations.-Claptrap.-The scene is laid.The development of scenic devices.-Memories of actresses. - The art of acting.

2476. Matthiessen, Francis O. American renaissance; art and expression in the age of Emerson and Whitman. New York, Oxford University Press, I94I. xxiv, 678 p. $\quad 4$ I-9633 PS20I.M3 A philosophical interpretation of intellectual and literary elements in the American tradition as exemplified by Emerson, Thoreau, Hawthorne, Melville, Whitman, and their associates.

F. O. Matthiessen (1902-1950) early established himself as one of the leading commentators on American literature with such works as Sarah Orne Jewett (Boston, Houghton Mifflin, 1929. 159 p.), The Achievement of T. S. Eliot; an Essay on the Nature of Poetry (Boston, Houghton Mifflin, 1935. I59 p.), Henry James, the Major Phase (New York, Oxford University Press, 1944. I9o p.), The James Family, Including Selections from the Writings of Henry James, Senior, William, Henry \& Alice James (New York, Knopf, I947. 706 p.), and Theodore Dreiser (New York, Sloane, 1951. 267 p.).

2477. Matthiessen, Francis O. The responsibilities of the critic; essays and reviews. Selected by John Rackliffe. New York, Oxford University Press, 1952. xvi, 282 p. 52-12569 PSi21.M3 A posthumous selection of fifty of his articles, originally published in various periodicals. The arrangement is more by subject (in broad categories such as modern poetry and literary critics and historians), rather than chronological. 
2478. Miller, Perry. The raven and the whale; the war of words and wits in the era of Poe and Melville. New York, Harcourt, Brace, 1956. $370 \mathrm{p}$. 56-6659 PS74.M5

A presentation of the conflict between the nationalists and the cosmopolitanites that centered in New York's literary circles during the middle of the igth century.

2479. More, Paul Elmer. Shelburne essays. Ist series. New York, Putnam, 1904. 253 p. 4-22974 PR99.M7, v. I

"All but one of these essays were written for magazines or for the daily press."

Partial Contents. - A hermit's notes on Thoreau.-The solitude of Nathaniel Hawthorne.-The origins of Hawthorne and Poe.-The influence of Emerson.-The science of English verse.-The religious ground of humanitarianism.

Paul Elmer More ( $1864-1937$ ) was with Irving Babbitt (q. v.) one of the leaders of the new humanists. Between 1904 and 192 I he published eleven series of "Shelburne essays." These revealed his international interests and his university studies in the classics. Among the discussions of More is Rebert Shafer's Paul Elmer More and American Criticism (New Haven, Yale University Press, 1935. 325 p.).

2480. More, Paul Elmer. A New England group and others; Shelburne essays, inth series. Boston, Houghton Mifflin, I921. 295 P.

$$
\text { 2I-5556 PRg9.M7, v. I I }
$$

Contents.-The spirit and poetry of early New England.-Jonathan Edwards.-Emerson.-Charles Eliot Norton.-Henry Adams.-Evolution and the other world. Samuel Butler of Erewhon.-Viscount Morley.-Economic ideals.-Oxford, women, and God.-Index to Shelburne essays.

248r. More, Paul Elmer. Selected Shelburne essays. New York, Oxford University Press, 1935. xiii, 297 p. (The World's classics, 434)

35-20684 PR99.M75

"The material here reprinted is selected from the eleven volumes of 'Shelburne essays' published between 1904-1921... With the exception of the study of Criticism the essays follow the chronological order of publication, and, save for a few minor corrections, the original text is reproduced exactly."-Preface.

Contents.-Criticism.-Lafcadio Hearn.-Christina Rossetti.-The Greek anthology.-George Gissing. - Thoreau's journal. - Chesterfield. - Sir Thomas Browne.-Shelley.-Thomas Henry Huxley.-Jonathan Edwards.-Viscount Morley.-Oxford, women, and God.
2482. Mott, Frank Luther. Golden multitudes; the story of best sellers in the United States. New York, Macmillan, I947. 357 p.

47-II742 Z1033.B3M6

Other works on best sellers include James David Hart's The Popular Book; a History of America's Literary Taste (New York, Oxford University Press, 1950. $35 \mathrm{I}$ p.) and Alice Payne Hackett's Fifty Years of Best Sellers, 1895-1945 (New York, Bowker, 1945. I 40 p.), a bibliographical work which was followed by a supplement: Seven Years of Best Sellers, 1945-195I (New York, Bowker, 1952, 23 p.). A new edition of the Hackett work, with the title Sixty Years of Best Sellers, is scheduled for publication in the second half of 1956 .

2483. Murdock, Kenneth B. Literature \& theology in colonial New England. Cambridge, Harvard University Press, 1949. 235 p.

49-10048 PSig5.R4M8

Murdock is a prominent scholar of American literature who has done most of his work in the field of colonial New England studies. This is exemplified by his biography Increase Mather, the Foremost American Puritan (Cambridge, Harvard University Press, 1925. 472 p.). He has also done considerable editorial work, notably in compilations such as Handkerchiefs from Paul, Being Pious and Consolatory Verses of Puritan Massachusetts . . . (Cambridge, Harvard University Press, I927. lxxiii, I34 p.).

2484. O'Connor, William Van. Sense and sensibility in modern poetry. Chicago, University of Chicago Press, 1948. $278 \mathrm{p}$.

$48-9231 \quad \mathrm{PS}_{324 . O_{3}}$ I948a

The chapters of the book are "The Dissociation of Sensibility," "The Employment of Myths," "The Break with Verism," "The Compromise with Prose," "The Influence of the Metaphysicals," "The Influence of the Pre-Modern Americans," "The Imagistic Symbol," "The Quality of Irony," "Tension and the Structure of Poetry," "The Isolation of the Poet," "Forms of Epigonism," "Tradition and Regionalism," "Forms of Dehumanization," "Forms of Obscurity," and "The Political Emphasis."

2485. Parrington, Vernon Louis. Main currents in American thought; an interpretation of American literature from the beginnings to 1920 . New York, Harcourt, Brace, 1927-30. $3 \mathrm{v}$.

Each volume has special t. p. $27-844^{\circ}$ PS88.P 3

Bibliography at end of each volume.

Contents. - I. The colonial mind, 1620-1800.2. The romantic revolution in America, 1800- 
1860.-3. The beginnings of critical realism in America, r860-1920; completed to I90o only.

"I have undertaken to give some account of the genesis and development in American letters of certain germinal ideas that have come to be reckoned traditionally American-how they came into being here, how they were opposed, and what influence they have exerted in determining the form and scope of our characteristic ideals and institutions. In pursuing such a task, I have chosen to follow the broad path of our political, economic, and social development, rather than the narrower belletristic; and the main divisions of the study have been fixed by forces that are anterior to literary schools and movements, creating the body of ideas from which literary culture eventually springs."-Introduction, v. I.

Parrington (1871-1929), in investigating the social, economic, and political backgrounds of American literature from the position of a Jeffersonian liberal, produced a leading and seminal work in American literary history. These volumes influenced a large scale re-evaluation by many literary critics, and characterized an entire critical movement. The first two volumes were awarded the Pulitzer prize; the third volume was left incomplete at the author's death.

2486. Pattee, Fred Lewis. Sidelights on American literature. New York, Century, 1922. 342 p. 22-17738 PSi21.P3

Contents.-The age of O. Henry.-A critic in C major [H. L. Mencken].-The prophet of the last frontier [Jack London].-The epic of New England.-On the terminal moraine of New England Puritanism [Mary E. Wilkins Freeman].-The shadow of Longfellow.-The modernness of Philip Freneau.-The centenary of Bryant's poetry.-Poe's "Ulalume."

2487. Pattee, Fred Lewis. The development of the American short story; an historical survey. New York, Harper, i 923.388 p.

$$
\text { 23-4306 } \mathrm{PS}_{374 . \mathrm{S}_{5} \mathrm{P}_{3}} 1923
$$

A discussion of the history of the short story in America. It is presented largely in terms of individual authors. The development of the technique of the short story is not discussed at any length.

2488. Pattee, Fred Lewis. The first century of American literature, 1770-1870. New York, Appleton-Century, 1935. 613 p.

$$
\text { 35-8357 PS88.P } 35
$$

2489. Pattee, Fred Lewis. The feminine fifties. New York, Appleton-Century, I940. 339 p. ${ }_{40}-8776$ PS2II.P3
A combination literary and social study of the decade of the 1850's.

24.90. Pattee, Fred Lewis. Penn State Yankee ... autobiography. State College, Pennsylvania State College, r953. $\quad 3^{84}$ p. illus.

$$
\text { 53-63206 PS } 353 \text { 1.A8Z5 }
$$

Pattee (1863-1950) was a New Hampshire farm boy who grew up to be the first regularly appointed professor of American literature, in which capacity he passed much of his life at Pennsylvania State College. He was a literary historian, anthologist, editor, and minor creative writer (of poetry and fiction) in his own right. His extensive, if conservative, interest in "new" literature can be seen in books such as $A$ History of American Literature since 1870 (New York, Century, 1915. 449 p.) and The New American Literature, I890-1930 (New York, Century, 1930. 507 p.).

2491. Perry, Bliss. The American spirit in literature; a chronicle of great interpreters. New Haven, Yale University Press, 19ı. 281 p. (The chronicles of America series, Allen Johnson, editor, v. 34) I 8-16732 PS88.P4

Perry (1860-1954) was a noted editor and educator. His autobiography, And Gladly Teach (included in the Education section of this bibliography) tells the story of his work in the field of American literature. He has also written general studies such as $A$ Study of Prose Fiction (Boston, Houghton Mifflin, 1920. 406 p.), which first appeared in 1902, and A Study of Poetry (Boston, Houghton Mifflin, 1920. 396 p.). He had written biographical studies of figures such as Dana, Whitman, and Whittier. He also published volumes of essays on predominantly literary subjects, as in The Amateur Spirit (Boston, Houghton Mifflin, 1904. I64 p.) and Park-Street Papers (Boston, Houghton Mifflin, 1908. 276 p.). His The American Mind (1912) is included in the Intellectual History section.

2492. Perry, Bliss. The praise of folly, and other papers. Boston, Houghton Mifflin, 1923. 230 p. 23-I5I66 PS2545.P4AI6 1923

Contents.-The praise of folly.-The written word.-Poetry and progress.-Dana's magical chance.-John Burroughs.-The Colonel's quality.--Emerson's most famous speech.-Emerson's savings bank.-James Russell Lowell.-Woodrow Wilson as a man of letters.-Literary criticism in American periodicals.

2493. Piercy, Josephine K. Studies in literary types in seventeenth century America ( $1607-$

I710) In two parts. New Haven, Yale University Press, 1939. 360 p. (Yale studies in English, v. 9I) 40-32466 PSi 86.P5 
Contents.-pt. I. Literary types: "The times opinionists." "The latest newes." The almanac. The scientific essay. Personal essay. Personal records. Dedications, prefaces, introductions. Satire and invective. Meditations. The sermon and religious discourse. The beginnings of biography. Cotton Mather.-pt. 2. Influences: Literary forms. Seventeenth century prose style. The classical inheritance. "The times opinionists" answered.Appendix A: Almanacs (in chronological order). Appendix B: S. Danforth, An astronomical description of the late comet ( 1665 ). Appendix C: Cotton Mather, Of poetry and of style. Samuel Sewall, On slavery. Thomas Thacher, A brief rule against small pocks.

2494. Pritchard, John Paul. Criticism in America; an account of the development of critical techniques from the early period of the Republic to the middle years of the twentieth century. Norman, University of Oklahoma Press, 1956. 325 p. 56-5992 PN99.U 5 P69

Through a presentation of significant and representative figures, this book gives an account of the development of literary principles in the United States. Pritchard's Return to the Fountains (Durham, N. C., Duke University Press, 1942. 27 I p.) discusses classical sources of influential American criticism prior to the contemporary period.

2495. Quin11, Arthur H. American fiction; an historical and critical survey. New York, Appleton-Century, 1936. xxiii, 805 p.

Bibliography: p. 725-772.

$$
3^{6-30036} \quad \mathrm{PS}_{371 . Q_{5}}
$$

A historical and critical study of both the novel and the short story in America. Authors who began to publish after 1920 are not included. Also omitted are "juvenile fiction and ... such interesting social developments as the dime novel or the detective story."

2496. Quinn, Arthur H., ed. The literature of the American people, an historical and critical survey. New York, Appleton-Century-Crofts, 195I. $1172 \mathrm{p}$.

Bibliography: p. $\left[9^{8} 5\right]-1107$.

Contents.-The colonial and revolutionary period, by Kenneth B. Murdock.-The establishment of national literature, by Arthur H. Quinn.The late nineteenth century, by Clarence Gohdes.The twentieth century, by George F. Whicher.

A history of American literature composed of monographic studies by scholars who are specialists in the literature of various periods. The bibliography has been made strictly selective to provide guidance of a positive character to standard works without including references to fugitive and derivative writings.

2497. Quinn, Bernetta. The metamorphic tradition in modern poetry; essays on the work of Ezra Pound, Wallace Stevens, William Carlos Williams, T. S. Eliot, Hart Crane, Randall Jarrell, and William Butler Yeats. New Brunswick, N. J., Rutgers University Press, 1955. 263 p.

55-9957 $\mathrm{PS}_{324 . \mathrm{Q}_{5}}$

Aims to give a sense of direction in the study of contemporary poetry by isolating the special theme of metamorphosis, and also to facilitate understanding the work of those believed to have made the present century distinctive in poetry.

2498. Rahv, Philip. Image and idea; fourteen essays on literary themes. New York, New Directions, 1949. I64 p. $\quad 49-8967 \quad \mathrm{PN}_{5} \mathrm{II}_{4} \mathrm{R}_{27}$

Partial Contents.-Paleface and redskin.-The cult of experience in American writing.-The dark lady of Salem.--The heiress of all the ages.-Attitudes toward Henry James.-Notes on the decline of naturalism.--Sketches in criticism. Henry Miller. Dr. Williams in his short stories. DeVoto and Kulturbolschewismus.

Rahv (b. 1908) is probably best known as an editor of Partisan Review, which post he assumed in 1934. He has also edited works of a number of authors and has compiled the anthology Discovery of Europe: the Story of American Experiences in the Old World (Boston, Houghton Mifflin, 1947. 743 p.), which in the form of extracts from diaries, journals, novels, etc., presents, with commentary, an account of the reactions of Americans visiting Europe.

2499. Raiziss, Sona. The metaphysical passion; seven modern American poets and the seventeenth-century tradition. Philadelphia, University of Pennsylvania Press, 1952. 327 p.

\section{2-9025 $\mathrm{PS}_{324} \cdot \mathrm{R}_{3}$}

An examination of modern American poetry in terms of the criticism of the last few decades. The seven poets analyzed are T. S. Eliot, J. C. Ransom, A. Tate, R. P. Warren, A. MacLeish, E. Wylie, and H. Crane (qq. v.). "In the present work a study is proposed of the character of metaphysical expression and the nature of the conditions that stimulated it, both in the seventeenth and the twentieth centuries."-Introduction.

2500. Rosenbach, Abraham S. Early American children's books, by A. S. W. Rosenbach, with bibliographical descriptions of the books in his 
private collection. Portland, Me., Southworth Press, 1933. lix, 354 p. illus.

33-33064 Z1037.AIR8 1933a

Arranged chronologically, $1682-1836$, with author and title and printers and publishers indexes.

This work is largely a collector's guide to an unusually extensive collection of children's literature. However, the annotations and the lengthy introduction make the book something of a history of the subject. The volume will serve as an introduction or a guide for those who wish to familiarize themselves with this relatively obscure bypath of American literature.

2501. Rourke, Constance M. American humor; a study of the national character. New York, Harcourt, Brace, 1931. 324 p.

\section{I-7953 PS $430 . R 6$}

A study treating of traditional types on which American humor has focused, such as the Yankee, the frontiersman, and the Negro. The work was reissued in 1953 as part of the Doubleday Anchor books series.

2502. Rusk, Ralph Leslie. The literature of the middle western frontier. New York, Columbia University Press, 1925. 2 v. (Columbia University studies in English and comparative literature) 25-11215 PS273.R8

Published also as thesis (Ph. D.) Columbia University, 1925.

Bibliographies: v. 2, p. 39-364.

A detailed study which stops arbitrarily at 1840 . Prof. Rusk later became a leading authority on, and editor of Emerson.

2503. Sherman, Stuart Pratt. Americans. New York, Scribner, r922. 336 p.

$$
\text { 23-224 PSi2I.S5 }
$$

Contents.-Mr. Mencken, the jeune fille and the new spirit in letters.- Tradition.-Franklin and the age of enlightenment.-The Emersonian liberation.-Hawthorne: a Puritan critic of Puritanism.Walt Whitman.-Joaquin Miller: poetical conquistador of the West.-A note on Carl Sandburg.Andrew Carnegie.--Roosevelt and the national psychology.-Evolution in the Adams family.-An imaginary conversation with Mr. P. E. More.

Sherman (1881-1926) was for some time (190724) a professor of English at the University of Illinois; in his last years he became editor of the literary supplement of the New York Herald Tribune. He early came under the influence of Babbitt and More (qq. v.) and the New Humanism, thus reinforcing his conservative tendencies. This led to his opposition to such commentators for the new generation as Mencken (q. v.). However, towards the end of his career, Sherman's writings took on a somewhat more "liberal" tone. As a spokesman for the highly conservative, he produced volumes such as The Genius of America; Studies in Behalf of the Younger Generation (New York, Scribner, 1923. 269 p.); The Main Stream (New York, Scribner, 1927. 239 p.), an attempt "to understand the entire 'conspiracy' of forces involved in the taste of his day"; The Emotional Discovery of America, and Other Essays (New York, Farrar \& Rinehart, 1932. 276 p.), a posthumous collection of previously published articles; and $O n$ Contemporary Literature (New York, P. Smith, 1931. 312 p.), which was first published in 1917 from articles originally appearing in The Nation. Jacob Zeitlin and Homer Woodbridge produced a two-volume study: Life and Letters of Stuart P. Sherman (New York, Farrar \& Rinehart, 1929).

2504. Sherman, Stuart Pratt. Points of view. New York, Scribner, r 924 . 363 p. 24-27630 PSi21.S 54

Contents.-Towards an American type.-Forty and upwards.-Unprintable.-For the higher study of American literature.-W. C. Brownell.-On falling in hate.-On falling in love.-American style.An apology for essayists of the press.-The signifcance of Sinclair Lewis.-Where there are no Rotarians.-Mr. Tarkington on the midland personality.-Oscar S. Straus.-Brander Matthews and the Mohawks.-A note on Gertrude Stein.--Samuel Butler: Diogenes of the Victorians.-The Disraelian irony.-George Sand and Gustave Flaubert.

2505. Sherman, Stuart Pratt. Critical woodcuts. New York, Scribner, 1926. $34^{8} \mathrm{p}$.

$$
\text { 26-8769 PN761.S }
$$

"The essays in this volume were all printed in 'Books,' the literary supplement of the Herald Tribune, in 1924 and $1925 . "$

2506. Sievers, Wieder David. Freud on Broadway. New York, Hermitage House, 1955. $479 \mathrm{p}$.

Bibliography: p. 455-46I.

$55-7873 \quad \mathrm{PS}_{35} \mathrm{I}_{5} \mathrm{~S}_{5}$

The work is a historical review of various American dramas from the end of the rgth century to the present; it was undertaken to discover the impact of Freudian concepts on the work of playwrights of the 2 oth century.

2507. Smith, Bernard. Forces in American criticism; a study in the history of American literary thought. New York, Harcourt, Brace, 1939. 401 p. 39-27825 PS88.S55

An interesting book, "Marxist" in tendency. Its thesis is that science is advancing while romanticism 
and the old genteel forces are in retreat. Most of the book presents social influences, but this becomes intrusive only towards the end.

2508. Smith, Thelma M., and Ward L. Miner. Transatlantic migration; the contemporary American novel in France. [Durham, N. C.] Duke University Press, I955. 264 p.

Bibliography: p. 193-245.

$$
\text { 55-6530 PSi6r.F } 76
$$

Through focusing on the American novelists Faulkner, Hemingway, Steinbeck, Dos Passos, and Caldwell, the authors present a picture of the reception of American fiction in France. The extensive bibliography lists books, articles, and reviews produced in France about American novels.

2509. Snell, George D. The shapers of American fiction, 1798-1947. New York, Dutton, 1947. $316 \mathrm{p}$. 47-307r $\mathrm{PS}_{37 \mathrm{r} . \mathrm{S}_{5}}$

A study of leading American fiction writers from J. F. Cooper and C. B. Brown to Hemingway, Farrell, Dos Passos, Dreiser, and their contemporaries.

2510. Spiller, Robert E. The cycle of American literature; an essay in historical criticism. New York, Macmillan, 1955. $3{ }^{18} \mathrm{p}$.

\section{$55-3833$ PS88.S6}

A brief, concise view of American literary culture, presented according to a theory of a cycle in literature. "When applied to the story of American literature as a whole, the cyclic theory discloses not only a single organic movement, but at least two secondary cycles as well: the literary movement which developed from the Eastern seaboard as a center, and culminated with the great romantic writers of the mid-nineteenth century; and that which grew out of the conquest of the continent and is now rounding its full cycle.in the twentieth century."-Preface.

25II. Spingarn, Joel Elias. Creative criticism and other essays. New York, Harcourt, Brace, 1931. 221 p. 3I-24I67 PN8I.S6 I93I Contents.-pt. I. Creative criticism: The new criticism. Prose and verse. Dramatic criticism and the theatre. Creative connoisseurship.-pt. 2. Other essays: The younger generation: a new manifesto. The American critic. The American scholar. The growth of a literary myth.-Appendix: Non credo. Notes on the new humanism (1913-14). A note on French scholarship. The seven arts and the seven confusions.

This is a revision of a book first published in 1917. Spingarn (1875-1939) was one of the more controversial critics of his generation. His other literary writings include some poetry and $A$ History of Literary Criticism in the Renaissance (New York, Published for the Columbia University Press by Macmillan, 1899 . $33^{\circ}$ p.).

2512. Stauffer, Donald A., ed. The intent of the critic, by Edmund Wilson, Norman Foerster, John Crowe Ransom [and] W. H. Auden. Princeton, Princeton University Press, 1941. 147 p. [Princeton books in the humanities]

4I-20238 PN8I.S7

Contents.-Introduction: The intent of the critic, by D. A. Stauffer.-The historical interpretation of literature, by Edmund Wilson.-The esthetic judgment and the ethical judgment, by Norman Foerster.-Criticism as pure speculation, by J. C. Ransom.-Criticism in a mass society, by W. $\mathrm{H}$. Auden.

2513. Stedman, Edmund Clarence. Poets of America. Boston, Houghton Miflin, 1885.

516 p. I8-13421 $\mathrm{PS}_{303 . S_{7}} \mathrm{I}^{1685}$

Contents.-Early and recent conditions.Growth of the American school.-William Cullen Bryant.-John Greenleaf Whittier.-Ralph Waldo Emerson.-Henry Wadsworth Longfellow.-Edgar Allan Poe.-Oliver Wendell Holmes.-James Russell Lowell.-Walt Whitman.-Bayard Taylor.The outlook.-Index.

Stedman (1833-1908) was one of the leading representatives of the genteel tradition in literature. His An American Anthology, 1787-1900 (Cambridge, Mass., Riverside Press, 1900. 2 v.) represents this taste in poetry; he gave much insight into the theory of the genteel tradition in The Nature and Elements of Poetry (Boston, Houghton Miftin, 1892. 338 p.); while it is exemplified in his own Poems (Boston, Houghton Mifflin, 1908. 475 p.), which went through many editions and stages during his own lifetime and after. His Life and Letters (New York, Moffat, Yard, 1910. 2 v.) was produced by Laura Stedman and George M. Gould. Other critics associated with Stedman were W. C. Brownell and George Woodberry (qq. v.).

2514. Stovall, Floyd. American idealism. Norman, University of Oklahoma Press, I943.

$235 \mathrm{p}$. 43-4567 PS I6g.I3S8

The author believes that the philosophy of democracy and of America is basically idealistic, and in this book he traces the progress of idealism in this country as it is revealed in its literature.

2515. Stovall, Floyd, ed. The development of American literary criticism, by Harry $\mathrm{H}$. Clark [and others] Chapel Hill, University of North Carolina Press, 1955. 262 p.

55-1459 PNg9. U $\mathrm{U}_{75}$ 
Bibliography: p. 247-253.

A series of articles which are arranged so as to form something of a connected history and criticism of American criticism, particularly its flowering in the 20 th century.

2516. Straumann, Heinrich. American literature in the twentieth century. London, New York, Hutchinson's University Library, 195 I. I89 p. (Hutchinson's University Library: English literature) 52-664 PS221.S8

"The aim of this book is to give an outline of Twentieth-Century American Thought and Letters. It is not meant to be a history of modern literature in the usual sense of the word, and does not aim at anything like completeness. ... The book is intended to be a study in attitudes. It attempts to describe the basic conceptions of life underlying the works of some of the outstanding writers of the century, and the values they believe in. Above all, it tries to establish the links between what novelists, dramatists, and poets, have expressed, and the views of some essayists and especially of the leading philosophers who, in fact, provide the natural framework of the whole."-Introduction.

2517. Taylor, Walter Fuller. The economic novel in America. Chapel Hill, University of North Carolina Press, 1942. $37^{8} \mathrm{p}$.

$$
\text { 42-362I I } \mathrm{PS}_{374 . \mathrm{S}_{7} \mathrm{~T}_{35}}
$$

Contents. - The environment. - The lesser novelists.-Mark Twain.-Hamlin Garland.-Edward Bellamy.-William Dean Howells.-Frank Norris.-Summary and conclusions.-Bibliography ( $p$. $34 \mathrm{I}-365)$.

Taylor has also written a history of American literature, The Story of American Letters, Rev. ed. (Chicago, Regnery, I956. 504 p.); the approach used is very largely one of essay studies of individual authors, with occasional survey chapters.

25I8. Thompson, Ralph. American literary annuals \& gift books, 1825-1865. New York, Wilson, 1936. I83 p. 37-14847 AY го.T5 1936 Thesis (Ph. D.) -Columbia University, 1936.

"A catalog": p. [102]-163; "Foreign gift books": p. [165]-166.

"Between I 825 and I 865 more than a thousand such miscellanies appeared in the United States; the number in other countries was probably even greater. My aim has been to explain the origin and character of the American examples and to make available an annotated catalog."-Preface.

2519. Trilling, Lionel. The liberal imagination; essays on literature and society. New York,

Viking Press, 1950. 303 p.

$$
\text { 50-6914 PS } 3539 \cdot R_{5} 6 L_{5} 1950
$$

Trilling (b. I905) is best known as a perceptive liberal critic who publishes frequently in periodicals. $\mathrm{He}$ is also a creative writer of some note, who has received praise for his novel, The Middle of the Journey (New York, Viking Press, 1947. 3 I0 p.), which attempts to deal with the problems of modern Americans and modern man.

2520. Trilling, Lionel. The opposing self; nine essays in criticism. New York, Viking Press, 1955. $232 \mathrm{p}$. 55-5871 PN511.T76

Books largely from the igth century are used as perspectives on the 2oth century. Although international in its literary perspectives, the book includes "William Dean Howells and the Roots of Modern Taste" and "The Bostonians."

252 I. Tyler, Moses Coit. A history of American literature, I607-1765. Ithaca, Cornell University Press, 1949. $551 \mathrm{p}$.

$$
\text { 49-II766 PSi85.T8 } 1949
$$

"In this reissue ... the preface and the text of the first edition of 1878 have been strictly followed except in the numbering of the footnotes... Changes made in the printings and editions of 1879 , $188 \mathrm{I}$, and $\mathrm{I} 897$ are added in bracketed notes in the present edition, as are likewise most of the marginal notes that Tyler put in his correction set of the two volumes of the first edition."-p. ix.

The Life of Moses Coit Tyler (Ann Arbor, University of Michigan Press, I933. 354 p.), by Howard Mumford Jones, relates the story of this famous scholar of early American literature.

2522. Tyler, Moses Coit. The literary history of the American revolution, $1763-1783$. New York, Published for Facsimile Library, by Barnes \& Noble, I94 I. 2 v. 4 I-627I PSi 85.T82 I94I Bibliography: v. 2, p. 429-483.

Contents.-v. 1. $1763-1776 .-v .2 .1776-1783$.

2523. Van Doren, Carl C. The American novel, 1789-1939. Rev. and enl. ed. New York, Macmillan, I940. $406 \mathrm{p}$.

Bibliography: p. $367-382$.

$$
40-4354 \quad \mathrm{PS}_{37} \mathrm{I} . \mathrm{V}_{3} \quad 1940
$$

Van Doren (1885-1950) distinguished himself as a scholar of the American scene in works such as his essays in Many Minds (New York, Knopf, r924. 242 p.); his anthology Modern American Prose (New York, Harcourt, Brace, I934. 939 p.); his general study What is American Literature? (New York, Morrow, I935. I28 p.); his distinguished biography, Benjamin Franklin (New York, Viking Press, I938. 845 p.); and many other historical and literary works, some of which are included elsewhere in this bibliography. His career is presented 
in his autobiography, Three Worlds (New York, Harper, 1936. 3I7 p.), which also reflects many aspects of life in America.

2524. Van Doren, Carl C. Carl Van Doren, selected by himself. New York, Viking Press, 1945. 628 p. (The Viking portable library) 45-35066 PS3543.A555A6 I945 A selection from his own numerous writings.

2525. Vestal, Stanley. The book lover's Southwest; a guide to good reading, by Walter S. Campbell (Stanley Vestal). Norman, University of Oklahoma Press, 1955. xii, $287 \mathrm{p}$.

55-6367 $\mathrm{Z}_{\mathrm{I25}} \mathrm{I} . \mathrm{S} 8 \mathrm{~V}_{4}$

A guide to literature about the Southwest and by authors from that region. The work covers all aspects of the region's "literature," from dictionaries to novels.

2526. Wagenknecht, Edward Charles. Cavalcade of the American novel, from the birth of the Nation to the middle of the twentieth century. New York, Holt, 1952. 575 p.

52-7022 $\mathrm{PS}_{371} \mathrm{~W}_{3}$

A standard work on the American novel. Major authors are discussed at length in full essays; lesser authors are covered by brief notes.

2527. Waggoner, Hyatt $\mathrm{H}$. The heel of Elohim, science and values in modern American poetry. Norman, University of Oklahoma Press, 1950. $\mathrm{xx}, 235 \mathrm{p}$. 50-9322 $\mathrm{PS}_{324}$. W3

Contents.-Poets, test tubes, and the heel of Elohim.-E. A. Robinson: the cosmic chill.-Robert Frost: the strategic retreat.-T. S. Eliot: at the still point.-Robinson Jeffers: here is reality.Archibald MacLeish: the undigested mystery.Hart Crane: beyond all sesames of science. Science and poetry: conclusions.

2528. Warfel, Harry R. American novelists of today. New York, American Book Co.,

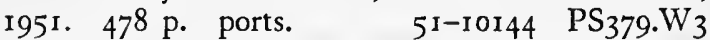

Made up of sketches of the life and writings of 575 contemporary American novelists, with emphasis on the decade of the 1940's. The work is inclusive rather than selective.

2529. Wellek, René, and Austin Warren. Theory of literature. New York, Harcourt, Brace, 1949. $403 \mathrm{p}$. 49-1007 $\mathrm{PN}_{45}$. W36 Bibliographical references included in "Notes" (p. 299-346). Bibliography: p. 347-387.

A scholarly discussion of literary theory, evaluation, research, and historiography. The literary work is viewed in its own right, not as a facet of some social or political movement, nor as an exemplar of the laws of economic determinism. In this respect the book shows a spreading method of approach to literature in the graduate schools. Wellek is at work on a four-volume History of Modern Criticism: 1750-1950, of which the Yale University Press has so far published two volumes. Warren is the author of The Elder Henry James (New York, Macmillan, 1934. 269 p.) and Rage for Order; Essays in Criticism (Chicago, University of Chicago Press, 1948. 164 p.).

2530. Wells, Henry W. The American way of poetry. New York, Columbia University Press, 1943. 246 p. (Columbia studies in American culture, no. 13 ) 43-12056 $\mathrm{PS}_{303}$. W 4

A study of American literary nationalism and the relation of American letters to English, European, and international traditions; special reference is made to the works of 16 major American poets who flourished from the time of the American Revolution to 1940.

2531. West, Ray B., ed. Essays in modern literary criticism. New York, Rinehart, 1952. 6I I p. $52-5602 \mathrm{PN}_{5}$. W 4

A volume of essays in which leading literary critics discourse on aspects of modern literary criticism.

2532. Williams, Stanley Thomas. The American spirit in letters. New Haven, Yale University Press, 1926. 329 p. (The Pageant of America [v. II]) 26-I2988 EI78.5.P2, v. II

The author has in this volume produced an extensively illustrated history of American literature which is founded on his theory that a nation's life is reflected in its literature. Williams (b. I 888), a professor of American literature at Yale University, has also written a Life of Washington Irving (New York, Oxford University Press, 1935. 2 v.) and other works.

2533. Williams, Stanley Thomas. The beginnings of American poetry, $1620-1855$. Uppsala,

195I. $148 \mathrm{p}$. (The Gottesman lectures, I) 54-4634 $\mathrm{PS}_{303}$. W 45

Bibliographical references included in "Notes" (p. $\left.\left[\mathrm{r}_{24}\right]-\mathrm{r}_{4} 8\right)$.

2534. Williams, Stanley Thomas. The Spanish background of American literature. New Haven, Yale University Press, 1955. 2 v. 54-5095 PSi $59 . S_{7} W_{5}$

A contribution toward placing European influences on American literature in proper critical perspective. The second volume is devoted in large part to individual studies of Washington Irving, William 
Cullen Bryant, Henry Wadsworth Longfellow, James Russell Lowell, George Ticknor, Bret Harte, William Dean Howells, and William Prescott.

2535. Wilson, Edmund. Axel's castle; a study in the imaginative literature of 1870-1930. New York, Scribner, 1931. 319 p.

$$
\text { 31-26550 PN771. W55 }
$$

Partial Contents.-Symbolism.-T. S. Eliot.Gertrude Stein.

The work of Edmund Wilson (b. 1895) as a forceful expository writer has gained him a large audience and following in a number of fields, most notably in literary criticism. As a creative writer he has produced Discordant Encounters; Plays and Dialogues (New York, Boni, 1926. 297 p.); the novel, I Thought of Daisy (New York, Scribner, 1929. 3II p.); a controversial volume of short stories, Memoirs of Hecate County (Garden City, N. Y., Doubleday, 1946. 338 p.); and Five Plays (New York, Farrar, Straus \& Young, 1954. 541 p.), dramas of ideas, within the experimental theater movement, which reflect life among New York intellectuals. He has also been accorded considerable attention for such volumes as Travels in Two Democracies (New York, Harcourt, Brace, 1936. 325 p.), a report on Russia and the United States; To the Finland Station; a Study in the Writing and Acting of History (New York, Harcourt, Brace, 1940. 509 p.), which traces modern revolutionary thought in Europe; Europe without Baedeker; Sketches among the Ruins of Italy, Greece \& England (Garden City, N. Y., Doubleday, I947. 427 p.); The Scrolls from the Dead Sea (New York, Oxford University Press, 1955. I2I p.), a bestselling report on a major discovery in the field of religion; and Red, Black, Blond, and Olive; Studies in Four Civilizations: Zuñi, Haiti, Soviet Russia, Israel (New York, Oxford University Press, 1956. 500 p.).

2536. Wilson, Edmund. The boys in the back room; notes on California novelists. San Francisco, Colt Press, 1941. 72 p.

$$
\text { 4I-5I88I } \mathrm{PS}_{379 .} \mathrm{W}_{5}
$$

Contents. - The playwright in paradise.-James M. Cain.-John O'Hara.-William Saroyan.-Hans Otto Storm.-John Steinbeck.-Facing the Pacific.Postscript.

2537. Wilson, Edmund. The wound and the bow; seven studies in literature. Boston, Hough-

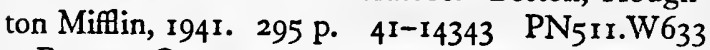

Partial Contents.-Justice to Edith Wharton.Hemingway: gauge of morale.-Philoctetes: The wound and the bow.
2538. Wilson, Edmund, ed. The shock of recognition; the development of literature in the United States recorded by the men who made it. Garden City, N. Y., Doubleday, Doran, I943. $1290 \mathrm{p}$. 43-9895 PS 55 . W5

Reissued in 1955 by Farrar, Straus \& Cudahy, New York.

A collection of articles about important American authors written by their contemporaries during nearly a century, starting with 1845 . The anthology is not only a collection of critical writings, it is also a contribution to the study of the development of American literature. A critical introduction has been provided for each selection.

2539. Wilson, Edmund. The triple thinkers; twelve essays on literary subjects. [Rev. and enl. ed.] New York, Oxford University Press, 1948. 270 p. $\quad 48-9262$ PN5II.W63 1948

First published in 1938 by Harcourt, Brace with the subtitle: "Ten Essays on Literature." The revised edition includes the essays "Mr. More and the Mithraic Bull," "Is Verse a Dying Technique?", "The Ambiguity of Henry James," "John Jay Chapman," "Marxism and Literature," and "The Historical Interpretation of Literature."

2540. Wilson, Edmund. Classics and commercials; a literary chronicle of the forties. New York, Farrar, Straus, 1950. 534 p. 50-10620 PS221. W55

"A selection of . . . literary articles written during the nineteen forties."

2541. Wilson, Edmund. The shores of light; a literary chronicle of the twenties and thirties.

New York, Farrar, Straus \& Young, 1952. 814 p. 52-13935 PS221. W 56

2542. Wilson, Edmund. Eight essays. Garden City, N. Y., Doubleday, 1954. 238 p. (Doubleday Anchor books. A37)

$$
\text { 54-7733 PS } 3545 . \mathrm{I}_{245} \mathrm{E}_{5}
$$

Partial Contents.-Hemingway: gauge of morale.-Abraham Lincoln: the Union as religious mysticism.-The pre-presidential T. R.-The Holmes-Laski correspondence.

2543. Wilson, Edmund. A piece of my mind; reflections at sixty. New York, Farrar, Straus \& Cudahy, 1956. 239 p.

57-5302 PS $3545.16_{245} Z_{53}$

A volume of autobiographical reflections and critical summation.

2544. Winters, Yvor. In defense of reason. Primitivism and decadence: a study of American experimental poetry. Maule's curse: seven studies 
in the history of American obscurantism. The anatomy of nonsense. The significance of The bridge by Hart Crane, or What are we to think of Professor X? New York, Swallow Press \& W. Morrow, I947. 6ri p. 47-2236 PSi2r.W53

Primitivism and Decadence was first published independently in 1937; Maule's Curse, which includes essays on Cooper, Melville, Jones Very, Emerson, and Dickinson, first appeared in 1938; The Anatomy of Nonsense, which has essays on H. Adams, W. Stevens, T. S. Eliot, and J. C. Ransom, was published in 1943. The volumes have not all been completely reproduced in this collection, although all the indicated essays have been included and represent nearly the whole of the earlier work.

The subjects and theorizing of Winters (b. 1900) are derived primarily from American literature. $\mathrm{He}$ is also well known for his poetry, which may be associated with the neo-classical school. Collected Poems (Denver, Swallow, I952. I43 p.) is actually a selection of those poems which he most wishes to preserve. $\mathrm{He}$ is also the author of a prominent study of Edwin Arlington Robinson (Norfolk, Conn., New Directions Books, 1946. 162 p.).

2545. Woodberry, George Edward. Makers of literature; being essays on Shelley, Landor, Browning, Byron, Arnold, Coleridge, Lowell, Whittier, and others. New York, Macmillan, 1900. $440 \mathrm{p}$. 0-2177 PR403. W7

Woodberry (1855-1930) was a critic and poet associated with Stedman (q. v.) and others in the "Genteel Tradition." As a professor of comparative literature at Columbia University, and as one of the more widely read and admired critics of his day, he had a great influence on literary studies at the end of the Igth and the beginning of the 2oth centuries. Besides his literary studies, his poetry, and some travel writing, he produced a number of important biographies of literary figures: Poe ( 1885 , revised I909), Hawthorne (I902), and Emerson (1907).

2546. Woodberry, George Edward. Heart of man, and other papers. New York, Harcourt, Brace \& Howe, I920. 323 p.

$$
\text { 20-20978 } \text { PS }_{335} \text { r.H5 } 1920
$$

Contents.-Heart of man.--The praise of English books.-Two phases of criticism.-Wendell Phillips; the faith of an American.

2547. Woodberry, George Edward. Studies of a literature. New York, Harcourt, Brace, I92I. 328 p. 2I-7433 PR99.W75 I92I "The author has collected in this volume besides articles that were contained in his earlier books some papers of later years."-Note.

2548. Woodberry, George Edward. Appreciation of literature, and America in literature. New York, Harcourt, Brace, I92I. 306 p.

$$
21-7434 \quad \mathrm{PN}_{45} \text {. W62 } 1921
$$

2549. Wright, Thomas Goddard. Literary culture in early New England, 1620-1730, by Thomas Goddard Wright . . . ed. by his wife. New Haven, Yale University Press, 1920. $322 \mathrm{p}$. 21-571 F7.W95

Bibliography: p. 295-304.

"The pages which follow will not attempt to weigh colonial literature, either to condemn or defend it ... but rather will attempt to determine that which lies back of any literature, the culture of the people themselves, and to study the relation between their culture and the literature which they produced. In the attempt to determine the culture of the people of New England the writer has made a study of their education, their libraries, their ability to obtain books, their use and appreciation of books, their relations with political and literary life in England, and their literature."-Introduction.

2550. Zabel, Morton D., ed. Literary opinion in America; essays illustrating the status, methods, and problems of criticism in the United States in the twentieth century. Rev. ed. New York, Harper, r95r. xxv, 890 p. 5I-2935 PN77r.Z2 I95I

Appendixes (p. [791]-89o): I. Recent works of American criticism.-2. Collections of contemporary American criticism.-3. American magazines publishing criticism.-4. Notes on contributors. -5 . A supplementary list of essays in criticism: 1900I950.-6. A note on contemporary English criticism.

\section{Periodicals}

2551. Accent; a quarterly of new literature. v. It autumn r940+ Urbana, Ill.

$$
4^{6-37972} \text { AP2.A243 }
$$

Since its inception Accent has included not only literary criticism and reviews, but also much fiction and poetry. It has held out against "commercial- 
ism," and it has been very receptive to younger, unknown writers, although it does include work by established authors. Its principal editors, Kerker Quinn and Charles Shattuck, included in Accent Anthology; Selections from Accent, a Quarterly of New Literature, 1940-1945 (New York, Harcourt, Brace, 1946. 687 p.) about 40 percent of the material that appeared in the first 5 volumes of the periodical.

2552. American literature; a journal of literary history, criticism, and bibliography. v. It Mar. $1929+$ Durham, N. C., Duke University Press. 30-20216 PSI.A6

Published quarterly by the Duke University Press with the cooperation of the American Literature Group of the Modern Language Association of America. Beginning with volume I, number 3, there has regularly appeared a list of "Articles on American Literature Appearing in Current Periodicals"; this has been one of the principal sources of Lewis G. Leary's Articles on American Literature, 1900-1950 (q. v.). The magazine has had a combined index of subjects, articles, and authors compiled by Thomas F. Marshall as An Analytical Index to American Literature, v. 1-20, Mar. I929-Jan. 1949 (Durham, N. C., Duke University Press, 1954. 154 p.).

\section{American quarterly. v. I + spring $1949+$ Philadelphia. $\quad 50-4992 \quad \mathrm{AP}_{2}$. A3985}

Published by the University of Pennsylvania and the American Studies Association.

Though the periodical is interested in all aspects of studies relating to American culture, considerable attention is devoted to literature. In the summer of r955 appeared the first of a scheduled annual series of bibliographies listing "Articles in American Studies." More than 200 periodicals were searched for material, and roughly half the citations resulting from this could be considered of direct literary interest, although frequently correlated with other fields.

2554. The Antioch review. v. I + spring r $94 \mathrm{I}+$ Yellow Springs, Ohio. 44-660 AP2.A562

A quarterly published at Antioch College, this is one of the many such periodicals published at colleges and universities throughout the country. While it contains fiction, poetry, and book reviews, as well as essays of literary criticism, it also devotes a fair amount of space to articles on non-literary matters. An anthology based on it, and edited by Paul Bixler, is The Antioch Review Anthology; Essays, Fiction, Potry, and Reviews from the Antioch Review (Cleveland, World Pub. Co., 1953. 470 p.).
2555. 'The Atlantic monthly, a magazine of literature, science, art, and politics. v. I + Nov. $1857+$ Boston. 4-I $2666 \quad \mathrm{AP}_{2} . \mathrm{A} 8$

From Nov. 1857 to Sept. 1865 title reads: The Atlantic Monthly, a Magazine of Literature, Art and Politics.

As a purveyor of creative literature, The Atlantic Monthly was more important in its early decades than it has been in recent years. However, it still reflects (largely through essays and reviews) the literary tastes of a large section of the better educated part of the public, as well as their interests in other fields.

2556. Chicago review. v. It winter 1946+ [Chicago, University of Chicago Press]

$$
\text { 55-35686 AP2. } \mathrm{C}_{5152}
$$

A literary quarterly published at the University.

2557. Harper's magazine. v. It June $1850+$ New York. $\quad 4^{-12670} \mathrm{AP}_{2} . \mathrm{H}_{3}$

Title varies: June I850-Nov. I900, Harper's New Monthly Magazine.-Dec. I900-May I939, Harper's Monthly Magazine (cover title: Harper's magazine).

A monthly magazine which includes some poetry, short stories, and literary essays, often by "name" authors, as well as articles on matters of general interest. An anthology based on it is Harper Essays (New York, Harper, 1927. 314 p.), edited by H. S. Canby. A recent paperback selection more fully representing the magazine's scope is Harper's Magazine Reader: A Selection of Articles, Stories and Poems ... (New York, Bantam Books, 1953. 372 p.).

2558. The Hudson review. v. It spring $1948+$ [New York] 50-2532 AP2.H886

A distinguished literary quarterly that includes poetry and fiction, as well as a considerable amount of literary criticism.

2559. The Kenyon review. v. It winter r $939+$ [Gambier, Ohio] Kenyon College.

$$
\text { 42-5I } 47 \text {. } \mathrm{AP}_{2} . \mathrm{K}_{426}
$$

A leading literary quarterly which has published a significant amount of important poetry and fiction, but which is most important for its literary criticism. Under the editorship of John Crowe Ransom (q. v.), it became a leading organ of the new critics, and especially of their leading representatives in the Southern agrarian movement. This aspect of the periodical is reflected in the anthology The Kenyon Critics; Studies in Modern Literature from the Kenyon Review (Cleveland, World Pub. Co., I95I. $34^{2}$ p.), edited by Ransom. 
2560. New directions in prose \& poetry. no. It $1936+$ New York, New Directions.

$$
\text { 37-I751 } \text { PS }_{536 . N_{37}}
$$

Title varies.

Intended as an-annual, the publication of this work has been somewhat irregular. It is edited by James Laughlin, who heads the New Directions press. The volumes contain experimental modern writing of many types and from many sources. The emphasis is American though the scope is international. Much of the material is published in these volumes for the first time, although some of it is republished from other, not readily available sources.

2561. The New England quarterly; an historical review of New England life and letters . . .

v. I + Jan. I928+ [Orono, Me., The University Press].

29-23850 Fi.N62

Imprint varies.

2562. The New Mexico quarterly review. v. It Feb. $1931+$ [Albuquerque, University of New Mexico] 35-9607 AP2.N6168

Title varies: 1931-40, The New Mexico Quarterly.

A literary quarterly which includes some general articles and which emphasizes the Southwest.

2563. New world writing. Ist + Apr. I952 + [New York] New American Library. (N. A. L. Mentor books) 52-1806 PN6o14.N457

Issued irregularly and in paperback format at popular prices, the publication is designed to make available to a large audience essays, short stories, and poetry relatively esoteric and experimental in their literary quality, in many ways corresponding to the contents of "little magazines" having limited circulation.

2564. The New York times book review. v. It $1896+$ New York.

AP2.N657

The weekly book review section, which now appears as a supplement to the Sunday edition, of The New York Times is probably by itself the most widely disseminated book review periodical in America. Its extensive coverage and its wide distribution render, it one of the most important of such publications.

2565. The New Yorker. v. It Feb. 21, 1925t New York. 28-5329 AP2.N6763

The New Yorker is a sophisticated, humorous weekly without the "serious" approach to high literature that may be detected in most literary periodicals. However, it has managed to maintain a high level of writing, and many of the country's prominent authors have come to be regarded as part of the "New Yorker school." The short stories which they have published are represented in books such as Short Stories from the New Yorker (New York, Simon \& Schuster, I945. 440 p.), which selects 68 stories from the periodical's beginning through September 1940, and in 55 Short Stories from the New Yorker (New York, Simon \& Schuster, 1949. 48o p.), which covers the preceding ro years. Their poetry is represented in The New Yorker Book of Verse; Anthology of Poems First Published in the New Yorker, 1925-1935 (New York, Harcourt, Brace, 1935. 311 p.). The magazine has also become famous for a new approach to short biography, a style represented in the anthology Profiles from the New Yorker (New York, Knopf, 1938. 400 p.). Among the most widely known and admired aspects of the magazine are its cartoons. These have appeared in a number of "New Yorker albums"; six of these were published by Doubleday Doran from 1928 to 1939 . A broad survey of the form may be seen in The New Yorker Twenty-Fifth Anniversary Album, 1925-1950 (New York, Harper, r95I. unpaged), which has been supplemented by The New Yorker 1950-1955 Album (New York, Harper, 1955 unpaged). These are considered by some to be among leading examples of modern American humor in the cartoon form. A book by an outsider about The New Yorker and its editor is Dale Kramer's Ross and the New Yorker (Garden City, N. Y., Doubleday, 1951. 306 p.).

2566. Partisan review. v. I + Feb./Mar. I934 + New York. 42-20197 HXI.P

Bimonthly, Feb. I934-Nov. 1935; irregular, Feb. 1936-Dec. 1937; monthly, Jan.-Sept. 1938; quarterly, fall I938-fall I939; bimonthly, Jan. 1940+

Volume numbers irregular; v. I-2 called no. I-9.

Publication suspended from Nov. 1936 to Nov. 1937, inclusive.

Title varies: Feb./Mar. 1934-Oct./Nov. 1935, Partisan Review. Feb.-June 1936, Partisan Review \& Anvil.

Editors: Feb./Mar. I934 + Philip Rahv and others.

The Partisan Review has since its inception become one of the most distinguished of literary reviews. It publishes material from both well established and new authors in the fields of poetry, fiction, and critical essays. It also contains articles on current cultural problems, and it has a distinguished book review section. Some of its best material has been anthologized in The Partisan Reader; Ten Years of Partisan Review, 1934-1944 (New York, Dial Press, 1946. 688 p.) and The New Partisan Reader, 1945-1953 (New York, Harcourt, Brace, 1953. 621 p.), both edited by William Phillips and Philip Rahv. Short stories from the 
magazine have been anthologized in the paperback volumes Stories in the Modern Manner (New York, Avon Publications, 1953. 282 p.) and More Stories in the Modern Manner (New York, Avon Publications, 1954. 252 p.).

2567. Poetry. A magazine of verse. v. I + Oct. 1912+ Chicago. 14-13059 PS301.P6

Under the editorship of Harriet Monroe (q. v.) Poetry became one of the leading mediums in America for the publication of modern poetry, and many of the leading poets of the first half of the 20 th century first achieved wide notice through appearing in this periodical. Subsequent editors have shown a similar receptivity to new poetry, and they have maintained the reputation of the periodical as the best one in America devoted to poetry. Appearing monthly, the magazine also includes reviews of books in the field.

2568. Quarterly review of literature. v. It autumn rg43t Annandale-on-Hudson, N. Y. 45-10088 AP2.Q29

The Quarterly Review of Literature has several times shifted its place of publication; for some years now it has been published at Bard College. It presents primarily creative literature (poetry, short stories, novelettes, drama) rather than criticism. It does not, however, exclude critical essays. About once a year an entire issue is devoted to one important modern author.

2569. Saturday review. v. It Aug. 2, 1924+ [New York] 27-5407 Zi219.S25

Title varies: 1924-51, Saturday Review of Literature.

Aside from works such as The New York Times Book Review, this weekly is probably the most widely distributed literary periodical in America. Its emphasis is on book reviews and general essays on the literary scene, although it also carries some poetry, a fair number of articles and editorials on the overall cultural scene, and a sizable number of reviews of long playing records. An early anthology, compiled while the magazine was almost exclusively literary in nature, is Designed for Reading; an Anthology Drawn from the Saturday Review of Literature, 1924-1934 (New York, Macmillan, 1934. 6r4 p.). Also based on the periodical is a recent paperback series of anthologies entitled Saturday Review Reader (New York, Bantam Books, $1951+$ ), of which three issues have so far appeared.

2570. The Sewanee review, quarterly. v. It Nov. $1892+$ Sewanee, Tenn., The University Press. 9-3313I $\mathrm{AP}_{2 . \mathrm{S}_{5}}$
Published at the University of the South, this is one of the leading literary periodicals in America, as well as the oldest in continuous publication.

257 I. The South Atlantic quarterly. v. I + Jan. I902 + Durham, N.C. 8-84 AP2.S75

The South Atlantic Quarterly is one of the oldest of the still functioning general and literary periodicals. In both aspects it has been a leading medium for the expression of Southern culture. An anthology from the magazine is Fifty Years of the South Atlantic Quarterly (Durham, N. C., Duke University Press, 1952. 397 p.), edited by William Baskerville Hamilton.

2572. Southwest review. v. I + June $1915+$ Dallas, Tex.

${ }_{7}$-4968 $\mathrm{AP}_{2} . \mathrm{S}^{-} 8_{3}$

Title varies: v. I-9 (June I9I5-July 1924) The Texas Review.

Published at the University of Texas, Austin, June 1915-July 1924; published at Southern Methodist University, Dallas, Oct. I $924+$

While this quarterly is general in nature, it includes some material of literary interest, and it publishes an annual literary number.

2573. The University of Kansas City review. v. $\mathrm{I}+$ winter $1934+$ [Kansas City] 48-27919 AP2.U735

Vol. I, no. $\mathrm{I}-4$ called v. 4 , no. $\mathrm{I}-4$ in continuation of the numbering of the university's University Bulletin.

A general literary quarterly.

2574. The Virginia quarterly review, a national journal of literature \& discussion. v. I + Apr. $1925+$ [Charlottesville, University of Virginia] 30-14637 AP2. V76

A quarterly which devotes considerable space to poetry and short stories, but which also includes articles on matters of general interest.

2575. The Western humanities review. v. It Jan. $1947+$ [Salt Lake City, Utah Humanities Research Foundation ] $\quad$ 48-27220 $^{8}$ AP2. $_{426}$

Title varies: $1947-48$, Utah Humanities Review.

A quarterly of general discussion which includes literary articles and creative writing.

2576. The Western review. v. [I]+ $1937+$ Iowa City, State University of Iowa.

$$
\text { 51-1705I } \mathrm{AP}_{2} . \mathrm{W}_{524}
$$

Titles varies: Rocky Mountain Review.

Editors: R. B. West and others.

The Western Review is a literary quarterly which provides a space emphasis on young writers. 
2577. Yale review. v. I-I9, May I892-Feb. I9I new ser., v. It Oct. I9II + New Haven, $1893+\quad 8-8158 \quad \mathrm{AP}_{2 . Y_{2}}$ Title varies: May I892-Feb. I9I, The Yale Review; a Quarterly Journal for the Scientific Discussion of Economic, Political and Social Questions. (Subtitle varies slightly.)
Preceded by the New Englander and Yale Review (1843-92).

The Yale Review is a general quarterly reflecting many aspects of American intellectual life and interests. It includes some literary material and a section of intellectual book reviews. 


\section{IV \\ Biography and Autobiography

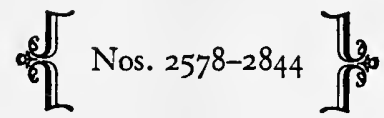

THIS section is primarily a supplement to the other sections; its purpose is to include biographical works, useful for the study of American history and culture, which would otherwise have been omitted. As in the other sections, we have striven towards some degree of balance, so that in a crowded field (e. g., Civil War diaries and journals) a good work may be left out in favor of another depicting a less well-represented aspect of American life. The material in this section is not meant to represent fully, in any respect, the field of American biography and autobiography. Any biography or autobiography pertaining directly to the subject field of another section of the bibliography has been left for possible inclusion in that section (e. g., a biography of an actress would appear, if at all, in the Entertainment section). The exceptions to this occur when a work does not easily or fully fall into one of our categories, or when it has particular significance in the development of American biography and autobiography, in which case, if it has not been selected for another section, it is included here. In short, while this section covers American biography and autobiography on the basis of its value as Americana, as literature, and as history, it does not cover any of these aspects thoroughly, but merely supplements the rest of the bibliography, which must be used through the index for any fuller view of the subject.

\section{LOUIS ADAMIC, 1899-195I}

Adamic came to America from Yugoslavia in 1913 at the age of 14 . Most of his writings concern the Americanization of immigrants; this includes such works as his novel, Grandsons (1935); My America, $1928-1938$ (1938), a journalistic series of impressions; and From Many Lands (1940), a somewhat fictionalized series of biographical studies of some immigrants. The Native's Return (1934) is a report of a visit to the land of his birth. His writings form a link in the social literature of the period, especially with regard to the foreign born and laboring classes in which he was so interested.

2579. Laughing in the jungle; the autobiography of an immigrant in America. New York, Harpers, 1932. 335 p. $\quad 32-8633$ Er69.5.A18

2580. CHARLES FRANCIS ADAMS, 1835-1915

Adams was a historian and a railroad executive, and both fields led to some of his writings: such as Three Episodes of Massachusetts History (1892), Studies Military and Diplomatic, 1775-1865 (191 I), Lee at Appomattox, and Other Papers (1902), and Railroads: Their Origin and Problems (1878). His interest in literature was evidenced by his distinguished biography, Richard Henry Dana (1890. 2 v.). Civil War letters exchanged between C. F. Adams, his father, and Henry Adams may be found in Worthington Chauncey Ford's two volume $A$ Cycle of Adams Letters, $186_{1-1865}$ (Boston, Houghton Mifflin, 1920).

2581. Charles Francis Adams, by his son, Charles Francis Adams. Boston, Houghton Mifflin, rgoo. 426 p. illus. (American statesmen, v. 29) o-1689 E467.I.A2A2 Er76.A54, v. 29

A life of a son of John Quincy Adams. C. F. Adams, Sr., was a statesman and a diplomat, though possibly best remembered as the father of Henry and Brooks Adams.

2582. Charles Francis Adams, 1835-1915; an autobiography; with a Memorial address de- 
livered November 17, 1915, by Henry Cabot Lodge. Boston, Houghton Mifflin, I916. 1x, 224 p. $16-6471$ E664.ArgA2

\section{MARY ANDERSON, $1872-$}

Mary Anderson was a Swedish emigrant who began in this country as a maid in Michigan, was later a factory worker, and then rose to be the second director of the Women's Bureau of the United States Department of Labor. Her autobiography reflects the position of employed women, particularly in industry, over a period of nearly a half century, hence depicting many of the advances made in this period in woman's situation in society.

2584. Woman at work, the autobiography of Mary Anderson as told to Mary N. Winslow. Minneapolis, University of Minnesota Press. 195I. $266 \mathrm{p}$.

5I-14305 HD6095.A668

\section{MARY ANTIN, I88I-I949}

2585. The promised land. Boston, Houghton Mifflin, 1912. 373 p. illus. 12-10316 E169.5.A66 1912

An immigrant's autobiographical account of the situation of Jews in Europe as contrasted with that of those in America.

\section{HERBERT ASBURY, 189I-}

Herbert Asbury was a descendant of Francis Asbury (1745-1816), who brought organized Methodism to America; this story Herbert Asbury tells in A Methodist Saint, the Life of Bishop Asbury (1927), a somewhat iconoclastic biography. Having broken with the fundamentalist views by which he was raised, Asbury turned to writing relatively liberal "informal" histories. One group dealt with the underworld of various cities: The Gangs of New York (1928), The Barbary Coast (1933) for San Francisco, The French Quarter (1936) for New Orleans, and The Gem of the Prairie (1940) for Chicago. Other works include Sucker's Progress, an Informal History of Gambling in America (1938) and The Golden Flood, an Informal History of America's First Oil Field (1942).

2587. Up from Methodism. New York, Knopf, 1926. $174 \mathrm{p} . \quad 26-17134 \quad \mathrm{BX} 8334 \cdot \mathrm{A} 65$

Autobiography.

2588. Carry Nation. New York, Knopf, 1929. xxii, 307 p. illus.

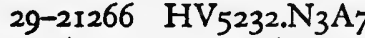

Carry Nation (I846-IgII) was a well-known champion of women's rights, prohibitionism, and general moral uplifting of all mankind, for which she worked assiduously and dramatically, leaving in the popular mind the image of a middle-aged woman chopping up the bars of the nation.

2589. GERALD AVERILL, I896-194-

Averill was a Maine woodsman who died shortly after completing his reminiscences of the forests and those who live there.

2590. Ridge runner; the story of a Maine woodsman. Philadelphia, Lippincott, 1948. 217 p. $4^{8-5365} \quad \mathrm{~F}_{25}$.A8

\section{RAY STANNARD BAKER, $1870-1946$}

Baker is probably best known for his biography of Woodrow Wilson (q. v.); however, he also achieved considerable renown for the autobiographical books he wrote under the pseudonym of David Grayson. These largely took the form of familiar essays in praise of rural life.

2592. Adventures in understanding, by David Grayson [pseud.] Garden City, N. Y., Doubleday, Page, 1925. 273 p.

$$
\text { 25-20632 PS } 3503 . \mathrm{A}_{72}
$$

2593. Adventures of David Grayson [pseud.] Garden City, N. Y., Doubleday, Page, I 925. 249, 232, 342, 208 p. 26-457 PS 3505. A $75 \quad 1925$ CoNTENTs.-Adventures in contentment.-Adventures in friendship.-The friendly road.Great possessions.

2594. Adventures in solitude, by David Grayson [pseud.] Garden City, N. Y., Doubleday, Doran, I93I. I80 p.

$$
\text { 3I-2830I } \mathrm{PS}_{3503} \cdot \mathrm{A}_{5448 \mathrm{~A}_{7}} \text { I93I }
$$

2595. Native American; the book of my youth. New York, Scribner, 1941. $336 \mathrm{p}$.

$$
4^{1-51934} \mathrm{CT}_{275} \cdot \mathrm{B}_{3}{ }_{13} \mathrm{~A}_{3}
$$

2596. American chronicle. New York, Scribner, 1945. 53I p. $\quad 45^{-244} \mathrm{PN}_{4} 874 \cdot \mathrm{B}_{25} \mathrm{~A}_{3}$ Autobiography.

\section{ALBEN WILLIAM BARKLEY, $1877-1956$}

Alben Barkley was a prominent elder statesmanpolitician from Kentucky who achieved fame not only for his national services, but also for his humor. His autobiography gives a good sample of American political humor. 
2598. That reminds me. Garden City, N. Y., Doubleday, 1954. 288 p. 54-10775 $\mathrm{E}_{74} 8 . \mathrm{B}_{3} \mathrm{I}^{8 \mathrm{~A}} 3$
2605. The Americanization of Edward Bok; the autobiography of a Dutch boy fifty years after. New York, Scribner, 1920. 46I p. illus. 20-1 $7333 \mathrm{PN}_{4} 874 \cdot \mathrm{B}_{2} \mathrm{~A}_{4}$

\section{WILLIAM BENTLEY, 1759-1819}

Rev. Bentley, a Unitarian minister, was known to his contemporaries as a prominent intellectual clergyman. His subsequently published diary for I784-I8Ig is now his main claim to be remembered. A mine of detail for historians, the work pictures not only the author, but more so life in a New England seaport at that period.

2600. The diary of William Bentley, D. D., pastor of the East Church, Salem, Massachusetts. Salem, Mass., Essex Institute, 1905-r 4.4 v. illus. 6-1094I $\mathrm{F}_{74} \cdot \mathrm{S}_{\mathrm{IB}} \mathrm{B}_{4} 6$

ARTHUR F. BERINGAUSE, 1919-

26or. Brooks Adams; a biography. New York, Knopf, 1955. 404 p.

Bibliography: p. [392]-404.

$$
\text { 55-8357 Di5. } \mathrm{A}_{3} \mathrm{~B}_{4}
$$

Brooks Adams (1848-1927), brother of Henry Adams (q. v.), was a distinguished thinker and historian. Most of his influence was behind the scenes or indirect, as that upon Theodore Roosevelt. In The Law of Civilization and Decay (1895) he presented an interpretation of history which was not only the first such theoretical work by an American, but also in its own rights a contribution to American and Western intellectual history.

\section{LAUNCELOT MINOR BLACKFORD,} I894-

Blackford, an Atlanta, Georgia, doctor, is a descendant of Mary Blackford. His life of her, while depicting a woman of character who was far from the clinging vine of historical romances, shows some of the way of life in Virginia and a sample of the anti-slavery sentiment that existed in the South during the Civil War and pre-Civil War period.

2603. Mine eyes have seen the glory; the story of a Virginia lady, Mary Berkeley Minor Blackford, $1802-1896$, who taught her sons to hate slavery and to love the Union. Cambridge, Harvard University Press, 1954. 293 P.

$$
54-5018 \quad F_{23} 0 . B 65 B 6
$$

\section{EDWARD WILLIAM BOK, 1863-1930}

Bok was an American editor who as a child came to America from the Netherlands. His autobiography was awarded the Pulitzer price in 1921 .

\section{CATHERINE (DRINKER) BOWEN, $1897-$}

Mrs. Bowen is one of the most popular of the practitioners of fictionalized biography. Basing her books on much research, she imaginatively extrapolates unwitnessed events, and then proceeds to present such scenes as biographical facts.

2607. Yankee from Olympus; Justice Holmes and his family. Boston, Little, Brown, 1944. xvii, 475 p. illus. $\quad 44-33^{8} 4$ E664.H773B6 "Material and sources": p. [433]-45I.

Oliver Wendell Holmes, Jr., was noted not only as a distinguished jurist, but also as one carrying on a notable American tradition; consequently, both his grandfather, a clergyman, and his father, the distinguished author-doctor (q. v.), are treated at some length in this book. Another view of the man may be gathered from the Holmes-Pollock Letters, the Correspondence of Mr. Justice Holmes and Sir Frederick Pollock, 1874-1932 (Cambridge, Mass., Harvard University Press, 194I. 2 v.), edited by Mark De Wolfe Howe.

2608. John Adams and the American Revolution. Boston, Little, Brown, 1950. xvii, 699 p. illus.

Bibliography: p. 646-676. 50-8182 $\quad \mathrm{E}_{322 . \mathrm{B} 68}$

A fictional biography of the younger years of a leading revolutionist who was to become the second President of the United States.

\section{HENRY MARIE BRACKENRIDGE, 1786-187I}

Brackenridge, a Pennsylvania-Scotch lawyer, had a long career in law, politics, and diplomacy. His travels were the basis of several books of historical importance.

2610. Recollections of persons and places in the West. Philadelphia, Kay [1834] 244 p. 3-20912 $F_{518 . B 78}$

One of the first descriptions of the pioneer West, meaning, at this time, in large part the Ohio Valley.

\section{II. GAMALIEL BRADFORD, 1863-1932}

Bradford was a Massachusetts recluse of ill health who devoted most of his life to writing. He originated the "psychograph," a method of short biog- 
raphy by means of which he attempted to extract the essentially vital aspects of a person's life, and through them to give a "soul picture." Although influenced by psychology, he aimed at an artistic product. His studies were highly popular, and they initiated a whole new school of American biography.

2612. Lee the American. Boston, Houghton Mifflin, 1912. 324 p. illus.

$$
\text { I2-7039 } \mathbf{E}_{467 \cdot 1 . L_{4} \mathrm{~B}_{77}}
$$

A study of Robert E. Lee (see also entries in index), the Confederate general.

2613. Confederate portraits. Boston, Houghton Mifflin, I914. xviii, 29I p. 8 port.

$$
\mathrm{I}_{4}-7092 \mathrm{E}_{4} 67 \cdot \mathrm{B}_{7} 8
$$

Contents.-Joseph E. Johnston.-J. E. B. Stuart.-James Longstreet.-P. G. T. Beauregard.Judah P. Benjamin.-Alexander H. Stephens.Robert Toombs.-Raphael Semmes.-The battle of Gettysburg.-Notes.

26r4. Union portraits. Boston, Houghton Mifflin, 1916. $33^{\circ}$ p. 4 port.

$$
\text { I6-1 } 1059 \quad \mathrm{E}_{467 . \mathrm{B} 782}
$$

Contents.-George Brinton McClellan.-Joseph Hooker.-George Gordon Meade.-George Henry Thomas.-William Tecumseh Sherman.-Edwin McMasters Stanton.-William Henry Seward.Charles Sumner.-Samuel Bowles.-Titles of books most frequently cited (p. [297]-298).-Notes.

2615. Portraits of American women. Boston, Houghton Miffin, I9I9. 276 p. ports.

$$
\text { 19-18303 } \mathrm{E}_{176 . \mathrm{B} 82}
$$

Contents.-Abigail Adams.-Sarah Alden Ripley.-Mary Lyon.-Harriet Beecher Stowe.-Margaret Fuller Ossoli.-Louisa May Alcott.-Frances Elizabeth Willard.-Emily Dickinson.

26r6. American portraits, 1875-1900. Boston, Houghton Mifflin, 1922. 248 p. ports.

$$
\text { 22-4659 CT2rg.B7 }
$$

Contents.-Mark Twain.-Henry Adams.-Sidney Lanier.-James McNeill Whistler.-James Gillespie Blaine.-Grover Cleveland.-Henry James.Joseph Jefferson.

26r7. Damaged souls. Boston, Houghton Mifflin, 1923. 284 p. ports.

23-9082 EI76.B8 $_{17}$

Contents.-Damaged souls.-Benedict Arnold.Thomas Paine.-Aaron Burr.-John Randolph of Roanoke.-John Brown.-Phineas Taylor Barnum.-Benjamin Franklin Butler.
2618. The journal of Gamaliel Bradford, I8831932, edited by Van Wyck Brooks. Boston, Houghton Mifflin, I933. $560 \mathrm{p}$.

$$
\text { 33-27386 PS } 3503 \cdot \mathrm{R}_{2} \mathrm{Z}_{5}
$$

26r9. The letters of Gamaliel Bradford, I9181931, edited by Van Wyck Brooks. Boston, Houghton Mifflin, 1934. 377 p.

$$
34-33655 \text { PS } 3503 \cdot R_{2} Z_{53} 1934
$$

2620. WILLIAM CABELL BRUCE, I860-1946

Bruce was a lawyer and a United States Senator who achieved considerable fame as a biographer. He was awarded a Pulitzer prize for his biography Benjamin Franklin, Self-Revealed (1917), which relied mainly on presenting the subject through extracts from his own writings, with transitional passages supplied by Bruce.

2621. John Randolph of Roanoke, 1773-1833; a biography based largely on new material. 2d ed., rev. New York, Putnam, 1939. xv, 66r, 803 p. illus. 39-25590 E302.6.R2B9 1939 First published in 1922 in 2 volumes.

John Randolph was a Virginia statesman of great force who, however, almost made a habit of opposition. An earlier (I882) biography by Henry Adams (q. v.) is well written, but considered by some critics to be prejudiced. Russel Kirk's Randolph of Roanoke, a Study in Conservative Thought (195I) outlines Randolph's ideas and their influence; the book was meant to be something of a supplement to Bruce's study.

\section{EDWARD McNALL BURNS, I897-}

Burns is a historian whose earlier works include a study (1938) of Madison's political and constitutional thought.

2623. David Starr Jordan: prophet of freedom. Stanford, Calif., Stanford University Press, 1953. 243 p. 53-5525 LD3025 I891.B87 Jordan was a famous ichthyologist and the first president of Stanford University; however, this biography is less concerned with his ichthyological and educational career than with his thought and crusades, so that the work becomes a chapter in the history of American thought.

\section{JOHN BURROUGHS, I837-1921}

Burroughs through his writings as a naturalist achieved a position in American literature (q. v.) $\mathrm{He}$ also wrote a number of autobiographical and biographical works, such as John lames Audubon 
(I902) and Walt Whitman, a Study (1896). His biographer, Clara Barrus, produced a two-volume Life and Letters of John Burroughs (1925).

2625. Camping \& tramping with Roosevelt. Boston, Houghton Mifflin, 1907. $110 \mathrm{p}$.

$$
\text { 7-31 } 86 \text { E757.B97 }
$$

Describes a trip in Yellowstone Park with Theodore Roosevelt in 1903, with an added section on a visit to Roosevelt at his home at Oyster Bay.

2626. The heart of Burroughs's journals. Boston, Houghton Mifflin, 1928. xvii, 361 p.

$$
\text { 28-23950 PSi226.A52 }
$$

2627. John Burroughs talks, his reminiscences and comments as reported by Clifton Johnson. Boston, Houghton Mifflin, I922. xvi, $35^{8} \mathrm{p}$. illus. * 22-18205 PSr226.A54

2628. My boyhood, by John Burroughs, with a conclusion by his son, Julian Burroughs. Garden City, N. Y., Doubleday, Page, 1922. 247 p. illus. 22-7305 PSi 226. A5

\section{NICHOLAS MURRAY BUTLER, I862- 1947}

Butler, who was a national and international statesman, is probably best remembered for his work during his long incumbency in the presidency of Columbia Inniversity.

2630. Across the busy years: recollections and reflections. New York, Scribner, 1939-40. 2 v. illus. 39-27850 LDi245 1902.A3

\section{HODDING CARTER}

Carter, who does not usually use his first name, William, is a liberal, smalltown newspaperman from the Mississippi delta area. His writings present Southern problems from a Southern perspective. In addition to his non-fiction, he has written some novels, notably The Winds of Fear (1944), a polemical study of relations between Negroes and whites.

2632. Where Main Street meets the river. New York, Rinehart, 1953. 339 p.

$$
\text { 53-6r } 33 \mathrm{PN}_{48} 8_{74} \cdot \mathrm{C}_{27} \mathrm{~A}_{3} \text { I } 953
$$

An account, with opinions on many issues, which traces the author's career since he started a small newspaper in 1932.
2633. PETER CARTWRIGHT, $1785-1872$

Cartwright was a clergyman who was long a Kentucky circuit rider, and then brought religion to frontier Illinois. Mrs. Helen Hardie Grant's Peter Cartwright, Pioneer (New York, Abingdon Press, 195I) presents a 2oth century view of this once influential Methodist.

2634. Autobiography of Peter Cartwright, the backwoods preacher. Edited by W. P. Strickland. New-York, Carlton \& Porter, 1857. $525 \mathrm{p}$. 12-3515 $\mathrm{F}_{545 . \mathrm{C}_{3} \mathrm{I}}$

Supplemented by his later Fifty Years as a Presiding Elder (1872). A "centennial edition" of the autobiography was published in 1956 by the Abingdon Press in Nashville, Tenn.

\section{CHARLES EDWARD CAUTHEN, ed.}

2635. Family letters of the three Wade Hamptons, 1782-19or. Columbia, University of South Carolina Press, 1953. xix, I8 I p. illus. (South Caroliniana; sesquicentennial series, no. 4)

$$
\text { 54-718I CS7I.H23 I953 }
$$

Letters of three Wade Hamptons (1754-1835, I79I-I858, I818-1902), which illuminate major events in the South during a period of more than a century.

\section{MARY BOYKIN (MILLER) CHESNUT, 1823-1886}

Mary Chesnut was a South Carolinian belle, wife of a U. S. Senator who later became a brigadiergeneral in the Confederate Army. She was acquainted with a large percentage of the great and near-great of the Confederate States.

2637. A diary from Dixie. Boston, Houghton Mifflin, 1949. $572 \mathrm{p}$.

49-11694 $\mathrm{E}_{4} 87 . \mathrm{C}_{52} \quad \mathrm{I} 949$

This diary of the Civil War period was first published in 1905. The 1949 edition has more material; it was edited by the historical novelist Ben Ames Williams (1889-1953), who used it as a source model for Linda Dewain in House Divided (1947).

\section{SAMUEL CHOTZINOFF, I889-}

Chotzinoff is a musician and critic who was born in Russia of Jewish parents. His autobiography traces the family's coming to America and the years from his life in the slums of New York to his adult success. His biography of Arturo Toscanini, the orchestral conductor, Toscanini: An Intimate Portrait, was published in 1956 (New York, Knopf. 148 p.). 
2639. A lost paradise; early reminiscences. New York, Knopf, r955. 373 p. $54-7202 \mathrm{ML}_{423} \cdot \mathrm{C}_{564} \mathrm{~A}_{3}$

2640. LOUISE AMELIA KNAPP CLAPPE, I8I9-1906

(SMITH)

Louise Smith Clappe was a doctor's wife who -in her letters gave a detailed description of life in a California gold-mining community.

264 I. The Shirley letters from the California mines, $1851-1852$; with an introd. and notes by Carl I. Wheat. New York, Knopf, 1949. xxix, 216 p. illus.

49-II095 F865.C58 1949

Twenty-three letters written by the author to her sister, Mary Jane, in Massachusetts. They were originally published serially, under the pseudonym of Dame Shirley, in The Pioneer; or, California Monthly Magazine, Jan. $1854-$ Dec. 1855.

\section{IRVIN SHREWSBURY COBB, 1876-1944}

Irvin S. Cobb was born in Kentucky. He later became a New York journalist, a World War I war correspondent, and a humorous columnist. While he wrote some serious fiction, he is better known for his works of humor in general and his autobiography in particular, which exemplifies much of the American attitude towards life in its comical aspects.

2643. Exit laughing. Garden City, N. Y., Garden City Pub. Co., 1942. 572 p.

Autobiography.

$$
42-36270, P_{3505} \text {. O1 } 4 Z_{5} \quad 1942
$$

\section{CYRENUS COLE, $1863-1939$}

Cole was born in Iowa and had a career as a newspaperman before he became a Congressman. In addition to an autobiography, he wrote a number of books which in large part deal with Iowa.

2645. I am a man; the Indian Black Hawk, a book . . . marking the one hundredth anniversary of the passing of Ma-ka-tai-me-she-kia-kiak. Iowa City, State Historical Society of Iowa, 1938. $312 \mathrm{p}$. 38-28006 E83.83.B638

Black Hawk ( $1767-1838$ ) was a famous Sauk Indian chief who composed his own autobiography, Life of Ma-ka-tai-me-she-kia-kiak . . . (Cincinnati, 1833), by means of dictation and translation, in order to explain his side of the Indian wars in which he had a prominent part; a new edition appeared in 1955 .
2646. MONCURE DANIEL CONWAY, I8321907

Conway, one of the most prominent figures of his day, was a leading clergyman, author, and liberal. Because of his stand against slavery, he was forced to leave his native Virginia. His many writings include a life of Thomas Paine which is generally considered one of the outstanding biographies of Igth-century America. A biography, Moncure Conway (New Brunswick, Rutgers University Press, I952) was written by Mary Elizabeth Burtis.

2647. The life of Thomas Paine; with a history of his literary, political and religious career in America, France, and England. To which is added a sketch of Paine by William Cobbett (hitherto unpublished) New York, Putnam, I892. 2 v. illus. $4^{-16014} \mathrm{JC}_{17} 8 . \mathrm{V}_{2} \mathrm{C}_{7}$

2648. Autobiography. Boston, Houghton Mifflin, 1904. 2 v. illus. 4-29207 BX9869.C8A3 I904

\section{DAVID CROCKETT, I786-1836}

Davy Crockett, frontiersman and politician, was a fable in his own lifetime. The tall tales told about him became a part of American folklore. A recent revival of the myth, with retouchings, has further removed him from even that degree of truth, robustness, and reality which is to be found in his autobiography (the authorship of which has been disputed)'. An attempt to identify "the Crockett God made" is James Atkins Shackford's David Crockett, the Man and the Legend no. 3353.

2650. Davy Crockett's own story as written by himself; the autobiography of America's great folk hero. New York, Citadel Press, 1955. 377 p. illus.

51-10010 F436.C

"Consists of ... A narrative of the life of David Crockett ... written by himself, published in 1834 ; An account of Col. Crockett's tour to the North and down East, published in 1834 , and Col. Crockett's exploits and adventures in Texas, published posthumously in $1836 . "$

"Col. Crockett's exploits and adventures in Texas" is a pseudo-autobiography generally ascribed to Richard Penn Smith.

\section{WILBUR LUCIUS CROSS, 1862-1948}

Wilbur Cross had a distinguished career as an English professor and Dean of the School of Graduate Studies at Yale University. In the course of his academic career he wrote Life and Times of 
Laurence Sterne (1909, rev. ed. 1925) and History of Henry Fielding (1918), both definitive works, and considered by some to be'among the best biographies in the English language. After retiring from his scholarly career, he was four times elected Governor of his native State of Connecticut. His autobiography reflects not only New England life, but also American academic and political life.

2652. Connecticut Yankee; an autobiography. New Haven, Yale University Press, 1943. 428 p. illus. $\mathrm{A}_{43-2896} \mathrm{~F}_{100 . \mathrm{C}_{7} \mathrm{~A}_{3}}$

\section{HOMER CROY, $1883-$}

Croy started life as a Missouri farm boy. After working in journalism, he became a novelist. $\mathrm{He}$ is probably best-known, however, for his autobiographical and biographical works.

2654. Country cured. New York, Harper, r 943. 282 p. 43-1487r PS 3505.R9554C6

Autobiography.

2655. Wonderful neighbor. New York, Harper, 1945. 204 p. $45-9878$ PS 3505. R $_{954} Z_{53}$

A book of autobiographical sketches depicting life in a Midwestern farm community during the author's youth.

2656. He hanged them high; an authentic account of the fanatical judge who hanged eightyeight men. New York, Duell, Sloan \& Pearce, 1952. $278 \mathrm{p}$. illus. 52-6782Law A biography of Isaac Charles Parker (1838-96), who for three decades was sole U. S. judge over a large frontier area.

2657. Our Will Rogers. New York, Duell, Sloan \& Pearce, 1953. $377 \mathrm{p}$.

53-10229 PN2287.R $74 \mathrm{C}_{7}$

A life of the cowboy-comedian-philosopher who achieved much of his fame as a journalist and as a motion-picture actor. His Autobiography (Boston, Houghton Miflin, r949) is actually a selection by Donald Day from the various newspaper columns, letters, etc., which Rogers wrote.

\section{JULIAN DANA, 1907-}

Dana is a California biographer whose name originally was Morgan Mercer. Lost Springtime, the Chronicle of a Journey Far Away and Long Ago (1938) is an account of a camping trip in the Sierras, during which the author manages to recount much early Californian history.
2659. Sutter of California. New York, Press of the Pioneers, 1934. 423 p. illus.

Bibliography: p. 397-401.

$$
\text { 35-27048 F865.S948 }
$$

One of several biographies of John Sutter ( $1803-$ 1880 ), on whose land gold was first discovered in California, this book was reissued by Macmillan in 1936. Another distinguished biography of Sutter is James Zollinger's Sutter, the Man and His Empire (New York, Oxford University Press, 1939).

2660. The man who built San Francisco; a study of Ralston's journey with banners. New York, Macmillan, 1936. 397 p. illus.

$$
\text { 36-29826 F869.S3Rr55 }
$$

William Chapman Ralston (1826-1875) was a capitalist whose career was much entwined with the early history of San Francisco, which receives considerable attention in this biography.

\section{EUGENE DAVENPORT, I856-194I}

266r. Timberland times. Urbana, University of Illinois Press, 1950. 274 p.

${ }_{50-6384} \mathrm{~F}_{572} \cdot \mathrm{G}_{4} 6 \mathrm{D}_{3}$

An autobiographical account of his youth, this book is also a record of how pioneer people lived and thought in the period when the Michigan timberlands were being cleared and turned into farms.

\section{PIERRE JEAN DE SMET, r80r-1 873}

Father de Smet was an early Jesuit missionary in the American Northwest. His published books include several on his journeys and his work. He also wrote knowingly on the Indians of the area.

2663. Life, letters and travels of Father PierreJean de Smet, S. J., I801-1873; missionary labors and adventures among the wild tribes of the North American Indians ... edited from the original unpublished manuscript journals and letter books and from his printed works, with historical, geographical, ethnological and other notes; also a life of Father de Smet . . . by Hiram Martin Chittenden and Alfred Talbot Richardson. New York, Harper, 1905 [ $\left.{ }^{\circ} 1904\right] 4$ v. illus.

$$
\text { 4-3358r } \text { F59r.S63 }_{5}
$$

2664. WILLIAM ORVILLE DOUGLAS, 1898-

While mainly known for his work in the legal profession, Supreme Court Justice Douglas in his autobiography depicted little of his court activities, presenting instead a regional book about mountain-climbing and fishing in the Northwest: 
2665. Of men and mountains. New York, Harper, 1950. xiv, $33^{8}$ p. $\quad$ 50-7078 F851.7.D68

\section{DANIEL DRAKE, $1785-1852$}

Drake was a leading pionee: doctor who established his fame in frontier Kentucky and Ohio.

2667. Pioneer life in Kentucky, $1785-1800$. Edited from the original manuscript, with introductory comments and a biographical sketch, by Emmet Field Horine. New York, Schuman, 1948. xxix, 257 p. illus. $\quad 48-7439 \quad F_{45}$ I.D76 1948 A restoration of the original text of a work which first appeared in 1870 .

\section{MARGARET L. (O'NEALE) TIMBER- LAKE EATON, I799?-1879}

Mrs. Eaton's autobiography, written in 1873 , is a crude but vivid defense of her reputation and an account of her activities in Washington social and political life during the administration of Andrew Jackson. Queena Pollack's biography Peggy Eaton, Democracy's Mistress (New York, Minton, Balch, 193I) offers further material for the sociologist and political historian. An impressive account is Samuel Hopkins Adams' fictional biography, The Gorgeous Hussy (Boston, Houghton Mifflin, 1934).

2669. The autobiography of Peggy Eaton. New York, Scribner, 1932. $216 \mathrm{p}$.

$$
3^{2-7318} \quad \mathrm{E}_{381} \text { E }_{15}
$$

2670. CHARLES WILLIAM ELIOT, 1834-1926

Charles W. Eliot was long a president of Harvard University. His writings are mainly scholarly, educational, or public-spirited in nature. However, he also wrote a distinguished short memoir of a guide who had been his friend to the time of his death.

2671. John Gilley, Maine farmer and fisherman. Boston, American Unitarian Association, $\begin{array}{llll} & \text { 1904. } 72 \mathrm{p} . & 4^{-27134} & \mathrm{~F}_{29} . \mathrm{S}_{5} \mathrm{E}_{4}\end{array}$

2672. PHILIP VICKERS FITHIAN, I747-I 776

Fithian was a schoolmaster, clergyman, and finally army chaplain. In his journal and letters he clearly recorded the reactions of the sections of the country he knew on the eve of the Revolution.

2673. Philip Vickers Fithian, journal and letters. Princeton, University Library, 1900-34. 2 v. illus. I-30673 EI63.F54
Volume $\mathrm{r}$, covering the years $1767-74$, has the subtitle: "Student at Princeton College, 1770-72, Tutor at Nomini Hall in Virginia, 1773-74." Volume 2 covers the period $1775-76$ and has the title continued as "Written on the Virginia-Pennsylvania Frontier and in the Army."

A revised edition covering the section for $1773-74$ was published in 1943 at Williamsburg, Va., by Colonial Williamsburg, Inc.

\section{CLAUDE MOORE FUESS, I885-}

While rising to a position as headmaster of a private New England school, Fuess wrote a number of scholarly, biographical, and historical works, many of them reflecting his academic connections, such as: An Old New England School (1917), Men of Andover (1928), Amherst (1935), and Stanley King of Amherst. (1955). His 1930 biography Daniel Webster (q. v.) is considered by many to be his masterpiece.

2675. Life of Caleb Cushing. New York, Harcourt, Brace, 1923. 2 v.

$$
\text { 23-12975 } \mathrm{E}_{415 \cdot 9 . \mathrm{C}_{9} 8 \mathrm{~F} 9}
$$

Cushing (1800-79) had an important judicial and diplomatic career, as well as serving some time as a Member of Congress.

2676. Rufus Choate, the wizard of the law. New York, Minton, Balch, r928. 278 p. illus. 28-86 $13 \quad \mathrm{E}_{340 .} \mathrm{C}_{4} \mathrm{Fg}$

Choate (1799-1859) was a leading igth-century lawyer and orator.

2677. Carl Schurz, reformer (1829-1906) New York, Dodd, Mead, 1932. xv, 421 p. illus. (American political leaders)

"Selected bibliography": p. 395-40r.

32-26442 E664.S $39 \mathrm{Fg} 2$

Schurz was a German-American liberal who led an active diplomatic, political, and military career; his life is to some extent a history of political ideas of the period.

2678. Joseph B. Eastman, servant of the people. New York, Columbia University Press, 1952. 363 p. illus. 52-8268 $\mathrm{HE}_{2754}$. $\mathrm{E}_{3} \mathrm{~F} 8$

Eastman (1882-1944) was a government career man whose career centered mainly about transportation; accordingly, this book is in some measure a review of the activities of the Interstate Commerce Commission during most of his lifetime.

\section{FERRIS GREENSLET, 1875-}

Greenslet was successively an editor for The Atlantic Monthly, a literary adviser for Houghton 
Mifflin, and then the occupant of several administrative positions in that publishing firm. His early work includes much literary criticism (largely book reviews), and several biographies of literary personages.

2680. Under the bridge, an autobiography. Boston, Houghton Mifflin, 1943. $237 \mathrm{p}$. 43-16298 $\mathrm{PS}_{35} \mathrm{I}_{3} \cdot \mathrm{R}_{4} 876 \mathrm{Z}_{5}$

268I. The Lowells and their seven worlds. Boston, Houghton Mifflin, I946. xi, 442 p.

illus. $\quad 46-25260$ CS7r.L9I5 1946

A multiple biography of ten generations (including James Russell and Amy Lowell) of a well-to-do Massachusetts family, this book reflects much of New England's history.

2682. HERMANN HAGEDORN, 1882-

Hagedorn, a longtime admirer and student of Theodore Roosevelt (q. v.), has used this lifelong interest as a topic source for many of his books, which frequently employ the biographical medium. These range from studies of aspects or portions of his life, through the editing of the Memorial Edition of Roosevelt's works, to The Rough Rider (1927), a novel dealing with the Spanish-American War activities of the president-to-be. However, Hagedorn has on occasion turned to other subjects, as in Edwin Arlington Robinson (1938), a life of the poet (q. v.); Prophet in the Wilderness (1947, rev. 1954), a life of Albert Schweitzer; and The Magnate William Boyce Thompson and His Time [1869-1930] (1935), an authorized biography. He ventured into collective biography in Americans (1946), a book of 17 biographical sketches designed originally to introduce foreigners to prominent Americans. In addition Hagedorn has written some cónventional poetry and drama; his greatest popular success in poetry may have been The Bomb that Fell on America (1946, rev. 1950), a statement on the moral implications of the atomic bomb, stated in a loose Whitman-Sandburg free verse.

2683. Roosevelt in the Bad Lands. Boston, Houghton Mifflin, I92r. xxvi, $49 \mathrm{r}$ p. illus. (Publications of the Roosevelt Memorial Association, I) 21-194I5 E757.HI42

A story of Roosevelt in Dakota that is also a story of frontier life.

2684. Leonard Wood, a biography. New York, Harper, 1931. 2 v. illus.

3I-24003 E18I.W83

Gen. Wood (1860-1927) was a friend of Theodore Roosevelt, a member of the "Rough Riders," a prominent candidate for a presidential nomination, and an administrator in Cuba and the Philippines.

"Authorities": v. 1, p. 430-436; v. 2, p. 496-503.

2685. Brookings; a biography. New York, Macmillan, 1936. 334 p. illus.

$$
{ }_{36-32578} \mathrm{CT}_{275} \cdot \mathrm{B}_{7554} \mathrm{H}_{3}
$$

Robert S. Brookings (1850-1932) was a merchant who, having made a fortune, became a philanthropist.

"Authorities": p. 317-324; "Publications of Robert S. Brookings": p. 325-326.

2686. The Roosevelt family of Sagamore Hill. New York, Macmillan, I954. 435 p. illus. 54-11834 E757.3. $\mathrm{H}_{3}$

A view of the Roosevelt family in their home at Oyster Bay, New York. The book follows Theodore Roosevelt to Washington during his years in the presidency.

2687. FRANCIS JOHN HALFORD, I902-1953 Halford was a medical doctor who practiced in the Hawaiian Islands.

2688. 9 doctors \& God. Honolulu, University of Hawaii, I954. 322 p. illus.

$$
\text { 54-10046 R722. } \mathrm{H}_{23}
$$

The story of the first 9 missionary doctors sent from the United States to the Hawaiian Islands in the rgth century.

\section{RALPH VOLNEY HARLOW, I884-}

2689. Gerrit Smith, philanthropist and reformer. New York, Holt, 1939. 50I p.

$39-4639 \mathrm{HV}_{2} 8 . \mathrm{S}_{3} \mathrm{H}_{3}$

Gerrit Smith (1797-1874) was a wealthy reformer, philanthropist, and statesman. He was long active in the anti-slavery movement, among others. His life story almost constitutes a history of American philanthropic activities in that period.

\section{RACKHAM HOLT, 1899-}

George Washington Carver, an American biography. Garden City, N. Y., Doubleday, Doran, 1943. 342 p. illus. 43-51 106 $\mathrm{S}_{417}$.C $3 \mathrm{H6}$

Carver was a Negro scientist who became famous for his work in the development of byproducts of the peanut. His biography in a way reflects the progress of the Negro in America.

\section{9r. PHILIP HONE, i $780-185 \mathrm{r}$}

Hone, at one time mayor of New York, was a member of the city's social and literary circles. 
His diary indicates the attitudes of the Whig "aristocracy," and it gives a comprehensive picture of life in New York City at that time. It was first published in 1889 as edited by Bayard Tuckermann. The text cited below was edited by Allan Nevins, an American historian and biographer whose works are listed under various subjects in this bibliography.

2692. The diary of Philip Hone, 1828-1851. New York, Dodd, Mead, 1927. 2 v. illus.

$$
\text { 28-26080 } \mathrm{F}_{128} \cdot 44 \cdot \mathrm{H}_{7} 8
$$

\section{MARK ANTONY DE WOLFE HOWE, I864-}

M. A. De Wolfe Howe was born in Rhode Island, but has become entrenched as the dean of Boston writers. His writings are based on much research, and are usually biographical in form, at times through the arranging and connecting of the subject's own writings. Howe has commonly written about Boston and New England figures in general, and people he himself has known in particular. While many of his books have been about less spectacular personages of history, he did in Holmes of the Breakfast Table (1939) produce a distinguished short biography of the prominent New England doctor-author (q. v.).

2694. Barrett Wendell and his letters. Boston, Atlantic Monthly Press, 1924. 350 p. illus. 24-24596 $\mathrm{PS}_{3158 . \mathrm{W}_{7} \mathrm{Z}_{53}}$

Wendell (1855-1921) was for 40 years a teacher of English literature at Harvard University, as well as the author of considerable literary criticism and history. This biography, composed largely of extracts from his letters, was awarded a Pulitzer prize for biography in 1925 .

2695. James Ford Rhodes, American historian. New York, Appleton, 1929. 375 p. illus. 29-9826 Ei75.5.R 44

2696. Portrait of an independent, Moorfield Storey, I845-1929. Boston, Houghton Mifflin, 1932. 383 p. illus. 32-11810 E664.S883 $\mathrm{H}_{7}$ Includes numerous letters written by Moorefield Storey. A book written to illustrate the position of the independent in American life.

2697. John Jay Chapman and his letters. Boston, Houghton Mifflin, 1937. 498 p. illus. 37-28704 PSr292. $\mathrm{C}_{3} \mathrm{Z}_{53}$

A life of Chapman ( $1862-1933$ ) composed largely of selected and arranged letters, with connecting statements, which combine to reveal the personality of this New York critic, essayist, translator, and commentator on religious and educational matters. Chapman himself produced some lightly autobiographical work in Memories and Milestones (1915), which is more a commentary on those he has known.

2698. A venture in remembrance. Boston, Little, Brown, 1941. 319 p.

Autobiography.

$$
4^{1-1} 6_{3} 65 \quad P_{3515.0858 Z} \quad 194 I
$$

\section{WILL JAMES, 1892-1942}

James, whose full name is William Roderick James, became an author and artist after a career as a cowboy. His various stories were quite widely read, but it is probably his autobiography, written in the "cowboy vernacular," which has continued to be most widely read, possibly because of its able picturing of the cowboy's life.

2700. Lone cowboy; my life story. New York, Scribner, 1930. $43^{1}$ p. illus.

$$
\text { 30-20657 } F_{596 . J 287}
$$

\section{ALVIN SAUNDERS JOHNSON, 1874-}

Alvin Johnson was born on a Nebraska farm, but went on to become an educator prominent in the fields of economics and social science. He founded the New School for Social Research and was the associate editor of the Encyclopedia of the Social Sciences (1930-35).

2702. Pioneer's progress, an autobiography. New York, Viking Press, 1952. 413 p.

$$
\text { 52-12704 } \mathrm{H}_{59 . J 6 \mathrm{~A}_{3}}
$$

\section{ALFRED KAZIN, 1915-}

Kazin is probably most generally known for his literary criticism (q. v.), but he has also published an autobiographical volume that is a lyrical evocation of his childhood in Brooklyn, N. Y., and which gives a view of city tenement life.

2704. A walker in the city. New York, Harcourt, Brace, 1951. 176 p. illus.

$$
{ }_{5}^{\mathrm{I}-\mathrm{I} 3797} \mathrm{PN}_{75} \cdot \mathrm{K}_{3} \mathrm{~A}_{3}
$$

\section{HELEN ADAMS KELLER, 1880-}

Helen Keller was a blind and deaf, and hence mute, person who was educated to speak, read (Braille), and take a useful place in society. She has become a leading example of how successfully a handicapped child may overcome its difficulties. Miss Keller, in Teacher: Anne Sullivan Macy 
(1955), has written a biography of the dedicated woman who led her out of the deaf and blind child's world of isolation.

2706. The story of my life, by Helen Keller with her letters (I887-190I) and a supplementary account of her education, including passages from the reports and letters of her teacher, Anne Mansfield Sullivan, by John Albert Macy. New York, Doubleday, Page, 1903. 44I P. illus.

$$
\text { 3-7188 HVI624.K4Ar5 }
$$

2707. The world I live in. New York, Century, 1908. 195 p. 8-30582 HV1624. $\mathrm{K}_{4} \mathrm{~A}_{2}$ "These essays and the poem in this book appeared originally in the Century magazine."-Preface.

2708. Midstream; my later life. Garden City, N. Y., Doubleday, Doran, 1929. xxiii, 362 p. illus. 29-23705 $\mathrm{HVI}_{24} \cdot \mathrm{K}_{4} \mathrm{AI}_{7} \mathrm{I929}$

2709. Helen Keller's journal, 1936-1937. Garden City, N. Y., Doubleday, Doran, 1938.313 p. $3^{8-27235} \mathrm{HVI}_{24} \cdot \mathrm{K}_{4} \mathrm{~A}_{26}$

\section{ERASMUS DARWIN KEYES, 1810-1895}

Keyes graduated from West Point in 1832 . His memoirs trace his career after this, from his position on the staff of Gen. Winfield Scott (who is discussed in detail), through his activity in Indian warfare, to his initial participation as a general in the Civil War.

271 I. Fifty years' observations of men and events, civil and military. New York, Schribner, 1884. 515 p: $\quad$ II-23243 EI8I.K44

\section{RICHARD WILLIAM LEOPOLD}

Leopold is a professor of American history at Northwestern University. His most recent blographical work is Elihu Root and the Conservative Tradition (1954).

2713. Robert Dale Owen. Cambridge, Harvard University Press, 1940. 470 p. illus. (Harvard historical studies . . . v. 45)

$$
\text { 40-34930 HX696. }{ }_{9} \mathrm{~L}_{5} 6
$$

This biography of Owen (1801-1877) illustrates the important infuence of one minor figure on the development of his period. Owen was active in many lines: socialism, politics, etc.

"A list of the writings of Robert Dale Owen": p. [419]-428. Bibliography: p. [429]-440.
2714. CHARLES AUGUSTUS LINDBERGH,
I902-

In 1927 Lindbergh became a popular hero when he flew across the Atlantic from New York to Paris. This pioneering effort still stands out in a lifetime devoted to aviation. His autobiography, which centers about this episode, is a closeup view of American aviation during the first third of the century.

2715. The Spirit of St. Louis. New York, Scribner, 1953. $562 \mathrm{p}$. illus.

Autobiography.

53-11546 TL540.L5A85

\section{I6. ROBERT MITCHELL LINDNER, 1914- 1956}

Lindner, a psychoanalyst of literary skill who practiced in Baltimore, had been a criminal psychoanalyst, and had a strong interest in criminals and their causes (as distinct from the traditional approach of their symptoms). This is revealed in books such as Stone Walls and Men (1946) and Prescription for Rebellion (1952).

2717. Rebel without a cause; the hypnoanalysis of a criminal psychopath. New York, Grune \& Stratton, $1944 \cdot 296 \mathrm{p}$.

$\mathrm{SG}_{44-211} \mathrm{RC} 602 . \mathrm{L}_{513}$

A case history of an actual, but atypical, PolishAmerican youth. The book, which depicts a slum childhood and the forming of a criminal, has been regarded as a fascinating, though tragic, major sociological document. At the same time, the novel means employed for obtaining the information, and the resultant unwilled and unmodified veracity, give this an unusual and almost unique position in the field of biography and autobiography.

2718. The fifty-minute hour: a collection of true psychoanalytic tales. New York, Rinehart, I955, ${ }^{\circ} 1954.293 \mathrm{p}$. 54-9863 RC50r.L5

True "short stories" about abnormal individuals; each comprises something of a case history, and hence is also something of a picture of abnormal types and the societal processes behind them. The stories have been praised for informative as well as literary qualities.

\section{CARL J. LOMEN}

Lomen went to Alaska at the age of Ig to look for gold; he stayed to go into a successful deerraising industry. Besides the reindeer industry, his book pictures the Alaskan Eskimo and the Klondike gold rush. 
272.0. Fifty years in Alaska. New York, McKay, 1954. $302 \mathrm{p}$. 54-13313 F9og.L86

\section{KATHARINE DU PRE LUMPKIN, $x 897-$}

2721. The making of a Southerner. New York, Knopf, 1947. 247 p. $47-312$ F215.L85

The autobiography of a sociologist who does much to explain Southern social conditions. She has achieved some of her objectivity towards the issue by her education and residence in the North.

\section{ALICE LEE MARRIOT'T, I910-}

Alice Marriott is an ethnologist who has written a number of books depicting the customs of Indian groups in the Southwest. Even in her autobiographical works, the main interest is in the Indians she observes.

2723. María, the potter of San Ildefonso. Norman, University of Oklahoma Press, 1948.

294 p. illus. (The Civilization of the American Indian [series]) 48-2101 E98:P8M28 A biography of María Montoya Martínez, a New Mexican Indian who became famous for her pottery.

2724. The valley below. Norman, University of Oklahoma Press, 1949. 243 p. illus. 49-7779 ${\text { F } 797 . M_{35}}$

An ethnologist's story of life in a predominantly Spanish American and Indian community in New Mexico.

2725. Greener fields; experiences among the American Indians. New York, Crowell, 1953.

$274 \mathrm{p}$. 53-8436 $\mathrm{E}_{9} 8 . \mathrm{CgM}_{3}$

\section{KATHRYN HARROD MASON}

Mason was a descendant of James Harrod (1746-1793?), founder of the first settlement in Kentucky; she wrote his biography in an attempt to rescue him from what she felt to be an unjust obscurity. In the course of the book she produces an excellent picture of frontier life.

2727. James Harrod of Kentucky. Baton Rouge, Louisiana State University Press, 1951. xxii, 266 p. illus. (Southern biography series)

Bibliography: p. [245]-254.

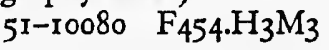

\section{JOHN JOSEPH MATHEWS}

Mathews is an Osage Indian who has been very well educated in the white man's tradition.
2729. Wah'kon-tah; the Osage and the white man's road. Norman, University of Oklahoma Press, 1932. 359 p. illus. ([The Civilization of the American Indian series $]$ ) $32-281_{53} \quad E_{99.08 M_{3}}$

A story of the Osage Indians and their country; based on the journal of Major Laban J. Miles (18441931), who in 1878 became an Osage agent and lived with them thereafter.

2730. Talking to the moon. Chicago, University of Chicago Press. I945. 243 p. illus.

$\mathrm{A}_{45-3207} \mathrm{CT}_{275} \mathrm{M}_{4} 6_{44} \mathrm{~A}_{3}$

A detailed observational story of a nature-lover living alone for to years on a Kansas prairie.

2731. Life and death of an oilman; the career of E. W. Marland. Norman, University of Oklahoma Press, 1951. 259 p. illus.

$$
\text { 5 } \mathrm{I}-\mathrm{r} 3242 \quad \mathrm{HD} 9570 . \mathrm{M}_{3} \mathrm{M}_{3}
$$

A study of an age and place through the study of the rise and decline of one of the last of the bigbusiness tycoons, Ernest Whitworth Marland ( $1874-$ I94I), an Oklahoma oilman.

\section{ROBERT MAUDSLAY, $1855-1939$}

Maudslay was an Englishman who settled in Texas in 1882 and engaged in sheep raising.

2733. Texas sheepman; the reminiscences of Robert Maudslay. Austin, University of Texas Press, 1951. $13^{8}$ p. 5 Letters to a niece which informally describe frontier life and the rapidly growing sheep industry.

\section{WILLIAM HENRY MAULDIN, 1921-}

Bill Mauldin achieved fame as a war cartoonist, then as an author. Most of his books combine the two media.

2735. Up front. New York, Holt, 1945. 228 p. illus. $\quad 45-348_{4} \quad D_{745 \cdot 2 . M_{34}}$

A story of the regular soldier, based largely on the author's experiences in the European theater of World War II. In large part the text was written around his cartoons.

2736. Back home. New York, Sloane, I947. 315 p. illus. 47-11625 EI69.M426

Copiously illustrated with the author's cartoons, this book reflects his experience as a returning veteran after World War II. The book generalizes enough to be a statement on the position of most veterans. 
2737. A sort of a saga. New York, Sloane, 1949. 301 p. illus.

49-I I 455 NCI $429 . M_{428} 1949$

The story of the author's childhood in New Mexico and Arizona.

2738. Bill Mauldin in Korea. New York, Norton, 1952. I7 I p. illus.

$$
5^{2-12878}{\text { DS } 918 . M_{34}}
$$

\section{DAVID JOHN MAYS, I896-}

Mays is a lawyer with an extensive knowledge of American history. $\mathrm{He}$ has written a number of legal works.

2740. Edmund Pendleton, 1721-1803; a biography. Cambridge, Harvard University Press, 1952. 2 v. illus. 52-5036 F230.P 425

A scholarly, thorough, and detailed study of a conservative-revolutionary jurist. The book also deals with Virginia and Revolutionary War politics.

\section{I. ELLIOTT TUCKER MERRICK, 1905-}

Elliott Merrick is the author of several books, fictional and non-fictional, dealing with Labrador and Vermont.

2742. Green Mountain farm. New York, Macmillan, 1948. 209 p.

$$
\text { 48-10795 } \mathrm{PS}_{3525 . \mathrm{E}_{394} \mathrm{G}_{7}}
$$

A story of how, in order to simplify life during the depression, he purchased a farm in Vermont, and his subsequent experiences and observations there.

\section{GEORGE MIDDLETON, I880-}

In his autobiography Middleton, a playwright, presents a view of the theatrical world during the 45 years in which he was active in it. Middleton, married to a daughter of Robert $M$. LaFollette, also knew many people prominent in the world of politics.

2744. These things are mine; the autobiography of a journeyman playwright. New York, Macmillan, 1947. 448 p. illus.

$$
\text { 47-3034I PS3525.I27 } Z_{5}
$$

\section{LEE GRAHAM MILLER, I902-}

2745. The story of Ernie Pyle. New York, Viking Press, 1950. 439 p.

50-89I8 $\mathrm{PN}_{4} 874 . \mathrm{P} 86 \mathrm{M}_{53} \mathrm{I950}$

Ernie Pyle (1900-1945) became famous during World War II for his work as a war correspondent.
A large mass market was reached with his books Here Is Your War (1943), Brave Men (1944), and the posthumous, postwar Last Chapter (1946). Pyle was killed in the Pacific theater of the war shortly before its close. His Home Country (1947) was a selection of articles published from 1935 to 1940, and it reflected the author's travels about America.

\section{MAX CARLTON MILLER, I90I-}

Max Miller writes autobiographical-reportorial books in a clear, modern journalistic style that reveals his quiet humor, unpretentiousness, moderate philosophizing, frustration in a complex world, his defeat, and his identity with the common man and underdog. His books are mainly anecdotes and sketches of various persons, places, and events with which he has been connected; sometimes they approximate essays, and sometimes they approximate the short-story form. A number of these have reflected his service with the Navy, such as Daybreak for Our Carrier (1944), describing life on an airplane carrier; The Far Shore (1945), the Normandy and Southern France invasions as seen by naval officer Miller; l'm Sure We've Met Before (195I), which presents what he saw of the Korean War; and Always the Mediterranean (1952), a story of his experiences with the American Sixth Fleet. Other books include The Man on the Barge (1935), a view of humanity and the meek as seen by a bargeman; $A$ Stranger Came to Port (1938), a novel about a businessman who escapes to a houseboat, a story which enables the author to give a good picture of the tuna industry and other harbor maritime activities; Harbor of the Sun (1940), a history of San Diego, California; Reno (194I), a picturesque-anecdotal story of Reno, Nevada; The Town with the Funny Name (1948), the author's nonguidebook view of La Jolla, California; The Cruise of the Cow (1951), a story of a cruise in the Gulf of California; and Speak to the Earth (1955), which deals with the petroleum industry.

2747. I cover the waterfront. New York, Dutton, 1932. $204 \mathrm{p}$.

32-26658 $\mathrm{PS}_{3525} \mathrm{I}_{554} \mathrm{I}_{2} \mathrm{I}_{932}$

A San Diego newspaperman's humorous account in sketch form of life along the waterfront; the work has become a reportorial classic.

2748. The beginning of a mortal. New York, Dutton, 1933. 253 p. illus.

$$
\text { 33-33492 PS } 3525 . I_{554} Z_{5} 1933
$$

Childhood and youth in a Washington State lumber town, on a Montana homestead, and in the small California town where he began as a cub reporter. 
2749. He went away for a while. New York, Dutton, 1933. $248 \mathrm{p}$.

33-6648 $\mathrm{PS}_{3525} \cdot \mathrm{I}_{554} \mathrm{H}_{4} \quad$ I933C

A story of the author's withdrawal to a coastal shack for purposes of meditation, interspersed with the thoughts resulting therefrom.

2750. The second house from the corner. New York, Dutton, I934. 254 p.

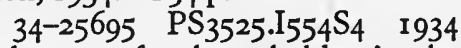

Autobiographical story of a householder in the San Diego suburbs, told mainly in terms of the people he meets and observes.

275I. Fog and men on Bering Sea. New York, Dutton, 1936. $27 \mathrm{I}$ p. illus.

36-49 I I F951.M56

A personal picture of the Alaskan coast and the Bering Sea.

2752. For the sake of shadows. New York, Dutton, 1936. $200 \mathrm{p}$.

36-2II7I PS $3525 . I_{554} \mathrm{~F} 6$ r936a

An account of the author's experiences as a scriptwriter in Hollywood.

2753. Land where time stands still. New York, Dodd, Mead, 1943. $236 \mathrm{p}$. illus.

43-4562 Fr246.M7

The record of a trip from San Diego, through the desert country, to Cape San Lucas at the tip of Lower California, with a view of the passive life of the Indian natives.

2754. No matter what happens. New York, Dutton, 1949. 249 p. illus.

An informal, rambling autobiography.

$$
49-5277 \quad \mathrm{PS}_{3525} \cdot \mathrm{I}_{554} \mathrm{Z}_{52}
$$

\section{JOSEPH MITCHELL, I908-}

Mitchell's career has been largely as a New York City reporter and as a New Yorker author. His humorous, descriptive works offer a vivid impression of his observations of New York City. This appears not only in his reportorial writing, but also in his semi-fiction, such as McSorley's Wonderful Saloon (1943) and Old Mr. Flood (1948).

2756. My ears are bent. New York, Sheridan House, 1938. 284 p.

$$
3^{8-4768} \mathrm{PS}_{3525 . I_{97}{ }_{4} \mathrm{M} 9} \mathrm{I}_{938}
$$

\section{JAMES MONAGHAN, I891-}

James Monaghan, who often signs himself Jay Monaghan, is a historian long concerned with Illinois history. His scholarly, well-written works include Diplomat in Carpet Slippers: Abraham
Lincoln Deals With Foreign Affairs (1945) and Civil War on the Western Border (1955). He has also produced a two volume Lincoln Bibliography, 1839-1939 (1943-45) and a pictorial work, This is Illinois (1949).

2758. Last of the bad men, by Jay Monaghan. Indianapolis, Bobbs-Merrill, 1946. 293 p.

illus. 46-473I $\mathrm{F}_{595 . \mathrm{H} 8 \mathrm{M} 6}$

At head of title: The legend of Tom Horn.

"List of sources": p. 275-284.

The life of Tom Horn (1860-1903), a Wyoming professional assassin who worked for a fee.

2759. The Great Rascal; the life and adventures of Ned Buntline. Boston, Little, Brown, 1952, 'I95I. 353 p. illus.

52-5003 PS2156.J2Z75

A biography of Edward Zane Carroll Judson (1823-1886), a low quality, dime-novel literary hack and general rogue of great popularity during the rgth century.

Bibliography: p. 312-333.

\section{HARRIET MONROE, I860-1936}

Harriet Monroe was a minor Chicago poet who established a reputation for herself by founding in 1912 and editing Poetry: A Magazine of Verse. Through this she "discovered" many of the more important American poets of the period and helped to find an audience for them. Her autobiography thus becomes a reflection of the literary life of the period.

276r. A poet's life; seventy years in a changing world. New York, Macmillan, 1938. 488

p. illus. $\quad 3^{8-27186} \mathrm{PS}_{24} 23 . \mathrm{A}_{4}{ }_{1938}$

\section{ANNA MARY (ROBERTSON) MOSES, I860-}

Familiarly known as "Grandma Moses," Anna Moses is an upstate New York country woman who took up painting at 80 , and thus as an artist began one of America's phenomenal success stories.

2763. Grandma Moses: my life's history. Edited by Otto Kallir. New York, Harper, I952. I $40 \mathrm{p}$. illus. 5I-II940 ND237.M78A22

\section{JOSEPH NELSON}

2764. Backwoods teacher. Philadelphia, Lippincott, I949. $288 \mathrm{p}$.

$$
\text { 49-10524 } \mathrm{PZ}_{3 .} \mathrm{N}_{33335 \mathrm{Bac}}
$$

The experiences of a teacher during his first year in an Ozark hillbilly community in Missouri. 
2765. GEORGE HERBERT PALMER, 18421933

For more than 40 years Palmer taught philosophy at Harvard, working with men such as Royce, James, and Santayana. While he wrote a number of philosophical, literary, and educational works, he is remembered most for his two "personal" books.

2766. The life of Alice Freeman Palmer. Boston, Houghton Mifflin, 1908. 354 p. illus.

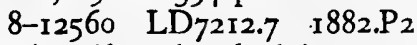

A life of the author's wife, who died in 1902. The book devotes much attention to her years as president of Wellesley College and her work to buiid it up. It is also a record of the personal relationship between two individuals with separate careers.

2767. The autobiography of a philosopher. Boston, Houghton Mifflin, $1930 . \quad 137 \mathrm{p}$.

$30-23585$ B945.P24 $\mathrm{A}_{3}$ I930

A somewhat poetic work which not only shows how the author came to his beliefs, but which also depicts a method of education and the principles by which a major university department of philosophy was built up.

\section{WILLIAM BELMONT PARKER, $187^{1-}$ I934}

Most extensively engaged in his lifetime in Hispanic activities (including the editing of a comprehensive series of Latin American biographies), Parker also produced some American biography. This included The Life and Public Services of Justin Smith Morrill (1944); Morrill (1810-1898) was a New Englander long known as the "father of the Senate" and familiar with many of the famous of his day.

2769. Edward Rowland Sill; his life and work. Boston, Houghton Mifflin, 1915. 307 p. illus. $\quad{ }_{15}-4670 \mathrm{PS}_{2} 838 . \mathrm{P}_{3}$ Sill (1841-1887) was a very unprolific poet from Windsor, Conn., who wrote in an EmersonianTennysonian tradition, producing some good minor poetry and light essays. Much of his life was passed in Ohio and California. This biography is made up largely of his letters, with Parker supplying connecting passages. Parker also edited The Poetical Works (Boston, Houghton Mifflin, I917) of Sill.

\section{JAMES PARTON, 1822-1891}

Parton was the first professional biographer in America, and he has been called the father of American biography. With The Life of Horace Greeley (1855), he established himself as a literary force and one of the best paid (and more prolific) authors of his period in America: His lively, real. istic, well-written, and well-organized volumes still hold a position in literature, but some also remain major sources. His first work in particular, and his life work in general form a historical landmark in this country's literature. While he ventured into other fields, his work was mainly biographical, occasionally collective. He usually wrote about Americans, although his life of Voltaire ( $188 \mathrm{r}, 2 \mathrm{v}$.) was a major work.

2771. Life and times of Aaron Burr ... New York, Mason, 1858 . $696 \mathrm{p}$.

$$
\text { 7-14130 } \mathrm{E}_{302.6 . \mathrm{B}_{9} \mathrm{P}_{27}}
$$

2772. Life of Andrew Jackson. New York,

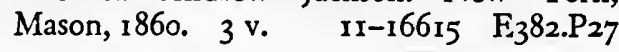

2773. Life and times of Benjamin Franklin. New York, Mason, $1864.2 \mathrm{v}$.

$$
\text { I0-5354 } \mathrm{E}_{302.6 . F 8 \mathrm{P}_{27}}
$$

2774. Famous Americans of recent times. Boston, Ticknor \& Fields, 1867. $473 \mathrm{p}$.

$$
\text { 6-1407 } \quad \mathrm{E}_{339 . \mathrm{P}_{27}}
$$

2775. Life of Thomas Jefferson, third President of the United States. Boston, Osgood, 1874 . $\begin{array}{llll}764 & \text { p. } & \text { II }-22428 & E_{332 . P 27}\end{array}$

2776. Flower, Milton Embick. James Parton, the father of modern biography. Durham, Duke University Press, 1951. 253 p. illus. (Duke University publications) ${ }_{51-14735}$ EI $_{175.5 . P} \mathrm{P}_{3} \mathrm{~F} 6$

Bibliography: p. [203]-211.

\section{ANGELO M. PELLEGRINI}

2777. Immigrant's return. New York, Macmillan, I95I. $269 \mathrm{p}$.

$51-7138 \quad E_{1} 84.18 P_{4}$

Autobiography of a college professor who emigrated from Italy, as a member of a peasant family, to Washington State at the age of nine in 1913 . The book includes an account of the author's return to Italy on a Guggenheim fellowship, and of his search for a definition of "Americanism."

\section{WILLIAM ALEXANDER PERCY, $1885-$ 1942}

Percy came from a prominent upper-class family and was well aware of his social responsibilities. During his life he was best known for his poetry, which was conservative in tenor; a volume of Collected Poems appeared in 1943. 
2779. Lanterns on the levee; recollections of a planter's son. New York, Knopf, 1941.

347 p. $\quad 4$ I-4570 PS 353 I.E65Z5 194I

An autobiography that depicts life in the Mississippi delta, and reflects the Southern "aristocrat's" view of life.

\section{LIZETTE WOODWORTH REESE, 1856- 1935}

As a minor poetess of considerable quality Lizette Woodworth Reese was well known through much of her long and relatively placid career for her short neo-Victorian lyrics. A volume of Selected Poems appeared in 1926, to be followed by poetry in volumes such as White April (1930), Pastures (1933), and The Old House in the Country (1936).

2781. A Victorian village. New York, Farrar \& Rinehart, 1929. $285 \mathrm{p}$.

29-20040 PS2693.V5 1929

Reminiscences of the author's childhood in Maryland, her teaching career in Waverly (near Baltimore), and her career as a writer. The town of Waverly again figures prominently in her somewhat autobiographical The York Road (I93I), a volume of essays, sketches, and poems on the village.

\section{JOHN ANDREW RICE, I888-}

Rice was raised in a South Carolina environment that still lived in the past. As an adult he became a liberal educator, finally cooperating in the founding of an experimental college. While much of his autobiography deals with the academic world of the twentieth century as he knew it, a very large part of it is devoted to his "eighteenth century" background.

2783. I came out of the eighteenth century. New York, Harper, 1942. 341 p.

Autobiography.

42-36390 LA2317.R $47 \mathrm{~A}_{3}$

\section{JACOB AUGUST RIIS, I849-1914}

Riis was a Danish-American journalist with a strong interest in social reform, particularly as it pertained to the worse aspects of urban life. In behalf of his interests he wrote a number of books describing such things as city slums.

2785. The making of an American. New York, Macmillan, 1901. xiii, 443 p. illus.

Autobiography.
2786. MARY (ROBERTS) RINEHART, 1876-

Mary Roberts Rinehart is a very popular and prolific, and hence very well paid, novelist who has written to entertain, rather than to create literature.

2787. My story; a new edition and seventeen new years. New York, Rinehart, 1948. 570 p.

illus.

First edition: 1931. $4^{8-9313} \quad \mathrm{PS}_{3535.173 Z_{5}} \quad{ }^{8} 4^{8}$

\section{ANDREW DENNY RODGERS, Ig00-}

Andrew Denny Rodgers III, has, as an author, specialized in biographies of people concerned with the botanical sciences. His scholarly works regularly include much related material on the special field of the biographee. He has also written some poetry, such as Rocks Before the Mansion (1940), a long poem which reflects the history of Ohio.

2789. John Merle Coulter, missionary in science. Princeton, Princeton University Press, 1944. 32I P. A44-2293 QK 31.C87R6

Coulter (1851-1928) was a botanist who was president of Indiana University and of Lake Forest College before he became a professor at the University of Chicago in 1885 , where he remained to the time of his death.

2790. Liberty Hyde Bailey; a story of American plant sciences. Princeton, Princeton University Press, 1949. 506 p. 49-1927 SB63.B3R6 Bailey (1858-1955) was a Michigan botanist and horticulturist. In 1888 he became professor of horticulture at Cornell University, becoming dean and director of the College of Agriculture of Cornell in 1903, from which he retired in 1913. He continued his scientific writings and remained generally active in his field long after his retirement. The book reflects much of agricultural research, conservation, and the development of agricultural colleges.

2791. Bernhard Eduard Fernow, a story of North American forestry. Princeton, Princeton University Press, 195I. 623 p.

$$
\text { Agr5I-517 } \mathrm{SD}_{129} \cdot \mathrm{F}_{4} \mathrm{R} 6
$$

Fernow (1851-1923). was the first professional forester in North America.

2792. Erwin Frink Smith; a story of North American plant pathology. Philadelphia, American Philosophical Society, 1952. 675 P. (Memoirs of the American Philosophical Society, v. 31)

52-II937 QK $31 . \mathrm{S}_{5} 8 \mathrm{R} 63$ QII.P612, v. 31 
Smith (1854-1927) was a New York plant pathologist who for much of his career was employed by the National Government.

\section{THEODORE ROOSEVELT, 1858-1919}

Theodore Roosevelt, President of the United States from I90I to I909, was born in New York City, but is mainly associated with the open country. A great sportsman and exponent of the outdoor life, he expressed his philosophy through the essays in American Ideals (1897) and The Strenuous Life (1900), as well as his numerous autobiographical writings. His more intellectual side may be seen in his biographies, such as The Life of Thomas Hart Benton (1887); his literary and general essays, as in $A$ Book-Lover's Holidays in the Open (1916); and other writings. A "Memorial Edition" of his works appeared in $1923-26$ in 24 volumes, and a "National Edition" in 20 volumes appeared in 1926.

2794. Hunting trips of a ranchman; sketches of sport on the northern cattle plains. New York, Putnam, 1885. 318 p. illus.

$$
3 \mathrm{I}-32858 \quad \mathrm{SK}_{45} \cdot \mathrm{R} 6 \quad \mathrm{I} 88_{5}
$$

An early volume recording some of his big-game hunting in the Midwest. Subsequent volumes of his hunting adventures include The Wilderness Hunter (1893), Ranch Life and the Hunting Trail (1902), African Game Trails (1910), and Through the Brazilian Wilderness (I9I4). Donald Day has edited a selection of these writings in The Hunting and Exploring Adventures of Theodore Roosevelt (New York, Dial Press, I955. 43I p.). Most of these works reveal not only his activities as a sportsman, but also his interests as a naturalist.

2795. Theodore Roosevelt; an autobiography. New York, Macmillan, I913. 647 p. illus. I3-24840 ${\text { E } 757 \cdot R_{79}}$

\section{CONSTANCE MAYFIELD ROURKE, I885-I94I}

Constance $M$. Rourke wrote a number of biographical and historical works interpreting the American scene. While most of these are predominantly biographical, American Humor (I93I) is a historical study of the national character as revealed through its humor. Some of her work, such as Davy Crockett (1934), was aimed mainly at a youthful audience, although a scholarly note at the end discusses sources and the validity of various parts of the myth.

2797. Trumpets of jubilee: Henry Ward Beecher, Harriet Beecher Stowe, Lyman Beecher,
Horace Greeley, P. T. Barnum. New York, Harcourt, Brace, I927. 445 p. $27-9542$ Er76.R85 Many aspects of American life in the early and middle Igth century are shown in this study of some of its leaders.

2798. Troupers of the Gold Coast; or, The rise of Lotta Crabtree. New York, Harcourt, Brace, 1928. 262 p. illus.

28-22487 PN2287.L65R6

The history of the early California theater is given through this biographical study of a leading entertainer.

\section{MARI SUSETTE SANDOZ, 1907-}

Mari Sandoz was the daughter of a Nebraska immigrant farmer who had been a Swiss medical student. Most of her writings vividly portray the frontier life she early knew. These include novels such as Slogum House (1937) and Miss Morissa, Doctor of the Gold Trail (1955), which have a biographical basis in history; and her more historical writings such as Cheyenne Autumn (1953), the tragic, slightly fictionalized history of the flight back to their native grounds of some Cheyenne Indians whom the American Army had sent to Indian Territory, and The Buffalo Hunters (1954), a story of the disappearing bison and the concomitant disappearance of the Plains Indians.

2800. Old Jules. Boston, Little, Brown, I 935. 424 p. illus. 35-2736r F666.S 34

A biography of the author's father, Jules Ami Sandoz (1857?-1928).

2801. Crazy Horse, the strange man of the Oglalas. New York, Knopf, 1942. 428 p.

$4^{2-5340}$ Ego.C94 $\mathrm{S}_{3}$

Bibliography: p. 4I7-422.

A biography of Crazy Horse (ca. $1842-1877$ ), a famous Oglala Sioux Indian chief.

\section{HENRY ROWE SCHOOLCRAFT, I793- I 864}

Henry R. Schoolcraft took part in a number of exploratory trips through the Mississippi Valley area while it was still largely a frontier wilderness. His reports on these and his extensive books on American Indians constituted a major contribution to the knowledge of the frontier and of the Indians. Longfellow and many other authors were influenced by and made use of these writings. In $185^{1}$ Schoolcraft published a volume of Personal Memoirs of a Residence of Thirty Years with the Indian Tribes, 
which took a rough diary form and thus supplied a near-autobiography of this scholar-frontiersman.

2803. Narrative journal of travels through the northwestern regions of the United States, extending from Detroit through the great chain of American lakes to the sources of the Mississippi River, in the year 1820. East Lansing, Michigan State College Press, 1953. 520 p.

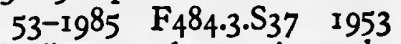

Included in the appendixes are letters, journals, newspaper accounts, official reports, and other materials relating to the expedition.

First edition: 1821.

\section{CHARLES COLEMAN SELLERS, I903-}

Sellers has written on such diverse biographical subjects as Charles Willson Peale (1947) and Benedict Arnold (1930).

2805. Lorenzo Dow, the bearer of the Word. New York, Minton, Balch, I928. 275 p.

illus. $\quad 28-24263 \quad \mathrm{BX}_{4} 495 . \mathrm{D}_{57} \mathrm{~S}_{4}$

Lorenzo Dow (1777-1834) was a Methodist minister who toured America and labored long and rigidly in behalf of his God. His once-popular writings have a confused history in alterations of text and titles, but of most interest is History of Cosmopolite, or The Dealings of God, Man, and the Devil, probably the two best-known titles under which his autobiographical work may be identified. Supplementing these is Vicissitudes Exemplified: Or the Journey of Life (1814), by his "Rib," Peggy Dow.

\section{VINCENT SHEEAN, 1899-}

Vincent Sheean established the journalistic type of book wherein the author's life is the nexus for observations of world events by a news reporter. Considered as one of the best such writers, Sheean has also written straight biography and much fiction, such as the novels Bird of the Wilderness (194I), Rage of the Soul (1952), and Lily (1954).

2807. Personal history. Garden City, N. Y., Doubleday, Doran, 1935. 403 p.

$$
35^{-27062} \mathrm{PN}_{4} 874 . \mathrm{S}_{4} 6 \mathrm{~A}_{3}
$$

London edition (H. Hamilton) has title: In Search of History.

Other volumes employing this personal-narrative technique include Between the Thunder and the Sun (1943) and This House Against This House (1946), both of which deal with problems of World War II.
2808. CORNELIA OTIS SKINNER, I901-

Cornelia Otis Skinner is a stage actress who has produced a number of humorous autobiographical books. These are light nonfiction, often in the form of sketches in series, designed to entertain, rather than seriously to reflect any aspect of society, or to be instructional in any other way. However, they nevertheless do to some extent reflect upperincome society and the entertainment world.

2809. Our hearts were young and gay, by Cornelia Otis Skinner and Emily Kimbrough. New York, Dodd, Mead, 1942. 247 p.

$$
42-36388 \quad \mathrm{PS}_{3537} \cdot \mathrm{K}_{533} \mathrm{O} 8
$$

2810. Family circle. Boston, Houghton Miffin, 1948. 310 p. 48-8306 $\mathrm{PN}_{2287 . \mathrm{S}_{4} \mathrm{~A}_{3}}$

28Ir. MONICA (ITOI) SONE, r9I9-

Mrs. Sone was raised in Seattle, Washington; her parents, who were Japanese, ran a small hotel in a poor district. Mrs. Sone's autobiography reveals much of the West Coast conflict of cultures and races that occurred between whites and Orientals, climaxing in the family's incarceration in a temporary camp in Idaho during World War II. The book is also a record of the Americanization of a group highly divergent culturally from the basically European group that dominates, with its variations, in this country.

2812. Nisei daughter. Boston, Little, Brown, 1953. $23^{8}$ p. 52-12618 EI $84 . J_{3} \mathrm{~S} 6$

Autobiography.

\section{BERT STILES, I920 or 21-1944}

Stiles was an American bomber pilot in Europe during the Second World War, in the course of which he was killed at the age of 23. His book is not only an account of war in the air, but is also the record of a youth's hopes and fears for the world, revealing a personality combination of idealism, unusual sensitivity, and occasional asperity.

2814. Serenade to the big bird. New York, Norton [1952, " 1947 ] $216 \mathrm{p}$.

$$
\text { 52-239 D790.S9 } 195^{2}
$$

First published in London in 1947.

\section{IRVING STONE, I903-}

Stone gave up a teaching career in economics to become a writer, primarily of plays and short stories. For a while he wrote pulp fiction in order 
to finance his career. With Lust for Life (1934), a fictionalized life of Van Gogh, he emerged as a biographer. This was followed by Sailor on Horseback (1938), a biography of novelist Jack London (q. v.). His goal was now to write biography that was interesting and vital as a novel. This led to an increasing fictional element in his otherwise carefully researched works, but also to greater acclaim and fame. While his biographies rapidly put him to the fore among fictional biographers, and were praised as novels, his straight novels in general received less attention.

2816. Clarence Darrow for the defense, a biography. Garden City, N. Y., Doubleday, Doran, I941. xi, $570 \mathrm{p}$. 41-20757Law

Darrow (1857-1938) was a liberal agnostic lawyer who took part in some of the more famous trials of his period. His autobiography, The Story of $M y$ Life, appeared in 1932.

2817. They also ran; the story of the men who were defeated for the presidency. Garden City, N. Y., Doubleday, Doran, 1943. 389 p. ports. 43-8018 Er76.S87

2818. Immortal wife, the biographical novel of Jessie Benton Fremont. Garden City, N. Y., Doubleday, Doran, 1944. 456 p.

$$
\text { 44-8140 } \mathrm{PZ}_{3.587872 \mathrm{Im}}
$$

Jessie Frémont (1824-1902) was the wife of the American explorer and geographer, John Frémont.

2819. Adversary in the house. Garden City, N. Y., Doubleday, 1947. $432 \mathrm{p}$.

$$
\text { 47-31015 PZ3.S87872Ad }
$$

A fictional biography of Eugene Victor Debs $(1855-1926)$, a leading Socialist who was five times a candidate for the presidency.

2820. The President's lady; a novel about Rachel and Andrew Jackson. Garden City, N. Y., Doubleday, 1951. $33^{8}$ p. $\quad 5^{\mathrm{I}-688}{ }_{5} \quad \mathrm{PZ}_{3} .587_{7}{ }_{72} \mathrm{Pr}$

2821. Love is eternal; a novel about Mary Todd Lincoln and Abraham Lincoln. Garden City, N. Y., Doubleday, 1954. 468 p.

$$
54-9678 \quad \mathrm{PZ}_{3.587872 \mathrm{LO}}
$$

\section{GEORGE TEMPLETON STRONG, 1820- 1875}

Strong started a diary while at Columbia College and continued it through most of the rest of his life. One of the classic American diaries, it reflects life in New York City at that period, especially as seen by a member of the upper classes. Except for a brief overlapping period, it follows and supplements Philip Hone's Diary (q. v.).

2823. Diary; edited by Allan Nevins and Milton Halsey Thomas. New York, Macmillan, 1952. 4 v. illus. 52-11147 E415.9.S86 3

Contenrs.- - . Young man in New York, 18351849.-2. The turbulent fifties, $1850-1859$. - 3. The Civil War, 1860-1865.-4. Post-war years, 18651875 .

\section{IDA MINERVA TARBELL, 1857-1944}

Ida M. Tarbell began her auctorial career in association with the muckrakers, producing, in addition to her journalistic work, a two-volume History of the Standard Oil Company (1904); this reflected what was to remain a basic concern with industry. Because of her interests, her autobiography showed much of the social issues of the day. Her late biographies were inclined to present in a favorable light and with praise the subjects, who supplied her with information. In addition to industry and social problems, she retained a lifelong interest in Lincoln, revealed in formerly popular books such as The Life of Abraham Lincoln (1900. 2 v.) and In the Footsteps of the Lincolns (r924).

2825. The life of Elbert $H$. Gary; the story of steel. New York, Appleton, 1925. xii, 36r p. illus. 25-22357 HD9520.G $\mathrm{T}_{3}$

2826. Owen D. Young, a new type of industrial leader. New York, Macmillan, 1932. xiv, $353 \mathrm{p}$. $3^{2-26673} \quad \mathrm{E}_{748} \mathrm{Y}_{74} \mathrm{~T}_{3}$

2827. All in the day's work; an autobiography. New York, Macmillan, 1939. 412 p. illus. $39-27284 \quad P_{3539 . A_{5} 8 Z_{5}} 1939$

\section{RICHARD TAYLOR, $1826-1879$}

Taylor's memoirs of the Civil War and the Reconstruction period form one of the classics of the South's numerous Civil War books. Prejudiced and bitter in his account of the Reconstruction era, Taylor is noted for his account of the Valley campaign of 1862 .

2829. Destruction and reconstuction: personal experiences of the late war. New York, Appleton, 1879. $274 \mathrm{p}$. 2-2262I $\mathrm{E}_{470}$.T 24

2830. Edited by Richard B. Harwell. New York, Longmans, Green, 1955. xxxii, 380 p. $\quad 55-5755 \quad E_{470 . T_{24}} 1955$ 
283r. STANLEY VESTAL, $1887^{-}$

Vestal is the pseudonym of Walter Stanley Campbell. An educator in Oklahoma, he has used his real name for a number of textbooks and scholarly works. His pseudonym is used for books about the West, particularly the old Southwest. These include many biographical works about the pioneers, explorers, trappers, Indian chiefs, etc., including books such as Kit Carson, the Happy Warrior of the Old West (1928), Warpath; the True Story of the Fighting Sioux Told in a Biography of Chief White Bull (1934), King of the Fur Traders, the Deeds and Deviltry of Pierre Esprit Radisson (1940), Bigfoot Wallace (1942), and Jim Bridger, Mountain Man (1946).

2832. Sitting Bull, champion of the Sioux, a biography. Boston, Houghton Mifflin, 1932. $\mathrm{xvi}, 35^{\circ} \mathrm{p}$. illus. 32-25143 E99.DIS627

2833. Joe Meek; the merry mountain man, a biog. raphy. Caldwell, Idaho, Caxton Printers, 1952. $33^{6}$ p. illus. 52-521I F880.M513

\section{ANTHONY F. C. WALLACE, 1923-}

Wallace as a biographer uses psychological and anthropological knowledge in an attempt to understand his characters and their situations.

2835. King of the Delawares: Teedyuscung, I7001763. Philadelphia, University of Pennsylvania Press, 1949. 305 P. maps.

$$
\text { 49-49266 E99. } \mathrm{D}_{2} \mathrm{~T}_{4}
$$

Teedyuscung was a Delaware chief who tried to harmonize the differences between the whites and the Indians.

\section{CHARLES WASHBURN}

2836. Come into my parlor; a biography of the aristocratic Everleigh sisters of Chicago. New York, National Library Press, 1936. 255 p.

A study of a case of prostitution in Chicago.

$$
\text { 37-76. } \mathrm{HQ}_{\mathrm{r}} \mathrm{P}^{6} \mathrm{C}_{4} \mathrm{~W}_{3}
$$

\section{EDWARD AUGUSTUS WEEKS, 1898-}

Edward Weeks has long been known as editor of The Atlantic Monthly. His autobiography at times takes the form of familiar essays; in it he depicts his childhood in New Jersey, life in the North Woods, his home in Boston, people he has known, and in general the life of a conservative-liberal American.

2838. The open heart. Boston, Little, Brown, 1955. 236 p. $55-10760 \quad \mathrm{PN}_{4} 874 \cdot \mathrm{W}_{3} 69 \mathrm{Z}_{5}$

\section{WALTER FRANCIS WHITE, 1893-}

White has achieved fame as general secretary of the National Association for the Advancement of Colored People and as a Negro white enough to pass as a white, who has nevertheless chosen to be a Negro and to work actively in behalf of other Negroes. His autobiography is accordingly a presentation of his view of race relations in America since the early part of the century. He has written a number of other books on the general subject, including How Far the Promised Land? (1955).

2840. A man called White, the autobiography of Walter White. New York, Viking Press, 1948. 382.p. 48-8621 Er85.97.W6A3

\section{REBECCA (YANCEY) WILLIAMS, 1899-}

284r. The vanishing Virginian. New York, Dutton, 1940. $277 \mathrm{p}$. $\quad 40-32286 \quad \mathrm{~F}_{23}$ I. Y 35

Sketches of the author's father, reflecting life in Virginia early in the 2oth century.

2842. Carry me back. New York, Dutton, 1942. $320 \mathrm{p}$.

42-2157I PS $3545 . I_{5343 Z_{5}}$

Autobiographical book about the author's childhood in Lynchburg, Virginia.

\section{HANS ZINSSER, $1878-194^{\circ}$}

Zinsser was a doctor, later a bacteriologist, who did much work abroad as well as in America. His first book, Rats, Lice, and History (1935), is an unusually well-written and witty "biography" of typhus which uses Sterne's Tristram Shandy for a model.

2844. As I remember him. Boston, Little, Brown, 1940. $443 \mathrm{P}$. 40-27536 Rr54.Z5 $\mathrm{A}_{3}$ An autobiographical pseudo-biography of "R. S." " this book reflects an American scientific humanist's outlook on life, and it also gives much on the progress of medicine. 


\section{V \\ Periodicals and Journalism}

$\llbracket \begin{aligned} & \text { A. Newspapers: General } \\ & \text { B. Newspapers: Periods, Regions, and Topics } \\ & \text { C. Individual Newspapers } \\ & \text { D. Newspapermen } \\ & \text { E. Foreign Language Periodicals } \\ & \text { F. The Practice of Journalism } \\ & \text { G. Magazines: General } \\ & \text { H. Individual Magazines } \\ & \text { I. The Press and Society }\end{aligned}$

TN A COUNTRY which aims at a government of the people, by the people, and for the people, an intelligent and informed public opinion is necessary, if the system is to function properly. From our colonial beginnings the task of informing the people has in large measure been carried on by periodicals, and, insofar as current events and public issues are concerned, principally by newspapers. This has placed on journalism a heavy responsibility, which has been met with varying degrees of success. The books listed in this chapter cover aspects of the development of journalism in this country; because of the prominent role individual editors and other journalists have played in this field, a proportionately large number of biographies and autobiographies have been included. There are also a number of works dealing with or reflecting problems of press responsibility.

Other phases of the history of the press which figure in this chapter are the provision of entertainment and the diffusion of culture. Both of these have often been closely connected, especially in the belletristic writing which has historically constituted a large proportion of American periodical publication. Because this field has been covered less extensively in books than have newspapers and newspaper journalism, the history, nature, and influence

of non-newspaper journalism and its practitioners are represented by fewer entries here than we could have wished. However, since much of this material overlaps with literature, journalistic editors and authors and periodicals appear at many other points in the bibliography, notably throughout Chapter I on Literature and in the list of periodicals at the end of Chapter III, Literary History and Criticism. To a less extent this is also true of newspapermenand the autobiographical work of journalists such as H. L. Mencken (especially his Newspaper Days, no. I604) and Theodore Dreiser should be considered as being as important to this chapter as to that section in which they appear. Much of this additional material may be located through the index.

\section{A. Newspapers: General}

2845. Emery, Edwin, and Henry Ladd Smith. The press and America. New York, Prentice-Hall, r954. 794 P. illus. (Prentice-Hall journalism series) 54-10508 $\mathrm{PN}_{4} 855$.E6
A history of American journalism for the college student. The first 14 chapters, primarily the work of Professor Smith, consider "The Heritage of the American Press" and cover the years 1704-1865. 
They are concerned less with details than with the principles upon which the profession was founded in this country. The remaining 15 chapters, chiefly the work of Professor Emery, "examine modern journalism-including newspapers, radio, television, magazines, and news-gathering organizations-and its role in an increasingly complex society." This function is seen mainly as "the continuing efforts by men and women to break down the barriers erected to prevent the flow of information and ideas upon which public opinion is so largely dependent." Throughout the book, the evolution of our mass media and the development of a tradition in American journalism are correlated to political, social, and economic trends. A valuable feature of the book is that at the end of each chapter there is provided a fairly extensive annotated bibliography of books, periodical articles, and monographs for further readings.

2846. Jones, Robert W. Journalism in the United States. New York, Dutton, 1947. xvi, 728 p. illus.

Bibliography: p. [705]-716.

This history of American newspapers, their publishers and editors, emphasizes the evolution of policies and practices. The author discusses the I 7 thand early 18 th-century origins of the doctrine of freedom of the press and the growth of such traditions as the interpretation of news and the advocacy of causes, as well as the post-Revolution assertion of political leadership in passing upon the merits of candidates, criticizing local and national administrations, and generally speaking with authority. $\mathrm{He}$ points out that the editor, in colonial days "merely a printer who issued a publication to which others contributed the ideas," became after the Revolution a civic as well as a political leader; and his paper, previously a sideline made up in the main of extracts from English newspapers together with a column or so of advertisements of the "classified want ad" type, thereafter supported him financially through "pressure of advertising" and, in taking sides on all public questions, not infrequently abused its privilege of freedom. Throughout the history of American journalism, however, many editors have striven for the ideals of accuracy and the public good.

2847. Mott, Frank Luther. American journalism; a history of newspapers in the United States through 260 years: 1690 to 1950 . Rev. ed. New York, Macmillan, 1950. xiv, 835 p. illus.

50-7326 $\mathrm{PN}_{4} 855 . \mathrm{M} 631950$

"Bibliographical notes" at end of chapters.

Designed especially for use as a teaching aid, this book combines certain attributes of a reference tool with a comprehensive and authoritative history of American journalism, principally newspapers. Arrangement is chronological by chapter within 10 sections, each marked off by events which ushered in a new period. Besides providing brief histories of individual newspapers and their makers, the author deals with: format and materials; concepts, coverage, and content of news; commentary on public affairs; provision of entertainment; advertising; and the relations between the press and the government, and the press and the public. Dean Mott also describes such trends of development as: the change in the status of editor from combined printer and entrepreneur to full-time professional; the rise in journalistic prestige during the Revolution; the emergence of the daily paper and the editorial in the early Republic; the advent of the penny press, sensational journalism, and the reporting of sports and society events in the $1830^{\circ}$ 's and, in the r860's and 70's, the final triumph of news over editorials as the primary. function of American newspapers. An almost equally massive textbook, Alfred McClung Lee's The Daily Newspaper in America (New York, Macmillan, 1937. xiv, 797 p.), which has unfortunately not been brought up to date in a revised edition, approaches the subject from the sociological point of view. "Significant developments in the manufacture of newspapers, in their advertising and publishing departments, and in society at large are here related to trends in editorial policy."

2848. Stewart, Kenneth, and John Tebbel. Makers of modern journalism. New York, Prentice-

Hall, 1952. 514 p. (Prentice-Hall journalism series) $\quad 5^{2-8617} \mathrm{PN}_{4} 87 \mathrm{I}_{7} \mathrm{~S}_{7}$

The authors state in their foreword: "This book is a history of American journalism told in terms of men and motives. It is a biographical history, intended to encompass the story of newspapers in America (and a few of the significant magazine, radio, and television leaders) by means of the interconnected lives and times of the men who have made, and are making, the free press of this country." After a brief survey of the colonial press and the early years of the Republic, the book devotes six chapters to late Igth- and early 2oth-century figures such as the Bennetts, Greeley, Dana, Pulitzer, Hearst, and Raymond. There follow chapters on the development of journalism outside the Northeast. The more recently established chains and prominent editors throughout the Nation are next considered. In the closing chapters some editors of 
magazines, columnists, and radio-television journalists are discussed.

2849. Villard, Oswald Garrison. The disappearing daily; chapters in American newspaper evolution. New York, Knopf, 1944. 285 p. $44-4038$ PN $4855 . \mathrm{V}_{47}$

This anecdotal report on the American press brings up to $1944 \mathrm{Mr}$. Villard's earlier work, Some Newspapers and Newspaper-Men, new and rev. ed. (New York, Knopf, 1926. 335 p.), and illuminates trends in "what was once a profession but is now a business." The noted editor and journalist finds these mainly negative: an "alarming mortality" among the dailies, with an accompanying tendency toward monopoly; the "appalling" loss of journalistic influence and prestige caused by the "reactionary and selfish character of much of the press"; and "marked deterioration" in the character and accuracy of reporting and editorials. The author expresses candid opinions of the press associations and of various newspapers, their publishers, editors, reporters, columnists, and correspondents. The recent lack of great editors he ascribes to the "commercialization of the press and its domination by the owners for whom the editors are but hired men."
2850. Wolseley, Roland E. The journalist's bookshelf; an annotated and selected bibliography of United States journalism. 6th ed. Chicago, Quill \& Scroll Foundation, 1955. 212 p.

First published in 1939. 55-10927 Z6940.W86 1955

A comprehensive list of the principal books pertaining to American journalism, intended as "a general guide for lay readers in journalism, working journalists, and scholars wishing to know of the major books published up to, but not including 1955." The books, each provided with a brief descriptive or evaluative note, are entered within 26 sections. Twenty-three correspond to the usual divisions of the field, such as business journalism or editorial writing; one lists biographies and autobiographies of journalists; one includes fiction and other creative writing about journalism both for adults and children; and the last is a miscellany. Cross references are provided, but the entries are not numbered. An introductory essay deplores the poverty of the literature, both as to quantity (only about 2500 titles in all) and quality, and suggests that journalism offers a challenge as a subject to American novelists, historians, biographers, and technical writers.

\section{B. Newspapers: Periods, Regions, and Topics}

2851. Andrews, J. Cutler. The North reports the Civil War. [Pittsburgh] University of Pittsburgh Press, 1955. 813 p. illus.

Bibliography: p. $76 \mathrm{I}-780$.

$$
55-6873 \text { E6og.A6 }
$$

Based upon manuscript as well as published sources, this is a massive yet lively and anecdotal chronicle of the Northern "special correspondents" of the Civil War and their reporting. The author notes the journalistic revolution caused by abnormal wartime conditions: an immense increase in newspaper circulation and consequent improvement in printing and makeup, a widespread introduction of Sunday and afternoon editions, and a realization that the prime requisite of a newspaper is prompt and adequately reported news. The newspapers' eagerness to outdo each other in news enterprise induced considerable rivalry among the Washington correspondents, whom Professor Andrews characterizes as preponderantly honest reporters circumscribed by "capricious censorship" and surrounded by a "fog of misinformation." The more than 300 roving field reporters who accompanied the Northern forces he calls "a heterogeneous lot," who, in many instances, endeavored to ingratiate themselves with the officers; their shortcomings are ascribed to the irresponsibility of their editors. The volume reprints numerous extracts illustrating how the major campaigns of the war appeared to the reporters accompanying the Union armies. Bernard A. Weisberger's Reporters for the Union (Boston, Little, Brown, 1953. 316 p.), a briefer and less systematic treatment, emphasizes rather the newspapers' point of view, contrasting the appearance of the war in the pages of Horace Greeley's New York Tribune and other Republican papers, with its appearance in James Gordon Bennett's New York Herald and other Democratic papers. A contemporary biography of one of the leading Civil War correspondents is William Elliot Griffis' Charles Carleton Coffin, War Correspondent, Traveller, Author, and Statesman (Boston, Estes \& Lauriat, 1898. 357 p.). As a result of his wartime experience, Coffin (1823-1896) became one of the most popular American historians of the period.

2852. Brigham, Clarence $S$. Journals and journeymen; a contribution to the history of early American newspapers. Philadelphia, University of Pennsylvania Press, 1950. xiv, r14 P.

$$
\text { 50-1032I } \mathrm{PN}_{4} 85^{8 .} \mathrm{B}_{7}
$$


The A. S. W. Rosenbach Fellowship in Bibliography.

Concerned with certain aspects of early American newspaper history, this collection of 15 informal lectures is an outgrowth of the author's History and Bibliography of American Newspapers, 1690-1820 (Worcester, Mass., American Antiquarian Society, 1947. 2 v.). He discusses late 18th- and early Igth-century efforts to record newspaper history and goes on to such matters as the similarity between early and modern newspaper titles, financial diffculties of the early publishers, time lag in the news, scurrility and political partisanship, and the careers of the 32 women who served as newspaper publishers in the years 1739-1820. Mr. Brigham remarks upon the historical value of the infinitely varied advertisements, the biographical and genealogical importance of the marriage and death records, and the political and social insights afforded by the Carriers' Addresses or New Year's Verses; and he indicates both scholarly accomplishments and lacunae in the field.

2853. Clark, Thomas D. The southern country editor. Indianapolis, Bobbs-Merrill, 1948. 365 p. facsims.

Bibliography: p. 339-346.

The rural press has been an important factor throughout the country, but through much of the South it was long the dominant and almost the only journalistic expression to be found, for the region was until recently overwhelmingly rural and agrarian. This makes a study of country editors more important for this area than for others, where metropolitan papers served a larger immediate group, and competed in many cases with rural papers through distant distribution. The South also has social problems, such as race relations and a oneparty system, which differentiate it from the rest of the country. The handling of these problems in the Southern rural press is discussed in some detail in this book, which gives its general history from the post-Civil War period to the near-present. It offers little in the way of statistics, which are unavailable in complete form, but is more concerned to study particular cases and representative situations. Although the author is sympathetic toward his editors, he has not hesitated to criticize the failings of Southern rural journalism. Professor Clark has also published three lectures on the part their rural newspapers play in the lives of the Southern people, in The Rural Press and the New South (Baton Rouge, Louisiana State University Press, 1948. 1 I I p.).

2854. Cook, Elizabeth Christine. Literary influences in colonial newspapers 1704-1750. New York [Columbia University Press] 1912. 279 p. (Columbia University studies in English and comparative literature) $\quad$ I3 $_{3}-2143 \mathrm{PN}_{4} 861 . \mathrm{C}_{72}$ Thesis (Ph. D.) - Columbia University, I912.

Bibliography: p. 266-272.

"An attempt to describe the most typical literary efforts, and to analyze the most typical literary influences" in nine 18th-century American weekly newspapers: The New England Courant, The New England Weekly Journal, The American Mercury (Philadelphia), The Pennsylvania Gazette, The New York Gazette, The New York Weekly Journal, The Maryland Gazette, The Virginia Gazette, and The South Carolina Gazette. The author demonstrates that the colonial paper, cut off from news by irregular communications and from politics by official attitudes, became "a definite type of literary weekly." The editor relied upon reprints from The Spectator and other English works, as well as upon imitations of the Addisonian essay, and gave space to such traditional subjects as philosophical speculation, anecdote, reminiscence, and connected narrative. Miss Cook discovers in colonial diction "the very tricks and manners of Addison and Steele," Pope's manner of polite formal compliment, the vein of Butler's Hudibras, grim Swiftian humor, and the forthright democratic spirit of The British Cato of Gordon and Trenchard.

2855. Emery, Edwin. History of the American Newspaper Publishers Association. Minneapolis, University of Minnesota Press, 1950. 263 p.

Bibliography: p. 25I-254.

A scholarly and detailed history of the controversial American Newspaper Publishers Association which leaves the reader to draw most of his own inferences. Chapters I-IV and IX trace the growth of this national trade association of daily newspapers from 1887 , when it was organized "primarily to further the business interests of its members," to 1949. The author, himself a professor of journalism, finds as continuing trends of activity the promotion of "group actions in the fields of advertising, mechanical development, labor relations, newsprint supply, circulation, and copyright and libel law." The ro remaining chapters deal with matters that have at times become special issues, such as postal rates and regulations, radio competition for news and advertising, development of effective and economical methods of production and transportation, and government actions affecting the publishing business.

2856. Griffith, Louis Turner, and John Erwin Talmadge. Georgia journalism, 1763-1950. Athens, University of Georgia Press, 1951. 4I3 p. illus. 
While the large papers and chains dominate the journalistic scene by their mere bulk, the greater part of American journalism has been carried on in relatively small and obscure papers, which have had the problem not only of bringing national and foreign news to their readers, but, more important in some respects, of presenting local news and views. Perhaps no one state may be said to have had a "typical" journalistic development; however, that of Georgia is in many ways representative of developments on a state level. This study of Georgia journalism, sponsored by the Georgia Press Association, opens with a survey, by Mr. Talmadge, of the development of Georgia newspapers from $\mathrm{r}_{7} 6_{3}$ to 1950. An expansion of Mr. Griffith's master's thesis, Part II is a history, based upon the official minutes, of the Georgia Press Association which was founded in 1887 to advance the business interests of the profession. Part III, an annotated directory of Georgia newspapers current in $195^{\circ}$, is a master's thesis by Mildred Lois Miscally, revised and enlarged by Mr. Griffith. James Johnston, editor of the first newspaper, The Georgia Gazette, in $\mathrm{r}^{6} 63$, is characterized as "the one important figure in early Georgia journalism," who "more than anyone else "established and sustained' the newspaper as an institution on Georgia soil." Henry W. Grady, editor of The Atlanta Constitution during the 1870's and 8o's, apostle of the "New South" and of the "New journalism" of Joseph Pulitzer, is considered the single most important publicist.

2857. Hooper, Osman Castle. History of Ohio journalism, I793-1933. Columbus, Ohio, Spahr \& Glenn, I933. I90 p. illus.

$\begin{array}{lll}34-667 & \mathrm{PN}_{4} 897 . \mathrm{O}_{33} \mathrm{H} 6\end{array}$ A pioneering history of Ohio journalism from its beginnings. The author distinguishes four periods: Jeffersonian-Federalist (1793-1815), during which the dominant idea of the territorial newcomers was freedom, statehood was won, and the Federalist papers fought a losing political battle; JacksonianWhig (1816-1856), when newspapers were established to promote the cause of John Quincy Adams, Clay, and Harrison against Jackson; Transition (1857-1900), which saw the formation of the Republican Party and the rise of the Republican reform press, the development of newspaper service to the community, and the appearance of evening papers; and the Present (190r-r933), in which the party organ per se has virtually disappeared, and community or city service is increasingly emphasized. Very briefly, Professor Hooper outlines the achievements of such notable figures as Charles Hammond of the Cincinnati Gazette, Edward W. Scripps of the Cleveland Penny Press, J. W. Gray and Charles F. Browne (Artemus Ward) of the Cleveland Plain
Dealer, and D. R. Locke (Petroleum V. Nasby) of the Toledo Blade.

2858. Nevins, Allan. American press opinion, Washington to Coolidge; a documentary record of editorial leadership and criticism, 1785-1927. Boston, Heath, 1928. xxv, 598 p. illus.

$$
\text { 28-24815 EI73.N52 }
$$

A collection of editorials from American newspapers selected according to Professor Nevins' theory "that specimens of the best work of Greeley, Dana, and Godkin are of immediate present-day interest to journalists, students, and many general readers; that some outstanding American editorials possess qualities entitling them to permanent preservation in easily accessible form; above all, that a wide variety of typical editorials from representative journals, chronologically arranged, will furnish a valuable record of the history of public opinion." Each of the four parts is introduced by a historical essay devoted to major trends and accomplishments of the press during its period. In the editor's opinion, no other American newspaper has equalled the long record of distinction maintained by The New York Evening Post under William Coleman, William Cullen Bryant, Carl Schurz, Edwin L. Godkin, Rollo Ogden, and Simeon Strunsky. Professor Nevins considers Horace Greeley preeminent among editors for the vigor, terseness, and persuasiveness of his writing in The New York Tribune and for his development of the modern American editorial page.

2859. Nevins, Allan, and Frank Weitenkampf. A century of political cartoons; caricature in the United States from I80o to Igoo. With 100 reproductions of cartoons. New York, Scribner, 1944. $190 \mathrm{p}$. 44-3029. EI78.4. N47 In this volume a professor of American history at Columbia University, and the former curator of prints at the New York Public Library, have combined to produce a work illustrating the development of the 19th-century political cartoon in the United States. Each page of text faces a page reproducing the cartoon (in a few cases two) on which the text is based. Many of the cartoons are annotated in terms of their relation to the development of the art, as well as to the political situation with which they deal. While the cartoons at first appeared as separately published prints, with improved graphic methods they found a home in the illustrated journals of the day, and eventually in the daily newspapers. This attractive volume affords a piquant record of the political currents of the century, and of course exhibits the evolution of styles in cartooning, but Professor Nevins, well-informed 
as he is, does not always succeed in explaining the more baffling aspects of these cartoons.

2860. Rosewater, Victor. History of coöperative news-gathering in the United States. New York, Appleton, 1930. xiv, $430 \mathrm{p}$.

Bibliography: p. $411-416$.

$$
\text { 30-10687 } \mathrm{PN}_{4} 855 \cdot \mathrm{R} 6
$$

The book begins with a discussion of early "systematic news-gathering." There follow chapters on the early means of disseminating news, such as horse express, railway express, transatlantic steamer, or telegraph. Subsequent chapters take up the problem of the forming of a news association in the Igth century, with attention concentrated on the Associated Press. The book concludes with a series of chapters on the major cooperative newsgathering agencies: the Associated Press, the United Press, and the International News Service. The author is mainly interested in presenting the story of the development of these agencies, and pays little attention to cooperative work within newspaper chains. The scope of the work does not permit any serious analysis of the social consequences of so great an increase in the freshness and quantity of the news, nor of the new problems of choice and balanced presentation confronting the editors of individual papers. Deadline Every Minute; the Story of The United Press, by Joe Alex Morris (New York, Doubleday, 1957. $35^{6}$ p.), published to mark the completion of the Association's first half-century, is based in large part on interviews and information from past and present staff members, and, along with multitudinous anecdotes of spectacular coups, reveals much concerning the development of news techniques.

286r. Rosten, Leo C. The Washington correspondents. New York, Harcourt, Brace,

1937. xx, 436 p. $\quad 37-375^{8} 3 \mathrm{PN}_{4} 899 . \mathrm{W}_{3} \mathrm{C} 68$

Bibliography: p. 393-421.

This book was written on a predoctoral fellowship, and was designed as an analysis of Washington press correspondents and their work. Because Washington as the Nation's capital is the source of a great portion of the Nation's news, an unusually large number of correspondents cover it for the $\mathrm{Na}$ tion's newspapers, news syndicates, and other media. The first part of the book covers the historical development and methods of Washington reporting; it opens with a review of presidential press relations, and proceeds to other news sources (government agencies, sub rosa gossip, story plants, etc.). The second part of the book is based largely on two questionnaires, and studies the backgrounds, views, and working situations of the correspondents. The third part attempts to discover to what degree the backgrounds and prejudices of the correspondents, and such news sources as government releases and formal conferences, affect the news which is published. A series of appendixes tabulate the results of the questionnaires. The author is better known for his humorous writings published under the name of Leonard Q. Ross.

2862. Tebbel, John W. An American dynasty. Garden City, N. Y., Doubleday, 1947. 363 p. illus. 47-30087 $\mathrm{PN}_{4} 899 . \mathrm{C}_{4} \mathrm{~T}_{3}$

This highly informative book opens with a detailed study. of Joseph Medill and the Chicago Tribune, in which he acquired a partnership in 1855. In 1874 he assumed full control and directed it until his death in 1899. Medill was one of the founders of the Republican Party, and a basic Republicanism has continued in the paper and the family to this day. Medill built his paper into a major influence in the Midwest, and the Tribune continues to have the largest and widest circulation in the area, although the extent of its influence has been disputed, since a majority of its readers seem often to vote Democratic. After Medill's death in 1899, the Tribune was controlled until I9I 4 not by a monarch, but by an editorial board consisting of Robert W. Patterson, Medill McCormick, and James Keeley. In I9I4 control was assumed by Robert Rutherford McCormick, who followed his grandfather's personalized journalism, to which he added an isolationism which at times seemed to regard the Eastern United States as an extension of Europe. A third part of the book is devoted to Joseph Patterson, another grandson of Joseph Medill; Patterson obtained control of the New York Daily News in Igrg and under his operation it became the most conspicuous tabloid in the country. Upon his death in 1946 control of the paper passed to a board headed by his sister, Eleanor ("Cissy") Patterson. Miss Patterson came into journalistic prominence when she became editor, working for the Hearst chain, of the Washington Herald in 1930; in 1937 she leased the Washington Times, so as to have an organ in which to express herself when she disagreed with Hearst. She purchased both these papers in 1939, combining them as the Washington Times-Herald, which paper she alined in the family tradition of slanted news, comics, personalities, and mass circulation. Some time after her death in 1948 the paper was sold to the liberal, independent Washington Post. The other papers, despite the death of the leading characters in An American Dynasty, continue to be edited as before. Their importance in American journalistic history resides in the fact that their combined circulation was surpassed only by that of the Hearst chain, though both groups on many leading issues ran counter to prevailing American beliefs. 
2863. Turnbull, George S. History of Oregon newspapers. Portland, Or., Binfords \& Mort, 1939. $560 \mathrm{p}$. illus. $\quad 40-1256 \quad \mathrm{PN}_{4} 897 . \mathrm{O}_{73} \mathrm{~T} 8$ A record of the progress of Oregon journalism, 1846-1939, from the founding of the pioneer Oregon Spectator at Oregon City, the first newspaper issued west of the Missouri River, to the operations of the modern metropolitan press. Parts I-II are devoted to the metropolitan newspapers, most of them dailies. The more important journals are accorded separate chapters, the lesser, paragraphs or even a sentence or two. Parts III-IX are devoted to special aspects of the subject: journalism by counties, arranged in chronological order of the founding of their first papers; reporting; society writing; Sunday features; sports writing; trade and class publications; and the growth of the newspaper business. Professor Turnbull emphasizes the political bent and personal journalism of the early papers, as well as the emergence in the I880's and 90's of the doctrine that news gathering and writing are the primary functions of the newspaper. He considers Harvey Whitefield Scott, editor of the Republican Oregonian, $1865-$ $1872,1877^{-1910}$, and C. S. Jackson, editor of the Democratic Oregon Journal, 1902-1919, as perhaps the most distinguished Oregon publicists.

2864. Watson, Elmo Scott. A history of newspaper syndicates in the United States, $1865-$

1935. Chicago, 1936. 98 p. illus.

$$
\text { 36-1847I } \mathrm{PN}_{4} 888 . \mathrm{S}_{9} \mathrm{~W}_{3} \mathrm{I}_{936}
$$

Bibliography: p. 86-89.

"A directory of newspaper syndicates in the United States": p. 90-94.

A history of American newspaper syndicates, originating in a thesis for the degree of master of science in journalism at Northwestern University. Chapters I-II describe the experiments of the 1840 's and 50's; the development in 186r of an auxiliary service of Civil War news, miscellaneous matter, and advertising for five Wisconsin weeklies by The Wisconsin State Journal; and the establishment in
1865, exclusively for country papers, of the first independent newspaper syndicate by Ansel Nash Kellogg (1832-1886). Chapters III-VIII and $X$ trace the expansion of syndicate operations among city dailies as well as country weeklies in every part of the country, the rise in numbers to some 130 businesses by 1935, and the elaboration of material offered into more than 1,600 separate features providing entertainment or enlightenment. Sunday magazines and the weekday use of syndicated fiction, special articles, and departmental matter have been important factors, the author believes, in reducing newspaper production costs and in stimulating circulation. The progress in mechanical means of reproducing syndicated features is incidentally described. Chapter IX is devoted to the cooperative press associations and the news agencies.

2865. Waugh, Coulton. The comics. New York, Macmillan, 1947. 360 p. illus.

$47-12339 \mathrm{NC}_{42} 6 . \mathrm{W}_{3}$

An informal and enthusiastic but detailed history of American comic strips, "largely put together from study of the actual comics as they have appeared in newspapers-both old and new." The author, himself a practitioner, surveys the field from its rather crude, sensational, and sadistic beginnings during the I89o's in the hands of James Swinnerton, Richard Felton Outcault, and Rudolph Dirks, to the literally illustrated, war-preoccupied strips of the early 1940's, and the reemergence of the earlier funny type in 1946 . The comic, a sequence of pictures with a continuing character, aims to build newspaper circulation and to provide informal entertainment for the masses. "The comic sells the paper; the paper gives the comic-strip character his chance to invade millions of homes and impress his personality on millions of hearts." A nationwide phenomenon since the development of feature syndication in 1915 , the strip normally appeals to basic human instincts and interests, and avoids racial, political, and other controversial matter.

\section{Individual Newspapers}

2866. Acheson, Sam Hanna. 35,000 days in Texas; a history of The Dallas News and its forbears. New York, Macmillan, 1938. 337 p. illus. $\quad 38-2754^{\circ} \mathrm{PN}_{4899 . D_{34} \mathrm{~N}_{4}}$

A history of The Dallas Morning News, founded in 1885, and of its parent journal, the Galveston Nerus, founded in the Republic of Texas in 1842 as "a struggling hope housed in a flimsy shack," but which had become by 1938 "the oldest business institution in Texas." Beside the presentation of news, both papers have been outspokenly concerned with state and national politics, particularly Democratic, and other public issues as well as local matters. Since the author quotes liberally from their pages, 
his book does not merely chronicle a pioneer publishing venture but reflects much of the political and social history of Texas. The first third of the volume traces the fortunes of the Galveston News to 1885 , by which time it had been for 30 years "the most widely circulated, the wealthiest and the most influential paper in Texas"; the remainder is devoted mainly to The Dallas Morning News, originally almost a facsimile of its elder, and the first example of American chain journalism.

2867. Ashton, Wendell J. Voice in the West; biography of a pioneer newspaper. New York, Duell, Sloan \& Pearce, I950. xv, 424 p. illus. 50-738 ${ }^{\circ} \mathrm{PN}_{4} 899 . \mathrm{S}_{3} 85 \mathrm{D}_{4}$

A history of the Salt Lake City Deseret News, which still bears the name of "the land of the honeybee" applied by the pioneer Mormons to Utah and the adjacent territories where they settled. Founded by them in 1850 , the News is now one of the oldest in continuous circulation in the West, and remains a major organ of the Mormon Church, for which it does much job printing, including books, other periodicals, and forms. Mr. Ashton's narrative is concise, sticks to facts, relates the paper's history to the general development of the intermountain West, and avoids the controversial issues involved in religious strife and the Mormons' relations with the outside world. He does, however, depict the early tribulations of the paper, and reports its failings along with its struggle to maintain the freedom of the press. There is a good bibliography (p. $[400]-404$ ) and an extensive index.

2868. Baehr, Harry W. The New York Tribune since the Civil War. New York, Dodd, Mead, 1936. 420 p. illus.

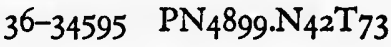

"Note on sources": p. 397-40I.

Although the New York Tribune was first issued in $\mathrm{I} 84 \mathrm{I}$, this detailed history, a $\mathrm{Ph}$. D. thesis, begins with 1865 , the year of "its real beginnings as a modern newspaper," and continues the chronicle to 1936. Chapters I-VI deal with the editorship of Horace Greeley, the founder; Chapters VII-XIX with those of Whitelaw Reid (from 1872), and his son and successor, Ogden Mills Reid (from I9I2). The author attributes the position of the paper in 1865 as the "greatest organ of public opinion in the United States" to Greeley's opposition to slavery, the force and unrivaled eloquence of his editorials, his zeal for news gathering and political reporting, and his promotion of such fields as book reviews and scientific reports. Yet even then, Mr. Baehr considers, Greeley was a "man who had outlived his time." Whitelaw Reid "strove with great success to achieve the ideal of a paper of brains."
Believing firmly in rugged individualism, the authority of law, and the widest freedom of individual initiative, he "voiced the underlying philosophy of the Tribune from the death of Greeley [ 1872$]$ down to the present [1936]." In I924 the New York Tribune purchased the New York Herald, and assumed the name New York Herald-Tribune. It is regarded by many as the leading Republican newspaper in the country.

2869. Berger, Meyer. The story of The New York Times, 1851-1951. New York, Simon \& Schuster, 1951. xiv, 589 p. illus.

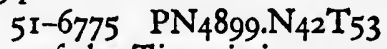

This centennial history of the Times is in a way an official biography, and it maintains much of the objectivity which has been so prominent a part of the paper's policy. The Times was founded in I 85 I by Henry Jarvis Raymond (1820-1869), whose goal was a conservative, objective news coverage. Raymond's career as a leading journalist and as a prominent Republican politician is studied in Ernest Francis Brown's Raymond of the Times (New York, Norton, I95I. 345 p.). Shortly after Raymond's death George Jones (I8II-I89I) took over as head and for a time continued the paper's conservative policy. He did almost no writing himself, but is important as the "first great businessman publisher." Under him the Times did some outstanding crusading, as in uncovering the Tweed Ring-Tammany Hall corruption. Under Jones there also occurred a notable policy shift; the Times, Republican since its inception, in 1872 opposed Blaine and supported Cleveland. Cleveland won the election, but the Times lost Republican advertising and went into a slump. After Jones' death, the paper was taken over by a group of employees. It was heavily in debt and its end seemed near when Adolf S. Ochs (1858-1935) took control in 1896. The bulk of this book is devoted to the story of the Times under Ochs, whose career is even more fully studied in Gerald W. Johnson's An Honorable Titan (New York, Harper, 1946. 313 p.). Ochs set out to restore the Times as a conservative, independent newspaper, with a policy of acting as "a forum for the consideration of all questions of public importance." He undertook to provide coverage of the "neglected non-sensational" news fields, such as financial and other commercial news, government affairs, books, education, and the like. The paper acquired a reputation as a bible for businessmen, rapidly built up advertising, and prospered in its nonsensational way. Many view it as America's foremost paper, and as usually having the most complete and accurate reports of worldwide general news, with major speeches and reports printed in full, elaborate studies of sociological problems, up-to- 
date reports for the layman on scientific advances, a wide coverage of commercial news, a leading book review section (see no. 2564), extensive reports on and criticism of the fine and popular arts, etc. After the death of Ochs in 1935, his policies were continued by his son-in-law, Arthur Hays Sulzberger (b. $189 \mathrm{r}$ ). It has continued to grow in size, circulation, and other aspects. Berger's book concludes with a list of the many Pulitzer prizes won by the paper and members of its staff, to which many more could now be added.

2870. Chamberlin, Joseph Edgar. The Boston Transcript, a history of its first hundred years. Boston, Houghton Mifflin, I930. 241 p. illus. $\quad 30-14830 \quad \mathrm{PN}_{4} 899 . \mathrm{B} 6 \mathrm{E} 8$

A review of the first century of The Boston Transcript (1830-1930), based upon its files, and told chiefly in terms of the personalities and achievements of its successive editors, who usually "represented conservative prosperity" in a conservatively prosperous New England city. The author, a staff member of the Transcript at the time of writing, devotes only 6 of his 21 chapters to the 2oth century. At its beginning, he notes, "the Transcript was indeed very welcome to the conservative classes as a reaction from the 'black journalism' of the time"; it soon espoused the arts, and eschewed sensationalism and the personal attack. Mr. Chamberlin clearly takes pride in the "respectable and intelligent character," the "recognized quality" of this Republican paper's readers, and does not question a policy that "has doubled the volume of the paper's advertising and trebled the rate in recent years, with no corresponding increase in the paper's circulation." The Transcript ceased publication in $194 \mathrm{I}$.

2871. Dabney, Thomas Ewing. One hundred great years; the story of The Times-Picayune from its founding to 1940. Baton Rouge, Louisiana State University Press, I944. 552 p.

$$
44-5253 \quad \mathrm{PN}_{4} 899 . \mathrm{N}_{32} \mathrm{~T}_{3}
$$

A composite history of The Times-Picayune, founded in 1837 and issued until April 6, 1914, as The Daily Picayune, and of roo years in the life of New Orleans, its sponsoring city. The author, a former staff member, attributes its initial success to its relative cheapness, to its "broader interpretation of news values, to the brevity of its stories, to its humorous slant, and to the freedom of the publishers from political entanglements, as well as their fearlessness and the good nature of their criticisms." During the War with Mexico ( $1846-48$ ), George Wilkins Kendall, a founder of the Picayune, "created the tradition of the war correspondent who followed the troops into battle to get the news." By Ig04, Mr. Dabney notes, the growing population of the city and the expanding operations of the paper forced "the retreat of the editor's personality," and the Picayune became "impersonal and objective, a factual medium, a means of marshaling data from which the public could draw conclusions, without the guidance of those it knew and trusted."

2872. Laney, Al. Paris Herald, the incredible newspaper. New York, Appleton-Century,

1947. 334 p. 47-1 1001 PN4899. N42H44

In 1887 the younger James Gordon Bennett (q. v.) decided to start a paper in France; in its first few decades the paper, named the Paris Herald after Bennett's New York Herald, reflected the owner's views of what it should be. In time it was transformed from not much more than a social column to a genuine newspaper catering primarily to Americans in Europe. It became a leading news source, and it continued to appear until the Germans occupied Paris in 1940. It resumed publication as the European edition of the New York Herald-Tribune, almost immediately after the American liberation of Paris. Mr. Laney's account is primarily his personal view of the paper as an editor there during the I920's and 30's, with a brief glance at its earlier and later history. The book reflects a relatively unusual activity of American journalism and also gives a picture of the work of foreign correspondents, many of whom began at, worked through, or cooperated with the Paris Herald. It also reflects the extensive activities of the surprisingly large number of Americans in Paris during Mr. Laney's sojourn.

2873. Nevins, Allan. The Evening Post; a century of journalism. New York, Boni \& Liveright, 1922. 590 p. illus.

$$
\text { 22-227I7 } \mathrm{PN}_{4} 899 . \mathrm{N}_{42} \mathrm{P}_{7}
$$

A history to the year 1922 of the New York Evening Post, established as a Federalist journal in r $80 \mathrm{r}$ by Alexander Hamilton and a group of his followers. Aiming to avoid a "mere office-history" at the one extreme and the whole panorama of igthcentury America at the other, the author has selected "the most important, interesting, and illuminating aspects and episodes of the newspaper's history." More than half of the book is devoted to the 50-year editorship (1829-78) of William Cullen Bryant, who by 1850 was firmly established as New York's foremost citizen. His editorial greatness is here attributed to the rhetoric of his grand style, his soundness of judgment and unwavering courage in maintaining it, and his consistent adherence to the principles of freedom and democracy. Other editors of the Post, among them Bryant's son-in-law, Parke Godwin, Carl Schurz, E. L. Godkin, and Rollo Ogden, are more summarily dealt with. 
2874. O'Brien, Frank M. The story of The Sun, New York: 1833-r928. New ed. New York, Appleton, 1928. xviii, 305 p. illus. 28-2925 PN4899. $\mathrm{N}_{442} \mathrm{~S} 8 \quad 1928$

A history of the New York Sun, founded in 1833 as a popular penny newspaper by Benjamin H. Day, who overcame the lack of facilities for the transmission of news "by the simple method of using what news was nearest at hand-the incidental happenings of New York life," and who brought the paper to the people by instituting the first newsboy carrier system. A reason for The Sun's popularity in the I85o's and 60's, when it lacked real news guidance, spirited editorials, or political prestige, was the light fiction introduced by Moses S. Beach, proprietor of the paper from 1852 to 1868 . Charles A. Dana, in his "reign" from I868-97, "revived American journalism from that trance in which it had forgotten that everybody is human and that the English language is alive and fluid." Chiefly to him and to his great editorial writer, Edward Page Mitchell, who retired in 1920, the author attributes the quality and renown of The Sun's editorial page. At the time of writing Mr. O'Brien was himself editor of The Sun.

2875. Smith, James Eugene. One hundred years of Hartford's Courant, from colonial times through the Civil War. New Haven, Yale University Press, 1949. $34^{2} \mathrm{p}$.

Bibliography: p. [328]-329.

49-I $1937 \mathrm{PN}_{4} 899 . \mathrm{H}_{35} \mathrm{C} 6$

A report on the first century, 1764-1865, of the Hartford Courant. "Embellished news reprints, rumors, lamentations, predictions," and other tidings from England, the West Indies, and port towns along the Atlantic filled this provincial journal until well into the Revolution, "all suggesting the deeprunning disapproval of an imperial meddling with the prosperity of trading." Strongly Federalist, the paper and its editors were "complacent and contented," Mr. Smith believes, during the first years of the Washington administration, but by 1800 were viewing Jefferson's presidency as "catastrophic," and saw Jackson's behavior in 1830 as a demonstration of an "unquenchable thirst for power." Van Buren was regarded as a mere henchman of Jackson and a plunderer of the public domain. In the 1850's, the Courant "drifted into the Republican party, supporting Lincoln's administration during the Civil War."

2876. The Sunpapers of Baltimore, by Gerald W. Johnson, Frank R. Kent, H. L. Mencken [and] Hamilton Owens. New York, Knopf, 1937. xii, 430, xvi p. illus. 37-9III $\mathrm{PN}_{4} 899 \cdot \mathrm{B}_{3} \mathrm{~S}_{76} 6$

A centennial history of The Sun and The Evening Sun of Baltimore, which together are affectionately known as the "Sunpapers." In Chapters I-VI, Mr. Johnson deals with the era of personal journalism and brings the narrative to the death of A. S. Abell, "the Founder," who, impressed by the financial success of Benjamin H. Day's The Sun, New York, invaded the realm of the penny press for the people in 1837 , and who established the policy "that the first business of a newspaper is to furnish its readers with the news in which they are interested, whether or not it conforms to the editor's prejudices." Mr. Kent, in Chapters VII-X, describes the papers' battles against the Democratic state machine in the r88's and 9o's. Mr. Mencken, in Chapters XIXVIII, considers the partnership of the founder's sons and the subsequent formation of a corporation. Author of the three concluding chapters, Mr. Owens describes efforts of the directors to build up the news and editorial departments of their journals. All four writers have been closely connected with the "Sunpapers."

\section{Newspapermen}

2877. [Bennett] Carlson, Oliver. The man who made news, James Gordon Bennett. New

York, Duell, Sloan \& Pearce, 1942. $440 \mathrm{p}$.

Bibliography: p. 423-428. $42-24810 \quad \mathrm{PN}_{4} 874 \cdot \mathrm{B}_{4} \mathrm{C}_{3}$

James Gordon Bennett ( $1795-1872$ ) was a Scottish immigrant whose early employment in this country was in jobs mainly connected with newspapers; in this connection he is said to have been "the first real Washington correspondent." In 1835 he founded the New York Herald and rapidly built it up to the newspaper of largest circulation in New York; in time it became the best known American paper in the world. This was due to Bennett's many innovations as a journalist. When he started the Herald, newspapers were organs of particular groups, usually political. Bennett conceived of the newspaper as an organ for the dissemination of news without partisan coloration. This radical view led to a far greater variety of material being included 
than had previously been considered suitable. This led to charges of sensationalism, and the bruising of many tender sensibilities. Denunciations of Bennett and the sales of his paper increased in a direct ratio. In adding topics to the categories of what might be considered news, and in consciously seeking information for full presentation, Bennett revolutionized journalism, so that most papers at the end of his career were far different from what they had been at its outset. Shortly after the Civil War Bennett turned the editorship of his paper over to his son of the same name (I84I-Igr8) who also played an important role in the history of journalism. Both are studied in Don C. Seitz's The James Gordon Bennetts, Father and Son, Proprietors of the New York Herald (Indianapolis, Bobbs-Merrill, 1928. 405 p.).

2878. [Bonfils and Tammen] Fowler, Gene. Timber line; a story of Bonfils and Tammen. Garden City, N. Y., Garden City Books, 1951, '1933. 480 p. $\quad 52-2466 \mathrm{PN}_{4} 874$. B623 $_{3} \mathrm{~F} 6$ I95I

A study of Frederick Gilmer Bonfils (1860-1933) and Harry Heye Tammen (1856-r924) and of 38 years of their newspaper; they became partners in 1895 and took over The Denver Post. The paper was a phenomenally successful example of yellow journalism, having set out to out-Hearst Hearst. In tracing its history, the author recounts so many digressive anecdotes that his work is as much a lively history of early Denver as it is a biography or study of the paper. Although an entertaining work that provides a good idea of the nature of the paper and the background against which it was produced, it undertakes no journalistic analysis. The author began his writing career as a reporter for the Post. The book itself is written in a lively journalistic style. Mr. Fowler's own autobiography, $A$ Solo in Tom-toms (New York, Viking Press, r 946. 390 p.), which has some warm admirers, is largely taken up by his boyhood, and only the last hundredodd pages describe his beginnings in journalism.

2879. [Bowles] Merriam, George S. The life and times of Samuel Bowles. New York, Century Co., r885. 2 v. $7-12040$ E66r.B78 $\mathrm{PN}_{4} 874 . \mathrm{B}_{3} \mathrm{M}_{4}$

Bowles (1826-1878) in his teens went to work for his father's paper, the Springfield Republican. In the mid-1840's the son was instrumental in changing the paper to a daily, and he assumed a rapidly increasing share of the writing and policy burden. Springfield, Massachusetts, was then a provincial town, but Bowles made his paper into one of the most important in the Nation. He thus became one of the first small-town editors to secure a national audience. Merriam's biography details much of his journalistic activity, which became increasingly tied in with the national events of the period, and prints copious extracts from his letters. From 1855 Bowles was one of the leaders of the new Republican Party, and his biography is an important source for its history during the next two decades.

2880. [Bradford] De Armond, Anna Janney. Andrew Bradford, colonial journalist. Newark, University of Delaware Press, 1949. $272 \mathrm{p}$. facsims. $\quad 50-34 \mathrm{I} 9 \mathrm{PN}_{4} 874 \cdot \mathrm{B66D}_{4}$ 1949a Bibliography: p. 247-25I.

Andrew Bradford (1686-1742) was one of the pioneers of printing in the middle colonies. The American Weekly Mercury, which he founded in Philadelphia in 1719, was the first newspaper in Pennsylvania and the third in the Thirteen Colonies. Since little is known about Bradford's apparently uneventful life, this University of Pennsylvania dissertation is mainly a study of the newspaper. Under Bradford it maintained itself as one of the best and most widely read newspapers in the Colonies. It is important not only as one of the better examples of colonial journalism, but also for the principles of the freedom of the press which Bradford expressed in it, thus providing Andrew Hamilton with many of the arguments used in the trial of John Peter Zenger (no. 293 I), the point usually taken to mark establishment of the freedom of the press in this country. After her husband's death in 1742 , Cornelia Bradford continued to publish the paper into 1746.

288r. [Dana] Stone, Candace. Dana and the Sun. New York, Dodd, Mead, r 938.431 p. 39-I I93I $\mathrm{PN}_{4} 874 . \mathrm{D}_{3} \mathrm{~S} 8 \mathrm{I}_{938}$

The early career of Charles Anderson Dana (1819-1897) included residence at Brook Farm and partial adherence to the Transcendentalist movement, editorial work under Greeley on the Tribune, and service as "foreign correspondent" in Europe observing the revolutions of $1848-1849$. His letters from Europe appeared in five papers and have been called the first "syndicated" column in American journalism. During the Civil War Dana disagreed with Greeley on editorial policy and resigned. Soon after he took an active part in the war as adviser and observer working with Lincoln, Stanton, and Grant. After the war, in 1868 , he was able to purchase the New York Sun, which he continued to edit until his death in 1897 . In these three decades he made the paper one of the foremost in American journalism. He made it a vehicle for news as such, but he also made it a personal organ noted for its style, vigor, and independence, so that it was read by many who disagreed with its somewhat erratic policies. Stone's biography, a Columbia University 
dissertation, emphasizes Dana's career with the Sun and is in large part an analysis of the editorial policies revealed in the paper. A more general biography is James Harrison Wilson's The Life of Charles A. Dana (New York, Harper, 1907. 544 p.). A history of the paper itself is by Frank O'Brien (no. 2874).

2882. Godkin, Edwin Lawrence. Life and letters; edited by Rollo Ogden. New York, Macmillan, 1907. 2 v. 7-12877 $\mathrm{PN}_{4} 874 . \mathrm{G}_{5} \mathrm{O}_{3}$

Godkin (1831-1902) was born in Ireland, educated for the law, and became a practicing journalist. In 1856 he came to America where, after touring the South as a correspondent, he founded the Nation (also treated in no. 2921). To this he applied his wide learning and considerable writing ability, making of it a periodical with whose views thinking contemporaries had to reckon, even when they disagreed. Its circulation was never large, but its influence on other journals was from the beginning extensive. In 1881 the Nation and the New York Evening Post effected a merger of sorts, whereby the weekly printed the editorial matter appearing during the week in the daily paper. Carl Schurz (q. v.) was editor-in-chief of both periodicals, with Godkin under him. In 1883 Schurz left, and Godkin became editor-in-chief, continuing in this position until his retirement, because of declining health, in 1900. In both the daily and the weekly paper he maintained his liberal position, never giving in to personal favoritism, waging battle for many worthy causes, and establishing an impressive record as an independent editor. The present work is made up largely of excerpts from the numerous writings of Godkin, especially from his letters. Volume 2 provides an incomplete bibliography (p. 260-268) of Godkin's books and articles.

2883. [Greeley] Van Deusen, Glyndon G. Horace Greeley, nineteenth-century crusader. Philadelphia, University of Pennsylvania Press, 1953. 445 p. illus.

Bibliography: p. [431] 437 .

Greeley (1811-1872) began newspaper work as an apprentice printer at the age of fifteen. He undertook a succession of printing ventures followed by publishing and editing ones, including literary and political periodicals. In 184 I he established the New York Tribune, and as its editor became one of America's leading journalists. Greeley was important as an idealistic crusader who fought for many reforms, some of them quite radical in his own day. He was of further significance in making his paper an organ for the vigorous expression of varying views on crucial issues; many of the leading writers and thinkers of his day were represented in the columns and on the staff of the Tribune. His career ended in anticlimax with his defeat in the 1872 presidential election, when he ran as the Democratic candidate against Grant. Greeley's vigorous and complex personality has inspired many biographies, from James Parton's early The Life of Horace Greeley (New York, Mason Bros., 1855.442 p.) to William Harlan Hale's Horace Greeley, Voice of the People (New York, Harper, 1950. 377 p.). His autobiography remains a valuable book for understanding Greeley: Recollections of a Busy Life (New York, Ford, 1868. 624 p.).

2884. [Hearst] Tebbel, John W. The life and good times of William Randolph Hearst. New York, Dutton, 1952. 386 p.

$$
{ }^{2-8}-825^{8} \quad \mathrm{PN}_{4} 874 . \mathrm{H}_{4} \mathrm{~T}_{4}
$$

It is generally agreed that Hearst (I863-I95I) was one of the greatest forces in American journalism; there is radical disagreement as to what he was a force for. Part of Hearst's vision was derived from the popularization techniques of Pulitzer (no. 2889). A man of extremes, boundless energy, and great inherited wealth (his father was a multimillionaire), Hearst set out to surpass Pulitzer. In the course of pursuing this ambition he created a newspaper empire across the country, attracted a phenomenal mass readership for his periodicals, entered on a grand scale into allied fields such as magazine publishing and radio broadcasting, and brought yellow journalism to its peak. However, it was not merely his sensationalism which aroused his opponents, but also the "causes" for which he fought in front page editorials, slanted news coverage, etc. With his tendency to extreme stands he managed, it has been said, to achieve the almost unique position of having at some time or other offended every person or group exposed to his papers. He also had large political ambitions, first as a candidate and then as a picker of candidates, and as a swayer of public opinion at the polls. Because of his certitude of rightness on so many occasions, and because of the mass communications power with which he backed up his convictions, Hearst usually aroused strong emotions in those exposed to him. For that reason the problem of writing a definitive biography is often regarded as insurmountable, at least for some time to come. Tebbel's account is an attempt to be objective, but for that very reason the many with extreme views of Hearst find it pallid and inadequate. An earlier and somewhat more colorful biography, which approximated a middle view, is Hearst, Lord of San Simeon (New York, Viking Press, 1936. 332 p.), by Oliver Carlson and Ernest Sutherland Bates. A more critical work which appeared in the same year is Ferdinand Lundberg's 
Imperial Hearst, a Social Biography (New York, Equinox Cooperative Press', I936. 406 p.), which was issued in 1937 in a Modern Library edition. Also published in the same year, and contrasting with these, was Mrs. Fremont Older's William Randolph Hearst, American (New York, AppletonCentury, 1936. 58 r p.), a semiofficial and extremely favorable presentation of the "most misunderstood man in America." A recent favorable study, but one of greater moderation, is John $\mathrm{K}$. Winkler's William Randolph Hearst, a New Appraisal (New York, Hastings House, 1955. 325 p.), a revision of the author's $W . R$. Hearst, an American Phenomenon (New York, Simon \& Schuster, 1928. 354 p.). Of special interest is William Randolph Hearst, a Portrait in His Own Words (New York, Simon \& Schuster, 1952. 309 p.), which, with the approval of Hearst, was compiled from his letters and other writings by Edmond D. Coblentz, who started working for Hearst in 1900.

2885. Howe, Edgar W. Plain people. New York, Dodd, Mead, 1929. 317 p.

29-7426 $\mathrm{PS}_{2014} \cdot \mathrm{H}_{5} \mathrm{Z}_{5} \quad \mathrm{Ig} 29$

E. W. Howe (1854-1937) spent most of his life as a small-town newspaper man. As editor of the Atchison, Kansas, Globe he achieved a modest national prominence for his philosophical paragraphs, and it has been said that for a while his paper was one of the most frequently quoted in the country. This autobiography therefore provides a good background for successful small-town journalism. Howe was also a literary figure of some note, and his work is discussed in the Literature chapter of this bibliography (nos. 959-963).

2886. McRae, Milton A. Forty years in newspaperdom; the autobiography of a newspaper man. New York, Brentano's, r924. xviii, 496 p. illus. 24-25208 $\mathrm{PN}_{4} 874 \cdot \mathrm{M}_{47} \mathrm{~A}_{3}$

McRae (1858-1930) established or bought control of many newspapers throughout the United States. Much of his work was done with E. W. Scripps (no. 28go), and their joint chain was known as the Scripps-McRae League, since transformed into the Scripps-Howard newspapers. McRae's loosely written autobiography reveals his acquaintanceship with many of the nation's leading newspapermen, and gives insight into much of the journalistic history of forty years. The remainder of the book is devoted to his wide travels and to general observations.

2887. [Nelson] Johnson, Icie F. William Rockhill Nelson and the Kansas City Star; their relation to the development of the beauty and culture of Kansas City and the Middle West. Introd. by Wil- liam Allen White. Kansas City, Mo., Burton Pub. Co., 1935. 208 p. $\quad 36-19204 \mathrm{PN}_{4} 874 . \mathrm{N}_{3} \mathrm{J6}$

Nelson $(1841-1915)$ and a partner founded the Star in 1880 . Shortly afterwards Nelson took over full control, maintaining the paper as a highly personal journal until his death. The paper was always "independent politically, ... [ [but] by no means ... neutral." It was conceived as a low-priced family journal, with emphasis on local affairs and general reading matter. With this policy it rapidly built up an extremely large circulation, and became quite influential throughout a large part of the Midwest. However, its greatest importance was as a crusading city paper. The Star was instrumental, through its campaigns, in advancing many programs for civil improvements: better roads, parks, public transportation, etc. While Nelson himself did not write for the paper, he maintained close personal control even when it became a large metropolitan publication. This biography is written in a spirit of admiration, but has no footnotes, no index, and no bibliography. The source even of direct quotations is often left in doubt. An earlier book is William Rockhill Nelson; the Story of a Man, a Newspaper, and a City (Cambridge, Riverside Press, 1915. 274 p.), a memorial volume written "by members of the staff of the Kansas City Star."

2888. Older, Fremont. My own story. New York, Macmillan, 1926. $\mathrm{xx}, 340 \mathrm{p}$.

26-19123 $\mathrm{F} 86.9 . \mathrm{S}_{3} \mathrm{O}_{43}$

Older (1856-1935) begins his book at the time when he became editor of the San Francisco Bulletin in 1895; he subsequently published a narrative of his earlier life: Growing $U p$ (San Francisco, San Francisco Call-Bulletin, 193I. 168 p.). The first part of his story is largely that of the newspaper's involvements in politics and his fight against corruption in the local government during the SchmitzRuef regime (190I-08). In the latter part of the book he presents his attempts to understand the criminal personality and his code of social responsibility in the sphere of crime. The author's frankness and questioning of motives make the book a good and characteristic report on journalistic activity during a corrupt administration. The same frankness made it injudicious for him to publish his "confession" while he was still editor of the paper; he resigned, rather than drop the Mooney case, in 1917. My Own Story was first published, in a briefer form, at San Francisco in 1919 and again at Oakland, California, in 1925.

2889. [Pulitzer] Barrett, James Wyman. Joseph Pulitzer and his World. New York, Vanguard Press, 194I. xvi, 449 p.

$$
4 \mathrm{I}-21082 \quad \mathrm{PN}_{4} 874 \cdot \mathrm{P} 8 \mathrm{~B}_{3}
$$


Joseph Pulitzer ( 1847 -I9II) was a Hungarian immigrant who began his journalistic career under Carl Schurz (q. v.) on the Westliche Post. After he learned English, he transferred to the St. Louis Post-Dispatch and rose rapidly in the journalistic world. In 1883 he went to New York, where he acquired ownership of the World, and soon built it into one of the most popular and influential of newspapers-partly from a talent for judging what was of popular interest, partly from a flair for uncovering and even creating sensational news. While Pulitzer introduced "yellow journalism," he also held a firm belief in the responsibility of the press. It was this motive that made him a major figure; this, with his battles for the liberty of the press, and his demand that newspapers present the facts of each case, helped raise the press to its latter-day level. $\mathrm{He}$ also founded the country's first school of journalism, at Columbia University. At the end of his career he established funds for annual awards in fields such as journalism, literature, and history. These were to go to books, articles, or cartoons presenting the atmosphere of American life, exemplifying good manners, promoting the public good, etc. The annual awarding of the Pulitzer prizes remains a major event, despite occasional controversy, and the prizes have distinguished some of the more important American work in the fields concerned. Barrett (who was city editor for the New York World when it came to an end 20 years after Pulitzer's death) regards Pulitzer as a great American and the greatest of journalists, and the paper itself as having been a major public institution. However, Barrett employs a sentimental, loosely anecdotal approach expressed in a staccato journalese that is inadequate to its theme. $\mathrm{He}$ is able to give a first hand account of much of the later history of the paper, and he does outline its earlier history, but leaves room for a more scholarly treatment.

2890. Scripps, Edward W. Damned old crank, a self-portrait of E. W. Scripps drawn from his unpublished writings; edited by Charles R. McCabe. New York, Harper, 195I. xvii, 259 p.

$$
5 \mathrm{I}-\mathrm{I} 0365 \cdot \mathrm{PN}_{4} 874 . \mathrm{S}_{37} \mathrm{~A}_{3}
$$

Scripps (I854-I926) was a midwestern journalist who achieved the distinction of establishing the first newspaper chain in this country; in the end he controlled newspapers in 15 states. He also established a news service, the United Press, which eventually supplied hundreds of newspapers. Much of his work was done with his brothers, James and George, and with Milton A. McRae (no. 2886). The Newspaper Enterprise Association was founded in I90I for the purpose of supplying syndicated material. Scripps insisted that all his newspapers be independent, while they strongly championed the working man. The book is a striking self-portrait of this man who worked vigorously for a full and honest presentation of the news, and who spoke for the workers of the country while most newspapers were speaking for the corporations; it is largely derived from the manuscripts produced by Scripps in his two attempts at autobiography. A study in some respects more detailed is Negley $D$. Cochran's $E . W$. Scripps (New York, Harcourt, Brace, 1933. 315 p.). A slightly earlier life is Gilson Gardner's Lusty Scripps (New York, Vanguard Press, I932. 274 p.).

289r. Sullivan, Mark. The education of an American. New York, Doubleday, Doran, 1938. 320 p. illus. $\quad 38-28922 \mathrm{PN}_{4} 874 . \mathrm{S}_{7} 8 \mathrm{~A}_{3}$

While Sullivan (1874-1952) was one of the leading political columnists of his day, and was busy to the day of his death in recording and commenting upon the contemporary scene, his autobiography has little to say of direct bearing on his journalistic career. Its primary value lies in its picture of the shaping of an American journalist, with its glimpse of his life on the family's Pennsylvania farm, and his approach to journalism. The picture of farm life is by itself an important piece of Americana. Through it the author brings out those elements which shaped his personality and his career. The volume closes with the Wilson administration, when Sullivan had been closely connected with Collier's for about a decade, but before he had become famous as a political commentator.

2892. [Watterson] Wall, Joseph Frazier. Henry Watterson, reconstructed rebel. With an introd. by Alben W. Barkley. New York, Oxford University Press, 1956. $362 \mathrm{p}$.

$$
56-5672 \quad \mathrm{PN}_{4} 874 . \mathrm{W}_{3} \mathrm{~W}_{3} \quad 1956
$$

Watterson (1840-I92I) was a Kentucky journalist who has been called the "last great personal editor"; his career spanned the years in which the old personal and largely political journalism gave way to the large mechanized, news-service newspaper. He began his career in 1858 as a reporter for The New York Times; there followed a variety of activities, largely connected with journalism, even while in the Confederate Army. In 1868 he became editor of the Louisville Daily Journal, which was soon merged with the Courier to become the JournalCourier, and retained it until he sold control in I9r8. He is credited with having been a major factor for the reunification of North and South during the years of strain after the Civil War. He was a major influence in his region, where his editorials were considered news, and as such were repeated by newspapers throughout the country. His style gave special force to his views, and for a' period he may well have been "the most widely 
quoted" man in America. An earlier study of this leading editor is Isaac F. Marcosson's "Marse Henry" (New York, Dodd, Mead, 1951. 269 p.). An important primary source which, however, runs to anecdote and general comment, is his own "Marse Henry"; an Autobiography (New York, Doran, I919. 2 v.).

2893. White, William Allen. The autobiography of William Allen White. New York, Macmillan, 1946. $669 \mathrm{p}$. illus.

$$
{ }_{46-16} 6 \mathrm{PN}_{4} 874 . \mathrm{W}_{52} \mathrm{~A}_{3}
$$

White (1868-1944) was editor of the Emporia, Kansas, Gazette from 1895 until his death. As editor of a small-town newspaper, he built up a position of national influence. He was not only an oracle in state and national politics, but, more important, he came to be regarded throughout the Nation as a spokesman for midwestern middle-class society. His editorials were reprinted or quoted in numerous papers, so that he was followed by millions, though he sold only a few thousand copies of his own paper. His autobiography, which at the time of his death had only reached I 923, was published posthumously, and in 1947 it was awarded a Pulitzer prize. It reflects not only the work of a leading journalist, but also the situation of a large part of American society for a period of nearly half a century. The story of White's entire life is told in Walter Johnson's William Allen White's America (New York, Holt, 1947. 62I p.). Mr. Johnson also edited Selected Letters of William Allen White, I899-1943 (New York, Holt, 1947. 460 p.).

2894. [Winchell] McKelway, St. Clair. Gossip; the life and times of Walter Winchell. New York, Viking Press, I940. I50 p.

$$
40-32480 \quad \mathrm{PN}_{4} 8_{74} \cdot \mathrm{W}_{7} \mathrm{M}_{25}
$$

Walter Winchell (b. 1897) started his career as a gossip columnist in the twenties. Scandalmongering and ordinary gossiping were new and natural additions to yellow journalism, and Winchell rose rapidly to national prominence. While his work appeared in the New York Mirror and other papers of the Hearst chain, a number of imitators arose to spread the latest rumors of divorce, adultery, romance, incompetence, larceny, etc., among the prominent. Winchell, however, was the one who rode the crest of the wave, and he achieved a vast following for his syndicated column, while millions tuned in on his radio (and later television) broadcasts. In the thirties Winchell became a great enemy of fascism, and the broad field of rumored subversion was added to his repertoire. While he had begun by making public the private life of entertainers and then added the social élite, he now broadened his activities, and is credited with the early demise of many a political and business career. His eminence was such that on occasion both the F. B. I. and prominent gangsters provided him with bodyguard protection. Because Winchell has scrupulously published the most embarrassing secrets of both his friends and his enemies, the latter group has tended to increase with the passing of the years. One result is that most studies of the man do not find his services to have been an unmixed blessing. McKelway's study was the first on Winchell to be published in book form; it was originally published in part in the New Yorker, and remains one of the more readable and objective studies; it deserves to be brought up to date. Lyle Stuart's The Secret Life of Walter Winchell ([n. p.] Boar's Head Books, 1953. 253 p.) is a hostile exposé. A friendly study which also follows Winchell's career past its peak of prestige is Edward Weiner's Let's Go to Press (New York, Putnam, 1955. 270 p.).

\section{E. Foreign Language Periodicals}

2895. Backlund, Jonas Oscar. A century of the Swedish American press. Chicago, Swedish American Newspaper Co., 1952. 132 p. illus. 53-17283 $\mathrm{PN}_{4} 88_{5} . \mathrm{S}_{3} \mathrm{~B}_{3}$

A brief review of the roo-year history (1851195I) of the Swedish language press in the United States, which omits the more ephemeral or insignifcant papers. Although the first publication, Skandinaven (New York, I851-53), was a news sheet, most papers of the first decade were denominational organs, and none survived infancy. Of the Swedish-
American newspapers of general circulation established in the 1870's, the author finds most notable the still surviving Svenska Amerikanaren Tribunen of Chicago and Nordstjernan of New York; less successful has been the Swedish-American journalism of the West. Only one percent of the 1500 Swedish papers that have commenced publication still appear. Mr. Backlund concludes with brief mention of the personalities of the profession and of the organs of special interests: religious, political, fraternal, and literary. 
2896. Kolehmainen, John I. Sow the golden seed. Fitchburg, Mass., Raivaaja Pub. Co., 1955. $150 \mathrm{p}$. illus. $55-32553 \mathrm{PN}_{4} 885 \cdot \mathrm{F}_{5} \mathrm{R}_{35}$

A history of the first 50 years of Raivaaja, a Finnish-language newspaper founded in 1905 in Fitchburg, Mass., to meet the needs of Finnish immigrants, as well as to propagandize for socialism. Although it remained socialist, it early turned against communism. The paper has achieved a national circulation, and even reaches the Finnish areas in Canada. It is of value not only as a study of an individual foreign-language newspaper, but also as an example of the "radical" press of the late igth and early 2oth centuries in America. The book opens with a discussion of the circumstances which led to the founding of the paper. Since the paper also ran a publishing company, this too is discussed, and a bibliography of the paper's publications is supplied at the end of the book. It might be noted that while the Raivaaja Publishing Company is the publisher, the book is not "official," but was compiled through private initiative. However, it is a favorable study which seeks to present the functioning of a foreign-language paper and its services to its community.

2897. Park, Robert E. The immigrant press and its control. New York, Harper, 1922. xix, 487 p. tables, diagrs. (Americanization studies)

$$
{ }_{22-2469} \mathrm{PN}_{4} 88_{4} \cdot \mathrm{P}_{3}
$$

A history and analysis of the immigrant press in America, which opens with a study of the factors leading to the establishment of foreign language presses. It continues with an analysis of the typical contents of foreign language newspapers, followed by a brief history of the immigrant press, and concludes with a section on the various means such as advertising and censorship, which have been used or suggested for the purpose of controlling these. Because of their topicality at the time of publication, much attention is given to World War I and its postwar issues as they were handled in such papers. Unfortunately, no more recent or inclusive history of the immigrant press as a whole has appeared. However, some of the language and nationality groups involved have received individual treatment in other books, a few of which are listed in this section. A brief study of the current situation of the immigrant press may be found in Brown and Roucek's One America (no. 4426).
2898. Soltes, Mordecai. The Yiddish press, an Americanizing agency. New York, Teachers College, Columbia University, $1950 . \quad x v i, 242 \mathrm{p}$. illus. $\quad 50-13966 \quad \mathrm{PN}_{4} 885 . Y_{5} \mathrm{~S} 6 \quad 1950$

Bibliography: p. [223]-230.

This work, written as a dissertation at Columbia University, was first published in 1924. The new "Foreword" offers something of a survey of more recent events, but the original text is unchanged. While the work is really a study of the Yiddish press in New York City, it reflects the Yiddish press throughout the United States, since the New York papers were national in influence and tended to provide a model for such papers elsewhere. The opening section of the book discusses the origin, development, and nature of the Yiddish press in New York. There follows a study of the readers of the newspapers. The author then turns to his main subject, the scope, frequency, and nature of the editorial materials presented. He concludes with some generalizations about the Yiddish press and its Americanizing efforts. While no up-to-date book in English has appeared on the subject, there is a more recent study in Yiddish, covering the Yiddish press in America from its founding in 1870 to the anniversary year of 1945, Joseph Chaikin's Yidishe Bleter in Amerike (New York, 1946. 424 p.).

289g. Wittke, Carl F. The German-language press in America. [Lexington] University of Kentucky Press, 1957. 3 I I p.

$$
57-5832 \quad \mathrm{PN}_{4} 885 \cdot \mathrm{G}_{3} \mathrm{~W}_{5}
$$

A history of the American German-language press from its beginning in 1732 through 1956 . Since this group was once the largest of the foreign language presses, and there have been hundreds of Germanlanguage newspapers, the author has not undertaken a tabulation of all of them, although he has studied a few in some detail. His study is primarily an attempt to discover the importance these publications have had in the Americanization of the immigrants, and the difficulties attending such publication ventures. Dean Wittke's “emphasis has been primarily upon the role which the German press and its readers played in American social, political, and economic history." The development of the press is traced for the most part in chronological order. Because the German press has been much reduced since World War I, the great bulk of the book is devoted to the press prior to the 1920's, although some attention is given it in its present diminished state. 


\section{F. The Practice of Journalism}

2900. Allen, John Edward. Newspaper designillus. ing. New York, Harper, I947. 478 p. 47-31234 $\mathrm{PN}_{4775 . A 6}$

The first part of Mr. Allen's book is in large part a presentation of the historical background of newspaper designing in America; however, since the author's main interest is in current good practice, much of his material is an explanation of various practices and how they evolved, rather than a general chronological study of newspaper designing as a whole. The second part of the book is a study of the present-day application of these practices. Little attention is given to the technical problems behind the design, and the book concentrates on such topics as the esthetics and the readability of various types, layouts, etc.

2901. Brown, Charles H. News editing and display. New York, Harper, I952. $457 \mathrm{p}$. illus. $\quad 52-10826 \quad \mathrm{PN}_{47} 8_{4} \cdot \mathrm{C}_{75} \mathrm{~B} 7$

This textbook for journalism students has been designed as a codification of the rules and practices of newspaper production in so far as they enter into the "desk man's job." It is emphasized that these are not final and unalterable procedures, but rather those generally accepted among newspaper staffs. In the preface the author thus outlines his book: "The first chapters explain the routine procedures of preparing copy for the printers. These are followed by chapters on headline writing and make-up. Then come chapters on fundamental policies and problems. ... Descriptions of the jobs of departmental editors comprise the final chapters." While the author has sought to distinguish between large and small newspapers, he notes his own bias in favor of the small ones, since they are the type for which the majority of journalism students will go to work.

2902. Elfenbein, Julien. Business journalism, its function and future. Rev. ed. New York, Harper, 1947. xxii, 359 p. illus., forms, diagrs. $47-4246 \quad \mathrm{PN}_{478} \cdot \mathrm{C}_{7} \mathrm{E}_{4} \quad 1947$ This book was designed primarily as a textbook for students of business journalism. It can also be used as something of a guide to the history and present state of the thousands of American business newspapers. House organs and noncommercial journals, sometimes included in this classification, are passed by. Using his more restricted definition, the author in his first part discusses the service these papers perform for the business world and for the community; this is followed by a brief history of the business press in America. Of special interest to the prospective business journalist is the second part of the book, a guide to the functions and methods of various staff members (publisher, editor, advertising sales manager, etc.) of a business paper. The appendixes include a chronological list of American business papers before 1900 ( $p$. 293-304), and a brief dictionary of trade terminology.

2903. Herzberg, Joseph G. Late city edition, by Joseph G. Herzberg and members of the New York Herald Tribune staff. New York, Holt, 1947. 282 p. 47-3126I $\mathrm{PN}_{4775 . \mathrm{H}_{37}}$ In 29 essays as many members of the Herald Tribune staff here discuss the activities involved in the preparation of a daily paper. While the point of departure is their own paper, the symposium is meant to present the general problems of any American large metropolitan daily. The emphasis of the book is on reportorial work in its many categories, but background rewriting, editing, arranging, etc., are not neglected. Each contributor speaks of his own specialty; thus Geoffrey Parsons, chief editorial writer, does the chapter on "The Editorial Page."

2904. Liebling, Abbott J. The wayward pressman. Garden City, N. Y., Doubleday, I947. 284 p. 47-11624 PN4867.L5 Mr. Liebling (b. I904) in the first part of this book presents a narrative of his career as a newspaperman in Providence and New York. In a humorous and anecdotal style the author presents a good picture of the development of a journalist, including his departure from newspaper reporting. The burden of his tale is the arbitrariness of newspaper owners, the precariousness of newspaper employment, and the dubious professional status of journalism. In his case the transfer was to The New Yorker, in which a large part of the book's material first appeared. In that magazine Liebling published a series of articles under the general title "The Wayward Press." These were perceptive analyses of sins of commission and omission by the press, particularly in New York City. This critical commentary, in addition to covering aspects of the journalistic world not usually dwelt upon by journalists in their how-to-do-it books, also reveals in- 
directly much of the inner workings of newspapers. Liebling's Mink and Red Herring, the Wayward Pressman's Casebook (Garden City, N. Y., Doubleday, 1949. 251 p.) is made up entirely of articles from The New Yorker, and in it he continues to underline the errors, carelessness, stagnancy, debatable publishing ethics, etc., found in a number of city newspapers.

2905. MacDougall, Curtis D. Newsroom problems and policies. New York, Macmillan, 194I. 592 p. 4I-934I PN473I.M27

This book is designed as an integrative textbook for the journalism student, and is meant to be "of value to the young person about to begin a newspaper career," especially "in forming a philosophy about the job." It focuses upon the problems of the newsroom employee, and the business and mechanical aspects of newspaper work enter only as they affect decisions on matters such as what should be printed and in what manner it should be presented. "How," for instance, "should newspapers handle news related to sex?" "What is libel and how can the newspapers avoid committing it?" The large number of "case studies" showing the actual handling of such problems in various papers enables the book to reflect much of the policy practices prevailing in the American press. The author's own views take account (as of I94r) of what exists, what is ideally desirable, and what steps in that direction are presently practicable. A book which discusses the techniques and policies of reporting is Victor J. Danilov's Public Affairs Reporting (New York, Macmillan, 1955. 487 p.), which "attempts to acquaint the embryo reporter with the various types of public affairs news, to point out where to look for it, and to show how to cover it." Of especial value is its detailed study of the structure and functioning of American governmental units, from the local to the national level.

2906. MacNeil, Neil. Without fear or favor. New York, Harcourt, Brace, I940. 4I4 p. $4^{0-27336} \mathrm{PN}_{4} 855 . \mathrm{M}_{3}$

When Mr. MacNeil wrote this book he had been assistant managing editor of The New York Times for about a decade. In it he describes the process of producing a newspaper, from gathering the news to committing it to the presses. The bulk of the book is made up of chapters on reporting and editing various types of news: politics, finance, sports, features, local news, etc. There are also a number of "policy" chapters such as "Without Fear or Favor," "Libel, Ethics, Principles," "Freedom of the Press," and "The Devil's Advocate," which last is a review of propaganda and slanted news releases. It is the American press, he believes, which "has made the United States the most successful democracy in history."

2907. Mott, Frank Luther. The news in America. Cambridge, Harvard University Press, 1952. 236 p. (The Library of Congress series in American civilization)

52-8218 PN4855.M65

"In this essay I have attempted to define and describe news in the United States, and the way it is assembled, edited, and disseminated." While his primary aim is thus expository, he carries it out in a critical manner throughout, and in the light of a major distinction: "the editor works under a double standard: he has to decide what news he will print, on the one hand, because his readers demand it for the easy reading which brings immediate responses, and what he will select, on the other hand, because he thinks it may, in the long run, affect the lives and fortunes of his readers." However, publishers, news-gatherers, and especially the readers themselves must divide with the editors the responsibility for the present state of things. "The chief fault and failure of American journalism today-and this applies to all media of information-is the disproportionate space and emphasis given to the obviously interesting news of immediate reward ('soft news') at the expense of the significantly important news of situations and events which have not yet reached the stage of being exciting for the casual reader ('hard news')." A second major distinction is developed in Chapter 8 , "Objective News vs. Qualified Report." Among the complexities of 2oth-century life, reporting no more than the overt event which catches the eyes is seldom enough; it is essential rather, in the words of Kent Cooper of the Associated Press, to have "reporting that digs below the surface and tells the true story" in its deeper significances. But such qualification of the apparent manifestly can lead to editorial tampering with the truth. Dean Mott, while he critically assesses such forms as the weekly news-magazine style of report and the weekly summaries of news which appear in Sunday or Saturday issues of newspapers, judges in conclusion that, "day in and day out, American reporters and editors generally do an honest and tremendously painstaking job."

2908. Rothstein, Arthur. Photojournalism: pictures for magazines and newspaper[s.] New York, American Photographic Book Pub. Co., 1956. I97 p. 56-1I558 $\mathrm{PN}_{47} 84 . \mathrm{P}_{5} \mathrm{R} 6$

This study of photojournalism begins with a brief history of the subject, but as a whole is more concerned with the current esthetics of journalistic photography and the technical problems of processing and layout. The numerous photographs re- 
produced are in part specimens of journalistic excellence, and in part illustrations of graphic work in progress in newspaper offices. A final chapter, "Privileges and Restrictions," discusses the still fluid subjects of the ethics and the law of photojournalism. An earlier study of one aspect of the field is Daniel D. Mich and Edwin Eberman's The Technique of the Picture Story (New York, McGraw-Hill, 1945. 239 p.); the authors were part of the staff of Look, and their material largely reflects the usages of that magazine. A study which uses the technique of Life magazine as its norm is Wilson Hicks' Words and Pictures, an Introduction to Photojournalism (New York, Harper, 1952. I71 p.). An idea of the life of at least one type of photojournalist may be obtained from Jimmy Hare, News Photographer (New York, Macmillan, 1940. 304 p.) by Cecil Carnes; this is a study of the career of James $\mathrm{H}$. Hare (1856-1946), an Anglo-American war-correspondent photographer whose half-century of activity all over the globe earned him fame as the greatest of news photographers.

2909. Rucker, Frank W., and Herbert Lee Williams. Newspaper organization and management. Ames, Iowa State College Press, 1955. 547 p. illus.

55-9003 PN4775.R8

In the preface the authors state their two purposes in writing this book: the first, "to outline and describe for those now active in newspaper work the best methods and practices used in producing and promoting newspapers," and the second, "to provide for journalism students a textbook revealing important details of newspaper organization and management, the challenging issues and problems that publishers must face, and the qualifications reeded for success in directing and managing newspapers." They analyze problems in fields such as newspaper organization, types of newspaper plant equipment, obtaining profitable advertising and public good will, reliable financial and accounting procedures, and maintaining satisfactory interstaff relationships.

2910. Sutton, Albert Alton. Education for journalism in the United States from its beginning to 1940. Evanston, Ill., Northwestern University, 1945. 148 p. (Northwestern University studies in the humanities, no. 10 [i.e. 14])

Bibliography: p. 125-126.

$$
\mathrm{A}_{45-4968} \mathrm{PN}_{4788 . S 8}
$$

This book opens with a historical survey of its subject, from the first program of education for journalism proposed by President Robert E. Lee at what is now Washington and Lee University, and the establishment of the first accredited school of journalism at the University of Missouri in 1908, through 1940, when the study was begun. Dr. Sutton next analyzes in detail the distribution of the schools teaching journalism and the nature of their courses. Of the 542 schools found to be offering one or more courses in journalism, only 32 were schools accredited by the American Association of Schools and Departments of Journalism, while 384 offered neither a major nor a minor in the subject. Attention is also given to the student body, job placements, and curriculum trends. The data accumulated has been brought together in a series of tables which appear both in the text and in the appendix. The information was obtained from questionnaires circulated to the institutions, nearly all of which responded. The story of one journalism school has been told in some detail in one of the volumes comprising the Bicentennial history of $\mathrm{Co}$ lumbia University: Richard Terrill Baker's $A$ History of the Graduate School of Journalism, Columbia University (New York, Columbia University Press, 1954. 144 p.).

2911. Thayer, Frank. Newspaper business management. New York, Prentice-Hall, 1954. $43^{8}$ p. illus. (Prentice-Hall journalism series)

$$
\text { 53-12347 PN4775.T5 I954 }
$$

This volume was designed as a textbook covering the major factors in the field of newspaper management, and many minor ones as well. While it is partly theoretical, it also includes much in the way of description of actual situations. The chapters cover such aspects as staff organization, circulation, advertising rates, promotion, accounting, and financing. An earlier book on much the same subject was James E. Pollard's Principles of Newspaper Management (New York, McGraw-Hill, I937. 462 p.).

2912. Wolseley, Roland E., and Laurence R. Campbell. Exploring journalism; with emphasis on its social and professional aspects. $3 \mathrm{~d}$ ed. Englewood Cliffs, N. J., Prentice-Hall, r957. 636 p. illus. (Prentice-Hall journalism series)

$$
\text { 57-9143 PN } 4775 . W 651957
$$

This textbook attempts to investigate those mass media which involve journalism in its broader meaning. Thus magazines, books, radio, and television are discussed as well as newspapers. In large part it discusses the requirements of the various media, standard operating techniques in each, and the professional responsibilities imposed by their social implications. This is carried from the problems of gathering straight news, writing it, front page makeup, etc., through those of interpretation and coverage. Each of the chapters concludes with a list of 
books that may be consulted for further information on the subject. The book originally appeared in
1943; for this edition it has been considerably revised and its coverage expanded.

\section{G. Magazines: General}

2913. Britt, George. Forty years-forty millions; the career of Frank A. Munsey. New York, Farrar \& Rinehart, 1935. 309 p. illus.

$$
35-20872 \quad \mathrm{PN}_{4} 874 \cdot \mathrm{M} 8 \mathrm{~B}_{7}
$$

Munsey (1854-1925) was a big businessman whose major field of operation was publishing. His principal venture was probably Munsey's Magazine, which was evolved in 1891 from Munsey's Weekly, an imitation of the humorous Life. In 1893 Munsey reduced the price from 25 to Io cents, thus reaching a mass market with his magazine, which was both cheaper and of poorer quality, though having more illustrations than its main competitors. It rapidly achieved the widest circulation of any magazine in America. Munsey in general worked for sales and did not hesitate to kill off any publication that failed to make him a profit. His various magazines were distinguished by a low grade of fiction, often staff-produced; non-crusading and politically conservative articles; an absence of sensationalism; and low prices. In time Munsey extended his activities to the newspaper field, never bringing creative ideas to journalism, but always an important factor in its financial affairs. $\mathrm{He}$ also wandered outside the field of journalism finance by such activities as becoming owner of the Mohigan grocery store chain. His positive contribution was that he got magazines into multitudes of low-income homes. Britt's biography is based on interviews and previously published accounts. While Britt did not have access to Munsey's private papers, his book remains a revealing and readable biography of this pioneering capitalist.

2914. Hoffman, Frederick J., Charles Allen, and Carolyn F. Ulrich. The little magazine; a history and a bibliography. Princeton, Princeton University Press, 1946. $44^{\circ} \mathrm{p}$. illus.

"List of references": p. [399]-403. $\mathrm{A}_{4} 6-\mathrm{I} 7 \mathrm{PN}_{4} 836 . \mathrm{H} 6$

The term "little magazine" refers not to physical size, but to smallness of circulation, usually, however, one of relatively high education and sophistication; further, the term is limited to primarily literary periodicals. Most of these appear quarterly, but a few appear monthly or at other intervals. By virtue of their small circulations, their price is usually relatively high, and their life expectancy is quite low. This type of periodical has existed in various guises for a long time, but it began its full flowering and became of major importance after 19ro. Accordingly, this book is a study of the little magazine in the 2oth century. It includes general chapters on the history of these periodicals by decades, as well as chapters on various types and subjects, such as poetry, regionalism, political directions, the use of psychoanalytic themes, and criticism. The main importance of the little magazines is that they have served as vehicles for new and experimental writers. Many modern American authors of literary importance have had their reputation established in such magazines before they were accepted by more remunerative publishers. Further, much literature of importance even by established writers appears in these periodicals long before it is published in book form. In addition to the history and analysis this study includes a bibliography (p. 233-398) of all little magazines, arranged chronologically by the year of the initial appearance of each, and each entry is supplied with a brief history and description.

2915. Mott, Frank Luther. A history of American magazines. Cambridge, Mass., Harvard University Press, $1938-57.4$ v. illus.

$$
\text { 39-2823 } \mathrm{PN}_{4} 877 \cdot \mathrm{M}_{3} \quad 1938
$$

"Chronological list of magazines" at end of each volume.

Contents. - [v. I] 1741-1850.-v. 2. $1850-$ 1865.-v. 3. $1865-1885$. -v. 4. 1885-1905.

Frank Luther Mott (b. 1886) in his continuing history of American magazines has presented the world with an outstanding scholarly and readable work which indirectly reflects much of American culture while it serves directly as an enlightened guide to one area of that culture. He attempts "to illustrate the main currents of the thought and feeling of the American people by some analysis of the contents of the magazines and by carefully chosen quotations from periodicals in order to give a proper idea of the integration of magazines with social movements." For the purposes of this history a magazine has been defined as any non-newspaper periodical appearing more often than semiannually. Each of the four volumes opens with extensive accounts of the principal events and characteristics of a period, and the main line of development in the magazines of that period. There 
follow individual chapters on the leading magazines. The periodicals individually treated are not necessarily all the leading ones begun in the period; for, when a periodical reaches its greatest importance in a later period, its history is given in full in the volume on the later period. Further, all these chapters on individual periodicals trace their history beyond the formal time limit of the volume to the date either of the periodical's end or of the writing of the volume in which it is discussed. While Dean Mott's work is remarkably detailed, it is not meant to serve as an exhaustive checklist, that function being left to Winifred Gregory's Union List of Serials (New York, Wilson, I943. 3065 p.). For the first 70 years a more detailed list including information on personnel is now available: A Register of Editors, Printers, and Publishers of American Magazines, $1741-1810$, by Benjamin M. Lewis (New York, New York Public Library, 1957. 40 p.). The first 50 years have received monographic treatment, in greater detail than Dean Mott's and with a different presentation and emphasis, in Lyon N. Richardson's A History of Early American Magazines, $1741-1789$ (New York, T. Nelson, 193I. $4^{\text {I } 4}$ p.).

2916. Noel, Mary. Villains galore; the heyday of the popular story weekly. New York, Macmillan, 1954. 320 p. illus. 54-9474 $\mathrm{PN}_{4} 877 . \mathrm{N} 6$

In the rgth century periodicals first began to reach a true mass market, and it was soon discovered that literacy did not necessarily prove either a desire or an ability to cope with large intellectual and esthetic matters. To the dismay of many, and the delight of millions, a "popular literature" was rapidly developed for this new "literate" market. In addition to cheap novels and newspapers, fiction magazines became purveyors of literary fare for the masses. Many of these periodicals were weeklies with most of their stories stolen from one another or written by members of the staff. They provided much of the popular entertainment of the time, serving the same function as movies, radio, and television in the 2oth century. Mary Noel's study of this phenomenon opens with an account of about 40 of the more popular story weeklies. There follows a group of chapters with more general comments on and analyses of the contents of such magazines, tracing from their earliest beginnings to the present era the various transformations of the theme of sweetness and violence which formed the substance of most such tales.

2917. Paine, Albert Bigelow. Th. Nast, his period and his pictures. New York, Harper, r904. $\mathrm{xxi}, 5^{8} 3, \mathrm{xx}$ p. illus.

$$
\text { 26-22753 } \mathrm{NC}_{4} 429 . \mathrm{N}_{3} \mathrm{P}_{3} \text { r904a }
$$

Thomas Nast (1840-1902) is remembered as one of the Nation's first and greatest cartoonists. Most of his work appeared in Harper's Weekly, where he advocated one political reform after another; his main achievements included uncovering the corruption of the Tweed Ring and helping to elect Grover Cleveland to the presidency. While it was a pictorial form in which he expressed himself, he may be regarded as one of the more important journalistic figures of the period. Paine's biography is not so much a study of Nast's personality as a record of Nast's work and influence. The book is therefore a valuable commentary on many aspects of the history of the period.

2918. Peterson, Theodore B. Magazines in the twentieth century. Urbana, University of Illinois Press, I956. 457 p. $5^{6-5683} \mathrm{PN}_{4} 877 . \mathrm{P}_{4}$ Bibliography: p. [397]-4I I.

This book reviews the "modern magazine" from its inception in the late rgth century to the present. It is regarded as having arisen out of the transformation from an agrarian to an industrial society, and the need for advertising goods that must be sold. Crucial dates in its evolution were the establishment of favorable postage rates ( 1879 ), the introduction of low-priced magazines (1893), and the conscious catering to popular taste, entered upon by The Saturday Evening Post under Lorimer from 1899. For this study the author has limited his attention mainly "to commercial magazines edited for the lay public." In attempting to cover so wide a field, Dr. Peterson first presents chapters on topics such as advertising in the modern popular magazine and the financial structure of its production. The magazines themselves are studied in groups, under categories such as journals now defunct and those still popular. Some attention is devoted to magazines intended for minorities. However, such periodicals as house organs, and scholarly and professional journals, are omitted from consideration.

2919. Wood, James Playsted. Magazines in the United States. 2d ed. New York, Ronald Press Co., 1956. 390 p. illus.

$$
\text { 56-10175 } \mathrm{PN}_{4} 877 . \mathrm{W6} 1956
$$

The author states his purpose in the preface: "This book attempts to show, from general magazines that were important in their time and from important nationally circulated magazines of today, what magazines are and in what directions they exert their social and economic influence. It traces and gauges the force of periodicals from Benjamin Franklin's General Magazine to the weeklies and monthlies of the present. It shows how magazines have both reflected and helped to mould American tastes, habits, manners, interests, and beliefs; how 
they have shaped opinion on public questions; how they have crusaded effectively for social and political reforms; and how magazine advertising, as well as magazine editorial content, has affected the American home and standard of living." The book, originally published in 1949, is thus more of a social study than a detailed history. Most of the chapters analyze intermagazine trends or developments, such as the handling of the slavery question and of political corruption, magazines during World War II, changes in and expansion of coverage, etc. Some chapters are studies of groups or types of magazines, such as the farm and grocery-store magazines. A few are primarily devoted to particular magazines, such as The Saturday Evening Post, The Reader's Digest, and The New Yorker. A selected bibliography appears on p. 379-383. A book written less for the magazine reader and more for the worker inside the magazine field is Roland E. Wolseley's The Magazine World; an Introduction to Magazine Journalism (New York, Prentice-Hall, 1951. 427 p.), which aims to present a picture of the work that goes into the production and distribution of American magazines.

\section{H. Individual Magazines}

2920. Bainbridge, John. Little wonder; or, The Reader's Digest and how it grew. New York, Reynal \& Hitchcock, I946. I $77 \mathrm{p}$.

\section{${ }_{46}-45^{8} 4 \mathrm{PN}_{4900} \mathrm{R}_{3} \mathrm{~B}_{3}$}

The Reader's Digest was founded in 1922 by DeWitt Wallace (b. 1889). It started out as an attempt to present in short form the best articles currently appearing in other periodicals. In time it developed to a point where most of its articles originated in its own editorial offices, but were ordinarily "planted" in other periodicals which received inducements of various kinds. With a strong undertone of conservatism and religious orthodoxy the Digest presents folksy stories and informative articles on current issues, with all complexities of language, problems, and thought removed for the benefit of the common reader. This has brought it the largest circulation of any magazine in the world; it also sets records in a number of foreign language editions, and appears in Braille and on phono-discs. Its multimillion circulation has made of it a major social force. Bainbridge's study, a large part of which appeared originally in the New Yorker, investigates the background of the magazine's production more than of its influence. The book is deftly and amusingly written, at times satirical, at all points based on much research (though retailing some gossip), and on the whole critical of its subject. In defense of the Reader's Digest it has been pointed out that its standards are no lower than those of many newspapers and magazines aimed at mass audiences, and that it obviously meets a mass desire, on which level it does much good.

2921. Grimes, Alan Pendleton. The political liberalism of the New York Nation, 1865-

1932. Chapel Hill, University of North Carolina
Press, I953. I33 p. (The James Sprunt studies in history and political science, v. 34)

$$
\text { 53-62070 F25I.J28, v. } 34
$$

$\mathrm{PN}_{4900 . \mathrm{N}_{3} \mathrm{G}_{75}}$

Bibliography: p. [123]-129.

The Nation was founded in 1865 by Edwin Lawrence Godkin (no. 2882) as a weekly journal that would express the views of "liberalism" in America. Today it still calls itself "America's leading liberal weekly since 1865 ." While its subject matter has largely consisted of current issues in domestic politics, it has also commented on world affairs in general, and its literary department has often achieved distinction. Its appeal has been to well cducated readers rather than to the masses, and its circulation has always remained relatively small. However, its select readership has established it as a highly influential periodical, and among its contributors have been many of the leading thinkers and writers of the country. An earlier book on the Nation was Gustav Pollak's Fifty Years of Amer. ican Idealism; The New York Nation, 1865-19I5 (Boston, Houghton Miffin, I915. 468 p.). After an introduction on editors and contributors, it traces the chronological development of the paper by outlining its treatment of leading issues from year to year and concludes with a selection (p. 237454) of "Representative Essays."

2922. Howe, Mark Antony De Wolfe. The Atlantic Monthly and its makers. Boston, Atlantic Monthly Press, 1919. I06 p.

19-4003 $\mathrm{PN}_{4900 . A_{7} \mathrm{H} 8}$

The Atlantic Monthly was founded in 1857 as a literary and current events magazine cultivating the American field. From the beginning it received contributions from leading authors, and it became an immediate success. With the passing of the 
decades the Atlantic became somewhat less literary and displayed a greater tendency to survey those factors going into the making of America. At present the general essay and review dominate the magazine, but it still publishes some poetry and short stories. Mr. Howe approaches the story of The Atlantic Monthly largely in terms of its successive editors: James Russell Lowell, James Thomas Fields, William Dean Howells, Thomas Bailey Aldrich, Horace Elisha Scudder, Walter Hines Page, and Bliss Perry, with a brief mention of Ellery Sedgwick, who became editor in 1909. His successor, Edward Weeks, took charge in 1938. On the occasion of the Atlantic's centenary Mr. Weeks combined with the managing editor, Emily Flint, to produce an anthology of selections from the magazine: Jubilee; One Hundred Years of the Atlantic (Boston, Little, Brown, I957. 746 p.). It emphasizes the current period, but also reflects much of the history and past importance of the Atlantic; this is further developed by the editorial introductions to the several parts of the volume.

2923. Johnson, Robert Underwood. Remembered yesterdays. Boston, Little, Brown, 1923. $\mathrm{xxi}, 624$ p. illus. 23-17557 $\mathrm{PN}_{4} 874 . \mathrm{J} 6 \mathrm{~A}_{3}$ Johnson (1853-1937) began work for the Century magazine in 1873; in 1909 he became editor, although he had long been doing much editorial work. His autobiography contains much information on his work for the magazine through 1913 , as well as the background of many projects undertaken by this magazine. The work also includes numerous short sketches of individuals connected with the periodical, most of them as contributors. Since the Century was a leader in the field of the general magazine, its contributors included a surprisingly large percentage of the prominent people of the period. Johnson's autobiography also deals with some nonjournalistic matters such as his service as Ambassador to Italy (1920-192I).

2924. Luxon, Norval Neil. Niles' Weekly Register, news magazine of the nineteenth cen-

tury. Baton Rouge, Louisiana State University Press, 1947. 337 p. 47-30723 JKI.L8 "Critical essays on authorities": p. 308-320.

In I81 I Hezekiah Niles (1777-1839) of Baltimore founded the Weekly Register, which soon became Niles' Weekly Register, and for the last 12 years of its existence (1836-1849) was known as Niles' National Register. At a time of partisan periodicals the register was outstanding for its near impartiality. It was designed as a periodical or record, meant to be of service to the future; in this it succeeded, and it remains a major source for the historian of the period. While foreshadowing a newspaper of record such as the New York Times, the Register was far larger than contemporary newspapers; indeed, it was often regarded as a magazine, and in this respect it may be regarded a forerunner of modern news magazines such as Time. However, like the Times rather than Time, the Register commonly printed important speeches, official reports, etc., in full or in large part. Less spectacular than many of its contemporaries, it nonetheless had a more substantial backing than most, and for most of its career had a national and international circulation surpassing that of any other American paper of the period. Dr. Luxon's book has a long chapter on the first editor, Hezekiah Niles, and individual chapters on the Register's presentation of slavery, the West, Anglo-American relations, and other political and commercial topics.

2925. Stewart, Paul R. The Prairie Schooner story; a little magazine's first 25 years. Lincoln, University of Nebraska Press, 1955. 203 P.

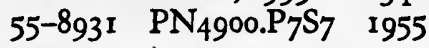

Bibliography: p. I99-203.

The Prairie Schooner began publication at the University of Nebraska in 1927. From the beginning it has placed an emphasis on creative writing, fiction and poetry, with some general expository articles and reviews. It has been particularly noted for the quality of its short stories. Originally it was regional in intent and in its contributors, but it rapidly became as general as the majority of little magazines. Unlike many of them, it has shown a conservative editorial bent, but has nevertheless maintained its quality. Dr. Stewart's study, a University of Illinois dissertation, approaches the periodical from several points of view, including its editorial policy and its financial history. It provides a useful supplement to The Little Magazine, by Hoffman, Allen, and Ulrich (no. 2914), by studying the development of one such publication in concrete detail.

2926. Tebbel, John W. George Horace Lorimer and The Saturday Evening Post. Garden City, N. Y., Doubleday, 1948. 335 p.

$$
{ }_{4}^{8-6490} \mathrm{PN}_{4} 8_{74 .} \mathrm{L}_{3} \mathrm{~T}_{4}
$$

Lorimer (1868-r937) joined the staff of The Saturday Evening Post as literary editor in 1898, at a time when it seemed to be a small and failing magazine. Next year he was appointed editor-inchief, and with new policies he rapidly made it one of the most successful magazines in the country. Its great popularity has been attributed to his "infallible" sense for the literary taste of the large middleclass audience. A large part of Mr. Tebbel's study is devoted to the fiction that appeared in the maga- 
zine, and to Lorimer's relations with the authors. In addition to a pro-Republican editorial page (which was progressive until continuing attitudes became conservative with the passage of time), the magazine featured numerous articles. The articles were informative, and were not written as a result of editorial dictation, but their acceptance usually depended upon the editor's agreement with the views expressed. The magazine also included es- says, autobiographical sketches, humor, and verse; and it flourished on its advertising. To the time of Lorimer's retirement in 1936 the policy in all departments was one of realism, but a realism tempered by the many taboos resulting from an applied turnof-the-century middle-class morality. Mr. Tebbel's admiring and sympathetic account is in large part based on interviews with those who knew the editor personally, or had business dealings with him.

\section{The Press and Society}

2927. Bird, George L., and Frederic E. Merwin, eds. The press and society; a book of readings. [Rev. ed.] New York, Prentice-Hall, 1951. $\mathrm{xv}, 655$ p. (Prentice-Hall journalism series)

$$
\text { 5I-IIoI6 PN4735.B5 I95I }
$$

First published in 1942 under title: The Newspaper and Society.

This volume, largely an anthology of writings on the press with introductory commentaries by the editors, is a textbook designed primarily for journalism students. It attempts to present historical perspective as well as the pros and cons of the various issues discussed. The first part, introductory in nature, discusses the nature of "public opinion" and the ways and means of press influence; here, as elsewhere, "press" means mainly newspapers, but includes other forms of mass communications, such as radio. The second part, "The Press at Work in Society," shows how the press functions, especially in terms of the selection or suppression of news, attitudes conveyed, methods employed, and press reliability. The concluding sections cover those forces which have molded the press as it is: chain ownership, pressure groups, press agents, government, etc. Each chapter of the book concludes with a list of further readings.

2928. Brucker, Herbert. Freedom of information. New York, Macmillan, 1949. 307 p.

$$
\text { 49-7938 }{ }^{2} \mathrm{PN}_{4735} \mathrm{~B}_{7}
$$

This book by the editor of the Hartford Courant (born in 1898) analyzes the American press in terms of its principles, functions, and methods. While much attention is given to its faults in reporting news, the main concern is to report what has been and is being done to improve American journalism. Mr. Brucker deals with such problems as the freedom of the press, governmental and economic controls and influences, and the nature and standards of objective reporting.
2929. Duniway, Clyde Augustus. The development of freedom of the press in Massachusetts. New York, Longmans, Green, Igo6. xv. 202. p. (Harvard historical studies, v. 12)

"Bibliographical notes": p. 175-186.

$$
\text { 6-15096 Z657.D93 }
$$

This book attempts to "explain the significant features of the rise of a free press in Massachusetts." It opens with a discussion of press control in England to 1603 . There follow chronological chapters on the changing censorship laws and controls in Massachusetts, which led to limited freedom of the press in the middle of the 17 th century, and to fairly full freedom during the Revolutionary War and after the adoption of constitutional guarantees. The book concludes with a chapter on the "reactionary tendencies" of $1789-1812$, and their subsequent modification. Since Massachusetts in many respects was typical of such problems throughout the Colonies, this book is significant for the early development of a free press in America.

2930. Pollard, James E. The presidents and the press. New York, Macmillan, I $947.866 \mathrm{p}$. 47-1213 $\mathrm{PN}_{4} 888 . \mathrm{P}_{7} \mathrm{P} 6$

An investigation of the relationships between the press and the presidents, from George Washington to Harry S. Truman. The story proceeds chronologically president by president, with each studied in considerable detail. Mr. Pollard's work is thus an important contribution to both political history and journalistic history. The later chapters add much to an understanding of present-day Washington news reporting and commentating.

2931. Rutherfurd, Livingston. John Peter Zenger, his press, his trial and a bibliography of Zenger imprints; also a reprint of the first edition of the trial. New York, Dodd, Mead, 1904. 275 p. $\begin{array}{llll}\text { illus. } & 4-8588 & Z_{232 . Z} R_{9}\end{array}$ 
Bibliography of the issues of the Zenger press, 1725-175 I: p. [133]-169.

Bibliography of the trial of John Peter Zenger: p. $[247]-255$.

Zenger (1697?-1746) was by origin a Palatinate German who came to this country as a youth. In I733 he established the New-York Weekly lournal, in which he printed criticisms of the administration of the royal governor of New York, William Cosby. This led to his arrest in I 735 on a charge of criminal libel. The judge was hostile, but, after listening to the brilliant pleadings of Andrew Hamilton of Philadelphia, the jury entered a verdict of not guilty. The case itself is regarded as crucial in the establishment of the freedom of the press in this country and is hence a starting point for the study of the principles of American journalism. Rutherfurd's study opens with a chapter on the political conditions and the general situation of the press in the period preceding the trial. The second chapter narrates the events leading to Zenger's arrest and the preparations for the trial. The third chapter is an account of the trial itself, with a summary of Zenger's subsequent career and of the effects of the trial on subsequent libel law. Also included is a reprint of Zenger's own ( 1736 ) verbatim account of the trial. While Mr. Rutherfurd's volume was originally published in a small edition, it has since been reprinted by photographic process (New York, Peter Smith, I941. 275 p.).

2932. Siebert, Fredrick Seaton. The rights and privileges of the press. New York, Apple-
ton-Century, 1934. xvii, $429 \mathrm{p}$.

$34-7^{8} 4$ Law

This book does not attempt to present the historical evolution of the rights and responsibilities of the press. It does attempt to describe the situation in America, as of its date, with regard to the limits of press privileges and rights, and it is designed to help the practicing journalist on points of law likely to arise. After an introductory chapter on the general subject of the freedom of the press, the first main section is "The Right To Gather News," with chapters on matters such as the rights of access to various governmental records and proceedings. The second section, "The Right to Publish News," covers the limitations upon it and seeks to indicate when stories become obscene and immoral, false and defamatory, professionally injurious, etc. The final section is "The Right to Comment" on the News," which is discussed with regard to individuals, institutions, and governmental personages and agencies. In keeping with the author's primarily legal viewpoint, the appendix contains a table of the many cases mentioned in the book (p.40r-4I8).

Siebert is also the author, with Theodore Peterson and Wilbur Schramm, of Four Theories of the Press: the Authoritarian, Libertarian, Social Responsibility, and Soviet Communist Concepts of What the Press Should Be and Do (Urbana, University of Illinois Press, 1956. I53 p.), which attempts to assess the main theories of press functioning, and their consequences for the form the press has taken in the United States and other nations. 


\section{Geography}

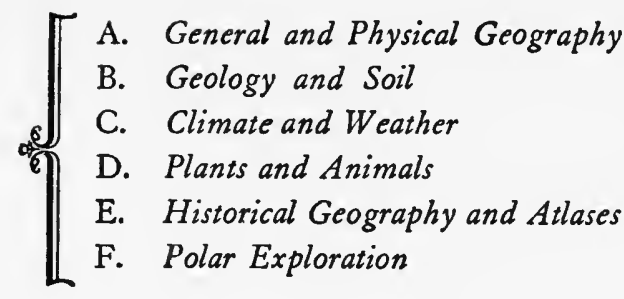

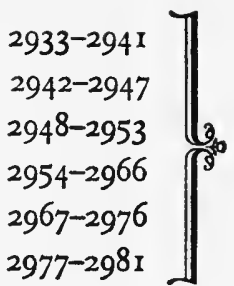

$\mathrm{T}$ HIS chapter offers a selection from the writings that describe the natural setting within which the civilization of the United States was brought into being, and upon which it must depend, as well as others that interpret the interrelations of continent and culture. The subject has long received the searching attention of scientific geographers and geologists, who have produced a vast literature merely to list which would require a number of volumes the size of this one. The great bulk of it, however, consists of scientific monographs and articles in professional journals, more or less completely technical in character, and inappropriate if not unintelligible to most of those whose primary interest lies in American civilization. From this whole literature we have therefore selected comparatively a mere handful of titles, which seem likely to be particularly helpful and interesting to students of that civilization. They are naturally, as a rule, the more general works, but some quite detailed and technical volumes (such as nos. 296r and 2969) have been included when they seemed to give valuable insights not readily obtainable elsewhere.

It will be noted that most of the manuals included in Sections A and B treat North America as a unit, since the northern and southwestern boundaries of the United States have little significance for the physiographer or the geologist. Two of the books in Section A (nos. $293^{8}$ and 2942) are concerned with the discipline itself, the pursuit of scientific geography in the United States, with the entire globe for its subject matter. The books on soil science in Section B deal with a subject that has been exhaustively pursued by the U. S. Department of Agriculture during the last 60 years, but that seems to be little adapted to summary treatment.

There is of course no sharp division between these and related titles that will be found in Chapter XXVII, Land and Agriculture. The selection in Section D on Plants and Animals is perhaps unfair to our native fish, reptiles, amphibians, and insects, as well as to several types of vegetation less conspicuous than the trees, all which groups have been effectively described in books intended for the general reader.

Section E on Historical Geography is less selective than its predecessors, for there is less to select from; the subject has hardly received the cultivation it deserves. Academic historians were in some degree alienated from a geographical approach by the rather exaggerated determination of an earlier school of which Miss Semple (no. 2975) was a representative. Messrs. Gilbert and Brown (nos. 2971, 2968, and 2969) have since exemplified a more fruitful approach to historical geography, but their followers remain few. (There is, however, much matter of geographical interest in the sections on Discovery and Exploration in Chapter VIII, General History.) It is furthermore true that more and more special- 
ized atlases of American history are a desideratum; here the high cost of printing has been one of the effective deterrents.

The final section on Polar Exploration calls attention to a sphere in which the specifically American contribution to a fundamentally international enterprise has been outstanding. We should not wish to omit mention of the achievements of Kane, Greely, Peary, and Byrd, and this seemed the most appropriate place to notice them. Works on the exploration of the North American continent will be found in Chapters VIII and XII below.

\section{A. General and Physical Geography}

2933. Atwood, Wallace W. The physiographic provinces of North America. Boston, Ginn, 1940. xvi, $535 \mathrm{p}$. 40-33578 GBi15.A8 "Selected references for additional reading" at end of each chapter.

The regional idea is essential to the progress of geography, and the fundamental basis of regional subdivision is neither climate, agriculture, politics, vegetation, industry, nor soil, but "contrasts in topography, or relief," which "are not made by human occupation or affected by it." The regions of this volume are the Atlantic and Gulf coastal plain, the Appalachian highlands (in northeastern and southwestern divisions), the Laurentian upland, the central lowlands, the interior highlands, the Great Plains, the Rocky Mountains, the Cordilleran plateaus, and the Pacific borderlands. For each one the author opens with a general description, proceeds to characteristic features, and concludes with "an approach to the human drama." The treatment here is bolder and in larger strokes than in either Bowman or Fenneman below. A selected list of topographic maps, usually those of the U. S. Geological Survey, follows the references for each regional chapter. The 281 illustrations are exceptionally well chosen and reproduced.

2934. Bowman, Isaiah. Forest physiography; physiography of the United States and principles of soils in relation to forestry. New York, Wiley, 1911. xxii, 759 p. II-29383 GBr21.B7

When Dr. Bowman undertook this work, a knowledge of the physiography of the United States "depended upon one or two short and general chapters on the subject, or upon a study of hundreds of original papers and monographs." In writing "a book on physiography for students of forestry," he produced an authoritative synthesis which has influenced all subsequent writing in the field. The first hundred pages expound the origin and features of soils, while the remainder survey 32 physiographic regions of the United States. Such regions are characterized by "uniformity of topographic expression," are often of great size, are widely varied in character, and in some instances exhibit features unique on the earth's surface. Five plate maps and 292 figures illustrate the text.

2935. Fenneman, Nevin M. Physiography of western United States. New York, McGraw-Hill, I93I. 534 P. $\quad 3$ I-4608 $^{-1-G_{124} \cdot W_{4} F_{4}}$

2936. Fenneman, Nevin M. Physiography of eastern United States. New York, McGraw-

Hill, 1938. 714 p. $\quad 38-9303 \quad \mathrm{GBr}_{24} \cdot \mathrm{E}_{4} \mathrm{~F}_{4}$

In these volumes physiography is equivalent to geomorphology and is limited to the genetic study of land forms; it "may be said to represent the overlap of the two major sciences," geology and geography. The materials for the two treatises are largely geological monographs, but the information derived from them has been organized rather than merely assembled, and the large proportion of purely descriptive material is included for "its evidential value in the interpretation of physiographic history." The author, a professor of geology at the University of Cincinnati, divides the western United States into 10 and the eastern into 13 "provinces." These are determined by a scheme of division "which makes possible the largest number of general statements about each." Both volumes have folding maps as well as plans and photographs in the text.

2937. The Geographical review. Readings in the geography of North America, a selection of articles from The Geographical review. New York, American Geographical Society, 1952. 466 p. (American Geographical Society [of New York] Reprint series, no. 5) 52-2969 E4r.G4 Bibliography: p. 221-226.

The Geographical Review assumed its present form in 1916 and began issuing volumes of reprints of its articles concerned with a particular area during World War II; the present volume coincided with the centennial of the American Geographical Society and with the I7th Congress of the International Geographical Union meeting in Washington 
and New York. It reprints by photographic process 22 of the more than 500 articles on North America published by the Review since 1916, selected to "present as wide a range as possible of the many areas of geographical research," and arranged in the order of their appearance in the Review, 1916-1950. Most of the articles have maps, charts, or photographs, and there is one large folding map in color to accompany Charles Warren Thornthwaite's "An Approach toward a Rational Classification of Climate" (1948), which revises the influential "The Climates of North America according to a New Classification" that Thornthwaite contributed to the Review in 1931. The other articles include James W. Goldthwait's "A Town that has Gone Downhill" [Lyme, N. H.] (1927); Wolfgang L. G. Joerg's "The Geography of North America: A History of Its Regional Exposition" (1936); Richard Hartshorne's "Racial Maps of the United States" (1938); and Edward L. Ullman's "The Railroad Pattern of the United States" (1940).

\section{James, Preston E., and Clarence F. Jones,} eds. American geography: inventory \& prospect. John K. Wright, consulting editor. Maps by John C. Sherman. Syracuse, N. Y., Published for the Association of American Geographers by Syracuse University Press, 1954. 590 p.

\section{$54-9225 \quad \mathrm{G}_{73} \cdot 3 \cdot \mathrm{U}_{5} \mathrm{~J}_{3}$}

This coöperative work "deals with the fruits of American learning in the last two generations," and "is written not only for the trained geographer, but also for the educated layman, for the apprentice geographer, and for workers in another discipline who may want to know what American geographers are thinking and doing and what they hope to accomplish." Its scope extends to American studies in world geography, and not merely in the United States or North America. Each chapter is followed by a series of references in which the relevant books and articles are enumerated. Chapters are deyoted to such varieties as historical, settlement, urban, political, agricultural, transportation, plant, animal, medical, and military geography. The volume concludes with discussions of field techniques, the interpretation of air photographs, and geographical cartography.

2939. Jones, Llewellyn Rodwell, and Patrick W. Bryan. North America, an historical, economic, and regional geography. [ [oth ed., rev.] London, Methuen; New York, Dutton, 1954. xvi, 582 p. $\quad$ 56-61 E38.J75 1954 A standard text by two English university geographers, originally published in 1924. The last major revision was that of 1938 . Prof. Jones died in 1947, but Dean Bryan has continued to make correc- tions and additions in the two editions published since. The organization of the book is indicated by the subtitle: Part I, "Historical Geography" (from the discovery to the Civil War), was originally written by Jones; Part II, "Economic Geography," has ten chapters by Bryan and five by Jones; Part III, "Regional Geography," was by Jones. This work of great clarity and concision is illustrated by 122 maps and plans. A shorter text, by an English geographer who has migrated to Indiana University, is Norman J. G. Pounds' North America (London, Murray, 1955. 230 p.). It devotes a chapter to New York City, and separate treatment to Canada.

2940. White, Charles Langdon, and Edwin J. Foscue. Regional geography of Anglo-America. 2d ed. New York, Prentice-Hall, 1954. xxii, $518 \mathrm{p}$. illus. 54-6526 Er69. W54 1954 "Selected bibliography" at end of each chapter.

$A$ revised and reorganized edition of a textbook originally published in 1943. Anglo-America is one of the two major divisions of the Western Hemisphere, divided from Latin America by the northern border of Mexico. Geographical "regions are formed by man as he adjusts himself to the natural environment"; they are determined by "the attitudes, objectives, and technical abilities of the settlers" as much as by the physical quality of the land, and they have ever-changing boundaries, readily altered by technological or economic innovation. The authors divide Anglo-America into 14 mutually exclusive regions, such as the Cotton Belt, the Agricultural Interior, the Subtropical Pacific Coast, and the Tundra, and a I5th, the American Manufacturing Belt, which extends discontinuously from Boston to St. Louis, and overlaps four of the other regions. Appendix A enables the reader to distinguish the authors' geographical regions from physiographic, climate, and soil regions as established by standard authorities. Subregions are distinguished within most of the 14. Under each region or subregion the authors describe the physical setting, sometimes the "sequent occupance," the major forms of economic exploitation, and, finally, "the outlook," which in some instances, especially the Atlantic Coastal Plain and the Piedmont, is difficult to forecast. An earlier, more detailed, and even more critically diagnostic regional survey, which unfortunately has not been brought up to date, is North America, Its People and the Resources, Development, and Prospects of the Continent As the Home of Man [rev. ed.] (New York, Harcourt, Brace, 1942. Io16 p.), by Joseph Russell Smith and Merton Ogden Phillips. An up-to-date textbook concentrating on utilization of the national resources, but considering them only under four large conventional regions, 
is Geography of North America, 3d ed. (New York, Wiley, 1955. 664 p.), by George J. Miller, Almon E. Parkins, and Bert Hudgins. Alfred J. Wright's United States and Canada; a Regional Geography, 2d ed. (New York, Appleton-Century-Crofts, 1956. $59 \circ \mathrm{p}$.), emphasizes the effect of constant change in the national economy upon the data of economic geography.

2941. Wright, John K. Geography in the making; the American Geographical Society, 185I1951. New York, The Society, 1952. xxi, 437 p. $52-I_{527} G_{3} \cdot A_{5} 6 W_{7}$

A centennial history of the leading American organization for the scientific study of geography, by an outstanding geographer who has been a staff member since 1920, and Director during 1938-49. Dr. Wright is concerned with the gradual transformation of the Society's function, from the advancement of exploration and the investigation of remote regions, toward the development of geography as a profession and an educational discipline. As landmarks he points out the presidency of Archer M. Huntington (1907-1I) and the service of Isaiah Bowman as director (1915-35). He gives special emphasis to the compilation of the "millionth map" of South America, which was undertaken in 1920, took 25 years to complete, and cost $\$ 570,000$.

\section{B. Geology and Soil}

2942. Eardley, Armand J. Structural geology of North America. New York, Harper, 195 I. 624 p. $22 \times 29 \mathrm{~cm}$. (Harper's geoscience series)

Bibliography: p. 6or-620.

$$
\text { 5I-I0958 } \quad \mathrm{QE}_{4} \mathrm{I} \text {. } \mathrm{E}_{2}
$$

An imposing textbook for advanced students which aims "to describe the structural evolution of the North American continent in post-Proterozoic time." The editor of the series calls it "the first book in any language which described in some detail the structural evolution of an area as large as a continent." The unusual shape provides for the numerous large maps and cross sections. No list is provided of the 343 numbered figures in the text. The author states that the backbone of the study resides in the two kinds of maps: the paleogeographic maps which show the surface distribution of the various rocks at different times in the past, and the more numerous paleotectonic maps which show the basins, arches, domes, and other structural features that formed during a certain time. The chapters "chronicle the crustal unrest of the continent" and treat of "the procession of deformational and sedimentary events," but emphasis has been placed on geographic position rather than on time. The structural terminology employed in the book is explained in Chapter 2.

2943. Hulbert, Archer Butler. Soil; its influence on the history of the United States, with special reference to migration and the scientific study of local history. New Haven, Yale University Press, 1930. $227 \mathrm{p}$.

30-30109 Ei56. HgI

"The material ... has been elaborated from an outline delivered on the Goldwin Smith lectureship foundation at Cornell University, New York, in 1925."-Preface.
Its title notwithstanding, this is no narrow monograph, but a general work on the historical geography of American settlement. Its seeks only to add the "edaphic" factor to such recognized ones as climate and waterways, and expressly disclaims "the devil of one idea" as a method of interpretation. The author discusses the five main classes of soils and reviews the sections of the Preliminary Soil Map of the United States, published by the U. S. Bureau of Soils in 1911. He notes that the settlers' ideas or prejudices concerning the virtues of soils, and vegetation as an index of soil quality, were positive influences. The final I4 chapters discuss soils and agriculture in successive phases of pioneer settlement from New England to the Pacific. An appendix calls for a new emphasis upon primary topography and original surveys in town, township, and county history.

2944. Kellogg, Charles E. The soils that support us; an introduction to the study of soils and their use by men. New York, Macmillan, 194I. $370 \mathrm{p} . \quad 4 \mathrm{I}-16797 \quad S_{591 . K 425}$

Modern soil science is a highly developed specialty whose technicalities tend to leave the ordinary reader far behind. Dr. Kellogg, successor to C. F. Marbut in charge of the U. S. Soil Survey, succeeds in making the subject both intelligible and significant to the layman in this attractively presented and produced primer. While the theme is the worldwide one of man in relation to the soil, the great majority of the examples are taken from American regions, and the "soils of the grasslands," "of the desert," "of temperate forested lands," and even "of warm and tropical lands" are all presented through appropriate examples within the continental United States. Appendix I provides an introduction to soil classification and soil maps. 
2945. Miller, William J. An introduction to historical geology, with special reference to North America. 6th ed. New York, Van Nostrand, 1952. 555 p. $\quad$ 52-638I QE65I.M5 1952

The author of this very successful textbook, first published in 1916, is Emeritus Professor of Geology, University of California at Los Angeles; the 6th edition is a thorough revision incorporating new topics and illustrations. The use of technical terms, especially the names of fossils, has been kept to a reasonable minimum. After eight introductory chapters on the elements of earth history, the book proceeds by treating successive eras and periods, from the Archeozoic to the Cenozoic, according to a uniform plan. Surviving formations and fossils from each age within the United States are emphasized:

2946. Mohr, Charles E., and Howard N. Sloane, - eds. Celebrated American caves. New Brunswick, Rutgers University Press, 1955. 339 p. 55-12228 GB604.M6

One of the features of American geology is the great number of large underground caverns which it includes-some 2000 in Kentucky, 1500 in Tennessee, 1200 in Virginia, and rooo in Missouri, to name only the leading states. Mammoth Cave in Kentucky has been in continuous operation as a natural showplace since 1816. The National Speleological Society, founded in 194I, aims "to foster interest in the knowledge to be gained from cave exploration, and to protect from thoughtless vandalism the national features of the underground world." Fifteen of its members have contributed to the present volume sketches of individual caves, caves of various regions, or of particular cave phenomena, such as vampire bats and prehistoric burials.

2947. U. S. Dept. of Agriculture. Soils and men. [Washington] U. S. Govt. Print. Off., 1938. I232 p. (Its Yearbook of agriculture, 1938)

$$
\begin{array}{lll}
\text { Agr 55-13 S21.A } 35 \quad 193^{8} & -1
\end{array}
$$

The United States Soil Survey was initiated in 1899 , and from 1910 to 1934 was under the direction of Curtis Fletcher Marbut (I863-1935). In cooperation with state research institutions it has produced several thousand maps and reports on particular localities and is responsible for nearly all the detailed knowledge of American soil varieties and their distribution. It has naturally developed a progressive refinement of technique and classification, which has rendered its earlier surveys more or less obsolete. The first large summary of its results was the U. S. Bureau of Soils' Bulletin no. 96, Soils of the United States, by Marbut, Hugh H. Bennett, Jesse E. Lapham, and Macy H. Lapham (Washington, Govt. Print. Off., 1913. 791 p.), which included a detailed soil map of the United States. Marbut's own lifework was summed up in "Soils of the United States," Part 3 of the Atlas of American Agriculture (q. v.) which appeared in the year of his death. The methods and objectives of the Survey have since 1903 been set forth in a succession of fieldbooks, the later being the Soil Survey Manual, issued in August ${ }_{295} \mathrm{I}$, by the U. S. Bureau of Plant Industry, Soils, and Agricultural Engineering (Washington [U. S. Govt. Print. Off.] 503 p.); it includes a "Special Bibliography" of recent (193750) surveys in contrasting soil regions (p. 447-454). The 1938 Yearbook, like its companion volumes, is a huge miscellany by various hands treating all aspects of the subject. It is included here because of Part V, "Soils of the United States" (p. [ror7]1161), in which members of the Soil Survey Division "bring together and summarize, on a comparatively small scale, the data accumulated during the past half century on the enormous variety of soils in this country." The descriptions are offered in conjunction with a map of the "soil associations" of the United States at the end of the volume. The Yearbook also contains "A Glossary of Special Terms" used in it (p. 1162-1180) and an alphabetical list of "Literature Cited" comprising 476 entries (p. 11811207).

\section{Climate and Weather}

2948. Flora, Snowden D. Tornadoes of the United States. [Rev. ed.] Norman, University of Oklahoma Press, 1954. xvi, $221 \mathrm{p}$.

$$
\text { 54-8922 QC955.F6 } 1954
$$

Tornadoes are more numerous and violent in the United States east of the Rockies than anywhere else in the world. The Director of the Weather Bureau for Kansas explains them, so far as they are understood, calculates their destructiveness, gives practical advice, and inventories the worst examples on record.

2949. Hoyt, William G., and Walter B. Langbein. Floods. Princeton, Princeton University

Press, 1955. 469 p. 54-6075 GBr215.H68 Bibliography: p. 433-443. 
Estimates of the damage caused by floods in the U. S. in an average year range from $\$ 200,000,000$ to $\$ 500,000,000$. The authors discuss the causes of floods, and the kinds of antidotes which human ingenuity can devise. They go on to expound the national flood-control policy, survey problems, projects, and plans in the several basins, and conclude with a detailed history of American floods since 1900.

2950. Kimble, George H. T. Our American weather. Maps and charts by Jean Paul Tremblay. New York, McGraw-Hill, 1955. 322 p. 54-97 I I QC983.K5

"There is nothing quite like American weather anywhere else in the world." Its highly individual "style" results from two main factors: the invasion of air masses from six different quarters, and a strongly articulated terrain which facilitates the flow of heat and cold while it restrains the flow of moisture. This individuality is elaborated in a monthby-month survey, in which the prevalent "spectacles of the weather parade," and their regional modifcations, are described. This popular presentation puts much solid meteorological information into an ingenious and palatable form.

295I. U. S. Dept. of Agriculture. Climate and man. Washington, U. S. Govt. Print. Off., 194I. xii, 1248 p. (Its Yearbook of agriculture, 194r) Agr 55-10 S21.A35 1941

A massive symposium undertaken before the transfer of the Weather Bureau from the Department of Agriculture to the Department of Commerce in 1940. It is in large part inspired by the progress in weather science achieved by Scandinavian scientists during World War I, when the importance of movements in the upper atmosphere was demonstrated, and since by American scientists, whose actual observations and measurements in this area have led to large research projects which prepare the way for long-range forecasting. Nearly half the book (p. 634-1228) presents climatic data in map or tabular form, for the United States as a whole, and particularly for each of the 48 States in alphabetical order, with respect to temperature, precipitation, and killing frosts. Several papers describe the methods of recent meteorology, including "How the Daily Forecast is Made" and the problems of forecasting floods. Two considerable sections deal with the influence of climate on agricultural settlement in various regions of the United States and in its territories, and with the relations of climate to particular crops such as cotton, tobacco, orchard crops, and livestock.
2952. Visher, Stephen S. Climatic atlas of the United States. Cambridge, Harvard University Press, 1954. 403 p.

$$
\text { Map } 53-3^{8} 3 \text { Gr2or.C8V } 5
$$

1954

Bibliography: p. 393-395.

The typical or average phenomena of American weather are presented in a series of ro3r figures, mostly maps of the continental United States, and the rest graphs. The first $37 \mathrm{I}$ are concerned with temperature; the remainder are divided among winds and storms, sunshine, humidity and evaporation, precipitation, consequences of climate in agriculture and topography, and climatic regions and changes. Over 400 of the maps are original compilations by Prof. Visher, and the remainder have been adapted to a uniform style. This reference book summarizes the result of decades of observation by the United States Weather Bureau and its coöperators. The American Automobile Association's Climatic Guide (Washington, I950. I3I p.) presents average monthly figures on temperatures, precipitation, humidity, wind, and cloudiness for $25^{\circ}$ American cities-a convenient compilation not merely for motorists. An older but still valuable compilation of climatic data will be found in Part 2, "Climate," of the Atlas of American Agriculture (q. v.).

2953. Ward, Robert De Courcy. The climates of the United States. Boston, Ginn, I925.

518 p. 25-21094 QC983. W3

The author was a professor of climatology at Harvard University, and his book, the product of 25 years of study and teaching, has retained its authority through three decades. It defines climate as average weather, but insists that mere averages are misleading, since "it is the irregular weather changes from day to day which give climates their real character." The author enumerates the seven major climatic controls, arrives at a working scheme of eight climatic provinces for the United States, and summarizes their outstanding features in Chapter 20. Its predecessors are largely topical, analyzing the phenomena of temperature, frost, prevailing winds, rainfall, snowfall, humidity and "sensible temperatures" (i. e., as affecting human comfort or discomfort), sunshine and cloudiness, thunderstorms, cold waves and blizzards, hot waves and the Indian Summer, and winds and breezes of various types. Concluding chapters consider the American climate in relation to health and to crops, and the climates of Alaska.

The Climates of North America, by Ward, Charles F. Brooks, and A. J. Connor, comprises Band II, Teil J (Berlin, Borntraeger, 1938. 424 p.) of a large Handbuch der Klimatologie, edited by W. Köppen and R. Geiger. The second and largest 
section, "The United States" (p. 80-903), was originally condensed by Ward from his I 925 volume, but was revised by Prof. Brooks of the Blue Hill Meteorological Laboratory, Harvard University, in the light of new contributions published through
1935. New maps were prepared, and 92 pages of tables compiled from published and unpublished materials of the U. S. Weather Bureau (p. 197288). The volume includes separate treatments of Mexico, Alaska, and Canada.

\section{Plants and Animals}

2954. Cahalane, Victor H. Mammals of North America. With drawings by Francis $L$. Jaques. New York, Macmillan, 1947. 682 p.

"List of references": p. $647-676$. 47-4195 QL715.C 3

2955. Hamilton, William J. American mammals; their lives, habits, and economic relations. New York, McGraw-Hill, I939. 434 P.

$$
\text { 40-27054 QL715.H16 }
$$

These two works complement each other admirably. Mr. Cahalane, who aims at "a popular book which will summarize existing information on the principal kinds of mammals of North America," has reduced the 1500 existing species and subspecies under 94 headings. For each he gives a generalized and quite lively life history, in which he consciously runs the risks of "humanizing" animal behavior, enumerates the principal varieties, gives a concise general description, identifies the distinguishing characteristics for the benefit of field observers, and delimits the geographical range. Mr. Hamilton has aimed to produce a "reference text" for layman, teacher, and professional zoologist alike, but, save for a technical chapter on classification, it is little behind the popular work in readability. Here the treatment is topical, such large subjects as adaptations, food, reproduction, hibernation, migration, and behavior receiving illustration from a variety of species. Chapters 14 and 15 discriminate between "Useful" and "Injurious Mammals"; but it is explained that "any mammal may be of considerable value in one locality and highly destructive in another." Mr. Jaques' drawings have a distinction lacking in the illustrations of American Mammals; the latter's photographs are poorly reproduced. A complete systematic account is provided by Gerrit $S$. Miller and Remington Kellogg's List of North American Recent Mammals (Washington, Smithsonian Institution, 1955. 954 p.).

2956. Ecological Society of America. Naturalist's guide to the Americas, prepared by the Committee on the Preservation of Natural Conditions of the Ecological Society of America, with assistance from numerous organizations and individuals, assembled and edited by the chairman, Victor $\mathrm{E}$. Shelford. Baltimore, Williams \& Wilkins, I926. $\mathrm{xv}, 76 \mathrm{I}$ p. 26-89o6 QHro2.E25

This unusual book was the result of seven years' effort by members of the Ecological Society to list "all preserved and preservable areas in North America in which natural conditions persist." Materials on Central America, and on South America north of the Amazon, are confined to p. 514-709. Section III attempts to arrive at the "original Biota of the Americas" (necessarily limited to general vegetation, mammals, and birds) and distinguishes I9 characteristic areas north of central Mexico. The bulk of the book (p. 87 ff.) consists of detailed descriptions of particular areas by various hands. The Society's larger objective was "the preservation of natural areas with original flora and fauna (or as nearly so as may obtain) and the maintenance of the natural biotic balance in existing preserves."

2957. Harshberger, John W. Phytogeographic survey of North America; a consideration of the phytogeography of the North American continent, including Mexico, Central America and the West Indies, together with the evolution of North American plant distribution. Leipzig, Engelmann; New York, Stechert, IgI I. lxiii, 790 p. (Die Vegetation der Erde, hrsg. von A. Engler und O. Drude, v. 13) DA

"Kurzgefasste deutsche Inhaltsübersicht," by $\mathrm{O}$. Drude: p. [xiii]-lxiii.

Dr. Harshberger believed that it was essential for the botanists of his day to leave "a record of the original appearance of the country before the march of civilization has destroyed primeval conditions," since "all future botanic and forestry work must be based on considerations of what was the native growth." He begins with a review of earlier botanic investigations and literature (p. 1-45) and continues with a bibliography in geographical arrangement (p. 45-92). Part 3 outlines the history of North American flora through geological time since the Cretaceous Period, discusses its relationship to other continental floras, and glances briefly at earlier at- 
tempts at its phytogeographic classification. Part 4, comprising about half the book, is a systematic review of the several zones, regions, formations and associations into which the author has divided the continent. In each area the author aims "to give a succinct account of the vegetation ... not exclusively from the floristic standpoint, but also from the ecologic."

2958. Herrick, Francis Hobart. The American eagle; a study in natural and civil history. New York, Appleton-Century, 1934. xx, 266 p.

$$
34-36763 \text { QL696. } \mathrm{A}_{2} \mathrm{H}_{4} 6
$$

"In the course of from fifty to sixty centuries the eagle has symbolized not only power, courage, and conquest, but freedom, independence, magnanimity, truth, the soul or its bearer, the Holy Spirit, and immortality." It was therefore not surprising that William Barton placed a heraldic eagle on the original design for the Seal of the United States; but it was an inspiration on the part of Charles Thomson, permanent Secretary of the Continental Congress, to alter this conventional fowl to Haliaeetus leucocephalus, the American or bald eagle. Mr. Herrick traces our eagle's heraldic appearances on successive seals and coins, and also describes its natural life in the eyries about Vermilion, Ohio. These he has approached by means of a 96 -foot steel observatory tower, enabling him to take a unique series of photographs of the American eagle at home.

2959. Livingston, Burton E., and Forrest Shreve. The distribution of vegetation in the United States, as related to climatic conditions. Washington, Carnegie Institution of Washington, I921. xvi, 590 p. (Carnegie Institution of Washington. Publication no. 284) 2I-I5878 QKII5.L8 "Literature cited": p. 587-590.

A first attempt "to discover quantitative relations between vegetation characters on the one hand and environmental conditions on the other" for the geographic area of the United States. The authors regard plant physiology as the key to causal relations within the field. Their problems have led them to work out the general vegetation zones of the United States, and to map the distribution of particular species or groups of species. The bulk of the book is taken up by detailed tables of climatic phenomena and of vegetation-climate correlations. The most important correlation discovered is that between vegetation zones and "the moisture ratio for the average frostless season."

2960. Martin, Alexander C., Herbert S. Zim, and Arnold L. Nelson. American wildlife \& plants, a guide to wildlife food habits; the use of trees, shrubs, weeds, and herbs by birds and mammals of the United States. New York, McGrawHill, I95I. 500 p. 5I-II545 QL756.M27

"Prepared under the direction of the United States Fish and Wildlife Service, Department of the Interior, at the Patuxent Research Refuge, Laurel, Maryland."

This manual provides detailed information concerning the foods upon which the several species of American wild birds and mammals depend. The object is to further wildlife preservation, but the attractive method of presentation-species by species with neat drawings and thumbnail maps showing distribution for each-affords a compact survey of present-day wildlife in the United States. Part II deals successively with water birds, land birds, birds of prey, fur and game mammals, small mammals, and "hoofed browsers." Part III reviews the plants, indicating the several animal species to which each is useful, and concludes with Io pages of tables: "Wildlife Plants Ranked According to Their Value."

296r. Morgan, Lewis H. The American beaver and his works. Philadelphia, Lippincott, 1868. 330 p. 6-26710 QL737.R6M84 Castor Americanus, physically a rather unimpressive rodent, is the only mammal beside man who has developed complex engineering skills. It was his misfortune to bear a pelt which was long regarded as the finest material for the hats of Western man; after two centuries of trapping he was threatened with extinction, but was saved, early in the rgth century, by the substitution of silk hats for fur ones. This classic monograph by the great pioneer of American anthropology pays especial attention to the beaver's dams, lodges, burrows, canals, and trails, which have so conspicuously modified the primeval American landscape, and to the callously cruel methods by which he has been trapped.

2962. National Geographic Society, Washington, $D$. C. The book of birds; the first work presenting in full color all the major species of the United States and Canada. Edited by Gilbert Grosvenor and Alexander Wetmore. With 950 color portraits by Major Allan Brooks. [2d ed.] Washington, National Geographic Society, 1939. 2 v.

$$
\text { 39-23274 QL676.N285 } 1939
$$

Contents.-v. I. Diving birds, ocean birds, swimmers, wading birds, wild fowl, birds of prey, game birds, shore birds, marsh dwellers, birds of the northern seas.-v. 2. Owls, goatsuckers, swifts, woodpeckers, flycatchers, crows, jays, blackbirds, orioles, chickadees, creepers, thrushes, swallows, tanagers, wrens, warblers, hummingbirds, finches, and sparrows. 
A popular presentation in the familiar manner of the National Geographic Magazine, the systematic sections being eked out by little articles on "Encouraging Birds around the Home," and the like. The systematic sections are written chiefly by Dr. Wetmore and T. Gilbert Pearson, with lesser contributions from Arthur A. Allen, Robert Cushman Murphy, and the illustrator, Major Brooks. Each such section opens with a general discussion of the group and concludes with descriptions of individual species which are by no means uniform in treatment. Major Brooks' "950 color portraits" appear on 204 plates reproduced from paintings. There are nearly as many halftones from photographs, a majority of them action shots of wild birds. A number of other popular treatments of the subject have appeared since, but nothing on the same generous scale. Arthur A. Allen's Stalking Birds with Color Camera, published by the National Geographic Society in $195 \mathrm{I}$ (328 p.), contains a large number of magnificent color photographs of American birds in their natural environment, but is neither comprehensive nor systematic.

2963. Peattie, Donald Culross. A natural history of trees of eastern and central North America; illustrated by Paul Landacre. Boston, Houghton Miflin, 1950. xv, 606 p. 50-10354 QK 48 r.P 4

2964. Peattie, Donald Culross. A natural history of western trees; illustrated by Paul Landacre. Boston, Houghton Mifflin, 1953. xiv, 75I p. 52-5263 QK $481 . P_{42}$

Mr. Peattie is a living representative of an old American tradition which combines sound natural knowledge with mastery of expression. These two books, which are to be supplemented by others on the trees of the South, and on "cultivated trees of exotic origin," review the native species in a uniform manner. The popular and Latin names are followed by alternative names, the range of the species, a description "couched in language using the minimum of technical terms," and finally a little essay in which landscape, historical circumstances, and economic factors are gracefully combined. There are frequent quotations from early naturalists, and the author often seizes upon a single example to make the species memorable: for the Swamp White Oak, for instance, he mentions the Big Tree of Geneseo, N. Y., "towering Ioo feet high with a circumference of 27 feet," beneath which in 1797 Robert Morris purchased much of western New York State from the Seneca Indians. Paul Landacre's stylized drawings contribute to the distinction of these volumes.
2965. Roe, Frank G. The North American buffalo; a critical study of the species in its wild state. Toronto, University of Toronto Press, I95I. 957 p. $\quad 52-16_{47}$ QL737. U $5 R_{73}$ Bibliography: p. 897-914.

The Bison Americanus, or historic American buffalo, "is the only known creature which has ever thronged in such prodigious hosts a geographical range which climatic and ecological characteristics or potentialities made a natural home for a really large white population." In consequence, it has affected North American civilization "perhaps more vitally than has ever been the case with any other species in its indigenous environment in any portion of the globe." Nevertheless, Mr. Roe, who disclaims biological expertness and has labored only "to ascertain and classify the historical evidence," has written a huge book polemic in purpose and sharply controversial in tone. He masses his evidence to prove that the buffalo had no uniformity or regularity in their migrations, and so could not have determined the course of the earliest human trails; and that the Indians were not habitually wasteful in their hunting of the buffalo herds, whose sudden disappearance must therefore have been the work of the white men.

2966. Weaver, John E., and Frederick W. Albertson. Grasslands of the Great Plains: their nature and use. With special chapters by $B$. W. Allred and Arnold Heerwagen. Lincoln, Neb., Johnsen Pub. Co., 1956. 395 p.

Bibliography: p. 379-387.

$$
\text { 56-9095 QK938.P7 } \mathrm{W}_{37}
$$

An exhaustive study of the natural vegetation of the "Mixed Prairie," the most extensive grazing area in North America, and especially as affected by a climate of extremes which is commonly called semiarid but is humid in some years and desertlike in others. Intensive local studies have made possible a profound understanding of the processes at work during the great drought of $1933-40$, the good decade of $1941-52$, and the renewed and even more severe drought of 1953-55. "Extended periods of drought are a part of the plains climate. The grasslands have survived throughout the ages. Slowly but surely the depleted vegetation was always restored .... It is only when man aids in the destruction by overgrazing and trampling and by plowing that conditions are worsened and the vegetation is destroyed." A companion volume by Prof. Weaver, North American Prairie (Lincoln, Neb., Johnsen Pub. Co., 1954. 348 p.), is equally meticulous, but without such striking applications. 


\section{E. Historical Geography and Atlases}

2967. Adams, James Truslow, ed. Atlas of American history. James Truslow Adams, editor in chief; $\mathrm{R}$ [oy] V. Coleman, managing editor. New York, Scribner, 1943. $360 \mathrm{p}$.

Map 43-I26 EI79.A3

A supplement to the Scribner Dictionary of American History (no. 3070), this atlas consists of 147 plates (usually one but sometimes two to a map) in black-and-white line, prepared by LeRoy $\mathrm{H}$. Appleton under the direction of 64 historians (whose names appear at the foot of their contributions). The editors aimed to produce "a concise, easy to use, carefully thought out, authoritative atlas," which "would interpret our history through the location of places as they actually existed and exactly where they existed at a given time." The maps are small $(24 \mathrm{~cm}$.) and simplified in their topography; but the selection of significant subjects, the comparatively brief time-span of each, and the restriction of detail to sites of contemporary importance, have attained the latter object more adequately than in any other general work of the kind. The result is a very useful companion to studies in many aspects of American history.

2968. Brown, Ralph H. Mirror for Americans; likeness of the eastern seaboard, I810. New York, American Geographical Society, I943. xxxii, 3 I2 p. (American Geographical Society. Special publication no. 27, edited by Elizabeth T. Platt)

Bibliography: p. [248]-259. 43-9759 Fro6.B9

2969. Brown, Ralph H. Historical geography of the United States. New York, Harcourt, Brace, I948. 596 p. 48-1500 EI79.5.B9

Bibliography: p. [539]-571.

The first title conceals a scientific purpose beneath a pleasant veneer of archaism: the real author invents a fictitious one, a Philadelphia collector of American geographical literature in the year $18 \mathrm{ro}$, who digests the contents of his shelves into a descriptive treatise of which "the style and the organization are both designed as composites of the geographical exposition of the time." There is a preliminary discussion of the literature itself, and many well-reproduced illustrations from contemporary sources, some of the maps being skillfully redrawn. The future is ingeniously kept open: "Will the Potomac become the great highway to the west? He would be foolhardy indeed who answered one way or the other."
The later work is a more straightforward application of the same basic method to the settlement and economic exploitation of successive areas of the United States and Canada. In each phase the physiography and vegetation of the land to be conquered are set against the institutional and technological equipment of the settlers, and the primary economy of the region is shown to emerge as a consequence of both factors, which have themselves become modified in the process. This treatment is applied to the occupation of the Atlantic Coast in the colonial period, of the Old Northwest to 1830, of Michigan, Wisconsin, and Minnesota to 1870 , and of the Great Plains and the Pacific Coast to the same year.

2970. Douglas, Edward M. Boundaries, areas, geographic centers and altitudes of the United States and their several states, with a brief record of important changes in their territory and government. $2 \mathrm{~d}$ ed. Washington, U. S. Govt. Print. Off., I932. 265 p. (U. S. Geological Survey. Bulletin 8I7) $\quad$ GS $_{34-40} \quad E_{179 . S . D}$ ) 1932 QE75.B9, no. 817a

The original form of this useful document, a compilation of precise information very difficult to find elsewhere, was issued by the Geological Survey in 1885, under the authorship of Henry Gannett, and the present edition is in fact the sixth revision. It defines the boundaries of the several accessions to the territory of the continental United States, the outlying possessions, and the 48 states, with emphasis upon peculiarities arising out of historical circumstances. A separate section outlines the history of the Public Domain. Ten tables of "General Statistics Relating to the United States" conclude the text.

297I. Gilbert, Edmund W. The exploration of western America, 1800-1850; an historical geography. Cambridge [Eng.] University Press, 1933. $233 \mathrm{p}$. $\quad 33^{-18707} \mathrm{E}_{179.5} \cdot \mathrm{G}_{56}$

In 1800 the trans-Mississippi West was largely terra incognita; by $185^{\circ}$ "the main geographical features of this vast area had been revealed." The author, who has since become professor of geography at Oxford, seeks "to reconstruct the geographical setting in which the explorers accomplished their work," and so to estimate the importance of geographical factors in the process. Six chapters are devoted to a geographical analysis of western America as of $1800-$ such systematic reconstruction being "the true function of historical geography." Concise narratives follow of the discovery of the 
northern, central, and southern trans-continental routes, and of the Great Basin and the routes over the Sierra Nevada. Noteworthy for its selection and arrangement of facts, the volume remains one of the most important English contributions to American studies.

2972. Lord, Clifford L., and Elizabeth H. Lord. Historical atlas of the United States. Rev. ed. New York, Holt, 1953. xv, 238 p.

53-10208 Gr201.SrL6 1953

"The startlingly rapid growth and development of the United States make its history particularly susceptible to visual portrayal . . . By mapping developments in particular fields every few years, so that one can almost see them grow or shift, this atlas tries to combine the usefulness of the animated [-cartoon] map with the advantages of being able to sit down ... for study at such length as need be." Thus there are maps of population density for every census year from 1790 to 1950 . The atlas also attempts to juxtapose basic social and economic maps against those for our political history. Map styles are frequently modelled on those of Paullin's atlas (no. 2974). Authors and publisher have produced an inexpensive volume, but, with 3I 2 maps on 196 medium-sized pages, the detail often becomes so minute as to bewilder. The authors warn that their work is meant, not as a reference atlas, but as a help for students.

2973. Muelder, Hermann R., and David M. Delo. Years of this land, a geographical history of the United States. New York, Appleton-Century, 1943. $243 \mathrm{P}$. 43-7107 Er79.5.M96

For the general reader, an outline of American history which emphasizes the geological and geographical factors in such large movements as discovery, colonization, the westward movement, national expansion, industrialization, conservation, and inter-American relations. The authors would not claim to be systematic or profound, but they are quite successful in placing familiar facts in unfamiliar perspectives, and in pointing out seldomrealized relationships between physical and historical phenomena.

2974. Paullin, Charles O. Atlas of the historical geography of the United States. Edited by

John K. Wright. Washington, Published jointly by Carnegie Institution of Washington and the American Geographical Society of New York, 1932. r62 p. 688 maps (part col.) on 166 plates (part double) ([Carnegie Institution of Washington. Publication no. 40I])

Map 32-54 Gr201.SrP3 1932

"This is the first major historical atlas of the
United States and probably the most comprehensive work of its kind that has yet been published for any country." After nearly 25 years it remains unrivaled. It was just 20 years in the making, work having been begun in Ig12 on a plan drawn up nine years earlier by J. Franklin Jameson, who closely supervised the enterprise through its first 15 years. Many scholars, scientists, libraries, archives, and Government agencies coöperated in its making. The text comments upon each individual map and indicates the sources upon which it was based. The major subdivisions are concerned with geography, cartography ( $1492-1867$ ), lands, population, boundaries, politics, reforms, and economics. In spite of the efforts lavished, all parts of the atlas are not of equal quality. The boundary maps, and those concerned with presidential elections and crucial votes in Congress, are outstanding; but the reproductions of old maps, which comprise the cartographic section and parts of several others, are too small for full legibility, and the military history section is quite unsatisfactory.

2975. Semple, Ellen Churchill. American history and its geographic conditions. Rev. in collaboration with the author by Clarence Fielden Jones. Boston, Houghton Miflin, 1933. $541 \mathrm{p}$.

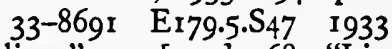

"Supplementary readings": p. [443]-468; "Literary reading lists": p. [469]-505.

The author, a follower of Friedrich Ratzel, was professor of anthropogeography at Clark University, and her book, originally published in 1903 , was long the standard work on geographical factors in American history. The present edition, which appeared the year after her death, included some additions and alterations from her pen, but the detailed task of bringing it up to date was carried out by $\mathrm{Mr}$. Jones. The majority of the chapters emphasize the geographic basis of striking events such as the Louisiana Purchase, the War of 1812 , and the Civil War; but there are also more analytical treatments such as "Geography of the Atlantic Coast in Relation to the Development of American Sea Power," "The Geography of the Inland Waterways," and "The Geographical Distribution of Railroads."

2976. Stewart, George R. Names on the land, a historical account of place-naming in the United States. New York, Random House, 1945. 418 p. $\quad 45-3640$ E155.S8

The study of place-names usually issues in an inventory, but Mr. Stewart has succeeded in interpreting the giving of such names within the continental United States as a significant historical process, and makes clear how "the names had grown out of the life, and the life-blood, of all those who had gone 
before." Particular names have been included $x$ ) as of large units, states or cities, interesting to all Americans; 2) as illustrating habits or fashions of place-naming; 3) as connected with the work of some individual; and 4) as of unusually interesting origin. The work achieves an original synthesis of geographical, linguistic, and historical factors. The considerable local literature is arranged by states in the Bibliography of Place Name Literature: United States, Canada, Alaska, and Newfoundland, by Richard B. Sealock and Pauline A. Seely (Chicago, American Library Association, 1948. 33 r p.).

\section{F. Polar Exploration}

2977. Byrd, Richard Evelyn. Little America, aerial exploration in the Antarctic, the flight to the South Pole. New York, Putnam, 1930. xvi, 422 p. $\quad 31-26036 \quad$ G850 $1928 . A_{3} \quad 193^{\circ}$ "The geological sledge trip, by Dr. Laurence M. Gould": p. 393-412.

2978. Byrd, Richard Evelyn. Discovery; the story of the second Byrd Antarctic expedition. New York, Putnam, 1935. xxi, 405 p.

$$
\text { 36-2704I G850 1933.A3 }
$$

Admiral Byrd (b. I888), if a comparatively late comer to Antarctic exploration (Amundsen reached the South Pole in 19II), has nevertheless a secure place through his systematic application of improved scientific equipment to permit continuous occupation, and prolonged observation and experiment. His narratives cover his first two expeditions, but he has not yet continued them to include several later and larger ones under Government auspices.

2979. Hobbs, William Herbert. Peary. New York, Macmillan, 1936. xv, 502 p.

$$
\text { 36-32070 G635.P } 4 \mathrm{H} 6
$$
465.

"Publications of Robert Edwin Peary": p. 456-

Robert Edwin Peary (1856-1920) engaged in 19 years of almost continuous Arctic exploration, beginning in $189 \mathrm{r}$, and concerned himself with a steady improvement of technique which would permit a final dash to the Pole itself by a few men and dog-sledges. His second attempt in 1905 was defeated by exceptionally severe weather, but his third brough him success on April 6, 1909. It was not until 1937 that Soviet scientists reached the Pole under conditions that permitted of extensive scientific observations. Unfortunately for Peary, an impostor of considerable literary skill, Dr. Frederick A. Cook, after wintering on the northern coast of Greenland, got in a claim to have reached the Pole the year before. Mr. Hobbs necessarily devotes much of his volume to a refutation of this claim and a description of the heated controversies which it engendered. In order to raise funds for his costly expeditions, Peary publicized his successive explora- tions at some length: Northward over the "Great Ice"; a Narrative of Life and Work along the Shores and upon the Interior Ice-Cap of Northern Greenland in the Years 1886 and $1891-1897$ (New York, Stokes, 1898.2 v.); Nearest the Pole: a Narrative of the Polar Expedition of the Peary Arctic Club in the S. S. Roosevelt, 1905-1906 (New York, Doubleday, Page, 1907. 4I I p.); and The North Pole, Its Discovery in 1909 under the Auspices of the Peary Arctic Club (New York, Stokes, I9ro. 373 p.).

2980. Mirsky, Jeannette. Elisha Kent Kane and the seafaring frontier. Boston, Little, Brown, 1954. 201 p. (The Library of American biography) $54-6886 \quad \mathrm{G} 635 \cdot \mathrm{K}_{2} \mathrm{M}_{5}$

Polar exploration is a cosmopolitan achievement to which many nations have contributed, and which can best be followed in a general narrative such as Miss Mirsky's To the Arcticl The Story of Northern Exploration from Earliest Times to the Present ([Rev. ed.] New York, Knopf, 1948. 334 p.). The American share, however, can be summarized in the lifework of four men: Kane, Greely, and Peary in the Arctic, and Byrd in the Antarctic. Kane (182057) was a young physician with a heart weakened by rheumatic fever, who headed two successive expeditions financed by the New York merchant Henry Grinnell, in search of the missing British explorer Sir John Franklin. His health gave way shortly after he completed the narrative of the second expedition. He was far in advance of his time in understanding the Eskimo adaptation to the Arctic climate. Kane's own narratives tell the story at considerably greater length: The U.S. Grinnell Expedition in Search of Sir John Franklin; a Personal Narrative (New York, Harper, 1853.552 p.) and Arctic Explorations; The Second Grinnell Expedition in Search of Sir John Franklin, 1853, '54, '55 (Philadelphia, Childs \& Peterson, 1856.2 v.)

298x. Mitchell, William. General Greely; the story of a great American. New York, Putnam, 1936. xiv, 242 p. $\quad 36-27206 \quad$ G635.G7M 5 Adolphus W. Greely (1844-1935) was placed in 
charge of the American station at Lady Franklin Bay on Ellesmere Island, northernmost of the eleven international circumpolar stations which, as a result of the International Polar Conference at Hamburg in 1879 , were to make observations during I 882-83. Greely and his 25 subordinates were taken to their station in the summer of $\mathrm{r} 88 \mathrm{r}$, but the relief ships of $\mathrm{r} 882$ and 1883 were incompetently commanded, and only Greely and six others were alive when Winfield S. Schley got through on June
22, I884. General Mitchell devotes the greater part of his concise and appreciative biography to the Arctic episode, but also calls attention to Greely's important work in the Signal Corps, the Weather Bureau, and in the early development of military aviation. Greely's own narrative was first published in 1886: Three Years of Arctic Service; an Account of the Lady Franklin Bay Expedition of 188184 and the Attainment of the Farthest North (New York, Scribner. 2 v.). 


\section{The American Indian}

\author{
$\llbracket \begin{aligned} & \text { A. General Works } \\ & \text { B. Archaeology and Prehistory. } \\ & \text { C. Tribes and Tribal Groups } \\ & \text { D. Religion, Art, and Folklore } \\ & \text { E. The White Advance } \\ & \text { F. The Twentieth Century }\end{aligned}$
}

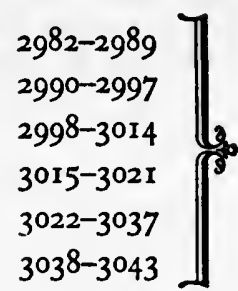

THE literature of the American Indian began with the Columbus Letter of 1493 , has 1 flourished through more than four and a half centuries, and continues to range from the romantic to the technically ethnological in the publications of the current year. The red man has ever exercised a compelling fascination upon the imagination of the European of all nationalities, and upon his American descendants, young or old, nor is this fascination diminished by increase of knowledge. The Indian makes an equally powerful appeal to scientific curiosity: the origins of his race, the sources of his culture, and the innumerable facets of his interrelations with the white man and his civilization have been and remain problems of the first importance for the systematic study of the human race. The Indian, however, is an abstraction: he exists only as a member of one among hundreds of individual tribes, speaking one among dozens of languages, and pursuing one among many contrasting ways of life. All of these subdivisions invite, and practically all have received, monographic treatment, resulting in an extraordinary accumulation of facts and an equally extraordinary proliferation of books. Few would maintain that this outpouring of monographs has been accompanied by a corresponding work of digestion and synthesis, for recent and good general works on the Indian, or on the larger aspects of Indian life and history, are rarer than they should be. We have, therefore, had the task of selecting a relatively small group of monographic studies, on particular tribes or on some aspect of Indian culture among one or a few tribes, as representative of the whole. Obviously many alternative choices could have been made with approximately equal justification. The monographic material is listed at length, under 253 tribal groups, in George Peter Murdock's Ethnographic Bibliography of North America, $2 \mathrm{~d}$

ed. (New Haven, Human Relations Area Files, 1953. 239 p.).

We have gone beyond the geographical limits of our proper subject, the United States, by including in Section B one title on the Maya and one on the Aztec civilization (nos. 2994 and 2997). This is on purely historical grounds: these cultures, along with that of the Incas in South America, were in all respects the highest developed in the New World by the Indian race, which is inadequately presented without them; the cultures of many other North American tribes were in some measure a diffusion and a dilution of these (cf. no. 3012); and the impingement of the Spaniards upon them was a decisive fact for the entire subsequent course of the European occupation of the New World. The user of this chapter will doubtless note that among the tribal studies the Indians of the Plains and of the Southwest predominate. This is largely because these alone survived in sufficient numbers, and with their original cultures reasonably intact, when anthropology had become a systematic discipline. Yet in smaller degree it is because to the American and the European imagination the Plains Indian is the American Indian par excellence, and his ways the 
proper ways of Indian kind-as is testified by the universal adoption of his war-bonnet.

In considering any Indian group, three varieties of fact may be distinguished: its culture prior to regular contact with white settlement; the processes of contact; and the consequences for the group. Some of our titles consider only one of these aspects or moments, but we have looked for books which take two or all three of them into consideration. The third aspect introduces the vexed questions of Federal Indian policy, which most of our authors criticize more or less severely. They do not, perhaps, always realize the advantage conferred by the wisdom of hindsight, as well as by an accumulated body of knowledge, affording an insight into the lives and minds of primitive peoples, which was not available a century ago. Two deficiencies which recent scholarship has hitherto failed to supply may be noted: any considerable study of individual Indians who have been absorbed into the white community, and documented studies of developments during the last quarter-century.

\section{A. General Works}

2982. Hodge, Frederick Webb, ed. Handbook of American Indians, north of Mexico. Washington, Govt. Print. Off., 1907-10. 2 v. (Smithsonian Institution. Bureau of American Ethnology. Bulletin 30) 7-35198 E77.H682

Bibliography: pt. 2, p. 1179-1221.

This immense compilation (2193 p.) had its inception as early as 1873 , and Mr. Hodge was engaged upon it from r889. It was originally conceived as a "tribal synonymy," attempting to order the multiple and conflicting nomenclature of Indian groups, but steadily expanded into an alphabetical arrangement of Indian knowledge of every kind. The original purpose appears in the 158-page "Synonymy" in vol. 2 (p. I02 $1-1178$ ). The majority of the articles are devoted to linguistic families, tribes, subtribes, towns, and villages. Another large group presents individual Indians of note. Fewer but longer articles deal with elements of material culture (copper, hammers), social organization (chiefs, confederation), custom (cremation, dance), relations to white societies (German influence, legal status), and aspects of civilized progress (education, Hampton Institute). While up-to-the-minute anthropologists regard "Hodge" as hopelessly out of date, both as to information and to "the concepts by which the material is organized," it must remain the first resort of every inquirer until it has been replaced by a work on the new lines equally systematic and meticulous.

2983. Kroeber, Alfred L. Cultural and natural areas of native North America. Berkeley, University of California Press, 1939. 242 p. maps ( 8 fold. in pocket) tables ( $\mathrm{r}$ fold. in pocket) (University of California publications in American archaeology and ethnology, v. $3^{8}$ )

$\mathrm{A}_{40}{ }^{-56} \mathrm{E}_{51 . \mathrm{C}_{5}}$, v. $3^{8}$

$\mathrm{E}_{98 . \mathrm{C}_{9} \mathrm{~K}} 73$
This work, which receives the almost uniform admiration of the recent generation of American ethnologists, was completed in 1931, but remained unprinted because of the depression, and was only partially brought up to date in 1936 and 1939. "It aims, first, to review the environmental relations of the native cultures of North America," and, second, "to examine the historic relations of the culture areas, or geographical units of cultures." It arrives, by refined methods of classification, at 84 areas dividing the whole continent, within each of which culture is relatively uniform. It discovers a number of close correspondences of physiographic provinces with cultural and ethnic areas, but explains why "any one set of natural factors, geologic, vegetational, climatic, or hydrographic," is unlikely to affect culture with uniform potency. In fact, "the interactions of culture and environment become exceedingly complex when followed out." This complexity, which tends to make generalization unprofitable, is increased when cultural intensityspecial content and special system-is considered.

2984. Roe, Frank G. The Indian and the horse. Norman, University of .Oklahoma Press, 1955. xvi, 434 p. (The Civilization of the American Indian [series]) $55-6359$ E98.H55 R6

Bibliography: p. 400-417.

Assembles the "scattered comparative data" provided by qualified observers in the past-from whom he excludes the plainsmen as habitual exaggerators of anti-Indian bias-and by recent anthropologists, in order "to summarize in conveniently co-ordinated form the existent evidence ... concerning the impact of the historic horse upon the principal horseraising tribes of the North American continent in the predominating aspects of chronology, geography, and tribal reactions." As in his book on the buffalo (no. 2965), Mr. Roe engages in strenuous 
refutation of the views of other writers with which he disagrees. He concludes that the horse "widened the Indian's spiritual horizon," and especially that of the squaw, but otherwise it "merely widened the stage on which the Indian had always moved, and enabled him to do more easily the things he had always done." The dog travois preceded the horse, which did not create nomadic habits, but enabled native products to be transported in increased bulk.

2985. Swanton, John R. The Indian tribes of North America. Washington, U. S. Govt. Print. Off., I952. 726 p. (8Ist Cong., $2 \mathrm{~d}$ sess. House. Document no. $3^{8} 3$ )

$$
\text { 52-61970 E51.U6, no. } 145
$$

E77.S94

Smithsonian Institution, Bureau of American Ethnology. Bulletin 145 .

Bibliography: p. 643-682.

This substantial volume, the result of years of work, presents a map of North America showing the location of the Indian tribes about $165^{\circ}$; when the earliest data is of a later year, the date is placed on the map along the tribal name. Dr. Swanton recognizes that "tribe" is a term of imprecise significance, and that only "a town and band map" would embody present-day anthropological concepts, but since the data for the latter are uncompiled, he proceeds with "a relatively conventional classification, having in view popular convenience." $\mathrm{He}$ organizes his data by States, in geographical order from Maine to California, followed by the remaining parts of the continent from Alaska to Central America. Under the "main entry" for each tribe are given long lists of subdivisions and villages, concise statements on connections, location, population at various periods, and "Connections in which they have become noted," and a longer history. The map is inserted in four large folding sections, and the text provides a work of basic reference.

2986. Underhill, Ruth Murray. Red Man's America; a history of Indians in the United States. Illus. by Marianne Stroller. Chicago, University of Chicago Press, 1953. 400 p. 53-10535 E77.U 456 Bibliography: p. $357-369$.

The author has aimed at a single-volume account of the history and culture of the Indians of the United States, based on the latest anthropological research but designed for "the average citizen." Two introductory chapters speculate on the original migrations to the Americas and describe "the high cultures of Nuclear America"-the Andean area, Central America, Yucatan, and the Valley of Mexico. Thenceforward the tribes of the United States are presented under ten major groups, with the text for each group considering origins, culture, and history after the first contact with Europeans. At the end of each chapter are tables of present reservations and numbers of surviving groups, if any, and a tabloid presentation of culture: food, hunting methods, clothing, house types, equipment, war, and games. A concluding chapter presents a favorable view of United States Indian policy, at least since r92I.

2987. Wissler, Clark, The American Indian, an introduction to the anthropology of the New World. 3d. ed. New York, P. Smith, r950. xvii, 466 p. $\quad A_{51-3696}$ E58.W832 "Linguistic tables and bibliography": p. [389]439.

2988. Wissler, Clark. Indians of the United States; four centuries of their history and culture. Garden City, N. Y., Doubleday, 1946. xvi, 3 I9 p. (The American Museum of Natural History. Science series)

$$
47-7240 \quad E_{77} \cdot W_{799} \quad 1946
$$

2989. Wissler, Clark. Indian cavalcade; or, Life on the old-time Indian reservations. New York, Sheridan House, r938. 35I p.

$\begin{array}{lll}3^{8-39407} & \mathrm{E}_{98} 8 \mathrm{~S}_{7} \mathrm{~W}_{57}\end{array}$ Clark Wissler (1870-r947) of the American Museum of Natural History and Yale University was a preëminent interpreter of the American Indian, to whose study he devoted his life. His experience extended from visits to the Indian reservations in preallotment days, which gave him a warm and personal appreciation of Indian character, to the refined ethnological techniques of our own day, which he did as much as anyone to develop. The American Indian, first published in I9I7 and last revised in 1938, has not been replaced as a lucid exposition of the anthropological approach. As an "outgrowth of museum experience," it assumes a point of - view "mainly taxonomic, or classificatory and descriptive." After identifying the food areas of the New World, it proceeds through methods of transportation, the textile arts, the ceramic arts, decorative designs, stone and metal work, social grouping, social regulation, ritual, and mythology, to a chronology of cultures and four major schemes of classification: culture areas, archaeological areas, linguistic and somatic types. Indians of the United States, originally published in 1940 , is more historical in approach and popular in appeal. Its theme is the Indians of the American frontier, their struggles to resist its advance, "their mode of life and its modifications due to residing among white people," and their outstanding personalities. The review of the tribes in Part II proceeds by language families. A chapter on "The Mystery of the Indian Mind" grapples with the genuine and long-standing problem of 
why the Indian and the white man, however well disposed, have had such difficulty in understanding one another. Indian Causalcade is a unique book of reminiscence and reflection based on the young anthropologist's visits to several reservations during the first five years of the present century.

\section{B. Archaeology and Prehistory}

2990. Griffin, James B., ed. Archeology of eastern United States. Chicago, University of Chicago Press, 1952. 392 p.

Bibliography: p. 371-392.

This volume in large format with double-column pages is formally a Festschrift in honor of FayCooper Cole, Emeritus Professor and Chairman of the Department of Anthropology at the University of Chicago, but it was so planned as to offer nearly complete coverage of the field indicated in its title. Of the 28 contributions, all but one by pupils of Prof. Cole, the great majority (22) are regional in scope, and usually general in their treatment of the region. Of the remaining six, three are generalsuch as "Twenty-five Years of Archeology in the Eastern United States," by Carl E. Guthe, and "The Ethnological Cultures and Their Archeological Backgrounds," by Fred R. Eggan-and the other three topical. The papers in general, and the regional ones in particular, are severely technical in nature, with great emphasis on such matters as stratigraphy, foci, and taxonomy, but the general rcader has no alternative for thorough coverage and up-to-date information. Figures 3-205, consisting of drawings, photographs, and maps, and usually complex, are placed at the end of the book.

2991. Holmes, William H. Handbook of aboriginal American antiquities. Part I. Introductory; the lithic industries. Washington, Govt. Print. Off., 1919. xvii, 380 p. (Smithsonian Institution. Bureau of American Ethnology. Bulle$\operatorname{tin} 60$ )

Bibliography: p. 368-372. 19-27642 E5r.U6, no. 6o $\mathrm{E}_{59 .} \mathrm{A}_{3} \mathrm{H}_{7}$

This impressive fragment is unfortunately the only completed portion of a monumental work projected by the first curator of the archaeological collections at the National Museum. It was to have extended to all the arts and industries practised by the native peoples, but is in fact limited to "the acquirement of the substances used in the arts" and "the manipulation of stone," on both of which it is more systematic and thorough than any other authority. After an exposition of archaeological first principles, chapters II-27 are concerned with aboriginal quarrying and mining, and describe in much detail surviving quarries, such as the unique red pipestone (catlinite) quarry at Pipestone, Minn. Chapters $28-36$ reconstruct the stone-shaping arts, and discriminate the several processes of percussion fracture, pressure fracture, fire fracture, crumbling, abrading, incising, and piercing. The second volume was to have dealt with the results: the implements, utensils, and other minor artifacts of stone.

2992. McGregor, John C. Southwestern archaeology. New York, Wiley, I94I. 403 p. $4 \mathrm{I}-26543 \quad \mathrm{E}_{7} 8 . \mathrm{S}_{7} \mathrm{MI5}$

"General bibliography": p. 380-392.

Ostensibly concerned with the archaeology of Arizona and New Mexico, this book is in fact largely confined to Arizona, which its covers very thoroughly. Precision has been arrived at in this field through the development of dendrochronology, based on the study of tree rings as uniform indicators of annual growth. Through the work of A. E. Douglass, a University of Arizona astronomer, which was begun in 1904 and achieved maturity in I929, a continuous ring series reaching back to A. D. 700 was established. As a result it has been possible to date the several sites and stages of the Mogollon Culture of the central mountain belt, which goes back to the time of Christ, the Hohokam Culture of the southern desert, and the Basket Maker Culture of the northern plateau. The great drouth of 1300 A. D. caused a great withdrawal southward, and the desertion of many northern sites.

2993. Martin, Paul S., George I. Quimby, and Donald Collier. Indians before Columbus; twenty thousand years of North American history revealed by archeology. Chicago, University of Chicago Press, 1947. xxiii, $582 \mathrm{p}$.

47-1434 E6r.M36

"A contribution of the Chicago Natural History Museum."

Bibliography: p. [521] -543 .

"This book has been written for the interested layman and for students taking introductory courses in anthropology. It is not intended as a general reference book for professional anthropologists"who can, however, hardly fail to find it a useful outline of nearly the entire field. The presentation is 
concise and lucid, and a three-page glossary precedes the text. The authors note the omission of Canada from the St. Lawrence to the Yukon, much of Alaska, and the Middle Atlantic Seaboard, from poverty of data or lack of space. Part I discusses archaeological method and the origin of the Indians. Part II describes arts and industries, including primitive trade and commerce. Part III presents the earliest cultures, and the "embarrassingly real" hiatus between them and the later ones, which go back only to about I A. D. The next four parts comprise the regional survey, with "The Plains Area" included under "Eastern North America." Part VIII, "Chronology and Correlation of Sequences of Cultures," consists of a chronological chart spanning four pages, with four more of commentary. The halftone illustrations are indifferently reproduced.

2994. Morley, Sylvanus Griswold. The ancient Maya. [2d ed.] Stanford University, Calif., Stanford University Press, 1947. xxxii, 520 p.

$$
\text { 47-4830 Fr435.M75 } 1947
$$

"Classified bibliography": p. 467-502.

The recovery of the Maya civilization, the author thinks, began with John L. Stephens' Incidents of Travel in Central America . . . (New York, Harper, 1841. 2 v.), and was continued by the English archaeologist, Alfred P. Maudslay, between r88I and 1894, by the Peabody Museum of Archaeology and Ethnology of Harvard University between 1885 and 1915, and, since the latter date, by the Carnegie Institution of Washington, which sent 25 annual expeditions to the Maya area. The present lavishly illustrated ( 95 plates and 57 figures) volume, by one of the Carnegie Institution's principal archaeologists, is a thoroughly assimilated synthesis of these results-“a complete picture of Maya civilization, harmoniously balanced, animated, and understandable," as a Mexican scholar has termed it. It falls into four parts: two chapters on the people and their country; five chapters of history from A. D. 317-1697, subdivided into the Old Empire (to 987), the New Empire, and the Spanish Conquest; nine chapters on ancient and modern manners and customs; and a final chapter of comparison and appraisal. Morleyana: $A$ Collection of Writings in Memoriam Sylvanus Griswold Morley-1883-1948 (Santa Fé, School of American Research and the Museum of New Mexico, 1950. 268 p.) is a tribute of admiration and love from 59 colleagues, perhaps the warmest ever paid to an archaeologist. John Eric S. Thompson's The Rise and Fall of Maya Civilization (Norman, University of Oklahoma Press, 1954. 287 p.) is a briefer outline which emphasizes the Maya intellectual achievement, with its curious disregard of the practical, and Maya religion; it has some excellent drawings from the ancient sculptures by Avis Tulloch.

2995. Sellards, Elias H. Early man in America; a study in prehistory. Illus. by Hal Story. Austin, University of Texas Press, 1952. xvi, 21 I p. 52-14173 $\mathrm{E}_{5} 8 . \mathrm{S}_{44}$

"A publication of the Texas Memorial Museum." Bibliography: p. 155-205.

Archaeological method has acquired a new chronological precision through the properties of radioactive Carbon ${ }^{14}$, the disintegration of which permits the age of organic matter to be determined within quite narrow limits. The present work reviews the several finds of the earliest artifacts in North America in the light of $\mathrm{C}^{14}$ datings of associated animal remains. Specimens from Gypsum Cave, Nevada, are some 10,500 years old; from Lubbock, Texas, some 9,900 years; from southern Nebraska, some 9,500 years. A picture emerges of "hunters of the plains" pursuing the elephant, the mastodon, the bison, the camel, and the sloth with weapons of some refinement as early as 8,000 B. C. Folsom points, once regarded as the oldest evidence of man in America, are now considered more recent than the Sandia points found in New Mexico. The book is handsomely produced with excellent drawings, but the text is rather severely technical.

2996. Shetrone, Henry Clyde. The moundbuilders; a reconstruction of the life of a prehistoric American race, through exploration and interpretation of their earth mounds, their burials, and their cultural remains. New York, Appleton, 1930. $508 \mathrm{p}$.

Bibliography: p. $491-496$.

30-22078 E73.S55

The mounds in question are found throughout the lands drained by the Mississippi and its tributaries, as far west as, roughly, the 95th meridian, and in all the Southeastern States as well. As conspicuous features of the trans-Appalachian landscape, they naturally became the first great problem in American archaeology; Thomas Jefferson was the first to excavate one (one of the simpler Virginia mounds), and William Henry Harrison, in his Discourse on the Aborigines of the Valley of the Ohio (Cincinnati [Printed at the Cincinnati Express] 1838. 51 p.), attributed them to a superior and vanished race, akin to the Aztecs, as did most of his contemporaries. Modern archaeology has reduced their importance by demonstrating their complete continuity with the Indian cultures that preceded and followed, although it has found no conclusive explanation of the fact that the custom of moundbuilding became extinct shortly before the arrival of the whites. The author, who was the Director of the Ohio State Archaeological and Historical Society, has provided a defini- 
tive summary of their varieties, contents, and relationships, and a clear definition of "the Moundbuilder burial complex."

2997. Vaillant, George C. Aztecs of Mexico; origin, rise and fall of the Aztec nation. Garden City, N. Y., Doubleday, Doran, 1941. xxii, $34^{\circ}$ p. (The American Museum of Natural History. Science series)

Bibliography: p. 299-325.

The Aztecs were comparative latecomers to the Valley of Mexico, about the middle of the 13th century, and they did not begin to establish their empire, first over neighboring and then over outlying tribes, until the second quarter of the 15th. Theirs was a blood-stained imperialism, for their conquests yielded victims for sacrifice to Huitzilopochtli, the War God-20,000 in one ceremony of 1487 , according to one Aztec source. The author, who was
Professor of Anthropology and Director of the University of Pennsylvania Museum when he died at the age of 44 , has based a popular interpretation of Aztec history and culture upon his own thorough knowledge of Mexican archaeology. The succession of pre-Aztec cultures in the Valley of Mexico is clearly,outlined, and Aztec origins are traced to Cholula in the State of Puebla. There is a chapter on the Aztec economy, domestic and tribal, and another offering a fascinating "Glimpse of Tenochtitlán," the Aztec capital which became Mexico City. The 64 plates and 28 text figures include many native drawings from the Codex Florentine of Bernardino de Sahagun's history. John Eric S. Thompson's Mexico before Cortez (New York, Scribner, 1933. 298 p.) is slighter and without much archaeological information, but is detailed and useful for Aztec religion, including ritual, the sacred feasts, the priesthood, and the temples and tombs.

\section{Tribes and Tribal Groups}

2998. Drucker, Philip. Indians of the Northwest coast. New York, Published for the American Museum of Natural History [by] McGrawHill, I955. 208 p. ([American Museum of Natural History, New York] Anthropological handbook no. 10)

Bibliography: p. 197-199.

$55-9543 \quad \mathrm{E}_{7} 8 . \mathrm{N}_{7} 8 \mathrm{D}_{7}$

The fourteen tribes, with such unfamiliar names as Tlingit, Kwakiutl, and Nootka, who parceled out the Northwest Coast from Yakutat Bay in southeast Alaska to Trinidad Bay in northern California, departed more widely from the popular conception of the American Indian than any other group. These tribes had practically no agriculture, but lived by fishing supplemented by hunting and berrygathering. They had, nevertheless, a complex culture, such as seldom accompanies so primitive an economy, and a highly original and striking repertory of art forms. This Handbook naturally emphasizes the material culture illustrated by the $\mathrm{Mu}$ seum's collections but also sketches in "the cultural background of the specimens by relating briefly not only how the various material objects were made and used, but recounting something of the general way of life of the makers and users." Like the other volumes of this series, it is a model of economical and efficient book-production.

2999. Grinnell, George Bird. The Cheyenne Indians, their history and ways of life. Photographs by Elizabeth $\mathrm{C}$. Grinnell and Mrs. J. E.
Tuell. New Haven, Yale University Press, I923. $2 \mathrm{v}$. 23-17688 E99. $_{53} \mathrm{G}_{77}$

3000. Grinnell, George Bird. The fighting Cheyennes. Norman, University of Oklahoma Press, 1956. xvii, 453 p. (The Civilization of the American Indian series)

First published in 1915 .

${ }_{56-10392} \mathrm{E}_{99 .} \mathrm{C}_{53} \mathrm{G8} \quad 1956$

Dr. Grinnell (1849-1938), explorer, hunter, naturalist, osteologist, and long-time editor and publisher of Forest and Stream, was also an old Indian hand whose experience went back to the year of his graduation from Yale (1870), and whose intercourse with the Cheyennes was continuous from 1890. He was never able to regard the Indian as a mere museum specimen: "a half-century spent in rubbing shoulders with them ... forbids me to think of them except as acquaintances, comrades, and friends." Much of his intimate knowledge was obtained through his interpreters, a man who had married into the tribe in $185^{\circ}$, and George Bent, the halfbreed son of Col. William Bent of Bent's Old Fort. The volumes of The Cheyenne Indians present, in the abundance of detail necessary to make the Indian viewpoint clear, their whole social life. Among other subjects, volume I deals with village life and camp customs, social organization, childhood, women, industries, subsistence, games, and tribal government; volume 2 with warfare, religious beliefs, disease and healing, and death 
customs. The latter also contains very detailed descriptions of the Medicine Lodge, or midsummer ceremony, and of the four-day Massaum ceremony, sometimes called the Crazy Dance. The Fighting Cheyennes is a detailed history of the tribe's wars from about 1819 . "A fighting and a fearless people, the tribe was almost constantly at war with its neighbors, but until 1856 was friendly to the whites." The first roo pages are concerned with the intertribal conflicts before that date, as recalled by Cheyenne tradition, and the subsequent narrative seeks to supplement white sources with Indian ones whenever the latter are available. The author's $B y$ Cheyenne Campfires (New Haven, Yale University Press, 1926. 305 p.) is a collection of 66 tales, arranged in the major classes of "War Stories," "Stories of Mystery," "Hero Myths," and stories about Wihio, the Cheyenne trickster. Dr. Grinnell had published similar collections for the Pawnees in 1889 , and for the Blackfeet in 1892 and 1913 .

3001. Haines, Francis. The Nez Percés: tribesmen of the Columbia Plateau. Norman, University of Oklahoma Press, 1955. xvii, $329^{\circ} \mathrm{p}$. (The Civilization of the American Indian series) 55-9626 E99. $\mathrm{N}_{5} \mathrm{H}_{28}$

Based on thesis, University of California.

Bibliography: p. 311-318.

The Nez Percés were a small but impressive tribe of intermediary culture, fishing for salmon in the Columbia and its tributaries, and also ranging widely to fight other tribes for a share of the Montana buffalo-hunting grounds. The author is chiefly concerned with their 90 years of contact with white civilization, from the arrival of Lewis and Clark in 1806 to the distribution of the tribal lands in 1895 . Turning points were the arrival of the Protestant missionaries, at the Nez Percés' own request, in the 1830's, and the Nez Percé War of 1877 , provoked by a series of white encroachments that followed the discovery of gold on their lands, and resulting in eight years of miserable exile at Fort Leavenworth.

3002. Heizer, Robert F., and Mary Anne Whipple, eds. The California Indians; a source book. Berkeley, University of California Press, 1951. $487 \mathrm{p}$.

$\begin{array}{lll}51-6195 I_{2} & E_{7} 8 . \mathrm{C}_{15} \mathrm{H}_{4}\end{array}$

The editors emphasize that this collection of essays is intended for a lay rather than a professional public, that it constitutes a survey rather than an encyclopedia for reference work, and is not meant as a substitute for Alfred L. Kroeber's authoritative but encyclopedic and highly technical Handbook of the Indians of California, published as Bulletin no. 78 of the U. S. Bureau of American Ethnology (Washington, Govt. Print. Off., 1925. 995 p.). The
California Indians consists of twelve contributions by Kroeber himself, as well as by Roland B. Dixon, E. W. Gifford, Sherburne F. Cook, and others. The essays are grouped under the headings "General Surveys," "Archaeology," "Historical Accounts (1775-1851)," "Material Culture," and "Social Culture." The California Indians, relatively unwarlike and divided into numerous groups with little political organization, offered minimal resistance to white penetration.

3003. Hyde, George E. Red Cloud's folk; a history of the Oglala Sioux Indians. Norman, University of Oklahoma Press, 1937. 331 p. (The Civilization of the American Indian [series])

"Brief bibliography": p. $321-324$.

$37-1605$ I $\mathrm{E}_{99} \mathrm{O}_{3} \mathrm{H}_{9}$

A careful history of the Oglala tribe, the first Sioux to pass west of the Missouri, from about 1650 to 1879 , when it was confined to a reservation and "broken to pieces by the policy then favored by the United States government." As such, it is largely the story of the Oglalas in relation to other Indian tribes and to the advancing whites. Mr. Hyde makes the valuable point that the living memory of the Plains Indians is reasonably valid for events 90 years in the past, but no earlier; his narrative becomes detailed only from 1834 . It was the migration from Minnesota to the Black Hills that transformed the Teton Sioux "from little camps of poor people afoot in the vast buffalo plains into seven powerful tribes of mounted Indians." In the final troubles of $1870-79$ he stresses the friendly role of the agency Sioux, the major group, who were nevertheless penalized equally with the hostiles in the final settlement.

3004. Lockwood, Francis C. The Apache Indians. New York, Macmillan, 1938. xvi, 348 p. 38-6746 E99.A6L6

Bibliography at end of each chapter.

An Arizona historian tells the history of the Apaches, naturally emphasizing their nuisance value in the history of the Southwest. "From the first, the Apaches have been the most hardy, warlike, mobile tribe known to history ... Pity was a feeling unknown to the Apache; cruelty an ingrained quality." Ethnological matters are disposed of in one 25-page chapter, and the years of peace since 1886 in another. The harassing of the relatively civilized Pueblo Indians, of the Spaniards, and of the Mexicans by these marauders from the desert is described at greater length, and the Apache troubles after Cochise went on the warpath in 1861 comprise the bulk of the book (p. 100-319). Uncle Sam never had so tough an Indian nut to crack: it took 14 years to dispose of Cochise $(186 \mathrm{r}-74)$, and an- 
other ten for Geronimo ( $1876-86)$. The author makes the most of the dramatic story and does not attempt to condone the treacheries to which the Federal authorities, in their desperation, sometimes resorted.

3005. Lowie, Robert $\mathrm{H}$. The Crow Indians. New York, Farrar \& Rinehart, 1935. xxii, $350 \mathrm{p}$. 35-9409 Eg9.C92Lgr3

"Sources": p. 335-339.

Mr. Lowie, Emeritus Professor of Anthropology at the University of California and one of the foremost American anthropologists, began his professional career with a visit to the Crow Reservation in 1907 , and on several returns, the latest in 1931, learned to speak Crow so well as to be conscious of its complexities and refinements, and of the limitations of his own knowledge. He ventured, indeed, to participate in the jeering and jesting which makes up so large a part of male Indian conversation, and notes that he usually got the worst of it. His book has thus the rare distinction of being based on Crow words for Crow ideas, and of exhibiting processes of thought radically different from our own. He gives a number of tales which he took down from the dictation of the septuagenarian Yellow-Brow. There are exceptionally intimate glimpses of club life, and of ceremonies such as the Sun Dance and the complex associated with the Tobacco Society. A final chapter adumbrates the Crow "World-View," in a book which displays Crow society and thought from the inside about as far as is possible for a white man tc do.

3006. Lowie, Robert $\mathrm{H}$. Indians of the Plains. New York, Published for the American Museum of Natural History [by] McGraw-Hill, 1954. xiii, 222 p. ([American Museum of Natural History, New York] Anthropological handbook no. I) 54-8815 E78.W5L6 Bibliography: p. 205-207.

The Plains Indians include six different linguistic families and a number of tribes who lived outside the short-grass regions, but are defined by a set of cultural traits prevalent among them and not similarly combined elsewhere: dependence on the buffalo, residence in skin-covered tepees, use of the horse for hunt and for transport, a peculiar style of decorative and of pictographic art, the sign language, the ideology of warfare, and the Sun Dance and other less conspicuous features of supernaturalism. This handbook, copiously illustrated with photographs, drawings, and diagrams, describes their culture from the time of their discovery until their virtually complete assimilation of white ways. There are large sections on material culture and social organization, and lesser ones on recreation, art, and supernaturalism. The conclusion calls attention to the appearance of particular Plains Indian features among tribes of other culture areas.

3007. Marriott, Alice Lee. The ten grandmothers. Norman, University of Oklahoma Press, 1945. xiv, 306 p. (The Civilization of the American Indian [Series]) $45-\mathrm{I}_{584} \quad \mathrm{E}_{99 .} \mathrm{K}_{5} \mathrm{M}_{3} 6$

The Ten Grandmothers are the ten medicine bundles of the Kiowas, which have not been opened since the 1890 's. On the chronological thread provided by the Kiowa year count, a painted mnemonic record beginning in $1832-33$, Miss Marriott has strung 33 "sketches," eyewitness accounts derived from the aged Kiowas Hunting Horse, Spear Woman, and Eagle Plume. They are retold simply, but with such great skill and delicacy as to convey the significance of the event to the participant. She had been able to assign them to specific years between 1847 and 1944, and each "represents Kiowa behavior under given circumstances at a given time .... Where the feelings of a person are described, it is only because he himself said that he felt that way." Such sketches as those of Hunting Horse's first war party, or of Spear Woman accepting her granddaughter as interpreter at the general store, demonstrate that imagination and literary art have their place in ethnology.

3008. Morgan, Lewis $\mathrm{H}$. League of the Ho-de-no sau-nee, or Iroquois. New Haven, Reprinted by Human Relations Area Files, 1954. 2 v. (Behavior science reprints) $55-3694 \quad$ E9g.I7M84 Bibliography: v. 2, p. 307-312.

3009. Hunt, George T. The wars of the Iroquois; a study in intertribal trade relations. Madison, University of Wisconsin Press, 1940. $209 \mathrm{p}$.

Bibliography: p. 185-200.

40-3755 E99.I7H8

Lewis Henry Morgan ( $18 \mathrm{r} 8-\mathrm{I} 88 \mathrm{I}$ ) was a practicing lawyer in Rochester, N. Y., in $185 \mathrm{I}$, when his epoch-making work on the Iroquois was published. The imprint listed is photographically reproduced from Herbert M. Lloyd's edition published by Dodd, Mead in Ig04. In his earlier home of Aurora, N. Y., Morgan had become a friend of Ely S. Parker, the Seneca sachem who later served as General Grant's military secretary and Commissioner of Indian Affairs. Morgan had been adopted into the Hawk Clan of the Seneca tribe in 1847 , and had organized a secret society modelled after the Iroquois Confederacy; League of the Iroquois originated in lectures to the society. His work has been called "the first scientific account of an Indian tribe given to the world," but it is safer to call it the first which sought to describe an Indian society sympathetically, from 
the inside, and as a whole. Morgan himself, who went on to become "the Father of American Anthropology" in a whole series of more technical and rigorous studies, soon came to realize its shortcomings, and especially its failure at several points to interpret Indian life in terms of itself. It remains, however, the classic description of the once-mighty Iroquois, and while many corrections of detail have appeared, no overall picture has been forth. coming to take its place. The work will always be a unique authority for the structure of the Iroquois League in Morgan's own day, and its careful descriptions of material culture have proved quite dependable. Frank G. Speck's The Iroquois, a Study in Cultural Evolution, 2d ed. ([Bloomfield Hills, Mich.] 1955. 94 p. Cranbrook Institute of Science. Bulletin no. 23), prepared as background material for interpreting exhibits and illustrated from objects in the Institute's museum, is a balanced survey in brief compass. Bernhard J. Stern's Lewis Henry Morgan, Social Evolutionist (University of Chicago Press, 1931. 221 p.) traces the development of Morgan's ideas and assesses his significance for his discipline. Mr. Hunt's volume, which dwells on the deficiencies of Morgan's historical information, puts forward an incisive economic interpretation of Iroquois history in the $I 7$ th century, with the European demand for furs as the primary factor. "The European trade was the major circumstance of all intertribal relations in the Great Lakes area, and the Iroquois and all their works were phenomena of that contact."

3010. Opler, Morris Edward. An Apache lifeway; the economic, social, and religious institutions of the Chiricahua Indians. Chicago, University of Chicago Press, 1941. xvii, 500 p. (University of Chicago publications in anthropology. Ethnological series) 4I-24474 E99.A6073 The life experiences of over 30 Chiricahua Apaches, three of whom have served as interpreters for the rest, are drawn upon for a presentation which, by introducing events "in the order in which they are experienced in the course of the normal Chiricahua Apache life-cycle," endeavors "to show how a person becomes a Chiricahua as well as to indicate what he does because he is a Chiricahua." The author aims to make the average Chiricahua intelligible and sympathetic, "in the sense that the reader understands what he has become in terms of what he has experienced." The subdivisions are therefore "Childhood," "Maturation," "Social Relations of Adults," "Medical Practice and Shamanism," "Maintenance of the Household," "Marital and Sexual Life," and "The Round of Life." There is naturally much of interest-such as the Apache's equation of aberrant sex behavior with witcheraft- but on the whole the author's treatment of his interview material is external and formal.

30Ir. Speck, Frank G. Penobscot man; the life history of a forest tribe in Maine. Philadelphia, University of Pennsylvania Press, 1940. xx, 325 p. $\quad$ 40-9335 E99.P $\mathrm{PS}_{7}$

"List of publications quoted": p. 313-317.

Professor Speck (1881-r950), who taught anthropology at the University of Pennsylvania for nearly 40 years, was an assiduous field worker whose investigations ranged widely over the tribes of the United States and Canada. However, in his annual visits to the Penobscot Indians of Maine between 1907 and 1918, he had the field largely to himself and produced the only full-scale study of a surviving group of the Indians of the northeastern United States. The Penobscot, who lived and hunted in the valley of the River to which they have given their name, took over elements of culture from both French and English, but remained largely isolated until about 1870 . The present work surveys their material culture with its many uses of birch bark, their arts, and social life (with special attention to "Relationship Restrictions"), but does not incorporate the work on religious beliefs and other topics which Dr. Speck had previously published in serials. On a return to Indian Island opposite Oldtown in 1936, he found that the tribe was increasing in numbers, and that the old culture was dying more slowly than he had anticipated, but also that 2othcentury urban ways were steadily prevailing.

3012. Swanton, John R. The Indians of the southeastern United States. Washington, U. S. Govt. Print. Off., I946. 943 p. I07 (i. e. rog) plates on 55 1., maps (part fold.) tables (I fold.) ([U. S.] Bureau of American Ethnology. Bulletin 137) 46-2658i $\quad$ E5I.U6, no. I37 $^{2}$

Bibliography: p. 832-856.

$\mathrm{E}_{78 . S_{55} S_{9}}$

Apart from the Five Civilized Tribes, the Indians of the Southeast have been comparatively little studied, and this massive volume, "in the main a collection of source materials," supplies a needed body of organized information. The aboriginal population during the first half of the 17 th century has been estimated at 172,000 , of which some 30,500 lived on the coast as against I4I,500 belonging to the horticultural tribes of the interior. The largest linguistic stock was the Muskoghean, with 66,600 members; the other stocks unique to the area, the Timucua and the Tunican, with 13,000 and 6,000 respectively, were inferior to the Iroquoian $(30,200$ : these were the Cherokees), the Siouan, and Algonquian colonies. After an exhaustive report on the I73 identifiable tribes (p. $8 x-216)$, the author turns 
to an equally exhaustive analysis of the aboriginal cultures, with abundant extracts from Spanish, French, and English observers of the 16th, 17th, and I8th centuries. "The cultures of all of the tribes of this area were basically the same," and their fundamental factors derived from the civilizations of Mexico, Central America, and Peru.

30r3. Underhill, Ruth Murray. The Navajos. Norman, University of Oklahoma Press, 1956. xvi, 299 p. (The Civilization of the American Indian series)

Bibliography: p. 275-288.

The Navajos, shepherds and horsemen of the rocky canyons and desert plateaus of New Mexico and Arizona, number 70,000 and are the largest Indian tribe in the United States. They speak a language allied to the Athapascan of British Columbia, and were relatively late comers to the Southwest; the author of this careful and balanced history of the tribe thinks that they arrived soon after I I o A. D. In their long relationship with Spaniards and Anglo-Americans, she notes three fresh beginnings: the acquisition of horses and sheep from the Spaniards, and the art of weaving from Pueblo refugees, toward the end of the 17 th century; their exchange of banditry for a settled life on their reservation in 1868; and the long-range rehabilitation program enacted in 1950 , under which the tribe's capital has risen to $\$ 15,000,000$. The Navajo Indians, by Dane and Mary Roberts Coolidge (Bos- ton, Houghton Mifllin, 1930. 316 p.), is a sympathetic description of their life a quarter of a century ago by a couple who had made regular tours of the reservation for 17 years; it emphasizes arts and crafts, and mythology and ceremonies.

3014. Wallace, Ernest, and Edward Adamson Hoebel. The Comanches: lords of the south plains. Norman, University of Oklahoma Press, 1952. xvii, 381 p. ([The, Civilization of the American Indian series $_{]}$)

Bibliography: p. 355-364.

52-1 1087 E99.C85 3

Throughout the Southwest the Comanche name "has become a synonym for wildness, fierceness, and savagery." For a century and a half the Comanches "successfully defended the High Plains and prairie country south of the Arkansas River against all intruders, red and white." The present book undertakes to "present the salient facts of Comanche history and culture in a way that will satisfy the interests and curiosity of the general reader and also the anthropologist and the historian." Few works on individual tribes have so successfully combined a presentation of historical circumstances with the analysis of culture. The cultural chapters make effective use of the distinctions and techniques of recent ethnology without descending into jargon or losing sight of the human beings who are being studied, and are quite free from either sentimentalism or patronizing.

\section{Religion, Art, and Folklore}

3015. Alexander, Hartley Burr. The world's rim; great mysteries of the North American Indians. With a foreword by Clyde Kluckhon. Lincoln, University of Nebraska Press, 1953. 259 p.

$53-7703 \mathrm{E}_{98 . \mathrm{R}_{3} \mathrm{~A}_{4}}$

A work first published 18 years after its completion and 14 years after the death of its author, a distinguished philosopher whose second subject was the thought-world of the American Indian. It selects eight types of Indian ritual "with the intention of showing his heritage and achievement at its best," and seeks to develop their implications concerning "the red men's conception of the natural world and of the human action which takes place within it." Among the ceremonies thus interpreted are the pipe or calumet rite, the rite of purification by the sweatbath, and the corn dance or corn ritual. Many analogies with early European or Asiatic ritual or philosophy are traced, not as evidences or diffusion, but as examples of the human mind drawing like instruction from natural experience. To the Indian mind, the author thought, the physical world is a sense-born phantasm; man is placed upon this earth to show his mettle; and the fulfiliment of this world's life lies beyond it.

30r6. Covarrubias, Miguel. The eagle, the jaguar, and the serpent; Indian art of the Americas. [v. I] North America: Alaska, Canada, the United States. New York, Knopf, 1954. xviii, 314 p.

$$
\text { 52-6415 E98. } \mathrm{A}_{7} \mathrm{C6}_{3}
$$

The well-known Mexican artist presents Indian art "as an important and little-known part of our continental heritage," hitherto insufficiently studied "from the combined points of view of its aesthetic values and its historical implications in an effort to understand the mental processes of its creators and the social factors that helped its formation." The 
new and broadly synthetic viewpoint, together with the creative ability of the author, give this work exceptional interest, and the splendid color plates, line drawings, and well-reproduced photographs have few rivals elsewhere.

3017. Douglas, Frederic H., and René d'Harnoncourt. Indian art of the United States. [2d ed.] New York, Museum of Modern Art, 1949, '1941. 204 p. 49-35040 E98.A7D6 1949 Bibliography: p. 195-203.

Based on an exhibition at the Museum of Modern Art prepared by Mr. Douglas, Curator of Indian Art of the Denver Art Museum, Mr. d'Harnoncourt, General Manager of the U. S. Indian Arts and Crafts Board, and Mr. Henry Klumb, architect, this exceptionally well-made volume is by no means an ephemeral production, but a concise and authoritative survey of a very large field. Nearly every page has one or two illustrations in very satisfactory halftone, and the 16 plates "indicating the traditional range of color in Indian art" are truly brilliant (in the original edition of I94I; the reissue of 1949 has only eight, mostly in duller hues). The two principal sections review "Prehistoric Art" in five main regions, and "Living Traditions" in eight culture areas. A concluding section on "Indian Art for Modern Living" distinguishes "good Indian work, done without the interference of whites," from the worthless knickknacks turned out for the tourist trade, which usually reflect the customer's rather than the maker's idea of Indian art. The participation of the Museum is thus justified: "This subtle control of its elements and the close relationship between function and form are what bring Indian work so near to the aims of most contemporary artists and make it blend with surroundings that are truly of the twentieth century."

3018. Ewers, John Canfield. Plains Indian painting; a description of an aboriginal American art. Stanford University, Calif., Stanford University Press, 1939. xiv, 84 p. 39-2775 $\mathrm{E}_{9} 8 . \mathrm{A}_{7} \mathrm{E}_{93}$

Bibliography: p. $7 \mathrm{x}-79$.

Buffalo hides, or robes with the hair left intact, were used as topcoats by the Plains Indians, being wrapped about the body with the head of the animal to the wearer's left. The painting of such hides with geometric designs, by women, and with life forms, by men, was generally practiced until the disappearance of the buffalo, but is now a lost art. Of the surviving specimens some are crudely done, but many "possess a decorative quality which is both unique and undeniably pleasing." This thorough monograph describes the technique of painting, classifies the patterns and forms, reviews the mentions by early explorers and travelers, notes other surfaces which the Indians painted, such as drums and tepee covers, and presents evidence for hide painting among other Indian groups, even in South America. An appendix lists the museum specimens examined by the author. The numerous illustrations are large and well reproduced.

3019. Park, Willard Z. Shamanism in western North America; a study in cultural relationships. Evanston, Northwestern University, 1938. $166 \mathrm{p}$. (Northwestern University. Studies in the social sciences, no. 2) $\quad 3^{8-14755}$ E98.R $_{3} P_{23}$

"The present study has developed from a dissertation presented for the degree of doctor of philosophy at Yale University [1936]."

Bibliography: p. 159-163.

Shamanism, in the author's labored definition, is "all the practices by which supernatural power may be acquired by mortals, the exercise of that power either for good or evil," and all associated concepts and beliefs. He spent three summers with the Paviotso or Northern Paiute of western Nevada, and devotes one of his two main chapters to an account of "Paviotso Shamanism" ( $\mathrm{p} . \mathrm{II}-7 \mathrm{I})$. This. he finds to be a comparatively simple affair; its dominant idea is that of curing diseases, and all other aspects are secondary. The second main chapter is a comparative study of "The Shamanistic Complex in Western North America," in which he particularly seeks to show the distribution of the elements of Paviotso shamanism "among the neighboring tribes of the Great Basin, the Plateau, California, and several of the so-called Western Rancheria tribes of the non-pueblo Southwest." He is surprised to find that these affiliations "cut across the conventional boundaries of culture areas." $\mathrm{He}$ allows his methodological perplexities to intrude upon his exposition, but his is the only recent investigation, and the largest comparative study, of a crucial topic in Indian thought and culture.

3020. Petrullo, Vincenzo. The diabolic root; a study of peyotism, the new Indian religion, among the Delawares. Philadelphia, University of Pennsylvania Press, the University Museum, 1934. I85 p.

Issued also as thesis (Ph. D.) University of Pennsylvania.

Bibliography: p. $183-185$.

Peyote is a species of small and spineless cactus, Lophophora Williamsii, limited to northern Mexico and southern Texas. Eaten, it produces first physical nausea, and then a state of psychic tranquility, exhilaration, power, and superiority, as well as an intensification of perception which tends toward the visionary. Once a minor cult of a few Mexican tribes, peyotism has become an all- 
sufficient religion in the Indian reservations east of the Rockies, through which worries are erased, cures performed, and revelations received. The two Delaware communities in Oklahoma acquired it, probably from the Comanches, about 1880 . Two main cults have developed, the Big Moon cult of John Wilson, in which Christian elements have mingled, and the Little Moon cult of Elk Hair, which adheres more closely to the traditional Delaware religion. The author visited the reservations in 1929-30 and obtained personal statements of religious experience from several Delawares, including the venerable Elk Hair himself. He carefully describes the considerable variety of ritual and creed that has developed within the two cults. Notwithstanding the violence with which peyotism has been attacked, it is difficult to discover anything either orgiastic or degraded in the objective account here given of it.

3021. Thompson, Stith, ed. Tales of the North American Indians. Selected and annotated by Stith Thompson. Cambridge, Mass., Harvard University Press, 1929. xxii, 386 p.

Bibliography: p. $[371]-386$.
A century of field work among the Indians has gathered "by far the most extensive body of tales representative of any primitive people," but most of them are scattered in sets of government reports, folklore journals, and publications of learned societies. Professor Thompson has therefore selected 96 "typical examples of such of these tales as have gained any general currency," whether in one culture area, or in the whole East or the whole West, or even over practically the whole continent. They are arranged in a classified order: mythological stories, mythical incidents, trickster tales, hero tales, journey to the other world, animal wives and husbands, miscellaneous, tales borrowed from Europeans, and Bible stories. In the latter part of his introduction, the compiler characterizes the tales of the several culture areas: the Eskimos and the California Indians have the smallest range of interest, while the Plains Indians have practically every class of tale current anywhere else. Elaborate "Comparative Notes" (p. [27I]-360), by listing all known parallels, "show the extent of the distribution of each tale and each motif." There are also a classified "List of Motifs Discussed in the Notes" ( $p$. $[361]-367)$ and, preliminary to the bibliography, a list of "Sources Arranged by Culture Areas and Tribes" (p. [368]-370).

\section{E. The White Advance}

3022. Cook, Sherburne F. The conflict between the California Indian and white civilization. Berkeley, University of California Press, 1943. 4 v. (Ibero-Americana 21-24)

$$
\text { A43-4II Fr40r.I22, no. 2I-24 }
$$$$
\mathrm{E}_{78 . \mathrm{C}_{5} \mathrm{C} 69}
$$

Includes bibliographies.

Contents.-I. The Indian versus the Spanish mission.-2. The physical and demographic reaction of the nonmission Indians in colonial and provincial California.-3. The American invasion, 1848-1870. -4. Trends in marriage and divorce since 1850 .

"The present work consists of an examination of the reaction of a primitive human population to a new and disturbing environment. As such it constitutes a study in human ecology . . . In particular, those factors are considered which lend themselves to at least semiquantitative treatment ... The effect of racial impact and competition was here unusually complete. It resulted in the substantial disappearance of the primitive population and the utter extinction of its civilization." The basic fact is a decline of the native population from 133,500 in 1770 to 20,500 in 1880 . An interesting conclusion is that Indians who remained outside the missions maintained themselves better than did the mission Indians, in spite of warfare, disease, and forced removal. "The racial fiber of the native decayed morally and culturally in the misions, . . . confinement, labor, punishment, inadequate diet, homesickness, sex anomalies, and other social or cultural forces, sapped his collective strength and his will to resistance and survival."

3023. Dale, Edward Everett. The Indians of the Southwest; a century of development under the United States. Norman, Published in cooperation with the Huntington Library, San Marino, Calif., by the University of Oklahoma Press, 1949. xvi, 283 p. (The Civilization of the American Indian [series]) 49-10762 $\mathrm{E}_{7} 8 . \mathrm{S}_{7} \mathrm{D}_{28}$ Bibliography: p. 26I-271.

In 1848 the Treaty of Guadalupe Hidalgo gave the United States a vast territory whose scanty population consisted of a few thousand whites and a variety of Indian tribes whose numbers are variously 
estimated at from 125,000 to 200,000 . Such white influence as they had undergone came from Spanish colonial culture and the Catholic Church. They were of two great classes: peaceful, sedentary, and agricultural tribes such as the pueblo dwellers of New Mexico and the Mission Indians of California, and "the wilder and more warlike tribes of the deserts and mountains." The author aims at "a broad general survey of the more important aspects of Indian administration in the Southwest, with special emphasis on those activities which have proved of permanent value." Developments during the Igth century are treated in chronological chapters for the three areas of California, Arizona and New Mexico, and Utah and Nevada, and conditions since 1900 in topical chapters with special attention to education and public health. In both centuries the crucial role of the Indian agent is emphasized.

3024. Debo, Angie. The rise and fall of the Choctaw Republic. Norman, University of Oklahoma Press, 1934. xvi, 314 p. (The Civilization of the American Indian [series])

Bibliography: p. 219-299.

$$
\mathrm{34}^{-\mathrm{I}} 8_{340} \quad \mathrm{E}_{99} \cdot \mathrm{C} 8 \mathrm{D}_{4}
$$

3025. Debo, Angie. And still the waters run. Princeton, Princeton University Press, 1940. 4I7 p.

Bibliography: p. [396]-402.

$$
4 \mathrm{I}-3348 \quad \mathrm{E}_{7} 8 . \mathrm{I}_{5} \mathrm{D}_{4}
$$

Miss Angie Debo (b. 189o) is a homegrown Oklahoma historian who has been the most productive disciple of Grant Foreman; the present volumes supplement and continue his own listed below. The Rise and Fall is a history of the Choctaws as a "domestic dependent nation," which emphasizes the period after removal to the Indian Territory, and especially the years from the close of the Civil War to the dissolution of tribal interests after "the surrender to the United States" in the Atoka Agreement of 1898. Topical chapters treat economic development, public finance, political institutions, crime and justice, and society. The Road to Disappearance (Norman, University of Oklahoma Press, 1941. 399 p.) performs the same task for the more conservative Creek nation. The Creeks were disheartened and impoverished by the Civil War; their subsequent "attempt to replace their group loyalties with the white man's individualism brought a spiritual collapse from which they never fully recovered." And Still the Waters Run is a grim narrative of developments after the Five Civilized Tribes had surrendered their tribal organization at the beginning of this century. "The orgy of exploitation that resulted is almost beyond belief. Within a generation these Indians, who had owned and governed a region greater in area and potential wealth than many an American state, were almost stripped of their holdings, and were rescued from starvation only through public charity." The Five Civilized Tribes of Oklahoma; Report on Social and Economic Conditions ([Philadelphia] Indian Rights Association, 195r. 35 p.) is a somber report on a survey conducted in the summer of 1949. "Appalling poverty" was still the prevailing condition among all but the oil-enriched Seminoles.

3026. Foreman, Grant. Indian removal; the emigration of the Five Civilized Tribes of Indians. Norman, University of Oklahoma Press, 1953. 4I5 p. (The Civilization of the American Indian [series]) 53-7431 E78.I5F8 1953

First published in 1932.

Bibliography: p. [387]-394.

3027. Foreman, Grant. The Five Civilized Tribes. Norman, University of Oklahoma Press, 1934. 455 p. (The Civilization of the American Indian [series])

Bibliography: p. 427-43I.

Grant Foreman (1869-1953) was an Oklahoma lawyer who, after serving with the Commission to the Five Civilized Tribes in 1899-1903, became an indefatigable student of the history of Oklahoma and of the Indian tribes within it, and was a pioneer in the intensive utilization of Federal archives and other little-known sources for these purposes. His histories are not remarkable for their arrangement and are by no means easy reading, but each is a thorough piece of research, with the primary sources quoted at length. Indian Removal covers the transfer of Choctaws, Creeks, Chickasaws, Cherokees, and Seminoles from their original homes to the Indian Territory, during $1830-1843$. Over 60,000 Indians were thus forcibly uprooted. "Inadequate preparation by the government and the appointment of a horde of political incompetents to posts of authority, resulted in woeful mismanagement and cruel and unnecessary suffering by the emigrants." The Five Civilized Tribes covers their first three decades (1832-1860) in their new homes, and describes "the rehabilitation and reconstruction of these immigrants after the demoralization and impoverishment caused by their forcible removal"-a period of remarkable development and progress. Other works by Mr. Foreman dealing with Indian history are Indians and Pioneers; The Story of the American Southwest before 1830 , rev. ed. (Norman, University of Oklahoma Press, 1936); Advancing the Frontier, 1830-1860 (University of Oklahoma Press, 1933); Sequoyah (University of Oklahoma Press, 1938); and The Last Trek of the 
Indians (Chicago, University of Chicago Press, 1946).

3028. Harmon, George Dewey. Sixty years of Indian affairs, political, economic, and diplomatic, 1789-1850. Chapel Hill, University of North Carolina Press, 1941. $428 \mathrm{p}$.

$$
\mathrm{A}_{42-2412} \text { E93. } \mathrm{H}_{274} \text { 1941a }
$$

Bibliography: $p .[383]-414$.

Thesis (Ph. D.) - University of Pennsylvania, 1930.

A review of the political, diplomatic, economic, and especially the financial aspects of Federal Indian policy during the first six decades under the Constitution. Throughout the period the primary objective of the Government was the acquisition of legal title to their lands and the transfer of the Indians themselves to reservations in the remote West. This aim, the employment of more direct coercion after 1825 , and the unsuitable method of proceeding by treaties appropriate only to negotiations between two genuine sovereigns, all gave Federal policy an inconsistent and arbitrary appearance. It had, nevertheless, a more humane side evidenced in the donation of agricultural equipment, the establishment of schools, the setting up of trust funds, and the payment of annuities. The intentions of the Government were regularly good, and the higher officials concerned were honest. A History of the United States Indian Factory System, 1795-1822, by Ora B. Peake (Denver, Sage Books, 1954. $34^{\circ}$ p.), describes this "first attempt of the United States Government to enter business in competition with private industry" in great detail from the original records in the National Archives, and emphasizes its economic failure.

3029. Kinney, Jay P. A continent lost-a civilization won; Indian land tenure in America. Baltimore, Johns Hopkins Press, 1937. xv, 366 p.

Bibliography: p. 345-349. 37-2999 E93.K56

A very detailed history of the Federal policy concerning Indian land tenure, written by a staff member with 25 years' service in the Bureau of Indian Affairs, chiefly from Government documents and to a lesser degree from unpublished files of the Bureau. His central theme is the allotment policy, of which he traces the early indications following the War of 1812 , and the experimental applications following the large-scale Indian removals of Jackson's second administration. The policy itself, as adopted in 1887 , was defeated in its main purpose by subsequent enactments. That of 1891 permitted the lease of allotment lands and produced "a tendency to stop farming and eke out an existence from rentals."
That of 1902 permitted heirs of a deceased Indian to sell an inherited allotment notwithstanding prior restrictions upon its alienation. The hundred million acres held by Indians in 1900 had shrunk to fifty million, of which only about thirty million had productive value, by 1933. The book's title and optimistic conclusion seem to have small relation to the facts presented.

3030. Macleod, William Christie. The American Indian frontier. London, Paul, Trench, Trubner; New York, Knopf, 1928. xxiii, $59^{8}$ p. (The History of civilization [Historical ethnology]) 28-24819 $\mathrm{E}_{5} 8 . \mathrm{MI}_{7}$

\section{Bibliography: p. 565-595.}

"The first attempt at an analysis of American frontier history made particularly from the viewpoint of the Indian side of the frontier development." It considers the Indians of Latin America as well as those to the north, but since the situation was there stabilized at a relatively early period, winds up this portion of the narrative with Part II. Part IV offers six chapters contrasting the fate of the Indians in the two spheres in such respects as slavery and forced labor, the success of Indian missions in the South and their failure in the North, and the Anglo-American frontiersman's attitude of hate and policy of extermination, to which nothing in Latin America corresponds. The later narrative summarizes the major conflicts of Indian and white, with emphasis on the multitribal reactions led by Pontiac and, half a century later, by Tecumseh, and on the Indians' "cry for a saviour" and the several Messiahs who responded in the later Igth century. Attempting a colossal task, the volume is an imperfect synthesis which does achieve some large views of value, if it seldom troubles to be fair to any Anglo-American settler or official. It has hitherto had no competitor.

303r. Pearce, Roy Harvey. The savages of America, a study of the Indian and the idea of civilization. Baltimore, Johns Hopkins Press, 1953. $\mathrm{xv}, 252 \mathrm{p}$. $\quad 53-6486 \quad \mathrm{E}_{93 . P_{4}}$

A study of the Indians' way of life as reflected in American thought and literature from 1609 , the year of Robert Johnson's Nova Britannia (London, S. Macham. 28 p.), to 1851 , the year of L. H. Morgan's League of the Iroquois (no. 3008). Its central concern is what the author calls the idea of savagism, the rise of which he dates from 1777 , the year of William Robertson's History of America (London, W. Strahan. 2 v.). Its acme he finds in the work of Henry Rowe Schoolcraft, and its death is implicit in Morgan's great work, which absorbs it "into a universal theory of progress." 
From the I770's Americans abandoned their attempt to see the Indian as a European manqué; he was now recognized as one radically different from their proper selves; bound inextricably in a primitive past, he could only be destroyed by the advance of civilization. The author relates his study to previous explorations of the ideas of primitivism, progress, and manifest destiny conducted at Johns Hopkins. If at times he indulges in artificial schematizations, he supplies the reader with a corrective in his extensive quotations from the sources.

3032. Peckham, Howard H. Captured by Indians; true tales of pioneer survivors. New Brunswick, N. J., Rutgers University Press, 1954. $23^{8}$ p. 54-II93I E85.P4

Captivities among the Indian tribes adjacent to the advancing frontier were a recurrent feature of pioneer life, and the narratives in which such experiences were described for a fascinated public were a form of American literature once as popular as it is now extinct. Mr. Peckham has made concise summaries of 14 such narratives, from Mary Rowlandson who was taken captive by King Philip's Narragansetts in 1676 , to Fanny Kelly who was taken by the Oglala Sioux in 1864 . While his condensations eliminate much extraneous matter, they are somewhat lacking in tension and color.

3033. Peckham, Howard H. Pontiac and the Indian uprising. Princeton, Princeton University Press, $1947 . \quad$ xviii, $346 \mathrm{p}$.

Bibliography: p. 326-332.

$$
\text { 47-I I04I } \quad \mathrm{E}_{3} \cdot 76 . \mathrm{P}_{4}
$$

Formally, a life of the Ottawa Chief (ca. I720I769), "a warrior of heroic proportions who set in motion the most formidable Indian resistance the English-speaking people had yet faced, or ever would face, on this continent." The author disclaims any attempt to rewrite Parkman's "monumental history" (included in Chapter VIII), but although he prints all of Pontiac's surviving speeches and dictated letters, the personal materials are so scanty as to leave the major interest in the dilemma of the Indians after the Peace of 1763 , and in the details of the uprising, for which Dr. Peckham has found much fresh material in the manuscripts of his own Clements Library. "Pontiac fought to restore the relative independence enjoyed by the western Indians and to force the British to change their fundamental policy toward peoples of inferior culture. His aims appear to us today just and ethical, even though his savage manner of warfare is revolting and his hope to maintain a primeval wilderness on the edge of civilization was impractical."
3034. Priest, Loring Benson. Uncle Sam's stepchildren; the reformation of United States Indian policy, 1865-1887. New Brunswick, N. J., Rutgers University Press, 1942. $310 \mathrm{p}$.

$$
\text { 42-8373 E93.P95 }
$$

A documented study of two decades of Federal Indian policy which utilizes Indian Office archives supplemented by the Papers of Secretary Carl Schurz and Senator Henry L. Dawes. The close of the Civil War and the accelerated occupation of the West made clear the need for a permanent solution of Indian problems. Down to 1880 the four policies of concentration, transfer, church nomination of Indian officials, and civilian advice through the Board of Indian Commissioners, were tried out and abandoned as failures. Intensive efforts at reform during the next seven years were summed up in the Dawes Severalty Act of 1887 , by which "individual ownership, citizenship, and sale of surplus land were finally accepted as the only possible means of improving American Indian affairs." The change was supported by nearly all the friends of the Indian, but was unacceptable to the great majority of the Indians themselves. It was the decision to dispense with gradualism, and use force in imposing it upon the tribes, rather than any flaw in the ideal of turning the Indian into an independent and self-reliant landowner, that produced the consequences so often deplored.

3035. Seymour, Flora Warren (Smith). Indian agents of the old frontier. New York, Appleton-Century, I94I. 402 p. 4I-12500 E93.S45 Indian policy was formulated in Washington, but its application to tribes and individuals usually depended upon "the Major," as even the most unmilitary Indian agent was regularly called. Mrs. Seymour sketches the early stages of the agent's evolution from "a commercial agent or consul" in an alien sovereignty, to an administrator with nearly complete discretion. Her narrative of the careers of particular agents begins with the changes of $1869-$ $7 \mathrm{I}$, when President Grant embarked upon a comprehensive peace policy, and Congress abolished the traditional procedure of making treaties with the tribes. A few of these agents have left memoirs, but the bulk of her materials are drawn from the annual reports of the Commissioners of Indian Affairs. In addition to such agencies as Laurie Tatum among the Kiowa, Thomas J. Jeffords among the Apaches, Father James H. Wilbur among the Yakimas, and William F. N. Arny among the Pueblos, Mrs. Seymour presents the achieverments of such army officers as Richard H. Pratt, who founded Carlisle Indian School, and Hugh L. Scott, whose rare knowledge and influence acquired in many frontier 
missions made him the War Department's foremost Indian specialist.

3036. Stewart, Edgar I. Custer's luck. Norman, University of Oklahoma Press, 1955. xvi, $522 \mathrm{p}$. 55-6368 E83.866.S85

Bibliography: p. 496-506.

A minute reconstruction of the most famous, and probably the most controversial, episode in two and a half centuries of Indian warfare. On June 25, 1876, at the Little Big Horn, a famous Civil War general (George Armstrong Custer, b. I839) and five troops of regular cavalry were killed to the last man by some 2500 Sioux and Cheyennes under the famous chiefs Sitting Bull and Crazy Horse. This outcome is traced to its remoter sources in the Indian policy and the internal politics of the Grant administration. After an exhaustive analysis of Custer's campaign, the author concludes that he, and especially his two subordinates, Reno and Benteen, allowed the Indians to score a startling success, "not by an overmastering strategy of their own but simply by taking advantage of the mistakes of the soldiers." Some four months later the capacity of the Plains Indians to offer further armed resistance was brought to an end.
3037. Tucker, Glenn. Tecumseh; vision of glory. Indianapolis, Bobbs-Merrill, 1956. 399 p. 56-8618 E99.S35 $\mathrm{T}_{35}$

"Bibliographical note": p. 366-367. "Bibliography": p. 368-38I.

By September I812 Tecumseh ( $1768-18 \mathrm{r} 3$ ) dominated a "prairie empire of almost half a million square miles, an area greater than that of the seventeen states of the Federal Union, extending from northern Ohio to the far Dakotas." "The ardent personality and militant patriotism of this Shawnee chief" had brought 32 tribes beneath his battle standard, and seemed about to check or reverse the American occupation of the Northwest. Thirteen months later he died in battle, his cause shattered. There is more evidence for Tecumseh's career than for any other Indian of comparable historical importance; Mr. Tucker has diligently assembled and sifted it, and has exploited its dramatic qualities to the full in an outstanding Indian biography. Tecumseh he assesses as exceeding all other Indian leaders, before or since his time, in knowledge and breadth of vision, in sincerity and humanity, in perseverance, racial patriotism, political sagacity, and military ability, and in sheer personal impressiveness.

\section{F. The Twentieth Century}

3038. Brookings Institution, Washington, D. C. Institute for Government Research. The problem of Indian administration; report of a survey made at the request of Honorable Hubert Work, Secretary of the Interior, and submitted to him, February 21, 1928. Lewis Meriam, technical director [of the survey] Baltimore, Johns Hopkins Press, 1928. xxii, 872 p. (Its Studies in administration [no. 17 ])

28-13503 E93.B873

This epoch-making survey was undertaken by the Institute for Government Research at the instance of the Secretary of the Interior in June 1926, and financed by the Institute entirely out of funds received from private sources. It was carried out by the Technical Director and a staff of nine specialists in such fields as law, economics, health, etc. A After seven months of field work, during which 95 jurisdictions were visited, another eight months were spent in preparing this report. The "Detailed Report," consisting of seven topical chapters, follows p. I 89; the volume begins with a "General Summary of Findings and Recommendations," and offers "A General Policy for Indian Affairs," as well as suggestions for the "Organization of the Federal Indian Work," and "Personnel Administration."
The basic fact of the Indian situation is that "an overwhelming majority of the Indians are poor, even extremely poor, and they are not adjusted to the economic and social system of the dominant white civilization." The ineffectiveness of the Bureau of Indian Affairs in educating and advancing the Indian has resulted from inadequate appropriations and, as a consequence, unqualified personnel. Reforms in Federal Indian policy since 1928 have nearly all stemmed from this searching diagnosis.

3039. La Farge, Oliver. As long as the grass shall grow. Photographs by Helen M. Post. New York, Alliance Book Corp., I940, I40 p. (The Face of America; Edwin Rosskam, editor)

$$
\text { 40-27492 E93.Li7 }
$$

A popular presentation of the Indian problem in the recent past, by an anthropologist and friend of the Indian who is also a successful novelist; the numerous photographs are excellent and finely reproduced. "I take the year I 923 as the nadir of the Indians"; they were expropriated, impoverished, diseased, despondent, and dwindling in numbers-all long-range consequences of the land allotment act of 1887. The later I920's saw a steady improvement 
in Indian administration; in 1933 John Collier became Commissioner of Indian Affairs, and in 1934 Congress passed the Indian Reorganization Act. The volume concludes with an enthusiastic presentation of the subsequent revitalization of tribal life, with an upswing in morale, prosperity, and vital statistics. There is no adequate summary of recent developments, which must be gathered from such formidable Congressional documents as the House Committee on Interior and Insular Affairs' Report with Respect to the House Resolution Authorizing . . . an Investigation of the Bureau of Indian Affairs (Washington, U. S. Govt. Print. Off., 1953-54. 1594, 576 p. $82 \mathrm{~d}$ Cong., 2d sess. House report 2503; 83d Cong., 2d sess. House report 2680).

3040. Lindquist, Gustavus E. E. The red man in the United States; an intimate study of the social, economic and religious life of the American Indian. New York, Doran, 1923. $46 \mathrm{r}$ p. illus. 23-ro398 $\mathrm{E}_{77} \cdot \mathrm{L}_{74}$

The American Indian Survey was initiated in I9I9 by the Interchurch World Movement, "at the request of Indian missionaries and workers gathered in conference at Wichita, Kansas"; it was taken over in 1921 by the Committee on Social and Religious Surveys and completed the following year. The Director, Mr. Lindquist, came from the International Committee of the Young Men's Christian Associations, and the text was prepared in part and edited throughout by Stanley Went. The Survey, "which is of a more comprehensive nature than has ever before been undertaken, has attempted to collect all the data available concerning social, economic, religious and educational conditions among the 340,000 Indians scattered through the United States," and especially such as "will assist the Protestant churches to extend their constructive work in the Indian field." Of the I92I total, 80,000 Indians were adherents of Protestant, and 65,000 of Roman Catholic Christianity. The book strongly advocates the assimilation policy, with tribal relations liquidated and "the Indian put on an individual basis"; it gives special attention to "the use of alcohol and peyote, the indulgence in degrading dances and the extent of sexual immorality, or non-morality." Its substance lies in Chapters 7-14 (p. 91-389) containing the geographical survey, with eight areas further subdivided by States, tribes, and reservations; reservations not individually described here appear in Appendix I (p. 40I-420). The state of schools and missions in each local unit is carefully described. The book has enduring value as a panorama of the reservations 35 years ago.
3041. Linton, Ralph, ed. Acculturation in seven American Indian tribes. New York, Appleton-Century, r940. xiii, $526 \mathrm{p}$.

$$
\text { 40-3756 E98.C9L6 }
$$

Bibliography at end of most of the chapters.

Contents.-Introduction, by Ralph Linton.The Puyallup of Washington, by Marian W. Smith.-The White Knife Shoshoni of Nevada, by J. S. Harris.-The southern Ute of Colorado, by M. K. Opler.-The northern Arapaho of Wyoming, by Henry Elkin.-The Fox of Iowa, by Natalie F. Joffe.-The Alkatcho Carrier of British Columbia, by Irving Goldman.-The San Ildefonso of New Mexico, by William Whitman.-Acculturation and the processes of culture change, by Ralph Linton.The processes of culture transfer, by Ralph Linton.-The distinctive aspects of acculturation, by Ralph Linton.

A volume of composite origin: the field work was financed by Columbia University and carried out between 1930 and 1937, while the theoretical framework was supplied by a subcommittee on acculturation, of which Prof. Linton was one of the members, appointed in 1935 by the Social Science Research Council. The subcommittee eventually worked out an impressive "Outline for Report on Acculturation in any Given Tribe," but only after the field work was completed. The seven reports here printed have all been organized, so far as possible, in conformity to this outline, but the material was not collected on its basis in the first instance. The reports are straightforward enough, and naturally concerned with white influence on Indian society rather than the converse. Prof. Linton's three concluding theoretical chapters do not confine themselves to the data presented in the preceding reports; they are primarily of interest to sociological theorists, but put one point effectively: "One of the most tragic features of our own dealings with the American Indians has been the constant changes in policy which, together with tribal removals, have rendered the adaptations which they successively developed successively unworkable."

3042. Mead, Margaret. The changing culture of an Indian tribe. New York, Columbia University Press, 1932. 313 p. (Columbia University contributions to anthropology, edited by Franz Boas, v. 15) 32-28812 $\mathrm{E}_{51 . \mathrm{C}_{7} \text {, v. I5 }}$

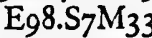

Miss Mead spent five months on the "Antler" (said to be the Omaha) Reservation in 1930 in order to investigate the little-known question of women's place in recent Indian society. She carried out her mission effectively, but her findings were most striking in their revelation of the degradation of Indian life as a whole in the latter days of the 
allotment policy. Women, for instance, had retained their lands more successfully than men, but a husband with a landed wife usually did his best to cash in his wife's heritage and squander the money. Women now had a larger economic role-because they still kept house and gardened, while their menfolk loafed or got drunk. They were still subject to a fixed theory of sexual morals with a puritanical double standard-but the Antler male regarded every unaccompanied woman as fair prey, and a great increase in the number of loose women and promiscuous young girls had been the consequence.

3043. U. S. National Resources Board. Land Planning Committee. Report on land planning. Part ro. Indian land tenure, economic status, and population trends, prepared by the Office of Indian Affairs, Department of the Interior. Washington, U. S. Govt. Print. Off., 1935. 73 p. 36-26092 HDi83. N3 $\mathrm{A}_{5}$ 1938, pt. Io

One of the eleven parts of a supplementary report of the Land Planning Committee, containing "a large volume of basic data and information" which could not be included in the National Resources Board's report to the President, Nov. 28, 1934. This part, prepared by the Office of Indian Affairs, presents the problems of most concern to its then director, John Collier. The first and largest section describes the "Complexities of Indian Land Tenure Arising from the Allotment System." The absurdities to which the heirship system had led are graphically illustrated by the estate of the Chippewa Lizette Denomie, whose original allotment of 80 acres had been distributed among 39 heirs, four of whom had an interest of .22 acre each, and two an interest of .II acre each. A "Social and Economic Survey of Selected Indian Reservations" "reveals the average Indian as a petty capitalist and an intermittent wage earner, rather than a commercial or even a subsistence farmer." "The Trend of Indian Population" criticizes earlier statistics and emphasizes the recent rapid growth, effected through mixed marriages; "the ratio of full bloods to mixed bloods has been declining very rapidly." 


\section{VIII \\ General History}

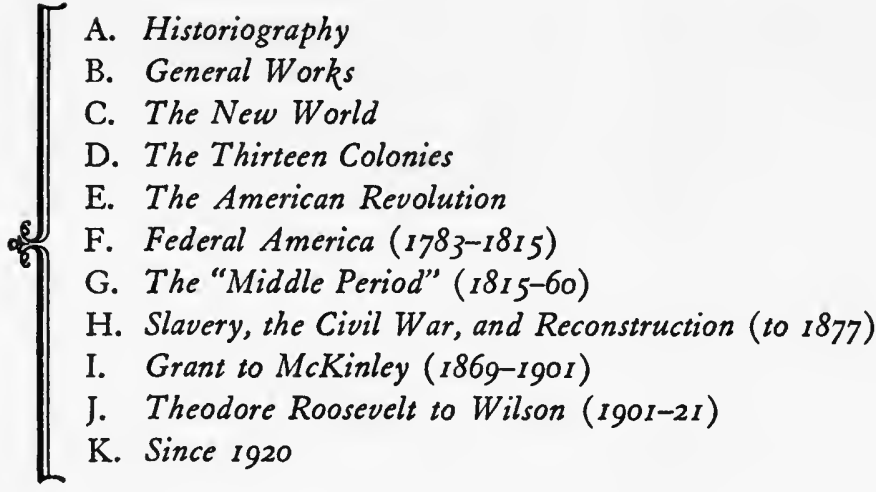

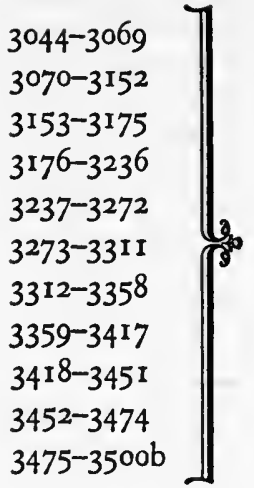

THE ATTEMPT to cover the history of the portion of the earth's surface which is now 1 the United States in some 450 titles would be a manifest absurdity if it were not for an important consideration which affects, not merely the selections for this chapter, but the work of library catalogers and classifiers, the writing of general American histories, and all thinking about the nature of history, whether by historians, social theorists, or philosophers. This same consideration has entered into the selections for nearly every other chapter, and has given a persistent perplexity to our whole enterprise which a number of quite arbitrary resolutions have by no means dispersed. Let us characterize it as briefly as possible.

The question "What is history?" gives rise to chains of thought sufficiently complex, and may receive answers ranging from the naive to the highly sophisticated. But this chapter is not entitled "History"; our whole Guide is concerned with history and the transitory present to which it leads, and we understand well enough what we mean by history even if we do not attempt to arrive at a watertight definition. Our question is rather: "What is General History?" What is history when it is not qualified as literary history, diplomatic history, religious history, economic history, constitutional history, or political history, or by any other adjective from the other 3 I chapters of this Guide, or from wider or narrower spheres? What, specifically, is American history, or the history of the United States, or of the American Nation, or of the American people, or of American civilization?

Seventy-five years ago this question would hardly have been asked, and, if it were, would have been immediately and dogmatically answered. "History is past politics, and politics is present history," Edward A. Freeman is supposed to have said, and the report has been seized upon because it condenses in an epigram the convictions of two generations of historians, preacademic and academic alike. History tout court was political history, conceived broadly enough to include constitutional, diplomatic, and military affairs as well as the fortunes of rulers, ministers, and parties. Other matters might be adduced when required to make these intelligible, and in practice, of course, other matters have always been adduced at length. In sum, proper history was the history of the State or of the relations of States. Twentieth-century historiography has been in large part a reaction against this Victorian orthodoxy. Dogmatic exclusiveness usually succeeds in provoking a contrary exclusiveness, and it was not long before there appeared 
vigorously worded manifestoes implying or asserting that the history of war and of politics was not worth studying at all. Neither, it came to be alleged, was more than a secondary and superficial manifestation, without real causal potency; the great changes took place in the depths of economic production, social organization, and human thinking and feeling. A single factor or sphere might be alleged as exclusively causal, reducing all the others to derivative and partially illusory phenomena: there is Marxian history, for instance, as well as Freudian history, and other radical simplifications with smaller followings. The multiplicity of spheres receiving newly intensive historical investigation became a perplexity and a burden to all who were looking for larger views, and "Synthesis" became a slogan which, as usual, was more easily pronounced than embodied.

We have no desire to promulgate a theory of history, but operation itself demands some theoretical assumptions. We can only hope that ours will seem to others as innocent and as simple as they do to us. We have supposed that, as long as there are records or remains, every sphere of human life, in the past as in the present, is worthy of serious and disciplined investigation. There is still no master key to man's mind or man's life, and until there is one there can be no definitive way of writing general history, whether of the race or of one of its units. But the human mind cannot cope all at once with the phenomena of life, in their natural entanglement and sporadicity. There must be a subordination which the mind imposes upon phenomena as much as it draws it from them. The mind's native approach to a temporal succession of events, which comprises a development or an evolution, is that of narrative, not different in kind from primitive folktale or heroic epic. General history, therefore, requires a focus, and must provide for movement. It should avoid negative dogmas of exclusion, but must have its own principles of selectivity. Especially in our own day does it require a skill in selection, in organization, and in combining description and analysis with narration, so subtle and varied as to be little distinguishable from the processes of the artist. If the history is that of a people with its own political organization, it neither should nor can dispense with the idea of the nation as a unifying concept.

Borrowing from various sources, but especially from Professor Richard B. Morris' Encyclopedia of American History (no. 3072), we have therefore conceived of this chapter as a selection of books which most effectively present the mainstream of American history, regarded as a movement which received its general form in 1492, and its special character in 1607 , effected its national determination in $1776-87$, and survived its greatest internal crises in $1861-65$ and $1929-33$, and its greatest external ones in I9I7-I9 and I94I-45. Beginning with Section C, there are few titles which could not plausibly have been placed in one or another of our topical chapters, just as there are many titles in those chapters which could just as plausibly appear here. In some cases, we are well aware, our dispositions have been quite arbitrary, and in a few they are recognized errors of judgment which the circumstances of publication do not permit us to rectify.

Section A on Historiography represents a new self-consciousness of the historical profession which is even now being gradually and somewhat painfully achieved. It is not an easy subject to study, for it is considerably more difficult to extract the ideas and attitudes of an historian from his work than it is those of a philosopher. There remain much detailed work to be done, and definitive surveys to produce. We have included here some titles on the collection and organization of historical materials in archives, historical societies, and museums, some manuals of historical research and editing which illustrate American practice, and some works on the teaching of American history.

Section B contains a great variety of general works on the whole course of American history, although some take their departure from 1776 or 1789 rather than from an earlier date. There are a number of reference books, but of a kind in which one may profitably or even pleasantly browse, if no one is likely to read them through. A number of collections of historical "documents" and other primary source materials are included; most of them are intended for use in college courses, and the more recent ones seek to present "problems" which will induce the student to reason as well as to remember. Other books produced for classroom use are the general surveys, in one volume or in two, with one author or more, and here the problem was the usual one of selecting a few titles from many whose resemblances are more remarkable than their differences. There are a number of guides to American biography and autobiography, of which the Dictionary of American Biography (no. 3080) is facile princeps; writings of individual biographers, supplementary to the biographies which appear in the topical chapters of this Guide, will be found in Chapter IV. The numerous biographies in the succeeding sections of this chapter are intended to be limited to figures who took a significant or at least a highly representative part in the main current of national development. And, finally, there are in Section B a number of titles which treat the westward movement of the American people as a major and continuing theme of American history, from 
the first settlements until the close of the rgth century. Books which consider the subject rather from the viewpoint of the successive Wests to be occupied will be found in Chapter XII on Local History, but we do not expect everyone to agree in detail with our distribution.

Section $C$ is chiefly concerned with the overture to American history: the revelation of the Western Hemisphere to European man from the great venture of Christopher Columbus until that point, some three centuries later, when the major outlines of the New World were clearly understcod. Here have also been placed a limited number of titles on the two European empires in America which preceded or accompanied the British colonization, which conditioned its development, and which have given a distinctive character to large parts of the Americas. Too often neglected are the West Indies (no. $3^{168}$ ), which since the 17th century have been the most cosmopolitan part of the New World, and which, during the first three centuries after their discovery, played a far more important role than they have since.

The remaining sections constitute in the main a straightforward chronological progression, but with two important qualifications: works concerned with the assertion of colonial rights against the imperial government, which went on for nearly 12 years before the actual outbreak of hostilities, are placed in Section $E$ rather than D. Similarly, works on slavery as a system and an interest, and the dispute which it engendered for three decades before secession, have been collected in Section $\mathrm{H}$, and the story prolonged to the withdrawal of the Federal troops from the South in 1877 . In the case of either war, and of the other national wars, books concerned with the more technically military aspects, the conduct of campaigns, the administration of the armed forces, and the lives of the principal commanders-if they did not become Presidents-will be found in Chapter $\mathrm{X}$ on Military History. Concerning Section $\mathrm{F}$ it may be said that the best books on the most important event within it, the making of the Federal Constitution, will be found in Chapter XXX on Constitution and Government. As for Section G, it was dubbed the "Middle Period" when the postCivil War perspective was far shorter than it is today, but since no better term has appeared to indicate the years of strenuous nationalism and democracy between the Peace of Ghent and the election of 1860 , we have retained it with the addition of quotation marks. Many of the most significant developments for Section I, covering the age in which American industry so spectacularly mushroomed and achieved its dominant position, are best described in Chapter XXIX on Economic Life. The breaks at IgOr and I92I are chiefly for convenience, and represent no endorsement of the "Presidential synthesis"-but who can deny that the three periods thereby set off have each a tone and temper of its own?

\section{A. Historiography}

3044. Adams, Herbert B. Historical scholarship in the United States, $1876-1901$ : as revealed in the correspondence of Herbert B. Adams. Edited by W. Stull Holt. Baltimore, Johns Hopkins Press, 1938. 314 p. (The Johns Hopkins University studies in historical and political science, ser. 56 , no. 4) 39-1218 H3r.J6, ser. 56, no. 4 EI75.5.AI797

3045. Jameson, John Franklin. An historian's world; selections from the correspondence of John Franklin Jameson. Edited by Elizabeth Donnan and Leo F. Stock. Philadelphia, American Philosophical Society, 1956. $3^{82}$ p. " (Memoirs of the American Philosophical Society, v. 42)

$$
\begin{array}{r}
\text { 56-6729 Q11.P6i2, v. } 42 \\
\text { Di5.J27A4 }
\end{array}
$$

Adams (1850-1901) built up the first successful American department of graduate study in history, at Johns Hopkins University (from 1876 ), initiated the publication of the Johns Hopkins studies ( 1882 ), led in the organization of the American Historical Association (1884), and served as its first secretary. Jameson (1859-1937) received the first $\mathrm{Ph}$. D. in history from Johns Hopkins (1882), edited the American Historical Review (1895-1901, 1905-28), headed the Bureau of Historical Research at the Carnegie Institution of Washington (1905-28) and the Manuscript Division of the Library of Congress (1928-37), and was the prime mover in bringing about the establishment of the National Archives (1934). Each man exerted a wide and salutary influence among the new and growing "guild" of academic historians, although his own published work remained relatively limited in quantity. These two collections of their correspondence, principally with other American historians, give much the best picture available of the first six decades of the new professional history in the United States. 
3046. Beale, Howard K., ed. Charles A Beard: an appraisal. [Lexington] University of Kentucky Press, 1954. 312 p.

$$
\text { 53-55I7 } \quad \text { Er } 75 \cdot 5 \cdot B_{37}
$$

"Bibliography of Beard's writings [by] Jack Frooman [and] Edmund David Cronon": p. $[265]-286$.

Charles A. Beard (1874-1948) was a unique figure among American historians, whose writings ranged over a wide variety of subjects, whose belief in democracy and the freedom of thought was basic and practical, and who followed his ideas wherever they led him, into economic determinism, into historical relativism, or into a narrow isolationist corner. His violent attacks on the foreign policy of President F. D. Roosevelt lost him much of the esteem in which he had been held and delayed the appearance of the present symposium, from which several of the original contributors withdrew, until after his death. Twelve friends and admirers contribute 13 essays on Beard as a historian, a historical critic, a political theorist, an interpreter of the Constitution, a teacher, and a public man, as well as in other lights and relationships. Professor Robert E. Brown of Michigan State University devotes a small volume, Charles Beard and the Constitution (Princeton, Princeton University Press, 1956. 219 p.), to a critical analysis of Beard's best-known and most controversial book, An Economic Interpretation of the Constitution of the United States (New York, Macmillan, 1913. 330 p.). He is led to deny "that the Constitution was put over undemocratically in an undemocratic society" by a personalty-interests group, and to affirm that it was, so far as conditions permitted, created by the whole people in their own best interests. Volumes by single hands on other historians who span the two centuries are Eric F. Goldman's John Bach McMaster, American Historian (Philadelphia, University of Pennsylvania Press, 1943. I94 p.), on the author of the famous History of the People of the United States (1883-1927. 9 v.), which is more original in plan than in execution; and Abraham S. Eisenstadt's Charles McLean Andrews, A Study in American Historical Writing (New York, Columbia University Press, I956. 273 p.), on the "historical science" of the Yale professor who did most to place the Thirteen Colonies in their contemporary setting as part of a great empire with its center at Whitehall.

3047. Carter, Clarence E. Historical editing. [Washington, U. S. Govt. Print. Off.] 1952. 5I p. (National Archives publication no. 53-4. Bulletins of the National Archives, no. 7)

A52-9688 Di3.2.C 3
Dr. Carter, since 193 I editor of the Territorial Papers of the United States, has drawn upon his long experience and the best recent practice in this general discussion of the problems that regularly arise in historical editing, especially for the benefit of staff members of the National Archives and of participants in the program of the National Historical Publications Commission. In its analysis of selection, transcription, and annotation, and in its emphasis upon responsibility "to furnish the material in its full and unaltered shape," it exemplifies the editorial standards of the historical profession in the United States.

3048. Caughey, John W. Hubert Howe Bancroft, historian of the West. Berkeley, University of California Press, 1946. $422 \mathrm{p}$.

$$
\text { A47-18 EI75.5.Big9 }
$$

A leading Pacific Coast historian writes a wellproportioned biography of his most conspicuous predecessor, $\mathrm{H}$. H. Bancroft (1832-1918), based on the latter's voluminous writings supplemented by his papers in the Bancroft Library and by contemporary newspapers. The house of $\mathrm{H}$. H. Bancroft \& Co., Booksellers and Stationers, set up in San Francisco in 1856 , prospered beyond anticipation, enabling its proprietor to assemble an extraordinary collection of imprints, manuscripts, and transcripts concerning the history of the United States west of the Rockies, and to employ a group of assistants to digest these sources for a large-scale history of the region, with Bancroft providing plans, editorial supervision, and a substantial share of the actual writing. Believing that Bancroft's early critics had seized upon some of his defects, so that "it came to be the fashion to disparage him not only for these shortcomings but in all that he had done," Professor Caughey emphasizes the great achievements involved in the 39 large volumes of the Native Races and the History of the Pacific States, and in the Bancroft Library of the University of California.

3049. Coleman, Laurence Vail. The museum in America; a critical study. Washington, American Association of Museums, 1939. $3 \mathrm{v}$. (730 p.) 39-27799 AMri.C6

Museums, even of natural history, constitute a concentration of nonliterary materials for history and may be regarded as a primary stage of the historiographical process. The first museum in the United States-the Charleston Museum, which originated in 1773 as a natural history collection of the Library Society of Charles-Town-antedated the Revolution, and by the end of 1938 the number of American museums had reached 2,489 , nearly four-fifths of which had been established during the previous 
quarter-century. The author, who has been director of the American Association of Museums since 1927, calls his work "a commentary on the condition, the strengths and weaknesses, and the limitations and opportunities of museums." Volume I reviews the whole development as a social movement and points to the rise of historic house and trailside museums as consequences of the automobile. It classifies existing institutions into museums of science, history, art, and industry; discusses their relations to locality, State, and Nation; surveys sources of $\mathrm{mu}$ seum income, which is never quite adequate; and describes the museum building of yesterday and today. Volume 2 is an analysis of museum work, the central function of which is display, necessitating a dual arrangement of materials into an exhibition and a reserve, or study, collection. Museum work, he concludes, "is capable of being a profession," and its personnel has achieved varying degrees of professionalism. Volume 3 classifies and lists museums by field ("General Museums," p. 487492), by control, and by location, and concludes with ten statistical tables (p. 663-678) and two chronological lists, of museums established before 1850 , including those which have ceased to exist, and of all buildings constructed for use as museums since I8r4, when Peale's Museum was built in Baltimore. Dr. Coleman has since published, under the same imprint, works on College and University $\mathrm{Mu}$ seums (1942. 73 p.) and Company Museums (no. 4716), and the first volume of a treatise on Museum Buildings (1950).

3050. Committee on American History in Schools and Colleges. American history in schools and colleges; the report of the Committee on American History in Schools and Colleges of the American Historical Association, the Mississippi Valley Historical Association, the National Council for the Social Studies. Edgar B. Wesley, director of the committee. New York, Macmillan, 1944. xiv, I48 p. $\quad 44-6$ I I EI75.8.C6

A reexamination of the purpose, extent, and qual. ity of instruction in American history provoked by World War II, sponsored by three learned societies, financed by the Rockefeller Foundation, and conducted from June through September 1943. The committee concluded that while the number of courses offered in American history was sufficient, there was too much overlapping in subject matter between them, too few college students took them, and improvement in the quality of curriculum and teaching was the major concern. Colleges were cautioned not to stress research at the expense of good teaching, and teachers urged to aim at significance in a limited number of topics rather than the meaningless enumeration of details. The Report offers a model organization for American history courses through the grades and an "Item Analysis of the Test of Understanding of United States History" (p. [125]-144) which revealed so much ignorance of the subject among diverse groups of testees.

305r. Craven, Wesley Frank. The legend of the Founding Fathers. New York, New York University Press, 1956: I91 p. (New York University. Stokes Foundation. Anson G. Phelps lectureship on early American history) 56-8593 Er $\quad$ 75.C.

"For better or for worse, the American community has consistently looked to its origins for an explanation of its distinctive qualities and thus for an explanation of what its future should hold." There was, however, a founding of the body social in 1607 and 1620 , and a founding of the body politic in 1776 and 1787 . Professor Craven devotes these exploratory lectures to the relative emphasis given to each founding, both in the historiography of various eras and in the ceremonial observances of successive anniversaries, and seeks as well the sources of the "debunking" impulse which has provided a countercurrent during the present century.

3052. Dunlap, Leslie W. American historical societies, I790-1860. Madison, Wis., Priv. Print. [Cantwell Print. Co.] 1944. $23^{8}$ p. $44-7046$ Er72.D8

Societies organized primarily to collect, preserve, and make available materials for history arose in Europe from the first decade of the 18 th century, and spread to the United States by its last. In Part 2 (p. 137-219) of this study, Dr. Dunlap sketches briefly the careers of the 65 local societies which arose in the United States between 1791, when the efforts of Rev. Jeremy Belknap brought about the organization of the Massachusetts Historical Society, and 1859, when the Historical Society of New Mexico was founded at Santa Fé. Part I discusses the movement as a whole, such general features as membership, finances, collections, and publications, and the value of these societies to our early writers, especially of state and local history.

3053. Hesseltine, William B. Pioneer's mission; the story of Lyman Copeland Draper. Madison, State Historical Society of Wisconsin, 1954. $3^{8} 4 \mathrm{p}$. $\quad 54-727$ I Er75.5.D763 "Materials for a biography": p. 357-359.

Draper $(1815-1891)$ spent much of his time from his $24^{\text {th }}$ year in journeys, largely made on foot, through the older Middle West, collecting or transcribing manuscripts, and taking down the oral testimony of the oldest inhabitants, especially concerning the warfare which harassed the earliest 
settlements. As the founder and long-time secretary of the State Historical Society of Wisconsin (1854I886), he was a pioneer in the collection and publication of historical source material, and in the organization of historical activities, in this part of the United States. The author unfortunately takes a rather dim view of Draper's character and of his failure to write the large-scale history he had planned, but he bases a very concrete and absorbing biography upon a thorough assimilation of the abundant personal materials in the Draper Collection at Madison.

3054. Hockett, Homer C. The critical method in historical research and writing. New York, Macmillan, 1955. 330 p. $55^{-1} 366_{4}$ EI75.7.H6 446 "A rewritten and expanded edition of the author's Introduction to Research in American History [1931]."

Bibliography: p. 265-295.

An introduction to method for graduate students in American history, which illustrates the timehonored canons of historical criticism from exclusively American examples, gives concrete bibliographical and procedural instructions for preparing a master's thesis, and proceeds to more general considerations on the past and present state of historical bibliography, research, and writing. A very typical product of American graduate schools of history, which throws much light upon the profession's understanding of its own tasks.

3055. Jordy, William H. Henry Adams: scientific historian. New Haven, Yale University Press, I952. xv, 327 p. (Yale historical publications. Studies, I6) 52-5362 Er75.5.AI755

Bibliography: p. 291-317.

Adams as a man of letters is considered under Literature (no. 688-700). Dr. Jordy's concern is with Adams' conception of "scientific history" as practiced in his History of the United States (nos. 3274-3275) and later formulated in his Letter to American Teachers of History (I910). Its pursuit, however, involves a widespread exploration of Adams' studies, thought, and character. The "master key" to the History is found in the positive philosophy of Auguste Comte. In the Letter's theory of inevitable degradation, Dr. Jordy thinks, the "erstwhile Comtist ... ended his writing career by turning Comte upside down." In The Mind and Art of Henry Adams (Boston, Houghton Miflin, 1957. $43^{\circ}$ p.) Jacob C. Levenson is concerned with Adams as man of letters, artist, and thinker, but urges that the only sound approach to these aspects is through a detailed study of "the first modern historical scholar in America." Adams' work after I89I was all stamped by his earlier practice of "the craft of history, as the one technical discipline to which Adams ever fully submitted." The continuity of Adams' second literary career with his first, and of Mont-Saint-Michel and Chartres and The Education of Henry Adams with the History of the United States is not easy to demonstrate, but the author does his sophisticated best.

3056. Kraus, Michael. A history of American history. New York, Farrar \& Rinehart, 1937.

607 p. 37-20447 EI75.K 73

3057. Kraus, Michael. The writing of American history. Norman, University of Oklahoma Press, I953. $387 \mathrm{p}$. 53-88 I5 EI $_{75} \cdot \mathrm{K}_{75}$

These two titles are actually successive editions of the same book. The later, according to its preface, "has been rewritten and expanded to carry the study to date," but the rewriting is relatively minor and the expansion in the nature of patchwork. On the other hand, there has been a general reduction of the original text, and much information concerning the earlier historians has simply been dropped. The 1937 volume is therefore still useful as the most comprehensive survey of American historiography hitherto made. The author's method, ideas, and style are sufficiently pedestrian, and there is rather more quotation from the histories themselves than is necessary for the purpose, but there is more basic information concerning the authors and their books than in any other single work. Old as it is, John Franklin Jameson's The History of Historical Writing in America (Boston, Houghton Mifflin, $189 \mathrm{I}$. I6o p.) contains still pertinent observations, and affords an introduction as pleasant as it is brief to the earlier historians. John Spencer Bassett's The Middle Group of American Historians (New York, Macmillan, 1917. 324 p.) contains, along with brief treatments of lesser writers, objective if somewhat condescending descriptions of the life and work of Jeremy Belknap, George Bancroft, Jared Sparks, and Peter Force, regarded as the major figures of "the old school [ that] came to its end with the advent of the critical spirit." Wendell Holmes Stephenson's The South Lives in History (Baton Rouge, Louisiana State University Press, 1955. I63 p.) includes a general review of historical scholarship concerned with the region, detailed studies of William E. Dodd, Ulrich B. Phillips, and Walter Lynwood Fleming, and an exceptionally thorough and valuable "Essay on Authorities."

3058. The Marcus W. Jernegan essays in American historiography, by his former students at the University of Chicago. Edited by William $T$. Hutchinson. Chicago, University of Chicago Press, 1937. $417 \mathrm{p}$. $3^{8-27}$ Ei75.5.M37 
Contents.-George Bancroft, by Watt Stewart.Richard Hildreth, by A. H. Kelly.-Francis Parkman, by J. P. Smith.-Hermann Eduard von Holst, by C. R. Wilson.-James Schouler, by L. E. Ellis.Woodrow Wilson, by L. M. Sears.-John Bach McMaster, by W. T. Hutchinson.-John Fiske, by J. B. Sanders.-James Ford Rhodes, by R. C. Miller.-Henry Adams, by $H$. S. Commager.Alfred Thayer Mahan, by J. W. Pratt.-Theodore Roosevelt, by $\mathrm{H}$. J. Thornton.-Frederick Jackson Turner, by Avery Craven.-Herbert Levi Osgood, by E. C. O. Beatty.-Edward Channing, by R. R. Fahrney.-George Louis Beer, by A. P. Scott.Clarence Walworth Alvord, by Marion Dargan, jr.-Claude Halstead Van Tyne, by P. G. Davidson.-Ulrich Bonnell Phillips, by Wood Gray.Albert J. Beveridge, by T. E. Strevey.-Vernon Louis Parrington, by W. T. Utter.

Professor Jernegan was one of the first to offer a graduate seminar in American historiography. His pupils have shown their appreciation in these informative and documented essays, from to to 27 pages in length, concerning 21 American historians whose work is finished, and who were mainly concerned with United States history prior to 1865 . Another four studies, including Charles Hirschfeld's "Edward Eggleston, Pioneer in Social History," appear in Historiography and Urbanization; Essays in American History in Honor of W. Stull Holt, edited by Eric F. Goldman (Baltimore, Johns Hopkins Press, 1941. 220 p.).

3059. National Council for the Social Studies. The study and teaching of American history. Richard E. Thursfield, editor. Washington, 1947. xviii, 442 p. (Its Yearbook, I7th, 1946)

3I-6192 H62. AIN 3 , no. 17

The National Council, the department of social studies of the National Education Association, offers this symposium primarily to secondary-school but also to elementary-school and college teachers, in order to improve the teaching and study of American history "as the essential core of any program for intelligent American citizenship in this interdependent world." Section 2 has chapters by six historians on the "Newer Interpretations and Emphases in American History," while Section 3 discusses the relations of American history to the other social studies and other school subjects. The four concluding sections are more directly concerned with pedagogical techniques: the articulation of American history with the several school grades, teaching methods and materials, "evaluation" and tests, and teacher training. 306o. Nye, Russel B. George Bancroft, Brahmin rebel. New York, Knopf, r944. x, 340, xii p.

Bibliography: p. [324]-340. 44-6406 EI $75 \cdot 5 \cdot B$ ig6

George Bancroft (1800-1891) published the 12 volumes of his History of the United States, from the discovery of America to the establishment of government under the Constitution, through 5 eventful decades of the Republic (1834-82). Written in an exuberant style, and pervaded by a robust faith in the Providential mission of the United States as the embodiment of liberty, democracy, and civilized progress, it brought its author immediate fame at home and abroad. Prof. Nye's life of the historian, which won a Pulitzer prize in biography, is based on the two main collections of Bancroft's manuscripts as well as his published writings, and emphasizes as much as his history his political and diplomatic career, and his influence as the thinker who, perhaps, "caught the spirit of his age best."

3061. Parker, Donald Dean. Local history; how to gather it, write it, and publish it. Rev. and edited by Bertha E. Josephson for the Committee on Guide for Study of Local History of the Social Science Research Council. [n. p.] 1944. xiv, I86 p.

Bibliography: p. 179-186.

$\mathrm{A}_{45-1091} \mathrm{E}_{175 \cdot 7 \cdot \mathrm{P}_{3}}$

The title page's authorship statement does duty for a rather more complex origin: the Committee discovered that Dr. Parker of the South Dakota College of Agriculture had already prepared an appropriate manuscript, which they proceeded to adapt and expand into. harmony with their own purposes, with Rodney Loeher and Richard H. Shryock as well as Miss Josephson supplying some writing or rewriting. The objective of the Council is to stimulate the writing of sound local history, as supplying essential materials for social science, and, since professionally trained historians are likely to be absorbed by larger themes, to supply laymen with a body of practical rules and suggestions for recording the significant past of their own communities. The three parts are concerned with gathering materials, from books in libraries to inscriptions on gravestones, with the processes of taking and organizing notes and of writing and documenting a text, and with various means of publishing and of obtaining community coöperation. Chapter 8 , largely the work of Dr. Shryock, is "A Model [i.e., exhaustive] Outline for a Local History."

3062. Saveth, Edward N., ed. Understanding the American past; American history and its interpretation. Boston, Little, Brown, 1954. 613 p. 53-7320 EI78.6.S $_{3} \quad 1954$ 
A carefully organized essay on the periods and types of American historiography precedes 30 selections from recent writers which the editor regards as outstanding interpretations of some topic or figure. To each of these he contributes an introduction indicating its place in the professional discussion of the subject. The result is an anthology affording an unusually clear perspective of its field. The Making of American History, edited by Donald H. Sheehan, 2d ed. enl. (New York, Dryden Press, 1954. 2 v. (912 p.)) presents rather longer extracts from 34 historians from Parton and Parkman to Henry $\mathrm{K}$. David and C. Vann Woodward, but has less of a positive contribution on the part of the compiler.

3063. Schellenberg, Theodore R. Modern archives: principles and te chniques. [Chicago] University of Chicago Press, 1956. $247 \mathrm{p}$. 56-58525 CD950.S 3

In the United States the archival profession has achieved self-consciousness and influence only since the establishment of the National Archives in 1934, followed by the organization of the Society of American Archivists in 1937 and the inauguration of its quarterly organ, The American Archivist, in the next year. During 1954 Dr. Schellenberg, Director of Archival Management at the National Archives, served as Fulbright lecturer in Australia, and there became concerned with the differences between American and foreign archival practices. His book is an outgrowth of his lectures, which he expanded to fill in a "well-rounded and well-considered statement on the basic principles and techniques of managing" modern public records-the first systematic American book on the subject. An introductory part considers the nature and relationships of archives and archival institutions. Part 2 is concerned with record management-the production, organization, and control of public records in the agency where they originate, as well as the policies that govern the disposal of noncurrent records. Part 3 expounds archival management, first in its essential conditions, and then in the principles governing its several functions: appraisal of potential accessions, physical preservation, arrangement of record groups and of the items within groups, finding aids and other descriptions, publications, and reference services to Government and public.

3064. Scott, Franklin D., and Elaine Teigler, eds. Guide to the American Historical Review, I895-1945; a subject-classified explanatory bibliography of the articles, notes and suggestions, and documents. With a foreword by Guy Stanton Ford. In American Historical Association. Annual report. I944; v. I. Washington, 1945. p. 65-292.

$$
\text { 46-25831 EI72.A6o 1944, v. I }
$$

The American Historical Review was established in 1895 by an ad hoc meeting held in New York City, and was at first controlled by a coöpting Board of Editors and financed by an Association of Guarantors. Two years later it entered into a contractual relationship with the American Historical Association, which did not acquire ownership until 1916. It has, nevertheless, since its foundation been the major periodical of the historical profession in the United States, and it has from the first issue aimed at the widest possible representation of all ages, areas, and aspects of human history. In the present Guide, American history occupies 82 pages, European and Near Eastern history 76 pages, and all other areas and varieties 50 pages. Nearly every American historical scholar of any eminence has contributed at least one article to its pages, and it supplies a reliable indication of changes in the prevailing subjects, ideas, and techniques among academic historians. The present Guide to the first half-century of the Review, prepared over a period of years by Professor Scott of Northwestern University and his assistant, is arranged in subject sections, and in an order "roughly chronological by content" within each, so that the Review's contribution to any period or topic is easily discerned. The entries for articles are provided with abstracts "intended to guide readers to the articles they wish to consult, not to compress the entire content," and there is a 7-page index of authors. The early history of the journal is charmingly narrated by its first and greatest editor, John Franklin Jameson, in an article contributed to the Review for its 25th anniversary: "The American Historical Review, 1895-1920," v. 26, Oct. 1920, p. I-17.

3065. Social Science Research Council. Committee on Historiography. Theory and practice in historical study: a report of the Committee on Historiography. New York, Social Science Research Council, I946. I77 p. ([Social Science Research Council] Bulletin 54, 1946) 46-3597 Di3.S6

Contents.-Foreword, by Merle Curti.-Grounds for a reconsideration of historiography, by C. A. Beard.-Controlling assumptions in the practice of American historians, by J. H. Randall, Jr., and George Haines, IV.-What historians have said about the causes of the Civil War, by H. K. Beale. Bibliography (p. 93-102).-Problems of terminology in historical writing: Note on the need for greater precision in the use of historical terms, by C. A. Beard. Illustrations, by Sidney Hook.Propositions.--Selective reading list on historiography and the philosophy of history, by Ronald Thompson. 
This report is the result of conferences and correspondence by a representative group of American historians seeking to arrive at agreement on the nature of their discipline as revealed by its relations with other fields in the social science area. The 21 "Propositions" (p. 133-140) were originally drafted by Charles A. Beard, but have been modified to meet the criticism of other historians; with the supporting essays they provide a recent example of coöperative and systematic thought on the part of the historical profession in the United States seeking to clarify its basic ideas and assumptions.

3066. U. S. National Archives. Guide to the records in the National Archives. Washington, U. S. Govt. Print. Off., 1948. xvi, 684 p. (Its Publication no. 49-13)

$$
\mathrm{A}_{49-10088} \mathrm{CD}_{3023} \cdot \mathrm{A}_{4} 6 \quad 1948
$$

3067. U. S. National Archives. Your Government's records in the National Archives. [Rev. by Bess Glenn under the direction of Philip M. Hamer and G. Philip Bauer. Washington, U. S. Govt. Print. Off.] 1950. viii, 102 p. [Its Publication no. 5I-4] A5I-917I CD3023.A46 $195^{\circ}$

The Federal Government has been accumulating records since 1774 , but during its first 160 years these were scattered, inadequately described, and under varying conditions of access or nonaccess. The creation of a unified National Archives, administering a coherent policy concerning the preservation and management of Federal records, was primarily the achievement of the American Historical Association and, more than any other individual, of John Franklin Jameson (no. 3045), but it required over a quarter-century of promotion before the first records were transferred to the new Archives building at the end of 1935. The present is the third general Guide to the records administered by the National Archives, its predecessors having been issued in 1937 (as part of the Archivist's Third Annual Report) and in 1940, but it is now seriously out of date. It describes over 813,000 cubic feet of records arranged by "Record Groups" in their numerical order; since this is, in general, the order of their acquisition by the Archives, it does not make for convenient use. Your Government's Records, of which a first and smaller edition appeared in 1946 , seeks to "put the National Archives and its vast store of records in a nutshell," and is particularly useful in that it arranges the record groups by branch and department. Records transferred to the Archives since June 30, 1947, are described in National Archives Accessions, a periodical supplement to the Guide which at first was a quarterly, but now appears at irregular intervals.
3068. U. S. National Historical Publications Commission. A national program for the publication of historical documents; a report to the President. Washington, 1954. $106 \mathrm{p}$.

$$
\text { 54-60038 Er } \text { I5.4.A417 }
$$

"A selective list of documentary historical publications of the United States Government": p. 98-106.

The publication of volume I of The Papers of Thomas Jefferson (no. 3292) on May 17, 1950, was marked by President Truman's announcement that he had instructed the National Historical Publications Commission to report on the possibility of further enterprises of like thoroughness and scholarship. This document, prepared by the Executive Director of the Commission, Dr. Philip M. Hamer, presents the results of nearly four years of consultation and planning, and reflects the tremendous stimulus given to documentary publications by Dr. Julian P. Boyd's example and President Truman's initiative. As a result of the Commission's recommendations, major editions of the complete papers of Franklin, J. and J. Q. Adams, Madison, and Hamilton have been handsomely endowed. The Commission's plans for its own documentary histories of the ratification of the Constitution and the Bill of Rights, and of the First Congress of the United States (1789-9I), are here set forth.

3069. Wade, Mason. Francis Parkman, heroic historian. New York, Viking Press, 1942.

$466 \mathrm{p}$. $\quad 42-25^{8} 5^{6} \quad \mathrm{E}_{175}$.5.P28

"Bibliographical note": p. 453-456.

Parkman's prose epic of the French Empire in North America is no. 317I below; this biography emphasizes "the heroic virtues: courage, self-reliance, perseverance, austerity, modesty," which went into its making, as its author struggled against the physical breakdown brought on by overdriving himself in his youth. Before his nervous and visual collapse in 1847 , Parkman ( $1823-1893$ ) had roughed it in the woods of New England and New York, toured Western Europe, and made two journeys into the American West, the second of which included his famous sojourn in a Sioux village (no. 3348). Mr. Wade quotes extensively from Parkman's own travel records here, and has presented them at length in his edition of The Journals of Francis Parkman (New York, Harper, 1947. 2 v. $(x x v, 718$ p.)). The remainder of the book tells how Parkman lost and regained the power to work, and then turned his handicaps into assets: having to digest his materials in his mind, he achieved a tighter organization of his narrative; and, employing his sleepless nights in mental composition, he arrived at a style at once economical, fluent, and muscular. 


\section{B. General Works}

3070. Aaron, Daniel, ed. America in crisis; fourteen crucial episodes in American history. New York, Knopf, 1952. 363 p.

$$
\text { 5I-13214 Er78.6.Ai7 }
$$

Probably I4 other episodes equally "crucial" could be selected, but these were the examples chosen at Bennington College in 1949-50 "for an experimental course designed to bring out the role and operation of values in American history." Each is a concise but serious attempt at interpretation of a striking event, from the Great Awakening of the 1740's to the Nazi-Soviet Pact of 1939, by an authority in the field.

3071. Adams, James Truslow, ed. Dictionary of American history; James Truslow Adams, editor in chief; R. V. Coleman, managing editor. $2 d$ ed. rev. New York, Scribner, 1942. 5 v. 44-1876 EI74.A43 I942 Index. New York, Scribner, 1942. $25^{8}$ p. $\quad E_{174 . A_{43}} 1942$ Index

3072. Morris, Richard B., ed. Encyclopedia of American history. New York, Harper, 1953. xv, 776 p. maps, diagrs. $53-5384$ Er74.5.M847

The Scribner Dictionary was begun in 1936 and first published in 1940; it bears the name of J. T. Adams, a historical popularizer of the interwar decades, but was largely the work of Roy V. Coleman and his staff, as well as "more than a thousand historians" to whom the 6,000 articles were farmed out. After 17 years it remains an indispensable work of reference, and the easiest first approach to many or most topics in the history of the United States from the discoveries down to the eve of World War II. It has the advantage of ready reference conferred by the alphabetical arrangement of its articles, and the inconveniences of such an arrangement applied to a subject matter which orders itself actording to geography and chronology. The articles vary in length from four or five lines ("Assiniboine, Fort") to three or four pages ("Civil War"), and nearly all have from one to six references at the end. A number of serious errors remain uncorrected even in the second edition. The valuable Atlas supplementary to this Dictionary has been separately listed in Chapter VI (no. 2967). Professor Morris' Encyclopedia is not greatly less comprehensive, and is an object-lesson in the quantity of information that may be crammed within a single pair of covers by intelligent organization, condensation, and book design. Here the material is arranged into a basic chronological section-the mainstream of national history-and six topical chronologies covering Expansion, Population and Immigration, the Constitution, the Economy, Science and Invention, and Thought and Culture. Three hundred brief biographies are alphabetically arranged, and there is a 40-page index with three columns to the page.

3073. Beard, Charles A., and Mary R. Beard. The rise of American civilization. New York, Macmillan, 1927. 2 v. 27-954I E169.1.B32 These thick volumes by one of the best-known Americans and his accomplished wife, Mary Ritter Beard (b. 1876 ), are a conscious attempt to return to the history of civilization, albeit within a single nation, as it was understood by Voltaire in the 18 th century and by Henry Thomas Buckle in the rgth. Ever since its publication The Rise of American Civilization has. won the highest encomiums from professional historians and laymen alike; critics of the highest qualifications have used such phrases as "the high-water mark of modern historic presentation in America," and "the most brilliant historical survey of the American scene." Certainly few readable works have ever been so successful in incorporating so much economic, social, and intellectual detail into a coherent general narrative. It remains true that the presentation is uncommonly fluid and formless, rendering the book relatively unserviceable for systematic students or classroom use. Written at a time when Dr. Beard had abandoned the extremer tenets of his economic interpretation, it takes a moderate view of the movement eventuating in the Constitution, but it gives a strong economic coloring to its account of the Civil War. Volume I is "The Agricultural Era" and Volume II "The Industrial Era," and the transition between them is effected by "The Second American Revolution" of 186I-65. This is viewed as the irrepressible conflict between two phases of society which overthrew the custodians of the old order, as the Southern planter aristocracy had constituted themselves, and effected a permanent shift of the center of political gravity in American society. The discussion of military matters is always jejune, and some readers will feel that the views and actions of leading American statesmen are regularly looked at through the wrong end of the telescope. Mrs. Beard saw to it that the circumstances of American women were given a larger place than is common in general histories. 
The same publishers issued a two-volumes-in-one reprint in 1930. The narrative, which comes down to 1926 , was continued on an even larger scale in America in Mid-Passage (no. 3479).

3074. Billington, Ray Allen. Westward expansion, a history of the American frontier, by Ray Allen Billington with the collaboration of James Blaine Hedges. New York, Macmillan, 1949. $873 \mathrm{p}$.

"Bibliographical note": p. 757-834.

49-3099 Er79.5.B63

Professor Hedges, a pupil of F. J. Turner, was to have collaborated in a joint enterprise, but was prevented by circumstances from contributing more than three chapters and a critical reading of the manuscript. The book was planned "to follow the pattern that Frederick Jackson Turner might have used had he ever compressed his voluminous researches on the American frontier within one volume," and Professor Billington explains that it is not a work of primary research, but "a synthesis of thousands of pages of writings-in texts, monographs, and learned journals-inspired by Professor Turner's original essays." "The Frontier Hypothesis" itself, and the criticisms it has encountered since 1925 , are considered in Chapter I and the corresponding part of the bibliography, with the conclusion that these "modified, but did not refute, [Turner's] basic doctrine." Both the text, which covers the whole period $1492-1896$, and the thoroughly annotated bibliography are well-nigh encyclopedic in their inclusiveness, and the text is studded with numerous small maps.

3075. Bolton, Herbert E. Wider horizons of American history. New York, AppletonCentury, I939. Xv, I9I p. (Appleton-Century historical essays) 39-13861 EI8.B75

Contents.-The epic of greater America.-Defensive Spanish expansion and the significance of the borderlands. - The Mission as a frontier institution in the Spanish-American colonies.-The Black Robes [Jesuits] of New Spain.

Essays advancing and illustrating the author's characteristic view that the broad phases of United States history are "common to most portions of the entire Western Hemisphere," and that "much of what has been written of each national history is but a thread out of a larger strand." The first essay "sketches in broad outline some of these larger aspects of New World history"; the others are "generalized treatments of special aspects of Western Hemisphere genesis" introduced in the first essay.

3076. Carruth, Gorton. The encyclopedia of American facts and dates, edited by Gorton
Carruth and associates. New York, Crowell, 1956. 708 p. (A Crowell reference book) 56-7789 $\mathrm{E}_{174 \cdot 5 \cdot \mathrm{C}_{3}}$

3077. Kull, Irving S., and Nell M. Kull. A short chronology of American history, 1492-1950. New Brunswick, Rutgers University Press, r952. $388 \mathrm{p}$. 52-937I EI74.5.K8

Mr. Carruth's compilation is also a chronology, from $986 \mathrm{~A}$. D. to 1955, and both volumes are extremely useful in diverse ways. The Kulls list some 10,000 events, largely in political, social, and economic history, in a single series, tersely and with little elucidation of the individual event; a supplementary volume to have been devoted to "the large field "of cultural and intellectual history" has not appeared. The Encyclopedia lists its events in four parallel columns, devoted to politics, the arts, economic, scientific, and educational developments, and to sport and entertainment. Events are frequently elucidated at some length, with glances before and after, and from $193^{2}$ on each annual column opens with a kind of profile of the year in its spheres. The Ir6-page index of the Encyclopedia and the 9o-page index of the Chronology add greatly to the reference value of each volume.

3078. Clark, Dan Elbert. The West in American history. New York, Crowell, 1937. 682 p. 37-4445 $\mathrm{E}_{17} 8 . \mathrm{C}_{57}$

"Bibliographical notes": p. [627]-654.

Professor Clark wrote his survey of "the important features of the history of the West as a whole," from the expedition of Panfilo de Narvaez (1527) to the "passing of the frontier" about 1890, both for college use and for the general reader. It did not catch on as a college text, but remains a quite readable volume in which parts 2 and 3 , from 1783 to the end, are organized topically, "with chapters arranged as nearly as possible in the order in which the subjects and problems with which they deal arose in the process of western settlement." The absence of footnote references is compensated for by a substantial bibliography arranged according to the 37 chapters of the book.

3079. Commager, Henry Steele, ed. Documents of American history. 5th ed. New York, Appleton-Century-Crofts, 1949. xxiii, 450, 759 p. (Crofts American history series)

49-49474 Er73.C66 I949

This collection of original source materials for American history, reprinted in full or in extract, has enjoyed a wider use in college courses than any similar compilation since its original publication in 1934. The fifth edition contains $5^{89}$ separate documents, each provided with a title, a reference to 
the source from which it was derived, a brief introduction in smaller type, and, in most cases, a few references for further study. Professor Commager states that he has tried to'limit his "selection to documents of an official and quasi-official character," but that he has not been completely consistent. Many important documents, he explains, have been omitted because they could not be included in extenso, and he was "not able to achieve a satisfactory condensation." In the fifth edition he was able to add 19 documents only by omitting 16 of those in the fourth, which is presumably why his textbook has remained unchanged since 1949. The practice of reprinting comparatively brief documents or other sources for students of American history began with the publication of the Old South Leaflets from I883; the first collection in book form was Albert Bushnell Hart's four-volume American History Told by Contemporaries (New York, Macmillan, r897-rgor; a supplementary fifth volume was added in 1929). The carefully delimited compilations of William MacDonald, Select Charters and Other Documents Illustrative of American History, 1606-1775; Select Documents Illustrative of the History of the United States, 1776-1861; and Select Statutes and Other Documents Illustrative of the History of the United States, $1861-1898$ (New York, Macmillan, 1899 (401 p.), 1898 (465 p.), 1903 (442 p.)) have a continuing value because of that quality. Since Professor Commager's last revision, Avery O. Craven, Walter Johnson, and Frederick Roger Dunn have compiled $A$ Documentary History of the American People (Boston, Ginn, 1951. xxiii, 872 p.), the 250 readings of which include interpretive essays by historians and others as well as primary sources, and Oscar Handlin has edited Readings in American History (New York, Knopf, I957. xxvi, 715, v p.), with 465 relatively brief and largely nondocumentary pieces arranged in 50 topical sections. Richard D. Heffner's $A$ Documentary History of the United States, expanded ed. ([New York] New American Library, 1956. 303 p. A Mentor book, $\mathrm{MD}_{7} 8$ ) calls for mention as presenting a large amount of basic material at a very small price. A very informative discussion by Wallace Evan Davies, "From Sources to Problems: A Guide to Outside Readings," appeared in the American Quarterly, v. 7, summer 1956, p. 127-146; and a review article by Robert J. Taylor, "Inexpensive Source Materials in Early American History," calling attention to a surprisingly large group of recent paperback publications, appeared in The William and Mary Quarterly, $3 \mathrm{~d}$ ser., v. I5, Jan. 1958, p. 95-1 10.

3080. Dictionary of American biography, published under the auspices of the American Council of Learned Societies. New York, Scribner, 1943. 21 v. 44-41895 EI76.D562 Index: volumes 1-20. New York, Scribner, 1943. 613 p. EI76.D562 Index Appleton's Cyclopaedia of American Biography, edited by James Grant Wilson and John Fiske, was originally published in 6 volumes in 1886-89. A useful reference work in its day, it still has value in carrying individuals whose reputation has since suffered an eclipse, and in giving short notices of the sons or other close relatives of important persons, whose limited but respectable achievements are often hard to trace. Appleton's was, however, never a completely dependable work-one ingenious forger contributed a whole series of quite fictitious lives-and it had no citations to sources of information, primary or secondary. It was shortly quite overshadowed by the British Dictionary of National Biography, originally published in 63 volumes between 1885 and I90I, which was undertaken by a commercial publishing house but carried out in accordance with the best scholarly standards of the day. After its completion two decades elapsed before it proved possible to set on foot an American enterprise on the same level. The American Council of Learned Societies was organized in 1919, and in 1922 appointed a committee of six scholars, headed by Dr. J. Franklin Jameson, to plan such a work. The committee eventually found a sponsor in Adolph S. Ochs of the New York Times, who made available $\$ 50,000$ a year for ten years, and enabled editorial work to begin in 1926 . The first editor, Allen Johnson of Yale University, fell a victim to Washington traffic in 1931 , but had completed six volumes and established the production of the work on firm principles. His assistant editor, Dumas Malone of the University of Virginia, brought the Dictionary to a triumphant conclusion with the publication of volume $\mathrm{XX}$ in 1936. The following year the publishers added an index volume, with sections on the 13,633 subjects of biographies; the 2,243 contributors; the subjects arranged by state or country of birth, by school or college attended, and by occupation; and distinctive topics discussed in the biographies. Supplement I, which appeared under the editorship of Harris E. Starr in 1944 , contains 652 additional biographies, largely of persons whose deaths occurred between the original selections and the end of 1935, but also of some whose memoirs "failed to be included in the earlier volumes, although their inclusion would have been appropriate." Nineteen pages of errata may be found at the beginning of volume $I$ of this reprint edition of 1943 , rarer in libraries than the original issue. A second supplement, including persons whose deaths occurred before the end of 1940, has been announced for publication in $195^{8}$. 
The Dictionary has received some criticism, but most of it springs from the appetite for more and more dependable brief biographies which the Dictionary itself has creatéd. The "D. A. B." will long remain a standard work of first resort for the student and scholar in the American field. Marion Dargan's Guide to American Biography [16071933] (Albuquerque, University of New Mexico Press, 1949-52. 2 v. in I) is a convenient biobibliography of the eminent, which annotates some titles, and gives special attention to brief biographies and volumes of biographical sketches.

308I. Faulkner, Harold U. A visual history of the United States. Illustrated by Graphics Institute. New York, H. Schuman, 1953. 199 p.

$$
\text { 53-10368 } \mathrm{E}_{178.5} \cdot \mathrm{F}_{3}
$$

The only book which consistently applies the new technique of "graphics"-the expression of all ideas primarily in pictographs with language used to supplement or expand-to the whole field of American history. It grew out of an Army education program during World War II, which called for a number of wall charts based on one of Professor Faulkner's textbooks; after the war Graphics Institute decided to proceed with "a comprehensive visual history," which was eight years in preparation, and for which Faulkner became the historical adviser and writer. The book's primary content is 76 "graphic idea layouts" planned by the Director of the Institute, Herbert Rosenthal, and largely drawn by Mel Bernstein; red and black ink are used, permitting five contrasting shades including white, gray, and pink. The "graphics" are of three main types: maps, charts for quantitative summaries, and simplified multiple cartoons for idea situations such as "Factors for and against a Successful War of Independence," or "The March of Fascism, 19221939." Anachronisms and inaccuracies can be found in the graphics, but are few and minor. The subject matter is arranged in nine units, partly chronological, such as "Division and Reunion," and partly topical, such as "Intellectual and Cultural Life." The volume affords a good introduction to American history for the visually minded, and has matter of interest even for the well-informed.

3082. Gabriel, Ralph Henry. The lure of the frontier; a story of race conflict. New Haven, Yale University Press, 1929. 327 p. (The Pageant of America [v. 2]) 29-22308 Er78.5.P2, v. 2 Er79.5.Gr 3

The expansion of the American people from 1670 , when Dr. John Lederer climbed the Blue Ridge and gazed at the lands beyond, to the Klondike Gold Rush of $1896-97$, organized around a sequence of illustrations, usually two to a page. They are regu- larly as well chosen as they are dismally reproduced, and are thoroughly explained by the accompanying text. A number of maps drawn or redrawn for this volume by Gregor Noetzel and others do provide very clear illustrations of individual situations in the movement of expansion. The circumstance that this volume was sold only with complete sets of The Pageant of America has kept it from enjoying a far wider usefulness than it has actually achieved.

3083. Handlin, Oscar, and others. Harvard guide to American history. Cambridge, Mass., Belknap Press, I954. xxiv, 689 p.

53-5066 Zi236. $\mathrm{H}_{27}$

In 1896 two Harvard professors of history, Edward Channing and Albert Bushnell Hart, issued a Guide to the Study of American History (Boston, Ginn. xvi, 47I p.) in order to "introduce readers to the evolving methods and growing literature of the historical discipline." That literature grew and grew, and 16 years later Frederick Jackson Turner, who came from the University of Wisconsin to Harvard in rgro, joined them in a revised and augmented edition, Guide to the Study and Reading of American History (Boston, Ginn, 1912. xvi, $65^{\circ}$ p.), which remained the standard work of the kind for over four decades, although during the later ones its increasing inadequacy was universally recognized and deplored. It required a team of six Harvard historians-the Arthur Meier Schlesingers Senior and Junior, Samuel Eliot Morison, Frederick Merk, and Paul Herman Buck in addition to Professor Handlin (whose name is deservedly first, since he and Mrs. Mary F. Handlin undertook the labor of getting the volume through the press)to bring out the third and present version, which was announced for publication more than once before its actual appearance. With a few exceptions, imprints later than $195^{\circ}$ are not listed. Of the three parts of the Harvard Guide, the first is a series of 66 essays and special lists on the more general aspects of American historical study, such as "Principles of Historical Criticism," "The Mechanics of Citation," "Guides to Manuscript Materials," "Bibliographies of American History," and "Scholarly Uses of Historical Fiction" (a very skillful classification by the elder Schlesinger). The second part is a sequence of $2 \mathrm{I}$ I bibliographical sections, primarily chronological and secondarily topical, covering American history from prehistoric times to 1953. Each section is divided into "Summary" (a brief outline of the subject), "General Works," "Special Works" (including many periodical articles), "Sources," and "Bibliography" (other lists of reference). The third part is a large index filling 143 double-column pages, which re- 
fers only to the principal entry for a work and ignores the repetitions in more abbreviated form. The student who can afford only one reference book in general American history would find this his natural choice.

3084. Hicks, John D., and George E. Mowry. A short history of American democracy. $2 \mathrm{~d}$ ed. Boston, Houghton Mifflin, I956. 854, Ixxv p.

Bibliographies at end of chapters. 56-2751 Ei78.1.H56 1956

Most college textbooks in American history now come in two volumes under multiple authorship; Professor Hicks' one-volume survey, originally published in 1943, has acquired a joint author in its third revision. As in nearly all such works, recent history is expanded at the expense of the remoter past: the period 1928-55 receives approximately the same number of pages as $1607-1815$. The art staff of Houghton Mifflin has supplied abundant illustrations from contemporary sources and numerous small maps of great clarity, and the chapter bibliographies are uncommonly full and effectively organized.

3085. A History of American life, edited by Arthur Meier Schlesinger and Dixon Ryan Fox. New York, Macmillan, I927-48. 13 v. Er69.1.H67

The Library has classified other sets, in which most of the volumes have later imprints without change of text, as EI69.I.H672 and EI69.r.H673. "Critical essay on authorities" in each volume.

3086. Vol. I. The coming of the white man, 1492-1848, by Herbert Ingram Priestley.

1929. XX, 4II p. 29-17105 EI78.P94

3087. Vol. 2. The first Americans, 1607-169o, by Thomas Jefferson Wertenbaker. I927. Xx, $35^{8} \mathrm{p}$. 27-243I7 Ergr. W5

3088. Vol. 3. Provincial society, $1690-1763$, by James Truslow Adams. I927. xvii, $374 \mathrm{p}$. 27-24316 EI95.A22

3089. Vol. 4. The revolutionary generation, $1763-$ I790, by Evarts Boutell Greene. I943. xvii, $487 \mathrm{p}$. 43-I6080 E320.1.G82

309o. Vol. 5. The completion of independence, I790-1830, by John Allen Krout and Dixon Ryan Fox. 1944. xxiii, 487 p.

$$
\text { 44-51219 E30r.K7 }
$$

3091. Vol. 6. The rise of the common man, 18301850, by Carl Russell Fish. I927. xix, 39r p. 27-24315 $\mathrm{E}_{338 . \mathrm{F}_{53}}$
3092. Vol. 7. The irrepressible conflict, $185^{\circ}$ 1865, by Arthur Charles Cole. 1934. xv, $468 \mathrm{p}$. 34-5502 $\mathrm{E}_{415 \cdot 7 \cdot \mathrm{C} 69}$

3093. Vol. 8. The emergence of modern America, 1865-1878, by Allan Nevins. 1927. xix, 446 p. 27-24314 E66r.N5

3094. Vol. 9. The nationalizing of business, 1878 I 898 , by Ida M. Tarbell. I936. xvi, 313 p. 36-28986 HCI05. $\mathrm{T}_{3}$

3095. Vol. Io. The rise of the city, I $878-1898$, by Arthur Meier Schlesinger. 1933. xvi, $494 \mathrm{p}$. 33-2887 $\mathrm{HT}_{23} \mathrm{~S}_{3}$

3096. Vol. II. The quest for social justice, I 8981914, by Harold Underwood Faulkner. 1931. xvii, 390 p. $\quad 3$ I-5574 E74I.F26

3097. Vol. 12. The great crusade and after, I9r41928, by Preston William Slosson. I930. xviii, 486 p.

30-22386 $\mathrm{E}_{741} \mathrm{I} . \mathrm{S} 6_{3}$

3098. Vol. 13. The age of the great depression, I929-I94I, by Dixon Wecter. I948. xiv, $434 \mathrm{p}$. 48-10172 E806.W43 1948a

This series was the first large-scale attempt to present the development of the United States through the canons of "the New History" or social history, for which an energetic propaganda had been made in the two decades before 1927. In it the four standard themes of traditional historiographypolitical, constitutional, diplomatic, and military narrative-were by design either eliminated or subordinated to economic, social, and intellectual factors. Inasmuch as the latter are less amenable to storytelling, description or analysis becomes at least as prominent as narrative. The editors of the venture were the elder Arthur Meier Schlesinger (b. I888), professor of history at Harvard from I924 to I954, whose New Viewpoints (no. 3139) was one of the best-known presentations of the new outlook, and Dixon Ryan Fox (1887-1945), a teacher of history at Columbia from I913 to 1934, in which year he became president of Union College at Schenectady, N. Y., leaving his volume of the series to be completed by another hand. The series was originally planned to comprise 12 volumes, of which 4 were published together in November 1927 , and 6 more appeared in the course of the following decade. The two stragglers were issued during World War II, and a I 3 th volume, continuing the series to the outbreak of that War, added in 1948 . The volumes of the series were usually hailed with enthusiasm on their first appearance, and most of the authors carried out their pioneer tasks with in- 
dustry, intelligence, and zeal. Several decades of use have led many to conclude that the volumes are lacking in cohesiveness, frequently fall into mere cataloging, and in quality vary rather widely from chapter to chapter. One critic pointed out that the division into periods defined by political dates was a basic inconsistency. But if they did not arrive at a definitive form for social history, they certainly constituted a great advance in its practice. The illustrations from contemporary sources are critically handled if inadequately reproduced, and the bibliographies are uncommonly full and well organized and annotated.

3099. Hofstadter, Richard. The American political tradition and the men who made it. New York, Knopf, I948. xi, 378, xviii p.

$$
\text { 48-8258 } \text { Er78.H727 }_{1948}
$$

These 12 "studies in the ideology of American statesmanship," as the author terms them, form an unusual and striking synthesis of the history of political and economic ideas with that of practical politics. One takes its title from a patrician "agitator," Wendell Phillips, and two others from groups of politicians, the Founding Fathers, and the "Spoilsmen" of the Gilded Age. The remainder are concerned with the ideas and careers of nine prominent statesmen from Jefferson to F. D. Roosevelt, all but two of whom (Calhoun and Bryan, who tried hard enough) reached the Presidency. They all, Professor Hofstadter insists, shared a common politicoeconomic creed, the tenets of which included the sanctity of private property, the value of opportunity, the necessity of competition to a beneficial social order, and the obligation of politics to preserve the competitive scheme. Since the time of Bryan, "progressive" thought has looked backwards, trying to undo the mischief of the recent past "and re-create the old nation of limited and decentralized power, genuine competition, democratic opportunity, and enterprise." The implied criticism is not developed into a positive doctrine. The author is a master of pertinent quotation from primary sources, and his admirable "Bibliographical Essay" (p. 349-378) reveals the vast reading out of which his shapely essays have come.

3roo. Leopold, Richard W., and Arthur S. Link, eds. Problems in American history. 2d ed. Englewood.Cliffs, N. J., Prentice-Hall, r957. xxi, 706 p. $\quad 57-6544$ Ei78.L5 1957 Along with Potter and Manning (no. 3106) and the Amherst multivolume Problems series (no. 3107 ), this represents the newer tendency in sourcebooks for college courses in history, wherein the extracts, mostly from contemporary writings, are organized so as to "provide conflicting and contrast- ing points of view on major events and controversies," as the present editors put it, and so to make their materials more meaningful for the pupil. Here the editors have recruited 20 specialists able to draw on firsthand research, each of whom presents one of " 20 closely integrated problems," "a complex of debates that evolve, the one out of the other, into the vast panorama of American history." They range from "The Sources of [Political] Authority," presented by Edmund S. Morgan, to "Global War and Postwar Crisis," by L. Ethan Ellis, but as usual in recent textbooks, the earlier development is slighted, 1829 and "Jacksonian Democracy" being reached in Problem 6. For reasons not explained, the contributors have been led to avoid "formal documents, such as statutes, treaties, court decisions, and diplomatic notes"-which certainly underlines one of the hazards of this approach. The original edition appeared in 1952; in the second the "focus" of many of the problems has. been sharpened by revision or recasting; each has been shortened by about one-fourth, resulting in a volume of 706 instead of 929 pages; and three substitutions of new authors and problems have been made.

3ror. Lillard, Richard G. American life in autobiography, a descriptive guide. Stanford, Calif., 'Stanford University Press, 1956. I40 p. 56-8689 Z53or.L66

An annotated bibliography of over 400 selected American autobiographies arranged in 22 occupational categories, and provided with an index of names and with special lists of the authors who are immigrants, Indians, Jews, or Negroes. The compiler aims his notes on matters emphasized, style, and reader-appeal at "present-day readers of all sorts." In order to include only books "that library patrons can get hold of," he has limited his entries to books published or republished since I900, and thereby narrowed the retrospective value of his guide. His thoughtful introduction analyzes the weaknesses, strengths, and significance of autobiographical writing: "the better American autobiographies are structured around a perception of change on two levels, the social on one and the personal and intellectual on the other."

3102. Matthews, William. American diaries; an annotated bibliography of American diaries written prior to the year $186 \mathrm{r}$, compiled by William Matthews with the assistance of Roy Harvey Pearce. Berkeley, University of California Press; 1945. xiv, $3^{8} 3 \mathrm{p}$. (University of California publications in English, v. 16) A45-1983 PErr.C3, v. I6 $\mathrm{Z}_{53} 05 . \mathrm{U}_{5} \mathrm{M}_{3}$

The diary, here defined as "a day-by-day record of what interested the diarist, each day's record be- 
ing self-contained and written shortly after the events occurred," is a relatively undistorted record of human experience whose value has always been recognized by historians of every aspect of civilization. This annotated list of all published American diaries which were begun between 1629 (the Rev. Francis Higginson's journal of his voyage to New England) and the outbreak of the Civil War is a valuable auxiliary to nearly all branches of American studies. Its usefulness is evidenced by the great variety of historical and other periodicals, memoirs, and family histories in which the diaries are printed.

Each diary is listed under the year of its first entry (alphabetically within the year). The diarist and his localities are identified, and his major interests noted, with travel and war naturally predominating, but by no means to the exclusion of other concerns in great variety. An index of localities is unfortunately lacking. Professor Matthews of the University of California at Los Angeles has gone on to elaborate the Canadian materials in this volume in his Canadian Diaries and Autobiographies (Berkeley, University of California Press, 1950. I30 p.), and to produce kindred lists of British diaries and autobiographies, but has unfortunately not dealt with American autobiographies, nor American diaries beginning later than 1860 .

3103. Morison, Samuel Eliot, and Henry Steele Commager. The growth of the American Republic. [4th ed., rev., and enl.] New York, Oxford University Press, 1950. 2 v. maps (part fold., part col.) 50-8134 Ei78.M85 $195^{\circ}$ Contents.-v. I. 1000-1865. Bibliography (p. [74I ]-789)-v. 2. 1865-1950. Bibliography (p. [829]-895).

Morison (b. 1887), a Harvard-trained teacher of history at Harvard, was the first holder of the first chair of American history in any British University, the Harold Vyvyan Harmsworth Professorship at Oxford. Endowed by Lord Rothermere in memory of a son fallen in World War I, it was to be filled only by American citizens. The most enduring result of Professor Morison's tenure (1922-25) was his two volumes, The Oxford History of the United States, $1783-1917$ (Oxford and New York, Oxford University Press, 1927), a narrative the scope and direction of which, the author wrote, were largely determined by "the questions asked by my English friends and pupils." This origin was evident in its strong emphasis upon Anglo-American relations and the campaigns of the Civil War; and the author's field of concentration could be inferred from the relatively thin treatment of the half-century after 1865. It nevertheless met with warmer appreciation at home than in Britain, and three years later Henry Steele Commager (b. I902), trained at
Wisconsin and domiciled at New York University, collaborated with Morison in converting it into a one-volume college text, incorporating much 19thcentury social history, while the original author added a preliminary section going back to 1763 . In 1937, following the characteristic evolution of American historical textbooks, it grew into a two volume work, with the second volume brought down to the election of 1936 . The third edition of 1942 "extended the story backward to the origin of man in America," as well as forward, and the fourth, entered above, reaches Truman's reelection in 1948. Despite the numerous patchings, it retains much of the stylistic vitality of the parent work, and notwithstanding the heaviest competition has maintained its place as a text for college courses. Other noteworthy college texts covering the whole of American history in two volumes are the following: Leland D. Baldwin, The Stream of American History (New York, R. R. Smith, I952); Harry J. Carman and Harold C. Syrett, $A$ History of the American People (New York, Knopf, 1952); Merle E. Curti, Richard H. Shryock, Thomas C. Cochran, and Fred Harvey Harrington, An American History (New York, Harper, 1950); and Robert E. Riegel and David F. Long, The American Story (New York, McGraw-Hill, 1955).

3104. Parkes, Henry Bamford. The United States of America, a history. New York, Knopf, 1953. xvii, 773, xxiv p. illus.

Includes bibliographies.

$$
\text { 52-12413 } \operatorname{E}_{178 . P_{25}}
$$

A one-volume college textbook covering the whole of United States history from "The Expansion of Europe" to "Society at Mid-Century [1950]." While political and economic matters are by no means skimped, numerous chapters are devoted to social, intellectual, and artistic developments, and these usually receive clear and concise expositions instead of the unenlightening catalogs of names and titles so frequently found in textbooks. Maps and illustrations are well drafted or chosen, and the end matter is exceptionally useful.

3105. Paxson, Frederic L. History of the American frontier, $1763-1893$. Boston, Houghton Miflin, I924. xvii, 598 p. 24-2338 I Er79.5.P34 "East of the frontier of $176_{3}$ the American groups are best to be examined as European frontiers in America; west of the line is an American frontier to be studied in contrast with the East." Professor Paxson was the first to make a detailed and unified narrative out of F. J. Turner's famous generalization, and pursued his theme through the admission of the six "omnibus States" in 1889-90. The postCivil War period, however, received relatively 
briefer treatment (p. $494^{\prime}$ ff.). Eight years later Paxson stated his conviction that, "after a generation of general currency, the Turner hypothesis stands today as acceptable as when it was launched" ("A Generation of the Frontier Hypothesis, 18931932," reprinted in The Great Demobilization and Other Essays. Madison, University of Wisconsin Press, 194I. 206 p.).

3106. Potter, David M., and Thomas G. Manning, eds. Select problems in historical interpretation. New York, Holt [1949-50] 2 v.

49-940r $\operatorname{Er}_{78} \mathrm{P}_{7} 8$

Volume 2 by Thomas G. Manning and David M. Potter, with the collaboration of Wallace E. Davies.

Contents.- [v. I] Nationalism and sectionalism in America, 1775-1877.- [v. 2] Government and the American economy, 1870-present.

These companion volumes constitute the most complex and refined development of the problem sourcebook yet to appear, and make a considerable demand upon both teacher and student-so much so that, the collaborator in the later volume thinks, they are best deferred to "the senior seminar or conference group level." Each volume singles out a major theme in American development, presents various of its aspects in terms of a series of related problems, and aims to make the student analyze the factors involved, "explore the complexity of the issues, and sense the multiplicity of the possible solutions." There are twelve 35 to 40 -page problems in each volume; the material presented under each problem is "a balance of fact, opinion, and commentary," with the editors largely providing "the knowledge which is the necessary condition to an investigation of the topics," and relating "each topic to the central subject of the Problem." The theme of the first volume culminates in "Interpretations of the Civil War," with a sequel on "The Political Status of the Negro after Appomattox"; that of the second in the NRA, NRLB, and other agencies of the New Deal, with a sequel on the OPA in World War II.

3107. Problems in American civilization; readings selected by the Department of American

Studies, Amherst College. Boston, Heath, 1949-57. $29 \mathrm{v}$.

A series of slender, paperbound volumes initiated in 1949 under the joint editorship of Earl Latham, George Rogers Taylor, and George F. Whicher; in the latest volumes Professor Taylor appears as the sole editor. The first eight to be published were issued as a numbered series; the subsequent ones have been without numbers, and it has seemed best here to list them all alphabetically by author. They are of course designed to provide "collateral read- ing" for college courses in American history, and they reflect the trend of the last 15 years to arrange source and documentary materials for such use in relation to controversial issues of the past and present. Each volume of the series has the same arrangement: the editor's Introduction outlines the "Problem" in a few pages; "The Clash of Issues" is a page of striking formulations from either side; there follow a dozen or so selections from contemporary sources and recent historians, and a brief final essay making "Suggestions for Additional Reading." The success of the series as a teaching medium appears from the fact that the first two Problems to be issued have now appeared in revised editions. It seems equally well calculated to provide the general reader with a striking intro duction to the topics with which it deals.

3ro8. Cope, Alfred Haines, and Fred Krinsky, eds. Franklin D. Roosevelt and the Supreme

Court. 1952. 109 p. $52-1656$ Law

3rog. Fenno, Richard F., ed. The Yalta Conference. 1955. II 2 .

$$
\text { 55-1646 } \mathrm{D}_{734 . C_{7}} \text { 1945i }
$$

3110. Greene, Theodore P., ed. American imperialism in 1898 . 1955 . $105 \mathrm{p}$.

$$
5_{55-1630} \mathrm{E}_{713 . \mathrm{G}_{7}}
$$

3III. Greene, Theodore P., ed. Wilson at Versailles. 1957. II 4 p. 57-1944 D644.G7

3112. Kennedy, Gail, ed. Democracy and the gospel of wealth. I949. $116 \mathrm{p}$.

$$
\text { 49-5916 Er69.1.P897, no. } 6
$$

3r13. Kennedy, Gail, ed. Education for democracy; the debate over the report of the President's Commission on Higher Education. 1952. II7 $\mathrm{p}$. 52-1017I LA226. $\mathrm{A}_{48}{ }_{5} \mathrm{~K}_{4}$

3114. Kennedy, Gail, ed. Evolution and religion; the conflict between science and theology in modern America. 1957. II4 p.

$$
57-1698 \quad \mathrm{BL}_{245} \cdot \mathrm{K}_{4}
$$

3115. Kennedy, Gail, ed. Pragmatism and American culture. 1950. II4 p.

$$
5 \mathrm{I}-7648 \quad \mathrm{~B}_{3} 32 . \mathrm{K}_{4}
$$

3116. Latham, Earl, ed. The Declaration of Independence and the Constitution. Rev. ed. 1956. 126 p. 56-14513 JKI46.L 1956 First published in 1949. 
3117. Latham, Earl, ed. John D. Rockefeller, robber baron or industrial statesman? 1949 .

II5 p. 49-5916 Ei69.r.P897, no. 7

3118. Rozwenc, Edwin C., ed. The Compromise of $1850 . \quad 1957.99$ p. $57-3018 \quad \mathrm{E}_{423} \cdot \mathrm{R} 8$

3irg. Rozwenc, Edwin C., ed. The New Deal: revolution or evolution? 1949. II3 P. 49-5916 Ei69.1.P897, no. 8

3120. Rozwenc, Edwin C., ed. Reconstruction in the South. 1952. I09 P. 52-1818 E668.R83

3121. Rozwenc, Edwin C., ed. Roosevelt, Wilson and the trusts. I950. II5 p.

$$
\text { 5I-7688 HD2785.R6 }
$$

3122. Rozwenc, Edwin C., ed. Slavery as a cause of the Civil War. 1949. 104 p.

$$
\text { 49-5916 Er69.1.P897, no. } 5
$$

3123. Sanford, Charles L., ed. Benjamin Franklin and the American character. 1955. $102 \mathrm{p}$. $55^{-2272} \mathrm{E}_{302.6 . \mathrm{F}^{2} \mathrm{~S}_{32}}$

3124. Taylor, George Rogers, ed. The great tariff debate, I820-1830. 1953. 95 p. 53-II70 $\mathrm{HF}_{3027 \cdot 3 \cdot \mathrm{T}_{3} 8}$

3125. Taylor, George Rogers, ed. Hamilton and the national debt. 1950. $108 \mathrm{p}$. ${ }_{5}^{\mathrm{I}}-7557 \mathrm{HJ} 8 \mathrm{ro6}_{3} \mathrm{~T}_{3}$

3126. Taylor, George Rogers, ed. Jackson versus Biddle; the struggle over the Second Bank of the United States. 1949. II9 p. 49-5916 Ei69.1.P897, no. 3

3127. Taylor, George Rogers, ed. The Turner thesis concerning the role of the frontier in American history. Rev. ed. 1956. 109 p.

First published in 1949. 56-1460I E179.5. T96 T3 1956

3128. Wahlke, John C., ed. The causes of the American Revolution. 1950. 108 p. 5I-7685 $\mathrm{E}_{210 . \mathrm{W}_{3}}$

3129. Wahlke, John C., ed. Loyalty in a democratic state. 1952. III p.

$$
\text { 52-1192 JKI } 759 . W_{33}
$$

3130. Waller, George M., ed. Pearl Harbor: Roosevelt and the coming of the war. 1953 . II 2 p. 53-I342 E806.W22
3131. Waller, George M., ed. Puritanism in early America. 1950. I15 P. 51-473I $F_{7} . W_{3}$

3132. Warne, Colston Estey, ed. Industry-wide collective bargaining: promise or menace?

1950. $113 \mathrm{p}$.

51-4732 Er69.r.P897, v. 9

3133. Warne, Colston Estey, ed. The Pullman boycott of $\mathrm{r} 894$; the problem of Federal intervention. 1955. $112 \mathrm{p}$.

$$
\text { 55-3476 HD5325.Rr2 } 1894 . \mathrm{C} 6
$$

3134. Whicher, George F., ed. The transcendentalist revolt against materialism. 1949.

107 p. 49-5916 Er69.r.P897, no. 4

3135. Whicher, George $F$, ed. William Jennings Bryan and the campaign of 1896.1953.

$109 \mathrm{p}$.

53-I34I E664.B87 W6

3136. Ziegler, Benjamin Munn, ed. Immigration, an American dilemma. 1953. $118 \mathrm{p}$.

$$
\text { 53-8474 JV6455.Z5 }
$$

3137. Riegel, Robert E. America moves west. 3d ed. New York, Holt, 1956. 659 p. illus. 56-6073 F591.R53 1956

Professor Riegel of Dartmouth College published the first edition of this textbook, as readable as it is informative, in 1930. His third revision adds a new chapter (38) on the Pacific Coast as well as "pertinent research of the past decade," and offers "completely redone" lists of readings (with very brief entries) at the end of each chapter. Chronologically the book extends from the outbreak of the American Revolution to the collapse of "Western Panaceas" with the defeat of Bryan in the Presidential election of 1896 . There are concretely descriptive chapters on the successive phases of daily living in the West and on the social consequences of diverse means of transportation. Concluding chapters are "The West is Fictionalized," which affirms that "the most distinctive of American experiences" still offers an unexhausted supply of raw material for the creative writer, and "The Historian Discovers the West," which is largely concerned with the "frontier hypothesis" of Frederick Jackson Turner and its critics (cf. no. 3147).

3138. Rippy, James Fred. America and the strife of Europe. Chicago, University of Chicago Press, 1938. 263 p. $\quad 38-25892$ EI75.9.R57 "Critical bibliography": [233]-250.

A small volume which takes a large view of the place of the United States in the world, as it considers the place which "the strife of Europe" has occupied in the several American ideologies of iso- 
lationism, democratic enthusiasm, pacificism, and expansionism. It furthermore illustrates how interEuropean conflicts have facilitated the two major movements of American expansion and the assertion of the Monroe Doctrine. The author found little to approve in the efforts of 2oth-century American statesmen to take $a$ hand in the maintenance of European peace.

3139. Schlesinger, Arthur Meier. New viewpoints in American history. New York, Macmillan, 1922. 299 p. 22-7401 EI75.9. 34 "Bibliographical note" at the end of each chapter. Contents.- The influence of immigration on American history.-Geographic factors in American development.-Economic influences in American history.-The decline of aristocracy in America.Radicalism and conservatism in American history.The role of women in American history.-The American Revolution.-Economic aspects of the movement for the Constitution.-The significance of Jacksonian democracy.-The state rights fetish.The foundations of the modern era.-The riddle of the parties.

3r40. Schlesinger, Arthur Meier. Paths to the present. New York, Macmillan, 1949. 3I7 p. $\quad 49-7676 \quad E_{178 . S_{33}}$

"For further reading": p. 278-302.

In New Viewpoints the author's object was "to bring together and summarize, in nontechnical language, some of the results of the researches of the present age of historical study and to show their importance to a proper understanding of American history." While the author sought to identify his "new history" with the emergence of academic historiography, he was actually concerned with the movement whereby "a record of arid political and constitutional development began to be enriched by the new conceptions and fresh points of view afforded by the scientific study of economics, sociology, and politics." Much of what seemed new in 1922 is now agreed commonplace, while some positions which then seemed self-evident now appear doubtful or worse, but Professor Schlesinger's volume remains a landmark in the expanding content of his discipline. Paths to the Present contains 13 essays grouped under 4 headings: "National Traits," "Government of the People," "War and Peace," and "Ampersand." Each is in some degree the pursuit of a single topic through the whole sweep of American history, and each evidences its author's extraordinary knowledge combined with the absence or successful concealment of any personal convictions. "Biography of a Nation of Joiners," "Food in the Making of America," and "Casting the National
Horoscope" all contain material hardly to be found elsewhere, and the rest take larger points of view than most treatments of their subjects.

3141. Schouler, James. History of the United States of America, under the Constitution. New York, Dodd, Mead, 1894-1913. 7 v.

Volumes I-5 rev. ed., I894. 2-4002 $\mathrm{E}_{301 . S_{372}}$

Contents.-v. I. 1783-1801. Rule of Federalism.-v. 2. 1801-1817. Jefferson Republicans.v. 3. $1817-1831$. Era of good feeling.-v. 4. $1831-$ 1847. Democrats and Whigs.-v. 5. 1847-1861. Free soil controversy.-v. 6. 186r-1865. The Civil War.-v. 7. 1865-1877. The Reconstruction period.

Schouler ( $1839-1920)$ was compelled by the failure of his hearing in $187 \mathrm{r}$ to relinquish a very successful career as a lawyer specializing in Civil War veterans' claims. He turned to the compilation of a number of legal textbooks, much used in their day, and utilized his leisure to embark upon a project long meditated: a continuation of George Bancroft's history of the United States from the adoption of the Constitution to the outbreak of the Civil War. After some delays he brought out the first volume, through W. H. Morrison of Washington, D. C., in 1880. The history won the favor of the general public, and achieved its original terminus with volume $V$ in $189 \mathrm{r}$; this was the first to be published by Dodd, Mead and Co. of New York, who thereafter handled the whole set. In 1899 and 1913 the author added volumes on periods to which his personal acquaintance extended and on which his opinions were firmly held: the Civil War and Reconstruction to the election of President Hayes. These volumes naturally drew the fire of the new race of academic historians as being too narrowly political and too unsympathetic with Southern secessionism. Today, after various failures to achieve total history, it is easier to appreciate the work for what it is: a detailed political, constitutional, diplomatic, and military history of the first century of the American Nation, chronologically precise, judiciously proportioned, and economically narrated. As by-products of his magnum opus, Schouler produced two volumes of shorter studies, containing a number of pieces noteworthy for their information or interpretations: Historical Briefs and Constitutional Studies, State and Federal (New York, Dodd, Mead, 1896 (310 p.) and 1897 (332 p.) respectively). In 1906 he published a sterling contribution to social history: Americans of 1776 (New York, Dodd, Mead. 317 p.), which reviews the state of society in the Thirteen Colonies on the eve of the Revolution. 
3142. Smith, Bernard, ed. The democratic spirit, a collection of American writings from the earliest times to the present day. $2 d$ ed., rev. New York, Knopf, 1943. xxxv, 923 p.

$$
\text { 43-51285 } \mathrm{PS}_{507 . S_{59}} \mathbf{1 9 4 3}
$$

3143. Angle, Paul M., ed. By these words; great documents of American liberty, selected and placed in their contemporary settings. Illustrated by Edward A. Wilson. New York, Rand, McNally, 1954. $560 \mathrm{p}$.

54-10616 EI73.A79

The Democratic Spirit is a collection of fairly extended extracts from roo American authors, "the truly democratic and characteristic works of the democratic writers of this country." The kinds of writing included range from political discourse to fiction and poetry embodying democratic aspirations or assailing some concrete wrong such as slavery. The literary extracts of the r 920 's and $30^{\circ}$ 's exemplify the anti-fascism and somewhat diffuse social protest of the day, when the American people "began to think of economic democracy as indispensable to liberty," now conceived "as a matter of decent living and collective effort as well as freedom from restraint." A note on each author precedes his work. By These Words is a smaller collection of 46 documents, from the Mayflower Compact of 1620 to President Eisenhower's inaugural address of 1953, presented in a more attractive format than is usual in such compilations, with uncrowded pages and interspersed sketches. Mr. Angle's well-proportioned introductions to each document supply infurmative backgrounds for the general reader.

\section{Smith, Theodore Clarke. The United States} as a factor in world history. New York, Holt, 194I. 142 p. (The Berkshire studies in $\begin{array}{lll}\text { European history) } & \text { 4I-IOIg2 EI83.7.S6 }\end{array}$ "Bibliographical note": p. $133^{-1} 3^{8}$.

A tour-de-force of condensation which considers American history from 1763 to 1940 from the standpoint of world history. The author identifies two main factors of persistent influence: the republicanism of American society deriving from the circumstance that no feudal aristocracy grew up in the Thirteen Colonies, and the economic importance of transatlantic commerce. He traces their presence through three periods: that of separation from Europe, to 1823 ; that of isolated democracy, to 1897 ; and that of the United States as a world power.

3145. Stone, Irving, and Richard Kennedy, eds. We speak for ourselves; a self-portrait of America. Garden City, N. Y., Doubleday, 1950. xvii, $462 \mathrm{p}$. 50-9974 Er76.S875

Extracts rarely exceeding 8 pages in length from
64 American autobiographies, mostly of the 2oth or later I 9 th century, and arranged in 7 rather esoteric categories which Mr. Stone explains in his introduction. For the most part the compilers have selected some striking or representative episode, but in a few instances they "undertook the task of weaving together in a cohesive whole" passages scattered through a book, "exercising extreme care not to alter either the meaning or the effect of a story." They hoped to create an interest which will send readers back to the original volumes, for which, unfortunately, they provide nothing more than short titles.

3146. Thistlethwaite, Frank. The great experiment; an introduction to the history of the American people. Cambridge [Eng.] University Press, 1955. $335 \mathrm{p}$. 55-4496 Er Er $^{2}$.T 35

The author is Fellow of St. John's College, Cambridge, and his book, the "result of several years' teaching American history to Cambridge undergraduates," aims "to provide the British student with a point of departure." He hopes, however, to interest American readers by identifying "the special characteristics that distinguish Americans from $\mathrm{Eu}$ ropeans"; they will be quite as much attracted by his multitude of striking insights and perspicuous generalizations. He takes as basic "the grand process of migration from Europe," which has brought into being "a new variant of western society"-_"the mobile society," which contrasts with the static and conformist societies of Europe. He further emphasizes that "American culture grew to maturity within an Atlantic world with nerve-centers" in Britain as well as America. He gives far more attention to economic factors than to political personalities, and in fact industrialists cut a greater figure in his pages than do statesmen. "In the midtwentieth century the American people still pursue their Revolutionary ideal," the most ambitious ever to command the allegiance of a great nation, and therefore, naturally if regrettably, one that "has never achieved full acceptance in practice." The Great Experiment is one of the most distinguished interpretations of American history to come from a European pen. Harold Plaskitt's The United States of America; the People, Their History, Institutions, and Way of Life [2d ed.] (London, University Tutorial Press, I953. 200 p.) is a revision after ten years of a wartime manual which attempted "to provide background information for the improvement of Anglo-American co-operation." It consists of 15 topical chapters, such as "The Constitution," "Culture and Entertainment," "Capital and Labour," and "Relations with the Outside World." It is selective, straightforward, and often considerably simpler than the subject matter it seeks to present. 
3147. Turner, Frederick Jackson. The frontier in American history. New York, Holt, 1950, '1947. 375 p. 53-482 EI79.5.T956 $195^{\circ}$ Contents.-The significance of the frontier in American history.-The first official frontier of the Massachusetts Bay.-The Old West.-The Middle West.-The Ohio Valley in American history.The significance of the Mississippi Valley in American history.-The problem of the West.-Dominant forces in Western life.-Contributions of the West to American democracy.-Pioneer ideals and the state university.-The West and American ideals.-Social forces in American history.-Middle Western pioneer democracy.

The American Historical Association, meeting at Chicago during the World's Fair year (1893), were told by a young assistant professor of history at the University of Wisconsin that, up to then, American history had been in essence the history of the colonization of the great West, that the frontier, "the hinter edge of free land," was the line of most rapid and effective Americanization and the salient factor in national unification, that frontier individualism had promoted democracy and transmitted it to the East and even to Europe, and that the American intellect owed its distinguishing characteristics to the lingering effects of frontier life. Seldom has a group of scholars proved so ripe for conversion; the "frontier hypothesis" speedily became a kind of orthodoxy among American historians and went for over 30 years without serious criticism. The present volume, one of the two that Turner (186I-1932) published during his lifetime, opens with the paper of 1893 and contains 12 more essays and addresses that he produced down to 1918; the original edition appeared in 1920. The Early Writings of Frederick Jackson Turner (Madison, University of Wisconsin Press, 1938. $3^{16}$ p.) includes a 40-page bibliography of writings by and about Turner, compiled by Everett E. Edwards, and an introduction on "Turner's Formative Years" by Fulmer Mood. Mr. Edwards has also compiled a volume of References on the Significance of the Frontier in American History (Washington, 1939. 99 p. U. S. Dept. of Agriculture Library, Bibliographical contributions, no. $25.2 \mathrm{~d}$ ed.); some later contributions to the debate are listed in the bibliography of Billington above (no. 3074). Three other books by Turner, two of them posthumous, are nos. 3356,3357 , and 3784 .

3148. Weyl, Nathaniel. Treason; the story of disloyalty and betrayal in American history. Washington, Public Affairs Press, 1950. 491 p. 50-66r6 EI79. W5
3149. Weyl, Nathaniel. The battle against disloyalty. New York, Crowell, 195I. $37^{8}$ p. $5^{1-3355} \mathrm{E}_{743 \cdot 5 \cdot \mathrm{W}_{4}}$

"Throughout the hundred and seventy-five years during which the United States has existed as a nation, mercenaries and psychopaths, zealots and misguided idealists, enemy agents and servants of antidemocratic faiths have betrayed their allegiance and struck at the foundations of the Republic." Treason passes briskly from Charles Lee, Benedict Arnold, John Fries, Aaron Burr, Thomas W. Dorr, John Brown, and Clement Vallandigham, to the pro-Nazis and the subversive Communists of our own day. No documentation is offered for these condensed narratives, but they are reasonably accurate if somewhat journalistic in manner. The Battle against Disloyalty is provided with "reference notes" at the end of the volume. It has some material on the secret service during the Civil War and World War I, but is largely concerned with the Communist and Nazi menaces since 1919, and the counterintelligence work, congressional investigations, legal prosecutions, and loyalty programs by which they have been combated.

3150. Wish, Harvey. Society and thought in America. New -York, Longmans, Green, 1950-52. 2 v. 50-9981 Er69.r.W65 ConTents.-v. I. Society and thought in early America; a social and intellectual history of the American people through 1865 .- v. 2. Society and thought in modern America; a social and intellectual history of the American people from 1865.

A general survey of American history with politics and economics subordinated to social and intellectual factors. If it is short on causality and may not cut very deep, it is exceptionally felicitous in its choice of material and in its organization. It is furthermore presented in a leisurely kind of exposition which avoids the cluttered patterns so common in general works of its type, and makes the student's task relatively pleasant. It naturally becomes less adequate as it approaches the complexities of the present day. Each volume has very pertinent illustrations from contemporary sources and a judiciously selected bibliography which the author has deliberately held down to a limited number of significant titles.

3151. Woestemeyer, Ina Faye, ed. The westward movement; a book of readings on our chang. ing frontiers. With the editorial collaboration of J[ohn] Montgomery Gambrill. New York, Appleton-Century, 1939. xx, 500 p. illus.

39-14444

$F_{591 . W 85}$ 
"Notes on the literature of the westward movement": p. 477-484; "Bibliography of sources quoted": p. 485-490.

This anthology originated as a "Professional Project" of the editor in her work for the Ed. D. degree at Teachers College, Columbia University, where Dr. Gambrill was a professor of history. In it the "Westward Movement" is broadly conceived, both chronologically and as a social process. Most of the extracts are from documents or the writings of participants or direct observers, but some are from such historians of the frontier as Parkman and Everett Dick. The arrangement is topical, with special attention to the several factors, chiefly economic, which entered into "The Lure of the West," and to the transmission of culture to the frontier, including a chapter on "Folk-lore, Ballads, and Literature." The editor has made rather too many excisions (indicated by 3 or 4 dots) from her selections, and the large body of contemporary illustrations is provided with quite inadequate identification.

3152. Woods, Henry F. American sayings; famous phrases, slogans and aphorisms. Rev. and enl. ed. New York, Perma Giants, 1950, ${ }^{\mathrm{c}}$ r949. $3^{12} \mathrm{p}$. 50-3259 PN6084.A5W6 $195^{\circ}$
Striking formulations of significant ideas make as well as reflect history, in the United States as elsewhere. Under the 4 categories of "Political and Civil," "War," "Sociological-Economic-Commercial," and "Popular," the compiler has arranged over 300 brief items, such as "The solid South" or "Tell it to Sweeney"; and has traced each to its origin, certain or presumed, with an individual or at least within a milieu. The items are in an approximate chronological order within each category, but are indexed by first words and, when possible, by individuals. The American Treasury, 1455-1955, compiled by Clifton Fadiman assisted by Charles Van Doren (New York, Harper, 1955. xxxii, 1108 p.) has an "Index of Familiar Words and Phrases," but is looser in idea and on a vaster scale. It contains a huge and various collection of pointed statements by Americans, sometimes on American themes and sometimes on things in general, and sometimes running to a page or more, but more often confined to a sentence or two. Dictionary of American Maxims, edited by David Kin [pseud. of David George Plotkin] (New York, Philosophical Library, 1955. 597 p.), is made up of briefer statementstwo sentences at most-on things in general; it makes no references and has no author index.

\section{The New World}

3153. Anghiera, Pietro Martire d'. De orbe novo, the eight Decades of Peter Martyr d'Anghera; translated from the Latin with notes and introd., by Francis Augustus MacNutt. New York, Putnam, 1912. 2 v. ports.

Bibliography: v. I, p. 49-54.

$$
\text { 12-24777 Er4r.A604 }
$$

Peter Martyr (1455-1526) was an Italian humanist scholar. In 1487 he went to Spain, where he became associated with the royal court and received clerical preferment. For most of the remainder of his life he occupied various positions connected with the court, such as tutor to the royal children and nobles, diplomatic envoy, historiographer, etc. In these positions he personally met the early Spanishemployed explorers, from Columbus on, and obtained access to most of the documents concerned with the New World. He wrote a succession of Latin letters on the exploration and development of the New World. A part of these writings were brought together in $15^{16}$ as De Rebus Oceanis et Orbe Novo Decades Tres. These three, with a fourth decade published in 1521 and four others published posthumously, have come to be known as the Decades (groups of ten letters; the term has no chronological significance), and together constitute the first formal history of the Americas. While this is mainly a chronicling of Spanish America during the first 30 years of discovery, it is of importance for American civilization as a whole, in that it shows the first generally circulated view of the New World, and traces the advances that led to the occupation of both continents.

3154. Augur, Helen. Passage to glory; John Led-
yard's America. Garden City, N. Y.,
Doubleday, r946. 310 p. $46-375$ G226.L5A8
Bibliography: p. 295-300.

John Ledyard (1751-1789) was born and raised in colonial Connecticut, and went on to become one of the last of the great world explorers. His career opened as a corporal of marines under Capt. James Cook, whom he accompanied on the last of his famous voyages of Pacific exploration. There he developed the conception of the colonies extending as a nation to the Pacific Ocean, and prospering with 
the opening of the fur trade in the Pacific Northwest. While this was brought about by men of the next generation, Ledyard worked toward it, and communicated his idea to Thomas Jefferson. Ledyard's own life ended in Egypt, as he was preparing to explore Central Africa, with the intention of thereafter exploring America from Kentucky westwards. Miss Augur's life of Ledyard is based on much research, but is primarily an interpretive study meant to show the importance of his vision of a continental America; it presents him as symbolically and physically completing mankind's circuit westward, from the Old World to the Old World, with the creation and unification of the New World between.

3155. Bakeless, John E. The eyes of discovery; the pageant of North America as seen by the first explorers. Philadelphia, Lippincott, $195^{\circ}$. 439 p. illus. $\quad 50-10588$ Er62. B3

As the author states in the preface: "The Eyes of Discovery is an effort to describe North America as the first white men in the area saw it: landscapes, forests, plains, animals, plants, streams, and Indians, as they existed before the inevitable change that began almost from the instant of the first white settlement. It is neither a story of adventure nor a book about Indians nor a history of exploration and colonization. Where the life of an explorer is touched upon at all, it is merely to explain who the man was and how he came to make his discoveries when he did. Because of this approach, many a great name of the ever-moving frontier does not appear at all." Furthermore, since many of the early explorers did not leave adequate descriptions of what they saw, the author has employed later writings where "it is possible to find good descriptions of primitive conditions in the books of visitors to America long after settlement had begun, for such things as waterfalls, prairie fires, buffalo, moose, lakes, rivers, and Indian ways changed very slowly." The book is not an anthology of early writings on American flora, fauna, and geography, but is rather a description of such matters with numerous pertinent quotations included in the author's text.

3156. Bishop, Morris. Champlain, the life of fortitude. New York, Knopf, 1948. 364 p. 48-8873 Fio30.1.B6

A professor of Romance languages at Cornell University has written the latest and most distinguished biography of Samuel, Sieur de Champlain (ca. $1567-1635$ ), the Father of New France. Champlain was a veteran officer of Henry IV's army in 1599, when he seized a chance opportunity to visit the Spanish Empire, where he saw such callous ex- ploitation of the Indians that he formed a very different ideal of colonization: honest trade and honest coöperation with the natives. The book is organized around Champlain's I2 voyages to the New World, and communicates to the reader the author's own admiration for this idealist, who devoted his "toughness, tenacity, foresight, courage" to "the foundation in America of a great kingdom, to be ruled with justice and mercy, by France, but for God." Champlain himself published four books on Canada, beginning with the Des sauvages of 1604; The Works of Samuel de Champlain, under the general editorship of Henry P. Biggar (Toronto, Champlain Society, 1922-36. 6 v.), gives both the French text and an English translation, while there is a convenient one-volume translation of the $16 \mathrm{r}_{3}$ and 1619 volumes, edited by William L. Grant, in the Original narratives of early American history series (no. 3207).

3157. Bolton, Herbert E., and Thomas M. Marshall. The colonization of North America, 1492-1783. New York, Macmillan, 1936. xvi, 609 p. maps. 38-34415 Ei88.B69 1936

A concise, nearly an outline account of European discovery, exploration, and colonization in North America, which covers not only what has since become the United States, but also the West Indies, Mexico and Central America, and Canada. The first main section, on "The Founding of the Colonies," traces the story from the discovery by Columbus to the latter part of the $17^{\text {th }}$ century. The second part, "Expansion and International Conflict," carries the story to 1783 , when Spain was active in the California area, Russia was penetrating the northwestern part of the continent, and the continental English colonies had achieved considerable maturity and established their independence. The final section of the book is a short group of six chapters on the Revolutionary War and the postwar governmental situation. Since this book, first published in 1920, was designed as a textbook, additional readings for students are included at the end of each chapter. However, these are now somewhat dated, as, unfortunately, is some of the textual material itself. However, no other survey of comparable scope has appeared to replace it.

3158. Bolton, Herbert E. The Spanish borderlands; a chronicle of old Florida and the Southwest. New Haven, Yale University Press, 1921. xiv, 329 p. plates, fold. map. (The Chronicles of America series, Allen Johnson, editor, v. 23) 21-I4807 EI73.C55, v. 23 E123.B7

"Bibliographical note": p. 297-303.

In a number of states north of the Rio Grande, 
and stretching from California to Florida, there exists an evident influence of Spanish culture, deriving from the times when these areas were occupied by the Spaniards as outposts for their New World empire. The Spanish exploration, settlement, government, and general colonial practices in this area are sympathetically described in this volume. The work opens with a series of chapters on the early explorers: Ponce de Léon, Cabeza de Vaca, Hernando de Soto, Coronado, and others. The author then discusses individually the areas of Florida, New Mexico, Texas, Louisiana, and California, and concludes with a chapter on the Jesuits on the Pacific coast. One of Professor Bolton's many detailed contributions to the history of these areas, Rim of Christendom; a Biography of Eusebio Francisco Kino, Pacific Coast Pioneer (New York, Macmillan, 1936. 644 p.), is a full-scale reconstruction, from long research in scattered primary sources, of the life of an indefatigable Italian-born Jesuit missionary to Lower California and Pimería Alta (the present Mexican Province of Sonora), who was "explorer, astronomer, cartographer, mission builder, ranchman, cattle king, and defender of the frontier."

3159. Brebner, John B. The explorers of North America, 1492-r8o6. New York, Macmillan, 1933. xv, 502 p. 4 fold. maps. (The Pioneer histories)

"Narratives" at end of each chapter. 33-31647 Eror.B83

A volume which seeks "to draw together as a related whole the explorations which first revealed the general character of the North American continent," and which are usually treated regionally or nationally. All quotations are from the explorers themselves, or from other contemporary narratives. The author closes with the return of Lewis and Clark from the Pacific Ocean, but is careful to explain that only the major features and routes of the continent were established in $r 806$, and that large areas, isolated or desolate, remained for the rgth century to reveal. A recent paperback reprint of this work (Garden City, N. Y., Doubleday, 1955. 431 p. Doubleday anchor books, $A_{44}$ ) is not an equivalent of the original edition, since it lacks the indispensable folding maps.

3160. Crouse, Nellis M. In quest of the western ocean. New York, Morrow, 1928. 480 p. maps. 28-6r72 Er2r.C95

Bibliography: p. 453-456.

When Columbus discovered America, he was looking for Asia. As it dawned upon Europeans that Asia had not been reached, an intense effort was made to find some water passage through or around the intervening land, for the fabled treas- ures of Asia still remained the prime goal, except for the Spanish, who had found gold and silver. Dr. Crouse's book is the story of the many attempts to locate the passage. After the joint outline of South and North America became known for the eastern shore of the continents, the attempts concentrated on a search for a Northwest passage; a belief in this was long encouraged by rumors and misconceptions. The author's story begins with the events impelling the Europeans to seek a passage westward to Asia, and closes in the latter part of the r8th century, when the project was finally abandoned as being relatively useless, should a passage exist, and when most possibilities for a passage had been eliminated. Meanwhile three centuries of explorations seeking a way to Asia had opened up America.

316r. De Voto, Bernard A. The course of empire; with maps by Erwin Raisz. Boston, Houghton Mifflin, r952. xvii, 647 p. $52-5261 \quad$ Er $_{79.5 . D 4}$

This book is a study of the factors involved in the discovery and exploration of North America, in so far as they affected the westward movement which resulted in the establishment of a continental American empire and nation. The story is traced through the crossing of the continent by the Lewis and Clark expedition in 1804-6. The author's purpose is to achieve a meaningful whole, viewing all "themes" in combination, rather than a study of the individual parts. The author in his preface presents the principal themes as "the geography of North America in so far as it was important in the actions dealt with; the ideas which the men involved in these actions had about this geography, their misconceptions and errors, and the growth of knowledge; the exploration of the United States and Canada, so much of it as was relevant to the discovery of a route to the Pacific Ocean; the contention of four empires for the area that is now the United States; the relationship to all these things of various Indian tribes that affected them." This is usually regarded as an outstanding work essential to an understanding of the West. While it may be De Voto's major book, his writing as a whole is discussed more fully under Literary History and Criticism (q. v.).

3162. Folmer, Henry. Franco-Spanish rivalry in North America, 1524-1763. Glendale, Calif., A. H. Clark Co., 1953. 346 p. fold. map. (Spain in the West, 7) 54-2218 Er3i.F6

Bibliography: p. [3 I I ] 333 .

This is a consecutive narrative of the rivalry between France and Spain for an area now largely included in the gulf coast of the United States, from Florida to Texas. This rivalry persisted through most of the colonial period and was terminated only by the liquidation of the French mainland empire 
by the Peace of Paris $\left(17 \sigma_{3}\right)$. While Spain claimed all of North America in consequence of the earliest discoveries, France did not recognize Spanish ownership of any area not actually settled by Spaniards. The resultant controversy in its various manifestations, including several outbreaks of overt warfare, is here chronologically traced to the point where France turned the Louisiana Territory over to Spain, and Spain left Britain in possession of Florida in compensation for Britain's restoration of Cuba to Spain. France thus being removed from the scene, her long rivalry with Spain in the gulf area was inherited by Britain, and eventually by the United States.

3163. Jane, Lionel Cecil, ed. Select documents illustrating the four voyages of Columbus, including those contained in R. H. Major's Select letters of Christopher Columbus; translated and edited with additional material, an introd. and notes, by Cecil Jane. London, Printed for the Hakluyt Society, 1930-33. 2 v. (Works issued by the Hakluyt Society. Second series, no. 65, 70)

$$
\text { 30-33946 Gi6r.H2, no. 65, } 70
$$

3164. Morison, Samuel Eliot. Admiral of the ocean sea; a life of Christopher Columbus. Maps by Erwin Raisz. Drawings by Bertram Greene. Boston, Little, Brown, I942. 2 v. illus., maps. 42-5606 EIII.M86 I942

Columbus (1451-1506) was born and raised in Genoa, Italy, where the original form of his name was Cristoforo Colombo. As a young man he became interested in the possibility of sailing west to discover an easy route to the East. He tried for years to interest people in a voyage of discovery, and finally did obtain some backing from Ferdinand and Isabella of Spain (in which country his name assumed the form of Cristóbal Colón). He sailed on August 3, 1492, and landed on an island in the Bahamas on October 12, 1492; this date is now cited as that of the discovery of America. Columbus explored the area and discovered Haiti and Cuba before returning to Europe. Back at court he received, among other titles, that of Admiral of the Ocean Sea. While he had not found the Cathay and $\mathrm{Ci}$ pango reported by Marco Polo, he was convinced that he had reached Asia, and that these lands were somewhere in the area. Additional voyages of discovery were made by him in 1493, I498, and 1502. While his discoveries led to the opening up of the New World, he himself did not know it, or refused to admit it. He died in the apparent belief that Cuba was part of Asia, and that the Malay Archipelago was just a little farther west than he had sailed. While most early biographies of Co- lumbus concentrated on his life on land, Admiral Morison's study concentrates on Columbus' voyages, since these comprise the most important part of his life's work. There is much on the problems and methods of navigation. The book, which was awarded a Pulitzer prize for biography, was also published the same year in a one-volume edition which retained most of the text, but eliminated most of the scholarly apparatus. The Select Documents, edited by Cecil Jane, are largely writings by Columbus about his voyages; they have the merit of immediacy, but the disadvantage of the author's ignorance of much that was involved. The works are presented in English translation with the Spanish text on the facing page. Both volumes contain an extensive introduction covering the period treated, and the first volume contains a list of works cited (p. cli-clv).

3165. Kirkpatrick, Frederick A. The Spanish conquistadores. 2d ed. London, A. \& C. Black, 1946. 366 p. maps. (The Pioneer histories) 47-26292 FI4II.K57 I946

This book, which first appeared in 1934, relates the story of Spanish conquests in the Americas. As such it traces in a roughly chronological manner the opening of new lands, centering the account about particular places and individuals. The book opens with several chapters on Columbus and the Caribbean islands, and carries the story to the second foundation of Buenos Aires in 1580, at which point "the vast semicircle of Spanish dominion in South America was complete." The author's intention was to present a single coherent narrative of the many conquests, which had hitherto usually been treated as so many individual matters.

3166. McCann, Franklin T. English discovery of America to 1585 . New York, King's Crown Press, 1952, ${ }^{\mathrm{c}}$ 1951. xiv, $246 \mathrm{p}$.

Bibliography: p. [227]-232.

$$
\text { 52-10564 EI27.MI5 }
$$

This Columbia University dissertation is not a study of English explorations in the New World, as one might conclude from the title; it is rather a study of how information was obtained and spread, so that the English came to know, or discover, America as a new continental land mass rather than a fragment of the Indies. Since this involved a revolution in traditional thinking about the world, the author starts by outlining the information and misinformation which was available in England up to the time of Columbus. He discusses the medieval beliefs about the world and nature, such as "the belief that gold, its growth controlled by the rays of the sun, was restricted to the torrid zone," and their 
influence on English acts and attitudes. He then takes up the European discoveries and the gradual assimilation of the new information, leading to changed concepts of the world and of England's potential role in it. He considers English voyages to America as a source of information, as well as the reports of foreign ones, insofar as they enlightened the English. The work concludes by indicating some of the influence of the "discovery" of America on the creative imagination of English writers in this early period.

3167. Mirsky, Jeannette. The westward crossings; Balboa, Mackenzie, Lewis and Clark. New York, Knopf, 1946. xv, 365, xiii p. illus.

$$
\text { 46-7299 E27.M5 }
$$

This book attempts to exhibit the continuity behind the three great continental explorations of Balboa, Alexander Mackenzie, and Lewis and Clark. In 1513 , after crossing the continent at its narrowest section, Balboa discovered the Pacific; he sought gold for the King of Spain, and obtained gold and pearls. His discovery renewed the hope that a water passage to the Pacific and to the East might be found. In the I770's Mackenzie was still seeking such a passage in the Canadian Northwest; he found a fortune in furs. While Lewis and Clark still hoped for a through waterway, their primary object was to open up the way for the new nation's expansion to the Pacific that Jefferson envisioned and that the Louisiana Purchase made possible; the fortune they found for their government was the commerce of the West. Their difficulties all but put an end to the old dream of a natural and easy crosscontinental water route. The bibliography (p. 36r365 ) is a guide to further reading, listing important primary sources and the main secondary studies for each of the three expeditions.

3168. Newton, Arthur P. The European nations
in the West Indies, 1493-1688. London, A. \& C. Black, I933. xviii, 356 p. maps. (The Pioneer histories) 33-18908 FI621.N46

Noting that the history of the West Indies has usually been told either in terms of individual islands, or in groups of islands possessed by a single European power, Professor Newton of the University of London here undertakes "to consider the history of the West Indies as a whole with attention to the history of individual islands only where it played a part in the general drama." He notes that, notwithstanding the tendency to consider the West Indies in terms of their parts, "to whatever Power the islands have belonged, they have been affected by the same broad movements, whether political, social or economic. Their growth in importance, their decline and their subsequent recovery have followed parallel lines and been affected by the same causes." These parallels he traces from the discovery of the islands by Columbus to the year 1688 , which was turning point in the history of the area. $\mathrm{U}_{\mathrm{p}}$ to that time much activity was on an individual or small group basis, with buccaneering playing a large role. After 1688 the rulers of Europe by treaty recognized the expediency of maintaining a civilized policy in the area. Thenceforward action in the West Indies was largely a matter of large, national naval movements.

3169. Newton, Arthur P., ed. The great age of discovery. London, University of London

Press, 1932. $230 \mathrm{p}$. 32-33560 Eio1.N 48 Contents. - Introduction-the transition from the medieval to the modern age, by A. P. Newton.Spanish civilisation in the great age of discovery, by A. Pastor.-Vasco da Gama and the way to the Indies, by E. Prestage.-Christopher Columbus and his first voyage, by A. P. Newton.-Asia or mundus novus? By A. P. Newton.-The first explorers of the North American coast, by H. P. Biggar.-The search for a western passage, by $H$. J. Wood.-The first circumnavigation, by J. A. Williamson.-The northern passages, by E. G. R. Taylor.

A volume originating in public lectures delivered at King's College in 1931, with the modest aim of "tracing out some undisputed facts concerning a few of the greatest of the explorers, and by setting them against the background of their times to recover something of the spirit in which all unconsciously they broke the prison bonds of the medieval world in which they had been reared and led the mass of mankind into a new era." Works which treat as a whole the great European movement of discovery and expansion are few; one, which deserves to be but has not been translated, is Georg Friederici's Der Charakter der Entdeckung und Eroberung Amerikas durch die Europäer (Stuttgart-Gotha, F. A. Perthes, 1925-36. 3 v.).

3170. Nute, Grace L. The voyageur. Illus. by Carl W. Bertsch. Reprint ed. St. Paul, Minnesota Historical Society, 1955. $288 \mathrm{p}$. 55-12180 Fio27.Ng6 1955

The voyageurs were the short, muscular, and tireless French boatmen from the villages of the lower St. Lawrence who operated the canoes and bateaux of the Montreal fur traders, and were the first white men to acquire a detailed knowledge of the western Great Lakes, the Upper Mississippi, and the region beyond as far as the Rockies. This book, which was first published in 1931 , concentrates upon the period $176_{3}-1840$, when the French Govern- 
ment had been eliminated, and they were in the employ of the Hudson Bay Company, the Northwest Company, and, after I808, of J. J. Astor's American Fur Company. Even "the great explorers, like Alexander Henry, Jonathan Carver, and Alexander Mackenzie, relied on their canoemen for knowledge of navigable streams, portages, wintering grounds, and other topographical features." The author has treated two of the French pioneers in the western Great Lakes area in a detailed and less popular manner: Caesars of the Wilderness: Médard Chouart, Sieur des Groseilliers, and Pierre Esprit Radisson, 1618-1710 (New York, Appleton-Century, 1943. $\mathrm{xvi}, 386 \mathrm{p.}$ ). A trans-Mississippi pioneer of the 18 th century is the subject of Nellis M. Crouse's La Verendrye, Fur Trader and Explorer (Ithaca, N. Y., Cornell University Press, 1956. 247 p.).

3171. Parkman, Francis. Works. New library ed. [Boston] Little, Brown, I902-3. $12 \mathrm{v}$. illus. $\quad 4$-I9I49 Fro3o.P24 I902 Parkman (1823-1893), one of the leading American literary historians, and regarded by some as the greatest historian of the Igth century, is also discussed in Section A on Historiography (no. 3069). Shortly after graduating from Harvard College in 1846 he journeyed over the Western plains along the Oregon trail, and for a time lived among the Sioux Indians. The stimulation which his imagination received from them and from the wilderness determined both the choice of subject for his historical work, and the manner in which it was executed. The hardships of the journey, however, had further impaired his already shaky health, and the execution of so large a scheme despite recurrent breakdowns and failures of vision was a moral triumph of the first order. His chosen theme was the struggle of France and England for the control of North America against a savage background, but he had first to describe the establishment of New France (Canada), a subject little known to readers of English. The successive volumes, appearing over a period of 27 years, have collectively been known by the name of France and England in North America. In the edition cited above this is used as a subtitle for the first 9 volumes, although it has been applied to the first I I volumes, which may in a sense be regarded as a single work. The first volume is Pioneers of France in the New World (originally published in 1865 ), a work which opens with the story of French and Spanish conflict in Florida, and continues with Champlain's activities in the Great Lakes region. The second volume, The Jesuits in North America in the Seventeenth Century (1867), tells the story of the Catholic missionaries of New France, and of their heroic martyrdoms and extraordinary influence on savage and settler alike. Volume three, La Salle and the Discovery of the Great West (1869), deals with the earliest attempts to settle in the Mississippi Valley. Volume four, The Old Regime in Canada (1874), is the story of the paternalistic and religiously absolute society which Louis XIV sought to impose upon the colonists. Volume five, Count Frontenac and New France under Louis XIV (1877), presents this governor as heroically attempting to maintain a deteriorating and impractical colonial situation. The next two volumes, entitled $A$ Half Century of Conflict (1892), cover the first half of the 18th century and include two major wars. The history of the Seven Years' War in America and the British conquest of Canada is covered in the eighth and ninth volumes, entitled Montcalm and Wolfe ( I 884). The roth and I Ith volumes are devoted to The Conspiracy of Pontiac and the Indian War after the Conquest of Canada; this work, first published in I851, was Parkman's initial historical work, although it follows the other works chronologically in terms of subject matter. The 12 th volume in this edition is The Oregon Trail (no. 3348). For those who are daunted by multi-volumed history, there are recent condensations of Parkman's work within a single pair of covers: notably, The Battle for North America, edited by John Tebbel (Garden City, N. Y., Doubleday, I948. 746 p.) and The Parkman Reader, edited by Samuel Eliot Morison (Boston, Little, Brown, 1955. 533 p.). Mr. Tebbel has nothing to match Morison's introduction, bibliography, and references to more recent literature, but he does have considerably more extensive extracts from the later volumes covering the AngloFrench wars of $1690-1763$.

3172. Pohl, Frederick J. Amerigo Vespucci, pilot major. New York, Columbia University Press, 1944. 249 p. illus. A44-5612 EI25.V5P6 Bibliography: p. [235]-240.

The Florentine, Amerigo Vespucci (145I-I5I2), for whom the Americas were named, has for centuries been the subject of much scholarly debate. Much of this has arisen from the conflicting evidence presented in his own writings, but conflicts also arise from the other scanty evidence. Pohl has resolved much of this by regarding as forgeries most of the material published under the name of Vespucci. With these presuppositions Vespucci appears as a distinguished explorer and brilliant cosmographer, whose name may properly be applied to the hemisphere, since he was the first to recognize that it was a New World and not Asia that had been reached. The same scholarly reasoning, however, leaves to John Cabot the credit of being the first European of the Age of Discovery to arrive at the continental land mass itself. Germán Arciniegas in 
Amerigo and the New World (New York, Knopf, 1955. $322 \mathrm{p}$.) accepts the writings allegedly by Vespucci as being genuine; since his book is meant to be a popular biography, the conflicts in evidence are not fully resolved, and Vespucci emerges as an even greater figure than Mr. Pohl presents him as being.

3173. Williamson, James A. The age of Drake. 3 d ed. London, A. \& C. Black, 1952. 399 p. maps. (The Pioneer histories)$$
\text { First published in } 1938 \text {. }
$$

The use of the name of Sir Francis Drake (1540?1596) in this book's title distinguishes it as a history of English maritime affairs in the age of Elizabeth. Drake himself plays a limited part in the book, for while he was one of the leading navigators, explorers, and "pirateers" of the period, his career typified, rather than constituted, his times. In this volume Dr. Williamson studies the factors, political, economic, demographic, religious, etc., which led to England's becoming a major sea power and in time a worldwide maritime empire. Only a small part of the book specifically deals with what is now the United States of America, but its whole theme is that movement which brought about the British occupation of the area.

3174. Williamson, James A. The voyages of the Cabots and the English discovery of North America under Henry VII and Henry VIII. Illustrated with thirteen maps. London, Argonaut Press, 1929. $290 \mathrm{p}$. 30-8622 E127.W72

In the I480's John Cabot (who may have been born Giovanni Caboto in Genoa, before moving to Venice) tried to induce the King of England to subsidize a voyage of exploration westward to Asia. However, Henry VII did not supply the requested backing until after Columbus had made his voyage for Spain. In 1497 and 1498 John Cabot, with his son Sebastian, made voyages to North America along a northerly route. The voyage of Cabot was the basis of the English claims to America, although
Amerigo Vespucci (no. 3172) claimed he had reached the continental land mass far to the south eight days earlier. Sebastian Cabot's geographical and exploratory activity was largely in the service of Spain; a detailed study of his career is José Toribio Medina's El veneciano Sebastián Caboto (Santiago de Chile, Impr. y Encuadernación Universitaria, 1908. 2 v.). Dr. Williamson's book concentrates on John Cabot's career and the work of Sebastian for England. The first part contains the documents on which the historian's knowledge of John Cabot and his expeditions is based. The second part analyzes that evidence, trying to resolve conflicting data and establish the sequence of events. The work is thus designed not only as a historical study of a phase in the opening of the New World, but also as an example in historical method. Williamson had previously dealt with the Cabots in less detail in Maritime Enterprise, 1485-1 558 (Oxford, Clarendon Press, 1913. $4^{16}$ p.), which tells the story of English maritime work in discovery and commerce under the first four Tudors; while basically English history, it does contain much background information on the opening of America.

3175. Wrong, George $M$. The rise and fall of New France. New York, Macmillan, 1928. 2 v. (925 p.) maps. 28-28986 Fio30.W95 Professor Wrong's work covers nearly the same ground as the successive volumes of Francis Parkman (no. 317r). However, Wrong has achieved a more compact form, and has had the advantage of recent scholarship, and so has added to or modified some aspects of Parkman's very thorough work. Professor Wrong's work is based on library research and thus lacks the sense of immediacy his predecessor was able to convey from personal experience, and it makes no attempt to compete as literature. At the same time, it does pay more attention to the European background and is written by a Canadian with somewhat different preconceptions from his Boston predecessor. The organization also differs, since Professor Wrong follows a more strictly chronological pattern.

\section{The Thirteen Colonies}

3176. Andrews, Charles M. The colonial background of the American Revolution; four essays in American colonial history. Rev. ed. New Haven, Yale University Press, 1931. 220 p. 3I-24004 E210.A55 193I

Contents.-The British colonies in America.The mother country and its colonial policy.-Con- ditions leading to the revolt of the Colonies-General reflections.

3177. Andrews, Charles M. The colonial period of American history. New Haven, Yale University Press, $1934-38.4$ v.

$34^{-18339 \quad \text { E1 } 88 . A 572}$ 
Charles McLean Andrews (1863-1943) of Yale University became one of the foremost scholars of the American colonial period. His books on the subject include Colonial Self-Government, 16521689 (New York, Harper, 1904. 369 p.), which appeared as the fifth volume of The American nation: a history, edited by Albert Bushnell Hart; Colonial Folkways: a Chronicle of American Life in the Reign of the Georges (New Haven, Yale University Press, I921. 255 p.), which is volume nine of The Chronicles of America series; and Our Earliest Colonial Settlements, Their Diversities of Origin and Later Characteristics (New York, New York University Press, I933. I79 p.), which deals with Roanoke, Virginia, Massachusetts, Rhode Island, Connecticut, and Maryland. The Colonial Period of American History is Andrews' major work, and the summation of his lifetime's scholarship; it is also one of the outstanding studies of the Thirteen Colonies in the $17^{\text {th }}$ century. In it he attempts regularly to present the Colonies from the English point of view, and thus to offset the tendency of earlier American historians to consider them in isolation. He furthermore takes into account all of England's Atlantic colonies, and not merely the mainland group that subsequently formed the United States. The first three volumes deal with the settling and development of the several groups of colonies, in a roughly chronological progression; the fourth volume is a partially independent study of "England's Commercial and Colonial Policy," with the emphasis upon the formative period in the I 7 th century, but with frequent looks ahead at developments down to the Revolution. The Colonial Background of the American Revolution, by many regarded as the most satisfactory explanation of that crucial event, tries less to present a balanced and complete picture of colonial America than to trace the developing forces and circumstances that led to the separation. The basic reason is found in the fact that English statesmen failed to realize that "the colonies in America were far more advanced, politically, socially, and morally, than the mother country and could no longer be held in leading strings."

3178. Boas, Ralph P., and Louise S. Boas. Cotton Mather, keeper of the Puritan conscience. New York, Harper, 1928. $271 \mathrm{p}$.

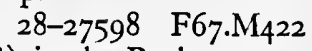

Cotton Mather ( $1663-1728$ ) in the Puritan community of Boston led a life of service as one of the colony's foremost theologians, and hence one of its foremost philosophers and politicians, in a society where church and state had been largely one. His life therefore presents a good view of Puritan society in a transitional stage when secular interests were asserting their autonomy. He was also one of the leading writers of the time, and his work is discussed under Literature (nos. 40-50), and Medicine and Public Health (no. 4826). His best-known work is the Magnalia Christi Americana (nos. 4344), which is a history of God's wondrous workings in His new land. This history remains a prime source for any who would understand the period, through sectarian views and a highly artificial style must be allowed for.

3I79. The Cambridge history of the British Empire; general editors, J. Holland Rose, A. P. Newton, E. A. Benians. v. I. The Old Empire from the beginnings to I783. New York, Macmillan; Cambridge, Eng., University Press, 1929. xxi, 931 p. 29-1466I DA30.C , v. I

This large and scholarly volume, to which many English historians and one American contributed, presents a balanced picture of the early development of the British Empire, and consequently sets the story of America in a larger framework. The history is carried through the Revolutionary War and the establishment of the United States of America. Considerable attention is paid to the outlook of the British home islands upon the Colonies, and the purposes, causes, and effects of various attitudes and laws are examined in some detail. There are chapters on the imperial bearings of international rivalries, sea power, international law, mercantilism, and constitutional theory. A. P. Newton's chapter on "The Great Migration, I618-1640," Lilian M. Penson's on "The West Indies and the SpanishAmerican Trade, I713-1748," and Eveline C. Martin's on "The English Slave Trade and the African Settlements" cover topics hard to find treated in compendious form elsewhere. An extremely thorough, now somewhat dated, bibliography is presented on p. 823-888.

3180. Crane, Verner W. The Southern frontier, 1670-1732. Durham, N. C., Duke University Press, 1928. 39I p. (Duke University publications)

Bibliography: p. 335-356.

South Carolina, founded in 1670 , remained a more or less isolated outpost of the British Empire for the next 60 years. As such, it enjoyed a practical monopoly of English trade with the Southern Indians, and developed an increasingly conscious opposition to the outpost of Spanish empire in Florida, and especially to the one which France established on the lower Mississippi at the close of the $17^{\text {th }}$ century. The frontier which resulted, and is so named in many 18 th-century documents, "was no line, but rather a zone, indeed a series of zones, merging into the wilderness. On its hither side it 
was an area of frontier settlements, at its outer edge a sphere of influence over Indian tribes, in contact and conflict with similar Spanish and French spheres." The Charles Town traders developed two main arteries into the Indian country, the Upper and the Lower Paths, bringing about the largest area of commercial and political hegemony and, as Governor Nairne put it in I705, "the greatest quantity of Indians subject to this Government of any in all America, and almost as many as all other English Governments put together." This interest developed "an Anglo-American sentiment of expansion" which spread from a few colonists and officials to the whole province, and only in the last decade of Professor Crane's period was communicated to the imperial administrators at Whitehall.

318I. Dow, George Francis. Every day life in the Massachusetts Bay Colony. Boston, Society for the Preservation of New England Antiquities, I935. $293 \mathrm{p}$. 36-I 84I F67.D68

The subjects covered in this volume range from details of the journey to America, through the nature of the buildings, home furnishings, clothing, medicaments, manufactures, and shipping to matters such as games, coinage, tombstone designs, and penology. The volume does not limit itself strictly to the Bay Colony, and is in part representative of all the Northern English colonies. The text is made up largely of contemporary facts and quotations, including personal narratives and statistical accounts. However, these and the numerous illustrations are presented with a minimum of interpretation by the author, who recognizes that much of the detail of the period has been lost, and who embarks on little of a speculative nature.

3182. Ellis, George E. The Puritan age and rule in the Colony of the Massachusetts Bay, 1629-1685. Boston, Houghton Mifflin, I888. 576 p. I-I $2030 \quad \mathrm{~F} 67 . \mathrm{E}_{47}$

The author states in his preface that his aim in this remarkably extensive work is to set forth "the motives of estrangement and grievance which prompted the exile of the Puritans to this Bay, and the grounds on which they proceeded to exercise their severe and arbitrary rule here. The points to be chiefly emphasized in this historic exposition are these: the relations of the Puritans, as Nonconformists, to the Church of England at the period of its reformation and reconstruction in the transition from the Papacy to Protestantism; the peculiar estimate of and way of using the Bible, characteristic of the Puritans under the critical circumstances of the time which had substituted the Book for the authority of the Papal and the Prelatical Church; their finding in that book the pattern and basis for a wholly novel form of government in civil and religious affairs, with an equally novel condition of citizenship; their attempt at legislation and administration on theocratic principles; and the discomfiture of their scheme as involving injustice, oppression, and intolerance." The story is carried to the loss of the colony charter, when Puritan rule ceased to be absolute and a royal governor was appointed. While the author displays a sympathetic understanding of many of the problems of the Puritans, he regularly maintains a scholarly objectivity towards his subject. The book is based on an extensive knowledge of the primary and secondary printed and manuscript materials available at that time. Subsequent scholarship has modified some points, and raised some new issues, but Ellis' study remains basically sound, as well as the most inclusive study, and nearly the only one which puts its main emphasis on the matters which the Puritans themselves regarded as primary.

3183. Franklin, Benjamin. Writings. Collected and edited, with a life and introd., by Albert Henry Smyth. New York, Macmillan, I907. Io v. illus. $\quad 33-12844 \quad E_{302 . F 82 ~} 1907$

Volume I contains bibliographical introduction (p. I-2I7) and the "Autobiography" (p. [2I9]439); writings and correspondence arranged chronologically, volumes 2-10 (p. 137); the "Life" by the editor, volume ro (p. 139-510), and list of correspondents and full indexes (p. $511-633$ ).

3184. Franklin, Benjamin. Letters to the press, 1758-1775, collected and edited by Verner W. Crane. Chapel Hill, Published for the Institute of Early American History and Culture at Williamsburg, Va., by the University of North Carolina

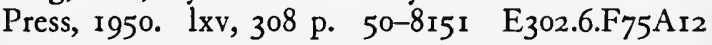

3185. Van Doren, Carl. Benjamin Franklin. New York, Viking Press, 1938. 845 p. ports. $3^{8-3 \text { I I93 E302.6.F8V } 32}$

“General bibliography": p. $[785]-788$.

3186. Crane, Verner W. Benjamin Franklin and a rising people. Boston, Little, Brown, 1954.

219 p. (The Library of American biography)

$$
\text { 54-5136 } \mathrm{E}_{302.6 . F 8 C 77} 1954
$$

3187. Stourzh, Gerald. Benjamin Franklin and American foreign policy. Chicago, University of Chicago Press, 1954. $335 \mathrm{p}$.

$$
\text { 54-9355 E249.S88 }
$$

Benjamin Franklin (1706-1790) had so versatile a genius it is impossible to offer an adequate, and 
at the same time short, summary of his career. Some aspects of it are treated in other sections of the bibliography, such as Literature, Science and Technology, Philosophy, and Education (consult the Index). He is included here as a leading statesman and diplomat of his period, although the other aspects of his life have equal importance in a broader conception of history. Franklin's career of public service began with minor offices in Pennsylvania. His first major office, held from I753 to 1774, was Deputy Postmaster General. In 1754 he represented Pennsylvania at the Albany Congress, where he presented a plan for the union of the Colonies. From 1757 to 1775 he spent most of his time abroad, as the agent for Pennsylvania at London, appointed to represent that colony's cause to the British Government; in time he was also appointed by Georgia, Massachusetts, and New Jersey as their agent. When conciliation failed he returned to America, where he served in the Continental Congress, and was chosen Postmaster General. During the war he represented the United States in France and obtained French support for the American cause. He was a member of the commission signatory to the Treaty of Paris (1783). In 1785 he returned to America, where for 3 years he served as president of Pennsylvania. He then represented that State at the Constitutional Convention, where he was prominent as an elder statesman. Shortly afterwards he died, the first American to have achieved international acclaim and renown, and by some regarded as the greatest figure of his era.

Franklin's collected Writings reveal not only his political role in history, but also the many other aspects of his personality. Almost everything he wrote is infused with the wit and style which has established him as one of the leading literary figures of the period. His extensive scientific and philosophical writings (separated here, although he wrote when science was still largely a part of philosophy) reveal his extensive contributions in these fields. His semiofficial and even some of his satirical works reveal his extensive governmental concerns and accomplishments. Finally, while his famous Autobiography (see nos. 123-127) covers his earlier years, his extensive correspondence reflects his many interests and roles, as well as his close connection with leading figures of the age. Regrettably, Smyth's edition of Franklin's writings is incomplete, largely because of the many Franklin items which have since been uncovered. However, a new edition of Franklin's writings is in preparation, and the first volume is scheduled for publication by the Yale University Press in the spring of 1959 .
Outstanding among the volumes needed to supplement Smyth's edition is Professor Crane's Benjamin Franklin's Letters to the Press, 1758I775, which covers the material written by Franklin for publication while he was a colonial agent in England. Since much of this was originally published anonymously or pseudonymously, and since many of Franklin's manuscripts for the period have been lost, extensive research was needed to uncover them. Crane's work reprints only such press letters as are not included in Smyth's edition; however, all pertinent material is traced, and reference made to Smyth when the letter is to be found there. Since Franklin's work in England has been relatively neglected, this volume is essential for an understanding of that phase of his career, and of the American position on political issues at that time. Of the many biographies of Franklin, Van Doren's 1938 publication surpasses earlier ones by its extensive use of intensive 2othcentury Franklin scholarship; and surpasses subsequent biographies by its wide scope, as well as in being in itself an outstanding example of the art of biography. An interesting earlier biography is William Cabell Bruce's Benjamin Franklin, Self-Revealed, a book consisting largely of extracts from Franklin's writings in a topical arrangement, with informed connecting passages by Bruce. A recent short and yet scholarly biography is Crane's Benjamin Franklin and a Rising People, which attempts to show the life of this "first American" as best reflecting those forces which led to the establishment of a new nation. Stourzh's scholarly Benjamin Franklin and American Foreign Policy, like a number of other studies, focuses on but one side of this many-sided genius. Stourzh attempts not only to depict Franklin's direct role in foreign affairs in behalf of America, but also to analyze Franklin's political thought. A work that approaches his foreign influence from quite another point of view is Alfred Owen Aldridge's Franklin and His French Contemporaries (New York, New York University Press, 1957. 260 p.), which discusses not only Franklin's activities in France, but more especially the French reaction to this sage from the American wilderness; for this purpose a large part of the book is devoted to presenting and discussing references to Franklin in contemporary French writings.

3188. Gipson, Lawrence Henry. The British Empire before the American Revolution: provincial characteristics and sectional tendencies in the era preceding the American crisis. Caldwell, Idaho, Caxton Printers, 1936-56. 9 v. maps.

$$
\text { 36-20870 DA500.G5 }
$$


Volumes 4-9, issued without subtitle, have imprint: New York, A. A. Knopf.

Contents.-1. Great Britain and Ireland.-2. The Southern plantations.-3. The Northern plantations.-4. Zones of international friction; North America, south of the Great Lakes region, I7481754.-5. Zones of international friction; the Great Lakes frontier, Canada, the West Indies, India, 1748-1754.-6. The great war for the Empire: The years of defeat, $1754-1757 .-7$. The great war for the Empire: The victorious years, 1758-1760.-8. The great war for the Empire: The culmination, 1760-1763.-9. The triumphant Empire: new responsibilities within the enlarged Empire, 1763r 766 .

Dr. Gipson (b. 1880) was a graduate of the University of Idaho when a Rhodes scholarship took him to Oxford for 3 years; from 1924 to $195^{2}$ he was professor of history at Lehigh University (Bethlehem, Pa.). Soon after his establishment there he embarked upon his investigations on this subject, which have been continuously subsidized by that university and several foundations, and which have grown into the largest and most imposing American historical work written in our day by a single hand. The author's purpose has been to produce a large-scale study of the British Empire between the Peace of Aix-la-Chapelle (1748) and the outbreak of the American Revolution, so as to provide a more adequate basis for the interpretation of the latter event than has hitherto been available. The first three volumes provide "a view of the old Empire in a state of tranquillity and equilibrium for the last time in its history." The next two concentrate upon "the problems involved in the expanding frontiers of the Empire," which were brought about by neither the central nor the colonial governments, but "primarily as the result of the restless activity of individuals or groups, with or without legal warrant." Volumes 6-8 narrate the conclusive struggle with France, as well as the European war into which it merged; this war is viewed as brought on by French aggression, taken up by the home government for the protection of vital colonial interests, and won by the energy and resources of Britain. The latest volume to appear offers "a detailed analysis of developments within the new acquisitions" of the Empire in the years immediately following the peace which brought them, and extends to the trans-Appalachian region, Nova Scotia, Canada, East and West Florida, four new West Indian islands, and Bengal. The work employs a thorough analysis of successive situations, proceeds at an unhurried pace, and is written in clear and straightforward prose.
3189. Graham, Gerald S. Empire of the North Atlantic; the maritime struggle for North America. Toronto, University of Toronto Press, 1950. xvii, $33^{8}$ p. maps. 50-14296 E45.G7

A narrative of the rise and supremacy of British sea power, with particular reference to its role in making Britain the principal colonial power in North America. Introductory chapters outline the long period of Spanish supremacy and the bases of French sea power, and sketch the rise of British sea power in the second half of the $17^{\text {th }}$ century. The long duel between Britain and France, from the outbreak of the War of the League of Augsburg (1689) to the conquest of Canada (1760), is then narrated at some length, with a unity of treatment deriving from the author's emphasis upon the maritime factors involved. There follow outlines of the War of the American Revolution and of the War of 1812 , as well as of the troubled period between them, useful as concise presentations from a British point of view. The author pursues the theme of British supremacy in the Atlantic into the age of iron and steam, when it was extended to all the oceans of the world, and then to its remarkably sudden disappearance as a consequence of the construction of the German High Seas Fleet in the first decade of the 2oth century. The author, a Canadian who has become Rhodes Professor of Imperial History at the University of London, has also published two more detailed studies of portions of his story: British Policy and Canada, 1774-I791; a Study in 18th Century Trade Policy (London, New York, Longmans, Green, 1930. 16i p. Imperial studies, no. 4), and Sea Power and British North America, 1783-1820; a study in British Colonial Policy (Cambridge, Harvard University Press, 1941. 302 p. Harvard historical studies, v. 46).

3190. Greene, Evarts Boutell. The foundation of American nationality. Rev. ed. New York, American Book Co., 1935. xii, 614, xiii-xl p. illus. 35-19098 Ei78.G752

Published in 1922 as volume I of $A$ Short History of the American People.

In this book Greene purposes to give the layman and the college student a view "of our early development as it appears in the light of . . . recent research and discussion." This is because, as he notes, the recent work of men such as Andrews, Osgood, and Turner has "made necessary the modification or abandonment of time-honored traditions." The study recognizes American colonial history as part of a much larger picture, but the emphasis is on the development of the Thirteen Colonies; the story is carried to the adoption of the Federal Constitution in 1789 . The bibliographies at the end of each chapter are designed to assist the general reader to fur- 
ther material, and are not intended to indicate scholarly sources.

319I. Greene, Evarts Boutell. Provincial America, 1690-1740. New York, Harper, 1905. 356

p. 7 maps. (The American Nation; a history, v. 6) 5-19070 E $E_{178 . A 54}$

"Critical essay on authorities": p. 325-340.

The period covered by this book was one in which the English colonies were rapidly expanding, and for that reason first giving evidences of unity, as the gaps between them were lessened or eliminated. At the same time it was a period in which the British colonial system was evolving, and in the process uncovering conflicts between the home government and the colonies. This evolution of colonial administration, along with the impact of the wars with the French and their Indian allies, fills a large part of this book. The narrative, which limits itself to the Colonies later to become part of the United States, and devotes little attention to the European background events, also covers other aspects of colonial history, including the commerce and culture of the period.

3192. Greene, Evarts Boutell. The provincial governor in the English colonies of North America. New York, Longmans, Green, 1898. 292 p. (Harvard historical studies, v. 7) 98-1530 JK66.G8

Appendix C. "List of authorities cited": p. 271278.

Before 1688 British colonial administration was confused by a diversity of origins and franchises, by an unformed and shifting policy, and by a rudimentary development of organization. After 1763 the heightened tone of policy, and the contrary reaction which it provoked in the Colonies, produced a quite altered set of administrative circumstances. The long and relatively stable intervening period therefore provides the best opportunity of "presenting a simple view of the normal working of the provincial constitution," and Professor Greene further provides for the homogeneity of his subject matter by excluding from consideration Connecticut and Rhode Island, where the survival of older charters preserved an elective governorship. Within these limits, this is a clear and well-rounded study of the more formal aspects of the office which was considerably the most important in royal and proprietary provinces alike: the governor commissioned and instructed by the British Crown. After two introductory chapters which trace the complex antecedents of the stabilized system after the Glorious Revolution, the book proceeds analytically, considering in turn the governor's appointment, tenure, and emoluments, his council, his executive powers, and his relations with the provincial judiciary. Last and most important are his relations with his chief rival, the popularly elected assembly, to which complex situation three chapters are devoted. In the latter half of the period, it is concluded, the assemblies everywhere encroached upon his executive functions, and "in some of the provinces the governor's power had been reduced within very narrow limits." A final chapter deals with the governor's legal and political accountability both to the home government and to the people of his province.

3193. Harper, Lawrence A. The English navigation laws; a seventeenth-century experiment in social engineering. New York, Columbia University Press, 1939. xiv, $503 \mathrm{p}$.

"Table of statutes cited": p. [449]-46o.

Bibliography: p. [4I ] -447 .

In this study of what Americans usually call the Acts of Trade, the author states that his chief purpose "is to analyze the process of social engineering, as exemplified by the Navigation Acts." His study concentrates on the second half of the 17 th century. The first part of the book deals with the origin of the laws, the second with their enforcement in England, and the third with their enforcement in the Colonies. The fourth part is a study of the results of the acts; for this purpose the time covered has been pushed both forward and backward so as to extend from the days of the Spanish Armada to the Victorian period. Since the acts were English in origin, designed to build up the English merchant marine and further mercantilist ideas of national prosperity, the subject has been approached from an English point of view. The author has treated the specifically American consequences of these acts in an essay, "The Effect of the Navigation Acts on the Thirteen Colonies," contributed to The Era of the American Revolution: Studies Inscribed to Evarts Boutell Greene, edited by Richard B. Morris (New York, Columbia University Press, 1939), p. 3-39.

3194. Keys, Alice Mapelsden. Cadwallader Colden; a representative eighteenth century official. New York, Columbia University Press, 1906. xiv, $375 \mathrm{p}$. 6-40257 Fi22.C69

Colden (1688-1 $\left.77^{6}\right)$ was of Scotch ancestry and came to America as a physician in 1710 . In 1720 he embarked on his long career of public service when appointed surveyor-general of New York. The following year he was appointed to the governor's council, and he still held that position when in $176 \mathrm{r}$ he became lieutenant governor, an office he held until his death, although its powers had largely disappeared with the outbreak of the Revolution. His 
long support of the royal authority, and his extensive activities in other fields, have enabled his biographer to write not merely his life, but also a political and social history of the province of New York in his time. His activities as a progressive scientist, especially in physics, botany, and medicine, as a philosopher, and as a historian of the Iroquois Indians, are reflected here, as they are on a larger scale in Colden's Letters and Papers, I7II-[I775] (New York, Printed for the New York Historical Society, 1918-37. 9v.).

3195. Labaree, Leonard Woods. Royal government in America; a study of the British colonial system before 1783. New Haven, Yale University Press, I930. 49I p. (Yale historical publications. Studies, 6) 30-25475 JK $54 . \mathrm{L}_{3}$

"Bibliographical notes": p. [449]-468.

This book undertakes to depict the system of royal government as a whole in the American Colonies prior to the end of the Revolution. On the ground that before 1675 the details of the political system "were so varied and the attitude of the English officials toward them so unsettled that the early years contribute little to the later story," the author begins his study with the situation in the last quarter of the 17 th century. In his preface he says that he has "tried to explain what the instruments were by which royal authority was exercised in America, what the machinery of royal government was and how it operated, what the governmental policies of the British officials were and what influences caused them to be adopted, and how the colonists reacted to these policies when the royal governors tried to apply them. Above all, I have concerned myself with that great contest between the assemblies and the crown over the royal prerogative, which is the central theme of the constitutional history of the colonies." Professor Labaree has collected the most important class of source materials for his study in his edition of Royal Instructions to British Colonial Governors, ${ }^{1670-1776}$ (New York, Appleton-Century, 1935. 2 v.). He is also the author of Conservatism in Early American History (New York, New York University Press, 1948. I82 p.), a series of lectures in which he traces the bases and influence of conservatism in the later colonial period.

3196. Miller, Perry. Roger Williams: his contribution to the American tradition. Indianapolis, Bobbs-Merrill, 1953. 273 p. (Makers of the American tradition series)

$$
53-8874 \quad \mathrm{~F} 82 . \mathrm{W}_{7} 88
$$

3197. Winslow, Ola Elizabeth. Master Roger Williams, a biography. New York, Macmillan, 1957. $328 \mathrm{p}$. 57-10016 F82.W692
Includes bibliography.

Williams (ca. I603-1683), the vigorous opponent of the Massachusetts theocracy and the founder of Rhode Island, is discussed as a writer in Chapter I on Literature (nos. 84-89). Professor Miller's volume is in part a selection from the writings there listed, with useful editorial notes (p. 26I-266), and in part a discriminating attempt to relate his thought both to the theological controversies of the $\mathrm{x} 7$ th century and to the subsequent tradition of American liberalism, which has hailed him as a forerunner, at times with more enthusiasm than understanding. Miss Winslow's study of Williams is the most recent full-length scholarly biography of him; in it the author attempts to balance out the early "harsh" judgments and more modern tendencies to make of the man a glorious myth. She remarks that our relative ignorance of Williams combined with the complexities of his personality guarantee that future biographies will vary in the interpretation. Another recent biography of note is Samuel Hugh Brockunier's The Irrepressible Democrat, Roger Williams (New York, Ronald Press, I940. 305 p.), in which Williams is viewed as a great man, although some earlier assumptions are called into question; Miller views this work as a "sad example of the misrepresentation that comes when Williams is presented too easily in the language of twentieth-century thought." A somewhat less critical and more favorable study, which has the same "twentieth-century thought" aspect as Brockunier, is James E. Ernst's Roger Williams, New England Firebrand (New York, Macmillan, 1932. $53^{8}$ p.); while highly partial to his subject, the author does take some account of the traditional controversy.

3198. Morison, Samuel Eliot. Builders of the Bay Colony. Boston, Houghton Mifflin, I930. xiv, $365 \mathrm{p}$. A30-1055 NN

Bibliography: p. [347]-355.

The copies in the Library of Congress are of a limited edition on finer paper, bearing the title Massachusettensis de conditoribus (F67.M86).

A series of biographical sketches of individuals representing the various aspects of life in the colony-"adventurous and artistic, political and economic, literary and scientific, legal, educational, and evangelical." The first four individuals discussed-Richard Hakluyt, Captain John Smith, Thomas Morton, and John White-prepared the way for the settlers of 1630 . The others include John Winthrop, Thomas Shepard, John Hull, Henry Dunster, Nathaniel Ward, Robert Child, John Winthrop, Jr., John Eliot, and Anne Bradstreet. This book is distinguished not only as an outstanding example of literary historical writing, but also as one of the few books conveying the nature, significance, 
and purpose of the Puritans with understanding and respect, thus enabling the modern reader better to appreciate and understand this group from which most Americans feel alienated, and towards which many feel hostile. The well-chosen illustrations on 45 plates add considerably to the merit of the book.

3199. Murdock, Kenneth Ballard. Increase Mather, the foremost American Puritan. Cambridge, Harvard University Press, 1925. xv, $44^{2}$ p. illus. 25-21276 F67.M477 "Appendix C. List of books referred to": p. [407]-415. "Appendix D. Checklist of Mather's writings": p. [416]-422.

Increase Mather $(1639-1723)$ was born in Dorchester, Mass., where his father was a leading and strict Puritan minister. In time the son himself became the foremost New England Puritan of his generation. In 1664 he became teacher at the Boston Second Church. Sometime later he became president of Harvard College, a position he held for nearly two decades. In I 688 he represented Massachusetts in England; his relative success, however, came when William III displaced James II toward the end of 1688 . Mather obtained a new charter for Massachusetts, and at the same time the unusual political privilege of being allowed to nominate the new officers for its government. He returned to Massachusetts, where he defended his diplomatic and political activities, but as before gave his main attention to the church. In the course of his career he also established himself not only as the most prolific author of his generation (political tracts, histories, sermons, etc.), but also one of the best in more strictly literary terms. Professor Murdock's biography of Mather shows him to have been an intelligent and unusually liberal person for his age. The book also attempts to depict that age to some extent; for Mather was not only involved in most of the public affairs of his day, but was also in many ways representative of his society; the book is thus as much general history as it is biography. An earlier life of Increase Mather was that by his famous son, Cotton Mather (q. v.): Parentator (Boston, B. Green for N. Belknap, i724. 239 p.), an outstanding example of colonial biography. Increase Mather's own autobiography has not yet appeared in book form.

3200. Nissenson, Samuel G. The patroon's domain. New York, Columbia University Press, 1937. 416 p. (New York State Historical Association series; D. R. Fox, editor; no. 5)

Bibliography: p. [389]-397.

$$
\text { 37-20744 Fi22.I. } \mathrm{N}_{5} 8
$$

According to the preface, "This attempt to describe the origin, the economic background and the political development and disintegration of the 'patroon system' as embodied in Rensselaerswyck, its one exemplar in New York, while complete within itself, serves also as an introduction to the history of the town and county institutions which for a time paralleled and ultimately supplanted the patroon's administrative organization." The book opens with a brief account of the founding and development of the Dutch West Indies Company, and its early commercial attitude towards New Netherland, later New York. There follows a history of the development during the 17 th century of Rensselaerswyck, the large manorial grant on both sides of the Hudson River just south of Albany, and the patroonship's relationship to the home country and the company, as well as, in the later stages, to the new English system of laws, as the English took over. In large part the work is thus a special study of the I7th-century development in New York of laws affecting land tenure.

3201. Original narratives of early American history, reproduced under the auspices of the American Historical Association; general editor: J[ohn] Franklin Jameson. New York, Scribner, I906-I7. I9 v. 7-6642 $\mathrm{E}_{187 . \mathrm{O}_{7}(\mathrm{~A}-\mathrm{Z})}$

Dr. Jameson, the editor of this series, states in a "General Preface to the Original Narratives of Early American History," which appears only in The Northmen, Columbus and Cabot, 985-1503 (no. 3215 ), that the plan of the series was approved by the American Historical Association at its annual meeting of December 1902, and that its purpose was to provide "a comprehensive and well-rounded collection of those classical narratives on which the early history of the United States is founded, or of those narratives which, if not precisely classical, hold the most important place as sources of American history anterior to I70o." Many of these, he noted, had become so scarce and expensive that no ordinary library could hope to possess a complete set. The series was to publish not extracts, but whole works or distinct parts of works. Works in English were to be reprinted from the earliest or best editions, and works in foreign languages from the best translations available, or in new translations if no satisfactory ones were obtainable. A few works were to be published from manuscript for the first time. The special editors were to supply introductions concerning the author and the value of his work as a source, as well as brief notes enabling the reader "to understand and estimate rightly the statements of the text." Each volume is supplied with facsimiles of title pages and of maps contemporary with the narratives and serving to illustrate them. "No subsequent sources," said Dr. Jameson, "can have quite the intellectual interest, none quite the senti- 
mental value, which attaches to these early narrations, springing direct from the brains and hearts of the nation's founders." The series has proved quite as useful as its distinguished planner hoped, and most of its volumes are currently available in reprint editions from Barnes and Noble, New York.

3202. Andrews, Charles McLean. Narratives of the insurrections, $1675-1690.1915 .414 \mathrm{p}$.

$$
\begin{array}{r}
{ }_{15-4852} \text { Er87.A563 } \\
\text { Er87.O7A6 }
\end{array}
$$

3203. Bolton, Herbert E., ed. Spanish exploration in the Southwest, 1542-1706. 1916. $487 \mathrm{p}$. I6-6066 F799.B69

3204. Bradford, William. History of Plymouth Plantation, 1606-1646; edited by William T.

Davis. I908. $\mathrm{xv}, 437 \mathrm{P}$.

$8-7375 \cdot$ F68.B802

See entry nos. $1-6$. $\mathrm{E}_{187 . \mathrm{O}_{7} \mathrm{~B} 7}$

3205. Burr, George Lincoln, ed. Narratives of the witchcraft cases, I648-I706. I9I4. xviii, $467 \mathrm{p}$. 14-9773 BFI573.A2B8

See entry no. 4 I.

3206. Burrage, Henry S., ed. Early English and French voyages, chiefly from Hakluyt, 15341608. 1906. xxii, $45^{1} \mathrm{p}$. $6-44365$ Er27.B96

3207. Champlain, Samuel de. Voyages, I604I6I 8; edited by W[illiam] L. Grant. I907.

$377 \mathrm{p}$

See entry no. 3156. 7-22899 FI030.r.C494

3208. Danckaerts, Jasper. Journal, 1679-1680; edited by Bartlett Burleigh James and J [ohn]

Frank Jameson. I913. xxxi, 313 p.

$$
\begin{array}{r}
{ }_{13}-1355^{6} \\
\text { Er62.Di8 } \\
\text { Er87.O7D3 }
\end{array}
$$

"The present translation is substantially that of Mr. Henry C. Murphy, as presented in his edition of 1867," under title: Journal of a Voyage to New York and a Tour in Several of the American Colonies in 1679-80, by Jasper Dankers and Peter Sluyter.

3209. Hall, Clayton Colman, ed. Narratives of early Maryland, I633-I684. I910. $460 \mathrm{p}$. I0-23763 Fi 84. Hi9

3210. Jameson, John Franklin, ed. Narratives of New Nederland, 1609-1664. I909. 478 p.

$$
\text { 9-24463 Fi22.I.J3I }
$$$$
\mathrm{E}_{187 .} \mathrm{O}_{7} \mathrm{~J}_{3}
$$

321 I. Johnson, Edward. Wonder-working providence, I628-I65I; edited by J[ohn] Franklin Jameson. I9I0. 285 p. I0-9809 F67.J675

3212. Kellogg, Louise Phelps, ed. Early narratives of the Northwest, 1634-1699. 1917. xiv, $382 \mathrm{p}$. I7-6235 $\mathrm{F}_{4} 82 . \mathrm{K}_{29}$

3213. Lincoln, Charles H., ed. Narratives of the Indian wars, 1675-1699. 1913. $316 \mathrm{p}$. 13-24819 E82.L73 $\mathrm{E}_{187 . \mathrm{O}_{7}} \mathrm{~L}_{5}$

3214. Myers, Albert Cook, ed. Narratives of early Pennsylvania, West New Jersey and Delaware, $1630-1707$. 1912. xiv, $476 \mathrm{p}$.

I2-46I I Fro6.M98

3215. The Northmen, Columbus and Cabot, 9851503: The voyages of the Northmen, edited by Julius E. Olson. The voyages of Columbus and of John Cabot, edited by Edward Gaylord Bourne. Igo6. xv, 443 p. 6-36882 Eıог.N87

3216. Salley, Alexander S., ed. Narratives of early Carolina, 1650-1708. 1911. $3^{88}$ p.

$$
\begin{array}{r}
\text { I I-9548 } \\
\text { Fi272.SI } 6 \\
{\text { EI } 87 . O_{7} S_{3}}^{2}
\end{array}
$$

3217. Spanish explorers in the Southern United States, 1528-I543: The narrative of Alvar Nuñez Cabeça de Vaca, edited by Frederick W. Hodge. The narrative of the expedition of Hernando de Soto by the gentleman of Elvas, edited by Theodore H. Lewis. The narrative of the expedition of Coronado, by Pedro de Castañeda, edited by Frederick W. Hodge. I907. xx, 4 II p.

$$
\begin{aligned}
& \text { 7-10607 E123.S } 75 \\
& \mathrm{E}_{18} 8 . \mathrm{O}_{7} \mathrm{~S}_{7}
\end{aligned}
$$

32r8. Tyler, Lyon Gardiner, ed. Narratives of early Virginia, 1606-1625. 1907. xv, $478 \mathrm{p}$.

$$
\text { 7-33220 F229. T994 }
$$

3219. Winthrop, John. Journal, "History of New England," 1630-1649; edited by James Kendall Hosmer. I908. 2 v. 8-I777I F67. W785 See entry nos. 90-9r.

3220. Osgood, Herbert L. The American Colonies in the seventeenth century. New York, Columbia University press, I930. $3 \mathrm{v}$.

$$
\text { 30-26656 Eigr.O83 }
$$

322I. Osgood, Herbert L. The American Colonies in the eighteenth century. New York, Columbia University Press, I924. 4 v. 24-3889 $\mathrm{E}_{195} \mathrm{O} 82$ 
The American Colonies in the Seventeenth Century, which first appeared during 1904, is a study of the political and administrative aspects of the development of the English continental colonies in the I 7 th century; it is thus also in part a study of the development of political institutions in this area. Social and economic aspects of colonial life are not discussed, except in so far as they play a role in the more political aspects of colonial history. The first two volumes of the work discuss the situation in the chartered and proprietary Colonies; the third volume studies the situation in the royal Colonies, in which category the British Government soon tried to place all the Colonies, in order more efficiently to administer them for what was considered the general welfare of the homeland. Because of the extent and thoroughness of Osgood's pioneering study, his work remains an authoritative exposition of the early development of American political institutions. The American Colonies in the Eighteenth Century is a continuation left by Professor Osgood (185519r8) of Columbia University in a state somewhat short of completion at his death. It was readied for and seen through the press by his pupil, Dixon Ryan Fox, who also produced a short biography: Herbert Levi Osgood, an American Scholar (New York, Columbia University Press, 1924. I67 p.). Taking up where the earlier work left off, in 1690 , these four volumes continue the political and institutional aspects of colonial history through the British conquest of Canada. Much attention is given . the four "Intercolonial Wars," as Osgood preferred to call them in lieu of their traditional names, and the longer administrations of individual governors in the larger provinces are given individual treatment. The creation of British agencies of colonial administration, and the origin and development of specific British policies are separately described. The position of the Church of England in the Colonies, and the effects of immigration and the tendency to westward expansion are considered. The political narrative conveys the impression that whatever the type of colonial government, colonial grievances and disaffection continued to increase in the face of British policy and administration.

3222. Peare, Catherine O. William Penn; a biography. Philadelphia, Lippincott, 1957. $448 \mathrm{p}$. 56-108 10 Fi52.2.P34

Bibliography: p. 427-444.

The most important event in the life of William Penn (I644-I718), without which he would probably have had small historical importance, took

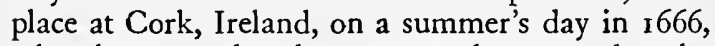
when he was reduced to tears, and converted to the doctrine of God as the Inner Light, by the testimony of the Quaker Thomas Loe. Miss Peare's biography is uncommonly penetrating in that it gives Penn's Quakerism its proper place at the center of his life, his character, and his influence upon the life of his day, and so upon all succeeding times. It is based upon prolonged research in the manuscript collections of the Historical Society of Pennsylvania and, secondarily, of Friends House, London, and although footnotes are dispensed with, documentation is provided by a series of page references at the end ( $p .415-426)$. The founding of Pennsylvania is placed against its contemporary English background of the Tory and High Anglican reaction that took hold in I68I, and led Penn to see no real solution for the Friends save an American refuge. "As Proprietor of Pennsylvania Penn had received almost absolute power from his monarch"; his greatness was evidenced by his immediate renunciation of this power for himself and his successors, "that the will of one man may not hinder the good of an whole country." On the other hand, William I. Hull's William Penn, a Topical Biography (London, New York, Oxford University Press, I937. 362 p.) emphasizes the peripheral many-sidedness of Penn's career, concerning which it assembles much out-of-the-way information. William Wistar Comfort's William Penn, 1644-1718, a Tercentenary Estimate (Philadelphia, University of Pennsylvania Press, I944. 185 p.) is a widely esteemed interpretative sketch which views Penn's career as an attempt to implement Quaker ideals.

3223. Quinn, David B. Raleigh and the British Empire. New York, Macmillan, 1949. 284 p. (Teach yourself history library)

$$
\text { 49-10375 DA86.22.R2Q5 I949 }
$$

A clear outline of English dealings with the New World in the later years of Elizabeth I and the first decade of James I, organized around the colorful if not wholly admirable personality of Sir Walter Raleigh (ca. 1552-1618), whom the author is careful not to overrate. However, Raleigh "advanced from the concept of a military settlement of hired men to the view that only a real community of men, women and children, having personal incentives to settle and prosper, could hope to succeed." This success, denied to Raleigh under Elizabeth, was made possible under James by "the slow quantitative development of English capitalism," permitting effort on a larger scale. Professor Quinn has also edited two extremely valuable documentary collections, one concerning Raleigh's half-brother and predecessor: The Voyages and Colonising Enterprises of Sir Humphrey Gilbert (London, Hakluyt Society, I940. 2 v.) and the other concerning Raleigh's settlements in North Carolina: The Roanoke Voyages, 1584-1590; Documents to Illustrate the English Voyages to North America under 
the Patent Granted to Walter Raleigh in 1584 (London, Hakluyt Society, 1955. 2 v.).

3224. Raesly, Ellis Lawrence. Portrait of New Netherland. New York, Columbia University Press, 1945. $37^{\circ} \mathrm{p}$. (Columbia University studies in English and comparative literature, no. I6I)

Bibliography: p. [345]-354.

A $45-1615$ Fi22.I.RI5

This Columbia dissertation is an attempt to present the "pattern and philosophy of life" of the Dutch colonists of New Netherland. The author studies such matters as the church in the New World, the political and social views of the colonists, the cultural interchanges between the Dutch and the Indians, and the early literary efforts of the Dutch in New Netherland. In the course of this he presents considerable information on the general history of the colony, and especially governmental affairs in so far as they affected the colony's cultural life.

3225. Root, Winfred Trexler. The relations of Pennsylvania with the British Government, r696-1765. [Philadelphia] University of Pennsylvania, I912. 422 p. ([Publications of the University of Pennsylvania. History]) I2-5677 F $152 . R_{7} 8$

"Bibliographical notes": p. 397-407.

In origin a University of Pennsylvania dissertation, this work studies in some detail the relations between the chartered and proprietary province of Pennsylvania and the British agencies of colonial administration, from the reorganization of the latter in 1696 to the second reorganization which followed the French and Indian War. While the author aims to throw light upon colonial administration in general, he is aware that the special circumstances of Pennsylvania differentiated it from other provinces: its establishment under Quaker auspices led in the earlier years of the period to much friction with Anglicans in the province and at home over the judicial oath and other issues, and in the later years to a succession of crises over provincial and imperial defense, to which the pacifist Quakers contributed little and that with reluctance. Furthermore, the Penns and their governors had none of the dignities of a king, and so fared worse in their struggle with the provincial assembly than did the royal governors elsewhere, so that by 1765 "within its sphere the legislature was scarcely less powerful than the British Parliament." But in its chapters on the administration of the acts of trade, the court of vice-admiralty, and the royal disallowance, this study exhibits in concrete example the same sort of situation that obtained in the colonies generally. While British control of the colonies in this age was not harsh or oppressive, Dr. Root concludes, the central fact of the imperial relation was the conflict of interest between a theory of empire primarily economic, and colonial views of religious and political separatism, individualism, and liberty.

3226. Rutledge, Joseph L. Century of conflict; the struggle between the French and British in colonial America. Garden City, N. Y., Doubleday, 1956. $530 \mathrm{p}$. maps. (Canadian history series, v. 2) 56-954I Frozo.R93

Mr. Rutledge, a Canadian magazine writer and editor, here presents the story of the French and English conflict for North America. The story, which tends to focus on personalities, opens with Governor Frontenac's arrival in Quebec in 1672 , and closes with the English victories at Quebec and Montreal some 90 years later, establishing English dominance on the continent. While events throughout North America are considered, the author's main interest is in the activities in and about Canada. The history itself, which covers much the same ground as Parkman (q. v.), but with details from more recent studies, is "an attempt to make characters and events move out of the stiff formalities of history, to find flesh and blood and a sense of immediacy in the crowding events."

3227. Sachse, William L. The colonial American in Britain. Madison, University of Wisconsin Press, 1956. 290 p. $\quad$ 56-5887 DAr25.A6S3 Dealing with persons who had settled in or been born in the thirteen mainland Colonies, and who later went to England prior to 1776, Sachse here attempts to study their motives for going to England and their activities and attitudes once there. Many went on business, a large proportion went to study, some retired to England after a successful career, a fair number returned because on economic or legal missions, official or semi-official, and some held "diplomatic" positions in England. Almost none traveled to England purely for pleasure, since the trip was so strenuous and expensive. Nevertheless, there was a strong drive to visit the homeland, and business reasons were often found. Most of the Americans visiting England came from the more populous and prosperous Colonies, such as Virginia, Massachusetts, South Carolina, and Maryland. Mr. Sachse pays some attention to English influences on the visitors, and their influences on England, but that difficult topic is not his main concern. The material for the study is in large part gleaned from diaries, journals, and letters, many still in manuscript. The work reflects much of colonial life and standards, while focusing on an important aspect of them. 
3228. Starkey, Marion L. The Devil in Massachusetts, a modern inquiry into the Salem witch trials. New York, Knopf, 1949. xviii, 310, vii p. $\quad 49-10395$ BFI576.S8 1949

"Selected bibliography": p. 301-310.

The Salem witch trials have already been mentioned under Burr's Narratives of the Witchcraft Cases (no. 3205), and they are also dealt with in several works appearing in the Literature section of this bibliography. Miss Starkey's account of the mass hysteria of 1692 in Salem is deliberately designed to have overtones for a later age. However, it is basically a straightforward and lively narrative of the trials and the events surrounding them, as well as some of the events that followed from them in later years. The work may also be considered a psychological study, for the author attempts to understand the mental functionings of those involved, and through psychology does make some of their strange behavior more comprehensible to a latter-day audience.

3229. Tolles, Frederick B. James Logan and the culture of provincial America. Boston, Little, Brown, 1957. 228 p. (The Library of American biography) 57-6439 Fr52.L85

Logan (1674-1751) was of Scottish descent, though born in Ireland. His father had been converted to Quakerism in 1671 , and the family underwent numerous difficulties because of their religion. In 1699 James Logan became secretary to William Penn, and the same year sailed with him to Pennsylvania. There he rose rapidly in political service, and for the rest of his life was a major factor in provincial affairs. He came as a scholar, and maintained wide interests throughout his life; he was also one of the leading American scientists of the period. However, he was best known as a leading spokesman for the conservative proprietary interest. In addition, he was for many years the leading peacemaker between the Whites and the Indians in the middle Colonies. Tolles' study traces this career in its many aspects of scholar, trader, diplomat, statesman, etc., and at the same time relates it to colonial life and government.

3230. Wallace, Paul A. W. Conrad Weiser, 16961760, friend of colonist and Mohawk. Philadelphia, University of Pennsylvania Press, 1945. xiv, 648 p. illus. $45-885^{8} \quad F_{152}$. W 4286

At the age of 13 Conrad Weiser was brought by his father from Württemberg in Germany to the New York frontier, and four years later he spent the winter with a Mohawk chief, acquiring the foundation of his unrivaled knowledge of Indian languages and customs. After ro years spent on his own farm in an Indian village, he transferred in I 729 to the Pennsylvania frontier, where his Iroquois connections gave him an exceptional influence in the Indian affairs of the province and made him, for two decades, the principal mediator between red man and white in the region. $\mathrm{He}$ is usually credited with the largest part in keeping the Iroquois Confederacy faithful to the English alliance. He shortly became a leading figure among the Pennsylvania Germans, furthering their efforts to retain their own culture by means of a Germanlanguage press. He also took a prominent part in German religious developments, deserting the $\mathrm{Lu}$ theran Church in which he was born for various Pietist departures, but ultimately returning to the Lutheran fold. During his last two decades he held a succession of appointments as magistrate and military officer under the provincial government, being almost the only German to do so. Mr. Wallace narrates his unique career in great detail, basing himself upon such primary sources as Weiser's own journals, in which many of his expeditions into the wilderness are recorded. Arthur D. Graeff's Conrad Weiser, Pennsylvania Peacemaker, published in 1945 as volume 8 of the publications of the Pennsylvania German Folklore Society, is on a somewhat smaller scale ( 406 p.), but equally based on original research.

3231. Wallace, Paul A. W. The Muhlenbergs of Pennsylvania. Philadelphia, University of Pennsylvania Press, 1950. $35^{8}$ p. illus. 50-5892 CS7r.M95 $195^{\circ}$

This book is a study of Henry Melchior Muhlenberg (I $11 \mathrm{I}-1787)$ and his three sons. The father came to America in 1742 as a Lutheran teacher and minister. The Lutheran religion continued to play a prominent role in the family history, as Muhlenberg, by regularizing lax procedures and developing a synodal organization, established an American center for the church. The father quickly established himself in America, and before long was head of one of the leading colonial families. In this respect, the book reflects not only life in Pennsylvania at that time, but the process of rapid Americanization, and even much of what lay behind the Revolutionary War. In that war one of the sons, Peter, left the pulpit to become a major general. Another son, Frederick Augustus, had a distinguished political career, and was the first speaker of the U. S. House of Representatives. The third brother, Henry, devoted himself to religion, but was also famous as president of Franklin (later Franklin and Marshall) College and as one of the leading botanists of the day. Thus the Muhlenbergs played a major part in the transition of America from colonialism to independence. 
3232. Wertenbaker, Thomas Jefferson. The founding of American civilization; the middle Colonies. New York, Scribner, 1938. $367 \mathrm{p}$. illus. 38-27360 Ei69.I.W 37

This history of the middle Colonies (New York, New Jersey, and Pennsylvania) preceded the author's volumes on the South and on Massachusetts, and had a considerably less worked-over subject matter. Here he describes the early settlements and their development. Much attention is devoted to architecture, while political matters are relatively slighted. Religious concerns, such as the affairs of Puritans in New Jersey and Quakers in Pennsylvania, are considered in so far as they influenced the establishment and development of communities. In this area diversity of language also played a prominent role and is well studied. The net effect is a close picturing of the everyday life in the middle Colonies, without much of the "grand stage" acting usually found in histories more concerned with political and military matters.

3233. Wertenbaker, Thomas Jefferson. The Old South; the founding of American civilization. New York, Scribner, 1942. xiv, 364 p. illus. $42-\mathrm{I}_{2} 3_{3}^{8} \quad \mathrm{~F}_{212}$. W5

This volume is a "study of Maryland, Virginia, North Carolina and South Carolina, for the most part during the colonial and early national periods," with the major emphasis on Virginia and Maryland. Topics such as "political history, church history, the plantation system, [and] slavery" have been neglected because of previous extensive studies of them. The book concentrates on the evolution of Southern society and the factors which went into its formation. To a large extent this is studied through the architecture of the period, "because it serves so admirably to illustrate the forces which created our civilization." Attention is also given to agricultural developments and to the tools and products of various classes of artisans. .

3234. Wertenbaker, Thomas Jefferson. The planters of colonial Virginia. Princeton, Princeton University Press, 1922. $260 \mathrm{p}$.

$$
\text { 23-3542 } \text { F }_{229} \text {. W } 493
$$

This history of colonial Virginia studies its economic foundations in such matters as the spread of population in relation to the cultivation of tobacco and transportation problems. Considerable attention is devoted to land grants, indentured servants, and the effects of slavery on types of tobacco grown, farming methods used, and the English home market. Extensive statistics are cited, and quit-rent rolls for the counties of Virginia in 1704-5 (p. 183-247) are printed in full. Thus the author impressively interprets Virginia as a to- bacco colony, whose development was first geared to the production of tobacco by white farmers; however, with the relatively late establishment of slavery in the colony, production shifted to low-grade tobacco mass-produced, the small farmer could no longer compete, and even the indentured servant became unprofitable to his master. In this way came about the splitting of Virginia society into an aristocracy and its slaves, the intermediate groups having fled the colony. Two earlier works of Dr. Wertenbaker, Patrician and Plebeian in Virginia, originally published in 1910, and Virginia under the Stuarts, $1607-1688$, originally published in 1914 , have recently been reprinted, along with this one, under the general title, The Shaping of Colonial Virginia (New York, Russell \& Russell, 1958. 239, 260, 27I p.).

3235. Wertenbaker, Thomas Jefferson. The Puritan oligarchy; the founding of American civilization. New York, Scribner, 1947. 359 p. illus. $\quad 47-30879 \quad$ F67. W4

This is a study of Massachusetts under Puritan government. Professor Wertenbaker refers to this regime as an oligarchy "since from its inception it was the government of the many by the few, a government by the comparatively small body of Church members." After reviewing the forces and events leading to the migration of the Puritans to Massachusetts, the author goes on to consider details of the establishment of the new governing communities. Matters such as the English manor prototypes for New England town designs are discussed, followed by a consideration of the new factors which inevitably transformed these prototypes in their practical application. While considerable attention is given to the activities of the clergy, the author also devotes space to such matters as architecture and literature. $\mathrm{He}$ closes with a discussion of the decline of Puritan power, which he sees as starting after the witchcraft trials, when the clergy had so disastrously lost their battle against rationalism.

3236. Wright, Louis B. The cultural life of the American Colonies, 1607-1763. New York, Harper, 1957. xiv, 292 p. illus. (The New American Nation series) $\quad$ 56-11090 E162.W89 Bibliography: p. 253-274.

In carrying out his aim "to provide a brief insight into the cultural developments of the thirteen British colonies which later became the United States," the author derives these developments from two main areas of colonial society: the agrarian aristocracies of Virginia, Maryland, South Carolina, and New York; and the aristocracy of trade which emerged in New England, New York City, 
and Philadelphia, and which owed its position to a widespread acceptance of "the gospel of work." The several elements of culture are topically and separately handled, from religion and education to science and the press, a treatment which has the disadvantage of blurring the considerable distinc- tions between the conditions of the 17 th century and those of the 18 th. The volume makes skillful use of the now huge body of monographic literature, much of it confined to the development of a single element in a single colony, and itemizes this in the considerable bibliography.

\section{E. The American Revolution}

3237. Abernethy, Thomas Perkins. Western lands and the American Revolution. New York, Appleton-Century for the Institute for Research in the Social Sciences, University of Virginia, 1937. $\mathrm{xv}, 4 \mathrm{I} 3$ p. maps. ([The University of Virginia Institute for Research in the Social Sciences. Institute monograph no. 25]) 37-20445 E210.Ar5

Bibliography: p. $37^{-}-39^{2}$.

A narrative account of the development of the trans-Appalachian West from the mid-1 8th century to the end of the Confederation period. The causal relationship of the Western land question to the American Revolution is held by the author to be not specific. The colonists' renunciation of British rule was the occasion of a rush to the West; while there is some discussion of the various land companies involved in the trans-Appalachian "land grab," this narrative is primarily concerned with the political consequences of the westward movement and with the policies of the Colonies, the Continental Congress, the several states, and the British Government which affected the acquisition of land in the West. Much of the discussion is devoted to the conflict of interests between the Virginians, with whom the author's sympathies appear to lie, and the Northern promoters, chiefly Franklin, Joseph Galloway, and other Pennsylvanians.

3238. Alden, John R. The American Revolution, I775-1783. New York, Harper, I954. 294 p. (The New American Nation series)

Includes bibliography.

$$
\text { 53-1 1826 E208.A35 }
$$

Though not entirely neglected, the description of the colonial home front is somewhat compressed, while the narrative of maneuver and battle, taking up more than half of the book, is set forth concisely and clearly. In addition to the military aspects of the Revolution, the British and European situations are more fully discussed than is customary in books on this scale. It is contended that British blundering in the years following 1763 brought on the revolt of the American Colonies, a revolt the colonials could probably have sustained alone, but which was hastened to a successful conclusion by European money and munitions, and finally by the avowed entrance of France and of Spain into the struggle. It is suggested that Trenton marked a turning point more significant than the British capitulation at Saratoga, or Howe's failure to crush the rebeilion in Pennsylvania. The American Revolution, the author concludes, "inspired and continues to inspire colonials of all colors to seek freedom from European domination."

3239. Bakeless, John E. Background to glory; the life of George Rogers Clark. Philadelphia, Lippincott, 1957. 386 p.

$$
\text { 56-11684 } \mathrm{E}_{207} \mathrm{C}_{5} \mathrm{~B}_{15}
$$

George Rogers Clark (1752-1818) was an heroic but tragic figure, who won the Old Northwest for the United States during the Revolution but died an embittered alcoholic, physically and mentally broken. In 1772 he made his first journey down the Ohio to the land which he later conquered with a few picked frontiersmen. His campaign, made in difficult terrain against heavy odds in favor of the British and their Indian allies, relied upon tactics of surprise. Clark held this territory for the United States for the duration of the War, but neither he nor his men received pay or supplies from the Continental Congress or from Virginia; his personal fortune and those of several other devoted patriots were expended in the effort, and Clark was saddled with a mass of debts which Virginia refused to assume. More or less desperate, after the Revolution he accepted a French commission to attack the Spanish territories west of the Mississippi, but nothing came of this plan. His subsequent attempts to obtain compensation or even relief were all futile, and Clark's personality deteriorated rapidly after 1805. James Alton James' edition of the George Rogers Clark Papers, $1777^{-1784}$ in the Virginia State Library (Springfield, Illinois State Historical Library, 1912-26. 2 v. Collections of the Illinois State Historical Library, v. 8, I9. Virginia series, v. 3-4) provides the basic documentation for Mr. Bakeless' biography as well as for his own Life of 
George Rogers Clark (Chicago, University of Chicago Press, 1928. 534 p.), a somewhat impersonal narrative which emphasizes the background of international relations and intrigue.

3240. Bakeless, John E. Daniel Boone. New York, Morrow, r939. $480 \mathrm{p}$.

$$
39-27625 \quad \mathrm{~F}_{454 \cdot \mathrm{B}_{724}}
$$

At head of title: Master of the wilderness.

"Bibliography and notes": p. [423]-465.

Daniel Boone (I734-1820) before his death had become to many the prototype of the American frontiersman. At the age of 12 or 13 years Boone was presented with a rifle by his father; thus began a career during which Boone was to be a hunter, Indian fighter, surveyor, militia officer, sheriff, magistrate, and legislator. Boone's life began on his father's farm in Pennsylvania and ended in Missouri, but it is Kentucky which hails him as its hero. Mr. Bakeless has made Boone the subject of a documented biography based on scattered original sources. Details of purely local interest have been largely disregarded. The Boone legend is subjected to a critical examination, but the Boone who emerges still bears the qualities which made him famous: courage, fortitude, endurance, and the ability to "think Indian."

324I. Brown, Robert Eldon. Middle-class democracy and the Revolution in Massachusetts, I69I-I780. Ithaca, Published for the American Historical Association [by] Cornell University Press, I955. $45^{8} \mathrm{p}$.

56-13503 F67.B86

Bibliography: p. 409-438.

The author believes that in Massachusetts the American Revolution was not what it has latterly been called: a dual struggle for independence from Britain and for a dissemination of democratic rights at home. It was a revolt against British control, but it was also a revolution intended to preserve a social order rather than to change it. Economics, politics, the educational system, religious organization, and the organization and political influence of the militia are all marshaled as evidence of the existence of an effective middle-class democracy in colonial Massachusetts. To a people thus accustomed to political, economic, and social democracy the danger in British imperial policies during the pre-Revolutionary period was soon apparent. The collision of this Massachusetts middle-class democracy and those policies, Mr. Brown asserts, explains the events of the years following 1760 in Massachusetts. It is suggested that the situation in Massachusetts was not fundamentally different from that in the other Colonies during the same period. A divergent view appears in Elisha P. Douglass' Rebels and Democrats; the Struggle for Equal Po- litical Rights and Majority Rule during the American Revolution (Chapel Hill, University of North Carolina [Press] 1955. 368 p.) which has rather a misleading title, since it is actually concerned with "the first democratic movement in America from its beginnings in the sporadic protests against the aristocratic domination of provincial governments up to its emergence as a political force during the formation of the first state constitutions" (I776), and closes with a brief explanation of why democracy made so little progress in the Nation as a whole during the Revolution.

3242. Burnett, Edmund Cody. The Continental Congress. New York, Macmillan, I94I. xvii, 757 p. 4 4I-20697 E303.B93 Bibliographical references included in Preface.

First assembled in September I774 as a consultative body of delegates from the Thirteen Colonies, the Continental Congress soon became the central government of the Revolutionary movement, and eventually of the union of free states it had called into being. Its provisional character lasted until I78I; the Articles of Confederation ratified in that year gave it a permanent basis but quite failed to endow it with adequate powers. This book is a study of the principal activities of the Continental Congress from its inception to its supersession by the government under the Constitution in 1789 . The Continental Congress is depicted as being at the very center of the Revolutionary scene, and the chronological arrangement of the narrative impresses on the mind the day-to-day problems with which the Congress was faced in that position. In apparent clumsiness and ineffectuality these problems were solved, merely debated, or ignored; however, the Continental Congress did bequeath to its successor a body of constructive legislation, principles, and practices built up during its precarious 15 years' existence. The basic source for the narrative was Letters of Members of the Continental Congress, edited by Dr. Burnett (Washington, Carnegie Institution of Washington, 1921-36. $8 \mathrm{v}$.), and it consists, in large part, of the extensive prefaces to those volumes reprinted or expanded.

3243. Dickerson, Oliver Morton. The navigation acts and the American Revolution. Philadelphia, University of Pennsylvania Press, I95I. $\mathrm{xv}, 344 \mathrm{p}$. 5I-I3206 E215.I.D 53

Bibliography: p. 302-335.

A discussion of representative American and British attitudes toward the Acts of Trade and Navigation, the provisions of those acts and their operation, and the role of the antitrade policy adopted by the British ministry after $176_{4}$ in the destruction of imperial unity. The author con- 
cludes that although in the span of a century a great and loyal colonial empire had been developed through the wise administration of the trade and navigation laws, that empire was destroyed within a decade when regulation for the sake of revenue rather than regulation for the sake of development became the object of British colonial trade policy. The resentment and disaffection caused by this shift to taxation and exploitation in the interest of an English political faction varied in different areas. Those in which the operation of the old practices was little disturbed by the new revenue program tended to remain loyal to their British allegiance; but in those trading centers in which the heavy taxation, excessive fees, and frequent seizures dictated by the new policy were concentrated, the movement for resistance and eventually for revolution took shape.

3244. Dorson, Richard M., ed. America rebels; narratives of the patriots. [New York]

Pantheon, 1953. 347 p. 53-6131 E275.A2D6

Fourteen selections, high spots "from the available abundance of Revolutionary narratives, memoirs, and journals." These Revolutionary chronicles, the compiler thinks, "form a true people's literature, rude and sturdy, marking the departure of American from English prose." The extracts include captivities with the British and the Indians, the misadventures of Loyalists, and social life in wartime Philadelphia, as well as glimpses of Lexington, Saratoga, Vincennes, and Yorktown. The bibliography lists 37 narratives as particularly worth the reader's attention. Rebels and Redcoats, by George F. Scheer and Hugh F. Rankin (Cleveland, World Pub. Co., 1957. 572 p.), draws upon a much larger body of personal sources from either side, but presents it, as a rule, in mere snippets embedded in a none-too-critical narrative provided by the authors.

3245. Frothingham, Richard. The rise of the Republic of the United States. I oth ed. Boston, Little, Brown, 1910. xxii, $640 \mathrm{p}$.

$$
\text { - I I-9466 E210.F96 }
$$

A work first published in 1872 , and frequently reprinted without change during the next four decades, which retains value, notwithstanding the immense amount of subsequent research, because of its clearly defined purpose and logical construction. The author had the single "object of tracing the development of the national life; a theme separate from the ordinary course of civil and military transactions, and requiring events to be selected from their relation to principles, and to be traced to their causes." The ideas of local self-government and of national union are followed from the forma- tion of the New England Confederation in 1643 to the inauguration of President Washington in 1789 . The work is solidly documented by quotations from and references to the printed sources available in 1872 . The author (1812-1880) was a worthy citizen of Charlestown, Mass., and was led to history by compiling its annals; he also wrote an extremely solid History of the Siege of Boston, $4^{\text {th }}$ ed. (Boston, Little, Brown, 1873. 422 p.) and a Life and Times of Joseph Warren (Boston, Little, Brown, 1865. xix, $55^{8}$ p.) which has not been replaced.

3246. Gipson, Lawrence $H$. The coming of the Revolution, $176_{3}-1775$. New York, Harper, 1954. xiv, 287 p. illus. (The New American Nation series)

Bibliography: p. 235-278.

54-8952 E209.G5

Concerning himself with British-colonial relationships during the period of political maneuver which followed the "Great War for the Empire" (175463), the author's thesis is that the American Revolution stemmed from the efforts of the British Government to administer more efficiently the much enlarged Empire, and from coincidental effort on the part of the American colonists, with the threat of hostile forces removed from their borders, to obtain a greater autonomy. The colonists found their field of political action restricted by a home government intent upon carrying out stricter policies. This, in turn, brought on a transformation of the colonial attitude from one of acquiescence in the traditional order of things to a demand for change. The conviction grew in the minds of the colonists that there were more disadvantages than advantages in their continuing to accept a subordinate position within the Empire. The growth of federalism and nationalism inevitably ended the period of political maneuver and brought on that of armed conflict.

3247. Gottschalk, Louis R. Lafayette comes to America. Chicago, University of Chicago Press, 1935. 184 p. $\quad 35^{-1} 5^{1} 3^{0} \mathrm{DC}_{14}$ 6.L.G6 Bibliography at end of each chapter.

3248. Gottschalk, Louis R. Lafayette joins the American Army. Chicago, University of Chicago Press, 1937. xv, $364 \mathrm{p}$.

$37-3884 \quad \mathrm{E}_{20} \mathrm{O}_{2} \cdot \mathrm{L}_{2} \mathrm{G}_{7}$

"Bibliographical notes" at end of each chapter.

3249. Gottschalk, Louis R. Lafayette and the close of the American Revolution. Chicago, University of Chicago Press, 1942. $45^{8}$ p. maps.

42-12337 E207.L2G68

"Bibliographical notes" at end of each chapter. 
3250. Gottschalk, Louis R. Lafayette between the American and the French Revolution (17831789) Chicago, University of Chicago Press, 1950. 46I p. 50-5286 DCi46.L2 $\mathrm{DC}_{59}$

"Bibliographical notes" at end of each chapter.

Born in 1757 , Marie Joseph Paul Yves Roch Gilbert du Motier, Marquis de Lafayette, grew up in a family which fortune and wise marriages had begun to favor. In 1774 , through his marriage to Marie Adrienne Françoise de Noailles, Lafayette became a protégé of the influential Noailles family. In 1777 he came to Philadelphia and was promptly commissioned major general by the Continental Congress. Thus began a career which made Lafayette during his lifetime and since a symbol of Franco-American coöperation and of liberalism. The first of Professor Gottschalk's volumes covers the pre-American years of Lafayette's life; the second is an account of the year and a half following his first landing in America and concludes with his return to France in I779; the remainder of Lafayette's American career is dealt with in the third volume; and the period $1783-89$, when Lafayette held a unique intermediary position between France and America, is the subject of the fourth and latest volume of this biography to be published. Étienne Charavay's Le Général La Fayette, 1757-1834 (Paris, Société de l'Histoire de la Révolution Française, 1898. 653 p.) contains an account of Lafayette's subsequent career, not altogether a prosperous or happy one, in which he took an active part in two French revolutions, and also made a second triumphant tour of the United States in 1824. The Lafayette myth has been scrutinized by Mr. Gottschalk, and his results indicate that Lafayette came to America in 1777 motivated less by liberal idealism than by a sense of frustration and dissatisfaction with affairs at home, by a desire for glory, and by the traditional French hatred of the English adversary. The symbol of Lafayette, the French noble enamored of American ideals of liberty, was the product of others who sought advantage in having Lafayette accepted as such, but once Lafayette became the symbol, he lived the role to such an extent that the symbol became the reality, and in later years, Lafayette deserved his reputation of being the outstanding liberal of his day. It is with this character development that Mr. Gottschalk's work is chiefly concerned. Other personal and idealistic links between the American and French Revolutions are discussed in this author's The Place of the American Revolution in the Causal Pattern of the French Revolution (Easton, Pa., American Friends of Lafayette, 1948. 22 p.). Another European who came to America to join with the colonists in their Revolution and later participated in a revolution in his native land,
Poland, is studied in two volumes by Miecislaus Haiman: Kosciuszko in the American Revolution (New York, Polish Institute of Arts and Sciences in America, 1943. 198 p.) and Kosciuszko, Leader and Exile (New York, Polish Institute of Arts and Sciences in America, 1946. 183 p.).

3251. Hendrick, Burton J. The Lees of Virginia; biography of a family. Boston, Little, Brown, 1935. 455 p. illus.

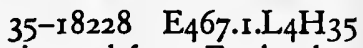

In 1640 Richard Lee emigrated from England to Virginia. In the colony he achieved in rapid succession the offices of clerk of the court, attorney general, sheriff of York County, secretary of state, and councillor. From Richard and his wife, Ann, descended a line whose members, not unlike the other families who comprised Virginia's oligarchy, looked upon public service as a birthright and a family responsibility. The author feels that the Lees illustrate that Virginia system at its most beneficent. The emphasis of the narrative is upon the activities of the members of the Lee family during the latter half of the 18 th century, their epic stage. With the fall of the Southern Confederacy the influence of the family ebbed, and the narrative ends here, with the observation that the work of the Lees survives in the State and Nation they did so much to build.

3252. Jameson, John Franklin. The American Revolution considered as a social movement.

Princeton, Princeton University Press, 1926. $157 \mathrm{p}$. 26-10868 E209.J33

"Lectures delivered in November 1925 on the Louis Clark Vanuxem Foundation."

The Revolutionary era is considered as a period of political and social reorganization tending in the direction of democracy. The author does not go into a recital of detail, but rather sketches in broad outline the changes which the American Revolution brought about in the social system of America with an emphasis on causes and effects. A wide variety of subjects are touched upon in these lectures: the status of persons, the land, industry and commerce, religion, and philosophy. Dr. Jameson believed that one cannot obtain a satisfactory view of any particular activity of men in the same country during the same period without examining their coexistent activities, for all such activities bear an intimate relationship one to another.

3253. Jensen, Merrill. The Articles of Confederation; an interpretation of the social-constitutional history of the American Revolution, I7741781. [Madison] University of Wisconsin Press,

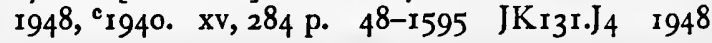


An account of the writing and ratification of the first Constitution of the United States, the Articles of Confederation, which regards the Articles as a constitutional expression of the philosophy of the Declaration of Independence, and a natural product of the Revolutionary movement within the American Colonies. The author emphasizes the conflicts arising out of the concrete issues which faced Americans during the Revolutionary period, and centered on group interests, social cleavages, and the relationships among the several states. The basic conflict, however, was that between radical and conservative elements, a struggle which unified the Revolutionary movements throughout the Colonies. Professor Jensen concludes that the fact that the Articles of Confederation were supplanted by another constitution is not proof of their failure; and that the failure of the Confederation government was brought about not by its inadequacy, but rather by the failure of the radicals to maintain the organization they had created to bring about the Revolution and the Confederation. The goal of self-government attained, the radicals "disintegrated with success," and the balance of political power shifted through the action of an aggressive conservatism which had learned not a little from its radical antagonists. A sequel is no. 3302 .

3254. Miller, Helen Day (Hill). George Mason, constitutionalist, by Helen Hill. Cambridge, Harvard University Press, 1938. xxii, 300 p. illus.

"Sources": p. [259]-262.

$$
3^{8-4827} \quad \mathrm{E}_{302.6 . \mathrm{M}_{45} \mathrm{M}_{5}}
$$

A member of Virginia's tidewater planter aristocracy, George. Mason ( $1725^{-1792}$ ), like others of his class, administered his plantation and served his parish and county and the neighboring town, in various official capacities, for most of his life. He served briefly in the Virginia House of Burgesses in 1759, and in the Virginia Assembly in 1786 . He was a member of the Virginia Conventions of 1775 and 1776 , and of the Federal Constitutional Convention in 1787 . He strongly opposed the ratification of the Constitution in the Virginia Convention of 1788 , among his objections being the absence of a declaration of rights, and the incorporation of the compromise between New England and the Southern States on the tariff and the slave trade. Mason's opposition to slavery was one of the constants of his long career. Though he appeared in the political arena, by nature he was retiring, and his great contribution as a constitutionalist was made in the role of an adviser, a political theoretician, and draftsman of important state papers, especially the Fairfax Resolves of 1774 and the Virginia Declaration of Rights of 1776 . The author portrays George Mason as epitomizing "the American Enlightenment as expressed through the democratic movement in Virginia."

3255. Miller, John C. Triumph of freedom, 17751783. With maps by Van H. English. Boston, Little, Brown, I948. xviii, 7 I 8 p.

Bibliography: p. [689]-705.

$$
\text { 48-6755 E208.M5 } 1948
$$

A comprehensive history of the Revolution which points out the continuity of American military experience. The author has placed an emphasis on military history, but he has not neglected the diplomatic, economic, political, and idealistic facets of the story; even propaganda is the subject of a chapter. Professor Miller's history is not entirely a tale of heroism and self-sacrifice, for there was much indifference and lethargy, as well as a morale which had been all but pulverized under the hammer of wartime inflation. Despite all of this, steadfast spirits, many of whom were in the Army, brought the Revolution to a successful conclusion. Aside from the victory attained, the value of the struggle of the "virtuous few" was, in the eyes of the author, the endowment of Americans with the principles and ideals which, however imperfectly realized, remain the goal of their collective endeavors. This volume is a sequel to the author's Origins of the American Revolution (Boston, Little, Brown, 1943. 519 p.), which puts heavy emphasis on the opposed outlooks of the conservative and radical wings of the Whig Party, and interprets the Declaration of Independence as a victory for the latter.

3256. Morgan, Edmund S. The birth of the Republic, 1763-89. [Chicago] University of Chicago Press, 1956. 176 p. (The Chicago history of American civilization) 56-11003 E208.M85

"Bibliographical note": p. 158-166.

A remarkably concise presentation of the political and constitutional essentials of the crucial quartercentury from the Peace of Paris to the ratification of the Constitution, which confines the war and diplomacy of the Revolution to one ro-page chapter because a separate volume on these aspects is in preparation for this very promising series. The antecedents of the Revolution are interpreted as the colonists' search for principles of government which would ensure the continuance of their real and present freedom. The "Critical Period," if less dark than once painted, was yet an exposure of the inadequacy of the Confederation to conduct foreign affairs, to regulate its finances, or even to maintain order. The constitutional movement was no conspiratorial reaction of the rich and well-born, but the work of a group of sincere libertarians, who compromised their disagreements over means in order to raise "a bulwark to protect what they had gained," 
as well as a base for further exploration of the principles of free government.

3257. Morgan, Edmund S., and Helen M. Morgan. The Stamp Act crisis; prologue to revolution. Chapel Hill, Published for the Institute of Early American History and Culture at Williamsburg, Va., by the University of North Carolina Press, 1953 . 3ro p. 53-1019o E215.2.M58

In an effort to insure contributions toward colonial defense from the American Colonies, the Grenville ministry in 1765 carried through Parliament the Stamp Act. Within a year the Act was repealed after a storm of protest had risen to meet attempts to enforce its provisions. The brief Declaratory Act which replaced the Stamp Act was no more acceptable to the Americans once they realized its meaning. This work aims to set forth the general issues which engendered and resulted from the passage of the Stamp Act. The method employed is that of viewing the situation through the eyes of Francis Bernard, the royal governor of Massachusetts, John Robinson, the royal customs collector in Narragansett Bay, Daniel Dulany, Maryland pamphleteer, Thomas Hutchinson, Massachusetts' lieutenant governor, and Jared Ingersoll and John Hughes, distributors of stamps for Connecticut and Pennsylvania, respectively. The significance of the Stamp Act crisis is held to be "the emergence, not of leaders and methods and organizations, but of welldefined constitutional principles. The resolutions of the colonial and intercolonial assemblies in 1765 laid down the line on which the Americans stood until they cut the connection with England. Consistently from 1765 to 1776 they denied the authority of Parliament to tax them externally or internally; consistently they affirmed their willingness to submit to whatever legislation Parliament should enact for the supervision of the empire as a whole."

3258. Mullett, Charles F. Fundamental law and the American Revolution, 1760-1776. New York, Columbia University Press, 1933. $216 \mathrm{p}$. (Columbia University. Faculty of Political Science. Studies in history, economics and public law, no. 385) 33-367 г H3r.C7, no. 385

Issued also as thesis (Ph. D.) Columbia University.

Bibliography: p. 198-2Ir.

During the decade and a half which preceded the American Revolution the colonists invoked the concept of "fundamental law" in their resistance to parliamentary authority in the realm of taxation and personal rights, and of internal legislation, and, finally, in any realm. The ideas advanced by the colonists to justify their position were not original; intellectual ammunition furnished by authorities from Sophocles to Blackstone was used by the colonists in their struggle to withstand British efforts to reduce their practical autonomy. This study aims to analyze the idea of fundamental law as it was employed by the American revolutionists. The first two chapters sketch the concepts held by those authors whom the leaders of colonial opinion quoted or referred to in their writings. The remainder of the work contains an examination of the ideas of fundamental law current in the Colonies. Dr. Mullett had previously reprinted, with an introduction, five pamphlets by one of the earliest men to give the Patriot cause a theoretical basis, in Some Political Writings of James Otis (Columbia, University of Missouri, 1929. 2 v.).

3259. Nevins, Allan. The American States during and after the Revolution, 1775-1789. New York, Macmillan, 1924. xviii, $728 \mathrm{p}$.

Bibliography: p. 679-69r. 24-2394 I $\quad E_{3} 03 . N_{52}$

A conspectus of State history from the beginning of the Revolution until 1789 which covers a wide range of topics: the Thirteen Colonies and their governments, the origin and early growth of the independent State governments, the development and revision of State constitutions, State politics, financial and social developments, the relation of the States to one another and to the central government, and the early settlement of the West. Professor Nevins finds that the States served a purpose even more important than that of providing a basis for the United States' system of dual government: they exercised a conservative function. They were the repositories of the political and institutional experience of the colonists. At the same time, new theories applied to old practices at the State level often resulted in fruitful experimentation. The success of the American people in forming and controlling their State governments gave them an increasing measure of self-confidence in their ability to control their political destiny. A full index increases the usefulness of this volume.

3260. Niles, Hezekiah. Principles and acts of the Revolution in America: or, An attempt to collect and preserve some of the speeches, orations, \& proceedings, with sketches and remarks on men and things, and other fugitive or neglected pieces, belonging to the Revolutionary period in the United States. Baltimore, Printed and published for the editor, by W. O. Niles, 1822 . $495 \mathrm{p}$.

$$
\text { 2-1934I E203.N69 }
$$

The compiler, Hezekiah Niles (I777-1839), was the editor and publisher of Niles' Weekly Register, in which such a collection was first suggested in 
November 1816 , and contributions solicited. It was proposed to present "an acceptable gift to the American people, by rescuing from oblivion a great variety of fleeting, scattered articles," belonging to the history of the Revolution, "whilst its feelings were fresh upon the heart and understanding of our heroes and sages." The result is a miscellany of quite various materials, which gives a vivid view of the Patriot cause as it appeared to its supporters and to their immediate descendants. Here are the ideas by which the Revolution was justified, and the rhetoric in which they were habitually clad. Since Niles set his materials up in print as they came in, his book is a frightful jumble which a preliminary Index is quite inadequate to control. Anticipating the centennial of the Revolution, Hezekiah's grandson, Samuel V. Niles, obtained recommendations from a surprising number of the "prominent statesmen and jurists" of the Gilded Age, and brought out a new edition: Centennial Offering. Republication of the Principles and Acts of the American Revolution (New York, A. S. Barnes, 1876. 522 p.). Since the contents have been rearranged, in chronological order under each colony or other heading, and the print and paper are much superior, it is considerably more convenient to use than the original edition.

3261. Robson, Eric. The American Revolution in its political and military aspects, $1763-1783$. London, Batchworth Press, 1955. 254 p.

55-147 I 2 E208.R6

An inquiry into the causes of the American Revolution and of the British failure to subdue the colonial rebellion, by an English scholar whose death in 1954 at the age of 36 caused widespread regret. Heightened by the failure of the British Government to understand or adjust to the American position, a conflict of political ideas, not "tea and taxes," is held to be the basic cause of the Revolution. By 1775 Great Britain and the Colonies had become so divergent in their notions of their proper relationship to each other that only separation or conquest remained as possible solutions of the colonial problem. A lengthy discussion of the British military performance in the Revolutionary War points out that a failure to adjust to strategical circumstances, a lack of determination, and low morale all tipped the scales against the mother country. A further handicap was the cumbersome operation of the government of 18 th-century Britain. Nevertheless the dominating factor in Britain's defeat was her political isolation resulting from the peace settlement of 1763 .

3262. Schlesinger, Arthur Meier. The colonial merchants and the American Revolution,
1763-1776. New York, Facsimile Library, I939. 647 p. $\quad 39-12039 \mathrm{HF}_{3025 . S_{3}} 1939$. Bibliography: p. 614-629.

Seeking a relaxation of commercial restrictions imposed by the parliamentary legislation of $1764-65$, the merchants of the North American commercial provinces, Professor Schlesinger maintains in this very influential book, originally published in 1918 , were the instigators of the first discontents in the Colonies. The events of the years $1767-70$ brought the mercantile interests to an even sharper realization than before of the growing power of the radical elements of colonial society; however, their withdrawal to conservatism was delayed while they allied themselves with the radicals to defeat the purposes of the East India Company. The outcome convinced the merchants, as a class, that their future welfare depended upon the maintenance of British authority. Some of them, hoping to control the situation from within, remained within the radical movement. With the meeting of the First Continental Congress, others threw aside the cloak of radicalism, and some of these became active Loyalists. With the outbreak of hostilities, economic interest caused many merchants to follow the line of least resistance and profess adherence to the colonial cause; others, anticipating a British victory, openly cast their lot with Great Britain. Following the Revolution, however, the mercantile interests once more closed their ranks and became a potent factor in the conservative counter-revolution which led to the adoption of the Constitution.

3263. Tyler, Moses Coit. Patrick Henry. Boston, Houghton, Mifflin, 1887. 398 p. (American statesmen, edited by J. T. Morse, Jr. [v. 3])

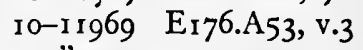
"List of printed documents": p. 424-429.

After an unpromising start in life Henry (1736I799) turned to the law and won immediate success practicing in upcountry courts; his fame spread to the whole province of Virginia when his legal eloquence won the "Parson's Cause" from the established church in $176_{3}$. Two years later he entered the House of Burgesses from Hanover County and at once won equal fame as political orator by a famous speech opposing the Stamp Act. His contemporaries regarded his rhetorical powers with awe, admiring or grudging, and his fame as the foremost orator of the American Revolution is secure. As a spokesman for upcountry interests and as a leader who took an uncompromising line against British claims, Henry won an unrivaled popularity with the electorate, and was chosen first Governor of the State of Virginia. Neither his stubborn opposition to the adoption of the Federal Constitution, which 
he painted as a new engine of despotism, nor his adhesion to the Federalist Party in the course of the next decade, succeeded in diminishing his prestige with the people of his State. Tyler's life, one of the few volumes in the American statesmen series which has not been overshadowed by the productions of latter-day scholarship, is a sterling piece of research, organization, and writing, perhaps too favorable to some of Henry's later tergiversations. Robert Douthat Meade's Patrick Henry: Patriot in the Making (Philadelphia, Lippincott, 1957. 431 p.) is based on an enormous amount of research in scattered primary sources, especially in Virginia courthouses, and it is not his fault if they make no great additions to the story. It carries the narrative to 1775 , and is to be followed by a second and concluding volume.

3264. Van Doren, Carl C. Secret history of the American Revolution. New York, Viking Press, r941. xiv, 534 p.

"General bibliography": p. [496]-499.

$$
4 I-24478 \quad E_{77} \cdot V_{23} \quad \text { I94I }
$$

A detailed narrative, based largely on the Clinton papers in the Clements Library, of British attempts to subvert loyalty to the Revolutionary cause and to draw adherents of all ranks into service as secret agents of the Crown. British exploitation of the doubts, hardships of service, defeatism, and personal ambition, which plagued many Americans during this time, did succeed in many instances, but failed in quite as many. The chief instance of success was the Arnold-André plot, and the maneuvers and negotiations necessary to tempt Arnold to treason are reconstructed in great detail. Other cases of treason are treated proportionately to the gravity of their effect upon the Revolution. Counterespionage by the revolutionists and the unswerving loyalty of many men served to defeat the British "fifth column." The postwar fates of some of the traitors are traced. Quotations from letters, memoirs, and courtroom testimony are employed by the author to convey the type of thinking and personality which led Americans either to oppose or support the Revolution. Another work by $\mathrm{Mr}$. Van Doren which throws light on a significant incident of the Revolution is Mutiny in January (New York, Viking Press, 1943. 288 p.). The unsuccessful mutinies of the Pennsylvania and New Jersey Line in January $178 \mathrm{I}$ are narrated in this welldocumented study of administrative neglect and British intrigue aimed at inducing the mutineers to desert.

3265. Van Tyne, Claude $H$. The causes of the War of Independence, being the first volume of a history of the founding of the American Re- public. Boston, Houghton Mifflin, 1922. 499 p. 22-16374 E210.V27 EI78.V28, v. I

3266. Van Tyne, Claude $H$. The War of Independence; American phase, being the second volume of a history of the founding of the American Republic. Boston, Houghton Mifflin, r929. 518 p. 29-23482 Er78.V28, v. 2

E208.V28

The first title is a consideration of the growth of the spirit of independence which made Americans discontented with their subordinate position in the British Empire. Factors in this growth, political, economic, social, and religious, are discussed. What political liberty the American colonists enjoyed was inherited, to a great extent, from the mother country. Furthermore, conditions of life on this frontier of the British Empire tended to encourage democratic views and to resist any backward political step of the more conservative homeland. Further, just as British political progress outstripped that of other European nations, so had the American Colonies advanced politically beyond England. The narrative ends with the outbreak of hostilities at Lexington and is continued in The War of Independence; American Phase. Until Burgoyne's surrender at Saratoga, and the subsequent conclusion of the alliance with France, the Revolution had been, outwardly at least, a family affair for the most part localized along the Atlantic seaboard of North America. With the entry of France the complexion of the struggle was transformed. The earlier limited struggle is all the author was able to describe before his death in 1930. He had previously contributed a one-volume narrative to the American Nation series: The American Revolution, 1776-1783 (New York, Harper, I905. xix, 369 p).

3267. Van Tyne, Claude $H$. The Loyalists in the American Revolution. New York, P. Smith, 1929. $360 \mathrm{p}$. 30-4956 E277.V242

First published in 1902.

The case for the Loyalists, or Tories, is sympathetically advanced in this documented account of those Americans whose rooted conservatism impelled them to resist the movement for American independence. To the author, loyalty to King and homeland was the "normal condition" in the Colonies, and the Tories, largely made up of landed gentry, merchants, Church of England clergy, local officials, and professional men, had no recourse but to preserve the status quo which had given them, rather than the Whigs, prosperity and royal favor. Contemporary journals and memoirs are used to create a clear picture of the "just and natural" stand of the Tories, as they initially protested against the 
Revolution on their home grounds, and then became underground agents, or served in the armies of the Crown, or fled to New York City or to England under the pressure of mobs or of laws designed to deprive them of civil rights. The life of the exiles in New York is treated at length, and may be compared with the lot of those who took refuge in England as described in Lewis Einstein's Divided Loyalties: Americans in England during the War of Independence (Boston, Houghton Mifflin, I933. xvi, 469 p.).

3268. Washington, George. Basic writings of George Washington, edited with an introd. and notes, by Saxe Commins. New York, Random House, 1948. xvii, 697 p. $\quad 4^{8-7853} \quad$ E $_{312.72} \quad 1948$

3269. Freeman, Douglas Southall. George Washington, a biography. New York, Scribner, 1948-57. 7 v. illus. $48-8880 \quad$ E312.F82 $^{2}$

Contents.-v. I-2. Young Washington.-v. 3 . Planter and patriot.- v. 4. Leader of the Revolution.-v. 5. Victory with the help of France.v. 6. Patriot and President.--v. 7. First in peace.

3270. Little, Shelby (Melton). George Washington. New York, Minton, Balch, 1929. $4^{8}$ I p.

Bibliography: p. $465-473$.

327r. Stephenson, Nathaniel Wright, and Waldo Hilary Dunn. George Washington. New York, Oxford University Press, 1940. 2 v. illus. 40-27358 $\mathrm{E}_{312 . \mathrm{S}_{2}}$

After the death of Dr. Stephenson in 1935 the incomplete work was revised, and the last seven chapters written by W. H. Dunn.

Contents.-v. I. I732-1777.-v. 2. I778-1799.

Dr. Freeman's biography of Washington (1732I799), the seventh volume of which was produced after his death by his assistants, John Alexander Carroll and Mary Wells Ashworth, is a large-scale treatment of the commander-in-chief of the Continental Army and the first President of the United States. More than a detailed account of the life of a Virginia planter, a full record of a public man, and a military biography, these seven volumes include a thorough examination and discerning appraisal of the Washington legend. The result is a biography which takes into account every phase and feature of Washington including his background, his behavior, and his development in private and public life. Above all, this is a study of the growth of a personality, not an account of the static existence of a paragon born. For those not wishing to cope with the mass of detail which
Freeman includes in his work, shorter narratives are those of Shelby Little in one volume and of Nathaniel Wright Stephenson in two. Basic Writings of George Washington, edited by Saxe Commins, is an effort to convey the main events of the period from 1753 to 1796 as perceived at the time by Washington. The 242 items contained in this collection were derived from The Writings of George Washington from the Original Manuscript Sources, $1745^{-1} 799$ (Washington, U. S. Govt. Print. Off., 193I-44. 39 v.). Prepared under the direction of the George Washington Bicentennial Commission and edited by John C. Fitzpatrick, this collection of approximately $\mathrm{I} 7,000$ items includes every Washington writing known up to the time that the last volume went to press, with one important exception: The Diaries of George Washington, 17481799 (Boston, Houghton Mifflin, 1925. 4 v.), also edited by Dr. Fitzpatrick. This concise and unintrospective record was not kept during the Revolution, and, unfortunately, is quite irregular during the Presidency. Two examples of studies of specific aspects of Washington's life are Samuel Eliot Morison's The Young Man Washington (Cambridge, Mass., Harvard University Press, 1932. 43 p.), and Charles Henry Ambler's George Washington and the West (Chapel Hill, University of North Carolina Press, 1936. 270 p.); the latter work is a discussion in some detail of the more important aspects, political, economic, and military, of Washington's interests and activities in the trans-Appalachian West, which he was almost the only statesman of his day to visit. The evolution of Mount Vernon, the home of Washington, from family seat to national shrine, including many details of the day-to-day activities of the United States' first first family, is described in Paul Wilstach's Mount Vernon, Washington's Home and the $\mathrm{Na}$ tion's Shrine (Garden City, N. Y., Doubleday, Page, 1916. xvi, 301 p.).

3272. Wrong, George M. Canada and the American Revolution; the disruption of the first British Empire. New York, Macmillan, 1935. 497 p.

"Authorities": p. 479-489.

The period under consideration extends from $176_{3}$ to the close of the American Revolution. Discussed are French Canada and its people, the military operations of the Revolution, the demands of the American peace commissioners as they affected Canada, and the problems of the American Loyalists. In addition, political, economic, and social conditions in Britain and the Colonies are subjected to a critical analysis. This Canadian scholar attributes much 
of the responsibility for the Revolution to British "stupidity and arrogance." Emphasis is placed upon the French culture of the Canadians, and, aside from provincial tactlessness on the part of the Americans who invaded Canada in 1775 , the reason as- signed for the failure of the Americans to woo successfully their northern neighbors is the Canadians' ingrained respect for authority, "derived less from loyalty to George III than from monarchical France and Catholic Rome."

\section{F. Federal America (1783-1815)}

3273. Abernethy, Thomas Perkins. The Burr conspiracy. New York, Oxford University Press, 1954. 301 p.

Bibliography: p. $276-284$.

54-6907 $\mathrm{E}_{334 . \mathrm{A} 6}$

Set against the background of the period of unrest following the formation of the Union is this detailed account of a conspiracy hatched by the pre-

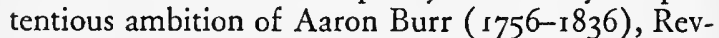
olutionary soldier, lawyer, United States Senator, and third Vice President of the United States. Burr envisioned himself as being at the head of an empire vaster than that which he had lost by a single vote in $180 \mathrm{r}$. From 1804 Burr's major objective was the separation of the Western States from the Union, with New Orleans as the capital and the Alleghenies as the eastern boundary of the new political unit. Also involved were filibustering expeditions into the Floridas and Mexico, and the settlement of the Bastrop lands. Ever an opportunist, Burr presented to anyone who would listen to his scheme only such purtions of it as would appeal to him as a prospective conspirator. The success of the conspiracy, which, Professor Abernethy asserts, next to the Confederate War "posed the greatest threat of dismemberment which the American Union has ever faced," depended upon disaffection in the West, the intrigues of certain Eastern Federalists, the adherence of various land speculators, soldiers of fortune, and office seekers, a war between the United States and Spain, and help from Great Britain. The basic patriotism and common sense of the frontiersmen, along with the defection of Burr's fellow conspirator, James Wilkinson, doomed Burr's plot, which ended in the farcical treason trial of 1807 at Richmond.

3274. Adams, Henry. History of the United States of America during the administration of Thomas Jefferson. With introd. by Henry Steele Commager. New York, A. \& C. Boni, 1930. 2 v. maps. ([His History of the United States of America, v. I-2 ]) 30-10226 E302.1.A24, v. I-2 Contents.-I. 1801-1805.-2. 1805-1809.

3275. Adams, Henry. History of the United States of America during the administration of James Madison. New York, A. \& C. Boni, 1930. $2 \mathrm{v}$. ([His History of the United States of America, v. 3-4]) 30-10227 E302.I.A24, v. 3-4 Contents.-3. $1809-1813 .-4$. I813-1817.

Adams (1838-19r8), who is also discussed under Literature (nos. 688-700) and in the preceding section on Historiography (no. 3055), was in 1870 more or less drafted by Harvard College to teach medieval history, of which he knew nothing. During the academic year of 1874-75 Professor Adams added a course in American history, and found the periods in which his own grandfather and greatgrandfather were major figures so absorbing that after two more terms he abandoned pedagogy for historical research and writing. The first fruit of his new interest was his edition of Documents $R e$ lating to New-England Federalism, $1800-1815$ (Boston, Little, Brown, I877. 437 p.). He had already begun searching and procuring transcriptions from national archives, and his History of the United States was evidently conceived by this time. It was, however, delayed, first by Adams' concentrated work on the Gallatin papers begun in 1877 (see no. 33Ir) and by the shattering effect upon him of his wife's breakdown and suicide in 1885 . Pulling himself together after a long trip to Japan, he worked intensively at the History, which was published, in three installments amounting to nine volumes, during $1889-9$ I. A completely individual work in outlook, style, and organization, it has fascinated three generations of students. The famous first six chapters, which survey the state of American society in 1800 , were doubtless inspired by the equally famous third chapter of Macaulay's History of England; the concluding four chapters, which view the social changes of the intervening 16 years in a balancing assessment and an agnostic temper, had no such model. The detailed narrative which intervenes is largely concerned with political, diplomatic, and military events; but those who complain of its deficiency in economic matters overlook the author's special competence in the realm of finance. The chapters on foreign relations are written on a genuinely international level, for Adams had thoroughly familiarized himself with Napo- 
leonic Europe. His sympathies, it has been pointed out, lie with the Northern Democrats; the Southern wing is ironically treated, while the Federalists are castigated. The essence of the History may be said to lie in its contrasting of the requirements of American nationhood with Jefferson's ideal of weak government, and in underlining the confusion to which the latter inevitably worked out in practice. "Already in 1817 the difference between Europe and America was decided." "American character was formed, if not fixed," but circumstances and not national policy had brought about this result.

3276. Adams, John. Works. With a life of the author, notes, and illus., by his grandson, Charles Francis Adams. Boston, Little, Brown, 1850-56 [v. I, I856] Io v. 8-19755 E302.A26

3277. Adams, John. Familiar letters of John Adams and his wife Abigail Adams, during the Revolution. With a memoir of Mrs. Adams. By Charles Francis Adams. New York, Hurd \& Houghton, I876. xxxii, $424 \mathrm{p}$.

$$
4^{-16982} \quad E_{322 .} A_{518}
$$

3278. Chinard, Gilbert. Honest John Adams. Boston, Little, Brown, 1933. 359 p. illus. 33-32200 $\mathrm{E}_{322 . \mathrm{C}_{47}}$

3279. Haraszti, Zoltán. John Adams \& the prophets of progress. Cambridge, Harvard University Press, 1952. 362 p. facsims.

$$
5^{2-5030} \mathrm{E}_{322 . \mathrm{H}_{3}}
$$

Born on a Braintree, Massachusetts, farm, John Adams ( $1735-1826$ ), after attending Harvard and casting aside aspirations to a career in the Christian ministry, served for a short while as a Worcester schoolmaster, and then turned to the practice of the law. Despite his social conservatism and his avoidance of any step which would tend to compromise his position as a legal practitioner, Adams became a leader of the Patriots and was sent to Philadelphia as a member of Massachusetts' delegation to the First Continental Congress. In the Second he soon became a wheelhorse of the Revolution, which took him out of his provincial surroundings and made him a national figure. Before retiring from public life in I8or, Adams served as a diplomatic representative of the United States in Paris, The Hague, and London, and then as first Vice-President and second President of the new Nation. In Honest John Adams, Dr. Chinard focuses his attention not on Adams' politics, but on the personality and beliefs of the self-made New England aristocrat, John Adams. Adams' defense of Captain Preston following the Boston Massacre was inspired by his fear of ochlocracy, but he was no less critical of rule by the few. He eventually incurred the enmity of both the radicals and their antagonists, and was eliminated from active politics. The author regards Adams as "the most realistic statesman of his age." A recent penetrating study is Stephen Kurtz' The Presidency of John Adams; the Collapse of Federalism, 1795-1800 (Philadelphia, University of Pennsylvania Press, 1957. 448 p.). The author does not view the Adams administration as the kind of negative hiatus which it is usually made to appear. He concludes that Jefferson's elevation to the Presidency "promised that political liberty might be assured of a healthy environment within which to grow, but it did not end the threat to liberty in America of that era. John Adams must be credited with having destroyed the instrument of repression and the influence of its champions [ the Provisional Army and the Hamiltonian Federalists] months before the election took place. His struggle for independence in 1799 and 1800 was no less significant or remarkable than that in which he had taken a leading part during 1775 and 1776 . In a very real sense, Adams' bold conduct allowed Jefferson to say with plausibility, 'We are all republicans-we are all federalists.'" John Adams' library, originally presented to the town of Quincy, has been deposited in the Boston Public Library since I893. More than a hundred of its volumes contain Adams' marginal notes, and these marginalia are the main substance of Mr. Haraszti's John Adams \& the Prophets of Progress. Excerpts from the texts upon which Adams commented are so arranged as to render the whole a running dialogue between him and the individual authors. The product is a rebuttal of the philosophes and a review of the age of the French Revolution and Napoleon. Mr. Haraszti has added accounts of the works upon which Adams commented, and upon their authors, ranging from Bolingbroke to Condorcet. In addition, there are chapters on Adams as a book collector and as a political theorist. In conclusion the author calls for a more general acceptance of Adams as a great political thinker. A new edition of the Adams papers is in prospect, but the standard one remains The Works of John Adams in ten volumes, edited by his grandson, Charles Francis Adams, over a century ago. Included in it are Adams' diary, sections of his autobiography, his longer essays, official papers, and personal letters. An indispensable supplement is the same editor's Familiar Letters of John Adams and His Wife Abigail Adams, during the Revolution, a rich commentary on family and Revolutionary affairs. There are some recent abridgments: George A. Peek's convenient edition, The Political Writings of John Adams: Representative Selections (New York, Liberal Arts Press, 1954. 223 p.), 
reprints the more cogent portions of Adams' rather diffuse theoretical writings on politics, with an introductory essay emphasizing his basic conservatism. The Selected Writings of John and John Quincy Adams, edited by Adrienne Koch and William Peden (New York, Knopf, 1946. xxix, 4I3, xxix p.), are taken from diaries, autobiographies, public papers, and letters; many of the selections are prefaced by notes explaining their contents and the circumstances which produced them, and there is an introductory biographical essay.

3280. Baldwin, Leland D. Whiskey rebels; the story of a frontier uprising. Decorations by Ward Hunter. [Pittsburgh] University of Pittsburgh Press, 1939. $326 \mathrm{p}$.

39- II763 $\quad \mathrm{E}_{3} \mathrm{I}_{5} \cdot \mathrm{B}_{52}$

"This book is one of a series relating western Pennsylvania history, written under the direction of the Western Pennsylvania Historical Survey sponsored jointly by the Buhl Foundation, the Historical Society of Western Pennsylvania and the University of Pittsburgh."

Bibliography: p. [303]-316.

Taxes on alcoholic beverages have been a regular resort of American public finance, but the excise act which Hamilton induced the Congress to pass in I79I bore with uncommon hardship upon the small farmers of western Pennsylvania. They had no marketable commodity save the product of their own small stills, and their differences with the local collectors of excise could be settled only by judicial process in the Federal court at distant Philadelphia. Three years of strenuous agitation succeeded in producing a relaxation of the latter rule, but lastminute prosecutions under the old rule touched off a crisis and some violence at midsummer of 1794 . Hugh $\mathrm{H}$. Brackenridge and Albert Gallatin succeeded in persuading the potential rebels to disperse and adopt peaceful means. While there was no rebellion, there was also little submission, and the President mobilized a little army of 13,000 militia from four states, which marched to Pittsburgh and occupied the western counties for a few weeks while conspicuous offenders were rounded up-to be later acquitted by the courts. Professor Baldwin's spirited narrative of this revealing episode is wholly in sympathy with the westerners, and he goes so far as to suggest that the whole affair was engineered by Hamilton in order to strengthen and perpetuate the Federalist regime.

3281. Bowers, Claude G. Jefferson and Hamilton; the struggle for democracy in America. Boston, Houghton Mifflin, 1933. xvii, 531 p. illus.

Bibliography: p. [513]-518.
A vivid description of what the author, a devoted Jeffersonian, defines as the struggle between the forces of democracy and aristocracy, which marked the first 12 years of the existence of the United States. Hamilton and Jefferson were the titans of the struggle, but behind them were others not neglected by Mr. Bowers. American society, with its drawing rooms, coffeeshops, and taverns, together with the more patently political arenas of the halls of the Congress, mass meetings, and public dinners, was the wellspring of this battle of fundamentals. To explain and give meaning to the controversy over the shaping of the Republic it is described complete with its prejudices and passions. To be sure, Federalist blackness is usually Stygian, and Democratic whiteness dazzling, and all the dramatic elements of the situation are much exaggerated. The work, originally published in 1925 , is based upon printed sources, but gains color from its numerous quotations from contemporary newspapers.

3282. Brant, Irving. James Madison. Indianapolis, Bobbs-Merrill, I94I-57. 5 v. $4^{1-19279} \mathrm{E}_{342 . \mathrm{B} 7}$

Contents.- - [v. I] The Virginia revolutionist.[v. 2] The nationalist, $1780-1787 .-[v .3]$ Father of the Constitution, $1787-1800$.- [ v. 4] Secretary of State, I800-1809.-[v. 5] The President, I809-1812.

3283. Hunt, Gaillard. The life of James Madison. New York, Doubleday, Page, 1902. 402 p. 3-421 I E342. $\mathrm{H}_{943}$

On his retirement from the Senate of the United States, William Cabell Rives (I793-I868), who had been a protégé of Jefferson, embarked upon a largescale life of James Madison (1751-1836). Rives' work on his History of the Life and Times of James Madison was interrupted by his second mission to France and by the secession crisis, but before his death he completed three large volumes (Boston, Little, Brown, 1859-68) which reached 1797. Madison's papers were purchased from Dolley Madison by the Government in several installments, leading to two official publications from them, in 3 volumes in 1840 and 4 in 1865 ; a more recent edition which does not, however, include everything in the older ones, is that of Gaillard Hunt: The Writings of James Madison (New York, Putnam, I900-10. 9 v.). Hunt published The Life of James Madison while this edition was in progress; it is a lucid and balanced treatment of its subject down to I8or, but has less than a hundred pages on Madison in Washington. Edward McNall Burns' James Madison, Philosopher of the Constitution (New Brunswick, N. J., Rutgers University Press, 1938. 212 p.) is a concise formulation of Madison's political views, 
setting his contributions to the Constitution against his theories of the State and of democracy, and indicating his relationship to other 18 th-century theorists. Rives' project of a large-scale life has been revived in our day by Mr. Irving Brant, a MiddleWestern newspaperman who was led to constitutional questions and thence to Madison by President Franklin Roosevelt's plan to change the Supreme Court. Five volumes published over a I6-year period have reached the Declaration of War in 1812 . Their reception has been mixed: some critics are obviously delighted with the author's trenchant espousal of the Democratic-Republican position; others find the work wearying in its incessant accumulation of detail, and the two latest volumes, which justify Madison's diplomacy on all occasions, have met with some incredulity. All regard the work as based on vast research in primary sources, and as providing the only detailed analysis of Madison's career after 1787 .

3284. Cresson, William P. James Monroe. Chapel Hill, University of North Carolina Press, 1946. xiv, 577 p. illus. $\quad 47-652 \quad \mathrm{E}_{372 . \mathrm{C}_{7}}$ "List of references": p. 549-559.

James Monroe (1758-1831) was the last and least endowed of the "Virginia dynasty," but by no means the least successful. Following his service as an officer in the Revolution, Monroe, impelled by financial necessity and fortunate in his gifts of honesty, ambition, influential sponsorship, and the ability to work hard and make friends, entered upon a career of public service which led him into a wide variety of offices, state and national, legislative and executive, at home and abroad. Though he was not particularly fortunate in his diplomatic missions, circumstance was not consistently favorable to success. When the Presidency was bestowed upon him in 1817 , his industry and judgment, the advice of such friends as Jefferson and Madison, and a strong Cabinet all combined to launch a most successful administration. Though his career in public office was lengthy and varied, the fifth President of the United States is perhaps best remembered for the "doctrine" of foreign policy which bears his name. This biography, which was published I 4 years after Dr. Cresson's death, and received its final revision from other hands, grants to Monroe the genius of apprehending the opportune moment for the formal enunciation of a principle which previously had been simply a matter of American public opinion and aspiration.

3285. Dauer, Manning J. The Adams Federalists. Baltimore, Johns Hopkins Press, I953. xxiii, 38I p. maps. 53-III7I E321.D23
This study of the supporters of John Adams within the Federalist Party is a detailed account of political circumstances and events. Professor Dauer's extensive geographical analysis of votes on major issues in the House of Representatives from March 1796 to May I802 supports his main thesis: the Federalist majorities which put through the Constitution and established the Federal Government depended upon an alliance between commercial districts and agricultural ones-especially those which produced cash crops for the international market. Through the manipulation of Hamilton and the "High-Federalists," Federal policy became increasingly the servant of commercial interests. During the French crisis of 1798-99, expensive armaments were put on foot which could have been justified by war, but without it could only cost the Federalist Party the support of overtaxed agrarians. The war which the Hamiltonians desired was avoidable, and Adams, who had wanted neither the regiments nor the taxes, made peace with France. Between Adams' lack of political finesse and Hamilton's apparent lack of common honesty, the Federalist Party went to the wall, and Jefferson led a united agrarian majority.

3286. Dodd, William E. The life of Nathaniel Macon. Raleigh, N. C., Edwards \& Broughton, 1903. xvi, 443 p. 4-456o E302.6.Mi7D6 "Sources of information": p. xvi.

Macon (1758-1837), after serving an apprenticeship in North Carolina politics as an adherent of the upcountry democracy led by Willie Jones, and fighting the adoption of the Constitution, sat continuously for nearly $3^{8}$ years in the Congress of the United States-in the House from 1791 to 1815 , and in the Senate until his voluntary retirement from public life at the close of 1828 . From the time that party divisions became discernible, he was among the most influential of the Democratic-Republicans, and he was considerably more representative of the Southern rank and file, and of the opinions which came to prevail in the party as a whole, than was its leader, Thomas Jefferson. To Macon strict construction of the Constitution became a kind of fetish. The interests of agriculture he regarded as paramount, and those of commerce as so antipathetic to them that no navy need be maintained to protect American merchantmen. Macon was one of the earliest to seize upon slavery as an essential interest of Southern agriculture, and to assert its constitutional immunity from national control; he was a forerunner of John Randolph and of Calhoun. The author hardly makes the most of Macon's completely negative conception of the role of the Federal Government, and his passion to restrict its appropriations. Macon was himself completely disinterested 
and devoid of personal malice, and retained his great popularity in his State and section through changing times.

3287. Driver, Carl S. John Sevier, pioneer of the Old Southwest. Chapel Hill, University of North Carolina Press, 1932. $240 \mathrm{p}$.

Bibliography: p. [219]-225.

$3^{2-30370} \mathrm{E}_{302.6 . S_{45} \mathrm{D} 8}$

Sevier (1745-1815), frontiersman, Indian fighter, land speculator, state senator, Congressman, only Governor of the State of Franklin, and the first Governor of Tennessee, moved into the West with the frontier and participated in the various activities of the border. His whole life was connected with the development of the West, and he died in its service. The author, in Sevier's behalf, points out that Andrew Jackson, Sevier's antagonist, who became the representative of the West in the eyes of the Nation, reflected the ideals and aspirations of the West after its civilization had been firmly established. Sevier, a more provincial figure, overshadowed by Jackson, the national figure, was the true representative of the old West, the ideal of the man who struggled and fought for the acquisition of the soil.

3288. Hamilton, Alexander. Alexander Hamilton and the founding of the Nation. Edited by Richard B. Morris. New York, Dial Press, 1957 . $\mathrm{xxi}, 6 \mathrm{r} 7 \mathrm{p}$.

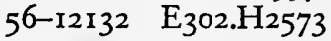

3289. Hamilton, Alexander. Papers on public credit, commerce and finance. Edited by Samuel McKee, Jr. New York, Columbia University Press, 1934. xxiv, 303 p.

$$
\text { 34-18967 HCr05. } \mathrm{H}_{1} 8
$$

3290. Schachner, Nathan. Alexander Hamilton. New York, Appleton-Century, 1946. 488 p. Bibliography: p. $473-48 \mathrm{r}$.

$$
4^{6-3861} \mathrm{E}_{302.6 . \mathrm{H}_{2} \mathrm{~S}_{25}}
$$

3291. Mitchell, Broadus. Alexander Hamilton. v. I. Youth to maturity, 1755-1788. New York, Macmillan, 1957. 675 p.

Bibliography: p. $647-666$.

$$
57-5506 \quad \mathrm{E}_{3} \mathrm{O2.6.H} \mathrm{H}_{2} \mathrm{M} 6
$$

Hamilton (1755-1804) was the Founding Father who was different. Born on the West Indian island of Nevis, he was ineligible for the Presidency of the United States. Technically illegitimate and selfsupporting from the age of $I 2$, he was even more completely a self-made man than Franklin. He was the only member of the Constitutional Convention to disapprove of republican government and to propose an elective monarchy; but this did not prevent him from joining with Madison to present the most effective apology for a new frame of government that has ever been penned (The Federalist, q. v.). Whether his military abilities were so transcendent as he and his warmer admirers supposed must remain unknown, since he never held an independent command; but his past mastery of finance and of the techniques of public administration was placed beyond question during his service as first Secretary of the Treasury of the United States (1789-95). Total estimates of Hamilton will probably differ as much in the future as they have in the past, according to the estimator's value of his concrete services as against what Henry Adams aptly termed "the adventurer in him." Both of the older editions of Hamilton's writings took strange liberties with their texts; the new one undertaken at Columbia University has not reached the stage of publication. Professor Morris' volume of selections is arranged in chapters, the progression of which is partly chronological and partly topical; there is a general introduction and much interspersed explanatory matter by the editor. The Secretary of the Treasury's epoch-making reports to Congress on the public credit (I790 and I795), on a national bank (I790), and on manufactures (I79I), together with his letter to President Washington which, in justifying the constitutionality of the bank, develops his doctrine of implied powers, are separately published by Dr. McKee in a volume of attractive format. Mr. Schachner's biography is well proportioned and solidly researched, using manuscripts to supplement printed sources. It takes a middle-ofthe-road position, and certainly does not gloss over its protagonist's errors of judgment or temper. Professor Mitchell is more enthusiastic in his admiration of Hamilton's genius; his first volume, which reaches the ratification of the Constitution, is based on an exhaustive searching of the sources, but once more it is true that the fresh material turned up makes no great alteration in the old picture. For the period after 1788 , The Intimate Life of Alexander Hamilton by his grandson, Allan McLane Hamilton (New York, Scribner, rgro. 483 p.), contains valuable material not to be found elsewhere.

3292. Jefferson, Thomas. Papers. Julian P. Boyd, editor. Princeton, Princeton University Press, 1950-56. I3 v. 50-7486 E302. $_{463}$

Associate editors: v. I-5, Lyman H. Butterfield and Mina R. Bryan; v. 6-8, Mina R. Bryan and Elizabeth L. Hutter; v. 9, Mina R. Bryan; v. I0-I2, Mina R. Bryan and Fredrick Aandahl; v. I3, Mina R. Bryan.

Contents.-v. I. 1760-1776.-v. 2. January I 777 to June I779.-v. 3. June 1779 to September I780.-v. 4. I October 1780 to 24 February I78I. - 
v. 5. 25 February 1781 to 20 May 1781 - v. 6.21 May 1781 to 1 March $1784 .-v$. 7. 2 March 1784 to 25 February $1785 .-v$. 8. 25 February to 31 October I785.-v. 9. I November 1785 to 22 June I786.-v. 10. 22 June to 3 I December 1786.-v. I I. I January to 6 August 1787.- -v. 12. 7 August 1787 to 31 March I788.-v. I3. March to 7 October I 788 .

- Index, volumes $\mathrm{x}-6$. Compiled by Elizabeth J. Sherwood and Ida T. Hopper. Princeton, Princeton University Press, 1954. 229 p. $\mathrm{E}_{302 .} \mathrm{J}_{463}$ Index

3293. Jefferson, Thomas. Writings. Collected and edited by Paul Leicester Ford. New York, Putnam, 1892-99. 1o v.

2-5666 $\mathrm{E}_{302 . J} \mathrm{~J}_{466}$

Contents.-v. I. 1760-1775.-v. 2. I7761781.-v. 3. $178 \mathrm{r}-1784$. -v. 4. $1784-1787 .-$ v. 5 . 1788-1792.-v. 6. 1792-1794.-v. 7. I795-1801. v. 8 . $1801-1806 .-v .9 .1807-1815 .-v$. I0. 18161826 .

3294. Jefferson, Thomas. Jefferson himself, the personal narrative of a many-sided American. Edited by Bernard Mayo. Boston, Houghton Miffin, 1942. xv, 384 p. illus.

$$
\text { 42-50339 } \mathrm{E}_{332 .} \mathrm{J}_{4} 6_{4}
$$

3295. Malone, Dumas. Jefferson and his time. Boston, Little, Brown, 1948-51. 2 v. illus. 48-5972 E332.M25

"Select critical bibliography": v. I, p. [457]-470; v. 2, p. [494]-504.

Contents.-v. r. Jefferson the Virginian.-v. 2. Jefferson and the rights of man.

3296. Randall, Henry S. The life of Thomas Jefferson. Philadelphia, Lippincott, r888. 3 v.

First published in 1857 .

$$
9^{-28978} \text { E332.RI9 }
$$

3297. Nock, Albert Jay. Jefferson. New York, Harcourt, Brace, ' ${ }^{1}$ 926. 340 p.

$$
\text { 26-13101 } \mathrm{E}_{332 . \mathrm{N}_{75}}
$$

Jefferson (1743-1826) was the author of the Declaration of Independence, the second Governor of the State of Virginia, the second Minister from the United States to France, the first Secretary of State of the United States, the second Vice President and third President of the United States, and the founder of the University of Virginia. Among the Founding Fathers, only Franklin was his peer in universality of mind, and his writings of every description, but particularly the voluminous correspondence which he maintained until a few weeks before his death, constitute an incomparable mirror of the general and especially the intellectual history of his age. The complete edition of The Papers of Thomas Jefferson planned and initiated by Dr. Boyd of Princeton University, with its careful inventorying of all surviving manuscripts and its abundance of elucidation in introductions and notes, naturally supersedes all previous editions as far as it has gone. But volume 13, the latest to appear, only reaches October 7,1788 , and the announced rate of publication has evidently slackened. It is still necessary, therefore, to resort to one of the older editions for the remainder of Jefferson's career; that of P. L. Ford is listed above as being the easiest to use. Professor Mayo's Jefferson Himself is a collection of extracts from Jefferson's brief autobiography, his letters, and his other writings, arranged in a chronological sequence so as to make a reasonably continuous narrative of his career in his own words. Dr. Malone is engaged upon a full-scale biography of Jefferson, incorporating recent scholarship and working out many problems hitherto unsolved or unapproached. He can perhaps at times be reproached with putting Jefferson's lack of straightforwardness in too favorable a light. Unfortunately his second volume, the latest to appear, only reaches the close of 1792 . For a detailed narrative from that point one may turn to the older work of Randall, which has the endorsement of Dr. Malone; it has not, he justly says, enjoyed the reputation it deserved because its author, a convinced Democrat, had the misfortune of publishing on the eve of an age of Republican domination, especially of the journals of literary opinion. Among a variety of briefer biographies, that of the late A. J. Nock has had warm admirers through three decades for its selection of material, charm of style, intuitive insight, and delicate characterization. Special studies are legion, and may readily be located through the bibliographies in Malone and elsewhere.

3298. Lewis, Meriwether, and William Clark. The journals of Lewis and Clark. Edited by Bernard De Voto. Maps by Erwin Raisz. Boston, Houghton Mifflin, r953. lii, $504 \mathrm{p}$.

$$
\text { 53-9244 } \mathrm{F}_{592.4} \quad 1953
$$

3299. Bakeless, John E. Lewis \& Clark, partners in discovery. New York, Morrow, 1947. 498 p. illus. 47-12243 $\mathrm{F}_{592.7 . \mathrm{B}_{3}}$

The Lewis and Clark expedition of $1804-6$, from St. Louis to the mouth of the Columbia River and back, is one of the high points in the exploration of the North American Continent and in the expansion of the United States; it is also one of the most fascinating of adventure stories. Planned by President Jefferson in order to make known the 
northern part of the Louisiana Territory purchased the year before, it was entrusted to a young man who enjoyed his personal confidence and was serving as his private secretary. Meriwether Lewis (1774-1809) chose as his colleague William Clark (1770-1838), under whom he had served in the regular army. Under their harmonious leadership, the expedition enjoyed an exceptional blend of good management and good fortune, and was successful in all its objectives. The reader has here a choice between a selection from the original journals of the expedition, chiefly those kept by the two leaders, and a joint biography which includes a narrative of the expedition emphasizing its day-to-day incidents. Mr. De Voto's narrative, written from a rather broader geographical viewpoint, forms the concluding portion of his The Course of Empire (no. 316r). His selection from the journals comes from the 7 -volume set edited by Reuben Gold Thwaites in 1904-5: Original Journals of the Lewis and Clark Expedition (New York, Dodd, Mead), and includes about half of the text available there, with a general introduction, some interspersed expository matter in italics, and brief footnotes. Dr. Bakeless devotes nearly three-fifths of his volume to his anecdotal narrative of the expedition, including a chapter on "Aboriginal Amours," and the rest to the earlier careers of his protagonists, to the brief later life and tragic end of Meriwether Lewis, and to the long public service and honorable old age of Governor Clark. For both the early and the late phases he has turned up much new information from scattered documents in archives and manuscript collections.

3300. Link, Eugene Perry. Democratic-Republican societies, I790-r8oo. New York, Columbia University Press, 1942. 256 p. (Columbia studies in American culture, no. 9)

42-5915 E3ro.L6 i942a

Issued also as thesis (Ph. D.) Columbia University.

Bibliography: p. [2I3]-242.

A detailed study of the popular societies which were a prominent feature of the last decade of the I8th century, which President Washington sought to stigmatize as "self-created," and which indeed spread into most States of the Union in an apparently spontaneous manner. Dr. Link has identified 42 such societies organized between 1793 and 1798 , of which 9 were in Pennsylvania and 5 each in Vermont, Virginia, and South Carolina. He has analyzed their membership in the few cases in which this is possible, and finds that it came from a rather wide range of society, with merchants, manufacturers, lawyers, doctors, and public officials the fellows of craftsmen and artisans of all descriptions. He finds that their membership was perceptibly continuous with the Sons of Liberty and other groups which advanced the American Revolution, and that they were conscious of their kinship with comparable organizations in England and on the Continent. After reviewing their activities he concludes that, although they were not without elements seeking political or economic self-aggrandizement, on the whole these societies aimed at the free and enlightened discussion of public issues, and were active in the promotion of schools and libraries as agencies of democratic education.

3301. McLaughlin, Andrew Cunningham. The Confederation and the Constitution, 17831789. New York, Harper, 1905. xix, 348 p. maps. (The American Nation: a history, edited by A. B. Hart, v. 10) 5-30250 Ei78.A54, v. ro "Critical essays on authorities": p. 318-336.

3302. Jensen, Merrill. The New Nation; a history of the United States during the Confederation, $1781-1789$. New York, Knopf, 1950. xvii, 433, xi p. $\quad 50-9344 \quad E_{33} . J 45 \quad 1950$

"Essay on the sources": p. 429-432.

The late Professor McLaughlin's volume remains, after half a century, a concise and lucid narrative of the events of greatest national concern from the peace negotiations which terminated the Revolution through the ratification of the new Constitution. He thus states his central theme: "The political task that confronted the people when independence from Great Britain was declared was in its essence the same that had confronted the British ministry ten years before-the task of imperial organization." He regards the Articles of Confederation as "an advance on previous instruments of like kind in the world's history"; they were chiefly defective in withholding from the central authority the powers of raising money and of regulating commerce. Attempts to make the best of the Articles were quite played out by the end of 1786 , when a deep gloom had settled upon conservative men, which gave energy to their efforts toward a radical change in the following year. None of this gloom is to be found in the pages of Professor Jensen's volume, which is a sequel to his Articles of Confederation (no. 3253). A spirit of optimism reigned in the new Nation, and is evident in the beginnings of a national literature. Society was in a state of vigorous health, and the grievances left over from the old order were under sharp attack from an active humanitarian movement. The economic prostration which follows protracted war was being alleviated by a remarkable outburst of commercial expansion and business enterprise. Even on the part of the central government there was substantial achievement: the domestic debt created by 
the Revolution was reduced, a national domain created, and a responsible staff of civil servants built up. The change initiated in 1787 was carried through by men who feared democracy and who wanted a national instead of a federal government. The book provides a more detailed account of many aspects of this period than is available in any other general work, but it resolutely turns a blind eye on the impotence, impecuniosity, and defenselessness of the Confederation.

3303. Malone, Dumas. The public life of Thomas Cooper, I 783-1839. New Haven, Yale University Press, r926. xv, 432 p. (Yale historical publications. Miscellany, 16)

$$
\text { 26-1538I } \mathrm{E}_{302.6 . \mathrm{C}_{7} \mathrm{M} 2}
$$

Thesis (Ph. D.)-Yale University, I 923.

"Bibliographical note": p. [402]-4I6.

Cooper-( I 759-1 839) was an Englishman, a scientific amateur, a religious and political radical, and a friend of Joseph Priestley, whom he accompanied to America in 1794. His American career was remarkable for its versatility, its vicissitudes, and its progress from a radical to an extremely conservative position in politics. As a Jeffersonian pamphlcteer he was sentenced to fine and six months' imprisonment for seditious libel against President Adams. He was appointed to office by the victorious Pennsylvania Republicans, but his independent course as a district judge cost him the favor of the more radical democrats, and in I8II he was removed from the bench in consequence of an address by both houses of the legislature. Cooper then served as professor of chemistry in two Pennsylvania colleges, and soon after transferring to South Carolina College, in 1820 , was chosen its president. Here he became the oracle of the state rights philosophy, repudiating the protective tariff, and defending slavery and nullification. Cooper's own papers were destroyed in their entirety, and Dr. Malone's volume is a fine work of reconstruction, illuminating the career of a man who, if not an original thinker, was a powerful agitator and controversialist, uncommonly influential in the political and intellectual developments of his time.

3304. Monaghan; Frank. John Jay, defender of liberty against kings \& peoples, author of the Constitution \& Governor of New York, President of the Continental Congress, co-author of the Federalist, negotiator of the Peace of 1783 \& the Jay Treaty of 1794, first Chief Justice of the United States. Indianapolis, Bobbs-Merrill, I935. 497 p. $\begin{array}{llll}\text { illus. } & 35^{-1} 8227 & \mathrm{E}_{302} \text {.6.J4 } & \end{array}$

"The sources": p. [465]-474.

A sympathetic narrative rich in the detail of the life and character of an aristocratic New Yorker who prided himself on the rectitude of his motives and his devotion to public duty. The author seeks to restore Jay (I745-1829) to public esteem, a task not facilitated by the fact that Jay, ever conscious of his dignity, wrote with the feeling that posterity was peering over his shoulder. In addition to the portrait of a moderate who felt that the British colonies were prompted and impelled to independence by necessity and not by choice, many details of the society of Jay's era, such as an entertaining section describing the rigors of life on the judicial circuit, are provided.

3305. Morison, Samuel Eliot. The life and letters of Harrison Gray Otis, Federalist, 17651848. Boston, Houghton Mifflin, 1913. 2 v. illus.

Bibliography: v. 2, p. [31 [1] -317 . 13-23631 $\mathrm{E}_{340.08 \mathrm{M} 8}$

Orator, and attorney of the first rank, Harrison Gray Otis entered politics during Washington's second administration. He was a leader in the movement of resistance to "Mr. Madison's War" which culminated in the Hartford Convention in I $8 \mathrm{I} 4$, a movement in which this native Bostonian exerted his greatest influence. Having succeeded in keeping the convention's action within the bounds of moderation and well short of even a hint of secession, Otis continued to justify the convention and its work during the remainder of his life, often to the detriment of his political carcer. In spite of the dying out of the Federalist Party, he continued to be elected to office by Massachusetts or Boston into the Jacksonian era. If no great statesman, Otis was an attractive figure who represented the best of the political and social organization which was the Federalist Party. The author has endeavored, in addition to setting forth the events of Otis' life, to describe critically Otis' ideas, feelings, and prejudices, and to discover the motives which guided his actions in the political crises of his day, whether they centered upon nationalism, sectionalism, or abolitionism. These volumes contain a wealth of information about the later and somewhat depressing years of the Federalist Party.

3306. Pratt, Julius W. Expansionists of 1812. New York, P. Smith, 1949, 'I925. 309 p.

Bibliography: p. $275^{-289}$. 49-9879 $\mathrm{E}_{357 . \mathrm{P}_{9}} \quad \mathbf{1 9 4 9}$

A scholarly study, solidly based on contemporary manuscripts and newspapers, of aspects of public opinion, diplomacy, and strategy before and during the War of 1812 . It shows that a general sentiment in the Northwest in favor of the acquisition of Canada, which had existed since the Revolution, became strongly activated when Tecumseh was supplied with British arms; that the South was 
eager to annex the Floridas, and East Florida was in part occupied before the declaration of war; that Northern sentiment compelled the Madison administration to withdraw from Florida, while the administration and Southern congressmen lacked enthusiasm for the Canada campaign; and that the idea of Manifest Destiny made its first general appearance at this time. At the time of its appearance Professor Pratt's book was hailed with enthusiasm, and has been often taken to show that the "real cause" of the War of 1812 was not maritime grievances but Western land hunger. This conclusion the author had been very careful to disclaim: without those grievances, he declared, "it is safe to say, there would have been no war." To bring about the War of 1812 , both sets of causes were probably essential.

3307. Roosevelt, Theodore. The winning of the West. New York, Putnam, I889-96. 4 v. fold. maps. $\quad$ I-8663 F 35 I.R79

Contents.-I. From the Alleghanies to the Mississippi, $1769-1776 .-2$. From the Alleghanies to the Mississippi, I777-1783.-3. The founding of the trans-Alleghany commonwealths, 1784-1790.4. Louisiana and the Northwest, 179I-1807.

Theodore Roosevelt was of the belief that the development of the Western country was such as to make the West peculiarly the exponent of all that is most vigorously American in the life of the United States. This vigorous study of the acquisition and settlement of the trans-Allegheny region from 1769 to 1807 concerns itself with the dramatic and picturesque. Of institutional or economic development one finds little information, but Indian warfare, intrigues involving the Westerners, French and Spaniards, and relations between the United States, Britain, and Spain concerning the Western country find places of prominence in a work which is clearly stamped with the emphatic personality of its author.

3308. Smith, James Morton. Freedom's fetters; the Alien and Sedition laws and American civil liberties. Ithaca, Cornell University Press, 1956. 464 p. (Cornell studies in civil liberty)

$$
\text { 56-2434 } \mathrm{E}_{327 . S_{59}}
$$

Passed in $\mathrm{I} 798$, the Alien and Sedition laws were ostensibly designed to protect the United States during time of war, but in that era, when there was a strong link between foreign influence and domestic faction, these laws could also be used by their sponsors, the Federalists, as an instrument for the repression of political opposition. In this first of two projected volumes the author, pursuing an investigation of the relationship between liberty and authority in a popular form of government, "concentrates as exclusively as possible on the enactment and enforcement of the Federalist measures of 1798 and attempts to assess their influence in shaping the development of the political process of republicanism, with its goals of majority rule and individual rights."

3309. Starkey, Marion Lena. A little rebellion. New York, Knopf, I955. 258 p.

$$
\text { 55-9292 F69.S85 }
$$

The "little rebellion" named after Captain Daniel Shays, of Pelham, Massachusetts, had few killings and no hangings, but great consequences in that it supplied power to the movement for a more perfect union. Miss Starkey retells this rather externally known episode of $1786-87$ in the terms of human experience and achieves a dramatic presentation without ascribing wickedness to either side.

3310. Walters, Raymond. Albert Gallatin: Jeffersonian financier and diplomat. New York, Macmillan, I957. $46 \mathrm{I}$ p.

Bibliography: p. $435-446$.

$$
57^{-8267} \quad \mathrm{E}_{3} 02.6 . \mathrm{Gr}_{\mathrm{6}} \mathrm{W}_{3}
$$

33ri. Adams, Henry. The life of Albert Gallatin. New York, P. Smith, I943. 697 p.

A $44-322$ NNC

"Reprinted under the auspices of the Out-ofPrint Books Committee of the American Library Association."

Gallatin ( $1761-1849$ ), a native of the Republic of Geneva, came to the United States at the age of 19, and, largely because of a Rousseauist enthusiasm for wild nature, settled in the far southwestern corner of Pennsylvania. The locale proved a disappointment, but Gallatin's uncommon abilities improved by an excellent education led almost at once to a political career among his frontiersman neighbors, and both in the Pennsylvania legislature and in the Congress of the United States his mastery of fiscal policy made him indispensable to the agrarian Republicans with whom he had allied himself. The same reason, together with a general capacity for policy, administration, and hard work of any kind, made him a prime reliance of Presidents Jefferson and Madison, but after nearly 12 years' service as Secretary of the Treasury he was forced out by the factious opposition of Southern party leaders in Congress. The remainder of his public career was employed in a succession of foreign missions, and his eighth and ninth decades were actively spent in private finance, enlightened publicism, and ethnological studies. Dr. Walters complains of his "relative obscurity today," but this is surely a consequence of the circumstances that Henry Adams did so solid a piece of work in his Life, originally pub- 
lished in 1879 , and that the Gallatin family kept the papers closed to investigators for the next 60 years. Dr. Walters' volume, which is guided by the wider interests of present-day historians and takes a deeper interest in Gallatin's personality, supplements rather than replaces the earlier work.

\section{G. The "Middle Period" ( $1815-60)$}

3312. Adams, John Quincy. Memoirs comprising portions of his diary from 1795 to 1848 . Edited by Charles Francis Adams. Philadelphia, Lippincott, $1874-77$. I2 v. $\quad 4-20138 \quad$ E377.A19

3313. Bemis, Samuel Flagg. John Quincy Adams and the Union. New York, Knopf, 1956. $\mathrm{xix}, 546 \mathrm{p}$. illus.

$55-927$ I $\mathrm{E}_{377 \cdot \mathrm{B}_{4} 6}$

When John Quincy Adams (1767-1848) became President in 1825 , he had already had a long career in American foreign affairs, which is covered in Professor Bemis' John Quincy Adams and the Foundations of American Foreign Policy (no. 3529). John Quincy Adams and the Union opens with the campaign of 1824 and the election of Adams by the House of Representatives after a four-way race, in which Andrew Jackson received the largest popular and electoral vote. As a minority President Adams struggled, without much success, for his program of national expansion and Federal development of the Nation's resources. In the 1828 election he was defeated by Jackson, and for a time retired to private life. However, in 1831 he was elected to the House of Representatives by his home district, and was repeatedly reëlected by large majorities until his death. As a Congressman he continued his independent career, acting in behalf of the Nation, rather than of his constituency or party, and fought for the cause of liberty. He alienated the Southerners, since he spoke and acted vigorously against slavery, and the Northern abolitionists, since as a constitutionalist he would not fully support their views. He frequently fought the Southern-dominated Congress to a standstill, often by himself, for most Northerners in Congress regarded Southern support as necessary for their political ambitions. While a source of constant irritation to the House of Representatives, he achieved the respect and admiration of most as the leading parliamentarian of his day, and as an amazingly well-informed elder statesman. In this period he came to be known as the Old Man Eloquent. As an independent, a representative of the old elite, and a champion of unpopular views, he never had a large popular following, but he nonetheless managed to play a major, shaping role in the Nation's destiny. Much of this is revealed in his Memoirs, which are usually regarded as factually accurate, however colored by his own views and prejudices; they remain a major source for information on the public affairs of the period. This very large work has been abridged for the layman and general student by Allan Nevins: The Diary of John Quincy Adams, 1794-1845; American Diplomacy and Political, Social, and Intellectual Life from Washington to Polk (New York, Scribner, 195I. xxxv, 586 p.). The Writings of John Quincy Adams (New York, Macmillan, 1913-17. 7 v.) were edited by Worthington Chauncy Ford, but the unfinished set stops with 1823 . A selective edition of Adams papers, to be published by Harvard University through the Belknap Press, is in preparation under the editorship of Lyman $\mathrm{H}$. Butterfield; meanwhile a microfilm edition of the papers has been made available by the Massachusetts Historical Society.

3314. Barker, Eugene C. The life of Stephen F. Austin, founder of Texas, 1793-1836; a chapter in the westward movement of the AngloAmerican people. Nashville, Cokesbury Press, 1925. xv, 55I p. illus. 26-9002 F389.A936

Bibliography: p. 525-534.

Stephen Fuller Austin was born in Virginia at the site of the lead mines of his father, Moses Austin $(1761-1821)$. The father soon moved westward, controlling lead mines in Missouri, but had his son educated in the East. After Stephen's return he served in the Missouri legislature from $18 \mathrm{I}_{4}$ to 1820 , and afterward went to New Orleans to study law. In 1820 his father obtained a permit from the Mexican Government for settling families in Texas, then a part of Mexico. Moses Austin died before acting on this, but his son took it up. In January 1822 Stephen Austin settled the first American colony in Texas. In the next dozen years he displayed an extraordinary ability in maintaining smooth relations with the Mexican political factions, obtaining many concessions from the government, and keeping the state open to American colonization. He is deservedly called "the father of Texas," for he was the dominant factor in all activities and decisions to the time of the Texan revolt and declaration of independence in 1835 . While until near the very end Austin had been loyal to Mexico, and though the 
future of Texas seemed to him more promising in association with that country than with the United States, his activities had brought about the Americanization of Texas, and led directly to American expansion across the Southwest to the Pacific. Dr. Barker also edited The Austin Papers (v. I-2. Washington, Govt. Print. Off., I924-28. 2 v. in 3; v. 3. Austin, University of Texas, 1927. xxxv, 494 p.), which include the official and private writings of both Moses and Stephen Austin.

3315. Bassett, John Spencer. The life of Andrew Jackson. New ed. New York, Macmillan, 1931. 2 v. in r. illus.

Paged continuously.

31-23245 $\mathrm{E}_{3} 82 . \mathrm{B}_{35}$

First published in 1911 .

3316. James, Marquis. Andrew Jackson, the border captain. Indianapolis, Bobbs-Merrill, 1933. 46r p. illus. 33-7933 E382.J26

This volume ends with the presidential campaign of 1824 .

Bibliography: p. [4I7]-424.

3317. James, Marquis. Andrew Jackson, portrait of a President. Indianapolis, Bobbs-Merrill, 1937. 627 p. illus. 37-28638 $\quad \mathrm{E}_{3} 82 . \mathrm{J}_{27}$ From 1824 to the end of Jackson's life.

Bibliography: p. [569]-578.

3318. Syrett, Harold C. Andrew Jackson: his contribution to the American tradition. Indianapolis, Bobbs-Merrill, 1953. 298 p. (Makers of $\begin{array}{lll}\text { the American tradition series) } & 53-8875 \quad \mathrm{E}_{3} 82 . \mathrm{S}_{97}\end{array}$

Jackson $(1767-1845)$ was born in a backwoods settlement in the Carolinas, where he early experienced many of the shocks and difficulties of frontier life. At the age of 13 he fought in the Revolutionary War, but was soon taken prisoner. After the war he went to Tennessee, where he practiced law, and helped draft the State constitution. After serving briefly in each House of the U. S. Congress, he sat upon the supreme bench of Tennessee for 6 years (1798-1804), but resigned and lived as a gentleman planter at The Hermitage near Nashville for nearly a decade. He had, however, retained his commission as commander of the Tennessee militia, and when the Creek Indians rose in 1813 , Jackson took the field against them. He overcame logistic difficulties, campaigned vigorously, and won hard-fought and complete victories. Rewarded with a major-generalship in the United States Army, he foiled a British descent on Mobile and concluded the war with a one-sided slaughter of the army attacking New Orleans (Jan. 8, 1815). He was at once established as the great popular hero of the war and a presidential possibility, and his further service on the Florida frontier and in the Senate was very much in the public eye. In 1824 he ran for President; while he received a plurality (in a field of four) of the electoral vote, the election by the House of Representatives went to J. Q. Adams. In 1828 and 1832 he was elected by large margins, and thus crystallized a political revolution which has been discussed in other books in this section (particularly Blau, no. 3319; Bowers, no. 3320; and Schlesinger, no. 3352). The introduction into national politics of government by the "common man" is also a major theme of Dr. Syrett's volume; like other books in its series, it is made up of extensive quotations from Jackson's writings (in fact mostly state papers penned by his lieutenants), supplemented by connective and explanatory expositions. After Jackson left the Presidency, he lived in semiretirement at The Hermitage, but remained a factor in national government. His career was long and intensively studied by Bassett, whose scholarly life remains a highly reliable guide. The twovolume biography by Marquis James is also based on much research, including materials unknown to Bassett. However, James is not a historian's historian in his presentation of the development of the problems Jackson faced; but his work has considerable literary merit, and allows a convincing, living image of Jackson to emerge from its pages. A selective edition of Jackson's Correspondence (Washington, Carnegie Institution of Washington, 1926-35. 7 v. Publication no. 371. Papers of the Department of Historical Research) was edited by John Spencer Bassett; for the ordinary reader it is heavy going, since Jackson's extraordinary personal magnetism never penetrated his writing.

3319. Blau, Joseph L., ed. Social theories of Jacksonian democracy; representative writings of the period 1825-1850. New York, Liberal Arts Press, 1954. 383 p. (American heritage series, no. I)

Includes bibliography.

$$
\text { 55-169 } \mathrm{E}_{33} 8 . \mathrm{B}_{55} \quad 1954
$$

In this volume Mr. Blau has brought together a group of writings expressive of the views held by the supporters of Andrew Jackson. After an introduction by the editor on the Jacksonian movement, his selections are classified in three parts: "The Ideal of Self Government," "Economic Themes," and "Social Criticism." The movement arose with a popular hero after the choice of the President had been won by the people; it won national following while creating a feeling of national unity at a time when the former leading groups were splitting up into pro- and anti-slavery factions; but, as the editor points out, the basic source of unity for the national movement was a widespread lower-middle-class opposition to eco- 
nomic control from Boston, New York, and Philadelphia. The movement itself was an alliance of diverse groups who presented a variety of positive programs, often in conflict with one another. The various facets of this movement, rather than the program which Jackson and his advisers forged, provide the material for this book. Another book which aims to present the varying and at times conflicting elements that made up Jacksonianism is The Jacksonian Persuasion; Politics and Belief (Stanford, Stanford University Press, 1957. 231 p.), by Marvin Meyers; in addition to a number of general chapters on causes, and a detailed analysis of particular groups of problems, the book devotes much space to the individual versions of Jacksonianism held by a number of contemporaries.

3320. Bowers, Claude G. The party battles of the Jackson period. Anniversary ed. Boston, Houghton Mifflin [pref. 1928$]^{{ }^{c}}{ }_{1922}$. xix, 506 p. front., ports.

38-20418 $\mathrm{E}_{3} 8 \mathrm{I}$.B792

"Books, papers, and manuscripts cited and consulted": p. $[48 \mathrm{r}]-487$.

In 1828 the Nation held its first Presidential election wherein the choice was in most States decided by the electorate rather than by the State politicians. The result was the election of the popular Jackson over the entrenched administration party. It also meant that for the first time political parties began to function on the vote-getting level that has since been familiar. This study of the 8 years of the Jackson administration opens with a survey of the physical and social scene in Washington at the time, and then turns to the narrative proper. While Jackson is something of a focal point, more attention is given to other leaders, such as the opposition Senators Henry Clay, John C. Calhoun, and Daniel Webster, and pro-Jackson politicians such as Martin Van Buren, Edward Livingston, Amos Kendall, Roger Taney, and John Forsyth. The story itself tends to be centered about individuals as much as about issues, and the examination of motives leads the author to a rather extensive revaluation of the traditional reputations of some of the leading figures. Most of the leaders emerge as something less than the pure heroes of legend, while a few, such as John Tyler, are elevated above their common reputation.

332r. Chambers, William Nisbet. Old Bullion Benton, Senator from the new West: 'Thomas Hart Benton, $1782-1858$. Boston, Little, Brown, 1956. 517 p. $\quad 56-9067 \quad \mathrm{E}_{340 . B_{4} \mathrm{C}_{5}}$

3322. Smith, Elbert B. Magnificent Missourian; the life of Thomas Hart Benton. Philadelphia, Lippincott, I958, ' 1957.35 I p.

$$
\text { 57-12384 } \mathrm{E}_{34} \mathrm{O}^{\circ} \mathrm{B}_{4} \mathrm{~S}_{56}
$$

Benton was elected Senator from Missouri in 1820 , and he continued in that office for three decades. In this period he became a leading spokesman, not only of men of the western frontier, but also of the common man. As such he became the leading "Jacksonian" Senator, and by his contemporaries was thought to be as important as Clay, Calhoun, or Webster. An early achievement was his leadership in the fight against the Bank of the United States. $\mathrm{He}$ also contributed to the country's financial history by his work on the currency; he was instrumental in establishing the revised bimetallism standards which lasted for many years. His advocacy of hard currency and his opposition to paper money earned for him the nickname of "Old Bullion." Benton also did much to secure Federal backing of the movement for westward expansion. In this matter one of his noteworthy stands was that opposing the extension of slavery to new states; this caused him some political difficulty, since he represented a slave-holding state. The politics of the period and his role in them are depicted in his voluminous Thirty Years' View (New York, Appleton, 1854-56. 2 v.), which has often been regarded as autobiography, although it is rather a slightly personalized political history. As such it is an outstanding example of its form, and a major item for understanding the political background of the period.

3323. Chitwood, Oliver Perry. John Tyler, champion of the Old South. New York, Appleton-Century, 1939. xv, $496 \mathrm{p}$.

$$
\text { 39-22996 } \mathrm{E}_{397 . \mathrm{C}_{4} 8}
$$

"This volume is published from a fund contributed to the American Historical Association by the Carnegie Corporation of New York."

3324. Morgan, Robert J. A Whig embattled; the Presidency under John Tyler. Lincoln, University of Nebraska Press, 1954. 199 p.

Bibliography: p. r9I-I95.

$$
\text { 54-8442 E396.M6 }
$$

Tyler (1790-1862) was born and educated in Virginia, where he served in the State Legislature as a young man. Subsequently he served in the U. S. House of Representatives (1817-2r). From 1825 to 1827 he was Governor of Virginia; this post he left to become U. S. Senator (1827-36). He resigned from the Senate when, on a matter of constitutional interpretation, he found he could not in conscience follow the instructions of the State Legislature. In the I 840 election "Tyler too" was Harrison's vice-presidential running-mate. He became President when Harrison died one month after taking office. Tyler's presidential term was marked by much discord, as he broke from his party because of his insistence on a strict interpretation of 
the Constitution. Despite the opposition from both parties, Tyler did accomplish a few important measures during his administration. He retired from political life at the end of his term, and did not reappear on the national scene until $186 \mathrm{I}$, when he headed the Washington Peace Conference, an unsuccessful attempt to reconcile North and South. Shortly afterwards he died in full support of the Confederacy. Because Tyler managed to antagonize both political parties of his period, he received considerable denunciation from all sides. This in turn influenced most historians, and he has usually been regarded as one of the minor Presidents. Chitwood's book is an attempt to rectify this situation and establish Tyler as a man of many qualities and more than minor importance. The book traces his entire career, but is more a political than a general biography. Mr. Morgan's book is also an attempt to improve Tyler's historical reputation, indicating Tyler's work in elevating the status of the Presidency, as well as the extent of his influence upon the political developments of the time.

3325. Cleaves, Freeman. Old Tippecanoe; William Henry Harrison and his time. New York, Scribner, I939. 422 p. illus.

\section{Bibliography: p. 392-401.}

$$
\text { 39-32515 E392.C64 }
$$

3326. Green, James A. William Henry Harrison, his life and times. Richmond, Garrett \& Massie, 194I. $53^{6}$ p. illus. $4^{1-25076} \quad$ E392.G8 Bibliography: p. 493-529.

Appendix l, The Harrison Literature: p. $447-483$. Harrison (I773-184I) was sprung from the first families of Virginia, and was the son of a signer of the Declaration of Independence. He entered the Regular Army in 1791, and for the next 23 years served with great credit in both military and civil posts in the Northwest Territory. He was Governor of Indiana Territory from 1800 to $\mathrm{I}_{1} \mathrm{I}_{3}$, carried out the administration's self-contradictory Indian policy as well as could be expected, and won striking victories at Tippecanoe (18II) and the River Thames (1813). But after resigning from his command in 1814 Harrison's career was for long anticlimactic: his personal finances went from bad to worse; he served in the national House of Representatives (1816-19) and Senate (1825-28) without making much of an impression; and during his brief tenure as Minister to Colombía succeeded in making himself distinctly unacceptable to the government of President Bolivar. During the 1830's he lived quietly and struggled with his debts, but he continued to be regarded by the Whigs as a presidential possibility. In 1840 the Whig managers settled upon him in preference to Clay and Webster, and entered upon a campaign of ballyhoo in which he was oddly identified with a log cabin and hard cider, and his victories of 25 years back were thrust in front of the actual issues of the day. Harrison won by a landslide, but contracted pneumonia in Washington and died in his $6 \mathrm{gth}$ year after a month in office. The antics of the campaign are described in Robert Gray Gunderson's The Log-Cabin Campaign ([Lexington] University of Kentucky Press, 1957. 292 p.). Dorothy Burne Goebel's William Henry Harrison, a Political Biography (Indianapolis, Historical Bureau of the Indiana Library and Historical Department, 1926. 456 p.) is at various points of political interest fuller than the two lives entered above. Of these Mr. Green's is somewhat adulatory, but is based on the author's collection of 1,600 items of Harrisoniana, and is worth consulting for the illustrations alone.

3327. Coit, Margaret L. John C. Calhoun, American portrait. Boston, Houghton Mifflin, 1950. 593 p. illus. $\quad 50-5234 \quad \mathrm{E}_{340 . \mathrm{C}_{5} \mathrm{C}_{3}}$ Bibliography: p. [573]-58r.

3328. Wiltse, Charles M. John C. Calhoun. Indianapolis, Bobbs-Merrill, 1944-51. 3 v. illus.

Bibliography at end of each volume.

Contents.-[v. I] Nationalist, I782-1828.[v. 2] Nullifier, 1829-1839.-[v. 3] Sectionalist, I 840-I 850 .

John Caldwell Calhoun $(1782-1850)$ was in 1808 elected to the legislature of South Carolina, his native State. In I81o he was chosen for the U. S. House of Representatives, where he played a leading role before and during the War of 1812 . His interest in military affairs and his nationalist outlook led Monroe to appoint him Secretary of War (1817-25). Subsequently he was twice elected Vice-President, under both John Quincy Adams and Andrew Jackson. As the sectional discord between North and South increased, Calhoun increasingly favored the South, and was soon formulating his doctrine of nullification. In 1832 he resigned from the vicepresidency to take a seat in the Senate, where he could speak more forcefully for South Carolina in particular and the South in general, while at the same time he eliminated his chance for the Presidency, as he shifted from national to sectional leadership. In the years that followed he became not only the spokesman and political philosopher of the South, but also a dominating figure in the Senate. As he fought against measures such as tariffs benefiting Northern manufacturers, and attempts to keep slavery out of the territories, he became more and more concerned with the declining minority position of the South. His cure for the situation 
through a government of "concurrent majorities" he presented in two treatises, $A$ Disquisition on Government and $A$ Discourse on the Constitution and Government of the United States, which first appeared posthumously in his collected Works (New York, Appleton, 1851-55. 6 v.). The set also includes his speeches and public papers and reports. To the end of his life he strove in the Senate to maintain the Union, if that could be done in terms acceptable to the South, but recognized that separation would probably occur. His arguments for nullification and the right of a state to withdraw from the Union bore fruit a decade after his death. Miss Coit's biography is a respectful attempt to understand and make vivid Calhoun and the events amid which he functioned. Professor Wiltse's three-volume work is a scholarly presentation of the details of Calhoun's life, but the very thoroughness of the study tends to obscure Calhoun's function in and meaning for his own period.

3329. Dangerfield, George. The era of good feelings. New York, Harcourt, Brace, 1952. $525 \mathrm{p}$.

Bibliography: p. [493]-512. $5^{\mathrm{I}-\mathrm{I} 4815} \quad \mathrm{E}_{371 . \mathrm{D}_{3}}$

An account of the personalities and circumstances behind the Treaty of Ghent (Dec. 24, 1814) introduces the subsequent events that led into "the Era of Good Feeling." This term is usually applied to the period of Monroe's presidency (1817-25), but the author extends it through 1829 , so as to cover the administration of John Quincy Adams, which he regards as concluding a period of transition in American history. In 1817 America had recently emerged "victorious" from the War of 1812 , and a feeling of nationalism and general well-being prevailed from 1817 through most of 1821 , while the Jeffersonian Republicans enjoyed almost universal support as a result of the self-discrediting actions of the Federalists during the war. In late 1821 the "good feeling," if not the "era," came to an end with an economic depression. In the years that followed there came to the fore questions such as national finances, slavery, and Western expansion, and with these arose a new party-the Democrats. The disputed election of J. Q. Adams presaged the transition from the concept of a non-interfering, limited central government to a centralized government that might on occasion interfere in behalf of oppressed minorities. The story ends with the elevation to the Presidency in 1829 of Andrew Jackson, "the voice of the people," and the first postWashington President not groomed for the position by "the administration."

3330. De Voto, Bernard A. Across the wide Missouri. Illustrated with paintings by Alfred
Jacob Miller, Charles Bodmer, and George Catlin. With an account of the discovery of the Miller collection by Mae Reed Porter. Boston, Houghton Mifllin, 1947. xxvii, $483 \mathrm{p}$.

Bibliography: p. $457-468$. $48-3175 \quad \mathrm{~F}_{592 . \mathrm{D}_{3} 6} \quad 1947 \mathrm{a}$

The author states in his preface that in this book he has, for the period $1832-38$, "tried to describe the [Rocky] mountain fur trade as a business and as a way of life; what its characteristic experiences were, what conditions governed them, how it helped to shape our heritage, what its relation was to the westward expansion of the United States, most of all how the mountain men lived." The book is liberally illustrated with contemporary pictures, especially those of Alfred Jacob Miller ( $1810-1874$ ), who in $1833-3^{8}$ accompanied William Drummond Stewart throughout the area. Since the volume was originally conceived as text for Miller's pictures, the story is still centered around the Stewart expedition, although it includes a full attempt to depict the fur trade of the Rockies during these years, when it was already moving into its decline. The book received the Pulitzer prize in history for 1948. While the author is probably best known for historical work such as this, he also produced much literary and critical work (nos. 2415-18).

3331. De Voto, Bernard A. The year of decision, 1846. Boston, Little, Brown, I943. Xv, $53^{8}$ p. illus. 43-4I9I $\mathrm{F}_{592 . \mathrm{D}_{3} 8}$

"Statement on bibliography": p. [523]-527.

The preface states that the purpose of this book "is a literary purpose: to realize the pre-Civil War, Far Western frontier as personal experience." The year 1846 was chosen because it "best dramatizes personal experience as national experience." The work is thus at once both a literary and a historical, and even to some extent a social, document. It focuses on the national events which arose from, were furthered by, or brought about the events on the Western frontier in 1846 , with some tracing of the carry-over into 1847 . The most obvious event of 1846 for standard history was doubtless the outbreak of the Mexican War. This, with Frémont's exploring activities which brought California into the Union, extended the United States to the Pacific. This was the year when America and Great Britain settled the boundaries of the Pacific Northwest. It was also the year in which migration along the Oregon Trail reached a high point, and Francis Parkman rode over much of the trail. In 1846 the Mormons began their two-year mass exodus to Utah. In addition to following these actions and their interacting aspects, De Voto frequently devotes attention to lesser individuals within the mainstream, such as the traders, trappers, and guides, and even 
presents the gruesome story of the Donner party, a group of California-bound emigrants who were stranded in the Sierras. Their story is more fully told in George R. Stewart's Ordeal by Hunger (New York, Holt, 1936. 328 p.).

3332. Dyer, Brainerd. Zachary Taylor. Baton Rouge, Louisiana State University Press, 1946. 455 p. illus. (Southern biography series) “C 47-I 42 E422.D995 "Critical essay on authorities": p. [420]-433.

3333. Hamilton, Holman. Zachary Taylor. Indianapolis, Bobbs-Merrill, I94I-5I. 2 v. illus.

Includes bibliographies. $4^{\mathrm{I}-278 \mathrm{I}} \quad \mathrm{E}_{422 . \mathrm{H}_{3}}$

Contents.-[ [ ] Soldier of the Republic.[2] Soldier in the White House.

Zachary Taylor ( $1784-185^{\circ}$ ) was born in Virginia and raised in Kentucky. Before becoming President, he served for 40 years in the Regular Army, and it is doubtless as a soldier that he made his greatest contribution to the Nation. In his early career he was active in those operations which made the Midwest from Indiana through Missouri safe for settlement. In the Mexican War he demonstrated a considerable generalship, and the ability to inspire confidence among his followers, thus leading to the defeat of enemy forces several times the size of his own. His victories brought him great popularity, which induced influential Whigs to back him for the Presidency. He was elected in 1848 , assumed office in 1849 , and died in 1850 . During his brief term he accomplished little, but the little did include the preliminary organization of the recent annexations, and, in international affairs, the Clayton-Bulwer Treaty. In his acts he soon showed himself a nationalist rather than a sectionalist, which rapidly lost him the support of the Southern Whigs, who thought they had elected one of their own. Dyer's work is a scholarly study of Taylor's life and importance. Hamilton's two-volume biography is much more detailed in its attempt to present a full picture of 'Taylor's historical role, and his importance as a leader in the opening of the West.

3334. Frémont, John Charles. Narratives of exploration and adventure; edited by Allan Nevins. New York, Longmans, Green, 1956. 532 p. maps. ${ }_{56-7867} \mathrm{~F}_{592 . F 8647}$

3335. Nevins, Allan. Frémont, pathmarker of the West. [New ed.] New York, Longmans, Green, 1955. 689 p. illus.

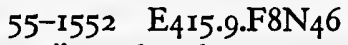

"Bibliographical note": p. 671-673.
While Frémont ( $1813-1890$ ) had a long, varied, and adventurous life as army general, Senator from California, mining magnate, railroad president, Republican presidential candidate in 1856 , territorial governor of Arizona, etc., the most important part of his career for its contribution to the development of America occurred in $1842-46$. In these years he led several expeditions exploring the West. His accurate and extensive scientific reports and his maps established him as one of the world's leading scientist-explorers. In 1842 Frémont explored the Oregon Trail into the Rocky Mountains; his 1843 expedition took him to Oregon, Nevada, and into California. Upon his return East he wrote another vivid report of his expedition; it was published with the first as Report of the Exploring Expedition to the Rocky Mountains in the Year 1842, and to Oregon and North California in the Years 1843-'44 (Washington, Blair \& Rives, I845. 583 p. [U. S. 28th Cong., 2d sess. House. Executive] Document no. I66). In the years that followed, this volume was widely reprinted, and stirred up much enthusiasm for the West and national expansion. In 1845 Frémont set out on another expedition, again working his way into California, where he was instrumental in bringing about its separation from Mexico. While acting as civil Governor of California, Frémont came into conflict with General S. W. Kearny, and was convicted of mutiny by a court martial. Although he emerged from the affair as a popular hero, Frémont's exploring career for the Government was over. His subsequent career was one of greater prominence than significance, since he was cut off from the field of work in which his main talents lay. Toward the end of his life Frémont began to write his autobiography, but died before completing it. A first volume, all that was ever published, appeared as Memoirs of My Life (Chicago, Bedford, Clarke, I887. 655 p.); this skips over his early years to concentrate on his Western expeditions; unfortunately, it adds little of value to his reports, and the biography by Professor Nevins gives a fuller picture of the man. The volume of Narratives of Exploration and Adventure contains selections from Frémont's Memoirs and his many reports; it is chronologically arranged, and contains material on pre-1 842 expeditions in which Frémont took part, though not as leader.

3336. Fuess, Claude Moore. Daniel Webster. Boston, Little, Brown, r930. 2 v. illus.

Bibliography: v. 2, p. [419]-430. 30-2965I $\mathrm{E}_{340} \mathrm{~W}_{4} \mathrm{~F}_{95}$

Contents.-I. I782-1830.-2. 1830-1852.

Webster $(1782-1852)$ was an outstanding statesman-politician, and one of the most influential Northerners of his period. In the House of Repre 
sentatives ( $1813-17,1823-27$ ) and in the Senate (1827-41, 1845-50) he expressed the views of New England conservatism, as well as the related views of the businessmen of the increasingly industrial North. However, Webster was also a strong constitutionalist with the outlook of a unionist, so that on occasion he moderated his position out of consideration for other sectional (usually Southern) interests and the national welfare-most notably in his support of the Compromise of $185^{\circ}$ put forth by Henry Clay (nos. 3342-3344). This led many Northerners to view him as a "fallen God," and published denunciations were numerous. Webster was also an important Secretary of State under three Presidents (Harrison and Tyler, I $84 \mathrm{I}-43$, and Fillmore, $1850-52)$. He argued a number of leading constitutional questions before the Supreme Court, and many regarded him as the outstanding constitutional lawyer of the period. His many speeches in Congress, on public occasions and in court, earned for him, in an age of oratory, a reputation as one of the Nation's foremost orators. Most of these have been brought together in his Writings and Speeches, national ed. (Boston, Little, Brown, I903. $18 \mathrm{v}$.), which unfortunately is incomplete for Webster's scattered correspondence. While Fuess' biography of Webster remains the most thorough study, and is usually regarded as a leading example of political biography, Richard N. Current's Daniel Webster and the Rise of National Conservatism (Boston, Little, Brown, 1955. 215 p.) in the Library of American biography series does bring out more clearly Webster's part in shaping a conservative political tradition in America.

3337. Garrison, George Pierce. Westward extension, 184I-1850. New York, Harper, 1906. 366 p. (The American Nation: a history, edited by A. B. Hart, v. I7.) $\quad 6-4635^{8} \quad \mathrm{E}_{178 . A_{54} \text {, v. I7 }}$ An older work which still provides a clear outline of a crowded decade. The author states in his preface that it has been his "principal aim to describe the expansion of the United States westward from the Louisiana Purchase to the Pacific Ocean, in such a way as to indicate the real forces which gave it impulse, and how they actually worked; and especially to show how it was affected by, and how it reacted upon, the contemporaneous sectionalizing movement which finally ended in the Civil War." Thus, - while a heavy emphasis has been placed on expansion, the book is in large measure a history of the United States for the period covered. It gives a continuous narrative of relations with Mexico in chapters $13-15$. The expansion problem is centered upon Texas, Oregon, and California, with some attention to Maine, the initial planning of a Panama Canal, and related problems. The political consequences of expansion are developed in chapters on the Wilmot Proviso and the Compromise of 1850 . Despite the predominance of expansion, the author finds space for the party struggle and for the domestic problems of the Tyler and Polk administrations. The author used Polk's diary in manuscript before it became widely known, and was one of the first to emphasize "the stern integrity and strength of his character."

3338. Ghent, William J. The road to Oregon, a chronicle of the great emigrant trail. New York, Longmans, Green, 1929. xvi, 274 p. illus. 29-9318 $\mathrm{F}_{592 . \mathrm{G}_{45}}$

This book opens with a discussion of the early explorers who established the Oregon Trail, largely following in the footsteps of animals and Indians. Next came the early missionaries and caravans, who followed the trail from its beginning in Independence, Missouri, to various points along its way or its branches, or to its end in Oregon. The author continues with the story of the heavy migration over the trail in the 1840's. Chapter seven is an attempt to establish the route of the trail. Ghent follows this with an account of the development of traffic over the trail in the $1850^{\circ}$ 's, and concludes by describing the decline in the use of the trail, as a result of the construction in the I860's of a railroad line to the Pacific. While this book is useful for its historical accuracy, and for its extended view of the implications of the use of the trail, a more vivid view of the trail itself may be gathered from Francis Parkman's The Oregon Trail (no. 3348).

3339. Going, Charles Buxton. David Wilmot, free-soiler; a biography of the great advocate of the Wilmot Proviso. New York, Appleton, 1924. xvii, 787 p. 24-21082 E340.W65G6 David Wilmot (1814-1868) was born and raised in Pennsylvania, and from 1834 to the end of his life was active in state and national politics. In 1845 he was elected to Congress as a Democrat, and for a while he showed himself to be a regular party man. However, he came to have increasing doubts about the entrenched power position of the South; these doubts found expression when in 1846 President Polk asked for an appropriation of $\$ 2,000$,000 for acquiring territory in consequence of the Mexican War. Wilmot proposed an amendment barring slavery from any territory to be acquired with the money. This became famous as the Wilmot Proviso; and, while it was not adopted, it was important as a precipitating factor in the North-South cleavage. On this principle Wilmot took an active part in the "Free Soil" campaign of 1848 . As a result of his stand, he left the Democratic Party, and was later instrumental in the founding and develop- 
ing of the Republican Party. While this one cause dominated Wilmot's life, so that Going's large biography is in large part the detailed story of the issue, Wilmot's extensive connections give his life story an importance for the entire period.

3340. Graebner, Norman A. Empire on the Pacific; a study in American continental expansion. New York, Ronald Press Co., 1955. 278 p. $\quad 55-10664$ Ei79.5.G7

"Bibliographical essay": p. 258-265.

This account of the extension of America to the Pacific in the 1840 's covers both the expansion from Texas through California as a result of the Mexican War, and the more northerly expansion through establishment of the southern half of the Oregon Territory as American, as a result of negotiations with Great Britain. The author contends that the interest in acquiring these large tracts of land was relatively minor, and that even the emotional force of the doctrine of Manifest Destiny was far from being the major causative force it has usually been considered to be. He presents a strong argument to prove that acquisition of these territories resulted rather from the growing American desire for the major Pacific ports of San Francisco and San Diego in California, and for control of Juan de Fuca Strait, giving access to Puget Sound in the Northwest. Behind this he perceives the driving force of the Eastern States, whose merchants desired Pacific outlets in order to control the developing trade with Asia.

3341. James, Marquis. The Raven; a biography of Sam Houston. Indianapolis, BobbsMerrill, 1929. 489 p. $\quad 39-2503 \quad F_{390 . H 8483}$

"Sources and acknowledgments": p. [465]-470.

Sam Houston (1793-1863) was born in Virginia, but raised in Tennessee. In 1823, after a varied military and legal career, Houston was elected to Congress, and in 1827 he was chosen Governor of Tennessee. In 1829 Houston's bride suddenly left him, without stating the cause. Rumors multiplied, and Houston resigned from the governorship, but never offered an explanation of what had taken place. Houston then went beyond the Mississippi and soon held a position of leadership among the Cherokees, who knew him as the Raven. In 1835 he entered into the Texan struggle for independence from Mexico, and thus began the career for which he is remembered, and because of which he has been awarded a high seat in the pantheon of American folklore. In 1836 Houston was appointed commander-in-chief of the little Texan army, and on April 2 I surprised Santa Anna and destroyed the van of his army at San Jacinto. Houston was promptly elected the first president of the new and victorious republic. For most of the remainder of his life Houston served his commonwealth as president of the Republic of Texas, as Senator from the new State of Texas, and as Governor of the State. He was Governor when the South seceded; Houston tried to keep Texas from seceding, and then tried to keep it from joining the Confederacy. He failed in both, and his governmental career was at an end. He lived long enough to see his prophecies of doom beginning to be fulfilled. James' biography, which is both scholarly and literary, was awarded a Pulitzer prize in 1930.

3342. Mayo, Bernard. Henry Clay, spokesman of the New West. Boston, Houghton Mifflin,

1937. $570 \mathrm{p}$. illus. $\quad 37^{-28} 854 \quad \mathrm{E}_{340 . C 6 \mathrm{M}_{2}}$ Bibliography: p. [527]-548.

3343. Van Deusen, Glyndon G. The life of Henry Clay. Boston, Little, Brown, 1937. 448 p.

illus. $\quad 37^{-24249} \mathrm{E}_{340 . C 6 V_{3}}$

Bibliography: p. [427]-437.

3344. Poage, George Rawlings. Henry Clay and the Whig Party. Chapel Hill, University of North Carolina Press, 1936. 295 p.

Bibliography: p. [279]-283. 36-18979 E340.C6P6

Clay ( $1777-1852)$ was born in Virginia, but after he had been admitted to the bar moved in 1797 to Kentucky. Here he practiced law, but was soon diverting most of his energy to politics. Elected to the State Legislature in 1803 , he was twice chosen by it to complete unexpired terms in the United States Senate. Sent to the national House of Representatives in $181 \mathrm{I}$, he was at once chosen Speaker, and first gave to that position much of the importance it still holds. A candidate for the Presidency or for nomination to it in each election from 1824 to 1848 , he always had an enthusiastic following, and may be said to have had extremely bad luck in missing the grand ambition of his life. After throwing his support to J. Q. Adams in 1824 , he served as his Secretary of State, and was afterwards elected to the Senate, where in that body's greatest days he shared its leadership with Calhoun, Webster, and Benton. First conspicuous as a spokesman of the New West, he was later best known as the protagonist of "the American system" of Federal support for internal improvements and domestic manufactures, but his posthumous fame has been principally that of the Great Compromiser, who led in the passage of the Missouri Compromise in 1820 , introduced the compromise tariff of 1833 , and originated the Compromise of 1850. Professor Mayo's biography was announced as a trilogy, but nothing has appeared sàve the first volume, which remains the most 
thorough study of Clay's early years down to the War of I8I2. Dr. Van Deusen's biography is the most complete modern account; a briefer one is provided by Clement Eaton: Henry Clay and the Art of American Politics (Boston, Little, Brown, 1957. 209 p.), a volume of the Library of American biography series. Mr. Poage studies Clay as the most conspicuous leader of the Whig Party from the election of 1840 through the Compromise of 1850 . For Clay's own writings, the world is still dependent upon the work of the Reverend Calvin Colton, who edited The Private Correspondence of Henry Clay (New York, A. S. Barnes, 1855. 642 p.) and The Speeches of Henry Clay (New York, A. S. Barnes, 1857. 2 v.). The Works of Henry Clay, published in 6 volumes by A. S. Barnes and Burr in I 857, and several times reprinted, consists of these together with a 3 -volume life of Clay by Colton, which is ponderous and prosaic. A complete edition of Clay's papers is in preparation at the University of Kentucky, under the editorship of James F. Hopkins.

3345. Monaghan, James. The Overland Trail. Indianapolis, Bobbs-Merrill, 1947. $43 \mathrm{I}$ p. illus. (The American trails series)

"Bibliographical note": p. 415-423.

$$
47^{-11789} \mathrm{~F}_{59} \mathrm{r}_{7} \mathrm{M}^{8}
$$

The term "Overland Trail" is used here to designate the north central route used by emigrants heading westwards in the rgth century before the construction of the cross-continental railroad. The route was by most of its users known as the Oregon Trail, but the author has not used that name because "parts of it were traveled by many more Mormons and Argonauts than by Oregon-bound pioneers." Mr. Monaghan's history is in large part told in terms of the adventures of various individuals and groups. Roughly the first third of the book is devoted to the period of early discovery and exploration, and tells the stories of Lewis and Clark, John Jacob Astor, Nathaniel Wyeth, and others. The book continues with the popularizing of one particular trail by John C. Frémont, and the subsequent thass migration of the 1840's. Episodes such as the Donner party, and the journey of Francis Parkman which led to his writing The Oregon Trail (no. 3348), are also narrated. These are followed by accounts of the migration of the Forty-niners, the brief flourishing of the Pony Express, and the advent of the railroad. Among other stories included is Mark Twain's journey over the trail by stagecoach.

3346. Moore, Glover. The Missouri controversy, 1819-1821. [Lexington] University of Kentucky Press, r953. 383 p.
Bibliography: p. [353]-375.

This study opens with a discussion of the historical background for the North-South sectionalism that by 1819 had become a serious divisive factor in the Union, and then takes up the controversy that arose when statehood was proposed for Missouri. This first focused national attention on the new sectionalism, and the problems inherent in it. The eventual Missouri Compromise provided that Missouri be admitted as a slave state, and Maine be admitted as a free state, while it was also agreed that in the future states admitted from north of $36^{\circ} 30^{\prime}$ should be free, and those from south of the line should be slave. This compromise set for several decades the pattern used to preserve a balance in the North-South conflict. Moore also studies public opinion in the various states, the economic factors behind sectionalism, and the political implications. An earlier work presenting less of the national bearings of the controversy, but offering more of a picture of Missouri itself, is Floyd Calvin Shoemaker's Missouri's Struggle for Statehood, 1804-1821 (Jefferson City, Mo., Hugh Stephens Printing Co., 1916. 383 p.).

3347. Nichols, Roy Franklin. Franklin Pierce, Young Hickory of the Granite hills. Philadelphia, University of Pennsylvania Press, I931. xvii, 615 p.

Bibliography: p. $571-584$.

Franklin Pierce (1804-1869) was born in New Hampshire, and early (1829-33) served in the State Legislature. In 1833 he was elected to the national House of Representatives, where he remained until he went to the Senate $(1837-42)$. In both Houses he showed himself a loyal follower ot the Jacksonians. After 1842 he practiced law in New Hampshire, while continuing to manage local Democratic campaigns, and served without distinction as a brigadier-general in the Mexican War. In 1852 he received the Democratic presidential nomination as a dark horse compromise candidate. $\mathrm{He}$ made no campaign speeches, but won the election in an electoral landslide which overwhelmed Whigs and Free Soil Democrats alike. As President he tried to satisfy all elements in his party, and so satisfied practically none. He was a nationalist who tried to reconcile the North-South conflict, but with little success. In foreign affairs he worked for "manifest destiny" on a number of fronts, but failed in practically all. Having failed to obtain renomination from the Democrats, he retired to private life in New Hampshire. With the advent of the Civil War, Pierce became hated for his opposition to abolitionism, his advocacy of a compromise with the South, and his opposition to the war. Professor Nichols' book is an attempt not only to write the President's biography, but also to under- 
stand Pierce and others like him who worked unremittingly for compromise, but achieved only obloquy from a nation torn by intense emotions.

\section{Parkman, Francis. The Oregon Trail;} sketches of prairie and Rocky-Mountain life. With an introd. by Henry Steele Commager. New York, Modern Library, 1949. xix, 366 p.

\section{9-49101 $\mathrm{F}_{592 . P_{2} 84}$}

Parkman has already been discussed a number of times in this bibliography (nos. 2281, 3069, and 3171). The Oregon Trail resulted from a journey he took along part of the trail in 1846 , while the first mass migrations westward were in progress. The book first appeared serially in Knickerbocker shortly after he had returned from his travels. It is still considered one of the leading books providing insight into Indian character and ways of life. It shows vividly what the West was like as white men first appeared on the scene in numbers. It is currently fashionable to lament the fact that Parkman did not appreciate the significance of the migration then taking place, and thus did not produce a book on the lines of Ghent's (no. 3338). Had he done so, we might now have a quite good book on the migrations; as it is, we have a superb work focusing on the Indian and wildlife background, and serving as an introduction to Parkman's later historical work. The Oregon Trail is available in many editions and can be read merely as an adventure story.

3349. Polk, James Knox. The diary of James K. Polk during his Presidency, 1845 to 1849 , now first printed from the original manuscript in the collections of the Chicago Historical Society. Edited and annotated by Milo Milton Quaife with an introd. by Andrew Cunningham McLaughlin. Chicago, McClurg, 1910. 4 v.

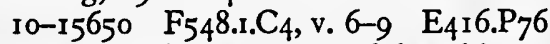

"This work forms volumes VI-IX of the Chicago Historical Society's collection, a special issue of 500 copies being printed for the purposes of that society."

3350. McCormac, Eugene Irving. James K. Polk, a political biography. Berkeley, University of California Press, 1922. $746 \mathrm{p}$.

Bibliography: p. [726]-731.

$$
\mathrm{A}_{22-821} \quad \mathrm{E}_{417} \cdot \mathrm{M}_{12}
$$

3351. Sellers, Charles Grier. James K. Polk, Jacksonian, I795-1843. Princeton, Princeton University Press, $1957.526 \mathrm{p}$.

$$
57-5457 \quad \mathrm{E}_{417 .} \mathrm{S}_{4}
$$

"Sources": p. 493-509.

Shortly after Polk (1795-1849) was born in North
Carolina, his family moved to Tennessee, where he was raised. He studied for the law, early entered State politics, and went on to the U. S. House of Representatives, where he served from I 825 to 1839 . In this period he established himself as a leader of the Jacksonian forces in Congress, and a popular politician of integrity with an unusual talent for stump speaking. In 1839 he followed his party's call and ran for Governor of Tennessee to save the State for the Democrats; he won this election, but lost in two subsequent tries. In 1844 Polk was being considered for the Democratic vice-presidential nomination, when the deadlock of the Van Buren and Calhoun forces led to his becoming the compromise candidate for the Presidency. Shortly after his inauguration in 1845 , he declared that the four main measures of his administration would be: "one, a reduction of the tariff; another, the independent treasury; a third, the settlement of the Oregon boundary question; and lastly, the acquisition of California." With single-minded purpose and untiring activity, Polk achieved all these measures in his one term in office, and refused a renomination. In his unremitting attention to his duties, Polk had worn himself out, and died a few months after leaving office. The biography by McCormac concentrates heavily on the presidential years, with a long section on the Mexican War. Mr. Sellers' study is meant to show Polk not merely in his political role, but as a human figure in his era; it stops short of the presidential years. A close view of Polk's White House activities may be found in his remarkable Diary; a selection from it was made by Allan Nevins and published as Polk: The Diary of a President, 1845-1849 (New York, Longmans, Green, 1952. 412 p.).

3352. Schlesinger, Arthur M., Jr. The age of Jackson. Boston, Little, Brown, 1945. $577 \mathrm{p}$. $\quad 45^{-8340} \mathrm{E}_{3} 8 \mathrm{r} . \mathrm{S}_{3} 8$ Bibliography: p. [529]-559.

This volume, which really deserves the overworked adjective "stimulating," does not attempt to offer a detailed narrative of Andrew Jackson's two administrations (1829-37), but is rather an interpretation of three decades of American history in the light of the renewal of the democratic impulse effected by Jackson and his lieutenants. The author seeks to show how the Jacksonian movement grew out of Jeffersonian democracy, as a changing social order required a peaceable revolution to preserve the reality of democracy in a changed context. The younger Schlesinger studies the intellectual, political, and economic forces at work, and reaches the conclusion that the Jacksonian revolution was not the triumph of Western radicalism over Eastern 
capitalism, as is usually thought; but, rather, that it was the triumph of the non-capitalists (farmers, factory workers, etc.) in all sections over the entrenched capitalistic groups. The author also shows most of the leading intellectuals of the day supporting the movement, and giving it a solid core of ideas. The ramifications of the movement are traced in the law, industrialism, religion, Utopian socialism, and literature. The dilution and disintegration of the impulse, under leaders less determined and less able than Jackson, are followed to the Civil War and even into the administration of Andrew Johnson. The "whole moral of the Jacksonian experience," the author suggests, was that "only a strong people's government could break up the power of concentrated wealth." The wide range of the book, and the forceful style with which the author has brought together the strands of his extensive scholarship, give it a vital quality in picturing the era and the forces that molded it.

3353. Shackford, James Atkins. David Crockett, the man and the legend. Edited by John B. Shackford. Chapel Hill, University of North Carolina Press, 1956. $33^{8} \mathrm{p}$.

Bibliography: p. 317-324.

$$
5^{6-13913} \quad F_{436 . C 9594}
$$

Davy Crockett is well known to most Americans as a folklore figure whose incredible adventures have been presented through almanacs, comic books, movies, television programs, children's tee-shirts, etc. The original of these stories was David Crockett ( $1786-1836$ ), a politician who throughout his life welcomed the retelling of tall tales about himself. He was born in Tennessee to the poverty usual among frontier families. However, he rose through military and judicial positions to represent his frontiersman neighbors in Congress. He served well the interests of these poor settlers, but lost office after breaking with the Jacksonians, largely because of their land policy. He returned to the advancing frontier, then in Texas, and was killed at the Alamo in the Texan war for independence. It is this historical person whose life is traced in Shackford's book, which is based on extensive research among previously neglected primary sources. The author also tries to rehabilitate as a piece of frontier literature, humor, and some truth the 1834 autobiography (nos. 2649-50). Here Crockett emerges as an archetypal frontiersman of great strength, courage, and determination, if on a somewhat diminished scale from the glories of folklore.

3354. Smith, Justin H. The annexation of Texas. Corrected ed. New York, Barnes \& Noble,

I94I. 496 p. A42-899 F390.S647 I94I

"Account of the sources": p. $471-476$.
When the United States purchased the Louisiana Territory it acquired some claims to Texas, but waived them in 1821, in exchange for Florida. However, neither Spain nor Mexico, after acquiring independence, succeeded in settling Texas. Settlement was largely by Americans, led first by Stephen Austin (no. 3314). Since the Mexican Government was highly unstable, Texas never developed any attachment to it. In 1835 , after the Mexican Government had become a military dictatorship, Texas declared its independence, and managed to maintain it under the leadership of Sam Houston (no. 334r), but sought to become a state of the American Union. Throughout the following decade the pros and cons for annexing Texas were loudly disputed in the United States. The main stumbling block was the issue of slavery. Westerners wanted Texas at any price, southerners wanted an extension of slave areas, and northerners opposed the idea of more slave-voting states. After much argument Texas was finally admitted to the Union, and conflicting views over its western boundary soon led to the Mexican War (no. 3689). It is the background to this phase of American expansion and North-South sectionalism that is examined in this book, originally published in I $1 \mathrm{I} I$. It was the first thorough study of this historical problem, and research for it was done in archives throughout the world, so that it is based almost exclusively on primary sources. In his thoroughness the author has also considered the attitudes and actions of foreign governments insofar as they concerned the transition of Texas from Mexican Province to independent republic and to American State.

3355. Stephenson, Nathaniel W. Texas and the Mexican War; a chronicle of the winning of the Southwest. New Haven, Yale University Press, I921. 273 p. illus. (The Chronicles of America series, Allen Johnson, editor, v. 24)

$$
\text { 2I-I } 4809 \text { EI73.C55, v. } 24
$$

$\mathrm{F}_{3} 89 . \mathrm{S}_{92}$

This is a concise account of Texas, from its beginnings through the stabilization of its boundaries at the end of the Mexican War. The book opens with a brief account of early American claims to Texas, the settlement of that area by Americans, and the relationship of those Americans to the central Mexican Government. It continues with an account of the growing friction between the government and the American settlers, the attempts of the United States to acquire the area by negotiation, and the final revolt of the colonists against Mexico, leading to the establishment of the Texan Republic. The author then reviews the actions which led to the annexation of Texas by the United States, and the conflicting boundary claims and territorial desires 
which resulted in the Mexican War. The course of the war is then traced, and the book concludes with the ratification of the treaty which resulted in America's acquisition of the Southwest (1848). The "Bibliographical Note" (p. 259-26I) at the end is now considerably out of date. The book itself, however, remains essentially valid, for subsequent research has added much detail, but has little altered the main outline of the story which is the substance of this volume.

3356. Turner, Frederick Jackson. Rise of the New West, 1819-1829. New York, Harper, 1906. xviii, 366 p. 9 maps. (The American Nation: a history, edited by A. B. Hart, v. I4)

$$
\text { 6-1 } 3695 \text { E178.A54, v. I4 }
$$

"Critical essay on authorities": p. [333]-352.

This volume, the only substantial narrative history completed by the celebrated formulator of the "frontier hypothesis" (no. 3147), is a general view of the United States from the panic of 1819 to the election of Andrew Jackson. The author finds the significance of the decade in the weakening of the nationalism which had flared out toward the end of the War of 1812 and had dominated the first years of the peace, and in the resurgence of sectional interests. However, national feeling, and the sense of alienation from Europe, remained powerful enough to allow the enunciation and general acceptance of the Monroe Doctrine in 1823 . The author surveys the situation in each of the three older sections, and then describes developments in the new one, the trans-Appalachian West, at some length, since it was the progress of civilization here which brought a completely new factor into the national composite. The domestic politics of the period, involving such issues as the Missouri Compromise, internal improvements, and the tariff, are interpreted in terms of the interests, the balance, and the alliances of sections. In progress at the same time but, the author confesses, not easy to depict, was "the formation of the self-conscious American democracy, strongest in the west and middle region, but running across all sections and tending to divide the people on the lines of social classes."

3357. Turner, Frederick Jackson. 'The United States, 1830-1850; the Nation and its sections. With an introd. by Avery Craven. New York, Holt, 1935. xiv, 602 p. maps.

$$
\text { 35-5282 } \mathrm{E}_{33} 8 . \mathrm{T}_{92}
$$

The author's incomplete manuscript was edited by M. H. Crissey, Max Farrand, and Avery Craven. "Chapter XIII [ Taylor administration and the compromise of $\left.185^{\circ}\right]$... was never written."
In this history of the period from 1830 to 1850 , which is in some degree a continuation of his Rise of the New West (supra), Turner pursues his theories of sectionalism and its influence on the development of the country. The bulk of the book consists in studies of the various sections (New England, Middle Atlantic States, South Atlantic States, South Central States, North Central States, and Texas and the Far West) throughout this period. There follow a series of chapters on the presidential administrations from Jackson through Polk. Chapters at the beginning and end bring this material together to some extent. Unfortunately, while Professor Turner spent i5 years in writing the book, he died without completing it, which fact is doubtless responsible for a lack of unity in the volume. Furthermore, only a limited amount of editorial work has been done upon it. Nonetheless, the work remains important for the questions it raises, its influence on subsequent historians, and its proWestern, pro-frontier view of national development.

3358. Woodford, Frank B. Lewis Cass, the last Jeffersonian. New Brunswick, Rutgers University Press, 1950. $3^{80} \mathrm{p}$.

Bibliography: p. $357-369$.

$$
\text { 50-974I } \mathrm{E}_{340 . \mathrm{C}_{3} \mathrm{~W} 66}
$$

Lewis Cass ( $1782-1866$ ) was born in New Hampshire. As a young man he moved to Ohio, where he entered into law practice in 1802 . He had served in the Ohio State Legislature, and he had taken part in the War of 1812 on the frontier, when at the end of $181_{3}$ he was appointed Governor of Michigan Territory, a position he held for 18 years. He was then appointed Secretary of War in Jackson's Cabinet, where he remained until $18{ }_{3} 6$. Subsequently he served as American Minister to France; in this position his anti-British maneuverings brought him great popularity at home. In 1844 he came near obtaining the Democratic nomination for the Presidency, but was passed over for Polk. Cass then entered the Senate, where he continued his work as a conservative nationalist until 1848 , when he received the presidential nomination. However, he lost to Taylor in a close election, partly because of a split in his own party, and partly because he was too conservative in a period of intense partisanship over such matters as slavery, territorial expansion, and internal improvements. He was then reelected to the Senate, where he remained until he became Buchanan's Secretary of State. He resigned from this position when Buchanan refused to strengthen Fort Sumter, with the Civil War but a few months away. Mr. Woodford's scholarly biography relates Cass' varied and influential career to the progress of the Nation's development. 


\section{H. Slavery, the Civil War, and Reconstruction (to 1877)}

3359. Bancroft, Frederic. The life of William $\mathbf{H}$. Seward. New York, Harper, 1900. 2 v. o-1693 $\mathrm{E}_{4} 15.9 . \mathrm{S}_{4} \mathrm{~B}_{3}$

A critical but sympathetic biography of Seward (1801-1872) whose aim in life, not entirely achieved, "was to be supremely great both in his generation and in history." Seward began his active political career in $183^{\circ}$ as an Antimason, joined the Whig Party in 1834 , and served in the United States Senate from 1848 until his appointment as Lincoln's Secretary of State. His opposition to slavery in the Senate was partially motivated by the increasing power of the antislavery movement in the North, which led him to enter the Republican Party in 1854. Although an acknowledged party leader, he failed of nomination to the Presidency in both 1856 and 1860 . As Secretary of State from I 86I to I869, Seward became, in the author's opinion, a diplomatist and statesman of the first rank. He was the first Secretary to publish diplomatic dispatches, a part of his campaign to mold public opinion in favor of the policies of the Government. His great triumph was his skillful checking of the interventionist aims of Great Britain and France in the Civil War, and the reduction of their unofficial interference by manipulating the sympathies of the European opponents of slavery. In the postwar years Seward supported Andrew Johnson's policy of moderation toward the South, forced France to withdraw from Mexico, and purchased Alaska from Russia in 1867 . Personally amiable and without malice, Seward is here characterized as "pre-eminently a man of theories and expedients, but he also had settled convictions and sound judgment."

3360. Barnes, Gilbert Hobbs. The antislavery impulse, 1830-1844. New York, AppletonCentury, 1933. 298 p. $\quad 33-38695 \quad E_{449} \cdot B_{2} 6_{4}$

"This volume is published from a fund contributed to the American Historical Association by the Carnegie Corporation of New York."

"Works consulted": p. 199-202.

This influential work traces the main current of antislavery agitation and organization in the United States to the great evangelical revival which reached its peak in 1830 , and in particular to the preaching of Charles Grandison Finney (1792-1875), a successful lawyer transformed into an itinerant Presbyterian revivalist of extraordinary fervor and persuasion. At Utica, N. Y., Finney not merely converted but gathered into his Holy Band a student at Hamil- ton College, Theodore Dwight Weld, and his older friend and mentor, Charles Stuart, a retired captain of the British Army. Finney's mission in New York City brought into line the wealthy and philanthropic merchants, Arthur and Lewis Tappan. In 1833 , on learning of the British measure for abolishing West Indian slavery, the New York group proceeded to organize the American AntiSlavery Society, which in the following year began its nationwide agitation for immediate abolition. In 1837 pamphleteering was subordinated to evangelism, as The Seventy were recruited and sent out to work in the rural counties. In the same year their efforts produced the flood of antislavery petitions to Congress, where they were "stowed away in the antechambers by waggon loads." Antislavery at once became a live political issue, and the first supporter of the petitions, J. Q. Adams, was soon joined by allies on the floors of Congress. "From first to last, throughout the antislavery host the cause continued to be a moral issue and not an economic one." The book is very largely based on original and previously unexploited sources such as the Weld, Lewis Tappan, J. R. Giddings, and J. G. Birney papers, and nearly one-third (p. 203-29I) consists of notes containing extensive extracts from them.

336r. Beale, Howard K. The critical year; a study of Andrew Johnson and Reconstruction. New York, Harcourt, Brace, 1930. 45.4 p.

Bibliography: p. 407-435. 30-14060 E668.B 354

The election year of 1866 is here critically examined through contemporary newspapers, private correspondence, local campaign speeches, and political sermons, in order to determine the true motives behind the campaigns of Andrew Johnson and the Radical Republicans. In the author's analysis, the election issue was not merely one of deciding the policy to be followed in dealing with the conquered South, but was also the decisive test of power between the rising industries and businesses of the Northeast, represented by the Radical Republicans, and the agrarian South and West, championed by Johnson. The victory of the Radical Republicans and the economic interests allied with them was achieved by adroit propaganda, appealing to the sectionalism and war-bred hatred of the electorate, rather than presenting any actual issues upon which they could express their preference. 
3362. Bowers, Claude G. The tragic era; the revolution after Lincoln. New York, Blue Ribbon Books [193-] xxii, $567 \mathrm{p}$.

\section{7-10370 E668.B7793}

Reprinted from the original edition (copyrighted 1929).

"Manuscripts, books, and newspapers consulted and cited": p. [54I]-547.

The late Ambassador Bowers (1879-1957) quoted with approval Hilaire Belloc's dictum that "readable history is melodrama," and of his three principal dramatizations of American history (cf. nos. 328I \& 3320) The Tragic Era is the most melodramatic. Anyone who wants to approach Reconstruction and the Gilded Age in Washington through a crowded and stirring narrative in which the whites are dazzling and the blacks Stygian will find this to his taste. For such history there must be dramatis personae, and Andrew Johnson and Thaddeus Stevens, cast respectively as Gabriel and Satan, have each a portrait-chapter to himself. There must be a backdrop, provided by a brilliant chapter on "Washington: the Social Background." Comic relief is provided by "The Great American Farce," as the impeachment trial of President Johnson is denominated. Peripeteia in the action are indicated by such chapter headings as "Military Satraps and Revolution," "The Falling of Rotten Fruit," and "The Red Shirts Ride." For all this, the volume is based upon a thorough knowledge of memoirs and biographies, supplemented from a few manuscript collections and a wide use of contemporary newspaper files. Mr. Bowers was neither an unlearned nor a careless historian, and his vigorous partisanship is harmless because it is so honestly avowed.

3363. Buck, Paul H. The road to reunion, 18651900. Boston, Little, Brown, 1937. 320 p. $37-4978$ E66r.B84

The morrow of Appomattox saw a North arrogant in victory, and a South "spent and exhausted, yet ready to offer stolid resistance" to aggression. During the 12 Reconstruction years, while the North was building its policy upon force, sectional division was perhaps intensified. But before as well as after 1877 , "the sturdy barriers of sectional antipathy and distrust crumbled one by one." Within a generation of Appomattox "an American nationalism existed which derived its elements indiscriminately from both the erstwhile foes." As the author states, virtually every activity of the American people during the period had some bearing upon sectional reconciliation, and he traces its progress in a variety of spheres: economic development and integration, the rise of a new generation in the South, the appearance of a new Southern literature hospitably received in the North, and the fraternizing of veterans' organizations. Perhaps the decisive element which permitted the "new patriotism" of 1898 was the acquiescence of leaders of Northern opinion in the disfranchisement of the Southern Negro.

3364. Cate, Wirt Armistead. Lucius Q. C. Lamar, secession and reunion. Chapel Hill, University of North Carolina Press, 1935. 594 p. illus.

Bibliography: p. 555-563.

35-9410 E664.L2 $\mathrm{C}_{37}$

Lamar (1825-1893), the nephew of Mirabeau Buonaparte Lamar and the son-in-law of Augustus B. Longstreet, was a Georgian by birth. He represented Mississippi in the two Congresses before the Civil War, drafted the Mississippi ordinance of secession, held a commission in the Confederate Army, and went to Europe as a Confederate commissioner. His real eminence, however, began in 1872, when he succeeded in winning election to the U. S. House of Representatives, and soon thereafter led in the elimination of carpetbag rule from Mississippi. His distinguished and conciliatory service in the U.S. Senate culminated in his appointment by President Cleveland, first as Secretary of the Interior in 1885 , and then to the Supreme Court in 1888 , in both of which positions the ex-Confederate became a living symbol of restored national harmony. Mr. Cate's biography is extremely laudatory, but has much reason for being so.

3365. Coulter, Ellis M. Travels in the Confederate States, a bibliography. Norman, University of Oklahoma Press, I948. xiv, 289 p. (American exploration and travel [II])

${ }_{48-7183} \mathrm{Z}_{1251 . S 7 C 68}$

Travel, in the ordinary sense, is a rarity if not an impossibility in wartime, and this annotated bibliography, which derives its title from the series of which it forms a part, is somewhat misleadingly named. Most of the 492 titles which are here described in considerable detail are the personal narratives, letters, or diaries of soldiers. Somewhat unexpectedly, Southern soldier-writers are in a decided minority; many who did write wrote late and from memory, and Dr. Coulter has excluded most of their publications as "almost worthless" for his purpose. Many of the Northerners, however, are here reproached with being prejudiced witnesses. A considerable proportion of the titles are Northern regimental histories, selected whenever the author was a member of the unit and included descriptive detail. The entries list the illustrations in each work, and the annotations give "some estimate of the nature of its content, its reliability, and the itinerary of the author." In addition to the book's express 
purpose of showing what the South was like in wartime, it is a valuable guide to personal materials on the campaigns in Southern territory.

3366. Craven, Avery O. The coming of the Civil War. [2d ed. Chicago] University of Chicago Press, 1957 . 49I $\mathrm{p}$.

57-8572 $\quad$ E $_{33} 8 . C_{92} \quad 1957$

The second edition of this work differs little from the first of 1942, but adds a preface in which the author tells that it arose out of an attempt to write a history of American democracy. He soon realized that the democratic process in the United States had "completely failed in the critical period that culminated in the Civil War," and this book was the result of his effort to find out why. He finds it necessary to go as far back as 1800 to provide an adequate background, and he approaches the situation from the angle of the South, "since that section's ways and institutions were under fire." Southern arguments in favor of slavery are represented as a reaction to an aggressive attack upon the institution within as well as outside the South. Rising emotionalism in the North engendered by decades of abolitionist propaganda is given the major blame for placing the two sections in irreconcilable frames of mind which left no alternative save secession and war. Despite the divisions which rendered the Democratic Party ineffectual in its efforts for compromise, the author believes that if the Republican movement had been less intransigent, slavery would ultimately have eliminated itself without any breach of the Union. Professor Craven nevertheless asserts that his conclusions "point out the tragedy of being human rather than of being either Southern or Northern."

3367. Craven, Avery O. Edmund Ruffin, Southerner; a study in secession. New York, Appleton, 1932. 283 p. $\quad 32-863$ I $\quad F_{230 . R 94}$ "Notes," containing bibliography: p. $26 \mathrm{I}-[27 \mathrm{I}]$.

A native of Prince George's County, Virginia, Edmund Ruffin (I794-1865) was one of the South's most noted agriculturalists -and became one of its earliest and most emphatic and fanatical secessionists. His writings on slavery and Southern rights vied in quantity with his writings on agriculture. As the founder of the League of "United Southerners, Ruffin was allowed to fire the first shot from Morris Island against Fort Sumter. He never held a civil or military commission from the Confederacy, but nevertheless committed suicide when it collapsed. Mr. Craven has written a penetrating study of this man who, however interesting, is less important as an individual than as a representative of the tone and temper of his section and class.
3368. Current, Richard Nelson. Old Thad Stevens, a story of ambition. Madison, University of Wisconsin Press, 1942. $344 \mathrm{p}$.

Bibliography: p. 323-328. 43-52549 $\quad \mathrm{E}_{415}$.9.S8 8 C8

Stevens (I792-1868) was a Vermonter by birth but became a lawyer and an iron manufacturer in central Pennsylvania. From 183 r he was a leading politician in the Antimasonic, Whig, Free-Soil, and Republican Parties, and always showed himself a zealous advocate of democratic measures and an intransigent foe of any form of aristocratic privilege. In the Pennsylvania Legislature in the 1830 's he did much to extend the system of free schools to the entire state. In the U.S. House of Representatives, from 1849 to 1853 and again from 1859 until his death, he was a vociferous opponent of slavery and the Southern slaveowners. During the Civil War he continued to assail Lincoln's administration for its allegedly slack conduct of the war, and on its close he became the most influential House member of the Joint Committee on Reconstruction. He led in the measures which wrecked Lincoln's plan of Reconstruction, hobbled the Johnson administration, and culminated in the impeachment and trial of President Johnson. He died soon after the latter's acquittal. This harsh and enigmatic figure has attracted a succession of biographers, none of whom can be said to have read the riddle and produced a definitive life, for which sufficient material probably does not exist. Mr. Current's life is based on solid research, but goes rather far in reducing Stevens' avowed passion for equality to a politician's love of power and a desire to make his party "a vehicle for industrialists like himself." The older work by James A. Woodburn, The Life of Thaddeus Stevens (Indianapolis, Bobbs-Merrill, 1913. $6_{20}$ p.), is still worth consultation, though it is not a biography in the modern manner.

3369. Dodd, William E. Jefferson Davis. Philadelphia, G. W. Jacobs, 1907. 396 p. (American crisis biographies) 8-820 $\mathrm{E}_{4} 67.1 . \mathrm{D} 26 \mathrm{D} 8$ Bibliography: p. $[384]-385$.

A sympathetic and relatively brief narrative of the tragic life of Jefferson Davis (1808-1889), soldier, planter, United States Senator, and President of the Confederate States of America. Davis is shown to have derived a love of order and discipline from his West Point training; he was also a man of deep affection for his family. His most salient characteristic, clearly manifested in public office, was his loyalty to his friends, whom he loaded with favors and defended at all times. Attention is given to his leadership of the Southern rights forces in 
the Senate. As Chief Executive of the Confederacy he was not as effective as his wishes and abilities permitted, because of the jealousy of the seceded states for their sovereignty. Much attention is also given to his decisions affecting the operations of the Southern armies. Having spent two years in a Federal prison after the collapse of the Confederacy, Davis retired to private life, promoting the rebuilding of the Southern economy, but only occasionally appearing to make a speech. A more detailed but as yet incomplete biography is Hudson Strode's lefferson Davis, [v. I] American Patriot, I808-186I (New York, Harcourt, Brace, I955. $\mathrm{xx}, 460$ p.)

3370. Dumond, Dwight Lowell. Antislavery origins of the Civil War in the United States. Ann Arbor, University of Michigan Press, 1939. I $43 \mathrm{p}$. 39-2II3I E449.D87

"List of additional readings": p. I3I-134. "Selected bibliography of proslavery and antislavery publications": p. 135-139.

Lectures delivered on the Commonwealth Foundation at University College, London, which analyze "the abolition indictment of slavery and trace the steps by which the defense of the institution forced men to proceed from a general discussion of the subject to a war against it." The antislavery movement is divided into three periods: The first ( 1787 1833) centered about the activities of the racist American Colonization Society for promoting the deportation of free Negroes to Liberia. The second ( $833-39$ ) was marked by the rise of the American Anti-Slavery Society and a clarification of the principles of antislavery doctrine. Slavery's loss of national approval, the rallying of the South to its defense, and the flight of abolitionists from slave to free states all made slavery a sectional issue. In the third (1839-6I) manumission became a political question with the formation of the Liberty Party by the antislavery forces, and the major parties became sectional parties vying for control of the Federal Government. The South's refusal to permit outside influence to set in motion economic and social forces in favor of constitutional abolition is regarded as the decisive factor in bringing about secession and war.

3371. Dumond, Dwight Lowell. The secession movement, 1860-186r. New York, Macmillan, 1931. 294 p. $\quad 3$ I-30548 E440.5.D88 $^{\text {. }}$ Bibliography: p. 273-286.

This is one of those historical studies which derive their value from carefully delimiting the field of investigation, and confining their attention to what lies within it. In this University of Michi- gan dissertation Professor Dumond aimed "to state the premises upon which the several groups of Southerners justified resistance to the Federal Government, and to trace the process of secession." $\mathrm{He}$ is aware that slavery was the bone of contention, and that vast economic and social interests were involved, but he is concerned with the expression of these in a Federal system of government under a written constitution. "The Republicans affirmed the right and duty of Congress to exclude slavery from the territories. The Southernrights men denied it to Congress, to the territorial legislatures, and to the people of a territory until they framed an organic law preparatory to admission as a state." This was the issue which split the Democratic convention, brought about the election of a Republican President, kept the Southern leaders from acquiescence in this result, and frustrated the various attempts to work out a compromise. The author extracts the constitutional interpretations implicit in the course of events from April 1860 to April I86I with great penetration.

3372. Dunning, William Archibald. Reconstruction, political and economic, $1865-1877$. New York, Harper, I907. xvi, 378 p. (The American Nation: a history. v. 22)

$$
\text { 7-24I64 EI78.A54, v. } 22
$$

"Critical essays on authorities": p. [324]-357.

The Reconstruction era is here seen not merely as a time when the victorious North imposed its will upon the defeated South, but as a time marked by a realignment of national powers and a readjustment of political forces which accompanied recovery from the wounds of civil war. It is this national, rather than Southern, transformation which occupies Professor Dunning here. The rival policies of the President and Congress in regard to Reconstruction and national administration are discussed in the light of their effect upon the Southern state governments and their colored and white populations. While social, economic, and political conditions in the country as a whole left much to be desired, public attention came to be focused upon the irresponsible exploitation of Negro suffrage in the South, and on the spread of corruption in the Federal Government which political adversaries called "Grantism." The final chapters deal with the resurgence of the South, the nullification of Negro suffrage, the exposure of scandals throughout the administration, and the questionable election of 1876 and its aftermath. Professor Dunning's seven Essays on the Civil War and Reconstruction and Related Topics (New York, P. Smith, 1931. 397 p.) deal principally with the constitutional and governmental aspects of Reconstruction. 
3373. Eaton, Clement. A history of the Southern Confederacy. New York, Macmillan, I954.

\section{I p.} 54-8772 $\mathrm{E}_{4} 87 . \mathrm{EI}_{5}$

Mr. Eaton's purpose is to "delineate the changes which occurred in the society of the Old South under the impact of war." The secession movement was a conservative revolt, "in that the South would not accept the rgth century," and all segments of society were of necessity deeply affected by the progress and fortunes of the war. Attention is focused upon the morale of the army and of the civilian population, and the eventual decline of the will to resist. The role of women, the attrition of cultural institutions, the attitude of Negroes, and the personalities of civil and military leaders are described, and there are summaries of Confederate strategy and logistics. Mr. Eaton has drawn upon letters, diaries, and other personal narratives in his effort to illustrate the "human drama" of the Confederacy. Similar in scope, treatment, and thesis, and even more detailed, is E. Merton Coulter's The Confederate States of America (no. 4076).

3374. Fite, Emerson David. Social and industrial conditions in the North during the Civil

War. New York, P. Smith, I930. 318 p.

First published in rior.

$$
\text { 30-26614 HC } 105.6 . F 6 \text { I930 }
$$

The considerable literature on civil society in the Confederacy is matched by a surprising dearth of titles for the situation north of the battle lines. The present volume, originally published over 45 years ago, is largely concerned with the wartime economic boom, in which agriculture, transportation, manufacturing, and commerce all participated, and in which capital and labor both shared. It also contains chapters on the progress, notwithstanding heavy Federal taxation, in municipal improvements, on the continuing foundation and endowment of colleges in spite of reduced attendance in them and in the high schools, on the prevalence of luxurious consumption and entertainment as usual which so outraged many an editorialist, and on the huge effort of organized charities to relieve the miseries, hardships, and dislocations caused by the war.

3375. Fladeland, Betty L. James Gillespie Birney: slaveholder to abolitionist. Ithaca, Cornell University Press, I955. 323 p.

Bibliography: p. 295-315.

$$
55^{-1} 3997 \quad \mathrm{E}_{340 .} \mathrm{B}_{65}
$$

Birney (1792-1857) was the son of a wealthy slaveowner of Danville, Kentucky, and in 1818 moved to Huntsville, Alabama, where he established a successful law practice, acquired a nearby plantation, and entered state politics. In the course of the next decade he was converted to Presbyterianism and acquired a strong conviction of the evil of slavery and the duty of acting to end it. In 1830 he joined the American Colonization Society, and two years later became one of its agents. By 1834 he was ready to emancipate his own slaves and ally himself with the American Anti-Slavery Society. His attempts to publish an antislavery journal in Kentucky led to the usual menaces, and his withdrawal to Ohio. He served as corresponding secretary of the Anti-Slavery Society and was the candidate of the Liberty Party for President, passively in 1840 and actively in 1844 , when he received 62,300 popular votes. An accident followed by a stroke eliminated him from public life in the following year. What an Alabama newspaper called his "retrograde progression" from slaveholder to colonizationist to abolitionist makes him one of the most interesting of the antislavery leaders. Miss Fladeland emphasizes the religious motives of his later career, and the sacrifices which he willingly incurred in their behalf.

3376. Fleming, Walter L., ed. Documentary history of Reconstruction, political, military, social, religious, educational \& industrial, $186_{5}$ to the present time. Cleveland, A. H. Clark, rgo6-7. 2 v. $\quad$ 6-39739 E668.F58

Walter Lynwood Fleming (1874-1932), an Alabaman by birth, was probably the best known of William A. Dunning's pupils at Columbia University, where he took his $\mathrm{Ph}$. D. in 1904. He taught history at West Virginia University, Louisiana State University, where he is commemorated by an annual lectureship in Southern history, and from 1917 at Vanderbilt University in Nashville. The present compilation, with nearly $95^{\circ}$ pages of text, has been regarded as a first-rate authority since its initial publication; a micro-offset reproduction was issued by Peter Smith in 1950. Volume I is chiefly concerned with the evolution of the Reconstruction policies of the Federal Government, and volume II with their concrete working out in the South, "with special reference to race relations, political morality, and economic, educational and religious matters." The phrase "to the present time" in the title means that materials on later conditions traced to Reconstruction policies, or on later reversals of such policies, are included in some chapters. The documents, most of which are extracts and relatively brief, include. state constitutions, Federal and state laws, Congressional documents, a wide range of contemporary publications including Southern newspapers, personal statements from a variety of sources, and previously unpublished pieces from the papers of President Johnson and the records of the War Department. The chapters are largely topical, and 
each opens with a brief introduction by the editor. Impressive as the compilation is, it is only reasonable to suppose that Dr. Fleming's conviction that Reconstruction was an abomination vindictively imposed upon the white people of the South had some influence in his selection of materials.

3377. Fleming, Walter $L$. The sequel of Appomattox; a chronicle of the reunion of the States. New Haven, Yale University Press, 1921. 332 p. (The Chronicles of America series, v. 32) 22-12154 Ei73.C56, v. 32 E668.F62

"Bibliographical note": p. 305-307.

An economical and closely knit narrative of the Radical Republicans' triumph and the decade during which their system of white disfranchisement was imposed upon the South by military rule. The moral and intellectual results were more permanent than the material ones of debt and impoverishment: "the pleasantest side of Southern life came to an end," and "there was a marked change in Southern temperament toward the severe." The restoration of home rule brought in a long period of political stagnation, the result of fear "lest a developing democracy make trouble with the settlement of 1877."

3378. Freeman, Douglas Southall. The South to posterity; an introduction to the writings of Confederate history. New York, Scribner, 1939. $235 \mathrm{p}$.

Bibliographical references in "Notes" (p. 205216); "A Confederate book shelf": p. 217-221.

Dr. Freeman's attempts to satisfy readers of Gone with the Wind (no. 1619) and other Civil War novels of the I930's who desired to go on to more serious fare, led to the present "brief history of Confederate history." Letters and diaries written during the war, the memoirs of participants both military and civil, noteworthy controversies in which the war was refought by the surviving leaders, the "matchless splendor" of the Official Records of the Rebellion (no. 3697) together with a few supplemental documentary publications, and the interpretations of European historians are reviewed. Its depth of knowledge and finish of style, which must make this one of the most readable and rewarding works of bibliography ever written, have made many a convert to the glamor of the Lost Cause.

3379. [Garrison, Wendell Phillips, and Francis Jackson Garrison] William Lloyd Garrison, 1805-1879; the story of his life told by his children. New York, Century Co., I885-89. 4 v.

$$
\text { II-I4856 } E_{449 .} \text { G }_{254}
$$

3380. Nye, Russel B. William Lloyd Garrison and the humanitarian reformers. Boston, Little, Brown [1955] 215 p. (The Library of American biography) 55-7470 E $_{449 . G_{25} 8}$

The comprehensive study of Garrison by his sons, providing a month-by-month account of his life through reprints of the majority of his letters, articles, and speeches, has been the primary source for all subsequent Garrison biographies, such as Lindsay Swift's William Lloyd Garrison (Philadelphia, G. W. Jacobs, 1911. 412 p.). The sons' sympathetic biography describes Garrison's impoverished youth in Newburyport, Massachusetts, where he was apprenticed to a local newspaper editor and himself entered the craft as the editor of the local Free Press in 1826 . In 1828 he took up, among other crusades, the cause of the immediate and complete manumission of the South's slaves. After a period which included lecture tours and a stay in jail, Garrison in 1830 founded the Liberator, the foremost emancipation journal. His advocacy of pacifism and nonresistance did not prevent his being mobbed during several speaking engagements. By I86I he was generally regarded as the leader of the abolitionists, and he hailed secession, which he thought would teach the South a lesson, but not the war. On the ratification of the $13^{\text {th }}$ amendment Garrison refused a $23 \mathrm{~d}$ term as president of the American Anti-Slavery Society and ceased publishing the Liberator. During his remaining years he turned his reformist energies to writing and preaching on behalf of free trade, women's rights, and other causes. Dr. Nye's brief volume makes Garrison's religious faith the central fact in his career, and likens his role to a guilty conscience of the North.

3381. Hart, Albert Bushnell. Slavery and abolition, 1831-1841. New York, Harper, 1906. $\mathrm{xv}, 360 \mathrm{p}$. (The American Nation: a history, v. I6) 6-24I28 EI78.A54

"Critical essay on authorities": p. [324]-343.

This contribution to the American Nation series by its editor has of late several times been described as obsolete or outmoded. It is listed here because, while more recent studies have done much to broaden our knowledge of the genesis and bases of abolitionism, and the details of plantation slavery, none has the same broad scope and balanced treatment. Here, in one modest-sized volume, is a description of slavery as an economic system and a way of life; the late attempt of the slave interest to find a theoretical justification for it; the ideas and activities of the abolitionists; and the impingement of abolitionism upon national politics and international relations through 1840 . Hart has been said to overemphasize the importance of W. L. Garrison, 
but in chapter XXI he offers evidence "which most conclusively shows how little Garrison is entitled to be taken as the typical or the chief abolitionist." He observes that down to 1840 the abolitionists had achieved practically nothing of a tangible kind, but that they had nevertheless "laid hold of a principle without which the republic could not exist-the principle, namely, that free discussion is the breath of liberty; and that any institution which could not bear the light of inquiry, argument, and denunciation was a weak and a dangerous institution."

3382. Hendrick, Burton J. Lincoln's war Cabinet. Boston, Little, Brown, I946. $4^{82}$ p. illus.

$$
4^{6-7733} \mathrm{E}_{45} 6 . \mathrm{H}_{4}
$$

A popular but substantial account of the activities and personalities of Lincoln's principal Civil War aides. The author credits Lincoln with genius in his appointing to Cabinet rank all his chief rivals for the Republican nomination. Each Cabinet member is described as to personality, political sympathies, contribution to the work of the Cabinet and the progress of the war, attitude toward Lincoln, role in party and national politics, and relations with fellow Cabinet members. Emphasis falls upon the efforts of Secretary of State Seward to control the Cabinet, the struggle for power between moderate and radical Republicans manifest in the debates over emancipation and McClellan's restoration to command, the relations of the Senate with the Cabinet, and the personal antagonism between Salmon Portland Chase and Montgomery Blair, which eventually weakened the cohesiveness of the original Cabinet, and led to the replacement of several of its members.

3383. Hendrick, Burton J. Statesmen of the lost cause; Jefferson Davis and his Cabinet. Boston, Little, Brown, 1939. xvii, $45^{2}$ p. illus.

$$
\text { Bibliography: p. [433]-439. }
$$

$$
39-28981 \quad \mathrm{E}_{4} 87 . \mathrm{H}_{47}
$$

3384. Patrick, Rembert W. Jefferson Davis and his Cabinet. Baton Rouge, Louisiana State University Press, 1944. 401 p. 44-9637 E487.P 3 Bibliography: p. $[369]-387$.

Mr. Hendrick studies the statesmanship and diplomacy of the ruling circle of the Confederacy through an analysis of the lives and personalities of its civilian leaders. While most of the South's generals were members of the aristocracy, the Cabinet posts and important diplomatic missions were largely filled by men of humbler origin. In showing how each Cabinet member failed to achieve his official goal, with the exception of the Postmaster General, Mr. Hendrick asserts that the statesmanship of the South was inadequate for the situation at hand. Dr. Patrick, in his volume which originated as a dissertation at the University of North Carolina, provides biographies of even the least distinguished members of the Cabinet and seeks to assess their contributions and their deficiencies in relation to the Confederate war effort.

3385. Henry, Robert Selph. The story of Reconstruction. Indianapolis, Bobbs-Merrill, I938. 633 p. $\quad 38-6264$ E668.H516 Bibliography included in "Acknowledgments": p. 595-597.

During Reconstruction there was something going on every minute, and Mr. Henry succeeds in getting an extraordinary proportion of it into his crowded pages. Like its predecessor, The Story of the Confederacy (no. 3698), "it is not so much an attempt to enlarge the knowledge of the period treated as to organize and present it in direct narrative form." The author's sympathies are clearly with the ex-Confederates, but his exemplary objectivity of tone allows the course of events to speak for itself. The $5 \mathrm{I}$ chapters are organized into 3 books: "Restoration," down to the passage of the Act of March 2, 1867, which, Congressman Garfield said, put "the bayonet at the breast of every rebel in the South"; "Reconstruction," down to the admission of reconstructed Georgia in mid-July, I870; and "Redemption," concerning which Mr. Henry says: "The story of the last six years of the period of Reconstruction is one of counter-revolution-a counter-revolution effected under the forms of law where that was possible; effected by secrecy and by guile, where that would serve; effected openly, regardless of the forms of law, with violence or the threat of violence, where that had to be. But the counter-revolution was effected, at a cost to the South and its future incalculably great, justified only by the still greater cost of not effecting it."

3386. Horn, Stanley F. Invisible empire; the story of the Ku Klux Klan, 1866-1871. Boston, Houghton Mifflin, 1939. 434 p.

"References": p. [42I]-422. $39-8 \mathrm{ro3}_{3} \mathrm{E} 668 . \mathrm{H}_{7} 8$

Extensive documentary evidence employed by the author shows that the Klan had innocuous beginnings as a social club in Pulaski, Tennessee, in December 1865, but rapidly grew into a powerful political league with the avowed purpose of protecting the South's white population at a time when they seemed to be without governmental support and in danger of subjection by their former slaves. Mr. Horn sets forth many details of the organization and methods of the Klan as it steadily increased in scope and in the violence of its attempts to restore the prewar position of the Southern whites. Mr. 
Horn believes in the essential honesty of the Klan's members, who realized the inherent dangers of such an extralegal agency, and "ceased its use as soon as it had served their purpose, their original objectives fairly well attained." Most of the book is devoted to a state-by-state examination of the Klan's activities and their effects upon Southern Negroes and whites, the Federal Government, and the local civil and military administration.

3387. Hyman, Harold Melvin. Era of the oath; Northern loyalty tests during the Civil War and Reconstruction. Philadelphia, University of Pennsylvania Press, 1954. 229 p.

Bibliography: p. [208]-222.

$$
\text { 54-7108 } \mathrm{E}_{45} 8.8 . \mathrm{H}_{9}
$$

3388. Dorris, Jonathan Truman. Pardon and amnesty under Lincoln and Johnson; the restoration of the Confederates to their rights and privileges, I86I-1898. Introd. by J. G. Randall. Chapel Hill, University of North Carolina Press, 1953. xxi, $459 \mathrm{p}$.

Bibliography: p. [423]-437.

$53^{-13363}$ E668. D713

Dr. Hyman's "era of the oath" extends from April I861, when, on the motion of Attorney General Bates, all employees of the Departments were required to take the oath of allegiance anew, to May I884, when Representative S. S. Cox of New York finally succeeded in his campaign to bring about the repeal of the surviving test oaths from the Civil War. During this time they had been imposed for a diversity of purposes, but, the author thinks, had increasingly become a mere means for the Radical Republicans in Congress to identify and reward their own partisans. The book is written with the loyalty oaths applied to academic personnel after World War II in mind, and heaps up evidence to show that the oaths of $186 \mathrm{I}-84$ failed as a means of determining loyalty, and that they operated to keep the honorable and conscientious out of office or franchise, and let the unscrupulous in. With this animus, it is hardly fair to the oath of future loyalty as used by President Lincoln, and, after his initial period of vindictiveness, by President Johnson in restoring the states of the Confederacy to the Union with their old ruling class still in charge. Four blood-stained years of civil war were to be forgotten in exchange for a simple pledge of future good behavior-conciliation could hardly go much further. This salient fact is also obscured in Dr. Dorris' Pardon and Amnesty, because of his somewhat naïve conviction that "the authorities at Washington" had no warrant for giving the seceders "the odious appellations of 'rebels' and 'traitors.' "The real proscription came when the congressional majority succeeded in writing their "ironclad test oath" into the I $4^{\text {th }}$ Amendment, and, by substituting a retrospective for a prospective oath, excluded the former Confederates from franchise and office. Dr. Dorris' volume puts in order for the first time the complex facts concerning the status of the active Confederates, in the eyes of the Federal Government, from the initial secessions to the final repeal of disability under the I 4 th Amendment on June 8, 1898. There are special treatments of the cases of Robert E. Lee and Jefferson Davis, and the general course of events in North Carolina.

3389. Jenkins, William Sumner. Proslavery thought in the Old South. Chapel Hill, University of North Carolina Press, 1935. 381 p. ([The University of North Carolina. Social study series])

Bibliography: p. 309-358.

35-I5259 $\mathrm{E}_{44}$ I.J $\mathrm{J}_{46}$

Soon after the Missouri crisis of 1820 the Old South began to produce a voluminous body of theoretical and polemical writing in defense of slavery, which by 1835 had acquired the status of orthodoxy within the section, and which continued to accumulate even after the outbreak of war in 1861 , and down to the collapse of the Confederacy. In the present volume Professor Jenkins aims "to indicate the various thought trends, to evaluate their significance, and to estimate their weight in the entire body of proslavery thought." He considers in turn theories of the nature, origin, and legal basis of slavery; of slavery's relation to the State, the Constitution, and republican government; of the moral and religious justification of slavery; of the racial basis of slavery (including the "plural origin" doctrine, which made the Negro a separate and not necessarily human species); and of slavery as an ordering of social classes and economic production. He finds that the defense of slavery was so elaborated in the thought of antiquity and the Middle Ages that the theorists of the Old South could draw upon these sources at length, and actually contributed little that was original. "The misfortune to the South was that its mental power was taken out of other fields of endeavor at a time when it could have been most fruitful in the development of a higher civilization."

3390. Lincoln, Abraham. Collected works. The Abraham Lincoln Association, Springfield, Illinois. Roy P. Basler, editor; Marion Dolores Pratt and Lloyd A. Dunlap, assistant editors. New Brunswick, N. J., Rutgers University Press, 195355. 9 v. illus. $\quad 53-6293 \quad \mathrm{E}_{457.91} 1953$ Contents.- - I. I $824-1848$. - 2. I 848-1858.-3. 1858-1860.-4. $\quad 1860-1861 .-5 . \quad$ 1861-1862. -6. 1862-1 863.-7. $186_{3}-186_{4}$. - 8. $186_{4}-186_{5}$. Index. 
3391. Angle, Paul M., ed. The Lincoln reader. New Brunswick, N. J., Rutgers University

Press, 1947. 564 p. illus. $47-30067 \quad E_{457 . A 58}$

Bibliography: p. [544]-547.

3392. Thomas, Benjamin P. Abraham Lincoln, a biography. New York, Knopf, 1952. xiv, 548, xii p. illus. $\quad 5^{2-6425}$ E$_{457 . T_{427}}$ r952.

Bibliography: p. [523] -548 .

3393. Sandburg, Carl. Abraham Lincoln; the war years. With $4 \mathrm{I} 4$ halftones of photographs and 249 cuts of cartoons, letters, documents .. . New York, Harcourt, Brace, 1939. 4 v.

$$
\text { 39-27998 } \mathrm{E}_{457 \cdot 4 . S_{3} 6}
$$

3394. Randall, James G. Lincoln, the President. New York, Dodd, Mead, 1945-55. 4 v. illus. (American political leaders)

Includes bibliographies.

$$
\text { 45-1004I } \mathrm{E}_{457 \cdot \mathrm{R}_{2}}
$$

Contents.-v. I-2. Springfield to Gettysburg.v. 3. Midstream.-v. 4. Last full measure.

3395. Basler, Roy P. The Lincoln legend; a study in changing conceptions. Boston, Houghton Mifflin, 1935. 335 p. illus.

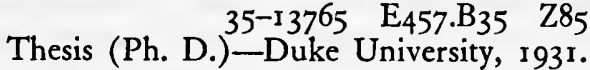

"A classified bibliography of poetry, fiction, and drama dealing with Lincoln": p. 309-[327].

In 1857 Lincoln (1809-1865) was a fairly successful attorney of Springfield, Illinois, whose most profitable client was the Illinois Central Railroad. $\mathrm{He}$ had only recently returned to politics as a $\mathrm{Re}$ publican after a retirement of some years; his earlier Whig career had included four terms in the Illinois Legislature and one in the U. S. House of Representatives $(1847-49)$. In $185^{8}$ he contested S. A. Douglas', seat in the U. S. Senate, and won national celebrity if not the election from the set debates in which they engaged throughout the State. He was still a minor candidate when the Republican Convention met at Chicago in 1860 , but the more famous leaders eliminated each other, and Lincoln as the Republican candidate carried the electoral college against a Democratic Party now split into fragments. Eleven of the fifteen slave states made his election the occasion for secession, and the retiring administration allowed them to organize their military resources without the least molestation. Resorting to arms to maintain the Union under such handicaps, Lincoln had to conduct a four years' war, of which the first two were largely frustration; and when victory was at last secure, he was assassinated by a mad actor. Lincoln's failure to domineer or engage in histrionics led most of his contemporaries to realize his greatness only in retrospect, but the popular instinct which has picked him out as one of the two greatest Americans, and has made him the lay saint of the democratic faith, is as sound as it is persistent. The foundation work, both in collecting Lincoln's writings and in writing his life and times, was performed in the last century by his secretaries, John G. Nicolay and John Hay. The first task has been recently completed in a quite definitive manner, in the Collected Works edited by Dr. Basler under the auspices of the Abraham Lincoln Association. Supplementary in some degree is David C. Mearns' The Lincoln Papers: the Story of the Collection, with Selections to July 4, I86I (Garden City, N. Y., Doubleday, 1948. 2 v. (xvii, 68 I p.)), but unfortunately Lincoln had accumulated very little down to 186o. Paul M. Angle's A Shelf of Lincoln Books: A Critical, Selective Bibliography of Lincolniana (New Brunswick, N. J., Rutgers University Press, 1946. xvii, $x_{42}$ p.) is a uniquely helpful guide to Lincoln literature down to its date, but of course cannot serve for the enormous output of the last dozen years. Dr. Angle's Lincoln Reader is an anthology of biographical materials concerning Lincoln, including both contemporaries and later writers, skillfully pieced together with some connective matter by the compiler. The late Benjamin P. Thomas, in Portrait for Posterity: Lincoln and His Biographers (New Brunswick, N. J., Rutgers University Press, 1947. xvii, 329 p.), offers penetrating estimates of attitudes and outlooks, especially of Lincoln's earlier biographers. Mr. Thomas went on to write his own biography, entered above; since its appearance it has been generally acclaimed as the best-balanced and most thoroughly informed one-volume life; but it is sometimes not very apparent that the subject was a great man. Mr. Sandburg's War Years is a vivid and tremendous panorama of Lincoln's Washington, but both it and his earlier Abraham Lincoln, The Prairie Years (New York, Harcourt, Brace, 1926. 2 v.) are for readers with leisure and patience. There is now a one-volume condensation of both: Abraham Lincoln, the Prairie Years and the War Years (New York, Harcourt, Brace, 1954. xiv, 762 p.). The late Professor Randall's Lincoln, the President is a work of immense scholarship, and probably treats its subject as objectively as anyone could whose sympathies were wholly with the aristocracy of the Old South. Professor Richard N. Current, who completed Dr. Randall's fourth volume, has also made a one-volume condensation, chiefly from those parts "which deal primarily with Lincoln the man and with his personal relationships": Mr. Lincoln (New York, Dodd, Mead, 1957. 392 p.). Dr. Basler's The Lincoln Legend aims "to show how poets, writers of fiction, dramatists, and occasionally biographers have, with 
the help of the folk-mind, created about Lincoln a national legend or myth which in conception is much like the hero-myths of other nations." Other biographies, documentary publications, special studies, and monographs are so numerous that space equal to the whole of this section could readily be filled with them.

3396. Meade, Robert Douthat. Judah P. Benjamin, Confederate statesman. New York, Oxford University Press, 1943. 432 p.

"Select bibliography": p. 415-4I7.

$$
\text { 43-11218 } \mathrm{E}_{4} 67 \cdot \mathrm{I} \cdot \mathrm{B}_{4} \mathrm{M}_{4}
$$

Born in the British West Indies of Jewish parents, Benjamin ( $18 \mathrm{I} \mathrm{I}-\mathrm{I} 884$ ) had three distinguished careers in one lifetime. After growing up in South Carolina, he settled in New Orleans and commenced his career as a leader of the American bar and as a legislator. His natural conservatism led him to join the Whigs, who in 1852 sent him to the U. S. Senate, where he worked for national expansion to increase the South's strength. After I 856 he became a Democrat and joined in the defense of Southern rights, and was among the first to advocate secession. His friendship with Jefferson Davis brought about his appointment as Attorney General of the Confederacy, and then as Secretary of War in September 186I. His career as Confederate statesman was his least fortunate, since he never had the confidence of the masses and was made a scapegoat for Confederate military failures. In 1862 he transferred to the Department of State, directing the Confederacy's desperate but vain efforts to obtain diplomatic recognition from the European powers. His third career began in I 866, following the Confederacy's collapse, when he fled to England and rapidly became a brilliant and successful barrister, limiting himself to cases before the House of Lords and the Judicial Committee of the Privy Council.

3397. Milton, George Fort. The eve of conflict; Stephen A. Douglas and the needless war. Boston, Houghton Mifflin, 1934. 608 p. illus.

Bibliography: p. $[571]_{-580}^{34-3608}$

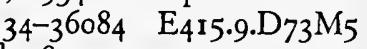

A sympathetic study which in two chapters passes over the youth and early career of Douglas ( $1813-1861$ ) so as to concentrate upon his service as Democratic Senator from Illinois in years of almost unintermitted sectional crisis ( $1847-61$ ). Douglas, his private utterances show, regarded slavery as "a curse beyond computation," but as one shielded by the Constitution from political interference. The Kansas-Nebraska Act of 1854 , which unleashed the later stages of the crisis and for which Douglas accepted full responsibility, was introduced primarily because Chicago and the Northwest needed a railroad to the Pacific, and could not get one before the political organization of the vast Platte country, which by the I85o's was long overdue. Southern Congressmen insisted upon equal rights for slaveowners in Kansas and Nebraska up to their admission as states, and Douglas, needing Southern votes and regarding the establishment of slavery in them as an economic impossibility, acquiesced. Thereafter he defended the measure as a genuinely democratic settlement, and strove to preserve the Union in spite of the extremists of either side, his unremitting efforts leading to his premature breakdown and death. At the close of 1857 Douglas, by denouncing the proslavery Lecompton Constitution for Kansas, broke with the Buchanan administration, thereby becoming increasingly estranged from the Southern rights leaders. Milton agreed with Alexander $\mathrm{H}$. Stephens (no. 3415) that "if the extremists of the South had not prevented, Douglas would have prevailed; the Civil War would not have occurred."

3398. Nevins, Allan. Ordeal of the Union. New York, Scribner, 1947. 2 v. illus.

$$
\text { 47-1 1072 } \mathrm{E}_{4} 15 \cdot 7 \cdot \mathrm{N}_{4}
$$

Contents.-v. I. Fruits of manifest destiny, I847I852. A note on sources (p. 561-562). -v. 2. A house dividing, $1852-1857$.

3399. Nevins, Allan. The emergence of Lincoln. New York, Scribner, 1950. 2 v. illus.

$$
\text { 50-9920 } \mathrm{E}_{415 \cdot 7 \cdot \mathrm{N}_{3} 8}
$$

Contents.-v. I. Douglas, Buchanan, and party chaos, 1857-1859.--v. 2. Prologue to civil war, 1859-1861. Bibliography (p. 491-506).

The first two installments of what is designed to be a large-scale history of the Civil War era. Professor Nevins believes that the Civil War could have been avoided had the people and their leaders acted together in solving the problems of slavery, sectional irritation, and the correct relations between the races. The conflict between the North and the South is viewed as essentially one between the rising force of national homogeneity and the declining influence of regionalism, and is shown to have gotten out of hand as it progressively preoccupied the passions rather than the reason of all Americans. Cultural and economic as well as political developments are traced to convey a complete picture of the America of the times when sectionalism took such a firm grip on men's tempers that civil war had to determine the future position of the Negro race in America. As the author shows, the Presidency, under Taylor, Fillmore, Pierce, and Buchanan, was never more devoid of initiative and leadership-at a time when such qualities were indispensable. On 
one point the author is emphatic: "of all the monistic explanations for the drift to war, that posited upon supposed economic causes is the flimsiest." Professor Nevins has used contemporary sources throughout in the form of speeches, diaries, letters, and periodicals.

3400. Nichols, Roy F. The disruption of American Democracy. New York, Macmillan, 1948. xviii, 612 p. illus. $\quad 4^{8-4344} \mathrm{E}_{43} 6 . \mathrm{N}_{56}$ Bibliography: p. 565-589.

Describes the progressive debilitation of the Democratic Party, called the "American Democracy" in the Igth century, during the years $1856-61$. The author treats at length the party conventions of 1856 and 1860 , the personal quarrels of leading politicians, the influence of sectional sentiments upon their actions, the splinter parties breaking off from the Democracy, and the relationship of the Democracy to Congress and to the opposition parties. The party itself is examined in the relations of its voters, machines, and leaders both on national and state levels. The Democracy is credited with working to establish coöperative government; however, "deeply affected by the shocks of the collisions occurring within the society in which it operated and of which it was a part, the party failed to overcome the divisive attitudes and was shattered." War came as a result of this failure. The book continues into a more critical period the study of the party which served as the author's doctoral dissertation at Columbia University: The Democratic Machine, $1850-$ 1854 (New York, Columbia University, I923. 248 p.).

340r. Nye, Russel B. Fettered freedom; civil liberties and the slavery controversy, I830186o. East Lansing, Michigan State College Press, 1949. 273 p. illus. $49-3656$ JC599. U5 $\mathrm{N}_{9}$

"Bibliography of sources": p. 253-269.

Analyzes the controversy between the North and South arising from divergent interpretations of the degree to which men may enjoy their natural and constitutional rights by tracing the history of the attempts to suppress the abolitionist movement. During their agitation to arouse the Nation against slavery, the abolitionists were subjected to mob violence, censorship, unconstitutional interpretations of the laws, discrimination in regard to employment, and other curtailments of civil rights"the freedoms belonging to the citizen as an individual and as a member of society." From evidence in the form of contemporary newspaper accounts, court and police records, and diaries, the author shows that the deprivation of the abolitionists' civil rights won for them a large body of supporters "who thought less of the wrongs of the slave than of the rights of the white man." The abolitionists were able to point out that the true issue of the sectional struggle was the extent to which civil rights may be curtailed in the interests of the majority.

3402. Phillips, Ulrich Bonnell. American Negro slavery; a survey of the supply, employment and control of Negro labor as determined by the plantation régime. New York, Appleton, 1918. $529 \mathrm{p}$.

I 8-I I 87 E44I.P549

3403. Stampp, Kenneth M. The peculiar institution: slavery in the ante bellum South. New York, Knopf, 1956. 435, xiii p.

“56-5800 E44I.S8 "Manuscripts consulted, and their locations": $p$. 43 I- $[436]$.

Professor Phillips' book is concerned with the rise, nature, and influence of slavery in the plantation system, which it supported and to which it owed its existence. The Negro is pictured by Dr. Phillips as a child-like being culturally and intellectually inferior to the white man. This work was usually considered as a definitive treatment until the publication of Professor Stampp's new synthesis from the same or similar sources to those employed by Dr. Phillips. Dr. Stampp assumes that "innately Negroes are only white men with black skins," and produces a history of slavery between $183^{\circ}$ and 1860 which incorporates the point of view of the slaves themselves, and shows in detail how the good intentions of humane masters were normally frustrated by the essential inhumanity of the system. Both refer to contemporary periodicals, letters, plantation journals, and items pertaining to the foreign and domestic slave trade; however, Dr. Phillips finds that slavery was essential to the rise of the cotton industry and beneficial, as a whole, compared with Negro life in Africa, while Dr. Stampp can find no philosophical justification for the "peculiar institution" except that it paid the master class. And it paid in the older slave states only because they raised a surplus of Negroes for sale and transportation to the newer states, from Alabama to Texas.

3404. Phillips, Ulrich Bonnell. The course of the South to secession; an interpretation. Edited by E. Merton Coulter. New York, AppletonCentury, 1939. 176 p. 40-2173 F213.P65

"Prepared and published under the direction of the American Historical Association from the income of the Albert J. Beveridge memorial fund."

Lectures delivered at Northwestern University in 1932 and originally published in the Georgia Historical Quarterly are here reprinted with the author's 
article, "The Central Theme of Southern History," prepared for the 1928 meeting of the American Historical Association. The lectures provide a historical rationale for the establishment of the Confederacy, while the theme of the article is that the South has always been and always will be the land of white supremacy. With this premise in mind, Professor Phillips' lectures assert that the United States from its colonization had no sectional interests or sentiments which could drive them apart. It was not until the I 820 's that slavery became an issue, and then it took the form of legislation and other activities to prevent slave revolts. Professor Phillips lays the main blame for secession at the door of the abolitionists, whose efforts to force the Federal Government and the Congress to intervene in Southern affairs eventually caused violent measures on the part of Southern "fire-eaters." This danger to slavery, Professor Phillips concludes, set in motion the Southern independence movement-“a program so much in keeping with American precedent and the gospel of self-government, so legitimated by state sovereignty, so long considered, and now supported by such a multitude of conservative citizens."

3405. Phillips, Ulrich Bonnell. The life of Robert Toombs. New York, Macmillan, r9r3. 28I p. I3-I7I29 E415.9.T6P5

Toombs (1810-1885) was a planter, lawyer, and political leader of ante bellum Georgia, in the State Legislature from 1837 and in the U. S. Congress after 1844 . A conservative Whig, he was ordinarily a moderate advocate of Southern rights, but at the peak of the crisis of 1850 he came out strongly in favor of the equal claim of the slave states to the territories in a series of speeches which established his fame. When the compromise was effected, he organized a Constitutional Union Party to defend it, and entered the Democratic fold only when the movement failed to spread beyond Georgia. Again he exerted a moderating influence until the crisis of r86o, when he took his stand on the Crittenden compromise measures and, on their rejection by the Republicans, came out for immediate secession. Failing to obtain election to the Presidency of the Confederate States, he was too unruly an individualist to succeed either as Secretary of State or as a brigadier-general, and was out of public life after 1862. He did not return until Reconstruction was over, but in 1877 and for a few years thereafter, until the failure of his health, was prominent in the reorganization of Georgia.

3406. Pierce, Edward L. Memoir and letters of Charles Sumner. Boston, Roberts Bros., I877-93. 4 v. illus. $\quad$ 13-19830 E415.9.S9P6
Contents. - I. I8II-I838.-2. $1838-1845 .-3$. I845-I 860.-4. I860-1874.

Born in Boston and prepared for the bar at Harvard, Sumner ( $181 \mathrm{I}-1874$ ) entered politics at the top when elected to the Senate in 1851 by a coalition of Democrats and Free-Soilers. Previously he had practiced law, traveled extensively in Europe, and delivered striking public addresses advocating world peace and equal rights for all races. He helped found the Republican Party and, after a vituperative speech on "The Crime against Kansas," was brutally assaulted on the floor of the Senate in 1856 by a South Carolina Representative whose uncle was a Senator from the same State. Sumner was absent from the Senate for the three and a half years required for his recovery. He was made chairman of the Senate Foreign Relations Committee in $186 \mathrm{I}$ and advised the Cabinet throughout the war in matters relating to international law. Although he had been a staunch supporter of Lincoln, Sumner broke with Andrew Johnson over Reconstruction policy and led the Senate in the impeachment proceedings of 1867 . During the Grant administration he defeated the President's plan to annex Santo Domingo, and was removed from his committee chairmanship for fear that he might harm the Alabama Claims negotiations then being conducted with Great Britain. $\mathrm{He}$ was still an erratic but powerful moral force when his heart gave out after a session of the Senate in March 1874. This biography by a devoted friend and admirer is old-fashioned and at times over-detailed, but is yet to be replaced.

3407. Pressly, Thomas J. Americans interpret their Civil War. Princeton, Princeton University Press, 1954. xvi, $347 \mathrm{p}$.

Viewing the Civil War as "the classic example of a major event in the history of the United States which has been explained and interpreted in a wide variety of quite different ways," the author treats it "as a specific case history which illuminates to some extent the problems of [historical] relativism and causation." Since the war "has seemed to involve vital issues of lasting significance, it has enlisted not only the interest of successive generations but also their loyalties and their emotions," and even recent utterances have been, in the phrase of the younger O. W. Holmes, "touched with fire." The survey is carried from the reactions of Motley, Bancroft, and Prescott to the attack on Fort Sum. ter, down to the present "confusion of voices."

3408. Randall, James G. The Civil War and Reconstruction; with supplementary bibliog- 
raphy. [2d ed.] Boston, Heath, 1953. xvii, 971 p. illus., maps. 53-1027 E468.R26 I953

"Bibliographical note": p. 88r-883. Bibliography: p. $885-935$.

First published in 1937 to supply the lack of "one volume of recent date which brings the whole period of conflict and readjustment [ $185^{\circ}-77$ ] into a scholarly synthesis and distills the findings of historical scholarship for the general reader." The only change in the 1953 edition is the addition of a ropage "Supplemental Bibliography" listing the principal books and articles which had appeared during the interval. There is no reason to suppose that this fresh material would have led the author to change his essential positions, those of a moderate "revisionist," convinced that the conflict between North and South was not "irrepressible," and that war might have been avoided if "something more of statesmanship, moderation, and understanding, and something less of professional patrioteering, slogan making, face-saving, political clamoring, and propaganda had existed on both sides." The work continues to be a widely used textbook and guide to perplexed scholars, since here alone, in brief compass, can they find not only the major political and military developments, but also "border problems, non-military development during the war, intellectual tendencies, anti-war efforts, religious and educational movements, propaganda methods, and the cacophony of voices that influenced public opinion," in a careful, lucid, and balanced treatment.

3409. Simms, Henry H. A decade of sectional controversy, $185 \mathrm{I}-186 \mathrm{I}$. Chapel Hill, University of North Carolina Press, 1942. 284 p.

Bibliography: p. 249-265.

$$
\text { 42-51250 } \mathrm{E}_{415.7 . S 6}
$$

The development of the Southern viewpoint during the decade preceding the Civil War is stressed. Extensive quotations from editorial comments by Northern as well as Southern newspapers illustrate the changes in popular opinion as political developments in the sectional controversy unfolded. The slavery issue was the prime manifestation of the conflict, and attention is focused on Southern sentiments and economic and political motives for its retention. This evidence shows, the author thinks, that the South was on the defensive since, in his judgment, it had no intention of extending slavery to free states, and there was no chance that slavery would take hold in the territories. Furthermore, the controversy over fugitive slaves was out of proportion to the number that actually escaped. Party rivalry is blamed as the principal cause of sectional antagonism, which was unduly magnified by vituperation and vilification on the part of Northern and Southern leaders at a time when conciliatory statesmanship might have resolved the most serious differences.

3410. Smith, William Ernest. The Francis Preston Blair family in politics. New York, Macmillan, 1933. 2 v. illus.

Bibliography: v. 2, p. 497-510.

33-13071 $\mathrm{E}_{415 \cdot 9 . \mathrm{B} 63 \mathrm{~S} 6}$

After the Adams family, Professor Smith believes, the Blairs were the second most influential family in roth-century American politics, participating in nearly every important event between 1828 and 1878. Francis Preston Blair (1791$1876)$, the Virginia-born founder of the dynasty, was a lifelong political journalist imported from Kentucky to sit in Andrew Jackson's celebrated Kitchen Cabinet. His two sons, Montgomery (1813-1883) and Frank P. Blair (1821-1875), began their political careers in Missouri as Free-Soil Democrats. Like their father, the sons adhered to whatever party at a given time best reflected their political views. All three became Republicans by 1860 and remained so until their views on Reconstruction clashed with the Radicals, which led them to return to the Democrats by 1868 . Frank became a Congressman from Missouri, and on the outbreak of the Civil War led the struggle to keep Missouri in the Union, and afterward had a stormy career as a major general. As a Democrat, Frank was the party's nominee for the Vice Presidency in 1868 and served as a Senator until 1873 . Montgomery Blair's career was primarily that of a judge and outstanding attorney until $186 \mathrm{r}$, when he was taken into Lincoln's Cabinet as Postmaster General. In 1864 he was ousted in consequence of an ultimatum from the Radicals in Congress. After a brief period as a Liberal Republican, Montgomery threw his weight behind the Democrats, going so far as to found a newspaper which challenged the validity of Rutherford B. Hayes' election.

34II. Stryker, Lloyd Paul. Andrew Johnson, a study in courage. New York, Macmillan, r930. xvi, 88I p. illus. 33-1228 E667.S924 "Authorities and abbreviations used": p. 838-844.

3412. Winston, Robert W. Andrew Johnson, plebeian and patriot. New York, Holt, 1928. xvi, 549 p. illus. 28-7534 E667.W78 Bibliography: p. 529-540.

Mr. Stryker's favorable appraisal of the life of President Johnson (1808-1875) is designed to eliminate misunderstandings about the man and his actions and policies which had persisted in history books and the popular mind since the days of Johnson's impeachment (March-May 1868). Here Johnson is described as a lifelong Unionist, born 
in Raleigh, North Carolina, who rose from the humblest beginnings to service as Democratic Governor and Senator from Tennessee before the Civil War. His extreme loyalty to the Union drew the notice of President Lincoln, who appointed him military governor of free Tennessee in 1861 , where he administered the first of Lincoln's Reconstruction schemes until his election as Vice President in I864. Having succeeded to the Presidency, Johnson, after considering the alternative, felt compelled to carry out Lincoln's moderate and wise plans for the rehabilitation of the South-much to the wrath of the Radical Republicans, who resolved to crush him. Johnson's repeated vetoes of extremist Reconstruction legislation so enraged his opponents that impeachment proceedings were instituted in an atmosphere of virtual congressional revolt. Johnson was acquitted and, although his administration was hobbled, did what he could to moderate the vindictive treatment of the South. Such was the bitterness of the Radicals that they spared no effort to defame Johnson during the remainder of his term and of his life. Mr. Winston's biography is a briefer treatment on the same lines and no less sympathetic. David Miller Dewitt's The Impeachment and Trial of Andrew Johnson (New York, Macmillan, 1903. 646 p.) is an objective and thorough account of this constitutionally unique episode.

3413. Thomas, Benjamin P. Theodore Weld, crusader for freedom. New Brunswick, N. J., Rutgers University Press, I950. $307 \mathrm{p}$.

Bibliography: p. [289]-30o.

$$
{ }^{50-9667} \mathrm{E}_{449} \cdot \mathrm{W}_{4} 6
$$

This first biography of "the greatest of the abolitionists" rescues Weld (1803-1895) from comparative obscurity. Born in Connecticut of a long line of Congregational ministers, Weld matured early, and undertook a lecture tour at the age of 17 . Converted by C. G. Finney in 1823 , he joined his Holy Band as an active evangelist, but for the first decade his special causes were temperance and manual labor. Not until 1833 did he concentrate upon abolition. In the following year, when he and his friends had been forced out of Lane Seminary, he became a fulltime agent of the American Anti-Slavery Society. His active antislavery career lasted only a decade, but in the quality of his converts, who included Henry Ward Beecher, Harriet Beecher Stowe, and James G. Birney, and in the extent and effect of the evangelizing which he conducted or organized in the rural counties of the West, he was of unique importance. In $184 \mathrm{I}$ he transferred to Washington and for two years advised and heartened the small but increasing antislavery group in Congress. In 1843 he withdrew to his farm, and returned to the public platform only once, during the Civil War, in order to rally support for the war effort. Weld avoided personal publicity of any kind, withholding his name from his antislavery writings and, so far as possible, from his other activities, and the crucial nature of his influence has been a rediscovery of recent historians.

3414. Villard, Oswald Garrison. John Brown, I800-1859, a biography fifty years after. [Rev. ed.] New York, Knopf, I943. $73^{8}$ p. illus. 43-1061 I E45I.V7I 1943

Bibliography: p. 599-709, [709a]-709d.

John Brown behind his whiskers looked and talked like an Old Testament prophet, and his strange and sanguinary role in the crisis years from 1856 to 1859 led to as wide a range of conflicting opinions as have ever accumulated about any historic figure. Before May 26, I 856, Brown was a migratory, debt-ridden nobody; after the killings on the Pottawatomie he was a national figure, sinister to some and to others a dauntless champion of righteousness. For the six weeks after October 16, 1859, when his attempt upon Harper's Ferry failed, the eyes and ears of the whole Nation were focused upon him. Mr. Villard was the first to assemble the complete facts about Brown and to put them into an intelligible order; when he came to revise his work after 33 years there proved to be remarkably little to add. He continued to regard Brown as a great figure. Abraham Lincoln spoke thus in February I 860: "An enthusiast broods over the oppression of a people till he fancies himself commissioned by Heaven to liberate them. He ventures the attempt, which ends in little else than his own execution." This would be the last word save for one thing: everything Brown did about slavery was perverse, criminal, and perhaps insane; but everything he said about it had the power and the truth of an Old Testament prophet. Such a contradiction eludes formulae.

3415. Von Abele, Rudolph R. Alexander $\mathrm{H}$. Stephens, a biography. New York, Knopf, I946. xiii, 337, x p. 46-696r E467.r.S85V6

This biography, which originated in a Columbia University dissertation, penetrates the psychological characteristics of one of the South's leading politicians. Born on a small farm in Georgia, Stephens (1812-1883) was always physically frail, but did become a successful lawyer and amass a personal fortune. He entered politics in 1836 by election to the Georgia Legislature as a Whig. In 1843 he was sent to the U.S. House of Representatives on his reputation as a champion of state sovereignty, and later defended slavery as a "stern necessity," going so far as to advocate the renewal of the African slave trade in order to extend slave territory. When he 
retired from the House in 1859 he was convinced that his new party, the Democracy, had triumphed over abolitionism. When secession was being debated in Georgia, Stephens argued against it, but accepted his election as Vice President of the Confederacy on February 9, I861, and served in that capacity throughout the war. His duties, beside presiding over the ineffectual Confederate Senate, included acting as chief negotiator with Washington for the exchange of prisoners, and for terms of peace. After the war he continued active in Georgia and national politics, returning to the House in 1872 , and devoted much time to writing history and to philanthropy. "Liberty under law was his theme and his religion"; however, liberty could be enjoyed only according to one's position in the order of society.

3416. Welles, Gideon. Diary of Gideon Welles, Secretary of the Navy under Lincoln and Johnson, with an introd. by John T. Morse, Jr. Boston, Houghton Mifflin, I9I I. 3 v.

Preface signed: Edgar T. Welles.

$$
\text { 38-344I6 } \mathrm{E}_{4} 68 . \mathrm{W}_{443}
$$

Contents.-I. I86I-March 30, I864.-2. April I, I 864-December 3i, I 866.-3. January I, I 867-June 6, i 869 .

This daily chronicle of people and events is regarded by most historians as one of the most useful and reliable sources for Civil War and early Reconstruction era leaders and politics, although the author did some revising after his retirement. Welles (1802-1878), a Connecticut man who had been a Democrat until $\mathrm{r} 854$, was chosen by Lincoln to represent New England in his Cabinet. The diary contains much information on his acts as Secretary of the Navy: he built a navy on an entirely new scale, raised the discipline and standards of the offcers and men, and worked for the development of new weapons and tactics. Attached to the cause and personality of Lincoln, and later of Johnson, Welles may be considered the spokesman of the relatively impartial liberal Republicans. In 1874 he published an interesting little volume, Lincoln and Seward (New York, Sheldon. 215 p.), to dispel the illusion that the Secretary of State had been the brains of the administration. Much can be learned of the personal traits and motivations of Union leaders and the de- velopment of policies during the war and peace from Welles' vivid characterizations of the important men with whom he came in contact. Gideon Welles, Lincoln's Navy Department, by Richard S. West, Jr. (Indianapolis, Bobbs-Merrill, 1943. 379 p.), is a sound biography which emphasizes his administrative achievement.

3417. Woodward, Comer Vann. Reunion and reaction; the compromise of 1877 and the end of Reconstruction. [2d ed.] Rev. and with a new introd. and concluding chapter. Garden City, N. Y., Doubleday, 1956. 297 p. (A Doubleday anchor book, $\mathrm{A}_{3}$ )

56-7531 E68r.W83 $195^{6}$

This work by Professor Woodward of Johns Hopkins University was originally published in I95I; the additional matter in the paperback edition is largely concerned with relating the main narrative to the earlier and later course of Southern politics. In it he completely rewrites the accepted version of the events whereby the disputed election of 1876 was resolved and a renewal of domestic strife averted. The principal evidence is to be found in the papers of President Rutherford B. Hayes, for it was Hayes' lieutenants who devised the plan of securing all the disputed electoral votes for their candidate by driving a wedge between those "Southern redeemers" who in ante bellum days had been conservative Whigs, and those who had been Democrats. The principal agents in this maneuver were Colonel Andrew J. Kellar of the Memphis Avalanche and General Henry Van Ness Boynton, Washington representative of the Cincinnati Gazette, and the chief bait was the promise of a Federal subsidy for the Texas and Pacific Railway Company. The Southern Congressmen in the deal abstained from the Democratic filibuster against the decision of the Electoral Commission, and Hayes became President. The North's more idealistic war aims were thus jettisoned in order to protect "the peculiar interests and privileges of a sectional economy" built up since I86I ; Reconstruction came to an abrupt end; compromise was once more the rule of American politics as it had been before I860; and a persistent partnership between Southern Bourbons and Northeastern industrialists was inaugurated.

\section{Grant to McKinley (I869-I90I)}

3418. Barnard, Harry. Rutherford B. Hayes and his America. Indianapolis, Bobbs-Merrill, I954. 606 p. illus. 54-II942 E682. B3 "Selected bibliography": p. 571-588.
34I9. Eckenrode, Hamilton J. Rutherford B. Hayes, statesman of reunion. New York, Dodd, Mead, 1930. 363 p. illus. (American political leaders)
30-12586 E682.E19 
Bibliography: p. 345-349.

Both of these biographies of Rutherford Birchard Hayes (1822-1893), 19th President of the United States, provide sympathetic and intimate portrayals of his human qualities as well as the salient facts of his life. Indeed, Mr. Barnard, whose work is distinguished by its elaborate detail and documentation, aims to present "not so much a biography of a president as a biography of a man who happened to become President." While serving as a fighting Union brigadier general in 1864 , Hayes was elected from Ohio to the United States House of Representatives, where, after cessation of hostilities, he served until elected Governor on the Republican ticket in 1867 . His performance as Governor earned him the rank of favorite son in Ohio, and he was a dark horse candidate for the Presidency in 1876 . Mr. Barnard substantially advances knowledge of the so-called tied election which hung upon one electoral vote; he believes that neither Hayes nor his opponent, Samuel J. Tilden, won a clear title, although the Presidency was awarded to Hayes. Both authors show Hayes' development from a partisan Stalwart supporter of Reconstruction to a liberal, a conciliator of the South, and a reformer, whose sound and well-managed but unspectacular administration of the Presidency in the years $1877-81$ brought respectability back to a party embarrassed by the corruption of the Grant era, and, more important, initiated the reunification of the Nation.

3420. Buck, Solon J. The Granger movement; a study of agricultural organization and its political, economic, and social manifestations, $1870-$ 1880. Cambridge, Harvard University Press, I913. 384 p. (Harvard historical studies, v. I9)

Bibliography: p. [313]-35I.

$$
\text { r3-r9662 HD2or.B8 }
$$

3421. Buck, Solon J. The agrarian crusade; a chronicle of the farmer in politics. New Haven, Yale University Press, 1920. 215 p. illus. (The Chronicles of America series, v. 45)

$$
\text { 20-490I EI73.C55, v. } 45
$$

"Bibliographical note": p. 203-206.

$\mathrm{HD}_{201 . B 75}$

The term Granger here refers to the general agrarian movement which centered in the secret and professedly nonpartisan order of the Patrons of Husbandry founded in 1867 . During the 1870 's, the Grange constituted a farmers' protest against the power and oppressiveness of big business. Dr. Buck cites as measures undertaken by the Grangers their efforts to subject the large railroads to public control, the formation of third parties in order to oust the industrial interest from its dominance of politics, and the encouragement of cooperatives in order to maintain their own economic independence of big-business-controlled industrial establishments and their agents, the middlemen. The Granger movement the author places as the initial organized effort in American history to bring about political, social, and economic reform. The second title is a more general treatment of the radical agitations undertaken by American farmers to improve their economic condition through legislation when industrialization of the West followed the Civil War. Dr. Buck sketches the course and evokes the spirit of the agrarian crusade from its inception with the Grangers, through the Greenback and Populist phases, which lingered until 1904, to its climax in the battle for free silver, from 1875 to 1896 . In general, the agrarians have desired greater governmental control of the Nation's economy and limitation of business competition. Dr. Buck's analysis shows that these desires have been fulfilled in part just as has the agrarian legislative program which, in the following examples, has been enacted into law: national and state regulation of railroad rates, popular election of Senators, graduated income taxes, postal savings banks, parcel post, and rural free delivery. The farmers had forced awareness of their interests upon the major parties, the author concluded (1920), and henceforth both Democrats and Republicans would adopt agrarian planks in their national platforms rather than hazard a repetition of the loss of the rural vote.

3422. Cleveland, Grover, Pres. U. S. Letters of Grover Cleveland, I850-1908; selected and edited by Allan Nevins. Boston, Houghton Mifflin, 1933. xix, $640 \mathrm{p}$.

33-35003 E697.C63

A selection from the correspondence of Grover Cleveland (1837-1908), 22d and 24th President of the United States, containing "nearly all of Cleveland's letters that are important to the student of his life or times." Trivial notes, letters referring to petty official matters, and occasional pieces have, for the most part, been omitted. Because Cleveland wrote more about public business than his private affairs or emotions, the editor has deemed it necessary to arrange the letters in 16 chapters, each prefaced by a brief introduction tracing the events of his life through the appropriate months or years. Cleveland "was Bunyan's Valiant-for-Truth," Professor Nevins believes, "transferred to a scene which sorely needed all his valor." His letters, both the formal, ponderous official messages and the simple, direct missives to friends, "are the work of a man who had the courage to say what he thought and say it plainly." "This forthrightness was based upon a stubborn independence of mind and soul." $\mathrm{He}$ refused to truckle to politicians for votes or to 
appoint mere friends to office, and he resisted the spoilsmen. He fought for civil service reform and for tariff revision downward. "He was willing to go to any length rather than abate his self-respect by a single concession."

3423. [Cleveland] Nevins, Allan. Grover Cleveland; a study in courage. New York, Dodd, Mead, r934. 832 p. illus (American political leaders)

\section{Bibliography: p. $767-772$.}

First published in 1932.

In this large, definitive biography which won a Pulitzer prize in 1933, Professor Nevins traces both the extraordinary personal growth and the equally amazing political career of Grover Cleveland. He was a hard-working Buffalo lawyer in $188 \mathrm{I}$, the author notes, a good Democrat, a man of integrity, determined, strong, and blunt, but also, slow, unimaginative, and limited. In November I88I, however, the simple, sturdy attorney was swept into office as mayor by a wave of public discontent with municipal misgovernment. Thereafter, his transformation into a successful party leader proceeded so rapidly that by $\mathrm{I} 88_{3}$ he was taking the oath as Governor of New York, and by 1885 as President of the United States. In Professor Nevins' opinion, the times were propitious for a "moral knight": Cleveland, as a reform mayor, made himself conspicuous "at the happiest possible time"; as Governor, he broke with Tammany in a demonstration of political fearlessness which "caught the public imagination as nothing else could." His first Presidential candidacy was "based upon a demand for administrative honesty joined with tariff reform," and his third "represented a combination of both with the principle of unyielding conservatism in all that affected finance and business."

3424. Croly, Herbert D. Marcus Alonzo Hanna, his life and work. New York, Macmillan, I9I2. 495 p. illus. I2-9I63 E664. $\mathrm{H}_{24} \mathrm{C}_{9}$

A sympathetic presentation of Mark Hanna (1837-1904) as the embodiment of free enterprise in economics, politics, and personal behavior. Born in Ohio of pioneer stock, Hanna became wealthy in the rising metropolis of Cleveland. In I88o, with the prosperity of his diverse financial interests assured, Hanna began dabbling in Republican politics, initially on the city and state levels, and led his State delegation to the national convention of 1888. He thenceforward devoted his full energies to making William McKinley President. According to the author, Hanna considered this activity his patriotic duty, and so successful was he that McKinley was elected Governor of Ohio in $\mathrm{r} 8 \mathrm{~g} \mathrm{I}$ and Republican Presidential nominee on the first ballot in 1896 . So effective, indeed, was Hanna's organization of the whole national party machinery that he was made Republican National Chairman. In 1897 he entered the Senate where he soon became the spokesman of big business and the protector of party patronage. The voting record cited here shows his overwhelming support for McKinley and later for Roosevelt policies, as well as statesmanship of considerable stature. However, in Mr. Croly's opinion, Hanna was at his best as a leader and organizer of the Republican Party, in which capacity he applied practical business management to politics and secured his party's financial stability.

3425. David, Henry. The history of the Haymarket affair; a study in the American socialrevolutionary and labor movements. New York, Farrar \& Rinehart, 1936. 597 p.

$$
36-36485 \mathrm{HX}_{4} 6 . \mathrm{C}_{4} \mathrm{D}_{3} \quad{ }_{1936}
$$

"Selected bibliography": p. 545-56r.

This Columbia University dissertation is a careful investigation of how the "Haymarket Bomb" came to be thrown in Chicago, May 4, I886, of its consequences, and of related aspects of the American and European scenes. The author considers the Haymarket affair an episode "of major significance in the annals of American labor and jurisprudence." "Labor's grievances," he observes, "sprang from the privileges and corruption of the American political system, the growth of a small, immensely wealthy class, the results of corporate industrial organization, and the economic and social condition of the wageearners at large and certain groups of them in particular." The setting of the Haymarket affair was composed of these factors, Professor David believes, together with "a body of confused revolutionary thought and an uncompromising revolutionary movement," which advocated "propaganda by deed" and drew its support from Chicago's unusually heavy foreign population. In his opinion, the eight radicals convicted of murder "must be considered innocent," in the light of the reliable evidence. He concludes that "capitalist interests through a willing press" pushed the whole affair in order to discredit labor, but that "in precipitating the noteworthy political movement on the part of labor in I886-r 887 , the Haymarket bomb had its most positive effect."

3426. Dennett, Tyler. John Hay: from poetry to politics. New York, Dodd, Mead, I933. 476 p. illus. $\quad 33-30803 \mathrm{E}_{6} 6 \mathrm{H}_{4} \mathrm{ID} 3$ "Appendix I. John Hay: a short list of his writings, by William Easton Louttit, Jr.": p. 45I-456.

A biography which underscores Hay's intellectual and emotional characteristics as well as the achievements of this poet, novelist, historian, and statesman 
(1838-1905). Hay lingered longer in youth than is usual, but in his capacity as a secretary to the President, 186I-65, he "won the confidence of Abraham Lincoln to a marked degree." Almost a radical for his era, Hay achieved fame in 1871 with his Pike County Ballads and violated literary convention, yet could not endure criticism. "John Hay's successes were obvious; his failures were more subtle." The author ascribes the latter to Hay's complex personality and an inability to integrate the conflicting qualities of heart and mind. He terms Abraham Lincoln: A History (New York, Century Co., 189o. 1o v.), written in collaboration with John G. Nicolay, "a good deal of a Republican document," and believes that through it Hay became "the apostle of the Republican party." In Professor Dennett's opinion, "Hay owed his position in life to his association with Abraham Lincoln; his position in American history he owed to his friendship with William McKinley," who appointed him Ambassador to Great Britain in 1897 , and Secretary of State in 1898 . He continued to serve under Roosevelt, with less independence than under his predecessor, and conducted important negotiations, affecting our policy toward the Far East and toward Britain, until his physical breakdown in 1905 .

\section{Destler, Chester McArthur. American} radicalism, I 865-190I, essays and documents. New London, Connecticut College, 1946. 276 p. illus. (Connecticut College monograph no. 3) 46-608I E66r.D45

A collection of II articles, 9 of them reprinted from journals, based on a revisionist interpretation of "western radicalism in terms of ideological interchange and conflict between western agrarians and urban radicals." Several papers, notably the sequences on the Pendleton fiscal program of 1867 and on the labor-Populist alliance in Illinois of 1894 , and the essay on "The Toledo Natural Gas PipeLine Controversy," are case studies in midwestern politics. The other papers offer a rather more generalized "consideration of whether, out of the ideological intercourse of country and city there had not developed in the late nineteenth century West a new radical synthesis. If its existence could be demonstrated such a novel but indigenous creed would give new meaning to the bitter conflicts that characterized the short-lived labor-Populist alliance of $1894-1896$." Together, the essays constitute the accumulation of the author's findings as of 1946 , and suggest possible lines of further investigation.

3428. Dulles, Foster Rhea. America in the Pacific; a century of expansion. $2 \mathrm{~d}$ ed. Boston, Houghton Mifflin, 1938. xiv, 299 p.

$$
\text { 38-27337 F970.D94 } 1938
$$

First published in 1932.

A survey of our expansion in the Pacific area during the rgth century. The ambition to obtain mastery of the Pacific and to control its opulent trade was a powerful motivating force, Professor Dulles believes, behind every American acquisition of territory on the Western Ocean from Oregon, California, and Alaska, to Samoa, Hawaii, and the Philippines. First awakened by the old China traders operating out of Atlantic seaports in the early Federal period, this ambition led shortly to the assertion of claims to territory on the Pacific coast for the development of naval bases and ports, and was a factor in the annexations of islands which reached a climax with the acquisition of the Philippine Islands in 1898 . The author is interested in Oregon and California not as natural extensions of the nation's boundaries secured in $1846-48$, but "as the basis and point of departure for Pacific empire." The theory of the expansionists of the day, he points out, was "that once established on the Pacific Coast, we would command the commerce of the East, and just so in 1898 did their imperialistic heirs contend that, given Hawaii and the Philippines, we would dominate this same trade." Only in the acquisition of the Philippines, Professor Dulles observes, did the policy of trade and empire ignore the American principles of democracy, and these have since been reasserted.

3429. Farrar, Victor J. The annexation of Russian America to the United States. Washington, W. F. Roberts, 1937. $142 \mathrm{p}$.

"Bibliographical note": p. $133^{\mathrm{I}-\mathrm{I}} 38$.

$$
\text { 37-33668 E669.F } 37
$$

A completely documented history of the purchase of Alaska by the United States in 1867. Mr. Farrar, relying upon Russian and American documents in the Department of State archives, sets forth Russia's reasons for selling Alaska and describes the diplomatic negotiations which culminated in the treaty. Besides discussing the arguments employed by Secretary of State Seward to secure congressional approval and appropriations for the purchase, the author clears up certain misconceptions regarding the reasons for the visit of the Russian fleet to America in 1863 and the mode of payment to the Russian government.

3430. Flick, Alexander Clarence. Samuel Jones Tilden; a study in political sagacity, by Alexander Clarence Flick, assisted by Gustav S. Lobrano. New York, Dodd, Mead, 1939. 597 p. illus. (American political leaders)

Bibliography: p. 535-553.

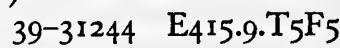


This biography traces the career of Tilden ( $1814^{-}$ r 886 ) as he moved from corporation counsel to reformer of New York politics, and candidate for the Presidency. Born and educated in the state, Tilden was a lifelong Democrat although it was not until I 874 that he held an elective public office. Admitted to the bar of New York City in $184 \mathrm{r}$, Tilden built up a lucrative practice as a lawyer for the major Eastern railroads, and amassed one of the country's largest personal fortunes. The ousting of the "Tweed ring" in 1872 while Tilden was Democratic State Committee Chairman was, as Mr. Flick points out, the personal triumph which made him a national figure. Elected Governor of New York in 1874 on a reform ticket, Tilden gained further prominence through his efforts to expose graft and corruption in the upstate "canal ring." $\mathrm{He}$ was the obvious Democratic reform candidate in 1876 , and although nominated and evidently preferred, if not elected, by the people, lost to Rutherford B. Hayes in the contested election, which is here analyzed in great detail.

3431. Fuess, Claude Moore. Carl Schurz, reformer (1829-1906). New York, Dodd, Mead, 1932. Xv, $42 \mathrm{I}$ p. illus. (American political leaders) $3^{2-2} 6_{442} \quad \mathrm{E} 664 . \mathrm{S}_{39} \mathrm{~F}_{92}$

"Selected bibliography": p. 395-40r.

A biography of Carl Schurz, in 1848 a German revolutionary, in 1852 an immigrant to the United States, by 1859 an orator and lecturer on such subjects as "True Americanism" and "American Civilization," and for nearly 50 years thereafter "the self-constituted, but exceedingly useful, incarnation of our national conscience." Schurz struggled between two ambitions, Dr. Fuess believes, politics and scholarship, but when he had to choose, he turned to practical affairs. His career was marked by contributions to four great victories: the abolition of slavery, preservation of the Union, maintenance of sound money, and establishment of the merit system in the civil service. Lincoln's Minister to Spain, 186r, Brigadier and then Major General of Volunteers, 1862-1 865, Republican Senator from Missouri, 1869-75, and Secretary of the Interior under Hayes, r877-8 r, Schurz "accomplished enough to entitle him to a position among the great practical reformers," the author concludes, and perhaps to a place among our greater statesmen. Dr. Fuess bases the latter opinion upon Schurz' nonpartisanship and independence in politics which set country ahead of party, his advocacy of ideals and his untarnished record in an age of corruption, his promotion of honest government, and his inspiring example of a foreigner's adaptation to American customs and institutions.
3432. Haworth, Paul Leland. The Hayes-Tilden disputed presidential election of 1876 . Cleveland, Burrows Bros., 1906. 365 p.

6-22324 $\mathrm{JK}_{526} \mathrm{I}^{8} 86 . \mathrm{H}_{4}$

An analysis of "the most remarkable electoral controversy in the history of popular government," based largely upon congressional documents. Although the material is voluminous, Professor Haworth notes, "much of the evidence contained in it is untrustworthy." Initial chapters discuss the issues of the 1876 election-the panic of 1873 , the sorry condition of the South, the exposure of corruption high in the Grant administration-which encouraged the Democrats and their candidate, Samuel J. Tilden, to charge the administration with misgovernment. This in turn forced the Republicans and their nominee, Rutherford B. Hayes, to attempt to create distrust of the Democrats by reviving the sectional issue. Succeeding chapters are devoted to the conduct of the election; the count of votes whereby Tilden appeared to have won a popular majority of 200,000 or more but to have lacked the one electoral vote necessary to election; the forwarding to Washington of double sets of returns from the disputed states of Florida, Louisiana, South Carolina, and Oregon; and the compromise that peacefully concluded the perilous situation (cf. no. 34I7). Both sides were guilty of fraud, and the Democrats of violence also, the author believes, but he views the outcome of the great contest as "in the main a just one."

3433. Haynes, Frederick Emory. James Baird Weaver. Iowa City, State Historical Society of Iowa, 1919. xv, 494 p. illus. (Iowa biographical series) $\quad 1_{9-27188} \mathrm{E}_{66} 6_{4} \mathrm{~W}_{3} 6 \mathrm{H}_{4}$

A biography of General Weaver (1833-1912), Union officer in the Civil War, prominent Iowa Republican in the years $1867-77$, DemocraticGreenbacker member of the United States House of Representatives, 1879-8 I and I 885-89, Greenbacker candidate for the Presidency, 1880 , Populist candidate for the Presidency, I892, and a Democrat after the campaign of 1896 . The author believes that Weaver was a pioneer, the first progressive, and a prophet, the precursor of Bryan, Theodore Roosevelt, and Wilson. As presidential candidate in 1880 , Weaver advocated a graduated income tax, postal savings banks, the initiative and referendum, direct election of United States Senators, protective labor laws, free silver, and expansion of the powers of government. He was fortunate, Mr. Haynes believes, in living to see many of his own measures enacted into law by the two great parties. 
3434. Hendrick, Burton J. The life of Andrew Carnegie. Garden City, N. Y., Doubleday, Doran, 1932. 2 v. illus. $32-29884 \quad \mathrm{CT}_{275} \cdot \mathrm{C}_{3} \mathrm{H}_{27}$

Bibliography: v. 2, p. 389-400.

An appreciative biography of Andrew Carnegie (1835-1919), multimillionaire and philanthropist, which is concerned chiefly with his nonbusiness activities. Although Mr. Hendrick records Carnegie's progress successively from telegrapher to railroad executive, organizer of Civil War railroad and telegraph services, oil man, securities dealer, bridge builder, and, finally, in 1873 , to manufacturer of steel by the Bessemer process, he does not attempt to analyze Carnegie's work as a business administrator and investing capitalist. The author notes that Carnegie, himself a fairly prolific writer, as early as 1886 published Triumphant Democracy (New York, Scribner. 5I9 p.), a criticism of the aristocratic principle, and, in an article of 1889 , set forth a Calvinist belief in the stewardship of wealth. He spent his last 20 years implementing this social gospel, his benefactions, principally in support of education, public libraries, and research, having amounted to $\$ 350,000,000$. An interesting supplement, in which Mr. Hendrick's work was completed by Daniel M. Henderson, is Louise Whitfield Carnegie: the Life of Mrs. Andrew Carnegie (New York, Hastings House, 1950. 306 p.); Mrs. Carnegie, over 20 years younger than her husband, lived until 1946 .

3435. Hesseltine, William B. Ulysses S. Grant, politician. New York, Dodd, Mead, I935. 480 p. illus. (American political leaders)

Bibliography: p. 453-46o.

$$
\text { 35-17052 E672. } \mathrm{H}_{46}
$$

A depreciatory revaluation of the political career of Ulysses S. Grant (1822-1885), r8th President of the United States. Professor Hesseltine characterizes him as a man not so much stupid and corrupt as peculiarly ignorant of the Constitution, militantly obstinate and imperious, unable to judge and inept at handling people. "Although he grew as a President," says the author, "his growth was that of a party politician, and he changed from the man who would be the President of all the people in 1869 into the man who could support the Republican party in the theft of the election of 1876 . As he acquired the ideology of the politician he lost the vision of the statesman, and became the 'safe' representative of the more reactionary economic interests of his day." Unimaginative and taciturn, yet sensitive, Grant's was a personality suppressed largely by unfortunate parental influences, the negative elements of which strongly conditioned his career. Psychologically the President was overshadowed by the general, and at
Grant's death the partisan bitterness and mistakes of his eight years in the White House (1869-1877) "were forgotten in the glories of the soldier and the heroism of the man."

3436. Hicks, John D. The American Nation. 3d ed. [Boston] Houghton Mifflin, I955. 776, ci p.illus. $\quad 54-13492$ E66r.H55 1955

"List of books cited": p. xxvi-lv.

This well-illustrated college text deals with American history of the years $1865-1954$; two-thirds of it is devoted to the events of the 2oth century. The author summarizes all significant movements, whether political, economic, or cultural, and discusses their effects upon the development of the country. Professor Hicks remarks such American achievements as the attainment of unsurpassed political democracy, the breaking down to a remarkable degree of class and caste barriers, the acquirement of a higher standard of living than the world has before known, and a relatively low spread between the rich and the poor; he is concerned that the tremendous advances made by American science have not been matched by equal accomplishments in literature. He has faith, however, in the ability of the United States to survive the stresses and strains of the cold war with its ideals and principles intact.

\section{Howe, George Frederick. Chester A.} Arthur; a quarter-century of machine politics. New York, Dodd, Mead, 1934. 307 p. illus. (American political leaders) $34-38337$ E692.H67 "Select bibliography": p. 292-295.

A friendly but not uncritical biography of Chester A. Arthur (1830-1886), who was prominent in New York politics for more than two decades, and became 2 Ist President of the United States in $188 \mathrm{I}$ upon the assassination of Garfield. He is depicted as a genial and cultivated man, viewed with respect by a few of his contemporaries because of his capable service as state quartermaster general during the Civil War, but distrusted by many because of his long association with Boss Roscoe Conkling, because of his advocacy of the spoils system while he served as collector of the Port of New York, 187178 , and because his nomination to the Vice-Presidency in 1880 was considered a sop to the followers of General Grant. Professor Howe characterizes Arthur in the Presidency as reassuring to the alarmists and disappointing to the machine politicians, conscientious, honorable, and dignified, a conservative and conciliator. Adequate rather than great, he rehabilitated the Navy, forwarded civil service reform, favored a Nicaraguan canal, and vetoed the Chinese exclusion bill. 
3438. Josephson, Matthew. The politicos, 18651896. New York, Harcourt, Brace, 1938. $760 \mathrm{p}$. 38-27301 E66r.J85

Bibliography: p. 709-7I9,

The thesis of this chronicle of the politics and key professional politicians of the age of big business which followed the Civil War is that "Governors, Senators, Presidents come and go; but the Party Organization goes on long after them, and its Inner Circle, its bosses, rule not for four or six years, but for a generation or for life tenure." The business-minded Northern politicians of the Reconstruction era "were literally Jekylls and Hydes," asserts the author: as Dr. Jekyll, they secured support by advancing a humane and libertarian ideology; as Mr. Hyde, they enacted measures of high capitalist policy, designed to hold out against future assault-charters and grants to railroads and land companies, special tariff duties, public contracts, and pensions, while they deliberately delayed the recovery of the conquered South and imposed upon it military rule "subject to the Republican Party Organization at Washington." Down to Garfield's death in $188 \mathrm{I}$, Mr. Josephson asserts, the ruling group of Senator-bosses operated the Republican Party as a patronage organization, deriving profit from the sale of office and assessments upon wages, as well as from the subsidies of bankers and industrialists. From i 88I to 1896 , the Republican grip on public office relaxed; it began the shift to politics of "interest" and "class," and the Democratic opposition not merely sloughed off the stigma of disloyalty but began to compete forcefully for capitalist backing.

3439. Lindsey, Almont. The Pullman strike, the story of a unique experiment and of a great labor upheaval. Chicago, University of Chicago Press, 1942. $3^{85}$ p. illus.

Bibliography: p. 364-37o.

$$
\text { 42-50022 HD } 5325 \cdot \mathrm{RI}_{2} \text { 1894.C } 54
$$

A history of the brief but intense struggle between labor and capital precipitated in 1894 when the American Railway Union's sympathetic boycott against Pullman cars, prompted by a strike of illpaid workers at the company town of Pullman, Illinois, met vigorous and massive resistance from the General Managers' Association. The author asserts that the aim of the managers was annihilation of the union and that they were prepared neither to negotiate nor to make the smallest concession. A vital part of their strategy, Professor Lindsey believes, "was to draw the United States government into the struggle and then to make it appear that the battle was no longer between the workers and the railroads but between the workers and the government." He describes John Egan, strike mana- ger of the association, as portraying the "situation in a manner as ominous and disturbing as possible in order to arouse the apprehension of the powerful 'interests' and hasten federal participation," and the United States Government as using injunctions, soldiery, and even arrests in a manner calculated to bring victory to the railroads and to nullify completely the aims and activities of labor. The American Railway Union, was, however, widely considered a force for anarchy in this restless era, the author concedes, a rallying point for an attack upon property, corporate control, and the economic machinery of the country.

3440. McMurry, Donald L. Coxey's army; a study of the industrial army movement of 1894 .

Boston, Little, Brown, I929. 33I p. illus.

Bibliography: p. [31 I ]-323.

$$
\text { 29-23512 HD8072.M23 }
$$

An interpretation of Jacob S. Coxey's "Commonweal of Christ," which relates it to the economic maladjustments of the 1890 's, other organized armies of unemployed marchers, the Populist "uprising of the people," and demand for free silver, as well as the grievances of the 2 million or more wage earners left idle after the panic of 1893 . The author believes that the idea of a march of the unemployed to the National Capital for succor originated farther west, but that "Jacob S. Coxey, of Massillon, Ohio, was the man who made it famous." Marching out of town on March 25, I894, with flags and symbolic banners flying, Coxey's picturesque army, together with his enthusiasm, ability to formulate a program, means to finance his ventures, and instinct for advertising, caused the association of his name with the whole movement, although other armies marched far greater distances to Washington led by such "Generals" as Lewis C. Fry of Los Angeles and Charles T. Kelly of San Francisco. Coxeyism was, in Professor McMurry's opinion, a symptom of the economic revolution in this country; it "showed certain reactions of the American frontier spirit to the growing industrialism which was replacing the old order."

344I. Mitchell, Stewart. Horatio Seymour of New York. Cambridge, Harvard University Press I938. xx, 623 p. illus. $\quad 38-9985 \quad E_{415.9 . S 5 M 6}$ Bibliography: p. [585]-594.

A political biography of Horatio Seymour (1810I886), a moderate Jeffersonian Democrat who began his career as an assemblyman from Utica, New York, in 1842 and climaxed it as Democratic candidate for the Presidency in the election of 1868 . Seymour was elected Governor of New York in 1852; in 1862, his gubernatorial victory as a Democrat in the midst of the Civil War, Dr. Mitchell believes, "pushed 
him into the position of the leader of the opposition to the forces that were swiftly and surely getting control of both the Congress and the Cabinet." As early as 1856 , Seymour had argued against abolition, prohibition, anti-Catholicism, and secession. He campaigned in 1862 with the slogan, "The Union as it was, and the Constitution as it is." He was accused of treason and a desire to obstruct the war, but the author regards him as "the hard-working object of unjust suspicion and long-lived slander," who honestly believed that emancipation, conscription, and the suspension of habeas corpus were unsound policies. The draft riots of July 1863 in the city of New York were magnified into a political myth, convenient ammunition for use during the campaign of 1868 , in which Seymour polled a substantial voie against Grant and "was not improbably the choice of the white men of the country."

3442. Muzzey, David Saville. James G. Blaine, a political idol of other days. New York, Dodd, Mead, 1934. 514 p. illus. (American political leaders)

Bibliography: p. 501-504.

A biography of James G. Blaine (1830-1893), acknowledged leader of the Republican Party for a quarter of a century, a contestant for the Presidential nomination in five successive elections, $1876-92$, and in 1884 the candidate. Idolized by many Americans as the "Plumed Knight," he was loathed by others as a corrupt politician. Avoiding adulation or denigration, Professor Muzzey explores the events of Blaine's life, assessing his achievements and the paradox of his character, and presenting him in the political setting of his time. The author finds that Blaine's chief public service was performed as Secretary of State under Garfield, I88I, and under Benjamin Harrison, 1889-92, when he encouraged closer political and commercial ties between the United States and the Latin American republics, and advocated the policy of peaceful arbitration among them. Professor Muzzey regards Blaine's conduct of the speakership of the United States House of Representatives (1869-75) as "brilliant," but considers his performance as Senator $(1876-8 \mathrm{I})$ rather less impressive. In the author's opinion, Blaine not only roused "men's emotions of patriotism, partisanship and prejudice, of personal devotion and resentment," but also spent perhaps too much of his "wonderful" talent in a constant effort to make his party seem better than it was.

3443. Nevins, Allan. Abram S. Hewitt: with some account of Peter Cooper. New York, Harper, 1935. 623 p. illus.
"A note upon sources": p. 603 .

The great age of American capitalism is seen at its best in this family history of the lives and achievements of Abram S. Hewitt (1822-1903), and of his father-in-law, Peter Cooper (1791-1883), both seitmade industrialists. Of the two, Hewitt receives greater attention, since the author regards him as the more intellectual and versatile. He was one of the first great American ironmasters, supplying guns and armor to Union forces during the Civil War, and a pioneer steel manufacturer; he was a leader of the Democratic Party, serving five terms in Congress from 1875 to 1886 , and reform mayor of NewYork City from 1887 to 1888 . Peter Cooper, inventor and idealist, Professor Nevins calls a "picturesque genius"; he was Hewitt's "partner in business, education, and philanthropy for forty years." He built the first American locomotive, accumulated a fortune from the manufacture of glue and gelatine, helped to finance the laying of the Atlantic cable, and founded Cooper Union. The author believes that Hewitt might have become a commanding figure had he concentrated upon a single objective, but "his life would have been less interesting, less a reflection of the important forces of American society, and less useful." Cooper, Professor Nevins declares, was a rare spirit but "as distinctively an American type as Benjamin Franklin, and one as quickly taken to the American heart."

3444. Nevins, Allan. Hamilton Fish; the inner history of the Grant administration. New York, Dodd, Mead, 1936. xxi, 932 p. illus.

\section{7-9994 E664. $\mathrm{F}_{52} \mathrm{~N}_{42}$}

This is both a biography of Hamilton Fish (1808. 1893), Secretary of State under Grant, and a history of the Grant administration, based upon the exceedingly rich and voluminous Fish papers. The major portion of the book falls into two divisions: the first devoted to Fish's activities in the field of foreign affairs, $1869-73$, when the controversy with Great Britain over the Alabama claims was settled and war with Spain was averted; the second to the "deeply disturbing" politics of the administration. Professor Nevins considers Fish a man of cautious good sense, moral elevation, and pacific temper, "the strongest figure in one of our most troubled Administrations." Grant the author regards as a contradictory person, intermittent in mental energy, at once weak and strong, naïve and inscrutable, reckless and plodding. Ignorant of law, civil affairs, economics, and history, awkwardly constrained before men of superior intellect, he was incapable of communicating with most of the best minds he might have used. "Grant's casual way of performing his duties; his easy acceptance of vicious personal influences; his negligence and favoritism in appointments; his careless inconsequentiality in 
handling Cabinet affairs; his detestation of reform because reformers were critics," all produced an aroma of corruption by the summer of 1872 and caused "the virtual collapse of the Grant Administration during 1876 " in all but foreign affairs. The book was reissued in 2 volumes in 1957 (New York, Ungar).

3445. Nixon, Raymond B. Henry W. Grady, spokesman of the new South. New York, Knopf, 1943. $x, 360$, xiv p. illus.

Bibliography: p. [35I] -360

$$
43^{-1} 5^{899} \text { E664.G } 73 \mathrm{~N}_{5}
$$

A sympathetic and sprightly biography of Henry Woodfin Grady (1851-1889), editor of The Atlanta Constitution and advocate of the utilization of the natural resources of the South, diversification of its agriculture, development of manufacturing to supplement the once almost exclusively agrarian eccnomy, adjustment of the Negro problem, and, especially, fraternity between North and South. As early as 1874 , the author notes, Grady was outlining his program for the economic regeneration of the South. By the 1880 's the Constitution liad become the most important organ of the movement toward a new South, as Atlanta was its booming industrial and commercial center, and Henry W. Grady the acknowledged spokesman for the Southern spirit of progress and good will. When he made his famous conciliatory speech, "The New South," at the annual dinner of the New England Society in New York, December 22, 1886, "Grady was the right man speaking the right word at the right time." "He was the only Southern speaker of the late eighties who had succeeded in gaining the attention and the confidence of the North to any marked degree; he was one of the few Southern editors whose writings had national circulation." $\mathrm{His}$ premature death was widely regretted as a national loss.

3446. Nye, Russel B. Midwestern progressive politics; a historical study of its origins and development, 1870-1950. [East Lansing] Michigan State College Press, I95I. 422 p. illus.

Bibliography: p. 387-4Io.

$$
\text { 5I-III44 F } 354 \cdot \mathrm{N} 8
$$

A comprehensive history of midwestern progressivism, the political movement among farmers, and, later, among labor and reform elements, against the alliance of industrialism and government, the big businessmen and the big bosses. Professor Nye describes the revolt in the 1870's which gave rise to such organizations as the Grangers, Populists, Nonpartisan Leaguers, Socialists, "progressives," and "insurgents." Their leaders strove for popular government, the destruction of monopoly privileges, elimination of corporations from political life, and protection of natural resources. Dealt with in some detail are the activities of men like John P. Altgeld of Illinois, William Jennings Bryan, Robert M. La Follette of Wisconsin, and George W. Norris of Nebraska. The midwestern progressives held the balance of power in Congress by 1910 and in 1912 were ready to form a party of their own, but when Theodore Roosevelt seized the leadership of the third-party movement many progressives declined to follow him. The strange result was that "a Virginia Democrat from Princeton" pushed through most of the measures for which the progressives had been battling for three decades. Thenceforward progressivism was in decline: "The first World War split it, the New Deal robbed it, the second World War brought it to the edge of its grave, and the disintegration of political lines in the forties killed it." Regional in spirit, it could not survive the triumph of nationalism and internationalism.

3447. Oberholtzer, Ellis Paxson. A history of the United States since the Civil War. New York, Macmillan, 1917-37. $5 \mathrm{v}$.

$\mathrm{r}_{7}-28462$ E66r.Or2

A detailed political and socioeconomic history of the years I865-1901, from the assassination of Lincoln to the emergence of the United States as a world power at the conclusion of the war with Spain. Volume I, dealing with the years I 865-68, reports the honest efforts of President Andrew Johnson to implement Lincoln's conciliatory Reconstruction policies, the revulsion of the North against the South's "Black Codes," and the rise of the Radical Republican congressional opposition with its "conquered provinces" theory. Devoted to the years 1868-72, volume II describes Johnson's attempt to prevent the Radical Congress from overriding the Constitution, his impeachment and trial, and, in the Grant era of "moral blindness," the rule of carpetbaggers and the appearance of protective associations like the Ku Klux Klan in the South, and the sovereignty in the North of political bosses and such robber barons as Cornelius Vanderbilt, James Fisk, Jr., and Jay Gould. Volume III covers the period $1872-78$, and deals, among other matters, with Grant's second administration, a "coarse and venal regime," the panic of $r 873$, the Hayes administration which removed Federal troops from the South and ended Reconstruction, and the Indian uprisings in the Far West. Volume IV, $1878-88$, discusses the "infirm character" of the Garfield administration, the surprisingly "discreet, conservative and just" Arthur administration, and the honesty, independence, and "responsible understanding of public duty" demonstrated by the first Cleveland 
administration. Covering the years I888-I90 I, volume $\mathrm{V}$ characterizes Benjamin Harrison's administration as honest, efficient, protectionist, and paternalistic, and Cleveland's second administration as sound on money, tariff, and civil service reforms but tactless and ignorant in foreign affairs. The author considers William Jennings Bryan "a rare bigot" rather than a "mountebank," and McKinley a mere recorder of the flow of popular thought. Mr. Oberholtzer (1868-1936) was a disciple of J. B. McMaster (no. 3046 note) and followed the method and style of the latter's History of the People of the United States. Since Mr. Oberholtzer's History was over 20 years in the writing, its manner and outlook had become rather old-fashioned by the time of its completion, and it has had more criticism than praise. It nevertheless remains the only large-scale general treatment of its period, and a thoroughly solid, informative, and honest performance.

3448. Olcott, Charles S. The life of William McKinley. Boston, Houghton Mifflin, I912. $2 \mathrm{v}$. illus. I6-10505 E7 I 1.6.O43

An authorized and admiring biography of William McKinley (1843-1901), 25th President of the United States, based not only upon his rather meager papers but also upon the recollections of his friends and associates, notably, George B. Cortelyou, William R. Day, Charles G. Dawes, and Myron T. Herrick. McKinley is characterized here as "a true, earnest, and consistent Christian," who aspired to a congressional career as early as 1869 . Beginning in 1877 , he served 6 terms in the U. S. House of Representatives, and 2 as Governor of Ohio (1892-96). He made a special study of the tariff and, "from the time of his first speech in Congress until the end of his life, McKinley sought to elaborate, clarify, and systematize the true 'American' policy of Protection." Mark Hanna's promotion of McKinley's successful candidacy in the presidential elections of 1896 and 1900 is attributed to Hanna's disinterested admiration of McKinley as a man, and to his belief that prosperity and the best business interests of the country "depended upon the reëstablishment and permanent maintenance of the principle of Protection, and that this could be accomplished only by the election of its foremost exponent to the Presidency." In Mr. Olcott's opinion, however, McKinley will be remembered not as the advocate of protection and sound money but as the President who successfully conducted the war with Spain and inaugurated a new era of expansion and international responsibility.

3449. Pratt, Julius W. Expansionists of 1898 ; the acquisition of Hawaii and the Spanish islands. New York, P. Smith, I95I, ' ${ }^{1936 . ~} 393$ p.
(The Albert Shaw lectures on diplomatic history, 1936.)

Bibliography: p. $36 \mathrm{I}-376$. $5^{2-7706} \quad \mathrm{E}_{713 . P 895} \quad 1936 \mathrm{a}$

A history of the rise and development in the United States of the movement for overseas expansion, from its uncertain beginnings under Benjamin Harrison in 1889 to its triumphant culmination in the treaty of 1899 with Spain. Professor Pratt analyzes the ideological background of the movement and surveys briefly Harrison's abortive efforts to secure strategic bases in the Caribbean area. He devotes major attention, however, to the question of the annexation of Hawaii which grew out of the revolution there in 1893 , both because there had been no previous treatment of the subject and because the proposal to annex the Islands focused public and congressional opinion upon the expansionist policy. When President Cleveland rejected the acquisition of Hawaii, the expansionists turned their attention to Spain's Caribbean colonies, and in 1898 saw the triumph of their policies in both spheres. The debates between proponents and opponents of the policy are explored, as are the attitudes of business and religious groups.

3450. Smith, Theodore Clarke. The life and letters of James Abram Garfield. New Haven, Yale University Press, 1925. 2 v.

$$
\text { 25-19753 E687.S66 }
$$

A sympathetic biography of James A. Garfield (183I-I88I), 2oth President of the United States, "set forth so far as possible in his own words through extracts from letters, journals, reminiscences and speeches," which give his "own commentary upon himself and his doings, his impressions of events and of contemporaries." The author finds the chief value of these judgments in their "abundance, good humor and candor," and observes: "It is Garfield himself who contributes the personal and psychological analysis." The selections, together with Professor Smith's connective text, illumine Civil War politics and the western campaigns, since Garfield served as colonel and brigadier general, $186_{1-1} 862$, and as major general of volunteers and chief of staff to Rosecrans in 1863 . The work also sheds light upon 17 years of congressional history (1863-1880) when Garfield served as a Republican Representative from Ohio, became known as a moderate and compromiser, and attained the chairmanship of the Committee on Appropriations. The author exonerates Garfield from complicity in the Credit Mobilier scandal, and defends his stand on the Salary Grab and other such issues. During the 4 months before his assassination in $188 \mathrm{I}$, President Garfield demonstrated 
"that he fully comprehended the nature of presidential authority and was prepared to exercise it firmly and quietly from the start."

3451. Woodward, Comer Vann. Tom Watson, agrarian rebel. New York, Macmillan, 1938. 518 p. illus. $\quad 38-8354 \quad$ E664. W 337 W6 Thomas E. Watson of Georgia (1856-1922), a controversial political figure, is viewed by Professor Woodward as a product of the "forces of intolerance, superstition, prejudice, religious jingoism, and mobbism." He struggled bravely against them during the 1890 's, first as an Alliance Democrat, then as the foremost Southern Populist, but was thwarted by them at every turn, and led into the futility and degeneration of his later career. Watson stood originally for the Southern farmer and his way of life, war upon Eastern industrialism, alliance with the agrarian West, conflict with other classes both within and outside the South, and the enlistment of the
Negro in the farmers' struggle. As the author shows, Watson's career was studded with crushing disappointments. The district from which he was easily elected to Congress in 1890 was gerrymandered by the Democrats in 1892 , and he was out of public office until 1920 when he was elected to the United States Senate. When he was Populist candidate for Vice President in 1896 , fusionist elements in his own party betrayed him. In his "forlorn crusade" of 1904 as Populist candidate for President, Watson became a defender of white supremacy and began his sorry but understandable swing toward reaction, sectionalism, and sensationalism. Articles in his weekly, the Jeffersonian, on the plutocracy and corporate privilege were replaced by vituperative attacks upon individuals and the "menaces"--the Catholic hierarchy, the Negro, the Jew. "A frustrated man and a frustrated class found that their desires and needs were complementary."

\section{J. Theodore Roosevelt to Wilson (I90I-2I)}

3452. Barck, Oscar Theodore, and Nelson Manfred

Blake. Since 1900 , a history of the United States in our times. Rev. ed. New York, Macmillan, I952. 903 p. illus.

First published in 1947 .

$$
\text { 52-2595 } \mathrm{E}_{741 . B_{34} \quad 1952}
$$

"Suggestions for further reading": p. 86I-885.

A textbook emphasizing the historical development of problems currently important to this country. Although ample treatment is accorded to social and cultural trends in America, more space is devoted to the two most impressive lines of development: "the steady expansion of the functions of government to deal with the complex problems of a new age and the increasing involvement of the United States in global politics." The authors see three significant tendencies of the last $5^{\circ}$ years: a nation largely indifferent to international affairs has been pushed by events into a position of dominant power in world affairs; it has been compelled not merely to defend democracy as a way of government and life but to reexamine its own institutions in the light of the democratic ideal; and its capitalist system has been put to the acid test of having to provide security and economic well-being for the whole people. There is still no cause for complacency: if wealth, productivity, and the general standard of living have soared, if education, good literature, music, and art have never been so accessible, national and international problems have grown even faster, and in greater complexity and difficulty than ever before.

3453. Bowers, Claude G. Beveridge and the progressive era [Boston] Houghton Mifflin, 1932. xxiv, 610 p. illus. 32-22530 E748.B48B6 Bibliography: p. [591]-593.

The well-documented political biography of a man who began his career as a Hamiltonian Republican but whose practical experience as a legislator carried him into the Progressive ranks. Beveridge (1862-1927) was at first a conservative nationalist, hostile to demagogy, and a believer in the obligations and the self-restraint of power. His dominant passion, Mr. Bowers believes, was for an imperialist national policy, expanding trade through colonialism; his consuming ambition, a leap from private life in Indiana to the United States Senate, which feat he accomplished in 1898 . By 1905 , however, Beveridge "had discovered that bigness and power do not necessarily make for the good of humanity." When he triumphed over the packers in 1906 with the passage of his meat inspection bill, he took "a long strike forward as a progressive and compromised some of his old relationships." Thereafter, he was engaged more and more in progressive battles for domestic reforms and "was moving into conflict with the major forces of his party"; he consistently supported Roosevelt, and was one of the insurgents under Taft. A Progressive in 
1912, "he was passionately in earnest about creating a great party, liberal according to his lights," says the author, "and he saw no hope in the party he had left." Unable to regain office, he devoted his later years to his monumental Life of John Marshall (q. v.) and an unfinished study of Lincoln.

3454. Clark, John Maurice. The costs of the World War to the American people. New Haven, Yale University Press, for the Carnegie Endowment for International Peace, 1931. 316 p. ([Carnegie Endowment for International Peace. Division of Economics and History. Economic and social history of the World War. American series])

$$
\text { 3I-28596 HC56.C } 33 \text {, no. } 3 \text { D635.C553 }
$$

An analysis of the costs of World War I to the United States wherein the fiscal allocations "are regarded as of little significance in themselves, their chief importance being as evidence of the outpouring of goods, the diversions of productive power from peace to war uses, and the sacrifices of the people, all of which constitute the more important realities behind the various sums of money which serve to call them forth." Professor Clark considers such matters as the nature of fiscal outlays for the war, how they were financed by the Federal, State, and local governments, or private organizations, and the effects of the war on manpower, agriculture, and industry. He estimates "the real social outlays for prosecuting the war" at 32 billion dollars, broken down by years thus: 1917,6 billions; 1918, 16 billiors; 1919, 9 billions; and 1920, I billion. At the time of writing (193I), he had concluded that the postwar prosperity, highest in the Nation's history, was higher than it would have been had there been no war, that the Great Depression cut deeper, and that the effect of the war in so deepening the depression outweighed its effect in heightening the boom.

3455. Goldman, Eric F. Rendezvous with destiny; a history of modern American reform. New York, Knopf, 1952. xiii, 503, xxxvii p.

$$
{ }^{2-6}-6418 \text { E66r.G } 58
$$

A lively history of the reform movements that culminated in the Wilson administration and, after the reaction of the r920's, the New Deal, emphasizing the ideas of the reformers and the influence which these ideas exerted in subsequent developments. Since these movements are interpreted as reactions to a rapidly industrializing and urbanizing America, the narrative begins with the late 1860 's, when these factors were becoming dominant, and the first reformers in Mr. Goldman's procession are therefore the patrician liberals of the Tilden school, who wanted a government "which the best people of this country will be proud of." After the episodes of the Georgists, the Farmers' Alliance, and the Populists, all currents run together in the Progressive movement of the early zoth century. Thus early emerged the recurrent dilemma of the progressives, which bewilders individuals as well as parties: should freedom of enterprise be restored by creating conditions of fair and equal opportunity, or should big business be accepted as inevitable and controlled by big or bigger government? These and other issues are conducted down to an open present, in a narrative in which social circumstances, liberal thought, and political action are nicely balanced, and which is sometimes quite individual in interpretation, but always thoroughly documented.

3456. Hechler, Kenneth W. Insurgency; personalities and politics of the Taft era. New York, Columbia University Press, I940. 252 p. (Columbia University. Faculty of Political Science. Studies in history, economics and public law, no. 470)

$$
\begin{array}{r}
40-33640 \quad \mathrm{H}_{3} \text { r.C7, no. } 470 \\
\text { E76r. } \mathrm{H}_{462}
\end{array}
$$

Issued also as thesis (Ph.D.) Columbia University. Bibliography: p. 227-248.

A history of the predominantly agrarian group of Republicans in Congress, who in 1909, inspired by the crusading spirit of Theodore Roosevelt, arose in rebellion against the reactionary "regulars." In the House of Representatives, the author notes, some 25 insurgents regularly fought the personal dictatorship of Speaker Cannon, and, at the high tide of insurgency, March 19, I910, "rallied fortytwo Republicans to join the Democrats in passing a resolution that stripped the Speaker of most of his personal power." Dr. Hechler names among the leaders George W. Norris of Nebraska, Edmond H. Madison and Victor Murdock of Kansas, John M. Nelson of Wisconsin, Miles Poindexter of Washington, Charles A. Lindbergh, Sr., of Minnesota, and Charles N. Fowler of New Jersey. The insurgents of the Senate strayed from the Republican position on a number of issues: revision of the tariff, which first split party solidarity in the special session of 1909; taxes; conservation; postal savings banks; railroad rate regulation; and reciprocity. In breadth of ideas and courage, the author believes, Robert M. La Follette of Wisconsin had no equal; also of importance, however, were Senators Moses E. Clapp of Minnesota, Albert B. Cummins and Jonathan P. Dolliver of Iowa, Joseph L. Bristow of Kansas, and Albert J. Beveridge of Indiana.

3457. Hibben, Paxton. The peerless leader, William Jennings Bryan. New York, Farrar \& Rinehart, 1929. xvi, 446 p. illus.

$$
\text { 29-24634 E664.B87H6 }
$$


"The first twenty-one chapters ... were completed by Paxton Hibben before his untimely death. The book as it stands was completed by C. Hartley Grattan."-p. [v].

Bibliography: p. 409-419.

A not uncritical interpretative biography of Bryan (1860-1925), which relates its subject to the intellectual, social, political, and economic milieu of his day. He is seen as "the perfect product" of the American Middle West, "where sentimentality took the place of knowledge and evangelism was the motive force of action." In the heyday of brass bands and torchlight political parades, "an era when oratory was all a man required to attain to any exalted position," Bryan possessed the equipment of the perfect orator. Yet victory was not in Bryan nor of him, Mr. Hibben maintains; even the Cross of Gold speech that won him the Democratic Presidential nomination in 1896 was defensive. "William Jennings Bryan was of those meek who may inherit but will never conquer the earth." More than a politician seeking votes, he "was the evangelist of a new hope for the helpless and disinherited," a hope which lay not in patient resignation but in self-help through political action. The Great Commoner, thrice defeated nominee for the Presidency, and Secretary of State under Wilson, I9r315, became a symbol of "emotional Democracy."

3458. Hofstadter, Richard. The age of reform; from Bryan to F. D. R. New York, Knopf, 1955. $328 \mathrm{p}$.

54-7206 E743. $\mathrm{H}_{3}$

This analysis postulates that reform has set the tone of American politics for the better part of the 2oth century. "The reform movements of the past sixty-five years fall readily into three main episodes, the first two of which are almost continuous with each other: the agrarian uprising that found its most intense expression in the Populism of the 1890 's and the Bryan campaign of 1896 ; the Progressive movement, which extended from about 1900 to 1914; and the New Deal, whose dynamic phase was concentrated in a few years of the 1930's." Professor Hofstadter's attention centers upon the ideas of the participants in these movements: their concepts of what was wrong, the changes they sought, and the techniques they found desirable. $\mathrm{He}$ is concerned with their most characteristic thinking as found in "middlebrow writers," the popular magazines, muckraking reports, campaign speeches, and articles by representative journalists and influential publicists. The author stresses and criticizes the Yankee-Protestant ethos of responsibility in PopulistProgressive thinking, the "notion that it is both possible and desirable to moralize private life through public action." He regards the New Deal as a drastic new departure in American reformism, prin- cipally in its experimental and managerial approach to problems of economic recovery and social welfare.

3459. Jessup, Philip C. Elihu Root. New York, Dodd, Mead, 1938. 2 v. illus.

$3^{8-31598} \quad \mathrm{E} 66_{4} \cdot \mathrm{R}_{7} \mathrm{~J}_{5}$

"Sources and bibliography": v. 2, p. 507-520; "Chronological list of the principal public speeches and papers of Elihu Root": v. 2, p. 52 I-552.

Based upon interviews with Root, as well as family papers and other sources, this is a massive biography of the Republican lawyer and statesman (1845-1937). His practice in the years $1865-99$, and after his retirement from the Senate in 1915, consisted mainly of cases connected with large corporations and the municipal government of New York. He is here characterized as a man of scientific and detached mind, a master of detail, and an able trial lawyer. Identified with Republican reform elements, Root believed in party regularity as a practical means to political ends, but was always ready to fight the machine on matters of principle. Professor Jessup describes Root's battles against political influence, inertia, personal jealousies, and self-interest, as well as his creation of the General Staff and the Army War College, during his service as Secretary of War under McKinley and Theodore Roosevelt (1899-1904). As Roosevelt's Secretary of State (1905-9), Root, in the author's opinion, proved "the possibility of practical altruism" toward Latin America. Ever devoted to the principle of peaceful arbitration, Root adopted a policy of patience, caution, and friendliness toward all. Professor Jessup considers his greatest diplomatic triumph the settlement of the longstanding Newfoundland fisheries dispute.

3460. Josephson, Matthew. The President makers; the culture of politics and leadership in an age of enlightenment, I896-igrg. New York, Harcourt, Brace, I940. 584 p. 40-3344I E712.J68

"Sources": p. 567-57I.

The years $1896-1919$ produced in this country not only a cultivated and socially-minded political era, but also a whole gallery of remarkable and diverse leaders who controlled the national party organizations and were, in effect, "President Makers." Mr. Josephson views this period as "the flowering of America's imperial age," and Mark Hanna, "Maker" of President McKinley, as the most important link between large business interests and professional politics. Among younger men and the literati, on the other hand, the author finds a sense of special duty as well as special privilege. Theodore Roosevelt and Woodrow Wilson "demanded on the part of the rich capitalists who so often supported 
their campaigns both self-denial and self-control." Progressives like the elder La Follette and Louis D. Brandeis "required of the citizens an alert public conscience, a growing knowledge of public affairs, and readiness to intervene intelligently at almost every point of the governing process." Mr. Josephson sees Theodore Roosevelt's Square Deal and Wilson's New Freedom as the true precursors of Franklin D. Roosevelt's New Deal, calls the Taft administration "an attempted 'Restoration," and dismisses the decade of Harding, Coolidge, and Hoover as "a miscarried 'Restoration."

346r. La Follette, Belle (Case) and Fola La Follette. Robert M. La Follette, June I4, I855June I8, 1925. Chapters I-XXVI by Belle Case La Follette and chapters XXVII-LXXII by Fola La Follette. New York, Macmillan, I953. 2 v. (xx, 1305 p.) illus. 53-13106 E664.Li6Li3

Bibliography: v. 2, p. I233-1253.

A warmly written, extensively documented family biography of Senator Robert M. La Follette of Wisconsin, begun by his widow and completed by his daughter. Born in a $\log$ cabin and associated in his youth with sturdy, courageous pioneer folk, La Follette, in his daughter's estimation, early acquired the enduring faith in the plain people that "was the compelling force throughout his many years of public service." He is depicted here as a man who took the issues directly to the voters, who won a place in the front ranks of the Republican Party, and who, in 1897 , began his long educational campaign in Wisconsin for direct primaries, railroad regulation, tax reform, conservation, and other measures which were enacted during his tenure as Governor, 1900-1905. In his long service as a United States Senator, his daughter points out, La Follette was nominally a Republican but steadily pursued an independent course. He stanchly supported many of Wilson's domestic and some of his foreign policies but, as an isolationist, he voted against the entry of the United States into World War I. Miss La Follette makes it clear that her father ran as an independent rather than a Progressive Party candidate for the Presidency in 1924.

3462. Mock, James R., and Cedric Larson. Words that won the war; the story of the Committee

on Public Information, 1917-1919. Princeton, Princeton University Press, 1939. xvi, 372 p. illus. 39-27871 D632.M64

Bibliography included in "Notes" (p. [347]-356).

Based on personal interviews with former members as well as intensive study of the files of the socalled Creel Committee of World War I, this history of its activities offers an illustration of war propaganda at work. The Committee on Public Infor- mation, a "propaganda ministry" set up by executive order on April 13, 1917, displayed "vigor, effectiveness, and creative imagination, in encouraging and then consolidating the revolution of opinion which changed the United States from anti-militaristic democracy to an organized war machine." Composed of journalists, scholars, press agents, editors, artists, and other manipulators of the symbols of public opinion, working in all media of communication, this "gargantuan advertising agency" sought to mobilize public thinking and emotion on behalf of the Wilson program and "to make it seem like something worth dying for." George Creel, committee chairman, deserves censure for impetuosity and "horseback decisions," in the authors' opinion, but should be credited for maintaining what freedom of the press there was. The senior author's Censorship, 1917 (Princeton, Princeton University Press, 194I. $25^{\circ}$ p.) shows how very little freedom of any sort remained. In times of crisis from the American Revolution onward, liberties have always been curtailed to some degree, especially freedom of speech and of the press, but only with the advent of World War I were all guaranteed rights abrogated save those to property. He describes in some detail these contraventions of liberty: censorship of the press, dispatches, wireless, cable, telegraph, and mail under supervision of the Censorship Board; and of newspapers, magazines, books, motion pictures, and public speech under the Department of Justice.

3463. Paxson, Frederic L. American democracy and the World War. Boston, Houghton Mifflin, 1936-48. 3 v. illus. $\quad 36-21132$ D6r9.P 42 Volume 3 has imprint: Berkeley, University of California Press.

Contents.-I. Pre-war years 1913-1917.-2. America at war, 1917-1918.-3. Postwar years: normalcy, 1918-1923.

A history of the United States, 1913-23, which includes socioeconomic aspects within a firm political framework. It was, on the whole, a younger generation rather than the Democratic Party, the author maintains, that took control of the Nation's affairs in 1913. "The real problem of democratic society was to determine how far it could go to keep the peace among conflicting interests. And for Democracy, as a political entity, it was a challenge whether it could step from minority to majority, from inexperience to responsibility, and deliver satisfaction where the Republican Party of McKinley, Roosevelt, and Taft had failed." The author regards as impressive the program of domestic legislation enacted in 1913 and 1914: the UnderwoodSimmons Tariff, Federal Reserve Act, Federal Trade Commission Act, and Clayton Anti-Trust Act. 
Wilson wanted no war and in fact desired a peace consistent with national safety and self-respect, but by 1916 was "desperate in his belief that unless the world could be brought to peace the United States would be driven to war." The American participation in World War I (1917-18) is regarded by Professor Paxson as an important chapter in the history of democracy in action, when a great nation with its mind finally made up acted with speed, directness, and reasonable efficiency in marshaling its resources, went wholeheartedly into combat 3000 miles away, forestalled a German victory, and marched home "carrying no plunder and asking none." He finds the retreat to "normalcy," begun in 1918 with the election of a Republican Congress and completed in 1920 by the election of a Republican President, as much a part of democracy as the wartime single-mindedness, although he deplores the lack of program, authority, and pattern at a time when preparation for peace was as imperative as winning the war had been.

3464. Pringle, Henry F. The life and times of William Howard Taft; a biography. New York, Farrar \& Rinehart, 1939. 2 v. ( I 106 p.) illus. $39-27878 \quad \mathrm{E}_{762 . P_{75}}$

Bibliography: v. 2, p. 1083-1086.

"Authorized but not official," this is a moderately critical biography of William Howard Taft ( $1857-$ 1930), based chiefly upon his private and official papers. Taft, a Republican, is pictured here as a man of peace, conservative, kindly, of judicial rather than political temper. He spent the greater part of his career in public life, rising through judicial offices, the Governor-Generalship of the Philippines and the Secretaryship of War, to serve from Igog to I 913 as President of the United States, and from 1921 to I930 as Chief Justice of the Supreme Court. Taft's worship of the law and strict construction of the executive power are emphasized, as are his "lifelong ineptitude in the complicated art of politics," and his inability to win public support for his measures or to popularize his accomplishments. The author credits Taft as President with the creation of a postal savings system and the initiation of a corporate income tax, and the advocacy of reciprocal trade agreements and civil service reforms; he deprecates 'Taft's discrimination against the congressional insurgents, his small knowledge of the problems of labor, industry or finance, and his "dollar diplomacy." That Taft, as Chief Justice, "was conservative, if not reactionary, in his political and social views is," in Mr. Pringle's view, "not open to question."
3465. Roosevelt, Theodore. Letters. Selected and edited by Elting E. Morison; John M. Blum, associate editor. Cambridge, Harvard University Press, I95I-54. 8 v. illus. 51-10037 E757.R7958

Contents.-v. I-2. The years of preparation, I868-r9oo.-v. 3-4. The Square Deal, I90I1905.-v. 5-6. The Big Stick, 1905-1909.-v. 7-8. The days of Armageddon, 1909-1919.

A selection of not quite 10,000 from the estimated I00,000 available letters of Theodore Roosevelt (1858-1919), most of them in the Library of Congress, intended to make readily accessible to historians those which seem necessary to reveal his thought and action "in all the major and many of the minor undertakings of his public and private life." Arranged chronologically, the letters selected are printed in their entirety. Purely routine and repetitive correspondence has been eliminated. Correspondence connected with the secondary and tertiary pursuits of this public figure who was also naturalist, historian, rancher, man of letters, and explorer, have been chosen to indicate only the continuity and depth of his concerns. Far more inclusive is the material concerning politics, especially letters about significant events such as the Anthracite Strike of 1902 and the battle over the Hepburn Act in 1906, or suggestive minor episodes, such as the disposition in 1902 of the Church lands in the Philippines. Letters about continuing issues-the tariff, state political organizations, the Indians, the fencing of Western lands-are included if they show developments or shifts in policy. Also included are letters dealing with applications of policy to.specific cases, if they are representative, as in the administration of the Five Civilized Tribes and of the Panama Canal, or if they possess unusual intrinsic interest, as in the case of the Warren Livestock Company. The editors have provided many brief notes, mostly identifications of addressees or persons mentioned in the letters. Of particular value are the "Chronologies" which appear as appendixes at the end of the evennumbered volumes.

3466. [Roosevelt, Theodore] Blum, John Morton. The Republican Roosevelt. Cambridge, Harvard University Press, 1954. $170 \mathrm{p}$.

$$
\text { 54-5182 E757.B65 }
$$

A brief but by no means slight interpretation of the purposes and methods of Theodore Roosevelt's public career, based mainly upon his published works. In the author's opinion, Roosevelt was "a professional Republican politician from New York" who "made a career of politics, studied and mastered politics," because he "loved power." Proficient in the processes of politics, administration, and legislation, he dominated and, for a time, strengthened 
his party; he exerted pressure upon and persuaded the public; he negotiated with and disciplined Congress, learning continuously to compromise and adjust. His purpose, both in domestic and foreign policy, remained governed by "those related constants: his quest for order, his faith in power" as a means of maintaining or imposing national and international stability and justice. Mr. Blum sees tragedy in the fact that "not all the techniques mastered, not all the expert and moral men summoned to advise, not all the intuition and compassion, not all the adroitness in negotiation or the measured sense of pace of change, not all the nice perceptions about social organization subdued his lust to rule."

3467. [Roosevelt, Theodore] Pringle, Henry F. Theodore Roosevelt, a biography. New York, Harcourt, Brace, I93I. 627 p. illus.

Bibliography: p. 607-612.

$$
3^{1-31893} \text { E757.P96 }
$$

A well-documented political biography of Theodore Roosevelt, nearly half of which is devoted to his years in the Presidency, I9OI-9. He is characterized here as a "violently adolescent" person, with a genius for the picturesque, restlessly and aggressively energetic, a jingo, an imperialist, and a conservative who was led "into strange bypaths of political thought" by his fury at the courts for their frequent nullification of Rooseveltian concepts. The core of his political philosophy is seen as "righteousness," coupled with "a due regard for opportunism" and compromise. He sought the "moral regeneration of the business world" through control of corporations, regulation of railroads, conservation, and protection of the rights of labor. He promoted, among other matters, subjugation of the Philippines, limited independence for Cuba, and the construction of the Panama Canal, besides serving as mediator in the Russo-Japanese War. Roosevelt broke with Taft and the Old Guard, turning to radicalism and "the program of William Jennings Bryan and the Democratic party," in Mr. Pringle's opinion, because of his desire to substitute control and perpetuation of the existing order for the Stalwarts' complacency and drift. The relationship of Roosevelt to radicalism and progressivism is more fully developed in Professor George E. Mowry's Theodore Roosevelt and the Progressive Movement (Madison, University of Wisconsin Press, 1946. 405 p.). Roosevelt, the author believes, served as the "advance agent of progressivism" by his continual preaching, leaving the work of legislation to later comers. Roosevelt himself underwent a slow development of his ideas and only "scaled the heights of radicalism," by placing human welfare before profits and property, in a speech delivered at Osawatomie, Kansas, in 1910. Combining Hamiltonian means with Jeffersonian ends, his New Nationalism offered the "concept of a master regulatory state." Mr. Carleton Putnam, who closed a career as an airline executive in order to undertake a full-length portrait of Roosevelt, "done both judicially and sympathetically," has published the first of four projected volumes: Theodore Roosevelt, v. I, The Formative Years, 1858-1886 (New York, Scribner, 1958. 626 p.). An impressive accumulation of detail, it takes for its epigraph a pronouncement of Roosevelt's in 1885 warning against the tyranny of the majority in a democracy.

3468. Sullivan, Mark. Our times, 1900-1925. New York, Scribner, 1936, '1927-35. 6 v.

$$
5^{\mathrm{I}-4248} \text { E741.S944 }
$$

Contents.-I. The turn of the century.-2. America finding herself.-3. Pre-war America.-4. The war begins, I909-1914.-5. Over here, 19141918. 6 . The twenties.

A report, in the best journalistic sense, on American life during the years I goo-1925, the purpose of which "is to follow an average American through this quarter-century of his country's history, to recreate the flow of the days as he saw them, to picture events in terms of their influence on him, his daily life and ultimate destiny." Actors and events are appraised according to their effects upon this average man, his emotions about them, and his influence upon them. The author has consulted not only formal documents, newspaper files, and other printed records, but also his own correspondence with participants and eyewitnesses, his on-the-spot notes, and newspaper dispatches. Politics is presented principally through the personalities of the Presidents and other conspicuous leaders, but each is regarded as achieving his eminence through his fitness to represent powerful social trends. The history of the people from 1900 to 1925 , Mr. Sullivan believes, was "determined less by politicians than by leaders in other walks of life." American achievements were "markedly more important in the fields of science, the invention and perfection of mechanical processes, and the extension of knowledge, than in the field of politics." Besides discussions of these, the author offers lively descriptions of a variety of matters such as prices, fashions, amusements, literature, music, and the theater. A noteworthy feature of these volumes is the abundant and well-chosen illustrations from contemporary sources.

3469. Wilson, Woodrow. Public papers. Authorized ed. Edited by Ray Stannard Baker and William E. Dodd. New York, Harper, I925-27. $6 \mathrm{v}$. in 3. 27-15113 E66o.W 722 
Bibliography edited by $H$. S. Leach: [v. 2] p. 475-506; [v. 4] p. 437-483; [v. 6] p. 543-636.

Contents.-[v. 1-2] College and state; educational, literary and political papers (1875-1913).[v. 3-4] The new democracy; presidential messages, addresses, and other papers (1913-1917).[v. 5-6] War and peace; presidential messages, addresses, and public papers (1917-1924).

A collection of the addresses, messages, and other public papers of Woodrow Wilson (1856-1924), 28th President of the United States. The editors have selected documents which best display his intellectual growth and express his principles and policies in the three fields of his greatest interestpolitics, education, and religion; they see in all a tendency "toward social and political change, even revolution." In Wilson's earliest writings, he is a historian and professor of jurisprudence, the leader of a reform movement at Princeton University, and an advocate of education as a means to a better social and political order. The presidential papers reveal a resolute leader, with a sense of responsibility to the unknown masses of men and above all to history, whose passion for peace was modified by a love of justice. Dealing with transcendent issues, the important public utterances of the great years of Wilson's second administration, 1918-19, are his finest, both in substance, and in "superb and moving simplicity." In the editors' opinion, "general readers will nowhere find a more succinct and felicitous presentation of the dominating American principles and ideals of the period, or a more powerful appeal for the realization of one of the exalted visions of mankind."

3470. [Wilson] Baker, Ray Stannard. Woodrow Wilson; life and letters. Potomac ed. New York, Scribner, I946. 7 v. illus.

$$
\text { 46-2000 E767.Bi6 } 1946
$$

Contents.-[v. I ] Youth-Princeton, I856r9ro.-[v. 2] Governor, 19ro-1913.- [v. 3] President, 1913-1914.- - [v. 4] Neutrality, 1914-1915.[v. 5] Facing war, 1915-1917.-[v.6] War Leader, 1917-1918.-[v. 7] Armistice, Mar. 1-Nov. I1, 1918.

A sympathetic, massive, and painstakingly documented biography of Wilson, consisting in large part of excerpts from the enormous collection of his public and private papers now in the Library of Congress. Mr. Baker had the advantage of personal acquaintance with Wilson and of conversation and correspondence with members of his Cabinet, members of Congress, and others closely associated with him at various stages of his life. The author attempts "to present the man as he was" through his own letters and memoranda, and provides only enough of the historical setting to explain Wilson's actions. In Mr. Baker's opinion, Wilson spent 54 years "in preparation, ten in living, three in dying." In 1885 he began a brilliant career as educator, writer, and lecturer on history and politics, but his labors as college professor and as president of Princeton University formed a "secondary course." His primary ambition was "to take an active, if possible a leading, part in public life." It was natural rather than astonishing, the author believes, that Wilson came confidently as Democratic nominee to the New Jersey gubernatorial race of rgro and to the presidential campaign of 1912. After long years of studying political organization, the development of representative government, and the then current public issues, he easily "out-generaled the most experienced bosses, dominated his party, came early to control Congress, and finally to stand forth preëminent as a world leader." Mr. Baker thinks that, as in his reforms at Princeton, his progressive legislation at Trenton, his magnificent early record in the Presidency, and his diplomacy in World War I, "Wilson seemed to succeed best in his first irresistible attacks-when he had his following securely behind him." In Woodrow Wilson and the People (Garden City, N. Y., Doubleday, Doran, 1945. 392 p.), Professor Herbert C. F. Bell describes Wilson's sustained effort to achieve "communion in thought and sentiment with the rank and file of his fellow countrymen." A somewhat highhanded crusader who believed in his "mission," he claimed position and responsibility as "political spokesman and adviser of the people," in the faith that they would follow the path of righteousness should the true issues be made clear to them.

347I. [Wilson] Baker, Ray Stannard. Woodrow Wilson and world settlement, written from his unpublished and personal material. Garden City, N. Y., Doubleday, Page, 1922. 3 v. illus.

$$
\text { 22-23 I12 D644.B27 }
$$

Based upon official minutes; reports, resolutions, memorandums, and less formal sources, this is a record of American policies and the struggle of Woodrow Wilson and his advisers to apply them at the Peace Conference of Paris, 1919, to the problems of the war-torn world. Baker attempts to illumine the issues and the actions as well as to assess defects and strengths of leadership. Volumes I-II contain the narrative, volume III the texts of the documents referred to or quoted in it. The author wrote from firsthand knowledge, having studied economic and political conditions in the allied countries during 1918, and served as a member of the American Commission at the Conference. In an effort to substitute a new order of mutual understandings for the old sanction of force, the Ameri- 
cans started with principles of justice-the selfdetermination of peoples, and a world association for mutual aid and protection-and attempted to have them applied by dispassionate scientists to a territorial settlement. The Americans were handicapped, however, in Baker's view, by a lack of knowledge of Europe's affairs, secret diplomacy, traditions, and needs, and, more especially, by the fading, both in Europe and the United States, of the high moral enthusiasm which marked the last year of World War I. Wilson, at the time of the armistice, had been the majority leader of world opinion; at the Peace Conference, "he was the leader of the opposition, a powerful opposition, but undoubtedly a minority." Although written first, this came to form the last part of Baker's Woodrow Wilson: Life and Letters. In Wilson and the Peacemakers (New York, Macmillan, I947. 2 v. in r), a critical reinterpretation of our participation in the making of the world settlement of 1919 and of American failure to honor Wilson's pledges, Thomas A. Bailey distinguishes between the cause of our entry into World War I-to defend the American principle of freedom of the seas-and the objectives of the peace-to save the world from Prussian autocracy, to make the world safe for democracy, and to end all wars. Wilson's aims were pitched too high, he believes, and did not command the support of the American people. Although Professor Bailey is in complete sympathy with Wilson's broad program and with his vision for the future, he finds that the President was tactless, stubborn, and unrealistic. In the author's opinion, American reservations about the Treaty of Versailles should have been resolved by compromise. "The United States had a world to gain and virtually nothing to lose by joining the League of Nations."

3472. [Wilson] Link, Arthur S. Wilson. Princeton, Princeton University Press, 1947-56. 2 v. illus.

47-3554 E767.L65 Contents. - [r] The road to the White House.-

[2] The new freedom.

Bibliography: v. [1], p. [529]-543; v. [2], p. [473]-488.

The first volumes in a large-scale and elaborately documented series devoted to a study of the life and times of Woodrow Wilson. In his analysis of Wilson's presidency of Princeton University (1902Io) Professor Link discovers a pattern of early success in reorganizing the university, increasing pressure for reform, resultant disharmony and frustration, and, in I9ro, defeat; he calls this pattern "the microcosm of a later macrocosm." Wilson's entry into politics in rgro as gubernatorial candidate of the conservative New Jersey Democratic machine, his disregard of the party leaders, and his victorious emergence from the campaign as one of the foremost progressive Democrats, the author considers "one of the miracles of modern politics." The second volume covers only the first two years of the Wilson administration, the New Freedom phase (1913-14) when tariff, tax, and currency reforms and antitrust legislation were enacted in answer to the demands of public opinion. Wilson's greatest contribution, his expansion and perfection of the powers of the Presidency, he achieved by asserting his position as spokesman of the people, by using public opinion as a spur to Congress, by affirming and establishing leadership of Congress, and by seizing party leadership.

3473. [Wilson] Link, Arthur S. Woodrow Wilson and the progressive era, Igro-rgi7. New York, Harper, I954. xvii, 33I p. illus. (The New American Nation series) 53-1 I849 E766.L5 "Essays on sources": p. 283-313.

A compact treatment of the political and diplomatic history of the United States from the beginning of the split in the Republican Party in Igro to the Nation's entry into World War I in I9I7, based on Professor Link's research for his monumental biography of Wilson (q.v.). After surveying briefly the political situation of 1910 , the various shades of progressivism, and the issues involved in the election of 1912, the author offers a closely reasoned analysis of Wilson's initial legislative program whereby he secured lowered tariff rates, the enactment of an income tax system, creation of the Federal Trade Commission, and, "crowning achievement of the first Wilson administration," the Federal Reserve System. Wilson's foreign policy, especially toward Latin America, Professor Link explains in terms of inherited commitments and problems, a subconscious "missionary impulse," naïveté, and imperialism, as well as a conscious ambition to be just, and to advance the causes of peace, democracy, and Christianity. In the author's opinion, Wilson found neither Great Britain nor Germany fighting the Great War for worthy objectives. It was "the German decision to gamble on all-out victory or complete ruin" which finally compelled Wilson to take the drastic action leading to war.

3474. Wish, Harvey. Contemporary America, the national scene since 1900. Rev. ed. New York, Harper, 1955. 714 p. illus.

Bibliography: p. $683-699$.

$$
\text { 54-11008 } \mathrm{E}_{741} \mathrm{~W} \mathrm{~W}_{78}
$$

1955

First published in 1948 .

Based upon the urban approach to culture, this history of 2oth-century America examines the trends among arts and sciences as well as politics and eco- 
nomics for clues to national motivation and the direction in which our civilization is moving. "Among the useful concepts of cultural integration," the author observes, "have been, first of all, the impact of the metropolis and technology upon our behavior, the rise, decline, and revival of the businessman's leadership in politics and popular culture, the diffusion of foreign as well as indigenous ideas here, and the basic patterns of diplomatic policies."
He notes a general faith in progress and the promise of American life, an acquiescence in urban dominance, an unfortunate encouragement of a standardized culture through "socially unregulated technology," a tendency toward concentration in businesses, and a steady growth of mass production. "Since the beginning of the century," Professor Wish believes, "a richer, more powerful, and more equitable society had emerged."

\section{K. Since 1920}

3475. Adams, Samuel Hopkins. Incredible era; the life and times of Warren Gamaliel Harding. Boston, Houghton Miftlin, r939. 456 p. illus.

Bibliography: p. 443-[445]. 39-30355 E786.A34

A newspaperman's biography of Warren Gamaliel Harding ( $1865-1923$ ) based less upon authoritative documents, most of which had been destroyed by the time of writing, than upon "word-of-mouth testimony" from informants, many of whom have preferred to remain anonymous. It also relies heavily upon an unpublished University of Syracuse dissertation by Dr. Harold F. Alderfer, "The Personality and Politics of Warren G. Harding." Mr. Adams regards the controversial, Ohio-born President as an attractive, warm, even endearing individual, if indifferently educated and imprecise of mind. To him Americanism and Republicanism were inseparable. His career in state politics was insignificant; his term in the United States Senate, 1915-21, was easygoing and negative. Unhampered by principles, he was a "pliant lay-figure for his party, raised to unexpected authority." In 1920 he became President through the efforts of Harry $M$. Daugherty, whose political protégé he was, and of the Senate oligarchy, whose creature he was expected to become. Harding's "conception of public service was to give a friend a job," and thereafter to depend upon his loyalty. Unfortunately for the $\mathrm{Na}$ tion, the President made "dreadful errors in the choice of friends and lieutenants."

3476. Allen, Frederick Lewis. The lords of creation. New York, Harper, 1935. 483 p. 35-20649 HGI8I.A57

"Sources and obligations": p. 465-473.

"This book is an attempt to tell the story of the immense financial and corporate expansion which took place in the United States between the depression of the eighteen-nineties and the crisis of the nineteen-thirties; to show how profoundly it altered the circumstances and quality of American life, why and how it ended in collapse, and what the collapse means to all of us." The why is of course stated in economic terms- "the era of high finance had so swollen the mass of claims upon the future that only roaring prosperity could sustain it; and the effort to sustain it even at the cost of purchasing power undermined the foundations of that prosperity"-but the whole development is related with so pervasive a sense of its interconnections with the rest of the national life that it is best regarded as a contribution to general history, and an unusually successful venture in placing contemporary history in perspective.

3477. Allen, Frederick Lewis. Only yesterday; an informal history of the nineteen-twenties. New York, Harper, 1931. xiv, 370 p. illus.

"Sources and obligations": p. $35^{8-361}$.

3478. Allen, Frederick Lewis. Since yesterday; the nineteen-thirties in America, September 3, 1929-September 3, 1939. New York, Harper, 1940. xiv, 362 p. illus. 40-27130 E741.A66

"Sources and obligations": p. 347-352.

Only Yesterday is a lively social panorama of the years November I I, 1918-November 23, 1929, forming an era between the close of World War I and the disastrous termination of "The Big Bull Market" on the New York Stock Exchange. Chapters I-III describe the American temper in the aftermath of war, 1918-20: the ebbing of wartime idealism, the slow death of the Wilson dream of a new world order, the Red scare and its attendant strikes, riots, and bombings, and the resulting Palmer raids, hysteria, and superpatriotism. Chapters IV-XI characterize the peacetime frame of mind: disillusionment; a sense of life's futility; and a desire both for entertainment and for excitement, through fads, dramatic events, scandals and crimes, sports, and such technological novelties as tabloids, radio, airplanes, and 
automobiles; together with a new freedom of manners, morals, thinking, and dress, induced by "the war neurosis," Freud, prohibition, lurid magazines, motion pictures, and the like. The three final chapters deal with the boom and subsequent crash of the New York stock market. Rather more conventionally organized, the sequel, Since Yesterday, continues the chronicle to the outbreak of World War II, September 3, 1939. Because he wishes "to give some idea of the high place from which the country fell during the economic collapse of 192932," Mr. Allen begins his narrative "with a study of things as they were on September 3, 1929." $\mathrm{He}$ stresses particularly as the heart of his story "the enormous economic and political transformation which took place," and tells it in terms of New Deal experiments, reforms in regulation and compulsion, subsidies, the rise of secular "religions of social salvation," pump-priming, and "economic royalism."

3479. Beard, Charles A., and Mary R. Beard. America in midpassage. New York, Macmillan, 1939. 977 p. (His The Rise of American civilization, v. 3) 39-I I 429 E169.I.B274

About two-thirds of this massive survey of American life and thought in the 1920's and 30's is devoted to political and economic history, the remainder to social and cultural affairs. Coolidge is viewed as an apostle of thrift, prudence, and simplicity, to whom both the domestic and foreign outlook ap peared "fair with prosperity and assurance," and Hoover as a firm believer in capitalism, foreign trade, and foreign investment. The administrations of both are shown to have favored the powerful business elements by special policies and by letting them alone in most of their operations. Yet, "under the most beneficient auspices," business was overwhelmed by panic and depression in 1929-32, and its leaders turned for succor to the Roosevelt administration during 1933 "in a spirit of cheerful compliance," which, however, rapidly dwindled. President Roosevelt nevertheless continued to act on his "conviction that it was the function of statesmanship to bring the real into closer conformity to the ideal-the conception of humanistic democracy." The discussion of contemporary entertainment centers in its sociology and its relation to economics and politics, that of the arts in their social concerns and their embodiment of the hurried and harried spirit of the age, and that of science in the advance and application of invention and discovery.

3480. [Coolidge] Fuess, Claude M. Calvin Coolidge, the man from Vermont. Boston, Little, Brown, 1940. 522 p. illus.

$$
\begin{array}{lll}
40-27145 & E_{792 . F 85}
\end{array}
$$

A very sympathetic biography of that apostle of common sense and hard work, Calvin Coolidge (1872-1933), 3oth President of the United States, tracing in great detail the Yankee heritage and environment that produced his laconic speech, frugality, industry, "conservative distrust of foreigners and innovations," caution, and "limited" outlook. His education at Amherst College, the author believes, was responsible for "many of Coolidge's ideas, perhaps his entire political philosophy." By rgo5 Coolidge was known in Northampton, Massachusetts, "as a shrewd politician, a good vote-getter, a chap who might possibly become Mayor or even go to Congress"; and in 1915, Frank W. Stearns, attracted by Coolidge's public record, not only pushed his campaign for Lieutenant Governor, but also wrote prophetically, "later, of course, he must be Governor and still later President." The author considers Coolidge an astute judge of men, a keen but ethical politician, and a "first-class" executive, whose accomplishments were chiefly negative: he checked the Boston police strike; he prevented waste and extravagance; and he blocked unwise legislation in Congress. Dr. Fuess' article, "Calvin CoolidgeTwenty Years After," in the Proceedings of the American Antiquarian Society, v. 63, Oct. 21, 1953 (Worcester, Mass., 1954), p. 35I-369, summarizes the reasons why he continues to believe that $\mathrm{Calvin}$ Coolidge ranks with John Quincy Adams, Hayes, and Cleveland, men "whose integrity and general record have made them stand out more for what they were than for what they did," and that Coolidge deserves our respect and admiration.

348r. [Coolidge] White, William Allen. A Puritan in Babylon, the story of Calvin Coolidge. New York, Macmillan, 1938. xvi, 460 p.

$$
\text { 38-34760 E792. W577 }
$$

A study of the years of the great speculative boom, 1923-29, as well as a life of Calvin Coolidge, "an old-fashioned, God-fearing primitive Puritan democrat." "The reaction of this obviously limited but honest, shrewd, sentimental American primitive to those gorgeous and sophisticated times-his White House years-furnished material for a study of American life as reflected in American business and American politics." This Yankee mystic, partisan Republican, and self-consecrated public servant "learned to love his party as a source of power, power for him, power for what he regarded as good government, the rule of the well-to-do; brains in short." Lacking in perspective and detachment, and quite unprepared to manage the speculative orgy entered into by a runaway finance capitalism, he played down the Teapot Dome scandals, announced that "the business of America is business," and pursued 
a cheap money policy which reduced the national debt but facilitated the "Coolidge bull market." In I928, "while the market was careening around like an untamed skyrocket, the President with his habitual avoidance of unnecessary responsibility went right on letting things go." If Andrew Mellon was his "bad angel," the United States Chamber of Commerce was his "alter ego." In all this, as the author declares, he was but reflecting the lust for prosperity which filled the American heart, and "following the democratic vision of the America of his age." The Autobiography of Calvin Coolidge (New York, Cosmopolitan Book Corp., 1929. 246 p.) is a characteristically brief, restrained, and prudent recital of the author's credo and the main events of his life.

\section{Donovan, Robert J. Eisenhower: the inside} story. New York, Harper, 1956. xviii, 423 p. illus. $\quad 56-9653$ E835.D6 A detailed, apparently uncensored, and candid, yet objective report of the actions taken by the Eisenhower administration during the initial three years (1953-55) of the President's first term, by a Washington correspondent who has had access to White House memorandums, minutes of Cabinet meetings, and the like, and has obtained interviews with key officials. The quoted conversations and discussions bear the mark of authenticity. Mr. Eisenhower (b. I890) is portrayed as a "man of good will," if limited in his contacts with civilian life, who has attempted to fulfill campaign commitments and "to go down the middle" of the road. He strengthened the organization of the executive branch and moved "to eliminate corruption from the government." At the President's request, Mr. Donovan notes, Congress broadened social security, adopted a new farm program, approved the St. Lawrence Seaway, and liberalized the Atomic Energy Act. Besides the successes, the author records the difficulties-conflicts of interest, congressional investigations, book burnings, the failure to enact Hawaiian statehood-and Mr. Eisenhower's reactions to both. Less intimate and immediate, but written in diary form with entries running from May $195^{\circ}$ to December 1955, is The Eisenhower Years, by Richard H. Rovere (New York, Farrar, Straus \& Cudahy, r956. 390 p.) It consists of the author's interpretative journalism contributed to The New Yorker, The Reporter, and Harper's dur. ing the period, and emphasizes foreign policy and the activities of Senator McCarthy, admittedly at the expense of economic issues. Kenneth S. Davis' Soldier of Democracy [new ed.] (Garden City, N. Y., Doubleday, 1952. 577 p.) is a sympathetic yet judicious biography which interprets General Eisenhower's life and career as symbols of American democracy and the American success story. The lat. ter half of the book deals with his World War II command.

3483. Feis, Herbert. The road to Pearl Harbor; the coming of the war between the United States and Japan. Princeton, Princeton University Press, 1950. 356 p. 50-9585 D753.F 4

A history of the diplomatic relations, chiefly between the United States and Japan, leading to American entry into World War II, from "the dreary years of the mid-thirties" to December 7, I94I, with a narrative in great detail from April 1940. It is based upon archives of the Department of State, the records of the International Military Tribunal for the Far East, the papers of President Roosevelt, Secretaries Henry L. Stimson and Henry Morgenthau, Jr., and Ambassador Joseph C. Grew, as well as other documents, and conversations with several American officials concerned. Professor Feis holds that, although by 1937 Japan had conquered large areas of Asia's mainland, the country still lacked means to achieve its needs and ambitions, and what means it had were jeopardized by the depression. Rather than see Japan lose status, the army and "excitedly patriotic youth" preferred to extend its empire. The advance was to be managed, the author believes, through strategy-deceit and persuasion-because of Japanese vulnerability, but the design failed. War came because, rather than yield to those whom she had tried to outwit, Japan threw herself against them. America's principal object was to keep out of trouble, and for a time, the "policy of existing as a great power, without acting like one, seemed to work well."

3484. Goldman, Eric F. The crucial decade: America, I945-1955. New York, Knopf, 1956. $298 \mathrm{p}$. 55-9285 E813.G6

A Princeton professor of history seeks to give meaning to the ro years following V-J day by placing "events in the larger perspective." He has submitted portions of his narrative to some 80 prominent participants in the events, thereby catching "many genuine errors." The seven Truman years are treated in greater detail than the three Eisen. hower years. The author's cinematic technique vividly recreates the march of crowded events which most of his readers will remember, and evokes the state of the public mind upon which they impinged. He disclaims partisanship, but his view. point is definitely left of center: this was, in essence, "an era in the national life when, for all minority groups, for all lower-status Americans, the social and economic walls were coming tumbling down." After 1952 the Eisenhower administration buffered 
"the exultant thrust of the right-wing Republicans," and contributed to the emergence of a national consensus on long-term welfare policies. Despite frequent bewilderment and some petulance, the author thinks, the American people are "proving mature enough to perform that most difficult of tasks-adjusting rapidly to the irritatingly and the frighteningly new."

3485. Hoover, Herbert C. Memoirs. New York, Macmillan, $195^{1-52}$. 3 v. illus. ConTents. . 1. Years of adventure, I8741920.- [v. 2] The Cabinet and the Presidency, 1920-1933.- [v. 3] The Great Depression, I929I94I.

The autobiography of the 3 Ist President of the United States, Herbert Clark Hoover (born 1874). The portions dealing with the years since I9I9 were written fairly soon after the occurrence of the events described. Arranged topically within a rough chronological order, these chapters express the author's semicontemporary impressions, which he has evidently seen no reason to alter. The first third of volume I deals with Mr. Hoover's boyhood in Iowa and Oregon, his education at Stanford University, and his highly successful pre-World War I career as a mining engineer and engineering consultant; the remainder tells the impressive story of Belgian relief, the United States Food Administration, and other activities connected with postwar European relief and reconstruction. Volume II relates the public career of $\mathrm{Mr}$. Hoover from his return to the United States in 1919, through his administration of the Department of Commerce, I92I-28, and through the development, reforms, and foreign policy of his term in the Presidency, 1929-32. Volume III is devoted to the Great Depression, the election of 1932, and "the continuation of the Depression from Mr. Roosevelt's inauguration in I933 until I941." Much of it is polemical in purpose. David Hinshaw's informal, anecdotal, and interpretative biography, Herbert Hoover: American Quaker (New York, Farrar, Straus, 1950. $x x, 469$ p.), stresses the spiritual, moral, and intellectual qualities of his friend and fellow Quaker, who believes passionately "in the essential goodness of people, in liberty and freedom; in democracy and in God's unfolding purpose for man." The author extols Mr. Hoover's "matchless integrity," great ability, and selfless public service; he seeks to explode "the myth of the Hoover-caused depression"; deplores "the Democratic party's smearHoover campaign" of 1932; and states that the President's recovery program had checked the depression by midsummer 1932 .
3486. [Hoover] Myers, William Starr, and Walter H. Newton. The Hoover administration; a documented narrative. New York, Scribner, 1936. 553 p. 36-27108 E8or.M94

Based upon Herbert Hoover's diaries and other data, "this is American history, as seen from the vantage point of the White House." Opinions and policies cited as his are from his own public or private declarations; comment of the authors has been kept to a bare "explanation of those forces which formed the background for the actions taken." The material is presented in the form of an almost daily log. Part I, "The Battle on a Hundred Fronts," comprising about two-thirds of the book, deals with crisis and depression measures. Here, it is stated: "The forces of depression were definitely checked and the road to full recovery was freed from obstacles during the Hoover Administration." Part II is devoted to "The Normal Tasks of Administration." The authors believe that Mr. Hoover's "claim to statesmanship is secure." Mr. Myers' companion volume, The Foreign Policies of Herbert Hoover, 1929-1933 (New York, Scribner, 1940. 259 p.), repairs the omission of foreign affairs from the earlier work; it surveys $\mathrm{Mr}$. Hoover's "far-reaching plans for the advancement of the interests of the United States, and for the furtherance of the cause of peace and human happiness throughout the world." It presents a somewhat rosy view of a period during which, under the impact of worldwide depression, international relations continued to deteriorate.

3487. [Hoover] Wilbur, Ray Lyman, and Arthur Mastick Hyde. The Hoover policies. New York, Scribner, I937. $667 \mathrm{p}$.

$$
\text { 37-32153 E8or. W55 }
$$

A massive exposition of President Hoover's principles and policies both in philosophy of government and in action. The authors, who were both members of his Cabinet, vigorously advocate the "traditional American principles, courageously and ably led by Herbert Hoover." He had as his goal advancement of the public welfare "within the framework of strong local as well as Federal Government and the development of understanding and voluntary co-operative action among free men." His doctrines and the actions taken are indicated mainly through quotations from his state papers and published reports, arranged in a rough historical sequence, together with explanatory and connective text supplied by the authors. The topics treated include measures of social, economic, communications, conservation and reclamation, regulatory, fiscal, relief, and foreign policy. 
3488. Leighton, Isabel, ed. The aspirin age, Igrg1941. New York, Simon \& Schuster, 1949. $491 \mathrm{p}$. 49-9336 Ei69.1.L526

The era between World Wars I and II is here presented in terms of significant, typical, or fantastic events, and the personalities who most strongly challenged the American imagination. The 22 chapters have been contributed by well-known authors, some of whom participated in the affairs described, while others were reporters on the scene or specially qualified observers. Hodding Carter, for example, a fighter in the struggle against the Louisiana politician, writes the chapter, "Huey Long: American Dictator," and Gene Tunney describes "My Fights with Jack Dempsey." Each chapter of 20 or 30 pages, preceded by a vignette of the author, characterizes a notable occurrence or person of a given year, from I9I9 ("The Forgotten Men of Versailles," by Harry Hansen) to I94I ("Pearl Harbor Sunday: The End of an Era," by Jonathan Daniels). The title derives from the editor's observation: "During these throbbing years we searched in vain for a cure-all, coming no closer to it than the aspirin bottle."

3489. Link, Arthur S. American epoch; a history of the United States since the 1890 's. New York, Knopf, 1955. xxii, 724, xxxvii p. illus.

Bibliography: p. [705]-724. 54-r3244 E74r.L55

Recent techniques make possible the printing in one volume of what a few decades ago would have been a 2- or 3-volume work; this is history on a generous scale, and illustrated with abundant photographs, maps, and graphs. It is also manysided history, with balanced attention to demographic, business-cycle, foreign-policy, social, and cultural factors. It has a strongly defined point of view, interpreting the whole period primarily in terms of "the progressive movement," and presenting Theodore Roosevelt, Wilson, Franklin Roosevelt, and Truman as the leaders of its successive phases. A striving after clarity and finality of judgment gives an occasional impression of dogmatic cocksureness, but there is an impressive amount of thoroughly organized information. Intended for the general reader, it is also usable as an advanced college text.

3490. Lyons, Eugene. The red decade, the Stalinist penetration of America. Indianapolis, Bobbs-Merrill, 1941. 423 p.

41-51867 HX86.L97 This book, ready for press just as Nazi Germany invaded Russia ( $194 \mathrm{I}$ ) in World War II, offered the timely message that Communist Party propaganda, "always and unswervingly, is determined by the
Kremlin's needs and the Kremlin's instructions," and has not the remotest relation to American interests. "Stalin's Fifth Column in America, as in all other nations, has only one set of 'principles': blind obedience to the will of Moscow. It has only one 'ideal': allegiance to a foreign dictator." Deliberately polemic in spirit, this work is intended as "an informal account of Bolshevism in our country" during the years 1930-40. At its height in 1938, "the incredible revolution of the Red Decade had mobilized the conscious or the starry-eyed, innocent collaboration of thousands of influential American educators, social workers, clergymen, New Deal officials, youth leaders, Negro and other racial spokesmen, Social Registerites, novelists, Hollywood stars, script writers and directors, tradeunion chiefs, men and women of abnormal wealth." It could not safely be ignored, since "our labor movement, politics, art, culture, and vocabulary still [194I] carry its imprint." Mr. Lyons, a naturalized Russian, believed the Great Depression to have been far more potent in shaping this phenomenon than "any of the masterminds on New York's Union Square."

3491. Perkins, Dexter. The new age of Franklin Roosevelt, 1932-45. [Chicago] University of Chicago Press, 1957. 193 p. (The Chicago history of American civilization)

"Suggested reading": p. $176-18 \mathrm{r}$.

$56-I_{2} 63 \quad \mathrm{E} 806 . \mathrm{P}_{4} 65$

A survey of the great changes instituted during the Roosevelt era which "emphasized, as never before, the dynamic role of the federal government," and introduced a wholly new and positive concept of its responsibility: to relieve want and unemployment through Federal agencies, to provide for the farmer a larger share of the national product, to develop national resources on a grand scale, to maintain industrial peace, and to operate the $\mathrm{Na}$ tion's credit system. Professor Perkins cites as examples of the substantial alterations produced in the socioeconomic order by the New Deal the advance of industrial unionism, the new political power of the farmer, and the increased self-awareness and influence of the dispossessed and underprivileged. Such alterations Roosevelt viewed with sympathy and hope. Absolving the President of both radicalism and autocracy, the author terms him a "transcendent success" on the domestic front and concludes that his broad view of Federal authority "has been sustained by time." However, the consolidation of the Good Neighbor policy toward Latin America was his only great achievement in foreign affairs. In Mr. Perkins' opinion, Roosevelt quickly and fully grasped the implications of the Nazi 
advance, but in action he was vacillating, and too often heeded "the siren voice of political opportunism."

3492. Rauch, Basil. The history of the New Deal, 1933-1938. New York, Creative Age Press, r944. $368 \mathrm{p}$. 44-8426 E806. R3

A study of the political philosophy and the economic policies of the Roosevelt administration during its first five years, based principally upon published official documents. The author believes that "experimental evolution is the key to understanding the history of the New Deal," and that a fundamental change occurred in 1934, the importance of which "justifies the designations First New Deal and Second New Deal." Grounded on a philosophy of economic nationalism and scarcity, the conservative "First" New Deal had recovery through higher prices as its primary aim and benefited mainly big business and the large farmers. The "Second" New Deal, initiated in 1934 as a deliberate reorientation, and manifesting a liberal philosophy of economic coöperation and economic abundance, had betterment through increased purchasing power and social security for all as its goal, and favored labor and smaller farmers. It "fundamentally altered and in some cases reversed" "First" New Deal policies and legislation in the fields of agriculture, industry, labor, tariff, money, and unemployment relief.

3493. Roosevelt, Franklin D. F. D. R.: his personal letters. Foreword by Eleanor Roosevelt; edited by Elliott Roosevelt. New York, Duell, Sloan \& Pearce, $1947-50.4$ v. illus.

47-II935 E807.R649

A chronologically arranged, carefully annotated collection of the personal correspondence of Franklin D. Roosevelt (1882-1945), together with explanatory connective text, published by the family as a service to historians, educators, and those who felt he "was in truth their friend." Volume I contains all of the early surviving letters, from the first childish communication dated 1887 to a note informing Endicott Peabody, headmaster of Groton School, of his engagement to Eleanor Roosevelt in I904. These letters, addressed chiefly to "My Dearest Mama and Papa," are valuable in reflecting formative influences upon the youth, in the Hudson Valley and at Groton and Harvard. Since his letters written in the years $1905^{-28}$ were ill preserved, volume II contains far less but very important material. Here are exhibited not only his growth in political experience as State senator and as Assistant Secretary of the Navy, but also the strengthening of his character during his long and courageous struggle against poliomyelitis. Volumes
III-IV cover the years 1928-45, when Roosevelt served first as Governor of New York (1929-32) and then as President of the United States (193345 ), and had less time for family affairs; they differ in character from the earlier volumes, containing "whatever family letters are available," but largely made up of correspondence, memorandums, and other messages to other persons concerning public matters. Of necessity selective, since much of the latter material is restricted for various reasons, these volumes are intended to illustrate White House routines, various facets of the President's personality, and his relationships to his close associates.

3494. Roosevelt, Franklin D. The Roosevelt reader; selected speeches, messages, press conferences, and letters of Franklin D. Roosevelt. Edited and with an introd. by Basil Rauch. New York, Rinehart, 1957. 391 p.

Selected bibliography: p. xiii-xiv. 57-3088 $\mathrm{E}_{742.5 \cdot \mathrm{R} 65}$

A selection from Roosevelt's writings, "designed to reduce the hazard of quantity to proportions reasonable enough to appeal to general readers as well as to more specialized students of American history." The material is intended "to reveal the qualities of Roosevelt's mind, character, and personality, as clues to the leadership which made them important." Because, in Professor Rauch's opinion, they constitute "his supreme acts of leadership" and were in very large part the instrumentalities of his renovation of this country's domestic and foreign policies, Roosevelt's great political speeches are accorded the most space. From transcripts of 986 press conferences "a generous lot of culled passages is offered," as giving "the most intimate perceptions of his leadership," as well as of "his tremendous talent for statesmanship by improvisation." His letters, considered disappointing by this editor, are only sparsely represented. The Roosevelt Treasury, edited by James N. Rosenau (Garden City, N. Y., Doubleday, 195I. 46r p.), is an anthology of descriptions and recollections by persons who knew him or had dealings with him, such as Josephus Daniels, Raymond Moley, Grace Tully, Winston Churchill, and Edward J. Flynn, together with some autobiographical passages by F. D. himself. Part I indicates the highlights of Roosevelt's preparation; part II suggests the personal qualities that either aided or hampered his effectiveness; and part III shows him in action in the various capacities required of presidential leadership. Roosevelt is "the hero rather than the subject" of an anthology edited by Milton Crane, The Roosevelt Era (New York, Boni \& Gaer, 1947. xiv, 626 p.), since its contents are the "thoughts, writings, and actions which his personality helped to shape." In an effort "to 
assemble a coherent and connected group of materials for a social history of the age," Mr. Crane has gathered the work, serious, humorous, or sentimental, of journalists, poets, dramatists, politicians, and novelists. Represented are writers as diverse as Carl Sandburg, H. L. Mencken, Thurman Arnold, John Steinbeck, E. B. White, Erskine Caldwell, and A. J. Liebling.

3495. [Roosevelt, Franklin D.] Freidel, Frank B. Franklin D. Roosevelt. Boston, Little, Brown, I952-56. 3 v. illus. 52-552I E807.F 74 Includes bibliographical references.

Contents.-I. The apprenticeship.-2. The ordeal.-3. The triumph.

3496. Burns, James MacGregor. Roosevelt: the lion and the fox. New York, Harcourt, Brace, 1956. 553 p. illus. 56-7920 E807.B835

In the first half of a projected six-volume biography, Professor Freidel sets forth in great detail the life of Franklin D. Roosevelt, from his school days at Groton to his victory in the presidential election of 1932. This monumental work relies heavily upon the Roosevelt papers and other documents, as well as the published memoirs of his colleagues and the recorded reminiscences of his associates, and quotes very generously from them. The author traces the development of Roosevelt's character and traits, his concepts and ideals evaluating them and showing how they affected his actions, and offers a lucid and penetrating analysis of the political record. This began in Igri when Roosevelt attempted to rally progressive Democrats against Tammany domination in the New York State Senate, and emerged "a new political luminary." Behind his complex political programs were "the frrm humanitarian tradition, Christian faith, and sense of noblesse oblige that he had inherited from his parents and learned from Endicott Peabody of Groton and Theodore Roosevelt. His were the background and attitudes, and the aspirations, to point him toward greatness." Nearly three-quarters of Professor Burns' political biography of Roosevelt is a study of his leadership in the Presidency to 1940 , his aims and methods, his successes and failures. The author views Roosevelt's personality as eminently practical and flexible, if infinitely complex, and even contradictory. "He had no over-all plans to remake America but a host of projects to improve this or that situation. He was a creative thinker in a 'gadget' sense: immediate steps to solve specific day-to-day problems." In Professor Burns' opinion, Roosevelt could dramatize the significance of the big decisive event-the depression, naked aggression abroad-but when the crisis was less striking, if no less serious, he was unsuccessful, as in the Supreme
Court packing, the congressional purge, and his efforts to convince public opinion of the need for collective security. Less a great creative executive than a skilled manipulator and brilliant interpreter, "he was always a superb tactician, and sometimes a courageous leader, but he failed to achieve that combination of tactical skill and strategic planning that represents the acme of political leadership."

3497. [Roosevelt, Franklin D.] Fusfeld, Daniel R. The economic thought of Franklin D. Roosevelt and the origins of the New Deal. New York, Columbia University Press, 1956, '1954. 337 p. (Columbia studies in the social sciences, no. 586)

Bibliography: p. [305]-320. 55-9065 $\mathrm{H}_{31 . \mathrm{C}_{7}, \text { no. } 5^{86}}$

This Columbia University dissertation is "a study of Roosevelt's economic philosophy: its sources in F. D. R.'s family background and education and in the Progressivism of Theodore Roosevelt and Woodrow Wilson; its development under the impact of contemporary economic problems and their proposed solutions; and its culmination in the political programs advocated by Roosevelt." The author observes that two important points emerge from his study: "In the first place, Roosevelt's thought was derived primarily from the climate of opinion of his time, out of which F. D. R. selected some ideas and rejected others," rather than from systematic study of the writings of philosophers, economists, or political theorists. "Secondly, F. D. R. was a man with a tremendously complex personality and a highly intricate system of beliefs." Dr. Fusfeld quotes Roosevelt's statements, places them "in the context of the ideas, political controversies, and problems of his time," and allows "the varied threads of his economic thought to emerge in all their complexity, complete or incomplete, consistent or inconsistent." Roosevelt, the author believes, was essentially a reformer, who accepted the concept of free enterprise but wanted to improve its performance, especially by means of planning and of Government responsibility for the functioning of the economy.

3498. [Roosevelt, Franklin D.] Ickes, Harold L. The secret diary of Harold L. Ickes. New York, Simon \& Schuster, 1953-54. 3 v. 53-9701 E8o6.I2

Contents.- - [v. I ] The first thousand days, 19331936.-v. 2. The inside struggle, 1936-r939.-v. 3. The lowering clouds, 1939-1941.

This is both the personal report of Harold L. Ickes and an intimate history of the Roosevelt administration for the years 1933-4I. Having had his official acts, interviews, and meetings carefully noted as they occurred, Mr. Ickes made weekly dictations 
of the full text of his diary and then destroyed the preliminary materials. Since it was thus written in the heat of the moment, and no amplifications or corrections were later made, the diary retains its immediacy and also its controversial attitude. The author presents his versions of battles and skirmishes within the administration over public works policies and projects, conservation, reclamation, slum clearance, politics, foreign affairs, the Supreme Court, and Government reorganization. Beginning with 1936, the journal reflects a shift in emphasis from domestic to foreign concerns as the dangers of the depression were superseded by those of war. Throughout, Mr. Ickes comments vigorously and candidly upon the President, fellow Cabinet members, and other public figures. Frances Perkins, who served as Industrial Commissioner when Roosevelt was Governor of New York and as Secretary of Labor during his whole Presidency, contributes sympathetic, honest, and perceptive reminiscences of him in The Roosevelt I Knew (New York, Viking Press, I946. 408 p.). "The core of Roosevelt's character was viability-a capacity for living and growing." This quality, she thinks, "accounts for his rise from a rather unpromising young man to a great man." In a large-scale biography which incorporates much personal knowledge, The Democratic Roosevelt (Garden City, N. Y., Doubleday, 1957. 712 p.), Rexford Guy Tugwell, who served as a member of the "Brain Trust" during Roosevelt's first term, provides new information concerning it as well as a highly personal interpreta. tion of the President's thoughts and motives. Mr. Tugwell discovers as the most persistent elements in Roosevelt's character and career his belief "in an external guidance" and his sense of "a commanding destiny" toward which he progressed with a "ferocious drive."

3499. [Roosevelt, Franklin D.] Sherwood, Robert E. Roosevelt and Hopkins, an intimate history. Rev. ed. New York, Harper, 1950. xix, I002 p. illus.

First published in 1948 . 50-6867 E807.S 45 I950

Based largely upon Harry Hopkins' personal and public papers, this is a history of American participation in World War II told in terms of Hopkins' relationship to Franklin D. Roosevelt, and his wartime activities as presidential aide. The author, also a White House familiar, contributes generously of his own reminiscences. The bulk of this important book deals in great detail with the political, diplomatic, and military affairs of the prewar and war years: the fight for lend-lease; aid to Great Britain, Russia, and China; the Atlantic Charter; and, for the 44 months after the attack of December 7, I94 I, on Pearl Harbor, the massive military effort exerted against the Axis Powers by the Allied Nations. Roosevelt and Churchill demonstrated "politicomilitary leadership on a global scale." Wanting nothing except to serve, Harry Hopkins acted as Roosevelt's personal negotiator with Churchill, Beaverbrook, Stalin, De Gaulle, and others, and, at the major wartime conferences, as an extraofficial resolver of disputes. In Working with Roosevelt (New York, Harper, r952. xiv, 560 p.), another former White House staff member, Judge Samuel I. Rosenman, presents his recollections of a I7-year association with Roosevelt and of the evolution of Roosevelt's social objectives and political philosophy. The author describes in detail how he, Harry Hopkins, Robert E. Sherwood, and others helped draft and polish the President's major speeches and messages, which, nevertheless, as finally delivered, "were his-and his alone-no matter who the collaborators were." Based upon the testimony of persons who knew him as well as upon printed sources, John Gunther's Roosevelt in Retrospect (New York, Harper, 1950. 410 p.) is an anecdotal but documented analysis, interpretation, and appraisal of Roosevelt's character, personality, and career. Roosevelt had "to a supreme degree," Mr. Gunther believes, important qualifications for statesmanship: courage, patience, a subtle sense of timing, capacity to relate the particular to the whole, idealism, fixed goals, and the ability to impart resolution to others. The author candidly admits that he also had a number of less attractive qualities.

3500. Schlesinger, Arthur M. The age of Roosevelt. [v. I] The crisis of the old order, 1919-1933. Boston, Houghton Miffin, 1957. 557 p. 56-10293 E806.S34

The first in a projected four-volume work, this is a vivid, anecdotal chronicle of events and currents of thought, especially in politics and economics, during the is years prior to Franklin D. Roosevelt's inauguration. Based not only upon documents but also upon memoirs, newspaper reports, journal articles, and personal interviews, this crisply written book conveys a strong sense of immediacy. Professor Schlesinger traces the antecedents of the New Deal, from the agrarian Populist challenge to business rule in the I89o's to Woodrow Wilson's New Freedom policies of I9I3-I6. He describes the Nation's post-World War I acceptance of business leadership, and equation of economic success with spiritual merit, as well as the social-welfare liberalism of those concerned to protect the individual from the hazards of industrial society. He shows the alienation of intellectuals and artists from business culture; assigns blame for the stock market collapse of 1929 and the subsequent depression; and sharply 
criticizes the structure of the economy, the failure of business leadership, and the lack of business morality. Besides a number of challenging conclusions, Professor Schlesinger offers incisive portraits of many public figures, and narrates Franklin Roosevelt's earlier career at some length.

3500a. Schriftgiesser, Karl. This was normalcy, an account of party politics during twelve Republican years: 1920-1932. Boston, Little, Brown, 1948. 325 p. $\quad 4^{8-5968} \quad$ E $_{743 . S_{3} 8} \quad 1948$ Bibliography: p. 299-306.

The author, who regards the rejection of the League of Nations as the "greatest political tragedy in the history of the United States," has sought to write an "account of Republicanism triumphant and the effect of this triumph upon the American people from Warren Gamaliel Harding's nomination in I920 through Herbert Clark Hoover's ruination in 1932." The author regards the choice of Harding as "a fraud upon the people," but, he observes, "Senator Harding was exactly fitted to play the role expected of him by the Senate oligarchy, the corruptionists, and Big Business." Mr. Schriftgiesser deplores "the abdication of the democratic spirit that was the fundamental crime perpetrated upon the people" in these "twelve disastrous years." This was not confined to the Republican incumbents, for the Democratic Party "forgot its historic heritage as the people's party and wanted to be the Party of Prosperity, too. It listened to the siren call of normalcy and turned its back on reform." Presidential leadership, he believes, "was unknown in Washington. Harding lacked the capacity to give it; Coolidge lacked the courage or the will; and Hoover lacked the opportunity." The author writes with much acerbity concerning the pattern of isolationism, "normalcy," and less government in business, that the Nation followed for nearly 12 years.

350ob. Truman, Harry S. Memoirs. Garden City, N. Y., Doubleday, 1955-56. 2 v.

Contents.-v. I. Year of decisions-V. T75 Years of trial and hope.

A very detailed personal report of Harry S. Truman's years in the Presidency of the United States (1945-53), based upon his private papers, official documents, some hitherto unpublished, and the recollections of a number of persons who were present when certain decisions were made. During his tenure, the author was animated by one overriding purpose, "to prevent a third world war." Volume I expresses the humility of the man who felt as if the moon, the stars, and all the planets had fallen on him when the death of Franklin D. Roosevelt thrust him suddenly into the Nation's highest office. Dealing mainly with the conclusion of World War II, this volume exhibits Mr. Truman's courageous approach to the momentous issues confronting him in I945, such as the termination of the war in Europe, Russian obstructionism, the use of the atom bomb, and the cessation of hostilities in the Pacific area, as well as his forthright judgments concerning persons and events. Volume II consists principally of a defense of the Truman administration and its program for transition from war to peace under heavy economic burdens and the financial drain of emergency relief to Europe and the Far East. Mr. Truman evidently believes that his efforts on behalf of atomic energy control and development have been his single most important achievement. 


\section{Diplomatic History and Foreign Relations}

$\left.\llbracket \begin{array}{rlr}\text { A. Diplomatic } \text { History } & \\ \text { Ai. } \quad \text { General Works } & 3501-3526 \\ \text { Aii. } \quad \text { Period Studies } & 3527-3542 \\ \text { Aiii. Personal Records } & 3543-3549 \\ \text { Aiv. } \quad \text { The British Empire } & 3550-3559 \\ \text { Av. } \quad \text { Russia } & 3560-3568 \\ \text { Avi. Other European Nations } & 3569-3573 \\ \text { Avii. Latin America: General } & 3574-3579 \\ \text { Aviii. Latin America: Individual Nations } & 3580-3587 \\ \text { Aix. Asia } & 3588-3597 \\ \text { B. Foreign Relations } & 3598-3608 \\ \text { Bi. Administration } & 3609-3616 \\ \text { Bii. Democratic Control } & 3617-3635 \\ \text { Biii. } \quad \text { Policies } & 3636-3642\end{array}\right]$

THE dual title and organization of this chapter are a consequence of the dual purpose of 1 this Guide: to deal not only with past developments but with present situations. To be sure, no book that has to be written, printed, proofread, bound, and released for publication can ever deal with the reader's present, but only with his recent past. Our books classified as Diplomatic History are primarily retrospective, concerned with the political dealings of the United States with the other nations of the world from the beginning of the American Revolution through World War II. The period since V-J day merges with the present without any breach of continuity as yet perceptible to us, and books concerned solely or principally with the postwar. period are therefore placed under Foreign Relations. An exception or two will be found in Section Aiii, the Personal Records of seven men important in formulating our policies in the recent past, and there are some other instances where the assignment of a title to one or the other class will perhaps appear arbitrary.

An extraordinary proportion of professional effort has gone into the writing of diplomatic history, probably because the records of diplomatic transactions are as a rule exceptionally full, carefully preserved, tidily arranged, and ordinarily kept secret, save for

discreetly selected excerpts printed under official auspices, for a period of years after their creation. There are numerous histories of the missions of individual ambassadors, of public opinion concerning a single crisis, or of periods of a few years in our relations with a single country-for none of which do we have room here. In Section Aii, Period Studies, we have aimed to select books on epochs important for the subsequent development of the United States, and in Sections Aiv-Aix, we have preferred titles covering, if not the whole span of our relationships with a particular area or nation, at least long and significant periods. International relations are not, of course, exclusively political or diplomatic, and some of the titles which appear here may have 
an equal claim to be placed in Section $\mathrm{F}$ of Chapter $\mathrm{XI}$, on International Influences in our Intellectual History.

The four sections on Foreign Relations we have at least attempted to keep current, but it is a field in which events move rapidly and new titles are published in perturbing quantity. Section Biii on Policies contains, along with a number of primarily factual expositions, a sampling of the numerous books in which amateurs as well as professionals offer a diagnosis or a remedy for what seems to them to be ailing in the international relations of the United States. Our selection has not aimed to emphasize any school of thought or course of policy, and our annotations reflect no opinions except those of the authors in question.

\section{A. Diplomatic History}

\section{Ai. GENERAL WORKS}

3501. The American foreign policy library. Cambridge, Harvard University Press, 1947-56. $15 \mathrm{v}$.

This series began to appear in 1947 under the editorship of Sumner Welles, Undersecretary of State from 1937 to 1943 ; he was eventually replaced by Professor Donald C. McKay of Harvard University. Authors of the individual volumes are recognized academic authorities on the history or the foreign relations of the areas or countries treated; many either teach at Harvard or received their graduate training there. The volumes range between $25^{\circ}$ and $35^{\circ}$ pages, save for the latest to appear, Mr. Wolff on the Balkans, which is considerably larger. After summarizing whatever geographic, economic, and historical information the author considers useful, each volume reviews the history of American relations with the nation or region, with principal attention given to recent events and to the major problems of the present day. The approach is scholarly, but the series is intended to provide a lay audience with the background material essential to an understanding of current events. Footnote references are dispensed with, but each volume concludes with a bibliographical essay arranged to correspond with the chapter headings.

3502. Brinton, Clarence Crane. The United States and Britain. [Rev. ed.] 1948. xiv, 312 p. $\quad 48-9542 \quad E_{183.8 . G 7 B 75} 1948$ "Suggested reading": p. [294]-302.

3503. Brown, William Norman. The United States and India and Pakistan. 1953. $308 \mathrm{p}$.

"Suggested reading": p. [291]-297. 52-12253 $\mathrm{DS}_{4} 80.84 . \mathrm{B}_{73}$

3504. Cline, Howard F. The United States and Mexico. I953. xvi, $452 \mathrm{p}$.
"Suggested reading": p. [430]-439.

3505. Dean, Vera (Micheles) The United States and Russia. [3d print., rev.] 1948. xvi, $336 \mathrm{p}$. $\quad 48-4500 \quad E_{183} 8 . R_{9} D_{4} \quad 194^{8}$

"Suggested reading": p. [307]-319.

3506. Fairbank, John King. The United States and China. 1948. xiv, $384 \mathrm{p}$.

$$
4^{8-735 \mathrm{I}} \quad \mathrm{DS}_{735} \cdot \mathrm{F}_{3}
$$

"Suggested reading": p. [350]-367.

3507. Hughes, Henry Stuart. The United States and Italy. 1953. $256 \mathrm{p}$.

"Suggested reading": p. 240-247.

$53-9038 \quad \mathrm{DG}_{577} \cdot \mathrm{H} 8$

3508. McKay, Donald C. The United States and France. I95I. xvii, 334 p.

$$
\text { 5I-I I } 375 \text { Er83.8.F8M }
$$

"Suggested reading": p. [310]-319.

3509. Perkins, Dexter. The United States and the Caribbean. 1947. 253 p.

"Suggested reading": p. [235]-240.

$$
\text { 47-11619 } \mathrm{F}_{2171 . \mathrm{P}_{4}}
$$

3510. Reischauer, Edwin O. The United States and Japan. I950. xviii, $357 \mathrm{p}$.

$$
\text { 50-3943 } \mathrm{E}_{1} 83.8 . \mathrm{J}_{3} \mathrm{R}_{4}
$$

"Suggested reading": p. [343]-347.

351 I. Scott, Franklin D. The United States and Scandinavia. 1950. xviii, $359 \mathrm{p}$.

$$
\text { 50-7563 DL } 59 . S_{35} \quad 1950
$$

"Suggested reading": p. [333]-344.

3512. Speiser, Ephraim A. The United States and the Near East. Rev. ed. 1950. xviii, 283 p. 48-6492 DS63.S6 1950

"Suggested reading": p. [255]-263. 
3513. Thomas, Lewis V., and Richard N. Frye. The United States and Turkey and Iran. 195I. $291 \mathrm{p}$. 5I-12394 EI83.8.T8T5

"Suggested reading": p. [167]-1 70, [279]-284.

ConTEnTs.-The United States and Turkey, by L. V. Thomas.-The United States and Iran, by R. N. Frye.

3514. Whitaker, Arthur P. The United States and Argentina. 1954. xv, $272 \mathrm{p}$.

"Suggested reading": p. [254]-262. $55-554 \mathrm{I} \quad \mathrm{F}_{2} 83 \mathrm{I}$. W 5

3515. Whitaker, Arthur P. The United States and South America, the northern republics. 1948. xix, 280 p. 48-6353 F2216.W 45 "Suggested reading": p. [255]-367.

3516. Wolff, Robert L. The Balkans in our time. 1956. xxi, 6I8 p. maps, tables. (Russian Research Center studies [23]) 56-6529 $\mathrm{DR}_{4} 8.5 . \mathrm{W} 6$ "Useful works in Western languages": p. [588]596.

Says the editor of the series, Donald C. McKay, in his Introduction: "The present volume on The Balkans in Our Time is a joint publication of The American Foreign Policy Library and the Russian Research Center Studies. The plan and focus of the volume follow very closely those of others in the Foreign Policy Library, but the much greater length and more detailed treatment reflect the interests of the Russian Research Center. The compromise between these two purposes is evident in the 'outsized' format in which the volume has been issued." It might be added that there is less material on American relations and interests than in most of the other volumes.

3517. Bailey, Thomas A. A diplomatic history of the American people. $5^{\text {th }}$ ed. New York, Appleton-Century-Crofts, 1955. xxviii, 969, xxxix p. (Crofts American history series)

55-7869 JX1407.B24 1955

A college textbook covering its subject from I775 to the present day, which was originally published in $194^{\circ}$ and has grown steadily thicker as the narrative of recent events has been added to successive editions. The principal emphasis is placed upon the role of public opinion, and the cartoons of successive periods are drawn upon for illustrations. There are 52 chapters in the latest edition, and the halfway point falls at the Venezuela crisis of 1893 . Lewis Ethan Ellis' A Short History of American Diplomacy (New York, Harper, 1951. 604 p.) is an alternative textbook for those who would prefer a briefer treatment.
3518. Bartlett, Ruhl J., ed. The record of American diplomacy; documents and readings in the history of American foreign relations. $3 \mathrm{~d}$ ed., rev. and enl. New York, Knopf, 1954. xxi, 790, xvi p.

Bibliography: p. 789-790. 54-2821 $\quad E_{1} 83 \cdot 7 \cdot B_{35} \quad 1954$

This work is designed to make available to college classes in American diplomatic history a collection of documents which will enable students "to compare policies adopted at different times regarding the same area or subject, trace the evolution of major policies, and examine the reasoning used to defend or advance American foreign interests." Intended to supplement general accounts of diplomatic history, the documents, both public and private and for the most part drawn from printed sources, are grouped in topical chapters which follow a general chronological progression but sometimes overlap. They begin with the colonial era and end with the Korean War. Short passages by the editor introduce each chapter. An alternative documentary textbook in American diplomatic history is edited by William Appleman Williams: The Shaping of American Diplomacy; Readings and Documents in American Foreign Relations, 1750-1955 (Chicago, Rand McNally, 1956. II $30 \mathrm{p}$.). It includes a selection of writings on each period of our diplomatic history by present-day historians, along with a selection of contemporary documents which, in some instances, duplicate those in Mr. Bartlett's collection.

3519. Bemis, Samuel Flagg, ed. The American secretaries of state and their diplomacy. J. Franklin Jameson, H. Barrett Learned, James Brown Scott, advisory board. New York, Knopf [1927-29] Io v. 27-8473 Er 83.7. B46 Volume $\mathrm{I}$ is devoted to a historical introduction by J. B. Scott on the diplomacy of the Revolution, and studies of the Confederation's two secretaries for foreign affairs, Robert R. Livingston and John Jay. In the subsequent volumes each secretary of state from Thomas Jefferson (1789-94) to Charles Evans Hughes (1921-25) is the subject of a study by an expert on the period or the subject. The essays vary in length, according to the length of the individual's term and the importance of his historical contributions. A bibliographical note for each secretary is appended. The set provides a valuable means of approach to the particular transactions of American diplomacy in detail. The Department of State has recently published an attractive short volume entitled The Secretaries of State, Portraits and Biographic Sketches (Washington, 1956. 124 p.) which includes all the secretaries to John Foster Dulles (from I953). 
3520. Bemis, Samuel Flagg. A diplomatic history of the United States. 4th ed. New York, Holt, 1955. Ior8 p. 55-5982 Er83.7.B4682 I955

This has been a standard textbook in the field since it was originally published in 1936 . The successive editions have made minor alterations in the original text, but have brought the book current with the momentous developments in recent international affairs. After a preliminary discussion of the role of America in European conflicts between 1492 and 1775, the author sketches the foundations of American foreign policy as established between 1775 and 1823; the diplomacy of continental expansion, 1823-99; and since 1899, the United States as a world power. This last phase now fills over half of the volume. The author deals with the rise and significance of such historic doctrines as the freedom of the seas, the Monroe Doctrine, avoidance of entanglement in European conflicts, Manifest Destiny, the self-determination of peoples, and international arbitration.

3521. Bemis, Samuel Flagg, and Grace Gardner Griffin. Guide to the diplomatic history of the United States, I775-r921. Washington, U. S. Govt. Print. Off., 1935. New York, P. Smith, I951. reprint: xvii, 979 p. $\quad 5^{2-6052} \mathrm{Z6}_{4} 65 . \mathrm{U}_{5} \mathrm{~B}_{4}$ I95I

The first and larger part of this monumental Guide is an annotated bibliography arranged under the headings of a minutely chronological review of American diplomacy, and under each heading the materials are classified as bibliographic aids, special works, printed sources, manuscripts, and maps. Chapter 23, long enough to stand as a separate part (p. 685-789), lists "General Works, Historical Publications and Aids." Part II consists of a I50-page essay on the sources for American diplomatic history, including printed state papers both American and foreign, and archival collections in the United States and abroad. The continuing demand for this indispensable guide led to its reproduction, through photographic process, by a commercial publisher 16 years after its appearance as a government document.

3522. Hill, Charles E. Leading American treaties. New York, Macmillan, 1931. 399 p.

$$
\text { 33-13294 JXI407.H5 I93I }
$$

This work, first published in 1922, is not a compilation of documents, but an approach to the history of American foreign relations through "the historical setting and the chief provisions of the leading American treaties," or arrangements involving groups of treaties. The settlements included are: the French alliance of $177^{8}$; the treaty of independence, 1783; Jay's treaty, 1794; the convention with France, 1800; the Louisiana purchase, 1803; the peace treaty of Ghent, I814; the conven- tion with Great Britain, 1818 ; the Florida purchase, I819; the Webster-Ashburton treaty, 1842; the peace treaty of Guadalupe Hidalgo, 1848 ; the treaties with Japan, I854 and 1858; the Alaska purchase, I867; the treaty of Washington, 1871 ; the peace treaty with Spain, I898; and the Panama Canal treaties from 1850 to 1902. A brief bibliography follows each chapter.

3523. Perkins, Dexter. The American approach to foreign policy. Cambridge, Harvard University Press, 1952. 203 p. (The Gottesman lectures, Uppsala University)

Bibliography: p. [ 193$]-195$.

$$
\text { 53-3288 Er } 83 \cdot 7 \cdot \mathrm{P}_{4} 6 \quad 1952
$$

A series of lectures delivered in 1949, explaining the factors influencing the formulation and implementation of American foreign policy. After a brief general summary of our foreign relations to 1945, Mr. Perkins deals with each factor separately. The drive to achieve and maintain hemispheric solidarity must not be confused with imperialism, nor should our economic system be held exclusively responsible for policy decisions. An overdeveloped sense of morality has led to the sacrifice of our national interests while militarism and pacificism alternately affect our emotions. A final chapter views the antagonism of the Soviet Union and the United States as "the largest and most significant fact in the contemporary world of politics," and assesses the relative advantages of each side, with only the sober conclusion that "the capacity of a great self-governing people to deal with a continuing world crisis will be tested in the years ahead as it has never been tested before."

3524. Savage, Carlton. Policy of the United States toward maritime commerce in war. Washington, U. S. Govt. Print. Off., 1934-36. 2 v. (U. S. Dept. of State. Publication no. 33I, 835)

$$
34-28033 \mathrm{JX}_{5207 . S_{3}} 1934
$$

Contents.-v. I. 1776-1914.-v. 2. 1914-1918.

A narrative and documentary history of the United States' contributions to the law of naval warfare. Consistently enunciated in numerous treaties, civil and admiralty court decisions, naval codes and governmental declarations, and carried out as normal procedures by American maritime officials, American doctrines concerning the immunities of neutral goods on enemy ships, and of enemy goods on neutral ships, continuous voyage, the validity of blockade, immunity of private property at sea, and contraband of war were adopted by most major maritime powers between 1783 and the beginning of World War I. Unrestricted submarine warfare, in violation of these rules of law, was a major cause of American participation in that war. Six hundred 
documents are appended, 431 of which concern World War I.

3525. Tate, Merze. The United States and armaments. Cambridge, Harvard University Press, 1948. $312 \mathrm{p}$. $\quad 48-5607 \quad \mathrm{JX}_{1974 . \mathrm{T}_{32}}$ "Much of the material of Part I ... is in [the author's] The Disarmament Illusion."

"Selective bibliography": p. 278-286.

A documented history of American participation in disarmament conferences and negotiations from I 794 to 1947. It discusses the agreements effecting disarmament on the Great Lakes, the Hague Conferences of 1899 and 1907 , our role in the Conference for the Reduction and Limitation of Armaments sponsored by the League of Nations in 1934, our interwar policy regarding naval disarmament, the program for disarming Germany and Japan following World War II, and our advocacy of the international control of atomic energy. Miss Tate concludes that as long as a nation must defend its own security, and international disunity and mistrust persist, there can be little hope for the achievement of true disarmament.

3526. Wilson, Robert Renbert. The international law standard in treaties of the United States. Cambridge, Harvard University Press, 1953. 321 p.

Bibliography: p. [291]-310.

$$
\text { 53-5063 JX1406. W5 }
$$

Of special value to advanced students of international law and foreign affairs, this book shows that America's foreign relations, as expressed by U. S. treaty practice, have been influenced by our traditional respect for the rule of law in domestic affairs. This survey of perfected international agreements which the United States has ratified from 1778 to 1950 records the number and variety of specific treaty references to international law or the law of nations. Much of the work is devoted to the analysis of treaties dealing with the pacific settlement of disputes, commerce and navigation, the independence and jurisdiction of states, and war and neutrality. A basis for comparison is provided in an appendix containing summaries of the treaty practices of Great Britain, France, Russia, Germany, Italy, and Japan.

\section{Aii. PERIOD STUDIES}

3527. Beale, Howard K. Theodore Roosevelt and the rise of America to world power. Baltimore, Johns Hopkins Press, 1956. 600 p. (The Albert Shaw lectures on diplomatic history, 1953) 56-10255 $\quad \mathrm{E}_{757 . \mathrm{B}_{4}}$
A study of the effect of one man upon America's role in world politics, this book is a personalized review of the revolution in American foreign policy which began in 1889 and ended in 1909, and which placed America in the position of a great power. Beginning with his entrance into public life, Theodore Roosevelt worked ceaselessly for America's overseas expansion. He was convinced that this was the only way to achieve the necessary power to support our messianic role, shared with Great Britain, of civilizing the world. As President, T. R. carried on U.S. foreign relations by means of personal and secret contacts with the heads of state of the great powers, and maintained American ability to take action whenever these negotiations were of no avail. Extracts from private and public correspondence, as well as speeches, articles, and interviews have been used to illustrate aspects of Roosevelt's character, such as his peculiar brand of racism, and their relation to his insights and conclusions on foreign policy, arrived at both as a private citizen and as a public servant.

3528. Bemis, Samuel Flagg. The diplomacy of the American Revolution. New York, Appleton-Century, 1935. 293 p. 5 fold. maps.

$$
\begin{array}{r}
\text { 35-8172 EI 83.7.B48, v. I } \\
\text { E249.B }_{44}
\end{array}
$$

"This volume is published from a fund contributed to the American Historical Association by the Carnegie Corporation of New York."

"Bibliographical note": p. 265-273.

As director of the European Mission of the Library of Congress from 1927-29, Dr. Bemis initiated the mass photocopying of materials for American history in European archives and libraries. These sources he combined with American ones and printed materials in order to present, he believed for the first time, "a balanced and somewhat condensed narrative of the diplomacy of American independence," in which "details have been subordinated to the significant factors and the broad movements." Four chapters are devoted to relations with France, three to Spain, three to the Netherlands, one to the Armed Neutrality, and five to the peace negotiations. To the author the essence of the story resides in the progressive entanglement of the United States in European diplomacy through the French alliance, and the bold stroke of Franklin, Jay, and Adams in 1782 , when they "broke their instructions and cut loose from French advice and control." The work's continuing value is confirmed by a 1957 reprinting in the series of Midland books issued by the Indiana University Press. 
3529. Bemis, Samuel Flagg. John Quincy Adams and the foundations of American foreign policy. New York, Knopf, 1949. xix, 588, xv p.

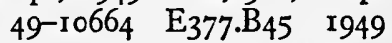

John Quincy Adams $(1767-1848)$ served as United States Minister to the Netherlands, Prussia, Russia, and Britain, was concerned with important questions of foreign policy in the Senate of the United States, and assisted in concluding the Treaty of Ghent, before embarking upon his memorable term as Monroe's Secretary of State (18 $17-25)$. Accepting the claim that Adams was America's greatest diplomatist, the author states, "more than any other man of his time he was privileged to gather together, formulate, and practice the fundamentals of American foreign policy-self-determination, independence, noncolonization, nonintervention, nonentanglement in European politics, Freedom of the Seas, freedom of commerce-and to set them deep in the soil of the Western Hemisphere." Adams is treated as a highly skilled statesman who took advantage of European wars and revolutions to advance the position of the United States as the predominant continental American power. The last 23 years of Adams' long life, as President of the United States and in the House of Representatives, are the subject of the author's John Quincy Adams and the Union (no. 3300), which has much of interest for diplomatic history although less exclusively concerned with it.

3530. Benton, Elbert J. International law and diplomacy of the Spanish-American War. Baltimore, Johns Hopkins Press, I908. 300 p. (The Albert Shaw lectures on diplomatic history, 1907)

8-9495 E723.B 47

After 17 years of quiet, in 1895 an insurrection, largely organized by exiled leaders in New York City, broke out in Cuba in protest against arbitrary Spanish rule and heavy taxation, very little of which was spent for Cuba's benefit. Spain reacted with drastic measures of repression, and for two and a half years the United States Government wrestled with the problem of maintaining an official neutrality while the sympathies of a majority of its citizens were warmly and sometimes actively on the side of the insurgents. Of the $7 \mathrm{r}$ expeditions in aid of the Cubans fitted out during this period, 33 were halted by Federal authorities. Both Spain and the United States were sufficiently exasperated when the destruction of the Maine in Havana harbor led to immediate intervention and war in an area where many neutrals had important interests. The author is scrupulously fair to the Spanish authorities, and is largely concerned with a critical review of American neutrality, warmaking, and treatment of neutrals in the light of the international law of the day. The two final chapters are concerned with the conclusion and implementation of the treaty of peace.

353x. Darling, Arthur Burr. Our rising empire, 1763-1803. New Haven, Yale University

Press, 1940. 595 p. 40-9340 E301.D23

Bibliography: p. [555]-565.

In spite of the dates on the title page, this book really begins with independence in 1776 , and constitutes a history of the most critical quarter-century in American foreign relations. Based on primary sources throughout, it is a work of the highest concentration and condensation, and incorporates few facts which it does not seek to interpret. The major, although not the exclusive theme, is the destiny of the Mississippi Valley, for the possession of which the new nation had as many as three rivals: Spain, France, and Great Britain. The detailed narrative is largely confined to our relations with those three powers. The culmination of the period, and conclusion of the book, is the "Achievement of Empire" with the Louisiana Purchase of 1803 . In it "the long quest of America's statesmen from Franklin to Jefferson, of Jay, Washington, Hamilton, Livingston, even John Adams, had come to achievement."

3532. Dulles, Foster Rhea. America's rise to world power, 1898-1954. New York, Harper, 1955. 314 p. (The New American nation series)

Bibliography: p. 283-30r. 55-6575 $\mathrm{E}_{744 . \mathrm{D} 8}$

"How, notwithstanding history, tradition, and emotion, Americans found themselves involved first with the fragments of the Spanish Empire in America, then in Pacific and Asiatic adventures, and finally in Europe, and how, through advance and retreat and advance they responded, is the central theme" of this book. In providing the historical background for the policies and decisions of the last half-century, the author, a professor at Ohio State University, is concerned only with those developments in foreign policy which marked the gradual and halting emergence of the United States as the leading world power.

3533. Dulles, Foster Rhea. The imperial years. New York, Crowell, r956. $34^{\circ} \mathrm{p}$.

$$
\text { 56-7790 E1 83.7. D78 }
$$

"Bibliographical notes": p. 314-325.

Of interest to the general reader rather than to the advanced student of American foreign relations, this book recreates the spirit, through quotations from contemporary speeches, newspapers, letters, memoirs, and documents, of the years between 1885 and IgIo. This age, characterized by the author as that of America's adolescence, began during the tradition. 
ally isolationist administration of Grover Cleveland, rose to its climax during the Spanish-American War, and declined with the end of Theodore Roosevelt's second administration. This decline was the result of the failure of Theodore Roosevelt and his contemporaries to realize that America's new position as a world power meant the abandonment of the traditional foreign policy of noninvolvement, and the formulation of a "coherent global policy."

3534. Fleming, Denna Frank. The United States and world organization, 1920-1933. New York, Columbia University Press, 1938. xiv, $569 \mathrm{p}$. $3^{8-30813}$ JXI975.5.U5F6

Professor Fleming of Vanderbilt University devotes this large volume, well documented, organized, and illustrated, to the years during which the United States, having decisively rejected the League of Nations and defeated the party which had sponsored it, maintained an official isolation from the Old World. He has small difficulty in demonstrating that this isolation was nominal rather than real, for after World War I the world had in fact become an economic and political unit. The consequence of its great withdrawal, therefore, was that the United States became involved in a succession of ad hoc negotiations, conferences, and cooperations, and brought forward a number of substitute means for guaranteeing the continuance of peace, instead of strengthening the central organs of international action to the point of real effectiveness. Well before I933 world-wide economic depression and the reappearance of unchecked aggression in Manchuria pointed to the failure of these half-way measures. This work continues the author's earlier study, The United States and the League of Nations 1918-1920 (New York, Putnam, 1932. 559 p.), and has for a companion volume his The United States and the World Court (Garden City, N. Y. Doubleday, Doran, 1945. 206 p.). A briefer account of the same period from much the same viewpoint is Allan Nevins' The United States in a Chaotic World; A Chronicle of International Affairs, 19181933 (New Haven, Yale University Press, 1950. 252 p. The Chronicles of America series, v. 55).

3535. Hyneman, Charles S. The first American neutrality; a study of the American understanding of neutral obligations during the years 1792 to 1815. [Urbana] University of Illinois, 1934. ${ }_{17} 8 \mathrm{p.}$ ([Illinois. University] Illinois studies in the social sciences. v. $\mathrm{xx}$, no. $\mathrm{I}-2$ )

$$
35^{-27650} \mathrm{H}_{3} \mathrm{I}_{4} \text {, v. } 20 \text {, no. } \mathrm{I}-2
$$

JXI4I2.H9

On cover: University of Illinois bulletin. vol. xxxii, no. 13 .

Bibliography: p. $167-171$.
A study of the legal relation of the United States toward belligerents during the wars of the French Revolution and Napoleon. This period of American neutrality marked "the transition from the era of benevolent or limited neutrality to the modern era of impartial conduct," and as such, the author believes, deserves study as a guide to the neutral obligations of the United States in any future war. The topics treated include aid to belligerent vessels, hostilities and seizures in American waters, the recruitment of American citizens, contraband trade, and the machinery for the enforcement of neutrality. The author's source material consists of diplomatic correspondence, court decisions, contemporary periodicals, and international law texts.

3536. Jordan, Donaldson, and Edwin J. Pratt. Europe and the American Civil War. With an introduction by Samuel Eliot Morison. Boston, Houghton Mifflin, I931. 299 p.

Bibliography: p. [269-290] 3I-5313 E469.8.J75

Part I, "England," is rewritten from a doctoral dissertation which Mr. Jordan submitted to Harvard University, and Part II, "The Continent," from a dissertation which Mr. Pratt submitted to Oxford; Prof. Morison read both and suggested their combination into a single work for the general reader. They jointly assess the part which public opinion played in determining the action of the English, French, and Spanish governments toward the American struggle. During the first two years opinion was sharply divided, and intervention was a real danger. But most pro-southerners did not want actual war, and therefore "Secretary Seward's policy of carrying a chip on his shoulder was entirely successful." Not long after the Emancipation Proclamation, liberal opinion in England, France, and Spain came out sharply on the side of the Union, and carried the indifferent majorities with it. The reintegration of the United States gave a "vast impetus" to European liberalism: it was the Parliament elected in 1865 which passed the Reform Bill of 1867 so crucial for British democracy.

3537. Langer, William L., and Sarell Everett Gleason. The challenge to isolation, 19371940. New York, Published for the Council on Foreign Relations by Harper, 1952. xv, 794 p. (Their The world crisis and American foreign policy) 51-1 1932 E744.L 3

3538. Langer, William L., and Sarell Everett Gleason. The undeclared war, 1940-1941. New York, Published for the Council on Foreign 
Relations by Harper, 1953. xvi, 963 p. (Their The world crisis and American foreign policy) 53-7738 ${\text { D } 748 . L_{3}}$

Well documented and abundant in detail, these companion volumes furnish a standard narrative of the international and diplomatic developments which preceded and precipitated United States entry into World War II. Beginning with President Roosevelt's "quarantine" speech of 1937, The Challenge to Isolation is a study of official American reactions and policies in the face of heightened Axis aggression and the stiffening resistance of Great Britain and France. The questions of Soviet alignment, Hemispheric defense, the character of American neutrality, and efforts toward a peaceful settlement occupy this volume, which closes with a consideration of the destroyers-for-bases deal with the British. The Undeclared War, 1940-194I narrates the Axis conquest of Europe and onslaught on Russia. The United States' moves in favor of the Allies such as lend-lease are considered along with our negotiations with Japan to achieve agreement in the Pacific. In both volumes, the personal efforts of President Roosevelt to draw the United States closer to the Allies, and particularly to Great Britain, receive close attention, and he is represented as overimpressed by Congressional opposition to his foreign policy, and as lagging behind general American sentiment in his support of Great Britain and France during the first year of the war. The authors achieve a balanced presentation of American relations with all areas of the world, as well as of the political and military events which drew us into World War II.

3539. Owsley, Frank Lawrence. King Cotton diplomacy; foreign relations of the Confederate States of America. Chicago, University of Chicago Press, 1931. 617 p. 3 I-16342 E $_{488.085}$

Bibliography: p. 579-591.

The Confederacy hoped that the European need for raw cotton might be used as a means for inducing diplomatic recognition and aid during the Civil War. European intervention was regarded as a guarantee of Confederate success. England and France, being the principal maritime countries and dependent on cotton, were the chief fields of Confederate activity. The Federal blockade produced a cotton famine in Europe as early as 1862 . However, Dr. Owsley maintains, the British cotton processors did not desire more cotton imports because the shortage made it possible to sell their existing stocks at a large profit. The wool, linen, munitions, steel, and shipping enjoyed a war boom. The unemployed cotton workers found work elsewhere. Britain refused to intervene, and Napoleon III was afraid to act alone.
3540. Reeves, Jesse S. American diplomacy under Tyler and Polk. Baltimore, Johns Hopkins Press, 1907. 335 p. (The Albert Shaw lectures on diplomatic history, 1906) 7-39215 E396.R33

Dr. Reeves was a specialist in international law who taught for 20 years at the University of Michigan. Here he treats the years $184 \mathrm{I}-49$ as a distinct diplomatic epoch in which was accomplished the final settlement of the three major boundary questions which had been outstanding since 1815 or even since 1783 . The northeastern boundary, a puzzle for over half a century because of the imperfect geographical knowledge incorporated in the peace treaty of 1783 , was settled by compromise in the Webster-Ashburton Treaty of 1842 . The northwestern boundary question, postponed rather than settled by the joint occupation of 1818 , was concluded in the Oregon Treaty of 1846 , again by a compromise line. The southwestern boundary, on the other hand, was settled by conquest, the results of which were embodied in the Treaty of Guadalupe Hidalgo, the last great step in the expansion of the United States. This book was one of the first to place a proper emphasis on the magnitude of President Polk's achievement.

3541. Seymour, Charles. American diplomacy during the World War. Baltimore, Johns Hopkins Press, I934. 417 p. (The Albert Shaw lectures on diplomatic history, 1933. The Walter Hines Page School of International Relations)

"Bibliographical note": p. 401-408. 34-1164I D6rg.S 43

Restricted to a study of American policy toward the European belligerents, this work centers around President Wilson who determined that policy in all its main aspects. The author, now president emeritus of Yale, asserts that Wilson held the United States apart from embattled Europe as long as practicable, but was "forced by the intolerable conditions of neutrality to bring America into the war and to promote a plan of international organization for peace." The ideals and the personal appeal of Wilson are viewed as determinative of the peace settlement of Versailles and of the League of $\mathrm{Na}$ tions. His personal contacts with diplomats and other leaders on both sides make up the core of the work. Comments of men such as Colonel House, Count Bernstorff, and others who negotiated for or with Wilson, are used to substantiate the well documented text.

3542. Updyke, Frank A. The diplomacy of the War of 18r2. Baltimore, Johns Hopkins Press, 1915. 494 p. (The Albert Shaw lectures on diplomatic history, 1914) 15-10499 E358.U66 Very formal diplomatic history, of which less than 
a quarter is devoted to the antecedents of the war, and more than three quarters to the efforts at peacemaking. The causes of the war are located in the British practice of impressing seamen from American vessels, and the British interference with American vessels trading to the Continent of Europe; on the second score French policy was equally highhanded, but America's "suffering at the hands of Great Britain was so much greater that she was warranted in declaring war upon that country alone." The negotiations at Ghent, which went on for the better part of four months, are narrated in great detail. Final chapters are on the complications which arose in executing some of the treaty's provisions, and on the Convention of 1818 and other acts in settlement of questions left open by the treaty; the question of the Newfoundland fisheries, indeed, is pursued as late as 1912.

\section{Aiii. PERSONAL RECORDS}

3543. Acheson, Dean G. The pattern of responsibility; edited by McGeorge Bundy from the record of Secretary of State Dean Acheson. Boston, Houghton Mifflin, 1952. xxi, $309 \mathrm{p}$.

$$
\text { 51-8864 E744.A217 }
$$

A collection of speeches and statements (I949-5I) selected by Professor (now Dean) McGeorge Bundy of Harvard University. The purpose was to provide an objective basis upon which to judge Mr. Acheson's performance as Secretary of State. "I am bound to say that I think it very hard indeed to square the record of man and policy with most of the charges that have been made," Dean Bundy states.

3544. Byrnes, James Francis. Speaking frankly. New York, Harper, 1947. 324 p.

$$
\text { 47-1175 D815.B9 }
$$

A discussion of the Yalta and Potsdam Conferences, at which he was present, and of various conferences of foreign ministers during his term as President Truman's first Secretary of State, 1945-47. The author believes that the details of postwar negotiations should be public property. He reproduces various high-level conversations at Yalta from his shorthand notes. Mr. Byrnes believes that Russian expansionist aims have been virtually the same since the Nazi-Soviet pact of 1939.

3545. Grew, Joseph Clark. Turbulent era; a diplomatic record of forty years, 1904-1945. Edited by Walter Johnson, assisted by Nancy Harvison Hooker. Boston, Houghton Miffin, 1952. 2 v. $\begin{array}{lll}\text { (xxvi, 156o p.) 52-5262 } & \text { E}_{748 . G 835 A_{3}}\end{array}$

The earlier parts of this work are principally composed of excerpts from the author's manuscript diary.
The first volume chronicles Mr. Grew's diplomatic career from 1904 to the completion of his first term as Under Secretary of State in 1927. The second volume is concerned with his service as Ambassador to Turkey (1927-32) and Japan (1932-41); and as Under Secretary of State again (1944-45). Since the diary notes were used as the basis of his $T e n$ Years in Japan, a more formal narrative of his mission, written by him in 1941, has been used here. The final sections are based on documents and reminiscences.

3546. Hull, Cordell. The memoirs of Cordell Hull. New York, Macmillan, 1948. 2 v. (1804 p.) 48-6761 E748.H93 The author was President Roosevelt's Secretary of State from 1933 to 1944 . The book was written with the assistance of Andrew $\mathrm{H}$. Berding, currently Assistant Director of the U. S. Information Agency, from the author's dictated remarks. After a brief relation of his early life in Tennessee and 23 years in Congress, the author concentrates on his term as Secretary of State. Topics treated include the recognition of the U.S. S. R., the reciprocal trade agreements policy, South American relations, American attitudes toward international organization, and Japanese and German aggression. Most of the second volume is devoted to World War II.

3547. Stimson, Henry L., and McGeorge Bundy. On active service in peace and war. New York, Harper, 1948. xxii, $698 \mathrm{p}$.

$$
{ }_{48-6427} \mathrm{E}_{74} 8 . \mathrm{S}^{8} 8_{3} \mathrm{~A}_{3}
$$

McGeorge Bundy, while still a Junior Fellow of Harvard University, prepared this book, which is in the third person, from Mr. Stimson's diary and other papers, and in constant contact with Mr. Stimson. Stimson (1867-1950) was Secretary of War from I911 to 1913 and again from 1940 to 1945 , Governor General of the Philippines from 1928 to 1929, and Secretary of State from I929 to 1933. Of greatest interest to the student of international affairs are his service as Secretary of State, when his determined opposition to Japanese claim on Manchuria marked him as one of the earliest advocates of collective action against aggression, and his second term as Secretary of War. During the latter, Mr. Stimson assisted in the making of many military decisions, including the opening up of the second front and the use of the atomic bomb, which profoundly affected wartime and postwar relations with our allies, and observed, at first hand, the conduct of our foreign affairs by virtue of his high and responsible office.

3548. Vandenberg, Arthur $\mathrm{H}$. The private papers of Senator Vandenberg, edited by Arthur H. 
Vandenberg, Jr., with the collaboration of Joe Alex Morris. Boston, Houghton Mifflin, 1952. xxii, 599 p. $52-5248 \quad \mathrm{E} 813 . \mathrm{V}_{3}$

A biographical narrative based upon liberal quotation from the Senator's diary, letters, and speeches covering the years from I939 to I95I, with major emphasis on the period following I94I. The main theme is the Senator's conversion from isolationism to Congressional leadership of the movement to increase United States participation in international organizations and politics. A long-time Republican member of the Senate Foreign Relations Committee, Senator Vandenberg (1884-195I) played a major role in effecting the passage of such foreign policy legislation as the ratification of the Charter of the United Nations, the Marshall Plan, and American participation in NATO. An advocate of bipartisan support of administration foreign policy, he was a delegate to the San Francisco Conference of 1945, the first and second sessions of the United Nations General Assembly, and the 1946 Paris Conference of Foreign Ministers.

3549. Welles, Sumner. Seven decisions that shaped history. New York, Harper, I951. xviii, $236 \mathrm{p}$. 5 I-I0044 D748. W 4

Sumner Welles, a specialist in Latin-American affairs who served as Assistant Secretary of State from 1933 to 1937 and as Undersecretary from 1937 to I943, here defends the foreign policy of Franklin D. Roosevelt, as well as his knowledge and skill in international affairs and the sincerity of his democratic purposes, against their numerous postwar critics. He incidentally justifies his own role on several occasions, particularly at the Rio Conference of 1942 , when, in order to avert a breach with Argentina and Chile, he appealed to the President over the head of Secretary Hull, who cuts a poor figure in this volume. Two major errors of Roosevelt's administration, the failure to declare against Hitler and to "quarantine" Japan, were forced upon Roosevelt against his best judgment. However, the failure to force Stalin to agree to a postwar settlement while Russia was heavily depending upon American assistance was Roosevelt's own, and is here attributed to his distrust of career Foreign Service men. There is also criticism of various foreign policies of the Truman administration, especially the abandonment of Chiang Kai-Shek.

\section{Aiv. THE BRITISH EMPIRE}

3550. Adams, Ephraim Douglass. Great Britain and the American Civil War. London, New York, Longmans, Green, 1925. 2 v.
"Primarily a study in British history in the belief that the American drama had a world significance, and peculiarly a British one." The unresolved struggle in England for democratic institutions is seen as influencing the attitude of the British territorial aristocracy toward the egalitarian tendencies of the North. The British ruling classes doubted whether the American Government could long endure, but the British people sympathized with its aims. For the latter, America was "fighting the battle of democracy."

3551. Allen, Harry C. Great Britain and the United States; a history of Anglo-American relations (1783-1952) New York, St. Martin's Press, 1955. I024 p. maps. 55-7753 Er 83.8.G7 447 Bibliography: p. $984-998$.

After a two-hundred page discussion of the economic, social, political, cultural, emotional, and diplomatic relations of the British and American peoples, the history of the relationship is analyzed in detail in three periods: $1775-1821,1821-98$, and I898-1952. The final period is regarded as that in which the United States, emerging as a world power, became aware of a common interest with Britain. The whole period of American national history, however, is seen as one of persistent progress from mistrust to cordiality, and also of increasing American preponderance. The author, a Fellow of Lincoln College, Oxford, disclaims having written a work of original research, but as a believer in "the necessity for cordial Anglo-American relations," has thoroughly digested the large literature of printed sources and secondary works.

3552. Brebner, John Bartlet. North Atlantic triangle; the interplay of Canada, the United States and Great Britain. New Haven, Yale University Press for the Carnegie Endowment for International Peace, Division of Economics and History, 1945. xxii, $3^{85} \mathrm{p}$. maps. ([The relations of Canada and the United States; a series of studies prepared under the direction of the Carnegie Endowment for International Peace, Division of Economics and History.]) A45-1973 Er83.8.C2B74 "Appendix: bibliographical notes": p. [329]-34I.

The $25^{\text {th }}$ and final volume in this very important series, which was published from 1936 to 1945 , and covers relations in the realms of population, settlement, the several spheres of economics, international law, and public opinion as well as in diplomacy. Prof. Brebner's book, although the most general in scope, "is not a summary of the volumes in the Series in which it appears. During the past ten years its main outlines have been used as a partial framework, or blueprint, for that Series." Like the series, it traces the relationship from the days 
of Samuel de Champlain on the levels of physiography, population movements, economic development, and politics and diplomacy. Its central theme is Canadian nationhood, which the Dominion has successfully asserted against the Empire of which it remains a part, and against the Republic which is its overshadowing neighbor. But, as the author shows, these and all related developments can be understood only within the larger picture of Anglo American relations, in which Canadian interests have only too frequently been relegated to a poor third place.

3553. Burt, Alfred L. The United States, Great Britain and British North America from the Revolution to the establishment of peace after the War of 1812. New Haven, Yale University Press, 1940. $44^{8}$ p. maps. (The relations of Canada and the United States [a series of studies prepared under the direction of the Carnegie Endowment for International Peace, Division of Economics and History]) 40-29766 Er 83.8.G7B9

This trenchantly written volume covers the period of conflict on the northern frontier of the United States against the background of general AngloAmerican relations, in abundant but not excessive detail. The points at issue in each of the major disputes that arose, and especially in boundary disputes, are isolated with a rare clarity. John Jay is given a double credit for the treaty of 1794 which destroyed his popularity: not only did it put off further conflict for two decades, but it "inaugurated the modern use of the judicial process in international affairs." Professor Burt deliberately challenges the theory that the land-hunger of the New West was the major cause of the War of 1812 ; he finds it rather in the cumulative exasperation of the American Government at the British refusal to come to any accommodation, even of a face-saving kind, on American maritime rights; save for the utter military unpreparedness, war would probably have come a year earlier. The Treaty of Ghent was only the initial step in a series of negotiations in which "the strong will to peace that prevailed in Washington and London made itself felt," and transformed "what was little more than a truce into a lasting peace."

3554. Dunning, William Archibald. The British Empire and the United States; a review of their relations during the century of peace following the Treaty of Ghent. With an introd. by the Right Honourable Viscount Bryce, O. M., and a pref. by Nicholas Murray Butler. New York, Scribner, rgr4. xl, 381 p. $\quad 14-18567 \quad$ Er 83.8.G7D9

A thoroughly digested review of relations between the United States, Great Britain, and Canada.
Specific topics treated include Canadian boundary disputes, Newfoundland fisheries, the right of search and African anti-slave patrol, British commentators on the United States, British policy concerning Texas, the Mexican War, the Civil War, and the Spanish-American War, British and American Latin-American policy, Alaska, Canadian internal affairs, the Venezuela dispute of 1895 , and Irish home rule.

3555. Keenleyside, Hugh Llewellyn, and Gerald S. Brown. Canada and the United States; some aspects of their historical relations. Rev. and enl. ed. New York, Knopf, I952. xxvi, 406, xii p. 51-13225 E183.8. ${ }_{2} \mathrm{~K}_{3} \quad 1952$

The original edition of 1929 "was the first published attempt at a comprehensive review of the history of the contacts between these two North American neighbors," and was much esteemed as a lucid narrative of essentials for the general reader. The new edition not only adds the events of the $1930^{\circ}$ 's and 40's, but incorporates the new information on earlier periods made available by the series on the relations of Canada and the United States (nos. 3552, 3553) as well as in the writings of individual scholars. The turbulent period of the Revolution and the War of 18 I $_{2}$ has been followed by over 140 years of peace on an unfortified frontier, but the authors' chapters following the Peace of Ghent are entitled "Moments of Crisis," "Major Boundary Disputes," "Minor Boundary Disputes," and "The Fisheries Controversy." They are concerned to make the point, in view of these and the persistence of annexationist sentiment in the United States, that the maintenance of peace since 1815 has not been an easy or automatic matter, but a true achievement of good sense in the conduct of international affairs by the two peoples.

3556. Levi, Werner. American-Australian relations. Minneapolis, University of Minne-

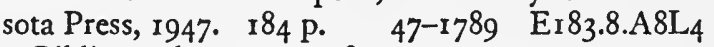
Bibliography: p. 174-180.

Early commerce, American whaling and sealing in the South Pacific, the California and Australian gold rushes, rgth-century imperialism, and the two world wars are treated. The rise of the United States as a predominant power in the Pacific was paralleled by the rise of Australia as another Pacific power, with major and sometimes conflicting interests.

3557. Roberts, Henry L., and Paul A. Wilson. Britain and the United States: problems in cooperation, a joint report prepared by Henry $L$. Roberts, rapporteur, a study group, Council on Foreign Relations, New York, and Paul A. Wilson, 
rapporteur, study group, Royal Institute of International Affairs, London. New York, Published for the Council on Foreign Relations by Harper, 1953. xvii, 253 p. 53-9066 Ex83.8.G7R68

A consideration of problems of most concern to the two nations during the period January 195I to June 1952, as discussed by a joint study group of the Council on Foreign Relations and the Royal Institute of International Affairs. Topics considered are: relations with the Soviet bloc, the United $\mathrm{Na}$ tions and collective security, economic policy, rearmament, global military problems, the political, economic, and military organization of Western Europe, and strategic problems in the Mediterranean, Middle East, and Far East.

3558. Soulsby, Hugh G. The right of search and the slave trade in Anglo-American relations, I814-1862. Baltimore, Johns Hopkins Press, I933. $185 \mathrm{p}$. (The Johns Hopkins University studies in historical and political science, ser. $\mathrm{LI}_{\text {}}$ no. 2)

$$
\text { 33-29624 H3r.J6, ser. 51, no. } 2
$$

Bibliography: p. I77-181.

JX5268.S6 1933

The African slave trade, which had been declared illegal by both the United States and Great Britain, was prolonged far into the 19th century because of diplomatic disagreement over the freedom of the seas, and because southerners regarded agreement on an antislave patrol as a preliminary to assault on slavery in the United States. By declaring the trade in slaves to be piracy, the two governments overcame the issue of freedom of the seas, but it was not until the Civil War that an effective patrol could be set up.

3559. Williams, Mary Wilhelmine. Anglo-American Isthmian diplomacy, 1815-1915. [Baltimore, The Lord Baltimore Press, 1916] 356 p. (Prize essays of the American Historical Association, 1914) 16-14677 JX $\mathrm{JX}_{1398 . W_{5}}$ 1916a

Thesis (Ph.D.-Leland Stanford Junior University, 1914)

Bibliography: p. 331-345.

Unravels the protracted Anglo-American disputes over the British occupation of parts of British Honduras, the Bay Islands, and the Mosquito Coast of Honduras and Nicaragua, and over a projected Isthmian canal connecting the Caribbean with the Pacific. The various settlements made in the Clayton-Bulwer Treaty of $185^{\circ}$ and the Hay-Pauncefote Treaty of 1901 are discussed. As cordiality between the two countries increased, the British ceased their efforts to counter American influence in Central America.

\section{Av. RUSSIA}

3560. Bailey, Thomas A. America faces Russia; Russian-American relations from early times to our day. Ithaca, Cornell University Press, 1950. $375 \mathrm{p}$.

Bibliography: p. 357-368.

50-10009 Er83.8.RgB 3

The author offers "a broad survey of RussianAmerican relations from earliest contacts to recent times," emphasizing American public opinion and diplomatic attitudes. Common distrust of England, he thinks, lay behind the Igth-century "friendship" of Russia and the United States. About half the book is devoted to the present century. Attitudes toward Russian claims on the Pacific Northwest, the visit of the Russian fleet to America during the Polish crisis of 1863 , the anti-Jewish pogroms of the late 19th and early 20 th centuries, the Russo-Japanese War, the Russian revolutions of 1905 and 1917 , and the Soviet regime are discussed.

3561. Barghoorn, Frederick Charles. The Soviet image of the United States; a study in distortion. New York, Harcourt, Brace, 1950. xviii, $297 \mathrm{p}$.

50-10897 DK69. B3

Half title: Institute of International Studies, Yale University.

The author served as press attaché in the American Embassy in Moscow, 1942-47. He regards Soviet propaganda against the United States as a major instrument of Russia's "aggressive foreign policy." His work studies the doctrine, opinions, and attitudes of the Soviet leadership as manifested in propaganda reaching the Russian people in the form of speeches, journalism, and literature, in which postwar American foreign and atomic policy, attitudes on war and peace, and the American domestic scene are interpreted. During his residence in the Soviet Union, the United States was first pictured as an ally, for whom there was only limited sympathy, and then as a rival not to be feared. In the Soviet propaganda image since the war, Americans become the slaves of capitalist exploitation, and American foreign policy essentially deceitful and aggressive. One chapter discusses the author's personal contacts with Soviet citizens and concludes that there is still a reservoir of good feeling toward the United States.

3562. Dennett, Raymond, and Joseph E. Johnson, eds. Negotiating with the Russians. [Boston] World Peace Foundation; I951. 310 p.

$5^{\mathrm{I}-8287} \quad \mathrm{DK}_{69} . \mathrm{D}_{4}$

Contents.-Negotiating on military assistance, 1943-1945, by J. R. Deane.-Negotiating under lend-lease, I942-1945, by J. N. Hazard.-Negotiat- 
ing the Nuremberg trial agreements, 1945 , by S. S. Alderman.-Negotiating at Bretton Woods, 1944, by R. F. Mikesell.-Negotiating to establish the Far Eastern Commission, I945, by G. H. Blakeslee.Negotiating on refugees and displaced persons, r946, by E. F. Penrose.-Negotiating on the Balkans, 1945-1947, by M. Ethridge and C. E. Black.-Negotiating on atomic energy, 1946-1947, by F. Osborn.Negotiating on cultural exchange, 1947, by E. J. Simmons.-Some Soviet techniques of negotiation, by P. E. Mosely.

Ten experts discuss their experiences in negotiations with Russia during the war years and after. Although each presents his own point of view, the common experience was that the Soviet negotiators were uniformly suspicious, even during periods of supposed cooperation, and without authority to depart from previously chosen positions. However, this did not preclude sudden changes in Russian policy, which were defended with equal tenacity although sometimes contradicting previous positions.

3563. Dulles, Foster Rhea. The road to Teheran; the story of Russia and America, I78r-1943. Princeton, Princeton University Press, 1944. 279 p. $\mathrm{A}_{44-531}$ E183.8.R9D8

"Bibliographical notes": p. 263-268.

The author is a professor of history at Ohio State University. Despite periods of marked friction, Russian-American relations were generally friendly throughout the whole period 178 r-1943. Common rivalry with Great Britain in the rgth century, the challenge of Germany and Japan in the 2oth, and a love of peace are seen as factors drawing the two peoples together, and ideological antagonism as a contrary influence. The isolationism of the United States and Russia is represented as a precipitating cause of World War II. The Axis attack drew them together once more.

3564. Laserson, Max M. The American impact on Russia, diplomatic and ideological, I784-

1917. New York, Macmillan, 1950. 441 p. 50-12185 Er 83.8.RgL 35

About half the book is devoted to the period up to the American Civil War. American influence is discovered in the writings of Radishchev, the relations of Alexander I with Jefferson and J. Q. Adams, the Decembrist revolt of 1825 , and Turgenev's antislavery attitude. The unfriendly attitude of $\mathrm{Pal}$ merston and Napoleon III toward the two countries tended to draw them together during the Civil War period. The writings of Herzen and Chernyshevski are examined for American allusions, and the influence of the writings of Henry George and George Kennan is discussed.
3565. Smith, Walter Bedell. My three years in Moscow. Philadelphia, Lippincott, 1950. 346 p. $\quad 49-5033^{2}$ Ei 83.8.R9S6 The author, our Ambassador to Russia during 1946-49, offers a personal narrative, stressing his impressions and experiences with Russians on both a high and low level. After discussing Molotov, Stalin, and their entourage, General Smith comments on Soviet diplomats, police state methods, economics, and propaganda; Titoism; the 1947 Moscow Conference; the Berlin blockade of 1948; and Russian religion and culture. He found the Soviet Union a land overshadowed by tyranny and poverty, the Soviet Government bent on world domination, and the American legation a conscientious group carrying on under serious difficulties.

\section{Sorokin, Pitirim A. Russia and the United} States. 2d ed. London, Stevens, 1950. 213 p. (The Library of world affairs, no. 15)

$$
\text { 52-1631 Er 83.8.R9S7 } 1950
$$

"Published under the auspices of the London Institute of World Affairs."

The author is professor of sociology at Harvard University. After an academic, journalistic, and political career in Russia, he was condemned to death by the Soviet Government, but was allowed to emigrate to the United States in 1923 . Like other commentators, he remarks on the unique period of unbroken peace between the United States and Russia. The vital interests of the two countries, he holds, have never conflicted. The continental position of both nations, their frontier experiences, and their ethnic diversity are seen as similar factors in development. The author believes that an "essential sociocultural similarity or congeniality" exists, and "presages still closer co-operation in the future."

3567. Stettinius, Edward R. Roosevelt and the Russians; the Yalta Conference; edited by Walter Johnson. Garden City, N. Y., Doubleday, r949. xvi, $367 \mathrm{p}$. 49-10915 $\mathrm{D}_{734 . \mathrm{C}_{7} \mathrm{~S} 8}$

A defense of the Roosevelt policy at the Yalta Conference of February 1945. The author was Secretary of State during Roosevelt's last months, I94445. Mr. Stettinius, who died just as this book was being published, denied that vital interests of the United States and the free world were sacrificed at Yalta. "It is not Yalta that is the trouble with the world today, but subsequent failures to adhere to the policies Yalta stood for and to carry out agreements that were reached there." Yalta, he maintained, represented not appeasement but an attempt to set the world on the road to lasting peace.

3568. Tompkins, Pauline. American-Russian relations in the Far East. New York, Mac- 
millan, 1949. xiv, 426 p. $\quad$ 49-48919 DS518.T62

"Undertaken initially in fulfillment of a requirement for the degree of doctor of philosophy [Fletcher School of Law and Diplomacy, 1948]."

Bibliography: p. 398-413.

The emphasis here is upon relations since 1917. American participation in the allied intervention in Siberia, 1918-20, is regarded as an act of political expediency, directed primarily at Japan. Other topics treated are the Washington Conference of 1921-22, the Japanese attack on China, and American policy toward Japan and Korea during World War II, as it affected Soviet relations. The author states that the rgth-century "friendship" of America and Russia was a byproduct of practical politics. With American intervention in the Pacific and growing cooperation with Great Britain, antagonism has increased. Dr. Tompkins regards the balance of power theory of world politics as certain to bring disaster at a time when the alternative is to unite or perish.

\section{Avi. OTHER EUROPEAN NATIONS}

3569. Chadwick, French Ensor. The relations of the United States and Spain, diplomacy. New York, Scribner, 1909. 610 p.

$$
\text { 9-31968 E⿺ } 83.8 . \mathrm{S}_{7} \mathrm{C}_{4}
$$

The author sees the Spanish-American War as the culmination of a long racial and cultural conflict. The deterioration of Spanish rule in Cuba is ascribed to Spain's failure to establish democratic institutions in the homeland. About half of the book is devoted to the diplomacy of the American Revolution, boundary problems, and the American attitude toward the independence movement in Latin America; the second half to the Cuban question in American politics and diplomacy.

3570. Clay, Lucius D. Decision in Germany. Garden City, N. Y., Doubleday, 1950. xiv, $522 \mathrm{p}$. 50-5813 DD257.C55

General Clay served as Deputy Military Governor, 1945-47, and as Military Governor, 1947-49; his book is rather impersonal and official in manner. The period was characterized by disagreement with Russia over German policy, culminating in the attempt of the Russians to drive the allies out of Berlin and the decision to establish a West German federal government. The author regards the unity of Germany as essential to European peace, for "no lasting stability may be expected as long as $65,000,000$ persons in the heart of Europe are divided against their will."

3571. Fogdall, Soren J. M. P. Danish-American diplomacy, 1776-1920. Iowa City, The Uni- versity, 1922. I7I p. (University of Iowa studies in the social sciences, v. 8, no. 2 ) 22-27280 $\mathrm{H}_{3} \mathrm{I} . \mathrm{I} 8$, v. 8, no. 2

Bibliography: p. 159-165. $\mathrm{JX}_{4} 28 . \mathrm{S}_{3} \mathrm{~F} 6$

Principal emphasis is placed on maritime rights, such as the rights of American men of war in the Revolution, and the right to be free of dues for transit of the Sound into the Baltic, which Denmark continued to collect until $\mathbf{1 8 5 7}$. The failure to buy the Danish West Indies in 1867, and their subsequent purchase in 1916 are discussed.

3572. Hayes, Carlton J. H. The United States and Spain: an interpretation. New York, Sheed \& Ward, 1951. 198 p. $\quad 5^{1-1} 3793 \quad \mathrm{E}_{183} 8.8 . \mathrm{S}_{7} \mathrm{H}_{3}$ "Select bibliography": p. 193-198.

The author, professor emeritus of history at $\mathrm{Co}$ lumbia University, served as Ambassador to Spain during 1942-45, and related his experiences in Wartime Mission in Spain, 1942-1945 (New York, Macmillan, 1945. 313 p.). This book is based on a series of lectures delivered at the College of the Holy Cross, Worcester, Mass. Old misunderstandings and prejudices are represented as having dis. rupted after the early 1890 's the good feeling which generally prevailed through the igth century. The author discusses misconceptions about Spain, contrasting political traditions, the Spanish Republic of 1931, the Civil War of 1936-39, and relations with Spain since 1939. General Franco, he is convinced, was never taken in by Hitler and was never a catspaw for the Axis. He maintains that Spain and Hispanic America are essential to the Atlantic community.

3573. Reitzel, William. The Mediterranean: its role in America's foreign policy. New York,

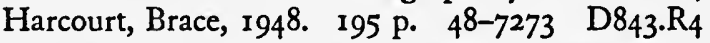
Issued by Yale Institute of International Studies. "References": p. [187]-189.

American official interest in the Mediterranean is here interpreted as principally a byproduct of World War II. In the author's judgment, "the key aim of an American policy for the Mediterranean will be to maintain its internal stability in order to be free to use it as a strategic unit." British interest in the area, it is pointed out, is more closely related to imperial interests, causing a basic divergence in point of view.

\section{Avii. LATIN AMERICA: GENERAL}

3574. Bemis, Samuel Flagg. The Latin American policy of the United States, an historical in- 
terpretation. New York, Harcourt, Brace, 1943. xiv, $470 \mathrm{p}$. $\quad 43-51167 \mathrm{~F}_{1418 . \mathrm{B}_{4}}$

Half-title: Institute of International Studies, Yale University.

Aims to provide in one volume a historical interpretation of Latin American policy since the beginning of the Republic. American policy, it is asserted, has been based upon the Nation's independence under a republican government, its continental expansion, and the security requirements of the resultant continental republic. "These fundamentals naturally favored independence for the whole New World, republican self-government for the new states, opposition to European intervention in their affairs ... a and political solidarity of the nations of the New World." The last part of the book is devoted to the "good neighbor" policy of Franklin D. Roosevelt, which the author regards as an attempt to base United States policy on the concept of hemisphere security rather than the security of the United States alone. The narrative is brought down to the Rio de Janeiro Conference of January 1942.

3575. Gantenbein, James W., ed. The evolution of our Latin-American policy, a documentary record. New York, Columbia University Press, 1950. xxvii, 979 p.

49-50406 FI4I8.G2

A collection of documents, largely drawn from U. S. Government publications, which go back as far as 1796 but mostly belong to the 20 th century. They are arranged under six principal headings: "General Principles," "The Monroe Doctrine," "Independence of Cuba," "The Panama Canal Concession," "Certain Controversies with Mexico," and "Interventions in Nicaragua, Haiti, and the Dominican Republic." Appendixes are concerned with selected documents of successive Pan American conferences and with other international agreements, in all but one of which the United States participated.

3576. Guerrant, Edward O. Roosevelt's good neighbor policy. Albuquerque, University of New Mexico Press, 1950. 235 p. (Publication of the School of Inter-American Affairs, the University of New Mexico. Inter-American studies, 5)

Bibliography: p. 215-225.

$$
\text { 50-5678 Fi418.G93 }
$$

In the estimation of Professor Guerrant, "the United States has never had a foreign policy toward any area that was more successful than the Good Neighbor Policy was from 1933 to 1945." That policy is here analyzed in five topical chapters: "Abandonment of Intervention," "Recognition of New Government," "Quest for Law," "Expanding Commerce," and "Cultural and Scientific Rela- tions." Two concluding chapters narrate relevant events during the crisis years of 1939-4I, and during World War II. Non-intervention, the author suggests, has been "criticized by liberal elements in those nations which were oppressed by tyrannical governments." After the death of President Roosevelt the efforts of the American Government to cultivate the good will of Latin America rather suddenly slackened.

3577. Perkins, Dexter. A history of the Monroe doctrine. [Rev. ed.] Boston, Little, Brown, 1955. xiv, 462 p. 55-10752 JXI425.P 3841955 Bibliography: p. [420]-435.

This work was originally published in 1941 under the title Hands Off, and continued as well as summarized the author's detailed studies contained in three works of distinguished scholarship: The Monroe Doctrine, $1823-1826$ (Cambridge, Harvard University Press, 1932. 280 p.); The Monroe Doctrine, 1826-1867 (Baltimore, Johns Hopkins Press, 1933. 580 p.); and The Monroe Doctrine, $1867-1907$ (Baltimore, Johns Hopkins Press, 1937. 480 p.). "In the field of politics," the author believed, "there are few more unqualified faiths than the faith of the American people in the Monroe Doctrine... There are few subjects, too, with regard to which it has been necessary to clear away so many misapprehensions." To this end he produced, for the general reader, his one-volume history of the Doctrine. While the background of this "prohibition on the part of the United States against the extension of European influence and power to the New World" included the conception of the two spheres, the separation of the New World from the Old, it never was intended to bar the way "to American diplomatic or physical action in other parts of the globe." British and French diplomacy in Texas, French intervention in Mexico, the Spanish reoccupation of Santo Domingo, the Venezuela-British Guiana boundary dispute, Isthmian Canal diplomacy, and American intervention in the Caribbean are among the episodes described. The new edition covers developments from I94 I to 1954, and, against those who regard the Doctrine as outmoded, contends that "the physical integrity of the cisatlantic area, and its protection against subversion, will continue to be a matter of concern."

3578. Stuart, Graham H. Latin America and the United States. $5^{\text {th }}$ ed. New York, Appleton-Century-Crofts, 1955. 493 p.

$$
\text { 55-5020 Fi418.S933 } 1955
$$

"Supplementary readings" at end of chapters.

This textbook, whose first edition goes back to 1922, aims "to give a brief and accurate survey of the diplomatic and commercial relations between 
the United States and those Latin-American countries with which our interests have been most closely related." After four preliminary chapters on Pan Americanism, the development of coöperation by conference, and the Monroe Doctrine, the course of United States interests and negotiations is traced in successive areas: Panama, Mexico, Cuba, the Caribbean, Central America, Argentina, Chile, and Brazil. This $5^{\text {th }}$ edition seeks to indicate the changes brought about by the Good Neighbor policy, which inaugurated a new era in the Latin American relations of the United States. "The Western Hemisphere has set up the Golden Rule as its goal for the relations between states. Justice and fair dealing no longer end at the national frontiers."

3579. Whitaker, Arthur Preston. The United States and the independence of Latin America, 1800-1830. Baltimore, Johns Hopkins Press, I94I. xx, 632 p. (The Albert Shaw lectures on diplomatic history, I938. The Walter Hines Page School of International Relations)

"Bibliographical note": p. 603-612.

$$
4 \text { I-1898I Fi418.W6 }
$$

These lectures analyze in considerable detail United States policy as affected by Napoleon's victory in Spain in 1808, the attitude of the despotic powers in Europe after 1815 , and the British policy toward Latin America. The "Black Legend" of Spanish cruelty, despotism, and duplicity had created a widespread prejudice which included the Latin Americans. Nevertheless, for both commercial and ideological reasons, the United States favored the establishment of independent republican regimes. In issuing the Monroe Doctrine, President Monroe "counted upon his very threat of war to forestall actual war," and to bluff the French "government into abandoning any plan it might have for intervening in America." Its novelty and its continuing importance both lay in the fact that it gave official sanction to "a special policy towards Latin America which was based on different principles from the policy of the United States toward the rest of the world."

\section{Aviii. LATIN AMERICA: INDIVIDUAL NATIONS}

3580. Evans, Henry Clay. Chile and its relations with the United States. Durham, N. C., Duke University Press, 1927. 243 P.

Bibliography: p. [221] 234 .

27-9852 $\mathrm{E}_{183} 8 . \mathrm{C}_{4} \mathrm{E}_{93}$

A Columbia University dissertation which reviews the relations of the United States with Chile from 1812 through the close of 1926 . Conspicuous episodes are the Spanish seizure of the Chincha Islands in 1864; the ro-year War of the Pacific, in which the United States prevented any European mediation but failed in its own; the attack on the Baltimore's crewmen in Valparaiso in $189 \mathrm{r}$, producing "the nearest approach to a war that the United States has ever had with a South American nation"; Chile's refusal to break with Germany during World War I; and the failure of American arbitration during the earlier stages of the TacnaArica dispute. "Possibly no better field could be chosen to illustrate the difficulties that beset the path of American diplomats when they attempt to assert a leadership for their own country in its relations with the sensitive and proud people of smaller nations."

358r. Fitzgibbon, Russell $\mathrm{H}$. Cuba and the United States, I900-1935. Menasha, Wis., Banta Pub. Co., I935. 31I p. 35-9034 Fi787.F56 Bibliography: p. [278].

The appointment of General Leonard Wood as Governor in 1900 is taken as the starting point. The establishment of the Cuban Republic, the intervention of $1906-9$, the Gomez, Menocal, Zayas, and Machado regimes, Cuban sugar and American tariff policy, American subscriptions to Cuban loans, and the abrogation of the Platt Amendment are among the subjects discussed. The author aims neither to defend nor attack American interventionism, but merely to present a "unified, objective, and scientific study."

3582. Hill, Lawrence F. Diplomatic relations between the United States and Brazil: Durham, N. C., Duke University Press, 1932. 322 p.

Bibliography: p. 306-316. 32- 18335 EI83.8.B $7 \mathrm{H}_{5} 6$

A historical narrative covering the period $1807-$ I930, with emphasis upon the rgth century. Attention is focused on the degree of neutrality practiced by each nation in the cours: of the international and civil wars and insurrections in which each was involved from the War of 1812 to World War I. Mr. Hill also examines commercial relations, the consequences of the abolition of the slave trade, the emigration of Confederate exiles following the Civil War, and Brazil's change from empire to republic in 1889 .

3583. McCain, William D. The United States and the Republic of Panama. Durham, N. C., Duke University Press, 1937. xv, 278 p.

Bibliography: p. 255-267. 37-2897 Fi566.M24

A study of the intervention of the United States in Panama and its subsequent effect upon diplo- 
matic relations with the Panamanian Republic. The author narrates in detail various disputes with the United States over the government of the Canal Zone and the internal affairs of Panama, involving such problems as the threat of revolution, the relations of American soldiers with local residents, expropriation of Panama territory for Canal purposes, interference in Panama road and railroad construction, and the renegotiation of treaty arrangements in the administrations of Coolidge and Franklin Roosevelt.

3584. Montague, Ludwell Lee. Haiti and the United States, 1714-1938. Durham, N. C., Duke University Press, 1940. xiv, 308 p.

$$
\text { 40-1 } 147^{\circ} \text { E } 183.8 . \mathrm{H}_{2} \mathrm{M} 6
$$

Thesis (Ph. D.)-Duke University, I935.

"Bibliography of works cited": p. 293-302.

It is maintained that since I 800 the United States has recognized that it has a vital strategic interest in the Caribbean and has not hesitated to defend it, on occasion even by military intervention in Haiti and the Dominican Republic. The book surveys the course of relations since the establishment of Haitian independence, discussing the American fear of a slave revolt, projects to colonize freed American slaves in Haiti, the recognition of Haiti by Lincoln, annexationist sentiment, American desire for a naval base, commercial penetration, the interventionist "corollary" of Theodore Roosevelt to the Monroe Doctrine, dollar diplomacy, Marine occupation, and the Good Neighbor policy.

3585. Parks, E. Taylor. Colombia and the United States, 1765-1934. Durham, N. C., Duke University Press, 1935. Xx, $554 \mathrm{p}$.

Bibliography: p. $492-529$.

$$
\text { 35-25823 } \mathrm{E}_{183} 8.8 . \mathrm{C}_{7} \mathrm{P}_{37}
$$

This substantial volume opens by narrating the early history of Colombia, which originally included Ecuador, Venezuela, and Panama. The United States recognized Colombian independence in 1822 , but relations were not put on a solid footing until the treaty of 1846 , negotiated at Bogotá by Benjamin A. Bidlack. It guaranteed Colombian sovereignty in the Isthmus of Panama and remained an important factor in the Canal question down to the Panama Revolution of 1903. Dr. Parks subjects some of the arguments whereby President Theodore Roosevelt justified his support of that revolution to severe criticism. The Wilson administration's attempt to indemnify Colombia with 25 million dollars went unratified by the Senate until I921, when the desire of American business interests to develop Colombian oil and other natural resources powerfully reinforced the desire for a rapprochement with the disgruntled Republic.
3586. Rippy, James Fred. The United States and Mexico. Rev. ed. New York, Crofts, 193I. 423 p. $31-18162$ EI83.8.M6R7 I93I

Bibliography: p. 387-396.

Two-thirds of the book is devoted to the period before 1900, with especial attention to the diplomacy of the Mexican War period and after. The expansionist program of President Buchanan in 1857 and French intervention in Mexico during the Civil War are discussed. The Pershing expedition against Villa and the diplomacy of Dwight W. Morrow are covered. American policy is represented as motivated by varying sentiments, sometimes aggressive, sometimes idealistic.

3587. Tansill, Charles Callan. The United States and Santo Domingo, 1798-1873; a chapter in Caribbean diplomacy. Baltimore, Johns Hopkins Press, 1938. 487.p. $\quad 38-32982 \quad E_{1} 83.8 . D 6 T_{3}$

At head of title: The Walter Hines Page School of International Relations; the Johns Hopkins University.

The subject is relations with both Haiti and the Republic of Santo Domingo in the period covered, with principal emphasis on the latter. The southern fear of a slave revolt in imitation of the events of I79I, war between Haiti and the Dominican Republic, and the expansionist policy of President Grant are considered, as well as various efforts to obtain naval bases on the island or to forestall their establishment by other nations. The author is professor of diplomatic history at Georgetown University, Washington, D. C.

\section{Aix. ASIA}

3588. Agwani, Mohammed Shafi. The United States and the Arab world, I945-1952. Aligarh, Institute of Islamic Studies, Muslim University, 1955. 184 , ix $\mathrm{p}$.

$$
\text { 57-15226 DS63.2.U5A65 } 1955
$$

This thesis submitted to the University of Utrecht offers a detailed critique of America's conduct toward the Arab States since the war. The author believes that American prestige, laboriously built up over the years by the efforts of American missionaries and educators, and confirmed by Wilsonian idealism, has recently been shattered by the United States' support of Zionism and of Israel, of reactionary native governments, and of the interests of British and French imperialism.

3589. Ballantine, Joseph W. Formosa, a problem for United States foreign policy. Washington, Brookings Institution, 1952. $218 \mathrm{p}$.

$$
53-5824 \text { DS895.F75 } \mathrm{B}_{27}
$$


After a brief discussion of Formosa under Chinese and Japanese rule, post-World War II developments and the problems posed for American foreign policy in Formosa are examined. Topics covered are: the neutralization of Formosa by the United States fleet, American economic and military aid, Formosa as a stake in the international struggle for power, and the Japanese peace treaty of 1952. Formosa having been kept in friendly hands, the problems now are how far the claims of the Nationalist government to rule the mainland should be countenanced, whether the Communist government should be recognized, and to what extent the United States may count on its allies for support in its Formosan policy. The stated purpose of the book is not so much to find answers as to assemble and arrange the facts necessary for decision. The author was Director of the Office of Far Eastern Affairs of the Department of State, 1944-45.

3590. Battistini, Lawrence $H$. Japan and America, from earliest times to the present. With 5 maps. New York, J. Day, I954. I98 p. (An Asia book) $\quad 54-5881 \quad E_{1} 83.8 \mathrm{~J}_{3} \mathrm{~B}_{3}$ I954

A rapid survey of diplomatic relations which reserves the greater part of its space for the war of I 94 I and its causes, and the occupation and rehabilitation of Japan. The reaction in American occupation policy as the Communist menace became apparent and the necessity of restoring Japan to full economic self-sufficiency are stressed. A more analytical treatment of current problems will be found in a symposium sponsored by the Institute of Pacific Relations of Hawaii, Japan and America Today (Stanford, Calif., Stanford University Press, 1953. I 66 p.).

3591. Battistini, Lawrence $H$. The United States and Asia. New York, Praeger, 1955. $37^{\circ}$ p. maps. (Books that matter)

Bibliography: p. 345-351.

$$
\text { 55-11534 } \mathrm{DS}_{5} 18.8 . \mathrm{B}_{35} \text { 1955a }
$$

Introduces the lay reader and the student to the development of our relations with the Pacific area as well as with Asia. From 1784 to the SpanishAmerican War (1898) our interest in Asia and the Pacific was essentially commercial, and accordingly United States policy in the area supported equality of trading rights and the maintenance of the sovereignty of Japan and China. The establishment of America as a Pacific power in 1898 forced the United States into active military and political participation in the Far East at a time when we maintained our isolation from the affairs of Europe. Relations with China were always friendly, but it was not until World War II that this interest manifested itself in the form of aid and advice to stop first the
Japanese, and then the Chinese Communists. The author shows how the United States originally encouraged the rise of Japan, but after I 907 worked to contain that Japanese expansion, which at last challenged our Pacific position in the I940's, to its own undoing. After summarizing our relations with Asian nationalism and the new Southeast Asian nations, the author concludes that we should assume the permanence of their nationhood, and afford them an example of the highest political morality in order to encourage them to resist Communist encroachment.

3592. Dulles, Foster Rhea. China and America; the story of their relations since 1784 . Princeton, N. J., Princeton University Press, I946. $277 \mathrm{p}$.

Bibliography: p. 263-267. $\mathrm{A}_{4} 6-14$ Ei83.8.C5D8

A survey for the general reader, half of which is concerned with Chinese-American relations before 1900. Mr. Dulles stresses the American dream of China as a vast market for American exports. He demonstrates that while the United States has always talked of friendship with China, in times of crisis, such as the Manchurian affair of I93I, it has merely sent diplomatic protests in order to protect our commercial interests, and then stood aside while events have taken their course. The Taiping rebellion, our Chinese exclusion laws, the Boxer rebellion, World War I, the Washington Conference of 1921, Chinese nationalism, the spread of Japanese aggression, and World War II are considered in their effect on our relations with China. The apathy and ignorance of the American public, and their failure to support government leaders who are better informed, are blamed by $\mathrm{Mr}$. Dulles for our failure to act constructively in behalf of China throughout the history of our mutual relations.

3593. Feis, Herbert. The China tangle; the American effort in China from Pearl Harbor to the Marshall mission. Princeton, Princeton University Press, I953. 445 p. maps.

$$
\text { 53-10142 } \mathrm{E}_{1} 83.8 . \mathrm{C}_{5} \mathrm{~F}_{4}
$$

An uncontroversial attempt to clarify the policy of the United States toward China during the period of hostilities with Japan and immediately after. The author regards our China policy as a "tale of crumpled hopes and plans that went awry," the reason being that the war in the Pacific ended abruptly before our effort in behalf of China reached its planned fullness. The military demobilization at the end of 1945 revealed a desire to renounce the burdens thrust upon us. The narrative is built about the rivalry of the Chinese Communists and Nationalists in the face of Japanese aggression, the Chinese-Russian agreement of 1945, the Hurley 
mission, and the Russian and Chinese Communist occupation of Manchuria.

3594. Griswold, Alfred Whitney. The Far Eastern policy of the United States. New York, Harcourt, Brace, $1938.53^{\circ} \mathrm{p}$.

$$
\text { 38-29014 DS518.8.G } 75
$$

At head of half-title: Institute of International Studies, Yale University.

Bibliography: p. 503-517.

Various events in the period $1898-1938$ are discussed as they reflected American policy: the annexation of the Philippines, the "Open Door" notes of John Hay, the failure of "dollar diplomacy," recognition of a special Japanese interest in China in the ambiguous Lansing-Ishii agreement of 1917 , the question of the German Pacific Islands after World War I, the consolidation of the status quo in the Washington treaties, Oriental exclusion as a diplomatic and political issue, the efforts of Secretary of State Stimson to apply sanctions against Japan, and the Roosevelt policy toward Japanese aggression in China.

3595. Grunder, Garel A., and William E. Livezey. The Philippines and the United States. Norman, University of Oklahoma Press, 1951. 315 p.

Bibliography: p. 286-305. 5I-6997 DS685.G75

A study in the origin and evolution of United States policy toward the Philippines during the past half century. Special attention is given to economic relationships, the evolution of political institutions, and the independence question. The defeat of the Spanish fleet in Manila Bay, 1898 , annexation and pacification, tariff problems, the problem of ecclesiastical lands, the Moros, the Jones Act of 1916, Governor-Generals Leonard Wood and Henry L. Stimson, the Commonwealth period, Japanese occupation; and reconstruction and independence are discussed. The importance of the islands as collaborators in the Far Eastern policy of the United States is stressed.
3596. Latourette, Kenneth S. The American record in the Far East, 1945-1951. New York, Macmillan, 1952. 208 p. 52-12394 DS518.8.L26 "Issued under the auspices of the American Institute of Pacific Relations."

The author's theme is the "ever deepening entanglement" of the United States in the affairs of the region, which he explains as the result of the historic westward movement of the American people. Despite the confusion of American aims in Asia, he maintains that an American policy exists, namely: sympathy for the attempt of the peoples of Asia to achieve their goals and ambitions; containment of Communism, by force if necessary, but also by financial, technical, and educational aid; support of the United Nations; maintenance of military bases; and subordination of Asiatic to European affairs in overall foreign policy. The American policy in China, where the Communists gained the principal benefit of the American defeat of Japan, was a failure; its success in other areas is only tentative. The author, who has a missionary background, regards the true struggle as ideological. Although he does not believe that democracy in the American sense is now possible in China, he condemns Chinese Communism as a perversion of the Western Christian tradition and a totalitarian creed.

3597. Oliver, Robert T. Why war came in Korea. New York, Fordham University Press; D. X. McMullen Co., distributors, 1950. xxvi, $260 \mathrm{p}$.

50-9923 $\mathrm{DSS}_{917} \mathrm{O}_{4}$

The strategic importance of Korea, the military buildup of North Korea, the military weakness of South Korea, the withdrawal of American troops, the inference that the United States would not defend Korea, and the danger to Soviet propaganda of a successful democratic regime in South Korea are adduced as reasons why war came. The author has been an adviser of Syngman Rhee.

\section{B. Foreign Relations}

\section{Bi. ADMINISTRATION}

3598. Brookings Institution, Washington, D.C. International Studies Group. The administration of foreign affairs and overseas operation; a report prepared for the Bureau of the Budget, Executive Office of the President. Washington, I95I. $\mathrm{xxv}, 380 \mathrm{p}$.
The study is intended to supplement the researches of the Commission on Organization of the Executive Branch (Hoover Commission). New problems in the postwar world are considered: the administration of foreign economic aid, military considerations affecting foreign affairs, the need for program coordination in the conduct of foreign affairs, and problems of personnel management. Is- 
sues are objectively stated, the arguments on both sides presented, and possible solutions suggested.

3599. Childs, James Rives. American foreign service; with a foreword by Joseph C. Grew. New York, Holt, 1948. 261 p.

$$
4^{8-5092} \mathrm{JX}_{1705} \cdot \mathrm{C}_{45}
$$

3600. U. S. Dept. of State. Secretary of State's Public Committee on Personnel. Toward a stronger Foreign Service; report. [Washington, U. S. Govt. Print. Off.] 1954. 70 p. ([U. S.] Dept. of State Publication 5458. Department and Foreign Service series, 36 ) SD54-7 JK851.A435

The first title is an introduction by a career diplomat to the organization and work of the Foreign Service as governed by the sweeping Foreign Service Act of 1946, which is printed as Appendix A (p. 157-21 I). Initial chapters trace the evolution of the Service since 1789 , and describe its career aspects, including the qualifications it demands. Its relations to other parts of the Department of State, and to other agencies of the U. S. Government, are considered. The Paris Embassy, the "showcase of the Diplomatic Service" with its 600 staff members ( 30 times the number in 1912), is then chosen for a case study and exhibited in operation at various levels: the ambassador, the administrative units, and the four main sections: political, consular, economic, and information and cultural relations. Appendix B offers comparative data on the British and French foreign services. Toward a Stronger Foreign Service is the work of a committee of prominent educators and business men which recommended integrating the Foreign Service with Department personnel and liberalizing and expanding recruitment policies, so that American representation abroad would be more adequate to our leading role in world affairs. Tables and charts supplement the background information of this study of the Foreign Service and its personnel. The Committee chairman, Henry M. Wriston, in his $D i$ plomacy in a Democracy (New York, Harper, 1956. II5 p.), stresses the importance of a Foreign Service composed of experts, whose pivotal role is preserving peace by maintaining the American alliance system and containing the aggressions of potential enemies.

3601. Hunt, Gaillard. The Department of State of the United States; its history and functions. New Haven, Yale University Press, 1914. $459 \mathrm{p}$. I4-I4205 JK853.H8

"Bibliographical note": p. [438]-439.

3602. Stuart, Graham H. The Department of State; a history of its organization, procedure, and personnel. New York, Macmillan, 1949. 517 p. $\quad 49-11378$ JK853.S84

These two works are both administrative histories of the Department of State; they supplement each other admirably, and the older of the two is by no means obsolete. Gaillard Hunt (1862-x924) served for many years in responsible posts in the Department and produced the first version of his work for use at the Chicago World's Fair of 1893 . It is particularly useful for the antecedents of the Department, the Continental Congress' Committee for Foreign Affairs, and the Confederation's Department of Foreign Affairs, and for the multiple functions, in addition to the conduct of foreign relations, which were imposed upon the Department of State after its organization in 1789 . At various times the State Department had competence in a variety of domestic concerns, such as patents, copyrights, census returns, the territories of the United States, the custody of historic documents, etc., which are now handled by specialized agencies; this book is the most convenient source of information for such activities. Professor Stuart, on the other hand, is almost exclusively concerned with the foreign affairs function, as the Department itself has been in the more recent period. He traces the organization, procedures, and personnel concerned in this function in a chronological treatment of the terms of successive secretaries of state from Thomas Jefferson (1790-93) to George C. Marshall (1947-49); his midway point falls in the administration of William Jennings Bryan (1913-15). "Policy problems are discussed only where they are vitally connected with, or illustrative of, the methods employed by the Department officials in the performance of their duties."

3603. Kent, Sherman. Strategic intelligence for American world policy. Princeton, Princeton University Press, 1949. $226 \mathrm{p}$.

$$
49-8503 \mathrm{JF}_{1525} \mathrm{I}_{6 \mathrm{~K}}
$$

The author, formerly professor of history at Yale University, has been associated with the Office of Strategic Services, the State Department, the National War College, and the Central Intelligence Agency. He defines intelligence as "the knowledge which our highly placed civilian and military men must have to safeguard the national welfare." $\mathrm{He}$ analyzes it into knowledge of three main kinds: basic descriptive, current reportorial, and speculative-evaluative. It takes an organization to produce such knowledge, and Part II deals with the organizational and administrative problems of central and departmental intelligence. Part III considers the activities required to produce intelligence, such as surveillance and research. The author is convinced that the integrity and objectivity of intelligence can be preserved only if the producers are kept adminis- 
tratively separate from the consumers. Roger Hilsman's Strategic Intelligence and National Decisions (Glencoe, Ill., Free Press, 1956. 187 p.) is an attempt to ascertain the doctrines concerning their functions and responsibilities that prevail inside and out of the national intelligence agencies, and to compare and criticize them in the interest of a greater interpenetration of knowledge and action. The research agencies, he believes, should "be thinking in terms of real problems and of the alternatives to meet these problems."

3604. McCamy, James L. The administration of American foreign affairs. New York, Knopf, I950. xiii, 364 , x p.

50-8595 JK853.M28 1950

The United States is here seen as lagging in the efficient organization of its foreign affairs agencies. The Department of State is criticized for its diffusion of activities, with "consequent confusion of total policy" and inadequate staff. The foreign affairs responsibilities of the President are not effectively coordinated, outside the work of the Bureau of the Budget, the National Security Council, and various other advisory bodies. The organization and use of information are criticized. Congress is seen as unable to fulfill its responsibility of devoting the necessary time and thought to the formulation of policy, and as failing to appropriate sufficient funds for the conduct of foreign relations.

3605. Snyder, Richard C., and Edgar S. Furniss. American foreign policy: formulation, principles, and programs. New York, Rinehart, I954. $864 \mathrm{p}$.

"Selected bibliography" at end of chapters.

A systematic introduction to the problems encountered by American foreign policy in our day, which are of so altered a character since I939 that the authors speak of "the revolution in American foreign policy." The historical introduction takes its departure from 1898 . The bulk of the text is in two parts, one on structure and processes of policy making, and the other on postwar politics in various spheres and areas. Attention is called to the multiplicity of agencies and voices in the American "decision-making process." Economic and ideological foreign policy receive separate treatment. In both Europe and the Far East, the "falsity of American wartime estimates" of capacities and intentions receives much of the blame for subsequent difficulties.

3606. Stuart, Graham H. American diplomatic and consular practice. 2d ed. New York, Appleton-Century-Crofts, 1952. $477 \mathrm{p}$.

$$
\text { 52-13689 JXI705.S75 } 1952
$$

Bibliography: p. 453-460.

A historical and functional study of the administrative practices of the Department of State and the United States Foreign Service. The organization of the Department, the Foreign Service, diplomatic duties, rights, and immunities, consular organization and practices, and a history of a representative embassy and consulate abroad (Paris) are among the subjects included. Lists of former secretaries of state and diplomatic representatives at various important posts are appended.

3607. Thomson, Charles A. H. Overseas information service of the United States Government. Washington, Brookings Institution, 1948. $397 \mathrm{p}$. 48-28231 E744. T5

An administrative history of various official services of the United States Government, I94I-48. The wartime operations of the Office of War Information are covered in detail. Since the Smith-Mundt Act, under which most of the Government's later information activities have been carried on, was not passed until 1948 , the book is of slight value for the period since its publication. The final fourth of the book is devoted to a discussion of Government information policies.

3608. Woodrow Wilson Foundation. Study Group, 1950-51. United States foreign policy: its organization and control; report. William Yandell Elliott, chairman. Pref. by Harry D. Gideonse. New York, Columbia University Press, I952. xviii, 288 p.

$$
\text { 52-14095 JXI416.W63 1950/5I }
$$

The report of a study group whose object was to stimulate academic interest in the theory and practice of United States foreign policy, and to select general problems of theoretical and practical signifcance for future study. The American system of politics by pressure and adjustment, it is maintained, has come under a new influence: its effect on foreign relations. Naiveté about human nature, the problem of national survival, the overemphasis on economic factors, and the necessity of combining morality with power are among the subjects discussed. The effect of the constitutional separation of powers on foreign policy is analyzed, and some changes making for greater efficiency are proposed.

\section{Bii. DEMOCRATIC CONTROL}

3609. Almond, Gabriel A. The American people and foreign policy. New York, Harcourt, Brace, 1950. 269 p. 50-6254 E744.A47 Half title: Institute of International Studies, Yale University. 
An attempt to place American foreign policy in its psychological and sociological context. The author considers complex questions of foreign policy as being frequently beyond the comprehension of nonspecialists, and states that the function of the public under a democratic regime is to set up certain policy criteria in the form of widely held values and expectations and judge the results of foreign policy thereby. What is needed, he concludes, is to inform and moderate the views of the leadership of the various interest groups which influence public opinion. Mr. Almond thinks that our professional idealism is particularly out of touch with moral and historical realities, and that it is unduly infuential upon the attitudes of women and young people.

36ro. Cheever, Daniel S., and Henry Field Haviland. American foreign policy and the separation of powers. Cambridge, Harvard University Press, 1952. 244 p. $\quad 52-5390 \quad J_{570 . C} 45$

The authors regard the relationship between the executive and legislative branches of government as the weakest and most critical link in the process of making our foreign policy. The present period is one of unprecedented difficulty, requiring extraordinary presidential powers, a consistency difficult to attain when our institutions encourage conflict between the President and Congress over foreign policy, and rapid decision. The book consists principally of a historical survey of relations between Congress and the President in the realm of foreign affairs, with special attention to the larger problems that have arisen since World War II. Various means of establishing cooperation through improved administrative techniques are suggested. Organizational adjustments must be accompanied by "a far stronger spirit of mutual trust between the two branches." Failure to achieve this, it is maintained, will be at the expense of American interests and prestige.

3611. Dahl, Robert A. Congress and foreign policy. New York, Harcourt, Brace, $195^{\circ}$. $305 \mathrm{p}$. 50-8588 JK1081. D32

Half title: Institute of International Studies, Yale University.

According to $\mathrm{Mr}$. Dahl, the traditional role of Congress in the process of foreign policy formulation, that of mediator between the preferences of the citizenry and the realities of international affairs as interpreted by executive proposals, is now made obsolete by the need for quick decisions. He discusses alternate solutions to the problem, which a democracy must solve in order to survive. An increased competence of the electorate in international affairs is desirable, but neither readily obtainable nor able to assert itself without adequate policy- making processes. The President's responsibility could go on expanding until it excluded Congress from any concern with foreign policy. The level of Congressional competence should be raised through more and better use of experts on committee staffs, and by establishing some agency to advise and assist Congress on policy alternatives. Collaboration between the executive and Congressional foreign policy specialists requires Congressional confidence in executive policy decisions, as is the case in Great Britain. Volume 289 of The Annals of the American Academy of Political and Social Science is entitled Congress and Foreign Relations (Philadelphia, 1953. 245 p.) and provides, in a group of informed articles, basic information on the processes of Congressional foreign policy functions and legislative-executive relations.

3612. Dangerfield, Royden J. In defense of the Senate; a study in treaty making. Norman, University of Oklahoma Press, 1933. xvii, 365 p. diagrs. (I fold.)

Bibliography: p. [353]-357.

The effect of the constitutional requirement that treaties obtain a two-thirds majority in the U.S. Senate is discussed on the basis of 832 treaties signed before 1928. The treaties which have led to violent controversy have been relatively few but of great importance. The history of the treaty-making power, the development of the Senate Committee on Foreign Relations, and cases of the amendment or obstruction of treaties are considered. The treaties studied are tabulated and classified in the appendix.

36r3. Graebner, Norman A. The new isolationism; a study in politics and foreign policy since 1950. New York, Ronald Press, 1956. 289 p. 56-11573 E835.G7

The "new isolationists," in the author's view, continue an unrealistic attitude toward foreign policy which grew up in the 19th century when America's swift successes were made possible by the British Navy and the European balance of power. The continuing illusion of American invincibility has led, in recent foreign relations, to an attitude rather than a policy of "unilateral action aimed at utopian moral goals." Soon after the election of 1948 the isolationists asserted themselves in and out of Congress and blamed the frustrations of our foreign policy upon "incompetence and even betrayal by successive administrations." The Truman and Eisenhower administrations have both come to terms with their critics by relying less upon negotiation, and more upon an inflexible attitude based upon military force, almost to the exclusion of diplomacy. The rest of the Free World has no stomach for a policy of liberation which must keep all on the brink of war, and 
would like to meet the altered Russian attitude since the death of Stalin with genuine negotiation, especially in the economic sphere. The author calls for "a flexible and imaginative [American] policy geared to a world that can find no alternative to coexistence."

36r4. Kirk, Grayson L. The study of international relations in American colleges and universities. New York, Council on Foreign Relations, 1947. II3 p. 47-5856 JXI293.U6K5

The author, at the time of publication professor of international relations, is now president of Columbia University. The book represents his reactions to a series of six regional conferences on teaching and research in international relations sponsored by the Council on Foreign Relations in 1946. The question of whether international relations should remain a subdivision of political science or become a separate discipline is taken up. Problems in undergraduate, graduate, and postdoctoral training and research are surveyed, and constructive suggestions made. Chapter 3 on graduate training reviews the types of professional career to which it may lead, and urges the rigorous selection of candidates by the universities which provide it.

3615. Markel, Lester. Public opinion and foreign policy, by Lester Markel and [others.] New York, Published for the Council on Foreign Relations by Harper, 1949. 227 p.

$$
\text { 49-I714 E744.M355 }
$$

ConTents.-Introduction: Opinion, a neglected instrument, by Lester Markel.-Foreign policy and opinion at home: Dark areas of ignorance, by Martin Kriesberg. The number one voice, by James Reston. The mirror called Congress, by Cabell Phillips. When the big guns speak, by H. W. Baldwin. More than diplomacy, by W. P. Davison.-Foreign policy and opinions abroad: Chart of the cold war, by Shepard Stone. Voices of America, by W. P. Davison. Assignment for the press, by C. D. Jackson. Two vital case histories, by Arnaldo Cortesi and "Observer."-Conclusion: Opportunity or disaster? By Lester Markel.

A cooperative project of the Council on Foreign Relations which had for chairman the Sunday editor of The New York Times. It is held that Americans have failed to give public opinion "the emphasis and direction it must have if it is to be the vital instrument we need." As a result, it is alleged, American foreign policy is understood neither at home nor abroad. Prejudice and lack of interest are presented as among the reasons why many Americans view foreign affairs with indifference. In their effort to present American policies and motives in a fair light, our agencies of information have to contend, not only with an unscrupulous Communist counter-propaganda, but with European stereotypes of American luxury and cultural vacuity.

3616. Westerfield, Bradford. Foreign policy and party politics: Pearl Harbor to Korea, by Holt Bradford Westerfield. New Haven, Yale University Press, 1955. $44^{8}$ p. $\quad 55-5990 \quad$ E806.W 455

Bibliography: p. 429-435.

Congressional reaction to administration foreign policy is examined statistically through its voting record, descriptively by party organization for foreign policy control and historically as manifested by the role of the parties in American foreign relations from World War II to the outbreak of the Korean War. The author contends that the problem of adequate democratic control of foreign policy may be resolved through partisanship, bipartisanship, or extrapartisanship. In the latter, a term coined by the author, the administration seeks to remove important foreign policy decisions from the presidential election by securing support outside party lines from influential opposition leaders, and by relying upon party discipline within its own party.

\section{Biii. POLICIES}

3617. American Foundation for Political Education. Readings in American foreign policy, edited by Robert A. Goldwin. 4th ed. Chicago, 1955. 3 v. maps. 55-4447 Ei 83.7.A55 1955

Contents. - v. I. Foreign Affairs in the American democracy. Growth and expansion. The United States and Europe. The United States and Latin America.-v. 2. The United States and the Far East. Some war aims in World War II. From "containment" to "retaliation."-v. 3. Present problems of American foreign policy. Some alternatives to present foreign policy. What principles guide American policy?

These volumes are intended to accompany a discussion program in American foreign policy sponsored by this Foundation for promoting "a more rational approach to politics." The selections, from contemporary books, articles, speeches, and public documents, are chosen to present alternative viewpoints on problems of foreign policy, and to provide the reader with a framework of facts sufficient to enable him to form his own judgment on past and present policies.

36I8. Baldwin, Hanson W. The price of power. New York, Published for the Council on Foreign Relations by Harper, 1948. 361 p.

Bibliography: p. 329-333.
48-61 $82 \quad$ E744.B2 
An attempt to discover the effect of the technical and political revolution growing out of World War II on the strategic position of the United States. The possible effect upon American democracy of the necessity to protect the American continent from attack is regarded as a key problem. The author considers a prodemocratic attitude more important to American defense than mere fear of Russia. Foreign policy must rest on aroused public opinion, not on predominance of the military in American counsels. Military, economic, strategic, intelligence, research, and human problems are discussed.

36rg. Barber, Hollis W. Foreign policies of the United States. New York, Dryden Press, I953. 614 p. $\quad 53-8259$ EI83.7.B34

The outstanding problems of American foreign policy in 1953 are outlined historically in this college textbook. After a definition of American foreign policy as determined by Congress and the administration, and as executed by the Department of State and the Foreign Service, the Cold War is treated in a discussion of American political and economic relations with the USSR and Western Europe. Secondly, attention is focused upon hemispheric relations within the Inter-American system and upon our relations with each nation in that system. There follows a summary of American relations with China and Japan. Finally there is a lengthy outline of America's role in the United Nations.

3620. Burnham, James. Containment or liberation? An inquiry into the aims of United States foreign policy. New York, J. Day, I953. $256 \mathrm{p}$. 52-12682 $\mathrm{E}_{744 \cdot \mathrm{B} 85^{8}}$

The author criticizes the policy enunciated by George Kennan in 1947, which he identifies as a policy of containment of Soviet Russia, as (I) ignoring Marxist ideology predicting an inevitable conflict between socialism and capitalism; (2) placing the United States at a disadvantage by adopting a purely defensive policy; (3) ignoring the fact that communism cannot be sealed off behind a definable border; (4) leaving vanquished peoples at the mercy of Communists; (5) lacking in moral appeal. He maintains that by consolidating the victories they have already obtained, the Communists will have won world domination. The author does not consider ideological considerations important, but nevertheless advocates an ideological campaign against communism. An extreme statement, which neglects ways and means, and is often unfair to the proponents of other views.
3621. Davis, Elmer Holmes. Two minutes till midnight. Indianapolis, Bobbs-Merrill, 1955. 207 p. 55-6823 E835.D38

The author, wartime Director of the Office of War Information, is a news analyst of long standing. In this work he considers the threat of mass destruction in the form of the hydrogen bomb and its fallout to the world as a whole and to the United States in particular. Time, he is convinced, is rapidly running out for the United States as the leading power in weapons of mass destruction. Although, at the time of the author's writing, the United States was gaining the upper hand in Europe, the Soviet Union was winning out in Asia, and this, the author thought, was the beginning of a course of victories which would ultimately compel the United States to wage war upon the Soviet Union and its growing body of satellites.

3622. Dulles, John Foster. War or peace. New York, Macmillan, 1950. $274 \mathrm{p}$.

50-725I $\mathrm{E}_{744 . \mathrm{D} 85}$

The author was an originator of the bipartisan foreign policy, and has been since 1953 Secretary of State. Here he regards an eventual war as probable, unless by "positive and well-directed efforts" it is fended off. The author frequently quotes from Stalin's Problems of Leninism, which he considers an authoritative guide to Soviet intentions. He puts his faith in the moral and religious sense of humanity, world organization, and constant vigilance. He declines to rely on materialism or militarism.

3623. Finletter, Thomas K. Power and policy; U. S. foreign policy and military power in the hydrogen age. New York, Harcourt, Brace, 1954. $408 \mathrm{p}$. 54-11328 E835.F5 A powerfully argued view of the consequences of the twin menaces, atomic fission and Russian aggression, for American foreign policy. Since the possibility of a devastating sneak attack will always be present, the primary aim of military policy must be decisive air-atomic superiority, and that of foreign policy a state of enforced universal peace and disarmament, as the only tolerable way out of present dangers. Recent American policies in both spheres are criticized as inconsistent half-measures.

3624. Fischer, John. Master plan U. S. A., an informal report on America's foreign policy and the men who make it. New York, Harper, 1951. 253 p. 51-13525 E744. F $_{55}$ An exposition of the foreign policy of the Truman administration, which is treated as consistently formulated and comparatively stable. As developed by the National Security Council, it is regarded as an attempt to "contain" Russia, through building up 
situations of strength in Europe and other potential danger points, and as aimed at the preservation of peace by making the consequences of aggression unattractive. China is not regarded as permanently hostile as long as the chance of "Titoism" exists. Technical assistance is regarded as a means of bringing about revolutionary changes favorable to the West.

3625. Kennan, George F. American diplomacy, 1900-1950. Chicago, University of Chicago Press, I951. 146 p. (Charles R. Walgreen Foundation lectures) $5^{1-12883} \quad \mathrm{E}_{744} \cdot \mathrm{K}_{3}$

The author was the first director of the Policy Planning Staff of the State Department, 1947, a member of the Institute for Advanced Study, Princeton University, 1950-1952, and Ambassador to Russia, 1952-1953. These Walgreen lectures, dealing with the relation of American diplomacy to two world wars, are followed by two articles on SovietAmerican relations originally printed in Foreign Affairs. The fifty years under consideration saw the United States move from a detached neutrality to leadership in international affairs. Mr. Kennan shows that during that period American foreign policy has normally been guided by a "legalisticmoralistic" approach to international relations. However, involvement in two global wars and in a cold war with the Soviet Union indicates that the conduct of other nations cannot usefully be judged as good or bad, nor as subject to the Anglo-Saxon concept of individual law. Our recent experiences with the Soviet Union have shown that American policy must be flexible enough to engage in war or political attrition, while continuing to build up the world's confidence in our spiritual and moral integrity.

3626. Morgenthau, Hans J. In defense of the national interest; a critical examination of American foreign policy. New York, Knopf, I95I. xii, 283, viii p.

5I-II2I7 E744.M68

An enlarged version of the author's Walgreen Foundation lectures delivered at the University of Chicago in the spring of 1950. American foreign policy, he maintains, can have only one aim: the preservation of the national security at all costs. However, we have been guilty of confusing the national interest with moral principles too often unrelated to political realities, even though the principles themselves are above reproach. Foreign relations must be conducted according to Hobbes'dictum that there is no law or morality outside of the state, and the national interest must be considered solely in terms of advantages to be gained and risks to be avoided. The morality of foreign policy decisions must not be debated, but only their efficacy in preserving our security. At the time of publication, the author believed that the vital objective of American foreign policy in Europe and Asia was the restoration, by means short of war, of the immediate post-World War II balance of power, i. e., the dislodgement of the Soviet Union from the areas it had brought under control since 1945 .

3627. Mowrer, Edgar A. The nightmare of American foreign policy. New York, Knopf, 1948. viii, 283, xxii p. 48-9096 E744.M75 The author, a journalist of wide experience, believes that President Roosevelt's policy of representing Soviet Russia as a democracy and failing to publicize Soviet diplomatic demands was an error. He does not believe that the USSR can be contained by the present system of sovereign states or by the United Nations as presently organized. He favors a grand alliance supplemented by regional Atlantic, Middle Eastern, Far Eastern, and European alliances.

3628. Osgood, Robert Endicott. Ideals and selfinterest in America's foreign relations; the great transformation of the twentieth century. [Chicago] University of Chicago Press, 1953. $491 \mathrm{p}$.

$$
\text { 53-10532 E744. O77 }
$$

A revision of the author's thesis, Harvard University.

The author argues that from the time of the Spanish-American War to World War II the United States failed to make a mature adjustment to its international environment, because it let ideals predominate and "failed, as a whole, to understand or act upon a realistic view of international relations." Alfred T. Mahan and Theodore Roosevelt are treated as realists whose imperialistic opinions discredited realism and encouraged isolationism following the American commitment in world affairs. A realistic balance between ideals and national self interest is advocated as essential. The disillusionment of the 1920's and the insecurity of the 30's and 40's are regarded as having been favorable to a realistic approach, although they were not realism itself.

3629. Reinhardt, George C. American strategy in the atomic age. Norman, University of Oklahoma Press, I955. $236 \mathrm{p}$.

55-6363 UA23.R 44

This book is a sequel to Atomic Weapons in Land Combat (Harrisburg, Pa., Military Service Pub. Co., 1953. 182 p.) written by Col. Reinhardt with Lt. Col. William R. Kintner. Col. Reinhardt, a follower of Sir Halford Mackinder's doctrine of geopolitics, finds the policy of containment an inadequate safeguard of American security. The openly conducted aggression of the Soviet Union must be opposed by a new policy which will exert direct 
pressure upon the aggressor. The United States must mass an overwhelmingly strong military force overseas which will directly threaten the Soviet Heartland. Once this is established, the United States must mobilize the non-Communist world in a coalition guided by the specific ideology of "cooperation-activity shared for mutual benefit"whose purpose is to defeat Soviet communism rather than merely to counter it.

3630. Reitzel, William, Morton A. Kaplan, and Constance G. Coblenz. United States foreign policy, 1945-1955. Washington, Brookings Institution, 1956. 535 p. maps, diagrs.

Bibliography: p. 485-5Ir.

$$
\text { 56-II440 E8I3.R }
$$

This survey, by members of the staff of the Brookings Institution, examines the position of the United States in the light of recent foreign policy decisions. In analyzing the effect of taking one course of action rather than another, the authors have divided the work into four parts. Part I reviews foreign policy goals determined during 1946-47. Part II assesses key decisions made as United States policy toward Russia developed from 1947 to 1950 . Part III discusses the decision to meet aggression with collective force, which has shaped United States policy since 1950. Part IV discusses the effect of this decision on the position of the United States in the international system of 1956, suggests methods for review of current foreign policy, and outlines action which may be taken in the future. The annotated bibliography is of value to students of international affairs.

3631. Summers, Robert E., ed. The United States and international organizations. New York, Wilson, 1952. I94 p. (The Reference shelf, v. 24, no. 5) 52-10267 JXI4I7.S8

Like the other volumes in this series, this small reference work is designed to provide a factual and analytical, though not exhaustive, background for the high school debater. Approximately 50 articles, speeches, and extracts from documents have been assembled on the general question of what type of international organization the United States should support. The articles are grouped under such topics as the United Nations and its strengths and weaknesses, NATO, the problem of regional security, the United States and European integration, world federation, American foreign policy in 1952, and the role of the United States in international affairs. Each section is preceded by an introduction written by the editor. A bibliography is included, mainly of works not utilized in the text.
3632. Tannenbaum, Frank. The American tradition in foreign policy. Norman, University of Oklahoma Press, 1955. $\quad$ i $78 \mathrm{p}$.

$$
55-6364 \quad E_{1} 83 \cdot 7 \cdot T_{35}
$$

An uncompromising reassertion of the democratic and moral bases of American foreign policy, in the light of "the doctrine of the co-ordinate state." Just as Rhode Island is of equal importance with Texas in the Union, so all states are of equal dignity in international relations, which must therefore be guided into an institutional and federal pattern. The importance of the ideal of the co-ordinate state is traced in our relationships with Latin America, the Far East, and the League of Nations. The author rejects the doctrine of Real-politik urged by Morgenthau and Kennan, and abhors the idea of dividing the world into Russian and American spheres of interest.

3633. U. S. President. U. S. participation in the U N; report by the President to the Congress for the year 1955. [Washington, U. S. Govt. Print. Off.] 1956. 277 p. ([U.S.] Dept. of State. Publication 63 I8. International organization and conference series, III, 115)

$$
\text { 47-32785 JX1977.2.U5 } \mathrm{U}_{32} \quad 1955
$$

The United Nations Participation Act of 1945 calls upon the President to transmit to Congress an annual report on United States participation in United Nations activities. These reports have regularly been prepared and published by the Department of State; variant titles were used before the present one was settled upon. The present report is the tenth, and begins with a brief account of the meeting of the United Nations held in San Francisco in June 1955 to commemorate the tenth anniversary of the signing of the Charter there. President Eisenhower's letter of transmittal affirms that the United Nations in its second decade "is increasingly vital and effective." The work of the Specialized Agencies such as the Food and Agricultural Organization and the International Monetary Fund is also included in this report. The report is organized under the following headings: "Maintenance of Peace and Security," "Economic and Social Cooperation and Human Rights," "Dependent Territories," "Legal and Constitutional Developments," and "Budgetary, Financial, and Administrative Matters." Appendixes outline the United Nations System and other organizational and statistical information; a list of all United States representatives within the System during 1955 occupies p. 271-274.

3634. The United States in world affairs, 1954. By Richard P. Stebbins and the research staff of the Council on Foreign Relations. New York, Published for the Council on Foreign Relations by 
Harper, 1956. 498 p. $\quad 32-26065 \quad$ E744.U66 1954

This annual review of the foreign relations of the United States has covered years since I93I, with the exception of the war years $194 \mathrm{I}-44$, for which no volumes were issued. Double volumes were issued for $1934-35$ and for 1945-47. The original compilers were Walter Lippmann and William O. Scroggs; Whitney H. Shepardson replaced Mr. Lippmann with the 1934-35 volume; John C. Campbell prepared the first three volumes after the war; and $\mathrm{Mr}$. Stebbins has been in charge since the 1949 volume. The present volume for 1954 is the first to omit a formal bibliography, which is replaced "by a more copious use of bibliographical footnotes at appropriate points in the text," but the classified "Chronology of World Events" (p. 465-487) is retained. After introductory chapters on the salient developments of the year, and on the political, military, and economic aspects of American foreign policy, the course of events is traced in four major areas, and a concluding chapter deals with "Disarmament and the United Nations." A companion series under the same imprint, Documents on American Foreign Relations, began with a volume for 1952, has reached that for 1955, and has frequently changed editors. A comparable series produced and published by the Brookings Institution of Washington, D. C., Major Problems of United States Foreign Policy, reached a sixth volume for I952-53, published in 1952 , but unfortunately none have appeared since. These annual volumes were more abstract in their approach, and were intended "to illustrate a technique for the study of the foreign relations of the United States closely approximating that used by Government officials in the formulation of foreign policies."

3635. Wilcox, Francis O., and Thorsten V. Kalijarvi, eds. Recent American foreign policy; basic documents 1941-1951. New York, AppletonCentury-Crofts, I952. xviii, 927 p. maps.

$$
{ }^{2-1}{ }^{2} 46 \mathrm{JX} \mathrm{J}_{4} 16 . \mathrm{W}_{5}
$$

Originally issued in 1950 as $A$ Decade of American Foreign Policy (Ist sess. 8r rst Cong., Senate document no. 123), this collection of the "more important documents and official statements bearing upon the foreign policy of the United States in the period following our entrance into World War II" was revised to include additional materials for the period 19505I. Topics covered are: wartime pronouncements regarding the postwar settlement; postwar conferences; the United Nations; the inter-American regional system; defeated and occupied areas; other areas of special interest; and current international issues. A brief commentary accompanies each item, a feature lacking in the original publication. The editors are members of the research staff of the Senate Committee on Foreign Relations.

\section{Biv. ECONOMIC POLICY}

3636. Brown, William Adams, and Redvers Opie. American foreign assistance. Washington, Brookings Institution, $1953.615 \mathrm{p}$.

Bibliography: p. $\left[5^{8} 7\right]-598$.

$$
\text { 53-II92 I HC6o.B7 }
$$

A detailed description of all forms of American assistance to foreign nations from the inauguration of Lend-Lease in March 1941 through the Mutual Security Program implemented in October $195 \mathrm{I}$. The authors emphasize that assistance for economic reconstruction, if less popular and more difficult to grasp, is no less important to ultimate security than military assistance.

3637. Ellis, Howard S. The economics of freedom; the progress and future of aid to Europe. By Howard S. Ellis assisted by the research staff of the Council on Foreign Relations. With an introd. by Dwight D. Eisenhower. New York, Published for the Council on Foreign Relations by Harper, r950. xviii, 549 p. $50-9247$ HC240.E43

A progress report on the Marshall Plan and its consequences by the staff of ten experts headed by Dr. Ellis, who was on leave from the University of California for the purpose. During two years the United States furnished between four and five billion dollars worth of aid, and European production rose by about 30 billion dollars in each year. "In comparison with the progress achieved after World War I toward reconstruction, rehabilitation and internal economic stability, Europe has scored a phenomenal success." Descriptive chapters are devoted to the objectives and methods of the program, to its financial complications, and to its implementation in the United Kingdom, Western Germany, France, and Italy.

3638. Harris, Seymour E., ed. Foreign economic policy for the United States. Cambridge, Harvard University Press, 1948. $490 \mathrm{p}$.

$$
\text { 48-4988 } \mathrm{HF}_{4} 455 . \mathrm{H}_{3}
$$

The work of 24 experts, most of them practicing economists. After individual discussions of our economic relations with Great Britain, Germany, Japan, Canada, Latin America, the U. S. S. R., and China, attention is focused on international economic agencies and tariff agreements, the European Recovery Program, and problems of international eco- 
nomic equilibrium. The editor states that the International Trade Organization, the International Monetary Fund, and the International Bank for Reconstruction and Development represent "a bit of sovereignty sloughed off the sovereign states and grafted on to the international agencies operating in behalf of all countries."

3639. Mikesell, Raymond F. United States economic policy and international relations. New York, McGraw-Hill, 1952. 341 p. (Economics handbook series) $51-12630$ HFI455.M 53

A comprehensive survey of American foreign economic policy. The first fourth of the book is devoted to the years 1919-39; the balance to the period since 1939, with major emphasis on the period since World War II. Monetary, investment, and defense policy are the leading topics discussed, with separate chapters on the Truman Doctrine, the Marshall Plan, and American objectives in Western Europe. The Truman Doctrine is regarded as marking the acceptance of international responsibility, the New Deal economic program having accustomed the American people to governmental action in economic affairs.

3640. Price, Harry Bayard. The Marshall plan and its meaning. Ithaca, N. Y., Cornell University Press, 1955. xvi, 424 p.

$$
\text { 55-14635 HC6o.P7 }
$$

"Published under the auspices of the Governmental Affairs Institute, Washington, D. C."

Born of the effects of World War II upon the economies of Europe, Asia, and Africa, the Marshall Plan was intended to ensure long-term recovery rather than to provide temporary relief. Analysis of 300 interviews with participating ERP officials, and of industrial, agricultural, and monetary statistics forms the basis of this evaluation, which shows that the Marshall Plan did place Europe in a position of economic stability. This survey covers all countries which received aid under the European Recovery Program as well as Asiatic countries which were granted aid by the other agencies of the Economic Cooperation Administration.
3641. U. S. Dept. of State. Point four, cooperative program for aid in the development of economically underdeveloped areas [prepared with assistance of an Interdepartmental Advisory Committee on Technical Assistance and of the staff of the National Advisory Council. Rev. Jan. 1950. Washington, 1950] 167 p. map, diagrs. (Its Publication 3719. Economic cooperation series, 24) $50-60118 \quad \mathrm{HC}_{59} . \mathrm{A}_{3} \mathrm{U}_{52} 1950$

Issued also without series title.

The official program of American technical assistance to underdeveloped areas, e. g., Asia, Africa, and Latin America, first proposed by President Truman in his 1949 inaugural address, is outlined. The encouragement of capital investment, both domestic and foreign, is proposed as a second means of stimulating the economic improvement and democratization of these regions. After a consideration of the problem, its financial aspects are explored.

3642. Woodrow Wilson Foundation. The political economy of American foreign policy; its concepts, strategy, and limits; report of a study group sponsored by the Woodrow Wilson Foundation and the National Planning Association. [William Y. Elliott, chairman] New York, Holt, 1955. Xv, 4I4 p. 55-6125 HFi 455.W6

An inquiry by a study group of nine prominent experts, who find the central objective of American foreign economic policy to be "the construction of a better integrated and more effectively functioning international economic system." Under present-day conditions, international economic re-integration can be brought about only through "a deliberate coordination of national economic policies either by cooperation among national governments or-more effectively and reliably - by supranational authorities." Means for increasing the effectiveness of such existing grouping as the European Payments Union are considered, as well as for opening up the domestic market of the United States to a greater flow of imports from Europe. The role of the United States in increasing and regularizing the flow of capital and technology to the underdeveloped countries is outlined. 


\section{Military History and the Armed Forces}

$\left.\llbracket \begin{array}{rlr}\text { A. General Works } & 3643-3652 \\ \text { B. The Army } & 3653-3665 \\ \text { C. The Navy } & 3666-3677 \\ \text { D. Wars of the United States } \\ \text { Di. The Revolution } \\ \text { Dii. I798-I848 } \\ \text { Diii. The Civil War } \\ \text { Div. The Spanish-American War } \\ \text { Dv. World War I } & 3678-3684 \\ \text { Dvi. World War II } & 3695-3689 \\ & & 3709-37-3708 \\ & \end{array}\right]$

THE United States has been, until very recent times, a quite unmilitary nation with a very I small standing army. Here the English tradition of distrust of armed forces, and control of military by civilian authorities, has continued or been strengthened, inasmuch as there has been no general agreement on the necessity of a large navy. Nevertheless, the nation was born in war, and has fought six considerable wars since, not to mention lesser conflicts such as the innumerable ones with Indian tribes on its western frontier. Each large war has demanded a sudden and severe effort of rearmament, and a corresponding one of organization which has usually proved the more difficult. Three of these wars have absorbed during their time nearly the whole of the national energies. Such being the case, the literature which is sampled in this chapter is an indispensable part of the national record, but it must not be taken to imply any predominance of the military element in American life, thought, or character. There have been Generals in the White House, but only three of them professional soldiers, and only one of these had spent his adult life in uninterrupted military service.

This relative unconcern for the military side of life is reflected in the literature. The United States has never undertaken any large-scale publication of the military records of the Revolution, the War of 1812, the Mexican War, or of World War I. Military history was for the most part a neglected subject in the graduate schools of American universities from their establishment, and especially from 19191939. The selections that follow contain only three works of academic origin earlier than World War

II: those of Hatch (no. 3681), Smith (3689), and Shannon (3702), and the second of these is a general history which might well have been placed in Chapter VIII. Nor, if we except the Civil War, was there any considerable output of such literature on the part of professional soldiers and sailors. Admiral Mahan (no. 3688) is the great exception, but the unfinished magnum opus of General Emory Upton (no. 3651) had to wait over 20 years for publication. Some valuable work has been contributed by leisured amateurs such as Gardner W. Allen and Hoffman Nickerson. In consequence of all this, there is no adequate general history of the U.S. Army, or general history of the Revolutionary War, or operational history of World War I. Since the last war, of course, the picture is entirely changed: the armed forces have their own large staffs of professional historians, and the universities are increasingly giving the subject its due emphasis.

The arrangement by sections that follows is selfexplanatory, save that Section A, General Works, 
is necessarily a mélange, including books on the civil-military relation, on national military policy, on veterans' problems and organizations, and on conscientious objectors, and a biography of a prophet of air power. There is no separate section on the Air Force simply because its independent status is too recent, whence the state of the literature does not warrant it.

\section{A. General Works}

3643. Bernardo, C. Joseph, and Eugene H. Bacon. American military policy, its development since 1775. Harrisburg, Pa., Military Service Pub. Co., 1955. $512 \mathrm{p}$. 55-7529 UA23. B43

A routine textbook which provides the only general survey of American military policy from the Revolution through the Korean War. Naval policy is included, but in subordinate and inadequate emphasis. The size of the Army receives chief attention, and questions of organization, training, staff, mobilization, and economic resources follow in importance. Public opinion is rather mechanically presented through brief extracts from newspapers and magazines. The authors regularly discount "the specter of militarism."

3643a. Brophy, Arnold. The Air Force; a panorama of the Nation's youngest service. Foreword by Robert L. Scott, Jr. [New York] Gilbert Press; distributed by Messner, 1956. $362 \mathrm{p}$. 56-6784 UG633. B76

This is the only comprehensive history of the United States Air Force in a single volume. The function, organizational structure, and type and number of equipment and personnel of Air Force staff, combat, operational, technical, transport, supply, and training commands are summarized as each comes into operation to repel a hypothetical attack on North America. Such branches as the Strategic Air Command, the Air University, the Military Air Transport Service, and the Air Materiel Command are described along with a short history of American military aviation from its formation as a unit in the Army Signal Corps in 1907 until the present (1955). Industry's contribution is acknowledged by the inclusion of short histories of the principal industries now under contract with the Air Force. Tables of casualty, personnel, aircrafft, and fiscal statistics help the average reader to realize the scope of the Nation's youngest service.

3644. Davies, Wallace Evan. Patriotism on parade; the story of veterans' and hereditary organizations in America, 1783-1900. Cambridge, Harvard University Press, I955. xiv, 388 p. (Harvard historical studies, v. 66)

55-II95I EI72.7. $\mathrm{D}_{3}$
"Bibliographical essay": p. [359]-367.

Although the Society of the Cincinnati was founded in 1783 , it remained "a poorly organized and ineffective affair," of negligible influence upon American life. The pattern for patriotic societies was really set by the survivors of the Civil War in the Grand Army of the Republic, and its extraordinary success led to a mushrooming of other groups of veterans and of veterans' relatives. This led, in the 1890's, to a rash of societies open only to persons of requisite pedigree, of which the Daughters of the American Revolution is the most conspicuous. This study traces their influence and interest in such varied subjects as veterans' preference, pensions, the teaching of history, immigration policy, labor disturbances, etc.

3644a. Dupuy, Richard Ernest, and Trevor N. Dupuy. Military heritage of America. New York, McGraw-Hill, 1956. 794 p. (McGrawHill series in history) 55-11169 EI81.D8

Bibliography: p. 729-752.

Written by a father-and-son team, both of whom hold the rank of colonel in the U. S. Army, this work, in a preliminary form, has been used by the Harvard Department of Military Science and Tactics since 1954 and is the only up-to-date survey of American "military history presented from the American point of view." In order to acquaint the general reading public with the art of war as practiced by Americans, all prominent battles and campaigns of the eight major wars participated in by the United States from the Revolution (1775-83) to the Korean War (1950-53) are outlined along with short accounts of Indian wars and police actions involving American forces. The nonmilitary reader is aided in following the operational accounts by numerous battle plans and maps in the text, clear definitions of the principles and terms of military strategy and tactics, and a brief account of world military history since the Battle of Marathon ( 490 B. C.). It is the authors' belief that the general rules of strategy and tactics have not changed and must be followed by United States forces in the future as they have been followed in the past. 
3645. Jones, Richard Seelye. A history of the American Legion. Indianapolis, BobbsMerrill, 1946. 393 p. $\quad 46-7962$ D570.AIJ6 Not an official history of the largest and most influential organization of World War I veterans, but written with full access to the Legion's quite complete official records. The author gives attention to organization and finances, and provides an objective treatment of such controversial issues as the bonus, education, and un-Americanism.

3646. Kerwin, Jerome G., ed. Civil-military relationships in American life. Chicago, University of Chicago Press, 1948. 18I p. (Chicago University. Charles R. Walgreen Foundation lectures)

48-7342 UA23.K 415

A series of eight lectures by Hanson W. Baldwin, Charles E. Merriam, T. V. Smith, Adlai Stevenson, and others. Their purpose "is to identify the change in conditions which has caused a much greater pervasiveness of the military in American life and at the same time to raise the question of how our cherished freedoms can be preserved by the safeguarding of the predominancy of civilian power."

3647. Levine, Isaac Don. Mitchell, pioneer of air power. New York, Duell, Sloan, \& Pearce, 1943. 420 p. 43-5105I UG633.M $45 \mathrm{~L}_{4}$ "Mitchell's own writings": p. 40I-405.

A biography based on Mitchell's own papers and sharing the strenuous partisanship of its subject. After his court-martial in 1925, William Mitchell resigned from the Army and devoted himself to propaganda on behalf of the major development of air power. He died in 1936 at the age of 56 , worn out by his struggle to convert a reluctant military hierarchy. In 1945 he was posthumously awarded the Medal of Honor and the rank of major general.

3648. Palmer, John McAuley. America in arms; the experience of the United States with military organization. New Haven, Yale University Press, I94I. 207 p. $\quad 4$ I-9795 UA25.P27

Far slighter than Upton's massive work (no. 3651 ), it pursues throughout our military history the single theme of a "well-organized militia" on the Swiss model, as recommended by General Washington in his "Sentiments on a Peace Establishment" of ${ }^{7} 783$. Our military ills are traced to its absence, and to the "ill-organized militia" and the "expansible standing army" which came to be substituted.

3649. Sibley, Mulford Q., and Philip E. Jacob. Conscription of conscience; the American state and the conscientious objector, 1940-1947.
Ithaca, Cornell University Press, 1952. 580 p. (Cornell studies in civil liberty)

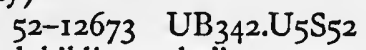
566.

"Selected and annotated bibliography": p. 549-

Because of inadequate records the treatment of the conscientious objector by draft boards and the armed services is sketchily presented, but the 12,000 inmates of Civilian Public Service Camps are thoroughly studied. The authors conclude that, largely because of the violent hostility of special groups channeled through veterans' organizations, only a very limited degree of tolerance was achieved.

3650. Smith, Louis. American democracy and military power; a study of civil control of the military power in the United States. Chicago, University of Chicago Press, I95I. xv, 370 p. (Studies in public administration)

$5 \mathrm{I}-\mathrm{I} 3393 \quad \mathrm{JK}_{55} 8 . \mathrm{S}_{5}$

A comprehensive analysis of a problem which has been present from the foundation of the Republic, but has become increasingly urgent with total war and continuing crisis. The book combines theoretical and historical considerations with administrative practice, in describing the control of national armed forces by the President, executive departments, Congress and its committees, and the judiciary.

365r. Upton, Emory. The military policy of the United States. 4th impression. Washington, Govt. Print. Off., I917. xxiii, 495 p.

War Department document no. 290. War 18-9 UA23.U 75 1917

Edited by Joseph P. Sanger, assisted by William D. Beach and Charles D. Rhodes, of the Military Information Division of the General Staff.

The classic indictment of the early failures of American democracy in maintaining an army of trained officers and men, and in providing for its effective organization and command. General Upton had covered the campaigns of 1862 when his death in I88I left the manuscript unfinished; it was rediscovered and published by Secretary Elihu Root in 1904 .

3652. Wecter, Dixon. When Johnny comes marching home. [Boston] Houghton Mifflin, 1944. 588 p. (A Life-in-America prize book) Bibliographical references included EI $8 \mathrm{r}$.W 43 (p. [559]-577).

A review of demobilization and veterans' problems after our first three major wars: the Revolution, Civil War, and World War I, with some appraisal of prospects from the viewpoint of 1944. Neces- 
sarily incomplete, it is based to a remarkable degree on veterans' own narratives and other primary sources. It emphasizes the common soldier's own attitudes, his adjustment during his first five years of civilian life, and the reaction that follows the high endeavor of war. Over the period covered, the nation's sense of responsibility toward the soldier substantially widened.

\section{B. The Army}

3653. Carter, William G. Harding. Creation of the American General Staff. Personal narrative of the General Staff system of the American Army. Washington, Govt. Print. Off., 1924. 65 p. ([U.S.] 68th Cong., Ist sess. Senate. Document 1I9) 24-26546 UB223.C

The Army entered the 2oth century without any effective agency of planning or higher command. During the next few years Elihu Root, Secretary of War, and W.H. Carter, Assistant Adjutant General, collaborated first to draft and secure the passage of the Act of Feb. 14, 1903, establishing a General Staff Corps, and then to organize the staff so authorized. General Carter's personal narrative must be sought in a Congressional document printed 20 years later.

3654. Carter, William G. Harding. The life of Lieutenant General Chaffee. Chicago, University of Chicago Press, 1917. $296 \mathrm{p}$.

18-32 Er $8 \mathrm{r} . \mathrm{C}_{43}$

Adna Romanza Chaffee (1842-1914) was an Ohio farm boy who enlisted in the Regular Army the day after Bull Run, and retired in 1906 as lieutenant general and chief of staff. His army career included a maximum of active service, as a cavalry officer under Sheridan, as an Indian fighter under Crook, in the Santiago campaign of 1898 , in command of the relief expedition to Pekin, and in pacifying the Philippines. General Carter tells a very plain tale, but the indomitable spirit of this hard-bitten old campaigner shows through.

3655. Elliott, Charles Winslow. Winfield Scott, the soldier and the man. New York, Macmillan, 1937. xviii, 817 p. $37-18570 \quad E_{403}$.r.S4E6

Bibliography: p. $769-78 \mathrm{r}$.

Scott (1786-1866) entered the Regular Army in 1808 , made his reputation and achieved general rank in the hardest fighting on the Niagara frontier $(1813-14)$, succeeded as commander-in-chief in I84I, conducted one of the most brilliant campaigns in history against Mexico City in 1847 , ran for President in 1852 , and did all he could to hold the Union cause together at the outset of the Civil War. Major Elliott aimed to write a definitive biography, and quotes at length from a great variety of original sources to produce a work of great detail, but no more so than the subject deserves. Scott's own Memoirs (New York, Sheldon, 1864. 653 p.) are rather naive and full of special pleading. There are reminiscences of value in the memoirs of his sometime aide, Erasmus D. Keyes (no. 27I I).

3656. Forman, Sidney. West Point; a history of the United States Military Academy. New York, Columbia University Press, 1950. 255 p.

Thesis-Columbia University. 50-8255 U410.LiF6

Bibliography: p. [229]-242.

The national Military Academy was founded in 1802 , enlarged in 1812 , and given its characteristic impress during the superintendency of Sylvanus Thayer in $1817-33$. Formed on French models, it has always emphasized a scientific curriculum, physical training, and rigid discipline, and has been the recurrent target of civilian criticism. This concise historical sketch emphasizes its success in training leaders.

3657. Ganoe, William Addleman. The history of the United States Army. Rev. ed. New York, Appleton-Century, 1942. 640 p.

$$
\text { 42-20792 Er8r.Gr7 } 1942
$$

"Selected bibliography": p. 557-593.

Those wishing to read a general narrative may be referred to Spaulding below (no. 3664), but the strictly chronological treatment and the marginal dating of every incident render this volume very useful for reference consultation. It provides indeed well-nigh the only peacetime annals of the Army in any printed work. There are no maps, but some serviceable appendices.

3658. Gillie, Mildred $\mathrm{H}$. Forging the thunderbolt, a history of the development of the Armored Force. Harrisburg, Pa., Military Service Pub. Co., 1947. $330 \mathrm{p}$. $47-6050 \quad \mathrm{UA}_{3} 0 . \mathrm{G}_{5}$

In Algeria early in 1943, American tanks proved that they could stand up to Rommel's armored veterans. The development which made this result possible is here described, beginning with the establishment of a permanent mechanized force in 1930 . 
The central figure is the younger Adna R. Chaffee (1884-194I), who wore himself out while hastening the organization and training of the Armored Force.

3659. Herr, John K., and Edward S. Wallace. The story of the U. S. Cavalry, 1775-1942. Boston, Little, Brown, r953. 275 p.

53-73.9 UE:23. $\mathrm{H}_{4}$

An appreciative sketch of the achievements of the mounted forces in the wars of the United States, copiously illustrated with prints and photographs well reproduced. General Herr was the last Chief of Cavalry of the United States Army. Nostalgic in tone, the book concludes with a plea for a limited retention of mounted troops in the establishment.

3660. Jacobs, James Ripley. The beginning of the U. S. Army, 1783-1812. Princeton, Princeton University Press, 1947. 419 p.

Bibliography: p. $\left[3^{8} 7\right]-397$.

47-5I40 EI8r.J2

This narrative treatment of the three post-Revolutionary 'decades emphasizes the Indian fighting which secured the settlements of the Old Northwest, the extraordinary intrigues of James Wilkinson, commander-in-chief after 1796, and the occupation, exploration, and policing of the Louisiana Purchase. The author condemns the "cheeseparing" of the Democratic administrations after 180r, and pronounces Secretaries Dearborn and Eustis unequal to their tasks of organization.

366r. Kreidberg, Marvin A., and Merton G. Henry. History of military mobilization in the United States Army, 1775-1945. [Washington] Dept. of the Army, r955. 721 p. illus. ([U. S.] Dept. of the Army. Pamphlet no. 20212) 56-60717 UI5.U64, no. 20-212 A preliminary draft of parts $\mathrm{I}-2$ was issued in 1953.

Bibliography: p. 698-705.

A study intended to provide staff officers, students at Army schools, and others with detailed information on past mobilizations-"the assembling and organizing of troops, materiel, and equipment for active military service in time of war or other emergency"-and their lessons. Brief accounts of the mobilizations of $1775,1812,1846,1861$, and 1898 precede comprehensive descriptions of the planning and preparations for United States participation in two world wars. The new and unexampled scale of operations in $1917-18$, and the need for economic mobilization caused nearly as much confusion and improvisation as in earlier wars, despite a degree of preplanning. The lessons learned from this experience were only partly utilized in the interwar period, since planning was based upon mobilization following rather than preceding the outbreak of war, and partial mobilization was already in progress by December 7, 1941. Integrated military, industrial, and agricultural mobilization plans must be made prior to any future wars, and must be flexible enough to meet limited as well as total war.

3662. Matthews, William, and Dixon Wecter. Our soldiers speak, I775-1918. Boston, Little, Brown, r943. 365 p. 43-4305 Er8r.M34 "Bibliography and acknowledgments": p. 360365 .

"The purpose of this book is to let the common soldier, private or noncom, tell the story of his share in America's wars." An anthology of extracts from soldiers' diaries and letters, rather hastily put together during World War II, it concentrates on material bearing on important operations.

3663. Prucha, Francis Paul. Broadax and bayonet; the role of the United States Army in the development of the Northwest, I815-1860. [Madison] State Historical Society of Wisconsin, 1953. $263 \mathrm{p}$.

53-65I I $\mathrm{F}_{597 .} \mathrm{P}_{7}$

A work of original research which stands almost alone in relating the Army's work to the peaceful processes of territorial expansion and social development. Studying the 13 army posts established in Wisconsin, Iowa, Minnesota, and northern Illinois, the author demonstrates their importance for Indian and land policy administration, as cash markets for the early settlers, and as centers of exploration, roadbuilding, and cultural development.

3664. Spaulding, Oliver Lyman. The United States Army in war and peace. New York, Putnam, 1937. $541 \mathrm{p}$.

Bibliography: p. 501-513.

The author aims "to trace the development of the Army, its physical and spiritual growth," rather than to concentrate upon military operations, but his book is nevertheless largely a concise narrative of campaigns from the Colonial Period through World War I. There are, in addition, occasional summaries concerning weapons and several chapters on the peacetime activities of the Army.

3665. U.S. Dept. of the Army. Office of Military History. The personnel replacement system in the United States Army, by Leonard L. Lerwill, lieutenant colonel, Infantry, United States Army. [Washington] I952-53. 2 v.

53-6oI5I UB323.A54 
Bibliography: v. 2, p. $457-468$.

Contents.-v. I. Colonial period-World War I.-v. 2. World War II.

Replacement being the current official name for the process historically known as recruitment, this constitutes a history of the raising of the armies of the United States during its successive wars. Designed for use in the Army school system, it is severely factual, but the first unitary treatment of a subject of special importance in a democracy.

\section{The Navy}

3666. Chapelle, Howard I. The history of the American sailing Navy; the ships and their development. New York, Norton, 1949. xxiii, $55^{8} \mathrm{p}$. 49-48709 $\mathrm{VA}_{5} 6 . \mathrm{C}_{5}$

Naval history from the standpoint of marine architecture, extending from colonial shipbuilding to the close of the era of sail about 1855 . Based on surviving ship-plans in the National Archives, the text is illustrated by 32 folding plans and 155 figures. The technical material is skillfully integrated with national affairs, naval policy, and naval administration.

3667. Knox, Dudley W. A history of the United States Navy. Rev. ed. New York, Putnam, 1948. xxiii, 704 p. $\quad 48-2547 \quad$ Ei 82.K77 1948

A concise, balanced, and accurate historical sketch of the Navy in action through World War II, with adequate emphasis on the strategic situations basic to the achievements of fleets or single vessels. There are numerous maps and diagrams, largely drawn from earlier publications. It contains little on the development of ships, weapons, administration, education, or bluejacket life.

3668. Metcalf, Clyde H. A history of the United States Marine Corps. New York, Putnam, 1939. $584 \mathrm{p}$. 39-6652 VE23.M45 Marines were authorized by the Continental Congress in November 1775, and the present Marine Corps has been in existence since July 1798. Originally adjuncts to the old type of ship-to-ship fighting, since the Mexican War marines have had their major employment in establishing overseas beachheads. During the first three decades of the 2oth century they were a primary instrument of the United States' policy in the Caribbean. Col. Metcalf describes their active operations down to 1938 in great detail, with incidental passages on their organization and administration. Jeter $A$. Isely and Philip A. Crowl's The U.S. Marines and Amphibious War; Its Theory and Its Practice in the Pacific (Princeton, Princeton University Press, 1951. 636 p.) provides a comparable chronicle for World War II.
3669. Mitchell, Donald W. History of the modern American Navy, from 1883 through Pearl Harbor. New York, Knopf, 1946. xiv, 477, $\mathrm{xxv}$.

Bibliography: p. $455-477$. 46-4382 Er 82.M65

"An interpretative and comprehensive general history" since the revival of 1883 , based entirely on printed materials and intended for the lay reader. Its balance of policy, matériel, organization, administration, and operations is superior to that of any previous history, and it incorporates such "previously underemphasized subjects" as naval aid in diplomacy and polar exploration, and naval aspects of the munitions problem. The author is critical both of the Navy's performance and of its personnel policies, particularly its failure to promote according to ability.

3670. Peck, Taylor. Round-shot to rockets; a history of the Washington Navy Yard and U.S.

Naval Gun Factory. Annapolis, United States Naval Institute, 1949. $\mathrm{xx}, 267 \mathrm{p}$.

49-1 $16 \mathrm{r}_{5}$ VA70. $\mathrm{W}_{3} \mathrm{P}_{4}$

The only full-length study of a Government navy yard, and one which effectively combines local circumstances, the current of national history, technological developments, and administrative changes. The Washington Yard, established with the city in 1800 , began specializing in ordnance in 1847 , and during the two World Wars became exclusively occupied with this function.

367x. Potter, Elmer B., ed. The United States and world sea power. Englewood Cliffs [N. J.] Prentice-Hall, I955. 963 p.

Bibliography: p. 923-938. 55-9323 Er 82.P8

A monster textbook which presents the naval history of Western Civilization since the Graeco-Persian Wars, but gives special attention to the place of the United States in that development. Since the emphasis is on major fleets and strategy, the American story down to $186 \mathrm{I}$ is treated as the small-scale affair that it was, but the Civil and subsequent wars receive the detailed treatment accorded to major 
conflicts. Despite the multiple authorship, a coherent point of view, and a balanced emphasis on both technological progress and fighting doctrine, contribute to a unitary impression.

3672. Puleston, William D. Mahan; the life and work of Captain Alfred Thayer Mahan. Neww Haven, Yale University Press, 1939. 380 p. 39-1096 6 E1 $82 . \mathrm{M}_{25} 6$

List of Mahan's writings: p. [359]-364.

Mahan (1840-19I4) saw service in the blockading squadrons of the Civil War and sat on the threeman War Board which directed the naval operations of the Spanish-American War. In the interval, and largely as a result of his appointment to the presidency of the Naval War College in 1886 , he had become a world-famous historian and the great theorist of the place of seapower in international relations. Captain Puleston uses Mahan's correspondence to elucidate the development of his characteristic outlook and doctrines, and to illustrate his remarkable influence abroad. Mahan's own From Sail to Steam; Recollections of Naval Life (New York, Harper, 1907. 325 p.) is more rewarding for its picture of the post-Civil War Navy than for any revelation of the man.

3673. Sprout, Harold H., and Margaret Sprout. The rise of American naval power, 1776I9I8. Rev. ed. Princeton, Princeton University Press, 1942. 404 p.

NNC

3674. Sprout, Harold H., and Margaret Sprout. Toward a new order of sea power; American naval policy and the world scene, 1918-1922. 2d ed. Princeton, Princeton University Press, 1943. $336 \mathrm{p}$. A43-2765 Ei82.S79 1943

The first title is an indispensable work which breaks new ground in reviewing the outlook of national authorities upon seapower from the outbreak of the Revolution, and the consequences in warships, trained personnel, and organization for combat. It formulates the lessons of America's successive naval wars and indicates the extent to which they have been heeded in subsequent policy. The sequel describes, on a much larger scale, the post-Versailles situation in world seapower, the revolt against "navalism" in America, and the partial limitation of naval armaments by the Washington Conference of I922.

3675. Taylor, Albert $H$. The first twenty-five years of the Naval Research Laboratory. Washington, Navy Dept., I948. 75 p.

\section{"Navexos $\mathrm{P}-549 . "$}

$$
4^{8-46752} \quad \mathrm{~V}_{394 . \mathrm{B}_{4} \mathrm{~T}_{3}}
$$

A concise account, by one of its original staff members, of the scientific organ of the Navy Department, which was first planned in 1916 but not brought into being until ig23. In spite of a lean budget, the Laboratory succeeded in developing radar and a host of other devices which profoundly affected marine warfare during I942-45.

3676. Turnbull, Archibald D., and Clifford L. Lord. History of United States naval aviation. New Haven, Yale University Press, I949. $345 \mathrm{p}$.

"Sources": p. [324]-331.

49-II8I8 VG93.T8

Not an official history, but prepared by two Navy historians with complete access to official records. It carries the story from Igro, when the Navy Department first assigned an officer to watch aviation developments, through World War I bombing, the first transatlantic flights, the first carriers, and the experimental bombings and controversies of the I920's, to the outbreak of World War II.

3677. U. S. Office of the Comptroller of the Navy. The naval establishment, its growth and necessity for expansion, 1930-1950. [Washington] 195I. $17^{8} \mathrm{p}$.

"NavEvox-P-ro38." 52-63190 VA53.A74

A document which seeks to explain and justify the increasing expense of the naval establishment over two decades. Apart from the element of inflation, the essential facts are that in 1950 there were 456,000 officers and men as against 116,000 in 1930 , 645 vessels as against 317 , and 14,030 aircraft as against 989. Many organizational charts and data are included.

\section{Wars of the United States}

\section{Di. WARS: THE REVOLUTION}

3678. Allen, Gardner W. A naval history of the American Revolution. Boston, Houghton Mifflin, 1913. 2 v. (752 p.)
"Sources of information": v. 2, p. [671]-686.

Utilizes British and American archival and other manuscript sources, as well as all primary records in print, to produce a very full narrative of all operations of warships under Continental commission, in which many extracts from first-hand authorities are 
incorporated. Within its sphere it is very nearly definitive, but it has only incidental treatment of the State navies, the privateers which so grievously harried British commerce, and of marine administration, which last receives thorough analysis in Charles O. Paullin's The Navy of the American Revolution (Chicago [Burrows] 1906. 549 p.). Nor does it enter into the fateful large-scale operations of the French, Spanish, and British navies from 1779, which may be followed in Sir William M. James' The British Navy in Adversity (London, Longmans, Green, 1926. 459 p.).

3679. Bolton, Charles Knowles. The private soldier under Washington. New York, Scribner, 1902. 258 p. 2-23616 E255.B69 Old as it is, this remains the only rounded treatment of the soldiers who made up the armies that won American independence. It is based upon a wide exploration of original materials, many of which are reproduced as illustrations. Among the subjects handled are firearms, the officer-private relationship, camp organization, diversions, hospitals, and transport.

3680. Frothingham, Thomas G. Washington, Commander in Chief. Boston, Houghton Miflin, 1930. 404 p. $\quad 30-24708 \mathrm{HE}_{312.25} . \mathrm{F}_{94}$

Covers Washington's education, prior military experience, and appointment, but is primarily a military history of the Revolutionary War, including both the operations conducted by Washington, and the others as seen from headquarters of the commander-in-chief of the Continental Army. It is based on the older editions of Washington's writings, but remains a clear and reliable outline.

3681. Hatch, Louis Clinton. The administration of the American Revolutionary Army. New York, Longmans, Green, 1904. 229 p. (Harvard historical studies, v. 10) 4-1599 E255. H36

"List of authorities cited": p. 210-215.

The American colonists, if sturdy material, "knew little of military training or military subordination." The Continental Congress and their commander-inchief had therefore the task of creating an effective military organization nearly from scratch, and this volume tells how they performed it and what major problems arose in its course. A major aim was the creation of a corps of officers, and questions of rank had to be settled, native officers given proper rights against a flood of foreign claimants, and reasonable incentives provided. The several outbreaks of insubordination toward the war's end are analyzed. A solid dissertation, which half a century of scholarship has failed to replace.
3682. Nickerson, Hoffman. The turning point of the Revolution; or, Burgoyne in America. Boston, Houghton Mifflin, I928. $500 \mathrm{p}$.

Bibliography: p. [48I]-486. 28-10475 E233.N63

A leisurely narrative of the campaign of Saratoga (1778) by a philosophical student of the art of war, with exceptional knowledge of the armies and campaigns of I8th-century Europe. Howe and Germaine spoiled the decisive blow which would have cut the Union in two, the General by planning the diversionary attack on Philadelphia, and the Minister by failing to veto it. Burgoyne himself ruined his remaining prospects by relaxing after his easy capture of Ticonderoga. His surrender brought France in, and "Yorktown was the child of Saratoga."

3683. Ward, Christopher. The War of the Revolution; edited by John Richard Alden. New York, Macmillan, 1952. 2 v. (989 p.)

Bibliography: v. 2, p. 943 -954.

$$
\text { 52-14233 } \mathrm{E}_{230} \text {. W } 34
$$

Mr. Ward published his detailed battle history of The Delaware Continentals, $1776-1783$ in 1941 (Wilmington, Del., The Historical Society of Delaware, 620 p.) and before his death two years later had expanded it into a nearly complete narrative of the military operations on land. Prof. Alden had only to add a chapter on G. R. Clark's campaign in the West, correct some slips, and add a few citations. The result has a minimum of background materials, as well as of strategic summaries and conclusions, but excels in the presentation of detailed and accurate battle reports. The narrative first disposes of "The War in the North," and then, a third of the way through volume 2, returns to 1775 and begins "The War in the South," concluding with Yorktown. Willard M. Wallace's Appeal to Arms (New York, Harper, 1951. 308 p.) gets a welldocumented military narrative into briefer compass, with considerably less tactical detail but more strategic commentary.

3684. Wildes, Harry Emerson. Anthony Wayne, trouble shooter of the American Revolution. New York, Harcourt, Brace, 1941. 514 p.

Bibliography: p. $4^{89-501 .}$

$$
4 \mathrm{I}-18202 \quad \mathrm{E}_{207} \mathrm{~W}_{35} \mathrm{~W}_{5}
$$

Wayne, a prosperous farmer-tanner of Chester County, $\mathrm{Pa}$., without military training or experience, was a rather flamboyant and convivial individual, who was yet a born leader of men, a close student of the military classics, and a commander who combined careful planning with great vigor of execution. This biography, which makes full use of Wayne's own papers as well as much supplementary research, 
is spirited enough, and indeed the first "to put the warrior-statesman in his proper social, economic, political, and military setting," but is considerably less successful in elucidating military operations.

\section{Dii. WARS: $1798-1848$}

3685. Allen, Gardner W. Our naval war with France. Boston, Houghton Mifflin [192-]

$323 \mathrm{p}$. $\quad 30-18792 \quad \mathrm{E}_{323}$. $\mathrm{A}_{422}$ "Sources of information": p. [283]-290.

First published in 1909.

3686. Allen, Gardner W. Our navy and the Barbary corsairs. Boston, Houghton Mifflin, 1905. 354 p. 26-9008 E335.A422 "Sources of information": p. [305]-311.

Although the U.S. Office of Naval Records and Library has since published extensive collections of Naval Documents on the quasi-war with France (7 v., 1935-38) and the Barbary wars (6 v., I93944), Mr. Allen's careful, documented, and unexciting volumes remain the most useful monographs for the earliest exploits of the restored Navy. For the diplomatic side of the second title, Ray W. Irwin's The Diplomatic Relations of the United States with the Barbary Powers (Chapel Hill, University of North Carolina Press, 1931. 225 p.) is somewhat, if not greatly, to be preferred.

3687. Beirne, Francis F. The War of 1812 . New York, Dutton, 1949. $410 \mathrm{p}$.

Bibliography: p. 393-395.

$$
4^{8-9712} \mathrm{E}_{354 \cdot \mathrm{B}_{44}}
$$

For a detailed and documentary general history of the War of 1812 , the student must still resort to Henry Adams' famous History of the United States, I80I-I8I7 (q. v.). Mr. Beirne, a Baltimore journalist, readily admits his primary indebtedness to Adams and to the topographical Pictorial Field-Book of Benson J. Lossing (New York, Harper, 1868. I084 p.), but he has digested these and other largely secondary authorities to good effect. His book is a clear, well-balanced, and critical outline, and a generally serviceable introduction to this exasperating conflict.

3688. Mahan, Alfred T. Sea power in its relations to the War of 1812. Boston, Little, Brown,

1905. 2 v. 5-33220 $\cdot \mathrm{E}_{354 \cdot \mathrm{M}_{21}}$

"The present work concludes the series of "The influence of sea power upon history." "-Pref.

A classic of naval history which begins by exploring the maritime antecedents of the war in Britain's conduct of her commercial policies and naval power after 1783 . By regularly defining the strategic situ- ation and the strategic aspect of operations, Admiral Mahan vividly reveals the naval War of 1812 , not as a spectacular series of single-ship actions, but as a progressive strangulation of American economic life.

3689. Smith, Justin H. The War with Mexico. New York, Macmillan, I9rg. 2 v.

$$
\text { 19-19605 E404.S66 }
$$

"Appendix-The sources": v. 2, p. 517-562.

A monumental narrative of the remoter and more immediate causes, the campaigns, the peace settlement, and the consequences of the comparatively brief war of $1846-1848$. The author estimated that he had examined over 100,000 manuscripts, 1200 books and pamphlets, and the files of 200 periodicals, and that nine-tenths of his material was new. He has eased the reader's task by removing scholarship, controversy, and references to a massive series of notes at the end of each volume, and presenting his results in a vigorous and colorful narrative. Criticism of the work has been aimed largely at its rather whole-hearted justification of the case of the United States concerning responsibility for the war. One chapter ( 30 in vol. 2) is devoted to the relatively unimportant naval operations. Readers preferring a briefer treatment will find a competent and balanced one in Robert Selph Henry's The Story of the Mexican War (Indianapolis, Bobbs-Merrill, 1950. 424 p.).

\section{Diii. WARS: THE CIVIL WAR}

369o. Catton, Bruce. Mr. Lincoln's army. Garden City, N. Y., Doubleday, I95I.

372 p. $\quad$ 5I-9468 E470.2.C37

Bibliography: p. 341-347.

3691. Catton, Bruce. Glory Road; the bloody route from Fredericksburg to Gettysburg. Garden City, N. Y., Doubleday, 1952. 416 p.

Bibliography: p. 363-37o.

${ }_{52-5538} \mathrm{E}_{470.2 .} \mathrm{C}_{36}$

3692. Catton, Bruce. A stillness at Appomattox. Garden City, N. Y., Doubleday, 1953.

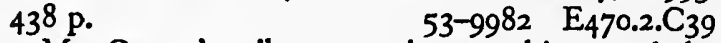

Mr. Catton's trilogy constitutes a history of the Army of the Potomac for the general reader which does not attempt a detailed narrative of operations, but concentrates on the personalities of the leaders, the criticism of generalship, and especially the combat experience of the common soldier. For the latter purpose he has drawn more upon regimental histories than other recent writers, and emphasizes the effects of heavy losses in individual units. He is at all times concerned with the effectiveness of 
supply and the state of morale. Few military histories have so vividly realized the feeling of war from the viewpoint of the individual participant.

3693. De Forest, John William. A volunteer's adventures; a Union captain's record of the Civil War. Edited, with notes, by James $\mathrm{H}$. Croushore. With an introd. by Stanley T. Williams. New Haven, Yale University Press, 1946. xviii, 237 p.

$\mathrm{A}_{4} 6-3486$ E6or. $\mathrm{D}_{3}$

Personal narratives of the Civil War are legion; that of De Forest (1826-1906) may be chosen to represent the others because of its author's skill as a novelist and man of letters. His manuscript, given its final revision about 1890 , was put together from wartime letters to his wife, and from articles published in Harper's New Monthly Magazine and The Galaxy during or shortly after the war. The first part, which describes the author's experience as a line officer of a Connecticut regiment serving on the lower Mississippi, has a first-hand intensity which does not recur in his narrative of Sheridan's valley campaign from the viewpoint of a staff officer at army corps headquarters.

3694. Freeman, Douglas Southall. R. E. Lee, a biography. New York, Scribner, 1934-35. 4 v. 34-3366o E467.r.L4F83 Bibliography: v 2, p. 59I-595; v. 4, p. 543-569.

3695. Freeman, Douglas Southall. Lee's lieutenants, a study in command. New York, Scribner, 1946. 4 v. 46-3415 E470.2.F7 1946 "Select critical bibliography": v. 4, p. 799-825.

Contents. - v. I. Manassas to Malvern Hill.v. 2. Cedar Mountain to Chancellorsville.-v. 3-4. Gettysburg to Appomattox.

Dr. Freeman was engaged for 19 years upon the biography, which at once took its place as a classic. As a study of Lee's generalship, its originality lies in its systematically taking account of the "fog of war," and of the primary function of military intelligence in every commander's strategy. Save in one or two instances, "the reader remains at Confederate G. H. Q. throughout the war and receives the intelligence reports only as they arrive." The massive accumulation of detail regularly strengthens the evidence for Lee's military and personal greatness. Lee's Lieutenants, six years in the making, was undertaken as a supplement to the earlier work, in order to do justice to the other leaders there overshadowed by Lee. It assumed the form of "a review of the command of the Army of Northern Virginia," during the 14 months before Lee was placed at its head, and on the subordinate levels thenceforward. "Where familiar battles again were described, the viewpoint would not be that of Lee but that of the men executing his orders or making decisions for themselves."

3696. Grant, Ulysses S. Personal memoirs. Edited with notes and an introd. by E. B. Long. Cleveland, World Pub. Co., 1952. xxv, 608 p. $\quad 52-5191$ E672.F7617

First published in $1885-86$.

The famous book was undertaken by the ex-President in order to provide an estate for his family, otherwise unprovided for, and completed, after eleven months of work, a week before he died of cancer of the throat. The first sixth is largely concerned with Grant's experiences in the Mexican War, the remainder with his campaigns during $1861-63$, and with the campaigns of $186_{4}-65$ in general. Seldom has a narrative of great events by the leading participant been so utterly free of pretension and fanfare. Grant speaks plainly of his superiors' mistakes in the early years, and as plainly admits his own: "I have always regretted that the last assault at Cold Harbor was ever made." Mr. Long's unobtrusive editing consists largely in supplying full names in brackets, and adding a number of corrective footnotes. Lloyd Lewis lived to complete only the first installment of what was to have been a large-scale modern biography: Captain Sam Grant (Boston, Little, Brown, 1950. $5^{12}$ p.). It is to be continued from June I86I by Bruce Catton, who has already contributed a graceful interpretative sketch: $U$. S. Grant and the American Military Tradition (Boston, Little, Brown, 1954. 201 p.).

3697. Henderson, George F. Stonewall Jackson and the American Civil War. With an introd. by Field-Marshal the late Right Hon. Viscount Wolseley. Authorized American ed. London, New York, Longmans, Green, 1937. xxiv, 737 p.

First published in two volumes, 1898 .

$$
\text { 38-30209 E467.I.JI5H55 } 1937
$$

Thanks to the unprecedented documentary publication of the U. S. War Department, The War of the Rebellion: A Compilation of the Official Records of the Union and Confederate Armies (Washington, 1880-1901. I30 v.), usually referred to as the Official Records of the Rebellion, it has been nearly as easy to study the Civil War in detail in Europe as in America. One of the earliest and most influential results of such study was the work of Col. Henderson, Professor of Military Art and History at the British Staff College. It is a brilliant presentation of Jackson (1824-1863) as a selfless Christian knight and a supreme master of the art of war comparable to Napoleon and to Wellington at their best. His death at Chancellorsville from the fire of his own men was a fatal loss to the Confederacy; Lee 
was left with no one "to whom he could entrust the execution of those daring and delicate manoeuvres his inferior numbers rendered necessary."

3698. Henry, Robert Selph. The story of the Confederacy. New and rev. ed. New York, New Home Library, 1943. 514 p.

First published in I931.

$$
\text { 43-18537 } \mathrm{E}_{4} 87 . \mathrm{H}_{544} \quad \mathrm{I} 943
$$

An outline of the war from the viewpoint of the Confederate armies, based on the principle that "the preponderance of power on the part of the North was so great that nothing short of perfect performance by Southern statecraft and Southern command could have reversed the result." In consequence, missed opportunities by Southern commanders are heavily emphasized. Mr. Henry, an experienced railroad executive, makes of it a very dramatic story, much admired by the late Douglas S. Freeman who, in 1936 , called it "at present the book with which to begin one's study of the period it covers and the book to which to return when everything else on the subject has been read."

3699. Lewis, Lloyd. Sherman, fighting prophet. New York, Harcourt, Brace, 1932. 690 p.

Bibliography: p. 655-669.

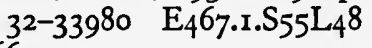

William Tecumseh Sherman (1820-189r) was an Ohio West Pointer with extensive Southern connections, who remained inflexibly loyal to the Union and the Constitution, but foresaw from the outset the magnitude of the effort that would be required to defeat the Confederacy. Of nervous temperament, habitually outspoken, and a trenchant penman, he had frequent clashes with politicians and the press, which delayed his recognition as an outstanding commander. Lewis' volume, studded with extracts from Sherman's own letters, builds up a portrait of this complex character in convincing detail. Basil H. Liddell Hart's Sherman; Soldier, Realist, American (New York, Dodd, Mead, I930. 456 p.) is somewhat better for operations, but Lewis' is a rounded presentation of an exceptional American.

3700. The Navy in the Civil War. New York, Scribner, 1883. 3 v. 5-1935I E591.N32

Contents.-v. I. Soley, James Russell. The blockade and the cruisers.-v. 2. Ammen, Daniel. The Atlantic Coast.-v. 3. Mahan, Alfred T. The Gulf and inland waters.

Identical in format with the same publisher's series of volumes on the Campaigns of the Civil War. But whereas the latter, although still worth occasional consultation, have been replaced in detail and as a whole, The Navy in the Civil War remains the only large-scale survey of its subject, and this in spite of the 30-volume publication of the U. S. Navy Department, Official Records of the Union and Confederate Navies (Washington, 1894-1922). Written by two naval officers and a professor at the Naval Academy, they are sound and sober narratives, but that of Commander Mahan, as he then was, lacks the philosophical depth of his later and greater writings.

3701. O'Connor, Richard. Sheridan, the inevitable. Indianapolis, Bobbs-Merrill, 1953. 400 p. $\quad 53-5847 \quad E_{4} 67.1 . S_{54} \mathrm{O}_{3}$

"Notes on sources": p. 36I-39I.

Philip H. Sheridan (183I-1888), the son of an Irish Catholic immigrant who settled in Somerset, Ohio, made his way against social and personal difficulties to graduate from West Point in 1853 . In the course of hard-fighting service as brigade and division commander in the West, he impressed himself on Grant, who brought him East to command the cavalry of the Army of the Potomac early in 1864. Here he crushed Stuart at Yellow Tavern, and Early in the Shenandoah Valley, and increasingly became Grant's reliance as his agent for offensive operations. He struck the hammer-blows of March-April I865 which forced Lee to surrender. Mr. O'Connor's vigorous narrative goes on to describe his later service, in charge of the final years of Indian warfare, and as commander-in-chief, but naturally emphasizes the great year in Virginia when Sheridan established himself as one of the great captains.

3702. Shannon, Fred Albert. The organization and administration of the Union Army, I 86I-1865. Cleveland, Clark, 1928. 2 v.

Bibliography: v. 2, p. [285]-294.

$$
{ }_{28-15871} \mathrm{E}_{491} \mathrm{~S}_{52}
$$

Since the Civil War soon called for unprecedented numbers of men under arms, the problem of raising and organizing this host naturally overstrained existing facilities, and involved much improvisation and sheer confusion. Prof. Shannon dwells so exclusively upon the mistakes as nearly to lose sight of the achievement, and he puts excessive blame upon what he terms "the state-rights fetish." His volumes nevertheless contain by far the most information assembled concerning the respective shares of Federal and State authorities in raising troops; the methods employed in procuring food, clothing, and munitions; the adoption and enforcement of the draft; the policies of paid substitutes for those who could afford them, and of bounties for volunteers, and their consequences; and the treatment of slackers and conscientious objectors. Another view of the administrative crisis after Sumter 
is contained in Alexander Howard Meneely's The War Department, 186I (New York, Columbia University Press, 1928. 400 p.).

3703. Thomason, John W. Jeb Stuart. New York, Scribner, 1930. 512 p.

30-28932 $\quad \mathrm{E}_{4} 67.1 . \mathrm{S}_{9} \mathrm{~T}_{4} 6$

"Jeb Stuart was a symbol, gonfalon that went before the swift, lean columns of the Confederacy." Captain Thomason of the Marine Corps tells us that he attempted, "not a history of a war, but a portrait of a splendid human soul, expressed through the profession of arms." The result, embellished with his own skillful drawings, glows with his enthusiasm, affection, and pride in the great Confederate cavalryman (1833-1864), and tells a great deal about the cavalry operations of the Eastern campaigns as well.

3704. Wiley, Bell Irvin. The life of Johnny Reb, the common soldier of the Confederacy. Indianapolis, Bobbs-Merrill, 1943. $444 \mathrm{p}$.

Bibliography: p. [419]-426. 43-3253 E6o7. W5

3705. Wiley, Bell Irvin. The life of Billy Yank, the common soldier of the Union. Indianapolis, Bobbs-Merrill, 1952. 454 p.

"Bibliographical notes": p. 438-446.

$$
\text { 52-5809 E49r.W69 }
$$

The citizen armies of the Civil War wrote home innumerable letters and kept an extraordinary number of diaries. Prof. Wiley has spent years in tracking down and digesting these materials, which he has combined with the Official Records of the Rebellion and other printed sources to reconstruct with complete fidelity the daily life of the soldier in either camp. There are chapters on drunkenness and other vices, heroism and cowardice, rations and ersatz rations, clothing, religion in camp, discipline and punishments, morale, etc. On completing the second work the author wrote: "The two were so much alike that the task of giving this book a flavor and character distinct feom The Life of Johnny Reb has at times been a difficult one."

3706. Williams, Kenneth P. Lincoln finds a general; a military study of the Civil War. With maps by Clark Ray. New York, Macmillan, 1949-52. $3 \mathrm{v}$.

Includes bibliographies.

The author is a professor of mathematics at Indiana University, but there is nothing amateurish about his close analyses of Civil War generalship from the evidence supplied in the Official Records of the Rebellion. He believes that when President Lincoln said, a few weeks after appointing him to the supreme command, "Grant is the first General I have had," he spoke the plain truth. Grant he describes as "the embodiment of the offensive spirit that leaves the enemy no rest," and "the most profitable and the most inspiring of all generals to study." The first two volumes describe the failures of generalship in the successive commanders of the Army of the Potomac, and the third follows Grant's Western campaign through June 1862 . 'Two or more additional volumes will be required to complete the work.

\section{Div. WARS: \\ THE SPANISH-AMERICAN WAR}

3707. Chadwick, French Ensor. The relations of the United States and Spain: the SpanishAmerican War. New York, Scribner, Igrr. 2 v.

Bibliography: v. 2, p. $475-478$.

II-23013 E715. $\mathrm{C}_{43}$

Chadwick was Admiral Sampson's flag-captain during the blockade and battle of Santiago de Cuba. His narrative of the war, by far the most thorough and detailed that has been written, is "intended in the main as a documentary history," printing in whole or part all important orders, telegrams, and reports, including those on the Spanish side in translation. These have been pieced together with such skill as to provide a narrative of true continuity, clarity, and suspense. Admiral Chadwick makes no attempt to conceal the disparity of force, and he resolutely keeps the Sampson-Schley controversy out of his book. The land campaigns, in Cuba, Porto Rico, and the Philippines, fall entirely within volume 2.

3708. Wilson, Herbert W. The downfall of Spain; naval history of the Spanish-American War. London, Low, Marston, I900. 45I p.

"Authorities": p. 442-444.

$$
{ }_{\mathrm{I}-27847} \quad \mathrm{E}_{727} \cdot \mathrm{W}_{74}
$$

$\mathrm{H}$. W. Wilson of London was the author of the standard Ironclads in Action (London, S. Low, Marston, I896. 2 v.) which, 30 years later, he would revise and expand into Battleships in Action (Boston, Little, Brown, 1926. 2 v.). Admiral Chadwick in I9II called this "the best naval history of the war," and drew upon it for authoritative comments at several points. Although published so soon after the war's end, it remains a remarkable example of what can be done when a Government publishes its documents fully and promptly, as did the United States, and a genuine expert analyzes them thoroughly. On one point Wilson revised his opinion by 1926: a number of instances of spontaneous combustion in warship magazines between 
1898 and 1914 led him to doubt that an external mine had destroyed the Maine.

\section{Dv. WARS: WORLD WAR I}

3709. Dickinson, John. The building of an army; a detailed account of legislation, administration and opinion in the United States, 1915-1920. New. York, Century, 1922. 398 p.

22-12553 UA25.D5

On April I, 1917, the United States, a completely unmilitary nation, had 127,000 men under arms. Nineteen months later the American Army consisted of $3,665,000$ men, of whom nearly two million were in Europe. This book supplies a thoughtful narrative of how the Selective Service Acts of 1917 were utilized to achieve this result.

3710. Harbord, James G. The American Army in France, I917-rg19. Boston, Little, Brown, 1936. xviii, 632 p. 36-645I D570. H275

General Harbord's experience was one of the most varied in World War I. During the first year of the A. E. F. he was Pershing's chief of staff; he commanded the Marine Brigade at Belleau Wood (May 1918) and the 2nd Division in the Soissons offensive (July); at its conclusion he took over the Services of Supply for the duration of the war. For each of these phases General Harbord provides a clear, direct, and critical narrative worthy of the intelligent and incisive administrator that he was. A more perfunctory outline covers the aspects of the A.E.F. with which he was not personally concerned.

3711. Holley, Irving B. Ideas and weapons; exploitation of the aerial weapon by the United States during World War I; a study in the relationship of technological advance, military doctrine, and the development of weapons. New Haven, Yale University Press, 1953. 222 p. (Yale historical publications. Miscellany, 57) 52-1397 I UG633.H6

"Bibliographical note": p. [179]-209.

One of the Air Force historians of World War II here applies his experience to explaining the aerial failure of $1917-18$. He tracks it down in the spheres of doctrine, equipment, and organization. The men in charge failed to develop any clear ideas concerning the purposes and composition of an American air force. They failed to recognize the fluidity of the technological factor, necessitating constant improvements in airplane design. They failed to create efficient agencies for decision, information, and research. As a result of their emphasis on quantity rather than quality of production, American-made planes proved obsolete by the time they began to reach the front in quantity, and the American air force had to be equipped with aircraft of allied manufacture.

3712. March, Peyton $C$. The nation at war. Garden City, N. Y., Doubleday, Doran, 1932. 407 p. $\quad 32-25157$ D570.M35 1932a General March (1864-1955) was the original selection for commander of the A. E. F.'s artillery and held that post, occupied in organizing and training, until Jan. 1918, when Secretary Baker recalled him to head the General Staff. His volume, from that early point, is in large part polemic, to justify the Staff against the criticisms, real or supposed, in General Pershing's reminiscences (no. 3715). March put the staff on 24 -hour duty, reorganized it according to function, reduced paper work, and drove it hard. "Raising the men; putting them in camps; clothing them; equipping them; training them; shipping them to France; sending ammunition, rifles, and supplies to France to make the A. E. F. a going concern: all that was done by the vast military hierarchy at home, working under me as Chief of Staff of the Army."

3713. Palmer, Frederick. Newton D. Baker; America at war. New York, Dodd, Mead, I93I. 2 v. 3I-2831 I D $570 . P_{32}$

Baker (1871-1937) was an Ohio Progressive with pacifist convictions whose selection for the War Department provoked some derision, but who proved an exceptionally able mediator between the military organization and civilian groups and interests. Palmer, an experienced war correspondent, used Baker's own papers as well as official war agency records to relate in detail Baker's distinguished services in coördinating the American war effort and facilitating the task of the soldiers at home and in France. Baker was made a special target by assailants of the Wilson administration, but the military leaders are well-nigh unanimous in testifying that his genuine concern for civil liberties did not in the least get in the way of his effective mastery of the gigantic administrative problems of his office.

3714. Palmer, Frederick. John J. Pershing, General of the Armies, a biography. Harrisburg, Pa., Military Service Pub. Co., 1948. 380 p. 48-8289 Er8r.P PI2

Palmer, a friend and admirer of "J. J. P.," completed this biographical sketch in 1940, and added the two final chapters after Pershing's death in I948. It is without references and contains little on Pershing's career before I9I7, and less on his life after 1919. However, it adds color to Pershing's own narrative (no. 3715) of his war experiences, and it emphasizes, as Pershing does not, the magnitude of his achievement in maintaining the integrity of 
the A. E. F. against the insistent pressure of the allied commands that American men and matériel be employed to fill the gaps in their own organizations.

3715. Pershing, John J. My experiences in the World War. New York, Stokes, 1931. 2 v. 31-10662 D570.P44 I931

Pershing (1860-1948) was in his $57^{\text {th }}$ year, the junior major general of the U. S. Army, and in charge of the Southern Department when, in May 19I7, he was chosen to head the American Expeditionary Force. He took over a decade in the careful preparation of these memoirs. They are strung upon entries in his official diary and mirror very faithfully the outlook from American G. H. Q. They are for the greater part concerned, as was Pershing, with problems of planning, organization, training, supply, and inter-allied relations in every sphere. Operations are encountered only in volume 2 , and are somewhat formally described.

3716. Sims, William Sowden. The victory at sea. In collaboration with Burton J. Hendrick. Garden City, N. Y., Doubleday, Page, 1920. 4 Io p. 20-18578 D589.U6S6

American warships played a vital part in winning World War I, for if our dreadnoughts never saw action, our cruisers and destroyers were numerous enough to permit the adoption of the convoy system, which finally shook off the German submarines' stranglehold upon British commerce. With the help of a veteran journalist, the commander of the American fleet in European waters tells the fascinating story in untechnical language.

\section{Dvi. WARS: WORLD WAR II}

\section{Arnold, Henry H. Global mission. New} York, Harper, I949. 626 p.

$$
\text { 49-10894 D790.A9 }
$$

The memoirs of a West Pointer of the class of 1907 who was assigned to military aviation in I9I I and succeeded to the command of the Air Corps the day before Munich (1938). The narrative of subsequent events, if somewhat cluttered and gossipy, is a unique depiction of the coming of age of the Air Force as a third arm of national defense.

3718. Bradley, Omar N. A soldier's story. New York, Holt, 195r. xix, 618 p.

$$
\text { 5I-II294 D756.B7 }
$$

A personal narrative of the Algerian, Sicilian, and Normandy campaigns which, although more chatty and anecdotal, closely parallels Eisenhower's (no. 3719) but affords instructive comparisons by giving the viewpoint of our most successful armygroup commander rather than that of SHAEF. A list of principal persons and a glossary are helpful in following the narrative.

3719. Eisenhower, Dwight D., Pres. U. S. Crusade in Europe. Garden City, N. Y., Garden City Books, I952. 573 p.

First published in 1948 52-2207 $\mathrm{D}_{743} \cdot \mathrm{E}_{35} \quad 1952$

The personal narrative of the Supreme Commander, Allied Expeditionary Forces, from his departure from the Philippines at the end of r 940 to the postwar occupation of Germany. It illuminates the processes of planning and coördinating, at the highest level, such gigantic combined operations as the African, Italian, and Normandy invasions.

3720. Merriam, Robert E. Dark December; the full account of the Battle of the Bulge. Chicago, Ziff-Davis Pub. Co., 1947. 234 p.

$$
\text { 47-4797 } \mathrm{D}_{75} 6.5 \cdot \mathrm{A}_{7} \mathrm{M}_{4}
$$

One of the Army's field historians, who was present during the fighting of Dec. 16, 1944-Jan. 16, 1945, interviewed many of the participants, and helped prepare the still unreleased official narrative, presents his own dramatic and critical interpretation. The primary blame for von Rundstedt's Ardennes breakthrough is placed upon the excessive optimism of American intelligence officers. The effort, however, quite exhausted Nazi offensive power.

372r. Morison, Samuel Eliot. History of United States naval operations in World War II. Boston, Little, Brown, I947+ $\quad$ 47-1571 $\quad$ D773.M6 Large-scale naval history on an unusual plan: the author has enjoyed all the facilities for writing official history, including participation in a number of the campaigns, but has taken personal responsibility for all statements of fact and opinion. The result has been generally acclaimed as contemporary history of rare authority, unity, and power, as interesting to the layman as the professional sailor. With the roth volume the huge work is approaching its conclusion.

3722. Pratt, Fletcher. War for the world; a chronicle of our fighting forces in World War II. New Haven, Yale University Press, 1950. 364 p. (The Chronicles of America series, v. 30) $5^{2-435^{8}}$ Ei $73 . \mathrm{C}_{5}^{8}$, v. 30

"Bibliographical note": p. [35I]-353.

A concise narrative of the two great wars which America conducted in 1941-1945, with neither the Pacific nor the European theater slighted. It presents the logistic basis of our expanding operations, and stresses the technological developments which, after one grim year of containment, gave superiority 
by land, sea, and air, and made offensive warfare and victory possible. The textbook edition of this noteworthy feat of condensation can be obtained separately from the series.

3723. Stilwell, Joseph W. The Stilwell papers, arr. and edited by Theodore $\mathrm{H}$. White. New York, Sloane, 1948. xvi, 357 p.

$$
\text { 48-6966 D8זi.S83 }
$$

Excerpts from General Stilwell's command journal, memoranda to self, and letters to his wife are interspersed with background passages by the editor to form the most completely personal record of any pivotal figure in World War II. While "Vinegar Joe" was hardly the ideal personality for liaison with an oriental power, his version of his struggle with what he regarded as Kuomintang laxity, deceit, and corruption has few counterparts.

3724. Studies in social psychology in World War II. Prepared and edited under the auspices of a special committee of the Social Science Research Council. [Princeton, Princeton University Press, 1949-50] 4 v. 49-2480 U22.S8

Contents.-V. I. The American soldier: adjustment during Army life, by S. A. Stouffer and others. - v. 2. The American soldier: combat and its aftermath, by S. A. Stouffer and others.-v. 3. Experiments on mass communication, by C. I. Hovland, A. A. Lumsdaine and F. D. Sheffield.-v. 4. Measurement and prediction, by S. A. Stouffer and others.

These massive volumes constitute the end product of the war-time activity of the Research Branch of the War Department's Information and Education Division. A study of soldiers' attitudes, it is based on 243 separate surveys by questionnaire, some involving as many as 25,000 men. The first two volumes are deeply revealing reflections of the states of mind prevalent in a vast citizen army; the last two are chiefly of interest to professional psychologists. The series is discussed from the latter point of view in Studies in the Scope and Method of "The American Soldier," edited by Robert K. Merton and Paul F. Lazarsfeld (Glencoe, 1ll., Free Press, 1950. 255 p. Continuities in Social Research).

3725. U. S. Bureau of the Budget. The United States at war; development and administration of the war program by the Federal Government. Prepared under the auspices of the Committee of Records of War Administration by the War Records Section, Bureau of the Budget. Washington, U. S. Govt. Print. Off., 1946. xv, 555 p. ([United States. Historical reports on war administration, Bureau of the Budget, no. I])

$$
\text { 47-32819 D769.A55 } 1946
$$

More than any previous war of the United States, World War II produced an enormous increase in governmental controls, and in the number and size of the agencies which exerted them. This is an administrative history of the Government's war effort, organized by essential functions rather than by the several agencies, merely to list which requires a I5-page appendix (p. 521-535).

\section{U. S. Dept. of the Army. Office of Military History. United States Army in World War} II. Washington, $\mathrm{I}_{947}+$ 47-46404 D769.A533

This monumental enterprise, to which only the Official Records of the Rebellion can be compared, was authorized by the Chief of Staff in 1946 . Behind it, says General Albert C. Smith, "lies the greatest mass of records and recollections ever produced-I 7,200 tons of records created by the U.S. Army alone." More than 85 volumes are planned, of which 27 have appeared as this chapter is completed. The work is arranged in a number of subseries: The War Department, of which 3 vols. have appeared; The Army Ground Forces, 2 vols.; The Army Service Forces and the Technical Services, 5 vols.; The War in Europe, 4 vols.; The War in the Pacific, 6 vols.; China-Burma-India, I vol.; Middle East, I vol.; Special Studies, 2 vols.; and Pictorial Records, 3 vols. The Chief Historian of the office, Kent Roberts Greenfield, is the general editor of the series, and also one of the authors in The Army Ground Forces subseries. He has also prepared a Master Index; Reader's Guide (1955. 8I p.) to the volumes thus far issued, in which the content of each volume is summarized, and its importance for the study of modern warfare analyzed. Dr. Greenfield has also discussed the general problems of writing contemporary military history in The Historian and the Army (New Brunswick, Rutgers University Press, I954. 93 p.). The series is on a grander scale than many users of this Guide will require, but since it will be years before it is completed and its results digested in works of lesser scope, it must be listed as the most authoritative source within its field.

3727. U. S. Office of Air Force History. The Army Air Forces in World War II. Prepared under the editorship of Wesley Frank Craven [and] James Lea Cate. Chicago, University of Chicago Press, I948-55. 6v. 48-3657 D790.A47

A coöperative official history, with sections or chapters by various hands under the general editorship of two professional historians. Volume I opens with a review of military aeronautics from I9171939. Volumes 2 and 3 cover the war in Europe, 4 and 5 the war in the Pacific. Volume 6 "deals with the Zone of the Interior-with the development of 
454 / A GUIDE TO THE UNITED STATES

an effective air organization, with the forging and distribution of weapons, with the recruiting and training of airmen." The series as a whole presents an abundance of detail, at times more than could be useful to anyone but the professional student of military aeronautics. 


\title{
Intellectual History
}

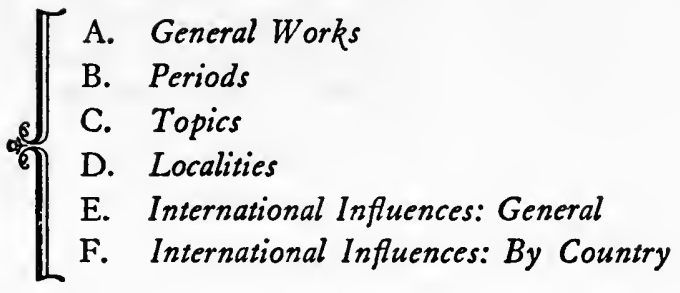

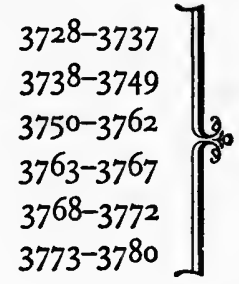

\begin{abstract}
A LTHOUGH intellectual history is the latest of the historical specialties to attain some 1 measure of separateness and autonomy, the present selection may seem scanty in comparison with the huge bibliography appended to Curti (no. 3729). Closer examination will show that the great majority of those titles fall within a single one of the humanities, arts, or sciences, and, insofar as they have proved suitable for inclusion here, appear in the appropriate section elsewhere. The titles which follow are those, as yet comparatively few, which take a general view of American intellectual life, or deal with "culture" or "civilization" conceived primarily as an activity of mind, or attempt to arrive at the "national character," or include a certain span of the humanities, arts, and sciences, or deal with the twoway international commerce in ideas, or handle some specific topic in so large and generalized a way as to display it in a wide context of thought and so to lift it out of the more specialized discipline to which it might at first seem to be confined. Thus Davies (no. 3752) deals with phrenology as a current in American reformist ideology and popular culture rather than as a dead end in the development of scientific psychology, and Egbert and Persons (nos. 3753 and $375^{\circ}$ ) expound socialism and evolution as

large trends in general American thought rather than as special doctrines of economics or biology. There can be no clear-cut dividing line in such groupings; there is much here that social, political, or literary historians should not miss, while anyone interested in the intellectual history of the United States will find many other titles to his purpose elsewhere in this Guide, and particularly in Sections VIII $A$ and $B$ (Historiography and General Histories), $\mathrm{XV} \mathrm{B}, \mathrm{C}$, and $\mathrm{D}$ (Social History and Thought), XVII (Science), XXII (Philosophy and Psychology), XXIII C (Religious Thought and Theology), XXVIII A and B (Economic Thought), XXIX A (Political Thought), etc.
\end{abstract}

\section{A. General Works}

3728. Cohen, Morris R. American thought; a critical sketch. Edited and with a foreword by Felix S. Cohen. Glencoe, Ill., Free Press, 1954. $360 \mathrm{p}$. 54-10667 B85r.C6

Cohen had for years aspired to write a major and systematic work on American thought-"not on technical philosophy but rather on the general ideas which are taken for granted in various fields"and made a beginning in a course of lectures delivered at Chicago the year after his retirement, 1939. The notes for these lectures were in part expanded into written expositions down to 1946 , the 
year before his death. His son and literary executor, Felix S. Cohen, put the completed or nearly completed portions into form for publication, but died before he could read the proofs. The sections on psychology, sociology, ethics, education, and literature, and a final summing-up had to be omitted. The volume as published contains substantial treatments of legal thought and general philosophy, lesser ones of economic and religious thought, and sketches of historical, scientific, economic, political, and aesthetic thought. An introductory chapter on the American tradition deals with such matters as the nature of intellectual leadership, the democratic dilution of education, and the prevalence of standardization and intolerance. Fragmentary as it is, the book is the only attempt of the kind by an original mind, and is crowded with illuminating perceptions and penetrating criticisms.

3729. Curti, Merle E. The growth of American thought. $2 \mathrm{~d}$ ed. New York, Harper, I95I.

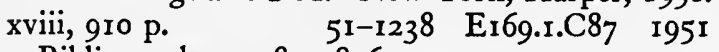
Bibliography: p. 8 or -876 .

The most complete survey of American intellectual history, which includes organized knowledge, speculation organized or traditional, as well as values, and pays special attention to related institutions such as schools and the press. All of these are so related to the whole social milieu as to constitute a social history of American thought. General tendencies rather than individual thinkers are emphasized here. The work is organized in chronological periods characterized by their leading ideas; the first third of the roth century, for instance, is taken to have been marked by patrician leadership in thought.

3730. Fox, Dixon Ryan. Ideas in motion. New York, Appleton-Century, 1935. 126 p. 35-34879 E169.1.F76

Contents.-Civilization in transit.-Culture in knapsacks.-A synthetic principle in American social history.-Refuse ideas and their disposal.

Four essays principally concerned with the diffusion of ideas throughout the United States. "Civilization in transit" distinguishes four stages in the development of professional life in a new country, from total dependence on foreign practitioners to final autonomy.

3731. Mumford, Lewis. The golden day; a study in American literature and culture. New York, Norton [1934?] 283 p.

$$
\text { 34-27096 Ei69.1.M943 }
$$

Published in 1926 under title: The Golden Day; a Study in American Experience and Culture.
An interpretive historical sketch of American culture, which becomes almost a diagnosis by a healer anxious to prescribe, and which ha had a combining influence on later interpreters. The title derives from the author's characterization of the years 1830-60, when "the old culture of the seaboard settlement had its Golden Day in the mind." "This period nourished men, as no other has done in America before or since. Up to that time, the American communities were provincial; when it was over, they had lost their base."

3732. Perry, Bliss. The American mind. Boston, Houghton Mifflin, 1912. 248 p.

$$
\text { 12-24430 } \mathrm{PS}_{3} \mathrm{r}_{4} \mathrm{P}_{4}
$$

Contents. - Race, nation, and book.-The American mind.-American idealism.-Romance and reaction.-Humor and satire.-Individualism and fellowship.

A common-sense examination of American literature as a mirror of American national character. Both are dominated by American idealism, which in literature most commonly manifests itself as sentimentalism. Romance and the reaction against it, and American humor and satire, are illustrated from both literature and life. The conclusion calls for "fellowship based upon individualism, and individualism ever leading to fellowship."

3733. Perry, Ralph Barton. Puritanism and democracy. New York, Vanguard Press, I944. 688 p. 44-4I893 Ei69.r.P47 Identifies the two main formative elements in the American national tradition as the Puritanism embodied in the New England theocracy, and the democracy of the Enlightenment given classic expression in the Declaration of Independence. Each is analyzed as a system of ideals, and the link between them found in the individualism which gave allegiance to ideas rather than to persons and institutions. Each is appraised, and found to have a large measure of validity for our day-they "reinforce one another's truths and aggregate one another's errors," but "also serve to correct and complement one another's limitations." The whole book is an unusual synthesis of historical and philosophical interpretation. In a lesser work, Characteristically American (New York, Knopf, 1949. 162 p.), Prof. Perry uses similar ideas in attempting the "teasing and baffling task" of defining national characteristics and devotes one lecture to William James as the classic exponent of American individualism.

3734. Potter, David 'M. People of plenty; eco nomic abundance and the American character. Chicago, University of Chicago Press, 1954. 
xxvii, 2 I9 p. (Charles R. Walgreen Foundation lectures) 54-12797 EI69.I.P6

In publishing his lectures at the University of Chicago (1950), the writer widens his original theme to include a discussion of national character and the respective contributions of historians and "behavioral scientists" to the concept. Economic abundance is then advanced as a kind of case study for American national character, and pursued through a sequence of relationships. It has, for instance, "given to the concept of 'democracy' a distinctive meaning in America which sets it apart from democracy in other parts of the world."

3735. Quinn, Arthur Hobson. The soul of America, yesterday and today. Philadelphia, University of Pennsylvania Press, 1932. 26I P. 32-I2287 $\quad$ EI75.9.Q56

Combines a brief interpretive sketch of the main stream of American history with a presentation of "the American soul" as manifested in its seven characteristic qualities of democracy, efficiency, liberality, provincialism, individuality, humor, and vision. Reflects the outlook of a sensible and wellinformed, if somewhat discursive, conservative.

\section{Rourke, Constance M. The roots of Ameri-} can culture and other essays. Edited, with a preface, by Van Wyck Brooks. New York, Harcourt, Brace, 1942. 305 p. 42-I9827 Er69.I.R78

Eight studies collected the year after the author's death, including "The Rise of Theatricals," "Early American Music," and "The Shakers." "Her work," says Mr. Brooks, "was mainly exploratory," but her delicate and sensitive approach to her subjects, and a type of statement at once cautious and precise, give it far more than a tentative value. Few writers on the arts have been so perceptively aware of the social milieu in which they exist, or have been able to deal so effectively with either side of the relationship.

3737. Wright, Louis B. Culture on the moving frontier. Bloomington, Indiana University

Press, 1955. $273 \mathrm{p}$. 54-6207 Ex69.I.W82

"Lectures delivered on the Patten Foundation at Indiana University in the spring of 1953."

Six lectures which deal with the transmission and diffusion of the Anglo-Saxon tradition-"the tradition of English law, the English language, English literature, and British religion and customs"-in the United States. After a general treatment of the colonial period, the author concentrates upon this process in the Kentucky borderland, in the Northwest Territory, and in California during the Gold Rush age. Two concluding lectures describe the "instruments of civilization," both spiritual and secular. The latter includes English belles-lettres, historical and legal books, textbooks, academies and colleges, women's clubs, lectures and lyceums, and country newspapers.

\section{B. Periods}

3738. Commager, Henry Steele. The American mind; an interpretation of American thought and character since the 1880 's. New Haven, Yale University Press, I950. $476 \mathrm{p}$.

Bibliography: p. [445]-467.

$$
\text { 50-6338 E.69.1.C673 }
$$

The author searches the writing of the last 70 years for "ideas that illuminate the American mind and ways of using ideas that illustrate the American character," drawing at will upon philosophy, religion, literature, politics, and the social sciences, but not seeking to present formal histories of any of them. His major theme is the transition from the traditional and self-confident America of the Igth century, by way of the "watershed of the'go's," to the fast-changing and troubled America of the 20th. The mass of material surveyed is not too successfully assimilated.
3739. Curti, Merle E., ed. American scholarship in the twentieth century. Cambridge, Harvard University Press, 1953. 252 p. (The Library of Congress series in American civilization)

The editor offers an essay on "The Setting and the Problems," seeking to relate the development of the social sciences and the humanities to national and world history and viewing the present situation as a schism between absolutists and instrumentalists. Louis Wirth interprets the social sciences as a conquest of more and more ground for quantitative methods, although many areas of social life remain subject to the artist and the humanistic scholar. Historical, literary, classical, and philosophical scholarship are presented by W. Stull Holt, René Wellek, Walter R. Agard, and Arthur E. Murphy, in essays which terminate on a note of qualified optimism. 
3740. Eggleston, Edward. The transit of civilization from England to America in the seventeenth century. New York, Peter Smith, I933. $344 \mathrm{p}$.

First published in $190 \mathrm{r}$.

A34-396 Er62.E283

Contents.--Mental outfit of the early colonists.Digression concerning medical notions at the period of settlement.-Mother English, folk-speech, folklore, and literature.-Weights and measures of conduct. - The tradition of education. - Land and labor in the early colonies.

Although this pioneer work has often been spoken of with condescension by latter-day scholars, it remains a remarkably concrete and intimate treatment of the popular mind in England and during the first two generations of settlement in America. It was an extraordinary achievement for the turn of the century, both in breadth of outlook and in the exploitation of a wide range of sources for a specialized purpose.

374I. Gabriel, Ralph Henry. The course of American democratic thought. $2 d$ ed. New York, Ronald Press, i956. xiv, 508 p. 56-6263 Er69.I.G23 I956

An eternal moral order, the free individual, and the national mission of America were the three essential doctrines of American democratic faith, universally assumed after 1815 . Mr. Gabriel analyzes them and sets them against the social and intellectual background of the "Middle Period," conducts them safdy through the fires of sectional controversy, sees them modified and developed so as to harmonize with the evolutionary naturalism and industrial revolution which followed 1865 , and leaves them facing rival systems of social belief in the post-Versailles age of disillusionment and insecurity. A diversity of thinkers have given their testimony by the way in what has been called an exceptionally perceptive attempt "to identify the central intellectual tradition of the United States."

3742. Miller, Perry. The New England mind; the seventeenth century. New York, Macmillan, I939. $528 \mathrm{p}$. 39-22760 F7.M56

3743. Miller, Perry. The New England mind: from colony to province. Cambridge, Harvard University Press, I953. 513 p.

53-5072 F7.M54

In the first of these volumes, the labors of a single scholar have restored the intellectual framework of a vanished, in this aspect forgotten, and much misunderstood age. To an exceptional degree, Massachusetts in 1630 was founded on the basis of a coherent system of thought, and this volume furnished the hitherto missing key to the comprehension of a whole society and its orthodoxy. The essential character of the New England mind derives from the circumstances that the founders were simultaneously Ramists in logic, Congregationalists in church policy, and "federalists" in theology-that is, they adhered to the doctrine of the Covenant of Grace worked out by William Perkins, William Ames, and John Preston, which was the only original contribution of Puritanism to its own system of ideas. From Colony to Province follows the fortunes of this orthodoxy in Church and State during the seven decades which followed the restoration of the Stuarts (1660-1730), and traces the effect of the progress of events upon that "dictatorship of the visible elect" which was the practical consequence of the Covenant theology. It is seen as a process of accelerating disruption, but one in which a very specialized, archaic, and rigid system died amazingly hard.

3744. Miller, Perry, ed. American thought: Civil War to World War I. New York, Rinehart, 1954. 345 p. (Rinehart editions, 70)

$$
\text { 54-7243 PS682.M5 }
$$

A compact and exceptionally unified anthology, presenting extracts from thirteen thinkers of the era which opened "when the mind of America was aroused and challenged by the twin invasions of Hegel and Darwin." The editor, who contributes a substantial introduction, has aimed to provide at least one explicit statement of "each of the controlling conceptions," and believes that his selections "do expound the crucial points of view by which Americans between 1865 and 1917 were ruled."

3745. Morison, Samuel Eliot. The intellectual life of colonial New England. [2d ed.] New York, New York University Press, 1956. 288 p.

$$
\text { 56-8487 F7.M82 } 1956
$$

First published in 1936 under title: The Puritan Pronaos.

"Primitive New England is a puritan pronaos to the American mind of the rgth Century, and of today"-not because of the books or new ideas produced there, but because the settlers of the 1630 's took steps to avoid the intellectual degeneracy which leads to spiritual decay, and made great sacrifices to import the apparatus of civilized life and learning. These lectures describe from contemporary sources Harvard College, elementary and public grammar schools, printing and bookselling, private and public libraries, pulpit literature, histories and political pamphlets, verse, and the beginnings of science. 
3746. Morris, Lloyd R. Postscript to yesterday; America: the last fifty years. New York, Random House, 1947. xxvi, 475 p.

Bibliography: p. $45 \mathrm{I}-465$.

$$
\text { 47-11260 E741.M65 }
$$

Aims to present the attitudes of the American people to the principal social changes that took place between 1896 and 1946, and so "to tell the story of the American mind and heart during the past 50 years." This is done, however, by a succession of highly-wrought sketches of individual figuresliterary men, journalists, philosophers, jurists, and social thinkers. The main theme is the widening breach, approaching "absolute polarity," "between two sets of standards; those by which American culture judged American society, and those which governed American life as it was actually being lived."

3747. Savelle, Max. Seeds of liberty; the genesis of the American mind. New York, Knopf, 1948. xix, 587 , xxxi p. illus.

$$
\text { 48-6861 } \quad \text { E169.1.S27 } 1948
$$

"Chapter nine . . . entitled 'Of music, and of America singing,' was written by Mr. Cyclone Covey."

The author has "attempted to find every important figure who flourished in the period between 1740 and 1760 and to find out what he was thinking, and where possible, why he thought as he did." He thus surveys the whole intellectual and cultural output of the colonies during these two decades, dealing in succession with religion, Newtonian science, philosophy, economic, social, and political thought, literary expression, painting, architecture, and music. At times he strains the facts in order to find liberty and a conscious nationalism burgeoning in every sphere.
3748. Wertenbaker, Thomas Jefferson. The golden age of colonial culture. [2d ed.] New York, New York University Press, 1949. 17 I p. (New York University. Stokes Foundation. Anson G. Phelps lectureship on early American history) 49-4583 $\quad \mathrm{E}_{1} 62 . \mathrm{W}_{48} \quad 1949$

Regarding the decades just preceding the American Revolution as the full development of colonial culture, characterized by elegance, good taste, and charm in its chief centers, the author emphasizes the diverse origins and patterns to be found in these. This view is developed in brief but well-balanced sketches of the cultural life of Boston, New York, Philadelphia, Annapolis, Williamsburg, and Charleston. Each sketch presents the civic background, and the local achievements in literature, architecture, music, the artistic crafts, the theater, and natural science.

3749. Wright, Louis B. The first gentlemen of Virginia; intellectual qualities of the early colonial ruling class. San Marino, Calif., Huntington Library, 1940. 373 p. $40-8029$ F229.W965

While Provincial Virginia produced very little in the way of a literature, its large landowners are here presented as "an aristocracy not only of wealth and position but of intelligence and learning." Although their concern for education produced only a somewhat haphazard system of private tutoring, they owned considerable libraries, which can often be reconstructed on the basis of surviving inventories. Supplementing these with other evidence, the author has worked out detailed case-studies of the literary culture of such figures of the first two generations as William Fitzhugh, Ralph Wormeley II, Richard Lee II, Robert Beverley II, the Carters, and the Byrds.

\section{Topics}

3750. Beard, Charles A., and Mary R. Beard. The American spirit, a study of the idea of civilization in the United States. New York, Macmillan, 1942. $696 \mathrm{p}$.

Bibliography: p. $675-683$.

Formally a 4 th volume of The Rise of American Civilization, this differs so radically from its predecessors as to warrant separate listing. Selected authors from Jefferson, Paine, and Adams to Irwin Edman and W. T. Stace are analyzed in order to elicit a composite formulation of the American idea of civilization. This embraces a conception of history as a struggle of human beings for individual and social perfection, a social principle which views all the agencies in the process of civilization as social products, and a respect for life, for "the utmost liberty compatible with the social principle," and "for the rule of universal participation in the work and benefits of society."

375 I. Boas, George, ed. Romanticism in America; papers contributed to a symposium held at the Baltimore Museum of Art, May 13, 14, 15, 1940. Baltimore, Johns Hopkins Press, 1940. 202 p. 40-32317 PS201.B6 Contents.-Democratic ibocalism, by E. F. Goldman.-New patterns of greatness, by Eleanor 
P. Spencer.-Thomas Cole and the romantic landscape, by W. L. Nathan.-The romantic lady, by R. P. Boas.-Books for the lady reader, by Ola E. Winslow.-The romantic interior, by Roger Gilman.-Early American Gothic, by Agnes Addison.-The Beethovens of America, by Lubov Keefer.-Romantic philosophy in America, by George Boas.

Five of the articles in this symposium deal with the arts-painting, architecture, and music-but there are also contributions on literature, philosophy, and general ideas. To Romanticism, the editor believes, we owe our sense of toleration for individualism, our interest in primitive man, and our love of rural nature. It was therefore, he concludes, a philosophy much more useful to America, with its medley of races and religions, than the traditional classicism.

3752. Davies, John D. Phrenology: fad and science; a Igth-century American crusade. New Haven, Yale University Press, 1955. 203 p. (Yale historical publications. Miscellany 62) 55-9438 BF868. 3

By treating phrenology from the inside and sympathetically, instead of from the outside and contemptuously, Dr. Davies is able to reveal the logic of its development and its interrelations with other aspects of American culture. To its originator, Franz Joseph Gall, his studies sought the physiological basis of physiological phenomena, but his disciples, Johann Gaspar Spurzheim and George Combe, turned it into an optimistic secular philosophy of social progress. In this form, it won a vogue in the course of the 1820's among upperclass discussion groups in the eastern cities; it was "phrenology made practical" by Orson and Lorenzo Fowler, in the form of craniometrical character readings and aptitude diagnoses, that swept American society like wildfire, and survived into the present century. This lucidly organized monograph deals with both levels of phrenology, and their effects in American education, psychiatry, penology, hygiene, literature, medicine, and religion.

3753. Egbert, Donald Drew, and Stow Persons, eds. Socialism and American life. Princeton, N. J., Princeton University Press, 1952. 2 v. (Princeton studies in American civilization, no. 4) $5 \mathrm{I}-5828 \mathrm{HX}_{3} . \mathrm{E}_{45}$

Volume 2 has special title: Bibliography, Descriptive and Critical. Bibliographer: 'T. D. Seymour Bassett.

In one of the most elaborate contributions to American intellectual history thus far made, various hands present the European background, Christian communitarianism, secular Utopianism, the de- velopment of American Marxism, and the relations of American socialism to philosophy, economics, political theory, sociology, psychology, literature, and art. The bibliography, which runs to 5 10 pages, is interlarded with so elaborate a commentary as to constitute an independent work in its own right.

3754. Ekirch, Arthur A. The idea of progress in America, 1815-1860. New York, Columbia University Press, I944. 305 p. (Columbia University. Faculty of Political Science. Studies in history, economics and public law, no. $5 \mathrm{II}$ )

$$
\begin{array}{ll}
\mathrm{A}_{44-56 \text { I I }} \mathrm{E}_{33} 8 . \mathrm{E}_{35} \text {, no. 51 I } \\
\text { i94a }
\end{array}
$$

Contemporary magazines and academic addresses have been ransacked in order to portray the general American faith in progress during this important period, and to analyze the idea in terms of the interests and groups which it served or promised to serve, such as the early labor movement, or "the rising class of industrial capitalists." Attention is also given to the defenders of social stability, who argued that an inevitable steady progress should not be jeopardized by rash attempts to speed its course. The South constituted a special problem to believers in progress, whether sympathetic or hostile to slavery. Programs for social renovation, and systematic expositions of the idea of progress receive separate chapters.

3755. Hofstadter, Richard. Social Darwinism in American thought, I860-1915. Philadelphia, University of Pennsylvania Press, 1944. I9r p. 44-8078 HM22.U5H6

"Prepared and published under the direction of the American Historical Association from the income of the Albert J. Beveridge memorial fund."

Bibliography: p. 177-186.

An incisive exposition, from a harshly critical viewpoint, of the reception of the doctrine of natural selection in America, its application to social phenomena, and its use during three decades to justify "a vision of competition as a thing good in itself." It was not until the mid-9o's that "the American middle class shrank from the principle it had glorified," and listened to the critics who were destroying the "flimsy logical structure" of Herbert Spencer's sociology. But Social Darwinism had its second flowering in a nationalist or racist form, and down to World War I was used to support overseas expansion.

3756. Jones, Howard Mumford. The pursuit of happiness. Cambridge, Harvard University Press, I953. I68 p. (The William W. Cook Foundation lectures, 7) 52-12265 BJ 148 r.J65

A most unusual book which might be called a case-study in American semantics. The well-known 
phrase of the Declaration of Independence is traced to its origin in the mind of George Mason and the Virginia Bill of Rights, and then pursued to a multitude of inferences and consequences in American life and thought since 1776 . It is "the pursuing and securing of happiness and safety as a fundamental constitutional element in our society" which is in question, and the appearance of the idea in a sequence of judicial decisions is noted. The book closes with the 2oth-century preoccupation with the "techniques of happiness"; in the shift of meanings "happiness becomes a problem in expertise."

3757. Parry, Albert. Garrets and pretenders; a history of bohemianism in America. New York, Covici, Friede, 1933. 383 p.

Bibliography: p. 359-369.

$$
\text { 33-27II4 PSi38.P }
$$

Henri Murger's vision of the aesthetic life in Paris has received the compliment of imitation in nearly every civilized nation, although "the French lightheartedness became somewhat rough and uncivilized in some of its American imitations." Mr. Parry follows the American phenomena from Pfaff's saloon on Broadway in 1854 , to the Bohemian Club of San Francisco, and back to Greenwich Village. There is no way, he warns, of isolating the poseurs from the sincere "gypsies of art."

3758. Persons, Stow, ed. Evolutionary thought in America. [Edited for the special program in American civilization at Princeton University] New Haven, Yale University Press, 1950. 462 p.

50-10345 $\mathrm{B} 8 \mathrm{i} 8 . \mathrm{P}_{4}$

Contents. - The theory of evolution: The rise and impact of evolutionary ideas, by R. Scoon. Evolution in its relation to the philosophy of nature and the philosophy of culture, by F. S. C. Northrop. The genetic nature of differences among men, by T. Dobzhansky. Evolutionary thought in America: Evolution and American sociology, by R. E. L. Faris. The impact of the idea of evolution on the American political and constitutional tradition, by E. S. Corwin. Evolutionism in American economics, 1800-1946, by J. J. Spengler. The infuence of evolutionary theory upon American psychological thought, by E. G. Boring. Naturalism in American literature, by $M$. Cowley. The idea of organic expression and American architecture, by D. D. Egbert. Evolution and moral theory in America, by W. F. Quillian, Jr. Evolution and theology in America, by S. Persons.

The second published symposium to originate from the Princeton Program of Study in American Civilization, and organized as a continuation of the first (no. 3768) in that it presents an intellectual stimulus from Western Europe, the context in which the new ideas asserted themselves, and the compromises and adjustments which resulted. The first three chapters are intended to provide the general background for the specifically American material which follows.

3759. Smith, Henry Nash. Virgin land; the American West as symbol and myth. Cambridge, Harvard University Press, 1950. 305 p.

$$
50-6230 \quad F_{591 . S 65} 1950
$$

The idea of the pull of a vacant continent beyond the frontier, drawing population westward and thereby giving American civilization its characteristic stamp, is to be found in Benjamin Franklin, and assumed a multitude of forms in literature and social thought before it received its classic statement from Frederick J. Turner in 1893. The author pursues the theme even into the dime novels which flourished after 1860 , but concludes by criticizing it as the persistence of an agrarian tradition which took no account of the industrial revolution, and which, in the light of World War I, even Turner found inadequate.

3760. Weinberg, Albert K. Manifest destiny; a study of nationalist expansionism in American history. Baltimore, Johns Hopkins Press, 1935. 559 p. $\quad 35-9403 \quad E_{179.5 . W}$. W5

"American expansionism is viewed here as an 'ism' or ideology, exemplified but by no means exhausted by the ideas of manifest destiny. The ideology of American expansion is its motley body of justificatory doctrines ... Taking the liberties necessary to an analytic history of ideas, this work considers separately the leading expansionist doctrines in the order in which successive annexationist movements brought each into focus, and with special reference to the issue or period in which it figured as chief, even if by no means sole, ideological determinant." The content extends from Thomas Paine's "natural right" to Woodrow Wilson's "world leadership."

$376 \mathrm{r}$. White, Edward A. Science and religion in American thought; the impact of naturalism. Stanford, Stanford University Press, 1952. II7 p. (Stanford University publications. University ser. History, economics, and political science, v. 8)

$$
\text { 52-5982 BL245. W63 }
$$

$\mathrm{AS}_{3} 6 . \mathrm{L}_{54}, \mathrm{v} .8$

The relationship of science and religion as viewed by representative thinkers "during the two generations in which naturalistic presuppositions were dominant in American thought." The author's viewpoint is that of Christian philosophy, but is implicit rather than explicit in his critical passages. The thinkers considered are John W. Draper, An- 
drew S. White, John Fiske, William James, David Starr Jordan, and John Dewey, and there is a concluding section on the fundamentalist controversy of the r920's.

3762. Wyllie, Irvin G. The self-made man in America; the myth of rags to riches. New Brunswick, N. J., Rutgers University Press, I954. 2ro p. 54-10602 Er69.r.W93

"A note on sources": p. 197-205.

Concerned "not with business history but intellectual history, and specifically with the realm of ideas about self-help under American conditions of opportunity," this book supplies a long-needed analysis of the American gospel of success conceived as money-making. Although anticipations may be found from early colonial times, the gospel attained its fullest development and influence in the period after $\mathbf{1 8 6 5}$, and although much battered in the years before I9I7, enjoyed a noteworthy rejuvenation during the prosperous r920's. The author has no difficulty in showing that it has always been a matter of simple faith, since the great majority of men at the top have always started a long way from the bottom.

\section{Localities}

3763. Bowes, Frederick P. The culture of eariy Charleston. Chapel Hill, University of North Carolina Press, 1942. 156 p.

$$
\mathrm{A}_{43}-857 \quad \mathrm{~F}_{279} \mathrm{C}_{4} \mathrm{~B} 6
$$

Revision of thesis (Ph.D.)-Princeton University, I94I.

Bibliography: p. [r37]-r45.

A Princeton dissertation which covers the first century of Charleston, from its foundation in 1670 to the Revolution. Religious life, education, books, libraries and publications, science, and literature and the arts are successively examined. This was the brightest period of the city's culture, for after the Revolution, "without the fertilizing contact of English culture, the intellectual life of Charleston became increasingly insular," absorbed in politics and the law.

3764. Bridenbaugh, Carl, and Jessica Bridenbaugh. Rebels and gentlemen; Philadelphia in the age of Franklin. New York, Reynal \& Hitchcock, 1942. $393 \mathrm{p}$. 42-22812 $\mathrm{Fr}_{5} 8.4 . \mathrm{B} 6$

"Bibliographical note": p. 373-379.

Presents I 8th-century Philadelphia as the American port of entry for the Enlightenment-secular, humanistic, and bearing democratic and individualistic implications. Philadelphia, while becoming the second city of the British empire, became also the first example in the Western World of a culture resting on a broadly popular base. Much social history is presented, but the emphasis is on education, printing and authorship, the fine arts and the art of living, the professions, and the rise of a scientific outlook.

3765. Davenport, Francis Garvin. Cultural life in Nashville on the eve of the Civil War. Chapel Hill, University of North Carolina Press, r94r. 232 p. 4I-I $227 \mathrm{~F}_{444 \cdot \mathrm{N}_{2} \mathrm{D}_{33}}$
Bibliography: p. $211-224$.

During the quarter-century preceding 1850 , "the influence of the frontier mind as a negative force" lay heavy upon Nashville, but the missionary work of Philip Lindsley, president of the university, and his professor of sciences, the South-born Gerard Troost, was preparing for a far-reaching change. Its manifestation in the pre-Civil War decade, in education, medicine, religion, music and the theater, libraries and publishing, and in architecture, forms the subject of this book. By i 850 , the author thinks, Nashville had earned its title, "the Athens of the South."

3766. Eaton, Clement. Freedom of thought in the old South. Durham, N. C., Duke University Press, 1940. 343 p. 40-5232 F209.E15

"This study of the cultural history of the South between 1790 and 1860 , in which freedom of thought and speech is the central theme, is offered as a case history in the record of human liberty and intolerance." The liberal culture of the older Southern aristocracy disintegrated soon after the death of Jefferson in 1826 . A thorough-going conservative reaction took its place, and set up taboos which put slavery and religious orthodoxy beyond the reach of criticism. There resulted an intellectual cordon sanitaire which sealed the South from Northern "isms."

3767. Miller, James M. The genesis of western culture, the upper Ohio Valley, 1800-1825. Columbus, Ohio State Archaeological and Historical Society, 1938. 194 p. ([Ohio State Archaeological and Historical Society] Ohio historical collections, v. 9) 39-715 F5 $_{5} 8 . \mathrm{M}_{55}$

Bibliography: p. $165-176$. $\mathrm{F}_{4} 86 . \mathrm{O}_{526}$, v. 9 
Covers the period of stable settlement, "during which the permanent centers of population were established and a permanent culture began to assert itself," and concentrates upon the principal towns: Pittsburgh, Marietta, Cincinnati, and Lexington. The activity of the several professions-ministers, lawyers, physicians, teachers, and journalists-is emphasized. "Backwoods ignorance contests with the forces of education far superior to the demands of frontier life, and the utter rout of the muscular powers of darkness can be explained only by the tremendous vitality of the frail forces of light."

\section{E. International Influences: General}

3768. Bowers, David F., ed. Foreign influences in American life; essays and critical bibliographies. Edited for the Princeton Program of Study in American Civilization. Princeton, N. J., Princeton University Press, 1944. 254 p. [Princeton studies in American civilization] A44-4627 Er69.1.B782 "Critical bibliographies": p. [173]-254.

A considerably more heterogeneous and uneven collection than the subsequent products of the Princeton Program of Study in American Civilization, but containing some material not easily found elsewhere. The 'editor, whose early death was a loss to American studies, contributed a theoretical discussion of "social and cultural impact," and a study of the effect of Hegel and Darwin upon the American tradition. Donald D. Egbert and R. P. Blackmur take large views, respectively, of foreign influences in American fine art, and of the American literary expatriates. The critical bibliographies are extensive, partially so because some individual titles are irequently repeated.

3769. Koht, Halvdan. The American spirit in Europe, a survey of transatlantic influences. Philadelphia, University of Pennsylvania Press, 1949. 289 p. (Publications of the American Institute, University of Oslo, in cooperation with the Dept. of American Civilization, Graduate School of Arts and Sciences, University of Pennsylvania)

"Selected bibliography": p. 279-280.

$$
\text { 49-8752 Er83.7.K64 }
$$

Offered as an avowedly incomplete picture, in the hope that a preliminary survey of the whole field will prove useful and provoke further studies. To gether with the European repercussions of the American Revolution and the Civil War, and the emergence of America as a world power, Dr. Koht treats a variety of nonpolitical influences: the reform movements of the earlier 19th century (peace, temperance, penology, etc.), invention, economic organization, technology, scientific cooperation, etc. The European vision of America also receives attention: the land of opportunity, and of the strange contrast between American idealism and the commercial spirit.

3770. Kraus, Michael. The Atlantic civilization: eighteenth-century origins. Ithaca, Cornell University Press, 1949. 334 p. 49-50435 $\mathrm{CB}_{4} \mathrm{Ir} . \mathrm{K}_{7}$ "Published for the American Historical Association."

Bibliography: p. 315-325.

In this formidable array of cultural data, based on a mass of monographic material as well as original sources both published and in manuscript, the author is concerned to stress the mutuality of the process: if America was the recipient in medicine and kindred fields, she was also giving greater substance to such concepts as political and religious freedom, economic opportunity, and humanitarian ideals, and hurrying the Western World to the realization of them. If Europe is still the biggest fact in North America, "North America has long been the biggest fact in Europe."

3771. Spoerri, William T. The old world and the new; a synopsis of current European views on American civilization. Zürich und Leipzig, M. Niehan, 1937. 236 p. (Schweizer anglistische Arbeiten; Swiss studies in English, 3. bd.)

$$
\text { 39-11768 Ei69.1.S75 }
$$

Issued also as an inaugural dissertation, Zürich. Bibliography: p. 233-236.

This Swiss writer had spent five years in the United States working his way through college and teaching, but, as he says, had been back in Europe long enough to de-Americanize himself without relapsing into the anti-American attitude common among intellectuals. He reviews the English, French, and German literature on America, 191836 , in an effort to explain the reactions, usually both adverse and violent, of some eminent observers. His own contribution consists largely of a classifcation-scientific investigators, reports, prophets of 
doom, literary critics, contrast critics, social reformers, and satirists-and of summaries with extracts of individual writers; but in a brief conclusion he asserts that a horror of reality and hunger for romance constitute the key to the American character.

3772. Visson, André. As others see us. Garden City, N. Y., Doubleday, r948. 252 p. 48-9390 Ei69.I.V53

A French intellectual who has become an Amer- ican citizen is able to present, because he formerly entertained them, the attitudes toward the United States of the intellectuals of western Europe. They arise, he is convinced, out of profound misunderstandings, most of them the result of ignorance, prejudice, envy, or fear. At the bottom of these he finds the "Athenian complex," insisting upon a cultural and intellectual superiority when political and economic leadership have been lost, and upon a privileged social position for the intellectuals themselves.

\section{F. International Influences: By Country}

\section{France}

3773. Faÿ, Bernard. The revolutionary spirit in France and America; a study of moral and intellectual relations between France and the United States at the end of the eighteenth century. Translated by Ramon Guthrie. New York, Harcourt, Brace, $1927.613 \mathrm{p}$. 27-23830 $\mathrm{DC}_{138 . \mathrm{F}_{32}}$ Bibliography: p. $57 ;-600$.

Originally a dissertation based on a very thorough study of all French putlications concerning America during the last three decades of the I8th century, this work is considerably more successful as a presentation of authors and books than as an interpretation of national states of mind. The author believes that "from I775 to I 800 there reigned an impassioned intellectual union between" France and America, symbolized by the reception of James Monroe by the National Convention in 1794, and that it was brought to an end only by the military dictatorship of Bonaparte. The critical bibliography is available only in the original French edition: Bibliographie critique des ouvrages français relatifs aux Etats-Unis, 1770-1800 (Paris, Champion, I925. I08 p.).

3774. Jones, Howard Mumford. America and French culture, I750-1848. Chapel Hill, University of North Carolina Press, 1927. 615 p.

Bibliography: p. 573-602. 28-255I EI83.8.F8J7

An ambitious pioneer study which tries to arrive at "the general American attitude toward things French" during an important century, as a prolegomenon to a survey of the American reception of French literature. The author first offers an analysis of American culture, which he sums up in the cosmopolitan spirit, the spirit of the frontier, and the middle class spirit-together with the urban spirit which was just emerging in 1848 . He deals successively with French migration, the French language, French art, religion, and philosophical and educational influences. "On the whole," he concludes, "it is in the departments of manners and fashions that the French have exerted their most notable influences in shaping American culture. In intellectual matters they have had vogue rather than influence."

3775. White, Elizabeth Brett. American opinion of France from Lafayette to Poincaré. New York, Knopf, 1927. 346 p.

$$
\text { 27-I2393 EI83.8.F8W5 }
$$

In spite of the subtitle, the text begins with the War of 1812 , and reaches the discussion of the French debt question in 1926 . The emphasis is upon public affairs, the successive regimes which have governed France, and phases of French policy. American opinion is derived from diplomatic correspondence, congressional debates, the utterances of prominent Americans, magazine articles, and especially newspaper editorials. Chapter 8 , "Signs and Portents," is concerned with educational, literary, and other intellectual interrelations.

\section{Germany}

3776. Long, Orie William. Literary pioneers; early American explorers of European culture. Cambridge, Harvard University Press, I935. 267 p. 35-18097 PS20r.L6

Essays on six New Englanders-George Ticknor, Edward Everett, Joseph G. Cogswell, George Bancroft, H. W. Longfellow, and J. L. Motley-who studied in Germany between 1815 and 1835 . Most of them matriculated at the University of Göttingen, and the earlier arrivals sought out the venerable 
Goethe. The author's commentary is somewhat naive, but the abundant extracts from his subjects' own letters and other writings make this a useful source for German-American intellectual relations.

\section{Great Britain}

3777. Heindel, Richard Heathcote. The American impact on Great Britain, 1898-1914; a study of the United States in world history. Philadelphia, University of Pennsylvania Press, 1940. $439 \mathrm{p}$.

40-3137I Er83.8.G7H5

By "impact" the author means British knowledge of or interest in the United States, opinions and attitudes about it, and the imitation or modification of the American example. The year 1898 , when the United States suddenly became an imperial power, was the annus mirabilis in which it was demonstrated that America had become an important factor in British life. Anglo-American intellectual relationships are examined in the fields of diplomacy, business, education, literature, entertainment, and social phenomena.

3778. Lillibridge, George D. Beacon of freedom; the impact of American democracy upon Great Britain, I830-1870. [Philadelphia] University of Pennsylvania Press, I954, '1955. 159 p.

"Bibliographical note": p. I5 154 -1 57 .

$$
\text { 54-1 154I E183.8.G7L } 54
$$

This dissertation by a pupil of Merle E. Curti examines the part played by the idea of American democracy in the strenuous class struggle in which the whole of British society was involved during the central four decades of the rgth century. Radical opinion is gleaned from newspapers, and middleclass liberal and conservative opinion from books, and from reviews such as the Westminster and the Quarterly. In the latter part of the period, radicals accepted the liberal leadership of John Bright and Richard Cobden, frequently called by their opponents "the two members for the United States." The author draws the moral that a nation's democratic idea is more readily exportable than its "Democratic movement," conceived as "attitudes, behaviors, institutions, and techniques."
Italy

3779. Torrielli, Andrew J. Italian opinion on America as revealed by Italian travelers, 1850-1900. Cambridge, Harvard University Press, 1941. 330 p. (Harvard studies in Romance languages, v. I5) A4I-3270 Er69.I.T66 I94I Based on thesis (Ph. D.)-Harvard University, 1940.

Exploits a considerable, and otherwise practically unused, body of publications, in order to present "not merely another work on American social history, but rather an examination of average Italian sentiment on problems of continuous moment." These problems, as illustrated by the American example, are the Negro question, democracy, education, the press, and the status of women, and of the arts. The author does very little summarizing, but gives his opinion that the Italian travelers in America had fewer axes to grind than many others.

\section{Japan}

3780. Schwantes, Robert S. Japanese and Americans; a century of cultural relations. New York, Published for the Council on Foreign Relations by Harper, 1955. $3^{80} \mathrm{p}$.

"Bibliographical essay": p. $333-372$.

By culture, Mr. Schwantes means "the whole pattern of life," and by cultural relations "all the ways in which peoples learn about each other." Those here described have been "unbalanced": "Americans have played a much greater part in the changes that have occurred in Japan over the past century than Japanese have in the equally great changes here. Japanese have been, on the whole, more interested in America than Americans have been in them." This largely one-way influence is traced in Japanese economic development, in political institutions and thought, and in education. Channels of communication are identified in the exchange of teachers, students, and cultural materials, and in the influence of American missionaries. Since the author is seeking lessons of value for present-day American foreign policy, broadly conceived, he naturally emphasizes the most recent period. 


\section{Local History: Regions, States, and Cities}

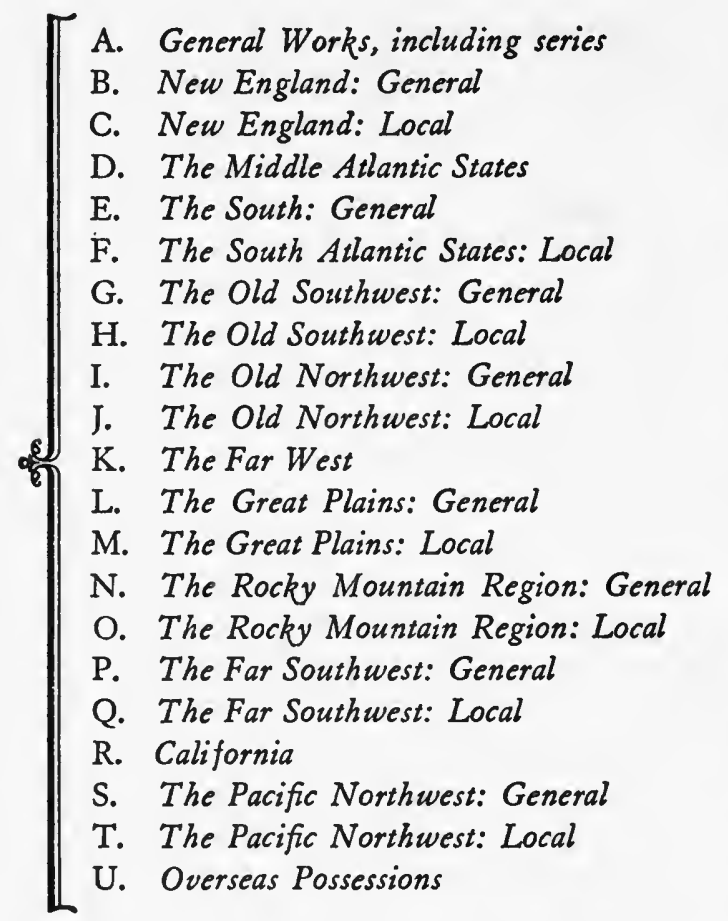

$\mathrm{T}$

HE concern of the present Guide is American civilization of today and the three and a half centuries of history which have led to it. From such a work local history and description, the literature concerned with the lesser units into which the nation is divided, and most of which preserve a degree of autonomy and spontaneity within it, could hardly be excluded. But obviously the problem of selecting, from a local literature which has been multiplying along with its subject matter, some 440 titles as best representative of the whole for the generalized purpose of the Guide, presents special difficulties. The result is a compromise which may please few, but, we trust, will not offend many.

The subtitle of the chapter indicates the three principal types of book which compose it, and points to two large classes deliberately excluded. County histories are legion and were an article of systematic manufacture in the last decades of the igth century. But the county is in origin an artificial unit, and while it bulked large in the older, rural America,

it has receded in importance to the average American of today. There are, furthermore, no fewer than 3,049 counties in the United States, and the choice of a handful could easily seem invidious. Town histories are equally missing, save for one of a New England community both unique and representative, Concord (no. 4037), and for the same reasons of multiplicity and diminishing significance. On the other hand, we have included individual 
treatments of some national parks and monuments which nearly everybody wants to visit, and very many do.

The subdivision of the chapter in the above table takes account of historical as well as geographical factors, and is merely for convenience in the arrangement of titles. States are placed following the region to which they are assigned, in a geographical order, and cities or other units are placed following their states, in an alphabetical order. Some states are variously allied, and we have assigned them to regions quite arbitrarily and without prejudice-Oklahoma to the Great Plains rather than to the Far Southwest, Idaho to the Pacific Northwest rather than to the Mountain States, and so forth. Here is one anomaly: the regional books in Section E, The South, usually span Sections F, G, H, and part of $P$ and $Q$, where we have put Texas.

We have meant to slight no region, state, or city. However, very few writers have dealt with the Middle Atlantic States as a past or present unity, and the one small volume below that does so, appears principally for the reason that it does. Nor do we have 48 state histories to match the 48 states, or a volume for each of the Nation's largest cities. This is because we have been looking for books which will have significance, not merely for the local patriot or antiquary, or for the historian looking for raw material, but for people who want to fit the area into their general picture of the United States, and are interested both in what gives it its distinctive character, and in what it has contributed to the character of the Nation as a whole.

The older state and local histories were usually guided by an antiquarian interest which led to large enumerations of persons, sites, and discrete events. They tended to concentrate upon origins and crucial episodes, and passed up the problem of representing latter-day complexities of development. With some distinguished exceptions, our selections are works of comparatively recent date.

Many of them are works of original research by professional historians, who have learned that sound local history requires just as great an intellectual effort as do other varieties, and aim to make their work significant by disclosing the larger historical currents as they assume a concrete shape in a par- ticular community. Some states emphasize their own history in their schools and universities, which may result in compact and well-ordered textbooks whose usefulness is not limited to the classroom. Many of our titles, however, are of non-academic origin and consist of attempts to arrive at the genius loci by general writers or journalists. Some are products of the wave of "regional writing" which began rolling in the I930's. They may lack the precision of scholarly history and geography, and some of their materials may require to be taken with a grain of salt, but when honestly done they make a distinct contribution which the others usually do not attempt, and they are regularly written to be read, while the academic product sometimes seems to be meant to discourage readers. Areas differ conspicuously in their productivity of modern works of either type. Why, for example, should Oklahoma be a veritable cornucopia of books of State and regional interest, while Missouri, immediately to the northwest, turns out practically nothing?

The greatest tide in recent America, which has run for over a century but seems only to grow in strength, is the tide of urbanization. It can hardly be said that historians and geographers, as distinct from the sociologists who view it as material for abstractions, have kept abreast of it. In America there are many great urban universities whose graduate schools produce learned monographs on ancient Greek pottery or the foreign policy of Bismarck, but never dream of searching for order and significance in the prodigious developments which have been going on under their noses. And there are many great cities unrepresented here by any history or even any title, because there is no up-to-date and comprehensive history to be had.

General works on the Westward movement and the frontier are contained in Chapter VIII, General History, and the more local ones on our successive Wests in this one, but the separation cannot be entirely clear-cut. The same kind of separation has been attempted between works on the slavery system and the crisis of $1854-1876$, assigned to Chapter VIII, and works on the South as a region, assigned here, but again it cannot be effected with completely satisfactory results.

\section{A. General Works, Including Series}

3781. Davidson, Donald. The attack on leviathan; regionalism and nationalism in the United

States. Chapel Hill, University of North Carolina
Press, 1938. $368 \mathrm{p}$.

38-96I4 Ei69.1.D 34

A collection of essays and studies, many of which appeared in periodicals from 1932 to 1937 , reviewing 
the development of regionalism or sectionalism in the United States as interpreted by various authors. The greatest hindrance to regionalism, the author thinks, is increasingly powerful national government, the leviathan that attempts to impose a uniform pattern on the regions. The main thesis is discussed from the standpoints of history, geography, politics, culture, economics, and social conditions. Although Mr. Davidson defends the South as a region, upholding its interests and tradition, he recognizes that the hope of a democratic America lies in the fusion of regionalism with nationalism. "The recognition of sectional diversity," he says, "is the true safeguard of national unity. The danger to national unity comes when diversity is ignorantly or willfully put aside as a thing of no importance, or when it is assumed that no diversity exists."

3782. Look. Look at the U. S. A., by the editors of Look. With regional introductions by Mary Ellen Chase [and others] Boston, Houghton Miftlin, 1955. 522 p. 55-81 or Er69.L842

An abridged and reworked version of a pictorial guide to the regions of the United States originally published in 9 volumes in 1946-48. The photographs, most of which occupy an entire page, are original, significant, and handsomely reproduced. The regional introductions are by well-known writers: Mary Ellen Chase on New England, Paul Horgan on the Southwest, Frederick L. Allen on New York City, Gerald W. Johnson on the Central Northeast, Louis Bromfield on the Midwest, David L. Cohn on the South, Wallace Stegner on the Central Northwest, and Joseph Henry Jackson. Many more fine photographs and vastly more detailed local information will be found in the original 9-volume edition, the sectional arrangement of which is the same as here.

3783. Odum, Howard W., and Harry Estill Moore. American regionalism; a cultural historical approach to national integration. New York, Holt, I938. 693 p. illus. $\quad 3^{8-15648}$ Er79.5.O43

In contrast to sectionalism (see Turner below), "regionalism assumes .... a great national unity and integrated culture in which each region exists . . . solely as a component unit in the whole." In Part I, the authors consider our natural regions, our cultural regions, and our service regions (governmental and non-governmental); in Part II, the historical and theoretical aspects of regionalism as they have been explored by social scientists, and in Part III the development of the six major regionsthe Middle States, the Northeast, the Southeast, the Far West, the Northwest and the Southwest-into a great nation, "in whose continuity and unity of development, through a fine balance of historical, cultural, and geographic factors, must be found the hope of American democracy and, according to many observers, Western civilization." The authors support their thesis with quotations from numerous sources.

3784. Turner, Frederick Jackson. The significance of sections in American history; with an introd. by Max Farrand. New York, Holt, 1932. $347 \mathrm{p}$. 33-1864 Er78.T96

Avery O. Craven and Max Farrand collected and edited these twelve scattered essays by the late Professor Turner relating to the sections of the United States: New England, the Middle States, the Southeast, the Southwest, the Middle West, the Great Plains, the Mountain States, and the Pacific Coast. $\mathrm{He}$ ascribes the individual characteristics of the sections to variations in physiography, the pressure of population, political attitudes towards industrial interests, and the economic, social, and religious aspirations of the people. He points out the necessity of shaping national action to "the fact of a vast and varied Union of unlike sections." "We have furnished to Europe," Professor Turner says, "the example of a continental federation of sections over an area equal to Europe itself, and by substituting discussion and concession and compromised legislation for force, we have shown the possibility of international political parties, international legislative bodies, and international peace."

3785. Wisconsin. University. Regionalism in America. Edited by Merrill Jensen; with a foreword by Felix Frankfurter. Madison, University of Wisconsin Press, 195I. xvi, 425 p.

Includes bibliographies.

51-6901 EI79.5. W56

The papers in this volume were delivered at a symposium on American regionalism sponsored by the Committee on the Study of American Civilization of the University of Wisconsin and held in April 1949. Men from various academic fields and from public life, all interested in regionalism as a field of research or of administration, give their concepts of regions and regionalism. Merrill Jensen, Rupert B. Vance, William B. Hesseltine, John F. Kienitz, John M. Gaus, Merle Curti, and other distinguished scholars and administrators have contributed papers to discussions of the development of regionalism since the 18 th century, three historic regions of the United States, the place of regionalism in American culture, and regionalism as a practical concept in the development and administration of Federal Government programs. Howard W. Odum says in the final paper: "It was in the regional quantity and quality of this continent 
that the first plantings and the later fruits of American democracy set the incidence of the American way of life as distinctive from that which had gone before."

\section{AMERICAN GUIDE SERIES}

3786. American guide series. [Compiled and written by the Federal Writers' Project and the Writers' Program] I936-43. I53 v.

New editions and reprints, $1939-56$.

The American Guide Series has been described as "our first real series of handbooks for the nation." It was begun soon after the organization of the Federal Writers' Project in the Works Progress Administration (later changed to Works Projects Administration) in the summer of 1935 , to provide work-relief for several thousand writers throughout the 48 states. In the summer of 1939 the Federal Writers' Project was superseded by the Writers' Program with the initiative placed in the hands of public sponsoring bodies in each of the states. The following entries represent the latest available editions of each of the state, territorial, and town guides, with the date of the earliest edition and the latest printing given in a note whenever they differ from the imprint date of the latest issue for which a printed card is available. Each of the state guides is arranged according to the major highways, and contains descriptions of towns, waterways, recreational areas, and points of historical interest. All are illustrated with photographs and maps. The new editions, in most instances, bring up to date the maps and tours, population figures, college enrollment, and other developments in the states' economic and cultural progress. The Assistant Commissioner of the WPA in I94I said that "the publication of the Writers' Program constitutes a unique example of cooperation between the community and the Nation with the aim of preserving the story of our American heritage in such form that it may become part of the consciousness of the widest possible number of Americans." The guides to several travel routes that cut across regional boundaries have been listed first. The series is here arranged by geographical regions, with the state guide first, and the city, town, or other area guides of that state following alphabetically, by locality.

\section{TRAVEL ROUTES}

3787. The Intracoastal Waterway, Norfolk to Key West. Washington, U. S. Govt. Print. Off., 1937. $143 \mathrm{p}$. $37-26563 \quad \mathrm{TC}_{23} \cdot 4 \cdot \mathrm{F}_{4}$
3788. The Ocean Highway; New Brunswick, New Jersey to Jacksonville, Florida. New York, Modern Age Books, 1938. xxix, 244 p.

38-12399 Fro6.F 44

3789. The Oregon Trail; the Missouri River to the Pacific Ocean. New York, Hastings House, 1939. $244 \mathrm{P}$.

Bibliography: p. 228-230.

3790. U. S. One, Maine to Florida. New York, Modern Age Books, 1938. xxvii, 344 p. 38-27179 FI06.F45 $\mathrm{GV} \mathrm{C}_{24} \cdot \mathrm{F}_{32}$

\section{NEW ENGLAND}

3791. Here's New England! A guide to vacationland. Sponsored by the New England Council, Boston. Boston, Houghton Mifflin, I939. I22 p. 39-15700 $\quad \mathrm{F}_{9} . \mathrm{F}_{44}$

3792. Maine, a guide 'down east.' Sponsored by the Maine Development Commission. Boston, Houghton Mifflin, r937. xxvi, 476 p. illus.

"Selected reading list": p. $[454]^{-}-458$. $3^{8}-30 \quad F_{25} \cdot F_{44}$

3793. Augusta-Hallowell on the Kennebec. Sponsored by the Augusta-Hallowell Chamber of Commerce. [Augusta] Kennebec Journal Print Shop, 1940. 123 p.

Bibliography: p. [108]

3794. Maine's capitol. Sponsored by the Department of Education of the State of Maine. Augusta, Kennebec Journal Print Shop, 1939. 60 p. $43-547$ I F $29 . \mathrm{AgF}_{4}$

3795. Portland city guide. Sponsored by the city of Portland. [Portland ${ }_{\text {F }}$ Forest City Print. Co., 1940. xiv, 337 p. 40-30610 F29.P9W8 "Selected reading list": p. [3I7]-3I8.

3796. New Hampshire, a guide to the Granite State. Francis P. Murphy, Governor of New Hampshire, co-operating sponsor. Boston, Houghton Mifflin, 1938. xxix, 559 p. illus.

"Selected reading list": p. 539-540.

$$
{ }_{36-6192} \quad F_{39} \cdot F_{43}
$$

3797. Vermont; a guide to the Green Mountain State. Sponsored by the Vermont State Planning Board. Boston, Houghton Mifflin, 1937. xxi, $392 \mathrm{p}$.

Bibliography: p. [372]-379.
$37-286_{48} \quad \mathrm{~F}_{54} \cdot \mathrm{F}_{45}$ 
3798. Massachusetts; a guide to its places and people. Frederick W. Cook, secretary of the Commonwealth, cooperating sponsor. Boston, Houghton Mifflin, 1937. xxxvi, 675 p. 37-28502 $\mathrm{F}_{70 . \mathrm{F}_{295}}$

"Fifty books about Massachusetts": p. [637]-638.

3799. The Berkshire hills. Sponsored by the Berkshire Hills Conference. New York, Funk \& Wagnalls, 1939. xiv, $368 \mathrm{p}$.

39-27644 $\mathrm{F}_{72 . \mathrm{B}_{5} \mathrm{~F}_{37}}$ 360.

"Berkshire sports, winter and summer": p. [277]-

$3^{800}$. Boston looks seaward, the story of the port, 1630-1940. Sponsored by Boston Port Authority. Boston, B. Humphries, 1941. 316 p.

42-9007 $\mathrm{F}_{73.63 . W 8}$

3801. Cape Cod pilot, by Jeremiah Digges [pseud. of Josef Berger] Sponsored by Poor Richard Associates. Provincetown, Mass., Modern Pilgrim Press, 1937. 403 p.

Bibliography: p. 390-39r.

3802. Springfield, Massachusetts. Springfield [Mass.] I94r. 84 p.

$$
4^{\mathrm{I}-8764} \quad \mathrm{~F}_{74 .} \mathrm{S} 8 \mathrm{~W}_{975}
$$

3803. State forests and parks of Massachusetts, a recreation guide. Boston, Dept. of Conservation, I94I. $5^{8}$ p. $\quad 42-368$ Io $\quad \mathrm{SD}_{428 . \mathrm{A}_{2} \mathrm{M}_{47}}$

3804. Rhode Island, a guide to the smallest State. Sponsored by Louis W. Cappelli, secretary of state. Boston, Houghton Mifflin, 1937. xxvi, $500 \mathrm{p}$.

Bibliography: p. [475]-479. $37-28_{4} 6_{3} \quad \mathrm{~F}_{79} \cdot \mathrm{F}_{3} 8$

3805. Connecticut; a guide to its roads, lore, and people. Sponsored by Wilbur L. Cross. Boston, Houghton Mifflin, 1938. xxxiii, 593 p.

"Selected reading list": p. $\left[5^{62}\right]-565$.

\section{MIDDLE ATLANTIC STATES}

3806. New York; a guide to the Empire State. Sponsored by New York State Historical Association. New York, Oxford University Press, 1946. $x x x i, 782$ (i. e. 798 ) p.

$$
\text { 46-5765 Fr24.W89 } 1946
$$

First published in 1940. Second printing, with corrections, 1946. Fourth printing, 1949.

Bibliography: p. 729-739.
3807. Albany-past and present. [Albany? 1938?] 27 p. $\quad 38-26487$ Fi29. $\mathrm{A}_{3} \mathrm{~F}_{43}$

3808. New York City guide. [Rev. ed.] New York, Random House, 'I939. xx, 680 p. 56-5152I Fi28.5.F 376 r939b

First published in 1939 .

Companion volume to New York Panorama.

"Books about New York": p. 627-635.

3809. New York panorama; a comprehensive view of the metropolis, presented in a series of articles. New York, Random House, 1938. 526 p. $3^{8-27618} \mathrm{~F}_{12} 8.5 \cdot \mathrm{F}_{3} 8$

"The present volume, although complete in itself ... constitutes in effect the general introduction to the New York City Guide."

38ro. Rochester and Monroe County. Rochester, N. Y., Scrantom's, 1937. 460 p.

Half-title: A history and guide. $3^{8-1950} \mathrm{~F}_{129} \mathrm{R}_{7} \mathrm{~F}_{43}$

Bibliography: p. 443-447.

38I I. New Jersey, a guide to its present and past. Sponsored by the Public Library of Newark and the New Jersey Guild Associates. New York, Viking Press, 1939. xxxii, $735 \mathrm{p}$.

Bibliography: p. 697-704.

$$
\text { 39-20654 } \mathrm{F}_{139 . \mathrm{F}_{45}}
$$

3812. The story of Dunellen. [Dunellen, N. J., Art Color Print. Co.] 1937. 1 II p.

Bibliography: p. 108.

$$
\text { - } 38-26489 \mathrm{~F}_{144 . \mathrm{D}_{9} \mathrm{~F}_{4}}
$$

3813. Livingston; the story of a community. [Caldwell, N. J., Printed by the Progress

Pub. Co.] 1939. I66 p. 4I-2862 FI44.L- IW7 $_{7}$

3814. Entertaining a nation; the career of Long Branch. [Bayonne, N. J., Jersey Print. Co.] I940. xiv, 2 I I p.

Bibliography: p. 198-200.

40-27599 FI44.L847

3815. Monroe Township, Middlesex County, New Jersey, 1838-1938. [New Brunswick, N. J.] 1938. $140 \mathrm{p}$.

Bibliography: p. 134-135.

38r6. Pennsylvania: a guide to the Keystone State. Co-sponsored by the Pennsylvania Historical Commission and the University of Pennsylvania. New York, Oxford University Press, 1940. xxxii, $660 \mathrm{p}$.

Fourth printing, 1950. 40-28760 Fi54. W94

"A guide to further reading": p. 623-629. 
3817. Story of old Allegheny city, sponsored by Hon. Cornelius D. Scully. Pittsburgh, Pa., Allegheny Centennial Committee, 1941. xviii, $236 \mathrm{p}$.

Bibliography: p. 227 . $4^{1-16289} \quad \mathrm{~F}_{159} \cdot \mathrm{A}_{4} \mathrm{~W}_{7}$

Has no map.

3818. Erie; a guide to the city and county. Sponsored by Charlie R. Barber, mayor of Erie. ${ }_{\text {[Philadelphia }}$ William Penn Association of Philadelphia, 1938. I33 p.

Bibliography: p. 128 .

3819. The Harmony Society in Pennsylvania. ${ }_{[}$Philadelphia $_{]}$William Penn Association of Philadelphia, I937. $3^{8} \mathrm{p}$.

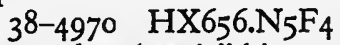

This is the "most complete and authentic" history to date of a practical experiment in communal living for a small group of people who settled in Butler County, Pennsylvania, 25 miles northwest of Pittsburgh, in 1804 .

3820. The Horse-Shoe Trail, sponsored by Henry N. Woolman, president, Horse-Shoe Trail Club, Philadelphia, Pa. 2d ed. ${ }_{[}$Philadelphia $_{]}$ William Penn Association of Philadelphia, 1939. $32 \mathrm{p} . \quad 40-36 \mathrm{I}_{7} \quad \mathrm{~F}_{154} \cdot \mathrm{F}_{45} \quad 1939$ First published in 1938 .

3821. Philadelphia, a guide to the Nation's birthplace. Sponsored by the Pennsylvania Historical Commission. [Philadelphia ${ }_{]}$William Penn Association of Philadelphia, 1937. xxxii, $704 \mathrm{p}$.

Bibliography: p. 690-691. $3^{8-23204} \mathrm{~F}_{15} 8 \cdot 5 \cdot \mathrm{F}_{35}$

3822. Delaware, a guide to the first State. New and rev. ed. by Jeannette Eckman; edited by

Henry G. Alsberg. New York, Hastings House, I955. xxvi, 562 p. $\quad 55-14794 \quad$ FI $_{64} \cdot \mathrm{F}_{45} 1955$ First published in $193^{8}$.

Bibliography: p. $\left[530^{0}-538\right.$.

3823. New Castle on the Delaware. 2d ed. Sponsored and published by the New Castle Historical Society. [Wilmington, Del., Press of W. N. Cann ${ }_{1}$ 1937: I42 p. $\quad 39-5465 \quad \mathrm{~F}_{174 \cdot \mathrm{N}_{5} \mathrm{~F}_{42}}$ First published in 1936 .

Bibliography: p. 139-142.

3824. Maryland, a guide to the old line State. Sponsored by Herbert R. O'Conor, Governor of Maryland. New York, Oxford University Press, 1940. xxviii, $561 \mathrm{p}$.

Fifth printing, 1948. 40-13919 FI81.W 75

Bibliography: p. 535-543.
3825. A guide to the United States Naval Academy. Sponsored by the United States Naval Academy. New York, Devin-Adair Co., I94I. $15^{8} \mathrm{p}$.

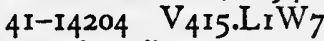

"Superintendents of the Academy": p. 53-74; "Outstanding graduates of the Academy": p. 75-92.

3826. Washington, D. C., a guide to the Nation's capital. Sponsored by the George Washington University. New York, Hastings House, 1942. $\mathrm{xl}, 528 \mathrm{p}$. 42-19931 Frg9. F $_{3} 8$ 1942

A revision and condensation of Washington: City and Capital, compiled by the Federal Writers' Project, 1937 .

"Selected reading list": p. 505-512.

$$
42-19931 \text { Frg9. } F_{3} 8 \quad 1942
$$

\section{THE SOUTH ATLANTIC STATES}

3827. Virginia; a guide to the Old Dominion. Sponsored by James $\mathrm{H}$. Price, Governor of Virginia. New York, Oxford University Press, 1946. xxix, 710 p. $\quad 4^{6-5684} \quad$ F231.W88 1946

First published in 1940. Third printing with corrections, 1946. I952 reprint listed in The Cumulative Book Index.

Bibliography: p. 647-667.

3828. Jefferson's Albemarle, a guide to Albemarle County and the city of Charlottesville, Virginia. Sponsored by the Charlottesville and $\mathrm{Al}$ bemarle County Chamber of Commerce. [Charlottesville, Jarman's] 194r. $157 \mathrm{p}$.

$$
4^{2-1913} \quad \mathrm{~F}_{232 . \mathrm{A}_{3} \mathrm{~W}_{7}}
$$

3829. Alexandria. Sponsored by the Young Women's Club of Alexandria. [Alexandria, Va., Williams Print. Co.] 1939. 27 p. $40-3986 \quad \mathrm{~F}_{234} \cdot \mathrm{A}_{3} \mathrm{~W} 8$

3830. West Virginia, a guide to the Mountain State. Sponsored by the Conservation Commission of West Virginia. New York, Oxford University Press, 1948. 559 p. $\quad 53^{-23405} \quad$ F241.W85 1948 First published in 194I.

Bibliography: p. 533-54I.

383r. The North Carolina guide; edited by Blackwell P. Robinson. Sponsored by the North Carolina Department of Conservation and Development. [New ed.] Chapel Hill, University of North Carolina Press, 1955. xxi, 649 p.

First published in 1939 .

$$
\text { 55-2216 } \quad{\text { F } 259 . F_{44}} \quad 1955
$$


3832. Charlotte, a guide to the Queen City of North Carolina. Sponsored by Hornet's Nest Post, no. 9, American Legion. [Charlotte] News Print. House, 1939. 74 P. $\quad 40-13106 \quad \mathrm{~F}_{2} 64 . \mathrm{C}_{4} \mathrm{~W}_{7}$ Bibliography: p. 68-69.

3833. Raleigh, capital of North Carolina. Sponsored by the Raleigh Sesquicentennial Commission. [New Bern, N. C., Printed by Owen G. Dunn Co., 1942] 170 p. 42-36985 F264.RIW7 "Books about Raleigh and North Carolina": p. [157]-158.

3834. South Carolina; a guide to the Palmetto State. Sponsored by Burnet R. Maybank, Governor of South Carolina. New York, Oxford University Press, I94I. xxvii, 5I4 p. $\quad$ 4I-52304 F269.W7 $_{7}$

Fourth printing, 1949 .

Bibliography: p. $479-486$.

3835. Beaufort and the Sea Islands. Sponsored and published by the Clover Club. Savannah, Ga., Review Print. Co., 1938. 47 p.

$$
39-30829 \quad \mathrm{~F}_{279} \cdot \mathrm{B}_{3} \mathrm{~F}_{44}
$$

3836. South Carolina State parks. Sponsored by the South Carolina State Commission of Forestry. [Columbia, South Carolina State Forest Service] 1940. $43 \mathrm{p}$.

$$
4 \mathrm{I}-5255^{\circ} \quad \mathrm{SB}_{4} 82 . \mathrm{S} \mathrm{W}_{7} \quad 1940
$$

3837. Georgia, a guide to its towns and countryside. Rev. and extended by George G. Leckie. Atlanta, Tupper \& Love, 1954. xxii, $457 \mathrm{p}$. First published in 1940 .

$$
\text { 54-10344 F29r.W94 } 1954
$$

Bibliography: p. 439-440.

3838. Atlanta, capital of the South, edited by Paul W. Miller. New York, O. Durrell, I949. xiv, $318 \mathrm{p}$. 49-10579 F294.A8W8 I949

First published in 1942 under title: Atlanta, a City of the Modern South.

Bibliography: p. 298-301.

3839. Augusta. Sponsored by City Council of Augusta. Augusta, Ga., Tidwell Print. Supply Co., 1938. 218 p. $\quad 38-15849 \quad \mathrm{~F}_{294} \cdot \mathrm{AgF}_{4}$ Bibliography: p. 205-208.

3840. The Macon guide and Ocmulgee National Monument. Sponsored by Macon Junior Chamber of Commerce. Macon, Ga., J. W. Burke, 1939. $127 \mathrm{p}$.

Bibliography: p. I19-120.
3841. Savannah. Sponsored by Chamber of Commerce, Savannah. Savannah, Review Print. Co., 1937. xiv, 208 p. $\quad 37-36384 \quad F_{294 .} S_{2} F_{4}$ Bibliography: p. 196-199.

3842. The story of Washington-Wilkes. Sponsored by the Washington City Council. Athens, University of Georgia Press, 1941. xiv, 136 p.

Bibliography: p. 127-129. $4_{4} \mathrm{I}-7353 \quad \mathrm{~F}_{294} \mathrm{~W}_{27} \mathrm{~W}_{7}$

Has no map.

3843. Florida; a guide to the southernmost State. Sponsored by State of Florida Department of Public Instruction. New York, Oxford University Press, I944. xxiv, $600 \mathrm{p}$.

$$
\text { 45-2317 } \quad F_{316 . F} 44 \quad 1944
$$

First published in 1939. Third printing, 1944. Fifth printing, 1947.

Bibliography: p. 553-565.

3844. Seeing Fernandina; a guide to the city and its industries. Co-sponsored by the City Commission, Fernandina. [Fernandina] Fernandina News Pub. Co., 1940. 84 p.

"Citations": p. 77-80. $4 \mathrm{I}-52476 \quad \mathrm{~F}_{3} \mathrm{I} 9 \cdot \mathrm{F}_{4} \mathrm{~W}_{7}$

3845. A guide to Key West. Sponsored by the Florida State Planning Board. Rev., 2d ed. New York, Hastings House, 1949. 122 p.

First published in $194 \mathrm{I}$. 50-1226 $\mathrm{F}_{319 .} \mathrm{K}_{4} \mathrm{~W}_{7} \quad \mathrm{I} 949$

Bibliography: p. I13-116.

3846. Planning your vacation in Florida: Miami and Dade County, including Miami Beach and Coral Gables. Sponsored by the Florida State Planning Board. Northport, N. Y., Bacon, Percy \& Daggett, 1941. xx, 202 p.

Bibliography: p. $184-188$.

$$
42-36652 \quad \mathrm{~F}_{3} \mathrm{Ig} \cdot \mathrm{M}_{6} \mathrm{~W}_{7}
$$

3847. Seeing St. Augustine. Sponsored by City Commission of St. Augustine. [St. Augustine] The Record Co., 1937. $73 \mathrm{p}$.

"Selected bibliography": p. 70-73. $^{38-12}$ $3_{38-12409} \mathrm{~F}_{3} \mathrm{Ig}_{9} \mathrm{~S}_{2} \mathrm{~F}_{4}$

\section{OLD SOUTHWEST}

3848. Alabama; a guide to the Deep South. Sponsored by the Alabama State Planning Commission. New York, Hastings House, 1949. xxii, 442 p. $\quad$ 52-37II F $_{326 . W_{7}} 1949$

First published in $194 \mathrm{I}$.

Bibliography: p. 413-423. 
3849. Mississippi; a guide to the Magnolia State. Sponsored by the Mississippi Agricultural and Industrial Board. New York, Hastings House, 1949. xxiv, 545 p. $\quad 49-5823 \quad F_{341} . F_{45} 1949$ First published in 1938 .

Bibliography: p. [523]-530.

3850. Mississippi gulf coast, yesterday and today, 1699-1939. Sponsored by Woman's Club of Gulfport. Gulfport, Miss., Gulfport Print. Co., 1939. $162 \mathrm{p}$. 39- $\mathrm{I}_{752} \quad \mathrm{~F}_{347 . \mathrm{G}_{9} \mathrm{~F}_{5}}$

3851. Louisiana; a guide to the State. Sponsored by the Louisiana Library Commission at Baton Rouge. New York, Hastings House, 194I. $\mathrm{xxx}, 74^{6} \mathrm{p}$.

Fifth printing, 1949 .

Bibliography: p. 704-716.

3852. New Orleans city guide. Rev. by Robert Tallant. Boston, Houghton Mifflin, 1952. 1x, 416 p. $\quad 52-I_{4722} \quad \mathrm{~F}_{379} \cdot \mathrm{N}_{5} \mathrm{~F}_{34} \mathrm{I}_{952}$

First published in 1938 .

Bibliography: p. [397]-401.

3853. Arkansas; a guide to the State. Sponsored by C. G. Hall, secretary of state, Arkansas. New York, Hastings House, 1941. xxvii, 447 p.

Second printing, 1948 . 4I-5293I F 4 II.W8

Bibliography: p. 397-407.

3854. Guide to North Little Rock, industrial center of Arkansas. [North Little Rock, Ark., Times Print. \& Pub. Co.] 1936. 20 p. 40-26499 $\mathrm{F}_{41} 19 \cdot \mathrm{N}_{6} \mathrm{~F}_{45}$

3855. Tennessee; a guide to the State. Sponsored by Department of Conservation, Division of Information. New York, Hastings House, 1949. $\begin{array}{llll}\text { xxiv, } 55^{8} \text { p. } \quad 49-5822 & F_{43} 6 . F_{45} & 1949\end{array}$

First published in 1939 .

"Selected bibliography": p. 529-535.

3856. Kentucky; a guide to the Bluegrass State. Sponsored by the University of Kentucky. [Rev. ed.] New York, Hastings House, 1954. xxix, $492 \mathrm{p}$. $\quad 54^{-1591} \quad \mathrm{~F}_{45} 6 . \mathrm{F}_{44}$ I954 First published in 1939 .

Bibliography: p. $462-470$.

3857. Old capitol and Frankfort guide. Sponsored by the Kentucky State Historical Society, Frankfort, Kentucky. [Frankfort, Ky.] H. McChesney, 1939. $98 \mathrm{p}$.

$$
39-26_{3} 82 \quad \mathrm{~F}_{459} \cdot \mathrm{F}_{8} \mathrm{~F}_{45}
$$

3858. Henderson; a guide to Audubon's home town in Kentucky. Sponsored by Susan Starling Towles, librarian, Public Library, Henderson, Kentucky. Northport, Bacon, Percy \& Daggett, 194I. $120 \mathrm{p}$. 42-I2802 $\mathrm{F}_{459} \cdot \mathrm{H}_{49} \mathrm{~W}_{7}$

3859. Lexington and the Bluegrass country. Sponsored by the city of Lexington. Lexington [Ky.] E. M. Glass, 1938. 149 p.

$$
\text { 39-8854 } \quad \mathrm{F}_{459} \cdot \mathrm{L}_{6} \mathrm{~F}_{4}
$$

3860. Louisville; a guide to the Falls city. Sponsored by the University of Kentucky; cooperating sponsor, the Louisville Automobile Club. New York, M. Barrows, 1940. xv, I 12 p.

$$
\text { 40-9812 F459.L8W8 }
$$

386r. Missouri, a guide to the "Show me" State. [Rev. ed.] Sponsored by the Missouri State Highway Dept. New York, Hastings House, 1954. 654 p. $\quad 55-3657 \quad F_{4} 66$. W85 $\quad 1954$

First published in 194I.

Bibliography: p. 596-611.

\section{OLD NORTHWEST}

3862. The Ohio guide. Sponsored by the Ohio State Archaeological and Historical Society. New York, Oxford University Press, 1946. xxxi, 634 (i. e. 650) p. $\quad 46-568 \mathrm{I} \quad$ F $_{496}$.W96 1946 First published in 1940. Third printing, with corrections, 1946. Sixth printing, 1952.

"Selected bibliography": p. 61 I-613.

3863. Bryan and Williams County. Sponsored by the city of Bryan. [Gallipolis, Ohio, Downtain Print. Co., 194I] II7 p.

Bibliography: p. 116-117. $43-2703 \quad \mathrm{~F}_{497} \cdot \mathrm{W}_{7} \mathrm{~W}_{7}$

3864. Chillicothe and Ross County. Sponsored by the Ross County Territory Committee, 1938 . [Columbus, Ohio, Heer Print. Co., 1938] $9^{1}$ p. Bibliography: p. 88. 39-19297 $\mathrm{F}_{499} \cdot \mathrm{C}_{4} \mathrm{~F}_{5}$

3865. Cincinnati; a guide to the queen city and its neighbors. Sponsored by the city of Cincinnati, Ohio. Cincinnati, Wiesen-Hart Press, 1943. xxiii, 570 p. $\quad 43-7_{7} \mathrm{I}_{2} \quad \mathrm{~F}_{499} \mathrm{C}_{5} \mathrm{~W}_{93}$

"Selected bibliography": p. 547-549.

3866. Findlay and Hancock County. Reproduced in cooperation with Findlay College. [Findlay, Ohio, 1937?] 52 p. $\quad \mathrm{A}_{40}-\mathrm{I} 949 \quad \mathrm{~F}_{499} \cdot \mathrm{F}_{4} \mathrm{~F}_{4}$ Bibliography: p. 5 I. 
3867. Fremont and Sandusky County. Sponsored by the Ohio State Archaeological \& Historical Society, Columbus. Co-sponsored by C. A. Hochenedel, safety-service director, city of Fremont. [Fremont? Ohio, 1940] II5 p.

"For reference": p. II5. 40-10659 $\mathrm{F}_{499} \cdot \mathrm{F}_{9} \mathrm{~W}_{75}$

3868. Lake Erie, vacationland in Ohio; a guide to the Sandusky Bay region. Sponsored by the city of Sandusky in cooperation with Ohio's Lake Erie Vacationland, Inc. ... Sandusky, Ohio, Stephens Print. Co., I941. I29 p.

"References": p. 129.

$$
4^{\mathrm{I}-\mathrm{I} 8975 \quad \mathrm{~F}_{497 . E 6 W_{7}}}
$$

3869. A guide to Lima and Allen County, Ohio. Sponsored by Lima Better Business Bureau, Inc. [Lima? Ohio, 1938] $64 \mathrm{p}$.

Bibliography: p. $6 \mathrm{r}$.

$$
\text { 39-8859 } \mathrm{F}_{499 \cdot \mathrm{L}_{73} \mathrm{~F}_{4}}
$$

$3^{8} 70$. Springfield and Clark County, Ohio. Sponsored by the Springfield Chamber of Commerce. [Springfield] Printed by the Springfield Tribune Print. Co., 1941. 136 p.

"References": p. 130-131.

$$
4 \mathrm{I}-26044 \quad \mathrm{~F}_{499} \cdot \mathrm{S}_{7} \mathrm{~W}_{7}
$$

387r. Urbana and Champaign County. Sponsored by the Urbana Lions Club. Urbana, Ohio, Gaumer Pub. Co., 1942. 147 p.

"Selected bibliography": p. 144 .

$$
42-16_{4} 68 \quad \mathrm{~F}_{499} \cdot \mathrm{U}_{7} \mathrm{~W}_{7}
$$

3872. Warren and Trumbull County. Sesquicentennial ed. Sponsored by Western Reserve Historical Celebration Committee. [Warren? Ohio] 1938. 60 p. 40-10660 $\mathrm{F}_{499} \mathrm{~W}_{2} \mathrm{~F}_{45}$ Bibliography: p. 60.

3873. Zanesville and Muskingum County. Reproduced in cooperation with Zanesville Chamber of Commerce. [Zanesville? Ohio, 1937] $3^{8} \mathrm{p}$.

Bibliography: p. 36 .

3874. Indiana, a guide to the Hoosier State. Sponsored by the Department of Public Relations of Indiana State Teachers College. New York, Oxford University Press, 1945. xxvi, 548 (i. e. 564) p. ${ }_{46-5683}$ F $_{526 . W_{93}} \quad 1945$

First published in 1941. Second printing, with corrections, 1945. Third printing, 1947.

Bibliography: p. 509-523.
3875. Illinois; a descriptive and historical guide. Rev., with addition, in 1946. Chicago, A. C. McClurg, 1947. xxii, 707 p.

First published in 1939 .

$$
\text { 47-30173 } \mathrm{F}_{54} 6 . \mathrm{F}_{45} \quad 1947
$$

"Fifty books about Illinois": p. 653-656.

3876. Cairo guide. Sponsored by Cairo Public Library. [Nappanee, Ind., E. V. Pub. House] 1938. 62 p. $\quad 39-33966 \quad \mathrm{~F}_{549} \cdot \mathrm{C}_{2} \mathrm{~F}_{4}$ Bibliography: p. 6I-62.

3877. Galena guide. Sponsored by the city of Galena. [Chicago?] 1937. $79 \mathrm{p}$.

"Galena bibliography": p. 78-79.

$39-8 \mathrm{IO}_{2} \mathrm{~F}_{549} \cdot \mathrm{G}_{14} \mathrm{~F}_{5}$

3878. Hillsboro guide. [Hillsboro] Printed by the Montgomery News, 1940. $92 \mathrm{p}$.

Bibliography: p. 92. $43-45^{63} \quad \mathrm{~F}_{549} \cdot \mathrm{H}_{67} \mathrm{~W}_{7}$

3879. Nauvoo guide. Sponsored by the Unity Club of Nauvoo. Chicago, A. C. McClurg, 1939. $49 \mathrm{p}$. $39^{-27124} \quad \mathrm{~F}_{549} \cdot \mathrm{N}_{37} \mathrm{~F}_{5}$

3880. Princeton guide. Sponsored by the city of Princeton. [Princeton, Ill., Republican Print. Co.] 1939. $4^{8}$ p. $\quad 4_{40-32949}$ F $_{549} \cdot \mathrm{P}_{93} \mathrm{~F}_{5}$

3881. Rockford. Sponsored by the city of Rockford, Illinois. Rockford, Ill., Graphic Arts Corp., I94I. I44 P. $\quad 4^{2-18201} \quad F_{549} \cdot R_{7} W_{7}$ Has no map.

3882. Michigan, a guide to the Wolverine State. Sponsored by the Michigan State Administrative Board. New York, Oxford University Press, 1946. xxxvi, 696 (i. e. 712) p.

$$
{ }_{46-5682} \quad \mathrm{~F}_{5} 66 . \mathrm{W}_{9} \quad 1946
$$

First published in 1941. Third printing, with corrections, 1946. Fifth printing, 1949.

Bibliography: p. $645-653$.

3883. Wisconsin; a guide to the Badger State. Sponsored by the Wisconsin Library Association. New York, Hastings House, 1954. 65I P.

First published in 194I. $\begin{array}{lll}55-3162 & F_{5} 86 . W_{97} & 1954\end{array}$

Bibliography: p. 578-590.

3884. Portage. Sponsored by Portage Chamber of Commerce. [Portage? Wis.] 1938. $85 \mathrm{p}$.

Bibliography: p. 83-85.
$40-4748 \quad F_{5} 89 \cdot P_{7} 6 F_{45}$ 
3885. Shorewood [a residential suburb of Milwaukee] Sponsored by Village Board of Shorewood. [Shorewood, Wis., 1939] ro9 p.

Has no map.

$$
40-7055 \mathrm{~F}_{5} 89 . \mathrm{S}_{5} 8 \mathrm{~F}_{5}
$$

3886. Minnesota, a State guide. Sponsored by the Executive Council, State of Minnesota. [Rev. ed.] New York, Hastings House, 1954. xxx, $545 \mathrm{p}$.

First published in 1938 . 54-589 F606.F $44 \quad 1954$

Bibliography: p. [498] -5 I I.

3887. The Minnesota arrowhead country. Sponsored by the Minnesota Arrowhead Association. Chicago, Ill., A. Whitman, I941. xxi, 231 p.

Bibliography: p. 2II-2I6. 4I-52030 F606.W93

3888. St. Cloud guide. St. Cloud, Minn., Greater St. Cloud Committee of the Chamber of Commerce, 1936. 63 p. $39-29347$ F614.S25 $F_{45}$

3889. Iowa, a guide to the Hawkeye State. Sponsored by the State Historical Society of Iowa.

New York, Hastings House, 1949. xxviii, 583 p.

First published in 1938 . 49-5480 F62r.F45 1949

Bibliography: p. [557]-564.

3890. A guide to Burlington, Iowa. 2d ed. (rev.) Sponsored by Burlington City Council. Burlington, Iowa, Acres-Blackmar Co., 1939. 80 p. First published in $193^{8}$. 43-8 I44 F629.B9F45 1939

3891. Guide to Cedar Rapids and northeast Iowa, sponsored by the Cedar Rapids Chamber of Commerce. Cedar Rapids, Iowa, Laurance Press, 1937. 79 p.

Bibliography: p. 79.

$3^{8-26504} \mathrm{~F}_{22}$. $\mathrm{C}_{3} \mathrm{~F}_{5}$

3892. A guide to Dubuque. Sponsored by the city of Dubuque and the Dubuque Chamber of Commerce. Dubuque, Iowa, Hoermann Press, 1937. $32 \mathrm{p}$. $3^{8-26488}{\text { F6 } 29 . D 8 F_{4}}_{4}$

3893. A guide to Estherville, Iowa, Emmet County, and Iowa great lakes region. Sponsored by the Chamber of Commerce, Estherville [Estherville, Iowa.] Estherville Enterprise Print, 1939. $3^{6} \mathrm{p}$. 40-10663 F629.E7 $\mathrm{F}_{45}$

3894. A guide to McGregor. Sponsored by the McGregor Service Club. McGregor, Iowa, J. F. Widman, 1940. 16 p. First published in $193^{8} .40-10732$ F629.Mr4 ${ }^{4}$

\section{GREAT PLAINS}

3895. North Dakota, a guide to the northern prairie

State. Sponsored by the State Historical Society of North Dakota. [2d ed.] New York, Oxford University Press, 1950. xix, 352 p.

First published in 1938 . 50-9076 $\mathrm{F}_{3} 6 . \mathrm{F}_{45} 1950$

Bibliography: p. 327-340.

3896. South Dakota, a guide to the State. Sponsored by the State of South Dakota. 2d ed. completely rev. by M. Lisle Reese. New York, Hastings House, 1952. xxvii, $421 \mathrm{p}$.

52-7601 F656.F $45 \quad 1952$

First published in $193^{8}$ under title: South Dakota Guide.

Bibliography: p. 383-393.

3897. Aberdeen, a middle border city. University of South Dakota, official sponsor; Friends of Aberdeen Committee, co-operating sponsor. [Aberdeen? S.D., Prairie League Workshop, 1940] 94 p.

Bibliography: p. [91]-94.

40-28669 F659.Ar $4 \mathrm{~W}_{7}$

Has no map of Aberdeen.

3898. A vacation guide to Custer State Park in the Black Hills of South Dakota. Sponsored by the Custer State Park Board. [Pierre, S. D., State Pub. Co.] 1938. $32 \mathrm{p}$.

$$
39-29346 \quad \mathrm{~F}_{557 \cdot \mathrm{C}_{22} \mathrm{~F}_{4}}
$$

3899. Mitchell, South Dakota; an industrial and recreational guide. Sponsored by the Mitchell Chamber of Commerce. [Mitchell? S. D.] I938. $32 \mathrm{p}$. 40-5435 F659.M68F5

3900. Guide to Pierre, the capital city and its vicinity. Sponsored by the Pierre Chamber of Commerce and the city of Pierre. [Pierre, S.D., State Pub. Co., 1937] 20 p. 40-5436 F659.P6F 45

3901. Nebraska, a guide to the Cornhusker State. Sponsored by the Nebraska State Historical Society. New York, Hastings House, 1947. xiii, $424 \mathrm{p}$.

First published in 1939.

Bibliography: p. 407-412.

3902. Old Bellevue. Sponsored by the Sarpy County Historical Society. Papillion, Neb., Papillion Times, 1937. $32 \mathrm{p}$.

"Selected references": p. 30 . $39-8853 \quad \mathrm{~F}_{74} \cdot \mathrm{B}_{4} \mathrm{~F}_{4}$ 
3903. Lincoln city guide. Sponsored by the Nebraska State Historical Society. Lincoln, Neb., Woodruff Print. Co., 1937. 87 p.

Bibliography: p. 79-8I.

$$
\text { 37-5002 } \quad \mathrm{F}_{674} \cdot \mathrm{L}_{7} \mathrm{~F}_{4}
$$

3904. Kansas; a guide to the Sunflower State. Sponsored by the State Department of Education. New York, Hastings House, 1949. xviii, $\begin{array}{llll}53^{8} \text { p. } & 49-5821 & \text { F686.F } 45 & 1949\end{array}$

First published in 1939 .

Bibliography: p. 523-529.

3905. The Larned city guide. Larned, Kan., Chamber of Commerce, 1938. $34 \mathrm{p}$.

Bibliography: p. 34 . $39-8855 \quad$ F689.L $\mathrm{L}_{34} \mathrm{~F}_{4}$

3906. A guide to Leavenworth, Kansas. Leavenworth, Kan., Leavenworth Chronicle, I940.

$67 \mathrm{p}$.

Bibliography: p. 67 .

43-9107 F689.L5W7

3907. A guide to Salina, Kansas. Sponsored by Salina Public Library Association. Salina, Kan., Advertiser-Sun, 1939. $55 \mathrm{p}$.

Bibliography: p. 54-55.

$$
4^{0-10664} \quad \mathrm{~F} 689 . \mathrm{S}_{2} \mathrm{~F}_{45}
$$

3908. Oklahoma, a guide to the Sooner State. Sponsored by the University of Oklahoma. [2d ed.] Norman, University of Oklahoma Press, 1947. xxvi, 445 p. 47-6373 F694.W85 1947

First published in 1941.

"Selected reading list": p. 422-427.

3909. Tulsa, a guide to the oil capital. Sponsored by the Tulsa Federation of Women's Clubs. Tulsa, Okla., Mid-West Print. Co., 1938. 79 p.

Bibliography: p. 75 . $3^{8-26703} \mathrm{~F}_{704} \cdot \mathrm{T}_{92} \mathrm{~F}_{5}$

\section{ROCKY MOUNTAIN REGION}

3910. Montana; a State guide book. Sponsored by Department of Agriculture, Labor and Industry, State of Montana. New York, Hastings House, 1949. xxiii, $430 \mathrm{p}$.

First published in 1939 .

$$
49-5522 \cdot F_{73} \text { I.F } 44 \quad 1949
$$

Bibliography: p. 425-429.

3911. Wyoming; a guide to its history, highways, and people. Sponsored by Dr. Lester C. Hunt, secretary of state. New York, Oxford University Press, 1941. xxvii, $490 \mathrm{p}$.

$$
4^{\mathrm{I}-52444 \quad \mathrm{~F}_{7} 6 \mathrm{r} . \mathrm{W}_{5} 8}
$$

Third printing, 1948.

Bibliography: p. 449-458.

3912. Colorado; a guide to the highest State. Sponsored by the Colorado State Planning Commission. New York, Hastings House, 194I. xxxiii, 5 I I p.

Sixth printing, $195 \mathrm{I}$.

"Selective reading list": p. 473-479.

3913. Ghost towns of Colorado. Sponsored by Ralph L. Carr, Governor of Colorado. New York, Hastings House, 1947. II 4 P.

$$
47-3230 \quad \mathrm{~F}_{77} 6 . \mathrm{W}_{7}
$$

3914. Utah; a guide to the State. Co-sponsored by the Utah State Institute of Fine Arts and the Salt Lake County Commission. New York, Hastings House, 1954. xxvi, 595 p.

First published in $194 \mathbf{I}$.

$$
\text { 54-I8I7 } \quad \mathrm{F}_{226} 6 \mathrm{~W}_{75} \quad \mathrm{I} 954
$$

Bibliography: p. 538-55I.

3915. Provo, pioneer Mormon city. Sponsored by the Utah State Institute of Fine Arts. Cosponsored by the Provo City Commission. Portland, Or., Binfords \& Mort, 1942. 223 p.

Bibliography: p. [202]-208.

$$
43-\mathrm{I} 606 \quad \mathrm{~F}_{344 . P 8 W_{7}}
$$

3916. Nevada; a guide to the Silver State. Sponsored by Dr. Jeanne Elizabeth Wier, Nevada State Historical Society. Portland, Oreg., Binfords \& Mort, 1940. 'xviii, 315 p. 4I-7I F84I.W77

"Supplementary reading list of Nevada books": p. 297-304.

\section{FAR SOUTHWEST}

3917. Texas; a guide to the Lone Star State. Sponsored by the Texas State Highway Commission. New York, Hastings House, 1940. xxxiii, $7 \mathrm{I} 8 \mathrm{p}$.

Fifth printing, 1949 . 40-27629 $\mathrm{F}_{39}$ I. W95

"A selected reading list of Texas books": p. 677682.

3918. Beaumont; a guide to the city and its environs. Sponsored by Beaumont Post 1806 , Veterans of Foreign Wars of U. S., Houston, Tex., Anson Jones Press, 1939 . xiv, $\mathrm{I}_{7} \mathrm{P}$.

$$
{ }_{40-4250} \quad \mathrm{~F}_{394} \cdot \mathrm{B}_{3} \mathrm{~F}_{4}
$$

3919. Corpus Christi, a history and guide. Sponsored by the Corpus Christi Chamber of Commerce. Corpus Christi, Corpus Christi CallerTimes, $1942.245 \mathrm{p} . \quad 4^{2-15129} \mathrm{~F}_{394 .} \mathrm{C}_{7} 8 \mathrm{~W}_{7}$ 
"A selected reading list of books for Corpus Christi": p. 233-239.

3920. The Denison guide. Denison Chamber of Commerce, cooperating sponsor. Denison, Tex., Denison Chamber of Commerce, 1939. 29 p. $4^{0-10658} \quad \mathrm{~F}_{394} \cdot \mathrm{D}_{3} \mathrm{~F}_{45}$

3921. Houston, a history and guide. Sponsored by the Harris County Historical Society, Inc. Houston, Tex., Anson Jones Press, 1942. $363 \mathrm{p}$. 42-1647 I $\mathrm{F}_{394 . \mathrm{H} 8 \mathrm{~W}_{7}}$

3922. Port Arthur. Sponsored by Hamilton Smith Post No. 797, Inc., Veterans of Foreign Wars of U. S., Port Arthur. Houston, Tex., Anson Jones Press, 1940. xvii, I64 p. $4^{\mathrm{I}-\mathrm{I} 2325} \quad \mathrm{~F}_{394} \cdot \mathrm{P}_{3} \mathrm{~W}_{7}$

3923. San Antonio, a history and guide. Sponsored by the San Antonio Conservation Society. San Antonio, Clegg Co., I94I. I I I p.

First published in $193^{8}$. $42-6788 \quad \mathrm{~F}_{394 . \mathrm{S}_{2} \mathrm{~W}_{96}}$ I94I

3924. New Mexico; a guide to the colorful State. Sponsored by the Coronado Cuarto Centennial Commission and the University of New Mexico. New and rev. ed. by Joseph Miller; edited by Henry G. Alsberg. New York, Hastings House, I953. xxxii, 47I p. 53-13543 F80r.W76 1953 First published in 1940 .

Bibliography: p. 436-440.

3925. Arizona, the Grand Canyon State; a State guide. Sponsored by the Arizona State College at Flagstaff. Completely rev. by Joseph Miller; edited by Henry G. Alsberg. New York, Hastings House, 1956. xxv, $532 \mathrm{p}$.

56-446 F81 I.W87 I956

First published in I940 under title: Arizona; $a$ State Guide.

Bibliography: p. 503-513.

3926. Mission San Xavier del Bac, Arizona; a descriptive and historical guide. Sponsored by

Arizona Pioneers' Historical Society. New York, Hastings House, 1940. $57 \mathrm{p}$.

Bibliography: p. 33-34.

$$
{ }_{40-27588} \mathrm{NA}_{5235} \mathrm{~S}_{25} \mathrm{~W}_{7}
$$

\section{CALIFORNIA}

3927. California, a guide to the Golden State. Sponsored by Mabel R. Gillis, California state librarian. [Rev. ed.] New York, Hastings House, 1954. xxxi, 716 $\mathrm{p}$.
First published in 1939.

Bibliography: p. $694-698$.

3928. Death Valley; a guide. Sponsored by the Bret Harte Associates. Boston, Houghton Mifflin, 1939. $x v, 75$ p. $\quad 39-2776 \quad$ F868. ${ }_{2} F_{4}$ Bibliography: p. [7r]

3929. Los Angeles; a guide to the city and its environs. Sponsored by the Los Angeles County Board of Supervisors. Completely rev., $2 \mathrm{~d}$ ed. New York, Hastings House, I95 I. liv, 44 I p. First published in I94I. 5I-II827 F869.L8W85 I95I

Bibliography: p. 421-427.

3930. Monterey Peninsula. Sponsored by California State Department of Education. Stanford University, Calif., J. L. Delkin, 1941. $207 \mathrm{p}$.

Bibliography: p. I94-198. $4^{\mathrm{I}-5{ }^{1883}}$ F869.M7W75

3931. San Diego, a California city. Sponsored and published by the San Diego Historical Society. [San Diego, r937] $13^{8}$ p.

Bibliography: p. 127-130.

$$
3^{8-27088} \quad \mathrm{~F}_{869} \mathrm{~S}_{22} \mathrm{~F}_{4}
$$

3932. Balboa Park, San Diego, California; a comprehensive guide to the city's cultural and recreational center. Sponsored and published by the Association of Balboa Park Institutions. [San Diego, Neyenesch Printers] I941. 83 p.

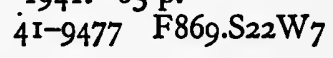

3933. San Francisco, the Bay and its cities. Sponsored by the City and County of San Francisco. [Rev. 2d ed.] New York, Hastings House, 1947. xvii, 53 I p. $47-1{ }^{1536} \quad$ F869.S3W95 1947 First published in 1940.

"A selected reading list": p. 50I-504.

3934. Santa Barbara; a guide to the Channel city and its environs. Sponsored by Santa Barbara State College. New York, Hastings House, I94I. xvii, 206 p. 4I-46I Io F869.S 45 W86

Bibliography: p. I94-197.

\section{PACIFIC NORTHWEST}

3935. Idaho, a guide in word and picture. Sponsored by the secretary of state of Idaho. [2d ed. rev.] New York, Oxford University Press, I950. xiv, $300 \mathrm{p}$.

50-13175 $\mathrm{F}_{746 . \mathrm{F}_{453}}$

First published in 1937 .

Bibliography: p. 287-289. 
3936. Tours in eastern Idaho. [Boise? 1939?] $36 \mathrm{p}$.

$39-26296 \quad F_{745} \cdot F_{47}$

3937. Oregon, end of the trail. Sponsored by the Oregon State Board of Control. Rev. ed. with added material, by Howard McKinley Corning. Portland, Oreg., Binfords \& Mort, 1951. xxxii, $549 \mathrm{p}$. 52-II474 F881.W76 I951

First published in 1940 .

Bibliography: p. 529-535.

3938. Mount Hood; a guide. Sponsored by the Oregon State Board of Control; cooperating sponsor, the Mount Hood Development Association. [New York] Duell, Sloan \& Pearce, 1940. xxvii, ${ }^{32} \mathrm{p}$.

Bibliography: p. 125 .

40-27505 F882. $\mathrm{H}_{5} \mathrm{~W}_{7}$

3939. The new Washington; a guide to the Evergreen State. Sponsored by the Washington State Historical Society. Rev. ed. with added material, by Howard McKinley Corning. Portland, Or., Binfords \& Mort, I950. xxx, 687 p.

$$
\text { 51-3893 F891.W9 I950 }
$$

First published in 1941 under title: Washington, a Guide to the Evergreen State.

Bibliography: p. [644]-653.

\section{OVERSEAS POSSESSIONS}

3940. A guide to Alaska, last American frontier, by Merle Colby. New York, Macmillan, 1939 . lxv, $427 \mathrm{p}$.

"Books about Alaska": p. 405-4IO. 39-27616 F909.F 45

3941. U. S. Puerto Rico Reconstruction Administration. Puerto Rico; a guide to the island of Boriquén, compiled and written by the Puerto Rico Reconstruction Administration in cooperation with the Writers' Program of the Work Projects Administration. Sponsored by the Puerto Rico Department of Education. New York, University Society, 1940. xli, 409 p. $40-35620$ FI958.U55

"Books about Puerto Rico": p. 392-402.

\section{AMERICAN FOLKWAYS SERIES}

3942. American folkways, edited by Erskine Caldwell. New York, Duell, Sloan \& Pearce, 1941-55. $26 \mathrm{v}$.

The American Guide Series created in the minds of many Americans a new consciousness of our history, historic sites, recreational spots, and folklore, and the literature of regionalism had been aborning since Frederick J. Turner discovered the place of sections in American history. In the summer of 1941, Duell, Sloan and Pearce, New York, began publication of the American Folkways Series, "designed to reflect the living features, the atmosphere and background of the various American regions-those qualities which have inspired the great American novels and are not to be found in histories or in textbooks." The series is under the general editorship of Erskine Caldwell, whose intimate knowledge of the region and people he portrays in his novels fits him to guide such a project. The authors, from Edwin Corle whose Desert Country (194I) launched the series, to Oscar Lewis whose High Sierra Country (1955) is the most recent, are by birth, adoption, or, at least, admiration for the manners and customs of the people, "natives" of the regions about which they write with instinctive feeling and knowledge. The titles of some of the volumes need geographical clarification, and we have borrowed freely from the authors' own descriptions.

3943. Atherton, Gertrude Franklin (Horn) Golden Gate country, by Gertrude Atherton. 1945. $256 \mathrm{p}$. 45-2766 F86r.A87

3944. Bracke, William B. Wheat country. 1950. $309 \mathrm{p}$.

50-6934 $\mathrm{F}_{591 . \mathrm{B}_{7} 8}$

"If one were to describe a large circle with a radius of roughly two hundred miles from the center of Kansas ... he would have put a perimeter around the Wheat Country." The area extends to the east and west boundaries of Kansas, to the south central section of the State, and in an arc into southern Nebraska.

3945. Callahan, North. Smoky Mountain country. $1952.257 \mathrm{P} . \quad 52-678_{3} \quad \mathrm{~F}_{443} \cdot \mathrm{G}_{7} \mathrm{C}_{3}$

The "Smoky Mountain country" extends from the Kentucky and Virginia State lines southward through East Tennessee and western North Carolina to Georgia.

3946. Carter, Hodding, and Anthony Ragusin. Gulf Coast country. 195I. 247 P.

5I-I0125 ${\text { F } 296 . C_{3}}$

The "Gulf Coast" extends about one hundred fifty miles from east to west along the Gulf of Mexico and penetrates no more than five miles inland from the sea. "The Coast is still a nation in itself, bearing no resemblance to the interior of Mississippi or Alabama along whose southern borders it skirts."

3947. Corle, Edwin. Desert country. I941. 357 p. 4I-5I799 F786.C8 I94I

This is a book about the arid regions of the 
American Southwest-the area between the Pacific Coast Range and the Rocky Mountains which includes such deserts as the Mojave, the Colorado, the Amargosa, and Arizona's western slope.

3948. Croy, Homer. Corn country. 1947. 325 p. 47-3772 $\mathrm{F}_{595 . \mathrm{C}_{9} 63}$

The "Corn country," in the center of the United States, stretches from western Ohio to the eastern part of Kansas, and from the southern part of Minnesota to central Missouri, and includes at least parts of Indiana, Illinois, Iowa, Nebraska, Wisconsin, and South Dakota.

3949. Day, Donald. Big country: Texas. I 947. $326 \mathrm{p}$.

$47-483 \mathrm{I} \quad \mathrm{F}_{3} 86 . \mathrm{D}_{3}$

3950. Graham, Lloyd. Niagara country. I 949. $32 \mathrm{Ip}$. 49-9928 Fi27.N6G7

To Canadians, Bostonians, New Yorkers, and Americans in general, the "Niagara Country" means different things. "If you pinpoint Niagara Falls and draw a circle with a radius of fifty miles and the Falls as the center, you will probably have the most common concept of Niagara Country."

3951. [Henry, Ralph Chester] High border country, by Eric Thane [pseud.] I942. 335 p. 42-3624I $\mathrm{F}_{597 . \mathrm{H}_{4}}$

Montana, Wyoming, the Dakotas, and the northern tongue of Idaho form the "High Border Country," which takes its name from the high plains and the high mountains, and forms the northern boundary of the United States, as opposed to the "low border" fronting Mexico.

3952. Kane, Harnett T. Deep Delta country. I944. xx, 283 p. 44-402II $\mathrm{F}_{377 . \mathrm{D}_{4} \mathrm{~K}_{3}}$

"Selected bibliography": p. 273-28o.

The hundred and fifteen miles or so from New Orleans to the Gulf of Mexico forms the Deep Delta of the Mississippi River, "a region in some ways like no other in the world."

3953. Kennedy, Stetson. Palmetto country. I 942. $340 \mathrm{p}$. $42-36_{42} 6 \mathrm{~F}_{3}$ I6. $\mathrm{K}_{3} 8$

The Palmetto country lies in the deepest SouthFlorida and the southern portions of Georgia and Alabama. The word palmetto is derived from the Spanish palmito, a diminutive palm tree.

3954. Le Sueur, Meridel. North Star country. 1945. $327 \mathrm{p}$. 45-37888 F606.L56

"The North Star Country, with Minnesota as its center, occupies almost the exact geographical center of North America and has three great drainage systems flowing in divergent directions through wide valleys of glacial loess." Here the Mississippi Valley "extends north to south through the elbow of the Minnesota River, a rich basin left by glacial invasion and occupied before the white man's coming by the great Sioux nation. The surface then tilts down northward, to the beaches of the dead Lake Agassiz whose dry basin makes the Red River Valley, the winter wheat area of North Dakota."

3955. Lewis, Oscar. High Sierra country. I955. $29 \mathrm{I} \mathrm{p}$.

$55-9834 \quad \mathrm{~F} 868 . \mathrm{S}_{5} \mathrm{~L}_{4}$

The Sierra Nevada range in east central California, with some attention to the Nevada towns just beyond it.

3956. Long, Haniel. Piñon country. 1941. 327 p. 4I-5I810 F786.L8

The land of the dwarf piñon trees which produce the piñon nut, an important food of the natives, embraces New Mexico, northern Arizona, southern Utah and Colorado, west Texas, and northern Mexico.

3957. McWilliams, Carey. Southern California country, an island on the land. I946. $387 \mathrm{p}$. 46-25084 F867.M25

Southern California is a coastal strip of land where the mountain ranges, the ocean, and the semidesert terrain meet. It includes part of Santa Barbara County, all of Ventura, Los Angeles, and Orange Counties, and those portions of San Bernadino, Riverside, and San Diego Counties "west of the mountains." The offshore Channel Islands are a part of the region although traditionally detached from its social life.

3958. Nixon, Herman C. Lower Piedmont country. I946. xxiii, $244 \mathrm{p}$.

Book notes: p. 234-238.

$4^{6-83330} \mathrm{~F}_{210 . \mathrm{N}_{5}}$

"This country is borderland between mountains and lowland plains, between mountaineers and cotton planters. It is land where the Appalachians, in their southwestward extension, fade away into small ridges and rolling hills. As the mountains disappear, the Piedmont Plateau on the east joins the Great Appalachian Valley, or series of valleys, on the west around the end of the Blue Ridge."

3959. Powers, Alfred. Redwood country; the lava region and the redwoods. 1949. xviii, $292 \mathrm{p}$. 49-5224 F861.P69

"Altogether, the volume's immense locale extends south and north along the [Pacific] coast-from Russian River [in California] to the Siuslaw River [in Oregon]." It is continued in the interior val- 
leys, and east of the Sierras and Cascades it includes large areas of Nevada, Oregon, and Idaho.

3960. Rayburn, Otto Ernest. Ozark country. I94I. 35I p. 4 4I-52073 F4I7.O9R 3

"The Ozark Country is an egg-shaped uplift sprawling in the mammoth bed of the Mississippi Valley." Unlike some geographers, the author restricts the region to the southern half of Missouri, the northwestern part of Arkansas, and a few counties in eastern Oklahoma.

396I. Stegner, Wallace E. Mormon country. 1942. $362 \mathrm{p}$. 42-2281 I $\quad$ F826.S75

The Mormon country includes all of Utah, most of southern Idaho, the southwestern corner of Wyoming, a strip of western Colorado, the northwestern corner of New Mexico, much of northern and central Arizona, and the eastern third of Nevada; however, Utah is the center of its religious and cultural life.

3962. Swetnam, George. Pittsylvania country. 1951. 315 p. 51-9280 Fi59.P6S85

The "Pittsylvania Country" is an irregular area centering about Pittsburgh, extending up the Allegheny and Monongahela Rivers and down the Ohio for some seventy-five miles or more. "It is bounded on the east by the middle ridges of the Allegheny Mountains and the Pennsylvania Dutch Country, on the north by the Erie Country, on the west by the flat Buckeye Country beyond the Steubenville Hills, and on the south by the Hill Country of West Virginia."

3963. Thomas, Jeannette (Bell) Blue Ridge country, by Jean Thomas. 1942. $338 \mathrm{p}$. 42-36174 F217.B6T5

The Blue Ridge country here described comprises the southern portion of the Appalachian Mountain range that runs from West Virginia through portions of Virginia, Kentucky, Tennessee, North and South Carolina to Georgia and Alabama.

3964. Vestal, Stanley. Short grass country. I94I. $304 \mathrm{p}$. $4 \mathrm{I}-52003 \quad \mathrm{~F}_{59 \mathrm{I} . \mathrm{V}_{4} 8}$

"From the Saskatchewan River in Canada southward for 1,500 miles, a strip of country averaging some 500 miles in width extends almost to Old Mexico-country once covered with an unbroken mat of buffalo grass, grama, mesquite . . . all short grasses-rarely even six inches high." By the "Short Grass Country" the author means only the southern section of this region, the High Plains. It includes the western half of Oklahoma and Kansas, Northwest Texas, and the plains of eastern New Mexico and Colorado.
3965. Webster, Clarence M. Town meeting country. $\quad 1945.246 \mathrm{p} . \quad 45^{-2984} \quad \mathrm{~F}_{4} \cdot \mathrm{W}_{4}$

Mr. Webster's "Town Meeting Country" is an area of some 3,000 square miles in southern New England, comprising most of Connecticut east of the Connecticut River, a slice of south central Massachusetts, and most of Rhode Island west of Narragansett Bay. Here the small mill cities are still dominated by the annual or semi-annual Town Meeting.

3966. White, William Chapman. Adirondack country. 1954. $315 \mathrm{p}$.

52-12652 $\mathrm{F}_{127} \cdot \mathrm{A}_{2} \mathrm{~W}_{5} \mathrm{I} 954$

Northeastern New York State, and particularly Adirondack State Park established in 1892-the largest of our state parks, with over two million acres in public ownership.

3967. Williams, Albert N. Rocky Mountain country. I950. $\mathrm{xxv}, 289 \mathrm{p}$.

50-6038 F721.W68

Neither the residents nor topographers agree about the area described as the Rocky Mountain country. The author advises the reader to ignore the atlas, and believe this: Rocky Mountain country is mostly the mountains in Colorado, plus the fringe along the southern border of Wyoming and the few fingers that jut down into New Mexico.

3968. Williamson, Thames R. Far north country. 1944. $236 \mathrm{p}$. 44-4015 F904.W68

\section{THE RIVERS OF AMERICA SERIES}

3969. The Rivers of America, as planned and started by Constance Lindsay Skinner [various editors] New York, Rinehart, 1937-56. $50 \mathrm{v}$.

The idea of telling the American saga through the story of its rivers originated with Canadian-born Constance Lindsay Skinner (1882-1939) who began her career as a teen-age newspaper correspondent and rose to distinction as a novelist, poet, and historian of America. About 1935 Miss Skinner selected the rivers and outlined the special folk stories for the original 24 volumes to be written by "novelists and poets," and published by Farrar and Rinehart (now Rinehart and Company, Inc.) New York. At the time of her death four years later six of the seven volumes which Miss Skinner edited had already appeared. In successive years the series has been greatly expanded, and edited, except for a brief period, by Carl Carmer, the well-known regional writer and collector of American folk songs, legends, and ballads, in collaboration, until their deaths, with the distinguished authors Stephen Vin- 
cent Benét and Hervey Allen. The stories of the lives of the people who held "civil rights, God, and the primer .... in honor on the banks of the rivers," their industries and architectural fads, and the "characteristic expression of the Folk mind" in religion, arts, crafts, and folklore, make up these volumes. The most recent, Henry Savage's River of the Carolinas: The Santee (1956), appropriately reminds us that our rivers will continue to witness future changes in our civilization, which will be as varied as the scenes they remember from time long past.

3970. SKINNER, CONSTANCE LINDSAY, ed.

All of the volumes originally edited by Miss Skinner, except Coffin's, contain her essay "Rivers and American Folk," in 13 pages at the end. It has been omitted from the revised editions of Havighurst and Niles, and from the reprint of Matschat's.

3971. Burt, Maxwell Struthers. Powder River; let'er buck; illustrated by Ross Santee. 1938. $3^{89} \mathrm{p}$.

Bibliography: p. $377-3^{80}$.

3972. Carmer, Carl L. The Hudson; illustrated by Stow Wengenroth. 1939. $434 \mathrm{p}$.

Bibliography: p. 408-42I.

39-27579 $\mathrm{F}_{127 .} \mathrm{H}_{8 \mathrm{C}}$

3973. Coffin, Robert P. Tristram. Kennebec, cradle of Americans; illustrated by Maitland de Gogorza. 1937. 292 p.

$37-27396 \quad \mathrm{~F}_{27} \cdot \mathrm{K}_{32} \mathrm{C} 6$

3974. Dana, Julian. The Sacramento, river of gold; illustrated by J. O'H. Cosgrave II. 1939. $294 \mathrm{p}$.

39-27898 $\mathrm{F}_{868 . \mathrm{S}_{13} \mathrm{D}_{27}}$

3975. Havighurst, Walter. Upper Mississippi: a wilderness saga; illustrated by David and

Lolitha Granahan. 1937. 258 p.

"Source streams": p. 245-250.

$37-37568 \quad \mathrm{~F}_{597 . \mathrm{H}_{35}}$

A revised edition, including only an account of the river itself, and omitting materials on the Scandinavian settlement and lumber industry of the upper Mississippi Valley, was edited by Stephen Vincent Benét and Carl Carmer, and published in 1944

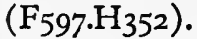

3976. Matschat, Cecile (Hulse). Suwannee River; strange green land; illustrated by Alexander

Key. 1938. 296 p.

Bibliography: p. 283-288.

$3^{8-19573} \mathrm{~F}_{3} \mathrm{I}_{7} \cdot \mathrm{S}^{\mathrm{SM}} 3$

Reprinted: London, W. Hodge, I951. 256 p. $\mathrm{F}_{317 . \mathrm{S}^{2} \mathrm{M}}$
3977. Niles, Blair. The James; illustrated by Edward Shenton. 1939. 359, [13] P.

"Sources": p. 343-349.

$$
\text { 39-27044 F232.J } 2 \mathrm{~N}_{5}
$$

A revised and enlarged edition was edited by Hervey Allen, and published in 1945 under the title: The James from Iron Gate to the Sea (335 p. F232.J2N5 1945).

3978. BENET, STEPHEN VINCENT, and CARL L. CARMER, eds.

3979. Beston, Henry. The St. Lawrence; illustrated by A. Y. Jackson. 1942. 274 p.

$$
\text { 42-24091 F1050.B47 }
$$

3980. Cabell, James Branch, and Alfred J. Hanna. The St. Johns, a parade of diversities; illustrated by Doris Lee. I943. 324 p.

Bibliography: p. 309-318.

$$
\text { 43-II5II } \mathrm{F}_{3} \mathrm{I}_{7} \cdot \mathrm{S}_{2} \mathrm{C}_{3}
$$

398r. Canby, Henry Seidel. The Brandywine; illustrated by Andrew Wyeth. 194r. 285 p. $4 \mathrm{I}-5328 \quad \mathrm{~F}_{157} \cdot \mathrm{C}_{4} \mathrm{C}_{23}$

"A selected bibliography": p. 269-27I.

3982. Carter, Hodding. Lower Mississippi; illustrated by John McCrady. 1942. $467 \mathrm{p}$.

"Selected bibliography": p. 443-45I.

$$
{ }_{42-23785} \mathrm{~F}_{396 . \mathrm{C}_{3}}
$$

3983. Clark, Thomas D. The Kentucky; illustrated by John A. Spelman, III. 1942. $43 \mathrm{I}$ p.

Bibliography: p. 4 I I-420. $4_{42-36052} \mathrm{~F}_{457} \cdot \mathrm{K}_{3} \mathrm{C} 6$

3984. Davis, Clyde Brion. The Arkansas; illustrated by Donald McKay. I940. $340 \mathrm{p}$. $40-2748_{3} \mathrm{~F}_{417} \mathrm{~A}_{7} \mathrm{D}_{37}$

"Acknowledgements": p. 328-330.

3985. Derleth, August W. The Wisconsin, river of a thousand isles; illustrated by John Steuart Curry. 1942. 366 p.

Bibliography: p. 339-345. $4^{2-23237} \mathrm{~F}_{5} 87 . \mathrm{W}^{2} \mathrm{D}_{4}$

3986. Gray, James. The Illinois; illustrated by Aaron Bohrod. I940. 355 p.

Bibliography: p. 337-344.

$$
40-34654 \quad \mathrm{~F}_{547} \cdot \mathrm{I}_{2} \mathrm{G}_{7}
$$

3987. Hansen, Harry. The Chicago; illustrated by Harry Timmins. 1942. $362 \mathrm{p}$. $42-25855 \quad \mathrm{~F}_{547 \cdot} \mathrm{C}_{45} \mathrm{H}_{3}$

"Sources": p. 349-354. 
3988. Masters, Edgar Lee. The Sangamon; illustrated by Lynd Ward. $1942.258 \mathrm{p}$. 42-I $554 \mathrm{I} \quad \mathrm{F}_{547 .} \mathrm{S}_{3} \mathrm{M}_{3}$

3989. Morgan, Dale L. The Humboldt, highroad of the West; illustrated by Arnold Blanch. 1943. $374 \mathrm{P}$.

Bibliography: p. 355-365. $43-7564 \quad \mathrm{~F} 847 . \mathrm{H} 85 \mathrm{M} 6$

3990. Streeter, Floyd Benjamin. The Kaw, the heart of a nation; illustrated by Isabel Bate and Harold Black. 194I. 37I p.

Bibliography: p. 353-359.

$$
4^{\mathrm{I}-3357 \quad \text { F68r.S8 }}
$$

399I. Tourtellot, Arthur Bernon. The Charles; illustrated by Ernest J. Donnelly. I94I. $356 \mathrm{p} . \quad$ 4I-52052 $\mathrm{F}_{72 . \mathrm{C}_{4} 6 \mathrm{~T}_{7}}$

Bibliography: p. 343-348.

3992. Way, Frederick. The Allegheny; illustrated by Henry Pitz. 1942. $280 \mathrm{p}$. $42-15895 \quad F_{157 . A 5} \mathrm{~W}_{3}$

Bibliographical references included in "Acknowledgements": p. 219-222.

3993. Wildes, Harry Emerson. The Delaware; illustrated by Irwin D. Hoffman. 1940. $398 \mathrm{p}$. 40-14246 Fro6.W65

"Acknowledgments and bibliography": p. 369$38 \mathrm{r}$.

3994. Wildes, Harry Emerson. Twin rivers, the Raritan and the Passaic; illustrated by Angelo di Benedetto. 1943. 390 p. 43-2434 FI42.R2 5 Bibliography: p. $371-3^{8} 3$.

3995. Wilson, William E. The Wabash; illustrated by John De Martelly. 1940. 339 p.

Bibliography: p. 325-332. 40-27193 $\mathrm{F}_{532}$.W2W6

\section{ALLEN, HERVEY, ed.}

3997. Davis, Julia. The Shenandoah; illustrated by Frederic Taubes. 1945. $374 \mathrm{p}$.

Bibliography: p. 363-369. $45-8434 \quad \mathrm{~F}_{232 . \mathrm{S}_{5} \mathrm{D}_{3}}$

3998. Fisher, Anne (Benson) The Salinas, upsidedown river; illustrated by Walter K. Fisher. 1945. xviii, $316 \mathrm{p}$.

Bibliography: p. 305-308.

3999. Footner, Hulbert. Rivers of the Eastern Shore, seventeen Maryland rivers; illustrated by Aaron Sopher. 1944. $375 \mathrm{p}$.

"Sources": p. 362-368.
4000. Smith, Chard Powers. The Housatonic, Puritan river; illustrated by Armin Landeck. 1946. $532 \mathrm{p}$.

Bibliography: p. 515-522.

400I. Vestal, Stanley. The Missouri; illustrated by Getlar Smith, maps by George Annand. 1945. $368 \mathrm{p}$.

Bibliography: p. 349-354. 46-4413 Fi02. $\mathrm{H}_{7} \mathrm{~S}_{5}$

4002. ALLEN, HERVEY, and CARL $L$. CARMER, eds.

4003. Banta, Richard E. The Ohio; illustrated by Edward Shenton. 1949. 592 p.

Bibliography: p. 561-577. 49-IIII5 F516.B18

4004. Campbell, Marjorie E. The Saskatchewan; illustrated by Illingworth $\mathrm{H}$. Kerr. 1950 . $400 \mathrm{p}$. 50-6401 Fro76.Ci8

Bibliography: p. $375-380$.

4005. Corle, Edwin. The Gila, river of the Southwest; illustrated by Ross Santee. I95I. $402 \mathrm{p}$.

Bibliography: p. 377-386.

4006. Davidson, Donald. The Tennessee; illustrated by Theresa Sherrer Davidson. I94648. 2 v. $\quad 46-1$ IgOI $\mathrm{F}_{21} 7 \cdot \mathrm{T}_{3} \mathrm{D}_{3}$ "A selected bibliography": v. I, p. 327-333; v. 2, p. $364-370$.

Contents. - v. I. The old river, frontier to secession.-v. 2. The new river, Civil War to TVA.

4007. Douglas, Marjory (Stoneman). The Everglades, river of grass; illustrated by Robert

Fink. 1947. $406 \mathrm{p}$.

Bibliography: p. $391-398$.

4008. Gutheim, Frederick A. The Potomac; illustrated by Mitchell Jamieson. 1949. $436 \mathrm{p}$.

"Bibliographical notes": p. 399-413. 49-11856 FI87.P8G8

4009. Hard, Walter R. The Connecticut; illustrated by Douglas W. Gorsline. 1947 . $310 \mathrm{p}$.

Bibliography: p. 299-30r.

47-3553 $\mathrm{F}_{12 .} \mathrm{C}_{7} \mathrm{H}_{3}$

40ro. Hill, Ralph Nading. The Winooski, heartway of Vermont; illustrated by George Daly. 1949. $304 \mathrm{p}$. ${ }_{49}-88_{44} \quad \mathrm{~F}_{57} \cdot \mathrm{W} 6{ }_{3} \mathrm{H}_{55}$

Bibliography: p. 283-293. 
40I I. Hislop, Codman. The Mohawk; illustrated by Letterio Calapai. I948. xv, $367 \mathrm{p}$.

Bibliography: p. 339-350.

$$
4^{8-9184} \mathrm{~F}_{127} \cdot \mathrm{M}_{55} \mathrm{H}_{57}
$$

4012. Howe, Henry F. Salt rivers of the Massachusetts shore; illustrated by John O'Hara Cosgrace II. xiv, $37^{\circ} \mathrm{p}$.

Bibliography: p. $35 \mathrm{I}-358$.

4013. Hutchison, Bruce. The Fraser; illustrated by Richard Bennett. 1950. $368 \mathrm{p}$. 50-10549 Fro89.F 7 H8

Bibliography: p. 35I-355.

4014. Minter, John Easter. The Chagres, river of westward passage; illustrated by William Wellons. 1948. xiv, 4 I 8 p.

Bibliography: p. 393-403.

$$
{ }_{48-7786} \mathrm{~F}_{15} 69 . \mathrm{C}_{4} \mathrm{M}_{5}
$$

4015. Roberts, Leslie. The Mackenzie; illustrated by Thoreau MacDonald. 1949. 276 p.

Bibliography: p. 255-256. 49-8302 Fro6o.9.M26R6

40r6. Stokes, Thomas L. The Savannah; illustrated by Lamar Dodd. I95I. 401 p.

Bibliography: p. 382-388.

$$
\begin{array}{lll}
{ }_{5} \mathrm{I}-93^{8} 7 & \mathrm{~F}_{277} \cdot \mathrm{S}_{3} \mathrm{~S} 8
\end{array}
$$

4017. Waters, Frank. The Colorado; illustrated by Nicolai Fechin, maps by George Annand. 1946. $400 \mathrm{p}$.

Bibliography: p. 389-393.

40I8. CARMER, CARL L., ed.
4019. Bissell, Richard P. The Monongahela; illustrated by John O'Hara Cosgrave II. 1952. $239 \mathrm{p}$.

Bibliography: p. 231-233. $5^{2-5562} \mathrm{~F}_{\mathrm{I}} 57 \cdot \mathrm{M}_{5} 8 \mathrm{~B}_{5}$

4020. Carmer, Carl L. The Susquehanna; illustrated by Stow Wengenroth. 1955. $493 \mathrm{p}$. $53-8227 \quad \mathrm{~F}_{157 . S 8 \mathrm{C}_{3}}$

Bibliography: p. 457-465.

4021. Dykeman, Wilma. The French Broad; illustrated by Douglas Gorsline. 1955. $37 \mathrm{I}$. 54-9349 F $443 . \mathrm{F} 8 \mathrm{D} 9$

Bibliography: p. 349-356.

4022. Holbrook, Stewart H. The Columbia; illustrated by Ernest Richardson. 1956. $393 \mathrm{p}$. 55-10527 F853.H6

4023. Savage, Henry. River of the Carolinas, the Santee; illustrated by Lamar Dodd. 1956 . $435 \mathrm{p}$.

Bibliography: p. 4II-4I5. ${ }_{5}^{6-6469} \quad \mathrm{~F}_{277} \cdot \mathrm{S}_{2} 8 \mathrm{~S}_{3}$

4024. Smith, Frank E. The Yazoo River; illustrated by Janet E. Turner. 1954. $362 \mathrm{p}$. 53-9242 $\mathrm{F}_{347} . \mathrm{Y}_{3} \mathrm{~S} 6 \quad \mathrm{I} 954$ "Acknowledgments and bibliography": p. 347350.

4025. Songs of the rivers of America; music arranged by Dr. Albert Sirmay. 1942. xi, 196 p. $\quad 43-2356 \quad$ Mi629.S225S6 To accompany the series The Rivers of America.

\section{B. New England: General}

4026. Brewer, Daniel Chauncey. The conquest of New England by the immigrant. New York, Putnam, 1926. 369 p. 26-12327 F9.B83

With all the fervor of his Puritan ancestry, the author laments the expansion of industrialism that brought increasing numbers of non-English speaking immigrants to New England after I880. His book, however, supplies a view, hardly to be found elsewhere, of the replacement of the old New Englanders by a foreign-born population. The author, however, did not "despair of the Yankee as a potent force in the community," although he wrote too soon to record how completely the newcomers have absorbed the old New England ideals of education, industriousness, and sobriety.
4027. Fox, Dixon Ryan. Yankees and Yorkers. New York, University Press, 1940. 237 p. (Anson G. Phelps lectureship on early American history, New York University)

40-1344I $\mathrm{F}_{\text {I22.F }} \mathrm{F}_{7}$

The occupation of New York lands by the people of New England during the colonial period and the "Great Migration" following the Revolution is the theme of these lectures, in which the similarities and differences of the Yankees and the "Yorkers" are brought out. Special attention is given to the clash of the two elements in the border area of uncertain ownership which became Vermont, and there is a very original chapter characterizing "Yankee Culture in New York." The author con- 
cludes: "There are characteristic differences which are creditable to each section, and each has found a benefit in the neighborly presence of the other."

4028. Holbrook, Stewart H. The Yankee exodus, an account of migration from New England.

New York, Macmillan, r950. xii, 398 p.

Bibliography: p. 364-371.

$$
\text { 50-7972 } \mathrm{E}_{179 \cdot 5 \cdot \mathrm{H}_{5}}
$$

This book pursues in an episodic and anecdotal manner the thesis explored by Mrs. Rosenberry (q. v.). The author follows his emigrants west of the Mississippi, and, in diminishing degree, the fortunes of their communities as far as the close of the igth century.

4029. Mussey, June Barrows, ed. Yankee life by those who lived it, by Barrows Mussey. [ Ist Borzoi ed., rev.] New York, Knopf, r947. $543 \mathrm{p} . \quad 47-1$ I79I F3.M87 I947

First published in 1937 under title: We Were New England.

In order to check as well as supplement the image of New England gathered from histories and novels, the author has "taken from the autobiographies of New Englanders those passages which show what it felt like to live in the cradle of the nation." Extracts from 48 writers, ranging from the famous to the humble and obscure, and arranged under ig topical headings, cover the three centuries before the Civil War. An alphabetical list of the persons who have been selected and their pertinent writings, with brief biographical comment, is brought together in "Yankee Lives:" p. 535-543.

4030. Rosenberry, Lois (Kimball) Mathews. The expansion of New England; the spread of

New England settlement and institutions to the Mississippi River, $1620-1865$, by Lois Kimball Mathews. Boston, Houghton Mifflin, Igog. xiv, $303 \mathrm{p} . \quad 9-29148$ F4.R8I

"Bibliographical notes" at end of each chapter excèpt I and ro.

Mrs. Rosenberry's enlargement of her Radcliffe College dissertation first traces the history of the New England frontier from the settlement to the Revolution, describes the institutions by which its advance was effected, and estimates the effect upon it of warfare with the Indians, later joined and supported by the French in Canada. The second half of the book is concerned with the "Great Migrations from New England toward the West" which began immediately after Yorktown and continued more or less steadily until the Civil War, creating a belt centering along the $43^{\text {rd }}$ parallel and extending west to the Mississippi. From 1787 "a second New England" was built up in Ohio, around Marietta and in the Western Reserve, and throughout the belt these "State builders" took with them their moral and intellectual ideals and institutions. "The history of New England," according to Mrs. Rosenberry, "is not confined to six states; it is contained in a greater and broader New England wherever the children of the Puritans are found."

4031. Wilson, Harold Fisher. The hill country of northern New England; its social and economic history, I790-1930. New York, Columbia University Press, 1936. xiv, 455 p. (Columbia University studies in the history of American agriculture, 3)

Bibliography: p. [403]-437.

37-755 $\mathrm{HDi}_{773} \mathrm{~A}_{2} \mathrm{~W}_{5}$

The region which the writer has singled out for study comprises most of Maine, New Hampshire, and Vermont, an area of scant population dependent upon farming. The author describes the impact of economic changes in the United States as a whole on northern New England: they terminated its selfsufficiency as early as 1830 , and precipitated a complete readjustment of its economic and social life. The author describes the transition from a "meatwool-grain region" to "a dairy-fruit-potato-poultryand-garden-truck crop territory," with closer contacts with the outside world, and a developing summer recreation trade. "This wide-spread adjustment in the agriculture of the hill country, with its accompanying abandonment of sub-marginal farms, was called 'a triumph of selection, increased efficiency, and specialization,' in a report issued by the Department of Commerce in 1930." By that date the "deserted farm, instead of being thought wantonly abandoned, was regarded as the inevitable result of a readjustment to modern conditions."

\section{New England: Local}

\section{NEW HAMPSHIRE}

4032. Bowles, Ella (Shannon) Let me show you New Hampshire. New York, Knopf, 1938. 368 p. illus.

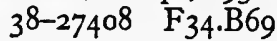

A native of New Hampshire, the author has long been identified with its cultural life. This book is a series of Mrs. Bowles' "impressions, supplemented by personal research in historical background, by information furnished by certain state departments," 
and other sources. The result is an unsystematic volume of pleasant and unpretentious topical sketches, all informed by a quiet but sincere love of the State.

\section{VERMONT}

4033. Newton, Earle W. The Vermont story; a history of the people of the Green Mountain State, 1749-1949. With a foreword by Allan Nevins and an introduction by Dorothy Canfield Fisher. Montpelier, Vermont Historical Society, 1949. x, 28I p. (The American States) 49-9803 F49.N 49

Bibliography: p. 272-274.

The director of the Vermont Historical Society has written, according to Dorothy Canfield Fisher, a "well-balanced, accurate and detailed account" of Vermont since its beginning. An initial chapter describes the land and the natural resources which have determined the development of the Green Mountain State. Part II chronicles events from the Bennington charter in 1749 to 1849 , when frustrations from a lag in industrial growth, poor transportation, and a discouraging outlook for agriculture made migration to the West attractive. Part III deals with economic progress, cultural growth, and local government during the century 1849 to 1949 . The book fills an immediate need for a readable onevolume history of the State and is lavishly provided with illustrations, many of them in color.

\section{MASSACHUSETTS}

4024. Hart, Albert Bushnell, ed. Commonwealth history of Massachusetts, Colony, Province and State; edited by Albert Bushnell Hart, with the cooperation of an advisory board of forty-two learned bodies. New York, States History Co., 1927-30. $5 \mathrm{v}$.

Bibliography at end of each chapter. 27-18867 $\mathrm{F} 64_{4} \cdot \mathrm{H}_{32}$

Contents.-v. I. Colony of Massachusetts Bay, 1605-1689. - v. 2. Province of Massachusetts, r689I775.-v. 3. Commonwealth of Massachusetts, I775I 820.- -v. 4. Nineteenth century Massachusetts, I820I889.-v. 5. Twentieth century Massachusetts, r889-I930.

Veteran American historian, Albert Bushnell Hart (1854-1943) performed a labor of love in bringing together the group of scholars who produced, in many instances from unpublished sources, this cooperative history of Massachusetts, and who maintained, under his experienced direction, a certain uniformity of style and treatment. All phases of public and private life-social, economic, cultural, religious, and political-have been treated in the successive epochs of the State's history from 1605 to the time of publication. In each volume the biography of a representative man of his community is presented to illustrate the character and ambitions of his fellow citizens: the elder John Winthrop, Cotton Mather, John Adams, Daniel Webster, and Charles William Eliot are the men thus singled out. The Commonwealth History has set the pattern for some, but unfortunately only a few, cooperative and scholarly histories of other states.

4035. Amory, Cleveland. The proper Bostonians. New York, Dutton, 1947. $3^{81}$ p. ([Society in America series ]) 47-1 1061 F73.37.A5 "Acknowledgments and bibliography": p. $36 \mathrm{I}-$ 367.

"Manufactured from interviews with Bostonians," this is a collective profile of the family-conscious, provincial, cultured, charitable, and yet frugal men and women who make up "the First Family Society of the Proper Bostonian." Far smaller than the Boston Social Register's 8,00o listees, it has yet "set its stamp on the country's fifth largest city [1940] so indelibly that when an outsider thinks of a Bostonian he thinks only of the Proper Bostonian." It is narrated in an informal, anecdotal style, with a sympathetic understanding of these sheltered beneficiaries of the great family trusts, and at the same time with a prying humor that penetrates rockbound custom for a glimpse of modernity.

4036. Winsor, Justin, ed. The memorial history of Boston, including Suffolk County, Massachusetts. 1630-1880. Issued under the business superintendence of the projector, Clarence F. Jewett. Boston, J. R. Osgood, r880-8I. 4 v.

$$
\mathrm{I}-\mathrm{I} 2246 \quad \mathrm{~F}_{73} \cdot 3 \cdot \mathrm{W}_{76}
$$

Contents.-v. r. The early and colonial periods.v. 2. The provincial period.- - . 3. The revolutionary period. The last hundred years, pt. i.- - v. 4. The last hundred years, pt. 2. Special topics.

The plan of this history originated with Clarence F. Jewett, "projector" of a number of large-scale coöperative histories during the 1870 's and 80's, who in December 1879 turned over its development to the distinguished Harvard historian and librarian, Justin Winsor. The subjects of the chapters were assigned to more than sixty writers competent in their special fields, and the editor added notes only as needed "to give coherency to the plan." The contributors included such notables as Charles Francis Adams, Jr., Henry M. Dexter, Francis S. Drake, George C. Ellis, Asa Gray, Edward Everett Hale, Thomas Wentworth Higginson, Henry Cabot Lodge, John Davis Long, Horace E. Scudder, Nathaniel S. Shaler, John Greenleaf Whittier (an 8-page poem), and Robert C. Winthrop. It has remained a classic among American city histories, 
and fifty years later "the fifth volume to this enduring quartet" was published by the Boston Tercentenary Committee: Fifty Years of Boston, a Memorial Volume Issued in Commemoration of the Tercentenary of 1930, Elisabeth M. Herlihy, chairman and editor (Boston, 1932. 799 p.). John T. Morse, Jr., a nonagenarian and the only surviving contributor to the Memorial History, contributed a review of it as a "Greeting" in this "fifth" volume.

4037. Scudder, Townsend. Concord: American town. Boston, Little, Brown, 1947. 421 p.

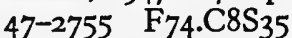

"Bibliographical notes and acknowledgments": p. $391-395$.

The site of the Massachusetts Provincial Congress in 1774-75, a battleground during the American Revolution, a community ruled by all its citizens in town meeting through three centuries, and the home of Emerson, Hawthorne, Alcott, and Thoreau, Concord has been chosen by the author as a typical American town in whose life the larger story of America is reflected. From its first settlement in I635 through World War II the narrative unfolds in the lives, actions, and words of its people, resurrected by the author from minutes of town meetings, which sometimes report debates, church records, journals, and newspapers (since $18 \mathrm{I} 7$ ), and placed in their regional and national setting through standard works of history and reference.

4038. Blanchard, Dorothy C. A. Nantucket landfall. New York, Dodd, Mead, 1956. $24 \mathrm{I}$ p. $\quad 5^{6-6648} \quad \mathrm{~F}_{72 .} \mathrm{N}_{2} \mathrm{~B}_{55}$

Nantucket is situated about 25 miles south of the Cape Cod peninsula across Nantucket Sound, and its island history has been shaped since the early I 7 th century by the wind and the sea. Its isolation offered refuge to liberty-loving settlers, its waters made it a famous whaling port, and its winds now fill the sails of a popular summer resort. The bibliography ( $p$. 236-24I) indicates the numerous sources drawn upon by the author to tell the story of the island's transformation from a sheep-raising colony, its unique part in the American Revolution and the War of 1812 , the partial destruction of the town by fire in 1846 , the California Gold Rush which drained its young men, the discovery of "coal-oil" which brought an end to whaling, and the summer-resort "boom" which brought the railroad and ultimately the automobile and airplane. The Indians, the Quakers, the men of action-Mayhews, Folgers, Macys, Coffins-and the tales of mutiny and shipwreck, are all part of the history of Nantucket, where a few handsome mansions, an old candle fac- tory that houses whaling relics, and a Quaker meeting house turned museum, are reminders of its unique and colorful past.

\section{RHODE ISLAND}

4039. Richman, Irving Berdine. Rhode Island, a study in separatism. Boston, Houghton Mifflin, 1905. 395 p. (American commonwealths)

Bibliography: p. [353]-385. 5-34I87 F79.R53

The author's principal object is "to point out the influence of Separatism in determining the course of events in Rhode Island during the I8th and Igth centuries." Part I, covering 1636-1689, summarizes the author's earlier and fuller work Rhode Island, Its Making and Its Meaning (New York, Putnam, 1902. 2 v.). The greater part of the volume is concerned with the century from 1690 to Rhode Island's ratification of the Constitution in 1790 (p. [65]-257). There is a substantial chapter on "The Son Rebellion" of 1842 (p. [285]-307) which finally brought Jacksonian Democracy to Rhode Island.

4040. Elliott, Maud (Howe) This was my Newport. Cambridge, Mass., Mythology Co., A. M. Jones, I944. xxiv, $279 \mathrm{p}$.

44-9074 F89. $\mathrm{N}_{5} \mathrm{E}_{4}$

This daughter of Julia Ward Howe won a Pulitzer prize, with Laura E. Richards, for the biography of her mother published in 1917. Here she reminisces about the Newport which has been the home of her people from the beginning, and which "has been called, not without reason, the nation's social capital." The mecca of Southerners after the American Revolution, it became the gathering place of Boston intellectuals and New York socialites following the Civil War. Mrs. Elliott quotes freely from family letters to illustrate the growth of literary and artistic traditions, and the social life and sports of the personalities that made up Newport society. In the concluding "Part Five-Naval and Military," the author gathers together "both personal memories, and recollections which have been handed down from preceding generations, of distinguished officers who ... have been connected with this little town where so much of our naval history has been made."

\section{CONNECTICUT}

404x. Shepard, Odell. Connecticut, past and present. New York, Knopf, 1939. xix, 316, xi p. 39-275 I I $\mathrm{F}_{94 . \mathrm{S}_{4} 8}$ 
With the enthusiasm of a "native son," and the impartiality of one "foreign-born" (Illinois in this instance), a professor of English at Trinity College, Hartford (1917-46), who is an author of note and a Pulitzer prize winner, sets down his interpretation of Connecticut. He describes the land and the landscape, significant historical episodes, old graveyards, farm and town life, and the trend of recent changes, and he discriminates the individuality of communities that, to a casual observer, look just alike. Dr. Shepard's observations are based on 20 years of traveling the highways and byways, and talking with the men, women, and children-Yankee born or immigrant-who make up the State. Those who still crave a heavier ration of historical and topographical fact he refers to Florence S. M. Crofut's Guide to the History and the Historic Sites of Connecticut (New Haven, Yale University Press, 1937. 2 v.).
4042. Osterweis, Rollin G. Three centuries of New Haven, 1638-1938. New Haven, Yale University Press, 1953. xv, $54 \mathrm{I}$ p.

52-12064 $\mathrm{Fr}_{4} \cdot \mathrm{N}_{60} \mathrm{O}_{3}$

Provided with funds left by the New Haven Tercentenary Committee of 1938 , the New Haven Colony Historical Society commissioned the author "to prepare a history of New Haven, which will be of interest to the general reader and of value to the historical scholar." This official Tercentenary History of the town from the landing at Quinnipiack on April 24, 1638, to 1938 is the result. It exemplifies the best canons of present-day social history by tracing in all aspects of community life the evolution of a semi-rural college town into a diversified modern city with a large immigrant population. The extensive bibliography (p. 437-479), chronology, and glossary at the end are of special interest to the scholar.

\section{The Middle Atlantic States}

4043. Thompson, Daniel G. Brinton. Gateway to a nation; the Middle Atlantic States and their influence on the development of the Nation. Rindge, N. H., R. R. Smith, 1956. 274 p.

Bibliography: p. 252-26o.

$$
\text { 55-11153 Fro6. T42 }
$$

Unlike New England, the South, and the Southwest, the Middle Atlantic area "has seldom been regarded as a unit," so that this book is "in a sense an adventure in sectional history." Recognizing the similarities in spite of the different customs and cultures among the inhabitants of New York, Pennsylvania, New Jersey, and Delaware, the author has explored the influence of the region on the political, industrial, and cultural growth of the Nation, especially during the colonial and early republican periods. The prevailing thought of the section has been "cosmopolitan and sophisticated," and no other has "maintained over the years such strong financial, commercial, and personal ties with all sections." The result is only a sketch, but the author hopes to stimulate others to study more intensely these states, that "have always been the nation's Atlantic gateway and have always been aware of our close ties to Western Europe."

\section{NEW YORK}

4044. New York State Historical Association. History of the State of New York. New York, Columbia University Press, 1933-37. Io v. 33-11644 Firg.N65
"Select bibliography" at end of most of the chapters.

Contents.-v. I. Wigwam and bouwerie.-v. 2. Under duke and king.-v. 3. Whig and Tory.-v. 4 . The new State.- $v .5$. Conquering the wilderness.v. 6. The age of reform.-v. 7. Modern party battles.-v. 8. Wealth and commonwealth.-v. 9. Mind and spirit.-v. Io. The Empire State.

The New York State Historical Association undertook the preparation and publication of this history at the suggestion of the State Executive Committee on the One Hundred and Fiftieth Anniversary of the American Revolution in 1925, which had been endorsed by the Regents of the University of the State of New York. The cooperative product of the "best qualified specialists" under the direction of a single editor, Alexander C. Flick, State Historian, it is similar in concept to the Commonwealth History of Massachusetts (q. v.). This is the first history of New York to cover the whole stretch of time from its geological beginnings, and at the same time "the whole range of human interests."

4045. Kouwenhoven, John Atlee. The Columbia historical portrait of New York; an essay in graphic history in honor of the tricentennial of New York City and the bicentennial of Columbia University. With a foreword by Grayson L. Kirk. Garden City, N. Y., Doubleday, 1953. $55^{\circ}$ p.

$$
\text { 53-8I8I } \text { FI }_{128.3 . \mathrm{K} 6}
$$

Partial Contents.-Plans and prospects, $16 \mathrm{r}_{4}-$ 1800.-The people get in the picture, $1800-1845$. - 
Mid-century panorama, $1845^{-1855}$.-Documents of change, $1855^{-1} 870$.- The city in motion, $1870-$ 1890.- Transit to the Greater City, I890-1910."The Shapes Arise," I910-1953.

Dating from 1626 to 1953 , the 900 reproductions of maps, drawings, prints, watercolors, paintings, and photographs that have been selected for this book are arranged in seven groups "representing successive phases in the evolution of the city and of man's consciousness of it." Brief essays and separate captions describe the pictures, and make of them an intelligible sequence unfolding the greatest urban development of the New World.

4046. Weld, Ralph Foster. Brooklyn is America. New York, Columbia University Press; 1950. 266 p. illus. $\quad 50-8082 \quad F_{129 .} B_{7} W_{42} \quad 1950$ Bibliography: p. [249]-254.

Brooklyn has been a familiar subject to the author since his doctoral dissertation (Brooklyn Village, 1816-1834) appeared in 1938 . This is a revision and expansion of a series of feature articles which he contributed to the Brooklyn Eagle in 1948. It deals sympathetically with all the ethnic groups that have entered into the city's population from the Dutch pioneers of the I 7 th century to the Puerto Ricans of the 2oth century. The Dutch, English, Irish, Germans, Negroes, Jews, Italians, Scandinavians, and lesser groups have all contributed characteristics to the American society which is Brooklyn. The city not only illustrates the necessity for practical cooperation and tolerance but practices them sufficiently to make them workwhich is a hint, perhaps, that "Brooklyn can pass on to the apprehensive peoples of the world."

4047. Nevins, Allan, and John A. Krout, eds. The greater city: New York, 1898-1948. New York, Columbia University Press, 1948. 260 p. 48-8678 Fr28.5.N4

Contents.-Past, present and future, by Allan Nevins.-Framing the Charter, by J. A. Krout.From Van Wyck to O'Dwyer, by Carl Carmer.The city's business, by Thomas C. Cochran.-The social and cultural scene, by Margaret Clapp.

The distinguished editors join with three other contributors to portray the progress of Greater New York since the consolidation of the five boroughs of Manhattan, Brooklyn, the Bronx, Queens, and Richmond in 1898 . During that eventful halfcentury the metropolis has achieved a real unity, originally lacking but now felt by its citizens amid all their diversity; it has controlled its growth and that of its region by zoning and other plans; it has created, or greatly strengthened, a group of outstanding institutions of higher culture; it has given women an unprecedented place in civic affairs; and it has adopted an entirely new social outlook giving rise to practical institutions and measures of social justice and social welfare.

4048. Still, Bayrd. Mirror for Gotham: New York as seen by contemporaries from Dutch days to the present. New York, University Press, I956. 417 p. illus. 56-11979 Fi28.3.S85

From books, articles, letters, and diaries the author has brought together contemporary commentaries on the New York scene, from the Florentine Giovanni da Verrazano's observations concerning his visit to New York Harbor in 1524, to Beverly Nichols impressions of the "international flavor of the metropolis" in the late 1940's. These commentaries by Americans, British, French, Italians, Germans, and Austrians describe the physical appearance of the city, its commercial activities, "the standard of living, attitudes, and day-to-day behavior of its varied population; and the ways in which the city exerted its ever widening influence in the national life." The extensive "Notes" (p. 34I372 ) and "Bibliography" (p. 373-399) indicate the research that underlies the selection of the excerpts as well as the introductory passages to each selection, and the more general descriptions with which the author opens each of his ten chronological chapters. A social history of New York from $185^{\circ}$ to 1950, Lloyd Morris' Incredible New York, High Life and Low Life of the Last Hundred Years (New York, Random House, 1951. 370 p.), emphasizes the city's habitually spectacular modes of enjoying itself, by day and by night, indoors and out.

4049. Wilson, James Grant, ed. The memorial history of the City of New York, from its first settlement to the year 1892. [New York] New-York History Co., I892-93. 4 v. illus., maps (part fold.), facsims. (part fold.)

$$
\text { I-I } 4318 \text { FI28.3. W74 }
$$

The editor of this history is widely known for his more extensive work: Appleton's Cyclopedia of American Biography, publication of which was completed in 1889 . In 1888 the venerable George Bancroft suggested to the editor that he prepare "an equally trustworthy history of the city of New-York of the same character as the one that has recently appeared concerning Boston" (no. 4036). Four years later the first volume of this comprehensive four volume history appeared. It is composed of contributions by well-known writers including, in addition to the editor, Marcus L. Benjamin, Moncure D. Conway, Berthold Fernow, Charles R. Hildeburn, Henry Phelps Johnston, John Austin Stevens, and William L. Stone. The chronological sequence begins with the "Exploration of the North American Coast Previous to the Voyage of Henry Hudson," 
and ends in the third volume with a review of the "Constitutional and Legal History of New-York in the Nineteenth Century." The fourth volume consists of chapters on special topics such as suburban areas, authors, libraries, newspapers and magazines, music, churches, statues and monuments, medicine, science, etc.

4050. McKelvey, Blake. Rochester, the waterpower city, 1812-1854. Cambridge, Mass., Harvard University Press, 1945. xvi, 383 p.

$$
\mathrm{A}_{45}-4785 \text { FI29.R7M } 24
$$

405 I. McKelvey, Blake. Rochester, the flower city, 1855-1890. Cambridge, Harvard University Press, 1949. xvii, 407 p. $\quad 49-10783$ Fi29.R7M23

4052. McKelvey, Blake. Rochester: the quest for quality, I890-1925. Cambridge, Harvard University Press, 1956. xiv, $432 \mathrm{p}$.

Bibliography: p. [395]-404.

$$
\text { 56-II284 } \mathrm{F}_{129} \cdot \mathrm{R}_{7} \mathrm{M}_{23} 8
$$

Written by the city historian, and supported by the municipal Kate Gleason Fund in the Rochester Public Library, these volumes represent a striking civic achievement. Each volume deals with a distinct period in Rochester's history. Its initial growth was the result of its location on the Genesee River, which early supplied the water power for the milling industry and served as an important local trade route. Its proximity to Lake Ontario encouraged commerce with Canada, and the opening of the Erie Canal in 1825 so increased economic activity that Rochester became within a few years "the boom town in America." With the potentialities of water power exploited by the mid-fifties, the citizens of the "Flower City" manifested an awakening civic and cultural pride. The emergence of individual and institutional leadership led to a period of growing civic achievement in the 7o's and 8o's, and culminated in "The Quest for Quality" from I890 to 1925. The history of Rochester in those 35 years is typical of many other communities, and the author says that this volume "may be read as a case history of urban advance in the period of American history which saw the most intense campaigns for civic reform, the most conscientious application of Christianity to social problems, the most rapid consolidation of corporate enterprise, and the weaving of old-American and immigrant social and cultural traditions into the fabric which still underlies contemporary American civilization."

\section{NEW JERSEY}

4053. Cunningham, John T. This is New Jersey, from High Point to Cape May. Maps by
William M. Canfield. New Brunswick, N. J., Rutgers University Press, 1953. 229 p.

$$
\text { 53-I 105I Fi34.C87 }
$$

Most of the material in these pages appeared originally in The Newark News, which has been cited by the State of New Jersey and the American Association for State and Local History for successive series of articles which have aroused renewed interest, both in New Jersey's history and in its contemporary scene. The 166 miles from High Point to Cape May include mountains, cities, farms, and beaches, and the author has appropriately grouped the 2I county sketches that comprise this book into sections on "The Hill Country," "The City Belt," "The Garden Spot," and "The Jersey Shore." There are brief lists of references at the end of each of the sketches. There is a pictorial map of the State and of each county by a News staff artist, and the numerous fine photographs are well reproduced.

\section{PENNSYLVANIA}

4054. Buck, Solon J., and Elizabeth Hawthorn

Buck. The planting of civilization in western Pennsylvania. Illustrated from the drawings of Clarence McWilliams \& from photographs, contemporary pictures, \& maps. [Pittsburgh] University of Pittsburgh Press, 1939. xiv, $565 \mathrm{p}$. 39-25307 $\mathrm{F}_{149 .} \mathrm{B} 8_{3}$

This book is one of a series relating western Pennsylvania history, written under the direction of the Western Pennsylvania Historical Survey sponsored by the Buhl Foundation, the Historical Society of Western Pennsylvania and the University of Pittsburgh.

The authors, an outstanding archivist and his wife, survey the history of western Pennsylvania in all aspects from the coming of the settlers to the War of 1812 -the economy, agriculture, and industry, social and intellectual life, and religion and politics. They analyze the natural environment, Indian culture, the French and British colonial systems, and the European background of the settlers in order to assess their impact on the civilization that developed on this new frontier, and laid the foundations for a vast industrial development. The book is written for the general reader, but "The Bibliographical Essay" (p. 496-537), indicating the large body of material which the authors have consulted, will particularly interest the scholar.

4055. Dunaway, Wayland F. A history of Pennsylvania. 2d ed. New York, Prentice-Hall, 1948. xviii, 724 P. (Prentice-Hall history series) 48-5945 FI49.D85 1948

Dr. Dunaway, professor emeritus of American 
history in the Pennsylvania State College, originally published this college textbook in 1935, and in the second edition added a chapter on events through World War II and revised the chapters on the economic and social history of the later period to incorporate recent developments. The volume is in two parts breaking at 1790; in each the earlier chapters form a chronological sequence largely concerned with political events, and the later ones deal first with economic topics and then with social ones such as religion and education. A chapter in Part I on "Social Life and Customs" has no counterpart in Part II, and a chapter in Part II on "Mineral Industries" has no predecessor in Part I. The author's method consists largely in the piling up of details, which makes some of the economic chapters in particular somewhat forbidding, but the volume covers its subject in a conscientious if rather unimaginative fashion, and the selected bibliographies at the end of each chapter afford a guide to the very extensive literature of Pennsylvania history.

4056. Martin, Asa Earl, and Hiram Herr Shenk, eds. Pennsylvania history told by contemporaries. New York, Macmillan, I925. xxi, 621 p. 25-4695 Fi49.M37

$24 \mathrm{I}$ extracts from carefully selected sources in Pennsylvania history have been brought together and arranged under I5 topical headings, "to illustrate Pennsylvania's relation to all the important national events. Thus the book is designed as a supplementary text, to be used in connection with any standard history of the United States in order to coördinate the history of Pennsylvania with that of the country as a whole."

4057. Stevens, Sylvester K., Ralph W. Cordier, and Florence O. Benjamin. Exploring Pennsylvania: its geography, history, and government. Maps by Harold Faye. New York, Harcourt, Brace, 1957. 624 p. $\quad 57-1473 \quad$ Fr $_{149 . S 76} \quad$ 1957

The Pennsylvania state historian collaborates with two educators in this textbook for secondary schools, which is so comprehensive and so attractively produced as to be considerably more suitable for the general reader than most publications of its kind. In addition to a geographical first chapter, a considerable historical survey which covers all aspects of life in Province and State, and descriptions of local, State, and national government at work, there are substantial treatments of conservation, community development, and of "How Pennsylvanians Make a Living." Besides other "teaching aids" which the general reader will probably ignore, there are lists of books and pamphlets, emphasizing State documents, and of audio-visual aids when available, at the end of each chapter.
4058. Rice, Charles S., and Rollin C. Steinmetz. The Amish year. New Brunswick, N. J., Rutgers University Press, I956. 224 p. illus. 56-10989 BX8117.P4R45

This book contains an unusual body of photographs, for the Amish disapprove of "today's hasty civilization" which includes cameras, radios, and television sets along with vehicles run by gasoline and motors run by electricity. It aims to tell how the Amish of Lancaster County, Pennsylvania, really live. The chapters are arranged by months, illustrating their characteristic activities from farm sales in January to the "simple and unadorned" Christmas celebration in December. The simplicity of Amish clothes, the tradition of barn-raising, the cultivation and curing of tobacco, the making of carriages, the "rare dignity" of their funerals and weddings, and the occasional unchaperoned barn dance and rodeo of the young are described in detail, so to "bring them back in focus as people instead of dolls on a gift-shop shelf or stylized figures on wall-paper." The Amish are typical of various groups in the United States who maintain a traditional way of life in the midst of 2oth-century change.

4059. American Philosophical Society, Philadelphia. Historic Philadelphia, from the founding until the early nineteenth century; papers dealing with its people and buildings. Philadelphia, 1953. 33 I p. (Its Transactions, new ser., v. 43, pt. I) 53-7540 QII.P6, n. s., v. 43, pt. I

"Part of old Philadelphia, a map showing historic buildings \& sites from the founding until the early nineteenth century, compiled by Grant Miles Simon," fold., in pocket.

In this volume the oldest learned and scientific society in America displays the interest of its members and that of other civic and patriotic organizations in the buildings of Philadelphia that have become a part of our national heritage. Luther $P$. Eisenhart, the editor of the Transactions of the American Philosophical Society, with the assistance of William E. Lingelbach, librarian of the Society, and two members of the National Park Service staff, chose the subjects and the authors of the papers. Philadelphia was the most communityminded of our colonial cities, embodying civic institutions in architectural forms, and it became the early capital of the United States, culturally as well as politically. This volume, copiously illustrated with plans and halftones, describes the surviving buildings and reconstructs the destroyed ones, either prominent in themselves, like Independence Hall or the First Bank of the United States or representative of the days when the Quaker City was the natural center of national life. 
406o. Pennell, Elizabeth (Robins) Our Philadelphia; illustrated with one hundred \& five lithographs by Joseph Pennell. Philadelphia, Lippincott, I9I4. xiv, 552 p. I4 $^{-20572} \mathrm{~F}_{158.5} \cdot \mathrm{P}_{372}$

Returning to their native Philadelphia after an absence of a quarter of a century, Mr. and Mrs. Pennell produced this superb volume made up of Elizabeth's memories of her youth and the social scene in which it was passed, and of Joseph's masterly drawings with the lithographic crayon-"his record of the old Philadelphia that has passed and the new Philadelphia that is passing." Mrs. Pennell found the new city altered in appearance, population, and culture, chaotic and distasteful, and utterly "unlike my old Philadelphia, the beautiful, peaceful town where roses bloomed in the sunny back-yards and people lived in dignity behind the plain red brick fronts of the long narrow streets."

406r. Baldwin, Leland D. Pittsburgh; the story of a city. Illustrations by Ward Hunter. Pittsburgh, University of Pittsburgh Press, 1937. xiii, $387 \mathrm{p}$.

37-21620 Fi59.P6B

This book is another in a series relating western Pennsylvania history written under the direction of the Western Pennsylvania Historical Survey sponsored jointly by the Buhl Foundation, the Historical Society of Western Pennsylvania, and the University of Pittsburgh.

"An impressionistic picture of the city's development" which covers the whole span of Pittsburgh's history but deals preponderantly with the more colorful period prior to the Civil War. The industrial and cultural development of the city since that time is confined to three chapters at the end. By 1860 "The Gateway to the West" had become an important manufacturing center and, with its 16 foundries and 25 rolling mills, was already specializing in iron and steel, but "the great age of the monopolies was still in the future." The cultural, social, and political accompaniments of this basic development, resulting in a "city of quaint and amusing contrasts," are concisely sketched.

\section{MARYLAND}

4062. Beirne, Francis F. The amiable Baltimoreans. New York, Dutton, 1951. 400 p. (Society in America series)

Bibliography: p. $3^{80-382}$.

$$
5^{1-7387} \quad F_{189 . B I B} B_{53}
$$

Distinguished for its port, monuments, medical center, row houses, and its "Belles and Beauties," Baltimore is portrayed in its social life, personalties, and institutions against a background of history since it was chartered in 1729 . The author's de- scription of religious customs, the sports, the Cotillion, the Assembly, and the Supper Club contribute to build up a picture of Baltimore high society, which is "informal" and "at the same time both subtle and complex." Other chapters deal with Baltimore's Germans, Jews, and Negroes, and one of "Gastronomical Reflections" describes the flourishing and the latter-day decline of the famous Maryland cuisine.

\section{DISTRICT OF COLUMBIA}

4063. Brown, George Rothwell. Washington, a not too serious history. Baltimore, Norman Pub. Co., 1930. 481 p. $31-3698 \quad F_{194 . B 87}$ Bibliography: p. [446]-450.

A well-known newspaper columnist, and writer on political, labor, economic, and governmental questions, has written an entertaining history of Washington, which reveals more of its social life than can be derived from any other single volume. $\mathrm{He}$ gives much attention to the rise and fall of newspapers, to racetracks, lotteries, and the slave trade, to the rending effects of the Peggy Eaton affair, and to the sociable gathering places which have since vanished from Pennsylvania Avenue. The leisured way of life which prevailed in central Washington before 1917, and which is here described with nostalgic charm, has vanished beyond recall.

4064. Bryan, Wilhelmus Bogart. A history of the National Capital from its foundation through the period of the adoption of the organic act. New York, Macmillan, I914-16. 2 v.

$$
\text { 14-7093 F194.B9 }
$$

Contents.-I. $1790-1814 .-2$. $1815-1878$.

Based mainly on original sources, this is a detailed history of Washington from the selection of the site, in $1790^{\circ}-91$, to the adoption, in 1878 , of the commission form of government which has been in operation ever since. Although old-fashioned in approach, and often desultory in exposition, it is honest, careful, and thorough, and still remains the principal authority for Washington history during the period which it embraces.

4065. Kiplinger, Willard M. Washington is like that. [6th ed.] New York, Harper, 1942. $522 \mathrm{p}$. 51-4631 Fig6.K 5 1942a Bibliography: p. 493-499.

A staff of newsgatherers, magazine writers, and authors of books helped the author, who as a journalist had been cognizant of the Washington scene since 1916 , to write a handbook on the "basic phases of Washington in the transition from war to peace and in the first stages of war." Since that 
time the men and details have changed, but the "machine as a whole runs on." It describes the workings of the Federal Government, and the functioning of the city which is host to the Nation and at the same time has "the earmarks of the average municipality of its size." It spells out the advantages and disadvantages of government service and living in Washington. Chapters on minority groups, the press, politics and lobbying, women's influence, and the "society swirl" with a yardstick for the social climbers, round out a comprehensive guide to the Nation's capital. While much of its information is now obsolete, no more comprehensive and realistic view has appeared since.

\section{E. The South: General}

4066. Cash, Wilbur J. The mind of the South. New York, Knopf, r94I. vii-xi, 429, xv p. 4I-I $848 \quad$ Frog. $_{3}$

The facts of history are analyzed to show that they fail to support the popular conception of civilization in the Old South as being divided between a ruling class of aristocracy and a "vague race" of poor whites. The author points to the emergence from frontier conditions of a "simple rustic figure," of intense individualism, romanticism, and puritanism, as the basic Southerner or "man at the center." The development of Southern society from the antebellum period to the late 1930's, and the psychological adjustments of Southerners to the economic, political, and social changes during those years, are traced to demonstrate that there is in the region as a whole "a complex of established relationships and habits of thought, sentiment, prejudices, standards and values, and association of ideas, which, if it is not common strictly to every group of white people in the South, is still common ... to all but relatively negligible ones." A paperback reprint appeared in 1955 (Garden City, N. Y., Doubleday. 444 p. Doubleday anchor book, A27).

4067. Cotterill, Robert S. The Old South; the geographic, economic, social, political, and cultural expansion, institutions, and nationalism of the ante-bellum South. $2 \mathrm{~d}$ ed., rev. Glendale, Calif., Arthur H. Clark, I939. 354 p.

Bibliography: p. [333]-344.

$$
\text { 39-12977 } \mathrm{F}_{213} \mathrm{C}_{72} \quad 1939
$$

An attempt to summarize the work of the generation of writers who followed Ulrich B. Phillips (q. v.) and produce a pioneer synthesis of Southern history, with the development of Southern nationalism providing as much of a central theme as the story affords. Before 1820 the South expanded rapidly, especially during the Great Migration of 1815-19, into the cotton lands of Alabama and Mississippi, but it remained a heterogeneous mass, divided by a multitude of conflicting interests. Southern nationalism, based on sentiment rather than interest, was suddenly crystallized by the Missouri controversy of 1820 , after which Southerners felt themselves to be a separate people, and all other Americans to be aliens. The basic cause of secession "was a love for the South so intense that it may be called patriotism"; the Civil War was lost through State rights, which kept the Confederate armies undermanned and undersupplied, but the Southern people were further unified and their spirit of nationalism intensified. The bibliography ( $p$. [333]-344) is limited to the titles which the author has found most useful in teaching the subject.

4068. Couch, William T., ed. Culture in the South. Chapel Hill, University of North Carolina Press, I934. xiv, 7 I I p.

$$
\text { 34-II54 F2I5.C84 }
$$

The director of the University of North Carolina Press (1932-45) brought together in this symposium the varying viewpoints of 3 I contributors, who, as observers or participants, had long been familiar with the history of Southern culture broadly conceived, the political patterns, agrarian and industrial problems, and social conditions. This is no nostalgic retrospect of plantation aristocracy, slavery, and the Confederacy, but a "picture of the more important aspects of life in the present South and their historic background," which takes soundings as "the broad stream of southern life, muddy and turbulent and torrential at times and places, goes on its way." The contributors include, in addition to the editor, Benjamin A. Botkin, Donald Davidson, Jay B. Hubbell, George Fort Milton, Broadus Mitchell, Herman Clarence Nixon, Edd Winfield Parks, Josephine Pinckney, Charles W. Ramsdell, Rupert B. Vance, and John Donald Wade.

4069. Dodd, William E. The Old South; struggles for democracy. New York, Macmillan, 1937. 3 I2 $\mathrm{p}$. 37-31240 F212.D6

Only one of the projected four-volume history of the Old South by the distinguished historian and 
educator, William E. Dodd (1869-1940), was completed. The leading subjects of this volume are the "free homesteads, freedom of religion, self government and free trade" that attracted Europeans to Virginia, Maryland, and the Carolinas in the 17 th century, and the struggles to maintain those freedoms, particularly against the agents of "Stuart economic nationalism," that laid the foundations of democratic government in the Old South.

4070. Eaton, Clement. A history of the Old South. New York, Macmillan, 1949. 636 p.

$$
\text { 49-50281 } \mathrm{F}_{213} \cdot \mathrm{E}_{2}
$$

\section{Bibliography: p. 595-6rg.}

A general history of the section down to I860, which selects its details so as to focus attention on the way of life of the people, and emphasizes "those characteristics which are peculiarly 'Southern' and the historic processes which produce them." Its integrating theme is "the emergence of a regional culture, created by all classes of Southern society rather than by an elite, aristocratic group." The author's realistic outlook, in which sympathy and criticism are nicely balanced, is particularly in evidence in the three chapters (XIX-XXI) which survey Southern society during the ante-bellum decade: "The Social Pyramid, in 1850-60," "Molding the Southern Mind," and "The Chrysalis Stage of Southern Culture." The "citations" at the end of each chapter include articles in periodicals, which do not appear in the bibliography.

4071. Hesseltine, William B. The South in American history. New York, Prentice-Hall, 1943. xiv, 69 I p. (Prentice-Hall history series, edited by Carl Wittke) 43-4910 F209.H48 I943 "Selected bibliography" at end of each chapter.

This revision of the author's $A$ History of the South (1936) is a college textbook which extends chronologically from the founding of Jamestown to the domestic and foreign problems of the late I930's. It presents the main current of political developments, and other aspects of history in strict subordination to this, in a detached, impartial, and unemotional if also somewhat colorless, manner. Its thesis, according to the author, "is that the South is American: its problems have been the nation's," and its "history is a vital part of the American story." Therefore, the book's "viewpoint is national rather than Southern, and it makes no attempt to meet the oft-uttered plea for 'the truth of history from the Southern standpoint.' "'

4072. A History of the South. Baton Rouge, $6 \mathrm{v}$. Louisiana State University Press, I947-53.

Major George Washington Littlefield, C. S. A.
(1842-1920), an "empire-building cattleman" and banker of Austin, Texas, who had a deep interest in the welfare of the South, and was convinced that no available histories adequately portrayed the Confederacy, established the Littlefield Fund for Southern History at the University of Texas in I9r4. Preparations for writing a ten-volume history of the South took shape in 1937. Meanwhile a similar project had been conceived at Louisiana State University, and the planning groups united to sponsor jointly $A$ History of the South in ten volumes, to be edited by Wendell Holmes Stephenson and E. Merton Coulter. Four volumes are still unpublished, but as presently projected they are: Vol. 2, The Southern Colonies in the Eighteenth Century, $1689-1763$, by Clarence Ver Steeg; Vol. 3, The Revolution in the South, $1763-1789$, by John Richard Alden; Vol. 4, The South in the New Nation, 1789-1819, by Thomas P. Abernethy; and Vol. Io, The Present South, 1913-1946, by George Tindall.

4073. (Vol. I) Craven, Wesley Frank. The Southern colonies in the seventeenth century, r6o7-1689. I949. xv, 45I p. 49-3595 F2I2.C7 "Critical essay on authorities": p. 4I 7-433.

The influence of England on the economic and political development of Virginia, Maryland, and Carolina is emphasized as the author traces the beginnings of the "peculiar qualities" which characterize Southern society.

4074. (Vol. 5) Sydnor, Charles S. The development of Southern sectionalism, $1819-1848$.

1948. 400 p. $\quad 4^{8-7627} \quad \mathrm{~F}_{213} \mathrm{~S}_{92}$

"Critical essay on authorities": p. 346-381.

The course of events that changed the South "from a position of great power in national affairs to the position of a conscious minority" is traced here.

4075. (Vol. 6) Craven, Avery O. The growth of Southern nationalism, I848-186r. 1953. $433 \mathrm{p}$. $53-r_{470} \mathrm{~F}_{213} . \mathrm{C}_{75}$

"Critical essay on authorities": p. 402-419.

The story of the breach that developed between the North and the South "as seen through the evolution of Southern attitudes towards national events." It is "an effort to explain how the American states drifted into civil war through the breakdown of the democratic process in government."

4076. (Vol. 7) Coulter, Ellis Merton. The Confederate States of America, r861-1865. I950. $644 \mathrm{p}$. 50-6319 $\mathrm{E}_{4} 87 . \mathrm{C} 83$

"Critical essay on authorities": p. 569-6r2.

Unlike most histories of this period, this volume does not center attention on the campaigns of the Civil War, but on secession and the problems faced 
by the Confederacy in maintaining a government and supplying an army, on the reactions of Southern society to the increasing stress of war, and on the internal dissensions of the Confederacy and its attempts to arrive at a negotiated peace.

4077. (Vol. 8) Coulter, Ellis Merton. The South during reconstruction, $1865-1877.1947$. xii, $426 \mathrm{p}$. $4^{8}-5161$ F216.C6

"Critical essay on authorities": p. 392-407.

This, the first volume of the series to be published, pictures the South as it was at the end of the Civil War with its economy disrupted and its government carried on by an army of occupation. The author describes "the ordinary activities of the people, as they sowed and reaped, went to church, visited their neighbors, sang their songs, and sought in a thousand ways to amuse themselves. The point of view ... is the South during Reconstruction-not Reconstruction in the South." Many direct quotations have been used to describe Southern reactions and desires during the period. The withdrawal of Federal troops in 1877 left the South, "within reasonable limits," to reconstruct itself.

4078. (Vol. 9) Woodward, Comer Vann. Origins of the new South, 1877-1913. I951.

$542 \mathrm{p}$. 51-14582 F215.W85

"Critical essay on authorities": p. 482-515.

Against a background of the social conditions that prevailed in the South after reconstruction, the author describes the South's progress on the road back to the political prestige which it had enjoyed during the ante bellum days.

4079. Odum, Howard W. Southern regions of the United States. Chapel Hill, University of North Carolina Press, 1936. 664 p. illus. (maps) tables, diagrs.

36-10075 $\mathrm{F}_{215} \mathrm{O}_{28}$

Bibliography and source materials: p. 605-620.

As part of a general regional survey under the sponsorship of the Southern Regional Committee of the Social Research Council, Dr. Odum's study is limited "primarily to the eleven Southeastern States corresponding more nearly to the 'Old South,' beginning with Virginia and comprising the five pairs of states: North and South Carolina, Kentucky and Tennessee, Georgia and Florida, Alabama and Mississippi, Louisiana and Arkansas." It analyzes the natural resources, the technological development, the agricultural and industrial economy, and the institutions and folkways of these regions in terms of accomplishments and potentialities, and, graphically illustrating comparisons with other regions, indicates the adjustments necessary for "more effective reintegration of the southern regions into the national picture and thereby toward a larger regional contribution to national culture and unity." Eleven years later, in his The Way of the South; Toward the Regional Balance of America (New York, Macmillan, 1947. 350 p.), Dr. Odum has "tried to continue the spirit, methods, and purposes of the Southern Regional Study." The South, he is convinced, "affords the best testing ground for regional planning in the United States," since "regional imbalance is more marked" there than elsewhere. "The South lacks balance between agriculture and industry, as well as in agriculture ... Particularly, the South is out of balance in its ratio of Negro to white and in its power to give equal opportunity to both."

4080. Osterweis, Rollin G. Romanticism and nationalism in the Old South. New Haven, Yale University Press, 1949. 275 p. (Yale historical publications. Miscellany, 49)

"Bibliographical note": p. [240]-26o.

The "cult of chivalry" was a major element in the romanticism which characterized the Southern States and contributed to differentiate them from the other regions of the United States. The author traces the origin, nature, accompaniments and significance of that cult as it was manifested in such centers as Richmond, Charleston, New Orleans, and the Southwest between the War of 1812 and 1861. "It provided the very essence" of Southern nationalism, which brought on the Civil $\mathrm{W}^{\top}$ ar, and surviving slavery and the plantation system is today "the surviving atavism of antebellum civilization."

4081. Owsley, Frank Lawrence. Plain folk of the Old South. [Baton Rouge] Louisiana State University Press, 1949. xxi, 235 p. (The Walter Lynwood Fleming lectures in Southern history, Louisiana State University)

49-II743 F2r3.O94

Church and county records, unpublished census reports and population schedules, the older town and county histories, and the biographies, autobiographies, and recollections of locally prominent citizens have been analyzed to recreate this picture of the plain country folk of the South who were neither rich planters nor poor whites. The group includes the small slave-holding farmers, the nonslaveholders who owned land which they cultivated, the herdsmen on the frontier, pine barrens, and mountains, and the tenant families whose agricultural production indicated thrift, energy, and selfrespect. In addition to maps of six precincts in the Alabama black belt, the book contains 9 I tables which illustrate the author's "sampling method" in arriving at his conclusion that these "Southern folk" were a closely knit people whose balanced economy 
helped to sustain the South during the Civil War and reconstruction, and who contributed leadership in local politics, and a large number of individuals to the professions. They were a "vital element of the social and economic structure of the Old South."

4082. Simkins, Francis Butler. A history of the South. [2d ed., rev., enl.] New York, Knopf, r953. xiii, 655 , xxiii p.

Bibliography: p. $617-655$. 52-8516 $\quad F_{209} S_{5} \quad 1953$

The first edition of this book was published in I947 under the title: The South Old and New; a History, 1820-1947; the new edition is considerably expanded, but remains, like the first, a frank presentation of the Southern conservative's outlook on the past. It contains five new chapters (II-VI) covering the colonial period and the Revolution, which depart from the view put forward in the original edition that the region did not acquire its true sectional character until about 1820 , when the Negro question first appeared as a political issue. More than half of the book deals with the period relatively neglected in general treatments-the New South from the Civil War to 1952. Although the South has made remarkable strides since World War II, the author points out that it has still not caught up with industrial and economic advances in the Nation as a whole, and retains many characteristics from the past which make it a region apart.

4083. Thorp, Willard, ed. A Southern reader. New York, Knopf, 1955. 760 p. illus. 53-9473 $\mathrm{F}_{209} \cdot \mathrm{T}_{4} 8$

An upstate New Yorker, who since childhood has found the South to be "the most exotic and exciting region in America," has brought together selections from the writings of more than a hundred Southerners or visitors to the South and arranged them in sections concerned with the land, the rivers, the people, agriculture, education, sports and pastimes, military achievements, the Negro, violence, politics, religion, cities and towns, business and industry, and the arts. There is an essay at the beginning of each section and a commentary upon the author or his work at the head of each extract. The Preface concludes with a table of cross-references between sections ( $\mathrm{p} . \mathrm{ix}-\mathrm{x}$ ). An index of the authors drawn upon, with the publications from which their selections have been taken, appears at the end.

4084. Vance, Rupert B. Human geography of the South; a study in regional resources and human adequacy. $2 \mathrm{~d}$ ed. Chapel Hill, University of North Carolina Press, I935. xviii, 596 p. (The University of North Carolina social study series)

Bibliography: p. 512-579.

$$
\text { Agr36-577 } \mathrm{HC}_{107} \cdot \mathrm{A}_{3} \mathrm{~V}_{3} \quad 1935
$$

"This volume attempts to give a synthetic treatment of the interaction of men and nature in the American South." It deals with the physical and cultural backgrounds of the region; with soils, forests, livestock, cotton and other staple crops, and industry; with the highland, delta, and piedmont sections as special cases; and with the influence of climate and diet on health, energy, and human adequacy. The analysis of statistical indexes of wealth, education, cultural achievement, health, law, and order gives the Southern states the lowest rankings in the Nation. The author pointed to regional planning as the means of reconstructing the South and bringing it up to the national level. In 1949 Dr. Vance and others connected with the Division of Research Interpretation of the Institute for $\mathrm{Re}$ search in Social Science of the University of North Carolina prepared, for the Committee on Southern Regional Studies and Education of the American Council on Education, a volume for the use of secondary schools: Exploring the South (Chapel Hill, University of North Carolina Press, 1949. 404 p.) which reviews the natural and industrial resources of the South, in a much simpler manner, and recommends the development of resources through planning and cooperation on the part of communities large and small.

\section{F. The South Atlantic States: Local}

\section{VIRGINIA}

4085. Gottmann, Jean. Virginia at mid-century. New York, Holt, 1955. 584 p.

55-814I F23I.2.G6

Bibliographical footnotes. "Bibliographical suggestions and acknowledgments": p. 562-570.
A French geographer, attached to the Institute for Advanced Study at Princeton, began 18 months of fieldwork in July 1953, and visited every county and city in the State. The result is this volume, copiously illustrated with photographs, maps, and graphs, "which attempts to describe the Commonwealth of Virginia as it is today and to examine 
objectively its resources, its problems, and its potentialities." The first part deals with demography, historical development, and regional divisions. The second analyzes the use of forests, farmland, and "the underground," manufacturing, and the phenomena of location. The third part presents the problems of metropolitan growth and its effects in migrations, highways, and schools in a tone of qualified optimism. There is a final assessment of "the personality of Virginia." The whole constitutes the most systematic, thorough-going, and up-todate survey of any state of the Union.

4086. Kocher, Alfred Lawrence, and Howard Dearstyne. Shadows in silver; a record of Virginia, 1850-1900, in contemporary photographs taken by George and Huestis Cook, with additions from the Cook collection. New York, Scribner, 1954. xxiv, $264 \mathrm{p}$.

54-5917 F231.K75

The major part of the photographs used here were made in Virginia between 1865 and 1900 by George S. Cook, "the dean of Virginia cameramen," and his younger son Huestis, but some are by other Virginia photographers whose plates were purchased by the Cooks. The compilers have grouped the photographs to illustrate the towns, taverns, and the country store; the plantation and countryside; and the social life of the people of Virginia during the last half of the igth century. Each group of photographs is provided with an introductory essay, and each photograph is accompanied by an identifying caption. The whole provides a remarkable graphic record of Virginia in an age of transition and readjustment.

4087. Rothery, Agnes Edwards. Virginia, the new dominion, illustrated by E. H. Suydam. New York, Appleton-Century, 1940. xiii, 368 p.

40-27455 F23r.R85 which combines a geographical with a topical ap proach and passes lightly from past to present, finding much to approve in each. This smoothly written volume maintains a quiet dignity of tone and imparts a quantity of various information in painless manner. "The lordly quality of independence" developed by the old Virginia planter has been inherited by the modern community-"there is no place in the United States where the people are more free from timorousness and arbitrary restrictions." The attractiveness of the volume is enhanced by $\mathrm{Mr}$. Suydam's graceful drawings, al though some should have been reproduced on a larger scale than they are here.

4088. Wertenbaker, Thomas J. Norfolk; historic southern port. Durham, N. C., Duke Uni- versity Press, 1931. $37^{8}$ p. (Duke University publications) $\quad 3 \mathrm{I}-3 \mathrm{I}_{34} \quad \mathrm{~F}_{234}$.N8W4

The well-known Princeton professor of history wrote this volume under contract with the city government of Norfolk. Emphasis is placed on the first two centuries of Norfolk's history, with the period from 1880 to 1930 treated in outline, "more as a sequel to the main body of the story, than as an integral part of the history itself." Norfolk's failure to develop into a port of the first importance is ascribed to "the short-sighted policy of the Virginia legislature" after 1835 , which denied her adequate railway connections.

\section{WEST VIRGINIA}

4089. Ambler, Charles Henry. West Virginia, the mountain state. New York, Prentice-Hall, 1940. xviii, 66o p. (Prentice-Hall books on history, edited by C. Wittke) $\quad 4^{0}-5238 \quad$ F24 $_{21 . A 523}$ $A$ History of West Virginia, published in 1933, is here rewritten to include supplementary data and new chapters on the Revolutionary and Civil War periods. Of its two parts, Part I deals with topography, early settlements, institutional beginnings, warfare, social conditions, education, and politics in western Virginia down to 1860 . The inhabitants of this area disapproved of Virginia's secession from the Union, and it was admitted as a separate State in 1862. West Virginia's political beginnings and industrial, cultural, and economic development to I940 are described in Part II. A "Roster of West Virginia State Elective Officers and her Senators and Representatives in Congress," and a list of "West Virginia Counties" appear in the appendixes. The author was a professor of history at West Virginia University from I9I 7 to 1947 .

\section{NORTH CAROLINA}

40go. Lefler, Hugh Talmage, and Albert Ray Newsome. North Carolina; the history of a southern State. Chapel Hill, University of North Carolina Press, 1954. xii, $676 \mathrm{p}$.

Bibliography: p. [6 $\mathrm{I}$ I] 639 .

$$
\text { 54-7904 F254.L39 }
$$

"This volume was designed to meet the requirements of the general reader who desires a comprehensive view of the state's history within reasonable compass," and "to serve as a text for college courses in North Carolina history." To fulfill that objective the authors have presented a narrative that deals with developments and leaders in the fields of agriculture, industry, transportation, trade, education, religion, literature, and social life, as well as with 
military and political history. The last six chapters deal with progress during the 2oth century, and the impact of outside forces such as two world wars, the depression of 1929, and the policies of the New Deal on the State's development. Lists of the "Chief Executives of North Carolina," "North Carolina Counties," and "Significant Dates," appear in the appendixes. Professor Newsome died in 195I leaving approximately half of the manuscript completed. The task was finished by Dr. Lefler, who, in 1956 , published the third edition of his North Carolina History Told by Contemporaries (Chapel Hill, University of North Carolina Press. 502 p.), a collection of contemporary accounts illustrating the political, social, and economic development of North Carolina from its colonial beginnings, to be used as a supplementary text for either high school or college courses.

\section{SOUTH CAROLINA}

4091. Taylor, Rosser H. Ante-bellum South Carolina: a social and cultural history. Chapel Hill, University of North Carolina Press, I942. 201 p. (The James Sprunt studies in history and political science, v. 25, no. 2)

Bibliography: p. [187]-198.

42-373II F25I.J28, v. 25, no. 2

In this study subsidized by the Southern Regional Committee of the Social Science Research Council, the author has used manuscript diaries, letters, and other records of South Carolinians in both private and public libraries, as well as printed sources, to reconstruct a picture of society as it appeared in the decades preceding the Civil War. There are substantial chapters on the life of women, medical practice, education, and religious life; but the author's main emphasis is upon the determination of the majority to resist social change, and to maintain special safeguards for a social system based upon Negro slavery.

4092. Wallace, David Duncan. South Carolina, a short history, 1520-1948. Chapel Hill, University of North Carolina Press, 1951. 753 p.

Bibliography: p. $[715]-721$.

$$
\text { 5I-I3847 } \mathrm{F}_{269} \text {. W26 }
$$

The author, of Wofford College at Spartansburg, S. C., died after completing this reduction of his three-volume History of South Carolina, published by the American Historical Company in 1934, and the work of seeing it through the press was completed by his son. Readers are referred to the larger work for citations of sources. Political developments receive the greatest space, but from time to time separate chapters are allotted to economic, social, intellectual, legal, and ecclesiastical affairs. The writer strove with much success to be "an impartial friend of the truth": "From 1832 to 1860 South Carolina was in effect not so much a part of the country as a dissatisfied ally, for the last thirteen years of the period only awaiting a favorable opportunity to dissolve the alliance." Less than a quarter of the book (p. 556-700) is devoted to the period since 1865 . Among the appendixes are a list of the governors since 1669 , population tables, by counties since 1790 , and a list of existing counties with the dates of their creation.

4093. Molloy, Robert. Charleston, a gracious heritage; illus. by E. H. Suydam. New York, Appleton-Century, i947. xiii, 3 I I p. plates. (Century city series) 47-II944 F279.C4M6 Bibliography: p. 293-297.

With "its reputation for aristocratic appearances, punctilious manners, and an atmosphere of unforgettable individuality," and a history that goes back to the I67o's, the charm of Charleston as the center of culture and social life in South Carolina is evoked in this description of its old streets and homes, churches and historic sites, and the world-famous gardens of its environs. The author describes the leisurely life, the affability, and the characteristic speech of a people who have withstood wars, fires, and hurricanes to maintain, in the face of modernity, the distinction and personality that are Charleston. The effectiveness of the text is enhanced by the "rich and perceptive drawings" of the late Edward H. Suydam, who died seven years before the book appeared; the Century city series includes this and 13 other volumes which he illustrated.

\section{GEORGIA}

4094. Coulter, Ellis Merton. Georgia, a short history. Rev. and enl. ed. of $A$ Short History of Georgia. Chapel Hill, University of North Carolina Press, 1947. 510 p.

"Select bibliography": p. [456]-474.

A southerner by birth, the author has been a member of the history faculty of the University of Georgia since rgrg and has written many contributions to Southern history. The first edition of this book appeared in 1933 to supply the need for a short history of the State. To the revised edition have been added "a great many short bits of information, and here and there longer passages, in addition to remaking the last chapter entirely, to bring the narrative up to the present." The volume covers 
the whole span of Georgia's history from its foundation as an "experiment in philanthropy" to the revision of the State constitution in 1945, but only a quarter of it is devoted to the years since 1865 .

4095. Meadows, John C. Modern Georgia. Rev. Athens, University of Georgia Press, 1954. 352 p. $\quad 55-15747$ F291.M4 1954 "Supplementary readings": p. 347.

First published in 1946 following a request from the chancellor of the University of Georgia that "a volume be prepared describing the physical and human resources of the state," this book was also revised in 1948 and 1951 . It includes much information about the composition of the population, the public schools and other educational facilities, the health and public welfare services, and the industries and government of the State. Some comparable data for the Southeast and for the United States have been given to illustrate Georgia's place in the region and in the Nation as a whole. The author, a professor of sociology at the University of Georgia, has written especially for college students, but believes that the book will interest the general reader who wants to know more about the problems of the State.

\section{FLORIDA}

4096. Hanna, Kathryn T. (Abbey) Florida, land of change. [2d ed., rev. and enl.] Chapel Hill, University of North Carolina Press, 1948. $455 \mathrm{p}$.

Bibliography: p. 4ro-435. ${ }_{48-9796} \mathrm{~F}_{3} \mathrm{Ir} . \mathrm{H}_{3} \quad \mathrm{I}_{948}$

A colony first of Spain, of Britain from 1763 to 1784, and then of Spain again, Florida played an important part in the early "international maneuverings" of the United States. The author emphasizes the influences of foreign domination that have persisted in the history of Florida. The last quarter of the book deals with the period since 1865 and includes a chapter on the Northern "developers" who gave Florida its modern character: Hamilton Disston of Philadelphia, Henry B. Plant, and Henry M. Flagler of Cleveland. The first edition appeared in 1941; this revision contains additional information on the development of the State in the 2oth century.

\section{G. The Old Southwest: General}

4097. Clark, Thomas D. The rampaging frontier; manners and humors of pioneer days in the South and the Middle West. Indianapolis, BobbsMerrill, r939. 350 p. 39-10115 Er6r.C57 Bibliography: p. [34I ]-350.

The author, a native of Mississippi, has been head of the history department of the University of Kentucky since 1945. He has departed from conven. tional methodology and selected humorous stories to present a "well-rounded picture of the life of the common man," phrased, in part, in the vernacular of the backwoods frontier. The principal source for his stories is the general sporting magazine, the Spirit of the Times, edited by William T. Porter from 1835 until his death in 1858 . The book covers the period from 1775 to 1850 and is confined generally to the region "west of the Allegheny Mountains, and within the boundaries of Tennessee and south of the Yankee line in Ohio, Indiana, and Illinois . . . as far west as the ends of Missouri and Arkansas." It is "highly flavored by the Kentucky influence, but so was frontier society."

4098. Dick, Everett N. The Dixie frontier, a social history of the Southern frontier from the first transmontane beginnings to the Civil War. New York, Knopf, 1948. xix, 374, xxv p.

Bibliography: p. 34I-374. ${ }_{48}^{8-5379} \mathrm{~F}_{396 . D_{5}}$

Not merely the Old Southwest and its transMississippi extensions in Arkansas and Missouri, but also the southern two-fifths of Ohio, Indiana, and Illinois were settled by a great migration of the Southern people which began flowing into Kentucky about 1775 , and did not end until the Civil War. In this whole vast area they created an essentially unitary, distinctively Southern frontier culture, which in many places persisted until and even after the Civil War. This culture Professor Dick of Union College, Lincoln, Neb., describes in a colorful series of topical chapters, without attempting to discriminate regional variations or temporal successions. They include, among the more usual subjects, "The Slave as Pioneer," "Going to Market," "Good Times," "Sports," "The Frontier Town," "Professional Amusement," "The Great Revival," "Frontier Justice," "Frontier Manufactures," "The Frontier Woman," "Border Food," "Pioneer Dress," and "Frontier Speech." Two final chapters on "Frontier Characteristics" attempt to 
strike no balance between the prevailing qualities of self-reliance, versatility, native intelligence, and hospitality, on the one hand, and the evidences of ferocity, shiftlessness, chicanery, and contempt for education which were inextricably mingled with them.

\section{H. The Old Southwest: Local}

\section{ALABAMA}

4099. Moore, Albert Burton. History of Alabama. University, Ala., University Supply Store, 1934. $834 \mathrm{p}$. 36-5627 $\quad \mathrm{F}_{326 . \mathrm{M} 823}$

Bibliographies at end of most of the chapters.

A topical history of Alabama, by a professor of history at the University of Alabama since 1923, this volume is a revision of the author's three-volume History of Alabama and Its People published in 1927. After a brief review of the local Indians and of the colonial regimes, the detailed narrative begins with "The Coming of American Pioneers" in the first decade of the Igth century, and continues to the election of 1934. The point of view is honestly and vigorously "Dixiecrat." A final chapter summarizes 2oth-century trends in political reform, local government, child welfare, education, prison reform, public health, and the conservation of natural resources.

\section{LOUISIANA}

4100. Louisiana. Legislative Council. Louisiana; its history, people, government and economy. Baton Rouge, 1955. 285 p. (Its Research study no. 7) $56-6253 \mathrm{I} \quad \mathrm{JK}_{477 \mathrm{r} . \mathrm{A}_{32} \text {, no. } 7}$ "This book presents information concerning the history, the people, the government, and the economy of Louisiana in brief, narrative form supplemented by valuable statistical data, thus making available in one place the highlights of the development of Louisiana." Originating in an idea of Senator Robert A. Ainsworth, chairman of the Legislative Council, and compiled by the Council staff under the direction of Emmett Asseff, it incorporates information provided by twelve departments of the Louisiana Government. Among the subjects treated by the 23 chapters are "Elections," "Louisiana Local Government," "Fairs and Festivals," "Highways," and "State Revenues and Expenditures." The introduction notes seven specific State trends by comparing figures of 1939 with those of 1953.

4ror. Tinker, Edward Larocque. Creole city: its past and its people. New York, Longmans, Green, 1953. 359 p. illus. $53-5615 \quad F_{379 . N_{5} T_{53}}$
Born in New York City, the author, after his marriage to Frances McKee of New Orleans in 1916, became interested in his wife's hometown, took up writing as a career, and has become an outstanding collector and authority on the French period and the French language in Louisiana and old New Orleans. Mr. Tinker has twice received the French Academy's Gold Medal for his writings in this field. In this book materials that have appeared in various periodicals are brought together to illustrate the amalgamation of the native population and the American influx which took place after 1803 and "the way in which each has modified the thoughts and habits of the other" so as to develop a new manner of life and to settle down into "a perfect union." With infectious enthusiasm for his subject, the author describes the picturesque characters of the port city-the French, the Cajuns, the free men and women of color-the succulence of Creole dishes, and the gaiety of the Mardi Gras in an informal history of "the City that care forgot."

\section{ARKANSAS}

4ro2. Fletcher, John Gould. Arkansas. Chapel Hill, University of North Carolina Press, 1947. 421 P. $\quad 47-30331$ F 4 rr.F5 "Acknowledgement": p. 403-405.

In 1936 the author, a Pulitzer prize winning poet, was commissioned by the leading newspaper of Little Rock to write The Epic of Arkansas in honor of the centenary of his native State. With a passionate interest in the cultural development of his people, he wrote this book about Arkansas ten years later. In it he combines an anecdotal history with a description of the two distinct types of population, one found in the Ozark Mountain region of the northwestern half of the State, and the other in the lowlands of the southeastern half. He describes the economic worlds of those types, mountaineers and sharecroppers, and analyzes the combination of Southern and frontier characteristics which has produced the "Arkansawyer." He looks askance at the development of industry in the State by outside interests, and at the influence of Northern attitudes on racial relationships, and insists that any human progress in Arkansas must come from within. 


\section{TENNESSEE}

4103. Abernethy, Thomas Perkins. From frontier to plantation in Tennessee; a study in frontier democracy. Chapel Hill, University of North Carolina Press, I932. 392 p. 32-12393 F436.A17 Bibliography: p. [365]-376.

Believing that the study of a single state with emphasis on its development as a community should throw new light on the growth of American democracy, the author selected Tennessee which is unique as the first state to undergo the territorial status, and as the site of the earliest "organized transmontane settlements." He traces the State's growth from the Wautauga settlement in 1768 to the Civil War and throws new light on the confict between the interests of land speculators and the welfare of the people. "The first offspring of the West was not democracy but arrant opportunism." However, the popular interest finally triumphed under the leadership of such men as William Carroll, Governor from 1821-35, and Andrew Johnson, Governor from 1853-57, who "never erred from his purpose of improving the condition of the masses, politically, economically, and intellectually," and was, in fact, "the only true and outstanding democrat produced by the Old South."

4ro4. Govan, Gilbert E., and James W. Livingood. The Chattanooga country, 1540-1951: from tomahawks to TVA. New York, Dutton, 1952. $509 \mathrm{p}$.

Bibliography: p. [469]-488. 52-5307 $\mathrm{F}_{444} \mathrm{C}_{4} \mathrm{G} 6$

From its domination by the Cherokee Indians, which lasted until 1838 , to the development of its natural resources by the Tennessee Valley Authority, the economic and social life of the Chattanooga region is analyzed "in the light of local, state and national events . . . to see how they were influenced by or contributed to the greater stream of history." The "Chattanooga country" is taken to include much of northern Georgia and Alabama and of western North Carolina as well as of southeastern Tennessee, and this work therefore escapes the cramping effects which artificial boundaries often exert upon local histories. Economic and social developments are given considerably more attention than political ones.

4105. Capers, Gerald M., Ir. The biography of a river town; Memphis: its heroic age. Chapel

Hill, University of North Carolina Press, 1939. $292 \mathrm{p} . \quad 39-2748 \mathrm{I} \quad \mathrm{F}_{444} \cdot \mathrm{M}_{5} \mathrm{C}_{3}$ "Bibliographical statement": p. [269]-279.

This "comprehensive outline of the history of Memphis before I900" was submitted to Yale Uni- versity in 1936 as a doctoral dissertation. The author chose his subject because of his conviction that cities have been neglected as approaches to the study of regions, and "are often more representative of fundamental economic interests than artificial political divisions like the state." Connected with the upper valley by the Mississippi River trade, and with the South by the local agriculture, Memphis was "born in 1819 of the westward movement and of cotton" and had its boom years in the 1840's and 50's. "Figuratively and literally, the South met the West in Memphis." Memphis neglected public sanitation and so lost its relative position among American cities through the terrible yellow fever epidemics of the 1870 's.

\section{KENTUCKY}

4106. Clark, Thomas D. A history of Kentucky. New York, Prentice-Hall, 1937. xv, 702 p. (Prentice-Hall history series, C. Wittke, editor)

Bibliography: p. 625-666.

$$
\text { 37-16054 F451.C63 }
$$

"Kentucky has been viewed as an important factor in the settlement of both the South and the trans-Mississippi West." Its history, from the conflict between English and French for the control of the western lands which later became Kentucky to the middle I930's, is traced in this college textbook, which attempts to set forth "the salient points of Kentucky's social, economic, and political growth." The Appendix includes a list of "The Governors of Kentucky."

4107. Davenport, Francis Garvin. Ante-bellum Kentucky, a social history, 1800-1860. Oxford, Ohio, Mississippi Valley Press, 1943. xviii, $23^{8}$ p. (Annals of America, v. 5)

$$
43^{-1} 754^{8} \quad \mathrm{~F}_{455} \cdot \mathrm{D}_{3} 6
$$

"Bibliography of manuscript sources": p. [227]228.

The first sixty years of the Igth century witnessed a rapid development of education, medicine, science, religion, the arts, and literature in Kentucky-an important outpost of civilization. The author adds a caution that this cultural progress was not evenly distributed in an area which contained both rich and poor, the ignorant and the learned, the conservative and the liberal, and the religious and the irreligious. $\mathrm{He}$ examines the elements of culture among the country folk, the townspeople, and in the colleges. In education he notes Kentucky's emphasis on the fields of medicine, surgery, botany, geology, and chemistry, and the activity of distinguished physicians, teachers, and naturalists. Social reform found expression in new legislation and 
state-controlled institutions for the less fortunate members of society. Cultural progress became articulate in a small group of artists and a much larger number of essayists, poets, journalists, and historians. All gave distinction to this period in Kentucky history, which "resembled the life of the growing nation and was part of it."

\section{MISSOURI}

4108. Gist, Noel P., and others, eds. Missouri, its resources, people, and institutions. Columbia, Curators of the University of Missouri, $195^{\circ}$. $605 \mathrm{p}$.

50-62749 $\mathrm{F}_{4} 66 . \mathrm{G}_{4}$
Includes bibliographies.

This book, prepared by the University of Missouri, "and presented to the people of Missouri as a public service," is the joint work of a number of specialists, writing in their respective fields of competence, to "describe and interpret Missouri's natural and human resources, to indicate significant changes that are occurring in various fields, and to appraise realistically the trends and situations which should be of concern to the people of the State." Its 28 chapters deal with such topics as water resources, mines and minerals, population, cities and towns, agriculture, manufacturing, public utilities, courts and administrative tribunals, social services, libraries, and the arts.

\section{The Old Northwest: General}

4109. Atherton, Lewis Eldon. Main Street on the Middle Border. Bloomington, Indiana University Press, I954. xix, 423 p. 54-7970 F354.A8

Recalling the social activities of the rural and village life to which he was born, and the stories, historical and otherwise, exchanged around the country store stove, the author writes with affection a cultural and economic history of midwestern country towns, limited for the most part to less than 5,000 population, during the years from $\mathrm{I} 865$ to $\mathrm{I} 950$. The Middle Border is defined as the region embracing the states of Ohio, Indiana, Illinois, Missouri, Michigan, Minnesota, Wisconsin, and Iowa and the eastern farming fringe of Kansas, Nebraska, and the Dakotas. A professor of history at the University of Missouri since 1946, the author has drawn upon country newspapers, reminiscences, autobiographies, and some manuscript sources, as well as representative fiction, to produce a solidly based regional synthesis. The prevalent sentiment of decline and decay, the author holds, is a consequence of false values and a materialistic doctrine of progress viewed as growth in numbers and real-estate prices; the amenities and possibilities of life in small, semi-rural communities have been allowed to lapse through disillusionment and lethargy.

4IIo. Baldwin, Leland D. The keelboat age on western waters. With chapter decorations by Harvey B. Cushman. Pittsburgh, University of Pittsburgh Press, I94I. xiv, 268 p.

Bibliography: p. [235]-252.

$$
\text { 4I-I0342 } \text { F }_{35} \text { I.Br8 }
$$

One of a series from the Western Pennsylvania Historical Survey sponsored jointly by the Buhl
Foundation, the Historical Society of Western Pennsylvania and the University of Pittsburgh, this book, in its original form, was a dissertation submitted to the University of Michigan in 1932. It deals, for the most part, with the three decades before the coming of the steamboat $\left(I_{7} 8_{3}-I_{8} 1_{5}\right)$ when keelboats, barges, and other varieties of watercraft were used on the Mississippi, the Ohio, and their tributaries to transport goods from the Great Valley to eastern markets via New Orleans, and immigrants in their search for new homes. Chapters are devoted to the "Art of Navigation" in shallow, winding, and snag-infested waters, the "River Pirates" who were largely eliminated by 1812 , and "Shipbuilding" for oceanic commerce. The boatmen, a robust and colorful tribe, "brought from New Orleans and Pittsburgh to the crude villages of the West some of the comforts and fashions of life, as well as the necessities," and the old "Mrs. Sippi" with her thousand tentacles "bound the nation into an indissoluble union."

4III. Bond, Beverley W. The civilization of the Old Northwest; a study of political, social, and economic development, 1788-1812. New York, Macmillan, 1934. 543 p.

34-I805 F479.B69

Following the American Revolution the necessity of attracting settlers to the area between the Ohio, the Mississippi, and the Great Lakes to protect it from Indian and foreign depredation became apparent. Once the lands were ceded to the Nation by Virginia, Connecticut, New York, and Massachusetts, Congress recognized the opportunity to work out a policy of land distribution on a demo- 
cratic basis with like terms to all applicants, and an ultimate "position of equality with the original states." The Land Ordinance of 1785 and the Government Ordinance of 1787 implemented that policy, and the blending of settlers from New England, the Middle States, and the South with other racial elements created a "hard-headed, democratic, and aggressive population" in the Territory of the United States northwest of the Ohio. The central theme of this book is "the development, institutional, social, and economic, of the civilization of the Old Northwest" in the period between 1788 and 1812 , during which the Northwest Territory was divided into the state of Ohio, and the territories of Indiana, Michigan, and Illinois.

4I12. Buley, Roscoe Carlyle. The Old Northwest; pioneer period, 1815-1840. Bloomington, Indiana University Press, 1951 [ ${ }^{\circ} 1950$ ] 2 v.

$$
\text { 52-6466 F484.3.B94 I95I }
$$

"Bibliographical essay": v. 2, p. [627]-646.

Published by the Indiana Historical Society as a contribution to the Sesquicentennial of Indiana Territory in 1950, this history brought honor to the author, and to the society as "the first historical society ever to publish a Pulitzer Prize winner." A native of Indiana, steeped in its tradition and lore, the author has written a detailed and documented account of the quarter-century that witnessed the flow of settlers into the Old Northwest following the War of 1812 , the admission of Indiana, Illinois, and Michigan to statehood, and the organization of the new Territory of Wisconsin. The progress of settlement, economic development, and politics is recorded in chronological chapters, while large topical ones deal with pioneer life, medicine, transportation, education, religion, and literature and science. The author has freely used the words of contemporaries and has employed colloquialisms and expressions of the period in his own text, in order "to capture something of the attitudes and beliefs, struggles and way of life of the time and place," in this "balanced summary of the record."

4II3. Garland, John H., ed. The North American Midwest, a regional geography. New York, $\begin{array}{llll}\text { Wiley, 1955. } 252 \mathrm{p} . & 55-9845 & \mathrm{~F}_{354 . G_{3}}\end{array}$ "Selected bibliography": 243-245.

Fifteen topical and regional specialists have contributed to this enthusiastic book. The Midwest is described as an inner zone including the WestCentral Lowland, the East-Central Lowland, the Eastern Lower Great Lakes, and the Upper Mississippi Valley, encircled by a periphery comprising the Upper and Lower Great Lakes, the Ohio Valley, the Ozark Upland, and the Lower and Upper Missouri Valley. The region is uniquely distinguished among continental interiors by its distance from the ocean, its diversity of transportation routes, its large metropolitan centers, its materials and markets for manufacturing, the productive capacity of its soils, its abundance of coal, iron, and other minerals, its unequaled water resources in the Great Lakes and the Mississippi, uniformly favorable climate for the production of high-yielding crops, and "the most optimistic people in the world."

4114. Hatcher, Harlan $H$. The Great Lakes. New York, Oxford University Press, 1944. ${ }^{8} 84$ p.

Bibliography: p. 371-374.

44-94I9 $\mathrm{F}_{55} \mathrm{I}_{\text {. }} \mathrm{H}_{36}$

A native Ohioan, the author rose from instructor to vice-president of the University of Ohio (I92251 ), and has written several books focused on the region of the Great Lakes. Forming the boundary between the United States and Canada, the Great Lakes are spanned by eight international bridges and a tunnel, which link the countries "in amity at the key points on the Lakes." The subject of this book is "the story of this mighty region-its formation, its discovery, the struggle for its possession, its exploitation, the rise of its cities, the history and romance of its ships." Part I is concerned with the discoverers from Cartier to La Salle; Part II with international conflict from de la MotheCadillac's foundation of Detroit to the Peace of Ghent; Part III with settlement and the spread of navigation; and Part IV with the rise of the mineral industries which have given the Lakes their modern economic character.

4115. Hubbart, Henry Clyde. The older Middle West, 1840-1880, its social, economic and political life and sectional tendencies before, during and after the Civil War. New York, AppletonCentury, 1936. 305 p. 36-1 $1022 \quad F_{4} 84 \cdot 3 . H 885$ Bibliography: p. 278-292.

By the older Middle West the author means the southern portions of Ohio, Indiana, and Illinois, "the region of the river valleys," the settlement of which, primarily by upland southerners and secondarily by Pennsylvanians, was complete by 1840 . Despite the book's comprehensive title, there are only four chapters on the social, cultural, and economic characteristics of the area, and the main theme is the reaction of the "Progressive Western Democracy" of the region to the sectional struggle inaugurated by the Mexican cessions of 1848 . "Here was the zone of doubtful states for whose control" the Southern masters of the Democratic Party contended with the new Republicanism which arose in the Lake Region; here arose "copperheadism," not a pro-Southern movement but one 
in which "thwarted westerners showed their sectional discontent;" and here protests against triumphant Republicanism went on continuously throughout the Gilded Age. The volume was published from a fund contributed to the American Historical Association by the Carnegie Corporation of New York.

4II6. Hutton, David Graham. Midwest at noon. Chicago, University of Chicago Press, 1946. $\mathrm{xv}, 35^{\circ} \mathrm{p}$. $\mathrm{A}_{46-1352} \mathrm{~F}_{354 . \mathrm{H} 8}$

Mr. Hutton, who was on an official mission in the United States during World War II, has produced one of the few books by an Englishman on an American region. Fascinated by the Midwest and its people, and finding few books "that told all about the region, its history, and its way of life," he has set down his "own impressions of the Midwest as it was, as it is, and as it yet may be." He leaves the reader to decide how much of what he records is peculiar to the region and how much is "just plain American." His exposition combines historical perspectives, economic analyses, personal observations, psychological characterizations, and social interpretations in about equal measure to make a rich and sympathetic volume which resists summary. So, the author finds, does the maturing Midwest itself: "its distinctive characteristics are those of its richly varied peoples, their neighborliness, their tolerance and conformity to one broad way of life, whatever they do for a living."
4117. Power, Richard Lyle. Planning Corn Belt culture; the impress of the upland southerner and Yankee in the Old Northwest. Indianapolis, Indiana Historical Society, 1953. xvi, 196 p. (Indiana Historical Society, Publications, v. 17)

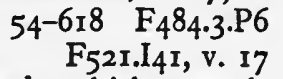

An original interpretative study which regards the settlement of the Old Northwest as a kind of culture conflict between upland southerners and Yankees from New England and New York. "The Southerners got there first"-indeed, had a forty years start, but after 1830 came the "Yankee invasion" with its cultural imperialism mingling religious, economic, and political motives. The author has drawn upon the papers of the American Home Missionary Society in the Chicago Theological Seminary, "a sort of Puritan equivalent of the Jesuit Relations," for interesting expressions of the viewpoint of the self-conscious New Englanders. Chapter IV assembles some of the consequences of "Living Side by Side," in farmways, shelter, cookery, language, and preaching. The author concludes that while by 1865 the Yankee felt that he had swept everything before him, and had indeed gained a tempered victory, in fact "neither strain won out by subordination of the other, but both were conquered as it were by. the region itself, were taken in hand by a process of blending, in which the final outcome was neither Yankee nor Southern, but 'Western.'"

\section{J. The Old Northwest: Local}

\section{OHIO}

4II8. Hatcher, Harlan H. The Western Reserve; the story of New Connecticut in Ohio. Indianapolis, Bobbs-Merrill, 1949. 365 p.

$$
\text { 49-9476 } \mathrm{F}_{497} \cdot \mathrm{W}_{5} \mathrm{H}_{27}
$$

"Acknowledgments and bibliographical note": p. 345-347.

The author's subject is the part of northeastern Ohio on Lake Erie which was "reserved" by Connecticut in 1786 when she ceded her other claims to western land, and retained until 1800 when, by agreement with the United States Government, jurisdiction was transferred to the Nation. It comprised some 5000 square miles. The author traces the history of the Western Reserve from its first settlement by a group from Connecticut under the leadership of Moses Cleaveland in 1796 to the mid2oth century. He points out that the New England influence is still found in the architecture and in the names of the older towns and villages, although it has been tempered by the assimilation of a foreign population attracted by the growth of the great industries which have given the region a strategic position at the heart of America. The publication of this volume coincided with the centennial of the Western Reserve Historical Society, which owns much of the source material used in its compilation.

4II9. Ohio. Development and Publicity Commission. Ohio, an empire within an empire. 2d ed. Columbus, r950. $214 \mathrm{p}$.

$$
\text { 5I-62008 } \mathrm{F}_{496 . \mathrm{O}_{35}} \text { I950 }
$$

"References and additional sources of information:" p. 213-214.

"The Ohio Development and Publicity Commission was created to develop and to disseminate information concerning the agricultural, historical, in- 
dustrial and recreational advantages and attractions of the State of Ohio." This book, the first edition of which appeared in 1944 , was sponsored by the Commission for those purposes. A group of specialists in their fields have contributed to the volume with GuyHarold Smith, chairman of the Department of Geography at Ohio State University, as editor-inchief. The full-page maps are used to illustrate distribution among the counties of population, agricultural products, manufactures, natural resources, transportation, cultural institutions, and various public services. A final chapter summarizes the characteristics of Ohio that are representative of the Nation as a whole, and concludes that "every phase of the State's life displays a legacy or benefaction from other parts of the country and of the world." The end matter includes a list of "Museums and Historical Points" (p. 187-90) and an "Organization Chart, State Government."

4120. Roseboom, Eugene H., and Francis P. Weisenburger. A history of Ohio. Edited and illustrated by James $\mathrm{H}$. Rodabaugh. [New ed.] Columbus, Ohio State Archaeological and Histori-

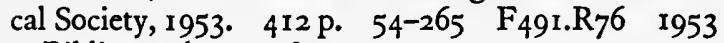

Bibliography: p. $385-402$.

The first edition of this history was published in 1934 in the Prentice-Hall history series, edited by Carl F. Wittke. Published for the Sesquicentennial of Ohio, this revision gives greater emphasis to social and cultural history, covers the period since 1934, and adds "to the knowledge of the State's intrinsic importance and of its significant role as one of the states of the American Union." The bibliographies have been expanded and the work provided with a remarkable body of illustrations-so many, in fact, that the new edition has been printed on slick paper and in larger format.

4121. Wittke, Carl F., ed. The history of the state of Ohio. Published under the auspices of the Ohio State Archaeological and Historical Society. Columbus, Ohio, 194 I-44. $6 \mathrm{v}$.

$$
4^{\mathrm{r}-747^{\mathrm{r}}} \mathrm{F}_{49 \mathrm{r} . \mathrm{W}_{7} 8}
$$

Contents. - I. The foundations of Ohio, by Beverley W. Bond, Jr. 1941.-2. The frontier state, 1803-1825, by William T. Utter. 1942.-3. The passing of the frontier, $1825-1850$, by Francis $P$. Weisenburger. 1941.-4. The Civil War era, 18501873, by Eugene H. Roseboom. I944.-5. Ohio comes of age, 1873-1900, by Philip D. Jordan. 1943.-6. Ohio in the twentieth century, 1900-1938, planned and compiled by Harlow Lindley. 1942 .

This definitive history was published with the financial assistance of the General Assembly of Ohio, "in connection with Ohio's observance of the r5oth anniversary of the organization of the North- west Territory and the establishment of civil government within its limits under the Ordinance of $1787 . "$ It is the result of the cooperative efforts of a group of outstanding scholars under the editorship of the well-known head of the Department of History at Ohio State University (1925-37), later professor of history at Oberlin College (1937-48). "Attention has been given in each volume to the more or less familiar aspects of Ohio's political history, but in addition, a real effort has been made to stress the economic, social, cultural and intellectual progress of the State. Art, architecture, religion, journalism, amusements, the theater and other phases of cultural and intellectual activities have received their fair share of emphasis." In volume $\mathrm{V}$, in fact, only four of the 13 chapters are concerned with politics, and of these two, on "Politics and Big Business" and "Bosses and Boodle," are concerned with its social-history connections. Volume VI comprises 17 chapters by 15 specialists, the last, appropriately enough, being one by Dr. Lindley on "The Sesquicentennial Celebration." Each volume is separately indexed, and, while there are footnote references, there are no bibliographies.

4r22. Harlow, Alvin F. The serene Cincinnatians. New York, Dutton, I950. 442 p. (Society in America series)

Bibliography: p. 422-428.

$$
\text { 50-10456 } \mathrm{F}_{499} \cdot \mathrm{C}_{5} \mathrm{H}_{35}
$$

A city of firsts in many of its cultural achievements and of superlatives in some of its public services and industrial performance, Cincinnati was known as the "Queen City of the West" by 1834 . The author thinks that the serenity found in Cincinnati is born of "the experience and philosophical composure of age, informed by historical consciousness, and with a strong blend of German imperturbability." Jolted occasionally by the discovery of graft and dishonesty in government and the slackening of public morals, Cincinnatians still face and solve their problems in a spirit of tranquility which, the author suggests, may become a casualty of the near future, since "poise is increasingly difficult to maintain in a global scientific arena." Much of the material for this book has been "garnered from Cincinnati newspapers of the past."

\section{INDIANA}

4123. Esarey, Logan. A history of Indiana. Inp.) dianapolis, B. F. Bowen, 1918. 2 v. (1148 19-I8II F526.E742 Contents.- - . From its exploration to 1850.-2. From 1850 to the present.

A native of Indiana, Logan Esarey (1873-1942) 
grew up in its southern hills at a period when many of the people who had contributed to the State's early history were still alive. As a teacher he was noted for his classes in Indiana and Middle West history, and for the outstanding collection of public documents, newspapers, diaries, letters, and other materials which he collected for the Indiana University Library. This scholarly history (Ist edition 1914) is based, for the most part, on primary sources, but the author complained that documentary material for Indiana had not been published by the State. No substantial changes were made in the second edition. From Chapter XI on, chapters of political narrative are interspersed with others on economic or social matters, and the organization of the book becomes rather desultory after 1865 is reached. Esarey's love for his native State found expression in a group of penetrating essays about pioneer life, five of which were published after his death, and have been much appreciated. Some ten years later another and very handsome edition of The Indiana Home (Bloomington, Indiana University Press, I953. I2I p.) was designed and illustrated by Bruce Rogers.

4124. Martin, John Bartlow. Indiana, an interpretation. New York, Knopf, 1947. xii, 300, xvii p.

Bibliography: p. 29I-300.

47-I I58I $\quad$ F $_{526 . M_{25}}$

A well-known crime reporter, whose first book was on the Upper Peninsula of Michigan, has set down here his interpretation of "the Hoosier character, the Hoosier thought, the Hoosier way of living." His data are in part gleaned from interviews with newspapermen, laborers, manufacturers, undertakers, retired madames, and a great variety of run-of-the-mill citizens, and his book, he says is journalism-but if so, it is assuredly journalism of a superior stamp. He opens with an original device: "Indiana, as a whole, viewed within the framework of a Hoosier institution, the State Fair." Three historical sections culminate in "The Golden Age" when, with James Whitcomb Riley, Booth Tarkington, and others, Indiana had a literature of its own. Recent tendencies are presented through the diverse personalities of four representative "Gentlemen from Indiana." Indiana is found to be "a place where the American kind of capitalistic democracy grew up in its native form," while "America is a larger Indiana."

4125. Thornbrough, Gayle, and Dorothy Riker, comps. Readings in Indiana history. Indianapolis, Indiana Historical Bureau, 1956. 625 p. (Indiana historical collections, v. 36 )

57-62616 $\quad \mathrm{F}_{521 . \mathrm{T}_{4}}$ F521.I38, v. 36
This anthology is based upon an earlier Readings in Indiana History compiled by a committee of the Historical Section of the Indiana State Teachers' Association and published by Indiana University in 1914. The selections are relatively short and include extracts not only from original sources but also, in lesser part, from recent scholarly writings including magazine articles. The extracts are grouped in 32 chronological or topical chapters, and many of them are preceded by brief introductions. The compilers regret the lack of "a good onevolume history of Indiana which can be read in conjunction with the Readings." They also find a dearth of suitable material for the later history of the State, and have in fact only 40 very miscellaneous pages on the years since 1865 .

\section{ILLINOIS}

4126. Illinois. Centennial Commission. The centennial history of Illinois, Clarence Walworth Alvord, editor-in-chief. Springfield, Ill., 1917-20. $6 \mathrm{v}$. (Its Publications, Introductory vol. and vol. $1-5$ )

Contents:

4127. (Introductory vol.) Illinois in 1818 , by Solon Justus Buck. 1917. $362 \mathrm{p}$.

$$
{ }^{17-17320} \quad \mathrm{~F}_{545 . B_{92}}
$$

4128. (Vol. I) The Illinois country, $1673-1818$, by Clarence Walworth Alvord. 1920. $524 \mathrm{p}$. 20-27288 F $\quad$ F4I.A47

4129. (Vol. 2) The frontier State, 1818-1848, by Theodore Calvin Pease. 1918. 475 p. I9-27083 $\quad \mathrm{F}_{545} \cdot \mathrm{P}_{34}$

4130. (Vol. 3) The era of the Civil War, 1848I 870 , by Arthur Charles Cole. 1919. $499 \mathrm{p}$.

19-7332 F $_{545 . C 68}$

4131. (Vol. 4) The industrial State, 1870-1893, by Ernest Ludlow Bogart and Charles Manfred Thompson. 1920. $553 \mathrm{p}$.

$$
\text { 20-27316 } \mathrm{HC}_{107 . \mathrm{I}_{3} \mathrm{~B} 6}
$$

4132. (Vol. 5) The modern Commonwealth, 1893-1918, by Ernest Ludlow Bogart and John Mabry Mathews. 1920. 544 p.

$$
\text { 20-27159 } \mathrm{F}_{546 . \mathrm{B} 67}
$$

These volumes on the history of Illinois from the coming of the first Europeans to the close of World War I were published in observance of the one hundredth anniversary of the admission of Illinois into the Union. The authors, a distinguished group, 
were all members of the faculty of the University of Illinois at the time the project was initiated. Dr. Buck's introductory volume presents a survey of the social, economic, and political life of Illinois at the close of the territorial period, followed by a detailed history of the process of admission. In the last two volumes the chapters of economic history and description are written by Prof. Bogart, and the political ones by his collaborators. Each volume has a substantial bibliography, and the latter ones have appendixes with tables of economic statistics. This was the first of the cooperative and scholarly multivolume state histories; the example of Illinois has since been followed by Massachusetts, New York, and Ohio, and, in a project as yet only very partially completed, by New Jersey.

4I33. Pease, Theodore Calvin. The story of Illinois. [Rev. ed.] Chicago, University of Chicago Press, I949. xviii, 284 p.

$$
\text { 49-11105 } \text { F541.P36 } 1949
$$

"This volume is an attempt to present a short, readable history of the state of Illinois, embodying the results of the latest research." The first edition which appeared in 1925 was based "to a considerable extent on the five-volume Centennial History of Illinois." This new edition was published as a contribution to the golden anniversary of the founding of the Illinois State Historical Society of which the author, who died in 1948, was a director for many years and president from 1946-47. Additions in the fields of British and French relations with the Illinois country have been made in this revision and the final chapter, completed by Mrs. Pease, covers another quarter century in Illinois' development.

\section{I34. Dedmon, Emmett. Fabulous Chicago. New York, Random House, 1953. 359 p. 53-692 I $\mathrm{F}_{548.5 . D_{4}}$}

Based on source materials found in the Chicago Historical Society, and in the files of certain Chicago newspapers, this narrative of social life in Chicago from r835 to 1930, with an "Epilogue" that summarizes to the date of publication, also contains in its acknowledgments the names of some of the city's first families. Here are lively descriptions of such matters as the social dictatorship of Mrs. Potter Palmer, invitations to whose New Year's Day receptions determined the makeup of high society; of the social accompaniments of the unforgettable World's Fair of 1893 , when the Infanta Eulalia of Spain and 28 million others invaded the White City; and the low life along the Levee, where were to be found the Everleigh Club and, until they were transferred to the Coliseum, the First Ward Balls of Aldermen Coughlin and Kenna. Educated in Chicago, the author has been associated with Chicago newspapers since $194^{\circ}$ as columnist, critic, and editor, and he writes with an obvious zest for his subject. The many interesting illustrations are obtained from the Chicago Historical Society and the Newberry Library.

4135. Lewis, Lloyd, and Henry Justin Smith. Chicago, the history of its reputation. New York, Harcourt, Brace, 1929. xii, 508 p.

"Sources": p. 495-497.

$$
{ }_{29-17674} \mathrm{~F}_{548.3 . \mathrm{L} 67}
$$

The lethal gangster wars of the I920's gave Chicago a worldwide notoriety which troubled many of its more sensitive citizens, and which was evidently responsible for the sub-title of this briskly anecdotal sketch of municipal history by two prominent local journalists. To them the city's vitality and joy in life, its absorption in the future, its incessant rebuilding of itself, and its herculean business enterprise are the essential Chicago, while political corruption and unpunished crime are only superficial and transient phenomena. "Four and a half million people, counting themselves part of metropolitan Chicago, were going somewhere and intended to get there." Mr. Lewis takes the story to the World's Fair of 1893 , and Mr. Smith carries it on to the municipal election of 1928 .

$$
\begin{aligned}
& \text { 4136. Pierce, Bessie Louise. A history of Chicago. } \\
& \text { New York, Knopf, I937-57. } 3 \text { v. } \\
& 37-880 \text { I F548.3.P54 } \\
& \text { Bibliography: v. I, p. [429]-455; v. 2, p. 515-547; }
\end{aligned}
$$
v. 3 , p. [547]-575.

This history is related to a wide range of studies in the sociology, economics, and politics of the Chicago metropolitan area conducted by the Social Science Research Committee of the University of Chicago, but only three of its projected four volumes have appeared. The author has served as a professor of American history at the University of Chicago since 1929. The first volume is the story of a frontier community from 1673 to 1848 , and "typifies the life of the Middle West before I850." The second begins with the construction of Chicago's first railroads and ends just before the Great Fire of 1871. The third proceeds from the fire, which resulted in a material loss estimated at $\$ 196,000,000$, and the amazing rebuilding which followed it, to the World's Fair of 1893, which marked "a new epoch in the aesthetic growth not only of Chicago but of the nation." Each volume has valuable tabular appendixes. Focusing trends on national affairs as they affected Chicago, these volumes are also a well-documented contribution to the history of the United States. At the time of the Century of Progress Fair in Chicago, Professor Pierce edited a volume containing impressions of 
Chicago by 47 travelers, foreign and domestic, from Père Marquette to Morris Markey: As Others See Chicago, Impressions of Visitors, 1673-1933 (Chicago, University of Chicago Press, I933. 540 p.). A brief sketch of the author precedes each selection.

\section{MICHIGAN}

4137. Bald, Frederick Clever. Michigan in four centuries. New York, Harper, I954. xiii, $498 \mathrm{p}$. 54-8934 F566.B2

"A selected list of books on Michigan history:" p. $477-481$.

Long the site of a fur trade between the Indians and the French or British, the territory that became the State of Michigan in 1837 was populated by settlers from New York, New England, and Europe. This book resulted from the interest of the son of a Swedish immigrant in the history of his State. Rising from poverty to the presidency of the State Normal College, and deploring the neglect of state history in the schools, Dr. John M. Munson left his estate for the publication of a history of Michigan, and a history of education there. Published under the direction of the Michigan Historical Commission, this book incorporates 2 I years of research by the author, a member of the Department of History at the University of Michigan. "An essential for good citizenship" in a state with so large a population born elsewhere, this history "is directed to the adult as well as to the youthful resident of the state." Six years prior to the publication of this book Dr. Milo Milton Quaife, described by Dr. Bald as the "dean of historians of Michigan and the Old Northwest," cooperated with Dr. Sidney Glazer in writing "a comprehensive history of Michigan suited to the needs of class room students and of mature readers generally": Michigan: from Primitive Wilderness to Industrial Commonwealth (New York, PrenticeHall, 1948. 374 p. Prentice-Hall history series).

4138. Pound, Arthur. Detroit, dynamic city; illustrated by E. H. Suydam. New York, Appleton-Century, 1940. 397 p.

Bibliography: p. 373-[378]

$$
4^{0-27234} \quad \mathrm{~F}_{574 \cdot \mathrm{D}_{4}} \mathrm{P}_{7}
$$

A native of Michigan, an experienced journalist, and the author of several studies of industrial America, Mr. Pound was well-equipped to write this narrative sketch of the rise of Detroit from a furtrading outpost in the early I 8 th century to the position of automobile capital of the world in the mid2oth. The city has been fortunate in its location at a strategic point by Antoine de la Mothe Cadillac in 1701 , and in the leadership of men such as Judge Augustus B. Woodward, the "driving spirit" in rebuilding the city after the devastating fire of 1805; in the foresight of Governor Lewis Cass who "gave courage to the territory and tone to society;" and in Henry Ford's determination to supply "cheap highway transportation for the common man." The citizens, throughout the history of Detroit, have faced consuming disasters, economic depressions, and labor disturbances with the energy and effectiveness characteristic of a vigorous people.

\section{WISCONSIN}

4139. Raney, William Francis. Wisconsin; a story of progress. New York, Prentice-Hall, 1940. xvii, 554 p. (Prentice-Hall books on history, edited by Carl Wittke) $40-7607 \quad \mathrm{~F}_{5} 81 . \mathrm{R}_{32}$

"Selected bibliography" at end of each chapter.

Long associated with education in Wisconsin, the author has been chairman of the Department of History and Government at Lawrence College, Appleton, since 1946. This history is designed "to provide a readable and up-to-date summary of the growth of Wisconsin from the arrival of the first European visitor in 1634 down to the present." After the organization of the Northwest Territory, nearly fifty years passed before settlers from the northern states, with a scattering from the South, reached the frontier that became the State of Wisconsin in 1848 . The next fifty years witnessed the flow of immigrants into the State from Germany, Norway, Sweden, Ireland, and other countries, the building of a network of railroads, and the exploitation of the lumber resources. While wheat production declined after 1870 , Wisconsin took the leadership of the Nation in dairying. Enlarging the functions of government in the interest of all its citizens, Wisconsin has become synonymous with progressive social experiments in government. The appendixes include a list of "Governors of Wisconsin," "Wisconsin Votes in Presidential Elections," and statistics of the "Population of Wisconsin" from 1830 to 1930 .

4140. Still, Bayrd. Milwaukee, the history of a city. Madison, State Historical Society of Wisconsin, 1948. $\mathrm{xvi}, 63^{8} \mathrm{p}$.

"Bibliographical note". 49-7868 F589.M6S8

The founder of Milwaukee was Solomon Juneau, a young French-Canadian fur-trader who began his residence there in 1818 , and turned town-promoter in 1833 . Milwaukee was incorporated as a village in 1838 , had grown into a town within a decade, and was a city by 1870 . Situated some 80 miles north of Chicago on the shore of Lake Michigan, and famous for its breweries even before the Civil War, 
it is now one of the chief ports on the Great Lakes and one of the world's leading centers for the manufacture of heavy machinery. In 1837 the first issue of the Milwaukee Sentinel asserted that "rigid enforcement of and prompt obedience to the popular will" was "the most vital principle of Representative Government." This philosophy has persisted and has made of Milwaukee, with its large foreign population, a laboratory for liberal social and political movements. Dr. Still, a professor of history at Wisconsin State College from I932 to 1938, published in the State's centennial year this full-scale history covering all aspects of the city's development. Since monographic material was lacking, it represents a noteworthy work of compressing voluminous primary sources. Milwaukee's century of city building, he concludes, "bore witness to the contribution of the sovereign citizen in underwriting urban growth." Population tables and a series of sketch maps illustrating that growth appear in the Appendix.

\section{MINNESOTA}

4I4I. Blegen, Theodore C. Building Minnesota. Boston, Heath, I938. xii, 450 , xvi p. illus. 38-29043 F606.B66

"Materials for further reading and study": p. i-iv at end.

4I42. Blegen, Theodore C. The land lies open. Minneapolis, University of Minnesota Press, 1949. 246 p. 49-48266 F606.B674

Dr. Blegen, the historian of Norwegian immigration (q. v.), has long been a professor of history at the University of Minnesota and was superintendent of the Minnesota Historical Society from 1931-39. Nearly 20 years ago he prepared Building Minnesota for use in the secondary schools of the State. Apart from its being written in rather simple sentences, from its chapters being grouped in "units" which are hardly different from other authors' "parts" or "books," and from the questions, problems, and projects added at the ends of chapters by Prof. Edgar B. Wesley, it differs little from a work for older students or readers. Half the volume is allotted to the period since the Civil War, and there are chapters on wheat raising, lumbering, flour milling, and iron mining. The Land Lies Open is a small volume presenting episodes of Minnesota history so as to give significant place "to the changing and developing life of the people at the grass roots of their existence." Six of the chapters have been rewritten from articles published in Minnesota History and other periodicals. Part I, "Channels to the Land," is concerned with explorers from De Soto to Henry R. Schoolcraft; Part II, "People on the Land," with aspects of settlement and culture. All writers on Minnesota history acknowledge their indebtedness to William Watts Folwell (I833I929), first president of the University of Minnesota, who began to write his magnum opus after his retirement at the age of 74 , and completed it before his death at $96 !$ A History of Minnesota (St. Paul, Minnesota Historical Society, I92I-30. 4 v. [The Society issued v. I of a new edition in 1956]) is eminently thorough and fair-minded, but it treats episodes in the early history of the State at such length as to make it unsuitable for a main entry here.

4143. Blegen, Theodore C., and Philip D. Jordan, eds. With various voices, recordings of North Star life. Saint Paul, Itasca Press, 1949. xxiv, 380 p. 49-1 1623 F606.B675

A source book of Minnesota history from the days of the French explorers, Radisson and Hennepin, to the close of the Igth century. Its editors have aimed "to relate the history of the North Star State in the words of those who actually took part in the making of that history," to be both accurate and colorful, and to include the words "of explorers, schoolteachers, missionaries, and just plain common folks-the basic builders of the state," as well as public documents. The 54 extracts are arranged in eleven topical sections and close with Governor John Lind's message to the legislature in 1899 , "in reality an inventory of Minnesota life and problems at the turn of the century."

\section{IOWA}

4I44. Cole, Cyrenus. A history of the people of Iowa. Cedar Rapids, Iowa, Torch Press, 1921. xiv, 572 p. maps. 21-2103 F621.C68 Cyrenus Cole (1863-1939) was born on an Iowa farm and became a leading newspaperman of Cedar Rapids; in the year this book was published he began 12 years of service as a Republican in the U.S. House of Representatives. His book is of a description surprisingly rare: a one-volume state history, inspired by John Richard Green and written in a dignified Victorian prose, which is yet comprehensive, wellinformed, and thoroughly digested. The writer was well acquainted with the leading Iowa political figures of his maturity, and perhaps gives more space to elections and officeholders than would a presentday historian of the people of Iowa; but he is never unmindful of developments in other spheres. His basic Republicanism does not lead him into any unfairness to Populists or Democrats; he limits himself 
to the opinion that, in the post-Civil War doldrums of Iowa, "Political doctors were not needed so much as industrial ones. But it took the people a long time to find this out."

\section{K. The Far West}

4145. Baumhoff, Richard G. The dammed Missouri Valley, one sixth of our Nation. New York, Knopf, 195I. 291 p. illus.

$$
5^{1-1} 1082 \quad F_{598 . B_{3}}
$$

"The Missouri basin is a continental funnel draining into the Mississippi River, a terrain that measures 529,350 square miles. It is roughly 1,300 miles long, and has extreme width of about 700 miles." Its major problems have been irregular water supply, floods, and erosion, and in 1945 the Missouri Basin Interagency Committee was set up to plan and administer a "federal program, with state cooperation, for protection, control, and development of the water and land resources." In the same year the St. Louis Post Dispatch which has consistently supported an eventual Missouri Valley Authority, assigned Mr. Baumhoff to cover the program and related topics. His book is, as he says, a journalistic report, but it presents the basic facts of geography and economics in an objective manner, and predicts that the outcome will be a Federal authority for the basin which will disappoint extremists, and "will not be greatly different in essence from an MVA shorn of some dubious elements," or a "Missouri Valley Anti-Authority Authority."

4146. Billington, Ray Allen. The Far Western frontier, 1830-1860. New York, Harper, 1956. 324 p. illus. (The New American nation $\begin{array}{lll}\text { series) } & 56-9665 & \text { F}_{591 . B}\end{array}$

Bibliography: p. 293-3II.

A well-informed, significantly selective, and skillfully organized general treatment of the three critical decades which saw the American occupation of the Far West prepared for, carried out, and consolidated. The author limits himself to describing those aspects of diplomacy and war "which immediately affected the settlement process." Professor Billington's volume is noteworthy for its objective presentation of the aspects of ruthlessness and decivilization which marked this great wave of expansion, and for its emphasis on the variety of Wests, each with its distinguishable frontier characteristics, which was the initial result. Since the settlement pattern was shaped by the accidental location of mineral wealth, the frontier of farms and villages in the Mississippi Valley was separated by nearly $\mathrm{I}, 000$ miles of prairie from the islands of settlement in the
Inland Empire of the Pacific Northwest, the Great Salt Lake Country, Arizona, New Mexico, the Washoe region, California, and Oregon. The great work of the 1850 's was that of the overland freighters and stage coachers, who linked this "galaxy of empires" with each other and with the East, and made possible the resumption of normal civilizing processes.

4I47. Briggs, Harold E. Frontiers of the Northwest; a history of the upper Missouri Valley.

New York, Appleton-Century, I940. xiv, 629 p. $40-\mathrm{I}_{2572} \mathrm{~F}_{598 . \mathrm{B} 84}$

Bibliography: p. 595-61 2.

The Upper Missouri Valley of this volume comprises the Dakotas, Montana, and Wyoming, "overlapping into Idaho and northern Colorado." Its history is here reconstructed, mostly within the three decades r 860-90, with an abundance of detail and documentation, and an academic dryness of manner which seldom ventures into commentary. The arrangement is largely topical, under six principal heads. "The Frontier of the Miner" is concerned with the strikes and rushes that went on at irregular intervals from 1859 to about 1877 , and incidentally disposes of "The Myth of Calamity Jane" (Martha Jane Canary, 1852-1903), whose "only claim to fame was her absolute lack of respectability." "The Frontier of the Buffalo" is concerned with the fate of the northern herd, which survived the southern herd but not the coming of the Northern Pacific, and disappeared after the winter of $188_{3}-84$. "The Frontier of Settlement" describes the attempts of the territorial governments to encourage immigration, and the projects of group colonization organized in the East and in Europe. The frontiers of the cattle rancher, of the sheepherder, and of agriculture are treated in comparable detail. Much the same area, but with Wyoming omitted, is handled in a radically different style in Bruce O. Nelson's Land of the Dacotahs (Minneapolis, University of Minnesota Press, 1946. 354 p.). Resulting from a University of Minnesota Fellowship in Regional Writing, it presents its material in a series of episodes whose dramatic aspects are emphasized. Folklore is drawn upon, and two of the episodes are cast in semifictional form. The author continues to a more recent period, telling the story of Arthur Townley and the Nonpartisan 
League, of Governor William Langer's moratorium upon farm foreclosures and evictions in 1933, and of the plans for flood control which led to the proposal of a Missouri Valley Authority.

4148. Chittenden, Hiram Martin. The American fur trade of the Far West; a history of the pioneer trading posts and early fur companies of the Missouri Valley and the Rocky Mountains and of the overland commerce with Santa Fe. Standard, Calif., Academic Reprints, 1954. 2 v. (xl, I029 p.) (American culture and economics series, no. I)

$$
\text { 54-7095 HD9944.U45 } \mathrm{H}_{5} \mathrm{I} 954
$$

General Chittenden (1858-1917) was an Army engineer with a variety of practical achievements to his credit, such as laying out the roads of Yellowstone National Park and planning the Lake Washington Canal. He nevertheless found time to publish four books on Western history between 1895 and I905, all of which have stood the test of time to a remarkable degree, subsequent research having filled in detail rather than rendered their conceptions and structure obsolete. The present work was originally published in three volumes in 1902 and has remained the basic work covering its subject during the period 1807-43; it required only to be supplemented by a detailed account of the trade in the Southwest, eventually supplied by Robert G. Cleland (no. 4r86). Mr. Stallo Vinton's contribution to his edition, originally published in 1935, chiefly consists of additional notes which are added to most chapters after those of the author. General Chittenden divided his text into five parts, of which Part II, "Historical," is the longest and most essential. Its principal subjects are the Missouri Fur Company, Astoria, the Rocky Mountain Fur Company, the American Fur Company, and the Santa Fe Trade. Part I describes the operations and characteristics of the fur trade; Parts III-V are concerned with contemporary events in their relation to the trade, colorful incidents during its course, and a general geographical description of the West, including the native tribes. Eight appendixes of original documents run to nearly one hundred pages. General Chittenden was ahead of his time in making a thorough use of all business records of the fur companies that he was able to discover.

4149. Coman, Katharine. Economic beginnings of the Far West, how we won the land beyond

the Mississippi. New York, Macmillan, 1925. 2 v. in I. 27-3060 HC107.AI7 7925

Bibliography at end of each volume.

Contents.-I. The Spanish occupation. Exploration and the fur trade.-2. The advance of the settlers. The transcontinental migration. Free land and free labor.
The general pattern of historiography has changed so greatly since 1912, when this work was originally issued (Miss Coman died in 1915, and the onevolume edition is an otherwise unaltered reprint) that what the author then described as an economic history would now be regarded as a general survey of Western history down to the Civil War, with perhaps less than average space allotted to diplomatic and military factors. It was largely a pioneer undertaking, and while of course it takes no account of the mass of detailed studies which have appeared since, it remains a clear outline of the essential developments in discovery, settlement, and trade from a clearly defined point of view. Miss Coman thought that the European colonial regimes stifled the normal development of the region, and were of necessity eliminated by the superior industrial efficiency of the advancing tide of American settlers. "The self-employed and self-supporting farmer took possession of the land in a sense not to be disputed." The outcome of the Civil War was only the concluding victory of "the ideal American typethe homestead farmer" in the long struggle between forced and free labor.

4I50. Quiett, Glenn Chesney. They built the West; an epic of rails and cities. New York, Appleton-Century, 1934. xx, 569 p.

Bibliography: p. 543-549.

$$
\text { 34-3546I } \text { F59I.Q85 }_{5}
$$

The West lost its frontier isolation and began to acquire its mature characteristics with the coming of the transcontinental railroads, usually dated from May 10, 1869, when the Union Pacific and the Central Pacific joined their tracks at Promontory Point, Utah. The large government subsidies received by the western lines gave their backers a great advantage in schemes of western development demanding capital. "One important source of revenue that was open to the backers of the early Western railroads was the building of cities." In this imposing volume Mr. Quiett reexamines the standard sources of railroad and municipal history for evidences of their interaction, and has no difficulty in demonstrating the importance of the railroads and their builders in the rise of Denver, San Francisco, Los Angeles, San Diego, Portland, Seattle, and Spokane. Takoma, Washington, is labeled "a railroad creation": the decision of the Northern Pacific in 1873 to locate its western terminus there in an instant "converted a raw sawmill village on the frontier of civilization into a potential city of importance." The author's favorite city-builder is evidently General William J. Palmer (1836-1909) of the unsubsidized Denver and Rio Grande. "No 
one had a keener eye for the scenic and commercial possibilities of a site," and he built cities that were permanent, such as Colorado Springs, which he added to the map in 1871 .

\section{The Great Plains: General}

415I. Brown, Mark H., and William R. Felton. The frontier years; L. A. Huffman, photographer of the plains. New York, Holt, 1955. $272 \mathrm{p}$.

Bibliography: p. 259-26I. $55-9876 \quad F_{595} \cdot \mathrm{H}_{7} \mathrm{~B}$ B

4152. Brown, Mark H., and William R. Felton. Before barbed wire. L. A. Huffman, photographer on horseback. New York, Holt, 1956. $256 \mathrm{p}$.

Bibliography: p. 237-243. 56-10507 $\mathrm{F}_{596 . \mathrm{B} 87}$

4153. Smith, Erwin E. Life on the Texas range. Photographs by Erwin E. Smith; text by J. Evetts Haley. Austin, University of Texas Press, 1952. I12 p. $\quad 52-13181 \quad$ SF85.S57

The two finest photographic records of the West of the Open Range seem to have been made at its northern and southern extremes. Laton A. Huffman (1854-1931) learned photography in his father's shop in lowa, and in 1878 came to Fort Keogh on the Yellowstone River in southeastern Montana to fill the unofficial position of post photographer, the remuneration being what he could make out of it. Save for a six-year exodus caused by hard times, Huffman spent the rest of his life as a professional photographer in Montana, and after 1905 lived by the sale of prints from his early negatives. Mr. Felton, Huffman's son-in-law, has drawn upon the family collection of glass plates, letters, and memoranda, and in both volumes the documentation of the photographs is careful and thorough. The Frontier Years illustrates the finale of buffalo hunting, the last Indian wars, Miles City and other frontier towns, and the transition from wagon train to railroad. Before Barbed Wire illustrates sheep as well as cattle herding and has fine pictures of early cow camps and ranch houses. The authors very properly underline Huffman's achievement in his early pictures taken on horseback with a $5^{0-}$ pound, slow-shutter, wet-plate camera. Erwin E. Smith (1886-1947) was a later comer than Huffman, and never established himself as a professional photographer. But he was a cowboy who knew the work and its problems thoroughly, and while the Open Range was gone by the time he began taking his pictures on Texas ranches in the early years of the present century, "he spent much of his time on the larger outfits because their work with cattle closely approximated that of the open range." The 80 photographs reproduced here were all chosen for permanent display in the Texas Memorial $\mathrm{Mu}$ seum, are nearly all outstanding for composition and contrast, and have the further advantage of better reproduction than Huffman's. Mr. Haley contributes a 15-page introduction on Smith's saddeningly unsuccessful life. The American West; the Pictorial Epic of a Continent, by Lucius M. Beebe and Charles Clegg (New York, Dutton, 1955. 5 II p.), is a vast collectanea of pictures from private and public collections, which depict "as many aspects of the West in the nineteenth century as its authors could come by." Many of them are wood engravings which appeared in the illustrated weeklies, and the presentation is sensational rather than systematic.

4154. Dale, Edward Everett. Cow country. Norman, University of Oklahoma Press, 1942. $265 \mathrm{p}$. $42-15483 \quad F_{59} 6 . D_{25}$

Professor Dale was himself a cowboy and rancher in his youth at the turn of the century, partner in "our old ranching firm of Dale Brothers" with his brother George, to whom he dedicates this volume. In addition to his well-known study of The Range Cattle Industry (q. v.) he has contributed a number of related articles to periodicals, including the American Hereford Journal and the Cattleman as well as historical journals. These he has assembled here and eliminated repetitive matter so as to form "a fairly consecutive story of ranching in the Great Plains." There are chapters on the antipathy between Texas trail-drivers and "Kansas Jayhawkers," on the contributions of Scots and Scottish capital to the range cattle industry, on cowboy humor, on ranching in Indian reservations, and on "The Passing of the Cow Country" as a distinct entity and way of life.

4155. Dick, Everett N. Vanguards of the frontier, a social history of the northern plains and Rocky Mountains from the earliest white contacts to the coming of the homemaker. New York, Appleton-Century, 1941. xvi, $574 \mathrm{p}$.

Bibliography: p. 519-545.

$$
4^{1-6157} \quad F_{591 . D 545}
$$


4156. Dick, Everett N. The sod-house frontier, 1854-1890; a social history of the northern plains from the creation of Kansas \& Nebraska to the admission of the Dakotas. New York, Appleton-Century, 1937. xviii, $55^{\circ} \mathrm{p}$.

Bibliography: p. 519-528.

$$
\text { 37-19335 } \mathrm{F}_{591 . D_{54}}
$$

Of these companion volumes the sequel appeared first by some four years. Vanguards of the Frontier covers much the same ground as a number of other works on the general history of the West, from the fur companies and the mountain men to the cattle ranchers of the Open Range and the migratory sheep herders of the northern Rockies. It obtains its special character from telling the story, so far as possible, from the viewpoint of the ordinary participant in these historic processes: the author is less concerned, for instance, with the organization and economics of the stage-coach companies, than with typical scenes and incidents encountered by stage-coach drivers and passengers. The Sod-House Frontier, on the other hand, was throughout a quite original synthesis, bringing for the first time within one pair of covers a view of the entire process of settlement which was more or less uniform throughout Kansas, Nebraska, and the Dakotas. Prof. Dick interviewed seven survivors from the days of settlement, and utilized reminiscences preserved in manuscript by historical societies or printed in local newspapers. The author gives a symbolic quality to the sod house, the expedient devised by pioneer settlers to provide shelter in a largely treeless land. The prairie sod was cut with a spade into bricks about three feet long, which could be built into houses as large as 20 by 16 feet, which usually leaked and might collapse, but could not burn or blow down, and had an average life of six or seven years. The life of these homesteaders is sympathetically and realistically described in all its characteristic aspects, from the use of buffalo chips as fuel to the "play parties" held in communities where dancing was taboo, and there are chapters on the "Beginning of Machine Farming," "The Grange," and the coming of the railroad, regarded in each community as a cause for celebration and sometimes "ardent wide-spread and all prevailing inebriety."

4157. Gard, Wayne, The Chisholm Trail. Norman, University of Oklahoma Press, I954. 296 p.

Bibliography: p. 265-280.

$$
54-6204 \quad F_{596 . G_{3}}
$$

4158. Wellman, Paul I. The trampling herd. New York, Carrick \& Evans, 1939. 433 p. 39-24712 F $_{591 . W_{42}}$
At head of title: The story of the cattle range in America.

"Some books to read": p. 417-4I9.

The most conspicuous events of Open Range days were the great cattle drives, in which herds of thousands of steers were conducted north from Texas by the trail bosses and their cowhands, running the hazards of Indians, rustlers, river crossings, and stampedes. The earliest recorded drive goes back to 1846 , but after the Civil War the practice was resumed on a larger scale and received its characteristic organization in 1867 , when Joseph G. McCoy, an Illinois cattle dealer, set up a stockyard at Abilene, Kansas, on the Union Pacific Railroad. The most important route followed by the drivers for a dozen years after 1867 got its name from an old Indian trader, Jesse Chisholm (1806-68), who had a post on the Arkansas River and made regular journeys south to the North Canadian-a rather small portion of the whole trail named after him. Mr. Wellman and Mr. Gard tell much.the same story but in antithetical manners: the former speaks in general terms and offers a multitude of anecdotes; the latter is concerned to date and document every circumstance. But Mr. Wellman is not inaccurate, and Mr. Gard is anything but dull. Both describe the gunplay which went on in Abilene and the other northern centers of the trade, and which has acquired a whole literature of its own. Dee Brown and Martin F. Schmitt's Trail Driving Days (New York, Scribner, 1952. xxii, 264 p.) is a picture book containing a good selection of contemporary photographs supplemented by prints of various kinds; the reproductions are often much too dark, and the text is decidedly thin.

4159. Kraenzel, Carl Frederick. The Great Plains in transition. Norman, University of Oklahoma Press, 1955. xiv, 428 p. maps, diagrs., tables.

Bibliography: p. 39I-4I8. $55-9628 \quad \mathrm{~F}_{591 . \mathrm{K}_{7}}$

By the Great Plains Mr. Kraenzel means the semiarid belt from the 98th meridian to the Rockies, often referred to as the High Plains. His own emphasis is largely sociological, but since most people have at their disposal only fragmentary information about the region, he has attempted to fill in "all other operative factors affecting the Plains-geographical, psychological, economic, historical, technological, and social," in a book "written in the Plains, about them, by one who is a part of them." The region has long been an exploited hinterland, and its people, whether rural or urban, belong to one or another minority group, whose objectives cannot be realized and who exist in a state of chronic frustration and irritation. They must all "adapt or get out": the adaptation to conditions, which has gone some way 
in agriculture, must be extended to all phases of life. The only solution lies in a regionalism whereby "the area can become a unity once again," and its keys for survival are the development of three basic traits: "the creation of necessary reserves, the introduction of flexibility into certain social operations, and the acquisition of mobility in still other aspects of the social order." The author goes on to give more concrete meaning to these somewhat abstract conceptions in various realms of living.

4160. Rister, Carl Coke. Southern plainsmen. Norman, University of Oklahoma Press, 1938. xviii, 289 p.

Bibliography: p. 263-279.

As here defined, the Southern Plains are divided from the Northern by the South Platte River, which runs through northern Colorado and southern Nebraska. They have a character of their own derived from their higher average temperature, longer growing season, and faster rate of evaporation. Prof. Rister here describes the life lived upon them from the early Igth century, when only a few white hunters ventured into this preserve of the Arapahoes, Cheyennes, Kiowas, and Comanches, down to the opening of the Oklahoma lands to settlement on April 22, 1889. He divides the subject into topical chapters and at times fails to make chronological progressions as clear as could be wished. His concern is with agricultural settlement rather than with grazing use, and he allots only one 15-page chapter to the "Life of the Range Rider," whom he finds neither romantic nor admirable. There are descriptions of the nocturnal raids of the Indians which went on until the mid- $70^{\circ}$ 's, of the great grasshopper plagues of $1868-69$ and $1874-75$ as well as of less spectacular hindrances to agriculture, and of the "breakdowns" or square dances in which the settlers relaxed from their harsh toil. Many settlers became discouraged and inscribed "Back to God's Country" on their wagon covers, but the majority held on by patience, cheerfulness, and reserving a surplus in good years to tide them over the lean ones.

416r. Rollins, Philip Ashton. The cowboy; an unconventional history of civilization on the old-time cattle range. Rev. and enl. ed. New York, Scribner, 1936. $402 \mathrm{p}$.

$$
36-27318 \quad F_{596 . R} R_{75} \quad 1936
$$

4162. Frantz, Joe B., and Julian Ernest Choate. The American cowboy: the myth \& the reality. Norman, University of Oklahoma Press, 1955. $232 \mathrm{p}$.

Bibliography: p. 203-222.
4163. Sonnichsen, Charles L. Cowboys and cattle kings; life on the range today. Norman, University of Oklahoma Press, r950. xviii, $3^{16}$ p. 50-14081 F596.S72

Mr. Rollins spent some years on the Open Range, in the late 8o's and early 9o's, and became a zealous collector of western Americana, eventually turning his collection over to Princeton University. His aim has been "to recount accurately the every-day life of the old-time Range," confining himself, with certain specified exceptions, to what he actually saw and heard. His book has been accused of taking too idealistic a view of cowboy character, but in matters of dress, equipment, and characteristic operations it receives the compliment of being frequently drawn upon by other writers on the subject. Messrs. Frantz and Choate are especially concerned with the vast proportions and wide range of the cowboy myth in American popular literature, entertainment, folklore, and life in general, and are moved thereby to many a quip. This heroic figure they set against the average cowboy of $1867-85$ - "merely a unique occupational type who was concerned with 'cow work' on the range, raising, rounding up, branding, trailing, haying, and mending." They are, however, compelled to concede that there is abundant historical basis for most of the standard ingredients of horse opera-with the exception of the marathon fist fights, for cowboys, untrained to use their fists, did their fighting with knife or revolver. The concluding four chapters review cowboy literature, both fiction and nonfiction. $\mathrm{Mr}$. Sonnichsen's volume was commissioned by the Rockefeller Committee at the University of Oklahoma in consequence of the debate which broke out in 1947 over the cattlemen of today in relation to the conservation of natural resources. During the first half of 1949 the author "traveled from end to end of what was once the Cattle Kingdom and is still the heart of the cattle country, learning everything" he could. The result is a miscellaneous reportorial volume that mirrors the variety of enterprise, personnel, and occupation which now characterizes the industry. He finds that "the all-round cowpunchers of the past are becoming victims of specialization," and that, "as the farm has merged with the ranch, the cowboy has merged with the hired man"-but a hired man who still wears the uniform of a horseman of the Plains and thinks of himself as one.

4164. Webb, Walter Prescott. The Great Plains. [Boston] Ginn, 1931. xv, 525 p. illus.

$$
\text { 31-20202 } \mathrm{F}_{591} \text {. W } 35
$$
first.

Bibliography at end of each chapter except the An epoch-making work of synthesis and inter- 
pretation which has been fundamental to practically all subsequent treatments of the region with which it deals. The Great Plains, and especially the High Plains from the 98th meridian to the Rockies, are a level and treeless region where the rainfall is insufficient for normal agriculture. These characteristics have affected all historic processes involving the human beings who have ventured into the area. The Plains Indians obtained horses from the Spaniards and, as soon as they had done so, became so formidable as raiders that no further expansion of Spanish colonization was possible. The Texans were more successful because they seized upon Samuel Colt's invention of the six-shooting revolver, which the rest of the country had rejected, and so became able to defeat the Indians from horseback. Once the Indian and the buffalo had been eliminated, the High Plains became a cattle kingdom because the industrial revolution had not yet devised the means whereby the agricultural frontier could expand into them. In the mid-I87o's a satisfactory barbed-wire fence was invented in Illinois and speedily produced a revolution on the Plains, effecting the transition from the open range to enclosed ranches, and permitting the advent of the homesteaders. The survival of both ranch and farm was made possible by the introduction of the windmill, which gave access to ground water and alleviated if it did not cure the dearth of water. This chronic dearth has led, in the eight dryest states, to a departure from the common law of water rights in favor of the arid-region doctrine of appropriation, or the Colorado system. In 1940 the Social Science Research Council devoted its Bulletin 46 to an assault upon Prof. Webb's conclusions by Fred A. Shannon, which has had small influence.

\section{The Great Plains: Local}

\section{NORTH DAKOTA}

4165. Kazeck, Melvin E. North Dakota; a human and economic geography. Fargo, North Dakota Institute for Regional Studies, North Dakota Agricultural College, 1956. $264 \mathrm{p}$.

Includes bibliography.

$$
5^{6-1} 3^{250} \mathrm{~F}_{3} 6 . \mathrm{K}_{3}
$$

"Can such of our problems as an obvious lack of industry, a decreasing or stationary population, a need for water conservation, a need for state planning, a need for better land use, and a lack of resources use be neglected and ignored any longer?" But North Dakota remains "one of the most exclusively agricultural States in the nation," and the three main chapters of this well-made geography deal with "The General Farming Area," a fringe along the eastern boundary, "The Cattle-Wheat Region," the large southwestern corner, and "The Wheat Region," the remainder including 32 out of the 53 counties. Industries are limited to flour milling, meat packing, potato processing, and some mineral use, especially since I95I, when oil was found in the west of the State, resulting in 6or producing wells by 1955. The industrial development so much wished for must depend upon conservation of resources and planning for their future use.

\section{NEBRASKA}

4166. Olson, James C. History of Nebraska. Line drawings by Franz Altschuler. Lincoln, University of Nebraska Press, 1955. 372 p. $54-8444$ F666.O48
"Suggested reading" at end of each chapter.

The author has sought to supply the long-standing "need for a one-volume general survey of the history of Nebraska which might serve as an introduction to the history of the state for the college student and the general reader." $\mathrm{He}$ apologizes for the result, particularly since "much of the basic research upon which sound synthesis must be based still remains to be done." In fact no State has any comparable volume which is its superior in comprehensiveness, selection of material, organization, modernity of outlook, and lucidity of writing. The author has at his disposal a gentle irony to which he treats Prof. Samuel Aughey and other learned proponents of the doctrine that "rainfalls follow the plough," which was used to attract homesteaders to central Nebraska in the early 1880 's. Some suggestive chapter headings are "The Eighties-Whose Prosperity?" "The Fading Frontier," and "Adapting Government to the Machine Age." There are excellent sketch maps for particular purposes, and occasional statistical tables highly pertinent to the argument. Mr. Altschuler's decorations are distinguished, as is the volume's entire format.

\section{KANSAS}

4167. Nichols, Alice. Bleeding Kansas. New York, Oxford University Press, 1954. 307 p. 54-5295 F685.N6

4168. Howes, Charles C. This place called Kansas. Norman, University of Oklahoma Press, 1952. 236 p. 52-3380 F69r.H68 
The history of Kansas is unique among the 48 states in that its first six or seven years were a period of continuous turmoil and of frequent violence and bloodshed, whereas the succeeding century has been one of prevailing tranquillity and peaceful development, in which significant trends and events are usually a part of large national or regional movements. Miss Nichols tells the story of the turbulent years between the Kansas-Nebraska Act of 1854 and the admission of Kansas to statehood in January I 86r, in a highly dramatic narrative with a strong pro-Southern bias. Since she cheerfully admits this, and makes abolitionists instead of border ruffians the villains of her story, the reader may do his own discounting, or consult a work in the pro-Northern tradition such as Leverett Wilson Spring's volume in the American Commonwealths series, Kansas; the Prelude to the War for the Union, rev. ed. (Boston, Houghton Mifflin, 1907. 340 p.). Mr. Howes' volume is "developed" from newspaper and magazine articles and notes left by his father, Cecil Howes, who for over 40 years was the Kansas City Star's statehouse correspondent in Topeka. The first two parts consist of brief chapters on standard historical topics; the last two, "The Stuff It's Made Of" and "Yesterday and Today," have chapters on folkways and episodes of social history, such as "From Saloons to Bootleggers to Bottle Stores," "The Water-Witching Vogue," and "Traveling under Wind Power."

\section{OKLAHOMA}

4169. McReynolds, Edwin C. Oklahoma; a history of the Sooner State. Norman, University of Oklahoma Press, 1954. 46I p. illus., maps.

Bibliography: p. 434-445. 54-10052 F694.Mr6

4170. Debo, Angie. Oklahoma, foot-loose and fancy-free. Norman, University of Oklahoma Press, I949. $25^{8}$ p. $\quad 49-48798 \quad$ F $_{700 . D_{4}}$

4I7r. Debo, Angie. Prairie City, the story of an American community. New York, Knopf, 1944. xiv, 245, viii p. illus. 44-4798 F694.D4 Mr. McReynolds has been a resident of Oklahoma since 1892 , and his book is a sober and systematic presentation of the early history of the area, and of the more formal elements in its economic and political development since the Civil War. It may be described as derivative, but only in the sense that it draws upon the detailed studies of such Oklahoma scholars as Foreman, Dale, Debo, and Gittinger in order to construct a unified narrative, from Coronado's expedition of 1540 to the gubernatorial election of 1950 . Six chapters of some 165 pages cover the Indian regime from the removal of the Five Civilized Tribes to about 1875 . The years since the acquisition of statehood in 1907 are covered as successive gubernatorial administrations, with some economic summaries in the penultimate chapter, and a final one on "The Culture of Oklahoma." Miss Debo's Oklahoma, on the other hand, is concerned with Oklahoma life and character, and incorporates only enough informal geography and history to serve as background for her social and psychological interpretations. The violence of Oklahoma politics is attributed to this basic cause: "a people agrarian in outlook and Jacksonian in politics had to cope with industrial problems developing with a speed never before attained in American history." Oklahomans are individualists without strong group loyalties of any kind, which makes on the one hand for originality and initiative, and on the other for bad politics, economic instability, "and other collective failures." In Prairie City Miss Debo displays true Oklahoman originality, for who before ever chose "to write of a typical, rather than an actual, community, a composite of numerous Oklahoma settlements, of which some are still in existence, and others have long been ghost towns"? The device was adopted for greater freedom of expression, but while the people are fictive, the chronology, statistics, and events are actual, and based upon the author's own home town of Marshall and its region; "even the conversations are recorded or remembered conversations." Readers may also compare the developments in Prairie City with those in Miss Debo's slender volume on Tulsa: From Creek Town to Oil Capital (Norman, University of Oklahoma Press, 1943. I23 p.). Three hundred years of American history-"Indian occupation, ranching, pioneering, industrial development, and finally disillusionment and the recasting of objectives-have been telescoped within the single life-time of some of the older Tulsans."

\section{N. The Rocky Mountain Region: General}

4172. Atwood, Wallace W. The Rocky Mountains. New York, Vanguard Press, 1945. 324 p. (American mountain series, edited by Roderick Peattie, v. 3) $45^{-11388} \quad F_{721 . A 8}$
Bibliography: p. 31 I-315.

Wallace W. Atwood (1872-1949), president of Clark University from 1920-46, was a field geologist as well as a professor of the subject in major universi- 
ties, and was attached to the U.S. Geological Survey from I90I. In 1909 he was assigned to make a model physiographic study of mountain erosion and sculpture, which took him into the high ranges from New Mexico to Alaska- "he has ridden with pack train the length of the sky-line trail," says Mr. Peattie in his introduction to his teacher's book. In this exceptional volume Dr. Atwood combined an outline, in untechnical language, of the geological evolution and structure of the Rockies with a vivid evocation and appreciation of mountain scenery and the life of pack train and mountain camp. Three final sections summarize the gold-mining strikes in various areas, the life of "Indians, Ranchmen, Farmers, and Tourists," and the 14 national parks of the Rockies, seven of which are Canadian. A general map and eight cross-sections are supplied by Erwin Raisz.

4I73. Garnsey, Morris E. America's new frontier, the Mountain West. New York, Knopf, 1950. xviii, 314, ix p. maps, diagrs.

Bibliography: p. 310-314.

$$
5^{0-7765} \quad{\text { F } 721 . G_{3}}^{19} \quad 195^{\circ}
$$

The eight states of the Mountain West are a new frontier, in the author's conception, only potentially, for their recent economic trends have exhibited small progress, and the present crucial stage must determine whether they will instead become a backwater-"an underdeveloped and neglected region whose resources have been irreparably exploited and destroyed." At present, with only 4.8 persons per square mile, they are underpopulated, and their labor remains relatively unproductive and unremunerated because they are confined to raw materials which are manufactured elsewhere. The region's balance of payments has been kept in equilibrium only by substantial Federal subsidies, which means that it is in effect a charge upon the other sections. The author offers the outline of a regional program based on the optimum utilization of Western resources of water and hydroelectric power, which could double the irrigated areas and increase power capacity so as to provide the basis for Western industrialization and minerals development. Such a program "will result in population growth, greater stability in the regional economy, a rise in per capita income, and an increase in the region's contribution to the wealth and security of the American people."

4174. Lavender, David. The Big Divide. Garden City, N. Y., Doubleday, I948. 321 p.

Bibliography: p. [299]-307.

$$
4^{8-1} \text { I660 F591.L39 }
$$

Mr. Lavender, a resident of Colorado and an enthusiastic connoisseur of his mountainous region, here essays a presentation of life in "those sections of the Rockies which lie inside Colorado, Wyoming, eastern Utah, and northern New Mexico," from the days of the mountain men to the present. This he achieves in 17 episodic or topical chapters, each more or less complete in itself, but so disposed as to form a reasonably chronological sequence. The first gold rush, just before the Civil War, resulted in "poor man's diggings, placer beds that could be stripped to bedrock with no other resources than hard work, ordinary tools, and limited capital." Subsequent chapters deal with the Mountain Utes, the silver stampedes of the later igth century, early transportation principally by mulepower, the narrowgauge mountain railroads, labor violence in the Cripple Creek district, the development of stock ranching, the conservation and reclamation movements, the rise of the tourist trade, and the modern sports of climbing and skiing. Mr. Lavender's story of his own experiences in mining and cattle ranching appeared in 1943: One Man's West (Garden City, N. Y., Doubleday. 298 p.).

4I75. Vestal, Stanley. Mountain men. Boston, Houghton Mifflin. 1937. 296 p. 37-8786 $\mathrm{F}_{591} . \mathrm{V}_{47}$

"Acknowledgments and bibliography": p. [293]296.

In the spring of 1822 the Missouri partners, William $\mathrm{H}$. Ashley and Andrew Henry, adopted a new method of conducting the fur trade: they advertised for roo enterprising young men to ascend the Missouri to its source and be employed there. These white trappers would meet at an annual rendezvous in some mountain valley previously agreed upon, turn over their year's take of furs, and receive their wages and a new outfit. Such was the origin of the mountain men, so called because they lived the year round in the Rockies. Mr. Vestal tells their story through the Mexican War in a succession of dramatic episodes, involving such figures as Jim Bridger, Jedediah Smith, Thomas Fitzpatrick, William Sublette, and Old Bill Williams. Some of his information is oral in origin, derived from his stepfather and from Indians of western Oklahoma.

4I76. West, Ray B., ed. Rocky Mountain cities; with an introduction by Carey McWilliams. New York, Norton, 1949. 320 p.

$$
\text { 49-1907 } \mathrm{F}_{591} \mathrm{~W}_{4} 6_{3}
$$

Contents.-Reno, the state city, by W. V. T. Clark.-The Coeur d'Alene, vulnerable valley, by J. K. Howard.-El Paso, big mountain town, by Duncan Aikman.-Cheyenne, cowman's capital, by Dee Linford.-Albuquerque, a place to live in, by Erna Fergusson.-Salt Lake City, city of the Saints, by D. L. Morgan.-Tucson, the folk industry, by June Caldwell.-Butte, the copper camp, by John 
Stahlberg.-Santa Fe, city of many molds, by Haniel Long.-Denver, reluctant capital, by C. A. Graham and Robert Perkin.--Notes on the contributors.

Sketches of life, the economic structure, and politics in nine cities of the intermountain West, together with Burke, Kellogg, and Wallace, the three towns of the Coeur d'Alene valley in northern Idaho. Mr. McWilliams presents them as case studies which demonstrate that the West "suffers from the effects of a too rapid, one-sided, and improvident industrialization."

4I77. Wolle, Muriel V. (Sibell) The bonanza trail; ghost towns and mining camps of the

West. Illustrated by the author. Bloomington, Indiana University Press, I953. xvi, 510 p. maps. 53-roorg F591.W853

"A Glossary of the Mining and Mineral Industry, by Albert H. Fay": p. $477-842$.

"Selected bibliography": p. 483-489.

During $195 \mathrm{I}$ and 1952 Mrs. Wolle, professor of fine arts in the University of Colorado, traveled over 70,000 miles by motor car, largely on mountainous back roads, seeking out and sketching the ghost towns of the West. She covered the eleven westernmost States of the Union, as well as the Black Hills of South Dakota, concentrating on the places where the earliest discoveries of precious metals were made, and those where the richest strikes were found. She includes not only the true ghost towns-"completely deserted, although buildings still line their streets"-but the partials, where a portion of the town remains inhabited, or where mining has been supplanted by other pursuits. Mrs. Wolle's drawings have the same qualities of emphasis and clarity as her writing, and when possible she has enlivened her accounts of the old mining communities by extracts from contemporary newspaper files. The ghost towns, to which her book forms so attractive a guide, she does not find depressing: "Behind the present ruins I see the once bustling cities whose teeming life made possible the West of today."

\section{O. The Rocky Mountain Region: Local}

\section{MONTANA}

4178. Howard, Joseph Kinsey. Montana; high, wide, and handsome. New Haven, Yale University Press, I943. 347 p.

$$
\text { A43-3702 F731.H86 }
$$

"Acknowledgments and bibliography": p. [330]339.

Howard (1906-195I) was a Montana journalist, editor of the Great Falls Leader, and his book, in spite of the unpropitious time at which it appeared, made a considerable stir and inaugurated a critical trend in the regional literature of the Mountain West. It is a vigorously written indictment of the elements of exploitation in successive phases of Montana's economy, which made it "an object lesson in American domestic imperialism." "Montana's is a cashcrop agriculture, hitherto exploited to the limit while the soil remained"; minerals have been extracted in the same spirit; and the development of hydroelectric power has been artificially retarded. The root of the State's economic disasters in the 1920's and 1930's, the author suggests, was the campaign of James J. Hill and the Northern Pacific to attract homesteaders, which increased the State's wheat acreage twelvefold in the decade after 1909, only to lead to dust storms and foreclosures in periods of drouth. Mr. Howard also edited Montana Margins, a State Anthology (New Haven, Yale Uni- versity Press, 1946. xviii, 527 p.), which has no such special emphasis, but aims only to picture life in the State "as it was and is." There are many magazine articles and newspaper extracts, poems, short stories, and episodes from novels in the II topical sections of this very representative selection.

\section{WYOMING}

4179. Hafen, Le Roy R., and Francis Marion Young. Fort Laramie and the pageant of the West, 1834-189o. Glendale, Calif., A. H. Clark, 1938. 429 p. $\quad 3^{8-7543} \quad$ F $_{7} 61 . H_{24}$

The Oregon Trail, a route well known to trappers from 1823, follows the North Platte River and crosses its tributary, the Laramie (so named as early as $182 \mathrm{I}$, from an otherwise unknown trapper), in border country between the high plains and the mountains. At this natural point for trade between Indian and white, in 1834 William Sublette and Robert Campbell constructed a fort which, after its rebuilding in 1840 or $184 \mathrm{I}$, was usually called Fort Laramie. From 184I on it was a landmark for the emigrants in their trains of covered wagons, and in 1849 it was bought by the United States from the American Fur Company and received a garrison of three companies, the majority mounted riflemen. From its purchase until as late as 1876 it was of 
importance in all the Indian affairs of the region. Near it, in the summer of 1854 , Lieutenant Grattan and his company were massacred by the Brule Sioux who, in their turn, were massacred a year later by General Harney's command. By 1890 the Fort's usefulness was past, and it was abandoned by order of the War Department. The authors' unadorned narrative, made up in large part of extracts from the sources, indeed makes a striking pageant of the Old West as seen from a single strategic viewpoint.

\section{COLORADO}

4180. Fritz, Percy Stanley. Colorado, the Centennial State. New York, Prentice-Hall, 1941. 518 p. (Prentice-Hall books on history, $\begin{array}{lll}\text { edited by Carl Wittke) 4I-I853 F776.F83 } & \text { (I) }\end{array}$

"Selected bibliography" at end of each chapter.

A textbook of standard type by the then assistant professor of history at the University of Colorado. After an introducton on general Western history, some 90 pages are allotted to the pioneer period, 50 to the territorial (186I-76: "the Centennial State" refers to the fact that Colorado was admitted to the Union during the hundredth anniversary of the Declaration of Independence), and 250 to the period of statehood. In addition to the usual topics, the last part has chapters on "The Settlement of the Western Slope" since I880, on "The Motor Age" since 1910, and on "Aesthetic and Cultural Attainments."

4181. Sprague, Marshall. Money mountain; the story of Cripple Creek gold. Boston, Little, Brown, 1953. $\mathrm{xx}, 342 \mathrm{p}$. illus.

Bibliography: p. [321]-327. $5^{2-12637} \quad \mathrm{~F}_{784 . \mathrm{C} 8 \mathrm{~S} 6}$

Cripple Creek, in the mountains 18 miles west of Colorado Springs, became the world's greatest gold camp in 1891 , boomed until 1902, maintained high production until 1917 , and down to $195^{2}$ yielded 625 tons of gold valued at $\$ 432,000$,000. The district's population rose from 15 to 50, I I I at the turn of the century, and has since sunk to 1,980 . This boom started not in a remote wilderness but in a ranching area, and was easily accessible, from I 895 by railroad. Mr. Sprague has used Cripple Creek and Colorado Springs newspapers, and has interviewed many survivors or descendants. $\mathrm{He}$ has been able to reconstruct the story through its leading personalities, and follows Bob Womack, the part-time cowboy who made the original strike on Oct. 20, 1890 , to his death, as a penniless paralytic, 19 years later. Of Cripple Creek's 28 millionaires, the most attention goes to the richest, Winfield Scott Stratton, “a weary, defeated carpenter who had spent most of his forty-four years working for three dollars a day," who cared nothing for his money nor for Colorado Springs society, and who, after giving or throwing away millions, left an estate of $\$ 6,000,000$ to establish a home for poor children and old people. There are detailed narratives of the miners' strikes of $1893-94$ and $1903-4$, and of the double fire which demolished the town in I 896 .

4182. Chittenden, Hiram Martin. Yellowstone National Park, historical \& descriptive. Rev. by Eleanor Chittenden Cress and Isabelle F. Story [5th ed.] Stanford, Calif., Stanford University Press, 1949. 286 p. plates, fold. map.

49-9516 $\mathrm{F}_{722 . \mathrm{C}_{54} \quad 1949}$

Yellowstone National Park in northwestern Wyoming, a natural wonderland containing the yellow walls of the Grand Canyon of the Yellowstone River, the upper and the lower Falls, fossil forests, and more geysers than are to be found in the rest of the globe, was not thoroughly explored until 1870 , and has been a Federal reserve since 1872 . General Chittenden (no. 4148), in the course of two official assignments there in the I8go's, gathered the materials for this comprehensive manual of the Park, which he revised a second time just before his death in 1917. It has since been kept up to date by the Stanford University Press, and provides full information on the discovery and early history of the region, its administration as a park by the Federal Government, and its physical characteristics and wildlife.

\section{UTAH}

4183. Hunter, Milton R. Utah, the story of her people, 1540-1947; a centennial history of

Utah. Salt Lake City, Deseret News Press, 1946. xvi, 431 p. illus. $\quad 46-8266 \quad$ F826.H85 $\quad 1946$

This revised edition of the author's Utah in Her Western Setting, 2d ed. (1943) was published in observance of the centennial of the arrival in 1847 of the Mormon pioneers in the valley of the Great Salt Lake. Having searched across four-fifths of the continent for a place to establish their new faith, they contributed to opening up the vast resources of the West by planting settlements in a presumed desert and developing irrigation projects. Early chapters deal with the Spanish exploration of the territory that became the State of Utah in 1896 , the fur traders and trappers, and Government explorations prior to the arrival of the Mormons. Their migration under the leadership of Joseph Smith, the founder, from New York to Ohio, Missouri, and Illinois, where Smith was killed, and the trek to Utah under Brigham Young are described in suc- 
ceeding chapters. The Mormon doctrine of plural marriage, and economic and political solidarity, led to conflicts between Mormons and non-Mormons, and in 1887 Congress passed more rigid laws against polygamy, which was discontinued in 1890 by a Manifesto issued by Wilford Woodruff, President of the Church. In the final chapter the author describes the impact of World War II on the development of Utah, and the economic and climatic advantages of Utah as a place to live.

\section{NEVADA}

4184. Lillard, Richard G. Desert challenge, an interpretation of Nevada. New York, Knopf, 1942. viii, 388, ix p. plates, maps (I fold.) 42-20630 F841.L5

Bibliographical references included in "Acknowledgments" (p. 385-388).

Geology and climatology, history and sociolegy are combined with guidebook data in this interpretation of the influences that have created this region of contrasts-the sixth state in area but the last in population, although it became a state in 1864 . Those influences, the author points out, came mostly from the outside. Nevada's fabulous mines early attracted attention, and the State suffered the consequences of the exploitation of its leading resource by a transient population. Chapters are devoted to the mining camps, and towns such as Virginia City and Goldfield, which have "lived on in contracted form," and the true ghost towns, which are reminders of more affluent years but are also "a genu- ine American antiquity as meaningful and signifcant as the trench mounds of Valley Forge and the white church at Lexington." A final chapter describes the prosperity of Reno and Las Vegas as "cosmopolitan divorce capitals." The author, a native of California, pursued advanced study at the universities of Montana, Harvard, and lowa, and this book is part of his doctoral dissertation at the last.

4185. Lyman, George D. The saga of the Comstock Lode; boom days in Virginia City. New York, Scribner, 1947 [ ${ }^{{ }^{1}}$ 1934] 407 p. 54-26534 F849.V8L92 I947

The Comstock Lode-named after Henry T. P. Comstock, a ne'er-do-well sheep-herder-was the West's richest strike (1859) and Virginia Citychristened by a drunken prospector known only as "Old Virginny"-was its most feverish boom town. Dr. Lyman, a San Francisco physician who was born in Virginia City after its heyday was over, has sought out the facts of its origin and first boom in a variety of original sources, and has presented them in so gasping and breathless a style that few readers would suspect the book's solid foundations. This story of grinding labor, sudden wealth, perpetual litigation, recurrent bloodshed, and riotous relaxations could well have endured a more sober and coherent narration, and so fact-filled a book deserved an index. It ends with the slump of 1865 , which came about when the surface ore had been skimmed off-but only $\$ 45$ million out of an eventual $\$ 900$ million had been extracted, and the Comstock's greatest days still lay ahead.

\section{P. The Far Southwest: General}

4186. Cleland, Robert Glass. This reckless breed of men; the trappers and fur traders of the Southwest. New York, Knopf, 1950. xv, 361, $\mathrm{xx}$.

Bibliography: p. $347-36 \mathrm{I}$. $50-6356 \quad \mathrm{~F}_{592 . \mathrm{C}_{2}} \quad 195^{\circ}$

In this volume Dr. Cleland, one of the permanent research staff of the Huntington Library since 1943, has utilized widely scattered manuscript sources to supply both a neglected chapter in the history of the American fur trade and a connected account of the real pioneers of the American Southwest. These were the intrepid and indefatigable "mountain men," who pursued the vanishing beaver along the desert or semidesert rivers of the Southwest, enduring terrible hardships and carrying on a merciless feud with the Indians of the region. Their ex- peditions, in which 50 to 100 men might participate either as bands of independent trappers, or under the auspices of partnerships or companies, continued for some 20 years after 1820 . The trade, however, was in decline after 1835 , the fashion in men's hats having turned from beaver to silk, and by 1845 the mountain men were "a fast-disappearing race." Meanwhile such skillful and daring explorers as Jedediah Strong Smith, James Ohio Pattie, Ewing Young, and Joseph Reddeford Walker had blazed the trails of the Southwest for the benefit of traders, soldiers, Government officials, and settlers.

4187. Fergusson, Erna. Our Southwest; photographs by Ruth Frank and others. New York, Knopf, 1940. $37^{6}$ p. $\quad 4^{0-7056}$ F786.F $_{49}$ 
A granddaughter of Southwestern pioneers, the author was born in Albuquerque. As a teacher in the public schools, a dude wrangler, and lecturer, she early gained an insight into the history and traditions that produced the people of the Southwest and their characteristic manners and customs. Here she interprets the region in terms of the significance of such cities as Fort Worth, San Antonio, El Paso, Tucson, Phoenix, Prescott, Gallup, Albuquerque, Santa Fé, and Taos, and the people whose Indian and Spanish descent has colored the civilization of the region. "Fred Harvey, Civilizer," "the man who made the desert blossom with a beefsteak," and went on to become a propagandist of the regional arts and crafts, gets a chapter to himself. A final chapter on "The Interpreters," a running commentary on Southwestern books and authors, does service for a bibliography.

4I88. Gregg, Josiah. Commerce of the prairies; edited by Max L. Moorhead. Norman, University of Oklahoma Press, 1954. xxxviii, 469 p. (American exploration and travel [17])

54-I0055 F800.G83 I954

"Gregg's bibliography [reconstructed by the editor ]": p. 445-447. "Editor's sources": p. 448454 .

Prompted by ill health to seek the curative air of the prairies, Josiah Gregg (1806-1850) set out with a merchant caravan from Independence, Mo., for Santa Fé in I83I, and by 1840 had crossed the Great Plains eight times. As a trader of American goods for Mexican silver and mules, he had developed a "passion for Prairie life" which he did not expect to survive. An avid reader with a natural scientific bent, Gregg made notes on the animals, the plants, and the Indians of the prairies, on the mineral resources of New Mexico, and the manners and customs of its people, and on his journeys to Mexico and Texas. During those journeys he blazed new trails, some of which became favorites with later comers, and gathered material for what became in 1845 "the most complete and reliable map of the prairies then in existence." His observations were published in 1844 as Commerce of the Prairies (New York, H. G. Langley. 2 v.), which "has been recognized for more than a hundred years as the classic description of the early southern plains and as the epic of the Santa Fé Trail." It has gone through "fourteen printings (seven during Gregg's own short lifetime) and came from the presses in England and Germany as well as the United States." Mr. Moorhead calls his volume the "first edition of Gregg's complete text, notes, and maps which also contains a biographical introduction, critical notes, and a list of the author's sources."
4189. Richardson, Rupert Norval, and Carl Coke Rister. The greater Southwest; the economic, social, and cultural development of Kansas, Oklahoma, Texas, Utah, Colorado, Nevada, New Mexico, Arizona, and California from the Spanish conquest to the twentieth century. Glendale, Calif., A. H. Clark, 1934. 506 p. $34^{-28934}$ F786.R524 "References for additional reading" at end of each chapter.

"As used in this book the Southwest or the Greater Southwest includes the country of the United States west of the eastern border of the Great Plains . . . and south of the northern boundaries of the tier of states extending from Kansas to California." This well-proportioned textbook deals mainly with the foundations of civilization as they were planted in that region from the coming of the first white men to the close of the Igth century. The spirit of the settlers was molded by the climate, Indian and Spanish influences, and the rapidity with which the area developed after it was acquired from Mexico in 1848 . A citizenry of "irrepressible optimism, social democracy, and resourcefulness" emerged. The discovery of gold in California, the development of the cattle and sheep industries, the building of railroads to the Pacific, and the establishment of thousands of farms and agricultural communities with their irrigation and reclamation projects, by the end of the century gave the Southwest a position of significance in the economic structure of the United States.

4190. Vestal, Stanley. The book lover's Southwest; a guide to good reading, by Walter $S$. Campbell (Stanley Vestal) Norman, University of Oklahoma Press, 1955. xii, $287 \mathrm{p}$.

Bibliography: p. 269-272.

$$
55-6367 \quad Z_{125} \text { S }_{2} 8 V_{4}
$$

Professor Campbell of the University of Oklahoma English Department, after writing or editing 2 I books on the Southwest under the pen name of Stanley Vestal, surveys its literature under his own. Arizona and the eastern halves of Oklahoma and Texas are excluded from consideration. The books considered are arranged by categories, with biography ( 16 subsections), description and interpretation, and history receiving the greatest amount of attention, but with substantial sections for folklore, humor, juveniles, poetry, and fiction. No assessment is attempted, as being beyond the powers of a contemporary, but the writer frequently gives vent to his enthusiasm. He certainly makes his point that, considering the newness of the region as an area of Anglo-American settlement, the quantity, variety, and quality of the literary achievement is impressive. A companion to the course taught by 
James Frank Dobie at the University of Texas, entitled Guide to Life and Literature of the Southwest, rev. and enl. (Dallas, Southern Methodist University Press, 1952. 222 p.), is especially strong on Texas, cowboys, cattle, and folklore.

419I. [Wertenbaker, Green Peyton] America's heartland, the Southwest, by Green Peyton [pseud.] Norman, University of Oklahoma Press, I948. xvii, 285 p. $\quad 48-10982 \quad F_{396 . W_{4}}$

Bibliographical references included in "Acknowledgments": p. 274-277.
This is the introductory volume to a series of books about the culture of the Southwest projected by the University of Oklahoma with funds from the Rockefeller Foundation. As an experienced journalist, the author describes the impressions which he has gathered from interviews and ten thousand miles of travel in the states of Arkansas, Louisiana, Texas, Oklahoma, and New Mexico. It is not offered as a scholarly study, but as a general survey and an impression to "explain why the Southwest is important to the life of our time, and how its people come to be the way they are."

\section{Q. The Far Southwest: Local}

\section{TEXAS}

4192. Goodwyn, Frank. Lone-Star Land; twentieth-century Texas in perspective. New York, Knopf, I955. 352 p. $\quad$ 55-7850 F39i.2.G6 "This book embraces the geology, geography, anthrofology, history, economics and culture of Texas. Selectivity is necessarily high, and all details are eschewed except those which delineate the essential peculiarities of the chosen area." The result is a genuine synthesis, presented in a clear and straightforward exposition, and illustrated by excellently chosen and reproduced photographs. The author is evidently fascinated by the personality of W. Lee O'Daniel, whose political career he treats at some length.

4193. Hogan, William Ransom. The Texas republic; a social and economic history. Norman, University of Oklahoma Press, 1946. $33^{8} \mathrm{p}$. ${ }_{46-8214} \mathrm{~F}_{390 . \mathrm{H} 6}$

Bibliography: p. 299-326.

For ten years before being admitted to the Union in 1846 , Texas was an independent republic. This volume describes everyday existence in that frontier democracy during those years. It is a record of "devout circuit riders, pioneer physicians and school teachers, unruly young lawyers, gun-bearing rowdies and duelists, town builders and land pirates, planters and farmers" who, at work and play, developed those characteristics which distinguish Texans from the citizens of other states. The author attributes much of Texas nationalism to its public-land system: here free land was obtained, not from a distant government in Washington, but from a national government that was close at hand, and that did what it could to discourage large-scale land speculation, especially by nonresidents.
4194. Richardson, Rupert Norval. Texas, the Lone Star State. New York, Prentice-Hall, 1943. xix, 590 p. [Prentice-Hall history series; Carl Wittke, editor] $\quad 43-2288 \quad \mathrm{~F}_{3} 86 . \mathrm{R}_{52}$ "Selected bibliography" at end of each chapter.

A book intended both for college classes and the reading public, whose purpose "is to provide, as far as the limitations of a single volume will permit, a complete survey of the history of Texas." It gives equal attention to the romantic and colorful period of Texas history, and to more prosaic events such as the development of education and the fluctuations of economic conditions. Approximately half the book is devoted to "the extension of farming into the Great Plains, the growth of industries, the revolution in transportation, efforts to regulate business, the program of social security, the regulations of agriculture, and the varied political history" of the years since $1876-a$ period hitherto neglected by historians. Lists of "Governors of Texas" and "United States Senators from Texas" form an Appendix.

4195. McCarty, John L. Maverick town, the story of old Tascosa. With chapter decorations by Harold D. Bugbee. Norman, University of Oklahoma Press, 1946. 277 p.

Bibliography: p. 26I-266.

$$
{ }_{4}^{6-6343} \mathrm{~F}_{394} \cdot \operatorname{Tr}_{7} \mathrm{M}_{3}
$$

Tascosa, high up in the Texas Panhandle, is typical of those communities in the West that once flourished, and then declined into ghost towns. For nearly a decade beginning in the late 1870 's, Tascosa as an open-range trading center and the "legal capital of ten counties in a cattle empire," was the center of all affairs, public and private, lawful and unlawful, as well as the home "of a group of great 'little' men both Mexican and Anglo-American." But the railroad never came, and the great 
flood of the Canadian River in 1893 merely hastened the death of an already moribund town. The author has based his narrative, made possible by a grant through the Texas State Historical Society from the Rockefeller Foundation, in large part on interviews with and letters from oldtimers, and on the unique file of The Tascosa Pioneer (1886-91).

4196. Haley, James Evetts. The XIT Ranch of Texas, and the early days of the Llano Estacado. [New ed.] Norman, University of Oklahoma Press, 1953. xiv, $258 \mathrm{p}$.

Bibliography: p. 247-252.

$$
\text { 53-88I8 F391.Hi6 } 1953
$$

The files of the XIT Ranch and its Chicago office, now in the archives of the Panhandle-Plains Historical Society at Canyon, Texas, together with letters, personal interviews, newspapers, books, pamphlets, and periodical articles have been used as sources for this chronicle of "the most extensive Western range ever placed under one barbedwire fence." Established in the middle 80's, the XIT Ranch included 3,050,000 acres of land in the Panhandle of Texas, patented by the State to a Chicago firm in payment for constructing the Capitol at Austin. The first edition of this book, published in 1929, was printed by the Farwell family of Chicago "as a privately issued memorial to their people, their associates, and their cowboys." A log of an 1892 cattle drive and the "General Rules of the XIT Ranch, January, I888" are published as appendixes.

4197. Horgan, Paul. Great river: the Rio Grande in North American history. New York, Rinehart, 1954. 2 v. (1020 p.)

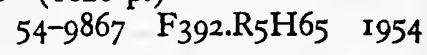

Bibliography: v. 2, p. 957-977.

Mr. Horgan, a writer of novels and other fiction who has lived in New Mexico since 1915, spent 13 years in the preparation of this book. He wished "to produce a sense of historical experience, rather than a bare record" of this river, nearly 2,000 miles long, whose "historical course takes us through something over ten centuries of time and through the chronicles of three cultures." The result is a stately pageant of the Indian and the Spanish Rio Grande in volume I, and of the Mexican and "The United States Rio Grande" in volume II. The author's ability to penetrate the inwardness of vanished cultures is evidenced in such chapters as "The Stuff of Life" in the Indian section, and "Collective Memory" and "Hacienda and Village" in the Spanish. Save for a chapter on the border troubles leading to General Pershing's Punitive Expedition of 1916-17, the detailed narrative ceases with the 1870's. "Finally all indigenous aspects of the river's three societies would be dissolved in the techno- logical uniformity of the national life in the twentieth century." The author's achievement was recognized with two annual prizes: the Bancroft prize and the Pulitzer prize in history.

\section{NEW MEXICO}

4198. Fergusson, Erna. New Mexico; a pageant of three peoples. New York, Knopf, I95I. 408 p. $\quad$ 5I-II094 F796.F 35 "Books recommended for further reading": p. 395-404.

Mrs. Fergusson describes the development of her native State under the influence of Indian, Spanish, and American civilizations, which are blended in this "land of enchantment." The backwardness of Spanish-speaking villagers is attributed to "the powcrful in politics, government, and even education," who have failed to impart the mastery of English that could be had "within one school generation, twelve years." Twentieth-century elements in New Mexico are described in chapters on "The Federal Man"-atomic scientist or conservationist, "Water"- the new dams, and the "Artist Discoverers" who have centered in Taos. A final chapter points out to tourists the natural wonders and other places of interest. The selected bibliography at the end is aimed at the general reader, and is arranged according to the chapters of the book. There is also a glossary of Indian and Spanish words and phrases characteristic of the region.

\section{ARIZONA}

4199. Lockwood, Francis Cummins. Pioneer days in Arizona, from the Spanish occupation to statehood, by Frank C. Lockwood. New York, Macmillan, 1932. xiv, 387 p. 32-29213 F81 r.L75

Arizona, in which the Grand Canyon, the Painted Desert, and the Petrified Forest are located, was the last state to enter the Union. It is noted for its mild winter climate and sunshine which have made southern Arizona a winter vacation and health resort; for the development of the Colorado River for irrigation and power; for its Indian tribes with their handicraft trade; and for its mineral resources. The author, associated in various capacities with the University of Arizona from 1916 to 1930, wrote this book to fill the need, which he discovered when he moved to Arizona, for a book that traces the political, industrial, social, and cultural beginnings of the State. He has brought together from interviews with pioneers, early newspapers, letters, diaries, reminiscences, government documents, and other sources, the material which he uses "to narrate in 
an orderly and graphic way the chief incidents that took place in Arizona from the coming of the Spaniards in 1539 to the achievement of Statehood in
I9I2." The literature of the State is described in a chapter on "Newspapers, Books, and Libraries" (p. 345-367).

\section{R. California}

4200. Caughey, John Walton. California. $2 \mathrm{~d}$ ed. New York, Prentice-Hall, I953. 666 p. illus. (Prentice-Hall history series) 53-9858 F86r.C 34 I953

"A commentary on Californiana": p. 595-634.

Professor Caughey of the University of California at Los Angeles published the original edition of this very successful textbook for college classes in 1940 . He allots a little over a third of the volume to the periods before American acquisition. California, first visited by the Spaniards in 1542 , was not settled by them until 1769 . The Mexican period, beginning in 1822 , was brief and "self-consciously transitional." Cattle raising was the prevailing economy until the Gold Rush transformed the north, and southern California remained predominantly pastoral until the boom of the $1880^{\circ}$ s. The growth of the State in population and wealth has been accelerated by subsequent booms, but has gone steadily on between them. California is its own region, and developments there have proceeded in relative independence of the rest of the United States. The annotated bibliography furnishes guidance to a literature that has become enormous. In the second edition some of the earlier chapters are expanded, and the story is continued down to "The Scene at Midcentury."

4201. Caughey, John Walton. Gold is the cornerstone. Berkeley, University of California Press, I948. xvi, 32I p. $4^{8-10984} \quad$ F865.C33 Bibliography: p. 30I-3I4.

4202. Ellison, William Henry. A self-governing dominion: California, 1849-186o. Berkeley, University of California Press, 1950. $335 \mathrm{p}$.

Bibliography: p. 315-322. 50-62714 F865. E5

The Chronicles of California, inaugurated by the University of California Press under the editorship of Professors Herbert E. Bolton and J. W. Caughey as a part of the State's centennial celebration, are a series of volumes on periods or topics of State history. Of the pair here listed, the first is a balanced narrative of the Gold Rush, and an estimate of its importance in California history. On Jan. 24, 1848, James Wilson Marshall, a carpenter constructing a mill at Coloma on land belonging to John W. Sutter, found fragments of gold in the millrace. Before winter most of the able-bodied males in California had turned gold miners, and in the course of 1849 the influx of outsiders brought the number of prospectors and miners to some 45,000 . The result was the stimulation of developments in California, the West at large, and the whole Pacific basin that would otherwise have taken a generation, or might not have occurred at all. One obvious consequence was that by Sept. 7,1850 , less than 32 months after the discovery of gold, California had become the 3Ist State of the Union. But for over a decade, because of her isolation, and the assumption of her citizens that they were a people apart, California's ultimate destiny remained undetermined. Not until 1860, Prof. Ellison believes, was a political contest first waged around national issues, and decided "by the rather general recognition that California could not stand as a self-governing dominion but only as an integral and dependent part of the United States." Other volumes published in the Chronicles of California have been Charles L. Camp's Earth Song: A Prologue to History (1952. I27 p.), Jeanne Skinner Van Nostrand and Edith M. Coulter's Californin Pictorial; a History in Contemporary Pictures, I786 to 1859 (1948. I59 p.), William W. Robinson's Land in California (1948. $29 \mathrm{I}$ p.), George E. Mowry's The California Progressives (1951. 349 p.), and Franklin D. Walker's $A$ Literary History of Southern California (1950. 282 p.).

4203. Cleland, Robert Glass. From wilderness to empire; a history of California, 1542-1900. New York, Knopf, I944. xii, 388 , xiv p. illus.

$$
44^{-2} 4^{22} \text { F861.C6 }
$$

4204. Cleland, Robert Glass. California in our time (1900-1940) New York, Knopf, 1947. viii, 320, $x x$ p. 47-30606 F866.C62

Dr. Cleland came to California at the age of four in 1889 , has visited all parts of the State, and has spent most of his life in studying its history. After $3^{0}$ years in the service of Occidental College, he transferred to the research staff of the Huntington Library in 1943 , and has since published a series of important works on California history, beginning with the present pair, and including a study of the fur trade in the Southwest (no. 4186). The above 
titles were originally planned as a one-volume history of the State, but were divided when the author became convinced that it would be impossible to do justice to the complex economic, political, and cultural developments of the 2oth century in a few chapters. From Wilderness to Empire is largely narrative incorporating many extracts from original sources, and does not slight the colorful and romantic aspects of the subject, but also contains descriptive chapters such as "Missions and Ranchos" and "California of the Ranges." The sequel traces "the over-rapid transformation of an agrarian region into a highly industrialized society," and the overtaking of northern California by southern, with much awe and some criticism. The concluding chapters are concerned with the false hopes aroused by the Townsend movement, the difficulties of the Japanese, Mexican, and "Okie" minorities, Hollywood as Bunyan's Vanity Fair magnified to huge proportions, and a review of California literature from its beginnings to John Steinbeck.

4205. Putnam, George Palmer. Death Valley and its country. New York, Duell, Sloan \& Pearce, I946. 231 p. $\quad 46-8329$ F868.D2P8 Bibliography: p. 219-220.

California's Death Valley, "the lowest, driest, and hottest place in America," is at the bottom of a volcanic trough on the eastern slope of the Sierra Nevada. Some 550 square miles of it are below sea level, and Badwater, 279.6 feet below, is the lowest land in North America-less than 80 miles from Mount Whitney, the highest peak in the United States. The Valley, which the author likens to an inferno in suspended animation, has been conspicuous in the American imagination ever since a train of '49-ers came to grief there, and has been a National monument since 1933. Mr. Putnam describes its kangaroo rats, chuckwallas, vinegaroons, and other strange fauna, its exploitation for Twenty Mule Team Borax in the 1880 's, and the legends of its eccentric prospectors, of whom Death Valley Scotty was much the best known. Some bibliographic sources include this volume in the American Folkways series (no. 3942), but the Library of Congress copies have no such indication.

4206. Mayo, Morrow. Los Angeles. New York, Knopf, 1933. $\mathrm{x}, 337$, xvi p.

"Bibliographical note": p. $331-337$.

$$
\text { 33-658I F869.L8M2 }
$$

4207. Carr, Harry. Los Angeles, city of dreams. Illus. by E. H. Suydam. New York, Appleton-Century, 1935. 35-18559 F869.L8C 3

A modern and scholarly treatment of the spectacular rise of Los Angeles to a high rank among the world's great cities is badly needed; these volumes, over 20 years old and journalistic in manner, are inadequate substitutes. Mr. Mayo relates the more dramatic episodes in the annals of Los Angeles from I 781 to the I920's, such as Collis P. Huntington's campaign to locate the artificial harbor at Santa Monica instead of San Pedro, and the Los Angeles Times dynamiting of Igro. This he does in a muscular style and with small sympathy, for he regards his subject as "an artificial city which has been pumped up under forced draught, inflated like a balloon, stuffed with rural humanity like a goose with corn." Harry Carr, who died the year after this book appeared, had been associated with the Los Angeles Times for nearly 40 years, and with the Hollywood studios in the days of their early celebrity. His topical chapters are more sympathetic in tone-to him, "Los Angeles is the ingredients of a cocktail, not yet shaken"-and studded with the reminiscences of an oldtimer who has watched the great transformation happen.

4208. Camp, William Martin. San Francisco: port of gold. Garden City, N. Y., Doubleday, I947. $\mathrm{xv}, 518 \mathrm{p} . \quad 47-11836 \quad$ F869. $\mathrm{S}_{3} \mathrm{C}_{25}$

4209. O'Brien, Robert. This is San Francisco; illus. by Antonio Sotomayor. New York, Whittlesey House, 1948. xv, $35^{\mathrm{I}} \mathrm{p}$.

$$
\text { 48-I 0991 F869.S } \mathrm{O}_{15}
$$

Mr. O'Brien came to San Francisco in 1939, and conducted a column, "Riptides," in the San Francisco Chronicle from 1946. His columns, and other materials gathered in the course of preparing them, are here organized into a "portrait of an American city" which stresses its less-known aspects and personalities. He divides the city into five main areas-"The Waterfront," "Old Town," "The Hills," "Main Stem," and "South of the Slot," and in each presents his material under particular streets and avenues. For each street the retrospective material is followed by an impression of the recent state of things. This organization certainly called for a better map than the very sketchy one which appears on the end papers. Mr. Camp explains that he has written "not a book about the City, but rather one about the Port, the water front of San Francisco." He recounts a number of episodes from earlier periods, such as Asbury Harpending's plot to capture San Francisco and hand it over to the Confederacy, but gives major space and emphasis to the creation of the facilities and the organization of the modern port, to the failure of the laws to protect sailors against crimps, shanghaiers, and brutal captains, to the movement to organize maritime workers which began in 1885 , and to the frequent waterfront disturbances which have ensued. 
4210. King, Clarence. Mountaineering in the Sierra Nevada. Edited and with a pref. by Francis P. Farquhar. New York, Norton, 1935. $320 \mathrm{p}$. 35-35677 F868. $\mathrm{S}_{5} \mathrm{~K}_{53}$

"Bibliographical notes": p. 317-320.

Clarence King (1842-1901) learned geology in the Sheffield Scientific School of Yale University, and soon after graduation joined the staff of the California State Geological Survey under Josiah Dwight Whitney and William H. Brewer. Much of the succeeding decade he spent in the geological exploration of the High Sierra, at first for the State Survey, and subsequently for the Federal Survey of the 4 oth Parallel, which he had suggested and of which he was placed in charge. These famous sketches were first published as articles in The Atlantic Monthly in $187 \mathrm{I}$, and appeared in book form the following year. They give vivid glimpses of the Yosemite and its region, and of Mounts Tyndall, Shasta, and Whitney (King's party named the highest peak in the United States after their chief) as they appeared to a pioneer of American mountaineering-for King "was almost alone among Americans of his day in having the desire to climb remote and difficult peaks."

42II. Russell, Carl Parcher. One hundred years in Yosemite; the story of a great park and its friends; with a foreword by Newton B. Drury.
Berkeley, University of California Press, I947. xviii, 226 p. illus., fold. map.

47-30335 F868.Y6R8 I947

The Yosemite Valley, named after the local Indian tribe but formed by the north fork of the Merced River, was first visited in 1833 , explored in $185 \mathrm{I}$, turned over to California as a public trust in 1864 , and restored to Federal ownership as part of a much larger Yosemite National Park in 1905. On the western slope of the Sierra Nevada about I50 miles due east of San Francisco, and containing some 1176 square miles, it is a natural wonderland of mountain valleys, sheer cliffs, towering peaks, waterfalls, giant sequoias, and abundant wildlife. Dr. Russell, who was Park Naturalist in 1923-29, brought out the first edition of this work in I93I, and in the second has expanded the original text from manuscripts contributed to the Yosemite Museum, and added the information called for by 16 years of development during which the Yosemite had eight million visitors. His volume is essentially a history, with chapters on the area's discoverers, pioneers, early tourists, mountain explorers, hotels, scientific interpreters, and administrators before and since the creation of the National Park Service in I9I6. There is no systematic description of its natural features, but there is a substantial "Chronology, with Sources" (p. [ 177$]-193$ ) and a "Bibliography" (p. [195]-2I3) of titles of historical interest.

\section{S. The Pacific Northwest: General}

4212. Freeman, Otis W. and Howard H. Martin, eds. The Pacific Northwest, an overall appreciation. 2d ed. New York, Wiley, I954. xvi, 540 p. 54-9235 HCio7.ArgF 1954

The Pacific Northwest includes Oregon, Washington, Idaho, and the mountain counties of western Montana-a region that has an "identity differentiated from other areas of the United States," mainly by its topography. The first edition of this book (1942) was also the "first comprehensive study of the resources of the region which concerns itself with the geographic bases involved." Here it has been revised to take account of the many changes that have taken place in the region since that date. Thirty professors and technicians have contributed to the five parts on "Changing Human Adjustment," "Physical Environment," "Exploitation and Conservation of Various Resources," "Agriculture," and "Industry, Commerce, and Urban Development." The numerous sketch maps illustrate single factors. Most of the chapters conclude with a set of references.
4213. Fuller, George W. A history of the Pacific Northwest. New York, Knopf, i931. xvi, 383, [ 16] p. 31-26862 F851.F96 Librarian of the Spokane Public Library (I9II36) and secretary of the Eastern Washington State Historical Society (I916-35), the author received historical recognition for The Inland Empire of the Pacific Northwest, a History (Spokane, H. G. Linderman, I928. 4 v.) and for this book, a notable one-volume contribution to the early history of the region. Its principal subjects are the Indian tribes, whose manners and customs were first observed by Lewis and Clark, and their uprisings; the explorers who converged on the Pacific Northwest from the sea and land; the great fur companies; and the missionary pioneers who planted the first American settlement in the region-the Methodists in the Willamette valley ( 1834 ). Less than half of the narrative is concerned with the beginnings of government, pioneer social life, and political and economic growth through the first quarter of the 
2oth century. A list of "Governors of the Territories and States" appears at the end.

4214. Winther, Oscar Osburn. The Great Northwest; a history. 2d ed., rev. and enl. New York, Knopf, r950. xviii, 49I, xxx p. (Western Americana)

Bibliography: p. 463-49I.

This historical survey of the Pacific Northwest from the period of exploration, through the fur trade era and the coming of the first missionaries and immigrants, to the present day was first published in 1947. In the revised edition the author has expanded Part II, "The Post-frontier Period, I883I950," which begins with the completion of the Northern Pacific Railroad. He emphasizes the influence of transportation, and especially of the railroads, on the development of the territory. There are chapters on the range cattle business, irrigation, husbandry, industry and commerce including the tourist business, hydroelectric power projects, politi- cal ferment, and social and cultural achievements. In the same year the author also published The Old Oregon Country; a History of Frontier Trade, Transportation and Travel (Stanford, Calif., Stanford University Press, 1950. $34^{8}$ p.). It includes much of the data that appeared in the 1947 edition of The Great Northwest, but the author hopes that "the more extended and detailed treatment here, with accompanying documentation, will be of added value to the readers." In his Farthest Frontier, the Pacific Northwest (New York, Macmillan, I949. 375 p.), which was supported by the Library of Congress Grants in Aid for Studies in the History of American Civilization, Sidney Warren acknowledges his appreciation to Professor Winther for his "helpful suggestions and comments." Mr. Warren's book is a chronicle of the society created by the pioneers down to the year 1910, when "the region was well on the way to maturity." It describes their homes, schools, medical facilities, newspapers, recreation, and cultural growth.

\section{T. The Pacific Northwest: Local}

\section{WASHINGTON}

4215. Meany, Edmond S. History of the State of Washington. New York, Macmillan, 1924. 4 I2 p. illus. 24-9257 F89r.M46 I924

Best known as an educator during his years of association with the University of Washington (1897-1935), the author had numerous business interests, served in the State House of Representatives (1891-93), and achieved recognition as the historian of his adopted State. Intended primarily for the general reader, but also usable as a textbook in high schools or colleges, this book was first published in I909. It is a "compact record" of the history of Washington State from the discovery and exploration of the Pacific Northwest by the Spanish, Russians, English, and, finally, the Americans under the leadership of such men as Robert Gray, Lewis and Clark, Charles Wilkes, and John Charles Frémont, to the year 1923. Separated from the Territory of Oregon in 1853 , Washington Territory became a State in I889, a late addition to the Union. The organization of the State, and its economic, political, and social development, occupy less than a fourth of the text. The last chapter is devoted to "Evidences of Recent Advance." Lists of counties, Territorial and State officers, and of State institutions form the appendixes.
4216. Morgan, Murray C. Skid Road; an informal portrait of Seattle. New York, Viking Press, 195I. $280 \mathrm{p}$. 5I-I4III F899.S $4 \mathrm{M}_{72}$

Seattle is located on the eastern shore of Puget Sound on Elliott Bay. The book's title was derived from the pioneer method of skidding logs by oxteams along the route to Yesler's sawmill-the business which first made Seattle look like a real town. Saloon keepers, show people, and others followed the loggers on the route later known as Yesler Way, "the northern limit of what Seattleites called 'our great restricted district." It is the story "of some who tried and failed and of some who achieved success without becoming respectable, of the life that centered on the mills and on the wharves. That is Seattle from the bottom up." It is told in the activities of such folk as Doc Maynard, "Seattle's first booster," who dreamed of making the city grow, and died before it reached maturity, the Mercer girls, imported for matrimony, and Mary Kenworthy, who challenged the Sinophobes. From more recent years, Mayor Ole Hanson and the general strike of 1919, Dave Beck and the labor movement, Lt. Governor Vic Meyers, the local wit, and others are given their part in the growth of Seattle. It has become one of the largest cities of the Pacific Northwest, and was made possible "by every sort of American and almost every sort of people." 
4217. Fargo, Lucile F. Spokane story. New York, Columbia University Press, 1950. $276 \mathrm{p} . \quad 5^{0-10471} \quad \mathrm{~F} 899 . \mathrm{S}_{7} \mathrm{~F}_{3} \quad 1950$ Bibliography: p. [26I] -270 .

A leader in the development of school libraries, the author began her career in Oregon and Washington. She spent 17 years as a librarian in Spokane, and had already written several books of fiction based on life in Dakota Territory and the Pacific Northwest, when she was invited by the Columbia University Press to write a book "picturing the life and culture of Spokane during successive phases of its development from fur trade days to the attainment of municipal adulthood in the early years of the twentieth century." She has approached her subject through the lives of those "whose activities have become a part of local lore," such as Ross Cox, the Walker family, Spokane Garry, the Ashlocks, Jim Glover, the "Father of Spokane," May Hutton, and others. She has produced an entertaining narrative for those who are "interested in the development of the so-called Inland Empire and its capital city." Titles which have been found useful as background material, because of "their human interest, lively style, and portrayal of social life and customs," have been included in the bibliography.

\section{U. Overseas Possessions}

4218. Pratt, Julius W. America's colonial experiment; how the United States gained, governed, and in part gave away a colonial empire. New York, Prentice-Hall, 1950. $460 \mathrm{p}$.

$$
\text { 50-11728 } \mathrm{F}_{970 . \mathrm{P}_{7}}
$$

The author has brought together in one volume a narrative of the United States' acquisition and government of Alaska and Hawaii; its administration of the Canal Zone and Panama Canal, the Virgin Islands, American Samoa, Wake and Midway Islands; its joint control, with Great Britain, of Canton and Enderbury Islands; and its interest in the Trust Territory of the Pacific Islands-the Marshalls, Carolines, and Marianas. The rise of our "Caribbean sphere of influence" is traced through the first two decades of the century, and our "retreat from empire" dated from the beginning of President Harding's administration (I92I). Economic conditions and causes of discontent, with "the remedies adopted or proposed, ranging from independence for the Philippines to proposed statehood for Alaska and Hawaii," are outlined. A summary of "United States-Philippines Relations after World War II" and of the "Government of the Trust Territory of the Pacific Islands" appears in the appendixes. The book describes the development in the overseas policies of the United States during the decade since William $\mathrm{H}$. Haas published his largely geographical description, The American Empire, a Study of the Outlying Territories of the United States (Chicago, University of Chicago Press, 1940. 408 p.).

\section{ALASKA}

4219. Gruening, Ernest Henry. The State of Alaska. New York, Random House, 1954. $606 \mathrm{p}$. 54-7799 F904.G7
As Governor of Alaska (1939-53) and Director of the Division of Territories and Island Possessions in the Department of the Interior (1934-39), the author gained an insight into Alaska's problems which enables him to analyze here, in a manner not previously attempted, the relations between the United States Government and the Territory, and the economic forces which have influenced the destiny of Alaska, especially in the period since 1912. Following a brief summary of the discovery of Alaska by Vitus Bering, its botanical exploration by Georg W. Steller (1709-1746), who also gave the world the first account of the seal and other furbearing marine animals, and the purchase of Alaska from Russia in 1867 , the author describes the neglect and indifference of the United States towards its new possession, and the struggle of the people of Alaska for more voice in the development of its resources and government. Almost half of the book is concerned with the period of the author's administration, during which World War II brought recognition to Alaska as a strategic military outpost, increased American interest in its development, and gave impetus to Alaska's determination "to fight on to validate the most basic of American principles-government by consent of the governed."

\section{HAWAII}

4220. Kuykendall, Ralph $S_{\text {; }}$, and Arthur Grove Day. Hawaii: a history, from Polynesian kingdom to American commonwealth. New York, Prentice-Hall, 1948. 33I p.

Bibliography: p. 301-308.

$$
{ }_{48-9650} \text { DU625.K } \mathrm{K}_{778}
$$

Located in the eastern half of the North Pacific, closer to America than any other important body 
of land, the Hawaiian Islands by reason of their strategic position have become, since their discovery by Captain James Cook in $177^{8}$, "the Crossroads of the Pacific." The native inhabitants are a part of the Polynesian family, and the Islands were first firmly united by Kamehameha I, who ruled from 1782 to 1819 and established the foundations of the Hawaiian kingdom. It endured until 1893 , giving place to a Republic which sought annexation to the United States, and obtained it in 1898. As professors at the University of Hawaii, the authors were well-equipped to write the "main narrative of $\mathrm{Ha}$ waii's history, from the days of the ancient feathercloaked warriors to the present time, when Hawaii's fight for statehood has made it an issue of national importance." A third of the book is devoted to the period since the annexation of the Hawaiian Islands to the United States. The book should interest residents of Hawaii, students of Pacific history, and the visitors who have added an extensive tourist trade to the Islands' basic sugar, pineapple, livestock, and fishing industries.

\section{PANAMA CANAL}

422 I. Mack, Gerstle. The land divided, a history of the Panama Canal and other isthmian canal projects. New York, Knopf, 1944. xv, 650, xxxiv p. $\quad 44-3323$ TC $773 \cdot M_{25}$

"Notes on map and diagram sources": p. 592-597. Bibliography: p. 598-650.

This is a comprehensive and scholarly, yet readable, history of the movement for a transportation route between the Atlantic and the Pacific from the discovery of the New World to I943. The prolonged controversies that preceded the selection of a route have led the author to describe in detail "all interoceanic canal projects throughout the length of the American continent from the Arctic Ocean to Cape Horn," with emphasis on a canal through Nicaragua, the most formidable rival of Panama. In addition to the location of the canal, the mode of construction, costs, tools, labor policies, treaties, concessions, and ownership became the subjects of endless controversies. Here the author attempts to combine "the political, economic, strategic, hygienic, and engineering aspects of the canal problem into a general history of the entire field." He deals with the early interest of the Spanish who first proposed to construct a canal as early as 1534; the French project directed by Ferdinand de Lesseps in the I880's; and finally the eradication of yellow fever from the Isthmus by William Crawford Gorgas (no. 4823), and the construction of the Panama
Canal by George W. Goethals (no. 4796). It was completed in 1914 on the eve of World War I, and improvements were in progress at the beginning of World War II. The land, says the author, had been divided, but the world was far from united.

\section{PUERTO RICO}

4222. Hanson, Earl Parker. Transformation: the story of modern Puerto Rico. New York, Simon \& Schuster, 1955. $4^{\mathrm{r} 6} \mathrm{p}$.

54-9797 $\mathrm{Fr}_{958 . \mathrm{H}_{3}}$

Puerto Rico is unique in its status as a free commonwealth associated with the United States and at the same time fully self-governed at home. Its emergence from a backward, undeveloped society since 1940, and especially since 1948 when Luis Muñoz Marín became the first Governor elected by the people, "stands as a symbol of progress" for other undeveloped lands in the world. A remarkable program of industrialization has been launched; strides have been made in the amount and distribution of income; public health services, education, and employment have been expanded; and the commonwealth has become a "social laboratory of world importance." At one time executive secretary of the Planning Division of the Puerto Rico Reconstruction Administration, the author, in 1952, took a class of students from the University of Delaware to Puerto Rico to study its achievements. Here he tells the story of Puerto Rico's "anguish, explosion, and current effort ... which should be better known than it is, if only because it reflects great credit and honor on the United States," and on the ingenuity and determination of a people. Rafael Pico, chairman of the Puerto Rico Planning Board since I942, discusses the economic, physical, and human characteristics of the various regions of Puerto Rico in The Geographic Regions of Puerto Rico (Rio Piedras, P. R., University of Puerto Rico Press, 1950. 256 p.), an expansion of his doctoral dissertation submitted to Clark University, Worcester, Mass., in 1938. Published as a Social Science Research Center study of the College of Social Sciences, University of Puerto Rico, and edited by Julian H. Steward and others, The People of Puerto Rico; a Study in Social Anthropology (Urbana, University of Illinois Press, 1956. $54^{\circ}$ p.) was undertaken "to analyze the contemporary culture and to explain it in terms of the historical changes which have occurred on the island, especially those which followed the transition from Spanish sovereignty to United States sovereignty a half century ago." 


\section{Travel and Travelers}

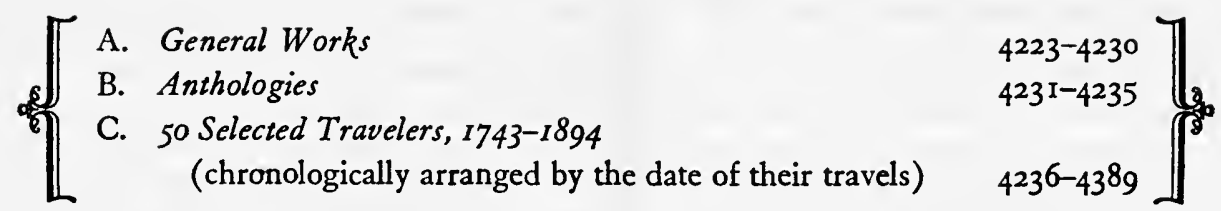

7 HE literature of travel in America, which begins with the Journals of Columbus, or, if 1 one prefers, with the Vinland Sagas, and continues unabated through the publications of the current year, is enormous. Arbitrarily enough, the present selection omits the literature of exploration, examples of which will be found in chapters VIII and XII, and is largely confined to travels in areas of the present continental United States after or during the process of settlement. This literature of travel has evoked and forms the subject matter of a secondary literature in which it is inventoried, described, or interpreted, in whole or in part. Section A is devoted to this secondary literature and includes a bibliography (no. 4229), works on the modes and mechanics of travel (nos. 4226, 4227), native reactions to the accounts of foreign visitors (nos. 4225, 4230 ), and dissertations dissecting a certain body of travel literature as to both information and interpretation (nos. 4223, 4224, 4228).

The primary literature is here presented in two forms: a group of anthologies which present extracts from it (or, in one case, a group of brief originals published for the first time: no. 4233) appropriately arranged, introduced, and commented upon, and a roster of 50 selected travelers, well assorted as to nationality, outlook, interests, and itinerary. While many substitutions could be readily made in this selection, we doubt whether much increase in all-round intrinsic quality would thereby be achieved. For each traveler we provide an identification, a concise statement of his route, and some indication of his separate personality. We have concentrated our travelers in the century and a quarter, 1740-1865, and have included only two men who fall after that period. While the literature after 1865 is quite as voluminous and readable as before, it does not, as a rule, have the same plain informativeness; it is rivaled by alternative sources relatively more copious and often more precise, and

it has not proved of equal value as materials for social and cultural historians. For each of our travelers we have listed his original publication or publications (sometimes in the best rather than the first edition), and, whenever available, an English translation for works in foreign languages, an American edition for works first published in Britain, and recent reprints or scholarly editions. In no case have we tried to list all versions or editions, although this has sometimes happened.

Both before and after 1865 travelers' narratives may tend to assume the form of essays on American society. There is no absolute line between some works we have listed here, and some which appear in our Section XV A, Some General Views of American Society. Crèvecoeur, Tocqueville, Bryce, and Siegfried were all travelers before they undertook their famous interpretations, and the works of Prince Murat, Mrs. Trollope, Miss Martineau, and Paul Bourget listed below may seem, in purpose and in form at least, to differ little from theirs. There is also a close relation between this chapter and Sections $\mathrm{XI} \mathrm{E}$ and $\mathrm{F}$, International Influences in our Intellectual History. Such influences are in part borne by travelers, and such works as Spoerri (no. 377I) and Torielli (no. 3779) would not be out of place here. 


\section{A. General Works}

4223. Athearn, Robert G. Westward the Briton. New York, Scribner, 1953. 208 p.

$$
\text { 53-11215 F594.A85 }
$$

A digest of the comments of British travelers in the Far West from 1865 to I900, significant because "by and large, these people were literate, intelligent, well-traveled," and furnished with a basis of comparison. They found, not the "Wild West" most of them had been led to expect, but "a frontier civilization trying desperately to look like the culture from which it sprang, and on the whole, ashamed of the few rowdies who had given it a bad name in its first hours." There is an annotated list of travelers alphabetically arranged (p. 187-202).

4224. Berger, Max. The British traveller in America, I 836-1860. New York, Columbia University Press, 1943. 239 p. (Columbia University. Faculty of Political Science. Studies in history, economics, and public law, no. 502)

$$
\text { 43-16988 H3r.C7, no. } 502
$$

Er65.B48 1943a

"Critical bibliography": p. 189-229.

This and Mesick below (no. 4228) are Columbia dissertations which, although two decades apart and published in different University series, are in effect continuous. Each notices briefly the travelers as a group, their motives and typical journeys, and then proceeds to a synthetic treatment of the major subjects contained in their books: customs, slavery, religion, education, etc. Mr. Berger has a chapter on democratic government to which there is no counterpart in the earlier volume. He attempts larger generalizations, and has furnished his bibliography with substantial annotations.

4225. Brooks, John Graham. As others see us; a study of progress in the United States. New York, Macmillan, 1908. $365 \mathrm{p}$.

8-3II47 EI68.B883

Brooks (1846-1938), a Unitarian clergyman turned labor economist and Progressive reformer, became fascinated with the literature of American travel, and determined to use it as a gauge for American social progress. His initial chapters offer a lively critique of our early critics, with much assessment of reliability by common sense methods. Bryce, Münsterberg, and $\mathrm{H}$. G. Wells receive extended reviews. The whole literature, he concludes, testifies to a "slow rise in social sensitiveness, and in social purpose to free ourselves from industrial and political tyrannies."

4226. Dunbar, Seymour. A history of travel in America, being an outline of the development in modes of travel from archaic vehicles of colonial times to the completion of the first transcontinental railroad. New York, Tudor, I937. I530 p. 38-708 I HE203.D77 1937

First published, I915.

Bibliography: p. [I445]-[ I48I].

A history of transportation and of internal migration as well as a history of travel, with much miscellaneous social history thrown in for good measure, but quite haphazard in arrangement. It contains, however, a mass of detailed information on the means and conditions of travel, and actual incidents of traveling endured by our hardy forefathers. It is abundantly illustrated from contemporary prints.

4227. Earle, Alice (Morse) Stage-coach and tavern days. New York, Macmillan, 1935.

449 p. $\quad 38-34442 \quad$ Er62.E2 1935

First published, 1900.

Mrs. Earle wrote her "social and domestic histories of colonial times" at a time when academic historians regarded such matters as beneath their notice. Her easy-going and gossipy volume on the oldtime taverns and the stagecoaches that ran between them has not been replaced. She tells of tavern landlords and tavern fare, of kill-devil (rum) and small drink, of signboards and ghost stories. There are chapters on "the pains of stage-coach travel," and on stage drivers and highwaymen. As is usual in her books, the greater part of the material is drawn from New England.

4228. Mesick, Jane Louise. The English traveller in America, 1785-1835. New York, Columbia University Press, I922. 370 p. (Columbia University studies in English and comparative literature) $\quad 22-16243 \quad E_{165 . M} 8$

See Berger above (no. 4224).

4229. Monaghan, Frank. French travellers in the United States, 1765-1932; a bibliography. New York, New York Public Library, 1933. xxii, II4 p. 33-22177 Z1236.M73

"I 806 title entries," including the various editions of an item and the translations, arranged alpha- 
betically by authors, with a "Selected chronological list of French travellers" (p. 107-108) and an index of places, persons, and important subjects.

"An attempt has been made to locate copies in two American libraries" (preferably the New York Public Library and the Library of Congress); 267 titles not yet located in America.

"Reprinted with additions and revisions from the Bulletin of The New York Public Library of MarchApril \& June-October 1932."

This bibliography includes not merely books of travel, but works of description, analysis, or criticism by French authors based upon an actual visit to the United States, and forms the most complete record of its kind. There are frequent annotations, some fairly long, on books or writers, as well as an introduction in which some fabricated "travels" are discussed. A few unnumbered entries represent prominent visitors who failed to leave any record of their impressions.
4230. Tuckerman, Henry T. America and her commentators. With a critical sketch of travel in the United States. New York, Scribner, r864. 460 p. 3-8368 EI57.T89

Contents.-Introduction.-Early discoverers and explorers.-French missionary exploration.-French travellers and writers.-British travellers and writers.-English abuse of America.-Northern European writers.-Italian travellers.-American travellers and writers.

A pioneer synthesis of American travel literature, by a literary gentleman of old New York City (1813-7r). Tuckerman aimed at a guide to the sources, a general view of American "traits and transitions" as therein reflected, and, incidentally, a "discussion of the comparative value and interest of the principal critics of our civilization." One of his conclusions is that foreign visitors are deficient observers of regional and personal variations in American life and character.

\section{B. Anthologies}

423I. Commager, Henry Steele, ed. America in perspective; the United States through foreign eyes. New York, Random House, 1947. xxiv, 389 p. $\quad 47-6240$ Er69.I.C67 Bibliography: p. $\left[3^{87}\right]-389$.

4232. Handlin, Oscar, ed. This was America; true accounts of people and places, manners and customs, as recorded by European travelers to the western shore in the eighteenth, nineteenth, and twentieth centuries. Cambridge, Harvard University Press, I 949. ix, 602 p. $49-7940$ Er6I.H3

Two anthologies of foreign travelers in America which hardly overlap. Mr. Commager's 35 extracts, from Crèvecoeur in 1782 to Victor Vinde in 1945, comprise brief and, in the main, generalizing and interpretive passages: "God made America for the poor" (Edward Dicey, I863); "Americans are boys" (de Madariaga, I928). Mr. Handlin's $4^{\circ}$ extracts, from Pehr Kalm in 1744 to André Maurois in 1939 , are in the main penetrating descriptions, with some reflective or critical commentaries. Mr. Commager has one Asiatic (No Yong-Park), but Mr. Handlin has a greater variety of continental Europeans, and many of his selections are here translated into English for the first time.

4233. Mereness, Newton D., ed. Travels in the American colonies, edited under the auspices of the National Society of the Colonial Dames of America. New York, Macmillan, 1916. 693 p. I6-9410 Er62.M57
Eighteen journals written between 1690 and 1783 and published for the first time, some from the Moravian Church Archives in North Carolina and some from the Draper Collection in Wisconsin, but most from transcripts made for the Library of Congress in British and French archives. Most of them record official errands of one kind or another; there are several missions to the Creeks, Cherokees, and Choctaws, and one French captivity among the Cherokees. A miscellany by ordinary observers, in which the realities of wilderness travel stand our the more starkly for the absence of any literary intention.

4234. Nevins, Allan, ed. America through British eyes. [New ed. rev. and enl.] New York, Oxford University Press, I948. $530 \mathrm{p}$. 48-7848 EI69.I.N52 I948

First edition published 1923 under title: American Social History as Recorded by British Travellers.

"An annotated bibliography": p. 503-519.

Substantial extracts from 30 British travelers, from Henry Wansey in 1794 to Graham Hutton who interpreted the Midwest in 1946. The compiler groups his travelers in periods, and provides each section with an introduction characterizing individual attitudes and insights as well as the general outlook. These periods receive the labels "Utilitarian Inquiry" (to I825), "Tory Condescension" (1840), "Unbiased Portraiture" (1870), "Analysis" (1922), and "Boom, Depression and War." 
4235. Tryon, Warren S., ed. A mirror for Americans; life and manners in the United States, 1790-1870, as recorded by American travelers. Chicago, University of Chicago Press, 1952. 3 v. (xx, 793 , v p.)

Bibliography: v. 3, p. $783-791$. 52-13949 Eı61.T78

Contents.- - I. Life in the East.-2. The Cotton Kingdom.-3. The frontier moves west.

An anthology containing 43 extensive extracts from Americans who traveled in and observed their own country. The editor furnishes an introduction to each writer, as well as more general ones. The final volume is in two parts, "The Valley of Democracy," on the trans-Appalachian West, and "Westward the Course of Empire," on the trans-Mississippi West. Passages have been deleted from, and words added to, the original texts without editorial indication.

\section{5o Selected Travelers, I743-i894 (chronologically arranged by the date of their travels)}

\section{1743. JOHN BARTRAM (1699-1777)}

The elder Bartram was the self-taught founder of American botany and the creator of the famous Botanic Garden a few miles from Philadelphia. In July and August 1743 , in company with Conrad Weiser and Lewis Evans, he went north through the wilderness to Oswego, where a preparatory conference with the Indians was held. Bartram's journal did not reach London until $175^{\circ}$, and was published without the author's knowledge "at the instance of several gentlemen" who thought that a better knowledge of the back country was desirable in view of increasing rivalry with France. The editor is rather apologetic for the lack of literary art in "this plain yet sensible piece," and for the journalist's concentration on "the several plants, and the various qualities of the soil and climate." Bartram took a keen interest in Indian ways, especially food preparation, hospitality, ceremonies, and techniques, and appends some concluding reflections on the origin of the red race, and the declining state of the Six Nations.

4237. Observations on the inhabitants, climate, soil, rivers, productions, animals, and other matters worthy of notice. Made by Mr. John Bartram, in his travels from Pensilvania to Onondago, Oswego, and the Lake Ontario, in Canada. London, J. Whiston \& B. White, 1751. 94 p. I-16152 Fi22.B129 4238. [Geneva, N. Y., W. F. Humphrey]
1895. 94 p. $\quad$ 16-9745

4239. 1744. ALEXANDER HAMILTON (17121756)

Dr. Hamilton was a graduate of the University of Edinburgh Medical School practicing at Annapolis, Md. Suffering from incipient tuberculosis, he set out on a leisurely journey for the benefit of his health, and covered 1624 miles in a little less than four months, venturing as far north as Albany, N. Y., and York, Me. He was a sharp and satirical observer, with a keen eye for oafish behavior, and his journal is unique for its glimpses of polite and convivial society in the colonial cities. The in habitants, he concluded, were more civilized in the great towns, "especially at Boston." His editor appends over 50 pages of notes which completely elucidate the text and practically constitute a guidebook to the Eastern Seaboard in 1744 .

4240. Gentleman's progress; the Itinerarium of Dr. Alexander Hamilton, 1744; edited with an introduction by Carl Bridenbaugh. Chapel Hill, Published for the Institute of Early American History and Culture at Williamsburg, Va., by the University of North Carolina Press, 1948. xxxii, $267 \mathrm{p}$. 48-28157 E162. $\mathrm{H}_{2 \mathrm{I}} \quad 194^{8}$

The Itinerarium was privately printed in 1907 .

\section{1748-1751. PEHR KALM (1716-1779)}

Pehr or Peter Kalm was a Swedish naturalist, a pupil of the great Linnaeus, a member of the Swedish Royal Academy of Sciences, and professor at the University of Abo in Finland. He was in the American colonies for nearly two and a half years, making his headquarters at Raccoon, N. J. (the present Swedesboro) and thence striking out into the back country of Pennsylvania and New York, with a three months' journey into French Canada. While his primary concern was with the flora and fauna, and their economic uses and potentialities, he was an indefatigable observer of every kind of natural and social fact, and was at pains to record them with a rare lucidity and precision. A fourth volume of his Resa remained unpublished and the manuscript was burnt, but many of the rougher 
notes upon which it was based were discovered and published by Elfving in 1929, and a translation of these is included in Benson's English version. Kalm thought that Pennsylvania "enjoys such liberties that a citizen here may, in a manner, be said to live in his house like a king."

4242. En resa til Norra America, på Kongl. Swenska Wetenskaps Academiens befallning, och publici kostnad, forrattad af Pehr Kalm. Stockholm, Tryckt på L. Salvii kostnad, 1753-61. $3 \mathrm{v}$. 2-5526 Ei62.KI4

Volume I and part of volume 2 treat of the author's travels in Norway and England.

4243. Pehr Kalms Resa till Norra Amerika, å nyo utgifven at Fredr. Elfving och Georg Schauman. Helsingfors, Tidnings- \& Tryckeri-aktiebolagets Tryckeri, 1904-15. 3 v. (Skrifter utg. af Svenska litteratursällskapet i Finland, v. 66, 93, I20) 40-34888 E162.KI44

4244. Pehr Kalms Resa till Norra Amerika, utgiven av Fredr. Elfving och Georg Schauman. Tilläggsband sammanställt av Fredr. Elfving. Helsingfors [Mercators Tryckeri Aktiebolag] 1929. 235 p. (Skrifter utg. av Svenska litteratursällskapet i Finland, v. 210) 40-34888 Er62.KI45

4245. Travels into North America; containing its natural history, and a circumstantial account of its plantations and agriculture in general, with the civil, ecclesiastical and commercial state of the country, the manners of the inhabitants, and several curious and important remarks on various subjects. Translated into English by John Reinhold Forster. London, The Editor, 1770-71. $3 \mathrm{v}$.

$$
\text { 2-13568 Er62.Kin }
$$

Volume I published at Warrington, printed by W. Eyres.

This translation omits a great number of details, and everything relating to England.

4246. The America of 1750; Peter Kalm's travels in North America; the English version of 1770 , revised from the original Swedish and edited by Adolph B. Benson, with a translation of new material from Kalm's diary notes. New York, WilsonErickson, 1937. 2 v. (797 p.)

$$
\text { 37-22.242 Ei62.Ki65 }
$$

"The part on Norway and England has been omitted ... The hitherto untranslated portion ... has been done into English by Miss Edith M. L. Carlborg .... and the present editor. The remainder . . . is based on Forster's translation."p. xv.
"A bibliography of Peter Kalm's writings on America": v. 2, p. 770-776.

\section{I773-1778. WILLIAM BARTRAM (I739- 1823)}

William Bartram was a younger son of John Bartram by his second wife, but the one who followed most completely in his worthy father's footsteps. Dr. John Fothergill, the English Quaker botanist, provided funds for him "to search the Floridas, and the western parts of Carolina and Georgia, for the discovery of rare and useful productions of nature, chiefly in the vegetable kingdom." $\mathrm{He}$ left Philadelphia for Charleston in April 1773 and did not get back until Jan. 1778 , when his father was dead and the city occupied by a British army. From Charleston he made two major tours: the first in 1773-75, up the rivers of Georgia and East Florida, and the second in 1776-77, into the Cherokee towns of the Southern Appalachians, and thence via the Creek towns to Mobile and the Mississippi. His concern with plants did not hinder Bartram from making major observations of snakes and frogs, and the longest list of American birds hitherto compiled. To Bartram the Indian was a noble savage indeed, closely and appreciatively viewed. Writers of the new romantic generation in England and France found an important source of poetic ideas and images in his book. It closes with a brief but systematic account of the Creeks, Cherokees, and Choctaws. If available, the contemporary editions with the copper plates are much to be preferred to the zoth-century reprints.

4248. Travels through North \& South Carolina, Georgia, East \& West Florida, the Cherokee country, the extensive territories of the Muscogulges, or Creek confederacy, and the country of the Choctaws; containing an account of the soil and natural productions of those regions, together with observations on the manners of the Indians. Embellished with copper-plates. Philadelphia, James \& Johnson, 1791. xxxiv, 522 p. Rc-2676 F213.B28

4249. The travels of William Bartram, edited by Mark Van Doren. New York, Macy-Masius, 1928. 414 p. (An American bookshelf) 28-3822 $\mathrm{F}_{213 . \mathrm{B} 288}$

4250. With an introd. by John Livingston Lowes. New York, Facsimile Library, exclusive distributors: Barnes \& Noble, 1940. 414 p. 40-II235 F213.B289 
425I. 1780-1782. FRANÇOIS JEAN, MARQUIS DE CHASTELLUX (1734-1788)

Chastellux accompanied Rochambeau's army to America with the rank of major general and was a highly cultured nobleman, of literary bent, and tinged by the Enlightenment. He made three journeys as his military service permitted; on the first (Nov. 1780-Jan. 1781) he went by way of West Point and Washington's headquarters to Philadelphia and Chester, and returned by way of Albany and Saratoga. In the spring of 1782 , starting from Williamsburg he made an excursion through Virginia to see the Natural Bridge. At the close of the same year he went from Hartford to Portsmouth, N. H., thence south to Boston, and eventually, by way of Washington's headquarters at Newburgh and Bethlehem, to Philadelphia. Chastellux was especially concerned to visit the earlier battlefields of the war then drawing to its close, and to narrate such of its incidents as came to his ears. He took a sympathetic interest in each home which he visited, and in its inhabitants, noting each "perfect beauty" that he encountered, and he turned a sharp eye on inns, innkeepers, and their accommodations. He describes the brilliant society of wartime Philadelphia and the crude lodgings of the Virginia backwoods alike with imperturbable good humor. The English versions of his book are provided with obtrusive annotations by the anonymous translator.

4252. Voyages de $\mathrm{m}$. le marquis de Chastellux dans l'Amérique Septentrionale dans les années 1780,1781 \& \& 1782. Paris, Prault, 1786. 2 v. 2-6014 Er63.C50

4253. Travels in North-America in the years 1780 , I 781, and 1782 . Translated from the French by an English gentleman [George Grieve], who resided in America at that period. With notes by the translator. London, G. G. J. \& J. Robinson, 1787. 2 v. 2-6666 Ei63.C54

4254. Also, a biographical sketch of the author; letters from Gen. Washington to the Marquis de Chastellux; and notes and corrections, by the American editor. New-York, White, Gallaher, \& White, 1827. $416 \mathrm{p}$.

$$
\text { I8-I } 8238 \quad \mathrm{Er}_{3} \cdot \mathrm{C}_{57}
$$

\section{5. $1783-1784$. JOHANN DAVID SCHÖPF (1752-1800)}

Dr. Schöpf was a native of Bayreuth educated in science and medicine at the University of Erlangen, and had made scientific travels in central Europe before taking his degree. The next year he came to America as chief surgeon of the Ansbach mercenaries in the pay of Great Britain, and on the con. clusion of hostilities took the opportunity of traveling before returning to Europe. He went from New York to Philadelphia, thence across Pennsylvania to Pittsburgh, back to Baltimore, and south to Charleston, where he took ship for East Florida. $\mathrm{He}$ is objective, equable, and indefatigable; $\mathrm{min}$ erals and mining are his first interest, but he records social matters and recent history with the same particularity. Morrison's translation has notes of identification and some of comparison at the end of each volume.

4256. Reise durch einige der mittlern und südlichen Vereinigten Nordamerikanischen Staaten nach Ost-Florida und den Bahama-Inseln unternommen in den Jahren 1783 und 1784 . Erlangen, J. J. Palm, I788. 2 v. 5-13744 E164.S37

4257. Travels in the Confederation, $1783-1784$. Translated and edited by Alfred J. Morrison. Philadelphia, W. J. Campbell, I9I I. 2 v.

$$
\text { II-1 } 2073 \mathrm{E}_{16} 6_{4} \cdot \mathrm{S}_{3} 8
$$

\section{I788. JACQUES PIERRE BRISSOT DE WARVILLE (I754-1793)}

Brissot was an active propagandist for the French Revolution who came to America "to examine the effects of liberty on the character of man, of society, and of government." No more enthusiastic book on the United States has been written; he was elated in Boston and rapturous in Philadelphia. Physically, he did not cover much ground; from Boston he went south as far as Mount Vernon, and north to Portsmouth just before he went home; but most of his stay was spent at Philadelphia, which he describes at some length. He admired the Quakers for the austerity of their worship, the serenity of their personal characters, and the simplicity, economy, industry, and perseverance of their way of life, to which he ascribed the prosperity of Pennsylvania. He gives special attention to the condition and character of the Negroes, free and slave, and to efforts toward their improvement, for the abolition of slavery and the slave trade, and for the recolonization of American Negroes in Africa. He spends much time abusing Chastellux, whom he regards as a courtly traducer of freemen!

4259. Nouveau voyage dans les États-Unis de l'Amérique Septentrionale, fait en $\mathrm{I} 788$. Paris, Buisson, I79I. 3 v. $\quad$ I-25369 Er64.B89 Half-title of v. 3: De la France et des États-Unis, ou De l'importance de la révolution de l'Amérique 
pour le bonheur de la France; des rapports de ce royaume et des États-Unis, des avantages réciproques qu'ils peuvent retirer de leurs liaisons de commerce, par Étienne Clavière, et J. P. Brissot (Warville). Nouvelle édition.

4260. New travels in the United States of America. Performed in 1788. Translated from the French. New York, Printed by T. \& J. Swords for Berry \& Rodgers, 1792.264 p.

42-29553 Er64.B8917 r792a

Contains a translation of the first two volumes only, of the three in the original French edition.

\section{6r. 1793. JOHN DRAYTON (1766-1822)}

Drayton, a member of one of the leading families of South Carolina, had completed his education in England, and was starting out in law and politics at Charleston when he undertook this tour of four and a half months in New York and New England in the latter part of 1793 . The book has three plates engraved from Drayton's own rather simple sketches. He took small interest in the New England countryside but was quite absorbed by the municipal life of New York, Providence, Boston, Portsmouth, and New Haven. At Boston he accompanied the selectmen on their annual visitation of the public schools. For these and for the other educational institutions of New England Drayton felt the greatest admiration, which he turned into effective action during his first term as governor, when he took the lead in establishing the University of South Carolina. On the return journey, the Connecticut Sabbath overtook him on the way to New Haven at Durham, where he had a triste séjour, and indignantly declined the landlord's invitation to attend meeting. Drayton was a sentimental and at times a tearful traveler, but his work is full of a desire to learn, and is completely free of all sectional rancor.

4262. Letters written during a tour through the northern and eastern states of America. Charleston, S. C., Harrison \& Bowen, 1794. $13^{8}$ p. Ar7-1387 Er64.D76

\section{I794-1798. MÉDÉRIC LOUIS ÉLIE MOREAU DE SAINT-MERY (1750- 1819)}

Moreau de St.-Méry was a Creole jurist who had collected the laws of the French West Indies. Resident in Paris, he was a leader in the early stages of the French Revolution, but was eventually proscribed and narrowly escaped the guillotine. After traveling from Norfolk to New York, he settled at Philadelphia, where he set up a bookstore and publishing house that became a center for French émigrés in America. His Voyage remained among his manuscripts in the Archives Coloniales until it was noted and put into print by Professor Mims. Mr. and Mrs. Roberts' translation of the Mims text is often loose and sometimes quite misleading. The Voyage is a composite manuscript: the basis is Moreau's journal, quite sketchy for his four years in Philadelphia, in which have been inserted a number of letters received, and descriptions of American cities: Norfolk and Portsmouth, Baltimore, New York and Brooklyn, and, at considerable length, Philadelphia. It is in the last that occur his unique observations on intimate manners and low life, that require to be taken with more caution than Mr. Roberts supposes. The Voyage is of course a principal source for émigré life in America during those years.

4264. Voyage aux Etats-Unis de l'Amérique, r793I798. Edited with an introd. and notes, by Stewart L. Mims. New Haven, Yale University Press, 1913. xxxvi, $44^{\circ}$ p. (Yale historical publications; manuscripts and edited texts, 2)

$$
\text { 14-1432 Er64.M83 }
$$

4265. Moreau de St. Méry's American journey, 1793-1 798, translated and edited by Kenneth Roberts [and Anna M. Roberts. Introd. by Stewart L. Mims. Garden City, N. Y., Doubleday, 1947. xxi, 394 p. $\quad 47-394$ I EI64.M832

4266. 1795-1797. FRANÇOIS ALEXANDRE FRÉDÉRIC, DUC DE LA ROCHEFOUCAULD LIANCOURT (17471827)

La Rochefoucauld-Liancourt was one of the most liberal of the French noblesse and active in many good works, but was nevertheless proscribed in the course of the Revolution, and became an exile in the United States. He traveled widely in order to dispel the ennui and melancholy that beset him, and he wrote voluminously concerning what he saw and what he was able to learn by interrogation. He did not cross the Alleghanies, and his intention of visiting the backcountry of Georgia and Carolina was frustrated by a fever which he contracted at Savannah, but he missed little else, and visited a number of towns more than once. His largest single journey, through the backcountry of Pennsylvania and New York into Canada, and back through New England to Philadelphia, occupied seven months of 1797. He modeled himself upon the tours of 
Arthur Young in France, and reports at length upon the processes of agriculture and the economic situation of particular farms. He includes essays on the government and laws of most of the States which he visited and concludes with general observations on the Constitution, public finance, commerce, and land system of the United States as a whole.

4267. Voyage dans les États-Unis d'Amérique, fait en 1795,1796 , et 1797. Paris, Du Pont, l'an VII de la République [1799] $8 \mathrm{v}$.

$$
\text { 8-1030 E164.L3 }
$$

4268. Travels through the United States of North America, the country of the Iroquois, and Upper Canada, in the years 1795, 1796, and 1797 ; with an authentic account of Lower Canada. London, R. Phillips, 1799. 2 v. $\quad$ 1-24772 Ei64.L33

Translated by $H$. Neuman.

\section{1795-1797. ISAAC WELD (1774-1856)}

Isaac Weld, Jr., was barely of age when he came from Ireland to America to inquire whether it could furnish an eligible and agreeable place of refuge from the convulsions of Europe. He spent a year and two or three months here, but a good half of his book is devoted to an extended tour of Canada. It is provided with some very competent illustrations from his own pencil. While he did not enter New England, or go further South than the Great Dismal Swamp, he has faithful descriptions of travel in the back country of Virginia, Pennsylvania, and New York. He is not contemptuous or malicious, but he found the conditions of life harsh and manners crude, and he left this continent "without a sigh, and without entertaining the slightest wish to revisit it." His book went through four editions by 1800 , was reprinted as late as 1807 , and was translated into French, Italian, Dutch, and German.

4270. Travels through the states of North America, and the provinces of Upper and Lower Canada, during the years 1795, 1796, and 1797 . London, J. Stockdale, i799. xxiv, $464 \mathrm{p}$.

$$
\text { 5-20874 Er64. } \mathrm{W}_{44}
$$

\section{1796-1815. TIMOTHY DWIGHT (1752- 1817)}

Dwight, New England clergyman, theologian, and poet, was chosen president of Yale College in I 795. For the preservation of his health, he devoted the autumn vacations to a regular course of traveling, and began taking notes which he wrote up at considerable length on his return to New Haven, in order that those who lived eighty or a hundred years later might know what had been the appearance of their country. New York he included in his observations as a majority of its inhabitants were derived from New England, and the rest intimately connected there by business, and other attachments. President Dwight was a most objective traveler, and a mighty purveyor of information; along with his topography, economic data, and descriptions of scenery, he gives many passages of local history and biographical sketches of local worthies. There are, he is careful to explain, no adventures, which "must be very rare in a country perfectly quiet, and orderly in its State of Society" - "I have not met with one." He continued his autumn tours through 1815 , after which they were suspended by the collapse of his health. His manuscripts were put through the press by his sons Timothy and William T. Dwight; to the travels proper, in volume 4 , they have added a number of dissertations, on the errors of European travelers, and on the language, learning, religion, manufactures, etc., of New England.

4272. Travels in New England and New York. New Haven, T. Dwight, I82I-22. 4 v.

I-7597 F8.D99

\section{1799-1802. JOHN DAVIS (1774-1854)}

Davis had been a wanderer since the age of I I when he came to America at 24 , and led the life of an itinerant schoolmaster and tutor up and down the Eastern seaboard from New York to Charleston. Since he did much of his journeying on foot, and conversed with every sort and condition of person from Aaron Burr to the Negro slave Dick, and since impecuniousness never affected his good nature, his book is full of bright glimpses of everyday life from angles which other travelers rarely attained. He had the experience of being refused a job by Secretary Gallatin, and he presents the first romantic version of the Pocahontas legend.

4274. Travels of four years and a half in the United States of America; during 1798, 1799, 1800, I801, and 1802. London, T. Ostell, 1803. $454 \mathrm{p}$. I-24800 Er64.D26

4275. With an introd. and notes by A. J. Morrison. New York, Holt, 1909. 429 p. 9-35909 E164.D28

\section{1802. FRANÇOIS ANDRÉ MICHAUX (1770-1855)}

Michaux was, like his father, a distinguished French botanist and came to the United States under 
the auspices of the Minister of the Interior, although apparently on a very limited budget. $\mathrm{He}$ was in this country for over 16 months, $180 \mathrm{r}-03$, but the western journey which is the main theme of his book occupied less than four months in the summer of 1802 . From Philadelphia he went by stage to Shippensburg, Pa., and from there to Pittsburgh he shared a horse with an army officer. He went down the Ohio in a dug-out canoe, and overland to Lexington, Ky., on foot. For the rest of his journey, to Nashville, and back through the Carolinas to Charleston, he had his own horse. His primary concerns were useful plants and the state of agriculture, but he also noted stockbreeding, manufactures, wages, the economy in general, and any cultivation of scientific interests. He had not intended to write up his travels and lamented his failure to record innumerable details which would have added to the interest of his narrative, which, however, is businesslike and informative.

4277. Voyage à l'ouest des Monts Alléghanys, dans les états de l'Ohio, du Kentucky, et du Tennessée, et retour à Charleston par les Hautes-Carolines, entrepris pendent l'an X-1802, sous les auspices de son excellence, M. Chaptal, Ministre de l'intérieur. Paris, Levrault, Schoell, 1804. 3I2 p.

$$
\text { I-24797 EI64.M62 }
$$

4278. Travels to the westward of the Allegany Mountains, in the states of the Ohio, Kentucky, and Tennessee, and return to Charlestown, through the upper Carolinas. Undertaken in the year $\mathrm{x}, \mathrm{1802}$, under the auspices of His Excellency M. Chaptal, minister of the interior. Faithfully translated from the original French, by B. Lambert. London, J. Mawman, I805. xvi, $35^{\circ} \mathrm{p}$.

$$
\text { I-24798 Er64.M63 }
$$

\section{I805-1812. SIR AUGUSTUS JOHN FOSTER, BART. (178o-1848)}

Foster, an English career diplomat with extensive connections in the aristocracy, spent three years in Washington as Secretary of Legation in 1805-08, and returned as Minister for a year's stay preceding the outbreak of the War of 1812 . During the summers he traveled into the valley of Virginia, and northward along the Atlantic seaboard. When English books of American travel became abundant and controversial, Foster began to work up his old notebooks into a book on the United States, but only a few excerpts were published during his lifetime. Foster's position gave him exceptional opportunities for knowing and describing the society of the capital and of the larger planters in its neighborhood. While he found Pennsylvania democracy quite uncongenial, he was highly appreciative of the settled communities of Long Island and New England. Much of his effort is wasted in an attempt to demonstrate that the respectable part of the American people is of English stock.

4280. Jeffersonian America: notes on the United States of America, collected in the years I805-6-7 and $11-12$. Edited with an introd. by Richard Beale Davis. San Marino, Calif., Huntington Library, 1954. $\mathrm{xx}, 356 \mathrm{p}$.

$$
\text { 54-8926 EI64.F76 }
$$

1954

\section{1807-1808. CHRISTIAN SCHULTZ}

Christian Schultz, Jr., was a young New Yorker who wished to visit Niagara and the great rivers of the West, and who, provoked at finding no information on record useful to would-be travelers, undertook to provide it himself. He therefore became the most systematic of travelers, reckoning the miles between towns and other landmarks, taking latitude and longitude at intervals, and compiling this into a preliminary 6-page Table of Distances. He furnishes precise information on the mode of traveling, the price of freights and other expenses, the time required, and the risks and dangers of the road. He claimed for himself only the merits of minuteness and fidelity, but in fact he is a straightforward reporter whose method and scope improve as he proceeds and his work, far from being a mere guidebook, is a neglected classic of American travel. He presents a complete picture of the keelboat age in the West as it affected the uncommercial traveler. At Pittsburgh he purchased a completely equipped Kentucky boat for \$130, and when this was destroyed by driftwood at the mouth of the Ohio, he had to pay $\$ 150$ for a New Orleans boat, which would have cost only half as much at Pittsburgh-and it had a leaky roof. $\mathrm{He}$ advanced part of their wages to two of his boatmen, only to have each decamp at the first good opportunity. He gives one of the few glimpses of the society of the French settlements in Missouri, where he was compelled to winter by ice in the Mississippi, and where, he thought, eternal dancing and gambling absorbed the inhabitants. His pictures of boating life on the Mississippi and of the waterfront life of Natchez recall the later work of Mark Twain.

4282. Travels on an inland voyage through the States of New-York, Pennsylvania, Virginia, Ohio, Kentucky and Tennessee, and through the territories of Indiana, Louisiana, Mississippi, and 
New-Orleans; performed in the years 1807 and 1808 ; including a tour of nearly six thousand miles. New-York, Isaac Riley, r8 ro. 2 v. in r.

$$
\text { I }-247^{89} \quad \mathrm{E}_{1} 64 . \mathrm{S}_{39}
$$

\section{1814-1819. HENRY COGSWELL KNIGHT (1788-1835)}

Knight was a New England minor poet, M. A. of Brown University, who spent some five years in the remoter regions of his own country, presumably being engaged as tutor by well-to-do planters. He summed up his experiences in six polished epistles to his brother, full of literary allusions and quaint turns of phrase, written from Philadelphia, Washington, Virginia, Kentucky, New Orleans, and the packet ship making the return voyage through the Gulf of Mexico. Knight, if a conventional poet, was highly sensitive to sectional differences in landscape, manners, speech, and artifacts, and his letters give vivid impressions of these contrasting locales. His New England viewpoint asserts itself from time to time, but not to any excessive or ill-natured degree; he occasionally deplores, but never denounces.

4284. Letters from the South and West; by Arthur Singleton, esq. [pseud.] Boston, Published by Richardson \& Lord, J. H. A. Frost, printer, 1824 . I59 p. I-21522 $\mathrm{E}_{213 . \mathrm{K} 69}$

4285. I8I6-I8I7. FRANCIS HALL (d. I833)

Francis Hall was a lieutenant of the $14^{\text {th }}$ Light Dragoons, who rose to the rank of colonel a few years later. From New York City he went north and made a tour of Canada before swinging back through backwoods New York and Pennsylvania to Philadelphia, and thence southward to Charleston, the whole journey filling almost one year. These objective and fact-filled pages are free of the least trace of bitterness from the war which had terminated barely a year earlier. Lieutenant Hall took a cheerful view of the minds, manners, morals, and prospects of ordinary Americans, and found the high point of his journey in his visit to the philosopher of Monticello.

4286. Travels in Canada and the United States, in I816 and I817. London, Longman, Hurst,

Rees, Orme, \& Brown, 1818. 543 p.

$$
\text { I-26822 Er65.Hig }
$$

4287. Boston, Republished from the London ed. by Wells \& Lilly, I818. 332 p. I-26824 Er65.Higr
4288. 1816-1817. BARON DE MONTLEZUN

This anonymous work is attributed to a Baron de Montlezun. The author represents himself as a veteran of the American War of Independence, who saw Washington at the siege of Yorktown. There was a Barthélemi-Sernin du Moulin de Montlezun de la Barthelle (b. 1762 ) in the Regiment of Touraine which fought there. The author went from Norfolk to New York, with a visit to Montpelier and Monticello, sailed to New Orleans, where he remained over a month, and on his return from Cuba spent three weeks at Charleston. A French Royalist, he is utterly scornful of the United States and its government, its cities and their people. Oddly enough, this contemptuous attitude does not interfere with much sharp observation and accurate description, or with an appreciation of the American "gentlemen" whom he met along his way-although he insisted that they were a very small minority.

4289. Voyage fait dans les années 1816 et I 817 , de New Yorck à la Nouvelle-Orleans, et de l'Orénoque au Mississippi; par les Petites et les Grandes-Antilles, contenant des détails absolument nouveaux sur ces contrées; des portraits de personnages influant dans les États-Unis, et des anecdotes sur les réfugiés qui y sont établis; par l'auteur des Souvenirs des Antilles. Paris, Gide fils, 1818. 2 v. 2-368-M2 Er65.M $_{7} 8$

\section{I818-1820. FRANCES (WRIGHT) D'ARUSMONT (1795-1852)}

The celebrated Fanny Wright on her first visit to America; she returned in 1824 and from 1829 lived in New York, and for two decades was a lecturer on behalf of feminism and other reforms. Her route on this occasion was largely a circle to Niagara, through Canada and Vermont, and southward to Washington; she pens a general social commentary in her letters from New York City. In her early outlook, America is a land of liberty and republican simplicity, a glowing contrast to the Old World.

4291. Views of society and manners in America; in a series of letters from that country to a friend in England, during the years 1818,1819 , and 1820. By an Englishwoman. London, Longman, Hurst, Rees, Orme, \& Brown, 1821. 523 p.

$$
\text { 2-9930 Ei65.D22 }
$$

4292. - From the ist London ed. with additions and corrections by the author. New York, E. Bliss \& E. White, 1821. 387 p.

$$
\text { 2-9929 E165.D23 }
$$


4293. 1823-1830. PRINCE ACHILLE MURAT (180I-1847)

This nephew of Napoleon Bonaparte and sometime Prince Royal of the Two Sicilies lived in America from 1823-30, when he returned to Europe in the hope that the Bonapartist cause might profit from the revolutions of that year. Meanwhile he had married an American wife and acquired a plantation near Tallahassee. The first four of the letters to Count Thibeaudau [sic; the usual form of the name is Thibaudeau] which compose this volume were written from Florida; they were published in 1830 as Lettres sur les Etats-Unis. The remaining six were written during his sojourn in Europe. Murat, a professed republican, presented American ways and institutions as models for European imitation, defending slavery as a tolerable and inevitable condition. His third letter, "Description des nouveaux établissemens," is a remarkable panorama of the successive stages of civilization in frontier areas. The story of Murat's life in America is reconstructed in Alfred J. Hanna's $A$ Prince in Their Midst (Norman, University of Oklahoma Press, 1946. $275 \mathrm{p})$.

4294. Esquisse morale et politique des États-Unis de l'Amérique du Nord. Paris, Crochard, 1832. xxvii, $389 \mathrm{p}$. 2-370 Ei65.M94

4295. A moral and political sketch of the United States of North America. With a Note on Negro slavery, by Junius Redivivus [pseud. of W. B. Adams] London, E. Wilson, 1833 . xxxix, $402 \mathrm{p}$. 3-18833 EI65.M95

4296. America and the Americans. Translated from the French and edited by H. J. S. Bradfield. New York, W. H. Graham, 1849. 260 p. 2-371 E165.M952

4297. 1825-1 826. BERNHARD KARL, DUKE OF SAXE-WEIMAR-EISENACH (I7921862)

The Duke of Saxe-Weimar was in command of the Dutch army and obtained leave of absence from the King of the Netherlands in order to fulfill a desire of his youth when he came to America in the summer of 1825 . He spent nearly eleven months in traversing the East from Boston to Charleston, and in making the great Southern circuit by New Orleans, St. Charles, Mo., and back by way of Pittsburgh. He had traveled over 7,135 miles when he wrote: "To my great and sincere regret, the hour at length arrived when I was constrained to leave this happy and prosperous land, in which I had seen and learned so much, and in which much more still remained to be seen and learned: sed fata trahunt homineml' 'The Duke, of course, met the best people in all parts of the country, especially resident foreigners of distinction.

4298. Reise Sr. Hoheit des Herzogs Bernhard zu Sachsen-Weimar-Eisenach durch NordAmerika in den Jahren 1825 und 1826 . Hrsg. von Heinrich Luden. Weimar, W. Hoffmann, 1828. $2 \mathrm{v}$. in $\mathrm{I}$. I-28054 EI65.B52

4299. Travels through North America, during the years 1825 and 1826 . Philadelphia, Carey, Lea, \& Carey, 1828.2 v. in I. ${ }_{2-356}$ Er65.B53

4300. 1827-1828. BASIL HALL (1788-1844)

Captain Hall of Edinburgh was a retired naval officer, a veteran of the Napoleonic wars who had traveled widely after their conclusion. During more than 13 months in America, he made a considerable tour of Upper Canada, and went from Boston to Savannah, and thence overland to New Orleans. He wrote little concerning his return by way of the Mississippi and Ohio Rivers. Capt. Hall was the first Briton to arouse the ire of the Americans as a betrayer of their hospitality, and substantial replies to his book were penned by Richard Biddle and Calvin Colton. He is indeed consistently critical, but his criticism all springs from his conviction that democracy is an inferior form of government and society; he argues his case at some length and is quite free from the irritability and captiousness which mark many of his successors. The letters of his wife, Margaret Hunter Hall (I7991876), have been edited by Una Pope-Hennessy: The Aristocratic Journey; Being the Outspoken Let. ters of Mrs. Basil Hall Written auring a Fourteen Month' Sojourn in America (New York, Putnam, 1931. 308 p.) Forty drawings which Capt. Hall made with the "camera lucida" were etched and published separately.

4301. Travels in North America in the years 1827 and 1828. Edinburgh, Cadell; London, Simpkin \& Marshall, $1829.3 \mathrm{v}$.

$$
\text { I-26817 EI65.HI7 }
$$

4302. Philadelphia, Carey, Lea, \& Carey, I829. 2 v. I-26818 EI65.HI7I

4303. 1827-1831. FRANCES (MILTON) TROLLOPE (1780-1863)

Mrs. Trollope came from England via New Orleans in order to set up a store for imported 
merchandise at Cincinnati and so recoup the family fortunes. She spent nearly four years in America, I827-3I, of which a little more than two were in Cincinnati. Cincinnati she would have liked much better if the people had not dealt so very largely in hogs, and the trouble with America was the want of refinement. Her strictures on their deportment succeeded in making Americans angrier than any foreign observer before or since, but Mark Twain thought that she was merely telling the truth. Mr. Smalley's introduction to his edition gives a complete and scholarly narrative of her American venture.

4304. Domestic manners of the Americans. London, Whittaker, Treacher, $1832.2 \mathrm{v}$.

$$
\text { 2-396 } \mathrm{E}_{16} 6_{5} \mathrm{~T} 8_{4}
$$

4305. London, Whittaker, Treacher; New York, Reprinted for the booksellers, 1832. 325 p. I6-25372 EI65.T842

4306. - Edited, with a history of Mrs. Trollope's adventures in America, by Donald A. Smalley. New York, Knopf, 1949. lxxxiii, 454,

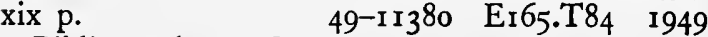

Bibliography: p. [444]-454.

\section{1832-1834. MAXIMILIAN ALEXAN DER PHILIPP, PRINZ VON WIED. NEUWIED ( $1782-1867)$}

This German princeling had already traveled in South America when he essayed the North American wilderness at the age of 5o. He crossed the continent from Boston to St. Louis and ascended the Missouri River to Fort Mackenzie, making considerable stays at Fort Union, and wintering at Fort Clarke. His interests are those of a naturalist and especially an anthropologist; he tells all he could learn of the way of life of the northwestern Indians and recreates the life of these outposts of the fur trade. He was accompanied by the artist Carl Bodmer, whose 8I "elaborately colored plates" form one of the great attractions of the original publication.

4308. Reise in das innere Nord-America in den Jahren 1832 bis 1834 . Coblenz, J. Hoelscher, $1839-4 \mathrm{I} .2 \mathrm{v}$. and atlas. 2-5381 EI65.W64

4309. Travels in the interior of North America. Translated from the German, by Hannibal Evans Lloyd. London, Ackermann, 1843. 520 p. 2-5382 Ei65.W65

The appendix on Indian languages and some matters of detail are omitted in the translation.
4310. 1833-1834. EDWARD STRUTT ABDY (I79I-I 846 )

This fellow of Jesus College, Cambridge, was an intensive rather than an extensive traveler, but he went southwestward into the valley of Virginia, and thence into Kentucky and to Cincinnati. He accompanied a British commissioner charged with investigating American prisons, and his earlier chapters have a strong "social science" interest: he reports very objectively on prisons, hospitals, orphanages and homes for juvenile offenders, schools, poorhouses, asylums for the insane and the deaf and dumb, and on wages, labor disputes, and strikes. However, his narrative soon develops an obsession with the Negro problem, and he heatedly assails, not merely slavery, but the "aristocracy of the skin" in general, so that he is equally condemnatory of the treatment of the free Negro in the North, and he tilts regularly against the American Colonization Society.

431 I. Journal of a residence and tour in the United States of North America, from April 1833 to October I834. London, J. Murray, 1835. 3 v. ${ }_{1-26} 63^{8}$ Er65.Ar3

\section{I833-1835. MICHEL CHEVALIER (1806-1879)}

Chevalier was one of the early French socialists and a publicist of great reputation in his own day. Sent by the French Ministry of the Interior to study American internal improvements, he spent nearly two years here. While most of his chapters are general discussions of aspects of society and public affairs, he devotes separate descriptions to Lowell, Mass., and its factory girls, Pittsburgh, Cincinnati and its hog-slaughtering, and the watering-place of Bedford Springs, $\mathrm{Pa}$. He is acute, philosophical, and critical without being hostile, and makes frequent comparisons of American with European society. A long chapter on intercommunications, surveying the canal and railroad systems built or in progress, reflects his original purpose.

4313. Lettres sur l'Amérique du Nord. 3. éd. rev., corr., augm. de plusiers chapitres et d'une table raisonnée des matières. Paris, C. Gosselin, I838. $2 \mathrm{v}$. II-22310 Ei65. 553

4314. Society, manners and politics in the United States; being - a series of letters on North America. Translated from the $3 \mathrm{~d}$ Paris ed. by Thomas Gamaliel Bradford. Boston, Weeks, Jordan, I839. $467 \mathrm{p}$. 
4315. 1834-1836. HARRIET MARTINEAU (1802-1876)

Miss Martineau was a frail English gentlewoman who had just emerged from impecunious obscurity and become a literary lioness, by means of her 9 volume Illustrations of Political Economy, an odd mixture of fiction and classical economic theory. She undertook to recuperate from her literary labors by travels in the United States, which lasted nearly two years, and included two western tours, one by way of New Orleans and one by way of the lake cities, with a winter in Boston between them. The first product of her visit, Society in America, is an extended moral assessment, topic by topic: politics and economics, the "idea of honour," women, children, sufferers, "utterance," and religion, with incidents from her travels introduced as illustrations under the appropriate heading. She concluded that "the civilization and the morals of the Americans fall below their own principles," as would any other subjected to so intense a spinsterly scrutiny. At the request of her publishers, she made further drafts upon her journals for her Retrospect of Western Travel, which aimed "to communicate more of my personal narrative, and of the lighter characteristics of men, and incidents of travel" than the first. It won a greater popular success, and should best be read before Society in Anzerica.

4316. Society in America. London, Saunders \& Otley, 1837. 3 v. $\quad$ I-2789o EI65.M 39

4317. - New York, Saunders \& Otley, 1837. $2 \mathrm{v}$ NNC

4318. Retrospect of western travel. London, Saunders \& Otley, $1838 . \quad 3 \mathrm{v}$.

$$
\text { 37-15429 Ei65.M379 }
$$

4319. London, Saunders \& Otley; New York, Sold by Harper, 1838.2 v. I-27893 $\mathrm{E}_{165 . \mathrm{M}_{3} 8}$

4320. 1835,1859 . RICHARD COBDEN ( $1804-$ 1865)

Cobden made two visits to the United States, the first in 1835 , before winning fame as the leader of the English radicals, and the-second in 1859 . On the first he went from New York to Pittsburgh and back to Boston; on the second he represented British investors in the Illinois Central Railroad and traveled extensively over its routes in private cars. During the first journey he was impressed by American technological and industrial enterprise; on the second he described the life of settlers on the western prairie and, with enthusiasm, the new free public schools.

4321. American diaries; edited, with an introd. and notes, by Elizabeth Hoon Cawley. Princeton, Princeton University Press. 1952. xii, $233 \mathrm{p}$. 52-5850 E166.C6

The manuscripts of the two diaries are in the British Museum (Add. mss. 43807 and 43808).

Bibliography: p. 221-224.

\section{1836. E.DMUND FLAGG (1815-189o)}

In the summer of 1836 this young Bowdoin graduate undertook a ramble over the prairies, "in the hope of renovating the energies of a shattered constitution." He sent in a series of travel sketches to the Louisville Journal and during the next year substantially reworked them for publication in book form. His "Far West" is not very far; he went by steamboat from Louisville to St. Louis, and thence up the Illinois River to Peoria. He transferred to horseback and rode in leisurely manner over the prairies of central Illinois as far as Decatur. He was of a literary and sentimental bent, and his style is often artificial and turgid. However, he rode with a mind open to the natural beauties and historical associations of the region, and so produced a very different kind of travel book from the majority of his contemporaries.

4323. The Far West: or, A tour beyond the mountains. Embracing outlines of western life and scenery; sketches of the prairies, rivers, ancient mounds, early settlements of the French, etc. New York, Harper, 1838. 2 v. $\quad$ I-870I F $_{353} \cdot F_{57}$

\section{1837-1838. FREDERICK MARRYAT (1792-1848)}

Captain Marryat, a British naval officer who had won sudden fame by his novels of seafaring life, came to America in May 1837 and traveled extensively in the Northeast and Northwest for about a year. He crossed Wisconsin from Green Bay, went up the Mississippi to Fort Snelling, and returned by the Ohio to the hot springs of Virginia. His object, he tells us, was "to ascertain what were the effects of a democratic form of government and climate upon a people which, with all its foreign admixture, may still be considered as English." These effects, it becomes evident after a few pages, were exclusively degenerative in nature: "The scum is uppermost ... The prudent, the enlightened, the wise, and the good, have all retired into the shade, preferring to pass a life of quiet retirement, rather than submit to the insolence and dictation 
of a mob." Marryat is the archetype of the irascible High Tory at large, resenting every intrusion upon his privacy, and ascribing every contretemps along his way to some sinister operation of the democratic principle. The diary comes to an end two-thirds of the way through the second volume of the first series, and the remaining volumes are filled with a series of topical essays on a variety of subjects.

4325. A diary in America, with remarks on its institutions. London, Longman, Orme, Brown, Green, \& Longmans, 1839.3 v.

First series.

$$
\text { 2-359 Ei65.M35 }
$$

4326. Philadelphia, Carey \& Hart, 1839. 2 v. $\quad \mathrm{I}-28313 \quad \mathrm{E}^{2} 65 \cdot \mathrm{M}_{3} 6_{4}$

4327. A diary in America, with remarks on its institutions. Part second. London, Longman, Orme, Brown, Green, \& Longmans, 1839. $3 \mathrm{v}$. I-28044 Ei65.M37

4328. Second series of a diary in America, with remarks on its institutions. Philadelphia, T.K. \& P. G. Collins, 1840.300 p.

$$
\text { I-28045 EI65.M375 }
$$

An appendix, "Discourse on the Evidences of the American Indians Being the Descendants of the Lost Tribes of Israel," is omitted from the American reprint.

\section{1837-1840. JAMES SILK BUCKING- HAM (1786-1855)}

Buckingham was an English ex-seaman, journalist, M. P., temperance and miscellaneous reformer and lecturer, and professional traveler. His second and third tours in America were guaranteed by a considerable subscription list. The original publication, America, covers the larger cities of the middle eastern seaboard, with a trip to Niagara via Albany. On his southern journey he went overland from Charleston to New Orleans and returned by a more northerly route which took him to the Virginia hot springs. In the final tour he visited New England and then went to St. Louis by way of Cincinnati, returning by the then novel route of the lake cities, Chicago, Milwaukee, Detroit, and Cleveland. Buckingham is the most indefatigable and encyclopedic of the English travelers, who aimed at producing a strictly impartial account, and deliberately gave more history, topography, "productions," and statistics in order to balance the usual concentration on manners. Viscount Morpeth praised his first two series as "most useful and satisfactory Guides and Text-Books," and Buckingham prefixed his letter to the third series.
4330. America, historical, statistic, and descriptive. London, Fisher, 1841 . 3 v.

$$
\text { I-26750 Er65.B92 }
$$

$433 \mathrm{I}$.

$$
\text { New York, Harper, 1841. } 2 \text { v. }
$$

4332. The eastern and western states of America. London, Fisher, $1842.3 \mathrm{v}$.

$$
\text { I-26752 EI65.B94 }
$$

4333. The slave states of America. London,

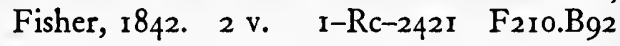

\section{1839-1846. THOMAS COLLEY \\ GRATTAN (1792-1864)}

Grattan was an Irishman who resided on the Continent for over 20 years, during which he acquired some literary reputation and the favor of the King of the Belgians. The latter was at least in part responsible for his appointment as British Consul at Boston, where he resided from I839-46. "Civilized America," it appears from the map in the first volume, consisted of the states of the eastern seaboard; the more westerly ones are divided into two degrees of rawness. The United States under its Constitution, Grattan thought, was "better adapted than any country on earth for securing the greatest amount of good to the greatest number of mankind," but far less so for the cultivation of the higher degrees of human excellence. In spite of his own considerable success as a public speaker, Grattan found life at Boston increasingly distasteful, and his topical chapters speedily turn into homilies on the deficiencies of American character and achievement. They reflect, however, an acquaintance both wide and intimate with the public life and public men of the 1840 's.

4335. Civilized America. London, Bradbury \& Evans, 1859. 2 v. 2-24I6 EI66.G8I

\section{1841-1846. SIR CHARLES LYELL (I $797-1875)$}

Lyell was the leading geologist of his day and a principal founder of the modern science. He traveled in the United States for over 10 months in $1841-42$, and for over eight months in $1845-46$. On both tours he traversed the Atlantic seaboard; on the first he went to Cincinnati and Cleveland; on the second he made the grand circuit through the lower South and up the Mississippi and the Ohio. Geology is, of course, his primary interest, and his books have much technical data and many diagrams. But his professional interests have wide 
relationships: he analyzes such standard American showpieces as Niagara, the Great Dismal Swamp, and the Big Bone Lick; he meets American geologists in various parts of the country; he delivers a series of Lowell lectures in Boston and later attends the third annual meeting of the Association of American Geologists there; he describes coalfields and the manner of their exploitation, etc. He is, in general, a cool, inteiligent, and scientifically detached observer. He observes that the English travelers, in general, compare the manners of a lower social class abroad with those of a higher one at home; and he perceives that slavery is a very complex problem, admitting of no simple, easy, or rapid solution.

4337. Travels in North America; with geological observations on the United States, Canada, and Nova Scotia. London, J. Murray, I845. 2 v. I-26862 Ex65.L97

4338. Travels in North America, in the years I84I-2; with geological observations on the United States, Canada, and Nova Scotia. New York, Wiley \& Putnam, 1845. 2 v. in I.

$$
\text { I-26864 Ex65.L974 }
$$

4339. A second visit to the United States of North America. London, J. Murray, r849. 2 v. I-26865 E.65.L.98

4340. New York, Harper; London, J. Murray, 1849. 2 v. I-26866 Ei65.L982

434 . 1842. CHARLES DICKENS (1812-1870)

Dickens celebrated his 3 oth birthday during the four and a half months he spent in America during the first half of $x 842$; he was already a novelist of the first fame, and his progress was a series of ovations. He traveled from Boston to Richmond, where he decided he had seen enough of slavery, and then went by canal boat to Pittsburgh and by steamboat to St. Louis, returning to New York via Niagara and Quebec. Dickens' emotional nature sees only black or white, and after glowing pictures of the philanthropic institutions of New England and the factory misses of Lowell, the scene promptly becomes and remains black. His concluding remarks lecture the Americans upon their attitude of suspicion, their tolerance of sharp practice, and that "monster of depravity," their press. Dickens' distaste for American life received further expression in the satire of Martin Chuzzlewit ( 1843 ). Many of his letters written during the tour are printed in the first volume of John Forster's biography (London, Chapman \& Hall, 1872 ).
4342. American notes for general circulation. London, Chapman \& Hall, r842. 2 v. 22-2285I Ex65.D53

4343. American notes and Pictures from Italy. London, Dent; New York, Dutton, 1926. xxii, 430 p. (Everyman's library, ed. by Ernest Rhys [no. 290] ) 36-37248 ACr.E8, no. 290 "First issue of this edition, r908; reprinted ... 1926."

Introduction by G. K. Chesterton.

\section{I846-1847. ALEXANDER MACKAY (1806-1852)}

Alexander Mackay, a Scot who had lived in Canada, came to the United States in 1846 to report the Oregon crisis for the London Morning Chronicle, and supplemented his long residence at Washington by a grand circuit tour via the Mississippi and Ohio Rivers. Of his three volumes, the first covers the East, the second the South, and the third the West, but each includes chapters on general topics suggested by the local circumstances. The whole is the most comprehensive report on the United States made by an Englishman before James Bryce. The tone, while critical on occasion, is eminently fair and discriminating; thus the author points out that the best of the South lies in its domestic, indoor life, quite unknown to those travelers who "were but depicting life as they saw it in the railway carriage, on the steamer, and in the bar-room." The book is dedicated to Richard Cobden, and America, Mackay says, "is the country for the industrious and hard-working man."

4345. The western world; or, Travels in the United States in 1846-47: exhibiting them in their latest development, social, political, and industrial; including a chapter on California. $2 \mathrm{~d}$ ed. London, R. Bentley, I849. 3 v. 5-3686r EI66.MI5

4346. From the $2 \mathrm{~d}$ London ed. Philadelphia, Lea \& Blanchard, 1849.2 v.

8-2679 Er66.Mr52

4347. $\begin{gathered}\text { 1847-1848. OLE MUNCH RÆDER } \\ (1815-1895)\end{gathered}$

Ole M. Ræder was a Norwegian lawyer and civil servant sent abroad to study foreign methods of legal procedure, who produced a massive report on the jury system in Britain and America. He was in the United States for over a year and spent much of it in the frontier settlements of Norwegian immigrants in Wisconsin. His letters home are here collected from their original newspaper publica- 
tion, or from unpublished manuscripts. His report on the frontier Norwegians, their situation as compared with what it had been at home, and their relations with their American neighbors, supply the central interest of a special type of traveler's narrative.

4348. America in the forties; the letters of Ole Munch Ræder, translated and edited by Gunnar J. Malmin. Minneapolis, University of Minnesota Press, 1929. xxi, 244 p. (Norwegian-American Historical Association. [Publications] Travel and description series, v. 3)

$$
\text { 29-28792 E1 } 84 . \mathrm{S}_{2} \mathrm{~N}_{3}, \text { v. } 3
$$

The Norwegian letters were originally published in Den Norske Rigstidende, a Christiania newspaper, in 25 installments from November 6, 1847 , to July 3,1848 .

\section{1848. JOHN LEWIS PEYTON (1824- 1896)}

Peyton was a young lawyer of Staunton,. Va., who, after a severe illness, was advised by his physician to "take a few months' run across the Alleghanies and among the northern lakes." This he did, from June 26-December 17,1848 , and went across Ohio to Sandusky, where he took a lake steamboat as far as Fond du Lac at the western end of Lake Superior. His narrative illuminates the hazards of western transportation at this period, for after a race his river steamboat blows up, and he gets to land by the help of a floating chair; his stagecoach breaks down in mid-Ohio, and he carries his trunk on his shoulder for 25 miles. A well-connected young Virginian, he is able to meet such nutables of the region as Henry Clay, John C. Crittenden, Lewis Cass, and Edward Bates. From Fond du Lac he crosses the wilderness to St. Paul, and sees Indian life at first hand. Peyton prepared his journals for publication in Britain, where he had represented the State of North Carolina during the Civil War, and where he remained for eleven years after its close.

4350. Over the Alleghanies and across the prairies. Personal recollections of the Far West, one and twenty years ago. London, Simpkin, Marshall, 1869. xvi, $377 \mathrm{p}$. I-8714 Er66.P48

\section{1849. BAYARD TAYLOR (1825-1878)}

Taylor, one of the most prominent literary figures of his generation, was still a journalist in the employ of the New York Tribune when Horace Greeley sent him to report the California Gold Rush in June r849. He went via the Isthmus of
Panama to San Francisco, roamed at length among the diggings, attended the State Constitutional Convention at Monterey, and on his return made an extremely hazardous crossing of Mexico from Mazatlan to Vera Cruz. As Taylor says, "The condition of California during the latter half of the year 1849 was as transitory as it was marvellous; the records which were then made can never be made again." The fortunate chance which brought a writer of real descriptive power on the scene resulted in a book of immediate popularity, which has remained a minor classic.

4352. Eldorado, or, Adventures in the path of empire; comprising a voyage to California, via Panama, life in San Francisco and Monterey, pictures of the gold region, and experiences of Mexican travel. 2d ed. New York, Putnam, 1850. 2 v. in $I$. I-Rc-822 F865.T23

4353. _- Introd. by Robert Glass Cleland. New York, Knopf, 1949. xxvii, 375 p. (Western Americana, planned in connection with California's centenary celebrations, 1946-50)

$$
\text { 49-IIIIO F865.T24 } 1949
$$

\section{1849-1851. FREDRIKA BREMER (1801- 1865)}

Fredricka Bremer was Sweden's first woman of letters and first prominent novelist, whose tales of domestic life, at once realistic and sentimental, won her an international reputation during the I830's. She spent nearly two years in America, and went in the East from Boston to Savannah, and in the West from St. Paul to New Orleans, with long residences in several parts of the Union. Her title is justified: she saw many American homes from the inside, and her leisurely, kindly, and often longwinded book affords an exceptionally intimate and domestic view. Hawthorne thought her "worthy of being the maiden aunt of the whole human race." Benson supplies an informative introduction, but his selections by no means exhaust the interest of the complete book.

4355. Hemmen i den Nya Verlden. En dagbok i bref, skrifna under tvenne års resor i Norra Amerika och på Cuba. Stockholm, P. A. Norstedt, 1853-54. $3 \mathrm{v}$. 2-2878 $\mathrm{E}_{1} 66 . \mathrm{B} 83$

4356. The homes of the New World; impressions of America. Translated by Mary Howitt. New York, Harper, I853. 2 v. 2-2879 Er66.B84

4357. America of the fifties: letters of Fredrika Bremer, selected and edited by Adolph B. 
Benson. New York, The American-Scandinavian Foundation, I924. xx, 344 p. (Scandinavian classics, v. 23) 25-26021 Ei66.B837

Selections from the preceding.

\section{8. $1851-1852$. JEAN JACQUES ANTOINE AMPÈRE (1800-1864)}

Professor Ampère of the Collège de France and the French Academy was the son of the famous scientist whose name is preserved in electrical terminology, and himself a distinguished classical and medieval scholar. He spent not quite five months in the United States and, in addition to covering the Atlantic seaboard, made a tour of the Northwest by steamboat and railway, marveling at such new, raw, and mushrooming communities as Buffalo and Chicago. In order to leave the country from New Orleans, he went by railroad from Charleston to Montgomery, and by steamboat down the Alabama to Mobile. He paused from time to time to pen little essays on American literature, the temperance movement, the Protestant denominations, etc. He came to America, he said, in order to see something entirely new, and his gracefully written Promenade is the work of an exceedingly intelligent, cultured, judicious, and even-tempered traveler.

4359. Promenade en Amérique; États-UnisCuba-Mexique. Nouv. éd., entièrement rev. Paris, Michel Lévy, 1856. 2 v.

First edition, 1855 .

$$
\text { 20-3056 Ei66.A525 }
$$

4360. 1851-1852. FERENCZ AURELIUS PULSZKY (I8I4-I897); TERÉZIA (WALDER) PULSZKY

Pulszky and his wife shared the exile of Louis Kossuth, the leader of an unsuccessful attempt to win Hungarian independence, and accompanied him on the American tour to which he was invited by a joint resolution of Congress. They arrived in December 1851 and continued their triumphal progress for six months, visiting all the larger cities of the Union, including Cleveland, St. Louis, and New Orleans. Madame Pulszky kept a diary of the tour, the extracts from which are considerably more interesting than her husband's interpolations. She took particular note of the Hungarians and Germans whom they met on the way, and breaks out against "the race-mongers"- the Celts and Gauls, the Latin, Slavonic and Tartar races and nations, "which in Europe are decried as unripe for liberty, become across the Atlantic good republicans, thriv- ing under the freest institutions of the world." In Cincinnati, where Kossuth addressed a gathering of 30,000, the Pulszkys attended a spiritualist seance of the Fox sisters.

436r. White, red, black. Sketches of society in the United States during the visit of their guest [Louis Kossuth] By Francis and Theresa Pulszky. London, Trübner, I853. 3 v. 2-22433 Eı66.P98

4362. White, red, black. Sketches of American society in the United States during the visit of their guests. By Francis and Theresa Pulszky. New York, Redfield, r853. 2 v.

$\mathrm{MB}$

\section{I852-1854. FREDERICK LAW OLMSTED (1822-1903)}

Olmsted was at this time a practical and improving farmer on Staten Island. Having a recurrent debate with one of his closest friends on the subject of slavery, he resolved to tour the South examining the institution as closely as possible, and arranged to report his experiences in letters to The New York Times. His first journey took three months (Dec. 1852-Mar. 1853); his second, from which the second and third publications on Texas and the back country derived, considerably longer (Nov. 1853-Aug. 1854). Olmsted then engaged in much historical, agricultural, and statistical research, and took his time in converting his journals and newspaper articles into the three solid travel books of 1856-60. The Cotton Kingdom was a condensation of the three, with a small proportion of additional material, commissioned by a British publishing house after the outbreak of the Civil War, and largely carried out by a journalist, Daniel R. Goodloe. Dr. Schlesinger's edition of this work includes a scholarly 50-page introduction which puts Olmsted's works in perspective. Olmsted passed from plantation to plantation, obtaining lodgings, engaging in conversation, and making discreet inquiries. His cool, judicious tone and his fairness to individuals strengthen the cumulative effect of this massive indictment of the slave system as a perpetuation of frontier backwardness.

4364. A journey in the seaboard slave states, with remarks on their economy. New York, Dix \& Edwards, 1856. 723 p. $7-35036$ F213.O49

4365. A journey through Texas; or, A saddle-trip on the southwestern frontier; with a statistical appendix. New York, Dix, Edwards, 1857. xxxiv, 516 p. Rc-2560 F391.O5I 
4366. A journey in the back country. New York, Mason Bros., 1860. xvi, 492 p. I-8724 F353.O5I

4367. The cotton kingdom: a traveler's observations on cotton and slavery in the American slave states. Based upon three former volumes of journeys and investigations. New York, Mason Bros., I86r. 2 v.

$\mathrm{Rc}-2428 \quad \mathrm{~F}_{213} \mathrm{O}_{53}$

4368. —_ Edited, with an introd., by Arthur M. Schlesinger. New York, Knopf, 1953. Ixiii, 626, xvi p.

Bibliography: p. $623-626$.

\section{I857-1858. CHARLES MACKAY (I814- 1889)}

Charles Mackay was an English journalist and verse-writer who had won fame by the popularity of the songs for which he had provided lyrics. He came to the United States for a lecture tour that occupied some six months and took him over the grand circuit in reverse: first to St. Louis, thence to New Orleans, and back through the lower South. An unusual feature of this travel book is the inclusion of several verses, such as "Down the Mississipp"," inspired by local circumstances and composed in order to relieve the tedium of long journeys. The author is interested in Americanisms and street nomenclature, and includes a succession of sketches or set pieces on such topics as night life on Broadway, New York fires and fire-fighters, American hotel life, Nicholas Longworth's vineyards near Cincinnati, etc. The second half of volume 2 is devoted to Canada.

4370. Life and liberty in America; or, Sketches of a tour in the United States and Canada in 1857-8. London, Smith, Elder, 1859. 2 v.

$$
\text { 2-22443 EI66.MI7 }
$$

$437 x$ New-York, Harper, 1859. I43 p. 9-15726 Ei66.Mi65

4372. 1859. HORACE GREELEY (18 81 I-I872)

The famous and influential editor of the New York Tribune did not take his own advice and go west until he was 48 . His route, after leaving the railroad, took him through Kansas, across the plains to Denver, and thence north to Salt Lake City. Crossing the mountains into California, he covered the mining and agricultural regions and went to San Francisco only when he was ready to return, nearly four months after leaving home. Greeley regarded his work as quite ephemeral, but it brought the outlook of a thorough-going democrat and egalitarian to this vast area, and was concerned to assess the spread of true civilization. The wildness of the West was distasteful but sure to be ephemeral; the pursuit of gold was little different from gambling. Mormonism was orderly and productive but oriental in its suppression of women; the Chinese in the West acquiesced in discrimination and oppression; and California had a greater future in fruit than in gold. The first of the West's concerns was the completion of a transcontinental railroad.

4373. An overland journey, from New York to San Francisco, in the summer of 1859 . New York, Saxton, Barker, $1860.386 \mathrm{p}$.

$$
\text { Rc-1223 F593.G79 }
$$

\section{I861-1862. ANTHONY TROLLOPE (1815-1882)}

This major Victorian novelist was the son of Mrs. Frances Trollope [no. 4303] and quite conscious that he was following in her footsteps. His stay in the country (Sept. I86I-Mar. I862) coincided with a comparatively quiet interval in the Civil War. He made two journeys into the West, as far as St. Paul the first time, and as Rolla, Mo., the second, visited several military encampments, and spent much time in Boston, New York, and Washington. While much of what he saw, especially in the West, got badly on Trollope's nerves, he made a conscientious effort to be fair, and to think of American society in its own terms. Messrs. Smalley and Booth have a scholarly introduction, notes, and appendices in their edition.

4375. North America. London, Chapman \& Hall, I862. 2 v. 2-4107 EI67.T84

4376. — New York, Harper, 1863. 623 p. 8-268o EI67.T842

4377. - Edited, with an introd., notes, and new materials, by Donald Smalley and Bradford Allen Booth. New York, Knopf, I95I. xxxvii, 555 p. 5I-I 1097 EI67.T843

Bibliography: p. 548-554.

4378. I86r-r862; r88 r. SIR WILLIAM HOW. ARD RUSSELL (1820-1907)

This correspondent of the London Times had established his fame by reporting the Crimean War in dispatches from the front. He came to Washing. ton in March $\mathrm{x} 86 \mathrm{I}$ and, after several weeks of viewing and interviewing, pushed on to Charleston, 
Montgomery, and New Orleans, and returned by way of Chicago in time for the Battle of Bull Run. His report of the Federal rout, unvarnished truth as it was, aroused unwarranted indignation in the North, and led to the termination of his mission as the campaigns of 1862 were about to open. His sketches of and conversations with the leaders on both sides, his evocation of the universal tension and excitement, and his glimpses of the hectic preparations for the great struggle have no counterpart, and have been heavily drawn upon by historians ever since their publication. By comparison, his travel notes of twenty years later, when he visited Arizona, California, and Colorado, are tame and touristic. Fletcher Pratt's edition is a drastic reduction which omits much of interest in the original.

4379. My diary North and South. London, Bradbury \& Evans, 1863. $2 \mathrm{v}$.

$$
\text { I-22502 EI67.Rg6 }
$$

4380. - Boston, T. O. H. P. Burnham, 1863 . xxii, $602 \mathrm{p}$. 32-332I Ei67.R963

4381. — Edited and introduced by Fletcher Pratt. New York, Harper, 1954. xiii, $268 \mathrm{p}$. 54-6027 Ei67.R9635

4382. Hesperothen; notes from the West; a record of a ramble in the United States and Canada in the spring and summer of $\mathrm{I} 88 \mathrm{I}$. London, $\mathrm{S}$. Low, Marston, Searle, \& Rivington, I882. 2 v.

$$
\text { 2-4r30 Ei68.Rg6 }
$$

\section{I865. SAMUEL BOWLES (1826-1878)}

Bowles was proprietor and editor of the Springfield Republican, and one of the most influential journalists of the Republican Party. On the conclusion of the Civil War, he and two other newspapermen accompanied the Speaker of the House, Schuyler Colfax, on a transcontinental tour. From Atchison, Kan., they went by overland stagecoach to Denver, Salt Lake City, and Virginia City, Nev., and from San Francisco north to Victoria, B. C. In Utah Colfax debated polygamy with Brigham Young, and in San Francisco they dined with the Chinese tongs. Bowles describes western scenery with the facility of a veteran journalist, but his major interest lies in mining, irrigation, and all the other sources of potential wealth in the West, which required only the completion of the transcontinental railroad to inaugurate a fabulous national prosperity.
4384. Across the continent: a summer's journey to the Rocky Mountains, the Mormons, and the Pacific States, with Speaker Colfax. Springfield, Mass., S. Bowles, 1865. xx, $452 \mathrm{p}$.

I-Rc-I502 $\mathrm{F}_{594 . B_{7} 6}$

\section{1866-1867. JAMES FOWLER RUSLING (1834-1918)}

General Rusling was sent by the Quartermaster General of the United States Army on a tour of inspection of its western posts, which occupied him for nearly eleven months before he took the homeward steamer from San Francisco in June 1867. He departed from the route of Greeley and Bowles in that he made a large southward loop in the Rockies from Denver to Fort Garland, where he saw General Sherman conclude a treaty with the Utes, and from Salt Lake City he went northwestward through the mushroom town of Boise, not three years old, and via the Columbia River to Portland. He also made a southern tour from Los Angeles to Tucson and Prescott, Arizona Territory, and found little there to please him. The military matters that took him west have no prominence in his narrative, which has a graphic power and a sparkle that would hardly have been anticipated from the circumstances of its origin.

4386. Across America: or, The great West and the Pacific coast. New York, Sheldon, I 874.

503 p. $\quad$ Rc-1535 F594.R94

\section{I893-1894. PAUL CHARLES JOSEPH BOURGET (1852-1935)}

Bourget, well-known as a French novelist and high-class journalist who specialized in psychologie contemporaire, sojourned in America during the year of the World's Fair. The itinerary form has completely disappeared, although there are chapters on life in Newport, the West, and the South; instead there are sections on women, business men, the lower orders, education, and American pleasures, including sport. The book drew a rather ill-natured rejoinder from Mark Twain, but after 60 years it seems a sympathetic and penetrating performance, in far closer touch with its subject than most of its many successors from French pens. M. Bourget found an invaluable lesson for France in the individualism upon which American democracy was founded, and which consisted "in multiplying indefinitely the centres of local activity, and consequently in continuously breaking up, by means of 
548 / A GUIDE TO THE UNITED STATES

localized action, the forces which, massed in groups, would be too powerful."

4388. Outre mer (notes sur l'Amérique) Paris, New York, A. Lemerre, 1895. $2 \mathrm{v}$. 25-12819 Ei66.B76
4389. Outre-mer: impressions of America. New York, Scribner, 1895. $425 \mathrm{p}$.

2-I 497 EI68.B77

This translation first appeared in the New York Herald. 


\section{Population, Immigration, and Minorities}

$\llbracket \begin{array}{ll}\text { A. } & \text { Population } \\ \text { B. Immigration: General } \\ \text { C. Immigration: Policy } \\ \text { D. Minorities } \\ \text { E. Negroes } \\ \text { F. Jews } \\ \text { G. Orientals } \\ \text { H. North Americans } \\ \text { I. Germans } \\ \text { J. Scandinavians } \\ \text { K. Other Stocks }\end{array}$

$\left.\begin{array}{l}4390-4403 \\ 4404-44^{17} \\ 44^{1} 8-4425 \\ 4426-4435 \\ 443^{6}-4451 \\ 4452-4462 \\ 4463-4469 \\ 447^{\circ}-4476 \\ 4477-4481 \\ 4482-4487 \\ 4488-4498\end{array}\right]$

$\mathrm{T}$ HE present chapter has proved exceptionally difficult to compile and to annotate, but the difficulty has been of different kinds in its several parts. With respect to "Population," it has not been easy to find enough suitable titles to make up a section adequate to its subject. The scientific study of population statistics, although no new idea, has only gradually revealed its possibilities, and these possibilities can only be realized when the statistics have been taken in such form and with such thoroughness as to make refined operations possible. Certain kinds of results, therefore, can be obtained only for I0, 20, or 30 years in the past; beyond that there is only conjecture. Another difficulty proceeds from the fact that no work on population can get too far away from its statistical tables, and such tables are not the favorite reading of anyone but a professional statistician. The titles offered here as a rule have a text in which ideas are developed in close association with a quantitative framework, and should daunt no reader who aims at deeper understanding.

With respect to "Immigration," we have a situation where public policy has followed a fairly consistent line for over three decades, but for the same period most of the literature has criticized that policy to a greater or lesser extent, and with varying degrees of harshness. It may well be that the policy is justifiable enough, but if its adherents do not write books to justify it, the defect cannot be supplied here.

General works on ethnic or other minorities in the United States pose a special difficulty, for to a rare degree they all say the same thing, and in the main are as like as two peas. Yet the unanimity of the

textbooks does not correspond to any like unanimity in the public mind, as can be learned from a glance at the daily newspaper. Here we have tried to select works with some degree of individuality.

The works on individual stocks, six of which have literatures large enough to warrant sections of their own, while the others are grouped in an omnibus section at the end, present another type of diffculty. Whether historical or contemporary, such a book must be written by one who is either a member of the group or an outsider. If an outsider, he may lack sympathy and special knowledge. If a member, he may find every virtue in his group and every fault outside it. We have tried to include the most fair-minded authors of each kind. Works on religious Judaism, the major ingredient of Jewish nationality, will be found in Chapter XXIII, Religion, Section G; and works on the Negro's church, which segregation has made into a separate and special entity, are entered in Section $\mathrm{K}$ of the same chapter. 
In conclusion, while much first-class work has been done in recent years on the ethnic history of the American people, both in general and in the way of particular groups, it is obvious that much re- mains to be done and that many aspects and peoples are inadequately covered. In the present vigorous state of national feelings and of American studies, it is unlikely that they will long remain so.

\section{A. Population}

4390. American Council of Learned Societies Devoted to Humanistic Studies. Committee on Linguistic and National Stocks in the Population of the United States. Report. Washington, U. S. Govt. Print. Off., 1932. p. 103-44I. incl. tables. 37-30356 Er 84.AiA6

Reprinted from the Annual Report of the American Historical Association for 1931.

Bibliography: p. 325-359.

Chapters X and XI of $A$ Century of Population Growth (no. 4400) deal with "Surnames of the White Population in 1790" and "Nationality as Indicated by Names of Heads of Families Reported at the First Census." They acquired an unanticipated importance in 1927 when the Quota Board made use of them in determining quotas of immigrants to be admitted under the "riational origins" plan enacted three years earlier, and in 1927 the American Council of Learned Societies appointed a committee under the chairmanship of Walter F. Willcox to reexamine the problem. The present publication includes, in addition to the concise report of the committee, a long study by a genealogist, Howard F. Barker, on "National Stocks in the Population of the United States as Indicated by Surnames in the Census of $1790 "$ ( $p$. 126-359) and two briefer ones by Marcus L. Hansen, "The Minor Stocks in the American Population of r79o," and "The Population of the American Outlying Regions in I79o." The committee's revised classification table differed in the following respects from A Century of Population Growth: English stock, 6o.I percent instead of 82.r; Scotch, 8.1 instead of 7.0; Irish (including Ulster), 9.5 instead of I.9; German, 8.6 instead of 5.6; Dutch, 3.I instead of 2.5; and French, 2.3 instead of 0.6 .

4391. Davis, Joseph S. The population upsurge in the United States. Stanford, Calif., Food Research Institute, Stanford University, 1949. 92 p. diagrs. (War-peace pamphlets, no. 12 )

$$
\text { 50-7898 } \mathrm{HB}_{35}{ }^{05} . \mathrm{D}_{3} 8
$$

A somewhat polemical pamphlet which was one of the earliest publications to emphasize the completely altered demographic outlook since World
War II. Earlier marriage, higher fertility rates, the reduction of maternity risk and infant mortality, longer life expectancy, and the persistence of immigration have all contributed to the accelerated population increase of the r94o's. The author rejects the notion of a "definable upper limit to our population" and believes that, "barring calamity and egregious policy blunders," it may increase indefinitely at changing rates and the American economy may continue to expand with it.

4392. Durand, John D. The labor force in the United States, I890-1960. New York, Social Science Research Council, I948. xviii, 284 p. 48-7397 HD 5724.D8

Prepared under the auspices of the Committee on Labor Market Research of the Social Science Research Council.

"References": p. 266-279.

The 1940 census was the first to make a complete count of the labor force of the United States, defined as all persons who work or seek work for economic gain, and excluding homemakers, students, rentiers, the incapacitated, and the superannuated. Since r 940 the Bureau of the Census has issued monthly data on the labor force. The author has used the labor statistics contained in the censuses from 1890 to estimate its earlier size, and has projected postwar trends into estimates for as late as r 960 . Separate chapters consider demographic factors affecting the labor force, economic factors, changing customs relating to the employment of women, and the wartime expansion of the labor force (from 54 to 66 million) and its subsequent contraction. The major changes in its composition are the reduced number of boys in their teens and of older men, and the increased and increasing number of women, especially married women. The final chapter asserts that a Federal labor force policy is indispensable. However, since an expanding labor force promotes national prosperity, the Government ought not, as a means of combating unemployment, to place undue restrictions upon the employment of youths and women, and it should encourage the employment of older men. 
4393. Hawley, Amos H. The changing shape of metropolitan America: deconcentration since 1920. Glencoe, Ill., Free Press, 1956. I 77 p. 55-1 $1000 \mathrm{HB} 2175 . \mathrm{H}_{3}$

This volume of modest size enjoys a triple sponsorship, shared by the Scripps Foundation, the Rockefeller Foundation, and the U. S. Housing and Home Finance Agency. It refines upon the conclusions of Donald J. Bogue's Population Growth in Standard Metropolitan Areas, 1900-1950, with an Explanatory Analysis of Urbanized Areas (Washington, Housing and Home Finance Agency, 1953. $76 \mathrm{p}$.). The author analyzes the 168 metropolitan areas which in 1950 contained $56 \%$ of the population of the United States, dividing each into central cities and satellite areas. Whereas in 1910 the satellite areas contained only $23.3 \%$ of the total metropolitan-area population, by 1950 they had risen to $41.6 \%$, and during the same period approximately 25 to 30 miles were added to the average radius of metropolitan influence. A reversal of tendency took place about 1920: previously there had been a rapid growth of centers at the expense of satellite areas, while since there has been a centrifugal movement to satellite areas to the detriment of growth in central cities. This general tendency is measured against such qualifying factors as the size of the central city, its average annual growth rate, the distance between such cities, the proportion of population employed in manufacturing, and regional location.

4394. Holbrook, Stewart $H$. The Yankee exodus, an account of migration from New England. New York, Macmillan, 1950. 398 p. maps.

Bibliography: p. 364-37r.

$$
\text { 50-7972 } \text { E }_{179.5} \cdot \mathrm{H}_{65}
$$

The author, a native of Vermont, considers the dispersion of the New Englanders throughout the rest of the Union to be "the most influential migration in all our history," but strangely ignored among the great movements that civilized the United States. Among the qualities which rendered the Yankee leaven exceptionally infuential he singles out their fanatical respect for education, their shrewdness and great industry in business, and their powerful urge to impose their moral notions upon their new homes. The body of the book is largely a treatment of individual Yankees in particular communities from New York State to the Pacific coast. Mr. Holbrook cheerfully concedes that his book is "little more than a footnote to what is needed to tell the Yankee story in full." In spite of its bewildering detail and low level of generalization, it is the only book which attempts to show how, through the migratory process, the standards and ideas of one section permeated all the others.
4395. Hutchinson, Edward P. Immigrants and their children, $1850-1950$, by E. P. Hutchinson for the Social Science Research Council in cooperation with the U.S. Dept. of Commerce, Bureau of the Census. New York, Wiley, 1956. xiv, 391 p. maps, tables. (Census monograph series)

56-5602 HB2595.H8

This volume continues and expands Niles Carpenter's 1920 Census monograph, Imnigrants and Their Children, 1920 (Washington, Govt. Print. Off., 1927. xvi, 431 p.), by "describing changes in the size, composition, and geographical distribution of the foreign stock from 1920 to 1950," and by presenting occupational data for the foreign stock from 1870 to 1950 . According to Mr. Hutchinson's interpretation of the figures, the drop in immigration since 1920 has brought about as wide an occupational distribution among the foreign stock as among the native stock. For "each of the many different immigrant peoples contributed its own complement of native endowment and acquired skills to its adopted country; and, as the data show, each found its own place in the territory and labor force of the United States." The 1950 Census monograph series is produced in cooperation with the Social Science Research Council and published by Wiley. Other volumes which have so far appeared, treating a variety of subjects on the basis of data gathered by the Bureau of the Census, are the following: Social Characteristics of Urban and Rural Communities, 1950, by Otis Dudley Duncan and Albert J. Reiss, Jr. (1956. xviii, 42I p.); Income of the American People, by Herman P. Miller (1955. xvi, 206 p.); and American Housing and Its Use; the Demand for Shelter Space, by Louis Winnick, with the assistance of Ned Shilling (1957. xiv, I43 p.).

4396. Kiser, Clyde V. Group differences in urban fertility, a study derived from the National Health Survey. Baltimore, Williams \& Wilkins Co., 1942. xii, 284 p. tables, diagrs.

Bibliography: p. 274-277.

$$
4^{2-22364} \mathrm{HB} 89 \mathrm{r} . \mathrm{K}_{5}
$$

The National Health Survey was an investigation conducted in 83 American cities by the U. S. Public Health Service during $1935-36$. On the basis of its data, the author attempts to relate marital fertility rates to the occupational, educational, and income status of the parents. Fertility rates of rural groups are presented for comparison, and the incidence of pregnancy wastage is studied. Economically retarded groups, it is concluded, produce more than their numerical share of births, but, whether or not because of the spread of contraceptive practices, there is evidence that "group differences in fertility are tending to diminish rather than increase." 
4397. Lively, Charles E., and Conrad Taeuber. Rural migration in the United States. Washington, U. S. Govt. Print. Off., I939. xxi, I92 p. maps, tables, diagrs. ([U. S.] Works Progress Administration. Research monograph 19) 39-29056 HV85.A 36 , no. I9 $\mathrm{HB}_{23} 85 . \mathrm{L} 5$

Issued also by the U. S. Farm Security Administration as its Social Research report no. I7 under the title: Migration and Mobility of Rural Population in the United States.

"Selected bibliography": p. 177-1 83 .

Because the data for detailed study of rural population movements before 1930 are quite inadequate, the authors have devoted only their first 25 pages to that era. Even though limited to the decade 1930-39, it remains the most substantial study of the internal migration of the United States. Concerned with the nature and characteristics of rural migration, it gives particular attention to the relationship of migration, or failure to migrate, to destitution and economic opportunity. Migration is studied in selected areas, in its relation to rural reproduction, and in its effects upon rural and urban life.

4398. Sutherland, Stella H. Population distribution in colonial America. New York, Columbia University Press, 1936. xxxii, 353 p. tables, fold. maps. $\quad 37-1006 \quad \mathrm{HB}_{19} 65 . \mathrm{S}_{4}$

Bibliography: p. [xvii]-xxxii.

This somewhat misleadingly entitled book is in fact an attempt to reconstruct the population statistics of the Thirteen Colonies in I775, on the verge of the Revolution, and to prepare a dot map, which here appears in three folded parts, with each dot representing 50 persons. The New England colonies all took censuses in 1774,1775 , or 1776 , but elsewhere it has been necessary to estimate on the basis of earlier and later censuses, or to use tax lists as a substitute or, in the case of Georgia, the "head grants," a list of land and lot grantees from 1754 to 1775. In the cases of Maryland and Virginia, the author has been content with figures of 1782 and $1782-85$ respectively. The estimated total is $2,507,180$, ranging from Virginia with 504,264 to Georgia with 33,054 . A considerable text discusses the growth of population in each colony in its relation to immigration, settlement, and economic development, but does not attempt to arrive at detailed figures for successive epochs. An appendix reproduces the official British detailed list of the colonies' imports and exports for I77I. Concerning her map the author remarks: "Away from the cities, with their tributary suburbs, there is little to relieve the monotonous level of rural density."
4399. Thompson, Warren S., and Pascal K. Whelpton. Population trends in the United States. New York, McGraw-Hill, I933. 4I5 p. (Recent social trends monographs)

33-27203 $\mathrm{HB}_{3505 . \mathrm{T}_{5}}$

One of the 13 monographs prepared under the direction of the President's Research Committee on Social Trends, named by Herbert Hoover in 1929 with Wesley S. Mitchell as chairman and William F. Ogburn as director of research. Investigation was carried on during 1930-32 through funds granted by the Rockefeller Foundation. For the present volume advance figures from the 1930 census were made available, and assistance was lent by the staff of the Scripps Foundation for Research in Population Problems at Miami University. The authors were limited to the analysis of objective data and sought to "give a more complete picture of population in the United States than has been available hitherto and to project past trends into the future." Chapters are concerned with population growth by race, region, and locality, the distribution of various stocks, the national origins of the white population, age and sex composition, marital condition, death and birth rates, and the effect of immigration upon population growth. Two final chapters discuss probable trends and "Population Policy." They are naturally colored by the Great Depression, in which a reduced rate of population growth is taken to be "a contributory factor," and they favor planning and strict control, including sterilization of the unfit as a means of improving the quality of population. In addition to the 88 tables and 36 graphs in the text, there is an appendix of 27 large tables (p. 339-408).

4400. U. S. Bureau of the Census. A century of population growth from the first census of the United States to the twelfth, I790-I900. Washington, Govt. Print. Off., I909. 303 p. maps (part fold.) diagrs.

9-35728 HAr95. A5

The first complete national census was that of Sweden in 1749 , and the first United States census of 1790 has some claim to have been the second. The Bureau of the Census, however, did not become a permanent organization until I902, soon after which it received custody of the surviving records of the first census, which had been published only in very summary form, and from which four States and two Territories had disappeared. This volume, compiled by the chief clerk of the Bureau, William S. Rossiter, resulted from the Bureau's decision to publish the returns in detail, and to present comparisons with the corresponding figures from later censuses. Chapter III deals with the first census act and the methods by which the census of 1790 was carried out. Bases for comparisons are established in Chapter IV, which includes a series of 
maps showing the counties of $179^{\circ}$ in comparison with the modern counties. Other subjects are the White vs. the Negro population, sex and age of the White population, the family and the proportion of White children, interstate migration, the foreignborn, slave statistics, and occupations and wealth. Pages $149-298$ are occupied by 40 general tables, the first 28 of which contain census material from the Thirteen Colonies. The remainder present the data of I790, Table I04 (p. 188-200) being "Population as Reported at the First Census, by Counties and Minor Civil Divisions."

440r. Vance, Rupert B. All these people; the nation's human resources in the South, by

Rupert B. Vance in collaboration with Nadia Danilevsky. Chapel Hill, University of North Carolina Press, 1945. xxxiii, 503 p. maps, tables, diagrs. $\quad 46-3393 \quad \mathrm{HB}_{3511 . V_{3}}$ "Bibliographic notes": p. 489-492.

This study of population pressure in the Southern States, related to national manpower needs and local economic development, is the only large work on the population of an American region. The fact that "Southerners are doing more to replace themselves in the next generation" than the inhabitants of any other area, and doing it on fewer resources, is presented as a continuing problem. The effects of population growth on Southern agriculture and industry and the educational needs of the area are described. There are 146 tables and 281 figures.

4402. Whelpton, Pascal K. Cohort fertility; native white women in the United States. Princeton, Princeton University Press, I954. xxv, 492 p. diagrs., tables. $\quad 52-5836 \quad \mathrm{HB}_{915}$. W47 A severely technical volume whose lithoprinted pages effect a new refinement in analyzing population developments in the United States during the years since 1920 . The available statistics are inadequate to a like treatment of any earlier period. Colored women have been excluded from the tables in part because the data for them are significantly less accurate, and foreign-born women because of their rapidly decreasing proportion to the whole. A "cohort" here means all native white women born in a single year, those born from July 1, 1899, to June 30 , 1900, being the cohort of 1900 . The cohorts considered extend from that of 1875 , with births as late as 1922, to that of 1933, whose births began in 1949. The essential information is contained in Tables A-L (p. [283]-[386]). Annual fertility rates "had a U-shaped trend from 1920 to 1949," but the old high level and the recent rise are qualitatively different: more women now have one, two, or three children than formerly, but fewer have five or more children. The operative cause of fluctuations in fertility, the author is sure, is the practice of birth control measures.

4403. Willcox, Walter F. Studies in American demography. Ithaca, N. Y., Cornell University Press, I940. xxx, $55^{6}$ p. tables, diagrs. $4 \mathrm{I}-2109 \mathrm{HB}_{3505}$. W5

"Bibliography of the more important writings of the author": p. 54I-547.

Dr. Willcox (b. I86r) is a pioneer and elder statesman of American demography, whose career has included 40 years as professor and dean at Cornell University and over 30 years' association with the U.S. Bureau of the Census, beginning with his service as chief statistician of the I th census (I900). This volume collects the pieces which he had hoped would grow into an Introduction to American Demography but, because of the deficiencies of American vital statistics, did not. All are informed by the broad and humane outlook of Igth-century social studies, so often lacking from the work of latter-day specialists. The first part, "Studies in American Census Statistics," contains, along with papers on the urban and rural, sex, age, race, literacy, and marital characteristics of the American population, one on the "Development of the American Census and Its Methods." The second part, "Studies in American Registration Statistics," discusses the birth, death, and cancer rates and other aspects of these state-compiled figures, which did not become nationwide until 1933. A final miscellaneous part includes a paper on "Statistical Societies and their Cooperation with Statistical Bureaus," and biographical sketches of Lemuel Shattuck and John Shaw Billings.

\section{B. Immigration: General}

4404. Abbott, Edith. Immigration; select documents and case records. Chicago, University of Chicago Press, 1924. xxii, 809 p.

$$
24-86_{50} \quad \mathrm{JV}_{455} \cdot \mathrm{A}_{7}
$$

4405. Abbott, Edith. Historical aspects of the immigration problem; select documents. Chicago, University of Chicago Press, I926. xx, 88I p. 26-27485 JV6455.A68 
These complementary volumes form a part of the University of Chicago social service series, and their compiler was for 18 years dean of that university's Graduate School of Social Service Administration. The earlier volume opens with two historical sections, on "The Journey of the Immigrant" since 1751 , and the "Admission of Immigrants under State Laws, I788-1882." The remainder of the material dealing with the admission, exclusion, and expulsion of aliens consists largely of federal court decisions, I892-1921, and of social case records drawn from the files of the Immigrants' Protective League of Chicago, 1912-23. The same files are drawn upon for the cases which illustrate "Domestic Immigration Problems" in Part III. The materials in Historical Aspects nearly all antedate 1882 , the year in which the control of immigration was assumed by the Federal Government. They are arranged within the following sections: "Causes of Immigration," "Economic Aspects of the Immigration Problem," "Early Problems of Assimilation," "Pauperism and Crime," and "Public Opinion and the Immigrant." No subsequently published volumes give as good an idea of the variety and character of the sources for the study of immigration.

4406. Brunner, Edmund de S. Immigrant farmers and their children, with four studies of immigrant communities. Garden City, N. Y., Doubleday, Doran, 1929. xvii, 277 p.

29-r r033 JV6606.A4 $\mathrm{B}_{7}$

A study of the foreign-born farming population, undertaken by the Institute of Social and Religious Research (New York City) in 1926-27, and necessarily based on the census of 1920 , which put the total at neariy one and a half million. Mr. Brunner concluded that the newcomers, judged by economic and technical standards, were making good on the soil; that their children were no more and no less intelligent than native children, whether judged by special tests or by their school records; that marriage outside the immigrant group increased substantially after World War I; that over two-thirds of the communities studied "were progressing more or less surely along a well-charted course leading toward complete assimilation into the life of rural America"; and that the younger generation were not deserting the church into which they were born, but were insisting "that their church shall be an American institution." The concluding portion of the book consists of four case studies of immigrant villages by different hands: Castle Hayne, N. C. (various stocks); Askov, Minn. (Danes); Petersburg, Va. (Czechs); and Sunderland, Minn. (Poles).

4407. Committee for the Study of Recent Immigration from Europe. Refugees in America, report of the Committee, by Maurice $\mathrm{R}$. Davie with collaboration of Sarah W. Cohn, Betty Drury, Samuel Koenig [and others] New York, Harper, 1947. $\mathrm{xxi}, 453 \mathrm{p}$. 47-2565 D8og.U5 6

A study of the immigration since 1933, taking refuge from Hitler and his allies, which is estimated at an approximate 275,000 persons, of whom nearly fourth-fifths are Jews by religion or race. Over half come from Germany and Austria, and most of the rest from Poland, Italy, Czechoslovakia, Russia, France, and Hungary. Unlike the earlier migrations, it is composed primarily of middle and upperclass persons, spearheaded by I 2 Nobel prize winners in science and literature, and including many names since listed in Who's Who or American Men of Science or both. It is here studied in a sample of $\mathrm{I}, 233$ replies to a questionnaire, from $638 \mathrm{com}$ munities in 43 states. The text, which makes skillfull use of excerpts from the individual replies, deals with the economic, occupational, social, and cultural adjustment of the refugees; the occupational experiences of businessmen and manufacturers, physicians, lawyers, teachers and scientists, artists and writers; and their opinion of America and Americans' opinion of them. "In general, the attitude of the American community toward the refugee has been preponderantly sympathetic and helpful," and the hopes of the vast majority, especially for their children, are now centered here.

4408. Erickson, Charlotte. American industry and the European immigrant, 1860-1885. Cambridge, Harvard University Press, I957. 269 p. (Studies in economic history)

$57-5485$ HD808r.A5E7

A study of the efforts of organized labor to obtain legislation preventing contract labor from entering the United States. "The thesis of this book is that contract labor was rare in America during the years after the Civil War, and never reached the proportions claimed by the advocates of a law against its importation." The exclusionist movement, Miss Erickson demonstrates, originated with the craft unions. They feared the importation of skilled workers from Europe as strike breakers, and manipulated the Knights of Labor and the American Federation of Labor until the passage of the Foran Act of 1885 , which excluded contract labor of all types. The author describes the haphazard labor recruiting methods of American industries to show that they had little to do with this legislation, which, she contends, was actually racist in motivation. Methods of distributing unskilled labor are also treated and the fact emphasized that the industries depended upon a ready reservoir of cheap foreign labor and had no interest in excluding it. 
4409. Ernst, Robert. Immigrant life in New York City, 1825-1863. New York, King's Crown Press, 1949. xvi, $331 \mathrm{p}$.

Bibliography: p. [297]-3 19 .

$$
\text { 49-9759 F128.9.A1E7 } 1949
$$

Between the opening of the Erie Canal and the draft riots of 1863 the foreign-born of Manhattan Island increased from less than 20,000 , or about $11 \%$, to 384,000 , or $48 \%$ of the whole. Of the latter, over 200,000 came from Ireland, 120,000 from Germany, and 27,000 from England. The author details the miseries of tenement life in congested lower Manhattan, but points out that the younger immigrants and their children were able, through their earnings, to improve their status and move to cleaner, safer neighborhoods, making way for newcomers from abroad. One reason for this was the vigorous labor movement, which carried on four decades of struggle for better wages and working conditions, and in which, for the most part, natives and immigrants worked toward the same ends, although the Germans usually had labor organizations of their own. The newcomers maintained a variety of military and social organizations, churches, and periodicals of their own, which contributed to New York's cosmopolitan appearance but did not prevent the assimilation of their children to American speech and habits. Once manhood suffrage was adopted in 1827 , Tammany Hall forestalled all opponents in the systematic cultivation of the foreign vote and thereby kept the Democratic Party in control during most of the period.

4410. Handlin, Oscar. Boston's immigrants, 1790I865; a study in acculturation. Cambridge, Harvard University Press, I94I. xviii, 287 p. tables, diagrs. (Harvard historical studies, v. 50)

Note on sources: p. [25I]-268.

$$
\mathrm{A}_{41-4664} \mathrm{~F}_{73} \cdot 9 \cdot \mathrm{A}_{1} \mathrm{H}_{3}
$$

An outstanding study, based upon a Harvard dissertation of 1940, of "the transformation of a neat, well managed city into a slum and disease ridden metropolis." Many immigrants entered the great commercial port of Boston, but few remained until the penniless Irish, fleeing from eviction and starvation at home, began arriving in quantity about 1835 . By 1865 there were 72,000 of them in a total population of 331,000 , more than double the number of all the other foreign-born. Without capital or training, they were confined to the least desirable occupations. They were crowded into the old mansions and disused warehouses of Fort Hill and the North End, without cleanliness, privacy, or proper ventilation, and epidemic diseases and tuberculosis rose to new levels. They remained the one element which took no part in Boston's thriving cultural life, and made fewer marriages out of their group than did
Boston's Negroes. The 1850's were marked by jarring group conflicts and Know-Nothing racism, but the strong loyalty and excellent military record of the Boston Irish in the Civil War led to a remarkable relaxation of antagonisms and discriminations, although it by no means ended their physical and cultural isolation.

44II. Handlin, Oscar. The uprooted; the epic story of the great migrations that made the American people. Boston, Little, Brown, I95I. 3 Io $\mathrm{p}$.

Bibliography included in "Acknowledgments" (p. 308-310).

An original book which attempts a generalized psychological history of the 35 million immigrants who came to America in the century after 1820, in terms of "alienation and its consequences." It was the collapse of the old village economy in central and eastern Europe which uprooted the peasant and started him on his way to the very different life of the New World. The native conservatism of these folk was increased by the harshness of their new circumstances and led them to cling firmly to the churches of their old communions, which they reconstructed here in minute detail, and to reject political radicalism, leaving a fair field for the local party boss and his system of special favors. The book concludes with an affecting evocation of transplanted peasants who had bogged down in the slums of the seaboard cities and become sweated, unskilled laborers; turned old folk, they still labored under "a consciousness that they would never belong." As an overall picture, it gives small place to the migration from farm to farm, and underestimates the degree of prosperity and rapid acculturation, especially among those elements closest to the older American stocks.

4412. Hansen, Marcus Lee. The Atlantic migra. tion, 1607-1860; a history of the continuing settlement of the United States. Edited with a foreword by Arthur M. Schlesinger. Cambridge, Harvard University Press, 1940. xvii, $391 \mathrm{p}$.

$$
40-6920 \mathrm{JV}_{4} 5^{\mathrm{I}} \cdot \mathrm{H}_{3}
$$

4413. Hansen, Marcus Lee. The immigrant in American history. Edited with a foreword by Arthur M. Schlesinger. Cambridge, Harvard University Press, I940. $230 \mathrm{p}$.

$40-35768$ JV645I.H33

Professor Hansen (1892-1938) was the son of a Norwegian immigrant to Wisconsin. A graduate of the University of Iowa, his work for his Ph. D. at Harvard was interrupted by service in World War I. He was the first to master the rgth-century immigration to America as an immense but unitary his- 
torical process, and to exhibit it at once in its roots, trunk, and branches. His death at 45 was a misfortune to American scholarship, but his published writings, and especially the two posthumous volumes listed here, were at once a solid achievement and a guide for all subsequent workers in the field. The Atlantic Migration was to have been the first volume of a three-volume work, with the others carrying the story from I860 to the 1920's. The recurrence of economic distress among the laboring classes of western Europe, rural and urban, in the years after 1815 , is emphasized, along with the common man's discovery of America, which, notwithstanding its hardships, "he did not hesitate to call a Utopia." Conditions on either side of the ocean responsible for the statistical fluctuations of the migration are clearly isolated. Five out of the nine essays of The Immigrant in American History are adapted from the course of eight public lectures which Hansen delivered at the University of London in 1935 on "The Influence of Nineteenth Century Immigration on American History," and discuss immigration in its relation to expansion, democracy, Puritanism, and American culture. All evidence the author's genius for solid generalization. "The Second Colonization of New England" puts into perspective the coming of the Irish after 1825 and the French Canadians after 1900 . The serious student will find no more suggestive aid than "Immigration as a Field for Historical Research."

4414. Kent, Donald Peterson. The refugee intellectual; the Americanization of the immigrants of 1933-1941. New York, Columbia University Press, 1953. $\mathrm{xx}, 3 \mathrm{I} 7 \mathrm{P}$.

Bibliography: p. [303]-307.

$$
53-7600 \quad \mathrm{E}_{8} 8 \cdot \mathrm{AIK}_{4}
$$

A study which continues, on a more minute scale, Refugees in America (no. 4407); it was undertaken in 1947 by the Oberlaender Trust in cooperation with the Carl Schurz Memorial Foundation. It is based upon 721 replies to questionnaires or interviews with German and Austrian professional persons, estimated to represent nearly $10 \%$ of the total immigration of such persons during I933-4I. It was found that 520 of the 721 were able to follow their former pursuits in the United States. The author concludes that if the immigrant is under 40 and has children, he has a decided advantage toward integration, and identifies other facilitating or retarding factors. However, "fine personal qualities" permit adjustment even under unfavorable conditions. In sum, "probably no other large group of immigrants has ever surpassed them in the speed with which they have adjusted to American culture."
44I5. Smith, William Carlson. Americans in the making; the natural history of the assimilation of immigrants. New York, Appleton-Century, 1939. xvii, 454 p. (The Century social science series)

Bibliography: p. 432-439.

"An endeavor to set forth the natural history of the assimilation of immigrants to America; it aims to present the more general aspects of the assimilative process which are common to all groups." Data have been largely selected from personal letters, as well as published and unpublished diaries, autobiographies, and life histories, to afford an understanding of immigrants and their children as persons, and of their problems in American society. To this end, the author presents the immigrants' point of view regarding the causes of immigration; their reception and settlement; the processes, stages, factors, and agencies of assimilation; and the effects of their heritage upon their way of life in a new environment. The second generation is seen as belonging neither to the immigrant society nor to the society of those longer established, and is studied from the point of view of its reception by the American social mélange. The immigrants' contribution to America in all fields is treated separately.

4416. Stephenson, George M. A history of American immigration, 1820-1924. Boston, Ginn, I926. $316 \mathrm{p}$.

"Select bibliography": p. 283-302.

A brief treatment of the great century of immigration to the United States, emphasizing "the part that immigration and the immigrants have played in the political history of the United States." Part I is introductory, reviewing the European background and characteristic settlement of seven major racial groups. Part II analyzes the American political reaction to the immigrants from the Know-Nothing movement through World War I, including the various schemes of restriction which came increasingly to the fore, the attitudes of immigrant groups to European conflicts, especially the war of IgI4, and the evolution of naturalization policy. A final part gives separate and very brief treatment to the condition and political vicissitudes of Oriental immigration.

4417. Wittke, Carl F. We who built America; the saga of the immigrant. New York, Prentice-Hall, r939. xviii, 547 p.

$$
\text { 40-137 JV6455. W55 }
$$

A general survey of the history of immigration to the United States by ethnic groups, which is necessarily based on secondary works, but has some aug- 
mentation from contemporary newspapers and public documents. The author, who is of German descent and has made distinguished contributions to the history of German immigration, was dean of Oberlin College when the book appeared, and has been dean of the Graduate School of Western Reserve University since I948. It is divided into three parts: "The Colonial Period," "The Old Immigration," and "The New Immigration and Nativism." Some racial groups, such as the Welsh, Swedes, and
Jews, are considered in each of the first two parts. There are also a few topical chapters: "The Immigrant Traffic" in its general conditions, in each of the first two parts; "Immigrant Utopias" such as the Harmony Society and Amana, lowa; "Culture in Immigrant Chests," largely a roll call of individual immigrants of outstanding achievement; and "Closing the Gate," which reviews restrictionist action and sentiment from 1729 to the national-origins law of I929.

\section{Immigration: Policy}

4418. Bernard, William S., ed. American immigration policy, a reappraisal. Edited by William S. Bernard; Carolyn Zeleny [and] Henry Miller, assistant editors. New York, Harper, I950. $\mathrm{xx}, 34 \mathrm{I}$ p. diagrs. 50-1 $20 \quad \mathrm{JV}_{50} 07 \cdot \mathrm{B}_{4}$

Bibliography: p. 315-330.

This "broad survey" of American policy, past, present, and future, is published under the sponsorship of the National Committee on Immigration Policy, and consistently maintains an internationalist point of view. The immigration policy of the United States which has prevailed since 1924 is criticized as anachronistic and reactionary in character, with discriminatory features which "have been increasingly conspicuous as contradictions of our democratic ideals and traditions." Chapter 2 demonstrates statistically that the preferred nations do not use their quotas, and that the North American nations, Canada and Mexico, have become major sources of immigration since 1924. Pairs of chapters are devoted to partly statistical arguments that immigration stimulates the American economy and maintains a moderate rate of population growth, and that immigrant adjustment, as reflected by a variety of indexes, has always progressed steadily and in recent times has been speeded up. There are concluding recommendations that the present annual limit of 150,000 persons be increased, "possibly doubled"; that the present system be operated with greater flexibility, especially in the case of quotas left unused; that small quotas be granted to Asiatic peoples; that the United States cooperate with the international organs concerned with immigration; and that a Congressional commission work out an equitable alternative to the national origins system.

4419. Divine, Robert A. American immigration policy, 1924-1952. New Haven, Yale University Press, 1957. 220 p. (Yale historical publications. Miscellany 66) 57-6336 JV6455.D5
"Bibliographical essay": p. 195-209.

An objective and well-proportioned narrative which puts the recent history of opinion and legislation concerning immigration into very clear perspective. The restrictive policy established in 1924 has been repeatedly challenged but with small success, for on crucial occasions it has commanded a majority of both houses of Congress, and relaxations have been partial and temporary. The application of the national origins system in 1927 led to two years of debate which did not alter the law but did increase minority group consciousness and stir up antagonisms among the various foreign elements. Mexican immigration, heavily increased since I92I, was reduced after 1929 through administrative action by the State Department without further legislation. The same device was used to cut off immigration during the depression, the total falling to 23,068 in 1933, the lowest figure in over a century. Congress refused to take action in favor of European refugees after 1933, but administrative action reduced the stringencies of the quota system and enabled an estimated 250,000 to enter. The Displaced Persons Act of 1948 was greatly watered down by the restrictionist bloc in Congress; it took a major effort to put through the 1950 measure which finally solved the problem. The old racialist views, the author finds, were common to the Southern and Western members of Congress who passed the McCarran-Walter Act of 1952 over the veto of President Truman.

4420. Garis, Roy L. Immigration restriction; a study of the opposition to and regulation of immigration into the United States. New York, Macmillan, r928. 376 p.

Bibliography: p. 355-37r

$$
32-1946 \quad J V 6507 . G_{3} \quad 1928
$$

Professor Garis of Vanderbilt University, writing in the turmoil of the immigration debate of the ig20's, was concerned to point out that it was no 
new thing, for the opposition to immigration could be traced back to early colonial days. As early as r639 Plymouth Colony required the removal of foreign paupers. While the background of opinion has been more thoroughly presented in Higham (no. 4422) and other books, this remains the most convenient description of actual legislation, colonial, state, and federal, through the Immigration Act of 1924. The débacle of the Alien and Sedition Acts at the close of the 18 th century had led to doubt concerning the competence of the Federal Government in this sphere, and it was not until the $1870^{\circ}$ and early 1880's that the Supreme Court definitely reestablished its right to supersede state enactments. Up to I92I, the author points out, restrictive laws were all qualitative, defining and excluding particular types of undesirables. The act of I92I was the first to apply a quantitative limitation in the form of an annual maximum figure. The utilization of the census figures of 1890 in the act of 1924 is expounded in detail. Oriental immigration is separately treated in two concluding chapters. The author was himself a believer in the case for restriction, but was careful to keep it separate from his factual expositions.

4421. Hartmann, Edward George. The movement to Americanize the immigrant. New York, Columbia University Press, 1948. 333 p. (Columbia University. Faculty of Political Science. Studies in history, economics and public law, no. 545) ${ }_{48-9245} \mathrm{H}_{3} \mathrm{r} . \mathrm{C}_{7}$, no. 545

Bibliography: p. 28r-325. $\mathrm{JK}_{1758 . \mathrm{H}_{35} \quad \text { I948a }}$

A Columbia dissertation which traces the course of an educative movement aiming at a rapid assimilation of the millions of immigrants who had come to America in the decades preceding World War I. It began with the organization of the North American Civic League for Immigrants in I907, gained momentum as German-American relations deteriorated, thrived during the war and its immediate aftermath, and died as the nation returned to "normalcy." Unlike other American social crusades, the Americanization drive was led by the intelligentsia, educators, and social workers and supported by industrialists and business and civic groups. Neither restrictive nor repressive, the movement sought to solve the problem of the immigrant's social isolation through night classes and personal guidance intended to mold him "into a patriotic, loyal, and intelligent supporter of the great body of principles and practices which the leaders of the movement chose to consider 'America's priceless heritage.'" The author evaluates the results of the program as both negative and positive: negative in that it caused some immigrants to band more closely together and led to a revival of nativism, and positive in that it brought native and foreign-born into closer contact and gave impetus to the budding adult education movement.

4422. Higham, John. Strangers in the land; patterns of American nativism, I860-1925. New Brunswick, N. J., Rutgers University Press, 1955. xiv, 43 I p. illus. 55-86or EI84.ArH5 "Bibliographical note": p. 399-4II.

A general history of the antiforeign spirit defined by the author as nativism and manifested in "the hostilities of American nationalists toward European immigrants." Its development is traced as it was affected by the successive impulses of American history, and as it affected, in turn, every level of society and section of the country-politically, economically, socially, and intellectually. Nativism, which had waned during the Civil War, experienced a complete renaissance as South and East European immigration increased in the I880's and 9o's. It ebbed and then flowed again following the turn of the century, reached its zenith with America's entry into World War I and the "roo per cent Americanism" movement, and died in the indifference of the Flapper Era, but not before it had achieved "the Nordic victory" of 1924. According to the author, "nativism as a habit of mind has mirrored our national anxieties and marked out the bounds of our tolerance"; he therefore considers his book as a study of public opinion.

4423. Solomon, Barbara Miller. Ancestors and immigrants, a changing New England tradition. Cambridge, Harvard University Press, 1956. $276 \mathrm{p}$.

"A note on sources": p. [2II]-22I. 56-10163 $\mathrm{F}_{4} . \mathrm{S} 67$

In this outgrowth of a Harvard doctoral dissertation, prosperous and educated descendants of old New England families are denominated "Brahmins," and the writings of such persons from about I 850 are examined for "the association of ideas which produced a rationale for immigration restriction." The crystallization was not effected until the I880's; the Massachusetts Society for Promoting Good Citizenship was founded in 1889 and the Immigration Restriction League in 1894 . A number of "Teutonist academicians," such as Henry Adams, Barrett Wendell, and Herbert Baxter Adams, historians, and Francis A. Walker, Richmond Mayo Smith, and William Z. Ripley, social scientists, are castigated for their contributions to the creation of "the Anglo-Saxon complex." A few distinguished New England thinkers are individually exonerated from participation in this "betrayal of the continuing faith in the potentialities of 
America's democratic people," which still lingers in the immigration laws of the land.

\section{U. S. Congress. Senate. Committee on the} Judiciary. The immigration and naturalization systems of the United States. Report pursuant to S. Res. 137, 8oth Cong., Ist sess., as amended, a resolution to make an investigation of the immigration system. Washington, U.S. Govt. Print. Off., 1950. xviii, 925, xxvi p. (8Ist Cong., $2 \mathrm{~d}$ sess. Senate. Report no. 1515 ) 50-60699 JV6416.A39 r 9500

This, the first general Congressional investigation of its subject since that of 1907-I I, was carried on for nearly three years with the late Senator Patrick McCarran as chairman. Part I, on "The Immigration System," has introductory chapters on the history of immigration and immigration policy, and the characteristics of the population of the United States. It then deals with "Enforcement Agencies," including the Immigration and Naturalization Service, the Board of Immigration Appeals, the Visa Division of the State Department, and the U. S. Public Health Service, and with "Excludable and Deportable Classes," “Admissible Aliens," including quota immigrants, nonquota immigrants, and nonimmigrants, "Adjustment of Status," "Procedures," and "Territories and Possessions." Part 2, on "The Naturalization System," has historical and statistical chapters, and discusses citizens, noncitizen nationals, ineligibles for citizenship, becoming a citizen, and how citizenship may be lost and regained. A brief third part deals with "Subversives." Appendix II (p. 805-810) is a synopsis of the recommendations of the committee, which appear in greater detail at the conclusion of most of the chapters; a number of them were embodied in the McCarran-Walter Act of 1952. The remaining appendixes (p. 8II925) are statistical tables.

\section{U. S. President's Commission on Immigra-} tion and Naturalization. Whom we shall welcome; report [Washington, U. S. Govt. Print. Off., 1953] $\mathrm{xv}, 3^{\mathrm{I} 9} \mathrm{p}$.

53-60119 JV6415.A4 1953 The passage of the McCarran-Walter Act over President Truman's veto in June 1952 was followed by much criticism and, in September, by the establishment of the President's Commission on Immigration and Naturalization with Philip B. Perlman as chairman and Harry N. Rosenfield as executive director. Instructed to report by January I, during October it received testimony in I I cities; these Hearings have been printed for the use of the House Committee on the Judiciary (Washington, U. S. Govt. Print. Off., 1952. 2089 p.). This Report condemns the existing law as embodying xenophobia and racial discrimination, and calls for the annual admission of one-sixth of I percent of the population at the last census (or 251,162 as against 154,657, under the census of 1940). All relevant functions should be consolidated in a new agency under a commission on immigration and naturalization, which would distribute the annual figure on the basis of the right of asylum, the reunion of families, needs in the United States, special needs in the Free World, and "general immigration." Conditions of admission and grounds for deportation of aliens should "bear a reasonable relationship to the national welfare and security."

\section{Minorities}

4426. Brown, Francis J., and Joseph S. Roucek, eds. One America; the history, contributions and present problems of our racial and national minorities. 3 d ed. New York, Prentice-Hall, 1952. xvi, 764 p. (Prentice-Hall education series) 52-1682 EI84.AIB87 1952

The most comprehensive and informative single volume on the American minorities; its usefulness since the first publication in 1937 is attested by the second revised edition of 1945 as well as the present revision. There are 5 I contributors including the two editors, and Part 2, the largest section of the book, contains concise presentations of the significant aspects and problems of 45 minority groups, down to Ukranian Americans, Estonian Americans, Hindu Americans, and Icelandic Americans. The majority of these are written by leaders in their own groups, and reflect the "very sense of group superiority that lies at the root of the problem." Part 3 describes certain activities of minority groups that influence cultural adjustment, such as the foreignlanguage press and radio. Part 4 analyzes various aspects of racial and cultural conflict. Part 5 appraises the role of government, the community, and especially of educational institutions in the development of intergroup understanding; its keynote can be gathered from the title of Maurice R. Davie's contribution: "Our Vanishing Minorities." The large bibliography (p. [703]-750) was specially revised for this edition; it follows the organization of the book, and contains many brief annotations. 
4427. Fairchild, Henry Pratt. Race and nationality as factors in American life. New York, Ronald Press Co., 1947. 216 p. (Humanizing science series) $\quad 4^{8-33} \mathrm{E}_{184 . \mathrm{AF}_{3}}$

Dr. Fairchild (1880-1956), long a professor of sociology at New York University, continued in his later years to assert a viewpoint which had become academically unfashionable or worse. Racial thinking and feeling, he maintained, were obstinate social realities which could not be exorcised by denying their existence or by alleging their unscientific character, especially since most of the opposing dogmas were equally unproved. He did not believe that all faults were on the side of the much-abused majority, and pointed to the Catholic Church's progressive invasion of a number of social fields, and to Jewry's own sentiments of superiority, exclusion, and discrimination. Doctrinaire liberal tenets of equality, and attempts to eliminate racial antipathies by legislation, merely promoted social turbulence. The achievement of intergroup harmony and the elimination of friction must proceed, like all genuine progress, from the heart of the individual, and must rest on an essentially religious base, the abandonment of the sense of self-centered superiority.

4428. Gittler, Joseph B., ed. Understanding minority groups. New York, Wiley, 1956.

$139 \mathrm{p}$. 56-ri777 Er84.ArG5

Contents.-The philosophical and ethical aspects of group relations, by Wayne A. R. Leys.-The American Catholic, by John LaFarge.-The United States Indian, by John Collier and Theodore $\mathrm{H}$. Haas.-The American Jew, by Oscar Handlin.The American Negro, by Ira De A. Reid.-The Japanese American, by Dorothy Swaine Thomas.The Puerto Rican in the United States, by Clarence Senior.-Understanding minority groups, by Joseph B. Gittler.

Eight papers originally presented at the Institute on Minority Groups in the United States sponsored by the University of Rochester in 1955 and edited by the chairman of its Department of Sociology. In his introduction President Cornelis W. de Kiewiet suggests that these lectures were themselves "part of the slow tide that is evening out the discriminations of American life," since scholarship is the great emancipator preparing the way for the legislator and the jurist. The editor, in his summing up, says that the basic problem is not group diversity but the acceptance of such diversity, and the avoidance of those reactions of prejudice and discrimination which impose minority status.

4429. Handlin, Oscar. The American people in the twentieth century. Cambridge, Harvard
University Press, 1954. 244 p. (The Library of Congress series in American civilization)

$$
\text { 54-8626 E169.1.H265 }
$$

Of narrower scope than its title suggests; the people in whom the author is principally interested are the immigrant hordes recently arrived at the beginning of the century, and who kept coming for another decade, and the depressed Negro population still largely confined to the South in 1900. He traces the fortunes of these groups against the economic tides of the half-century, and especially under the impact of two world wars. World War I produced a narrow restrictive nationalism and bitter conflicts; but World War II produced a nationalism which had lost its exclusive character, and left men to find new values in their ethnic affiliations and traditions.

4430. Handlin, Oscar. Race and nationality in American life. Boston, Little, Brown, 1957. $300 \mathrm{p}$. 57-5827 Er 84.ArH25

"Notes and acknowledgments": p. [281] 287 .

A number of Professor Handlin's articles and papers of the 1950's are here revised and amplified with additional essays in order to form an orderly analysis of "the horror"-racism and its consequences in totalitarianism and genocide. The book's point of departure is the origins of Negro chattel slavery in the $17^{\text {th }}$ century, and the exclusion of Orientals, Negroes, and Indians from the ideal of national homogeneity in the rgth. Racism, however rooted in emotion, expressed itself in a series of ideas which came to permeate much of rigth century science. The dubious science in the roro report of the Immigration Commission and the 1923 Laughlin report is emphasized, and in particular the invalidity of the contrasts between the "new immigration" and the "old." In the concluding portions of the book the author presents evidence that, particularly since World War II, inflexible isolationism, racial thinking, and racial antagonisms are all on the decline in this country. A nationalism free of restrictive and exclusive elements need not conflict with the traditional democratic mission of America.

4431. McDonagh, Edward C., and Eugene S. Richards. Ethnic relations in the United States. New York, Appleton-Century-Crofts [1953] xiv, 408 p. (Appleton-Century-Crofts sociology $\begin{array}{lll}\text { series) } & \text { 52-13692 Er84.ArMr } 37\end{array}$

"Selected readings" at end of each chapter.

4432. Marden, Charles F. Minorities in American society. New York, American Book Co.,

1952. 493 p. (American sociology series)

52-972 EI $84 . \mathrm{ArM}_{3}$ 
"Suggested reading" at end of each chapter.

Both titles are textbooks for college courses in sociology, and their general similarity in approach, materials, and point of view is more noticeable than their differences of detail. Professor Marden of Rutgers University calls attention to the originality of his book in taking "as its central unit, not minorities as such, but rather the relations, or the dynamic interaction, between the minority and its reciprocal," which he calls the dominant. The varieties into which he classifies these relations are four: "native"foreigner, white-colored, ward-wardship, and religious (Catholic-Protestant and Jewish-gentile). While, as the author believes, the ultimate prospect for all minorities is complete assimilation, "it is not certain whether or when white Americans are going to be able to eliminate their 'race-color' consciousness." This should not hinder believers in "the American creed" from oppportunistic activity to reduce discrimination, with the least arousal of antagonism, on various fronts. The first title is unusual in its "biracial authorship," for Professor Richards of Texas Southern University is a Negro. Its three major parts are concerned with understanding, analyzing, and with improving ethnic relations. The authors point to the originality of the analytical part, which provides a common frame of reference in "the status system of the United States," and examines the social or interpersonal, the educational, the legal, and the economic status of seven major ethnic groups. Most of the chapters contain one or more extracts from articles in sociological periodicals. The authors conclude that the United States has probably made the greatest progress of any modern nation "in testing the traditional assumptions that ethnic differences and social inequality are inherently linked."

4433. Rose, Arnold M., and Caroline Rose. America divided, minority group relations in the United States. New York, Knopf, 1948. xi, 342, ix p. $\quad 48-9862 \quad$ EI84.AIR68 1948

Bibliography: p. 329-342.

4434. Rose, Arnold M., ed. Race prejudice and discrimination: readings in intergroup relations in the United States. New York, Knopf, 195I. xi, 605, vi p. 51-II305 EI84.ArR7

The authors of America Divided, producing the first general survey of their subject in 16 years, hoped to pull together all recent scientific study and scholarly writing in their field, but were compelled by its voluminousness to confine themselves to the most important topics and salient facts. Minority problems are defined as distortions in the mind of the majority, and 12 minority groups comprising
43 out of our I3 I millions are identified. The positions of minorities are then discussed with respect to American economic life, law and justice, and political and social life. Descriptive chapters on group self-identification and the minority community are followed by analytical ones which minimize race differences and note that present-day theories of race prejudice are inadequately grounded in empirical research. A concluding chapter on recent and future trends suggests that relations among nationality and racial groups are improving, but among religious groups are deteriorating. The second title is an anthology made up principally of articles from scholarly periodicals, with a few extracts from books; the editor contributes introductions to each of the five parts and the 58 selections. The arrangement follows that of America Divided, save that Part V, "Proposed Techniques for Eliminating Minority Problems," with seven selections, has no counterpart there. The book brings within one pair of covers a quantity of scattered and quite valuable material.

4435. Warner, William Lloyd, and Leo Srole. The social systems of American ethnic groups. New Haven, Yale University Press, I945. 318 p. tables, diagrs. (Yankee City series, v. 3) A45-3302 Er84.AIW25

The third in this series of volumes on the social structure of an old New England community as it appears to a group of social anthropologists applying the techniques developed in studying more primitive societies. The research was performed during $1930-35$ by a staff of 25 field workers, analysts, and writers, as a part of the larger investigation. A part of the text written by Dr. Srole formed his doctoral dissertation submitted to the University of Chicago in I940. The method varies, as in other volumes of the series, between mathematical tabulations of social distance, expressing intangibles in decimal points, and imaginatively fictive "case histories." The ethnic groups studied are the Irish, French Canadians, Jews, Italians, Armenians, Greeks, Poles, and Russians, with the Yankees at one pole as a positive absolute, and the Negroes at the other as a negative one. "Each group enters the city at the bottom of the social heap (lower-lower class) and through the several generations makes its desperate climb upward. The early arrivals, having had more time, have climbed farther up the ladder than the ethnic groups that followed them." The unassimilated portion of each ethnic group usually has a status structure of its own. Later chapters consider the ethnic groups in their bearing upon the family, the church, the school, and private associations. 


\section{E. Negroes}

4436. Crum, Mason. Gullah; Negro life in the Carolina Sea Islands. Durham, N. C., Duke University Press, 1940. xv, $35^{\mathrm{I}} \mathrm{p}$.

Bibliography: p. [345]-35I.

$$
\text { 40-3494I EI85.93.S } \mathrm{S}_{7} \mathrm{C} 85
$$

Most of the titles in the present section are concerned with the interaction of Negro and white communities amid the increasing complexities of industrial civilization. This one differs in presenting the life of an isolated Negro community where, at the time of writing, relatively few changes had "taken place in their mode of living and their outlook upon life since Emancipation." These Sea Islands of South Carolina, from Georgetown to Port Royal Sound, are cut off from the coastal plain by a belt of wide swamps infested by the cottonmouth moccasin, and were little frequented from the fall of the slave regime at the end of 186 I until the construction of modern hard-surfaced roads. In 1940 the sea island Negroes were largely tenant farmers, raising cotton and corn on exhausted land, living in poverty and chronic debt, and on a diet of cornbread, molasses, and fatback. Their speech is the Gullah dialect, incomprehensible to the outsider, "perhaps the most peculiar of all American forms of speech." It is, nevertheless, almost wholly English, derived from the speech of indentured servants, with only a score of African words. The author has traced the Biblical lineage of the Gullah spirituals, in parallel passages which "show how deeply the slaves of the Carolina coast draw upon the dramatic episodes of the Old and New Testaments, and particularly the apocalyptic passages." The remainder of the book is a historical treatment of plantation days and the aftermath of Emancipation, with frequent quotations from source materials.

4437. Davie, Maurice R. Negroes in American society. New York, Whittlesey House, 1949.

$542 \mathrm{p}$.

"References" at end of chapters.

49-II574 EI85.6. $\mathrm{D}_{3}$

A texibook by a Yale professor of sociology which aims to give a factual, scientific analysis and is explicitly "eclectic in character"-i. e., is based on other sociological literature rather than on any personal experience or investigations of its author. This gives the book the relative advantage of being less exacerbated and hortatory in tone than many recent writings on the subject. Four historical chapters are followed by substantial analyses of the situation of the Negro in economic life, education, religion, family life, housing, crime, and suffrage. Interesting chapters on subjects not always so well covered in general works include "Negro Health and Vitality," "The Negro Question in Wartime," "Lynching and Race Riots," and "Race Mixture and Intermarriage." The controversies of the present and the recent past are reviewed in chapters on "Segregation and Discrimination," "The Doctrine of Racial Inferiority," "The Negro's Reaction to His Status," and "The Future of the Negro." The author believes that the indirect approach to a change of attitudes on race relations is more effective than the direct one, and points out that "American Negroes now rate in education, health, economic status, and other measures of achievement far above the total population of all but a few very favored nations."

4438. Davis, Allison, Burleigh B. Gardner, and Mary R. Gardner. Deep South; a social anthropological study of caste and class. Directed by W[illiam] Lloyd Warner. Chicago, University of Chicago Press, 1941. xv, $55^{8}$ p. tables.

$$
4{ }^{\mathrm{I}-23} 6_{45} \mathrm{HN}_{79} \cdot \mathrm{A}_{2} \mathrm{D}_{3}
$$

An exploration of a Southern community's organized system of sentiments and attitudes as expressed in the social practices of whites and Negroes and in the beliefs they hold about themselves and about each other. A white man and his wife and a Negro and his wife, all trained in social anthropology at Harvard, were sent to live for two years in an unnamed city of the deep South. Over half of its 10,000 inhabitants were Negroes, and the adjacent rural areas were over 80 percent Negro. They attempted to discover group attitudes less by formal interviews than by stimulating free discussions with members of both the white and Negro communities, as soon as these had come to accept the investigators as belonging to their own social groups. Southern society, they conclude, is rigorously divided into two racial castes; there are classes within each caste and cliques within each class. However, there is a relatively slight differentiation of class within the Negro caste, and both castes attempt to conceal their class feelings in deference to democratic and Christian dogmas. On occasion force and intimidation may be used to maintain caste divisions. Caste and class have changed and are changing through time, but remain recognized and observable systems. Over half the book is devoted to the relation of caste and class to the cotton econ- 
omy of the area, and a long final chapter to their relation to the white monopoly of local government.

4439. Drake, St. Clair, and Horace R. Cayton. Black metropolis; a study of Negro life in a northern city. With an introd. by Richard Wright. New York, Harcourt, Brace, 1945. xxxiv, 809 p. maps, diagrs. 45-9257 $\mathrm{F}_{54}$ 8.9. $\mathrm{N}_{3} \mathrm{D} 68$

"A list of selected books dealing with the American Negro": p. 793-796.

This thick volume originated in a scries of projects financed by the Works Projects Administration and directed by Professors Cayton and William Lloyd Warner of the University of Chicago. They gradually broadened from a study of juvenile delinquency in Chicago's South Side to that of "the description and analysis of the structure and organization of the Negro community, both internally, and in relation to the metropolis of which it is a part." The Negro ghetto was the Black Belt, a narrow tongue of land, seven miles in length and one and a half in width, in which, together with five smaller South-Side areas, 90 percent of Chicago's 337,000 Negroes were solidly packed. This work sketches the historical development of the Belt, analyzes the nature of the "color-line" in this Northern city and the movements across it, and describes the "job ceiling" which kept Negroes from competing as individuals for any type of job for which they were qualified, and concentrated them in semiskilled and unskilled occupations. Part III describes the ways of life of "Bronzeville" in a variety of spheres and on three class levels. In conclusion the authors stress the contradiction between the principle of fixed status and that of free competition, which prevails elsewhere in American urban society, and describe the problem as essentially a moral one.

4440. Franklin, John Hope. From slavery to freedom; a history of American Negroes. 2d ed., rev. \& enl. New York, Knopf, r956. xv, 639, xlii p. $\quad 56-13200 \quad$ Ex85.F825 1956 "Bibliographical notes": p. 605-639.

Professor Franklin's volume, originally published in 1947, was at once recognized as the most successful of all attempts to tell the story of the American Negro in a single volume. In order to put his story in its proper perspective, the author has maintained "a continuous recognition of the main stream of American history and the relationship of the Negro to it," as well as "a discreet balance between recognizing the deeds of outstanding persons and depicting the fortunes of the great mass of Negroes." The close of the Civil War forms a halfway point in the volume. Negro beginnings are traced in chapters on "Early Negro States of Africa" and "The African Way of Life," and the introduction to America in chapters on "The Slave Trade" and the origins of the slave system in the Caribbean Islands. A chapter on "That Peculiar Institution" of the Old South is followed by one on the "Quasi-Free Negroes," North and South, of the years before 1860. "Losing the Peace" is the author's description of the gradual overthrow of the Reconstruction settlement and the triumph of White Supremacy. Interesting chapters describe "A Harlem Renaissance" following World War I and the immense benefits which Negroes received from the New Deal. Separate chapters are devoted to the progress of the Negro in Latin America and in Canada. Rayford W. Logan's The Negro in the United States, A Brief History (Princeton, Van Nostrand, 1957. 19I p. An Anvil original, no. I9) is an inexpensive paperback with only i4 pages on the years before 1865 . However, it gives a concise outline of the Negro's upward struggles since that year, together with 28 selected documents (p. 106-182) and a select bibliography (p. 183-185). Langston Hughes and Milton Meltzer, in A Pictorial History of the Negro in America (New York, Crown, 1956. 3r6 p.), present a very interesting and various body of illustrations, most of them contemporary with their subject matter, and provided with an adequate textual commentary.

444r. Frazier, Edward Franklin. The Negro family in the United States. Rev. and abridged ed. New York, Dryden Press, 1948. xviii, 374 p. (The Dryden Press sociology publications) $4^{8-7000}{\text { EI } 85.86 . F_{74} \quad \text { I948 }}$

Professor Frazier describes this edition as a popular condensation, carried out by Mrs. Bonita Valien, of the first, published by the University of Chicago Press in I939 (xxxii, 686 p.). Ernest W. Burgess, editor of the University of Chicago sociological series in which it appeared, described it as the most valuable contribution to the literature of the family since the publication, 20 years earlier, of Thomas and Znaniecki's Polish Peasant in Europe and America (no. 4495). As he remarks, the transplantation of the Negro from Africa to America, the transition from slavery to freedom, and the migration from the plantation to the metropolis produced uniquely great and sudden dislocations in the family life of a people, and so exhibit "a social institution subjected to the severest stresses and strains of social change." The special value of the study lay in its combination of such precise statistics as could be obtained with a multitude of personal narratives collected by the author from Chicago and Harlem Negroes. Since the tables have disappeared and the documentary material has been considerably reduced in the abridgement, many students will prefer the original edition. The four successive 
phases of the Negro family in America are defined by the author as primarily matriarchal, patriarchal, unstable, and equalitarian, but these abstractions give only a faint idea of the richness of his materials.

4442. Frazier, Edward Franklin. The Negro in the United States. Rev. ed. New York, Macmillan, 1957. xxxiii, 769 p. maps, diagrs., tables.

Bibliography: p. 707-752. 57-5224 EI $85 . F 833 \quad 1957$

A comprehensive sociological treatment of the Negro race in the United States, originally published in 1949. It approaches the subject historically and emphasizes "the emergence of the Negro as a minority group and his gradual integration into American life." The Negro is regarded, not as an atomized individual, but "as a part of an organized (or disorganized) social life which forms a more or less segregated segment of American society." Of the historical sections, Part I on the slave régime emphasizes the Negro's role in the social organization of the plantation, in which role he was able to take over the culture of the whites. Part 2 dwells upon the racial conflict which developed during and following Reconstruction, eventuating in the establishment of a quasi-caste system. Part 3 analyzes "The Negro Community and Its Institutions" with respect to population, rural and urban communities, social and economic stratification, the family, the church, fraternal organizations, and business enterprise. Part 4, on "Intellectual Life and Leadership," describes educational institutions, the press and literature, social movements, and the Negro intelligentsia. Part 5 deals with "Problems of Adjustment," including crime, delinquency, and race relations. In conclusion, Dr. Frazier examines the "Prospects for Integration of the Negro into American Society" and finds that they have been improved by all recent social changes. The permanence of these changes is guaranteed by the international situation, for upon America's treatment of the Negro at home depends her "bid for the support of the colored majority in the world."

4443. Johnson, Charles S. Into the main stream, a survey of best practices in race relations in the South, by Charles S. Johnson and associates, Elizabeth L. Allen, Horace M. Bond, Margaret McCulloch [and] Alma Forrest Polk. Chapel Hill, University of North Carolina Press, 1947. xiv, 355 p. $\quad 47-30299$ Ei85.6I.J624

Dr. Johnson has been associated with Fisk University at Nashville since 1928 and its precident since 1946. In this volume, however, he writes as Director of the Race Relations Division of the American Missionary Association, which conducted the survey upon which it is based. Seven hundred "respon- sible and informed" individuals in the South cooperated with the project, and Dr. Johnson credits "the main structure" of the volume to Miss McCulloch, who analyzed their contributions. The book is more general in scope than a strict interpretation of its subtitle would imply; the subject matter actually extends to the improving condition of the Southern Negro in most of the spheres of life: citizenship (including the use of the ballot and appointment to government service), employment, education (including college courses on the Negro or on race relations), the "moulding of attitudes" by a variety of media, public health, the churches, and the Y.M. and Y. W. C. A. In a number of sections the items of information follow no clear pattern of arrangement. In his Introduction Dr. Johnson points out the factors at present favorable to interracial harmony and concludes: "The totality of these incidents and programs undoubtedly suggests progress and a will to change, both of which have been accelerated by the war."

4444. Johnson, Charles S. Patterns of Negro segregation. New York, Harper, 1943. xxii, $332 \mathrm{p}$. 43-1802 Ei85.61.J625 Bibliographical footnotes.

"A study of social behavior in interracial contact situations in selected areas of the United States," for which a field staff of five conducted interviews in three counties of the rural South and five Southern cities, as well as in border and Northern cities. Part $I$ is concerned with patterns of segregation and discrimination for, in the author's opinion, "there can be no group segregation without discrimination," and "in equity any segregation that is not mutual or voluntary is discrimination." The patterns are described for residential areas, educational institutions, recreational facilities, law enforcement, relief and welfare, public buildings, transportation, hospitals, hotels and restaurants, stores, places of amusement, professional services, and, at greater length, for occupations and industries. An important chapter describes "The Racial Etiquette in Public Contacts and Personal Relations," while another on "The Ideology of the Color Line" is based upon statements by white persons most of whom justified segregation. Southern state legislation enforcing segregation is analyzed, as well as the civil rights laws of several Northern states aimed against discrimination. Part II is concerned with the "Behavioral Response" of Negroes to these patterns, the interview material being classified into "Acceptance," "Avoidance," and "Hostility and Aggression." Dr. Johnson thinks that urbanization and industrialization have been the principal agents in eroding the old customs, and that they will continue to operate in the same direction. Comer Vann 
Woodward's The Strange Career of Jim Crow (new and rev. ed. New York, Oxford University Press, I957. I83 p. A Galaxy book, GB6) originated in James W. Richard lectures delivered at the University of Virginia in I954. It convincingly demonstates that most of the patterns described by Dr. Johnson did not, as is generally supposed, originate at the time the South regained its autonomy in the I $870^{\circ}$ 's, but nearly two decades later, as a weapon employed by the Bourbons to defeat the Populist movement of the I 890 's, and that they were initiated in the western states of the South, and only graduallv spread to the Atlantic seaboard.

4445. Logan, Rayford W. The Negro in American life and thought: the nadir, I877-igor. New York, Dial Press, 1954. 380 p.

$$
\text { 54-600o Ei } 85.6 \text { r.L64 }
$$

Professor Logan of Howard University assesses the status of the Negro and the opinion of the Northern press concerning the Negro between the Compromise of 1877 , which withdrew Federal troops from the South, and the assassination of President McKinley. President Hayes had not meant to abandon the poor colored people of the South, but the "honorable and influential Southern whites" dishonored their side of the bargain and nullified the Reconstruction amendments. The nadir was reached with President McKinley's “callous disregard for the protection of the constitutional rights of Negroes." By igoo "what is now called secondclass citizenship was accepted by presidents, the Supreme Court, Congress, organized labor, the General Federation of Women's Clubs-indeed by the vast majority of Americans, North and South, and by the 'leader' of the Negro race [Booker T. Washington]." Yet from 1865 to 1900 , as the author himself tells us, the Negro population doubled in numbers, increased in literacy from 18.6 percent to 55.5 percent, and began organizing its own banks (in 1888). The ideals of the Abolitionists and the Radical Republicans were obscured for the time being, but the record indicates slow and painful progress rather than any real nadir.

4446. Myrdal, Gunnar. An American dilemma; the Negro problem and modern democracy, by Gunnar Myrdal with the assistance of Richard Sterner and Arnold Rose. [gth ed.] New York, Harper, I944. lix, 1483 p.

$$
\text { 48-10226 Ei 85.6.M95 } 1944
$$

Bibliography: p. I I 44-I 80 .

The Carnegie Corporation of New York was convinced by the late Newton $\mathrm{D}$. Baker that it needed more and better organized knowledge of the American Negro of today before it could intelligently disburse its funds on his behalf. In 1938, therefore, it brought over an impartial Swedish social economist, Dr. Myrdal of the University of Stockholm and the Swedish Senate, as director of "a comprehensive study of the Negro in the United States, to be undertaken in a wholly objective and dispassionate way as a social phenomenon." Dr. Myrdal took much advice, and in 1939 engaged a staff of six, including Ralph J. Bunche and Dorothy S. Thomas, while some 70 other persons worked on special projects or as assistants to the principal investigators. In addition to the works by Johnson and Sterner listed in this section (nos. 4444 and 4448), two other of the resulting special studies were published by Harper: The Myth of the Negro Past, by Melville J. Herskovits (r941. xiv, 374 p.), and Characteristics of the American Negro, edited by Otto Klineberg (I944. 409 p.). The unpublished manuscripts of some 35 other studies were deposited in the Schomburgk Collection of the New York Public Library. The completion and publication of Dr. Myrdal's overall report were considerably delayed by the war, but since its appearance it has been generally accepted as the principal authority in its field. Summary is impracticable, but the titles of the eleven parts into which the 1,024 pages of the main text are divided give an idea of its comprehensiveness and organization: "The Approach," "Race," "Population and Migration," "Economics," "Politics," "Justice," "Social Inequality," "Social Stratification," "Leadership and Concerted Action," "The Negro Community," and "An American Dilemma." Dr. Myrdal's conclusion is that the progress of "social engineering" now permits the redemption of America's greatest failure and the realization of America's own innermost desire, the final integration of the Negro into modern democracy. The final quarter of the work consists of ten appendixes and over 250 pages of footnotes. Readers daunted by the massiveness of $A n$ American Dilemma may prefer the condensation prepared by one of Dr. Myrdal's assistants, Arnold M. Rose: The Negro in America (New York, Harper, 1948. xvii, 325 p.).

4447. Reid, Ira De A. The Negro immigrant, his background, characteristics and social adjustment, 1899-1937. New York, Columbia University Press, 1939. 26I p. (Studies in history, economics and public law, edited by the Faculty of Political Science of Columbia University, no. 449) 39-19999 H3r.C7, no. 449 JV6895. $\mathrm{NH}_{4} \mathrm{R}_{4}$ I939a

Bibliography: p. 253-258.

A model study of the acculturation problems of a group of erstwhile members of a majority who must become members of a minority and find a place within the Negro class structure. At the time of writing, the Negro immigrants in the United States, 
nearly all of Caribbean origin, numbered some I00,000 persons, 60 percent of whom lived in New York City. Dr. Reid based his report on personal histories, government documents, and his own observations as a participant in the group life of these immigrants in New York City. His evidence shows that the members of the group tend to resent relegation to a minority status and adopt radical views with respect to increasing Negro rights in the United States. Native Negroes usually regard them with hostility as foreign competitors for jobs, and dub them "monkey-chasers." There are careful expositions of the number, sources, and background of the Negro immigration, its population characteristics, and the degree, form, patterns, and trends of its interracial and intraracial adjustment. A separate chapter contains excerpts from life histories.

4448. Sterner, Richard M. E. The Negro's share; a study of income, consumption, housing and public assistance [by] Richard Sterner in collaboration with Lenore A. Epstein, Ellen Winston, and others. New York, Harper, I943. 433 p. incl. tables.

43-8019 EI85.8.S8

One of the supplementary volumes in the study of the American Negro sponsored by the Carnegie Corporation of New York and planned by Dr. Myrdal (no. 4446). Dr. Sterner, a specialist on social questions in the service of the Swedish Government, came to the United States with Dr. Myrdal. The conditions reflected in this book are almost exclusively those of the I93o's, before the full employment which was created by wartime conditions and has outlasted them. Part I, concerned with "Living Conditions," deals with the Negro"s flight from agriculture, his employment and unemployment, family incomes and expenditure, food consumption, and rural and urban housing. Part II, on "Social Welfare," endeavors to ascertain the Negro's share in various forms of public assistance. Dr. Sterner does not facilitate the reader's task by chapter summaries or general conclusions, and ordinarily one must go to his tables to discover the relative position of the Negro. Thus a sample group of Southern Negro nonrelief families had median income ranging from $\$ 445$ to $\$ 870$; white nonrelief families from the same areas ranged bewteen $\$ \mathrm{I}, \mathrm{I} 33$ and $\$ 2,356$. None of the Negro groups approached the "so-called maintenance level" of \$1,26r. An up-todate survey, which would document the general improvement of the last 15 years, is much to be desired.

4449. Washington, Booker T. Up from slavery, an autobiography. With an introd. by Jonathan Daniels. London, Oxford University
Press, 1945, '1901. 244 p. (The World's classics, 499) 49-39047 Er $85.97 . W_{3162}$

4450. Mathews, Basil J. Booker T. Washington, educator and interracial interpreter. Cambridge, Harvard University Press, $194^{8}$. xvii, $35^{\circ} \mathrm{p}$. 48-8652 Ei $85 \cdot 97$.W 249

Washington (1856-1915), the son of a slave woman and a white father, was, from I88I to his death, the first "Principal" of Tuskegee Institute, Tuskegee, Alabama, which he made into a leading Negro educational center. After early years as a laborer and handyman, his formal education began at Hampton Normal and Agricultural Institute in 1872. Washington's appointment to head the infant Tuskegee Institute was the pivot of his life since it enabled him to work for what he considered the most important goal of the newly freed Negroes: economic independence. Under Washington, Tuskegee became a training school where Negroes could learn practical agricultural and mechanical skills in a novel curriculum planned by him, with the students' work contributing to the upkeep of the school as well as to their own development. Outside the Institute he founded a number of associations for Negro professional men and women and raised large amounts of money for the Institute and other organizations benefiting the Negro. With his Atlanta speech of 1895 he won world-wide recognition as the spokesman and leader of the American Negro. His advocacy of the evolutionary betterment of Negro status won for him both praise and criticism from Negroes and whites alike. Much of his last 15 years was spent in travel, delivering lectures and organizing interracial conferences, both here and abroad. Up from Slavery is a classic autobiography, but in concentrating upon certain aspects of its author's career and message hardly tells the whole story, even down to its date of publication (I90I). A fuller narrative is provided by $\mathrm{Mr}$. Mathews' admiring biography, and even by Samuel R. Spencer's concise life in The Library of American Biography series: Booker T. Washington and the Negro's Place in American Life (Boston, Little, Brown, 1955. 212 p.).

445I. Weaver, Robert C. The Negro ghetto. New York, Harcourt, Brace, 1948. xviii,

404 p. maps. $\quad 4^{8-7373}$ Ei85.89.H6W 4

Bibliography: p. 371-375.

The author confines his inquiries to the residential or spatial separation of the races in the North, which is the peculiar manifestation of Negro segregation in that part of the country. The concentration of migrated Negroes into segregated areas is of comparatively recent origin, a result of the general 
housing shortage during the depression of the $1930^{\circ}$ 's. Mr. Weaver seeks to determine the economic and social patterns making for the solidification of Black Belt areas in Northern cities. Active opposition to the dispersal of Negroes in these cities, he shows, is led by building, real estate, and home-finance groups, and carried out by restrictive covenants and by inhospitable treatment and social ostracism on the part of white residents who fear an influx of Negroes into their neighborhoods. Mr. Weaver analyzes these fears, in which race prejudice and concern for property values are mingled, and appeals for the establishment of educational programs in interracial living and increases in the housing available to minorities. Much of the information is drawn from housing problems in Chicago.

\section{F. Jews}

4452. Commentary. Commentary on the American scene; portraits of Jewish life in America, edited by Elliot E. Cohen. Introd. by David Riesman. New York, Knopf, 1953. 336 p.

$$
5^{2-6413} \quad E_{184} J_{5} \mathrm{C}_{6}
$$

4453. Ribalow, Harold U., ed. Mid-century; an anthology of Jewish life and culture in our times. New York, Beechhurst Press, 1955. 598 p. 54-10691 E184.J5R5

Commentary has been published under the auspices of the American Jewish Committee since the close of 1945 and is generally regarded as the leading American periodical for Jewish culture. In the first title its editor has drawn upon its department called "From the American Scene" for 20 pieces by I7 writers. Journalism in the best current American manner, they give vivid glimpses of Jewish life in a variety of aspects, such as "The Jewish Delicatessen" and "The Jewish College Student: New Model." The majority derive from the New York City area, but others describe San Francisco, Tuisa, a Chicago suburb, and an unnamed New England community. The editor of Mid-century has been editor of Congress Weekly and The American Zionist; his father, Menachem Ribalow, one of whose pieces is included, was until his death in 1953 "perhaps the most prominent Hebrew writer in the United States." It assembles 45 articles from 16 periodicals, including 7 from Commentary, 6 from Congress Weekly, and also 8 from non-Jewish periodicals, "by the most notable names in AmericanJewish scholarship, theology, philosophy, culture, and journalism." They are grouped in four sections: "First Person Singular," "Belonging and Survival," "Culture," and "Zion." Some of the articles are concerned with Jewish problems in general, but the majority are in whole or part concerned with American Jewry. The volume closes with 9 pages of "Biographical Notes" on the 53 contributors.
4454. Edidin, Ben M. Jewish community life in America. New York, Hebrew Pub. Co.,

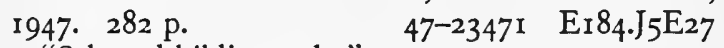

"Selected bibliography": p. 273-277.

A comprehensive description of Jewish group life in the United States, in its structure, agencies, functions, problems, and aspirations, which takes its departure from the average local Jewish community rather than from American Jewry as a whole, and treats each topic in its historical development. Simply written, it is intended for students, teachers, parents, and group leaders, and is suitable for junior and senior high school classes or adult study groups. Chapters on the development of American Jewish communities are followed by analytical ones on the school, the synagogue, and the community center, which, although relatively a newcomer, now ranks with the other two "as one of American Jewry's three chief communal institutions." There follow descriptions of cultural activity, such as that of the Histadruth Ivrith, of social service, occupations, the struggle against anti-Semitic discrimination, and aid for Zionism. Miscellaneous community organizations, such as the B'nai B'rith, receive a long chapter, and the "year-round job" of raising funds another. American Jews still regard the community idea as essential to individual happiness, but "in every American Jewish community new ideas and methods are being tried."

4455. Handlin, Oscar. Adventure in freedom: three hundred years of Jewish life in America. New York, McGraw-Hill, 1954. 282 p.

$$
54-10634 \quad E_{1} 84.55 \mathrm{H}_{29}
$$

Written for the tercentenary of the first Jewish immigration to America, this is neither a complete history nor an assessment of "contributions," but an effort at interpretation of the main lines of development, particularly in their bearing upon the problems of the present. The flight of the Jews from Eastern Europe after 1870 rapidly altered the character of American Jewry and led to its bifurca- 
tion into two separate communities, only gradually reintegrated after World War I. Among the factors which promoted the reintegration of the Jewish community were "the free and fluid society of the United States," in which the rigid lines of social division tended to disappear, and the increasing virulence of anti-Semitism both in Europe and in America, where discrimination and exclusion in social life, education, and the professions were on the increase until World War II. The old antiSemitism died in that war, and American Jews have become increasingly assimilated to the standards and tastes of American middle-class culture.

4456. Gordon, Albert I. Jews in transition. Minneapolis, University of Minnesota Press, I949. xviii, 33I p. $\quad 49-10489$ F614.M5G67

The author served as a rabbi of Adath Jeshurun Synagogue during 1930-46 and used this opportunity to apply the "participant-observer technique" of social anthropology to the Jewish community of Minneapolis. His main theme is "the changes that have occurred in the beliefs, practices, and institutions of the European Jews" who settled there, and made adaptations in their original cultural patterns. For ten years he recorded the conversations and comments that he heard, not stenographically but in recollection, and has combined these oral materials with written ones such as synagogue records and the files of the American Jewish World, a Minneapolis weekly. He obtained substantial personal histories from four of the oldest members of the community, born in the I 860 's; these comprise Part III of the book. "There is," he finds, "a decreasing emphasis upon ritual and form in the religious life" of the community, and "the dietary laws are gradually disappearing," even from the home, but some ceremonies and holidays have been revived or elaborated. The Jews of Minneapolis, although completely loyal to the United States, go on living in two cultures, and seem likely to continue doing so. They comprise only 4 percent of the city's total population, about the same proportion as the Jewish population of the whole United States.

4457. Janowsky, Oscar I., ed. The American Jew, a composite portrait. New York, Harper, 1942. xiv, $322 \mathrm{p}$. 42-23786 E $184 . J_{5} J_{3}$

Partial Contents.-Historical background, by O. I. Janowsky.--Judaism and the synagogue, by D. de S. Pool.-Jewish education, achievements and needs, by I. B. Berkson.-The cultural scene: literary expression, by Marie Syrkin.-Hebrew in Jewish culture, by A. S. Halkin.-Structure of the Jewish community, by A. G. Duker.-Economic trends, by Nathan Reich.-Anti-Semitism, by J. J. Weinstein.-Current philosophies of Jewish life, by Milton Steinberg.-Zionism in American Jewish life, by Sulamith Schwartz.-Evaluation of the portrait of American Jewish living: The Jewish community and the outside world, by G. N. Shuster. The national being and the Jewish community, by H. M. Kallen.-Selected bibliography (p. [287]298).

4458. Friedman, Theodore, and Robert Gordis, eds. Jewish life in America. New York, Horizon Press, 1955. 352 p.

$55^{-I} I_{4} 62 \quad \mathrm{E}_{1} 8_{4} \cdot \mathrm{J}_{5} \mathrm{~F}_{7} 8$

Partial Contents.-American Jewry: fourth century, by Robert Gordis.-Religion: American orthodoxy, retrospect and prospect, by Emanuel Rackman.-Jewish tradition in 2oth century America: the conservative approach, by Theodore Friedman.-The temper of reconstruction, by $\mathrm{H}$. M. Schulweis.-Reform Judaism in America, by S. S. Cohon.-Secularism and religion in the Jewish labor movement, by C. B. Sherman.-Culture: The East Side, matrix of the Jewish labor movement, by Abraham Menes.-American Jewish scholarship, by S. B. Freehof.-Hebrew culture and creativity in America, by Jacob Kabakoff.-Jewish literature in English, by Charles Angoff.--Yiddish literature in America, by N. B. Minkoff.-Jewish education in the United States, by W. B. Furie.-Jewish music in America, by H. D. Weisgall.--Visual arts in American Jewish life, by S. S. Kayser.-The community: Interfaith relations in the United States, by M. N. Kertzer.-Impact of Zionism on American Jewish life, by A. G. Duker.-The American rabbi: his changing role, by $\mathrm{B}$. J. Bamberger.-Notes on the authors.

Of these two coöperative surveys of Jewish life in America, the earlier was begun as an educational project of Hadassah, the Women's Zionist Organization of America. The authors believed that a Jewish homeland in Palestine, where Jewish culture would not be ancillary to a majority culture, was indispensable under any circumstances; they were, nevertheless, according to Dr. Janowsky, "completely identified with American culture and the American way of life." The second survey, published 13 years later, originated in a tercentenary issue of the magazine Judaism and was sponsored by the American Jewish Congress. It assumes "the permanent framework of all forms of Jewish activities on the American locale," and the author who deals with Zionism believes that "it will have to fight for its place in the American Jewish community." The earlier survey is the more comprehensive; the later one is more detailed in its treatment of religion and culture, and offers, its editors think, "the kind of tempered appraisal of the mainstreams of American Jewish creativity rarely to be found in contem- 
porary writing." The voting record of Jews during the 1952 presidential election is analyzed in Lawrence H. Fuchs' The Political Behavior of American lews (Glencoe, Ill., Free Press, 1956. 220 p.) as part of an historical and sociopolitical study undertaken to determine why most American Jews are political liberals.

4459. The Jewish people, past and present. v. 4 . 300 years of Jewish life in the United States. New York, Jewish Encyclopedic Handbooks, Central Yiddish Culture Organization (CYCO) 1955. $455 \mathrm{p}$. 46-7394 DS I02.4.J 4, v. 4

This large and handsomely produced volume results from the collaboration of eleven contributors, eight editors, and five translators. The section on general history is conventional enough, and the sections on religious movements and communal life present material readily available elsewhere. Jacob Lestschinsky's section on economic and social development presents much demographic information, with special attention to occupations and social structure. Philip Friedman on political and social movements traces the development of American Zionism. Mark Wischnitzer, in charting the impact of American Jewry on Jewish life abroad, describes rebuilding after World War I, and during the Nazi persecutions, and the United Jewish appeal. Abraham Menes, in describing the Jewish labor movement, places its golden age between Igor and I9I8, culminating in the "great revolt" of rgogthe strike of 60,000 cloakmakers. Samuel Niger deals with Yiddish culture, including the Yiddish theater of the I880's, and Joshua Trachtenberg describes American Jewish scholarship, which includes not only Talmudics and Rabbinics, but also historical, sociological, and cultural studies. There are frequent halftone cuts of persons and buildings.

4460. Joseph, Samuel. Jewish immigration to the United States from I88I to I9I0. New York, Columbia University, Igr4. 209 p. (Columbia University, Faculty of Political Science. Studies in history, economics and public law, v. 59, n. 4 ; whole no. I45) I4-15042 H3I.C7, v. 59

Bibliography: p. 207-209.

JV6895.J6J6

In 1880 more than half of the Jews in the world were located within the Eastern European Pale, the majority, in Poland and Western Russia, subjects of the Czar, and large minorities in Galicia, a province of Austria-Hungary, and Moldavia, a province of Rumania. Their condition, which had in many respects improved during the reign of the liberal Czar Alexander II, took a drastic turn for the worse after his assassination in $\mathrm{I} 88 \mathrm{I}$. New and harsh laws were decreed, and "that combination of murder, outrage, and pillage-the pogrom" was unleashed against them. During the three decades $1881-1910$, $1,562,800$ Jewish immigrants came to America, constituting 8.8 percent of the total immigration. 7 I percent of these Jews came from Russia, and most of the remainder from Austria-Hungary. This workmanlike dissertation compares the immigration from the three nations and describes the whole stream as essentially a family movement of permanent settlers largely concentrating in the North Atlantic States. The text is supplemented by 69 statistical tables (p. 158-196).

$44^{6} \mathrm{I}$ Levinger, Lee J. A history of the Jews in the United States. [4th rev. ed.] Cincinnati, Union of American Hebrew Congregations, 1949. xxiii, 6r6 p. illus. (Commission on Jewish Education of the Union of American Hebrew Congregations and the Central Conference of American Rabbis. Union graded series)

$$
\text { 49-49296 Er84.J5L664 I949 }
$$

Bibliographical references at end of chapters or sections.

A textbook for classes of the high school level in Jewish schools, the first edition of which appeared in I930. It is considerably more comprehensive and better balanced than a number of books on the subject written for adult Jews, and its very simplicity and methodical procedure make it a useful guide for the gentile reader. Rabbi Levinger organizes his text around the three main waves of Jewish immigration, the Sephardic Jews of Spain before 1840 , the German Jews during most of the Igth century, and the Russian Jews after 1880. Emphasis is placed upon the development of Jewish religious, charitable, and educational institutions in the United States, and upon outstanding individuals from Judah Touro of Newport (1775-1854) to Governor Herbert $\mathrm{H}$. Lehman. Bertram Wallace Korn's Eventful Years and Experiences (Cincinnati, American Jewish Archives, 1954. 249 p.) is an interesting collection of eight studies in American Jewish history mostly during the central decades of the igth century. One is on the Jewish refugees of 1848 , another is a panorama of "American Jewish Life in I849," and a third tells the story of Maimonides College of Philadelphia, the first Jewish theological seminary in America (1867-73). A summary of local Jewish history and a guide to and description of places of Jewish interest in each state, the District of Columbia, and New York City and its environs is contained in $A$ Jewish Tourist's Guide to the U. S., by Bernard Postal and Lionel Koppman (Philadelphia, Jewish Publication Society of America, 1954. xxx, 705 p.). 
4462. McWilliams, Carey. A mask for privilege: anti-Semitism in America. Boston, Little, Brown, I948. 299 p. 48-60II Ei84.J5MI6

In the summer of 1877 Joseph Seligman, a New York banker, was refused accommodation at a Saratoga Springs hotel-cone of the first major overt manifestations of anti-Semitism in the United States," which the author regards as proceeding from the triumph of a new generation of industrial tycoons and "the corrosion which the industrial revolution had brought about in the American scheme of values." Anti-Semitism in America differs from its European counterpart in that limitations have been imposed, not by the state, but "by our 'private governments'-industry and trade, banks and insurance companies, real estate boards and neighborhood associations, clubs and societies, colleges and universities." The book exhibits many personal views, elliptical arguments, and controversial acerbities, but it brings together a wide range of information on anti-Semitic utterances, "The System of Exclusion," the activities of "crackpot" agitators and associations, and recent anti-Semitic incidents. In Chapter ro, "No Ordinary Task," the author outlines a program of education, legislation, and other social action to eradicate this "most treacherous, deceptive, and tenacious of social prejudices," the appearance of which is invariably "a symptom of social sickness, a manifestation of social disorganization."

\section{G. Orientals}

4463. Chêng, Tê-ch'ao. Acculturation of the Chinese in the United States; a Philadelphia study, by David Te-chao Cheng. Philadelphia, 1948. 280 p. tables. A50-1331 E184.C5 47

"Printed in China."

Bibliography: p. [26I]-274.

A University of Pennsylvania dissertation which studies the Race Street Chinatown of Philadelphia. The author is a Cantonese-speaking Chinese who worked there as a Christian missionary during $1940-44$, and in 1942 undertook a study of its economic occupations, which was subsequently expanded to include its institutions as a whole, with emphasis upon culture contact and change. Nearly all its residents come from an area of Ioo square miles along the southern coast of the province of Kwantung, and Part I describes the people of this part of China, their community life, and their philsophical outlook. Part II sketches the history of the Race Street Community, which dates from about 1870 , and analyzes the occupations, the social organizations and customs, the education, and the family, religious, and recreational life of its members. In Part III the author draws up "A Balance Sheet of Acculturation" which indicates that, despite the ghetto-like segregation that has been the rule since 1894 , the culture traits which the Philadelphia Chinese "have adopted from the American culture are definitely more than the culture traits which they have transplanted from the Old World and retained." Dr. Cheng's research terminated in 1944 and his preface is dated June 1946; his book reflects the wartime opening of "the door of racial and occupational discrimination," which he expected to be permanent.
4464. Coolidge, Mary (Roberts) Smith. Chinese immigration, by Mary Roberts Coolidge. New York, Holt, Igog. 531 p. tables. (American public problems, edited by Ralph Curtis Ringwalt)

"Selected bibliography": p. 505-517.

This is an old book, but the Chinese immigration with which it deals had come to an end 27 years before its publication, and it remains the only comprehensive treatment of the subject. From the Gold Rush of 1849 until the opening of the transcontinental railways 20 years later manual labor was in heavy demand in California, and from 1852 Chinese coolies were imported in numbers, averaging 16,000 a year for three decades. With the opening of the railroads, however, a flow of white workers came from the East to glut the labor market and to begin an exclusionist agitation which extended to occasional riot and massacre. Mrs. Coolidge described this movement in some detail and emphasized that the exclusionist enactments of $1882-92$ were clear violations of the Treaty of 1880 with China. China's resentment of American discrimination was shown by her failure to renew the Treaty of 1894 and by a boycott of American goods. The book reviews the Chinese background of the immigrants, and their ways of life in America, and contends that they were more industrious, better behaved, and no less assimilable than many groups of European immigrants.

4465. Ichihashi, Yamato. Japanese in the United States; a critical study of the problems of the Japanese immigrants and their children. Stanford University, Calif., Stanford University Press, 1932. $426 \mathrm{p}$. 32-22696 EI84.J314 
"Select bibliography": p. 409-4I7.

The author was professor of Japanese history and government at Stanford, and his book remains, after 25 years, the most comprehensive account of Japanese immigration to the United Stat.s. It is prefaced by an analysis of Japanese immigration in general, which was a drop in the bucket in comparison with Japan's rapid population increase, and of Japanese immigration to Hawaii, where nearly as many went as to the continental United States. Japanese immigration to the United States was negligible before 1890 and after 1908 was greatly reduced by the Gentlemen's Agreement. In the peak year, 1907, 9,948 Japanese entered, and the total Japanese population rose to 138,800 by 1930 . The author describes the character, causes, and geographical distribution of the immigration; the employment of the Japanese in domestic service, city trades, and especially in agriculture; the movement toward and measures of exclusion; and the characteristics and problems of the American-born Japanese. They are taller, longer of limb, and heavier than Japanese children born and bred in Japan, and they are as intelligent and "as emotional as the average American." Their difficulties under discrimination, especially in the realm of employment, are objectively and effectively discussed.

4466. La Violette, Forrest E. Americans of Japanese ancestry; a study of assimilation in the American community. Toronto, Canadian Institute of International Affairs, 1946. $185 \mathrm{p}$.

$$
\mathrm{A}_{4} 6-5078 \text { Er } 84 . \mathrm{J}_{3} \mathrm{~L}_{3} \text { I946 }
$$

"Unpublished material" [theses and dissertations]: p. $18 \mathrm{r}-\mathrm{r} 82$.

A University of Chicago dissertation based upon research in the Seattle, Portland, San Francisco, and Los Angeles areas begun in 1934, and continued at intervals until the evacuation of 1942 . It emphasizes "the social context of the term nisei [the American-born second generation, exclusive of the $k i b e i$, sent back at an early age for education in Japan] as it has developed between the cessation of immigration in 1924 and Pearl Harbor in 1941, with the chief emphasis placed upon Japanese family and community life." It is through the family that the Nisei receive three sets of attitudes which link them most strongly to the ancestral culture: "submission and recognition of authority and prestige of the parents, acceptance of family responsibilities and maintenance of inviolate integrity of family status within the community," but the level of conformance is lower than is expected in Japan. The vocational problems of the Nisei, to whom only a limited variety of occupations and restricted opportunities within them have been available, and their marriage problems, such as too costly wedding re- ceptions, are described. The author stresses the applicability of his studies to Canadian conditions, pointing out that Canada and the United States are the only two nations in the world concerned with assimilating so divergent a group, and that it is surprising "that the first generation of Americanborn children of Japanese parents have already progressed so far in this movement requiring a number of generations."

4467. Leong, Gor Yun. Chinatown inside out, by Leong Gor Yun. New York, B. Mussey, I936. $256 \mathrm{p}$. 36-22486 Er 84.C5L56

An inside view, journalistic in style but based on wide personal knowledge, of New York's Chinatown, taken as typical of these segregated communities in a number of the larger American cities. Since the exclusion of Chinese immigration in the I880's, these picturesque districts have remained static or dwindled, but their position as "the most exclusive of all the alien colonies in America" has altered little. The conditions described by $\mathrm{Mr}$. Leong, however, are those of two decades ago, when he found that the ordinary residents of Chinatown, and especially the foreign-born, were exploited by the local "charitable and benevolent" association, a government within a government, and by the Tongs, some of which had turned into rackets. On the other hand, the average Chinese American received some assistance from his family association and from organizations for self-help, such as the Chinese Hand Laundry Association. Chinatown was a man's world, with a ratio of ten males to one female, and the most popular diversions, in order of favor, were gambling, resort to prostitutes, opium-smoking, and drinking. The author predicted the extinction of the old Chinatowns within a generation or two, but the process is as yet by no means complete. The volume is illustrated by excellent photographs, mostly taken for the purpose.

4468. Mears, Eliot Grinnell. Resident Orientals on the American Pacific coast; their legal and economic status. Chicago, University of Chicago Press, 1928. xvi, 545 p. tables, diagrs.

"Select documents": p. [43I ]-526.

$$
\text { 30-2364 Ei } 84.06 \mathrm{M}_{33}
$$

For practically as long as it has been occupied by the United States, "the Far West has sternly fought the coming of Oriental peoples to the American mainland." The present volume is concerned with the result as seen in the contrasting status of citizens, aliens eligible to citizenship, and aliens ineligible to citizenship in California, Oregon, and Washington. The author calls his study "one of laws, regulations, and judicial decisions and their actual opera- 
tion," but in fact there is quite as much about the state of mind which produced the laws, and the actual economic and social condition of the Pacific coast Chinese and Japanese, as about the purely legal aspects. There is a discussion of the degree to which their nationals here have been protected by our treaties with Japan and China, and by the guaranties of the United States Constitution and its amendments. No specific Act of Congress denied citizenship to Orientals, but the Federal courts have more or less consistently interpreted the naturalization laws, originating in 1790 , to that effect. The Pacific States have passed laws forbidding intermarriage, alien ownership of land, the public employment of Orientals, and even hunting and fishing by them. The author believed that in 1928 the West Coast was displaying a more friendly attitude toward both races than it had in the recent past.

4469. Thomas, Dorothy Swaine, and Richard S. Nishimoto. Japanese American evacuation and resettlement. Berkeley, University of California Press, 1946-52. 2 v. A47-1448 D753.8. $\mathrm{T}_{4}$

Contents.-v. I. The spoilage, by D. S. Thomas and R. S. Nishimoto.-v. 2. The salvage, by D. S. Thomas with the assistance of C. Kikuchi and J. Sakoda.

The most spectacular displacement of population in the whole of American history was the removal of nearly IIo,ooo persons of Japanese birth or ancestry from the Pacific coast early in 1942, and the internment of nearly all of them in ten "relocation centers," two of which were as far east as Arkansas. A group of social scientists at the University of California at once perceived the possibilities of such an upheaval for an intensive study of social processes, and with the financial backing of the University and three foundations were able to keep on foot, if not on so elaborate a scale as they had originally planned, an Evacuation and Resettlement Study from February 1942 through December I945, "by which time the program of resettlement was about completed." The majority of the staff observers were recruited from among the evacuees, and their major task was "to record and analyze the changes in behavior and attitudes and the patterns of social adjustments and interaction" among the interned. The three major "laboratories" of the Study were the Poston center in Arizona, the Minodoka center in Idaho, and especially the Tule Lake center in northern California, but spot observations were made in five of the other seven centers, and from April 1943 the "associational life of the resettling evacuees" was studied from a Chicago office. Tule Lake forms the principal subject of The Spoilage; it soon came to be used for the segregation of persons classified as disloyal, in some cases on somewhat technical grounds, and it was here that the bulk of the complaints, strikes, threats, and murder and other violence took place, culminating in the renunciation of American citizenship by 70 percent of the citizens there interned. The Salvage consists of two parts, the first and briefer of which is "Patterns of Social and Demographic Change," wherein the consequences of the great upheaval are surveyed in the perspective of the whole history of the Japanese immigration to the United States. The net effect was "the dispersal beyond the bounds of segregated ethnocentered communities into areas of wider opportunity of the most highly assimilated segments of the Japanese American minority." Part II presents the life histories of fifteen persons who were resettled in the East or Middle West, selected for their representative character; Mrs. Thomas expresses her gratitude "for their willingness to relive, 'for the record,' the traumatic period following Pearl Harbor." Two other studies of the great evacuation have been published by the University of California: Removal and Return; the Socio-economic Effects of the War on Japanese Americans, by Leonard Bloom and Ruth Riemer (1949. 259 p.), and The Managed Casualty; the Japanese-American Family in World War II, by Leonard Broom and John I. Kitsuse (I956. 226 p.), The origins of the evacuation policy are tracked down by Morton Grodzins in Americans Betrayed; Politics and the Japanese Evacuation (Chicago, University of Chicago Press, 1949. xvii, 444 p.).

\section{H. North Americans}

4470. Burma, John H. Spanish-speaking groups in the United States. [Durham, N. C.] Duke University Press, I954. 2I4 p. (Duke University Press sociological series [no. 9])

Bibliography: p. [199]-209.

$$
\text { 53-8273 Er } 84 . \mathrm{M}_{5} \mathrm{~B} 8
$$

The Spanish-speaking is the one foreign-language group in the United States that has continued to increase since the Quota Act of I92I and has now become the fourth largest in the country. Based upon a large monographic literature rather than personal investigation, this is the only work to treat the group as a whole and to consider its common cultural and religious core as well as the racial, historical, and 
social diversity of its component groups. The Hispanos, descendants of the Spanish colonists of New Mexico annexed in $\mathrm{x} 848$, persist as inbred communities whose customs and social structures look back to the r6th century. The largest group are the Mexican-Americans, more Indian than Spanish in race, who can be found throughout the United States, but in the Southwest constitute a minority subject to varying degrees of discrimination. The Filipinos are Malays in race; as the smallest and most dispersed group, their minority problems resemble those of the Chinese. The Puerto Ricans as American citizens are not subject to the quotas and other restrictions hindering the entry of Filipinos and Mexicans; their problems arise from the facts that about a third are negroid, and nearly all have concentrated in the slums of New York City. They are the subject of a monograph by Charles Wright Mills, Clarence Senior, and Rose Kohn Goldsen: The Puerto Rican Journey; New York's Newest Immigrants (New York, Harper, 1950. 238 p.). The Filipino element was studied at a time when it was numerically more important than it is today, under the auspices of the Institute of Pacific Relations, in Bruno Lasker's Filipino Immigration to Continental United States and to Hawaii (Chicago, University of Chicago Press, 1931. xxii, 445 p.).

4471. Gamio, Manuel. Mexican immigration to the United States; a study of human migration and adjustment. Chicago, University of Chicago Press, 1930. xviii, 262 p.

Bibliography: p. $249^{-25} 5^{30}$.

$$
3^{0-15640} \mathrm{JV6} 698 . \mathrm{M6G}_{3}
$$

4472. Gamio, Manuel, comp. The Mexican immigrant, his life-story; autobiographic documents collected by Manuel Gamio. Chicago, University of Chicago Press, 1931. $288 \mathrm{p}$.

$$
3^{\mathrm{I}-285^{8} \text { I }} \text { JV6798.M6G } 28
$$

Both volumes are the result of an investigation sponsored by the Social Science Research Council, with some assistance from the Mexican Government, during 1926-27. The author and his assistants visited the states of Guanajuato, Jalisco, and Michoacan in west central Mexico, from which the majority of the immigrants come, and the principal Mexican groups in the United States, in New York and the Middle West, especially Illinois and Indiana, as well as in California and the Southwest. The author found the official American statistics to be much inflated, since they failed to incorporate any adequate record of the large number of Mexicans who returned home. He viewed the whole transaction as an economic phenomenon motivated by the continuing misery of the Mexican lower classes, which made American wages and the relatively low cost of manufactured articles in the United States outweigh the hazards of illegal entry and any amount of discrimination-economic and social. The majority of immigrants did not desire citizenship, and those who did secure it remained attached "to the local Mexican-American culture such as prevails in many communities in the Southwest." However, the author believed that the Mexican revolutionary movement had been stimulated by immigrant contact with the standard of living in the United States. An unusual and revealing chapter presenting "The Songs of the Immigrant" affords a transition to Dr. Gamio's second volume, made up almost exclusively of 76 "guided interviews" and other personal statements by immigrants both male and female. They were translated into English by Robert C. Jones, and have evidently been classified into chapters each provided with a brief introduction by Robert Redfield of the University of Chicago. The headings include: "The Economic Adjustment," "Conflict and Race-consciousness," "The Leader and the Intellectual," "Assimilation," and "The Mexican-American."

4473. Hansen, Marcus Lee. The mingling of the Canadian and American peoples. v. I. Historical. Completed and prepared for publication by John Bartlet Brebner. New Haven, Yale University Press; for the Carnegie Endowment for International Peace, Division of Economics and History, 1940. xviii, 274 p. maps (I fold.) (The Relations of Canada and the United States [a series of studies prepared under the direction of the Carnegie Endowment for International Peace, Division of Economics and History])

$$
40-273^{89} \quad \mathrm{E}_{1} 83.8 . \mathrm{C}_{2} \mathrm{H}_{27}
$$

4474. Truesdell, Leon E. The Canadian born in the United States; an analysis of the statistics of the Canadian element in the population of the United States, 1850 to 1930. New Haven, Yale University Press; for the Carnegie Endowment for International Peace, Division of Economics and History, 1943. xvi, 263 p. maps, tables, diagrs. (The Relations of Canada and the United States [a series of studies prepared under the direction of the Carnegie Endowment for International Peace, Division of Economics and History])

$$
\mathrm{A}_{43-\mathrm{I}} 23^{8} \mathrm{HB}_{301} \text {. } \mathrm{C}_{3} \mathrm{~T}_{7}
$$

Because of Professor Hansen's untimely death in I938, his work had to be completed by Professor Brebner of Columbia University. It is a narrative history of the exchange of populations between the regions which are now the United States and Canada, from its colonial beginnings down to 1939 . This exchange is interpreted as part of an integrated North American Westward Movement, motivated 
by the individual pioneer's land-hunger, and made possible by unrestricted mobility across the unfortified boundary. Significant shifts of population were brought about by the Revolutionary War, when Tories fled to Canada, the Canadian Insurrection of 1837 , when Canadians sought political asylum in the United States, constant variations in economic conditions and land distribution, the availability of rich farm land at different times in the prairie states and provinces, the attraction of bounty money for enlistment in the Union Army during the Civil War, and the lure of high pay in the expanding industries of the United States. The companion volume, by a chief statistician of the U. S. Bureau of the Census, is built around 121 tables and 36 graphs. During the 80 years for which figures were available, the Canadian-born in the United States increased from $147,7 \mathrm{II}$, or 0.64 percent of the population, to $1,286,389$, or 1.05 percent of the population. In 1930 they were concentrated in New England and New York City, about the Great Lakes, and in the cities of the Pacific coast. Some 77.3 percent, in fact, were living in urban areas. Nearly 30 percent were of French mother tongue, this being practically the same proportion as obtained in Canada itself. The increase since 1900 has been slower, "and the characteristics of the group as a whole have become those of a relatively static population." Another volume in the same series, The American-Born in Canada, by Robert H. Coats and Murdoch C. McLean (Toronto, Ryerson Press, 1943. xviii, 176 p.), offers a similar statistical analysis of a group which increased from 63,000 , or 2.6 percent of the population, in 1851 to 344,574 , or 3.3 percent of the population, in 1931, and was much more evenly distributed over the whole settled area.

4475. McWilliams, Carey. North from Mexico, the Spanish-speaking people of the United States. Philadelphia, Lippincott, 1949. 324 p. (The Peoples of America series)

$$
\text { 49-7084 F786.M215 }
$$

This volume, which effectively synthesizes a mass of historical and sociological material, is primarily a presentation of racial and cultural conflict in the Southwest, inspired by the author's indignation on behalf of the underdog. He attacks what he describes as "The Fantasy Heritage," a sentimental emphasis upon the purely Spanish elements in the beginnings of the borderlands, at the expense of the living Mexican-Indian tradition, which is quite as important to the mixed cultural heritage of the Southwest. This attitude he regards as a part of the long-existing "determination to subordinate the Spanish-speaking minority in the Southwest," one of the means being "to drive a wedge between the native-born and the foreign-born and to cuitivate the former at the expense of the latter." The only "Mexican Problem" which Mr. McWilliams recognizes is the stubbornness of the dominant AngloSaxons "in not recognizing the real character of the culture which prevails in the borderlands."

4476. Taylor, Paul Schuster. An American-Mexican frontier, Nueces County, Texas. Chapel Hill, University of North Carolina Press, I934. 337 p. illus. $\quad 34-39877 \quad \mathrm{~F}_{392 . N 8 \mathrm{~T}_{3}}$

The author climaxed a series of ten monographs on Mexican Labor in the United States (Berkeley, University of California Press, 1928-34. 3 v.) with this remarkably vivid and penetrating analysis of economic and social conditions in the Texas county which includes the city of Corpus Christi, upon which an army of cotton pickers converges each midsummer, and which led the counties of the entire United States in cotton production in 1930. He saw it as "the locus of long historical contacts and conflicts of four peoples-Indians, European (or American) whites, Negroes, and Mexicans." Here Spanish settlement began soon after the middle of the I8th century, and the first Americans established themselves in 1839 . By 1859 all the original grantees had sold out to Americans; but by 1929 there were 29 Mexican laborers who had risen through tenancy to the proprietorship of very small farms, and 879 Mexicans owned town lots, some having achieved middle-class status. The original cattle industry had been completely replaced by short staple cotton culture, with Mexicans providing nearly all the year-round laborers and the majority of the transients. Mexicans and Negroes were once on easy terms, but now the Mexicans, in order to raise their standing, had been impelled "toward efforts to present themselves in the eyes of the whites. as a group dissociated from, and superior to, the Negroes." The author has the art of exhibiting large issues in a small setting.

\section{Germans}

4477. Faust, Albert Bernhardt. The German element in the United States with special reference to its political, moral, social and educational influence. New York, Steuben Society of America, 1927. $2 \mathrm{v}$. in $\mathrm{I}$. illus. 
Bibliography: v. 2, p. [477]-562.

This work on an encyclopedic scale by Professor Faust of Cornell University won a prize awarded by the Germanic Department of the University of Chicago in 1907 for the best book on the subject, was first published by Houghton Mifflin in 1909, was awarded the Loubat prize by the Prussian Academy of Sciences in I9II, and was published in a German translation at Leipzig in 1912 . The 1927 edition undertaken on the initiative of the Steuben Society is described as a complete revision, although most of the new material is incorporated in an Appendix (v. 2, p. [607]-73o). Old-fashioned as the work is in its approach, it remains the most comprehensive treatment and indispensable to any serious student of the subject. Volume I contains descriptions of all German settlements in the Thirteen Colonies, beginning with the founding of Germantown, $\mathrm{Pa}$., in 1683 , and goes on to particularize the part taken by Germans in the Revolution, and in the Westward Movement through the settlement of California. Volume 2, after estimating the number of persons of German blood in the United States at $271 / 2$ percent of the total population, goes on to survey the achievement of individuals of German birth or descent in American agriculture, manufactures, politics, education, music, the fine arts, the theater, literature, and journalism. A concluding chapter on social and moral influence offers "the joy of living" and "care of the body" as Germanic benefactions, and identifies as Germanic traits law-abiding character, honesty, love of labor, sense of duty, etc.

4478. Hawgood, John A. The tragedy of German-America; the Germans in the United States of America during the nineteenth centuryand after. New York, Putnam, 1940. xviii, 334 p. $4^{0-35196} \mathrm{E}_{18} 8_{4} \cdot \mathrm{G}_{3} \mathrm{H}_{27}$

The author, who taught modern history at the University of Birmingham from I93I, studied in both Germany and the United States, and carried out his research for the present volume on grants from the Rockefeller Foundation in 1928 and 1934 . It is primarily a study of the significance of the hyphen in the term "German-American," with its implication of resistance to Americanizing tendencies, which became so vexed an issue during World War I. After I8I5 any concentration of German immigrants tended to retain a pride in their own culture and language, and to oppose "the strong Sabbatarianism and the growing temperance movement of the Yankee stock in the Middle-Western States," becoming distinctive "islands in a sea of Americanism." In addition there were concerted efforts by settlement societies or other agencies to plant communities wherein German civilization could remain independent of outside influences, and develop unhampered by the restrictions then obtaining at home; Part II describes such ventures in Missouri, Illinois, Texas, and Wisconsin. A crystallization resulted from the Know-Nothing onslaught of the $185^{\circ}$ 's, drawing the whole German-speaking body together in self-defense. "Germans in America between 1855 and I9I5 lived not in the United States, but in German America, and lived and wrote for German America." It took World War I, "with its hatreds and its persecutions, its propaganda and its coercion," to bring this era and this mentality to an end.

4479. Wood, Ralph, ed. The Pennsylvania Germans. Princeton, Princeton University Press, 1942. 299 p. 42-36243 Fi6o.G3W66 Contents.-Pennsylvania, the colonial melting pot, by A. D. Graeff.-The Pennsylvania German farmer, by W. M. Kollmorgen.-The sects, apostles of peace, by G. P. Musselman.-Lutheran and Reformed, Pennsylvania German style, by Ralph Wood.-The Pennsylvania Germans and the school, by C. S. Stine.-Journalism among the Pennsylvania Germans, by Ralph Wood.-Pennsylvania German literature, by $\mathrm{H}$. H. Reichard.-The Pennsylvania Germans as soldiers, by A. D. Graeff.-The Pennsylvania Germans as seen by the historian, by R. H. Shryock.-Appendix: 'The Pennsylvania German dialect, by A. G. Buffington.

4480. Klees, Frederic. The Pennsylvania Dutch. New York, Macmillan, 1950. 451 p.

Bibliography: p. 445-45I. 50-1 I 837 Fr6o.G $3 \mathrm{~K}_{5}$

Mr. Wood's collection of ten papers by eight authors, some of whom are and some are not of Pennsylvania German descent, "tries to interpret the Pennsylvania Germans to their fellow Americans and to themselves." The editor remarks that "he was surprised to find that a common denominator developed spontaneously throughout all the chapters, namely, that the Pennsylvania German character was moulded by the fact that the Pennsylvania Germans were farmers practically and spiritually." Mr. Klees' volume is more detailed and more miscellaneous, but it is written with an evident affection for its subject which draws the reader on into the bypaths of Pennsylvania Dutch folkways and art. Mr. Klees, incidentally, regards "Dutch" as the traditionally correct term and enters a protest against the neologism, "Pennsylvania German." "Their strong concentration in a relatively small area enabled this people to stay Dutch," and "in preserving their own culture they succeeded in doing what no other non-English group in colonial America was able to do." The basis of their culture, 
however, he finds not in farming but in religion, with the three principal religious groups, "plain people" (Mennonites, Amish, Dunkards), "church people" (Lutherans, Reformed, United Brethren), and Moravians each forming a radically different cultural pattern of its own. Each chapter is headed by a neat pen-and-ink drawing by the author. The Maryland Germans, a History, by Dieter Cunz (Princeton, Princeton University Press, 1948. 476 p.) tells the story of a related group who remained less isolated, but put a strong stamp upon the community in which they settled.

448 I. Zucker, Adolf E., ed. The Forty-eighters, political refugees of the German Revolution of 1848 . New York, Columbia University Press, 1950. xviii, 379 p. illus.

50-7743 Er $84 . G_{3} Z 8$ 1950

Contents. - The European background, by C. J. Friedrich.-The American scene, by O. Handlin.Adjustment to the United States, by H. B. Johnson.-The Turner, by A. J. Prahl.-The Fortyeighters in politics, by L. S. Thompson and F. X. Braun.--The radicals, by E. W. Dobert.--The Fortyeighters in the Civil War, by E. Lonn.-Carl Schurz, by B. Q. Morgan.--Biographical dictionary of the Forty-eighters, by A. E. Zucker.

A volume planned in commemoration of the centenary of the Revolution: by "a number of us who had been working in this field," at the Philadelphia headquarters of the Carl Schurz Memorial Foundation in February 1948. A "Forty-eighter" is de- fined as "one who came to the United States from German-speaking territory as a result of his participation in the Revolution of 1848 "; his actual arrival in the United States, of course, might be delayed until the latter 1850 's. Their number cannot be precisely determined, since the great majority of German immigrants were coming for economic reasons, but was small-Dr. Zucker regards 4,000 as a conservative estimate. However, their influence was vastly greater than their numbers, and few immigrant groups have had so large a proportion of persons of distinction. Dr. Zucker's "Biographical Dictionary" of over 300 names is a compilation of permanent value. The average reader will find these interpretive essays more serviceable than the detailed volume on the same subject from a single pen: Carl F. Wittke's Refugees of Revolution (Philadelphia, University of Pennsylvania Press, 1952. 384 p.). It is, however, a work of great learning, and has chapters with little or no counterpart in the symposium, such as "Non-German Fortyeighters," "The Politics of the Post-War Years," "The German Social Pattern," and "Learning and Letters." Dean Wittke has also written substantial biographies of two of the most remarkable personalities among the Forty-eighters: Against the Current; the Life of Karl Heinzen (1809-80) (Chicago, University of Chicago Press, 1945. 342 p.) and The Utopian Communist; a Biography of Wilhelm Weitling, Nineteenth-Century Reformer (Baton Rouge, Louisiana State University Press, 1950. 327 p.).

\section{J. Scandinavians}

4482. Babcock, Kendric Charles. The Scandinavian element in the United States. Ur-

bana, University of Illinois, I9I4. $223 \mathrm{p}$. (University of Illinois studies in the social sciences, v. 3 , no. 3) $\mathrm{I}_{5}-8448 \mathrm{H}_{3} \mathrm{I}_{4}$, v. 3 , no. 3 $\mathrm{E}_{184} \mathrm{~S}_{2} \mathrm{~B} 12$

University of Illinois Bulletin, v. 12, no. 7 .

"Critical essay on materials and authorities": p. I83-204.

A work, obviously outmoded in some respects, which retains value as one of the very few treatments of immigration from the three Scandinavian nations as a whole. In 1910-12, after a century of steady growth, the population of Sweden was only $5,600,000$, of Norway 2,390,000, and of Denmark $2,775,000$. The passage, therefore, of $2,200,000$ Scandinavians to the United States between 1820 and 1912 was an extraordinary mass exodus. In none of the three were there the oppressive political, military, or social conditions to be found on the continent; the migration therefore was essentially an exchange of scanty economic resources and opportunities for the richer ones offered by the fertile prairies of the Mississippi Valley. Some information is offered concerning the Danish immigration, which totaled 278,277 between 1820 and 1913, or only about two-fifths of the Norwegian figure during the same period. "The Danish element in America has always lacked unity and solidity," a fact which the author attributes to the weak influence of the schism-ridden Danish Lutheran Church. During the same years 696,4 or Norwegians entered the United States, as against $1,071,835$ from more populous Sweden. 
4483. Benson, Adolph B., and Naboth Hedin. Americans from Sweden. Foreword by Carl Sandburg. Philadelphia, Lippincott, 1950. $44^{8}$ p. (The Peoples of America series)

Bibliography: p. [427]-434.

$50-5150 \quad \mathrm{E}_{1} 84 . \mathrm{S}_{23} \mathrm{~B}_{32} 8$

This work is in large part based on, or continues, the symposium which the authors edited, as well as contributed to, on the occasion of the New Sweden Tercentenary: Swedes in America, 1638-1938 (New Haven, Yale University Press, 1938. xvi, 614 p.). Part I, "Historical Background," is a somewhat conventional chronological sketch of Swedish groups, individuals, and movements in the United States. Part II, "Religious Life," considers the Swedish participation in five other churches as well as the Lutheran, including the Methodists and the Mission Friends, the pietistic wing of the Swedish state church. Part III, "Denominational Education" briefly reviews the history of seven institutions of Swedish origin, the largest of which is Augustana College, established at Rock Island, Illinois, in 1875 after a somewhat migratory existence since 1858 . Part IV, "American Activities," calls the roll of a multitude of Swedish Americans of distinction in a variety of fields, such as architects and builders, health specialists, musicians and actors, aviators and airplane builders, and businessmen. Small pride seems to be taken in their major activity in America: agriculture.

4484. Blegen, Theodore C. Norwegian migration to America. Northfield, Minn., NorwegianAmerican Historical Association, 1931-40. 2 v. illus. (facsims.) maps, diagrs.

$$
\text { 3I-20308 EI } 84 . \mathrm{S}_{2} \mathrm{~B} 6
$$

4485. Blegen, Theodore C., ed. Land of their choice; the immigrants write home. [Minneapolis] University of Minnesota Press, 1955. $463 \mathrm{p}$. $\quad 55-9368 \quad \mathrm{E}_{1} 84 . \mathrm{S}_{2} \mathrm{~B}_{55}$

The two-volume work originated in the author's doctoral dissertation at the University of Minnesota, but was greatly amplified through a large collection of documentary material which he made as a Guggenheim Fellow in Norway during 1928-29. The whole is a vividly concrete social history of Norwegian immigration during the central decades of the igth century. The first volume bears the limiting dates $1825-60$; it "traces the genesis and early expansion of Norwegian immigration, explores the European backgrounds, and interprets the movement in a setting of international history." It describes two types of literature which had not previously received due emphasis: the "America books" and the "America letters." The first vere handbooks of information for Norwegians on con- ditions in America; one of the earliest and most influential examples, which broadened the geographical scope of the movement in Norway, was Ole Rynning's True Account of America for the Information and Help of Peasant and Commoner, published at Christiana in 1838 . "America letters" were written by immigrants to their relatives and friends at home, in increasing numbers from the mid-r83o's, and were often published in the local press; "one gets the impression of a vast advertising movement." Land of Their Choice is an anthology of such letters in translations made by either Dean Blegen or his research assistant, Borge Madsen; many first appeared in the publications of the Norwegian-American Historical Association. Here they are arranged in groups of two kinds: letters from various individuals illustrating a particular topic, or series of letters from a single individual. The second volume of the larger work bears the subtitle The American Transition; it aims to present the dynamic process whereby the immigrant was merged into the life of the New World. The topical chapters into which it is organized pursue their subjects to various points in the later igth century, but the bulk of the evidence presented falls before 186o. After years of study the author continued to think that Ole E. Rolvaag (no. $1720-1723$ ), in his masterpiece Giants in the Earth and his other novels, recorded and interpreted the American transition "with deeper insight and greater effectiveness than any other writer."

4486. Nelson, Helge. The Swedes and the Swedish settlements in North America. Lund, C. W. K. Gleerup; New York, A. Bonnier; 1943. 2 v. (Skrifter utg. av Kungl. humanistiska vetenskapssamfundet i Lund, 37)

Translated by Professor 45-7045 E1 $84 \cdot \mathrm{S}_{23} \mathrm{~N}_{35}$

Bibliography: v. x, p. [410]-418.

Contents.-r. Text.-2. Atlas (73 maps).

The author of this unique work "took part in the great emigration investigation in Sweden during the first decade of the present century," and after becoming professor of geography at the University of Lund undertook a large-scale study of Swedish colonization in Canada and the United States from the geographical point of view. Receiving subsidies from the Swedish Government, the Swedish-American Foundation, and various Swedish learned bodies, he traveled widely in Canada and the United States in 1921, 1925, 1926, and 1933. The principal subject of his book is the changing geographical distribution of the Swedish stock in the United States, and from 1890, the first Census which broke down the numbers of the foreign-born by counties, he has been able to present a series of statistical maps for 
the states with the greatest Swedish concentration, and especially for Minnesota (I9 maps). Other major concerns are the causes and conditions of settlement in particular areas and the economic occupations of the settlers. Of the 24 chapters, 13 are devoted to a geographical survey, region by region, of the actual settlements, with numerous maps and photographs, many of them taken by the author on his tours. He does not neglect the large urban concentrations of Swedes in Worcester, Mass., New York City, Chicago, Minneapolis, and St. Paul, which are demographically treated. However, the Swedes have been less attracted by the cities than many other racial groups, and "the Swedish stock of the first and second generations alone no doubt owns more improved land in the United States than all the cultivated area of the Swedes at home."

4487. Qualey, Carlton C. Norwegian settlement in the United States. Northfield, Minn., Norwegian-American Historical Association, 1938. 285 p. illus., tables, diagr. (Publications of the Norwegian-American Historical Association)

38-6266 EI84.S2Q8
Issued also as thesis (Ph. D.) Columbia University.

Bibliography: p. [253]-272.

A solidly documented narrative history of the dispersion and settlement of Norwegian immigrants in the Middle West from 1834 to about 1885 , with some mention of settlement elsewhere and of earlier and later date. Separate chapters are devoted to Illinois, where the Fox River Settlement of 1835 constituted the first Norwegian community beyond the Appalachians; to Wisconsin, where Jefferson Prairie just across the Illinois line was settled in 1839; to Iowa, reached by Norwegians in the same year; to "the glorious new Scandinavia" which sprang up in Minnesota in the mid-r850's; to the Dakotas; and to Michigan. The three peaks of Norwegian immigration occurred in $1866-73,1880-$ 93-with 1882, when over 28 ,000 entered, as the peak year of all-and in 1900-19II. Chapter IX considers "Islands" of Norwegian settlement in other parts of the United States. Dot maps show the concentration of Norwegians in the United States in 1930, and in individual states at earlier dates from 1870 to 1900 .

\section{K. Other Stocks}

4488. Berthoff, Rowland Tappan. British immigrants in industrial America, 1790-1950. Cambridge, Harvard University Press, I953. 296 p. maps, diagrs.

Bibliography: p. [213]-275.

Down to the I850's immigration from Great Britain (as distinct from Ireland) to the United States was comparatively small, but from that decade through the I920's a fluctuating but usually considerable stream crossed the Atlantic, reaching a peak of over 800,000 during the 1880 's. Until the work of Mr. Berthoff, who is himself a Welshman, less was available to the ordinary reader on this than on any other major current of immigration, and his book illuminates a very important sector of our ethnic history. Making use of trade journals, labor union publications, state documents, and other primary sources, he has been able to display this influx as in great part one of skilled laborers, bringing with them experience and techniques which secured them prompt employment at high wages in the great American industrial expansion which began before the Civil War but was much accelerated after its close. These English, Scotch, and Welsh craftsmen played an important part in the development of the American textile, mining, and iron and steel indus- tries, and one only quantitatively less important in our pottery, papermaking, quarrying, building, and maritime trades. In fact, "nearly the whole English silk industry migrated to America after the Civil War." These craftsmen also took their share in the organization of labor, and their relatively conservative outlook was reflected in the American Federation of Labor, a league of craft unions of skilled artisans. The immigrants themselves valued their national heritages and developed their own organizations, periodicals, sports, and amusements, but the second generation, with no linguistic or other serious obstacle to assimilation, speedily became indistinguishable from other Americans, and "the BritishAmerican community dwindled after the first World War." Wilbur S. Shepperson's British Emigration to North America: Projects and Opinions in the Early Victorian Period (Oxford, Blackwell, r957. $\mathrm{xvi}, 302$ p.) is based upon solid research in both British and American sources, but is limited to the period 1837-60, and is primarily concerned with organized efforts to promote emigration, and the discussions which they provoked at home.

4489. Ford, Henry Jones. The Scotch-Irish in America. New York, P. Smith, 194I. 607 p. $\quad 42-36197 \quad$ Ei $84 . S_{4} F_{9}$ I94I 
4490. Dunaway, Wayland F. The Scotch-Irish of colonial Pennsylvania. Chapel Hill, University of North Carolina Press, 1944. $273 \mathrm{p}$.

\section{Bibliography: p. 233-257.} 44-9454 Fi6o.S 4 D8

Professor Ford's volume, originally published in I9I5 by the Princeton University Press, was uncommonly successful in putting into perspective the extraordinary story of the Scotch-Irish, and in underlining their importance as a formative element in the development of the Thirteen Colonies. His starting-point is the Ulster Plantation of 1609 , undertaken as a means of keeping Catholic Ireland in subjection, but largely filled up by an unanticipated migration, not of Englishmen, but of lowland Scots. In the 18 th century Presbyterian Ireland shared the economic disabilities imposed by the London Parliament upon Catholic Ireland, and in bad times Ulstermen sailed for America in large numbers. The first wave of 1717-18 came to New England, where Presbyterians and Congregationalists often failed to see eye to eye; subsequent waves, from 1727 to 1773 , went rather to Pennsylvania. Professor Dunaway is concerned with them there, but his book too has more than a merely provincial significance, for he considers the dispersion which took place from about 1735, when the Scotch-Irish advance reached the mountain barrier, and was deflected southwestward into the valleys of Maryland and Virginia, and the piedmont region of the Carolinas. Ford stresses the importance of the ScotchIrish for American Presbyterianism and for American educational institutions, both preparatory to the ministry and providing popular education. Dunaway adds substantial accounts of their economic activities and their social life and customs, and has a chapter on their position in the politics, law, and government of provincial Pennsylvania. Ford has a fuller treatment of the very important contribution of this stock, alienated from the Crown by British policy toward Ireland, to the revolutionary movement.

4491. Graham, Ian Charles Cargill. Colonists from Scotland: emigration to North America, 1707-1783. Ithaca, N. Y., Published for the American Historical Association [by] Cornell University Press, I956. $2 \mathrm{I}_{3}$ p. ${ }_{56-58450} \mathrm{EI}_{1} 8_{4} \cdot \mathrm{S}_{3} \mathrm{G}_{7}$

Bibliography: p. I9I-206.

The importance of the migration of Ulster Scots to the Thirteen Colonies has long been understood; this volume provides for the first time a documented study of the migration from Scotland itself. This movement was only made possible by the union of the Scottish and English Parliaments in 1707, and remained small and sporadic until $\mathbf{1} 768$, when there suddenly began a much larger stream which went steadily on until halted by the Revolutionary War. In 12 years, the author estinates, about 25,000 persons left Scotland, "a far greater loss of people than the country had ever known before." The greater number came from the Highlands, where to the chronic poverty of the peasantry was now added the outright evictions made by improving landlords, but economic depression and unemployment brought a substantial group from the Lowlands. The greatest concentration, about 5,000, settled in North Carolina. Unlike the Ulstermen, the Scots of Scotland remained loyal to the Crown with a unanimity and stubbornness exasperating to the Patriots, and not a few of the immigrants of $x$ 768-75 in the next decade removed to Canada, thenceforward the focus of Scots emigration. Chapter VI considers the Scottish-born merchants who resided in the coastal cities of the Colonies throughout the I8th century, and were of particular importance in the tobacco trade of the Chesapeake region.

4492. Halich, Wasyl. Ukrainians in the United States. Chicago, University of Chicago Press, I937. I74 p. 37-287I9 EI84. $\mathrm{U}_{5} \mathrm{H}_{3}$ Bibliography: p. 163-168.

The Ukraine, the black-soil steppes north of the Black Sea drained by the Dniester and the Dnieper, is inhabited by millions of people who speak a separate Slavic language, and have in recent times aspired to a separate national status, although they have never enjoyed actual independence save for a brief period during I9I9-20. American immigration statistics did not distinguish them from other Russian nationals until 1899 , but from that year through 1914, when their numbers entering had reached a peak, about 250,000 came to the United States. By far the largest number went to Pennsylvania, where the majority became coal miners, and other large groups settled in New Jersey, Ohio, and Illinois. The present volume is strongly colored by Ukrainian nationalism (there is, it seems, a "pro-Russian faction"), but gives a clear account of the Ukrainian participation in American industry, agriculture, business, and the professions, and describes Ukrainian ethnic organizations, the Ukrainian Catholic (Uniate) Church, the Ukrainian press, and a variety of social activities in various parts of the United States. "Their social and economic improvement, although a slow, hard climb, has been a steady one."

4493. Lucas, Henry S. Netherlanders in America; Dutch immigration to the United States and Canada, 1789-1950. Ann Arbor, University of Michigan Press, 1955. xix, 744 p. (University of Michigan publications. History and political science, v. 2I) 55-8647 EI 84.D9L8 
Between 1820 and 1949 265,539 Netherlanders came to the United States and 70,000 to Canada. Mr. Lucas' purpose is to tell their story from their own point of view, since his lifelong interest in Dutch immigration has led him to accumulate primary source material in the form of interviews with surviving pioneers, as well as other personal memorabilia relating to the Dutch settlements and their internal life and structure. The emphasis of the study is upon Dutch settlements in the Middle West and particularly in Michigan, where the author grew up. It was, in fact, the centenary in 1947 of the founding of Holland, Michigan, by the Seceders from the established Reformed Church of the Netherlands which embarked Professor Lucas, a grandson of one of the settlers of 1847 , upon this volume. "Religion determined the pattern of Dutch settlement in America," and the Dutch communities remained self-contained cultural and ethnic islands until the 2oth century, when Dutch immigration fell off sharply and the expansion of American cultural and economic activity began to impinge upon all isolated groups, with World War I, as usual, constituting a turning point. This definitive volume provides information on every Dutch settlement in the country and, when possible, the reasons for its success or failure. Topical chapters deal with religion, education, and the press and politics of the Dutch communities.

4494. Pellegrini, Angelo M. Americans by choice. New York, Macmillan, 1956. $240 \mathrm{p}$. 56-I24I Er $84.18 \mathrm{P}_{39}$

Dr. Pellegrini, whose Immigrant's Return (New York, Macmillan, I95 I. 269 p.) presented his own life story as well as his impressions of an Italian journey, here sketches the lives of six representative West Coast Italian-Americans of an older generation. $\mathrm{La}$ Bimbina, a peasant mother, who found life in America no less toilsome, but rewarding instead of merely futile, and died at 70 "at the end of the day's labor," is the author's own mother, recalled in respect, gratitude, and affection. The sketch of a "dean of winegrowers" in the Napa Valley conveys a variety of information on the conditions of viniculture on California soil. Other sketches concern the rise and fall of a big-town bootlegger; the mother of a family of winegrowers who had kept a first-class boarding house in her younger days and excelled in her Italian cuisine; an itinerant swindler from the petty bourgeoisie who had "done a little of everything-except work"; and a contracting ditchdigger-“at sixtynine years of age he was still in the ditch eight hours a day," but he had established his sons when he dropped dead digging to clear his own vineyard. The mingled candor, strength, and tenderness which the author has put into this gallery of sketches promote his purpose of mutual understanding.

4495. Thomas, William I., and Florian Znaniecki. The Polish peasant in Europe and America. [2d ed.] New York, Knopf, 1927. 2 v. (2250 p.) 27-25039 $\mathrm{DK}_{411 . T_{5}}{ }_{1927}$

This famous work was first published during 1918-20 in five smaller volumes; this second edition has the same text, with a few errors corrected, but is rearranged and provided with a brief index. It owes its unique reputation and influence to its inclusion, on an unprecedented scale, of social documentary materials, usually translated from Polish into English. In volume $I$ are no fewer than 50 series of peasant letters, each series provided with an introduction in which the circumstances of the correspondents are described and the persons mentioned are identified. The series have been placed in three main groups, identified as between members of family-groups, between husbands and wives, or as exhibiting personal relations outside of marriage and the family. Volume 2 concludes with the largest single document in the work, the autobiography of Wladek Wiszniewski (p. 1915-2226), who progressed from Lubotyn in the Province of Kalisz to the Chicago stockyards, but did not much like them. Many chapters in the rest of the work consist in whole or part of translated documentary material. Serious readers have always received a powerful impression from this exceptional mirror into the minds of an immigrant group. The authors begin with a sketch of Polish social organization; in volume 2 they analyze social "Disorganization and Reorganization in Poland," and pass on to "Organization and Disorganization in America" (p. $1467-1827$ ). This contains their epoch-making description of the Polish-American community and its "super-territorial" organization. It also contains a large section on the "Disorganization of the Immigrant," in which the "decay of the personal lifeorganization of an individal member of a social group" is regarded as eventuating in the break of the conjugal relation, murder, the vagabondage and delinquency of boys, or the sexual immorality of girls, with abundant documentary evidence on each head. It must be remarked that at times the gap between the flesh and blood of the documents and the abstract theorizing of the professors is glaringly wide.

4496. Williams, Phyllis H. South Italian folkways in Europe and America; a handbook for social workers, visiting nurses, school teachers, and physicians. New Haven, Published for the Institute of Human Relations by Yale University Press, 1938. xviii, $216 \mathrm{p}$. 38-16630 EI84.I8W6 
4497. Federal Writers' Project. New York (City). The Italians of New York; a survey prepared by workers of the Federal Writers' Project, Works Progress Administration in the City of New York. Sponsored by the Guilds' Committee for Federal Writers' Publications. New York, Random House, 1938. xx, 24I p. (The American guide series)

Bibliography: p. 227-230. $3^{8-27087} \quad \mathrm{~F}_{128.9 . \mathrm{I}^{2} \mathrm{~F}_{4}}$

In the absence of any solid and large-scale treatment of the great Italian immigration to the United States-some $4,650,000$ persons in the century after I 820-these two titles will do duty as concrete views of limited but representative aspects of the field. Miss Williams' book is based on her "contact for eleven years with over five hundred Italian and Italian-American families" resident in the metropolitan area of New Haven, Conn. Most of them came from Sicily or the five southernmost provinces of the Italian peninsula, and were peasants and fishing folk at home. She goes into most of the spheres of everyday life, such as housing, diet and household economy, recreation and hospitality, religion and superstition, and death and mortuary practices, and in each describes first the folkways that obtained in Italy, and next the modified ones that she has found in America. Her outlook is consistently that of a social worker, but of a well-informed and shrewd one, and she warns that superstitions and other "deep-seated customs, if swept aside at all, are dissipated gradually." The Italians of New York [City] is a slighter compilation, but it is well illustrated with photographs taken for the Writers' Project group who produced it, and it passes in review the public aspects of one of the largest ItalianAmerican communities. "Their Share in Building and Developing New York" describes the varieties of economic occupations which maintain them, and there are chapters on religious life, civic and social life, intellectual and cultural life, the professions, creative work in art and literature, and specifically Italian amusements and entertainments.

4498. Wittke, Carl F. The Irish in America. Baton Rouge, Louisiana State University Press, 1956. 319 p.

Bibliography: p. 295-306.

This work on the southern or Catholic Irish as distinct from the Ulstermen or Protestant ScotchIrish is not offered as a definitive study, but aims to fill a gap in the literature of immigration history by applying proper standards of historical objectivity to "the major aspects of Irish immigration to the United States and with the repercussions from America upon Ireland in the long struggle for Irish independence from England." Some attention is given to the political exiles of 1798 , but in the main the book takes its departure from the increased migration of the 1820 's. Chapters are devoted to the Irish as canal-building and railroad-building laborers, as firemen and policemen, and as farmers. Their special relationship to the Catholic Church and to urban and national politics is described. "The Fenian Fiasco," Anglophobia, and Irish Nationalism culminating in the State of Eire are among the international aspects of the subject. "There are American Irish who have never escaped from the slums. ... The majority, however, have attained middle-class respectability." 


\section{Society}

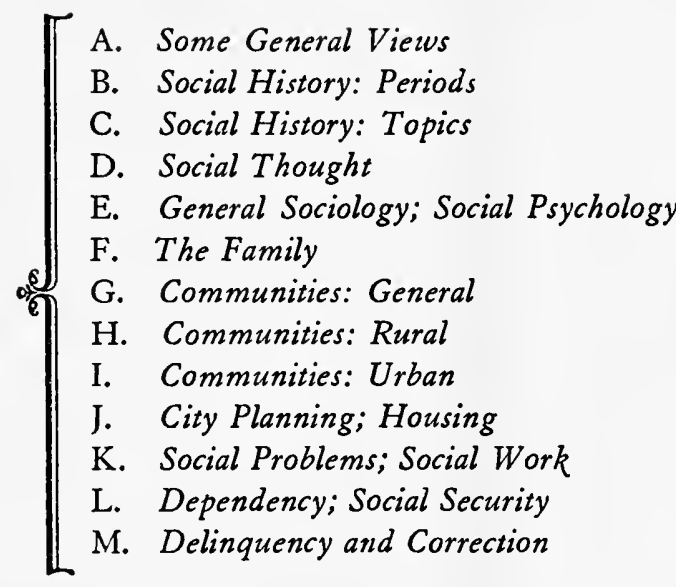

$\left.\begin{array}{l}4499-4513 \\ 45^{14}-4522 \\ 4523-4534 \\ 4535-4545 \\ 4546-455^{8} \\ 4559-4573 \\ 4574-4578 \\ 4579-45^{8} 5 \\ 45^{86}-4599 \\ 4600-4613 \\ 4614-4627 \\ 4628-4638 \\ 4639-4660\end{array}\right]$

$\mathrm{T}$ HIS chapter lists works which deal with American society, and necessarily exhibits all the difficulties which go with that concept: it is in part an abstraction and in part a residue-what is left when political and economic phenomena have been removed. The titles below include much that is professional or academic sociology, and much that is not. The "General Views" of Section A are in part some famous perspectives of the past, and in part some more recent volumes which seemed not out of place standing beside them. The two social history sections may seem quite inadequate to represent a subject which has received so much recent emphasis, but here, as in Chapter XI, many of the titles which a social historian would unhesitatingly claim as his own are, for our purpose, subject to a more precise classification and appear elsewhere. There is of course nothing absolute about the division into "Periods" and "Topics"; it is merely a convenient way of indicating that in the titles of the first group there is a wider coverage of social phenomena over a relatively limited period, and in those of the second a more limited coverage over a relatively longer period. Again our social histories cannot be sharply divided from a number of works in general history (Chapter VIII) and intellectual history (Chapter XI). Some users would perhaps prefer a single chronological arrangement for all of them, and for political and economic history as well; but in this alternative, periods would be found to overlap

as much as do categories, and the works on contemporary situations in each realm would lack specific background.

The majority of works in Section D deal with academic sociology, and the remainder of the chapter, for the most part, consists of the writings of professional sociologists or social workers. In the main our arrangement follows the Library of Congress classification (HM-HV), but our Section J completes the treatment of urban phenomena with works on city planning which the Library classifies under Fine Arts (NA) and on housing which it classifies under Economics (HD), as it does the works on social security in Section $L$.

Concerning the technical literature written almost exclusively by the faculties of the departments of sociology in American universities, several points should be made in elucidation of our selections. The 
most frequent objective of this literature, it is fair to say, is to arrive at universal rules of social behavior. The bulk of this literature is great, but the greater part of it is concerned with man as man and not with man in the United States of America. Some books ostensibiy universal in subject matter turn out on examination to be in fact wholly concerned with American examples, and such have been unhesitatingly selected if they meet our requirements in other respects.

A large proportion of sociological literature consists of textbooks written for college courses which, like all such textbooks, are more remarkable for their similarities than for their differences. We can, of couse, give only an example or two of each type, and our selection never implies that any text has an absolute superiority over its numerous competitors.

A recent tendency in academic sociology has been the identification of scientific method with measurement, the devising of means for measuring such things as attitudies, and the production of mono- graphs consisting very lärgely of figures. While far from disputing the interest of such studies for other professionals, or their importance in developing knowledge about society, we have in most cases found that their limited scope and frequently tentative conclusions have stood in the way of their selection for a general guide of this kind.

American sociology has from its beginnings been of rationalistic, diagnostic, and reformist if not reconstructionist temper or outlook. The core of the curriculum has normally been a course in American social problems wherein attention is concentrated upon areas of disorganization, maladjustment, and failure. This tendency is naturally reflected in the works available for selection in this chapter, and so inevitably in the works selected. In consequence, to some this chapter may seem to emphasize the negative aspects rather than the positive achievements of American civilization, but this has not been because of any bias in this direction on the part of its compilers.

\section{A. Some General Views}

4499. Bryce, James Bryce, viscount. The American commonwealth. London and New York, Macmillan, i888. 2 v.

$$
\text { 9-13055 JK246.B9 } 1888
$$

This classic surpassed in elaboration and penetration any studies which Americans had produced on their own government and politics, and at once became a standard text for courses in these subjects. Its author went on to a distinguished career in British politics, but succeeded in bringing out new editions in 1893 and (with the help of Charles A. Beard) in rgro. However, we list the original edition as the best worth reading. It inaugurated the serious study of American political parties. It is, nevertheless, a more comprehensive work, as appears from its Parts IV, V, and VI. Part IV is an elaborate treatment of public opinion, in both its failures and its successes. Part $\mathrm{V}$ is a miscellany including discussions of the supposed and true faults, and the strength of American democracy, as well as its availability for European imitation. Part VI deals with social institutions, and has chapters on the bar, railroads, Wall Street, the position of women, and the pleasantness of American life. Bryce's American Commonwealth: Fiftieth Anniversary, edited by Robert C. Brooks (New York, Macmillan, 1939. 245 p.), a symposium sponsored by the American Political Science Association, is naturally political in emphasis.
4500. [Crèvecoeur, Michel Guillaume St. Jean de, called Saint John de Crèvecoeur] Letters from an American farmer; describing certain provincial situations, manners and customs ... and conveying some idea of the late and present interior circumstances of the British colonies in North America. Written for the information of a friend in England, by J. Hector St. John. London, T. Davies, 1782. 318 p. $\quad 2-6756 \quad$ Er63.C82

4501. Crèvecoeur, Michel Guillaume St. Jean de, called Saint John de Crèvecoeur. Letters from an American farmer. Reprinted from the original ed. with a prefatory note by W. P. Trent and an introd. by Ludwig Lewisohn. New York, Boni, I925. xxxvii, 355 p. 26-24569 Er63.C827 $^{2}$

After a wandering existence Crèvecoeur settled on his farm, Pine Hill, in Orange County, N. Y., in 1769 , and in the years before the Revolution is thought to have produced his vivid sketches of the husbandman's life. $\mathrm{He}$ is one of the first to view America "as the asylum of freedom, as the cradle of future nations, and the refuge of distressed Europeans," and an even greater pioneer in pointing out that altered conditions of life were producing a new man, the American. Some materials not used in the edition of 1782 were rediscovered and pub- 
lished as Sketches of Eighteenth Century America (New Haven, Yale University Press, 1925. 342 p.).

4502. Croly, Herbert D. The promise of American life. New York, Macmillan, 1909. $468 \mathrm{p}$. 9-28528 HN64.C89

The American nation "is committed to the realization of the democratic ideal; and if its promise is to be fulfilled, it must be prepared to follow whithersoever that ideal may lead." The essence of the American achievement is that its "economic, politi$\mathrm{cal}$, and social organization has given to its citizens the benefits of material prosperity, political liberty, and a wholesome natural equality." On these premises the author conducted a searching inquiry into the quality of American civilization, and worked out principles of reconstruction in the spirit of individual emancipation and constructive individualism. Much of it is of present pertinence as well as of historical interest.

4503. Fortune. U. S. A., the permanent revolution, by the editors of Fortune in collaboration with Russell W. Davenport. New York, Prentice-Hall, 1951. xvii, 267 p.

$$
\text { 51-10804 Ei69.1.F75 }
$$

"Originally published as the February, I95I, issue of Fortune magazine."

A closely argued and somewhat overemphatic volume which seeks to demonstrate that the American way of life is founded upon and generated by principles of universal application. The presentday working of this "American system" of liberty, equality, and constitutionalism is illustrated in the spheres of business, politics, labor, and local community affairs. These conclusions can be generally applied to the problems of present day civilization, and used to dissolve the caricature of American life which prevails abroad, and to promote a positive American foreign policy.

4504. Nef, John U. The United States and civilization. Chicago, University of Chicago Press, 1942. xviii, 421 p. ([Chicago. University] Charles R. Walgreen Foundation lectures)

$$
{ }_{42-16} \mathrm{I}_{9} \mathrm{~B}_{57 \cdot \mathrm{N}_{4}}
$$

A diagnostic interpretation of American society in the light of the development of Western Civilization since the Middle Ages and its present material, moral, and intellectual crisis. The overemphasis of means, in the enormous expansion of science, technology, industrialism, and economic life since about I $45^{\circ}$, has led to the neglect and decay of the ends of civilization: humanism, religion, moral philosophy, and art. Among the expedients suggested are a return to the humanities in education, the endowment of noneconomic institutions, and the strengthening of government within constitutional and democratic limits.

4505. Siegfried, André. Les Etats-Unis d'aujourd'hui. Paris, Colin, 1927. 326 p. (Bibliothèque du musée social) $\quad 27^{-26676}$ Ex69.1.S56

4506. Siegfried, André. America comes of age, a French analysis. Translated from the French by Henry H. Hemming and Doris Hemming. New York, Harcourt, Brace. 1927. $35^{8} \mathrm{p}$. 27-9637 EI69.1.S57

4507. Siegfried, André. Tableau des Etats-Unis. Paris, Colin, 1954. 347 p.

$$
\text { 54-34192 E169.1.S56813 }
$$

4508. Siegfried, André. America at mid-century. Translated by Margaret Ledésert. New York, Harcourt, Brace, 1955. 357 p.

55-7422 Er69.r.S 568

M. Siegfried's concise survey of American social, economic, and political life in the age of Coolidge was instantly acclaimed, by Europeans and Americans alike, for its interpretative virtuosity, its clear delineation of what "oft was thought but ne'er so well expressed." The translators' title, however, was singularly misleading, for maturity was quite lacking in the America Siegfried envisaged: a welter of races in the melting-pot, with the older strains rather desperately striving to keep America Protestant and "Anglo-Saxon." The second volume, issued 27 years later, is not a revision, "but a completely new book." It lacks the clarity and concentration of the old, and while it contains many fine aperçus, it has received no such general admiration. The underlying outlook of the two volumes remains the same: in 1927 the chief contrast between Europe and America was that "between industrial mass production which absorbs the individual for its material conquests, as against the individual considered not merely as a means of production but as an independent ego." By 1954 there is no longer anything French intellectuals can do about it: "The classical tradition will survive, but the American will be a highly developed Homo faber rather than the Homo sapiens as conceived by Socrates."

4509. Tocqueville, Alexis C. H. M. C. de. De la démocratie en Amérique. Paris, Gosselin,

I $835.2 \mathrm{v}$.

45ro. Tocqueville, Alexis C. H. M. C. de. Democracy in America. Translated by Henry

Reeve. London, Saunders \& Otley, 1835-40. 4 v. $9-21576 \quad \mathrm{JK}_{2} \mathrm{I} 6 . \mathrm{T}_{7} \quad \mathrm{I} 835$ 
4511. Tocqueville, Alexis C. H. M. C. de. Democracy in America. Translated by Henry Reeve. Edited with notes, the translations rev. and in great part rewritten, and the additions made to the recent Paris editions now first translated by Francis Bowen. Cambridge, Mass., Sever \& Francis, I862. 2 v. 9-21574 JK216.T7 I862

4512. Tocqueville, Alexis C. H. M. C. de. Democracy in America. The Henry Reeve text as rev. by Francis Bowen, now further corr. and edited with introd., editorial notes, and bibliographies by Phillips Bradley; foreword by Harold J. Laski. New York, Knopf, r945. 2 v.

$$
\text { 45-3119 JK2r6.T7 r945 }
$$

"Editions of Democracy in America": v. 2, p. 385-391. "A bibliography of items relating to Democracy in America and its author": v. 2, p. 3924 OI.

De Tocqueville traveled in the United States in I 831-32, studying American penitentiaries on behalf of Louis-Phillippe's Ministry of Justice. He used the opportunity to observe American democracy, not only as a system of government, but as the basic characteristic of an entire society, and so to forecast for Europeans the shape of things to come. Even the first part, which appeared in 1835 , goes far beyond a mere study of government; it discusses the advantages which American society derives from a democratic government, the consequences of the unlimited power of the majority, the causes which mitigate it, and the factors which tend to perpetuate democracy. The second part, which followed in I 840 , is primarily a sociological inquiry into the implications of democracy, in the spheres of intellect, feeling, and manners. Here he raises, for the first time, such enduring topics as the addiction of Americans to practical rather than to theoretical science, the taste for physical well-being in America, and the creation of an industrial aristocracy. Much is abstract, and much obsolete, but few books of social observation have remained so obstinately contemporary. Tocqueville's American visit is thoroughly documented in George W. Pierson, Tocqueville and Beaumont in America (New York, Oxford University Press, 1938. 852 p.).

4513. Years of the modern; an American appraisal. John W. Chase, ed. New York, Longmans, Green, 1949. 354 p. $\quad 49^{-1}$ I770 EI69.1.Y Contents.-Portrait of the American, by $\mathrm{H}$. S. Commager.-American freedom: a method, by A. Barth.-The genius of the radical, by W. Hamilton.-The faith of a skeptic, by A. Johnson.-The saving remnant: a study of character, by D. Riesman.-The American economy: substance and myth, by J. K. Galbraith.-Education under crossfire, by P. Miller.-Of science and man, by $H$. Brown.-Americans and the war of ideas, by E. D. Canham.-Our armed forces; threat or guarantee, by C. T. Lanham.-Peace: our greatest challenge, by S. Welles.-An adventure in ideals, by N. Cousins.

A symposium of twelve interpretative essays, on selected but essential aspects of American life, each by an authority in his field chosen for his ability to relate it to the rest of life, and to phrase his convictions with clarity and force. "It might be called a creative inventory of our times."

\section{B. Social History: Periods}

4514. Allen, Frederick Lewis. The big change: America transforms itself, 1900-1950. New York, Harper, I952. 308 p.

$$
\text { 52-8455 Er69.r.A4717 }
$$

An optimistic interpretation of American social evolution during the first half of the 20 th century. At the turn of the century the gulf between wealth and poverty was immense. Fifty years later the gap had been effectively narrowed, and there had also been a narrowing of the gap in ways of living, and the emergence of an "all-American standard" for the whole population. Business had found a new frontier in the purchasing power of the poor, and new-style corporations were concerned with the social benefits of their policies. In short, the United States was evolving, not toward socialism but past socialism.
4515. Billington, Ray A. The Protestant Crusade, I 800-1860; a study of the origins of American nativism. New York, Rinehart, 1952, " $193^{8}$. 514 p. 52-14020 BXI406.B5 1952

Bibliography: p. 445-504.

Charts a popular upheaval through the 30 years of its violence, and traces its roots back to the English Reformation and the defensive nationalism of the Elizabethan Age. Its manifestations are pursued in religious controversy and propaganda for mass consumption, and in overt violence; in political organization leading to the establishment of a separate party, the Know-Nothings; and in the transfer of hostility from the Catholic Church to the immigrants in general. Well-documented, it achieves a notable synthesis. 
45I6. Branch, Edward Douglas. The sentimental years, 1836-1860. New York, AppletonCentury, 1934. 432 p. 34-36082 Ei66.B82

A view of the various facets of a people's life during the quarter-century between Jackson and Lincoln, which becomes, the author thinks, "a social discussion of the first generation of the American middle class." Sentimentalism, his key to the period, he regards as "the immature phase of the Romantic Movement" in which reality is neither recognized nor judged. A lively panorama of such developments as feminism, the temperance movement, phrenology, spiritualism, and Perfectionism is presented, with the author intent on making the worst of everything.

4517. Bridenbaugh, Carl. Myths and realities; societies of the colonial South. Baton Rouge,

Louisiana State University Press, I952. 208 p. (The Walter Lynwood Fleming lectures in southern history, Louisiana State University)

"Bibliographical note": p. [197]-200.

$$
\text { 52-13024 } \mathrm{F}_{212 . \mathrm{B}_{75}}
$$

In 1776 there was no South or Southerners, but three or even four distinct social patterns, if the North Carolina one which the author mentions but does not describe be included. He analyzes the Chesapeake Society of Virginia and Maryland, where the planters had consistently lived beyond their means but furnished a distinguished leadership in political and religious liberalism; the Carolina Society where a genuinely prosperous "planting plutocracy arose on the basis of fortunes amassed in rice and indigo or in trade and sought to transform itself into an aristocracy after the Old World pattern"; and the Back Settlements, a land of "amazing antitheses" where conventions were thinner and a rough sort of equality was maintained, and which largely disappeared after the Revolution.

4518. Kraus, Michael. Intercolonial aspects of American culture on the eve of the revolution, with special reference to the northern towns. New York, Columbia University Press, 1928. 25 I p. (Columbia University. Faculty of Political Science. Studies in history, economics and public law, no. 302)

"List of authorities": p. 227-244.

$\mathrm{H}_{3 \mathrm{r} . \mathrm{C}_{7} \text {, no. } 302}$ $28-236_{4} \mathrm{I} \quad \mathrm{E}_{1} 6_{3} \cdot \mathrm{Kg}$

A careful investigation of a field largely neglected or even denied existence in earlier histories: "the many influences, subtle or obvious, which were creating for the colonists a common fund of experience," and so preparing the intercolonial coöperation which took place after 1765 . These factors, as apparent in Boston, New York, and Philadelphia, are traced in the spheres of business, social relationships, religion, printing, education, art, medicine, and science. The special interest does not prevent a faithful mirroring of colonial society in general.

4519. Morris, Lloyd R. Not so long ago. New York, Random House, 1949. xviii, 504 p. 49-II 404 Ei6g.I.M83

Three agencies, the motion pictures, the automobile, and the radio, in their essential development and their social effects since 1896 . "Probably never before in human history have three instruments of such incalculable social power been developed in so short a time. All three were perfected in the United States, within the memory of a generation still active today. Yet, together, they have completely transformed our society, civilization and culture." The author is particularly concerned to trace the effects of these inventions on manners and morals.

4520. Riegel, Robert ${ }^{\circ}$. Young America, 1830r840. Norman, University of Oklahoma Press, 1949. $435 \mathrm{p}$. 49-50089 $\quad$ E338.R $_{5}$ Aims to present a cross-view of civilization in a transitional decade, excluding only the well-known political events of the age of Jackson. The great majority of the references are to strictly contemporary sources. "The effort has been to present a comprehensive view of how people earned their livings, how they amused themselves, and what were their thoughts and their ideals." There are chapters on business, the wage earner, woman, reformers, doctors, scientists, and sports. The United States, he concludes, was well embarked on the "revolutionary project of developing an entire people rather than only a few selected groups."

4521. Stewart, George R. American ways of life. Garden City, N. Y., Doubleday, I954. 310 p. 54-7323 Ei6g.I.S84

Realistic surveys of various aspects of American social life from 1607 to the present day, including such comparatively neglected topics as food, drink, clothing, sex, play, and holidays. "Personal names" is based on extensive research by the author in original records, and is a field which he has practically to himself. Originally prepared for an Athenian audience, much of the matter will be quite as enlightening to the author's own countrymen.

4522. Tyler, Alice (Felt) Freedom's ferment; phases of American social history to 1860 . Minneapolis, University of Minnesota Press, I944. $608 \mathrm{p}$. $\mathrm{A}_{44-463} \mathrm{BR}_{5} \mathrm{I} 6 . \mathrm{T}_{9}$

Bibliography and notes: p. 551-589.

The religious and reform movements of the early Republic are here presented as twin manifestations 
of the desire to perfect human institutions. "The American reformer was the product of evangelical religion, which presented to every person the necessity for positive action to save his own soul, and dynamic frontier democracy, which was rooted deep in a belief in the worth of the individual. The result was a period of social ferment, sometimes a little mad, a little confused about directions, but always full of optimism, of growth, and of positive affirmation." Within this framework are straightforward accounts of Transcendentalism and Mormonism, religious and secular utopias, reform movements in education, penology, and welfare, and the temperance, peace, feminist, and anti-slavery crusades.

\section{Social History: Topics}

4523. Asbury, Herbert. The great illusion; an informal history of prohibition. Garden City, N. Y., Doubleday, 1950. 344 p.

$$
\text { 50-10358 HV5089.A74 }
$$

Develops the antecedents of Prohibition at reasonable length, and finds the crucial decision in the elections of 1916, well before wartime conditions prevailed or "our boys" were off in Europe. "At most the war may have hastened ratification by a few years ... The American people wanted prohibition and were bound to try it; for more than a hundred years they had been indoctrinated with the idea that the destruction of the liquor traffic was the will of God and would provide the answers to most, if not all, of mankind's problems." Prohibition's fairest flower was an appalling moral collapse, the almost complete breakdown of law enforcement throughout the United States, and the taking over of the importation, manufacture, and distribution of illegal liquor by the underworld. An opinionated but well-documénted record.

4524. Benson, Mary Sumner. Women in eighteenth-century America; a study of opinion and social usage. New York, Columbia University Press, 1935. 343 p. (Columbia University. Faculty of Political Science. Studies in history, economics and public law, no. 405) H3r.r. C7, no. 405

$$
\text { 35-6356 HQi416.B4 i935a }
$$

"Bibliographical essay": p. 317-333.

A study of the status of women during a crucial century, primarily as set forth by theorists both in Europe and America, but also "as reflected in legislation, in the activities of women themselves, and in the comments of prominent Americans and travellers." Franklin and Rush were American innovators who wrote effectively in favor of wider opportunities and responsibilities for women, but the bulk of American writing reflected European ideas. In society itself, American conditions had modified the European tradition: upper class women had a greater part in economic activity; lower class women received better treatment. Definite advances were made during the century, but at its close the fear of radicalism was restricting further developments.

4525. Bestor, Arthur E. Backwoods utopias; the sectarian and Owenite phases of communitarian socialism in America, r663-1829. Philadelphia, University of Pennsylvania Press, 1950. $288 \mathrm{p}$. 50-6447 $\mathrm{HX}_{54 . \mathrm{B}_{4}}$

At head of title: American Historical Association. "Bibliographical essay": p. 245-268.

This work defines with a new precision the Communitarian point of view: it aimed to produce a small, voluntary, experimental community, which would accomplish an immediate root-and-branch reform, and provoke general imitation in the great world outside. The "holy commonwealths" are inventoried, beginning with Plockhoy's established on the Delaware in 1663; there were 34 of them prior to 1825 , and 130 before the Civil War. Robert Owen's communitarian proposals made a wider appeal than any predecessors, because free of all narrow sectarian restrictions. But after Owen's complicated and expensive failure, the sectarian communities went prosperously on until the Civil War turned them into economic backwaters.

4526. Curti, Merle E. The roots of American loyalty. New York, Columbia University Press, 1946. 267 p. A46-2131 Ei69.1.C89 "Bibliographical note": p. [249]-256.

An examination of the sources and nature of American patroitism, particularly during the formative century which followed 1776 . The subject is inseparable from the development of American nationalism, and the author emphasizes the manner in which particular groups, such as Negroes or immigrants from continental Europe, have developed a sense of participation in the national life. A great variety of printed sources have been ransacked for evidence-including the usually ignored Fourth of July oration, which, "for all its bombast 
and platitudes, epitomized the whole pattern of American patriotic thought and feeling."

4527. Habenstein, Robert W., and William M. Lamers. The history of American funeral directing. Milwaukee, Bulfin Printers, r955. $636 \mathrm{p}$. 55-12014 GT $3150 . \mathrm{H}_{3}$ This work, sponsored and copyrighted by the National Funeral Directors Association of the United States, devotes its first 200 pages to a description of the pre-Christian, medieval, and early English background, and then embarks upon an analysis of American developments as objective as it is massive. No grim detail is slighted: the evolution of the coffin (which became the casket in the course of the r860's), of the hearse, and of the embalmer's art are concretely charted. The authors pause at intervals to reconstruct the typical funeral of the period. The later chapters emphasize the rise of the professional spirit, the differentiation of the embalmer from the funeral director, and the development of national associations in the field. There are numerous illustrations from contemporary sources, happily more often comic than gruesome. The volume is thoroughly documented. A related subject is presented in Charles L. Wallis' Stories on Stone; a Book of American Epitaphs (New York, Oxford University Press, r954. 272 p.), a classified anthology of inscribed tombstones of originality, character, and humor, conscious or unconscious.

4528. Krout, John Allen. The origins of prohibition. New York, Knopf, i925. 339 p.

Bibliography: p. 305-328. 25-16666 HV $5089 . \mathrm{K}_{75}$

A social history of the "temperance movement," largely impelled by the power of evangelical Protestantism, down to $185 \mathrm{I}$. The temperance societies which sprang up locally, and were federated in the American Society for the Promotion of Temperance in 1826 , became racked by dissension over the consumption of wine and malt liquors. In the 1840 's came the Washingtonian or total abstinence movement, but also a growing conviction that persuasion would never be adequate and must be replaced by legal coercion. The first result was the Maine Law of $185 \mathrm{x}$. Chapter 10 surveys the huge literary output of the temperance reformers.

4529. Langdon, William Chauncy. Everyday things in American life. New York, Scribner, 1937-41. 2 v. 37-34608 Er6r.L32 384 .

Bibliography: v. [I], p. 335-340; v. [2], p. 383-

Contents.-v. I. 1607-1776.--v. 2. 1776-1876.

A simple and straightforward presentation of the development of material culture in America, with copious illustrations. The first volume, because of simpler subject matter, is a more unified production than the second. Transportation and manufacture, as well as domestic equipment, are included.

4530. Mann, Arthur. Yankee reformers in the urban age. Cambridge, Belknap Press of Harvard University Press, 1954. 3r 4 p.

"Bibliographical note": p. [245]-248. $54-5020 \quad \mathrm{HN}_{80} \mathrm{~B}_{7} \mathrm{M}_{3}$

Boston is utilized as a case study in urban socialreform thinking during the two seminal decades, r880-rgoo. While the author emphasizes that the reformers were only an articulate minority, and the mass of the citizens remained indifferent or hostile to liberalism, the book leaves rather an impression of a multiplicity of workers engaged in intense activity. Irish Catholic liberals, radical rabbis, Protestant social gospelers, academic dissidents, radical freelance intellectuals, trade-union "collective individualists," and feminists contributed their strands of criticism and vision. John Boyle O'Reilly, Frank K. Foster, Frank Parsons, and Vida D. Scudder are among the leaders who "rejuvenated the languishing spirit of reform to meet the problems of the modern, urban-industrial culture."

4531. Rawson, Marion (Nicholl) Of the earth earthy; how our fathers dwelt upon and wooed the earth. New York, Dutton, I937. 4 I 4 p. $37-23647$ Ei6r.R285

Suggestive and nostalgic essays on vanished forms of our material culture, with pen-and-ink illustrations by the author. Here one finds the forms and functions of those mysterious entities so frequently encountered in our early literature: the lime-kiln, the hop-yard, the malt-house, saltpetre beds, the shot-tower, the salt-yard, the seine loft and field, sail and rigging lofts, the ropewalk, the charcoal pits, the peat bog, and many others. The author has written a number of other books in similar vein, such as Forever the Farm (New York, Dutton, I939. $3^{80}$ p.), but none so original as this.

4532. Schlesinger, Arthur M. Learning how to behave, a historical study of American etiquette books. New York, Macmillan, 1946. $95 \mathrm{p}$. 46-8ir2 Ei6r.S25

A concise survey of a copious branch of American writing. Domestic manuals replaced imported ones with the advent of Jacksonian democracy, and provided a means for social groups rising out of peasantry or poverty to assimilate an old heritage of social refinement. After the Civil War, an etiquette of heightened formal convention provided a special form of display for the new rich and their imitators. 
This artificiality disappeared quite suddenly after World War I, leaving a vacuum which has been very imperfectly filled.

4533. Wecter, Dixon. The hero in America, a chronicle of hero-worship. New York, Scribner, I94I. $530 \mathrm{p}$.

Bibliography: p. 493-5r3.

Aims "to look at a few of those great personalities in public life-Washington, Franklin, Jefferson, Jackson, Lincoln, Lee, Theodore Roosevelt-from whom we have hewn our symbols of government, our ideas of what is most prizeworthy as 'American'." Equally significant as signposts of folk approval are minor heroes and hero types-Johnny Appleseed, the Unknown Soldier, Lindbergh. The author notes the absence of women, artists, scholars, and saints, as well as physicians and lawyers, from the heroic register.
4534. Wecter, Dixon. The saga of American society; a record of social aspiration, I607-

1937. New York, Scribner, 1937. 504 p.

37-15575 Ei6r. W43

"A note on bibliography": p. 485-493.

A lively panorama of Society with a capital S, defined as "the overt manifestation of caste," active, conspicuous, articulate, specialized. A chapter is devoted to the assimilation of plutocracy to aristocracy, a vital problem of society since the rise of the great industrial fortunes. The Blue Books, and other means of limiting and recognizing the socially elect, are analyzed. Other topics are the gentleman's club, the predominance of women, the society page as a power and not merely a picture, and marriage with titled Europeans. The author is critical and often ironical, but never contemptuous or denunciatory.

\section{Social Thought}

4535. Barker, Charles A. Henry George. New York, Oxford University Press, r 955. 696 p. $55^{-625} \mathrm{I} \quad \mathrm{HBr}_{9} . \mathrm{G}_{4} \mathrm{~B}_{3}$

To Prof. Barker, George's Progress and Poverty ( 1879 ) is "a moral Mount Whitney in American protest." While the book is primarily "a devastating attack on land monopoly," it is just as effective "against monopolism in any form, unless that monopolism be truly necessary in economics and truly public in administration." "No other book of the industrial age, dedicated to social reconstruction and conceived within the western traditions of Christianity and democracy, commanded so much attention." These convictions animate the author's immense researches in primary materials, and justify the extremely detailed narratives of the evolution of George's ideas, his participation in California and New York politics, and his campaigns of propagandism in the British Isles and at home. A final chapter deals with the "triple legacy of Georgism," in the single tax doctrine, in municipal reformism, and in "moral and intellectual Georgism." Readers desiring a more concise presentation of George's life and thought will find it in Albert J. Nock's Henry George, an Essay (New York, Morrow, I939. 224 p.), and a treatment largely limited to ideas in George R. Geiger's The Philosophy of Henry George (New York, Macmillan, r933. 581 p.).
4536. Bernard, Luther L., and Jessie Bernard. Origins of American sociology; the social science movement in the United States. New York, Crowell, r943. 866 p. $43-$ I $_{0237} \mathrm{HM}_{22 .} \mathrm{U}_{5} \mathrm{~B}_{4}$

The chief predecessor of the modern academic discipline, sociology, was the social science movement, originally transplanted to the United States as an ardent practical democratic idealism, but in the course of time losing most of its futile utopianism, acquiring greater logical and scientific discipline, and falling into line with respectable scientific method. The period covered is approximately $1840-90$, and the major topics are the associationist phase, the influence of Comte, the systematizing phase (G. F. Holmes, James O'Donnell, R. S. Hamilton, and R. J. Wright), the nationalist or Carey School, the neo-classical school, and the American Social Science Association (r865-1909). "Social Science" itself is regarded as a transitional stage embodying residual theological and metaphysical elements. A cumbersome volume, but full of information for intellectual history.

4537. Chugerman, Samuel. Lester F. Ward, the American Aristotle; a summary and interpretation of his sociology. Durham, N. C., Duke University Press, 1939. $591 \mathrm{p}$.

Bibliography: p. 559-560. 
Ward (1841-1913) worked out his doctrines of sociology during the 40 years he was a government official in Washington, laboring for 14 years on the production of his first book, Dynamic Sociology ( 1883 ). Only during the last seven years of his life did he profess the subject at Brown University. Mr. Chugerman disposes of Ward's biography in one chapter, and devotes the rest of his book to a systematic presentation of Ward's ideas and his claims to greatness as a thinker. Ward was the Yankee Aristotle because, like the Greek thinker and also like Comte and Spencer in his own day, he worked out a massive synthesis of the sciences and the naturalistic philosophy of his age. To Ward evolution was the key to the cosmos, and sociology the crown of the sciences and the only sure instrument of progress through social reconstruction. American sociology has ever since retained the naturalistic and reformist stamp which Ward gave to it.

4538. Dorfman, Joseph. Thorstein Veblen and his America. New York, Viking Press, I934. $556 \mathrm{p}$. $\quad 34-39873$ HBII9.V4D6

"Bibliography of Thorstein Veblen": p. 519-524.

Veblen (1857-1929), the son of Norwegian immigrants, was an economist whose very original views soon led him to transcend the orthodox boundaries of his subject and make striking and controversial contributions to social theory. This detailed biography utilizes the lecture-notes taken by his students and includes summaries of his principal writings, among which The Theory of the Leisure Class (New York, Macmillan, I899. 400 p.) and The Theory of Business Enterprise (New York, Scribner, 1904. 400 p.) are the best known.

4539. Jandy, Edward C. Charles Horton Cocley, his life and his social theory. New York, Dryden Press, 1942. 319 p.

Bibliography: p. 270-28r.

$$
\text { 42-22102 HM22.U6C65 }
$$

Cooley (I864-I929) was professor of sociology at the University of Michigan and one of the founders of American academic sociology, and in particular of social psychology. The author of this Michigan dissertation devotes his first two chapters to Cooley's life, and the remaining four to an exposition of his social theory. In summarizing, the author declares that while Cooley's abstract and philosophical approach, his tendency to generalize on the basis of scant data, and his "ethico-religionism" are things of the past, his view of "the interdependent nature of the individual and society," his emphasis on public opinion, and his analyses of social institutions pervade more recent literature, and assure him an enduring place in the history of sociology.
4540. Odum, Howard W., ed. American masters of social science; an approach to the study of the social sciences through a neglected field of biography. New York, Holt, 1927. 4 II p. 27-8909 $\mathrm{HM}_{22 . \mathrm{U} 6 \mathrm{O}_{4}}$

Contents.-Pioneers and masters of social science, by H. W. Odum.-John William Burgess, by W. R. Shepherd.-Lester Frank Ward, by J. Q. Dealey.-Herbert B. Adams, by J. M. Vincent.William Archibald Dunning, by C. E. Merriam.Albion Woodbury Small, by E. C. Hayes.-Franklin Henry Giddings, by J. L. Gillin.-Thorstein Veblen, by P. T. Homan.-Frederick Jackson Turner, by C. Becker.-James Harvey Robinson, by H. E. Barnes.

Sketches of nine "masters," who include political scientists, historians, and economists as well as sociologists, are presented primarily as "an approach to teaching and research in the social sciences." The sketches present the subject's outlook and ideas as well as the facts of his life. While the careers of these men coincided with the periods during which their disciplines achieved autonomy in American higher education, the editor emphasizes their versatility, enabling them to range "over a broad field of social interest" and social statecraft.

454I. Odum, Howard W. American sociology; the story of sociology in the United States through 1950. New York, Longmans, Green, I951. 501 p. 5I-I2390 $\mathrm{HM}_{22 .} \mathrm{U}_{5} \mathrm{O}_{4}$ I95 I

A presentation of the professional and organizational aspects of its subject. The largest section is concerned with the careers and work of the successive presidents of the American Sociological Society, from Lester F. Ward in 1906-07, to Leonard Cottrell, the 4oth, in 1950 . The next largest lists, with some commentary of a general kind, college texts in sociology since 1883 , both general and special. Chapter 23 describes American sociological journals and their editors. The concluding chapters, "Toward inventory," discuss a few trends but attempt no large synthesis or jucigment. Rather a compendium of serviceable information than a definitive history of its subject.

4542. Page, Charles Hunt. Class and American sociology; from Ward to Ross. New York, Dial Press, 1940. 319 p.

$$
40-8685 \mathrm{HM}_{22 .} \mathrm{U}_{5} \mathrm{P}_{3} \text { I940a }
$$

Issued also as thesis (Ph. D.) Columbia University.

Contents.-The fathers and their times.-Lester Frank Ward.-William Graham Sumner.-Albion Woodbury Small.-Franklin Henry Giddings.Charles Horton Cooley.-Edward Alsworth Ross.- 
Conclusion.-Notes and bibliography (p. [255]312).

A study of the concept of class in the work of six of the "fathers" of American sociology. All were concerned with the role of class forces in American life; after their day American sociology turned to detailed empirical research in problem areas of narrower scope. The present concern with class, not merely as a socio-economic aggregate, but as a sociopsychological phenomenon rooted in personal attitudes, is a return to their viewpoint. But "they were all, in one way or another, impressed by the anti-class elements of American democracy," and by the emphasis of our middle class "upon the common elements of a society and its negation of all separating barriers."

4543. Ross, Edward Alsworth. Seventy years of it; an autobiography. New York, Appleton-Century, 1936. 34I $\mathrm{p}$.

36-274 I6 HM22.U6R6

Ross (1866-195I) after being expelled for his opinions from Stanford University in 1900 , settled down to a long teaching career at the University of Wisconsin. He was one of the founders of our academic sociology, but little of his formal doctrine appears here; rather does it exhibit him in the role of stormy petrel. An uncompromising democrat, he fearlessly spoke out against all tendencies which might undermine the roots of American society in liberty and equality. His reminiscences are miscellaneous, and often naively bumptious, but they reflect his wide acquaintance with other societies, his indifference to fashionable currents of opinion, and his ability to penetrate to the essence of social tendencies.
4544. Starr, Harris E. William Graham Sumner. New York, Holt, 1925. 557 p.

25-II703 $\mathrm{H}_{59 . \mathrm{S}_{7}}$

Sumner (1840-1910), the most stalwartly independent of all American social scientists, had a remarkably varied career, in the course of which his views altered from orthodox Congregationalism through classical economic doctrine to ethnological relativism. At all stages his complete honesty, clear expression, and uncompromising assertion made him a formidable factor in current discussion at various levels. This admiring but objective biography quotes at length from his correspondence and digests his doctrines in their several subjects and stages.

4545. White, Morton G. Social thought in America, the revolt against formalism. New York, Viking Press, 1949. $260 \mathrm{p}$. 49-48242 $\mathrm{H}_{53} \cdot \mathrm{U}_{5} \mathrm{~W}_{5}$

The subtitle defines the book's subject: the style of thinking which dominated America for almost half a century, an intellectual pattern compounded of pragmatism, institutionalism, behaviorism, legal realism, and economic determinism. Its major representatives were Justice O. W. Holmes, Thorstein Veblen, John Dewey, James Harvey Robinson, and Charles A. Beard. Their common ground was the rejection of abstractionism in favor of historicism and cultural organicism, although their following came rather from their apparent contribution to the advent of a more rational society. The treatment is critical as well as expository, but the balance is favorable: in spite of all their fuzziness and lack of logic, "their example should serve to encourage those social scientists who are more interested in achieving a good society than in measuring attitudes toward toothpaste."

\section{E. General Sociology; Social Psychology}

4546. Barneth, James $H$. The American Christmas; a study in national culture. New York, Macmillan, 1954. I73 p. 54-I2566 GT $4985 . B_{3}$ According to the author, this "is a pioneer effort in the sociological study of American holidays," which seeks "to show how the past and the present, the religious and the secular, are fused in the pattern of the national festival so that it draws vitality from many and varied sources." Historically, this one is a recent development, its legal recognition by all the states and territories taking place between 1836 and 1890 . Its intensive commercial exploitation falls after 1920. The social role of Santa Claus and the social content of Christmas art are developed. Christmas "has become a diffuse, popular cult," "nourished by the tie of family life, by affection for children, by a willingness to aid the needy, and even by the profit-seeking activities of modern business." In it even the secular-minded can readily participate.

4547. Caplow, Theodore. The sociology of work. Minneapolis, University of Minnesota Press, I954. $330 \mathrm{p}$. 54-8208 HM21... 3

The author defines his subject as "the study of those social roles which arise from the classification 
of men by the work they do," and proceeds upon the assumption that a complex society like the United States "is maintained by the mutual dependence of highly specialized and differentiated occupational groups." While he aims at generalized conclusions, his exposition depends upon American subject matter, with only an occasional introduction of foreign situations for contrast. His book, he says, is primarily an essay on the division of labor, and he has much to say concerning the measurement of occupational status, vertical and other kinds of mobility, occupational institutions, and occupational status. In the United States today, he observes, "poverty has come to mean the absence of status symbols rather than hunger and physical misery." This and many comparable insights add up to a penetrating exposition of the nature of jobs and of job-holding in present-day America, viewed as social rather than merely economic facts.

4548. Chapin, Francis Stuart. Contemporary American institutions; a sociological analysis. New York, Harper, 1935. 423 p.

35-II7I2 $\mathrm{HN}_{57 . \mathrm{C}_{5}}$

Prof. Chapin's analysis proceeds from the principle that "social institutions are essentially psychological phenomena that consist of a configuration of segments of the behaviors of individuals." On this basis he describes the political and business institutions of the local community, the family, the school, the Protestant church in an urban environment, social welfare agencies, and even the New Deal. He gives many tables and diagrams illustrative of social situations. He concludes with various theories and projects of social measurement, typical of the direction sociological investigation was about to take, and indicating why his would be the last general survey of the kind.

4549. Cuber, John F., and William F. Kenkel. Social stratification in the United States. New York, Appleton-Century-Crofts, I954. 359 p. 54-10606 HT609.C8

The authors attempt to supply a practical textbook for a field hitherto without one, although research output within it has been immense. "Part I is a semantic, theoretical, and methodological orientation to stratification literature." Part II consists of critical analyses of eight important field studies of social stratification in America, with special attention to the validity of the methods employed in each. Part III contains both theoretical and specific conclusions; there are, for instance, varying stratification systems in various American communities, rather than a single all-embracing system, and individuals have multiple statuses rather than a single well-defined one. In a final evaluation of the
American stratification system, the authors discuss four often-heard negative judgments, and present four favorable factors, such as high vertical mobility, and rectification of some of the inequities in lifechances, but most of their conclusions remain quite tentative.

4550. Davis, Kingsley, ed. Modern American society; readings in the problems of order and change [by] Kingsley Davis, Harry C. Bredemeier [and] Marion J. Levy, Jr. New York, Rinehart, 1949. $734 \mathrm{p}$. 49-5542 HN57.D3

"All the materials in the book are designed to help the student understand what gives order and disorder, unity and disunity, to our society as a whole." The most convenient approach to this problem the editors find "in the relation between our system of values as it is expressed in the American ethos and as it is reflected in the actual functioning of our society." The selections from books and periodicals pursue those themes under the following headings: "The New Urban Environment", "The Economic Framework", "Our Class System", "Race Versus Democracy", "Education and Public Opinion", "The Separation of Church and Society", "Recreation: Leisure and Escape", "Modern Marriage and the Family".

4551. Ebersole, Luke E. American society, an introductory analysis. New York, McGrawHill, 1955. 510 p. 55-7274 $\mathrm{HN}_{57 . \mathrm{E}_{2}}$

$\mathrm{L}$ ssigned for courses in introductory sociology and general social science, this is a much simpler treatment than Williams' (no. 4558), with far less employment of technical jargon. "It is hoped that it will be useful also in courses in the field of American studies." The main divisions are "People," "Communities," "Classes," and "Institutions." The first deals with population, immigration, and minorities. "Classes" discusses social stratification, identifying six social classes in the United States, and social mobility. Family, economic, governmental, educational, and religious institutions are described. A final chapter identifies ten processes which have been changing our society: invention, industrialization, urbanization, centralization, specialization, bureaucratization, stratification, mobility, secularization, and assimilation.

4552. Miller, Delbert C., and William H. Form. Industrial sociology; an introduction to the sociology of work relations. New York, Harper, I95 I. $896 \mathrm{p}$.

51-9367 HD696r.M55

A large scale textbook which "seeks to introduce new research, integrate available materials, and provide a frame of reference for the study of work rela- 
tions." In the authors' view, industrial sociology is a relatively new discipline based upon the recent "rediscovery that working cannot be divorced from living. It is now known that production, profit, and industrial peace depend in large measure on the recognition that industry is a complex of interacting groups and individuals." The largest sections of the book are devoted to the social organization of the work plant or factory, and the social adjustment of the worker through successive periods of his life, from the family to retirement. A final section is devoted to more general considerations on the interdependence of industry and community, and of industry and society.

4553. Mills, Charles Wright. White collar; the American middle classes. New York, Oxford University Press, 1951. xx, $378 \mathrm{p}$. 5I-5298 HT69o.U6M5

Bibliographical references included in "Acknowledgments and sources" (p. 355-363).

The "new middle class," made up of managers, salaried professionals, salespeople, and office workers, has grown up beside the older middle class of farmers, businessmen, and free professionals, and now outnumbers it by a substantial margin. This untechnical and often rather arbitrary book has the field to itself in seeking to characterize the outlook and the dilemmas of its several worlds. The business managers have become cogs in a business machinery that has routinized greed. Bureaucracy and commercialization are spreading through the professional world. In the great salesroom, "it is the salesmen who have put their personalities up for sale." In "the enormous file," the work has been "standardized for interchangeable, quickly replaceable clerks."

4554. Odegard, Peter $\mathrm{H}$. The American public mind. New York, Columbia University Press, 1930. 308 p. 30-27934 Er69.I.O23 Bibliography: p. 280-29r.

"Why do we behave like Americans? Whence come our ideas and ideals?" A straightforward account of American public opinion as of its date, as influenced by family, church and school, the press, political and special interest propaganda, and the popular arts. The author hardly answers his own questions, but presents a lively view of surface phenomena.

4555. Riesman, David. The lonely crowd; a study of the changing American character. In collaboration with Reuel Denney and Nathan Glazer. New Haven, Yale University Press, $195^{\circ}$. xvii, 386 p. (Studies in national policy, 3) 50-9967 BF755. $\mathrm{A}_{5} \mathrm{R}_{5}$
4556. Riesman, David. Faces in the crowd; individual studies in character and politics. In collaboration with Nathan Glazer. New Haven, Yale University Press, 1952. 751 p. (Studies in national policy, 4) 52-5357 BF8I8. $R_{5}$

Highly original studies in American social psychology, which attempt to isolate and illustrate some recent changes of high signinicance. As the United States has passed from a growing population to a more stationary one with lower birth and death rates, the older patterns of individual character, tradition-directed or inner-directed, have increasingly yielded to the other-directed pattern. This type, whose conformity rests on "sensitive attention to the expectations of contemporaries," pursues a fluctuating series of short-run goals and tends to live in a world largely made up of interpersonal relations. The habits of thought and action of the creators and brokers of prestige receive wide imitation. Varying attitudes in politics, work, and play are elaborated. The sequel presents 20 individual portraits, based on interviews some of which are presented in full. They seek to answer: "what sort of person is this, in terms of his character; how is his conformity secured, what is his political style-that is, how does he handle the political world as part of his total lifeorientation?"

4557. Warner, William Lloyd. Democracy in Jonesville; a study in quality and inequality. New York, Harper, 1949. xviii, 313 p.

49-10212 $\mathrm{HN}_{57} \cdot \mathrm{W}_{3}$

A study of social classes and social mobility in a small Illinois town [actually Morris, Grundy County] used as a laboratory for studying the social structure governing American capitalism. The emphasis is on the factors determining the rise and fall of families in the social scale. These elements are studied against the varying backgrounds of childhood, the mill, local associations and social clubs, the churches, the Norwegians as a distinct group, the high school, and party politics. The conclusion is that the American Dream is one thing, and the complexities of status another, but that without the Dream social mobility would stiffen into rigidity.

4558. Williams, Robin M. American society; a sociological interpretation. New York, Knopf, r95I. xiii, 545 p.

$$
\text { 5I-I I055 } \mathrm{HN}_{57} \cdot \mathrm{W}_{55}
$$

A pioneer attempt to obtain a systematic view of the total American social structure, which applies the basic concepts and approaches of sociology to kinship and the family, to social stratification, and to economic, political, educational and religious institutions. The results are cautiously and tentatively 
rather than dogmatically stated. Among the general characteristics of social organization in the United States are these: a relatively slight development of stable groups of Gemeinschaft character, an enormous proliferation of formally organized special-interest associations, and an increasingly strategic position of large-scale centralized organizations in the total structure. "Major value-orientations in America" are spelled out at length, from " 'achievement' and 'success'" through "material comfort" to "racism and related group-superiority themes."

\section{F. The Family}

4559. Bossard, James H. S. The sociology of child development. Rev. ed. New York, Harper, 1954. 788 p. 53-94II HQ78I.B67 r954

The chief emphasis of this book is upon "the social situations in which children live and grow from infancy to maturity." While the primary interest is in child behavior, the social context to which it is related is regularly American. There are chapters on interaction among the siblings, the bilingual child, the role of the guest, the child and the class structure, growing out of the family, and children who reject their parents. The final section presents the changing status of childhood: in America children "are viewed in terms of equality with other members of the family and recognized as coequal personalities in the emerging democracy of the family."

4560. Calhoun, Arthur W. A social history of the American family from colonial times to the present. New York, Barnes \& Noble, 1945. 3 v. in $\mathrm{I}$.

"Copyright, I9I7[-19] .. . Reprinted 1945."

Bibliography at end of each volume.

Contents.-1. Colonial period.-2. From independence through the Civil War.-3. Since the Civil War.

Remains, after four decades, considerably the most detailed historical presentation of sex and family life in the United States. In substance it consists of extracts from contemporary sources strung together on a loose framework by a conventional and not too penetrating commentary. Since these subjects were discussed by our fathers in tones usually alarmist, and lapses from the writers' standards were ncted rather than the contrary, the book is often a better guide to past opinion than to past fact.

456r. Cavan, Ruth (Shonle) The American family. New York, Crowell, i953. 658 p. $53-5389 \mathrm{HQ}_{535} \mathrm{C}_{33}$

"Supersedes the author's... The Family [1942]."
A college text written from the socio-psychological point of view, and including charts and other quantitative matter. Part I presents the general issues and considers the family in relation to rural life, migration, and urbanism. Part II studies the family in relation to social classes and social mobility. Part III contains a detailed psychological treatment from adolescence to old age, with special attention to dating, sex expression, adjustment in marriage, and divorce. The author concludes that the process of family disintegration has passed its climax, and that a new reintegration of the family with other institutions has begun to take place.

4562. Furnas, Joseph C. How America lives. New York, Holt, 1941. $372 \mathrm{p}$.

$4 \mathrm{I}-5 \mathrm{I} 597 \mathrm{HN} 57 . \mathrm{F}_{7}$

First published in the Ladies Home lournal.

The patterns of life and the budgets of 16 American families, ranging from wealthy industrialists to persons on relief or colored sharecroppers in Mississippi. The treatment is marked by journalistic slickness and some optimism, but is nevertheless a very concrete sampling of actual family life in its economic context just before World War II. There are review chapters on American housekeeping, diet, fashion, "beauty culture," housing, and home decoration.

4563. Groves, Ernest R. The American woman; the feminine side of a masculine civilization. Rev. and enl. ed. New York, Emerson Books, r944. $465 \mathrm{p}$. 44-2372 HQi4io.G73 I044

Regarding woman, from the scant attention she gets in American historical writing, as the forgotten sex, the author traces woman's advance in status in a setting of masculine dominance. He aims to follow the general movement that brought the average woman closer to the privileges and resources of men, rather than to catalogue the noted women of the past. This has come about in two related currents: an increasing encroachment upon masculine special privileges, led by aggressive and gifted women lead- 
ers, and the momentum of a material and intellectual progress that is making the equality of men and women more natural.

4564. Hollingshead, August de B. Elmtown's youth, the impact of social classes on adolescents. New York, Wiley, 1949. 480 p.

\section{9-3279 HQ796. $\mathrm{H}_{5}$}

"This study is one of a series made under the auspices of the Committee on Human Development of the University of Chicago."

A study of 735 adolescent boys and girls in a Middle Western Corn Belt community, in order to analyze the way its social system organizes and controls the social behavior of young people reared in it. The social structure is graded into five classes, and the different attitudes and behavior which each class displays are traced in high school life, in cliques and dates, religion, jobs, and recreation. The "withdrawees" who have left school before completing its work, are separately studied. The conclusion indicates that our class system, which revolves about the gospel of success and escapes legal regulation because it is extra-legal, "is far more vital as a social force in our society than the American creed."

4665. Kinsey, Alfred C. Sexual behavior in the human male [by] Alfred C. Kinsey, Wardell B. Pomeroy [and] Clyde E. Martin. Philadelphia, Saunders, I948. Xv, $804 \mathrm{P}$.

\section{8-5I95 HQ18.U5 $\mathrm{K}_{5}$}

"Based on surveys made by members of the staff of Indiana University, and supported by the $\mathrm{Na}$ tional Research Council's Committee for Research on Problems of Sex by means of funds contributed by the Medical Division of the Rockefeller Foundation."

Bibliography: p. $766-787$.

4566. Kinsey, Alfred C., and others. Sexual behavior in the human female, by the staff of the Institute for Sex Research, Indiana University. Philadelphia, Saunders, I953. xxx, 842 p.

Bibliography: p. 763-81o. 53-III27 HQ18.U516

Formally, Dr. Kinsey and his associates' statistical inquiry into the overt sexual activity of a sample of the whole American population is a study in human biology and so ineligible for this bibliography. Actually it furnishes much the largest body of concrete evidence concerning actual patterns of sex behavior at various social levels, in various environments, and at different ages, and is therefore a contribution to the description of American society.
4567. Kyrk, Hazel. The family in the American economy. Chicago, University of Chicago Press, 1953. xvii, 407 p. 53-12266 HQ535.K9 Bibliography: p. 395-398.

The family is also an economic unit, and this book analyzes the economic position of American families in terms of incomes, prices, and standards of living. Families are regarded, not as fixed units, but as groups of individuals living through life-spans during which they will have differing economic characteristics. Among the subjects discussed are the components of family income, contributors and claimants to such income, amount and adequacy of family incomes, provision for the future through saving and insurance, the economic position of homekeeping women, the cost of living, and the standard of living.

4568. Landis, Paul H. Adolescence and youth; the process of maturing. 2d ed. New York, McGraw-Hill, 1952. $461 \mathrm{p}$.

$$
\text { 52-6542 HQ796.L27 } 1952
$$

A study of the gap between childhood and adulthood which emphasizes "the infringement of the social processes on the developing organism" and treats adolescence "as a dynamic process which leads the growing organism through a molding series of social experiences," all in an American context. After more general considerations concerning the personality-forming process, the author analyzes what he takes to be the three critical phases of adjustment: attaining moral maturity, the transition to marital adulthood, and the struggle for economic adulthood. The concluding part studies the school as the major agency of social adjustment. The volume is liberally supplied with tables, graphs, and diagrams. The same author's Understanding TeenAgers (New York, Appleton-Century-Crofts, I955. 246 p.) presents much the same material in abbreviated and more readable form.

4569. Lumpkin, Katharine Du Pre, and Dorothy (Wolff) Douglas. Child workers in America. New York, McBride, I937. 321 p.

Bibliography: p. 307-313.

37-27309 $\mathrm{HD}_{250 . \mathrm{U}_{3} \mathrm{~L} 85}$

The Fair Labor Standards Act of 1938 effected a major improvement in the field of child labor, and by the 1950's its worst abuses had largely disappeared. The present work retains historical value as a summary of a problem of long standing just before the turn of the tide, when much effort expended on reform seemed strangely futile. The nature of the constant pressures toward child exploitation, as well as the attitudes which made it possible, are here rather bitterly described together 
with efforts at amelioration through an entire century.

4570. Mudd, Emily (Hartshorne) The practice of marriage counseling. New York, Association Press, 1951. xix, 336 p.

Bibliography: p. 23I-249.

$$
\mathrm{A}_{5} \mathrm{I}-7952 \mathrm{HQ} 728 . \mathrm{M} 83
$$

Marriage counseling is a development of the last quarter-century which has enlisted a variety of professional skill channeled through a growing number of national and local organizations. The author, who has been director of the Marriage Council of Philadelphia since its establishment in 1932, discusses the objectives of these services, and gives sample cases, including both those in which counseling has helped and those in which it has failed. Appendix $B$ is a series of reports from functioning services on their operations.

4571. Sirjamaki, John. The American family in the twentieth century. Cambridge, Harvard University Press, 1953. 227 p. (The Library of Congress series in American civilization)

$53-6035 \quad \mathrm{HQ} 535 . \mathrm{S}_{5}$

A condensed, integrated, and lucid essay which interprets the findings of social scientists for general readers. The present American family "is a small nuclear family centered largely upon its immediate members, settled in independent residence, dissociated from all but closely connected relatives, and lasting only through the adult years of its spouses and often not even so long." Its isolation from its larger kin group makes it more easily broken, but spouses work harder at their marriages because they know they have to. The concern for individualiza- tion of family members is large; wives have been brought near to legal parity, and children endowed with privileges. It is the family that best serves Americans' needs, and probably the one they want.

4572. Truxal, Andrew G., and Francis E. Merrill. Marriage and the family in American culture. New York, Prentice-Hall, 1953. 587 p.

53-10245 HQ536.T68

A standard college text in which the presentation of the family from the biological, psychological, and social aspects is regularly related to American conditions of today. The present edition has been extensively revised to include new materials derived from the scientific study of courtship and of personality. The sixth and final part, "The Dynamics of the Family," is largely concerned with the disintegrative tendencies of recent years, against which positive measures to stabilize and reorganize the family, such as marriage counseling and family life agencies, have been relatively ineffective.

4573. Wattenberg, William W. The adolescent years. New York, Harcourt, Brace, 1955. 510 p. 55-2109 HQ796.W32

A textbook which surveys the physical and psychological phenomena of adolescence in their social setting-ostensibly in that of Western Culture but practically in that of the United States. The author aims to help the reader "deal more understandingly with young people and with the adolescent in himself and in every adult he knows." "Problem areas" isolated in the third section include sex, social relationships, ideals, concepts of self, power and mastery, vocational choices, and personality troubles. It relies less on quantitative and more on case history materials than Landis (no. 4568).

\section{G. Communities: General}

4574. Ferguson, Charles W. Fifty million brothers; a panorama of American lodges and clubs. New York, Farrar \& Rinehart, 1937. $389 \mathrm{p}$.

"Selected list of sources": p. $36 \mathrm{I}^{-1}-380$. 37-1762 HS6r.F 4

Popular and very sketchy, but the only book which brings into one view such diverse associational phenomena as the Masons, college fraternities, the Knights of Pythias, women's clubs, the "Fascist shirts" of the 1930's, chambers of commerce, Negro lodges, the D. A. R., the Elks, the Eastern Star, and many others. The author believes that these clubs and secret orders "have grown and multiplied simply because they provided the only natural basis for normal group life in a country historically deprived of it."

4575. Hillman, Arthur. Community organization and planning. New York, Macmillan, 1950. $\mathrm{xviii}, 37^{8} \mathrm{p}$. 50-5240 $\mathrm{HV}_{40 . \mathrm{H} 62}$

"The methods by which communities deliberately change their structure and way of life is the theme of this book." The planning of communities should develop as a rational process and a conscious art. 
The major goal of planning is to substitute orderly processes of problem-solving for the remnants of anarchy in modern societies. Organized action in community life may proceed through community centers and community councils. Functional areas in which community planning takes place include services to children and youth, social work, recreation programs, and race-relations programs. The relationship between policymaking and administration, and between national and local planning, are considered.

4576. Kinneman, John A. The community in American society. New York, Crofts, I947. $45^{\circ} \mathrm{p}$. 47-5625 HMi3r. $\mathrm{K}_{5}$

Aims to arrive at the common elements in both rural and urban communities, and to show their interrelations and interdependence. Special attention is given to the relatively unexplored field of small but independent metropolitan centers, of from 25,000 to roo,ooo population. Community is regarded as essentially a socio-psychic phenomenon, an expression of consciousness of kind or attachments to certain basic interests, and provides the web of consciousness by which institutions function. As criteria of community relationships, newspaper circulation and hospitalization are given special consideration. Later chapters discuss leadership, change, conflict, and crises in the community.

4577. Lundberg, George A., Mirra Komarovsky, and Mary Alice McInerny. Leisure: a suburban study. New York, Columbia University Press, 1934. 396 p. 34-27255 HN79.N4L9
"Selected bibliography": p. $\left[3^{8} 7\right]-3^{89}$.

A study of the employment of leisure time in Westchester County, N. Y., a suburban area which enjoys "a higher plane of living than has hitherto [1934] been approached in any time or place." 2,460 individuals supplied diaries covering some 4,460 days, from which it appeared that the average leisure hours per diem for the entire group was $7 \cdot 4$. The exact time spent by various classes in various activities is worked out: the average was 108 minutes for eating, 90 for visiting, 57 for reading, etc. The authors do not find that suburbia makes a very constructive use of recreation, and wish local government to provide facilities, opportunities, and leadership for more rewarding activities.

4578. Marden, Charles F. Rotary and its brothers; an analysis and interpretation of the men's service club. Princeton, Princeton University Press, 1935. I78 p. 35-2259I HF5001.A2M3 r935a

This Columbia dissertation studies the luncheon clubs of business executives and professional men which call themselves service clubs and are joined in loose national or international federationsRotary, Kiwanis, Lions' Clubs, etc. Their welfare activities are found to be of limited scope, and personal and sporadic in nature, while little concrete evidence has appeared for their claim to be active in elevating the ethical level of business enterprise. The clubs are interpreted as new bases of association, sought after the decline of traditional ones, among the professional and business class, and especially as a means of dignifying the dominant position of the business class.

\section{H. Communities: Rural}

4579. Baker, Oliver E., Ralph Borsodi, and Milburn L. Wilson. Agriculture in modern life. New York, Harper, 1939. 303 p. editor.

Preface signed: Baker Brownell, supervising

This coöperative work grew out of a conference on distributive society and the possibilities of decentralization held at Northwestern University in 1938. Mr. Baker, whose section on "Our Rural People" is much the largest, is concerned with rural poverty, the drift of farm youth and wealth to the cities, and the difference between rural and urban birth rates. Mr. Borsodi offers "A Plan for Rural Life," and Mr. Wilson discusses "Science and Folklore in Rural
Life." All are concerned with the salvage of the independent farm as a natural and self-sufficient way of life stable enough "to balance against the pressures of insecurity and dependency and statism and confusion that make this age so troubled."

4580. Burchfield, Laverne. Our rural communities, a guidebook to published materials on rural problems. Chicago, Public Administration Service, r947. 20I p. $\quad 47-3889 \mathrm{HT}_{42 \mathrm{r} . \mathrm{B} 78}$ "General publications on rural affairs": p. 199201.

Aims to furnish those "interested in the problems of rural America with brief factual statements about major areas of rural life and annotated bibliographies 
where they may gather additional information. Specialists will find somewhat elementary the statements in sections concerned with their own specialties." Each chapter consists, after the initial "statement," of a summary of the literature under subtopics, followed by a list of precise references in alphabetical order. The main topics include schools, the Agricultural Extension Service, library service, the church, medical care and health services, welfare services, housing, recreation, and community organization.

458r. Kolb, John H., and Edmund de S. Brunner. A study of rural society. $4^{\text {th }}$ ed. Boston, Houghton Mifflin [1952] $532 \mathrm{p}$.

$$
\text { 52-10515 HT42I.K62 } 1952
$$

A textbook on contemporary American rural society woven about the theme of the growing interdependence in modern society-country and town, agriculture and industry, American and other societies. It is organized into four main parts, on population, the agrarian basis of rural society, group relations, and social institutions-established and recognized ways of getting things done. There are numerous tables, graphs, charts, and diagrams. Chapters are devoted to rural communities, rural interest groups and classes, and rural-urban relationships. Foreign instances are introduced for comparison.

4582. Nelson, Lowry. American farm life. Cambridge, Harvard University Press, 1954. 192 p. (The Library of Congress series in American civilization) $\quad 54-9332 \quad \mathrm{HN}_{57 . \mathrm{N}_{4} 6}$

A characterization of farm life in the United States for foreigners and city-dwellers, which emphasizes the increasing approximation of rural to urban living, and the consequent interdependence of these unequal segments of society. "The technological frontier" is the principal element of change: the permeation of farm life by machinery, agricultural research, and improved farm management, has profoundly affected rural life in its political, economic, and social aspects, and turned the "new farmer" into a kind of suburbanite.

4583. Rural life in the United States, by Carl C. Taylor [and others] New York, Knopf, 1949. xviii, 549, xii p. 49-74II HT42I.R8

Bibliography: p. 535-549.

Eight members of the U. S. Bureau of Agricultural Economics have combined to write a textbook in general rural sociology which deals with all important structural and functional aspects of rural society, all major geographic areas of the country, and all major problems of rural life. Part 2, on rural organization, has separate treatments of the home and family, education, religion, local government, health, welfare, and recreation and art. Part 3 , on rural people, deals with population, occupational patterns, standards of living, and the special problems of landowners, tenants, and laborers. "Part 4 is unique in a book on rural sociology because it discusses seven different type-farming areas of the United States as if each were a cultural region," and "could well be considered a start toward the development of the cultural anthropology of American rural life."

4584. Smith, Thomas Lynn. The sociology of rural life. $3 \mathrm{~d}$ ed. New York, Harper, 1953.

\section{0 p. $\quad 53-5573 \mathrm{HT}_{421 . S_{55}} 1953$}

Attempts to assemble in a single volume, suitable for college sophomores, the essential facts and basic principles derived from the application of scientific method in the study of rural social relationships, with nearly all the subject matter drawn from the United States. The main topics are the rural population, rural social organization, and social processes in rural society. The processes analyzed and illustrated are competition and conflict, coöperation, accommodation, assimilation, acculturation, and social mobility. The most significant new factor is the improvement of communications by the telephone, telegraph, radio, television, automobile, and good roads, so that rural people are now in constant contact with one another and with townsfolk and city people, and the isolation and lagging change of rural communities are largely overcome. Abundantly illustrated with maps, photographs, charts, and tables.

4585. [Withers, Carl] Plainville, U. S. A. [by] James West [pseud.] New York, Columbia University Press, 1945. xv, $23^{8} \mathrm{p}$.

$$
\mathrm{A}_{45}-\mathrm{I}_{3} \mathrm{HN}_{57} \mathrm{~W}_{5} 8
$$

A cultural-anthropology approach to the life of a small and very rural Missouri town, which preserves a real sense of the human beings dealt with, and avoids both condescension and partisanship. The prevailing background is the persistent poverty which haunts such communities. The author's major interest is in discriminating the social classes and working out their attitudes toward each other. A chapter, "From Cradle to Grave," works out the typical life pattern of average Plainville people. There is much attention to the changes brought about by urban industrialism, and its draining off of Plainville's young people. 


\section{Communities: Urban}

4586. Carr, Lowell Juilliard, and James Edson Stermer. Willow Run; a study of industrialization and cultural inadequacy. New York, Harper, 1952. xxii, $406 \mathrm{p}$.

Bibliography: p. 395-399.

$$
\text { 5I-I I } 892 \quad \mathrm{HN}^{2} \mathrm{o} . \mathrm{W}_{5} \mathrm{C}_{3}
$$

In a mushrooming wartime community between Detroit and Ann Arbor the new Ford bomber plant produced 8,685 planes and an acute housing crisis. The authors seek to place responsibility for the latter, after thoroughly documenting the social consequences of deficient housing, and reject the devil theory, which blames the Ford Company, and the individual incompetence theory. Their solution blames gaps or blind spots in our industrial culture itself, such as the lack of any accepted method for defining a social community crisis, and of any accepted procedures for "structuring overall coöperation" in such a crisis. In short, "we have not yet learned how to live with social change."

4587. Hallenbeck, Wilbur C. American urban communities. New York, Harper, I95I.

617 p. $\quad$ 5I-II920 HTi23. H3

$A$ rounded text on American urban sociology which has many quantitative illustrations but keeps them subordinate to the general exposition of the subject. It seeks to demonstrate that cities are the focal points in the dynamics of American society, and that rapid change demands a high degree of adaptability, which cities have failed to attain. Their hope lies in a more comprehensive planning, scientific and democratic in basis and purpose. "The Form and Structure of Cities," "Organized Life in Cities," and "Patterns of Urban Structure" form the major divisions of the text.

4588. Harrison, Shelby Millard. Social conditions in an American city; a summary of the findings of the Springfield survey. New York, Russell Sage Foundation, 1920. 439 p.

$$
\text { 20-21 20I HN8o.S7 } 77
$$

A condensation of one of the best-known examples of the older type of social survey, that of the capital of Illinois conducted in I9I4 under the direction of the Department of Surveys and Exhibits, Russell Sage Foundation. Separate reports in nine fields-public schools, care of mental defectives, insane and alcoholics, recreation, housing, charities, industrial conditions, public health, the correctional system, and city and county administration-were published from I9I4; these were eventually collected in two volumes, and with the present one as a third, published as The Springfield Survey (New York, Russell Sage Foundation, 1918-20. 3 v.). The age of the materials constitute them a suggestive guide to the spheres in which extraordinary improvement has taken place in the last four decades, and to those other spheres in which comparatively little progress can be assumed.

4589. Havighurst, Robert J., and Hugh Gerthon Morgan. The social history of a war-boom community. New York, Longmans, Green, I951. $\mathrm{xix}, 356 \mathrm{p}$.

5 I-I I $494 \mathrm{HN} 80 . \mathrm{S}_{545} \mathrm{H}_{3}$

The authors tell what happened to the people and institutions of Seneca, Ill., a small town on the Illinois River, when it acquired a shipyard for LST vessels and saw its residents increase from 1,235 to 6,600 between 1942 and 1944 . They hope thereby to study the adaptation of social institutions to rapid social change, the adaptation of people to new conditions of living, and the influence of a crisis on the long-time history of a community, and to record one significant bit of American life during wartime. Relations between old and new residents were kept to a minimum, temporary prosperity brought no change in the local business structure, and Seneca emerged from the war boom relatively unchanged, with the familiar basic characteristics of a midwestern rural town.

4590. Hayner, Norman S. Hotel life. Chapel Hill, University of North Carolina Press, 1936. I95 p. 36-7540 TX9I.H37

"Selected bibliography": p. [183]-185.

Concerned with hotel life in general, but the great majority of the examples are American. Problems of urban culture are found in an accentuated form in the hotel. Its population is an aggregation of displaced individual units. Contacts are usually anonymous and casual. "The detachment, freedom, loneliness, and release from restraints that mark the hotel population are only to a lesser degree characteristic of modern life as a whole."

4591. Klein, Philip. A social study of Pittsburgh; community problems and services of Allegheny County, by Philip Klein and collaborators. New York, Published for the Social Study of Pittsburgh and Allegheny County by Columbia University Press, $193^{8}$. xxvi, $95^{8} \mathrm{p}$.

$$
3^{8-3294} \text { HN8o.P6K5 }
$$


A study made in $1934-36$, under the auspices of the Citizens' Committee and financed by the Buhl Foundation of Pittsburgh, in order to render social services and agencies more effective. As the subtitle indicates, it is in two parts: the first (to page 347) describes social and economic conditions in city and county, building on the famous prior survey of r907-8; while the second and larger investigates the state of social and health services. Their cost and support, planning and coördination, and personnel and facilities for training are studied. The services are then reviewed by type. The study made practical recommendations in each sphere, some of which had been made effective by the time of publication.

4592. Lynd, Robert S., and Helen Merrell Lynd. Middletown, a study in contemporary American culture. Foreword by Clark Wissler. New York, Harcourt, Brace, I929. 550 p.

29-26I77 HN57.L8

Issued also as thesis (Ph.D.) Columbia University.

"The Institute of Social and Religious Research ... financed the investigation."-Preface.

4593. Lynd, Robert S., and Helen Merrell Lynd. Middletown in transition; a study in cultural conflicts. New York, Harcourt, Brace, r937. xviii, 604 p. 37-27243 HN57.L84

The pioneer and classic "attempt to deal with a sample American community after the manner of social anthropology." A small middle western city of 35,000 population was chosen (it is now common knowledge that Middletown is Muncie, Indiana); in ten years it had increased to 50,000. The investigation for the first volume was carried out in $1924-25$, and that for the sequel in $1935-36$. The Lynds arrived at a six-fold analysis of social data, the first, dominant and largely determinant of the others being "Getting a Living." This was also found to be the field most subject to rapid change. The other heads are: "Making a Home," "Training the Young," "Using Leisure,", "Engaging in Religious Practices," and "Engaging in Community Activities." The second most obvious area of rapid change was leisure, where traditional recreations were much reduced by the automobile, cinema, and radio. Middletown in Transition reports on the effects of a decade of boom followed by depression. For the most part, these had but continued the trends clearly perceptible in 1925. The volume concludes with a reconstruction of "the Middletown Spirit" dominated by the business mentality, and a meditation on its ineffectiveness in grappling with the real problems of the community.
4594. Peterson, Elmer T., ed. Cities are abnormal. Norman, University of Oklahoma Press, 1946. xvi, $263 \mathrm{p}$. 46-4670 HTi23.P 45 Conrents.-Cities are abnormal, by E. T. Peterson.-The ecology of city and country, by P. B. Sears.-It was not always so, by W.S. Thompson.What we are and what we may become, by P. L. Vogt.--Biological truths and public health, by Jonathan Forman.-An architect protests, by $\mathrm{H}$. $\mathrm{H}$. Kamphoefner.--Social man and his community, by J. J. Rhyne.-Economic verities by S. C. MicConahey.-Government of the people, by $\mathrm{H}$. C. Nixon.-To clear the dross, by Louis Bromfield.A farm reporter looks ahead, by Ladd Haystead.The atomic threat, by W.S. Thompson.-Moral and cultural aspects of decentralization, by $R$. $L$. Smith.-No blueprint for Utopia, by E. T. Peterson.

From various angles and by various hands, the case for "an orderly decentralization under a diverse pattern" for America is presented. There is no virtue in bigness, or in efficiency when it damages the human mechanism, or in relying upon government for all positive action, or in increasing interdependence, which is simply "dependence multiplied by ten or ten thousand." The clinching argument is that an urban manpower surplus becomes parasitical, while no such surplus develops on selfsufficient farms.

4595. Thorndike, Edward L. Your city. New York, Harcourt, Brace, 1939. 204 p.

"Data and sources": p. 172-187. 39-274I5 HTi23.T

This unique book records the results of a threeyear statistical study of 3 Io American cities. Many of the statistics used come from the census of 1930, a year of severe depression. Over a million separate items were handled in constructing a calculus for rating the general goodness of life in different cities. While the results heavily favor suburban cities such as Pasadena, Evanston, and Montclair, and equally disfavor Southern cities with their depressed Negro populations, there are yet significant differences when these classes are both excluded. "At least fourfifths of the difference of cities in goodness is caused by the personal qualities of the citizens and the amount of their incomes."

4596. Voss, Joseph Ellis. Summer resort: an ecological analysis of a satellite community. Philadelphia, I94I. $152 \mathrm{p}$.

$$
\mathrm{A}_{4} \mathrm{I}-4069 \mathrm{HN80. \textrm {O } _ { 3 } \mathrm { V } 6}
$$

Thesis (Ph. D.)-University of Pennsylvania, I94I.

Bibliography: p. I40-I44.

Ocean City, N. J., was founded to serve as a Summer Methodist Camp Meeting in 1880 , went through 
a frenzied boom and crash during the 1920's and is now "a relatively conservative and efficient seaside resort community." "During the winter months, there are more than two dwellings for every individual in the community, while in the summer there are more than two persons for every room on the island." Mr. Voss studies the business of recreation, "the family resort family," and the nature of government, education, and cultural relations in this hybrid urban-rural community dependent for its existence upon seasonal migrations from other communities.

4597. Waterman, Willoughby Cyrus. Prostitution and its repression in New York City, 1900-1931. New York, Columbia University Press, 1932. 164 p. (Columbia University. Faculty of Political Science. Studies in history, economics and public law, no. 352)

$$
\begin{array}{r}
\text { 32-18865 HQ146.N7 } W_{35} \text { i932a } \\
\text { H }_{31 . C_{7}, \text { no. } 35^{2}}
\end{array}
$$

"Bibliography of sources quoted": p. $160-162$.

One of the very few objective and documented studies in this obscure field. It reviews the several measures strengthening the confusing and overlapping laws applicable to prostitution. In surveying action by the police and the courts, attention is drawn to the creation of a headquarters Vice Squad in 1924, and improvements in the technique of investigation. Privately organized groups, such as the Committee of Fifteen and of Fourteen, operated on public opinion throughout the period. The results are seen as a probable reduction in the overall quantity, the elimination of soliciting and "parlor houses," and a great shift in methods and loci.
4598. Whyte, William F. Street corner society; the social structure of an Italian slum. Enl. [2d] ed. Chicago, University of Chicago Press, r955. xxii, $366 \mathrm{p}$.

55-5152 HV6439.U5 $\mathrm{W}_{5} 1955$

"Cornerville" in "Eastern City" has been an Italian neighborhood since 1915, and the younger generation of its "little guys" divide into corner boys, who center their social activities upon particular street corners, with their adjoining barbershops, lunchrooms, poolrooms, or clubrooms, and college boys, a small group of young men who have risen above corner-boy level through higher education. The author lived with Doc and his gang of Nortons, and with Chick and his Italian Community Club, long and intimately enough to understand both groups from the inside, and he has traced the relationships of both groups to the gambling, racketeering, and the politics of the area. His appendix gives a lively picture of the investigator's experiences and dilemmas.

4599. Zorbaugh, Harvey Warren. Gold coast and slum; a sociological study of Chicago's Near North Side. Chicago, University of Chicago Press, 1929. $\mathrm{xv}, 287 \mathrm{p}$. 29-12607 $\mathrm{F}_{548.5 . \mathrm{Z} 89}$

A sociological analysis of Chicago's "Lower North Side" which presents urban contrasts, urban disintegration, and the pathology of urban life in singularly concentrated and dramatic form. In this area the physical distances and the social distances do not coincide: people who live side by side cannot become neighbors. The life of the apartment-dwellers of the Gold Coast is set against "the world of furnished rooms" which lies next to it.

\section{J. City Planning; Housing}

4600. Abrams, Charles. The future of housing. New York, Harper, 1946. xix, 428 p.

Bibliography: p. 415-419. 46-8659 HD $7293 . \mathrm{A}_{2}$

A searching individual study of the housing problem which finds the abuses of the home-building industry responsible for shoddy city planning, poor construction, inadequate repairs, recurrent housing shortages, and the slum problem. Neither wage increases nor shelter cost reduction will resolve the dilemma of the low-income family, which calls for public action. A detailed criticism is offered of Federal housing measures and administration, and ten aims set up for a national housing program, including a revitalized industry, urban redevelop- ment, adequate rental housing, a sound mortgage system, and stabilization of the real estate pattern.

460r. Bridenbaugh, Carl. Cities in the wilderness; the first century of urban life in America, 1625-1742. [2d ed.] New York, Knopf, 1955. 500 p. $\quad 55^{-8593}$ Ergr.B75 1955 Bibliography: p. 483-486.

4602. Bridenbaugh, Carl. Cities in revolt; urban life in America, 1743-1776. New York, Knopf, 1955. xiii, 433, xxi p. 55-7399 Er62.B85 "Bibliographical note": p. 427-[434].

Five representative towns-Boston, Newport, New York, Philadelphia, and Charleston-are se- 
lected, and 1742 made the terminus "because in many respects it seems definitely to mark the end of an era in colonial town life." Colony records, and municipal records when available, are ransacked in order to present a detailed picture of development along four lines: physical aspects, economic life, urban problems, and social life. The author believes that colonial cities, although never holding more than ro percent of the total population, "exercised a far more important influence on the life of early America than historians have previously recognized."

The sequel traces, through an eventful 33-year period, the "astonishing expansion" of the five cities in population and municipal services. In the same years, their inhabitants "discarded forever their I7th-Century traditions and fatefully and irrevocably accepted the symbols and ways of modernity." He is not concerned to tell the story of the movement for independence, but rather to illustrate the enlightenment of the public mind, through which "decades before independence the cities became the birthplace of American nationality."

4603. Burton, Hal. The city fights back; a nationwide survey of what cities are doing to keep pace with traffic, zoning, shifting population, smoke, smog, and other problems. Narrated and edited by $\mathrm{Hal}$ Burton from material developed by the Central Business District Council of the Urban Land Institute. New York, Citadel Press, I954. 318 p.

Bibliography: p. 313-318.

$$
\text { 54-9343 NA9030.B95 }
$$

The Central Business District Council of the Urban Land Institute has been organized to offer information and guidance to any community which seeks to rehabilitate its own central business district. This is one area where money and coöperation have been readily forthcoming to implement planning, and this book is able to present many successful programs to eliminate congestion and decay. The prize example is Pittsburgh, where the 400 acres of the Golden Triangle "have been taken apart and put together again in the years just past."

4604. Churchill, Henry S. The city is the people. New York, Reynal \& Hitchcock, I 945. I 86 p. $\quad 45-6336$ NA9ogo. 5

A condensed presentation of city development, the accumulation of urban disorder, and the case for city planning on the widest scale. America has been able to plan new towns, but has had no success in the re-planning of existing cities, for "slum clearance" programs disregard all collateral planning problems. Physical and economic planning have meaning only in reference to social objectives-"the end is a livable city, suited to modern technologies of living."

4605. Colean, Miles L. Renewing our cities. New York, Twentieth Century Fund, I953. I8I p. $\quad$ 53-9616 NA9108.C6

A closely knit little book which organizes the problems of American city structure and planning under the concept of renewal. The essential problem, of assuring a continuity of renewal, "can be solved only by devising means for preventing the accumulation of worn-out-parts and avoiding stagnation within an otherwise dynamic urban structure." Renewal is a distinct problem, considerably larger than slum clearance, desirable as the latter may be. Current strivings toward renewal in various cities are described, and the essentials of an effective program outlined.

4606. Gallion, Arthur B. The urban pattern; city planning and design. In collaboration with Simon Eisner. New York, Van Nostrand, 1950. 446 p. $\quad 50-13672$ NA9030.G26 1950

Bibliography: p. 419-433.

"This book attempts a critical examination of the processes by which cities are planned and built, appraises some of the results, describes some of the defects, and poses a few suggestions . .." The first part presents the evolution of the city pattern in western civilization, and some European innovations are described in the last part, but the central bulk of the book is concerned with the problems of city pattern and city planning in the United States. Hope lies in the formulation of a Master Plan, to provide a pattern for future development of each metropolitan area in the United States. A wealth of illustrations, diagrams as well as photographs, assist in understanding the factors involved.

4607. Lewis, Harold MacLean. Planning the modern city. New York, Wiley, 1949. 2 v. 49-7402 NA9030.L393

Based on The Planning of the Modern City, by Nelson P. Lewis, first published in 1916 (New York, Wiley. 423 p.).

The most comprehensive manual of planning for American cities, in which foreign instances are introduced when found useful. The six principal elements of a city plan are identified as: (I) the transportation system in and out of the city; (2) the intra-urban transit system; (3) the street system; (4) park and recreation facilities; (5) the location of public buildings; (6) the pattern of land uses, effectuated primarily through comprehensive zoning. Part 5 in volume 2 considers such special problems as airports, parking, and planning for the urban region, and the 
final part is devoted to the legal, economic, and administrative aspects of physical planning.

4608. Straus, Nathan. Two-thirds of a nation; a housing program. New York, Knopf, 1952. xiii, 29I, xvii p. 5I-II99I HD7293.S77

Two-thirds of all the families in the United States have incomes of less than $\$ 80$ a week. The hard core of the housing problem is the fact that "there is practically no new housing produced by private enterprise at a figure the average American family can afford." "In America, millions of well-paid, well-dressed families live in slums." This up-to-date discussion analyzes the elements of housing costs, criticizes FHA policies, and offers many constructive suggestions on the individual and the civic levels toward the reasonable goal of a comfortable home for every American family.

4609. Tunnard, Christopher, and Henry Hope

Reed. American skyline; the growth and form of our cities and towns. Boston, Houghton Mifflin, 1955. 302 p. $\quad 55^{-6553 ~ H T i 23 . T 85 ~}$

The "American townscape" has at all times reflected our people and history, and its patterns have been molded by economic, social, and political forces. The authors review this causal relationship throughout American history and distinguish seven eras of the American city pattern: colonial, to 1776 ; the Young Republic, to 1825 ; romantic, to 1850 ; the age of steam and iron, to 1880 ; the expanding city, to r9Io; the city of towers, to I933; and the regional city since 1933. There are numerous plans, sketches, and photographs.

46ro. Twentieth Century Fund. Housing Committee. American housing, problems and prospects. The factual findings by Miles L. Colean. The program by the Housing Committee. New York, The Twentieth Century Fund, 1944. xxii, $466 \mathrm{p}$.

Bibliography: p. 44I-455.

44-4203 $\mathrm{HD}_{97} \mathrm{I}_{5} \mathrm{U}_{52} \mathrm{~T}_{9}$

Results of an over-all survey of the housing problem in the United States, the first of its kind and still unreplaced. The survey found that while traditional subdividing practices had created much waste and disorder, and while traditional forms of the house could receive simplified layout, composition and structure, the crux of the problem lay elsewhere. "The disorganized and warring group of organisms known euphemistically as the building industry," and the intricate and disorganized nature of the market result in a situation where the benefits of mass production do not become available to the consumer. Government intervention has avoided basic solutions. "No halfhearted attack can clear away the traditional obstacles in the housing industry." A detailed program of improvement on all fronts is suggested.

\section{I I. U. S. President's Advisory Committee on Government Housing Policies and Pro-} grams. Recommendations on Government housing policies and programs, a report. Washington, 1953 . 377 p. $\quad 53-63272 \quad \mathrm{HD}_{7293 . A 587}$

This Committee was established by Executive Order on Sept. 12, 1953, divided its work among five subcommittees, and reported three months later. Its primary objective was to ensure "that every action taken by Government in respect to housing should be for the purpose of facilitating the operation of" a strong, free, competitive economy. The numerous specific recommendations have as their more general objectives: (I) to provide special aids to local communities and property owners in conserving and renewing decaying neighborhoods; (2) to maintain and improve the existing housing supply by loans for modernization or repair; (3) to encourage private building activity; (4) to facilitate the free operation of the mortgage market by creating a National Mortgage Marketing Corporation; (5) to provide housing for low-income families, especially those displaced by redevelopment programs; and (6) to improve the organization of Federal housing activities.

46I2. Walker, Mabel L. Urban blight and slums; economic and legal factors in their origin, reclamation, and prevention. With special chapters by Henry Wright, Ira S. Robbins [and others] Cambridge, Harvard University Press, 1938. xvi, 442 p. (Harvard city planning studies, no. I2)

"References": p. [429]-442.

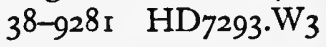

The first major study of urban blight, the state of deterioration which attacks residential areas and leads to slums. Blighted areas are marked by high but falling land values, congested but decreasing population, obsolete and unfit housing on which improvements and repairs are no longer being made, a large proportion of abandoned buildings and rental vacancies, etc. Typical blight situations in American cities of various sizes are concretely analyzed. The writer thinks that project planning, zoning, and building regulation and taxing policies on the part of the local government can do much to help, but that the core of the problem is the creation and rationalization of a large-scale homebuilding industry which can produce houses which the lower-income third of the urban population can afford. 
46r3. Woodbury, Coleman, ed. The future of cities and urban redevelopment. Chicago, University of Chicago Press, 1953. xix, 764 p. 53-7679 NA9o3o.W64

This coöperative volume is one of the results of the Urban Redevelopment Study carried out in I948-5I under the auspices of Public Administration Clearing House and other organizations, and directed by Coleman Woodbury. Urban redevelopment is defined as "those policies, measures, and activities that would do away with the major forms of physical blight in cities and bring about changes in urban structure and institutions contributing to a favorable environment for a healthy civic, eco- nomic, and social life for all urban dwellers." In addition to more general materials, this volume contains substantial sections on the relation of urban redevelopment to industrial location, to the urbanite (including results of the Attitude Survey), and to local government organization in metropolitan areas. Mr. Woodbury warns that progress in the field calls for many more able leaders and a higher degree of community subgroup morale than are present today. A companion volume, Urban Redevelopment: Problems and Practices (Chicago, University of Chicago Press, 1953. 525 p.) is of a more technical nature, something of a manual for redevelopers.

\section{K. Social Problems; Social Work}

46I4. Addams, Jane. Forty years at Hull-House; being "Twenty years at Hull-House" and "The second twenty years at Hull-House." With an afterword by Lillian D. Wald. New York, Macmillan, r935. 462, 459 p.

35-27460 $\mathrm{HV}_{4} \mathrm{I}_{96 . \mathrm{C}_{4} \mathrm{H}_{73}}$

A classic which combines autobiography, an account of the establishment, operations, and growth of the largest and most famous settlement house in the United States, and the writer's concern with various reform movements, particularly feminism and pacifiism. In The Second Twenty Years, indeed, the latter aspects have come to displace the settlement as the center of interest: Hull-House is but the seat of a woman of international fame who seeks to exert a national and an international influence on behalf of her favorite causes.

4615. Andrews, Frank Emerson. Philanthropic giving. New York, Russell Sage Foundation, 1950. $318 \mathrm{p}$. 50-10963 $\mathrm{HV}_{91 . \mathrm{A}_{7}}$ The large extension of government services to the less fortunate has not been paralleled by a corresponding decline in private giving. Philanthropic contributions fell to a low of $\$ 715,000$ in 1933 , but have since climbed steadily, reaching a record figure of over 4 billions in 1948. The present volume is the result of an extensive fact-finding inquiry and presents tabular and other information concerning the sources and the destination of these vast sums. Special attention is given to fund-raising enterprises, religious agencies, education and the arts, the financing of research, and the effect of tax laws. Practical advice is given in chapters on avoiding charity rackets, and on the interrelations of recipient and donor. 46r6. Andrews, Frank Emerson. Corporation giving. New York, Russell Sage Foundation, 1952. 361 p. $\quad$ 52-11787 $\mathrm{HV}_{95} \cdot \mathrm{A}_{76}$ Corporation giving is a new factor in American philanthropy, having risen to its recent level of more than 200 million dollars only in 1944. The motives are various, but that of tax savings is only one among many, while the corporation's sense of duty to its community is most frequently avowed. While only 5 percent of total philanthropic giving, corporation giving is "actually a very significant factor, and sometimes the chief reliance, in the areas in which corporations are accustomed to give." On a survey of 326 foundations, it was found that 44.3 percent of their gifts were to welfare agencies, 26.6 percent to health agencies, and 21.2 percent to education. A new development is the corporation foundation, nine of which were found in the survey sample.

4617. Barnes, Harry Elmer. Society in transition. $2 d$ ed. New York, Prentice-Hall, $195^{2}$. 878 p. $\quad 52-7578 \mathrm{HN}_{15} \cdot \mathrm{B}_{23}{ }_{1952}$ A textbook which surveys American social problems within the frame of reference of "cultural lag," i. e., it regularly assumes that institutional development has fallen behind technological, and that wholesale remodeling of social forms and habits is both possible and desirable. The author states that he has provided "the most complete survey of important social problems to be found in any book in the field," as well as "illuminating historical perspectives on each" of them. In a single volume he has assembled a very large body of facts and representative opinions in such problem areas as population, immigration, race contacts, health, marriage, housing, poverty, mental disease, and crime. 
4618. Bruno, Frank J. Trends in social work as reflected in the Proceedings of the National Conference of Social Work, 1874-1946. New York, Columbia University Press, 1948 . xvi, $387 \mathrm{p}$.

$$
\text { 48-2295 HV91.B75 }
$$

In 1874 a handful of public charity officials from four states met in New York and organized the National Conference of Social Work; it has since grown to a body of 7,000 members. The original concerns were dependency, mental disease, delinquency, and problems of health; these have been widened to include the whole field of the public and private social services. The emergence of new issues and the shifting of points of view are seen clearly in the subjects before the Conference, as it turns to the protection of children, the organization of charity, or the problem of transiency, and the whole serves as a mirror of practical social thinking in the United States over a 75 -year period.

4619. Cuber, John F., Robert A. Harper, and William F. Kenkel. Problems of American society: values in conflict. 3 d ed. New York, Holt, 1956. 510 p. 56-6080 HN57.C8 1956

Among the many college textbooks on American social problems, this one is unique in that it adopts a clear-cut frame of reference, and employs it with much consistency throughout. The authors adopt the principle which they attribute to the late Richard C. Fuller, "that social problems arise in a society because ends, objectives, or values fostered by various persons and groups run at cross-purposes." The sociologist thereby adopts the role of interpreter of values rather than that of value advocate. The opposing values leading to opposing attitudes are identified in 17 major fields, including mental health, crime, adolescence, social class, race, populations, etc. The authors question the value of the concept of social disorganization as currently used by sociologists, it being a value-judgment applied to social change. Inasmuch as the authors regularly approve "rational" as against traditional ("extra-logical") values, their attitudes are seldom as neutral as they imply.

4620. Dulles, Foster Rhea. The American Red Cross, a history. New York, Harper, $195^{\circ}$. 554 p. 50-8717 HV577.D8

"Bibliographical notes": p. 540-543.

The new emphasis of the armed forces on current history led to the establishment of a Historical Division by the American Red Cross, and the production of a series of monographs available at its national headquarters. This work digests these monographs into a unitary history for the general reader, with special emphasis on the period since
1939. In origin an international organization for war relief, the American Red Cross has always been distinctive for the equal emphasis on relief of domestic disasters on a large scale. Notwithstanding its humanitarian purpose, the American Red Cross has had a somewhat stormy and controversial career, which aspect is not slighted here.

4621. Fink, Arthur E., Everett E. Wilson, and Merrill B. Conover. The field of social work. New York, Holt, 1955. 630 p.

$$
\text { 55-6052 } \mathrm{HV}_{40} \text {.F5 I955 }
$$

A comprehensive introduction to the subject. The first two chapters dispose of public welfare and social security, and the third presents a history of the private and voluntary agencies which engage in social work. The bulk of the book considers the major categories of social work: family social work, welfare services for children, school, psychiatric and medical social work, the correctional services, and social group work. Most of these chapters have specially contributed case histories appended. Concluding chapters deal with methods of organizing communities for all-round service, and with social work as a profession with its own standards, organizations, training, and literature.

4622. Fosdick, Raymond B. The story of the Rockefeller Foundation. New York, Harper, I952. $336 \mathrm{p}$. 5I-II9I3 HV97.R6F6

The president of the Foundation from 1936 to 1948 summarizes its principles and achievements in a history intended for laymen. Emphasis is placed on the role of Frederick T. Gates, the former Baptist Minister who served as the elder Rockefeller's adviser in philanthropy from 1892 . A national charter was sought for the Foundation in 1910, but a storm of obloquy broke out, and a New York incorporation was substituted in 1913. The four associated trusts spent nearly $\$ 822,000$,000 through 1950. During the first i5 years public health and medical education were chiefly cultivated, but since 1928 a multitude of projects in the natural sciences, agriculture, social science, and the humanities have been subsidized. The personal philanthropies of the younger Rockefeller, which reflect an extraordinary range of cultivated interests in the spheres of art, archaeology, city development, education, and libraries, are modestly but effectively described in Mr. Fosdick's John D. Rockefeller, Jr., A Portrait (New York, Harper, 1956. 477 p.).

4623. Glenn, John M., Lilian Brandt, and F. Emerson Andrews. Russell Sage Foundation, 1907-1946. New York, Russell Sage Foundation, 1947. 2 v. $\quad 47-12385$ HV97.R8G55 
Early in 1907 Mrs. Margaret Olivia Sage established the Russell Sage Foundation with a capital of $\$ 10,000,000$, the income to be applied "to the improvement of social and living conditions in the United States." Its first Director, John M. Glenn (1907-3I), took a part largely advisory and supervisory in the preparation of these volumes. During its first $4 \mathrm{I}$ years covered here, the Foundation spent $\$ 21,000,000, \$ 9,000,000$ in grants and $\$ 12$,ooo,ooo in research and other direct work of its own. The narrative covers the administrative development of the Foundation, and its activities at various periods in such realms as recreation, child hygiene, charity organization, remedial loans, industrial studies, etc. Appendixes list all grants and all but minor publications. The result is a detailed picture of one of the most intelligently conducted and successful foundations for social purposes.

4624. Kennedy, Albert J., and others. Social settlements in New York City, their activities, policies, and administration, by Albert J. Kennedy, Kathryn Farra and associates. New York, Published for the Welfare Council of New York City by Columbia University Press, 1935. xix, 599 p. (Studies of the Research Bureau of the Welfare Council, no. 2) 35-36r3 $\mathrm{HV}_{4} \mathrm{Ig} \mathrm{6} . \mathrm{N}_{6} \mathrm{~K}_{4}$ A survey begun in the winter of $1927-28$ by the Research Bureau of the Welfare Council of New York City at the request of United Neighborhood Houses. It covers the 80 settlements which existed at the outset, although the number had been reduced to 73 by the time of publication. Of these 2 were in the Bronx, 15 in Brooklyn, and $6_{3}$ in Manhattan, especially on the Lower East Side. Chapters by several hands cover types such as boys' or women's clubs, functions such as music or the teaching of English and citizenship, publications, membership, and administration. Considerably the most detailed body of information on this special form of social work.

4625. Merrill, Francis E. Social problems on the home front, a study of war-time influences. New York, Harper, 1948. $25^{8}$ p.

$$
{ }_{4}^{8-1366} \quad \mathrm{HN}_{57} \cdot \mathrm{M}_{37}
$$

"Sponsored by the Committee on War Studies of the Social Science Research Council."

A study, based on statistics whenever available, "of the role of World War II in initiating, intensifying, or modifying certain social problems in the United States." It is not found to be true that war merely intensifies the maladjustments of peacetime society; in bringing about virtually full employment and a high collective morale, the War had many unanticipated positive consequences, such as the rise in the marriage and birth rates, the decline in the number of suicides, and the decrease in prostitution. Social problems might be transformed: "Never before were so many American families broken for so long," leading to modifications in family roles not easily assessed. "World War II had a differential effect upon social problems, intensifying some, alleviating others, and creating still others in a society made more dynamic by the pressures of total war."

4626. Watson, Frank Dekker. The charity organization movement in the United States, a study in American philanthropy. New York, Macmillan, 1922. 560 p. 22-25386 $\mathrm{HV}_{91 . W_{3} 8}$

Thesis (Ph. D.)-University of Pennsylvania, I9II.

"Selected bibliography": p. 543-553.

Charitable societies were formed in the cities during the second half of the I8th century, and one of modern type, the New York Society for the Prevention of Pauperism, appeared in 1817 . The panic of 1873 and the prolonged depression that followed revealed unemployment as a national problem, and demonstrated that the simple old ways of helping the needy were almost incredibly wasteful and inefficient. Organizational experiments were made in Germantown and Boston, but the Buffalo Charity Organization Society launched at the end of 1877 was the first to achieve city-wide integration, and was widely copied. In I905 came the Field Department of the Charity Organization Society of New York City, followed four years later by the Charity Organization Department of the Russell Sage Foundation, which offered technical guidance and training to all local societies.

4627. Weaver, William Wallace. Social problems. New York, Sloane, r95 r. 79I p. 51-12929 $\mathrm{HNi}_{5} . \mathrm{W}_{4}$

A textbook for college courses which gives less emphasis "to theoretical or systematic treatment of problem situations in general," but concentrates on the problems themselves in their American settings. These are grouped under the headings of personal crises (mental disorders, alcoholism, prostitution, etc.), family discord (including illegitimacy), group tensions, and insecurity (unemployment, old age, war, etc.). The conclusion on public policy is grave in outlook; in addition to the old obstacles to progress, the parsimony of nature, the limitations of human endowment, and cultural inertia, there are now world ferment and the insatible demands of modern war. 


\section{Dependency; Social Security}

4628. Best, Harry. Blindness and the blind in the United States. New York, Macmillan, I934. xxii, 7 I4 p. 34-1429 HVI795.B 4 I934 "The present work is a revision and expansion of The Blind: Their Condition and the Work Being Done for Them in the United States [1919]."Foreword.

A complete treatise on this class of the handicapped, with abundant statistical tables. It covers the causes of blindness and the possibilities of preventing it; the general condition of the blind as to numbers (about 100,000 in 1930), education, economic condition, and legal treatment; the provision of education for blind children; intellectual and material provision for the adult blind; and interested organizations. For all his objective data, the author believes that "there is no such thing as a "problem of the blind;' there are as many problems as there are blind persons to be dealt with."

4629. Best, Harry. Deafness and the deaf in the United States, considered primarily in relation to those sometimes more or less erroneously known as "deaf-mutes." New York, Macmillan, 1943. xix, 675 p. 43-17957 HV2545.B42 1943

"A revision and expansion of The Deaf: Their Position in Society and the Provision for Their Education in the United States, published in 1914."Foreword.

The distinction in the subtitle is made because a large proportion of the deaf can be taught more or less perfect articulation. The book is a treatise as comprehensive as its author's work on the blind. It deals with the nature and causes of deafness, the possibilities of its prevention, and the separate problem of the hard of hearing. The numbers of the deaf (57,000 in 1930) and their economic condition and legal treatment are described. Organizations for and of the deaf are inventoried. The education of deaf children is studied at length, with chapters on the history and methods of such training.

4630. Brown, Josephine Chapin. Public relief, 1929-1939. New York, Holt, 1940. xvii, 524 p. 40-34168 $\mathrm{HV}_{91 . \mathrm{B}_{7}}$

Bibliography: p. 477-5II.

As a result of the depression of 1929 , "a system of local poor relief which had remained practically unchanged for a century and a half was superseded not only by new methods but by a new philosophy of governmental responsibility for people in need." This work, based largely on Government documents, reviews the old methods prevailing in 1929 , their makeshift extension followed by complete breakdown in the years 1929-33, and their replacement by the vast administrative machinery of the Federal Emergency Relief Administration and, after 1935, the Works Progress Administration.

463r. Burns, Eveline M. The American social security system. Boston, Houghton Mifflin,

1949. xviii, 460 p. 49-5180 HD7125.B86

The Social security act amendments of 1950, an appendix. Boston, Houghton Mifflin, r95I. 447-48I p.

HD7125.B86 Appx.

A treatise concerned primarily with income security programs, which aim to assure a certain minimum of income to some or all, especially through cash payments. The Social Security Act of 1935, as amended in 1939, 1946, and 1950 (these last changes are described in the separately published Appendix) leaves much to local regulation, and excludes three programs created by separate federal laws: Railroad Retirement, Railroad Unemployment Insurance, and Veterans' Security. The treatment throughout is analytical, by type of insurance or beneficiary. The conclusion is concerned with suggestions toward a rational system; one has by no means been achieved as yet.

4632. Creech, Margaret. Three centuries of poor law administration; a study of legislation in Rhode Island. Introductory note by Edith Abbott. Chicago, University of Chicago Press, 1936. xxii, 33 p. (Social service monographs, no. 24)

Issued also as thesis ( $\mathrm{Ph}$. D.) U Chicago.

Appendixes: 1. List of laws of Rhode Island relating to the poor.-2. List of judicial decisions under the poor law.-3. Select documents relating to the history of poor relief in the colonial period and the late eighteenth century.-4. Thirteen case histories, 1644-1724.-5. Select documents relating to the history of poor relief in the modern period.

Chronologically the most extensive review of State action in alleviation of poverty and dependency. Rhode Island early took over the Elizabethan poor law and provided for the appointment of overseers of the poor. A major factor from the beginning was 
the efforts of towns to prevent the settlement of persons who might become dependents, continued in later times by the enforcement of rigid residential requirements. As late as 1936 there remained "a poor law with general principles unchanged, administered by governmental units a few miles in area, with limited taxing power and without provisions for skilled service or for uniformity of standards."

4633. Gagliardo, Domenico. American social insurance. Rev. ed. New York, Harper, 1955. 672 p. $\quad 55-6775 \quad$ HD7125.G $34 \quad 1955$

Aims to give a reasonably full-length picture of the American social insurance movement, complex and undergoing change as it is. Describes what we have, how we got it, and what the results have been, in four major fields: old age, unemployment, occupational disability, and health. Imperfections in the system as it has evolved are pointed out. The author, a professor of economics at the University of Kansas, includes 72 statistical tables.

4634. Gillin, John Lewis. Poverty and dependency; their relief and prevention. $3 \mathrm{~d}$ ed. New York, Appleton-Century, 1937. 755 p.

$$
\text { 37-2328 } \mathrm{HV}_{3} \mathrm{I}^{\mathrm{I}} \mathrm{G}_{4} \quad \mathrm{I} 937
$$

Bibliography: p. 679-735.

Remains the most systematic general treatment of these related problems, which signify "lack of adjustment between the people composing a population and the economic and social circumstances in which they live." The enormous extent and expense of the problems are estimated. The conditions, physical and socio-economic, are analyzed and pronounced removable. A historical section traces the institutions and methods of dealing with dependents, including Old World antecedents of American practices. The classes of dependents, from the aged to the unemployed, are separately considered. Finally, preventive agencies and methods are described, and a generally melioristic viewpoint and program outlined.

4635. Industrial Relations Research Association. The aged and society. Ed.: Milton Derber. Champaign, Ill., I950. 237 p. (Its Publication no. 5) 5I-r473 HQ106o.I455

"The United States is experiencing the impact of greater life expectancies more than any other nation, for the typical life span of its population is the longest ... If greater length of life, so avidly desired by the individual, is not to become a curse to society, effective accommodations must be made to it." The fifteen papers in this "research symposium" are concerned with the statistical bases of the problem, the older worker in industry, security in old age, and a variety of problems of psychology and adjustment, such as "The Politics of Age."

4636. Irwin, Robert B. As I saw it. New York, American Foundation for the Blind, 1955.

205 p. $\quad 55^{-2408} \mathrm{HV}_{1792 . \mathrm{I}_{7} \mathrm{~A}_{3}}$

Dr. Irwin (1883-1951) lost his sight at the age of five, but went on to complete his education at Washington and Harvard Universities, and devoted his life to bettering the condition of all handicapped like himself. After his retirement as director of the American Foundation for the Blind in 1949, he planned a history of work for the blind to be called Fifty Years of Progress. The portions completed at the time of his death are published in this handsome memorial volume, and include concise accounts of such developments as libraries for the blind, the talking book, braille periodicals, and the American Foundation for the Blind. Of special interest, from the pen of this indomitably independent man, are "Earning a Living without Benefit of Sight" and "The Importance of Power to Move about at Will," an appreciation of the "seeing eye" dogs.

4637. Kessler, Henry $H$. Rehabilitation of the physically handicapped. Rev. [i. e. $2 d_{]}$ed. New York, Columbia University Press, 1953. 275 p. 53-10047 HV301r.K42 1953

Rehabilitation, originally identified with the needs of the war disabled, has been extended to the larger requirements of the civilian, and has evolved from the idea of isolated and fragmentary assistance to "the modern concept of integrated and continuous service." The author, who has served in rehabilitation work since 1919, reviews the types of disability, defines the principles of rehabilitation, including vocational guidance and training and selective placement, summarizes recent legislation, and outlines a national program. The bibliography which appeared on p. [253]-26I of the first edition (1947) has been replaced in the second with a directory of "Major Centers and Agencies for the Handicapped" (p. [253]-258). A somewhat more journalistic approach to the subject will be found in the work of two medical men attached to The New York Times: Howard A. Rusk and Eugene J. Taylor, New Hope for the Handicapped (New York, Harper, 1949. 231 p.).

4638. Riis, Jacob A. How the other half lives; studies among the tenements of New York. With illustrations chiefly from photographs taken by the author. New York, Scribner, 189o. xv, 304 p. 4-II775 HV4046.N6R55

A classic of social reporting, which so effectively thrust under genteel American noses the state of the 
tenements and the slum-dwellers of lower Manhattan that the issue could no longer be ignored. The human squalor and degradation which were the consequences of over half a century of unregulated industrialism, hitherto noted in statistical reports and official documents, were now set forth in vivid human terms. Several sequels from Riis' pen followed this: The Children of the Poor (1892), The Battle with the Slum (1902), and Children of the Tenements (1903).

\section{Delinquency and Correction}

4639. Barnes, Harry Elmer, and Negley K. Teeters. New horizons in criminology. $2 \mathrm{~d}$ ed. New York, Prentice-Hall, i951. 887 p. 5I-I454I HV6025.B3 I95I

A comprehensive and detailed textbook in criminology and penology which the authors describe as "an exercise in informed crusading for a more rational, humane, and effective handling of the whole problem of crime." A section on factors favorable to criminality opens with a disclaimer of dogmatism: the most unfavorable conditions will not inevitably drive a given person to crime, or the most favorable ones absolutely insure him against it. Capital punishment is pronounced a barbarous survival, and the cruelty and futility of the modern prison developed at length. The new edition emphasizes the "revolution in crime" during the war decade: the development and political infiltrations of syndicated gambling and criminality, and the growth of rural and juvenile crime. Against this may be set progress in rehabilitative treatment inside and out of institutions.

4640. Bates, Sanford. Prisons and beyond. New York, Macmillan, 1936. 334 p.

$$
36-32878 \text { HV8665.B33 }
$$

The author, after heading the Massachusetts Department of Correction for nine years, became the first chief of the new Federal Bureau of Prisons. He takes the average American county jail to be the antithesis of everything desirable in a reformatory institution. He argues that we can improve our prisons, with new and more adequate buildings, decent living conditions, improved diet, better qualified guards, and educational facilities, and yet deter the potential criminal. An adequate system must be "built around the concept that all its prisoners must be returned to society, and that society is not protected unless they are returned more efficient, more honest, and less criminal than when they went in."

4641. Clemmer, Donald. The prison community. Boston, Christopher Pub. House, I940. 34I p. 40-14007 $\mathrm{HV}_{9466 . \mathrm{C}_{55}}$
The result of a study of the inner life of a prison containing 2300 inmates carried out in $1931-34$ by a sociologist of the Illinois Department of Public Welfare. He presents it as "the 'Middletown' of American prisons," with observations on social relations, social groups, leadership, leisure time, the sexual pattern, prison labor, etc.

4642. Deutsch, Albert. The trouble with cops. New York, Crown Publishers, 1955. 243 p. 55-7239 HV8 $138 . \mathrm{D}_{4}$

Mr. Deutsch is an experienced social scientist who from time to time undertakes journalistic inquiries into specific problems, which he handles forcefully but not sensationally. The present volume was expanded from a series of articles in Collier's and deals with the "police crisis" of 1952-54 evidenced in a nation-wide series of front-page scandals brought to light in one metropolitan force after another. There is much here concerning participation in rackets, brutality and other illegal treatment of suspects, blackmail and "entrapment" by vice squad members, and other prevalent abuses. The basic cause is found in the fact that "the generality of America's 200,000 local police officers remain undertrained, underpaid, unappreciated, with meager chances for advancement." The development of training, standards, and incentives that will turn the "Alatfoot" into a professional require a wiser attitude toward police problems on the part of our urban democracies.

4643. Dressler, David. Probation and parole. New York, Columbia University Press, 195 I. 237 p. $\quad$ 5I-I0476 HV9278.D73

A director of the New York State Division of Parole seeks to articulate a rationale of probation and parole, and to provide in one volume a fulllength statement on the philosophy, administration, and processes of each. He defines them as services designed to benefit society and the maladjusted individual in society, which must be recognized as casework functions with a law-enforcement orientation and responsibility. The first and crucial factor is selection, which, if poorly done, can render all 
subsequent supervision and treatment ineffectual. Mr. Dressler has provided anecdotes and lessons from his own professional career in his Parole Chief (New York, Viking Press, 1951. 310 p.).

4644. Ellingston, John R. Protecting our children from criminal careers. New York, PrenticeHall, 1948. 374 p. $\quad 48-3450 \quad$ HV9o6g. E56 $^{8}$ During $1938-40$ the American Law Institute carried out the task of redesigning the pattern for the administration of criminal justice for youth, arriving at a model Youth Correction Authority Act. In 194 I California set up its Youth Authority on this basis, and after six years was imitated by Minnesota, Wisconsin, and Massachusetts. Mr. Ellingston's book is a vigorous denunciation of traditional methods; jails, state schools, reformatories, and prisons are so many schools for crime and depravity. The schools and camps of the California Authority are praised as breaking the stagnant pattern of children's institutions. The State Authority is seen as a lever for effecting the reform of delinquency control at the community level.

4645. Glueck, Sheldon. Crime and justice. Cambridge, Mass., Harvard University Press, 1945. 349 p. A45-4442 HV8665.G55 I945

"Based on eight lectures delivered to a lay audience at the Lowell Institute, Boston, in the spring of 1935."-Pref.

A comprehensive diagnosis of the entire American system of criminal justice, whose ills primary result from the fact that "society is attempting to enforce the laws and to control crime with instruments largely outworn." One major improvement could be effected by drafting "a more realistic criminal code to replace the existing tangle of legislative and judge-made law." There is also needed a unified, centrally directed system of justice, administered by a Department of Justice within each state. No reform can become effective unless there is a greatly improved personnel of well-trained officials devoted to the public weal. Furthermore, "far-reaching and deep-probing attacks are necessary along the entire front of social pathology," but especially in the realm of family disintegration.

4646. Glueck, Sheldon, and Eleanor T. Glueck. 500 criminal careers. New York, Knopf,

1930. xxvii, 365, xvi p. 30-2673 HV6793.M4G5

4647. Glueck, Sheldon, and Eleanor T. Glueck. Later criminal careers. New York, The Commonwealth Fund, 1937. 403 p.

$$
\text { 37- } 188_{38} \mathrm{HV}_{793} \cdot \mathrm{M}_{4} \mathrm{G}_{52}
$$

4648. Glueck, Sheldon, and Eleanor T. Glueck. Criminal careers in retrospect. New York,
The Commonwealth Fund, 1943. 380 p. (Harvard Law School studies in criminology)

$$
\text { 43-17001 HV6783.G5 }
$$

These three volumes study the life histories of the 5 Io prisoners released from the Massachusetts Reformatory whose sentences expired in 1921 and 1922 , and follow them up at 5, 10, and 15 years after the original release. The first volume provides background material on the reformatory movement and the Massachusetts reformatory and parole system. The second studies recidivism among the 454 survivors and suggests that maturation is the underlying influence in reform. The third considers the response of offenders to peno-correctional treatment and explores the possibilities of predicting individual behavior.

4649. Glueck, Sheldon, and Eleanor T. Glueck. Five hundred delinquent women. With an introd. by Roscoe Pound. New York, Knopf, I934. xxiv, 539 p.

34-34029 HV6046.G6

An investigation of 500 cases whose paroles from the Massachusetts Reformatory for Women at Framingham expired between I 192 I and I924. It was undertaken at the instance of Mrs. Jessie S. Hodder, superintendent of the Reformatory for some two decades, who introduced many reforms and desired some evaluation of her years of effort. The authors offer eleven case-histories in detail and proceed to an analysis of pre-commitment data concerning family background, childhood and adolescence, sexual and marital life, and legal entanglements. The regime of the Reformatory and the circumstances of parole and of behavior after release are examined. The methodology of the study is fully set forth in Appendix A. The whole remains considerably the largest body of concrete information concerning women offenders in the United States.

4650. Glueck, Sheldon, and Eleanor Glueck. Unraveling juvenile delinquency. New York, Commonwealth Fund, 1950. xv, 399 p. (Harvard Law School studies in criminology) 50-10259 HV9069.G55

4651. Glueck, Sheldon and Eleanor Glueck. Delinquents in the making; paths to prevention. New York, Harper, 1952. 214 p.

51-II917 HV9069.G552

Of this pair of publications the first is a full statistical and methodological account, and the second a summary of results for the general public, of a major ten-year study. A group of 500 delinquent boys were elaborately compared with a group of 500 non-delinquent boys, so chosen that matching in pairs could be carried out. As a group, the delinquents proved to be "mesomorphic" in physique, 
energetic and aggressive in temperament, hostile and suspicious in attitude, concrete and unmethodical in intellect, and reared in homes of little affection or stability. The authors have worked out a series of prognostic tables offered as usable at the point of school entrance.

4652. Hamilton, Charles, ed. Men of the underworld; the professional criminals' own story. New York, Macmillan, 1952. 336 p.

$$
5^{2-4275} \mathrm{HV}_{67} 85 . \mathrm{H}_{3}
$$

There is a surprisingly large literature of personal narratives by American criminals of one kind or another, produced with varying degrees of assistance from another party or parties. This anthology gives a fair sampling, with sections on the "underworld," racketeering, prison life, and the road back from prison. Unfortunately the editor's commentary is journalistic in tone and his extracts are unaccompanied by proper dates and citations. However, his sources are listed in his bibliography ( $\mathrm{p}$. 327-330).

4653. Lewis, Orlando F. The development of American prisons and prison customs, $177^{6-}$ 1845 , with special reference to early institutions in the State of New York. [Albany?] Prison Association of New York [1922] $350 \mathrm{p}$.

\section{Bibliography: p. 347-350.}

$$
\text { 23-5484 } \mathrm{HV}_{9466 . \mathrm{L}_{4}}
$$

4654. McKelvey, Blake. American prisons; a study in American social history prior to 1915. Chicago, University of Chicago Press, 1936. xiv, 242 p. (University of Chicago. School of Social Service Administration. Social service series) 37-1625 $\mathrm{HV}_{9466 . \mathrm{M}_{3}}$

"Bibliographical note" at end of each chapter.

Mr. Lewis went minutely through contemporary sources, especially state documents, in order to present a detailed picture of prisons and imprisonment during the first seven decades of the Republic. It is, of course, largely a record of horrors. Dr. McKelvey, building on Lewis' presentation of "the institutional side," is chiefly concerned with new theories of penology and movements of reform based upon them. He pauses, however, to review "the state of prisons in the nineties." The two works, taken together, provide a fairly rounded history of American penological development down to World War I.

4655. Smith, Bruce. Police systems in the United States. Rev. and enl. New York, Harper, 1949. 351 p. $\quad 49-48594$ HV8138.S58 1949

There are about 40,000 separate and distinct public police agencies in the United States, and the coördination of these into a united and effective front against crime is a complex business. This treatise, noteworthy for taking into account the varying viewpoints of the professional police officer, the civilian administrator, and the general public, places these systems against the two major problems of crime and traffic, and then discusses the systems by category: federal agencies, state forces, city police, etc. Separate chapters are given to State-Federal relationships, police control and leadership, principles and types of organization, and the central services developed since 1893 by the International Association of Chiefs of Police.

4656. Tannenbaum, Frank. Crime and the community. Boston, Ginn, 1938. $487 \mathrm{p}$. $3^{8-13156}$ HV6025. $\mathrm{T}_{3}$

Bibliography at end of each chapter except chapter 20.

A thoroughly social interpretation of crime in the United States which rejects all single-factor theories. "American criminal activity has persisted because it was called into being and perpetuated by those complex and overlapping social strains which have characterized the growth and development of American life. Not until the American community changes profoundly will the character and the amount of crime in it also change." Among the chapters in which criminal behavior is very realistically fitted into its social setting are "Education for Crime," "Organized Crime," "Politics and Crime," "Politics and Police," and "The Philosophy of the Professional Criminal." The two concluding parts of the book present well-documented and strongly critical accounts of the administration of criminal justice, and of "Punitive Processes."

4657. Teeters, Negley K., and John Otto Reinemann. The challenge of delinquency; causation, treatment, and prevention of juvenile delinquency. New York, Prentice-Hall, 1950. 819 p. $\quad 50-12402$ HV9069.T375

Bibliography: p. [739]-783.

A professor of sociology and the probation officer of a Philadelphia court unite to produce a college text which presents the history of its subject, an appraisal of theories of causation, and a description and evaluation of the existing social machinery. No single theory of causation is found to be satisfactory; a "multiple causation" theory is considerably more cautious, although no given set of unfavorable conditions will necessarily produce delinquency, or their opposites necessarily prevent it. Under "Control and Treatment," juvenile courts, probation, and various types of commitment are described. The final section discusses community programs of prevention, and an appendix presents 15 case histories. 
4658. Thrasher, Frederic $M$. The gang; a study of 1,313 gangs in Chicago. $2 \mathrm{~d}$ rev. ed. Chicago, University of Chicago Press, 1936. xxi, 605 p. $\quad 36-35233 \quad \mathrm{HV}_{4339} \mathrm{U}_{7} \mathrm{C}_{4} \quad{ }_{1936}$

"Selected bibliography": p. 554-580.

The gang has grown considerably more lethal in the past two decades, but Dr. Thrasher's study of Chicago gangs carried out in the early r920's remains the most thorough study of a regular urban phenomenon. The gang, a symptom of disorganization in the larger social framework, offers a substitute for what society fails to give, and provides relief from suppression and distasteful behavior. Various aspects of gang life such as its playgrounds, "junking," gang warfare, and sex, are illustrated. Gang structure, action, and leadership are analyzed, and the gang is considered in its relation to organized crime and to politics.

4659. Vollmer, August. The police and modern society. Berkeley, University of California Press, 1936. 253 p. (Publications of the Bureau of Public Administration, University of California)

Bibliography: p. 238-24I. $3^{6-27477} \mathrm{HV} 8138 . \mathrm{V} 65$

A review of police problems "as the policeman on patrol daily encounters them," by the long-time Chief of Police of Berkeley, Calif., also a distinguished criminologist. These problems are con- sidered in four main groups: major crimes, vice, traffic, and general service. There is much room for improvement in the realm of personnel; by improved standards of selection and training, "police work can attain the full dignity of a profession." The author believes that our services have traveled as far toward crime control as they have been permitted to; but "the police are undermined, demoralized, and unsupported by the very public that they are paid to protect."

4660. Wilson, Orlando W. Police administration. New York, McGraw-Hill, 1950. 540 p. 50-12455 HV7935. $\mathrm{W}_{4} 8$

A substantial textbook by the dean of the School of Criminology at the University of California, written for the critical student of police problems. It analyzes the organization structure, administrative practices, and operating procedures of police forces in this country. In view of widely divergent police patterns, it describes what the author regards as superior practices in all branches and at all levels of police service-"we do not progress so long as we sit on the fence." There are sections on patrol, traffic, records, buildings and equipment, personnel, discipline, and public relations. An "administrative check list" of 300 questions provides a ready-made inquiry into the efficiency of any police department (p. 513-528). 


\section{XVI}

\section{Communications}

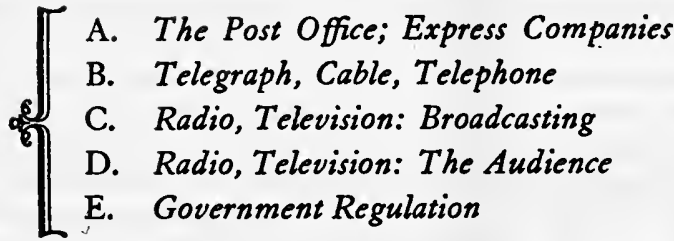

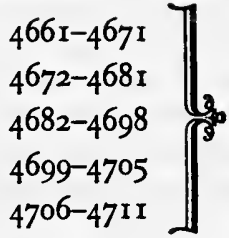

$\mathrm{I}^{\mathrm{N}}$

N THIS chapter books have been selected which tell the story of telecommunication in the United States as various media have successively emerged to influence the economic, social, and intellectual development of the Nation. The expansion of the postal system from an intercolonial service on the eastern seaboard into a medium for transcontinental communication followed the westward migration of settlers, and with the help of the short-lived Pony Express dispelled the notion of the Rocky Mountains and the deserts as impassable barriers between the two sections of the country. By the middle of the I 9 th century the postal service was rivaled by the growing network of telegraph wires, which in the two decades before 1852 reached 23,283 miles, and the merchant, banker, journalist, and men of other callings had discovered the value of the telegraph in their business ventures. Invented by Alexander Graham Bell, the telephone emerged as a big industry during the last quarter of the 19 th century, as a potent modifier of everyday habits, and as an instrument of industrial and social expansion.

In spite of the influence of these media of communication, there is a scarcity of literature, suitable for this bibliography, on the Post Office, the Express Companies, and the Telegraph, Cable, and Telephone (Sections A and B). This is by no means the case with the more recent arrivals, Radio and Television (Sections $\mathrm{C}$ and $\mathrm{D}$ ). In the first two sections the items listed represent most of the historical litera-

ture available in book form on those subjects, while the items in Sections $C$ and $D$ are merely typical of $a$ much larger body of literature that reflects the development of broadcasting. Books have been selected for their illustration of the profound effect that both of these agencies of mass communication are exerting on the social, educational, and moral qualities of their audiences. Because of the rapid development of radio and television into timeconsuming, ubiquitous influences in American life, as well as into big industries with associated careers, a few production handbooks that will probably be of interest to others as well as those who may consider such careers, have been included. The omission of any title is not to be considered as criticism, but may mean only that the selection had to be limited in order to maintain proportion and balance.

\section{A. The Post Office; Express Companies}

466r. Chapman, Arthur. The Pony Express; the record of a romantic adventure in business; illustrated with contemporary prints and photographs. New York, Putnam, 1932. $319 \mathrm{p}$.

Bibliography: p. 311-314.

$$
3^{2-9124} \mathrm{HE} 6375 . \mathrm{C}_{4}
$$

The Pony Express was a by-product of the con- troversy between the proponents of the southern and central routes for the overland mail to California. It was inaugurated on April 3, 1860, by William $\mathrm{H}$. Russell of the freighting firm of Russell, Majors and Waddell, to demonstrate the practicability of the central route for year-round travel. Only one trip was missed in its 18 months of weekly and semi- 
weekly service. The excessive cost of operation, the failure to obtain an enlarged mail contract, and the joining of the telegraph lines from the East and West in October 1861 brought the Pony Express to an end. The writer, a newspaper reporter, magazine editor, and author of other books on the West, concludes that the Pony Express contributed to the development of the West by speeding up the news service to and from the Pacific, disproving the theory that the Rocky Mountains formed an impassable barrier in winter, and minimizing the terror of the desert.

4662. Chu, Pao Hsun. The Post Office of the United States. 2d ed. New York, 1932. 148 p. 33-2965 HE6371.C55 1929

Thesis (Ph. D.) - Columbia University, I929.

Bibliography: p. 139-148.

The footnote references and bibliography indicate the scholarly nature of this history of the Post Office. The author, a Chinese student who came to the United States on a government scholarship, regards the Post Office as an agency for the collection and dissemination of human thought and thereby one of the active contributors to the speed and solidarity that mark the growth of civilization. He traces the development of the English postal system as the forerunner of the American, the emergence of the modern Post Office in the 17 th century, the origin of the Federal postal monopoly, and the reforms which have fundamentally changed the theory and practice of postal finance.

4663. Cushing, Marshall $\mathrm{H}$. The story of our Post Office; the greatest Government department in all its phases. Boston, A. M. Thayer, 1893 . r034 p. 9-16667 HE6371.C98

The author utilized his experience as a journalist, congressional secretary, and private secretary to Postmaster General John Wanamaker to give a detailed account of the complicated machinery that underlay the business of the Post Office Department. A description of the buildings occupied by the Department, the duties of the Postmaster General, the various functions of his assistants, the publications of the Department, the establishment of routes and offices, the equipment, pay and work of clerks, money orders and supplies, free delivery, the Dead Letter Office, inspectors and smuggling, brief biographies of postmasters and other personalities as well as statistics and anecdotes have their places in this vivid picture of the Post Office as it was in the last decade of the igth century.

4664. Fowler, Dorothy (Ganfield) The Cabinet politician; the Postmasters General, 18291909. New York, Columbia University Press, 1943. 344 p. 43-10238 HE6499.F6
Manuscripts: p. [309]-3II. Bibliography: p. [313]-323.

The Postmaster General became a Cabinet officer in 1829 . During the next 80 years the tradition was established whereby "this Cabinet position has been given to the foremost politican of the Party. He has usually been the manager of the new President's campaign for the nomination and election and has frequently been the chairman of the national committee, for the Presidential nominee has, since 1896 , selected that officer." Mrs. Fowler describes the Post Office as an agency of political patronage and reviews the political activities of its heads from William T. Barry to George von Lengerke Meyer.

4665. Geddes, Virgil. Country postmaster. New York, Austin-Phelps, 1952. 230 p.

52-1 $2228 \mathrm{HE}_{3} 85 . \mathrm{G}_{4} \mathrm{~A}_{3}$

This book by a little-theater playwright presents the human interest side of the postal system. It relates in anecdotal style the experiences of the author as postmaster for ten years in a New England village. It pictures the life of the people as viewed from a post office window, the small town politics, the enforcement of postal regulations, the illegal use of the mails, and the maintenance of rural routes. "Where else," asks the author, "could one, who constantly enjoys the study of humanity, have such a laboratory as the post office in a small town?" He concludes that, "what holds the great postal system together is not the postal laws and regulations, however important they may be, but the spirit of democracy in both those who work within it and those who patronize it."

4666. Hafen, LeRoy R. The overland mail I8491869; promoter of settlement, precursor of railroads. Cleveland, A. H. Clark, I $1926.36 \mathrm{~s}$. 26-176 8 HE6 $375 . \mathrm{H}_{3}$

"Bibliography of references cited": p. 333-34I.

The trek of the Mormons to Utah in 1847 and the discovery of gold in California in 1849 accelerated the demand for extension of the mail service overland to the Pacific. The author tells the story of the transportation of the mails by stage coach and Pony Express on all available routes to the West during the 20 years that preceded the driving of the Golden Spike at Promontory Point on May 10, I869. He relies on Government documents, contemporary newspapers, and the personal narratives of travelers and other participants in the events which have been described.

4667. Harlow, Alvin F. Old waybills; the romance of the express companies. New York, Appleton-Century, r934. 503 p.

$34-700 \mathrm{I} \mathrm{HE}_{5} 896 . \mathrm{H}_{3}$ 
Bibliography: p. 489-[497]. .

This is the author's third book in his series on American communication and transportation. The history of the Adams, American, Southern, and Wells, Fargo Express Companies, which reached their zenith in the early I89o's and combined in 1918 to become the American Railway Express Company, is interwoven with stories of the colonial expressmen, the rise and fall of smaller companies, the stage coach and Pony Express, and the impact of these modes of communication on society.

4668. Kelly, Melville Clyde. United States postal policy, by Clyde Kelley. New York, Appleton, 1931. $320 \mathrm{p}$. $3 \mathrm{I}-2244^{8} \quad \mathrm{HE}_{37 \mathrm{I}} \mathrm{K}_{4}$ In this review of the development of the policies underlying the U. S. postal service, a member of the House of Representatives for 20 years, who had served on its Post Office Committee, describes the postal establishment as the "keystone in the arch of American unity." Through service it "helps to obliterate sectional lines and to neutralize class prejudice."

4669. Rich, Wesley E. The history of the United States Post Office to the year I829. Cambridge, Harvard University Press, 1924. I90 p. (Harvard economic studies ... v. 27)

$$
\text { 24-22903 HE637I.R5 }
$$

Thesis (Ph. D.)-Harvard University, 1917 .

Bibliography: p. 175-181.

This dissertation is a scholarly history of the beginnings of the postal service in the colonies under British rule, its unification under Benjamin Franklin as the first national Postmaster General (1775), and its extension from 1789 to 1829 , the year in which the Postmaster General became a Cabinet officer. Chapters describe the Post Office as a public service and its internal organization, financial operations, and postal policies. A chapter traces the growing political importance of post office patronage. The appendixes contain biographical notes on the Postmasters General, and tables showing the growth, appropriations, receipts and expenditures of the Department from its inception until 1829 .

4670. Roper, Daniel C. The United States Post Office, its past record, present condition, and potential relation to the new world era. New York, Funk \& Wagnalls, 1917. xvii, $3^{82} \mathrm{p}$.

Bibliography: p. 374-375.

$$
\text { I7-24056 HE637I.R6 }
$$

The author, who served as First Assistant Postmaster General from I913 to 1916 , has written a general history of the U. S. Post Office, whose mission he describes in its rural, urban, and international aspects as "social, commercial and intellectual." He tells the story of the postal service from its colonial beginnings to 1917 when, he says, World War I marked the "end of an old and the beginning of a new era." The American story is prefaced by a chapter on "Postal Service and Civilization." The Appendix contains a glossary, a list of officials of the Post Office Department, I775-1917, and a chronology of postal events.

4671. U. S. Commission on Organization of the Executive Branch of the Government (1947-

1949) The Post Office; a report to the Congress, February 1949. [Washington, U. S. Govt. Print. Off.] 1949. 2I p.

$$
\begin{array}{lll}
49-4578 \text { I } & \text { HE633I I949.A523 } \\
\text { JK643.C47A55, no. } 4
\end{array}
$$

Issued also as House document no. 76, 81st Cong., Ist sess.

Established by a law approved July 7, 1947, the Commission, through its Chairman, the Honorable Herbert Hoover, transmitted the report of its findings concerning the Post Office Department to the Congress less than two years later. As Appendix I to this Report, Robert Heller and Associates, Cleveland, published the results of their study for the Commission under the title Management Organization and Administration of the Post Office Department ([Washington, U. S. Govt. Print. Off.] 1949. 74 p.). The basic diagnosis of the Commission: "Although the Post Office is a business-type establishment, it lacks the freedom and flexibility essential to good business operation." The Heller task force recommends legislation "to establish the Post Office Department as a revolving fund agency of the Executive Branch . . . accountable to the Congress but with methods more in accord with modern business practice." Greater flexibility in expenditures and reasonable freedom from restrictive laws and regulations are indicated changes.

\section{B. Telegraph, Cable, Telephone}

4672. Barbash, Jack. Unions and telephones; the story of the Communications Workers of America. New York, Harper, 1952. $246 \mathrm{P}$. 52-8460 HD6515. T33 $\mathrm{B}_{3}$
The Communications Workers of America were established as recently as 1939, and did not arrive at any great numbers or infuence until World War II was over. Mr. Barbash, a Washington economist, 
tells its story in order "to give CWA members a sense of pride in CWA traditions and history," as well as "to tell the general reader interested in the labor movement something about a union which reflects most of the main currents of union development in this generaiton." His book is included here for the incidental light which it frequently throws upon the organization and operations of the telephone industry, and for its Chapter 9, "Telephones and Corporations," which concisely presents the economics of the industry from the union point of view.

4673. Danielian, Noobar R. A. T. \& T.; the story of industrial conquest. New York, Vanguard Press, 1939. $460 \mathrm{p}$.

$$
\text { 39-29705 } \mathrm{HE} 88_{4} 6 . \mathrm{A}_{55} \mathrm{D}_{3}
$$

The results which may be achieved by the various systems of industrial control are emphasized by the author, sometime financial and utility expert for the Federal Communications Commission. The Bell Telephone System has been selected as typical of the industries which have experienced periods of uncontrolled monopoly, competition without regulation, the protection of state regulation, Federal "ownership" during World War I, and regulated monopoly. The book is based, to a great extent, on the record of the Telephone Investigation authorized by Congress in 1935 and conducted by the Federal Communications Commission (no. 47Io).

4674. Dilts, Marion May. The telephone in a changing world. New York, Longmans, Green, 1941. xiv, 219 p.

4I-51774 HE873r.D5 194I Bibliographical references in "Notes": p. 197210.

Since the telephone was first successfully demonstrated in 1876 , it has become a universal medium for the exchange of ideas between individuals. Communication between persons in neighboring cities had developed into transcontinental service by I915, and transoceanic telephone service between New York and London was established in 1927. This nontechnical history, written by a former member of the technical staff of the Bell Laboratories, traces the economic and social impact of that development on this and other countries. The book includes chapters on "Telephone Operators" and "Telephone Directories."

4675. Harlow, Alvin F. Old wires and new waves; the history of the telegraph, telephone, and wireless. New York, Appleton-Century, 1936. xiv, 548 p. 36-27399 $\mathrm{TK}_{5115 . \mathrm{H}_{3}}$ Bibliography: p. 527-538.

Although this is a history of the three great means of communication, more than two-thirds of the book is devoted to the development of the telegraph. It contains chapters on Samuel F. B. Morse, the inventor, Henry O'Reilly, who extended "the wires over a vaster field than any which promoters had yet dared to contemplate," and the first Atlantic cable. The evolution of the telephone and Alexander Graham Bell's struggle over patents, and the story of wireless communication are traced up to the organization of the big radio broadcasting chains. The author relates deeds of heroism accomplished by means of wire and wave during peace and war, which add human interest to the story.

4676. Mabee, Carleton. The American Leonardo, a life of Samuel F. B. Morse; with an introd. by Allan Nevins. New York, Knopf, 1943. xix, $420, \mathrm{xv}$. 43-I 967 TK $5243 . \mathrm{M}_{7} \mathrm{M}_{3}$

Thesis (Ph. D.) -Columbia University, 1942.

References: p. 38I-420.

A young scholar, who had access to a collection of Morse letters, diaries, photographs, and paintings, portrays his subject not only as the inventor of the telegraph, but also as an artist whose career in painting began in his youth and continued with varying success until 1837 when he gave it up to devote his energies to the development of the telegraph. Allan Nevins, in the Introduction, says that "Morse was something better than a great inventor; he was one of the great representative Americans of his time, a leader in many activities, and a man who enriched the national culture in various ways." The theme of Morse as an artist has been further explored by Oliver W. Larkin in Samuel F. B. Morse and American Democratic Art (Boston, Little, Brown, 1954. 215 p.).

4677. McDonald, Philip B. A saga of the seas; the story of Cyrus W. Field and the laying of the first Atlantic cable; illustrated from contemporary prints and portraits. New York, WilsonErickson, 1937. 288 p. $37-21616$ TK56ri.M 3 Bibliography: p. 281-282.

The story of life in the United States during the latter half of the rgth century has been interwoven with the biography of an enthusiastic, energetic promoter whose foresight and courage inspired capitalists and scientists on both sides of the Atlantic to use their money and talents to produce a material link between the Old World and New. The author describes the influence of the Atlantic cable on international commerce, diplomacy, and news service; and the interest of Cyrus Field, in later years, in the transit system of New York, the laying of a Pacific cable, and other projects of public benefit. In the Preface, the author mentions the letters and autobiographical notes printed in Cyrus W. Field, edited 
by his daughter, Isabella Field Judson (New York, Harper, 1896.332 p.) as being "the best source of original documents."

4678. Mackenzie, Catherine D. Alexander Graham Bell, the man who contracted space. Boston, Houghton Mifflin, 1928. $382 \mathrm{p}$. 28-28948 TK6143. $\mathrm{B}_{4} \mathrm{M}_{3}$

A narrative of the career of the versatile inventor of the telephone, who was also the oustanding genius of his generation in the education of the deaf, the financier of the Volta Bureau, the founder of the Aerial Experiment Association, and the guiding spirit in the establishment of the magazine Science. The author was for ten years Mr. Bell's secretary and the custodian of his papers. Out of that experience and the many conversations of those years she tells with enthusiasm and directness the story of his life "in terms of the work he did and the way he did it."

4679. Rhodes, Frederick Leland. Beginnings of telephony. New York, Harper, 1929. xvii, 26I p. 29-22388 TK6015.R5 "Sources of information consulted": p. 239-244.

Associated with the American Bell Telephone and the American Telephone and Telegraph Company as an electrical engineer, the author is well known for important work in connection with standardization of materials, apparatus, and practice in overhead and underground wire systems. In this book he makes available to students and workers interested in the early history of the telephone and in the field of electrical communications, the information which he has gathered from experience and original sources. The emphasis is on the origin and early development of such technical devices as the microphone transmitter, the telephone cable, and the switchboard. The Appendixes include a "List of the Most Important Law Suits Arising out of the Infringement of Alexander Graham Bell's Telephone Patents, with a Brief Description of the Circumstances of Each Suit;" "Early Uses of the Word Telephone;" and a "Numerical List of United States Patents Cited."
4680. Thompson, Robert L. Wiring a continent, the history of the telegraph industry in the United States, 1832-1866. Princeton, Princeton University Press, r947. xviii, 544 p.

Thesis-Columbia University.

$$
\text { 47-1 } 2502 \quad \mathrm{HE}_{7775} \cdot \mathrm{T}_{5}
$$

Bibliography: p. [518] 526 .

The idea of an electromagnetic telegraph crystallized in the mind of Samuel F. B. Morse in 1832 , and the Western Union Telegraph Company emerged in 1866 from a consolidation of all the individual companies that had sprung up during the years between. The author tells the story of men and events connected with those companies as he has found them in such sources as the John Dean Caton Papers, which he describes as "invaluable for an insight into the telegraph wars of the I850's and I860's"; the Samuel F. B. Morse Papers, which deal with the inception of the telegraph and patent controversies; and the Henry O'Reilly Papers, "the most important manuscript collection on the telegraph in existence."

468r. Ulriksson, Vidkunn. The telegraphers, their craft and their unions. Washington, Public Affairs Press, 1953. 218 p.

Bibliography: p. 210-21 I.

$$
\text { 52-1286I HD6515.T } 325 \mathrm{U}_{5}
$$

The author, now on the faculty of the University of Wisconsin, has been a member of the Order of Railroad Telegraphers since 1918, and writes out of the conviction that the labor movement "has been and will continue to be one of the main bulwarks of our democratic way of life." Following a brief chapter on "Early Telegraph History," the evolution of unionism in the industry is sympathetically traced from the organization of the National Telegraph Union in 1863 down to 1951 . A final chapter on "The Telegraph Fraternity" describes some of the interests and attitudes of a group who "have for the most part always regarded themselves as belonging in the professional category.

\section{Radio, Television: Broadcasting}

4682. Abbot, Waldo, and Richard L. Rider. Handbook of broadcasting; the fundamentals of radio and television. $4^{\text {th }}$ ed. New York, McGrawHill, 1957. 531 p. illus.

$$
\text { 56-9620 PNig9r.5.A2 } 1957
$$

"Glossary": p. 46i-470.

Bibliography: p. 516-520.

Designed to give students "basic knowledge of every activity in a broadcasting station from announcing to producing, from writing to the technical 
operation," this Handbook has been used for twenty years as a textbook for elementary classes in the field of broadcasting. In this new edition Richard L. Rider, supervisor of television and motion pictures at the University of Illinois, has collaborated with the original author to expand the data on television. Those chapters and sections that deal with the fundamentals basically the same for both media have been retained, with supplementary information concerning TV, so as "to create a combined text which would be valuable for . . . students of radio and television." In 195 I Edgar E. Willis undertook "to provide a foundation on which advanced courses in specific phases of radio and television can be based; and to serve as a general introduction to broadcasting for those students who will take no other courses in the field," in Foundations in Broadcasting: Radio and Television (New York, Oxford University Press, 195 I. 439 p.).

4683. Archer, Gleason L. Big business and radio. New York, American Historical Co., 1939. 503 p. $\quad 39-29972$ TK6548.U6A82

An organizational history of the rise of the great broadcasting companies from 1922 to 1929 , with the following decade much more sketchily treated. The author has been allowed access to the files of the Radio Corporation of America and the General Electric Company, and so documents the struggle between the "Radio Group" and the "Telephone Group" for the control of radio more thoroughly than is common for recent business history. The achievements of William S. Paley, "the magician who has built the great Columbia network," and of David Sarnoff, who completed the unification of R. C. A., are acclaimed. Subsequent chapters deal with the Government's antitrust suit against R. C. A. and the consent decree of Nov. 21, 1932, the effects of the depression on the industry, and the beginnings of television.

4684. Barnouw, Erik. Handbook of radio production; an outline of studio techniques and procedures in the United States. Illustrated by Victor Barnouw. Boston, Little, Brown, 1949. 324 P. 49-612 TK6570.B7 29

The author, who is now (1956) Editor, Center for Mass Communication, Columbia University Press, points out that since the air is the property of the people to be used only with the consent of the Federal Communications Commission and for public service, American radio is distinguished from other mass media by the wide participation of national and local groups in the production of programs. More than 60 percent of his handbook is devoted to the coördinated work of the production team. He describes the talents and techniques used by the actor, the sound man, the musician, the announcer and speaker, and the engineer and director. Excerpts from various programs and a script, with production notes, are given to illustrate the problems of the team, with a "Production Directory" at the end. It is a companion volume to the author's Handbook of Radio Writing, rev. ed. (Boston, Little, Brown, 1947. 336 p.).

4685. Callahan, Jennie (Waugh) Television in school, college, and community. New York, McGraw-Hill, 1953. 339 p. illus.

Bibliography: p. 295-322.

$$
\text { 53-8992 LBi 044.7.C } 33
$$

During 1952-53 educators and other leading citizens filed petitions with the Federal Communications Commission to reserve some 209 frequencies for noncommercial television stations with educational purposes. This book has been written for those who have the responsibility for establishing educational TV stations, and writing and producing the programs. The list of sources includes materials available from TV producing groups, listed by states, as well as from the Joint Committee on Educational Television, the National Association of Educational Broadcasters, and the U.S. Office of Education. For other books and serials on educational television, by Charles $\mathrm{A}$. Siepmann and others, see Chapter XXI, Section F, on Methods and Techniques of Education.

4686. Chester, Giraud, and Garnet R. Garrison. Television and radio, an introduction. 2d ed. New York, Appleton-Century-Crofts, 1956. 652 p. illus. $\quad 56-7206$ TK6550.C $43 \quad 1956$ "Glossary of studio terms": p. 619-625.

Bibliography: p. $627-636$.

The authors, who have had experience in radio and television teaching and research as well as in broadcasting, have made important changes in this enlarged edition "to reflect the new facts and new interests" which have developed since the first edition appeared in 1950 under the title Radio and Television. However, the basic intention of the authors is the same: "to provide a comprehensive, up-to-date textbook for introductory courses in broadcasting" which are offered in several hundred colleges and universities. Part I deals with the social aspects of radio and television, including "Educational Radio and Television" and "Standards of Criticism." Part II is devoted to studio practices and techniquestation organization, talking on the air, types of programs, acting, directing, and "Broadcasting as a Career." Script excerpts are provided for practice so that the text may be used as a "working handbook." 
4687. Commission on Freedom of the Press. The American radio, a report on the broadcasting industry in the United States, by Llewellyn White. Chicago, University of Chicago Press, r947. xxi, $259 \mathrm{p}$.

"Note on sources": p. 252-255.

One of a series of studies prepared by the Commission, which "was created to consider the freedom, functions, and responsibilities of major agencies of mass communication in our time." The author, who served as the assistant director of the Commission, points out the defections of the radio industry in fulfilling its obligations to the public, redefines the responsibilities of the industry within the framework of Federal regulation, and makes recommendations to the broadcasters, the FCC, and the public. "Freedom and accountability," the Commission concludes, "must represent the joint achievement of the industry, of community groups, and of government, acting in proper relation to one another."

4688. Cumming, William $\mathrm{K}$. This is educational television. [Ann Arbor? Mich.] 1954. 264 p. illus. $\quad 54-62768$ LBro $44.7 . C 85$

Dr. Cumming of the Department of Journalism at Michigan State College, and more recently Television Producer-Coordinator of its station WKAR$T V$, believes that "television has the potential for becoming a highly significant tool in the total educational process." As a guide to educators and public service leaders still in doubt as to their course, he has made this survey of the actual achievements of the leading colleges and universities in the educational TV field, including, of course, his own, and has sought to describe and appraise their presentations. "Material for the book was gathered, in large degree, from personal interviews conducted across the country and from observation and participation in television operations." Statistics showing the "Enrollments for Educational Television Programs that Teach" appear in the Appendix. Directories of "Colleges Offering Courses in Television," and "Technical Schools for Television," appear in Edwin B. Broderick's Your Place in TV; Handy Guide for Young People (New York, McKay, 1954) p. II3-124.

4689. De Forest, Lee. Father of radio; the autobiography of Lee De Forest. Chicago, Wilcox \& Follett, 1950. 502 p.

$$
\text { 50-9446 } \mathrm{TK}_{5739 . \mathrm{D}_{4} \mathrm{~A}_{3}}
$$

Radios in some 50 million homes in 1955 are the contribution which the inventive genius of Lee De Forest has made to civilization. He completed his new "grid Audion" in 1906; 4I years later Charles F. Kettering said, "The spectacular growth of electronics to an enormous industry employing over a million workers and benefiting untold millions of people in all parts of the world may be said to have begun with that event." Believing that he knows better than anyone else many circumstances of the early history of radio and television, Mr. De Forest describes for the first time many episodes in their development. He tells of his youth in Iowa and Alabama, his literary, musical, and scientific education, his early inventions, and his experiments with wireless preceding the Audion. His narrative covers the beginnings of radio broadcasting, of sound films, and of television. There is also much detail concerning the organization of his companies, and the litigation which followed.

469o. DeSoto, Clinton B. Two hundred meters and down; the story of amateur radio. West Hartford, Conn., American Radio Relay League, 1936. I84 p. 37-376 TK6547.D 4

"This work is publication no. 13 of the Radio Amateur's Library, published by the League."Verso of t.-p.

By the year 1908 considerable numbers of amateurs were taking up wireless telegraphy as a hobby, and their interference with regular channels of communication led to the Radio Act of 1912, which confined them to wavelengths of 200 meters or less. Within this limit the "ham" flourished, and made the transition to radio, so that there were in 1936 "approximately 46,000 licensed amateur transmitting stations." The amateurs' organization into the American Radio Relay League and the International Amateur Radio Union, their contributions to the improvement of apparatus and communications, and their volunteer work in emergencies, are among the topics presented in this unusual volume, which certainly ought to be brought up to date.

4691. Ewbank, Henry L., and Sherman P. Lawton. Broadcasting: radio and television. New York, Harper, 1952. 528 p.

Selected bibliography: p. 504-515.

$$
\text { 52-5432 PNig9r.5.E9 }
$$

The principal aim of the authors is "to describe our radio and television systems, consider the public service responsibilities of these important mass media, and suggest standards for evaluating broadcast programs." Government and nongovernmental control of broadcasting; the preparation and direction of various types of programs, including those for special audiences; methods of audience measurement; and the economic and social effects of listening are presented in nontechnical language, especially for college students and for program staff members of radio and television stations. 
4692. Hutchinson, Thomas H. Here is television, your window to the world. With ninetyfour illus. [Completely rev. ed.] New York, Hastings House, 1950. xvi, $368 \mathrm{p}$.

Glossary: p. 365-368.

$$
\text { 51-61 TK6630.H87 } 1950
$$

The author taught what was perhaps the first college class in television programming in 1940 at the Washington Square Writing Center of New York University, and has had much practical experience in producing and directing TV programs. In this textbook, originally published in 1946, he describes in detail "The Tools of Television"-the studio, the camera, sound, the control room, the projection booth, the transmitter, and the receiverrepresentative types of "Television Programs," and "The Commercial Aspect"-advertising programs and "spots," large and small-station operation, networks, theater television, and jobs. The final chapter summarizes the progress of TV in England, Holland, Germany, France, and America.

4693. Maclaurin, William Rupert. Invention \& innovation in the radio industry, by W. Rupert Maclaurin with the technical assistance of $R$. Joyce Harman. With a foreword by Karl T. Compton. New York, Macmillan, 1949. xxi, 304 p. illus. (Massachusetts Institute of Technology. Studies of innovation) 49-8314 TK6547.M28 Bibliography: p. 292-298.

The author has chosen the radio industry as the subject of the first in a projected series of books on the consequences of technological changes in a number of industries. He traces the story of radio through the lives of the Europeans who did the fundamental research, to the advance engineering techniques developed in the industrial laboratories of the United States and applied to the industry. Chapters are devoted to patent litigation, and to the rise of industrial research in the fields of television and frequency modulation. Dr. Maclaurin concludes that technological innovation has positive effects on our economy, and that the rational handling of industrial research prepares the Nation not only to fight a war but to fight a depression.

4694. O’Meara, Carroll. Television program production. New York, Ronald Press, 1955. 36I p. illus. 55-609 I PNi992.5.O6

The author, a former producer-director for NBCTV in Hollywood and New York, bases this book on notes gathered while he was being trained in television production by NBC. It is a practical manual for the TV producer, often technical but regularly concrete and clear, which deals both with his means-camera, title devices, film and slides, lighting, etc.-and with standard types of programs in the studio and "remote telecasts" outside it, such as sports events. Concluding chapters introduce color TV and censorship problems.

4695. Phillips, David C., John M. Grogan, and Earl H. Ryan. Introduction to radio and television. New York, Ronald Press, 1954. 432 p. illus. $\quad 54-7650$ PNig9i.5.P5

A book for those who want a general understanding of radio and television, as well as for those who plan careers in the two media and will pursue further specialized courses. It contains chapters on "Regulation of Radio and Television," "Films for Television," "Educational Television," and "Audience Measurement." Appended are a "Glossary of Radio and Television Terms" and specimen "Radio and Television Scripts."

4696. Seehafer, Eugene F., and Jack W. Laemmar. Successful radio and television advertising. New York, McGraw-Hill, I951. 574 p.

$$
\text { 5I-2828 HF6I } 46 . \mathrm{R}_{3} \mathrm{~S}_{4}
$$

American business has practiced selling through the medium of the radio for over 30 years, and through TV since its large-scale introduction. In the course of this experience certain well-established principles have emerged, upon which "creative thinking" in broadcast advertising can proceed. This text, originally issued in mimeographed form in 1947 , aims to formulate these principles, and to illustrate their operation throughout both media. The techniques of the retail advertising campaign, the problems of the national advertiser, and the art of selling time, are essentially the same, whether radio or TV is employed. The appendixes include a "Timing Table for Radio Commercials" and a glossary.

4697. Stasheff, Edward, and Rudy Bretz. The television program; its writing, direction, and production. [2d ed.] New York, Hill and Wang, $1956.356 \mathrm{p}$. illus.

$$
\text { 56-13991 PNi992.5.S8 } 1956
$$

Although television is often regarded as being a new form of art, one of its principal functions has been the broadcasting of dramatic entertainments originally devised for media of longer standing. The essential differences between television and its forerunners - theater, films, and radio-are pointed out in order to emphasize how directors, writers, actors, and production personnel must adjust their techniques to the new medium. Technicalities are illustrated from original scripts, including a photographic reproduction of one complete director's script for a [Dave] "Garroway at Large" program. The chapter on "Marketing the Script," as well as a book by Max Wylie, Radio and Television Writ- 
ing, rev. and enl. (New York, Rinehart, 1950. 635 p.), will interest those who would like to write for television.

4698. Waller, Judith C. Radio, the fifth estate. 2d ed. Boston, Houghton Mifflin, 1950. 482 p. illus. (Houghton Mifflin radio broadcasting series) $\quad 50-9766 \mathrm{HE}^{2} 698 . \mathrm{W}_{3}$ 1950 Bibliography: p. 455-468.

The author is Director of Public Affairs and Edu- cation of the National Broadcasting Company's Central Division. Her book naturally stresses religious, agricultural, children's, and other types of public service programs, as well as educational broadcasting. It is, however, a rounded treatment of the subject as a whole, and for the general reader is probably the most serviceable introduction to radio as it was at its peak. The original publication was in 1946 , and this revision includes only a six-page section on television.

\section{Radio, Television: The Audience}

4699. Bogart, Leo. The age of television; a study of viewing habits and the impact of television on American life. New York, Ungar Pub. Co., 1956. $34^{8} \mathrm{p}$. 56-12046 HE8698.B6

Written for viewers who are interested in the effect of television on people rather than with its technical aspects, this book is based mostly on studies "which have used the interview method of asking people what television has meant in their lives." Following chapters on the growth of TV and the nature of its audience appeal, the author explores the content of TV programming, and analyzes its effect on reading, the movies, spectator sports, advertising, politics, and juvenile audiences. "The Status of TV Research" is summarized in an appendix, which observes that "remarkably little is known about the broadcasters themselves."

4700. Chappell, Matthew N., and Claude E. Hooper. Radio audience measurement. New York, Daye, I944. xvi, 246 p. illus. 44-5827 HE97 $3 . \mathrm{C}_{5}$

The development of the radio as an advertising medium early impressed on the industry the need for measuring listening habits to determine the effectiveness of various types of programs on the buying habits of audiences. The data obtained from sampling measurements, made by major audience service organizations in 1929, 1934 and 1943, have been supplemented through surveys conducted by the major networks, by advertising agencies carrying radio accounts, and by other research groups. In this book the writers examine separately each method used in collecting such information, and the effectiveness of the method for the segment of the population chosen for study.

470r. Columbia University. Bureau of Applied Social Research. Radio listening in Amer- ica; the people look at radio-again. Report on a survey conducted by the National Opinion Research Center of the University of Chicago, Clyde Hart, director; analyzed and interpreted by Paul F. Lazarsfeld and Patricia L. Kendall. New York, Prentice-Hall, r948. 178 p.

49-450 HE8698.C654

A second survey of listening habits sponsored by the National Association of Broadcasters to determine the public's attitude toward radio. The first study, conducted under the direction of Harry $\mathrm{H}$. Field and Paul F. Lazarsfeld, was published by the University of North Carolina Press in 1946: The People Look at Radio ( $15^{8}$ p.). Seventy percent of the audience gave radio in general a rating of excellent or good; serious criticism was confined to a relatively small minority.

4702. Parker, Everett C., David W. Barry, and Dallas W. Smythe. The television-radio audience and religion. New York, Harper, 1955. $\mathrm{xxx}, 464 \mathrm{p}$. diagrs., tables. (Studies in the mass media of communication) $\quad 55-8526 \quad$ BV656.3.P3

"This volume has grown out of the first serious effort to understand the effects of religious programs broadcast over radio and television. But it is also far more than that: because it undertakes to trace effects within the setting of a concrete community and in the lives of particular individuals, this study reveals a great deal about the total impact of newer methods of communication on an American city and its inhabitants." Conducted by the Communications Research Project supervised by the Yale University Divinity School under the chairmanship of Liston Pope, it analyzes the "church-relatedness" of families in New Haven, Connecticut, and the attitudes of ministers towards broadcasting. It surveys television and radio set ownership and contrasts the personality traits of the audiences that listen with 
those that do not listen to religious programs. The authors believe that its central and most important finding is "that in programming for religious use of the mass media, the ingenuity and flexibility of the planners must match the complexity of needs and circumstances of the potential audience." It will serve as a pilot study for those who desire to apply the techniques of the survey to a similar study of other communities.

4703. Siepmann, Charles A. Radio, television and society. New York. Oxford University Press, 1950. 410 p. 50-8505 HE8698.S529 Chapter bibliographies included in "Appendix VII": p. $\left[3^{8} 9_{1}-398\right.$.

"The first purpose of this book is to bring the general reader the history of a cultural revolution and to show what has been discovered by research concerning the effects of radio and television upon our tastes, opinions, and values. The second purpose is to deal with broadcasting as a reflection of our time and to throw light upon the problems of free speech, propaganda, public education, our relations with the rest of the world, and upon the concept of democracy itself." The author emphasizes ascertained facts, and is cautious in generalization and criticism, but suggests that "the greatest threat to our culture results from the general underestimation, in mass communication, of the public's potentialities." Materials for further study of the effect of TV on family life, public life, and children; its role in advertising and education; and the standards of American broadcasting will be found in the collection of readings: Television and Radio in American Life, edited by Herbert L. Marx, Jr. (New York, Wilson, I953) and published as volume 25 , no. 2 , of The
Reference Shelf series. It includes an extensive bibliography.

4704. Stewart, Raymond F. The social impact of television on Atlanta households. [Emory University, Ga.] 1952. 137 p.

Bibliography: p. $135^{-1} 37$.

$$
\text { 52-41391 HE8698.S } 8
$$

This is representative of several studies based on interviews that have been made in widely separated areas of the United States on the influence of television on children and on family life in general. This study includes a survey of television ownership in Atlanta, the owners' "interaction with society," and the patterns of behavior within the television family. The owners reported that they went out less in the evening, went to bed later, and engaged in less family conversation.

4705. Wylie, Max. Clear channels; television and the American people, a report to set owners. New York, Funk \& Wagnalls, 1955. 408 p.

54-9743 HE8694.W87

A book concerned with the place of television in American society, by an author who has been a radio and television producer, a college teacher, and an advertising agency executive. He criticizes the critics of television and defends its effects on education, adult reading habits, and the morals of children. He raises the controversial issues of televising sports and governmental functions; challenges educators to learn the techniques of TV broadcasting and to take advantage of the channels reserved by the FCC for cultural programs; and points to television as a medium for the improvement of public health in the United States.

\section{E. Government Regulation}

4706. Edelman, Jacob M. The licensing of radio services in the United States, 1927 to 1947; a study in administrative formulation of policy. Urbana, University of Illinois Press, 1950. 229 p. (Illinois studies in the social sciences, v. 31 , no. 4) 50-63485 HE8693.U6E 4

Bibliography: p. 224-226.

$\mathrm{H}_{3}$ I. I 4 , v. $3 \mathrm{I}$, no. 4

The development of the body of rules and decisions that has governed radio broadcasting since the organization of the Federal Radio Commission in 1927 is traced through its first two decades, with the leading policy developments of $1947-5^{\circ}$ described in footnotes. The author thinks that, on the whole, regulation by independent commission has proved "an adequate device for maintaining a continuing surveillance" over an area of rapid change and many controversial issues. Certain "striking departures from declared policy" by the Commission, usually in the direction of greater profitability of broadcast operation, have resulted from the fact that at its hearings the industry is strongly repre. sented, while "groups that represent listeners are rare, and those that do arise become impotent with impressive regularity." Laurence F. Schmeckebier in The Federal Radio Commisison; Its History, Activities and Organization (Washington, Brookings Institution, 1932. $162 \mathrm{p}$. Institute for Gov- 
ernment Research. Service monographs of the United States Government, no. 65) describes in detail the regulatory functions of that body, which was superseded in 1934 by the Federal Communications Commission.

4707. Herring, James M., and Gerald C. Gross. Telecommunications; economics and regulation. New York, McGraw-Hill, 1936. 544 p. illus. 36-23240 $\mathrm{HE}_{206 . \mathrm{H}_{4}}$

The economic and public service aspects of the telegraph, including submarine telegraphy, telephone, and radio industries, are traced in this book from the beginnings of those industries to the passage of the Communications Act of 1934. To this end chapters deal with revenue and expenditures, criteria for rate adjustments, concentration of ownership, and State, National, and international regulation. The authors believe that the Act of 1934 laid the groundwork for the accomplishment of its central purpose: so to regulate communication by wire or radio as to make available to the people of the United States a rapid, efficient, nation-wide, and world-wide service with adequate facilities at reasonable charges. The book is now considerably out-of-date, but remains quite unreplaced.

4708. Rhyne, Charles S. Municipal regulations, taxation and use of radio and television. Washington, National Institute of Municipal Law Officers, 1955. 84 p. ([National Institute of $\mathrm{Mu}$ nicipal Law Officers, Washington, D. C.] Report no. 143 ) 55-24929 JS 35 I.N3, no. I43

Most cities are themselves users of radio frequencies, regularly in their police and fire departments, and sometimes in municipal programs and stations. They are called upon to take regulatory action about such problems as interference with radio and television reception, the erection of transmitters and antennas, community television systems, the examination and licensing of TV and radio repairmen, and even program content. They have also to secure some contribution from commercial radio and TV stations to the cost of municipal government. This handbook attempts to bring together information on the present state of municipal action in these fields and prints some typical ordinances and regulations in an appendix.

4709. Robinson, Thomas Porter. Radio networks and the Federal Government. New York, Columbia University Press, 1943. 278 p.

$$
\text { A 43-2030 HE9711.U } 5 \text { R6 } 1943
$$

Thesis (Ph. D.)-Columbia University, I943.

Bibliography: p. [265]-267.

Between 1937 and 194 I Congress and the Federal Communications Commission investigated the three great radio networks-the National Broadcasting Company and the Columbia and Mutual Broad casting Systems-as a form of monopolistic control of individual stations. This dissertation draws upon the hearings of the Senate Interstate Commerce Committee and of the Commission to illustrate the operation of network control in such matters as artist contracts, station rates, and the rejection of programs, and emphasizes the relationship between the Commission and NBC. Convinced that network organization is economically inevitable, the author takes exception to a number of the new regulations which the Commission promulgated subsequent to the investigations.

4710. U. S. Federal Communications Commission. Investigation of the telephone industry in the United States. Letter from the Chairman, Federal Communications Commission, transmitting a report of the Federal Communications Commission on the investigation of the telephone industry in the United States, as unanimously adopted by the Commission . . . Washington, U. S. Govt. Print. Off., r939. xxv, 661 p. illus., tables, diagrs. (76th Cong., Ist sess. House. Document 340)

39-26969 HE8803.A5 1939

Referred to the Committee on Interstate and Foreign Commerce and ordered printed with illustrations June 14, 1939.

This report resulted from a joint resolution of the Congress, approved by the President on March 15, 1935. The investigation took four years and naturally focused upon the American Telephone and Telegraph Company, whose officials exert "effective nation-wide control" over the Bell Telephone System, and of which the Western Electric Company is the manufacturing department. It covers such aspects of the industry as corporate and financial history; capital structure; intercompany relationships; service contracts; accounting methods; apportionment of investment, revenues, and expenses between state and interstate operations; methods of competition; the effect of monopolistic control upon telephone rates and charges; and the reasons for failure to reduce rates and charges during years of declining prices. The Commission concluded that this investigation had provided it "with basic data to serve as the foundation for the inauguration and development of continuous and efficient administrative processes in the highly technical field of telephone regulation." "During the course of the investigation, and as a result of the direct efforts of the investigatory staff, telephone-rate reductions now aggregating in excess of $\$ 30,000,000$ were effected in the interest ... of the American telephone-using public." 


\section{4 / A GUIDE TO THE UNITED STATES}

4711. U. S. President's Communications Policy Board. Telecommunications, a program for progress; a report. Washington, U. S. Govt. Print. Off., I95I. $238 \mathrm{p}$.

5I-60572 $\mathrm{HE}_{7763 . \mathrm{A}_{44}} \mathrm{r}_{95 \mathrm{I}}$

A summary of the information concerning the radio, telephone, and telegraph services gathered during a year's study by the President's Communications Policy Board. The five problems examined are: policies and plans for reconciling the conflicting interests and needs of Government and private users of the spectrum space; management of the total telecommunications resources to meet the changing demands of national security; a national policy for international telecommunications agreements; maintaining a sound telecommunications industry; and strengthening the Government's own organization to cope with those issues. Concerning the last problem, the principal recommendation of the Board was the establishment "in the Executive Office of the President a three-man Telecommunications Advisory Board to advise and assist the President in the execution of his responsibilities in the telecommunications field." 


\section{Science and Technology}

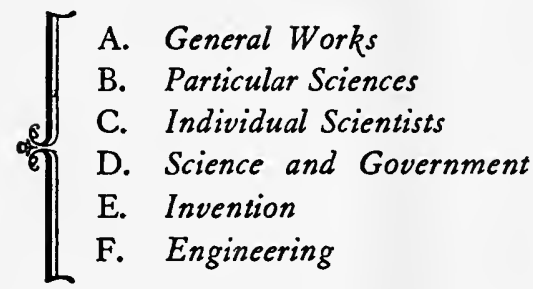

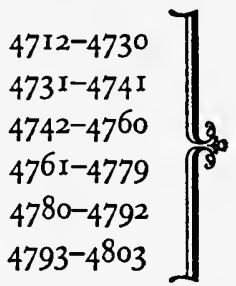

T HE recognition of science as a determining factor in American economic and social progress has been furthered by its decisive influence on the political future of the United States as shaped by two world wars. A comparison of this chapter with others in this bibliography makes it clear that the history of the physical sciences and their application has been somewhat neglected by the historical profession. Several reasons have been advanced for this-the difficulty of sorting the purely American contributions from the larger framework of world science, neglect in preserving the letters and papers of scientists, the hesitation among historians to invade specialized fields, and the apparent indifference of scientists to interpreting the achievements of science in relation to other aspects of American life. The books in Section A by Hindle (no. 4718), Jaffe (nos. 4721, 4722), Johnson (no. 4723), and Struik (no. 4730) show that a start has been made toward the coverage of certain periods and geographical areas, although much remains to be done in the basic sciences to fill up the outline provided by Oliver in his History of American Technology (no. 4727). Section B indicates that certain sciences have received more attention than others, and that the complete history of mathematics, physics, and other branches remains to be written. To round out the picture, histories of representative scientific societies, and collective biographies of scientists in general, or of scientists working in a particular branch, have been added to the first two sections. Section $\mathrm{C}$ contains a selection of biographies of individual scientists,

many of whom are great names reflecting major advances in their fields, while others are probably more representative than great. The publications in Section $\mathrm{D}$ describe the interrelations that have developed between science and government, especially the Federal Government, in the service and defense of human welfare. It includes histories of major organizations such as the Smithsonian Institution (no. 4775) and the National Science Foundation (no. 4778, annotation), and surveys of Federal aid to scientific research and resources in terms of manpower and materials, as well as treatments of certain Government agencies whose functions are primarily scientific. In Sections $E$ and $F$ histories of invention and engineering science, and biographies of inventors and engineers have been assembled to illustrate the application of science in technological achievements which fulfill human needs. However, the technological aspects of medicine, agriculture, and the graphic arts will be covered in other chapters.

\section{A. General Works}

4712. American men of science; a biographical directory. 9th ed. Edited by Jaques Cattell. Lancaster, Pa., Science Press., 1955-56. 3 v. 6-7326 Q141.A47
American Men of Science originated as a manuscript reference list for the Carnegie Institution of Washington. The latest edition has been divided into three volumes to accommodate "a phenomenal 
recent expansion in almost every field of science." The first volume, "Physical Sciences," includes biographical sketches of living scientists in the fields of the physical, mathematical, chemical, and geological sciences. Volume II, "Biological Sciences," includes those in the fields of zoology, botany, medical research, and affiliated areas. Volume III, "The Social \& Behavioral Sciences," contains names and fields not previously found in American Men of Science. To the biographies of those in the fields of psychology, geography, and anthropology, which appeared in the earlier editions, have been added many names in other branches of the social sciences such as economics, sociology, and government. The three volumes form an outstanding reference tool in all fields of science. In I95 I the U. S. Department of Labor published as its Bulletin no. 1027: Employment, Education, and Earnings of American Men of Science, by Theresa R. Shapiro and Helen Wood (Washington, U. S. Govt. Print. Off. $4^{8}$ p.), which is a statistical analysis based upon a questionnaire sent out to gather information for a "roster of key scientists for use by the National Research Council, the Department of Defense, and other agencies concerned with our supply of scientific personnel, and to provide data for the 1949 edition of The Biographical Directory of American Men of Science."

4713. Bates, Ralph S. Scientific societies in the United States. New York, Wiley, 1945. 246 p. $\quad 45-5801$ Qri.ArB3

"A publication of the Technology Press, Massachusetts Institute of Technology."

Bibliography: p. 193-220.

As the first extensive history of the work of American scientific societies, this book fills "a gap in the literature dealing with the intellectual history of our country." It traces their growth and influence from the organization of Benjamin Franklin's Junto in 1727 , which laid the foundation of the American Philosophical Society, the oldest scientific society now in existence in America, to the year 1944. Recognized as "outstanding agencies for increasing and diffusing the world's store of knowledge," national, state, and local scientific bodies proliferated during the period of "National Growth, 1800-1865," which witnessed the founding of the National Academy of Sciences to furnish technical advice to the government in the prosecution of the Civil War. Specialization was the dominating idea of the years 1866 to 1918 , which saw the foundation of national societies in the various branches of science and technology. During the period Igrg to 1944 American scientists found their places in international scientific organizations; the National Research Council and other councils co- ordinated, directed, and initiated scientific projects; and American science reached a maturity that created interest in its own history.

4714. Bell, Whitfield J. Early American science, needs and opportunities for study. Williamsburg, Va., Institute of Early American History and Culture, I955. 85 p. 56-2II Q127.U6B 35

Sponsored by the Institute of Early American History and Culture, this is the first in a series of studies in several specialized fields that have been inadequately investigated. Of its two parts, the first surveys, and documents with bibliographical footnotes, the categories in which further study is needed. The second part is a bibliography, classified in sections on "The General History of Science"; "History of Science in America (to about 1820)"; "Periodicals, Devoted to, or Often Publishing Contributions to, the History of Science"; and "Fifty Early American Scientists (to about 1820 )." Titles cited in the first part are as a rule not repeated in the second. The author hopes that the study will suggest to students new subjects and materials that should be explored in every aspect of the history of early American science. To assist them, "the staff of the Institute will gladly provide, when it can, further specific sug. gestions for research on any of the topics mentioned here or on others like them."

4715. A Century of science in America, with special references to the American journal of science, 1818-rgr8. New Haven, Yale University Press, I918. $45^{8}$ p. (Yale University. Mrs. Hepsa Ely Silliman memorial lectures) $\quad$ 19-218 Q127.U6C 3

Contains bibliographies.

Fourteen scientists contribute chapters in the areas of their competence to this volume commemorating the centennial of the founding of the American Journal of Science, "the only scientific periodical in this country to maintain an uninterrupted existence since that early date." The chapters throw light on the scope of the papers published in the Journal, and the development of the particular branches of science as they emerged from 1818 to 1918 . Four chapters on various phases of geology by Charles Schuchert, Herbert E. Gregory, Joseph Barrell, and George Otis Smith, reflect the prominent place which geological notes and papers have occupied in the Journal since its inception. Other chapters are devoted to Paleontology, by Richard Swann Lull; Petrology, by Louis V. Pirsson; Mineralogy, by William E. Ford; the Geophysical Laboratory of the Carnegie Institution of Washington, by R. B. Sosman; Chemistry, by Horace L. Wells and Harry W. Foote; Physics, by Leigh Page; Zoology, by Wesley R. Coe; and Botany, by George L. Goodale. The increase in the amount of periodical scientific literature during 
the century under discussion indicates the growing place of scientific investigation in the intellectual life of the period.

4716. Coleman, Laurence V. Company museums. Washington, American Association of $\mathrm{Mu}$ seums, 1943. I73 $\mathrm{p}$. 43-51215 Ti79.C6

The director of the American Association of Museums points out that 80 business companies in the United States-manufacturing corporations, commercial houses, railroads, public utilities, newspapers, banks, and insurance companies-are known to have museums of their own. He gives a brief history of the museum movement in business, which had its beginning in the Igth century, and describes the usefulness of museums as builders of company morale, as reference tools, and as vehicles for good public relations. He discusses all phases of museum work-management, quarters, collecting, exhibition, and interpretation of the collection to visitors. The field work for this study was carried out in 1942 by Carl C. Curtiss, who also compiled the descriptive directory of "Company Museums in the United States" which appears in the Appendix. Organizers and managers of such museums will find this book a useful guide, and for the student of American technological development it contains a wealth of suggestions and sources.

4717. Fairchild, Herman Le Roy. A history of the New York Academy of Sciences, formerly the Lyceum of Natural History. New York, The Author, I887. Igo p. I-6I7 QIr.N67

Founded in $18 \mathrm{I} 7$ for the study of natural history, "particularly as it relates to the illustration of the physical character of the country we inhabit," the New York Academy of Sciences is the fourth oldest scientific society in the United States. In 1836 it opened its own Lyceum Building at 56r-65 Broadway, only to lose it 8 years later as a consequence of the financial panic of 1837 . In 1876 it adopted its present name in order to accommodate "those working in all departments of science." Ten years later the Academy's recording secretary put together this modest account of its first seven decades from its minutes and other records, and included chapters on its foundation, original members, offcers, collections, library, and publications, as well as biographical notices of its leading members. The Academy's second 70 years, even more productive than the first, remain unchronicled.

4718. Hindle, Brooke. The pursuit of science in Revolutionary America, 1735-1789. Chapel Hill, Published for the Institute of Early American
History and Culture, Williamsburg, Va., by University of North Carolina Press, 1956. 410 p. $56-4168$

"Bibliographical note": p. 387-392. Q127.U6H5

The author's interest in this subject began with his doctoral dissertation, The Rise of the American Philosophical Society, 1766-1787 (Philadelphia, 1949. 66 1.). Of the book's three parts, the first depicts the group in America, England, and on the Continent who studied the natural history of the colonies, and through correspondence and exchange of specimens created intercolonial and international bonds. The second period $(1763-75)$ is characterized by the rise of scientific societies and the publication of astronomical observations which impressed Europeans with a new maturity in American scientific thought. In the third period, the men, the institutions, and the interrelations that had sustained science were disrupted by the Revolution. However, such statesmen as Washington, Franklin, Jefferson, and Adams were determined that science should flourish in America, and that the spark which had been kindled should not die. The "unprecedented richness of modern America is a monument to the faith of the Revolutionary generation in the power and beneficence of science, just as its form of government is a monument to their faith in man's capacity to govern himself."

4719. Hornberger, Theodore. Scientific thought in the American colleges, 1638-1800. Austin, University of Texas Press, I945. 108 p.

$$
\mathrm{A}_{46-1632} \mathrm{Q} 8 \mathrm{8} \text {. } \mathrm{H}_{77}
$$

Published as Project no. 67 of the University Research Institute.

Of the 27 colleges which existed in the United States prior to 1800 , the author gives some information about 16 , although only Harvard, Yale, William and Mary, Princeton, Columbia, Pennsylvania, Brown, and Dartmouth had enough of a history by that date to make it proper to speak of their cultural influence. From 1640 to 1690 geometry, physics, and astronomy held a very minor place in the curriculum. During the next 50 years "natural philosophy," botany, zoology, and chemistry emerged as regular subjects, and experimental demonstrations with "philosophical apparatus" in the classroom became the rule. An analysis of the attitudes of representative alumni toward science leads the author to conclude that those of the first period shared an enthusiasm for the "new science" which, in the years 1690 to 1740 , gave way to a growing sense of conflict between science and religion. However, "by the end of the 18 th century . . . 'science' had become a word to conjure with." A beautifully illustrated book by I. Bernard Cohen, Some Early 
Tools of American Science (Cambridge, Harvard University Press, 1950. 201 p.), describes in detail the "philosophical apparatus" at Harvard University from 1764 to 1825 and, in certain aspects, is also a history of science as taught at Harvard during that period.

4720. Industrial research laboratories of the United States. roth ed. Comp. by James F. Mauk. Washington, National Academy of Sciences, National Research Council, 1956. 560 p. (National Research Council Publication 379)

$$
\text { 21-26022 Ti76.165, no. } 379
$$

A directory of 4,834 nongovernmental research laboratories including those maintained by commercial firms and trade associations, independent commercial laboratories, and independent nonprofit laboratories. Testing and university laboratories are not included. The addresses, names of presidents, and, in some cases, of other executive officers are given, and the size, makeup, and activities of the research staff are described. The great increase in the number of laboratories listed since the first edition appeared in 1920 is an indication of the growing dependence of business and industry on research.

472I. Jaffe, Bernard. Men of science in America; the role of science in the growth of our country. New York, Simon \& Schuster, r 944. xl, 600 p. 44-5618 Q127.U6J27

"Sources and reference material": p. 555-57I.

Contents.- - I. Thomas Harriot (naturalist and mathematician), bringing the seeds of science to America.-2. Benjamin Franklin (natural philosopher), the first fruit of American science.-3. Benjamin Thompson (physicist), science faces the tumult of the American Revolution.-4. Thomas Cooper (chemist), science advances slowly in the newborn Republic. -5 . Constantine Samuel Rafinesque (botanist), American science ventures out across new frontiers.-6. Thomas Say (entomologist), science caught in the first uprush of an industrial revolution.-7. William T. G. Morton (anesthetist), American makes medical history.-8. Joseph Henry (physicist), the United States government establishes a new incubator for science. - 9 . Matthew Fontaine Maury (hydrographer), America contributes to the science of the sea.-1o. Louis J. R. Agassiz (biologist), the repercussions of Darwinism in the United States.-I I. James Dwight Dana (geologist), Federal and state surveys aid the advances of science.-12. Othniel Charles Marsh (paleontologist), dinosaurs and other fossils of our gilded age.-13. J. Willard Gibbs (mathematical physicist), America in the new world of chemistry.14. Samuel Pierpont Langley (aeronautical engi- neer), American science gives men wings.-I5. Albert Abraham Michelson (physicist), America participates in the revolution of modern physics.16. Thomas Hunt Morgan (geneticist), American science come of age.-17. Herbert McLean Evans (anatomist), American science pioneers in two new related fields.-I8. Edwin Powell Hubble (astronomer), giant instruments and huge foundations for American science.- r 9. Ernest Orlando Lawrence (nuclear physicist), the turn of the tide in world science.-20. Future of science in America.

"With a view to finding possible relationships between the kind of science which developed in America and the type of civilization which has flourished here," the author bases his selection of 20 scientists on the significance of their contributions as pioneer research, with emphasis on the pure sciences and the workers' awareness of the social scene in which they worked. He thereby illustrates the interdependence between scientific progress and political and social history in the United States.

4722. Jaffe, Bernard. Outposts of science; a journey to the workshops of our leading men of research. New York, Simon \& Schuster, 1935. xxvi, 547 p. 35-31946 Q127.U6J3

"Sources and reference material": p. 517-529.

Selecting 13 Americans eminent for scientific research in as many different fields, the author interviewed them, visited their laboratories, and studied their scientific papers. Seeking to "give the average reader some idea of the tremendous activity going on behind the doors of the laboratories of science," he outlines the development of their specialties and against this background presents the significance of their specific achievements. Separate chapters describe and evaluate the work of Thomas Hunt Morgan in genetics, Aleš Hrdlička in anthropology. William $\mathrm{H}$. Welch in bacteriology and immunology, Maud Slye in cancer research, John Jacob Abel in endocrinology, Adolf Meyer in psychiatry, Elmer $\mathrm{V}$. McCollum in nutrition, Leland $\mathrm{O}$. Howard in entomology, Robert A. Millikan in atomic physics, Arthur H. Compton in radiation, George Ellery Hale in astrophysics, Charles G. Abbot in meteorology, and Richard C. Tolman in astronomical cosmology. All of these scientists save Morgan, who died soon after his interview, reviewed and approved Jaffe's account of their work. The volume gives a vivid panorama of American scientific investigation two decades ago.

4723. Johnson, Thomas Cary. Scientific interests in the Old South. New York, AppletonCentury, for the Institute for Research in the Social Sciences, University of Virginia, 1936. 217 p. 
(University of Virginia. Institute for Research in the Social Sciences. Institute monograph no. 23) 36-28317 Q127.U6J6

This is "a study of the attitude of the planters, politicians, and professional men of the Cotton Kingdom and of their wives and daughters toward the natural sciences." The author analyzes the faculties, curriculum, and apparatus found in the colleges and "female academies" in order to illustrate the interests of teachers and students in scientific writing, societies, and study. The appearance of articles on chemistry, physics, astronomy, and botany in the newspapers and periodicals; the popularity of lectures on the natural sciences; attempts to establish museums; and the formation of circles bent on scientific investigation witness to the South's awareness of the achievements of science. The author includes chapters on scientific developments in cities as wide apart, traditionally and culturally, as Charleston and New Orleans, and concludes that "the common assumption that the Old South was a gloomy region cut off from the scientific light of the Occidental world seems to be unsustained by the evidence."

4724. Jordan, David Starr, ed. Leading American men of science. New York, Holt, 1910. 471 p. 17 port. (Biographies of leading Americans, $\begin{array}{lll}\text { edited by W.P. Trent) } 10-26275 & \text { Q14I.J7 }\end{array}$ Contents.-Benjamin Thompson, Count Rumford, physicist, by Edwin E. Slosson.-Alexander Wilson [and] John James Audubon, ornithologists, by Witmer Stone.-Benjamin Silliman, chemist, by Daniel Coit Gilman.--Joseph Henry, physicist, by Simon Newcomb.-Louis Agassiz, zoologist, by Charles Frederick Holder.-Jeffries Wyman, anatomist, by Burt G. Wilder.-Asa Gray, botanist, by John M. Coulter.-James Dwight Dana, geologist, by William North Rice.-Spencer Fullerton Baird, zoologist, by C. F. Holder.-Othniel Charles Marsh, paleontologist, by George Bird Grinnell.-Edward Drinker Cope, paleontologist, by Marcus Benjamin.-Josiah Willard Gibbs, physicist, by Edwin E. Slosson.-Simon Newcomb, astronomer, by Marcus Benjamin.-George Brown Goode, zoologist, by D. S. Jordan.-Henry Augustus Rowland, physicist, by Ira Remsen.-William Keith Brooks, zoologist, by E. A. Andrews.

"Short and sympathetic biographies of [17] leaders in American science, each one written by a man in some degree known as a disciple." Dr. Jordan chose the subjects and the authors, but was compelled to turn the remainder of the editorial work over to Dr. Slosson. Simon Newcomb, author of the sketch of Joseph Henry, died while the work was still in progress, and was promptly added to the list of subjects. American scientific progress for more than a century is largely summed up in the work of these men, whose lives span the years 1753 to 1909 .

4725. Knapp, Robert H., and Hubert B. Goodrich. Origins of American scientists; a study made under the direction of a committee of the faculty of Wesleyan University. Chicago, University of Chicago Press for Wesleyan University, Middletown, Conn., 1952. xiv, 450 p. 52-1461 I Q127.U6K55

This book may be considered, in part, an attempt to answer some of the questions raised by the President's Scientific Research Board in its report (no. 4779) which indicated a shortage of scientific personnel in relation to the probable requirements of the American nation. This study is the result of a statistical analysis of several hundred institutions in an attempt to establish their effectiveness in the education of scientists, and intensive case studies of 22 smaller colleges (Appendix, p. 299-43I). It sets up criteria for the selection of students by colleges and recommends colleges of "broad intellectual emphasis" to students. The information regarding types of institutions which have been most successful in training scientists should be helpful to all who plan a scientific education. The authors also evaluate comparable studies of scientific personnel, pointing out the limitations of some. Special weight is given to Stephen S. Visher's Scientists Starred, 19031943, in "American Men of Science" (Baltimore, Johns Hopkins Press, 1947. 556 p.), which studies the education, birthplace, distribution, background, and developmental factors of those regarded by their colleagues as outstanding scientists.

4726. A Memorial of George Brown Goode, together with a selection of his papers on museums and on the history of science in America. Washington, Govt. Print. Off., 1901. 515 p. 110 port. (Annual report of the Board of Regents of the Smithsonian Institution ... 1897. Report of the U.S. National Museum, pt. 2)

14-I9898 Qir.U5 I897, pt. 2

The memorial meeting was held February 13, 1897 , in the lecture room of the United States National Museum, under the auspices of the Joint Commission of the Scientific Societies, and in cooperation with the patriotic and historical societies of Washington.

Report of the meeting held in commemoration of the life and services of George Brown Goode, with a memoir by Samuel P. Langley: p. I-6I.

Papers by George Brown Goode (p. 63-477): Museum-history and museums of history.-The genesis of the United States National Museum.The principles of museum administration.-The museums of the future.-The origin of the national scientific and educational institutions of the United 
States.-The beginnings of natural history in America.-The beginnings of American science.The first national scientific congress (Washington, April, I844) and its connection with the organization of the American Association.

The published writings of George Brown Goode, 1869-1896. By R. I. Geare: p. 479-500.

Dr. Goode, although cut off by pneumonia in his 46 th year, accomplished more than most men during his life $\left(185^{1-96)}\right.$. He was an authority on fishes, and co-author of the monumental Oceanic Ichthyology (Washington, Govt. Print. Off., 1895. 2 v.). Since 1887 he had been Assistant Secretary of the Smithsonian Institution, in charge of the National Museum, and was the outstanding museum administrator of his day. Many of the papers collected here are still, after six decades or more, among the most valuable writings on their subjects.

4727. Oliver, John W. History of American technology. New York, Ronald Press, 1956. 676 p. $\quad 56-6269$ T2r.O45

"The distinction of this volume is that it represents the first comprehensive historical account of American technology and invention as a basic contribution to the nation's culture," says Guy Stanton Ford in a brief foreword. Largely a compilation from secondary authorities, it derives its value from its systematic inclusiveness, and from its regular emphasis on the technological foundations of economic developments which are in other respects well known. Even in the $17^{\text {th }}$ century the American colonists designed new tools, and devised new methods of cultivating the soil, tanning leather, and processing wool and flax: already "American technology was born." "The 'homespun' age was on its way out during the second decade of the igth century." In America's industrial revolution, unlike England's, the workers, farmer-mechanics trained in the workshops of New England, welcomed the machine. As early as 1798 Eli Whitney evolved "the system of interchangeable parts and thus paved the way for America's unique contribution to world technology-mass production." By 1850 America had become "a nation alert to science" as the principal agency of social progress. The author pursues his subject with unflagging enthusiasm through the age of steel and the electrical age, and concludes with an optimistic glance at the potential effects of automation. The footnote references at the end of each chapter are supplemented when necessary by a bibliographical note.

4728. Scientific and technical societies of the United States and Canada. 6th ed. Washington, National Academy of Sciences, National Research Council, 1955. 447 p.

$27-21604$

$\mathrm{AS}_{15} . \mathrm{H}_{3}$
This handbook appeared first in 1908 , and further editions were published between 1927 and 1948 . In this edition entries are limited to "membership group organizations," and other categories, such as trade associations with research activities, have been eliminated. The data on Canadian associations have been supplied by the National Research Council of Canada. In addition to the address, names of officers, and date of organization, the purpose, number of members, frequency of meetings, size of library, research funds, medals awarded, and publications of the societies are given.

4729. Special Libraries Association. Science-Technology Division. Handbook of scientific and technical awards in the United States and Canada, r 900-1952. Edited by Margaret A. Firth. New York, Special Libraries Association, 1956. xxiv, 49I p.

56-7004 Q141.S63

A "selected listing of the most important awards presented by certain of the scientific and technical societies in the United States and Canada to individuals in recognition of their meritorious achievement in scientific fields." Awards granted by foundations, universities, publishers, and companies are not included. The separate listings for the United States and Canada are arranged alphabetically under the names of the societies. The recipients are listed chronologically under the names of the societies. Personal name, award title, and subject indexes permit of ready reference. Through 1928 only the names of recipients are supplied. Reference to published sources of information about their lives and the circumstances of the awards are cited from 1929.

4730. Struik, Dirk Jan. Yankee science in the making. Boston, Little, Brown, 1948. xiii,

$430 \mathrm{p}$.

Bibliography: p. $\left[3^{87}\right]-416$. 48-8195 Q127.U6S8 1948

A professor of mathematics at the Massachusetts Institute of Technology investigates science and technology in the stable community of New England between $I 780$ and 1860 , on the premise that the history of science "must include its sociology." The colonial and revolutionary periods are briefly treated in two preliminary chapters. In $1780 \mathrm{New}$ England had only a few scientists, with interests limited to astronomy, medicine, or agronomy, and this situation was not greatly altered during the Federalist period. Only with the Jacksonian period, opening about 1830 , did there arise "a mass interest in science and technical questions." Major scientific institutions were founded, civil engineering became an influential profession, and technological advances permitted modern industries to assume their shapes. By 1863 , when President Lincoln or- 
ganized the National Academy of Sciences, "New England science had grown into American science."
Sketches of many significant figures in pure science and technology are incorporated in the narrative.

\section{B. Particular Sciences}

4731. Browne, Charles Albert, and Mary Elvira Weeks. A history of the American Chemiical Society, seventy-five eventful years. Washington, American Chemical Society, 1952. 526 p.

Includes bibliographies.

53-238 QDi.A58

Partial contents.-Precursors.-Beginnings.The secession period.-The new order.-The twenty-fifth anniversary, before and after.-Specialization and dangers of disunion.-Strivings for consolidation.-International relations, I876-19I4.The American Chemical Society and the First World War.-The Society completes its first half century.-The start of the Society's second half century.-The American Chemical Society during the Second World War.-The postwar reorganization.-Growth and readjustment.-Increasing professional consciousness.-International relations, 1918-1951.-Contributions of the Divisions.-Publications.-Awards, memorial lectures, and research foundations.-The diamond jubilee.

Dr. Browne, historian of the American Chemical Society from 1945 until his death in 1947, completed only nine chapters of this history. Dr. Weeks of the staff of the Kresge-Hooker Scientific Library at Wayne University completed the unfinished chapters and supplied the supplemental material. The Preface is, for the most part, a memorial to Dr. Browne.

4732. Chittenden, Russell $\mathrm{H}$. The development of physiological chemistry in the United States. New York, Chemical Catalog Co., 1930. 427 p. (American Chemical Society. Monograph series, no. 54) 30-32722 QP 5 I4. $\mathrm{C}_{5}$

The American Chemical Society, by arrangement with the Interallied Conference of Pure and Applied Science (1919), undertook the production of a series of scientific and technological monographs of which this study is one. The author's association with the first laboratory of physiological chemistry in America at the Sheffield Scientific School, Yale University, where he was professor of the subject from I882 to 1922, has given him exceptional competence to write this history. He traces the development of physiological chemistry in the United States from 1870 to the late 1920 's in the scientific laboratories and investigations, the personalities and writings, and the universities and experimental stations which have contributed to the "knowledge of the chemicophysiological processes of the animal body."

4733. Fairchild, Herman Le Roy. The Geological Society of America, 1888-1930. A chapter in earth science history. New York, The Society, 1932. xvii, 232 p. 32-24464 QEI.G218F 3

At the request of the Council of the Geological Society of America, the secretary of the Society from 1891 to 1906 , who also served as president in 1912 , has written a history of the Society from its formal organization by himself and twelve Fellows, since deceased, on December 27, 1888, to 1930 . The story of the Society and its offshoots-the Paleontological Society, the Mineralogical Society of America, and the Society of Economic Geologists-is preceded by an historical sketch of geological science from its Greco-Latin beginnings during the five centuries before Christ, to its development in Western Europe and America through the year 1888 . While this history was in the press the Society was bequeathed some four and a quarter million dollars, which placed it among the wealthiest scientific societies in the United States.

4734. Geiser, Samuel W. Naturalists of the frontier. [2d. ed., rev. and enl.] Dallas, University Press, Southern Methodist University, 1948. $296 \mathrm{p}$. 48-7357 QH26.G $42 \quad 194^{8}$

"Principal sources": p. 264-269.

Contents.-The naturalist on the frontier.Jacob Boll.-In defense of Jean Louis Berlandier.Thomas Drummond.-Audubon in Texas.-Louis Cachand Ervenberg.-Ferdinand Jakob Lindheimer.-Ferdinand Roemer, and his travels in Texas.-Charles Wright.-Gideon Lincecum.Julien Reverchon.-Gustaf Wilhelm Belfrage.Notes on scientists of the first frontier.

The beginnings of science in the Southwest, especially Texas, and the struggle for economic survival on the frontier are presented in the biographies of these early naturalists. The second edition contains one biography and a chapter on scientific study in the Old South prior to $185^{\circ}$ which did not appear in the first (1937). The author says that the men whose lives have been sketched here are but a handful compared with the scores of workers "who dur- 
ing the frontier period contributed to our cultural and scientific advance," and appends a "Partial List of Naturalists and Collectors in Texas" (p. 270284 ), which gives some biographical information and references to sources. Joseph A. Ewan suggests that his Rocky Mountain Naturalists (Denver, University of Denver Press, 1950. $35^{8}$ p.) may be used as a companion piece to Geiser's book. It contains biographical sketches of Edwin James, John C. Frémont, Charles C. Parry, Edward L. Greene, Thomas C. Porter, Harry N. Patterson, Marcus E. Jones, Eugene Penard, and Theodore D. A. Cockerell; a 200-page roster of Rocky Mountain naturalists (1682-1932); and bibliographical notes.

4735. Haynes, Williams. Chemical pioneers; the founders of the American chemical industry. New York, Van Nostrand, 1939. 288 p.

$$
\text { 39-1746r } \operatorname{TP}_{3} 39 \cdot \mathrm{H}_{3} 8
$$

Originally published serially in Chemical Industries, and projected as a two-volume work, the second volume of which apparently has not been published. After describing the pioneer efforts of John Winthrop, Jr., in I 7 th-century Massachusetts, the volume outlines the lives of 15 men born between $180 \mathrm{I}$ and 1865 whose activities extended from pure research to the development of practical processes and the organization of complex manufacturing enterprises. The progress of a new technology and a new industry is illustrated in these sketches of George D. Rosengarten, Martin Kalbfleish, Alexander Cochrane, James Jay Mapes, Eugene R. Grasselli, George T. Lewis, Lucien C. Warner, Edward Mallinckrodt, August Klipstein, Ernest C. Klipstein, Martin Dennis, Jacob Hasslacher, John F. Queeny, and Frank S. Washburn.

4736. Meisel, Max. A bibliography of American natural history; the pioneer century, 1769r865; the rôle played by the scientific societies; scientific journals; natural history museums and botanic gardens; state geological and natural history surveys; federal exploring expeditions in the rise and progress of American botany, geology, mineralogy, paleontology and zoology. Brooklyn, N. Y., Premier Pub. Co., 1924-29. 3 v. 24-30970 Z7408.U5 $\mathrm{U}_{5}$

Contents. - v. I. An annotated bibliography of the publications relating to the history, biography and bibliography of American natural history and to institutions, during colonial times and the pioneer century, which have been published up to r924; with a classified subject and geographic index; and a bibliography of biographies.- - v. 2. The institutions which have contributed to the rise and progress of American natural history, which were founded or organized between 1769 and $1844 .-v$. 3. The institutions founded or organized between 1845 and
1865. Bibliography of books. Chronological tables. Index to authors and institutions. Addenda to v. I.

This work presents in a convenient form so much information concerning the sciences, persons, and institutions with which it is concerned that it is far more than a bibliography. It traces "bibliographically the rise and progress of natural history in the United States, from the formation of an active American Philosophical Society at Philadelphia in 1769 , to the close of the Civil War in 1865, , and is an invaluable guide for all those who are interested in the several branches of natural history which, otherwise, have very limited representation in this chapter. In volumes 2 and 3, the institutional bibliographies, arranged according to date of foundation, are each preceded by a brief history of the organization in question.

4737. Merrill, George P. The first one hundred years of American geology. New Haven, Yale University Press, 1924. xxi, $773 \mathrm{P}$.

$$
\text { 24-2II75 QEr3.U6M6 }
$$

The author was Head Curator of Geology, U. S. National Museum, from 1897 until his death in 1929. This was his third and most comprehensive book on the history of North American geology up to the end of the igth century. Progress during that century, according to Merrill, was "due almost wholly to the accumulation of observed facts and the conclusions drawn therefrom," large deductive hypotheses and synthetic research being impossible until toward its close. Chapter I deals with a period dominated by the Scottish-born William Maclure who made the first geological map of the United States ( 1809 , rev. 1817 ), described as "the first map of its scope in the history of geology." Chapter II describes the influence of Amos Eaton, "the most prominent worker as well as the most profuse writer of the decade." Chapters III to VIII outline the work of State surveys during the five decades from 1830 to 1880 , and the national surveys which culminated in the establishment of the U. S. Geological Survey in 1879 . The former are documented in even greater detail in Merrill's Contributions to a History of American State Geological and Natural History Surveys (Washington, Govt. Print. Off., 1920. 549 p.). The book concludes with a discussion of the age of the earth as variously estimated by a number of geologists and other scientists.

4738. Smallwood, William Martin. Natural history and the American mind. In collaboration with Mabel Sarah Coon Smallwood. New York, Columbia University Press, 1941. xiii, 445 p. illus. (Columbia studies in American culture, no. 8) $\quad 4^{\mathrm{I}-\mathrm{I}_{686}} \quad \mathrm{QH}_{21} \mathrm{U}_{5} \mathrm{U}_{5}$

Bibliography: p. [355]-424. 
"Broadly speaking, natural history included all the concrete sciences," but usually in the form of composite observations without the application of rigorous deductive method. The authors trace this habit of mind in the writings of explorers and travelers in the new continent, and its occasional penetration into the curricula of the colonial colleges. In the course of the I8th century natural history became a serious avocation in Charleston, Philadelphia, New York, and Boston, where it stimulated the establishment of museums, societies, and scientific journals. One chapter deals with the part played by the microscope, and the last records the passing of the exploring naturalist, whose place was taken first by the classifying naturalist, and then by the scientific specialist. The authors have selected for inclusion in this book those individuals who seem typical of the "naturalist's period" (1725 to 1840 or 50). The extensive bibliography indicates the wide-spread research that has gone into this study which, like natural history itself, is miscellaneous and scattering, but contains many interesting glimpses of early American culture.

4739. Smith, David Eugene, and Jekuthiel Ginsburg. A history of mathematics in America before 1900. Chicago, Published by the Mathematical Association of America with the cooperation of the Open Court Pub. Co., 1934. 209 p. (The Carus mathematical monographs, no. 5)

$$
\text { 34-9605 QA27.U5S6 }
$$

The monographs in this series are intended for teachers and students specializing in mathematics, for scientific workers in other fields, and for laymen who wish to increase their knowledge without prolonged study. Here the authors are primarily interested in original research in higher mathematics. They consider the racial inheritance of the colonists, and their limited needs even for applied mathematics. The development of college work, the formation of scientific societies, and the publication of a few mathematical articles in journals still left "modern mathematics ... substantially unknown in America in the 18 th century." The third chapter surveys the work of the igth century down to 1875 , largely "a time of preparation for action." The final chapter, nearly half the book, covers the last quarter of the century, which "saw laid the foundations upon which the scholars of today have so successfully built." It points out the original work then accomplished in algebra, theory of functions, quantics or forms, transformations, calculus, differential equations, theory of numbers, probability, geometry, and other branches.
4740. Smith, Edgar F. Chemistry in America; chapters from the history of the science in the United States. New York, Appleton, rgr4. xiii, $35^{6} \mathrm{p}$. 14-5967 QDi8.U6S6

By the end of the 18 th century chemistry was already a part of the curriculum of the University of Pennsylvania and the American Philosophical Society (1743), although devoted to other subjects, did not exclude chemistry from its interests. "The earliest chemical contribution from this country, bearing the date September 10, 1768 , appears on the pages of the Transactions of this Society" [in vol. r, 1789]. From that beginning, the author has brought together a miscellany of original materials such as lectures, monographs, and letters, with brief biographies of Benjamin Silliman, Robert Hare, J. Lawrence Smith, M. Carey Lea, Oliver Walcott Gibbs, and others, illustrating the development of chemistry in America for more than a hundred years. Several quite long pieces, such as Thomas P. Smith's Sketch of the Revolutions in Chemistry (Philadelphia, 1798), are reprinted in full. The result is an unsystematic source book rather than "chapters of history."

4741. Welker, Robert Henry. Birds and men; American birds in science, art, literature, and conservation, 1800-1900. Cambridge, Belknap Press of Harvard University Press, 1955. $230 \mathrm{p}$.

$$
\text { 55-1 1608 QL68I. W4 }
$$

Selected bibliography: p. [213]-220.

The birds of North America have been described in the writings of explorers, naturalists, and literary men since Columbus, but modern ornithology in the United States began at the opening of the 19th century, when the pioneer specialist, Alexander Wilson (1766-1813), made his tour of the eastern cities, the Ohio and Mississippi Valley frontier, and the Deep South in search of material for his American Ornithology (Philadelphia, 1808-14. 9 v.). Mr. Welker's book is a guide to our I9th-century ornithological literature, and to its interrelations with American belles-lettres, painting, and popular attitudes. In addition to chapters on Wilson and Audubon, the bird artist who was unknown until discovered by Wilson, there are discussions of the place of birds in the writings of Thoreau, Emersen, Whitman, Burroughs, and others. By the end of the century groups for the study and protection of birds had organized the fights against bird-destroying "boys, pot-hunters, women," in a movement for state and federal protection laws which became wide-spread early in the 2oth century. A well selected series of plates illustrates the steady progress in drawing birds, and some instances in which Audubon helped himself to Wilson's sketches. 


\section{Individual Scientists}

4742. [Agassiz] Marcou, Jules. Life, letters, and works of Louis Agassiz. New York, Macmillan, 1895.2 v. illus. 4-17043/2 $\mathrm{QH}_{3} \mathrm{I} . \mathrm{A}_{2} \mathrm{M}_{3}$

His reputation already established by his work on the classification of fishes, the geological distribution of fossil fish, and the glacial theory of the earth, Louis Agassiz (1807-1873) came to the United States in 1846 to deliver a series of Lowell Institute lectures, and remained to become a leader among American naturalists. The author was "the last survivor of the small band of European naturalists who came to America with him," and strove to temper admiration with justice. The quotations are limited to "letters of Agassiz, addressed to practical naturalists, his contempcraries, working on kindred subjects," but include none used by Mrs. Elizabeth Cary Agassiz in her life of her husband (1885). The first volume covers Agassiz' life from his birth in a village in French Switzerland to his arrival in Boston 39 years later. The second narrates his life in the United States-his professorship at Harvard, his association with scientific organizations and expeditions, and his relations to the intellectual society of the period. "By far the most important contribution of Agassiz to natural history during his life in America," Marcou thought, was the Essay on Classification published in 1857 as the introduction to a massive work on the natural history of the United States which was left incomplete after four volumes had appeared. An annotated list of publications concerning Agassiz and a catalog of his scientific writings appear in the Appendixes. Louis Agassiz, Scientist and Teacher, by James D. Teller (Columbus, Ohio State University Press, 1947. I45 p.) discusses "the effect that his personality and vigorous method of attacking the unknown had on the development of teaching and research in America."

4743. [Audubon] Herrick, Francis H. Audubon the naturalist, a history of his life and time. 2d ed. New York, Appleton-Century, 1938. 2 v. in $\mathrm{I}$. illus. $\quad 38-27162 \quad \mathrm{QL}_{31} \mathrm{I} \cdot \mathrm{AgH}_{4} \mathrm{I}_{938}$

"Original documents": v. 2, p. [313]-379.

Bibliography: v. 2, p. $40 \mathrm{I}-46 \mathrm{I}$.

The son of a French planter in Santo Domingo, John James Audubon (1785-1851) left France in I 803 for his father's American estate, Mill Grove, located along Perkiomen Creek in Pennsylvania. It was there that he became interested in American bird life and carried out the first "banding" experi- ment, repeated a hundred years later by the Bird Banding Society, "in order to gather exact data upon the movements of individuals of all migratory species in every part of the continent." From about 1805 he was more or less constantly engaged in drawing or painting birds, which he continued after his removal to Kentucky in 1807 , and even after financial disaster overtook him in $18 \mathrm{rg}$. He eventually found a London engraver and publisher for The Birds of America, which appeared in 87 numbers of 5 plates each during the years $1827-38$. The 435 hand-colored copper-plate engravings were finally bound into four elephant folio volumes, at $\$ 1,000$ the set. The venture was supported by 82 American and 79 European subscribers. Audubon's text explanatory of the engravings was separately published at Edinburgh as Ornithological Biography (183 I-39. $5 \mathrm{v}$.). The present life, the first edition of which appeared in 1917 , is crowded with biographical detail, in part derived from a "unique and extraordinary collection of Audubonian records" which the author discovered in a small French town. Audubon has become the patron saint of American nature students and wildlife conservationists: the numerous State and local Audubon societies bear his name; Mill Grove has been made into a memorial and sanctuary; and I95I was designated as the Audubon Centennial Year.

4744. [Baird] Dall, William Healey. Spencer Fullerton Baird; a biography, including selections from his correspondence with Audubon, Agassiz, Dana, and others. Philadelphia, Lippincott, 1915. xvi, 462 p. 15-11472 QL31.B25D2

Baird (1823-1887) was the second Secretary of the Smithsonian Institution (1878), who also became the first U. S. Commissioner of Fish and Fisheries, and organized the work of the Commission, the predecessor agency of the present Fish and Wildlife Service. This biography is based on data collected and arranged by his daughter, Lucy Hunter Baird, Baird's original journal extending from 1838 to 1887 , and a quantity of miscellaneous material collected by Herbert A. Gill, an associate in the Fish Commission. The greater part of its text consists of letters written to or by other scientists, which afford an intimate and lively view of the scientific life in midcentury. As an officer of the Smithsonian Institution from I 850 , Baird developed and maintained the National Museum, and as Commissioner of Fisheries he won international recognition through his scien- 
tific research into the maintenance of food-fish populations.

4745. [Bartram] Earnest, Ernest P. John and William Bartram, botanists and explorers, 1699-1777, 1739-1823. Philadelphia, University of Pennsylvania Press, 1940. 187 p. (Pennsylvania lives)

Bibliographical note: p. I8I-I82. $4 \mathrm{I}-86 \quad \mathrm{QK}_{3} \mathrm{I} \cdot \mathrm{B}_{3} \mathrm{E}_{3}$

John Bartram, described by Linnaeus as the "greatest natural botanist in the world," established a botanical garden on his farm on the Schuylkill River as early as 1729 or $\mathbf{1 7 3}$. He won a reputation before Franklin, whom he willingly joined in creating a scientific and cultural center in Philadelphia. He became one of the nine founders of the American Philosophical Society. By correspondence and exchange of plants, by traveling throughout the colonies and publishing their observations, John Bartram and his son William made the natural history of America known to Europeans. Here the author attempts to clear up some problems that still remain concerning William, but deals more fully with John, "because of his pioneer work, his great originality, and the lack of any complete study of his life and work." See also nos. 4236-4238, 4247-4250.

4746. [Bowditch] Berry, Robert Elton. Yankee stargazer; the life of Nathaniel Bowditch. New York, McGraw-Hill, r94I. 234 p.

"Among the sources": p. 225-227.

$$
4 \mathrm{I}-28345 \quad \mathrm{QB}_{3} 6 . \mathrm{B}_{7} \mathrm{~B}_{4}
$$

The author has used Nathaniel Bowditch's sea journals and notebooks, the memoirs of his sons and friends, and the diaries of contemporaries to produce this biography of the New England astronomer and mathematician. Bowditch (1773-1838) had little formal schooling, but read scientific books during his years in a cooper shop and a ship chandlery. Life on the Salem water front aroused his interest in navigation, and his ability to make calculations impressed Captain John Gibaut, who offered him a chance to go to sea. Six of the twelve chapters describe Bowditch's experiences on the five voyages which he made between 1795 and 1803 , and the observations which led to his publications on celestial navigation. The New American Practical Navigator (1802), known as "the seaman's bible," or more simply as "Bowditch," became the textbook in private schools of navigation, and standard equipment in most sea chests. Regularly reprinted, it has been published since 1868 by the U. S. Government. In later years Bowditch published his translation of the Mécanique céleste, and "made an epoch in American science by bringing the great work of Laplace down to the reach of the best American students of his time." Bowditch modestly dis- claimed comparison with seminal minds like Laplace and Newton, but his works have been "the greatest single influence on United States navigation and seamanship."

4747. [C ompto n] Compton, Arthur Holly. Atomic quest, a personal narrative. New York, Oxford University Press, 1956. $370 \mathrm{p}$. 56-1II14 QC773.AiC65

This book is at once a history of atomic energy and the personal narrative of one of the outstanding scientists responsible for initiating and carrying through the wartime atomic project in the United States. The author (b. 1892) describes the research that led to the release of atomic energy in useful amounts, the proposal of an atomic weapon to the government, the preparation of the atomic explosives, and the decisions which preceded their use in World War II. In view of the unprecedented destructiveness of atomic weapons, the author concludes that "we can see the powers that shape our destiny working with us toward the elimination of war." Dr. Compton's early life is briefly narrated in Chapter 3. From 1945 to 1953 he was chancellor of Washington University in St. Louis, where he sought to go beyond the traditional education program, and to create a "new vision of world affairs" and "an enduring civilization where men and women can rise to the best that is in them." George O. Robinson's And What of Tomorrow (New York, Comet Press Books, 1956. I78 p.) combines a narrative of "the atomic adventure" of the Manhattan Project with many human interest stories illustrating the devotion of the scientists and other workers to their task. The names of universities and other organizations participating in long-term research programs for the adaptation of atomic energy to peacetime uses suggest the possibilities opening before us.

4748. [Cope] Osborn, Henry Fairfield. Cope: master naturalist; the life and letters of Edward Drinker Cope, with a bibliography of his writings classified by subject; a study of the pioneer and foundation periods of vertebrate paleontology in America. With the co-operation of Helen Ann Warren. Illustrated with drawings, and restorations by Charles R. Knight under the direction of Professor Cope. Princeton, Princeton University Press, 1931. xvi, 740 p. 31 - Ir $875 \quad \mathrm{QH}_{31 . C 8 O_{72}}$

Edward Drinker Cope (1840-1897) was the rival of Othniel C. Marsh in the field of vertebrate paleontology, and the controversy between the two continued for 25 years. The appearance of this biography of Cope hastened the publication of Schuchert's life of Marsh (no. 4754). The author has had access to the lifelong correspondence of Cope with 
his family, which throws "new light on his personality" and "forms a priceless picture of the United States in the Civil and post-Civil War period." The years of exploration and discovery (to I880), the period of research, publication, and interpretation (to I889), and Cope's professorship in the University of Pennsylvania are described in detail. Chapter 7 tells how Cope applied "his wonderful powers of generalization and induction" to shine "forth as a creative thinker alike in Herpetology, Ichthyology, Geology, Mammalogy," as well as in vertebrate paleontology, and so deserves the title of "Master Naturalist." The classified bibliography of Cope's principal papers fills $15^{\circ}$ pages $(591-740)$.

\section{9. [Dana] Gilman, Daniel C. The life of} James Dwight Dana, scientific explorer, mineralogist, geologist, zoologist, professor in Yale University. New York, Harper, 1899. 409 p. 99-5509 QE22.D26G4

Bibliography of Dana's writings: p. 385-394.

Dr. Gilman, famous as the first president of Johns Hopkins University, had been a colleague of Dana at Yale, where he taught geography until 1872 . $\mathrm{He}$ calls his life of Dana (1813-1895) "personal rather than scientific." However, Dana's "Scientific Correspondence" forms Part II of the book (p. $219 \mathrm{ff}$.) and more than a hundred pages are devoted to the U. S. Exploring Expedition under Captain Charles Wilkes $(1838-42)$. It was his reports as the mineralogist and geologist of that expedition, published between 1846 and 1854 , which established Dana's position in those fields at home and abroad. As editor of the American Journal of Science, as author of $A$ System of Mineralogy ( 1837 ) and a Manual of Geology (1862) which went through numerous editions, and as the first Silliman Professor of Natural History (later changed to Geology and Mineralogy) at Yale, he remained at the head of his profession, and received many academic honors and scientific medals.

4750. [Franklin] Franklin, Benjamin. Benjamin Franklin's Experiments; a new edition of Franklin's Experiments and observations on electricizy. Edited, with a critical and historical introd., by I. Bernard Cohen. Cambridge, Harvard University Press, 194I. xxviii, 453 p.

$$
\mathrm{A}_{41} \mathrm{I}-4483 \text { QC5I6.F85 I94I }
$$

"Bibliographical table": p. 158-16r.

Benjamin Franklin (1706-1790) was able to devote only six or seven years to concentrated scientific inquiry, but they brought him enduring fame as the world's foremost "electrician." During the years 1747-49 "he laid the foundations of modern electrical science," and in his book he introduced much of its enduring terminology. In characteristic I8thcentury style, Franklin put his scientific writings into the form of letters; those collected in his Experiments and Observations on Electricity were addressed to Peter Collinson, Ebenezer Kinnersley, and others of scientific bent, and are supplemented by a number of letters to Franklin commenting upon his theories. Mr. Cohen's text is in part based upon Franklin's manuscript letters, which are fuller than the printed versions. His long and scholarly introduction deals with Franklin's scientific interests in general, electrical knowledge before Franklin, the nature and significance of Franklin's electrical discoveries, and the editions and translations of Experiments and Observations which appeared between 1751 and 1774 .

475I. [Gibbs] Wheeler, Lynde Phelps. Josiah Willard Gibbs; the history of a great mind. Rev. ed. New Haven, Yale University Press, 1952. $270 \mathrm{p}$. $\quad 52-\mathrm{I}_{422} \quad \mathrm{QA}_{29} . \mathrm{G}_{5} \mathrm{~W}_{5} 1952$ Bibliography: p. [25I ] -256 .

The scion of an old Connecticut family, Willard Gibbs (1839-1903) received the fifth doctorate conferred by Yale, the first American university to recognize graduate study, and was professor of mathematical physics there from $187 \mathrm{I}$ until his death. The author, a former student of Gibbs, evaluates the work of his teacher as an exponent of thermodynamics, statistical mechanics, and optics, and describes him as a quiet, unassuming scholar completely devoid of the eccentricities usually ascribed to genius. But a genius he was, with "a mind which proceeded from ascertained facts to their utmost implications by such rigorous logic that not one of his conclusions has ever been found in error." Gibbs' influence was exerted almost entirely through his writings, which received early recognition and interpretation abroad. The publication ( $1876-78)$ of his paper "On the Equilibrium of Heterogeneous Substances," which was something of an act of faith on the part of the Connecticut Academy of Arts and Sciences, proved a landmark in the development of modern physics and in the spread of Gibbs' fame. The enduring importance of his work dealing with the relations of heat to other forms of energy was emphasized by Yale University on the Iooth anniversary of his birth in a brochure prepared by the President's Committee on University Development: A Professor's Theory and Its Practical Uses: The Work of J. Willard Gibbs and Some Applications to Industry. Its calls Gibbs "one of the great scientists of modern times, and one of the architects of the industry which is so important a part of our civilization." 
4752. [Henry] Coulson, Thomas. Joseph Henry, his life and work. Princeton, Princeton University Press, 1950. $352 \mathrm{p}$.

Bibliography: p. $344-346$. 50-7249 QC16. $\mathrm{H}_{37} \mathrm{C} 6$

The director of museum research, Franklin Institute of the State of Pennsylvania, has written the first full-length biography of this rgth-century physicist in order to establish his rightful place among America's great men of science. Henry (1797-1878) lost his own papers by fire in 1865 , so the author has relied heavily on the letters found among the manuscript records of the Smithsonian Institution for glimpses into his life and work. The first half of the book is devoted, for the most part, to Henry's experiments during his tenure as professor at Albany Academy, and at Princeton. About I 830 he discovered the principles of electromagnetic induction which, with his ten other basic discoveries in the electrical realm, have been essential to practically every commercial application of electricity, including the telegraph, telephone, and radio. The last half of the book describes Henry as the first director of the Smithsonian Institution (from I 846), and as a protagonist in the "telegraph controversy" with Samuel F. B. Morse, as to their respective shares in its invention. It summarizes his place in science as a discoverer, an organizer, and an exponent of the value of collective research.

4753. [Jefferson] Martin, Edwin T. Thomas Jefferson: scientist. New York, Schuman, 1952. $289 \mathrm{p}$. ${ }_{52}-7559 \quad \mathrm{E}_{332 . \mathrm{M}_{33}}$

References: p. 261-283.

Thomas Jefferson (1743-1826) "enjoyed a high contemporary repute both as a statesman of broad culture and as a scientist, who applied 'philosophy' for the good of his native country and the general human welfare." His correspondence reveals his dual devotion to science and to public service. This is the most extensive analysis to date of Jefferson's broad and insatiable interest in science. It is not only a study of the man-his scientific characteristics, attitudes, practices, and principles-but also a history of American scientific development during his age-inventions, the study of fossils, geology, meteorology, etc. Jefferson's eagerness to refute the misrepresentations of America made by Buffon, DePauw, Raynal, and other Europeans, led to the publication of his Notes on the State of Virginia (178I-82) (nos. 150-153). Chapter 9 on "Politics, Religion, and Science" quotes from contemporary sources to illustrate how Jefferson was assailed by his political opponents because of his concern for science. Dr. Charles A. Browne's study of the sources of some of Jefferson's scientific opinions: Thomas lefferson and the Scientific Trends of His Time (, Wal- tham, Mass., Chronica Botanica Co.] 1944. [363]423 p.), reprinted from volume 8 , number 3 of the Chronica Botanica, is conveniently brief.

4754. [Marsh] Schuchert, Charles, and Clara Mae LeVene. O. C. Marsh, pioneer in paleontology. New Haven, Yale University Press, 1940. $\mathrm{xxi}$,54I p. $\quad 40-14583 \quad \mathrm{QE}_{707} \cdot \mathrm{M}_{4} \mathrm{~S}_{32}$

Dr. Schuchert made the acquaintance of Marsh in 1892 , and in 1904 succeeded to his chair of paleontology at Yale; Miss LeVene, as a staff member of Yale's Peabody Museum of Natural History, processed the Marsh Papers. Othniel C. Marsh (18311899) was a nephew of the eminent philanthropist George Peabody, who presented Yale with the Museum in 1866 . In the same year the Yale Corporation established the first American chair of paleontology for the nephew, but attached no salary to it until I8g6. Professor Marsh therefore felt free to put his major efforts into exploring the Far West for fossil remains, with results summed up in his two great monographs published by the U.S. Geological Survey in 1896: The Dinosaurs of North America and Vertebrate Fossils [of the Denver Basin]. In 1882 he became the vertebrate paleontologist of the U. S. Geological Survey, which did compensate his services, and obtained much of his later collections. Marsh was the originator of the "authentic skeletal restorations" of the dinosaurs, which caught the public eye and brought him contemporary fame. The volume concludes with a "List of Marsh Genera" (p. 495-50I) and a chronological list of some 300 titles written by Marsh (p. 503-526).

4755. [Millikan] Millikan, Robert A. Autobiography. New York, Prentice-Hall, 1950. xiv, 3 II p. 50-7302 QC16.M58 3

To the names of the world-renowned physicists who have been awarded the Nobel prize, that of Robert A. Millikan (1868-1953) was added in 1923, "for his work on the uniform electric charge and the photo-electric effect." His fame was first established by his experimental measurements of the electric quantum of elements, which he succeeded in determining within one-thousandth of a degree of exactitude. Appointed professor of physics at the University of Chicago in 1902, Millikan served as director of the Norman Bridge Laboratory of Physics and executive head of the California Institute of Technology from 1921 until 1945. Written in a style "not beyond the comprehension of a twelfthgrade student who has had an elementary course in physics," Millikan's autobiography reflects the impact of the physical sciences on modern life. It narrates such episodes in his life as the experimental proof of the existence of the photon, the organiza- 
tion of the National Research Council, the mobilizing of science for both World War I and II, and the building of Caltech into a great research center for science and engineering. The reader is conscious throughout of Dr. Millikan's views on the relationship between science and religion, and on the responsibility of the United States for the maintenance of world peace.

4756. [Newcomb] Newcomb, Simon. The reminiscences of an astronomer. Boston, Houghton Mifflin, 1903. 424 p. 3-24278 QB $36 . \mathrm{N}_{5}$

Simon Newcomb's (1835-1909) important investigations in planetary and lunar motion brought him honorary membership in more than forty scientific organizations in some eighteen nations, and honorary degrees from at least seventeen universities in ten nations. The results of his investigations have been adopted, more or less completely, by all nations for use in their nautical almanacs. A century after his birth he became the first astronomer to be elected to the American Hall of Fame. Newcomb tells in a simple, direct fashion the story of his coming from Nova Scotia to the United States as a teacher, his chance meeting with Joseph Henry, his work as an astronomer and mathematician at the Naval Observatory, and his superintendence of the American Ephemeris and Nautical Almanac. $\mathrm{He}$ describes his interests in such diverse subjects as psychical research, education, and political economy. More than an autobiography, his Reminiscences portray the status of science and the work of scientists at home and abroad during the last half of the Igth century.

4757. [Powell] Darrah, William C. Powell of the Colorado. Princeton, Princeton University Press, 1951. $426 \mathrm{p}$.

Bibliography: p. [40I]-412.

$$
\text { 51-11671 Q143.P8D25 }
$$

The author, a paleobotanist and engineer interested in the history of American science, spent ten years gathering the materials for this biography of a man who was both a distinguished geologist and a great public servant. It emphasizes his struggle to conserve the natural wealth of the West, to record the history of the American Indian, and to promote scientific research by the Government. After engaging in privately financed explorations in 1867-69, John Wesley Powell (1834-1902) made a thorough survey of the Colorado region on behalf of the Department of the Interior. In the report, Exploration of the Colorado River of the West and Its Tributaries, compiled by Powell for the Smithsonian Institution, he pointed out that the formation of canyons is due to corrosive action of rivers on rocks, and coined phrases which have become part of every geologist's vocabulary. With his position as a geologist established, Powell took a leading part in the movement which in 1879 consolidated the overlapping government ventures into the U.S. Geological Survey. The Bureau of American Ethnology was established at the same time; Powell was put at its head, and in the following year took over the Survey, administering both agencies until 1894 , when ill health compelled him to relinquish the Survey. Other recent publications reflect a lively interest in "the Major": in 1954 appeared another full-length biography, by Wallace Earle Stegner (q. v.). Paul Meadows' John Wesley Powell: Frontiersman of Science is number Io in the new series of University of Nebraska studies, July 1952 (106 p.).

4758. [Rittenhouse] Ford, Edward. David Rittenhouse, astronomer-patriot, 1732-1796. Philadelphia, University of Pennsylvania Press, 1946. 226 p. (Pennsylvania lives)

${ }_{46-5428} \mathrm{QB}_{3} 6 . \mathrm{R}_{4} \mathrm{~F} 6$

This is the first full-length biography of Rittenhouse (1732-1796) since the Memoirs, by his nephew, William Barton, appeared in 1813. Born near Germantown, Pa., of Mennonite stock, Rittenhouse at in received an uncle's legacy of tools and books which aroused his interest in mathematics and mechanics. As a farmer, maker of clocks and mathematical instruments, he spent the first 35 years of his life at Norriton. During $1767-71$ he built two brass orreries, working models of the solar system, which went to the Colleges of New Jersey and of Philadelphia, and were among the wonders of their day, greatly enhancing the reputation of their maker. He interrupted this labor in order to prepare for and make observations of the transit of Venus on June 3, 1769 , with the aid of specially designed instruments, which earned him a place among the world's astronomers. After moving to Philadelphia in 1770, Rittenhouse began a daily record of weather data which he kept up until his death. He was frequently engaged on boundary and canal surveys during the colonial period. He served on the Committee of Safety during the American Revolution, became a member of the General Assembly, state treasurer, and first Director of the U. S. Mint.

4759. [Silliman] Fulton, John F., and Elizabeth H. Thomson. Benjamin Silliman, I779I864, pathfinder in American science. New York, Schuman, 1947. 294 p. (Life of science library)

$$
\text { 47-1 } 1526 \text { Q143.S56F8 }
$$

Historical Library, Yale University School of Medicine, Publication no. 16.

"Bibliography and sources": p. 279-284.

Born in Fairfield, Connecticut, during the Ameri- 
can Revolution, Benjamin Silliman reached maturity at a period when a widespread interest in chemistry was emerging. When only 23 he was elected to the newly created chair of chemistry and natural history at Yale, where he taught for more than half a century. Silliman made few original contributions to science, but won distinction as an "ambassador of science" through effective teaching, and by founding a medical school, a department for postgraduate study, and in 1847 , the original chairs of the Sheffield Scientific School. His influence was extended outside the University by his founding of the American Journal of Science (1818), which was "intended to embrace the circle of the physical sciences with their applications to the arts and to every other useful service," and, after 1833 , by public lectures in cities as far away as Pittsburgh and New Orleans. This, the first comprehensive biography of Silliman since I866, is based on family letters as well as on manuscript materials in Yale University and other repositories.

4760. [Torrey] Rodgers, Andrew Denny. John Torrey; a story of North American botany. Princeton, Princeton University Press, 1942. $352 \mathrm{p}$. 42-19817 QK $31 . T_{7} \mathrm{R} 6$
Bibliography: p. [316]-333.

The history of American botany of the rgth century has been written by the author, a grandson of Sullivant, in this and two other books: "Noble Fellow," William Starling Sullivant (New York, Putnam, 1940. $36 \mathrm{I}$ p.), and American Botany, 1873-1892: Decades of Transition (Princeton, Princeton University Press, 1944. 340 p.), which deals particularly with Asa Gray and his associates. The taxonomic work of John Torrey (1796-1873), botanist and chemist, influenced all those who followed him, although his reputation was eventually eclipsed by Asa Gray (1810-1888). Much of the information in this book derives from Torrey's own correspondence, never before collected. Torrey spent most of his life in New York City, and some of his best known works are on the flora of his native state. He collaborated with Asa Gray in compiling the Flora of North America (New York, 1838-43), which describes all indigenous and naturalized plants growing north of Mexico, arranged according to "the natural system." He prepared botanical catalogs for the United States Exploring Expedition under Captain Wilkes, the Frémont Exploring Expedition to the Rocky Mountains, and others.

\section{Science and Government}

476r. Baxter, James Phinney. Scientists against time. Boston, Little, Brown, 1946. 473 p. 46-7204 Q127.U6B3

The Office of Scientific Research and Development was created in I94I "for the purpose of assuring adequate provisions for research on scientific and medical problems relating to the national defense." In this official history of the OSRD, the president of Williams College tells the story of the transition in methods of warfare up to the use of the atomic bomb. He describes the race for superiority in new weapons in World War II, the new devices that were developed, the contributions of chemical research to the prosecution of the war, the discovery and use of new medicines for the treatment of military personnel, and the selection and training of scientists. A series of volumes, Science in World War II, covers in much greater detail the operations of OSRD. In that series Irvin Stewart's Organizing Scientific Research for War (Boston, Little, Brown, I948. 358 p.), an administrative history of the Office, is of special interest for the relationship between government and science during a period of emergency. The OSRD was terminated by Executive Order in December 1947, and its liquidation entrusted to the National Military Establishment (now the Department of Defense).

4762. Brookings Institution, Washington, D. C. Institute for Government Research. Service monographs of the United States Government. Baltimore, Johns Hopkins Press, 1919-28. Io v.

$\mathrm{JK}_{42 \mathrm{I}}$.AIB6

The Institute for Government Research was established in 1916 as an "independent institution to consider the problems of public administration, and particularly those of the National Government, for the purposes of making known the most scientific practical principles and procedures that should obtain in the conduct of public affairs." Financed from the outset by the late Robert S. Brookings, in 1927 it was combined with two other such enterprises to form the Brookings Institution. As the basis for a comprehensive study of the organization and operation of the National Government, the Institute published this series of monographs describing the history, activities, and organization of some 55 United States Government agencies. Each mono- 
graph contains a bibliography which lists relevant Government documents and other sources. The following have been selected as being particularly pertinent to the interrelations of science and Government. Numbers $I$ and 9 were published by D. Appleton and Company, New York.

4763. I. The U. S. Geological Survey ... I919. $163 \mathrm{p}$. 19-9267 QE76.B7

4764. 9. The Weather Bureau ... by Gustavus A. Weber. 1922. 87 p.

$$
\text { 22-19464 Q875.U7 } \mathrm{W}_{4}
$$

4765. ro. The Public Health Service... by Laurence F. Schmeckebier. 1923. 298 p. 23-8224 RAII.BI9S

4766. 16. The Coast and Geodetic Survey ... by Gustavus A. Weber. 1923. I07 p. 23-8296 QB296.U85 1923

4767. 31. The Patent Office ... by Gustavus A. Weber. 1924. $127 \mathrm{p}$.

$$
\text { 24-4936 } \mathrm{T}_{223} \cdot \mathrm{P}_{2} \mathrm{~W}_{4}
$$

4768. 32. The Office of Experiment Stations ... by Milton Conover. I924. I78 p.

$$
24-8456 \text { S21.E9C6 }
$$

4769. 35. The Bureau of Standards . . . by Gustavus A. Weber. 1925. 299 p.

$$
\text { 25-23707 QCioo.U58 } 1925
$$

4770. 39. The Naval Observatory . . . by Gustavus A. Weber. 1926 . $101 \mathrm{p}$.

$$
\text { 26-9845 QB82.U85 }
$$

477I. 42. The Hydrographic Office . . . by Gustavus A. Weber. I926. II2 p. 26-15570 $\mathrm{VK}_{597 .} \mathrm{U}_{5} \mathrm{~W}_{4}$

4772. 52. The Bureau of Chemistry and Soils . . . by Gustavus A. Weber. 1928. $218 \mathrm{p}$.

$$
29-2042 \quad \mathrm{~S}_{5} 85 . \mathrm{W}_{4}
$$

4773. Gellhorn, Walter. Security, loyalty, and science. Ithaca, Cornell University Press, 1950. $300 \mathrm{p}$. (Cornell studies in civil liberty)

$$
\text { 50-14649 UB270.G } 42
$$

The contributions of science toward winning a war, and the expanding reliance of national defense on scientific developments have restricted, in some areas, the exchange of ideas between scientists whose individual freedoms have been curtailed in the national interest. Made possible by a grant from the Rockefeller Foundation, this is one of Cornell's series of studies of "the impact upon our civil liberties of current governmental programs designed to ensure internal security and to expose and control disloyal or subversive conduct." It deals with the administration of security policies in "sensitive" areas of scientific research. Chapter 8 emphasizes the need for fair procedures, and the author's "Concluding Thoughts" warn that "the focus upon opinion as a measure of loyalty tends to discourage the holding of any opinion at all."

4774. National Academy of Sciences, Washington, D. C. A history of the first half-century of the National Academy of Sciences, 1863-19r3. Edited by Frederick W. True. Washington, I913. 399 p. 13-35434 Q1 I.N286

"To afford recognition to those men of science who had done original work of real importance and thereby to stimulate them and others to further endeavors; and to aid the Government in the solution of technical scientific problems having a practical bearing on the conduct of public business," Congress chartered the National Academy of Sciences in 1863. The story of the Academy's accomplishments during its first 50 years includes a chapter on "The Academy as the Scientific Adviser of the Government." In that role its studies have shaped the creation of various Government agencies such as the U. S. Forest Service and the Geological Survey. In addition to its many publications in the several sciences, the National Academy, since 1877 , has published a series of Biographical memoirs which often contain information concerning American scientists not otherwise available. The National Research Council originated in 1916 , when the National Academy addressed President Wilson, offering to coördinate the non-governmental scientific and technical resources of the country with the military and naval agencies of the Government in the interest of national security. The Council was reorganized on a permanent basis in 1919. A History of the $\mathrm{Na}$ tional Research Council, 1919-1933 (Washington, The Council, 1933. 61 p.) has been published as no. Io6 of the Council's Reprint and circular series.

4775. Oehser, Paul H. Sons of science; the story of the Smithsonian Institution and its leaders. New York, Schuman, 1949. xvii, 220 p. (Life of science library) $49-526$ QII.S8O 4 Selected bibliography: p. 205-208.

A concise history by the chief of the Smithsonian's Editorial and Publications Division. Built and organized with funds provided by the will of James Smithson (1765-1829), English scientist, "for the increase and diffusion of knowledge among men," the Smithsonian Institution was incorporated in 1846. It may well be thought of as the first Ameri- 
can foundation of national scope, for "it enjoys the advantages of a privately endowed institution and at the same time is an establishment of the United States government." The history of the Institution is here organized around the careers of its secretaries, all of whom have been scientists: Joseph Henry, physicist (to 1878); Spencer. Fullerton Baird, biologist (to 1887); Samuel Pierpont Langley, physicist and astronomer (to 1907); Charles Doolittle Walcott, geologist (to I928); Charles Greely Abbot, astrophysicist (to 1945); and Alexander Wetmore, biologist (to 1952). The growth of the Institution is also traced in an increasing diversity of function and complexity of organization. The ten subordinate bureaus added from time to time include the National Museum, the Bureau of American Ethnology, the International Exchange Service (for scientific publications), the Astrophysical Observatory, the National Zoological Park, the National Gallery of Art, and the National Air Museum. The author supplies a "Chronology of Principal Events," 18261948 (p. 187-203) and 39 well-chosen illustrations in gravure.

4776. Price, Don K. Government and science, their dynamic relation in American democracy. New York, New York University Press, 1954. 203 p. (James Stokes lectureship on politics)

$$
\text { 54-8164 Q127.U6P7 }
$$

The author, after serving with several research organizations and government agencies, including the Research and Development Board of the Department of Defense, of which he was deputy chairman, became vice president of the Ford Foundation in 1954. He draws upon this varied experience for the present "series of essays," based upon lectures delivered at New York University in 1953. In them he suggests "that the activities of scientists, which had always been unusually influential in the public policies of the United States, were becoming responsible for significant changes in the nature of the American governmental system," and that "a whole series of most profound and most neglected problems" were thereby created. He concludes that there is a necessity for "creating the kind of responsible political and administrative systems within which free science will have its fullest opportunity for public service." The only hope for such a system, according to Mr. Price, "is to build in part on the generalist with a background in general management and general public affairs, and in part on the man who has become a generalist after a thorough grounding in one of the specialized sciences or in its engineering or managerial application." Chapter II, "Freedom or Responsibility," deals with the organization of the National Science Foundation, "the only general-purpose science agency in the government."

4777. U. S. National Resources Committee. Science Committee. Research-a national resource. Washington, U. S. Govt. Print. Off., 1938-41. 3 v. 39-26187 Q18o.U5 $U_{45}$

Volumes 2-3 prepared for the Science Committee of the National Resources Planning Board.

Volume I issued also as House document 122, 76th Congress, ist session.

Contents.- 1 . Relation of the Federal Government to research. Report of the Science Committee of the National Resources Committee.-2. Industrial research. Report of the National Research Council.-3. Business research. Report of an advisory committee of the Social Science Research Council.

Proceeding on President Franklin Roosevelt's postulate that "research is one of the nation's very greatest resources," the Science Committee, composed of members designated by the National Academy of Sciences, the Social Science Research Council, and the American Council on Education, conducted this study of Federal aid to research, and of the place of research, including natural and social science, in the Federal Government. Each volume contains a summary of findings and recommendations for improvements in the area covered by the volume. A number of these called for greater coöperation between Government and private research agencies.

4778. U. S. Office of Scientific Research and Development. Science, the endless frontier. A report to the President by Vannevar Bush. July 1945. Washington, U. S. Govt. Print. Off., I945. I84 p. 45-36413 Q127.U6A53 1945

In 1944 President Roosevelt requested Dr. Vannevar Bush, Director of the Office of Scientific Research and Development ( $194 \mathrm{I}-46$ ), to recommend means of applying its wartime experience in times of peace, "for the improvement of the national health, the creation of new enterprises bringing new jobs, and the betterment of the national standard of living." Among Dr. Bush's recommendations was the creation of a national research foundation to develop a national policy for scientific research and scientific education. After five years of congressional debate, an act embodying compromises to satisfy divergent views was passed in 1950, creating the National Science Foundation. On March I7, 1954, President Eisenhower issued Executive Order I052I concerning Government scientific research and the responsibilities of the National Science Foundation and other Federal agencies. The text of the order is given in Appendix $\mathrm{V}$ of the 
National Science Foundation's Annual Report for I954 (Washington, U. S. Govt. Print. Off.), which also outlines the "Current Aspects of American Science," and the "Program Activities of the National Science Foundation."

4779. U. S. President's Scientific Research Board. Science and public policy. A report to the President by John R. Steelman. Washington, U. S. Govt. Print. Off., 1947. 5 v.

$$
\text { 47-46212 Qi8o.U5 } \mathrm{A}_{47}
$$

"The administration of research; a selective bibliography": v. 3, p. 253-324.

In an Executive order issued October 17, 1946, the Chairman of the President's Scientific Research Board, with the assistance of the Board, was instructed "to investigate and report upon the entire scientific program of the Federal Government." Social science research was omitted from this study, as well as the content of the research programs of the War and Navy Departments. Volume I, "A Program for the Nation," sketches the country's position in scientific research, and makes recommendations by which the Government can assure maximum benefits to the Nation. Volume II, "The Federal Research Program," reviews the details of the Government's scientific work, agency by agency, and discusses typical projects. Volume III, "Administration for Research," analyzes the Government's administration of its own research programs, points out problems and policy issues, and makes recommendations for modernizing procedures. Volume IV, "Manpower for Research," deals with the shortage of scientists and teachers, and its threat to progress. Volume V, “The Nation's Medical Research," discusses progress in medical and allied sciences, outlines the Federal program, and makes recommendations for its administration.

\section{E. Invention}

4780. Amdur, Leon H. Patent fundamentals. New York, Boardman, 1948. 305 p. illus. T223. T2A55 1948

First published in 194r.

A main objective of this book "is to enable the layman and the student to attain a rapid, yet sound, understanding of the U. S. Patent System." The author explains in simple language the nature of inventions that, according to law, can be patented, the legal protection afforded the patentee, and the preparation and prosecution of an application for a patent. Concrete examples illustrate the procedures. The book includes the first "full and clear exposition" of the grant of patents on new and distinct varieties of plants, which became part of the patent law in 1930. A final chapter considers patents as transferable property, and briefly compares the patent system of the United States with those of foreign nations. George V. Woodling's Inventions and Their Protection, 2d ed. (New York, Boardman, 1954. 496 p.) brings developments in the patent system up to date (1953).

4781. Berle, Alf K., and Lyon Sprague De Camp. Inventions and their management. $3 \mathrm{~d}$ ed. Scranton, International Textbook Co., 1951. xxv, $742 \mathrm{p}$. $5^{\mathrm{I}-1495^{8}} \mathrm{~T}_{212 .} \mathrm{B}_{43} \quad$ 195I

Bibliography: p. 671-673.

Presents in one volume the principles and practices that control the technical, legal, and business procedures of invention. The authors' purpose has been to keep their book, originally published in 1937, up to date by providing information of service to inventors and business men who are undertaking creative work in the field of inventions and their management. In addition to explaining the whole process of patents and patent law, the book contains chapters on trade-marks and copyrights, and legal cases illustrating more than half of the topics. Chapter 4 is a concise description of the organization and functions of the U. S. Patent Office. There is a substantial "Glossary" (p. 679-70I) of legal terms and words used in a special sense in patenting. Floyd L. Vaughan explores the developments which have circumvented the original objectives of the patent law, and suggests remedies in his United States Patent System (Norman, University of Oklahoma Press, i956. 355 p.).

4782. Bryan, George S. Edison, the man and his works. New York, Knopf, 1926. 350 p. 26-19839 $\mathrm{TK}_{140 . \mathrm{E}_{3} \mathrm{~B}_{7}}$

Bibliography: p. 331-337.

"The Wizard of Menlo Park" became, for the American popular mind, the embodiment of American inventive genius, and almost a figure of American folklore, other men's inventions being readily attributed to him. Nevertheless, Edison's fame is not undeserved, for he has hardly a parallel in the duration, continuity, and multiplicity of his inventive activity. His first patent was applied for in 1868 , in his $22 \mathrm{~d}$ year, and he continued to invent, adapt, 
and improve until the failure of his health a year or two before his death in 1931. His methods were peculiarly adapted to the expanding American economy of the post-1 865 period, for he sought devices that could be converted to wide public use and manufactured in quantity. To Edison the act of invention was but the prelude to an industrial organization for exploiting the result, and he was able to exploit other men's inventions as well as his own. Bryan's biography is a clear outline by a wholehearted admirer; one by Frank L. Dyer and Thomas C. Martin, Edison, His Life and Inventions (New York, Harper, 1929. $2 \mathrm{v}$.) was originally published in 1910 , and was only partially revised when it was brought up to date 19 years later; but it is a great repository of information, much of it deriving from Edison himself.

4783. Burlingame, Roger. March of the iron men, a social history of union through invention. New York, Scribner, 1938. xvi, 500 p. illus.

$$
\text { 38-27712 T21.B8 }
$$

The author, a biographer, historian, and editor, traces the influence of invention on American society from the $r 7^{\text {th }}$ century to the close of the Civil War. The early settlers were immersed in the necessities of building, agriculture, and communication, and the first American inventor was Benjamin Franklin. Inventions during the period of the American Revolution improved the materials of war-gunpowder, small arms, etc. Later inventions were geared to the growing industrial economy and produced the steamboat, cotton gin, power loom, electro-magnetic telegraph, reaper, vulcanized rubber, and many other products. It is the author's belief "that the instruments invented in this phase were the instruments of our eventual union and that ... they made that union a fact before, politically, it was recognized." Engines of Democracy, Inventions and Society in Mature America (New York, Scribner, 1940. 606 p.) deals with the period after 1865 , but not in chronological arrangement: "events did not follow one another in orderly sequence." In these books $\mathrm{Mr}$. Burlingame has sought to present technical developments in common terms intelligible to the layman. Each book contains a list of "Events and Inventions," and a bibliography.

4784. Flexner, James T. Steamboats come true; American inventors in action. New York, Viking Press, 1944. 406 p. 44-7758 VM615.F63 "Bibliography of principal sources": p. 379-381.

This account of American inventors of the steamboat is scholarly, yet written in a style appropriate for the layman. It deals primarily with John Fitch, the pioneer, his contemporary, James Rumsey, and
Robert Fulton, the promoter, in their individual contributions to the application of the steam engine to water transportation, described as "the first American invention of world-shaking importance." A brief survey of their forerunners is crowded into the first chapter. In the last it is pointed out that Robert Fulton's importance was not his originality but his ability to build a steamboat on principles evolved from the experiments of many who had tried unsuccessfully to produce finished and working products. In 1912, when the centenary of the introduction of navigation by steam was being celebrated in Europe, Henry W. Dickinson, Assistant Keeper of the Science Museum, South Kensington, produced from the archives of England and France and from original sources in the United States, a life of Robert Fulton, Engineer and Artist (London, New York, John Lane, 1913. 333 p.), one of the few examples of a biography of an American by an English writer.

4785. Holland, Maurice, and Henry F. Pringle. Industrial explorers. New York, Harper, 1938. 347 p. 28-29154 T39.H6 1928 Maurice Holland, Director of Engineering and Industrial Research, National Research Council (I923 to I942), and Henry F. Pringle, writer, cooperate to sketch the careers of 19 of the nation's leaders of industrial research. They outline Willis $R$. Whitney's research in the field of electrical engineering, William H. Miller's improvement of design theory and methods in aeronautical engineering, Samuel C. Prescott's experiments in the chemistry of the roasted coffee bean, John A. Mathew's development of high-speed and noncorrosive steels, E. C. Sullivan's tests in the glass laboratories that produced Pyrex, and George D. McLaughlin's improved methods of tanning. The biographies of these and $r_{3}$ other scientists describe the research which has led to many products now commonplace in daily life.

4786. Iles, George. Leading American inventors. New York, Holt, 1912. xv, 447 p. illus. (Biographies of leading Americans, edited by W. P. Trent) $\mathbf{1 2}_{2-27835}$ T $_{39}$.I5

Contents.-John and Robert Livingston Stevens.-Robert Fulton.-Eli Whitney.-Thomas Blanchard.-Samuel Finley Breese Morse.-Charles Goodyear--John Ericsson.-Cyrus Hall McCormick.-Christopher Latham Sholes.-Elias Howe.Benjamin Chew Tilghman.-Ottmar Mergenthaler.

Brief and eulogistic biographical sketches of 13 American inventors, who, within little more than a century, conceived and perfected inventions which have profoundly altered our ways of living. 
4787. Kaempffert, Waldemar B., ed. A popular history of American invention . . . with over five hundred illus. New York, Scribner, 1924. 2 v. 24-25794 T2I.K5

A group of editors of scientific journals, teachers, and scientists have contributed chapters to this history of American invention through the first quarter of the 2oth century. Volume I deals with the development of "Transportation" by railroad, inland waterway, electric car, automobile, and airplane; "Communication" through the printed word, telegraph, telephone, radio, camera, motion picture, and phonography; and "Power" through steam and electricity. Volume II deals with devices and techniques for "Exploiting Material Resources," such as iron, steel, copper, oil, coal, and lumber, and with "Automatic Labor-Saving Devices." Written in a style that appeals to the layman as well as to the scientist, the work provides a standard account up to the date of its preparation, and needs only to be brought up to date by incorporating the developments of the last three decades.

4788. Kelly, Fred C. The Wright brothers; a biography authorized by Orville Wright. New York, Farrar, Straus, \& Young, 1951. 340 p. 5I-I 660 TL540.W7K 4 195 I

The author's aim in this life, first published in 1943, has been "to satisfy the curiosity of the average, non-technical reader regarding the work of the Wright brothers, and to do so as simply as possible." Wilbur (1867-1912) and Orville Wright (18711948) interested themselves in aeronautics in 1896 and progressed steadily to the first successful powered Alight at Kitty Hawk, N. C., on December I7, 1903. The last two chapters include "Patent Suits," and an explanation of "Why the Wright Plane was Exiled." In 195I the author edited a selection of letters from the Wright manuscripts deposited in the Library of Congress and not generally available until 1960: Miracle at Kitty Hawk: The Letters of Wilbur and Orville Wright (New York, Farrar, Straus, \& Young. $4^{82}$ p.). Appealing again to the general reader, the book contains those letters which reveal the achievements and personalities of the Wright brothers, and omits those dealing with highly technical problems. More recently Oberlin College on the Wilbur-Orville Wright Memorial Fund sponsored the publication of The Papers of Wilbur and Orville Wright, Including the ChanuteWright Letters and Other Papers of Octave Chanute, edited by Marvin W. McFarland (New York, McGraw-Hill, 1953. 2 v.), which was prepared for the press with notes, appendixes, and bibliography by the Aeronautics Division of the Library of Congress. These papers, arranged chronologically, include the technical cor- respondence of the Wright brothers from 1899 to $194^{8 .}$

4789. Mirsky, Jeannette, and Allan Nevins. The world of Eli Whitney. New York, Macmillan, 1952. xvi, 346 p. $52-4520 \mathrm{TS}_{570 . \mathrm{W}_{4} \mathrm{M}_{5}}$ Bibliography: p. 317-337.

This "first modern study of an American genius" is based primarily on the collection of Whitney's ( $1765-1825$ ) papers in the Yale University Library, which fully document his business career but yield only fragmentary bits of information concerning his personal life. It describes the influence of the cotton gin on the agriculture of the South, where it revitalized the plantation system and slavery, and emphasizes, more fully than has been done before, the impact of his manufacture of firearms on the economic and industrial life of the whole country. The authors quote from Whitney's letters to illustrate his concept of the processes of the machine tool industry which made him the "father of mass production" and "changed the social and economic growth of the North and gave it its industrial might." He wanted, he wrote, tools "similar to an engraving on copper plate from which may be taken a great number of impressions perceptibly alike." Constance McLaughlin Green in her recently published Eli Whitney and the Birth of American Technology (Boston, Little, Brown, 1956. 215 p.), which presents much the same story in concise form, and acknowledges its indebtedness to Miss Mirsky, describes Whitney as "the forerunner of the specialist of the business age," with "a completely singletrack mind" and a "passion for efficiency" uncharacteristic of his own day.

4790. Prout, Henry G. A life of George Westinghouse. New York, Scribner, 1922. 375 p. 23-26510 $\mathrm{T}_{40} \mathrm{~W}_{4} \mathrm{P}_{7}{ }_{1922}$

George Westinghouse ( $1846-1914$ ) left no private letters, journals or note-books. The material for this book has been gathered from business records, and from the memories and impressions of contemporaries who were close to him, "some of them almost from the beginning of his active life." The author has had the aid of a committee of the American Society of Mechanical Engineers in digesting and coordinating this data. The diversity of Westinghouse's inventions and business enterprises has determined the division of the book into chapters each dealing fully with one topic, with preliminary and concluding chapters describing Westinghouse's personality and his influence on the development of America. The Appendix contains a list of more than 375 patents. Outstanding among them in social effect are the invention of the air brake and its 
application to railroading, and the use of alternating current for electric power transmission.

479r. Pupin, Michael I. From immigrant to inventor. New York, Scribner, 1923. 396 p. 23- $13553 \mathrm{TP}_{40 . \mathrm{P} 8 \mathrm{~A}_{3}}$

Pupin (1858-1935), a peasant's son born in a Bosnian village, came to America at the age of 16 , and became professor of electromechanics at Columbia University and the inventor of many improvements in telegraphy, telephony, and the $\mathrm{x}$-ray. His autobiography, the kind of success story that can only happen here, was a best-seller in its day and received a Pulitzer prize.

4792. Thompson, Holland. The age of invention; a chronicle of mechanical conquest. New Haven, Yale University Press, 1921. 267 p. (The
Chronicles of America series, Allen Johnson, editor ...v. 37 ) $2 \mathrm{I}-\mathrm{I} 5265$ Ei73.C55, v. 37

Abraham Lincoln edition. Tig. T5

Bibliographical note: p. 247-254.

Sometime editor-in-chief of the Book of Knowledge, and contributor to many encyclopedias and journals, Holland Thompson outlines the personalities of some of the outstanding American inventors from Benjamin Franklin to the Wright brothers, and points out the significance of their achievements in the development of the United States. However, he avoids giving undue importance to the work of individuals by grouping together the "Pioneers of the Machine Shop," "The Fathers of Electricity," and others whose progress was mutually interdependent.

\section{F. Engineering}

4793. American Institute of Chemical Engineers.

Twenty-five years of chemical engineering progress; silver anniversary volume, . . . edited by Sidney D. Kirkpatrick. New York, Published by the Institute and for sale by D. Van Nostrand Co., I933. $373 \mathrm{p}$. 33-16724 TP20.A5

Contents.-Chemical engineering research. Acids and heavy chemicals in retrospect.-Organic chem:cal industries.-Solvents.-Petroleum refining.-Electrochemical industries.-Electrometallurgical industries.-Pulp and paper manufacture.Coal processing.- Sugar industries.-High pressure synthesis-basis of new chemical engineering industries.-Soap and glycerine industries.-Chemical and engineering advances in the rubber industry.Paints, varnishes and lacquers.-Modern plastics.Vegetable oil production.-Lime industry.-Glass manufacture.-Fractional distillation.-Evaporation in the United States in theory and practice.-Bibliography of articles on evaporation (p. 277-279).Continuous mechanical separations.-Purification of water for sanitary and industrial uses.-Stream pollution and waste disposal.-A statistical survey of the chemical engineering industries, 1908-1933.Chemical engineering education.

Advances in chemical engineering, between the founding of the American Institute of Chemical Engineers in 1908, and 1933, are described by "leading authorities in the fields which they represent." World War I furnished the impetus which chemical engineering needed to make it a recognized profession, and the statistical survey of the industries involved in Chapter 24 measures the progress made during the quarter-century.

4794. Anderson, Oscar E. Refrigeration in America; a history of a new technology and its impact. [Princeton] Published for the University of Cincinnati by Princeton University Press, I953. 344 p.

"Bibliographical note": p. 321-325. ${ }_{52-{ }_{3} I_{4} 8} \mathrm{TP}_{494} \cdot \mathrm{U}_{5} \mathrm{~A}_{7}$

The author describes his book as an introductory survey of the relation of refrigeration to our national development and points out the need for further detailed research. He records the main trends in technological progress, describes the uses of refrigeration, explains resistance to its application, and gives some indication of its social and economic effects. The application of refrigeration to food supply and the manufacture of ice falls into three periods: the years prior to 1890,1890 to 1917 , and 1917 to 1950. Chapters are devoted to improvements in refrigerated transportation, the introduction of frozen foods, and the wider use of locker plants and home freezers. In the last chapter the Tennéssee Valley Authority is selected as an illustration of the potentialities of refrigeration in relieving the problems of large distressed rural areas.

4795. Bathe, Greville, and Dorothy Bathe. Oliver Evans; a chronicle of early American engineering. Philadelphia, The Historical Society of Pennsylvania, I935. xviii, 362 p. illus., maps, facsims. 
"Books and principal pamphlets, written and published by Oliver Evans between the years 1792 and 1819": p. 344-345.

The scattered and little-known facts concerning Oliver Evans (I755-18I9) are here brought together and many of his letters and papers printed in full. Unbroken by chapters, this first full-length biography of a pioneer in the construction of high-pressure engines throws much light upon the functioning of the early patent laws, and the primitive engineering equipment of the period. Born in Delaware, by 1793 Oliver Evans moved to Philadelphia, where in succeeding years he was a constructor of mills, a burr-millstone manufacturer, and a dealer in bolting cloth and plaster of Paris. For nearly 30 years he went on improving the mechanism of his engines and boilers. His correspondence with Tobias Lear, Robert Livingston, and Thomas Jefferson concerning his improvements in their mills indicates that he was better known in his own day than he has been since. As the authors point out, his life span fell just a few years too early for his talents to achieve their potential social effect.

4796. Bishop, Joseph Bucklin, and Farnham Bishop. Goethals, genius of the Panama Canal; a biography. New York, Harper, 1930. xiv, 493 p. 30-2257I TAr40.G58B5

The elder Bishop, Secretary of the Isthmian Canal Commission from 1905 to I9I4, died before finishing the fifth chapter of this authorized biography of his close friend, and his son completed the task. Graduating from the Military Academy in 1880 , George Washington Goethals (1858-1928) served in the Engineer Corps in all grades from second lieutenant to colonel. In 1907 President Roosevelt appointed Goethals to construct the Panama Canal, and to assume all responsibilities for the government of the Canal Zone. Having opened the Panama Canal to world shipping in I9I4, Goethals was made a major general and remained as governor of the Canal Zone until he retired late in Igr6. Recalled to active duty in December I9I7, Goethals became director of purchase, storage, and traffic, in charge of the transport of supplies and the movement of all troops within the United States and overseas. Returning to the retired list in I9I9, Goethals served as consulting engineer on many important waterway projects. The tributes after his death praised his inflexible justice as strongly as his professional and administrative abilities.

4797. Blake, Nelson M. Water for the cities; a history of the urban water supply problem in the United States. Syracuse, N. Y., Syracuse University Press, 1956. 34I p. (Maxwell School series, 3) 56-13576 TD223.B5
This original study started out as an investigation of how New York, Philadelphia, Baltimore, and Boston came to recognize the vital importance of water supply to the health and functioning of those communities and took steps to provide it during the years 1790 to 1860 . It has been expanded to include brief accounts of such developments in other cities, and, in the last two chapters, the accomplishments of water supply engineering from 1860 to the present day. Progress in private and public control of urban water supply are traced from the time when American cities drew their water almost exclusively from springs, wells, and cisterns, to the building of great reservoirs such as those created by the Hoover and Parker dams across the Colorado River. In the background is the story of municipal growth and the political struggle that usually accompanies expansion in public works. The references (p. 288$33 \mathrm{I}$ ) indicate an extensive use of state and municipal documents supplemented by newspapers.

4798. Copley, Frank Barkley. Frederick W. Taylor, father of scientific management. New York, Harper, I923. 2 v. 23-1 $753^{\circ} \mathrm{T}_{58 . \mathrm{T}_{42} \mathrm{C} 6}$ An admiring and thoroughly documented life of Frederick W. Taylor (1856-1915), the first to apply scientific method to the manufacture of a given product from a certain amount of raw material with minimum waste and friction. In 1878 he entered the Midvale Steel Company as an apprentice, and rose from gang boss to foreman of the machine shop, to master mechanic, chief draftsman, and finally chief engineer within a period of six years. At Midvale he laid the foundation of his system of scientific management, and from 1898 gave it more concrete form at the Bethlehem Steel Company, which employed him to analyze its operations. Taylor devoted the latter years of his life to promoting scientific management or "Taylorism," as it became popularly known. His principal book, The Principles of Scientific Management (New York, Harper, I9I I. I44 p.), within two years was translated into French, German, Dutch, Swedish, Russian, Lettish, Italian, Spanish, and Japanese. He was also the inventor of a number of industrial machines and processes, such as the heat treatment of high-speed tool steel.

4799. Fraser, Chelsea C. The story of engineering in America. New York, Crowell, I928. 47I p. 28-24165 TA23.F8

Bringing together in one volume historical landmarks and typical processes in the construction of roads, railroads, bridges, tunnels and subways, dams and reservoirs, canals, harbor improvements, lighthouses, mines, and buildings, this book is aimed at the nontechnical reader interested in the accomplish- 
ments of American engineering from colonial days through the first quarter of the 2oth century. Written in a simple style, it contains many drawings of typical constructions.

4800. Hoover, Theodore Jesse, and John Charles Lounsbury Fish. The engineering profession. 2d ed. Stanford, Stanford University Press, 1950. xv, 486 p. $\quad 50-126_{42}$ TA $157 . H_{5} 6 \quad$ 1950 Includes bibliographies.

Two outstanding educators and consultants in the fields of civil and mining engineering have prepared a vocational guide for those considering one of the branches of engineering as a profession, and a "progress report" to the experienced engineer on the characteristics of engineering. It describes the qualifications and duties of civil, mining, mechanical, electrical, chemical, and other engineers. Changes in practice since the first edition appeared in I94 I have necessitated extensive revision, especially in the sections on municipal engineering and electronics. There are chapters on the education of an engineer and the new opportunities for participating in community welfare, as well as tables showing salaries, and the functional, industrial, and geographic distribution of engineers. The chapters on engineering education and salaries in Esther L. Brown's The Professional Engineer (New York, Russell Sage Foundation, 1936. 86 p.) afford comparisons evidencing progress in training and in opportunities. The recent edition of Lowell O. Stewart's Careers in Engineering: Requirements, Opportunities, $3^{\mathrm{d}} \mathrm{ed}$. (Ames, Iowa State College Press, 1956. I05 p.), furnishes much practical information in brief compass.

4801. Steinman, David B. The builders of the bridge; the story of John Roebling and his son. 2d ed. New York, Harcourt, Brace, 1950. $457 \mathrm{p}$. $\quad 50-8862$ TAi40.R7S8 $195^{\circ}$

\section{Bibliography: p. $421-445$.}

The author is himself an experienced bridge engineer who, three years after the first edition of this book (1945), was put in charge of the reconstruction of the Brooklyn Bridge. Its original builders were John August Roebling (1806-1869) and his son, Washington Augustus Roebling (1837-1926). The father, educated as a civil engineer at Berlin, Prussia, came to America in $183 \mathrm{I}$. In $184 \mathrm{I}$ he introduced the first wire cable, and in $1845-46$ at Pittsburgh he constructed first a canal aqueduct and next a bridge, both on the suspension principle. The whole of Part 3 is devoted to the construction of the Brooklyn Bridge between 1867 and 1883 . An unlucky accident caused John Roebling's death while the survey was still under way in July 1869 . His son carried it to completion, but in 1872 was paralyzed by the caisson disease which had already killed three workmen, and thenceforward had to direct the work from his sickroom. The opening of the bridge on May 24, 1883 , a landmark in civic and engineering history, was marked by a triumphal celebration. The book, as the author tells us, "has been a labor of love, in the truest sense, with no counting the cost."

4802. Turnbull, Archibald Douglas. John Stevens, an American record. New York, Century, 1928. xvii, 545 p. 28-12356 VMr40.S7T8

Stevens (1749-1838) of Hoboken, N. J., an amazingly versatile engineer and inventor best remembered for his improvements in steam transportation by sea and land, also designed tunnels, bridges, and projectiles. He was likewise a competent entrepreneur and the founder of a great fortune. This detailed biography is based on Stevens' own papers and incorporates many extended excerpts from them.

4803. Yost, Edna. Modern American Engineers. Philadelphia, Lippincott, I952. I82 p. 52-5172 TAI39.Y65

Contents.-Robert Ernest Doherty, engineering educator.-Ralph Edwards Flanders, mechanical engineer.-Arthur Ernest Morgan, civil engineer.Vannevar Bush, electrical engineer.-Scott Turner, mining engineer.-J. Brownlee Davidson, agricultural engineer.-Harold Bright Maynard, industrial engineering consultant.-Ole Singstad, civil engineer-John Robert Suman, petroleum engineer.-Carl George Arthur Rosen, research engineer.-Stanwood Willston Sparrow, automotive engineer.-Harold Alden Wheeler, radio and television engineer.

Each of the 12 men whose biographies make up this book was selected by the author, with help from the staffs of various national engineering societies and other authorities in the profession, "as an engineer recognized by his peers as a man of high achievement." Some of the engineering fields omitted in this book are covered in the author's Modern Americans in Science and Invention (Philadelphia, Stokes, 1941. 270 p.). 


\section{XVIII}

\section{Medicine and Public Health}

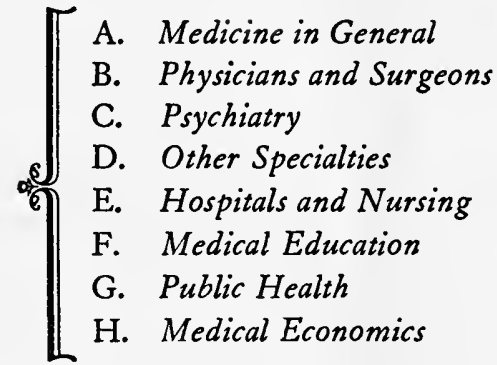

$4804-48 \mathrm{I} 7$
$48 \mathrm{I} 8-4832$
$4833-4840$
$484 \mathrm{I}-4844$
$4845-4854$
$4855-486 \mathrm{I}$
$4862-488 \mathrm{I}$
$4882-489 \mathrm{I}$

$\mathrm{T}$ HE literature of American medicine is of course enormous, but we are here concerned only with that fairly limited portion of it which is intelligible to the layman, and displays the subject in its historical development and its relationships to the larger social fabric. Section A includes a few general histories, and the later ones a number of more specialized historical treatments; but, in the main, it is fair to say that the historical exploration of the development of American medicine is only very imperfectly accomplished. Until the Igth century, that development is primarily of interest to the American social historian, but in the course of that century the United States becomes one of the major sources of medical discovery, and begins to take the lead in medical organization. Behind all progress, however, stands the individual physician, and medical biography and autobiography is a branch of the literature which has proliferated amazingly in the last two or three decades. The sampling presented in Section B could be indefinitely expanded, for every year sees a new crop of personal narratives, each with its own angle of vision, and seldom devoid of interest or instruction.

The prominence given to psychiatry, which occupies Section C, follows almost inevitably from the prevalence of the subject in contemporary thought and writing. The entries could have been readily increased to three or four times their present number, which is by no means the case with Section D, in which the other medical specialties are gathered. There remains to be done much research and writing concerning the origin and development of these offshoots from the main trunk of American medicine.

The two following sections reflect the remarkable development of two institutions, the hospital and the medical school, from their modest i8th-century beginnings. The increasing number, size, and complexity of both have brought their special problems, discussions of which take their place beside more purely historical works in each section.

Section $G$ on public health includes some titles on the early American epidemics, the most potent stimulus to activity in the field, and on the problem of disease in general. Other works discuss the beginnings of the movement, its professional aspects, and the extent of the public health resources presently available to the American people.

The increasing efficiency of medical care has concurrently increased its expense, so that the cost of treatment and hospitalization bears heavily or even crushingly upon the average family budget. This has led to various proposals for distributing the burden throughout the community, and these again to much controversy, reflected in a large and growing body of publication, of which we can present only a sampling. 


\section{A. Medicine in General}

4804. Burrage, Walter L. A history of the Massachusetts Medical Society, with brief biographies of the founders and chief officers, 1781-1922. [Norwood, Mass.] Priv. Print., 1923. 505 p. 23-18826 RI5.M5B8

Chartered by the Commonwealth of Massachusetts in 1781 "to promote medical and surgical knowledge ... as well as to make a just discrimination between such as are duly educated ... and those who may ignorantly and wickedly administer medicine," the Massachusetts Medical Society is the oldest medical society in the United States with a continuous record of its meetings from its founding to the present. The Secretary of the Society utilizes its manuscript records to tell the story from 1765 , when efforts were first made to form a state medical society, to 1922. Notwithstanding the leadership exercised by Pennsylvania men of medicine, the Medical Society of the State of Pennsylvania was not organized until more than 75 years later. The story of that Society has been edited by Dr. Howard $\mathrm{K}$. Petry: A Century of Medicine, 1848-1948; the History of the Medical Society of the State of Pennsylvania ([Harrisburg?] 1952. 404 p.).

4805. Cannon, Ida M. On the social frontier of medicine; pioneering in medical social service. Cambridge, Harvard University Press, 1952. $273 \mathrm{p}$. 52-8215 HV687.5.U $\mathrm{U}_{52} \mathrm{M}_{33}$

Notes and references: p. $261-266$.

Dr. Richard Clarke Cabot was one of the first to recognize the relationship between the social and economic background of patients and their medical problems. He made a great contribution to medical progress when he secured the appointment of a social worker in the Out-Patient Department of the Massachusetts General Hospital in 1905, and thereby laid the foundation for the growth of medical social service in the United States. The author, who for 3 I years was the Chief of the Social Service Department of the Massachusetts General Hospital, traces the evolution of that service through the years of resistance on the part of the medical staff to its final, full acceptance and establishment as an official department of the Hospital. She goes on to describe the spread of social service to other hospitals and public health services, and the advances in medical science during the first half of the 2oth century which have changed the hospital care of patients.
4806. Fishbein, Morris. Fads and quackery in healing; an analysis of the foibles of the healing cults, with essays on various other peculiar notions in the health field. New York, Covici, Friede, 1932. $384 \mathrm{p}$. 32-28086 R7ro.F55

The American Medical Association has long prosecuted its war against certain methods of healing and has attacked them from time to time in the pages of its Journal. The long-time editor of that Journal (1924-1949) traces the evolution of medical fads from the earliest time in this series of essays, many of which had already appeared in his Medical Follies (1925. 223 p.) and New Medical Follies (r927. 235 p.), published by Boni \& Liveright. Chapters are devoted to such subjects as homeopathy, eclecticism, mind healing, osteopathy, chiropractic, naturopathy, and food and drinking fads of the Americans.

4807. Fishbein, Morris. A history of the American Medical Association, 1847 to 1947; with the biographies of the presidents of the association, by Walter L. Bierring, M. D.; and with histories of the publications, councils, bureaus and other official bodies [by various authors] Philadelphia, Saunders, 1947. 1226 p. Med ${ }_{47-46} \mathrm{R}_{5} \cdot \mathrm{A}_{55} \mathrm{~F}_{5}$

The increase in the number of medical colleges during the first half of the Igth century gave rise to a demand for standardization of the curriculum. Through the efforts of Dr. Nathan Smith Davis of Binghamton, New York, delegates and members of the medical profession from different parts of the United States met in the Academy of Natural Sciences in Philadelphia in May 1847 , and organized the national association "for cultivating and advancing medical knowledge; for elevating the standard of medical education; for promoting the usefulness, honor, and interests of the medical profession; for enlightening and directing public opinion in regard to the duties, responsibilities, and requirements of medical men; for exciting and encouraging emulation and concert of action in the profession, and for facilitating and fostering friendly intercourse between those engaged in it." Dr. Fishbein writes and edits a centennial history of the Association and its influence on medical progress in the United States during its first hundred years.

4808. New York Academy of Medicine. Committee on Medicine and the Changing Order. 
Medicine in the changing order. New York, Commonwealth Fund, 1947. $24^{\circ} \mathrm{p}$. (Its Studies)

Med 47-Ior4 R723.5. $\mathrm{N}_{4}$

This Committee was appointed by the Council of the New York Academy of Medicine in December 1942 to explore the effect of changes which are taking place in our economic and social life on medicine in its various aspects. In this report the Committee makes recommendations concerning the improvement of medical care in both urban and rural areas through the extension of hospital services, and a wider distribution of public health and nursing services. The pros and cons of voluntary prepayment plans and compulsory insurance in a free society are canvassed.

4809. Packard, Francis R. History of medicine in the United States. New ed. New York,

P. B. Hoeber, I93I. 2 v. 32-I3 RI5I.P12 1931

Bibliography: v. 2, p. [124I]-I 266.

The editor of the Annals of Medical History (1917-1942) tells the story of medicine in the United States to the closing years of the igth century, venturing into the 20 th century in only a few cases. The incidence of epidemics in the colonies, the rise of medical legislation, the founding of hospitals, medical schools and periodicals, and the development of medical practice are interwoven with the lives of the physicians, surgeons, and medical specialists who participated in and influenced those events. The chapters on "The Medical Department of the Army from the Close of the Revolution to the Close of the Spanish-American War," by Col. Percy M. Ashburn; and "The History of the Medical Department of the U. S. Navy," by Lt. Cmdr. Robert P. Parsons, are of special interest. In $1929 \mathrm{Col}$. Ashburn published a comprehensive History of the Medical Department of the United States Army (Boston, Houghton Mifflin. 448 p.).

4810. Pickard, Madge E., and Roscoe Carlyle Buley. The Midwest pioneer, his ills, cures, \& doctors. Crawfordsville, Ind., R. E. Banta, I945. $339 \mathrm{p}$. $\quad S$ G $_{45-165}$ Ri5r.P "Bibliographical note": p. [307]-324.

This is "a nontechnical account of pioneer medicine" in the Middle West prior to $185^{\circ}$. It describes the "afflictions" that had followed the settlers West, the home remedies, the bleeding, purging and blistering of the doctors, the growth of irregular medical sects, and the rise of the drug trade. Against this background of the pioneers' struggle to find relief from pain, the authors trace the development of medical schools, societies, literature, and legislation under the leadership of Daniel Drake, the Samuel Grosses and others. The bibliographical note at the end is supplementary to the more important medical books which have been mentioned in the text and the notes, and is "intended in part to round out a brief guide to the study of early mid-western medicine."

48I 1. Reed, Louis S. The healing cults; a study of sectarian medical practice: its extent, causes, and control. Chicago, University of Chicago Press, 1932. I34 p. (Publications of the Committee on the Costs of Medical Care, no. 16)

$$
\begin{array}{r}
\text { 32-26695 Ri52. } 665, \text { no. I6 } \\
\text { RM700.R38 }
\end{array}
$$

"References" at end of each chapter.

The Committee on the Costs of Medical Care was "organized to study the economic aspects of the prevention and care of sickness, including the adequacy, availability, and compensation of the persons and agencies concerned." This publication of the committee describes the evolution of osteopathy, chiropractic, naturopathy, Christian Science, and certain types of faith healing, as well as the number, geographical distribution, economic and legal status of the practitioners, in order to complete the picture of medical services available in the United States.

4812. Shafer, Henry Burnell. The American medical profession, 1783 to 1850 . New York, Columbia University Press, 1936. $271 \mathrm{p}$. (Columbia University. Faculty of Political Science. Studies in history, economics and public law, no. 417) 36-20187 $\mathrm{H}_{31 . \mathrm{C}_{7}, \text { no. } 417}$

Bibliography: p. 250-257. RI5I.S45 I936a

A study of medical progress during more than half a century following the American Revolution, a period in which the foundation was being laid for the scientific growth of the medical profession which followed the discovery of anesthesia in the I840's. The author, a historian rather than a member of the medical profession, describes in detail the status of American medicine at the close of the 18 th century, the founding of medical colleges and societies, the increase in the publication of medical literature, the growing awareness of the varying value of the remedies and methods employed, and the development of a code of medical ethics during those years of "transition from medieval customs to modern methods."

4813. Shryock, Richard H. American medical research, past and present. New York, Commonwealth Fund, 1947. $35^{\circ}$ p. (New York Academy of Medicine. Committee on Medicine and the Changing Order. Studies)

Med $47-2507 \quad \mathrm{R}_{737 . S_{4} 8}$

Notes and References at end of chapters. 
Although medical practice, medical education, and hospitals had become a part of the American scene by the close of the 18 th century, they depended on the medical sciences developed by the British, the French, and the Germans. The impetus given to medical research by William Henry Welch in his pathological laboratory in 1878 and later at the Johns Hopkins Medical School, was bearing fruit by 1895 when American medicine began to "emerge on a level of cultural independence." Dr. Shryock, a historian who has increasingly specialized in medical history, traces the advances in medical research through the era of private support, the period of great philanthropies, and the gradual development of public-supported research programs. The last chapter summarizes the impact of World War II on medical research and some early post-war programs. The integration of research, teaching, and practice is examined in Medical Research: $A$ Midcentury Survey, published for the American Foundation (Boston, Little, Brown, 1955. 2 v.).

4814. Sigerist, Henry E. American medicine; translated by Hildegard Nagel. New York, Norton, 1934. 3I6 p. 34-40281 Ri5r.S52 Bibliography: p. 289-304.

The author, professor of medicine at the University of Leipzig, and more recently the William $\mathrm{H}$. Welch Professor of the History of Medicine at Johns Hopkins University, presents a historical sketch of American medicine from the colonial period to the early 1930's. It is based on four years of intensive study, and a tour through the United States during which he visited medical schools, laboratories, and hospitals, and observed the conditions of medical practice and public health service. Dr. Sigerist, with some misgivings concerning his American audience, portrays for Europeans the America which he foresees as the center of gravity of the medical sciences. His book has not been replaced as the most convenient brief introduction to its subject.

4815. Stern, Bernhard J. American medical practice in the perspectives of a century. New York, Commonwealth Fund, 1945. 156 p. ([New York Academy of Medicine. Committee on Medicine and the Changing Order. Studies])

Bibliographical footnotes.

$$
\mathrm{SG}_{45-126} \mathrm{R}_{723 \cdot 5 \cdot \mathrm{S} 8}
$$

The first in a series of studies made under the auspices of the Committee established by the Council of the New York Academy of Medicine. The author, a teacher of sociology rather than a medical man, looks at medicine not as an isolated science, but as a segment of life which is affected by and contributes to the economic, social, and technological changes of the period. Chapters on the specialist and the general practitioner, the income of physicians, and the distribution of doctors and medical services, are illustrated by statistics and cases so as to show the effect on the profession and the general welfare. The study concludes with the thought that the "problems of medical practice that are agitating the public today are primarily concerned with the provision of a high quality of curative and preventive medical service to all people," regardless of income, race or geographical location.

4816. Thatcher, Virginia S. History of anesthesia, with emphasis on the nurse specialist. Philadelphia, Lippincott, 1953. 289 p.

$$
\text { 53-9092 RD79. } \mathrm{T}_{49}
$$

Research in the use of gases as anesthetics was begun in England before 1800, but successful experiments in the administration of ether were finally made in the United States in the I 840 's. This was America's first great contribution to the medical profession-the means of painless surgery. The author, editor of American Association of Nurse Anesthetist Publications, says that her purpose is "to extend the knowledge of anesthetists about themselves beyond the framework of personal reference and of already published histories." The place of the nurse as an anesthetist and the organization, history, and sphere of influence of the National Association of Nurse Anesthetists are described in detail.

4817. Truman, Stanley R. The doctor, his career, his business, his human relations. Baltimore, Williams \& Wilkins, 1951. I5I p.

$$
{ }_{5 \mathrm{I}-2566} \mathrm{R}_{727} \cdot \mathrm{T}_{7}
$$

The transition from medical student to practicing physician is a neglected phase of medical training, according to the author. He has written this book to interpret, within the framework of the "Principles of Medical Ethics of the American Medical Association" (Appendix A), the professional problems as well as the patient-physician relations, public relations, and interprofessional situations which confront the young doctor. Selection of a community in which to practice medicine, planning a functionally efficient office, selection of assistants, maintenance of records, and insurance and savings are discussed, and also summarized at the end in a "Check List of Things To Do When You Start in Practice." One part of the author's theme receives more detailed treatment in James E. Bryan's Public Relations in Medical Practice (Baltimore, Williams \& Wilkins, 1954. 301 p.). 


\section{B. Physicians and Surgeons}

4818. [Beaumont] Myer, Jesse S., comp. A new print of Life and letters of Dr. William Beaumont. With an introd. by Sir William Osler. St. Louis, C. V. Mosby, 1939. xxxi, 327 p.

$$
\text { 39-16649 Rr54.B35M8 } 1939
$$

"Literature references and abstracts of cases of gastric fistulae prior to that of St. Martin": p. 308312; "Summary of literature consulted": p. 313-315.

Born in Vermont in 1785 , William Beaumont served his medical apprenticeship there until 1812, when he left for Plattsburg, New York, and joined the army as surgeon's mate. Ten years later, Beaumont was stationed at Fort Mackinac when he was called to treat a young French Canadian, Alexis St. Martin, who had been accidentally shot, leaving a cavity in his abdomen which would not heal. This afforded Beaumont the opportunity to observe the functioning of the digestive system, to conduct experiments with the gastric juices, and to gain preëminence in the advancement of physiology through the publication of his keen and methodical observations. Dr. Myer's biography was first published in I 912 on the one hundredth anniversary of Beaumont's entry into the pracice of medicine, and is based on a collection of manuscript memoranda, diaries, letters, etc., in possession of Beaumont's daughter, Mrs. Sarah Keim of St. Louis. This reprint contains several hitherto unpublished letters written by Alexis St. Martin, and a "Present-day Appreciation of Beaumont's Experiments on Alexis St. Martin," by Dr. Andrew C. Ivy, which does not appear in the earlier printing. At at meeting of the International Congress of Physiologists in I929, William Beaumont was "figuratively canonized as the patron saint of American Physiology," and in 1953, one hundred years after his death, the Michigan State Medical Society issued the Beaumont Memorial Number of its Journal (February I953) in which the projected Beaumont Memorial on Mackinac Island, where he carried out some of his first experiments, is described.

48r9. [Billings] Garrison, Fielding $\mathrm{H}$. John Shaw Billings; a memoir. New York, Putnam, 19I5. 432 p. I5-9723 RI54.B . $_{59} \mathrm{G}_{3}$ "Bibliography of the writings of Dr. John S. Billings, by Miss Adelaide R. Hasse": p. 4II-422. Billings (1838-1913) stands out in the world of medicine as the organizer of the tools of medical research. As a student at the Medical College of Ohio he became conscious of the need for a great medical library in the United States. His opportunity came at the close of the Civil War when unused hospital funds were diverted to the Surgeon General's Library and he was placed in charge. The first volume of Dr. Billings' monumental work, the Index Catalogue, appeared in 1880 . The first issues of its companion publication, Index Medicus, planned as a monthly guide to current medical literature, had appeared in 1879 . He represented American medicine at the meeting of the International Medical Congress at London in $188 \mathrm{I}$, where his address, Our Medical Literature, was received with enthusiasm. Dr. Billings' experiences as a medical officer during the Civil .War, his part in the construction and organization of the Johns Hopkins Hospital and Medical School and the New York Public Library, as well as his activities in the fields of hygiene and sanitary engineering, and vital and medical statistics, are also treated in this Memoir by the assistant librarian of the Surgeon General's Library (1889-1922), a pioneer American historian of medicine.

4820. [Blackwell] Ross, Ishbel. Child of destiny, the life story of the first woman doctor. New York, Harper, 1949. 309 p.

Bibliography: p. 295-298. 49-10905 Ri54.B623 R6

The education of women as physicians in the United States had its beginning in October 1847 when the Geneva Medical School of western New York accepted the application of the ambitious and tenacious but modest Elizabeth Blackwell (I82I1910), who, in 1832, had emigrated from Britain to the United States with her parents. After graduating and pursuing her studies abroad, Elizabeth Blackwell returned to New York where she opened the New York Infirmary, for "providing and furnishing medicines and medical and surgical aid to such persons as may be in need thereof, and unable by reason of poverty to procure the same; also the training of an efficient body of nurses for the service of the community; and also the employment of medical practitioners of either sex, it being the design of this Institution to secure the services of well qualified female practitioners of medicine for its patients." The New York Infirmary, rising ten stories high on Stuyvesant Square, is now a superb general hospital, which celebrated its Ioo years of service in 1954. So influential was the example of Elizabeth Blackwell that by the turn of the century $7,3^{87} 7$ 
women were practicing medicine in the United States.

4821. [Cushing] Fulton, John F. Harvey Cushing, a biography. Springfield, Ill., Thomas, 1946. 754 p. (Yale University. School of Medicine. Yale Medical Library. Historical Library. Publication no. 13) Med 46-15I Rr54.C96F8

Dr. John F. Fulton, Sterling Professor of the History of Medicine at Yale University, and Harvey Cushing's literary executor, has interwoven the story of Cushing's life with selections from family papers, diaries, and case histories, with their caricatures and meticulous drawings, to produce a biography of the eminent brain surgeon which appeals to laymen as well as to medical students. As Resident in Surgery at Johns Hopkins Medical School in the late 189o's, Cushing (1869-1939) was surrounded by such men as William Henry Welch, William Osler, and William S. Halsted, Surgeon-in-Chief, who profoundly influenced his career as a surgeon. A paper on trigeminal neuralgia, which Cushing read before a joint meeting of the Philadelphia Neurological Society and the College of Physicians in April I 900 , stands as an important landmark in the history of neurosurgery because of the unusual detail and illustrations. In this, and later writings, Cushing's illustrations set a standard which has left a mark on American surgery, and his methods established neurological surgery as a recognized specialty of prime importance to the medical profession throughout the world. In 1950, a less monumental but competent biography entitled Harvey Cushing: Surgeon, Author, Artist, by Elizabeth H. Thomson (New York, Schuman. 347 p.) was published as one of the books in The life of science library.

4822. Flexner, James Thomas. Doctors on horseback; pioneers of American medicine. New York, Garden City Pub. Co., 1930. 370 p.

$$
\text { 39-25572 Ri53.F5 } 1939
$$

Contents.-Seer and Continental soldier: John Morgan, 1735-1789.-Saint or scourge: Benjamin Rush, 1745-1813.-A backwoods Galahad: Ephraim McDowell, 1771-1830.-Genius on the Ohio: Daniel Drake, $1785-1852$.- Two men and destiny: William Beaumont, 1785-1853 [and Alexis St. Martin].The death of pain: Crawford W. Long, $1815-1878$; William T. G. Morton, 1819-1868.-Selected bibliographies (p. 355-359).

The author, who collaborated with his distinguished father in writing the biography of William Henry Welch (no. 483I), writes these six sketches for the general reader to show how "in the settlements of a new nation there appeared doctors of genius, explorers who, without laboratories or instruments of precision or even any formal training, made great discoveries that helped usher in the age of modern medical science."

4823. [Gorgas] Gibson, John M. Physician to the world; the life of General William C. Gorgas. Durham, N. C., Duke University Press, 1950. 315 p. (Duke University publications)

Bibliography: p. [295]-307.

$$
\text { 50-1088I RA424.5.G6G5 }
$$

As a sanitarian Gorgas (1854-1920) applied the principles established by the Reed Commission to free Havana and the Panama Canal Zone of mosquitoes and yellow fever, and as Surgeon General of the U.S. Army during World War I he safeguarded the health of the largest body of men ever to wear the American uniform up to that time. "His vision and his initiative translated the known scientific facts concerning yellow fever into practical accomplishment, thereby making possible the control of this scourge of the tropics and the building of the Panama Canal." Presenting an honorary degree from Johns Hopkins University, Dr. William Welch described Gorgas as a "physician and sanitarian of the highest eminence, who, by his conquests over pestilential diseases, has rendered signal service to his profession, to his country, and to the world." The author of this admiring biography is a journalist, a State health department official, and, like his subject, an Alabamian.

4824. Gross, Samuel D. Autobiography of Samuel D. Gross, M. D. . . . emeritus professor of surgery in the Jefferson Medical College of Philadelphia. With sketches of his contemporaries. Edited by his sons. Philadelphia, G. Barrie, 1887 . $2 \mathrm{v}$.

${ }_{15}-9084$ Ri54.G77 $\mathrm{A}_{3}$

As a surgeon, teacher, and author, Samuel D. Gross (1805-1884) was one of the most influential physicians in Igth-century America, and one of the earliest to create American medical literature of importance. He writes the story of his life with the hope of stimulating the ambitious to work for the advancement of science and the amelioration of human suffering. Born in Pennsylvania, Gross graduated from Jefferson Medical College in Philadelphia, to which he returned to occupy the chair of surgery between 1865 and 1882 . Among his contributions were his surgical handbook entitled $A$ System of Surgery; Pathological, Diagnostic, Therapeutique, and Operative (Philadelphia, Blanchard \& Lea, I859. 2 v.) which went through many editions, and the Lives of Eminent American Physicians and Surgeons (Philadelphia, Lindsay \& Blakiston, 186r. 836 p.) which he edited and published "to popularize the profession, and to place its services and claims more conspicuously, than has yet been 
done, before the American people." The founding of the American Surgical Association by Dr. Gross in 1880 , "to foster surgical art, science, education and literature," is typical of his continuing interest in the development of surgery in America.

4825. Hertzler, Arthur E. The horse and buggy doctor. New York, Harper, 1938. 322 p. $3^{8-27572} \mathrm{R}_{54} \cdot \mathrm{H}_{39} \mathrm{~A}_{3}$

Arthur Emanuel Hertzler (1870-1946), surgeon, teacher, founder of a hospital, and author, has taken time out from his scientific monographs on surgical pathology and other medical subjects, to record for posterity one phase in American life, which through the development of better communications, hospitals, and specialization, is fast becoming a tradition. Set in Kansas, and interspersed with human incidents, Dr. Hertzler's own story is typical of that which might be told by any doctor-surgeon who practiced his profession in a small community and its surrounding countryside during the latter part of the igth century and the first quarter or more of the 2oth. Dr. Hertzler pictures the difference between the medical education available to him and to the students of the I930's; the changes in modes of transportation from horse and buggy to automobile; the contrasts between the bedside doctor and the office physician, the kitchen operation and hospital surgery, and between the days of epidemics and those of immunity, and he summarizes the effects of such changes on medical care in the United States.

4826. [Mather] Beall, Otho T., and Richard $\mathrm{H}$. Shryock. Cotton Mather, first significant figure in American medicine. Baltimore, Johns Hopkins Press, 1954. 24I p. (Johns Hopkins University. Institute of the History of Medicine. Publications. Ist ser.: Monographs, v. 5)

$$
\text { 54-8009 F67.M4218 }
$$

Reprinted from volume 63 of the Proceedings of the American Antiquarian Society.

The cultural significance of medical thought in the English colonies at the beginning of the 18th century is illustrated in the life of Cotton Mather ( $1663-1728$ ), whose role in medical history is fully told for the first time. He recognized in medicine "an immediate opportunity to apply science to the welfare of mankind," and his activity during the smallpox epidemic of I $72 \mathrm{I}$ is his major contribution to medical practice. His use of inoculation "was the first positive achievement in preventive medicine." See also item no. 40.

4827. [Mayo] Clapesattle, Helen B. The Doctors Mayo. Minneapolis, University of Minnesota Press, I94I. xiv, 822 p.

$$
\text { 4I-5203I RI54.M } \mathrm{M}_{33} \mathrm{C}_{3}
$$

Bibliographical notes: p. 7I7-799.

The Mayo Clinic is a living, world-renowned memorial to Dr. William W. Mayo (I8rg-rgri) and his two sons, who molded it as deftly as their skills have shaped the techniques, the teaching, and the practice of surgery since the end of the roth century. The author, editor of the University of Minnesota Press, has had access to correspondence and other manuscripts, newspaper clippings, and transcripts of interviews for the basis of her life of the Mayos, which is also the story of the Midwest as it emerged from pioneer days, and of medicine as it developed from the horse-and-buggy period to the age of clinicians. Her book was translated into several foreign languages, and reprinted in 1943 by the Garden City Publishing Company (Garden City, N. Y., 822 p.); a second edition, condensed for quick reading, was published in 1954. The Mayos' contribution to medicine began in surgery, but, in the words of the author, "their reputation rests upon the integrated, cooperative form of medical practice and education they developed," which "is part of the heritage of all medicine and of every American."

4828. [Mitchell] Earnest, Ernest P. S. Weir Mitchell, novelist and physician. Philadelphia, University of Pennsylvania Press, 1950. 279 p. 50-8063 Ri54.M66 $\mathrm{E}_{3}$

The list of institutions and individuals who permitted Dr. Earnest to use their collections of Mitchell papers, and the "Notes" (p. 245-274) indicate the extensive research that has gone into this biography of Silas Weir Mitchell (1829-19I4) of Philadelphia, who gained prominence in his own day for his work on injuries of the nerves, his "rest cure" for nervous diseases, his discovery of the nature of rattlesnake venom, and his writings, both scientific and fictional. Treating nerve wounds during the Civil War, Mitchell gave impetus to the infant science of neurology, and his critical address before the 5oth annual meeting of the Medico-Psychological Association, in 1894 , stimulated the movement for improved institutions for the care of the mentally ill. Like Oliver Wendell Holmes, and more recently Somerset Maugham and A. J. Cronin, Mitchell drew on his medical experiences in touch with the intimate lives of his patients to produce novels. In 1952 David M. Rein published a study of those novels: S. Weir Mitchell as a Psychiatric Novelist (New York, International Universities Press. 207 p.). Both Earnest and Rein agree that Mitchell's "accomplishments deserve to be recalled more widely and wrought into the tradition of American culture." 
4829. [Osler] Cushing, Harvey W. The life of Sir William Osler. London, New York, Oxford University Press, 1940. xviii, 1417 p. 40-2775I $\mathrm{R}_{4} 89 . \mathrm{O}_{7} \mathrm{C} 8 \quad 1940$ "Originally published in 1925 in a two-volume edition."-Foreword.

William Osler (1848-1919) was born in Canada and spent the last 15 years of his life in England, but the fruitful interlude of 21 years in the United States entitles him to a place among those who laid the foundations of modern American medicine. Becoming professor of clinical medicine at the University of Pennsylvania in 1884 , his bedside instruction was an innovation in the Philadelphia school. Through the influence of William $\mathrm{H}$. Welch, Osler was appointed Physician-in-Chief of the new Johns Hopkins Hospital in 1886 , and was primarily responsible for the organization of the clinic. During I6 years of assocation with the Johns Hopkins Hospital and Medical School, Osler published his magnum opus, The Principles and Practice of Medicine, (which reached its r6th edition in 1947) and investigated the etiology of typhoid fever, malaria, pneumonia, and other major diseases, so that his "greatest professional service was that of propagandist of public health measures." In 1926 Cushing received the Pulitzer prize for this Life, which is regarded as one of the great medical biographies.

4830. [Rush] Goodman, Nathan G. Benjamin Rush, physician and citizen, $1746-1813$. Philadelphia, University of Pennsylvania Press, 1934 . 421 p. 34-33318 Ri54.R9G65

Bibliography: p. [377]-406.

This is the first full-length biography of one of the most versatile figures in I8th-century America. Becoming a professor in the first medical school in the colonies in 1769 , Rush through his lectures and writings exerted an influence on the medical profession that was still apparent at the close of the century. As a physician he started the practice of medicine among the underprivileged of Philadelphia, in whose welfare he always maintained a keen interest; introduced new theories concerning the cause and cure of diseases which antagonized some of his colleagues; led the fight against epidemics, and championed the humane treatment of the mentally ill. Benjamin Rush threw his energies behind the cause of independence and became a member of the Continental Congress, a signer of the Declaration of Independence, and an influence in the medical department of the Continental Army during the Revolution. His published writings, which $\mathrm{Mr}$. Goodman has listed in his bibliography, and the more recently published collection of the Letters of Benjamin Rush, edited by Lyman H. Butterfield, and published for the American Philosophical So- ciety as volume 30 , parts I-2, of its Memoirs (Princeton, N. J., Princeton University Press, 195I. 2 v.) show that he was a prolific writer, and fearless in expressing his opinions on any topic in which he was interested.

4831. [Welch] Flexner, Simon, and James Thomas Flexner. William Henry Welch and the heroic age of American medicine. New York, Vi-

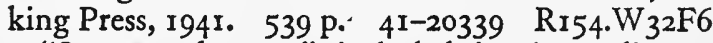
"Source references" included in Appendix C; Notes to the text, p. 466-524.

This biography is also the story of developments in medical sciences from the r870's to the I930's as shaped by William Henry Welch (1850-1934), who is often called the "Dean of American Medicine." He was born in Connecticut, the son and grandson of physicians; and educated at Yale, at the College of Physicians and Surgeons of Columbia University, and abroad. Impressed by the advances in histology, chemistry, physiology, and pathology which he observed in Germany, Dr. Welch founded America's first pathological laboratory at Bellvue Hospital Medical College in 1878 , and pioneered in the growth of American medical research. As professor of pathology in Johns Hopkins University, he helped to organize the Hospital in 1889 and the Medical School in 1893 as great medical centers for teaching, research, and clinical medicine. Known at home and abroad for his experiments in pathology and bacteriology, his interest in public health and sanitation, and his association with the Rockefeller Institute of Medical Research and the Journal of Experimental Medicine, Dr. Welch was the recipient of many honors and awards on both sides of the Atlantic. At the time of his 8oth birthday, Dr. Welch took pride in his thought that "America is now paying the debt which she owed so long to the Old World by her own active and fruitful participation in scientific discovery and the advancement of the science and art of medicine and sanitation." Donald H. Fleming in his recent brief biography, William H. Welch and the Rise of Modern Medicine (Boston, Little, Brown, 1954. 216 p.), places the work of the Flexners first on his list of "Acknowledgments."

4832. Young, Hugh $\mathrm{H}$. Hugh Young, a surgeon's autobiography. New York, Harcourt, Brace,

1940. $554 \mathrm{p}$. 40-33II7 Rr54.Y63 $\mathrm{A}_{3}$

Dr. Young's story of his life (1870-1945) opens with his early years in Texas, and his education in Virginia and Maryland, and closes with a description of his civic activities, his travels, and his hobbies. The central portion reviews the development of urology as one of the early medical specialties in the United States, and the author's service at home as 
director of the Brady Urological Institute of Baltimore, and overseas as director of the A. E. F.'s Division of Urology. Dr. Young's researches in the field of his preëminence continued as long as he lived; he submitted an article for publication in the
November 1945 issue of the Journal of Urology, just one month before his death. The book has numerous stories of cases, simply presented, and a series of remarkable technical drawings; it should appeal to both the layman and the physician.

\section{Psychiatry}

4833. American Psychiatric Association. One hundred years of American psychiatry. New York, Published for the American Psychiatric Association by Columbia University Press, 1944. xxiv, 649 p. A44-1921 RC435.A6

The publication of this volume commemorates the rooth birthday of the American Psychiatric Association, which was founded in Philadelphia on October 16,1844 , by thirteen physicians, all of them superintendents of hospitals for the mentally ill. Thirteen authorities in the field have contributed chapters on the history of psychiatry, and of the Association; the story of mental hospitals, and of psychiatric research, literature, and therapies; the development of mental hygiene; military psychiatry; psychology in relation to American psychiatry; the growth of psychiatry as a specialty; its legal aspects; and its influence on anthropology in America. Psychiatry, according to Dr. Gregory Zilboorg, who writes the Foreword, "touches on every aspect of the psychological and sociological problems which make up our civilized living, healthy and diseased. This volume is therefore intended to represent a survey of psychiatry as a growing cultural force." It contains bibliographical footnotes, a list of "Some important books in American psychiatry published in the last twenty-five years": p. ${ }_{[266}-269$, and a list of American psychiatric periodicals": p. 269-271.

4834. Beers, Clifford Whittingham. A mind that found itself; an autobiography. Garden City, N. Y., Doubleday, Doran, 1935. 434 p. $35-6068 \quad \mathrm{RC}_{439 . B_{4}} \mathrm{r} 935$

This is the "twenty-fifth anniversary edition" of Clifford Beers' autobiography, first published in 1908. Certain pages which have served their purpose have been deleted from this edition, but interesting letters and an account of important work that has grown out of the publication of the book have been appended. As a young business man Beers suffered a severe mental upset, and in his story he describes the condition and treatment of the mentally ill as he experienced them in several institutions in which he was a patient. Its publication heralded the beginning of a new era in the manage- ment of the mentally ill, second only to that which Dorothea Dix had instigated in the middle of the rgth century. In 1909 Beers helped to found the National Committee for Mental Hygiene, which broadened its scope to include activities outside of hospitals, and guided mental-hygiene activities for forty years. The establishment of the Phipps Clinic for psychiatry at Johns Hopkins, through the infuence of Dr. William Welch and the philanthropist, Henry Phipps, illustrates the interest which the autobiography stimulated. The American Foundation for Mental Hygiene, founded by Beers in 1928 to raise funds for the National Committee, and for state and other agencies in the field, is a memorial to Beers' achievements.

4835. Bryan, William A. Administrative psychiatry. New York, Norton, 1936. 349 p.

Bibliography: p. 339-34r. $37-27130 \quad \mathrm{RC}_{439 . \mathrm{B} 885}$

Dr. Bryan was for years superintendent of the State Hospital at Worcester, Mass., which was established in 1832, and has often led in new methods. In this book he describes the organization and problems of a psychiatric hospital for those who wish to prepare for the specialty of administration. Chapters are devoted to building the staff, the nursing programs, the standards of care; medical, surgical, and psychiatric services; the social worker, the teaching program, and research; the clinic with its mental hygiene program as a factor in preventive medicine, and the relation of the administrator and staff to community groups. Under improved and skilled administration, the author foresees "the mental hospital of the future as a powerful and leading factor in the public health of the community."

4836. Deutsch, Albert. The mentally ill in America; a history of their care and treatment from colonial times. 2d ed., rev. and enl. New York, Columbia University Press, 1949. xx, 555 p.

Bibliography: p. [520]-537.

$$
\text { 49-7527 RC443.D4 } 1949
$$

The first edition, published in 1937, was made possible by the American Foundation for Mental 
Hygiene. In the second edition the author adds a review of recent trends toward prevention and better treatment of mental illness in the United States including the National Mental Health Act of 1946 authorizing the Federal Government to give substantial support to research, to training psychiatric personnel, and to expansion of services for those who do not require hospitalization. The subject is approached from the standpoint of the social historian, who illustrates how improvements in personnel, techniques, and institutions follow changes in social attitudes. This is the story of another episode in American life illustrating the combined efforts of doctors, social workers, philanthropists, and governmental units to improve the well-being of a less fortunate segment of the population.

4837. Deutsch, Albert. The shame of the States. New York, Harcourt, Brace, 1948. 188 p. $4^{8-9247} \mathrm{RC}_{443 . \mathrm{D}_{4} \mathrm{I} 5}$

Believing that civilization in the United States will be judged, to a great extent, by the public's attitude toward the care and treatment of the mentally ill, Deutsch attempts to revitalize the crusade started by Dorothea Dix by publishing the results of his survey of existing conditions in certain psychiatric hospitals in selected areas. The author considers the action taken by the American Psychiatric Association in 1946 , in urging every state mental hospital superintendent to take the lead in exposing to public view any bad conditions within his knowledge, as a milestone toward attaining a higher level of institutional care. The last chapter is devoted to Deutsch's idea of an "ideal state mental hospital," which he believes will become a reality through the efforts of an enlightened and aroused public.

4838. Greenblatt, Milton, and others. From custodial to therapeutic patient care in mental hospitals; explorations in social treatment. New York, Russell Sage Foundation, 1955. 497 p.

$$
\text { 55-II724 RC439.G82 }
$$

Bibliography, compiled by Frederic L. Wells: p. $431-484$.

This book is the result of a project sponsored by the Russell Sage Foundation to study patient care in mental hospitals, and to explore the utilization of the whole environment-the physical resources as well as the social interaction between doctors, nurses, aides, and patients - in the cure or improvement of the patient. Considered by the Foundation as among the "best of those teaching and research institutions that are concerned with the advancement of psychiatric treatment," the Boston Psychopathic Hospital was selected to estabish coöperative relations with the Bedford V. A. Hospital and the Metropolitan State Hospital in Waltham, "in order to test the applicability of principles and practices such as those used by it." Part I traces the evolution of practices developed at the Boston Psychopathic Hospital, and Parts II and III comprise the report on improvements achieved at the other two hospitals. William L. Russell in The New York Hospital; a History of the Psychiatric Service, $177^{1-1936}$ (New York, Columbia University Press, I945. 556 p.) describes the progress of that institution's Bloomingdale Asylum and Payne Whitney Clinic. The theory of social structure is the basic thesis of Alfred H. Stanton and Morris S. Schwartz in The Mental Hospital, a Study of Institutional Participation in Psychiatric Illness and Treatment (New York, Basic Books, 1954. 492 p.). The indication is that a transition is rapidly being made from custodial restraint of the insane in asylums to the curative treatment of the mentally ill, through improvement of the social environment, in hospitals.

4839. Marshall, Helen E. Dorothea Dix, forgotten samaritan. Chapel Hill, University of North Carolina Press, 1937. 298 p.

Bibliography: p. $\left[27 \mathrm{I}_{1}-287\right.$.

$37-98 \mathrm{II}_{5} \mathrm{HV}_{2} 8 . \mathrm{D}_{6} \mathrm{M}_{3}$

This scholarly dissertation on the life of Dorothea Dix, published 50 years after her death, tells the story of one of America's great pioneer social workers, which is also a chapter in the development of institutional treatment of the mentally ill in the United States. Following a survey of the county jails, almshouses, state penitentiaries, and other institutions, Dorothea Dix presented memorials to the state legislatures, and to Congress in 1848 , in which she represented the mentally ill as "wards of the nation"- a broadened concept of governmental responsibility. Dorothea Dix erected her own monument in service to her fellow man through the $\mathbf{3 2}$ hospitals which were established by her efforts in the United States, as well as several abroad. Her childhood, and her work as Superintendent of Nurses during the Civil War, are other episodes of great interest.

4840. White, William Alanson. William Alanson White; the autobiography of a purpose. With an introd. by Ray Lyman Wilbur. Garden City, N. Y., Doubleday, Doran, 1938. xix, 293 p.

Bibliography: p. [275]-293.

$$
3^{8-13677} \mathrm{RC}_{439} \text {. W5 }
$$

William Alanson White (1870-1937) was one of the founders of modern psychiatry. An exponent of what has been labeled the genetic concept in psychiatry, he emphasized the importance of environment and adequate research into the problems of each individual patient as essential to treatment. He 
turned to occupational therapy, hydrotherapy, and psychotherapy as methods of dispensing with restraint. Advocating coöperation between the legal profession and psychiatry in dealing with criminals, his interest in forensic problems led in 1934 to the organization of a Section on Forensic Psychiatry of the American Psychiatric Association. Much of the Autobiography deals with his years in Washington as administrator of Saint Elizabeths Hospital, which he helped to make one of the leading mental hospitals in the country. He broadened the area of his influence through courses in nervous and mental diseases and psychiatry at Georgetown and George Washington Universities. His book, Outlines of Psychiatry, first published in 1907 , reached its fourteenth edition in 1935 , and has been called a "classic, particularly from the pedagogic standpoint." The William Alanson White Psychiatric Foundation was created by a group of friends and associates in 1933 to perpetuate Dr. White's work.

\section{Other Specialties}

4841. American Academy of Pediatrics. Committee for the Study of Child Health Services. Child health services and pediatric education; report of the Committee for the Study of Child Health Services, the American Academy of Pediatrics, with the cooperation of the United States Public Health Service and the United States Children's Bureau. New York, Commonwealth Fund, 1949. xxv, $270 \mathrm{p}$.

References: p. 257-258. $49-2785$ RJ $42 . U_{5} \mathrm{~A}_{62}$

Supplement: Methology and tabulations on services. New York, Commonwealth Fund, r949. I. v. (various pagings)

RJ42.U5A62 Suppl.

By the end of the rgth century the American Pediatric Society had been founded; the organ of the profession, Pediatrics, established; and a considerable literature on the diseases of childhood published in the United States. Pediatrics had taken its place among the early specialties of the medical world. The organization of the American Association for the Study and Prevention of Infant Mortality in rgog, the creation of the U. S. Children's Bureau in 1912, the White House Conferences of 1919, 1930, and 1940 , the passage of the Social Security Act in 1935, and the inauguration of a nationwide study of child health services by the American Academy of Pediatrics in 1944, of which this volume is the report, are all milestones in the development of the child health movement. Part I of this study surveys the pediatric aspects of private practice, hospitals, and community health agencies, while Part II is an evaluation of facilities for training physicians who are responsible for child health care. The study aims to promote the Academy's objective: "preventive, diagnostic, and curative medical services of high quality, which, when used in cooperation with other services for children, will make this country an ideal place for children to grow into responsible citizens."
4842. Carr, Malcolm Wallace. Dentistry, an agency of health service. New York, Commonwealth Fund, 1946. xxiv, 219 p. (New York Academy of Medicine. Committee on Medicine and the Changing Order. Studies)

$$
\mathrm{SG}_{46-319} \mathrm{RK}_{34} \cdot \mathrm{U} 6 \mathrm{C}_{3}
$$

"References" at end of most of the chapters.

The development of dentistry as an autonomous profession is traced during more than a century of growth. The first 75 years were devoted to improving techniques through research and discovery, and to establishing an educational system, and a code of practice. More recently, and especially since the passage of the Social Security Act in 1935 made funds available for dental divisions in state health departments, the American Dental Association has been directing the profession toward a place in the public health program and stimulating communities to concern themselves actively with their local dental problems. This proceeds from the profession's growing consciousness of its responsibility in a changing society, and of its responsibility for coöperation with community groups in improving the nation's health. The problem has also been explored by Alfred J. Asgis in Professional Dentistry in American Society; a Historical and Social Approach to Dental Progress (New York, Clinical Press, 1943. 260 p.).

4843. Horner, Harlan $H$. Dental education today. Chicago, University of Chicago Press, 1947. 420 p. Med 47-6ro RK9r.H6

The author is secretary of the Council on Dental Education of the American Dental Association, and his study is based on a survey of dental schools in the United States conducted by the Council principally in 1942-43, with a view toward standardization and accreditation. The chapters deal with organization and plans, financial management and support, faculties, students, curriculum, teaching, 
and auxiliary agencies. Pointing out defects and limitations as well as accomplishments, the author concludes that American dental schools have clearly won world leadership. In his words, "the great challenge of the future to all agencies of dentistry in common-schools, examining boards and practitioners-lies in the inescapable responsibility of carrying to humankind the fruits of the science and of the art the profession already possesses."

4844. Hubbell, Alvin A. The development of ophthalmology in America, 1800 to 1870; a contribution to ophthalmologic history and biography; an address delivered in abstract before the Section of Ophthalmology of the American Medical Association, June 4, 1907. Rev. and enl. Chicago, American Medical Association Press, rgo8. I97 p.

$$
\text { 8-8 } \mathrm{r}_{4} \mathrm{O} \mathrm{RE}_{30 .} \text {.U6 } \mathrm{H}_{9}
$$

George Rosen in his doctoral dissertation, The
Specialization of Medicine with Particular Reference to Ophthalmology (New York, Froben Press, r944. 94 p.), says that "ophthalmology and otology were among the very first specialties to appear... As a result these fields of practice have an older tradition as specialties and enjoy the prestige of established achievement." Dr. Hubbell, professor of clinical opthalmology in the University of Buffalo, describes the American contribution to that tradition in brief sketches of institutions and the individuals who, through research and clinical observation, have developed ocular surgery and other techniques, and have disseminated their findings in publications on the anatomy, physiology, and pathology of the eye. A chapter is devoted to the transition period during which the treatment of diseases of the eye passed from the general physician and surgeon to the ophthalmological specialist, whose position was well established by 1870 .

\section{E. Hospitals and Nursing}

4845. Chesney, Alan M. The Johns Hopkins Hospital and the Johns Hopkins University School of Medicine, a chronicle. Baltimore, Johns Hopkins Press, 1943. 318 p. SG $44-2$ R747.J62 5

With approximately 30 years of service at the Johns Hopkins Hospital and School of Medicine, where he progressed from student, instructor, and associate professor to dean, Dr. Chesney has combined his years of experience with the official records of both institutions to write their history from the incorporation of the University and the Hospital in 1867 to the opening of the School of Medicine in 1893. This first volume was published on the 5oth anniversary of the opening of the School of Medicine, but the second volume, interrupted by the war years, has not appeared. Dr. Chesney tells the story of the unusual trust created by Johns Hopkins, and the careers of great figures of American medicineJohn Shaw Billings, William $\mathrm{H}$. Welch, William Osler, William S. Halsted, Franklin B. Mall, and others-as they assisted in the organization and development of a University unique in the medical annals of the United States. Richard H. Shryock in his brochure, The Unique Influence of the Johns Hopkins University on American Medicine (Copenhagen, Munksgaard, 1953. 77 p.), tells how well the foundation had been laid for future growth in these words: "To Hopkins ... the country was indebted after 1890 for a veritable revolution in the nature and status of medical sciences-with all that this implied for human welfare. This was a de- velopment of major importance in the social and cultural life of the nation, and the meaning of the Hopkins epic is missed if these wider relationships and consequences are ignored. Here is a tradition which should and will be maintained, no doubt in changing forms adapted to changing circumstances." The history of The Johns Hopkins School of Nursing, 1889-1949, by Ethel Johns and Blanche Pfefferkorn (Baltimore, Johns Hopkins Press, I954. $4^{16}$ p.), rounds out the story of this medical center.

4846. Columbia University. New York State Hospital Study. A pattern for hospital care; final report ... by Eli Ginzberg. New York, Columbia University Press, r949. xxiv, $368 \mathrm{p}$.

49-50231 RA98r.N7C6 1949

This study is a report by Columbia University to the Joint Survey and Planning Commission on the present and potential financial position of the voluntary general hospital in New York State. Requests from leaders of voluntary hospital groups for State aid, and the responsibility of the Commission "for developing a long-range construction program to provide facilities which would insure adequate hospital, clinic, and related services for all the people of the State," gave impetus to the study. It seeks to provide a basis for the allocation of Federal funds to construct, expand, or rebuild hospitals in designated areas. In addition to questions concerning the financial position of voluntary general hospitals, the study explores the major challenges which 
confront those hospitals within the next few years, the role of municipal hospitals, and the problems of providing care for patients suffering from chronic diseases, tuberculosis, or mental diseases. It suggests action that can be taken on an individual, communal, and State level to improve the present system and to insure its sound development. In the last chapter the responsibilities of the various organizations in New York State for hospital care are outlined and suggestions offered for an integrated program.

\section{Commission on Hospital Care. Hospital} care in the United States; a study of the function of the general hospital, its role in the care of all types of illness, and the conduct of activities related to patient service, with recommendations for its extension and integration for more adequate care of the American public. New York, Commonwealth Fund, 1947. xxiv, 631 p.

Includes bibliographies.

$$
\text { Med } 47-56 \text { RA98r.A2 } \mathrm{C}_{57}
$$

In October 1944 the American Hospital Association organized its Commission on Hospital Care in order to make a comprehensive survey of hospitals and determine their part in the postwar life of America. Its report discusses the trends in administration and organization that underlie the future development of hospital service, and describes the factors which affect the size and use of hospital facilities and the need for them. It analyzes the physical, service, and financial aspects of existing hospitals. From the pilot project set up in Michigan to serve as a pattern for study in other states, it derives suggestions for the integration of specialized services in the general hospital, and an estimate of additional facilities necessary to provide adequate service to the public. A final section presents methods of financing hospital care, the legal status of hospitals, and their interrelations with governmental and voluntary health agencies. The U. S. Public Health Service cooperated with the Commission in collecting the data for this survey: "The arrangement was unique in that it established a means whereby a voluntary and a governmental agency collaborated in the study and analysis of a public problem." As a sequel to this work the Commission on Financing of Hospital Care was established in November 195I, "to study the costs of providing adequate hospital services and to determine the best systems of payment for such services." The results of that study were published as Financing Hospital Care in the United States (New York, Blakiston, 1954-55. 3 v.). Volume I deals with "Factors Affecting the Costs of Hospital Care;" volume 2, "Prepayment and the
Community;" volume 3, "Financing Hospital Care for Nonwage and Low-Income Groups."

4848. Corwin, Edward H. L. The American hospital. New York, Commonwealth Fund, r946. 226 p.' (New York Academy of Medicine. Committee on Medicine and the Changing Order. Studies.) SG ${ }_{46-293}$ RA981.A2C6 "References" at the end of each chapter.

The adaptation of anesthesia to operative procedures in the 1840 's, the development of new techniques and clinical laboratories, the concentration of population in cities and the popular acceptance of hospitalization insurance plans, and the accumulation and distribution of wealth have all stimulated the growth of general and specialized hospitals. From 178 in 1873 , the year in which the first list of hospitals in the United States was published, the number had increased to 6,655 in 1943 , the year in which the Committee on Medicine and the Changing Order began its study. The author, who was executive secretary of the Committee on Public Health Relations of the New York Academy of Medicine, examines all phases of the American hospital-ownership, finance, geographical distribution, training of nurses and interns, organization of medical services including outpatient departments, and hospital architecture. The American hospital, he concludes, "has not adjusted itself adequately to the income levels of all groups of people or to the needs of all geographic areas. It has not uniformly reached the level of excellence it is potentially capable of achieving." In his final chapter he offers a whole series of practical suggestions calculated to promote these ends.

4849. McGibony, John R. Principles of hospital administration. New York, Putnam, 1952.

540 p. 52-1 $\quad$ 1467 RA97r.M247

The chief of the Division of Medical and Hospital Resources, U. S. Public Health Service (r949-53) describes, among other functions of hospital administration, methods of measuring community needs for hospital services, and raising funds for construction. The principles of functional hospital design and organization will be of special help to those interested in efficient operation. The book fills a need in hospital literature for trustees, administrators, doctors, nurses, and students.

4850. Morton, Thomas G. The history of the Pennsylvania Hospital, r751-1895. Publication authorized by the contributors at their annual meeting, May 1893 , and directed by the Board of Managers. Philadelphia, Times Print. House, I895. 575 p. $\quad 9-1727$ RA982. $55 P_{47}$

The Pennsylvania Hospital in Philadelphia, 
founded in $175 \mathrm{I}$, is the oldest institution intended solely for the care of the sick and injured in the United States. The idea of establishing a hospital was conceived by Dr. Thomas Bond, who, with the assistance of Benjamin Franklin and others, raised funds among their fellow citizens for the support of the hospital. Compiled from original documents, the History contains a chapter on the treatment of the mentally ill whose cause was championed by Benjamin Rush. The maintenance of a community hospital by public subscription provided a pattern for the future development of hospitals in the United States.

\section{New York Academy of Medicine. Commit-} tee on Public Health Relations. Infant and maternal care in New York City; a study of hospital facilities. Edward H. L. Corwin, general director of study. New York, Columbia University Press, 1952. xv, 188 p. 52-II549 RG962.N4N 1952

This study illustrates the concern of a metropolitan community for the health and welfare of its children. A team consisting of an obstetrician, a pediatrically trained nurse, and a pediatrician visited 104 hospital maternity services in New York City. This report presents the facts which they obtained concerning every aspect of the lying-in and nursing services in the hospitals of the city. Specific shortcomings are summarized in the last chapter as a basis for the improvements to be desired.

4852. Roberts, Mary M. American nursing; history and interpretation. New York, Macmillan, 1954. 688 p. $\quad 54^{-12563} \quad \mathrm{RT}_{4} \cdot \mathrm{R} 6$ Bibliographies at end of chapters.

The author, editor emeritus of the American lournal of Nursing, selects 1900, the year of the Journal's founding, and 1952, when the unification of several nursing associations was completed, as the termini of her history of American nursing. The first two chapters picture the American scene at and before the turn of the century and describe the influence of Florence Nightingale, and certain military and religious groups, on the profession in the United States. The transition from private duty to public health nurse, the growing recognition of the practical nurse as part of the nursing profession, the genesis and growth of nursing schools and professional organizations, and wartime duties and peacetime services are interpreted against changes in economic and social concepts, and scientific improvements. The part nurses play in the World Health Organization and international health programs is the subject of the last chapter. The author points out that the development of international nursing activities is a challenge to those nurses who believe that "anything that contributes to the exchange of creative ideas across boundary lines contributes to the welfare of mankind."

4853. Washburn, Frederic A. The Massachusetts General Hospital; its development, r9co1935. Boston, Houghton Mifflin, 1939. 643 p.

$$
\text { 39-17718 RA982.B7 } \mathrm{M}_{53}
$$

Officers of the Massachusetts General Hospital: p. 576-633.

The director emeritus of the Massachusetts General Hospital tells its story during the period of its greatest growth, relating events that occurred prior to 1900 only when they have not appeared in earlier histories, or have been found pertinent to developments that followed the turn of the century. The General Hospital, which cared only for the poor in r9oo, expanded its plant by the addition of the unique Baker Memorial for the benefit of people of moderate means, and the Phillips House for those well able to pay more than the cost of their care. By 1935, with its Out-Patient Department and its services for the mentally ill at McLean, the Hospital was caring for all groups in the community. Changes in administration which provided a more functional organization are described, with the consequent growth of research, the formation of special clinics, and the improvement of facilities for patients, for the investigation of disease, and for the teaching of medicine. Dr. Washburn has written not only an interesting account of the Hospital, but also a "vital chapter in the history of the progress of medical science and administration."

4854. Yost, Edna. American women of nursing. Rev. ed. Philadelphia, Lippincott, 1955. xxiii, 197 p. $\quad 55-3216 \quad \mathrm{RT}_{34 . Y_{7}}$ I955 Contents.-M. Adelaide Nutting.-Lillian Wald. Annie M. Goodrich.-Isabel M. Stewart.-Sister M. Olivia Gowan.-Estelle Massey Osborne.-Florence G. Blake.-Anne Prochazka.-Theodora A. Floyd. -Lucile Petry Leone.

Modern nursing in the United States was inspired by the services of Florence Nightingale in the Crimean War. Supported by the democratic action of a group of women in New York City who banded together and made a public appeal for funds, the first nurses' training school "to be based definitely on Miss Nightingale's uncompromising doctrine which insisted on the need for full authority for the matron or superintendent of the school who must be a nurse, not a physician or layman," was opened at Bellvue Hospital on May 1, 1873. The author has chosen for inclusion in this book the lives of interesting women whose stories tell something of the problems and struggles which have confronted the nursing profession. "They have done a good job, they are women of whom democracy may well be proud." 


\section{F. Medical Education}

4855. Allen, Raymond B. Medical education and the changing order. New York, Commonwealth Fund, 1946. I42 p. (New York, Academy of Medicine. Committee on Medicine and the Changing Order. Studies) $\mathrm{SG}_{4} 6-252$ R735.A46 Bibliographical footnotes.

The medical profession is increasingly focusing attention on man in his economic and social environment which is constantly changed by technological advances. Medical education aims to produce physicians who recognize the influence of emotional and mental reactions on the physical manifestations of disease. Dr. Allen, dean of the College of Dentistry, Medicine, and Pharmacy, University of Illinois, describes the development of the techniques of medical education, points out some of the deficiencies, and suggests some improvements. "Medicine of the future," he says, "if it is to progress as a social as well as a biological science must broaden its outlook and adjust its educational program accordingly. Medicine is coming of age as a social science in the service of society." The problems of medical education and recent progress in their solution are also described by a group of medical educators in a series of papers which appeared in the Journal of Medical Education and have been reprinted as Medical Education Today, Its Aims, Problems, and Trends (Chicago, Association of American Medical Colleges, 1953. 123 p.). Experiments in methods of teaching and in integrating certain related science courses, which are in progress at Harvard, Western Reserve, the University of Colorado, and other medical schools, are given as illustrations of the "attempt to restructure the teaching program to accommodate comprehensive medicine."

4856. Carson, Joseph. A history of the Medical Department of the University of Pennsylvania, from its foundation in 1765 . With sketches of the lives of deceased professors. Philadelphia, Lindsay \& Blakiston, 1869 .

8-7557 R747.P42 I869

Through the influence of Dr. John Morgan and Dr. William Shippen, formal medical education in the American colonies began with the organization of the Medical Department of the College of Philadelphia in 1765 . This history is the expansion of a lecture delivered by the author on the occasion of its centenary. The growth of the school up to the American Revolution, its union with the University of Pennsylvania, and its progress through one hundred years, are told in the lives of the founders and professors, whose courses in the medical sciences, combined with clinical instruction in the Philadelphia Almshouse, did much to shape the pattern of medical education in the United States.

4857. Commission on Graduate Medical Education. Graduate medical education; report. Chicago [University of Chicago Press] I 940. 303 p. 40-33806 R737.C6

This report may be considered as a supplement to the Final Report of the Commission on Medical Education (no. 4858) which dealt only briefly with problems in the graduate field. It does not attempt to survey present practices, but to bring together the best medical and educational thought concerning the internship, the residency, postgraduate education, and specialty boards, with the hope of stimulating improvements in these areas which will lead to better-trained physicians and better medical care of the patient. To place internships and residencies in their proper perspective in the educational program, and to arouse a feeling of mutual responsibility between hospitals and interns for providing training in return for service, a study of the situation in 77 hospitals in New York City was prepared by the New York Committee on the Study of Hospital Internships and Residencies: Internships and Residencies in New York City, 1934-1937, Their Place in Medical Education (New York, Commonwealth Fund, 1938. 492 p.).

4858. Commission on Medical Education. Final report. New York, Office of the Director of Study, 1932. 560 p. 33-1ro9 R745.C86

Regulations and specifications formulated by the American Medical Association, the Association of American Medical Colleges, and various state licensing boards, by 1918 , had transformed medical education from apprentice and commercial school training to a university enterprise with precise standards applying to students, teaching staff, hospital facilities, premedical requirements, and curriculum. The elevated standards reduced the number of schools and of students, and increased the cost so that medical education reached a static plateau. New discoveries and points of view, and changing university aims and methods as well as social conditions, created the need of broadening the scope of medical education. The Commission on Medical Education 
was organized as an independent body by the Association of American Medical Colleges in 1925 to study existing conditions. Attention is focused on the training of the medical student to meet the health needs and to understand the social and economic conditions of the community in which he becomes a practicing physician, and as such, a leader in health and other community programs. To accomplish this objective the Commission divides the study into chapters on the relationship between the medical profession and the general public, the need of postgraduate education, specialization, internship and licensure, and the medical courses that form the basis of the training. "Emphasis," says the Commission, "must be kept constantly upon the fact that only through a sufficient number of properly trained physicians can a community expect to meet its responsibility for the care and prevention of illness and the protection of health."

4859. Ebaugh, Franklin G., and Charles A. Rymer. Psychiatry in medical education. New York, Commonwealth Fund, 1942. xxiv, 619 p.

Bibliography at end of each chapter.

$$
\text { 42-5906 RC607.E24 }
$$

Concerned with psychiatric education as a phase of medical training both for general practice and for specialization, this study is largely based on data collected during a survey of 66 psychiatric schools in the United States during 1932, and from followup questionnaires in 1934,1938 , and 1940 . Training of the staff, curriculum from preclinical through postgraduate years, and hospital and other clinical facilities are explored. The authors use the 4-year course in psychiatry at their own University of Colorado as an illustration of the essential features in psychiatric training. The section on postgraduate education considers the need of advanced training and opportunities in the field. In summing up, the authors recognized that psychiatry in the early I940's had not completely succeeded in breaking through its isolation, and that to succeed, it "must permeate the curriculum ... [and] graduates of medical schools must learn to treat the whole patient-a total person with a mind as well as a body."

4860. Norwood, William Frederick. Medical education in the United States before the Civil

War. Philadelphia, University of Pennsylvania Press, 1944. xvi, $4^{87}$ p. $\quad S_{44-196} R_{745 . N 6}$ Bibliography: p. 435-462.

Prior to 1800 medical education passed through periods of apprenticeship to the few English or continental-trained doctors found in the American colonies, study abroad, and training at the infant medical schools such as those founded at the College of Philadelphia ( 1765), King's College ( 1768), Harvard (1783), or Darthmouth (1797). During the first half of the new century an increasing population and a continuous westward migration created a growing demand for doctors and so for medical schools. These sprang up without regulation, and often only for the financial gain of the promoters. Largely in order to improve the standards of the medical schools the American Medical Association was organized by leaders of the profession in 1847 . The author surveys the development of the American system up to 1860 in this study of the medical schools of Pennsylvania, New York, New England, the Old South, and the country west of the Appalachian Mountains. In Part VIII he explores the financial support of medical schools, the cost of medical training, the curriculum, textbooks, teaching problems, and degrees and licensure. The period also witnessed the entrance of women into the medical profession, and the rise of sectarian groups such as the homeopaths and Thomsonians. "Medical education in the United States . . . in the century before the Civil War, constitutes a significant and unique chapter in the social history of the country."

486r. Survey of Medical Education. Medical schools in the United States at mid-century. [By] John E. Deitrick and Robert C. Berson. New York, McGraw-Hill, 1953. xxii, $3^{80} \mathrm{p}$.

$$
\text { 53-604I R745.S85 }
$$

A report on the Survey Committee's visits to $4 \mathrm{I}$ representative medical schools from September 1949 to May 195I, prepared by the director and associate director of study. The basic premises are stated in the Introduction in which the functions of medical schools-education, research, service, finances, operation, curriculum and teaching methods, and advanced education and training-are discussed. A Subcommittee on Preprofessional Education, under the chairmanship of Aura E. Severinghaus, also prepared a survey: Preparation for Medical Education in the Liberal Arts College (New York, McGrawHill, 1953. 400 p.), which rounds out the picture of medical education at mid-century. In summing up the authors say: "The greatest need of medical schools today is clear, critical thought, by men who are sincerely interested in the education of students and who have an understanding of educational principles, a knowledge of science, and familiarity with social and economic trends. Such men must have courage and faith in the idea that the quality of medical education in the last analysis will determine the future of medicine in the United States." 


\section{G. Public Health}

4862. Bachman, George W. Health resources in the United States; personnel, facilities, and services. Washington, Brookings Institution, $195^{2}$. xvi, $344 \mathrm{p}$.

52-12128 RA407.3. 3

This is primarily a statistical review of the state of the Nation's health in I950 as it has been affected by the advances in medical science, and the increase in medical facilities and the control of communicable diseases since Igoo. Data collected by the Committee on Costs of Medical Care ( I928-3I), the Public Health Service in the National Health Survey (1935-36), the Blue Cross Commission and other groups are analyzed. The examination of the problem of personnel includes an inventory of physicians, dentists, professional nurses and auxiliary personnel, and a special study of medical group practice of which the Mayo Clinic was one of the first examples in the United States. An inventory of the hospital system as a whole with emphasis on the general hospital, and of facilities for special health problems and for certain classes such as the Armed Forces and the industrial workers, forms the third part of the survey. A study of the Nation's health was also prepared by the President's Commission on the Health Needs of the Nation: Building America's Health ([Washington, U. S. Govt. Print. Off.] 1952-53. 5 v.). This, as well as the Brookings Institution's study, assumes the joint responsibility of both private and public agencies for public health in a democracy.

4863. Cavins, Harold M. National health agencies, a survey with especial reference to voluntary associations, including a detailed directory of major health organizations. [Washington] Public Affairs Press, 1945. $25 \mathrm{I}$ p.

\section{$\mathrm{SG}_{45-276} \mathrm{RA}_{42 \mathrm{I} . \mathrm{AIC}_{3}}$}

"This study is concerned primarily with the rise of the national voluntary health agency as a social phenomenon of the early twentieth century, as a significant phase of public health history, as an important agent of health education, and as a movement characteristically American." Against the background of economic, social, and scientific developments, the author traces the origin and history of such major professional organizations as the American Psychiatric Association, and representative agencies of the promotional or educational type like the National Tuberculosis Association. Bringing this information together in a single volume for the first time provides a useful source of informa- tion for the student of the public health movement. In the same year a book which, the authors say, "complements the present Study," was published under the auspices of the National Health Council: Voluntary Health Agencies by Selskar M. Gunn and Philip S. Platt (New York, Ronald Press, I945. 364 p.).

4864. Chicago-Cook County Health Survey. The Chicago-Cook County Health Survey conducted by the United States Public Health Service. New York, Columbia University Press, 1949. xlviii, r317 p. $\quad 49-11489 \mathrm{RA}_{448 . \mathrm{C}_{4} \mathrm{C}_{4}}$

Aroused during World War II by the Selective Service reports on the health of the nation's young men, the citizens of the Chicago-Cook County area organized this survey in 1946 . It "represents a landmark in the evolution of co-operative community enterprises designed to bring the benefits of preventive medical, sanitary engineering, and nursing services to every individual in the community." The findings and recommendations represent the corporate opinions of the U.S. Public Health Service and a group of recognized local experts, whose first purpose was "to make a fact-finding inventory of all the health forces in this field and to appraise the strength and weakness of their functional capacity," in order "to determine whether or not community public health resources are being used in such a way as to obtain a maximum of service for the money expended." The results are described in three parts. Part I deals with all phases of "Environmental Sanitation" from water supplies and mosquito control to swimming pool sanitation and housing. Part II, "Preventive Medicine," details the activities of official and voluntary health agencies, from collecting public health statistics and control of communicable diseases to nutrition services and health education. Part III describes facilities and services for medical care available in the area. Dr. Thomas Parran, Surgeon General of the United States from 1936 to I948, thought that this undoubtedly would "establish a pattern for many similar surveys in other areas of the country."

4865. Cohn, Alfred E., and Claire Lingg. The burden of diseases in the United States. New York, Oxford University Press, 1950. I29 p.

$$
5^{\mathrm{I}-\mathrm{I} 304} \mathrm{RA}_{407 \cdot 3 . \mathrm{C}_{57}}
$$

References: p. 127-129. 
Tables basic to figures in The burden of diseases. New York, Oxford University Press, 1950. $69 \mathrm{l}$. RA407.3.C57 Tables

Dealing for the most part with the period 1900 to I940, two authorities in the field of medical statistics have examined the mortality figures gathered by the U. S. Bureau of the Census, and the morbidity statistics collected during certain surveys by the U. S. Public Health Service, and other groups, to present a picture, through graphs, charts and interpretation, of the incidence of diseases upon various age groups, and the changes in the percentage of deaths at specific ages. Such a study is important in any public health program because it demonstrates "how the results may effect shifts of emphasis in the study of disease, and in the provision society must make for those who are ill, or for those who, having escaped fatal illness through the advances of modern medicine, become charges upon the community in other ways." Comparable events in other countries have been included for "the light that is shed on the state of the various medical cultures."

4866. Hiscock, Ira V. Community health organization. $4^{\text {th }}$ ed. New York, Commonwealth Fund, 1950. 278 p. $\quad 50-6043 \quad \mathrm{RA}_{425} \mathrm{H}_{5} \quad 1950$

This fourth edition of a manual designed for the use of health officers, public health nurses, and teachers, brings up to date the developments in community health affairs which have affected their organization and administration during the past ten years. The author, who is chairman of the Department of Public Health, Yale University, defines the functions of the National Government, the State and the municipality in the public health program of the Nation, and details a plan for community health organization that "contains the elements of the best current practice in the country, considered in relation to a theoretical community of 100,000 population."

4867. Howard, William Travis. Public health administration and the natural history of disease in Baltimore, Maryland, I797-1920. Washington, Carnegie Institution of Washington, I924. 565 p. (Carnegie Institution of Washington. Publication no. 351) 24-24629 RA448.B 3 H6

Bibliography: p. $563-565$.

Two health ordinances, enacted soon after the organization of the new city government of Baltimore in 1797 , and revised many times in the next I23 years, formed the basis of practically all subsequent local public health legislation. The Baltimore Department of Health, in continuous operation since the Committee of Health was set up in 1793 , is the oldest permanent municipal body devoted primarily to the public health. The evolution of the Health Department and the administration of the public health laws of Baltimore are traced by Dr. Howard, who laid the foundation for this study during four years of service as assistant commissioner of health in 1915-1919. The author presents such physical data as local topography, population, commercial expansion, and wealth, and such sociological factors as the prominence of medicine, medical men, and education in the development of the city, to illustrate their influence on the etiology and the control of disease. Chapters are devoted to diseases common to the area, mortality statistics, and the part which various diseases have played in determining policies of public health administration in Baltimore.

4868. Jacobs, Philip P. The control of tuberculosis in the United States. Rev. ed. New

York, National Tuberculosis Association, 1940. $3^{8} 7 \mathrm{p}$. 40-34615 RA644.T7J25 I940

"Selected references" at end of most of the chapters.

Published posthumously, this revised edition is dedicated by the National Tuberculosis Association as a memorial to the author (1879-1940), who was director of personnel and publications of the Association. Some historical aspects of the anti-tuberculosis movement beginning with Drs. Hermann M. Biggs, Livingston Trudeau, and others who applied the scientific principles of Robert Koch, discoverer of the tubercle bacillus in $r 88 r$, are discussed in Part I. In Part II the methods that have contributed to the success of the movement are discussed, as well as the relationships between physicians and laymen, public and private officials, tuberculosis and other health agencies, and local, state, and national organizations. Programs for the control of tuberculosis, led by that of the National Tuberculosis Association, have been grouped together in Part III. The decline in the death rate from tuberculosis in the United States during the years 1900-1955 from I 94.4 to 9.4 per 100,000 population is the best evidence of the progress which has been made through the cooperation of individuals, private organizations, and public agencies.

4869. Mott, Frederick D., and Milton I. Roemer. Rural health and medical care. New York, McGraw-Hill, 1948. xvii, 608 p. (McGraw-Hill ser. $\begin{array}{lll}\text { in health science) } & 48-3784 & \mathrm{RA}_{427 .} \mathrm{M}_{73}\end{array}$

The authors, who are officials in state health organizations, have prepared a study of the health conditions and medical facilities available to one segment of the population which is increasingly a concern of the Nation. Former Surgeon General Thomas Parran in a foreword describes the book as "the essence of current knowledge on virtually 
every aspect of rural health status and medical care ... With broad social perspective it describes the economic and historical developments out of which arise present difficulties in rural medical services. It presents an integrated story of health conditions, medical resources and services, and organized efforts for health improvement in rural areas. In conclusion, it offers recommendations for future action which merit careful study."

4870. National Health Assembly, Washington, D. C., 1948. America's health; a report to the Nation. Official report. New York, Harper, 1949. 395 p. $\quad 49-4679$ RA445.N28 1948

Organized by the Federal Security Administrator, the National Health Assembly met in Washington, D. C., in May 1948, to discuss all factors involved in preparing a ro-year plan for "expanding the health resources of this nation and raising the health standards of the entire population." The Assembly was divided into fourteen sections which conducted panel discussions, exploring and making recommendations concerning such problems as the $\mathrm{Na}$ tion's need for more doctors and other medical personnel, more hospitals, and more health department units; the problems of chronic disease, maternal and child health, and rural health; and medical research and the cost of medical care. The success of a nation-wide health program depends not only on the determination of the citizens who sponsor community and state participation, but also on the health of other nations. Encountering problems of international character, the Assembly devoted one evening to them. It was pointed out that the United States has accepted its responsibilities to other nations by joining the World Health Organization.

4871. Pelton, Walter J., and Jacob M. Wisan, eds. Dentistry in public health. $2 \mathrm{~d}$ ed., completely rev. and rewritten. Philadelphia, Saunders, 1955. 282 p. $\quad 55-5207 \quad \mathrm{RK}_{52 . P_{4}} 1955$

Includes bibliographies at end of chapters.

Dental public health is service provided for communities and administered by departments of health at all levels-Federal, State, and local. The authors point out that surveys of health conditions in given areas are prerequisite to dental health programs and discuss the methodology of collecting and classifying data according to the dental needs of the American people, and the resources available for their treatment. Chapters describe the control of dental caries by fluoridation of water, the need of educating the public and plans available for payment of dental services. The second edition has been completely reorganized to include advances that have been made in dentistry since the first appeared in 1949.
4872. Powell, John H. Bring out your dead; the great plague of yellow fever in Philadelphia in 1793. Philadelphia, University of Pennsylvania Press, 1949. 304 p: 49-50068 RC211.P5P6 1949 Bibliographical references included in "Notes": p. $287-294$.

Recurring epidemics of smallpox and yellow fever were the worst health crises faced by the small but growing towns of the Colonial and Federal Periods. The most disastrous decade opened with the Philadelphia epidemic of 1793 , which the author calls "one of the great tragic episodes in the human history of this land." It was the problem of the whole people, and the banding together of a group of citizens to function as an emergency committee, the setting up of an isolation hospital on Bush Hill, and the issuing of certain sanitary rules, temporary expedients though they were, bore the seeds of a community public health program. Much of the story centers around Dr. Benjamin Rush, "Philadelphia's amazing citizen," who, like other physicians of the day, described the disease accurately, and noted the presence of mosquitoes, but left it to Walter Reed and his associates to establish the causal relationship between the two in the early 1900's. Howard A. Kelly tells the story of the disease, and the investigations which led to its control, in his Walter Reed and Yellow Fever, $3 \mathrm{~d}$ ed. rev. (Baltimore, Norman, Remington, 1923. 355 p.).

4873. Sappington, Clarence O. Essentials of industrial health. Philadelphia, Lippincott, 1943. 626 p. illus.

References: p. 604-6ro.

$43-8345 \quad \mathrm{RC}_{96} . \mathrm{S}_{3}$

Following the outbreak of war in 194I, the mobilization of all manpower, the expansion of industries, the shifting of population with its related problems of transportation and nutrition, housing and sanitation, and the diminishing number of physicians, focused attention on the increasing importance of the health of industrial workers to the national economy. Medical schools quickly responded to the need by emphasizing in their courses the fundamentals of industrial health. According to the author, a consulting industrial hygienist and editor of Industrial Medicine until his death in 1949, this book outlines a recently instituted course for undergraduates and represents the application of preventive medicine and public health to industry. It outlines the administration of a health program in industrial plants, the protection of workers from environmental hazards, the coördination of industrial and community health services, and the contribution of industrial medicine and traumatic surgery to the maintenance of the health of workers. More recently, twenty authors have contributed to a book on Modern Occupational Medicine, edited by 
Allan J. Fleming and Constance A. D'Alonzo (Philadelphia, Lea \& Febiger, 1954. 414 p.), which "represents the combined experience of a group that has spent many years specializing in industrial medical practice."

4874. Smillie, Wilson G. Public health administration in the United States. 3 d ed. New York, Macmillan, 1947. $637 \mathrm{p}$.

Med 48-888 RA445.S55 1947

Increased knowledge concerning epidemiology and environmental sanitation, the discovery of new antibiotics and techniques for the detection of carriers of infection, interest in the economics of nutrition, and the health programs of communities, have contributed to the "idea that provision of comprehensive medical care for all the people was a community function, and that a communitywide plan ... must encompass preventive service as well as curative and rehabilitation facilities." Against this background the author, who is professor of public health and preventive medicine, Cornell University Medical College, describes the methods of controlling communicable diseases, the basic activities of health agencies, and the organization of municipal, rural, and state public health programs. The evolution of a national health program is traced in the last chapter, and the Appendix contains the minimum qualifications that have been set up by the Committee on Professional Education of the American Public Health Association for health officers, public health nurses and engineers, health educators, and school physicians. This third edition has been rewritten to reflect developments in the field, and changes in social attitudes brought about by economic depression and war, since the first appeared in 1935 .

4875. Smillie, Wilson G. Public health: its promise for the future; a chronicle of the development of public health in the United States, 16071914. New York, Macmillan, 1955. 501 p. 55-4356 $\mathrm{RA}_{424 . \mathrm{S}_{5} 8}$

The author's interest in the historical development of public health grew out of a request to select the outstanding men in the field, and the names selected appear in the Appendix. He divides his narrative into "The Colonial Period-1600-1790"; "The Pioneer Period-1790-186r"; and "The Period of Development-The Civil War to World War I." The terminus 1914 has been selected as the end of a period in American life, as well as the beginning of Dr. Smillie's association with the public health field. From his study he concludes "that the advances in public health in America have been an accurate index of our advancing civilization in all its aspects and connotations. Thus, it becomes an axiom that the degree of the development of public health service, as a well-established and effective community function, is a true measure of the stage of civilization of a nation."

4876. Tobey, James A. Public health law. 3d ed. New York, Commonwealth Fund, 1947. $\begin{array}{llll}\text { xxi, 419 P. Med 47-2428 RA445.T63 } 1947 & \end{array}$ Selected bibliography: p. $\left[3^{8} 1,-3^{83}\right.$.

New court decisions on various aspects of public health law, changes in governmental organization and administration, and important legislative trends have been added to this edition. Part I deals with "Public Health Law and Administration"; Part II with "Powers and Duties of Health Departments"; Part III with "Liability"; and Part IV with "Legislation and Law Enforcement." The book will be useful in interpreting for the layman, the social worker, the health officer, and the lawyer, the health functions of the Federal Government, the State, and the community, as they have developed within the framework of the Federal Constitution and acts of Congress, state constitutions and legislation, and municipal charters and regulations.

4877. Top, Franklin H., ed. The history of American epidemiology, by C. E. A. Winslow [and others] St. Louis, Mosby, 1952. $190 \mathrm{p}$.

Includes bibliographies.

$$
\text { 52-10820 RA650.5.T6 }
$$

Contents. - The colonial era and the first years of the Republic (1607-1799) the pestilence that walketh in darkness, by C. E. A. Winslow.-The period of great epidemics in the United States (1800-1875), by Wilson G. Smillie.-The bacteriological era (1876-1920), by James A. Doull.-The twentieth century - yesterday, today, and tomorrow (1920-), by John E. Gordon.

This symposium was originally presented at the 2oth anniversary session of the Epidemiology Section of the American Public Health Association in 1949. Since public health services, both municipal and national, had their origin in measures to protect the people from contagious diseases, this study of America's contribution to the control of epidemics, and of the shift in emphasis during the last fifty years to the mass problems provided by other diseases, is also the story of the primary function of the public health movement. The impact of contagious diseases on colonial society has been described at greater length by John Duffy, in his Epidemics in Colonial America (Baton Rouge, Louisiana State University Press, 1953. 275 p.).

4878. U. S. Public Health Service. Environment and health; problems of environmental health in the United States and the Public Health 
Service programs which aid States and communities in their efforts to solve such problems. [Washington] 195I. I52 p. (Its Publication no. 84)

$$
\text { 5I-6I655 RAir.Bi8 i95ia }
$$

The Public Health Service "has the responsibility of carrying on, stimulating, and fostering research; of supporting the work of the State and local health agencies, which bear most of the burden of administration." The share of the Service in the field of environmental sanitation, including radiological health, is described in this book. "The contribution to date is a matter of public pride: its measure is the margin between prosperity and destitution, between civilization and barbarism."

4879. Whipple, George Chandler. State sanitation; a review of the work of the Massachusetts State Board of Health. Cambridge, Harvard University Press, 1917. $2 \mathrm{v}$.

$$
\text { I7-I3246 RA84.DiW } 5
$$

Said Lemuel Shattuck, who conducted a sanitary survey of Massachusetts as early as 1849 : "It is the duty of the State to extend its guardian care, that those who cannot or will not protect themselves, may nevertheless be protected; and that those who can and desire to do it, may have the means of doing it more easily." In this spirit Massachusetts organized the first state health department in the United States in 1869 , and thereby set up the pattern for similar departments throughout the Union. "The primary object of this book," according to the author, "is to set forth the past work of the Massachusetts State Board of Health so that it may be known by people of the present generation." The abstracts from the reports and scientific articles published by the State Board between 1870 and 1914 show "the evolution of thought in the realm of sanitation during nearly fifty years." A third volume of this work was planned, to include a guide to the annual reports and a series of biographical sketches, but it was evidently never published.

4880. Williams, Ralph C. The United States Public Health Service, r798-r950. Washington, Commissioned Officers Association of the United States Public Health Service, 1951. 890 p. 52-82 RAIr.BrgW 5
Bibliography: p. $84 \mathrm{I}-847$.

The origin of the U. S. Public Health Service is to be found in the Marine Hospital Service which came into being with the Act for the Relief of Sick and Disabled Seamen in 1798 . The former Assistant Surgeon General of the Service tells the story of the various functions of the agency through 152 years of growth and concludes with a summary of its extensive programs in 1950. They include grants to states for general public health and for hospital construction, operation of certain types of hospitals and outpatient clinics, and extensive research through the National Institute of Health, as well as staffing and directing teams of experts to carry out health projects under the Point Four Program and the Economic Cooperation Administration. In r950 the United States continued to play an active part in the World Health Organization, which "is working all over the world toward its goal of winning for all people the highest possible level of health."

4881. Winslow, Charles E. A. The life of Hermann M. Biggs, physician and statesman of the public health. Philadelphia, Lea \& Febiger, I929. $432 \mathrm{p}$.

Bibliography: p. $\left[4^{1} 3\right]^{-420}$.

"Broadly speaking, the fundamental significance of Biggs' work lay in the modernization of public health administration in conformity with the new knowledge concerning the origin, nature and spread of infectious diseases." At Bellevue Hospital Medical College, Hermann Biggs progressed from lecturer on pathology in 1886 to professor of the practice of medicine in 1912 . He organized the department of pathology and bacteriology of the New York City Health Department in 1892 and became director of the first municipal bacteriological laboratory in the world. Outstanding among his contributions were the introduciton of diphtheria antitoxin into this country in I894, and his life-long and vigorous fight against tuberculosis. His achievements are of enduring value in the world of medicine, and to the general public, "which has begun to realize, however inadequately, the relation of personal and public health to the other interests and the welfare of modern society and civilization."

\section{H. Medical Economics}

4882. Bauer, Louis Hopewell. Private enterprise or government in medicine. Springfield, Ill., C. C. Thomas, 1948. $201 \mathrm{p}$. Med 48-I I33 RA4II.B 3948
Bibliography: p. 199-20r.

Dr. Bauer's experience as a member of national and state medical associations, an officer in the Medical Corps, U. S. Army, specializing in aviation 
medicine, and a member of the New York State Public Health Council, has brought him in contact with many divergent views concerning health care and its insurance. In this book he describes the deficiencies in the medical system of the United States, pointing out, however, that health conditions in the United States are superior or equal to those in foreign countries in which health insurance is compulsory. He traces the growth of government in medicine by analyzing Federal legislation enacted especially since the recommendations of the Committee on the Costs of Medical Care were published in 1932. He outlines the history of the voluntary insurance system in the United States, and the programs of the American Medical Association which, he says, "has done more to improve the standards of medical care . . than all other organizations put together." In his summary of ideals, Dr. Bauer suggests solutions to existing problems, emphasizing the need for voluntary health insurance, subsidized when necessary by funds provided by a government agency. "Finally," he says, "with a system of medical care which is the best in the world, let us keep it in principle, revising it and improving it where necessary, but not discarding it for a system ... which has never given as satisfactory results as our own."

4883. Committee on the Costs of Medical Care. The costs of medical care; a summary of investigations on the economic aspects of the prevention and care of illness, by Isidore S. Falk, C. Rufus Rorem [and] Martha D. Ring. Chicago, University of Chicago Press, 1933. xviii, 623 p. (Its Publications, no. 27) 33-27129 Ris2.C65, no. 27

$\mathrm{RA}_{4} \mathrm{I}_{3} \cdot \mathrm{F}_{3}$

In 1927, during a conference in Washington of representative physicians, health officers, social scientists, and others interested in the costs and distribution of medical services, the nucleus of the Committee on the Costs of Medical Care was created. Composed of fifty members and financed through the generosity of eight private research foundations, the Committee published 28 books and pamphlets covering every aspect of medical care. This publication is a summary of its five years of investigation.

4884. Committee on the Costs of Medical Care. Medical care for the American people; the final report. Chicago, University of Chicago Press, 1932. 213 P. (Its Publications, no. 28)

$$
\text { 32-28169 Ri52.C65, no. } 28
$$

$\mathrm{RA}_{413}$.C6

This publication summarizes the Committee's conclusions and recommendations, and in the words of the chairman, Ray Lyman Wilbur, "affords for the first time a scientific basis on which the people of every locality can attack the perplexing problem of providing adequate medical care for all persons at costs within their means. It is hoped that the report may thus aid materially in bringing greater health, efficiency, and happiness to all the people."

4885. Davis, Michael M. Medical care for tomorrow. New York, Harper, 1955. 497 p.

$$
\text { 54-6444 RA4 }{ }^{10 . D_{3}}
$$

References: p. 447-487.

Writing from the viewpoint of persons who receive medical care, the author analyzes the economic, social, and intraprofessional forces which have changed medical practice and will change it further in the future. Of the four parts, Part I deals with "Basic Elements in Medical Services": need and demand for care, cost, organization, and personnel; Part II, "Evolution in Organizations," traces the development of the A. M. A., hospitals, clinics and group practice, and describes the distribution of public health services and Federal, State, and local funds for medical care; Part III, "Evolution in Economics," reviews the growth of health insurance from the consumer's point of view, and the increasing interest of government in medical care between I 91 I and 1952; and Part IV, "Programs and Outlook," discusses the costs of medical care in relation to the national economy and personal finances, the choice of doctors and the various methods of paying them, and the controversy over proposals for national health insurance. The author says: "According to the scale of values developed in this book, we would do well to depend primarily on insurance in order to achieve organized and comprehensive medical services, unified professionally around the patient as a person, administered democratically, and available financially to all."

4886. Goldmann, Franz. Voluntary medical care insurance in the United States. New York, Columbia University Press, 1948. $228 \mathrm{p}$.

$$
\text { 48-7044 RA } \mathrm{RA}_{4} \mathrm{I}_{3} \text {.G62 }
$$

Dr. Goldmann, a professor in the Harvard University School of Public Health and author of several books on financing medical care, describes the principles underlying medical care insurance, trends in development in the United States, and the attitudes of such voluntary organizations as the American Medical Association, the American Hospital Association, the National Grange, and labor unions, toward voluntary hospitalization plans and group practice. He analyzes cash indemnity plans, nonprofit hospital and physician service plans like the Blue Cross and Blue Shield, and individual and group practice plans, pointing out their limitations and potentialities, and raising the question of direct subsidy by taxes. The author says that the "chance 
for voluntary medical care insurance to make real progress within its natural limitations, to help tens of millions of self-supporting people develop the capacity and opportunity to lead personally satisfying and socially useful lives ... . lies in the combination of group prepayment and group practice .... and in the inclusion of comprehensive professional services and hospitalization in one program." Emphasis on voluntary health insurance plans, such as the Blue Cross hospital plans and those sponsored by the medical societies, is the principal theme of $\mathrm{Na}$ than Sinai, Odin W. Anderson, and Melvin L. Dollar in Health Insurance in the United States (New York, Commonwealth Fund, 1946. II5 p.) which appeared as one of the Studies of the New York Academy of Medicine Committee on Medicine and the Changing Order.

4887. Klem, Margaret C., and Margaret F. McKiever. Management and union health and medical programs. Washington, U. S. Dept. of Health, Education, and Welfare, Public Health Service, Division of Occupational Health, 1953. 276 p. ([U. S.] Public Health Service. Publication no. 329) 54-61546 $\mathrm{HD}_{7102 . \mathrm{U}_{4} \mathrm{~K}_{55}}$

Bibliography: p. 263-276.

This is the third in a series of studies on health and medical facilities in industry prepared by these authors for the U. S. Public Health Service. It emphasizes provisions for medical care outside the plant for workers, and sometimes their families, sponsored by employees' organizations, or management, or both. Industrial Health and Medical Programs, in which Walter J. Lear collaborated (Washington, 1950. 397 p. Public Health Service publication no. 15), covers the broad field, and Small Plant Health and Medical Programs (Washington, 1952. 213 p. Public Health Service publication no. 215), deals with problems peculiar to small plants. The present volume traces the development of management and union programs, and discusses program characteristics, administration, and financing under collective bargaining. Selected programs are classified by services, and the health services and welfare benefits of two industrywide programs are described.

4888. Means, James H. Doctors, people, and government. Boston, Little, Brown, 1953. 206 p. 53-10240 RA395.A3M4

Dr. Means, who has had years of association with the unique plant organizations, clinics, research programs, and teaching staff of the Massachusetts General Hospital, says in his Preface: "The American people are entitled to the best medical service which science and art permit, and which they can afford to buy. They are entitled to get it at the lowest price consistent with high quality, or have it given them if they cannot pay." He points out that medicine will follow the economic, social, and political pattern of the country it serves; that doctors, in order to give adequate medical care, must have education, the benefits of research, medical facilities, and a fair remuneration in their practice; that the people, dissatisfied with the uneven distribution of medical care and its high cost, have aroused the interest of government in providing relief through legislation. He gives both sides of the controversy between conservative organized medicine and the proponents of government control. Prepayment insurance plans, and certain comprehensive health plans, as well as group practice plans, that are being tested in certain communities and industries today, are outlined. A plea is made for gradualism and experiment; for co-ordination of government, private, and nongovernmental community effort to achieve an integrated national health plan that will be a joint undertaking of public and private medicine. Suggestions for achieving that co-ordination in a country of free enterprise are indicated in the last chapter and summed up by Dr. Means: "In brief then, if a teaching hospital like the Massachusetts General were united with a medical care plan like HIP [Health Insurance Plan] in New York, together with an adequate Blue Cross, and if it found ways and means to pay the premiums of those who could not afford to do so themselves, placed all its doctors on salary and made all its patients available for teaching, it would be reaching the ideal which I have in mind."

4889. Rothenberg, Robert E., and Karl Pickard. Group medicine \& health insurance in action. New York, Crown Publishers, 1949. xxviii, 278 p.

References: p. 46. 49-10662 RA413.R73

The Health Insurance Plan of Greater New York, the first large-scale, community-wide prepayment plan sponsored and directed by community representatives, was incorporated in 1944 and began operation in 1947. Its objective was to assemble, through experience, reliable actuarial data on which to base the operation of a prepayment plan which would provide complete medical service for a fixed annual premium, and to collect dependable statistics as to the number of services, the amount of physician's time, and total cost of the medical care required by a family, or a certain quota of population. The Central Medical Group of Brooklyn is one of the 26 groups organized to serve the persons insured by the Health Insurance Plan. Prepared by the chairman, the secretary, and the administrative counsel of the Group, this volume is the report of its experiences during the first two years. It outlines 
the basic staff organization, space and facilities required, and other information necessary to any medical group that organizes under the prepayment insurance plan. "The physicians of the Health Insurance Plan reaffirm their faith in voluntary, prepaid, comprehensive health insurance for the lowincome group as a means of bringing much needed medical care to a large segment of the population. They wish also to restate their belief that medical group practice offers a mechanism whereby that goal can be reached most advantageously."

4890. Serbein, Oscar N. Paying for medical care in the United States. New York, Columbia University Press, I953. xxiv, 543 p.

Bibliography: p. $[497]-524$.

53-12029 RA412.5.U6S

Large-scale development of voluntary medical care insurance in this country started in the 1930's. At the end of 1951 about $48,000,000$ persons were eligible for hospital benefits, about $43,000,000$ for surgical benefits, and about 12,000,000 for medical benefits. In February r951, Columbia University, under a grant from the Health Information Foundation, established the Medical Payments Project to study the methods used by people of the United States in paying for medical care. In Parts I and II the author discusses the sources and research meth- ods used in preparing this book, and the problems which people face in meeting the cost of illness. In other chapters he analyzes and evaluates the various prepayment plans such as commercial medical care insurance, Blue Cross, Blue Shield, and other industrial and governmental plans in a manner which should interest anyone who participates in prepaid medical insurance, or contemplates doing so.

4891. Tannenbaum, Samuel A., and Paul Maerker Branden. The patient's dilemma; a public trial of the medical profession. [New York Coward-McCann, 1935. xiv, 278 p.

35-24870 R707.T3

A physician and a layman advance in this book what they describe as "the hideous truth about the commercial side of the practice of medicine." The findings of the Committee on the Costs of Medical Care are used to illustrate the uneven distribution of medical care, the exorbitant fees paid by certain segments of the population, and the imbalance of the earnings of average doctors. The authors urge physicians to take the methods of competitive business out of the profession, and advocate the establishment of a tax-supported public health system to provide adequate service for the patient and adequate compensation for the physician. 


\section{Entertainment}

$\left.\llbracket \begin{array}{rr}\text { A. General Works } & 4892-4896 \\ \text { B. The American Stage } & 4897-4906 \\ \text { Bi. History } & 4907-4912 \\ \text { Bii. Criticism } & 4913-4926 \\ \text { Biii. Particular Stage Groups, Theaters, Movements, etc. } & 4927-4939 \\ \text { Biv. Biography: Actors and Actresses } & 4940-4943 \\ \text { Bv. Biography: Directors, Producers, etc. } & 4944-4946 \\ \text { C. Motion Pictures } & 4947-4951 \\ \text { Ci. History } & 4952-4956 \\ \text { Cii. Special Aspects and Analyses } & 4957-4963 \\ \text { Civ. Biography: Actors and Actresses } & \\ \text { D. Biography: Directors, Producers, etc. } & 4964-4966 \\ \text { Di. Forms of Entertainment } & 4967-4972 \\ \text { Dii. The Dance in America } & 4973-4976 \\ \text { Diii. Vaudeville and Burlesque } & 4977-4982\end{array}\right]$

THE distinction in this bibliography between "Entertainment" and "Sports and Recreation" 1 is explained in the prefatory note to the latter. Within this section, drama (through the media of the stage, motion pictures, radio, and television) bulks as most important. That is so much the case that the section might almost be defined as various means and aspects of presenting drama. The concern here is with its performance and its implications. The more literary aspects are to be found in the Literature section of the bibliography.

It is to be regretted that so many of the books in these allied fields have been written in a popular fashion for a mass audience, while relatively few scholarly and reliable studies have appeared. Because the entertainment field has been dominated by individual personalities, there has been a parallel emphasis in the publication of a large number of biographies and autobiographies and relatively few survey or integrating studies. This relationship is also reflected in the selection, which is more biographical than for most other sections of this work.

It might be noted that subsections here interlock more extensively than may be immediately apparent. Not only do the people concerned, especially the performers, move more readily and frequently from

one medium to another, but even much of the subject matter is carried over. In this way books become plays, then motion pictures, radioscripts, and finally television plays in a common sequence of evolution. However, the process may crisscross in almost any manner. Despite this, each has its own individuality and significance. The books involving overlapping subject matter have been arranged according to their dominant aspect, for most entertainers work predominantly (though not exclusively) through some one medium.

Although it is closely related to this section, musical entertainment has been left to the Music section, 
of which it is a more integral unit. By the same token, most books on radio and television appear under Communications. The few books on these subjects in this section are intended to represent the sizable entertainment, as distinct from the communication, aspects of these media. The emphasis throughout is on audience-directed activities, not activities with extensive audience participation.

\section{A. General Works}

4892. Green, Abel, and Joe Laurie, Jr. Show biz, from vaude to video. New York, Holt, I95I. 6r3 p. 5I-I379I PNig62.G7

This comprises a history of half a century of American entertainment business, although the book was not written for scholarly purposes. The style and language are that of the entertainment world dialect exhibited by trade organs such as Variety. There is also, as part of the style, a heavy cramming of information without much exposition or analysis. The result is more a reference book than a reading text.

4893. Hurlbut, Jesse Lyman. The story of Chautauqua. New York, Putnam, 1921. 429 p. illus. $\quad 2 \mathrm{I}-\mathrm{I} 4568$ LC6301.C5H8

Chatauqua brought culture and education (and, not always incidentally, entertainment) through many media (opera, drama, lectures, etc.) to millions. Hurlbut has here recorded Chatauqua history, from its beginnings to its heights. We Called It Culture; the Story of Chautauqua (Garden City, N. Y., Doubleday, 1948. 272 p.), by Victoria and Robert Ormond Case, tells the story with more perspective, but also more superficiality. Marian Scott's Chautauqua Caravan (New York, Appleton-Century, 1939. 3ro p.) gives a closeup through the story of one participant's view.
4894. Revett, Marion S. A minstrel town. New York, Pageant Press, 1955. 335 p. illus. 55-12267 $\mathrm{ML}_{3556 . \mathrm{R}_{4}}$

A history of entertainment in Toledo, Ohio, from the I840's to the end of the Igth century. The book takes its title from the dominance in entertainment of the traveling minstrels. The sections of the book are "Minstrels," “"Theater," "Circus," and "Local Music." Because of the systematic booking of traveling entertainers, and because of the small amount of local-origin entertainment, this book is meant to depict the development of entertainment in general throughout the area "west of the Alleghanies and east of the Rockies."

4895. Seldes, Gilbert V. The great audience. New York, Viking Press, 1950. 299 p. 50-10499 PNig9r.6.S

Movies, radio, and television are analyzed with the actual and the potential audience in view, and with the pecuniary, esthetic, and moral implications scanned.

4896. Theatre arts. Theatre arts anthology, a record and a prophecy; edited by Rosamond Gilder [and others] New York, Theatre Arts Books, 1950. 687 p. 50-11079 PN2020.T55

One hundred and thirty-two carefully selected articles which comprehensively survey theatrical arts from 1916 to 1948. Criticism and commentary at a high level.

\section{B. The American Stage}

\section{Bi. HISTORY}

4897. The Best plays. 1894/99+ New York, Dodd, Mead. illus.

20-21432 PN6I12.B45

Title has frequently varied through forms such as The Burns Mantle Best Plays and the Year Book of the Drama in America and The Best Plays and the Year Book of the Drama in America.
Now edited by Louis Kronenberger (b. 1904). The work has been edited in the past by Garrison P. Sherwood, John A. Chapman (b. 1900), and Robert Burns Mantle (1873-1948).

Indexes: 1899/1909-1949/50. I v.

This work emphasizes the drama in New York giving a detailed record of performances there and regularly choosing the "best" plays from the New York productions of the previous theatrical season. 
The plays are normally presented in an abridged form, so that these volumes may not be relied on for full texts. As drama in other American cities has been becoming increasingly important, the section on non-New York productions has in recent years been increased in size and scope.

4898. The Best short plays. $1937+$ New York, Dodd, Mead. 38-8006 PN6120.A4B 44

Title varies: $1937-1951 / 52$, The Best One-Act Plays.

Editor: $1937+$ M. Mayorga.

An annual.

4899. Coad, Oral Sumner, and Edwin Mims, Jr. The American stage. New Haven, Yale University Press, 1929. 362 p. illus. (The Pageant of America [v. 14]) 29-22306 EI78.5.P2, v. I4

An extensive and informative guide to the American stage; the text is accompanied by a multitude of well-ordered illustrations. In contrast to this, and produced for the "popular" audience, is Daniel C. Blum's A Pictorial History of the American Theatre, rev. 3 d ed. (New York, Greenberg, 1956. 319 p.), which is a book of illustrations with very little text.

4900. Gagey, Edmond M. Revolution in American drama. New York, Columbia University Press, 1947. 315 p. 47-11297 PS 35 I.G $_{3}$

$A$ history and assessment of the revolution in manners, morals, and artistry that, beginning in 1917, transformed the professional theater of Broadway. Joseph Wood Krutch's The American Drama Since 1918, an Informal History (New York, Random House, I939. 325 p.) presents not so much a history of the period as incisive, evaluative essays on it. Ward Morehouse's Matinee Tomorrow, Fifty Years of Our Theater (New York, Whittlesey House, 1949. $34^{\circ}$ p.) also covers the 2oth-century drama, but more as a history of changing tastes; it is not intended for the scholar, but it is an interesting account for the layman or the general student of American culture.

4901. Houghton, Norris. Advance from Broadway, 19,000 miles of American theatre. New York, Harcourt, Brace, ${ }^{c}$ I94I. $4^{1} 6$ p. 4I-22I79 PN2266.H6

Little theaters, summer theaters, academic theaters, and almost all other any-distance-off-Broadway American theaters are examined in this concise and clear book, which resulted from a 19,000 mile trip made to examine the situation. Kenneth Macgowan's earlier Footlights Across America (New Yurk, Harcourt, Brace, 1929. 398 p.) somewhat similarly traces the nature and implications of the noncommercial theater; Albert McCleery and Carl
Glick's Curtains Going UP (New York, Pitman, 1939. 412 p.) surveys the little theater movement across the country with an examination of 184 community theaters.

4902. Hoyt, Harlowe R. Town Hall tonight. Englewood Cliffs, N. J., Prentice-Hall, 1955. 292 p. illus. 55-9886 PN2256. H6

"This is the story of the country theater in the eighties and nineties, and though it treats somewhat specifically with the visitors and people of a little Wisconsin town, it is the story of each of the Town Halls that spotted the nation during those twenty years. And in the main that story is identical . . . Each of them ... played the same plays, met with the same misadventures, and made their amateur productions from scripts purchased from the same play agencies. Except for the amateurs, this was equally true of the show boats that played the Mississippi River towns. ... The only difference was the producing company and the playing cast. ... There was a strange uniformity in all of these shows, including make up, costuming and stage business."Prologue.

4903. Morris, Lloyd R. Curtain time; the story of the American theater. New York, Random House, 1953. $3^{80}$ p. illus.

\section{3-6914 PN2221.M68}

This warmly nostalgic narrative of the American theater since 1815 aims to revive for the general reader all the splendors of its romantic past. For the early theater the emphasis is on the performers, rather than the plays or theaters, recognizing that the individuals presenting early dramatic entertainment in America themselves constituted the outstanding ingredient.

4904. Quinn, Arthur Hobson. A history of the American drama, from the beginning to the Civil War. 2d ed. New York, Crofts, 1943. $530 \mathrm{p}$. 43-I1974 PS $332 . Q_{5} 1943$

"First printing, November, I923."

"A list of American plays": p. [423]-497.

Bibliography: p. [393]-421.

4905. Quinn, Arthur Hobson. A history of the American drama from the Civil War to the present day. New York, Crofts, 1936. 296, 432 p. illus. $\quad 3^{6-27316} \mathrm{PS}_{332}$.Q55 1936

The text of the two volume edition of 1927 , with an added chapter (The new decade, 1927-1936). The bibliography and play list have been completely revised and reset. Cf. Foreword to the revised edition.

"General bibliography and list of American plays, 1860-1936": p. [303]-402. 
The two volumes together comprise an impressive, scholarly history of American drama; by virtue of style, it is approachable mainly as a reference book. A readable, concise, one-volume history is Glenn Hughes' A History of the American Theatre, 1700r950 (New York, French, 1951. 562 p.). Valuable for its illustrations is the one-volume edition of The American Theatre, by John Anderson, and The Motion Picture in America, by René Fülöp-Miller (New York, Dial Press, r938. 430 p.); Anderson gives a good account of his subject, but Fülöp-Miller's account suffers from age (it had appeared seven years earlier in German) and possibly from translation. The student of American drama will also be interested in George O. Seilhamer's History of the American Theatre (Philadelphia, Globe Printing House, r888-9r. 3 v.), which meticulously traces American drama from 1749 to 1797 . Of antiquarian interest is William Dunlap's $A$ History of the American Theatre (New York, Harper, 1832. 420 p.), by the "father of American drama."

4906. The Theatre book of the year ... a record and an interpretation. $1942 / 43+\mathrm{New}$ York, Knopf. annual. $43-51298 \quad \mathrm{PN}_{2266 . \mathrm{A}_{2} \mathrm{~T}_{4}}$ 1942/ 43 + by G. J. Nathan.

Mostly Mr. Nathan's personalized criticism, with small doses of data and no illustration. May with interest be compared to and supplemented by Theatre World, edited by Daniel C. Blum, 1944/45+ (New York, Theatre World), which offers no criticisms, a little data, and profuse illustration. George Jean Nathan has written numerous books of criticism expressive of his personality. Among these are Passing Judgments (New York, Knopf, 1935. 271 p.); The Morning After the First Night (New York, Knopf, 1938. 281 p.); Encyclopaedia of the Theatre (New York, Knopf, r940. 449 p.); The Entertainment of a Nation (New York, Knopf, 1942. 290 p.); and The Theatre in the Fifties (New York, Knopf, 1953. 298 p.).

\section{Bii. CRITICISM}

4907. Atkinson, Justin Brooks. Broadway scrapbook. New York, Theatre Arts, 1947. 312 p. illus. $\quad 47-12086$ PN2277.N5A8

The influential drama critic of The New York Times collects 70 of his reviews from its Sunday drama section, beginning with The Petrified Forest (1935) and reaching Born Yesterday (1947).

4908. Bentley, Eric R. The dramatic event, an American chronicle. New York, Horizon

Press, 1954. 278 p. 54-12279 PN2266.B 45
A collection of dramatic essays from The New Republic, largely critical of plays produced in New York in the period 1952-54. There are included a chapter on "The American Drama (I944-I954)" and a section of the critic's "Afterthoughts."

4909. Brown, John Mason. Seeing things. New York, McGraw-Hill i946. 34 I p.

$$
\text { 46-6335 } \mathrm{PS}_{3503 . R 81945 S_{4}}
$$

The critic presents selections from his wide-ranging "Seeing Things," a column which appears each week in the Saturday Review. Subsequent installments have been Seeing More Things (New York, Whittlesey House, I948. 347 p.); Still Seeing Things (New York, McGraw-Hill, I950. 335 p.); and As They Appear (New York, McGraw-Hill, 1952. 258 p.). Other critical works by him include: Upstage, The American Theatre in Performance (New York, Norton, 1930. 275 p.); Two on the Aisle; Ten Years of the American Theatre in Performance (New York, Norton, 1938. 321 p.); and Broadway in Review (New York, Norton, 1940. 295 p.).

4910. Isaacs, Edith (Rich) ed. Theatre, essays on the arts of the theatre. Edited by Edith J. R. Isaacs. Boston, Little, Brown, I927. 34I p. illus. 27-2398I PN2020.I8

The editor of Theatre Arts Monthly presents here a collection of 30 essays by various hands, on theater as art rather than as commercial venture. The editor contributes a general introduction and briefer ones to each of the eight sections.

49ri. Woollcott, Alexander. The portable Woollcott, selected by Joseph Hennessey. New York, Viking Press, I946. 735 p. (The Viking portable library) $\quad 46-25135 \quad \mathrm{PS}_{3545 . O_{77}} \mathrm{I}_{946}$

Woollcott (r887-1943) was a full-time drama critic only for the six years beginning in 1922, and this convenient anthology contains much of his ornate and highly mannered writing in other spheres; but it gives a good idea of his personality, which many found fascinating and others infuriating. His critical writings include Shouts and Murmurs (New York, Century, 1922. 264 p.); Enchanted Aisles (New York, Putnam, 1924. 260 p.); and Going to Pieces (New York, Putnam, 1928. 256 p.).

4912. Young, Stark. Immortal shadows, a book of dramatic criticism. New York, Scribner, 1948. $290 \mathrm{p}$. 48-II512 $\mathrm{PN}_{2277 . N_{5} \mathrm{Y} 6}$

After about two decades as a theatrical critic, the author, upon retirement from the field, selected these critical articles from those published in various periodicals. The Pavilion: Of People and Times 
Remembered, of Stories and Places (New York, Scribner, 1951. 194 p.) is an autobiographical work which in part reflects Young's connection with the theater. The author also gained attention with novels, his most prominent one being the Civil War novel, So Red the Rose (New York, Scribner, I934. 43 I p.).

\section{Biii. PARTICULAR STAGE GROUPS, THEATERS, MOVEMENTS, ETC.}

4913. Carson, William G. The theatre on the frontier; the early years of the St. Louis stage. Chicago, University of Chicago Press, 1932. 361 p. illus.

Bibliography: p. 331-335.

32-1 I 827 PN2277. $\mathrm{S}_{2} \mathrm{C}_{3}$

A scholarly, detailed history of the first quarter century ( $1815-1840$ ) of the St. Louis stage. There is much social and literary interest, as well as dramatic.

49r4. Clurman, Harold. The fervent years; the story of the Group Theatre and the thirties. New York, Knopf, 1945. 298 p. illus.

$45-5287$ PN2297.G7 $\mathrm{C}_{5}$

The Group Theatre (193I-4I), which attempted to bring art to the commercial stage, here has its story told from the personal point of view of one who attended at its birth and now delivers the funeral oration.

4915. Davis, Hallie (Ferguson) F. Arena, by Hallie Flanagan. New York, Duell, Sloan \& Pearce [1940] 475 p. illus.

Bibliography: p. 439-447.

$$
\text { 4I-23I } \mathrm{PN}_{2266 . D_{37}}
$$

In 1935 , when there were some 25,000 unemployed theater people, Harry Hopkins put Mrs. Flanagan in charge of Federal Theater, a project of the Works Progress Administration. She gives an impressionistic view of its four years' work (a detailed production record and financial statement are appended) and discusses the Congressional dissatisfaction which brought it to a sudden end on June $30,1939$.

4916. Deutsch, Helen, and Stella Hanau. The Provincetown; a story of the theatre. New York, Farrar \& Rinehart, 1931. 313 p. illus. 3I-30075 $\mathrm{PN}_{2297 . P 7} \mathrm{D}_{4}$

A somewhat naive narrative of the Provincetown Theater, which originated on Cape Cod but developed an extension in Greenwich Village, New York City, from 1916 to 1929, with an analysis of its productions play by play. The Provincetown enjoyed the greatest prestige of any theater in
America in its day, and introduced the early plays of Eugene O'Neill (q.v.).

4917. Dunn, Esther C. Shakespeare in America. New York, Macmillan, 1939. 210 p. 39-30566 PR $3105 . \mathrm{D} 8$

Shakespeare in American culture from the Colonial era through the Igth century: productions, including those on the Ohio and Mississippi frontier and in Gold-Rush California; Shakespeare in the schools and colleges and in the thought of some eminent rgth-century figures; and American Shakespeare scholarship-including the Baconian theory, which had its inception here.

4918. Gagey, Edmond McAdoo. The San Francisco stage, a history. Based on annals compiled by the Research Dept. of the San Francisco Federal Theatre. New York, Columbia University Press, 1950. 264 p. illus.

50-8015 $\quad \mathrm{PN}_{2277} \cdot \mathrm{S}_{4} \mathrm{G}_{3} 195^{\circ}$ Bibliography: p. [229]-233.

A detailed history, emphasizing the Igth century. The annals on which it was based were made available in mimeographed form as San Francisco Theatre Research (San Francisco, $1938-422_{[} ?_{1}$ ) under the editorship of Lawrence Estavan.

4919. Gillmore, Margalo, and Patricia Collinge. The B. O. W. S. New York, Harcourt, Brace, 1945. I73 p. illus.

45-35239 PN2297. $\mathrm{U}_{5} \mathrm{G}_{5}$

An account of the American Theatre Wing's overseas production for servicemen of The Barretts of Wimpole Street. Reflects an aspect of U.S. O. wartime activities.

4920. Houghton, Norris. But not forgotten; the adventure of the University Players. New York, Sloane, 1952, ' 1951.346 p. illus.

$$
\text { 52-258 } \mathrm{PN}_{2297} \cdot \mathrm{U}_{55} \mathrm{H} 6
$$

An informal history of the 1928-32 career of the University Players at Cape Cod and Baltimore. The story of an experimental, "progressive," theatrical group.

4921. Isaacs, Edith (Rich) The Negro in the American theatre. New York, Theatre Arts,

1947. I 43 p. illus. 47-II394 PN2286.I8 While her subject goes back to 1821 , when James Hewlett was playing Shakespeare with the African Company in New York City, Mrs. Isaacs dates her "foreground" from I9I7 and Ridgeley Torrence's Three Plays for a Negro Theatre, and describes the individual stars and noteworthy all- or part-Negro productions of the following three decades. 
4922. Kendall, John S. The golden age of the New Orleans theater. Baton Rouge, Louisiana State University Press, 1952. 624 p. illus.

Bibliography: p. $[606]^{5-608 .}$ $5 \mathrm{I}-1_{4} 6 \mathrm{I}_{5} \mathrm{PN}_{2277} \cdot \mathrm{N}_{4} \mathrm{~K}_{4}$

The history of English-language drama in New Orleans during the first three-quarters of the igth century.

4923. MacMinn, George R. The theater of the golden era in California. Caldwell, Idaho, Caxton Printers, r94r. 529 p. plates, ports., facsims.

Bibliography: p. [509]-515. 4 I-100I8 $\mathrm{PN}_{2275} \mathrm{C}_{3} \mathrm{M}_{3}$

A social history of the California theater during the gold rush decade. Many of the most popular entertainers of the day came West to take their share of the new wealth; among them, the author singles out Lola Montez for special attention.

4924. Odell, George C. D. Annals of the New York stage. New York, Columbia University Press, 1927-49. $15 \mathrm{v}$.

27-5965 $\mathrm{PN}_{2277 . \mathrm{N}_{5} \mathrm{O}_{4}}$

By the time of his death in 1949 Odell had brought this highly detailed history of the New York stage to 1894 . He noted each season's productions at all of the principal Manhattan theaters, from time to time giving complete casts, and devoted briefer chapters to dramatic events in Brooklyn, Williamsburgh, Greenpoint, Queens, Staten Island, etc. Each volume is lavishly illustrated. New York's centrality for the American stage lends this work an importance for drama throughout the Nation. The work is supplemented by The Best Plays of 1894-1899 (1955) and other volumes in The Best Plays series (q.v.).

4925. Schoberlin, Melvin, From candles to footlights; a biography of the Pike's Peak theatre, 1859-1876. Denver, F. A. Rosenstock, The Old West Pub. Co., 1941. 322 p. illus.

$$
4 \mathrm{I}-\mathrm{I2} 800 \quad \mathrm{PN}_{2275} \mathrm{C}_{6 \mathrm{~S}} 35
$$

"List of Colorado theatres, $1859-1876$ ": p. 26527 I.

Bibliography: p. 293-300.

A history of the theater in Colorado during its territorial period. The Pike's Peak gold rush began in May 1859 and the theater followed in September, when Apollo Hall was opened in Denver City.

4926. Sper, Felix. From native roots; a panorama of our regional drama. Caldwell, Idaho, Caxton Printers, 1948 34I p. illus.

Bibliography: p. [279]-334.
Since he rejects "the sentimentality of the localcolor school," Mr. Sper emphasizes the late emergence of genuine regional drama in the United States, but notes some early treatments of the Indian, the Negro, and the Yankee. He then surveys the existing drama area by area, from "Yankee Lust"(!) to "Pacific Panorama," noting Broadway plays concerned with regional themes as well as local productions of all type. Robert E. Gard's Grassroots Theater; a Search for Regional Arts in America (Madison, University of Wisconsin Press, 1955. 263 p.) is largely an autobiographical account of the author's searching out of regional material for purposes of turning it into regional, rural drama.

\section{Biv. BIOGRAPHY: ACTORS AND ACTRESSES}

4927. Barnes, Eric W. The lady of fashion; the life and the theatre of Anna Cora Mowatt. New York, Scribner, 1954. 402 p. illus.

$$
\text { 54-10366 PN2287.R54 } \mathrm{B}_{3} 1954
$$

London edition (Secker \& Warburg) has title: Anna Cora.

Includes bibliography.

Anna Cora (Ogden) Mowatt Ritchie (18r9-187o) was a distinguished actress of the $1840^{\circ}$ 's and 50's. Having come from the respectable element of New York society, she aided in raising the prestige of the then non-respectable profession of acting. The book is of value not merely as a record of theatrical operations in this period, but also for its depiction of the social scene. The work is in large part based on Mowatt's Autobiography of an Actress (1854).

4928. Bankhead, Tallulah. Tallulah: my autobiography. New York, Harper, 1952. 335 p. illus. $\quad 5^{2-7278} \mathrm{PN}_{2287} \mathrm{Br}_{7} \mathrm{~A}_{3}$

This daughter of a famous Alabama family, a first-magnitude star since she took London by storm in 1923, gets into her story much of her famed flamboyance and caustic wit.

4929. Barrymore, Ethel. Memories, an autobiography. New York, Harper, 1955. 3 10 p. illus. $\quad 55-6565 \quad \mathrm{PN}_{22} 87 . \mathrm{B}_{3} \mathrm{~A}_{3}$

The Barrymore-Drew family has long held a dominant position in American acting. In this volume Ethel Barrymore (b. 1879), the "first lady of the American theater," presents the story of her life; because of her long and distinguished career and her family associations, it also has some general stage history. 
4930. Binns, Archie. Mrs. Fiske and the American theatre, by Archie Binns, in collaboration with Olive Kooken. New York, Crown Publishers, 1955. 436 p. illus.

$$
\text { 55-10173 } \mathrm{PN}_{2287} \mathrm{~F}_{5} \mathrm{~B}_{5}
$$

"It is rudimentary to say that Mrs. Fiske [18651932] was an American actress. She was the most purposefully American of them all; she discovered her own native playwrights; she took her productions, the best of their time, to the farthest reaches of the continent and to Americans who never saw Broadway; and she battled for ideals far beyond the confines of the theatre. ... [She was] one of the best minds of her time: the acknowledged leader of the American stage for a generation, a skilled and successful playwright, an actress who was rated with Duse and Bernhardt, a producer who was probably the best outside Europe, the triumphal champion of Ibsen in America, the discoverer of some of the best American playwrights of the early twentieth century."--Preface.

4931. Blum, Daniel C. Great stars of the American stage, a pictorial record. New York, Greenberg, 1952. I v. 52-1087I PN2285.B6 Many portrait and on-stage photographs of limited quality in the reproductions; enthusiastic biographical sketches accompany the pictures. Older stage stars are presented in somewhat dated, but more thorough treatment in William Winter's The Wallet of Time (New York, Moffat, Yard, 1913. 2 v.). Biographical profiles of more recent theatrical personalities are presented in Margaret Case Harriman's Take Them Up Tenderly (New York, Knopf, 1944. 266 p.). A series of somewhat longer sketches on some prominent figures may be found in Maurice Zolotow's No People Like Show People (New York, Random House, 1951. 305 p.).

4932. Courtney, Marguerite (Taylor) Laurette. New York, Rinehart, 1955. 433 p. illus. 54-10448 PN2287.T25 C6

A biography, by her daughter, of Laurette Taylor, who contributed 50 years of her life to the theater. This book is not merely a record of her stage triumphs, but also an analysis of her complex personality. Since her whole life was given to the theater, while life "bored" her, this presents not only the "makings" of an actress, but also a considerable segment of stage history.

4933. Fowler, Gene. Good night, sweet prince. New York, Viking Press, 1944. 477 p.

illus. $\quad 43^{-1857 I} \quad \mathrm{PN}_{2287}$. B $35 \mathrm{~F} 6$

The life of John Barrymore (1882-1942). John Barrymore himself wrote a much earlier autobio- graphical book, Confessions of an Actor (Indianapolis, Bobbs-Merrill, I926. I3 8 p.). His brother, Lionel Barrymore, discusses the family, with emphasis on Lionel, in his We Barrymores (New York, Appleton-Century-Crofts, 195I. 3 I I p.). See also (supra) Ethel Barrymore's autobiography.

4934. Jefferson, Joseph. "Rip Van Winkle": The autobiography of Joseph Jefferson. New York, Appleton-Century-Crofts, I950. 375 p. illus. 50-7350 PN2287.J4A3 I950

Originally published in 1890 .

Joseph Jefferson (1829-1905) was the son of an actor and began his stage career at the age of four; it continued for $7 \mathrm{I}$ years! He was a flexible actor, but it was his fortune to become identified with his most popular role, as this retitled reprint attests. With wider scope, but somewhat dated and usually considered "less appealing," is William Winter's Life and Art of Joseph Jefferson, Together with Some Account of His Ancestry and of the Jefferson Family of Actors (New York, Macmillan, I894. 3 I9 p.), a revision of The Jeffersons, first published in $\mathrm{I} 88 \mathrm{I}$.

4935. Kahn, Ely J. The merry partners; the age and stage of Harrigan and Hart. New York, Random House, 1955. 302 p. illus.

$$
\text { 55-8149 } \mathrm{ML}_{42} \text {. } \mathrm{H}_{3} \mathrm{~K}_{3}
$$
$\mathrm{PN}_{22} 87 . \mathrm{H}_{247} \mathrm{~K}_{3}$

Edward Harrigan and Tony Hart were partners and leading comedian entertainers in musical comedy productions in New York during the 1870's and I880's. Harrigan wrote the scripts which they performed. This joint biographical study gives an insight into musical comedy as an aspect of the stagecraft of the period and also the popular music of the time.

4936. Le Gallienne, Eva. With a quiet heart, an autobiography. New York, Viking Press, 1953. 311 p. illus. 53-5201 $\mathrm{PN}_{22} 87 . \mathrm{L}_{3} \mathrm{~A}_{35}$

The autobiography of a prominent actress. The book covers the two decades subsequent to the period covered by her earlier autobiography, $A t 33$ (New York, Longmans, Green, 1934- 262 p.).

4937. Moses, Montrose J. The fabulous Forrest; the record of an American actor. Boston, Little, Brown, 1929. xxi, 369 p. illus.

Bibliography: p. 345-355.

$$
\text { 29-27822 PN2287.F6M6 }
$$

Edwin Forrest (1806-1872) was America's first tragedian, and he has been called the most popular actor America has produced. This book attempts to present not only the actor, but the actor as a 
product of his times. The work is therefore of value as an analysis of the mid-nineteenth-century society.

4938. Ruggles, Eleanor. Prince of players: Edwin Booth. New York, Norton, I953. 40I p. illus.

"Notes on sources": p. $377-386$.

53-5986 $\mathrm{PN}_{2287} \cdot \mathrm{B}_{5} \mathrm{R}_{9}$

This life of the famous igth-century actor largely supersedes William Winter's Life and Art of Edwin Booth (New York, Macmillan, I893. 308 p.). Stanley P. Kimmel's The Mad Booths of Maryland (Indianapolis, Bobbs-Merrill, 1940. 400 p.) is more a psychological study of three famous actors than a story of dramatic achievement.

4939. Winter, William. Life and art of Richard Mansfield, with selections from his letters. New York, Moffat, Yard, igı. 2 v. illus. 10-3307 $\mathrm{PN}_{2287 . \mathrm{M}} 4 \mathrm{~W} 6$

Winter (1836-1917) was a leading New York drama critic and a prolific biographer of contemporary actors. He here presents (in large part through personal letters) the life of Mansfield (1857-1907), a famous actor and close friend of the author. Not just a chronicle, this book seeks to reveal the man's character.

\section{Bv. BIOGRAPHY: DIRECTORS, PRODUCERS, ETC.}

4940. Kinne, Wisner Payne. George Pierce Baker and the American theatre. Cambridge, Harvard University Press, 1954. 348 p. illus.

$$
\text { 54-8632 } \mathrm{PN}_{228} 7 . \mathrm{B}_{15} \mathrm{~K}_{5}
$$

A biography of the first college professor to teach practical playwriting and playproducing. Because of his work at Harvard from 1905 to 1924 , and then at Yale until his retirement in 1933, he has been called "the father of modern American playwrights."
4941. Langner, Lawrence. The magic curtain; the story of a life in two fields, theatre and invention, by the founder of the Theatre Guild. New York, Dutton, r951. 498 p. illus.

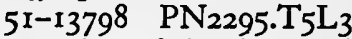

A leading patent attorney writes of the theatrical world in which he has figured so prominently. Born in South Wales in I89o, Mr. Langner came to the United States in 19ro, and 9 years later organized the Theater Guild, of which he has remained a principal director for 40 years. Its productions through r950 are listed in Appendix VIII.

4942. Sobel, Bernard. Broadway heartbeat; memoirs of a press agent. New York, Hermitage House, I953. 352 p. $53-12014 \quad \mathrm{PN}_{228} 7_{7} \mathrm{~S}_{2} \mathrm{~A}_{3}$ Mr. Sobel, now in charge of public relations for the Celanese Corporation of America, reviews his life between the two World Wars, when he was press agent for Earl Carroll, Florenz Ziegfeld, Jr., Metro-Goldwyn-Mayer, and a diversity of other clients.

4943. Timberlake, Craig. The Bishop of Broadway: the life \& work of David Belasco.

New York, Library Publishers, 1954. 49I p. illus. 54-II646 PN2287. $\mathrm{B}_{4} \mathrm{~T}_{5}$

Belasco ( $1853-1931$ ) was a would-be playwright who attained fame and fortune as a stage manager and play producer. This book presents a picture of the Western frontier theater (Belasco started in San Francisco) and later New York City. Belasco, who made many stars, brought about lavish and popular productions. He was not notably original, but he did have an ability to perfect tendencies and gage the taste of his audience. A two-volume, somewhat eulogistic Life of David Belasco (New York, Moffat, Yard, I918) was undertaken by William Winter (1836-1917), and completed after his death by his son, Jefferson Winter.

\section{Motion Pictures}

\section{Ci. HISTORY}

4944. Jacobs, Lewis. The rise of the American film; a critical history. New York, Harcourt, Brace, 1939. 585 p. illus.

Bibliography: p. $54 \mathrm{I}-564$.

39-32345 PNr993.5.U6J2

Remains, after 20 years, the most detailed and best-documented history of its subject, with special emphasis upon the evolution of form and content, the work of the leading directors, and the organization of the industry. A famous early work is Terry Ramsaye's $A$ Million and One Nights (New York, Simon \& Schuster, 1926. 2 v.). A French view of the American film may be obtained from Robert Florey's Hollywood d'hier et d'aujourd'hui (Paris, Éditions Prisma, 1948. $38 \mathrm{r}$ p.). Another French view of it, as seen in the context of world production, may be found in Histoire du cinéma, nouv. éd. definitive ([Givors] Martel, 1953- 
54. 2 v.), by Maurice Bardèche and Robert Brasillach. Paul Rotha in The Film Till Now, rev. and enl. ed. (New York, Funk \& Wagnalls, 1949. $755 \mathrm{p}$.) also presents it in world perspective.

4945. Seldes, Gilbert V. The movies come from America. New York, Scribner, 1937. 120 p. illus. 37-28786 PNig93.5.U6S 4

This work was published in London by Batsford under the title Movies for the Millions, and can be regarded as a clear and reasonably brief conspectus of the American cinema for British readers, with some instructive comparisons. The earlier chapters are historical, the later analytical; but all are constructively critical, for Mr. Seldes believed that the movies were'a big and good thing, but could easily be made better than they were. This quality allows a book, written when color film and TV were still looming on the horizon, to retain much of its original interest.

4946. Taylor, Deems, Marcelene Peterson, and Bryant Hale. A pictorial history of the movies. Rev. and enl. New York, Simon \& Schuster, 1950. 376 p. illus.

$$
\text { 50-8567 PNi993.5.U6T3 } 195^{\circ}
$$

A chronologically arranged book consisting largely of pictures of stars and stills from motion pictures. A pictorial selection from the silent film alone is Daniel C. Blum's A Pictorial History of the Silent Screen (New York, Putnam, 1953. 334 p.). Blum also edits an annual, Daniel Blum's Screen World (v. It 1949+ New York, Greenberg), each volume of which handles, through reproduced stills and some screen credits, American films produced in the preceding year and some foreign films released here; there are an obituary section and an index at the end.

\section{Cii. SPECIAL ASPECTS AND ANALYSES}

4947. Commission on Freedom of the Press. Freedom of the movies; a report on self-regulation from the Commission . . . Chicago, University of Chicago Press, r947. $240 \mathrm{p}$.

At head of title: By Ruth A. Inglis.

47-30119. $\mathrm{PN}$ 1994.A2 $\mathrm{C} 6$

"A note on sources": p. 220-224.

The history and state of film censorship are considered and the implications for film quality are discussed.

4948. Powdermaker, Hortense. Hollywood, the dream factory; an anthropologist looks at the movie-makers. Boston, Little, Brown, 1950. 342 p. 50-10280 PNi993.5.U65P6
This book is the result of a one-year sociological study of a famous Pacific coast community. Another analysis of the community is found in Leo C. Rosten's Hollywood; the Movie Colony, the Movie Makers (New York, Harcourt, Brace, 1941. 436 p.).

4949. Ross, Lillian. Picture. New York, Rinehart, 1952. $25^{8}$ p. $\quad$ 52-9607 PNr997.R 8

In an attempt to obtain and present an insight into the American motion picture industry the author has reported on the production of the film The Red Badge of Courage from the stage of initial conferences through final release and publicity. The material originally appeared as a series of articles in The New Yorker. A similar work, Case History of a Movie (New York, Random House, I950. 242 p.), by a person within the industry was done by Dore Schary for the film The Next Voice You Hear, which was produced with the assistance of Charles Palmer.

4950. Thorp, Margaret (Farrand). America at the movies. New Haven, Yale University Press, 1939. 313 p. illus. 39-31325 PNi993.5.U6T5

Mrs. Thorp analyzes who goes to the movies and why, and discusses the influences of films. Leo A. Handel in Hollywood Looks at Its Audience; a Report of Film Audience Research (Urbana, University of Illinois Press, 1950. 240 p.) shows how the film industry evaluates audience reaction.

4951. Wolfenstein, Martha, and Nathan Leites. Movies; a psychological study. Glencoe, Ill., Free Press, 1950. 316 p. illus.

50-7374 PNi995.W63

A psychological-sociological study of the American films (contrasted with those of England and France); the book probes the basic themes and patterns in films; which it regards as ready-made versions of the widespread and (nearly) universal daydreams of our culture. In this way it presents new insights into present-day America and Americans.

\section{Ciii. BIOGRAPHY: ACTORS AND ACTRESSES}

4952. Bainbridge, John. Garbo. Garden City, N. Y., Doubleday, 1955. 256 p. illus. $55-5589 \mathrm{PN}_{2} 778 . \mathrm{G}_{3} \mathrm{~B}_{3}$

A biography of Swedish-born Greta Garbo (b. 1905), who has been called the screen's greatest actress. She came to America early in her career. Her 
last film was released in 1941; since then she has been living in retirement.

4953. Huff, Theodore. Charlie Chaplin. New York, Schuman, 195 I. 354 p. 51-10104 $\mathrm{PN}_{2287} \mathrm{C}_{5} \mathrm{H} 8$

Charlie was born Charles Spencer Chaplin at London in 1889; his parents were both in vaudeville. Mr. Huff offers a minimal biography, but very full descriptions and appreciations of his films from the Keystone comedies of 1914 to Monsieur Verdoux (1947) and a wealth of illustrations. A complete chronological list of the films and "Biographical Sketches of the People Professionally Associated with Chaplin" are appended. Among other recent biographies of Chaplin are Pierre S. R. Payne's The Great God Pan (New York, Hermitage House, 1952. $301 \mathrm{p}$.), which is primarily a study of Chaplin's film work, and Peter Cotes and Thelma Niklaus' The Little Fellow [rev. ed.] (London, Bodley Head, 1952. $160 \mathrm{p}$.), which is more recent, but shorter.

4954. Menjou, Adolphe, and Morris M. Musselman. It took nine tailors. New York, Whittlesey House, 1948. $23^{8}$ p. illus.

48-5637 PN2287.M58 3

The life of Adolphe Menjou (b. 1890) is almost a history of the movies as he has lived it. It traces his career of 34 years in pictures, during which he had parts in 146 films.

4955. Pickford, Mary. Sunshine and shadow. Garden City, N. Y., Doubleday, 1955. 382 p. illus. $55-5580 \quad \mathrm{PN}_{2287} . \mathrm{P}_{5} \mathrm{~A}_{3}$

Mary Pickford (b. 1893 ) was one of the most popular film stars. She started as a child actress, and even as an adult she played child roles, and met with little success when portraying mature individuals. Her extreme popularity, which brought her the nickname of "America's Sweetheart," makes this autobiography a useful document for interpreting mass culture, especially insofar as the silent films are concerned. The first part of the book has a place in the history of the film; the second part is largely personal.

4956. Taylor, Robert Lewis. W. C. Fields, his follies and fortunes. Garden City, N. Y., Doubleday, 1949. $34^{\circ} \mathrm{p}$. ports.

$$
\text { 49-1I132 } \mathrm{PN}_{2287} \cdot \mathrm{F}_{45} \mathrm{~T}_{3}
$$

A life of the vaudeville star turned film comedian (1879-1946), which reflects much of the entertainment world of his period. A succession of very amusing anecdotes develop the view that Fields' whole life was pervaded by his highly original and sardonic comic spirit.

\section{Civ. BIOGRAPHY: DIRECTORS, PRODUCERS, ETC.}

4957. Feild, Robert D. The art of Walt Disney. New York, Macmillan, 1942. 290 p. $42-36248 \quad \mathrm{NC}_{7} 765 . \mathrm{F}_{4}$

Walt Disney's work is presented as a technical and commercial problem; an attempt is made to establish criteria for judging it as art. It serves, to some extent, as a history of Disney's work; Disney was a pioneer in the field of the animated cartoon, in which he rapidly acquired a commanding lead.

4958. Griffith, Richard. The world of Robert Flaherty. New York, Duell, Sloan \& Pearce, 1953. 165 p. illus. 51-10886 PNr998.A F F $_{5}$ Flaherty (1884-195I) is called "the father of the documentary film," but it is less the fact of paternity than the beauty, dignity, and narrative power of his work that gives him enduring significance. Mr. Griffith documents the making of Tabu, Man of Aran, Louisiana Story, and the others with extracts from Flaherty's diaries and letters, and provides over 70 illustrations, mostly from the films.

4959. Mayer, Arthur. Merely colossal, the story of the movies from the long chase to the chaise longue. [New York] Simon \& Schuster, 1953. 264 p. $\quad 53-5739$ PNi993.5.U6M3

The humorous as well as informative autobiography of a man who has spent much of his life in the business of films: distributing, showing, advertising, importing, etc.

4960. Noble, Peter. Hollywood scapegoat; the biography of Erich von Stroheim. London, Fortune Press, 1950. 246 p. illus.

Bibliography: p. 17 I-184. 52-21529 PNr998.A3V65

This English life of von Stroheim (b. 1885), the Vienna-born actor-director, takes the line that "he was the one chosen to be sent out into the wilderness to perish, to atone in some measure for the sins and extravagances of Hollywood during the fantastic 1920's. He had directed at least six masterpieces, yet Hollywood banished him because he was feared by the money-men." He did not perish, but has been successful as a leading character actor.

496r. Smith, Albert E. Two reels and a crank, by Albert E. Smith in collaboration with Phil A. Koury. Garden City, N. Y., Doubleday, 1952. 285 p. illus., ports.

52-11617 TR8 $49 . \mathrm{S}_{5} \mathrm{~A}_{3}$

Albert E. Smith, in partnership with Jim Blackton, conducted the Vitagraph Company from 1896 to 1925, when it was sold to the Warners for "a sizable fortune." Mr. Smith here reminisces of 
the shoestring days of the industry, when a comedy could be produced for $\$ 3.5^{\circ}$ plus the cost of the film at eight cents a foot.

4962. Vidor, King W. A tree is a tree. New York, Harcourt, Brace, 1953. 315 p. illus. 53-922I PNig98. $\mathrm{A}_{3} \mathrm{~V}_{5}$

The autobiography, judiciously limited to his cinema career, of King Vidor (b. I895), who learned to direct movies in Galveston, Texas, and went to Hollywood in 1915. The Appendix lists the 51 films he directed between 1918 and 1952 . Although they include such classics of the silent films as The Big Parade, The Crowd, and Hallelujah,
Mr. Vidor seems most deeply impressed by his Duel in the Sun (1946), "one of the ten biggest box-office grossers of all time."

4963. Zukor, Adolph. The public is never wrong. New York, Putnam, 1953. 309 p. illus. 53-8164 PNr998.A3Z8

A businessman of the films tells his life story, largely in terms of film history as he has seen it and the people he has known. The book was written with the collaboration of Dale Kramer. An earlier biography of Zukor is William H. Irwin's The House that Shadows Built (Garden City, N. Y., Doubleday, Doran, 1928. 293 p.).

\section{Other Forms of Entertainment}

\section{Di. RADIO AND TELEVISION}

4964. Allen, Fred. Treadmill to oblivion. Boston, Little, Brown, I954. 240 p. illus. 54-III32 PNig9I.4.A6A3

Fred Allen (1894-1956; real name, John Florence Sullivan) was a humorist of dry wit who for many years expressed in humor many aspects of American life. His career included stage, film, and some television, but the emphasis in this autobiographical work is on his radio program. The book not only presents the problems of such entertainment (sponsors, script-writing, etc.), but it also presents material from the programs. The book closes with his last regular program in 1949.

4965. Gross, Ben. I looked and I listened; informal recollections of radio and TV. New York, Random House, 1954. 344 p.

$$
\text { 54-7806 PNig91.5.G7 }
$$

In 1925 Gross became radio editor of a New York daily newspaper. After having spent nearly three decades growing up with the radio, and subsequently the television industry, he presents in this autobiographical book its informal history-especially in its entertainment aspects.

4966. Mackey, David R. Drama on the air. New York, Prentice-Hall, 195I. 468 p. illus.

$$
\text { 51-6240 PNI991.7.M3 }
$$

With an emphasis on radio acting and production, ". . . the purpose of this book is to describe the concepts and activities basic to the presentation of drama on the air, in the areas of script, acting, and production." There is a good bibliography on radio drama in particular and some radio history in general.

\section{Dii. THE DANCE IN AMERICA}

4967. Amberg, George. Ballet in America, the emergence of an American art. New York, Duell, Sloan \& Pearce, r949. 244 p. illus. 49-1689 GVr787.A43

Also published by the New American Library with title: Ballet.

A critical and historical study. The emphasis is heavily modern, in view of the author's statement: "While there has been some form of the ballet in America for more than a century and a half, the native American ballet is barely fifteen years old." Preface.

4968. Armitage, Merle, ed. Martha Graham. Los Angeles, M. Armitage, 1937. 132 p. illus. 39-2400 GVI785.G7 $\mathrm{A}_{7}$

Articles by John Martin, Lincoln Kirstein, Evangeline Stokowski, Stark Young, Wallingford Riegger, Edith J. R. Isaacs, Roy Hargrave, James Johnson Sweeney, George Antheil, Margaret Lloyd, Louis Danz, and Martha Graham. This book is a group of articles discussing or simply lauding Martha Graham, one of the leading exponents of the modern dance. Barbara B. Morgan's Martha Graham, Sixteen Dances in Photographs (New York, Duell, Sloan \& Pearce, I94I. I60 p.) presents a photographic study of the dancer.

4969. Chujoy, Anatole. The New York City Ballet. New York, Knopf, 1953. 382 p. illus. $\quad 52-64 I_{2} \quad \mathrm{GV}_{17} 86 . \mathrm{N}_{4} \mathrm{C}_{45}$

Although the New York City Ballet was not organized until 1948, Mr. Chujoy tells the story of its predecessor enterprises from "October I933, when Lincoln Kirstein and his friend and Harvard 
classmate Edward M. M. Warburg brought George Balanchine and Vladimir Dimitriew from Europe to establish the School of American Ballet." The book acclaims the work of Messrs. Kirstein and Balanchine in creating, from Russian models, "an American institution to be proud of."

4970. De Mille, Agnes. Dance to the piper. Boston, Little, Brown, 1952. 342 p. illus. 52-I19 GVI785.D $36 \mathrm{~A}_{3} \quad \mathrm{I}_{952}$

The autobiography of a rich girl who climbed the ladder to success as a dancer and choreographer. She was one of the revolutionaries in the establishing of an "American" dance.

4971. Magriel, Paul D., ed. Chronicles of the American dance. New York, Holt, 1948. 268 p. illus. $\quad 48-9068 \quad$ GVI623.M $_{33}$

"Notes and bibliographical data": p. 263-268.

Written largely as a series of chronologically arranged monographs by various authors on individuals and groups of dancers. Because of this manner of treatment, and because of its emphasis on theatrical dancing, the work is not a full history of dancing in America, although its range is wide. A work of wider scope, but for a shorter period, edited by Doris Hering for Dance Magazine, is 25 Years of American Dance (195I), rev. and enl. ed. (New York, Orthwine, 1954. 236 p.), a heavily illustrated work which covers the entire field of the dance in modern America, from recreational and social dancing through dancing in plays, motion pictures, and on television. Theatrical dancing in America since r 900 is studied in Winthrop B. Palmer's Theatrical Dancing in America (New York, Ackerman, 1945. 159 p.), which has much material on ballet. A dancer's view of the problems and aesthetics of the modern theatrical dance is given in Elizabeth $S$. Selden's The Dancer's Quest (Berkeley, University of California Press, 1935. 215 p.).

4972. Magriel, Paul D., ed. Isadora Duncan. New York, Holt, 1947. 85 p. illus.

47-3097 GVi785.D8M3

"The material in this book is made up largely from issues of the periodical, Dance Index."

Appendices: Chronology. Bibliography of Isadora Duncan (p. 73-78). Albums and books of drawings of Isadora Duncan (p. 79).

A short book of essays (by John Martin, Carl Van Vechten, A. R. Macdougall, and Gordon Craig) on Isadora Duncan (1878-r927), a pioneer of the modern dance. An illustrated memorial volume of essays by the dancer, with forewords by various people, is Duncan's The Art of the Dance, edited by Sheldon Cheney (New York, Theatre Arts, 1928. 147 p.).

\section{Diii. VAUDEVILLE AND BURLESQUE}

4973. Dillon, William A. Life doubles in brass. Ithaca, N. Y., House of Nollid, 1944. 234 p.

illus. 44-8823 PNig67.D 47

Will Dillon, born in 1877 in upstate New York to an Irish family with theatrical inclinations, progressed though traveling medicine shows, blackface minstrel shows, and repertory stock companies to Broadway vaudeville, as an "eccentric singing comedian." He was also an indefatigable writer of popular songs, and appends some sentimental specimens.

4974. Laurie, Joseph. Vaudeville: from the honkytonks to the Palace. New York, Holt, 1953.

56r p. 53-9590 PNr967.L3

The honky-tonks, gambling houses and saloons providing entertainment during the r $870^{\circ}$ 's and 80's, were the future vaudeville's cradle of talent. $\mathrm{Mr}$. Laurie, however, is mainly concerned with the vaudeville of the 2oth century down to the great collapse of 1932, when its disappearance from the Palace Theater on Broadway symbolized its final dispossession by the movies. He gives vivid, slangfilled sketches of the conditions of work, representative acts, and leading managers. An earlier, less memoiristic and less animated history of vaudeville is Douglas Gilbert's American Vaudeville, Its Life and Times (New York, Whittlesey House, I940. 428 p.).

4975. Marston, William Moulton, and John Henry Feller. F. F. Proctor, vaudeville pioneer. New York, R. R. Smith, I943. I9I p. illus. 44-I55 PNig67.M3

The life of Frederick Freeman Proctor (18511929), a producer of vaudeville shows in New York City.

4976. Sobel, Bernard. Burleycue; an underground history of burlesque days. New York, Farrar \& Rinehart, I93I. 284 p. illus.

$$
\text { 3I-335I2 PNig67.S6 }
$$

Burlesque began as travesty of classical tragedy, but since about 1869 its essence and its prosperity have resided in its revelation of the female form, by tights or otherwise. Mr. Sobel skims over its principal aspects and persons from Lydia Thompson and the British Blondes-an obese lot by presentday standards-to Ann Corio, a more streamlined type. 
Div. SHOWBOATS, CIRCUSES, ETC.

4977. Barnum, Phineas $T$. Struggles and triumphs: or, The life of P. T. Barnum, written by himself. Edited, with an introd., by George S. Bryan. New York, Knopf, 1927. 2 v. illus. 27-13922 GVi811.B3A3 I927C

"Based upon 'The life of P. T. Barnum written by himself' (New York, 1855); the I869 (Hartford) issue of 'Struggles and triumphs; or, Forty years' recollections of P. T. Barnum'; and the 1889 (Buffalo) issue of the condensed version of 'Struggles and triumphs.'"

Barnum kept adding and subtracting from his autobiography as it passed through its many editions. Accordingly, there is no one complete, definitive text. Bryan has here edited a composite text. Morris R. Werner's Barnum (New York, Harcourt, Brace, 1923. 38I p.) is a biography based on the autobiography and outside materials.

4978. Graham, Philip. Showboats; the history of an American institution. Austin, University of Texas Press, 1951. 224 p. illus.

Bibliography: p. 203-210.

$$
5 \mathrm{I}-\mathrm{I}_{4} 160 \quad \mathrm{PN}_{2293} \cdot \mathrm{S}_{4} \mathrm{G}_{7}
$$

Showboats, which first appeared on the Mississippi and its tributaries in 1831 and lasted for over a century, were long a major medium of entertainment from Pittsburgh to New Orleans. An autobiographical book recording this aspect of the dramatic art is Billy Bryant's Children of Old Man River; the Life and Times of a Showboat Trouper (New York, Furman, 1936. 303 p.).

4979. Havighurst, Walter. Annie Oakley of the Wild West. New York, Macmillan, 1954. 246 p. illus.

54-12424 GVII57. $\mathrm{O}_{3} \mathrm{H}_{3}$ Annie Oakley (1860-1926) was from childhood an incredibly accurate marksman with a shotgun or rifle. So uniform was her success with the most unlikely targets that for years she was able to travel widely and profitably as a popular entertainer. The peak of her career was perhaps her 17 successive years as a star of Buffalo Bill's Wild West show.

4980. Mannix, Daniel P. Step right up! New York, Harper, 195I. 270 p. 5I-2123 GVI835.M3

Says Mr. Mannix, formerly The Great Zadma, of his venture into fire-eating and sword-swallowing: "I worked under canvas for the best part of three years and either performed or saw performed all the stunts I tell about in this book. . . . Except for combining the events of chronologically separated occasions into one summer, I've told the story of a travelling American carnival as I experienced it-only changing the names of the people with whom I worked."

4981. McPharlin, Paul. The puppet theatre in America, a history; with a list of puppeteers, 1524-1948. New York, Harper, 1949. 506 p. illus., facsims. $\quad 49-8939$ PNi978.U6M22

A history of puppets in America, from the beginning to 1948 , just before the television revival. The large amount of material and its ordering makes the book usable as a reference work.

4982. Robeson, Dave. Al G. Barnes, master showman, by Dave Robeson, as told by Al G. Barnes. Caldwell, Idaho, Caxton Printers, 1935. 460 p. illus. 35-12032 GVI811.B27R6

The life story of a circus manager who specialized in wild, trained, and performing animals, and to whom Maud the mule and Nero the first riding lion were real individuals. 


\section{XX \\ Sports and Recreation}

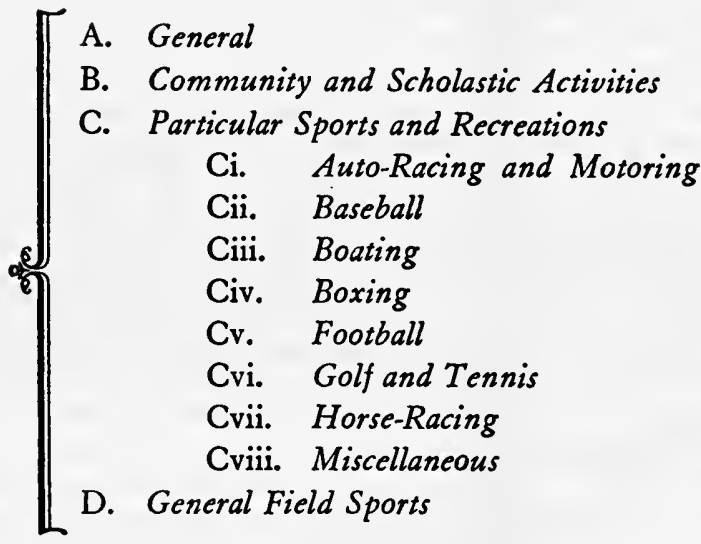

$\left.\begin{array}{l}4983-4996 \\ 4997-5000 \\ 5001-5007 \\ 5008-5015 \\ 5016-5022 \\ 5023-5033 \\ 5034-5045 \\ 5046-5053 \\ 5054-5057 \\ 5058-5064 \\ 5065-5097\end{array}\right]$

$\mathrm{A}^{\mathrm{S}} \mathrm{THE}$ leisure time of the average American has rapidly increased, the ways in which A this time is passed have become increasingly important factors in the life of the Nation. This is further accentuated by the fact that increased specialization and routinization of jobs has decreased the percentage of those who live for their work, and enormously increased the number of people who live by it, but for something else. Leisure activities have taken on many aspects. One of the main categories is sport and recreation. While many of the sports are so commercialized and non-participatory in nature that they might well be included under Entertainment (q. v.), not to mention commerce itself, and while much entertainment is attended primarily for purposes of recreation, we have chosen to use Entertainment in its more traditional sense (covering spectacles such as drama, motion pictures, vaudeville, the circus, etc.), and to regard activities such as athletics as in a distinct category. To word it another way, the distinction is made in consideration of whether or not the activity is widely regarded among its followers as a participation activity (Sports and Recreation) or as a generally and basically non-participation activity (Entertainment).

Accordingly, this section covers such sports as football, baseball, tennis, sailing, horse-racing, and auto-racing, as well as the allied field sports, hunting and fishing. Some activities of the kind are, however, not included because of a lack of suitable books: basketball, swimming, billiards, hockey, bi-

cycling, etc.; while other important sports and recreations are merely touched on: hiking, camping, skiing, etc. For all these there is ample literature in the form of manuals and guides, but little in the way of books treating them as significant experience or placing them individually in the picture of life in America. For these the student will find some information in the general histories of sport and recreation. Just as the manuals have been excluded, so too the various handbooks, encyclopedias, and annuals of individual sports (notably baseball and football) have been left out. Usually these are mainly compendia of records (often statistical) and do little to indicate any significance in the game for American experience. As such they are of value primarily to the game's fans, and secondarily to the specialist, while their value to the general student of American history and culture is limited. 
It has been found impossible to represent the sports strictly in proportion to their importance. In some fields such as baseball, there is a vast literature, but mainly for young readers. In most fields the books are written for aficionados of the sport, and in a style with little appeal to the literate lay reader, and often with a wealth of statistical detail of interest chiefly to the fans. Also, many of the books are uncritically written with little concern for the distinction between truth and fable, and with much attention to the fame and glory of the moment. On the other hand, a few sports have had capable writers among their followers: notably hunting and fishing (which are probably the most widespread adult participation sports); yachting (which is certainly a minority sport); and also boxing (which in comparison to other sports has been surprisingly well, though not extensively, written up).

It should also be noted that these subjects are occasionally touched upon (directly or tangentially) in other sections of the bibliography. Books such as Lloyd Morris' 'Not So Long Ago under Society and the baseball literature of Ring Lardner in the Literature section may well be of interest to the student. For such material the appropriate sections and the index should be used.

\section{A. General}

4983. Cozens, Frederick W., and Florence Scovil Stumpf. Sports in American life. Chicago, University of Chicago Press, 1953. $366 \mathrm{p}$.

$$
\text { 53-12897 } \quad \mathrm{GV}_{5} 83 . \mathrm{C} 68
$$

Two University of California sociologists study the 2oth-century penetration of American society on every level by the practice and the enthusiastic fanship of organized sports and physical recreations. They describe the latter-day importance of sports in labor and industry, the school, the church, journalism, broadcasting, and even in war. They find sport a vast and beneficent force for unification in American life, narrowing the gaps between social classes and ethnic groups. Unlike most commentators, they wholeheartedly approve of spectator sports, "the cement of democracy." "The bleachers are equally cordial to coal-miners, politicians, and bank presidents."

4984. Danzig, Allison, and Peter Brandwein, eds. The greatest sport stories from The New York Times; sport classics of a century. New York, Barnes, 195I. 680 p. illus. 5I-I4836 GVI9r.N 4

"From the files of The New York Times have been selected eyewitness accounts of the most celebrated events in the field of sports dating from the first year of publication of The Times, now celebrating its centennial anniversary."-Introduction.

A similar volume, Wake Up the Echoes, edited by Bob Cooke and selected from the sports pages of the New York Herald Tribune was published in 1956 (Garden City, N. Y., Hanover House. 25 I p.).

4985. Dulles, Foster Rhea. America learns to play; a history of popular recreation, $1607-$ 1940. New York, P. Smith, 1952, '1940. xvii, $44 \mathrm{I}$ p. illus.

Bibliography: p. 375-390.
An attempt to present the main aspects of popular recreation. "Recreation is considered in its popular sense-the leisure-time activities that the American people have pursued over three centuries for their own pleasure. At all periods of history men and women have probably spent the greater part of their leisure in informal talk, in visiting and entertaining their friends, in casual walks and strolls, and sometimes in reading for their own amusement. But these more simple activities are hidden in the obscurity that shrouds private lives. Organized, public recreation has consciously been adopted as the basis for this record."-Preface.

4986. Durant, John, and Otto Bettmann. Pictorial history of American sports, from colonial times to the present. New York, Barnes, 1952. $280 \mathrm{p}$. 52-8298 GV583.D85

With text as well as pictures on nearly every page, this overall narrative hits the high spots of five periods, moving from "Captain Smith to General Grant" in the first 45 pages. The remaining four are "The Gas-lit Era, I87I-1898," "The Rise of Sports, 1900-1918," "The Golden Age, I919-1930" ("an age of champions, of extraordinary events and superb performances, an age of public idolatry and fabulous purses"), and "Sports for Everybody, 1931-1952."

4987. Gallico, Paul. Farewell to sport. New York, Knopf, 1938. 346 p.

$$
3^{8-27340} \quad \mathrm{GV}_{53} \cdot \mathrm{G}_{3}
$$

Mr. Gallico was for 13 years $(1923-36)$ a sports writer for the New York Daily News, and has since become a prolific writer of fiction. This reflective book devotes individual chapters to three boxers (Jack Dempsey, Primo Carnera, Gene Tunney) and to Tex Rickard, "the world's greatest prizefight 
promoter," Babe Ruth, the king of baseball, and Helen Wills Moody, the queen of tennis. The remaining chapters discuss particular sports or special topics such as the Negro in sport. A recurrent theme is the national hypocrisy which insists that, in certain sports, professional athletes must maintain, by various subterfuges, their "amateur" status. Mr. Gallico had one relapse into sports writing in 1942, when he published Golf Is a Friendly Game (New York, Knopf. 274 p.) and Lou Gehrig, Pride of the Yankees (New York, Grosset \& Dunlap. 185 p.).

4988. Kieran, John. The American sporting scene, with pictures by Joseph W. Golinkin. New York, Macmillan, 194I. 21 I p. illus. (part col.) $4 \mathrm{I}-52016 \quad \mathrm{GV}_{5} 83 . \mathrm{K}_{47}$

Anecdotes and reminiscences of the world of sports; the text is in a measure written about the paintings and sketches of Golinkin. The book catches some of the mood of sports, including the non-professional's role, although there is no attempt to attain either a historical or comprehensive contemporary survey of the sporting world.

4989. Kirby, Gustavus T. I wonder why? New York, Coward-McCann, 1954. 180 p. illus. 54-10148 GV697.K5 $\mathrm{A}_{3}$

Mr. Kirby, born in 1874 , pursued careers as a New York lawyer and art dealer. Active in athletics at Columbia College in the 'go's, he has been an official of the International Olympics since the second Games (1900), and has received six decorations from European governments. His autobiography is largely a procession of anecdotes, but expresses his conviction that "only through sport can there ever be a true democracy in this world."

4990. Krout, John Allen. Annals of American sport. New Haven, Yale University Press, 1929. 360 p. (The Pageant of America [v. 15]) 29-22307 $\quad \mathrm{GV}_{53} \cdot \mathrm{K}_{7}$ EI78.5.P2, v. 15

Although conceived as a picture book, this is considerably the fullest and most dependable general history of American sports down to the midI920's, and the one best related to other aspects of national history. Unfortunately the pictures, as always in this exasperating series, are as poorly reproduced as they are admirably selected from original sources. After a general review of outdoor diversions in the colonial era, Dr. Krout deals successively with the turf, yachting and rowing, fishing and hunting, baseball, football, and golf, and has chapters on "The Day of the Athletic Club" and "The Coming of the Gymnasium." The "General
Bibliography" (p. 338-347) covers the whole 15volume series; the list for sports is limited to page 347 .

4991. Lardner, John. Strong cigars and lovely women. New York, Published for Newsweek by Funk \& Wagnalls, 1951. 127 p.

5I-I 4397 PN6I6I.L3574

A selection from the author's columns which appeared in Newsweek, 1949 to 195 I.

John Abbott Lardner, son of the famous Ring Lardner (q. v.), is a leading sports writer who is known for his style and the humor which he introduces into his articles. An earlier collection was It Beats Working (Philadelphia, Lippincott, 1947 . 253 p.), a selection of his articles that appeared in Newsweek from 1939 to 1945 . He is also the author of White Hopes and Other Tigers (Philadelphia, Lippincott, 195I. I9० p.), a history of heavyweight boxing in the U. S. from 1910 to 1930 .

4992. Manchester, Herbert. Four centuries of sport in America, 1490-1890. New York, Derrydale Press, I93r. 245 p. illus.

"List of sources": p. [233]-245. $32-2523 \quad \mathrm{GV}_{5} 83 \cdot \mathrm{M}_{3}$

A well-illustrated volume whose purpose is "to follow the history of sport in America from that of the Aztecs and Indians down through the sports of the white man to about a generation ago." The point of view is historical rather than technical, and the author seeks to give the story of each period with the high spots of each sport, rather than its minor details. A more detailed, but unillustrated work with a smaller range is Jennie Holliman's American Sports, 1785-1835 (Durham, N. C., Seeman Press, 1931. 222 p.).

4993. Paulison, Walter M. The tale of the Wildcats; a centennial history of Northwestern University athletics. [Evanston? Ill.] $\mathrm{N}$ Men's Club, Northwestern University Club of Chicago, Northwestern University Alumni Association, I95I. xiv, 223 p. illus. $\quad 52-8032$ GV69r.N6P3

The centennial celebrated is the founding of Northwestern University, 1851-55; its football team, once the "Fighting Methodists," has been known as the Wildcats since 1924; this volume covers all college athletics but naturally gives most space to football (p. 17-63). Baseball was earlier, in unorganized form from the beginning, organized from 1869 , and intercollegiate from $187 \mathrm{I}$. Football has been played since 1876 , organized since 1879, and intercollegiate since 1882. Track, tennis, basketball, swimming, etc., are all narrated, with a complete roster of lettermen and intercollegiate 
scores at the end, and many fine plates reproducing photographs of teams and individual stars.

4994. Rice, Grantland. The tumult and the shoutting; my life in sport. New York, Barnes, 1954. 368 p. illus. 54-9I73 GV697.AIR52 Henry Grantland Rice was for many years a leading sports columnist. He was well known for his work on a long series of short sport films. His autobiography, completed shortly before his death, is less his life story than a presentation of the world of sports as he saw it. Rice also wrote much popular sports and moral verse.

4995. Smith, Walter W. Views of sport [by] Red Smith. New York, Knopf, r 954. 293 p. 53-6862 GVig1.S62
This is a second selection of articles from the author's column "Views of Sport," in the New York Herald Tribune; the first was entitled Out of the Red (New York, Knopf, I950. 294 p.). Smith (b. I905) may write on any aspect of his field. His approach is usually anecdotal and frequently humorous.

4996. Zaharias, Mildred Babe (Didrikson), and Harry Paxton. This life I've led; my autobiography, by Babe Didrikson Zaharias as told to Harry Paxton. New York, Barnes, 1955. 242 p. illus. 55-10217 GV964. $\mathrm{Z}_{3} \mathrm{~A}_{3}$

Mrs. Zaharias has been called "the greatest woman athlete." Raised in an impoverished Texas family, she became a leading athlete in several fields, including golf, basketball, baseball, and track.

\section{B. Community and Scholastic Activities}

4997. Butler, George D. Introduction to community recreation, prepared for the National Recreation Association. 2d ed. New York, McGraw-Hill, 1949. xiv, 568 p.

49-7982 GVI71.B85 1949

'The term 'community recreation' is applied in this volume to recreation services that are provided for the benefit of all the people. Special consideration is given to those forms of recreation which require a considerable degree of organization and leadership and in which participation plays an important role. Because governmental agencies provide a large and increasing proportion of such services, this book is devoted primarily to the work of these agencies. It deals with recreation as a function of local government ... Commercial recreation .... is not included ..."

". . Major consideration is given to problems ... related to the town and city rather than the rural community."-Preface.

Bibliography: p. 533-548.

4998. Neumeyer, Martin H., and Esther S. Neumeyer. Leisure and recreation; a study of leisure and recreation in their sociological aspects. Rev. ed. New York, Barnes, 1949. 4 I I p. 49-8054 GVI4.N4 1949 The aim of the authors is "to present an informative treatment of the place of recreation in modern society ..." Their emphasis is on group activities. Something of a world view is presented, although basic orientation is to the United States. Chapter titles include: "Recreation Movement in the United
States," "Conditioning Factors of Leisure and Recreation," "Leisure and Personality," "Preparing for Leisure," "Theories of Play and Recreation," "Recreation and Social Maladjustment," "Commercial Recreation," "Community Recreation: Public Agencies," "Community Recreation: Semipublic and Private Agencies," "Recreation Leadership," and "Methods of Recreation Research."

4999. Savage, Howard J., and others. American college athletics, by Howard J. Savage . . . and Harold W. Bentley, John T. McGovern, Dean F. Smiley, M. D., with a preface by Henry S. Pritchett ... New York, Carnegie Foundation for the Advancement of Teaching, 1929. xxii, $383 \mathrm{p}$. (The Carnegie Foundation for the Advancement of Teaching. Bulletin no. 23)

29-23787 GV583.53

$\mathrm{LB}_{2334 . \mathrm{C}_{4} \text {, no. } 23}$

A report on an investigation into the function of athletics in American higher education, as well as the financing of both athletics and the athletes. "The fundamental causes of the defects of American college athletics are two: commercialism," and a failure to develop the educational potentialities latent in the sports themselves. Little has changed since 1929; for instance, our athletes and student managers are still "puppets pulled by older hands."

5000. Whitten, Charles W. Interscholastics; a discussion of interscholastic contests. Chicago, Illinois High School Association, 1950. xv, 27I p. 50-14804 GV583. W5

"This book has been written to serve two pur- 
poses. It is a record of the growth and development of the Illinois High School Athletic Association and its successor, the present Illinois High School Association. It is also a record of my own convictions as to the educational philosophy underlying the interscholastic activities carried on under the aegis of the association."-Foreword.
Interscholastic athletic activities are the rule throughout the United States, but few of them have had published histories. This book may be taken as partially illustrating the systems that have been built up. The philosophy behind it is unusually conservative for a sports figure and probably comes closer to that of many humanists.

\section{Particular Sports and Recreations}

\section{Ci. AUTO-RACING AND MOTORING}

500r. Catlin, Russ. The life of Ted Horn, American racing champion. Los Angeles, F. Clymer, 1949. 223 p. illus.

$$
\text { 49-50131 GV1029. } \mathrm{H}_{5} 6 \mathrm{C}_{3}
$$

Horn was a leading automobile racer. His biography is largely a history of major racing developments from $193 \mathrm{I}$ to his death in 1948 .

5002. Chase, Harold B. Auto-biography; recollections of a pioneer motorist, 1896 to I9II. New York, Pageant Press, 1955. I74 p. illus.

$$
\text { 55-1 1223 GVI021.C5 }
$$

Reminiscences of a motoring enthusiast who started while the recreation was new and still far from standard.

5003. Clymer, Joseph Floyd. Indianapolis 500 mile race history. Los Angeles, 1946. $320 \mathrm{p}$.

illus.

NNC

A history of the leading automotive race in America. An annual supplement, Indianapolis Race History, has been published by Mr. Clymer since 1946 . The author has written much on racing and has published many works by himself and others on this sport. A short popularized history of the race from its beginning in 1909 to 1955 is Brock W. Yates' The Indianapolis 5oo; the Story of the Motor Speedway (New York, Harper, 1956. 147 p.).

5004. Lozier, Herbert. Auto racing, old and new. [Greenwich, Conn., Fawcett Publications] 1953. I44 p. illus. (A Fawcett book, no. 184) 53-29624 GV 1029.L6

A history of automobile racing, especially in America. The arrangement is by race, with chronological subdivision. Most attention is given to the Indianapolis races.

5005. Partridge, Bellamy. Fill 'er up; the story of fifty years of motoring. New York, McGraw-Hill, 1952. 235 p. illus.

$$
\text { 52-10850 GV1021.P3 }
$$

"Chronology of the Motor Car:" p. 219-227.

A rather loosely written chronicle of various aspects of the automobile's conquest of American life, especially in its earlier stages. Among its highlights are the first American automobile race, in Chicago on Thanksgiving day, 1895 , when the winner averaged 5.05 miles per hour; the organization in New York City of the Automobile Club of America, followed by the first automobile parade ever seen in America (1899); the federating of the clubs into the American Automobile Association in 1902; and the Glidden Tours held under its auspices during each summer from 1905 to 1913 .

5006. Shaw, Wilbur. Gentlemen, start your engines. New York, Coward-McCann, 1955. 320 p. illus. $\quad 55-8980$ GV I029.S 43

The personal narrative of an automobile racer, born in 1902, who began competing in 1921 and won the Indianapolis 500 (see no. 5003) in 1927 with his "little Jynx Special." strong in 1954, when his career was cut short by a fatal airplane crash. Another auto-racer's autobiography is Peter De Paolo's Wall Smacker; the Saga of the Speedway (Cleveland, Ohio, Thompson Products, 1935. 271 p.).

5007. Wagner, Fred J. The saga of the roaring road, by Fred J. Wagner as told to John M. Mitchell. Los Angeles, F. Clymer, 1949. I89 p. illus. 49-5081 GV1029.W25 1949

"Fred Wagner was the dean of race starters, and during his career officiated at auto races at nearly every track and course in the United States."Foreword.

The book is more a group of reminiscences than an organized history; however, the scope of Wagner's activity makes it valuable for the early history. The book was first published in $193^{8}$. In this edition, the text is not altered, but photographic material has been added. 


\section{Cii. BASEBALL}

5008. Barrow, Edward G., and James M. Kahn. My fifty years in baseball. New York, Coward-McCann, 195I. 216 p. ports.

5I-IOg8I GV865. $\mathrm{B}_{3} \mathrm{~A}_{3}$

Mr. Barrow, born in 1868 , entered the business side of baseball in 1894 , and got his first club (Paterson, N.J.) to manage in 1896 . He is proudest of having developed Hans Wagner, "the greatest ball player of all time," and of having "changed Babe Ruth from a left-handed pitcher into a full-time outfielder," with spectacular results. After two seasons with the Boston Red Sox, he became business manager of the New York Yankees in 1920, and succeeded Jacob Ruppert as their president in 1939, retiring in 1945 when the club was sold. His life story, taken down by Mr. Kahn, is objective, even-tempered, and most informative.

5009. Bartlett, Arthur C. Baseball and Mr. Spalding; the history and romance of baseball. New York, Farrar, Straus \& Young, 195I. 295 p. 51-9661 GV865.S7 $\mathrm{B}_{3}$

The life of Albert G. Spalding (1850-1915), a sporting goods businessman who as a baseball executive turned the game into big business.

5010. Graham, Frank. Lou Gehrig, a quiet hero. New York, Putnam, 1942. $25^{\circ}$ p. illus. $42-8657$ GV865. $\mathrm{G}_{4} \mathrm{G}_{7}$

A sports journalist's biographical tribute to Henry Louis Gehrig (1903-194I), one of baseball's heroes and one of the outstanding modern professional players of the game. In 1939 he retired from the game because of a fairly rare and incurable form of infantile paralysis which was causing his muscles to wither.

5011. McGillicuddy, Cornelius. My 66 years in the big leagues; the great story of America's national game, by Connie Mack (Cornelius McGillicuddy) Philadelphia, Winston, 1950. 246 p. illus. $\quad 50-7521$ GV865.M27 $\mathrm{A}_{3}$

Connie Mack (1862-1956) was a baseball executive who came to be known as the "grand old man" of the game. He was best known as the manager of the Philadelphia Athletics.

5012. Ruth, George H., and Robert B. Considine. The Babe Ruth story as told to Bob Considine. New York, Dutton, I948. 250 p. illus. 48-6219 GV865.R8A3

George Herman Ruth, universally known as Babe Ruth (1894-1948), emerged from an "incorrigible" youth in Baltimore to enter professional baseball in I913, and to become its most spectacular and popu- lar star after joining the New York Yankees in 1920. In I921 he made his incredible record of I77 runs in 152 games, and during his 21 -year period in the American League (1914-34) he made the record slugging percentage of .692. In 1930 his salary was raised from $\$ 70,000$ to $\$ 80,000$ a year. A swift physical decline forced his retirement in 1935, and this honest book does not conceal the despair of the star who can play no more, or the agonies of his final illness-in the course of which he succeeded in completing this autobiography and the Hollywood film, The Babe Ruth Story, which was its counterpart.

5013. Smith, Ira L., and H. Allen Smith. Low and inside; a book of baseball anecdotes, oddities, and curiosities. Garden City, N. Y., Doubleday, 1949. 243 p. $\quad 49-8968$ GV873.S 8

A collection of baseball anecdotes that appeared in print prior to I918. This book was supplemented by the authors' Three Men on Third; a Second Book of Baseball Anecdotes, Oddities, and Curiosities (Garden City, N. Y., Doubleday, 195I. 250 p.), which brought the coverage up to the time of compilation.

5014. Smith, Robert Miller. Baseball; a historical narrative of the game, the men who have played it, and its place in American life. New York, Simon \& Schuster, 1947. xiv, 362 p. illus. $47-4836$ GV863.S 44

"BASEBALL is a private appreciation of a game I have played and watched as long as I can remember. It is an investigation of the manner in which the game began in this country, and a partial account of its place in the life of the nation for one hundred years. It is an attempt to bring to life a few of the great games and to revivify some of professional baseball's bygone heroes. It is an amateur effort to explain why baseball has meant so much to so many Americans."-Foreword.

A more recent history of professional baseball is Frederick G. Lieb's The Baseball Story (New York, Putnam, I950. 335 p.).

5015. Spink, J. G. Taylor. Judge Landis and twenty-five years of baseball. New York, Crowell, 1947. $306 \mathrm{p}$. ports.

47-3905 GV865.L 3 S6

A biography of Kenesaw Mountain Landis ( 1866 I944), who in I 920 was appointed the first baseball commissioner (frequently called the "Baseball (zar"), in which position he regulated organized baseball and did much to establish baseball "law." $\mathrm{He}$ held this position until his death in 1944; in 1945 "Happy" [Albert Benjamin] Chandler was elected the second baseball commissioner. 


\section{Ciii. BOATING}

5016. Barrett, J. Lee. Speed boat kings; 25 years of international speedboating. Detroit, Arnold-Powers, 1939. 143 p. illus.

$$
\text { 40-27200 GV835. } 33
$$

Not a general history of motorboat racing in the United States, this book centers upon Gar Wood (Commodore Garfield A. Wood of Detroit), his mechanic Orlin Johnson, and the builders of his speedboats, Chris Smith and his son Jay of Algonac, Mich., and enthusiastically narrates their joint attempts to win the Harmsworth Trophy for America. Put in competition by the future Lord Northcliffe in 1903, it was first won by Wood in his Miss America I at Cowes in 1920, and successfully defended by him through 1933 .

5017. Elder, George W. Forty years among the Stars. Port Washington, Wis., Schanen \& Jacque, 1955. 352 p. illus. 55-5745I GV811.E4 A history of the Star (a small yacht), of the Star organization, and of Star racing.

5018. Gardiner, Frederic, M. Cruising North America. New York, Dodd, Mead, 194I. xii, $34^{\circ}$ p. illus., maps. $\quad 4$ I-I $4788 \quad$ GV8 $15 . G_{3}$

This book was designed to be an introduction to the cruising areas, inland as well as coastal, of North America. It illustrates the local range of yachtsmen.

5019. Hoyt, Charles Sherman. Sherman Hoyt's memoirs. New York, Van Nostrand, 1950. xii, $34^{8}$ p. illus. (A Van Nostrand sporting book) 50-10884 GV815.H6

A book of reminiscences of changes in yachting over a period of 60 years; the author is mainly concerned with sail yachts.

5020. Kelley, Robert F. American rowing; its background and traditions. New York, Putnam, 1932. xiv, 27 r p. illus.

$$
\text { 32-2669o GV796. } \mathrm{K}_{4}
$$

A well-organized and clearly written history of competitive rowing in America, which is now chiefly a college sport but was by no means so in its origins. Amateur racing and rowing clubs began to flourish in the 1830's; professional crews and single scullers emerged in the 1850's. Edward Hanlan (18551908), who was born in Toronto but dominated United States races from 1876 to 1884 , is remembered as the greatest pro. Philadelphia's Schuylkill River Navy, organized in 1858 , remains "the oldest governing body of sport in America." Harvard and Yale first raced in 1852 , and have done so annually since 1876; multi-college regattas have been held since 1871 , and the major one, the Poughkeepsie
Regatta, since 1895 . The colleges have kept up the old sport as mass interest has turned to speed. An appendix ( $p$. 255-271) lists winners in various events.

5021. Klein, David, and Mary Louis Johnson. They took to the sea, including personal accounts of the voyages of Joshua Slocum, Jack London, Rockwell Kent and other small-boat voyagers. New Brunswick, N. J., Rutgers University Press, 1948. viii, 342 p. illus. $4^{8-1} 442$ GV811.K66

Annotated bibliography: p. [333]-339.

Crossing the open sea in a small sailing ship is, to the compilers of this volume, "a contest of wood and canvas against wind and water which presents an unchanging challenge to man's courage, skill, and ingenuity." They provide two introductory chapters as well as connective matter between their topically arranged selections. Most of the 13 authors excerpted are, like the three named in the subtitle, Americans, but they include two Frenchmen, and Englishman, and a Norwegian. The voyagers traversed the North and South Atlantic, the South Pacific, the Indian Ocean, and the Mediterranean; the earliest was Joshua Slocum, who sailed around the globe between Apr. 24, 1895, and June 27, 1898.

5022. Loomis, Alfred F. Ocean racing; the great blue-water yacht races, 1866-1935. New York, Morrow, 1936. xii, 295 p. illus. 36-14301 GV827.L6 1936

A history of open ocean yacht racing, starting with the first transatlantic race in 1866 . As with most sports writing, the book is meant for aficionados of the sport, but the layman can easily sidestep much of the specialized discussion.

\section{Civ. BOXING}

5023. Dempsey, Jack. Round by round, an autobiography. Written in collaboration with Myron M. Stearns. New York, Whittlesey House, McGraw-Hill, 1940. 285 p. illus.

$$
40-30806 \text { GVIr32. } \mathrm{D}_{4} \mathrm{~A}_{3}
$$

Born in 1895 and originally named William Harrison Dempsey, the author was a popular world heavyweight champion boxer from 1919 to 1926 .

5024. Durant, John, and Edward Rice. Come out fighting. New York, Duell, Sloan \& Pearce, 1946. $245 \mathrm{p}$. 46-25213 GV1121.D8

A pictorial history of boxing in America.

5025. Fleischer, Nathaniel S. Black dynamite, the story of the Negro in the prize ring from 1782 to 1938 , by Nat Fleischer. New York, C. J. O'Brien, 1938-47. 5 v. illus. (Ring athletic library)
38-1973I GVII3I.F65 
A detailed history, largely in biographical form, of leading Negro boxers; according to the author, "About 60 per cent of the top flight boxers are of that race." Certainly they have played a very important role in the sport, and the sport has played a prominent role in their national life.

The first volume deals with American Negro fighters in the early years. Volume two has the individual title of "Jolting Joe," the Amazing Story of Joe Louis and His Rise to World Heavyweight Title; "Homicide Hank," the Socking Saga of Henry Armstrong. Volume three is entitled: "The Three Colored Aces": George Dixon, "Little Chocolate"; Joe Gans, "The Old Master"; Joe Walcott, "The Barbados Demon"; and Several Contemporaries. The title of the fourth volume is: "Fighting Furies," Story of the Golden Era of Jack Johnson, Sam Langford, and Their Contemporaries. The title of volume five is "Sockers in Sepia," a Continuation of the Drama of the Negro in Pugilistic Competition.

5026. Fleischer, Nathaniel S. The heavyweight championship; an informal history of heavyweight boxing from I7Ig to the present day [by] Nat Fleischer. New York, Putnam, 1949. xv, 303 p. illus. 49-4955 GVI121.F6

This history of heavyweight boxing deals with the subject on an international level. However, because of the contemporary dominance of America in this field, all but the early portions are almost as though the scope had been exclusively American.

5027. Fleischer, Nathaniel S. John L. Sullivan, champion of champions, by Nat Fleischer. New York, Putnam, I95I. xiii, 242 p. illus. $5^{1-10380}$ GVII32.S95 $\mathrm{F}_{3}$

A biography of John Lawrence Sullivan (18581918), a leading American heavyweight pugilist, and one of the heroes and myths of his age. Earlier biographies include Roy F. Dibble's John L. Sullivan, an Intimate Narrative (Boston, Little, Brown, 1925. 209 p.) and Donald Barr Chidsey's John the Great, the Times and Life of a Remarkable American, Iohn L. Sullivan (Garden City, N. Y., Doubleday, Doran, I942. 337 p.).

5028. Graziano, Rocky. Somebody up there likes me; the story of my life until today. Written with Rowland Barber. New York, Simon \& Schuster, 1955. 375 p. illus.

$$
54-12365 \text { GVI1 } 32 . G_{2} \mathrm{~A}_{3}
$$

Graziano (born in 1921 and originally named Rocco Barbella) was middleweight champion in 1947-48. This book is written in the East Side New York and general hoodlum argot in which he was raised. In addition to depicting the business of boxing, the book has interesting sidelights on a slum childhood, juvenile delinquency, and "modern" penology.

5029. Johnston, Alexander. Ten-and outl The complete story of the prize ring in America. 3d ed. rev. New York, Washburn, 1947. 401 p. illus. 47-31138 GVI125.J6 1947

A clearly planned and written narrative, for the most part, of the highlights of the heavyweight championship from the first decade of the Igth century, when Tom Molyneux, born a slave on a Virginia plantation, was known in New York City as Champion of America. Chapters 18-23 cover "The Lighter Divisions," from middleweights to flyweights. First published in 1927, the book was twice brought up to date by means of additional chapters.

5030. Louis, Joe. The Joe Louis story. [Written with the editorial aid of Chester L. Washington and Haskell Cohen] New York, Grosset \& Dunlap, 1953. 197 p. illus.

$$
\text { 53-11991 GVI132.L6A3 } 1953
$$

First edition published in 1947 under title: $\mathrm{My}$ life story.

Joseph Louis Barrow was born into a poor Negro farm family in Alabama in 1914. He rose to become world heavyweight champion and held the title from 1937 to 1949 .

5031. Tunney, Gene. A man must fight. Boston, Houghton Miftin, I932. 288 p. illus.

32-29070 GVII32.T8A 3

Autobiography of a champion heavyweight boxer who in 1928 retired undefeated. A second autobiographical work by Tunney (b. 1898) is Arms for Living (New York, Funk, 1941. 279 p.). A biography of him is Nat Fleischer's Gene Tunney, the Enigma of the Ring ( ${ }_{[}$New York, Hubner ${ }_{1}$ I93r. 127 p.).

5032. Van Every, Edward. Muldoon, the solid man of sport; his amazing story as related for the first time by him to his friend, Edward Van Every. New York, Stokes, 1929. xiv, 364 p. illus. 29-19300 GVi132.M85 3

William Muldoon (1845-1933) became famous as a trainer of boxers, and came to be known as "the father of American boxing."

5033. Williams, Joseph P. TV Boxing book. illus. New York, Van Nostrand, 1954. 186 p. 54-11831 GVII33. W5

A "nationally known sports columnist" (who shares the profession's distaste for straightforward exposition in plain language) analyzes the depress- 
ing financial effect which, strangely enough, the transfer from ringside to fireside audiences has had on the boxing business, and goes on to expound the fine points of the sport, including its refereeing and judging, for members of "the Living Room Athletic Club."

\section{Cv. FOOTBALL}

5034. Buchanan, Lamont. The story of football in text and pictures. New York, Vanguard Press, 1952. 256 p. 52-13438 GV940.B8 1952

Pictures of college (none of professional) football each with accompanying text, from the late igth century through the season of 1951. There are some wood engravings from the illustrated weeklies, and some very spirited drawings by Frederick Remington (p. 35-36), but mostly photographs, in a dull sort of reproduction, of stars, coaches, and actual plays. The latter demonstrate, at any rate, the progress of photography: the earlier ones are almost invariably blurred, but the modern fast shutter makes nearly all the more recent ones crisp and clear.

5035. Cohane, Tim. The Yale football story. New York, Putnam, 1951. 369 p. illus. 5I-13447 GV958. ${ }_{3} \mathrm{C} 6$

Since, unlike baseball, football in America is largely a collegiate sport, this history of football at one of the oldest Eastern universities represents the dominant tradition of the game. In Gridiron Grenadiers (New York, Putnam, 1948. 320 p.) Cohane presented a similar history of football at West Point.

5036. Danzig, Allison. The history of American football: its great teams, players, and coaches. Englewood Cliffs, N. J., Prentice-Hall, I956. 525 p. 56-9844 GV938.D35

The story of the evolution of the game of football in America. Much of the material was gathered in the course of the author's more than a quarter of a century reporting football for The New York Times.

5037. Grange, Harold E. The Red Grange story, the autobiography of Red Grange, as told to Ira Morton. New York, Putnam, 1953. 180 p. illus. [Putnams sports series]

$$
\text { 53-8i6r GV939.G7 } \mathrm{A}_{3}
$$

Red Grange (b. I903), the son of a Pennsylvania lumberjack, carried ice and played high school football at Wheaton, Ill., and became the "Galloping Ghost" of the University of Illinois team during 1923-25, when he once made four long touchdown runs in 12 minutes. On graduating, he at once entered professional football, which enjoyed small repute in 1925 but has improved since, and was for another decade the mainstay of the Chicago Bears. He did not coach for long, but has since had great success as a radio and TV sportscaster. His old coach, Robert C. Zuppke of Illinois, calls him "the greatest name in football" and "nearer to being the perfect football player than anyone I have ever known."

5038. Heffelfinger, W. W. This was football, by W. W. "Pudge" Heffelfinger, as told to John McCallum. New York, Barnes, I954. 192 p. illus. 54-II793 GV939. $\mathrm{H}_{37} \mathrm{~A}_{3}$

Pudge Heffelfinger was one of the earliest, and is still considered by many to be one of the greatest, of football athletes. Active in the game over a period of 50 years, he know many of the personalities in the sport, and this book is in large part anecdotal reminiscences about others.

5039. Luckman, Sid. Luckman at quarterback; football as a sport and a career. Chicago, Ziff-Davis, I949. xxi, 233 p. illus.

49-10297 GV939.L82

The autobiography (actually told to Norman Reissman of Chicago, who reads like a sports journalist) of the son of a Jewish immigrant from Germany. Mr. Luckman began playing football at Erasmus Hall High School in Brooklyn, starred for Columbia (class of 1939), and in the next ro seasons gained 14,303 yards passing for a professional team, the Chicago Bears.

5040. Roberts, Howard. The Big Nine; the story of football in the Western Conference. New York, Putnam, 1948. 259 p. illus.

48-8953 GV95I.R53

A history of football in a Midwestern league which is one of the outstanding collegiate football associations in America. Roberts is also the author of The Chicago Bears (New York, Putnam, 1947. 248 p.), the story of a professional football team.

504I. Rockne, Knute K. The autobiography of Knute K. Rockne, edited, with prefatory note, by Bonnie Skiles Rockne (Mrs. Knute K. Rockne) and with introd. and postscript by Father John Cavanaugh, C. S. C. Indianapolis, BobbsMerrill, I93 r. 296 p. illus.

3I-30240 GV939.R6A3

Knute Rockne (I888-r93I) was Notre Dame's football coach; in this capacity he brought fame to the university and to himself. Considered by many to be the greatest of football coaches, he has prob- 
ably had more books written about him than any other football personality. These include Huber William Hurt's memorial Goals, the Life of Knute Rockne (New York, Murray Book Corp., 193 I. $27 \mathrm{I}$ p.), which is extensively illustrated, and Eugene [Scrapiron] Young's With Rockne at Notre Dame (New York, Putnam, I95I. 3I2 p.), a somewhat autobiographical work that tends toward being a biography of Rockne.

5042. Samuelsen, Rube. The Rose Bowl game. Garden City, N. Y., Doubleday, I95I. 299 p.

illus. $\quad$ 5I-12 I08 GV957.R6S3

Pasadena, California, has held its Tournament of Roses each New Year's Day since 1890, and ever since 1916, when Brown met Washington State, its principal feature and financial prop has been a football game between the best-scoring Pacific Coast college team and a successful and prestigious team selected from elsewhere in the country. Mr. Samuelsen describes the first $3^{6}$ games in great and anecdotal detail, and gives a statistical summary of each in an appendix (p. 265-299).

5043. Stagg, Amos Alonzo. Touchdown! As told by Coach Amos Alonzo Stagg to Wesley Winans Stout. New York, Longmans, Green, 1927. 352 p. illus. 27-1975I GV951.S8

Coach Stagg (b. I862), the most durable man in the whole history of sport, played baseball and football for Yale in the '80's, and began his service as director of physical education and football coach at the new-fledged University of Chicago in 1892, the year before the World's Fair. When he dictated this autobiography he had long been known as "the Old Man," but had six more years of service before retiring in 1933 with a total of $4 \mathrm{I}$ years. He at once began coaching for the College of the Pacific, and took on his latest assignment, with Stockton College, in his tenth decade! His book tells much about the early days of college football, including the "dirty work" that marred it, and about the shoestring beginnings of athletics at Mr. Rockefeller's university.

5044. Wallace, Francis. The Notre Dame story. New York, Rinehart, 1949. 275 p. 49-10793 $\mathrm{LD}_{4} \mathrm{Ir}_{3} \cdot \mathrm{W}_{3}$

Notre Dame is an Indiana Catholic university that was made famous by its football team. This book tells the story of the school through the development of the story of its football and the life of Knute Rockne (q. v.), its great football coach. Wallace is a sportswriter who specializes in football and Notre Dame. In Dementia Pigskin (New York, Rinehart, 1951. 252 p.) he presented a general, non- sequential, and frequently humorous view of the world of the football fan.

5045. Ward, Archie. The Green Bay Packers, the story of professional football [by] Arch Ward. New York, Putnam, I946. 240 p. illus. $47-751 \quad$ GV956.G7 $W_{3}$

An enthusiast's history of a professional football team; the book also reflects much of the general history of professional football in America.

\section{Cvi. GOLF AND TENNIS}

5046. Danzig, Allison. The racquet game. New York, Macmillan, 1930. 283 p. illus.

30-4629 GVroo3. $\mathrm{D}_{3}$

A study of court tennis, rackets, squash rackets and squash tennis. The subjects are approached through a presentation of their origin, history in America, personalities of the games, and the method of play.

5047. Jacobs, Helen Hull. Beyond the game, an autobiography. Philadelphia, Lippincott, 1936. 274 p. illus. $\quad 36-14873$ GV994.J3 $\mathrm{A}_{3}$ Jacobs (b. I908) was a leading tennis player who between 1923 and 1931 was seven times the U. S. woman champion.

5048. Keeler, Oscar B. The Bobby Jones story, from the writings of O. B. Keeler, by Grantland Rice. Atlanta, Tupper \& Love, I953. 304 p. illus.

53-I3I59 GV964.J6K 4

Jones, one of the greatest of golf players, retired from the game in 1948. This biography is made up from articles written by Keeler, a sportswriter and golf enthusiast who knew Jones throughout almost all of his career. Keeler died in 1950.

5049. Marble, Alice. The road to Wimbledon. New York, Scribner, I946. I67 p. illus. 46-5902 GV994.M3A3

Autobiography of a Californian who became woman tennis champion four times between 1936 and 1940.

5050. Riggs, Robert L. Tennis is my racket, by Bobby Riggs. [New York] Simon \& Schuster, 1949. xxii, 245 p. illus.

Riggs (b. Igr 8 ) has $49-8951 \quad$ GV994.R $54 \mathrm{~A}_{3}$ championships. His autobiography presents not only his own career in the sport, but presents at some length sketches of prominent tennis players he has known. 
5051. Sarazen, Gene. Thirty years of championship golf; the life and times of Gene Sarazen, by Gene Sarazen with Herbert Warren Wind. New York, Prentice-Hall, r950. xi, 276 p. illus.

$$
5^{0}-7427 \quad \mathrm{GV}_{9} 64 . \mathrm{S}_{3} \mathrm{~A}_{3}
$$

The life story of a professional golfer who won the National Open in 1922 and 1932, among other awards. His original last name was Saracini (b. 1901).

5052. Tilden, William T. My story, a champion's memoirs. New York, Hellman, Williams, 1948. 335 p. illus. $4^{8-3054}$ GV994.T5 $A_{33}$ Tilden (I893-I953) has generally been adjudged the best tennis player of the first half of the 2oth century. In his long amateur career he won many national and international awards. In I93 I he became a professional, and subsequently won a number of professional awards. An earlier version of his autobiography was Aces, Places and Faults (London, Hale, 1938. 304 p.).

5053. Wind, Herbert W. The story of American golf, its champions and its championships. New York, Simon \& Schuster, 1956. 564 p. illus. 56-13439 GV981.W5 1956

A revised edition of a history of American golf which first appeared in 1948 . It has the game starting in this country in 1888; the emphasis is on championship golf, amateur and professional. An earlier book which also starts from 1888 is Harry B. Martin's Fifty Years of American Golf (New York, Dodd, Mead, 1936. 423 p.).

\section{Cvii. HORSE-RACING}

5054. Akers, Dwight. Drivers up; the story of American harness racing. [2d ed.] New York, Putnam, 1947. xv, 392 p. illus.

Agr 47-373 $\mathrm{SF}_{339} \mathrm{~A}_{5} \quad 1947$

Harness racing is a special type wherein the horse trots as fast as he can but must not break into a run; nowadays he draws a sulky and driver, but in the early days he might bear saddle and jockey. Mr. Akers, whose history was first published in 1938, reminds us that, before the motor age, trotting races were not confined to special tracks, but were everyday events on city avenues and country roads. The prehistoric age of American harness racing ended with the formation of the New York Trotting Club in I825; a highlight of the '60's was the long rivalry in trotters between Commodore Vanderbilt (no. 5935) and Robert Bonner of the New York Ledger. Harness racing survives to lend variety to present-day racing; its recent status is surveyed in Frank A. Wrensch's Harness Horse Racing in the
United States and Canada (New York, Van Nostrand, I95I. 219 p.).

5055. Hervey, John. Racing in America: 1665I865.... written for the Jockey Club. New York, Priv. print., The Jockey Club, 1944. 2 v. illus. 44-6592 $\mathrm{SF}_{347} \cdot \mathrm{H}_{4}$

A large, detailed, de luxe history of the early days of horse-racing in America. The work is supplemented by Walter S. Vosburgh's Racing in America, r866-r921 (New York, The Jockey Club, I922. 249 p.) and John Hervey's Racing in America: 19221936 (New York, The Jockey Club, 1937. 293 p.).

5056. Parmer, Charles B. For gold and glory; the story of thoroughbred racing in America.

New York, Carrick \& Evans, 1939. 352 p. illus., tables.

39-30807 $\mathrm{SF}_{347 \cdot \mathrm{P}_{3}}$

The story of how 2oth-century horse-racing in America developed out of early beginnings in England and then Virginia.

5057. Winn, Matt J. Down the stretch; the story of Colonel Matt J. Winn, as told to Frank G. Menke. New York, Smith \& Durrell, r944. xvi, 292 p. illus.

$45-\mathrm{I}_{4} \mathrm{I}_{4} \mathrm{SF}_{33} \mathrm{~W}_{5} \mathrm{~W}_{5} \mathrm{~A}_{3}$

The autobiography of a leading horse-racing personality. A brief history of the Kentucky Derby, with which he has most prominently been associated, is included.

\section{Cviii. MISCELLANEOUS}

5058. Bent, Newell. American polo. New York, Macmillan, 1929. xxix, 407 p. illus.

29-16932 GViori.B 4

Polo originated in medieval Persia, and was introduced into America, via British India and England, by the younger James Gordon Bennett in 1876 . The leading club, the Meadow Brook Club of Nassau County, Long Island, was incorporated in I88I by August Belmont, Jr., and others. Although it penetrated the U.S. Army, and international matches with England have been played since 1886 , it has remained a preserve of "Society" and of wealth, with a very limited popular following. Mr. Bent also tells how polo ponies are bred, gives hints for beginners, and calls the roll of leading American performers.

5059. Best, Katharine, and Katharine Hillyer. Las Vegas, playtown U. S. A. New York, McKay, I955. I 78 p. 56-1202 F849.L $35 \mathrm{~B}_{4}$

A study of Las Vegas, Nevada, the flashy gambling center of America. Since this "recreation" is 
legal in Nevada, the state has become a focal point for many gambling activities which are prohibited in other states of the Union.

5060. Fleischer, Nathaniel S. From Milo to Londos; the story of wrestling through the ages, by Nat Fleischer. New York, C. J. O'Brien, 1936. 330 p. illus. (The Ring athletic library, book no. 13)

37-9io GVirg5.F5

The author gets from Milo of Croton to George Washington in one chapter, and a second takes him to William Muldoon (1845-1933), "the Solid Man" (as Ned Harrigan dubbed him in a popular song) and likewise "the Father of American Wrestling." Thereafter we proceed match by match and play by play ("every time Gotch tried to turn he was brought back by the crotch") to Frank Gotch, to Frank Hackenschmidt, to Strangler Lewis (who perfected the head lock), to Stanislaus Zbyszko, to Jim Londos, and then to chaos. There is a wealth of terrifying illustrations.

506r. Griffin, Marcus. Fall guys, the Barnums of bounce; the inside story of the wrestling business, America's most profitable and best organized professional sport. Chicago, Reilly \& Lee, I937. 215 p. $\quad 37-5807$ GVII95.G75

A journalistic narrative of wrestling, "America's most popular and best organized sport," from the days of "the peerless champion," Frank Gotch, who won the title in 1904 and retired undefeated in 1912 , to the accession of Dean Dutton to a disputed championship in 1936. The author notes the scandals which increasingly cast shadows over the game and points out that, while wrestlers are very well paid ("raw-boned country bumpkins who are possessed of incomes of from twenty-five to thirty thousand dollars yearly [1937]"), they run great risks and usually leave the ring with severe physical disabilities. The book of course does not reach the latter days of wrestling buffoonery on TV.
5062. Jay, John C. Skiing the Americas; with photographs by the author. New York, Macmillan, 1947. 257 p. illus.

$4^{8-5053}$ GV854.J35

Mr. Jay, skier, ski expert, ski cinematographer, ski lecturer, and ski enthusiast, answers the questions which his audiences had been putting to him for ten years past in this very informal but pleasant book, which describes the ski resorts of the East, the Midwest, the Rocky Mountain West, and the Pacific Northwest, and points out the skiing available during the several seasons of the year. The author credits the beginning of organized skiing in America to a Dartmouth undergraduate, Fred Harris, who founded the Dartmouth Outing Club in I9ro; but it was not until the Olympic Winter Games of I932 at Lake Placid that the sport began to snowball here. An attractive chapter describes Mr. Jay's "dream trip" as escort for the Chilean Ski Team, visiting in two months every big ski resort in the United States.

5063. Lester, John A., ed. A century of Philadelphia cricket. Philadelphia, University of Pennsylvania Press, I95r. 397 p. illus. 5I-12299 GV9r3.L4

Cricket was once a fairly popular game in some parts of America, but has gone into a period of decline. This book traces its rise and subsequent decline in a leading city where it has now ceased to be an important social force.

5064. Longstreth, Thomas Morris. The Catskills. New York, Century, 1918. 32I p. illus., map. $18-191_{4} 6$ Fi27. $\mathrm{C}_{3} \mathrm{~L} 8$

$\mathrm{T}$. Morris Longstreth in this record of a hiking and camping trip through the Catskills provides an example of a common American pastime (hiking and studying nature-in the backyard by the hour, or in the country by the day and week) and at the same time gives a good view of life in these mountains. A similar book is his The Adirondacks (New York, Century, I9r 370 p.).

\section{General Field Sports}

5065. Brown, J. Hammond, ed. Outdoors unlimited; a collection of stories and articles which reflect the current American scene of the recreational outdoors. Sponsored by the Outdoor Writers Association of America. New York, Barnes, I947. xiv, $343 \mathrm{p}$. Agr 47-272 SK $33 . \mathrm{B} 85$

The emphasis in this book is on the various aspects of hunting and fishing in present-day America.
There are, however, a few stories which reflect the "recreational outdoors" as a communing with nature for its own sake.

5066. Buckingham, Nash. De shootinest gent'man, and other tales. New York, Putnam [ ${ }^{\mathrm{C}}$ 1934, I943] 222 p. illus.

$$
\text { 43-4482 } \text { SK }_{33} \cdot \mathrm{B} 89
$$

1943 
Buckingham (b. 1880 ) is one of the foremost American authors in the field of hunting and fishing literature. A number of his works were first published during the 1930's in de luxe, limited editions; trade editions of these appeared in the I940's. His writings take the form of sketches, short stories, essays, and reminiscences, but they are regularly based on personal experiences. The setting is often Southern, and the period covered ranges as far back as the late Igth century. Some of his earlier books are probably among his best known. Later books include Ole Miss' (New York, Putnam, 1946. I78 p.), Blood Lines (New York, Putnam, r947. 192 p.), and Hallowed Years (Harrisburg, Pa., Stackpole, 1953. 209 p.). Much of his work first appeared in field sports periodicals.

5067. Buckingham, Nash. Mark right! Tales of shooting and fishing. New York, Putnam [ ${ }^{\mathrm{r}} \mathrm{1936}$, 1944] ig6 p. illus.

$$
44-3008 \quad \mathrm{SK}_{33} \cdot \mathrm{B} 885 \quad \mathrm{I} 944
$$

5068. Buckingham, Nash. Tattered coat. New York, Putnam, 1944. xiv, 210 p. illus. $45^{-248}$ SK $_{33} \cdot \mathrm{B} 893$

5069. Buckingham, Nash. Game bag; tales of shooting and fishing. New York, Putnam, 1945. xv, I85 p. illus.

$$
\text { Agr 46-152 } \text { SK }_{33} \cdot \mathrm{B}^{6} 83 \quad 1945
$$

5070. Cook, Beatrice G. Till fish us do part; the confessions of a fisherman's wife. New York, Morrow, 1949. 249 p.

$$
\text { Agr 49-412 } \mathrm{SH}_{441 . \mathrm{C}_{598}} 1949
$$

The wife of a doctor-fisherman reports experiences while fishing in coastal and inland waters of Washington state. Her approach is humorous and personal; but she does manage to convey not only an impression of fishing as a recreation, but also of life in an American family. A later book of the same type by her is More Fish to Fry (New York, Morrow, 1951. 280 p.).

5071. Field and stream. Field \& stream treasury; memorable articles and stories selected from the pages of America's number one sportsman's magazine. Edited by Hugh Grey and Ross McCluskey. Illustrated with original photographs, drawings, advertisements, and covers from the sixtyyear file of the magazine. New York, Holt, 1955. $35 \mathrm{I}$. $\quad 55-10675 \mathrm{SK}_{33} \cdot \mathrm{F}_{3} 83$

A selection of material from a magazine whose history goes back to 1895 . The work is meant to constitute "a sort of informal running history of hunting and fishing over the last 75 or roo years." An earlier anthology from this periodical is The
Field and Stream Game Bag (Garden City, N. Y., Doubleday, 1948. 306 p.), edited by Robeson Bailey.

5072. Goodspeed, Charles Eliot. Angling in America; its early history and literature. Boston, Houghton Mifflin, 1939. xiii, 380 p. illus. 39-20033 $\mathrm{SH}_{4} 63 . \mathrm{G} 6$

A well written and scholarly history of early American fishing, starting with the fishing practices of the Indians. A bibliographical checklist of American fishing publications to I 900 is included.

5073. Grey, Zane. Tales of swordfish and tuna. New York, Harper, 1927. 203 p. illus.

27-20012 SH691.S8G7

Zane Grey was a most successful author of Western romances; this aspect of his writing is discussed in the Literature section (q. v.) of this bibliography. In later life he wrote a number of autobiographical works on his outdoor activities. Tales of Lonely Trails (New York, Harper, 1922. 394 p.) was largely an account of hunting, camping activities in Arizona. His books on fishing include Tales of Fishes (New York, Harper, I9rg. 266 p.), Tales of Fishing Virgin Seas (New York, Harper, r925. 216 p.), and Tales of Southern Rivers (New York, Harper, 1924. 249 p.). Most of these books were heavily illustrated with photographs taken by the author. An anthology selected from his fishing writings is Zane Grey's Adventures in Fishing (New York, Harper, 1952. 263 p.).

5074. Grey, Zane. Tales of fresh-water fishing. New York, Harper, r928. 227 p. illus. 28-20833 $\mathrm{SH}_{44}$ I.G6

5075. Heilner, Van Campen. Salt water fishing. 2 ed., rev. New York, Knopf, 1953. xviii, 330, xxiv p. illus. (Borzoi books for sportsmen) Bibliography: p. 329-330.

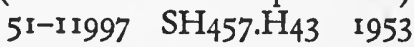

An earlier book of fishing experiences by Heilner is Adventures in Angling; a Book of Salt Water Fishing (Cincinnati, Kidd, I922. 233 p.).

5076. Herbert, Henry William. Frank Forester's Fish and fishing of the United States and British provinces of North America. Illustrated from nature, by Henry William Herbert. New ed., rev. and corr. with an ample supplement by the author, together with a treatise on Fly-fishing, by "Dinks" [pseud.] New York, Woodward, I859. xxiv, [ I7]-512 p. I7-20300 $\mathrm{SH}_{44} \mathrm{I}_{2} \mathrm{H}_{53} \quad 1859$

First published, for copyright advantage, in London in 1849; the first American edition appeared in 1850 . 
Herbert (1807-1858) came to New York from England in 1831 . In this country he embarked on a career as educator, editor, journalist, novelist, artist, historian, poet, translator, and naturalist. Of his "literary" accomplishments he was proud; but his less favored sports writing he published under the pseudonym of "Frank Forester." Today he is remembered almost exclusively for these works, which, in their own category, have become classics. He has been called the Shakespeare of sports writing for his nostalgic picture of field sports (especially hunting) in his day, and for his sports novels, which also present a vivid picture of hunting as a recreation in the middle of the igth century. The Warwick Woodlands, or, Things as They Were There, Ten Years Ago (Philadelphia, Zieber, I 845. I 68 p.) is his masterpiece and the work which has been most reprinted in the ensuing years; a recent edition is cited below. A complete Life and Writings of Frank Forester (New York, Orange Judd, 1882) was undertaken, but was never carried beyond the second volume.

5077. Herbert, Henry William. Frank Forester's [pseud.] fugitive sporting sketches; being the miscellaneous articles upon sport and sporting, originally published in the early American magazines and periodicals. Edited with a memoir of Herbert, and numerous explanatory notes, by Will Wildwood [pseud. of Frederick E. Pond] Westfield, Wis., 1879. I47 p. I2-22887 $\mathrm{SK}_{33} \cdot \mathrm{H}_{54}$

Herbert's early book on hunting and the game birds of North America was American Game in Its Seasons, rev. ed. (New York, Woodward, 1873 . 343 p.)., which was first published in 1853 .

5078. Herbert, Henry William. Frank Forester's horse and horsemanship of the United States and British provinces of North America. Rev., corr., enl., and continued to I87I, by S. D. \& B. G. Bruce. New York, Woodward, 1871. 2 v. illus.

$$
\text { 12-15989 } \mathrm{SF}_{283} \cdot \mathrm{H}_{54}
$$

Added title-pages, engraved: The horse of America ... .

This work was first published in two volumes in 1857 by Stringer and Townsend in New York.

5079. Herbert, Henry William. Frank Forester [pseud.] on upland shooting; edited, and with supplementary chapters, by $A_{[}$rthur] $R$. Beverley-Giddings. New York, Morrow, 1951. 276 p. illus. $\quad 5^{\mathrm{I}-7267} \quad \mathrm{SK}_{324} \cdot \mathrm{U}^{2} \mathrm{H}_{4}$

A selection of chapters from The Complete Manual for Young Sportsmen . . . (New York, Stringer \& Townsend, I856. 480 p.) and Frank Forester's Field Sports of the United States and British Prov- inces of North America, 8th ed. [rev.] (New York, Townsend, 1858. 2 v.), which was first published in Great Britain in 1848 and in the United States in 1849 .

5080. Herbert, Henry William. [The sporting novels of Frank Forester [pseud.] The Hitchcock ed.] New York, Derrydale Press, 1930. 4 v.

CtY

A modern, fine press reprint edition of 750 copies. This corresponds to the earlier, typographically and editorially poorer, "omnibus" edition of the same works in Frank Forester's Sporting Scenes and Characters (Philadelphia, Peterson, I88I. 2 v.). Contents.-v. I. The Warwick Woodlands (1845).-v. 2. My Shooting Box (1843).-v. 3. The Quorndon Hounds (1852).-v. 4. The Deerstalkers (1843). Henry William Herbert, Frank Forester, by Harry Worcester Smith.

5081. Holder, Charles Frederick. Big game at sea. New York, Outing Pub. Co., Ig08. xv, 352 p.' illus. 8-9755 $\mathrm{SH}_{441 . \mathrm{H}_{73}}$

The author discusses deep sea fishing, the game fish, and his personal experiences. The chapters originally appeared as articles in various periodicals.

5082. Holder, Charles Frederick. Life in the open; sport with rod, gun, horse, and hound in southern California. New York, Putnam, Ig06. $\mathrm{xv}, 40 \mathrm{I}$ p. illus., 66 plates. $6-\mathrm{I}_{2} 862 \quad \mathrm{SK}_{55} \cdot \mathrm{H}_{72}$

An account of some of the author's hunting and fishing experiences.

5083. Holder, Charles Frederick. The log of a sea angler; sport and adventures in many seas with spear and rod. Boston, Houghton Mifflin, I906. $385 \mathrm{p}$. 6-876I SH 44 I.H $\mathrm{H}_{75}$

Considered by some to be one of the truly outstanding books in the literature of angling. The first 12 chapters are drawn from the author's "experiences during a continuous residence of five or six years, winter and summer, on the extreme southwestern portion of the Florida reef, where Loggerhead looks into the west." Later chapters describe fishing among the islands "strung along the coast of Southern California, a chalice of emeralds in settings of silver," off Cape Cod, and for tarpon near the mouth of the Rio Grande.

5084. Holder, Charles Frederick. Recreations of a sportsman on the Pacific coast. New York, Putnam, igro. 399 p. illus.

$$
\text { I0-I } 1406 \mathrm{SH}_{473} \cdot \mathrm{H}_{75}
$$

The author recounts deep-sea and inland fishing experiences. 
5085. Lytle, John Horace. "Point!" [by] Horace Lytle. Harrisburg, Pa., Stackpole, 1954. $232 \mathrm{p}$. illus. 54-12762 SK17.L9A3

An autobiographical work by an Ohio hunter and hunting-dog fancier; the book is largely an account of his experiences with his dogs.

5086. Prime, William C. I go a-fishing, by W. C. Prime. New York, Harper, 1873. 365 p. 12-21568 $\mathrm{SH}_{441 . \mathrm{P}_{95}} \quad \mathrm{I}_{73}$

Prime (1825-1905) was a meditative New York lawyer and scholar who loved to wander among northeastern hills while fishing or hunting, or just walking. His books include Along New England Roads (New York, Harper, 1892. 200 p.) and Among the Northern Hills (New York, Harper, 1895. 209 p.).

5087. Rutledge, Archibald $\mathrm{H}$. Wild life of the South. New York, Frederick A. Stokes, 1935. 253 p. illus. 35-I719I QH81.R9783 Archibald Rutledge (b. I883) comes from a low country area, formerly a rice plantation, in South Carolina; this he usually uses as a setting for his writings. Some of his best work is that of a nature lover and hunter describing his hunting experiences and the woods and swamplands, with much attention given to the animals inhabiting them; these books include Plantation Game Trails (Boston, Houghton Miflin, 1921. 300 p.), Days Off in Dixie (Garden City, N. Y., Doubleday, Page, I924. 298 p.), and Children of Swamp and Wood (Garden City, N. Y., Doubleday, Page, 1927. 280 p.). Further aspects of life on his plantation are treated in the short stories of Old Plantation Days (New York, Stokes, I92I. 344 p.) and the somewhat sentimental Peace in the Heart (Garden City, N. Y., Doubleday, Doran, 1930. 316 p.). Home by the River (Indianapolis, Bobbs-Merrill, 194I. 167 p.) records Rutledge's experiences and observations at, as well as some of the historical bàckground of, the family plantation at Hampton, S. C. Rutledge has also written much conservative poetry, a recent volume of selections being Brimming Tide, and

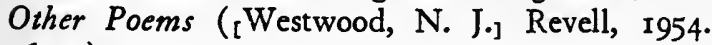
$160 \mathrm{p}$.$) .$

5088. Rutledge, Archibald $H$. An American hunter. New York, Stokes, 1937. 46I p. illus. 37-33916 SK $33 \cdot R_{77}$

5089. Rutledge, Archibald H. Hunter's choice. New York, Barnes, 1946. 210 p. illus. Agr $47-16_{3} \quad \mathrm{SK}_{33} \cdot \mathrm{R}_{7} 8 \quad \mathrm{I}_{946}$
5090. Rutledge, Archibald $H$. Those were the days. Richmond, Dietz Press, 1955. 462 p. ${ }^{56-707} \mathrm{SK}_{33} \cdot \mathrm{R} 85$

An autobiographical book emphasizing the author's hunting and fishing experiences early in the 2oth century.

5091. Sandys, Edwyn. Sporting Sketches. New York, Macmillan, 1905. 389 p. illus. $5^{-29978} \quad \mathrm{SK}_{31} \mathrm{~S}_{3}$

Sketches of hunting and fishing at the turn of the century; many of the articles first appeared in Outing. Another book by Sandys recording much personal experience is $U$ pland Game Birds (New York, Macmillan, I902. 429 p.); to this T. S. Van Dyke (q. v.) contributed a short concluding section on "The Quail and the Grouse of the Pacific Coast."

5092. Schaldach, William J. Coverts and casts; field sports and angling in words and pictures. New York, Barnes, 1943. 138 p. illus.

$$
43^{-18} 85^{2} \quad \mathrm{SK}_{33} \cdot \mathrm{S}_{35}
$$

5093. Schaldach, William J. Currents \& eddies; chips from the log of an artist-angler. New York, Barnes, 1944. $13^{8} \mathrm{p}$. illus.

$$
\text { Agr 45-ror } \mathrm{SH}_{44 \mathrm{I}} . \mathrm{S}_{35}
$$

Both books are mainly a presentation of autobiographical anecdotes about the pleasures of fishing. Schaldach, long associated with Field and Stream, was both an artist and a writer, as well as an outdoors sportsman. His work dealt with the hunting and fishing that fascinated him.

5094. Smith, Onnie Warren. Musings of an angler, by O. Warren Smith. New York, Barnes, 1942. $\mathrm{xv}, \mathrm{I} 87 \mathrm{p}$. illus.

$$
\text { 42-10914 } \mathrm{SH}_{44 \mathrm{r} . \mathrm{S} 65}
$$

Smith (1872-1941) was fishing editor of Outdoors. A conscious follower of Walton and Prime, he did not "merely fish for fish"; his writings were an attempt to present the "aesthetic" rather than the scientific and technical aspects of fishing.

5095. Van Dyke, Henry. Little rivers. A book of essays in profitable idleness. New York, Scribner, I895. 291 p. illus.

$$
\text { I4-I080 PS } 3 \text { II7.L } 51895
$$

5096. Van Dyke, Henry. Fisherman's luck and some other uncertain things. New York, Scribner, 1899. $247 \mathrm{p}$. illus.

$$
\text { 99-万I46 PS } 3 \text { II7. } 55 \quad 1899
$$

Van Dyke was a clergyman, and later a professor at Princeton University. His many books, which were popular in his own day, included Victorian verse and criticism, travel books, and volumes of 
essays, such as Days Off, and Other Digressions (New York, Scribner, 1907. 322 p.). Because of his interest in Europe and his wide travels, his books are seldom exclusively American in subject matter; but they do reflect the relative commonplace of the much-traveled American of the late Igth and early 2oth centuries. The first book entered above views rivers mainly as places for fishing.
5097. Wylie, Philip. Denizens of the deep; true tales of deep-sea fishing. New York, Rinehart, 1953. 222 p. $\quad 53-9238 \mathrm{SH}_{457 . W 88}$ Stories of deep-sea fishing and fish by a forceful author who has devoted much of his time to the sport of fishing. He is widely known for his popular novels which are discussed in the Literature section of this bibliography. 


\section{XXI}

\section{Education}

$\left.\llbracket \begin{array}{rr}\text { A. General Works } \\ \text { Ai. Historical and Descriptive } \\ \text { Aii. Philosophical and Theoretical } & 5098-5114 \\ 5115-5130 \\ \text { B. Primary and Secondary Schools } \\ \text { Bi. General and Historical Works } & 5131-5146 \\ \text { Bii. Preschool and Primary Grades } & 5147-5151 \\ \text { Biii. Secondary Schools } & 5152-5159 \\ \text { C. Colleges and Universities } & 5160-5190 \\ \text { Ci. General and Historical Works } & 5191-5204 \\ \text { Cii. Individual Institutions } & 5205-5212 \\ \text { E. Education of Special Groups } & 5213-5223 \\ \text { F. Meachers and Teaching } & 5224-5231 \\ \text { G. Contemporary Problems and Controversies } & 5232-5239 \\ \text { H. Periodicals and Yearbooks } & 5240-5249\end{array}\right]$

T T HAS been said truly that education is an essential part of the lifeblood of a democracy. Without its benefits citizens cannot participate usefully in the duties and responsibilities that devolve upon them under this form of government; nor can competent leaders of the people be developed without the wisdom and understanding that characterize the properly informed and educated mind. Throughout the course of the country's history the American people have proved their acceptance of such ideas by developing various types of schools, colleges, and universities, as the need for them has been understood.

One result of this continuing national interest in education is an enormous body of literature that has been produced at an increasing rate, with the passage of the years and the growth of the population to be educated. Such a mass of material on the subject poses a difficult problem of selection within the proper compass of a guide. The aim, therefore, in assembling the references that follow has been necessarily only to illustrate typical categories under which the subject may be studied and to provide general orientation rather than inclusive treatment of any topic.

To the student of American civilization who is interested in education only as a facet of the whole

culture, Section A is particularly addressed. It should be noted here that a number of titles included in Section Aii, such as nos. $5^{116}$ and 5121, arè actually histories of educational philosophy or educational theory, and therefore might, with equal justification, have been placed in Section Ai. Sections $B$ and $C$ are designed to serve as an introduction to the principal types of educational institutions developed in the United States, while Section D indicates selected cases in which specialized education is provided either within or without the bounds of the more traditional institutions. The opportunities and experiences of the teacher in American society are briefly touched upon in Section E.

A population growing as rapidly as that of the 
United States, and also one increasingly aware of the many benefits of education, has contributed to greatly increased enrollments in and demands upon all types of educational institutions. Overcrowding, inadequate financial resources, and the requirements of students drawn from groups lacking homogeneous experience and training are among the unfortunate effects of this otherwise desirable influx. In order to meet resulting problems, traditional theories and practices have been reviewed, and, in many cases, principally on the elementary and secondary school levels, revolutionary innovations in methods and techniques have been introduced. An unusual number of textbooks in which these newer concepts are embodied are therefore included in this list, to serve as primary sources for the study of controversial as well as traditional ideas presently at work. Sections $F$ and $G$ focus attention upon these aspects of the contemporary American scene. Section $\mathrm{H}$ provides a brief list of periodicals and yearbooks which may be used for keeping abreast of American education as it develops currently and in the future.

Throughout the list entries have been annotated to indicate additional sources of bibliographical guidance contained within individual volumes. It is hoped that in this way the serious student may be aided in extending his exploration of the relation of education to the development of American civilization.

\section{A. General Works}

\section{Ai. HISTORICAL AND DESCRIPTIVE}

5098. Alexander, Carter, and Arvid J. Burke. How to locate educational information and data; an aid to quick utilization of the literature of education. 3d ed., rev. and enl. New York, Bureau of Publications, Teachers College, Columbia University, I950. xix, 44I p.

Includes bibliographies.

$$
\text { 50-7005 Z711.A37 } 1950
$$

Manual, which may also be used as a textbook, designed for students desiring to explore the literature of education through the use of library collections and reference books.

5099. Allen, Hollis P. The Federal Government and education. New York, McGraw-Hill, I950. xvii, 333 p. (McGraw-Hill series in education) $\quad 50-6536 \quad$ LC89.A6

The original and complete study of education in the United States, on all levels from primary to graduate, made by the task force on public welfare for the Commission on Organization of the Executive Branch of the Government, popularly known as the Hoover Commission, the object being to determine the proper role of government in education. Dawson W. Hales' Federal Control of Public Education (New York, Bureau of Publications, Teachers College, Columbia University, x954. I44 p.) reconsiders the principle of local control of public education in the light of forces now at work in contemporary American life and culture.

5100. American Council of Learned Societies. Liberal education reexamined; its role in a democracy. New York, Harper, 1943. xiv, r34 p. 43-51269 LCI89. 512
A preliminary draft was issued in 1940 under title: Liberal Education and Democracy.

Bibliography: p. 121-134.

Report of a committee appointed in $194^{\circ}$ by the American Council of Learned Societies to investigate recent educational trends in the humanities and to consider the causes responsible for them on all levels of school and university; prepared under the direction of the chairman, Theodore M. Greene, professor of philosophy, at Princeton and later at Yale University. Liberal Education Reconsidered (Cambridge, Harvard University Press, 1953. 46 p.) is Professor Greene's Inglis Lecture at Harvard (I952) on desirable goals for liberal education and methods of achieving them.

5ror. Burns, James A. The Catholic school system in the United States; its principles, origin, and establishment. New York, Benziger, r908. 415 p. 8-18343 LC50r.B7

Bibliography: p. $\left[3^{87}\right]-399$.

Covers the history of the Catholic school and college movement from its beginning in colonial times through the year 1840 ; addressed to all students of education, whether Catholic or non-Catholic.

5102. Burns, James A. The growth and development of the Catholic school system in the

United States. New York, Benziger, I912. 421 p.

Bibliography: p. 382-390.

$$
\text { r2-22334 LC50r.B72 }
$$

Continuation of the author's earlier work, with emphasis on improvement and development; written by a former president of the theological school of the Congregation of the Holy Cross, Holy Cross College, Washington, D.C. 
5103. Butts, R. Freeman. The American tradition in religion and education. Boston, Beacon Press, 1950. xiv, 230 p. (Beacon Press studies in freedom and power) 50-7586 BR5 $16 . \mathrm{B} 85$

Bibliographical references to books and documents included in "Notes": p. 213-224.

Supplies a historical perspective on the struggle for the separation of church and state in America. Fundamental principles of secular education are also reviewed and appraised in Vivian T. Thayer's The Attack Upon the American Secular School (Boston, Beacon Press, 1951. 257 p.). Church, State, and Freedom, by Leo Pfeffer (Boston, Beacon Press, 1953. 675 p.), examines the implications and consequences of religious freedom for which the Constitution of the United States provides, giving much attention to the impact of the doctrine on American education. An encyclopedic work on all aspects of the rélation of church and state in America, including educational aspects of the problems involved, is provided in Anson Phelps Stokes' Church and State in the United States (q. v.).

5r04. Butts, R. Freeman, and Lawrence A. Cremin. A history of education in American culture. New York, Holt, 1953. 628 p.

$$
\text { 52-I3892 LA205.B88 }
$$

Deals with the interrelation of American culture, intellectual development, and education during four periods: Colonial, pre-Civil War, post-Civil War, and post-World War I; suggests applications to be made to contemporary educational problems; and documents each chapter by means of bibliographical references at the end. The authors are members of the faculty of Teachers College, Columbia University.

Harold O. Rugg's Foundations for American Education (Yonkers-on-Hudson, N. Y., World Book Co., 1947. $826 \mathrm{p}$.) is a strongly individual and personal book that ranges freely over American life, culture, psychological theories, and modern educational movements, progressive as well as traditional.

5105. Douglass, Aubrey A. The American school system. Rev. ed. New York, Farrar \& Rinehart, 1940. xviii, 745 p. (Farrar \& Rinehart series in education) 40-12406 LA210.D6 1940

Bibliography at end of each chapter.

Surveys the system of education that operates in the United States on various levels from kindergarten to graduate school; additional chapters deal with questions related to adult, rural, and vocational education, the instructional staff, finances, etc.

5106. Educational Policies Commission. Policies for education in American democracy. Washington, Educational Policies Commission, Na- tional Education Association of the United States and the American Association of School Administrators, 1946. 277 p. $\quad 46-3664$ LA210.E 464

The Commission acknowledges indebtedness to Charles A. Beard for preparing the first draft of Book I, The Unique Function of Education in American Democracy (1937); to Dr. George S. Counts for aid in the preparation of Book II, The Education of Free Men in American Democracy (1941); and to Dr. William G. Carr for contributing to the composition of Book III, The Purposes of Education in American Democracy (1938). Three publications influential on American educational thinking here reprinted in their essential parts in response to numerous requests. Cf. Foreword.

The Educational Policies Commission, a commission of the National Education Association of the United States and the American Association of School Administrators, has issued various other publications that treat of education in relation to American civilization. These include: Learning the Ways of Democracy (1940. 486 p.); Moral and Spiritual Values in the Public Schools (1951. 100 p.); Education for All American Youth, rev. ed. (1952. 402 p.); and Public Education and the Future of America (1955. 98 p.).

5107. General education in school and college; a committee report by members of the faculties of Andover, Exeter, Lawrenceville, Harvard, Princeton, and Yale. Cambridge, Harvard University Press, 1952. I42 p. 52-13591 LB2350.G45 "The broad purpose of this study is to integrate the work of the school and college in the area of general education. More precisely, it is to plan the last two years of secondary school and the first two years of college as a continuous process, conceived as a whole."-Chapter I, "Main Objectives," p. 8.

5108. Knight, Edgar W. Education in the United States. 3d rev. ed. Boston, Ginn, 195I. 753 p. 5I-I034I LA205.K6 195 I

Covers all periods from the beginning to the middle of the 2oth century and provides a general bibliography supplemented by suggested readings listed at the ends of chapters; written by the Kenan Professor of Education at the University of North Carolina, whose various works on American education include: Readings in American Educational History (New York, Appleton-Century-Crofts, 195I. 78I p.), a documentary source book for all periods, edited jointly with Clifton L. Hall; Fifty Years of American Education (New York, Ronald Press, 1952. 484 p.), a review and appraisal of education from 1900 to 1950 ; and $A$ Documentary History of Education in the South before 1860 (Chapel Hill, University of North Carolina Press, 1949-53. 5 v.), 
a compilation designed to gather and preserve original sources for definitive studies.

5rog. Lee, Gordon C. An introduction to education in modern America. New York, Holt,

1953. 555 P. 52-I1594 LA209.2.L43

Bibliographical references are supplied at the ends of chapters.

Textbook on education as a social institution, for students contemplating a career in teaching; designed also as a guide for the layman seeking an introduction to American education in the context of contemporary world conditions; written by an associate professor of education on the faculty of Pomona College, California.

5110. Monroe, Paul, ed. A cyclopedia of education: New York, Macmillan, IgI I-13. $5 \mathrm{v}$.

illus. II-I5I I LBI5.M6

- Reprint. New York, Macmillan, 1914-15. 5 v. illus. 39-19604 LBI5.M6 I9I4

- Reprint. New York, Macmillan, 1926-28 [v. $1-2,1928] 5 \mathrm{v}$. in 3. illus. 30-33076 LB15.M6 1928

Much out of date at the present time but still historically important for its bibliographies and for authoritative signed articles by more than I,000 specialists who contributed to it; world-wide in scope, with special emphasis on American education.

5III. Monroe, Walter S., ed. Encyclopedia of educational research, a project of the American Educational Research Association. Rev. ed. New York, Macmillan, 1950. xxvi, $1520 \mathrm{p}$. $5^{0}-5222$ LB15.M62 $195^{\circ}$

Differs from the typical encyclopedia in that it is composed of reviews, evaluations, and syntheses of the literature of educational research. Includes useful signed articles by specialists, fairly extensive selective bibliographies, and indications of additional research that should be undertaken. For a current guide to similar research, see the Review of Educational Research, described in Section $\mathrm{H}$ below, devoted to Periodicals and Yearbooks.

5112. Patterson's American education. v. 52. Willmette, Ill., Educational Directories, 1955 . $652,72 \mathrm{p}$. 4-12953 Lgor.P3, v. 52

Published rgo4 through 1953 as Patterson's American Educational Directory; guide to the location and composition of schools, colleges, and universities. Highly condensed entries also provide names of administrators, officials of boards of education, librarians, and others engaged in educational work in America. Several supplementary lists include names of public libraries, names of educational associations and societies, and a classified directory of institutions according to their fields of specialization. Continued by the publication of an annual volume.

5113. Slosson, Edwin E. The American spirit in education. New Haven, Yale University Press, 1921. 309 p. (The Chronicles of America series, Allen Johnson, editor, v. 33)

"Abraham Lincoln edition."

$$
\text { 21-14875 LA205.S6 }
$$

"Bibliographical note": p. 287-290.

Compact historical survey of education from the colonial period through World War I; emphasizes early education given in different sections and the continuing influence of statesmen and educators who contributed to the theory and practice of education in America; includes a chapter on colonial colleges and one on the [Morrill] Land Grant Act.

51 I4. U. S. Office of Education. Biennial survey of education in the United States, 1916/18+ Washington, U. S. Govt. Print. Off., 1921 +

$\mathrm{E}_{21-504}$ LA209.A $_{37}$

Issued first as separate chapters and reissued biennially as a survey. Constitutes a repository of statistics, accompanied by summaries, relating to various phases of state and city school systems, higher education, public secondary day schools, and special education for exceptional children. From 1916/18 to 1940 the publication appeared as part of the Bulletin of the United States Office of Education.

\section{Aii. PHILOSOPHICAL AND THEORETICAL}

5115. Babbitt, Irving. Literature and the American college; essays in defense of the humanities. Boston, Houghton Mifflin, 1908. 262 p.

$$
\text { 8-8540 LCiorr.B2 }
$$

Partial Contents. - What is humanism?-The college and the democratic spirit.-Literature and the college.-Literature and the doctor's degree.The rational study of the classics. - Academic leisure.

Document of the movement in American education familiarly known as the "New Humanism"; written by its leading exponent, who opposed the philological emphasis then current in American literary scholarship and advocated a humanistic approach that brought together for study the great ideas found in the content of philosophical as well as literary works.

5116. Curti, Merle E. The social ideas of American educators. New York, Scribner, 1935. 
xxii, 6ry p. (Report of the Commission on the Social Studies, American Historical Association, pt. ro) 35-4578 LA23Ir.C8

"Bibliographical notes": p. 593-60o.

Educators whose social ideas are considered include: Horace Mann, Henry Barnard, Booker T. Washington, G. Stanley Hall, William James, Edward L. Thorndike, and John Dewey. The colonial and Revolutionary backgrounds, the education of women, the schools and business enterprise, education in the South, and the education of Negroes are among the topics developed.

5117. Dewey, John. The school and society. Rev. ed. Chicago, University of Chicago Press, 1945. 164 p. I5-I8II8 LB875.D4 I9I5 First published in 1899 .

Lectures delivered to raise money for the Laboratory School (called also the "Dewey School") conducted $1896-1904$ in the Department of Pedagogy of the University of Chicago, for the purpose of providing good elementary education and of adding equipment to facilities for the study of education comparable to those available in laboratories to teachers of the physical sciences; inspired numerous changes and reforms in the teaching of children in widely separated parts of the world.

5II8. Dewey, John. Democracy and education; an introduction to the philosophy of education. New York, Macmillan, 1929. xii, 434 p. (Textbook series in education)

$$
\text { 30-10933 LB875.D35 r929 }
$$

"Published March 1916. Reprinted ... January 1929."

Represents "an endeavor to detect and state the ideas implied in a democratic society and to apply these ideas to the problems of the enterprise of education."-Preface, p. v.

5IIg. Dewey, John. Experience and education. New York, Macmillan, 1938. xii, i 6 p. (The Kappa Delta Pi lecture series [no. ro]) 38-86I8 LB875.D3943

Written a number of years after the first formulation of the author's theories of education, the book may be used to discover differences existing between Dewey's own ideas and the deductions drawn from them by some of those who sought to apply them.

5120. Dewey, John. Education today. Edited and with a foreword by Joseph Ratner. New

York, Putnam, 1940. 373 p.

40-31507 LB875.D39

Collection of the author's briefer writings dealing with his philosophy of education during more than 40 years. John Dewey, His Contribution to the
American Tradition, edited by Irwin Edman (Indianapolis, Bobbs-Merrill, 1955. 322 p.), provides another more general collection of selections from the enormous body of Dewey's writings. Melvin C. Baker's Foundations of John Dewey's Educational Theory (New York, King's Crown Press, Columbia University, 1955. 218 p.) not only reviews Dewey's educational thought but also considers misunderstandings of it.

5121. Hansen, Allen O. Liberalism and American education in the eighteenth century. With an introd. by Edward H. Reisner. New York, Macmillan, r926. $x x v, 317$ p.

$$
\text { 26-18069 } \mathrm{LA}_{206 . \mathrm{H}_{3}}
$$

Issued also as thesis ( $\mathrm{Ph}$. D.) Columbia University.

Bibliography: p. 265-296.

Designed "to be both an exposition of sources and a source book," the work presents analyses of various plans for education in I8th-century America, including those of Benjamin Rush, Robert Coram, James Sullivan, Nathaniel Chipman, Samuel Knox, Samuel H. Smith, Lafitte du Courteil, Du Pont de Nemours, and Noah Webster; concludes with a summary of elements in the philosophical basis for the education of the period. A contribution to the history of education in the Igth century is made by the author's Early Educational Leadership in the Ohio Valley (Bloomington, Ill., Public School Pub. Co., 1923. r20 p.), a study of educational reconstruction through the work of the Western Literary Institute and College of Professional Teachers, 1829I 84 I.

5122. Honeywell, Roy J. The educational work of Thomas Jefferson. Cambridge, Harvard University Press, 1931. xvi, 295 p. (Harvard studies in education, v. I6) $\quad 3 \mathrm{I}-\mathrm{I} 1362 \quad \mathrm{E}_{332 .} \mathrm{H}_{77}$

Authorities and sources: p. 174-197.

Bibliography: p. 289-295.

Views Jefferson's proposals for primary, secondary, and higher education as parts of his larger plans for political and social reform; emphasizes their importance because of the wide dissemination of Jefferson's ideas; reproduces the texts of his famous educational documents, among them "A Bill for the More General Diffusion of Knowledge"; "A Bill for Establishing a System of Public Education"; "Report of the Commissioners Appointed to Fix the Site of the University of Virginia"; and "Organization and Government of the University of Virginia." Charles F. Arrowood's Thomas lefferson and Education in a Republic (New York, McGraw-Hill, I930. I84 p.) also reprints a number of Jefferson's writings on education preceded by a 
briefer introduction on his services to public education in Virginia and on his theory of education.

5123. James, William. Talks to teachers on psychology. New ed. with an introd. by John Dewey and William H. Kilpatrick. New York, Holt, 1938. xv, $23^{8} \mathrm{p}$. 39-27497 LBI051.J34 I939

American educational and literary classic, in which James presented to the teachers of his own time, for use in the schools of that day, ideas concerning applications of his own psychological theories. First published in 1899 .

5124. Kallen, Horace M. The education of free men. New York, Farrar, Straus, I949. xix, 332 p. 49-49023 LB875.KI6

Called by the author "an essay towards a philosophy of education for Americans," the work is based on years of inquiry and is dedicated to the ideal of making American schools effective agencies for developing and preserving the freedoms promised in the Declaration of Independence.

5125. [Mann, Horace. Public education in Massachusetts] In Massachusetts. Board of Education. Report, together with the report of the secretary of the board. Ist-I2th. Boston, Dutton \& Wentworth, State Printers, 1838-49. [Washington, 1947-52] I2 v. 53-18466 Li60.BI8

Facsimile edition of Mann's reports while secretary of the Massachusetts Board of Education, made possible through a cooperative arrangement between the Horace Mann League and the Hugh BirchHorace Mann Fund of the National Education Association.

Famous documentary source for evaluating Mann's contribution to public education in America; may be used to advantage with Burke A. Hinsdale's Horace Mann and the Common School Revival in the United States (New York, Scribner, I898. 326 p. [Also published in 1937]). Louise Hall Tharp's Until Victory: Horace Mann and Mary Peabody (Boston, Little, Brown, I953. 367 p.) is a lively narrative of Mann's public and private life, including his presidency of Antioch College. Edward I. F. Williams' Horace Mann, Educational Statesman (New York, Macmillan, I937. 367 p.) emphasizes, against the social background of Mann's own time, his importance in the development of a democratic America, for the benefit of teachers, administrators, parents, and the general public.

5126. Mosier, Richard D. Making the American mind; social and moral ideas in the McGuffey readers. New York, King's Crown Press, 1947. 207 p. 47-5812 PEIII7.M23M6

Bibliography: p. [179]-204.
Studies the basic ideas and values embodied in materials found in the McGuffey readers, the spread of these concepts by means of these textbooks, and the effects on American culture, from 1836 to about rgoo, that may be attributable to wide familiarity with the readers.

5127. Shoemaker, Ervin C. Noah Webster, pioneer of learning. New York, Columbia University Press, 1936. $347 \mathrm{p}$.

$$
\text { 36-22936 } \mathrm{PE}_{4} \cdot \mathrm{W}_{5} \mathrm{~S}_{5} \quad \text { 1936a }
$$

Issued also as thesis (Ph. D.) Columbia University. Bibliography: p. [3I ] -33 I.

Assesses Webster's general connection with American education and particularly the great influence exerted on the teaching of reading and the development of American English by his American Spelling Book, first issued in 1783 as part one of his $A$ Grammatical Institute (1783-85). The spelling book was republished in successive editions that resulted, according to various estimates, in the circulation of between 62 and 80 million copies before 1889 . Harry R. Warfel's Noah Webster: Schoolmaster to America (New York, Macmillan, I936. 460 p.) emphasizes Webster's importance for the study of early national culture. The Letters of Noah Webster (New York, Library Publishers, 1953. 562 p.) have been edited with an introduction by Warfel.

5128. Thursfield, Richard E. Henry Barnard's American journal of education. Baltimore, Johns Hopkins Press, I945. 359 p. (The Johns Hopkins University studies in historical and political science, ser. 63 , no. I)

$$
\begin{aligned}
& \text { A46-2670 H3r.J6, ser. 63, no. I } \\
& \text { LII.A7I5 I945a }
\end{aligned}
$$

Issued also as thesis (Ph. D.) Columbia University.

"Bibliographical note": p. 327-329.

"The present investigation attempts to portray the tremendous contributions [of the Journal published from 1855 to 1882 ] ... in the development of a profession, in the transmission of educational ideas from Europe, in expanding and shaping the eclectic structure of American education, in continuing and modifying the American educational tradition, and in effecting social change."-Preface, p. 7 .

5129. Whitehead, Alfred N. The aims of education. New York, Macmillan, 1929. 247 p. 29-10I64 LB875.W 48

Collected educational essays and addresses of one of the most eminent philosophers and mathematicians of recent times; designed as a protest against teaching and learning inert ideas, i. e., those received but not tested or acted upon. Provides also a series 
of proposals concerning the use of education to stimulate and guide the student's own self-development. Discussion is based on English educational practices, but the author considered his general principles equally applicable in America. A book seriously considered by American educators.

5130. Woody, Thomas, ed. Educational views of Benjamin Franklin. New York, McGrawHill, 1931. xvi, 270 p. (McGraw-Hill education classics)
Discusses the origin and influence of Franklin's ideas on education. Includes reprints of various papers he wrote on the subject, as for example: "Idea of the English School"; "Proposals Relating to the Education of Youth in Pennsylvania"; and "Constitution of the Public Academy in the City of Philadelphia." Benjamin Franklin and the University of Pennsylvania (Washington, Govt. Print. Off., 1893.450 p.), edited by Francis N. Thorpe for the United States Bureau of Education, is a study of Franklin's influence on university education.

\section{B. Primary and Secondary Schools}

\section{Bi. GENERAL AND HISTORICAL WORKS}

513I. Aikin, Wilford M. The story of the eightyear study, with conclusions and recommendations. New York, Harper, 1942. 157 p. ([Progressive Education Association. Commission on the Relation of School and College] Adventure in American education, v. I)

42-36126 LB2350.A5 Publications ...

Adventure in American Education (New York, Harper, 1942-43. 5 v.), of which Aikin's work is the summary in volume I, gives results of an investigation of 30 secondary schools for the purpose of achieving a better integration of training in school and college; undertakes also to determine the relative success in college of students trained in progressive and in traditional schools. The larger work has been called "the most elaborate investigation ever made of transition from school to college," a contribution of the Commission on the Relation of School and College, of the American Education Fellowship, a name once used by the Progressive Education Association.

5132. Beale, Howard K. Are American teachers free? New York, Scribner, 1936. xxiv, 855 p. (Report of the Commission on the social studies, American Historical Association, pt. 12)

Bibliography: p. 793-800. 36-30655 LA210.B 4

\section{Beale, Howard K. A history of freedom of} teaching in American schools. New York, Scribner, 194I. xviii, 343 p. (Report of the Commission on the Social Studies, American Historical Association, pt. 16) $\quad 4^{\mathrm{I}-5920} \mathrm{LB}_{1775 . B_{4}}$ Bibliography: p. 29I-298.
The foregoing entries describe two companion studies that deal with academic freedom below the college level. The earlier book resulted from a detailed investigation of freedom in teaching after World War I; the later publication traces the development of freedom for teachers from colonial to contemporary times. In each case obstacles to such freedom also are emphasized. For references concerning academic freedom in higher education see, entries for a book by Richard Hofstadter and Walter P. Metzger, with its companion volume by Robert M. MacIver, both cited in Section Ci., devoted to Colleges and Universities-General Works.

5134. Conant, James B. Education in a divided world; the function of the public schools in our unique society. Cambridge, Harvard University Press, 1948. X, 249 p. 48-8522 LA209.2.C6

Examination of public education in the structure of American society; emphasizes the citizen's obligation to know the schools in action and to consider the teacher's potential contribution to the welfare of the nation. Includes three chapters on general education. One of the author's many educational contributions while he was president of Harvard University (1933-53).

A later work, Education and Liberty; the Role of the Schools in a Modern Democracy (Cambridge, Harvard University Press, 1953. I68 p.), is focused on education of boys and girls from 12 to 20 years of age through a comparison of such education in the United States with that of several nations in the British Commonwealth; includes a chapter on the American college.

5135. Council of State Governments. The fortyeight State school systems. Chicago, 1949. $245 \mathrm{p}$. 49-45258 LB2805.C66

Report of a study made at the request of the Gov- 
ernors' Conference; deals with the organization, administration, and financing of public elementary and secondary education. Similar aspects of higher education are treated in a report to the Governors' Conference entitled Higher Education in the FortyEight States (Chicago, 1952. 317 p.).

5136. Counts, George S. Education and American civilization. New York, Bureau of Publications, Teachers College, Columbia University, 1952. xii, 491 p. 52-9979 LA210.C63 Includes bibliographical footnotes.

Based on research initiated by the staff of the Horace Mann-Lincoln Institute School of Experimentation, established at Columbia University in 1943; develops fundamental ideas of the American social heritage, the hazards implicit in totalitarian states for democratic societies, and the type of education that may help to combat tendencies dangerous for a free people; a work which has been called "essentially a study of the social, cultural, and moral foundations of the program and curriculum of our American common schools."-Preface, p. ix.

5137. Cremin, Lawrence A. The American common school. New York, Bureau of Publications, Teachers College, Columbia University, 195I. xi, 248 p. (Teachers College studies in education) 5I-10599 LA215.C7

Bibliography: p. 222-24I.

The origins of American political, social, and educational ideas, their impact on one another, and the developments that resulted in the evolution of the public school are considered from the colonial period to the middle of the rgth century.

5138. Cubberley, Ellwood P. Public education in the United States, a study and interpretation of American educational history. Rev, and enl. ed. Boston, Houghton Mifflin, 1934. xviii, 782 p. illus. (Riverside textbooks in education)

Bibliographies at end of each chapter.

$$
34^{-2426} \text { LA205.C8 }
$$

1934

Traces evolution of public education in relation to social, political, and industrial forces that shaped American life through the Igth century and the beginning of the 2oth. A special feature of the work is the evaluative annotations supplied with numerous selected references at the ends of chapters. His Readings in Public Education (Boston, Houghton Mifflin, I934. 534 p.) reprints laws and other documents signficant in American educational history.

5139. Edwards, Newton. The courts and the public schools. Rev. ed. Chicago, University of Chicago Press, 1955. xvii, 622 p.

$$
\text { 55-5122 Law }
$$

Views the maintenance and operation of the school system as one of the major public enterprises of the United States; therefore, the legal principles that govern the actions of school boards, superintendents of schools, principals, and teachers are discussed and documented by numerous legal references to specific cases tried in the courts. The book is an outgrowth of a course in the legal and constitutional basis of school administration, given for a number of years by the author at the University of Chicago.

5140. Edwards, Newton, and Herman G. Richey. The school in the American social order. Boston, Houghton Mifflin, I947. $880 \mathrm{p}$.

47-435I LA205. $\mathrm{E}_{3}$

Education in American schools is related to the civilization of which the schools are a product and a part, in three periods of American social development: the colonial, the national to 1860 , and the industrial, from 1860 to I945. A selected bibliography follows each of the 20 chapters.

5141. Hales, Dawson W. Federal control of public education; a critical appraisal. New York, Bureau of Publications, Teachers College, Columbia University, 1954. xiii, 144 p. (Teachers College studies in education) $54-7225$ LC89.H22

Based on the author's thesis, Columbia University, published in microfilm form under title: The Rise of Federal Control in American Education.

Bibliography: p. 125-135.

Traces local, state, and federal control of education in relation to the history of public education in the United States, from 1830 to the present time.

5142. Herrick, Virgil E., and others. The elementary school. Englewood Cliffs, N. J.,

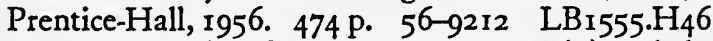

"This book has five major purposes: (I) to help the reader appreciate the historical breadth and continuity of elementary school development in America and to perceive pertinent European influences; (2) to present the reader with the concept of the elementary school as a responsible, dynamic agency, educating children in a demanding and complex American society; (3) to reveal the nature and use of the important bases upon which decisions in education are made; (4) to examine and critically analyze present elementary school practices as they now exist in the different kinds of school programs and in the many important curriculum areas; and (5) to consider as honestly and constructively as possible what this analysis means for the future."-Preface.

5143. Monroe, Paul. Founding of the American public school system; a history of education 
in the United States, from the early settlements to the close of the Civil War period. v. I. New York, Macmillan, r940. xiv, 520 p. illus.

$$
\text { 40-27340 LA2I2.M63 }
$$

Dr. Monroe, professor of education at Columbia and Barnard and "the dean of American writers in the field of educational history," died in 1947 without carrying his story beyond 1860 . His first chapter describes the European backgrounds of the American development, and emphasizes its vocational as well as its religious origins. His narrative does not attempt a comprehensive social and intellectual synthesis, but limits itself to "the more commonplace idea of education as a school process," relating, however, this development to dominant political and economic forces. For both the colonial and the early national periods, the material is presented under the categories of primary, secondary, and higher education. The volume is largely based upon a fresh body of primary source material, selections from which, confined to Massachusetts, New York, and Virginia, are contained in a microfilm supplement of Readings, reproduced from the author's manuscript and deposited in selected libraries.

5144. Mort, Paul R., and Walter C. Reusser. Public school finance: its background, structure, and operation. 2d ed. New York, McGraw-Hill, 195r. xxii, 639 p. (McGraw-Hill series in educa-

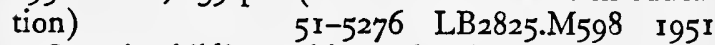

Contains bibliographies and technical exercises.

Includes three books and four supplements. Book I emphasizes current fiscal problems "that harass schools and threaten indirectly to bring about unwanted structural changes"; Book II reflects recent changes on the operational side and deals with budgetary and auditing matters; Book III spells out the pressing problems of state and Federal fiscal policy; part of the contents of the first edition are covered in the four supplements. Cf. Preface to the second edition, p. ix. Much the same ground is covered in Arvid J. Burke's Financing Public Schools in the United States (New York, Harper, 195I. 584 p.).

5145. Page, Walter Hines. The school that built a town; with an introductory chapter by Roy

E. Larsen. New York, Harper, 1952. 109 p. 52-8488 F215.P13 1952

Three essays, originally published under the title The Rebuilding of Old Commonwealths, which include: The Forgotten Man (1897); The School That Built a Town (Ig0r); and The Rebuilding of Old Commonwealths (rgo2).

Classic statement of the case for public education, particularly in the southern United States, by a notable journalist and diplomat who received his own education (through undergraduate college) in southern institutions.

5146. Warner, William L., Robert J. Havighurst, and Martin B. Loeb. Who shall be educated? The challenge of unequal opportunities. New York, Harper, 1944. xii, 190 p. illus. 44-4389 LA21o.W 33

Bibliographical references included in footnotes (p. 175-179); Working bibliography: p. 181-186.

Two scholars from the University of Chicago and a third from the University of California at Berkeley, representing respectively the fields of anthropology and sociology, education, and child welfare, present the effects of class differences and "caste" systems operating against the use of education in public schools to realize the democratic ideal of equal opportunity for all members of American society; depicts conditions before 1945 .

\section{Bii. PRESCHOOL AND PRIMARY GRADES}

5147. Caswell, Hollis L., and A. Wellesley Foshay. Education in the elementary school. $2 \mathrm{~d}$ ed. New York, American Book Co., I950. xvii, 406 p. (American education series)

$$
\text { 50-13041 LBi555.C } 35 \text { 1950 }
$$

Presents the elementary school as the central unit in American education from nursery through professional school; reviews developments that have now culminated after half a century and recognizes contributions made by experimental work in this field. Supplementary readings are suggested after chapters; general references are supplied at the conclusion of the work, p. 391-392. The first of the two authors is president of Teachers College, Columbia University, and the second is a professor and director of educational research at Ohio State University.

5148. Gans, Roma, Celia Burns Stendler, and Millie Almy. Teaching young children in nursery school, kindergarten, and the primary grades. Yonkers-on-Hudson, N. Y., World Book Co., 1952. 454 p. (New-World education series) 52-1768 LBI $140 . \mathrm{G}_{2} 6$ Covers the education of children between the ages of four and nine; written by three university professors working in the field, in nontechnical language for the use of parents, administrative officers of schools, nurses, social workers, and teachers.

5149. Gesell, Arnold L., and Frances L. Ilg. Child development, an introduction to the study of human growth. New York, Harper, 1949. 2 v. in $1\left(403,475\right.$ p.) illus. $49-50170$ BF $721 . G_{477}$ 
Each volume previously published separately.

Includes bibliographies.

Contents. - - . Infant and child in the culture of today (1943).-2. The child from five to ten (1946).

Studies of the understanding, guidance, and psychological care of children in a democratic society; used extensively by American parents and teachers. This edition includes the complete text of both earlier volumes, together with an added Foreword by Dr. Gesell, entitled "Child Development and the Science of Man." Dr. Gesell was for many years professor of child hygiene at the Yale School of Medicine. His own researches and those of Dr. Ilg while both were associated in the Clinic of Child Development at Yale provide the basis for much of the two studies.

5150. National Society for the Study of Education. Committee on Early Childhood Education.

Early childhood education. Edited by Nelson B. Henry. Chicago, National Society for the Study of Education; distributed by the University of Chicago Press, 1947. xii, 390 p. (National Society for the Study of Education. Yearbook, $46 \mathrm{th}, \mathrm{pt}$. 2)

6-16938 LB5.N25, 46th yearbook, pt. 2

Composed of a series of articles by individual specialists or groups of specialists; concerned particularly with the sociological background of primary education, with child development, and with progress and application of knowledge in this branch of education; includes numerous lists of books recommended for reading.

515I. Otto, Henry J. Elementary-school organization and administration. 3d ed. New York, Appleton-Century-Crofts, I954. 7I9 p.

$$
\text { 54-52I4 LB2805.O76 I954 }
$$

The author, graduate professor of elementary administration and curriculum, University of Texas, addresses his book to administrators of and teachers in American elementary schools; a historical and statistical study of fundamental aspects of this segment of education; extensively documented by means of numerous footnotes.

\section{Biii. SECONDARY SCHOOLS}

5152. Brown, Elmer E. The making of our middle schools; an account of the development of secondary education in the United States. New York, Longmans, Green, I903. xii, 547 p.

Bibliography: p. [48I] -518 . 3-1867 LA222.B87

Bibliographical notes at end of chapters.

Classic expression of educational thought and history at the beginning of the 2oth century which has not been superseded; written by a former United States Commissioner of Education.

5153. Chisholm, Leslie L. The work of the modern high school. New York, Macmillan,

1953. $542 \mathrm{p}$. 53-1883 LBi607.C47

Written to develop a clear understanding of each part of the modern secondary school in the United States, the work is divided into four parts: (I) the place of education in American life; (2) the content of what should be taught; (3) the program that is in harmony with the needs of youth today; and (4) the plan of action that may be followed in building a good educational program. References to pertinent publications are provided at the end of each chapter except the last.

5154. Douglass, Harl R. Modern administration of secondary schools; a revision and extension of Organization and administration of secondary schools. Boston, Ginn, 1954. 601 p.

54-9748 LB2822.D6 1954

Designed as a textbook for college and university classes and as a handbook for professional workers in the field of secondary education; written by the director of the College of Education, University of Colorado.

5155. Heely, Allan V. Why the private school? New York, Harper, 1951. 208 p.

5I-3394 $\mathrm{LC}_{47} \cdot \mathrm{H}_{4}$

Analysis of the functions proper to the independent, nondenominational private school in American democratic society, its curriculum and methods of teaching, problems of ethical and religious training, and other miscellaneous questions; written by the headmaster of Lawrenceville School, Lawrenceville, New Jersey. Roland J. Mulford's History of the Lawrenceville School, 1810-1935 (Princeton, Princeton University Press, 1935. 358 p.) describes the evolution of this preparatory institution for boys during its existence of nearly $15^{\circ}$ years, first as a small academy, nonconformist and middle-class in its sympathies, and currently as a notable private school.

5156. Keller, Franklin J. The comprehensive high school. New York, Harper, I955. 302 p. $\quad 54-12239$ LBr607.K 37

Bibliography: p. 287-290.

Considers the scope of various high schools and their accomplishments in relation to the definition of a comprehensive high school as one that "combines all the best features of an academic high school and a vocational high school, and therefore serves the needs of all youth in the community"; based on a survey involving a study of the literature, inquiries 
addressed to 2,220 educators, and field trips to visit some 77 schools. Favorable presentation of the case for vocational education, by the principal (1955) of the Metropolitan Vocational High School of New York City.

5157. Koos, Leonard V. Junior high school trends. New York, Harper, 1955. I 7 I p. (Exploration series in education) $\quad 55-6777 \quad \mathrm{LBI}_{23} \cdot \mathrm{K} 63$

Review of the history, aims, and development of the junior high school as part of American education during a period of some fifty years; written by an authority on the subject who, after a long professorial career at the Universities of Minnesota and Chicago, in 1946 became director of research for the American Association of Junior Colleges. An annotated bibliography is supplied (p. 145-165) and documentation by means of bibliographic footnotes is given throughout.

5158. Leonard, John P. Developing the secondary school curriculum. Rev. ed. New York, Rinehart, 1953. 582 p.

52-I40I6 $\mathrm{LBI}_{628 . \mathrm{L}_{4}} 1953$

Provides a background of social, political, industrial, and agrarian developments that affected changing educational ideas and theories, particularly as these have been reflected in repeated revisions of curriculums; traces recent developments in detail, e. g., core courses and unit instruction; copiously documented by footnotes referring to reports of im- portant committees and commissions as well as to other official and unofficial publications. Other studies that may be compared with this are Fundamentals of Curriculum Development, by B. Othanel Smith, William O. Stanley, and J. Harlan Shores (Yonkers-on-Hudson, World Book Co., 1950. 780 p.); Reorganizing the High-School Curriculum, rev. ed. by Harold B. Alberty (New York, Macmillan, 1953. 560 p.); and 'Stephen Romines' Building the High School Curriculum (New York, Ronald Press, I954. 520 p.). Developing a Curriculum for Modern Living, by Florence B. Stratemeyer and others (New York, Teachers College, Columbia University, 1947. $55^{8}$ p.), makes detailed recommendations resulting from a cooperative investigation of the type of curricular development thought suited to modern elementary and secondary schools.

5159. Miller, George F. The academy system of the state of New York. Albany, J. B. Lyon, 1922. I8I P. 23-4874 LA337.M5

Thesis (Ph. D.)-Columbia University, 1916.

Bibliography: p. I79-180.

The American academy prepared the way for the high school, which finally superseded it. Historically, academies in the United States occupied an important place in the transition from colonial education to that of the late Igth century. The foregoing study of the system in New York is illustrative of its wider use in America for a hundred years following 1787 .

\section{Colleges and Universities}

\section{Ci. GENERAL AND HISTORICAL WORKS}

5160. American Council on Education. Cooperative Study of Evaluation in General Education. General education: explorations in evaluation; the final report. Paul L. Dressel, director; Lewis B. Mayhew, assistant director. Washington, American Council on Education, I954. xxiii, 302 p.

54-11007 LCiori.A6

Nineteen universities and colleges, widely separated as to type and locality, cooperated in the study, in an effort to determine the status and effectiveness of programs in "general education," offered in the institutions of the United States. The movement in favor of such education has been variously defined, but may be said to represent substantially a reaction against overspecialization, too free an election of unrelated subjects, narrowness in technical and professional preparation for vocational purposes, and the failure of American education adequately to stress the attainment of learning that should be the common experience of all educated men and women.

516r. American universities and colleges. 7 th ed., 1956. Mary Irwin, editor. Washington, American Council on Education, 1956. I223 p. 28-5598 LA226.A65 9956

Reference work providing information chiefly in the following categories: statement concerning accrediting, requirements for admission, degrees granted, administrative and teaching staff, library, finances, brief historical details.

5162. Bogue, Jesse P. The community college. New York, McGraw-Hill, I950. xxi, 390 p. (McGraw-Hill series in education)

$$
\text { 50-8962 LB2329.B6 }
$$


Bibliographical footnotes.

Covers philosophies, functions, history, contributions, organization, and administration of junior colleges designed to provide education suited to individual communities; written by the executive secretary of the American Association of Junior Colleges.

5163. Commission on Financing Higher Education. [Reports and publications ${ }^{\mathrm{N}} \mathrm{New}$ York, Columbia University Press for the Commission on Financing Higher Education, 1951-53. 12 v.

Dramatic increase in enrollment, declining income of private institutions, overcrowding, and increased costs experienced by state and private universities, caused grave anxiety during the past decade. The Association of American Universities therefore requested the Carnegie Corporation of New York and the Rockefeller Foundation to underwrite the Commission on Financing Higher Education, to study and report upon all phases of the problems involved. The reports and other monographic publications of the Commission are described in the following items.

5164. Allen, Harry K. State public finance and State institutions of higher education in the United States. 1952. $196 \mathrm{p}$.

$$
\text { 52-12300 LB2342.A4 }
$$

5165. Axt, Richard G. The Federal Government and financing higher education. 1952. 295 p. 52-14740 LCi 73. A97 $^{2}$

5166. Current operating expenditures and income of higher education in the United States, I930, I940, and I950; a staff technical paper, compiled by William V. Campbell [and others] 1952. xvii, 97 p. (chiefly tables)

$$
\text { 52-14777 LB2342.C66 }
$$

5167. Government assistance to universities in Great Britain; memoranda submitted by Harold W. Dodds [and others] 1952. x, 133 p. 52-8830 LB2901.C6

5168. Higher education and American business. 1952. $37 \mathrm{p}$. 53-3015 LB2336.C6

5169. Hofstadter, Richard, and C. De Witt Hardy. The development and scope of higher education in the United States. I952. x, 254 p.

Bibliographical footnotes.

$$
\text { 52-1474 I LA226. } \mathrm{H}_{55}
$$

5170. Hollinshead, Byron S., and Robert R. Rodgers. Who should go to college? With a chapter on the role of motivation in attendance at post-high-school educational institutions. 1952. xvi, $190 \mathrm{p}$. 52-14133 LB2351.H64

Bibliographical references included in "Selections from the Literature" (p. [166]-184).

5171. Millett, John D., ed. An atlas of higher education in the United States; the geographical distribution of accredited four-year colleges, universities, and technical schools in 1950. 1952. [57] p. maps.

$$
\text { Map 52-909 Gizor.E6M5 }
$$

1952

5172. Millet, John D. Financing higher education in the United States; the staff report of the Commission on Financing Higher Education. 1952. xix, 503 p. diagrs., tables.

Bibliographical footnotes.

$$
\text { 52-14622 } \mathrm{LB}_{2342 . \mathrm{M}_{4} 8}
$$

5173. Nature and needs of higher education; the report of the Commission on Financing Higher Education. 1952. xi, I91 p.

$$
5^{2-14642} \mathrm{LB}_{232 \mathrm{r}} \mathrm{C}_{54}
$$

5174. Ostheimer, Richard H. A statistical analysis of the organization of higher education in the United States, I948-1949. I95I. xviii, 233 p. tables.

$5^{\mathrm{I}-\mathrm{I} 4360 \quad \text { LA266.075 }}$

5175. Ostheimer, Richard H. Student charges and financing higher education. I953. xix, 217 p. diagrs., tables. 53-10191 LB2342.08 Bibliographical footnotes.

5176. Coulter, Ellis M. College life in the Old South. [2d ed.] Athens, University of Georgia Press, I95I. 320 p. illus.

Bibliography: p. 299-305.

$$
\text { 5I-7109 LDig83.C6 I95I }
$$

Considering the evolution of the University of Georgia typical in its region, a professor in the history department of that institution has analyzed its history and development from the turn of the 18 th century to the immediate aftermath of the Civil War, in order to show the effects of higher education on the privileged class in the South of that day.

First issued in 1928 and now reissued with minor changes and corrections.

5177. Earnest, Ernest P. Academic procession; an informal history of the American college, 1636 to 1953. Indianapolis, Bobbs-Merrill, I953. 368 p. $\quad 53-9859$ LA229. EI7

Briefly examines major forces that have operated in American higher education and the extent to which individual institutions have fitted their stu- 
dents to live and work in the society that produced them. Numerous references to literary, historical, and educational sources are supplied in "Notes," p. 341-359. Dr. Earnest is chairman of the department of English, Temple University.

5178. Five college plans: Columbia [by] Dean Herbert E. Hawkes; Harvard [by] Dean A. Chester Hanford; Swarthmore [by] President Frank Aydelotte; Wabash [by] President Louis B. Hopkins; Chicago [by] Dean Chauncey S. Boucher; with an introd. by John J. Coss. New York, Columbia University Press, 1931. I15 p.

$$
\text { 32-1980 LB2341.F5 }
$$

Lectures describing new educational programs designed to improve curriculums in five representative colleges after World War I; objectives of the changes include providing for individual differences in students and the creation of superior institutions flexible enough to serve the requirements of life in the postwar world.

5179. Flexner, Abraham. Universities, American, English, German. New York, Oxford University Press, I930. 381 p. $\quad 30-32829$ LAr83.F6

The longest part of the book consists of a drastic criticism of American universities on the score of disproportionate emphasis on vocational courses, mass-production methods, and intellectual standards alleged to be far below those of English and German universities. Valuable as a provocation to discussion and review of problems, the book has been considered by various critics to be neither dispassionate nor the source of balanced evidence concerning conditions in many institutions. The author, a distinguished educational figure, was for nine years director of the Institute of Advanced Study, Princeton.

5180. Harvard University. Committee on the Objectives of a General Education in a Free Society. General education in a free society. With an introd. by James Bryant Conant. Cambridge, Harvard University Press, 1945. xix, 267 p.

$\mathrm{A}_{45-4180} \mathrm{LAA2}_{2}$. $\mathrm{H}_{4}$ I945a

Report of an analysis of the curriculum of Harvard University and an inquiry into the problems and desiderata of general education not only at Harvard but in American schools and colleges throughout the country; one of the numerous studies made by committees in various institutions with the aim of improving education after World War II.

5I8I. Hofstadter, Richard, and Walter P. Metzger. The development of academic freedom in the United States. New York, Columbia University Press, 1955. xvi, 527 p. 55-9435 LA205.H55
Prepared for the American Academic Freedom Project at Columbia University, directed by Robert M. MacIver.

Bibliographical footnotes.

Contents.-The age of the college, by $\mathrm{R}$. Hofstadter.-The age of the university, by W. P. Metzger..

Historical study primarily of academic freedom of faculty members in American colleges and universities, from the beginning of these institutions to the recent past. Provides the backgrounds of religious, intellectual, and political issues involved; explores also a variety of other related topics, such as academic government, professional organizations of academic men, the rise of Darwinism in American thought, and the relation between big business and academic freedom. The authors are members of the faculty of Columbia University. Their book should be read with its companion volume, Robert M. MacIver's Academic Freedom in Our Time (q. v.).

5182. The Idea and practice of general education. Chicago, University of Chicago Press, I950.

333 p. $\quad$ 50-12496 LDg06.5.I3

An account of the progress made during nearly twenty years in developing an academic program at the College of the University of Chicago; written by present and former members of the faculty as a contribution to the exchange and communication of ideas concerning new forms of undergraduate education in America.

5183. Kelly, Robert L. The American colleges and the social order. New York, Macmillan, 1940. $380 \mathrm{p}$. $\quad 40-33507 \mathrm{LA}_{225} . \mathrm{K}_{4}$ "References and notes": p. 347-369.

Historical study of American higher education and particularly of the liberal arts colleges from colonial to recent times, with special emphasis on the relations of such colleges to the society of which they have been a significant part.

5184. McDowell, Tremaine. American studies. Minneapolis, University of Minnesota Press, 1948. 96 p. $\quad 48-9983$ LB232r.M33

Contents.-I. Time and the colleges.-2. General education.-3. American studies.-4. Curriculums in American studies.-5. American courses.6. The Minnesota program.-7. Region, nation, world.

". . . based chiefly on firsthand observations of procedures in more than thirty colleges and universities"; immediately descriptive of specific programs in American Studies, but ultimately concerned "with the broad pattern of higher education in the United States."-Foreword. 
The author has been chairman of the Program in American Studies at the University of Minnesota since 1945 .

5185. MacIver, Robert M. Academic freedom in our time. New York, Columbia University

Press, I955. xiv, 329 p. 55-9094 LB2332.M28 Bibliography: p. [305]-320.

Prepared for the American Academic Freedom Project at Columbia University, directed by the author, formerly Lieber Professor of Political Philosophy and Sociology at Columbia University. After defining academic freedom, MacIver devotes the principal sections of his work to the following topics: the recent climate of opinion concerning freedom in the United States; academic government in relation to academic freedom; freedom required by the student and the teacher; and the university and the social order. The book emphasizes an analysis of the contemporary situation in the United States, problems that are present, and the significance of this type of freedom in the life of the nation. The general theme of the volume and its companion work, Hofstadter and Metzger's The Development of Academic Freedom in the United States (q. v.) is that of the Bicentennial of Columbia University: "Man's right to knowledge and the free use thereof."

5186. Ross, Charles D. Democracy's college; the land-grant movement in the formative stage. Ames, Iowa State College Press, 1942. 267 p.

Notes and references: p. $183-229$.

$$
\text { 42-1 } 1686 \text { LA226.R65 }
$$

Introductory and selective bibliography: p. 231254.

Historical study of the meaning of the land-grant college in American educational development after Abraham Lincoln in 1862 signed the Morrill Act appropriating great areas of public land for the establishment in every state of a college for the people "to promote the liberal and practical education of the industrial classes in the several pursuits and professions of life." For current achievement in I930 see a Survey of Land-Grant Colleges and Universities, directed by Arthur J. Klein for the United States Office of Education (Washington, U. S. Govt. Print. Off., 1930. 2 v.).

More recently, the Association of Land-Grant Colleges and Universities has published Some Educational Questions Confronting the Association . . . (Washington, 1948. 52 p.), which is a manual of inquiry into considerations suggested by the report of the President's Commission on Higher Education (q. v. under U. S. below).
5187. Smith, Huston. The purposes of higher education. Foreword by Arthur H. Compton. New York, Harper, 1955. 218 p.

$55-6970 \quad \mathrm{LB}_{232} \mathrm{r} . \mathrm{S}_{57}$

Presents a moderate position with respect to various opposing ideas in American higher education. These include freedom versus authority, egoism versus altruism, and the individual versus the state. Considers the aims of liberal education with reference to knowledge, abilities, appreciations, and motivations. Based on deliberations conducted for I 8 months by a faculty committee charged with studying the curriculum of Washington University, St. Louis, and with formulating a statement of the objectives of liberal education to be used as a basis for curriculum development.

5188. Thwing, Charles F. A history of higher education in America. New York, Appleton, 1906. xiii, 501 p. 6-35963 LA226.T56 Although written half a century ago, this comparative study of numerous institutions remains a contribution to American cultural and educational history, by virtue of its vigorous portrayal of persons, conditions, and events that shaped the founding and development of American colleges and universities.

\section{U. S. President's Commission on Higher Ed-} ucation. Higher education for American democracy, a report. Washington, U. S. Govt. Print. Off., 1947. 6 v. illus.

George F. Zook, chairman.

$4^{8-50042} \mathrm{LA}_{22} 6 . \mathrm{A}_{4} 8$

Contents.-v. I. Establishing the goals.-v. 2. Equalizing and expanding individual opportunity.-v. 3. Organizing higher education.-v. 4. Staffing higher education.- v. 5. Financing higher education.-v. 6. Resource data.

Embodies the results of a study made by the commission established in July 1946, by President Harry $\mathrm{S}$. Truman, to seek a comprehensive view of higher education in the United States, and to assess present problems and future requirements. Among the latter the commission outlined federal financial assistance on a large scale if the basic aim were to be achieved of providing equal opportunities for higher education to all qualified persons. The character of the debate over the report may be learned from Gail Kennedy's Education for Democracy (Boston, Heath, 1952. II7 p. Problems in American civilization, readings selected by the Department of American Studies, Amherst College.

$$
\text { LA226. } \mathrm{A}_{4} 8 \mathrm{~K}_{4} \text { ). }
$$

5190. Veblen,Thorstein. The higher learning in America. Introd. by David Riesman. Stan- 
ford, Calif., Academic Reprints, 1954 [ ${ }^{\mathrm{C}}$ 1918] xx, $286 \mathrm{p}$. (American culture and economics series, no. 3) 54-7096 LA226.V 1954

First published in I9I8, the work constituted a scathing attack on the conduct of universities by governing boards and officials dominated by the concepts of businessmen, to the great detriment of an honest search for knowledge. David Riesman, introducing the present edition, comments: "Though the details of the Veblen legend may be in error, he is surely, for those contributions, entitled to his place in the history of intellectual freedom."

\section{Cii. INDIVIDUAL INSTITUTIONS}

519I. Becker, Carl L. Cornell University; founders and the founding. Ithaca, N. Y., Cornell University Press, 1943. $240 \mathrm{p}$.

44-r95 LDi369.B 4

Series of lectures tracing the English influence on early classical education in America; the development of interest in scientific research and in training for agriculture and the mechanic arts as related to the Morrill Land-Grant College Act of I862; and the founding of institutions such as Cornell. Texts of various documentary sources are provided, p. 139-190; a bibliography is supplied, p. 207-215; and references and notes are listed, p. 219-240.

Cornell as part of American social history after the Civil War is portrayed in Walter P. Rogers' Andrew $D$. White and the Modern University (Ithaca, N. Y., Cornell University Press, r942. 259 p.).

5192. Cheyney, Edward P. History of the University of Pennsylvania, I740-1940. Philadelphia, University of Pennsylvania Press, 1940. $\mathrm{x}, 46 \mathrm{r} \mathrm{p}$. 40-32494 LD $4528 . \mathrm{C}_{45}$

"The printed and manuscript material used in the preparation of this volume and all other known references to the history of the University have been listed, and this list will be preserved in the University library in accessible form for the use of subsequent investigators."-Preface.

5193. Cole, Arthur C. A hundred years of Mount Holyoke College; the evolution of an educational ideal. Published for Mount Holyoke College. New Haven, Yale University Press, 1940. 426 p.

$$
\text { 40-27310 LD7093.C } 58
$$

Reflects "the changing concepts in education and in society throughout a century especially notable for the widening of opportunities for women."Preface p. [iii]. Includes biographical essays on Mary Lyon (1797-1849) and Mary E. Woolley (1863-r947).
5194. Curti, Merle E., and Vernon R. Carstensen. The University of Wisconsin; a history, 1848-1925. Madison, University of Wisconsin Press, 1949. 2 v. illus. $\quad 48-47638$ LD6 $28 . C 8$

Includes bibliographical footnotes and a bibliographical note, v. 2, p. 597-60r.

Study of a state university, its origins, aims, growth, financial support, faculty and administration, students, and finally its status in the first quarter of the twentieth century; aims to relate the development of this individual institution to the social and intellectual movements of the Middle West and of America as a whole. Published in commemoration of the hundredth anniversary of the founding of the university.

5195. Flexner, Abraham. Daniel Coit Gilman. New York, Harcourt, Brace, 1946. I73 p. 46-7929 LD2626 1876.F55

Bibliographical references included in "Acknowledgments" (p. 165-r66).

Develops the thesis that by the far-reaching influence of Gilman at Johns Hopkins a new type of American institution was created, in which teaching and research were combined and that this example was followed until it became standard in the United States; documented by quotations from Gilman's works, such as University Problems in the United States (New York, Century, 1898. 3r9 p.) and The Launching of a University and Other Papers

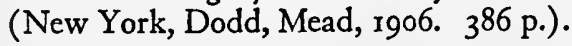

5196. Henderson, Algo D., and Dorothy Hall. Antioch College: its design for liberal education. New York, Harper, 1946. xiv, 280 p. 47-97 LDr7 $1 . \mathrm{A}_{53} \mathrm{H}_{4}$

Account prepared under the direction of the president of Antioch College, Yellow Springs, Ohio, at the end of 25 years of experimentation with the "Antioch Plan," a curriculum leading to the A. B. and B. S. degrees; programs included in the plan require 5 years for completion and combine $3 \mathrm{em}$ phases: ( $\mathrm{I}$ ) liberal education; (2) experience as workers off the campus; and (3) the development of democratic group responsibility in college government.

5197. A History of Columbia College on Morningside. New York, Columbia University Press, I954. viii, 284 p. illus. (The Bicentennial history of Columbia University) 54-8016 LDI248. $\mathrm{H}_{4} 8$

Bibliographical footnotes.

Contents.-The college: a memoir of forty years, by I. Edman.-The Van Amringe and Keppel eras, by L. Trilling.--Reconstruction in the liberal arts, by J. Buchler.- "Most glad to teach," by C. W. Everett.-After class, by F. W. Boardman, Jr.-The 
lion afield, by J. N. Arbolino.- The men from Morningside, by G. R. Hawes.-A liberal arts college in a metropolitan university, by I. Edman.

5198. Jones, Barbara (Siatter) Bennington College; the development of an educational idea. New York, Harper, I946. 239 p.

47-3008I LD7251.B4792J6

Covers the development of the educational program of a "progressive" college for women during the first I4 years of its life (I932-45) and outlines the main departures from conventional educational practices; originated in a series of research studies subsidized by the Whitney and the Rockefeller Foundations.

5199. Kennedy, Gail, ed. Education at Amherst: the new program. New York, Harper, 1955.

$330 \mathrm{p}$. $\quad 55^{-8552}$ LDI53.K $_{4}$

Documents the curricular revisions and innovations undertaken by a traditional four-year liberal arts college to meet the educational problems and opportunities that developed in the United States, particularly after World War II. Two reports comprise the major part of the book: that of the Faculty Committee on Long Range Policy, from which developed the changes first put into effect in 1946-47; and that of the Review Committee on the New Program, which provides information on the results of the changes as of 1954. For observations on earlier offerings at Amherst see the following entry.

5200. Le Duc, Thomas $\mathrm{H}$. Piety and intellect at Amherst College, I865-1912. New York, Columbia University Press, 1946. I65 p. (Columbia studies in American culture, no. I6)

$\mathrm{A}_{4} 6-2753 \mathrm{LD}_{153 . \mathrm{L}_{4}}$

"An - earlier draft ... was submitted to Yale University ... for the doctoral degree [1943]."Preface.

Bibliography: p. [153]-155.

Not designed as a comprehensive factual history of events in the life of Amherst College, but rather as a study of ideas current at the college and expressed in its curriculum and classes during the second half of the Igth century; also explores the role of a representative undergraduate college of that time in the life of the community of which it was a part, and thus relates it to the cultural history of the United States. For contemporary offerings at the college see the preceding entry under Gail Kennedy.

5201. Michigan. University. The University of Michigan, an encyclopedic survey. Wilfred B. Shaw, editor. v. I + Ann Arbor, University of Michigan, I94I + 42-36603 LD 3278 .A24
Presents a factual and historical study of a large state university in its entirety: origin and growth, administration, schools, departments, faculty, instruction, students, alumni, libraries, and museums; includes frequent bibliographies that emphasize references to official documents of the institution and the state; a publication to be completed in 4 volumes and 9 parts.

A comparable study of a large metropolitan university is The University of Chicago Survey (Chicago, University of Chicago Press, 1933. I2 v.).

5202. Minnesota. University. Bureau of Institutional Research. A university looks at its program; the report of the University of Minnesota Bureau of Institutional Research, 1942-1952. Ruth E. Eckert and Robert J. Keller, editors. Minneapolis, University of Minnesota Press, 1954. 223 p. (Minnesota studies in higher education)

$$
\text { 54-8209 } \mathrm{LD}_{3326.5 . \mathrm{A}_{47}}
$$

Enrollment trends, curriculum development, staff activities, and undergraduate and graduate instruction are among the matters considered in 23 selected studies representing the university's continuing program for studying its own procedures and offerings.

5203. Morison, Samuel Eliot. Three centuries of Harvard, 1636-1936. Cambridge, Harvard University Press, 1936. $512 \mathrm{p}$.

$$
\text { 36-14160 LD2151.M65 }
$$

Brief history of Harvard University. More detailed treatment of different periods in the life of the institution and of its relation to American culture and education in a wider sense is found in the uncompleted Tercentennial History of Harvard College and University, 1636-1936, which includes The Founding of Harvard College (1935), Harvard College in the Seventeenth Century (2 v., 1936), both by Dr. Morison, and The Development of Harvard University Since the Inauguration of President Eliot, 1869-1929 (1930), a cooperative volume edited by him. Dr. Morison at the time of his recent retirement was Jonathan Trumbull Professor of History at Harvard University.

5204. Wertenbaker, Thomas J. Princeton, I7461896. Princeton, Princeton University Press, 1946. 424 p. illus. A47-267 $\mathrm{LD}_{4609 .} \mathrm{W}_{4}$

Bibliographcial footnotes.

Written by a senior professor of American history at Princeton; reviews the institution's history, evaluates the contribution of the original founders and their successors, explains educational policies, recounts past services to the nation, and brings back the student life of the past. Cf. Foreword, p. v. 


\section{Education of Special Groups}

5205. American Association for Gifted Children. The gifted child, edited by Paul Witty. Boston, Heath, I951. xii, $33^{8} \mathrm{p}$.

$$
5 \mathrm{I}-2586 \text { I.C3965.A6 }
$$

Annotated bibliography on gifted children by Elise H. Martens: p. [277]-323.

Collection of nontechnical essays by specialists; discusses the problems of the gifted child, factors involved in identifying the gifted, the waste of talent and leadership inherent in wrong methods of education for this valuable segment of the population, etc. A useful brief treatment of the same subject is the Educational Policies Commission's Education of the Gifted (Washington, 1950. 88 p.). A progress report covering ten years of work in this field at the Hunter College Elementary School is provided in Educating Gifted Children, by G. H. Hildreth and others (New York, Harper, I952. 272 p.). Programs for gifted boys and girls applied in a variety of schools, school systems, and projects are summarized in $A$ Survey of the Education of Gifted Children, by Robert J. Havighurst and others (Chicago, University of Chicago Press, 1955. I 4 p.), which includes an annotated bibliography, p. IO3-II3.

5206. Ashmore, Harry S. The Negro and the schools. Chapel Hill, University of North Carolina Press, r954. 228 p. diagrs., tables.

54-10392 LC2801.A87

List of studies upon which the book is based: p. 216-217; selected reading and research materials: p. 2I 8-220.

An objective appraisal of racial segregation and other biracial aspects of the educational system in the United States; written in summary by the director of a research project from data supplied by a staff of 45 scholars, whose work was made possible by the Fund for the Advancement of Education, with money supplied by the Ford Foundation. The book was published before the United States Supreme Court rendered its decision on May 17 , 1954, declaring that segregation is a denial of the equal protection of the laws and therefore is unconstitutional. The same data formed the basis for a volume about desegregation in some 24 communities, published as Schools in Transition, edited by Robin M. Williams and Margery W. Ryan (Chapel Hill, University of North Carolina Press, 1954. 272 p.). White and Negro Schools in the South; an Analysis of Biracial Education was edited by Truman M. Pierce, director of the Southern States Cooperative Program in Educational Administra- tion, and four coordinators in the program (Englewood Cliffs, N. J., Prentice-Hall, I955. 338 p.). The historical aspects of Negro education are presented in The Education of the Negro in the American Social Order, by Horace M. Bond (New York, Prentice-Hall, 1934. 501 p.). A detailed study of the problems and challenges of higher education in this field is found in the National Survey of the Higher Education of Negroes, by the United States Office of Education (Washington, U. S. Govt. Print. Off., 1942-43. 4 v.).

5207. Baker, Harry J. Introduction to exceptional children. Rev. ed. New York, Macmillan, 1953. $500 \mathrm{p}$.

53-8275 LC 3965. B $32^{2} \quad$ I953

Textbook for college and university students and for the use of clinical and diagnostic agencies concerned with children having physical, neurological, mental, and other handicaps; includes brief sections on children who learn rapidly and on the mentally gifted child (p. 273-295); numerous references are provided at the ends of all important parts of the work; written by the director of the Psychological Clinic, Detroit Public Schools. Additional references for exploring the same and related problems are Educating the Retarded Child, by Samuel A. Kirk and G. Orville Johnson (Boston, Houghton Mifflin, 195I. 434 p.); Arch O. Heck's The Education of Exceptional Children, $2 \mathrm{~d}$ ed. (New York, McGraw-Hill, 1954. 513 p.); and John E. Wallace Wallin's Education of Mentally Handicapped Children (New York, Harper, I955. 485 p.). A compendium of essays and bibliographical suggestions concerning many phases of this problem is found in Special Education for the Exceptional (Boston, P. Sargent, 1955. 2 v.), edited by Merle E. Frampton and Elena D. Gall, which includes signed contributions by numerous specialists in work for students suffering from special conditions of health, and other physical or mental handicaps.

5208. Butterworth, Julian E., and Howard A. Dawson. The modern rural school; with chapters by Stanley Warren [and others] New York, McGraw-Hill, I952. 494 p. (McGraw-Hill series in education) $\quad 5 \mathrm{I}-\mathrm{I}_{2592} \mathrm{LBr}_{5} 67 . \mathrm{B}^{2} 65$

Includes bibliographies, and a list of visual aids: p. $47^{1}-47^{6}$.

Presents the social and economic bases of the unique problems in the field of rural education; outlines a program for meeting the educational needs of rural America and specifies requirements for implementing that program. Dr. Butterworth is 
professor emeritus of rural education at Cornell University; Dr. Dawson is director of the Division of Rural Service of the National Education Association.

5209. Handbook of adult education in the United States. [3d ed.] Mary L. Ely, editor. New York, Institute of Adult Education, Teachers College, Columbia University, 1948. 555 p.

$$
\text { 34-270II } \mathrm{LC}_{525} \mathrm{I}^{\mathrm{I}} \mathrm{H}_{3} \mathrm{r}_{948}
$$

Survey articles by specialists and a composite record of activities that have as their purpose the stimulation of adults to inform and educate themselves for the better performance of their functions as human beings and as useful members of a democratic society; includes an extensive section on programs carried on by groups and associations organized in the interest of adult education (p. 303514); a list of references suggested for supplementary reading is also provided ( $\mathrm{p} .[5 \mathrm{I} 5]-528$ ). Other pertinent and more recent publications are Paul L. Essert's Creative Leadership of Adult Education (New York, Prentice-Hall, r95I. 333 p.) and Homer Kempfer's Adult Education (New York, McGraw-Hill, 1955. 433 p.).

52ro. Kerrison, Irvine L. H. Workers' education at the university level. New Brunswick,

N. J., Rutgers University Press, 1951. I77 p.

Bibliography: p. $146-155$.

$$
\text { 5I-14I70 LC505I.K4 }
$$

Report on the efforts, failures, and successes of some fifty universities offering programs in workers' education; provides a point of departure for the development of labor-management education.

Education of workers in industry by means of apprenticeship, day trade schools, part-time and evening study, correspondence courses, and training within industry are treated in Arthur B. Mays' Essentials of Industrial Education (New York, McGraw-Hill, 1952. 248 p.). Philip R. V. Curoe's Educational Attitudes and Policies of Organized Labor in the United States (New York, Teachers College, Columbia University, 1926. 202 p.) is a thesis which traces the relation of labor groups to the development of public school education in America from 1840 to 1925 .
521 I. Prosser, Charles A., and Thomas H. Quigley. Vocational education in a democracy. Rev. ed. Chicago, American Technical Society, 1949. $575 \mathrm{p}$. 49-8838 LCro43.P8 I949 First edition by C. A. Prosser and C. R. Allen.

Emphasizes the social and economic needs for vocational education of secondary grade, also the schools, teachers, and facilities that will make the programs effective; written by two specialists who have been active for many years in this type of educational work. A second study of the subject, Vocational Education: America's Greatest Resource (Chicago, American Technical Society, r950. $3^{87}$ p.), by John A. McCarthy, Assistant Commissioner of Education in New Jersey, stresses the relation of the Government of the United States to vocational education and the legislation by which Federal participation may be implemented. A third evaluation of this type of education, which institutes comparisons with similar programs in other countries, is found in Alfred Kähler and Ernest Hamburger's Education for an Industrial Age (Ithaca, Published for the Institute of World Affairs by Cornell University Press, 1948. 334 p.).

5212. Woody, Thomas. A history of women's education in the United States. New York, Science Press, 1929. 2 v. illus. (Science and education, edited by J. McKeen Cattell, v. 4, book I-2)

Bibliography: v. 2, p. $481-589$. 30-1557 LCi752.W6

Although written over 25 years ago this work has never been superseded as the standard historical presentation of the subject. Of special value are the documentation by references to abundant contemporary sources, the emphasis on social and institutional changes, and the sections on academies, seminaries, colleges, and professional education. In 1924 Dr. Woody became professor of education at the University of Pennsylvania. An analysis of contemporary problems and opportunities connected with the education of women is found in Educating Women for a Changing World (Minneapolis, University of Minnesota Press, 1954. 302 p.), by Kate (Hevner) Mueller, who has had rich experience as a teacher and educational administrator.

\section{E. Teachers and Teaching}

5213. Barzun, Jacques. Teacher in America. Boston, Little, Brown, I945. 32 I p.

$45^{-1} 5^{80} \quad \mathrm{LB}_{232} \mathrm{x} \cdot \mathrm{B}_{25} 8$

Essays, frequently satiric and critical, concerning the academic scene and intellectual life on American campuses as known by the author, a professor at Columbia University, who received his early education in France. 
5214. Chase, Mary Ellen. A goodly fellowship. New York, Macmillan, 1939. 305 p. 39-27971 LA2317.C48 83

"This book is the story of a life spent in teaching . . . a complement, perhaps a sequel, to $A$ Goodly Heritage written ten years ago."-Foreword. Miss Chase, a writer on New England and other themes, has been a professor of English literature at Smith College since 1929.

5215. Cronkhite, Bernice (Brown) ed. A handbook for college teachers, an informal guide. Cambridge, Harvard University Press, 1950. xi, $272 \mathrm{p}$.

Bibliography: p. $[263]-267$.

50-7896 LB2321.C73

Based on extracurricular lectures and discussions, chiefly by distinguished educators, arranged by the Radcliffe Graduate School for graduate students at Harvard and Radcliffe who plan to become college teachers. The topics developed include: relations between teacher and student; varieties of teaching methods applicable in the humanities, natural sciences, and social sciences; visual and other aids to teaching; effective methods of speech; professional relations; research and publications; obtaining a teaching position; and educational developments and trends in relation to American society.

5216. Elsbree, Willard S. The American teacher. New York, American Book Co., ${ }^{\circ} 1939$. $566 \mathrm{p} . \quad 39-17288$ LB1775. E57

Includes suggested readings.

Tells of the evolution of the teaching profession in American public schools during the past three centuries. Staff Personnel in the Public Schools (New York, Prentice-Hall, 1954. $43^{8}$ p.), written jointly by Elsbree and E. E. Reutter, Jr., deals with selection, certification, and in-service education of teachers, as well as with other administrative matters affecting teachers.

5217. Fuess, Claude M. Creed of a schoolmaster. Boston, Little, Brown, 1939. 195 p. $39-27185$ LB1607.F8

Written after long association with an independent private school, the book indicates the general course that the author considers right for modern secondary education to follow; includes chapters on "The Transition from School to College" and "The Promise of Progressive Education." Dr. Fuess, who was headmaster of Phillips Academy, Andover, Massachusetts, from 1933 to 1947 , has published a later book of the same character, Independent Schoolmaster (Boston, Little, Brown, 1952. 37 I p.).

5218. Highet, Gilbert. The art of teaching. New York, Knopf, 1950. xviii, 291 p.
Bibliographical references included in Notes: p. 283-29r.

Humanistic exposition of the art of teaching, the methods to be used, the practices of great teachers from antiquity to the early 2oth century, and the place of teaching in everyday life; written by the Anthon Professor of Latin at Columbia University, who was educated at Glasgow and Oxford Universities, and taught at the latter before coming to this country.

5219. Johnson, Alvin S. Pioneer's progress, an autobiography. New York, Viking Press, 1952. 4 I3 p. 52-12704 $\mathrm{H}_{59}$.J6A3

Economist, editor, encyclopedist, educator, and champion of adult education, Dr. Johnson's experience included appointment at some half-dozen important universities, and the directorship of the New School for Social Research from 1923 to 1945. The story of his life throws light on numerous aspects of American education and culture.

5220. McCuskey, D o r othy. Bronson Alcott, teacher. New York, Macmillan, 1940. 217 p. illus. 40-35I43 LB695. $\mathrm{A}_{3} \mathrm{M}_{3} \quad 1936$

Study based on manuscript sources, and submitted originally as a doctoral dissertation at Yale University; establishes Alcott as a progressive educator in his own or any day, by tracing his work at the Temple School, Boston, as superintendent of the Concord, Massachusetts, Public Schools, and as dean of the Concord School of Philosophy. May be used with George E. Haefner's dissertation, $A$ Critical Estimate of the Educational Theories and Practices of A. Bronson Alcott (New York, 1937. 130 p.).

5221. Perry, Bliss. And gladly teach. Boston, Houghton Mifflin, 1935. $315 \mathrm{p}$.

35-16598 $\mathrm{PS}_{2545} \cdot \mathrm{P}_{4} \mathrm{Z}_{52}$

Intimate insight into education at Williams College, and at Princeton and Harvard Universities, provided by the autobiography of a distinguished professor who taught in all three institutions between 188I and $193^{\circ}$ and who was famous for his Harvard courses in American literature.

5222. Peterson, Houston, ed. Great teachers, portrayed by those who studied under them. New Brunswick [N. J.] Rutgers University Press, 1946. xxi, 35 I p. 46-I1976 CTro5.P 44 Partial Contents. - Socratic Yankee: Mark Hopkins, by L. W. Spring.-Garman of Amherst: Charles Edward Garman, by W. A. Dyer.Quaker scholar: Francis Barton Gummere, by Christopher Morley.-P rincet on schoolmaster: 
Woodrow Wilson, by A. P. Dennis.-Columbia galaxy: John Dewey and others, by Irwin Edman."I become Agassiz's pupil": Jean Louis Rodolphe Agassiz, by N. S. Shaler.-Beloved psychologist: William James, by D. S. Miller.-Wisconsin historian: Frederick Jackson Turner, by C. L. Becker.-“Kitty": George Lyman Kittredge, by S. P. Sherman,-Emerson the lecturer: Ralph Waldo Emerson, by J. R. Lowell.
5223. Smith, Shirley W. James Burrill Angell: an American influence. Ann Arbor, University of Michigan Press, 1954. $380 \mathrm{p}$.

54-14913 $\mathrm{LD}_{3275}$ I871.S6

Details of Angell's own education, his work as a teacher, and primarily his presidency, in turn, of the University of Vermont and of the University of Michigan, contribute to an understanding of American educational history from I 840 to 1909 .

\section{F. Methods and Techniques}

5224. Douglass, Harl R., ed. Education for life adjustment, its meaning and implementation, by Maurice R. Ahrens [and others] With a foreword by Raymond W. Gregory. New York, Ronald Press Co., 1950. 491 p. (Douglass series in education)

\section{Bibliography: p. 459-473.} 50-7899 LBro27.5.D6

The life adjustment movement has been promoted by the National Commission on Life Adjustment for American Youth, a body originated in 1947 by the United States Commissioner of Education. This work comprises a series of essays by specialists and is designed to assist school officials and communities to equip American young people to live democratically and with satisfaction as profitable members of society, in the home, at work, and as citizens; addressed particularly to the requirements of those less well-served by the schools than students going on to higher education or into skilled occupations. The editor's own work, Secondary Education for Life Adjustment of American Youth (New York, Ronald Press, 1952. 630 p.), discusses social changes in America in relation to education suitable for a democratic society. The Commission on Life Adjustment Education for Youth (1947-1950) issued a report on Vitalizing Secondary Education (Washington, Federal Security Agency, Office of Education, r95r. ro6 p.).

5225. Faunce, Roland C., and Nelson L. Bossing. Developing the core curriculum. New York,

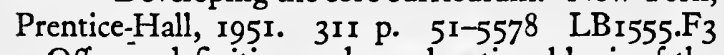
Offers a definition and an educational basis of the "core curriculum" in a democratic society, together with the methods of implementing the idea in the community, the school, and the classroom.

5226. Flesch, Rudolf F. Why Johnny can't readand what you can do about it. New York, Harper, 1955. 222 p. 55-6577 LBI573.F55 Strongly advocates teaching elementary reading by the phonetic method and castigates methods other than this now used in such teaching; controversial book that has aroused much discussion and examination of the reading abilities of young Americans. A reply to this is The Truth about Your Child's Reading, by Sam Duker and Thomas P. Nally (New York, Crown, 1956. I8r p.).

5227. Grambs, Jean D., and William J. Iverson. Modern methods in secondary education. New York, Sloane, 1952. 562 p.

References at ends of chapters. 52-10179 LBI607.G66

Undertakes to set forth the over-all task of the American high school which, along with the elementary school, is the common school of all the people; relates present conditions to the necessary changes in methods of teaching and aims to give beginning teachers the basis of a sympathetic understanding of contemporary problems. The authors are members of the faculty of the School of Education of Stanford University.

5228. Hardee, Melvene D., ed. Counseling and guidance in general education. Edited under sponsorship of the National Committee on General Education, Association for Higher Education, National Education Association. Yonkers-onHudson, World Book Co., I955. xix, 444 p. (Professional books in education)

Bibliography: p. $427-434$. 4 Bibliographical foot notes.

Symposium composed of chapters written by professors and administrators in American colleges and universities. The high school teacher who is charged with responsibility for taking part in guidance work without special training for the task is served by Leslie L. Chisholm's Guiding Youth in the Secondary School (New York, American Book Co., $195^{\circ}$. $44 \mathrm{I}$ p.). General Clinical Counseling in Educa- 
tional Institutions, by Milton E. Hahn and Malcolm S. MacLean (New York, McGraw-Hill, I950. 375 p.), draws together the theories and ideas of scientific clinical counseling developed by psychologists during World War II and applies them to the professional practice of counseling in educational work. Counseling Theory and Practice (New York, Ronald Press, I954. 307 p.), by Harold B. and Pauline N. Pepinsky, is addressed to advanced students and professional counselors interested in making a contribution as psychologists and also as practitioners; emphasizes the scientific basis of the subject.

5229. Lindquist, Everet F., ed. Educational measurement. With chapters by Gordon V. Anderson [and others] Washington, American Council on Education, 195I. xix, 8I9 p. illus.

Includes bibliographies. 5 I-9853 LB3051.L5

Sponsored by the standing Committee on Measurement and Guidance of the American Council on Education and written by 20 specialists, assisted by some 50 additional collaborators, to provide a comprehensive handbook and textbook on the theory, techniques, and functions of educational testing and measurement. An additional reference book on the subject is Oscar K. Buros' The Fourth Mental Measurements Yearbook (Highland Park, N. J., Gryphon Press, I953. II63 p.). It covers the work of $1948-51$, lists 793 tests, 596 reviews of tests, $4,4 \mathrm{I} 7$ references on the construction, validity, use, and limitations of tests, and 429 reviews of books in the field. Harold Gulliksen, professor of psychology, Princeton University, in his Theory of Mental Tests (New York, Wiley, 1950. 486 p.) brings together in one volume technical developments in test theories during the last 50 years and elaborates those he considers to be of especial interest. Clay C. Ross' Measurement in Today's Schools, $3 \mathrm{~d}$ ed., revised by Julian C. Stanley (New York, PrenticeHall, I954. 485 p. Prentice-Hall psychology series) stresses a functional approach to educational measurement in a work that resulted from long experience while teaching college classes in the subject. Frank S. Freeman's Theory and Practice of Psychological Testing, rev. ed. (New York, Henry Holt,
1955. 609 p.), amplifies his earlier discussions of test standardization, tests of specific aptitudes, and the results of recent researches in the field, and describes a number of specific tests.

5230. Siepmann, Charles A. Television and education in the United States. Paris, UNESCO, 1952. I3I p. (Press, film and radio in the world today) 53-9290 LBro 44.7. 5

Provides information concerning television and its use in schools, colleges, and universities, the educational policies of television networks, and the effect of television on audiences; indicates the cautions that are in order when the medium is used educationally. Teaching Through Radio and Television (New York, Rinehart, I952. 560 p.), by William B. Levenson and Edward Stasheff, has the twofold purpose of improving school broadcasting and encouraging more effective educational programs. Since I94I the Association for Education by RadioTelevision has provided current news and information through its periodical, The Journal of the $A E R T$. Beginning with I930 a group currently entitled the Institute for Education by Radio and Television has issued its yearbook under the title, Education on the Air.

5231. Wittich, Walter A., and Charles F. Schuller. Audio-visual materials: their nature and use.

New York, Harper, 1953. 564 p. (Exploration series in education) $\quad 52-\mathrm{I}_{2772} \mathrm{LBI}_{043} . \mathrm{W}_{5} 8$

Based on nine years' experience in work with teachers on the use in the schools of graphic teaching aids, radio, motion-picture film, television, etc. Copious illustrations are supplied, while bibliographies and lists of sources from which audio-visual materials may be obtained are added at the ends of chapters. Briefly discusses the place in contemporary American education filled by such aids to perception and understanding.

Edgar Dale's revised edition of his Audio-Visual Methods in Teaching (New York, Dryden Press, 1954. 534 p.) emphasizes the theory of learning underlying the use of these materials in teaching, the various types of materials to be used, and their application in the classroom, from the elementary grades through high school.

\section{G. Contemporary Problems and Controversies}

5232. Bell, Bernard I. Crisis in education. New York, Whittlesey House, McGraw-Hill, I949.

$237 \mathrm{p}$. 49-86 I2 LA209.2. 44
Written as a challenge to American complacency, the book deplores faults observed in all levels of education in the United States, particularly with refer- 
ence to persistent adolescence and the lack of intellectual and spiritual qualities. Nine steps in reformation are proposed in conclusion (p. 200-230). Canon Bell is not only a clergyman of the Epsicopal Church, but also an experienced educator who has served as a college president and as a professor at Columbia University.

5233. Bestor, Arthur E. Educational wastelands; the retreat from learning in our public schools. Urbana, University of Illinois Press, 1953. 226 p. 53-9761 LB875.M345

Denunciatory criticism of professional "educationists" and their educational effects by a professor of history in the University of Illinois. A later work by the same hand, The Restoration of Learning (New York, Knopf, 1955. 459 p.), incorporates material from the earlier book, and in Part Three (p. [219]-393) suggests means of "redeeming the unfulfilled promise of American education."

5234. Bode, Boyd H. Progressive education at the crossroads. New York, Newson, 1938. $128 \mathrm{p}$. $\quad 3^{8-13086}$ LB875. B 518

Reasonable and dispassionate examination of "progressive" education by a critical progressive. Carleton W. Washburn, a past president of the Progressive Education Association, in $A$ Living Philosophy of Education (New York, J. Day, 1940. 585 p.) equates progressivism with efforts to incorporate in practice scientific discoveries pertinent for education. Lucy Sprague Mitchell's Our Children and Our Schools (New York, Simon and Schuster, 1950. 5 ro p.) pictures progressive education at the Bank Street Schools in New York.

5235. Hutchins, Robert M. The conflict in education in a democratic society. New York,

Harper, 1953. I12 p. 53-8539 LB875.H96

Stating his belief that "graduation from an American university is no guarantee of literacy," the former president and chancellor of the University of Chicago criticizes the prevalence in America of four contemporary pedagogical doctrines he believes to be detrimental to sound education in any society: the doctrine of adjustment or adaptation to the total environment; the doctrine of immediate needs; the doctrine of social reform; and the doctrine of no doctrine at all. The writer's additional controversial and critical writings on American educational themes include The Higher Learning in America (New Haven, Yale University Press, 1936. 119 p.) and No Friendly Voice (Chicago, University of Chicago Press, 1936.196 p.).

5236. Scott, Cecil W., and Clyde M. Hill, eds. Public education under criticism. New
York, Prentice-Hall, I954. 4I4 p. (Prentice-Hall education series)

54-5871 LA209.2.S35

Extensive anthology of articles gathered from miscellaneous journals written for and against secondary education as provided in American schools; selections are arranged under such headings as Philosophy, Progressive Education, The Fundamentalists, Teacher Education and Teachers, etc. A second anthology has been edited by Henry Ehlers, under the title Crucial Issues in Education (New York, Holt, 1955. 277 p.). It includes selections culled from publications of the past ten years concerning freedom, learning, religion and public education, separation of church and state, racial segregation in schools, progressive education, and classroom methods and materials.

5237. Smith, Mortimer B. The diminished mind; a study of planned mediocrity in our public schools. Chicago, H. Regnery, 1954. $150 \mathrm{p}$. 54-1 1285 LA209.2.S6

A parent who has served on a board of education, the author expresses his vehement opposition to certain theories and practices in contemporary public education in America, notably those called the "Core Curriculum," "Life Adjustment," and "Social Reconstruction." $\mathrm{He}$ aims to present evidence in support of the thesis that learning, in the traditional sense of disciplined knowledge, is fast declining in our public schools. His earlier and more theoretical work, And Madly Teach (Chicago, H. Regnery, 1949. 107 p.), has been called a primer for parents.

5238. Thayer, Vivian T. Public education and its critics. New York, Macmillan, 1954. I70 p. (The Kappa Delta Pi lecture series)

54-9475 LA209.2. T47 Considers dispassionately efforts by pressure groups to restrict freedom of teaching and negate the separation of church and state.

5239. Woodring, Paul. Let's talk sense about our schools. New York, McGraw-Hill, 1953. 215 p. $\quad 53-9020$ LA209.2.W65 Partial Contents. - The shadow of John Dewey.-What is progressive education?-The teachers college in America.-The American teacher.-Academic and other freedoms.-Free enterprise and the teacher.-What we know about how we can teach.-The fundamental issue.-Appendix: Related reading, with comments.

Review and appraisal by a professor of psychology of the grounds upon which American public schools are currently being criticized as intellectually arid, undisciplined, and blighted by the predominance of methods over content. 


\section{H. Periodicals and Yearbooks}

5240. American Association of School Administrators. Yearbook. Ist + I923 + Washington. $\quad \mathrm{E}_{23}-\mathrm{I}_{42} \mathrm{~L}_{13} \cdot \mathrm{A}_{3} 6_{3}$

Published by the Association, a department of the National Education Association of the United States.

Volumes are monographic in character, as indicated by their individual titles, of which the following are examples: 1932, Character Education; 1934, Critical Problems in School Administration; 1935, Social Change and Education; 1936, The Social Studies Curriculum; 1938, Youth Education Today; 1939, Schools in Small Communities; 1941, Education for Family Life; 1949, American School Buildings; and 1953, the American School Curriculum. Each volume is produced by a committee of members selected for the purpose.

5241. The Education index. Ist + 1929/30t. A cumulative author and subject index. New York, H. W. Wilson. 30-23807 Z5813.E23

Issued monthly (except in June and August) and cumulated periodically within each year. Annual and biennial cumulations are also provided. Indexes more than 120 journals, proceedings of societies, bulletins, and other educational serials, and adds references to various monographic materials. A special feature of each number and volume is an index of book reviews, entered in a group under the words, "Book reviews." American interests predominate but material on education in other countries is also indexed when found in the serials analyzed.

5242. The Educational forum. v. I + Nov. $1936+$ Menasha, Wis., George Banta Pub. Co.

$$
\text { 37-35898 Lir.E29 }
$$

Published four times a year.

Supersedes the Kadelpian Review.

Some numbers in two parts, the second part being a supplement including news of Kappa Delta $\mathrm{Pi}$, an honor society in education, of which this journal is the organ.

Articles are broad in interest, being concerned not only with all phases of education in the United States, but also to some degree with education throughout the world. Numerous book reviews are written and signed by specialists; currently (1957) edited by E. I. F. Williams.

5243. John Dewey Society. Yearbook. Ist + New York, Harper, 1937 +
Monographic studies on such varied topics as the place of the teacher in society, freedom of teaching, democracy and the curriculum, workers' education, intercultural education, and the American elementary school. The society, formed to study the interaction of eduration, society, and culture in the United States, honors John Dewey's leadership in American thought and education but is not committed to any specific educational doctrine. Cf. Foreword, vol. I, p. v.

5244. The Journal of higher education. v. It Jan. I930+ Columbus, Ohio State University.

Issued monthly (except July-Sept.). E32-99 LiI.J78

Currently edited by R. H. Eckelberry.

Professional journal addressed to teachers and administrators; deals with significant investigations of problems of higher education in the United States, whether instructional, curricular, administrative, or concerned with personnel.

5245. NEA journal. v. I + Apr. 19r3t [Washington, National Education Association of the United States] 24-482I Lri.Ni5

The organ of the National Education Association, designed to keep teachers abreast of educational affairs in America, important educational news, and publications considered particularly significant.

5246. National Society for the Study of Education. Yearbook. Ist -5 th [1895]-99; [new ser.] Ist $+1902+$ Chicago, University of Chicago Press, $1895+$ 6-16938 LB 8 .N25

Official publication of the Society. Yearbooks are published in two parts, each devoted to a special topic developed in a series of sections written by specialists or by a committee of specialists. Emphasis is placed on recording research, on innovations, and on modern developments. Typical subjects treated include: changes and experiments in liberal arts education; vocational education; education of exceptional children; education in rural communities; general education; audio-visual materials of instruction; mass media and education; modern philosophies and education; and mental health in modern education.

5247. Review of educational research. v. It Jan. I93I + Washington, American Educational Research Association, a department of the National Educational Association of the United States.

33-19994 LiI.R 35 
Published five times a year, beginning with February, each issue of the journal is devoted to aspects of a specific educational topic, e. g., "Educational Organization, Administration, and Finance" (Oct. 1955); "Growth, Development, and Learning" (Dec. 1955); "Educational and Psychological Testing" (Feb. 1956). Edited (1956-57) by Tom A. Lamke. Substantial bibliographies are provided with reviews of the literature. May be used currently to supplement W. S. Monroe's Encyclopedia of Educational Research, described in this chapter under General Works: Historical and Descriptive.

5248. School and society. v. It Jan. 2, 1915+ Education. New York, Society for the Advancement of Issued biweekly; edited (1956) by William W. Brickman.
In general, provides a leading article in each number that discusses a timely educational topic, followed by briefer papers relating to various types of education in the United States; includes "News and Notes" of persons and events, and brief lists of recent educational and related publications.

5249. The School review; a journal of secondary education. v. It Jan. $1893+$ Chicago, University of Chicago Press. 6-I409o Lir.S55

Issued monthly (except June, July, and Aug.). Index: v. I-10, 1893-1902. I v.

Features educational news and comments; articles on all phases of secondary education; selected, annotated references on a different topic in each number; signed book reviews, and lists of current publications. Issued under the direction of the Department of Education, University of Chicago; edited ( 1956) by Maurice L. Hartung. 


\section{XXII}

\section{Philosophy and Psychology}

\author{
喝 \\ A. Philosophy: General Works \\ B. Representative Philosophers \\ C. Psychology
}

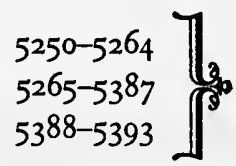

$\mathrm{T}$

HIS CHAPTER seeks to give some idea of the American achievement in the two fields of philosophy and psychology, which were originally one in academic organization and in the public mind, and have now become almost completely divorced. It has been prepared with the full realization that both have been international inquiries coterminous with the higher developments of Western civilization. Until the Igth century was well advanced American philosophy was little more than a reflection of contemporary European currents. Transcendentalism, however much it may have derived from weightier German models, certainly developed a tone and temper all its own; while with the pragmatic movement, which gradually crystallized during the $1890^{\circ}$ 's, American philosophical thinking took a quite independent line, and began in its turn to make an impression on Europe, although most of the early reactions there were, to put it mildly, negative. American philosophy has gone its own course ever since, with the two-way currents of influence normal between nations of the West, tempered by the fact that Americans usually pay more attention to what is going on in Europe than vice versa.

Section A consists of some general histories and historical anthologies of American philosophy, usually intended for classroom use, together with some accounts of individual movements or schools, and symposiums intended either to develop a particular point of view, or to give a cross section of American philosophical thinking at the time of publication. Specifically religious philosophy, as well as theology, will be found in the following chapter. Much additional matter of relevance to American philosophy is contained in Chapters I on Literature and XI on Intellectual History.

Section B presents I 8 American philosophers from Jonathan Edwards to the present day, some of whom were eminent in their time and representative of

historic currents of thought, while a few are thinkers of true originality and power, whose ideas are alive today and seem likely to remain so. Under each philosopher the entries are arranged in conformity with the pattern adopted in Chapter I on Literature, and more fully explained in its introduction: individual works arranged by the date of the original edition (although the entry here is often a later edition or reprint, preferred as more readily available); collected works; selected works; and biographical or critical studies. Some earlier figures of note, such as Cotton Mather and Benjamin Franklin, who are treated at length elsewhere, and whose specifically philosophical writings are neither numerous nor striking, have not been included here, although they usually receive some attention in histories of American philosophy. Two men, James McCosh and A. N. Whitehead, are included notwithstanding the facts that their minds were formed in Britain and they came to America in middle age with important work behind them, for each became thoroughly domesticated, and was looked up to by numerous disciples of native birth. American philosophy has tended, especially since the $1890^{\circ}$ 's, to have its being within the universities; of the many professors who have done distinguished work during the last 70 years we have been able to give individual treatment only to a handful. Two subjects 
which have flourished in the latest period, symbolic logic and general semantics, have been well-nigh ignored here: the first is so bristling with technicalities that books suited for the general reader remain to seek, while the second is still far from any definitive form or agreed body of doctrine.

Psychology, which since William James has increasingly allied itself with the natural sciences, is now flourishing inside the universities and out, where a host of "applied" specialists give counsel to diverse enterprises; she quite overshadows her elder sister, who has shared in the general diminishment of the humanities in the present technical age. Our entries for this section are nevertheless few, because among a host of textbooks, monographs, and reported experiments, general views of the American contribution to psychology remain scanty. One whole aspect of present-day psychology, that which takes its origin in the diagnosis and treatment of mental disease or disturbance, is treated not here but in Section C (Psychiatry) of Chapter XVIII on Medicine and Public Health.

\section{A. Philosophy: General Works}

5250. Adams, George P., and William Pepperell Montague, eds. Contemporary American philosophy; personal statements. New York, Macmillan, 1930. 2 v. (Library of philosophy)

$$
\text { 3I-15738 B934.C6 1930a }
$$

"Principal publications" at end of each statement.

Thirty-three professors of philosophy, representing colleges and universities from Harvard and $\mathrm{Co}$ lumbia to Michigan and California, present in this work their principal philosophic beliefs and the influences which they suppose to have given rise to them. Some of these "philosophic autobiographies" stress early life experiences, while others are nearly all theory. An exceptionally attractive paper is the introduction by George Herbert Palmer ( $1842-$ I933); writing as "a kind of representative of the philosophic young men of my time," he deals not only with his personal experiences and beliefs, but with the golden age of philosophy at Harvard. Contributors to the symposium were selected by a vote of the membership of the American Philosophical Association.

5251. Anderson, Paul Russell, and Max Harold Fisch. Philosophy in America from the Puritans to James, with representative selections. New York, Appleton-Century, 1939. 570 p. (The Century philosophy series)

Bibliography: p. [543]-562. 39-13842 B85r.A5 In large part this is an anthology of writings by American philosophers. The plan followed called for the inclusion of documents not readily accessible; this has led to a somewhat heavier emphasis on the early periods, with extracts from work by figures such as Samuel Johnson, Cadwallader Colden, Ethan Allen, Thomas Cooper, Benjamin Rush, and Samuel Stanhope Smith, as well as by later and better known philosophers. Introductions to each of the volume's four parts help to provide a general view of the main currents of development of philosophy in the United States.

5252. Barrett, Clifford, ed. Contemporary idealism in America. New York, Macmillan, 1932. 326 p. 32-31170 B941.B3 Contents.-In dedication: Josiah Royce, by G. H. Palmer.-Introduction, by Clifford Barrett.Continuity of the idealist tradition, by C. M. Bakewell.-The ontological argument in Royce and others, by W. E. Hocking.-On the meaning situation, by G. W. Cunningham.-The philosophy of spirit: idealism and the philosophy of value, by W. M. Urban.-The principle of individuality and value, by J. A. Leighton.-The finite self, by E. S. Brightman.-God and cosmic structure, by J. E. Boodin.-The theory of moral value, by $R$. A. Tsanoff.-The meaning of obligation, by C. W. Hendel, Jr.-The revival of idealism in the United States, by R. F. A. Hoernlé.

In this book a dozen philosophers take their stand for philosophical idealism, and express their sense of the inadequacy of the dominant realist move. ment. These idealists are basically in the tradition of Josiah Royce (q. v.).

5253. Blau, Joseph L. Men and movements in American philosophy. New York, PrenticeHall, I952. 403 p. $\quad 52-8596$ B851.B52

"Footnotes and suggested reading": p. 357-383.

"What is attempted here is an introductory account, stressing the more formal side of our philosophic history, to provide a background for the general reader and the beginning student which will enable them to read further both in and about American philosophy." Each of nine periods or movements is first discussed in a general way, and then through three of its representative figures. 
5254. Creative intelligence; essays in the pragmatic attitude, by John Dewey [and others]. New York, Holt, I917. 467 p. $\quad$ I7-6640 B832.C7

ConTENTs. - The need for recovery of philosophy, by J. Dewey.-Reformation of logic, by A. W. Moore.-Intelligence and mathematics, by $\mathrm{H}$. C. Brown.-Scientific method and individual thinker, by G. H. Mead.-Consciousness and psychology, by $\mathrm{B}$. H. Bode.-The phases of the economic interest, by $\mathrm{H}$. W. Stuart.-The moral life and the construction of values and standards, by J. $H$. Tufts.-Value and existence in philosophy, art, and religion, by $\mathrm{H}$. M. Kallen.

Pragmatism, indubitably the best known specifically American contribution to philosophy, has not been defined, either by its exponents or its opponents, in such manner as to win general assent, and there is perhaps a wider span of opinion among its adherents than is the case with other major schools of thought. It can be given a narrow logical definition, such as "the doctrine that the whole meaning of a conception expresses itself in practical consequences," but it can be more generally regarded as a serious attempt to domicile in philosophy the evolutionary viewpoint and the crucial importance of scientific experiment. The latter views appear in the "Prefatory Note" to the present work, which identifies the authors' attitude with "the ideas of the genuineness of the future, of intelligence as the organ for determining the quality of that future so far as it can come within human control, and of a courageously inventive individual as the bearer of a creatively employed mind." Of the eight contributors to this symposium, five taught in the Middle West and two on the Pacific coast; their essays discuss the application of the pragmatic attitude to logic, mathematics, physical science, psychology, ethics, economics, and to esthetics and religion. Three of the major figures identified with pragmatism, Dewey, James, and Peirce, appear in the following section on individual philosophers. An interesting anthology, Pragmatism and American Culture, edited by Gail Kennedy, is entered in Chapter VIII above (no. 3II5). Two expositions dating from the era when the movement was gaining self-consciousness and public attention are Henry Heath Bawden's The Principles of Pragmatism, a Philosophical Interpretation of Experience (Boston, Houghton Mifflin, 1910. 364 p.) and Addison Webster Moore's Pragmatism and Its Critics (Chicago, University of Chicago Press, 1910. 283 p.). The criticism that pragmatism sought to operate in a metaphysical void was answered by Sidney Hook in his earliest book, The Metaphysics of Pragmatism (Chicago, Open Court Pub. Co., 1927. I 44 p.). A study of the movement's greatest sphere of practical influence, the primary and secondary schools of the United States, is John L. Child's American Pragmatism and Education, an Interpretation and Criticism (New York, Holt, 1956. 373 p.). The movement has had some foreign affiliations; the English ones are noticed in Emmanuel Leroux's Le Pragmatisme américain et anglais, étude historique et critique (Paris, Alcan, I923. 429 p.). Its students have naturally searched for American antecedents prior to James and Peirce; a work of this type is Eduard Baumgarten's Der Pragmatismus: R. W. Emerson, W. James, J. Dewey (Frankfurt am Main, Klostermann, 1938. 483 p.).

5255. Essays in critical realism; a co-operative study of the problem of knowledge. London, Macmillan, 1920. $244 \mathrm{p}$. 2I-I 105I B835.E7 CoNTENTs.-The approach to critical realism, by D. Drake--Pragmatism versus the pragmatist, by A. O. Lovejoy.-Critical realism and the possibility of knowledge, by J. B. Pratt.-The problem of error, by A. K. Rogers.-Three proofs of realism, by G. Santayana.-Knowledge and its categories, by R. W. Sellars.-On the nature of the datum, by C. A. Strong.

A further symposium in which five American professors of philosophy joined with Charles Augustus Strong, an Englishman who had taught at Columbia, and George Santayana (nos. 5365-5377), then resident abroad, to present an epistemological doctrine upon which they were in fairly complete agreement, although they held "somewhat different ontological views." Their principal aim was to convict the "new realists" of 1912 (no. 5260) of a naive view of knowledge, and to replace it with a more sophisticated and complex one, in which the character-complexes or "essences" of perception are distinguished from the sense of their outer existence. There is thus a triple relationship between the mind, the essences of perception, and the existents known, and the validity of any cognitive experience "must be tested by other means than the intuition of the moment." This symposium, together with its predecessor, made epistemological debate the major interest of American philosophy for more than a decade.

5256. Frothingham, Octavius Brooks. Transcendentalism in New England; a history. New York, Putnam, 1876. 395 p. I0-28608 B905.F7

The author, some of whose work is discussed in the annotation to his life of George Ripley (no. 2279), was a Unitarian clergyman whose views eventually became too advanced even for the elastic limits of that fold. He says that transcendentalism actually did not exist outside New England; but he treats of its antecedents in Europe, as well as describing its American beginnings, its practical 
applications (notably Brook Farm), and its outstanding personalities. Sympathetic, uncritical, and written in the formal style of the period, his account is in part based on personal knowledge and remains valuable as a sourcebook. Perry Miller's The Transcendentalists (no. 2346) is an anthology of writings by those who took part in this philosophical movement.

5257. Hook, Sidney, ed. American philosophers at work; the philosophic scene in the United States. New York, Criterion Books, 1956. 512 p. 56-1 1398 B934.H6

This anthology attempts "to meet the natural and almost universal curiosity about what American philosophers are doing, about what lies at the center of their contemporary intellectual concern." The editor states that all important philosophical movements are represented, but that practical considerations have prevented the inclusion of all important individual thinkers. Most of the contributions are reprints of magazine articles; a smaller number are extracts from books published or to be published; a very few are papers printed for the first time. Nine philosophers contribute to part I on "Logic and Scientific Method," ten to part 2 on "Metaphysics and Theory of Knowledge," and ten to part 3 on "Ethics and Social Philosophy." At the end is a section of "Biographical Notes" on contributors (p. 499-507). The editor remarks that American philosophers are independent thinkers, that most of them adhere to no school, and that they rarely agree.

5258. Kallen, Horace M., and Sidney Hook, eds. American philosophy today and tomorrow. New York, Furman, 1935. 518 p.

\section{$3^{6-722} \mathrm{~B} 934 \cdot \mathrm{K}_{3}$}

Five years after the appearance of Contemporary American Philosophy (no. 5250), a different pair of editors produced a similar volume comprising the views of "twenty-five representative American thinkers." These are described as the younger generation (their birth dates range from 1873 to 1907 , as against 1859 to 1885 for the earlier group). Space limitations forced the editors to include only those who had not previously published their philosophic self-portraits. The atmosphere in this volume is less formal than in the earlier work; nearly all are trained philosophers, but not all have become teachers of philosophy, which makes for greater diversity of theme.

5259. Muelder, Walter G., and Laurence Sears, eds. The development of American philosophy; a book of readings. Boston, Houghton Miflin, I940. $533 \mathrm{p}$. 40-33273 B851.M8 Contents.-pt. 1. Early philosophical theology and idealism.-pt. 2. The period of the American enlightenment.-pt. 3. Transcendentalism.-pt. 4 . Evolution.-pt. 5. Idealism from William T. Harris to James E. Creighton.-pt. 6. Pragmatism and critical empiricism.-pt. 7. Realism and naturalism.pt. 8. Recent perspectives in American idealism.

This anthology puts less stress on the early period than does the one of Anderson and Fisch (no. 525I). It nevertheless covers more ground, for it continues well beyond James to such contemporary philoso phers as Santayana, Edgar S. Brightman, and Sidney Hook. In addition to providing introductions and bibliographies for each part, the editors, with the object of helping the student to develop a sense of philosophical criticism, have wherever feasible included "a critical discussion of a school of thought by an outstanding representative of another point of view"; thus Arthur O. Lovejoy is brought in to reply to the pragmatists. and Irving Babbitt to reply to the naturalists.

5260. The New Realism: cooperative studies in philosophy. New York, Macmillan, I9I2. $491 \mathrm{p}$. $\quad$ 12-18627 BDi6r. $\mathrm{N}_{4}$

ConTENTs.-Introduction.-The emancipation of metaphysics from epistemology, by W. T. Marvin.A realistic theory of independence, by R. B. Perry.A defense of analysis, by E. G. Spaulding.-A realistic theory of truth and error, by W. P. Montague.-The place of illusory experience in a realistic world, by E. B. Holt.-Some realistic implications of biology, by W. B. Pitkin.

Both manifesto and symposium, this was the first in a series of similar volumes which gave to contemporaries a sense of significant development in American philosophy, and certainly indicated that the long-unchallenged reign of neo-Hegelianism in the universities was at an end. "The Program and First Platform of Six Realists," reprinted here as an appendix, appeared in the Journal of Philosophy, Psychology, and Scientific Method for July 21, 1910; the same six, teachers of philosophy at Columbia, Harvard, Princeton, and Rutgers, elaborated their views in the present volume. The "Introduction" (p. I-42) is a joint statement upon which all agreed; the six essays which follow are more personal developments of the same general outlook. All six sought an escape from subjectivism, with which they identified the hitherto reigning philosophy, idealism, based upon "the fallacy of argument from the ego-centric predicament." All sought a return "to that primordial common sense which believes in a world that exists independently of the knowing of it," and that can be directly presented in consciousness. This did not lead to monism, for the things of thought were as real as the things of sense, logical entities as real as physical ones. 
5261. Schneider, Herbert W. A history of American philosophy. New York, Columbia University Press, 1946. xiv, 646 p. (Columbia studies in American culture, no. 18) A47-737 B851.S4

This survey which relates philosophical ideas to the general development of American society, ranges from the work of John Cotton and Thomas Hooker to that of John Dewey. It includes not only professional philosophers, but also philosophical belletrists, historians, scientists, and economists, and therefore approximates a general intellectual history. Numerous quotations convey the individuality of the several writers. The "Guides to the Literature" at the end of each part point the way for further exploration of the periods covered, and are supplemented by occasional lists of the most important works of an author or the major publications of a period. So far as contemporaries are concerned, Professor Schneider does not claim comprehensiveness, asserting that "a decidedly new chapter in American philosophy is being written, the outlines of which we still cannot see." A companion volume is American Philosophic Addresses, 1700-1900 (New York, Columbia University Press, I946. 762 p. Columbia studies in American culture, I7), edited by Joseph L. Blau. It aims to provide the student with specimen works of literary value which elaborate the ideas dealt with in Schneider's History. There are presented 27 pieces, all but one of which were prepared for oral delivery, as sermons, orations, lectures, etc. Each is provided with a short introduction which places it in its historical context and supplies a chronology of the writer's life. All these addresses, the editor says, "have one distinguishing characteristic; all are speculative in nature." Each is "a popularized statement of a philosophic outlook as well as a call to a particular action or belief."

5262. Townsend, Harvey Gates. Philosophical ideas in the United States. New York, American Book Co., 1934. 293 p.

"Selected bibliography": p. $\begin{aligned} & 34-18313 \\ & 267-284\end{aligned}$

$$
34-18313 \quad \mathrm{~B} 858 . \mathrm{T} 6
$$

A comparatively brief, simple, and undogmatic introduction to the history of American philosophy. To some degree it is dependent upon the more elaborate research of I. Woodbridge Riley's American Philosophy, the Early Schools (New York, Dodd, Mead, I907. 595 p.), and does not attempt to add to the latter's account of unpublished materials through the early national period. Professor Townsend aims at a genetic method of presentation, and divides our philosophical history into four welldefined periods: one of almost exclusively British influence, until the Revolution; a brief period of
French influence; one dominated by German thought and romantic temper, beginning about 1820 and lasting until after the Civil War; and, finally, one of increasing independence and of conscious, professional philosophy. However, he finds that the dominant note of American philosophy has been idealism, in the sense of the ancient doctrine "that the invisible kingdoms furnish the foundation for the visible." A final chapter on "evolutionary naturalism" discusses the thought of James Mark Baldwin, John Dewey, and George Santayana.

5263. Wells, Ronald Vale. Three Christian transcendentalists; James Marsh, Caleb Sprague Henry, Frederic Henry Hedge. New York, Columbia University Press, 1943. 230 p. (Columbia studies in American culture, no. I2) Bibliography: p. [217]-224. 43-13153 B905. W4

This work, which originated in a Columbia University dissertation, traces the careers of three lesser figures who were drawn into the transcendentalist movement from an orthodox theological background. Marsh (1794-1842), a Congregational minister, was president and later professor of philosophy for many years at the University of Vermont. Henry (1804-1884), of the same communion, became an Episcopalian and served as rector, editor of The Churchman, and professor of mental and moral philosophy at New York University. Hedge (1805-1890), a Unitarian, was long professor of ecclesiastical history at Harvard. Each in his separate way made a significant contribution to transcendentalist doctrine.

5264. Wiener, Philip P. Evolution and the founders of pragmatism. Cambridge, Harvard University Press, 1949. $288 \mathrm{p}$. 49-10659 B8I8.W63

Through the informal discussions of a group of philosophical liberals who met at Harvard College in the 1860's and early 1870's, there arose the movement known as pragmatism, one of the most important in American thought. The issues discussed in these meetings as a result of the publication of Darwin's Origin of the Species, and the points of view of the members as given in their writings, both published and unpublished, are treated comprehensively in this book, which is addressed to the specialist. Professor Wiener expounds in detail the development of the pragmatic ideas of Chauncey Wright, Charles S. Peirce, and William James; in addition he presents valuable accounts of minor members of the Harvard group: John Fiske, Nicholas St. John Green, and Oliver Wendell Holmes, Jr. 


\section{B. Representative Philosophers}

5265. AMOS BRONSON ALCOTT, I799-I 888

Alcott, a New Englander who referred to his own version of the transcendentalist philosophy as "personalism," made a greater impression through the spoken word than through his many published writings. His main work, the journals in 50 manuscript volumes, has never been published in its entirety, but only in extracts (no. 187). His writings are largely vitiated by an artificial style which, his contemporaries testify, was not carried over into his natural and forceful conversation. Consequently it was as a lecturer, an educator, and a friend of most of the prominent transcendental. ists that he exerted his greatest influence. His friendship with Emerson was particularly close and is studied in Hubert H. Hoeltje's Sheltering Tree; a Story of the Friendship of Ralph Waldo Emerson and Amos Bronson Alcott (Durham, N. C., Duke University Press, 1943. 209 p.). Alcott as a teacher is studied in McCuskey's Bronson Alcott, Teacher (no. 5220). Alcott, who was quite unworldly, undertook a number of ventures which ended in failure. The most conspicuous was his attempt to found a model community, Fruitlands, where a few persons might lead an ideal life as a "consociate family." He and his associate, the Englishman Charles Lane, who put up the money, adopted such impractical ideals and devoted so much more time and energy to philosophical discussion than to agriculture, that their "new Eden" was doomed almost from the start. An account of the experiment compiled from contemporary sources is Clara E. Sears' Bronson Alcott's Fruitlands (Boston, Houghton Mifflin, 1915. I85 p.).

5266. Shepard, Odell. Pedlar's progress; the life of Bronson Alcott. Boston, Little, Brown, 1937. xvi, $546 \mathrm{p}$.

"Bibliographical note": p. 523-528.

37-10152 B908.A54 5 r937a

An earlier and more detailed life of Alcott, but without some of the information at Shepard's disposal, is A. Bronson Alcott. His Life and Philosophy (Boston, Roberts, I893. 2 v.), by F. B. Sanborn and William T. Harris (q.v.).

5267. MORRIS RAPHAEL COHEN, I880-I947

Cohen was born in Minsk, Russia, and brought to New York's East Side at the age of 12; the privations of his youth were doubtless responsible for the chronic ill-health which hampered his career and especially the major works he planned but was unable to complete. His first philosophical inspiration came from Thomas Davidson, a Scottish neoHegelian of wide interests but unsystematic temper; after a few years of teaching in the public schools he was able to attend the Harvard Graduate School in the great days of the Philosophy Department, and obtained his $\mathrm{Ph} . \mathrm{D}$. in I906. After six painfully frustrating years he at last obtained an appointment in philosophy from the College of the City of New York (I9I2), and taught there and at the University of Chicago (from 1938) until the failure of his health in 1942 . He did not achieve a complete formulation of his philosophical ideas, of which he gave a preliminary expression in Reason and Nature below. Most of his writings offer partial aspects or applications of his philosophy; a number of his books were posthumously assembled, through the editorship of his son, Felix S. Cohen, out of miscellaneous publications and incomplete manuscripts. Cohen combined a strong sense of traditional values with a conviction of the importance of the scientific outlook and the need for a reformed logic. His most finished work is concerned with the philosophy of scientific method: An Introduction to Logic and Scientific Method (New York, Harcourt, Brace, 1934. 467 p.), which he wrote with Ernest Nagel; $A$ Preface to Logic (New York, Holt, 1944. 209 p.); and the posthumously collected Studies in Philosophy and Science (New York, Holt, 1949. $27^{8}$ p.). Cohen called himself "a stray dog unchained to any metaphysical kennel"; his thought rejects the transcendental, but gives a greater role to the active human reason than does other recent naturalism; he rejects ethical absolutism, but finds the formulation of ethical principles a necessity in the ordering of human conduct. Cohen's influence upon his pupils and associates was enormous; he was, without much doubt, a philosopher whose greatness is inadequately expressed in the corpus of his writings. His doctrines and some of the problems which he raised are discussed in Freedom and Reason: Studies in Philosophy and Jewish Culture, in Memory of Morris Raphael Cohen (Glencoe, Ill., Free Press, 1951. 468 p.), edited by Salo W. Baron, Ernest Nagel, and Koppel S. Pinson.

5268. Reason and nature; an essay on the meaning of scientific method. [2d ed.] Glencoe, Ill., Free Press, 1953. xxiv, $470 \mathrm{p}$.

53-133 I I B945. $\mathrm{C}_{53} \mathrm{R}_{4} \mathrm{I} 953$

Originally published in $\mathrm{I} 93 \mathrm{I}$, this was the author's first book, and remained the most considerable state- 
ment of his general philosophical outlook. He described it as an "effort to formulate a more or less integrated view of life and existence without aban. doning the painfully critical methods and standards of science." He was fully aware that it was an incomplete work, but published it as a stopgap to meet what he considered a grave need for a new philosophical approach. As soon as it appeared he began to make notes for the second edition, which incorporates his considered revisions made over a period of 16 years.

5269. Law and the social order; essays in legal philosophy. New York, Harcourt, Brace, 1933. $403 \mathrm{p}$. Law 33-13199

Cohen was long concerned with legal philosophy and its relationship to social problems. Reason and Law; Studies in Juristic Philosophy (Glencoe, Ill., Free Press, 1950. 2 I I p.) reflects this concern. He made an original contribution to the philosophy of history in The Meaning of Human History (La Salle, Ill., Open Court Pub. Co., 1947. 304 p.), one of the most distinguished American works in this field.

5270. A Dreamer's journey; ... autobiography. Boston, Beacon Press, 1949. $318 \mathrm{p}$. 49-788I B945.C54 $\mathrm{A}_{3} 1949$

"Bibliography of the published writings of Morris R. Cohen": p. 291-303.

Cohen did not complete this autobiography, and some of its earlier chapters which appear continuous were but portions or sketches of what he intended to write. Books 7 and 8 are a collection of personal essays and fragments assembled by the author's son. Two of these essays are concerned with Judaism; a larger collection of Cohen's writings on this subject was made in 1950: Reflections of a Wondering Jew (Boston, Beacon Press, 1950. r68 p.). The extraordinary range of Cohen's mind is exhibited in a collection of his articles from periodicals which he published shortly before his death: The Faith of a Liberal (New York, Holt, 1946. 497 p.); the I2 sections into which its $5 \mathrm{I}$ items are grouped include "Politico-Economic Issues," "Literature and Literary Criticism," and "Education"; and there are essays on "Why I am not a Communist" and "Baseball as a National Religion."

\section{JOHN DEWEY, 1859-1952}

Since the death of William James, Dewey has been the most influential of American philosophers. His emphasis on educational theory and the practical applications of philosophy has resulted in large-scale changes in American education; these are discussed in Chapter XXI on Education (q.v.).
His other wide-ranging interests have also given him influence, at minimum as an opponent to be answered, in most philosophic fields actively cultivated in the first half of the 2oth century. Dewey started as a neo-Hegelian interested in resclving the conflict between theology and science, especially with respect to the Darwinian theory of evolution. During the 1890 's he developed into a pragmatist following the lead of William James, and then went beyond James to head his own school of philosophy. His philosophy is grounded on his belief in the experimental approach of science and his postulate that experience is the fundamental source of knowledge and conduct. This has caused him to be called an experimentalist; he has referred to his own philosophy as instrumentalism. It should be noted, however, that despite the "materialistic," "pragmatic," "scientific," and "experiential" aspects of Dewey's philosophy, it has at its core a considerable amount of the idealism which has been inherent in most American philosophy, as seen in its main line of development through such thinkers as Jefferson, Emerson, and James. Nature is regarded as malleable by mind. In fact, it is this "idealism" that has led a number of Marxists to write strong attacks on Dewey and Deweyism. These constitute but a small part of the many works which have been written about Dewey, as a leading and controversial philosopher; such writings are represented here only in part. Dewey himself during a long lifetime was unusually prolific, so that it has been possible to cite here only a part of his writings, selected as representative of his varied interests.

5272. Psychology. New York, Harper, 1887.
427 p. This, Dewey's first published book, was intended as a textbook, and is in many ways derivative. It shows his interests and position in his early years, and it has the additional merit of being one of the early attempts to establish psychology as an independent science separate from philosophy. A third, slightly revised edition appeared in 1891 .

5273. Ethics. Rev. ed. By John Dewey and James H. Tufts. New York, Holt, 1938. 528 p. 38-3161 I BJ 1025.D $53 \quad 1938$

This widely used textbook expounds Dewey's moral position; in large part it deals with the ethical problems of modern economic societies. The volume was first published in briefer form in 1908 . Tufts was Dewey's colleague during his ro years at the University of Chicago (1894-1904) and was sole author of a number of works on ethics, as well as translator of Wilhelm Windelband's standard His. tory of Philosophy. 
5274. The Influence of Darwin on philosophy, and other essays in contemporary thought. New York, Holt, rgro. 309 p.

$$
\text { ro-10721 B945.D4314 rgro }
$$

Essays of interest as showing separately some of the pragmatic and idealistic elements which Dewey was later to fuse more fully into a philosophic system. "The influence of Darwin upon philosophy resides in his having conquered the phenomena of life for the principle of transition, and thereby freed the new logic for application to mind and morals and life."

\section{Essays in experimental logic. Chicago,} University of Chicago Press, r9r6. 444 p. 16-14107 $\mathrm{BC}_{50 . \mathrm{D}_{42}}$

Dewey made his first generalized philosophical statement about knowledge in Studies in Logical Theory (Chicago, University of Chicago Press, 1903. 388 p.). A more fully developed statement appeared in Essays in Experimental Logic, which incorporated and revised part of the material in the earlier work, and added much that was new. This is then, in a sense, his first full statement of his theory of the relation of knowledge to experience and experiment, and thus of his basic philosophy of instrumentalism. The ideas were briefly presented with an application to education in How We Think (Boston, Heath, rgro. 224 p.). A further elaboration of his general theory of logic may be found in his Logic, the Theory of Inquiry (no. $528_{3}$ ).

5276. Reconstruction in philosophy. Enl. ed. with a new introd. by the author. Boston, Beacon Press, 1948. xlvii, 224 p.

$$
\text { 49-1 } 234 \text { B945. } \mathrm{D}_{43} \mathrm{R}_{4} \quad \mathrm{I}_{948}
$$

This book originated in lectures delivered at the Imperial University of Japan in I9rg and was first published the following year. Dewey sought "to exhibit the general contrasts between older and newer types of philosophic problems" in the changed conceptions of nature provided by science, of experience and reason, and of the ideal and the real, pointing to reconstruction in logic, morals, and social philosophy. In the introduction to the 1948 edition Dewey expressed his "firm belief that the events of the intervening years have created a situation in which the need for reconstruction is vastly more urgent than when the book was composed," and chided recent philosophical tendencies for retreating from the actual.

5277. Human nature and conduct; an introduction to social psychology. With a new introd. New York, Modern Library, I930. $33^{6}$ p.
(The Modern Library of the world's best books) 30- $19598 \quad \mathrm{BF}_{57 .} \mathrm{D}_{4} \quad \mathrm{r} 93^{\circ}$

In this work, which first appeared in 1922, Dewey treats from the point of view of "the structure and workings of human nature, of psychology when that term is used also in its wider sense," what used to be called morals, including in that term "all the subjects of distinctively humane import, all of the social disciplines as far as they are intimately connected with the life of man and as they bear upon the interests of humanity." This is generally regarded as one of Dewey's more important books, and some consider it his first major philosophical work.

5278. Experience and nature. Chicago, Open Court Pub. Co., 1925. 443 p. (Lectures upon the Paul Carus Foundation. Ist ser.) 25-4301 B945.D $43 \mathrm{E} 8$

Dewey's first large-scale statement of his conclusions in the crucial borderland where epistemology and metaphysics meet. Since thinking originates in a problematic situation, the world in which thought operates must have the characters of "genuine hazard, contingency, irregularity, and indeterminateness." The human enterprise is summed up in "the striving to make stability of meaning prevail over the instability of events." A doctoral thesis which studies this aspect of Dewey's philosophy is John J. Battle's The Metaphysical Presuppositions of the Philosophy of John Dewey (Fribourg, 1951. 128 p.). A somewhat similar analysis of the Deweyan premises (tacit and explicit) is William Taft Feldman's The Philosophy of John Dewey, a Critical Analysis (Baltimore, Johns Hopkins Press, 1934. 127 p.).

5279. The Public and its problems, an essay in political inquiry. Chicago, Gateway Books, 1946. 224 p. $46-7355$ JC25r.D47 1946

In this book, originally published in 1927 , Dewey applies his basic idea of problem-solving inquiry to the realm of politics. The public is distinguished from the individual, the state, and the government. Mastery of the arts of inquiry and of communication will permit an organized, articulate public to come into being; the machine age, by perfecting its machinery, will become a means instead of the master of life; and democracy will come into its own.

5280. The Quest for certainty: a study of the relation of knowledge and action. New York, Minton, Balch, 1929. 3r8 p. (Gifford lectures. I929)

29-23500 BDr6r.D 4

By the quest for certainty Dewey means the history of philosophy before the "scientific revolution," 
and the certainty which it sought to obtain in immutable ideas and absolutes is in the nature of things impossible. By its predispositions toward "the universal, invariant, and eternal," the classical tradition in philosophy opened a gulf between theory and practice. Modern science has closed the gulf in the natural realm, with spectacular results, but it still dominates man's thinking in the social and moral realm. The consequent separation of means and ends is most clearly perceptible in the present state of industrial life, brutalized by the failure to regard it "as the means by which social and cultural values are realized."

5281. Philosophy and civilization. New York, Minton, Balch, 1931. 334 p.

$$
\text { 3 } \mathrm{I}-28 \mathrm{I}_{47} \quad \mathrm{~B} 945 . \mathrm{D}_{43} \mathrm{P}_{5}
$$

A collection of 18 philosophical and psychological essays which takes its name from the initial one, and includes Dewey's account of “The Development of American Pragmatism" (p. 13-35). All its varieties have an essential tenet: "the formation of a faith in intelligence, as the one and indispensable belief necessary to moral and social life."

5282. Art as experience. New York, Minton, Balch, 1934. 355 p. $34^{-27080}$ N66.D 4

A work which, deriving esthetic values from vital ones, forms an integral part of Dewey's philosophy.

5283. Logic, the theory of inquiry. New York, Holt, $1938 . \quad 546$ p. $\quad 38-27918 \quad$ BC $_{50 . D_{43}}$

This presents a further development of Dewey's theory of logic, which he had earlier presented in Essays in Experimental Logic (q.v.). It seeks to ascertain the common pattern or structure of all inquiry, whether in common sense or in science, and to trace the genesis of the logical forms which accrue when subject matter is subjected to controlled inquiry. Of interest in connection with this work is Horace S. Thayer's The Logic of Pragmatism; an Examination of John Dewey's Logic (New York, Humanities Press, 1952. 22 I p.). An early historical treatment of Dewey's logical theories may be found in Delton T. Howard's John Dewey's Logical Theory (New York, Longmans, Green, 1918. 135 p. Cornell studies in philosophy, no. II).

5284. Freedom and culture. New York, Putnam,

The abandonment of the ideal of freedom in the totalitarian states of Europe induced the octogenarian philosopher to restate the interrelations of human nature, culture, and democracy. Democracy, he found, was in real peril, but less from without than from within our own institutions and attitudes. It could be maintained and perfected "only by ex- tending the application of democratic methods, methods of consultation, persuasion, negotiation, communication, co-operative intelligence, in the task of making our own politics, industry, education, our culture generally, a servant and an evolving manifestation of democratic ideas." Since for Dewey freedom, democracy, and liberalism were all practically identical, his somewhat earlier Page. Barbour lectures at the University of Virginia, Lib. eralism and Social Action (New York, Putnam, 1935. 93 p.), present a similar argument in briefer compass.

5285. Problems of men. New York, Philosophical Library, 1946. 424 p.

$$
\text { 46-25157 B945. } \mathrm{D}_{43} \mathrm{P}_{7}
$$

A collection, by the author, of his late essays, originally published as separate articles in various periodicals.

5286. Knowing and the known. By John Dewey and Arthur F. Bentley. Boston, Beacon

Press, 1949. 334 p. 49-48030 BDr6r.D38

In this book Dewey (aet. 90) and Bentley (aet. 79) undertake an investigation comparable to the work of the linguistic and semantic schools of philosophic approach that developed in recent decades. This particular work is a "terminological inquiry" resulting from "a startling diagnosis of linguistic disease not only in the general epistemological field, where everyone would anticipate it, but also in the specialized logical field, which ought to be reasonably immune." The authors accordingly proceed to seek out means for the eventual relative immunization of logic to such linguistic disease.

5287. Intelligence in the modern world; John Dewey's philosophy. Edited, and with an introd. by Joseph Ratner. New York, Modern Library, 1939. xv, 1077 p. (The Modern Library of the world's best books)

39-27121 B945.D4IRI7

This big volume compiled by one of Dewey's most devoted disciples contains 85 substantial selections, drawn from 19 of Dewey's books as well as from a number of periodical articles, and arranged under $2 \mathrm{I}$ headings. It is thus a comprehensive survey of his thought. The "Introduction to John Dewey's Philosophy" (p. 3-24I) and the "Editor's Note," on p. 525-566, are themselves the equivalent of a moderate-sized book.

5288. John Dewey: his contribution to the American tradition. [Edited by] Irwin Edman. Indianapolis, Bobbs-Merrill, 1955. 322 p. (Makers of the American tradition series)

$54-9487 \quad \mathrm{~B}_{945} \cdot \mathrm{D}_{4} \mathrm{IE}_{3}$ 
A volume of selections from Dewey's writings, seldom less than a full chapter in length, grouped under seven headings and preceded by a general introduction from the pen of the editor, a professor of philosophy at Columbia who died shortly after completing it. In accord with the principles of the series, the selections are made to illustrate "the contributions that John Dewey has made to the remaking of American ideas and institutions." This involves outlining his general philosophical position, but excludes much that is technical.

5289. Essays in honor of John Dewey, on the occasion of his seventieth birthday, October 20, 1929. New York, Holt, 1929. 425 p.

$$
\text { 29-24486 B29.E8 }
$$

Contents.-Personality: how to develop it in the family, the school, and society, by Felix Adler.Religious values and philosophical criticism, by $\mathrm{E}$. S. Ames.-Evolution and time, by A. G. A. Balz.Art, action, and affective states, by H. C. Brown.Two basic issues in the problem of meaning and of truth, by Edwin Burtt.-Kant, Aquinas, and the problem of reality, by Cornelius Clifford.-A pragmatic approach to being, by W. F. Cooley.-Consolation and control. A note on the interpretation of philosophy, by J. J. Coss.-A philosophy of experience as a philosophy of art, by Irwin Edman.Dimensions of universality in religion, by $\mathrm{H}$. L. Friess.-A criticism of two of Kant's criteria of the aesthetic, by Kate Gordon.-A pragmatic critique of the historico-genetic method, by Sidney Hook.Certain conflicting tendencies within the presentday study of education, by W. H. Kilpatrick.Causality, by S. P. Lamprecht.-Externalism in American life, by M. T. McClure.-The empiricist and experimentalist temper in the middle ages. A prolegomenon to the study of mediaeval science, by Richard McKeon.- The nature of the past, by $\mathrm{G}$. H. Mead.-A functional view of morals, by S. F. MacLennan.-A materialistic theory of emergent evolution, by W. P. Montague.-What is meant by social activity? By E. C. Moore.-The cult of chronology, by Helen $\mathrm{H}$. Parkhurst.-Dualism in metaphysics and practical philosophy, by J. H. Randall, Jr.-Prolegomena to a political ethics, by A. K. Rogers.-Radical empiricism and religion, by H. W. Schneider.-The role of the philosopher, by T. V. Smith.-A methodology of thought, by John Storck.-Individualism and American life, by J. $\mathrm{H}$. Tufts.-Looking to philosophy, by Matilde C. Tufts.-Some implications of Locke's procedure, by F. J. E. Woodbridge.

5290. The Philosopher of the common man; essays in honor of John Dewey to celebrate his eightieth birthday. New York, Putnam, I940. 228 p. $\quad 40-830$ or B945.D44 45

Contents.-Ratner, Sidney. Foreword.-Kallen, H. M. Freedom and education.-Murphy, A. E. Dewey's theory of the nature and function of philosophy.-Nagel, Ernest. Dewey's reconstruction of logical theory.-Barnes, A. C. Method in aesthetics.-Randall, J. H., Jr. The religion of shared experience.-Hamilton, Walton. A Deweyesque mosaic.-Patterson, E. W. Pragmatism as a philosophy of law.-Hu, Shih. The political philosophy of instrumentalism.-Dewey, John. Creative democracy, the task before us.

529I. Hook, Sidney, ed. John Dewey, philosopher of science and freedom; a symposium. New York, Dial Press, r950. 383 p.

$$
\text { 50-7272 B945. } \mathrm{D}_{44} \mathrm{H}_{473}
$$

Contents.-John Dewey and the spirit of prag. matism, by H. M. Kallen.-Dewey and art, by I Edman.-Instrumentalism and the history of philos. ophy, by G. Boas.-Culture and personality, by L. K. Frank.-Social inquiry and social doctrine, by H. L. Friess.-Dewey's theories of legal reasoning and valuation, by E. W. Patterson.-Dewey's contribution to historical theory, by S. Ratner.-John Dewey and education, by J. L. Childs.-Dewey's revision of Jefferson, by M. R. Konvitz.-Laity and prelacy in American democracy, by H. W. Schneider.-Organized labor and the Dewey philosophy, by M. Starr.-The desirable and emotive in Dewey's ethics, by S. Hook.-John Dewey's theory of inquiry, by F. Kaufmann.-Dewey's theory of natural science, by E. Nagel.-Concerning a certain Deweyan conception of metaphysics, by A. Hofstadter.-Dewey's theory of language and meaning, by P. D. Wienpahl.-Language, rules and behavior, by W. Sellars.-The analytic and the synthetic; an untenable dualism, by M. G. White.-John Dewey and Karl Marx, by J. Cork.-Dewey in Mexico, by J. T. Farrell.-A selected bibliography of publications by John Dewey (p. $3^{81-382}$ ).-Some publications about John Dewey (p. $3^{8} 3$ ).

On reaching his 7oth birthday, John Dewey was the unrivaled dean of American philosophers, and was accordingly honored with a Festschrift by his colleagues, pupils, and friends, in which all contributors acknowledged "a common stimulus in the leading ideas of a fertile mind," but presented their own thoughts. Mr. Dewey having reached his 8oth birthday in remarkably good order, a further symposium was produced, the contributors to which aimed to state his key ideas for the general public in unacademic language. On his goth birthday Mr. Dewey was still alive and a national committee to celebrate it was formed, which sponsored the third symposium, with 20 contributors, largely professors 
of philosophy, all concerned with particular aspects of Dewey's thought or influence.

5292. Hook, Sidney. John Dewey, an intellectual portrait. New York, John Day, 1939. 242 p. 39-27986 B945. $\mathrm{D}_{44} \mathrm{H}_{47}$

A nontechnical statement of Dewey's leading ideas in a variety of fields, together with a statement of important criticisms and a reply to them, by one of Dewey's best-known followers.

5293. Leander, Folke. The philosophy of John Dewey; a critical study. Göteborg, Elanders Boktryckeri Aktiebolag, I939. I54 p. (Göteborgs kungl. vetenskaps- och vitterhets- Samhälles handlingar. 5. följden, ser. A, bd. 7, no. 2)

$\mathrm{A}_{4} \mathrm{I}-4 \mathrm{I} 23 \mathrm{AS} 284 . \mathrm{G}_{7}$, föl. 5, ser. A, bd. 7, no. 2

"The aim of this book is a critical inquiry into the basic postulates of Dewey's philosophy."-Introduction.

5294. Schilpp, Paul A., ed. The philosophy of John Dewey. [2d ed.] New York, Tudor Pub. Co., I951. 718 p. (The Library of living

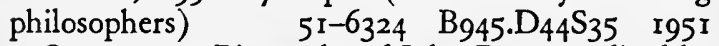

Contents.-Biography of John Dewey, edited by Jane M. Dewey.-Descriptive and critical essays on the philosophy of John Dewey.-The philosopher replies. John Dewey: Experience, knowledge and value: a rejoinder.-Bibliography of the writings of John Dewey (p. 6I I-686).

This volume is intended to supplement Dewey's own writings by providing something of a resolution of conflicting interpretations. It consists of "a series of expository and critical articles written by the leading exponents and opponents of the philosopher's thought," followed by the philosopher's reply. The book first appeared in 1939; the principal change in the second edition is the bringing up to date of the bibliography.

5295. White, Morton G. The origin of Dewey's instrumentalism. New York, Columbia University Press, 1943. I6I p. (Columbia studies in philosophy, no. 4)

$$
\text { 43-1850 B945.D44W } 45 \quad \text { r943 }
$$

A documented study of Dewey's progressive "conversion" from idealism to instrumentalism.

5296. Nathanson, Jerome. John Dewey; the reconstruction of the democratic life. New

York, Scribner, 1951. 127 p. (Twentieth century library) $5 \mathrm{I}-6859$ B $945 . \mathrm{D}_{44} \mathrm{~N}_{3}$

A concise presentation of Dewey's ideas in the fields of philosophy, education, and psychology, together with an estimate of his influence.
5297. JONATHAN EDWARDS, I703-1758

In Puritan New England philosophy was conceived of as the basis for and rationalization of theology. Edwards was the leading exponent of the Congregationalist Calvinism of his day. A welleducated man, he was aware of philosophical movements in Europe, and could draw upon them in constructing his notable defenses of orthodoxy, such as The Great Christian Doctrine of Original Sin Defended (Boston, S. Kneeland, $175^{8}$. xviii, $3^{86}$ p.) and his famous Enquiry into the freedom of the will (no. 26). Edwards was also a master of the new expository prose, and thus one of the major figures in colonial literature; his main writings are listed and discussed in Chapter I on Literature (nos. 2I3r).

5298. The Philosophy of Jonathan Edwards from his private notebooks. Edited by Harvey G. Townsend. Eugene, University of Oregon, I955. xxii, 270 p. (University of Oregon monographs. Studies in philosophy, no. 2)

55-63038 B870.A5 I955

Contents.-Of being.-The mind.-Miscellanies.

5299. Miller, Perry. Jonathan Edwards. [New York] Sloane Associates, 1949. xv, $34^{8} \mathrm{p}$. (The American men of letters series)

$$
\text { 49-50164 BX 7260. } \mathrm{E}_{3} \mathrm{M}_{5} 1949
$$

"A note on the sources": p. 33I-333.

The life of Edwards was eventful only in its intellectual development, and Professor Miller is concerned here with tracing his career as a thinker. More details of his life as a clergyman and paterfamilias are given in Ola Elizabeth Winslow's Jonathan Edwards, 1703-1758 (New York, Macmillan, 1940. 406 p.). Another study of Edwards' philosophical position is Arthur B. Crabtree's Jonathan Edwards' View of Man; a Study in Eighteenth Century Calvinism (Wallington, Eng., Religious Education Press, 1948. 64 p.).

\section{RALPH WALDO EMERSON, 1803-1882}

The leading figure in the transcendental movement, Emerson was considered by Royce to be one of the three outstanding American philosophers. He was not so much a systematic thinker as a poetic philosopher more inclined to trust his intuition than his reason. He was nevertheless a scholar familiar with many of the world's philosophies, and these he in large measure assimilated into his work, which had as its base the Puritan tradition that had been developing for several centuries. Because Emerson's philosophy was expressed in essays, lectures, and poetry of unusual merit, his works appear in 
Chapter I on Literature (nos. 280-306), where he is discussed in greater detail.

530r. Gray, Henry David. Emerson; a statement of New England transcendentalism as expressed in the philosophy of its chief exponent. Stanford University, Calif., The University, 1917. I Io p. (Leland Stanford Junior University publications. University series [29]) 17-30128 $\mathrm{PSi}_{42} \cdot \mathrm{P}_{4} \mathrm{G}_{72}$

Published also as thesis (Ph. D.) Columbia University, 1905 .

Bibliography: p. [105]-107.

\section{JOHN FISKE, 1842-190I}

Fiske's importance is that of a lucid popularizer who introduces a nation to new ways of thought. Influenced principally by the philosophy of Herbert Spencer, Fiske early endorsed Darwinian evolutionism. Much of his popularity resulted from his "reconciling" the new scientific doctrines with the theological orthodoxies which he continued to accept. Throughout his mature life he was important not only for his widely read books, but also for the innumerable lectures he delivered. His first important book was Myths and MythMakers (Boston, Osgood, 1873. 25 I p.), which revealed one of his wide-ranging interests. He then started building up his lectures into books; his published articles had already established for him a considerable reputation. In the late 1870 's he began to devote most of his attention to history, which remained his main field of activity to the time of his death in rgor. In history too he was not an original investigator, but a re-stater and popularizer from other historians of his day. In both fields he always displayed rare vigor and lucidity of style and a real probity in his presentation of the find ings of others. These qualities made him one of the outstanding popular educators and intellectual leaders of the last quarter of the Igth century. After his death his work was collected in a set, The Writings of John Fiske (Cambridge, Mass., Riverside Press, I 902. 24 v.). A recent interpretation of the nature and evolution of Fiske's thought is H. Burnell Pannill's The Religious Faith of John Fiske (Durham, N. C., Duke University Press, 1957. 263 p.), which views his work as a restatement of the "core of the Christian message which the new science of his day had developed."

5303. Outlines of cosmic philosophy; based on the doctrine of evolution, with criticisms on the positive philosophy. With an introd. by Josiah Royce. Boston, Houghton Mifflin, 1903. 4 v.

$$
\text { 4-21706 } \mathrm{B}_{945} \cdot \mathrm{F}_{43} \mathrm{O}_{76}
$$

First issued in 1874 , this is Fiske's principal contribution to philosophy, in which he presents a complete outline of the new cosmology. It long ranked as a major philosophical work and was highly praised by many of the evolutionary movement's scientific and philosophic leaders, who were glad to have Fiske as an ally.

5304. The Letters of John Fiske, cdited by his daughter, Ethel F. Fisk. New York, Macmillan, 1940. 706 p. 41-r 890 EI75.5.F47 Mrs. Fisk's volume presents her father's letters without any index, introduction, or identifying footnotes. Fiske's letters are lively and unstudied; their interest is such as to make a modern biography to supplement them seem desirable. John Spencer Clark's The Life and Letters of John Fiske (Boston, Houghton Mifflin, I9I7. 2 v.) presents its letters mainly in extracts comprising part of a biographical whole. It is a completely admiring work by a friend and engages in frequent discussion of the philosophy and theology of Fiske's day. A brief sketch by a friend is Thomas Sergeant Perry's John Fiske (Boston, Small, Maynard, 1906. I05 p.).

\section{WILLIAM TORREY HARRIS, I835-1909}

Harris began his career as a teacher in St. Louis. He early came under the influence of $A$. Bronson Alcott (q.v.); then, through his reading of Theodore Parker (q.v.), he was led to study Goethe and Kant. In 1858 he met Henry C. Brokmeyer (1828-1906), the Prussian-born philosophic ironmolder. Through him Harris discovered the philosophy of Hegel, which proved a decisive and dominant factor in his life and views. Under Brokmeyer's lead he took a prominent role in the founding and developing of the Hegelian St. Louis school of philosophy. Aspects of this movement and of the roles of Brokmeyer and Harris are discussed in Frances B. Harmon's The Social Philosophy of the St. Louis Hegelians (New York, 1943. I12 p.) and in Henry A. Pochmann's New England Transcendentalism and St. Louis Hegelianism; Phases in the History of American Idealism (Philadelphia, Carl Schurz Memorial Foundation, I948. I44 p.), which also gives considerable attention to the influence of Bronson Alcott. In I 867 Harris founded the Journal of Speculative Philos$o p h y$, the first journal of its kind in America, and a leading organ for new philosophers until its demise in 1893; it also introduced to America much of the work of Hegel and his German followers. Because of poor health, Harris in 1880 resigned his position of superintendent of the St. Louis public 
schools and went to Massachusetts to take part in the founding of the Concord School of Philosophy. In I 889 he became United States Commissioner of Education, a position which he held until 1906. In this period he built up a reputation as a great educator, which has proved more lasting than his contemporary fame as a leading philosopher. While his philosophy of absolute idealism was rather more sophisticated and formally logical than that of the transcendentalists, it was largely derivative, and represented the end of a movement rather than the beginning of one. The fact that the St. Louis school as a whole produced no important literary work has contributed to its posthumous obscurity. Harris himself wrote much, but most of it took the form of articles and pamphlets, and his use of language was ordinarily lifeless.

5306. Hegel's logic. A book on the genesis of the categories of the mind. A critical exposition. Chicago, S. C. Griggs, 1890. xxx, 403 p. II -16863 B2949. $\mathrm{L}^{2} \mathrm{H}_{3}$

This exposition of the logic of Hegel was Harris' most important single book and a focal work for the Hegelian and neo-Hegelian movements in America. It has been said that in it he cleared up some of Hegel's own obscurities.

5307. Psychologic foundations of education; an attempt to show the genesis of the higher faculties of the mind. New York, Appleton, I898. $\mathrm{xxxv}, 400 \mathrm{p}$. (International education series, edited by W. T. Harris, v. 37)

$6+30238$ LBI05 I.H $_{3}$

This is a statement of Harris' philosophy of education in the light of the faculty psychology, which by 1898 was rapidly dying out. Studies of Harris' role in education and his educational philosophy include John S. Roberts' William T. Harris; a Critical Study of His Educational and Related Philosophical Views (Washington, National Education Association of the United States, 1924. 250 p.) and Carl L. Byerly's Contributions of William Torrey Harris to Public School Administration (Chicago, 1946. 219 p.).

5308. Introduction to the study of philosophy. Comprising passages from his writings selected and arr. with commentary and illustration, by Marietta Kies. New York, Appleton, 1889 . 287 p. 10-28629 $\mathrm{BD}_{3}$ I. $\mathrm{H}_{3}$

While Harris himself did not succeed in organizing his philosophical system into one work, Marietta Kies, in a master's thesis at the University of Michigan, did manage to select passages from his articles and books in such a way as to present a synoptic view of his system.
5309. Leidecker, Kurt E. Yankee teacher; the life of William Torrey Harris. New York, Philosophical Library, 1946. xx, 648 p.

$$
\mathrm{A}_{49-9816} \mathrm{LB} 875 . \mathrm{H}_{25} \mathrm{~L}_{4}
$$

This, the only full-scale biography of Harris, leaves much to be desired as to organization and indexing, but contains a wealth of detail gleaned from his diaries and personal correspondence. It treats his philosophical activities as fully as his other pursuits. Other works on Harris and his philosophy include William Torrey Harris, 1835-1935; a Col. lection of Essays, Including Papers and Addresses Presented in Commemoration of Dr. Harris' Cen. tennial at the St. Louis Meeting of the Western Division of the American Philosophical Society (Chicago, Open Court Pub. Co., I936. I36 p.), edited by Edward L. Schaub, and William Torrey Harris; the Commemoration of the One Hundredth Anniversary of His Birth (Washington, U.S. Govt. Print. Off., 1937. 70 p.), edited for the U. S. Office of Education by Walton C. John. A more specialized study is Thomas H. Clare's The Sociological Theories of William Torrey Harris (St. Louis, Mo., 1936. 262 p.).

\section{I0. WILLIAM ERNEST HOCKING, 1873-}

Dr. Hocking was for 30 years a professor of philosophy at Harvard University until his retirement in 1943 , and was widely in demand for special lectures in other institutions at home and abroad. A philosopher in the idealist tradition, he has given relatively little attention to epistemology or metaphysics, but has concentrated upon working out an idealist view of religion, ethics, and human personality, usually in harmony with orthodox Christianity. His general survey of problems and characteristic solutions, Types of Philosophy, rev. ed. (New York, Scribner, I939. xix, 520 p.), was originally published in 1929 and has been widely used as a college textbook for nearly three decades. Professor Hocking has also been extensively concerned with social and political problems, in books such as Man and the State (New Haven, Yale University Press, 1926. 463 p.), The Spirit of World Politics, with Special Studies of the Near East (New York, Macmillan, 1932. 571 p.), Freedom of the Press, a Framework of Principle; A Report from the Commission on Freedom of the Press (Chicago, University of Chicago Press, 1947. 242 p.), Experiment in Education; What We Can Learn from Teaching Germany (Chicago, Regnery, 1954. 303 p.), and The Coming World Civilization (New York, Harper, 1956. 2 ro p.). Dr. Hocking's first 54 years of publication are itemized in a compilation of Richard C. Gilman, The Bibliography of William Ernest Hocking, from 1898 to 1951 (Waterville, 
Me., Colby College, I95I. 63 p.); it lists 207 books (18), pamphlets, addresses, articles, and letters to the press, and includes an index of principal ideas and references.

5311. The Meaning of God in human experience; a philosophic study of religion. New Haven, Yale University Press, 1912. xxxix, 586 p. 12-14946 BL51.H6

Dr. Hocking's first book, which established his reputation as a thinker of consequence. Written in the light of the religious thought of his "honored masters," Royce and James, it is an attempt to reinstate, on the one hand, religion as a valid and essential form of human experience, and, on the other, philosophy as a sound and reasonable interpreter of religion. Neither idealism nor pragmatism has presented an adequate view of religion; it is mysticism, conceived as a practice of union with God, which supplies their deficiencies. "There is no creativity in human life without the Absolute as one party thereto." Living Religions and a World Faith (New York, Macmillan, r940. 29I p.) is "a discussion of the rightful future relationships of the great religions, what attitudes they should hold to one another, and with what justification we might look forward to the prevalence of one of them as a world faith."

5312. Human nature and its remaking. New and rev. ed. New Haven, Yale University Press, 1923. xxvi, 496 p. 24-362 BF7rr.H6 r923

Dr. Hocking's highly original treatise on ethics, which first appeared in 1918 , assumes that original human nature is a group of instincts, which require to be transformed in order to achieve a social order or the supersocial orders of art and religion. The book originated in an effort to challenge a group of tendencies, Nietzscheian, Freudian, and others, which the author lumps together under the name of moral realism. It affirms that only the mind, rather than any instinct or group of instincts, can experience satisfaction, and insists that, over and above the work of society, there must be the work of the individual will, kept in mind of its proper goals by religion, and most adequately by Christianity.

53r3. The Self, its body and freedom. New Haven, Yale University Press, I928. I 78 p. (The Terry lectures) 28-894I BF 1 Ir.H6 In these lectures delivered at Yale on the D. H. Terry Foundation, the author is concerned "with the old question, How is the self set in the world of nature?" and aims to contribute in "an untechnical way toward our sense of proportion in psychology." The self is called "a system of purposive behavior emerging from a persistent hope"; the body is regarded as an organ of the self as is, to some extent, the whole of nature; while freedom is the essence of selfhood, and every act of a living self a free act. A later inquiry in a related field is The Lasting Elements of Individualism (New Haven, Yale University Press, 1937. I87 p.), which the author describes as "a study in the philosophy of history-looking forward! It is hostile not to pragmatism, but to mere pragmatism: it believes that our experimentalism is destined to transform itself into a version of the 'dialectic method' whereby mere groping takes on a rational direction and destination. Out of the flux, certainty."

\section{What man can make of man. New York, Harper, 1942. $62 \mathrm{p}$.}

$$
\text { 42-I7I92 } \mathrm{BD}_{43} \mathrm{r} . \mathrm{H}_{52}
$$

A small book which is an epitome of Dr. Hocking's views on the crucial issues of the age. A democratic world cannot be based on the biological or the psychological human creature, but only on the human soul devoted to goals of equality and fraternity which lie beyond scientific measurements.

5315. Science and the idea of God. Chapel Hill, University of North Carolina Press, I944.

$124 \mathrm{p}$. 44-8718 BL240.H715

In these lectures, originally delivered on the J. C. McNair Foundation at the University of North Carolina in 1940, Dr. Hocking reviews the uneasy truce between science and religion; insists that, while science can tolerate an inactive or nominal God, religion requires an active one; and points out the ill consequences of "getting on without God" in psychology, in sociology, and in cosmology.

5316. The Meaning of immortality in human experience, including Thoughts on death and life, rev. New York, Harper, 1957. 263 p.

57-10950 $\mathrm{BD}_{42 \mathrm{I}} \mathrm{H}_{2}$

A volume built up out of lectures at three universities, which incorporates a revised edition of the author's Thoughts on Death and Life (New York, Harper, 1937. 260 p.). Its temper is far from dogmatic, but it emphasizes the crucial nature of death and survival for human thinking, and employs the relativistic doctrine of a plurality of spaces to suggest that the conditions which make for the concrete freedom of the creative self make equally for the possibility of survival.

\section{GEORGE HOLMES HOWISON, 1834- I9I 7}

Among the exponents of idealism was Howison, whose theory of personalistic pluralism resembled 
the philosophy of Borden P. Bowne (1847-19ro), but was arrived at independently. While he holds a firm, if minor, position in the history of American philosophy, Howison's most notable contribution was his long service as professor of mental and moral philosophy at the University of California. His principal statement of his own philosophy was The Limits of Evolution and Other Essays, $2 \mathrm{~d}$ ed., rev. (New York, Macmillan, 1904. 450 p.).

5318. George Holmes Howison, philosopher and teacher. A selection from his writings, with a biographical sketch, by John Wright Buckham and George Malcolm Stratton. Berkeley, University of California Press, 1934. 4 I8 p.

34-17950 B945. $\mathrm{H}_{71} \mathrm{~B} 8$

"A list of Howison's published writings": p. $3^{81-}$ 387; "A partial list of references to Howison in philosophical publications": p. 389-390.

\section{HENRY JAMES, I811-1882}

James early revolted against traditional religion but retained his intense religious inclinations. After studying and criticizing the philosophy of Swedenborg, he formulated his own philosophical system, which has affiliations both with the Christian tradition and with transcendentalism, but is on the whole an extremely original formulation. God is the assumed starting-point, the Creator and the only reality; Nature is the preliminary and imperfect stage of creation; Society, or "aggregate humanity" redeemed by a pure and altruistic love of man for man, is its redeemed and perfected stage, the incarnation of God. Democracy, completed on a social and moral level instead of merely a political one, is the forerunner of redeemed Society. These views were expressed in such books as Substance and Shadow: or Morality and Religion in Their Relation to Life: an Essay upon the Physics of Creation (Boston, Ticknor \& Fields, 1863. 539 p.), Society the Redeemed Form of Man, and the Earnest of God's Omnipotence in Human Nature: Affirmed in Letters to a Friend (Boston, Houghton, Osgood, 1879. 485 p.), and the autobiographical fragment and the book, "Spiritual Life," in his posthumous Literary Remains (Boston, Osgood, I885. 47 I p.), edited by William James. All are individual in style and organization, and far from easy to read or comprehend, which is sufficient to account for James' very limited influence in his day and since. The elder James has to a large extent been overshadowed by his towering sons, Henry James, Jr., the novelist, and William James, the philosopher. This intellectually prominent family is presented in Francis $\mathrm{O}$. Matthiessen's The James Family: Including Selections from the Writings of Henry James, Senior,
William, Henry, \& Alice James (New York, Knopf, 1947. 706 p.), and in Clinton Hartley Grattan's The Three Jameses; a Family of Minds: Henry James, Sr., William James, Henry James (New York, Longmans, Green, 1932. 376 p.). An independent biography of Henry James, Sr., is Austin Warren's The Elder Henry James (New York, Macmillan, 1934. 269 p.). He is also discussed at length in the autobiographical works of his son Henry James, Jr., under whom they are entered in Chapter I on Literature.

5320. Young, Frederic Harold. The philosophy of Henry James, Sr. New York, Bookman Associates, 195I. xiv, $33^{8} \mathrm{p}$.

5I-5328 B921.J24 66

A study of James' philosophy, which originated as a Columbia University dissertation. Through the use of frequent quotations the author attempts to present all the key passages from James' writings. The bibliography (p. 321-332) is meant to be exhaustive.

\section{WILLIAM JAMES, I842-1910}

William James, son of Henry James, Sr. (vide supra) and brother of the novelist Henry James, Jr. (q. v.), is America's best-known philosopher. Often classed as a pragmatist, he called himself a "radical empiricist" whose method was "pragmatism." He first studied to become a painter, and when he had decided he was not an artist, studied medicine without intending to practice. He began his career as an instructor in physiology at Harvard; when philosophical problems became paramount for him, he transferred to the Department of Philosophy. This crossing of lines was evidenced throughout his work, but especially in his first major publication, Principles of Psychology. In this and subsequent works James revealed himself not only as an eminent thinker, but also as a quite original stylist, whose unexpected phrasing could illuminate the most technical matters and suggest the widest relationships of his subject. While his stylistic merits have retained for his works a wide general audience, it is the basic substance of his work which has earned for him an international audience and the reputation of being one of America's few truly great thinkers. One of James' most important works, The Varieties of Religious Experience (1902) is entered in the next chapter (no. 5431).

5322. The Principles of psychology. Authorized ed., unabridged. [New York] Dover Publications, $1950,{ }^{c} 1918.2$ v. in I.

$$
\text { 50-780I BFI2I.J2 } 1950
$$


This work, which first appeared in 1890 , was one of the major books of the period. While it contains many philosophical observations and implications, it is notable as a work that led to the establishment of psychology as a separate science rather than a subdivision of philosophy. In it James rejected the traditional concept of the mind's independence of the body; both were presented as aspects of a single natural phenomenon. While the book has been superseded in some details, it remains a basic work in the science of psychology as well as a milestone in the history of philosophy.

5323. The Will to believe, and other essays in popular philosophy. London, New York, Longmans, Green, 1937. xvii, 333 p.

$$
\text { 38-30375 B945.J23W5 } 1937
$$

Contents.-The will to believe.-Is life worth living? - The sentiment of rationality.-Reflex action and theism.- The dilemma of determinism.The moral philosopher and the moral life.-Great men and their environment.-The importance of individuals.-On some Hegelisms.-What psychical research has accomplished.

A collection of ro essays, most of which were originally delivered as lectures before philosophy groups in a number of colleges, first published in I897. In them James discusses moral and religious problems in the light of his attitude of radical empiricism. Further papers of the same type will be found in Talks to Teachers on Psychology; and to Students on Some of Life's Ideals (New York, Holt, I899. 301 p.).

5324. Pragmatism, a new name for some old way of thinking; popular lectures on philosophy. London, New York, Longmans, Green, 1940. 308 p. $\quad 43-44203 \quad$ B832.J $2 ~ 1940$

5325. The Meaning of truth, a sequel to "Pragmatism." New York, Longmans, Green, I909.

$\mathrm{xxi}, 297 \mathrm{p}$. 9-27102 B832.J4

ConTENTs.-The function of cognition.-The tigers in India.-Humanism and truth.-The relation between knower and known.-The essence of humanism.-A word more about truth.-Professor Platt on truth.-The pragmatist account of truth and its misunderstanders.-The meaning of the word truth.-The existence of Julius Caesar.-The absolute and the strenuous life.-Professor Hébert on pragmatism.-Abstractionism and "relativismus."-Two English critics.-A dialogue.

5326. A Pluralistic universe; Hibbert lectures at Manchester College on the present situation in philosophy. New York, Longmans, Green, I909. $404 \mathrm{p}$. 9-9478 B804.J2
Contents.-I. The types of philosophic thinking.-2. Monistic idealism.-3. Hegel and his method.-4. Concerning Fechner.-5. The compounding of consciousness. -6 . Bergson and his critique of intellectualism.-7. The continuity of experience.-8. Conclusions. Notes.-Appendixes: A. The thing and its relations. B. The experience of activity. C. On the notion of reality as changing.-Index.

An aura of frustration hovered over James' last years. He had damaged his heart in 1898 by overindulgence in mountaineering, and it was progressively giving out. A rounded, systematic, and definitive statement of his essential philosophy was greatly desired, by others and by himself. He was, however, in enormous demand for public lectures, and did not like to refuse, especially since he was convinced of the desirability of converting the larger public to the empirical outlook. He therefore undertook to lecture upon pragmatism at the Lowell Institute, Boston, in the closing months of 1906, and repeated the lectures at Columbia early in 1907, before audiences of a thousand. The lectures were worked into shape for publication by the early summer, and Pragmatism had a popular effect such as few philosophical books have ever achieved. It also involved its author in a tide of acknowledgment, explanation, and controversy which absorbed his energies. This led him to collect his papers on the same or related themes, the oldest of which, "The Function of Consciousness," went back to 1885, in The Meaning of Truth. Nor could a further invitation to lecture at Oxford University in May 1908 be declined, for here was an opportunity to take "the scalp of the Absolute" in the very citadel of its defenders. But, as he complained to one of his chief allies, "this job condemns me to publish another book written in picturesque and popular style"-A Pluralistic Universe. His sands ran out, and the "concise, dry, and impersonal" treatise that he had desired to write remained forever unwritten.

5327. Essays in radical empiricism. New impression. London, New York, Longmans, Green, 1938. 282 p. $43^{-1} 5^{820} \quad$ B945.J23E7 1938 Editor's preface signed: Ralph Barton Perry.

Contents.-Does "consciousness" exist?-A world of pure experience.-The thing and its relations.- How two minds can know one thing.The place of affectional facts in a world of pure experience.-The experience of activity.-The essence of humanism.-La notion de conscience.-Is radical empiricism solipsistic?-Mr. Pitkin's refutation of "radical empiricism."-Humanism and truth once more.-Absolutism and empiricism.

These essays, first published posthumously in 
I912, are interconnected and had been brought together before his death by James, who apparently intended some such work as a presentation of his essential philosophical position. The work has therefore more unity than most such collections.

5328. Memories and studies. New York, Longmans, Green, IgII. 4 I I p.

$$
\text { I I-26966 B945.J23 M5 } 19 \text { I I }
$$

A volume of essays and addresses which James had been planning to bring together, and were posthumously edited by his brother, Henry James.

5329. Collected essays and reviews. New York, Longmans, Green, 1920. $5^{16}$ p. Preface signed: Ralph Barton Perry.

2I-I 12 B945.J2 I 1920

A collection of 39 articles and reviews which had not previously appeared in book form.

5330. The Letters of William James, edited by his son, Henry James. Boston, Atlantic Monthly Press, I920. 2 v. illus.

$$
\text { 20-23198 B945.J24A } 1920
$$

These letters reveal the pith and charm of James' informal style, as well as reflecting his strong family attachments, wide range of interests, frequent travels, and a farflung and unusually interesting body of friends, together with the progress of his career and the development of his thought.

5331. The Philosophy of William James, drawn from his own works; with an introd. by Horace M. Kallen. New York, Modern Library, 1925. 375 p. (The Modern Library of the world's best books) 26-948 B945.J24 $\mathrm{A}_{5} \quad 1925$

"The works of William James": p. 37I-375.

The "selections which make up this book have been chosen with the view of presenting the philosophy of William James systematically in his own words and in convenient compass, with some approximation to that rounded wholeness he himself would have given it had he lived to complete his work." Dr. Kallen was a pupil of James, and was chosen by him to edit the uncompleted manuscript of Some Problems of Philosophy (New York, Longmans, Green, IgII. 236 p.), which James had in. tended as an introduction to the subject.

5332. Selected papers on philosophy. London, Dent; New York, Dutton, I929. xvi, 273 p. (Everyman's library [no. 739])

$$
\text { 37-5572 ACr.E8, no. } 739
$$

"First published in this edition 1917."

Introduction by C. M. Bakewell.

"The principal works of William James": p. xiii-xv.
Contents.-On a certain blindness in human beings.-The gospel of relaxation.-The energies of men.-Habit.-The will.-Philosophy and its critics.-The will to believe.-The sentiment of rationality.-Great men and their environment.-What pragmatism means.-Humanism and truth.-The positive content of religious experience.

5333. Essays in pragmatism. Edited with an introd. by Alburey Castell. New York, Hafner Pub. Co., I948. xvi, I76 p. (The Hafner library of classics, no. 7) 49-1II5 B945.J23E67

ConTEnTs. - The sentiment of rationality.-The dilemma of determinism.-The moral philosopher and the moral life.-The will to believe.-Conclusions on varieties of religious experience.-What pragmatism means.-Pragmatism's conception of truth.

Selections from James' more popular writings in inexpensive editions designed for college students or the general reader. A brief, very untechnical, and entirely admiring summary of James' thought was prepared by Lloyd R. Morris for Scribner's Twentieth century library: William James; the Message of a Modern Mind (New York, 1950. 98 p.).

5334. Perry, Ralph Barton. The thought and character of William James, as revealed in unpublished correspondence and notes, together with his published writings. Boston, Little, Brown, 1935. 2 v.

Bibliography at end of each volume.

$35^{-25} 802$
Contents.-1. Inheritance and vocation.-2. Philosophy and psychology.

Perry (1876-1957) was a pupil and colleague of James who edited two of his posthumous books and prepared an Annotated Bibliography of the Writings of William James (New York, Longmans, Green, 1920. 69 p.). A quarter-century after James' death he produced this monumental study of the man and his philosophy, which was rewarded with the Pulitzer prize in biography in 1936 . He drew upon some 500 additional letters not included in Henry James' edition of 1920 . In 1948 he published a "briefer version" of this work in one volume (Cambridge, Harvard University Press. 402 p.) which gave less attention to James' immature views, but also incorporated some new manuscript material of importance. An invitation to lecture at Indiana University gave Perry the opportunity to sum up James' thought in a nontechnical way, and to indicate the development of his own thinking out of certain of its strands: In the Spirit of William James (New Haven, Yale University Press, 1938. 2 I I p.). Perry himself taught philosophy at Harvard for 44 years $(1902-46)$ and excelled in summaries of re- 
cent thought for the student or general reader, such as Present Philosophical Tendencies: a Critical Survey of Naturalism, Idealism, Pragmatism, and Realism (New York, Braziller, 1955. xv, 383 p.), originally published in 1912, and Philosophy of the Recent Past; an Outline of European and American Philosophy since I860 (New York, Scribner, I926. $230 \mathrm{p}$.). His chief original contributions lay in the field of value theory: General Theory of Value (Cambridge, Harvard University Press, 1950, '1926. xvii, 702 p.) and Realms of Value; a Critique of Human Civilization (Cambridge, Harvard University Press, I954. 497 p.).

5335. In commemoration of William James, $1842-$ 1942. New York, Columbia University

Press, 1942. 234 p. 42-52I45 B945.J24I5

Contents.-pt. I. Papers presented at the Conference on Methods in Philosophy and the Sciences, New School for Social Research, New York City, November 23, I94I: Remarks on the occasion of the centenary of William James, by Henry James. Remembering William James, by H. M. Kallen. A debt to James, by D. S. Miller. William James as psychologist, by E. B. Holt. William James as empiricist, by John Dewey. Two questions raised by "The moral equivalent of war," by J. S. Bixler.pt. 2. Papers presented at the annual meeting of the Eastern division, American Philosophical Association, Vassar College, Poughkeepsie, New York, December 29, 194I: If William James were alive today, by R. B. Perry. The psychology of William James in relation to philosophy, by G. S. Brett. William James and the facts of knowledge, by D. C. Williams. William James as a moralist, by $\mathrm{H}$. W. Schneider.--pt. 3. Papers presented at the annual meeting of the Western division, American Philosophical Association, University of Wisconsin, Madison, Wisconsin, April 24, 1942: Jamesian psychology and the stream of psychological thought, by J. R. Kantor. William James' pluralistic metaphysics of experience, by Victor Lowe. William James today, by Charles Morris.-pt. 4. Papers from other occasions: William James, philosopher of faith, by E. W. Lyman. William James and the crisis of philosophy, by Arnold Metzger. The founder of pragmatism, by W. H. Hill.

These addresses were assembled by Professors Brand Blanshard and Herbert W. Schneider.

5336. Wisconsin. University. William James, the man and the thinker; addresses delivered at the University of Wisconsin in celebration of the centenary of his birth. Madison, University of Wisconsin Press, 1942. $147 \mathrm{p}$.

Contents -William 43-52550 B945.J24W5
G. C. Sellery.-The distinctive philosophy of William James, by M. C. Otto.-William James, man and philosopher, by D. S. Miller.-William James and psychoanalysis, by Norman Cameron.-The William James centenary dinner: Introductory remarks, by C. A. Dykstra. William James and the world today, by John Dewey, read by Carl Boegholt. William James in the American tradition, by $\mathrm{B}$. $\mathrm{H}$. Bode.-The Sunday service: William James as religious thinker, by J. S. Bixler.

\section{JAMES McCOSH, I811-1894}

$\mathrm{McCosh}$ was born and raised in Scotland, where he entered the ministry in 1834 ; however, he soon found himself siding by conviction with the liberals, and with them left the established Church of Scotland to found the Free Church of Scotland. $\mathrm{McCosh}$ was influenced by the then flourishing Scottish school of philosophy, and at the University of Edinburgh came under the influence of William Hamilton. These debts are reflected in The Scottish Philosophy, Biographical, Expository, Critical, from Hutcheson to Hamilton (New York, R. Carter, 1875. $48 \mathrm{I}$ p.), written after he came to America. McCosh's early acceptance of Hamilton's position was soon modified, however, as he discovered a closer affinity for the intuitionism of earlier thinkers of the Scottish school. His dissatisfaction with the naturalism implicit in J. S. Mill's System of Logic (1843) led him to write his first book, The Method of Divine Government, Physical and Moral (Edinburgh, Sutherland \& Knox, I850. 531 p.). This gained him attention in philosophical circles and led to his appointment to a chair at Queen's College, Belfast, Ireland, where he remained for 16 years. His writings at Belfast included two of his most important philosophical works: The Intuitions of the Mind Inductively Investigated (London, J. Murray, I86o. 504 p.) and An Examination of Mr. J. S. Mill's Philosophy; being a Defence of Fundamental Truth (London, Macmillan, r866; $2 \mathrm{~d}$ ed., with additions, New York, Carter, I87I. 470 p.). In 1868 he came to America to assume the position of president of the College of New Jersey (Princeton), which he filled with distinction for 20 years. Here he continued to write, but it was probably as a lecturer and educator that he had his greatest influence. His introduction of a modified Scottish intuitionism of "fundamental truth," leading to a "common-sense realism," brought a new philosophical mode to this country and was widely influential. $\mathrm{McCosh}$ was also a crucial figure in the controversy centering about the Darwinian theory of evolution, for in the r87o's he was one of the few ministers in the United States to defend the theory, which he viewed as adding to the glory of God's creation; 
his views were expressed in The Religious Aspect of Evolution (New York, Putnam, 1888. I 09 p.). In America he became increasingly interested in psychology and produced several widely read books dealing with the subject. Notwithstanding his earlier career in the British Isles, he may be said to have become the most representative American philosopher of his day. He was genuinely receptive to new discoveries and ideas without losing his grasp of religious fundamentals, and is likely to remain a figure both interesting and estimable.

5338. Christianity and positivism: a series of lectures to the times on natural theology and apologetics. New York, R. Carter, 1871. 369 p.

$$
\text { 30-11323 BL51.M2 }
$$

Ten lectures delivered the same year at Union Theological Seminary in New York.

5339. The Emotions. New York, Scribner, 1880. $255 \mathrm{p}$. $10-21236 \quad \mathrm{BF}_{53}$ I.M2

An attempt to understand the psychical problems of the emotions. The author does not "overlook their physiological concomitants and effects," but he enters "little into controversy."

5340. Psychology: the cognitive powers. New York, Scribner, 1886. 245 p. 10-19670 BFI21.M2

534I. Psychology: the motive powers, emotions, conscience, will. New York, Scribner, I887. $267 \mathrm{p}$. 10-19671 BF121.M22

Widely used as textbooks, these works remained in print into the 2oth century, when Jamesian and other psychologies in large part superseded McCosh's work.

5342. Realistic philosophy defended in a philosophic series. New York, Scribner, 1887. $2 \mathrm{v}$ I2-36367 $\mathrm{B} 835 . \mathrm{M}_{3}$

Contents.-I. Expository.-2. Historical and critical.

The first volume is a collection of McCosh's philosophical papers, which in large part had been published as separate booklets. The second volume is a series of studies of other philosophers.

5343. First and fundamental truths, being a treatise on metaphysics. New York, Scribner, 1889. $360 \mathrm{p}$.

II-3I4I4 BDIII.MI8

A work which sums up the author's final philosophical position. In part it is a reconsideration and rewriting of $A n$ Examination of Mr. J.S. Mill's Philosophy; being a Defence of Fundamental Truth (r866), mentioned above.
5344. The Life of James McCosh; a record chiefly autobiographical, edited by William Milligan

Sloane. New York, Scribner, 1896. 287 p. 4-16947 $\mathrm{LD}_{4} 605 . \mathrm{A}_{3} \quad{ }_{1868}$

Bibliography, by Joseph H. Dulles: p. [269]-282.

Some of McCosh's co-workers and students, during the last years of his life, wished to preserve a record of his activities. To this end they induced him to set down reminiscences from time to time; these have here been incorporated with other material to form a composite biography.

\section{CHARLES SANDERS PEIRCE, I 839-I9I4}

Opinions of Peirce have varied greatly; he has even been called the greatest philosopher of the Igth century. Certainly he has had an extensive influence in the development of thought. However, his attempts at precision resulted in a difficult style, which, combined with his assumption of wide philosophical knowledge in his readers (he said he was writing for but one in millions), have left him with a considerable reputation among philosophers and virtual anonymity among the laity. Peirce began his career as a scientist, with intensive training in physics and chemistry, and followed this with extensive incursions into other scientific fields, such as geodesy, astronomy, and psychology. Science was thus a major factor in the development of his philosophy, for which he coined the word "pragmatic." With the development of a quite different and more popular pragmatism by his friend, William James, Peirce named his system "pragmaticism." While Peirce produced no one systematic work intended to expound his philosophy, he did write numerous papers (many of them unpublished during his life) which were intended to lay a massive foundation for a new philosophy for the modern age.

5346. Collected papers. Edited by Charles Hartshorne and Paul Weiss. Cambridge, Harvard University Press, I93I-35. $6 \mathrm{v}$.

$$
\text { 3I-30898 B945.P43 C6 I93I }
$$

Since a great part of Peirce's writings were still in manuscript form at the time of his death, much of his work appeared for the first time in the Collected Papers. Of this set the editors write in the introduction to volume $\mathbf{I}$ : "The more important of these manuscripts of Peirce, as well as his published papers, have now been brought together in some ten volumes which will appear in rapid succession. The first volume contains in outline his system, so far as it can be presented, his writings on scientific method and the classification of the sciences, his doctrine of the categories, and his work on ethics. The next volume deals with the theory of signs and meaning, traditional logic, induction, the science of discovery 
and probability; and the third volume reprints his published work on modern logic. The fourth includes his unpublished original contributions to the foundations of mathematics, logic and graphs. The fifth volume contains his papers on pragmatism. The sixth is concerned with metaphysics. It is expected that the remaining volumes will contain his writings on physics and psychology, as well as his reviews, letters and biography." After a 23-year interval, the publication of volumes 7 and 8 under a new editor, Arthur W. Burks, was scheduled by the Harvard University Press for 1958.

5347. Chance, love, and logic; philosophical essays. Edited with an introd. by Morris R. Cohen; with a supplementary essay on the pragmatism of Peirce, by John Dewey. New York, Harcourt, Brace, I923. xxxiii, 318 p. (International library of psychology, philosophy and scientific method) 23-II $850 \quad$ B $945 . \mathrm{P}_{43} \mathrm{C}_{5}$

Professor Cohen's volume of selections was made in an attempt to present a "developed and coherent" account of Peirce's philosophy, and did much to secure a wider appreciation of his importance. While the selections themselves are not supplied with editorial commentary, the introduction is intended to "help the reader concatenate the various lines of thought contained in these essays." The two collections which follow reflect the continuing demand for representative writings of Peirce's among students of philosophy.

5348. The Philosophy of Peirce; selected writings. Edited by Justus Buchler. London, K. Paul, Trench, Trubner, 1940. 386 p. (International library of psychology, philosophy and scientific method) ${ }_{41-5564} \mathrm{~B}_{445 . P_{4} \mathrm{IB} 8}$

Published in the United States by Harcourt, Brace \& Co. Republished in 1955 by Dover Publications (New York) under the title: Philosophical Writings of Peirce.

5349. Essays in the philosophy of science. Edited with an introd. by Vincent Tomas. New York, Liberal Arts Press, 1957. 271 p. (The American heritage series, no. 17 )

$$
\text { 57-2087 B945.P4rT6 }
$$

5350. Buchler, Justus. Charles Peirce's empiricism. With a foreword by Professor Ernest Nagel. New York, Harcourt, Brace, 1939. xvii, 275 p. (International library of psychology, philosophy and scientific method)

$$
\text { 40-4294 B945.P44B8 I939 }
$$

This Columbia University dissertation is probably the most serviceable of the attempts to extract a coherent doctrine from Peirce's Collected Papers, fragmentary as they are, and presenting a developing rather than a unitary and static outlook. Buchler regards Peirce as primarily an empiricist, and thinks that such of his metaphysics as is incongruous with his empiricism is of secondary importance. This empiricism he characterizes as public empiricism, supporting a theory of common or cooperative inquiry. Manley $\mathrm{H}$. Thompson's The Pragmatic Philosophy of C. S. Peirce (Chicago, University of Chicago Press, 1953. 317 p.) is more critical and narrower in scope, being concerned with the limitations involved in Peirce's approach to philosophy.

5351. Feibleman, James. An introduction to Peirce's philosophy, interpreted as a system. New York, Harper, 1946. xx, 503 p.

${ }_{4} 6-8096 \quad \mathrm{~B}_{945} \cdot \mathrm{P}_{44} \mathrm{~F}_{4}$

"This book has two aims, the first of which is to offer an introduction to the general philosophy of Charles S. Peirce, who may fairly be described as one of the greatest philosophers America has thus far produced." The second is "to exhibit the system which seems to be inherent in Peirce's philosophy." Mr. Feibleman is himself a professor of philosophy at Tulane University, simultaneously conducting a real estate business. The life of the academic philosopher in America is to some extent reflected in his autobiographical Philosophers Lead Sheltered Lives (London, Allen \& Unwin, 1952. 321 p.). Feibleman's own philosophical works include Christianity, Communism, and the Ideal Society; a Philo. sophical Approach to Modern Politics (London, Allen \& Unwin, 1937. 419 p.); In Praise of Comedy, a Study in Its Theory and Practice (London, Allen \& Unwin, 1939. 284 p.); The Revival of Realism; Critical Studies in Contemporary Philosophy (Chapel Hill, University of North Carolina Press, 1946. 333 p.); The Theory of Human Culture (New York, Duell, Sloan \& Pearce, I946. 36r p.); Aesthetics; a Study of the Fine Arts in Theory and Practice (New York, Duell, Sloan \& Pearce, 1949. 463 p.); and Ontology (Baltimore, Johns Hopkins Press, r95x. 807 p.), which is probably his major work to date. Feibleman has also written fiction such as The Long Habit (New York, Duell, Sloan \& Pearce, I948. 365 p.), a novel which uses an island near the Mississippi Delta for setting, and poetry, including Death of the God in Mexico (New York, Liveright, I931. 90 p.), Journey to the Coastal Marsh ([Cummington, Mass.] Cummington Press, 1946. [22] p.), Trembling Prairie ([Lexington, Ky.,] Hammer Press, 1952. 73 p.), and The Dark Bifocals (Lexington, Ky., Hammer Press, 1953. $4^{8}$ p.). 
5352. Gallie, Walter B. Peirce and pragmatism. Harmondsworth, Middlesex, Penguin Books, 1952. 247 p. (Pelican books, A 254)

$53-3033 \quad \mathrm{~B}_{945} \cdot \mathrm{P}_{44} \mathrm{G}_{3}$

Professor Gallie, who has since become professor of logic and metaphysics at the Queen's University, Belfast, North Ireland, "tries to make clear, in a form freed from Peirce's more difficult technical terms, the organic unity of three main parts of his thought: his theory of knowledge, his Pragmatismsomething very different from the popular Pragmatism of James-and his metaphysics both critical and constructive." It is one of the very few English studies of American philosophy.

5353. Wiener, Philip P., and Frederic H. Young, eds. Studies in the philosophy of Charles Sanders Peirce. Cambridge, Harvard University Press, 1952. 396 p. $\quad 52-54$ II $\quad$ B $945 . P_{44} W_{5}$

Twenty-four studies of various aspects of Peirce and his philosophy. This work is part of a design to submit Peirce's philosophy as a whole, or system, to methodical and searching criticism. The authors represented were all engaged in special studies of Peirce and his work.

\section{JOSIAH ROYCE, 1855-1916}

With William James and Peirce (qq.v.) Royce is usually considered one of America's "classic" philosophers. He early developed a close friendship with James, who encouraged the younger man in his work; after a time the influence worked both ways. While James was a pragmatist in method, Royce called himself an "absolute pragmatist"; this touches on one of the main points of disagreement between the two; for while Royce accepted pragmatism in some measure, he was primarily an idealist who believed in the existence of absolute truth. This idealism was in some measure a development of his early religious training. This is reflected in his first important book, originally published in 1885, The Religious Aspect of Philosophy; a Critique of the Bases of Conduct and Faith (New York, Harper, 1958. 484 p.). This was followed by California from the Conquest in 1846 to the Second Vigilance Committee in San Francisco; a Study of American Character (New York, Knopf, 1948. xxxvii, 394 p.), first published in I886, which in its history of a decade was "meant to help the reader toward an understanding of two things: namely, the modern American state of California, and our national character as displayed in that land." This work revealed the basic tenets of his philosophy as well as his interest in his native State. This interest was further pursued in his one novel, The
Feud of Oakfield Creek (Boston, Houghton Mifflin, 1887. 483 p.). Royce's next book was The Spirit of Modern Philosophy (New York, Braziller, 1955. 519 p.), first published in 1892 , and based on lectures meant to give "some account of the more significant spiritual possessions of a few prominent modern thinkers." Written before Royce became a predominantly "technical" philosopher with his own fully developed system, the book is stylistically one of his most successful. A more teghnical and abstract presentation of the basic themes of this book may be found in Lectures on Modern Idealism (New Haven, Yale University Press, 19r9. 266 p.), first delivered at Johns Hopkins University in 1906. Royce's continued interest in ethics was evinced in Studies of Good and Evil; a Series of Essays upon Problems of Philosophy and of Life (New York, Appleton, 1898. 384 p.). His maturing philosophical view and his continuing concern with the state of American society (which he hoped to assist to an idealist outlook) is expressed in Race Questions, Provincialism, and Other American Problems (New York, Macmillan, 1908. 287 p.). There followed William James, and Other Essays (New York, Macmillan, igr r. 3 or p.), a collection meant further to illustrate the philosophy of The World and the Individual (vide infra). His more specifically religious interests again came to the fore in his lectures published as The Sources of Religious Insight (New York, Scribner, 1912. 297 p.), which concludes with a restatement of the basic idea of The Philosophy of Loyalty (vide infra). A selection of miscellaneous, mostly early, essays was posthumously published as Fugitive Essays (Cambridge, Harvard University Press, 1920. 429 p.), a work of some importance, since the ideas of Royce's major works were often amplified and most clearly illustrated in lectures and essays. A considerable number of these miscellaneous writings have unfortunately remained unpublished.

5355. The World and the individual; Gifford lectures delivered before the University of Aberdeen. Ist series: The four historical conceptions of being. New York, Macmillan, r 900. xvi, 588 p. o-402 B $945 \cdot \mathrm{R}_{3} \mathrm{~W}_{7}$, ist ser.

5356. The World and the individual; Gifford lectures delivered before the University of $\mathrm{Ab}$ erdeen. 2d series: Nature, man, and the moral order. New York, Macmillan, 1901. xx, 480 p.

$$
\mathrm{r}-27347 \mathrm{~B} 945 \cdot \mathrm{R}_{3} \mathrm{~W}_{7}, 2 \mathrm{~d} \text { ser. }
$$

These two series of lectures, revised and considerably extended for publication, are usually regarded as Royce's most important work in metaphysics. $\mathrm{He}$ characterized them, in relation to his earlier 
work, as "a deliberate effort to bring into synthesis, more fully than I have ever done before, the relations of Knowledge and of Will in our conception of God," and as necessarily centering upon "the true meaning and place of the concept of Individuality." The four conceptions of being considered in the Ist series are mysticism, realism, and critical rationalism, which are in turn criticized and rejected, and absolute idealism, which of course survives scrutiny. "You are in God," the reader is assured, "but you are not lost in God." The $2 \mathrm{~d}$ series is concerned with developing the implications of this view for cosmology, ethics, and religion.

5357. The Philosophy of loyalty. New York, Macmillan, 1936. $409 \mathrm{p}$.

$$
\text { 38-33154 BJI533.L8R6 1936 }
$$

This best known of Royce's books, first published in 1908 , presents a doctrine of the need of a basic ethical motivation in man's life. The loyalty propounded is to this general idealism, rather than to the narrow loyalties of particular causes, persons, etc., although it finds expression through these. It is summed up in the conception of "loyalty to loyalty" as the highest virtue. This takes care of the individual, but the world must sort out and harmonize discrepant or conflicting loyalties.

5358. The Problem of Christianity. Lectures delivered at the Lowell Institute in Boston, and at Manchester College, Oxford. New York, Macmillan, 1913. $2 \mathrm{v}$. 13-10606 BRI21.R67

Contents.- - I. The Christian doctrine of life.2. The real world and the Christian ideas.

This is Royce's final statement of his general position, the outcome of his "philosophical study of certain problems belonging to ethics, to religious experience, and to general philosophy." In it he develops his idea of loyalty as "the practically devoted love of an individual for a community," and presents Christianity as being "in its essence, the most typical, and, so far in human history, the most highly developed religion of loyalty." Royce sidesteps the entanglements of dogmas, controversies, and institutions found in historical Christianity, since he is concerned with the "essence of Christianity" rather than with such particulars.

5359. Logical essays. Edited by Daniel S. Robinsōn. Dubuque, Iowa, W. C. Brown, I95I. 447 p. 5I-8059 B945.R63L6

5360. The Social philosophy of Josiah Royce. Edited, with an introductory essay, by Stuart Gerry Brown. [Syracuse, N. Y.] Syracuse University Press, 1950. 220 p. 50-10512 H35.R87
5361. The Religious philosophy of Josiah Royce. Edited, with an introductory essay, by Stuart Gerry Brown. [Syracuse, N. Y.] Syracuse University Press, 1952. 239 p.

$$
\text { 52-4152I B945.R6IB7 }
$$

In the first title Dr. Robinson, director of the School of Philosophy of the University of Southern California, has made a valuable collection of practically all of Royce's writings on logic. Royce took up the subject quite late in his career, largely through the stimulation of C. S. Peirce, but subsequent logicians have abundantly recognized the quality and the importance of his contributions. Save for one book review of the nineties, all these papers were published between Igor and I9I4, and only one of them has appeared in other collections of Royce's essays. This is an unusual piece of bookmaking: the first 12 pieces are reproduced from typewritten copy, while the remaining 5 are photographically reproduced from the original publications. Mr. Brown, who is professor of citizenship and American culture in the Maxwell School of Citizenship of Syracuse University, aims in the last two titles "to make the core of [Royce's] social and religious thought once more available for all students of American philosophy and culture." He contributes a substantial introduction, "From Provincialism to the Great Community," to the earlier one.

5362. Cotton, James Harry. Royce on the human self. Cambridge, Harvard University Press, 1954. xiv, $347 \mathrm{p}$.

Bibliography: p. [303]-3II.

Because of Royce's conceptions of the human self as intricately related, and because of this idea's centrality to his philosophy, this book deals with nearly all of Royce's work. Considerable reliance has been placed on unpublished material, though only as a source of illustrations, not of new ideas. As an extension of the central theme, one chapter is devoted to the relations between William James, C. S. Peirce, and Royce.

5363. Marcel, Gabriel. Royce's metaphysics. Translated by Virginia and Gordon Ringer. Chicago, Regnery, I956. I80 p.

$$
\text { 56-I } 854 \text { B945.R64M33 }
$$

Originally written in French (La Métaphysique de Royce. [Paris] Aubier, I945. 224 p.), this is one of the most distinguished and thorough studies of Royce's philosophy, although it limits itself to studying Royce's solution of the problem of metaphysics. A Norwegian dissertation on Royce appeared in 1934: Sverre Norborg's Josiah Royce, Puritaner og Idealist (Oslo, Lutherstiftelsens Forlag. 44 I p.). 
5364. Smith, John Edwin. Royce's social infinite: the community of interpretation. New York, Liberal Arts Press, I950. $176 \mathrm{p}$.

Bibliography: p. 17I-173.

$$
\text { 50-6708 B945.R64 } 65
$$

This Columbia University dissertation studies Royce's fusion of Christianity and his own idealism, as expressed in his idea of a community, created by individual minds linked together by the special kind of knowing he named interpretation, and sustained by that loyalty which was the supreme good of life.

\section{GEORGE SANTAYANA, 1863-1952}

Santayana taught philosophy at Harvard University for 22 years, but the greater part of his published work was produced after his resignation in 19I1. Many of Santayana's works have been in a predominantly literary vein; these are entered in the Literature section of the bibliography (nos. 1733-1742, of which $173^{8}$ and 1739 are of special philosophic interest). This interest in literature has been carried over into his philosophical writings, which are noted for their stylistic qualities. It is also to be traced in his very philosophic conceptions, for his system has been called a poetic naturalism. His pervasive interest is in moral philosophy (outside traditional theologies), but he is basically a naturalist who starts with the view that all ideas must be explained in the context of the environment wherein they arise. He does not believe that any moral value exists in nature, but he does think that the philoscpher may, through the contemplation of all arts and sciences, arrive at a general view of nature and human nature, and then ascribe value to any human enterprise insofar as it realizes the excellences which nature makes possible. Influenced primarily by the earlier Greeks and by Spinoza, Santayana combined two principles seldom joined: "naturalism as to the origin and history of mankind, and fidelity in moral sentiment, to the inspiration of reason." This accounts for the frequent approaches to paradox in his writings, and for those passages, no less startling for their being numerous, in which he cancels with his left, or naturalistic hand, the elaborate constructions of his right, or rationalistic one. He has had many admirers, but few followers among professional philosophers.

5366. The Sense of beauty, being the outlines of aesthetic theory. With a foreword by Philip

Blair Rice. New York, Modern Library, 1955. 268 p. (The Modern Library of the world's best books, 292) $55-10656 \quad$ N66.S23 1955a

This book, which first appeared in 1896, was Santayana's first philosophical volume. It remains one of the important works in the field of the philosophy of aesthetics.

5367. The Life of reason; or, The phases of human progress. One-volume ed., rev. by the author in collaboration with Daniel Cory. New York, Scribner, 1954. 504 p. 54-477 B945.S23L7 1953

This work, which originally appeared in five volumes in $1905-6$, is considered by some critics to be Santayana's major work. It rapidly became one of the leading documents of naturalistic philosophy. It successively studies reason in common sense, society, religion, art, and science. In this edition, which has been somewhat abridged as well as revised, the author undertook to clarify obscurities in the original version.

5368. Winds of doctrine, and Platonism and the spiritual life. New York, Harper, 1957. 312 p. (Harper torchbooks, TB 24)

$$
\begin{array}{lll}
57-10533 & \mathrm{~B}_{945} \mathrm{~S}_{23} \mathrm{~W}_{7} \quad 1957
\end{array}
$$

A paperback reprint of two works, the first of which was originally published in 1913 and the second in 1927. Winds of Doctrine originally bore the subtitle Studies in Contemporary Opinion, and consists of six essays, some of which review the general trends of the day in philosophy, while two subject the views of Henri Bergson and Bertrand Russell to severe critical scrutiny. This volume also contains the essay which coined a phrase that has been of some importance in American intellectual history: "The Genteel Tradition in American Philosophy." Lumping together the older schools under a word that had acquired an aura of absurdity, he gave impetus to the movement for eliminating the lingering influence of Protestantism, and particularly the inculcation of moral responsibility, from American higher education. Eighteen years later he detected in the so-called "New Humanism" a possible resurgence of these elements, and returned to the attack in a small volume, The Genteel Tradition at Bay (New York, Scribner, 1931. 74 p.). The second title defines spirit as "an overtone of animal life, a realization, on a hypostatic plane, of certain moving unities in matter," and spiritual life as "disintoxication from the influence of values."

5369. Character and opinion in the United States. New York, Norton, 1934. 233 p. (White oak library) 34-28429 B945. $\mathrm{S}_{23} \mathrm{C}_{5} \mathrm{I} 934$

Contents.-The moral background.-The academic environment. - William James. - Josiah Royce.-Later speculations.-Materialism and idealism in American life.-English liberty in America.

First published in 1920, after having been given as lectures in England, this work attempts to interpret the American people and the philosophy of this 
country. The work is written from a very personal point of view, centering in Santayana's experiences at Harvard, his knowledge of the Boston area, and his views on New England. Most examples are chosen from within this area, and a large part of the book is a discussion of philosophers and the Department of Philosophy at Harvard, with some conclusions about the American temper drawn from these.

5370. Scepticism and animal faith; introduction to a system of philosophy. [New York] Dover Publications, 1955. $314 \mathrm{p}$.

55-14672 B $945 . \mathrm{S}_{23} \mathrm{~S}_{3} \quad 1955$

This new edition presents in unaltered form the text of the first edition of 1923. The work may serve as an introduction to Santayana's philosophy, and as such may be regarded as an epistemological foreword to Realms of Being (vide infra). Everyday common sense realism, or animal faith, is regarded as a sounder theory of knowledge than the artificial doctrines of philosophic schools, which in concentrating on some facts ignore most of the others.

5371. Realms of being. One-volume ed., with a new introd. by the author. New York, Scribner, 1942. xxxii, 862 p.

$\begin{array}{lll}42-36200 & \mathrm{~B}_{945} \cdot \mathrm{S}_{23} \mathrm{R}_{42}\end{array}$

Contents.-The realm of essence.-The realm of matter.-The realm of truth.-The realm of spirit.

This work was originally issued as four separate volumes between 1923 and 1940. This is a full statement of Santayana's mature philosophy. Matter is the unknowable but omnipotent basis for the other realms. Essence is "the infinite multitude of distinguishable ideal terms," the set of signals through which alone man knows the realm of matter. Truth is the limited realm of identity between essence and existence, but the truth of human experience is partial and relative. Spirit is the imaginative reshaping of the realm of matter into orderly and harmonious structure, but it has no significance apart from its physical substratum.

5372. The Idea of Christ in the Gospels; or, God in man, a critical essay. .New York, Scribner, 1946. 266 p. 46-25ro9 BT20r.S263

An interpretation of the Gospels in the light of Santayana's special variety of naturalism, which called religions "the great fairy-tales of the conscience." One bemused critic called it "the most devout book ever written by an unbeliever." However, the idea of Christ as expressed in the Gospels is found "to be vivid indeed, but not intellectually clear," and earthly lives modeled upon it "hardly present a satisfactory view of human perfection."

5373. Works. Triton ed. [New York, Scribner] 1936-37. I4 v. $37^{-6}$ I $_{48}^{8}$ B945.S2 $193^{6}$

5374. The Philosophy of Santayana; selections from all the works of George Santayana. New and greatly enl. ed., edited, with a new pref. and an introductory essay, by Irwin Edman. New York, Scribner, 1953. lxii, 904 p.

$$
\text { 53-I1902 B945.S2I } 1953
$$

5375. Butler, Richard. The mind of Santayana. Chicago, Regnery, 1955. 234 p.

$$
\text { 55-10827 B945.S24B8 }
$$

In this study of Santayana's philosophy emphasis is placed on Scepticism and Animal Faith and Realms of Being (qq. v.), with lesser note taken of his other works. Excluded from consideration is The Life of Reason (q. v.), since Santayana told Mr. Butler that he considered it immature, and that even the revised version had been done when he was too weak to undertake it effectively. A dissertation which studies The Life of Reason in some detail is Milton Karl Munitz' The Moral Philosophy of Santayana (New York, Columbia University Press, 1939. II6 p.).

5376. Howgate, George W. George Santayana. Philadelphia, University of Pennsylvania Press, 1938. 363 p. 39-7881 B945.S24 H6

Aiming at a biography of Santayana's mind, the author presents the facts of his life, his literary productions, and his philosophic doctrines in a balanced volume which lacks only the last 15 years of a career that remained remarkably productive even in its ninth decade.

5377. Schilpp, Paul A., ed. The philosophy of George Santayana. [2d ed.] New York, Tudor Pub. Co., 1951. 710 p. (The Library of living philosophers) $\quad 5^{\mathrm{I}-6325} \quad \mathrm{~B} 945 . \mathrm{S}_{24} \mathrm{~S}_{35}$ I95I

In the first part of this book a number of Santayana's supporters and opponents comment upon his work. In the second part Santayana presents his replies to criticisms made or problems raised in the first part. A notable feature of the book is the extensive bibliography (p. 609-68o).

\section{PAUL WEISS, I90I-}

With the rapidly increasing specialization in all fields of knowledge in the 2oth century the relative number of philosophers who take all knowl- 
edge for their domain has been steadily declining. Weiss, a professor of philosophy at Yale University, is here included as a leading representative of the diminished younger generation of universal philosophers. He was a student of Alfred North Whitehead, whose influence may be traced in much of his work. However, over the years he has been constructing a system of obvious originality, although growing out of what has gone before. All his books to date have been written as solid contributions to philosophy, and have not been simplified for lay readers. Professor Weiss' work has so far been predominantly concerned with problems arising from logic, the nature of reality, man's place in nature, and ethics.

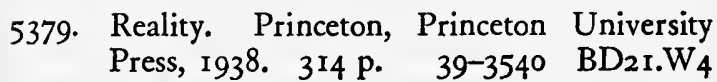

5380. Nature and man. New York, Holt, 1947. xxii, $287 \mathrm{p}$. 47-1847 BD 43 I. W32

538r. Man's freedom. New Haven, Yale University Press, 1950. 325 p.

50-7197 BD21. W39

5382. Modes of being. Carbondale, Southern Illinois University Press, 1958 . 6r7 p.

$$
\text { 57-I1877 B945.W396M6 } 195^{8}
$$

\section{ALFRED NORTH WHITEHEAD, I86I- I947}

Whitehead was born in England and while teaching at Trinity College, Cambridge, and at the University of London developed a reputation as a leading mathematician and logician. In 1924 he came to America and taught at Harvard for 12 years. While the general principles of his philosophy had been developed in England, some of his major philosophical works were written in America. This philosophy he called a philosophy of "organism," which may be regarded as a philosophical theory of relativity in which everything has an active relationship with everything else. This fitted in with the trend to philosophies of schematic progress, as distinct from the "static morphological universe" inherent in most earlier systems. The accord between Whitehead's philosophy and the state of modern knowledge was such that he became a highly influential philosopher, and the acknowledged leader of a widespread movement in America. For this reason, while he remains basically English (as McCosh in an earlier generation remained basically
Scottish), some understanding of his work is necessary for anyone who would understand recent developments in American philosophy.

5384. Alfred North Whitehead: an anthology. Selected by F. S. C. Northrop and Mason W. Gross. Introductions and a note on Whitehead's terminology, by Mason W. Gross. New York, Macmillan, 1953. $928 \mathrm{p}$.

53-I2II2 BI674. W35IN6

5385. Schilpp, Paul A., ed. The philosophy of Alfred North Whitehead. [2d ed.] New York, Tudor Pub. Co., 1951. 797 p. (The Library of living philosophers)

$$
5 \mathrm{I}-6323 \quad \mathrm{Bi}^{6} 64 \cdot \mathrm{W}_{3} 8 \mathrm{~S}_{35} \quad \text { 195 I }
$$

This volume contains a number of essays on the philosophy of Whitehead, including a very long one by Victor Lowe on "The Development of Whitehead's Philosophy." There are also some "Autobiographical Notes" and an extensive bibliography. Because of Whitehead's advanced age and illness at the time this work was compiled, he did not write a reply to the commentaries, although the other volumes in the series of which this is a part do have such a feature. Instead, he contributed some hitherto unpublished essays which he considered expressive of his final position.

\section{CHAUNCEY WRIGHT, $1830-1875$}

Though he himself did not use the term pragmatism, Wright's philosophy was in many ways a precursor of that movement. He was trained in mathematics and physics, and he developed a strong interest in philosophy. As a result, his philosophy was scientific rather than metaphysical. Because of his close examination of scientific method and his belief in the importance of scientific psychology for the further development of philosophy, he foreshadowed a number of aspects of modern philosophical movements.

5387. Philosophical discussions. With a biographical sketch of the author by Charles Eliot Norton. New York, Holt, 1877. xxiii, 434 p. 10-29063 B945. W $73 \mathrm{P}_{5}$

This volume contains the greater part of the author's published philosophical writings, most of which had appeared as periodical articles. A further insight into his life and thought may be gleaned from his Letters (Cambridge, John Wilson, I878. 392 p.). The connecting commentary by James Bradley Thayer enables this to serve as something of a biography. 


\section{Psychology}

5388. Fay, Jay Wharton. American psychology before William James. New Brunswick, N. J., Rutgers University Press, 1939. 240 p. (Rutgers University studies in psychology, no. I)

$$
\text { 39-13495 BFro8. } \mathrm{U}_{5} \mathrm{~F}_{3}
$$

"Chronological table of American works and foreign sources": p. 219-226.

"Bibliography of primary sources in American psychology before I89o": p. 227-232.

The publication of James' Principles of Psychology (no. 5322) in 1890 was so epoch-making an event as to cast his predecessors in the shade, and led to the impression that the earlier history of the discipline here was a blank-an impression which has assumed the guise of fact in some serious works on psychology. Dr. Fay has no difficulty in showing that psychology was studied here from the beginnings of American academic thought, on much the same lines as in Europe; that it was a branch of moral philosophy down to about 1776 , and a branch of "intellectual philosophy," after Scottish models, down to $186 \mathrm{r}$; and that during the next 30 years German influences were mixed with English ones in the prevalent "philosophy of the mind." As the author says, if psychology is exclusively a natural science and there was no psychology in America before James (1842-1910), then equally there was no psychology in Europe before Wilhelm Wundt (1832-1920).

5389. Heidbreder, Edna. Seven psychologies. Student's ed. New York, Century Co., I933.

450 p. $\quad 33-1339 \quad \mathrm{BF}_{95} \cdot \mathrm{H}_{4} 1933$

Dr. Heidbreder regards systems of psychology as programs of action, without which few facts could be collected; as bases of morale, without which inquiry would be vague and aimless; "as ways and means of arriving at knowledge, as temporary but necessary stages in the development of a science." After preliminary chapters on systems as such, on prescientific and the beginnings of scientific psychology, she outlines seven systems prominent in the American psychology of 1933 . They are the structuralism of Edward B. Titchener; the independent and individual system of William James; the functionalism developed at the University of Chicago under J. R. Angell and Harvey Carr; the behaviorism of J. B. Watson (no. 5393); the dynamic psychology developed at Columbia especially by Robert S. Woodworth (no. 539I); the Gestalt school; and psychoanalysis. The first and the last two are, as she says, "outright importations from Europe," but are treated here as influences in American psychology. She disclaims having treated all important schools or thinkers, or all divergences of opinion within the schools chosen as representative. Psychology, she thinks, "is a science that has not yet made its great discovery," and until it does the diversity of systems is both inevitable and desirable.

5390. Krech, David, and Richard S. Crutchfield. Elements of psychology. New York, Knopf, 1958. $700 \mathrm{p}$. $\quad 5^{8-5044} \mathrm{BF}_{121 . K_{73}}$

5391. Woodworth, Robert S., and Harold Schlosberg. Experimental psychology. Rev. ed. New York, Holt, I954. 948 p. illus.

52-I3912 BFi8I.W6 1954

These two titles are selected from the hundreds available as characteristic of American psychology as it is conceived by the vast majority of its academic practitioners at the present day: an experimental and quantitative natural science, with its most valued results obtained from the use of special apparatus in psychological laboratories. The first is a general textbook written by two members of the Department of Psychology at the University of California, and very lavishly produced by Mr. Knopf with 2 color plates, 25 tables, I57 figures, and 168 "boxes," of which most contain research evidence for the generalizations in the text, but some "provide the reader with an opportunity to carry out his own demonstration experiments." The four parts of the book are concerned with "Perception," "Motivation and Emotion," "Adaptive Behavior," and "The Individual." The key to the last part, which includes "the apex of psychology," the study of personality, lies in "quantifying individual differences." Each of 24 chapters is furnished with a glossary, defining such terms of art as "synesthesia" and "volume color" in chapter 2, "Bogardus social distance scale" and "cognitive dissonance" in chapter 25. The most representative figure in American laboratory psychology is probably Robert S. Woodworth (b. 1869), who received his Ph. D. from Columbia University in 1899 and taught psychology there for nearly 40 years, becoming professor emeritus in 1942. His lectures on Dynamic Psy. chology (New York, Columbia University Press, I9I8. 210 p.) provided the profession with a new and laboratory-oriented system, while his textbook, 
Psychology (originally published by Holt in I92 I, and still in print in its 5 th edition of 1947 ) was for years the most widely used in introductory college courses. The first edition of Experimental Psychology appeared in $193^{8}$ and was developed out of mimeographed predecessors which Professor Woodworth had used since I910 in his Columbia course in the subject. In preparing the substantially altered second edition, from which much purely historical material has been dropped, the octogenarian experimentalist had the assistance of Professor Schlosberg of Brown University. After an introductory chapter on the principles of experiment, the book expounds methods and results in 25 separate fields, including "Reaction Time," "Association," "Psychophysics," "Conditioning," "Maze Learning," "Memory," and "Problem-Solving: Thinking." One of the 3 chapters on "Emotion" has a section on "Lie Detection." The subject index runs to 39 double-column pages (p. 9ro-948), while the "Bibliographic Index of Authors" (p. 85 $\mathrm{x}-909$ ) requires a 4 -column table of abbreviations. The front end papers contain "Logarithmic and Probability Scales," and the rear ones "Four-place Logarithms."

5392. Roback, Abraham A. History of American psychology. New York, Library Publishers, 1952. xiv, 426 p. illus. 52-I 1499 BF ro8.U5R6 The only substantial history of psychology in the United States from its beginnings to the present day, by a psychologist who was trained in the Harvard laboratory under Hugo Münsterberg. As several reviewers observed, it is a somewhat uneven work, but what it lacks in uniformity and objectivity is compensated for by the author's thorough knowledge of the doctrines he describes and his original and outspoken critical approach. Dr. Roback has always been an independent and very much his own man, taking his line from no system or institution. He has always had a strong sense of the limitations of purely experimental and physiological psychology, and the book bears traces of his old controversies, including the title of the chapter on behaviorism: "Psychology out of Its Mind." Since he is not unduly impressed by current fashions, he renders full justice to neglected figures of the recent past such as G. Stanley Hall, Morton Prince, William McDougall, and his own teacher, Münsterberg, once the most conspicuous psychologist in the country, the eclipse of whose reputation is attributed to his failure to establish any personal bond with his students. There are chapters on Freud's influence in America; on the Gestalt school, which the author characteristically hails as a creation of the Jewish race and which, he says, is dying out only because it is being absorbed into general psychology; on operationism, which he regards as an attempt to apply the rules of the physics laboratory to psychology; on "Factorial Analysis and General Semantics," including an appreciative treatment of Alfred Korzybski; and on neoscholastic psychology, which is treated with respect. A final chapter on "The Phenomenal Expansion of American Psychology," standing for the companion volume mentioned in the Preface, briefly reviews 14 specialized branches of psychology and some current trends. The United States now has the largest number of psychologists, including many of the foremost, an output of books and articles greater than in all other countries, and a leadership which conveys obligations along with authority.

5393. Watson, John B. Behaviorism. [Rev. ed. Chicago] University of Chicago Press, 1958,

'I930. 308 p. illus. (Phoenix books, $\mathrm{P}_{23}$ ) 58-14680 BFI99. W/ $195^{8}$

Behaviorism, an extreme development of functionalism, is usually regarded as an original American contribution to psychology, which it reduces to a study of the movements of muscle or gland. It is dependent upon physiology, and based upon laboratory experiments, primarily with animal subjects, and it rejects both introspective method and the concept of consciousness. Notwithstanding a number of more or less complete anticipations, it is usually regarded as having been founded by John Broadus Watson (b. 1878 ), who was trained in animal psychology at the University of Chicago, was for some years a professor of psychology at Johns Hopkins, and after 1920 pursued a successful career with large advertising firms. Mr. Watson contributed an interesting autobiographical sketch to A History of Psychology in Autobiography, v. 3, edited by Carl A. Murchison (Worcester, Mass., Clark University Press, 1936), p. 271-281. The volume listed above originated in popular lectures at the Cooper Union in New York City; a more technical exposition of the author's principles is given in Psychology from the Standpoint of a Behaviorist, $3 \mathrm{~d}$ ed., rev. (Philadelphia, Lippincott, 1929. xvii, $45^{8}$ p.), originally published in 1919. Behaviorism has not only aroused much controversy at home, but has attracted considerable attention abroad, as appears from two French studies: Pierre Naville's La psychologie, science du comportement; le behaviorisme de Watson, 9. éd. ([Paris] Gallimard [ $\left.{ }^{\mathrm{c}} 1942\right] 253$ p.), and André Tilquin's Le behaviorisme; origine et développement de la psychologie de réaction en Amérique (Paris, J. Vrin, 1942. 53r p.), which contains a substantial bibliography of behaviorist literature ( $\mathrm{p}$. [51 I $]-528)$. 


\section{Religion}

$\llbracket \begin{aligned} & \text { A. General Works } \\ & \text { B. Period Histories } \\ & \text { C. Church and State } \\ & \text { D. Religious Thought; Theology } \\ & \text { E. Religious Bodies } \\ & \text { F. Representative Leaders } \\ & \text { G. Church and Society } \\ & \text { H. The Negro's Church }\end{aligned}$

$\left.\begin{array}{l}5394-5404 \\ 5405-5417 \\ 5418-5422 \\ 5423-5438 \\ 5439-5473 \\ 5474-5483 \\ 5484-5497 \\ 5498-5502\end{array}\right]$

RELIGIOUS motives were dominant in the founding of Plymouth Colony in 1620 be regarded at all closely, its promoters will be seen to have emphasized religious aims and taken great pains to provide the new plantation with the ministrations of the Church of England. It is probably a safe assertion that until some date quite late in the rgth century, religion remained a greater concern with the majority of Americans than any secular interest. In the middle of the 2oth, notwithstanding the multiplication of competing factors and various secularizing influences, it remains a major interest of the average American, and over roo million persons, or nearly two-thirds of the total population, have become members of churches. Clergymen, however they may complain of crowded schedules, find leisure to write in the 2oth century as they did in the 17 th, and the literature of American religion through four centuries is staggering in its volume. The following hundred-odd titles that have been selected from the mass are of course inadequate to do justice to the great pageant of American religion, and three or four times as many would still leave many corners or aspects uncovered. We have tried, however, to make them as representative as possible of the extraordinary variety of religious life in this country, and, while avoiding works written from a narrow sectarian viewpoint, have sought to deal objectively and fairly with as many denominations and movements as our space will permit. The churches with the largest memberships have necessarily been emphasized, but some lesser ones are included because of their striking originality in belief, practice, or social effect.

The eight sections into which the chapter is divided attempt to deal with inseparable but distinguishable aspects of American religion: its development in the stream of history from 1607 to the present day; its relationship to government, especially since 1776 ; its exposition by men of thought; the churches which are its practical vehicles; the men who have been eminent in the churches; the churches as both cause and effect in their social environment; and, finally, the Negro's church. ${ }^{1}$ Some works on individuals appear not in Section $\mathrm{H}$, Representative Leaders, but in Section D, Religious Thought (Niebuhr and Tillich, nos. 5432 and 5433) or in Section E, Religious Bodies (no. 5464, Joseph Smith, whose biography is essential to the understanding of the Mormon Church). A number of other clergymen whose writings are noteworthy are given individual treatment in Chapter I, Literature; and certain philosophers similarly treated in the preceding chapter are much concerned with religion, in particular James McCosh (nos. 5337-5344),

\footnotetext{
${ }^{1}$ The three titles on Judaism (nos. 5458-5460) should be considered in connection with the larger group on the Jews as a racial minority in Section $\mathrm{F}$ of Chapter XIV.
} 
Josiah Royce (nos. 5354-5364), and William E. Hocking (nos. 5310-5316).

Certain important themes recur in a number of the sections that follow. One is the westward movement of the churches which followed or accompanied the movement of the American people; and a related one is the changing position of the churches in an increasingly urbanized America. Another is the practically complete independence of the American churches from governmental support and controls, since the Revolution at any rate; this has not prevented a vast influence of the churches upon Government as upon every other aspect of social life. As early as 1831 de Tocqueville (nos. 4509-45I2) found that here the spirit of religion and the spirit of liberty, instead of marching in different directions as in France, "were intimately related and that they reigned in common over the same country." Anther theme may be succinctly described in Edmund Burke's phrase, "the dissidence of dissent"; the process whereby the Puritan Separatists came out of the established church has become a permanent char- acteristic of American life; nearly every group which has constituted itself around some apparently small difference of belief or practice has survived, albeit in small numbers-only the Shakers (no. 5469), who abjured biological reproduction, have died out-and new religious bodies, inside or outside the Christian framework, are still being generated. A countertendency has arisen in the movement toward church union or reunion; since it has been more effectual in the sphere of joint social action than in doctrinal or liturgical assimilation, the few titles that deal with the subjects are included in Section I, Church and Society. Yet another theme is the influence on traditional religion of the new scientific views of the universe and of life which were developed in the course of the igth century, and received a unifying bond in Darwin's doctrine of the evolution of species. A final theme is that of secularization inside religious life as well as outside, which many find operative in recent years, so that America has been called, of all the nations of Western civilization, at once the most religious and the most secular.

\section{A. General Works}

5394. Hall, Thomas Cuming. The religious background of American culture. Boston, Little, Brown, 1930. xiv, $34^{8}$ p. $\quad 3^{0-18755} \quad$ BR515. $\mathrm{H}_{2} 8$ "General bibliography": p. [315]-326; "Chapter bibliographies": p. [327]-337.

A Presbyterian clergyman who taught at Union Theological Seminary and at Göttingen here qualifies the widely held concept of the dominant part played by Puritanism in American civilization, and focuses his study on the tradition of dissent, which he considers the most striking feature of American religion. He traces its beginning tQ $\mathrm{Wyclif}$ and the Lollards in 14th-century England. The individualistic heresies that rejected the authority of church and priesthood to put reliance on God's word alone were persecuted and pushed underground, but continued to spread among the lower classes for two centuries. Dr. Hall limits the name of Puritans to the small party of Protestants which rose to political importance in Elizabeth's time, and he claims that Puritanism supplied hardly more than leaders to the New England settlement. In Anglican Virginia and Congregational New England alike, the great body of colonists were "of the class from which Dissent drew its members." The spread of toleration after 1660 was accompanied by widespread religious indifference, furthered by frontier conditions and punctuated by revivals, "the symptom of Dissent."
Established religion collapsed during the Revolution, and the complete separation of church and state in the Constitution recognized the indpendent character of American Christianity. The writer traces the forms of dissent through the later history of American Protestantism, finding throughout American culture a strong element of "respectful indifference to any pronounced religious faith."

5395. Hudson, Winthrop S. The great tradition of the American churches. New York, Harper, 1953. $282 \mathrm{p}$. 53-6417 BR516. $\mathrm{H}_{75}$

The great American tradition of religious freedom, with churches purely voluntary and complete absence of state control, is examined in this cogently argued volume by Professor Hudson of the ColgateRochester Divinity School. He seeks to show that at the high point of American church development, placed in the $1890^{\circ}$ 's, the voluntary principle was considered to be the secret of the power and influence of religion in American life. He is chiefly concerned with the situation in the churches during the 19th century, analyzed in part through individual preachers, Lyman Beecher, Charles G. Finney, Dwight L. Moody, and others, and in part through the achievements and failures of the churches resulting from acceptance of the voluntary principle. With the spread of the "social gospel," 
and the diversion of church activities into many fields apart from religion, there has come, he warns, an oversecularization: "The Church Embraces the World: Protestantism Succumbs to Complacency." $\mathrm{He}$ considers that the churches are running the risk of having no distinctive message, and that as a result they may be tempted to become tools of the state in the promotion of national self-interest. He calls for the restoration of voluntary discipline through conversion and a recovery of Christian faith.

5396. Makers of Christianity. [v. 3] From John Cotton to Lyman Abbott, by William Warren Sweet. New York, Holt, 1937. 35 I p.

$$
\text { 34-36057 BRI 45.M23, v. } 3
$$

"Selected bibliography": p. 335-343.

Biographical sketches of more than 30 individual leaders who have influenced the religious life of America, from the Puritan John Cotton to the late Igth-century apostle of the social gospel, Walter Rauschenbusch, and the teacher of evolutionary philosophy reconciled with Christian faith, Lyman Abbott. The first two volumes of this set, by other hands, recounted great Christian lives from Christ to Charlemagne, and from Alfred the Great to Schleiermacher. Dr. Sweet begins with "The Founding Fathers": Cotton, James Blair of Virginia who founded William and Mary College, the Scotch-Irish Presbyterian Francis Makemie, and the Lutheran Henry M. Mühlenberg. His next chapter presents "Apostles of Religious Liberty": the Lords Baltimore, William Penn, and Roger Williams. He continues through the Great Awakening (Jonathan Edwards and George Whitefield), the Revolutionary and Constitutional period, the transAllegheny pioneers, the missionary heroes, the revivalists and reformers, and the leaders of modern liberal Christian thought.

5397. Mayer, Frederick E. The religious bodies of America. 2d. ,ed. Saint Louis, Concordia Pub. House, 1956. 591 p.

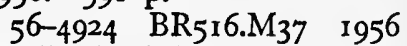

A comprehensive handbook of the doctrines and practices of the religious bodies of America, compiled by the author during his 25 years of teaching theology in two Lutheran seminaries. Dr. Mayer died in 1954, the year of the first edition. His own viewpoint is admittedly Lutheran, but he aims at an objective and unbiased interpretation, based on what he calls the "creedal position" taken by each church in its profession of faith. He classes the 256 separate denominations reported in the 1936 census under 12 major families. For each familyEastern Catholics, Roman Catholics, Lutherans, Reformed bodies, Arminian bodies (Methodists, etc.), "Unionizing" churches, the "Enthusiastic or Inner Light" bodies (Quakers, Mennonites, etc.), the Millennial groups-he outlines the historical background and doctrinal principles before examining the tenets of individual churches in the family. A long chapter on "Interdenominational Trends and Organizations" includes simple and helpful explanations of modernism, fundamentalism, and neo-orthodoxy. In "Anthropocentric and AntiTrinitarian Bodies" Unitarianism and Swedenborgianism are included with Judaism. The last two chapters deal with groups which Dr. Mayer considered to be outside Christianity-Christian Science and other healing cults, and "esoteric" sects such as Theosophy. The work is extensively documented in long footnotes and bibliographies at ends of chapters.

5398. Mead, Frank Spencer. Handbook of denominations in the United States. Rev. and enl. ed. New York, Abingdon Press, r956. 255 p. $\quad 55-10270 \quad \mathrm{BR}_{5} 16 . \mathrm{M}_{3} 8 \quad 1956$

Bibliography: p. 229-237.

A more concise work than Mayer (above), this handbook, originally published in $\mathrm{I} 95 \mathrm{I}$, contains short accounts and statistics of some two hundred and fifty American church denominations. The arrangement is basically alphabetical, but churches that stem from a common source are grouped under the collective name. Thus the table of contents begins with "Adventists," under which come SeventhDay Adventists, Advent Christian Church, Primitive Advent Christian Church, Church of God, Life and Advent Union. Next is a single denomination, The African Orthodox Church. The names within a group are distinguished from succeeding names only by a slight indention, and the reader may find it more convenient to turn at once to the full index. The statements for each church put less emphasis on theological concepts than do those of Mayer. They are factual statements, in simple and readable style, of history, organization, present status, missions, statistical data (not always consistent), and of doctrine in brief outline. Concluding pages give headquarters of denominations, statistics of church membership in 1955, and a glossary of theological and ecclesiastical terms.

5399. Niebuhr, Helmut Richard. The kingdom of God in America. Chicago, Willett, Clark, 1937. xvii, 2 I5 p. $\quad 37^{-28492}$ BT $94 . N_{5}$ "Notes": p. 199-210.

Dr. H. Richard Niebuhr and his brother, Dr. Reinhold Niebuhr, are prominent representatives of the neo-orthodox movement in modern American theology. The theme of these historical and interpretative lectures is that the dominant idea of 
Protestantism in America has always been the kingdom of God, but this has had three successive meanings. In the Puritan theocracy and no less in the other Protestant sects of the colonial settlements, the kingdom of God meant the absolute sovereignty of God. During the Great Awakening and later evangelical revivals, it meant the reign of Christ. In the social gospel of modern religion, it has come to mean the kingdom of God on earth. Dr. Niebuhr expands this idea in general terms as well as in relation to individual religious leaders. In a final chapter on "Institutionalization and Secularization" he suggests that in the "moment of petrifaction," when the liberalism that replaced the old evangelical pattern has itself become institutionalized, the many signs of concern for an aggressive Christianity are "indications of a spiritual unrest which might become the seed plot of new life." A recent book by Reinhold Niebuhr is largely focused on the spiritual unrest of the mid-2oth century. Pious and Secular America (New York, Scribner, 1958. 150 p.) comprises nine essays written or published in 1956 and 1957 on "journalistic" themes. The first, which gives its title to the volume, and the second, "Frustration in Mid-Century," analyze the "paradox" that the United States is "at once the most religious and the most secular of Western nations," and point out the "naive and simple" nature of the current religious revival. Other subjects treated include higher education, the conflict with Russia, the Negro question, the relations of Christians and Jews, and the "universal community." The last essay, "Mystery and Meaning," attempts to explain the relation of the mystery of creation to the human problem of sin.

5400. Sperry, Willard L. Religion in America. Appendices compiled by Ralph Lazzaro. Cambridge [Eng.] University Press; New York, Macmillan, 1946. 317 p. (American life and in$\begin{array}{llll}\text { stitutions .... I) } & 46-7760 & \mathrm{BR}_{5} 15 . S 67 & 1946\end{array}$

A widely admired interpretation of the history and the present state of religion in America, presented informally for a British wartime public by the late Dean of the Divinity School of Harvard University. Initial "Presuppositions" point out salient differences between American religious life and that of the Old World. The primary one is disestablishment: "America is naked of 'the Church" in the historic sense of that word, as Europe has known it and used it. The place of the church is taken by 'denominations.' "Dean Sperry's three other points of distinction are the individualistic character of American religion, its "immense and indubitable optimism," and the sympathetic interest taken in it by non-church-going intellectuals. These four themes reappear throughout his accounts of religion in the Colonies, the causes and consequences of separation of church and state, the denominations, parish life, theological thought, and religious education. He devotes admittedly disproportionate space to the small independent sects, which he takes to be the most distinctive feature of the American religious scene. The chapter on American Catholicism is adapted from Theodore Maynard's book of I94I (no. 5445). Mr. Lazzaro's appendixes give various details of church history and statistics.

5401. Sweet, William Warren. The story of religion in America. [2d rev.ed.] New York, Harper, 1950. 492 p.

Bibliography: p. 453-472.

$$
\text { 50-10239 } \mathrm{BR}_{515 . \mathrm{S}_{2}} 195^{\circ}
$$

Until Dr. Sweet published the first edition of this influential work in 1930, the theme of religion in America had been treated almost exclusively in denominational terms. The professor of the history of American Christianity at the University of Chicago sought in one comprehensive and readable volume to trace through the complicated pattern of American religious life the "common thread" of "an individualism in religion such as existed nowhere else." The religious and political radicalism of the first colonial settlements established this tradition, which was carried on, with the westward movement of the frontier, in the multiplication of small sects and independent churches. Revivalism, from the Great Awakening to the end of the Igth century, was the emotionally extravagant way in which religion was brought to the masses. The consequences of slavery included the rise of many separatist Negro churches. In the 20 th century the independent sects still increase in number and diversity, although the centralization of American culture has been reflected in the larger units of church life. Dr. Sweet's last two chapters, "World War I: Prosperity and Depression" and "Through a Decade of Storm to the MidCentury" (the latter added in the 1950 edition), stress the movement of the Protestant churches toward union, as well as their.secularized aspects and their political ideas.

5402. Sweet, William Warren. Revivalism in America, its origin, growth, and decline. New York, Scribner, 1944. xv, 192 p.

$$
\text { "Selected bibliography": p. } \begin{array}{r}
44-6536 \\
183-188 .
\end{array}
$$

5403. Weisberger, Bernard A. They gathered at the river; the story of the great revivalists and their impact upon religion in America. Boston, Little, Brown, 1958. 345 p. illus.

$$
5^{8-7848} \quad \mathrm{BV}_{3773} \cdot \mathrm{W}_{4}
$$


"Bibliographical comment and notes to chapters": p. $275-332$.

These two historical studies of revivalism differ widely in approach, coverage, and style. Professor Sweet's little volume consists of essays interpreting, from the viewpoint of the religious historian, the nature of revivalism-“"primarily the individualizing of religion." It concentrates on the colonial Great Awakening and the Great Revival of 1800 , with its aftermath on the frontier, subjects treated in greater detail by this author in other works (nos. $54^{10}-54^{16}$ ). Here he briefly outlines the by-products of the Western revivals in educational institutions, antislavery movements, and the like, and barely glances in his last chapter, "Revivalism on the Wane," at the city revivals, organized like business enterprises by D. L. Moody and his successors. The earlier evangelism, when the preacher in highly emotional terms called on each individual to work out his own salvation was, he says, in tune with the independent democratic temper of young America. $\mathrm{He}$ attributes a part of the late igth-century decline in revivalism to the spread of the social gospel, whose advocates, in their enthusiasm to save society tended to overlook the individual sinner. Dr. Weisberger, whose lively style is that of the social historian, writes a more detailed history, interpreting revivals and revivalists in purely secular terms, with emphasis on the personalities of the evangelists. Comments on the colonial and Western revivals provide an introduction for the bulk of his text devoted to the city revivalists. Among the evangelists treated in biographical style are Lyman Beecher and Charles Grandison Finney, great preachers of the 1820's and 1830's in New England and the New West respectively. The central figure is the most successful of all the lay savers of souls, who made revivalism into a professional technique carried out through the force of his personality-“"To thousands of his converts, God must have looked uncannily like Dwight L. Moody." In the hands of Moody's successors, the revival campaigns "put on the trappings of vaudeville." The last chapters are devoted to the most spectacular evangelist of all, Billy Sunday. Dr. Weisberger ends by speculation on the possibility of a revival suited to the age of mass communication, led by a public figure who could "deck the faith of the fathers in the fashion set by Madison Avenue's 'communicators." "

5404. Williams, John P. What Americans believe and how they worship. New York, Harper, 1952. $400 \mathrm{p}$. 52-5477 $\mathrm{BR}_{516 . \mathrm{W}_{47}}$

A comparative survey of the leading religions of the United States, by the chairman of the Department of Religion of Mount Holyoke College, which should prove as interesting to the general reader as to the student. His presentation of each faith includes some historical background, a sketch of doctrine and church government, description of the form of worship, and sometimes a biographical note on a representative leader. The treatment is factual, vivid, and objective, with stress upon social aspects. The subtitles of the chapters are designed to impress on the memory the salient quality of each church or group of churches; thus the first, the Roman Catholic Church, is characterized as "Defender of a Revelation." Protestantism in general is discussed at length, and then follow chapters on the Lutheran Churches, the Protestant Episcopal Church, Presbyterians, Congregationalists and Unitarians, Baptists and Disciples, Quakers, and Methodists. Judaism is sympathetically described as "The Mother Institution." Finally there are two group chapters, "Recent Religious Innovations," taking in such sects as the Seventh-Day Adventists, Mormons, Christian Scientists, Jehovah's Witnesses, and Unity, and "Nonecclesiastical Spiritual Movements," a sampling of astrology, naturalistic humanism, hedonism, nationalism, etc.

\section{B. Period Histories}

5405. Garrison, Winfred Ernest. The march of faith; the story of religion in America since 1865. New York, Harper, I933. $332 \mathrm{p}$. 33-1 $1236 \mathrm{BR}_{525} \cdot \mathrm{G}_{3}$

"Sources and bibliography": p. 309-316.

A swift-paced narrative of American religious history since the Civil War, treated as inseparable from the economic, political, scientific, and cultural life of the time. The opening chapters, which sketch the Reconstruction era, the westward move- ment, and the "Gilded Age" of financial speculation, are primarily social history, although focused on religious activity. With a chapter on Moody and Sankey and other revivalists Professor Garrison turns more specifically to the history of religion. He recounts with interesting detail of men and events the spread of the new liberalism in religious thought, efforts at church union (he is himself prominent in the world ecumenical movement), the rise of the social gospel, and the increased activity of missions 
in America's age of overseas expansion. The records of individual denominations are briefly reviewed, a chapter being given to Roman Catholicism and another to the formation of the interdenominational Federal Council of the Churches of Christ. Social history is again to the fore in the chapters on the connection of churches with big business and their role in the First World War and the postwar years of prosperity. Finally the author examines miscellaneous doctrines, the groups outside the main Protestant sects, mystic and non-Christian cults, etc., and concludes with the argument that religion must deal in the matters of political concern, but should do so in a tolerant rather than a crusading spirit.

5406. Humphrey, Edward F. Nationalism and religion in America, I774-1789. Boston, Chipman Law Pub. Co., 1924. 536 p.

Bibliography: p. [517]-532.

$$
\text { 24-12770 } \mathrm{BR}_{520 . \mathrm{H}_{75}}
$$

In the formative years of the American Nation, the period covered in this historical monograph, "the pulpit was the most powerful single force in America for the creation and control of public opinion," and religion, according to the author, was one of the more potent factors in the forging of the United States. Because of the separation of church and state in the new Republic, he points out, most American historians have deliberately omitted the religious element from constitutional history, in spite of its importance, to which both de Tocqueville and Bryce testified. Dr. Humphrey analyzes in a scholarly manner, with many quotations from contemporary sermons and documents, the contributions or the opposition of the various churches to political independence during the Revolution. This forms the first part of his book; the second part treats the independent and national organization of the churches during the Confederation. It also includes chapters on the separation of church and state, the influence of the churches in the Continental Congress and in the making of the Constitution, and their welcome of the new National Government.

5407. Johnson, Charles A. The frontier camp meeting; religion's harvest time. Dallas, Southern Methodist University Press, 1955. 325 p. illus.

Bibliography: p. 303-319.

$55-8783 \quad \mathrm{BX} 8475 . J 6_{4}$

The author, studying evangelical revivalism in the trans-Allegheny West from 1800 to 1840 , describes the frontier camp meeting as one of the most important social institutions serving to tame backwoods society. Recreating "Camp Meetin' Time" through historical analysis documented from contemporary accounts, appraisals, sermons, and hymns, he is at pains to correct the caricatures and distortions which, he thinks, have pervaded igthcentury fiction, the biased writings of non-Methodist churchmen, and even secular histories. It was the Methodist itineracy system which chiefly developed the camp meeting technique, and the Methodists were almost alone in using it after 1805, although open-air gatherings were usual during the Great Revival or Second Great Awakening of 1800 , and the first planned camp meeting was probably under Presbyterian auspices. To the "most fabulous of all great Revival meetings," at Cane Ridge in Bourbon County, Kentucky, in 1801, there came Baptist and Methodist preachers as well as 18 Presbyterian ministers; the "frenzied worship" continued for six days, with attendance anywhere between ten and twenty-five thousand. The "falling exercise," "the jerks," rolling, dancing, singing, and barking were engaged in by an estimated one to two thousand converts. The writer follows the camp meeting from this primitive form into its maturity under Methodist discipline, which endeavored to restrain emotional excesses. He tells of individual circuit riders, the evangelical doctrine they preached, camp meeting hymnody, and the social life in the "Tented Grove"- "the most mammoth picnic possible." $\mathrm{He}$ cites contemporary endorsements and criticisms. By the 1840's the institution was dying out, supplanted by permanent auditoriums and cabins invading the old forest camp sites, and by the churches in the rising towns.

5408. Morais, Herbert M. Deism in eighteenth century America. New York, Columbia University Press, 1934. 203 p. (Columbia University. Faculty of Political Science. Studies in history, economics and public law, no. 397)

"List of authorities": p. 179-193.

$$
\begin{array}{r}
34-23477 \text { H3r.C7, no. } 397 \\
\text { BL276o.M6 i934a }
\end{array}
$$

A dissertation, exhaustively documented, which studies the "remarkable spread of scepticism" in America during the latter I 8th century. The liberal philosophy of the Age of Reason, as it appeared among the educated upper classes in the colonies and during the Revolution, did not for the most part extend to atheism. Jefferson, who sought to do away with clericalism and return to the pure teachings of Jesus, was more typical of American deism than were radicals such as Ethan Allan, whose ponderous book of $\mathrm{i}^{78}$, Reason the Only Oracle of Man, was the first American text explicitly to reject Christianity. The author examines the European background of deism, its spread in colonial America through the importation of rationalistic books and the introduction of Newtonian science, its leaders and influence during the Revolution, and its mili- 
tant stage in the early national period. Inspired by the French Revolution, Thomas Paine published his Age of Reason in 1794, attacking the principle of Biblical revelation. There arose a vigorous atheistic movement, led by a former Baptist clergyman, Elihu Palmer, with a widespread establishment of deistic societies and freethinking newspapers. Dr. Morais traces the course of deism, and the opposition of the clergy and colleges, through the turn of the century to its collapse following the explosion of evangelical Christianity in the Second Great Awakening.

5409. Schneider, Herbert W. Religion in 2oth century America. Cambridge, Harvard University Press, 1952. 244 p. illus. (The Library of Congress series in American civilization) 52-8219 ${\text { BR } 525 . S_{34}}$

This closely written book by a professor of philosophy and religion at Columbia convincingly explains the transformation of religious habits, ideas, and institutions that has taken place in America during the last 50 years. The first three chapters survey the secularization and socialization of religious life. Religion is now, Dr. Schneider states, "one of America's biggest businesses," conducted by trained professionals among whom laymen are in. creasingly numerous; religious activities are chiefly directed, not to the salvation of individual souls, but against secular evils and social problems; religion, "like government," pervades all areas of life-education, medicine, politics, business, art: "Anything can be done religiously, and nothing is safe from ecclesiastical concern." The author examines the changes in America's religious conscience, the rapprochement of psychiatry and religion, the far-reaching spread of the social gospel, and its recent more realistic "rethinking." The second half of the text, which is separated from the first three chapters by a set of illustrative "Exhibits," is an analysis of changing trends in theological thought-the various reactions to Igth-century liberalism of fundamentalism, neo-orthodoxy, existentialism, humanism-and of the modern "art of worship." The last chapter discusses the interpretation of "Varieties of Religious Experience since William James." A useful compilation supplementing this is volume 256, March 1948, of the Annals of the American Academy of Political and Social Science, Organized Religion in the United States, edited by Ray H. Abrams (Philadelphia, 1948. 265 p.). Papers by a variety of experts are arranged in five groups: "Our Contemporary Religious Institutions," "Relationship to Other Institutions" (state, class, family), "The Churches and Social Action," "Trends and Future Prospects," and "Statistics and Bibliography."
5410. Sweet, William Warren. Religion in colonial America. New York, Scribner, 1942. xiii, $367 \mathrm{p}$. 42-19309 BR520.S88 "Selected bibliography": p. 34I-356.

5411. Sweet, William Warren. Religion in the development of American culture, 17651840. New York, Scribner, 1952. xiv, $33^{8}$ p.

Bibliography: p. 315-332.

52-9960 BR520.S882

The author of The Story of Religion in America (no. 540r) has spent a lifetime studying the religious history of his country, and writes of it in the style of the urbane scholar addressing a literate lay public. Religion in Colonial America is the first installment of a general history by periods. It relates the transplanting of 17 th-century Western European religion to the Colonies, and the adaptation of the various faiths to the physical, social, and political conditions of their new setting. The first arrivals, the Anglican Church in Virginia, and the Puritans in New England, founded state churches; after the Restoration ( 1660 ) adherents of other faiths-Baptists, Quakers, R om a n Catholics, Lutherans, German pietists, Scotch-Irish Presbyterians-increasingly brought diversity, individualism, and liberalizing influences to the American religious scene. Dr. Sweet begins with a general chapter on the religious motives in the planting of the Colonies (said Hakluyt, "greatly for the inlargement of the gospill of Christ"), then tells the story of each denomination through the whole period. His last chapters deal with the Great Awakening in New England and the South, and the general advance toward disestablishment and religious liberty. Ten years later there followed Religion in the Development of American Culture, 1765-1840. Here the stress is on the radical factor in American religion, especially on the frontier. The better pioneers, Dr. Sweet says, were nonconformists or heretics, "impatient of the old and open-minded to the new and untried," who found opportunity for self-expression in the new West. "The story of experimentation in organized religion on the frontier constitutes one of the most significant and important aspects of the development of the new western civilization and culture." The first three chapters on religion during the Revolution, and the subsequent breaking of Old World ties to form new national organizations are, as in the preceding volume, traced through the separate threads of the individual denominations, and these same threads are followed in the account of the westward movement. Then come chapters on general aspects: "Barbarism vs. Revivalism," "Religion and Our Cultural Foundations" (the founding of colleges and seminaries), "The Revolt against Calvinism," 
missions, and "The Frontier Utopias": Mormons, Shakers, and other religious communities. An epilogue accepts, "with modifications," F. J. Turner's thesis of the frontier as the central theme in American history of this period. The third and fourth volumes of this series, which will bring the story to the present day, are still awaited.

5412. Sweet, William Warren, ed. Religion on the American frontier, $1783-\left[185^{\circ}\right]$ New York and Chicago, 1931-46. 4 v.

5413. [Vol. I] The Baptists, 1783-1830, a collection of source material; general introd. by Shirley Jackson Case. New York, Holt, 1931. $652 \mathrm{p}$.

Bibliography: p. $629-637$. $3^{\mathrm{I}-26855 \quad \text { BX6235.S8 }}$

5414. Vol. 2. The Presbyterians, 1783-1840, a collection of source materials. New York, Harper, 1936. 939 p. 36-15032 BX8935.S75 Bibliography: p. 888-917.

5415. Vol. 3. The Congregationalists, a collection of source materials. Chicago, University of Chicago Press, 1939. 435 p.

Bibliography: p. [405]-418.

$$
\text { 39-33291 BX7131.S9 }
$$

5416. Vol.4. The Methodists, a collection of source materials. Chicago, University of Chicago

Press, 1946. 800 p.

Bibliography: p. [731]-770.

$\mathrm{A}_{47-717} \mathrm{BX} 8235 . \mathrm{S}_{92}$

The sources on which Dr. Sweet based this frontier study and his history of Methodism (no. 5458) were assembled in a comprehensive search of the manuscript and out-of-print collections of church and seminary libraries in the region. He has made a share of his labors accessible to other scholars in this 4 -volume collection of source materials for the
Baptist, Presbyterian, Congregationalist, and Methodist churches in the trans-Allegheny West. Each volume begins with a general introduction of about a hundred pages explaining the status of the denomination at the end of the Revolution, and the stages and various aspects of its westward migration. Then come extracts from letters and reports, church minutes, the memoirs of preachers and missionaries, records of conferences and of church trials, and a sampling of documents of many other varieties. Each volume includes a long bibliography.

5417. Winslow, Ola Elizabeth. Meetinghouse Hill, 1630-1783. New York, Macmillan, 1952. 344 p. illus. 52-11102 BR530.W5

A social picture of religion in colonial New England, with the meetinghouse on the hilltop "in sharp focus." The writer's purpose, carried out with bal. ance and charm, is, "by recalling typical procedures in relation to various aspects of community life, to suggest attitudes which [the meetinghouse] helped to establish and patterns of group action which it helped to make habitual." She has based her interpretation on town and church records, sermons, diaries, letters, and other memorials of the theocratic New England of the 17th and 18 th centuries. Her narrative incorporates many wellchosen quotations. Of the five books, the first, "Bound Up Together in a Little Bundle of Life," describes, mostly by means of particular instances, the establishment of congregation, meetinghouse, and village. Book 2, "Zion is Not a City of Fools" (Cotton Mather), is on the learning and the sermons of the clergy. Book 3, "Noises about the Temple," describes "Where to Set," how to sing, etc. Book 4 deals with the "Rule of the "Lord Brethren," the government and authority of the congregation. Book 5, "Powder in the Meetinghouse," illustrates the close association of the New England pulpit with the cause of liberty.

\section{Church and State}

5418. Blau, Joseph L., ed. Cornerstones of religious freedom in America. Boston, Beacon Press, 1949. 250 p. (Beacon Press studies in freedom and power)

"List of sources": p. 246-247.

A compilation of notable documents illustrating the history of American religious liberty. The editor writes a general introduction and an explanatory headnote for each of the themes under which he has arranged the extracts from writings and speeches. The headings are: "Colonial Stirrings" (Roger Williams and William Penn); "Building the Wall of Separation" (Jefferson and Madison); "The Affirmation of Civil Rights for Religious Minorities" (including a speech on the Maryland "Jew Bill," 1819); "Resistance to Enforced Sabbath Observance" (1830); "On Keeping Religion Out of Politics" (Zelotes Fuller, The Tree of Liberty, 1830); "Resistance to Imposed Religious Forms" (from $A$ Report on Appointing Chaplains to the Legislature 
of New York, 1832); "On Keeping Religion Out of Public Schools" (Horace Mann, I848); "On Keeping God Out of the Constitution" (1873 and 1876); and "The Fight against Released Time" (Justice Felix Frankfurter's concurring opinion in a case regarding religious education during school hours, 1948).

5419. Greene, Evarts B. Religion and the state; the making and testing of an American tradition. New York, New York University Press, 1941. I72 p. (Anson G. Phelps lectureship on early American history. New York University. Stokes Foundation)

42-1794 BR516.G67

Six lectures by a distinguished historian, outlining concisely, informally, and interestingly the main themes of church-state relationships in America. Professor Greene begins with the European antecedents, in Protestant and Catholic countries alike, of an established church in which ecclesiastical and temporal control were closely associated. Next he examines the transplantation of these ideas to New Spain, New France, New Netherland, Anglican Virginia, and Puritan New England. His third lecture introduces the liberalizing factors in the British colonies-the Rhode Island "livelie experiment" in religious freedom, the policy of Lord Baltimore and other proprietary governors of toleration for rentpaying tenants, and William Penn's "first fundamentall" of freedom of faith and worship. The Act of Toleration (1688), the -Great Awakening, the penetration of 18 th-century rationalism, all aided dissent, till on the eve of the Revolution church establishment was everywhere losing ground. The religious history of the Revolutionary and Federal eras is discussed in a chapter called "Separation." Chapter V, "After Separation," describes the situation after the last disestablishment act, passed by Massachusetts in 1833 , and the persisting churchstate relations in exemptions from taxation, in the law of church property, and in politics. The last chapter turns to the difficult question of education, in which more than in any other department the American tradition of disestablishment is tested. (See also nos. 5491 and 5494.) The valuable "Bibliographical Notes" (p. 147-162) are arranged by chapters.

5420. Stokes, Anson Phelps. Church and state in the United States. New York, Harper, 1950. 3 v. illus. $\quad 50-7978 \quad \mathrm{BR}_{5} \mathrm{r} 6 . \mathrm{S} 85$ "Critical and classified selected bibliography": v. 3 , p. $769-836$.

The late author of this classic and encyclopedic work, a noted Episcopalian cleric and educator, published it after retiring as canon of Washington Cathedral. Professor Gabriel of Yale University, of which Dr. Stokes had been Secretary for over 20 years, speaks in his introductory note of the author as "guided by the historian's ideal of objectivity and the desire to uncover all pertinent material." The subtitle shows the vast terrain covered in the three large volumes: "A Historical Survey, Source Book, and Interpretation of Documents and. Events Showing the Growth of Religious Freedom under the Friendly Constitutional Separation of Church and State, and the Resulting Influence of Religion in All Major Phases of National Development; also a Study of the Status of Churches Including Synagogues and Other Religious Groups under Federal and State Consstitutions, Statutes, and Judicial Decisions; Authoritative Opinions of Courts, Church Bodies, Statesmen, Religious Leaders, and Publicists on Matters at Issue; and a Discussion of Contemporary Problems of Adjustment." Adjectives used by reviewers pay tribute to the monumental character of the work: "spacious, erudite, and magnanimous," "unique," "definitive." Those pressed for time may limit themselves to Part 8, a "Summary and Interpretation" (v. 3, p. 629-726) of the preceding seven. Part 9 includes, in addition to the monumental bibliography, a table of dates and six documentary appendixes, the last of which is a compilation of the "Provisions in State Constitutions Regarding Religious Freedom."

542r. Torpey, William G. Judicial doctrines of religious rights in America. Chapel Hill, University of North Carolina Press, 1948. $376 \mathrm{p}$.

Bibliography: p. [333]-37r. 48-8404 Law

A legal study, beginning with an historical analysis of relations of government to religion, and then examining many aspects of religious freedom as interpreted, especially by the State courts. Under the first heading, "Delegated and Police Powers as Limitations upon Religious Freedom," there are discussed such matters as pacifism and conscientious objectors, postal laws prohibiting use of mails to defraud, refusals to salute the flag, Sunday laws, laws against fortunetelling. In many of these cases, which seem to run to oddities, the courts have ruled that religious liberty was not violated. Religious organizations are next considered with respect to their legal status, the finality of their decisions, the right of religious assembly, and the exemption of church property from taxation. Then the author turns to the religious rights of the individual in marriage and divorce, in conflicts over child control, in education, in court trials, and in bequests for religious purposes. Many of these cases likewise turn on what seem eccentricities of faith and conduct. The text is in easy narrative style, with footnote references to the many cases cited (tabulated in 
the bibliography), and each chapter ends with a simple and useful summary.

\section{Zollmann, Carl F. G. American church} law. St. Paul, West Pub. Co., 1933. xv, $675 \mathrm{p} . \quad 33-442 \mathrm{I}$ Law

A standard handbook of church law, covering comprehensively statutes in force of the Federal Government and the States relating to religious matters. Published first in 1917 with the title, American Civil Church Law, as volume 77 of the Columbia University Studies in history, economics and public law, it has been revised and expanded to encompass new material. It begins with a "Table of Constitutional Provisions Cited" (U.S., AlabamaWyoming), and ends with a 40-page table of nearly
2500 cases. Each chapter opens with a list of the numbered sections into which it is divided. The sections state the legal issue under consideration: e.g., Ch. I, Sec. 29, "The Legal Effect of Antenuptial Promises in Mixed Marriages." The first two chapters on religious liberty and religious education include a number of the more unusual claims made on religious grounds, and upheld or rejected by the courts. Most of the laws, however, relate to matters of regular procedure or administration: the forms, natures, and powers of corporations, church constitutions, implied trusts, schisms, church decisions, and such material matters as tax exemption, the rights of clergymen and church officers, the acquisition, protection, and liability of church property, pew rights, and cemeteries.

\section{Religious Thought; Theology}

5423. Bainton, Roland $\mathrm{H}$. Yale and the ministry; a history of education for the Christian ministry at Yale from the founding in 1701. Line drawings by the author. New York, Harper, 1957. 297 p.

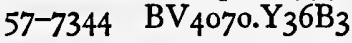

5424. Williams, George Huntston, ed. The Harvard Divinity School: its place in Harvard University and in American culture. Boston, Beacon Press, 1954. xvi, 366 p. illus.

$$
54-8425 \quad \mathrm{BV}_{4070 . \mathrm{H}_{4} 6 \mathrm{~W}_{5}}
$$

These histories are rather different in scope, for while the Yale volume takes its departure from the founding of the college in 1701, the Harvard one starts only with the "tentative beginnings" of a separate divinity school in $181 \mathrm{I}$, leading to its establishment as a separate department in 1819. Yale followed suit and set up a divinity school in 1822 , but the first six chapters of Professor Bainton's book are concerned with the training of a learned ministry during the first 12 decades of the college. After four years spent in earning their bachelor's degrees, candidates would undergo an apprenticeship in the homes of the "graduate faculty," Connecticut pastors who were themselves Yale graduates. The author paints an impressive picture of Yale as "the creation, instrument, and leader of an entire community embracing the Connecticut valley as far north as Northampton, and taking in the southern fringe of Massachusetts and Rhode Island." The remaining 14 chapters narrate the history of the divinity school, with special attention to the "New Haven theology" which prevailed for some decades after its foundation, movements of moral reform, the acquisition of separate buildings, and distinguished teachers of several generations. Nor is it a backward-looking book for, in Dr. Bainton's opinion, "the last quarter of a century has been the greatest in the history of the Yale Divinity School," with a rigorously selected student body of the highest quality, ten percent of whom are women. Acting Dean Williams' volume on the Harvard School over which he presides is a coöperative work, with three chronological chapters contributed by Conrad Wright (to 1840 ), Sydney E. Ahlstrom (to I88o), and Levering Reynolds, Jr. (to the present); while the late Dean Willard L. Sperry has a briefer one on student life during the igth century. Three supplementary essays, by Deans Sperry and Williams and Ralph Lazzaro, are concerned with "Theology at Harvard and Its Place in American Culture." Here Dean Sperry has the crucial subject of "Preparation for the Ministry in a Nondenominational School," for the School abandoned its Unitarian origins during the mid-1gth century, and since 1865 has been "pan-Protestant and ecumenical" in outlook. . Excellent portraits of 34 members of the faculty and a chronological chart at the end increase the value of the book.

5425. Ferm, Vergilius T. A., ed. Contemporary American theology; theological autobiographies. New York, Round Table Press, 1932-33. 2v 33-2542 BR525.F4 "Principal publications" at end of each "autobiography."

Twenty-three of America's leading theologians contributed to these two volumes, for which they 
were asked to set down "in an intimate manner" their personal stories of religious development. The editor's introductions to each volume outline some of the main trends of contemporary Protestantism. Most of the writers are professors of theology in universities or seminaries. In their spiritual experience they reflect the tremendous shifts in religious thinking that have taken place in the 2oth century. In general they have revolted against liberalism as lacking in inner values (one writer came to see in liberal religion "merely a comfortable rationalization of middle-class prosperity"), and have turned toward modernism or conservatism. "Certain agreements and convergences" appear in these confessions of faith-the search for indubitable fundamentals, for social implications, loyalty to organized religious expression, the acceptance of higher criticism-but from a viewpoint tempered with imagination and poetic insight, an unconcern for absolutes. In theology, as in scientific investigation, says the editor, there is "the spirit of open-mindedness, a place for possibilities as yet unrealized, for convictions open to correction." "If the loss is great in dogmatic authority, the gain is great in the realm of faith and credibility."

5426. Finkelstein, Louis, ed. American spiritual autobiographies, fifteen self-portraits. New York, Harper, 1948. xvi, 276 p. 48-9493 BL72.F5

Con t E N T s.-M. L. Wils on.-George N. Shuster.-Alvin S. Johnson.-Lyman Bryson.Raphael Isaacs.-Harry J. Carman.-Harry Emerson Fosdick.-Rufus M. Jones.-Mary K. Simkhovitch.-William Foxwell Albright.-Mary McLeod Bethune-Charles S. Johnson.-William G. Constable.-Jacob S. Potofsky.-Simon J. Finkelstein.Biographical sketches.

5427. Finkelstein, Louis, ed. Thirteen Americans: their spiritual autobiographies. New York, Institute for Religious and Social Studies; distributed by Harper, 1953. 296 p. (Religion and civilization series) 53-5437 Er76.I5

Contents.-Clarence E. Pickett.-Ordway Tead.-Henry Norris Russell.-Edwin Grant Conklin.-Richard McKeon.-Erwin D. Canham.-Elbert D. Thomas.-Judith Berlin Lieberman.-Channing $H$. Tobias.-David de Sola Pool.-Basil O'Connor.-Willard L. Sperry.-Julian Morgenstern.

Two collections of autobiographical essays, all of which are "frank self-revelations" and concentrate on "the problems and influence of character and spirit." The 1948 volume arose from original lectures at the interdenominational Institute for Religious and Social Studies. Its 15 essays are by as many leaders of varied faiths who have contributed largely to American intellectual and spiritual life. The editor explains that they were selected "for a certain spiritual quality permeating their lives and actions which we may comprehend under the general term, saintliness, though it varies greatly from person to person." The biographical notes at the end of the book show that the majority represent a variety of professions outside the ministry - the social sciences, philosophy, science, public affairs, medicine, etc. The second volume includes II lectures delivered at the Institute and 2 essays written for the compilation. The editor comments that "the writers of these autobiographies differ from other people only in the extent of their dedication, and in the scope of causes they serve, but not in kind."

5428. Foster, Frank Hugh. A genetic history of the New England theology. Chicago, University of Chicago Press, 1907. xv, $568 \mathrm{p}$.

$$
\text { 7-8502 } \quad \mathrm{BX}_{7250 . \mathrm{F}_{7}}
$$

A time-honored doctrinal history of the distinctive New England school of theology which took its departure from Jonathan Edwards' revivalist preaching of predestination in 1734 . After a chapter on Puritanism and its decline, the writer concentrates on dogmatics, reviewing Edwards' battle with the anti-Calvinistic Arminians in his treatise on freedom of the will, and analyzing his other metaphysical concepts. He then examines the deterministic teachings of Edwards' successors, Joseph Bellamy, Samuel Hopkins, Jonathan Edwards the younger, and others. This uncompromising modification of Calvinism was the dominant school of thought in New England Congregationalism and in American Christianity in the latter 18 th century. At the opening of the rgth century there arose within it two schisms, Unitarianism, which the writer studies in the teaching of W. E. Channing, and Universalism (Hosea Ballou's Treatise on the Atonement, and the essays of Walter Balfour denying the existence of hell). The later trends of the New England theology, as adapted to a changing environment, are next analyzed through the doctrines of individual leaders-Nathanael Emmons, Nathaniel W. Taylor, Horace Bushnell, Charles G. Finney, Edwards A. Park. The last chapter records the sudden collapse of Calvinism in 1880 , under the impact of Darwinism and of Biblical criticism. The theological thought of Congregationalist and other Protestant preachers who succeeded the New England school was expounded by Dr. Foster in a series.of lectures at the Andover Newton Theological School in r934. This work, The Modern Movement in American Theology, published posthumously in 1939 (New York, Revell, 219 p.), had the subtitle: "Sketches in the History of American Protestant Thought from the Civil War to the World War." It analyzes 
the currents in Protestant thought resulting from Darwinism and the attempt to reconcile science, philosophy, and the modern world with theology, religion, and Christianity. The schools of Horace Bushnell and Henry Ward Beecher, the teaching of George A. Gordon, William N. Clarke, Henry C. King of Oberlin College, and other leaders of liberal and radical thought are described.

5429. Furniss, Norman F. The fundamentalist controversy, 1918-r931. New Haven, Yale University Press, 1954. 199 p. (Yale historical publications. Miscellany, 59)

$54-5082 \quad \mathrm{BT}_{7} 8 . \mathrm{F}_{2}$

5430. Cole, Stewart G. The history of fundamentalism. New York, R. R. Smith, I93I. xiv, $360 \mathrm{p}$. 31-10666 B B $_{78} 8 . \mathrm{C}_{56}$

Bibliography: p. $34^{\mathrm{I}-35^{\circ}}$.

Dr. Furniss' well-documented dissertation begins with a lively account of the sensational Scopes trial at Dayton, Tennessee, in the summer of 1925. At the extravagantly publicized "monkey trial" the complete discomfiture of William Jennings Bryan through the rigorous cross-questioning of the freethinking defense attorney, Clarence Darrow, spotlighted the fundamentalist controversy. The author studies in detail the conservatives' battle for the literal acceptance of the Bible as against evolutionary science and modernism in theology, which had begun at the turn of the century and was waged with greater fervor after the First World War. In the opening "Analysis of the Fundamentalist Crusade" he outlines the general course of militant fundamentalism and the characteristics of the movement, among which he alleges violence, ignorance, and egotism. He next examines fundamentalist organizations and their attempts to secure laws against the teaching of evolution; the central body, the World's Christian Fundamentals Association (founded at the Moody Bible Institute in Chicago in 1919) within 2 years spread its campaigns into 25 states. The third and longest section analyzes the controversy within the separate churches-both the Northern and Southern branches of Baptists and Presbyterians were sharply divided, Methodists and Episcopalians slightly troubled, the Disciples of Christ deeply shaken. A postscript comments on the decline of the aggressive movement with the death of Bryan and the spread of scientific knowledge into the regions which had furnished its support. Dr. Furniss cites Stewart G. Cole's The History of Fundamentalism as the most comprehensive history of the conflict over modernism. This work is focused on doctrinal aspects of the conflict within the churches and pays minor attention to the antievolution campaign.
5431. James, William. The varieties of religious experience, a study in human nature; being the Gifford lectures on natural religion delivered at Edinburgh in I901-1902. New York, Modern Library, 1936. xviii, 526 p. (The Modern Library of the world's best books)

First published in 1902.

$$
37^{-27013} \text { BRi10.J3 } 1936
$$

"The description of man's religious constitutions" is William James' own summation of these famous lectures which formed the starting-point for the modern study of the psychology of religion and are ranked among the most important of American contributions to religious thought. Proceeding from physiological psychology, the founder of philosophical pragmatism examined case histories of religious experience in the light of his "radical empiricism." With vivid analysis and felicitous citation he explored religious hallucinations, the "healthy-mindedness" of liberal religion (particularly the "mind-cure" movement), the opposite pole of pessimism, the divided self, conversion, saintliness, mysticism, and other characteristics of religious experience. "I have loaded the lectures," he said, "with concrete examples, and I have chosen these among the extremer expressions of the religious temperament." In the last chapters he sums up the phenomena in the general terms which he considers common to all religious persons: "We have in the fact that the conscious person is continuous with a wider self through which saving experiences come, a positive content of religious experience which, it seems to me, is literally and objectively true as far as it goes." To this he added his "overbelief" that there exist other worlds of consciousness from which higher energies may filter into our lives from communion with the ideal in faith and prayer.

5432. Kegley, Charles W., ed. Reinhold Niebuhr: his religious, social, and political thought, edited by Charles W. Kegley and Robert W. Bretall. New York, Macmillan, 1956. xiv, 486 p. (The Library of living theology, v. 2)

$$
56-13522 \mathrm{BX}_{4} 827 \cdot \mathrm{N}_{5} \mathrm{~K}_{4}
$$

5433. Kegley, Charles W., ed. The theology of Paul Tillich, edited by Charles W. Kegley \& Robert W. Bretall. New York, Macmillan, I952. xiv, $37^{\circ} \mathrm{p}$. (The Library of living theology, v. I) $\quad 52-13200 \quad \mathrm{BX}_{4} 827 . \mathrm{T}_{53} \mathrm{~K}_{4}$

Perhaps the most vigorous theological thinking in America during the turbulent present has been that of the two theologians chosen as subjects of the first volumes in a series paralleling the Library of living philosophers edited by Paul A. Schilpp (nos. 5294, 5377, and 5385). The editors follow the same form, each volume including the subject's 
"intellectual autobiography," essays on different aspects of his work by leading scholars, his reply to interpretation and criticism, and a full bibliography of his writings. The third and fourth volumes of the series, as announced, are to go outside America, to treat the Swiss theologians Karl Barth and Emil Brunner, whose "neo-orthodox" or "neo-supernaturalist" doctrines have close relationships with Tillich and Niebuhr. These are works to be read by trained theologians. Reinhold Niebuhr first received attention as a critic of social conditions, and is known primarily as a Christian ethical and political thinker. He has been prominent in what Paul Tillich, writing the first essay on Niebuhr, speaks of as "the theological revolution" against liberalism in the United States. His doctrine is labeled "neoorthodox," although, Dr. Tillich says, there is nothing in the world more unorthodox than "the spiritual volcano Reinhold Niebuhr." Since $193^{\circ}$ he has been professor of applied Christianity at Union Theological Seminary. Tillich left Germany at the beginning of the Hitler era and became Niebuhr's colleague at the Union Theological Seminary, which he left to go to the Harvard Divinity School in 1954. For the last quarter-century the two have led in the enunciation of dialectical theology. Tillich is currently publishing his Systematic Theology (Chicago, University of Chicago Press, I95I-57. 2 v. $(300,187$ p.); v. 2 has title Existence and the Christ), which correlates philosophic questions with existential theological answers stemming from revelation. There are interpretative chapters on the theology of Niebuhr and Tillich in David Wesley Soper's Major Voices in American Theology: [v. I] Six Contemporary Leaders (Philadelphia, Westminster Press, 1953. 217 p.). The author, chairman of the Department of Religion of Beloit College in Wisconsin, has written several other "readable" books on contemporary theology. Besides the two above-mentioned men, his study covers the Methodist evangelical theologian Edwin Lewis of Drew University, Nels F. S. Ferré, the "postcritical" professor of philosophical theology at Vanderbilt University, and $\mathrm{H}$. Richard Niebuhr and Robert Calhoun of Yale, the first of whom teaches that man is justified by hope, and the second, by work. A second volume of Mr. Soper's Major Voices in American Theology, entitled Men Who Shape Belief (1955. 224 p.), gives somewhat briefer accounts of II additional theologians divided into 2 groups. The first, including John Luther Adams, Douglas V. Steere, John A. Mackay, Walter M. Horton, John C. Bennett, Wilhelm Pauck, and Harris Franklin Rall, has the title "A Central Theme: God, the Lord of History." The second part, "Alternative Trends," treats the "Church-centered" theology of W. Norman Pit- tenger, the Biblical literalism of Louis Berkhof, the theology of "exclusive immanence" of Henry $N$. Wieman, and the "theistic finitism" of Edgar S. Brightman.

5434. Long, Edward Le Roy. Religious beliefs of American scientists. Philadelphia, Westminster Press, 1952. 168 p.

$$
\text { 52-9193 BL240.L66 I952 }
$$

A study, which originated as a Columbia University dissertation, of the thought of natural scientists who have been sufficiently concerned with the meaning of life to write books expressing their beliefs. In all the writings surveyed the author discovers the search for a basis on which to reconcile science and religion. The men whose published credos are selected for discussion are 2oth-century Americans, most of whom have written since the controversy over evolution in the twenties. The two parts are "Approaches through Science" and "Approaches through Religion." In the first appear, among many others, the well-known names Alfred Einstein and David Starr Jordan, who equated God with the cosmic order; Arthur H. Compton, who recognizes God as first cause; and Henry Fairfield Osborn, Robert A. Millikan (no. 4755), and Lecomte Du Noüy, who, like the philosopher Alfred N. Whitehead (nos. 5383-5385), see God as the ruler of evolution. In part 2 the writer analyzes books by scientists who, starting from belief in the Bible as literal truth or as of unique significance, try to fit contemporary scientific knowledge to Christian faith.

5435. Neumann, Henry. Spokesmen for ethical religion. Boston, Beacon Press, I95I. xvii,

173 p. 5 I-III43 BJI58I.N27

The ethical movement is associated particularly with the name of Felix Adler, a Hebrew scholar and agnostic who, having rejected Reform Judaism, in 1876 founded the Ethical Culture Society. This book, written by a longtime leader of the society for its $75^{\text {th }}$ anniversary, expounds at length its principles-that the essence of religion is not creeds but good deeds, "to treat one another in ways which do most credit to the name human." The first four chapters are devoted to Adler, his formation of the society and of the "Workingman's School," now the Ethical Culture School, in which children of different faiths are brought together for nonsectarian moral education; his reform efforts on behalf of labor; his religious outlook; and his teaching of ethical living by community and nation. There follow chapters on Adler's chief disciple, John Lovejoy Elliott, other American leaders, and spokesmen in England, Germany, and Austria. The last three chapters explain the basic ideas of ethical religion: "Unity in Diversity," "How to Tell Right from 
Wrong," "Why a Religion?" The latter may be summarized in the statement which for many years appeared on the announcements of the ethical socities: "We interpret religion to mean fervent devotion to the ethical ideal." The educational ideas of the Ethical Culture Society incorporated those of a short-lived earlier movement, the Free Religious Association, which in the last third of the I th $^{\text {th }}$ century asserted that philanthropy and social reform were an integral part of religious faith. This group is the subject of a historical monograph by Prof. Stow Persons of Princeton University: Free Religion, an American Faith (New Haven, Yale University Press, 1947. 168 p.). An offshoot of radical Unitarianism, this "spiritual anti-slavery society" was launched by a few young clergymen in New England in 1867 . Numerically the association was an insignificant group; its maximum membership during the seventies may have been five hundred; by the mid-eighties it was in decline, many of its members back in the Unitarian fold. Its views, expressed in its organ, The Index, edited by Francis Abbott, and largely written by him and his colleague, William J. Potter, influenced the later humanistic theism of the Unitarians, and particularly the emergence of the social gospel.

\section{Smith, Hilrie S. Changing conceptions of original sin; a study in American theology} since 1750 . New York, Scribner, 1955. 242 p.

$$
55-9682 \quad \mathrm{BT}_{720 . \mathrm{S}_{5}}
$$

An illuminating study of the doctrine of original sin ir American religious thought, first presented as lectures at Princeton Theological Seminary by a professor of Duke University Divinity School. Dr. Smith explains the Puritan concept, the "federal" or "covenant" doctrine of inherited corruption through Adam's disobedience, which dominated colonial theology-“"In Adam's fall, We sinned all." In the 18th century Jonathan Edwards and his followers upheld this Calvinistic tenet of native and inherited depravity against the repudiation of infant damnation by the English Daniel Whitby and John Taylor and their American disciples, the precursors of the Unitarian revolt. In the reth century a modified form of the Calvinist position was maintained by Nathaniel W. Taylor at New Haven, and later by Horace Bushnell, and was opposed by the Unitarian Harvard school, led by Andrews Norton. The liberalism that followed Darwin rejected the fall of man and argued that sin originated in man's refusal to respond to his higher nature. This trend, dominant in late Igth and early 2oth century thought, was challenged by Walter Rauschenbush, and in our own day by Niebuhr and Tillich, who have returned to a doctrine of original sin as indis- pensable to an understanding of the human situation and of the Christian doctrine of grace.

5437. Wieman, Henry Nelson, and Bernard Eugene Meland. American philosophies of religion. Chicago, Willett, Clark, 1936. 370 p.

Bibliography: p. 353-359.

36-15871 BL51.W55

Professor Wieman of the University of Chicago is himself one of the prominent voices in liberal American theology at the present time. $\mathrm{He}$ and Professor Meland are both "empirical theists," whose thought is close to that of John Dewey, Shailer Mathews, and others who derive their idea of God from the experience of value in the scientifically apprehended world of events. This book, designed for college use, surveys, defines, and labels contemporary types of religious thought as presented by individuals. It opens with a general section of orientation as to the background and traditions of American philosophies of religion. Then four main types are distinguished, "rooted in the traditions," respectively, of supernaturalism, idealism, romanticism, and naturalism. Within these are many shadings. Supernaturalists are traditionalist or neosupernaturalist. The idealists include absolutists, modern mystics, and personalists. Within romanticism come ethical intuitionists, and philosophic, theological, or aesthetic naturalists. These last shade off into the "rooted" naturalists, who may be evolutionary theists, cosmic theists, religious humanists, or empirical theists. The volume ends with a short symposium, "The Present Outlook in Philosophy of Religion," by representatives of the four main branches, with summaries by the editors.

5438. Williams, Daniel Day. The Andover liberals; a study in American theology. New

York, King's Crown Press, i941. 203 p.

Bibliography: p. [193]-199.

42-480 BV4070.A56- $5941 \mathrm{a}$

The liberal movement in American Protestant thought found its most vigorous early expression at Andover Theological Seminary in Massachusetts during the years 1880 to 1895 . This stronghold of Calvinism, founded by the Congregationalists in I 808 , had been throughout the century a major battlefield of old and new faiths. Until $188 \mathrm{I}$, when Edwards A. Park (no. 5428) retired, Calvinist orthodoxy held the fort; in that year a new faculty, trained in the German critical-historical approach and in evolutionary philosophy, began to champion evangelical religious liberalism. Their journal, the Andover Review (1884-93), was the organ of the new theology. Dr. Williams' study, which originated as a Columbia University dissertation, re- 
views the history of Andover and outlines the new developments in thought and their enunciation by the faculty and by the Review. Toward the close of the century, as strikes and labor troubles increase, the Andover theologians turned more and more to social problems. The movement culminated in
"Social Christianity," marked by the establishment of a settlement house, Andover House in South Boston, in 1892. "The House's Head Resident found himself wondering if after all the trade union movement, and not the church, might be God's right arm in the bringing in of His Kingdom."

\section{E. Religious Bodies}

5439. Braden, Charles S. These also believe; a study of modern American cults \& minority religious movements. New York, Macmillan, I949. $\mathrm{xv}, 49 \mathrm{r}$. 49-89I7 BR5I6.B697

The author, a liberal Methodist, is an emeritus professor of the history and literature of religions at Northwestern University. Most writings on the groups here treated, he explains, have aimed "either to exploit the strange, bizarre elements which many of them do undoubtedly contain ... or to expose their weaknesses, refute their claims, laugh at their idiosyncrasies and so to discredit them." His is a careful scholarly study, based, insofar as each group would permit, on its own files of source materials. The lucid analysis of each comprises: essential historical facts; an explanation of its major distinctive religious ideas and their divergences, from and relationships to normative Protestant or Catholic faith; the form of organization; significant practices, social or economic as well as religious; the basic motivations to which they appeal; and current trends. The cults or minority religious bodies here examined are: The Peace Mission movement of Father Divine; Psychiana; New Thought; Unity School of Christianity; Christian Science; Theosophy; the I Am Movement; the Liberal Catholic Church; Spiritualism; Jehovah's Witnesses; Anglo-Israel; the Oxford Group movement; and Mormonism. Appendix A is a short selected bibliography (p. 453-46o), Appen$\operatorname{dix} B$ is a brief dictionary of 18 other modern cults not included in the study. In $195^{8}$ Dr. Braden published a full-length objective "case study" of one of these religious bodies: Christian Science Today; Power, Policy, Practice (Dallas, Southern Methodist University Press. 432 p.). As his title indicates, his primary interest is not in the life of Mary Baker Eddy, but in the modifications of her teaching and the development of Christian Science thought and practice during the half-century since her passing, and in the means whereby the Board of Directors of the Mother Church in Boston have maintained their authority over 3 II5 congregations throughout the United States and the world. It includes a very useful bibliography (p. 403-417).
5440. Clark, Elmer Talmage. The small sects in America. Rev. ed. New York, AbingdonCokesbury Press, 1949. $25^{6} \mathrm{p}$.

Bibliography: p. $236-240$.

$$
\text { 49-10200 BR5I6.C57 } 1949
$$

On the numerous little religious bodies, "for the most part unknown to even well informed persons," this book, first published in 1937, has been the standard and, until recently, the only publication of its kind. The author emphasizes that the descriptions are his own rather than those of representatives of the several groups; the latter would as he has found, entail endless repetition and much obscurity. "A glance at the U.S. Census of Religious Bodies will show the results of that procedure." (In this connection it might be noted that the Census of Religious Bodies has not been taken since 1936, and in the r 960 census religious distinctions are to be omitted from vital statistics.) Dr. Clark's attention is focused on the distinctive principles of the sects, and on their points of difference rather than on the agreements, which, he reminds us, "are far more numerous and important than differences. In spite of superficial appearances the churches are nearly all alike, and the strife or contention between them has been greatly exaggerated." In a running narrative which includes generalizations on sectarianism he examines about a hundred churches, denominations, and sects, grouping them by "the types of mind to which their leading principles appeal." His seven main categories are the pessimistic or adventists, the perfectionist or subjectivist, the charismatic or pentecostal, the communistic, the legalistic or objectivist, the egocentric or New Thought, and the esoteric or mystic. The last two groups must be sought in the Appendix.

544I. Drummond, Andrew L. Story of American Protestantism. Boston, Beacon Press, 1950. 418 p. 50-12382 BR515.D8 1950 Bibliography: p. 407-413.

The writer is a Scottish theologian. His account of the metamorphoses of the Protestant faiths transplanted from England, Scotland, Holland, and 
Germany to the New World is in vivid narrative style. Of five books, the first four are historical: "Colonial Genesis," "Unification" (the Great Awakening, the Revolution and post-Revolutionary "ebb-tide"), "Sectionalism" (the New England theology and growth of sectarianism), and "The Frontier and the Faith." The last part, "Modern American Religion (1865-1940)," is a general examination of the Protestant churches-the seven big denominations rather than the multiple small sects which account for only 3 percent of American church membership. Dr. Drummond is concerned to explain to British readers the vigor of the American churches and the strength of the tradition of free Protestantism in the national life. He looks appraisingly at the social gospel, men and methods in evangelism, the liberal theology, eminent preachers, recent tendencies toward a renascence of worship, and interdenominational trends. He has made effective use of secondary sources, and his pages are filled with pertinent detail and telling quotation.

5442. Ferm, Vergilius T. A., ed. The American church of the Protestant heritage. New York, Philosphical Library, 1953. 48r p.

$$
\text { 53-7607 } \mathrm{BR}_{5} \mathrm{I} 6 . \mathrm{F}_{45}
$$

Contents.-The Moravian Church, by J. R. Weinlick.-The Lutheran Church in America, by V. Ferm.-The Mennonites, by J. C. Wenger.-The Presbyterian Church in America, by C. M. Drury.The Protestant Episcopal Church in the United States of America, by W. H. Stowe.-The Reformed Church in America, by M. J. Hoffman.-Unitarianism, by E. T. Buehrer.--The Congregational Christian churches, by M. M. Deems.-Baptist churches in America, by R. G. Torbet.-The United Presbyterian Church in America, by W. E. McCulloch.The Society of Friends in America (Quakers), by W. E. Berry.-The Evangelical Mission Covenant Church and the free churches of Swedish background, by K. A. Olsson.-The Church of the Brethern, by D. W. Bittinger.-The Evangelical and Reformed Church, by D. Dunn.-Methodism, by E. T. Clark.-The Universalist Church of America, by R. Cummins.-The Evangelical United Brethern Church, by P. H. Eller.-Seventh-Day Adventists, by L. E. Froom.-Disciples of Christ, by R. E. Osborn.-Churches of Christ, by E. West.-The Church of God (Anderson, Indiana), by C. E. Brown.

Twenty-one spokesmen for different Protestant denominations here explain their churches, giving the European background, the historic development in America, characteristic features of doctrine, organization, leadership, and other information. Most of the contributors are professors of religious history, and the chief emphasis is on history. Each article is followed by notes, a bibliography, and a list of serial publications of the church described.

5443. [Baptist] Torbet, Robert G. A history of the Baptists. Philadelphia, Judson Press, I950. $53^{8} \mathrm{p}$.

Bibliography: p. 509-526.

50-9198 BX623r.T6

By a professor of history at the Eastern Baptist Theological Seminary, this is an attempt to tell concisely but inclusively the story of the Baptists, who in their several branches constitute the largest single family of American Protestants. The book opens with a brief review of Baptist principles-dependence on the Bible as the sole rule for faith and practice, the church composed of baptized believers, the autonomy of the local congregation, religious liberty, and the separation of church and state-and of the heritage of the Anabaptists of the Reformation. Part 2 summarizes the history and present position of British and European Baptists; although found in almost every country they are nowhere numerically strong except in America. Well over half the text (p. 215-508) is devoted to the American Baptists. From the little band that surrounded Roger Williams, through the great revivals and the missionary expansion, doctrinal dissensions, movements in evangelism and education, widespread foreign missions, and the modern social gospel (whose prophet, Walter Rauschenbusch, was a Baptist), the narrative is carried swifty to the present day. The appendixes include a chronological table, 1525-1950, and a table of Baptist bodies in the United States (6 with more than 100,000 members, and nearly 40 with fewer). The American story is told in far greater detail in an older work originally published in 1894 , Albert H. Newman's History of the Baptist Churches in the United States, 6th ed., rev. and enl. (New York, Scribner, 1915. 545 p.), and its source materials are excerpted in William W. Sweet's collection, Religion on the American Frontier (nos. 5412-5416).

5444. [Catholic] Blanshard, Paul. American freedom and Catholic power. $2 \mathrm{~d}$ ed., rev. and enl. Boston, Beacon Press, 1958. 402 p.

Bibliography: p. $36 \mathrm{I}-365$.

$$
5^{8-6240} \text { BXI770.B55 } 195^{8}
$$

5445. O'Neill, James M. Catholicism and American freedom. New York, Harper, 1952.

287 p. 5I-1r945 BXr406.O5

Mr. Blanshard's much-debated book on the Catholic Church as an organ of political and cultural power was first published in 1949. The 1958 revision includes a review of events of the decade since its appearance and an account of the storm 
of controversy it aroused. The author, a lawyer and a liberal in religion, declares in his "Personal Prologue: The Duty to Speak": "There is no doubt that the American Catholic hierarchy has entered the political arena, and that it is becoming more and more aggressive in extending the frontiers of Catholic authority into the fields of medicine, education, and foreign policy." He describes his study as a review of contemporary facts, and each statement is carefully documented, in large part from Catholic sources. Mr. Blanshard first discusses the working of the hierarchy and its relation to the state, then analyzes Catholic teaching and practice in regard to individual issues-education, medicine, birth control, marriage and divorce, censorship, science, political ideologies, etc. In a second book from the same publisher, Communism, Democracy, and Catholic Power (Boston, 1951. 340 p.), he extends his indictment of Catholic authoritarianism to the world scene. Catholic answers to this polemic have been numerous and indignant. The most detailed is by Mr. O'Neill, a teacher of rhetoric and debate, a former chairman of the Committee on Academic Freedom of the American Civil Liberties Union and a Catholic layman. His volume attempts to show "that Mr. Blanshard's basic thesis [that the Catholic Church is an enemy of American freedom] is false, and that the discussion of the belief and practice of American Catholics which he presents in support of his thesis is so biased and inaccurate as to be substantially worthless."

5446. The Commonweal. Catholicism in America, a series of articles from The Common-

weal. New York, Harcourt, Brace, 1954. 242 p.

$$
54-5256 \text { BXi406.C53 }
$$

5447. Putz, Louis J., ed. The Catholic Church, U. S. A. Chicago, Fides Publishers Association, 19்56. xxiii, $415 \mathrm{p}$.

$$
\text { 56-11629 BXI406.P84 }
$$

The widely esteemed weekly review The Commonweal is edited by Catholic laymen. Its attitude is predominantly that described by the Protestant theologian Reinhold Niebuhr in one of the essays in this symposium: "the Church finding a creative place in the moral and political reconstruction of a modern industrial society." The book reprints 17 essays published in the journal during 1953, all, except Dr. Niebuhr's and Will Herberg's "A Jew Looks at Catholics," by Catholic laymen. The foreword by President George N. Shuster of Hunter College sets the keynote of seeking to allay tensions still felt in the mid-2oth century between Catholics and non-Catholic Americans. The first essay, "Catholicism in America," by William P. Clancy, an editor of Commonweal, outlines and deplores the extreme positions ("Mr. Paul Blanshard on the one side and his Catholic counterparts on the other") in which Catholicism is considered a threat to American democracy and, conversely, "the only force left strong enough to combat an increasingly arrogant secularist invasion of culture." The other essays examine, not uncritically, Catholic separatism, and the Catholic position in politics, isolationism, social reform, radicalism, education, science, arts, letters, and the movies. Another recent symposium, expository rather than analytical in treatment, is The Catholic Church, U.S.A. The 23 articles contributed by Catholic scholars, several of them priests, are grouped in three parts: the first is on the history, structure, and organizational workings of the Church. Part 2 is arranged by regions, showing the diversity of the church in New England, the Deep South, the Pacific coast, etc. The last part concerns the life and influence of the church in social and intellectual spheres. The quality of Catholic social thought is exemplified, for instance, in the essay by the Rev. John La Farge, S.J., on "The Catholic Church and Racial Segregation." Father La Farge, associate editor of the national Catholic weekly America, has been closely concerned with and written much on race relations. He has also recently published $A$ Report on the American lesuits, with photographs by Margaret BourkeWhite (New York, Farrar, Straus \& Cudahy, 1956. 236 p.). Extended from an article for Life, it is a splendidly illustrated outline of the history and current activities of this indefatigable order.

5448. Ellis, John Tracy. American Catholicism. [Chicago] University of Chicago Press, 1956. 207 p. (The Chicago history of American civilization) 56-1 $1002 \mathrm{BX}_{4} 406 . \mathrm{E}_{4}$

Bibliographical references included in "Notes": p. $160-180$.

"Suggested reading": p. 188-197.

5449. Ellis, John Tracy, ed. Documents of American Catholic history. Milwaukee, Bruce Pub. Co., 1956. xxiv, 677 p.

$$
\text { 56-13199 BXI405.E4 }
$$

Monsignor Ellis of Catholic University is managing editor of the Catholic Historical Review and a noted historian. His first volume embodies four lectures concisely sketching in broad general lines the history of American Catholicism. The divisions are chronological, the first lecture covering the colonial period, 1492-1790. The second, "Catholics as Citizens," runs from the inauguration of the hierarchy in the United States under Bishop Carroll in 1790 to 1852 , the year of the first national plenary council. "Civil War and Immigration," 1852-1908, describes the violent anti-Catholic agi- 
tation of the Know-Nothing Party, and the great increase of Catholic population through the Irish, German, and South European immigrations. The last lecture, "Recent American Catholicism," brings the story up to 1956 . The record of the Church in America reveals, according to the author, "the maximum of loyalty and service to every fundamental ideal and principle upon which the Republic was founded and has endured." He lays much stress on the discrimination against Catholics that has prevailed throughout the four-century story. Dr. Ellis had earlier published a larger bibliography than the one in this volume: $A$ Select Bibliography of the History of the Catholic Church in the United States (New York, McMullen, 1947. 96 p.) with 775 entries, most of them books, and with brief annotations for the greater part. The large volume of Documents is likewise in chronological order, selected from the source materials of Catholicism in America. They begin with the Papal Bull of Demarcation in 1493 and end with the Encyclical of 1939, Sertum laetitiae, celebrating the I5oth anniversary of the American Hierarchy. Their great variety includes inspiring records of missionary faith and heroism; expressions of tolerance, patriotism, and charity; and contributions to art and letters, social thought and action, and political thought.

5450. Maynard, Theodore. The story of American Catholicism. New York, Macmillan, 1941. xv, $694 \mathrm{p}$.

Bibliography: p. 649-675.

An eminently readable historical narrative by a Catholic scholar, poet, and man of letters. One Protestant reviewer called his book "mythology, antiProtestant polemic, propaganda, history and criticism blended into a literary masterpiece." The chronological narrative ends with the death of Cardinal Gibbons in 1920. In the penultimate chapter Dr. Maynard reviews the cultural contribution of many Catholic writers, poets, artists, and musicians, and in the last, "The Corporate Vision," he discusses briefly the social action of the church, the liturgical revival, and other aspects of her estate in the second quarter of the 2oth century. He takes issue with those who have claimed that the Catholic Church is inherently incompatible with the culture of the United States. He recognizes, he says, "dangers of Catholic disintegration here. But they do not come from American thought or American institutions; they come from the spirit of the times, from which Americanism itself is in danger." A later book by Dr. Maynard, The Catholic Church and the American Idea (New York, Appleton-Century-Crofts, 1953. 309 p.), is a fuller and equally forceful statement of Catholic participation in and contributions to American civilization. In his most recent work, Great Catholics in American History (Garden City, N.Y., Hanover House, 1957. 26I p.), he briefly relates the life stories of 21 Catholic saints, heroes, and leaders beginning with the Jesuit Fathers and ending with $\mathrm{Al}$ Smith.

5451. Shea, John D. Gilmary. A history of the Catholic Church within the limits of the United States, from the first attempted colonization to the present time. New York, J. G. Shea, I88692. $4 \mathrm{v}$.

$$
\text { 35-16425 BXI406.S5 } 1886
$$

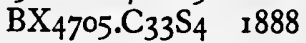

Shea (1824-1892) abandoned a novitiate in the Society of Jesus in order to write the history of his church in America, and his magnum opus is one of the chief monuments of American Catholic scholarship, representing prolonged research in original source materials. The four volumes cover: I, the Catholic Church in the colonies, English, French, and Spanish; 2, the life and times of Bishop John Carroll (1763-1815); 3, I808-1843; 4, 18431866. A projected fifth volume was never completed. All the volumes have many illustrations, "portraits, views, maps, and fac-similes." Practically every page is crowded with footnotes, many of them including comment, additional data, and quotation as well as references. The work, while outmoded in some respects, remains impressive in its scholarship, eloquence, earnestness, and objectivity. Shea's voluminous output consisted largely of documentary publications, but his History of the Catholic Missions among the Indian Tribes of the United States, 1529-1845 (New York, E. Dunigan, 1855. 514 p.) deserves separate mention.

5452. [Christian Science] Beasley, Norman. The cross and the crown; the history of Christian Science. New York, Duell, Sloan \& Pearce, 1952. $664 \mathrm{p}$. 52-9086 BX693I.B4

5453. Beasley, Norman. The continuing spirit. New York, Duell, Sloan \& Pearce, 1956. $403 \mathrm{p}$. 56-5050 BX6931.B38

The first work is a history of the beginnings and widening acceptance of the teachings of Mary Baker Eddy, from her own healing and her discovery of "the Christ Science" in 1866 to her death in I910. The second book takes up the story of the church at that point, with some backward glances, and carries it to the present day. The author disclaims any connection with the First Church of Christ, Scientist, and in his preface to the second declares that he wrote both works on the basis of his own research, "carried on in sources wholly outside the Archives of the Mother Church." His single purpose, he says has been to present "an independ. 
ent, documented history of what Mary Baker Eddy left to her followers." His treatment of the discoverer and founder of Christian Science is uniformly sympathetic, and her position in the controversies which surrounded her is justified at each step of his full narrative of the persecutions, financial worries, intrigues, conflicts, and apostasies through which she maintained the leadership of a great and powerful religious movement. The crowded detail includes frequent and lengthy extracts from her writings, but contains nothing on the doctrinal sources of her new faith--at least, none since the third century A. D.--and leaves the impression that it was entirely self-contained. In the second book less attention is paid to the doctrines of Christian Science than to its organization, litigation, publishing, and other activities.

5454. [Congregational] Atkins, Gaius Glenn, and Frederick L. Fagley. History of American Congregationalism. Boston, Pilgrim Press, I942. $432 \mathrm{p}$.

Bibliography: p. [409]-4I6.

42-18901 BX7135.A75

In the last chapter of this substantial history of the Congregational churches in America, the authors appraise the Congregational polity as "An Adventure in Liberty." "The right and duty of the church member to administer his own church business with a direct control; a minimum of ecclesiastical machinery; willing obedience to majority discussions; a disciplined respect for the right of the minority. Congregationalism believes this to be necessary to the liberty of a Christian man, and whatever else is built must be upon this foundation." The story of the church which became American Congregationalism begins with its background of separatism on the Continent and in England, the group of exiles in Holland, and the Pilgrim Fathers in the New World. The Mayflower Compact is one of the covenants, the forms which united the saints into visible churches, reproduced in the Appendix. Among the Puritan churches of New England, the name Congregational "just growed." Landmarks in the story are the "New England Way," the adoption of the Cambridge Platform of Church Discipline (1648), the Great Awakening, the Revolution, the "departure" of the Unitarians, the expansion into the Northwest Territory, the growth of national consciousness and social concern, and the formation of the National Council and the Benevolent and Mission Boards. The forms of organization at successive periods are carefully noted.

5455. [Disciples of Christ] Garrison, Winfred Ernest, and Alfred T. De Groot. The
Disciples of Christ, a history. St. Louis, Christian Board of Publication, 1948. 592 p.

Bibliography: p. $57 \mathrm{x}-576$. $49-7481 \quad \mathrm{BX}_{73}{ }^{15 . G_{33}}$

A coordinated and well-rounded history of the group of reunionist, congregational, noncreedal churches known as the Disciples of Christ and the Churches of Christ. The authors are both Disciples, and Dr. Garrison is recognized as one of the country's eminent professors of church history (no. 5405). This denomination originated as a direct outgrowth of the Great Western Revival in two separate movements of secession from the Presbyterian Church, the Stone movement in Kentucky in 1803 (Barton W. Stone's parish was Cane Ridge, scene of the most famous camp meeting), and Thomas Campbell's movement in western Pennsylvania in 1809 . Basic ideas of both were a reunion of all Christian churches without sectarian division (resulting, of course, in the creation of new sects), and the Bible as sole authority, without "human" additions of creeds and ecclesiasticism ("anyone who could get an audience could preach"). The name of Disciples was first used by the Campbellites during the vigorous evangelism of Walter Scott around 1830 . In the next decade the two bodies merged, and the first national convention was held in 1849. In growth through missionary effort along the advancing frontier, in planting churches, in preaching and publishing, and in establishing schools," the story of the Disciples parallels that of the country." Since the census of I906 the conservative branch, gradually differentiated by the accumulation of small differences in matters of practice, has been listed separately under the name of Churches of Christ.

5456. [Episcopal] Manross, William W. A history of the American Episcopal Church. [2d ed., rev. and enl.] New York, MorehouseGorham, 1950. xiv, 415 p.

Bibliography: p. $373-386$.

$$
\text { 50-8326 } \mathrm{BX}_{5} 880 . \mathrm{M}_{35} \quad \mathrm{r} 950
$$

5457. Addison, James T. The Episcopal Church in the United States, 1789-1931. New York, Scribner, 1951. 400 p.

Bibliography: p. $3^{82-385}$.

$$
\text { 5I-10050 } \mathrm{BX}_{5} 880 . \mathrm{A}_{33}
$$

The first of these two histories is a standard reference work, calm and dignified in style; it might even be termed prosaic. Dr. Manross covers a host of facts, names, and events. For the colonial beginnings he has depended on I9th-century histories, but much of his later text is from primary sources. Almost half the book is taken up with the slow expansion of the church in the colonies, the un- 
successful efforts to secure an American episcopate, and the serious decline during the Revolution when the Anglican clergy by and large inclined to the Loyalist side. The author feels this decline is often exaggerated; by 1785 the first General Convention met, and after a few years of reorganization and recuperation a vigorous revival and expansion were under way, led by the great Bishops John Henry Hobart and Alexander Viets Griswold, representing respectively High Churchmanship and Evangelicalism. Equally fact-crowded treatment is given to the establishment of missions in the West and abroad, the effects of the Oxford Movement (AngloCatholicism) and of rgth-century liberalism, and to institutional and organizational factors in the present-day church. Dr. Addison's book covers the same story (to I93I) in very different fashion. His narrative is rapid and colorful, focusing on the social environment and on great individual leadersamong others, the Revolutionary Bishop William White, Bishops Griswold, Hobart, Philander Chase, R. C. Moore, and Alonzo Potter, Dr. W. A. Mühlenberg, the missionary Bishop William $\mathrm{H}$. Hare, the great preacher Phillips Brooks, and in the 2oth century Bishops William Lawrence and Charles $\mathrm{H}$. Brent. The writer offers more exposition of doctrine than does Dr. Manross and points out some weaknesses and failures of the church as well as its rich contributions to American Christianity.

5458. [Judaism] Glazer, Nathan. American Judaism. [Chicago] University of Chicago Press, 1957. 175 p. (The Chicago history of American civilization) $\quad 57-8574$ BM205.G5

5459. Levy, Beryl Harold. Reform Judaism in America; a study in religious adaptation. New York, I933. 143 p.

$$
\text { 34-4818 BM205.L45 } 1933
$$

5460. Sklare, Marshall. Conservative Judaism; an American religious movement. Glencoe, IIl., Free Press, 1955. 298 p.

\section{5-7332 BMig7.5.S $45 \quad 1955$}

Mr. Glazer focuses his concise history on two main tendencies of Jewish religion in an American environment. - The tiny communities of dignified, upper-class Orthodox Jewish merchants in early America represented both Judaism, the tradition of the law pervading the whole of life, and "Jewishness," the ethnic separateness of the Jewish people. With the large-scale immigration of refugees from the German ghettos (1825-80), there came in influences fostering religious as well as political freedom, and Reform Judaism rose concurrently with an increasing social and economic merging of the well-dispersed Jews into the new land of liberty.
But with the flood of East European Jewry-nearly 2 million immigrants between 1880 and 1920 , concentrated in the New York area- "Jewishness" revived, bringing on the one hand, militant irreligion, socialistic politics, and Zionism, and on the other, extreme orthodoxy. The process of integration of these newcomers with the Jewish community and the general stream of American life is analyzed from a sociological viewpoint. The author seeks to show that "Jewishness" has virtually disappeared, and that the practices of Judaism have been adjusted to the mores of the American middle class. He ends with a discussion of the revival since 1940, paralleling that in other faiths, of all forms of Judaism, Orthodox, Conservative, and Reform. The following two titles originated in dissertations at Columbia University. Dr. Levy's Reform Judaism has long been the standard treatment of this movement for a modernist revision of Jewish religious thought. Reform Judaism stemmed from the enlightenment and the struggles of the German Jews for civil liberties, and in America shaped itself so as to fit the Jews into the prosperous, comfortable, and liberal society of the late rgth century. The volume is in three parts, "Re-Making the Prayer-Book" (doing away with part of the rigid Mosaic ritual), "Attempts at a Theology" (movements toward rationalism and their leaders), and "Practical Issues and Rabbinical Reasoning." Mr. Marshall Sklare's Conservative Judaism is a wellorganized study of the school which rose as a halfway house between the tendency of Reform Judaism toward complete assimilation into the larger gentile community, and the ethnic exclusiveness of Orthodox Judaism. Its doctrinal center is the Jewish Theological Seminary in New York, founded in 1886 to counteract the influence of the Reformist school, the Hebrew Union College in Cincinnati.

546r [Lutheran] Wentz, Abdel R. A basic history of Lutheranism in America. Philadelphia, Muhlenberg Press, I955. $430 \mathrm{p}$.

\section{$55-7765 \quad \mathrm{BX} 804 \mathrm{I} \cdot \mathrm{W}_{3} 8$}

5462. Spaude, Paul W. The Lutheran Church under American influence; a historico-philosophical interpretation of the church in its relation to various modifying forces in the United States. Burlington, Iowa, Lutheran Literary Board, 1943. 435 p. 43-10142 BX8041.S65 Bibliography: p. [403]-429.

The Basic History is a standard text by a cleric and historian prominent in Lutheran circles at home and abroad. His story is framed in the political and social history of America. The great name of the early days is Henry M. Muhlenberg, who in the 
middle I70o's organized the congregations of German and Swedish Lutherans in Pennsylvania and the neighboring Colonies into the first synods. In the I820's a large measure of unity was achieved, with a general synod and a seminary at Gettysburg, but separatism increased with national discord and with the immigration of several million Germans and Scandinavians into the Middle West. Although essentially one in the basic tenets of their conservative doctrine (Luther's "Church, conscience, and the Book"), the various bodies have developed a great variety in organization and practice. At one time there were 150 Lutheran groups; there are now fewer than 20. Their divisions as to points of faith and polity, and the trends of the modern age toward union in liturgy, in social action, in welfare and relief work, and in synods, conferences, and councils, at home and abroad, form the chief theme of Dr. Wentz' later chapters. His general bibliographical note (p. $3^{85-388)}$ describes 7 historical works, all but 2 from the rgth century. Mr. Spaude's work is not a chronological narrative but, as its subtitle indicates, an interpretation of the development of the Luiheran Church in America. The first 40 pages describe the Lutheran movements in the European homelands. Then American Lutheranism is analyzed with respect to the chief influences it has undergone-democracy, industrial organization, Sunday schools, secret societies, universities, modern financial organizations, the social gospel, "evolution," the other Protestant faiths, rationalism, revivalism, and ecumenical trends.

5463. [Methodist] Sweet, William Warren. Methodism in American history. Revision of 1953. Nashville, Abingdon Press, 1954. 472 p. illus. $\quad 54-5943$ BX8235.S9 1953

The history of Methodism in America, springing out of the great spiritual urge of John Wesley (r703-r79r) and rapidly spread by the colorful means of the revival meeting and the circuit rider, is one that lends itself to the style of its leading historian, at once expert scholar and vivid interpreter. Dr. Sweet was ordained in 1906, and served as a Methodist pastor for five years before taking up his life work of religious historian (nos. 5401-5402, $5410-5416)$. In this narrative persons and events play a larger part than doctrine. Despite the temptations offered by the exciting early days, by Wesley, Devereux, Jarratt, Asbury, and by the explosive westward expansion of the church, the author gives equal attention to later phases of Methodism in the history and social development of the Nation. The book was first published in r933, and ended with a chapter "[Methodism] Faces the Great War and Its Aftermath." For the revision 20 years later a long chapter has been added, "Through Two Decades of
Storm and Stress, 1933-1953," in which are reviewed the concerns of Methodism with the depression, Nazism, neo-orthodoxy (with which Dr. Sweet does not go along), prohibition and its end, pacifism, World War II, peace programs, Protestant-Catholic tension, and the ecumenical movement. An appendix outlines the church's organizational structure. This is a complex matter, involving various institutions and procedures developed over the years. For a full understanding, reference may be made to a scholarly monograph by Nolan Bailey Harmon: The Organization of the Methodist Church; Historic Development and Present Working Structure, rev. ed. (Nashville, Methodist Pub. House, r953. 288 p.). A painless introduction to Methodist history is the handsome quarto picture book put together by Elmer Talmage Clark, An Album of Methodist History (New York, Abingdon-Cokesbury Press, 1952. 336 p.). This contains reproductions of contemporary prints and other illustrations of Methodist beginnings. The first section covers the life and times of John and Charles Wesley, their families, associates, and successors in Britain and its colonial possessions; the second and longer section illustrates American Methodism.

5464. [Mormon] Brodie, Fawn (McKay). No man knows my history; the life of Joseph Smith, the Mormon prophet. New York, Knopf, r945. ix, 476, xix p. illus.

Bibliography: p. $466-476$. $45-948 \mathrm{I} \quad \mathrm{BX} 8695 . \mathrm{S}^{\circ} \mathrm{B}$

5465. West, Ray Benedict. Kingdom of the saints; the story of Brigham Young and the Mormons. New York, Viking Press, 1957. $3^{89} \mathrm{p}$. illus. 57-6437 BX86ri. W4

Mrs. Brodie's biography of Joseph Smith is a work of intensive scholarship, widely praised as the best history of the prophet and seer upon whose revelations the Church of Jesus Christ of the Latter-Day Saints was founded. The author has searched out and scrutinized carefully the evidence on all sides of the strange story, and her picture of her subject is impartial and in the main sympathetic. Her account ends with the martyrdom of Joseph Smith in Carthage, Illinois, in 1844 . In her first appendix she quotes documents on his early life; in the second she disposes of the Spaulding-Rigdon Theory of the authorship of the Book of Mormon. Appendix C identifies the plural Mesdames Smith. The bibliography is brief and selective, and does not attempt to list "the legion of secondary source books that furnished background for the life and times of Joseph Smith." Mrs. Brodie's title is taken from a speech made by the prophet himself a few months before his death. "I don't blame anyone for not believing 
my history," he said. "If I had not experienced what I have, I could not believe it myself." His biographer's suggested answer is that he was essentially a romantic author whose imagination made his romance more real to him than reality. The author of Kingdom of the Saints, who comes of Mormon stock and grew up as a devout believer, is more ready to accept $S$ mith as a genuine religious mystic whose transcendent experience could not be proved and must be believed. This, Mr. West says, is "the only point of view that can present the Mormon religion for what it is, the basis of a belief which holds the faith of almost a million and a half today." He protests against the usual treatment of the Mormon story "as a comic episode in American history." His narrative covers the whole epic but is sketchy regarding Joseph's revelation and the founding of the church. Mr. West's protagonist is rather Brigham Young, the Moses who led the exodus of the saints and established their "foursquare" kingdom, a Zion at once spiritual and material. Essentially a religious history, it emphasizes the faith by which the heroic pioneers accomplished their latterday miracle. Nels Anderson's Desert Saints; the Mormon Frontier in Utah (Chicago, University of Chicago Press, 1942. xx, 459 p.) is a remarkably vivid picture of the frontier community created by the Mormon Church in Utah down to about 1877 , emphasizing the partial achievement of its ideal: an economic autarchy of religiously dedicated families from which both riches and poverty had been eliminated. The many original sources used by the author are listed in his bibliography (p. 447-452).

5466. [Presbyterian] Slosser, Gaius J., ed. They seek a country; the American Presbyterians, some aspects. New York, Macmillan, 1955. xvi, 330 p. illus. 55-14554 BX8935.S55

Bibliography: p. 322-324.

Thirteen lectures delivered at an historical symposium are here published to form an overall sketch of the Presbyterian Church in the United States. The arrangement is roughly chronological, the first chapter by the editor being on Old World originsCalvinism and its manifestations in Northern Ireland, Scotland, and England. "Beginnings in the North" covers the colonial era, and tells how the great missionary, Francis Makemie, established the first intercolonial Presbytery in the Middle Colonies in 1706 , "at least four decades earlier than any other intercolonial body among American churches." "Beginnings in the South" deals particularly with the Scottish settlements of the Carolinas. "The United Presbyterian Church" and "The Reformed Presbyterian Church in America" explains the schisms of the rgth century and the resultant groupings. "The Founding of Educational Institutions," by W. W. Sweet, is an important chapter in the church's history. The Presbyterian contribution to the Revolution, the Constitution, and the Government of the United States are examined in "Service in Founding and Preserving the Nation." There are chapters on missionary expansion at home, on the antislavery struggle, and on events and trends in the early and later 19 th century. K. S. Latourette contributes a chapter on his specialty, "Service Overseas." The last is "Today and Tomorrow: the Road Ahead," with three authors. In each chapter four pages reproduce portraits of important leaders, thumbnail biographies of whom are included in a "Who's Who" appendix. The last group (after p. 270) includes six presidents and five other statesmen. A recent compilation of documents is The Presbyterian Enterprise; Sources of American Presbyterian History, edited by Maurice W. Armstrong, Lefferts A. Loetscher, and Charles A. Anderson (Philadelphia, Westminster Press, 1956. 336 p.). The interesting selections are tied together by brief historical notes.

5467. [Quaker] Thomas, Allen C. A history of the Friends in America. 6th ed., rev. and enl. Philadelphia, Winston, 1930. 287 p. (Pennsbury series of modern Quaker books)

Bibliography: p. $257-280$.

$$
3^{0-2} 7^{8} 32 \quad \mathrm{BX}_{7} 635 . \mathrm{T}_{5}
$$

1930

5468. Brinton, Howard H. Friends for 300 years; the history and beliefs of the Society of Friends since George Fox started the Quaker movement. New York, Harper, 1952. 239 p.

$$
5^{2-5424} \mathrm{BX}_{7} 63 \mathrm{r} . \mathrm{B}_{7}
$$

The older of these titles, first issued in 1894, is a highly condensed history of the Society of Friends, from its beginnings in England with the mystic experience ( 1646 ) of the founder, George Fox, and his preaching of the Inner Light. By 1656 members of this "cursed set of heretics" had reached New England, and in spite of persecution by colonial governments from Massachusetts to Virginia, its spread was rapid. The visit of Fox himself in 1672 made many converts, while the acquisition of Pennsylvania as a proprietary colony by William Penn and the British Toleration Act of 1689 gave the congregations of Friends a settled status by 1700 . In the I 8 th century notable aspects of Quaker history were the excellent relations with the Indians, leadership in opposition to slavery, and the sufferings of pacifist Friends during the Revolution. The early rgth century brought divisions-Orthodox, Hicksite, and Wilburite Friends-confirmation of the antislavery stand, and the first educational foundations. The account of later years summarizes events through the First World War. The revised edition was the 
work of William Brinton Harvey. Dr. Brinton's book is theological rather than historical, concentrating on Quaker faith and practice- "To Wait upon the Lord," "The Light Within as Experienced," "The Light Within as Thought About," etc. He declares Quakerism to be "an explicit and developed manifestation" of a third form of Christianity besides Protestantism and Catholicism. There is a short historical chapter: "The Four Periods of Quaker History and Their Relation to the Mystical, the Evangelical, the Rational, and the Social Forms of Religion." The famous work of the Friends' Service Committee, as well as activities among Negroes and Indians, in education, and in international relations, are described in a chapter on "The Meeting and the World."

5469. [Shaker] Melcher, Marguerite (Fellows) The Shaker adventure. Princeton, Princeton University Press, 194I. 319 p.

$$
4^{\mathrm{I}-5 \mathrm{I} 750} \quad \mathrm{BX}_{9765 . \mathrm{M}_{4}}
$$

Annotated bibliography: p. 294-30I.

A warmly sympathetic history of the "moral and industrious, though eccentric, people" called Shakers and their handicraft culture. This interesting communitarian sect, now almost extinct, grew up around an Englishwoman, "Mother Ann" Lee, to whom it had been revealed in a vision that she was the female incarnation of Christ in the second coming, and who in 1774 led a band of nine Believers to their adventure in America. The account of the beginnings and early days is written with respect for, if not complete acceptance of, Mother Ann's spiritual gifts. The principles of the Shakers, so called from their extreme bodily manifestations of the spirit in worship, were the confession of sins, community of goods, celibacy (new members were by conversion, children, if any, by adoption), and withdrawal from the world. Guided by fresh revelations, advancing under persecution, and spreading with the revival of the early 1800 's, the Society of the United Believers, commonly called Shakers, in their peak period between 1840 and 1860 numbered some 6,000 members, established in I 8 rural communities from Maine to southwest Kentucky. Men and women lived and worked side by side with sex eliminated through religious emotion. Farmers and craftsmen, thorough and practical, they achieved a "hand-minded" society which provided economic security and peace, and has left to machine-age collectors a treasure of craftsmanship. Mrs. Melcher has made extensive use of Shaker records for her detailed story.

5470. [Unitarian] Cooke, George Willis. Unitarianism in America; a history of its origin and development. Boston, American Unitarian Association, 1902. 463 p. illus.

$$
\text { 3-605 } \mathrm{BX}_{9} 833 \cdot \mathrm{C}_{7}
$$

547I. Wilbur, Earl Morse. A history of Unitarianism. Cambridge, Harvard University

Press, 1945-52. 2 v. A45-3134 BX983r.W49

ConTENTS.-[ $\mathrm{I}]$ Socinianism and its antecedents.-[2] In Transylvania, England, and America.

5472. Wright, Conrad. The beginnings of Unitarianism in America. Boston, Starr King Press; distributed by Beacon Press, 1955. 305 p. "Bibliographical appendix": p. [28I]-29I.

"Bibliographical note": p. [292]-294.

55-8 138 $\mathrm{BX}_{9833 . \mathrm{W}_{7}}$

The time-honored work by Dr. Cooke is still the one full-scale history of American Unitarianism. In Dr. Wilbur's authoritative modern study only the last four chapters (v. 2, p. 379-487) are devoted to the doctrine in the New World. The movement in America, although preceded in general by the liberal thought of the Reformation (Dr. Wilbur goes back in his first volume to antecedents in the Apostolic Age) and influenced by the writings of English rationalists and deists, was essentially an outgrowth of New England Puritanism. Dr. Wright's interesting monograph illuminates the doctrine of free will, usually referred to as Arminian in 18 th-century New England, which preluded the Unitarian break with Calvinism. The r8th-century liberals, he says, combined the three tendencies of Arminianism, supernatural rationalism, and anti-Trinitarianism. Their great spokesmen were Charles Chauncy and Jonathan Mayhew; their chief opponent was Jonathan Edwards with his defense of original sin. The new trends of thought, nourished by the revolutionary social and political climate, spread widely; Dr. Wright in an appendix lists 60 ministers identified as Arminians from their printed sermons and tracts, and over 20 more reputed to be "new divinity" men. His story ends with the open breach of 1805 , when the election of the liberal Henry Ware as Hollis Professor of Divinity at Harvard opened the socalled Unitarian Controversy. For half a century Unitarian views were set forth in a torrent of controversial books, pamphlets, and magazines, and by such spokesmen as William E. Channing, R. W. Emerson, and Theodore Parker. In 1825 the American Unitarian Association was formed as a missionary and publication agency; in the Convention of 1865 the national body was organized in much its present form. Dr. Cooke's history is detailed as to men, publications, and events. His last chapters are concerned with the growth of denominational consciousness, the ministry, social and educational work, and missions and philanthropies. 
Dr. Wilbur's more concentrated account highlights the controversial path of Unitarianism as a more or less spontaneous development among liberal thinkers in many countries and ages.

5473. [Universalist] Eddy, Richard. Universalism in America, a history. Boston, Universalist Pub. House, $1884-86.2$ v.

$$
\text { 43-32304 BX9933. } \mathrm{E}_{3}
$$

1884

Contents.-I. 1636-1800.-2. 1801-1886.

Bibliography: p. 485-599.

Universalism, the doctrine of the eventual salvation of all men through divine grace, has been advanced since early Christian times, and came to America through many channels. This work, which in spite of its age is the only adequate history of the Universalist Church of America, examines at great length and with abundant quotation the evidences of Universalism in various creeds and in the thought of individuals, and the evolution of the church through the i8th and igth centuries. The first great leader, John Murray, organized the denomination in New England in 1785 as the "Independent Christian Society, commonly called Universalists." At a convention of the New Eng- land groups in 1803 there was adopted a Profession of Belief and a Plan of Church Government. Hosea Ballou (1771-1852), whose Treatise on the Atonement, published in 1805 , was one of the normative texts of the movement, strongly infuenced the Universalists toward Unitarian views. The later history of the church is here told in detail as to individual spokesmen, publications, and organizational aspects. Volume 2 includes chapters on the spread of the Universalists outside New England and on educational institutions (Tufts College was founded as a Universalist theological school). The concluding large bibliography catalogs "all that has been published in America either for or against the doctrine of Universal Salvation" through the year 1886. Over the years the Universalists have drawn progressively closer in their radial liberalism to the Unitarians, and in the 1950's steps are being taken toward an organic merger of the two bodies. In 1957 the Universalist Historical Society in Boston published a little book, The Universalist Church of America, a Short History, by Clinton Lee Scott (124 p.). It is little more than an outline, preliminary to a definitive history of Universalism which Dr. Scott has been commissioned to write.

\section{F. Representative Leaders}

5474. [Asbury, Francis] Asbury, Herbert. A Methodist saint; the life of Bishop Asbury. New York, Knopf, 1927. xiv, 355 p. illus.

Bibliography: p. [337]-342.

$$
\text { 27-5884 BX8495.A8A8 }
$$

5475. Duren, William Larkin. Francis Asbury, founder of American Methodism and unofficial minister of state. New York, Macmillan, 1928. $270 \mathrm{p}$. illus. 28-23317 BX8495.A8D8

Francis Asbury (1745-1816), whose "premiership among church founders and religious leaders of the New World is probably one of the most unchallenged facts connected with the history of our country" (Duren), in $177 \mathrm{I}$ was sent by John Wesley as a missionary to the three-hundred-odd adherents of the new movement in America. He began at once the itinerant career which he followed for 45 years. In 1784 he was appointed by Wesley superintendent of the Methodist work in America, and at a conference of all Methodist ministers was elected and ordained, assuming the title of bishop. Until his death he rode over the country from Georgia to Maine and westward to Kentucky, always triumphing over ill health, always preaching, convert- ing, establishing churches (approximately nine hundred), and organizing and directing conferences. His Journal, published in three volumes in 1821 (New York, N. Bangs \& T. Mason), is a notable source for the study of American social as well as religious history. The two biographies here listed, published a year apart, are very different in tone. The first, by a collateral descendant, is a popular work, satirical in its characterization, if not of the circuit-rider bishop and saint, at least of his colleagues and the backwoods society in which they moved. The second, by a Southern Methodist minister, admiringly sets forth the sterling virtues of "the mightiest spiritual beacon that ever blazed on this continent."

5476. [Beecher] Hibben, Baxton. Henry Ward Beecher: an American portrait. New York, Doran, 1927. 390 p. illus.

"Sources cited": p. 357-367. 27-19865 $\mathrm{BX}_{7260} \mathrm{~B}_{3} \mathrm{H}_{5}$

Beecher (1813-1887), the great preacher who for 40 years swayed an audience reaching far beyond the confines of his own Plymouth Congregational Church in Brooklyn, is here the subject of a long 
"portrait," painted in the vivid style of the modern psychological biographer. His influential career as crusader against slavery, and for evolution and woman suffrage, is interpreted as giving highly emotional expression to the changing standards of American society during his long lifetime. During his boyhood the Calvinistic doctrine of predestination to hell-fire, as preached by his father, Lyman Beecher, had hardly been shaken; in three decades it gave way to the easy liberalism of the Gilded Age-with Beecher playing the part of drum major in the parade, our author says. The earlier biog. raphies of Beecher were all laudatory; Hibben's critical analysis tends toward irony, and finds fitting illustrations in contemporary cartoons. Sensational aspects tend to be uppermost, not only in the account of the cause célèbre of 1875 , when Theodore Tilton sued Beecher for adultery, but throughout the entire story of the man who represented God as "loving man in his sins for the sake of helping him out of them." In the middle years of the rgth century, one of the great influences in breaking down the harsh individualism of the Puritan heritage and humanizing the "new theology" was the Congregational minister of Hartford, Conn., Horace Bushnell. "He insisted upon experience in theology, leveled the dividing wall between nature and the supernatural, and set Christ in the middle of the Christian system" (Hopkins in no. 5489). His most recent biographer, Barbara M. Cross, in Horace Bushnell: Minister to a Changing America ([Chicago] University of Chicago Press, 1958. 200 p.), finds that his sermons and books, and especially Christian Nurture (1847) "mapped the course by which orthodoxy was moving toward liberal Protestantism." Another famous voice of the period, though on the opposite side of the religious platform, was the "professional agnostic," Robert G. Ingersoll. In Royal Bob (Indianapolis, Bobbs-Merrill, 1952. 314 p.) Clarence $\mathrm{H}$. Cramer gives a sympathetic interpretation of the orator who, for many years after his "plumed knight" speech of 1876 , was the premier lecturer of the Nation on Science versus Religion, as well as on the Republican Party. The writer gives more space to Ingersoll's political activities than to his religious scepticism.

5477. [Carroll] Guilday, Peter K. The life and times of John Carroll, Archbishop of Baltimore (1735-1815). New York, Encyclopedia Press, 1922. 2 v. illus. 22-10425 BX $4705 . \mathrm{C}_{33} \mathrm{G} 8$

This monumental biography of the first archbishop of the Roman Catholic Church in the United States is also considered to be an authoritative account of the Roman Church of the English-speaking New World in his time. Episodes given careful treatment include: the story of the Roman Catholic part in the Revolution, including Carroll's Canadian mission for the Continental Congress; Carroll's post-Revolutionary controversy with the apostate priest Charles Wharton; his fight to preserve the church from Protestant attack and French political intrigue; the reconstruction of the church and the establishment of the American hierarchy (1784-90); the development of religious orders and of education (Georgetown College, founded in 1789). The late author, professor of church history at the Catholic University of America, wrote solidly and in great detail, making exhaustive use of archival materials in Europe and America. He concluded with a critical essay on the sources, published and unpublished, both for Carroll's life and for the history of the church. Annabelle McConnell Melville's scholarly, but more spirited and readable, biography is confined in its scope to the life, work, and influence of its subject: John Carroll of Baltimore, Founder of the American Catholic Hierarchy (New York, Scribner, 1955. $33^{8}$ p.).

5478. [Gibbons] Ellis, John Tracy. The life of James Cardinal Gibbons, Archbishop of Baltimore, 1834-1921. Milwaukee, Bruce Pub. Co.,

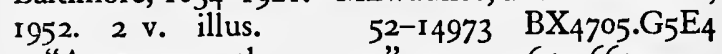

"An essay on the sources": v. 2, p. 65I-669.

The outstanding figure in recent Catholic history in America was James Gibbons. Born in Baltimore of Irish immigrant parents, he became archbishop in 1877 , and the second American cardinal in 1886 . A firm believer in democratic institutions, he took a leading and patriotic part in humanitarian, social, and public affairs. His liberal and conciliatory views were influential in Rome and in national policy alike, and made him a powerful force in the accommodation of the Catholic Church and its huge new immigrant community to American life. His winning personality brought him warm friendships with great and small, and he served as adviser to presidents and popes as well as to his flock. This full and authoritative, if somewhat pedestrian, biography is by the professor of 'church history at the Catholic University of America, which Gibbons was instrumental in founding.

5479. [Jones] Hinshaw, David. Rufus Jones, master Quaker. New York, Putnam, 1951. 306

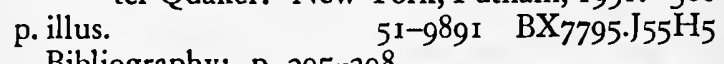
Bibliography: p. 295-298.

Jones (1863-1948), professor of philosophy at Haverford College, chairman for almost 30 years of the American Friends' Service Committee, and the spiritual leader of present-day Quakerism, died in 1948. This biography, by a close friend and associate of many years, includes his reminiscences in its picture of the growth of a modern saint. It opens 
with a short appreciation of Dr. Jones, "the inspiration and the leader of the effort that had turned the century-long gaze of Quakerism from attempted inward ecclesiastical purity through disciplinary don'ts to the outward effort of perfection through spiritual and humanitarian service." A few chapters sketch the history of Quakerism and of the Jones family of South China, Maine. Then Rufus Jones is described in the various phases of his inspiring career as teacher, minister, lecturer, author-he wrote over fifty books and is widely known as an outstanding modern interpreter of religious mysticism-and as organizer of the great relief service which exemplifies the Quaker way of life to the world. The brief bibliography includes the main sources on Quakerism, but lists only a few of Dr. Jones' many published writings, for which one may turn to the compilation of Nixon Orwin Rush: $A$ Bibliography of the Published Writings of Rufus $M$. Jones (Waterville, Me., Colby College Library, I944. 54 p.).

548o. [Moody, Dwight L.] Moody, William R. D. L. Moody. New York, Macmillan, I93o. 556 p. illus.

Bibliography: p. 543-548.

In the latter years of the rgth century, while the new stirrings of evolutionary science were manifest in the sermons of $\mathrm{H}$. W. Beecher and the agnostic oratory of Robert Ingersoll, the dwellers in America's growing cities were thronging in their millions to hear the fundamental Word of God brought to them by the lay evangelist, Dwight L. Moody (1837-r899). He did not confine his exhortations to this country: with his organist helper, Ira D. Sankey, he carried out a two-year mission to England ( $1873-75)$, where he was the instrument of the greatest religious revival of the century. He directed his notable business talents and energies to saving souls through lay enterprises as well as revival meetings. Starting from his Chicago North Market Sabbath School (1858), the programs of religious social service to which his organizational genius gave form expanded into the national system of Young Men's Christian Associations, the Sunday School movement, Northfield Seminary for girls and Mount Hermon School for boys, the Chicago Bible Institute, and the Bible Institute Colportage Association. His vigorous work in missions and conferences in the colleges led directly to the Student Volunteer Movement, which stimulated the expansion of American foreign missions. This biography by his son is informal in arrangement and lavish in quotation from Moody's letters and speeches. Interesting recent biographies of earlier and later evangelists are George Whitefield, Wayfaring Witness, by Stuart C. Henry (New York, Abingdon Press, 1957.
224 p.), and Billy Sunday Was His Real Name, by William G. McLoughlin ([Chicago] University of Chicago Press, 1955. 324 p.). A largely biographical treatment of the whole course of revivalism in America is Weisberger's They Gathered At the River (no. 5403).

5481. [Parker] Commager, Henry Steele. Theodore Parker. [2d ed.] Boston, Beacon Press,

1947. 339 p. illus.

$\mathrm{A}_{4}{ }^{8-998} 3 \mathrm{MnU}$

Bibliography: p. [3II]-33I.

The great New England radical clergyman and reformer who is brought to life in this interpretative biography never withdrew, and was never expelled, from the Unitarian Church in which he had been ordained in 1837. But most of its pulpits were closed against him and the unsettling Higher Criticism that he and his transcendentalist friends imported from Germany. His services in Boston were held in what he called the Twenty-eighth Congregational Society, where for 13 exciting years he preached freethinking religion, transcendental philosophy, and the abolition of slavery to audiences numbering in the thousands. He wrote his long farewell letter to the society, "Theodore Parker's Experience as a Minister," as he sailed away to die of tuberculosis in Italy: it is here called "not only the best brief account of Parker's public career but also the most satisfactory history of the Boston of the forties and fifties of the last century that has ever been written." The other sources on which Professor Commager has largely based his portrayal of the man who was a part of the flowering of New England are the writings, betters, and recorded conversations of Parker's contemporaries.

5482. [Rauschenbusch] Sharpe, Dores Robinson. Walter Rauschenbusch. New York, Macmillan, 1942. 463 p. $42-12945 \quad B X 6495 \cdot R_{3} S_{4} 8$ The great influence of Walter Rauschenbusch (1861-1918), whose name "stands out as a beacon" in the history of the social gospel in America, was principally exercised through his writings. As a young Baptist minister in New York in the late eighties and nineties he had worked much with poor German immigrants; during a year of study abroad he had become interested in Fabian socialism, the Salvation Army, and consumers' cooperatives; and the depression of 1893 confirmed his belief that the Kingdom of God must be realized on this earth. In preaching, in social and organizational activities, and especially in his books, Rauschenbusch drove home this message, and after his publication in 1907 of Christianity and the Social Crisis (New York, Macmillan. 429 p., he was hailed as prophet and leader. His later books, Prayers of the Social Awakening (Boston, Pilgrim Press, 1910. 126 p.), 
Christianizing the Social Order (New York, Macmillan, 1912. 493 p.), The Social Principles of lesus (New York, Association Press, 1916. 198 p.), and $A$ Theology for the Social Gospel (New York, Macmillan, 1917. 279 p.), added to his prestige. This admiring and affectionate biography, by a former student and secretary, was written at the request of the Rauschenbusch family and the Colgate-Rochester Divinity School, where Professor Rauschenbusch taught church history from 1902 until his death in 1918. The narrative of his life is combined with interpretations of his writings, in chapters with such titles as "The Prophet's Pen," "The Social Philosopher," and "The Thunder of the Prophet."

5483. Wise, Stephen S. Challenging years; the autobiography of Stephen Wise. New York, Putnam, 1949. xxiv, 323 p. illus.

$$
\text { 49-48677 } \mathrm{BM}_{755} \cdot \mathrm{W}_{53} \mathrm{~A}_{3} \quad 1949
$$

In this autobiography Rabbi Stephen Wise ( $1874-$ 1949) emphasizes the causes and beliefs for which he battled rather than personal details. The son and grandson of rabbis, Stephen Wise at the age of 20 was appointed pastor of a Conservative Jewish synagogue in New York. In 1900 he was called to a temple in Portland, Oregon, where he became known as a vigorous fighter for child labor laws and a liberal in politics, social thought, and religion. He came back to New York in 1906 to found the Free Synagogue, which he served as rabbi for over 40 years, preaching Reform Judaism and working for civic, social, and Jewish causes. In 1897 he had been the moving spirit in founding the Federation of American Zionists, and throughout his life he strove ardently in the cause of the Jewish homeland. The American Jewish Congress (1917), the Jewish Institute of Religion (the liberal rabbinical seminary) (1922), and the World Jewish Congress (1936) were among other organizations he was instrumental in founding and active in serving. A powerful speaker, he was among the first of his faith to preach to Jews and Christians alike, and he played a prominent role in interfaith movements. Challenging Years was written in the last year of his life. The prophet of American Reform Judaism in the rgth century was Rabbi Isaac M. Wise (1819-1900), unrelated to Stephen. This inspiring leader, imbued with the ideas of the Enlightenment, came from Bohemia in a wave of political immigration in 1846 . After a few years of preaching modernization of the ritual in Albany, he settled in Cincinnati and became the acknowledged head of the large Jewish community of that city. He was the founder and president for 25 years of Hebrew Union College, and the founder of the Union of American Hebrew Congregations and the Central Conference of American Rabbis. He was instrumental in the preparation of the revised prayer book, Minhag America (the rite in American style). His life and influence have been recently summarized in a contribution to the valuable Library of American biography, edited by Oscar Handlin: Israel Knox's Rabbi in America; the Story of Isaac M. Wise (Boston, Little, Brown, 1957. I73 p.).

\section{G. Church and Society}

5484. Cronin, John F. Catholic Social principles; the social teaching of the Catholic Church applied to American economic life. Milwaukee, Bruce Pub. Co., 1955. 803 p.

$$
\text { 55-1755 } \mathrm{HN}_{37 \cdot \mathrm{C}_{3} \mathrm{C}_{6} 9} \mathrm{I}_{955}
$$

A comprehensive and practical textbook by the assistant director of the Department of Social Action of the National Catholic Welfare Conference. Parts I and II, "The Christian Social Order" and "Social Principles in Economic Life," are universal in scope, each chapter beginning with pertinent passages of the social encyclicals and other papal directives for social action, from the Rerum Novarum of Pope Leo XIII in 1891 to the messages of Pius XII in 1949. The interpretation that follows is focused on American problems. The subjects covered include social justice; the "unsound philosophies" of individualism, socialism, and communism; "The Ideal Social Order"; the rights and duties of capital; the social problems of labor; property; the state in economic life; and social reform. Part III is concerned with "American Catholic Social Thought" and covers such matters as the Catholic approach to big business, to the cooperative movement, to rural life, etc. Annotated reading lists and a correlation of the encyclicals and other authorities with the chapters of the book are given in appendixes. A more elementary text for high schools by Father Cronin, Catholic Social Action (Milwaukee, Bruce Pub. Co., 1948. 247 p.), is on practical social programs in the United States.

5485. Douglass, Harlan Paul. The Protestant church as a social institution, by $\mathrm{H}$. Paul 
Douglass and Edmund de S. Brunner. New York, Published for the Institute of Social and Religious Research by Harper, I935. xv, 368 p. diagrs.

Bibliography: p. 356-362. 35-2275 BR516.D66

The Institute of Social and Religious Research was organized in I92I for the investigation by scientific methods of socioreligious phenonmena, with Dr. Douglass as its research director. By the time of its dissolution in October 1934 it had been responsible for 48 research projects relating to rural and urban churches, home and foreign missions, Christian education, the racial aspects of organized religion, and the cooperation and unity of religious forces. (Dr. Douglass was closely concerned with the last theme, and later served as secretary to the Commission to Study Church Unity of the Federal Council of the Churches of Christ.) This solid work is the final report of the institute, quite balanced and comprehensive, and a veritable mine of socioreligious information, with its findings statistically illustrated in 19 tables and 45 charts. After a general and historical introduction the main text (p. 3I-234) is devoted to an account of "Institutional Factors and Processes"-church membership, the church in the community, its organization and the ministry, activities in education and social welfare, finances, etc. Part 3, "Conditioning Factors," surveys environmental influences, cooperation and integration of the churches, and the intellectual and religious climate. The last part, "Foreshadowings," looks at future prospects and policies, notably regarding the church unity movement. Reviewers have called the work "a religious Middletown."

\section{Douglass, Harlan Paul. Protestant coopera-} tion in American cities. New York, Institute of Social and Religious Research, 1930. xviii, 514 p. diagrs.

Bibliography: p. 496. 3I-I893 BX8.D67

5487. Douglass, Harlan Paul. 'Church unity movements in the United States. New York, Institute of Social and Religious Research, I934. xxxviii, $576 \mathrm{p}$.

34-21128 BX8.D66

The first title was one of a series resulting from a statistical survey of urban churches made by the institute. In the 1920's there were in the 50 largest cities of the United States nearly 18,000 churches, of many varieties, involved singly, cooperatively, or competitively in many forms of religious and social activity. To bring the complicated and ponderous machinery of all these into some kind of system was the aim of the federation movement. The author classifies the organizations of federation in five orders: local churches; locally organized denominational a gencies; interdenominational agencies; nonecclesiastical extensions and allies; national or regional administrative machinery of the denominations. Of the two parts, the first is a general report on the movement, on the forms and structures of church federations; membership or participation short of membership; cooperative activities; agencies, resources, and methods; and other aspects of cooperation. The second part is a shorter technical report on specific processes-the committee system, the paid staff, religious education, social service, the work of women's departments, and financing and publicity. The second title, prepared in response to the interest shown in the first, was compiled after questionnaires were sent to more than 20,000 persons. The answers, summarized in over 150 tables, provide the basis for a detailed examination of American opinion regarding church union. There are three parts: "Objective Trends and Popular Reactions," "Ecclesiastical Thinking and Proposals," and "Prospects of Church Union," and methodological appendixes. The chief federal body resulting from the American movement of interchurch organization, The National Council of the Churches of Christ in the United States of America (1950), is itself a merger of 12 interdenominational agencies, the largest of which was the Federal Council of the Churches of Christ in America. It includes also organizations for foreign and home missions, missionary education, women's groups, religious education, the Church World Service for relief, etc. A description will be found in Mayer's Religious Bodies (no. 5397). A lucid account of the Federal Council was written by John A. Hutchison: We Are Not Divided; a Critical and Historical Study of the Federal Council of the Churches of Christ in America (New York, Round Table Press, I94I. $33^{6}$ p.).

5488. Herberg, Will. Protestant, Catholic, Jew; an essay in American religious sociology. Garden City, N.Y., Doubleday, 1955. 320 p. $55-7661 \quad \mathrm{BR}_{5} 25 . \mathrm{H}_{4} 6$

"List of chief works cited": p. [299]-313.

A sociological study of the religious situation in mid-2oth-century America. The author, who has lectured in Protestant, Jewish, and Catholic institutions alike, here interprets the paradox which he finds reflected in every aspect of contemporary religious life: "pervasive secularism and mounting religiosity." His first two chapters deal with the "triple melting-pot" of the land of immigrants, in which, he says, ethnic separateness has almost disappeared and the only differentiating element between descendants of the great immigrant groups is religion. He next discusses the contemporary upswing in religion in American society, explaining lucidly the sociological factors of the shift in Amer- 
ican character-structure from "inner-direction" to "other-direction" (David Riesman's terms from no. 4555), and of the need for security in the age of crisis and spiritual chaos. Next comes a chapter on the place of religion in the American Way of Life, following which the three religious communities of Protestantism, Catholicism, and Judaism are first examined as to general history, philosophy, and present trends, and then compared and contrasted. Their fundamental unity is disturbed by many and serious "religio-communal tensions," but "the interfaith idea" is offered as a reasonable and practicable resolution. The last chapter conveys the author's criticism of the secularism of American religion, which he sums up as "so naïvely, so innocently man-centered."

5489. Hopkins, Charles Howard. The rise of the social gospel in American Protestantism, 1865-1915. New Haven, Yale University Press, 1940. $35^{2} \mathrm{p}$. (Yale studies in religious education, I4) 4I-IIOI HN39.U6H6 ig40a

A general account of the movement in socioreligious thought that began with the general stirrings of humanitarian reform in the middle of the Igth century and gained momentum until the First World War reshaped the doctrines of liberal groups in all Protestant sects. "America's most unique contribution to the great ongoing stream of Christianity," Dr. Hopkins calls the social gospel, "the result of the impact of the industrial revolution and its concomitants upon American Protestantism." In distinction to the old orthodoxy with its insistence upon the salvation or damnation of the individual soul, the social gospel applied the teachings of Christ and the message of salvation to society as a whole, its economic life and social institutions, and offered an essentially collectivist ethic for a capitalistic age. Its origins, exponents, expressions, and institutions-culminating in the Federal Council of the Churches of Christ in America-were numerous, and Dr. Hopkins has woven together many strands into a well-organized and interesting presentation. His footnotes cite a huge literature, and he speaks of more than fifteen hundred items utilized in his research. The Urban Impact on American Protestantism, 1865-1900, by Aaron I. Abell (Cambridge, Harvard University Press, 1943. 275 p. Harvard historical studies, v. 54), describes one phase of social Christianity, the effects of the post-Civil War urbanization on American Protestantism. This impact was a double-edged affair: the urban workers looked to religion to win them a better economic order, and the cities called on the churches for social service as well as spiritual aid. The writer traces the channels of organized aid from the beginnings of the Young Men's Christian Associations in the 1850's, and notices a variety of missions, organizations, and associations: the Salvation Army, the "institutional church" movement, various brotherhoods and sisterhoods, and many other forms of social service.

5490. Hopkins, Charles Howard. History of the Y.M.C.A. in North America. New York, Association Press, 1951. 818 p. illus.

$$
\text { 5I-II674 BVio3o.H6 }
$$

The Young Men's Christian Association was born in London on June 6, 1844, when 12 young drygoods assistants met under the leadership of George Williams, a Congregationalist Sunday school worker who had been inspired by the revivals of the American evangelist Charles G. Finney. In 1851 the association was introduced into North America, with beginnings simultaneous in Boston and Montreal; within 3 years it had spread to most large cities and many smaller ones and its growth has been continuous. For the Y.M.C.A.'s centenary Dr. Hopkins was commissioned by the Committee on Historical Resources to prepare this definitive history, based on the important collection of records in the Bowne Historical Library maintained by the national council in New York. The exceedingly detailed narrative is divided into chronological sections: $185^{1-}$ 1865, 1865-1895, 1895-1940, and 1940-1951. In the I 890 's, under the impulse of the general missionary expansion, the Y.M.C.A. movement spread abroad. Much attention is given in the later chapters to its world functions.

549I. Institute for Religious and Social Studies, lewish Theological Seminary of America. American education and religion: the problem of religion in the schools; a series of addresses, edited by F[rederick] Ennest Johnson. - New York, Institute for Religious and Social Studies; distributed by Harper, 1952. 211 p. (Religion and civilization series) 52-12044 LCIII.I58

The problem discussed in these 12 thoughtful essays, based on lectures delivered at the institute in 1950-51, is stated by the editor in the introductory paper: "How can public education, in accord with its function of putting each generation in possession of its full cultural heritage, do justice to the religious phase of that heritage without doing violence to religious liberty as constitutionally safeguarded?" The authors express the viewpoints of agnostic, Jewish, Catholic, and liberal Protestant educators, university and college presidents, spokesmen for privately supported colleges and schools of education, and for elementary and secondary public schools. In summarizing, Dr. Johnson found a 
consensus that "the educative process has a unitary quality which makes a dualism of the secular and the religious unrealistic," particularly in higher education; and also that the Supreme Court decision of 1948 outlawing the released-time plan for religious education (the McCollum case) was "remote from the realities of the educational system." $\mathrm{He}$ was able to note that since the delivery of the lectures the Supreme Court had reversed itself on the releasedtime plan (the Zorach case, 1952), and that two influential educational bodies had recommended substantive religious instruction in the schools. The most vigorous defense of purely secular education in the volume was "An 'Experimentalist' Position," by a former secretary of the Ethical Culture Schools, Dr. Vivian T. Thayer. His ideas were more fully expressed in the same year in one of the Beacon studies in freedom and power: The Attack upon the American Secular School (Boston, Beacon Press, I95I. 257 p.). Another notable study on this topic of mid-2oth century debate is The American Tradition in Religion and Education, by R. Freeman Butts, entered in the chapter on Education (no. 5103).

5492. May, Henry Farnham. Protestant churches and industrial America. New York, Harper, 1949. $297 \mathrm{p}$. $\quad 49-8 \mathbf{r}_{59} \mathrm{HN}_{39 . U 6 \mathrm{M}_{3} 8}$ Bibliography: p. $267-290$.

A study of the influence of American religion on the developing social thought of the industrial age (1828-95). The author writes as a historian rather than a theologian in his examination of movements, sermons, and the writings of churchmen and other leaders of opinion. His focus is on attitudes toward labor in the struggle of liberal thought against the laissez-faire theory upheld by traditional Protestant orthodoxy. In his first period (1828-6I) he describes "The Conservative Mold" and its support of the social status quo against the anticlerical radicalism of the Jacksonian era. "The Summit of Complacency" was reached in the years $186 \mathrm{r}-76$, when the great industrialists piled up their millions and poured out bounty for religious and charitable work, while conservative clerics justified "the Divinely-regulated and unchangeable social order." The last period (1877-95) is treated in two parts, "Sources of Change"-the economic facts of strikes, depressions, unemployment, and bankruptcies, accompanied by mounting waves of liberal and humanitarian, socialist and radical protest-and "Social Christianity." Dr. May attributes a large measure of the success of American progressivism to the moral aid of the social Christian movement.

5493. Miller, Robert Moats. American Protestantism and social issues, 1919-1939. Chapel
Hill, University of North Carolina Press, 1958, $3^{85}$ p. $\quad 5^{8-1243} \mathrm{HN}_{39 . U 6 M_{59}}$

Bibliography: p. 351-370.

The social attitudes of American Protestantism during the between-war years of prosperity and depression are here surveyed with respect to the basic controversial problems of society-"civil liberties, labor, race relations, war, and the contending merits of capitalism, socialism, and communism." The author's concern is with the eight largest Protestant groups and the Federal Council of the Churches of Christ; on some matters he reviews systematically the position taken by each group. After a long general sketch of the churches in the social order a section is devoted to each of the large issues. In the 1920's they were "Corpulent and Contented," although a "Dissenting Report" called for replacing the profit motive with the service motive. "A Footnote to the 1928 Election" suggests that a vote against Al Smith was not necessarily an effect of bigotry, but might proceed from a sincere support of the 18 th Amendment. Three chapters record the churches' move to the left during the depression, while a fourth notes the large conservative element that did not move. The writer has attempted to lighten his serious matter with frequent touches of humor and irony, especially through pointed quotation. Large amounts of primary and secondary source materials are listed in the extensive bibliography.

5494. Rian, Edwin H. Christianity and American education. San Antonio, Naylor Co., 1949. 272 p.

Bibliography: p. 24I-254. $49-9753 \mathrm{LC}_{427} \cdot \mathrm{R}_{5}$

An expansion of a series of lectures delivered at the Princeton Institute of Theology by a Presbyterian college president. In I936 Dr. Rian was one of the organizers of the Orthodox Presbyterian Church, a body formed in protest against modernistic tendencies in the Presbyterian Church, which, however, he subsequently rejoined. His conservative viewpoint is expressed here only in the few pages in which he offers conclusions, and the bulk of the text is factual. He devotes his first and longest section to an account of American public schools, beginning with their history, and then discussing present-day philosophies of education, textbooks, and what he considers the disrupting and disintegrating effects of naturalistic education. John Dewey is his bugbear. A second section presents Roman Catholic education, quite objectively up to the last three pages, in which the writer explains his reasons for considering the system "erroneous and inadequate." These two parts are offered as perspective for the last, Dr. Rian's real point of concern: "Protestant Schools." Here he 
is outspoken in his criticism. He finds Protestant education in tragic plight, "weak, hesitant, and largely ineffective as an answer to naturalism and as an exposition of Christianity."

5495. Silcox, Clarice Edwin, and Galen M. Fisher. Catholics, Jews and Protestants; a study of relationships in the United States and Canada. New York, Published for the Institute of Social and Religious Research by Harper, 1934. xvi, $369 \mathrm{p}$.

35-I I5I BL2520.S5

A report based on a series of case studies in 20 large cities of the United States and Canada, undertaken by the institute at the request of the National Conference of Jews and Christians. The purpose was to elucidate problems of interfaith relations through a survey of actual contacts and relationships between Catholics, Jews, and Protestants in particular communities, in order to determine the forces dividing them or bringing them together. The material is presented in leisurely, somewhat discursive, but eminently readable style. The writers begin with a rapid review of the historical backgrounds of the three communions and their tensions and conflicts in America. The divisive aspects of discrimination and social distance are discussed in respect to business, employment, real estate, social and political life, and immigration. Next, relations in social work and education, intermarriage, and conversion and proselytization are examined for both isolating and cohesive elements. Last, the field of cooperation is outlined in its philosophies and in measures of national or local scope. A short epilogue points out the chief philosophical differences in the three faiths which cause organized religion to make for divisiveness rather than integration. Although of great sociological interest, the work has been criticized as based on partial impressions and inadequate statistics.

5496. Spann, John R. ed. The church and social responsibility. Nashville, Abingdon-Cokesbury Press, 1953. 272 p. $\quad 53-81_{3} 6 \mathrm{HN}_{31 . S_{75}}$

A set of essays interpreting the convictions of American Protestantism about the social order, the general viewpoint being that the Christian church bears responsibility for social conditions and must provide redemptive measures for society. The 15 writers are specialists, most of them professors in university schools of religion or seminaries. "Biographical Notes" on them are supplied (p. 259-264). Their papers, all in plain language addressed to laymen, are grouped in four parts: "The Social Ministry of the Church," "Basic Human Rights and the Community," "The Church and the Economic Order," and "The Church and the Political Order." The center of attention is American society, al- though one essay, "New Testament Sources of the Social Ministry of the Church," by Donald T. Rowlingson, is straight theology, and two or three others-e.g., "World Economic Problems," by Eddy Asirvatham, and "The Church and World Political Order," by Walter M. Van Kirk, have no local limitations. Another symposium of the same year, Christian Faith and Social Action, edited by John A. Hutchison (New York, Scribner, 1953. 246 p.), is in the nature of a Festschrift to Reinhold Niebuhr, whose concluding essay gives its title to the volume. The 13 contributors are all members of the Frontier Fellowship, a group founded under Niebuhr's inspiration as the Fellowship of Socialist Christians (1930; name changed in 1947). The editor explains in the first paper, "Two Decades of Social Christianity," that the aim of the fellowship is to understand and interpret Christian faith in ways relevant to contemporary society and its problems; their "thinking is inescapably oriented" to Niebuhr, their teacher and associate. Like him they are deeply concerned with the appraisal of Marxist thought and with criticism of the social gospel as "theologically shallow" and "socially unrealistic." They write for theologically trained readers. W.E. Garrison, literary editor of the Christian Century, summarizes the position of the fellowship as "moving to the right theologically and to the left socially."

5497. Wisbey, Herbert A. Soldiers wit h o u t swords; a history of the Salvation Army in the United States. New York, Macmillan, I955. 242 p. illus.

"Sources": p. 229-234.

"This book was written to provide a concise, accurate, objective history of the Salvation Army in the United States that would be of use both to Salvationists and to students of American social and religious history." Its occasion was the 75th anniversary of the Salvation Army in the United States, which can be precisely reckoned from the "invasion" of New York City on March 10, I880, when Commissioner G. S. Railton and seven English lasses, having made a long and stormy voyage from London, held their first official service on the dock. The parent British body had been founded by William and Catherine Booth in 1865 (the name was not used until 1878); and like it the American army aimed its ministry at the swarming urban poor, the "unreached and unchurched" who felt out of place in middle-class churches, and whose sufferings were regarded as being largely the penalty of their own idleness and vice by too many Protestants. The army immediately fixed public attention by its uniforms, martial music, and generally spectacular methods, but in spite of the "mud, bricks, stones, tomatoes, rotten eggs, dead cats and 
rats, and buckets of water" with which its early meetings were often pelted, it gained willing workers from American young people, and converts of varying degrees of permanence among the dwellers in the slums where it evangelized. The army has never acquired the least snobbery, and the colorful evangelism of the early days has not been aban- doned, but it has been supplemented by a fine variety of social services conducted along approved lines. The least interesting parts of the book are concerned with the various jurisdictional disputes arising out of the effort to keep the American along with the other national groups under unitary leadership; and it is quite weak in statistics.

\section{H. The Negro's Church}

5498. Fauset, Arthur Huff. Black gods of the metropolis; Negro religious cults of the urban North. Philadelphia, University of Pennsylvánia Press, 1944. 126 p. illus. (Publications of the Philadelphia Anthropological Society, v. 3)

$$
44-3761 \quad \mathrm{BR}_{5} 6_{3} \cdot \mathrm{N}_{4} \mathrm{~F}_{3} \text { I } 944 \mathrm{a}
$$

The anthropologist who wrote this University of Pennsylvania dissertation is himself partly of the Negro race, and is thus equipped by background, entrée, and point of view for the interesting anthropological, psychological, and sociological research involved. Beginning with a general statement on Negro cults, he describes in systematic detail five groups currently functioning in Philadelphia: the Mt. Sinai Holy Church of America, Inc., the United House of Prayer of All People ("Daddy Grace" is not, like Father Divine, God, but has taken over while God is on vacation), the Church of God (Black Jews), the Moorish Science Temple of America, and the Father Divine Peace Mission Movement. For each group he starts with a short "testimony," and describes its origin, organization, membership, finance (in the case of Father Divine information was not forthcoming), beliefs, ritual, and other practices. The material and treatment are of feature-story quality. Dr. Fauset then compares these cults with evangelical Christian denominations, and seeks to ascertain why they attract followers, and the degree to which they promote economic, social, and cultural advance. Finally he calls into question the generally accepted idea of the peculiar "religiosity" of the American Negro. His conclusion is that such cults result from "the comparatively meager participation of Negroes in other institutional forms of American culture"-i.e. from race discrimination.

5499. Loescher, Frank S. The Protestant church and the Negro, a pattern of segregation. New York, Association Press, 1948. I59 p. 48-7076 BR563. $\mathrm{N}_{4} \mathrm{~L} 6$

A foreword by Bishop Scarlett of the Episcopal diocese of Missouri sets the tone for this clear, hard- hitting monograph: "This book will be unpleasant reading for those who love the Church." The author, who wrote the work as a doctoral thesis in sociology, is a member of the Society of Friends and a specialist in race relations. The facts he assembles demonstrate that segregation is the normal practice of the Protestant churches. First he examines the general problem and "What the Churches say"; this is illustrated in appendix I with abstracts of pronouncements by church conventions and interchurch groups, notably the Federal Council of the Churches of Christ, which show an advance in thinking on race relations between 1908 and 1947 . Next comes "What the Churches Do," nationally, regionally, and locally, and in denominational schools and colleges; this is illustrated in the statistical appendixes II and III. Of the eight million Protestant Negroes, approximately seven and a half million are in separate "Negro" denominations, and the other half million in separate Negro churches in the "white" denominations. Only a tiny minority of local churches accept Negro members, and most of those are in communities where the Negro population is too small to maintain its own church. The last chapter is on policies and programs aiming at racial integration.

5500. Mays, Benjamin Elijah, and Joseph William Nicholson. The Negro's church. New York, Institute of Social and Religious Research, 1933. 321 p. $33-6349 \quad \mathrm{BR}_{5} 63 . \mathrm{N}_{4} \mathrm{M}_{3}$

The first comprehensive survey, not as yet superseded, of the Negro church in the United States. Made by the Institute of Social and Religious Research at the request of Negro leaders, it is based on a firsthand study of 609 urban and 185 rural churches selected as a representative sample. A sentence in the Preface gains added force a quarter-century later: "In view of the recent extensive migrations of Negroes from country to city and from South to North, together with the extension of education and sophistication among the Negro population as a whole, it may be considered for- 
tunate that this study was made while the older patterns of religious life were still to be found." The analysis, reinforced by statistics, covers the place of organized religion in Negro life, its historical development, the ministry, church membership, buildings and programs, worship, fellowship and community activities, and finances, first for urban churches, and then for rural ones. In both areas consideration is given to whether the Negro is "overchurched." The last chapter, "The Genius of the Negro Church," suggests that in spite of the discouraging condition of Negro church life in a number of respects, which are "in part the result of the failure of American Christianity in race relations," "the Negro Church has potentialities to become possibly the greatest spiritual force in the United States." Another institute study also examines the Negro's share in organized religion: Divine White Right, by Trevor Bowen (New York, Harper, 1934. 310 p.). The subtitle indicates its scope: "A Study of Race Segregation and Interracial Coöperation in Religious Organizations and Institutions in the United States." A separate section by Ira De A. Reid, "The Church and Education for Negroes," deals principally with the Negro mission schools and colleges in the South.

550r. Richardson, Harry V. Dark glory, a picture of the church among Negroes in the rural South. New York, Published for Home Missions Council of North America and Phelps-Stokes Fund by Friendship Press, 1947. xiv, 209 p. $47^{-24753} \mathrm{BR}_{5} 6_{3} . \mathrm{N}_{4} \mathrm{R}_{5}$

"A selected reading list": p. I94-I97.

"The church is still the predominant institution in the rural South. It is the Negro's chief agency of social expression and it enjoys greater freedom than any other community institution. The pastor as leader of the most important institution commands a unique authority, in spite of his limitations, that no other community leader enjoys." This thesis is maintained through its various aspects by the writer, an influential Southern religious leader formerly at Tuskegee Institute. His first seven chapters cover the historical background, the general setting and present conditions in four selected counties of Alabama, South Carolina, Arkansas, and Virginia, church buildings, church membership (Negroes are predominantly Baptist and Metho- dist), and programs for adults and young people. The next five chapters are concentrated on the ministers, their training, their knowledge of rural affairs, and their attitudes and influence in general and regarding social problems, race relations, etc. Finally plans for their better training are outlined. In this connection the Program for a Better Trained Rural Ministry sponsored by the Phelps-Stokes Fund, with which the writer was at the time associated, is emphasized.

5502. Woodson, Carter G. The history of the Negro church. 2d ed. Washington, Associated Publishers, 1945. 322 p. illus.

\section{6-279 BR563. $\mathrm{N}_{4} \mathrm{~W} 6 \quad 1945$}

In these days when churchgoers are kept constantly aware of the missionary effort to carry the Gospel to the Africans at home, it is hard to realize that for the first century or more of slavery in the English Colonies of America the conversion of Negroes to Christianity was frowned upon. Although royal decrees and special colonial laws had been passed to make it lawful for Christians to be held as slaves, the masters on the plantations generally feared the mental improvement which religious teaching might bring their laborers. The Catholic priests and missionaries in Maryland were the first to preach to all regardless of color. The few attempts at conversion of the Negroes made by clergymen of the Anglican Church and by Quakers in the Southern and Middle Colonies during the I 8 th century are described individually by Dr. Woodson in the first chapter of this detailed history. It was not until the Baptist and Methodist evangelical campaigns at the turn of the rgth century that the slaves were Christianized in substantial numbers; then Negro preachers arose, and separate Negro churches were formed in cities and on the plantations. In the 1830 's, after the slave revolt led by the preacher Nat Turner in Virginia, the frightened slaveowners put restrictions on Negro preaching in the South, and the great development of independent Negro churches did not come until after Emancipation. This book, by a prominent Negro historian (1875-1950), professor at Howard University, traces the history of the Negro church in terms of movements and men, and has been a standard authority since its first publication in $192 \mathrm{I}$. 


\section{Folklore, Folk Music, Folk Art}

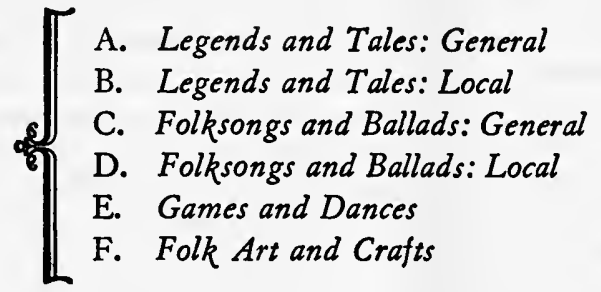

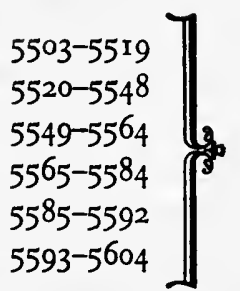

$\mathrm{O}$ NE OF THE major encyclopedias defines the scope of folklore as "the material as well as the intellectual culture of the peasantry." This raises a primary consideration in approaching American folklore: there is and has been no American peasantry, properly so-called. Cultivators of the American soil have avoided both the name and the conditions which it implies; and American public policy has equally aimed, by and large, to prevent such conditions from arising, or at least from developing into permanent disabilities or status. Of all such policies, the most powerful antidote to the status of peasantry and its concomitant folk culture is that of universal and free public education, available to children of every race and condition in every area, through secondary school or beyond. This ideal, first grasped by Thomas Jefferson and gradually made a reality during the past century, makes for a maximum of intercommunication between every part of American society, and so wars upon that isolation which is recognized to be the natural soil of a folk culture. It seeks to make a child's opportunities to some degree independent of the condition of his parents, so that he need not inherit their status. In large degree, therefore, the American way of life is incompatible with a folk culture. The past 60 years, however, have witnessed an intense cultivation of American folklore and folk music, and the past 30 of folk art, by the learned and the sophisticated, which they have succeeded in communicating, if not to the largest public, at least to large groups of amateurs, urban and suburban.

This seeming paradox is easily resolved. The Jeffersonian ideal, if early proclaimed, was belatedly and gradually embodied, and is not yet perfected. Until the Igth century was well advanced, large sections of the American people remained in relative isolation, with little or no schooling, and in

greater or lesser degree dependent upon traditional lore, and what they could add to it, for the enrichment of their lives. The frontier, which did not disappear until about 1890 , pushed on ahead of schools and printing presses, and out of its occupational and other interests usually amplified the traditions brought with it in various characteristic and colorful ways. Areas or classes which did not share in the main tide of American progress, such as the mountainous and other parts of the rural South, and the Negro nearly everywhere, conserved their old lore and modified it very gradually. Furthermore, about 1820 began a real influx of genuine peasantry from the nations and ethnic groups of Europe, each with a different body of traditional notions. These were of course subjected to an Americanization that was sometimes a deliberate policy but far more often an undirected social process, which had a limited effect upon the immigrant generation, but a much more thorough one upon their children and grandchildren. Traces of tradition, however, have usually been left.

The American Folklore Society, founded in 1888 , defined as its first aim "the collection of the fastvanishing remains of Folk-Lore in America." Their alarm was undue, since successful collecting goes on seven decades later, but they had indelibly ex- 
pressed their sense that American folklore was a fringe phenomenon, a perishable residue, and a quite different matter from European folklore. The elaborate and sometimes grotesque theoretical structures that have been reared on the basis of Old-World folklore could never have been educed from the American variety. Yet another difference has been concisely put by Ruth Benedict: in native American folklore "self-expression is at a maximum and historical analogues are almost non-existent." One consequence has been that in recent years American academic folklorists have claimed for their subject matters that would have been dubiously regarded by the brothers Grimm or E. B. Tylor, and some of their recent compilations have been miscellanies that seem to escape any clear and distinct definition.

However, the latter-day tendency of Americans to seek refuge from the standardized present in a more colorful past has made all the esthetic kinds of folk culture marketable commodities. The titles which follow fill the distance between two extremes: rigorous academic collections in which the ipsissima verba of elderly rustics are reverently recorded, collated, and annotated; and frankly popular works in which traditional materials are cheerfully reworked for their value as healthy entertainment. Both kinds must be included if the American folklore interest of today is to be faithfully mirrored here. The arrangement of the entries that follow is self-explanatory. One warning needs to be given: the boundaries between the folk arts and their sophisticated counterparts remain indistinct. There is no clear demarcation between the first two sections here and Chapter I on Literature, where will be found such a folk classic as the Brer Rabbit corpus of Joel Chandler Harris; nor between folk music and the sections on popular music in the next chapter; nor between folk art and the section on Decorative Arts in Chapter XXVI. Folk art is a more recent interest than the other contents of this chapter, going back little more than three decades; but intensive cultivation has produced collections and a literature no less interesting than exist for the older pursuits.

\section{A. Legends and Tales: General}

5503. Allen, Jules Verne. Cowboy lore; illustrated by Ralph J. Pereida. [7th ed.] San Antonio, Tex., Naylor, r950. xvi, 164 p.

$$
\begin{array}{rr}
5^{0-2725} \mathrm{~F}_{596 . A_{3} 8} & 195^{\circ} \\
\mathrm{Mr6}_{29 . A_{4} 6} & \text { I950 }
\end{array}
$$

"The songs were taken down and set to music by Mrs. G. Embry Eitt."

Billed as "The Original Singing Cowboy," the late Jules Verne Allen was long a favorite entertainer in rodeos and open-air exhibitions, and later won a wider popularity through his recordings and radio broadcasts. Nearly forty of Allen's favorite songs, provided with piano accompaniments, make up a large portion of this book, but other aspects of cowboy life and lore are also presented. Part I describes the real life and work of cowhands, as opposed to the Hollywood version, and appends to much miscellaneous information a few tall stories. Other parts describe the history and methods of cattle brands and earmarks, and define English and Spanish terms from the cowboy's occupational lingo. The frontispiece illustrates the equipment of the cowpoke and his pony, identified in English and Spanish, from the brand, or fierro, to the stirrup, or estrivo. The book was originally published in 1933 .

5504. Beckwith, Martha Warren. Folklore in America, its scope and method. Pough- keepsie, N. Y., Vassar College, The Folklore Foundation, 1931. $76 \mathrm{p}$. (Publications of the Folklore Foundation, no. II) 32-4724 GRro5.B4

"Selected references": p. 67-76. GRI5.V3, no. II

The term "folklore" was introduced by the British scholar William Thoms, in 1846 , to supplant the vaguer names "popular literature" and "antiquities." The scope and limitations of the discipline have been a matter of some debate since 'Thoms' day, and Miss Beckwith's careful definition is but one of several possible ones. In her first chapter Miss Beckwith differentiates between "folk knowledge" in general and folklore by linking the latter more closely with its German counterpart, Volks. kunde or folk art. It is only the artistic part of the folk tradition which the present definition of folklore includes. Thus the folklorist is not concerned indiscriminately with all popular tradition, but only with that which transcends utility in being "touched by poetic thought," imagination, and fantasy. The "art" in folklore differs from sophisticated artistic expression in that, though originally the product of an individual's creative imagination, the folk art work takes on the character of a group creation, through generations of repetition and variation. The folk group which is the true custodian of folk. lore is defined as a group of limited sophistication 
and restricted contact outside the group itself. The isolation of the folk group can be geographical, linguistic, racial or national, or occupational. The definition is concluded with a brief discussion of the extent to which folklore is allied with literature, on the one hand, and cultural anthropology, on the other. The remaining chapters trace the develop. ment of the scientific study of folklore, first in Europe, with special attention to Germany, Scandinavia, and Great Britain; and finally in the United States. The author points out early signs of literary interest in popular lore and literature, but finds the first scientific approach only in the rgth century, with the work of the brothers Grimm. For America's part, special emphasis is placed on the New World vestiges of the British ballad, first given prominence in the great contributions of Francis James Child, author of The English and Scottish Popular Ballads (no. $555^{\circ}$ note).

5505. Blair, Walter. Mike Fink, king of Mississippi keelboatmen. By Walter Blair and Franklin J. Meine. New York, Holt, 1933. xiv, 283 p. illus.

Bibliography: p. 269-283.

33-5924 $\mathrm{F}_{353 . \mathrm{B} 62}$

The introduction discusses the processes whereby the American folk hero has developed from historical personage to romantic demigod recreated by the popular imagination. Kit Carson, Wild Bill Hickok, and Daniel Boone are a few of those instanced as real people whose real exploits have been touched by the creative muse of the folk, transcending history and outdistancing fact. One of the most colorful of the frontier heroes, Mike Fink, started looking for new frontiers from the river village of Pittsburgh, where he had been born about 1770 . A crackshot Indian fighter whose practical jokes included shooting off an Indian's scalplock, a fighting keelboatman on the Ohio and Mississippi whose immortal boast was "I can outjump, out-run, and out-fight any man on the Massassip,," and at the end a trapper on the Missouri, Mike Fink led a legendary life of courage and cruelty, cunning and violence. Tracing the oral and early printed accounts of Mike's adventures, the epilogue recounts the birth and growth of the legend. The same authors have recently edited a further work which examines the subject from a more scholarly point of view: Half Horse, Half Alligator; the Growth of the Mike Fink Legend ([Chicago] University of Chicago Press, 1956. 288 p.).

5506. Blair, Walter. Tall tale America, a legendary history of our humorous heroes. Illustrated by Glen Rounds. New York, CowardMcCann, I944. 262 p. $44-8461 \quad$ PS $_{45}$ r.B55
"Proof (a bibliographical note)": p. 257-262.

With tongue firmly set in cheek, Walter Blair sets out to recount America's history in terms of the legendary heroes who have been important figures in popular tradition. Fact and folklore are mingled freely and seasoned with witty improvements by the author, who "fixed up fact after fact to make it truer than it ever was before." Exploits of Mike Fink, Davy Crockett, Johnny Appleseed, Paul Bunyan, Pecos Bill, and John Henry are humorously related, together with those of earlier heroes around whom legends have long clustered, beginning with Lief the Lucky, Columbus, and Ponce de Leon. Asserting that "We've Still Got Heroes," the last chapter reminds us of our recent tall tales about "shipyards, gremlins, and marines" and "the bewildering Pentagon building." There are a number of other books of American folk tales designed for popular reading, all of which cannot be mentioned here. Two recent ones which present some favorite tales in an attractive format are Burl Ives' Tales of America (Cleveland, World Pub. Co., 1954. 305 p.) and Maria Leach's The Rainbow Book of American Folk Tales and Legends (Cleve. land, World Pub. Co., 1958., 318 p.).

5507. Boatright, Mody C., ed. Backwoods to border. Mody C. Boatright [and] Donald Day, editors. Austin, Texas Folklore Society, 1943. xv, 235 p. illus. (Publications of the Texas Folklore Society, no. I8) 43-18054 GRr.T4, no. I8

The 18th yearbook of the Texas Folklore Society marked the retirement of J. Frank Dobie as editor, although he remained an active contributor and supporter. The articles range over various standard aspects of folklore in the Southwest, including tales of ghosts, animals, heroes, and heroines, and legends, anecdotes, jargon, and rope-jumping rhymes. More unusual is a description of the custom of grave decoration among the Negroes, Mexicans, and Indians of the Southwest, and an account of the cowhands' bulldogging and branding techniques at a branding roundup. "The Arkansas Traveler," that widely popular combination of humorous dialog and fiddle-playing, is the subject of an especially penetrating study by Catherine Marshall Vineyard, who compares versions of the skit and while tracing its history and origin finds some distant cousins.

5508. Boatright, Mody C. Folk laughter on the American frontier. New York, Macmillan, 1949. I82 p. 49-49204 PN6r6r.B663

The Easterner's idea of frontier life, as being full of crudity, violence, and sloth, seems to have been the starting place for the grandiose exaggerations which characterize much of the frontier's own hu- 
mor. The tall tales and anecdotes which Professor Boatright has assembled in these pages abound in rough-and-tumble fights, ridiculous in the degree of their brutality, and pioneer hardships, impossibly extreme. The subjects of the 13 chapters include "Backwoods Belles," one of whom killed a marauding wolf with her wooden leg, and another who could "eat more wildcat steaks raw than any other living critter in creation." One of the rugged frontiersmen encountered in "Manners and Men" is tobacco-chewing Davy Crockett, who "was hugeously ashamed to spit on that splendiferous carpit," not realizing the function of an elaborately painted cuspidor. In his final chapter Professor Boatright attempts to discover the basis of frontier humor and concludes by taking issue with such writers as Lewis Mumford and Van Wyck Brooks, who thought that the pioneers used humor as "a grim release of frustrated hopes." Buoyancy, rather than despair, is in Professor Boatright's view the source of American frontier humor.

5509. Boatright, Mody C., ed. Folk travelers: ballads, tales, and talk. Edited by Mody C. Boatright, Wilson M. Hudson [and] Allen Maxwell. Austin, Texas Folklore Society; [distributed by] Southern Methodist University Press, Dallas, 1953. 26r p. illus. (Publications of the Texas Folklore Society, no. 25)

$$
\text { 53-12578 GRr.T } 4 \text {, no. } 25
$$

The migrant nature of folklore is the key to the title of this installment in the Texas Folklore Society's series, and the subject of J. Frank Dobie's lead article, "The Traveling Anecdote." Many tales and tale-motifs have traveled widely, and some, such as the famous story of the Tar Baby, recorded in Uncle Remus, have been around the world many times over thousands of years. For the most part, the volume stays close to the Southwest, with discussions of Spanish cattle brands and tall tales, and of magic and weather lore from the Texas-Mexican border country.

5510. Botkin, Benjamin A., ed. Sidewalks of America; folklore, legends, sagas, traditions, customs, songs, stories, and sayings of city folk. Indianapolis, Bobbs-Merrill, I954. xxii, 605 p. illus. $54-9485$ GRI05.B 57

In stating his case for collecting urban lore, the editor points out that "wherever you find people you find folklore-that is, a body of traditions, collective symbols and myths, folkways and folksay, rooted in a place and in ways of living and looking at life." The folk groups reflected in this miscellany are urban groups and ethnic and religious groups within each city. The 16 chapters include American city tales and anecdotes dating from early in the last century to the recent rise of suburbia, but make no attempt to present them in chronological order. Not overlooking city folk music, Dr. Botkin has included ballads such as "The Milwaukee Fire," urban industrial songs such as "The Homestead Strike," and a large assortment of children's rhymes and songs, and of peddlars' street cries.

5511. Botkin, Benjamin A., ed. A treasury of American folklore; stories, ballads, and traditions of the people. With a foreword by Carl Sandburg. New York, Crown, I944. xxvii, $932 \mathrm{p}$. 44-4275 GRI05.B 58

"A book of American folklore," the compiler thought, "should be as big as this country of oursas American as Davy Crockett and as universal as Brer Rabbit." In both size and variety, this onevolume introduction to American folk literature embodies much of Dr. Botkin's sense of the breadth and inclusiveness of his subject. Part I, "Heroes and Boasters," recounts the exploits of classical American folk figures such as Crockett, Pecos Bill, and Stormalong. It brings to our attention some modern ones as well in Joe Magarac the Hunkie Steelman, and Popeye. The "Jesters" in part 3 tell American anecdotes, proverbs, and gags from popular tradition and from the folk-inspired and folk-oriented works of such writers as Carl Sandburg. Not to be overlooked are the recent urban "Little Moron" jokes and "Knock Knock, Who's There" riddles. The tall tales treated in part 4, "Liars," include some whoppers about remarkable insects and "fearsome critters," and Mark Twain's "Jumping Frog." Washington Irving's "The Devil and Tom Walker" is one of the legends in part 6, although most come directly from folk tradition. The songs and rhymes, many of whose melodies are included, range from traditional Anglo-American ballads to modern jingles and rope-skipping chants. Although there is no general bibliography, the footnotes are many and detailed. The songs are indexed by titles and first lines and by the names of their collectors and editors, while the other material is thoroughly indexed by names and subjects.

5512. Botkin, Benjamin A., ed. A treasury of railroad folklore; the stories, tall tales, traditions, ballads, and songs of the American railroad man. Edited by B. A. Botkin and Alvin F. Harlow. New York, Crown, 1953. xiv, 530 p. illus. 53-9973 GR920.R3B6

The joint product of a railroad historian and an American folklorist, this large anthology examines both historical fact and oral lore connected with the development of railroading in the days of steam. Real and legendary personalities who worked at all 
levels of the business are encountered, from John Henry and Casey Jones to Jay Gould and Andrew Carnegie. Jones' disaster is one of several examined at length. Other sections discuss the "Banditti of the Rails," including the first train holdup, and several of the James boys' jobs, and present many "Blues, Ballads, and Work Songs," with tunes and historical notes.

5513. Clough, Benjamin C., ed... The American imagination at work; tall tales and folk tales. New York, Knopf, r947. xix, 707 p.

Bibliography: p. 7or -707 . $47-30583$ GRI05.C55

This large collection of American folk tales and tall tales draws on material collected from the oral tradition by such folklorists as Richard Dorson, Harold Thompson, Richard Chase, Vance Randolph, and Herbert Halpert. Other items are taken from more purely literary sources, from writers so diverse in period and outlook as Captain John Smith, Cotton Mather, Washington Irving, Mark Twain, Stephen Vincent Benét, and Bennett Cerf. Loosely arranged by type and subject matter, the yarns cover "history, semi-history and pseudohistory," "witchcraft and other satanic mischief," "the animal kingdom," "explorers, pioneers, benefactors, demigods, supermen, myth-makers, and jokers," and a number of "hardy perennials."

\section{Davidson, Levette J. A guide to American} folklore. [Denver] University of Denver Press, 195I. I32 p. 5I-10205 GRI05.D3

In his first chapter "What is Folklore?" the author gives the discipline a broader definition than does M. W. Beckwith in her Folklore in America (no. 5504). The present study applies the term in general to "the traditional expressions of unsophisticated groups of people, expressions that are oral or informal in transmission." Thus Professor Davidson, with the more recent folklorists, tends to place less emphasis on artistic standards in folk literature, and more on authentic tradition as a key to better understanding of the cultural group. The author agrees with earlier scholars that folklore thrives best in isolated, homogeneous, and unlettered societies, but finds that it also flourishes in clubs, fraternities, schools, and other such groups in urban society: "We all, more or less, follow folk patterns, enjoy folk creations, and pass along folklore." The remaining I 4 chapters of this handbook make brief examinations of the several types of folklore: myths, legends, customs, songs, crafts, etc., defining and commenting upon each, and appending bibliographies and study questions for each. Appendixes trace the development of American folklore scholarship; list many of the outstanding experts, with their fields of specialty; and survey the sources available to the student of folklore in America's museums, libraries, and archives.

5515. Federal Writers' Project. Lay my burden down; a folk history of slavery. Edited by B. A. Botkin. Chicago, University of Chicago Press, I945. xxi, 285 p. illus. A45-5576 $\mathrm{E}_{444 . F_{2} 6}$

Edited by Dr. Botkin from the numerous manuscript narratives of former slaves collected during the 1930's by the Federal Writers' Project, Lay My Burden Down constitutes a group autobiography of the Southern Negroes to whom the time of slavery was still a personal, albeit distant, memory. Aiming at the general reader, the editor has maintained a clear and concise narrative style without sacrificing the personal language of the original sources. The book is divided into five general sections: "Mother Wit," "Long Remembrance," "From Can to Can't," "A War among the White Folks," and "All I Know about Freedom." Both factual narrative and folklore figure importantly in the reminiscences. Tall tales, anecdotes, ghost stories, and myths-many of them involving Lincoln and other important figures of the day-come from the many informants blessed with "mother wit." Personal recollections of slavery days vary widely, according to the informants' individual experiences. Some of the accounts are strongly tinged with nostalgia, others with bitterness. One of the former slaves even shows sympathy for the Ku Klux Klan! Nevertheless, most of the contributors would seem to agree with the one who said, "Freedom is better than slavery, though. I done seed both sides."

5516. Hoffman, Daniel G. Paul Bunyan, last of the frontier demigods. Philadelphia, University of Pennsylvania Press for Temple University Publications, 1952. xiv, 213 p.

Bibliography: p. 193-201.

$$
\text { 52-12005 } \mathrm{PS}_{46} 6 \mathrm{r} . \mathrm{B} 8 \mathrm{H} 6
$$

Although Paul Bunyan is among the most widely known of American folk heroes, his position as a genuine folk character is surprisingly precarious. Considered by some authorities to have been invented out of whole cloth by professional writers, the good-natured giant owes at least a large proportion of his current popularity and many of his individual exploits to printed sources. That Paul himself originated in the oral tradition, however, is convincingly demonstrated by Professor Hoffman. Paul's first appearance in print was as recent as I9Io, in a newspaper story whose authentic lumberwoods vocabulary suggests a traditional oral source. In scholarly fashion the author analyzes the popular Paul Bunyan literature and the poetic treatments by Robert Frost, Carl Sandburg, and Louis Unter- 
meyer, as well as the surviving fragments of oral literature which probably originated in the last century. He appends an index to the motifs in the Bunyan tales, both literary and oral.

5517. Johnson, Guy B. John Henry; tracking down a Negro legend. Chapel Hill, University of North Carolina Press, 1929. 155 p. (University of North Carolina. Social study series)

$$
\begin{aligned}
& \text { 29-23914 PS 46r.J6J6 } \\
& \text { ML-3556.J7J7 }
\end{aligned}
$$

"Bibliography of John Henry": p. [152]-155.

"The songs about John Henry," states Professor Johnson, "are at the heart of the legend which has sprung up around him." By gathering and analyzing the available hammer songs and ballads (some of which are here accompanied by their melodies) about the mighty steel driver, and comparing their widely conflicting patches of evidence with what documentation and individual recollections he could locate, the author, while unable to obtain the complete facts, has at least laid the ground for betterinformed speculation and set an example for other such studies of the factual bases of American songlegends. An examination of the development of the steam drill and the physical conditions of the Big Bend Tunnel in West Virginia leads him to the conclusion that the famous contest between man and machine could, at least, have taken place, and that, under the right circumstances, such a steel driver as John Henry could well have been the victor. The relationship between John Henry and another ballad hero, the murderer John Hardy, long a thorny matter in American Negro folklore, is found to be only a confusion of two separate Negro steel drivers. Hardy, whose exploit is well documented, appears to have entered the annals of folk legend some time after the John Henry tradition was already well established. Mention should also be made of a similar study, later by a few years, Louis W. Chappell's scholarly John Henry, a Folk. Lore Study (Jena, Frommannsche Verlag, I933. I 44 p.), which supports many of Professor Johnson's conclusions while it clarifies and corrects others.

5518. Journal of American folklore. v. I. Apr./ June I888. Philadelphia, American Folklore Society. quarterly. I7-28737 GRI.J8 Published in Boston by Houghton Mifflin, 1888I9ro.

Index: Vols. I-40, I888-1927. I v. (Issued as v. 14 of the Memoirs of the American Folklore Society (GRr.A5, v. 14).

The American Folklore Society, the parent organization devoted to the study of folklore in the New World, was founded in 1888 , with Professor
Alcée Fortier of Tulane University as its first president. Through its Journal of American Folklore and other publications, including monographs and bibliographies, this active organization has contributed most significantly to the study of British, French, Spanish, and Negro lore in Canada, the United States, and Latin America, as well as the indigenous lore of the American Indian. The vast amount of material in the Journal's first 70 volumes has recently been made more accessible to the researcher by 'Tristram P. Coffin's An Analytical Index to the Journal of American Folklore (Philadel. phia, American Folklore Society, 1958.). Among the first regional offspring of the American Folk. lore Society was the Texas Folklore Society, which held its first meeting in I9II and got out the first of its annual volumes in 1916, under the editorship of Stith Thompson. Professor Thompson's successor was J. Frank Dobie who, after a brief World War I interim, presided over the Publications of the Texas Folklore Society until 1943, when the editorial work was taken up by Mody C. Boatright and others. This series of yearbooks continues to offer a wide variety of legends, tales, songs, ballads, and other lore from the Indian, Spanish, Negro, and AngloSaxon peoples of the American Southwest. A number of the Texas Society's Publications are individually listed elsewhere in this chapter. The number of folklore periodicals devoted to specific areas, States, or subjects is large and growing. The most important include the Southern Folklore Quarteriy (founded in 1937), Western Folklore (originally the California Folklore Quarterly, 1942-46), New York Folklore Quarterly (1945), and Midwest Folklore (195I). These publications have not rigidly restricted themselves to their particular areas in the range of their contents but, like the Journal of American Folklore, show evidence of a growing interest in the general field of folklore, including its international aspects.

5519. Price, Robert. Johnny Appleseed; man and myth. Bloomington, Indiana University Press, 1954. xv, 320 p. illus.

Bibliography: p. 299-303.

$54-7972 \quad \mathrm{~S}_{4} \mathrm{r}_{7} \cdot \mathrm{C}_{45} \mathrm{P}_{7}$

In an oral literature replete with vigorous, swashbuckling, swaggering, and sometimes brutal heroes, the folk memory of John Chapman (1774-1845) is unique. Legend tells us that, although he ran from Mansfield to Mt. Vernon, Ohio, in 24 hours in order to summon armed help for settlers threatened by an Indian attack, Chapman himself would never use a gun against another man, whether white or Indian. Nor would he permit animals or insects to suffer for his own comfort. Already a popular legend long 
before his death, the earliest printed account of Chapman appeared in England in 1817 , and does not describe Johnny Appleseed, the popular planter of Midwestern orchards, so much as the religious mystic and "extraordinary missionary" for the New Church of Swedenborg. As far as is possible, Professor Price has attempted to separate fact from legend, and proves, among other things, that while the itinerant pioneer, missionary, and nurseryman was not without his eccentricities, the popular notion that he was a pauper is far from correct. In tracing the development of the Appleseed myth, however, the author concludes that, in the final analysis, its worth "no longer lies merely in the dead facts that may have inspired it but in the new, living and creating force that it has become in the present."

\section{B. Legends and Tales: Local}

5520. Boatright, Mody C. Tall tales from Texas. Illustrated by Elizabeth E. Keefer; foreword by J. Frank Dobie. Dallas, Tex., Southwest Press, 1934. xxiv, 100 p. 34-24636 $\mathrm{PZ}_{3} . \mathrm{B}_{304} \mathrm{Tal}$

The ideal audience for a frontier tall tale, or "windy," was a credulous greenhorn, who was often treated to exaggeration regarding the potency of poisonous serpents, dreadful aspects of fantastic beasts, and extraordinary feats of strength and speed by heroes of the Southwestern plains. But, as J. Frank Dobie points out in his "Preface on Authentic Liars," even when no tenderfoot was about the authentic liar took his art seriously and told his tale with the gravity of "a historian of the Roman Empire," expecting "neither credulity nor the establishment of truth," but creating his tale as an end in itself. In this book there is a young greenhorn to provide his more experienced cronies with the opportunity and incentive to summon up a large assortment of "windies" on all manner of subjects, culminating in accounts of the genesis, exploits, and exodus of Pecos Bill and his beloved first wife, Sluefoot Sue.

5521. Boatright, Mody C., ed. Texas folk and folklore. Edited by Mody C. Boatright, Wilson M. Hudson [and] Allen Maxwell. Drawings by José Cisneros. Dallas, Southern Methodist University Press, I954. $35^{6} \mathrm{p}$. (Publications of the Texas Folklore Society, no. 26)

54-I I 299 GRi.T4, no. 26

The indigenous Indians, the Spanish settlers from Mexico, the Anglo-American settlers, and their Negro slaves formed four distinct racial groups and cultural traditions in Texas which maintain, to a great extent, their several identities. All four of these traditions are drawn upon freely in this collection, which includes tales of the Kiowa-Apache and the Alabama-Coushatta, together with Mexican, Negro, and Anglo-American tales, jokes, legends, and ghost stories. Another branch of folklore covered is music, with white and Negro ballads and songs, and Mexican corridos. Rounding out the collection are examples of folk-medicine, plant lore, games, and proverbs, and an account of a highly poetic and moving Negro folk sermon. The volume is one of a series which has been issued regularly by the society since 1916 .

5522. Botkin, Benjamin A., ed. New York City folklore: legends, tall tales, anecdotes, stories, sagas, heroes and characters, customs, traditions, and sayings. New York, Random House, 1956. 492 p. illus.

56-8815 Fi28.B6

Urban popular tradition, previously presented in the editor's Sidewalks of America (no. 5510), is further exploited in a volume devoted to the largest city of the Nation and the World. "The focus of the book," the editor observes, "is on the quintessence of New York," rather than on the many individual ethnic, linguistic, and occupational groups which exist within the whole. At the same time certain neighborhoods and "cities within the city" are given attention in chapters such as "You Walk around a Corner, and It's a Different World," "Peacocks on Parade," and "Playtown and Playboys." While the book's organization is informal and follows no strict historical pattern, a wide range of New York City history is covered, from the earliest encounters between the Indians and Dutch to the latter days of Grover Whalen, Jimmy Walker, Casey Stengel, and Toots Shor, all of whom are represented in the editor's selection of New York City folklore. It is unlike Dr. Botkin's other anthologies in that music does not figure importantly, although a few street cries and chants are included.

5523. Botkin, Benjamin A., ed. A treasury of Mississippi River folklore; stories, ballads, traditions, and folkways of the mid-American river country. New York, Crown, 1955. xx, 620 p. 55-IOI72 GRIO9.B58

While cultural homogeneity has often been regarded as an ideal breeding ground for pure folklore, and has been a vitally important factor in the South, New England, and other regions of America, 
the keynote of the mid-American river country is, as Dr. Botkin points out, diversity. "From frigid Lakes and North Woods to semi-tropical Gulf, the river country has ... been a region of extremes and sharp contrasts and violent changes." Over the length of the Mississippi, there is a greater amalgamation of ethnic and cultural groups than has been encountered in most of the other areas dealt with in the editor's "Treasury" series. As a result the legends and tales, heroes and outlaws, language and customs, and ballads and blues of the Mississippi country are related to diverse cultural traditions: those of the Anglo-Saxon, the Frenchman, the Negro, the Indian, the German, and the Scandinavian; and include occupational lore of the trapper, the lumberman, the farmer and plantation laborer, and the.industrial worker.

5524. Botkin, Benjamin A., ed. A treasury of New England folklore; stories, ballads, and traditions of the Yankee people. New York, Crown, 1947. xxvi, 934 p. 47-11615 GRIo6.B6

Following the same broad treatment of written and oral lore as the editor's popular Treasury of American Folklore (no. 55II), this anthology presents a large quantity and variety of legendary and real local New England characters, stories, anecdotes, customs, and music. In a brief introduction, "New England as a Folklore Country," Dr. Botkin describes the close-knit New England culture as an ideal ground for the preservation of folklore, because of its "strong sense of 'nationality' rooted in 'racial remembrance." The book's five sections range over the earlier source literature, Artemus Ward, Josh Billings, and The Farmer's Almanack, as well as the purely oral lore gathered in recent years by the Federal Writers' Project and individual collectors.

5525. Botkin, Benjamin A., ed. A treasury of Southern folklore; stories, ballads, traditions, and folkways of the people of the South. With a foreword by Douglas Southall Freeman. New York, Crown, 1949. xxiv, $776 \mathrm{p}$.

$$
\text { 49-II786 GR I08.B6 }
$$

A further regional installment in Dr. Botkin's series on folk taste and fancy, $A$ Treasury of Southern Folklore sets forth local loyalties and prejudices, heroes and desperadoes, stories, customs, and music. One type of hero is presented in a particularly interesting chapter, "The Peoples' Choice," which recalls Southern politicians and political commentators who have captured the popular imagination, from Patrick Henry and John Calhoun to Huey Long and Will Rogers. Moonshine, mint juleps, hush-puppies, and burgoo are among the "Pleasures of the Palate" described in part 4, "Southern Folk- ways." As is customary in this series, the editor concludes with a large assortment of songs and ballads, with melodies.

5526. Botkin, Benjamin A., ed. A treasury of Western folklore. Foreword by Bernard De Voto. New York, Crown, 1951. 806 p. illus.

$$
\text { 5I-12013 GRIog.B6 }
$$

"To the New Yorker," one of this anthology's selections avers, "anything west of Hoboken is the West." Most Easterners locate the frontier along the far slope of the Alleghenies, for one's concept of the West changes with one's point of view. However, all commentators, even those who regard the West as being a state of mind, agree that the West, wherever it is, is a place of vastness and diversity. Like the West itself, Mr. Botkin's third regional miscellany of American folklore is expansive and varied. The tales, anecdotes, language, customs, and songs, reprinted with connecting editorial commentary, offer a panorama of the hard and high living and the fast and frequent dying which all of us associate with the story of westward expansion. As in its two predecessors, the focal point is Anglo-American tradition. Strung upon this thread, however, are the contributory traditions of the Western Indian and the Spanish American. In a loose historical and geographical order, the collection offers folkways, folk-say, and a considerable amount of straight history of the struggles of the settlers against nature, the Indians, and each other. There are tales and songs of sandstorms and earthquakes, of Crazy Horse and Cochise, and of Clay Allison and Billy the Kid. Nor does the editor ignore the 2oth century's contributions to Western folklore, with the coming of industry, wealth, and Hopalong Cassidy. Readers desiring a smaller collection may turn to Duncan Emrich's volume in the American customs series: It's an Old Wild West Custom (New York, Vanguard Press, 1949. 313 p.), which has selections in most of the categories offered by Dr. Botkin, as well as an illustrated study of branding irons and saloon fixtures.

5527. Brewer, John Mason. The Word on the Brazos; Negro preacher tales from the Brazos bottoms of Texas. Foreword by J. Frank Dobie; illus. by Ralph White, Jr. Austin, University of Texas Press, 1953. I09 p. 53-10834 GRI03.B7

The folk sermon in the religion of the Southern Negro, which has been better preserved in the Brazos bottoms of Texas than in most places, is characterized by its superb poetic imagery, its musical nuance, and its striking use of parables and anecdotes. Many of the stories in this collection originated as exempla from the pulpit, while others were told about preachers and religious matters in 
general by members of the flock. Both are known as "preacher tales." All of the tales, which Dr. Brewer relates in an authentic idiom, show a gen. uine gift of wit and humor: The Reverend gently chides the Sister Rosies who cry out "Ride, salvation, ride!" until the collection hat is passed, when they change to a less enthusiastic, "Walk, salvation, walk." The charm and humor of these tales of "Bad Religion," "Good Religion," "Baptizings, Conversions and Church Meetings," "Heaven and Hell," and "Preachers and Little Boys," reflect the happiness which this folk found in their religion, without detracting from the sincerity and humility of their belief.

5528. Carrière, Joseph Médard, ed. Tales from the French folklore of Missouri. Evanston, Ill., Northwestern University, 1937. 354 p. (Northwestern University studies in the humanities, no. I) $\quad 3^{8-6249} \quad$ GRiro.M $77 \mathrm{C}_{3}$

In the village of Old Mines, in Washington County some 25 miles from the Mississippi River, Dr. Carrière found a small community which retained the language and traditions of the French pioneers who settled the area in the I8th century. The 73 tales which he here presents appear in the dialect in which he recorded them, and are arranged into three general categories: "Animal Tales"; "Or. dinary Folk-Tales," which include tales of magic, religion, and of the stupid ogre, and novelle or romantic tales; and finally, assorted "Farces, Anecdotes, and Cumulative Stories." The dialect, which strongly resembles some Canadian-French dialects but also includes some English influences, is closely analyzed along with the stories. Each tale is preceded by a brief English summary. Additional helps include a glossary, and lists of tale types and motifs, arranged in accordance with the scholarly classification set up by Antti Aarne and Stith Thompson.

5529. Chase, Richard, ed. The Jack tales; told by R. M. Ward and his kindred in the Beech Mountain section of western North Carolina and by other descendants of Council Harmon ( $1803-$ 1896) elsewhere in the Southern mountains; with three tales from Wise County, Virginia. Illustrated by Berkeley Williams, Jr. [Boston] Houghton Mifflin, 1943. 201 p. 43-12028 GRiro.N8C5

Some Americans may be surprised to learn that the resourceful young man who climbed a beanstalk and slew a giant is also the hero of a large and widely known cycle of tales, brought to the New World from England, and still told in several regions, including the Southeastern States where Mr. Chase heard them. In this collection are 18 adventures of an Americanized Jack, an easygoing country boy far removed from his dashing English cousin, and of his brothers, Will and Tom. The ancient origins still show through in appearances of a Woden-like stranger with magical powers, and a unicorn, described as "just some kind of little old yearlin' bull that didn't have but one horn." Most of the tales come from the tradition of a single family, descendants of "Old Council" Harmon, all in the vicinity of Beech Mountain, North Carolina. Mr. Chase has combined different versions, clarified the dialect, and retold the stories in a manner which will best appeal to his readers, and especially to the children for whom Jack's escapades are a constant source of delight. At the same time he has preserved the characteristic Southern mountain idiom. Serious students of folklore will not overlook the special appendix prepared by Dr. Herbert Halpert, which makes a brief survey of the folktale in America and lists Old World parallels to Mr. Chase's selections, with references to the relevant literature. Five years later Mr. Chase issued a further and more general collection: Grandfather Tales; AmericanEnglish Folk Tales (Boston, Houghton Mifflin, 1948. 239 p.). Its 25 traditional tales were taken down by Mr. Chase or others in Virginia, North Carolina, and Kentucky. The title originated thus: when Mr. Chase explained to one of his informants just the sort of tales he was looking for, the reply was, "Oh, you want the old grandfather tales: 'Jack and Will and Tom,' 'Chunk o' Meat,' 'The Two Lost Babes'-them old impossibilities. Is that what you're after?" As in the earlier collection, the author has reworked his sources for greater readability, and gives references to them in an appendix. Melodies are given in the popular old-shaped notation. This volume, like its predecessor, is illustrated with the pen-and-ink drawings of Berkeley Williams, Jr.

5530. Davidson, Levette J., and Forrester Blake, eds. Rocky Mountain tales. With drawings by Skelly. Norman, University of Oklahoma Press, 1947. xiv, 302 p. 47-3645 GRrog. D3

The Rocky Mountains and the plains around them have been the birth-place of many of America's most attractive legends, and the theater of much fact which has acquired legendary status. In the present collection the compilers have gathered from many printed sources tall tales, historical incidents, and accounts of many of the natural phenomena for which the region is famous. The first chapter introduces Jim Bridger, a wild and woolly frontiersman, who is still remembered as one of the greatest spinners of fabulous yarns. "Old Jim's" tales of the petrified forest and the glass mountain are among those recounted. Another remarkable personality encountered is the "Pikes Peak Prevaricator," Sergeant 
O'Keefe, whose Munchausen-like tales of superhuman feats are recorded at length.

5531. Dobie, James Frank. Coronado's children; tales of lost mines and buried treasures of the Southwest. Illustrated by Ben Carlton Mead. Garden City, N. Y., Garden City Pub. Co., 1934. xiv, $3^{67} \mathrm{p}$.

34-33497 F786.D633

Professor Dobie asserts that the gold fever which drove the conquistadores in search of the legendary Seven Cities of Cibola, the Gran Quivira, and El Dorado, did not die out with the coming of permanent settlers but persists more strongly than ever. In evidence he has printed here (the original edition was in 1930) a large number of tales current in America's Southwest of lost or hidden gold and other treasures. The legends abound in lost mines, rich caches guarded by Indians, pirate treasure buried by Lafitte and guarded by his shade, and many other tales of the endless quest of prospectors and adventurers. Appended are detailed bibliographical notes and a glossary of Mexican and other localisms of the Southwest.

5532. Dobie, James Frank, ed. Tales of old-time Texas; illustrated by Barbara Latham. Boston, Little, Brown, 1955. $336 \mathrm{p}$.

55-10755 GRiro.T5D63

Adventurous tales of lost mines and hidden treasures, not unlike those encountered in the preceding Coronado's Children, are to be found in this new collection, but there is a great deal more. There are tall tales on many subjects, including the Texas weather; pure fantasy; and historically based tales revolving around such heroes as Jim Bowie and Sam Bass, best-known and -liked of the latter-day Robin Hoods of Texas folklore. Intentionally omitted are Roy Bean, whom the author regards as a character unworthy of folk-hero status, and Pecos Bill, described as a comparatively recent non-folk invention. While the introduction laments that there has been a loss of zest and flavor in the transition from telling to printing, the author's long personal experience with Texas tales and storytellers has enabled him to preserve much of the original language and style.

5533. Dorson, Richard M. Bloodstoppers \& bearwalkers; folk traditions of the Upper Peninsula. Cambridge, Harvard University Press, 1952. 305 p. 52-5394 GRiro.M6D6

Michigan's Upper Peninsula retains a vast amount of traditional lore among each of the varied groups which make up its population. Emphasizing tales, but also including superstitions, customs, cures, food, songs, and other lore, Professor Dorson's study is based on his own collecting in the area. Commencing with the region's original inhabitants, the author examines "Indians Stuffed and Live," discrediting several of the romantic Indian legends contrived for the tourist trade, but revealing many vastly more fascinating tales he found still current among the Indians themselves. Part 2, examining some of Upper Michigan's Old-World traditions, describes the loup-garou and other beliefs and tales of the French-Canadian settlers; the language and customs of the "Cousin Jacks," the Michiganders of Cornish descent; tales and jokes of the Finns; and folk medicine among the Slovenians. Native lore, including detailed chapters on traditions of the miners, lumberjacks, and lake sailors, occupies part 3.

5534. Dorson, Richard M. Jonathan draws the long bow. Cambridge, Harvard University Press, 1946. 274 p. A46-4126 GRro6.D6 "Note on the printed sources for New England folktales": p. 26i-263.

In a concise preface, the author defines his sphere of operation as New England folktales "lodged in print." Recognizing printed sources-memoirs, journals, local histories, newspapers, and other ephemera-as important sources and transmitters of popular tradition, Professor Dorson has located and organized a substantial corpus of New England folktale literature without resorting to oral sources. After an introductory chapter on the background of the New England storytelling tradition, the tales themselves are presented, with analytical and historical commentary, under the general headings of "Supernatural Stories," "Yankee Yarns," "Tall Tales," and "Local Legends." The last chapter, "Literary Folktales," observes that "a fertile folklore eventually infiltrates into and nourishes creative writings." Folkloristic influences and usages in the works of such New England writers as John G. C. Brainard, John Greenleaf Whittier, Daniel P. Thompson, Harriet Beecher Stowe, Robert P. Tristram Coffin, and Walter Hard are treated at length.

5535. Dorson, Richard M., ed. Negro folktales in Michigan. Cambridge, Harvard University Press, 1956. 245 p. illus.

$$
\text { 56-6516 GRio3.D6 }
$$

This book, the first collection and study of Negro folklore in the North, provides the editor with the opportunity to examine in detail the survival of rural Southern Negro traditions in urban areas of the North. Professor Dorson found that his best storytellers tended to be those with more immediate Southern connections, for the faster pace of the new society takes its toll. In the words of one of the storytellers, a hard-working and increasingly suc- 
cessful resident of Benton Harbor, Arkansas-born and Missouri-bred: "I haven't told any tales since I left Missouri; no time for it up here." After introductory chapters which describe the towns visited in southern and central Michigan, the informants, and their storytelling art, 165 stories which Professor Dorson collected on paper or on tape recordings are presented. The classifications are: "Animal and Bird Stories"; tales about "Old Marster" and his crafty slave, John; tales about the colored man; "Horrors"; "Hoodoos and Two-Heads"; "Spirits and Hants"; "Witches and Wonders"; "The Lord and the Devil"; "Preachers"; "Liars and Irishmen"; and "Fairy Tales." The informants and the tale types and motifs are indexed, and there are detailed comparative notes.

5536. Duke University, Durham, N. C. Library. Frank C. Brown Collection of North Carolina Folklore. The Frank C. Brown Collection of North Carolina Folklore; the folklore of North Carolina, collected by Dr. Frank C. Brown during the years I9I2 to 1943, in collaboration with the North Carolina Folklore Society. General editor: Newman Ivey White. Wood engravings by Clare Leighton. Durham, N. C., Duke University, 195257. 4 v. illus. (Duke University publications) 52-10967 GRiı.N8D8

The immense quantity of folklore materials which the late Frank C. Brown (1870-1943) collected in North Carolina during more than thirty years, in collaboration with the North Carolina Folklore Society, is the source for this largest of all publications of American folklore, a memorial to Professor Brown. Under the general editorship of the late Professor White, who died in 1948, and of Paull F. Baum, and with a staff of 9 associate editors who cover the many fields represented, first 5 and then 7 volumes were planned: I, "Games and Rhymes, Beliefs and Customs, Riddles, Proverbs, Speech, Tales and Legends"; 2, "Folk Ballads"; 3, "Folk Songs"; 4, "The Music of the Ballads"; 5, "The Music of the Folk Songs"; 6 and 7, "Superstitions." The last three have yet to appear. All of the materials published are given as they were collected from the folk tradition, and are accompanied by detailed documentation as to sources and history and by bibliographical references. All of the materials are indexed for reference use. Professor White's "General Introduction" discusses the mean. ing and significance of folklore; describes the surprising extent to which ancient custom survives in 2oth-century urban society; traces the history of folklore scholarship; and goes on to explain the "History, Nature, and Growth" of the Brown collection. Further introductions by the associate editors open volumes 2 and 4 , and the six parts of volume $I$.
5537. Espinosa, José Manuel. Spanish folk-tales from New Mexico. New York, American Folklore Society, Stechert and Co., agents, I937. xix, 222 p. (Memoirs of the American Folklore Society, v. 30)

"Printed in Germany." 38-9815 GRI.A5, v. 30

Bibliography: p. [187]-188.

Despite the change in New Mexico's government and economy when it became a part of the United States, in much of the State the old Spanish culture has remained unchanged. Moreover, the author tells us, many of the traditions of Old-World Spain are better preserved here than in the Spanish-American countries to the South, where Indians have exercised a greater influence. The present collection prints an assortment of $\mathrm{II}_{4}$ tales, taken down from the informants word for word, in the language in which the compiler heard them. There has been no attempt to employ phonetic notation, but the author has reproduced the authentic dialect and grammar in standard Spanish orthography. The subject classifications of the tales are: magic tales, religious tales, picaresque tales, romantic tales, short tales and anecdotes, and animal tales. The author's bibliographical notes are accompanied by English summaries of all the tales. This first detailed scholarly study of the area now has a newer and larger companion in Juan Bautista Rael's Cuentos Españoles de Colorado y Nuevo Méjico (Stanford, Calif., Stanford University Press, 1957. 2 v.). Like his predecessor, Mr. Rael gives his 518 tales in the original language, with introduction, notes, and summaries in English.

5538. Fife, Austin, and Alta (Stephens) Fife. Saints of sage \& saddle; folklore among the Mormons. Bloomington, Indiana University Press, 1956. 367 p. illus. 56-1 1997 BX86ri.F5

Isolated from outside influences by geographical and social distance, and bound together by their common faith, the followers of the prophet Joseph Smith were in a position to develop a folklore uniquely their own throughout the past century. Seeking the "authenticity not of history but of folk. lore," the authors reexamine many of the legends, customs, tales, and songs which grew up among the Mormons. Among the early Mormon leaders who assumed the stature of folk hero was the colorful cowboy-preacher, J. Golden Kimball, and a large number of traditional "J. Golden yarns" are included in the Fifes' chapter on "The Golden Legend." Tales, some humorous and some full of pathos and tragedy, are recorded, covering a wide range of subjects: the Saints' early persecution in the East and Middle West, their dealings with Indians, the establishment of their great city in the desert, and plural wives. The many songs of the 
Mormon folk, which sympathetically interpret their theology and history, are dealt with in several chapters and at particular length in the epilogue: "Lyre of the Lord's Anointed." Among other aspects of Mormon folklore described are pioneer arts and crafts, illustrated by photographs.

5539. Gardner, Emelyn Elizabeth. Folklore from the Schoharie hills, New York. Ann Arbor, University of Michigan Press, 1937. xv, 35I p. illus. 37-7981 GRI Io.N7 $_{3}$

Bibliography: p. 322-331.

Only some 40 miles west of Albany, and $15^{\circ}$ miles from New York City, in Schoharie County, the author found a region whose isolation from modern life and wealth in ancient folklore were comparable to the remotest parts of the Southern Appalachians or the Ozarks. Beginning in 1912 with the collection of traditional ballads, Miss Gardner went on to discover a varied body of folklore which included, in addition to songs and ballads, legends, witchcraft, ghost stories, folk tales, children's rhymes and games, riddles, and superstitions. The folk-tale tradition was found to be particularly rich, as appears in the hundred pages devoted to it. After a general description of the people and her experiences in getting acquainted with them, the author details at some length the history and topography of the region, the ethnic backgrounds of the inhabitants, and social conditions at the time of her study.

\section{Johnson, Guy Benton. Folk culture on St.} Helena Island, South Carolina. Chapel Hill, University of North Carolina Press, 1930. 183 p. ([University of North Carolina. Social study series])

Bibliography: p. 174-179.

30-32135 Er 85.93.S7J67

The Sea Islands, just off the coasts of South Carolina and Georgia, have retained a rather distinct Negro culture which has been studied at some length by anthropologists, sociologists, and folklorists. Other important folklore studies and collections are Elsie Clews Parsons' Folk-Lore of the Sea Islands, South Carolina (Cambridge, Mass., 1923. xxx, 219 p. Memoirs of the American Folk-lore Society, v. I6), Nicholas Ballanta's Saint Helena Island Spirituals (New York, Schirmer, I925. xviii, 93 p.), and Lydia Parrish's Slave Songs of the Georgia Sea Islands (New York, Creative Age Press, 1942. xxxi, 256 p.). The present study is one of a series jointly sponsored by the Institute for Research in Social Science of the University of North Carolina and the Social Science Research Council, which includes Thomas J. Woofter's Black Yeomanry (New York, Holt, 1930. 29I p.) and which deals to a large extent with the customs, folkways, and mores of St. Helena. Dr. Johnson's study takes three other branches of St. Helena folklore and examines them in detail. The first is the dialect of the Negroes of the area, Gullah, that singular English dialect known for its incomprehensibility to English-speaking outsiders. Dr. Johnson traces the cultural background of Gullah and describes its pronunciation and structure. Folk songs, with particular emphasis on spirituals, are dealt with in the second chapter. Here, as in the language, the author finds a greater kinship with the white American tradition than with Africa. Folk tales, riddles, proverbs, toasts, rhymes, games, and beliefs conclude this detailed study.

\section{Kittredge, George Lyman. The old farmer} and his almanack; being some observations on life and manners in New England a hundred years ago, suggested by reading the earlier numbers of Mr. Robert B. Thomas's Farmer's Almanack, together with extracts curious, instructive, and entertaining, as well as a variety of miscellaneous matter. Boston, W. Ware, 1904. xiv, 403 p.

4-37I29 F5.K62

Reasoning that nothing, with the possible exception of a newspaper, "is more strictly contemporary than an almanac," the great American literary scholar and teacher, Professor Kittredge of Harvard (1860-194I), undertook a careful study of the celebrated Farmer's Almanack as a means of gaining a personal, contemporary, and unembellished glimpse of life in New England at the end of the i 8 th century and through much of the 19th. Established in 1792 by Robert $B$. Thomas (1766-1846), it was compiled by him at West Boylston in the heart of Massachusetts, until he died while reading proof for the 1847 issue. While intended primarily as a guide for the planting and harvesting of crops based on astronomical calculations, the almanac became much more. The "new, useful, and entertaining matter," which included general news items, proverbs, anecdotes, and what today's newspapers call "household hints," helped to keep volumes of the Farmer's Almanack on countless New England bookshelves, beside the Bible and Pilgrim's Progress. For the social historian, and even more for the folklorist, it is a treasured source of popular riddles, customs, anecdotes, folk cures, superstitions, plant and anima! lore, and tales. Professor Kittredge's work first sketches the life of the Almanack's founder, and then proceeds to describe the Almanack's views on a wealth of subjects, with many extended quotations and facsimiles of the original illustrations. As Kittredge says in his introduction, "the temptation to go farther afield has been irresistible," resulting in fascinating historical discourses on witchcraft (a subject further developed in his Witchcraft in Old and New England (Cambridge, Harvard Univer- 
sity Press, 1929. 64I p.)), astrology, the calendar, and many specific beliefs and superstitions.

5542. Masterson, James R. Tall tales of Arkansaw. Boston, Chapman \& Grimes, I943. 443 p. illus. $\quad 43-6036 \mathrm{PS}_{2} 66 . \mathrm{A}^{2} \mathrm{M}_{3}$

In arriving at a theory of Arkansas humor, Dr. Masterson finds that, like most American frontier humor, it manifests itself in boisterous wit, heavy satire, and tall talk, devoted to the themes of laziness, ignorance, squalor, illiteracy, boasting, drinking, fornicating, and other rough-and-ready pastimes from the half-horse, half-alligator tradition. This analysis, the subject of the present book's last chapter, is based on the large collection of tall tales and anecdotes which occupy the preceding 20 . The author's study of Arkansas tall talk goes back as far as a pair of 18th-century French captains who sent home some highly imaginative accounts of their experiences among the Akanças Indians, and the slightly later tales of Arkansas pioneer life recounted by Davy Crockett. The great line of Arkansas humorists goes back to Colonel Charles F. M. Noland and Major Thomas Bangs Thorpe, whose contributions to William T. Porter's Spirit of the Times, under the pseudonyms "Pete Whetstone" and "Tom Owen the Bee-Hunter," receive much of Dr. Masterson's attention. Other memorable chapters deal with "The Arkansas Traveler," the state's infamously slow trains, and a classic political oration in rebuttal of an attempt to change the name of Arkansas. The notes (p. 306-395) and bibliography (p. 396-425) are on a monumental scale.

5543. Randolph, Vance. Ozark superstitions. New York, Columbia University Press, 1947. $3^{6} 7 \mathrm{p}$.

Bibliography: p. [34I]-35I.

47-3899 GRiı..A8R 3

The author introduces this collection with a refutation of the city dweller's notion of the "hillbilly" as a "simple child of nature whose inmost thoughts and motivations may be read at a glance." On the contrary, "the hillman is secretive and sensitive" and "his mind moves in a tremendously involved system of signs and omens and esoteric auguries." Mr. Randolph deals with this complex system according to the various subjects and functions of the superstitions in the rural society, among them, weather signs, witches, cures, courtship and marriage, childbirth, ghosts, and death. Largely of British stock and descended from pioneers who came from the Southern Appalachians, the Ozark people are found to retain many of the AngloAmerican traditions familiar to students of Southeastern folklore. To these customs have been added a very few from American Indian lore, such as the sprinkling of cornmeal into a coffin before burial.
5544. Randolph, Vance. We always lie to strangers; tall tales from the Ozarks. Illustrated by Glen Rounds. New York, Columbia University Press, 1951. $309 \mathrm{p}$.

Bibliography: p. [273]-294.

$$
\text { 5I-10537 PS } 558 . \mathrm{A}^{\mathrm{I}} \mathrm{R}_{3}
$$

Confounding an outlander with a string of whoppers is not at all the same thing as lying, in the view of an Ozark taleteller. Mr. Randolph says that the real storytellers, whom he has known as their good friend and neighbor, are a singularly honest and dependable group. Tall tales are something else again, to be regarded as a prize form of entertainment, particularly when a credulous "furriner" is about. At such times it becomes a point of honor among the Ozark folk to support the contentions of one's fellows with encouragement, affirmation, and even a little embellishment. Mr. Randolph has heard many tall tales in the Ozarks and has recorded them diligently and accurately, preserving the true regional flavor. The yarns selected for this collection have to do with razorback hogs and other "fabulous monsters," prodigious crops, hunting, supermen, and the weather. The large index includes names and subjects, and the bibliography, also large, is extensively annotated.

5545. Randolph, Vance. Who blowed up the church house? and other Ozark folk tales. New York, Columbia University Press, 1952. $232 \mathrm{p}$. 52-4469 GRi Io.M77 $\mathrm{R}_{3}$

After completing his book of tall tales, We Always Lie to Strangers (no. 5544) this indefatigable collector of Ozark lore set about publishing a series devoted to the longer tales of the Ozarks. The title entered above was followed by two more from the same publisher: The Devil's Pretty Daughter (1955. 239 p.) and The Talking Turtle (1957. 226 p.). Mr. Randolph's method in gathering his stories has been to establish them carefully, either with the aid of a recording machine, the shorthand transcriptions of an assistant, or his own notes. Pointing to the greater freedom a storyteller takes in his narrative, the collector has not attempted the strictly verbatim repetition desirable in the publication of songs and rhymes. The changes are minor, however, and the idiom is retained in all its freshness. Other changes-literary coloring, the composition of versions from different sources, and so forth-are not indulged in at all. These books do much to bridge the gap between the needs of the professional folklorist and the layman. The stories themselves, regardless of their careful documentation, are good for plenty of laughs, and it may be mentioned that Mr. Randolph has provided a large amount of authentic material for radio comedians and comic strips. Valuable to students and scholars 
are the detailed comparative notes citing European and American parallels on each of the tales by Dr. Herbert Halpert. All three volumes are illustrated by Glen Rounds.

5546. Roberts, Leonard W., ed. South from Hellfer-Sartin; Kentucky mountain folk tales. Lexington, University of Kentucky Press, 1955. $287 \mathrm{p}$. 55-7002 GRiro.K4R6

The ro5 tales in this collection, many of them with one or more variants, were collected by the author in the hill country of eastern Kentucky. This isolated, strongly Anglo-American folk culture yielded many tales with familiar Old-World analogues. Some have close counterparts in the collections of Grimm, and there are a number of the popular "Jack Tales." Arranged according to the Aarne-Thompson classification, the book is divided into "Animal Tales," "Ordinary Tales," "Jokes and Anecdotes," and "Myths and Local Legends." Significantly, there is only one animal tale, because of the relative scarcity in the area of Negroes, in whose folklore animals play a more important role. The author collected most of the tales with the aid of a tape recorder, which insured the accuracy of his transcriptions. Appendixes give the sources of each tale and list motif numbers.

5547. Sale, John B. The tree named John. With twenty-two silhouettes by Joseph Cranston Jones. Chapel Hill, University of North Carolina Press, 1929. I51 p. illus. 29-20773 GRro3.S 3 The tree named John was an elm. Aunt Betsey had selected it as the name tree for her mistress' newborn grandson because the tall straight sapling was tough, an early budder, and a fast grower-good omens for the child's future. This book tells the story of the child's rearing, in which
Aunt Betsey, assisted by the other plantation $\mathrm{Ne}$ groes, played a most important part. In describing his childhood and youth on a Mississippi plantation around the turn of the century, the author describes many of the folkways of the Negroes he knew: superstitions, proverbs, religion, and talesincluding some of the animal tales popularized in Joel Chandler Harris' Uncle Remus stories.

5548. Thompson, Harold W. Body, boots \& britches. Philadelphia, Lippincott, 1940.

530 p. 40-2174 F120.T55

The title is a Dutchess County expression roughly corresponding to "lock, stock and barrel." While Professor Thompson denies that any one volume could sum up the lore and legendry of New York State, "body, boots and britches," his book is a big step in that direction. The legendary figures of New York come from a wide range of ethnic and occupational groups, and include pirates, Indian fighters, outlaws, sailors, whalers, "canawlers," soldiers, and many others. Some of these tales and heroes have found their way into American letters, among the latter Tom Quick, Tim Murphy, Nat Foster, and Nick Stoner, "Injun fighters" all, whose exploits, real and legendary, probably influenced Cooper's "Leatherstocking." David Harum, too, has his traditional New York State counterpart in David Hannum, celebrated "hoss trader" and perpetrator of the still-remembered Cardiff Giant hoax. Ballads, proverbs, place names, tall tales, and other pieces of New York State lore also form a part of the author's panorama. He has not forgotten the interests of scholars and has been careful to list the sources, printed and oral, from which he and his students have drawn. His informal presentation and humorous style make this book unsually attractive to readers.

\section{Folksongs and Ballads: General}

5549. Buchanan, Annabel (Morris), ed. Folk hyms of America. New York, Fischer, 1938. xl, $94 \mathrm{p}$.

Fischer edition, no. 7375 .

Bibliography: p. xxxv-xl.

Except for the efforts of a few scholars like George Pullen Jackson (nos. 5554-5555 and 5577), religious American folksongs have yet to be accorded the scholarly and popular attention which their secular counterparts have received. This collection of 50 folk-hymns with piano accompaniment is well suited to popular use and makes a useful supplement to the more academic collections and studies of Professor Jackson. The hymns themselves are preceded by a sketch of the background of American folk hymnody, and are provided with historical and analytical notes. The old modal tunes, many of them traceable to secular British ballads and songs, are music of great beauty, and the texts, some from the pens of known authors like Charles Wesley and Isaac Watts and some traditional, are an impressive evidence of the religious convictions of our pioneers. The piano arrangements are smooth and polished, but simple 
enough (mostly in four-part chorale style) to fit the simple eloquence of the verses and melodies.

5550. Coffin, Tristram P. The British traditional ballad in North America. Philadelphia, American Folklore Society, 1950. xvi, 188 p. (Publications of the American Folklore Society. Bibliographical series, v. 2) 51-1318 ML 3553.C6 Bibliography: p. 171-181.

An important part of American folk music has its roots in the British. Isles, and for some 70 years a major field of scholarly investigation has been the British ballad, or narrative song. A great many books and articles have been devoted to more specific definitions and accounts of the AngloAmerican ballad. The great American work on British balladry, around which subsequent studies have oriented themselves, is Francis James Child's The English and Scottish Popular Ballads (Boston, Houghton Mifflin, 1883-98. 5 v.), which has recently undergone a modern reprinting by photographic process (New York, Folklore Press, 1956. $5 \mathrm{v}$. in 3.). A one-volume abridgment, edited by Helen Child Sargent and George Lyman Kittredge and first issued in 1904, is also available (Boston, Houghton Mifflin, $\mathrm{C}_{1932 .}$ xxxi, 729 p.). Since Child's time numerous books and collections have been published which discuss and give evidence of British ballads in all the English-speaking parts of the world. Two recent American collections which compare ballads of the Old and New Worlds are MacEdward Leach's The Ballad Book (New York, Harper, 1955. 842 p.) and Albert B. Friedman's The Viking Book of Folk Ballads of the EnglishSpeaking World (New York, Viking Press, 1956. $\mathrm{xxxv}, 473$ p.). These books, as has been customary with modern ballad scholarship, include ballads of British origin which are not contained in Child's collection, as well as a large number of native American ballads. The present work is primarily a bibliographical key to Child ballad scholarship in America. Its greatest value is, Mr. Coffin points out on his introduction, as a research aid to the ballad scholar, "particularly the student of ballad variation." "A Critical, Bibliographical Study of the Traditional Ballad in America" ( $p$. 29-162), in addition to comprehensive references, provides summaries of the principal "story types," and discussions of pertinent problems and theories arising out of each ballad. An introductory essay describes variation in traditional ballads, both with respect to altered words and phrases, which Mr. Coffin calls "textual variation," and to major extensions, abbreviations, or alterations in the basic plot, which he calls "story change." Also included is the author's index to borrowing in the Child ballads which was previously published in The Journal of American Folklore; it traces the movement of lines and stanzas from one ballad to another.

5551. Doerflinger, William Main, comp. Shantymen and shantyboys; songs of the sailor and lumberman. New York, Macmillan, 1951. xxiii, 374 p. illus. 5I-577 Mi977.S2D 57

Music editors: Samuel P. Bayard, Hally Wood, and Joseph Wood.

Bibliography: p. 363-371.

Despite their opposed elements, the shantyman of the sailing vessels and the shantyboy of the lumber camps have a great deal in common. Both lived lives of hard physical work and, far from civilization and its pleasures, both were forced to provide their own entertainment in off hours. Moreover, technological advances have condemned the vocations and traditions of both to a progressive extinction which is now virtually complete. By faithfully recording the recollections of the last of the oldtime sailors and lumbermen and adding his own historical commentary, Mr. Doerflinger has compiled a book which is as entertaining as it is authentic. The sea shanty is a functional song used to set and maintain the pace of group tasks on board ship. The author organizes his chapters on the shanty according to function, giving many examples of the shorthaul, halyard, and capstan shanties. Ballads and other songs sung for entertainment in the forecastle round out the nautical portion of the collection. The shantyboy's name comes not from a work song but from his log huts or shanties. The songs and ballads used for lumber camp entertainment originated in Maine and the Maritime Provinces of Canada, and eventually spread to the Great Lakes, the Northwest coast, and wherever the jacks went to work the big woods. For both groups unaccompanied tunes and complete texts, often in more than one version, are given in a well-documented and accurate form. The illustrations are plentiful and the detailed plan of a square-rigger is especially helpful.

5552. Greenway, John. American folksongs of protest. Philadelphia, University of Pennsylvania Press, I953. $34^{8}$ p. 53-6929 ML3551.G7 "Musical transcriptions [unacc. melodies] by Edmund F. Soule."

"Songs of social and economic protest on records": p. 311-327.

Bibliography: p. 329-338.

An interesting aspect of American history is reflected in this study of songs of social and political unrest. The Knights of Labor, the Pullman strike of 1893, Coxey's Army, the I. W. W., the Negro's 
struggles before and after emancipation, and many other social movements and events are represented in the large collection of topical songs which $\mathrm{Mr}$. Greenway has assembled. Topical songs with political and social "messages" have never had a very secure position in the folk repertory. A few songs left over from political campaigns and labor movements have caught on and been preserved in the oral tradition, but for the most part such songs rarely live long after the events which produced them. It is probable that many of the songs in this collection were contrived by fairly sophisticated intellects, and it is doubtful whether most of these got much closer to the folk than the printed song sheets and books distributed at meetings and rallies. Since oral perpetuation is implicit in the usual concept of folk music, some readers will feel that "American Songs of Protest," omitting any invocation of the folk tradition, would have been a more appropriate title. In his introduction, Mr. Greenway advances what is probably the best possible argument on behalf of protest songs as folklore. Those who find it unconvincing can still regard these songs and Mr. Greenway's contribution as of genuine importance to the study of American social history.

5553. Ives, Burl, comp. The Burl Ives songbook; American song in historical perspective. Illus. by Lamartine Le Goullon and Robert J. Lee. New York, Ballantine Books, 1953. 303 p. M53-555 Mr629.IgB8

"List of Burl Ives recordings": p. 297-300.

This handsome collection of songs with piano accompaniments and guitar chords will be popular for years to come among all who enjoy singing for the fun of it. As the subtitle implies, the contents are arranged in a roughly historical order, with chapters for the following epochs: "Colonial America, I620-I775"; "Revolutionary America, I775I790"; "The Growing Country: On the Sea, r7901850"; "Religious, Professional and Folk Singing, 1800-1850"; and "The Frontiers of America, 1800I850." Included are many of the most popular Anglo-American ballads and lyric songs-"Barbara Allen," "Edward," "The Golden Vanity," "The Fox," and "Paper of Pins," to name a few-as well as such native products as "Springfield Mountain," "Careless Love," and "The Grey Goose." To round out the historical perspective, there are a few songs not strictly in the folk tradition, but popular in their time and since. Among them are William Billings' hymn "Chester," Francis Hopkinson's "My Days Have Been So Wondrous Free," and Henry Clay Work's "Grandfather's Clock." The Burl Ives Songbook makes no claim to scholarly accuracy or completeness. The commentary is not very useful for study and the texts and melodies have been freely altered to suit the editor's taste. What it does is to present, in a highly singable form, some of the favorite songs of America's most popular ballad singer, as he sings them. The piano arrangements were made by Albert M. Hague. Mr. Ives' Wayfaring Stranger (New York, Whittlesey House, 1948. 253 p.), an anecdotal autobiography, describes his Illinois childhood (he was born in 1909) and his struggles as a music student and art-singer before he achieved success with the songs of his own family's traditional heritage. His description of life in a rural Midwestern community is especially entertaining and colorful.

5554. Jackson, George Pullen, ed. Spiritual folksongs of early America; two hundred and fifty tunes and texts with an introd. and notes. [2d ed.] Locust Valley, N. Y., J. J. Augustin, I953. 254 p. illus. M53-86I Mi629.JI47S85 1953

Bibliography: p. [24I]-244.

Originally published in 1937 , this was the first of three valuable collections of white spirituals prepared by Professor Jackson. The others are Down-East Spirituals and Others, $2 \mathrm{~d}$ ed. (Locust Valley, N. Y., J. J. Augustin, 1953. 296 p.), the first edition of which appeared in 1943, and Another Sheaf of White Spirituals (Gainesville, University of Florida Press, 1952. 233 p.). The three volumes bring a total of more than 900 religious folksongs and their unaccompanied melodies into print. The material is organized into three types of sacred vocal music: religious ballads, folk-hymns, and revival spiritual songs. The first group is comprised of narrative solo songs, many of which, like "The Cherry Tree Carol" and "Dives and Lazarus," come from ancient British tradition. The folk-hymns are largely congregational songs of praise, while the revival spiritual songs are what the author describes as "sung-topieces hymns," a fragmentary type of congregational song which evolved a simple repetitive form well suited to the revivalist camp meetings on the rgth century frontier. Within each of the three groups, the songs are arranged according to the modal and melodic kinship of their tunes.

5555. Jackson, George Pullen. White and Negro spirituals, their life span and kinship, tracing 200 years of untrammeled song making and singing among our country folk, with 116 songs as sung by both races. New York, J. J. Augustin, 1944. 349 p. illus. 44-3923 ML 355 I.J I7

For many years the spiritual has commonly been regarded as an exclusively Negro form of musical expression of purely African lineage. The lifelong studies of the late George Pullen Jackson (18741953) have contributed immeasurably to a reassess- 
ment of this concept. The aim of this work is to demonstrate the Negro's debt to the hymnody of white pioneer America. The book is divided into two large parts, the first of which traces the development of congregational singing practices among the Methodists, Baptists, Shakers, and the many religious sects, large and small, which appeared on America's frontiers. The second part analyzes the body of Negro religious folksong in relation to the white tradition and describes many textual, melodic, and rhythmic peculiarities of the Negro variants of white spirituals. The most convincing evidence for Professor Jackson's thesis is massed together in Chapter XV, "The Tune Comparative List," which presents I 6 white melodies side by side with their Negro counterparts.

5556. Laws, George Malcolm. Native American balladry; a descriptive study and a bibliographical syllabus. Philadelphia, American Folklore Society, 1950. $276 \mathrm{p}$. (Publications of the American Folklore Society. Bibliographical series, v. I)

Bibliography: p. 267-270.

$$
\text { 5I-I3I9 } \mathrm{ML}_{355 \text { I.L }}
$$

The classic folk-ballads which our early settlers brought from the British Isles have always overshadowed the narrative songs which originated on this side of the Atlantic, in the eyes of collectors and scholars and even of the folk themselves. Mr. Laws' catalog of native American ballads still current in the oral tradition clearly shows that the indigenous product, while secondary, nevertheless constitutes a notable portion of the living folk tradition. His text puts forward a general definition of the ballad as dramatic narrative and continues with chapters on several aspects of American ballads, including the American "ballad makers," about whom much more is known than about their early British counterparts, and some pertinent remarks on the ballad as a record of fact. The classified catalog of American ballads in the appendices makes Mr. Laws' book a valuable reference tool. The first appendix lists the ballads still to be found in oral tradition and gives brief summaries, a stanza or two of text, extensive bibliographical references, and notes on history and distribution. The ballads have been classified, according to topics and functions, in nine categories: "War Ballads," "Ballads of Cowboys and Pioneers," "Ballads of Lumberjacks," "Ballads of Sailors," "Ballads about Criminals and Outlaws," "Murder Ballads," "Ballads of Tragedies and Disasters," "Ballads on Various Topics," and "Ballads of the Negro." The second appendix gives a similar treatment to ballads about whose currency the author is doubtful. There follow lists of traditional songs which, for want of strong narrative elements or for other reasons, fail to qualify as bal- lads, and lists of songs of probable Old-World origin. Together with T. P. Coffin's The British Traditional Ballad in North America (no. 5550) and Mr. Laws' American Balladry from British Broadsides (Philadelphia, American Folklore Society, 1957. 315 p. Publications of the ... Society. Bibliographical and special series, v. 8), this work completes a general bibliographical survey of living American balladry undertaken by the American Folklore Society.

5557. Lomax, John A. Adventures of a ballad hunter. Sketches by Ken Chamberlain. New York, Macmillan, I947. 302 p.

47-30155 $\mathrm{ML}_{429 . U 68 \mathrm{~A}_{3}}$

John Avery Lomax (1872-1948) began to collect and study the traditional songs of America's frontier in his youth during the closing decades of the last century-long before most Americans regarded their folk music and literature as of any importance. On the advice of one of his professors, the disillusioned young Lomax destroyed his first collection of cowboy song and ballad texts as worthless. It was not until Lomax went to Harvard and attracted the attention of Barrett Wendell and George Lyman Kittredge that his efforts were recognized. The rest of his life was devoted to gathering songs from Western prairies and saloons, Southern fields and prison camps, and many other areas of America. His extensive collection became the nucleus of the Archive of Folk Song in the Library of Congress. Adventures of a Ballad Hunter is only secondarily an autobiography; primarily it is a record of Lomax's many years' experience as a collector of folk music. Huddie "Leadbelly" Ledbetter, James "Iron Head" Baker, Dock Reed, and Vera Hall are a few of the folk-singing personalities whom Lomax discovered and who appear in its pages. It is written in an informal style which makes it attractive to general readers as well as to students who wish to benefit from the author's experience in the field.

5558. Lomax, John A., comp. American ballads and folk songs, collected and compiled by John A. Lomax and Alan Lomax; with a foreword by George Lyman Kittredge. New York, Macmillan, 1935. xxxix, $625 \mathrm{p}$.

38-9495 Mr629.L85A52 Bibliography compiled by Harold W. Thompson: p. 613-621.

The nearly 300 pieces in this popular collection (originally published in r934) represent a wide variety of spirituals, white and Negro, as well as a large assortment of ballads; lyric and social songs; songs of the cowboy, lumberman, sailor, and miner; and the Negro's work songs, hollers, and blues. A few venture beyond the English language, being samples of Creole Negro and Spanish-American 
lyrics. The principal source is the oral tradition itself, from which the Lomaxes made sound recordings, but a few of the songs are taken from other published collections. For the sake of completeness the editors have made up some of the texts by putting together stanzas from more than one source. The tunes, transcribed by Mary E. Gresham, are presented without instrumental arrangements or harmonizations. An important complementary collection by the same authors is Our Singing Country; a Second Volume of American Ballads and Folk Songs (New York, Macmillan, 1941. xxxiv, 416 p.). Here the topics are approximately the same as in the earlier volume, with the addition of some unusual items such as Negro songs from the Bahamas, French songs and ballads from southwestern Louisiana, and instrumental dance tunes. The tunes for the later book were transcribed by Mrs. Ruth Crawford Seeger, who supplies a noteworthy introduction on the principles of authentic transcription and performance.

5559. Lomax, John A., comp. Best loved American folk songs (Folk song: U.S.A.) Collected, adapted, and arr. by John A. Lomax \& Alan Lomax. Music arrangements by Charles Seeger \& Ruth Seeger. [4th ed.] New York, Grosset \& Dunlap, 1954, ${ }^{\mathrm{C}}$ 1947. xvi, $407 \mathrm{p}$.

$$
\text { M54-202I Mi629.L85F6 } 1954
$$

First published in 1947 under the title Folk Song: $U$. S. A., this collection has since enjoyed a steaciy popularity. Intended as an album for singing, Best Loved American Folk Songs differs from the authors' earlier collections by the inclusion of piano accompaniments and a somewhat larger format. John Lomax and his son Alan selected what they considered the III best American folksongs. The categories into which they are divided are songs of children and animals, lovers, dancers, soldiers, sailors, lumbermen and pioneers, cowboys, farmers, railroadmen, bad men and jailbirds, and spirituals. The emphasis is strongly on native American materials rather than imported British or foreignlanguage songs. Mr. and Mrs. Seeger have arranged the music for voice and piano, with guitar symbols, in a simple folk-like style. Songs as well as sections are provided with informative introductions.

5560. Lomax, John A., comp. Cowboy songs and other frontier ballads. Rev. and enl. Collected by John A. Lomax and Alan Lomax. Edward N. Waters, music editor. New York, Macmillan, 1945. xxxviii, 43 I p.

$$
\begin{array}{r}
\text { 46-II45 PS595.C6L6 I945 } \\
\text { Mr629.L85C7 } 1945
\end{array}
$$

The first edition of John Lomax's Cowboy Songs appeared in 1910. Since then it has undergone a number of printings and, in the present revised form, remains an indispensable source on the songs of the West. "Home on the Range," "The Buffalo Skinners," and "The Dreary Black Hills" are a few of the songs which this historic collection first brought to public attention. The improvements in the present edition are many. There are nearly twice as many songs. The rather haphazard arrangement of the first edition has been replaced by a subject-function classification with such headings as "Up the Train," "The Round-Up," "Dodge City, the End of the Trail," and "Campfire and Bunkhouse." The former practice of supplying piano accompaniment for the few melodies has been discarded by the music editor, Edward N. Waters, in favor of printing the melodies unaccompanied. This accomplishes the twofold purpose of allowing space for more music and freeing the songs from arbitrary harmonic confines.

5561. Odum, Howard W., and Guy B. Johnson. The Negro and his songs; a study of typical Negro songs in the South. Chapel Hill, University of North Carolina Press, 1925. $306 \mathrm{p}$.

$$
\text { 25-13744 } \mathrm{ML}_{3556 . \mathrm{O}_{3}}
$$

This study is one of a series on the story of the American Negro, which also includes the same authors' Negro Workaday Songs (1926. 278 p.) and Newbell Niles Puckett's Folk Beliefs of the Southern Negro (1926. xiv, 644 p.), both from the same publisher. The Negro and His Songs studies the Negro singer and his religious, social, and work songs. The song texts and the Negro's attitude toward them are analyzed with particular emphasis on their sociological significance. No music is included, but there are texts of more than two hundred songs, and an index to them.

5562. Sandburg, Carl, ed. The American songbag. New York, Harcourt, Brace, 1927. xxiii, 495 p. illus. 28-68r M1629.S21 $3 A_{5}$ "An American bookshelf of song": p. xii-xiii.

In his introduction, Carl Sandburg calls this collection "a ragbag of strips, stripes, and streaks of color." This assemblage of " 280 songs, ballads, ditties, brought together from all regions of America," was for the benefit of everyone who enjoys singing and, even though 30 years and many other similar collections have come and gone since it first appeared, The American Songbag is still foremost in the affections of those who sing for relaxation and delight. All manner of songs are included; there are the ancient "Tarnished Love Tales": "Barbara Allen," "Pretty Polly," and "The Maid Freed 
from the Gallows"; several musical installments of the saga of "Frankie and Her Man"; the shape-note hymns from The Missouri Harmony; and the "Darned Fool Ditties"; "The Horse Named Bill" and "Abdul, the Bulbul Ameer." Soldiers and sailors, lumbermen and railroad men, convicts and hobos, and many more groups have contributed to the making of The American Songbag. The piano arrangements have been made by a number of different musicians in varying styles, while a few of the songs are appropriately left unaccompanied.

\section{Seeger, Ruth (Crawford) American folk} songs for children in home, school and nursery school; a book for children, parents and teachers. Garden City, N. Y., Doubleday, 1948. I9o p. 48-9384 Mi629.S $4 \mathrm{~A}_{5}$

Both as a mother and a teacher, the late Ruth Crawford Seeger had a great deal of firsthand experience in using folk music in the development and education of young children. More concerned with such applications than with folklore research, Mrs. Seeger's detailed notes discuss the use of the songs at home and in school, and include suggestions for improvised games and the playing of the piano accompaniments. The songs come both from previously published collections and directly from the oral tradition. They are indexed not only by first line and title, but by subject (birds, food, snow, sunshine, etc.) and rhythmic applications (clapping, running, skipping, etc.). Both this collection and two supplementary ones, Animal Folk Songs for Children (Garden City, N. Y., Doubleday, 1950. 80 p.), and American Folk Songs for Christmas (Garden City, N. Y., Doubleday, 1953. 80 p.), are illustrated with woodcuts by Barbara Cooney, and arranged with simple and idiomatic piano accompaniments by Mrs. Seeger. The three collections have become popular with adults as well as children.

5564. White, Newman I. American Negro folksongs. Cambridge, Harvard University Press, 1928. 501 p. 28-21279 $\mathrm{ML}_{3556 . \mathrm{W}_{4}}$ Bibliography: p. [469]-480.

The large number of song texts and documentary notes make this one of the most useful works on Afro-American folksong. The first chapter outlines the history of Negro music in America, with special emphasis on the changing attitudes of the white man, as well as the Negro, toward the music. Although there have been many significant contributions to Negro folksong scholarship since 1928, the late Professor White's summary of the several views obtaining up to that time is still a concise and pertinent introduction to the subject. In the controversy over ancestral African versus Christian white influences, the author tends to favor the side of New World assimilation later championed by George Pullen Jackson (no. 5554), and takes issue with the racial views earlier set forth by Henry Edward Krehbiel in his important study, Afro. American Folksongs (New York, Schirmer, I9I4. I76 p.). The songs and commentary are arranged according to function ("Religious Songs," "Social Songs," "Work Songs"), and subject matter ("Songs about Women," "Songs about Animals," "Recent Events," "The Seamier Side"), with a few special categories reflecting social trends ("The Reaction from Religion," "Race Consciousness"). White's main concern was with the texts of the songs, and his conclusions are based on the literary rather than the musical aspects of the songs. The appendixes include 15 tunes, however, in addition to some interesting specimens of Negro folksong texts from pre-Civil War sources.

\section{Folksongs and Ballads: Local}

5565. Arnold, Byron, comp. Folksongs of Alabama. University, Ala., University of Alabama Press, 1950. 193 p.

Bibliography: p. 187-1 88 . $50-14684 \quad \mathrm{Mr}_{29} \cdot \mathrm{A}_{77} \mathrm{~F} 6$

Mr. Arnold collected the 153 songs in this book from Alabama singers during the summer of 1945 . In his introduction and notes the editor describes a relatively current oral song tradition, whose richness is well proved by the songs themselves. Unlike most folksong collections, which group the songs in historical perspective or classify them ac- cording to plot or function, the present work focuses its attention on the singers. Mr. Arnold treats each singer individually, sketching his background and, in many cases, including a photograph. He follows with a selection from the singer's repertory, in the order in which they were sung to him. By this method not only the informants, but the social characteristics of this folk-song-producing area, are clearly outlined. The wide diversity in social, economic, and educational status represented by the singers is noteworthy. The songs, for all of which tunes are provided, represent some of the most wide- 
spread ballads of British and native origin, together with a sampling of standard play-party songs and Negro spirituals.

5566. Barry, Phillips, Fannie Hardy Eckstorm, and Mary Winslow Smyth. British ballads from Maine; the development of popular songs with texts and airs; versions of ballads included in Professor F. J. Child's collection. New Haven, Yale University Press, I929. xlvi, 535 p.

$$
\text { 29-20553 } \mathrm{ML}_{3553 . \mathrm{B}_{2} 8}
$$

PRI $181 . \mathrm{B}_{4} 8$

Phillips Barry (1880-1937) was one of the earliest and most learned pioneers in American folksong scholarship. Although most of his work centered around the British ballad in New England, the many articles he contributed to periodicals such as the Journal of American Folklore, the Bulletin of the Folk-Song Society of the Northeast (of which he was founder and editor), and the Southern Folklore Quarterly, cover a wide range of investigation. He never wrote a general book on American folk music, but some of his articles provided the material for such a work after his death. Edited by Dr. George Herzog and Herbert Halpert, Barry's Folk Music in America (New York, U. S. Works Progress Administration, Federal Theatre Project, 1939. I 3 p.) was distributed in mimeographed form and, despite its comparative rarity today, remains a muchused work of scholarly theory and reference. Fiftysix Child ballads, with variants, make up the major portion of British Ballads from Maine, which Barry prepared with collaborators. In addition to these, there are eight ballads which the editors describe as "secondary"-distinct ballads related to or derived from Child ballads (see no. $555^{\circ}$ note). "Traces" or vestiges of some ballads in the memory of the region's inhabitants, with "jury texts" supplied by the editors, are separated from the more or less complete ballads actually collected, and placed in the final section of the book. The notes, which are both historical and analytical, are informative and detailed. Most of the melodies were transcribed by Dr. George Herzog. Barry's introductory essay discusses the music of the ballads, with attention to such stylistic features of ballad melody as mode and structure.

5567. Beck, Earl Clifton. Lore of the lumber camps. [Rev. and enl. ed. Ann Arbor] University of Michigan Press, 1948. 348 p. illus. (University of Michigan studies and publications)

Bibliography: p. 343-344.

49-7123 Mig77.L8B4 1948

For the greater part of the Igth century, the Michigan woods were the center of America's logging industry. In the $1830^{\circ} \mathrm{s}, 40^{\circ} \mathrm{s}$, and $50^{\circ} \mathrm{s}$, lum- bermen took part in the general Westward migration and brought to the forests around the Great Lakes the songs, legends, and traditions of the New England lumber woods. The present book is a revised enlargement of Dr. Beck's Songs of the Michigan Lumberjacks (I94I), but the emphasis is still on songs and on Michigan. Of the I 8 songs and ballads which describe the work, the leisure, the tragedy, and the humor of the lumberman's life, 23 are provided with music. The final chapter recounts some of the jacks' favorite tall tales, including several redoubtable exploits of Paul Bunyan. The literature on lumberjack songs is small; Franz L. Rickaby's earlier Ballads and Songs of the Shantyboy (Cambridge, Harvard University Press, 1926. xli, 244 p.) and Phillips Barry's The Maine Woods Songster (Cambridge, Powell Print. Co., 1939. I02 p.) supplement Dr. Beck's Michigan collection. An introduction on the history of Michigan's lumber industry, concise descriptive headnotes for each song, and a profusion of photographs and drawings of log brands add considerably to the book's usefulness.

5568. Belden, Henry Marvin, ed. Ballads and songs collected by the Missouri Folklore Society. [ $2 \mathrm{~d}$ ed. Columbia, University of Missouri] I955. Xx, 532 p. (University of Missouri studies, v. I5, no. I)

$$
\text { 55-7519 ML } 355 \text { r.B35В26 } 1955
$$

5569. Randolph, Vance, ed. Ozark folksongs, collected and edited by Vance Randolph; edited for the State Historical Society of Missouri, by Floyd C. Shoemaker [and] Frances G. Emberson. Columbia, State Historical Society of Missouri, 1946-50. 4 v. illus.

Bibliography: p. xvi-xx.

47-1554 Mr629.R2309

In collaboration with the Missouri Folk-Lore Society, the late Professor Belden (1865-1954) and his pupils began collecting the material represented in the first title in 1903. The result of many years of field work and transcription is one of the most valuable of the scholarly collections devoted to a specific region. The book was originally published in 1940; the second edition incorporates a few corrections and additions which Belden had made in his personal copy. More than 300 songs were found in all parts of Missouri, representing a wide variety of traditions. As has become customary, the first part of the collection is devoted to Missouri versions of the Child ballads (see no. $555^{\circ}$ note), and the next to other ballads of British origin. The later journalistic ballads, topical songs, and other indigenous items are treated at length, and chil- 
dren's games and play-party songs, religious songs, and a few songs imported into southeastern Missouri from France round out the geographical and stylistic representation. Professor Belden was primarily concerned with texts, but realized the vital role of music in the ballads and included some tunes which had been transcribed by his students. Vance Randolph's Ozark Folksongs complements Belden's volume with an exhaustive collection from the highlands of Missouri and Arkansas. Containing 883 songs in 1644 versions, 828 of which are given with unaccompanied melodies, these four impressive volumes prove to be the largest of all published American folksong collections, regional or general. Concerned with ballads and songs of British origin, the first volume prints the Ozark versions of $4 \mathrm{I}$ Child ballads and of 89 later importations. The succeeding volumes deal with native songs and ballads of the West, the Civil War, and the Negro, and temperance songs, game and play-party songs, and religious songs. A general introductory chapter in the first volume prescribes effective procedures in the technique and diplomacy of field collecting, a topic on which the author is a high-ranking expert. Substantial headnotes to the songs supply general background and bibliography. The last volume concludes with indexes of titles, first lines, towns, and contributors.

5570. Botkin, Benjamin A. The American playparty song, with a collection of Oklahoma texts and tunes. Lincoln, Neb., 1937. 400 p. $3^{8-1} 348$ GV 177 I.B58 1937

Thesis (Ph. D.)-University of Nebraska, 193I.

Published also as the University Studies of the University of Nebraska, vol. 37, no. I-4.

Bibliography: p. $383-3^{8}$.

The play-party is a completely American term designating a peculiarly American institution. In the preface Dr. Botkin points out that although dance-songs are well-nigh universal, there is nothing quite like the play-party outside of America. Several factors went into its making. Fiddles, fifes, and other musical instruments were often scarce items on the American frontier, so that dance music had to be provided by the dancers' own voices. True dancing, however, was taboo because of the religious beliefs of many of the pioneers. The simple rhythmic stepping, skipping, running, and jumping patterns of the play-party provided a vigorous sort of recreation which took the place of dancing. The first half of The American PlayParty Song is a detailed historical and stylistic analysis. Dr. Botkin carefully traces the playparty's connection with game, song, and dance, and points out the improvisatory elements of the texts, which intermingle snatches from traditional ballads and songs with incongruous bits of square-dance calls, spontaneous jingles, and nonsense syllables. Part two is devoted to 128 play-party song texts, 62 of them with tunes. Dr. Botkin gathered his material in Oklahoma, but his findings and examples have nationwide application and significance. The notes accompanying the songs and their variants give full data on the informants, directions for playing the games, and bibliographical references. Tunes, titles, first lines, subjects, and authorities are meticulously indexed, making this a valuable reference book as well as a definitive study of a neglected aspect of American folk recreation.

5571. Brewster, Paul G., ed. Ballads and songs of Indiana. Bloomington, Indiana University, 1940. $376 \mathrm{p}$. (Indiana University publication. Folklore series, I) $\quad 4^{0-28299} \mathrm{PS}_{571.16 B 7}$

Bibliography: p. I6-2I. $\mathrm{ML}_{3551 . \mathrm{B} 83 \mathrm{~B}_{2}}$

Although Mr. Brewster observes that "balladsinging, as an active tradition, is practically nonexistent in Indiana," this collection from one of America's less isolated regions indicates that considerable vestiges of such a tradition have survived. Of the roo pieces the first 27 are Child ballads (see no. $555^{\circ}$ note), with numerous variants. The other types included are later ballads and lyric songs, of both British and native origin, game songs, and a carol-" "The Twelve Days of Christmas." Most of Mr. Brewster's collecting was done in the southern part of the State, and all of the songs are from white, Anglo-Saxon tradition. There are 37 unaccompanied tunes.

5572. Cox, John Harrington, ed. Folk-songs of the South, collected under the auspices of the West Virginia Folk-Lore Society. Cambridge, Harvard University Press, 1925. xxxi, 545 p.

$$
\begin{array}{r}
\text { 25-4180 PS } 55 \text { 1.C6 } \\
\text { ML } 356 \text { I.C8 }
\end{array}
$$

Although the title and much of the material in the collection apply to the South in general, this collection is focused upon West Virginia, where Dr. Cox was a professor. The introduction describes the formation of the West Virginia Folk-Lore Society and its collecting activities preparatory to the publication of this book. About 35 of the 185 songs are Child ballads (see no. $555^{\circ}$ note). These figures do not take into account the numerous versions of many songs and ballads which are included. Miss Lydia I. Hinkel of West Virginia University edited the 29 tunes which are appended to the collection (p. 519-532). Photographs of 
many of the informants are included which, together with some introductory remarks about them, allow us to see the ballad-singers of the area as real persons.

5573. Eddy, Mary O., comp. Ballads and songs from Ohio. Introd. by James Holly Hanford. New York, J. J. Augustin, 1939. xxvii, $330 \mathrm{p}$.

Bibliography: p. xxv-xxvii.

For the most part this collection is based on an intensive study of a relatively small area of northeastern Ohio. The author collected the songs and ballads from oral and manuscript sources in her hometown of Perrysville, Ashland County, and in Canton, Stark County. In the light of the geographical limitation, the collection is remarkably large and varied. The various ethnic groups which settled the area are discussed in the preface, which also briefly outlines the history of the region. The proportion of British ballads is large, including particularly good versions of "Lamkin" (ballad 93 in Child's collection) and "The Bramble Briar." Still more unusual are the early native American topical ballads, "Major Andrew's Execution," about the death of Major John André during the American Revolution, and two local ballads recording Indian battles of the I780's and 90's: "A Song on the Death of Colonel Crafford" and "On the Eighth Day of November." The more recent lyric songs include a good selection of Irish imports. There are 153 songs in the collection, most of them with melodies. Professor Hanford's introduction discusses folksong in general terms and briefly traces its study from Bishop Percy, in the 18 th century, to John A. Lomax and other collectors of our own day.

5574. Flanders, Helen (Hartness), and Marguerite Olney, comps. Ballads migrant in New England. With an introd. by Robert Frost. New York, Farrar, Straus \& Young, 1953. xiv, 248 p.

$$
\mathrm{M}_{53}-55^{2} \mathrm{M}_{1} 6_{29} . \mathrm{F}_{5} 8 \mathrm{~B}_{3}
$$

The rich store of ballads from Vermont and other New England States now preserved in the Helen Hartness Flanders Collection at Middlebury College has provided material for a number of valuable books by Mrs. Flanders and, more recently, for recordings as well. Several factors make the present collection distinctive. More than half of the contents are Child ballads (see no. $555^{\circ}$ note), and there are some unusual ones. "Babylon," "The Bonny Earl of Murray," "Adam Gorman," and two Robin Hood ballads have been reported in the United States rarely or never. There are, moreover, local ballads such as "Kingston Jail" which are seldom found elsewhere. Mrs. Flanders describes the arrangement of the book as a "vagantes" procedure, with the songs ordered much as the collectors found them instead of according to Child numbers, etc. In this way, the collectors' experience of acquiring the material here and there, with indirection and interruption, is in a measure imparted to the reader. The occasional commentary, with elements of historical background and personal association, also helps the reader "to share vicariously the excitement of ballad-hunting." In keeping with a book designed for general reading rather than scholarly reference, the documentation and bibliographical notes are minimal. The melodies were transcribed by Miss Olney who shared in the original collecting. A brief introduction by Robert Frost describes in poetic fashion the nature of oral tradition.

5575. Gardner, Emelyn Elizabeth, and Geraldine Jencks Chickering, eds. Ballads and songs of southern Michigan. Ann Arbor, University of Michigan Press, 1939. xviii, 50 I p. illus.

Bibliography: p. 49x-494.

$$
\text { 39-28434 M1629.G23 Bi8 }
$$

The 201 songs and ballads in this collection were culled from 7 Michigan counties over a period of about 25 years. The material is organized according to subject: "Unhappy Love," "Happy Love," "War," "Occupations" (where the Michigan lumberjacks figure prominently), "Disasters," "Crimes," "Religion," "Humor," and "The Nursery." Within each category the songs are arranged in a more or less chronological order, with the Child ballads (see no. $555^{\circ}$ note) at the beginning of each section. Melodies are provided for about a fourth of the collection, and the headnotes give historical and collecting data. The titles of other songs which the collectors found in Michigan are appended, with sources ( $p .477-483$ ). The volume's general attractiveness is enhanced by line drawings of rural Midwestern scenes.

5576. Hudson, Arthur Palmer. Folksongs of Mississippi and their background. Chapel Hill, University of North Carolina Press, 1936. 32I p. 36-23296 ML355I.H8I936 $\mathrm{PS}_{57 \text { I.M7 }} \mathrm{H} 8$

As its title implies, Professor Hudson's collection devotes much attention to a study of the peoples and backgrounds which have preserved the white folk-music tradition in Mississippi. The first quarter of the book, specifically concerned with backgrounds, asserts the predominance of British and Irish groups, a thesis which is borne out by the clear British-Isles lineage of the collected songs. Finding three social and economic levels among the first Mississippi immigrants, Professor Hudson credits both the planter aristocrats and the humble tillers of the poorest soil with a knowledge and love of the 
traditional ballads of their common heritage, but reserves for the middle group, the small landholders, the greatest share in the importation and perpetuation of the tradition. The songs themselves include imported folksongs, with a rich supply of Child (see no. $555^{\circ}$ note) ballad variants; native American songs, subdivided according to regional origins and subject matter; and a miscellaneous group of comic, nursery, play-party, and game songs. Financial limitation prevented the publishers from printing the tunes which Dr. Hudson collected with the song texts, but, with the editorial assistance of Dr. George Herzog and Herbert Halpert, they were later published in a mimeographed volume, Folk Tunes from Mississippi (New York, U. S. Works Progress Administration, Federal Theatre Project, 1937. 45, xxii l.).

5577. Jackson, George Pullen. White spirituals in the Southern uplands; the story of the fasola folk, their songs, singing, and "buckwheat notes." Chapel Hill, University of North Carolina Press, 1933. xv, 444 p. illus.

33-3792 ML355I.J2

Bibliography: p. 434-436; "List of song books in the four-shape notation": p. [25]; "Important sevenshape song books ... I832 ... [to] I878": p. 323; "Southern musical periodicals": p. 389 .

The part-singing movement in colonial New England gave rise to a tradition of religious song which lasted through the Igth century and which, in a few rural areas, still continues. This, the first of Professor Jackson's many studies of the subject, tells how the singing movement evolved its characteristic "buckwheat" notation system, with differently shaped noteheads representing different pitches, and ultimately moved from the urban centers to the young Republic's Western frontiers-down the Shenandoah Valley and across the Appalachians. The book gives a large number of song texts and tunes, but differs from Jackson's other white spiritual books in that it is primarily a history rather than a collection. Folk tradition though it was, the white spiritual was perpetuated not only by word of mouth, but by the many songbooks, published in various systems of "buckwheat" notes, which were used by many in the Southern Highlands. Some of the most celebrated and enduring songbooks were "Singin' Billy" Walker's Southern Harmony ( 1843 ), and B. F. White and E. J. King's The Sacred Harp (1844), both in the old "fasola," four-shaped notation; and the Harp of Columbia, which W. H. and M. L. Swan published in 1848 , employing the city-influenced seven-shaped system. The numerous books of this sort, and the men who made them, form a significant part of Dr. Jackson's history. The melodies are analyzed in detail, and classification according to tune, text, and function is discussed. A chapter on the Negro spiritual compares texts and melodies from the white and Negro traditions and outlines the problems which the author was later to treat at length in his White and Negro Spirituals (no. 5555).

5578. Korson, George G., ed. Minstrels of the mine patch; songs and stories of the anthracite industry. Philadelphia, University of Pennsylvania Press, 1938. 322 p.

$$
\begin{array}{r}
39-95^{8} \mathrm{PS}_{508 . \mathrm{M}_{5} \mathrm{~K} 6} \\
\mathrm{M} 629 . \mathrm{K}_{4} \mathrm{M}_{5}
\end{array}
$$

Bibliography: p. $321-325$.

In the introduction to this book, Mr. Korson tells of his first experiences with the traditional song literature of the Pennsylvania anthracite miners, and his surprise at finding that it was an area of folk music which, unlike the songs of lumbermen, cowboys, and sailors, had gone virtually unnoticed. Songs and Ballads of the Anthracite Miner (New York, F. H. Hitchcock, 1927. xxviii, I96 p.) was his first attempt to rectify this situation. Mr. Korson has gone on to publish other books on the songs of the American coalminers and has thereby opened a whole important field of study in American folklore. Minstrels of the Mine Patch is a greatly enlarged edition of the earlier book of anthracite miners' songs. The "mine patch" of the title is the small village of shacks which grew up on the mining site, around a "breaker," the building in which anthracite is processed. The earliest miners having been Irish, Welsh, Scottish, or English immigrants, Mr. Korson found that a majority of their songs were in the English language, with a particularly strong Irish element in the musical style. $\mathrm{He}$ also found effects of the later Slavic immigrations. In addition to the songs and ballads, for which a few tunes are included, the author relates many tales, legends, and superstitions of the miners, and describes disasters, strikes, and the notorious exploits of the "Molly Maguires," all of which figure importantly in the miners' songs and lore. The appendixes give biographical sketches of the singers and, many of the ballads having been of known authorship, the creators of the miners' songs, together with a glossary of technical terms and jargon. Mr. Korson went on to produce a complementary study: Coal Dust on the Fiddle; Songs and Stories of the Bituminous Industry (Philadelphia, University of Pennsylvania Press, 1943. xvi, 460 p.), which is considerably larger in its geographical scope. Whereas the anthracite industry is centralized in a small area of Pennsylvania, Mr. Korson's search for material on the bituminous industry took him to Ohio, Indiana, Illinois, Kentucky, Alabama, Tennessee, Virginia, and West Virginia as well as his home State. As in the anthracite study, the author 
here combines the songs, tales, and superstitions of the miners with an absorbing account of the history of the bituminous mine-worker in America. Once again the tragic lives of the miners, mine disasters, and labor-management troubles figure importantly in Mr. Korson's account and in the songs. Thirteen of the songs appear with tunes, as transcribed by Ruth Crawford Seeger.

5579. Korson, George G., ed. Pennsylvania songs and legends. Philadelphia, University of Pennsylvania Press, 1949. 474 p. illus. 49-9849 ML 355 I.K85

The variety of ethnic and occupational groups comprising Pennsylvania's population make the State something of a microcosm of the United States as a whole, and this book a summing up of many aspects of American folklore. After the initial English colonization, the 18 th-century immigrants included peoples from other parts of the British Isles and from Northern and Western Europe, including a large body of Germans-the so-called "Pennsylvania Dutch." The editor's introduction describes these early groups and the later immigrants from Southern and Eastern Europe, emphasizing the contributions each has made to the Pennsylvania folk tradition. The essays which follow are detailed studies of 13 specialized phases of Pennsylvania folksong and lore, each by a notable authority on the subject. Several ethnic groups are examined, including the area's aboriginal inhabitants, whose descendants still retain their identity and ancient lore. The legends and tales of several groups are presented, as well as their songs. The occupational groups included are the Conestoga wagoners, canallers, railroaders, lumberjacks and raftsmen, coalminers, and oilmen. The industrial songs of Pittsburgh bring the occupational studies up to the present time. The chapters dealing with music have numerous song texts and airs.

5580. Linscott, Eloise Hubbard, ed. Folk songs of old New England. New York, Macmillan, I939. xxi, $337 \mathrm{p}$.

"References": p. 319-337.

40-27042 $\mathrm{Mi}_{629} \cdot \mathrm{L} 64_{4} \mathrm{~F}_{7}$

Many familiar British and American ballads and lyric songs, as well as some which are less familiar, are given in this large collection of New England songs and tunes, but it is in the area of country dance tunes and game songs that Miss Linscott's book offers the greatest amount of fresh material. The words and music are accompanied by descriptions of how the games and dances are executed. Some of these are to be found in other local collections, but many appear to be rare outside of New England. In addition to these a fourth section deals with popular sea shanties and fo'castle songs. The headnotes for each song or tune detail the author's sources and give some historic background. Nearly 200 tunes are included, most of them arranged with piano accompaniment. The appendixes include biographical data on Miss Linscott's singers, fiddlers, and dance-callers.

558r. Morris, Alton Chester, ed. Folksongs of Florida. Musical transcriptions by Leonhard Deutsch. Gainesville, University of Florida Press, 1950. xvi, 464 p. illus.

Bibliography: p. 45I-457.

$50-9048$ Mr629.M858

Following a procedure similar to A. P. Hudson's in his Folksongs of Mississippi (no. 5576), Professor Morris prefaces this State collection with a valuable study of the social, cultural, and folkloristic history of the region. The first section, "Songs of the New World," includes a number of unique local items such as "The West Palm Beach Storm" and the "Miami Hairikin." The cowboy and lumberjack songs, however, must have traveled long distances before reaching Florida. A large number of English and Scottish ballads, both in and out of the Child canon, are represented in "Songs of the Old World." A special rarity, never previously reported in the United States, is "Lord Derwentwater" (ballad 208 in Child's collection), called by Professor Morris' informant "The King's Love Letter." Bahaman versions of British songs, a Negro rowing song, and an American Indian version of a white hymn are a few of the other items of special interest. Condensed from Professor Morris' doctoral dissertation, Folksongs of Florida is still a large and comprehensive collection, totaling 243 songs plus variants. A number of unaccompanied tunes are included.

5582. Scarborough, Dorothy. A song catcher in Southern mountains; American folk songs of British ancestry. New York, Columbia University Press, 1937. xvi, 476 p. illus.

37-4992 Mi629.S29S6

On one of Dorothy Scarborough's trips into the Blue Ridge, a young mountain boy recommended a friend as a good source of local ballads: "He's a song catcher, he is." The term applied so well to Miss Scarborough and her quest that she adopted it and employed it in the title of this book. $A$ Song Catcher in Southern Mountains was nearly finished at the time of Miss Scarborough's death in 1935, and was prepared for publication by John H. H. Lyon and Vernon Loggins. The first part describes collecting experiences in the Blue Ridge Mountains, Buchanan County, Virginia, and western North Carolina. These colorful background 
chapters form an attractive introduction to the Anglo-American ballads and songs which occupy the major part of the book. Appended to the collected ballad texts are unaccompanied tunes and a discussion of the modal aspects of the music. Miss Scarborough's last work does for the people of the Southern Appalachians what her On the Trail of Negro Folk-Songs (Cambridge, Harvard University Press, 1925. 289 p.) had done with the secular songs of Southern Negroes.

5583. Sharp, Cecil J., comp. English folk songs from the Southern Appalachians; comprising two hundred and seventy-three songs and ballads with nine hundred and sixty-eight tunes, including thirty-nine tunes contributed by Olive Dame Campbell. Edited by Maud Karpeles. London, Oxford University Press, H. Milford, 1932. $2 \mathrm{v}$. 33-3796 Mi629.S53E6 I932

Bibliography: v. I, p. 427-430; v. 2, p. 402-405.

At a time when the ballad and other forms of folk music were considered the domain of students of literature, ethnology, and folklore, Cecil Sharp (1859-1924) began a more musically oriented approach to the subject. With careful attention to the transcription of the melodies, Sharp first covered his native England and the rest of the British Isles, and then followed the British songs across the Atlantic. With the assistance of Miss Maud Karpeles, who took down the words while he notated the music, Sharp spent parts of 1916, 1917, and 1918 studying the British traditional songs preserved by the mountain people of the Southeastern United States. In addition to the material gathered by Sharp and Karpeles, English Folk Songs from the Southern Appalachians prints 39 tunes, with texts, which Olive Dame Campbell had collected in the region between 1907 and r9ro. First published as a single volume in $19 \mathrm{r} 7$, the col- lection was reissued in its present enlarged form after Sharp's death, but still based on his transcriptions. It was reprinted in 1952, with an additional prefatory note by Miss Karpeles describing the changes she had observed in the area during a 195I field trip. The first volume contains ballads, and the second songs, hymns, nursery songs, jigs, and play-party games. Both the editor's preface and Sharp's introduction give special attention to the stylistic characteristics of the melodies, which are printed with the song texts. The introduction also gives a general description of the region and the ethnic background of its inhabitants.

5584. Thomas, Jeannette (Bell). Ballad makin' in the mountains of Kentucky, by Jean Thomas; with music arr. by Walter Kob. New York, Holt, 1939. xviii, 270 p.

$$
\text { 39-31805 } \mathrm{ML}_{355} \mathrm{I}^{\mathrm{T}} \mathrm{T}_{4} \mathrm{~B}_{2}
$$

Miss Jean Thomas has spent her life among the people of the Kentucky highlands, and has brought much of their music before the public by means of her books and the annual folk festivals held at her rustic cabin near Ashland. Known to her Kentucky neighbors as "the traipsin' woman," Miss Thomas traveled throughout the area both as a circuit judge's stenographer and as a ballad collector. Emphasizing the native ballads of recent origin, Ballad Makin' describes the hill people who still compose ballads and the events which inspired their compositions. The chapters deal with the ballads and their makers according to subject matter: feuds, which the hill people usually call "troubles" or "wars"; chanteys, composed by ballad makers who have never even seen a large river; war, flood and fire; the railroad; "stillin' and drinkin" "; "killin" "; laments and farewells; and "hymn makin'" The ballad makers and ballad subjects are illustrated by photographs and the songs are printed in simple piano arrangements.

\section{E. Games and Dances}

5585. Brewster, Paul G. American nonsinging games. Norman, University of Oklahoma Press, 1953. 218 p. illus. $53-5476$ GVI203.B68

Students of folklore have long collected and studied the traditional games of children as significant vestiges of ancient beliefs, customs, and rituals. The author points out, however, that most collectors have emphasized singing games to the near exclusion of those in which music figures slightly or not at all. This large collection of nonsinging games is an important step toward supplying the earlier omissions. In an effort to make his material useful to teachers and recreation leaders, as well as to folklorists, Mr. Brewster separates his description of each game from his ethnic and historical analyses, bibliographical notes, and other scholarly apparatus. The games, which he gathered from students and friends, and other non- 
literary sources, are presented in 14 general categories, including "Guessing Games," "Forfeit Games," "Hiding Games," "Ball Games," "Paper and Pencil Games," and "Courtship Games." Many variants are included for the rope-jumping, ball-bouncing, and other games, such as hopscotch, nine versions of which are given.

5586. Chase, Richard, comp. Hullabaloo, and other singing folk games. Illus. by Joshua Tolford. Boston, Houghton Mifflin, 1949. 57 p. 49-8127 GV1771. 5

Mr. Chase's foreword states that the "golden age" for singing games falls between the years of eight and eleven. The games and play-parties in this collection seem to be directed toward children in this group, but teen-agers in some areas continue to find them of recreational value. The games involve simple group steps and dramatic action, taken from the traditional Midwestern play-parties, and employ popular play-party songs which direct the action of the group as it sings them. Many of the games, such as "Goin' to Boston," "Pawpaw Patch," and "Three Dukes," are still popular in some parts of the country, while others, "The Allee Allee O," recently collected in New England, and the ancient British "Roman Soldiers," are seldom heard. Mr. Chase's language and diagrams will be easily understood by youngsters, and the tunes, six of which are given piano settings by Hilton Rufty, are in a simple singing style.

5587. Mayo, Margot. The American square dance. Illus. by Selma Gorlin. [Rev. and enl.] New York, Sentinel Books, 1948. II9 p. $4^{8-8015}$ GVI763.M3 1948

Bibliography: p. I $16-[120]$.

Miss Mayo's American Square Dance Group in New York has for many years been an important factor in the renewed urban interest in American folk dancing. Her handbook is designed to give useful hints to other organizations and individuals wishing to join in an increasingly popular form of recreation. "The term "square dance" is used here not to describe a particular form, but is applied to American folk dances in general, including square sets, quadrilles, longway sets, running sets, play-party games, and round dances, each of which is described. After some further hints on the music, calling, and the general planning of a squaredance party, 13 dances are described and their direction indicated with the aid of illustrations. Also included are an illustrated glossary of squaredancing terms, ro tunes in piano arrangements ( $p$. 96-104), and suggestions for "Dancing to Recorded Music" (p. 106-114).
5588. Newell, William Wells. Games and songs of American children. New and enl. ed. New York, Harper, 1903. xv, 282 p.

3-29283

GVI203.N54

Mig93.N49

"Collections of children's games": p. [267]-269.

"Comparisons and references": p. 270-282.

Although the first edition of this collection appeared as long ago as 1883 , it is still generally recognized as the standard source on the immense subject of the folklore of children's games in America. An introductory chapter describes the rhyme and chant formulas which characterize a large part of children's game lore, compares them with the ballad and the dance, and speculates on their origins, which in many cases are quite ancient, and their diffusion in the Old and New Worlds. The author also took into account the children themselves, contrasting their resourcefulness in invention with their conservatism in the retention of old traditions: "The formulas of play are as Scripture, of which no jot or title is to be repealed." For these reasons, in the absence of excessive organization by adults, the game traditions of children are of particular interest to students of strictly orally transmitted custom. Mr. Newell's 15 basic chapters group the games according to subject, function, and type of activity. Among them are "Love-Games," "Histories," "The Pleasures of Motion," and "Ball, and Similar Sports." Counting-out rhymes, the chants used to determine who will be "it" at the beginning of a game, are also accorded a generous chapter. In addition to quoting the rhymes, describing the play, and, in many cases, providing the music for $19^{\circ}$ games, Dr. Newell's text makes some comments upon the games' distribution here and abroad, and on their origins. Added to this edition is a final chapter of miscellaneous additional games and variants, and a Preface offering further suggestions on the Old-World origins of American games, making particular reference to this book's British counterpart, Lady Alice Gomme's The Traditional Games of England, Scotland, and Ireland (London, D. Nutt, 1894-98. 2 v.).

5589. Putney, Cornelia F. Square dance U. S. A. Musical arrangements by Jessie B. Flood; historical background and descriptive material by Cornelia F. Putney. Dubuque, Iowa, W. C. Brown, 1955. I 10 $\mathrm{p}$. 55-4642 GVi763.P8

The square-dance revival, which continues to grow in many parts of the country, has a continual need for practical books offering new dances and tunes, together with instructions on the fundamentals of calling, playing, and execution. Although there are some general historical notes by Prof. Louise Pound and by the author, this book, con- 
veniently published in a spiral binding, is meant for application rather than study. There are hints for the musicians, the callers, and the program planners, followed by a wide selection of dances and tunes, some new and some traditional. Singing calls, which have been popular in some parts of the country for many years, are also included, with their music. All of the music is given in simple piano arrangements. A final section is devoted to accounts of recent developments in the square-dance revival in several parts of the country.

5590. Ryan, Grace L., comp. Dances of our pioneers. Music arrangement by Robert $T$. Benford; illus. by Brooks Emerson. New York, A. S. Barnes, 1939. I96 p.

39-27508 Mr629.R95 1939 The characteristic American quadrille whose four-sided formation gives it the name of square dance remains the favorite among the dances of our pioneers, and so bulks greatly in this collection as in most others. Nevertheless, there are other groupdance forms, notably the contra and circle dances and, of course, the couple dances, which have long enjoyed great popularity, particularly in the Eastern States. These too play their part in this popular book of instruction, which was originally published in 1926. Among the contra dances are a variety of reels and hornpipes, and the circles include the popular hybrid Sicilian Circle and Paul Jones. Some of the couple dances outlined are schottisches, polkas, and waltzes. The directions are made plain by drawings and diagrams, and an introductory chapter defines the standard terms. There are over two dozen tunes, in piano arrangements, and the directions frequently cite appropriate calls.

5591. Shaw, Lloyd. Cowboy dances, a collection of Western square dances; with a foreword by Sherwood Anderson. Appendix, cowboy dance tunes arr. by Frederick Knorr. Rev. ed. Caldwell, Idaho, Caxton Printers, 1949. 417 p.

"Phonograph records": p. [395]-4I3.

$$
49-4858 \quad \mathrm{GV}_{17} 67 . \mathrm{S}_{5} \quad 1949
$$

Lloyd Shaw has long been an active performer and teacher of American country dancing and a student of its history as well. Both aspects of his experience are evident in this book on the folk dances of the West. As in most recent books on the square dance, practical considerations figure importantly, and many square-dance enthusiasts will benefit from the descriptions of 75 dances, some with several variants, which are included and illustrated by diagrams and by photographs of $\mathrm{Mr}$. Shaw's popular cowboy-dance troupe. There is also much historical and ethnic analysis. The first chapter traces the distinctive Western square dances back through the Kentucky running sets and the New England quadrilles, eventually to European ancestors. Further notes observe the natural evolution and adaptation which have characterized the unique cowboy-dance forms, just as the Old World names, Polka and Varsovienne, became "Pokey" and "Varsity Anna." In a companion volume, The Round Dance Book (Caldwell, Idaho, Caxton Printers, 1948. 443 p.), Mr. Shaw has made a similar practical and historical examination of other American folk dances, including polkas, waltzes, schottisches, and circle mixers.

5592. Withers, Carl, comp. A rocket in my pocket, the rhymes and chants of young Americans. Illus. by Susanne Suba. [New York] Holt, 1948. 214 p. illus. $48-488$ I PZ8.3.W76Ro

This selection of varied rhymes and chants, taken from the folklore of modern American children, is designed primarily for the children themselves, but Mr. Withers points out in his postscript that adults too will find them entertaining and instructive. From the first ("Silence in the courtroom!/The monkey wants to speak") to the last ("If this book should chance to roam,/Box its ears and send it home"), virtually all of this children's lore was collected directly from or verified in the oral tradition. The I4 chapters include popular rhymes for ballbouncing, rope-jumping, and counting-out. Among the mental exercises and tricks in which children find constant delight are tongue twisters, spelling rhymes, riddles, and finger-plays. Although no music is provided, a few are meant to be sung ("The Bear Went Over the Mountain," "The Green Grass Grows All Around"), but most of the items are in the rhyme and chant categories. Mr. Withers has appended a brief note explaining his procedure in gathering the material, suggesting ways in which it might be used, and stressing the value of children's folklore to educators, sociologists, and child psychologists. The contents are indexed, but for children's rather than for scholars' use; there is no bibliography or list of sources.

\section{F. Folk Art and Crafts}

5593. Bolton, Ethel (Stanwood), and Eva (Johnston) Coe. American sampler. [Boston]
Massachusetts Society of the Colonial Dames of America, 1921. $416 \mathrm{p}$. 
This monumental treatise was promoted by Mrs. Barrett Wendell and the Massachusetts Society of Colonial Dames in order to record the domestic virtues of our ancestors, and to supply the lack of publications on early American needlework, of which the sampler was "the primary basis and training school." It covers the period from the earliest settlements to 1830 , after which year samplers declined rapidly in quality and quantity. The examples were obtained primarily from New England, but other state societies, especially the New Jersey Dames, lent their assistance so that other regions could be represented. The earliest mention of a sampler is in an English account book of 1502, and by 1630 it was a well-established form, a longitudinal pattern book in cloth in which the housewife worked specimens of such designs as she wished to use in her incessant needlework, "practically the only relaxation of most women." The earliest American samplers that have survived seem to be quite as old as their English counterparts. By the I 8th century the sampler had become transformed into a square or horizontal display piece with elaborate design and lettering demonstrating the girl's or young lady's proficiency. Here the general description of each period is followed by a register of existing samplers, listed alphabetically by their makers and with their I921 owners named. Separate plates illustrate 126 of them, but only the dozen colored plates begin to do justice to their subjects. There are also a roo-page anthology of sampler verse; an enumeration of early girls' schools in which needlework was taught; a much too brief section on "Materials, Designs, Stitches"; and a special treatment of "Embroidered Heraldry," not all specimens of which are genuine samplers.

5594. Christensen, Erwin O. The Index of American design. Introd. by Holger Cahill. New York, Macmillan, 1950. xviii, 229 p. 378 illus. (part col.)

Bibliography: p. 219-22I.

The complete "Index of American Design," whose more than 15,000 documentary paintings are now housed in the National Gallery of Art, was prepared between 1935 and 1942 by the Federal Art Project. The present volume, drawn from that immense collection, covers a great diversity of indigenous folk arts and crafts from the first white settlement to the end of the last century. The water-color illustrations, which show a remarkable realism and accuracy in detail, are accompanied by a historical and comparative commentary by Mr. Christensen. The first section, "Our Wide Land," deals with several minority groups which have made significant contributions to American folk art. These include the Pennsylvania Germans, whose objects of daily use are richly decorated with predominant bird and tulip motifs; the Shakers, whose furniture and utensils show an extreme simplicity of form and perfection of workmanship, together with great ingenuity; and the peoples of the Southwest, who combined Spanish and Indian traditions in their religious objects, furniture, woven baskets, and saddles, spurs, and stirrups. Some of the other arts illustrated and described are ship figureheads, tavern signs and cigarstore Indians, weather vanes and hitching posts, whittling and wood carving, toys, and carrousel horses, and such gadgets as an apple peeler and a fly catcher. The final section, "The Years Pass," makes chronological surveys of lights, lamps, and candlesticks; of costume; and, finally, of the "Symbols of a Nation": the American Eagle, personifications of Liberty and Justice, and portraits of American heroes. This enumeration does not begin to exhaust the contents of an extraordinarily rich volume.

5595. Colonial Williamsburg, inc. The Abby Aldrich Rockefeller folk art collection: a descriptive catalogue by Nina Fletcher Little. [Williamsburg, Va., Published by] Colonial Williamsburg; distributed by Little, Brown, Boston, 1957. xvi, 402 p. 165 col. illus. 57-625 I N6510.C66

Abby Greene Aldrich (1874-1948), the daughter of Senator Nelson W. Aldrich of Rhode Island, married the younger John D. Rockefeller in Igor. In 1929 she was a cofounder of the Museum of Modern Art, and subsequently made many gifts to its collections. In the early 1930's, advised by Edith Gregor Halpert and Holger Cahill, she began to accumulate American folk art, and before long put together the first of the great collections in the field, which was first exhibited as a unit by Colonial Williamsburg in 1935. Most of it was presented to this Rockefeller family foundation in the same year; portions of it which had been given to the Museum of Modern Art and to the Metropolitan Museum were reunited with the main collection after Mrs. Rockefeller's death, and a special building has now been erected to house and exhibit it. The total is 424 pieces in all kinds, of which 165 are here reproduced in fine colored plates printed in England, while the remaining 259 are described in some detail in a catalog (p. $349-382$ ) following the illustrations. Both the illustrations and the catalog are arranged under the following six media categories: "Paintings in Oil"; "Paintings in Watercolor and Pastel"; "Needlework and Painted Textiles"; "Paintings on Glass"; "Fracturs, Calligraphic Drawings, and Engravings"; and "Sculpture in Wood and Metal." Notes on the 
illustrations are on the facing pages, and the $5^{8}$ artists whose names are known or surmised are indexed on p. $389-390$. The volume is a contribution to the subject as monumental as it is beautiful, and a worthy memorial of the collector. Meanwhile another very remarkable collection, limited to paintings in various media, was put together by Colonel and Mrs. Garbisch. In 1954 a representative group of 300 paintings and 200 miniatures was presented by them to the National Gallery of Art, which has published two installments of American Primitive Paintings from the Collection of Edgar William and Bernice Chrysler Garbisch (Washington, U. S. National Gallery of Art, 195457 ), each reproducing Ioo oil paintings in halftone.

5596. Drepperd, Carl W. Pioneer America, its first three centuries. Garden City, N. Y., Doubleday, 1949. 311 p. 49-10623 Ei6r.D74

The author illustrates the social history of America, through the Igth century, through its popular arts and crafts. Of particular interest to collectors of antiques, the text outlines the background of pioneer artifacts and tells of their makers. The chapters cover architecture, cooking utensils, firearms, tools, jewelry, toys, pottery, tin, pewter, and silverware, and many other gadgets and frills of early America which the collector of today seeks out. In his introductory chapter Mr. Drepperd underrates his interesting commentary by calling this a picture book, but it is true that the illustrations, mostly black and white drawings, are abundant. Many of the items here described or pictured are properly classified as decorative or industrial rather than folk art, but the latter element is pervasive enough to justify the book's inclusion in this chapter. The same consideration applies to Mr. Drepperd's A Dictionary of American Antiques (Garden City, N. Y., Doubleday, 1952. 404 p.), which defines for collectors more than 15,000 terms such as acorn basket, embroidered pictures, persimmon beer, and zephyr moss. Many of the entries are for individual craftsmen or manufacturers, and some, such as those for Chippendale or ironstone, are miniature historical essays. Separate pages are devoted to small drawings, as many as twenty to a page, and there is a brief entry bibliography ( $p$. 398-404).

5597. Ford, Alice E. Pictorial folk art, New England to California. New York, Studio Publications, I949. I72 p. (An American Studio book)

Bibliography: p. I69-17o. 49-48983 ND205.F65

An introduction to American folk art for the general reader, which emphasizes its variety but is not, as the title might suggest, geographical in its structure. There is, to be sure, a section on "Regional Painting and Drawing," which introduces the Shaker "spirit prickings" of the 1840's and 50's and the santos of Spanish New Mexico as well as more familiar fractur and Indian material; but the others are concerned with types such as portraiture, landscape, religious and allegorical painting, and "scrimshaw" incising on whalebone. There is a brief narrative of the "rediscovery" of this art, which Miss Ford dates from the mid-rg20's when Mrs. Isabel Carleton Wilde began her collecting, and a postscript on recent or contemporary "primitives": Joseph Pickett, John Kane, Horace Pippin, Grandma Moses, and Clara Williamson. A concluding "Evaluation" protests against the recent tendency to magnify with the name of "abstractionism" what is in fact only the ineptitude of the untutored. The bulk of the book (p. $5 \mathrm{I}-\mathrm{I} 60$ ) is devoted to halftone reproductions which, unfortunately, are regularly too crowded (sometimes four to a page) and too dark.

5598. Gould, Mary Earle. Early American wooden ware \& other kitchen utensils. Fully illustrated by the author. Springfield, Mass., Pond Ekberg Co., r942. 230 p. 42-18677 Eı6r.G6 The author's collecting specialty is antique wooden utensils and receptacles, handmade in America's colonial period. Her collecting has centered in New England, but familiarity with the woodworker's craft in other colonies has enabled her to make some observations on regional varieties. The early chapters describe the raw materials with which the pioneers worked and the tools they used to fashion their simple utensils. Also discussed are the means of determining the function, locale, and authenticity of various pieces of antique wooden ware. The succeeding chapters describe the utensils themselves: bowls, mortars and pestles, buckets, baskets, and sieves, and how they were made and used. The book is illustrated by nearly 150 photographs.

5599. Lichten, Frances. Folk art of rural Pennsylvania. New York, Scribner, 1946. xiv, 276 p. $\quad 47-\mathrm{II}_{92} \quad \mathrm{NK} 835 \cdot \mathrm{P}_{4} \mathrm{~L}_{5}$

560o. Stoudt, John J. Pennsylvania folk-art; an interpretation. Allentown, Pa., Schlechter's, 1948. xix, 402 p. $49-855 \quad \mathrm{NK}_{35} \cdot \mathrm{P}_{4} \mathrm{~S}_{7} \mathrm{I}_{94} 8$ Bibliography: p. [397]-402.

Miss Lichten's volume is a labor of love throughout, and one of the most thorough and sympathetic studies of a folk art that has been made. The art of the Pennsylvania Dutch, she emphasizes, was the flowering of a peasant culture, for the Germans who came to Penn's province exchanged oppression and 
poverty for freedom and, in time, a solid prosperity earned by frugality and hard labor. The first halfcentury of the province had little to show, but by about 1750 the land had been conquered, the log huts of the settlers had been replaced by substantial stone houses most of which are still standing, and decoration of a naive but distinctively original kind was lavished upon all the objects of craftsmanship. The second half of the 18 th century was the great age of this folk art; after 1800 designs became simpler and labor less lavish; while after 1850 industrialism destroyed it altogether. In $1891-92$ Dr. Edwin Atlee Barber made the finest collection of Pennsylvania decorated ceramics for the Philadelphia Museum, but appreciations of its other achievements had to wait for the antique fever of the I920's. Miss Lichten, whose authority in the field was developed as supervisor of the Pennsylvania "Index of American Design," arranges her book by the materials upon which the craftsmen worked, beginning with clay, flax, and wool. Of exceptional interest are "The Salvage Arts," which turned textile fragments into quilts, and rags into rugs or into illuminated paper. The illustrations are excellently reproduced, and accompanied by unusually satisfactory explanatory letterpress. The concluding 30 pages reproduce a variety of original designs in their original colors, always gay and often garish. Mr. Stoudt's volume does not approach Miss Lichten's in the quality of its numerous illustrations, but it provides a valuable supplement by relating the images used in decoration to the symbolism of the German Pietistic sects. "The motifs and designs of the folk-art of Eastern Pennsylvania are non-representational expressions of traditional Christian imagery." The rod of Jesse, the rose of Sharon, the dove who is the believer languishing for the Savior, the pelican who is Christ, and the peacock who stands for the Resurrection are among the images identified.

5601. Lipman, Jean (Herzberg). American primitive painting. New York, Oxford University Press, 1942. $15^{8}$ p. $\quad 42-14277$ ND205.L5

"Selected bibliography": p. 139-142.

Although American primitive painting is not often regarded by folklorists as a branch of their science, the anonymity of most of the artists and the naiveté of their style lead many observers to regard their work as folk art. In the introduction the author discusses the meaning of the word "primitive" in the history of American art. Antiquity is not an important factor, for the height of the primitive school fell in the middle of the last century. Nor is it determined by prevailing features of the society as a whole. Rather the "primitiveness" of such work lay in the artist's experience and attitudes, and the effect which these had on his productions. The primitive painters, most of whom are unknown by name, were unschooled in the classical sense and developed independently of European tradition. The result is akin to abstraction, for visual qualities are deemphasized in favor of geometric forms, restricted movement, emphasized contour lines, and heightened color-contrast. A group of plates near the beginning of this book effectively demonstrates the differing values of the academic and primitive schools. Except for some historical and analytical notes, the balance of the work is given over to illustrations, some in color: portraits, landscapes, and various kinds of decorations, which show the range of the primitive school. Mrs. Lipman has also published an important volume on our relatively little known folk sculpture: American Folk Art in Wood, Metal and Stone (New York, Pantheon, 1948. I93 p.). Its substance lies principally in its 183 illustrations, a few of which are in color.

5602. New York. Museum of Modern Art. American folk art; the art of the common man in America, 1750-1900. New York, Museum of Modern Art, 1932. 52 p.

Bibliography: p. 47-52.

$$
\text { 32-34218 N6505. } \mathrm{N}_{44}
$$

This illustrated catalog, published in connection with an epoch-making exhibit at the Museum of Modern Art, did much to establish the present vogue of folk art among the art public. It covers the useful and decorative arts in America during the latter part of the 18th and all of the rgth centuries. A substantial introduction by Mr. Holger Cahill ( $p$. 3-28) discusses the relative merits of the terms "primitive," "provincial," and "folk" in describing this type of art, and settles on the last. He suggests that "folk art" best characterizes this kind, made by "the common people," expressing their ideals, and fulfilling their needs. He further describes the historical background of the largely unknown and untutored house painters, sign painters, portrait limners, carpenters, cabinetmakers, shipwrights, wood carvers, stonecutters, metalworkers, blacksmiths, sailors, and all the other artist-artisans whose work is illustrated from the exhibition. There are 175 items in the catalog (p. 29-46) and 172 finescreen halftone plates.

5603. Pinckney, Pauline A. American figureheads and their carvers. New York, Norton, 1940.

223 p. 32 plates on $161 . \quad 4 \mathrm{I}-\mathrm{II}_{72} \quad \mathrm{VM}_{308 . \mathrm{P}_{5}}$

Bibliography: p. 204-2 ro.

Not only figureheads, but billetheads, stem and 
stern decorations, and all products of the shipcarver's art are included in this history of American ship sculpture. The chapters, in historical sequence, trace the ancestry of American figureheads through shipcarvings of Egypt, Phoenicia, Rome, Scandinavia, and Western Europe, and then tell what has been discovered about the American carvers and their craft. The masters Simeon and John Skillin of Boston, and the Philadelphia craftsman, William Rush, who made an important contribution to the first American Navy, are studied in particular detail. The author's fullest sources are Navy records, since the merchant fleet, large as it was, is poorly documented for the I8th and Igth centuries. With the advent of ships of iron and steel, figureheads fell into disuse, although some futile efforts were made to adapt metal figures to the new vessels. At the conclusion of her book, the author introduces the few remaining practitioners of an art which has been virtually extinct since the turn of the century. Some drawings and many photographs illustrate extant figureheads and carvings, some in a fine state of preservation, while others were too much "exposed to the hazards of wind and sea and to the blasts of powder and shot."
5604. Robertson, Elizabeth Wells. American quilts. New York, Studio Publications, 1948. I52 p. $4^{8-2815^{8}}$ NK91 12.R6

Bibliography: p. $15^{1-152}$.

"A quilt is anything made of two pieces of material with padding between and held together with stitches." From this bare definition Miss Robertson proceeds to develop the esthetic as well as the utilitarian values, the social connotations, the techniques, and the folklore of quilts. She begins by sketching in the background of frontier society, its development of the quilting party, and the origin out of necessity of techniques and traditions such as the "crazy quilt." Succeeding parts describe the fabrics such as calico, gingham, and percale; their manufacture, dyeing, and printing or painting; and give instruction in the stitches and patterns for the benefit of modern quiltmakers. Part four gives a particularly complete account of the standard designs (birds, flowers, fruits, stars, and many others), their sources, and their nomenclature. Over half the volume ( $\mathrm{p} .6 \mathrm{I}-150)$ is given to photographic halftones of specimens the greater part of which are in public museums, with a smaller number drawn from private collections. 


\section{Music}

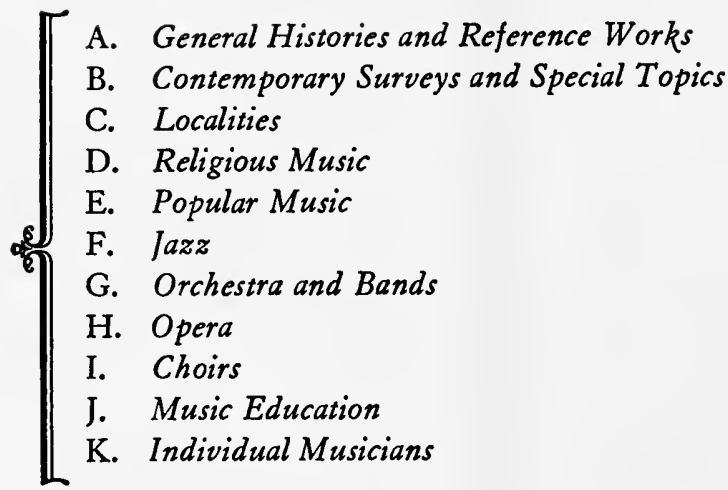

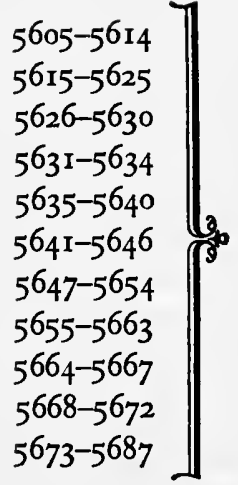

$\mathrm{I}^{\mathrm{N}}$ $\mathrm{N}$ 1858, two and a half centuries after the first settlement, when Longfellow published The Courtship of Miles Standish, the elder Holmes published The Autocrat of the Breakfast Table, Lincoln met Douglas on the hustings of seven Illinois towns, and Theodore Roosevelt was born, no one wrote a book on American music, and if anyone had, it could only have been a thin and shamefaced volume. Of all the great Western traditions, the one which had made the transit to America in the most attenuated or mutilated form was the musical heritage. On the eve of the Civil War there were none too lively survivals in folksong and hymnody, a somewhat desultory concert life in the cities of the Northeastern seaboard, and a rousing welcome for any visiting star with news value, but the only really flourishing musical institution was a strange if delightful domestic hybrid, the minstrel show. Indeed, by 1858 , the United States had generated its own antimusical tradition, which is still with us: music had somehow come to be regarded as detracting from the manliness of the American male, and the Yankee style of humor took the professional musician for a figure of fun.

The past century has seen a complete transformation of this picture, gradually at first and then with much acceleration. Its early manifestations were in large measure the effects of the new concentrations of wealth which followed the Civil War: thus during its first 37 years the Boston Symphony Orchestra was maintained by the bounty of one wealthy man. By whatever means, the cultivation of an active concert life has spread from its early

centers to every metropolitan area in the country, and the support of a symphony orchestra has become an article of municipal patriotism. After the Civil War the American composer of large-scale music began to make his appearance, at first usually trained in Germany or on German models; latterly eclectic or resolutely nationalist. There has come about a definite stratification of music, which can be roughly indicated by the labels of highbrow (subscription symphony concerts, string quartets, harpsichord recitals, etc.), middlebrow (pop concerts, sophisticated musicals, café singers, etc.), and lowbrow (the Hit Parade, hill-billy); it is the lower two which are the best remunerated. The extraordinary phenomenon of jazz (Section F), which spread out of the Negro quarter of New Orleans in the second decade of this century, and has become America's only large musical export, can and does exist at all three levels. Its relation to the old tradition of "serious" or "classical" music remains uncertain and shifting, but there has been and is 
much cross-fertilization, the most conspicuous example being the attractive figure of George Gershwin (no. 5678).

Doubtless because of the relative recency of these developments, the literature of American music is rather recent and rather scanty; save in the fields of jazz and singers' autobiographies, the following pages list a quite considerable proportion of it. The titles have been chosen to exhibit American music, and especially music in performance, in close relationship with American society, and to give samples of the varieties of musical experience in America. Section B contains a number of surveys or diagnoses of the musical state of the Nation; nearly all evidence a considerable sense of dissatisfaction. In spite of the tremendous increase in musicians, organizations, and audiences, there is a lingering uneasiness that "serious" music is still something of an exotic, artificially and precariously maintained. In the perspective of a century it is safe to say that difficulties thus reflected spring out of the recent rapid changes in technology, economic life, and society: the musical heritage of the West has been assimilated, coexists in a reasonable relationship with the current of popular musicmaking, and, whatever adaptations of means may prove necessary, is in not the slightest danger of being jettisoned.

\section{A. General Histories and Reference Works}

5605. Ewen, David, comp. American composers today, a biographical and critical guide. New York, H. W. Wilson, 1949. 265 p. illus. 49-8927 ML39o.E82

Mr. Ewen circulated a questionnaire in gathering the information for this dictionary, and most of the entries are ingeniously fitted together from the words supplied by the composers themselves. At the end of each biography is a list of principal works, recordings if any, and one or more references to other literature. The "American" in the title is hemispheric in scope, and includes, along with approximately I 30 composers whose careers have largely unfolded in the United States, several Canadians, ro Latin Americans (including the late Manuel de Falla), and well over 4o Europeans whose careers were thoroughly established abroad before they came to this country. Although some of this last group have now returned to their original homes, it cannot be denied that those who remained have contributed to the cosmopolitan product that is American music. Mr. Ewen's definition of "today" is similarly broad, since the birthdays of his composers range from 1853 to 1923 . This wide stretch has apparently resulted from the dividing line between a pair of similar compilations, earlier in date and international in scope: Composers of Today (New York, H. W. Wilson, 1934. 314 p.) and Composers of Yesterday, issued by the same publisher three years later $(488$ p.). Users of the present work are referred to the latter for the biographies of such men as Charles T. Griffes and Victor Herbert, even though their music is still very much alive, while a number of lesser talents, dead for as long as 27 years, have been carried over into this newer compilation simply because they were alive in 1934. With no second edition of Composers of Yesterday, there was no other place to put them.

5606. Historical Records Survey. District of Columbia. Bio-bibliographical index of musicians in the United States of America since colonial times. 2d ed. Washington, Music Section, Pan American Union, 1956. xxiii, $439 \mathrm{p}$.

Bibliography: p. xvii-xxiii.

$$
\mathrm{PA}_{57-4} \mathrm{ML}_{106 . \mathrm{U}_{3} \mathrm{H} 6}{ }_{1956}
$$

"A list of special studies, biographies, and autobiographies pertaining to the persons whose names appear in the Index": p. 421-439.

In a subject area that has been comparatively as little studied as is unfortunately the case with American music, a volume such as this can be the most useful reference tool available. With only two general histories in the field, too little notice has been taken of the multiplicity of singers, instrumentalists, and even composers who make up the total picture of our musical life. But if there are only two general histories, there are a variety of more restricted studies of special periods, regions, and topics. If in one's reading a name has been picked up, it often becomes a very real problem to find out something more about the person. This union index of a large part of the musical literature earlier than World War I, which was planned by Keyes Porter and completed under the supervision of Dr. Leonard Ellinwood, is often the simplest and quickest solution to that problem. Unpretentious in appearance, it is nonetheless the most sought-after volume by those working in the field, and was particularly hard to come by before the second printing made it more accessible. The Historical Records Survey had quietly slipped away 
before the volume was completed, and in $194 \mathrm{I}$, when the Pan American Union was persuaded to step in and see that the compilation was not entirely lost, funds were available only for a first edition of 500 copies.

5607. Howard, John Tasker. Our American music, three hundred years of it. With supplementary chapters by James Lyons. 3 d ed., rev. and reset. New York, Crowell, 1954 xxii, 841, A77 p. illus. $\quad 54-11944$ ML200.H8 1954

Bibliography: p. 693 -743.

5608. Chase, Gilbert. America's music, from the Pilgrims to the present. New York, McGraw-Hill, I955. xxiii, 733 p.

Bibliography: p. 679-706.

$$
\text { 54-9707 ML200.C5 }
$$

These are the only two books that attempt to cover the whole field of American music. When Mr. Howard published his first edition in 1931, there were numerous studies of special periods or aspects of the subject, but he nevertheless had much original research to carry out in addition to bringing earlier work into focus. He was able to locate the descendants of a number of important early figures, such as Francis Hopkinson, James Hewitt, Oliver Shaw, and Benjamin Carr, as well as closer relatives of Lowell and William Mason, Edward MacDowell, Ethelbert Nevin, and Horatio Parker, and thus could offer much new documentation in his book. Even in this edition revised by James Lyons the basic strength of the earlier editions is apparent, and $\mathrm{Mr}$. Howard's formulation of our musical history still remains very useful. Nevertheless, by the time Gilbert Chase set out to reformulate that history, the study of sociology and folk music had changed many musicological attitudes. Whereas Mr. Howard was willing to take the amateurs and rather inexpert im. migrant professionals of the early igth century much on their own terms, Mr. Chase views their efforts and affectations more sceptically. He casts his book into three sections with significant headings: "Preparation," "Expansion," and "Fulfillment." Only during the last two or three decades, he feels, has serious American music made any real contribution to the art. Largely because of this strong element of interpretation in the Chase book both volumes can still be profitably used. In devoting his space to the development of the total picture, Mr. Chase slights many details and individuals. Howard's index therefore runs to 97 pages, while Chase's has only 23. However, Mr. Chase's book makes better reading, partly because of his challenging thesis, but also because there are fewer unrelated facts to cope with.
5609. Reis, Claire (Raphael). Composers in America; biographical sketches of contemporary composers with a record of their works. Rev. and enl. ed. New York, Macmillan, 1947. xvi, $399 \mathrm{p}$. 47-31210 ML390.R38 1947

Mrs. Reis, by dint of much hard work, social prestige, and the financial backing she could thereby obtain, has been one of the best friends the American composer has had. In her semiautobiographical Composers, Conductors, and Critics (no. 5620) she tells of her work as chairman of the League of Composers for 25 years. By bringing together in the present book information on the composers of North America and their works, she puts them further in her debt. In the earlier editions (1930, 1932, and 1938) she limited herself to "significant living composers, American-born or American citizens," but in the present edition she redefined its scope to include a rather large number of foreignborn composers who had come here and made a definite contribution to American music. The period covered is very much the same as that in Ewen's American Composers Today (no. 5605), which goes back to Arthur Foote (1853-1937) whereas Mrs. Reis starts with Edgar Stillman Kelley (1857-1944), but both have as their youngest composer Peter Mennin, born in 1923. In between these extremes, the distribution by date of birth is similar, but Mrs. Reis gives a larger number of somewhat shorter biographies. She includes 234 composers who were born in the United States or who were brought here young and untrained; 8 who were born in Canada but have pursued at least part of their careers in the United States; 42 others who were born and trained abroad but were in the United States by the 1920's and showing distinct signs of acclimation; and finally 44 composers who arrived here in the later 1930's and early I940's largely because of political events abroad. At the end she lists 424 names without individual comment, indicating that neither she nor Mr. Ewen has exhausted the potentialities of the subject. Madeleine B. Goss' Modern Music-Makers, Contemporary American Composers (New York, Dutton, 1952. 499 p.) has essays on 37 composers, some of whom are very little known, and furnishes a good full-page photograph of each.

56ro. Sonneck, Oscar George Theodore. A bibliography of early secular American music (18th century). Rev. and enl. by William Treat Upton. [Washington] Library of Congress, Music Division, 1945. xvi, 616 p. illus.

$$
\text { 45-35717 MLi20.U5S6 } 1945
$$

56I. Dichter, Harry, and Elliott Shapiro. Early American sheet music, its lure and its lore, 
1768-1889. Including a directory of early American music publishers. New York, Bowker, 194I. xxvii, $287 \mathrm{p}$.

4I-7397 MLx12.D53

"Famous American musical firsts": p. xxv-xxvii.

"Lithographers and artists working on American sheet music before 1870 , by Edith $\mathrm{A}$. Wright and Josephine A. McDevitt": p. 249-257.

Bibliography: p. 259.

Although neither of these books is designed primarily for reading, both are valuable introductions to important bodies of primary material and each has much to offer in addition to its list of titles. Most of the entries in both are thoroughly annotated, and Sonneck in particular usually provided a historical essay on each of the more important melodies (see, for instance, his discussion of "Washington's March"). Mr. Upton's revision of Dr. Sonneck's book, originally published in 1905 , covers a briefer period, stopping at the end of $x 800$, and so is able to offer as comprehensive an alphabetical listing as could be brought together. One or more library locations are given for most of the entries; the others are known only through advertisements or other descriptions. The main bibliography (p. $1-487$ ) is followed by lists of early articles and essays on music, of composers, songsters, first lines, patriotic music, opera librettos, and publishers, printers, and engravers. The Dichter-Shapiro book aims only at reporting important editions of songs celebrated in their own day, many of which are still well known in our day. The titles are presented in chronologically arranged groups, sometimes devoted to editions of a single famous song, and sometimes to songs of like subject matter-"Skating Items," "Railroad Items," and so forth. The sections usually have an introductory paragraph giving the general setting, and each entry is annotated, sometimes extensively. The illustrations, which include 32 facsimiles, are especially attractive.

5612. Sonneck, Oscar George Theodore. Early concert-life in America (1731-1800). New York, Musurgia, 1949. $33^{8} \mathrm{p}$.

A50-7306 ML200.3.S6 1949

This is a photographic reproduction of the original edition published at Leipzig by Breitkopf and Härtel in 1907; the author headed the Music Division of the Library of Congress from 1902 to 1917 , and was chiefly responsible for the eminence which its collections and services have ever since enjoyed. With the persistence of a German-trained scholar and the enthusiasm of an American, Sonneck (18731928) diligently examined every 18 th-century American newspaper, magazine, book, and piece of music he could find. The newspapers proved an especially valuable repository of information on
American concert-life, which began in the 1730's, flourished during the decade before the Revolution, and was resumed in the mid-r 780 's. Sonneck's account is based on program announcements, around which is woven a thorough and perceptive discussion of the details of this growth, the whole giving, as Carl Engel said, "the first methodical and correct picture of musical conditions in America prior to $\mathrm{x} 800 . "$

56r3. Turpie, Mary C., comp. American music for the study of American civilization. [v. I] Formal compositions. Folk and popular songs. Minneapolis, Program in American Studies, University of Minnesota [1955] 901.

$$
\text { 55-1919 MLi20.U5T8 }
$$

This annotated bibliography was assembled to record materials relevant to the study of American cultural history. The first two sections in the volume are devoted to serious music and folksongs; a projected third section will include jazz. An intentionally abbreviated list of 130 "formal compositions" is arranged by composers, and followed by I 58 folksongs, arranged by title. Annotations describe the music and locate it in currently available song collections and on records, while an index lists the subjects of the songs. The book has no specified audience; those who are commissioned with the task of planning a concert of American music can use it advantageously. College teachers of American civilization will be able to draw from it, as will public school teachers in building "units" around events in American history. The annotations display a resolute antipathy to any evidences of "romanticism."

5614. Upton, William Treat. Art-song in America; a study in the development of American music. Boston, Oliver Ditson Co., 1930. 279 p. illus.

30-33445 ML2811.U7

A supplement to Art-song in America, 1930-1938. [Boston] Oliver Ditson Co., r938. 41 p. ML281x.U7 Suppl.

In surveying an unexpectedly large field from various viewpoints, Mr. Upton produced a compilation which is more encyclopaedia than narrative. It has probably been most valuable to singers in search of American repertoire, and notes on that repertoire. The main volume covers the period from the Revolutionary Francis Hopkinson to 1930, and the supplement extends through 1938. Most of the composers are American by birth, and the works of a few, such as Stephen Foster, are probably thought of today as popular rather than art songs. Mr. Upton's extensive coverage of early 2oth-century composers is noteworthy; 
these men must be thought of today as backwardlooking in comparison with the important European composers of their time. The discussion includes biographical material, but its principal value is for analyses of, and comments on, the musical idiom of these songs.

\section{B. Contemporary Surveys and Special Topics}

5615. Barzun, Jacques. Music in American life. With a foreword by Edward N. Waters. Garden City, N.Y., Doubleday, 1956. 126 p.

$$
\text { 56-765I ML200.5. } \mathrm{B}_{3}
$$

Dean Barzun of Columbia University, who includes music in his multifarious interests, analyzes in this essay the state of music in America at the midcentury. He is concerned with economics as well as art, and he is especially interested in the new and unprecedented relation between amateur and professional at a time when "music lovers" are increasing while musicians find the going harder and harder. Popular music, our philosophy of education, government subsidies, music criticism, and the anomalous position of the composer are among the many topics discussed. The author's outlook is moderately optimistic, but he does not attempt to gloss over a number of disquieting factors in the total situation. The book is one of a series initiated and sponsored by the Committee on Musicology of the American Council of Learned Societies. In the same year appeared another general view, this time from the inside, by a widely esteemed American composer, Roger Sessions (b. 1896). His Reflections on the Music Life in the United States (New York, Merlin Press, 1956. I84 p. Merlin music books, v. 6) is unmarked by clarity or grace of writing, but it is the product of genuine reflection and offers many valuable insights. He points out, for instance, that in the absence of both patronage and subsidies, musical enterprises must be entrusted to managers who are competent businessmen, and that it is the necessity of remaining solvent, not abstract or perverse "commercialism," which assimilates such situations to the dynamics of business. He is particularly concerned, of course, with the relation of American composers to the European heritage, deprecates a one-sided striving after nationalism, and welcomes the influence of Arnold Schönberg, "one of the truly great figures of our time," as an enrichment of American resources.

56r6. Browne, C. A. The story of our national ballads. Rev. and enl. ed. New York, Crowell, I931. 3I5 p. illus.

$$
\text { 3I-10497 ML-355I.B88 I93I }
$$

National songs owe their success to popular tradition. In the process they usually acquire an aura of anecdotes and assemble an entourage of inspirers, authors, composers, singers, promoters, and their descendants. A few writers have attempted to make their way to the original sources, often with somewhat complex and inconclusive results. Such a study was Oscar G. T. Sonneck's Report on "The Star-Spangled Banner," "Hail Columbia," "America," and "Yankee Doodle" (Washington, Govt. Print. Off., I909. 255 p.). By I914, additional material had necessitated a complete new edition of "The Star Spangled Banner" (Washington, Govt. Print. Off., I9I4. II5 p.) alone! Browne's book employs the opposite approach, with no particular attempt at critical scholarship, and selects anecdotes usually on the basis of their story-value. Some of these, especially those concerning the earlier songs, were dubious or worse even at the time of the first edition of I9I9. The revised edition has individual treatments of 16 songs from "Yankee Doodle" to "America the Beautiful," and concluding chapters on the songs of the Spanish American War and World War I.

5617. Clarke, Eric. Music in everyday life. New York, Norton, I935. 288 p.

$$
35-6558 \quad \mathrm{ML}_{3795} \cdot \mathrm{C}_{59 \mathrm{M} 8}
$$

This book was written in response to two queries which the Carnegie Corporation of New York asked Mr. Clarke to answer: "What aspects of music in America to-day seem the most important? How can music best be furthered?" The author describes his work as a panorama of the musical landscape for the eyes of the ordinary citizen, and while it is the landscape of the mid-r930's, a surprisingly large number of his conclusions remain pertinent more than two decades later. The great desideratum, Mr. Clarke believed, was to make the transition from musical activity called into being by the generosity of wealthy patrons to a musical culture based on universal musical literacy springing out of true enjoyment and love. "A nation of music lovers" will place less emphasis on the exceptionally talented individual and on success as the goal of a musical career, and more on the cultivation of music as "a language which everybody is capable of understanding if not of speaking," and on amateurs playing together for enjoyment. With such goals in mind the author examined the study of music, performance and reproduction, the musical profession, and helps to music such as libraries, publications, and 
foundations; and at most points made constructive suggestions marked by realism and good sense.

5618. Gelatt, Roland. The fabulous phonograph, from tin foil to high fidelity. Philadelphia, Lippincott, 1955. 320 p. illus.

55-9154 MLio55.G 4

Despite biographies of such inventors as Edison (no. 4780) and Berliner and despite fragmentary studies and technical writings on many of its aspects, the phonograph had to wait some 75 years before it achieved, in this book, a sound and substantial recounting of its history. The book deals with foreign as well as domestic phases of that history, but inevitably the bulk of its pages have to do with the technical, commercial, and artistic development of sound recordings in the United States. Edison's basic invention goes back to the fall of 1877 , but the commercial recording of music was not begun until $r 890$. By 1895 various improvements had warranted the large-scale promotion of the original cylinder recording, but Emile Berliner was already in the field with his potentially superior disc. The Victor Talking Machine Company joined the disc-users in I90I, and the exploitation of operatic stars and arias on its Red Seal records was the first artistic and business triumph in the field; but the production of cylinders was kept up until rgrr. Technical improvements have since gone hand in hand with the addition of further areas of repertory to the phonograph's resources.

5619. Leiter, Robert David. The musicians and Petrillo. New York, Bookman Associates, 1953. 202 p. illus.

Bibliography: p. [196]-197.

The "organized" musician in America, and especially the American Federation of Musicians, is the object of this sympathetic but reasonably objective study. The author deals both with the short history of musicians' unions in this country and with the many present-day problems raised by the various forms of "canned" music (except television, the full impact of which had not been felt at the time this book was written). The drawbacks as well as the advantages of strongly centralized unionism are discussed, and the part played by James Caesar Petrillo (b. 1892) and other personalities in shaping the destinies of the organized muscian is narrated. Petrillo, a dance-band musician who turned to union politics when he "lost his lip," became the dictator of the Chicago Federation of Musicians in 1922 and of the American Federation of Musicians, succeeding Joseph N. Weber, in I940. His rigorous maintenance of the economic interests of union members soon made him a national figure.
5620. Reis, Claire (Raphael). Composers, conductors, and critics. New York, Oxford University Press, 1955. 264 p. illus.

55-8122 $\mathrm{ML}_{423} \cdot \mathrm{A}_{2} \mathrm{R}_{4}$

For over 30 years Mrs. Reis has been a leading missionary for contemporary music in the United States; for 25 of those years (1923-48) she was chairman of the League of Composers (now merged into the American Section of the International Society for Contemporary Music), which provided modest financial help to composers in the form of commissions, arranged international exchanges of composers and performers, and in general waged the battle for contemporary music. Her book is largely a report on that battle, partly narrative and partly anecdotal. Its tone is enthusiastic but not hortatory, and it contains few value judgments on, or qualitative comparisons of, individual composers or their works.

5621. Rothenberg, Stanley. Copyright and public performance of music. The Hague, $M$. Nijhoff, 1954. xv, I88 p. 56-I4II Law

Bibliography: p. [177]-179.

An American Fulbright scholar in Holland and a leading Dutch publisher joined forces to produce the most useful book on American copyright law and common law as they apply to music. It discusses not only statutes and legal theory, but also actual cases and the performing rights societies such as ASCAP (The American Society of Composers, Authors, and Publishers) and BMI (Broadcast Music, Inc.). Differences between European and American law with regard to performing rights are pointed out. The style of the book is sufficiently free of legal jargon for it to be readily usable by the interested layman.

5622. Sargeant, Winthrop. Geniuses, goddesses, and people. New York, Dutton, 1949.

317 p. 49-10549 ML423.S

Written by a well-known music critic and former orchestra musician, this book has been included less for its biographical sketches (some devoted to nonmusicians such as Lana Turner and Frank Lloyd Wright) than for its opening section of reminiscences and anecdotes. These reminiscences give a uniquely perceptive and amusing glimpse into that workaday orchestra world that audiences never see and that those who write of music and its star performers seldom touch upon. Among the biographical sketches, first published in Life, is one of Arturo Toscanini (under whose baton the author served for some years) that retains its interest despite later and more pretentious biographies. Another valuable illumination of a little-explored area of American 
musical life is contained in the relevant portion (Part 6, p. 433-574) of Arthur Loesser's Men, Women, and Pianos (New York, Simon \& Schuster, 1954). Technical developments - to which America contributed its share-and the evolution of the piano industry; concert artists and the music they played; piano rolls, recordings, and broadcasting; the role of the parlor piano in American life: these and other aspects of the piano from colonial times to the present are described soundly and urbanely by a noted American pianist, teacher, and critic.

5623. Smith, Cecil Michener. Worlds of music. Philadelphia, Lippincott, I952. 328 p.

$$
5^{2}-953^{8} \text { ML200.5.S53 }
$$

There are 12 worlds in this cosmography of American musical life as it appeared to one viewera leading music critic and journalist-at the midpoint of the 2oth century. These worlds are those of individual managers, the Columbia concert management, the organized audience, the performer, New York, the "provinces," the opera, the orchestra, the composer, the dancer, the electrical technician, and the music teacher. The book undertakes to demonstrate, sometimes with resignation and sometimes with asperity, how these worlds all revolve around a single sun: the concentration of managerial power in the hands of a few men whose goal is business success rather than artistic excellence. Even if one is inclined to discount this thesis to a greater or lesser degree, the book contains many vivid glimpses of professional music circles from the inside which most laymen will find unusually revelatory. A similar charge was brought, more harshly and with somewhat different emphases, in Paul S. Carpenter's Music, an Art and a Business (Norman, University of Oklahoma Press, 1950. 245 p.).

5624. Taubman Hyman Howard. Music as a profession, by Howard Taubman. New York, Scribner, 1939. 320 p.

$$
\text { 39-27946 ML_3795.T23 M9 }
$$

Mr. Taubman, who has been a music journalist for 30 years and is now music editor of The New York Times, is an exceptionally gifted exponent of technical and professional matters for the layman. This book was written just before World War II, when the baritone Nelson Eddy was earning over half a million dollars a year, while thousands of other musicians were drawing a subsistence from the Federal Music Project. It was admirably calculated to achieve its purposes, to "clear away some of the illusions and give a few elementary tips to aspirants for a musical career or to their patents or vocational counselors," and even to discourage "some prospects from trying music as a career and turning them to a field where there is more assurance of a living." The developments of the last two decades both inside and out of the realm of music have been so far-reaching that no one should now resort to the book as a practical guide to details, but it remains a vivid picture of professional life in the interwar period, enlivened by many apt anecdotes. The author's essential thesis, that many feel themselves called but few are chosen by the great Amercan audience, continues to be valid. There are good chapters on "The Prodigy," "First Public Appearances," and especially on "Building a Career," which drives home the point that for success a concert artist needs not only the "break" which brings him to public notice, but the imaginative and intelligent exploitation of his opportunity.

5625. Zanzig, Augustus Delafield. Music in American life, present \& future. With a foreword by Daniel Gregory Mason. London, New York, Oxford University Press, 1932. 560 p. illus.

Bibliography: p. [547]-552. 32-4346 ML $3795 . Z_{2}$

Despite its misleading title-for it deals hardly at all with the professional music activity that constitutes the heart of "music in American life"-this book offers much of both historical and sociological interest to the student of American life. Written at the instance of the National Recreation Association, it surveys amateur musical activity in this country toward the beginning of the Great Depression-in the home, in school, in church, in industry, in playgrounds, museums, and summer camps, and especially in the "community singing" groups that grew to importance at the time of World War I. Although there are differences in scope and in emphasis, it may be compared with Mr. Barzun's book of the same title (no. 5615), which surveys essentially the same scene one depression, one war, and one generation later.

\section{Localities}

5626. Aldrich, Richard. Concert life in New York, 1902-1923. New York, Putnam, 1941. xvii, 795 p. 41-266I4 ML200.8.N5A6

"Harold Johnson of the Library of Congress . . . selected the reviews and articles and compiled the index of concert performances in New York from the scrapbooks of Mr. Aldrich."-p. viii.

5627. Downes, Olin. Olin Downes on music; a selection from his writings during the half- 
century 1906 to 1955. Edited by Irene Downes, with a pref. by Howard Taubman. New York, Simon \& Schuster, 1957. 473 p. illus.

56-9923 ML6o.D73

Although the musical culture of the United States seems to have been widely diffused throughout its larger cities during the rgth century, since World War I-or perhaps somewhat before-New York has been the musical capital of the country. Artists feel they must make their debuts there, the concert season is longer and more intense, and most of the business side of music is concentrated there. The music critics of the chief New York newspapers are thus in a particularly strategic position for taking the musical pulse of the country. After gaining experience in other jobs, in $189 \mathrm{I}$ Richard Aldrich (1863-1937) joined the staff of the New York Tribune, where he frequently assisted its chief music critic, Henry E. Krehbiel (see nos. 5658-5659). When William J. Henderson moved from The New York Times to The Sun in 1902, Aldrich succeeded him as the Times' chief music critic, and served until the spring of r923. In the meantime, Olin Downes (1886-1955) had begun his career as a music critic at the age of 20 on the Boston Post, and was a thoroughly experienced writer when he was chosen to succeed Aldrich on the Times in January I924. The two books above are made up of selected reviews and "Sunday articles" by the two men. All of Aldrich's reviews come from the Times, whereas in the Downes volume the first 76 pages were drawn from the Boston Post. Between them they cover the high spots in New York's musical life for more than half a ceritury. That life, to be sure, is viewed through the eyes of two individuals who were living very much in the thick of things, and these accounts do not take the place of an objective history. Since the extracts in both books are arranged chronologically, they do give an extremely graphic presentation of changing customs, institutions, and attitudes that form the primary stuff of music history.

5628. Ayars, Christine Merrick. Contributions to the art of music in America by the music industries of Boston, I640-1936. New York, H. W. Wilson, I937. $\mathrm{xv}, 326 \mathrm{p}$.

Bibliography: p. 307-314.

$$
\text { 37-3847 ML200.8.B7A8 }
$$

Every musician is aware, if only subconsciously, of what an important role the music industries play in musical life, not merely in supplying the means of musicmaking but even in determining the course of musical evolution-as when the many technical improvements in wind instruments during the first half of the rgth century made possible the complex bands of today, not to mention the virtuoso wind playing required by orchestral composers since the time of Wagner. Yet the writers who satisfy the public's curiosity about composers and performers, and who instruct students and listeners alike in everything from "appreciation" to xylophone technique, seldom give a page to the instrument makers, the music engravers or copyists, the publishers, or the musical publicists themselves. The present book, which originated as a master's thesis at Boston University, is a unique study of the music industries in a leading American music center, and its value goes far beyond the information it provides about music in Boston itself. Its three main sections are devoted to music. publishing (including music journals), music engraving and printing, and instrument making, and there are extensive appendixes which include lists of makers and descriptions of their extant instruments. Even unmusical historians and sociologists will find much to interest them, such as the discussion of the Revere family's music-engraving and bell-founding activities.

5629. Gerson, Robert A. Music in Philadelphia; a history of Philadelphia music, a summary of its current state, and a comprehensive index dictionary. Philadelphia, Theodore Presser, r 940. 422 p. illus. $\quad 41-1276 \quad \mathrm{ML}_{200.8 .} \mathrm{P}_{5} \mathrm{G}_{4}$

Bibliography: p. 418-422.

In his University of Pennsylvania doctoral dissertation, Mr. Gerson has attempted to cover the entire history of Philadelphia music from 1700 to 1939. More than half the volume is concerned with the 2oth century and deals not only with all types of music in performance but with the varieties of music education, with church music, music publishers, and the manufacturers of phonographs, records, and radios. A wide variety of secondary works, together with a number of primary sources, have contributed a huge body of data which overflows into an "IndexDictionary of Philadelphia Music" (p. 365-414). The volume of this factual material has proved too great for the achievement of either a meaningful organization or a provocative interpretation of it; but the resulting compilation does serve as a convenient concentration of information concerning the cultural history of an important center of American music.

5630. Swan, Howard. Music in the Southwest, r825-r950. San Marino, Calif., Huntington Library, 1952. $3^{16} \mathrm{p}$. illus.

Bibliography: p. 295-300.

$$
\text { 52-14504 ML200.7.S } 74 \mathrm{~S}_{9}
$$

The rapid economic growth of this region of the United States has been accompanied by a no less remarkable musical growth. Omitting the Indian and Spanish periods in California, which have been 
thoroughly covered elsewhere, this history begins with the Mormon settlers of Utah, who had their own hymnody and "a particular regard for band music." The author traces the evidences of musical activity in the mining camps of Arizona and Nevada (especially Virginia City), in the final phase of the old Spanish institutions of California, and in the "cow counties" of the south of the State, which were filling up with immigrants from the East. The last six chapters narrate the rise of serious music in southern California and particularly in Los Angeles, where a season of eight symphony concerts was presented as early as 1893-94. Mr. Swan's book is not a technical treatise or a musicological study, but a colorful if somewhat miscellaneous portrayal of the development of musical life as an integral part of a region's social and economic development. The verses of several Mormon folk and railroad songs, and an amusing set of "Rules which should be Observed in Dancing Parties [St. George, Utah, 1887]," are among the appendixes. Mrs. Adella Prentiss Hughes' Music Is My Life (Cleveland, World Pub. Co., 1947. 319 p.) is a view of the development of the concert life of Cleveland through the eyes of the woman who managed most of it during half a century.

\section{Religious Music}

5631. Davison, Archibald. Protestant church music in America. Boston, Schirmer Music Co., 1933. $182 \mathrm{p}$. 34-53 $\mathrm{ML}_{3111 . \mathrm{D}_{2} 6 \mathrm{P}_{7}}$

"Four brief lists of hymns, anthems, organ selections and junior choir selections": p. 173-175.

The eminent professor of music at Harvard (b. I883) here presented a statement of his lofty conception of religious music. The first half of his book is a vigorously written polemic exposing those "Attitudes and Conditions" which have depressed Protestant standards of sacred music: indifference, complacency, isolation, deficient music education, individualism, association (bad music loved for the childhood memories it evokes), tradition, prejudice, and disorganization. In the second half, "The Theory and Practice of Church Music," Dr. Davison develops the more positive aspects of his credo. His ideals are austere, and he is willing to leave many of the best tunes to the devil; but his reasons are always presented logically and convincingly. In "The Uses of Music in Worship," he justifies these ideals with arguments both esthetic and religious, and in a long section on "The Material of Sacred Music (p. 94150)," he provides one of the few astute and wellillustrated analyses of its musical idiom.

5632. Ellinwood, Leonard Webster. The history of . American church music. New York, Morehouse-Gorham Co., 1953. xiv, 274 p. illus. 53-13402 ML200.E4

"Biographies of American church musicians"; p. $201-242$.

This history of American church music, while extensive and thorough, does not attempt to be exhaustive. For instance, if one compares its contents with those of Foote's Three Centuries of American
Hymnody (no. 5633), one finds that the two books have very little material in common. Dr. Ellinwood, an expert on pre-Renaissance church music, a deacon of the Washington Cathedral, and a Library of Congress cataloger of books on religion, has investigated a number of the less-known phases of this history. The book is divided into three chronological parts, with the breaks at 1820 and 1920, and there are chapters on such subjects as "[Religious Music] in New Spain," "Singing Schools and Early Choirs," "The First Organs and Bells," "The Oxford Movement and Boy Choirs," "Organ Repertory," and "[Contemporary] Matters Liturgical." Appendix B, "Selected Music Lists," is largely devoted to the repertory of the Washington Cathedral for the decade 1911-5I, which extended from medieval plainsong to strictly contemporary American, English, Canadian, and Russian compositions. The book is well illustrated, and its material is carefully documented and presented in an authoritative and scholarly manner.

5633. Foote, Henry Wilder. Three centuries of American hymnody. Cambridge, Harvard University Press, 1940. $4^{18} \mathrm{p}$.

$$
\text { 40-34386 ML3III.F6T } 4
$$

This objective and readable book by a distinguished Unitarian clergyman remains the most satisfactory general history of American religious music, although it is throughout more concerned with the words, and their quality as poetry and religious thought, than it is with the tunes and their quality as music. The mainstream of this tradition, beginning with the Bay Psalm Book of 1640 , is traced with little deviation into bypaths, but the author finds space for a surprising number of anecdotes 
and other details. To Dr. Foote the great age of American hymn-writing fell in the four decades 1845-85, and he discovered, somewhat surprisingly in view of the coldly intellectual atmosphere supposed to have prevailed there, "that, throughout the nineteenth century, Harvard produced by far the most notable succession of hymn writers in the English-speaking world coming from any single institution." The only serious omission is the gospelsong tradition, the early history of which must be traced in George Pullen Jackson's White and Negro Spirituals (no. 5555), while its 2oth-century history remains to be written. Dr. Foote acknowledges his debt to three more general books which are indispensable to the study of American hymnody: Louis F. Benson's The English Hymn (New York, Doran, 1915. 624 p.), Percy A. Scholes' The Puritans and Music in England and New England (London, Oxford University Press, 1934. 428 p.), and John
Julian's Dictionary of Hymnology, rev. ed. (London, J. Murray, I907. xviii, I768 p.).

5634. Metcalf, Frank J. American writers and compilers of sacred music. New York, Abingdon Press, 1925. 373 p. illus.

25-18159 MLio6. $\mathrm{U}_{3} \mathrm{M}_{3}$

This biographical dictionary covers the 18 th and 19th centuries; it includes the better-known men, but its chief value is for brief, factual sketches of lesser-known figures. A pioneer scholar in this field, Metcalf (1865-1945) drew upon a huge and diversified body of source and secondary material. Some of his information has since been corrected or superseded, and much of it appears relatively insignificant now. But his scholarship still provides us with a convenient and generally reliable compilation of the biographical and bibliographical details of early American religious music.

\section{E. Popular Music}

5635. Goldberg, Isaac. Tin Pan Alley; a chronicle of the American popular music racket. New York, John Day Co., x930. 34 I p. illus.

$$
\text { 30-31878 ML-3551.G64 } \mathrm{T}_{4}
$$

Tin Pan Alley did not receive its name until the turn of the century, but it crystallized out of American popular musicmaking in the early I 890 's, when a cluster of songwriters and publishers settled along I 4 th Street in lower Manhattan, then the theatrical and amusement center of New York. The name, which Mr. Goldberg attributed to "a minor American poet," is elsewhere derived from "the tinny quality of the cheap, over-used pianos in music publishers' offices." The Alley moved uptown in stages as the theaters did, and with the advent of cinema and radio it has become a function of the motion picture and air-wave industries. Mr. Goldberg attributed the Alley's basic idea-“"the scheme of building [one's] songs around and into stage productions"- to Charles $\mathrm{K}$. Harris, who reached the Alley via Milwaukee and Chicago. Goldberg was considerably more interested in the music itself than in the mechanics of song selling, publishing, and plugging, and his impressionistic and rhapsodic writing does not make it easy to come at a fact. $\mathrm{He}$ carried his sketch of American popular music back to blackface minstrelsy, and included a somewhat irrelevant chapter on Sousa, de Koven, and Victor Herbert. The book nevertheless has the virtues of a pioneer work, full of enthusiasm for its subject: the Tin Pan Alley song "establishes a vital circuit with the life out of which it arises" and expresses "the real philosophy of the multitude-its aims and aspirations, its simple notions of hell, purgatory and paradise."

5636. Kahn, Ely J., Jr. The Voice; the story of an American phenomenon. New York, Harper, 1947. xvii, I25 p. illus.

$$
47-2598 \quad \mathrm{ML}_{4} 20 . \mathrm{S}_{5} 6 \mathrm{~K}_{3}
$$

"The Voice" is, of course, Frank Sinatra (b. I9I7), who shot from relative obscurity in 1941 to major celebrity in 1943. Most of the material in this slim book appeared originally in the pages of The New Yorker and dates from a relatively early period in Sinatra's career when he was notorious as the idol of teen-age girls but had not yet solidified his reputation as a singer or made a new one as a straight actor in motion pictures. Mr. Kahn is therefore less interested in providing a consecutive picture of Sinatra's development, although he discreetly works in a few biographical facts, than in viewing with amazement the extraordinary antics of the teenagers. Sinatra therefore serves as the focal point of Kahn's story, but it is rather the teen-agers who supply the "American phenomenon" of the title.

5637. Paskman, Dailey, and Sigmund G. Spaeth. "Gentlemen, be seated!" A parade of the old-time minstrels. With a foreword by Daniel Frohman; profusely illustrated from old prints and photographs and with complete music for voice and 
piano. Garden City, N.Y., Doubleday, Doran, 1928. xvii, 247 p. illus. $\quad 28-15892 \quad \mathrm{ML}_{3561 . \mathrm{P}_{2} \mathrm{G}_{3}}$ $\mathrm{PN}_{3}$ 195.P 3

The tradition of blackface, beginning in 1828 with "Daddy" Rice (Thomas Dartmouth Rice, 18081860) and extending into our own day with $\mathrm{Al}$ Jolson (1888-1950) and Eddie Cantor (b. 1892), could hardly fail to make an interesting subject for a book. This one is a miscellany of history (not especially reliable), songs (both texts and music), anecdotes, biography, and scripts. Its value as a reference source is slight, but as a book to be read for pleasure, it captures much of the carefree disorganization which characterized Negro minstrelsy, the most popular form of stage entertainment in the United States from the 1840 's through the 1870 's.

5638. Smith, Cecil Michener. Musical comedy in America. New York, Theatre Arts Books, 1950. 374 p. illus. 50-58209 ML200.S6

Light musicodramatic entertainments have regularly been with us in one form or another, at least since the early 18 th-century beginnings of opera buffa in Italy and of the ballad opera in England, but Mr. Smith settles on the performance of The Black Crook in New York in I 866 as the time when "the popular musical stage in the United States reached major dimensions." From this point down to the presentation of Rodgers and Hammerstein's South Pacific in 1950, Mr. Smith manages to say something about practically every revue, operetta, and musical comedy produced on Broadway. This material is offered in chronological order, save when some composer has risen to particular eminence and a series of his musical comedies may be discussed in sequence. As a whole, however, the book is a tapestry of titles and personalities with little attempt to sort out trends or force the material into patterns, and hence probably offers a truer picture of the chaotic Broadway stage, with its fashions and fads and foreign influences, than would a more formal history.

5639. Spaeth, Sigmund G. A history of popular music in America. New York, Random House, 1948. xv, 729 p. $\quad 4^{8-8954}$ ML281r.S7

"Additional popular music from Colonial times to the present": p. 587-657. Bibliography: p. 658662 .

America's most significant contribution to the world of music, many think, is to be found in its tough and virile popular music, pre-eminently the improvisatory style of performance deriving from the Negro and known successively as ragtime, jazz, swing, and "bop." This is by no means, however, the only type of popular music created in America that has found wide acceptance in many countries throughout the world, and indeed, since jazz is essentially a style of performance, it is more difficult to export than are the products of Tin Pan Alley and Broadway. It is to these latter that Mr. Spaeth devotes his attention almost exclusively. He does give something over 200 pages to the major songs of our "infancy" and "adolescence," but in this space he only reaches the I880's, whereas nearly 400 pages are devoted to the next 70 years. Furthermore, Mr. Spaeth's mastery of his subject increases strikingly as he approaches the 2oth century and is able to enrich his researches out of personal experience. This should not be surprising, for there seems to be something essentially contemporary about popular music, and few people are interested in it once it has ceased to be popular. Indeed, even with popular music not yet forgotten interest seems concentrated on specific "hit" songs rather than on their composers or the general evolution of a style, and hence Mr. Spaeth's book resembles more an annotated chronological bibliography than an ordinary history book. One famous song after another is briefly cited or discussed. The chronological tale is interrupted infrequently by a few pages devoted to the careers of such outstanding popular composers as Irving Berlin, Jerome Kern, George Gershwin, Cole Porter, and Richard Rodgers, but for the most part there is a steady progress year by year through the crop of popular songs. Such a diet of details needs an exceptional appetite to make it palatable in any quantity, but Mr. Spaeth's grasp of the popular music of the 2oth century makes his book excellent for reference, especially since his facts are generally accurate and his index is unusually full. Julius Mattfeld's Variety Music Cavalcade, 1620-1950 (New York, Prentice-Hall, 1952. 637 p.) is more strictly bibliographical in form, but is essentially not very different from Mr. Spaeth's book. The early years are covered by periods or decades, and finally there are annual lists. Each group is preceded by a paragraph giving nonmusical contemporary events as background, but the songs themselves are simply listed without commentary. Mr. Mattfeld does give their publishers, a type of information deliberately omitted by Spaeth, and he has space for rather more entries. The two books complement each other in several respects, but Mattfeld's is essentially a reference volume and could be read even less comfortably than Spaeth's.

5640. Wittke, Carl F. Tambo and bones; a history of the American minstrel stage. Durham, N.C., Duke University Press, 1930. 269 p.

$$
3^{\mathrm{I}-2026} \mathrm{ML}_{28} 80 . \mathrm{W}_{4}
$$

$\mathrm{PN}_{3}$ 195. W5

In the show-business tradition of "comics" and "straight-men," Paskman and Spaeth's book on min- 
strelsy (no. 5637) could be described as a "comic history," the present volume as a "straight history." The books complement each other insofar as Paskman and Spaeth recapture the fantasy of these entertainments, while Dean Wittke's account is more sober, factual, and objective. The first three chapters trace its history of 100 years, bringing in more details and organizing them better than do Paskman and Spaeth. The great days of the minstrel show, the author points out, were over by $188 \mathrm{o}$, but the form took nearly half a century to die out, its extinction being marked by the sudden and final closing of the Al G. Field Minstrels in the spring of 1928. The last two chapters are concerned with performance techniques, originally standardized by the E. P. Christy Minstrels, and brief biographies of notable minstrels. What Dean Wittke's book lacks in charm and vitality is made up in reliability.

F. Jazz

5641. Blesh, Rudi, and Harriet (Grossman) Janis. They all played ragtime, the true story of an American music. New York, Knopf, 1950. xviii, $33^{8}$, xviii p. illus.

50-12082 ML 356 1.J3B 49 1950

"It has been two generations since ragtime piano came along to give its own first decade in the public eye the name of the 'Gay Nineties.' It was unmistakably a new idea in music. America took it straightway to its heart-it was love at first sight. And, following America by a matter almost of months, Europe too fell under the syncopated spell." So begins this story of one of the important phases of jazz-a style that lived a flourishing, colorful existence and that still exerts a strong effect on modern jazz. The Chicago World's Fair of 1893 first brought the ragtime players to the notice of a large pubiic, and they held the center of the stage until the jazz craze began in 1917 , a year also marked by the death of one of the pioneers, "the king of ragtime composers," Scott Joplin (b. 1868). The other major figure in Mr. Blesh's narrative is John Stilwell Stark (1841-1927), publisher and propagandist of "classic ragtime." Chiefly by means of interviews, both with surviving musicians and with others who knew them, the authors have reconstructed a detailed account of the development of ragtime, with informed observations about the music, which they have examined extensively. Appendixes (p. 273-338) include a "Chronology of Important Ragtime Dates," "Lists of Ragtime and Other Compositions," "A List of Disk Phonograph Records," "A Selected List of Cylinder Phonograph Records Prior to 1914," and "A List of Player-Piano Rolls."

5642. Feather, Leonard G. The encyclopedia of jazz. Foreword by Duke Ellington. New York, Horizon Press, 1955. 360 p. illus.

$$
\text { 55-10774 } \mathrm{ML}_{356 \text { r.J3 }} \mathrm{F}_{39}
$$

The core of this encyclopedia is a group of biographies of $r, 065 \mathrm{jazz}$ musicians (p. 75-332). The sketches are mostly short, but succinctly written and full of information. Clustered around the biographies are other sections, some of which are equally useful, while others merely add dispensable decoration to the cake. Among the former are "A Brief History of Jazz," "What Is Jazz? A Musical Analysis," "A Basic Collection of [50 LP] Jazz Records (p. 338-344)," "Glossary of Terms Used by Jazz Musicians" (from the Apple to zoot), "Jazz Organizations," "Record Companies," and a selective bibliography (p. 35I-353). The "Hall of Fame" and "Giants of Jazz" are necssarily controversial and so of dubious value in a reference book, and the "Birthdays" can satisfy nothing more urgent than the curiosity of juvenile devotees. The book is profusely illustrated with good photographs, which include many published for the first time, and are usually so perceptively and vividly conceived as to constitute important documents by themselves.

5643. Lomax, Alan. Mister Jelly Roll; the fortunes of Jelly Roll Morton, New Orleans Creole and "inventor of jazz." Drawings by David Stone Martin. New York, Duell, Sloan \& Pearce, 1950. xvii, 318 p. illus. $50-8436 \mathrm{ML}_{4}$ I0.M82L6

From a recorded autobiography, from numerous interviews with contemporaries,' and from a broad acquaintance with the music and the personages of jazz, Alan Lomax has narrated here the extraordinary life of one of the most colorful figures of American music, christened Ferdinand Joseph Morton (1885-194I) but universally known as Jelly Roll Morton. His "autobiography" was recorded during most of a month (May 1938) for the Archive of Folk Song in the Library of Congress by Mr. Lomax, and this source supplies the warp and woof of his skillfully woven fabric. The book reads almost like a fantasy, although Mr. Lomax points out some of Jelly Roll's illusions about himself, but if it seems extravagant here and there, the atmosphere it recreates is authentic, which is an 
important thing for a man of Morton's genuine creativity. The story is rather a sad one, for Morton, after reaching a peak of fame and prosperity during the I920's, had difficulty in making a living during the depression, and his health was ruined when, soon after the Library recordings were concluded, a roughneck Negro stabbed him in a cheap Washington tavern. On the practical side, the appendixes include some of Jelly Roll's best tunes and arrangements, a chronological list of his copyrighted compositions ( $p .292-296$ ), and an extensive discography (p. 297-318).

5644. Ramsey, Frederic, and Charles Edward Smith, eds. Jazzmen. New York, Harcourt, Brace, 1939. xv, 360 p. illus.

39-31807 ML $356 r . R_{24} \mathrm{~J}_{2}$

The editors, aided by contributions from William Russell, Stephen W. Smith, Wilder Hobson, Roger Pryor Dodge, and others, cover the three cities where jazz arose, New Orleans, Chicago, and New York, together with the hot jazz of 1939 , in 15 chapters. They describe the all-important atmosphere of these locales and give vivid material on the outstanding individuals and groups that took part in creating jazz, including Louis Armstrong, Bix Beiderbecke, King Oliver and his Creole Jazz Band, The Austin High School Gang, The Five Pennies, and others. These people and places have frequently been written about since lazzmen appeared, but hardly with more skill or devotion.

5645. Sargeant, Winthrop. Jazz: hot and hybrid. New and enl. ed. New York, Dutton, 1946.

$287 \mathrm{p}$. $\quad 4_{6-7084} \mathrm{ML}_{356 \text { r. }} \mathrm{J}_{3} \mathrm{~S}_{3} \mathrm{r}_{946}$

Bibliography: p. 267-274.

The first serious studies of jazz appeared in Europe. Of the American books which followed them, Mr. Sargeant's (first published in 1938) vras one of the first to approach jazz music analytically. In both the first and the present edition, the author's purpose is "to define jazz, to analyze its musical anatomy, to trace its origins and influences, to indicate the features that distinguish it from other kinds of music and that give it its unique place in the music of the world." Mr. Sargeant's ideas on the origins of jazz are as speculative and open to objections as are those of other writers before and since, but his analyses of scale-structure, rhythm, melody, harmony, form, and instrumentation are so clearly done that they will be long and widely meaningful, even if they leave room for occasional differences of detail. Mr. Sargeant, in conclusion, does not believe that jazz is a fine art.

5646. Stearns, Marshall W. The story of jazz. New York, Oxford University Press, 1956.

367 p. illus.

56-8012 ML356r.J3S8

Dr. Stearns, a professor of English literature at Hunter College who is also president of the Institute of Jazz Studies, is notably thorough in showing connections of jazz with other forms of music, and his tracing of the strands that make up the fabric of jazz has been termed panoramic. The multiple genesis from West Africa, Latin America, and early Afro-America; the multitude of components from blues, work songs, spirituals, minstrel shows, and camp meeting music; and the styles indigenous to particular centers of its flourishing life, from New Orleans to 52nd Street, create a complex problem in presentation, solved here with thoroughness and clarity. Jazz harmonies, melody, rhythm, and instrumentation are dissected in generally clear and perceptive fashion, and many of jazz's hitherto elusive traits are particularized.

\section{G. Orchestras and Bands}

5647. Grant, Margaret, and Herman S. Hettinger. America's symphony orchestras, and how they are supported. New York, Norton, 1940. 326 p. $\quad 40-27266$ ML3795.G82A5

This study of the economic problems of American symphony orchestras on the eve of ${ }^{\circ}$ World War II, made in order to find means of improving their financial stability, was financed by the Carnegie Corporation of New York and carried out by the National Orchestral Survey under the chairmanship of J. Frederic Dewhurst. Questionnaires were filled out by 16 major orchestras (with budgets of $\$ 100,000$ or more) and by approximately 135 secondary ones, professional, semiprofessional, or largely amateur. These documents were supplemented by interviews and by audience studies in three communities. The basic facts are set forth in Chapter 3, "Orchestra Budgets and Sources of Income," but the variation between orchestras of different types was so great as to make brief summary impossible. Chapter 9 contains suggestions for "Increasing the Operating Income," and Chapter ro for "Meeting the Operating Deficit." The authors saw little likelihood "that in the predictable future symphony orchestras can be made entirely self-supporting," but thought that the best prospects lay in measures "to build the 
orchestra firmly into the community as an integral cultural force," and especially through "a careful diversification of services," including children's and youth concerts. Appendix A, Mrs. Miles Benham's plan of work and organization for the Women's Committee for the Cincinnati Symphony Orchestra, 1939-40 (p. 285-300), is a formidable document.

5648. Howe, Mark A. De Wolfe. The Boston Symphony Orchestra, 1881-1931. Semicentennial ed., rev. and extended in collaboration with John N. Burk. Boston, Houghton Mifflin, 1931. 272 p. illus. $\quad 3$ I-11067 ML200.8.B7B7 I93I

5649. Johnson, Harold Earle. Symphony Hall, illus. Boston. Boston, Little, Brown, 1950. 431 p. 50-9646 ML200.8.B72S95 1950 Henry Lee Higginson ( $1834-1919$ ) was frustrated in his attempt to become a professional musician, although he went to Vienna for the purpose; at the age of 33 he entered the family banking house of Lee, Higginson, and Co., and within 13 years had accumulated a fortune sufficient to permit his heart's desire-to give Boston a permanent, professional symphony orchestra (I88I). For 37 years "The Major" paid the annual deficits of the Boston Symphony; only in the last year of his life did he turn its affairs over to a board of trustees, one of whose members was Mr. Howe. - Not till its fourth season did the orchestra secure a conductor capable of building a first-class organization; but after five seasons under Wilhelm Gericke, whom Higginson had lured from the Vienna Opera, the Boston Symphony was ready for the leadership of Arthur Nikisch, the greatest virtuoso conductor of his day. $\mathrm{Mr}$. Howe's concise narrative was originally published in 1914 , when the orchestra was about to enter its years of crisis: its German conductor, Karl Muck, and its predominantly German personnel made it the target of hysterical attack during the war years; Higginson had set his face against unionization of the players; and Higginson's own finances were shaken by the war. Mr. Burk's supplementary narrative (p. 130-172) tells how these were all resolved during, and in large part through, the leadership of Pierre Monteux. Mr. Johnson's volume, issued to celebrate the 5oth anniversary of the building which has been the orchestra's home since 1900 , is able to survey the whole quarter-century (1924-49) of Serge Koussevitzky, the Russian whose incandescent leadership reconciled Boston to an extraordinarily varied repertory. Its appendixes listing works performed by and soloists appearing with the orchestra (p. 3II420) supersede those in Howe. Chapter V, "Concert Life," reviews the recitalists and musical organizations other than the Boston Symphony that have appeared in the Hall. At the end of Chapter VI is a brief and hardly adequate description of the unique and delightful Boston Pops-summer programs of lighter music, with the audience at refreshment tables.

5650. Mueller, John $\mathrm{H}$. The American symphony orchestra; a social history of musical taste. Bloomington, Indiana University Press, 1951. 437 p. illus. 51-13728 ML200.M8

Mr. Mueller, a professor of sociology at Indiana University, describes his book as "an analysis and survey of the public life of orchestra compositions as performed in American symphony orchestras, with the intention of tracing" and accounting for their fluctuations. It is based on 15 years' study of the programs of 17 leading American orchestras, and has numerous graphs and diagrams. After a brief presentation of the European background and the American beginnings of "the concert system," he gives in Chapter 3 "profiles" of these 17 orchestras in the order of their establishment, which provide a very convenient concentration of widely scattered information. Chapter 4, "Life Spans of Composers in the Repertoire," identifies the six leaders, in the order of their long-term popularity, as Beethoven, Brahms, Wagner, Tchaikovsky, Mozart, and Bach (for the period r $945^{-50}$ Richard Strauss was in $5^{\text {th }}$ place and Bach only Ioth). The remaining composers are divided into those "with low and stable trends" such as Haydn and Handel; those "in the ascending phase" such as Strauss and Sibelius; those "in the descending phase" such as Schumann and Schubert; those "with full life cycles" such as Dvorak and Grieg; and "the forgotten names" such as Spohr and Raff. Chapter 5, "National Sources of the Orchestral Repertoire," reveals that Austro-German music has slipped from a near monopoly of 80 percent to a mere huge lead of $5^{\circ}$ percent; that Russian music, after running neck and neck with French for three decades, took a secure lead after 1920; and that since about 1905 American music has done better than English, Czech, Scandinavian, or Italian. Contemporary American composers run behind contemporary foreigners only because of the popularity of Prokofieff and Shostakovitch. Chapter 6 is a miscellany, with sections on "Management and Union" and "The Audience and Its Folkways," especially its listening and applause habits. The concluding chapter is an abstract and inconclusive discussion of the bases of musical taste.

565I. Otis, Philo Adams. The Chicago Symphony velopment, 1891-1924. Chicago, Clayton F. Summy Co., 1925. 466 p. illus.

25-903I ML200.8.C5O84 
5652. Russell, Charles Edward. The American orchestra and Theodore Thomas. Garden

City, N.Y., Doubleday, Page, 1927. xx, 344 p. illus. 27-25803 MLi211.R88

Mr. Otis (1846-1930) became trustee, member of the Executive Committee, and secretary of the Orchestral Association during its fifth season (1895), and continued to serve until his death. His volume consists of conscientious annals of both the association and the orchestra which it maintained. Receipts and expenses of each season are regularly given; after the completion of Orchestra Hall in 1904, the rental of its offices frequently enabled the orchestra to conclude a season with a modest profit. The soloists of each season are listed, sample programs incorporated, and memorial performances given particular notice. The Appendix (p. 39I448 ) lists the members of the association and the personnel of the orchestra season by season. $\mathrm{Mr}$. Otis was justly proud of his long association with Theodore Thomas, the hero of the second title, which received the Pulitzer prize for biography in 1928 . Thomas (1835-1905), the son of the Stadtpfeifer of Esens in East Friesland, Germany, was brought to America at the age of 10 , and made appearances as a violin prodigy. In 1862 he organized an orchestra of his own, which lasted under varying circumstances until 1888 , and from 1869 he and it engaged in regular and widespread tours, which introduced artfully constructed orchestral programs to communities quite unfamiliar with them. The success of hs missionary efforts could be measured by the "Thomas Festivals" of later years, when he and his band joined with local choruses in large concerted works. The great proliferation of "the grand orchestra" in 2oth-century America is here regarded as being largely the result of his work. Certainly Appendix G, "Works Introduced into this Country by Theodore Thomas" (p. 323-335), speaks for itself. Thomas was succeeded as conductor of the Chicago Orchestra by Frederick Stock (1872-1942), a German-born violist recruited for the season of 1895, who had gradually assumed the position of assistant conductor. Mr. Otis' annals cover Mr. Stock's first 19 seasons, but his final 18 , and the checkered fortunes of the orchestra since his death, have yet to be chronicled.

5653. Schwartz, Harry Wayne. Bands of America. Garden City, N.Y., Doubleday, 1957. 320 p. illus. 57-6697 MLi3ri.S35

A chatty, knowledgeable volume based primarily on hearsay and personal recollections, and chiefly concerned with the so-called "military" bands from
Patrick S. Gilmore (1829-1892) through J. P. Sousa-actually touring or town bands that were once as much a part of American show business as vaudeville or blackface minstrelsy. The author is perhaps unduly pessimistic about the passing of this form of entertainment, forgetting the thousands of school bands that are going concerns today-not to mention the "big time" bands of Goldman and the armed services. A no more scholarly but likewise unique treatment of true military bands, those of the armed services, is William Carter White's $A$ History of Military Music in America (New York, Exposition Press, 1945. 272 p.).

5654. Sherman, John K. Music and maestros; the story of the Minneapolis Symphony Orchestra. Minneapolis, University of Minnesota Press, 1952. 357 p. illus. 52-11107 ML200.8.M52M58

The author, familiar with his subject from his daily activity first as music critic and then as arts editor of the Minneapolis Star and Tribune, was born five years before the inauguration of the Minneapolis Symphony on November 5, 1903. Minneapolis itself was a mere 36 , having been incorporated in 1867 , and has frequently congratulated itself on being the youngest city to form an orchestra of national prominence. This it achieved, furthermore, under the direction of a local musician, for Emil Oberhoffer (1867-1933), if Bavarian by birth, had been identified with the musical life of the Twin Cities for about a decade when he undertook the leadership of the new orchestra, with such success that his resignation in 1922, after increasing friction with the orchestra's chief sponsor, was generally regarded as a municipal calamity, and after three decades he was still warmly remembered. He inaugurated the policy of farflung orchestral tours, making the Minneapolis Symphony better known in the country than many older, bigger, and more sedentary orchestras. Mr. Sherman, with a journalist's instinct for the newsworthy and an uncommon narrative skill, has woven the various strands and levels of the orchestra's life into what is probably the most readable history of an American, if not of any orchestra. The regimes of each of Oberhoffer's successors-Henri Verbrugghen (I924-3I), Eugene Ormandy (1932-36), Dimitri Mitropoulis (1938-49), and Antal Dorati (since 1949)-are individually characterized. The excellent "Listings for Reference" (p. 303-340) provided by Carlos Fischer, an orchestra veteran of 1903 , include complete personnel and out-of-town engagements, abridged repertoire, and recordings as of September 1952. 


\section{H. Opera}

5655. Graf, Herbert. Opera for the people. Minneapolis, University of Minnesota Press, 1951. 289 p. illus. 5I-13790 MLi7ir.G7

The author's preface states that the aim of his book is to offer "sufficient facts and suggestions to stimulate further thinking about the production of opera in America . . . and thus to contribute to the progress of opera as an integral part of the life of the American community." Drawing on his wide experience as stage director for some of the world's leading opera companies as well as for opera in films and television, Mr. Graf thoroughly covers the problems confronted in the production of opera, including adequate English translations, sponsorship, stage direction ("the stepchild of grand opera production in America"), buildings, and the training of the singers. The second section of the book records developments toward a popular American opera, emphasizing the musical theater on Broadway, and opera in communities, schools, motion pictures, and television. In his last section, "Blueprint for the Future," the author suggests ideas for the model opera house, ways to obtain financial support, patterns of cooperation with existing musical activities, and other information pertinent to any group interested in establishing a local opera company.

5656. Hipsher, Edward Ellsworth. American opera and its composers. A complete history of serious American opera, with a summary of the lighter forms which led up to its birth. Philadelphia, Theodore Presser Co., r934. 478 p. illus.

Bibliography: p. $45 \mathrm{I}-453$.

$$
\text { 35-2381 MLi7Ir.H } 1934
$$

The bulk of this book is devoted to short sketches of American composers who have written operas. These are arranged alphabetically and give a brief sketch of the composer and the names of his most important operas, as well as occasional anecdotes, illustrations, and plots. This section is preceded by a brief history of American opera, and followed by a survey of ballet and masque and a conclusion which observes, as of 1925, a flowering of American operatic culture. To the author an American opera is one "written in America, by one who is either a native or who has been long enough a resident to have $a b$ sorbed something of American life. Or, it might be written by an American composer temporarily abroad." Mr. Hipsher is generous toward operas which he considers American, but he does not regard American opera as having reached its zenith. Mean- while he does not decry foreign influences; rather he sees these as contributing to a culture from which will someday be written the "great native American Opera."

5657. Kolodin, Irving. The story of the Metropolitan Opera, 1883-1950, a candid history. New York, Knopf, 1953. xx, 6o7, xxxviii p. illus. 52-12212 MLi711.8. N32M45

This is a critical history of the major seat of opera in America. The first two sections cover the social and economic aspects of the Metropolitan. The major part of the book, "Operas and Artists," is chiefly concerned with the repertory, the performers, and the productions from 1883 to $195^{\circ}$. The detailed assessment of the caliber of individual performances reflects extensive research by the author. Of reference value is the "Compilation of Works" at the end (p. 597-607), which lists the operas, ballets, and choral pieces presented from 1883 to 1952 , and gives the seasons in which each was produced and the number of performances. There are abundant and well selected illustrations.

5658. Krehbiel, Henry Edward. Chapters of opera; being historical and critical observations and records concerning the lyric drama in New York from its earliest days down to the present time. $3 \mathrm{~d}$ ed., rev., with an appendix containing tables of the opera seasons, 1908-igir, etc. New York, Holt, 19ı1. xvii, 460 p. illus.

12-262 MLr711.8. $\mathrm{N}_{3} \mathrm{~K}_{73}$

5659. Krehbiel, Henry Edward. More chapters of opera; being historical and critical observations and records concerning the lyric drama in New York from 1908 to 1918 . With illustrations and tables of performances within the period described. New York, Holt, rgrg. xvi, 474 p.

$$
\text { 20-217 MLi7 Ir.8. } \mathrm{N}_{3} \mathrm{~K}_{74}
$$

Among a galaxy of distinguished music critics of early 2oth-century New York, Henry Edward Krehbiel (1854-1923) was the finest scholar. His research in the history of New York opera was accurate, but limited to highlights; for a more complete and detailed picture, Odell's Annals of the New York Stage (no. 4924) must be consulted. Among local histories of American opera, however, Krehbiel's work remains the finest. A few monographs, less detailed and usually less reliable, cover other cities, but the best accounts are usually to be 
found in the large general histories of local stages, such as Reese D. James' Old Drury of Philadelphia (Philadelphia, University of Pennsylvania Press, 1932. xv, 694 p.) and Arthur Herman Wilson's A History of the Philadelphia Theatre, 1835 to 1855 (Philadelphia, University of Pennsylvania Press, 1935. 724 p.) for early Philadelphia, and Edmond M. Gagey's The San Francisco Stage (no. 4918) for San Francisco. Chapters of Opera summarizes the years before 1825 and then delves into the beginnings of Italian opera in New York, a favorite subject of Krehbiel's. The next few decades are passed over lightly, but a more detailed narrative resumes with the early impresarios (the memoirs of two of whom are of great interest: Max Maretzek's Crotchets and Quavers (New York, S. French, I855. 346 p.), and James Henry Mapleson's The Mapleson Memoirs (New York, Bedford, Clarke, i888. = v.)). The establishment of the Metropolitan Opera, the rage for Wagner, and the success of Oscar Hammerstein are discussed, as Krehbiel's narrative begins to incorporate material from his own experience and his writings as critic for the New York Tribune, whose staff he joined in 1880. More Chapters of Opera carries this survey from Igog through 1918. The musical problems of the times are discussed frankly, with acute critical insight, and in a dignified style. Whereas Chapters of Opera derives much of its worth from historical objectivity, the main value of the sequel is its critical commentary on the contemporary scene by one of the most capable and respected critics of the day.

5660. Moore, Edward C. Forty years of opera in Chicago. New York, Liveright, I930. 430 p. illus. 3i-26070 MLi7ir.8. $\mathrm{C}_{5} \mathrm{M}_{7}$

To write the history of four decades of opera in a great city is no mean task; to relate this history in an interesting and readable style requires even greater skill. Here is a wealth of information concerning the growth of opera in Chicago, but, unfortunately, it often takes the form of a tedious account of board meetings, correspondence, and finances, interspersed with anecdotes of temperamental singers. The absence of a table of contents and chapter headings lessens the value of the book. Statistics of performances from 1910 to 1929, board members and officers of each season, soloists, and cities visited on tours are listed in the appendix.

5661. Sonneck, Oscar G. T. Early opera in America. New York, G. Schirmer, I915. 230 p. illus.

15-5039 MLI7II.S73

Contents.-pt. I. Pre-Revolutionary opera.-pt. 2. Post-Revolutionary opera.

Sonneck's histories of I8th-century American music remain definitive. Some details in the his- tory of early opera have been filled in since this book was published, but few of its facts have been corrected, nor has its organization of the material been improved upon. The section on pre-Revolutionary opera is concerned with performances by one Tony Aston as early as 1703 , and with the more successful founding attempts about I750, particularly those of the company of Hallam and Henry in Philadelphia. During the decade after the war, theatrical performances were forbidden, and Sonneck's next section concerns the circumvention and breakdown of this ban. When performances were again legalized in 1792, a rapid growth took place. With Hallam's "Old American Company," now in New York, the Wignell-Reinagle "New Company" in Philadelphia, and smaller companies in Boston and Charleston, the author is enabled to organize this period by cities, with an "Epilogue" on the French opera companies. Although some of Sonneck's information is taken from George O. Seilhamer's History of the American Theatre [I74997] (no. 4905 note) most of it is drawn from his own research, especially in early newspapers. The details of the text are complemented by large charts of performances. Within the text the details alternate with digressions which reveal the insight of a profound scholar in American music history.

5662. Taubman, Hyman Howard. Opera-front and back, by H. Howard Taubman. New York, Scribner, 1938. $3^{88} \mathrm{p}$.

$$
\text { 38-10497 MLi7II.8. N3 } \mathrm{T}_{22}
$$

The opera fan who desires to look at the human side of operatic personalities and obtain a glimpse of backstage (as well as onstage) catastrophes, will find this book to his taste. The author, for many years on the staff of The New York Times, and since the death of Olin Downes its chief critic, has collected many fresh tales of personalities, rehearsals, and operatic performances at the Metropolitan. In the course of his barrage of anecdotes Mr. Taubman painlessly communicates a vivid idea of the multiple functions and the immense labor involved in bringing about a unified operatic production. A chapter of considerable interest is "What Audiences Pay For," which lists the most popular operas presented at the Met during the ten seasons 1924-34, as well as those most frequently performed during the 27 years of Gatti-Casazza's management. Many excellent photographs of backstage scenes at the Metropolitan are reproduced at the end of the book.

5663. Thompson, Oscar. The American singer; a hundred years of success in opera. With 108 illustrations. New York, Dial Press, 1937. 426 p. 37-4988 ML400.T8A5 
Oscar Thompson (1887-1945) was successively music critic of the New York Evening Post and Sun, esteemed for his high standards in criticism of vocal performances. This volume, however, contains a minimum of his astute evaluations and limits itself to brief biographical sketches of important singers associated with the American operatic stage. Mr. Thompson's criteria for inclusion are broad, and many artists are listed only because they were born in this country, or spent their flourishing years here. The well-written sketches include a chronological framework, the singer's most important roles, and frequently anecdotal material and an evaluation of the singer's significance in the development of American opera. The sketches are put in a roughly chronological progression, from Julia Wheatley, who made her singing debut in 1835 , to Richard Bonelli, who returned to America in 1925 .

\section{Choirs}

5664. Bergmann, Leola M. (Nelson). Music master of the Middle West, the story of F. Melius Christiansen and the St. Olaf Choir. Minneapolis, University of Minnesota Press, 1944. 230 p. A44-5713 ML410.C543B4 "Sources": p. 202-209.

According to the preface this is a threefold story: "of the St. Olaf College as a center of Norwegian Lutheranism in America; the life story of F. Melius Christiansen as it unfolded in that setting; the story of his work in music and how it grew from regional to national significance." The author of this Iowa dissertation, a former member of the St. Olaf Choir, succeeds in catching the personality of this prominent choral director and composer. Frederik Melius Christiansen (1871-1955) was of Norwegian birth, came to America in 1888 and completed his musical education here and in Germany, and became director of music at St. Olaf's College (Northfield, Minn.) in 1903. The choir was his foundation and its national prestige the work of his skill and devotion. Lists of published compositions by Christiansen (p. 210-216), the St. Olaf Choir series compiled and edited by him, tours of the choir, and programs from I9I2 to 1944 appear in the appendix.

5665. Hastings, Thomas. The history of forty choirs. New York, Mason Bros., I854. 23I p. 6-12632 $\mathrm{ML}_{3925 . \mathrm{H}_{35}}$

Thomas Hastings ( $1784-1872$ ) ranks with Lowell Mason as the most influential teacher of sacred music in 19th-century America. From his experience he drew this collection of 40 "parables" illustrating the vicissitudes of the typical unpaid church choir of the day. These tales do not purport to recount musical history, of course, but rather are concerned to point a moral; their drift would seem to be that godliness finds a reflection in musical ability, and vice versa. Nevertheless these faded Victorian pages frequently reveal social mores and performance practices of religious music about $185^{\circ}$, such as a more formal treatment would probably miss.
5666. Messiter, Arthur H. A history of the choir and music of Trinity Church, New York, from its organization, to the year 1897 . New York, E. S. Gorham, I906. 324 p. illus.

$$
\text { 7-20654 ML20o.8. } \mathrm{N}_{5} \mathrm{~T}_{7}
$$

Trinity Church was chartered in 1697 and opened for services the following March; Dr. Messiter examines its first two centuries in order "to sketch the history in this country of that system of Church music which is called Anglican, as distinct from Gregorian, Roman, and Lutheran." The resources of a commercial metropolis enabled Trinity to take the lead in many developments: here, in 1741 , was installed the first organ in the Colonies; and here in I 770 the organist, William Tuckey (late of Bristol Cathedral) organized a performance of Handel's Messiah a year before its first presentation in Germany. Church and organ were burned during the Revolution, but a new building was consecrated in 1790 and a new organ imported from England. In 1846 another Bristol man, Edward Hodges, Mus. Doc. Cantab., became organist and choirmaster of the again rebuilt church, and inaugurated a choir of 26 voices, men, women, and boys. From that year the author is able to present specimen programs and to describe the musical part of the service in great detail. Dr. Henry S. Cutler of Boston, who took over in $185^{8}$, soon eliminated females from the choir, and got it into surplices from October 1860 , when the Prince of Wales' attendance overawed the opposition. Messiter, a graduate of the Royal Academy of Music, was musical director from 1866 to 1897 , and made Trinity a citadel of Victorian taste and practice.

5667. Walters, Raymond. The Bethlehem Bach Choir; an historical and interpretative sketch. Boston, Houghton Miftlin, 1918. 289 p. illus. 18-26489 ML20o.8. B56 2

The rich musical tradition of the early German settlers of Pennsylvania and North Carolina, while still to be fully elucidated, is now increasingly ap- 
preciated in consequence of an organization of the archives and special festivals at Winston-Salem, N.C., and Bethlehem, $\mathrm{Pa}$. The silver anniversary of the Bethlehem festivals was celebrated in this volume, compiled by a member of the executive committee who was also dean of Swarthmore College. Introductory chapters summarize the beginnings of the Collegium Musicum in 1744, the flour- ishing years through 1825 , and the revival of the tradition in 1880 . The first 25 festivals, held annually after 1900 , as well as some special programs, are next described, with summaries of the music performed and quotations from favorable New York reviews. Sketches of the important leaders and performers, and lists of other personnel, complete the volume.

\section{J. Music Education}

5668. Birge, Edward Bailey. History of public school music in the United States. New and augm. ed. Philadelphia, Oliver Ditson Co., 1939. 323 p. illus. 39-25132 ML200.B5 1939

Bibliography: p. 312-314.

Out of date and limited in scope though it is, this history provides a useful if pedestrian survey of institutions, trends, and some of the people most active in public school music from 1838 to the 1930's. The author discusses the New England singing schools, the pioneer period in Boston, the beginnings of method and of emphasis on reading music, and the newer, faster developments of the 2oth century, such as the formation of nationwide music teachers' associations. Optimistically he concludes: "School music is no longer cloistered. Its spirit is that of co-operation and helpfulness. School and community are rapidly coming together." The historian will find the book especially useful for its rosters of organization officers and its many photographs of public school music leaders. The first edition of 296 pages was published in 1928 .

5669. Davison, Archibald T. Music education in America, what is wrong with it? What shall we do about it? New York, Harper, 1926. 208 p. 26-1 $1_{32} \mathrm{MT}_{3} \mathrm{U}_{5} \mathrm{D}_{26}$

Unlike Mr. Birge's book (no. 5668), this is not a historical study, but a stocktaking of what music meant to America in the 1920's and of how Americans were then teaching it to their children. In the three decades since its appearance we have come a long way from what Mr. Davison (professor of music and choral conductor at Harvard University) then found to be the general attitude. The "average American" liked a bit of popular music, jazzy and sentimental, but considered good music a nonessential frill and was unwilling to support its teaching in the schools. The book is nevertheless still worth reading, apart from its historical significance, in order to judge exactly how far we have come and how valid the author's suggestions for improvement remain.
5670. Jeffers, Edmund V. Music for the general college student. New York, King's Crown Press, 1944. $213 \mathrm{p}$. A44-1922 MTr8.J4 "Selected bibliography on music for the general college student": p. [189]-192; "Bibliography of works cited in text": p. [193]-213.

This doctoral dissertation (Teachers College, Columbia University) sketches the development of music teaching in American colleges, with special reference to Harvard, Vassar, and Oberlin. It is useful for its figures (supplementing those in Randall Thompson's College Music; an Investigation for the Association of American Colleges (New York, Macmillan, I935. xviii, 279 p.)) and its "philosophies of college music," but the fact that it does not consider the music programs of the larger universities restricts its value.

5671. Riker, Charles Cook. The Eastman School of Music; its first quarter century, I92I-1946. Rochester, N. Y., University of Rochester, 1948. 99 p. illus.

49-2415 MT4.R6E247

A history of this outstanding school of music necessarily extends major credit to three men: George Eastman, Rush Rhees, and Howard Hanson. Eastman ( $1854-1932$ ), whose fortune was accumulated by the development of an inexpensive portable camera, also endowed the School of Medicine and Dentistry of the University of Rochester. Rhees (1860-1939) was president of the university during I900-35, the period of Eastman's donations. Dr. Hanson (b. 1896), a composer and conductor of note, has been director of the school since 1924, and is chiefly responsible for its determined emphasis on American music of past and present. Mr. Riker records the devoted and unselfish contributions of each in the growth of the Eastman School of Music. The history of the school is traced from its beginnings to the time of publication with an outline of its departmental structure and of its many and varied activities. The widespread and significant influence that this institution has had on the American musical world is evident in the lists of publications and of 
recordings, and the roster of musically prominent alumni, which appear in the appendixes.

5672. Spalding, Walter Raymond. Music at Harvard; a historical review of men and events.

New York, Coward-McCann, I935. xiv, 3 Io p. illus. $35-20135 \mathrm{ML} 200.8 . \mathrm{C}_{2} \mathrm{H}_{3}$

Mr. Spalding (b. 1865) was a Harvard graduate and a professor of music there from 1903 until his retirement; and this book is a labor of love, albeit a prosaic one. Formal instruction in music began in the academic year of $1862-63$, when John Knowles Paine (1839-1906) was engaged, at the very foot of the list of college officers, as instructor in music; in 1875 his achievement of the rank of full professor indicated that music had established itself in the liberal arts curriculum. But Professor Spalding's narrative has a much earlier point of departure, for music-making at Harvard long antedates musicteaching, and the students' orchestra, which rejoices in its traditional name of the Pierian Sodality, was organized on March 6, 1808. In 1837 it gave birth to the Harvard Musical Association for graduates, which has done much to further the musical life of Boston. The chapel choir dates from about 1814 and the glee club from 1833 , but their potentialities were realized only with the coming of Archibald T. Davison (b. 1883) in 1910, who made them the means of revitalizing college choral music and Protestant church music throughout the United States. The list of distinguished graduates of the department of music includes such composers as Arthur Foote, Frederick S. Converse, Edward Burlingame Hill, Daniel Gregory Mason, John Alden Carpenter, Roger Sessions, Robert Nathaniel Dett, Randall Thompson, Virgil Thomson, and Walter Piston; as well as Ralph Kirkpatrick, the scholar-harpsichordist; Hugo Leichtentritt, the musicologist; and Henry T. Finck, Richard Aldrich, Arthur Elson, and John N. Burk, critics or writers on music.

\section{K. Individual Musicians}

5673. Anderson, Marian. My Lord, what a morning; an autobiography. New York, Viking Press, 1956. $312 \mathrm{p}$. illus. 56-10402 ML420.A6A3 $A$ frank and factual autobiography, in which the famous Negro contralto describes her youth in Philadelphia, where she was born in 1902, her early training and subsequent concert career. There are chapters discussing her recordings, concert life, and repertory. The issue of race prejudice is handled with candor, and her musical philosophy is amply expounded. It is pleasantly free from the usual vices of prima donna autobiography.

5674. [Barber] Broder, Nathan. Samuel Barber. New York, Schirmer, 1954. I I $\mathrm{p}$.

$$
\text { 54-13121 ML410.B23 B7 }
$$

This brief study of Samuel Barber (b. 1910) is divided into two parts; the smaller on "The Man" includes numerous extracts from the composer's letters, and the larger on "The Music" has many musical illustrations. Mr. Barber became a student at the Curtis Institute of Music in Philadelphia when it opened in 1924, and during his nine years there formed his lifelong friendship with the young Italian, Gian-Carlo Menotti. Mr. Broder describes his failure to make a career as a baritone, his frequent visits to Europe, and his service in the Army during World War II, when after a period spent transporting pianos he was commissioned to write a symphony for the Army Air Forces. In later years he has been one of the few American writers of serious music "earning enough from his compositions, in royalties, performance fees, and commissions for new works and awards, to enable him to devote all his time to composing." $\mathrm{He}$ is, nevertheless, a fastidious composer, and his opera from 1927 to I953 number only 30. In part two Mr. Broder supplies a 13-page essay on "The Style" ("an attempt to fuse an essentially lyric spirit with an awakened awareness of the restlessness and discordance of our times") and descriptions of individual works in seven categories, from music for single voice to miscellaneous orchestral pieces. The Appendix (p. roo-rog) includes a chronological list of works, a discography (both 78's and LP's), and a list of eight articles about Barber. There are 16 pages of excellent photographs.

5675. [Copland] Berger, Arthur V. Aaron Copland. New York, Oxford University Press, 1953. I20 p. 53-9I83 $\mathrm{ML}_{4}$ I0.C.C56B4

Mr. Copland, whom many regard as the foremost living American composer, was born in Brooklyn (I900), the son of Jewish immigrants from Lithuania. On finishing high school he studied harmony and composition with Rubin Goldmark, and in I921 obtained his desire of going to Paris, where he was for three years the pupil of Nadia Boulanger. In the mid-r93o's he abandoned his "esoteric" idiom and tried to say what he "had to say in the simplest 
possible terms"; he was rewarded by a gratifying popular acclaim for his scores written for broadcasting ("Music for Radio," 1937), for schools, films, and ballet, and became a regular recipient of awards and commissions. Arthur Berger (b. 1912), himself a composer of distinction, began his career as a disciple of Copland's and writes from a large personal knowledge of both the man and his music. He calls attention to Copland's "economy of means, the transparency of his textures, the preciseness of his tonal vocabulary." There is no artificiality in Copland's later manner, for "he has found the means of idealizing American folk tunes in their own terms and in terms of his own native experience." Julia Smith's Aaron Copland (New York, Dutton, 1955. $33^{6}$ p.) cannot match Mr. Berger's interpretative insight, but it is done on a larger scale, adds some recent compositions, has much more biographical information, and, by discussing the music along with this material, makes the interrelationship of the two more evident. Both works have appendixes listing Mr. Copland's compositions, recordings, and writings.

5676. Damrosch, Walter J. My musical life. New York, Scribner, 1930. 390 p. illus.

$$
\text { 30-23573 ML422.Di6 } 1930
$$

Damrosch (1862-1950) was born in Breslau, Germany, where his father Leopold conducted the Philharmonic Orchestra, but was brought to America at the age of nine. Responsibility and opportunity were thrust upon him by his father's sudden death in mid-season at the beginning of 1885 ; his intelligence, honesty, tact, and impressive personality ensured him a great career in spite of his lack of a first-rate musical talent. His autobiography was written in I922 save for a final chapter, "Music and Modern Magic," added to the present edition of 1930. Since he retired after 23 years' service as the regular conductor of the New York Symphony Orchestra in 1926, the greater part of his career as an operatic and orchestral conductor is sufficiently covered: his taking up his father's work as conductor of German and especially Wagnerian opera at the Metropolitan; his founding of the Damrosch Opera Company in 1894 when the Met was slighting Wagner; his work with the Oratorio Society of New York; his "crusading" tours of the United States with his orchestra; and his experiences during the trying times of World War I. To this point it is a clear picture of American musical life as the dean of American conductors saw it. What the book does not cover is its author's final and most original phase, when his conduct of the NBC Music Appreciation Hour from 1929 to I 942 made "Papa Damrosch" a familiar and a favorite personality in the homes and schoolrooms of the country.
5677. [Foster] Howard, John Tasker. Stephen Foster, America's troubadour. [Rev. ed.] New York, Crowell, 1954, ${ }^{\circ}$ I953. xv, 433 p. illus. 53-III33 ML4Io.F78H6 1954

"The published works of Stephen Foster": p. 403412.

"Give me the making of the songs of a nation, and I care not who makes its laws." More than any other man Stephen Foster (1826-1864) made the songs of America; they brought him contemporary celebrity and posthumous veneration, but in life he achieved neither happiness nor dignity. This wayward son of a solid Scotch-Irish merchant of Pittsburgh abandoned commerce when he found he could support himself by selling his songs to publishers such as Firth, Pond and Co. of New York (later he arranged a preliminary sale to E. P. Christy's Minstrels). Even after marriage and the birth of a daughter his royalties should have been adequate to middle-class comfort, but in the course of the r85o's Foster separated from his family and began a solitary life in New York City in which alcohol increasingly took over from music. As late as I 860 he could produce a ballad as absolute as "Old Black Joe," but within four years he died in complete squalor. The golden melancholy of Foster's plantation songs is unique, but he could bring off extraordinary successes in quite different veins ("Oh Susanna," "Jeanie with the Light Brown Hair"), and it would be hard to point to another untutored composer of comparable achievement. Mr. Howard's volume, originally published in I934, incorporates the fragmentary evidence more or less in full and so makes rather heavy going, but is indispensable to anyone who wishes to form his own idea of this attractive but elusive songmaker. An early bibliography of the sheet music by Walter Whittlesey and O. G. Sonneck has been completed in James J. Fuld's A Pictorial Bibliography of the First Editions of Stephen C. Foster (Philadelphia, Musical Americana, 1957. 25, [18r] p.).

5678. [Gershwin] Ewen, David. A journey to greatness; the life and music of George Gershwin. New York, Holt, 1956. 384 p. illus. 56-6192 ML410.G288E9

Lists of the composer's works: p. $330-355$. Discography: p. 356-362. Bibliography: p. 363-368. Gershwin (1898-1937), whose father was born Morris Gershovitz in St. Petersburg, Russia, began life on New York's East Side, but by no means in poverty or deprivation. Music was his own discovery and choice; he had good classical teachers from his I $4^{\text {th }}$ year, but followed popular music with intensity, and left high school to become a song plugger in Tin Pañ Alley. By Igrg he had produced his first musical comedy score (" $\mathrm{La}, \mathrm{La}$ 
Lucille") and his first song hit ("Swanee"); after the ovation which greeted Paul Whiteman's performance of his "Rhapsody in Blue" on February 12, 1924, he was an international figure. A succession of Broadway shows and motion picture scores, together with a steady stream of royalties from publications and performances, brought him wealth as well as fame. He made further ventures into symphonic jazz ("Piano Concerto in F," "An American in Paris"), which continue to divide critical opinion and to be very widely performed. His folk opera, "Porgy and Bess," which Mr. Ewen describes as his one completely successful "mingling of the serious and the popular," has had a greater balance of critical favor. An undiagnosed brain tumor struck Gershwin down in his $3^{8 \text { th }}$ year and at the height of his powers. Until critical opinion concerning this quite unprecedented talent and career has crystallized, Mr. Ewen's openmouthed success story will need little revision. In the year after the composer's death Merle Armitage gathered from 36 of Gershwin's friends tributes or reminiscences, which vary greatly in character but are nearly all marked by a sharp sense of personal loss. The roll of contributors to Armitage's George Gershwin (New York, Longmans, Green, $193^{8}$. 252 p.) is impressive-including, among others, Paul Whiteman, Walter Damrosch, DuBose Heyward, Rouben Mamoulian, Arnold Schönberg, Serge Koussevitzky, Eva Gauthier, and Olin Downes-and it is likely to remain a sourcebook of value. The Gershwin Years, by Edward Jablonski and Lawrence D. Stewart (Garden City, N.Y., Doubleday, 1958. 313 p.), also derives some immediacy from a reminiscent introduction by Carl Van Vechten and the active cooperation of Ira Gershwin, George's elder brother. The straightforward chronicle in which the authors alternate is provided with a wealth of illustrations, many of them from Ira's collection of family photographs.

5679. Gottschalk, Louis Moreau. Notes of a pianist. During his professional tours in the United States, Canada, the Antilles, and South America. Preceded by a short biographical sketch with contemporaneous criticisms. Edited by his sister, Clara Gottschalk. Translated from the French by Robert E. Peterson. Philadelphia, Lippincott, I88I. 480 p. 6-37 II ML410.G68G6 Gottschalk (1829-1869), the first native American pianoforte virtuoso and composer of noteworthy music for the piano, was born in New Orleans of an English father and a Creole mother. At $\mathrm{I}_{3}$, for the completion of his musical education he was sent to Paris, where he studied with Berlioz. He began the career of a concert pianist in Europe and did not return to America until 1853. His compositions were long despised by the elect, but while many are thick sentimentalism or empty display, others have lately been discovered to incorporate rhythms regarded as characteristically American. Gottschalk died in Rio de Janeiro, where he had been entertaining the Emperor of Brazil, and his personal property of value was confiscated under a Brazilian droit d'aubaine; his family had great difficulty in retrieving the trunk in which the diaries of his tours were contained. His sister, Clara Gottschalk Peterson, prepared them for publication, and her husband, Dr. Peterson of Philadelphia, translated them from Gottschalk's French. Gottschalk was an alert and observant traveler, and his record of concert life from 1853 to 1868 is well-nigh unique; at Sandusky, Ohio, he was arrested in mid-recital because a $\$ 6.00$ license fee had not been paid to the town. The brief life by his sister which preceded the diaries may now be supplanted by Vernon Loggins' Where the Word Ends; the Life of Louis Moreau Gottschalk (Baton Rouge, Louisiana State University Press, I958. 273 p.), which utilizes the Gottschalk manuscripts in the New York Public Library as well as a number of supplementary printed materials. He describes Gottschalk as "a man of pity-a prey to relatives, friends, and doting women," who wore himself out trying to satisfy the financial demands of his growing string of dependents. A record of American musical life in the next decade is supplied by the master of French operetta, Jacques Offenbach, who described his American sojourn of 1876 in Offenbach en Amérique (Paris, Calmann Lévy, 1877. $x x x i, 252$ p.). Two American translations appeared the same year; a recent one by Lander MacClintock has the title Orpheus in America (Bloomington, Indiana University Press, I957. 200 p.).

5680. [Griffes] Maisel, Edward M. Charles T. Griffes; the life of an American composer. New York, Knopf, 1943. xviii, 347, xi p.

$$
\text { 43-6607 ML4Io.G9134M2 }
$$

Charles Tomlinson Griffes (1884-1920) is the classic American example of the composer who is cut off by death just as he arrives at the fullness of his powers and wins public acclaim. Mr. Maisel's biography, filled with extracts from Griffes' letters and diaries, makes fascinating reading, but lacks clarity of outline as well as a list of works, and is a difficult book to use. It probably exaggerates the lugubriousness of Griffes' story, which is that of a delicate boy who became the favorite pupil of Miss Broughton, the English spinster who taught piano in Elmira, N.Y., and who lent the money to give him four years of advanced study in Berlin. On his return (1907) he became music instructor 
at Hackley School in Tarrytown, N.Y., which prepared boys for ivy-league colleges. Here Griffes' limited income, slow recognition, fastidious tastes, and homosexual inclinations doubtless provided an element of strain. Mr. Maisel emphasizes overwork, and Griffes did sit up late copying his scores as opportunity at last came his way; but the influenza epidemic of 1919 cut down many more robust people than he. His musical development had led him from German to French, Russian, and oriental models, but his later work in this vein is finished and effective, and his long piano sonata (1918), quite individual in style, indicates that he had not exhausted his potentialities. Mr. Maisel analyzes it at length and calls it "the first major utterance in American music."

568I. [Herbert] Waters, Edward N. Victor Herbert; a life in music. New York, Macmillan, 1955. xvi, $653 \mathrm{p}$. 55-1675 $\mathrm{ML}_{4}$ Iо $\mathrm{H}_{52} \mathrm{~W}_{3}$

"Compositions by Victor Herbert": p. 577-592. "Phonograph recordings made by Victor Herbert":

\section{p. 593-595.}

Herbert (1859-1924) was born in Dublin of upper-class Irish parents, but his youth was spent in Stuttgart, Germany, where he received a thorough musical education and became a promising cello virtuoso. He came to America in 1886 when Walter Damrosch, recruiting talent for the Metropolitan, engaged the singer Herbert wished to marry, and obligingly included her suitor as a member of the orchestra. After miscellaneous beginnings as orchestra and chamber musician, soloist, conductor, and composer of instrumental music, his first large opportunity came when the players of the late Patrick Gilmore's celebrated military band chose him as their leader (1893-1900). The next year he entered the sphere which made him the most conspicuous American musician: for The Bostonians he composed his first operetta, "Prince Ananias" (1894). In the following 30 years he composed no fewer than 43 such works; "The Serenade" ( 1897 ), "Babes in Toyland" (1903), "The Red Mill" (1906), "Naughty Marietta" (1910), and several others were the greatest successes in the musical theater of their day. Herbert was also a capable and successful conductor of the Pittsburgh Symphony Orchestra (1898-1904), leaving only because of a widening breach with its manager; he thereupon formed his own orchestra for lighter music. He made two attempts at opera seria: "Natoma" (I9II), which utilized Indian themes, and "Madeleine" ( I914), but neither gave much satisfaction at the time or since. Mr. Waters here tells for the first time the full story of Herbert's successful lawsuit against the blackmailing Musical Courier (1902), his advocacy of the Copyright Act of 1909, and his part in founding the American Society of Composers, Authors, and Publishers (ASCAP) in rgr4. Most reviewers have demurred at Mr. Waters' high revaluation of the operetta music, but nearly all agree that this is a masterly piece of research and documented biography, a lifelike portrait of a great musical personality, and an exceptionally solid contribution to four decades of American music history.

5682. [Ives] Cowell, Henry, and Sidney (Robertson) Cowell. Charles Ives and his music. New York, Oxford University Press, 1955. 245 p. illus. Bibliography: p. $235-238$.

54-10000 ML410.I94C6

The musical career and fortunes of Charles Ives (1874-1954) are probably the most singular of any considerable composer in music history. The son of the town bandmaster of Danbury, Conn., he obtained a diversity of musical training and experience in his youth, and at 14 was "the youngest organist in the State." But his father, wearying of handto-mouth finance, entered a bank two years before his death; and on graduating from Yale Ives entered a New York insurance office. In 1907 he set up his own agency, affiliated with Mutual Life of New York; it was extremely successful, and a pamphlet setting forth his own ideas became "the Bible of insurance agents." Meanwhile, and especially from I910 to 1918 , he went on composing great quantities of music, in a great variety of forms; the "Chronological List of Compositions" (p. 21 I-233) is a long one. A severe illness in 1918 damaged his heart and brought his production to an almost complete stop; in 1929 he retired from business and spent his remaining quarter-century in valetudinarian comfort. His music was almost completely unknown and unplayed, but from time to time a zealous advocate appeared. After Henry Bellamann and Nicholas Slonimsky had failed to arouse public interest, in 1939 John Kirkpatrick finally succeeded with his performances of the "Concord Sonata." From the beginning Ives had gone his own way in polyphony (melodic lines set against each other, "each with its own key and perhaps also its own rhythm"), harmony ("at a time when consecutive extreme dissonances were unknown, Ives used them constantly"), melody ("in the extension of his motifs, Ives sometimes employs melodic inversion, retrograde and inverted retrograde"), rhythm ("in some spots and in some ways probably more involved than that to be found in any other written music"), and form (the creation of "an underlying unity out of a large number of diverse elements, used asymmetrically"). After World War I the musical avant-garde began doing many of the things which Ives had been doing 25 years earlier; when his music was at length per- 
formed, critics found it influenced, among others, by Hindemith-who had not begun to compose until Ives had stopped, and of whose music Ives had never heard a note!

5683. [MacDowell] Gilman, Lawrence. Edward MacDowell; a study. New York, J. Lane, 1909. I90 p. illus. 9-609 $\mathrm{ML}_{4}$ Io.M $_{2} \mathrm{G}_{52}$ MacDowell ( $186 \mathrm{I}-1908)$ was born in New York City, studied music at Paris and Frankfort, and at the age of 19 became head piano teacher at the Darmstadt Conservatory. On returning to America in 1884 he pursued a career as pianist and composer until 1896 , when "the assurance of an income freed from precariousness" led him to undertake the organization and direction of the new Department of Music at Columbia University. Eight years of administration and heavy teaching, combined with continued composition and occasional performances, brought him to the point of nervous exhaustion, and his resignation in 1904 failed to halt a progressive mental collapse: his creation was over and death ahead. His professorship had been offered to him as "the greatest musical genius America has produced," and Gilman considered, 13 years later, that "he gave to the art of creative music in this country its single impressive and vital figure." Seldom has so unrivaled a contemporary reputation been succeeded by such complete neglect; it was MacDowell's misfortune that his disappearance from the scene coincided with a revolutionary change in musical fashions, and his great creative achievement was shortly regarded as old hat. Gilman's memorial volume, which has had no successor, is divided into two parts: "The Man" consists of a brief biography and a character study; "The Music-Maker" characterizes his style as a refined and sincere romanticism, traces his emergence as "A Matured Impressionist," and has separate treatments of his piano sonatas and songs. A "List of Works" ( $p$. $181-190)$ is appended.

5684. [Mason] Rich, Arthur Lowndes. Lowell Mason, "the father of singing among the children." Chapel Hill, University of North Carolina press, 1946. 224 p. $4^{6-7444}$ ML410.M398R5 $_{5}$ "Lowell Mason's writings": p. r38-r72. "Other related sources": p. I72-194.

Lowell Mason (1792-1872) made significant contributions both to sacred and to public school music in this country. The two careers are interwoven in Mason's activities, so that although, as its subtitle indicates, this book is concerned with Mason's teaching, it is also important to the study of his sacred music. The story of Mason's life and of the Boston Academy of Music, the school he founded in 1833 , is painstakingly related and well documented. His importance is strikingly demonstrated in chapter 9, where parallel texts show how Mason's statements anticipate significant quotations from music educators of today. But while Mason's importance remains unquestioned, other students of American music history credit him with less priority and originality than does Mr. Rich. The extensive bibliography adds to the value of the work.

5685. [Rodgers] Taylor, Deems. Some enchanted evenings; the story of Rodgers and Hammerstein. New York, Harper, 1953. 244 p. illus. 53-7750 ML4 10.R6315 $\mathrm{T}_{3}$

Other composers may have written more significant music for the Broadway stage during the first half of the 2oth century, but Richard Rodgers (b. 1902) has indubitably been the most consistently successful. Throughout his long professional career, he has been associated with only two lyrists: Lorenz Hart from 1918 to 1942 and, after Hart's death, Oscar Hammerstein II (b. 1895). Mr. Taylor casts his book into four parts: the first covers Rodgers' early years, his meeting with Hart, and the musical comedies and motion pictures they wrote together; the second goes back to sketch Hammerstein's earlier theatrical experiences. Part three deals with the Rodgers and Hammerstein collaborations, while in the short part four Mr. Taylor says what little he has to say on a variety of topics, contrasting typical Hart and Hammerstein lyrics, describing a characteristic Rodgers melody with 14 short musical examples, and ending with brief accounts of "Victory at Sea" and "Me and Juliet," which had apparently been produced after the main body of the book had gone to press. Mr. Taylor admits in his introduction that there are difficulties in writing a biography of two personal friends whom he admires inordinately, and there is here no probing of personalities, no adverse criticism, and no careful weighing of the relative merits of other writers for the contemporary Broadway stage. These limitations are offset by Mr. Taylor's deft pen and ready wit, and if the descriptions of so many shows follow a repetitive pattern, the essential facts are all assembled for convenient reference. David Ewen has devoted a single volume to Richard Rodgers (New York, Holt, 1957. $37^{8}$ p.).

5686. Samaroff Stokowski, Olga. An American musician's story. New York, Norton, 1939. 326 p. illus. $\quad 39-27277 \mathrm{ML}_{4} 17 . \mathrm{SI}^{8} \mathrm{Al}_{2}$

The author was born Miss Hickenlooper in San Antonio, Texas; was for a few years Mme. Boris Loutzky of Berlin and St. Petersburg; became Olga Samaroff at the outset of her concert career in 1905 (her manager rejected not only her maiden name but all the Anglo-Saxon surnames in her ancestry); 
added Stokowski when she married the conductor of the Cincinnati Symphony in I9II (the year before his transfer to Philadelphia); and retained his name after her separation from Leopold Stokowski in r923. Madame Samaroff Stokowski (1882-1948) had an exceedingly varied musical career: as a student at the Paris Conservatoire and in Berlin; as an informal coach to Geraldine Farrar; as a touring pianist in America and Europe; as wife of the conductor of a major orchestra; as an early maker of piano records for Victor; as a teacher at the Juilliard Graduate School of Music from its opening in 1925, and at Philadelphia Conservatory; as music critic for the New York Evening Post; as founder of the Schubert Memorial, a foundation which enables promising young American musicians to give concerts; and as a pioneer in the "Layman's Music Courses" intended to create more "active" and responsive musical audiences. All these phases are narrated dispassionately and with some reflective commentary, and the final chapter is an equally thoughtful view of American musical life in general.

5687. [Schuman] Schreiber, Flora Rheta, and Vincent Persichetti. William Schuman. New York, G. Schirmer, 1954. 139 p.

$$
\text { 54-14322 } \mathrm{ML}_{4} \mathrm{I}^{\mathrm{I}} . \mathrm{S}_{3} 86 \mathrm{~S}_{3}
$$

Miss Schreiber contributes part one, "The Man" (p. I-48). Mr. Schuman (b. IgIo) comes of a middle-class German Jewish family of New York City; for his first two decades his musical interest was limited to participation in a jazz band and the composition of popular songs. The first concert of serious music he ever attended, the New York Philharmonic's on April 4, I930, brought about what can only be called a conversion; he began the study of music theory, and in 1936 became a pupil of Roy Harris at the Juilliard Graduate School. An outpouring of compositions in a variety of forms resulted, and by $1945 \mathrm{Mr}$. Schuman was chosen to head the Juilliard School, which he has done ever since, with some diminution but no suspension of his composition. There is an abundance of good photographs. Mr. Persichetti, himself a composer and a member of the Juilliard faculty, writes part two, "The Music." Schuman's style, he says, is marked by "the strong-flavored energy that generates a constant boil of movement," but is always based on singable melodies, and is definable as "structural derivatives of melodic character." Five works are analyzed at length with numerous examples in musical notation. The Appendix ( $p$. 126-134) has lists of works, records, and articles by and about Schuman. 


\section{Art and Architecture}

$\llbracket \begin{array}{ll}\text { A. } & \text { The Arts } \\ \text { B. Architecture: General } \\ \text { C. Architecture: Special } \\ \text { D. Interiors } \\ \text { E. Sculpture } \\ \text { F. Painting } \\ \text { G. Painting: Individual Artists } \\ \text { H. Prints and Photographs } \\ \text { I. Decorative Arts } \\ \text { J. Museums } \\ \text { K. Art and History }\end{array}$

$\left.\begin{array}{l}5688-5697 \\ 5698-5703 \\ 5704-5725 \\ 5726-5732 \\ 5733-5740 \\ 5741-5759 \\ 5760-5776 \\ 5777-5783 \\ 5784-5793 \\ 5794-5800 \\ 5801-5807\end{array}\right]$

THE WORKS listed in this chapter, which deals with the visual arts and with practi1 tioners, collections, and exhibitions thereof, range from the scholarly and the critical to the popular. Although a widespread interest in the arts did not arise in this country until the Igth century, a very considerable literature on American art has accumulated, principally since the I920's, from which we can present only a selection intended to be both representative and stimulating. Certain somewhat arbitrary omissions have been made. For example, books on the architecture of single states and cities have been almost wholly excluded. Section $\mathrm{C}$ includes only six monographs devoted to individual architects, of whom but one is an exponent of the modern idiom; alternative or additional choices will doubtless occur to the reader. Sculpture, treated in Section E, may appear to have been slighted, but it would seem that American achievements in this field are rather less distinguished than those in architecture or painting, a conclusion warranted, perhaps, by the scarcity of published material on the subject. In Section G, a mere sampling, only three contemporary artists have received full treatment; many others are briefly presented in three albums of recent paintings listed in the previous section. Some omissions reflect the nonavailability of material. Thus, if the great post-Civil War exemplar of the mystical strain in American painting, Albert Pinkham Ryder, receives less than his due share of attention, it is because of a lacuna in art scholarship. In Section $H$,

prints and photographs are interpreted as high art, as art for the people, and as records of the American scene and event; more material of the last kind is included in Section K. There is, of course, no clear line of demarcation between the decorative arts treated in Section I, such as the metalwork, glassware, pottery, and needlework produced by artisans and craftsmen prior to the industrial revolution, and the folk arts and crafts-quilting, figureheads, samplers, kitchenware, and the likedealt with in Chapter xxiv. In each will be found titles of interest to both the student and the collector. During recent years, the picture book has become an exceedingly popular medium for the portrayal of American history; selections for inclusion in Section $\mathrm{K}$, however, have been drawn from those which notice the artistic as well as the documentary elements, and which accompany their pictures with a substantial text of some kind. 


\section{A. The Arts}

5688. Baur, John I. H. Revolution and tradition in modern American art. Cambridge, Harvard University Press, 1951. I70 p. (The Library of Congress series in American civilization)

$$
5^{\mathrm{x}-\mathrm{r} 3 \mathrm{I}^{2}} \mathrm{~N} \mathrm{~N}_{5} \mathrm{r2.} \mathrm{B}_{3}
$$

Defines and traces the development of the chief movements, particularly those revolutionary in subject or form, such as impressionism and abstract art, in American painting and sculpture of the last 50 years. The author considers the relations of the new schools to each other, their reflections of the American scene or their transformation from the European to the American idiom, and their effects upon traditional survivals. Three final chapters are concerned with the position of the artist in modern civilization, current trends in art and criticism, and the "Americanism" of American art. The 199 illustrations, averaging two or three to the page, are in black and white.

5689. Cahill, Holger, and Alfred H. Barr, eds. Art in America; a complete survey. New York, Reynal \& Hitchcock, 1935. 162 p.

"Lists and bibliographies": p. I53-162.

$$
3^{6-1288 \quad \mathrm{~N} 6505 . \mathrm{C}_{32}}
$$

A broad historical review of the American arts by a number of contributors, sponsored by the General Federation of Women's Clubs with the cooperation of several museums and the National Broadcasting Company. Part I deals with painting, sculpture, and architecture from their respective beginnings to the Civil War. Part II continues the annals of these arts from 1865 to 1934 , and adds brief essays on stage design, photography, and the motion picture. Both of the main sections are revisions of separate 1934 publications. There are numerous halftones in the text and a group of 17 colored plates following page 62 .

5690. Dunlap, William. A history of the rise and progress of the arts of design in the United States. New ed., edited, with additions, by Frank W. Bayley and Charles E. Goodspeed. Boston, Goodspeed, 1918. 3 v. $18-11108$ N6505.D9 1918 Bibliography: v. 3, p. 346-377.

First published in 1834 by William Dunlap, who "became permanently a painter" only at the age of $5 \mathrm{I}$, this work has since served as a primary source of information for the student of early American art. Dunlap's method was to present a history of painting, and in smaller degree of engraving, architecture, and sculpture, through a series of biographical notices of the artists, from John Watson, a portrait painter who came to the colonies in 1715 , to Freeman Rawdon, a New York engraver, born in 1804 . He gives three chapters of autobiography, some notes on technical developments, accounts of the establishment of the early academies, and information upon early collectors and collections. The editors have ventured upon "judicious pruning and corrections of conspicuous errors" in the text as originally printed, and have provided a list of several hundred additional artists working in this country before I835 (vol. 3, p. 281-343).

5691. Kouwenhoven, John A. Made in America; the arts in modern civilization. Garden City, N.Y., Doubleday, 1948. xv, 303 p.

Thesis-Columbia University.

$$
\text { A49-I905 N6505.K6 r948a }
$$

"List of sources and references": p. [27r]-29o.

Develops the theme that the unique factor of a "democratic-technological vernacular" tradition has been overlooked in the interpretation of American arts and culture. "The purest form of this vernacular," says the author, "is represented by technological design." This functional, vernacular design, characterized since the middle of the Igth century by economy, simplicity, and flexibility, has interacted with the "tradition of cultivated taste" which emanated from Europe. "It is in their interpenetration and in their alternate ascendancy in the work of different men and different periods that the history of American art consists." Dr. Kouwenhoven traces the increasing influence and acceptance of vernacular forms and techniques from "Fordism," time and motion studies, and jazz, to literature and the fine arts.

5692. La Follette, Suzanne. Art in America. New York, Harper, 1929. 36r p.

29-29377 N6505. $\mathrm{L}_{3}$

A critical history of the arts in America from the 17 th century to 1929, and of the changes in taste evoked by the evolution of its social, cultural, and economic structure. To the author the United States has always been a nation of "cultural poverty." "The Puritan sought to suppress the artistic impulse in order that it might not divert him from spiritual interests; his descendants sought to suppress it in order that it might not divert them from material interests." Early colonial art was utilitarian, ornament being subordinated to structure. 
In the 18th century, under European influences, ornament became an integral part of structure and eventually even weakened it. In the 19th, under the egalitarian influences of the frontier West and machine industry, the main drift was "toward the dull and the commonplace in art"; the appeal of a picture lay in subject, not artistic merit. Except for skyscraper and factory, architecture during the years I900-1925 was bound to "archaeology," but modern painting taught the public to seek "significance rather than verisimilitude." The 103 gravure illustrations average one or two to a page.

5693. Larkin, Oliver W. Art and life in America. New York, Rinehart, r949. xviii, 547 p. 49-11231 N6505.L37

"Bibliographical notes": p. 483-514.

Interprets for the informed layman the American arts and the ways in which they have expressed our manner of living, and provides for the general student of American civilization a very serviceable introduction to American art history. The six major sections together span the years 1600-1945. As the author observes, usefulness was the chief criterion of the colonial arts. The buildings and sculpture of American neoclassicism served as symbols of political independence. The Jacksonian era saw a flourishing "art for the people" in a proliferation of genre paintings which furnished popular subjects for the new lithographs, and saw, as well, a persistence of "art by the people" in the richness and variety of the so-called primitives. The last three decades of the igth century, when size and slickness were the international fashion, were a time of malaise for true artists, but a few continued to seek "palpable truth" in "an age of surfaces"; and there was a whole new departure in architecture. The 2oth century has seen the rise of urban realism and the development among artists of social consciousness and participation. Closely linked to the text is a brilliant repertory of illustrations.

5694. Lynes, Russell. The tastemakers. New
York, Harper, 1954. 362 p. 54-8968. Er69.r.L95

A popular and readable survey of popular taste in the visual arts from the advent of Jacksonian democracy, when "taste became everybody's business and not just the business of the cultured few," to the present day. The "tastemakers" are those who have sought to influence the public's preference, from Andrew J. Downing and James J. Jarves to Pepsicola and Corning's Glass Center. The author, editor of Harper's Magazine, does not believe that American taste is improving, but thinks that varieties and conflicts in taste are a sign of artistic vitality.
5695. Mumford, Lewis. The brown decades; a study of the arts in America, 865-1895. [2d ed.] New York, Dover, 1955. 266 p.

Includes bibliographies.

$$
\text { 55-14851 N6510.M8 } 1955
$$

Originally published in $193 \mathrm{I}$ and based upon lectures delivered by the author in 1929, this book is written in an informal vein for the layman. It emphasizes the positive aspects of American culture in the reckless and extravagant years 1865-95. "Beneath the crass surface," observes Mr. Mumford, "a new life was stirring in departments of American thought and culture that had hitherto been barren, or entirely colonial and derivative." The creative manifestations of the "brown decades" have been overlooked, he believes, and he points out the accomplishments of philosophers and men of letters as well as the shift in the whole culture to a concern with the industrial and plastic arts. "The architect, the engineer, the landscape architect, the painter, all rode in together on the rising tide of industrialism." Mr. Mumford considers, among others, the architects Louis Sullivan, H. H. Richardson, and the young F. L. Wright; John A. Roebling, designer of the Brooklyn Bridge; Frederick Law Olmsted, planner of New York's Central Park; the painters, Ryder, Eakins, George Fuller, and Homer; and Alfred Stieglitz, "photographer and interpreter."

5696. New York. Museum of Modern Art. Abstract painting and sculpture in America, by Andrew Carnduff Ritchie. New York, I95I. 159 p. 51-10619 ND212.N395

"Catalogue of the exhibition .... January 23 to March 25, 1951," by Margaret Miller: p. 148-156.

Bibliography, by Bernard Karpel: p. 156-159.

A picture book and catalog of Mr. Ritchie's selections for an exhibition of abstract art of the years I $912-50$ "which seeks to display, at as high a level of quality as possible, enough distinctive examples of abstract painting and sculpture produced by Americans, or foreigners long resident in America, to give the observer and reader a sufficient appreciation of the variety and extent of this form of art in this country." "Protest against the established order of traditional perspective, naturalistic space and color, conventional subject matter," in Mr. Ritchie's opinion, forms the factor common to all motivations toward abstract art. Recent work he classifies into the following, admittedly somewhat arbitrary, categories: pure geometric, architectural and mechanical geometric, naturalistic geometric, expressionist geometric, and expressionist biomorphic. Unfortunately, only a few of the many illustrations are in color. An earlier sampling assembled by Sidney Janis, Abstract \& Surrealist Art in America (New York, Reynal \& Hitchcock, 1944. 146 p.), 
presents work by 30 2oth-century painters classified as abstract, and 30 more classified as surrealist; the layman would find it difficult to say why some pieces are assigned to the one school rather than to the other, and the paucity of color plates certainly does not make for clarification.

5697. Purcell, Ralph. Government and art, a study of American experience. Washington, Public Affairs Press, 1956. I29 p.

$$
\text { 56-8543 N6512.P8 }
$$

Government in America-Federal, State and local-has done considerably less than in Europe to encourage the fine arts, but its total patronage has been by no means negligible. This volume traces that patronage in all fields save the most important one-the architecture of public buildings. From
I817 to 1933 the Federal Government commissioned a number of murals, acquired some paintings, and engaged a few painters to report Western expeditions or wartime scenes. From 1933 to 1939 the Roosevelt administration subsidized several thousand artists stranded by the economic collapse, not only through the Federal Art Project of the Works Progress Administration, but also by the embellishment of public buildings through the Treasury's Fine Arts Section. Contemporary trends include the wide circulation of exhibitions of American art abroad by the State Department, and a remarkable development of collections and activities at the $\mathrm{Na}$ tional Gallery of Art. The author concludes: "If private patronage of the Arts declines as it seems likely to do, patronage by the government will become a necessity if the Arts are to continue."

\section{B. Architecture: General}

5698. Andrews, Wayne. Architecture, ambition and Americans; a history of American architecture, from the beginning to the present. New York, Harper, 1955. 315 p. 55-8014 NA705.A5 "A selected bibliography": p. 289-303.

A report on architectural taste in the AngloAmerican main current of United States history, taste being defined as "the record of the ambition which leads the architect to spend more time and energy than is reasonable, and the client, often but not always, to invest more money than common sense would dictate." This, then, is a chronicie mainly of imposing residences, "those that were the last word in their time and place." The steady economic advance of the United States in the rgth century kept generating new fortunes, the masters of which looked for fresh ways to impress their neighbors and thereby encouraged professional architects and builders to make stylistic innovations. Mr. Andrews delights in the resultant variety that ranges from the formal, impersonal architecture created for the "symbolic businessman," to the informal, irregular styles created in our own day. He has spent 16 years and has visited 39 States in making the splendid photographs which illustrate this lively and catholic record of the mansions of America.

5699. Fitch, James Marston. American building; the forces that shape it. Boston, Houghton

Mifflin, 1948. 382 p. $\quad 4^{8-5133}$ NA705.F5

The "umbilical relationship between men and buildings" forms the chief concern of this thoughtprovoking, if somewhat doctrinaire, book. Its first third traces the major forces that have shaped American architecture from the beginning to the Victorian era and the Columbian exposition of 1893 , and even here the point of view is that of the technologist. The latter two-thirds explores the "nature and function of contemporary building equipment ... in relation to the respective environments which they modify": the atmospheric, thermal, luminous, sonic, spatial, and animate elements, in the author's classification. In order to achieve his ideals of the multiple use and the flexible organization of space, "democratic long-range planning" is necessary. A democratic esthetic can achieve rising standards of quality, he believes, only when an increase in the quantity and continuity of building makes intense creative activity possible.

5700. Hamlin, Talbot Faulkner. The American spirit in architecture. New Haven, Yale University Press, 1926. 353 p. The Pageant of America, v. 13) 26-9196 NA705. $\mathrm{H}_{3}$

Ei78.5.P,v.13

A picture book, presenting an exceptionally large and varied selection of materials, but the 832 halftones are small and indifferently executed. The author gives half of his space to developments since 1880 and presents such types as railroad stations, state capitols, county courthouses, museums, banks, public libraries, tombs, monuments, schoolhouses, university buildings, factories, warehouses, apartment houses, hotels, and theaters. He points out the representative and the horrible as well as the excellent. The text emphasizes environment and local 
materials, contact with the mother country, particularly England, economic conditions, urbanization, and westward expansion as factors of primary importance in the development of American architecture.

5701. Mumford, Lewis. Sticks and stones; a study of American architecture and civilization. [2d ed.] New York, Dover, 1955. $23^{8}$ p. 55-14852 NA705.M8 1955

First published in I924, this important chronological survey of American architecture demonstrates "how architecture and civilization develop hand in hand." Mr. Mumford traces here the major trends: the "medieval tradition" of the "close villagecommunity" in 17th-century New England; the early 18th-century derivations from the Renaissance; the vernacular work of the craftsmen, and the classical work of the educated gentlemen and professional architects of the early republic, among them Jefferson and Latrobe. The "period of disintegration" in the early Igth century was followed by a number of discordant styles and combinations of them. The durable in romanticism was expressed by $\mathrm{H}$. $\mathrm{H}$. Richardson's continuator, Louis Sullivan. McKim, White, Hunt, and Burnham exemplify the magnificence and opulence of the ensuing "imperial age," while a new electicism was pursued by Bertram Goodhue. The subsequent "machine age" and the dilemmas posed by it to the architect and to society form the subjects of Mr. Mumford's final chapters.

5702. Pickering, Ernest. The homes of America, as they have expressed the lives of our people for three centuries. New York, Crowell, I951. 284 p. (The Growth of America series)

"Architectural structures," in Professor Pickering's opinion, "form the most permanent and revealing record of a civilization." Domestic architecture has yielded to the pressures of climate and geography, and has "expressed the materials, construction, and social order of the time." About two-thirds of the book is devoted to the colonial, the Georgian and Federal periods, and the Roman and Greek revivals. The "era of confusion," after 1865 , and the present century are more sketchily presented, since the author is considerably more interested in outstanding examples of early design than in the more recent constructions which constitute the great majority of American homes. Numerous halftones illustrate the text.

5703. Tallmadge, Thomas E. The story of architecture in America. New, enl. and rev. ed. New York, Norton, 1936. 332 p.

First published in 1927 .

$$
\text { 36-23858 NA705.T3 } 1936
$$

A history of American architecture from the 1630's to 1935, written by an architect primarily for the layman. Stylistic periods are defined as: "The Colonial-1630-1800," subdivided into Early American, 1630-1700, and Georgian, 1700-1800; "The Post-Colonial-r790-1820"; "The Greek Revival1820-1860"; "The Parvenu Period-I860-1880"; "The Romanesque Revival-r876-I893"; "Eclecticism-1893-1917"; and since 1917. Separate chapters consider Spanish and Creole architecture, the World's Fair of 1893, and Louis Sullivan as the precursor of functionalism. Particular attention is paid to architectural details and the ornamentation of both exteriors and interiors. Although nothing in our architectural history is "more beautiful, more vigorous, more expressive of its times" than Georgian of 1750, "the skyscraper is far and away the most important architectural achievement of America, her great gift to the art of building." Along with numerous halftone illustrations are a few typical plans.

\section{Architecture: Special}

5704. Bridenbaugh, Carl. Peter Harrison, first American architect. Chapel Hill, University of North Carolina Press, 1949. xvi, $195 \mathrm{p}$. illus. $\quad 49-9109$ NA737. $\mathrm{H}_{3} \mathrm{~B}_{7}$

"Published for the Institute of Early American History and Culture at Williamsburg, Virginia."

A "biographical essay" about Peter Harrison (1716-1775) who arrived as a colonist at Newport, R.I., in I739. This English seaman became the master of no fewer than ro skills, among them shipbuilding and woodcarving, as well as "America's first important architect." In his design of the Redwood Library at Newport, 1749, Harrison introduced the Palladian style of architecture to this country, and so anticipated Thomas Jefferson in the revival of classical models. Although Harrison was possessor of "the largest and best-selected architectural library of colonial America," the plans for his churches, synagogue, and market at Newport, Boston, and Cambridge, Mass., were those "of the designer, not the copyist." His story is here documented from the fragmentary surviving sources and 
set forth against the background of contemporary colonial history.

5705. Condit, Carl W. The rise of the skyscraper. Chicago, University of Chicago Press, 1952.

$255 \mathrm{p}$. 52-6468 NA712.C65

A comprehensive history of the Chicago school of architecture and of the evolution of the commercial skyscraper, from the time of the great fire of 1871 to World War I, and from the first structural innovations of the engineers to the functional designs and architectonics of men like Dankmar Adler, Sullivan, Burnham, and William Holabird. The work is based in large part upon contemporary periodicals, the records of engineering and architectural firms, and the files of commercial photographers. Although it designed every type of building, the "Chicago school is associated with the invention and mastery of steel framing and with the consequent development of the modern office building, hotel, and apartment block." Their success is attested by "the largest concentration of first-rate commercial architecture in the world. The ro8 halftones from photographs have been carefully selected.

5706. Forman, Henry Chandlee. The architecture of the Old South: the medieval style, 1585-1850. Cambridge, Harvard University Press, I948. $203 \mathrm{p}$.

Bibliography: p. [185]-I9I.

Based upon the author's wide field experience in archaeology, this book incorporates lectures originally presented at Goucher College. "It is our premise ... that en bloc American architecture of the Southern Colonies in the sixteenth and seventeenth centuries belonged to the English medieval period, which, far from terminating with the accession of Elizabeth, continued until close to 1700. Distançe did not dilute or corrupt the style in America." An introductory section considers our English late Gothic heritage; Parts II-III, constituting the bulk of the book, deal respectively with Virginia and Maryland architecture; and Part IV devotes brief chapters to the medieval architecture of Bermuda, North Carolina, South Carolina, and Georgia. Professor Forman's many sketches and plans include reconstructions of ruined or vanished edifices and contribute in large measure to the comparisons made in his text between American buildings and their English prototypes.

5707. Garvan, Anthony N. B. Architecture and town planning in colonial Connecticut. New Haven, Yale University Press, 1951. xiv, 166 p. (Yale historical publications. History of art, 6) "Bibliographical note": p. 152-159.
"An investigation of the relationship between domestic architecture and the demography and national origins of colonial Connecticut." The book, an outgrowth of a dissertation, makes use of aerial pho tographs, as well as manuscript land surveys and other cartographical materials. "The colony's architecture, town plans, and land division were like its settlers-rural, Protestant, and English." Choosing a site with an eye both to defense and to pasturage, the settlers reserved "a few central acres within the village unit for a meetinghouse and for the minister's own house." Beyond the symmetrical center lay an area of "wandering, haphazard lanes" which frustrates 2oth-century traffic and is often scrapped by the modern planner. Since conservatism marked Connecticut design, style changes from English models were made chiefly in "small things and subtle details." An original "rich variety of architecture" gave way to the predominance of the "clapboard lean-to house, directly descended from the yeoman post-enclosure farmhouse of eastern England," which crowded out the other styles and furnished the basis for later developments. Many plates and figures illustrate the text.

5708. Hamlin, Talbot F. Benjamin Henry Latrobe. New York, Oxford University Press, 1955. xxxvi, 633 p. $\quad 55-8$ I $_{7} \quad \mathrm{NA}_{737} \cdot \mathrm{L}_{34} \mathrm{H}_{3}$

Based upon the "priceless Latrobe papers and sketchbooks" as well as other sources, both primary and secondary, this Pulitzer prize winning book is a detailed biography of Benjamin Henry Latrobe $\left(176_{4}-1820\right)$, the "single-minded creator of the architectural profession in the United States." His designs for the Bank of Pennsylvania and the water system of Philadelphia (1798) established him at once as "the most accomplished and imaginative of the architects and engineers in the United States." Restrained and geometric in much of its composition, his revolutionary work was "naturally classic in detail and turned always to Greek precedent for inspiration." He achieved his ambition "to establish architecture as a high and respected profession" through his own works, such as the Baltimore Cathedral (1805) and portions of the United States Capitol (1803-17), and through the accomplishments of his students, Robert Mills and William Strickland. Numerous plates and figures illustrate the text.

5709. Hamlin, Talbot F. Greek revival architecture in America: being an account of important trends in American architecture and American life prior to the War Between the States. New York, Oxford University Press, 1944. xl, 439 p. 
"A list of articles on architecture in some American periodicals prior to $185^{\circ}$, by Sarah Hull Jenkins Simpson Hamlin": p. [356]-382.

Bibliography: p. $[383]-409$.

A broad yet detailed history of Greek revival architecture in the United States during the years 1820-60. Seeking monumental permanence and conceived in terms of function rather than of archaeology, this architecture was inspired by classical Greek style, using its details, but incorporating them in original building forms. Greek revival architecture received a "distinguished start" in the designs of Benjamin Henry Latrobe as early as 1798 . The use of Greek style did not become universal, however, until the late 1820 's, and then largely through the work of two of Latrobe's pupils, Robert Mills (17811855) and William Strickland (1787-1854), who brought the movement to its mature structural inventiveness, soundness of construction, and excellence of execution. It flourished in a culture "learned, founded on classic myth, classic literature, classic art." The "emergence of the millionaire was as fatal to the artistic ideals of the Greek Revival as were the speed, the speculation, and the exploitation that produced him."

5710. Hitchcock, Henry Russell. The architecture of H. H. Richardson and his times. New York, Museum of Modern Art, 1936. xxiv, 3II p. 36-3985 NA737. $\mathrm{R}_{5} \mathrm{H}_{5}$

A study of the architectural accomplishments of Henry Hobson Richardson (1838-1886) in the light of the setting within which he worked. The author has visited almost all of Richardson's extant buildings and has had access to his sketchbooks. During the 1850's, the intellectuals had succeeded in terminating the Greek revival, and with it a certain integrity of constructon. "It is in relation to this almost complete loss of the sense of architecture as sound building that Richardson's achievement after the Civil War is most remarkable." He developed a personal style characterized chiefly by "massive walls, lintel-covered openings, ... broad arches," and vigorous polychromy; he "was ready to find inspiration in any part of the past that appealed to him. The Romanesque was perhaps most useful." A great individual, he raised American architecture "from the slough of the late sixties." By the I880's, he had achieved an "excessive popularity, which led to over-production." The text is illustrated by 145 photographic reproductions of drawings, façades, and plans.

571 1. Hitchcock, Henry Russell. In the nature of materials, 1887-r941; the buildings of Frank Lloyd Wright. New York, Duell, Sloan \& Pearce, 1942. Xxxv, $143 \mathrm{p}$. $42-13893 \quad \mathrm{NA}_{737} \mathrm{~W}_{7} \mathrm{H}_{5}$
"Chronological list of executed work and projects: 1887-194I": p. 105-130.

5712. Wright, Frank Lloyd. An American architecture. Edited by Edgar Kaufmann. New York, Horizon Press, 1955. 269 p.

55-1227I NA737. $\mathrm{W}_{7} \mathrm{~K}_{3}$

Professor Hitchcock's book aims "to display as fully as may be the architectural work and projects of Wright, with particular emphasis on the expression of the 'Nature of Materials.' " Subordinated to the section of plates and linked closely to it, the introductory text provides a rapid historical survey of Frank Lloyd Wright's architecture. Parts I-II show the influences exerted upon him, especially by Richardson's followers and by Sullivan, and the steps by which he attained maturity during the late I880's and the I89o's. Parts III-VI are devoted to Wright's mature work of the years IgoI-4I. Mention is made of such buildings as the Willitts House (1902), a masterpiece among the Prairie houses; Taliesin (1911-25), his own studio, dwelling, and farm, which "quite literally grows" from the hillside; and the Imperial Hotel at Tokyo (1915-22), a "building which is from foundation to roof all of new materials and new devices compounded." Also considered are the California houses of the 1920's, illustrating Wright's "capacity to renew again and again his architectural imagination by drawing on the implications of particular uses of materials and the opportunities of very carefully chosen sites," the Kaufmann House, "Falling Water" (1936), and the Johnson Administration Building (1936-39), the two latter "widely recognized as classic masterpieces even before they were finished." The 413 photographs and plans are accompanied by descriptive captions. A special 92-page issue of the Architectural Forum (v. 88, Jan. 1948), devoted wholly to the architecture of Frank Lloyd Wright, complements Professor Hitchcock's volume by showing many of the architect's later designs. This issue was "completely designed and written by him; the plans and sketches appear as they were drawn by the 50 young men who now compose the Taliesin Fellowship." A number of his Usonian houses are depicted, as are group housing projects, more ambitious dwellings, commercial and industrial establishments, buildings for Florida Southern College, and others.

The editor of An American Architecture has skillfully excerpted from various of the author's writings published between 1894 and 1954 in order to present the basic principles upon which his architecture is founded. His ideal of "organic architecture," conceived as one with its setting and environment, and designed "for human use and comfort," is amply set forth in the 262 illustrations of projects 
and completed works from the period 1893-1955, some of which have never before been published.

5713. Kimball, Sidney Fiske. Domestic architecture of the American colonies and of the early republic, by Fiske Kimball. New York, Scribner, 1922. $\mathrm{xx}, 314 \mathrm{p}$. 22-24675 NA707.K 45

"Chronological chart": p. [263]-269.

"Notes on individual houses": p. [27I]-30o.

In this pioneer work, Dr. Kimball, with the "aid of building contracts and accounts, inscriptions, and original designs, as well as inventories, wills, deeds, and other documents in favorable cases," indicates the dates and original forms of nearly 200 houses erected in the English colonies and American republic between the time of settlement and 1835 . The i 7 th-century colonial style was "still essentially mediaeval," but with the opening of the 18 th century the "academic spirit and the academic architectural forms" prevailed. "The triumph of literal classicism in 1825 , with its ideal formal schemes of temple and rotunda, had been prepared by Jefferson's prophetic insistence on these very types, from the time of the Revolution itself." Many plans and elevations are included among the 219 illustrations and figures.

5714. Morrison, Hugh S. Early American architecture, from the first colonial settlements to the national period. New York, Oxford University Press, 1952. xiv, 619 p. 52-7831 NA707.M63

"Reading suggestions" at end of each chapter.

A comprehensive but concise one-volume history of architecture in the North American colonies from St. Augustine in 1565 to San Francisco in 1848 . Professor Morrison surveys such edifices as houses, churches, forts, log cabins, markets, mills, and public and institutional buildings. He covers all the styles, English, Dutch, French, Spanish, and, to a lesser extent, Swedish, that were developed from the time of the first settlements: to the American Revolution on the Atlantic seaboard; to 1803 in French Louisiana; and to 1848 in the Spanish colonies. The primary emphasis is placed upon the colonial style of the $x 7^{\text {th }}$ century and the Georgian style of the I 8 th, and the conditions under which they were produced. The author has made use of all of the earlier literature, and has presented the several styles "both in text and illustrations, by a selection of typical ... examples, by monuments of unusual historical importance, and particularly by buildings that are dated with reasonable certainty." $\mathrm{He}$ has further attempted "to bring out the distinctive quality and color of architecture in the many different regions of the country." Many of the 484 illustrations were specially drawn for this work.
5715. Morrison, Hugh S. Louis Sullivan, prophet of modern architecture. New York, Museum of Modern Art and W. W. Norton, 1935. 391 p. 36-27013 NA737.S9M6

"A bibliography of the writings of Louis Sullivan": p. 306-309.

"General bibliography": p. 310-317.

An enthusiastic evaluation of the achievements of Louis Henry Sullivan (1856-1924) in architecture, of his theories concerning it, and of his position in relation to present-day architectural practice. His Wainwright Building (1890), "the first successful solution of the architectural problem of the high [office] building," incorporates Sullivan's "whole conception of architectural design as the symbolic expression of an emotion aroused by practical conditions." To him, the thesis that form follows function "was simply natural law." "His work and his thinking have made architecture once more plastic in the hands of the creative artist, and rendered possible the development of a true architectural style in the present day." The book includes 87 illustrations and 16 figures. John Szarkowski's The Idea of Louis Sullivan (Minneapolis, University of Minnesota Press, 1956. I61 p.) is an album of halftone reproductions of photographs, most of them quite clear, documenting the architect's fundamental concepts as to functional forms, "vertical continuity," and organic systems of ornamentation; accompanying them is a "Profile of Louis Sullivan," together with quotations from Sullivan and others germane to the pictures. Just before he died Sullivan completed a lyrically written sketch of his own life, The Autobiography of an Idea (1924; reprint with additional material by Ralph Marlowe Line, New York, Dover Publications, 1956. 333 p.), which seeks to reveal the origin and development of his central conception: "a sane philosophy of a living architecture, good for all time, founded on the only possible foundation-Man and his powers," issuing in a functional, democratic, and indigenously American style of both structure and ornament.

5716. Mumford, Lewis, ed. Roots of contemporary American architecture; a series of thirty-seven essays dating from the mid-nineteenth century to the present. New York, Reinhold, 1952. 454 p.

52-10519 NA710.M8

A collection of papers, together with an introductory essay and biographical sketches by $\mathrm{Mr}$. Mumford of the 29 writers whose work appears here. The book assembles a "body of thought that helped form modern architecture in the United States during the last century." Later interpretations, mainly the editor's own, fill gaps in the first-hand documents. The writers, among them critics, historians, naturalists, and regional planners, as well 
as architects, range from Horatio Greenough (1805-1852) to Matthew Nowicki (1910-1950). The American tradition of architecture Mr. Mumford defines as "a mode of thinking and feeling, of planning and organizing and building, that Americans became conscious of only after they had established their political independence, had thrown off their colonial ways, and had begun to create a new mold for their life, in which past habits were modified by new processes, new activities, new purposes." The point of departure was a break with the concept of an architectural absolute, and it was made in architectural writings long before it was translated into new building forms.

5717. New York. Museum of Modern Art. Built in USA, 1932-1944, edited by Elizabeth Mock. New York, 1944. $127 \mathrm{p}$.

$$
\text { 44-7779 } \text { NA712. }_{45}
$$

5718. New York. Museum of Modern Art. Built in USA: post-war architecture, edited by Henry Russell Hitchcock and Arthur Drexler. New York, Distributed by Simon \& Schuster [1952] I $28 \mathrm{p}$. 53-568 NA712. $\mathrm{N}_{47}$

Two catalogs designed to accompany exhibitions of outstanding modern American architecture that were assembled by the Museum of Modern Art in I944 and 1952. Listing 47 edifices chosen by a committee mainly "on the basis of total design," the first volume is perhaps strongest in the field of domestic architecture. This was an area in which the American architect had "had the most opportunities and the freest hand." During the years $1932-44$, he was interested particularly in the "straightforward use of material," and a more intimate adaptation of structure to climate and topography, as well as in the exploitation of such materials as reinforced concrete and laminated wood, the strength of which permitted a new freedom of design in both plan and elevation. Choice of the 43 buildings included in the I952 catalog has been the "final responsibility" of Professor Hitchcock, whose criterion is a double one, "quality and significance of the moment." His introduction notes that "it has been business, interested in the advertising value of striking architecture, which has sponsored many of the more luxurious-and not to balk at a word-beautiful buildings of the last few years." Modern design, the author observes, is nationally standardized but not monolithic, and the "international mode" has been thoroughly domesticated. Both catalogs provide a two-page spread for each building dealt with, including a brief description of its salient architectural features, a plan, and photographs of exterior and, usually, of interior views.
5719. Newcomb, Rexford. Architecture of the Old Northwest Territory; a study of early architecture in Ohio, Indiana, Illinois, Michigan, Wisconsin, \& part of Minnesota. Chicago, University of Chicago Press, 1950. xvii, 175 p.

Bibliography: p. $162-167$.

$$
50-9051 \quad \mathrm{NA}_{725} \cdot \mathrm{N}_{4}
$$

"The result of some thirty years of observation and study," this comprehensive synthesis "attempts to set forth, for the first time, a connected story of the career of architectural art in the Old Northwest from the earliest days down through that moving formative period which came to a close with the Civil War." Mr. Newcomb begins with a discussion of French colonial architecture of the early i 8th century, which he reconstructs, so far as possible, from contemporary descriptions and travel reports. He goes on to describe the half-faced camps, forts, and cabins of the American pioneers, and to discriminate Southern and New England influences in the more ambitious structures derived from early American styles. Examples of the Georgian and Federal modes are few, he observes, and "in general, it was the Greek Revival-in its heyday during the developing period of the Northwest," the years $1825-60-$ "that followed the cabin when better homes could be built." The text is illustrated by 97 plates and 49 figures.

5720. Place, Charles A. Charles Bulfinch, architect and citizen. Boston, Houghton Mifflin, 1925. xiv, 294 p. $\quad 25-27877 \quad \mathrm{NA}_{737 . B 8 \mathrm{P}}$

This biography of Charles Bulfinch ( $1763-1844$ ), the first American architect of native birth, relies upon oral tradition as well as family letters, contemporary journals, the Boston town records, and other documents. The Hollis Street Church in Boston ( 1788 ) was apparently his first executed design, and the State House at Hartford, Connecticut (1796), was the first public building constructed from his plans. His design of a state house for Massachusetts was adopted in 1795 , and he enjoyed a "connection with this structure ... more personal and intimate than with any other of his designs." He executed a number of residences, churches, and public buildings in the Federal style during the years 1796-1818, among them the Massachusetts General Hospital. The remainder of his career, 18 18-30, he devoted to the Capitol at Washington. "Bulfinch's work ... . was to complete the wings partially restored by Latrobe after the destruction by the British troops in 1814 , and to construct the central portion for the most part from plans made by Latrobe, making such changes as were necessary." The illustrations consist in large part of photographs of buildings long since demolished. 
5721. Pratt, Dorothy, and Richard Pratt. A guide to early American homes. New York, McGraw-Hill, 1956. 2 v. 56-10867 NA7205.P68 Contents.- - I] North.-[2] South.

An informal handbook to surviving American houses of the years $1680-1850$, designed for tourists to use in conjunction with road maps. Geographically arranged, brief histories and descriptions are furnished of more than 900 early homes in the I4 states of the North between the Atlantic seaboard and the Mississippi, and of nearly 700 in 16 states of the South including Missouri and Arkansas. Approximately two-thirds are public museums; the remainder are private dwellings, many of which are conditionally open to visitors. General commentary on the architecture of each state is provided, as is specific information regarding locations of the houses, requirements for admission, and ownership. There are numerous rather small black-and-white illustrations, predominantly of façades.

5722. Pratt, Richard. A treasury of early American homes. New York, Whittlesey House [1949] vii, 136 p. 49-50069 NA7205.P7 These 22 color-illustrated articles, devoted to fine American homes, many of them manorial in scale, of the period $1650-1850$, were originally published in the Ladies' Home Journal. With the exception of the ones in Natchez, New Orleans, and Monterey, all of the houses covered lie within the region of the English colonies along the Atlantic seaboard, from Woodstock, Vermont, and Portsmouth, New Hampshire, to Charleston. An introduction provides a thumbnail history of American domestic architecture. Deliberately subordinated to the illustrative material, the chronologically arranged text is limited to historical summaries, and to descriptions of the major features of the houses and of the interiors and furnishings depicted. Similar in format, The Second Treasury of Early American Homes, by the author in collaboration with his wife, Dorothy Pratt (New York, Hawthorn Books, 1954. I44 p.), is an "entirely new collection of early American homes in color." "Chosen for their age and their charm together," the 57 houses and more than 140 interiors delineated here are geographically arranged-south from Maine to Georgia, and west to Tennessee. The color is less satisfactory in the sequel, the reds and yellows having an unnatural intensity.

5723. Sanford, Trent Elwood. The architecture of the Southwest; Indian, Spanish, American. New York Norton, 1950. 312 p.

Lists of pueblos and missions: p. 276-299.

$$
\text { 50-1064I NA720.S }
$$

An architectural history of the American Southwest, where Indian, Spanish, and Anglo-American cultures are blended. Part one considers Pueblo Indian architecture which culminated during the years 1050-1300. Comprising the bulk of the book, parts two to five are devoted to Spanish architecture, particularly to the influential I 7 th-century SpanishPueblo style in which Spanish ideas and methods were applied "to an indigenous architecture of local materials put in place by Indian labor," and to the florid I8th-century Spanish baroque. A concluding section is devoted to Anglo-American contributions to the architecture of the Southwest, the most notable, perhaps, being Thomas Oliver Larkin's I9th-century adaptation of the Cape Cod mode to adobe in a two-story house with a hipped roof and a balcony. Numerous halftones illustrate the text. Rexford Newcomb's Spanish-Colonial Architecture in the United States (New York, J. J. Augustin, 1937. $39 \mathrm{p}$. I30 plates) briefly describes and illustrates, in many halftones and measured plans, and drawings, surviving Spanish-Colonial structures, as well as the best modern adaptations of the old styles in the "regional vernaculars" of Florida, Texas, New Mexico, Arizona, and California.

5724. Sloane, Eric. American barns and covered bridges. New York, W. Funk, I954. I 12 p. 54-12510 NA8201.S6

This book springs out of its author's enthusiasm for antique American handhewn woodwork, its materials and tools, and its characteristic end products. The importance of wood in early American life, the importance of seasoning, and the characteristics of native American woods are described. Early American tools are described and illustrated in the author's skiliful drawings or diagrams. Barn design altered little in the two centuries after 1650; the author admires New England and Pennsylvania patterns and compares them at length, but considers that, in the trans-Allegheny migration, "many of the arts of woodworking and seasoning were lost." Covered bridges were devised at the very end of the I8th century and continued to be built for about 70 years; the covering strengthened the structure, and kept water out of the joints, and rain and snow off the roadway. There are some I60o left, but they are disappearing very rapidly. American Yesterday (New York, W. Funk, 1956. I23 p.) pursues the author's nostalgic interest in antique artifacts down a number of curious byways, such as foot stoves, hammocks, weathervanes, and shutters, and has the same kind of attractive illustrations.

5725. Waterman, Thomas Tileston. The dwellings of colonial America. Chapel Hill, University of North Carolina Press, $1950.3^{12}$ p. 50-14735 NA707. W 42 
Bibliography: p. 29I-293.

"Glossary of architectural terms": p. 294-298.

"This study of the dwellings of colonial America is confined to the period between the first English settlement and the close of the Revolution, and to the area occupied by the United States in $1783 . "$ The four main chapters trace, in considerable detail, the patterns of evolution, and the intricate and varied influences involved in the domestic architecture of the Southern colonies, the Delaware Valley and Pennsylvania, the Hudson Valley and eastern New Jersey, and New England. Each chapter discusses the primitive one-room shelters of the original settlers, the vigorous, even "homely" styles of the ifth century, and the mature and sophisticated Georgian mode of the r8th. Numerous photographs of exteriors, interiors, and details, together with the author's plans, illustrate the text.

\section{Interiors}

5726. Brazer, Esther (Stevens). Early American decoration; a comprehensive treatise revealing the technique involved in the art of early American decoration of furniture, walls, tinware, etc. Memorial [i. e. 2d] ed. Springfield, Mass., Pond-Ekberg, 1947. 265 p.

First published in 1940 .

$$
4^{8-490} \quad \mathrm{NK}_{4}{ }_{403} \cdot \mathrm{B}_{7} \quad 1947
$$

A study of 18 th- and early Igth-century American methods of applying designs in one or more colors to the surfaces of movables and interior walls, based upon the author's observations of the designs themselves, her research in early instruction books, and her own experiments. In the hope that "antique furniture and tinware, old-time decorated walls and floors, may be restored with their proper designs and with their own methods of painting," she works out the old principles of design, the first of which is that decorative design must emphasize construction; the materials, tools, and their properties and uses; and the various techniques of design, such as stenciling, brush-stroke painting, striping and banding, freehand bronze painting, gold leaf work, japanning, retouching, restoring, and antiquing. A final part offers a "step-by-step pictorial exposition" of the copying of the old decorations. Mrs. Brazer contributes many photographs and drawings, some in excellent color.

5727. Cornelius, Charles Over. Early American furniture. New York, Appleton-Century [1936?] xx, 278 p. 36-13493 NK2406.C6 1936 Bibliography: p. 263-268.

First published in 1926.

This history of the development of American furniture from the I 7 th century to 1850 shows the "growth in artistic consciousness from a time when utilitarianism predominated over esthetic demands .... to the time when a highly organized society expressed itself in sophisticated terms." Ex- ecuted by carpenter-joiners, the earliest furniture preserved the "primitive rectangular character inherited from medieval times." By the first decade of the 18 th century, cabinetmaking had achieved a new excellence, and the "baroque forms, based preferably upon the curved rather than the straight line, began to affect the structure"; especially influential were the light and delicate classical proportions of Sheraton's designs. From 1820 to 1850 , when mechanical methods predominated, "interest was less in esthetic values" than in ingenuity. The book is illustrated by $\sigma_{3}$ photographic plates and 12 figures.

5728. Cornelius, Charles Over. Furniture masterpieces of Duncan Phyfe. Measured detail drawings by Stanley J. Rowland. Garden City, N.Y., Published for the Metropolitan Museum of Art by Doubleday, Page, 1922. 86 p.

$$
\text { 22-23282 } \mathrm{NK}_{2439} \mathrm{P}_{5} \mathrm{C} 6
$$

An examination of the "sincere craftsmanship and consummate artistry" of Duncan Phyfe (r768I854), New York cabinetmaker, in the first quarter of the Igth century. The author sees Phyfe, in his earlier practice, as heir to the age of George Hepplewhite and Thomas Sheraton, "able to profit by all the accomplishments of the last great English cabinet-makers," and to "pick and choose those treatments which his native good taste and feeling for his craft told him were legitimate and appropriate for his use." In a second phase, he adopted many motifs of Directoire and Consulate origin, but "combined them skillfully with those of his earliest practice, still keeping the delicate scale and fine finish of the latter." Mr. Cornelius analyzes in detail the architectural proportions, lines, and decorative methods and motifs, particularly the acanthus and lyre, of Phyfe's best-designed chairs and benches, sofas, tables, and other pieces. Five plates of detail drawings supplement the 56 halftone photographs of whole pieces. Duncan Phyfe and the English 
Regency, 1795-1830, by Nancy V. McClelland (New York, W. R. Scott, 1939. 364 p.), stresses the "beauty and suavity" of the tables, chairs, sofas, window seats, and the like, which Phyfe produced before 1825 , as well as the "clean, well-defined lines, the accents of light and shade, and the flatness of carving that might actually have been done by a sculptor of stone or marble."

5729. Kettell, Russell Hawes, ed. Early American rooms; a consideration of the changes in style between the arrival of the Mayflower and the Civil War in the regions originally settled by the English and the Dutch. Portland, Me., SouthworthAnthoensen Press, 1936. xvii, 200 p.

"Color schedule": p. xvii.

$$
\text { 37-392 } \mathrm{NK}_{2003} \cdot \mathrm{K}_{4}
$$

Mr. Kettell and i 9 collaborators here present 12 chapters on 12 rooms, "permanently available for public study," each of which was a center of social activity in its own particular time. Of the rooms, one is from 17 th-century and 6 are from 18 th-century New England; one each is from I8th-century New York, Philadelphia, and Virginia; one is from early Igth-century New Jersey, and one from Victorian New York. Included are living rooms, dining rooms, and parlors, as well as a drawing room, a barroom, and a ballroom. Each chapter contains a discussion of the history and everyday living of the period; a general exposition of the contemporary styles exemplified by the room under consideration; a document "selected to throw light on the period as a whole or on some particularly colorful aspect of it"; and 2 leaves of a contemporary newspaper in type replica. The drawings in direct orthographic projection show the room completely furnished. One plate for each room reproduces its color scheme.

5730. Little, Nina Fletcher. American decorative wall painting, 1700-1850. Sturbridge, Mass., Old Sturbridge Village, in cooperation with Studio Publications, New York, 1952. xvi, 145 p. 52-10836 ND2606.L 58

"Selective bibliography": p. 138-140.

A pioneer survey based mainly upon the author's investigations of old buildings, museum materials, and 18 th-century newspaper advertisements. Because little of such painting has survived in the South, most of her examples come from New England houses. Earlier techniques included graining, marbleizing, and japanning of woodwork, painting of wall panels and overmantels in scenic or still life motifs, and decoration of fireboards and floors. By the end of the 18 th century, panoramic scenes, stenciled patterns, and freehand floral designs were being painted directly on the plaster walls. Decora- tive wall painting gave way to machine-printed paper in the mid-rgth century. There are lists of painters, with biographical sketches, and of important works in and out of museums (p. 129-138.) A few of the 146 illustrations are in badly blurred color.

5731. Miller, Edgar G. American antique furniture, a book for amateurs. New York, M. Barrows [1948, '1937] 2 v. (I I06 p.)

First published in 1937 .

$$
\text { 48-9713 NK2406.M55 } 1948
$$

Designed "not only to show to the amateur collector what is fine, but also to show what is not fine," these elaborately detailed volumes provide a wealth of information about furniture produced, chiefly in America, during the years $1650-1840$, as well as 2,II5 illustrations of the objects described. The photographs, taken for the most part especially for the work, are of articles in private homes rather than museums. After four introductory chapters dealing with sundry matters such as the danger of encountering fakes, each chapter is devoted to a chronological treatment of a single type of furniture, as for example, the sofa, highboy, cupboard, mirror, and clock. The very extensive footnotes consist of documentation, explanation or amplification, and pithy comment; they are, in the author's opinion, almost as important as the text, "and sometimes are more interesting."

5732. Rogers, Meyric R. American interior design; the traditions and development of domestic design from colonial times to the present. New York, Norton, '1947. 309 p.

Bibliography: p. 297-302.

$$
\text { 47-12416 NK2003.R6 }
$$

"This book is intended to survey ... the tradition, evolution and qualities of the American domestic interior," from 1630 to 1947. Four of the five chapters trace the development of design in American household furniture and accessories from colonial times to 1920. The author analyzes successively the Jacobean style of the 17 th century, the Queen Anne and Chippendale styles of the 18 th, the Federal and Empire styles of the rgth, and the "battle of the styles" which extended into the first decades of the 2oth century. The concluding chapter, "The Age of Social Readjustment," takes the story from 1920 to 1947 , and discusses the implications of Functionalism for the future. Each chapter summarizes briefly the political, economic, social, and architectural background of its period. A glossary and biographical notes, together with 196 illustrations and 39 plates, a number of them colored, complete the volume. 


\section{E. Sculpture}

5733. Brummé, Carl Ludwig. Contemporary American sculpture. New York, Crown, 1948. $15^{6} \mathrm{p}$. $4^{8-9357 \quad \mathrm{NB} 212 . \mathrm{B}_{75}}$

"Biographical notes": p. 145-149.

Bibliography: p. 150-156.

5734. Schnier, Jacques P. Sculpture in modern America. Berkeley, University of California Press, 1948. 224 p. $4^{8-11026} \quad \mathrm{NB}_{205} . \mathrm{S}_{35}$ Bibliography: p. $65-67$.

The first of these picture books presents, in the words of William Zorach's introduction, "all directions and schools of thought in sculpture, in this way giving an over-all picture of what is happening today." "In this survey," states Mr. Brummé, "emphasis is, of course, placed on the younger sculptors, for the task of further developing a contemporary esthetic direction is primarily theirs." In their work, a "broadened perspective plus the findings of 2othcentury experimenters in pure form have engendered the esthetic philosophy of form needed in our age of individual expression." Having virtually eliminated text in order to conserve space, Mr. Brummé has arranged the 130 illustrations alphabetically by sculptor, from George Aarons to William Zorach.

After pointing out the indebtedness of rgthcentury American sculptors to European artists, $\mathrm{Mr}$. Schnier turns to a style the development of which, in the years 1909-12, represents "a turning point in the evolution of sculpture in this country." He notes three major trends in the treatment of representational content. In the one "followed by the majority of American sculptors, easily recognizable subject matter is integrated into effective designs, but with no attempt at realistic interpretation." In that of the pure abstractionists, Alexander Calder, Isamu Noguchi, and, more recently, Claire Falkenstein, "forms have been completely divorced from representational content, and the entire emphasis is placed on formal arrangement." In that of the surrealists, "recognizable elements are arranged in a completely unreal and bizarre manner or combined with abstract forms." The 139 plates are classified under the headings: heads, figures, animals, reliefs, and explorations in form.

5735. Cortissoz, Royal. Augustus Saint-Gaudens. Boston, Houghton Mifflin, 1907. 85 p.

$$
\text { 7-40526 } \mathrm{NB}_{237 . \mathrm{S}_{2} \mathrm{C} 8}
$$

An appreciation of the work of Augustus Saint-
Gaudens (1848-1907) by Royal Cortissoz (1869I948), who was for many years art editor of the New York Herald-Tribune. He believes that SaintGaudens "was not only our greatest sculptor, but the first to break with the old epoch of insipid ideas and hide-bound academic notions of style, giving the art a new lease of life and fixing a new standard." His own style "was remarkable for its blending of polish with freedom." He executed portrait medallions of delicacy, spontaneity, and realism during the $1870^{\circ}$ 's and ' 80 's. In modeling the single draped figure of the Adams Monument (1887), SaintGaudens was "the poet, the dramatist, intermingling with the concrete qualities of plastic art the more elusive qualities of mind and soul." His other great triumphs were portraits in the round and on the scale of the public monument: Admiral Farragut, Abraham Lincoln, and Deacon Chapin in the '80's; the Robert Gould Shaw Memorial, unveiled in 1897; and the equestrian statue of General Sherman, unveiled in 1903. The text is illustrated by 24 heliotype plates.

5736. Cresson, Margaret (French). Journey into fame; the life of Daniel Chester French. Cambridge, Harvard University Press, $194 \% \mathrm{xv}$, $316 \mathrm{p}$.

Bibliography: p. $[315]-316$.

$47-30328 \quad \mathrm{NB}_{237} \cdot \mathrm{F}_{7} \mathrm{C}_{7}$

An intimate and anecdotal biography of Daniel Chester French (1850-1931) by his daughter. She delineates a man of great energy, self-confidence, and tenacity of purpose, a career of ever-increasing artistic significance, and a financial success in the true Igth-century American tradition. When his first commission, "The Minute Man," a symbol of the youth, vigor, and determination of the country, was unveiled at Concord, Mass., in 1875, this New England sculptor "suddenly vaulted into fame." The claim has been made for his greatest work, the colossal seated figure in the Lincoln Memorial dedicated at Washington in 1922, that it has "established the image of Lincoln for posterity." Although herself a sculptor, Mrs. Cresson offers relatively little analysis of her father's style, noting only his efforts to gain "crispness in modeling" and "a kind of native classicism" in him.

5737. Fite, Gilbert C. Mount Rushmore. Norman, University of Oklahom Press, 1952. xiv, 272 p. 
"Selected bibliography": p. 255-260.

Based upon both official and private records, this is mainly a history of the association of Gutzon Borglum (1867-194I) with the controversial Mount Rushmore National Memorial. The sculptor was commissioned in the early I920's to carve in the Black Hills of South Dakota a "gigantic monument" commemorating some aspects of American history. Impressed by the size and greatness of the United States, he wished to leave behind a "monument which would stand for all time as a record of supreme achievement-a monument to the nation and to himself." Even on a reduced scale the work was beset by financial difficulties and personal conflicts, and the last of the four enormous figures of Washington, Jefferson, Lincoln, and Theodore Roosevelt was not unveiled until July 2, 1939. Criticism of the colossi has come chiefly from two sources: those who account them a desecration of nature, akin to the incising of initials in the bark of a tree, and others who object to the romantic naturalism of Borglum's style. The 32 photographs document the evolution of the memorial.

5738. Gardner, Albert Ten Eyck. Yankee stonecutters; the first American school of sculpture, r800-1850. New York, Published for the Metropolitan Museum of Art by Columbia University Press, 1945. 84 p. $\quad 45-8846 \quad$ NB2Io.G $_{3}$

These informal essays attempt to place early igthcentury American "sculptors and their works in relation to the life of the time." George Washington, as a symbol of liberty and national unity, was the "most important single factor in the encouragement of the sculptural arts in the young nation." After I815, the rebuilt Capitol and other public buildings had "to be redecorated in an appropriate classical manner to satisfy the Greco-Roman republicans of the New World." Most of the artists concerned were "timid, provincial amateurs of art" aiming at faithful copies mechanically produced. William Rimmer (1816-79), however, was a creative artist far above his contemporaries, whose works are presented "unadorned with anecdote, as direct studies in the art of sculpture, and not as petrified dramas." Horatio Greenough (1805-52) also towered over the rest, but as a thinker who grasped the basic principles of functionalism and organic relationships. The author lists sculptors, stonecutters, carvers, and modelers in America before 1800; sculptors born between 1800 and 1830 , for whom brief biographies are supplied; and some born between $18_{30}$ and 1850 . The illustrations, averaging two to a plate, are clearly reproduced.
5739. Smith, Chetwood, and Mary Smith. Rogers groups, thought \& wrought by John Rogers, by Mr. and Mrs. Chetwood Smith. Boston, C. E. Goodspeed, I934. I45 p. $\quad 35-932 \quad$ NB237.R65S6

A biography of John Rogers (1829-1904), based upon his letters, scrapbooks, and catalogs, together with an illustrated catalogue raisonné of his work. This New England sculptor, who enjoyed a tremendous popular vogue in the years $1860-90$, illustrated with his statuettes especially the humorous and sentimental aspects of everyday life. He modeled and patented 80 clay sculptures from which plaster casts were made and sold, in a variety of shades of pearl and slate grays, fawn, snuff, and cinnamon browns. Among the most popular of the "Rogers Groups" were "The Slave Auction" and other frankly abolitionist pieces; "Coming to the Parson," often used as a wedding present; "The Charity Patient"; and "Playing Doctor." "The last two, together with 'Fetching the Doctor' and 'The Foundling', were much used for decorating doctors' offices; in fact, the Medical Record advertised them." It is estimated that there were sold 100,000 of these "real and friendly creatures, made by the man who was justly called 'The Laureate of Home." "

5740. Taft, Lorado. The history of American sculpture. New ed., with a supplementary chapter by Adeline Adams. New York, Macmillan, r930. 622 p. 30-326ri NB205.T3 1930

"General bibliography": p. 6o7-618.

This history of his predecessors and contemporaries by the eminent sculptor, Lorado Taft (I8601936), first appeared in 1903, and was revised for an edition of r924. The first artists noticed, men like William Rush and John Frazee, were woodcarvers and stonecutters, who labored without education and without a tradition. Tutored in the Italian classical style, Horatio Greenough, Hiram Powers, and Thomas Crawford began their real work in the $1830^{\circ}$ 's and soon attained national prominence. They chiseled realistic portrait busts and drew inspiration from myth, allegory, and the Bible for their "ideal figures." Between 1850 and 1876 , "timidly but hopefully American sculpture began to grow contemporaneous in spirit; the 'actual' crept at last upon the stage, while classic themes gradually receded." With the unveiling of his statue of Admiral Farragut in 188r, Augustus SaintGaudens "took his place at the head of American sculpture." "Our sculpture is pledged mainly to the safe and sane," Mrs. Adams observed in her chapter, but "as the passion for novelty increases, the faith in fundamentals declines." There are numerous illustrations in a halftone which did not improve with successive reprintings. 


\section{F. Painting}

574I. American painting today. Washington, American Federation of Arts, 1939. I 79 p. 40-209 ND212.A57

A picture book containing 249 monochrome and ro color reproductions of easel paintings in oil, watercolor, tempera, and gouache, and of murals in fresco, tempera, and oil, executed mainly during the r93o's. Many of the plates first appeared in the Magazine of Art. "The effort has been to illustrate, on a wide front, by means of a great variety of visual material picked by successive editors, what American painters, known and unknown, young and old, conservative and liberal, have been doing in the past ten years or so." In his introduction, Forbes Watson notes the domination of the art world by the School of Paris and by French dealers during the 1920's, and the subsequent rediscovery of his own country as a source of inspiration and subject matter by the American painter. Thanks to the depression and the artist relief program of the Federal Government, "we are moving away from a period which produced individuals of unquestionable capacity into a period when we are laying the foundations of a great body of art."

5742. Barker, Virgil. American painting, history and interpretation. New York, Macmillan, I950. xxvii, 717 p. 50-10368 ND205.B29

A comprehensive and carefully organized interpretative history of American painting through the colonial and "provincial" periods, which latter is dated from I 790 to 1880 . These large periods are further subdivided, and within each lesser era the known painters are minutely classified, principally by their subject matter, but also by their region, function ("Painters working for reproduction") or style ("Poetic figure painting"). Major figures receive one or more chapters to themselves; the lesser ones are grouped as many as 19 to the chapter. Attention is given to the painters' own ideas of their art, and to the social milieu in which they worked. The "provincial" period actually witnessed a complete transformation in the basis and nature of American painting, for as late as 1775 most of the native-born American painters remained at the craft level. "The exceptions were as striking in quality as they were few in number: [Matthew] Pratt [1734-1805],with his subtle tastefulness; [Robert] Feke [c. 1705-c. 1750], with his talent; and Copley, with his genius." Patronage of painting by wealthy merchants permitted its existence as an art, but only after 1820 was there a demand for pictures other than portraits. The post-Civil War trio, Ryder, Homer, and Eakins, "became in their achievements representatively American to a degree which had probably been impossible before their time." There are 100 halftone illustrations; the thorough bibliography follows the organization of the book.

5743. Born, Wolfgang. American landscape painting; an interpretation. New Haven, Yale University Press, 1948. $228 \mathrm{p}$.

48-8092 NDi351.B6

A review of the sequence of styles in American landscape painting which selects for study "signifcant examples of the trends determining the evolution." "The roots of the American landscape proper were the topographical drawing, water color, and print," the harbor view being the most popular from mid-I 8th century to the beginning of the Igth. The romantic Washington Allston "ushered in the development of American landscape painting" in 1804 with two scenes of imaginative mood, but the first authentic school of landscape painters, which flourished at mid-century, was inspired by the scenic beauty of the Hudson River Valley. The panoramic school of $1840-70$ reflected the "mentality of the American expansion" in a weakness for melodrama and show. After the Civil War, however, a break in tradition occurred, and, under French influence, dramatized presentation of subject was superseded by a succession of technical interests. The 142 blackand-white illustrations are disappointingly small and dark.

5744. Born, Wolfgang. Still-life painting in America. New York, Oxford University Press, 1947. xiv, 54, [98] p. 47-5146 NDI390.B6 An interpretation of American still-life painting "all but forgotten by art historians until the present century," which distinguishes a succession of styles and schools. The objectivist "botanic-decorative" style, initiated about 1810 at Philadelphia by the remarkable Charles Willson Peale family, launched the American still life as an independent art form. Up to the Civil War, flower and fruit pieces were favorite subjects with amateur and primitive painters. The best still-life painter of the mid-century was John F. Francis (1810-1885), who departed from convention in order to study volumes, textures, and colors. In the 1880 's, William M. Harnett (1848-92) scored a tremendous success with his 
"heightened interpretation of reality expressed by the old technique of the trompe l'oeil" only to be quite forgotten after his early death. Charles Demuth (1882-1935) "was the first American painter who undertook to adapt the achievements of French post-impressionism to the American feeling for mechanization." "The quiet labor of American still-life painters" has achieved "the establishment of a consistent American tradition." The 134 gravure illustrations, averaging one or two to a page, are quite clear. In After the Hunt; William Harnett and Other American Still Life Painters, 1870-1900 (Berkeley, University of California Press, I953. I89 p. I36 illus.) Alfred V. Frankenstein tells the story of a remarkable course of detective work by which he was enabled to establish the canon of Harnett's genuine work ( 102 extant and 2I lost paintings), and to distinguish it from the work of his skillful admirer and disciple, John Frederick Peto of Philadelphia (1854-1907), most of whose surviving canvases had been given Harnett signatures by later forgers. Another unique personality of the American trompe-l'oeil school, John Haberle of New Haven (1856-1933), whose canvases "bestow fantastic consequence on the inconsequential" and so suggest the surrealists, is given a chapter to himself.

5745. Boston. Museum of Fine Arts. M. and M. Karolik collection of American paintings, 1815 to 1865 . Cambridge, Published for Museum of Fine Arts, Boston [by] Harvard University Press, I949 [i.e., I95I] lx, 544 p.

$$
5 \mathrm{I}-8 \text { I36 }_{3} \quad \mathrm{ND} 210 . \mathrm{B}_{73}
$$

An elaborate, alphabetically arranged catalogue raisonné, together with monochrome plates, of the 233 paintings which Mr. and Mrs. Maxim Karolik presented to the Boston Museum of Fine Arts in 1948. Because many of the artists are forgotten or virtually unknown, biographies have been supplied. The collectors had "one purpose only: To show what happened in this country in the art of painting in the period of half a century ... and to show the beginning and the growth of American landscape and genre painting." In his introductory essay, "Trends in American Painting, I815 to 1865 ," John I. H. Baur notes that although realism was a sine qua non of art, the broadly romantic spirit of the age demanded an "image of the Ideal." Painters who failed to conform to the standard of idealized realism tended to be "forgotten." Among the recently rediscovered talents represented here are Martin J. Heade and Fitz Hugh Lane, realists in landscape, James G. Clonney and William T. Ranney, realists in genre, and John Quidor, a nonrealist.
5746. Brown, Milton W. American painting, from the Armory Show to the depression. Princeton, Princeton University Press, I955. 243 p.

Bibliography: p. 201-237.

$$
\text { 53-10147 ND212.B74 }
$$

Based upon contemporary reports and articles, exhibition catalogs, and interviews, this is a survey of a transitional period in American art (I913-29) when modern European concepts of art displaced the older American tradition of conservative realism. The radical tendencies emanated from two sources: the native, socially critical realism of Robert Henri and the "Ash Can School," and the controversial French modernism and estheticism introduced later by Alfred Stieglitz. The artistic revolution was confined to small art groups until the radicalism of the I9I3 exhibition at the New York Armory of modern European and American art shocked the public and many artists. Dr. Brown discusses the reactions of critics and collectors, and traces the emergence of Cubism, Fauvism, and related tendencies as well as the continuation of the realist strain. Numerous rather dark gravure illustrations are included.

5747. Burroughs, Alan. Limners and likenesses; three centuries of American painting. Cambridge, Harvard University Press, 1936. 246 p. (Harvard-Radcliffe fine arts series)

Bibliography: p. [223]-226.

$$
\text { 36-10264 ND205.B8 }
$$

An historical critique of the American tradition in painting from its 17 th-century beginnings to "American Modernism" of the I930's, distinguished by its author's ensyclopedic knowledge of individual painters and their works, methods of authentication, and artistic techniques. As early as 1670 , he believes, an American taste had begun to form. The early qualities of the art of the limner, "static realism, self-sufficiency, and friendly charm," recur in American painting "like a theme with variations, scarcely heard at times because of the louder themes of English and European art, yet nevertheless existent." Although the realistic tradition continued through the Federal period, mainly under the dominance of English practice, two major waves of French influence, the neoclassical after 1800 and the impressionistic after 1880 , came to replace direct realistic feeling with an admiration for technical effects. Yet the author found "groups of American painters" who were "working away from European domination in taste" and who were engaged in a "struggle for nationality," for a "simple, realistic view." The r9I halftone illustrations average two to a page. 
5748. Encyclopaedia Britannica. Conterhporary American painting; the Encyclopaedia Britannica Collection, edited by Grace Pagano. New York, Duell, Sloan \& Pearce, 1945. xxviii, [24I] p. $45-35086$ N5220.E5 $1945^{a}$

An album of reproductions of the 116 paintings by as many artists that were in the Encyclopaedia Britannica Collection in 1945. Some 40 plates are in color. This frankly experimental and incomplete collection, assembled with the aid of a committee of specialists, is intended to illustrate the "trends, times, and personalities" of about the last 30 years. Emphasis has been placed upon "American painting of still living artists," and particularly the regionalism of the 1930's. Each full-page reproduction is accompanied by a photograph of the artist, a brief description of his background and the subject matter and method of his work, and, in nearly every instance, his own statement of his intention in the painting illustrated. An introduction by Donald Bear traces the inheritance of the 2oth-century American artist and discusses such divergent traditions of contemporary American painting as regionalism and the American scene, the painting of manners, of message or protest, and of mood or sensibility, experimentalism, and abstract art. Peyton Boswell's Modern American Painting (New York, Dodd, Mead, 1939. 200 p.) consists of an album of 86 color illustrations of paintings, chiefly modern, originally reproduced by Life magazine for its "Pageant of America" series, together with a historical sketch of the principal movements and trends in American art, brief, alphabetically arranged biographies of the artists, and a catalog of the paintings. A very few of the paintings illustrated were commissioned by Life. A second edition with 89 color illustrations and slightly condensed text was published in 1940. In 1942, the latter edition was reissued by Garden City Publishing Company, but with much inferior color printing.

5749. Flexner, James Thomas. America's old masters; first artists of the New World. New York, Viking Press, 1939. 332 p.

Bibliography: p. 317-326.

$$
\text { 39-27903 ND207.F55 }
$$

These four popularly written biographical essays constitute a history of the work of the first great native-born American painters, who "enjoyed a greater European acclaim than was to come to any other American artists for at least a century." Benjamin West ( $173^{8-1820}$ ), in 1760 the first American artist to study abroad, was before long regarded "all over the world as the leading exponent of the "grand style' " of neoclassic art, and went on to become a founder and a president of the Royal Academy, a close friend of George III, and a precursor of the
French romanticists. At heart a realist, John Singleton Copley (1738-1815) produced portraits of great solidity and power in Boston, but when he removed to London, deteriorated artistically under the pressure of a sophisticated environment. Charles Willson Peale ( $1741-1827$ ), a "craftsman so able that he became a universal genius," was "one of the most charming portrait painters of the early American tradition." "Well-nigh incomparable" in the painting of faces, Gilbert Stuart (1755-1828), "who had never learned to draw, was uncertain in executing full-lengths." The 33 plates are tolerably reproduced in black and white.

5750. Flexner, James Thomas. First flowers of our wilderness. Boston, Houghton Mifflin, 1947 . xxi, 367 p. (His American painting, I) $47-\mathrm{I}_{2171} \quad \mathrm{ND}_{207 . \mathrm{F}_{57}}$

"Bibliography of general sources": p. 323-[326].

5751. Flexner, James Thomas. The light of distant skies, 1760-1835. New York, Harcourt, Brace, 1954. 306 p. (His American painting, 2) 54-9727 ND207.F58 "Bibliographies and source references": p. [25I]283.

The first in a projected many-volume social history of American painting, these books attempt "to show the relationships between life in America and the long tradition of American painting." The author reveals how colonial portraiture, progressing from the "provincial version of the illuminators' tradition" common to the primitive izth-century limners, reached its culmination in the work of John Singleton Copley ( I737-1820), "the first man to express American life in art maturely, profoundly, and with beauty." With the exception of John Trumbull ( $1756-1843$ ), who called his historical paintings "my national work" but "considered it more important to be a gentleman than a painter," these early professional painters were "nurtured in a craftsman's world." The following generation of gentleman painters, on the other hand, men like Washington Allston and Samuel F. B. Morse, who were born to prosperity and political power, boasted of being artists and connoisseurs but were stifled by affectations of taste. When the new equalitarian forces accompanying "that plebeian on horseback, Andrew Jackson," prevailed, these older men were supplanted by popular young landscape and genre painters. Each volume contains a formal catalog of its numerous illustrations.

5752. Gruskin, Alan D. Painting in the U.S.A. Garden City, N. Y., Doubleday, 1946. 223 p. 47-791 ND212.G77

Bibliography: p. 213-215. 
An album of 140 reproductions of paintings by American artists who were living in 1946, of which 63 are well processed in color and 77 in halftone; they average one or two to a large page. The selection aims to provide a cross section of modern trends. Several popular periodicals and business organizations have lent color plates to the author, a New York art dealer. Mr. Gruskin's loosely organized sequence of observations urges the reader "to look and keep looking at pictures" for true esthetic satisfaction, points with pride to the many flourishing museums and commercial galleries and the widely circulated popular magazines that bring painting to the public, proposes collections of modern art and the encouragement of living artists, and furnishes a historical vignette of American art.

5753. Monro, Isabel Stevenson, and Kate $M$. Monro. Index to reproductions of American paintings; a guide to pictures occurring in more than eight hundred books. New York, Wilson, 1948. 73 I $\mathrm{p}$. 48-9663 ND205.M57

An index to reproductions of the paintings of "artists of the United States occurring in 520 books and in more than 300 catalogs of annual exhibitions held by art museums." Each painting is entered in two or three places: under the artist, whose dates are given if obtainable, together with title of the picture, and a brief entry for the book where the reproduction may be found; under title and alternative title or titles; and, in some cases, under subject. Preceding the main index are a "List of Works Indexed" and a "Key to Symbols Used for Locations of Paintings." The compilers have listed attributed works and have entered the large number of portraits under the sitters as well as the artists; they have also noted the locations of paintings in permanent collections so far as stated in the books indexed.

5754. New York. Metropolitan Museum of Art. Ioo American painters of the 2oth century; works selected from the collections of the Metropolitan Museum of Art. New York, 1950. xxiii, III $\mathrm{p}$. 50-13015 ND212. $\mathrm{N}_{39}$

A picture book consisting of roo reproductions, 8 of them in color, of works by as many American painters in the collections of the Metropolitan Museum of Art. Ten of the paintings were executed before 1900, and while canvases of the I930's and 40 's are abundant, there are only 8 pieces from the years 1916-29. In his brief introduction, Robert Beverly Hale asserts that modern American artists, if neither wholly understood nor appreciated, have "caught the essence of our country" and our times. If modern art is violent, dealing "with weird dreams," and "filled with broken shapes," that is because the artist is in part a prophet... the shadows that have lately haunted us have for some time been visible upon his canvas."

5755. Richardson, Edgar P. American romantic painting; edited by Robert Freund. New York, E. Weyhe, I944. 50 p. 168 plates on 841 . 45-878 ND205. $\mathrm{R}_{5}$

Catalog with biographical notes: p. $23-50$.

An album of 236 paintings from the first three quarters of the igth century, held in American public collections, or in a minority of instances, by private owners, and reproduced in usually clear halftone, but often on too small a scale. Colonial painting, the introductory text affirms, had been strong but narrow; about the turn of the century there took place a great change in the imagination which enabled painting to deal with "the whole circle of inner and outer experience," and to become "an art as wide as our national life." The grandiose designs of Allston and his fellows of the first generation ended mostly in disappointment. The second romantic generation of the 1830 's, less aspiring, produced smaller canvases appropriate to private houses, and secured a far wider response. Among the third generation of the $1850^{\circ} \mathrm{s}$, the spreading weakness, sentimentalism, and breakdown in the color sense were resisted by only a few major talents, who soon became isolated figures. After 1876 , "romantic art became unfashionable and rapidly disappeared." David Howard Dickason's The Daring Young Men (Bloomington, Indiana University Press, 1953. 304 p.) discusses the American Pre-Raphaelite movement of the latter half of the Igth century, which advocated "truth to nature" and served as a "lively, corporate antidote to the materialism and artistic stagnation of 'American Victorianism,'" but produced no artists of outstanding talent.

5756. Richardson, Edgar P. Painting in America; the story of 450 years. New York, Crowell,

1956. 447 p. (The Growth of America series)

Bibliography: p. 417-427.

56-7793 ND205.R 53

The thesis of this survey of American painting is that painting is both an art and a craft, sharing the "unpredictable nature of the imagination" and the "social character of an organized skill in human society," and that nowhere is the mutual action and reaction of these two elements "more striking, their interplay more curious, than in their creation of a new national tradition of painting in America." Mr. Richardson considers American artists largely within the context of his theory: whether they belonged to the currents of their day, like West, Allston, Whistler, and Marin; whether they did not belong to those currents, like Homer, Ryder, and Hopper; or whether the direction of attention was 
opposed to the artist's natural bent and produced a fatal conflict, as with John Vanderlyn. Lesser painters are usually treated in groups, with each receiving a sentence or brief paragraph to himself. The author interprets the century of painting from 1780 to 1876 as successive phases of romanticism and devotes to them three large chapters, considerably more than to any other school or movement. Most of the 172 halftone illustrations are quite unhackneyed; there are also 17 plates in indifferent color.

5757. Turpie, Mary C. A selected list of paintings for the study of American civilization. Minneapolis, Program in American Studies, University of Minnesota [1953] rog 1.

54-31893 ND45.T85

"Books and catalogs useful for illustrations": 1 . I0I-106.

"An elementary guide to resources for the study of American civilization through painting"; only murals have been omitted as insufficiently studied. The 712 paintings selected are not necessarily great, but all "are cultural documents which contribute significantly to an understanding of American life past or present-either as sheer illustration, or as revelation of representative tastes and attitudes, or as the commentary of an artist who interprets-or even rejects-his own milieu in his own terms." Dating from 1666 to 1950 , the paintings are arranged alphabetically by artist within three chronological divisions. Dates and present locations of the paintings are provided so far as known, together with descriptive and interpretative annotations. Most of the paintings listed are in public collections; for those privately owned, reproductions or slides are available, and references are furnished to these for both classes. Appended are directories of firms and institutions that can supply slides and inexpensive reproductions.

5758. Walker, John, and Macgill James. Great American paintings from Smibert to Bellows, 1729-1924. New York, Oxford University Press, 1943. 36 p., ro4 plates on 561 .

"Catalogue notes": p. 21-26.

$$
\text { 43-1 } 8438 \quad \mathrm{ND}_{205} \cdot \mathrm{W}_{35}
$$

"Suggestions for further reading": p. 27-3I.

Reproductions of carefully chosen paintings, of which the eight in color are quite unsuccessful, while the remainder in monochrome are on the dark side. The great majority are from public collections. The compilers terminate with the work of Bellows because it seems "to close an epoch in American style." The brief text distinguishes two currents in American style: a realistic main stream, from the portraits of Copley to the "Ash-can School," which "has usually been on the level [sic] with the best con. temporary painting of its kind done in Europe"; and a secondary one, "imaginative, poetic, at its best visionary," which "has been on the whole more derivative, more inclined to be literary and selfconscious." The latter produced "only one artist of outstanding genius, Albert Ryder" (1846-1917).

5759. Wehle, Harry B. American miniatures, I730-1850; one hundred and seventy-three portraits selected with a descriptive account by Harry B. Wehle ... \& a biographical dictionary of the artists by Theodore Bolton. Garden City, N. Y., Garden City Pub. Co., 1937. xxv, 127 p. $4^{8}$ plates on 271 37-6103 NDi337.U5 $\mathrm{W}_{4} 1937$

First published in 1927 .

"General bibliography of early American miniature painting": p. [I I5]-II8.

A descriptive history of American portraiture "in little," closely tied to the 48 color and halftone plates which usually reproduce the miniatures full-size. Most miniaturists, the author notes, working with water colors on ivory, learned "to build up their textures and to state their forms by the cautious means of stippling and hatching" in a minute and dexterous fashion. In 18 th-century Philadelphia, James Peale (I749-1831) became a "prolific worker," and Henry Benbridge (1744-1812) painted in a style "only a little less masterly than Copley's." Edward Greene Malbone (1777-1807) moved from New England to New York, Philadelphia, and the South, and painted the "finest miniatures in the history of the art in America." During the first two decades of the rgth century, the bustling city of New York attracted ambitious and talented young miniaturists. The advent of photography about the middle of the century, however, together with the decline of the aristocratic heritage, first corrupted, and then killed, the art of miniature painting. Mr. Bolton's dictionary includes 47 names, a number of which are well known in the larger art forms.

\section{G. Painting: Individual Artists}

5760. [Allston] Richardson, Edgar Preston. Washington Allston, a study of the romantic artist in America. Chicago, University of Chicago
Press, 1948. 233 p. 48-8917 ND237.A4 $\mathrm{R}_{5}$ "Catalogue of the existing and recorded paintings of Washington Allston [by] Edgar Preston Richard- 
son and Henry Wadsworth Longfellow Dana": p. 183-219.

Bibliography: p. 220-228.

A critical study of the art of Washington Allston $\left(1779^{-1843)}\right.$ and a reappraisal of his position as our first full-scale romantic artist, based on the Dana Collection and family tradition. An uneven and by no means prolific painter ( 183 finished works) he was nevertheless "the pioneer in creating an ideal art upon American soil." He wished, moreover, to explore the whole range of painting: monumental, narrative, portrait, landscape and architectural, and animal and still life. "His work and the influence of his life as an artist were felt throughout the imaginative being of this country in its first years of independent effort." After its I8th-century apprenticeship, American painting became "an instrument of the reflective and imaginative life." Allston, chief figure in this enlargement of scope, introduced dramatic and lyric sentiment, quiet reverie, and meditation. The 59 halftone illustrations are printed on 30 leaves.

5761. [Bingham] Christ-Janer, Albert. George Caleb Bingham of Missouri; the story of an artist. New York, Dodd, Mead, 1940. xx, I7I p. $40-7789 \quad \mathrm{ND}_{237} \cdot \mathrm{B}_{59} \mathrm{C}_{5}$

"Selected bibliography": p. 146-148.

A scholarly biography which aims "to analyze and clarify the genre work of George Caleb Bingham [181 1-1879] by presenting some hitherto unpublished drawings" and to amplify knowledge of his life and personality from recently discovered letters and other new sources. Although Bingham, like many of his contemporaries, painted portraits for a living, he aspired to genre painting, "to pictures that tell a story." The Missouri painter completed the first canvas in his "river life" series, "Jolly Flatboatmen," early in 1844 , and by 1851 was working upon the first in a political series, "County Election" and "Canvassing for a Vote." The subjects and spirit of these series won them a contemporary popularity: their painstaking design and drawing, derived from prints of Renaissance masters, impress present-day artists and critics. Besides the 56 illustrations of Bingham's figure drawing on 4 leaves, there are 8 halftone plates and 6 in unsatisfactory color.

5762. [Burchfield] Baur, John I.'H. Charles Burchfield. [Research by Rosalind Irvine] New York, Published for the Whitney Museum of American Art by Macmillan, 1956. 86 p. 56-322 $\mathrm{ND}_{237} \cdot \mathrm{B}_{8} \mathrm{gB} 3$

"Selected bibliography": p. [82]-85.

Based largely upon the artist's journal, "an illuminating record of his thoughts, feelings, struggles and artistic aims over nearly half a century," this biography and critique of Charles Burchfield (b. 1893) grew out of a retrospective exhibition of his watercolors and drawings (his oils are relatively few and unsuccessful), held at the Whitney Museum in January and February 1956. From 1917 to 1921 in Salem, Ohio, Burchfield painted fantastic and decorative scenes chiefly in calligraphic style, fanciful interpretations of nature, or symbolic representations of moods. In Buffalo, New York, from ig2 I to 1943, he depicted the city, alternating "a predominantly esthetic pleasure in the shapes and textures of the industrial scene" with concern for its romantic moods. His realist-industrial phase is his best known and most honored. In I943, Burchfield abandoned realism, weather-beaten houses, and industry, and has since painted the changing moods and aspects of nature in a fusion of his early fantastic manner with the technical skill and painterly style acquired in the realistic works of his maturity. Five of the 75 variously-sized illustrations are in color.

5763. [Copley] Parker, Barbara Neville, and Anne Bolling Wheeler. John Singleton Copley; American portraits in oil, pastel, and miniature, with biographical sketches. Boston, Museum of Fine Arts, 1938. 284 p. 130 plates on 651 .

$$
3^{8-4135} \quad \mathrm{ND}_{237} \cdot \mathrm{C}_{7} \mathrm{P}_{3}
$$

This is a massive catalogue raisonné consisting of descriptions of all portraits believed to have been painted by Copley before he left for England in June 1774. Biographical sketches of the sitters, an unusual feature in such a work, precede the descriptions of the portraits; those for portraits belonging to the Boston Museum of Fine Arts are by G. Philip Bauer. For the other biographies, the authors have gone to primary sources when standard authorities have failed. Descriptions of the portraits are limited in most instances to their sizes and colors; when direct evidence is lacking, datings are based "entirely on grounds of style." The portraits are listed in three sections: oils; pastels, drawings, and engravings; and miniatures; and in each section are arranged alphabetically by sitter. A section on "Attributed Portraits" includes a number that present problems as yet unsolved. A final section lists a group of unlocated portraits known, through references in unquestioned sources, to have been painted by Copley.

5764. [Eakins] Goodrich, Lloyd. Thomas Eakins, his life and work. New York, Whitney Museum of American Art, 1933. 225 p.

Bibliography: p. [217]-220. 33-5157 ND237.E.15G6

A biography of Thomas Eakins (1844-1916) and an analysis of his art, together with a chronologically 
arranged catalog of his 515 known pieces, and 72 halftone plates. Eakins, whose temperament was remarkable for its blend of artistic and scientific capacities, began his long career as a painter in the early 1870's. The masterpiece of these years was "The Gross Clinic," painted in 1875 . "In its truth of characterization, its formal strength and balance of design, it shows. a power and completeness of realism that could be matched by no other American painter of the time." The artist executed his most important commission, the similarly conceived but less formally portrayed "Agnew Clinic," in 1889. Like its predecessor, it was rejected by the art critics, and Eakins fell into obscurity during the 8o's and 9o's. Recognized belatedly in the decade rgoo-rgro, he painted, during this culminating phase of his career, more portraits than in any corresponding period. In his era, "Eakins stands out as an isolated figure, belonging to no school"; few of his contemporaries "approached his humanity, understanding of character, penetration into the heart of truth, or formal power."

5765. [Homer] Goodrich, Lloyd. Winslow Homer. New York, Published for the Whitney Museum of American Art by Macmillan, 1944. 24 I p. 63 plates on 321.

Bibliography: p. 234-236. $44-7780 \quad \mathrm{ND}_{23} \cdot \mathrm{H}_{7} \mathrm{G} 6$

Based upon family tradition, contemporary accounts, and the artist's letters, this is a biography and an analysis of the work of Winslow Homer (1836-1910), a self-made Boston painter who began as a magazine illustrator. His earlier oils, of everyday army life in the Civil War, however unsophisticated, "were pieces of direct, simple naturalism, showing no trace of any other artist's style." His favorite theme, at first, was country life, with emphasis upon "pretty girls and fashion," but he executed a notable series of sympathetic scenes from Negro life in the I87o's. After settling at Prout's Neck, Maine, in 1884 , Homer turned for his dominant themes to the sea and the wilderness and the men who wrested a living from them. He reached the "climax of his art" during the 189o's with his watercolors of the forests and lakes of the Adirondacks: nothing like their "resonant" color harmonies and breadth of treatment had before been seen in American watercolor painting. Homer also produced some of his greatest and most influential seascapes in the 1890 's. The recognition he then achieved has proved enduring, but to this critic "he was a powerful naturalist rather than a great plastic artist." The 93 illustrations in black and white average two to a page.
5766. [Inness] McCausland, Elizabeth. George Inness, an American landscape painter, 1825-1894. New York, American Artists Group, 1946. xvi, $87 \mathrm{p}$. $\quad 46-3370 \quad \mathrm{ND}_{237} \mathrm{I}_{5} \mathrm{M}_{3}$

Catalog of the exhibition, February 25 to March 24, 1946: p. 73-82.

Bibliography: p. $84-87$.

George Walter Vincent Smith, who collected the art of his American contemporaries over a span of 70 years, regarded George Inness as an important artist, and purchased his canvases from the painter himself. The museum which Mr. Smith founded in Springfield, Mass., and which now bears his name, celebrated its first half-century, therefore, with an exhibition of 44 Inness canvases assembled by the director, Cornelia Sargent Pond; it was subsequently shown in Brooklyn and in Montclair, N. J., where Inness lived and painted during his later and more prosperous years. Miss McCausland presents the artist as one of the most authentic if least appreciated of Igth-century American painters, a master of American landscape who maintained the best ideals of the Hudson River School in a drabber age, and whose quite independent style eschews spurious bigness and cultivates instead a calm and often radiant serenity: "the land will endure, his paintings say, the coming storm will pass, the harvest will ripen." "Those closed-in valleys were the common home and amphitheater of American life." Unfortunately the 40 illustrations, mostly half-page halftones, quite fail to convey the hazy glow of the paintings themselves.

5767. [Marin] Helm, MacKinley. John Marin. Boston, Pellegrini \& Cuhahy in association with the Institute of Contemporary Art, 1948. $255 \mathrm{p}$. $\quad 48$-10619 ND237. $\mathrm{M}_{24} \mathrm{H}_{4}$

A biography and sympathetic analysis of the works of John Marin (1870-1953), who, as early as the 1890 's began "inventing his own private symbols for the American landscape." In I9I4, having discovered Maine to be his spiritual home, he began "to play deliberate tricks with reality for plastic effect." His range included violent renditions of the Manhattan scene, Maine seacoast pieces with framework and broadly indicated planes, and lyrical landscapes and seascapes. There are 64 halftone and 9 color plates. To John Marin: Tributes (Berkeley, University of California Press, 1956. [78] p.), Mr. Helm contributes a "Conclusion to a Biography" which is actually a final and equally admiring appraisal. In this collection of tributes and appreciative essays occasioned by the John Marin Memorial Exhibition, organized by the Art Galleries of the University of California, Los Angeles, 1955/56, Duncan Phillips hails Marin as a poet-painter independent of all isms, whose "genius 
for explosions of line and color, especially in the Manhattan street scenes, was dedicated to the theme of energy." Frederick S. Wight, in another eulogistic survey, suggests that "Marin's art rose in three waves, his etchings, his water colors and his oilsand it is not certain that the third wave is not the greatest." Marin's own theories are expressed in The Selected Writings of John Marin (New York, Pellegrini \& Cudahy, 1949. 24I p.), which consists of revealing and thought-provoking letters written to his friends, particularly Alfred Stieglitz, from Igro to I949, expounding his views of art, current events, people, and life in the Maine country.

5768. [Mount] Cowdrey, Mary Bartlett, and Hermann Warner Williams. William Sidney Mount, 1807-1868, an American painter, by Bartlett Cowdrey and Hermann Warner Williams. New York, Published for the Metropolitan Museum of Art by Columbia University Press, 1944. xiii, $54 \mathrm{p}$.

Bibliography: p. [43]-47.

$\mathrm{A}_{44-4242} \mathrm{ND}_{237 . \mathrm{M} 8}{ }_{55} \mathrm{C}_{7}$

A catalog, album, and brief study of the landscape, flower, and genre paintings of William Sidney Mount, the first native-born artist to venture largely outside the profitable field of portraiture. He was a reporter of the American scene in the heyday of nationalism, depicting everyday life in the rural Long Island community in which he had been reared. In the I830's, he won the public with his individuality, realism, and "good-natured fun," and the critics with his luminous style and sound craftsmanship. The pioneer catalog of 168 paintings is a "reasonably complete" listing of Mount's major works exclusive of portraits, but "does not pretend to the rank of a catalogue raisonne." The 78 illustrations in gravure average two or three to a page and are very clear even when rather too small.

5769. [Peale] Sellers, Charles C. Charles Willson Peale. Philadelphia, 1947. 2 v. (Memoirs of the American Philosophical Society, v. 23, pt. I-2)

$$
\text { 47-5562 ND237.P27 } \mathrm{S}_{43}
$$

$$
\text { QII.P6r2, v. } 23
$$

Volume I published in 1939 under title: The Artist of the Revolution; the Early Life of Charles Willson Peale.

Bibliography: v. 2. p. 424-440.

Based mainly upon his diaries, drafts of letters, and Autobiography, this is a detailed scholarly biography of Charles Willson Peale, inventor, "candid and direct" portraitist of the revolutionary era, and founder of the first American museum of natural history and of the first American academy of art. Peale, a student of Benjamin West at London in 1767 and 1768 , by the 70 's and 80 's was painting such notables as Washington, Lafayette, and Steuben, among others, in a style distinguished not so much for flair or sophistication as for strength and sincerity. Although his drawing was sometimes poor and his sitters awkwardly posed, "his coloring was delicate and harmonious." The museum, conceived in the ideal of pure science and opened in the I780's, "was this artist's masterpiece, built up through many years of tireless labor." To it, and to Peale's successive ventures into politics, war, science, invention, and hygiene, the author devotes considerably more space than to his achieve. ment as a painter.

5770. [Remington] McCracken, Harold. Frederic Remington, artist of the Old West. Philadelphia, Lippincott, I947. 157 P.

$$
\text { 47-I } 1799 \mathrm{ND}_{237} \cdot \mathrm{R}_{3} 6 \mathrm{M}_{3}
$$

Based upon his own books, articles, manuscript diaries, and notebooks, as well as the recollections of his contemporaries, this is an anecdotal biography of Frederic Remington (186I-1909), foremost portrayer of the American frontier West. It was still "the land of the riders of the open cattle range and of the war trail," in I880 when the youthful New Yorker first roamed it, and to record its way of life for permanent preservation became his main purpose. In Arizona, Wyoming, the Dakotas, and Montana, this largely self-taught artist found his subjects: cowboys, troopers, Indians, and, in particular, the horses of the West. The drawings for an edition of Longfellow's The Song of Hiawatha in I89o firmly established Remington's reputation as an illustrator. In 1895 , he added sculpture to his media with "Bronco Buster." An arrangement with Collier's Weekly in I903 permitted him the freedom to paint as he pleased, and he produced "His First Lesson," "Fight for the Water Hole," and the many other fine pictures for which he is best known today. The "Bibliographic Check List of Remingtoniana" (p. 123-155) establishes the first appearance of each of the 2,739 drawings and paintings completed by the artist and published in $4 \mathrm{I}$ periodicals and 142 books. There are 29 line drawings and 48 plates, of which 32 are in color of varying adequacy, 8 are halftones, and 8 reproduce bronzes.

5771. [Sargent] Mount, Charles Merrill. John Singer Sargent, a biography. Ncw York, Norton, I955. xv, 464 p. 55-13654 ND237.S3M6 "Sargent's works in oil": p. 427-453.

This is an artist's sympathetic biography of John Singer Sargent (1856-1925), best known as portrait painter to the English and American haut monde of the Edwardian era. The author has drawn upon many hitherto unavailable materials, 
such as diaries and private papers of Sargent's associates, to fill the lacunae created by the destruction of the artist's own papers. From 1887 to 1909 , after which he declined all but a very few commissions from industrial and financial tycoons, Sargent was hailed both in the United States and in England for his portraits revealing fundamental traits of character, for their smartness, even sumptuousness of style, realistic illusion, fine values, and impressionistic color. The 54 halftone illustrations are reproduced on 12 leaves. Evan Charteris' John Sargent (New York, Scribner, r927. 308 p.) affectionately celebrates the life and work of his friend of 30 years' standing, and points out the "splendour" of Sargent's personality, "his dynamic energy, his largeness of outlook, his complete immunity from what was small or unworthy." Sargent's Boston (Boston, Museum of Fine Arts, 1956. 132 p.), by David McKibbin, commemorates the centennial of Sargent's birth with an essay that emphasizes both the architectural aspects of his decorations for the Museum and the importance of his portraits as "footnotes for history." A catalog of the centennial exhibition (p. 67-75) and an alphabetically arranged checklist of his portraits (p. 8I-132) are included.

5772. [Sheeler] Rourke, Constance M. Charles Sheeler, artist in the American tradition.

With $4^{8}$ halftones of paintings, drawings, and photographs by Charles Sheeler. New York, Harcourt, Brace, 1938. 203 p.

$$
3^{8-2760 r} \quad \mathrm{ND}_{237 . S_{47} \mathrm{R} 6}
$$

An "informal biography" of Charles Sheeler (b. I883), whose work makes a "fresh and original use of the American subject" and reflects "forms which strongly and essentially belong to us." The author has drawn upon Sheeler's own notes and conversations, and has so interwoven halftone reproductions of his paintings and drawings as to show the development of his art from the early experimental phases to those of maturity. "A pathfinder in the use of American traditions," he has employed "the proportionate ratios, the materials, and the final design of the provincial buildings at hand": in Bucks County architecture, the communal architecture at Ephrata, and Shaker architecture and crafts. In the I920's he discovered "the industrial subject for American art," and in his portrayals of this, "immense intricacies of structure have been boldly reduced to essentials." For many years Sheeler supported himself by photography, painting only on weekends. His photographs are noteworthy for their sense of inherent design and their rendering of textures; a few are included among the illustrations.
5773. [Sloan] Goodrich, Lloyd. John Sloan. New York, Published for the Whitney Museum of American Art by Macmillan, 1952. 80 p. ${ }_{52-7168} \mathrm{ND}_{237} \cdot \mathrm{S}_{57} \mathrm{G} 6$

"Selected bibliography": p. 78-8o.

A brief critique of the work of John Sloan (18711951), who began his career in 1892 as a Philadelphia newspaper illustrator and who found himself as an artist only after he moved to New York in 1904 and began painting his unique glimpses of the life of lower Manhattan. Thereafter "his art had that quality of being a direct product of the common life, absolutely authentic and unsweetened, that has marked the finest genre art of all times." Applicable to many other canvases is his own statement about his "Sixth Avenue and 3oth Street": "it has surely caught the atmosphere of the Tenderloin, drab, shabby, happy, sad, and human." After having depicted the contemporary spectacle for a quarter century, Sloan very largely abandoned it in 1928 for an "intensive study of the nude," in which he experimented with "linework to complete the modeling," but achieved no such individuality as in his earlier manner. There is no list of the many illustrations, three of which are in color. Van Wyck Brooks' John Sloan; a Painter's Life (New York, Dutton, 1955. 246 p.) is a sympathetic narrative by a friend of long standing, emphasizing the personal traits and relationships of "this good man, fearless, truthful, innocent and wise."

5774. [Stuart] Whitley, William T. Gilbert Stuart. Cambridge, Harvard University Press, 1932. xiv, 240 p. 32-13585 ND237.S8W 5

A history of the life and particularly the works of Gilbert Stuart (I 775-1828), largely based upon contemporary newspapers, periodicals, and memoirs from which the author quotes very generously. Stuart, a pupil of Benjamin West, first achieved success with "Portrait of a Gentleman Skating," exhibited at the Royal Academy in 1782. A master portraitist, he was greatly admired for the exactitude of his likenesses and characterizations, for originality and power, and in 1787 he was dubbed by the London World "The Vandyck of the Time." Stuart returned to the United States in 1793, achieving his ambition to paint George Washington in 1795 . Dissatisfied with the first study, the artist destroyed it after making several copies. In 1796, Stuart painted the full-length figure of Washington, renowned as the Lansdowne portrait, of which he made several copies; shortly thereafter, he painted from life the famous head of Washington now at the Boston Athenaeum. "This and the Lansdowne portrait, whether exact likenesses or not, represent Washington with the distinction he deserves, and give him the appearance of a great man, as the world 
regards him." In 1805 , Stuart settled permanently at Boston where, notwithstanding his persistently Bohemian temperament, his success was "immediate and complete," and his authority in matters of art became "unquestioned in America."

5775. Trumbull, John. The autobiography of Colonel John Trumbull, patriot-artist, 1756I843; edited by Theodore Sizer. Containing a supplement to [the editor's] The Works of Colonel John Trumbull. New Haven, Yale University Press, 1953. xxiii, 404 p. 53-777 I ND237.T8A 32

First published in $184 \mathrm{I}$, this is the shrewd and vigorous but defensive and not altogether candid memoir of John Trumbull, aide-de-camp to General Washington, student of Benjamin West in London, portrayer of major events and personages of the American Revolution, and occasional architect, mercantile speculator, and minor diplomat. Drawn by the octogenarian from abundant recollections as well as private papers, it has been meticulously edited and provided with copious notes; an appendix (p. 29I$3^{82}$ ) supplies much additional information, especially concerning Trumbull's later life, from contemporary sources. Sixty percent of the book is devoted to the quarter of his life spent in Europe. It is filled with vivid descriptions and estimates of Old Masters, European architecture and landscape, and with vignettes of historical events and such notable persons as Edmund Burke, Talleyrand, and Lafayette. Trumbull records his decision of 1785 to make the events of the Revolution his principal subjects, and reports fully the transaction whereby his four large canvases, including the "Declaration of Independence" were commissioned for the United States Capitol in 1817 and executed by 1824 . Professor Sizer's The Works of Colonel John Trumbull (New Haven, Yale University Press, I950. II7 p.) consists mainly of a complete checklist in which portraits are arranged alphabetically by sitter and historical subjects chronologically by event. All types are listed, including mythological, allegorical, literary, and religious subjects, landscapes, figure studies, architectural drawings, and maps. Sketches and studies are listed along with the finished compositions. Brief sections are devoted to Trumbull's prices and painting techniques. Forty-six halftone illustrations are reproduced on 20 leaves.

5776. [Whistler] Pennell, Elizabeth R., and Joseph Pennell. The life of James McNeill Whistler, by E. R. and J. Pennell. 5th ed., rev. Philadelphia, Lippincott, I9r I. xx, 449 p. Ar2-142 ND237.W6P4 igria

An authorized biography of Whistler (18341903), the expatriate American painter and dandified wit who was idolized by his followers and abused or misunderstood by most of the Victorian press. Mr. and Mrs. Pennell, noted etcher and writer, respectively, were intimate friends as well as warm admirers of the artist, and present much information in his own words as well as reminiscences from members of the Whistler coterie. Although his etchings were hailed as comparable to those of Rembrandt, Whistler's paintings of 1859 and the early 6o's were neither so well nor so consistently received. To both he brought realism and a sense of pattern and design. In 1865 , Whistler sent to the Academy "the most complete, the most perfect picture he ever painted, 'The Little White Girl.'" Whistler first exhibited a portrait as an "Arrangement" and an impression of night as a "Nocturne" in r872; such titles established his name for eccentricity, and for almost 20 years "ridicule was his portion." In the 1870 's, he began great portraits, among them, "Mother," "Carlyle," and "Miss Alexander," but not until the 90's was he "acknowledged as one of the great artists of the century." Numerous halftone plates reproduce oils, etchings, pastels, watercolors, and drawings.

\section{H. Prints and Photographs}

5777. Jackson, William $H$. Picture maker of the Old West, William H. Jackson; [text] by Clarence S. Jackson. New York, Scribner, 1947. $308 \mathrm{p}$.

47-3048r F59r. $_{3}$

Assembled by his son from the family collection and supplementary sources, this album reproduces in chronological sequence 393 splendid photographs, sketches, and paintings of the frontier Far West by an artist whose long life span (1843-1942) paralleled the white man's conquest of the region. The views of railroad building, mining towns, Indians, pueblos, the wonders of the Yellowstone and Yosemite Valleys, mountains, including the Grand Teton, the Mountain of the Holy Cross, and Pike's Peak, and the Mesa Verde and other cliff dwellings are taken with an artist's eye for composition and tonal contrasts. Based largely upon Jackson's early diaries and notebooks, a running commentary accompanies 
the pictures, and treats mainly of his expeditions of $1870-78$ as a staff member of the Hayden Geological and Geographical Survey.

5778. Peters, Harry T. Currier \& Ives, printmakers to the American people. Garden City, N.Y., Doubleday, Doran, 1929-31. 2 v.

$$
\text { 30-1290 NE2415. } \mathrm{C}_{7} \mathrm{P}_{4}
$$

5779. Peters, Harry T. America on stone; the other printmakers to the American people; a chronicle of American lithography other than that of Currier \& Ives. [Garden City, N.Y., Doubleday, Doran] 1931. 415 p. $\quad 31-33726 \quad \mathrm{NE}_{23} 3 \mathrm{P}_{4} \mathrm{P}_{4}$ These companion works by an enthusiastic collector survey the whole of American lithography from the first experiments made by the painter, Bass Otis, in 1819 to the decline of this popular art in the I880's. "Chief among these printmakers, because they served over a longer period, seem to have issued more prints, and more good prints, and filled the need most completely, were Currier \& Ives, who had predecessors and competitors, but really no rivals." Currier and Ives employed skilled artists and offered for sale at low prices a wide variety of effectively drawn and colored pictures of easily understood American subjects: horses, seascapes, landscapes, especially of New York, political cartoons, portraits, notable events, everyday life, and scenes of romantic, sentimental, moralizing, or humorous intent. From 1840, when Nathaniel Currier scored his first great success with a lithograph of the sinking Lexington, to the 1880's, "his business was a national institution." The total number of prints produced, as distinct from copies, is estimated at "more than 4317." Five other lithographic firms maintained substantial catalogs of prints for general distribution, on a smaller scale than Currier and Ives, but the remaining publishers, approximately Ioo in number, relied chiefly upon jobs commissioned for special purposes: commissioned portraits, maps, illustrations for books and periodicals, music sheets, advertisements, architectural plans, phrenological charts, and the like. Although these firms and artists enjoyed far less stability than Currier and Ives, all of the old printmakers "attempted to succeed by making art within the means of all-truly a great endeavor." Volume one of Currier \& Ives, Printmakers to the American People contains reproductions of 142 prints and originals and a checklist of all Currier and Ives prints known in 1929; volume two includes reproductions of 177 prints, 24 in color, and 1600 "newly discovered" titles, here completed to 1931. America on Stone includes 18 colored and 136 black-and-white plates, as well as 20 other reproductions inserted in the "prologue." It takes the form of an alphabetical list of all firms, individuals, craftsmen, and artists concerned in the production of lithographs, with information concerning their productions. Successive addresses are given for print publishers.

5780. Reese, Albert. American prize prints of the 20th century. New York, American Artists

Group, 1949. xix, 257 p. 49-1 I 409 NE508.R4

"A brief description of the principal graphic processes": p. xvii-xix.

"Biographical notes": p. 235-257.

An alphabetically arranged album reproducing, in clear if occasionally dark halftone, a selection of 216 prize-winning prints, including wood engravings, etchings, lithographs, drypoints, woodcuts, and serigraphs, by Americans still living in 1949, and 14 prints by deceased artists, a number of whom had accomplished their major work before the awarding of prizes became general practice. About two thirds of the prints were produced in the 1940's, most of the remainder in the 1930's. Each reproduction is accompanied by a paragraph which interprets its subject and, in most instances, quotes the artist as to his intention. Citing the names of Edward Hopper, Reginald Marsh, and Stow Wengenroth, among others, the introductory text asserts that the contemporary American practitioners of this "democratic medium" constitute the "finest school of printmakers in our history." The prints employ the styles of realism, impressionism, "super-realism," or nonobjectivism; their subjects range through the American rural and urban scenes, industry and machinery, manners, customs, and occupations, emotion, and pure decoration.

5781. Taft, Robert. Photography and the American scene, a social history, 1839-1889. New York, Macmillan, 1938. 546 p.

$$
3^{8-30617} \mathrm{TR}_{23} \cdot \mathrm{T}_{3}
$$

The first survey of the "effects of photography upon the social history of America, and in turn the effect of social life upon the progress of photography." News of Daguerre's process first reached this country in September 1839 . By 1845 Mathew B. Brady was collecting portraits of all the notable persons he could induce to sit. Daguerrotypy was replaced by collodion (wet plate) photography during the 50's, and in $1857^{\prime \prime}$ "the paper photograph assumed a position of commanding importance in this country-a position which it has maintained." "Card photographs" of soldiers, the eminent, and the notorious, popular from 1860 to I 866, made necessary the family album; and stereoscopes appeared in most homes during the $185^{\circ}$ 's, 60 's, and 70 's. After the Civil War, William Kurtz and others won success with the "cabinet size" por- 
trait, which required skillful posing, lighting, and handling of background. George Eastman, in the I880's, made technical advances with a gelatin process dry plate, flexible film, and a roller holder system. In I889 he introduced the portable and relatively inexpensive Kodak, which opened up the whole world of amateur photography. The numerous halftone illustrations are as clear as their small size permits.

5782. Weitenkampf, Frank. American graphic art. New ed., rev. and enl. New York, Macmillan, 1924. $328 \mathrm{p}$.

Bibliography: p. $291-298$.

$$
\text { 24-12503 } \mathrm{NE}_{505} \cdot \mathrm{W}_{4} \mathrm{I} 924
$$

First published in I912.

A topically arranged review of the whole field of American printmaking from the 18th century to about the end of the rgth, when the printing processes became debased through commercial exploitation, and photography administered the coup de grâce. The book reflects the author's vast experience, but salient personalities and tendencies are often obscured by the dense mass of details. Mr. Weitenkampf surveys the history of etching, engraving, mezzotint, aquatint, wood engraving, and lithography. He discusses the application of their techniques not only to creative art but to such secondary undertakings as the reproduction of paintings; illustrations for books, textbooks, periodicals, "tokens," and "keepsakes"; caricatures, cartoons, and social satires for the humorous press; as well as bookplates, business cards, certificates, and other lesser productions. There are numerous illustrations and halftone plates.

5783. Zigrosser, Carl. The artist in America; twenty-four close-ups of contemporary printmakers. New York, Knopf, 1942. xxi, 207 p. $4^{2-25527} \mathrm{NE}_{5} 08 . \mathrm{Z}_{45}$

Character sketches and summations of the achievements of 24 artists, most of them personally known to the author, each of whom "is typical in his or her own way of some one achievement or creative emphasis." As a group, they constituted in 1942 a "cross-section of the American printmakers now in their prime." The oldest of the artists considered was the photographer, Alfred Stieglitz (1864-1946), the youngest, Federico Castellón, born in I9I4. Some are better known for their paintings, like John Marin (1870-1953), George Biddle, Yasuo Kuniyoshi, and Thomas Hart Benton; others, like John Taylor Arms, Rockwell Kent, Paul Landacre, and Thomas W. Nason, are more exclusively printmakers. "Perhaps the most exciting and important in our art history," their day has seen the transition of American graphic arts "from provincialism to the beginnings of a national school." The "fertilizing influence" of these artists "has been one of the most important factors in the growth of the American school of art all over the country." The illustrations, two to a leaf, are arranged in groups of four, each consisting of a portrait of the artist and three typical works.

\section{Decorative Arts}

5784. Avery, Clara Louise. Early American silver. New York, Century, 1930. xliv, $37^{8}$ p. (Century library of American antiques)

"Bibliographical note": p. $36 \mathrm{r}-364$. 30-30325 NK7112.A8

A general survey of early American silver from mid-I $7^{\text {th }}$ century to the classic revival of the late 18th century. The first part of the book divides into chapters on the seven areas: Massachusetts, Rhode Island, Connecticut, New York, Philadelphia and the Delaware Valley, Virginia and Maryland, and Charleston, South Carolina. Since Boston produced the bulk of the early silver, with a longer and fuller sequence of styles than other localities, the chapter on Massachusetts is elaborated into ten chronological sections. The remainder consists of a chapter on the silversmiths and their methods, another describing the elaborate coats of arms which indicated ownership, and a far longer one (p. 273359) tracing the "course of development of characteristic objects, such as the beaker, standing cup, tankard, tea-pot." There are $\sigma_{3}$ halftone plates and 33 line drawings which show characteristic shapes and their dates.

5785. Harbeson, Georgiana (Brown). American needlework; the history of decorative stitchery and embroidery from the late 16 th to the 20 th century. New York, Coward-McCann, 1938. xxxviii, $232 \mathrm{p}$. $\quad 38-29098 \quad \mathrm{NK}_{9212 . \mathrm{H}_{3}}$

"An historical outline of decorative stitches used by American women in various embroidery techniques. Examples have been selected from each period in the country's development." If much of the design has come from sources abroad, the simplicity of American taste has been expressed in adap- 
tations of or departures from the originals, and in 1938 the author found evidence that American work was reverting to the "purely decorative and interpretive effects" achieved in the early 17 th century. Part one is devoted to the needlework of the American Indian, and includes the use of porcupine quills and beads. Parts two to five are concerned with colonial, early national, Victorian, and 2oth-century embroideries. Each section describes the materials, methods of working, and designs of its needlework. Among the varieties shown are objects for use, such as chair seats, pillowslips, or altar cloths, and purely decorative work, such as samplers of various eras, needlepoint pictures, or embroidered maps. The numerous halftone illustrations and 5 colored plates indicate the various stitches and the uses to which they were put, but in most instances are rather too small to show much detail.

5786. Hayward, Arthur $\mathrm{H}$. Colonial lighting. New ed., rev. Boston, Little, Brown, 1927. xxiv, $\mathrm{s} 68 \mathrm{p}$. ${ }_{27}-5863 \quad \mathrm{NK}_{3} 6 \mathrm{oo}_{3} \mathrm{H}_{3} 1927$

First published in 1923 .

A record for collectors of American antique lamps, lanterns, and candleholders, of the progress made by artificial lighting from the colonial era to the r850's, when gas and kerosene superseded lard oil, fish and whale oil, and camphene as illuminants, and rendered obsolete the early lamps and candlesticks. Mr. Hayward describes the lamps used, from the first crude iron open-wick Betty lamps to the graceful pressed glass lamps manufactured by the Sandwich Company; iron and tin lanterns, many of them intricately pierced; and the numerous types of candlesticks, stands, sconces, moulds, and the like, made of iron, tin, pewter, wood, brass, glass, silver, and earthenware. Most of the II4 illustrations, averaging one or two to a page, are of pieces in private collections, including that of the enthusiastic author, who offers much advice to amateurs.

\section{Kauffman, Henry. Early American copper, tin, and brass. New York, McBride, r950. \\ II2 $\mathrm{p}$. \\ Bibliography: p. I12. \\ 50-1 I 33 NK806. $\mathrm{K}_{3}$}

A brief but pioneer survey of early American copper, tin, and brassware, based upon contemporary wills, vendues, bills of lading, and, especially, newspaper advertisements. The first piece reported is a primitive early 18 th-century copper weather vane by Shem Drowne (1683-1774); the last are brass buttons, furniture, hardware, andirons, bells, clocks, and the like, cast in the early igth century just prior to the industrial revolution. The author describes such articles as copper and brass warming pans, kettles, pans, coffeepots, ladles, and stills; decorated tin boxes, trays, and footwarmers; and plain tin candle boxes, ovens, sconces, and other lighting devices. The author quotes freely from advertisements of prominent craftsmen and includes lists of coppersmiths, braziers, brass founders, and tinsmiths ( $p$. 108-III). Many of the articles reproduced in the 91 gravure illustrations are in the author's collection.

5788. Laughlin, Ledlie Irwin. Pewter in America, its makers and their marks. Boston, Houghton Mifflin, 1940. $2 \mathrm{v}$. 41-1939 NK8412.L3

Bibliography: v. 2, p. [16r]-[192].

Based upon contemporary sources, published and unpublished, and addressed to the beginner as well as the experienced collector, this is a history of American pewter (domestic vessels made of an alloy of tin and lead) from the mid-1 7 th century, when "at least four pewterers were at work in the Massachusetts Bay Colony," to the 1850's after which pewter ware was usually silverplated. The early makers have been grouped in approximately chronological order within 7 regional units: Massachusetts Bay, Rhode Island, the Connecticut Valley, New York City, Albany, Pennsylvania, and the South. The craftsmen of the britannia (pressed ware made from thin pewter sheets) period, ca. 1830 to ca. 1855, have been separately and more briefly treated in an alphabetical arrangement. All are included in the alphabetical checklist which forms Appendix I. Among the subjects of other chapters are: pewterers' marks, household pewter, ecclesiastical pewter, fakes, and notes on collecting. Reproduced on 78 gravure plates are small but clear photographs of nearly 700 plates, dishes, and basins, porringers, tankards, pots, and beakers, spoons and ladles, coffee and teapots, pitchers, candlesticks, and lamps.

5789. McKearin, George S., and Helen McKearin. American glass. 2000 photographs, 1000 drawings by James L. McCreery. New York, Crown, 1948. xvi, $634 \mathrm{p}$.

Glossary: p. xv-xvi.

$$
4^{8-2187} \quad \mathrm{NK}_{5} \mathrm{II}_{2 . \mathrm{M}_{2} 6} 1948
$$

Bibliography: p. 615-617.

First published in I94I.

Addressed primarily to the critical collector, this is a detailed history of the development of American glassmaking from the 18 th century to the 1890 's. Chapters one to four are devoted mainly to 18 thcentury glass: the South Jersey ware made of bottle glass on Dutch or German peasant lines, the brilliant and delicately colored flint glass and fine ware produced by the great Pennsylvania house of Henry William Stiegel, and the engraved presentation pieces manufactured by John Frederick Amelung. Chapters five to eight deal with the fine flint, blown and molded, cut and engraved table and decorative 
wares manufactured from I 820 to the $1860^{\prime}$ 's, as well as the pressed glass produced on a large commercial scale from the I820's to the I89o's, by the New England Glass Company, the Boston and Sandwich Company, and other glassworks. The three concluding chapters describe such special forms as paperweights, commercial bottles, and pictorial flasks. The text includes "Blown Three Mold Charts" (p. 285-33I), "Bottle Charts" (p. 512582), and "Chronological Chart of American Glass Houses" (p. $\left.5^{83}-61_{3}\right)$.

5790. Sonn, Albert H. Early American wrought iron. With three hundred and twenty plates from drawings by the author. New York, Scribner, 1928. 3 v. 28-24035 NK8212.ArS6 Bibliography: v. 3, p. 243-244.

An attempt to record, mainly in drawings, such specimens of early American wrought iron "as are still in existence, whether on old buildings, in museums, in private collections, or among the treasure-trove of dealers in antiques." A brief initial chapter sketches the development of the iron industry from the establishment of the first successful colonial ironworks at Saugus Center, Massachusetts, I685, to the advent of machine production about I850, "which gradually displaced the hand-wrought articles of the earlier period." The remainder of the book describes, and the plates illustrate, various types of: knockers, latches, and locks; bolts, hinges, hasps and handles; and gates, railings, balconies, lanterns, newels, weather vanes, foot scrapers, shutter fasteners, fireplace accessories, candle snuffers, and other articles. Mr. Sonn's text is often desultory, but his drawings are attractive and his work inspired by a sincere affection for "the pleasing variety of design, the artistic conception and beauty of workmanship displayed in early American wrought iron."

579I. Spargo, John. Early American pottery and china. Garden City, N.Y., Garden City Pub. Co. [1948, '1926] xvii, 393 p.

$$
4^{8-10842} \mathrm{NK}_{4006 . S_{7}} \mathrm{I}_{948}
$$

"Bibliographical notes": p. 373-376.

"Largely given to historical record" of the major American potteries producing wares up to the Centennial of 1876 , this is a handbook designed for the amateur collector wanting "to be aided in identifying and classifying specimens, and to be intelligently informed concerning their history, their contribution to the development of ceramic art in this country, their makers, and so on." The development of pottery (opaque ware) is traced from the simple domestic earthenware jugs, pans, and platters of the mid-1 $7^{\text {th }}$ century potters to the fine stoneware, Rockingham, flint enamel, and scroddle wares pro- duced at Bennington, Vermont, by Julius Norton and Christopher Webber Fenton 200 years later. The "era of porcelain" (translucent ware) opens with the incorporation of the Jersey Porcelain and Earthenware Company in 1825 and is continued to the designs created for the Centennial Exposition by the sculptor, Karl Müller. Two chapters are devoted to "folk-pottery," slip-decorated and sgrafitto ware, produced mainly by the Pennsylvania Germans from the I730's to the I860's. The 64 plates are in black and white; keys to the potters' marks are provided in an appendix (p. 358-372).

5792. Stiles, Helen E. Pottery in the United States. New York, Dutton, I94I. 329 p. $4 \mathrm{I}-15157 \quad \mathrm{NK}_{4} 005 . \mathrm{S}_{7}$

A survey of recent American pottery: china or porcelain, stoneware, Parian, Jasper, fine earthenware or semi-porcelain, and common earthenware, which regards it as an art newly matured. The Ohio-West Virginia pottery district in 194I ranked "first in the number and size of its ceramic industries"; in it were manufactured kitchen, industrial, and art wares, and, especially, domestic tablewares, among them "American Modern," designed by Russel Wright for Steubenville Pottery, and "Manhattan Shape," created by Viktor Schreckengost for American Limoges China Company. The most important products of New Jersey, the second ranking area, were the dinnerware designed by Frank G. Holmes for Lenox Incorporated, and "sanitary ware" of vitrified china. Ceramic sculpture and handmade pottery have been executed by Waylande Gregory, Russell Barnett Aitken, and many other "studio potters." Sections are devoted to the employment of decorative tile and terra cotta in recent architecture. The numerous illustrations are in black and white.

5793. Vanderpoel, Emily (Noyes) American lace \& lace-makers. Edited by Elizabeth $\mathrm{C}$. Barney Buel. New Haven, Yale University Press, 1924. xx, I4 p. 24-28973 NK9412. V3

An album of I I halftone plates showing samples of lace made in America, chiefly from the colonial era to the early Igth century, and drawn in large part from the collection of the Litchfield (Conn.) Historical Society. Pieces illustrated include trimming, handbags, pillowcases, bedspreads, collars and guimps, dress skirts, veils, caps, shawls, kerchiefs, and the like, as well as details, patterns, and lacemaking equipment. Plates I to 13 exhibit lace made by North and South American Indians. A very brief introduction surveys American lacemaking and describes the types of lace produced: lace made with the needle, or needlepoint lace; and lace made on 
a pillow with bobbins, or pillow lace. Distinction is drawn between the lace industry as introduced by Dean Walker about 1820 at Medway, Massachusetts, and lacemaking as an art pursued especially by young gentlewomen of the 18 th and early igth centuries.

\section{J. Museums}

5794. Coleman, Laurence Vail. Historic house museums. Washington, American Association of Museums, 1933. $187 \mathrm{p}$.

"Directory": p. 113-159.

$$
\text { 34-27050 NA7205.C6 }
$$

Bibliography: p. 160-165.

Chiefly a manual of operations for the management of historic house museums. These are buildings which "achieve importance by withstanding the assaults of time," or "by acts of man that create hallowed associations." As far back as 1850 , the State of New York acquired Washington's headquarters at Newburgh, and by 1933 "all but a few of the very youngest states" had begun to preserve their historic houses. The author advocates administration of them by organizations having custody and immediate control, under Government sponsorship and supervision. He offers practical advice about the financing of such museums, their restoration, preservation, and furnishing, supplementary collections and buildings, and attracting and guiding visitors, and outlines the possibilities of "the museum resort." The 66 gravure illustrations average two to a plate. Ralph E. Carpenter's The Fifty Best Historic American Houses, Colonial and Federal, Now Furnished and Open to the Public (New York, Dutton, 1955. I12 p.) is a convenient and well-illustrated little book for the tourist-if everyone is likely to have some alternative "best"but is limited to the East between New Hampshire and Virginia. John Drury's Historic Midwest Houses (Minneapolis, University of Minnesota Press, 1947. 246 p.) presents brief descriptions and photographs, usually of exteriors, of 87 structures in the 12 states from Ohio to the Dakotas; more than half of these were museums open to visitors.

5795. Howe, Winifred E. A history of the Metropolitan Museum of Art, with a chapter on the early institutions of art in New York. New York [Printed at the Gilliss Press] 1913-46. 2 v. illus.

13-4III N6ro.H75

Volume 2 has imprint: New York, Published for the Metropolitan Museum of Art by Columbia University Press.

The authorized history of the Metropolitan Museum of Art from its projection by the Art Committee of the Union League Club in 1869 to 1941 ; for the years 1905 to 1912 the two volumes overlap. By March 1871, Miss Howe records, the Trustees could announce the purchase of 174 paintings, "principally Dutch and Flemish, but including representative works of the Italian, French, English, and Spanish schools," as a nucleus of its permanent gallery. On April 5, 1871, a committee of the Museum secured the State Legislature's authorization to construct a suitable building in Central Park. The story thereafter is told in terms of: expansion in space, acquisitions, and services in the Dodworth Building, $1871-73$, the Douglas Mansion, $1873-79$, and the Metropolitan Museum Building, 1880-1941; the loyalty and generosity of such friends as Henry G. Marquand, J. Pierpont Morgan, Robert W. de Forest, and George Blumenthal; and the development of a philosophy of Museum purposes and practice.

5796. New York. Metropolitan Museum of Art. American Wing. A handbook of the American Wing, by R[ichard] T. H. Halsey and Charles O. Cornelius. 7th ed., rev. by Joseph Downs. New York, 1942. xxxii, 32 I p.

$$
\text { 43-1249 N6ri.A6A3 } 1942
$$

A guide to the 2I original American rooms of the colonial, revolutionary, and early republican periods installed in the American Wing, as well as to its galleries and alcoves. The book is divided into three main sections corresponding to the floor plan of the Wing: third floor, the first period, from the earliest years of permanent settlement in New England through the first quarter of the I8th century; second floor, from the second quarter of the 18 th century to the early republic; and first floor, the third period, from about 1790 to 1825 . Besides summarizing the architectural history of its period, each section describes the design, decoration, and materials of its furniture, metal work, textiles, pottery, and glass, and describes in some detail the origin, structure, and furnishings of the several rooms. These have been salvaged from old houses from New Hampshire to Virginia. Contemporary advertisements are liberally quoted; the $13 \mathrm{I}$ blackand-white illustrations are small but clear. A tribute to Mr. Halsey (1865-1942), the organizer of the American Wing, follows the preface (p. $x-x v i)$. 
5797. New York. Museum of Modern Art. Painting and sculpture in the Museum of Modern Art, edited by Alfred H. Barr, Jr. New York, Museum of Modern Art, distributed by Simon \& Schuster, 1948. $327 \mathrm{p}$.

First published in 1942 .

$$
4^{8-10843 \quad N_{22} . \mathrm{M}_{9} \mathrm{~A}_{4} \quad 1948}
$$

An album of halftone reproductions of "less than half" of the 660 paintings and 137 pieces of sculpture owned by the Museum of Modern Art in 1948, together with an alphabetically arranged catalog (p. [297]-324) of its whole collection. Paintings are grouped in 20 sections, each prefaced by a descriptive paragraph; sculpture in 4, of generally similar order. The sequence is very roughly chronological, "not so much by artists and works as by idea, style and movement, action and reaction:" After the primitives of various dates come the late rgth-century European pioneers of modernism, then the early 2oth-century traditionalists and expressionists, American and European. Cubism, which spread rapidly through Europe and America just prior to World War I, is followed by abstract art with its dogma of pure form, and by the various countermovements that arose in the 1920's and became dominant in the r930's. Mr. Barr's introduction explains the method of eliminations whereby the collection is to be kept modern. Handsomely commemorating its 25th anniversary is the Museum's Masters of Modern Art (New York, distributed by Simon \& Schuster, 1954. 239 p.) which reproduces in excellent color or black and white many of the "best or most characteristic" works of art in the collection. Each piece is identified, described, and evaluated. Demonstrating the "variety, excellence of achievement, and vigor" of the visual artspainting, sculpture, drawing, prints, photographs, motion pictures, and industrial arts-produced in 40 countries during the last 75 years, this lively, unpretentious book is full of pertinent quotations from artists and critics.

5798. Whitney Museum of American Art, New York, Catalogue of the collection. New York, Published by Rudge for the Whitney Museum of American Art, r93r. 238 p.

$$
\text { 32-5001 N6r8.A6 I931 }
$$

5799. Whitney Museum of American Art, New York. The Whitney Museum and its collection: history, purpose, and activities [and] catalogue of the collection. New York, 1954. [4I] p.

First published in 1935 .

$$
55-1142 \text { N618.A65 } 1954
$$

5800. Whitney Museum of American Art, New York. Juliana Force and American art; a memorial exhibition, September 24-October 30, 1949. New York [r949] 75 p.

$$
\text { 50-4507 N6r8.A63 }
$$

The alphabetically arranged first catalog of the Whitney Museum lists its collection at its opening in 1931 - "for the most part by living artists, of some five hundred paintings in oil and water-color, one hundred fifteen pieces of sculpture, drawings, etchings, lithographs and works in other mediums, to the number of seven hundred." The Museum and its predecessors, the Whitney Studio, Whitney Studio Club, and Whitney Studio Galleries, 191430, were organized by Gertrude Vanderbilt Whitney (1876-r942), the sculptor, in the "belief that America has an important contribution to make in the arts, that in order to make this contribution effective, a sympathetic environment must be created in which the artist may function to the fullest extent of his power." Preoccupied as it is with contemporary American expression, the Museum owns only a few works of the recent past which are precursors of modern tendencies, but has organized valuable exhibits of the work of early American artists. The illustrations of 172 paintings and prints and 37 pieces of sculpture are in a rather dark halftone. The catalog of 1954 , by no means so elaborate, lists 490 paintings, 212 watercolors, gouaches, and pastels, I 97 drawings, and 134 pieces of sculpture, a total of 1,033 works; it also reports the Museum's main activities, such as exhibitions, acquisitions for the permanent collection, lending works to other institutions, research, and publications. Juliana Force and American Art offers tributes to the Museum's first director (1876-1948) from her friends, including John Sloan, Guy Pène de Bois, and Alexander Brook, celebrates her long connection with the Whitney enterprises (1914-48), and provides a catalog (p. 67-74) of the memorial exhibition held in her honor in 1949.

\section{K. Art and History}

5801. Davidson, Marshall. Life in America. Boston, Houghton Mifflin, 1951. 2 v.

$$
5^{1-7084} \operatorname{Er}_{78.5 .} \mathrm{D}_{3}
$$

"Published in association with the Metropolitan Museum of Art."

Bibliography: v. 2, p. 463-472. 
"A graphic survey of American history," particularly of the social, economic, and cultural scene. Drawn mainly from museum collections and other public sources, the gravure illustrations are reproduced from paintings, drawings, photographs, prints, and the like, for the most part contemporary with their subjects, which "faithfully, expressively, and completely depict the American past." The closely linked and lively text, based upon both primary and recent published materials, serves as framework for the pictures and as connective where they are lacking. Volume one is arranged topically in five chronologically subdivided sections. The subjects treated are: colonial America; westward expansion to the Pacific; maritime progress, from packets to clippers and iron steamships; agriculture, from handtools to machinery; and industry, from the handicraft tradition to mass production. Volume two portrays American entertainment and play, the invasion of the city by farmer and immigrant and the growth of urban centers and services, and the tightening of the Nation through development of arteries and vehicles of transportation. A final section, "The Democratic Mold," presents the American political system and libertarian way of life.

5802. McCracken, Harold. Portrait of the Old West; with a biographical check list of western artists. New York, McGraw-Hill, 1952. 232 p. 52-9455 ND225.Mr8 A chronicle of the work and careers of the pioneer artists who were "graphic historians" of the Old West. In the 1820 's, the first Western artists produced only static Indian portraits, disappointing both as art and as documentation, but in the $1830^{\circ} \mathrm{s}$ George Catlin (1796-1872) began to create a documentary record of animated and realistic scenes from the life of the Plains Indians, and initiated a "popular interest in painting the Indians and frontier life." As the frontier steadily receded, however, from 1849 to 1870 , the old Indian and wildlife subjects were supplanted by the Indian fighter, the range, and the cowboy. Charles M. Russell was a cowboy-artist in Montana during the I880's; Charles Schreyvogel depicted the trooper and the infantryman of the Plains in the 9o's; and through both decades Frederic Remington searched for remnants of the Old West and found enough to document it. There are 39 plates in off-key color, and 47 halftones, besides numerous illustrations in the text.

5803. Murrell, William. A history of American graphic humor. New York, Whitney Museum of American Art, 1933-38. 2 v.

$34-4666 \mathrm{NC}_{14} 20 . \mathrm{M} 8$
Volume 2 has imprint: New York, Published for the Whitney Museum of American Art by Macmillan, 1938 .

"A partial list of works consulted or referred to": v. I, p. [24I]-242; v. 2, p. [265]-267.

A panorama of the development of American graphic humor from its 18 th-century beginnings to 1938. All three categories, cartoon, caricature, and humorous drawing, utilize economy of line and aim to provoke ridicule, but have as separate subjects, respectively, topical political or moral issues, individual physical peculiarities or idiosyncrasies of manner, and ridiculous social situations. Although Benjamn Franklin is credited with attempting "to symbolize a political situation" as early as 1747 , not until the Embargo and the War of 1812 did graphic humor become bolder and more frequent. In the years $1817-28$, an unbroken production of humorous illustration and social caricature began, which formed a species of graphic reporting, and the Jackson administration (1829-37) provoked a flood of separately published cartoons. A journalistic medium for sustained attack was lacking, however, until Harper's Weekly began to publish the great political cartoons of Thomas Nast (I8401902) in the Johnson administration. Since then, American graphic humorists have presented "a broad visual commentary on the lighter and seamier sides of the principal men, women, and movements of our heterogeneous civilization." A number of the 479 black-and-white illustrations are too small to be wholly effective.

5804. New York. Metropolitan Museum of Art. Life in America; a special loan exhibition of paintings held during the period of the New York World's Fair, April 24 to October 29 [1939] New York [Scribner Press] 1939. xxix, $230 \mathrm{p}$.

$$
39-27465 \mathrm{ND}_{203} \mathrm{~N}_{4}
$$

A chronologically arranged annotated catalogue of 290 paintings, together with small halftones of most of them, selected to form an exhibition of life in America during the 300 years from 1616 to 1915 . Of the 145 lenders, 78 were private owners, and 67 were institutions. The lively and informative notes accompanying the reproductions of portraits, landscapes, and genre pictures characterize their subjects and quote freely from pertinent contemporary sources. In his introduction to the "picture chronicle," "A Visual Account of Life in America" Harry B. Wehle surveys rapidly both the "taming of the continent" and the artistic recording of the personages and events concerned. The latter must depend for the most part upon obscure painters, although West, Copley, and Homer in their early years, and Morse and Eakins were able reporters. 
5805. St. Louis. City Art Museum. Mississippi panorama, being an exhibition of the life and landscape of the Father of Waters and its great tributary, the Missouri. [St. Louis] 1949. 227 p. 50-13673 N5020.S325 1949

The partly annotated and illustrated catalog of an exhibition of more than $35^{\circ}$ paintings, drawings, prints, and photographs, together with river boat models and pieces of ships' equipment, held at the City Art Museum of St. Louis in 1949. The $71 / 2$ by 348 -foot Dickeson and Egan moving panorama (1850), last of its kind devoted to the Mississippi, was the central feature of the display which aimed to show not only the art inspired by the rivers but to review "American social history as it unfolded along the Mississippi and the Missouri in the last century." In a preliminary essay, Perry T. Rathbone, Director of the Museum, points out that the river painters were first of all explorers and recorders: poetry and romance were not added by them but inhered in the life they portrayed. Four color plates accompany the numerous halftones.

5806. Taft, Robert. Artists and illustrators of the Old West, 1850-1900. New York, Scribner, I953. xvii, $400 \mathrm{p}$. 53-7577 N6510.T27

$A$ very detailed and thoroughly documented account of "the actual experiences of a number of artists and illustrators, most of whom personally witnessed some part of the marvellous transformation of the region beyond the Mississippi-chiefly the Plains and the Rockies-in the half century extending from 1850 until I900." These men, many of them obscure and untrained amateurs, served as artists with official surveys and expeditions, as artists traveling on assignment for Harper's Weekly or Frank Leslie's Illustrated Newspaper, or as independents on wagon, and later, railroad trains. John M. Stanley and Heinrich Balduin Möllhausen depicted views and Indians and Indian modes of life. William Jacob Hays was a painter of animals, chiefly buffaloes and prairie dogs. After the Civil
War, Theodore R. Davis and Alfred R. Waud of Harper's, and many others recorded the tide of emigration, Indian troubles, and the expanding Western scene. The 90 halftone illustrations are reproduced on 36 leaves.

5807. U. S. Library of Congress. An album of American battle art, 1755-1918. Washington, U. S. Govt. Print. Off., I947. xvi, 3 I9 p. $4^{8-45628} \quad \mathrm{~N} 8260 . \mathrm{U}_{4}$

An album of 150 full-page reproductions in gravure of American prints, drawings, photographs, and pictorial maps, most of which depict battles, although some are portraits, and others are scenes of military life. Based upon an exhibition held at the Library of Congress in 1944 and drawn in the main from the Library's collections, they are arranged chronologically in 10 sections, each representing a war or group of wars from "The French and Indian War and Its Aftermath, 1755-1765," to "The First World War, I917-1918." Each has a brief introduction by the editor, Donald H. Mugridge, giving a historical framework for the group of plates, and special attention is given to graphic processes and the artists who made use of them or whose work was reproduced by them. Each illustration is provided with an annotation which describes it in technical terms and explains its historical significance. Selection of illustrations has been governed to some extent by the ease or effectiveness with which they could be reproduced; scene and artist are usually but not invariably of the same era. Pictorial Americana, $2 \mathrm{~d}$ ed. (Washington, Library of Congress, 1955. 68 p.) is a catalog of photographic negatives available in the Library's Prints and Photographs Division, "published for the convenience of those who may wish to obtain positive prints"; the originals, mostly prints and magazine illustrations, reflect American history through 1899, or are views, or are social materials here classified by subject matter. 


\section{Land and Agriculture}

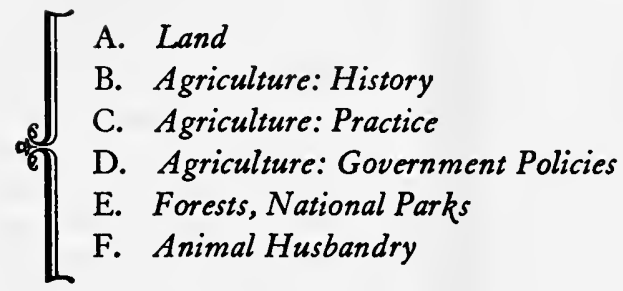

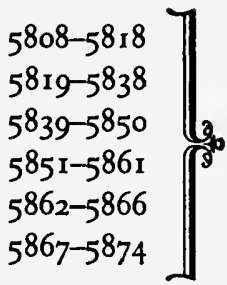

A GRICULTURE is normally thought of as a part of American economic life, which is $A$ the subject of the next chapter. It has been given separate and prior treatment, in part for convenience, since the economic chapter is large enough as it is, but also because of a real priority, historical and logical, in its subject matter. Through the first two and a half centuries of our history, America was a land of farmers. Not until after the Civil War-and, some have argued, largely because of it-did the industrial interest come to outweigh the agricultural, and not until the second decade of the present century did the urban population come to outweigh the rural. Urbanized and industrialized man remains quite dependent upon agriculture for his food, and less completely so for his clothing and shelter; its priority in economic process therefore persists, if it is less overwhelming than a century ago. Americans still tend to follow Thomas Jefferson in regarding the agrarian way of life as healthier in several senses than its alternatives, and as supporting a democratic order in society and government more effectively than any other. For these and other reasons the state of American agriculture has been a special object of public solicitude for nearly a century. Agricultural research and education have been so effectively subsidized that they have led to one of the greatest paradoxes in economic history: as cultivated acreage and agricultural manpower have been shrinking, output has gone on increasing, and regularly produces commodity surpluses beyond effective demand which threaten to send prices tobogganning. This situation has, during the past 25 years, occasioned an exceptional degree of Government subsidization, exceptionally wide Government controls, and a continuing stream of diagnosis, criticism, and commentary. A vast literature has grown up over the century, from which the titles that follow are a

selection of the less technical works that will have significance for those of us who are not farmers or are not actively engaged in wrestling with the farmer's problems.

Just as agriculture is prior to other forms of economic activity, so the land is historically and logically prior to the forms of its cultivation, and our first section includes titles on land use, soil conservation, public land policies, the public domain, and land speculation and values. Works with a more strictly geographical approach appear in Chapter VI. The next three sections divide the books on agriculture according to whether they emphasize its history, its current practice, or the Government policies which affect it; but these aspects are by no means mutually exclusive, and titles in one section may have much of interest for one or both of the others. As in similar situations elsewhere, we have not hesitated to select books which take decided views on recent developments, as being the most likely to arouse the lay reader's interest, but of course no endorsement of these views is implied. The concluding sections lump the national parks, which could as well have gone in Section A, with books on our forests and their industries, and bring together all animal enterprises, whether catching fish, preserving wildlife, or breeding horses. 


\section{A. Land}

5808. Bennett, Hugh Hammond. Soil conservation. New York, McGraw-Hill, I939. xvii, 993 p. illus. (McGraw-Hill series in geography) 40-1 $134 \quad \mathrm{~S}_{223} \cdot \mathrm{B}_{3} 6$

This volume presents a comprehensive statement of the science and practice of soil and water conservation by the Chief of the Soil Conservation Service, U. S. Department of Agriculture (1935-52), who is known throughout the United States and abroad for his leadership in the soil conservation movement. In part I he traces the problem of soil erosion in the United States back to the wasteful exploitation of land by the early settlers; compares it with the problem in other countries, and presents its economic and social effects on the welfare of our people. In part 2 the development of the national plan for soil conservation, based on acts of Congress and administered by the Department, is traced, and present-day conditions in the several regions of the United States are described. Dr. Bennett's briefer manual, Elements of Soil Conservation, appeared in a second edition in 1955 (New York, McGraw-Hill. $35^{8}$ p.). The story of the conservation movement and the man who led it is told in a popular, somewhat journalistic style by Wellington Brink: Big Hugh, the Father of Soil Conservation (New York, Macmillan, 1951. 167 p.).

5809. Clawson, Marion. Uncle Sam's acres. New York, Dodd, Mead, 1951. xvi, 414 p. illus. 5I-10247 HD216.C 55

Bibliography: p. 393-397.

The director of the Bureau of Land Management, U. S. Department of the Interior (1948-52), describes the kinds of land, including national parks and national forests, owned by the United States. He tells how they were acquired, and in large part disposed of, and how the fourth of our area that remains in Federal ownership is administered. Using "relatively simple terminology and exposition," the author directs his book to those primarily interested in the outdoors and its use, to Federal and State employees in land and resources administration, and to students in both college and high school. The policies and politics that determine the management of the public lands are analyzed in the last chapter, where it is predicted that the public lands and the Federal Government's control over them will expand in an effort to conserve our minerals, timber resources, grazing land, national parks, and waterpower as they become increasingly important to the total national economy.
5810. Graham, Edward H. Natural principles of land use. New York, Oxford University Press, 1944. 274 p. Agr 44-202 S493.G65 Bibliography [in large part annotated]: p. 233$26 \mathrm{I}$.

Associated with the Soil Conservation Service since I94I as chief biologist, and then as director of the Plant Technology Division, the author has had abundant opportunity to observe the normal processes of the landscape and to study the best methods of plowing, fertilizing, and irrigating the land for the conservation of the soil, forests, and wildlife, and for increasing its potential productivity. He has written this nontechnical book to help the land management biologist as well as the man who operates and lives on the land, by pointing out "something of the relation and importance of natural ecological principles to land management methods." The 32 plates are accompanied by concise descriptions and contribute greatly to the reader's enlightenment.

5811. Hibbard, Benjamin Horace. A history of the public land policies. New York, P. Smith, 1939. xix, 591 p. (Land economics series, edited by R. T. Ely) 39-6945 HD216.H5 1939 Bibliography: p. 573-579.

This basic volume was first published in 1924 by the Macmillan Company. While head of the department of agricultural economics, University of Wisconsin (I919-32), the author used the manuscript as the basis of a seminar, and several of the chapters were revised by members of the class. The result is a detailed and somewhat technical history of the acquisition of the public domain, and the various policies that have been followed in its disposition since 1780 . Special attention is given to the origins and the operation of the Homestead Act of 1862 . Numerous tables show sales and receipts, bounty land warrants issued, Federal grants for roads, railroads, and education, etc. In the last chapter the Federal land policies are reviewed and criticized. The author points to the reservation of forest land from private entry as "the most commendable act on the part of the government during the past half century," and to the great need for a Federal policy concerning grazing land, which, as Dr. Peffer describes (no. 5813), was adopted in 1934.

5812. Hoyt, Homer. One hundred years of land values in Chicago; the relationship of the 
growth of Chicago to the rise in its land values, 1830-1933. Chicago, University of Chicago Press, 1933. xxxii, 519 p. 34-44 HD268. ${ }_{4} \mathrm{H6}$ r933a Bibliography: p. [496]-499.

Fascinated by the growth of Chicago from a dozen log huts in 1830 to an urban population of $3,376,436$ in 1930 , with a corresponding rise in the value of the land from a few thousand dollars to five billion, and convinced by his experience in the real estate business that an understanding of the past movement of land prices was indispensable for any rational real estate investment policy, the author undertook this study for his $\mathrm{Ph}$. $\mathrm{D}$. thesis at the University of Chicago. He gathered material from the records of the Chicago Title and Trust Company, the annual land-value maps, newspaper files, appraisals, and from tax-assessment records. Part I traces the history of the city's growth in relation to the rise in land values during four booms: those of the canal and railroad eras, 1830-62; the boom that followed the Civil War and the Great Fire, I863-77; the boom of the first skyscrapers and the first World's Fair, 1878-98; and the land boom that preceded and followed World War I, r8g8-r933. Part 2 analyzes the relation of the growth of Chicago to the rise of its land values, and works out the Chicago real estate cycle and the mechanism of the Chicago land market. "The result," says Prof. $\mathrm{H}$. A. Millis, "is a distinct contribution both to the economic and social history of Chicago and to urban land economics."

58r3. Peffer, E. Louise. The closing of the public domain: disposal and reservation policies, r900-50. Stanford, Stanford University Press, r951. 372 p. (Stanford University. Food Research Institute. Miscellaneous publications, no. ro) 5I-1046I $\mathrm{HD}_{216 . P_{44}}$ $\mathrm{TX}_{34}$ I.S8, no. ro

This scholarly study is organized around the major legislation dealing with the public lands from the passage of the Reclamation Act in 1902 to the creation of the Bureau of Land Management in 1946, which marks the official closing of the old public domain. It details the struggle between the concept of "land held in escrow pending transfer of title" to individuals, corporations, or States, and the demand of conservationists for reservations "held in perpetuity in the interest of the collective owners, the people of the United States." Out of that struggle grew the Federal management of public lands, with the control of grazing (established by the Taylor Grazing Act of 1934), the development of waterpower sites, the classification of certain mineral lands, and the building up of the national forests and parks for economic and recreational use in the public interest.
5814. Robbins, Roy M. Our landed heritage: the public domain, 1776-1936. New York, P. Smith, I950, ' ${ }^{1942 .} 450$ p. maps.

55-21591 HD216.R6 I950

"Selective bibliography of secondary references": p. $[427]-433$.

Originally published in r942, "this volume presents perhaps the first attempt to integrate American land history with the other forces that have shaped our civilization." It traces the political, economic, and social effects of the policies underlying the development and disposition of the land owned by the Federal Government, from the cession of Western lands by the States following the American Revolution to the withdrawal of all public lands from private entry in 1935. Much of its content is derived from the Congressional Globe and Congressional Record, reporting the arguments for and against the several measures which determined Federal land policy.

5815. Sakolski, Aaron M. The great American land bubble; the amazing story of landgrabbing, speculations, and booms from colonial days to the present time. New York, Harper, 1932. 373 p. 32-29324 HDigr.S3

From the colonial charters granted by England to individuals and companies to the Florida real estate "boom" of the 1920's, the author presents the most comprehensive study to date of the more important speculative land transactions which have left their imprint on the development of the United States. The Western land ventures of the Ohio Company, the Georgia Yazoo land frauds of the I8th century, the colonization of Texas by the Austins, and the "land grabbing" that accompanied the California Gold Rush of 1849 , are among the instances described. Although land speculation generated panics such as that of 1837 , it gave impetus to the building of roads, canals, railroads, and towns.

5816. U. S. Dept. of Agriculture. Atlas of American agriculture. Physical basis including land relief, climate, soils, and natural vegetation of the United States. Prepared under the supervision of O. E. Baker, Bureau of Agricultural Economics. Washington, U. S. Govt. Print. Off. 1936. $6 \mathrm{v}$ in r. Agr 36-297 S441.Ar5 r936a

This atlas was originally planned in 1916 as a monumental undertaking including sections on crops, livestock, size of farms, rural population, etc., but after some experimental advance sheets had been issued, "it was decided to confine the publication of data in atlas form to the physical conditions, which are more or less permanent." Much of the other material assembled was published in the Yearbook and other publications of the Department. The 
Atlas as finally published has, therefore, rather more kinship with the titles entered in our Chapter VI on Geography than with most of the other titles in the present chapter. However, the sections by Joseph B. Kincer on "Temperature, Sunshine, and Wind" and "Precipitation and Humidity," by William Gardner Reed on "Frost and the Growing Season," by Curtis F. Marbut on "Soils of the United States," by Homer L. Shantz on "Grassland and Desert Shrub," and by Raphael Zon on "Forests" are basic to any geographical approach to American agriculture. Each section consists of an extensive text, as well as a series of maps, most of which are colored.

5817. U. S. Dept. of Agriculture. Land. Washington, U. S. Govt. Print. Off. [1958] 605

p., 64 p. of plates. (Its Yearbook of agriculture, I958)

"A summary in charts and maps": p. 263-276. Agr 58-32I S21.A35 $195^{8}$

This latest yearbook of the Department of Agriculture, edited by Alfred Stefferud, is concerned with the use, management, present trends, and future of public and private lands in the United States. It consists of 67 relatively brief and untechnical papers arranged under ro general headings; the majority of the papers are of double, triple, or even quadruple authorship. The section on public lands includes essays on these relatively unfamiliar subjects: "The Management of State Lands," "Getting and Using Lands in Time of War," and "The Management of Tribal Lands." A large section deals with "Some Financial Aspects of Land Use"; its final paper tells us that "Getting Started in
Farming Is Hard." Another large section on conservation concludes with "Information on Land from Airphotos," indicating the peacetime uses of a wartime technique, and including 16 pages of airphotos of typical farm regions throughout the United States. Of special interest are the concluding sections, "Our Growing Needs and Problems" and "Planning for a Better Use." In the former, Professor M. Mason Gaffney of the University of Missouri puts the pertinent question, "Urban Expansion-Will It Ever Stop?" There is practically no bibliographical apparatus, but there is a considerable index.

5818. Van Dersal, William R. The American land, its history and its uses. London, New York, Oxford University Press, r943. xvi, 215 p. 43-I4I46 $\mathrm{S}_{44} \mathrm{I} . \mathrm{V}_{3}$

This book fills the need for a general introduction to the American land, and how it is used for agriculture, including livestock, for forests and woodlands, and for wildlife and recreation. In the first two chapters the land as it was in the beginning is contrasted with the land as it is now. The author interprets the change which has taken place as equivalent to the development of European culture into a truly American civilization. In nine chapters, comprising over half the book, he traces the origin of certain basic crops and describes their contribution to that development. Concluding chapters describe the menace of erosion to our fertile topsoil, and the new methods of farming, such as contour cultivation and terracing, which are reducing its destruction.

\section{B. Agriculture: History}

5819. Barger, Harold, and Hans H. Landsberg. American agriculture, I899-r939; a study of output, employment and productivity. New York, National Bureau of Economic Research, 1942. xxii, $44^{\circ}$ p. (Publications of the National Bureau of Economic Research, no. 42) "Charts: sources and notes": p. [409]-4r3. 43-2979 HDi76r.B3

Charts and graphs are extensively used to illustrate the authors' analysis of the results of a number of studies of agricultural "output" and its constituent parts. Part I describes agriculture as a segment of the Nation's industry, and defines "output as consisting of those products which are not consumed in further processing within agriculture but are available for consumption elsewhere." In part 2 their index to the aggregate product of agriculture is explained, as well as the rise, or in some cases the decline, of individual products, as both are affected by foreign market and domestic demand. The growth of nutrition as a science and the changes in dietary habits which affect consumption are discussed in a chapter on "Agriculture and the $\mathrm{Na}$ tion's Food." The development of agricultural technology, from improvements in machinery to bettered strains of plants and animals, is reviewed in part 3 as a prelude to a comparison of output with changes in the volume of agricultural employment. Output has increased, and may be expected to increase, as the number of workers declines. In part 4, "Summary and Conclusions," the authors point out that long-range factors such as technical progress and thanges in population and in demand 
for foodstuffs will continue, as they have in the past, to force agriculture to adjust itself to changing conditions.

5820. Bidwell, Percy Wells, and John I. Falconer. History of agriculture in the northern United States, 1620-1860. Washington, Carnegie Institution of Washington, 1925. 512 p. (Carnegie Institution of Washington. Publication no. $35^{8}$ ) $25^{-1} 345^{8} \quad \mathrm{~S}_{44} \mathrm{r} . \mathrm{B}_{5}$ HCror.C75, no. 5

This is the fifth in the series of Contributions to American economic history projected in 1904 by the Department of Economics and Sociology of the Carnegie Institution of Washington. Parts I-3, by Dr. Bidwell, deal with developments in field husbandry, livestock, farm labor and equipment, trade in agricultural products, and land tenure, principally in New England and the Middle States during the years 1620 to 1840 . Part 4 , by Dr. Falconer, covers the two decades 1840 to 1860 , characterized as "The Period of Transformation," and describes the shifting of crops, dairy farming, and livestock from area to area as it was influenced by climate and soil, labor, transportation, and markets. Chapters are devoted to agricultural machinery, to the diffusion of information, and to each of the major crops, as well as to animal production. An extensive classified and critical bibliography (p. 454-473) adds to the book's value as a reference work for students of American economic history.

5821. Carrier, Lyman. The beginnings of agriculture in America. New York, McGrawHill, 1923. xvii, 323 p. illus. (Agricultural and biological publications; C. V. Piper, consulting editor)

Bibliography: p. 308-312.

23-594I $\mathrm{S}_{441 . \mathrm{C}_{3}}$

The author aims to bring together "from widely separated and often nearly unavailable sources pertinent facts and observations on the early history of agriculture, especially in America," and has liberally sprinkled his text with extracts from contemporary writers. Against a background of economic and social conditions in each of the Colonies, aboriginal agriculture and the indigenous plants, as supplemented by the introduction of European crops and cultivated by simple imported farm implements, are described in full. The author demonstrates in detail that Indian agriculture had actually reached a complex stage of development, and that its methods as well as its crops were in large part taken over by the white settlements. The closing chapters discuss the effect of the introduction of slavery, the development of commerce, and the manufacture of alcoholic beverages on colonial agriculture.
5822. Cohn, David L. The life and times of King Cotton. New York, Oxford University Press, 1956. 286 p. 56-10457 HD9076.C56 A socioeconomic history which tells "something of an agriculture that fashioned the life of a great region and profoundly affected the destiny of the whole American people." The first seven chapters trace the story of cotton from Eli Whitney's cotton gin, which brought about profound internal changes in the United States and gave cotton a place of international importance, through the Civil War, which precipitated the breaking-up of plantations into small family farms and the spread of sharecropping. In the last four chapters the author describes the spread of cotton cultivation westward, the movement of the cotton-textile industry from New England to the South, and the increase of competition from foreign countries and man-made fibers, against a background (after 1929) of Government measures to bolster farm prices. Mr. Cohn does not conclude on an optimistic note: "While cotton is fighting a losing battle for a diminishing share of the home market, it is fighting a spectacularly losing battle in the export market." The latest phase of this historic crop is analyzed by James $\mathrm{H}$. Street in The New Revolution in the Cotton Economy; Mechanization and Its Consequences (Chapel Hill, University of North Carolina Press, 1957. xvi, 294 p.). Harvesting machinery was not introduced on a large scale until the latter years of World War II, but by 1955 nearly one-fourth of the American crop was mechanically harvested, and in the western cotton regions virtually all stages of production had been mechanized. Mr. Street treats these developments as a problem in "the cumulative character of technical progress," and seeks to determine their relation to the decline in the agricultural labor force and in share tenancy in the cotton areas. A comprehensive history of another major Southern crop, if one of less geographical extent than cotton, is Joseph Carlyle Sitterson's Sugar Country; the Cane Sugar Industry in the South, 1753-1950 ([Lexington] University of Kentucky Press, 1953. 4I4 p.). Save for one chapter on sugar in the Florida Everglades since I88o, it concentrates upon southern Louisiana and eastern Texas. The first part, more than half of the whole, is concerned with slavery times; the second narrates the recovery of sugar culture from the dislocations of the Civil War, and from the mosaic disease which nearly extinguished it during the rg20's.

5823. Gray, Lewis Cecil. History of agriculture in the southern United States to 1860 , by Lewis Cecil Gray, assisted by Esther Katherine Thompson. Washington, Carnegie Institution of 
Washington, 1933. 2 v. (Carnegie Institution of Washington. Publication no. 430)

Bibliography: v. 2, p. [943]-1016.

$$
\begin{array}{r}
\text { 33-6309 S445.G8 } \\
\text { HCror.C75, no. } 7 \\
\text { AS } 32 . A 5, \text { no. } 430
\end{array}
$$

This companion work to Bidwell and Falconer (no. $5^{820}$ ) rounds out the history of agriculture in the United States prior to the Civil War. The first volume describes the beginnings and development of agriculture during the colonial period, in Virginia, Maryland, the Carolinas, the lower Mississippi Valley, the Gulf coastal plains, Georgia, and Florida. Chapters are devoted to the various agricultural industries of the period with emphasis on the tobacco industry. A striking contrast is drawn between the Southern plantation with its "capitalistic type of agricultural organization in which a considerable number of unfree laborers were employed under unified direction and control in the production of a staple crop," and the small self-sustaining farms of the North. However, the author points out in greater detail than has been done before that "the great majority of the Southern people lived on small farms and worked with their own hands." The second volume covers the period of transition from colonial to national economy, extending from the American Revolution to the Civil War. It analyzes the development of the national economy, agricultural industries, and methods of husbandry. The statistics, the wealth of footnotes, the extensive bibliography, the many maps, charts, and tables, with the comprehensive index, evidence the years of research (since 1908) and patient organization that went into these volumes. In scholarly fashion, the author has achieved his goal of attempting to interpret "the way of life of a great section of our country, which was almost entirely agricultural, to describe its system of agricultural organization, to discern, if possible, the forces that moulded its socioeconomic life, and trace the interrelations of its economy and its institutions."

5824. Hedrick, Ulysses P. A history of horticulture in America to 1860 . New York, Oxford University Press, I950. 55I p. $50-6898 \quad \mathrm{SB}_{3} . \mathrm{H}_{4}$ Bibliography: p. 515-523.

A distinguished horticulturist of New York State undertakes to supply the lack, not only of any general history, but of any thorough regional or State histories of American horticulture. His book "is primarily concerned with gardening, fruit growing, and viticulture; not with gardens, orchards and vineyards . . . The places described in this text are only those that are significant examples of progress." Part I covers the colonial period and, after an initial chapter on "Indian Gardens," proceeds geographi- cally, but here and later the author is careful to discriminate the contribution in plants and arts of Spaniards, Dutch, Swedes, and Germans, upon which, in most areas, British Isles horticulture was eventually superimposed. Part 2 covers the years. from the Peace of Paris to the Civil War according to a more minute chronological breakdown in the older areas, and to a less minute one in the areas. more newly settled. Part 3 has chapters on four topics: botanic explorers and gardens, "The Dawn of Plant Breeding," "Horticultural Literature" from I 700, and "Horticultural Societies" from 1790.

5825. Holt, Rackham. George Washington Carver, an American biography. Garden City, Doubleday, Doran, 1943. $34^{2}$ p. illus.

43-5 II06 $\mathrm{S}_{417} \cdot \mathrm{C}_{3} \mathrm{H} 6$

George Carver (1864?-1943) did not know when he was born, but it must have been during the last year or two of Negro slavery. Since his education had to be entirely self-financed, he was about 30 before he obtained his degree from one of the landgrant colleges, the Iowa State College of Agriculture and Mechanic Arts. Two years later Booker T. Washington (nos. 4449-4450) called him to the post he was to hold for the rest of his life, in charge of agriculture at Tuskegee Institute. Effective in his teaching, he was a genius in the laboratory which he had created out of odds and ends. Here, in an extraordinary series of experiments in chemical analysis and synthesis, he revealed the potentialities of the peanut and the sweet potato, and opened the way for a badly needed diversification of Southern agriculture. The peanut, not even regarded as a crop in 1896 , stood second to cotton as a source of cash for Southern farmers by 1940. Carver's own writings consisted chiefly of leaflets and articles giving practical hints to Negro and other small Southern farmers; an article of 1915 is typical: "The Fat of the Land-How the Colored Farmer Can Live on It Twenty-one Times Each Week." Mrs. Holt's biography is largely a succession of anecdotes derived from Dr. Carver or his friends, but they are cumulatively impressive. Of Carver's many achievements the greatest was certainly this: the contempt and indignities he had had to endure from ignorant whites did not leave a trace of rancor or resentment in him. (This title also appears as no. 2690 in Chapter IV on Biography and Autobiography.)

5826. Hutchinson, William T. Cyrus Hall McCormick. New York, Century Co., 1930-35. 2 v. illus. 30-30678 $\mathrm{HD}_{94} 86 . \mathrm{U}_{4} \mathrm{M}_{35}$

This is a definitive biography of an important inventor, and a history of the influence of the reaper on the agricultural development of the Middle West, and of the building of a great manufacturing dynasty 
in Chicago. Each volume is complete within itself with bibliographical guide and index. The first volume, "Seed-Time, 1809-1856," traces the life of Cyrus Hall McCormick (1809-1884) from its beginnings in the Valley of Virginia, where he worked with his inventive father in the manufacture and sale of farm equipment, and finally invented the reaper. It carries him to the eve of the Civil War, with a manufacturing business established in Chicago that had brought him recognition as an outstanding entrepreneur. The controversy as to whether Cyrus or his father, Robert McCormick, was the real inventor is reviewed in chapter 5 and is adjudged in favor of the son. The second volume, "Harvest, 1856-1884," carries the narrative of the harvest-machine industry to the inventor's death in r 884, and also describes McCormick's activities in the church, in politics, and in philanthropy. In the centennial year of the invention, Cyrus McCormick, grandson of the inventor, published The Century of the Reaper (Boston, Houghton Mifflin, 1931. 307 p.), which provides a convenient briefer narrative, considerably indebted to Hutchinson's massive re. search.

5827. Neely, Wayne Caldwell. The agricultural fair. New York, Columbia University Press, 1935. 313 p. (Columbia University studies in the history of American agriculture, edited by H. J. Carman and R. G. Tugwell, 2)

Bibliography: p. $\left[\begin{array}{c}35-27113 \\ 265]-290 .\end{array}\right.$

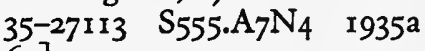

Following the English custom, which originated in medieval times, fairs for the sale of agricultural products were held during the colonial period, but owe their crystallization as a distinctive American institution to Elkanah Watson of Pittsfield, Mass., who promoted the first "modern" fair in $181 \mathrm{r}$. The author presents the development of the agricultural fair, with its economic, educational, recreational, and social aspects, against a background of changing society. A period of decline following 1820 was succeeded by one of expansion after 1840. "The core of the agricultural fair is the exhibition of agricultural products for prizes." The county fair, as it is now usually called, illustrates the pride of a people in improving and displaying the products of their labor for the mutual benefit of all.

5828. Phillips, Ulrich Bonnell. Life and labor in the Old South. Boston, Little, Brown, I929.

xix, 375 p. 29-II204 F209.P56

As a student of history and a young instructor, the Georgia-born Phillips (1877-1934) was struck with the idea that the interpretation of the South by historians had been distorted. He believed that a study of the Old South "from the inside" was needed, and by the time he wrote this book had already spent years of research among plantation records, diaries, account books, and correspondence, some of which he found in the garrets of Southern houses. In the first chapter he describes the soil and climate that determined the crops and the organization of labor as well as the habits of life and tempers of men-plantation owners, overseers, and slaves. He describes the plantation as a "homestead, isolated, permanent and peopled by a social group with a common interest in achieving and maintaining social order," and as a factory, a school, a parish, a pageant, and a variety show. He reviews the Southern scene from the "big house" and relates sympathetically the instances of friction that weakened the socioeconomic bonds holding planters and slaves together. Awarded a $\$ 2,500$ prize offered by Little, Brown and Company in 1928 for the best manuscript on American history, this book was the first in a projected series of three on the South. The second, The Course of the South to Secession (no. 3404), left incomplete at the time of his death, was sponsored by the American Historical Association with deep appreciation of Phillips' "fruitful labor."

5829. Robert, Joseph C. The story of tobacco in America. New York, Knopf, 1949. xii, 296, xxiv p. illus. $\quad 49-8562$ SB273.R58

The influence of tobacco on the economic, political, and social history of the United States is traced from the time when smoking by the natives of the New World was observed by the earliest explorers to its present position as a big business, in 1948 yielding $\$ 1,300,280,000$ in Federal excise taxes. The low price of the staple in Virginia of the 1670's led to Bacon's Rebellion, and in the first decade of the 2oth century created conflicts, such as the Kentucky Black Patch War, between the tobacco trusts, the farmers, and certain protective associations. Its use as currency in the era before the American Revolution strained the relations between the colonists and England, led to the famous Parson's Cause, and carried Patrick Henry into prominence as a defender of American rights. The staple helped to create the pattern of the Southern plantation based on slave labor, and of sweatshop conditions among the cigar manufacturers in the New York tenements. The author describes the nicotine habits of Americans in all strata of society-from chewing, sniffing, and dipping to smoking cigars and cigarettes-as well as the numerous anti-tobacco movements that have attempted to dictate social habits. Considered a "divinely-sent remedy for virtually all ailments of the human body" in mid-r6th century, its effect on health in the 2oth is the subject of extensive research by the medical laboratory. 
5830. Rogin, Leo. The introduction of farm machinery in its relation to the productivity of labor in the agriculture of the United States during the nineteenth century. Berkeley, University of California Press, 1931. 260 p. illus. (University of California publications in economics, v. 9)

$$
\begin{gathered}
\mathrm{A}_{3 \mathrm{I}-750} \mathrm{H}_{3 \mathrm{I} . \mathrm{C}_{2} \text {, v. } 9} \\
\text { S75I.R6 I93I }
\end{gathered}
$$

Issued also as thesis ( $\mathrm{Ph}$. D.) Columbia University. "Index of authors cited": p. 244-25I.

This is a study of the machinery used in the tillage of the soil, and in cultivating, threshing, and harvesting wheat, and the resulting effects upon the manhour requirements for crop production. Part I relates the development and utilization of the various types of plows, the harrow, and the field cultivator. In sections $1-3$ of part 2 , the introduction and use of harvesting machinery, the threshing machine, and seeding machinery are traced. The author has ascertained the man-labor requirements as affected by the various types of machinery, and in the last chapter compares those requirements at the beginning with those at the end of the rgth century. For instance, in 1830 it took over 64 hours to put in and secure an acre of winter wheat by hand; in 1895 the same operations could be effected by machinery in little more than two hours! The numerous illustrations, statistical tables, extensive footnotes, and bibliography are of special value for the research worker.

5831. Saloutos, Theodore, and John D. Hicks. Agricultural discontent in the Middle West, 1900-1939. Madison, University of Wisconsin Press, 195I. 58I p. $\quad 5 \mathrm{I}-4287$ HDr773. $\mathrm{A}_{3} \mathrm{~S}_{3}$

This is an enlargement of Dr. Saloutos' doctoral dissertation, to which his teacher Dr. Hicks has contributed chapters I, 2, and 4. Wisconsin, Illinois, Minnesota, Iowa, Missouri, the Dakotas, Nebraska, and Kansas are described as the center of discontent where movements for agrarian reform flourished. In the early years of the 2oth century, the antimonopolistic philosophy of the Middle Western farmers was voiced in Congress by such leaders as Robert M. LaFollette of Wisconsin, George Norris of Nebraska, and Henrik Shipstead of Minnesota, who sought reforms in railroad regulation, the tariff, taxation, conservation, and other spheres. The authors analyze the economic and political role of the American Society of Equity, the Nonpartisan League, the Farmers Union, and the American Farm Bureau Federation. They describe the efforts of the cooperative movement, the Farm Bloc, thirdparty ventures, and the New Deal to get higher prices, better credit facilities, surplus-control regulations, cooperative methods of marketing and purchasing, and other measures to better the farmer's position. During this period the "trust busting" tactics of the agrarians were abandoned in favor of building "restrictive devices patterned to a great degree after those of industry."

5832. Schafer, Joseph. The social history of American agriculture. New York, Macmillan, 1936. 302 p. 36-27407 HDigr.S 4

This book originated in a series of lectures given at the University of London by Dr. Schafer (1867I94 I), superintendent of the State Historical Society of Wisconsin for 20 years. While each chapter was prepared as a rounded treatment of a distinct topic, the whole is "a comprehensive survey of the social history of agriculture." Chapter I, "Land for Farmers," traces the continuing conflict between squatters and speculators, and the attempts made from time to time to democratize the land laws so as to favor actual settlers. Chapters 2 and 3 contrast the "Primitive Subsistence Farming" which characterized the advancing frontier with the "Big Business Farming" which is as old as the tobacco plantation, and prevailed in Middle Western wheat growing and Great Plains ranching. "Improved Farming" describes the movement, which acquired momentum in the older sections of the country about r83o, to halt soil exhaustion, diversify crops, and breed better livestock. "Professional Farming" describes the application of scientific analysis and experimental methods to American agriculture, the decisive step in which was the Morrill Act of 1862 providing for agricultural education in the landgrant colleges. "Social Trends in Rural Life" describes the old landholding aristocracies, the rise of an agricultural democracy of "worker-farmers," and the problem of maintaining it in the face of a large influx of European immigrants of peasant status and mentality. The concluding chapters are "Po litical Trends in Rural Life" and "The Outlook for Farmers," the latter of which has hardly been borne out by subsequent developments.

5833. Taylor, Carl C. The farmers' movement, 1620-1920. [New York] American Book Co., 1953. 519 p. (American sociology series)

Bibliography: p. 501-508. 53-9515 HDi76r.T25

A volume which achieves an exceptionally large perspective by running "a conceptual thread through an elaborate and diverse body of recorded history." Mr. 'Taylor maintains that a farmers' movement has existed not merely since the 1870 's but since early colonial days, for it is as old as commercial agriculture in America. It arose out of and still revolves about the issues of prices, markets, and credits, originated "with the awareness of farmers that they had become a part of the price 
and market economy," and has been "continued by the more or less organized efforts of farmers either to protect themselves against the impact of the evolving commercial-capitalist economy or to catch step with it." The various farmers' revolts, only a few of which have been marked by violence or bloodshed, are the high tides in a movement unified by. a continuing body of ideologies and sentiments, and taking the form of a series of recurrent farmer "publics." Although Mr. Taylor calls his book "a sociological analysis," it is primarily a historical characterization of successive forms of protest, from the plant-cutters of Stuart Virginia to the Nonpartisan League and the cooperative marketing movement. In fact only the first 87 pages are concerned with developments prior to the Civil War.

5834. Taylor, Henry C., and Anne (Dewees) Taylor. The story of agricultural economics in the United States, 1840-1932; men, services, ideas. Farm finance section by Norman J. Wall. Ames, Iowa State College Press, 1952. xxvi, 1121 p.

$$
\text { 52-14651 HD } 1761 . \mathrm{T}_{28}
$$

The Taylors present in one large and comprehensive volume the development of thinking about the business phases of farming. They analyze the contributions of schools, experiment stations, colleges, and the Federal Government to the various practices that determine success or failure in agrarian industries and play an important part in the national welfare. The taking of the first agricultural census in 1840 marks the beginning of Government information services to meet the needs of farmers, and r932 is the "dividing line between two eras." Dr. Taylor (b. 1873) is particularly well qualified to write a book of this scope: he was the first professor of agricultural economics in a land grant institution, the organizer and first chief of the U. S. Bureau of Agricultural Economics, and the author of the first book (I905) to bear "agricultural economics" in its title. The subjects of marketing, rural finance, agricultural labor and wages, transportation, and taxation, which were omitted in his early work but have come to importance since, are adequately covered in the present study. The authors have made "writers of the period tell the story," and afford direct access to the source material which, until now, has been widely scattered. The very thorough index by Adelaide R. Hasse serves also as a bibliography.

5835. Thornton, Harrison John. The history of the Quaker Oats Company. Chicago, University of Chicago Press, 1933. 279 p.

$$
\text { 33-14986 HD9039.Q3 } T_{5} 1933
$$

Bibliography: p. 258-267.

The Quaker Oats Company, which was incorporated in I901 as a New Jersey holding company, but one unit of which goes back to 1832 , is typical of the many processing enterprises that have grown out of agricultural production. The author of this University of Chicago dissertation had access to company records for his account of the individuals, the technological changes, the financial growth, the expanding markets, and the advertising methods that have consolidated several smaller business units into a great industry. He begins his story with the cultivation of oats as it spread westward from the Eastern seaboard, describes the processes of the early millers, inspired by Ferdinand Schumacher (I 822I908), the "Oatmeal King," and narrates the expansion of the company as manufacturers of rolled oats, "puffed rice" and "puffed wheat," animal feeds, and related products. From the conquest of the American breakfast table by cereals hot or cold to the building of world markets, "the story of the Quaker Oats Company is part of the unfolding economy of American life."

5836. True, Alfred Charles. A history of agricultural education in the United States, 1785 1925. Washington, U. S. Govt. Print. Off., 1929. 436 p. illus. (U. S. Dept. of Agriculture. Miscellaneous publication no. $3^{6}$ )

Contribution from Extension Service.

$$
\text { Agr. 29-1 } 377 \text { S533.T837 }
$$$$
\text { S2r.A46, no. } 36
$$

Bibliography: p. 397-420.

As Director of the Office of Experiment Stations (1893-1915) and of the States Relations Service (1915-23), Dr. True of the U. S. Department of Agriculture was intimately associated, during the period of their greatest expansion, with agencies of agricultural education whose history he wrote in two other works issued as Department of Agriculture Miscellaneous publications, nos. 15 and 251 respectively, by the U.S. Government Printing Office: $A$ History of Agricultural Extension Work in the United States, 1785-1923 (Washington, 1928. 220 p.), and A History of Agricultural Experimentation and Research in the United States, 1607-1925, Including a History of the United States Department of Agriculture (Washington, 1937. 32 I p.). The present history of agricultural education in its relation "to the general development and progress of science and education and to the background of economic conditions and of organizations of various kinds for the promotion of agriculture and country life," begins with the post-Revolutionary period, when the foundations of the American system were being modeled upon European schools and literature. From 1820 to 1860 the growth of agricultural societies and publications, fairs, state boards of agriculture, and of general education evoked a move- 
ment for public support which resulted in the establishment of land grant colleges under the Morrill Act of 1862 . The book deals in large part with agricultural education since the passage of that act and extends to an analysis of agriculture in the elementary curriculum of the 1920's.

5837. U.S. Dept. of Agriculture. Farmers in a changing world. [Washington] U.S. Govt.

Print. Off., 1940. 1215 p. illus. (Its Yearbook of agriculture, 1940) Agr 55-7 S21.A35 $194^{\circ}$

A brief chronology of American agricultural history: p. $1184-1196$.

This noteworthy volume of the distinguished series of agricultural yearbooks which has been appearing since 1894 has the largest scope of any. More than 70 authors contribute to an analysis of the economic, social, and technological changes which have been taking place especially since 1920 , and of the farmer's reactions to them. The seven parts into which the symposium is divided indicate its scope: "The Farmer's Changing World," “Agriculture and the National Welfare," "The Farmer's Problems Today and the Efforts to Solve Them" (p. 385-937), "Farm Organizations," "What Some Social Scientists Have to Say," "Democracy and Agricultural Policy," and "Essentials of Agricultural Policy." The contents are summarized in a long preliminary essay by the editor, Gove Hambidge, "Farmers in a Changing World-a Summary" (p. I-Ioo). The final essay, by the then Chief of the Bureau of Agricultural Economics, Howard R. Tolley, "Some Essentials of a Good Agricultural Policy" (p. 1159-1183), sums up the ideas and the objectives of the farm policies of the New Deal. An idea that recurs throughout the volume is expounded by Louis H. Bean in "The Farmer's Stake in Greater
Industrial Production": if the latter could be increased to a point near capacity, "not all farm problems but many of the worst of them would disappear." That increase was on the point of taking place.

5838. Wilcox, Walter W. The farmer in the Second World War. Ames, Iowa State College Press, 1947. 4 Io p.

Agr 47-260 HDi76r.W 44

This Government-sponsored study aims to give "an integrated picture of the important economic forces affecting United States farmers during the second World War." It brings together from scattered sources, including interviews and correspondence with Government officials, the significant facts relating to agricultural production, marketing, manpower, and farm prices and wages. In many instances it makes comparisons with similar factors during World War I. To a great extent it is an interpretation of Government programs as they affected agriculture, and of farmer reaction to those programs. World War II brought about a shift from programs created to help the farmer in a depressed period to programs for meeting warcreated scarcities. After describing price policies in general and in the several fields of agriculture, the author analyzes the economic implications of such policies for the future, examines Government management of the food supply in relation to winning the war, and describes the technological processes that increased output in spite of reduced manpower. He concludes: "Though substantial progress has been recorded in farm families' standard of living and in the legislation designed to improve and stabilize their income, the basic problems remain unsolved."

\section{Agriculture: Practice}

5839. Black, John Donald. Farm management [by] John D. Black [and others]. New York, Macmillan, 1947. 1073 p.

$$
\text { Agr 47-314 } \mathrm{S}_{5} 6 \mathrm{r} . \mathrm{B}_{53}
$$

"Further reading" at end of most of the chapters.

A massive textbook for advanced courses in agricultural colleges by John D. Black, Marion Clawson, Charles R. Sayre, and Walter W. Wilcox; the advantage of quadruple authorship is that each author is most familiar with the farming of a different major region of the United States. The manager of a farm business, who in the United States is usually also a farm laborer, has "to organ- ize it, to plan the work and direct it from day to day, and to plan, and on most farms actually conduct, the buying and selling and the financing or credit operations." He should analyze his problems in terms of his farm as a whole, and according to the methods of Farm Management, which "is applied Science-not just applied Economics, but also applied Biology, Physics, Chemistry, Geology, Meteorology, Psychology and even Sociology." Part 2, "Systems of Farming," distinguishes between one-crop, specialized livestock, diversifiedcrop, feed-and-livestock, and crop-and-livestock farming. Part 3, "Principles and Methods of 
Analysis," includes a chapter on "Measutes of Success and Factors of Success in Farming." Part 4, "Problems of Management," has chapters on the management of farm equipment, of labor on farms, and of land. Part 5 is on "Management by Types of Farming" determined by the product such as wheat or sheep, but it also has chapters on "Irrigation Farming," "The Management of Farm Woodland," and "Part-Time and Self-Sufficing Farming." The authors emphasize that farm management is essentially the farmer's reaction to external factors, principally weather, prices and costs, and technological advance.

5840. Black, John Donald. The rural economy of New England, a regional study. With the assistance of the Committee on Research in the Social Sciences and the Graduate School of Public Administration of Harvard University. Cambridge, Harvard University Press, 1950. xxiv, 796 p. diagrs., maps. $\quad 50-9844 \mathrm{HDr}_{773} \cdot \mathrm{A}_{2} \mathrm{~B}_{5}$

This substantial volume is the result of 30 years' intensive study of the rural land-use economy of New England by a Harvard professor of economics, drawing upon successive national censuses and "the whole research effort of the six New England Agricultural Experiment Stations since they were founded, and of the federal research agencies cooperating with them." It is presented as "a case study in regional analysis," showing what can be achieved for other areas by the same kind of detailed study. Dr. Black regards it as particularly significant because New England has undergone the maximum of industrial and urban development, and "the distribution of land uses between rural and urban which one finds in New England-among crops, pasture, woodlot, and forest, among pleasure ground, country home, and suburban home-is likely to characterize, in some future period, almost as large a part of our national domain as is the more largely agricultural distribution" of the Midwest and South. Chapter I4 (p. [250]-27I) is a sketch of New England agricultural history' aiming to show how and when it acquired its present characters: "largely a region of dairy cows and fluid milk, hay and pasture, and poultry and vegetables for local consumption," and "a region mainly of ordinary family-sized farms interspersed freely in many sections with part-time, country-home, and other residential farms." The author concludes that "the great retrogression that set in before the Civil War" in New England agriculture leveled out about 1920, that its forestry should soon "round the turn," and that residential and recreational use should continue to expand. But all these depend upon New England industry and trade maintaining themselves, and all will go better if active policies replace the recent tendency to drift and stagnate.

5841. Davis, John H., and Kenneth Hinshaw. Farmer in a business suit. New York, Simon \& Schuster, 1957. 24I p. 57-7308 HDi76r.D35 Dr. Davis was Assistant Secretary of Agriculture in President Eisenhower's first administration, and has since been with the Harvard Graduate School of Business Administration; his collaborator handles publications and public relations for Eastern States. Farmers' Exchange. Dr. Davis has been engaged in working out a new approach, of which he has given a technical and statistical analysis with another collaborator, Ray A. Goldberg: A Concept of Agribusiness (Boston, Division of Research, Graduate School of Business Administration, Harvard University, 1957. xiv, 136 p.). With Mr. Hinshaw he aims at a popular presentation of the idea by means of a fictional narrative of three generations of an Oregon family farm, with interlarded commentary. "The Earthbound Era" lasted from about I880 to I920. "The Transition," from about 1920 to I940, saw farmers overwhelmed by problems, because "confronted with the necessity of buying a modern standard of living instead of being able to create it to a considerable degree directly from the soil of their farms." In the present "Agribusiness Era" the supply of farms, productive operations on farms, and the preparation of farm products for the market are three inseparable and interdependent stages of a single economic process. The greatest needs are for "versatile, better, and more appealing ways to market agricultural products," and for more research to find new crops or new uses for present overproduced crops. There is no master plan for agricultural salvation, but "little by little we can win the battle of the farm problem by developing successful agribusiness programs for each type of farming or each farm product."

5842. Fetrow, Ward W., and Ralph H. Elsworth. Agricultural cooperation in the United States. Washington [U. S. Govt. Print. Off.] 1948. 214 p. (U. S. Farm Credit Administration. Bulletin 54) Agr 48-486 HG2051.U5A574, no. 54

"This publication is designed to provide information on some of the more general phases of the cooperative movement among farmers and also a description of the organizations and the methods of operation of associations in the various fields of cooperative endeavor." The introductory matter includes a brief historical sketch, a statement of principles, and a statistical treatment of the extent of cooperative activity. "Cooperation in Farm Production" (p. 1 $7^{-28}$ ) is a relatively minor aspect, but does include the mutual irrigation companies of 
long standing and various product-improvement groups. "Cooperation in Marketing Farm Products" (p. 29-135) is much the longest section and describes the area of greatest success. In 1945 there were 7,400 marketing associations, with an estimated membership of 2,895,000 and an estimated annual business of $\$ 4,835$ millions. "Cooperative Purchasing of Farm Supplies" (p. 14I-154) became a major development only after 1920. In I945 it numbered 2,750 groups, 1,610,000 members, and an annual business of $\$ 8$ 10 millions. "Cooperative Farm Business Services" (p. 155-185) includes financing, insurance, and telephone organizations. Cooperation flourishes, but the mortality of cooperative organizations has been and remains high; 15,530 defunct marketing or purchasing groups are of record. The reasons for this are only very tentatively arrived at.

5843. Haystead, Ladd, and Gilbert C. Fite. The agricultural regions of the United States. Norman, University of Oklahoma Press, I955. xx, $288 \mathrm{p}$.

55-9620 $\mathrm{S}_{44} \mathrm{I}_{2} \mathrm{H}_{35}$

"Notes on sources and additional reading": p. $276-28$ o.

5844. Mighell, Ronald L. American agriculture, its structure and place in the economy. For the Social Science Research Council in cooperation with the U. S. Dept. of Agriculture, Agricultural Research Service, and the U.S. Dept. of Commerce, Bureau of the Census. New York, Wiley, 1955. $187 \mathrm{p}$. (Census monograph series)

$$
\text { 55-8г79 } \mathrm{HD}_{7} 6 \mathrm{r} . \mathrm{M}_{4} 8
$$

The first title is a concise economic geography of American agriculture which emphasizes its diversity and its efficiency. It is intended for all "interested in why the greatest industrial nation in the world should also have the largest farm output and be one of the most varied in agricultural production." The average American farm of 1950 included 215.3 acres, each worth $\$ 64.96$ (as against figures of 133.7 and $\$ 19.02$ for 1880 ) but no one could point to a typical American farm. There is, however, a typical American farm product, corn, which "has something over six hundred uses, ranging all the way from bourbon whiskey to the sizing that makes the paper in magazines slick." The remaining II chapters survey as many regions, from "New England: Land of Abandonment" to "The Western Slope: Land of Tomorrow." Sketch maps, dot maps, and 89 well-constructed statistical tables permit a very rapid apprehension of essential factors. Dr. Mighell of the Agricultural Research Service of the Department of Agriculture provides a statistical view of American agriculture based upon the I950 census (for other volumes in the series see no. 4395). He furnishes a number of dot and other maps, but for the most part his tabulations of "Agriculture in the Total Economic Process," "Dimensions of the Agricultural Plant," "Structure of Commercial Farms" by scale and type, "Farm Tenure and Debt," and "Social Features of the Structure of Agriculture" apply to American agriculture as a whole.

5845. Larson, Adlowe L. Agricultural marketing. New York, Prentice-Hall, 1951. xiv, 519 p. 5I-3575 HDg0o6.L28

A simply written textbook by a professor of agricultural economics at Oklahoma State University of Agriculture and Applied Science. Marketing is defined as "the performance of business activities that direct the flow of goods and services from producer to consumer"; it becomes a subject for separate study as the degree of specialization in the economy increases. Part $\mathrm{I}$ is a general discussion of the market for agricultural products as determined by population, employment, national and family income, consumption, and export outlets, and this market's place in the national economy. Part 2 describes the several types of marketing agencies, local, wholesale, and retail. Part 3 analyzes the operations or marketing functions of these agencies under two categories: monetary handling. which includes buying and selling, risking, and financing; and physical handling, which includes storage, transportation, and standardization. Part 4 describes the marketing process in four major commodities: grain, cotton, livestock, and dairy products. Part 5 introduces the theory of pricing, and assesses the effect of monopolistic tendencies in recent price developments. The sixth and last part has chapters on seven "problem areas": marketing costs, information, and research; trade barriers; futures trading; agricultural cooperation; and Federal policies.

5846. McWilliams, Carey. Ill fares the land; migrants and migratory labor in the United States. Boston, Little, Brown, I942. 4 I9 p.

Bibliography: p. [39I] -4 I I.

$$
\text { 42-5664 HDi525.M } 35
$$

The plight of the migratory workers was little noticed until they began arriving in California by the tens of thousands. Attention was focused on them by John Steinbeck's novel of 1939, Grapes of Wrath (no. I777), which was followed in quick succession by the investigations of the La Follette and Tolan Committees, the inquiry of the Temporary National Economic Committee into technological changes in agriculture, and other forms of publicity. As chief of the Division of Immigration and Housing for the State of California from 1938 
to 1942 , the author was directly concerned with problems of migratory labor. He emphasized the people and their plight in this book, but also indicated the forces which had produced two types of agricultural migrants-those displaced from their own farms and those who were habitual migratory workers. Book I deals with the problems of migrants in the highly industrialized agriculture found in California and Arizona. Book 2 is documented from the Congressional investigations which revealed that the California situation was paralleled in many respects by conditions in Colorado, Ohio, Indiana, the east coast, and elsewhere. Book 3 describes conditions in the homes from which the California migrants came, and argues that the dust storms of Oklahoma and Texas had been given too much of the blame for a manmade situation. Book 4 is concerned with the agricultural revolution of the 2oth century, during which technological advances have brought about a swing from farm ownership and family operation to farm tenancy, and have turned the hired hand into the migrant laborer. It reviews measures taken by State and Federal governments to relieve the situation and considers long-range programs for its solution. Most of this dislocation was resolved by the manpower shortage of World War II, but the bad days described in this indignant book have remained a potent factor in all subsequent measures to maintain American agriculture.

5847. Malott, Deane W., and Boyce F. Martin. The agricultural industries. New York, McGraw-Hill, I939. 483 p.

$$
\text { 40-1402 HD9005.M3 } 1939
$$

"Selected bibliography": p. 463-476.

The handling and processing of agricultural products have grown during the past century from household industries into fully developed elements of our economic structure. This volume "is designed to present the business aspects of purchasing, processing, financing, and marketing the chief agricultural raw materials entering into American industry and commerce, and to analyze the business problems peculiar to those industries." The industries that use such raw materials as milk, livestock, cotton, grain, sugar, tobacco, and wool are treated in separate chapters. In developing their thesis the authors have used not only Government documents and other published data, but also over $15^{\circ}$ actual business problems collected by them from these industries for use in a course on agricultural industries in the Harvard Business School. The authors emphasize that these industries handle the essential food and clothing requirements of the American people, and provide the cash income for our farm population. Their gth and last chapters, "Summary and
Conclusions," argues the similarity if not identity of interest between farmer and "processor": "Both are concerned with making the farmer's product more attractive to the consumer and encouraging the use of it in greater quantities," so that "it is extremely shortsighted for the farmer to consider the processor and handler of agricultural products as an inevitable antagonist." Government programs which help the farmer only by multiplying difficulties for the processor are neither democratic nor economically sound.

5848. Murray, William G. Agricultural finance; principles and practice of farm credit. 3 d ed. Ames, Iowa State College Press, 1953. 419 p. 53-12178 HG2051.U5M88 1953

This third edition of a comprehensive textbook originally published in I94I is a study of the credit principles which guide or should guide the borrowing of funds by farmers, and of the lending organizations which have grown in number and complexity since the Federal Farm Loan Act of 1916 added Federally sponsored agencies to the banks, insurance companies, and individuals already in the field. A new chapter on risk insurance and investment and a second chapter on commercial banks have been added to this third edition. Other changes take account of new legislation, recent statistics, and farm credit changes which have occurred since the second edition (1947). Part I seeks to consider credit principles from the vantage points of both borrower and lender, and includes a chapter on "Buying a Farm on Credit." Part 2 now requires Ig chapters to describe the sources and varieties of credit available to the farmer; 12 of them deal with Federal sources as against 5 for other lenders. The Federal Government's battle against farm tenancy in the United States and its measures taken to turn tenants into owner-operators are summarized in the last chapter. The author concludes that, despite the small success of earlier measures, the recent conservative policy of restricting loans during periods of high prices, "plus a widespread movement on the part of farmers generally to pay debts rather than to increase them," will promote a movement up the ladder from tenancy to ownership.

5849. White, John M. The farmer's handbook. New ed., rev. by N. W. Sellers. Norman, University of Oklahoma Press, 1952. $462 \mathrm{p}$. 52-14154 S501. W54 1952

Mr. White says in his preface: "I have endeavored to condense and put into this book the results of my own experience of fifty years as a farmer, a county agent, a district agent, and a specialist of the United States Department of Agriculture and the Agricultural and Mechanical College of Oklahoma." The first edition of 1948 went through 
seven printings and rapidly became a standard reference work. The book aims to present in concise form and simple language the most up-to-date information on farm methods gathered from the most reliable sources, and is "intended to be as useful to the farmer as a good cookbook is to the housewife." The material is arranged in topical sections, and alphabetically by subtopics within each section. The first nine sections deal with agriculture, from grain crops to berries, and the next six with stockraising, from beef cattle to poultry and rabbits. Diseases and pests and their antidotes are regularly described. There follow "Feeds and Feeding," "Soil Management," "Beekeeping," "Fish and Wildlife," "Farm Engineering," and "A Little about a Lot," from agricultural colleges to weights and measures. The text is interspersed with numerous photographs, diagrams, and tables, and there is both a glossary of farm terms (p. 433-44I) and a substantial index. The Farmer's Handbook provides a rapid overall view of the best farm practices in the United States.

5850. Wilcox, Walter W., and Willard W. Cochrane. Economics of American agriculture. New York, Prentice-Hall, 1951. 594 p.

51-6252 HDi76r. W4 435 A textbook for general courses in agricultural economics which seeks to give a comprehensive picture of its subject by first describing each segment or problem area in American agriculture, and then introducing modern economic analysis to further the understanding of each. These analyses, the authors say, have been kept at an elementary level, but the average reader will find them abstruse enough. Part I, "Developing Efficiency in the Production of Farm Products," presents the nine major type-of-farming areas into which farm management specialists have classified the country, discusses the most profitable level of capital and labor input and of crop production, and finds that "most farms in the United States are smaller than optimum according to economic standards," but that the average size is steadily rising. Part 2, "Problems in Acquiring and Managing Land," discusses the distribution of farm people (owners, tenants, hired workers), the economic classes of farms (largescale, part-time, etc.), the problems of tenancy and the extent of inheritance, and the economic effects of taxation. Part 3, "Marketing Farm Products in an Interdependent Economy," concludes that, although more than half the consumer's farm-product dollar goes for processing and distributing, he is in fact choosing to spend his money for additional services (such as packaging) making for greater convenience. The remaining three parts are "Toward an Understanding of Farm Prices," "Farmers in the National and World Economy," and "What Government Aid Do Farmers Need?" References for further study occur at the end of each of the 32 chapters.

\section{Agriculture: Government Policies}

5851. Bailey, Joseph Cannon. Seaman A. Knapp, schoolmaster of American agriculture. New York, Columbia University Press, 1945. $307 \mathrm{p}$. (Columbia University studies in the history of American agriculture, no. 10)

$$
\mathrm{A}_{45-5256} \mathrm{~S}_{4} \mathrm{r} 7 . \mathrm{K} 6 \mathrm{~B}_{3}
$$

I945a

"Selected bibliography": p. [28I]-29o.

Knapp (I833-191 I) began life as a schoolmaster, and was vice president of Ripley Female College at Poultney, Vt., in 1866 , when an accident in a softball game nearly cost him a leg and drove him to an Iowa farm for the restoration of his health. Here his strength of mind and character led to a brilliant series of achievements, as leader of the Iowa stockbreeders, professor of agriculture and then president of Iowa State College, director of the colonization experiment at Lake Charles, La., and creator of the rice industry of the Southwest. From 1898 he was associated with the U.S. Department of Agriculture, and in the course of introducing oriental crops into the lower South, and combating the boll weevil menace which became acute in I903, he hit upon the demonstration farm technique, or Terrell [Tex.] plan, whereby a local farmer who volunteered to adopt the recommended methods was guaranteed against financial loss. "The right psychological key which unlocked the door to the farmer's cooperation had been found." During Dr. Knapp's remaining years he spread this method through the South as "the Farmer's Cooperative Demonstration Work" of the Department, and three years after his death Congress established it on a national scale by the Smith-Lever Act (I9I4). Dr. Bailey's Columbia dissertation is in large part based on original records of the Department of Agriculture and gives a vivid picture of a strong personality and a public-spirited career that deserves to be remembered.

5852. Baker, Gladys. The county agent. Chicago, University of Chicago Press, I939. xxi,

$226 \mathrm{p}$. (Studies in public administration, v. II)

$$
\text { 39-21222 } \mathrm{S}_{533 \cdot \mathrm{Br}_{7}} \text { r939a }
$$


Prepared as a dissertation at the University of Chicago, and in large part based on observation and interviews in the field, especially in Iowa, this is an administrative study of the key man in recent agricultural organization, who began about 1906 "as an adult itinerant vocational teacher" and by 1939 brought national agricultural programs to localities "as a promoter, adviser, semiadministrator, and even as an administrator." He simultaneously represented the Federal, State, and county governments, and might also be "closely allied with a semiprivate farm organization which he has in part built up." The first four chapters describe the origins and evolution of the office from the invasion of the Mexican boll weevil through the peacetime measures of the Roosevelt administration. The remaining four describe the divided responsibility of and for the county agent, the financial support which he received from private as well as public funds, the selection, training, and emoluments of agent personnel, and the Negro county agents who in I5 states paralleled among their own people, on a lower technical level and for less pay, the work of the white agents, but were usually dependent upon "the tolerance and at least mild support" of the latter, and were confronted by tremendous obstacles.

5853. Benedict, Murray R. Farm policies of the United States, I790-I950; a study of their origins and development. New York, Twentieth Century Fund, I953. xv, 548 p.

$$
\text { 53-7172 HDi76r.B37 }
$$

5854. Benedict, Murray R. Can we solve the farm problem? An analysis of Federal aid to agriculture. With the report and recommendations of the Committee on Agricultural Policy. New York, Twentieth Century Fund, 1955. xix, 6oI p. 55-8796 HDi76r.B35

5855. Benedict, Murray R., and Oscar C. Stine. The agricultural commodity programs; two decades of experience. New York, Twentieth Century Fund, 1956. xliii, 5 ro p.

$$
\text { 56-12417 HDgoo6.B } 42
$$

These three volumes incorporate the most detailed analysis and critique of the farm policies of the United States during the last three decades (roughly, since the enactment of the McNary-Haugen Act in 1927) that has been made. In I95I the Twentieth Century Fund undertook "to give the general public an impartial, over-all picture of the vast governmental operations in the field of agriculture and of their causes and effects," and engaged Dr. Benedict, professor of agricultural economics at the University of California, as research director and Dr. Stine, a former assistant chief of the U.S. Bureau of Agricul- tural Economics, as associate director. Since Dr. Benedict had been at work for some time on a general history of United States farm policies, he was commissioned to complete it under the fund's auspices. The result is the first and largest volume, which is not, however, so much more retrospective in scope as its title seems to indicate. The first seven chapters (p. 3-137) are a topical survey of developments down to 1913 , largely derived from secondary works, and the detailed narrative begins only with the Wilson administration. The thorough-going chronological treatment of agitation, legislation, administration, and production and price statistics that follows is the counterpart of the analytical treatment in the two following volumes. Dr. Benedict's part of Can We Solve the Farm Problem? defines the changing nature of the problem since I920, describes eight different sorts of programs in as many chapters, and concludes with one entitled "Two Decades of Experience: What Conclusions Are Warranted?" It is followed by the "Report of the Committee on Agricultural Policy" (p. 483-530); this committee of 12 appointed by the fund to study the research findings was headed by Jesse W. Tapp, chairman of the board of the Bank of North America, and included representatives of farm organizations, professors of economics, and others. Its report speaks of "the overrigidity of the policies and programs of the past few years," and suggests in several places that price supports and stored surpluses have been excessive, and that there has been too little "reliance on automatic adjustments in the market." The Agricultural Commodity Programs, in which Dr. Stine appears as co-author, opens with a substantial "Introduction and Summary" ( $p$.

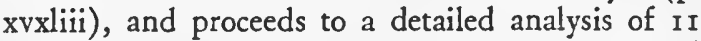
programs from cotton and tobacco to potatoes and fluid milk. August Heckscher, director of the Fund, notes its "particular interest which derives from showing the extremely subtle variations, both of method and effect, which arise in the application of farm policy."

5856. Deering, Ferdie. USDA, manager of American agriculture. Norman, University of Oklahoma Press, I945. xvi, 213 p. illus.

$\mathrm{Agr} 45-370 \quad \mathrm{~S}_{21} . \mathrm{C}_{9} \mathrm{D}_{4}$

An interesting and well-organized inquisition into the organization and policies of the Department of Agriculture, conducted from the outside by the editor of The Farmer-Stockman of Oklahoma City. "The USDA has failed," the author says, "primarily because its 'solutions' have been based on the theory of providing an artificial foundation for farm prices, and its methods have been to build more and bigger agencies to handle the problems." The author makes concrete suggestions for streamlining the 
Department into "a comprehensible and efficient" unit of government with the primary purpose of providing the farmer with know-how and services not otherwise available. It should be noted that this book was published at a time when the Department was in an abnormal situation brought about by World War II.

5857. Harding, Thomas Swann. Two blades of grass, a history of scientific development in the U. S. Department of Agriculture. Norman, University of Oklahoma Press, I947. xv, $352 \mathrm{p}$. illus.

Agr. 47-I59 $\mathrm{S}_{21 .} \mathrm{C}_{9} \mathrm{H}_{3}$

The Department of Agriculture was created in 1862 "to acquire and to diffuse among the people of the United States useful information on subjects connected with agriculture in the most general and comprehensive sense of that word." The author, associated. with the research activities of the Department since 1910, presents a popular account of the scientific investigations and publications through which the Department has fulfilled its "general designs and duties" since its activities were started in the Patent Office in 1839 . Against a background of expanding organization and shifting bureaus, he emphasizes research in the fields of food and drugs, economic entomology, plant sciences, forests, animal diseases, soil analysis, nutrition, household appliances, and textiles. He also describes, somewhat in detail, the bulletins, circulars, journals, and other publications of the Department on subjects closely allied with daily living and available to the public.

5858. Huffman, Roy E. Irrigation development and public water policy. New York, Ronald Press, 1953. 336 p. 53-10006 HDi735.H8 Bibliography: p. 309-326.

The author first summarizes the history of irrigation and public policy concerning it in the United States, and then proceeds to develop analytically such subjects as the nature and administration of water rights, the relation of irrigation to land policy, the organization and operation of irrigation projects, the development of irrigated farms, the integrated use of irrigated land, and programs of river basin development. The emphasis throughout is on their social as well as their economic aspects. He believes that "as a nation, we should be mature enough to map out a long-range policy regarding land reclamation which will assure the continued strength of the nation and be acceptable to most of its citizens." He first isolates I4 factors which should be determinants for irrigation policy, from national and Western population growth to national security and our foreign trade policies, and concludes by suggesting 20 components of a sound irrigation policy for the
United States. They are necessarily rather abstract, as may be seen from no. 5: "The family farm should remain as a basic objective in the expenditure of public funds for irrigation development but it should be a concept consistent with modern agriculture."

5859. McConnell, Grant. The decline of agrarian democracy. Berkeley, University of California Press, 1953. $226 \mathrm{p}$.

53-9387 $\mathrm{HD}_{4} 484 . \mathrm{M}_{25}$

The striking title conceals a subject considerably more limited in scope: the American Farm Bureau Federation and its influence on recent farm policies. The creation of the county "bureaus" was the work of the county agents originated by Seaman A. Knapp and systematized by the Smith-Lever Act of 1914 (nos. $5^{851}$ and 5852); the name, little appropriate for an organization of farmers, was accidental in origin but was officially adopted in 1916. State federations were formed beginning in 1915, and the national federation of State federations was organized in 1920. The membership fluctuated until I934, but steadily increased thereafter, reaching $1,452,000$ in 1951 . Dr. McConnell seeks to demonstrate that an organization which was called into being to further technical instruction by the county agent has become his master and the greatest power structure in rural America, and that it represents the large-scale and prosperous farmers rather than the small-scale and marginal farmers. Its new strength conferred by the New Deal farm policies was employed to destroy the Farm Security Administration, the New Deal's device to assist the small farmer. Its influence is traced in the postwar struggles over the administration of agricultural programs (the federation's favorite agency is naturally the Extension Service, which it controls) and in the defeat of the Truman administration's Brannan Plan in 1948. The author regrets that "an intensified social stratification has occurred within agriculture, the source of much of our equalitarian tradition."

5860. Schickele, Rainer. Agricultural policy: farm programs and national welfare. New York, McGraw-Hill, 1954. 453 p.

$$
\text { 53-9004 HDi76r.S22 }
$$

The chairman of the Department of Agricultural Economics at North Dakota Agricultural College has written this book "for the student of rural America, be he farmer, businessman, labor leader, public servant, college student, or instructor." $\mathrm{He}$ aims "to explore how agricultural policies can improve living conditions for farm families and serve the economic welfare of the community at large." The first two parts discuss the general problem of 
policy-making in a free society and other fundamentals. Part 3 is concerned with programs in production credit, soil conservation, and other landuse policies. Much the largest is part 4, "Farm Price Policy" (p. 136-307), which justifies Government support of farm prices on the ground that farmers are peculiarly vulnerable to price fluctuations, and "could not apply the price support devices which industry, trade, and labor had developed so effectively through their own private collective action." Part 5, "Programs for Improving Income Distribution," defines the family farm as the goal of land tenure policy and calls the Farmers Home Administration established in 1937 " a break for the small farmer." The background of Federal price support policies is illuminated by Gilbert C. Fite in his life of a man whose concept of agricultural equality triumphed in 1933 and has remained basic ever since: George N. Peek and the Fight for Farm Parity (Norman, University of Oklahoma Press, 1954. 314 p.).

5861. Soth, Lauren. Farm trouble. Princeton, Princeton University Press, 1957. 221 p. diagrs.

57-5459 HDr76r.S79

Mr. Soth has taught economics at a land-grant college and been an editor for the Department of Agriculture; he now handles the editorial page of the Des Moines Register and Tribune. His sharply written little volume takes a darker view of the agricultural situation and of recent trends and policies than do most commentators. Agriculture, he is convinced, remains a sick industry, with per capita farm income running about half of per capita nonfarm income. The lower third of American farmers, on the more isolated, small, and technologically backward farms, suffer real poverty and are out of the stream of the 2oth-century American life. Acreage controls have not been successful, for the supply of farm products has been growing faster than the relatively inelastic demand for them, and seems likely to go on doing so. There are "too many farmers"; in spite of the relative and absolute shrinkage of farm population, too many persons have to share agriculture's share of the national income. Acreage control and price supports have been in conflict with a freer foreign trade policy. Soil conservation programs have been carried through, but only with the effect of increasing production; true conservation should take land out of use. Mr. Soth refrains from dogmatism, but suggests that the program of price supports limited to a few basic crops has not been a success, that "a strait-jacket of monopoly controls" has been created, and that direct payments to farmers or a general food subsidy are alternatives more consistent with free enterprise.

\section{E. Forests, National Parks}

5862. Allen, Shirley W. An introduction to American forestry. 2d ed. New York, McGrawHill, 1950. 413 p. (American forestry series)

$$
\text { 50-4768 SD 371.A6 I950 }
$$

As a professor of forestry and sometime president of the Society of American Foresters, the author has been asked numerous questions about forestry which he here attempts to answer for the benefit of students, teachers, and practicing foresters. This new edition brings up to date changing techniques and policies, while the background material has been little altered. In general it covers the nature of forest resources; the development of the science, art, business, and public policy of forestry in the United States; and the shares of Federal, State, and local governments in practicing forestry. The chapter on education, with its survey of opportunities, will be of special interest to those who plan to pursue forestry as a profession. References for further study are given at the end of chapters.

5863. Boerker, Richard H. D. Behold our green mansions; a book about American forests.
Chapel Hill, University of North Carolina Press, 1945. xv, 313 p. illus. Agr $45-148$ SDi43.B6 The emphasis throughout this book is on "forest reservation for multiple use, with human welfare as the ultimate object." Following a description of the forest and timber regions of the United States, chapters are devoted to the beneficial uses of our forests for recreation, wildlife conservation, and livestock range, for the control of the water supply and soil erosion, and for the sustained supply of lumber and other forest products. The ravages of fire, insect enemies, and tree diseases are reviewed against a background of State and Federal programs for the protection and development of the forests. The peculiarities and potentialities of forests in the Southern States are summed up in a separate chapter. In a final plea the author urges that the logging industries and the public cooperate to conserve our forests and "to produce permanent communities of healthy, happy, busy [forestry] workers with all the social, cultural, and recreational benefits they have a right to expect from a great democracy." 
5864. Horn, Stanley F. This fascinating lumber business. Indianapolis, Bobbs-Merrill, I95I. 313 p. illus. 5I-r410I HD9755.H6 I95I The lumber business, based on the "product of the saw and planing mill," is described as the biggest and most important of the forest-products industries. It is widely scattered in logging camps and sawmills throughout the vast timber regions of the North, South, East, and West, with outlets in the retail lumber yards of the 48 States. The author, who has been associated with lumbering for $3^{\circ}$ years, presents the highlights of the whole industry. Allied forest products, the economics of the industry from transportation to grading and inspection, the importance of lumber in wartime, and recent advances in equipment and techniques are among the subjects discussed. The last chapter, which reviews research projects on the best possible utilization of wood, illustrates the importance of the industry to the national economy.

5865. Shirley, Hardy L. Forestry and its career opportunities. New York, McGraw-Hill,

1952. 492 p. illus. (The American forestry series) $52-6001 \quad S_{371 . S_{5}}$

Based on materials used in a course in general forestry for freshmen at the State University of New York, College of Forestry, this book is intended to help beginning students to decide if forestry is to be their work. The author first traces the development of forestry, the lumber industry, the manufacture of wood products, and their importance in the national and world economy. He further points out the social benefits derived from forestry-wildlife, soil, and watershed protection, and recreation-which justify the care of the forests and therefore the profession. The chapters that follow describe the employers of foresters, employment opportunities, education and research, and programs in progress which afford worthwhile compensation and opportunities for service. On the 5oth anniversary of its founding, the Society of American Foresters published a history of the growth of the profession in America: Fifty Years of Forestry in the U.S. A., edited by Robert K. Winters (Washington, 1950. 385 p.).

5866. Tilden, Freeman. The national parks, what they mean to you and me; introd. by Newton
B. Drury, Director of National Park Service, 194051. New York, Knopf, 1951. xviii, 417, xxi p. illus. 51-II226 Ei60.T5 1951 The national parks appealed to Alfred Knopf, the publisher of this book, "as an element in our culture and a symbol of the American way of life regarding which the public should be made more aware," and he asked the National Park Service to suggest an author to prepare a definitive work on them. Freeman Tilden, a veteran writer, was selected as the man who "knew the national parks and "what makes them tick." Describing the national monuments and parks from Washington to Florida, and from California to Maine-the forests, canyons, caves, deserts, glaciers, and volcanoes-the author points out the spectacular creations of nature which may be found in those recreational areas. He analyzes the structure and operation of the National Park Service in its efforts to conserve wildlife and the forests from commercial exploitation, and "to provide for the enjoyment of the scenery, the natural wonders, and historic objects . . . in such manner and by such means as will leave them unimpaired for the enjoyment of future generations." The fourth edition of Devereux Butcher's Exploring Our National Parks and Monuments (Boston, Houghton Mifllin, 1954. 288 p.) has a slighter text, but is more copiously illustrated. It appears under the auspices of the National Parks Association, and the first edition was published in 1947. In the fall of I9I4 Stephen Tyng Mather (1867-1930), a wealthy Chicago manufacturer of borax, wrote a letter of complaint concerning the national parks, and was invited by his old classmate Franklin K. Lane, Secretary of the Interior, to come to Washington and run them himself. His tenure, first as assistant to the Secretary and then as first Director of the National Park Service (19r7-29), saw the establishment of principles for their acquisition, maintenance, and administration, and the development of a true service to handle the host of tourists brought by the new automobiles. Robert Shankland's Steve Mather of the National Parks, 2d ed., rev. and enl. (New York, Knopf, 1954. xii, 346, xxii p.) describes and assesses his achievement, and indicates subsequent progress along the lines he laid down.

\section{F. Animal Husbandry}

5867. Crowell, Pers. Cavalcade of American horses. New York, McGraw-Hill, r95I.

3 II p. illus.
$5 \mathrm{I}-\mathrm{I}_{2662} \mathrm{SF}_{2} 8_{4} \cdot \mathrm{U}_{5} \mathrm{C}_{7}$
Recognizing the companionship between horse and man through the ages, and the usefulness of the horse in opening up the American wilderness to 
civilization, the author tells the story of individual breeds against a background of history, anecdote, and legend. He presents the bloodlines, training, and records of great American saddle horses, Arabian horses, quarter horses, Morgan horses, standard bred horses, Tennessee walking horses, thoroughbred horses, and Western horses. This procession of racers, trotters, riding horses, carriage teams, show horses, cow ponies, cavalry mounts, and plain utilitarian horses leads to a better understanding of all breeds, and the place which they occupy or have occupied in American life.

5868. Dale, Edward Everett. The range cattle industry. Norman, University of Oklahoma Press, 1930. 216 p. 30-25282 SFig6.U5Di 8 Bibliography: $\mathrm{p}[197]-208$.

The author narrates the rapid growth and sudden decline of the ranch industry on the Great Plains from the close of the Civil War to the 1920's. He begins with Texas, the original home of large-scale ranching in the United States. He describes the close relationship that developed between the Great Plains and the corn belt of the East, through the exchange of cattle for breeding and feeding, and through Eastern credit channels. "Whatever may have been the ranchmen's faults," says the author, "they were in many areas advance agents of civilization, and their contribution toward the upbuilding of the West has been enormous." It is pointed out that careful scientific study should be given to the utilization, conservation, and restoration of ranges, the improvement of water facilities, the optimum size of one-family ranches, and to marketing and financing-much of which has been accomplished through Federal legislation since the publication of this book.

5869. Dowell, Austin Allyn, and Knute Bjorka. Livestock marketing. New York, McGrawHill, I94 I. 534 p. illus. 4I-5423 HD9433.U4 D6

This book has been prepared for the use of students, county agricultural agents, marketing agencies, packers, and others concerned with the production and marketing of livestock and the distribution of meats. It analyzes the business activities involved in the flow of animal products from producers to consumers. The various methods of slaughtering and marketing livestock are described as they have been changed by new techniques, economic forces, and legislation. Chapters deal with grade standards for livestock and meats; prices; the regulation and supervision of the packing industry; cold-storage lockers; and the distribution of meats through wholesale and retail outlets. "Selected Readings" appear at the end of chapters.
5870. Gabrielson, Ira Noel. Wildlife management. New York, Macmillan, 195I. 274 p. Agr 5I-501 SK36r.GI3

Out of his experience as Director of the U.S. Fish and Wildlife Service from 1940 to 1946 , and as president of the Wildlife Management Institute since that date, the author has produced a book about a new profession-the wildlife manager, who "as the business manager of a great resource, must first maintain the resource, and second, utilize it to the greatest possible advantage of the nation and its people." The place of research and the education of both the public and the technician in wildlife management are reviewed, as well as the need for regulation of the human harvest of the wild population, and of regular inventories. Chapters 6 to ro deal with wildlife itself-refuges, artificial propagation, population control, and the manipulation of environment. Noting a decline in standards of conduct among sportsmen, the author suggests some rules that should be followed and points out the need for more personnel, law enforcement, and cooperation to preserve the economic and recreational value of the Nation's wildlife.

587r. Hohman, Elmo Paul. The American whaleman; a study of life and labor in the whaling industry. New York, Longmans, Green, r928. xiv, 355 p. illus. 28-2932I $\mathrm{SH}_{3} 8 \mathrm{r}$.H6 Bibliography: p. 336-347.

A colorful work based on a wide range of original sources-logbooks, consular letters, crew lists and accounts, and other whaling manuscripts. The major section (part 2) is the story of the whaling industry at its height during the years 1833 to 1860 . Part I gives the background with its origins in Europe, and part 3 traces the decline of the industry from a position of economic and industrial importance to New England and the whole Nation until its disappearance in the early years of the 2oth century. The author gives us an insight into the lives of the crews, their working conditions and wages, the dangers encountered, and the discipline demanded by the rigors of their trade. Whaling is one of those industries which have played their part in the growth of the Nation only to succumb to the ravages of war and weather, and to technical and economic developments resulting in alternative products. The early stages of this picturesque industry are portrayed by Edouard A. Stackpole: The Sea-Hunters; the New England Whalemen during Two Centuries, 1635-1835 (Philadelphia, Lippincott, 1953. 510 p.).

5872. McFarland, Raymond. A history of the New England fisheries. [Philadelphia] University of Pennsylvania, 19I I. 457 p. ([Publica- 
tions of the University of Pennsylvania. Series in political economy and public law])

$$
\text { II-2088 } \mathrm{SH}_{221 . \mathrm{M}_{3}}
$$

Bibliography: p. $33^{8-363}$.

Aside from books on whaling there is little literature, except diffuse government publications, on the history of the fishing industry. This book was written to fill in the story of the cod, mackerel, and inshore (including shellfish) fisheries. It shows the development and importance of the New England fisheries from early colonial days to the time of publication, with full attention to their role in commerce, legislation, and international affairs. Chapter XVIII, "The Evolution of the Fishing Schooner," goes into the changes in the furnishings of vessels, in the equipment used for fishing, and in the methods of curing the catch. Donald J. White's The New England Fishing Industry (Cambridge, Harvard University Press, 1954. 205 p. Wertheim Fellowship publications) is "a study in the interrelations of wages and prices and factor and product markets" limited to the fresh and frozen finny fish sector of the industry in Boston and four other Maine and Massachusetts ports; it nevertheless throws much light on recent developments in the New England fisheries as a whole.

5873. Osgood, Ernest Staples. The day of the cattleman. Minneapolis, University of Minnesota Press, r929. 283 p.

29-19222 $\mathrm{SF}_{196 . \mathrm{U}_{5} \mathrm{O}_{7}}$

Thesis (Ph. D.)-University of Wisconsin, 1927.

Bibliography: p. 259-268.

The author of this Wisconsin dissertation used an important collection of manuscript material in the office of the Wyoming Stock Growers' Association at Cheyenne, Wyoming, as well as public documents, newspapers, and other published sources. It studies a great enterprise which grew up on the High Plains between 1845 and the early I90o's. In narrating the rise and fall of the Open Range, it treats of the Indian barrier and its overcoming, the cattle boom of the early I880's, the development of cattlemen's organizations, the cattlemen's attempts to monopolize the public domain, and, finally, the climatic and economic disaster of the late eighties. This brought about a transition from the great range outfits to smaller ranches with controlled pasturage and irrigation. The range cattle industry had attracted outside capital to aid in the development of a new area, had stimulated railroad building to carry its products to the Eastern markets, and had done much to lay the economic foundations for the settlement of the West.

\section{Towne, Charles Wayland, and Edward} Norris Wentworth. Shepherd's empire. With drawings by Harold D. Bugbee. Norman, University of Oklahoma Press, 1945. 364 p.

Bibliography: p. 335-347.

$$
\text { Agr } 45-33 \mathrm{I} \quad \mathrm{SF}_{376} \mathrm{T6}
$$

The role of sheep in opening up the Southwest, including California, is traced against a colorful background of history from the days of the Conquistadors to the mid-2oth century. The authors point out that the natural endurance of sheep under harsh physical conditions, their grazing habits, and their flocking instincts have provided nourishment for explorers, soldiers, miners, and emigrants in their penetration of the region. They vividly portray the problems of sheep husbandry-trailing the flocks; lambing and shearing; and protecting the herds from Indian raids, range wars, preying animals, and poisonous plants. The last chapter introduces the "Men behind the Flocks," the pioneer sheepmen responsible for the great ranches and herds and the improvement of breeds. Based on a thorough combing of printed material as well as many unpublished personal contributions, and incorporating many striking anecdotes, it has interest for student and general reader alike. Ten sketch maps, each illustrating a single topic, facilitate the reader's task. Three years later Mr. Wentworth, who, in his quarter-century of service with Armour and Co., was able to visit all the livestock-producing areas of the country and obtain veteran sheepmen's reminiscences and personal records, brought out his own massive volume, America's Sheep Trails; History, Personalities (Ames, Iowa State College Press, 1948. xxii, 667 p.). It deals with all parts of the United States from the earliest times, and concludes with a series of topical chapters such as "Financing the Sheep Business," "The Disease Problem," "The Public Lands," and "Cattle-Sheep Wars." There are statistical, biographical, and bibliographical (p. 622-632) appendixes. While it goes considerably beyond the needs of the ordinary reader, it contains materials of immense interest, and abundantly fulfills its object of recording "the part sheep played in building the United States." 


\section{XXVIII}

\section{Economic Life}

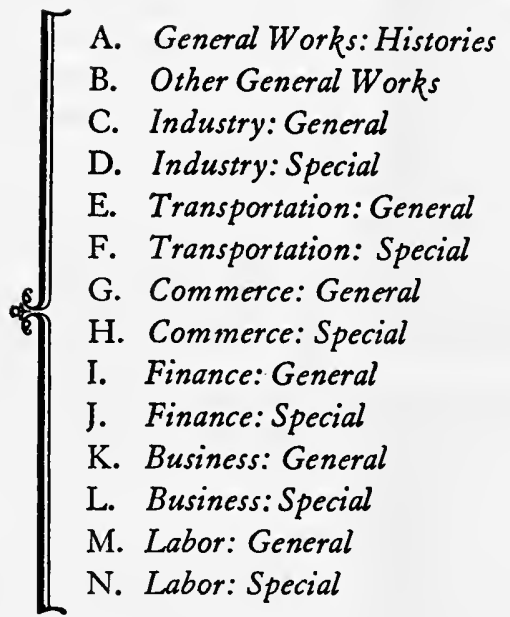

$\left.\begin{array}{l}5875-5883 \\ 5884-5900 \\ 5901-5906 \\ 5907-5919 \\ 5920-5925 \\ 5926-5943 \\ 5944-5950 \\ 5951-5964 \\ 5965-5975 \\ 5976-6002 \\ 5976-6002 \\ 6011-6030 \\ 6031-6042 \\ 6043-6058\end{array}\right]$

"THE BUSINESS of America is business," said Calvin Coolidge, a prophet of much honor 1 in his own country and era. If we amend his dictum a little and say, "The business of American scholarship is business"-meaning by the last word, of course, the whole economy energized by managerial enterprise-we are merely stating a statistical truism. The output of American books, periodicals, documents, reports, etc., concerned with economics in general and with the American economy and its constituent parts in particular not only far exceeds that for any other of the arts and sciences, but falls not too far short of equalling their combined total. This is therefore the chapter in which we have from the outset realized the complete impossibility of our task-the hopelessness of representing either the literature or the facts lying beyond it in any selection of volumes which can be contained within the framework of this volume. We have therefore been, from necessity not perversity, considerably more arbitrary than usual in choosing and ordering our material. This is clear enough from our section headings, which, once general works have been cleared, simply take six of the largest and most abstract categories and divide the books under them into "general" and "special" works. We shall make no determined defense against those who find that some of our "general" titles should have been "special," or vice versa. We

shall do no more against those who find Sections $\mathrm{K}$ and $L$ on business holding titles which should have gone elsewhere: in them we have merely sought to bring together a number of books particularly concerned with the problems which were once said to confront capitalists or entrepreneurs, and are now said to confront management. The distinction between "general" and "special" does, to be sure, reflect one of our concerns, which has been to represent, not only the larger forms and currents of economic activity, but the concrete units-companies, individuals, and even machines-in which these abstractions have their only being. Thus we have not only The Transportation Industries and Economics of Transportation, but books on General Motors, Commodore Vanderbilt, and the steam locomotive. Our desire to present sample units in each of the cate- 
gories has led us to include a substantial number of "business histories," and so to give what some may regard as undue prominence to the Harvard School of Business Administration, which was one of the earliest and has remained one of the largest producers in the field. That a multitude of types and forms in each of the six categories, each of great statistical, monetary, or human importance, remain unrepresented we are only too well and painfully aware, but we could not make another volume out of this chapter. A final word is probably needed in recognition of the fact that American economic life is and has always been a battlefield, in books and out. We seek to hold no position and to draw nobody's fire, but we should find it difficult to contradict Mr. Bray.
Hammond when he says (in no. 6000 below) that business enterprise has been "the most powerful continuing influence in American life ever since Independence." Recent policies, arising in the economic as well as the political sphere, have not striven to shut off this great primary source of wealth and welfare, but rather, in the first place, to keep it from being self-defeating and, in the second, to make it work for the prosperity of as many as possible instead of as few as possible. While such aims are not universally approved, they are very widely so, and to the majority, therefore, economic arguments now turn about matters of degree and of the effciency of means rather than about absolute principles of natural law or abstract ethics.

\section{A. General Works: Histories}

5875. Cochran, Thomas C., and William Miller. The age of enterprise, a social history of industrial America. New York, Macmillan, 1942. 394 p.

Bibliography: p. 359-368.

42-22792 $\mathrm{HC}_{103 . \mathrm{C} 6}$

A dramatic rendition of American history from 1800 to $193^{\circ}$ as propelled by the ventures of free enterprise, which in a century transformed village America into the richest urban and industrial power of the world. The authors describe the expanding frontier and swelling population, the machine-age revolutions in transport and industry, and the exploitation of the country's vast natural resources. They examine broad trends of business and investment and their reflection in social and cultural life. As climax of the age of unlimited free opportunity, they point to the moral justification of the entrepreneurs and their empires of railroads, oil, and steel, by means of the creed of the survival of the fittest provided by Herbert Spencer, evolutionary apostle of laissez faire. They next trace the downfall of the system in which seeds of decay were already planted: "The machine, an instrument of competition, tended always to become mother to monopoly." In their analysis free enterprise, running a downward path through panics, depressions, and labor troubles, before the turn of the century gave way to finance capitalism. This in turn reached its climax of Big Business in the 1920's. By the time the crash came, according to the authors, individual initiative in America had "surrendered" to institutional enterprise, and now survives only as "the language of free competition."

5876. Dorfman, Joseph. The economic mind in American civilization. New York, Viking
Press, 1946-49. 3 v. 45-1 1318 HBirg.A2D6 "Bibliographic notes" at end of each volume.

Contents.-v. I-2. 1606-1865.-v. 3. 18651918.

A work of basic scholarship, summarizing and synthesizing economic theories expressed by individual American spokesmen. The first two volumes cover "the age of commerce," from Governor Winthrop and the Puritans to the crushing of aristocratic agrarianism in the Civil War. In the author's view, the heritage of concepts brought over by the colonists prevailed into the Igth century, with foreign commerce thought of as the chief source of wealth, to be pursued in a society of rigid classes, motivated or justified by "the traditional sanctions and rhetoric of religion and humanitarianism." Writers were both men of affairs and of thought, like Penn, Franklin, Hamilton, Jefferson, Thomas Paine, and Robert Fulton. In the early roth century the Old World pattern was again followed, as "systematic" economic doctrine emerged among academic writers on political economy, who interpreted the teaching of Ricardo and Malthus in differing Southern and Northern versions of laissez faire. The third volume, published three years later, covers the economic thought of "the age of industry," when, against a background of turbulent and unrestrained individualism, the rise of labor problems, and the growth of monopoly, new currents of reform-radicalism, liberalism, or "marginalism,"were expressed by the trained professional economists of the new century. Dr. Dorfman closes with the first attempts to integrate sociological thought with orthodox economics, in the "disturbing voice" of Thorstein Veblen and his chief heir, Wesley C. Mitchell, the two masters to whom the study is 
dedicated. Volumes 4 and 5, covering 1918-33, are announced as this chapter goes to press.

\section{The Economic history of the United States.} New York, Rinehart, 1945-51. 5 v. 45-7376 $\mathrm{HCl}_{103 .} \mathrm{E}_{25}$

A cooperative history, to which a group of noted scholars are contributing, planned in 1929 as a ninevolume series, and still in process; it was conceived as a full, balanced, and readable survey of American economic history for the general reader and to supplement college texts. Each volume has for its concluding chapter a full bibliographical essay. Four volumes, 1, Colonial Period to 1775; 2, 1775-1815; 3, Agriculture, 1815-1860; and 6, Industry, 18601897 , are still in preparation (in 1959). The first of the self-contained volumes to appear was The Farmer's Last Frontier, Agriculture, 1860-1897 (v. 5, 434 p.), by Professor Fred A. Shannon of the University of Illinois, one of the editors of the series. Two more were published in 1947, George Soule's Prosperity Decade; from War to Depression, 19171929 (v. 8, 365 p.), and Broadus Mitchell's Depression Decade; from New Era through New Deal, 1929-194I (v. 9, 462 p.). In I95I there appeared The Transportation Revolution, 1815-1860, by George Rogers Taylor (v. 4, 490 p.), and The Decline of Laissez Faire, 1897-1917, by Harold U. Faulkner (v. 7, 433 p.). Professor Faulkner of Smith College, whose standard one-volume college text, American Economic History, first published in 1924, is now in its 7 th edition (New York, Harper, 1954. 816 p. Harper's historical series), is also one of the board of editors of the Rinehart series.

5878. Hacker, Louis M. The triumph of American capitalism; the development of forces in American history to the end of the nineteenth century. New York, Columbia University Press, 1946. $460 \mathrm{p}$.

47-3113 HCro3.Hr46 1946

"Authorities cited in the text": p. 439-445.

For the great triumph in America of the capitalist system, initiated in and inherited from Europe, Professor Hacker offers three fundamental explanations: from the earliest settlements the climate of ideas was capitalistic; the state, established by revolt against oppressive authoritarianism, has aided instead of restricting private enterprise; and the ideal of equal economic opportunity for all has never been lost from sight. He traces the development of capitalism from the city-states of medieval Italy through the Age of Discovery to its participation in the settlement of the thirteen Colonies. He analyzes in this continent the course of American mercantile capitalism, which long remained in fetters to British mercantilism, but after 1783 "had the whole world, productively and geographically, ... over which to range." The transition to industrial capitalism did not gain momentum until after the depression of 1837-43, but during the Civil War the new capitalists "succeeded in capturing the state and using it as an instrument to strengthen their economic position." By 1900 the "grand design" of industrial capitalism in the exploitation of the continent was essentially complete: heavy industry and the urban network were in being, and both producer and consumer goods were being turned out in an endless stream. Professor Hacker's success story is written in general terms, with only occasional references to individuals; his protagonist throughout is American capitalism itself, which in one century "created the potentialities of physical abundance and left behind the legacy of political freedom."

5879. Janeway, Eliot. The struggle for survival; a chronicle of economic mobilization in World War II. [Roosevelt ed.] New Haven, Yale University Press, 1951. $3^{82}$ p. illus. (The Chronicles of America series, v. 53)

$$
\text { 52-158 HCr806.4.J.33 195I }
$$

"Bibliographical note": p. 362-372.

This "chronicle" of the war on the home front is written in administrative rather than economic terms. The author, a business analyst and writer formerly connected with Time and Fortune, is less concerned with the stages and processes of economic mobilization than with the "Battle of Washington." His thesis is that Roosevelt, the inspired politician, guided the war effort, and incidentally left behind an unprecedented complexity of governmental organization, "by the techniques of pure democracy -by provoking participation from the people instead of by imposing discipline upon them." It was the momentum of production achieved through the anonymous energies of the people that carried the day, despite rather than because of the expendable leaders with whom the President experimented in his appointments to the successive agencies. $\mathrm{Mr}$. Janeway's account of these, from the War Production Board and the suppressed Baruch Plan for Industrial Mobilization to Byrnes' Office of War Mobilization and Reconversion, dwells largely upon the personalities and maneuvers of the leaders, and their manipulation by the President.

5880. Josephson, Matthew. The robber barons; the great American capitalists, 186r-1901. New York, Harcourt, Brace, 1934. 474 p.

Bibliography: p. 455-460.

$$
\text { 34-4665 HGr8r.J6 }
$$

The apt phrase that Mr. Josephson chose for the title of this book on the outstanding industrialists of the latter rgth century is now well fixed in the 
vocabulary of American economic history. The Robber Barons, published in the second year of the New Deal, marked its writer's shift from his earlier preoccupation with such literary crusaders as Rousseau and Zola; his style remains that of the romantic biographer. $\mathrm{He}$ acknowledges in the preface the inspiration of Charles and Mary Beard in his attempt to depict these "prime actors in the drama" of the age, and his use of his enormous and lively research material is clearly influenced by his reading of Thorstein Veblen (no. 4538). In his picture the captains of industry-Jay Gould, Andrew Carnegie, Cornelius Vanderbilt, J. Pierpont Morgan, James Fisk, James J. Hill, and the rest-emerge unvarnished as Veblen's "pecuniary man" in his "kinship with the delinquent." The antisocial aspects of their acquisition and use of power are illustrated on every page, and the building of their empires is chronicled as "the fearful sabotage practiced by capital upon the energy and intelligence of human society." Their positive economic functions receive little notice.

588r. Kirkland, Edward C. A history of American economic life. 3d ed. New York, Appleton-Century-Crofts, I95I. 740 p. maps, diagrs. 51-10989 HCro3.K5 195 I

Bibliography: p. $683-728$.

A textbook first issued in 1932, now in its third revision; the author for many years has been professor of American history at Bowdoin College. It surveys comprehensively the progress of American economic life from the voyages of discovery to the "day before yesterday." Its concern is with human activity rather than with policies or politics, which are subordinated to the lifelike detail of economic fact in accounts of the development of commerce, agriculture; industry, labor, and finance. The original work ended with the First World War, and in I939 Professor Kirkland added a section called "Technical Change and Government Polity" to the older ones, "The Colonial Age," "The Agricultural Era," and "The Industrial State." Much emphasis is given to the relations of government and business, particularly in the last chapters where, as with most conscientious historians looking at the immediate past, the narrative is speeded up and illustration that might suggest personal judgment held to a minimum. All three editions have an excellent critical bibliography, arranged by chapters; that of 195I has increased only three pages over that of 1932 , but is completely reworked to omit outdated material and include the latest scholarship.

5882. Myers, Gustavus. History of the great American fortunes. New York, Modern Library, 1936. $73^{2}$ p. (The Modern Library of the world's best books) 36-31209 HCi03.M8 I936 Previously published in three volumes.

This well-known book was brought out originally in I9I0, two years after the copyright had been filed, by a Chicago publisher, Charles H. Kerr \& Co. The author's previous book, on Tammany Hall, had dealt with political corruption, and in a period of muckraking, none of the established New York publishers would touch his new history. Myers, however, had based his work, a study of capitalism from the Marxist standpoint, on painstaking and abundant research which, while not always accepted as the whole truth, has influenced and provided documentation for two generations of writers. His aim was to show "that the great fortunes are the natural, logical outcome of a system based upon factors the inevitable result of which is the utter despoilment of the many for the benefit of a few." In this frame of reference and beginning with colonial dispossessions of the Indians, he tells the stories of the most conspicuous fortunes built up by land speculation, and from railroads, trusts, banks, and industry-J. J. Astor, C. W. Field, Cornelius Vanderbilt, Jay Gould, J. P. Morgan, and J. J. Hill, with a host of lesser multimillionaires woven in. The evidence he quotes all goes to support the "inevitable burden" of his work, an unrelieved tale of fraud and plunder.

5883. Wright, Chester W. Economic history of the United States. 2d ed. New York, McGraw-Hill, 1949. xxi, 94I p. maps, diagrs. (Business and economics publications)

Bibliography: p. $911-926$. 49-8742 $\mathrm{HClO}_{103} \mathrm{~W}_{98} \mathrm{I949}$

In 1944 the author retired as professor emeritus from the University of Chicago where he had taught economics for 30 years. His book was first published in $194 \mathrm{I}$; in the present edition an additional chapter brings the narrative down to 1947 . His primary purpose is to explain the efforts of the American people to raise their standards of living, and through analysis of causes and results to arrive at precepts for the future. The book is intended for students of economics, and because of its size is probably more suited to reference than to classroom use. It covers the entire course of the American economy from that of the Indians, with chief attention to the period since 1860 . Many statistical tables and graphs are used throughout. These are particularly interesting in the last two chapters, where Professor Wright summarizes and evaluates the achievement of the American people, comparing standards of living in $177^{\circ}$ and 1930 . In spite of the attainment in this country of the highest standard for the average man that the world has known, the conclusions drawn for the future are sobering. 


\section{B. Other General Works}

5884. Coyle, David Cushman. Conservation, an American story of conflict and accomplishment. New Brunswick, N. J., Rutgers University Press, 1957. 284 p. illus.

$$
\text { 57-10962 } \mathrm{HC}_{103 \cdot 7 \cdot \mathrm{C} 68}
$$

Serious efforts to conserve the natural resources of America began only toward the close of the 19th century with the first legislation for Federal forest reserves, and the association of "the Prophet," the forester Gifford Pinchot, and President Theodore Roosevelt in the establishment of the U.S. Forestry Service. The first two parts of this book, by a writer known for his forceful popularizations of public economic questions, go deeply into the controversy which was stirred up by Pinchot's idea of public intervention to prevent waste, not only of forests, but also of farm and range lands, groundwater, irrigation, river basins, and waterpower. The "gospel of conservation" enunciated in 1907 made little headway against "reaction, war, and 'normalcy" " until 1933. Under the New Deal the public works program was planned so as to forward many branches of conservation. Mr. Coyle describes the activities of the Civilian Conservation Corps and the Soil Conservation Service, the programs and resultant battles over irrigation and hydroelectric power projects and policies, rural electrification, and the TVA and subsequent attempts at river basin development. In the same terms of accomplishment and opposition he outlines the conservation of fuels, minerals and metals, and wildlife. His last section examines the world situation. Franklin D. Roosevelt and Conservation, 1911-1945, compiled and edited by Edgar B. Nixon (Hyde Park, N. Y., General Services Administration, National Archives and Records Service, Franklin D. Roosevelt Library, 1957. 2 v. (1314 p.)), documents Roosevelt's long connection with the conservation program. It is a selection from the mass of papers in the Roosevelt library dealing with conservation of soil and water, forests, wildlife, and scenic areas, with footnotes referring to the whole body of relevant material. The standard textbook for class use in agricultural colleges, Conservation in the United States, by Axel F. Gustafson and three colleagues at Cornell, is now in its third edition (Ithaca, N. Y., Comstock Pub. Co., 1949. 534 p.). It is a straightforward and well-illustrated exposition of the principles of conservation, the establishment of policies and laws with respect to public and private lands, and the elements involved in the conservation of soil, water, forests, national parks, grazing lands, fish, wildlife, and mineral resources. A truly beautiful book on the historic, literary, and artistic background of conservation is by the curator of research at the Art Institute of Chicago, Hans Huth: Nature and the American: Three Centuries of Changing Attitudes (Berkeley, University of California Press, 1957. 250 p.). The ideas regarding Nature of Puritans, poets and philosophers, novelists and travelers, artists and scientists are traced, with abundant quotation, from the ruthless days of the pioneers to our own times. The fascinating illustrations include 64 full-page reproductions of paintings, drawings, and photographs, and half as many vignettes and woodcuts scattered through the text.

5885. Fainsod, Merle, and Lincoln Gordon. Government and the American economy. Rev. ed. New York, Norton, 1948. xvii, 935 p.

$$
\text { 48 }-4472 \mathrm{HD}_{3} 616 . \mathrm{U}_{47} \mathrm{~F}_{3} \quad 1948
$$

"Selected readings": p. 893-908.

By two Harvard professors, one of government, the other of business administration, this long text is a comprehensive survey of the influence of the American government on the national economy. An introductory section reviews the economic background, the politics of business, labor, agriculture, and pressure groups, and provisions of constitutional law relevant to the economy. The authors then rehearse the policy and action of the Government as promoter of business, agriculture, labor, and consumer interests. Their central and longest section explains government regulation of private enterprise in general historical perspective and in application to special fields-railroads, public utilities, investment and securities, trusts and monopolies, fair trade, and others. The last group of chapters treats of the Government itself in business, through public corporations, measures for conservation of natural and human resources, and the planning and control of the war economy. Final consideration goes to the problems of the "mixed" economy of government enterprise, partially government-regulated private enterprise, and relatively uncontrolled free enterprise which characterizes the postwar period. Throughout, emphasis is laid on the evolution of government activities in harmony with the public interest. 
5886. Galbraith, John Kenneth. The affluent society. Boston, Houghton Mifflin, $195^{8}$. $368 \mathrm{p}$. 58-8512 HBI7I.GI4

A challenge to the usual demand for ever-increasing production as the solution of most economic ills is here eloquently and controversially voiced. In his usual provocative style Professor Galbraith argues that the "greater production" concept is a myth established in days of scarcity and no longer valid in the contemporary American society of abundance. He traces its background as "conventional wisdom" from Ricardo down to present-day thinkers. Then he examines the ancient preoccupations of economists: productivity, inequality, insecurity. Today, he says, production has come to be regarded as the indispensable remedy, and equality and security are identified with it. But production has now reached the point where it must first create the consumers' wants it seeks to satisfy-the "Dependence Effect" he calls this-and the urgency of the wants can no longer be used to defend the urgency of the production. He makes unorthodox comments on such "illusions" as national security, consumer credit, etc., and suggests that the pressure for more production leads to inflation, price instability, and higher unemployment without helping our social imbalance. "The line which divides our area of wealth from our area of poverty is roughly that which divides privately produced and marketed goods and services from publicly rendered services." Among the solutions he offers are: increasing unemployment compensation in times of rising unemployment; raising money through sales taxes; placing greater emphasis on spending for public purposes.

5887. Galbraith, John Kenneth. American capitalism; the concept of countervailing power. Rev. ed. Boston, Houghton Mifflin, 1956. 208 p. ${ }_{56-4515} \mathrm{HB}_{501 . \mathrm{G}_{3}} 1956$

This brilliant essay on modern economic theory is written in an epigrammatic style uncommon to the profession, and may be read with pleasure as well as profit by the layman. Professor Galbraith's fellow economists have accused him of oversimplification, but since the first publication of the Harvard economist's book in $195^{2}$ it has received much attention from them. He joins other postwar thinkers (Berle, not in itself undesirable in an "opulent" economy. Drucker, Lilienthal) in defending big business as His thesis is that the American capitalist economy is no longer regulated by free competition, regarded as indispensable in the tradition of the classical economists. According to orthodox theory, the present American system of oligopoly, in which the chief industries are controlled by a few large units that dictate prices to any smaller competitors, is bound to work out in disaster. The fact that it has not, Pro- fessor Galbraith attributes to the replacement of competition by what he calls "countervailing power." The competitors may regulate policy by agreement among themselves, but their power is balanced by power on the opposite side of the market: by the big trade unions, and by government regulation. Because of countervailing power and the use of the Keynesian formula against depression, the author is confident that in time of peace, if not in case of war, American capitalism will not break down.

5888. Gruchy, Allan G. Modern economic thought; the American contribution. New York, Prentice-Hall, r947. $670 \mathrm{p}$.

Bibliography: p. $63 \mathrm{r}-655$.

$$
\text { 47-4709 } \mathrm{HBII}_{19 . \mathrm{A}_{2} \mathrm{G}_{7}}
$$

The contributions to modern economic thought of six 2oth-century economists form the subject matter of this close analysis. Professor Gruchy writes six interrelated essays on the "institutional economics" of Thorstein Veblen, the "collective economics" of John R. Commons, the "quantitative economics" of Wesley C. Mitchell, the "social economics" of John M. Clark, the "experimental economics" of Rexford G. Tugwell, and the "administrative economics" of Gardiner C. Means. In introductory and concluding chapters he defines their common orientation, for which he borrows from the South African philosopher-statesman, Jan Christiaan Smuts, the adjective "holistic." $\mathrm{He}$ describes this as constituting a new school of economic theory for which orthodox economics, based on the concept of every economic system as "a simple and stable mechanism" in which fixed laws for the separate parts can be deduced, gives place to the view of economic order as a dynamic process of evolution. In the approach of the new theorists the findings of cultural anthropology, sociology, and social psychology are utilized. The writer's digests of the six economists are less controversial than his claim that their interrelated theories constitute a unitary school of American economic thought.

5889. Harris, Seymour E. The economics of mobilization and inflation. New York, Norton, 1951. $308 \mathrm{p} . \quad 5 \mathrm{I}-\mathrm{I} 3080 \quad \mathrm{HC}_{106.5} \cdot \mathrm{H}_{318}$ Bibliography: p. 288-29I.

Professor Harris, who has taught economics at Harvard since the twenties, is well known to his profession. To a wider public his name is familiar as an adviser on financial matters to the Federal Government in many capacities since 1942, when he joined the Policy Committee of the Board of Economic Warfare. This book, written in the second year of the Korean War, and addressed to a specialist audience, is his tenth work-and, he 
hopes, his last-relating to mobilization and war. To the problem of balancing the increase of output, the primary end of mobilization, by the stabilization of prices, his answer is a vigorous fiscal policy embodied in sharply increased taxation, with a minimum of price and other direct controls. He examines in this context questions of resources, material and human, public finance, the effectiveness of controls, and the inevitably uneven and unfair incidence of inflation. He suggests that the mistakes of 1950-51 might have been avoided by a more thorough study of the well-documented lessons of World War II.

589o. Harris, Seymour E. The economics of New England; case study of an older area. Cambridge, Harvard University Press, 1952. xvii, 3 I7 p. maps. 52-503I HCro7. $\mathrm{Al}_{1} \mathrm{H}_{3}$

Among the many official committees on which Professor Harris has served was the Committee on the New England Economy of the U.S. Council of Economic Advisers, appointed in 1950 to study the causes of the severe business recession of the previous year in New England, and to recommend measures for long-range improvement of the regional economy, particularly as to job opportunities. The Committee submitted a report, The New England Economy; a Report to the President ([Washington] 1951. xxxvi, 205 p.), in July I95I, shortly before Harris' book went to press. The two cover much the same ground, analyzing the general decline of this old economic region, its loss of industries and population to more newly developed areas, its resistance to technological change and to Federal aid, its shortages of raw materials, its high costs of transportation and power, its unfavorable tax structure, and many related factors. Professor Harris' book presents somewhat greater detail on certain points, such as the desirability of the St. Lawrence seaway, and has a different arrangement and emphasis from the official report. Although there are many difficulties, he is hopeful that an absolute decline in New England may be averted, and that he may be able to tell his students, as he has not during the last few decades, that "there is no strong economic reason for migrating to the South or West." Another and still more comprehensive report on The Economic State of New England was brought out in 1954 by the National Planning Association's Committee of New England (New Haven, Yale University Press, I954. $73^{8}$ p.). Five economists worked with two successive directors of research to produce the $\mathrm{r} 8$ chapters of the survey. The authors look to "upgrading"-increasing the value of output per man-hour-as a means of expanding personal and regional income, and view the future with confidence.
5891. Hoover, Calvin B., and Benjamin U. Ratchford. Economic resources and policies of the South. New York, Macmillan, 195I. xxvii, 464 p. diagrs.

Bibliography: p. 44I-453.

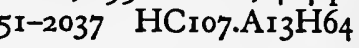

This comprehensive assessment of Southern economic resources and policies was authorized by the National Planning Association's Committee of the South in 1946, and carried out by the Committee's Director of Research and a fellow economist of Duke University. A general statistical review of land, population, and retarding factors is followed by an analysis of the change in living standards between 1929 and 1948 in the region often referred to as "the Nation's Number One Economic Problem." During these years the per capita income rose from 47 percent to 65 percent of the non-Southern average (in 1956 it was above 70 percent), a decline in agricultural income, due largely to the fall in cotton, having been balanced by an increase in manufacturing wages and salaries, and a notable boost from Federal payrolls, military and civilian. Specific developments and trends in the various sectors of the economy are next examined: if cotton is down, tobacco and other crops are up. The text is illustrated by a hundred-odd statistical tables and charts; in most of those relating to human beings there is no analysis by race.

5892. Lilienthal, David E. TVA; democracy on the march. 2oth anniversary ed. New York, Harper, 1953. xxiv, 294 p. illus.

53-7202 TK $1425 \cdot$ M8L53 1953

When the Tennessee Valley Authority was created by Act of Congress on May I8, 1933, Mr. Lilienthal was named one of its directors. In I94I he became chairman, and after the first decade of TVA he expounded it in a book, first published in 1944, which appeared in American and British pocket book editions and was translated into ro or more languages before this "twentieth anniversary edition." It is not a full account of the development of TVA, but an eloquent statement of the writer's faith in the principles, procedures, and success of this plan for unified development of natural resources and raising living standards, under public control but with the cooperation of local bodies. TVA before and since its creation has been a subject of controversy in the United States, defended or attacked in the long-continuing struggle over the public versus the private ownership of power-a favorite phrase of its enemies is "creeping socialism." But after ro years it had attracted worldwide interest and had become a symbol of what man can do to change his physical environment. In the 1953 edition $\mathrm{Mr}$. Lilienthal added a chapter on "The TVA Idea Abroad," and, besides the completely revised bibli- 
ography, two appendixes, one of which is a digest and bibliography of TVA-type developments in many countries. The writer, who served for four years as chairman of the Atomic Energy Commission and is now chairman of the Development and Research Corporation of New York, published in the same year a book advocating new concepts: Big Business: a New Era (New York, Harper, I953. 209 p.). Here his argument is that, with government's expanded role in economic affairs as safeguard, the actual benefits of Big Business to social and economic advancement should now be recognized, without the "prejudice created by abuses long since corrected ... an antiquarian's portrait of another America."

5893. National Industrial Conference Board. National income in the United States, r7991938, by Robert F. Martin, director Economic Research Division, the Conference Board. New York City, National Industrial Conference Board, 1939. $\mathrm{xv}, \mathrm{I}_{4} 6$ p. (Its Studies, no. 24I)

39-27201 HB6or.N 35

"This study offers the most complete estimates of national income in the United States that are available for the I40-year period beginning in r799 ... Though in the nature of such estimates they are not comprehensive and perfect, they are the best approximations possible in the present state of our information in this field, and they present in the most compact form a composite picture of America's economic development such as no other series of statistics can." These estimates occupy 46 tables and II charts, arranged in a briefer explanatory text whose chapters include "The National Income Totals," "Kinds of Private Production Income," "Industrial Sources" of such income, and "Government as a Source of Income." The "total realized national income," in dollar figures adjusted by the general price level, rose from 1,092 millions in 1799 to 69,130 millions in 1938. During the same period the per capita realized income, again in adjusted figures, rose from $\$ 2$ I I to $\$ 531$, but the latter figure was regularly exceeded, sometimes by as much as $\$ 100$, during the years 1910-1931. A long appendix (p. ro5146) explains the sources and the methods used in constructing the estimates. The text is simply and clearly written, and adapted, as the studies of the Conference Board usually are, for wide use by businessmen.

5894. Slichter, Sumner H. The American economy, its problems and prospects. New York, Knopf, 1948. vii, 214, ix p.

$$
\text { 48-8583 HCio6.5.S } 47
$$

A revision and expansion of five lectures given at a Stanford University business conference the previous summer by the Lamont Professor of Economics at Harvard, well known as an adviser to government and private organizations on economic trends and business prospects. In a glance at the basic characteristics of our system he stresses the change of recent years to what he calls "a laboristic economy," with wealth and power increasingly in the hands of the employee class. The first problem he examines is that of labor relations, for many years the field of his chief study (see no. 6038), and of measures needed to keep the rapid rise of modern trade unionism from bringing about conflict in industry. He considers economic stability, expressing approval of credit and fiscal controls, and international economic policy, speaking for greatly increased imports and reduced tariffs. He analyzes our prospects from both a pessimistic and an optimistic outlook, and finally attempts to answer the question, "How Good Is the American Economy?" The answer is: "far better than most people realize." A further group of lectures by Professor Slichter at Stanford in July 1950 was published as What's Ahead for American Business (Boston, Little, Brown, 1951. 216 p.). As in the earlier talks, he set forth in clear outline, sometimes with figures, his views of problems, causes, effects, and prospects. A chapter was added on the implications of defense economy resulting from the Korean War. He was still optimistic, ready to accept the idea of more government regulation without fear of socialism. He also contemplated without worry a period of rising prices and a certain degree of inflation, an attitude which he retains a decade later.

5895. Taylor, Horace, and others. The American economy in operation. New York, Harcourt, Brace, 1949. xiv, 846 p. diagrs. 49-8736 $\mathrm{HC}_{\mathrm{o}} \mathrm{06} . \mathrm{T}_{4} 6$

A composite work by members of the department of economics of Columbia University, revised almost yearly between 1932 and I94I, replacing earlier texts for a course in contemporary civilization. Essentially a study in political economy, its account of the purely economic aspects is interwoven with the political elements involved. There are nine sections, each with several chapters and many subheadings within chapters. The basic facts of national economic resources and national product, organization and control of production, management-labor and other intergroup relations, money and credit, public finance, and international relations are set forth, with regular attention to current trends. Special emphasis is laid on factors making for stability and on patterns of control. The concluding section examines the values of a mixed 
economy of private enterprise and government participation, especially with regard to economic planning and full employment. The long time-lag between the predecessor work and this new volume was deliberate, so as to permit an adequate perspective on problems and policies arising in the postwar world.

5896. Twentieth Century Fund. America's needs and resources, a Twentieth Century Fund survey which includes estimates for 1950 and 1960. By J. Frederic Dewhurst and associates. New York, 1947. xxviii, 812 p. tables, diagrs.

$$
\text { 47-3562 HCro6.5. } \mathrm{T}_{9}
$$

5897. Twentieth Century Fund. America's needs and resources: a new survey, by J. Frederic Dewhurst and associates. New York, 1955. xxix, ${ }_{11}{ }^{8}$ p. illus., maps, tables.

55-6987 $\mathrm{HC}_{106.5 . \mathrm{T}_{9}} 1955$

The Twentieth Century Fund's comprehensive source book of measurements of the American economy in all its fields is described by the director in his foreword as "a moving picture of accomplishments and probabilities," one from which we will "begin to realize America's vast economic and social potential." Dr. Dewhurst, an authority in the field of economic statistics, was aided in the huge research project by 26 economists, and most of the chapters are cooperative rather than individual efforts. The six sections cover in lucid statistical analysis, with supporting tables, "Basic Trends," "Consumer Requirements," "Capital Requirements," "Government Costs and Foreign Transactions," "Resources and Capacities," and, as a final summary, "Needs vs. Resources." There are 225 tables in the text, over 40 graphic "figures," and 32 appendixes of additional data. The 22-page index reveals the all-embracing scope of the inquiry. After eight years the Twentieth Century Fund, of which Dr. Dewhurst is now executive director, brought out a revision: America's Needs and Resources: a New Survey. Whereas the first survey had been centered on the changes from the depression economy to that of the full war effort, and the reflection of consumer shortages on the postwar scene, the later, volume "finds its major focus in the phenomenal postwar boom, in the long-range upsurge of the economy which this latest boom accentuated, and in the significance of our expanding economy for the future well-being of our nation." The chief change in arrangement is the addition, in the section on "Resources and Capacities," of two new chapters: "Technology: Primary Resource," and "Productivity: Key to Welfare." The tables have increased to 352 , and the figures to 105 .
5898. U. S. National Resources Committee. The structure of the American economy. Washington, U. S. Govt. Print. Off., 1939-40. 2 v. maps, tables, diagrs. 39-29155 HCro6.3.A5 1940

Part 2 issued by the National Resources Planning Board.

Contents.-I. Basic characteristics. A report prepared by the Industrial Section under the direction of G. C. Means.-2. Toward full use of resources. A symposium by G. C. Means, D. E. Montgomery, J. M. Clark, A. H. Hansen, [and] Mordecai Ezekiel.

One of the best known publications of the $\mathrm{Na}$ tional Resources Committee, which in 1935 succeeded earlier committees that formed part of the planning apparatus of the New Deal. In mid-I939 the Committee was in turn succeeded, under the Reorganization Plan of that year, by the National Resources Planning Board, the change occurring between issuance of the first and second volumes of this report. The document was presented by Secretary of the Interior Ickes to the President as "the first major attempt to show the inter-relation of the economic forces which determine the use of our natural resources." Director of the project was Dr. Gardiner C. Means, known as joint author with Adolf A. Berle of The Modern Corporation and Private Property (no. 60I I). Part I has 400 pages, of which fewer than half are text analyzing through statistics the structure of wants and resources; of production in geographical, functional, and financial aspects; and of organization, price, and controls. There follow over 200 pages of appendixes giving detailed statistics. The much shorter part 2 ( $4^{8}$ p.) contains five essays by Dr. Means and other economists, offering suggestions for the more effective use of resources. A more recent look is taken by the National Planning Association in a concentrated survey by Gerhard Colm and Theodore Geiger, with the assistance of Manuel Helzner: The Economy of the American People; Progress, Problems, Prospects (Washington, National Planning Association, 1958. 167 p. Planning pamphlet no. 102). Their informative analysis of the high productivity and consumption achieved by the American economic system includes the factors of national resources, labor, business management, capital, values, and institutions. Problems weighed are the balance in economic growth, the residue of poverty still with us, concentration of power in industry, and the role of the United States in the world economic picture. Summing up, the authors consider whether the new American economic system with its large-scale organization in business and government can offer the greatest possible freedom of choice and opportunity to the individual. Their 
conclusion is that, while the American system cannot be defined as capitalistic or socialistic in the traditional sense of these terms, it serves the national interests of the American people.

5899. Ward, Alfred Dudley, ed. Goals of economic life. New York, Harper, 1953. 470 p. ([The Ethics and economics of society]) 52-12049 $\mathrm{HB}_{72 .} \mathrm{W}_{3}$ This symposium introduced a series undertaken by a study group of the Federal Council (later the National Council) of the Churches of Christ in the United States of America, investigating modern economic life in relation to spiritual and moral values. Fifteen essays, by as many distinguished authors, are focused on problems in achieving a less materialistic society. These are arranged in three groups; the first, by leading economists, is on "The Role of Values in Our Economy." The second group is by political scientists who examine "Our Economy in Democratic Perspective"-in its dependence upon government, and its relation to law and to principles of freedom and justice. The third group, "Our Economy in Other Perspectives," studies economic man from the viewpoints of biology, anthropology, psychology, philosophy, and the Christian faith. The five other volumes in this Harper series consider particular aspects of the economy in relation to ethics. These are: Kenneth E. Boulding, The Organizational Revolution (1953. 286 p.); Howard Bowen, Social Responsibilities of the Businessman (1953. 276 p.); American Income and Its Use, by Elizabeth E. Hoyt and others ( 1954 . 362 p.); Christian Values and Economic Life, by John C. Bennett and others (1954. 272 p.); and one based on extensive polling, The American Economy-Attitudes and Opinions, by Alfred Dudley Ward (1955. 199 p.). Not included in the series, but prepared in connection with it, in part as a summarization, is Ethics in a Business Society, by
Marquis W. Childs and Douglass Cater (Harper, 1954. I9I p.). The series is being continued with a slight change in title (Series on ethics and economic life), three new volumes having been brought out by Harper in 1956-57: Walter W. Wilcox, Social Responsibility in Farm Leadership (1956. I94 p.); John A. Fitch, Social Responsibilities of Organized Labor (1957. 237 p.); and Wilbur L. Schramm, Responsibility in Mass Communication (1957. 39 I p.).

5900. Whitaker, Joe Russell, and Edward A. Ackerman. American resources, their management and conservation. New York, Harcourt, Brace, I95I. 497 p. illus., maps.

5I-2124 HCio6. W56

Intended for wider educational use than in college courses, American Resources, by two geographers, offers the general public a readable account of American problems and accomplishments in the field of conservation. The approach, they show, was for long negative: "Many of the countries settled by Europeans rank with the United States in intensity of resource destruction, but none reaches the range and magnitude of the destruction found in this country ... [which] stands among the foremost examples in the damage done to its natural-resource base during the comparatively short span of three centuries." Now, and particularly because of the studies and plans of the 1930's, "recognition of the need for conservational resource management has led to remedial programs on local, regional and national levels." The authors examine five major groups of resources: cultivable lands, grassland and forests, water resources, mineral resources, fish and wildlife, and other recreational resources. The last chapter is written as a guide to action by the individual citizen, urging his cooperation through personal effort against waste, through support of official programs, and through social pressures.

\section{Industry: General}

5901.- Adams, Walter, ed. The structure of American industry; some case studies. Rev. ed. New York, Macmillan, I954, 590 p. illus. 54-1083 I HC106.A34 1954

"Suggested readings" at end of chapters.

Fourteen economists here analyze individual major industries that present varying degrees of free competition, monopoly and oligopoly, government price support programs or controls, and government regulation. Thirteen case studies follow a systematic outline, each in three sections: 1 , histori- cal background and present institutional patterns, including modifications in the war and postwar periods; 2, marketing structure and price policy; 3 , public policy and government programs or recommendations. The first industry treated is the highly competitive one of agriculture. Then follow: the chronically "sick" industries of cotton textiles and bituminous coal; residential construction, which, although the nation's second largest industry, is so diversified that it "deserves the title 'industry' as a matter of courtesy only"; the monopolistic indus- 
tries of steel, chemicals, petroleum, automobiles, cigarettes, motion pictures, tin cans; the regulated air transportation industry; and last, the newspaper industry, symbol of free enterprise and a free press, but whose market structure now "exhibits the familiar patterns of local monopoly, monopolistic competition, oligopsony, and oligopoly." (These terms both imply control of market price of a particular commodity by a few big units acting more or less in concert: oligopoly by the sellers, oligopsony by the buyers.) In the last two chapters an attempt is made to formulate patterns of public policy and labor union activity consonant with a free-enterprise economy.

5902. Alderfer, Evan B., and Herman E. Michl. Economics of American industry. 2d ed.

New York, McGraw-Hill, r950. 716 p. illus., maps. 50-11314 $\mathrm{HC}_{106.4 . A_{5} 8} 1950$

Bibliography: p. 691-707.

A textbook on American manufacturing, based on material used in courses on industrial management and economic theory at the Wharton School of Finance and Commerce, University of Pennsylvania, and first published in 1942. The second edition includes an appraisal of trends of the wartime and postwar expansion of the entire economy. The writers take the individual industry approach, glancing first at the field of manufacturing as a whole, in which over a quarter of American wageearners are engaged, and concluding with a study of changing industrial patterns. The competitive factors which govern variations in stability are a chief point of their analysis of each separate form of enterprise. They also discuss the relation of each to the economic order in general, and its institutional structure, technical processes (described in simple language), and historical evolution. Eight major groupings are distinguished, and within these sections are chapters on individual industries: e.g., the part on chemical process industries is divided between the chemical industry (including a brief reference to atomic energy), the petroleum industry, the paper industry, and the rubber industry.

5903. Allen, Edward L. Economics of American manufacturing. New York, Holt, I952. 566 p. illus. 52-7011 HD9725.A65

A textbook by a professor at American University in Washington who is concerned with the present-day industrial plant of the nation and makes little use of historical perspective. Out of the $45^{\circ}$ odd general types reported in the 1947 Census of Manufactures he has chosen 19 individual industries for discussion. His treatment is systematic, with several subdivisions within chapters; for each industry, with slight variations, he examines its relative size and importance, use patterns, exportimport relations, relations with the Federal Government, corporate ownership and control, location and capacity, technology, input and cost factors, financial factors, private investment, profits, and future outlooks. Illustrations, in part of technical processes and in part graphic charts, assist in keeping the presentation clear and factual. Besides the selected bibliography (p. 542-555), there is a useful final chapter rehearsing sources of data from government statistics and reports, trade association releases, trades publications, and financial services.

5904. Clark, Victor S. History of manufactures in the United States. New York, Published for the Carnegie Institution of Washington by McGraw-Hill, r929. 3 v. illus.

Bibliography: v. 3, p. $400-442$.

$$
\text { 29-10065 HD9725. } \mathrm{C}_{52}
$$

This full-scale general history is one of the distinguished series sponsored by the Carnegie Institution of Washington, Contributions to American economic history (see also Commons, no. 6033; Johnson, no. 5948; and Meyer, no. 5923). The first volume, covering $1607-1860$, was published in I916, and had become standard by the time it was reprinted to accompany the two concluding volumes. Dr. Clark, an economic analyst whose basic area studies of Australia, the Far East, and Latin America had been prepared for the Bureau of Labor Statistics before the First World War, used for this work a quantity of original source material, identified in extensive footnotes. The presentation, on classic lines, paints a broad picture of the development, organization, and economic interactions of manufacturing as a whole and of its more important branches. The second volume, I860-1893, has three chronological divisions: the Civil War, Reconstruction, and "Big Industry in the Making"; volume 3, 1893-1928, is called "The Industrial State." In the last two volumes special attention is given to the iron and steel industry, "by which the progress, prosperity, and developmental tendencies of manufacturing in general were determined and illustrated."

5905. Fabricant, Solomon. The output of manufacturing industries, $1899-1937$, by Solomon Fabricant, with the assistance of Julius Shiskin. New York, National Bureau of Economic Research, 1940. xxiii, 685 p. tables, diagrs. (Publications of the National Bureau of Economic Research, no. 39)

$$
\text { 4I-4080 } \mathrm{HD}_{9724 . \mathrm{F}_{3}}
$$

Text and statistical tables analyze total American manufactured product during three decades of great expansion and one of depression. The writer is an authority in this field, having been with the research 
staff of the National Bureau of Economic Research since 1930, and its director since 1953 . The statistics are focused on long-term changes in volume and composition of the output of manufacturing industries. The beginning date was chosen as the first year for which "reasonably adequate" data were collected by the United States Census of Manufactures. The first chapters are on manufacturing in general and give first a summary of output, next an explanation of the statistical methods and materials used for the computation of relative numbers, and then a review of changes and trends in output of major and other industries. Part 2 examines the output of individual manufacturing industries. There are 66 tables and 24 charts in the text, and appendixes concerned largely with index numbers. A second volume in the series, by Dr. Fabricant alone, is Publication no. $4 \mathrm{I}$ of the Bureau: Employment in Manufacturing, 1899-1939, an Analysis of Its Relation to the Volume of Production (New York, 1942. 362 p.). This analyzes the statistics of factory employment and of labor per unit (interchangeably the number of men used in production of a unit of goods, or the volume of production per man employed) in relation to the growth of output. A later study by Dr. Fabrican measures The Trend of Government Activities in the United States since 1900 (no. 6136).

5906. Glover, John George, and William Bouck Cornell, eds. The development of American industries, their economic significance. $3 \mathrm{~d}$ ed. New York, Prentice-Hall, 195I. xxvii, II21 p. illus., maps. 5I-2589 HCI03.G5 I95I

A survey of American industrial life, assembled and edited by New York University specialists in industrial management, now in its third edition within 20 years and well established as a reference work. It consists of encyclopedic articles on some 40 leading industries, contributed by representative agencies in each field. The first chapter, by the American Federation of Labor, with the name of President William Green attached, is on "Labor's Contribution to Industry." The articles follow a general pattern, each devoting some space to historical development and presenting facts on the present position, including such aspects as raw materials, processes and technological advances, location, marketing, competition, legislation, financing, and chief centers or in some cases names of leading firms. Many statistical tables are used. The following industries, some of which are not manufactures, are treated: agriculture, meat packing, fishing, lumber, textiles, leather, petroleum, coal, iron and steel, copper, zinc, aluminum, magnesium, lead, chemicals, pharmaceutical products, sugar, pulp and paper, rubber, glass, paint, varnish and lacquer, machine tools, electricity, power, shipbuilding and shipping, railroads, automobiles, aeronautics, telegraph, telephone, motion pictures, radio and television, newspapers, book publishing, retailing, banking, and travel.

\section{Industry: Special}

5907. Barger, Harold, and Sam H. Schurr. The mining industries, I899-r939, a study of output, employment and productivity. New York, National Bureau of Economic Research, 1944. xxii, 452 p. diagrs. (Publications of the National Bureau of Economic Research, no. 43)

$$
\text { 44-3218 HD9506.U62 } 3
$$

This statistical study of a single sector of industry forms part of this Bureau's series dealing with trends of productivity in American industry (like no. 5905 in the preceding section). The authors attempt to assess in total output and manhours of labor the results of technological change, new methods of production, shorter workdays, and other factors affecting productivity. The analysis is in three parts: "Output and Employment," "Technological Change,". and "Technological Change and Production in Individual Industries" (coal, petroleum, iron, copper, stone quarrying). Part 4 , a résumé, con- cludes that "mining, alone among types of economic endeavor, must reckon with depletion of its resources," and that the level of productivity will inevitably deteriorate unless continually buttressed by technological advances. The appendixes include statistical tables, technical questions of measurement, and a glossary of minerals and mining terms.

5908. Carr, Charles C. Alcoa, an American enterprise. New York, Rinehart, 1952. 292 p. illus. $\quad$ 51-14776 HD9539.A7U53

The story of the Aluminum Company of America, commonly known as Alcoa, began with the "electrolytic fusion of aluminum oxide by twenty-two-yearold Charles Martin Hall, in an Ohio woodshed in 1886." This experiment "touched off an industrial chain reaction which . . has been a classic example of American enterprise at work." The narrator of this case history of a major industry was a news- 
paperman and for 15 years director of public relations for Alcoa; he has used the Company's records as sources. In 1888 a small group of young Pittsburgh businessmen founded the Pittsburgh Reduction Company, with patents giving a legal monopoly of the Hall process and a capital of $\$ 20,000$. In 1907 , with the Mellon family as bankers and large stockholders, the name was changed to the present form. Alcoa's first taste of trouble with the Federal government came with the Wickersham wave of trustbusting in I912. In 1922 the Federal Trade Commission began an exhaustive probe into the Company's affairs, which ended to Alcoa's satisfaction in 1930. Lawsuits were brought by competitors; in 1937 the Department of Justice filed 140 charges of monopolistic practices, and the antitrust case went on till 1950. "The Company came out of it as a lawabiding concern and as an asset to the life we know as the "American Way." "Mr. Carr ends his 62year history of Alcoa with an appendix detailing labor negotiations from 1935 to 1950 ; its labor relations, he says, had "a better-than-average rating."

5909. Chapman, Herman $H$. The iron and steel industries of the South, by H. H. Chapman with the collaboration of W. M. Adamson [and others] University, Ala., University of Alabama Press, 1953. 427 p. maps, diagrs. (Alabama University. Bureau of Business Research. Printed series, no. 17)

Bibliography: p. [418]-423.

A report occasioned by the approaching exhaustion of the high-grade Lake Superior ores, carried out with the collaboration of the Tennessee Valley Authority by a staff of geologists and economic statisticians. A general introduction reviews the iron and steel industry of the United States, including such aspects as ownership concentration, the effects of government policy, and the location of raw materials and producing centers. Part 2 examines the natural resources of the South, particularly the Southeast, and part 3 surveys the iron and steel industries of the region, their history, recent trends, ownership, mining and operating problems, etc. Part 4 deals with the market for the Southern iron and steel processing and fabricating industries. Part 5 considers possibilities and offers very tentative conclusions concerning the future of the industry in the South.

59ro. Cole, Arthur Harrison. The American wool manufacture. Cambridge, Harvard University Press, 1926. 2 v. illus. 26-5173 HD9895.C6

Bibliography: v. 2, p. 303-314.

This remains the standard work tracing the growth of the wool industry from its colonial infancy to the mass production of the large-scale modern factory. The author gives a full account of processes, technological advances, changing industrial form, markets, foreign competition, the labor force, and the influence of the tariff upon development. His sources are cited, with frequent elaboration of detail, in long footnotes. The first volume covers the household industry of the colonies, with handicraft fullers, carders, or weavers playing a minor part; the first factories with the newly invented power-driven machinery introduced from England in the I79o's; the period of transition down to 1830 , with Americans making technical advances in power looms, and especially in the "carde américaine," the condensing apparatus for wool-carding invented by John Goulding in the I820's; and the development of distributing agencies stimulated by expanding communications and the Western market. Between 1840 and 1870 the industry increased between 12- and 15-fold, in spite of a heavy increase in importation of wool and worsted. The period of industrial maturity, after 1870 , to which Dr. Cole's second volume is devoted, is concerned largely with the protection by tariff of the American industry from foreign competition and innovation. During this half-century new processes as a rule were introduced from abroad, the American innovations residing in the standardization of the fabric and in mass-production techniques, which have permitted high-quality production on a large scale.

5911. Davis, Pearce. The development of the American glass industry. Cambridge, $\mathrm{Har}$. vard University Press, 1949. xiv, 316 p. (Harvard economic studies, v. 86) $49-975^{8} \mathrm{HD}_{9623} \cdot \mathrm{U}_{45} \mathrm{D}_{3}$ Bibliography: p. [295]-305.

An academic study by a professor in the department of business and economics at the Illinois Institute of Technology, reviewing approximately 300 years of American glassmaking. The introductory chapter of general history begins with Pliny, the second chapter with a glass-making venture in Virginia in 1608 or 1609 . A chronological account of development to the time of the Civil War is followed by an outline and evaluation of tariff policy from 1820 to 1860 . In the succeeding period the author is concerned largely with improved processes, labor problems, and tariff policy, and gives separate chap. ters to individual branches: the window glass indus. try, the glass container industry, pressed and blown glass, and plate glass. The writing is for a professional audience.

5912. Dutton, William Sherman. Du Pont; one hundred and forty years. [3d ed.] New York, Scribner, 1951. 408 p. illus. 
The brilliant record of the Du Pont Company of Wilmington, Del., founded by the French émigré Eleuthère Irénée du Pont in 1802 for the manufacture of gunpowder, and now holding world leadership in production based on chemical research, is in no way dimmed by the writer of this "business biography." $\mathrm{He}$ states forthrightly that his account is an "inside" view, "the Du Pont Company as seen by Du Pont men." From romantic scenes of family history in Revolutionary France to the end of the First World War, the narrative reads like a novel through whose pages move the lofty and dramatic figures of four generations of Du Ponts. Powdermasters and patriots, they followed, at least until the I87o's, "a road of work, sweat, and grimy hands." With the development of industrial dynamite and the formation in 1872 of the Powder Trust, and guided by the organizing genius of General Henry A. Du Pont and the inventor's vision of Lammot Du Pont, the road turned into a network leading to new regions, the hands to the cleaner work of signing checks that bought up patents and competitors. The tremendous contribution of Du Pont to Allied victory in the First World War is here emphasized with statistics that controvert any hint of "war profits." From 1919 on, the story becomes a dramatic description of the new fields opened in Du Pont's great research laboratories: dyes, plastics, cellulose, rayon, nylon, cellophane-altogether more than 10,000 separate items, "a bewildering array of chemical progeny contributed to the welfare and security of the United States in peace, and also to its great might in war."

5913. History of Standard Oil Company (New Jersey) [New York] Harper, 1955-56. 2 v. illus.

"A study by the Business History Foundation, Inc."

Contents.- $[\mathrm{I}]$ Pioneering in big business, I882-rgr I, by R. W. Hidy and M. E. Hidy.-2. The resurgent years, I9II-I927, by G. S. Gibb and E. H. Knowlton.

In 1947 the Standard Oil Company of New Jersey granted unrestricted access to the company's records and complete freedom of publication to the Business History Foundation, as well as a substantial gift of money. The volume by the Hidys is the first in a series of thoroughly documented histories and studies, and narrates the general ${ }^{\circ}$ history of the Company from its organization in 1882, through the period when it became the holding company and operating unit for the complex of enterprises popularly known as Standard Oil, to the trustbusting decision of the U.S. Supreme Court in IgrI which lopped off 33 affliates. The corporation's confidence is justified, for what emerges is no dia- bolical conspiracy, but a group of able administrators clearheadedly pursuing the logic of capitalistic enterprise, and reducing costs through the economies of large-scale operations, while keeping profits high through differentiation of products, and the development of new producing areas, new machinery, and new processes. Naturally, men of their generation were slow to learn "that dominance in power brought the responsibility of applying that power with restraint." The second volume of this series, The Resurgent Years, 1911-1927, appeared in 1956. In it much attention is given to labor policy, new processes, and the search for sources of oil abroad. The list of companies through which the Standard Oil Company (New Jersey) operated in the United States and abroad in these 17 years fills an appendix (p. 63I-664). They fall into 3 groups: 60 closely affiliated, whose earnings were consolidated with those of New Jersey Standard; 58 non-consolidated, in which New Jersey held stock; and I24 affiliates of the "consolidated" companies, over which the New Jersey company exercised remote control.

5914. McLean, John G., and Robert W. Haigh. The growth of intergrated oil companies. Boston, Division of Research, Graduate School of Business Administration, Harvard University, 1954. xxiv, 728 p. illus. $\quad 54-64$ I 7 HD9565.M282

A survey of the oil industry with regard to its predominant structural form, vertical integration. This is defined as "the process of increasing the number of distribution and processing steps in an industry's cycle of activities which are under the ownership, management, or control of a single company." To such a structure the oil industry, with its comparatively simple steps from natural resource to consumer-production of crude oil, transportation, refining, marketing-is especially adapted. The authors offer this contribution to the technical study of consolidation in industry as a case history, establishing the underlying facts through a detailed examination of integration decisions with extensive statistical exhibits. Part I describes the situation in 1950, while the later parts are concerned with how it got that way. In parts 2 and 3 the industry is considered first as a whole and then through the particular cases of seven large integrated companies, four of them former components of the Standard Oil Trust. The last section, before a final summary, studies the decline of the small refining companies, which in 30 or 40 years sank from 28 to 15 percent of the total output. The writers avoid expression of "moral and economic judgment on the performance of the large integrated companies," but their facts suggest that the managements have been less concerned with maximum profits than with assurance of raw materials and markets. 
5915. Nevins, Allan. John D. Rockefeller; the heroic age of American enterprise. New York, Scribner, 1940. 2 v. $(683,747$ p. $)$ illus.

$$
4 \mathrm{I}-649 \text { CT275.R } 75 \mathrm{~N}_{4}
$$

59r6. Nevins, Allan. Study in power: John D. Rockefeller, industrialist and philanthropist. New York, Scribner, 1953. 2 v. (44I, 501 p.) -illus.

53-9394 C'T275.R $75 \mathrm{~N}_{42}$

Bibliographical references included in "Notes" (v. I, p. 403-44I; v. 2, p. 437-466). "Bibliography of official documents": v. 2, p. 483-484.

Two versions of the author's highly praised biography, in his long study for which he enjoyed full access to the Rockefeller family papers, as well as to those of some of Rockefeller's chief opponents. The new version has been substantially shortened, especially in the part relating to Rockefeller's early years, while new material is added on the benefactions; it is still, "emphatically," a biography, not a business history. From the author's objective viewpoint, and with the perspective of almost half a century since Ida $M$. Tarbell wrote her History of the Standard Oil Company (New York, McClure, Phillips, I904. 2 v.), the destructive and exploitative aspects of the swift transformation of the American economy from 1865 to 1900 are far outweighed by the imfortance of the final constructive gains. "Had our pace been slower and our achievement weaker . . . the free world might have lost the First World War and most certainly would have lost the Second." The two parts of Rockefeller's career, the organization of a colossal industry and the distribution of an enormous fortune (his gifts in organized undertakings which have set models for philanthropy ran to $55^{\circ}$ million dollars), Professor Nevins sees as "dominated by logic and plan." "Innovator, thinker, planner, bold entrepreneur, [Rockefeller] was above all an organizerone of the master organizers of the era ... By virtue of this organizing power, backed by keenness of mind, tenacity of purpose, and firmness of character, he looms up as one of the most impressive figures of the century which his lifetime spanned."

5917. Rickard, Thomas Arthur. A history of American mining, by T. A. Rickard. New York, McGraw-Hill, 1932. 4I9 p. illus. (A. I. M. E. scries) 32-20628 TN23.R 45

A general history, published under the auspices of the American Institute of Mining and Metallurgical Engineers, and adapted to a student audience. The author had been editor of several mining journals, and his style combines feature-story writing, suited to tales of discovery and exploits of pioneers, with the reportage of economic facts. The treatment is neither chronological nor systematic, and gives evidence of being a reworking of separate articles. Gold, silver, copper, and lead are the metals on which attention is focused. The chapters are for the most part on regions; California, Alaska, Arizona, the Comstock Lode of Nevada, Lake Superior, the Great Salt Lake, the Black Hills of South Dakota, Butte, and other mountain areas are glanced at in relation to prospecting and their celebrated mining enterprises. One chapter tells of "The Great Diamond Hoax," when in 1872 two prospectors "salted" a mysterious region vaguely located in Arizona, Colorado, or Wyoming, and realized large sums from excited investors in the East.

5918. Schroeder, Gertrude G. The growth of major steel companies, 1900-1950. Baltimore, Johns Hopkins Press, 1953. 244 p. illus. (The Johns Hopkins University studies in historical and political science, ser. 70 , no. 2)

$$
\begin{array}{r}
\text { 53-III75 HD9515.S } 35 \\
\text { H3I.J6, ser. 70, no. } 2
\end{array}
$$

Bibliography: p. 237-239.

The author of this doctoral thesis has devised techniques of statistical analysis through which she studies 12 major firms in the iron and steel industry that together control over 80 percent of the country's total steel capacity. She approaches them in two groups: first the "Big Three" which account for over half the total, U. S. Steel, Bethlehem Steel, and Republic Steel, all formed through major mergers near the turn of the century; and then nine smaller independent firms. For each she gives a brief narra. tive history and then discusses factors of external expansion through consolidation and acquisition, internal expansion through additions to plant and equipment, and the direction, purposes, and financing of the expansion. She analyzes the income of each firm and its distribution, with illustrative tables of gross and fixed assets, long-term investment, and distribution through taxes, reinvestment and dividends. Her summary points out similarities and dissimilarities between the firms and attempts to establish objective patterns of growth. The technological processes of iron and steel production, rather than the economic aspects, form the subject matter of a series of articles written for the trade journal Steel, and arranged in book form by an associate editor of that publication, Dan Reebel: $A B C$ of Iron and Steel, 6th ed. (Cleveland, Penton Pub. Co., 1950. $\mathrm{xv}, 423$ p.). The 27 separate papers are by as many experts-executives, technical directors, or research consultants of large firms. The first two explain the mining, reserves, transportation, and handling of iron ore. Other chapters describe operations involved in the production of scrap iron, 
pig iron, open-hearth steel, Bessemer steel, etc., and in the construction of various finished products, from bars to high-alloy steel castings. There is a subject index.

5919. Tryon, Rolla Milton. Household manufac. tures in the United States, 1640-186o; a study in industrial history. Chicago, University of Chicago Press, 1917. 413 p. tables.

\section{Bibliography: p. 377-397.}

$$
\text { 17-13932 HCio5. } \mathrm{T}_{7}
$$

An economico-political study of clothing and other textile products, house furnishings and necessities, and utensils and tools for home and farm, as made in the households of America before the triumph of mechanization. Throughout the Colo nial period, except for a few expensive imported luxuries, almost everything was made at home. This condition persisted on the frontier well into the mid-rgth century, although in the towns the replacement of homemade articles by goods made by workers in shops or by machines in factories was well under way by 1810 and generally complete by 1860 . Professor Tryon analyzes the political and economic factors affecting home industries during the Colonial period, and traces the gradual but steady changes occurring from the Revolution to the first census of manufactures in 1810 (when, according to a table reproduced from "notably fallible census figures," the total value of textiles made in the home was as twelve to one against those made elsewhere). The household products are viewed, with some description of the techniques and ingenious contraptions used by our ancestors. Finally the stages of the transition to commercial production are studied, with statistics that reveal the final passing of home industry as a factor in the economic life of the country.

\section{E. Transportation: General}

5920. Barger, Harold. The transportation industries, 1889-1946; a study of output, employment, and productivity. New York, National Bureau of Economic Research, 195I. xvi, 288 p. diagrs. (Publications of the National Bureau of Economic Research, no. 5I) 5I-2346 $\mathrm{HE}_{203} \cdot \mathrm{B}_{3}$

A statistical analysis of changes in commercial transportation over nearly 60 years, including the Second World War period. The author, an expert of the National Bureau of Economic Research, uses tables and charts to show comparative amounts of traffic carried, the roles of the various agencies of transportation, the number of employees, their individual output, and the trends of technological progress which account for the greatly expanded productivity. From 1889 to 1939 the combined passenger and freight traffic of all commercial carriers increased fivefold, and from 1939 to 1946 it almost doubled again. Output per worker in I 946 was four times the $188 \mathrm{~g}$ level, and productivity from 1889 to 1939 increased at an average annual rate of 2.2 percent, most strongly in the newer industries of airlines and pipelines. The first part of the text surveys the whole field of transportation for hire; the second separately treats five industries: steam railroads, electric railroads, pipelines, waterways, and airlines. Basic statistical tables for the five industries are given in appendixes, as are the techniques of measurement used. The work is a companion volume to Hultgren's below.
5921. Dearing, Charles L., and Wilfred Owen. National transportation policy. Washington, Brookings Institution, 1949. xiv, $459 \mathrm{p}$.

\section{9-1 $1772 \mathrm{HE}_{206 . \mathrm{D}_{4}}$}

A critical study of the role of the Federal Government in relation to transportation, undertaken at the request of the Hoover Commission on governmental reorganization. The authors first examine Federal promotion of transportation facilities and services, such as control of airways, maintenance of airports, air-mail payments, comparable aid to transport on waterways and highways, and special needs for national defense. They then turn to the question of government regulatory action, centering attention on railroads. In conclusion they summarize what they regard as the defects of national transportation policy and make detailed recommendations for reorganizing the Federal agencies involved. They consider that in neither the executive nor legislative branches of government is any overall view taken of transportation policy; that promotional activities are confused with regulatory measures; that the railroads are discriminated against by continuing patterns of rate regulation set up to prevent monopoly in the days before the rise of heavy competition from highways and air transport. They recommend the establishment of a department of transportation, under which all Federal promotional, operating, and programing activities would be coordinated, and of a regulatory commission which 
would administer a revised program applicable to all forms of transportation.

5922. Hultgren, Thor. American transportation in prosperity and depression. [New York] National Bureau of Economic Research, 1948. xxxiii, 397 p. diagrs. (National Bureau of Economic Research. Studies in business cycles, no. 3)

"Note on sources": p. 383-386.

49-643 HE275r.H84

The Bureau's contributions on business cycles were initiated in the 1920's by its director, Wesley C. Mitchell, the chief exponent of business cycle theory. In this study railroads receive major attention, as the chief agency of transportation for which statistics are available to illustrate cyclical changes over a large number of years. Of the 12 chapters, Io relate to aspects of the railroad industry, I to all "Other than Steam Railroad Transportation," and I to future prospects for booms or depressions. Over I50 tables and many graphs give statistics of freight carried, passenger-miles, traffic units, number of workers, man-hours, revenue, etc. Data begin with 1882 , when a record of tonnage handled by all railroads was initiated, and for the most part end with 1938; "the trough in that year was followed by one of the longest of all business cycles, swollen in amplitude and extended in time by a great war." The writer considers it unduly optimistic to expect unbroken full employment and prosperity through the next few decades.

5923. Meyer, Balthasar Henry, ed. History of transportation in the United States before I860; prepared under the direction of Balthasar Henry Meyer, by Caroline E. MacGill and a staff of collaborators. Washington, Carnegie Institution of Washington, 1917. xi, 678 p. 5 maps. (Carnegie Institution of Washington. Publication no. 215 C)

I7-174I2 $\mathrm{HE}_{203} \mathrm{M}_{4}$

Bibliography: p. 609-649. HCror.C75, no. 3

Number 3 in the large-scale series of Contributions to American economic history prepared by the Department of Economics and Sociology of the Carnegie Institution (see also Clark, no. 5904). Dr. Meyer, an authority on railroad legislation and a member of the Interstate Commerce Commission, acted as editor, the text being put together by Miss MacGill of the University of Wisconsin from special studies, published or in manuscript, furnished by over 20 contributors. All their material, much of which is regional in scope, was used; it is rich in details of local records, descriptions of construction, tables of costs and of goods carried, and the like; but the volume as a whole lacks the unity of a closely-studied work from a single hand. It is heavily documented, with long footnotes and chapter bibliographies drawing extensively on regional sources. The first half of the text is on land routes and waterways before the coming of the railroads: roads, trails, and highways; rivers and canals. The second half is mostly railroad history, again in large part by regions: New England, New York, the Middle Atlantic States, the South and "the West." The latter is, of course, the Middle West, for the book ends with railways to the Pacific still in the project stage.

5924. Van Metre, Thurman W. Transportation in the United States. 2d ed. Brooklyn, Foundation Press, I950. 401 p. maps. (University business-economics series)

Includes reading lists.

$$
\text { 50-14639 } \mathrm{HE}_{203} . \mathrm{V}_{3} \quad 1950
$$

A textbook by the professor (now emeritus) of transportation in the Graduate School of Business of Columbia University, for use in general transportation courses, covering the entire field of domestic transportation, with the greatest space devoted to railroads. The initial chapters are historical, glancing at early highways and canals, and going more deeply into railroads: their beginnings, development, present system, consolidation, and mechanical advances. "Other agencies" are lumped: motor vehicles, airplanes, shipping, and pipe lines. The business of transportation is explained, again with chief emphasis on railroads; here are covered organization; the carriage of freight, passengers, express packages, and mail; and, cursorily, their financial aspects. The third part treats shippers and carriers, and rates and theories of ratemaking. In the last part the history of Federal regulation is reviewed, with the stress once more on railroads. Professor Van Metre sees little hope for a speedy achievement of coordination and cooperation in the transportation business. He finds one important reason for this in "the profound distrust with which railroad interests and the 'government' usually regard each other"; he views darkly the possible solution of government ownership.

5925. Westmeyer, Russell E. Economics of transportation. New York, Prentice-Hall, 1952. 74I p. $\quad 52-9966 \mathrm{HE}_{203}$. W4

In 1950 the railroads of America were still carrying about 60 percent of the nation's freight, although passenger traffic had shifted heavily (over 84 percent) to the private automobile. Professor Westmeyer concludes his introductory chapter with two statistical tables published annually since 1937 by the Interstate Commerce Commission, showing the volume of intercity traffic handled by various agencies-railroads, motor carriers, inland waterways, 
pipelines, airlines, and private autos. His book, a text for advanced study, interprets the significance of these figures chiefly in terms of economic and public utility aspects of the transportation field. As in all general studies of this subject, railroads have pride of place, because of their longer history and greater area of controversy as between public and private interests, as well as their continuing predominance as carriers; furthermore, the patterns developed for their regulation have formed the basis. for regulating the newer agencies of transport. In a concluding analysis of the basic transportation problems of the United States, and canvassing of possible solutions, the writer emphasizes the "crying need" for a comprehensive national policy, in which railroads, airlines, motor carriers, and the rest would be coordinated as parts of a national transportation system.

\section{F. Transportation: Special}

5926. Bruce, Alfred W. The steam locomotive in America; its development in the twentieth century. New York, Norton, 1952. 443 p. illus. 52-14477 TJ605.B78

A technological history, "with special reference to improvements in basic elements of the steam locomotive, different forms of power transmission from steam cylinder to rails, and the development of individual locomotive types in both main-line and special services." Except for a chapter on early history and two chapters outlining the development of steam locomotives and of power transmission from I90I to 1950, the arrangement is functional rather than chronological. A chapter on the steam locomotive industry reviews the larger commercial building firms, and information on companies and output as well as technical matters is given in tables and charts. The illustrations are photographs of locomotive types and sketches of their basic elements, such as fireboxes, cylinders, and mainrods. In the last chapter the author, himself a steam locomotive builder, explains today's competitors, among them the dieselelectric engine which is now forcing the steam locomotive into retirement. A popular account of the engineering aspects of railroads is presented by Robert Selph Henry, vice-president of the Association of American Railroads, in This Fascinating Railroad Business, $3 \mathrm{~d}$ ed., rev. (Indianapolis, BobbsMerrill, 1946. 521 p.). The first chapters describe the rails and the business of laying them out, the construction of bridges and tunnels, systems of rail control, etc. Next the steam engines in their various phases are explained, and the types of cars. There are chapters on railroad shops and their work, stations, supplies, the freight service and its growth, and the principles of ratemaking. Organization and management are described in general terms. An "Anatomy" of American railroads lists the Class I lines and their intercorporate relationships, with brief statements of ownership and miles of track. Statistics are of 1943 .
5927. Cochran, Thomas C. Railroad leaders, $1845-1890$; the business mind in action. Cambridge, Harvard University Press, 1953. 564 p. maps. (Studies in entrepreneurial history)

$52-9383 \quad \mathrm{HE}_{2752 . \mathrm{C} 6}$

The author and his wife have searched special collections and the archives of several major railroads, and analyzed the letter files of 6r managing executives of the chief railroads of the country between 1845 and 1890 . The opinions expressed on business concepts are offered as "a cross section of the ethics or 'spirit' of developing capitalism," as well as new material for railroad history. ("Irresponsible" operators are excluded.) Sixteen chapters are devoted to separate aspects of the analysis, such as "Ownership and Control," "Innovation," and "Some Social Attitudes." These account for less than half the text. The rest consists of samples of correspondence of the $6 \mathrm{r}$ executives, from William R. Ackerman of the Illinois Central to George Henry Watrous of the New York, New Haven, and Hartford. Brief biographical data head each selection. In 1950 there were published two special histories of individual railroad systems. Main Line of MidAmerica; the Story of the Illinois Central, by Carlton J. Corliss (New York, Creative Age Press. 490 p.) is written to commemorate the centennial of the company's charter, obtained in $185 \mathrm{I}$. It is a full and well-rounded account of the conception, building, organization, and operation of the Illinois Central. Interest beyond that of railroad specialists is supplied by the inclusion of many personal stories, from a Lincoln anecdote to the "Saga of Casey Jones." The other work is John Debo Galloway's The First Transcontinental Railroad: Central Pacific, Union Pacific (New York, Simmons-Boardman. 319 p.). The author was a railroad engineer, and his book concentrates on engineering aspects: the background, projects and surveys, and location and construction of the two great lines during "a decade of heartbreaking effort." In $186_{3}$ the Central 
Pacific was begun in Sacramento, the Union Pacific in Omaha, and the two met in 1869 at Promontory, Utah, linking East with West.

5928. Harlow, Alvin F. Old towpaths; the story of the American canal era. New York, Appleton, 1926. 403 p. illus.

Bibliography: p. 391-403.

$$
\text { 26-22668 } \mathrm{TC}_{23} \cdot \mathrm{H}_{3}
$$

A history of the now almost completely abandoned artificial waterways which before the railroad age carried a heavy proportion of the nation's freight and played a crucial part in the opening of the interior. Most famous was the Erie Canal, "Clinton's Ditch," 364 miles long, built in $1817-25$ under Governor DeWitt Clinton of New York. "It directed the movement of populations, fixed the destinies of cities, States and whole sections of America and left traces, still visible, of its handiwork upon the nation." The peak of canal-building enthusiasm came in the 1820 's, when over 800 miles of canals were opened to navigation in New York, Pennsylvania, Delaware, and Maryland, with 1300 miles more nearing completion in 1830 ; by midcentury the system was already passing. Mr. Harlow chronicles, with detail of local and human interest, the state-by-state construction of canals, their operation, and their gradual replacement by railroads. "Life on the Canal" and "Traveling by Canal" are fascinating chapters of social history. When the book was written, "the last of their race," a two-boat "fleet" drawn by three horses on the towpath, still moved on the Delaware and Raritan Canal from New Brunswick to Trenton. The ride is described: "Probably nowhere else in all the neurotic whirl of our present-day business and social life may we find so real a motion picture of America as it was a century ago." Most of the delightful illustrations are contemporary prints.

5929. Hunter, Louis C. Steamboats on the Western rivers; an economic and technological history, by Louis C. Hunter with the assistance of Beatrice Jones Hunter. Cambridge, Harvard University Press, 1949. xiii, 684 p. illus. (Studies in economic history) 50-5138 HE627.H8

A monumental survey of steam navigation on the Ohio, the Mississippi, the Missouri, the Arkansas, and their tributaries, footnoted exhaustively from a wide variety of documents and reports, journals and newspapers, histories and travel memoirs. The first steamboat, the New Orleans, commanded by Nicholas Roosevelt, made the voyage from Pittsburgh to New Orleans in $1811-12$, and by 1817 traffic by steam was well established on the Western rivers. Dr. Hunter presents its rise, flowering, and decline on a topical rather than a chronological basis. His work has three parts: "The Steamboat as an Economic Instrument," which includes the introduction, structural evolution, and mechanical development of the boats and the techniques of their operation, the improvement of rivers, and the gory chapter of accidents; "The Steamboat as a Business Institution" including organization and finances, the experiences of passengers in cabins and on deck, and crews and officers; and finally, "Peak and Decline," carrying developments through the Civil War and the fatal postwar competition from the railroads.

5930. Hutchins, John G. The American maritime industries and public policy, 1789-r914; an economic history. Cambridge, Mass., Harvard University Press, 1941. xxi, 627 p. (Harvard economic studies, v. 7I) A 41-3915 VM23.H8

Bibliography: p. [583]-606.

A substantial history of shipbuilding and the shipping industries in America, with special emphasis on national maritime policy. The first part is on the general question of public regulation of maritime industries, with two chapters respectively on policy and techniques. Part 2, chapters 3-II, study comprehensively the era of wooden ships and smallscale enterprise, covering timber resources, methods of shipbuilding, the industry in Colonial days and from 1789-1830, the great shipbuilding boom of $1830-56$, and the international position of our merchant marine from 1830 to the Civil War. The third part is on metal ships and large-scale enterprise, 1863-1914. Here attention is paid to international competition, the organization of the big shipbuilding industries and shipping lines, and government controls, contracts, and subsidies. The long bibliography includes sections on official documents, Federal, state, and foreign, and on general works by subject.

5931. Jordan, Philip D. The National Road. Indianapolis, Bobbs-Merrill, I948. 442 p. illus. (The American trails series)

$$
\text { 48-6393 HE } 356 . \mathrm{C} 8 \mathrm{~J} 6
$$

"Bibliographical note": p. 415-43I.

A narrative history of the great Cumberland Road, the first turnpike constructed by the Federal Government. The trail followed by the young surveyor, Major Washington, and by Braddock's army was projected by Act of Congress of 1806 as a national highway, to run from Cumberland, Md., to the fast-opening Old Northwest. Built as far as Wheeling by 1818 , it was pushed on to incorporate in Ohio the pioneer road known as Zane's Trace. Political opposition in the East to the "mismanagement" of Federal funds held up construction of the western half; in Jackson's time maintenance and repairs 
were taken over by the States, and the building and ownership of the western part were later assumed by Indiana and Illinois. By the time its broken-stone surfacing had been laid to Vandalia, Ill., canals and railroads had already cut into its importance as chief route of travel to the Mississippi. In the I920's this importance was revived in U.S. Route 40. Mr. Jordan's account was written before that, too, had waned, overshadowed by the Pennsylvania Turnpike. The sources for his spirited if none too clearly arranged study include many personal journals and local records, and he enlivens his economic and political account of the building and use of the road with colorful anecdotes of frontier days. Not pioneer roads but the means of travel over them form the subject of another lively contribution to transportation history, Six Horses, by Captain William Banning and George Hugh Banning (New York, Century, I930. 4 Io p.). The first-named author had himself been a stagecoach driver for Western Union. The stories assembled in this volume are mostly of individual heroes of the days of overland travel to the Pacific by stagecoach. The first illustration is a modern photograph of "The Old Typical," familiar from a thousand "Westerns," the Concord Coach, drawn by six horses along a prairie road.

5932. Kennan, George. E. H. Harriman, a biography. Boston, Houghton Mifflin, 1922. 2 v.

illus. $\quad 22-9508 \quad \mathrm{HE}_{2} 754 \cdot \mathrm{H}_{2} \mathrm{~K}_{3} 6$

The most detailed biography of Edward Henry Harriman (1848-1909), who directed the policies of the Union Pacific from 1898 until his death, and extended its control over other lines so as to create an imposing railroad empire. The author, a journalist who had earlier written on several controversial phases of Harriman's career, here vigorously defends "certain transactions which, during Mr. Harriman's life, were widely misrepresented or misunderstood." Much of these volumes is devoted to rebutting accusations against the financier growing out of the stock market crisis of rgor, the New York State investigation of the Equitable Life Assurance Society, of which Harriman had been a director, and the Interstate Commerce Commission's investigation of his purchases of railroad stock in 1906-7. Kennan of course shared in the general appreciation of Harriman's extraordinary mastery of railroad management and finance, which had been applied to smaller New York State lines and to the Illinois Central for two decades before he assumed command of the Union Pacific. Besides railroad matters, the book tells of the boys' club which Harriman founded and maintained, his scientific expedition to Alaska in 1899 , and his bequest of wild lands along the Hudson River to the State of New
York. Two concluding chapters eulogize the tycoon's character and business methods, and quote tributes from friends and colleagues.

5933. Kirkland, Edward Chase. Men, cities and transportation, a study in New England history, 1820-1900. Cambridge, Harvard University Press, 1948. 2 v. illus., maps. (Studies in economic history) $4^{8-756} \mathrm{HE}_{207 . \mathrm{K}_{5}}$

"Published in cooperation with the Committee on Research in Economic History, Social Science Research Council."

"The story of eight decades, wherein New England shifted from a network of waterways and roads to one of steel rails and railroad consolidation" is here told by a professor of history at Bowdoin College. His scheme of reference is comprehensive, taking in turnpikes, coastal shipping, waterways and canals, and the rise of the steamboat, as well as "the new world of the railroad." Professor Kirkland's research into local and institutional records has been deep, and the flavor of New England history permeates his broad survey. He examines many aspects of railroad history: the "railroad scheme" which began indoctrination in the new mode of transport, the first railroads of Vermont, New Hampshire, and Maine, the routes to New York, regulation, crises, failures, monopoly, and the final consolidation of 1900 into three main systems: the Boston and Albany, Boston and Maine, and New York, New Haven, and Hartford. There are chapters on railroad commissions, financing, rates and services, labor, and leaders. Illustrations are from contemporary portraits or records. The result is the most thorough and illuminating regional study of transportation history that has been made.

5934. Labatut, Jean, and Wheaton J. Lane, eds. Highways in our national life; a symposium. Princeton, Princeton University Press, 1950. xvi, 506 p. illus., maps. 50-7728 $\mathrm{HE}_{355}$.L 3

"Under the editorial sponsorship of the Bureau of Urban Research, Princeton University."

Bibliography: p. 476-493.

Forty-five specialists, including historians, sociologists, economists, engineers, landscape architects, city planners, and of course officials, contribute these essays covering practically all phases of the highways of our "nation on wheels." The first nine are historical, following the road as a fundamental institution of mankind from the prehistoric trails of early man to the age of the automobile. The rest of the papers are analytical, beginning with a sociological group which examine the effects of spatial mobility on American urban, suburban, and rural society, as well as on relations across national borders. There follow papers on economic and legal 
aspects, and on the problems of highway engineering and highway operation. Mr. Labatut in his final summation calls for a better sense of proportion regarding highways-"more horse sense brought up to the HP level."

5935. Lane, Wheaton J. Commodore Vanderbilt; an epic of the steam age. New York, Knopf, 1942. xiv, 357, xii, p. illus.

$$
\text { 42-36093 } \mathrm{CT}_{275} \mathrm{~V}_{23} \mathrm{~L}_{3}
$$

"Bibliographical note": p. [326]-357.

In I810 young Cornelius Van Derbilt ( 17941877), son of a Dutch farmer on Staten Island, borrowed from his mother $\$ 100$ for a small boat and started a ferry service to Manhattan. Using his tiny earnings as venture capital in coast-wise shipping, "a field notorious for ruthless competition and crude trickery," he built up fleets which controlled the Eastern coast and by the Nicaraguan transit linked New York with the Pacific. In I 853 the "Commodore," now one of America's richest men, took a pleasure cruise in European waters on his yacht, the North Star, was feted extensively, and was eulogized in the London press: "It is time that the millionaire should cease to be ashamed of having made his fortune. It is time that parvenu should be looked upon as a word of honor." By the sixties the septuagenarian Vanderbilt's interests had shifted from ships to railways, and from his epic battles in the stock market with Daniel Drew, Jim Fisk, Jay Gould, and the other giant speculators of his day, he emerged in control of the New York Central and Hudson River, as well as lines to Chicago. This biography of the self-made builder of steamship and railroad empires is focused on the business aspects of a spectacular career. By a Princeton specialist in transportation history, and based on such primary sources as exist, supplemented by a "judicious" use of secondary works, it is full, readable, and without marked sensationalism.

5936. Morison, Samuel Eliot. The maritime history of Massachusetts, $1783-1860$. Boston, Houghton Mifflin, I941. 420 p.

Bibliography: p. 399-[410].

$$
4 \mathrm{I}-277_{2} \quad \mathrm{H}_{3} \text { 16r.M4M6 I94I }
$$

5937. Albion, Robert Greenhalgh. Square-riggers on schedule; the New York sailing packets to England, France, and the cotton ports. Princeton, Princeton University Press, 1938 . 37x p. illus.

Bibliography: p. [345]-353. $3^{8-16737} \mathrm{HE}_{7} 67 . \mathrm{N}_{5} \mathrm{~A}_{7}$

Professor (since I95I, Rear Admiral, Ret.) Morison's history of Massachusetts ships and seamen, merchants and shipowners, shipbuilders, and the towns that lived by the East-India and China trade, the "sacred codfish," or whaling, really deserves a place on the shelves of seafaring adventure rather than among ponderous and often technical works on "transportation." To be sure, it is solid and wellrounded history of an important era and mode of commerce, with appendix of statistics and bibliography, but his material is of the stuff of romance, and his writing-as he said in his I92I preface-"for your enjoyment." The I94I edition has a supplement of letters received from readers, of "correction and supplement"; the "supplement" is largely anecdotal, childhood memories or family seafaring tradition, and the "corrections" are the technicalities of the devotees of sail. The author himself is sailorman and prose poet as well as historian. In his final word picture he evokes nostalgically the vision "vouchsafed our fathers, when a California clipper ship made port after a voyage around the world." With the passing of the clipper came to an end the maritime history of Massachusetts, as distinct from that of America. "It was a glorious ending! Never, in these United States, has the brain of man conceived, or the hand of man fashioned, so perfect a thing as the clipper ship." Another noted American maritime historian, Professor Albion of Princeton University, undertook an intensive survey of the history of the port of New York (no. 595I). SquareRiggers on Schedule is a detailed expansion of part of the material covered in the larger work. It is an exhaustive research study of the earliest packet lines, combining narrative with well-documented facts and figures, and enlivened by picturesque and romantic anecdote. Illustrations are well-chosen contemporary maritime prints and portraits.

5938. Morris, Lloyd R., and Kendall Smith. Ceiling unlimited, the story of American aviation from Kitty Hawk to supersonics. New York, Macmillan, I953. $4^{1} 7 \mathrm{p}$. illus. 53-1 1423 TL $521 . M_{5}^{8}$

The writers produced this book to coincide with the $5^{\text {th }}$ anniversary of powered flight. It is a popular history of inventors, plane designs, flyers, and the achievements of aviation in peace and war. The business aspects of the aeronautics industry receive slight attention. Part 1 , "Dawn of the Aerial Age," is almost entirely devoted to the Wright Brothers, and begins at Kitty Hawk with the first plane raised by its own power for a 59-second flight in 1903. Part 2, "Men Try Their Wings," continues with the Wrights, Curtiss, and other experimenters, and with patents and early flights. The airplane was ready for the First World War, its part in which is chronicled in part 3, "War in the Skies," ending with a chapter on the "dishonored prophet," General Billy Mitchell. The interwar years were "The Era of Expansion," and here government policy, the organization of aircraft firms 
and airlines, and questions of competition versus monopoly share the interest with the record-making flights of many pilots, "Lindbergh and His Contemporaries." The last part of the story, "The Second World War and After," pictures America in the age of air travel when the "spaceship" is no longer science fantasy but an experimental problem. The many excellent photographs are grouped in sections following the five parts.

5939. Nevins, Allan. Ford. By Allan Nevins with the collaboration of Frank Ernest Hill. New York, Scribner, r954-57. 2 v. illus.

Bibliography: v. I, p. $653-664$.

$54^{-6} 305$ CT275.F $68 \mathrm{~N}_{37}$

Contents. - I. The times, the man, the company.-2. Expansion and challenge, 1915-1933.

The Ford Archives at Dearborn contain the largest collection of Fordiana, as well as of Company records, in existence. All has been opened to the two distinguished authors for the unlimited research needed for this monumental work, which is at once full biography of the eccentric genius Ford and detailed history of the Ford Motor Company-in essence, through the Company's affiliations and rivalries, a history of the automotive industry, and of "mass production [which] has changed the lineaments of our economic and social life more profoundly than any other single element in the recent history of civilization." Ford: the Times, the Man, the Company covers the years through 1915, describing Ford's childhood and early life; the epoch of pioneering in horseless carriages; Ford's first experiments with racing cars; the founding of the Company with Malcomson, Couzens, the Dodge Brothers, and others; and the Model A in 1903. The battle to bring the automobile within the reach of the common man was won in 1908 with the Model $\mathrm{T}$, the epochmaking "ungraceful, bouncing, noisy, tough-looking, and endlessly useful new Ford." Then came victory over monopoly in the Selden patent suit, removal of the plant to Highland Park, and the revolutionary technology of the moving assembly line. The trinity of mass production, low prices (in $1914, \$ 440$ ), and high wages was consummated in 1914 with the five-dollar day. The Sociological Department was established to investigate the workers, mostly recent immigrants, as to their economic, social, and moral qualifications for the minimum wage. $U_{p}$ to that point the book is entirely factual, with documentation for almost every paragraph; it ends with analysis of Ford's character and the dangers implicit in his paternalistic control. Ford: Expansion and Challenge continues the work through the First World War and the twenties, "the crowded years of war, boom, and incipient depression." As before, the story of Ford, his associates, and the industry is told in fully rounded and absorbing detail as to technological, social, political, and personal aspects. In his fervent faith in mass production, lower prices, and high wages as moulders of a better age, in his appearance and personality around which clustered anecdote and legend, in his place at the center of the "epochal controversy" between capitalism and socialism, Ford became a worldwide symbol of the second industrial revolution. His dictatorial sway as one of the last great despots of the industrial world made inevitable the comparison often drawn with Mussolini. "Happily, the Ford Motor Company was far greater than its chief author. That complex and powerful corporation represented a pooling of the energies and brains of countless men." Late in the same year as the first volume, which represented "the best documentation and ... . the most complete work on the subject thus far attempted," there was published Roger Burlingame's Henry Ford, a Great Life in Brief (New York, Knopf, I955 [i.e. 1954] 194 p.). A paperback edition was issued as a Signet key book by the New American Library in 1956 ([New York] 1943 p.). As concise as the Nevins and Hill volumes are detailed, the writer in his pointed pages has highlighted the essentials of the Ford epic and brilliantly interpreted the man who had called history bunk, and "never once allowed the impossibilities of the past to limit the possibilities of the future."

5940. Pound, Arthur. The turning wheel; the story of General Motors through twenty-five years, Igo8-1933. Garden City, N.Y., Doubleday, Doran, 1934. xvi, 517 p.

Bibliography: p. $49^{1-499 .}$

34-6ог6 HD9710.U52P6

The frontispiece of this anniversary volume is a medal by Norman Bel Geddes commemorating the 25th birthday of the General Motors Corporation. The author, working from company records, has written a popular history of the firm and its products-Oldsmobile, Buick, Oakland and Pontiac, and Cadillac; their consolidation in General Motors; the rise of Chevrolet and its merger with General Motors in 1918; and subsequent developments. He begins with two preliminary chapters on the predecessors of the automobile, given added interest by the amusing drawings by William Heyer with which the book is illustrated. He includes chapters on research and construction ("Body by Fisher"), on stockholder interest, marketing, financing and insurance for buyers, employee benefits, and public relations. The first appendix is a chronology of significant dates in the evolution of self-propelled 
vehicles and of General Motors; other appendixes are lists of officers and directors and notes on subsidiaries and affiliates.

5941. Smith, Henry Ladd. Airways abroad, the story of American world air routes. [Madison] University of Wisconsin Press, I950. 355 p. illus. $\quad 50-1473^{8}$ TL521.S52

The establishment of America's share of today's world-covering network of commercial airlines began with government monopoly. Its first ro years are the history of Pan American Airways, which was organized by Juan Trippe in 1927, and granted exclusive overseas airmail contracts. This "chosen instrument" policy permitted the line's great expansion, its trans-Pacific service initiated in 1935, a trans-Atlantic one in 1939, and a magnificent contribution during the war. Competition was called for in the Civil Aeronautics Act of 1938 , and from then on the story of international airways becomes one of involved conflict, bilateral and multilateral, between rival lines, executive agencies, Congress, foreign airlines and the United States and foreign governments. The postwar industry has emerged from international conferences and Federal action as one of regulated competition at home and abroad, supervised by American authorities and the International Civil Aviation Organization. The present vivid account is focused on enterprises and policymaking; if not always crystal clear, the fault is the subject's rather than the author's. Each chapter is followed by references and a useful note on sources, a large proportion of which are Civil Aeronautics Board, Congressional, and ICAO documents. The writer had published an earlier history, similarly concerned with competition, financial intrigue, and government regulation: Airways; the History of Commercial Aviation in the United States (New York, Knopf, 1942. 430 p.).

5942. Taff, Charles A. Commercial motor transportation. Rev. ed. Homewood, Ill., R. D. Irwin, I955. 673 p. $\quad 55-9353 \quad \mathrm{HE}_{5} 623 . \mathrm{T}_{3}{ }_{1955}$

A textbook on the industry of transportation by truck and bus, by a professor of transportation at the University of Maryland. The mushroom growth of the motor carrier during the last 30 years, the extension of hard-surfaced highways, and the methods of financing highways are outlined, with striking graphic illustration, in part $\mathrm{I}$. The bulk of the text is devoted to "property-carrying aspects," with chapters on the various types of trucks, their management and operations, classification, financing, rates and ratemaking, regulation and control by Federal and state governments, and policies of the Interstate Commerce Commission, under whose authority trucks were brought by the Motor Carrier Act of 1935. Part 3 is on buses, with two chapters explaining the elements of intercity passenger operations, and one on urban bus transit. At the end is an 8-page bibliography.

5943. Wilson, George Lloyd, and Leslie A. Bryan. Air transportation. New York, PrenticeHall, 1949. ix, 665 p. illus., maps.

$$
\text { 49-49212 } \mathrm{TL}_{552 .} \mathrm{W}_{48}
$$

A general treatment of the subject for students of the economic aspects of air transportation. The historical background and modern development of aviation, types of aircraft, airports and civil airways are outlined in the first part. The longer second part explains the system of commercial air transportation, domestic and international, carrying mail, passengers, and freight. Among the aspects discussed are organization, services, rates and charges, coordination, safety, insurance, and employee and public relations. There is a short survey of the principal airlines of Europe, Asia, Africa, Australasia, and the Western Hemisphere. The last chapters discuss government aid and regulation on the municipal, State, Federal, and international levels. The appendix is a digest of the "charter" of American aviation, the Civil Aeronautics Act of 1938 . The same field of business aspects is covered in Commercial Air Transportation, by Professor John H. Frederick of the University of Maryland, now in its fourth edition (Homewood, Ill., R. D. Irwin, I955. 547 p.). Less attention is paid to historical development and to international air transportation, and rather more to policies of the Civil Aeronautics Board and to the practical details of financing airlines, handling passengers and cargo, etc. A bibliography follows the text, and the appendixes give the Act of $193^{8}$ and changes proposed in the Senate Bill of 1954. Last may be mentioned a specialized study of air transportation in relation to a single but important sector of fiscal policy: Richard W. Lindholm's Public Finance of Air Transportation, a Study of Taxation and Public Expenditures in Relation to a Developing Industry (Columbus, Bureau of Business Research, College of Commerce and Administration, Ohio State University, 1948. I 78 p.). This is a technical and statistical analysis of the effects of specific taxes and tax rates, which still amount to a substantial subsidy of air transport. The taxes are of four sorts: gasoline taxes, property taxes, taxes on corporate net income and capital stock, and social security taxes. The author offers a number of findings and recommendations, some of a general nature, some specific to the airlines. 


\section{G. Commerce: General}

5944. Barger, Harold. Distribution's place in the American economy since 1869. Princeton, Princeton University Press, 1955. xviii, 222 p. diagrs. (National Bureau of Economic Research. General series, no. $5^{8)}$ 55-10677 $\mathrm{HF}_{3021 . \mathrm{B}_{3}}$

Bibliography: p. 152-215.

It has not infrequently been noticed that today more people are needed to get food, clothes, and other commodities from the farmer or manufacturer to the customer than in the days of our grandfathers. This fact has been statistically demonstrated in impressive detail by Professor Barger and his staff, from sources whose enumeration requires over 60 pages. For the past three decades, they demonstrate, there has been little change in the merchant's share of the retail sales dollar. A sharp increase in the percentage of salesmen in the total labor force and a corresponding decline in the percentage of farmers, miners, factory workers, etc., have been balanced by a very much larger rise in output per manhour among the latter than among workers in the wholesale and retail trades. Reliable figures were available for these decades, but for the years before World War I the Bureau has had to piece together scraps of information. What emerges is the conclusion that ever since the Civil War the role of the distributor has been rising in proportionate importance and that of the producer falling, while the output of the latter has increased, just as in the last 30 years; and the buyer's dollar between 1869 and rgrg turned definitely, though slowly, in the direction of the salesman. The Bureau presents these conclusions through tables, charts, and text addressed to a professional audience.

5945. Converse, Paul D., and Harvey W. Huegy. The elements of marketing, by Paul D. Converse and Harry W. Huegy, with the collaboration of Robert V. Mitchell. 5th ed. New York, Prentice-Hall, 1952. $968 \mathrm{p}$.

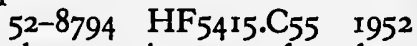

In accordance with the great increase of workers in distribution recorded by Professor Barger (above), marketing has become increasingly a subject of study in American universities and business schools. This textbook, first published in 1921, has as authors and collaborator two full professors and an assistant professor of marketing of the University of Illinois. They begin with a definition of marketing: it is often called distribution; it "makes goods and services more valuable by getting them where they are wanted" (place utilities), "when they are wanted" (time utilities), "and transferred to those people who want them" (possession utilities); a simplified definition says "marketing is the business of buying and selling." The various elements of the marketing process are then expounded in detail. Over roo pages at the end set problems related to individual chapters, written in the concrete style of case histories: e. g., how the Orangeburg Company pays its salesmen. Short bibliographies follow the chapters. That on "General Marketing" lists 3o-odd works, of much the same character, a number of them similarly going through periodic revision for class use. Typical are two, both revised since the present work appeared: Harold H. Maynard, Theodore N. Beckman, and William R. Davidson, Principles of Marketing, 6th ed. (New York, Ronald Press, 1957. 798 p.); and Charles F. Phillips and Delbert J. Duncan, Marketing; Principles and Methods, 3 d ed. (Homewood, Ill., R. D. Irwin, 1956. 789 p.).

5946. Heck, Harold J. Foreign commerce. New York, McGraw-Hill, 1953. 512 p.

52-I15II $\mathrm{HF}_{303} \mathrm{I}_{4}$

Four of the five parts into which this volume is divided deal with foreign commerce as an aspect of the economy of the United States, while the last part reviews intergovernmental organizations- the International Monetary Fund, International Bank, etc.-and international trade agreements. The transactions carried on abroad by American merchants, the services that facilitate them, and the conditions that restrict them are the focus of the study. First the significance of foreign commerce is examined, wih a statistical analysis of the patterns of world trade. Export and import businesses are explained, and the parts played in connection with them by banks, brokers, transportation, insurance, postal services, government, and other agencies described. Financial considerations discussed include balances of payments, foreign exchange, and foreign investments. The fourth part is on customs, tariffs, restrictions on exports, and government promotion of foreign trade. The book is designed for college courses, with section headings within chapters and a 9-page bibliography.

5947. Humphrey, Don D. American imports. New York, Twentieth Century Fund, 1955. xviii, 546 p. diagrs. $\quad 55-8798 \mathrm{HF}_{303 \text { I.H86 }}$ 
This analysis of the "import deficit" of the United States was authorized in 1950 by the Twentieth Century Fund and the National Planning Association; as the statistical data in general reflect the scene of 1949, its importance is now largely historical. The American export surplus and the resulting worldwide dollar shortage are shown to result from the great expansion of domestic industry rather than from restrictions on products from abroad. The tariff, trade agreements, and other barriers to importation are historically reviewed, and a chapter contributed by Professor Calvin B. Hoover, a colleague of the author's at Duke University, gives the viewpoint of the European exporter. Individual imports that might be increased are statistically studied-such raw materials as hides and skins, wool, fats, and oils; various agricultural items; minerals and petroleum; and "luxuries," tourism, and shipping. Domestic industries that might suffer thereby are shown to be "relatively stagnant, low-wage industries," such as fur felt hats, blue-mold cheese, handmade glass, and watches. The summing up ends with a policy statement by the NPA's Committee on International Policy. Its recommendations for a substantial reduction of the tariff and more liberal trade agreements are aimed at improvement of the economic health of the free world. A more recent and less technical study is by Samuel Lubell: The Revolution in World Trade and American Economic Policy (New York, Harper, 1955. 143 p.). In an attempt to disprove the widespread "illusion" that lowering United States tariffs and removing international trade restrictions would go far to solve the world's economic problems, the author analyzes the world picture. Asia's dollar crisis is caused by its greatly increased need for imports, he finds; the British troubles come from concentration on the sterling bloc; Western European efforts are aimed at integrating the resources and markets of the overseas areas with the home countries; the trade policy of the Soviets is aimed above all at splitting the free world. He outlines certain desirable objectives and offers some suggestions for their attainment.

5948. Johnson, Emory R., and others. History of domestic and foreign commerce of the United States, by Emory R. Johnson, T[hurman] W. Van Metre, G[rover] G. Huebner, and D[avid] S. Hanchett. Washington, Carnegie Institution of Washington, 1915; reprinted 1922. 2 v. $(363$, 398 p.) maps. ([Carnegie Institution of Washington. Publication no. 215A])

30-23704 HF $3021 . J 61922$

This valuable reference work is one of the notable series of Contributions to American economic history sponsored by the Carnegie Institution's Depart- ment of Economics and Sociology (see also Clark, no. 5904; Meyer, no. 5923; Commons, no. 6033). The late Professor Johnson of the University of Pennsylvania, an expert on transportation, was editor, and contributed most of the first part, a history of commerce in the Colonial era and through the Revolution. Two chapters on fisheries and the coastwise trade in this period were by Dr. Van Metre, who was responsible also for the second and third parts, which complete volume I: "Internal Commerce of the United States," and "The Coastwise Trade," both extending from 1789 to the early 2oth century. The second volume contains "The Foreign Trade of the United States since 1789," by Professor Huebner, with a preliminary chapter by Professor Johnson; "American Fisheries," by Dr. Van Metre; and "Government Aid and Commercial Policy," by Dr. Hanchett, with a chapter on tariff provisions by Dr. Huebner. The contributors were all on the faculty of the University of Pennsylvania. A number of unpublished monographs by other collaborators were used in preparing the final text. The work is heavily documented, with footnotes, a formal classified bibliography (v. 2, p. 363-386), and a bibliographical essay on sources (p. 352-362).

5949. Richert, Gottlieb Henry. Retailing, principles and practices. 3d ed. New York, Gregg Pub. Division, McGraw-Hill, 1954. 498 p. illus. $\quad 53-12060 \quad \mathrm{HF}_{5429 . R_{52}} 1954$

The writer is identified as a specialist in distributive education of the U. S. Office of Education. In his preface explaining the need for teaching this subject he speaks of the retail store as "a romantic enterprise," as well as a complex business. The textbook is for the young person who intends to go to work in a store, and it is all the more concrete for that. It includes an account of the "Merchants of America-Hall of Fame" opposite the Chicago Merchandise Mart, and scattered throughout it are pictures and brief biographical sketches of America's most successful retail merchants. The chapters cover all aspects of the retail business, even to illustrations of "proper wrapping methods." An appendix lists trade associations. A comparable textbook addressed to college students is Retailing; Basic Principles, by Pearce C. Kelley and Norris B. Brisco, 3d ed. (Englewood Cliffs, N. J., PrenticeHall, I957. 620 p.). The authors are respectively a professor of marketing at the University of Oklahoma and the general operating manager of a large department store. A long bibliography (p. 585609), referring largely to periodical material, is arranged to follow the individual chapters, on such subjects as "Inventory and Stock Control," "Effective Retail Personnel," and "That All-Important Person [the customer]." The standard textbook 
on wholesaling is by Professor Theodore N. Beckman of Ohio State University and Nathanael $\mathrm{H}$. Engle, formerly assistant director of the U. S. Bureau of Foreign and Domestic Commerce: Wholesaling, Principles and Practice, rev. ed. (New York, Ronald Press, I95I. 746 p.). It has four parts: "The Nature and Evolution of Wholesaling," "Modern Wholesaling in the United States and Abroad," "Operation and Management of a Wholesale Business," and "Economic and Governmental Aspects of Wholesaling."

5950. Rosenthal, Morris S. Techniques of international trade. New York, McGraw-Hill, 1950. $x v, 554$ p. 50-804 I HFroo7.R6 I950

This volume of basic information about the techniques of importing and exporting, written by the president of the National Council of American Importers, rehearses and explains the practical matters involved in international trade. The author discusses the significance and form of the written contract, methods and instruments of shipment, customs procedure and tariffs in the United States and abroad, marine insurance, packing, financing through consignment and open account, drafts and letters of credit, foreign monetary systems, air freight, and communications. Many examples of individual transactions and facsimiles of typical documents are included. The appendixes include a number of international agreements, and the "Revised American Foreign Trade Definitions" of I94I issued by the National Foreign Trade Council. The work is a revision of Technical Procedure in Exporting and Importing published in 1922.

\section{H. Commerce: Special}

5951. Albion, Robert Greenhalgh. The rise of New York port (1815-1860) by Robert Greenhalgh Albion, with the collaboration of Jennie Barnes Pope. New York, Scribner, 1939. xiv, $458 \mathrm{p}$. 39-27I72 $\mathrm{HE}_{554 . \mathrm{N} 7 \mathrm{A6}}$

Bibliography: p. [423]-47o.

The whole history of the port of New York, says Dr. Albion, is too complex for compression into one volume. In this work he surveys "the significant middle period when New York definitely drew ahead of its rivals and established itself as the chief American seaport and metropolis." The author had already published Square-Riggers on Schedule (no. 5937), which expands a portion of the material here covered; his plans for histories of New York as a port before 1815 and after 1860 were interrupted by the war, and his later contributions have been in naval history. The present volume is broad in its scope, describing the operations of trade in New York itself, in domestic and foreign markets and in ports of call; the activities of the waterfront; the ships, their routes and mariners; the personalities of "merchant princes"; and travelers' impressions. For the general reader there are provided "shipwrecks, slavers, and pirates"; for the scholarly, analysis of the growth of commerce and statistical data, much of the latter being tabulated in appendixes. The book is profusely illustrated with reproductions of contemporary prints and portraits.

5952. Baer, Julius B., and Olin Glenn Saxon. Commodity exchanges and futures trading; principles and operating methods. [New York]
Harper, I949. 324 p. 49-7144 HG6o46.B 3 I949 Revision of 1929 publication with the title Commodity Exchanges, by Julius B. Baer and George P. Woodruff.

Commodity exchanges such as the New York Cotton Exchange, the Chicago Board of Trade (wheat and corn), the Rubber Exchange, the Silk Exchange, the Cocoa Exchange, and the National Metal Exchange, are associations of traders organized for buying and selling their particular commodities, chiefly through futures contracts. These are contracts for "to arrive" deliveries drawn up according to the rules of the organization as to unit of amount (e. g., a standard bale of cotton), quality, and time of delivery. This involves a form of insurance for producer, dealer, and processor, which takes the form of "hedging." Hedging is the device whereby the purchaser who bas contracted to deliver a processed commodity-e. g., a miller promising a quantity of wheat flour-and is buying a quantity of wheat at today's price, contracts to sell a like quantity of unprocessed wheat at the going market price on the date when he delivers his flour. He will thus be protected against loss if the market has fallen, and if the market has risen, his profits on the first purchase will be offset by the price he will have to pay for the future purchase of wheat. This technical study, by two specialists in business law, describes the mechanics of futures trading on the American exchanges with emphasis on their legal aspects. Little attention is given to international markets. The role of the speculator is defended as of social value. 
5953. Brown, William Adams. The United States and the restoration of world trade; an analysis and appraisal of the ITO charter and the General agreement on tariffs and trade. Washington, Brookings Institution, 1950. $57^{2} \mathrm{p} . \quad 5^{0}-77^{0} 3 \mathrm{HF}_{55} \cdot \mathrm{B}_{7}$

A study of the primary instruments of international commerce proposed under United Nations auspices. The late author, an economist at the Brookings Institution, had served in the State Department and acted as an observer at conferences for a proposed International Trade Organization. After a glance at our fundamental foreign trade policies and at the background of international efforts toward multilateral agreement on commercial relations, he reviews the history of ITO and the General Agreement on Tariffs and Trade (GATT). The UN Economic and Social Council (ECOSOC) in 1946 set up a Preparatory Committee on Trade and Employment which met at London and Geneva and drew up a draft charter, which was presented to ECOSOC at a conference in Havana in November 1947. Here the so-called Havana Charter for an International Trade Organization was promulgated, to be submitted for ratification to member states. As a means of immediate partial implementation, GATT was signed by 23 countries at the Geneva meeting of the preparatory committee, and has subsequently received several amendments. Dr. Brown explains the content and implications of the two instruments, and then appraises them in terms of United States policy. In the last chapter he reviews the unsatisfactory alternatives of action if the United States should reject the Charter. Its text is analyzed provision by provision in the appendix. [The United States has not been willing to accept the provisions of ITO, and as of 1959 it is a dead letter. GATT is in force as an informal agreement on certain limitations of restrictions; it has no administrative apparatus beyond an annual meeting of the signatories. In 1955 an Organization for Trade Cooperation (OTC) was agreed upon to serve as an administrative body for GATT; it has not yet been ratified by all member states.]

5954. Campbell, Persia C. The consumer interest: a study in consumer economics. New York, Harper, 1949. $660 \mathrm{p}$. 49-2885 HB8or.C3

An evaluation from the consumer's viewpoint of America's "total economic activity in terms of the end results in consumer goods, and the satisfactions derived from their use by the different families and individuals in the community"-in other words, "What comes from all our getting and spending? And do we want what we get, or get what we want?" First, the standard of living is defined in material and subjective ways, for instance, in terms of purchasing power, social status, and personal satisfac- tion. The writer discusses "Consumers at Market," indicating patterns of choice in expenditure, with many interesting details and statistics. Shopping for price advantage is set against shopping for quality, and the advantages and disadvantages of buying on credit are analyzed. The last section, "Factors in Supply," appraises the relation to the consumer of the retail store, farm production, and industry, with special regard to the part played by government in regulation and control. In a final chapter Miss Campbell surveys the "consumer movement" for educating the buyer and forming an enlightened public opinion in the field.

5955. Carson, Gerald. The old country store. New York, Oxford University Press, 1954. 330 p. $\quad 54-5290 \quad$ HF $_{5429 . C_{296}}$

The past tense prevails in this engaging account of the typical institution which tied together the rural community of Igth-century America and provided its full-time social center. For his material the writer has drawn on such sources as old ledgers and journals, newspapers, diaries, "drummers'" cards, local history, folksay, and personal reminiscence. The narrative is studded with anecdotes and verses, illustrated with facsimiles and gay pen drawings. Chronologically, Mr. Carson divides his account into two halves at the Civil War. The chapters have pleasant titles: "How to Live without Money" (your cordwood in trade for cigars), "The Thrivingest People in the World" (peddlers), "A Man of Many Parts" (The storekeeper, hero of local legend). "The Drummers of Pearl Street" describes the country merchant's buying trip to New York, before the day of the traveling salesman. The latter, "The Man Who Brought the News," arrived about the middle of the century. "From Cradle to Coffin" is the country-store inventory; "Sittin' Round the Old Store Stove" is the lore of the cracker-barrel colloquium. Patent medicines are looked at in "One for a Man, Two for a Horse." The story ends with the coming of the dissolvents: the mail-order catalog and the Model T. "With the departure of the country store-counter, stove, and settle-there is no longer any point of assembly. The congress has adjourned, sine die."

5956. Emmet, Boris, and John E. Jeuck. Catalogues and counters; a history of Sears, Roebuck and Company. [Chicago] University of Chicago Press, $195^{\circ}$. xix, 788 p. illus.

Bibliography: p. [753]-773.

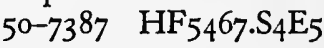

Sears, Roebuck and Company, according to its former retail merchandise manager, Dr. Emmet, is "perhaps the outstanding example of mass merchandizing"; in 1948, \$2,296,000,000 worth of goods were 
sold through its 632 retail stores, II mail-order plants, and $34 \mathrm{I}$ order offices. The authors present here a full business history, with special attention to the policies and methods by which the firm has cut the high cost of distribution to the benefit of the American consumer. The Sears, Roebuck story falls into three chronological stages. The first extends from 1886, when Richard W. Sears (1863I9I4) started a little business in Chicago advertising the sale of watches by mail, to his resignation as president of the $\$ 50$ million company in 1908 . A. C. Roebuck, watchmaker and cofounder, had sold out early, and his place had been filled by Julius Rosenwald, who succeeded Sears as president. The middle period of maturity in selling by catalog lasted from I 908 to 1025; hard hit by the business crisis of I921, the Company had been saved only by Rosenwald's "grand gesture" of advancing $\$ 20$ million of his cwn fortune, and had undergone an extensive reorientation in sales methods and operation. The third period, from 1925 to 1948 , saw the development of retail stores, a great expansion of over-thecounter sales, and the many other changes that have come with the growth of the American economy in general, and of Sears, Roebuck in particular.

5957. Gibbons, Herbert Adams. John Wanamaker. New York, Harper, 1926. 2 v. illus. 26-183II E664. W24 $\mathrm{G}_{4}$

Bibliography: v. 2, p. 469-48I.

John Wanamaker's long and eventful life, from 1838 to 1922 , is one of the brilliant success stories of America's age of enterprise. To this biographer, friendly though not eulogistic, it was "the spirit of radiant adventure" that animated the great merchant in his many activities in business, religion, and politics. Dr. Gibbons gives equal attention to all sides of Wanamaker's career: in religious endeavor, the Y. M. C. A., the Bethany Chapel, the Moody and Sankey and other revivals; in State, municipal, and national politics (he was rewarded by Benjamin Harrison for his zeal in the campaign of 1888 with the Postmaster Generalship); and in business, with the establishment of one of America's first great department stores. The modest shop for men's clothing, Oak Hall, which he and his brother-in-law began in 186r, became in ro years the biggest retail store of its kind in the country, largely through Wanamaker's genius for publicity. In 1876 , taking advantage of the many visitors to Philadelphia for the Centennial Exhibition, Wanamaker converted the old Pennsylvania Railroad freight depot into the Grand Depot, a combination of drygoods and clothing store. In 1877 it became "a new kind of store," with departments for drygoods, notions, and "all things for the ready-dress needs of the people." Its rise to the huge establishment in Philadelphia and New York was not, the writer emphasizes, automatic growth, but the result of Wanamaker's combination of bold venture, foresight, and faith.

5958. Hower, Ralph M. The history of an advertising agency: N. W. Ayer \& Son at work, 1869-1949. Rev. ed. Cambridge, Harvard University Press, 1949. xliii, 647 p. illus. (Harvard studies in business history, 5)

First edition, 1939 .

49-10653 HF6r81.A8H6 1949

A case study in the history of advertising, based on "inside materials" - the firm's records, interviews with employees and clients-by an independent researcher, a professor at the Harvard Graduate School of Business. The record of N. W. Ayer \& Son, Inc., of Philadelphia, one of the oldest advertising agencies in America, is presented as illustrative of "the creative work of the business man," its success "a synthesis of the ideal and the useful, of the right and the profitable." The book is in two distinct parts, the first 200 pages tracing the general history of the agency from its small beginning in 1869 with a list of I r religious newspapers for which to procure advertisements, to the big organization of the present day. The second part is an objective analysis of particular aspects of the Ayer development as typical of the rise of professional advertising, with stress on their social significance. To the library profession, the company is most familiar as publishers of the famous guide, now called $N . W$. Ayer \& Son's Directory, Newspapers and Periodicals, which has come out annually since 1880 .

5959. Hower, Ralph M. History of Macy's of New York, 1858-19r9; chapters in the evolution of the department store. Cambridge, Harvard University Press, 1943. xxvii, 500 p. diagrs. (Harvard studies in business history, 7)

A $43-1889 \mathrm{HF}_{5465 . U 6 \mathrm{M} 27}$

The first 60 years of America's largest single retail store comprise its founding and early development by Rowland $\mathrm{H}$. Macy and his first partners (1858-87), and its expansion under the direction of two generations of Strauses (1888-1919). A second volume to cover later years was projected but has not been published. In this history of the great "cheap store," the author's second contribution to this Harvard series in business history, the style is semipopular, and the pages lightened with personal names and stories, quotations of sprightly advertising in verse and prose, and portraits of store personalities. Emphasis is on the functions of retailing, and Dr. Hower offers evidence to prove that Macy's was "among the two or three stores in both Europe and America which first completed the transition from specialized stores 
to modern department stores," with an ever-increasing variety of goods for sale in quantity at the lowest unit price. An interesting central chapter describes the composition and working conditions of the sales force of the eighties. In the era of direction by Isidor and Nathan Straus and their sons, the author's attention is focused on the evolution of store facilities and of policies of expansion, advertising, competitive pricing, and employee relations.

5960. Jones, Fred Mitchell. Middlemen in the domestic trade of the United States, I8001860. Urbana, University of Illinois, 1937. 8I p. (Illinois studies in the social sciences, v. 21 , no. 3) 37-27875 $\mathrm{HF}_{3027 \cdot 3 . J 62}$ $\mathrm{H}_{3} \mathrm{I} . \mathrm{I}_{4}, \mathrm{v} .2 \mathrm{I}, \mathrm{no.} 3$

University of Illinois Bulletin, v. 34, May 25, 1937. Bibliography: p. 72-77.

A historical monograph describing the operations of middlemen-wholesalers, jobbers, commission merchants, selling agents, brokers, auctioneers, retailers, public markets, and peddlers-in the commerce of the United States before the Civil War. It gives special attention to regulation of their operations by Federal, State, and local authorities. There is much interesting detail, which incidentally shows that few modern devices are new; even the chain store had its prototype in the three or more stores owned in different parts of Tennessee by Andrew Jackson. Where available, statistics have been gathered. In the appendix are tables of auction sales over a period of years, and of retail stores $(57,565$ in all $)$ in the United States in 1839 .

596r. Lebhar, Godfrey M. Chain stores in America, 1859-1950. New York, Chain Store Pub. Corp., 1952. 362 p. diagrs.

$$
\text { 52-7108 HF } 5468 . L_{332}
$$

A history of the chain store system by the editor of the trade journal, Chain Store Age. Mr. Lebhar chronicles the birth of the chain stores (the date chosen is 1859 , the year of the founding of the Great Atlantic and Pacific Tea Company) and their rise through the years to the strength shown in the census of 1948 ; its figures indicate that of $1,770,000$ stores in the United States, only 105,000 or 6 percent are chain stores, but they account for 23 percent of the total retail volume. The struggle against the opposition of the independent stores in regard to price cutting is reviewed, with citation of many legal cases and decisions, anti-chain-store tax bills, acts of the Federal Trade Commission, etc. The crusade against the chains began in the 1920's and rose in intensity until the passage of the Robinson-Patman Act in 1936, after the American Retail Federation had been investigated as a "superlobby." The tide turned when the Patman bill of $193^{8}$, which attempted to impose a punitive tax on chains, was killed in 1940, the hearings contributing importantly to a public understanding of the economic and social value of the chain-store system of distribution. In his last chapters the author discusses this value in relation to the community, the farmer, and the employees of the chain store, and the chain stores' prospects for the future.

5962. Sandage, Charles H., and Vernon Fryburger. Advertising: theory and practice. $5^{\text {th }}$ ed. Homewood, Ill., R. D. Irwin, I958. 690 p.

$$
5^{8-9767} \mathrm{HF}_{5} 823 . \mathrm{S}_{25}{ }^{195^{8}}
$$

This college textbook examines advertising, "a dynamic force in our economy," in all its facets. The first part, "Basic Value Functions," outlines the history of advertising and discusses its social and economic aspects, among them the factor of truth, the role of advertising as a buyer's guide, and the advertising of ideas rather than products (including "advertorials"). Next its practical aspects are treated: the background of fact gathering, consumer research, product and market analysis, the stages in preparing and reproducing the advertisement, and the advertising media. The methods of testing the effectiveness of advertising provide interesting chapters which range from the comparatively simple technique of submitting samples to a consumer jury to such complicated mental feats as "unaided-recall" and "psychological scoring." Finally, the organization and functions of the modern advertising agency are analyzed. As might be expected, the illustrations are spirited and of great variety.

5963. Seligman, Edwin R. The economics of instalment selling; a study in consumers' credit, with special reference to the automobile. New York, Harper, 1927. 2 v. tables, diagrs.

Bibliography: v. I, p. 339-346.

$27-24759 \mathrm{HF}_{55} 68 . \mathrm{S}_{4}$

A thorough historical and theoretical study by a well-known Columbia University economist, which remains the most authoritative examination of the nature and operations of instalment selling in America. This form of consumer's credit began in 1807 with "high-grade business," instalment sales of furniture, sewing machines, pianos, and books; but a period of "low-grade selling," carried on particularly in New York City by unscrupulous ped. dlers, brought the system into disrepute. It was revivified by the largest and most significant applica. tion, to automobiles, after which there developed the special instruments of the finance company and the Morris Plan banks. Professor Seligman explains methods of instalment credit, estimates the extent of 
instalment selling, and analyzes instalment sales as to their nature and characteristics. He examines the question of luxuries and necessities in connection with the automobile, and the effects of instalment credit on the consumer, on business conditions, and on the credit structure. In each case the institution is defended as one that, when abuses and improper practices are cleared away, will be reckoned as constituting "a signal and valuable contribution to the modern economy." The large second volume, prepared by the author's associates, contains a group of specialized statistical studies, several of them concerned with instalment sales of automobiles. A more recent work, The Economics of Instalment Buying, by Reavis Cox (New York, Ronald Press, 1948. 526 p.), is a comprehensive reference guide to the structure, organization, and management of instalment buying (or selling), its economic functions and consequences, and its future outlook. The author, professor of marketing at the University of Pennsylvania, was director of research for the Retail Credit Institute of America, by which the volume was sponsored.

5964. Warbasse, James P. Co-operative democracy through voluntary association of the people as consumers; a discussion of the co-operative movement, its philosophy, methods, accomplishments, and possibilities, and its relation to the state, to science, art, and commerce, and to other systems of economic organization. $5^{\text {th }}$ ed. New York, Harper, I947. 324 p. $\quad 47$-II74I $\mathrm{HD}_{2965 . W_{3}}$ I947
Bibliography: p. 316-319.

The most considerable American contribution to cooperation literature is this book by one of its leading exponents. The late Dr. Warbasse was founder and for many years (I9I6-4I) president of the Cooperative League of the U. S. A.; on the title page of this fifth edition of the work he appears as president emeritus. He presents cooperation as a world development. After consideration of its meaning and methods, and a short chapter on the Rochdale pioneers, he reviews in summary form the status of cooperative societies in about 60 countries. Then he considers the forms of expression of cooperation, its relationship with government, and its significance in regard to politics, profit business, the labor movement, etc., using world experience for illustration. The book has been translated into nine languages. Dr. Warbasse had himself lectured and given courses on cooperation in a hundred universities in eight countries. The purely American aspects of cooperation are recorded with extensive detail in a recent book by a government specialist on cooperatives, Florence E. Parker: The First I25 Years; a History of Distributive and Service Cooperation in the United States, 1829-1954 ([Chicago, Cooperative League of the U. S. A.] 1956. 462 p.). Less fully, but with notable clarity, the subject of cooperation and its particular manifestations in America are set forth in a guide for public school teachers by Charles Maurice Wieting: The Progress of Cooperatives, with Aids for Teachers (New York, Harper, 1952. 210 p.).

\section{Finance: General}

5965. Blough, Roy. The Federal taxing process. New York, Prentice-Hall, 1952. 506 p. (Prentice-Hall economics series)

Bibliography: p. 48I-494.

$$
\text { 52-8597 HJ238r.B55 }
$$

Professor Blough, a tax expert long connected with the U. S. Treasury Department and congressional tax committees, prepared this book while teaching at the University of Chicago in 1946-50. He is now principal director of the Department of Economic Affairs of the United Nations. In this closely written study of the making of tax policy he is particularly concerned to show how policy is formulated amid the fundamental and clashing disagreements of its framers about the public interest it is to serve. He examines tax programs and pressure groups, the passage and application of the tax laws, and the administration of taxation by the Bureau of Internal
Revenue. "Considerations Relating to the Level of Taxation" include the controversy over deficit spending and a balanced budget; "Considerations Relating to the Distribution of Taxes" include national prosperity, the problem of fairness, regulatory taxation (e. g., on alcoholic liquors), and Federal-State tax relations. The last chapter examines the bearing of the Federal taxing process on the carrying out of national policies.

5966. Dewey, Davis Rich. Financial history of the United States. I2th ed. New York, Longmans, Green, 1934. xxxviii, 600 p. diagrs. (American citizens series) $\quad 34-3657^{\circ} \quad \mathrm{HJ}_{24}$ I.D4 1934

A standard work since 1903 , in its final edition covering in highly compressed form the whole course of public finance from Colonial days to the depression of the 1930's. The author, elder brother of 
John Dewey, was professor of economics and statistics at the Massachusetts Institute of Technology from 1893 to 1933 , and, among other distinguished posts, editor for many years of the American Economic Review. His text is preceded by a 20-page bibliography divided into subject sections, and short lists of references are put at the heads of chapters. The themes followed chronologically in his history are taxation and internal revenue, coinage and paper money, the banks, the tariff, the silver question, and the administration of the Treasury. The volume is of lasting interest; Professors Studenski and Krooss in their new Financial History of the United States (no. 5973) acknowledge their debt to it and declare it "will continue to be a classic in the field."

5967. Guthmann, Harry G., and Herbert E. Dougall. Corporate financial policy. $3 \mathrm{~d}$ ed. New York, Prentice-Hall, 1955. 766 p. illus.

\section{5-5754 HG 4 OII.G85 1955}

Two professors of finance begin by defining and charting the field of corporation finance. Their exposition covers lucidly and in detail legal forms of business organization other than corporations, the formation and control of the corporation, its stock and bonds, factors determining the pattern of longterm financing, and the financial aspects of promotion. Next various branches of corporation finance are examined: public utilities, railroads, investment banking, security exchanges, the subscription sale of securities, and employee and executive stock ownership. Techniques of budgeting and short-term financing are explained. Then the writers proceed to the advanced stages of the corporation's career: expansion and consolidation, mergers, holding companies, refinancing and recapitalization, failure, receivership, reorganization, and so on to corporate dissolution and liquidation. That note is too sad on which to end, even in a text for advanced study, so the final chapter becomes a soothing and hopeful review of the social aspects of corporate financing. The long bibliography (p. 724-766) is arranged in the form of chapter references.

5968. Hansen, Alvin H. Fiscal policy and business cycles. New York, Norton, I94I. 462 p. $4{ }^{1-7728} \quad \mathrm{HB}_{37}{ }^{\mathrm{II}} \mathrm{H}_{315}$

In his introduction to this book on fiscal policy as an instrument for regulating the national income and its distribution, the author gives emphatic voice to the conviction that for a decade has dictated his vigorous advocacy of the Keynesian doctrine. "The twin scourges that affict the modern world-Depression and War-are not altogether unrelated. Bad as the Treaty of Versailles was, a steady improvement in international political relations could have been expected had we had the vision and courage to stop the Great Depression dead in its tracks and move forward to higher levels of real income and employment.... The ultimate causes of the failure to achieve a world order in the political sphere must be sought in the facts of economic frustration." Professor Hansen, who held the Littauer Chair of Political Economy at Harvard from I 937 until his retirement, has been the leader of the American theorists who believe in a dual economy of Federal spending and private investment, and in increasing the public debt as a way of combating depression. He here develops these views in an examination of the economic situation of the 1930's; the changing role of fiscal policy and its application to the full use of resources through "compensatory" spending and taxation; incentives to investment; and wartime financing. Like other economists at home and abroad, he predicted a postwar slump.

5969. Kendrick, Myron Slade. Public finance; principles and problems. Boston, Houghton Mifflin, 1951. 708 p. illus. $51-9072 \quad \mathrm{HJ}_{257} \cdot \mathrm{K}_{4}$ A text for advanced study by a professor at Cornell University, who attempts to balance the older views of the orthodox laissez-faire economists and those of the enthusiastic followers of J. M. Keynes who advocate heavy government spending in order to maintain a high level of employment and national income. The main exposition is in three parts, "Public Expenditures" (their increase, the causes thereof, and how to control them), "Public Revenues," and "Fiscal Policy." The second is by far the longest, with 2I chapters covering the historic development and present status of State, local, and Federal taxation, the taxation of property, estate and inheritance taxes, the taxation of motor vehicle transportation (called "taxes as price equivalents"), the taxation of business, income tax, and the general problems of tax administration and (with charts) the incidence of taxes. The last chapter warns of dangers in a policy of expansion spending: "Only after the possibilities of correcting the known defects of the economy have been explored has the policy of spending for its general effect any claim to consideration." Another useful textbook, Public Finance, by Alfred G. Buehler, is now in its third edition (New York, McGraw-Hill, 1948. $74^{\circ}$ p.). In straightforward expository chapters the author defines public finance and describes the range of Federal, local, and State expenditures and grants, fiscal organization, budgetary procedure, government accounting, and the tax system in its many phases. The volume ends with a consideration of Federal methods of borrowing and the economic significance of the public debt. 
5970. Paul, Randolph E. Taxation in the United States. Boston, Little, Brown, 1954. $830 \mathrm{p}$. 54-6282 HJ2362.P 35

The late writer, a tax lawyer who had served as advisor to the President and the Treasury Department in New Deal days and who during the war was Assistant to the Secretary of the Treasury in charge of foreign funds control, was influential in the formation of recent tax policy in America, on which he wrote extensively during three decades. This book is addressed to the informed general reader, as well as to economic historians and tax experts, in an urbane style as little difficult as possible considering the subject matter. Although the main themes are the income tax and estate and gift taxes, other aspects of the Federal tax system are not neglected in the comprehensive historical analysis of the basic issues involved in tax and fiscal policy. Except for a rapid roo-page review of tax history before World War I, the treatment is full, with a detailed account of the economic climate and of the political and legal struggles accompanying the introduction of each new tax. The final chapters are a theoretical study of the judicial process in relation to taxes, and an appraisal of the existing system, including Mr. Paul's views on progressive (i. e., graduated) taxation. Taxation is naturally a primary interest of American thinkers on financial problems, and notable studies of the whole subject or of special aspects are numerous. Sidney Ratner's American Taxation, Its History as a Social Force in Democracy (New York, Norton, 1942. 561 p.) is a comprehensive historical survey from 1789 , in which the cumulative developments in tax reform are shown in relation to general social conditions. The emphasis is on "the endeavor of the American people... to forge taxes which should be not only sources of revenue but also instruments of economic justice and social welfare." A standard historical work with chapters grouped around individual revenue acts from 1909 to 1939 is Roy G. and Gladys C. Blakey's The Federal Income Tax (New York, Longmans, Green, 1940. $64^{\circ}$ p.). A useful analysis of tax problems at the end of the war, published as a research study of the Committee for Economic Development, is Postwar Taxation and Economic Progress, by Harold M. Groves (New York, McGraw-Hill, I946. 432 p.). The publications of the U.S. Congress Joint Committee on the Economic Report are important for the genesis of tax legislation. A particularly valuable compendium representing the views of many leading spokesmen is Federal Tax Policy for Economic Growth and Stability; Papers Submitted by Panelists Appearing before the Subcommittee on Tax Policy (Washington, U. S. Govt. Print. Off., 1955. 930 p. 84th Cong., Ist sess. Joint Committee Print).
5971. Poole, Kenyon E., ed. Fiscal policies and the American economy. New York, Prentice-Hall, r951. 468 p. illus. (Prentice-Hall economics series) $\quad 5^{\mathrm{I}-9449} \mathrm{HJ}_{263 . P 6}$

A group of essays interpreting modern theory in regard to fiscal policy, which reflect the changing thought of the years of depression and wartime inflation. The first paper, by the editor of the symposium, is a brief historical treatment, "Background and Scope of American Fiscal Policies." There follow: "Monetary Aspects of Fiscal Policy," by Roland I. Robinson; "Fiscal Policy, Employment, and the Price Level," by Henry M. Oliver; "Debt Management," by Henry C. Murphy; "Government Expenditures and Their Significance for the Economy," by John F. Due; "Financial Institutions as a Factor in Fiscal Policy," by Harry C. Guthmann; "Repercussions of the Tax System on Business," by E. Gordon Keith; "The Fiscal System, the Distribution of Income, and Public Welfare," by John $\mathrm{H}$. Adler, with an appendix, "The Statistical Allocation of Taxes and Expenditures in 1938/39 and 1946/47," by Eugene R. Schlesinger; and "International Aspects of Fiscal Policy," by Frank W. Fetter. Each essay is followed by a short list of references. The editor of the symposium, a professor of economics at Northwestern University, published in I956 a treatise on this subject: Public Finance and Economic Welfare (New York, Rinehart. 640 p.). The complex field of government finance and fiscal policy is fully covered, with special stress on the cyclical and long-term effects of fiscal policy upon economic stability and social security.

5972. Prochnow, Herbert V., ed. American financial institutions. New York, Prentice-Hall, 195I. $799 \mathrm{p}$ 51-11568 HGr8r.P73

This collective work covering the entire American financial structure is designed as an integrated text in the fields of finance, money, banking, etc. Seventeen of the 25 contributors are connected with universities and schools of business administration, while the other 8 are executives of banks or other financial institutions. Among the subjects treated, with special attention to their interrelations and their bearing on the national economy, are commercial banks, the Federal Reserve system, savings and loan associations and mutual savings banks, real estate and agricultural financing institutions, commodity exchanges, stockbrokerage and stock exchanges, investment banking, trust companies, international banks, the United States Treasury, insurance companies, institutions for consumer credit, personal finance, and government regulation. The last chapter reviews the leading trade associations in the financial field. The treatment in all is expositional, with clarity the first objective. 
5973. Studenski, Paul, and Herman E. Krooss. Financial history of the United States: fiscal, monetary, banking, and tariff, including financial administration and state and local finance. New York, McGraw-Hill, 1952. 528 p.

$$
\text { 5I-12649 HGi81.S83 }
$$

The first general history of American finance published since the Second World War, this textbook by two professors at New York University deals with government policies and the administration of taxation, money and banking, and the tariff, stressing the political and economic issues involved. The chapters are in mainly chronological sequence, grouped in three periods: from Colonial times to the Civil War; from 186I to 1916; from World War I to 1950. Nonfederal finance receives attention throughout, and in each section a chapter is devoted to state and local government finance. Almost half the text is given to the third section, which lucidly sets forth the financial aspects of the New Deal, World War II, and the first postwar years. The many statistical tables are exceptionally easy of comprehension by the nonspecialist reader, to whom, as well as to students, the work is directed.

5974. Westerfield, Ray Bert. Money, credit and banking. Rev. ed. New York, Ronald Press Co., I947. I096 p. maps, diagrs.

$$
\text { 47-1136o } \mathrm{HG}_{153} \cdot \mathrm{W}_{42}
$$

5975. Chandler, Lester V. The economics of money and banking. Rev. ed. New York, Harper, 1953. 742 p. illus.

$$
\text { 53-5076 HG221.C } 448 \quad 1953
$$

Dr. Westerfield, now emeritus professor of political economy at Yale where he held a chair for 30 years, is also a practicing banker. This treatise has been a standard text and reference work for several decades. In accord with the author's interests, it covers comprehensively both financial theory and practice, philosophy and institutions. Its three themes, money, credit, and banking, are developed simultaneously in his argument as they are in the world of finance. The nature of money and monetary systems, the history of national coinage and paper money, the instruments of credit, the functions, management, and operations of banks, the history of banking, the Federal Reserve System, and foreign exchange are among the many aspects treated at length. In the same general field but more definitely focused on the relationship of the monetary and banking system to the present-day functioning of the American economy is The Economics of Money and Banking by Professor Chandler of Princeton. This text is designed as a general introduction to monetary studies for college undergraduates, and lays much emphasis on elementary principles. After $2 \mathrm{I}$ chapters explaining the functions and kinds of money, monetary standards, banking, the Federal Reserve System, and other financial institutions, the author devotes 7 chapters to a discussion of monetary theory, using equations and symbols. The most formidable in appearance are those of national income analysis, GNP (gross national product) and other concepts, to measure which there are constructed mathematical functions, schedules, or curves. The last few chapters explain postwar international transactions and relationships involving money.

\section{J. Finance: Special}

5976. Abbott, Charles C. The Federal debt, structure and impact. With policy recommendations of the Committee on the Federal Debt. New York, Twentieth Century Fund, r953. xvii, 278 p.

$$
\text { 53-5982 HJ8II9.A58 }
$$

5977. Murphy, Henry C. The national debt in war and transition. New York, McGrawHill, 1950. 295 p. 50-6930 HJ8119.M8 From the national debt of about a billion dollars that remained stable through the period from 1895 to I9I6, the United States through two major wars, a depression, and the cold war, has increased the figure of what it owes to about \$26o billion, or "close to $\$ 1,700$ for every man, woman and child in the country." These statistics are reported in 1953 in a survey started by the Twentieth Century Fund in 1948 but postponed because of the tax increase brought about by the Korean War and rearmament. The study, directed by Dr. Abbott of the Harvard Business School, involved an examination of the post-World War II situation, the impact of the debt on the Treasury and the Federal Reserve, and the effect of Korea, and then an analysis of the debt problem and conclusions. The last section, as in most Fund studies, is a report by a committee which reviewed the research findings, summarizing and offering recommendations as to Federal debt management for steady economic growth. The story of war finance is told by Mr. Murphy, former assistant 
director of research and statistics of the Treasury Department. Although the viewpoint is that of the government, the author reasserts that "the government represents the whole people," and that officials of the Treasury and the Federal Reserve System make a conscientious effort to hear and adapt themselves to the points of view expressed by representatives of all segments of the economy. After giving a brief review of the depression, he discusses "Setting the Pattern of War Finance," against the realization that taxation is preferable to borrowing, but insufficient to finance a major war. He then explains the techniques of borrowing through war loans, savings bond programs, etc. His final appraisal is that, though the job could have been done better- "What job couldn't?"- -there is no doubt that the war borrowing program was a success.

5978. Allen, Frederick L. The great Pierpont Morgan. New York, Harper, 1949. 306 p.

port. 49-8274 CT275.M6A6

"Sources and obligations": p. 283-297.

A biography which is less economic history than personal interpretation of the preeminent banker (1837-1913) who, it was widely believed, controlled American finance in the early 1900's. The late editor of Harper's Magazine speaks of his book as an attempt at a middle course between earlier extremes of "one-sidedly laudatory and one-sidedly derogatory" accounts. He begins with Pierpont Morgan's appearance, a few months prior to his death, before the Pujo congressional committee which in 1912 was investigating the "money trust." The famous statement of the financier, that commercial credit is based primarily on character-" "a man I do not trust could not get money from me for all the bonds in Christendom"-is the author's point of departure to which he returns in his conclusion. On the way he has followed Morgan from his youth through his natural entrance into the banking world via his father's firm; his partnerships first with C. H. Dabney and then with Anthony J. Drexel; the establishment of J. P. Morgan and Company in 1895; his victories over competitors; his great role in government financing; his reorganization of railroads; and his consolidation of the U. S. Steel Corporation. The great monetary dealings are outlined against a sympathetically drawn background of Morgan's personal life, tastes, princely travels, and activities as a prodigious collector of art and literature. All these matters are related in much greater detail-often of high interest-and with much less reflective commentary, by his admiring son-in-law, Herbert L. Satterlee, in J. Pierpont Morgan; an Intimate Portrait (New York, Macmillan, I939. xvi, 595 p.).
5979. Brown, John Crosby. A hundred years of merchant banking, a history of Brown Brothers and Company, Brown, Shipley \& Company and the allied firms, Alexander Brown and Sons, Baltimore; William and James Brown and Company, Liverpool; John A. Brown and Company, Browns and Bowen, Brown Brothers and Company, Philadelphia; Brown Brothers and Company, Boston. New York, Priv. print, r909. xxxiii, 374 p. plates.

9-27455 $\mathrm{HG}_{26}$ 13.B24 $_{3}$

5980. Hidy, Ralph W. The House of Baring in American trade and finance; English merchant bankers at work, 1763-r86r. Cambridge, Harvard University Press, 1949. xxiv, 631 p. illus. (Harvard studies in business history, I4) 49-1 1255 HG 49 I0. ${ }_{5}$

"Notes and references": p. [483]-6i6.

The frontispiece of Brown's classic history of the growth of a private banking firm in foreign business shows four old gentlemen, with white hair and spectacles, grouped about a table beneath the portrait of a fifth-Alexander Brown and his four sons. The father came from Ireland and in 1800 began a small business in Baltimore importing Irish linens, and rapidly expanded to other goods. He had to pay in sterling, and accepted payment in sterling bills, drawn against shipments of tobacco, etc., from Baltimore to England; he became a free buyer of commercial sterling, and built up "a goodly share of the Sterling Exchange business in this country." His four sons, who compensated with business acumen for their weak sight, were taken into partnership and established in branches or allied firms. The oldest son opened a firm in Liverpool in 1810 , and Brown acquired ships, and issued credits on the Liverpool house for other American merchants. The Philadelphia branch, under the third son, was established in 1818 , and in 1825 the New York branch was opened under the youngest son. This book, which combines the charm of well-written family history with a revealing account of the methods of private banking and the transition from mercantile to industrial capitalism, is by the son of the New York Brown, who had himself been a partner in the firm for almost half a century. Dr. Hidy studies in detail the operations of a famous London house of merchant bankers which for about 25 years specialized in financing American trade and marketing American securities. His principal source was the Baring papers in the Public Archives of Canada, selected materials dealing primarily with the business of the house in the United States and Canada. Notwithstanding the dates in Dr. Hidy's title, his narrative is detailed only after the Peace of Ghent (I8I5). America was the major interest of Baring Brothers and Company only from 1828 to 
I842, after which year the repudiation of their financial obligations by so many American States led the house to reduce its dealings, and to curtail them drastically in 1853 . "The London firm felt that it assumed responsibility to both buyer and seller when it publicly marketed the securities of any government or corporation," and the boom-and-bust character of the American economy, and the wildcat outlook of so many American promoters, led the Barings to give preference to Canadian, European, and Latin American bond issues after 1853.

5981. Dice, Charles Amos, and Wilford John Eiteman. The stock market. $3 \mathrm{~d}$ ed. New York, McGraw-Hill, 1952. 460 p. illus.

$$
\text { 5I-r26or } \mathrm{HG}_{4551 . D_{5}}{ }^{1952}
$$

5982. Leffler, George L. The stock market. 2d ed. New York, Ronald Press Co., 1957. 629 p. illus. $\quad 57-68$ I I HG 455 I.L 35 I957

The first of these two expository works on the stock market is addressed to investors, students of the market, and the general public. The various kinds of securities offered, the relations of brokers with customers, the operations of the New York Stock Exchange, the various types of stock purchasing (on margin, short sale, stop-loss order and hedge, averaging and pyramiding, calls, puts, spread, straddle, etc.), and all other aspects of the stockbroker's trade are explained in as simple terminology as the subject allows. The second volume is of the same general type, although more strictly in textbook presentation. First published in $195 \mathrm{I}$, it has been revised to reflect "substantial changes" in the stock market during the intervening years.

5983. Goldenweiser, Emanuel A. American monetary policy. New York, McGraw-Hill, 195I. xvi, 391 p. diagrs. (Committee for Economic Development. Research study)

$$
\text { 5I-5868 } \mathrm{HG}_{538.6^{2}}
$$

A study of the policymaking of the Federal Reserve System, by the late former director of the division of research and statistics for the Board of Governors of FRS (1926-45). The examination of Federal Reserve instruments of monetary management, of policy decisions through four defined periods (1917-32, 1933-39, World War II, postwar), and of institutional operations and relationships of the Federal-Reserve is set in a theoretical framework. Dr. Goldenweiser discusses the role of money in the economy, the objectives of monetary policy, and the evolution of FRS ideas before he begins his chronological account. He follows this with a review of principles of monetary policy in which he sets down "certain simple and unequivocal rules" in line with FRS practice, the last of which involves the general aim of "contributing to economic stability." The appendix contains tables of statistics. A note is added on the research program of the Committee for Economic Development, listing and describing the studies published in the series of which this volume forms a part. In 1948 Professor George Leland Bach of Carnegie Institute of Technology in Pittsburgh, a former staff economist serving the Board of Governors of FRS, conducted a study of the System for the Hoover Commission (Commission on the Reorganization of the Executive Branch of the Government). His monograph, Federal Reserve Policy-Making (New York, Knopf, 1950. 282 p.), is a report on that study. It is in four parts, of which the first is a historical outline of "Federal Reserve Organization and the Policy Responsibilities." Parts 2 and 3 are discussions of "Internal Policy Formation" and "External Relations in Policy-Making." Part 4 is an analysis of "The Lessons of Monetary Experience." The writer is particularly concerned to show that official policymaking is not carried out in accord with the clear theories formulated by professional economists in the agencies, but is influenced by the pressures of other officials and of special interest groups, and the de facto policy of the administration. An interpretation of the workings of the Federal Reserve through the case history of an individual bank during the first 20 years of the System was prepared as a doctoral thesis at Columbia University by Lawrence E. Clark: Central Banking under the Federal Reserve System, with Special Consideration of the Federal Reserve Bank of New York (New York, Macmillan, 1935. 437 p.). His analysis stresses the function of the bank as a public service.

5984. Gras, Norman S. B. The Massachusetts First National Bank of Boston, 1784-1934. Cambridge, Harvard University Press, 1937. xxiv, 768 p. plates. (Harvard studies in business history, 4) $3^{8-16} 6_{39} \mathrm{HG}_{2} 6 \mathrm{I}_{3} \cdot \mathrm{B}_{74} \mathrm{~F}_{54}$

The late author of this scholarly history of the second bank established in the United States was professor of business history at Harvard from 1927 to $195^{\circ}$, and editor of the series in which his book appeared. The study, based on unpublished records in the Baker Library and in possession of various New England banks, is in three parts. The first is a general introduction, which in just over 200 pages gives a running account of the Bank's history, prefaced by an 8-page chronology. Part 2 presents documents illustrating that history from its origins to 1865 , when the Bank entered a period of stagnation: the letter and petition that launched it in 1784 , the original charter and its modifications in 1792 
and 1812 , extracts from the "Stockholders' Minute Book" and the "Directors' Records" (p. 221-529), and lists of officers. Part 3 gives tabulated statistics for the same period, including comparative figures for other Massachusetts banks. The venerable Bank was rejuvenated after 1903; Dr. Gras thus diagnoses its long period of decline: "The Bank responded to the opportunities for gain from sea traffic and from purely local trade, but it failed in the early part of the nineteenth century to participate in the development of New England as a whole and it failed in helping Boston secure the financial dominance in New England that its commercial position justified."

5985. James, Frank Cyril. The growth of Chicago banks. New York, Harper, 1938. 2 v. (1468 p.) ports. $\quad 38-33677 \quad \mathrm{HG}_{2} \mathrm{I}_{13} \cdot \mathrm{C}_{4} \mathrm{~J}_{3}$ Bibliography: v. 2, p. II27-II57.

A history of the country's second largest money market, treated under the broad aspects of Chicago finance in its interrelations with the political and economic development of the community from a frontier outpost to a great metropolis. The narrative is divided chronologically, the two volumes being The Formative Years, 1816-1896, and The Modern Age, 1897-1938. The Chicago banks, growing with the region, were deeply involved in Illinois politics; by 1871 they had made the city the financial center of the West. In the later period the banks tended to lose their regional character and to become "so intimately woven into the structure of the national money market that the financial independence of Chicago tended to decline," even as the city became one of the financial capitals of the world. This study was sponsored by the First National Bank of Chicago. Written by a distinguished financial historian, it is designed for the enjoyment of a specialist audience; the typeface is luxurious, there are color reproductions of portraits of individual bankers, and exhaustive documentation is given in notes following the chapters. Among the appendixes is a 250-page "Summary of Historical Data Regarding the Creation, Growth and Dissolution of Banks and Financial Houses Operating in Cook County from 1863 to 1938." A heavily statistical study of Chicago as a financial center is The Chicago Credit Market, Organization and Institutional Structure, by Melchior Palyi (Chicago, University of Chicago Press, 1937. 448 p.). It was published as no. 33 of the Social science studies directed by the Social Science Research Committee of the University of Chicago. The text deals strictly with the organizational aspects of the leading Midwestern credit market and shows the interrelation of savings institutions, security exchanges, call-loan and commercial paper markets, and unit and branch banks. The many tables in the appendix go far beyond analysis of market structure, and present data relating the Chicago market to the economic growth of the area and to the country as a whole.

5986. Kemmerer, Edwin Walter, and Donald L. Kemmerer. The ABC of the Federal Reserve System. 12th ed. New York, Harper, 1950. $229 \mathrm{p}$.

Bibliography: p. 215-220. $50-6526 \quad \mathrm{HG}_{25} 6_{3} \cdot \mathrm{K}_{4} \quad 195^{\circ}$

Professor Edwin W. Kemmerer of Princeton University published the first edition of this famous work in 1918. The 12th edition, revised by his son, keeps the same character of a guide in nontechnical language, making as plain as possible to the lay reader the complexities of the Federal Reserve System. It begins with a short explanation of banking systems and their main defects, most serious of which in Igth-century America was decentralization. Then there is outlined the framework of the Federal Reserve System, which was superimposed in 1914 on many thousands of independent banks. There follows an examination of the methods and history of the Federal Reserve Banks, through the Act of I913 and its subsequent amendments, in the First World War, the "open market" of the I920's, the period of bank failures and the Great Depression, the New Deal and its reforms in banking, and the Second World War. In the last chapter suggestions are given "the intelligent citizen" as to what writings to consult and what to look for in them in order to understand trends of the national economy. Another and briefer simplified story of the Federal Reserve System and its influence on the flow of credit and money is presented in an official pamphlet well illustrated with charts: The Federal Reserve System, Its Purposes and Functions, by the Board of Governors of the Federal Reserve System, 2d ed. (Washington, 1947. 125 p.). The last chapter summarizes: "Experience over four decades shows that reserve banking is of vital importance to the national economy. Provision of bank reserves has come to be the major Federal Reserve function."

5987. Lamont, Thomas W. Henry P. Davison; the record of a useful life. New York, Harper, 1933. xxii, 373 p. ports. $33-156_{32} \quad \mathrm{HG}_{24} 6_{3} . \mathrm{D}_{3} \mathrm{~L}_{3}$

This biography of "Harry" Davison (1867-1922), written by "his friend and partner," devotes fully as much attention to the subject's character, personal affairs, and distinguished public services as to his brilliant banking career. From the bottom step in a village bank he rose in 10 years to the presidency of a New York bank. Founder of the Bankers' Trust Company, a director of the First National Bank, influential in curbing the money panic of 1907, a designer of the Federal Reserve System, a Morgan partner, and chairman in 1910 of the Six- 
Power Chinese Loan Conference (Chinese Consortium) in Paris, he became one of America's most powerful figures in national and international finance. His outstanding public service was as chairman of the Red Cross War Council during the First World War, when in two annual drives he raised first $\$ 115$ million, and then $\$ 170$ million for the Red Cross war chest. Mr. Lamont's admiring, intimate, affectionate, and readable story has for its last appendix the citation accompanying the award of the Distinguished Service Medal to Davison.

5988. Larson, Henrietta M. Jay Cooke, private banker. Cambridge, Harvard University Press, 1936. xvii, $5^{12}$ p. illus. (Harvard studies in business history, 2) 36-36152 $\mathrm{HG}_{2463 . \mathrm{C}_{3} \mathrm{~L}_{3}}$ Jay Cooke's private banking partnership, formed in Philadelphia in $186 \mathrm{I}$, sprang into rapid prom. inence through the sale of Civil War bonds. He sold Treasury notes in Pennsylvania in 1861 , and in October 1862 was appointed by Secretary of the Treasury Chase as special agent for the "fivetwenties," a 6 percent loan callable in 5 years and maturing in 20. His high-pressure salesmanship, reaching the small investor through advertising and agents, marked "a notable achievement in the history of American finance." In 1864, after the Treasury had failed in its own attempt to float a large loan, Cooke was again called upon to act as government subscription agent, and his campaign for the victory loan resulted in an unprecedented over-subscription. After the war he turned to financing business undertakings, and in 1869 became heavily involved in active promotion of the Northern Pacific Railroad. Through overextension and other errors, his firm failed in 1873 , precipitating the panic and depression which ended the postwar boom. In this business biography, extensively documented from Cooke's voluminous manuscripts and other contemporary sources, Dr. Larson ranks the "Tycoon," as his partners called him, as an outstanding leader in the history of American business. "He was the first in America to stand out dramatically and efficiently as an active investment banker operating on a large scale ... Though he himself failed, those who later followed his general strategy succeeded."

5989. Lewis, Cleona. The United States and foreign investment problems. Washington, Brookings Institution, I948. xviii, 359 p. maps.

48-4989 $\mathrm{HG}_{4538 . \mathrm{L}_{45}}$

This investigation of the outlook for American private investment abroad was written by a Brookings Institution specialist in 1948 , the year that saw the inception of the Marshall Plan, and published just as the Truman Plan (Point Four Program) was announced. Dr. Lewis' standard work, America's Stake in International Investments (Washington, Brookings Institution, 1938. 7 10 p. The Institute of Economics of the Brookings Institution. Publication no. 75), is brought up to date in the present volume, with statistical data and other information showing the post-World War II position of the United States as the world's principal creditor nation. The first part explains the nature of foreign investments and reviews America's capacity for foreign investment, and the respective positions of debtor and creditor countries in 1938 and in 1947. Part 2 is on opportunities for developmental capital abroad, obstacles to future investors from the policies of foreign countries, and the responsibility of the private investor. Part 3 explains the United States Government's part in foreign investment-the war an dpostwar lending agencies, culminating in the European Recovery (Marshall) Plan. In her summary and conclusions Dr. Lewis states that, although the government encourages export of American capital, private investment cannot compete with government loans and grants. Since the publication of this work official policy has turned in creasingly toward the stimulation of private investment abroad, particularly in the underdeveloped areas. A series of useful handbooks of "basic information for United States businessmen" has been in course of publication by the U. S. Bureau of Foreign Commerce since 1953, of which the I7th is Investment in Nigeria (Washington, 1957. 182 p.).

5990. Mowbray, Albert H., and Ralph H. Blanchard. Insurance, its theory and practice in the United States. $4^{\text {th }}$ ed. New York, McGrawHill, 1955. 569 p. illus. (McGraw-Hill insurance series) 54-12254 HG805I.M75 1955

5991. Stalson, J. Owen. Marketing life insurance; its history in America. Cambridge, Harvard University Press, 1942. xl, gi I p. illus. (Harvard studies in business history, 6 )

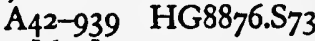

"Notes and references": p. [649]-714.

5992. James, Marquis. The Metropolitan Life, a study in business growth. New York, Viking Press, 1947. 480 p. illus.

Bibliography: p. $457-464$.

$47-30046 \mathrm{HG} 8963 . \mathrm{M}_{52} \mathrm{~J}_{3}$

These three books represent three distinct approaches to the subject of insurance. The first has been a standard college text since 1930, and is now revised after the death of Professor Mowbray by the editor of the McGraw-Hill insurance series. It covers all branches of insurance, beginning with a discussion of the theory of risk, insurance, and 
prevention, and explaining in detail the various types of insurance contracts, the kinds of insurance companies, their market, premium rates, and other financial and organizational arrangements, together with the elements of governmental supervision and the question of risk management. Dr. Stalson's thick volume is a scholarly history of the life insurance business in America, in detail from the "revolution of 1843" which introduced mutuality (the policyholders are the shareholders) and led to a vastly expanded volume of business. It emphasizes the roles of the soliciting agents and the general agents (wholesalers), and their evolving relationships to the home offices. Like the rest of this Harvard business history series, it includes important appendixes of statistical and other tabulated data. The third book, by a Pulitzer prize-winning biographer recently deceased, is more lively writing, geared to a general audience. It sketches briefly the origins of the insurance business, reaching after two chapters the foundation of the Metropolitan Life Insurance Company in 1868 . The rest of the narrative tells of the rise, development, and organization of the great company, its relations with other insurance firms and with government investigators and legislation, its trusteeship methods, and its influence on the economic and social welfare of the country.

5993. The New York money market. New York, illus. Columbia University Press, 1931-32. 4 v.

\section{Bibliography at end of each volume.}

$$
3 \mathrm{I}-32268 \mathrm{HG}_{1} 8_{4} \cdot \mathrm{N}_{5} \mathrm{~N}_{4}
$$

A series of studies produced under the auspices of the Columbia University Council for Research in the Social Sciences. The scope is broad, the term money market being defined to include "all the funds available for productive, commercial, or speculative purposes, as well as the mechanism by which these funds are gathered together from holders not immediately requiring their use, and redistributed in answer to the needs of various classes of borrowers." It comprises the call loan market (the salient feature), the commercial paper market, the investment market, and relationships with the banks and the Treasury. The first volume, prepared as a thesis, is by Margaret G. Myers: Origins and Development. This is a historical study divided into two distinct periods, from before 1800 to the $\mathrm{Na}$ tional Bank Act of 1863 , and from 1863 to the passage of the Federal Reserve Act of 1913. Within these periods the treatment is topical: e. g., "The Origin of the Investment Market," "The Government and the Money Market before 1863," "The Commercial Credit System from 1863 to I913." The three other volumes deal with aspects of the money market from 1913 to 1932. Volume 2, Sources and Movements of Funds, contains a dis- cussion of "The Basis of Money Market Funds," by Benjamin Haggott Beckhart, and one of "The Ebb and Flow of Money Market Funds," by James G. Smith. Volume 3, by Mr. Beckhart, is Uses of Funds, covering bankers' loans, the commercial paper market, and the acceptance market. The last volume, External and Internal Relations, contains contributions by Mr. Beckhart on "Federal Reserve Policy and the Money Market, 1923-1931," by William Adams Brown, Jr., on "The Government and the Money Market," and by James G. Smith on "Money Market Periodicities and Interrelationships." Although obviously meant for a specialized audience, this thoroughly documented work is notably clear and readable.

5994. Pickett, Ralph R., and Marshall D. Ketchum. Investment principles and policy. New York, Harper, I954. $820 \mathrm{p}$.

$$
\text { 53-11678 } \mathrm{HG}_{4521 . P_{5}}
$$

This textbook, focused on the problems of the individual investor, is not for the beginner in the financial field; the authors assume that "the student has knowledge of the basic principles of economics, accounting, and corporation finance." There are three parts; the first, "The Background of Investment," includes a discussion of the management of savings, a review of the chief aspects of corporate financing, and general considerations on the selection and analysis of investments. Part 2 describes fully the individual "Instruments of Finance"life and other types of insurance, securities of Federal, local, and foreign governments, real estate investments, and common-stock investment in the securities of various kinds of enterprise: manufacturing, merchandising, mines, railroads, public utilities, etc. The last part, "Investment Policy," explains the mechanics of investing, the regulation of securities, and factors to be considered such as political risks, taxation, and general business conditions. The final chapter is direct advice to the investor concerning his over-all program. Each chapter is followed by a short list of selected readings.

5995. Smith, Darrell Hevenor. The General Accounting Office, its history, activities and organization. Baltimore, Johns Hopkins Press, 1927. 215 p. (Institute for Government Research. Service monographs of the United States Government, no. 46)

Bibliography: p. 196-205.

5996. Mansfield, Harvey C. The Comptroller General; a study in the law and practice of financial administration. New Haven, Yale University Press, 1939. 302 p. $\quad 39-8570 \quad \mathrm{HJ}_{9802 . \mathrm{M}_{3}}$ 
5997. U.S. Congress. House. Committee on Government Operations. The General Accounting Office; a study of its organization and administration with recommendations for increasing its effectiveness; seventeenth intermediate report. Washington, U. S. Govt. Print. Off., 1956. 133 p. diagrs. (84th Cong., $2 \mathrm{~d}$ sess. House report no. 2264) 56-61520 HJ9802.A522 1956

"The General Accounting Office, according to the Budget and Accounting Act of $192 \mathrm{r}$, is an independent establishment of the United States Government with auditing, quasi-judicial, investigating, and other duties." So begins Mr. Smith's history and description of the activities and organization of this Federal service. The General Accounting Office comes under the legislative branch, and reports to Congress its findings as to financial conditions of government agencies. The Comptroller General is appointed for a term of 15 years, probably in agreement with the dictum of Fisher Ames in the debate upon the Treasury Department Act of 1789 : "The science of accounts is at best but an abstruse and dry study; it is scarcely to be understood but by an unwearied assiduity for a long time." Mr. Mansfield quotes this sentence as a motto for his analysis and appraisal of the General Accounting Office. His book was written shortly after the term of the first Comptroller General had ended (in 1936, when the retiring official shook the dust of the place from his feet, emitting to the press blasts against New Deal fiscal policy). The author is highly critical of the administration of the office, suggesting that the Comptroller General has functioned, not as the independent critic of and useful check on the executive use of public funds that he was intended to be, but as a "petty tyrant." During the depression and World War II the use of government corporations for many types of enterprise was greatly expanded, most of them operating on budgets and programs not subject to congressional approval and with expenditures which were not audited by the General Accounting Office. In 1945 two pieces of legislation, the George Act and the Government Corporation Control Act, brought the corporations under uniform controls, which included provision for auditing and reports by the General Accounting Office. Legislation in 1946, 1949, and $195^{\circ}$ has further affected the development of the Office. Its present status is succinctly explained in the $195^{6}$ Report of the House Committee on Government Operations, The General Accounting Office.

5998. Smith, James G. The development of trust companies in the United States. New York,

Holt, 1928. xxi, 613 p. (American business series) 28-5049 HG $4352 . S 6 \quad 1928$

The corporate fiduciary or trust company in
America had its phenomenal development in the wake of the huge fortunes accumulated in the age of enterprise, as an instrument for the conservation of that wealth. In the 50 years before 1928 , the number of such companies in the United States had increased from 39 to 2,731 . The present monograph, prepared as a doctoral thesis at Princeton, is a substantial study analyzing the nature and functions of trust companies, reviewing the origins of trusteeship and the history of corporate fiduciaries in the United States from 1818 , when "the embryo of the modern corporate fiduciary emerged as a collateral feature of a [Boston] life insurance company," and explaining the problems of trust companies in America in the late 1920's. To arrive at current practice and problems, the author in 1925 sent an II-point questionnaire to 2,500 banks and trust companies, and received 255 useful replies, upon which his analysis is based. The author appends a long bibliography (p. $4^{8} 7-563$ ) in two parts, first a general list, and then a list of periodical articles arranged by topics.

5999. Smith, Walter B. Economic aspects of the Second Bank of the United States. Cambridge, Harvard University Press, 1953. 314 p. (Studies in economic history)

52-5408 HG2525.S6

Bibliographical references included in "Notes" ( $p$. [265]-307).

60oo. Hammond, Bray. Banks and politics in America, from the Revolution to the Civil War. Princeton, Princeton University Press, 1957. $771 \mathrm{p}$.

Bibliography: p. 747-76o.

57-8667 $\mathrm{HG}_{2472 . \mathrm{H}_{3}}$

"The Second Bank of the United States was founded in 1816 under a charter from the United States Government and functioned under this charter until March 3, I836. The Treasury needed such an institution as a depository for the revenue and as an agency for the transfer and disbursement of its funds." It was favored by business groups and financiers, and opposed by agrarian interests. After early troubles, it operated smoothly through 1829 . "The years between 1830 and 1836 were dominated by the struggle to prolong its life by a renewal of its Federal charter. Failing to secure this authorization from Washington, the Bank did business under a charter from the state of Pennsylvania from 1836 to 184r. During these last five years its career was spectacular, and it ultimately failed early in $184 \mathrm{I}$." Dr. Smith's scholarly study relates the history of the Second Bank to its place in the broad economic history of the United States, subordinating the political aspects of the spectacular contest between Nicholas Biddle, its leader and president, and its enemy, President Jackson, and his followers, to the statistical analysis of American financial development through- 
out the period. The Bank War of the $1830^{\prime}$ 's is also central to Mr. Hammond's impressive synthesis of banking history with general history, for it was the desire to interpret that war properly that embarked him upon his protracted researches. He formulates the essence of his book thus: "It reflects the political and cultural force of business enterprise, which seems to me to have been the most powerful continuing influence in American life ever since Independence. The rival force in the early igth century was agrarianism, formerly dominant but no longer so. These two fought about banks, because banks provide credit, and credit is indispensable to enterprise." Notwithstanding this broad outlook, Mr. Hammond is well aware that his book's value is strictly dependent upon his mastery of all the technical aspects of early banking, and this it abundantly displays. He brings multiple and cumulative evidence for his conclusion that "the Jacksonian revolution" was in fact the conquest of the economy by a group of self-made men born on farms, whose "skill in propaganda, in cant, and in demagogy" employed the agrarian ideology to accomplish aims the opposite of agrarian. "From possession of what was generally considered the best monetary system in the world, the country fell back into one of the most disordered." It was rich and expansive enough to bear the consequences.

6001. Smithies, Arthur. The budgetary process in the United States. New York, McGrawHill, 1955. xxi, 486 p. (Committee for Economic Development. Research study)

$$
\text { 54-11767 } \mathrm{HJ}_{205} \mathrm{r} . \mathrm{S}_{5} 8
$$

In 1929 Federal expenditures were slightly less than $\$ 3$ billion, but in the fiscal year 1954 the United States Government spent $\$ 68$ billion. The budgetary techniques, however, had evolved from earlier procedures with little change to fit the transformed economy. The present work prepared for the Committee for Economic Development is a comprehensive survey of the budgetary process with specific proposals for its improvement. The author, now a professor at Harvard, served as chief of the economic branch of the Bureau of the Budget from 1943 to 1948. His basic presupposition, he says, is "that government decision-making can be improved by the clear formulation of alternatives-regardless of the extent to which the final decisions are influenced by bargains between the President and the Congress, the influence of organized groups, or the pressure of local and regional interests." He examines the process in detail, reviewing its historical development (including the reforms recommended by the Hoover Commission in 1949-50) and the budget in operation, as prepared by the President, considered by Congress, and executed and reviewed by both the legislative and executive branches. He then sets forth general proposals for reform. The second half of the study deals with specific areas of the budget, defense and nondefense programs, and the significance for the national economy of balancing or failing to balance. Speaking of the present process, he considers it "not far short of miraculous that [it] works as well as it does."

6002. Stern, Siegfried. The United States in international banking. New York, Columbia University Press, 1951. 447 p.

Bibliography: p. [427]-43I.

$$
\text { 5I-I4805 } \mathrm{HF}_{3031 . S 8}
$$

During and after the First World War American banking houses began to take over from England "the world's purse strings," and by the end of the Second World War the United States was securely established as the predominant power in world finance. The operations of international banking are carried out mainly in a few large institutions. The author for many years headed the foreign departments of various New York banks, and his work is aimed at specialists in finance. It includes a rapid historical review of United States international banking from I914 to 1945 ; discussion of the problems of foreign credit, foreign exchange, foreign fund control, etc., in wartime; description of government corporations in this field (the Export-Import Bank and such war agencies as the Defense Supplies Corporation); and a review of silver policy during the I930's. The longest part, which accounts for over half the text, is a country-by-country analysis of the relations of American banks with the rest of the world. Finally, the organizational aspects are explained, and a short chapter speculates on the outlook for the future.

\section{K. Business: General}

6003. Bright, James R. Automation and management. Boston, Division of Research, Graduate School of Business Administration, Harvard University, 1958. 270 p. illus.

$$
5^{8-5968} \mathrm{HD}_{45 . B 67}
$$

Professor Bright has been engaged since 1954 in research on the implications for management of the new technological developments called automation, insofar as they relate to factory productivity. The first part of his book explains the nature of auto- 
matic manufacturing, how it is coming about, and where: it can be done profitably with electric lamps but not with shoes. Part 2 covers the data of research into the programs of 13 plants that have adopted automation systems. Part 3 is the author's analysis of the critical areas of automation as affecting management, based essentially on the study of these 13 plants. Here are chapters on how most economically to manage "downtime," when the interdependent machines for any reason stop; on what happens to the productivity and skilled status of the automated work force; on personnel problems; on sales-holding up to the light in each case satisfactory and unsatisfactory factors. Finally the author offers a mainly optimistic "Interpretation of Automation, Its Effect on the Factory and Its Impact on Management." A typical warning is that automation newly installed always needs "debugging"; the system invariably begins by breaking down.

6004. Clark, John M. Social control of business. 2d ed. New York, Whittlesey House, McGraw-Hill, 1939. xvi, 537 p. (Business and economics publications) $\quad 39-27584 \quad \mathrm{HD}_{45} \cdot \mathrm{C}_{5} \quad \mathrm{r} 939$

"References for further reading" at end of each chapter.

In the first half of this philosophic study of the control exercised by society on the individual businessman or corporation, Professor Clark analyzes into their fundamentals the conceptions, growth, and purposes of social control, and the legal aspects of formal and informal institutions that serve as agencies of control. The entire second half of the first edition (1926) dealt with the particular major field of public utilities and trusts. Eventful years passed before the present edition, to which the author added a section examining the policies of the "new era" of depression, of New Deal experimentation in state control, and of the full development of totalitarianism abroad. His gual for the American people is "democratic efficiency," and his preferred method one of "democratic gradualism," in which the social order and the individualistic man may move together toward cooperation. "By developing cooperative features and organizations within our system, we may develop cooperative impulses, habits, and customs, and these may enable us to develop more cooperative institutions, and so on, as far as our inherent capacities will carry us. First steps must be tried without waiting for human nature to be fully ready for them, but complete revolutions on this principle are precarious."

6005. Cochran, Thomas C. The American business system; a historical perspective, 19001955. Cambridge, Harvard University Press, I957.
227 p. (The Library of Congress series in American civilization) 57-12964 HCro6.C6 38

Professor Cochran's concentrated historical perspective of the 2oth century falls naturally into two eras, divided by the spectacular collapse of 192930. His theme is the relation of business to society; his treatment of it is in general terms. In I900 American businessmen, he says, were an elite group who believed in a self-regulating economy in which they could take care of themselves without responsibility for the welfare of others. Technological change, especially in mass production and transportation, has been the chief cause of a shift in industrial management from owner to professional executive, whose broader outlook involves social accountability. The collapse of the age of industrial control by giant corporations and of financial control by big investment houses was followed by the fundamental revisions of the I930's. "Political and social innovations, fathered by depression, were passed on to a period of war and prosperity where they took on new meanings and gave a new form to American society." The spread of bureaucracy in both government and business has proceeded hand in hand with managerial enterprise; public relations have become a primary concern; it is accepted that governmental controls must stabilize the economy. With an ever-rising standard of living the social prestige of great wealth has declined, and the big businessman is hardly distinguishable from the average American.

6006. Dimock, Marshall E. Business and government. 3d ed. New York, Holt, 1957. 559 p. illus. $57-5696 \quad \mathrm{HD}_{3} 616 . \mathrm{U}_{47} \mathrm{D}_{5}{ }_{1957}$

Professor Dimock, who has held a variety of Federal administrative positions of consequence, now heads the graduate department of government at New York University. His widely used textbook, originally issued in 1949, has followed an opposite course to that normally taken by the successful college manual in our day: successive editions have become smaller instead of larger. In this third edition he has made a special effort "to convey an insight into the inner workings of government because students of economics and business administration have little time in their formal education to acquire this kind of knowledge, and yet it stands them in good stead once they graduate into the world of practical economic affairs." This edition stresses public policy formation, institutions, and pressure groups more than did its predecessors, but the policy areas dealt with remain the same: "pressure groups and big government; the independent enterprise system and concentrated economic power; organized labor and industrial disputes; agricultural policy, which also includes the 
cooperative movement and the conservation of natural resources; the cold war, tariff policy, technical assistance, and the international and domestic aspects of atomic energy; public-utility regulation and public ownership and operation; the public control of banking, investment, and insurance; general methods of coping with depressions," etc.

6007. Gras, Norman S. B., and Henrietta M. Larson. Casebook in American business history. New York, Crofts, 1939. 765 p.

39-31004 HFiII8.G7

In his courses at the Harvard Graduate School of Business Administration Professor Gras regularly used the case method for instruction. This volume illustrates American business history through $3^{8}$ cases of individual businessmen or companies, presented in analytical narrative and in excerpts from letters, records, and other primary sources. The cases are American, with only five exceptions; these include the first, Sir Thomas Smythe (1558(?)-1625) and the Virginia Company, and the last, the Hugo Stinnes Konzern which was liquidated in Germany in 1925-26. In between are some of the most famous names of men, firms, banking houses, speculations, etc., in the American economic scene from early Colonial days to 1938 . Each case is developed at considerable length, with additional pieces of information crammed into long footnotes. The cases are put in three groups, distinguished as mercantile capitalism (ending with J. J. Astor in 1848), industrial capitalism, and finance capitalism and combination in business. The last hundred pages analyze business trends, with chronological periods as "cases," showing the rise of specialization and the tendency toward combination in periods of varying price movements. A varying number of references are appended to each case.

6008. Owens, Richard N. Business organization and combination. $4^{\text {th }}$ ed. New York, Prentice-Hall, 1951. 562 p.

\section{I-5302 $\mathrm{HD}_{2741.085} \mathrm{I} 95 \mathrm{I}$}

An exposition of the various forms of noncorporate and corporate business enterprise. The former include the single proprietorship, the partnership, the joint-stock company, and the business trust, which are described in clear and easily understandable terms. Regarding corporations, Professor Owens gives their historical background and then discusses the theory of legal entity, the charter, the kinds and uses of stocks and bonds, the legal regulation of issue and sale of securities, the role of directors, and procedures in corporate dissolution and reorganization. A special section explains the investment company, which may be a joint-stock company, a business trust, or a corporation. A long part on industrial combinations considers trade associations, gentlemen's agreements, pools, cartels, consolidated companies and holding companies, leased companies, cooperatives, and the general economic significance of combination. A final part is on government regulation, with some background from the common law preceding a review of state and federal antitrust legislation. There are short reading lists at the end of chapters. A somewhat different approach to his subject matter is used by Professor Owens in a more recent book, Introduction to Business Policy (Homewood, Ill., R. D. Irwin, 1954. 474 p.). He is concerned here with theoretical and practical aspects of business policies and objectives-their meaning and significance, their formulation and administration, the organizational roles of stockholders and directors, and policies governing production, sales, public relations, and finance.

6oog. Petersen, Elmore, and Edward Grosvenor Plowman. Business organization and management. $3 \mathrm{~d}$ ed. Homewood, Ill., R. D. Irwin, 1953. 634 p. illus. 53-2866 $\mathrm{HF}_{535}$ r.P48 1953

"A definitive treatment of the principles of organization and management that are the energizing elements of all types of business, large or small, and wherever managerial leadership is required." The authors, who both write from long experience as business executives, explain management as consisting essentially of directives and controls, with its various levels of authority-directors' level, executive level, supervisory level-being determined by the factor of efficiency in control. Departmentation and funciionalization, to which chapters are devoted, are not such formidable concepts as the terms suggest; they lead directly to organization charts, with which the text is well provided. Managerial responsibilities are scrutinized in the realms of centralization, decentralization, communication, efficiency, and incentive. The last chapter is direct advice to the student preparing for a career in management.

6oro. Sutton, Francis X., and others. The American business creed, [by] Francis X. Sutton, Seymour E. Harris, Carl Kaysen, [and] James Tobin. Cambridge, Harvard University Press, 1956. 414 p. 56-8553 HCro6.S88

In this study a sociologist, Mr. Sutton, has collaborated with three economists to examine the ideology of American business as expressed by its spokesmen. The content of the "creed" is expounded in the first 12 chapters according to its chief themes-the American system of business enterprise, the functions of ownership, the relations 
of businessmen with labor and with customers, the relations of government with business, the value of competition, business cycles, money, and the values of a good society. The illustrations are quotations or digests of public statements of business leaders in speeches, writings, and testimony before congressional committees, and examples from advertising and the literature of business associations. In comparison with the normal tenets of modern social science, the creed is revealed as essentially conservative, individualistic, and moralistic. In the last six chapters the authors seek to show that this business ideology is determined largely by "deeplying motivational forces." They suggest that it is less real belief than symbolical expression, intended to resolve the strains inherent in American business institutions and the tensions of the business executive, in conflict with other demands of society. But, they point out, "the rigidity of the business creed should not be exaggerated. American business now gives at least de facto acceptance to a multitude of laws and practices which it earlier opposed as dangerous to the commonwealth or morally repugnant."

\section{Business: Special}

6orr. Berle, Adolf A. The modern corporation and private property, by Adolf A. Berle, Jr., and Gardiner C. Means. New York, Macmillan, 1937. $396 \mathrm{p}$. diagrs.

38-III39 HD2795.B53 I937

In 1932, at the darkest point of the Great Depression, this epoch-making book appeared. Its authors, both to become prominent in the "Brain Trust" of the New Deal, were respectively a finance lawyer and professor of corporation law at Columbia Law School, and a practicing and research economist. Based on a series of technical and statistical studies of corporation development and finance, the book presented their conclusions concerning the "unrecognized" but "far advanced" "corporate revolution" through which, the writers believed, America was passing. Their first table lists, with their gross assets, the 200 largest nonbanking corporations in the United States, which "form the very framework of American industry." "The translation of perhaps two-thirds of the industrial wealth of the country from individual ownership to ownership by the large, publicly financed corporations vitally changes the lives of property owners, the lives of workers, and the methods of property tenure. The divorce of ownership from control consequent on the process almost necessarily involves a new form of economic organization of society." The evolution and legal position of the corporate system in which economic power is now concentrated are studied, and the virtues and dangers of the system examined. The dangers, in the authors' view, lay in the corporations' lack of legal responsibility, which permitted them to turn aside all efforts at Federal regulation, and even to attempt to dominate the national government. The influence of this study was evident in the Temporary National Eco nomic Committee's hearings during 1938-40, and in the antitrust actions of Thurman Arnold, Assistant Attorney General during 1938-43; and its views have entered into the substance of practically all later discussions in its field.

6or2. Berle, Adolf A. The 2oth century capitalist revolution. New York, Harcourt, Brace,

1954. I92 p. 54-II327 $\mathrm{HD}_{273}$ r. B 4

In 1954 Professor Berle expanded a lecture series on the corporation as a quasi-political institution into this thought-provoking book. He joins several other recent appraisers (for instance, Galbraith, no. 5886, and Lilienthal, no. 5892) in suggesting that the modern corporation is beneficial to society. The old checks of free competition and "the judgment of the market place" (the influence of investors) have been replaced by the force of public opinion and by the competition among the giants of the "oligopoly" to give the best service to their "constituency," a public which must be kept satisfied. Otherwise, nationalization! "The real guarantee of nonstatist industrial organization in America is a substantially satisfied public." The writer compares the unwritten but developing laws of the corporation for the protection of individual rights (as in cases of security hearings) to the medieval institution of the Curia regis, the King's Court, through which the king redressed grievances according to his conscience. He shows the corporation to be a powerful instrument in international affairs, where hope may be brighter for economic than for political agreement. In conclusion he describes the social role of the corporation, which through huge planned expenditures for public welfare, education, and community development, may be shaping the "City of God" of the future. One of the first economists, after World War II, to voice the idea that big business was not a force for evil in social and political 
life was Peter F. Drucker, whose much-quoted Concept of the Corporation (New York, John Day, 1946. 297 p.) was written after 18 months' experience as an outside consultant on management to General Motors.

6or3. Bonbright, James C., and Gardiner C. Means. The holding company, its public significance and its regulation. New York, McGraw-Hill, r932. 398 p. diagrs.

$$
\text { 32-8783 }^{\mathrm{HD}_{2} 795 . \mathrm{B}_{5}}
$$

A study of a special aspect of the problem of combination in business, which appeared a few months before Mr. Means' more far-reaching work in collaboration with Professor Berle (no. 6oIr). Particularly during the 1920's, the public utility enterprises of the nation had been largely centralized through a few great holding company systems-for instance, in gas and electricity, the United Corporation Group, the Electric Bond and Share Group, and the Insull Utility Group-which were powerful enough to evade or disregard laws for their control by public service commissions. The authors examined the theory of the holding company and its status as an alternative to other forms of combination. Then they scrutinized the record of the public utility holding companies, the railroad holding companies (the Van Sweringen system was at that time particularly in the public eye), and the bank holding companies. In their final evaluation they suggested that the holding company system is popular with business promoters, first, in that it is the most facile of all the possible legal devices for combining independent enterprises, and second, that it is the least subject to social control. The latter aspect they considered a danger justifying "grave public concern and criticism."

6or4. Davis, Joseph Stancliffe. Essays in the earlier history of American corporations. Cambridge, Harvard University Press, I9I7. 2 v. diagrs. (Harvard economic studies, v. 16 )

$$
\mathrm{I}_{7}-\mathrm{r}_{2} 885 \mathrm{HD}_{27} 85 . \mathrm{D}_{3}
$$

6015. Evans, George Heberton. Business incorporations in the United States, I80o-r943. [New York] National Bureau of Economic Research, 1948. I84 p. illus. (Publications of the National Bureau of Economic Research, no. 49) 48-105I4 HD2785.E85

Dr. Davis' four long historical essays on corporations in 18 th-century America have attained the rank of a classic in business history. Three are in the first volume: "Corporations in the American Colonies," "William Duer, Entrepreneur," and "The 'S. U. M.': the First New Jersey Business Corporation." All are interesting narratives, with his- torical fact interpreted in its legal, economic, and social significance. The writer first describes the several types of public and private corporations chartered either by the British government or, the great majority, by the Colonial governments: they were boroughs, towns, local administrative boards, colleges, churches, library companies, marine societies, etc. The essay on William Duer (1742-1799), the New York patriot, financier, and land speculator, who was prime mover in the abortive Scioto land enterprise and whose failure and arrest for debt initiated the panic of 1792 , studies "a typical bull operator in a boom period," one besides of doubtful morality whose career ended in deserved disaster. The S. U. M. was the Society for Establishing Useful Manufactures, incorporated by the New Jersey Legislature in 1791 , promoted by Alexander Hamilton, raison d'être of the town of Paterson, and still in existence at the time of writing. In volume 2 the fourth and longest essay, "Eighteenth Century Business Corporations in the United States," describes banking companies, corporations for improving communications, for insurance, water supply, manufacturing, and other matters. The list of charters is given in an appendix. The published and unpublished sources for the four essays fill a 50-page bibliography. A very different approach to the subject is made in Professor Evans' study. Nine chapters of running analysis are accompanied by 44 tables and 26 charts compiled by the National Bureau of Economic Research. The first chapters explain the nature of the study, of particular interest for its implications as to business cycles, and the significance of an incorporation. During the first three quarters of the igth century most incorporations were effected by special charter; they have a chapter to themselves. Next trends in business incorporations from 1875 to 1943 are examined, followed by statistical tabulations: the number of incorporations and their authorized capital stock; large, medium, and small business corporations; and an industrial classification. The last two chapters examine the fields of corporate enterprise and the relationship of the number of incorporations to business cycles. Further statistics of incorporations by separate States, periods, etc., are set forth in 90 pages of appendixes.

6or6. East, Robert A. Business enterprise in the American revolutionary era. New York, Columbia University Press, 1938. 387 p. (Columbia University. Faculty of Political Science. Studies in history, economics and public law, no. 439) 39-2808 HCro5.E24 1938a

Bibliography: p. $330-356$. $\mathrm{H}_{3}$ I. $\mathrm{C}_{7}$, no. 439

A history of business undertakings in America 
from 1775 to 1792 , in the preparation of which the author used an overwhelming array of material, published and unpublished-public records, family papers, business papers, letters, diaries, memoirs, travels, biographies, local histories, and specialized historical studies. His special interest lies in the transition from the individual mercantile enterprise of the late Colonial period to the beginnings of industrial capitalism. The change was evidenced most clearly in new mechanisms and opportunities for investment: joint-stock companies, factory projects for textile manufactures, companies for land speculation, communication projects, the new commercial banks of the 1780 's, and the like, which were superseding the earlier partnerships or personally supervised investments. Much of the study concentrates upon the individual promoters who grasped the opportunities offered by the new economic forces of the Revolution, and prepared the way for a more developed capitalist system. Noteworthy among the many whose transactions the author records are the Connecticut trader and Commissary General of the Continental forces, Jeremiah Wadsworth, and the Philadelphia merchant and financier, Robert Morris.

6or7. Haynes, Benjamin R., and Harry P. Jackson. A history of business education in the United States. Cincinnati, Southwestern Pub. Co., 1935. I59 p. 35-2923 HFII3I.H3

On cover: Monograph 25.

A clearly written and organized outline which draws upon a considerable number of monographs, articles, and other secondary works for its facts. The private business school or "commercial college" sprang up in our Eastern cities during the second quarter of the Igth century; it is "peculiarly American; nothing exactly like it is known in other countries." It enjoyed a practical monopoly of business education for decades, but from about 1890 , after some 15 years of tentative beginnings, the public high schools moved into the field in a vigorous manner, and were soon offering a wide variety of courses designed to train young people for a business career. Several cities established high schools of commerce, with their whole curriculum focused upon efficient business training: the first was opened at Washington, D. C., in 1890 , and enrolled 160 boys and 150 girls for its first year. The first venture at the college level was the Wharton School of Finance and Commerce at the University of Pennsylvania, founded in $188 \mathrm{r}$; it had no imitators until 1898. The authors follow the spread of commercial training in junior high schools, correspondence schools, denominational schools, and other varieties, in a regularly concise and instructive manner. 6or8. Holden, Paul E., Lounsbury S. Fish, and Hubert L. Smith. Top management organization and control. Stanford University, Calif., Stanford University Press, 1941. xvii, 239 p. diagrs. ([Stanford business series $]$ )

$$
\text { 4I-542I } \mathrm{HD}_{3} \mathrm{I} . \mathrm{H} 6
$$

6org. National Institute for Commercial and Trade Organization Executives. Trade association management; textbook for trade association management curriculum. Editor: Delbert J. Duncan; assistant editors: Paul H. Sullivan [and] Minita Westcott. Rev. ed. [Chicago] I948. I90 p. $\quad 48-4488$ HD242r.N25 1948 The subtitle of the first work explains its nature: "a research study of the management policies and practices of thirty-one leading industrial corporations, conducted under the auspices of the Graduate School of Business, Stanford University." The arrangement reverses the work of research; the last section is provided by the data sheet used in the field interviews on which the study was based, while the book begins with a succinct summary and conclusions regarding the findings. These have been collated in a general treatment without reference to individual companies. The long central sections explain organization practices concerning top management, operations, staff, and committees; all phases of control practices; and the functions, composition, organization and procedure of the board of directors. A textbook for executives in a more specialized field is Trade Association Management. This ready reference guide has 7 parts, the first 4 giving the history, objectives, and policies of trade associations and analyzing their membership and (in the longest section of 14 chapters) their activities and services. The last 3 parts contain advice for management concerning operating problems, financial budgeting and control, and the qualifications of the executive. The 2 I chapters are by as many "leading association executives."

6020. Kaplan, Abraham D. H. Big enterprise in a competitive system. Washington, Brookings Institution, 1954. $269 \mathrm{p}$.

$$
\text { 54-4577 } \mathrm{HCr}_{106.5} \mathrm{~K}_{3} 6
$$

6021. Kaplan, Abraham D. H. Small business: its place and problems. New York, McGraw-Hill, I948. xiv, 28r p. diagrs. (Committee for Economic Development. Research study) 48-10456 $\mathrm{HC}_{106 . \mathrm{K}_{2} 7}$

The first entry grew out of an investigation conducted by Brookings Institution with the aim of clarifying the role of big business in the American system and helping to establish a rational basis for public policy in this area. Big business is supported 
in practice by the public, but at the same time excites constant suspicion lest it may bring about a break. down of the competitive system. Dr. Kaplan reviews lucidly the development of public opinion and policy in this regard, and the factors underlying the concept of competitive enterprise. He sums up statistical evidence as to concentration of industry in production, markets, and financial power, taking a particular look at the performance of the hundred largest industrial corporations. Then he analyzes the performance of the big corporations in relation to competition. In his summary and conclusions he states forthrightly that "the business of the American industrial giant is still primarily that of a competitor producing and distributing for the market," and that, rather than stifling competition, big business has contributed to the "scope, vitality, and effectiveness" of the system. The same writer had a few years earlier prepared a thorough report for CED on Small Business. Although the statistical data need revision, it remains useful as a reference work for definitions, and on the patterns of small business, its management, financing, and competitive techniques. The last topics considered are education and public policy in relation to small business.

6022. Maurer, Herrymon. Great enterprise; growth and behavior of the big corporation. New York, Macmillan, 1955. 303 p.

$$
55^{-1} 3880 \text { HD } 2785 \cdot \mathrm{M}_{37}
$$

A popular "general perspective" of the large corporation, based on an examination of the behavior of 50 large companies. The extensive checking of the life histories of these companies was performed by the research staff of Fortune, in which parts of the book appeared as articles. The 50 firms are listed on pages 18-19, with statistics for the year 1953: total assets almost $\$ 82 \frac{1}{2}$ billion; total earnings almost $\$ 4$ billion; close to 4 million employees. Mr. Maurer describes "The Look of the Large Corporation," traces the history of early enterprise, examines the activities of the "corporate center," and explains corporate organization and management. He concludes with a chapter on the relation of the corporation to society, emphasizing the basic need of the big business enterprise to understand and explain itself "in such a way that the public understands that [its] social responsibilities and economic activities ... are so inextricably intermingled as to amount to the same thing."

6023. Miller, William, ed. Men in business; essays in the history of entrepreneurship. Cambridge, Harvard University Press, 1952. $350 \mathrm{p}$.

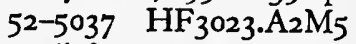

A set of readable and well-documented essays, published under the auspices of the Research Center in Entrepreneurial History at Harvard University. The II writers are young economists and historians whose work reflects recent theories of psychology and sociology as well as of the Schumpeter school of economics. The first three are on entrepreneurship abroad. The others, in roughly chronological order, study selected American promoters and family or elite groups engaged in new forms of business enterprise from the time of the Revolution. The emphasis throughout is on the personality and social standing of individuals, and their impact upon the political, social, and economic affairs of their day. Among those treated are the Lowell-HigginsonCabot, Brown, and other family groupings that dominated the beginnings of Massachusetts industry; John Stevens of Hoboken and of the first steamboats; Henry Noble Day, the militant Christian railroad promoter of the new Middle West; Frank Julian Sprague, the "father of electric traction"; and Henry Varnum Poor, "philosopher of management," whose railroad manuals introduced an information service for investment. In the last essay Mr. Miller looks at the 2oth-century change from "individualistic, innovative, venturesome" entrepreneurship to an orderly and restrained "Business Elite in Business Bureaucracies."

6024. Porter, Kenneth Wiggins. John Jacob Astor, business man. Cambridge, Harvard University Press, 1931. 2 v. illus. (Harvard studies in business history, 1 )

$$
3 \mathrm{I}-2856 \mathrm{I} \quad \mathrm{CT} 275 . \mathrm{A} 85 \mathrm{P} 6
$$

"Bibliographical note": v. 2, p. [1299]-1305.

John Jacob Astor (1763-1848), whose career exemplifies the double transition from petty trader to mercantile capitalist to industrial entrepreneur, has long served as archetype of the self-made man of business in America, the land of boundless opportunity. He arrived by steerage from Germany via England in 1784 , with a stock in trade of seven flutes. A shipboard acquaintance led him into the fur trade; he soon established himself as a leading fur merchant trading to Europe, and by constant new ventures, hard work, and hard bargaining built up a huge fortune. In 1800 he ventured a cargo to China, and as the China trade prospered used his capital to organize the American Fur Company and the Pacific Fur Company, intended to monopolize the fur trade of the Far West. The latter and its central depot of Astoria on the Columbia River were casualties of the War of 1812 , but the war brought other opportunities of large profit. His fortune of at least $\$ 20$ million, the greatest of his era in the United States, came in large part from his real estate investments in New York City. Dr. Porter's rounded narrative of Astor's life is a solidly based business biography, for which he had access 
to voluminous collections of primary sources. Each volume includes an extended section of "Documents," reproducing letters, agreements, contracts, and other business papers. Further light on Astor's Pacific venture is afforded by Washington Irving's Astoria (no.39r).

6025. Silberling, Norman J. The dynamics of business; an analysis of trends, cycles, and time relationships in American economic activity since 1700 and their bearing upon governmental and business policy. New York, McGraw-Hill, 1943. 759 p. diagrs. 43-6816 HB 37 I I.S 48

This work, posthumously published, was by a professor of business research who had also headed his own research corporation. It is a study in measurement, analyzing long-term trends of the American economy through quantitative data, mostly as represented in index numbers. With mathematical formulae and graphic charts, in a style difficult for nonspecialist readers, the writer has studied trends of population growth, production and trade, price levels, national and farm income, building and real estate, transportation, banking, international monetary policy, interest rates and stocks, corporate earnings and capital investment, consumer income, wage income, and business forecasting. In a final chapter on "The Future of Production and Capital" he expresses anti-Keynesian views, declaring that programs of public works, etc., express a "philosophy of stagnation" with a "corollary of bureaucratic capitalism."

6026. Stocking, George W., and Myron W. Watkins. Monopoly and free enterprise. With the report and recommendations of the Committee on Cartels and Monopoly. New York, Twentieth Century Fund, 1951. xv, 596 p.

$$
\text { 5I-9279 } \mathrm{HD}_{273}{ }^{\mathrm{I}} \mathrm{S}_{7} 6_{5}
$$

The final product of a major investigation of the problems of international cartels and domestic monopoly undertaken by the Twentieth Century Fund in 1944. The research was directed by Professors Stocking and Watkins, both specialists in industrial economics. Two volumes of the same authorship and publisher preceded this, Cartels in Action (1946. 533 p.), a case history of international cartels in eight important fields, and Cartels or Competition? (1948. 5 I6 p.), which appraised the international cartel movement in terms of its effect on the economic life of the United States. The present work embodies a well-organized review of the theory, history, and experience of industrial concentration in America, of oligopolistic competition in practice, of antitrust legislation, of government regulation of trade, and of the policies of big business. For this it makes use of many scholarly studies of the two previous decades as well as of the findings of TNEC and other congressional investigating committees, and of Supreme Court decisions. Its argument is a notable assertion of the doctrine that the economic goal of a democratic society is a competitive private enterprise system, genuinely free alike from bureaucratic and from monopolistic control. The appended program of the Fund Committee calls for vigorous enforcement of the antitrust laws.

6027. Taussig, Frank W., and Carl S. Joslyn. American business leaders; a study in social origins and social stratification. New York, Macmillan, 1932. xiv, 319 p. $\quad 32-2543^{8} \mathrm{HF}_{5353} \cdot \mathrm{T}_{3}$

6028. Newcomer, Mabel. The big business executive; the factors that made him, r900-1950. New York, Columbia University Press, 1955. 164 p. illus. 55-10287 $\mathrm{HF}_{5500 . N_{37}}$

6029. Warner, William Lloyd, and James C. Abegglen. Big business leaders in America. New York, Harper, 1955. 243 p. illus.

55-8545 $\mathrm{HF}_{5500 . \mathrm{W}_{25}}$

In the first-named, long-standard work a noted Harvard economist collaborated with a colleague in the department of sociology. Their data were assembled from over 7,000 answers to a questionnaire returned by individual business leaders selected from Poor's Register of Directors for 1928. The respondents are classified as to business status, geographic distribution, type of business, size of business, and age and time factors. Their occupational origins for two generations back are examined in comparison with studies of social mobility made by Professor Pitirim Sorokin and others. Environmental conditions are analyzed with regard to influential connections, financial aid, general schooling, and special business education. (A high percentage is shown to have had college training, but over 70 percent had no formal business training.) These two sets of factors are correlated with business achievement. The authors conclude that, although 70 percent of the business leaders come from the business and professional classes representing only ro percent of the American population, the sons of laborers are handicapped by lack of innate ability rather than of opportunity. Among the appendixes is an interesting selection of "remarks" made by respondents. A later study in this field is that of Professor Newcomer of Vassar College. Her sample is drawn from the controlling groups of three generations (1900, 1925, 1950) in over 400 of the largest railroad, public utility, and industrial corporations. The introduction explains the purpose, scope, method, and sources of the work, 
and two chapters treat the nature and functions of the board of directors of a big company. Next the origins of the leaders are statistically analyzed as to nationality, religion, politics, income, fathers' occupations, and family income. The education of executives is discussed in a long chapter, and then their early business careers and executive service are surveyed. The last three chapters bring forward evidence on incentives, on qualifications of the executives, and on trends in the education of business administrators. In giving reasons why leadership has become professionalized, the author places first the greater degree of education now required for executives. Her conclusion for the future is that standards will increasingly be set by the graduate schools of business administration. In the same year a comparable book was addressed to a general audience by two sociologists of the University of Chicago, Professors Warner and Abeg. glen. In this the statistical analysis is limited to a few charts, and the emphasis is on personal qualities. The leaders are characterized as a "birth and mobile class," their "Royal Road: Higher Education." Factors in successful careers, such as personalities, wives, and public activities, are examined, and getting ahead is regarded as a calculated, coldblooded and dog-eat-dog process.

6030. [Thorp, Willard L., and Walter F. Crowder] The structure of industry. Washington, U. S. Govt. Print. Off., I94I. xv, 759 p. ([U.S.] Temporary National Economic Committee. Investigation of concentration of economic power. Monograph no. 27)

$$
\text { 4I-503II HCro6.3.A5127, no. } 27
$$

At head of title: 76 th Congress, 3 d session. Senate committee print.

Running title: Concentration of economic power.

This is one of the most substantial of the 40-odd monographs prepared by economists to assist the investigations of the TNEC into industrial concentration. Dr. Thorp, Mr. Crowder, and their assistants studied American industry from 1890 to 1937 with the aim of segregating trends that lead to monopoly. In the first part general trends in the size and scale of operations of manufacturing industries are examined. Part 2 analyzes the structure and functions of integrated manufacturing operations. A short chapter summarizes the progress of the merger movement with graphic representation. Brief notes are given on the history of concentration in seven selected industries. Part 5 is on "The Concentration of Production in Manufacturing," indicating the extent and areas of concentration, leading producers, the relation of concentration to various product characteristics, and changes in concentration. Part 6 analyzes the product structure of the 50 largest manufacturing companies. Each of the two last sections have long appendixes of statistics. The presentation of the whole is quite objective, and based on scientific techniques of economic measurement.

\section{Labor: General}

6031. Barbash, Jack. The practice of unionism. New York, Harper, 1956. 465 p.

$$
\text { 56-9325 HD6508.B353 }
$$

References, comments, and suggested readings: p. 4 I I- 446 .

6032. Hardman, Jacob B. S., and Maurice F. Neufeld, eds. The house of labor; internal operations of American unions. New York, PrenticeHall, 1951. xviii, 555 p. (Prentice-Hall industrial relations and personnel series)

$$
\text { 5I-2599 'HD6508. } \mathrm{H}_{27}
$$

The Practice of Unionism is a survey of the principles and working rules of the modern trade union. General concepts are illustrated with cases of union practice since 1933 and particularly since passage of the Labor-Management Relations (Taft-Hartley) Act in 1947. The incentives for joining and organizing labor unions are Mr. Barbash's first considera- tion. There follow expositions of the organization, administration, and structure of unions; an examination of the terms and procedures in the union's central business of collective bargaining under the Taft-Hartley provisions; and an account of its utilization of the weapons of strikes, picket lines, and boycotts. Union efforts to influence government and politics are explained as following a public policy of which the welfare state is "a shorthand description." The author writes severly of racketeering and communism in unions, calling them "labor pathology." In describing the functions and services of the group of "union technicians" to which he himself belongs, he emphasizes that the labor specialist does not make policy. Another work by the professional branch of the labor movement is The House of Labor, prepared under the auspices of the Inter-Union Institute, as the result of a cooperative study by leading staff members of a number of na- 
tional unions. Mr. Hardman was chairman of the Institute, and Professor Neufeld is with the New York State School of Industrial and Labor Relations at Cornell University, where many of the "labor technicians" receive their training. The 45 chapters, to which almost 50 specialists have contributed, are in 8 groups. First is a general appraisal of the current state of the unions, their leaders and membership, and the labor movement as a whole. The succeeding parts cover political activities at home and abroad, union publicity and public relations, research and industrial engineering, welfare, health and community services, union administration, educational activities, and the functions and aims of the union staff.

6033. Commons, John R., and others. History of labour in the United States. New York, Macmillan, 1918-35. 4 v. I8-9293 HD8066.C7 HCior.C 75 , no. 4

Bibliography: v. 2, p. [539]-587; v. 3, p. 70r74I; v. 4, p. 639-66r.

Contents.-v. I. Introduction, by J. R. Commons. Colonial and Federal beginnings (to 1827 ) by D. J. Saposs. Citizenship (1827-1833) by Helen L. Sumner. Trade unionism (1833-1839) by E. B. Mittelman. Humanitarianism (1840-1860) by $\mathrm{H}$. E. Hoagland.-v. 2. Nationalisation (1860-1877) by J. B. Andrews. Upheaval and reorganisation (since 1876 ) by Selig Perlman.-v. 3. Introduction to volumes 3 and 4 , by J. R. Commons. Working conditions, by D. D. Lescohier. Labor legislation, by Elizabeth Brandeis.-v. 4. Labor movements, by Selig Perlman and Philip Taft.

The first two volumes of this classic work constituted the fourth study in the Carnegie Institution series of Contributions to American economic history (see Clark, no. 5904; Johnson, no. 5948; Meyer, no. 5923) and appeared in 1918 (reprinted last in 1935). Like the rest of the series, it was preceded by the preparation and publication of various monographs and documents. Most notable was $A$ Documentary History of American Industrial Society, edited by Dr. Commons and associates under the auspices of the American Bureau of Industrial Research (Cleveland, A. H. Clark, 1910-II. II v.). This compilation of records has provided basic source material not only for the present work but for all subsequent studies in American labor history. Volumes 3 and 4 of the History of Labour continued the original study from 1896 to 1932 , and were prepared by colleagues and former students of Professor Commons at the University of Wisconsin. In his introduction this distinguished student of industrial relations gives his own witness to changes in labor organization: "In the course of twenty- five years I saw an industry evolve not only from merchant capitalism to employer capitalism, but also from struggles for 'proletarian dictatorship' to the concerted regulations of constitutional government."

6034. Dulles, Foster Rhea. Labor in America, a history. New York, Crowell, 1955. 42 I p. (The Growth of America series)

55-Iroog HD8066.D8 I955

The voluminous studies of Professor Commons and his associates have been drawn on heavily by Professor Dulles in his history for the general reader. In 21 fast-moving chapters he narrates the whole story of American labor from the indentured servant system of Colonial days to the merger of the A.F. of L. and the C. I. O. in 1955. He traces the growth of the national organization of labor-the precursors, the National Labor Union, the Knights of Labor, the American Federation of Labor, the Congress of Industrial Organizations-in perspective against national socioeconomic and political development. Before turning to the teaching of history Mr. Dulles had been a newspaperman, and his training is reflected in his objective and balanced selections from the inexhaustible source material of the modern labor unions. An introduction to tradeunion history designed for a wide audience including school and workers' education groups is Labor in America, by Harold U. Faulkner and Mark Starr, new rev. ed. (New York, Oxford Book Co., 1957. 330 p.). Most of it is a simple retelling of the story of labor from the medieval guilds to the great unions of World War II and the postwar passage of the Taft-Hartley Act. A chapter explains in simplest terms the structure and functions of unions. The last two chapters, on current union activities and on trends and prospects of 1949-56, take into account the AFL-CIO merger.

6035. Peterson, Florence. American labor unions, what they are and how they work. Rev. ed. New York, Harper, 1952. 270 p. illus. $5^{\mathrm{I}-\mathrm{I} 194^{8} \mathrm{HD}_{508 .} \mathrm{P}_{2} 195^{2}}$

6036. Dankert, Clyde E. Contemporary unionism in the United States. New York, PrenticeHall, r948. xv, 521 p. diagrs. (The Prentice-Hall industrial relations and personnel series)

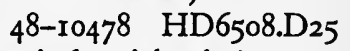

By a former chief of the industrial relations division of the U. S. Bureau of Labor Statistics, American Labor Unions is a handbook of noteworthy conciseness and clarity. The historic growth of the labor movement is outlined in less than 50 pages. The structure and internal government of federated organizations (A.F. of L., C. I. O., 
and the railroad brotherhoods) and of national and local unions are next explained, with precise details as to membership rules, finances, and dues. Benefit programs, public relations, and educational activities are given a separate section. The relations of unions and management are discussed as regards collective bargaining, disputes, strikes, and settlements under the National Labor Relations Act, the Taft-Hartley Act, and the mediation of Federal agencies. The last part examines the international relations of American trade unions. At the end are a glossary of labor terms and a directory of unions in 1951. The same general field is covered in greater detail in the earlier work by Professor Dankert, addressed to a college or professional audience. This objective analysis includes a review of American trade union history, and separate treatments of the structure, government, principles, and activities of the A. F. of L. and the C. I. O. The labor legislation of the New Deal and the wartime and postwar position of labor are taken into account. The text was largely completed before the passage of the Taft-Hartley Act in 1947, and although the writer describes its major features, experience had not yet revealed its full significance.

6037. Reynolds, Lloyd G. Labor economics and labor relations. 2d ed., with revisions. Englewood Cliffs, N. J., Prentice-Hall, 1956. 722 p. illus. $\quad 56-44059 \mathrm{HD}_{4901 . R_{47}}{ }_{1956}$

This serviceable text by a Yale professor of economics has two distinct parts. The first is a thorough discussion of trade unions, their history, growth, and philosophy, and of the processes of collective bargaining, the public control of labor relations, and the role of labor in politics. The new edition covers conditions and events of 1955. The second part is a study of "The Economics of the Labor Market." Here the author leaves the field of organized labor to examine the broader questions of labor supply and the labor market, of employment and unemployment, of wages and wage determination, and of minimum standards of real income. Throughout he stresses public policy in these fields. A short epilogue aims to sum up the entire labor problem, arriving at a "balance-sheet" of trade-unionism. It is, Dr. Reynolds decides, "a conservative social force and becoming increasingly so as it grows older." $\mathrm{He}$ is inclined to consider that, despite many deficiencies, trade-unionism tips the scale on the side of social usefulness. Reference may be made here to a still more recent study of the role of trade unions in the welfare state: John A. Fitch's Social Responsibilities of Organized Labor (1957), mentioned above as one of Harper's Series on ethics and economic life (no. 5899).
6038 . Slichter, Sumner H. The challenge of industrial relations; trade unions, management, and the public interest. Ithaca, N. Y., Cornell University Press, 1947. I96 p. (The Messenger lectures on the evolution of civilization, 1946)

$$
\text { 47-3448 HD8072.S6r65 }
$$

One reviewer said that this little book, embodying six lectures given by Professor Slichter at Cornell University, "may be regarded, by all odds, as the best single volume on modern industrial relations." The author's writing on labor questions goes back to his thesis at the University of Chicago in I918, The Turnover of Factory Labor, with foreword by John R. Commons (New York, Appleton, rgrg. 460 p). A major work, Union Policies and Industrial Management (Washington, Brookings Institution, I94 I. 597 p. The Institute of Economics of the Brookings Institution. Publication no. 85), is a well-rounded examination of collective bargaining. In the present lectures he looks at the labor movement in general, the effect of unions on management, union wage policies, the government of unions, the problem of industrial peace, and the control of unions in the public interest. Central to his discussion is his view that trade unions constitute the greatest private economic power in the community, and that their policies are a major determinant of national prosperity and industrial democracy.

6039. Taft, Philip. The structure and government of labor unions. Cambridge, Harvard University Press, 1954. xix, 312 p. tables. (Wertheim Fellowship publications in industrial relations)

54-8633 HD6508. T27

A close study of the internal aspects of unions, which begins with a survey of radicalism in American labor. Professor Taft takes a cross-section of union history to show that the membership of the unions, in spite of vigorous attempts by Communist leaders, has always rejected radical philosophy. He examines on the same pattern elections and competition for office, dues, initiation fees, and salaries of officers, and "does not shy away from investigating the most intimate aspect of union life, namely, how and for what reasons unions discipline their members" ("Foreword" by S. H. Slichter). Three chapters are case histories of particular unions. "The Unlicensed Seafaring Unions" have been important targets for Communist agitation and the scene of incessant intra- and interunion battles. The two largest unions of C. I. O., the Automobile Workers' Union and the Steel Workers' Union, are compared in detail. An individual case study is made of the expanding and aggressive Teamsters' Union (three years too early for comment on its disciplinary expulsion from AFL-CIO). The au- 
thor returns to the theme of democratic theory in a last look at the present state of the unions: "Far from perfect, unions fundamentally reflect the will of their members. They not only fulfill a vital need for the workers' representation and protection in industry, but they are the most effective guarantee against Communist infiltration into American labor."

6040. Twentieth Century Fund. Employment and wages in the United States, by Wladimir S. Woytinsky and associates. New York, 1953. xxxii, $777 \mathrm{p}$. 53-7170 HD8072.T8

This extensive survey presents a tremendous array of data on American labor and its remuneration, past and present (from before 1870 to and including 1950), which is set down statistically in tables (242 in the text, 118 in the appendix) and 86 graphs and maps. These are embodied in a full expository text, documented in footnotes. The whole is designed to provide reliable source material for future studies. The coverage is indicated in the foreword: "The working people of the United States and their conditions of labor: the size, make-up and distribution of the labor force; the various occupations represented and the numbers of workers employed in each; the ebb and flow of employment and unemployment; the wages that American workers are paid and how their wages are determined; their hours of labor and other working conditions and the regulations and controls that government has imposed upon them; labor unions and the role they play in the vast drama of wages and employment; the underpinnings of insurance which have been set up to make the worker's life more secure; and finally, the relation of all these basic facts to the operation of the economy as a whole."

6041. Ulman, Lloyd. The rise of the national trade union; the development and significance of its structure, governing institutions, and economic policies. Cambridge, Harvard University Press, r955. xix, 639 p. diagrs., tables. (Wertheim publications in industrial relations)

$$
\text { 56-5175 HD6508. } \mathrm{U}_{4}
$$

In the first five parts of this long and scholarly monograph the writer analyzes the historical development of the trade union movement in the late rgth and early 2oth century. By the turn of the century, he finds, the nationally organized union had achieved maturity as to its governing institutions, its relationships with local unions and other labor bodies, its strike and wage policies, and its work rules. Among causes for nationalization he emphasizes the important factor of geographical mo- bility-the "traveling member" who moved to new ground for a job-and the financial and other co. ordinated assistance which the national organization could provide to support local strikes. His special research sources were the constitutions, proceedings, and journals of five national unions, the Bricklayers', Carpenters', Printers', Molders', and Bottle Blowers'. In his sixth part he examines the wage and strike policies of these and other national unions and compares them with employers' policies. In the seventh he proceeds to the theory of labor unions, criticizing the older views of J. R. Commons and Selig Perlman, and offering his own hypothesis based on a profit motivation of labor matching the individualism of American enterprise; it is this which has produced a dynamic "business unionism" concentrated upon collective bargaining.

6042. Yoder, Dale. Manpower economics and labor problems. 3d ed. New York, McGraw-Hill, 1950. 66r p. illus.

$$
\text { 50-8II9 HD8072.Y6 } 1950
$$

Previous editions published under title: Labor Economics and Labor Problems.

A comprehensive work on manpower as "the most versatile, valuable, and complicated resource of modern societies," and on the problems arising out of the use of this resource in our society. The first four chapters are devoted to theoretical and historical examination of the general theme. Then particular aspects are studied as to practice and policy: wages; employment and unemployment; the labor of such special groups as women, children, the aged, and the handicapped; and questions of status in industry. It is only in the last third of the book that Professor Yoder focuses his attention on organized labor. He examines American trade unions (in 1949 amounting to approximately onefourth of the total labor force) in respect to the practices, policy, and economic implications of collective bargaining. Last he looks at industrial relations, reviewing such devices for "maximized cooperation" as profit sharing, employee stock ownership, employee representation, and union-management collaboration, but suggesting that the "simple virtues" of honesty, sincerity, and integrity are more important in establishing mutual confidence. The author is director of the Industrial Relations Center at the University of Minnesota and a frequent consultant to government agencies on manpower problems. His big textbook, Personnel Management and Industrial Relations, $4^{\text {th }}$ ed. (Englewood Cliffs, N. J., Prentice-Hall, 1956. 941 p.), has been a standard work in its field since its first appearance in $193^{8}$. 


\section{N. Labor: Special}

6043. Anderson, Hobson Dewey, and Percy E. Davidson. Occupational trends in the United States. Stanford University, Calif., Stanford University Press, 1940. 618 p. tables, diagrs.

$\mathrm{HB}_{2595 . A 6}$

Recent occupational trends in

American labor; a supplement. Stanford University, Calif., Stanford University Press, 1945. vii, 133 p. incl. tables.

40-35443 HB2595.A6 Suppl.

This useful study brings together and interprets statistics from the decennial Census of Occupations; the original volume and the supplement together cover Bureau of the Census records from 1870 through 1940. After a 70-page introduction summarizing general occupational trends and causal factors, the arrangement is by major occupational groups: agriculture, fishing and forestry, extraction of minerals, manufacturing and mechanical industries (with I4 subgroups), transportation and communications, trade, public service, professional service, domestic and personal service, and clerical occupations. The tables and charts reveal a great variety of facts regarding the distribution of American manpower over 70 years. The supplement draws upon the Sixteenth Census of the United States: 1940. Population. v. 3. The Labor Force (Washington, U. S. Govt. Print. Off., I943. 5 pts.), and also upon an important statistical monograph of the Bureau of the Census prepared by Dr. Alba M. Edwards: Sixteenth Census of the United States: 1940. Population. Comparative Occupation Statistics of the United States, 1870 to 1940 (Washington, U. S. Govt. Print. Off., 1943. 206 p.).

6044. Bridenbaugh, Carl. The Colonial craftsman. New York, New York University Press, 1950. 214 p. (New York University. Stokes Foundation. Anson G. Phelps lectureship on early American history)

50-7479 $\mathrm{HD}_{2346 . \mathrm{U}_{5} \mathrm{~B}_{7}}$

Although the author declares in his preface that he writes because everything else on Colonial crafts is from the antiquarian viewpoint, "still this little work for "the casual reader" stands out in a selection of writings on American labor as a rare example of antiquarian charm. The focus of interest, it is true, is the skilled workman and his economic progress, but plenty of detail about his product finds its way into the pages. Part of the antiquarian flavor may be attributed to the illustrations, all reproductions of engravings in the French Encyclopédie of 1762-76 showing the work of the several crafts. The several lectures are on the craftsman of the rural South and of the rural North, the urban craftsman (two lectures), the craftsman at work, and the craftsman as a citizen. At the outset the author warns against "surrounding the artisan with the haze of romance," and reminds us that only the best 18 thcentury craftwork has been preserved in modern collections, and that many articles were distinctly inferior in quality.

6045. Brissenden, Paul F. The I. W. W.; a study of American syndicalism. [2d ed.] New York, Russell \& Russell, 1957. xxii, $43^{8}$ p.

Bibliography: p. $3^{8} 7-428$. 57-69i1 HD8055.I5B55 1957

The Industrial Workers of the World held its 27th convention in 1955,50 years after its launching in 1905. The outstanding example of the anarchosyndicalist union in America, it was a direct successor of the militantly radical Western Federation of Miners, and was promptly joined by the extremer element of the American Federation of Labor. Its membership was drawn largely from unskilled labor of alien origin, and it openly avowed Marxist doctrine and favored the use of violence and sabotage. Its founders included its best-known leaders, Eugene V. Debs, "Big Bill" Haywood, Daniel DeLeon, and Vincent St. John. The "Wobblies" or the "Bummery" (their "red book" song, "Hallelujah, I'm a Bum," is familiar at least to the older generation today) conducted innumerable strikes, the most famous of which was at Lawrence, Mass., in 1912. They opposed World War I, and were violently suppressed after Congress passed the Anti-Espionage Act in 1917. Their influence and membership have since considerably declined. In his new preface to a history standard since 1919 Professor Brissenden comments that one of the most remarkable things about the I. W. W. is its survival. He denies that it is a Communist organization.

6046. Chamberlain, Neil W. Collective bargaining. New York, McGraw-Hill, I95I. 534 p.

illus. $\quad 5$ I-220I HD6 $483 . \mathrm{C}_{4} 8$

6047. Chamberlain, Neil W., and Jane Metzger Schilling. The impact of strikes, their social 
and economic costs. New York, Harper, 1954. 257 p. (Yale Labor and Management Center series) 53-11958 $\mathrm{HD}_{5324 . \mathrm{C}_{42}}$

Dr. Chamberlain, well known as a writer in the labor field, is assistant director of the Labor and Management Center at Yale University. His textbook, Collective Bargaining, was the first to be devoted exclusively to the subject. In it, he says, he has consciously stressed "the developmental character of collective bargaining, its change over time," and he finds a surprisingly modern instance among the printers of New York City as early as 1809 . The source material incorporated includes a verbatim report of a bargaining conference in chapter 3 , and sample agreements on grievance procedure and on collective bargaining (both between General Motors and the United Automobile Workers, 1950) in the appendixes. Two chapters discuss the bargaining unit, which is by no means necessarily coextensive with company or union, and another the factors which enter into the "tricky" concept of bargaining power. The politics of bargaining are viewed both from the union and the management side; and its economics are investigated with respect to the problem of relative wage rates, the effect on national income levels, and the degree to which the bargaining process raises the specter of monopoly. In a final chapter on "The Role of Collective Bargaining in American Society," the functions and values of competition and cooperation are appraised, with the conclusion that a healthy economy requires "a proper admixture of the two." In The Impact of Strikes Dr. Chamberlain collaborated with a research assistant who had worked with him on a book in the same series published the year before: Social $R e$ sponsibility and Strikes (New York, Harper, 1953. 293 p.). Both books are concerned with the social and economic effects of strikes on union members, management, and the public. In the earlier study a method was devised for rating the impact of strikes on consumers, industrial users, suppliers, and public opinion. In the later one the same procedure is again described, and used to analyze strikes in coal mines, railroad service, and the steel industry. Conclusions are based upon the overall cost of strikes and whether their effect on the public is so damaging as to warrant government intervention. The writers offer their strike-rating procedure as an example of the kind of analysis that will aid the ex. ecutive branch in making decisions of public policy.

6048. Douglas, Paul H. Real wages in the United States, 1890-1926. Boston, Houghton Mifflin, 1930. xxviii, 682 p. diagrs. (Publications of the Pollak Foundation for Economic Research, no. 9) 30-1 2884 HD $4975 . D 6$

"Bibliographical note": p. [655]-667.
The author has been a professor of industrial relations at the University of Chicago since 1920; his career as United States Senator began in 1948. This authoritative 35 -year study of rising living standards is introduced by a thorough discussion of the problem of ascertaining real wages as determined by purchasing power, through measurement of money wages and living costs. Professor Douglas then analyzed statistically the movement of living costs from 1890 to 1926 , and, for the same period, the movement of wage-rates and hours of work, the movement of actual money and real earnings of employed workers, and of unemployment and the real earnings of the wage-earning class as a whole. A concluding chapter summarizes findings.

6049. Goldberg, Arthur J. AFL-CIO: labor united. New York, McGraw-Hill, 1956.

319 p. (McGraw-Hill labor management series) 56-r 1047 HD8055.A5G66

In 1935 the issue of craft versus industrial unions, which had been a main jurisdictional problem of the A. F. of $\mathrm{L}$. from its earliest days, came to a head. The labor policies of the New Deal, protecting the right of workers to organize and bargain collectively, had opened the way for unionization of the great number of unskilled workers in the mass-production industries. After the 1935 A. F. of L. convention, which refused to grant unrestricted industrial union charters, the Committee for Industrial Organization was formed, headed by John L. Lewis, Charles P. Howard, Sidney Hillman, David Dubinsky, and other leaders of industry-wide unions. $\mathrm{Al}$ though repudiated by the A. F. of L. Executive Council, the C. I. O. launched successful organizational drives and by 1938 could transform itself into the federated Congress of Industrial Organizations, with Lewis as first president. Raiding, fussing, and feuding with the A. F. of L. ensued, but with the coming of war rivalry diminished and the policies of the two movements drew closer. Preliminary negotiations for unity began in 1953 with a noraiding agreement, and in 1955 the merger was accomplished. This study is by the former general counsel of the United Steelworkers, now special counsel of AFL-CIO. He begins with a succinct historical review of these developments. He then analyzes the new joint constitution and its implications, devoting chapters to the labor monopoly question, communism and corruption, racial discrimination, public policy, and the future role of labor. Appendixes give texts of the new constitution, the merger agreement, and other documents.

6050. Gompers, Samuel. Seventy years of life and labor; an autobiography. New York, Dutton, 1925. 2 v. ports. $25-5990$ HD8073.G6A3 
Appendix: His last year, an epilogue, by Florence Calvert Thorne: v. 2, p. [527]-557.

New one-volume ed. r943. 557,629 p. 44-638 HD8073.G6A3 1943

As a small boy in East-side London, Samuel Gompers (1850-1924) heard the tramp of the unemployed silk weavers of his neighborhood, whose jobs had been swept away by new machinery. Their cry, "My wife, my kids want bread and I've no work to do," taught him "the worldwide feeling that has ever bound the oppressed together in a struggle against those who hold control over the lives and opportunities of those who work for wages. That feeling became a subconscious guiding impulse that in later years developed into the dominating influence in shaping my life." Much of the history of the A. F. of L. is revealed in this autobiography of the great labor pioneer. As one of its creators and its president, save for the one year of Socialist domination, 1895 , from 1886 to his death in 1924 , he was chief architect of its growth, and its character and policies were largely determined by his convictions. The posthumously published work included a biographical appendix by Miss Thorne, who had been his assistant in the research needed to check and supplement his recollections. In 1957 Miss Thorne published Samuel Gompers, American Statesman (New York, Philosophical Library. r75 p.), principally concerned with setting forth, in large part in his own words, Gompers' philosophy of the labor movement.

6051. Lombardi, John. Labor's voice in the Cabinet; a history of the Department of La'Jor, from its origin to I92I. New York, Columbia University/ Press, 1942. 370 p. (Columbia University. Faculty of Political Science. Studies in history, economics and public law, no. 496)

$$
\text { 43-46r } \mathrm{HD}_{4} 835 . \mathrm{U}_{4} \mathrm{~L} 6 \mathrm{I} 942
$$

Bibliography: p. 359-366. $\mathrm{H}_{3}$ r. $\mathrm{C}_{7}$, no. 496

In his first 70 pages Dr. Lombardi summarizes the precursors and origins of the Department of Labor. The new Department charged with representing the interests of the workers was established in 1913, crowning over a half-century's efforts on the part of organized labor. William B. Wilson of Pennsylvania, a former labor leader and Congressman, was named the first Secretary of Labor. The Department absorbed the Bureau of Labor Statistics, created in 1884 in the Department of the Interior, and from the former Department of Commerce and Labor (1903) took over the Bureaus of Immigration and Naturalization, now consolidated, and the $\mathrm{Di}$ vision of Information of the Immigration branch, now reorganized as the U. S. Employment Service. Finally it took from the same Department the Chil- dren's Bureau, which had been set up, after a hard legislative battle, only the year before. Dr. Lombardi gives fuller treatment to his chapters on the organization of the Department, and to the succeeding part on "War Activities." In 1917 the Department was put on a war footing, and the Secretary of Labor appointed War Labor Administrator in charge of an independent war agency. After the armistice came the "return to normalcy," which the author calls "Reaction." His study ends in I92I with the retirement of Secretary Wilson, whose final report to the President spoke of the workers' dream fulfilled.

6052. Lorwin, Lewis L. The American Federation of Labor; history, policies, and prospects, by Lewis L. Lorwin, with the assistance of Jean Atherton Flexner. Washington, Brookings Institution, 1933. xix, 573 p. (The Institute of Economics of the Brookings Institution. Publication no. 50) 33-16879 HD8055.A5L6

"References for further reading": p. 548-555.

The late Dr. Lorwin was an internationally known expert on labor economics, who served as advisor to the International Labor Office as well as to the American Government in the 1930's and '40's. His standard history of the evolution of the A. F. of L. was written in the dark days of unemployment just before the passage of the National Industrial Recovery Act, while the author was on the staff of the Brookings Institution. He views the A. F. of L. as "shaping and molding many human relations which are the very essence of our individual and social life." The first four parts are chronological: "Foundations, 1864-98" (the Federation was not organized until 1886 , but Dr. Lorwin carried his account of its precursors back to an abortive International Industrial Assembly of North America projected in 1864); "National Expansion, 18991914"; "World War and Industrial Democracy, I914-24"; and "Prosperity and Depression, 192533." The last part is an analysis of policies, problems, and prospects at the outset of the New Deal. The appendixes include groups of tabulated statistics from 1850 to 1932 and a summary of trade union organization and status in the various industries.

6053. Millis, Harry A., and Emily Clark Brown. From the Wagner Act to Taft-Hartley; a study of national labor policy and labor relations. [Chicago] University of Chicago Press, 1950. $723 \mathrm{p}$.

Bibliography: p. 679-687.

50-7091 $\mathrm{HD}_{7} 8_{34} \cdot \mathrm{M}_{55}$

This study of labor legislation and government policy is in three parts and an epilogue. First there is a careful analysis of the Wagner Act and 
of 12 years' experience of collective bargaining under its provisions. This section was written entirely by Dr. Brown, who had begun the study while working as an analyst for the National Labor Relations Board in 1942-43. Part 2 tells "How the Taft-Hartley Act Came About," and part 3 analyzes critically the Labor-Management Relations Act of 1947, to give it its formal title. These two parts were planned and in part written by Dr. Millis, who retired as Chairman of NLRB in 1945, but died in 1948 before the text was completed. His rich experience in the administration of the Wagner Act and as arbitrator in many industrial disputes formed part of the source material for the book. The epilogue, "What Industrial Relations Road for the United States?" had been drafted as his last chapter by Dr. Millis and was made up without expansion from his notes. He speaks of the Wagner Act as the Magna Carta of American Labor. He sees in collective bargaining the hope not only for better wages, hours, and working conditions, but for increased stability and regular progress in democratic society.

6054. Powderly, Terence V. The path I trod; the autobiography of Terence V. Powderly, edited by Harry J. Carman, Henry David, and Paul N. Guthrie. New York, Columbia University Press, 1940. xiv, 460 p. illus. (Columbia studies in American culture, no. 6)

40-9071 $\mathrm{HD} 8 \mathrm{o}_{73} \cdot \mathrm{P}_{69} \mathrm{~A}_{3}$

An outstanding figure of American labor in the I880's and Grand Master Workman of the order of the Knights of Labor, Powderly (1849-1924) experienced (say his editors) "fame, notoriety, adoration, and detestation" unequalled by any other labor leader of the period. The order, founded in 1869 as a secret society, was the first attempt at a national union of workers in general, not organized by trades. Powderly worked in a Scranton, Pa., locomotive yard, was fired for his activities in the Machinists' and Blacksmiths' Union after the panic of 1873 , and joined the Knights of Labor in 1874 . He was active in politics as well as in union affairs, and was mayor of Scranton from 1878 to 1884 . As leader of the Knights from 1883 to 1893 he followed a conciliatory policy in labor disputes, and resigned when the extremists, who had come increasingly into the order during the labor troubles of the late I880's, gained control of the executive board. He had become a lawyer, and his campaign work for McKinley led to his appointment as CommissionerGeneral of Immigration in 1897. With only one 4-year break, he held a succession of Federal offices concerned with immigration or labor until the illness that preceded his death. The Path I Trod was written in his later years, and is concerned almost entirely with the Knights of Labor experience. The standard history of the Knights of Labor for three decades has been Norman J. Ware's The Labor Movement in the United States, 1860-1895; a Study in Democracy (New York, Appleton, r929. 409 p.).

6055. Purcell, Theodore V. The worker speaks his mind on company and union. Cambridge, Harvard University Press, 1953. xix, 344 p. illus. (Wertheim Fellowship publications)

53-9040 HD9419.S72P8

A unique study of the human problems of industry as revealed in interviews with workers at the Chicago stockyards plant of Swift \& Company. This ultramechanized plant for mass production is the center of an important local union of the CIO United Packinghouse Workers; its working community comprises 6,00o men and women, Negroes and whites, native and foreign-born. The author, a Jesuit priest, shared the life of the community for a year and a half, and by arrangement with both the UPWA and the Swift Company management interviewed a carefully selected sample of 300 production workers. His questions centered on the allegiance felt toward the two organizations to which they belonged, the company plant and the local union, and the answers showed that nearly everyone was pulled in both directions. Organized along vertical lines in the UPWA, the local had been dominated for a time from the outside by the Communist Party, but in less than four years the members had won back control for themselves. Father Purcell's questions brought out the thoughts and feelings of workers about their work, hopes, fears, ambitions, satisfactions, and needs, and the part played by company and union in all these. The responses are extensively quoted, and have usually been found more interesting than the conclusions drawn. Another recent work of interest for human relations in industry, also based on interviews, is by Charles R. Walker and Robert $H$. Guest: The Man on the Assembly Line (Cambridge, Harvard University Press, 1952. 180 p.). The authors were attached to the Institute of Human Relations of Yale University, and their research entailed talks with 180 workers on an automobile assembly line. The talks were conducted in the men's homes, with the aim to bring out their attitudes and opinions about their jobs, their relations to fellow workers and supervisors, their working conditions, pay, promotions, and relations to the union. The focus of interest was the effect of assembly-line work, paced and repetitive, on the satisfactions derived from labor. 
6056. Smith, Abbot Emerson. Colonists in bondage; white servitude and convict labor in America, 1607-1776. Chapel Hill, Published for the Institute of Early American History and Culture at Williamsburg, Va., by the University of North Carolina Press, 1947. $435 \mathrm{P}$.

"Bibliographical note": p. 397-417.

$$
4^{8-5154} \quad \mathrm{HD}_{4} 875 . \mathrm{U}_{5} \mathrm{~S}_{5}
$$

6057. Morris, Richard B. Government and labor in early America. New York, Columbia University Press, r946. xvi, 557 p.

A 46-961 HD8068.M65

Mr. Smith's account of white indentured servants, redemptioners, political prisoners, and convicts in the American colonies is constructed from contemporary records which he studied at length in libraries and archives of the British Isles, the United States, and the West Indies. From the interesting evidence assembled he concludes that more than half, and perhaps two-thirds, of all persons who came to the colonies south of New England were originally servants; that the notorious "spirits" who lured emigrants away from England and Ireland by deceits ranging from lies to kidnapping were winked at by the merchant-traders and the law; that the emigrants included a large proportion of scoundrels for whom the colonies were the last refuge; that, though the servants were often badly treated, there were many reasonable laws for their protection. Whereas modern writers have magnified the virtues of the indentured servants, all contemporaries denounced them as practically worthless. Of the servants, hardly one in ten, the author estimates, established himself as a solid and useful citizen after his term of service ended. "The fundamental human problem in colonization was simply that of adaptation, and the white servants did not come from the most adaptable levels of society." The redemptioners, who often brought families, were more responsible. The laws relating to bond labor are also set forth in the second part of Government and Labor in Early America. The longer first part, after a general glance at the labor population and labor conditions before and during the Revolution, is concerned with free labor. The relationship between government and the artisan and laboring classes is examined as to the regulation of wages; concerted action, political or otherwise, among workers; terms and conditions of employment; and laws regarding maritime labor and the military service. Most of the book deals with the Colonial period, but one chapter is given to the regulation of wages by the States and Congress during the Revolution. The action of politically minded combinations of mechanics and laborers, masters and journeymenfor instance, the merchant-led Sons of Liberty-during and immediately after the Revolution is discussed, and the chapter on military service includes a section on artificers and laborers in the Continental and British armies.

6058. Updegraff, Clarence M., and Whitley P. McCoy. Arbitration of labor disputes. New York, Commerce Clearing House, I946. 29I p. 46-4335 $\mathrm{HD}_{5504 . \mathrm{A}_{3} \mathrm{U} 6}$

In this useful book the authors had the double purpose of providing lawyers with a reference work on the law of arbitration as applied to labor disputes, and of offering a practical guide for the layman who might be called on to arbitrate. They oblig. ingly point out in the foreword the chapters which will be useful for the general reader, and the heavier chapters to be read by the lawyers, with which they group most of the appendixes containing specimen legal forms and a table of cases. The more easily understood chapters include a general introduction discussing the historic background, scope, and types (whether voluntary or compulsory) of arbitration, and the advantages of arbitration or conciliation over litigation in various types of labor controversies; an examination of the selection of arbitrators, with regard to their qualifications, jurisdiction, and compensation; patterns of agreements to arbitrate and of submissions; standard procedure in hearings; and types of cases commonly arbitrated. 


\section{XXIX}

\section{Constitution and Government}

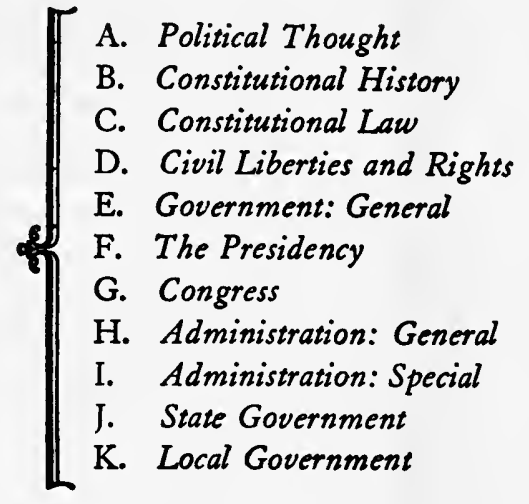

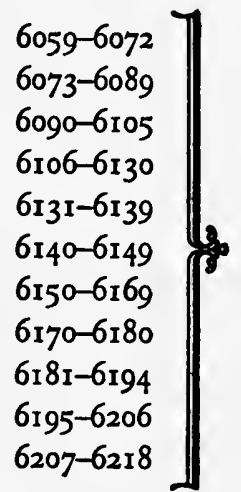

7 HIS and the following two chapters aim to offer a representative sample of the litera1 ture dealing with the political institutions and practices of the United States. The judiciary, the third semi-independent branch of the government of the United States and of the state governments, and the laws which it interprets and applies, are put off to Chapter XXX. However, most of the general treatises on American government in Section $\mathrm{E}$ below, and sorne of the general works on state government in Section $\mathrm{J}$, have sections on the national or state judiciaries. The personnel and policies of American government are determined principally by the process we call politics, which depends upon elections held according to fixed rules at regular intervals, and is dominated by political parties organized for the purpose of winning the elections. These and related matters are reserved for Chapter XXXI, but again the general works of Section E below have usually a section concerned with what it is fashionable to call the dynamics of government.

The present chapter is concerned with the literature of American government in general, on the national, state, and local levels. It is also concerned with the political thought which has accompanied our practical development, with the constitutions upon which our national and state governments are based, and with the executive and legislative branches of the Federal Government. Historical works in these sections usually begin no earlier than the Federal Convention of 1787 , but some go back to 1775 , and some, especially in Section A on politi-

cal thought, to the 17th century. For the most part, however, works on American governments during the Colonial and Revolutionary periods will be found in Sections D and E of Chapter VIII on General History: We may particularly note, from the first, numbers 3182, 3192, 3195, 3220, and 3221, and from the second, numbers $3242,3245,3253$, 3256 , and 3259 .

Section A on political thought represents a subject which was very little studied before 1920, but which has proved increasingly rewarding as it has been more intensively cultivated. The literature has now grown to a point where can be included several examples of general surveys, books of readings, period histories, and treatments of particular topics and tendencies. Constitutional history, the subject of Section B, was of far earlier cultivation, although most of the earlier specimens seem today excessively abstract and formal. It derives its peculiar character from the fact that, be- 
ginning in 1776 , state and nation committed their constitutional rules to paper for all to read, and made alterations in them more difficult and more solemn than an ordinary act of the legislature. This did not, however, eliminate the necessity for application and interpretation, in which the last word is spoken by the courts and particularly by the Supreme Court of the United States. Thus has developed the elaborate field of constitutional law, the subject of Section C; in it, however, many landmarks of long standing have been swept away by developments since the famous Supreme Court crisis of 1937. Works on particular clauses of the Constitution, however historical in approach, have been entered here rather than in Section B. Most of the civil liberties and rights enjoyed by Americans are based upon the particular wordings of their constitutions, and are therefore made the subject of Section D. Most of the works there entered have arisen out of the conflict between traditional rights and new security measures since the end of the last war, and there has seemed to be little point in trying to minimize their inevitably controversial tone. The general works on American government in Section $\mathrm{E}$ will be found to be mostly designed for college courses, and this points to an undesirable but undeniable situation: there are comparatively few books on our government designed for the general reader, and even fewer good ones. Most of the works on the Presidency in Section F emphasize the increasingly crucial nature of the office, and the well-nigh impossible demands it makes upon the man who has to fill it. The books in Section G on the Congress are remarkably varied in character, but they do not begin to exhaust its aspects, historical or contemporary. Sections $\mathrm{G}$ and $\mathrm{H}$ present another major study of our day which hardly predates the 1920's: the systematic study of public administration, both in its general principles and its Federal manifestations. The literature is already copious, and can only be sampled here; but is doubtless only a fraction of what it is destined to become. Concerning the works on State and local governments in the last two sections, we shall say only that we have had to rely on too large a proportion of titles published before America's entry into World War II. Since 194 I the study of grassroots government has been overshadowed by national and international affairs.

\section{A. Political Thought}

6059. Carpenter, Jesse T. The South as a conscious minority, $1789-1861$; a study in political thought. New York, New York University Press, I930. 315 p. 30-30930 F213.C29 "A selection of materials consulted": p. [26I]297.

This Harvard dissertation studies the political thinking of the ante-bellum South which, the author believes, consciously sought protection within the Union from the political power of the Northern majority. Dr. Carpenter conceives of his subject as democracy's greatest and most challenging problem-the relation of numerical majority rule to effective minority protection. He takes the position that the Southern States, united by economic and social bonds, considered themselves a distinct nationality, a separate and different people. He regards the South as having borne an excessive portion of the burdens of the Federal government, while the North was receiving a disproportionate share of the benefits, and as evolving in self-protection a political philosophy of effective minority defense in government. He finds that four major sources of minority protection were in turn relied upon: the principle of local self-government, advanced and defended from the establishment of the
Federal government in 1789 to the adoption of the Missouri Compromise in 1820; the principle of the "concurrent voice," relied upon chiefly during the I820's I830's, and I840's; the principle of constitutional guarantees, depended upon from the admission of California in 1850 to the election of Abraham Lincoln in 1860; and, finally, the principle of Southern independence, resorted to after Lincoln's election.

6o6o. Coker, Francis W., ed. Democracy, liberty, and property; readings in the American political tradition. New York, Macmillan, 1942. $\mathrm{xv}, 88 \mathrm{I}$ p. 42-14710 JKII I942a

The purpose of this collection is to indicate the main contours of the American political tradition by means of excerpts from a variety of sources-essays, addresses, public documents, revolutionary pronouncements, and formal treatises. The selections have been chosen to represent the classic American discussions concerning the problem of locating political control, the lines to be drawn between governmental authority and individual liberty, the nature and limits of property rights, and the problem of political change. The time span covered is more than 300 years (1630-1941). Professor Coker points 
out that the major steps toward a liberal democracy were not taken until after the close of the Colonial period. The principal trend has been toward a more general acceptance of the ideal values of democratic government-freedom of opinion, equality before the courts, and freedom of economic enterprise. The editor notes divergences of opinion about these ideals, as well as some downright repudiations of them.

6061. Ekirch, Arthur A. The decline of American liberalism. New York, Longmans, Green, 1955. 401 p. 55-II447 Ei83.E4

A history of American liberalism which identifies it with the classical philosophical values of the I8thcentury Enlightenment, and especially with individual liberty and decentralized government. Professor Ekirch equates the decline of these concepts with the trend, since the American Revolution, toward ever greater political, economic, and social centralization and concentration of control. $\mathrm{He}$ views the rise and fall of the liberal tradition in the United States as a succession of crises and an overall decline. The rising Colonial and Revolutionary liberalism was tempered by a conservative reaction after the war. Exemplified partly by Jeffersonian and Jacksonian democrary, a reviving liberalism was smothered by the Civil War and reconstruction. Although the author finds evidence of a liberal recovery early in the 2oth century, he consider progressivism in the United States to have been delusive, the reaction after World War I disastrous, and the liberal retreat since World War II nothing less than a rout. He offers no smallest comfort to liberals in this somber book; he sees, rather, the further decline of liberalism "clearly outlined against the future's darkening horizon," and the end of an era of individual and social freedom. A less rigid definition of liberalism, permitting a more hopeful view of the future, could be conceived.

\section{Grimes, Alan P. American political thought. New York, Holt, 1955. 500 p. $55-6047$ JA84. U5 $\mathrm{G}_{7}$}

A history which sets forth the thesis that, in the main, American political thought draws upon ideas that are neither American in origin nor even explicitly political in concept, and to a great extent consists of articulations and modifications by Americans of European political thought. Thus Puritan political thinking derived mainly from Calvinism. American thought of the Revolutionary period stemmed primarily from John Locke. In the author's opinion, late Igth-century liberalism was an offshoot of the theories of John Stuart Mill and the classical economists. Social Darwinism obviously came from England and, for a time, conditioned political thinking here. More recently, the thought of John Maynard Keynes has inspired American economic and political theory and practices. As Mr. Grimes points out, however, American political thought has always employed prevailing theories relevant and applicable to American conditions. Jefferson, for example, used Locke but in respect to a particular situation which imparted to Jeffersonian thinking a quality of its own. Similarly, John Adams reinterpreted Blackstone in the light of his own views of the past and of the American environment. Where American political thinking has been most original, as in the controversies over slavery and the nature of the Union, it has still been relevant to situations peculiar to America.

6063. Hartz, Louis. The liberal tradition in America; an interpretation of American political thought since the Revolution. New York, Harcourt, Brace, I955. 329 p.

$55-5242 \quad \mathrm{E}_{175} \cdot 9 \cdot \mathrm{H}_{37}$

A learned if somewhat impressionistic interpretation of the American world conceived as "a liberal society, lacking feudalism and therefore socialism and governed by an irrational Lockianism." That society, in the author's view, has been a triumph for the liberal idea, an ideological victory helped forward by the magnificent material setting of the New World, in which the laborer has not felt tied to his situation for life. America, "born free," did not have a feudal structure to destroy, and so developed not a self-conscious proletariat but a victorious middle class. In Dr. Hartz's estimation, this circumstance shattered would-be elites such as the Virginia aristocrats of 1785 , the Federalist party, and the reactionaries of the Old South. The Whigs of $184^{\circ}$ transformed the egalitarian thunder of the Democrats, retaining Hamilton's grandiose capitalist dream but combining with it the Jeffersonian concept of equal opportunity. Thus arose a dynamic and competitive social outlook which united the two great traditions of the American liberal community. Even the capitalistic collapse of 1929-33 gave rise, not to a new birth of Marxism, but to a movement within the liberal framework, "which sought to extend the sphere of the State and at the same time retain the basic principles of Locke and Bentham." The uniqueness of the American experience proves, however, a serious disability for the exercise of world leadership, since we cannot understand the necessities of societies which were not born free, and continue to find the alien unduly alarming.

6064. Lewis, Edward R. A history of American political thought from the Civil War to the World War. New York, Macmillan, 1937. 56r p. 37-4045 JA84. $\mathrm{U}_{5} \mathrm{~L}_{4}$ 
"References" at end of each chapter.

"Table of cases": p. 537-54r.

A survey of the period between the end of the Civil War and America's entry into World War I, which aims at "a consideration of the entire stream of our political thought and not merely the classical and somewhat technical subjects of the theory of the state and of sovereignty." Since this stream "did not flow from the contributions of a few great leaders of thought, but has been made by the contributions of many persons and influences," the author has drawn upon the utterances of public men, judicial decisions, and party platforms as well as the writings of reformers and academic theorists. Among the subjects separately treated are the Civil War Amendments, "The Power of the Courts over Legislation" and the development of opposition to this power, "The Nature and Source of Law," "The Theory of Political Action," "Conservatism," "Socialistic Thought," "The Struggle for Political Control," and "The Tests of Political Action." Mr. Lewis expounds his authorities with great objectivity, but from time to time states his own moderate and balanced opinions, carefully labeling them as such. He does not, for example, concede that the Progressive movement was a failure because it did not anticipate the problems of a later age. It was able "to achieve an equilibrium for the moment, to adjust the conflict of interest and desires of the time, so that there [was] no explosion," which is all that any program can do.

6065. Mason, Alpheus Thomas, ed. Free government in the making; readings in American political thought. 2d ed. New York, Oxford University Press, 1956. $896 \mathrm{p}$.

First published in 1949 .

$$
\text { 56-5765 JKII 1956.M } 35
$$

In order to portray the meaning and significance of the American political tradition, this book samples the ideas and words of the men who helped form it. The 22 chapters, arranged in chronological order, are drawn largely from primary sources, beginning with the writings of such 1 th-century English and American political thinkers as John Locke and Roger Williams, continuing with 18 thand 19th-century leaders like Benjamin Franklin, Alexander Hamilton, Thomas Jefferson, Andrew Jackson, and Salmon P. Chase, and concluding with recent utterances by such persons as Franklin D. Roosevelt, Herbert Hoover, and Adlai E. Stevenson. Earlier portions of the book are concerned with the Revolutionary ferment, the establishment of national power, and the extension of the base of popular power. Nineteenth- and twentieth-century individualism, romanticism, liberalism, and dissent are represented by the works of such writers as
Emerson, Whitman, Finley Peter Dunne, Edward Bellamy, Brooks Adams, and Russell Davenport. Introductory essays provide historical background for the readings, which "exhibit our best minds in action-opposing, discussing, deliberating, compromising, deciding, building institutions of government." The volume attempts to display divergent views, the issues at stake, and the weight, form, and flavor of the argument.

6066. Merriam, Charles Edward. American political ideas; studies in the development of American political thought, 1865-1917. New York, Macmillan, 1929. 48I p.

First published in 1920 .

$$
30-31103 \quad J A 84 . U_{5} \mathrm{M}_{5}
$$

A pioneer study of some of the chief tendencies of American political ideas since the Civil War, which shows them in their relation to each other and to the social and economic conditions out of which they grew. The late Professor Merriam of the University of Chicago looked for the theories as best expressed, whether in political institutions, laws, judicial decisions, administration, or customs; in the utterances of statesmen, publicists, or the leaders of causes; or in the formal statements of systematic philosophers. He regarded them all as parts of the progressive adaptation of democratic ideas to new social and economic conditions. Among the most significant tendencies of the period, he concluded, were the steady concentration of political and economic institutions, and the socialization of the state. The nation gained in power and prestige as the states sank toward the position of subordinate agencies, and the devotion to local self-government declined. The federal executive emerged with increased prestige, as the legislative suffered from popular confidence in its integrity or competence, and the courts from lack of confidence in their impartiality. Another feature of the period was the abandonment of the doctrine of weak government as a necessary defense of liberty. But it proved far from easy to make the transition to the later doctrine of strong and aggressive government, and meanwhile a mushrooming capitalism was able to escape effective control. "Democratic faith was stronger than democratic works."

6067. Rossiter, Clinton L. Conservatism in America. New York, Knopf, 1955. 326 p.

Bibliography: p. [309]-[327].

$$
\text { 55-5614 JK } 31 . \mathrm{R}_{5} 8
$$

Professor Rossiter calls his book "a study of the political theory of American conservatism-of the principles that have governed our conservatives in the past, that appear to govern them in the present, and that ought to govern them in the future." $\mathrm{He}$ 
distingiushes temperamental, possessive, and practical conservatism from "the last and highest kind," philosophical conservatism; and his spectrum of political attitudes reads thus: revolutionary radicalism, radicalism, liberalism, conservatism, standpattism, reaction, and revolutionary reaction. His historical survey proceeds from the Puritan oligarchy to the contemporary "middle group" represented by the late Senator Taft and Presidents Eisenhower and Hoover, and the "conservative intellectuals" such as Peter Viereck and Russell Kirk. The book is essentially an attempt to arrive at a formulation of conservatism viable for intelligent and humane Americans conscious of their heritage. Chapter 6 takes "A Hard Look at American Conservatism," and castigates it for its anti-intellectualism, materialism, and indifference to all social values save the freedom of economic enterprise. Chapter 7 asserts the necessity of "A Conservative Theory for American Democracy," which will build "democratic freedom on the solid foundations of co-operative individualism and balanced pluralism." The final chapter, "A Conservative Program for American Democracy," calls for the creation of a new tradition of public service, a sincere defense of civil liberties at every level, and a concerted effort to redeem the three grievous failures of American democracy: in peaceful world leadership, in justice to the Negro, and in the creation of an authentic popular culture.

6068. Rossiter, Clinton L. Seedtime of the Republic; the origin of the American tradition of political liberty. New York, Harcourt, Brace, I953. xiv, $55^{8}$ p. $53-5647 \quad \mathrm{JK}_{3}$ I.R6

"This book is a study of the political ideas that sustained the rise of liberty in Colonial and Revolutionary America." The leaders of the Revolution, Dr. Rossiter maintains, held, not a doctrine hastily improvised to justify resistance, but rather a noble philosophy that was the product of generations of colonial experience. Part I describes the total environment-government. religion, economy, social structure, and intellectual life-of the thirteen Colonies as one favorable to the rise of liberty, and the "factors of freedom" most influential in creating such an environment. Part 2, the core of the book, presents the lives and philosophies of six representative political thinkers of the Colonial period: Thomas Hooker, Roger Williams, John Wise, Jonathan Mayhew, Richard Bland, and Benjamin Franklin. Part 3 analyzes the political thinking of the pre-Revolutionary decade on the rights of man and the pattern of government, which produced no masterwork but was remarkably consistent. In conclusion, the author sums up the guiding faith of the Revolutionists in II major tenets. "The political theory of the American Revolution-a theory of ethical, ordered liberty-remains the political tradition of the American people."

6069. Spitz, David. Patterns of anti-democratic thought; an analysis and a criticism, with special reference to the American political mind in recent times. New York, Macmillan, 1949. 304 p. 49-8944 JC 48 r.S65

This Columbia University dissertation is an inquiry into the nature and validity of the arguments leveled against democracy. It posits that the democratic state contains at least two central ingredients which set it apart from all other forms of the state: the free play of conflicting opinions and the constitutional responsibility of the rulers to the ruled. Majority rule, moreover, always fluctuating, temporary, and never fixed, is a necessity of the democratic state, together with free and unhampered minorities. Conversely, the doctrines of antidemocratic thought are viewed here as simply those ideas which deny the possibility or challenge the desirability of democracy. Typical, in recent American thought, of the former are James Burnham's theory of the ruling class as organizational necessity and Lawrence Dennis' theory of the ruling class as a conspiracy of power. Among the doctrines which reject the democratic state as undesirable in its operations and consequences, Dr. Spitz places Ralph Adams Cram's theory of the irrationality and incompetence of the average man, Madison Grant's theory of Nordic racial aristocracy, Edward M. Sait's concept of biological aristocracy, George Santayana's theory of natural aristocracy, and the restrictive authoritarianism of Irving Babbitt. The author refutes each in detail and finds democracy, with its conjunction of order and freedom, alone wholly commendable.

6o7o. Wilson, Francis Graham. The American political mind; a textbook in political theory. New York, McGraw-Hill, 1949. 506 p. (McGraw-Hill series in political science)

$$
\text { 49-8235. JA84. U5 } \mathrm{W}_{5} \text {. }
$$

A history of American political ideas from the first English settlements to the atomic era, which emphasizes their close dependence upon the general current of national history. What is fundamental and persistent "in this evolving, fragmentary, conflicting, and changing body of political philosophy that makes up the American mind," and what is superficial and ephemeral, depends upon the interpreter's conception of destiny, his sense of "a predominance in history." Professor Wilson from time to time emphasizes that the conservative case has been as important in the making of the American tradition as its opposite. American liberalism, he believes, took form as a conflict between the 
Southern agrarians and the Hamiltonian capitalists, and its maturity "was the clarification of this conflict." Without the debate over slavery, "it is hardly possible that the sense of national unity, of the mission of American democracy to the rest of the world, could have been shaped." A chapter on "The Emergence of Modern Conservatism" views it as the counterpart of the industrial revolution which followed the Civil War and created a "new economic aristocracy." Two final chapters, on World War II and its aftermath, indicate that all shades of American opinion are committed to the maintenance of democracy, and that "part of the old and traditional will inevitably remain in the changing democracy of tomorrow." Each chapter is followed by a very useful "Selected Bibliography."

6071. Wiltse, Charles Maurice. The Jeffersonian tradition in American democracy. Chapel Hill, University of North Carolina Press, 1935. $273 \mathrm{p}$. 36-27502 JCi76.J45W48

A study of the political ideas of Thomas Jefferson which assumes that they form a fairly complete and coherent system. Dr. Wiltse has attempted a logical reconstruction of Jefferson's "most mature position" about the fundamental problems of government, basing it upon the mass of Jefferson's writings and public utterances. In the author's opinion, although the Jeffersonian state has passed into history, Jefferson's influence has been one of the most enduring in our national life because, as leader of a school of political thought, he stood for liberalism, for humanitarianism, for freedom, for the welfare of "abstract man," all of which concepts have been transmitted through him into the democratic tradition. Dr. Wiltse views him as preeminently a practical thinker, whose theory of the state was centered in practical solutions to concrete problems, yet who nevertheless drew upon a conscious intellectual heritage. Jefferson's political philosophy is seen to rest upon two basic ethical assumptions-that the end of life is individual happiness and that the purpose of the state is to secure and increase such happiness. It has therefore left to American democracy a dual tradition, on the one hand of democratic individualism, as exemplified by John Taylor, Calhoun, Jackson, and Lincoln. On the other hand, it has given rise to a tradition of social democracy, exemplified by Henry George, the Populists, the Progressives, and the New Deal. "The times may stress now one and now the other, but in historical perspective the two have advanced and will advance together."

6072. Wright, Benjamin Fletcher. American interpretations of natural law; a study in the history of political thought. Cambridge, Harvard University Press, 1931. 360 p. (Harvard political studies) 3I-30867 JA84.U5W67

Professor Wright analyzes briefly the various meanings attached to the concept of natural law, evaluates its place in political theory, discusses the writings of certain of the makers of American constitutional law, and surveys illustrative judicial opinions. He traces the few r7th-century American interpretations of natural law directly to the theologicopolitical conceptions of medieval times and of the Reformation. In the century preceding the Civil War, when political speculation was most active in America, the idea of natural law was used in defense of the most diverse causes, and played a part of some importance in most of the controversial and systematic political theories; it was of scarcely less importance in the development of written constitutions. The individual rights phase of natural law received its classic expression in the Declaration of Independence. In the slavery controversy, natural law was the principal theoretical weapon of both sides-the antislavery forces discoursing of the rights of men, the proslavery of the natural laws which ordain inequality. Both a speculative concept and a controversial weapon, the idea of natural law was generally discarded after the Civil War even when not explicitly repudiated.

\section{B. Constitutional History}

6073. Boyd, Julian P. The Declaration of Independence; the evolution of the text as shown in facsimiles of various drafts by its author, Thomas Jefferson. Princeton, Princeton University Press, 1945. $46 \mathrm{p}$. A $45-1832$ JK 128. B66 Revised edition of the author's contribution to a brochure issued in 1943 by the Library of Congress as a part of the bicentennial celebration of the birth of Thomas Jefferson.
A 46-page textual analysis of the various drafts of the Declaration of Independence showing the genesis and evolution of this state paper, together with 32 pages of facsimiles. These latter, not altogether legible, reproduce all of the known drafts of the Declaration in Jefferson's hand, as well as other documents closely related to the official printed version, which appears here as it was first inserted in the "Rough Journal" of Congress. As Dr. Boyd points 
out, Jefferson was almost sole author in the sense of phraseology, the contributor of clear and felicitous prose, but this "great apologia of the American Revolution" was formed from many sources, and was, indeed, as Jefferson himself termed it, "an expression of the American mind." What Dr. Boyd finds new in the Declaration is that "here, for the first time, a political society formally declared the purpose of the state, enumerated some of man's natural rights, and affirmed the right of revolution." As prepared by Jefferson and adopted by Congress, the Declaration was a philosophical justification of independence; its author acted as his country's advocate before the tribunal of world opinion.

6074. Dumbauld, Edward. The Declaration of Independence and what it means today. Norman, University of Oklahoma Press, I950. 194 p. illus.

Bibliography: p. 171-189. 50-969I JKI28.D8

An analysis of the Declaration of Independence, passage by passage, providing a commentary upon the political philosophy propounded in it and upon the historical background of ideas and events against which it was written. An introduction discusses briefly the drafting, revising, and adoption of the Declaration, as well as the three official texts of the document. The commentary supplies precedents for the theoretical portions of the Declaration; for instance, it traces the famous phrase, "all Men are created equal," to Euripides, Ulpian, Milton, Locke, Pufendorf, and Vattel, and notes that "more disposed to suffer" is actually a verbal echo of Locke's Treatises of Government. It is particularly useful in explaining the 28 charges against King George III which form so large a part of the document and are the least self-explanatory to modern readers. Thus the charge, "He has made Judges dependent on his Will alone, for the Tenure of their Offices," is illuminated by the attempts of six colonies during the 1750's and 1760's to give their judges tenure during good behavior, all defeated by the royal disallowance or other prerogative acts. Differing from critics of the Declaration such as Rufus Choate, who in 1856 spoke of its "glittering and sounding generalities," and George Santayana, who in 1945 called it "a salad of illusions," Dr. Dumbauld emphasizes the permanent value of its philosophy of government as a man-made device for promoting human welfare-the servant, not the master, of the people.

6075. The Federalist. The Federalist; a commentary on the Constitution of the United States, being a collection of essays written in support of the Constitution agreed upon September 17, 1787, by the Federal Convention, from the original text of Alexander Hamilton, John Jay [and] James
Madison, with an introd. by Edward Mead Earle. New York, Modern Library, I94I. xlv, 618 p. (The Modern Library of the world's best books [139]) 4I-5I534 JKI54 I94I

Written to advocate the adoption of the Constitution, these 85 newspaper essays, which first appeared in book form in $\mathrm{r}_{788}$, are generally considered the most important American contribution to the literature of political science. Together, they form an exposition of the ideas dominant in the political philosophy of the 18 th-century Whigs on the means of securing both civil liberty and efficient government, on the principles of federal government, and on the balance of power in such a government among the executive, legislative, and judicial branches, and between the Federal and State governments. This series of essays, setting forth the political needs of the country as well as the principles of the new Constitution, was planned by Hamilton in an effort to persuade the citizenry of New York, a crucial but doubtful State in the matter of ratification. For this purpose he enlisted the aid of Madison and Jay. Hamilton interpreted the needs of the country, the powers of the executive, and the functions of the judiciary. Madison explained the legislative branch of the proposed government, and Jay the conduct of foreign relations. The authorship of a number of the essays is still uncertain, as between Hamilton and Madison. In the forefront of those concerned with the initiation, formulation, and adoption of the Constitution, both were superbly endowed to elucidate it.

6o76. Holcombe, Arthur N. Our more perfect union; from eighteenth-century principles to twentieth-century practice. Cambridge, Harvard University Press, 1950. 460 p. $50-937 \mathrm{I} \mathrm{JK}_{31} \mathrm{I} . \mathrm{H}_{7}$

An intensive historical analysis of the American experiment in self-government. Professor Holcombe first examines the principles of the framers of the Constitution, and then interprets and evaluates those principles in terms of contemporary politics and the conditions of the modern world. He affirms his belief that the postulates of 1787 , as they have come to be applied in American politics, are sound, and are valid not only for Americans, but for peoples everywhere who feel the need for better political order in the world. In the author's opinion, however, the Constitution is still an unfinished experiment, the principles of which require further extension if the United States is to maintain a satisfactory position in international affairs. The creators of the American republic, he concludes, were aware of the proneness of the holders of power to its abuse. To protect the governed, the framers of the Constitution adopted a system of checks and 
balances that has worked remarkably well. Two instrumentalities, the separation of powers among the three coordinate branches of government, and the division of power between Federal and State agencies, they incorporated in the Constitution. The third, unforeseen by the founders, the normal operation of a bipartisan system in politics, has made for moderation.

6077. Kelly, Alfred H., and Winfred A. Harbison. The American Constitution, its origins and development. Rev. ed. New York, Norton, 1955. 1037 p. 55-1422 JK 31.K4 1955

"Selected readings": p. 949-978.

A massive constitutional history designed for the "average undergraduate student or general reader," orginally published in 1948 . The narrative begins with the period $1607-1789$, covering the whole Colonial era, the Revolution, and achievement of national unity under the Articles of Confederation and the Constitution, when the principal institutions and ideas of the American constitutional system were developed. It continues through the second period, 1789-1865, when the Federal government was established under the Constitution, and the Confederacy's attempt to destroy the Union was defeated. Finally, the authors survey the third great epoch in American history, the years from 1865 to the present. Most of its constitutional problems have arisen, they indicate, from successive attempts to adjust the constitutional system to the requirements of modern urban industrial society. Professors Kelly and Harbison find one great theme running through all three centuries of American history: the government of laws, not men.

6078. McLaughlin, Andrew C. A constitutional history of the United States. New York, Appleton-Century, 1936. 833 p.

\section{First published in 1935 .}

$$
\text { 37-3529 JK } 31 . \mathrm{M}_{25} \text { г936a }
$$

A history of the development of American constitutional principles beginning in 1754 with the Albany Plan of union, which marked the beginning of an effort to single out what should be turned over to a central government or agency of central administration. In the discussion of the years I754-87, the purpose has been to dwell upon the emergence of the constitutional system, but some attention has been paid to the transformation of the Colonies into self-governing commonwealths and to the principles upon which State constitutions were established. Professor McLaughlin attributes two major creative achievements to this Revolutionary era: the establishment of limited government and the founding of the Federal state.
Yet, he finds, the nature of the union, the position of the States, and the authority of the Supreme Court were still matters of dispute in the 1820 's. By the I 830 's, however, the Court under the leadership of John Marshall had attained a position of judicial authority, and Jackson as national leader of the people had established a "new presidency." The controversy over the constitutional structure of the union was, of course, only resolved by civil war. The last subject treated in detail is the interpretation of the I 4 th Amendment; the continuation from 1876 to the 1930's is only a sketch (p. 760-794). American history, the author believes, "is the history of a people entering upon the great adventure of popular government and marching forward with a considerable degree of achievement." Professor McLaughlin (1861-1946), who taught at the University of Chicago from 1906 to 1929 and served for many years as an editor of The American Historical Review, produced other works of distinction in this and related fields. Among them are: Lewis Cass (Boston, Houghton Mifflin, 1891. 363 p. American statesmen [v. 24]); The Courts, the Constitution and Parties (Chicago, University of Chicago Press, 1912. 299 p.); and Steps in the Development of American Democracy (New York, Abingdon Press, I920. 2 Io p.).

6079. McLaughlin, Andrew C. The foundations of American constitutionalism. New York, New York University Press, 1932. I76 p. (New York University. Stokes Foundation. Anson G. Phelps lectureship on early American history)

$$
\text { 33-3303 JK268.M25 }
$$

A collection of six lectures, which aim to trace briefly the historical origins of some of the basic principles of the American constitutional system. Professor McLaughlin has deliberately emphasized here the influence of New England religious and economic practices and doctrines in the background of the Federal Convention of 1787 . These he finds rooted in the creed enunciated by the Puritan Separatists in the late 16 th and early 17 th centuries: the doctrine of individual liberty and the theory and fact of compact and covenant. This creed, he believes, the Pilgrim Fathers not only asserted but, in simple fashion, rendered concrete $\mathrm{He}$ stresses the further fact that the Pilgrims were forced to act cooperatively, and at first entirely as a community, because of their joint-stock arrangement with London merchants. They thus combined business and religion, the church and the corporation, the covenant and the joint-stock agreement. In this duality Professor McLaughlin discovers the "essence of the theory of democracy, as a system of government, and the center of free constitutionalism." 
6080. New York (State) Constitutional Convention Committee. Constitutions of the states and United States. [Albany, J. B. Lyon Co.] 1938. I845 p. (Its [Reports, v. 3])

$$
\text { 38-28224 JK } 3425 \quad 1938 . A_{32}
$$

A compilation of the complete texts of the constitutions of the 48 States and of the United States, prepared under the direction of Charles Poletti, chairman of the New York State Constitutional Convention Committee, for use by members of the New York State Constitutional Convention of 1938. As published here, the constitutions contain all provisions in force on January $\mathrm{r}, 1938$. All clauses of the original documents and all amendments are given in full unless they have been repealed. Editorial insertions are indicated by brackets. In his introduction, Mr. Poletti observes that the wealth of constitutional experience presented in this volume may suggest desirable provisions, but may also indicate the dangers inherent in certain clauses. Particularly, he warns against the inclusion of certain types of detailed provision in the basic law, pointing to the regular amendment and reamendment of such clauses, and the danger of turning what should be a fundamental law into a welter of conflicting and overlapping provisions and of breaking down the distinction between a constitution and statute law. Comparison between the average State constitution and that of the United States, he notes, reveals the superior judgment of those who drafted the basic law of the Nation.

608I. Randall, James G. Constitutional problems under Lincoln. Rev. ed. Urbana, University of Illinois Press, 1951. xxxiii, $596 \mathrm{p}$.

Bibliography: p. $53^{1-563}$.

$$
\text { 5I-1577 JK201.R3 195I }
$$

A study of the constitutional problems which the Civil War thrust upon the Lincoln administration. Professor Randall regards secession as an extraconstitutional matter. To him, the most practical and serious question of $1860-6 \mathrm{I}$ was not the constitutionality of secession but the wisdom and desirability of it. He discusses such problems as the consistency of war powers, both presidential and congressional, with the Constitution, as well as the validity of numerous war measures-the Emancipation Proclamation, the creation of special war courts, the confiscation of property, the creation of special war crimes-and congressional approval of many executive acts which bordered on legislation, notably, of course, Lincoln's suspension of the privilege of habeas corpus. He notes the double nature of the conflict, as both war and rebellion, the existence of the Confederate States as a de facto government with belligerent standing, and, under Lincoln's moderating influence, the reluctance of the Federal govern- ment to prosecute for treason. In Professor Randall's opinion, Lincoln went farther than any other President in assuming executive power independently of Congress; the judiciary played a passive rather than an active part in the emergency; but the Constitution, "while stretched, was not subverted."

6082. Read, Conyers, ed. The Constitution reconsidered. New York, Columbia University Press, 1938. xviii, 424 p. $38-39088$ JK271.R33 A collection of 27 papers read before a meeting of the American Historical Association at Philadel phia in 1937 to mark the sesquicentennial of the United States Constitution. Organized in three groups, the essays consider the background of political, economic, and social ideas which determined the thinking of the Constitutional Convention and found expression in its work; analyze some portions of the Constitution itself; and study its influence both upon American and upon foreign political thought and action. The consensus is that the Constitution has been successfully adjusted to later times, new problems, and fresh currents of opinion; it has provided a framework for living usages, and a flexible pattern for an economic order, a political state, and a nascent culture. The Constitution is seen as a deliberate and rational effort to shape the world of social relations to humane ends by devising a mechanism of government able to guarantee life, liberty, and the pursuit of happiness. Among the writers included are Charles A. Beard, Henry Steele Commager, Robert M. McIver, and Herbert W. Schneider.

6083. Sanders, Jennings B. Evolution of executive departments of the Continental Congress, 1774-1789. Chapel Hill, University of North Carolina Press, r935. $213 \mathrm{p} \quad 35-3939 \quad \mathrm{JK}_{4} 11 . \mathrm{S}_{32}$

Bibliography: p. [193]-203.

A study of how the executive agencies of the Continental Congress developed, how they functioned separately and in cooperation, and how they and the choice of their personnel were affected by congressional politics. Part I deals with the period to $178 \mathrm{I}$, during which Congress gradually abandoned the attempt to exercise executive functions exclusively through its own members. Action by the whole body or by special committee was soon supplanted by a system of standing committees for permanent concerns such as war or treasury administration. But this overburdened the abler members and left legislation to the less gifted. The expedient of boards, partly of members of Congress and partly of nonmembers, or of nonmembers subject to a committee of members, was resorted to, without much improvement. Part 2 describes the general reorganization of $178 \mathrm{I}$ whereby three major departments, 
for finance, war, and foreign affairs, were set up under individual nonmember administrators. When Robert Morris resigned under fire in 1784 he was replaced by a board of three nonmember Treasury commissioners. Chapters concerning the Post Office, 1775-89, and the Secretary of Congress, 1774-89, appear in this part because both were operations headed by individual nonmembers from the beginning. Much of the procedure and personnel of these departments was carried over into the departments set up under the Constitution. Dr. Sanders' book is drier than need be, but indispensable as the only detailed treatment of a very important subject. He had previously described The Presidency of the Continental Congress, 1774-89, 2d printing, rev. (Chicago, 1930. 76 p.); it was chiefly of formal and ceremonial importance and had next to nothing in common with the executive presidency after 1789 , with which it has sometimes been mistakenly linked.

6o84. Swisher, Carl Brent, American constitutional development. 2d ed. Boston, Houghton Mifflin, 1954. I I 45 p.

First published in 1943 .

$$
\text { 54-2606 JK } 31 . \mathrm{S}_{9} \quad 1954
$$

A history which takes the position that the Constitution of the 1950's is much further from the Constitution of the 1870 's than was the latter from the Constitution as originally applied. The author therefore devotes approximately half of this volume to an account of American constitutional development in the 2oth century. He attempts to show not merely the nature and scope of the Constitution during particular periods, but also the causes of changes and the manner in which they were accomplished. The judiciary, Congress, and the executive branch of the Government, the author believes, have all played important parts, both positively and negatively, in these developments. Accordingly, he has made ample use of congressional debate and maneuver, and of Supreme Court decisions, which often mark "the periphery of permitted constitutional expansion." Among the Presidents who played negative parts or who sought to restrain contemporary constitutional expansion he lists Van Buren, Buchanan, Benjamin Harrison, and Coolidge. Jefferson, Jackson, Lincoln, Wilson, and Franklin D. Roosevelt, who enlarged the powers of their office, he regards as "makers of the Constitution" in a very real sense.

6085. Swisher, Carl Brent. The growth of constitutional power in the United States. Chicago, University of Chicago Press, 1946. 26r p. ([Chicago. University. Charles R. Walgreen Foundation for the Study of American Institutions. Lectures]) A $_{46-543} \mathrm{JK}_{34 . S_{93}}$
An examination of the American constitutional system which devotes particular scrutiny to the changes induced by war, depression, and the development of mass-production industrialism. Although Professor Swisher is interested primarily in fairly recent events and in the current status of our constitutional system, he makes some use of early history when conditions and climates of opinion differed greatly from those of the present, and demonstrates the shift in ideology from the theories of Edmund Burke and Adam Smith, Alexander Hamilton and Thomas Jefferson, to those of Herbert Hoover and Wendell Willkie, Henry Wallace and Franklin D. Roosevelt. He believes that the Constitution, besides establishing areas of immunity from government control, embodies the spirit of "rightness"- the judges have always interpreted it not only as requiring right procedure but as incorporating the basic moral principles of the periodand has been kept righteous by the infusion of new concepts of rightness as they have matured in the national community. Professor Swisher considers more sweeping operation of government controls inevitable under mass-production industralism, but remains untroubled about the increasing centralization of power in the Federal government, since he finds a variety of checks still standing as barriers to the misuse of power.

6086. Thorpe, Francis Newton, comp. The Federal and state constitutions, colonial charters, and other organic laws of the states, territories, and colonies now or heretofore forming the United States of America. Compiled and edited under the Act of Congress of June 30, 1906. Washington, Govt. Print. Off., 1909. 7 v. (59th Cong., 2d sess. House. Document 357) 9-3537I JKI8 1909 List of authorities: v. I, p. xv-xxxv.

Save for an initial group of Federal documents and commissions, charters, and plans of union, 14921754 , the materials of this indispensable official compilation are arranged alphabetically by state or territory. Arrangement under the alphabetical headings is chronological. Cetrain acts of Congress and treaties with other nations governing territories acquired by annexation, cession, or conquest are also printed in full. Explanatory footnotes are provided, and an index to the whole appears in volume 7 . Here, as in no other work, is contained the whole American experiment with government limited by fundamental law, and the extraordinary variety of means that have been employed to achieve essentially identical ends.

6087. U.S. Constitutional Convention, 1787. The records of the Federal Convention of 1787 ; 
edited by Max Farrand. Rev. ed. New Haven, Yale University Press, 1937. 4 v.

37-25324 JKI4I 1937a

A collection of all available records-previously unpublished, scattered through various printed volumes, or issued in unsatisfactory form, before the first edition of this work (1911) - of the convention which framed the American Constitution at Philadelphia in 1787 . The editor's primary aim was to establish and to present his material "in the most trustworthy form possible." All records of each day's session are gathered together, affording maximum convenience for their collation. Crossreferences to the more important subjects and an exhaustive general index (v. 4: p. 127-230) take the place of subject headings. A special index ( $v$. 4: p. 107-123) provides, in addition, references enabling one to trace the origin and evolution of every clause adopted. Although the journal of the Convention, kept in the form of minutes by William Jackson, and Madison's notes of the debates are the most important documents published here, other notes and memoranda are included such as those of Robert Yates of New York, Rufus King of Massachusetts, James McHenry of Maryland, William Pierce of Georgic, William Paterson of New Jersey, and Alexander Hamilton. Volumes I and 2 contain the proceedings of the Convention. In volume 3 are printed the texts of supplementary records, the Virginia, Pinckney, New Jersey, and Hamilton Plans, and all significant references to the Convention in the letters and other writings of the 55 delegates, of whatever date. In the 1937 revision the three volumes of the original edition are reprinted with only minor corrections, while the additional volume 4 contains "Further Additions and Corrections" (p. I I-89) and the two indexes, greatly improved over those in the original volume 3. The only considerable source that has turned up since 1937 is the notebook of John Lansing, edited by Joseph Reese Strayer under the title The Delegate from New York (Princeton, Princeton University Press, 1939. I25 p.). It differs little from the well-known notes of Lansing's colleague Robert Yates.

6088. Van Doren, Carl C. The great rehearsal; the story of the making and ratifying of the

Constitution of the United States. New York, Viking Press, 1948. 336 p. illus.

$$
\text { 48-657 JKI46. } \mathrm{V}_{3} \quad \text { I948a }
$$

"Sources and acknowledgments": p. 32I-322.

A history of the framing and ratification of the Constitution of the United States during 1787 and 1788 , based mainly upon the original records of the
Federal Convention in 1787 , and of the State conventions which ratified or rejected the Constitution. Dr. Van Doren has also made expert use of the contemporary press, and of the diaries, letiers, and other memorabilia of the principal figures. His method of letting them speak in their own words, of presenting the argument in action, brings alive the great personalities and the complex issues of a crucial moment in American history, when a league of jealous and sovereign States was boldly converted into the Federal government. Both Washington and Franklin, as well as many lesser men, came to the Convention persuaded that the American experiment in self-government could not survive without major changes in its structure. The decisive step in the Convention was "The Federal Compromise" agreed to on July 3: the stalemate between the large and the small States was broken by the solution, anticipated by Roger Sherman but moved by Franklin, of representing States in the lower house in proportion to their population, and giving them equal votes in the Senate. The title and the preface suggest the analogy between the States of the Confederation in 1787 and the sovereign states of the United Nations in 1948, but it is not pursued in the text.

6089. Warren, Charles. Congress, the Constitution, and the Supreme Court. New rev. and enl. ed. Boston, Little, Brown, 1935. 346 p.

First published in 1925

$$
35-24270 \quad \mathrm{JK}_{3} \mathrm{I} . \mathrm{W}_{3} \quad 1935
$$

A history which deals with the United States Supreme Court in its =elation to acts of Congress, specifically, with the Court's authority to determine when Congress has overstepped the bounds set for it by the Constitution, and to curb attempts by Congress to alter or amend the Constitution. Mr. Warren also presents the views of early Congresses upon the principle of judicial review, a brief description of each case in which the Court had, by 1935, held an act of Congress unconstitutional, and a review of the Court's cases particularly affecting labor, whether or not they were decided on constitutional grounds. Arguing that there had been slight need for changes in these powers of the Court, the author attacks various proposals made to abolish or impair them. The Court, he affirms, in its decisions declaring acts of Congress invalid, has dealt with statutes whose constitutional defects were later remedied by properly drawn legislation or by constitutional amendment, or with cases that involved rights of citizens, States, or other components of the Federal government-rights of extreme importance to maintain, and which would have been abrogated had Congress had the power to set aside the Constitution. 


\section{Constitutional Law}

6ogo. Association of American Law Schools. Selected essays on constitutional law, compiled and edited by a committee of the Association of American Law Schools. Chicago, Foundation Press, 1938. 5 v. in 4. 38-29140 JK268.A75

A collection of approximately 300 papers by more than 170 professors of law, judges, practicing lawyers, and political scientists reprinted from law reviews and other legal periodicals, bar association reports, political science journals, and, in a few instances, from books out of print or not readily accessible. In selecting the essays, the editorial group headed by Douglas B. Maggs, assisted by several hundred scholars and lawyers, considered the needs especially of judges and practicing lawyers, students and teachers in law schools, and students and teachers in political science departments. The articles and notes published here collect and collate decisions, trace the development of doctrine, and examine critically both decisions and doctrines; many project what their authors believed to be tendencies and trends. Material was sought on all Federal constitutional questions litigable in the courts. Constitutional questions not litigable, constitutional questions in the field of international law, and problems of State constitutional law were disregarded. Book I, "The Nature of the Judicial Process in Constitutional Cases," includes historical studies deemed of permanent importance and broad treatments of basic ideas. Book 2, "Limitations of Governmental Power," deals with restrictions held to result from the constitutional guarantees of personal and property rights. Book 3, "The Nation and the States," "weighs the constitutional questions which grow out of the federal nature of our governmental system." Books 4 and 5 examine, respectively, the constitutional aspects of "Administration" and "Taxation." Each book carries its own table of contents, its own table of cases, and a subject index, while Book $I$ has in addition some bibliographical aids. Caveat: Book 5 is in volume 1 ; otherwise book and volume numbers coincide.

6091. Cooley, Thomas M. A treatise on the constitutional limitations which rest upon the legislative power of the states of the American union. 8th ed., with large additions, considerations of amendments, and giving the results of the recent cases, by Walter Carrington. Boston, Little, Brown, 1927. 2 v. (cciii, 1565 p.)

$$
\text { 27-9874 JK241.C77 }
$$

"List of cases cited": p. xxiii-cxcv.

Characterized by lucidity of style and organization, this classic work, first published in 1868 , is still valuable to the student of constitutional problems. Its purpose was to present such an explication of constitutional principles as should serve, together with its references to judicial decisions, legal treatises, and historical events, as a guide to the study of the powers denied to the States under the Constitution. Although the volume was thus based upon authority and precedent, and its stated aim was to demonstrate the law rather than the views of the author, it was not without a philosophy of jurisprudence or of the social order. Admittedly, Judge Cooley of the Michigan Supreme Court wrote in full sympathy with the restraints imposed upon the exercise of the powers of government, and with faith both in the checks and balances of the republican system and in public opinion. His chapters on the protection of personal liberty and property were exceptionally strong and have been highly influential. In the eighth edition, cognizance was taken of the vast industrial and social changes which had occurred since publication of the seventh in 1903, and some new text was added. Reports of important and pertinent cases were brought forward to June $1,1926$.

6092. Corwin, Edward S. The Constitution and what it means today. [12th ed.] Princeton, Princeton University Press, I958. 344 p.

$$
58-34767 \text { Law }
$$

"Table of cases": p. 31 I-337.

This edition of a standard work first published in This edition of a standard work first published in I 920 brings decisions of the Supreme Court, which constitute its principal substance, forward approximately to $195^{8}$. Explanations of currently prevailing doctrine and practice are accompanied by brief summaries of their historical development. Among the important matters considered are judicial review, the commerce clause, the executive power, the war power, national supremacy, and freedom of speech, the press, and religion. The book shows how powerful and pervasive the doctrine of national supremacy has become since the "Constitutional Revolution" of 1937, when the Court returned to Chief Justice Marshall's concepts. The constantly augmented flow of discretionary power to the President in an era of crisis is noted with the comment that "a vacuum is all that Judicial Review 
has to offer in such a situation." Judicial review is, nevertheless, regarded here as taking on increasingly "the character of a species of arbitration between competing social interests rather than of adjudication in the strict sense of the term, namely, the determination of the rights of adverse parties under a settled, statable rule of law." The author offers crisp comments upon the "censorship of quite indefinite scope" exercised by the Court, and upon such recent topics as the desegregation cases, the tactics of the Governor of Arkansas, Presidential disability, and the Vice President's status and duty in this event.

6093. Corwin, Edward S. A constitution of powers in a secular state; three lectures on the William $\mathrm{H}$. White Foundation at the University of Virginia, April 1950, and an additional chapter. Charlottesville, Va., Michie, 1951. 126 p.

$$
5^{\mathrm{I}-62174} \mathrm{JK}_{303 .} \mathrm{C}_{5}
$$

An analysis of the judicial translation of the power requirements of national crisis-two world wars, the Great Depression, and a fundamentally altered outlook upon the purpose of government-into the vocabulary of constitutional law. "In general terms," says Professor Corwin, "our system has lost resiliency and what was once vaunted as a Constitution of Rights, both State and private, has been replaced by a Constitution of Powers. More specifically, the Federal System has shifted base in the direction of a consolidated national power, while within the National Government itself an increased flow of power in the direction of the President has ensued." This consolidation has been registered in our constitutional law, he believes, through the changed attitude of the Supreme Court, which has in recent years asserted canons favorable to a strongly centralized government of indefinite rather than enumerated powers. "Presidential autocracy" has become the dominant element in our constitutional system. As remedies, Professor Corwin suggests basing public policy on the related ideas of consensus, compromise, and moderation, keeping legislation a still available procedure of government in the meeting of crisis conditions, and reconstructing the Cabinet chiefly from the membership of Congress.

6094. Corwin, Edward S. Liberty against government; the rise, flowering and decline of a famous juridical concept. Baton Rouge, Louisiana State University Press, 1948. 210 p.

$$
4^{8-8664} \mathrm{JC}_{599 .} \mathrm{U}_{5} \mathrm{C} 66
$$

Constitutional liberty exists if government itself operates under constitutional restraints when it seeks to impose restraints upon the people, and juridical liberty is the kind of constitutional lib- erty which results from the specialized type of checks and balances known as judicial review. Chapter 2 deals with the Roman and English precedents for this American development, and particularly with the ideas of John Locke, who transmuted the law of nature into the rights of men, and these into the rights of ownership. These were developed by the early American bench and bar into the doctrine of vested rights, which maintained that existing property rights were superior to reform legislation, and reached the apogee in the $1830^{\circ}$ 's. Since the Civil War the history of juridical liberty has been bound up with the due process clause of the I4th Amendment. The Supreme Court was long in realizing its potentialities, but finally in the $1890^{\circ}$ it followed the leaders of the American Bar in reading it as an endorsement of economic laissez-faire, "trimmed down to the doctrine of freedom of contract in the field of industrial relations." By this time, as an endorsement of "the prerogative of great corporations in dealing with unorganized workingmen," it had become an anachronism, and fell an easy victim to the constitutional revolution of the 1930's. The author makes clear his regret that "liberty" and "equality" have come to appear as opposed values, and that so great a tradition has had so unworthy an end.

6095. Fenn, Percy Thomas. The development of the Constitution. New York, AppletonCentury, 1948 xix, 733 p. $4^{8-\text { III3 }_{3}}$ JK 268.F 4 A casebook for undergraduate students, composed of the doctrines and dicta of the judges of the $\mathrm{Su}$ preme Court, excerpted from their decisions or dissenting opinions. It emphasizes the nature of the judicial power, the policy-making functions of high courts in general and of the Supreme Court in particular, and the evolution of constitutional jurisprudence. Parts $\mathrm{I}$ and 2 isolate and examine the controlling principles of constitutional law. Emphasis is here placed upon the establishment by the Court of the power to invalidate legislative enactments and upon the due process clause of the 14th Amendment. Parts 3 and 4 analyze two great governmental powers: the taxing power and the power to regulate commerce. "The former implements the whole federal system; the latter provides the basis for the national power." Part 5 abandons the topical order so as to deal unitarily with the great cases of the New Deal, but includes some earlier ones in which the Court reviewed federal protection of the general welfare. Professor Fenn places the essentials of the working constitutional system of the country in the fields of due process, taxation, and commerce. "On the exercise of the judicial power in these fields," says he, "the Court bases its supervision of the policies of government." Introductions precede 
most of the chapters and more or less elaborate notes follow a number of the cases. Unfortunately the only index furnished is a listing of the cases selected.

6096. Frankfurter, Felix. The commerce clause under Marshall, Taney and Waite. Chapel Hill, University of North Carolina Press, 1937. II4 p. (The Weil lectures on American citizenship [1936])

37-888 $\mathrm{HF}_{1455} \cdot \mathrm{F}_{7}$

Three short essays, originally delivered as lectures at the University of North Carolina in 1936, which analyze the direction given to the law of the commerce clause of the Constitution by Chief Justices Marshall, Taney, and Waite, who held office, save for an i I-year break, from I801 to 1888 . He traces the ideas "which they drew out of the commerce clause as the means for limiting state powers in their inroads upon national policy, whether found in the commerce clause itself or expressed in Congressional legislation." All three Chief Justices were preoccupied with the restrictive rather than the affirmative use of the clause empowering Congress "To regulate Commerce with foreign Nations and among the several States, and with the Indian Tribes." The doctrine, first outlined by Marshall, that the commerce clause, by its own force and without national legislation, authorizes the Court to place limits upon state jurisdiction, attained equilibrium in Waite's period. Thereafter the issues concerned application rather than the doctrine itself. Justice Frankfurter places Taney second only to Marshall in our constitutional history, and Waite, though "not of their flight," in the great tradition.

6097. Mott, Rodney Loomer. Due process of law; a historical and analytical treatise of the principles and methods followed by the courts in the application of the concept of the "law of the land." Indianapolis, Bobbs-Merrill, 1926. 1xxxi, $702 \mathrm{p}$. 26-I 3490 Law

This elaborately theoretical book, which originated as a University of Wisconsin dissertation, traces "the origin and development, as well as the application, of those principles which the courts have developed as part of the concept of due process of law." It occurs in the Constitution, as the requirement that no person shall be deprived of "life, liberty, or property without due process of law," in the 5 th and 14th Amendments. The study first reviews the background literature of the Anglo-American tradition of resistance to the exercise of arbitrary power, beginning with "the law of the land" (lex terrae) in the 39th section of Magna Carta, and including the declarations of rights drawn up by the States in their constitutions of the Revolutionary period.
Dr. Mott points out that "the simplest and most farreaching of constitutional phrases" first appeared in the 5th Amendment (I79I), which applies only to Federal action. This limitation, together with a desire to protect the loyal citizens and freedmen of the South after Appomattox, led Congress to propose the I 4 th Amendment (I868), which applies only to the States. Although the courts have greatly broadened the scope of due process and applied it with increasing frequency, they have steadily upheld the concept of the balance of convenience between private rights and public welfare. At the heart of the decisions, rendered chiefly in the spheres of taxation and the police power, have been the principles of "administrative convenience, balance of convenience, or public purpose."

6098. Orfield, Lester Bernhardt. The amending of the Federal Constitution. Ann Arbor, University of Michigan Press, 1942. xxvii, 242 p. (Michigan legal studies) $\quad 4 \quad 2-36735 \quad J K$ I68.07 Bibliography: p. [223]-233.

A collection of articles, reprinted for the most part from law journals, which survey from various angles the process of constitutional amendment as developed during the first I $5^{\circ}$ years of the nation's existence, and which quote many judicial and other official opinions concerning Article Five of the Constitution, which provides for amendments. The book enters the field of constitutional law in its analysis of the genesis, justiciability, and scope of the amending power, and the procedure of amendment. From jurisprudence is drawn the discussion of the relation of the amending power to the concept of sovereignty. The reform of the amending process itself is investigated from the standpoint of political science and legislation. Professor Orfield comments upon the frequently repeated doctrine of the $\mathrm{Su}$ preme Court that the people are sovereign, that they adopted the Constitution and may alter it. Before they can correctly be called sovereign, he believes, the Constitution must be amended "so as to permit a majority of the electorate of the entire country to amend the Constitution." The federal principle could be preserved by requiring a majority of the voters in each State, or at least in each of a majority of States. The present arrangement, whereby "the people do not participate in a single stage of the amending process," he regards as an anachronistic survival of the 18 th-century distrust of democracy.

6099. Rottschaefer, Henry. The Constitution and socio-economic change; five lectures delivered at the University of Michigan, March 24, 25, 26, 27, and 28, 1947. Ann Arbor, University of Michigan 
Law School, 1948 [i.e. 1949] xvi, 253 p. (Michigan. University. Law School. The Thomas M. Cooley lectures, ist ser.) 49-2548 Law The chief purpose of this book is "not only to describe and analyze the process by which constitutional adaptation occurred during the crisis induced by the most severe economic depression of modern times, but also to develop the implications of the constitutional theories and doctrines that constitute the constitutional law of today." Although these lectures trace the prior evolution of the constitutional principles invoked by the Supreme Court in support of its decisions affecting depression legislation, for the most part they survey actions taken during the years $1933-48$. In this period the Court so construed the Constitution as to sustain a great expansion of Federal power, the relaxation of important limitations on State powers, more extensive and intensive regulation of business, and an increased protection of personal liberty in areas other than business. The real question, in the opinion of the author (1948), was not whether there would be a general retreat from these positions, but how much further the trends were likely to be carried. "The dogma," he wrote, "that government should assume an important and permanent role in achieving economic stability and a more just social order is not likely to be discarded."

6roo. Story, Joseph. Commentaries on the Constitution of the United States: with a preliminary review of the constitutional history of the colonies and states before the adoption of the Constitution. $5^{\text {th }}$ ed., by Melville M. Bigelow. Boston, Little, Brown, 1891. 2 v.

"Cases cited": p. [xxi]-xxxiv.

$$
\text { 2-7028 JK2II.S7 I89I }
$$

A legal classic of continuing importance and reputation first published in 1833 by Joseph Story $(1779-1845)$, Associate Justice of the United States Supreme Court from i 81 r. Most of the materials were drawn from the discussions of the Constitution in The Federalist (no. 6074), and Chief Justice Marshall's judgments on constitutional issues. The author disclaimed any ambition to interpret the theory of the Constitution himself, but rather sought to set forth "the true view of its powers, maintained by its founders and friends, and confirmed and illustrated by the actual practice of the government." As originally conceived by Story, his Commentaries had three large divisions. The first sketched the charters, constitutional history, and ante-Revolutionary jurisprudence of the colonies, the principles common to all, and the diversities among them. The second reviewed the constitutional history of the Revolutionary states, and the rise, progress, and decline of the Confederation.
The third narrated the origins and adoption of the Constitution and explained all of its provisions, the principles on which they were founded, and the objections with which they had been assailed. Editors of subsequent editions have added references to amendments and adjudications down to January 1891 , including a number of decisions from the lower Federal courts and from State courts as well as the Supreme Court, together with some other public papers.

6ror. Twiss, Benjamin R. Lawyers and the Constitution; how laissez faire came to the Supreme Court. Princeton, Princeton University Press, 1942. 271 p. 42-19388 JK271.T9

The author's dissertation (Princeton University, I938), the origin of the present work, was being enlarged and revised at the time of his regrettably early death. The manuscript was prepared for publication by Professor Edward S. Corwin. Its controversial purpose was to "analyze the vital function of the bar as liaison between businessmen and judges, and to show how protests against government interference with private enterprise were translated into formal constitutional limitations." Dr. Twiss aimed to show that the development of American constitutional law during the period 18751935 was primarily the work of a relatively small group of lawyers whose clients were great financial and business concerns. These members of the bar sought to insulate the judges from any theories or facts save those consistent with their own doctrines of individualism, laissez faire, and limited government power. The lawyers and the judges brought together the "American political philosophy of government limited by absolute fundamental rights, the theory of non-interference with self-regulating economic laws, and the legal and constitutional devices of property, contract, states rights, and judicial review to form the American constitutional doctrine of freedom of private enterprise. That doctrine flourished in the Supreme Court until the Revolution of I937." The author found in the law schools and the law-school journals, however, an awakening skepticism toward this judicial doctrine. And in upholding the National Labor Relations Act, he believed, the Supreme Court had "finally recognized that there can be a danger to liberty from private sources as well as from government."

6102. U.S. Constitution. The Constitution of the United States of America. Analysis and interpretation; annotations of cases decided by the Supreme Court of the United States to June 30, 1952. Prepared by the Legislative Reference Service, Library of Congress, Edward S. Corwin, editor. Washington, U. S. Govt. Print. Off., 1953. xxxiv, 
I36I p. (82d Cong., $2 d$ sess. Senate. Document no. 170 ) $53-6353^{\circ}$ Law

A revised edition of a publication produced under the same auspices in 1938 and more simply titled The Constitution of the United States (Annotated). It is a large-scale commentary on the Constitution as interpreted and applied by the Supreme Court, and it proceeds through the document and its first $2 \mathrm{I}$ Amendments in the most minute manner, section by section, and, for the more complex sections, clause by clause. Thus Article I, Section I, requires just two and a half lines of print, but it is followed by 15 pages of commentary, organized under 3 main headings and 21 subordinate ones. For all provisions of the Constitution it gives "the currently operative meaning," but for the most important ones it also traces "the course of decision and practice whereby their meaning was arrived at by the Court's official interpreters." Supreme Court decisions are the major source for the commentary, but they are supplemented by acts of Congress, executive orders and regulations, the proceedings of the 1787 Convention, dissenting opinions, and legal or historical treatises. In Dr. Corwin's view, the Constitution's capacity for growth has resided far more in the Supreme Court's power of judicial review than in the process of amendment. He therefore gives special attention to certain broader doctrines, especially of the nature of the Federal system and the relation of governmental power to private rights, which have influenced the Court and concerning which it has on occasion changed its mind. His "Introduction" (p. $\mathrm{ix}-\mathrm{xxxi}$ ) is particularly concerned with such doctrines. The commentary is followed by a list of the 73 acts of Congress which the Court has held unconstitutional in whole or part (p. 1241-1253), a massive alphabetical "Table of Cases" (p. 1257-r333), and an "Index" (p. 1337-1361), which is less detailed because of the elaborate tables of contents that, in the commentary, precede each Article and each Amendment.

6103. Weaver, Samuel P. Constitutional law and its administration. Chicago, Callaghan, 1946. xxxvii, $684 \mathrm{p}$. $\quad 46-6268 \quad \mathrm{JK}_{2} 68$. W 4

A I-volume textbook intended for colleges, universities, and law schools which do not use the casebook system of education, or as a supplement to the many casebooks available, and as a handbook for lawyers and others who desire a better understanding of the Constitution and its application to modern conditions. Briefly considered are: the fundamental law of 1787 ; the 21 Amendments in force in 1946; statutes implementing this law; decisions of the courts interpreting and construing it; and the established customs and usages of the Federal government, as well as certain inherent powers. The book traces the evolution of the fundamental law of 1787 into an "Enlarged Constitution," and the development of a new federalism. Emphasis is placed upon the recent recognition of new powers supported by new doctrines. This process of change has included "the overruling of precedents upon the subject of taxation, and precedents defining many of the limitations and guarantees of individual rights; the expansion of the war powers of the President; the increase of the powers of the Chief Executive; the enlargement of the economic powers of the Federal Government"; the creation of many new administrative boards and commissions; and the recently evolved doctrine of inherent powers of the Federal Government in external and foreign affairs. A final part analyzes the three major powers remaining to the States: the police power, the power of taxation, and eminent domain. The author provides many quotations from opinions and statutes, but considers that casebook method in the field has become too unwieldy.

6104. Willoughby, Westel Woodbury. The constitutional law of the United States. 2d ed. New York, Baker, Voorhis, 1929. 3 v. ( Ixvii, 2002 p.)

First published in 1910.

"Table of cases" prepared by Leon Sachs: v. I, p. xix-lxvii.

A systematically arranged and, as of 1929, complete exposition of the constitutional law of the United States, whose purpose is "to ascertain and to discuss critically the broad principles upon which have been founded the decisions rendered by the Supreme Court of the United States in the leading cases, and thus to present, as a systematic whole, a statement of the underlying doctrines by which our complex system of constitutional jurisprudence is governed." This work sets forth the processes of judicial reasoning by which they have been established, suggests corollaries that may be drawn from them, and indicates the relations which they bear to each other and to the more general doctrines of American public law. Extensive quotation is made from the language of the Supreme Court. By an examination of the statutes of Congress, Professor Willoughby has attempted to show the increase of Federal regulation and the manner in which the Federal government exercises the constitutional powers vested in it. Among the principal subjects dealt with are: the division of powers between the United States and the states, Federal supremacy and its maintenance, citizenship and naturalization, Federal powers of taxation, the powers of Congress, regulation of commerce, the Federal judiciary, the powers and duties of the President, the separation of powers, and due process of law. 
6105. Wright, Benjamin Fletcher. The contract 39-4050 JK $37 \mathrm{r}$.C6W7 clause of the Constitution. Cambridge, Harvard University Press, 1938 . xvii, $287 \mathrm{p}$.

"Cases cited": p. [261]-277.

A study of the nature and the significance for American constitutional and economic history of Article I, Section ro, Clause I, of the Constitution, which forbids the States to pass laws impairing the obligation of contracts. The author accepts Dr. Corwin's view that the doctrine of vested property rights has, from the beginning, been the basic doctrine of American constitutional law, and adds that, so far as the Supreme Court was concerned, during the rgth century this doctrine was identified with the contract clause. His book is based upon all of the contract clause cases (about 500) brought before the Court, and while the leading decisions are emphasized, the lesser ones are treated in bulk for their economic significance. He considers that the limited, relatively specific meaning which the clause bore in 1787 was developed by judicial expansion into one far more inclusive and of much greater economic significance by 1835 or 1864 , but he thinks that this expansion fitted in remarkably well with the democratic sentiment of the times. The important interpretations-that the clause includes contracts to which a State is a party, that a corporate charter is a contract, that it protects a contract for tax exemption, and that it prohibits retrospective bankruptcy or stay laws-were laid down while the Court was headed by Marshall and Taney ( $180 \mathrm{I}-$ 64 ). After 1890 the contract clause was overshadowed by the due process of law clauses in the Court's mediation between property rights and public requirements.

\section{Civil Liberties and Rights}

6ro6. American Academy of Political and Social Science, Philadelphia. Civil rights in America, edited by Robert K. Carr. Philadelphia, I95I. $23^{8}$ p. (Its Annals, v. 275)

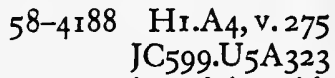

These 19 articles provide a summation of the mid2oth-century status of American civil liberties. The conscious and deliberate attempt to give practical meaning to the specific guaranties of the Bill of Rights has found expression chiefly in Supreme Court decisions handed down since 1920. These decisions, especially those concerning freedom of speech and press, have placed the States under Federal judicial discipline in areas within which the States have been the main offenders. The Supreme Court has also defined and protected religious liberty. The Civil Rights Division of the Department of Justice, set up as a section in 1939, has devoted itself to enforcement of the peonage laws, the laws protecting citizens in their right to vote for Federal officers, and laws punishing such crimes as police brutality or official participation in lynchings. Beginning with New York in 1945, some States have enacted antidiscriminatory legislation-fair employment practice laws, fair educational practice laws, prohibitions of discrimination in places of public accommodation. A number of private organizations operate primarily in the field of civil liberties and rights, among them the American Civil Liberties Union, the National Association for the Advancement of
Colored People, and the American Jewish Congress. This is all taken here as evidence of progress in "social engineering." On the debit side, however, are listed private discrimination against the American Negro and other minority groups, rigid local censorship of books, magazines, and motion pictures, and, most serious, the threats posed to civil liberty by unwisely chosen and operated policies and procedures for combating communism.

6ro7. Brown, Ralph Sharp. Loyalty and security; employment tests in the United States. New Haven, Yale University Press, 1958. xvii, 524 p. (Yale Law School studies, 3)

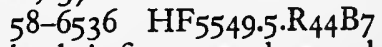

"The purpose of this book is first to explore and synthesize our disorderly growth of loyalty and security measures, and then to suggest ways of correcting or eliminating their apparent excesses." It surveys the standards, procedures, and effects of nearly every kind of employment test used as an internal security technique in the United States. Among them are the administrative arrangements of of the Federal government for dealing with its employees, with military personnel, and with defense contractors' employees, the various State and local test oaths and administrative programs, and tests administered by private employers and labor unions. These tests are actually "concerned with disloyalty, and essentially with one form of disloyalty: a preference for communism," or, put another way, "a treasonable state of mind that may lead to a treason- 
able act." Professor Brown examines the justification for loyalty and security tests and makes recommendations for restricting them to "the limited circumstances in which political employment tests are necessary and defensible." Loyalty and security tests have been practiced, he believes, with too much rigor and too little humanity, and have needlessly impaired the freedoms of belief, speech, and association protected by the First Amendment.

6ro8. Chafee, Zechariah. The blessings of liberty. Philadelphia, Lippincott, $1956.350 \mathrm{p}$. $56-6563 \mathrm{JC}_{599 .} \mathrm{U}_{5} \mathrm{C}_{4} 8$

The late Professor Chafee (1885-1957) taught at the Harvard Law School for 40 years, and was esteemed as one of the most disinterested defenders of American civil liberties. In the present volume he collected his addresses and articles of $1944-56$ on the subject. The third paper reviews freedom of speech and of the press since 1917, postulating a period of struggle and criminal prosecutions, 191720; a period of growth, 1920-30; a period of achievement, 1930-45; and a recent period of renewed struggle and subtle suppressions. The first essay, "Watchman, What of the Night?", lists i encroachments upon liberty which have taken place since 1945; asserts that the present trends, if continued into an indefinite future, will produce "more indirect and subtle suppressions of liberty"; but expresses confidence that the American people will bring about a major reversal in the near future. Other papers discuss the McCarran Act (the Subversive Activities Control Act of 1950) in relation to the Bill of Rights; the proposed loyalty oath of the American Bar Association; "The Right not to Speak" under the Fifth Amendment; and the diverse forms of attack upon academic freedom. Professor Chafee's last thought was: "The blessings of liberty, though weakened, are ours if we want them, to hold and make strong. The flag still flies, and the city is not yet fallen."

6rog. Chafee, Zechariah. Free speech in the United States. Cambridge, Harvard University Press, 1946. xviii, 634 p.

"Bibliographical note": p. [569]-57 I.

$$
48-3488 \text { JC591.C52 } 1946
$$

A synthesis of all of Professor Chafee's ideas on freedom of speech, and a discussion of the major court decisions upon it, mainly from ig20 to March 3I, I94I. A number of the chapters are reprinted, some revised and some not, from other publications. "This book is an inquiry into the proper limitations upon freedom of speech," states the author, "and is in no way an argument that any one should be allowed to say whatever he wants anywhere and at any time." More specifically, he examines the nature and scope of the First Amendment to the Constitution. Its framers, he believes, sought to preserve the earlier victory abolishing censorship, and to win a new one by abolishing prosecutions for sedition. "The true boundary line of the First Amendment," he writes, "can be fixed only when Congress and the courts realize that the principle on which speech is classified as lawful or unlawful involves the balancing against each other of two very important social interests, in public safety and in the search for truth." In his opinion, every reasonable attempt should be made to maintain both interests unimpaired. The great public interest in free speech should be sacrificed to censorship or punishment only when it really imperils the public safety by direct and dangerous interference.

6r 10. Cornell University. Cornell studies in civil liberties. Robert E. Cushman, advisory editor. Ithaca, Cornell University Press, 1946-57. $15 \mathrm{v}$.

A group of 15 studies (nos. 61 I I-6125) concerning civil liberty and security made under the general direction of Professor Robert E. Cushman of Cornell University and supported chiefly by a grant from the Rockefeller Foundation. Beginning in 1948 a number of scholars, working independently under Professor Cushman, began investigation of the impact upon our civil liberties of current government programs designed to ensure internal security and to expose and control disloyal or subversive conduct. The seven reports issuing from this particular research, one edited and one written by Walter Gellhorn, and one each by Edward L. Barrett, Jr., Vern Countryman, Lawrence H. Chamberlain, Robert K. Carr, and Eleanor Bontecou, cover the work of Federal and State un-American activities committees and the operation of Federal, State, and local loyalty and security programs. Stimulus for these inquiries was presumably furnished by President Truman's Loyalty Order of 1947 , which forms the hard core of the program to assure the loyalty of Federal employees, although it was preceded by less farreaching measures and has since been supplemented in important ways.

6iri. Barrett, Edward L. The Tenney Committee; legislative investigation of subversive activities in California. Ithaca, 195I. $400 \mathrm{p}$.

$$
\text { 5I-IIII8 HX91.C } 3 \mathrm{~A}_{5} \text { r949ac }
$$

Covers the work of the "Little Dies Committee" of the California State Senate, which employed the doctrine of association to identify Communists and their sympathizers, and sought to punish them by publicity and other means during the period I94I-49. 
6i12. Bontecou, Eleanor. The Federal loyaltysecurity program. Ithaca, $1953.377 \mathrm{p}$. 53-10749 JK 734.B6

Appendixes (p. 272-366): 1. Executive orders.2. Statutes and regulations relating to the employment, dismissal, and investigation of employees of the executive branch of the Federal government.3. Extracts from exhibits accompanying report of the President's Temporary Commission on Employee Loyalty. - 4. The training of investigators.5. Sample rules and regulations.-6. The Attorney General's list.-7. Listing of subversive organizations.

An objective study, copiously documented, which relates the development of the loyalty-security program to the work of the Dies Committee in the late 1930's, and to subsequent piecemeal efforts to deal with suspected subversives in Federal employment through the Civil Service Commission and the Federal Bureau of Investigation. The mechanics of adjudicating charges of disloyalty and security risk under the full formal program initiated in 1947 are dealt with, as are problems arising from the investigative process, and the techniques and standards of judgment involved.

6113. Carr, Robert K. Federal protection of civil rights; quest for a sword. Ithaca, 1947. 284 p. 48-5II7 JC599.U U $\mathrm{C}_{35}$

An analysis of the work of the Civil Rights Section (now Division) of the United States Department of Justice, which was established in 1939 to pursue a course of "aggressive protection of fundamental rights inherent in a free people." Chapter I notes that although the function of the Constitution in protecting civil rights against interference by government is in general that of a shield, some provisions can serve as a sword. In some instances, the Federal government can take positive measures to safeguard civil liberties by prosecuting State and local officials, or private individuals who infringe them. Chapters I-4 deal with the Civil Rights Section's early efforts to discover, clarify, use, and develop the existing Federal law of civil liberty, both constitutional and statutory, most of which was vague, inadequate, and dating from the Reconstruction period. Chapters 5-6 outline the development of administrative techniques and legal strategy by the Section and classify the kinds of cases handled by it, such as police brutality, election irregularities, peonage, freedom of communications, and conflicts between labor and management. A final chapter discusses as of 1947 "The Sword and the Future."

6114. Carr, Robert K. The House Committee on Un-American Activities, 1945-1950. Ithaca, 1952. $489 \mathrm{p}$. 52-I $4423 \quad \mathrm{E}_{743 \cdot 5 \cdot \mathrm{C}_{3}}$
"List of publications of the House Committee on Un-American Activities": p. 464-469.

A history of the first six years of the Committee's existence after its establishment as a permanent agency of Congress by "one of the most remarkable procedural coups in Congressional history." Two of its more celcbrated episodes were the hearings on the Hollywood writers and the Hiss-Chambers controversy. Sober and reflective in its review of the Committee's activities, this inquiry concludes with the comment: "On balance the good things the ... Committee has done are outweighed by the bad," and the suggestion that its work be handled by other standing committees of Congress.

6II5. Chamberlain, Lawrence $H$. Loyalty and legislative action; a survey of activity by the New York State Legislature, I9I9-1949. Ithaca, I951. 254 p. $\quad 5$ I-I 4490 JC599.U U2 $\mathrm{N}_{52}$ A detailed and carefully documented examination of the Lusk, McNaboe, and Rapp-Coudert investigations of disloyalty, and of associated events and consequences, including dismissals of teachers by the Board of Higher Education of New York City.

6ir6. Countryman, Vern. Un-American activities in the State of Washington; the work of the Canwell Committee. Ithaca, I95I. 405 p.

$$
\text { 51-14732 } \mathrm{HX}_{91 .} \mathrm{W}_{3} \mathrm{C} 6
$$

An appraisal as well as a thoroughly documented report of the work during $1947-50$ of the Joint Legislative Fact-Finding Committee on Un-American Activities in the State of Washington and of the University of Washington's Committee on Tenure and Academic Freedom. Both groups attempted to determine whether certain "radical" professors were academically incompetent, or were guilty of deliberately seeking to undermine the foundations of the republic and therefore of the abuse of academic freedom.

6117. Cushman, Robert E. Civil liberties in the United States; a guide to current problems and experience. Ithaca, 1956. $24^{8} \mathrm{p}$.

$$
\text { 56-13957 JC } 599 . \mathrm{U}_{5} \mathrm{C}_{2}
$$

"Selected readings" at end of chapters.

A comprehensive outline of the practice which obtained in the whole field of civil liberties during the decade following World War II. Professor Cushman, an authority on the subject and advisory editor of the series, has sought to do three things: to indicate the status of each civil liberty at the close of the war; to summarize the principal developments which occurred regarding each in the period covered; and to point out the unsolved problems, together with some of the more important proposals for dealing with them. Venturing neither opinion 
nor solution but admitting to a bias in favor of the protection of civil liberty, he presents his material under nine headings: "Freedom of Speech, Press, Assembly, and Petition"; "Academic Freedom"; "Freedom of Religion: Separation of Church and State"; "The Right to Security and Freedom of the Person"; "Military Power and Civil Liberty"; "The Civil Liberties of Persons Accused of Crime"; "Civil Liberties and National Security"; "Civil Liberties of Aliens"; and "Racial Discrimination."

6i18. Gellhorn, Walter. Security, loyalty, and science. Ithaca, $1950.300 \mathrm{p}$.

$$
5^{0-1} 4649 \quad \mathrm{UB} 270 . G_{42}
$$

An examination of Federal government and university actions regarding security of technical information and the loyalty of scientists, which concludes that national policies on secrecy in scientific matters were, as of 1950, intelligently formulated but too rigidly applied, and were hindering the advance of scientific knowledge.

6irg. Gellhorn, Walter ed. The states and subversion. Ithaca, 1952. $454 \mathrm{p}$.

52-10508 Law

Condensed reports by seven contributors on legislation and other official actions of States and municipalities to control subversion, which indicates that by 1952 the States had departed from the idea of guilt as personal to the accused. There was a widespread admission of the doctrine of guilt by association in both legislation and investigations. The reports on California, New York, and Washington receive book-length treatment elsewhere in the series (nos. 6III, 6115-6116).

6120. Konvitz, Milton R. The alien and the Asiatic in American law. Ithaca, 1946. xiv, 299 p.

Bibliography: p. 280-283. 47-30101 JX $4265 . \mathrm{K} 65$

Although it draws substance from the decisions of other Federal courts and from State and national law, this is a study primarily "of how the United States Supreme Court has reacted to problems relating to the alien and to the American citizen of Asiatic descent. It is also a study of the past and present legal status of these groups, and an attempt to make a contribution to the field of legal and political sociology." Among the subjects considered are: the right of citizenship, the retention of it, the right of land ownership, work laws, segregation, miscegenation, and the World War II relocation of persons of Japanese extraction, including American citizens. The author is severely critical of the discriminations found in American law. 6r2 I. Konvitz, Milton R. Bill of Rights reader; leading constitutional cases. Ithaca, 1954. xix, $591 \mathrm{p}$. 54-12758 Law

Partial contents.-2. The rule of law.-3. Freedom of religion.-4. Freedom of assembly and petition.-5. Freedom of speech and press: some basic principles.-6. Freedom of speech and press: the clear and present danger doctrine.-7. Freedom of speech and press: the problem of loyalty. -8 . Freedom of speech and press: censorship and contempt by publication.-9. Personal security.-ro. Freedom from race discrimination.-11. Freedom of labor.

Intended for "the average, educated American who is interested in the great issues and the great debates of his day." Of the nearly 80 cases included, all but a few were decided by the Supreme Court. They deal with all provisions incorporating civil and political liberties in the original Constitution and the Civil War Amendments, as well as in the Bill of Rights proper (Amendments I-IO). In order to show some decisions in their context of disagreement and conflict, Professor Konvitz has included concurring and dissenting opinions.

6122. Konvitz, Milton R. Civil rights in immigration. Ithaca, 1953. $216 \mathrm{p}$.

$$
\text { 53-1266o Law }
$$

A critique of American immigration policy, more particularly of discrimination enacted into, and hardships and inequities arising under, legislation relating to the admission, exclusion, deportation, and naturalization of immigrants. Dr. Konvitz considers the problems of whom to admit, making special reference to the system of quotas by national origin; of whom to send back to the country of origin, paying special attention to the questions of fair hearings and proper grounds for deportation; and of whom to make citizens.

6r23. Konvitz, Milton R. Fundamental liberties of a free people: religion, speech, press, assembly. Ithaca, 1957. $420 \mathrm{p}$.

$$
\text { 57-13950 JC599.U5 } \mathrm{K} 6
$$

A topical history of the First Amendment freedoms which argues that they stand in intimate relation to each other, "that freedom of conscience and religion implies freedom of thought and freedom of teaching, and that freedom of speech and press is indispensable to religious beliefs which may be laden with unpopular judgments about the conduct of political and economic affairs in the city of man." Besides these, such others are considered as the freedom not to speak and not to listen, and the right to privacy. In discussing literary freedom, Professor Konvitz distinguishes works of 
artistic purpose from "dirt for dirt's sake," and pleads for the right of the former to the protection of the First Amendment. He urges public support of the press in its claims to freedom of information. $\mathrm{He}$ argues against invasion of the First Amendment freedoms by coercive or restrictive legislation because he regards them as indispensable means to the effective and intelligent operation of the democratic process, essential to the foundations and the security of the republic.

6124. Sibley, Mulford Q., and Philip E. Jacob. Conscription of conscience; the American state and the conscientious objector, 1940-1947. Ithaca, 1952. $\quad 5^{80} \mathrm{p} . \quad 5^{2-12673} \mathrm{UB}_{342 . U_{5} \mathrm{~S}_{52}}$ "Selected and annotated bibliography": p. 549566.

An inquiry into the treatment accorded conscientious objectors in the United States during World War II. It investigates such matters as the classifcation of objectors, the church-operated Civilian Public Service camps, and the objectors' work in forestry, agriculture, medical research, and hospitals for the insane. It finds little but problems unsolved and failures: the disappointments in religious, educational, and self-government programs; the erosion of morale; economic hardships; and an uneasy partnership between the "Historic Peace Churches" and the Selective Service. Conditions were particularly bad in the government camps, operated primarily for "troublemakers"; here rebellious objectors engaged in slowdowns and other forms of obstruction, and were naturally met by increased repression. Substantial classes of conscientious objectors, such as nonreligious objectors, remained outside the limits of official tolerance, and were given terms in Federal prisons. The authors remark that the "c. o.'s" neither had nor developed any unity of outlook or program, that the measures of restraint adopted proved futile and pernicious, and that "the conflict between conscience and the state" was far from being resolved during World War II.

6r25. Smith', James Morton. Freedom's fetters; the Alien and Sedition laws and American civil liberties. Ithaca, $1956.464 \mathrm{p}$.

See no. 3308 .

$$
5^{6-2434} \quad \mathrm{E}_{327 .} \cdot \mathrm{S}_{59}
$$

6r26. Emerson, Thomas I., and David Haber, eds. Political and civil rights in the United States; a collection of legal and related materials. Foreword by Robert M. Hutchins. Buffalo, Dennis, 1952. xx, I209 p. (United States case book series) 52-4386 Law

A comprehensive collection of cases and other materials taken from nearly all areas in which the freedom of American individuals and private groups is of juridical concern. The editors are concerned with the following rights: security of the person from bodily harm, involuntary servitude, and the fear of physical restraint; procedural safeguards for individuals who come into conflict with the law; the right to exercise the franchise; the right of full freedom of political organization and political expression; freedom of all other forms of expression; academic freedom; freedom of religion and the separation of church and state; and, finally, equality of legal status and opportunity for all persons. Professors Emerson and Haber find that a steady expansion and refinement of political and civil rights took place between 1787 and the close of World War II, reaching a peak during the late 1930's and early I940's, but that between 1945 and 1952 the trend was reversed. This retreat from the practices of democratic freedom the editors attribute to a variety of factors, both internal and external, particularly to the increasing complexity of our industrial society and to the turbulence of world conditions. The retrogression may be temporary, they observe with restrained optimism, since the legal tools for maintaining these rights are significantly improved over those of any past period.

6127. Ernst, Morris L. The first freedom. New York, Macmillan, 1946. xiv, 316 p. $46-1639 \mathrm{JC}_{599 .} \mathrm{U}_{5} \mathrm{E}_{7}$

"Partial bibliography": p. 272-278.

The "first freedom" is that of communication and thought guaranteed by the Bill of Rights. Although Mr. Ernst believes this country to be remarkably free from that political censorship of the press, radio, and motion pictures which characterizes so many nations under dictatorship, he finds real danger in the rise of "monopolies of the mind." In only $\mathrm{II}_{7}$ cities of America, for example, did competing daily newspapers exist as of 1946; one-third of all regular radio networks were interlocked with newspapers. Thus there had been concentration of control in these "separate" indus. tries, and the firm interlacing of what should be competitive media of communication. The market place of free competition for motion pictures was destroyed through interaction between a combination of the five major companies and the Hays office. The author finds the causes of the concentration economic, the dangers essentially spiritual, menacing "our greatest contribution to the history of mankind." He offers a number of practical suggestions for the restoration of "competition of thought" in the United States. As the greatest proponents of the first freedom, says Mr. Ernst, we "must get our own house in order before we can rightfully assume that place of leadership in the 
family of nations which our rich tradition warrants." Another New York lawyer, who specialized in rights cases and was for many years national director of the American Civil Liberties Union, was Arthur Garfield Hays ( $188 \mathrm{I}-1954$ ). In Let Freedom Ring (New York, Liveright Pub. Corp., r937. 475 p.), originally published in 1928 and enlarged nine years later, he gave witty but earnest accounts of cases in which he had been concerned as counsel for the Union over a I5-year period.

61 28. Kelly, Alfred H., ed. Foundations of freedom in the American Constitution. New

York, Harper, 1958. xviii, 299 p.

Bibliography: p. 25I-257.

$$
\text { 58-7976 Law }
$$

Partial contents.-Introduction, by J. B. Oakes.-What liberty means to free men, T. V. Smith.-Where constitutional liberty came from, by A. H. Kelly.-The great liberty: freedom of speech and press, by Z. Chafee.-Constitutional liberty and the communist problem, by J. W. Peltason.-Constitutional liberty and congressional investigations, by R. K. Carr.-Constitutional liberty and loyalty programs, by A. F. Westin.

Six essays on constitutional liberty, prepared originally as pamphlets for the Freedom Agenda program of the Carrie Chapman Catt Memorial Fund in $1954-56$. This program was designed to combat the nationwide sense of fear, suspicion, and hostility aroused by the tensions and frustrations of the world situation and by sensational charges of widespread communist infiltration into government and the professions. Affirmatively, the plan was designed to promote a greater awareness of the meaning of the Bill of Rights and all our constitutional guaranties, a greater relaxation in our attitude toward nonconformity, and a greater appreciation of the basic values of liberty, freedom, and individual liberty. The last three papers have been extensively rewritten, and demonstrate the great improvement in the state of American civil liberty which has been brought about since 1954 by the healthy correctives of politics, law, public opinion, and, especially, the decisions rendered by the Supreme Court. The reaction described in these essays forms strong testimony to the continued vitality of the ideal of constitutional liberty in the United States.

6129. Konvitz, Milton R. The Constitution and civil rights. New York, Columbia University Press, 1947. 254 p. A 47-1116 JK1726.K6

A discussion of the legal aspects of Federal and State legislation for the protection of the civil rights of minorities in the United States. Civil rights in their limited and technical sense refer "to the rights of persons to employment, and to accommodations in hotels, restaurants, common carriers, and other places of public accommodation and resort," as enumerated in the Federal Civil Rights Act of 1875 and in various acts against discrimination on the statute books of 18 States. The author noted that in 30 American States, as of 1946 , no civil rights legislation had been enacted, and that, as the Constitution and statutes had been construed by the Supreme Court, the scope of the Federal civil rights acts was extremely narrow. He analyzed significant $\mathrm{Su}$ preme Court decisions on racial discrimination from the Civil Rights Cases of 1883 to the Screws Case of 1945. He discussed the extent of Federal authority in cases of lynching and of discrimination in employment. The final chapter glanced hastily at the large body of laws which, in 20 States, imposed discrimination or segregation, and at the even larger body of local custom behind it. Appendixes give samples of proposed Federal laws and of existing State ones. The book is now chiefly useful as a background for the debates and sweeping changes of the past decade.

6rzo. Stouffer, Samuel A. Communism, conformity, and civil liberties; a cross-section of the nation speaks its mind. Garden City, N.Y., Doubleday, 1955. $27^{8} \mathrm{p}$. illus.

$55-7160 \quad \mathrm{JC}_{599} \mathrm{U}_{5} \mathrm{~S}_{2}$

"Notes on materials from other surveys as related to the findings in this volume": p. 274-278.

An analysis and interpretation of American attitudes toward "the communist conspiracy" both inside and outside the country, and toward those "who in thwarting the conspiracy would sacrifice some of the very liberties which the enemy would destroy." The study is based upon field work done in 1954 among more than 6,000 men and women from all walks of life by interviewers from the American Institute of Public Opinion and the National Opinion Research Center. The general conclusion reached is that great social, economic, and technological forces are slowly, even imperceptibly, spreading tolerance and respect "for others whose ideas are different." Professor Stouffer warns of the necessity of vigilance as the price of liberty, however, and of the difficulties faced by its special guardians-the press, radio, television, and national and local political leaders--in distinguishing between the evils of communism and a dangerous disregard for civil liberties. Harold D. Lasswell's National Security and Individual Freedom (New York, McGraw-Hill, I950. 259 p.) provides a rather elaborate theoretical framework for this dilemma, intended to supply criteria whereby any particular safeguard may be judged for its effects upon liberty, whether in the sphere of government, of social institutions, or of the individual. Civil Lib. 
erties under Attack (Philadelphia, University of Pennsylvania Press, 1951. I55 p.) consists of six lectures delivered at Swarthmore College. Henry Steele Commager, Robert K. Carr, Zechariah Cha- fee, Walter Gellhorn, Curtis Bok, and James P. Baxter divide between them the subjects of civil rights, measures aimed at radicalism or subversion, and menaces to science, the arts, and education.

\section{E. Government: General}

6r3I. Anderson, William. The units of government in the United States, an enumeration and analysis. New ed., completely rev. Chicago, Public Administration Service, I945. 48 p. illus. ([Public Administration Service, Chicago] Publication no. 83)

45-35 I0 JS345 I945.A57

"First published, 1934 ... New edition, completely revised, 1942; reprinted, with appendix, 1945."

A statistical study of all the units of government operating in this county as of January I, 194I. Professor Anderson attempted to learn how many distinct units were functioning, their principal classes and characteristics, and the areas and populations served by them. He discusses trends with respect to increases and decreases in the number of local units, the question whether too few or too many such units exist, and the optimum size for urban and rural units. $\mathrm{He}$ is interested chiefly in administrative efficiency and fiscal economy. In urban as in rural areas it is desirable, he believes, to have only a single important administrative unit in each defined area. $\mathrm{He}$ finds per capita expenditures in cities of from 30,000 to 300,000 about the same with only a slight upward tendency as sizes increases, although above the latter figure increase appears to be more pronounced. The ordinary county expenditures per capita, including overhead, decrease very noticeably when population reaches 30,000 to 35,000 , but thereafter decline less rapidly. The author would reduce the number of local units for the average State from 3,500 to approximately 370 .

6r32. Binkley, Wilfred E., and Malcolm C. Moos. A grammar of American politics; the naiional government. $3 \mathrm{~d}$ ed., rev. New York, Knopf, 1958.806 p. $\quad 5^{8-5009} \quad J_{274 . B} \cdot{ }_{57} \quad 1958$

6r 33. Binkley, Wilfred E., and Malcolm C. Moos. A grammar of American politics; the national, state, and local governments. $2 \mathrm{~d}$ ed., rev. and enl. New York, Knopf, 1952. I059 p. (Borzoi books in political science)

$$
\text { 5I-III02 JK274. B57 } 1952
$$

"Supplementary reading": p. 747-77I, 1051-1059. A large-scale textbook, originally published in
1949, by a veteran professor at Ohio Northern University and Professor Moos of Johns Hopkins, who in $195^{8}$ joined the White House staff as a speechdrafting aide to the President. For their treatment of State and local governments one must consult the fuller edition of $195^{2}$ (p. $\left[7^{8} 7\right]-1059$ ), but the larger portion concerned with the national government has received a further revision, the preface of which is dated September 1957. The new book is 20 pages longer than the corresponding portion of the 1952 edition; the introductory chapter is retitled "Social Forces in American Politics," instead of "The Dynamics of American Government," and partially rewritten; and three chapters contributed by economic specialists have been replaced by four written by the authors (although one of these, "Agriculture and Conservation," proves to be in fact Dr. Walter W. Wilcox's original contribution with very minor revisions). The organization remains the same: besides two sections on the executive branch and one each on the legislative and judicial, four others deal with the constitutional foundations, citizenship, "Institutions of Popular Control," and "Major Federal Functions."

6r34. Burns, James MacGregor, and Jack Walter Peltason. Government by the people; the dynamics of American national, state, and local government. $3 \mathrm{~d}$ ed. Englewood Cliffs, N. J., Prentice-Hall, 1957. 990 p. illus.

Bibliography: p. 919-956. 57-8221 JK274.B855 I957a

A large-scale textbook by Professor Burns of Williams College and Professor Peltason of the University of Illinois, first issued in 1952. Like its predecessors, the third edition is available in the full form entered above, or in a shorter one dealing with the national government only, or in a paperbound reprint of seven chapters entitled The Dynamics of American State and Local Government; and there is a teaching manual for the edition prepared by Walter S. Wilmot, Jr. The authors state that they have tried to make their book effective for training in critical thinking, citizenship, and liberal education by organizing it around five basic problems: keeping popular government stable and yet progres- 
sive; achieving a balance between liberty and order; achieving the best representation of the people in a democratic manner; securing the optimum degree of popular control of our leaders; and answering the challenge of Communists and other antidemocrats. The book differs from older textbooks on the subject in that it precedes its descriptions of the actual institutions and operations of government with lengthy treatments of the essentials of democratic government; the Constitution, particularly as creating a system of federalism; civil liberties and their safeguards; and especially part 4, "The People in Politics." Here the subdivisions are "The Dynamic Role of Interest Groups," "Public Opinion: the Voices of the People," "Political Behavior," "Party Politics and Party Problems," and "Appeal to the Voters." Another element unlikely to be found in early textbooks is chapter 19, "The Bureaucrats," which takes the line that "government officials are people"; if they do not reach ideal standards of performance, this is in large part because of specific hindrances which the people have it in their power to eliminate.

6135. Chatters, Carl H., and Margorie Leonard Hoover. An inventory of governmental activities in the United States. Chicago, Municipal Finance Officers Association of the United States and Canada, 1947. I5 p. 47-4357 JK $421 . C_{3}$

A pamphlet which lists the major services or activities performed by governments in the United States, and indicates what levels of governmentFederal, State, county, or city-administer them. About 400 specific activities of government are tabulated here under 15 major headings such as "Protection to Persons and Property," "Development and Conservation of Natural Resources," "Health," and "Public Assistance and Social Services." The level or levels of each activity are indicated. Federal activities include the traditionally central operations which the Federal government administers directly-national defense, regulation of money, the post office-regulatory functions; and research, promotional, and supervisory activities that make special use of the grant-in-aid device. While any governmental activity not constitutionally granted to the Federal government is reserved to the States, in practice the States have delegated responsibility for the direct administration of most activities, other than regulatory services, to their local units, the county governments. Municipal government functions are as varied as is necessary to meet local needs, and special districts deal with exclusively local problems.

6136. Fabricant, Solomon. The trend of government activity in the United States since 1900.
New York, National Bureau of Economic Research, 1952. xix, 267 p. illus. (National Bureau of Economic Research. Publications, no. 56)

$5^{2-7402} \mathrm{JK}_{42 \mathrm{I}} \cdot \mathrm{F}_{1} 8$

The title is not self-explanatory: Dr. Fabricant means government activity directly affecting the economy and capable of statistical measurement. His chief aim is to contrast the economy of 1950 with that of 1900 , when "on the whole people still thought in terms of 'the less government, the better," "and to determine the character and the pace of the increases in government activity which are so apparent. But even in 1900 government was not a negligible factor: it held about 7 percent of the nation's capital assets and employed about 4 percent of the labor force. By $195^{\circ}$ these percentages had become respectively 20 and 12.4, and of the consolidated net sales of business 5 percent was made to government. After presenting detailed tables and graphs for the increasing "absorption" of these resources by government, Dr. Fabricant considers the relative shares of the Federal government and of state and local governments in these developments. While the increase in the Federal share is great, the lesser units still bulk large: if in 1900 they employed 73.2 percent of all government workers, in 1949 they still employed 49.I percent of the total. There follow chapters on the "Functional Classification of Government Activity" and "Productivity in Government and the Output of Government Services." "Interstate Differences in Government Activity," even on a per capita basis, are surprisingly wide. The appendixes contain detailed tables of government employment, capital goods, and expenditures.

6137. Ogg, Frederic A. Ogg and Ray's Introduction to American government, by William H. Young. rith ed. New York, AppletonCentury-Crofts, 1956. 953 p. illus. (The Century political science series) ${ }_{56-5483} \mathrm{JK}_{42 \mathrm{I}} \mathrm{O}_{5} \quad 1956$

A standard textbook on American government since 1922, now revised and somewhat changed in emphasis by Professor Young of the University of Wisconsin, who has largely rewritten the chapters dealing with the democratic process in part $\mathbf{r}$, and those concerned with the units and functions of the Federal government in part 2. He has replaced the historical introduction by a chapter on the American people and society. Taking advantage of recent studies of political behavior and group politics, he has put a stress upon the democratic method and upon the American people, for whom and by whom our governmental system is operated, at least equal to, if not greater than, that put upon the Constitution by the original authors in previous editions. He has made far fewer emendations in part 3 , which discusses the structure, powers, functions, financing, 
and problems of the state governments. Part 4, devoted to local government-county, city, town, township, village, and district-has also been left virtually unaltered. In 1932 Messrs. Ogg and Ray launched a briefer text, Essentials of American Government, which reached a 7 th edition in 1952 (New York, Appleton-Century-Crofts. 774 p.).

6138. Schmeckebier, Laurence. Government publications and their use. 2d rev. ed. Washington, Brookings Institution, 1939. xv, 479 p. (Brookings Institution, Washington, D. C. Institute for Government Research. Studies in administration, no. 33） $39-22433 \mathrm{Z}_{1223 .} \mathrm{Z}_{7} \mathrm{~S}_{3} \quad 1939$

First published in 1936.

"Catalogs and indexes": p. 5-6r; "Bibliographies": p. 62-75.

A descriptive guide to the indexes, bibliographies, catalogs, and other important sources of information concerning government publications, chiefly Federal, but with some attention to those of the States. The purpose is "to indicate the limitations and uses of the indexes, to explain the systems of numbering and methods of titling, to call attention to some outstanding compilations or series of publications in several fields, and to indicate how the publications may be obtained." Although it specifically cites many publications by title, this volume is not a catalog, bibliography, or checklist. Chapters I-4 and I6 contain general information applicable to nearly all classes of publications. The other I I describe publications dealing with laws and legislative proceedings, court decisions, administrative regulations, Presidential papers, foreign affairs, reports on operations, organization and personnel, and maps. An introduction to the study of government publications for library school students, Anne Morris Boyd's United States Government Publications, 3d ed. rev. by Rea Elizabeth Rips (New York, Wilson, r 949 [i.e. I952] xx, 627 p.), provides a checklist. arranged principally by the organization of the government-the Federal courts, the Executive Office of the President, the departments, independent establishments, and emergency agencies.

6r39. Zink, Harold. Government and politics in the United States. 3d ed. New York, Macmillan, 1951. I008 p. 5I-3675 JK274.Z44 I95I

First published in 1942.

"Selected bibliography" at end of each chapter.

The initial chapter of this large college text outlines the different kinds of government, including the democratic forms. A separate section, "Foundations of the Commonwealth," includes such chapters as "Pressure Groups and Pressure Politics," "The Role of Public Opinion," and "The Obligations and Responsibilities of Citizenship." Succeeding chapters examine in detail the operations, agencies, institutions, powers and duties, financing, and policy of the Federal government, as well as its relations with business, agriculture, and labor. The book provides briefer surveys of the functions, administration, and services of State, territorial, and local governments. The author discusses the operational methods of the various branches and divisions of the several governments, as well as projects of reform and reorganization. There are noteworthy, chapters on "Public Personnel Administration," "Social Security and Public Housing," and "Public Planning and Conservation." Throughout, he gives careful attention to the American type of democracy, to its special characteristics, to its accomplishments, and to its shortcomings. Professor Zink's large text has had no recent revision, but there is a $195^{8}$ edition of his briefer course: American Government and Politics: National, State, and Local, by Harold Zink, Howard R. Penniman, and Guy B. Hathorn (Princeton, N. J., Van Nostrand. 446 p.).

\section{F. The Presidency}

6r40. Binkley, Wilfred E. President and Congress. New York, Knopf, 1947. 312 p.

$$
\text { 47-1 } 135 \text { JK } 5 \text { I6. B5 } 1947
$$

First published in 1937 as The Powers of the President, by Doubleday, Doran \& Co. "This edition completely rewritten, expanded, and reset."

Bibliography: p. 30I-3I2.

A study of the historical relationship between the American Presidency and Congress and of efforts made to find a workable adjustment within it. In Professor Binkley's opinion, the problem of inte- grating the executive and legislative branches of the government has not yet been permanently solved. The Presidency, as originally established by the Federalists under the Constitution, was assigned a position of leadership and the executive departments were to constitute a ministry, but the agrarians, headed by Jefferson, launched a drive against the executive, particularly Hamilton in the Treasury Department. The author believes that John Adams contributed to the decline of the executive, and that under Madison government leadership passed 
definitely to Congress. Nevertheless the election of Andrew Jackson in 1828 marked the emergence of the concept of the President as "the tribune of the people." Ever since, Professor Binkley believes, powerful interests have always been uneasy when a popular, aggressive leader has even threatened to reach the Presidency. The author views the function of the President as the discovery and promotion of the public welfare. Less sanguine about Congress, he sees it as most successful when it brings about an equilibrium among conflicting interests.

6141. Brownlow, Louis. The President and the Presidency. Chicago, Public Administration Service, 1949. 137 p. (Chicago. University. Charles R. Walgreen Foundation [for the Study of American Institutions] Lectures)

$$
49-6223 \mathrm{JK}_{5} 16 . \mathrm{B}_{74}
$$

An informal analysis of the Presidency based upon six lectures delivered at the University of Chicago in 1947. Regarding the Presidency as a unique and peculiarly American institution created both by law and by custom, Mr. Brownlow examines the attributes of the office and shows how the men who fill it are chosen, how they are equipped for the task, what is expected of them, and what help they need in meeting the expectations. The institutional aspects of the Presidency are considered principally as they have been since 1900 when, in the author's opinion, the Presidency emerged in its modern phase with the succession of Theodore Roosevelt. Because Mr. Brownlow regards the man as inseparable from the institution, he takes the two together, showing how the Presidents have influenced the Presidency, changing it from time to time by weight of their personalities, and how the Presidency has influenced the Presidents, sometimes reshaping them into different individuals. The author has relied upon his own observations and reflections, including a personal knowledge of eight Presidents, rather than upon documentary research.

6142. Chamberlain, Lawrence $H$. The President, Congress and legislation. New York, Columbia University Press, 1946. 478 p. (Columbia University. Faculty of Political Science. Studies in history, economics and public law, no. 523)

$$
\text { A } 46-4849 \mathrm{H}_{31 . \mathrm{C}_{7} \text {, no. } 523}
$$

Bibliography: p. 465-473.

$\mathrm{JK}_{5} 8_{5} \cdot \mathrm{C}_{5} \mathrm{I} 946 \mathrm{a}$

A survey of the relative contributions of the President and Congress to legislation enacted during the years 1882-1940, which considers in detail the legislative histories of 90 selected statutes in ro categories: agriculture, banking and currency, business, government credit, immigration, labor, national defense, natural resources, railroads, and tariff. As- signing credit for these on a tabular basis, and noting areas in which the President or the Congress has been especially conspicuous, the book shows the joint character of the American legislative process. It does not reveal any tendency toward increasing Presidential domination of that process. Theodore Roosevelt was the first President of the United States, the author asserts, to pursue a policy of executive dominance in legislation. Woodrow Wilson's particular contribution was a more deliberate and effective party leadership. Franklin D. Roosevelt, with his multidimensional leadership, did much to reduce Congress to a secondary function in legislation. As Dr. Chamberlain points out, all three were forceful men who came to office when the social and economic development of the nation had rendered the need for progressive legislation acute.

6r43. Corwin, Edward S. The President, office and poivers, 1787-1948; history and analysis of practice and opinion. [3d ed., rev.] New York, New York University Press, 1948. xvii, 552 p. (New York University. Stokes Foundation. James Stokes lectureship on politics)

$$
4^{8-7474} \quad \mathrm{JK}_{5} \mathrm{I} 6 . \mathrm{C}_{3} \quad 1948
$$

A partly historical, partly analytical and critical, study in American public law, originally published in 1940. The central inquiry concerns the development and contemporary status of Presidential power and of the Presidential office under the Constitution. Its political aspects are also considered, since in only a few instances have previous practice or agreed doctrine foreclosed all choice between alternative theories of the Constitution. Personal traits of individual Presidents are duly commented upon if they have materially affected the development of the office and its powers. In the author's view, the Constitution was sufficiently vague to initiate a struggle between two concepts of executive power: the theory that it should always be subordinate to the supreme legislative power, and the theory that it should be, within generous limits, autonomous and self-directing. Generally speaking, the history of the Presidency has been one of aggrandizement. Professor Corwin considers that Presidential power today not only is enormously increased by the delegation from Congress of sub-legislation called "administrative regulations," but also is "dangerously personalized." He suggests as a remedy a new type of Cabinet constructed from a joint legislative council to be created by the two houses of Congress and to contain its leading members.

6r44. Hobbs, Edward H. Behind the President; a study of Executive Office agencies. Washington, Public Affairs Press, 1954. 248 p.

$53-5789 \quad \mathrm{JK}_{5} 18 . \mathrm{H6}$ 
A history and critical analysis of the expanding group of staff agencies which, beginning with the creation of the Bureau of the Budget in $192 \mathrm{I}$, have provided administrative management for the Presidency. When Congress gave him the authority in a Reorganization Act, President Franklin Roosevelt by executive order combined them into the Executive Office of the President in 1939, at which time they comprised the White House Office, the Bureau of the Budget, the National Resources Planning Board, the Liaison Office for Personnel Management, and the Office of Government Reports. Provision was then made for "such office for emergency management as the President shall determine in the event of a national emergency or the threat of one." A chapter each is devoted to the first three agencies mentioned above, and one each to the Council of Economic Advisers, the National Security Council, the National Security Resources Board, the emergency agencies, and staff machinery under President Eisenhower. The Executive Office was planned to keep the President systematically informed of matters of top-level importance, to assist him in preparing for future programs, to protect him from the nuisance of subordinate affairs that could dissipate his time and energies, to place priority matters before him promptly, and to aid him in securing compliance from subordinates. Mr. Hobbs thinks that these objectives have been achieved "to a modest degree."

6145. Learned, Henry Barrett. The President's Cabinet; studies in the origin, formation and structure of an American institution. New Haven, Yale University Press, 1912. 471 p.

"List of authorities": p. 404-427.

$$
\text { I2-I466 JK6ri.L5 }
$$

A pioneer historical analysis of the President's Cabinet which explains the formation of the advisory council as well as the establishment of the structural offices which provide its members, but which is limited to the anatomy rather than the functions of the Cabinet. Professor Learned considered the President's council not so much a conscious derivation from any body in existence when it was created as the expression of a need as old as governmentthe need of a corps of closely associated assistants qualified to aid a vigorous and effective chief magistrate. Shortly after Congress enacted laws in 1789 for the establishment of the three secretaryships of State, War, and Treasury and of the Office of Attorney General, Washington brought these four officers together as an advisory council, which by 1793 was popularly termed the Cabinet. By 1912 five other department heads had been added to the President's council: Secretary of the Navy, 1798; Postmaster General, 1829 (an instance of an office of long stand- ing being raised to Cabinet rank); Secretary of the Interior, 1849; Secretary of Agriculture, I889; and Secretary of Commerce and Labor, 1903. As the author emphasizes, the law created the principal officers or members of the Cabinet, but the Cabinet itself was the creation of President Washington. His practice became custom, and the Cabinet has remained a customary and not a statutory body.

\section{Milton, George Fort. The use of presiden-} tial power, 1789-1943. Boston, Little, Brown, I944. 349 p. $\quad 44-3756 \quad \mathrm{JK}_{516 . \mathrm{M}_{5}}$ "Bibliographical note": p. 323-327.

An historical examination of the office and powers of the American President from George Washington to Franklin D. Roosevelt. Mr. Milton sees a continuing, if not orderly, increase in the power of the Presidency that is in line with the general readjustment of executive and legislative importance in the modern world of accelerated change. In his opinion, the Constitution, crisis, and custom have combined to vest great power in the President: as chief of state, he embodies the people's elective will; as chief of foreign relations, he has, from the beginning, functioned as sole organ of this country in its external relations; as Commander-in-Chief of the Army and Navy, he has enormous power in time of war, rebellion, or other high crisis; and, as chief of government, he bears direct responsibility for the huge executive branch of the government. Inseparable from the person of the President, also, are his position as chief of his party, as leader of public opinion, and as spokesman for the nation. The author focuses attention upon those whom he considers the strongest PresidentsWashington, Jefferson, Jackson, Lincoln, Cleveland, Theodore Roosevelt, Wilson, and Franklin D. Roosevelt-in order to discover how they used their power, the emergencies they confronted, their discoveries of authority for action, and the consequences for the Presidential office.

6147. Patterson, Caleb Perry. Presidential government in the United States; the unwritten constitution. Chapel Hill, University of North Carolina Press, I947. 301 p. 47-30530 $\mathrm{JK}_{5} \mathrm{I}_{6 . \mathrm{P}_{3}}$

Bibliography: p. [28I]-296.

Professor Patterson contends that the United States has substituted a political for a constitutional democracy, that Congress and the Supreme Court are becoming the agents of the President, and that we have gone entirely too far toward an executive type of government, which is subject to almost no legal checks, and is responsible only to the ballot box. The chief check on the national government therefore becomes the two-party system. With this in mind, the author proposes a readjustment in the 
relation between the President and Congress. The President, he believes, should be made to act through ministers chosen from and responsible to Congress. Forming a Cabinet, these ministers would supervise operations of the Federal agencies and represent them in debate upon the floors of Congress. The prime minister would be selected by a caucus of the majority party in Congress. He, in turn, would select the other ministers with the approval of the caucus. The author suggests 24 ways in which his proposal would aid in adapting our constitutional system to a more practical and responsible scheme of control. The adoption of some modification of the British system of a responsible Cabinet has frequently been urged, but has never received any significant degree of public support.

6r48. Smith, A. Merriman. A President is many
men. New York, Harper, 1948. 269 p. 48-6989 JK 516.565

An informal and anecdotal report on the intricate operations of the 2oth-century Presidency by a White House correspondent. Mr. Smith says that "the Presidency, despite the high honors that go with it, has become a four-year sentence to hard labor." A modern President, the author believes, is as powerful as his ability to influence public opinion; his power has grown in direct ratio to the development of mass media of communication. He needs the qualities of an excellent actor, a capable financier, an able administrator, and a good student of military science, geography, farming, and international affairs. Under constant siege from those who want something, the President is advised by his romember Cabinet and his inner circle of intimates; he has on his staff a team of idea-men and speechwriters, a large secretariat, and a group of public relations experts. Mr. Smith describes the organization of this staff as well as that of the White House domestic entourage, and such matters as entertainment, ceremonial visits, Presidential travel, and the persons with whom the President regularly has to deal, among them politicians, reporters and photographers, and the writing and present-making public.

6149. Stanwood, Edward. A history of the Presidency. New ed., rev. by Charles Knowles Bolton. Boston, Houghton Mifflin [193-?] 2 v.

$$
\text { 37-31629 JK5Ir.S7 } 1930
$$

Contents. - [v. I] From 1788 to $1897 .-[$ v. 2] From 1897 to 1916 , with additions and revisions to 1928.

Stanwood (1841-1923) was a staunch Maine Republican who served briefly as secretary to James G. Blaine (no. 3442) and became editor of the Boston Advertiser and of the Youth's Companion. In $188_{4}$ he published his History of Presidential Elections, which went through four editions by 1896 , and received its present and less appropriate title in 1898 . A second volume was added in 1912, and the author's last revision of it was made before the election of 1916 . In the final printing C. K. Bolton of the Boston Athenaeum, who was Stanwood's sonin-law, corrected some errors and added appendixes of platforms and tables for the elections from 1916 through 1928, but did not expand the narrative. Stanwood devoted a chapter to each presidential election from 1788 to 1912 , treating concisely and concretely the state of the electoral machinery, the political parties in the field, the major issues, the platforms adopted (usually in full), the selection and qualifications of the candidates, and significan incidents of the campaign. Tables are given for votes in the party conventions, when repeated balloting was necessary to reach a result, and for the popular and electoral votes of all significant candidates. A final chapter discussed "The Evolution of the Presidency" from the viewpoint of 1916. Eugene $\mathrm{H}$. Roseboom's A History of Presidential Elections (New York, Macmillan, 1957. 568 p.) is a livelier narrative covering the elections through 1956 , and more up-to-date in its historical points of view, but by no means rivals Stanwood as a convenient source of essential information.

\section{G. Congress}

6150. Alexander, De Alva Stanwood. History and procedure of the House of Representatives. Boston, Houghton Mifflin, I916. xv, $435 \mathrm{p}$. 16-11 176 JK $1316 . \mathrm{A}_{3}$

A documented history of the organization and procedures of the United States House of Representatives from 1789 to 1911 , when Representative Alexander of Buffalo concluded seven successive terms. It shows how such Speakers as Henry Clay,
Samuel J. Randall, Thomas B. Reed, and Joseph G. Cannon set precedents and shared in establishing customs. Mr. Alexander considered deciding questions of order the most difficult of the Speaker's functions, and exercising his right of recognition the most embarrassing, although the latter had become materially restricted by the use of privileged motions, measures, and reports, and privileged business on fixed days of the week. In fact, by the close 
of the 6rst Congress in 1911 , the Speaker was virtually shorn of power save for the appointment of committees, and the right of recognition for motions to suspend the rules. The author disapproved of the change made at the first session of the $62 \mathrm{~d}$ Congress, by which all standing committees were elected instead of appointed by the Speaker, because, to him, that officer embodied public and concentrated responsibility, and because no one else held so great an interest in the success of his party and its administrations. Among other subjects treated at less length are: the remaining officers of the House and their duties and privileges; methods of voting; rules; the order of business; and committees. It is regrettable that no subsequent Member of the House has continued Alexander's very useful work.

6151. Bates, Ernest Sutherland. The story of Congress, r789-1935. New York, Harper, 1936. xvii, $468 \mathrm{p}$. 36-9206 JKI021.B3

"A modest record of the doings of Congress for the information of the general reader," organized in nine chapters: "The Federalist Foundation," I 789 I8or; "Jeffersonian Democracy," r8or-29; "Jacksonian Democracy," I829-45; "Compromise with Slavocracy," 1845-61; "Overthrow of Slavocracy," 1861-77; "Industrial Capitalism," I 877-1901; "Era of Reforms," I90I-21; "Finance Capitalism," I92I33; and "The New Deal," I933-35. These are subdivided by Presidential administrations, and further subdivided by Congresses, 74 in all. Mr. Bates supplies a lively and useful panorama, from which can conveniently be learned the major issues, figures, and incidents of any Congress; but he takes sides rather emphatically and rigidly. In his opinion, the fundamental issue which has confronted American democracy from the beginning is whether the United States "in the last analysis should be ruled by the judiciary or the legislature, by the immediate representatives of the plutocracy or by the distant representatives of the people." However inadequately, he believes, Congress and the President have more neariy represented the masses of the people than has the Supreme Court, which has tended to give priority to the rights of property.

6152. Burns, James MacGregor. Congress on trial; the legislative process and the administrative state. New York, Harper, 1949. xiv, 224 p.

An inquiry into the low prestige which, the author thinks, Congress enjoys with the general public, the basic reason for whici he finds in the national legislature's excessive localism and consequent failure to promote the general welfare. The average Congressman, Professor Burns argues, adequately represents any interests of his district that are united and vocal, but when local opinion on national issues is divided he is likely to straddle. Some Congressmen, he writes, are so completely absorbed by organized local interests that they are themselves pressure politicians, "lobbyists in disguise." Defects in congressional organization, he believes, allow unfair districting, unrepresentative committees, the monopoly of policy-making chairmanships by persons qualified only by length of tenure, and obstruction through filibusters, all of which lessen or destroy the effectiveness of Congress, and weaken it as an instrument of majority rule. The national legislature in his opinion thus tends to dissolve into an aggregate of blocs and of individuals unwilling or unable to withstand their pressures; and, lacking machinery for control or discipline in the legislature, the majority party cannot hold its members to the program which it has pledged to the voters. Professor Burns particularly dreads the paralysis which selfish obstructionism could produce in some future economic crisis. He offers six concrete suggestions intended to bring about "the wholesale reconstruction of our obsolete and ramshackle party system," one corollary of which is that the disloyal, those who use the party to gain election and then ignore its program, must be "purged"-read out of the party.

6153. Chamberlain, Joseph P. Legislative processes, national and state. New York, Appleton-Century, 1936. 369. ([The Century political science series])

Bibliography: p. 355-357.

A textbook "organized," in the words of the preface, "for the use of a class in legislation, in which an endeavor was made to give the students a working notion of the way in which laws are placed on the statute books in the United States Congress and the state legislatures, rather than a mere description of the functioning parts of the legislatures. It is based on experience in preparing and handling bills, and even more on the aid of men who have themselves been members of Congress or state legislatures, or who have served those bodies." Legislatures, the author remarks, "are law-declaring rather than lawmaking bodies." Changing social conditions require gradual modification of the rules governing society, and such modification is today being sought through legislation more often than through the slower and sometimes clumsier method of court action. As administration expands, the scope of legislative activity broadens, since only through legislation can new government organizations be established or existing ones be adjusted to greater loads. The need for changes in existing machinery is frequently first noticed by the executive officers in charge of operations. Through them come requests for improvements which only the legislature can 
make. The author considers in detail the organization which has evolved in Congress and the legislatures for the accurate drafting of bills and the enactment of them into law.

6154. Dimock, Marshall Edward. Congressional investigating committees. Baltimore, Johns Hopkins Press, 1929. 182 p. (Johns Hopkins University. Studies in historical and political science, ser. 47, no. I) 29-906 JKII23.A2D5 1929 $\mathrm{H}_{3}$ I.J6, ser 47 , no. $\mathrm{I}$

Bibliography: p. $177-178$.

A study of all congressional investigations conducted in this country between 1789 and 1929 . Comparing the functions of the investigative committee in the United States to those of like agencies in other modern constitutional governments, the author traces the English origin of the congressional committee of inquiry, and points out that the power of investigation, as a procedure both of Parliament and of Congress, is an implied one, based upon custom rather than constitution or statutes. This prerogative consists of three functions: investigations of the qualifications and conduct of the legislative membership; investigations in pursuance of the lawmaking functions, such as provide for future or emergency legislation or establish administrative commissions; and investigations of the executive departments for determining their needs, for supervision, for discipline, or for control of public funds. Of the total number of investigations, about 190 were authorized by the House, and $x 25$ by the Senate, while I5 were the work of joint committees. By far the largest number of investigations occurred during the Presidencies of Grant and Harding. Dr. Dimock saw the Senate emerging as the prime inquisitor, "the vitriolic critic and persistent regulator of the government." Although he recognized the dangers to personal rights and immunities that could arise from the system, the author considered investigations valuable.

6155. Galloway, George B. The legislative process in Congress. New York, Crowell, 1953. $689 \mathrm{p}$. 53-11621 JK1061.G32

"In a sense ... a successor to, rather than a revision of," the author's Congress at the Crossroads (1946).

A documented and well-organized descriptive analysis of the organization and operation of Congress. It points out that, although the power and prestige of the executive branch of the Government increased enormously during the first half of the 2oth century, Congress not only changed little, continuing to function with old machinery and methods, old facilities and services, but actually declined as an original source of legislation in comparison with the administration. Moreover, since 1887 , Congress has delegated to more and more commissions the power to issue rules and regulations under the general principles of established law. However, with the great growth of administrative activity, supervision and control of administration through appropriation, investigation, amendment of existing laws, the requirement of reports, the approval or removal of personnel, and the review of foreign relations have become some of the most important congressional functions. Dr. Galloway objects to the "centrifugal forces" of the committee system, which have become dominant in congressional policy-making, and suggests a number of reforms needed in congressional machinery, procedures, and political outlook.

6156. Harlow, Ralph Volney. The history of legislative methods in the period before 1825. New Haven, Yale University Press, 1917. 269 p. (Yale historical publications. Miscellany, 5) I7-30I35 JK $1029 . \mathrm{H}_{3}$

Based upon the author's doctoral dissertation, this is a history of the growth of committee systems in the lawmaking bodies of the colonies and states from $175^{\circ}$ to 1790 , and in the House of Representatives from July 24, 1789, when a Committee of Ways and Means was appointed, to 1825 , when the caucus, the standing committee system, and the speakership had become firmly established in the House. As early as 1797 , Dr. Harlow notes, party affiliation was becoming an important factor in the selection of committees, and by 1813 standing committees were admittedly made up in the interest of the dominant party. The development of the powerful speakership and of the committee system from I 8 I I to 1825 accompanied the casting off of the executive dominance which had marked Jefferson's administrations, although neither institution made the House independent of an active executive. As the author indicates, President, Cabinet, congressional leaders of the party organization, or the Speaker might and did have the whiphand at various times. The balance of power was generally in the House, but members of the Cabinet were influential in legislative affairs, and the organization of the House did and does permit the application of powerful pressure by the executive. To Dr. Harlow, such application is all to the good: "The wheels of the government have never run more smoothly than when the president has been in a position to drive Congress."

6157. Harris, Joseph P. The advice and consent of the Senate; a study of the confirmation of appointments by the United States Senate. Berkeley, University of California Press, 1953. $457 \mathrm{p}$.

53-1 1239 JK $1274 . \mathrm{H}_{3}$ 
A history of the Senate's confirmation or rejection of Presidentially appointed officers of the United States, from 1787 to the present, together with an analysis of the operation and the effects of the practice. Because constitutional issues have been raised in controversies over the respective functions of the President and the Senate in appointments, special attention is given to the debates about the appointing power in the Constitutional Convention of 1787 . The problem of which officers should be appointed by the President and confirmed by the Senate, and which should be otherwise appointed, is central to the discussion. In Professor Harris' opinion, the requirement of senatorial confirmation of appointments has worked fairly well for certain classes of officers, and has provided, as the framers of the Constitution intended, a safeguard against unfit appointees; for others it has worked badly, resulting in empty formalities of little significance, or perpetuating partisan and patronage appointments in positions which properly belong in the career civil service. The extension of the requirement of senatorial confirmation from Justices of the Supreme Court and diplomatic representatives to thousands of minor positions is contrary, the author believes, to the spirit if not to the provisions of the Constitution. He would restrict the President's appointments to the top political and policy-making positions.

6158. Haynes, George $H$. The Senate of the United States, its history and practice. Boston, Houghton Mifflin, 1938. 2 v. ( 1118 p.) illus. $3^{8-38772}$ JKII61.H28

"References" at end of most of the chapters.

A large-scale history of the United States Senate and of the development of its practices, legislative, executive, judicial, and investigative, based on original sources throughout. Chapter I describes the planning of the Senate in the Federal Convention of 1787 as the upper branch of a bicameral legislature, based upon equal representation of the states. Chapter 2 deals with the important work of the First Congress in setting precedents in such matters as titles for government officials, confirmation of Presidential appointees, ratification of treaties, cooperation between the two branches of Congress, initiation of important measures, and amendment of many bills, which it could not, under the Constitution, originate. Subsequent chapters deal with such topics as the election of Senators, Senate officers and organization, rules and procedure, debate, Senate influence in financial legislation, investigations, treaty-making and foreign relations, "advice and consent," and the relationship between the Senate and the President as well as between the Senate and the House. As Professor Haynes ob- serves, almost every phase in the Constitution which pertains to the Senate reflects compromise. "The result was a legislative body unique in its basis of representation, in its relation to the Executive and to the other branch of Congress, in its procedure, and in its weighty non-legislative powers." The Senate was designed to serve as somewhat of an executive council to the President, as a check on the House, as guardian of the small States, as protector of all against encroachment by the new centralized power, and as the people's defender against "the turbulency of democracy." Its original basis has been changed, but it still retains its old prestige, and a special constitutional value which resides in its independence of judgment.

6I59. Kammerer, Gladys M. The staffing of the committees of Congress. [Lexington] Bureau of Government Research, University of Kentucky, 1949. $45 \mathrm{p}$. 49-47303 JK ro67.K3

Based on interviews, this is a very brief survey of the qualifications and methods of selection of the staff members, professional and clerical, appointed by the committees of both houses of Congress under the Legislative Reorganization Act of 1946 . Examination is made of the staffing of the 15 standing committees permitted the Senate and the 19 permitted the House of Representatives. "Fifteen committees are parallel in each house," observes the author, "and furnish pointed contrasts as well as similarities. Four committees are found only on the House side; those on House Administration, Merchant Marine and Fisheries, Un-American Activities, and Veterans' Affairs." The 15 parallel committees have to do with agriculture, appropriations, the armed services, banking and currency, the District of Columbia, expenditures in executive departments, foreign affairs, interstate and foreign commerce, judiciary, labor, the post office and civil service, public lands, public works, rules, and taxation. The author finds a marked superiority in the quality of the Senate committee staffs. She considers the makeup of a few of the special committees and concludes that there is need for improvement in the recruitment and selection process, and that less emphasis should be placed on the employment of lawyers.

6r6o. McGeary, Martin Nelson. The developments of congressional investigative power. New York, Columbia University Press, 1940. 172 p. (Columbia University. Faculty of Political Science. Studies in history, economics and public law, no. 465)

$40-5782$ JKI123.A2M 19402

Bibliography: p. $161-165$. $\mathrm{H}_{3}$ I.C7, no. 465

An analysis of the congressional investigation. 
particularly as it operated between 1929 and $194^{\circ}$. The author credits investigations with illuminating many dark problems and even carefully hidden skeletons, but declares that they have also obfuscated issues and nullified worthwhile accomplishments. Furthermore, they have varied widely in purpose and procedure as well as results. The Senate has functioned as the more important investigator, both as to quantity and significance, especially since 1933, when the emphasis shifted from checking the administration to collaborating with it. As Dr. McGeary observes, in both the Senate and the House more investigations are killed than are accepted, but the importance of even the threat of investigation should not be overlooked. He classifies congressional investigations as those which assist Congress in drafting laws, determining the desirability of legislation, or molding public opinion, and those which assist Congress in its supervision of administrative officers. These last comprise about a third of recent inquiries. Investigations of congressional membership form only a fraction of the total.

6r6r. Pepper, George Wharton. In the Senate. Philadelphia, University of Pennsylvania Press, 1930. I48 p. 30-28947 JKII6r.P6

An anecdotal and sprightly, yet in the main detached, account by Mr. Pepper (b. 1867) of his completion of the deceased Boies Penrose's term as United States Senator from Pennsylvania during the years 1922-27. At the time of his appointment Mr. Pepper was without political experience and appeared to the Republican stalwarts, particularly to the Philadelphia machine controlled by William S. Vare, as "an outsider, a novice, an untrained beneficiary" of a reward he had not earned. The machine defeated him in the following election. Offering pungent characterizations of the more notable of his colleagues, he argues that although Senators differ in ability, they possess, on the whole, a high average. In Mr. Pepper's opinion, the most effective Senators are those who at once understand their subjects and refrain from wounding the sensibilities of their colleagues. He describes procedures and rules of the Senate, the committee system, the seniority principle, pressures, conferences, the filibuster, and special services and information required by constituents. He sees the Senate's function as essentially regulatory, a check upon the Executive and upon legislative action initiated by the House.

6162. Riddick, Floyd M. The United States Congress; organization and procedure. Manassas, Va., National Capitol Publishers, I949. 459 p.

First published in $194 \mathrm{I}$.
A useful but technical and minutely detailed handbook on House and Senate legislative machinery and political and parliamentary procedures. The author, who is assistant parliamentarian of the Senate and editor of the "Daily Digest" of the Congressional Record, points out the great difference in the methods of the houses for transacting business. Of the two, the Senate, with only $96 \mathrm{mem}$ bers, has a less rigidly fixed set of rules, and much looser, less specifically defined, and less regulatory parliamentary law. The House, on the other hand, with 435 members, proceeds under rigidly limited debate, with individual consideration giving way to the will of the whole membership in any test case, so as to permit of dispatch in its business. The two chambers also call up business in differing ways, the Senate's system being far the simpler. Dr. Riddick underscores the ability of the standing committees and their chairmen to shape legislation in both chambers, as well as their influence in the enactment or the blocking of a given law.

6I63. Schmeckebier, Laurence F. Congressional apportionment. Washington, Brookings Institution, I94I. 233 p. ([Brookings Institution, Washington, D. C. Institute for Government Research. Studies in administration, no. 40]) 4 I-3I46 JKI33I.S 35

A detailed description of the "five modern workable methods" of apportionment to each state of Congressmen in the House of Representatives and votes in the electoral college, which, according to the Constitution, should follow each decennial census. These methods, all mathematically consistent, are: the method of major fractions, the method of equal proportions, the method of harmonic mean, the method of smallest divisors, and the method of greatest divisors. The apportionment ratio is obtained by dividing the population of the entire country by the number of representatives, which, since I9ro, has been 435. Difficulty arises from the fact that seldom if ever does any apportionment ratio divide exactly into the population of any State. Always there is a remainder which may vary from a small to a large fraction of the ratio. Controversy has arisen at every reapportionment since the adoption of the Constitution over selection of the States to receive additional members for their fractional population above the ratio. A major purpose of apportionment is to equalize the average population of congressional districts. The author demonstrates that the difference between average populations is always least if the method of equal proportions is used. This method provides the most equitable distribution among States regardless of size and is therefore to be preferred. 
6164. Taylor, Telford. Grand inquest: the story of congressional investigations. New York, Simon \& Schuster, $1955 \cdot 35^{8} \mathrm{p}$.

54-9803. JKI123.A2 $\mathrm{T}_{3}$

An expansion of various addresses and lectures concerning the powers of legislative investigative committees delivered during 1953. Mr. Taylor, a distinguished lawyer and former associate counsel to a Senate committee, was deeply concerned at the time of writing over "the internal crisis of confidence" in the United States, which he attributed directly to congressional investigations. He here sets forth and tellingly analyzes 162 years of such investigations, beginning with "The Ordeal of Major General Arthur St. Clair," first Governor of the Northwest Territory in 1792, and touching upon all important probes down to and including the "dull, dramatic, farcical, enlightening, and frightening" McCarthy-Army hearings of 1954. The author finds that there has been a recent distortion of the historic mission of legislative inquiries to expose administrative corruption or inefficiency, and to discover the facts and circumstances with which the law-making process is concerned; he finds, too, the approach of a situation in which political sentiments are scrutinized by roving inquisitions which punish dissent by a kind of outlawry. He sees in this last a "native-American" challenge to "middle-class liberalism." Although he himself attempts to dispel "the illusion of investigative omnipotence" by citing constitutional limitations on the investigations of Congress and the doctrine of judicial review, he observes that it has not been extinguished.

6r65. Voorhis, Horace Jeremiah. Confessions of a Congressman. By Jerry Voorhis. Garden City, N. Y., Doubleday, 1947. 365 p.

$$
\text { 47-II4I2 E743.V6 }
$$

An informal memoir of the author's ro-year service (1937-47) as a Democratic Congressman from California, written shortly after his defeat for reelection. He offers frank and reflective comments upon such matters as his reasons for entering politics, campaigning, the relations between Congressmen and pressure groups, the seniority rule, the operation of the committee system, and the Congressman's job as it is and as it should be. Calling himself a "progressive," Mr. Voorhis also discusses legislation and a number of important issues with which Congress was confronted during his terms of office, among them the Supreme Court packing plan, the Fair Labor Standards Act, the Flannagan school lunch program, the McMahon Atomic Energy Control Act, the Dies committee, and postwar planning. He approves of nearly all New Deal legislation and credits Franklin D. Roosevelt with two great contributions to American political thought: establish- ment of the principle that mass unemployment is a national problem for which the Federal government is responsible, and the broadening of the concept of America's world position to include world leadership. Enlightened, critical, and self-critical, this is a very unusual sort of book.

6166. Walker, Harvey. The legislative process; lawmaking in the United States. New York, Ronald Press, 1948. 482 p. (Series in political science)

Bibliography: p. 459-467.

An introductory text and handbook which "describes the machinery set up in the United States for determining and declaring the will of the people. It attempts to evaluate objectively the defects in this machinery and the impediments which have been allowed to accumulate in the path of its smooth operation. And, finally, it suggests a direction for future progress." The nature of law is first briefly considered, since, in the author's opinion, any systematic study of the legislative process must be concerned with law as an end-product as well as with the devices by which it is brought into being. Next treated are the making and development of constitutions at both the national and State levels. There follow a number of chapters devoted to statute lawmaking. The provinces, at all levels of government, of the "political inventor," the professional politician, the party member, the pressure-group member, and the legislator are thoroughly examined. Also dealt with in detail here are legislative procedure, including the organization of the legislative body; rules and order of business; the introduction, reference, consideration, and enactment of bills; and such special matters as legislative research and drafting. The functions of the Executive and of the courts in relation to the legislative process receive due attention, and the work concludes with chapters on executive, judicial, and popular lawmaking.

6167. Willoughby, William F. Principles of legislative organization and administration. Washington, Brookings Institution, 1934. xiv, 657 p. ([Brookings Institution, Washington, D. C.] Institute for Government Research. Principles of

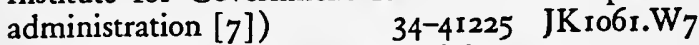
"Bibliographic note": p. 627-648.

An analysis of the several factors involved in organizing the legislative branch of government and in providing for its practical operation, together with a statement of the alternative choices in the handling of each of these factors, and an indication of the ways in which they have actually been managed by modern governments, especially by the national and State governments of the United States. 
Parts $I$ and 2 present a broad picture of the place of the legislative branch in the government of any modern state; its relations to the electorate, the executive, administration, and the judiciary; the nature of its functions; and its general structure. Part 3, constituting just over half of the volume, is devoted to a more intensive study of the technical problems faced by any legislative body in devising a workable system of internal organization and methods of procedure that will enable it most efficiently to perform its duties. Professor Willoughby found legislative organization and procedure of supreme importance in determining the character of government, the question of legislative leadership, and the extent to which party government should be actually as well as nominally a dominant feature of our political system. Progress toward responsible party government must be sought, he believed, in the acceptance and strengthening of the caucus system. The State legislative situation he considered "unsatisfactory in the extreme."

6r68. Wilmerding, Lucius. The spending power; a history of the efforts of Congress to control expenditures. New Haven, Yale University Press, 1943. 317 p. A $44-\mathrm{I}_{2} 6 \mathrm{HJ}_{2013} \mathrm{U}_{5} \mathrm{~W}_{5}$

The main purpose of this book is to demonstrate that although Congress has the exclusive right of granting supplies of money to the Executive and of appropriating them to the several branches of the public service, it has not nor ever has had any practical means of ascertaining after the event whether its financial authority has been either respected or infringed. The first chapter shows by a collection of instances that circumstances repeatedly occur which make it a duty in officers of high public trust to assume authority beyond the appropriation laws, and that when they do, the unwritten laws of necessity and of the public safety have been deemed, by liberals and conservatives alike, to supersede the written laws of appropriation. As the subsequent eight chapters indicate, the doctrine of specific appropriations was early established in theory but not in practice. The efforts of Congress to compel obedience to the appropriation laws by itemizing appropriations and other devices have been largely "self-defeating." The last four chapters analyze efforts of Congress to maintain retrospective control over departmental appropriations through financial reports, congressional investigations, and the General Accounting Office. These attempts, "while not self-defeating, have been ineffective." "The author does not attempt to show how Congress can make its right to control the public expenditures real as well as nominal.

\section{Young, Roland. The American Congress. New York, Harper, 1958. 333 p.}

\section{8-5081 JKro6r.Y59}

Mr. Young sees Congress' primary function as "that of establishing a basic legal pattern of order for society. This in turn leads to the additional requirements for creating an autonomous legislative organization to make policy and for establishing continuing relations with the government bureaucracy and with the society which is governed." Although the various functions of Congress may be performed with varying degrees of effectiveness, no one of them may be permitted to lapse completely for any length of time, the author believes, without destroying the legislative system and its complex interrelationships with other government institutions. He analyzes in some detail the electoral system of recruitment and the composition of Congress, as well as the operation of the legislative process, the powers inherent in it, and the influences to which it is subject, and concludes with a few generalizations on the proper sphere and activities of Congress as an instrument of government.

\section{H. Administration: General}

6r7o. Caldwell, Lynton K. The administrative theories of Hamilton \& Jefferson; their contribution to thought on public administration. Chicago, University of Chicago Press, 1944. 244 p. ([Studies in public administration])

$$
\mathrm{A}_{44-4703} \mathrm{JK} \text { I7r.ArC } 3
$$

A study of the crucial period in American history "when the theory and practice of administration in the new general government were in process of formation." Both the administrative and the politi- cal systems of the United States, Mr. Caldwell argues, were founded upon the divergent theories and practices of Hamilton and Jefferson. Each developed a coherent, well-considered plan of administration based upon the type of society toward which he hoped America would grow. Hamilton triumphed for a brief period of splendid construction (1789-95) with the establishment of the Treasury Department, the Mint, and the first Bank of the United States, but Jefferson ruled in spirit over the 
following century. In the author's opinion, neither ideal has triumphed over the other, and their reconciliation remains an unsolved problem. The fundamental difference in the administrative ideas of Hamilton and Jefferson appears to lie in their attitudes toward the control of political power. Hamil. ton stood for responsible and Jefferson for limited government; Hamilton admired the British system of centralized ministerial responsibility, while Jefferson preferred the accepted American notions of the separation of powers and local home rule.

6171. Graves, William Brooke. Public administration in a democratic society. Boston, Heath, 1950. xvi, 759 p. illus.

$$
\text { 50-5971 JK } 421 . G_{74}
$$

"Selected references" at end of chapters.

A textbook, based upon the author's 25 years of study and experience in the field of state, local, and Federal administration. It proceeds from the basic concept of administration "as concerned with the transaction of all of the public business, whether legislative, executive, or judicial; whether international, national, state, or local." Regarding the individual department or agency as the core of the administrative system, Dr. Graves gives special attention to the problems of coordinating organization, personnel, and fiscal operations in the actual processes of internal management. He has sharply differentiated such internal control-policy formulation, organization for production, production itself, and administration-from external relations, or the execution of policy. The latter concerns the relations of the entire agency with persons and groups outside it, and, generally, with that portion of the public that is benefiting by its services or subject to its regulations. In establishing these regulations, the administrative agencies make extensive use of quasi-legislative and quasi-judicial powers. Dr. Graves discerns two "indisputable" trends in modern government: "a definite shift from legislation to administration as the vital element in the process of governing," and a correspondingly more modest view of its own function taken by the Supreme Court.

6r72. Hyneman, Charles S. Bureaucracy in a democracy. New York, Harper, 1950. xiv, $586 \mathrm{p}$. $\quad 50-6789 \quad \mathrm{JK}_{421 . \mathrm{H} 8}$

"Bibliographic note" at end of chapters.

"The primary concern of this book is to consider what can be done to make our federal bureaucracy function as the faithful servant of the American people." The descriptions of the structural organization of the administrative branch of the national government, its activities, and the way it goes about them are kept to a minimum and are incidental to an analysis of how the bureaucracy is or may be given direction and may be kept answerable to the people. Four basic assumptions underlie the argument: that bureaucracy must be judged by its use of power, not by its size or cost; that all administrators should exercise their power within limits acceptable to the American people as a whole; that the great power of modern bureaucracy can be turned toward ends unacceptable to the people, and may be so turned unless proper direction and control are provided for our administrative establishments; and finally, that elective officials must be the primary reliance for directing and controlling the bureaucracy. There is democratic government, Professor Hyneman believes, only when vigorous competition for popular approval exists among men who desire to hold public office and to exercise the authority of government. These men must make public affairs their business, know their business, inform the public, and put programs into practical operation.

6r73. Short, Lloyd Milton. The development of national administrative organization in the United States. Baltimore, Johns Hopkins Press, 1923. xviii, 514 p. ([Brookings Institution, Washington, D. C.] Institute for Government Research. Studies in administration [no. ro])

Bibliography: p. 483-49o.

$$
24-986 \mathrm{JK}_{4} 1 \mathrm{I} . \mathrm{S}_{5}
$$

This University of Illinois dissertation remains the only comprehensive view of the development of administrative agencies and functions in the Federal government from its beginnings in 1775 through the second decade of the 20 th century. After introductory chapters on the function and the constitutional basis of administration, administrative beginnings under the Continental Congress, and the reorganization of government under the Constitution, Dr. Short deals with each department in turn. He records within each the emergence of important officials; the creation of boards, bureaus, offices, corps, or other subordinate organizations or institutions; the addition or loss of functions by statute or administrative order; and all important measures of reorganization. He breaks off in 1860 and supplies an "Outline of Administrative Organization" for that year; it fills just 2 pages, and may be compared with the 8-page outline of the situation at the date of publication. For the earlier period a single chapter is sufficient to deal with "The Post Office, the Attorney General's Office, and the Detached Services." With 1860 Dr. Short starts over and goes through the departments again, bringing them down to 1923 . "The Departments of Commerce and Labor" could still share a chapter, but the "Permanent Detached Agencies" and the "Administrative War Agencies" 
of 1917 required separate ones. The volume is inevitably formal, external, and tolerable only in small dosages; but it remains an enormously useful digest of essential information.

6r74. Van Riper, Paul P. History of the United States civil service. Evanston, Ill., Row, Peterson, 1958. 588 p. $58-5927$ JK68r.V3 Bibliographical notes at end of chapters.

"Presidents and Congresses may decree, but clerks carry out." This detailed history of the civil service of the executive branch of the Federal government reflects the author's sense of "power in a massive and continuous sense" arising out of "the cumulative impact of a vast quantity of earthy, day-by-day decisions and actions." The book was completed on the $75^{\text {th }}$ anniversary of the Pendleton Act of 1883, which established the Civil Service Commission and began the process of introducing the merit system, implemented by competitive examination, relative security of tenure, and political neutrality, into the federal service. The earlier periods, of "gentlemanly" tenure and of a triumphant spoils system, are treated with relative brevity (p. II-95). Convinced of the increasing importance of public administration in modern society, Dr. Van Riper devotes as much space to the 25 years since 1933 as to the 50 preceding it. He pays particular attention to the effects of the party overturns of 1932 and 1952, the crisis of World War II, and the sudden death of President Roosevelt upon the civil service in general and the merit system in particular. He does not neglect technicalities such as recruitment, positionclassification, and pay schedules, but he achieves much of his aim of relating civil service history to its political, economic, and religious background, and makes plausible his conclusion that ours "has been a civil service more completely democratic than any yet devised," "based upon the idea of a classless society." Seventeen years earlier the U. S. Civil Service Commission had issued a History of the Federal Civil Service, 1789 to the Present (Washington, U. S. Govt. Print. Off., 1941. 162 p.) which is considerably briefer and more formal, but also emphasizes the fortunes of the merit system as the essence of the story.

6175. White, Leonard D. The Federalists. New York, Macmillan, 1948. $53^{8} \mathrm{p}$. 48-7016 JKini.ArW 4

6176. White, Leonard D. The Jeffersonians, 1801-1829. New York, Macmillan, 1951. xiv, $57^{2} \mathrm{p}$. 5I-12490 JKI80. W5
6177. White, Leonard D. The Jacksonians, 18291861. New York, Macmillan, r954. 593

p. $54^{-12436}$ JK20r.W 45

6178. White, Leonard D. The Republican era, r869-rgor. New York, Macmillan, r958. 406 p. $\quad$ 58-6209 JK23r. W5

The subtitle of each of these volumes, "A Study in Administrative History," is inadequately descriptive of their scope. Not only does this work collectively span more than a century, $1789-1901$, in the history of the organization and practical operation of the United States Government, but also, by means of vignettes of the participants, and of apposite quotations from their public reports, office memoranda, and private letters, it re-creates their ideas, ideals, and their philosophy of management, and reflects the flow of contemporary events. In the first period, from 1789 to 1801 , when precedents were being made, the Federalists dominated the political scene, and their views about administration generally prevailed, but the Jeffersonian Republicans, or Democrats, forced them to give ground at some important points. The late Professor White, although appreciative of Washington's moral caliber, offers highest praise to Hamilton's "superlative" administrative ability and to his creation, the Treasury Department. The author finds that the Jeffersonian era of administration (1801-29) was in fact a projection of the Federalist tradition of a strong Executive and of the gentleman in political life. During these years the system of administration did not have to accommodate itself to new tasks or unaccustomed duties, since the time was one of consolidation and growth rather than innovation. The four Democratic-Republican Chief Executives-Jefferson, Madison, Monroe, and John Quincy Adams-sought to maintain executive leadership, with widely varying degrees of success, but recognized the responsibility of the executive branch and administrative system to Congress. The Jacksonian era Professor White describes as a period full of constitutional debate, party strife, and sectional confict, creating tensions which overshadowed normal operation of the government. In his opinion, the most important influences upon the administrative system during the years from Jackson to Lincoln were: the wide enfranchisement of adult male citizens, their organization into a national party system, the consequent surge of democratic sentiment, and increased participation of these ordinary citizens in office. The author not altogether convincingly defends Jackson's introduction of the principle of rotation in office, but admits that "the public service from 1829 to 1861 was engaged in a 
ceaseless struggle to protect its old standards against heavy odds and a tireless army of miners and sappers." The years 1869 to I90I, from Grant to McKinley, marked the culmination of Jacksonian theory and practice, although Federalist doctrine again made itself felt in a new partnership with democratic ideas. Professor White points to two major administrative problems of the age-the relation of Congress to the President and of both to the administrative system, and the reform of the civil service system. He notes the gradual restoration to the Presidency of the authority which had been virtually destroyed during Johnson's administration, but remarks, also, upon the remaining power of the Senate. Without an administrative staff, the President was barred from an active part in management and was oriented to Congress rather than to the executive departments. Only with enactment of the Pendleton Act in 1883 did there begin a steady improvement in the civil service and the partial formation of a government-wide administrative system. Although the Act, in Professor White's opinion, marked a fundamental turning point in the history of the Federal administration, it was no miracle worker, and brought about no transformation in the relations between Congress and the Executive.

6r79. White, Leonard D. Introduction to the study of public administration. 4th ed. New York, Macmillan, 1955. 531 p.

55-1669 $\mathrm{JK}_{42 \mathrm{r} . \mathrm{W}_{45}} \mathrm{I} 955$

The author's last revision of a well-known and widely used textbook which, on its original publication in 1926, was practically alone in the field. It is a methodical analysis and critique of American public administration which stresses the larger issues of policy rather than details. Public administration is here defined as "all those operations having for their purpose the fulfillment or enforcement of public policy." The management of public business is assumed to be a single process, substantially uniform in its essential characteristics wherever observed, and there is no separate treatment of local, State, and Federal administration, although the relations between them are analyzed, and the majority of illustrations are taken from the Federal sphere. Among the subjects of the 34 chapters are "The Servicewide Management Agencies," "Headquarters-Field Relationships," "The Line Function," "Rise of Public Personnel Management," "Government Career Service," "Position Classification," and "Power and Responsibility." Professor White notes the pre- occupation of Federal administration with international affairs, defense, and atomic energy, with the task of keeping the national economy on a fairly even keel, with the progressive development of decent standards of living for the whole people, and with fiscal policy. One foundation for future American democracy, he concludes, is a sound administrative system able to discharge its tasks with competence and integrity. In his opinion, "we have gained, but whether we have gained relatively to the work to be done is an open question."

6180. Willoughby, William F. Principles of public administration, with special reference to the national and state governments of the United States. Baltimore, Johns Hopkins Press, 1927. xxii, 720 p. ([Brookings Institution, Washington, D. C.] Institute for Government Research. Principles of administration [5]) ${ }^{28-574} \quad \mathrm{JK}_{42} \mathrm{r}$. W4 8 Bibliography: p. 657-716.

This pioneer work is a systematic analysis of the organization and operation of the administrative branch, mainly of the national government and secondarily of the State governments, through which the popular will is put into execution. Directed to students of political science and officials having to do with general legislation, it starts from the premise "that, as regards our national government at least, the great political problem now confronting us is that of securing economy and efficiency in the actual administration of governmental affairs. This problem ... has to do with the work of Congress as the board of directors of the government corporation as well as with the organization and procedure of the executive departments and other administrative services. It also requires an especially careful consideration of the duties of the President as head of the administration." The author advocated that the office of the Chief Executive be expanded and strengthened into that of a general manager, with the line of administrative authority running from the several operating services, through the departments to which they belong, to the Chief Executive and from the latter to the legislature. Under this principle of administrative organization, the administrative branch, both in organization and in practical operations, would be a single, integrated, and harmonious whole. This consideration of "General Administration and Organization" occupies part I; the three remaining parts analyze the principles of personnel and financial administration in great detail, and the administration of matériel more briefly. 


\section{Administration: Special}

6r81. Cushman, Robert E. The independent regulatory commissions. New York, Oxford University Press, 1941. xiv, 780 p.

$$
4 \text { I-I7004 JK9or.C8 }
$$

"Produced ... under the auspices of the Institute of Public Administration [New York]."Preface.

A comprehensive survey of the legislative history of the regulatory commission movement, beginning with the establishment of the Interstate Commerce Commission in 1887 , forms the first group of chapters in this massive volume. A second records the more important facts about and analyzes the legal status of those commissions, boards, or authorities which, in I94I, lay entirely outside the ro regular executive departments of the Federal government, were subject to no direct control by any Cabinet member or the President, and had for their major tasks the exercise of some form of restrictive or disciplinary control over private conduct or private property. A third division of the work deals with British agencies set up to do work analogous to that performed by the American commissions. Here Professor Cushman makes a pioneering effort to focus the methods and results of British experience upon the American regulatory problem. The four final chapters offer a critical examination of certain basic problems connected with the independent regulatory commissions. These questions grow out of the independence and divided responsibility of the commissions, the merger in them of powers-quasijudicial, quasi-legislative, administrative, executive, and investigative-which many critics and students believe incompatible, their relation to the important task of policy planning in the regulatory field, and their structure and personnel.

6r82. Douglas, Paul H. Economy in the national government. Chicago, University of Chicago Press, 1952. 277 p. illus. 52-1 $737 \mathrm{HJ}_{257 . D 67}$ A pithy argument in favor of economies in the Federal expenditures, based on lectures which the Senator from Illinois delivered in $195 \mathrm{I}$ on the Walgreen Foundation at the University of Chicago. Part I presents facts concerning the size, growth, and major areas of the Federal budget, points out the crying need for economy, and describes budgetary procedure and the appropriation process. P $3 . \mathrm{rt}$ 2 discusses waste and nonessential expenditures in both military and civilian programs, and suggests savings in personnel, the elimination of logrolling, the reduction of public works to essential projects, and economies in the financing of the armed services. Part 3, very brief and less adequate, deals with possible increases in revenues by closing tax loopholes, and the practical political problems of achieving a balanced budget. Appendixes consider the economics of compensatory budgets.

6183. Fish, Carl Russell. The civil service and the patronage. New York; Longmans, Green, 1905. 280 p. (Harvard historical studies, v. II)

"List of authorities": p. 252-266.

$5-7370 \quad \mathrm{JK}_{73} \mathrm{I} \cdot \mathrm{F}_{5}$

The standard history of policy and practice in the United States government from 1789 to 1905 in regard to appointments to public office. The earliest plans before the Federal Convention, the author notes, proposed to transfer the appointing power from Congress to the Executive. Its solution-that the President appoint the highest officers "by and with the advice and consent of the Senate"-has withstood the test of time. From his own sense of the proper and practical, Washington established certain basic principles for the filling of offices, among them fitness for the post as a sine qua non, apportionment among the States, a previously successful career (especially for the judiciary), promotion from state to national office, and political orthodoxy. Minor appointments were left to members of the Cabinet. Fish assigned to Jefferson the introduction of the spoils system into the national service, since his administration was the first to make party service a reason for appointment and opposition a cause for removal. Jackson is credited with completing the spoils system by adding the principle of rotation in office and by disregarding fitness for the duties of it. "Not until r 829 did the genuine spoils system come into existence; and since that date it has flourished without break, though with some recent [1905] diminution."

6184. Gervasi, Frank H. Big government; the meaning and purpose of the Hoover Commission report. New York, Whittlesey House, 1949. 366 p. diagrs. 49-10899 JK6 63. 47 A $_{5} 87$

A journalist's review of the work of the Commission on Organization of the Executive Branch of the Government (1947-49), headed by ex-President Herbert Hoover. His purpose is "to scrutinize the report of the Hoover Commission, assess its merits and demerits, and to present in brief and compact form what American taxpayers paid $\$ 2,000$, 000 to find out." The recommendations of the Commis- 
sion are found to be no mere dusting off of previous proposals, but rather "an exploration of the outermost boundaries of government functions in the light of their cost, their usefulness, their limitations, and their curtailment or elimination." The Presidency itself is discussed, as well as the "transaction of the public business in the departments, bureaus, agencies, boards, commissions, offices, independent establishments, and instrumentalities of the executive branch." Althpugh Mr. Gervasi is not wholly uncritical of the aims and recommendations of the Commission, he approves in general of the reforms suggested because he believes they will "ensure better government at a price the people can afford." $\mathrm{He}$ is convinced that modernization of the executive branch of the United States government is imperative, both for the proper performance of its duties to its own people and for the discharge of its international responsibilities.

6r85. Graves, William Brooke, comp. Reorganization of the executive branch of the Government of the United States; a compilation of basic information and significant documents, I912-1948. Washington, 1949. xiv, 425 p. ([U. S.] Library of Congress. Legislative Reference Service. Public affairs bulletin no. 66)

49-45834 JKrio8.A35, no. 66

"Originally prepared for the Commission on Organization of the Executive Branch of the Government, the Hon. Herbert Hoover, chairman."

A compilation of materials pertaining to executive reorganization in the Federal government prior to the work of the Hoover Commission. Of its five sections, the first is a chronological listing of all important legislative and executive actions taken; in it are included not only reprints of acts of Congress and executive orders, but also mention of bills introduced, hearings held, resolutions offered, reports issued, and the like. The second section shows that, in the majority of instances, important surveys of administrative organization have been authorized by the Congress rather than the Executive. Section 3 , the core of the work, presents a documentary history of the significant efforts at reorganization initiated by authorized survey commissions from 1912 to 1948 . Support of one or more plans for the reorganization of the administrative machinery, it appears, was given by Presidents Taft, Harding, Hoover, Franklin D. Roosevelt, and Truman. Section 4 reports proposals for reorganization of the executive departments emanating in whole or in part from private sources, and section 5 contains statements on the subject by Presidents.

6I86. Kammerer, Gladys M. Impact of war on Federal personnel administration, r939-1945.
Lexington, University of Kentucky Press, $195 \mathrm{I}$. $372 \mathrm{p}$.

5I-10526 JK69r. $\mathrm{K}_{3}$

A study of "the greatest test public administration has faced in this country." Changes of a fundamental character were wrought in personnel administration by the sudden expansion of the Federal service under the impact of total war. The principal changes considered are: the centralization of responsibility for recruitment in the Civil Service Commission; the adoption of an aggressive new approach to recruitment; a deterioration in standards of qualification for employment; fresh emphasis on loyalty in the absence of other standards; the development of training programs; increased mobility within the service; intensified pressures for higher pay; controls over the volume of Federal employment; the evolution of employee-relations programs; and the reorganization of the Civil Service Commission for improved personnel management. In the author's opinion, wartime personnel administration made several permanent contributions to the improvement of the Federal service. These included the preservation of merit system principles, success in recruitment for expanded government service, progress in the building of training programs, a realization of the importance of employee relations in the public service, and a new appreciation of personnel administration itself.

6187. Macmahon, Arthur W., and John D. Millett. Federal administrators; a biographical approach to the problem of departmental management. New York, Columbia University Press, 1939. xiv, 524 p. 39-I437I JK 731.M23

This very unusual book on "the apex of the pyramid" of governmental personnel is in three parts. The first and most theoretical considers the requirements of management in the Federal departments, and how these requirements were met at the time of writing. Departmental leadership, it is argued, must be both administrative and political; the administrative requirement calls for "a focal personality who will direct the flow of command and integrate the work of a flexible group of supervisors"; the political requirement calls for advisory aides free from routine responsibility who will assist the Secretary in "the formulation of policy and its popularization." Part 2 is a "biographical" history of the under secretaries and assistant secretaries in the Io departments since these offices were instituted (the earliest Assistant Secretary, in the Treasury Department, goes back to 1849 , but there was an Assistant Postmaster General as early as 1789, and two more by 1836 . The first Under Secretary, in the State Department, dates from 1909). The authors find that "haphazard political considerations have been the outstanding factors in the selection of 
Assistant Secretaries," too many of whom have been "idling cogs in the national machine." Part 3 deals with the chiefs of the relatively autonomous bureaus, but arranges the material according to the mode of tenure and recruitment of these offices. The chapters proceed from classified chiefships filled by promotion to the "Survivals of Political Recruitment," of which six clear cases were found as of 1938. "It is time," the authors conclude, "to bring all bureau chiefs within the merit system."

6r88. Mosher, William E., J. Donald Kingsley, and $\mathrm{O}$. Glenn Stahl. Public personnel administration. 3d ed. New York, Harper, $195^{\circ}$. 652 p. 50-1240I JK765.M6 $195^{\circ}$

First published in 1936.

Bibliography: p. 6ri $1-632$.

The emphasis of this book is upon the development of policy and the techniques of administration which contribute to the selection, retention, and productivity of the best available talent for the public service. It takes less account of the need for basic reform or elimination of the spoils system, although it is recognized that much remains to be accomplished in these matters, particularly at the state and local levels. More space is devoted to the problems of selection and the development of personnel within a public jurisdiction, and the human relations connected with modern management, than is given to the details of recruitment and examination, or to the central personnel agency. Good morale, the authors conclude, is the most valuable asset of any large-scale organization: "its consequences are measured in terms of personal satisfactions in the constant development of new ideas leading to improvements in methods, and, finally, in more and better output." To build up morale, leadership is required as well as sound placement procedures, fair wage policies, assurance of income in periods of illness and old age, good working conditions, opportunities for participation and growth, recognition of work well done, justice, and fairness. The authors propose a number of remedies for what they consider the inadequacy of the typical civil service commission.

6189. Reynolds, Mary (Trackett). Interdepartmental committees in the national administration. New York, Columbia University Press, 1939. 177 p. (Columbia University. Faculty of Political Science. Studies in history, economics and public law, no. 450)

Bibliography: p. $\begin{array}{r}39-151 \\ 65-169 .\end{array}$

$39-15177 \quad \mathrm{JK}_{42} \mathrm{r} \cdot \mathrm{R}_{4} 8 \quad \mathrm{r} 939 \mathrm{a}$

A study of administrative relationships exhibited in the interdepartmental committees which functioned actively between 1933 and 1937 . A number of them were appointed before Franklin D. Roosevelt took office as President; some of them had been abolished by the time of writing. Mrs. Reynolds holds that interdepartmental relationships are a necessary, proper, and permanent part of administration in the Federal government, that the systematic and intelligent conduct of them is a major problem of administration, and that among the useful techniques for the conduct of interdepartmental affairs is the interdepartmental committee. She distinguishes three types: the exploratory or research committee, the functional coordinating committee, and the institutional coordinating committee. These have been effective, she believes, in five kinds of administrative action: the exploration, drafting, and integration of legislative proposals; research and general investigation; facilitation of administrative programs for which single agencies are responsible but which have certain interdepartmental aspects; the conduct of administrative programs by the committees themselves; and, finally, exchange and clearing of information concerning common problems.

6rgo. Smith, Darrell Hevenor. The United States Civil Service Commission; its history, activities and organization. Baltimore, Johns Hopkins Press, 1928. I53 p. ([Brookings Institution, Washington, D. C.] Institute for Government Research. Service monographs of the United States government, no. 49) 28-18298 JK681.S6

Bibliography: p. 140-149.

A monograph designed for the use of legislators and public administrators, which details the history and development of the United States Civil Service Commission from the passage of the Pendleton Act-"an act to regulate and improve the civil service of the United States"-which established it in I883 through the Retirement Act of 1920 and the Classification Act of 1923 . The following functions of the Commission are described: recruiting, examination, certification, recording, and "post-appointment activities." Also treated in detail are the organization and staff which, as of 1927 , handled these matters. The Commission proper consisted of three Commissioners, appointed by the President and responsible directly and solely to him; not more than two of them might be adherents of the same political party. They were assisted by administrative, technical, and field services which are here particularized down to the last clerk and laborer. Appendixes give the laws and regulations governing operations of the Commission, appropriations, receipts, expenditures, and other data.

6rgr. Smith, Harold D. The management of your government. New York, Whittlesey House, McGraw-Hill, r945. 179 p. 45-ro439 JK 4 rr.S6 
A series of 13 papers concerning management of the public business, and especially fiscal planning and policy, prepared for various audiences. The author, Director of the Bureau of the Budget from 1939 to 1946 , aimed at a clearer understanding by the public of the process of management. He argued that all management, however complex, begins with planning. Although a distinction exists between the planning of basic goals through the legislative process and the planning by administrators to reach those goals, the two types are neither separate nor segregated. The interchange of information between Congress and the Executive must be continuous so that each may keep in mind its relationship to the other. This relationship between the legislative branch, with its determination of broad policy programs, and the administration, with its duty of executive management, "largely determines the success or failure of democratic government." The hopes, fears, and aspirations of the people find expression in the enactments of the legislature, which are, in turn, modified by the findings, experience, and ideas of the administration. The budget, as the most important instrument of legislative control and of administrative management, is at the core of democratic government.

6rg2. Spero, Sterling D. Government as employer. New York, Remsen Press, 1948. 497 p. 48-10699 HD8008.S65

A study of employment relations in the public service at the Federal, state and municipal levels. Dr. Spero takes exception to the theory of government as "sovereign employer" against which strikes or other militant actions are attacks tantamount to treason. He maintains that "it is a primary obligation of those in authority in a free society to guard the rights of citizens including the freedom of association of those citizens employed by the government. Limitation of this freedom is justifiable only when it interferes with the right of government to make and administer public policy." $\mathrm{He}$ analyzes the antistrike and other legislation which restricts civil servants in their capacity as workers, and the laws and regulations which affect their capacity as citizens. He describes the rise of the trade union movement as it has affected employee organizations, and the labor policies of the Federal, state, and municipal governments. "Despite the valiant work of the civil service reform movement," the author concludes, "the merit concept is not yet accepted either by the politicians or the general public."

6193. Torpey, William G. Public personnel management. New York, Van Nostrand, 1953.
$43 \mathrm{I}$ p. illus. (Van Nostrand political science series) 53-5462 JK765.T6

An analysis of each aspect of personnel management: organization, functions, objectives, processes, procedures, and the problems of administration. In seeking solutions to such problems, the author attempts to combine the practical approach of the practitioner with the academic approach of the educator. He deals with the executive branches of all levels of American government, Federal, state, and local. Upon the effective administration of personnel, he believes, depends the success or failure of every undertaking of management. "Administrative goals, policies, and plans fail of accomplishment when inadequate consideration is afforded the human aspects of organization." Although public personnel management is but one part of public administration, its importance becomes a matter of growing concern to the responsible chief executive of a jurisdiction and to his department heads as the scope and complexity of government functions increase. Mr. Torpey discusses in great detail the tools of personnel management, among them position-classification plans, pay plans, rules for recruitment and examination, training programs, rules for promotions, transfers and separations, grievance procedures, and retirement programs.

6194. Wooddy, Carroll $H$. The growth of the Federal government, 1915-1932. New York, McGraw-Hill, I934. 577 p. (Recent social trends monographs) 34-7178 JK 42 I.W6

A supplement to Recent Social Trends in the United States, a report issued by the President's Research Committee on Social Trends named by President Hoover in 1929. The aim was, in part, to make available the materials upon which that report based its conclusions about trends in the functions and expenditures of the Federal government. Restricted in scope to the civil functions of the government, the present study analyzed in some detail the development of each Federal agency during the years $1915-32$, furnishing a brief sketch of the origin and history of the agency; lists of the activities of I9I5 and of those subsequently added; tables of expenditures for each year or selected years of the period; an analysis of the causes and extent of growth, supported by such tables as could be supplied; and such evidence as was available in 1934 concerning probable changes which might affect the future development of each agency. Although this volume was concerned primarily with civil activities in the period ending with fiscal 1932, the discussion was expanded to include the sweeping changes made and proposed up to January 1934 because of President Roosevelt's emergency program of 1933. 


\section{J. State Government}

6195. Allen, Robert S., ed. Our sovereign state. New York, Vanguard Press, 1949. xxxviii, 23-413 p. 49-1 1566 JK2413.A4

CoNTENTs.-Introduction: the shame of the states, by R. S. Allen.-Massachusetts: prisoner of the past, by W. V. Shannon.-New York: backslider, by R. G. Spivack.-Pennsylvania: bossed cornucopia, by H. A. Lowe.-Georgia: paradise of oligarchy, by T. Collier.-Ohio: oxcart government, by R. L. Maher.-Illinois: the "new look," by D. E. Chamberlain.-Wisconsin: a state that glories in its past, by W. T. Evjue.-Louisiana: beak too big for its belly, by R. S. O'Leary.-Nebraska: Norris: in victory and defeat, by J. E. Lawrence.-Texas: owned by oil and interlocking directorates, by $\mathrm{H}$. Stilwell.Utah: contrary state, by E. Linford.-California: the first hundred years, by R. V. Hyer.

$A$ vigorous indictment, in the muckraking tradition, of American State government, with i2 States singled out for individual treatment by the contributors, most of whom are journalists. In his introduction, Mr. Allen accuses State government of "all the worst evils of misrule in the country. Venality, open domination and manipulation by vested interests, unspeakable callousness in the care of the sick, aged, and unfortunate, criminal negligence in law enforcement, crass deprivation of primary constitutional rights, obfuscation, obsolescence, obstructionism, incompetence, and even outright dictatorship are widespread characteristics." These ills are rooted in the State constitutions, which discriminate against the cities and are full of inequalities profitable for the great business, utility, and press interests. The antilabor, antispending, antiliberal rural-dominated legislatures the editor calls "the most sordid, obstructive, and anti-democratic, law-making agencies in the country." $\mathrm{He}$ attributes the situation, which is everywhere much the same, to absurdly low pay and to crippling limitations upon the length of sessions, which render the legislators susceptible to pressure and manipulation. There is no index.

6rg6. Anderson, William, and Edward W. Weidner. State and local government in the United States: New York, Holt, 1951. xx, 744 p. illus.

"For further reading" at end of chapters.

$$
5^{\mathrm{I}-\mathrm{II}^{1} \mathrm{I}_{3}} \mathrm{JK}_{2408 . \mathrm{A}_{7}}
$$

A college textbook on State and local government. Where the two are interrelated, as in constitutional status, politics and election activities, personnel and financial problems, and numerous public services, State and local aspects of the subject are discussed together. The State, rural, and urban governmental structures are, however, considered separately so as to enable the student to grasp the organization of each. It is emphasized that the division of public functions under the Constitution of the United States is between the Federal government and the States. Local governments exist within a State in a legal sense because the State created them and empowered them to perform its functions in the several localities. Although the courts concede to cities, villages, and boroughs certain "proprietary," "local," or "municipal" functions, even these exist only because the State has authorized them. All courts authorized by the State are considered State courts, though they may be called "county" or "municipal" courts. Close interdependence, even integration, between State and locality has become discernible in almost all fields, among them education, health and social welfare, highways, agricultural and labor laws, law enforcement, and, particularly, finance.

6197. The Book of the states. v. 12; 1958-1959. Chicago, Council of State Governments, 1958. $53^{8} \mathrm{p}$. 35-I 4333 JK2403.B6, v. 12

A biennial publication of the Council of State Governments containing current material in text and tables concerning the organization, finance, and major services of the State governments. Their executive, legislative, and judicial branches are dealt with, as are interstate relations, of which the Council is only one instance. A concluding section, "The State Pages," devotes a page of names, facts, and figures to each State and territory. Emphasis is given to developments of the two years preceding publication of each volume, which is issued at the beginning of even-numbered years. This permits presentation of important data about the legislative sessions of the immediately preceding odd-numbered year, during which most of the legislatures hold their regular sessions. The $195^{8-59}$ edition of this authoritative work and its supplements differ somewhat in content and timing from their predecessors. The set has heretofore consisted of two volumes in a biennium-a major reference book and one supplement; it will include three volumes for 1958-59the present major book and two supplements. The first of these, to be published at the beginning of 1959, will list elective administrative officials and legislators of all the States. Replacing rosters pre- 
viously included in the major work, a new supplement will appear in mid-1959, providing comprehensive lists of State administrative officials, whether appointed or elected.

6rg8. Carey, Jane (Clark). The rise of a new federalism; federal-state cooperation in the United States, by Jane Perry Clark. New York, Columbia University Press, 1938. xviii, 347 p.

$$
3^{8-275^{8}} \quad \mathrm{JK}_{325} \cdot \mathrm{C}_{34}
$$

"Selected bibliography": p. [321]-340.

"This volume is intended to favor neither 'federal centralization' nor 'states' rights'; it aims, rather, to indicate and describe some of the ways in which the federal and state governments have cooperated and how effective their joint activity has been," particularly in dealing with certain economic and social problems through legislation and administration. Cooperation between the judicial branches of the Federal and State governments is not considered. Although such cooperative efforts as grants-in-aid, tax credits, joint control of commerce, and joint activity of Federal and state administrative agencies have survived judicial review, the author considers them unwieldly and relatively ineffectual, an inevitable result of the haphazard and unplanned ways by which they have grown. The fact that the States use Federal machinery to carry out State laws is not without its great importance, she believes, but it is the use by the Federal government of State organizations and personnel to carry out Federal laws-the combination of Federal control and decentralized State administration-that "appears destired to play an increasingly important part in the development of the American federal system."

6rg9. Council of State Governments. Federalstate relations. Report of the Commission on Organization of the Executive Branch of the Government pursuant to Public law 162, 8oth Congress. Washington, U. S. Govt. Print. Off., I949. 297 p. (81st Cong., Ist sess, I949. Senate. Document no. 8I) $49-46_{374} \mathrm{JK}_{325} \cdot \mathrm{C}_{3}$

This history and analysis of Federal-State relations distinguishes two basic planes upon which the national government and the State governments have lived together from the beginning to the present-commitment to a common existence in the face of common cares, and the practical division of powers between the units concerned in the Federal system. Four phases of development are distinguished: the period before adoption of the Constitution when most of the major problems were posed but few answers were found; the Federalist period, 17871800 , when the meaning of the Constitutional provisions was first explored, and a large measure of cooperation between the national government and the States was developed; the third period, $1800-$ 1913, one of crosscurrents dominated at first by the great national-regional conflict which culminated in the Civil War and later by the unification of the country, when conflicting trends pushed at once toward separation of the national government from the States and toward their close collaboration; and, finally, the period $1913-48$, when forces long conducive to the solidarity of national and State policy came to the fore. The report calls for cooperation and teamwork between Federal and State governments, with understanding and support from the people. State responsibilities as well as rights must be accepted and exercised; overcentralization of control and power in the national government must be avoided.

6200. Council of State Governments. Committee on State-Local Relations. State-local relations; report. [Chicago] 1946. $228 \mathrm{p}$.

47-3168 JK2445.C62 1946

A description of State-local relations as they existed in 1946, together with the Committee's conclusions in regard to them. The Committee offers no panacea for this complex problem. "Rather, it has set forth a series of propositions designed to stimulate thinking and study about state-local problems, to encourage the cooperation of state and local officials in the solution of their common difficulties, and to indicate possible solutions to some of the most pressing problems." Two principal objectives are suggested for any program in the field: the strengthening of local units of government so that they may meet their day-to-day administrative tasks promptly and efficiently and attain meaningful local democracy; and the improvement of State supervision of local affairs so that activities of State-wide concern will be carried out at a uniformly high level of performance. These objectives may best be achieved, it is asserted, if States, which bear the primary responsibility for a well-ordered system of State-local relations, will grant larger power to local units, subject those powers to flexible administrative supervision rather than to detailed legislation, aid localities in securing stable and adequate revenues, and promote the enlargement and consolidation of local governments.

6201. Fesler, James W. The independence of state regulatory agencies. Chicago, Public Administration Service, 1942. 72 p. ([Public Administration Service, Chicago] Publication no. 85)

$$
\text { 42-5I } 444 \mathrm{JK} 2445 \cdot \mathrm{F}_{4}
$$

A study of the independence of State agencies engaged in the regulation of utilities, labor conditions, the sale of alcoholic beverages, banking and insurance, and the practice of the professions. Institutions 
of 12 States divided among the principal regions were selected for investigation as being representative of all such agencies. These agencies are found to have certain features in common: they all operate in areas of special interests and pressure groups; and the regulatory processes with which they are concerned combine legislative, judicial, and administrative elements. Mr. Fesler attempts to discover how, under the circumstances, the public interest may best be served. He finds objectionable features in complete independence of the agencies, and in integration of them under the governor, or under the legislature. He believes that because of the susceptibility of these agencies to pressure groups, and the varying degrees to which the interests of such groups coincide with the public interest, each type of regulatory agency deserves distinctive treatment in the establishment of its intergovernmental relationships, and its own degree of independence. All such agencies, in his opinion, should answer to both governor and legislature.

6202. Graves, William Brooke. American state government. [4th ed.] Boston, Heath, 1953. 946 p. 53-11 136 JK2408.G7 1953

First published in 1936 .

"Selected references" at end of chapters.

A textbook which reports and analyzes "significant developments in the forward movement of the states in the period since World War II." Dr. Graves emphasizes the importance of State government in the American tradition. Various factors contribute to the growing importance of the States, he believes, among them such general ones as expanding services, increased costs, and the close relationship between the State and the individual. He finds other factors peculiar to the States-the training they provide for future Federal officials; their function as laboratories for experimentation with political machinery, social policies, and administrative techniques; their position as the key units in the American system of government to which the Federal government on the one hand and local units on the other "owe their origins, powers, and continued existence." Recent and unprecedented demands made upon the States for housing, education, highways, the construction and modernization of mental and other institutions, and unemployment insurance, among other fields, suggest a new era of the service or welfare state. Such a tremendous growth of services imposes heavy administrative problems upon the States. Overlapping and duplication of effort must be eliminated through a rational division of functions.

6203. Lipson, Leslie. The American governor from figurehead to leader. Chicago, Uni- versity of Chicago Press, 1939. xxi, 282 p. (Studies in public administration, v. 9)

Bibliography: p. 269-275.

$$
39-27456 \quad \mathrm{JK}_{2447 \cdot \mathrm{L}_{5}} 1939
$$

This University of Chicago dissertation analyzes the proper relationship between the legislative and executive branches of State governments, and especially the problem of enhancing executive authority while safeguarding popular participation and control through the legislature. Leadership is regarded as not merely compatible with democracy but essential to its successful functioning, and the leadership of the governor in the executive and legislative branches forms the chief interest of this book. Four States have been selected for special emphasis: New York, because its government is on a larger scale than any other; Massachusetts, because it represents the political habits and traditions of New England and was called upon to rectify defects of organization at an earlier date than most others; Virginia, because it represents the South, where the normal dominance of one party simplifies some of the administratice problems; and Illinois, in the Middle West, because it exemplifies the difficulty of establishing honest administration in a milieu of spoils-system politics. Starting as "a mere creature of the legislature," the author observes, the governor won real power during the first decade of the 20 th century, and became a leader by supplanting the party boss. The short ballot, the executive budget, and administrative consolidation were generally achieved in the following decade.

6204. Porter, Kirk H. State administration. New York, Crofts, 1938. $45^{\circ} \mathrm{p}$.

Bibliography: p. 434-440.

$$
3^{8-3289} \quad \mathrm{JK}_{2} 443 \cdot \mathrm{P} 6
$$

An outline of the numerous activities regularly engaged in by each of the 48 States as of $193^{8}$, together with proposals for organizing agencies suitable for the proper administration of these activities. Professor Porter furnishes an outline of the administrative agencies-offices, departments, boards, commissions, and bureaus-which he considers appropriate, with some modifications, for any one of the States. He discusses the work to be done, suggests methods of organizing administrative units, and offers various recommendations, but warns that seldom is there one correct solution to any problem of the kind. He presents a synopsis of the typical State administrative structure, with the governor at the top. In descending order will be the principal administrative officers, popularly elected and provided for in the State constitution; heads of departments, popularly elected but provided for by statute; administrative officers appointed by the governor; and finally, plural agencies of every type. Professor 
Porter advocates "sound principles of integration," and the concentration of power and responsibility in the chief executive. "One of the principal theses of this book," he writes, "has been that the governor should have full and direct power over a few important staff agencies through which he would be able to exercise all the authority and influence that he ought to have."

6205. Wilcox, Jerome K., ed. Manual on the use of state publications. Sponsored by the Committee on Public Documents of the American Library Association. Chicago, American Library Association, 1940. $342 \mathrm{p}$.

$$
\text { 40-27368 ZI223.5.AIW66 }
$$

Each chapter of this comprehensive guide to state publications has been contributed by a specialist. The preface outlines the work: "Part I, Importance, Character and Use, presents in five chapters critical analyses of present state reporting and uses made by various groups of state publications. Part II, Bibliographical Aids, brings together in four chapters state government organizations and bibliographies of individual state lists of publications and of all important articles concerning state publications. Part III, Basic State Publications, in nine chapters treats each important group of state documents bibliographically and critically. The final chapter in Part III, compiled by Mrs. [Carolyn L.] Hale, is an attempt to bring together all important recent information on state functions, by functions, each in three categories as far as possible: (I) list of directories; (2) digests of laws and studies of the state functions; and (3) bibliographies of publications. Part IV is a directory of national associations of state officers with indications of their chief publications. Part $\mathrm{V}$ is a digest of information on state printing plants and state printing laws and a digest of the laws in each state concerning the exchange and distribution of state publications." There is a subject index.

6206. Zimmermann, Frederick L., and Mitchell Wendell. The interstate compact since r 925. Chicago, Council of State Governments, I95I. I32 p.

$51-625^{8} 3$ Law

Designed for the use of officials, lawyers, and students of government, this is a study of the background, scope, nature, and some potential uses of the compact as an instrument of interstate and national state coordination. The compact clause, the authors note, is the only provision of the Constitution that furnishes a means of positive cooperation among the states of the Union. Enforceable by the Supreme Court and by Congress, the compact is a fiexible legal instrument which affords a mech. anism for administration and for regulation upon a multistate as well as a regional basis. Until the I920's the need for interstate cooperation was "rudimentary," and the compact was used mainly in settling disputed boundary lines, but in recent times, and especially since World War II, it has been increasingly utilized to deal with such matters as the interstate control of crime, cooperative protection of oil and gas resources, water allocation, pollution control, fisheries, forest protection, education, and metropolitan area development. The authors classify compacts as boundary-jurisdictional, boundaryadministrative, regional-administrative, administrative-exploratory-recommendatory, and administrative-regulatory. In the order mentioned, these roughly chart chronological progress in the use of the device. The compact has further potentiality, in the authors' opinion, "as a means of securing both vertical and horizontal coordination in our federal system-of uniting the powers of the national government with those of a group of states through a single legal mechanism."

\section{K. Local Government}

6207. Allen, Robert S., ed. Our fair city. New York, Vanguard Press, 1947. $3^{87} \mathrm{p}$. $47-30142$ JS $323 . \mathrm{A6}$ Contents.-Boston: study in inertia, by L. M. Lyons.-New York: "greatest city in the world," by Paul Crowell and A. H. Raskin.-Philadelphia: where patience is a vice, by T. P. O'Neil.-Miami: heaven or honky-tonk? By Henning Heldt.Birmingham: steel giant with a glass jaw, by Irving Beiman.-Cleveland: study in political paradoxes, by R. L. Maher.-Detroit: city of conflict, by Leo
Donovan.-Chicago: unfinished anomaly, by W. H. Pierce.-Milwaukee: Old Lady Thrift, by R. S. Davis.-Memphis: satrapy of a benevolent despot, by G. M. Capers.-St. Louis: boundary-bound, by C. F. Hurd.-Kansas City: gateway to what? By W. G. Clugston-Denver: civic schizophrenic, by Roscoe Fleming.-Butte: city with a "kick" in it, by J. K. Howard.-Seattle: slave and master, by R. L. Neuberger.-San Francisco: the bedlam dozes, by Charles Raudebaugh.-Los Angeles: rainbow's end, by Maury Maverick and R. E. G. Harris. 
All but two of these reports on the governments of 17 cities are by veteran newspapermen writing on their home towns. As Mr. Allen observes in his introduction, each American community has a personality, derived from its origin, locale, and history, yet all are plagued by certain universal municipal maladies. These chapters tell "the same old story of boodling bosses and businessmen, of horrendous slums, of dirt and filth, disease and vice, of gross and shameless waste, of mismanagement and misrule, of crass disregard of public health and human dignity." "There is not a city in the country, large or small," the editor asserts, "where business is not the primary stultifying, corrupting, and antidemocratic influence." But, he adds, "there is not a city whose sins of omission and commission are not due directly to the apathy, irresponsibility, and cowardice of its citizens." Among the evils noied by his contributors are parasitic suburbs and satellite communities, the dominance of outside capital, crippling State interference in municipal affairs, conflicting urban authorities, the indifference of the press, and, most important, the lack of a deeprooted tradition of honest, intelligent, and competent municipal management. These are very much the same evils discovered 40 years earlier by Lincoln Steffens, and set forth in his famous muckraking work, The Shame of the Cities (New York, McClure, Phillips, I904. 306 p.). His purpose was to "burn through our civic shamelessness and set fire to American pride."

6208. Chicago. Home Rule Commission. Modernizing a city government; report. [Chicago] University of Chicago Press, 1954. xiv, $422 \mathrm{p}$. 54-1339I JS708.A53

The Commission deals with problems relating to the improvement and modernization of the structure of the city's government and to added homerule powers. Introductory in character, part I describes the organization and procedures of the Commission, presents its view of its assignment and responsibility, indicates the economic factors underlying the vast growth of Chicago, and explains the structure of city government that obtained in 1954 . Part 2 is concerned with modernization, particularly of the city council, which the Commission would reduce in size; of the budget, which it would alter to the executive, performance type; and of the mayor's office, to which it would attach an administrative officer and a small professional staff. Part 3 analyzes home rule and offers recommendations to increase it. The Commission examines the adequacy of Chicago's powers of local government in four major areas: the structure and form of government; services; police powers; and revenue powers. Finding Chicago's powers of local government inadequate in the first of these areas, the Commission proposes that the state legislature authorize changes. It concludes that, with legislative grants readily securable in the other areas, Chicago enjoys substantially as much power as do the constitutional home-rule cities.

6209. Gill, Norman N. Municipal research bureaus, a study of the nation's leading citizensupported agencies. Washington, American Council on Public Affairs, 1944. $178 \mathrm{p}$.

$$
44-6805 \mathrm{JS}_{302 . \mathrm{G}_{5}}
$$

A history and analysis of the municipal research movement, which deals with 20 citizen-supported research bureaus. The programs of nearly all of these quasi-public but inadequately supported municipal organizations have stressed efficiency first and economy second in local government. Advocating improved methods of levying and collecting taxes, budget and accounting procedure, independent audits and centralized purchasing, and the recruiting and training of municipal personnel, these bureaus have also sought to formulate long-range policy and better service in such matters as public health, police and fire protection, education, traffic control, transportation, street lighting and cleaning, and refuse collection, as well as to promote efficiency and standardization in the construction of streets, sewers, and school and other public buildings. The author notes the social welfare aspects of the bureaus' work for relief, housing, higher standards of living, and construciive planning. He suggests several further areas of study by the bureaus, among them intergovernmental, social, and economic problems. And finally he urges broad representation of the citizenry, especially of young civic leaders, upon bureau boards; progressive policies; more use of modern methods of public relations; and greater professionalization of bureau staffs.

6210. Hodges, Henry G. City management; theory and practice of municipal administration. New York, Crofts, 1939. xx, 759 p. illus. 39-18457 JS33..H6

A textbook on municipal government, amply provided with organization charts, which presents the practice as well as the theory of city management. It pleads for a professional personnel trained in public administration, to whom public service is a career; the effective direction of workers; and skillful financial planning. Centralized control of properly grouped functions is viewed as the directing principle, and integrated responsibility the chief weapon of democratic control in city management. The greatest strides in city management have been made, the author believes, through the gradual acceptance of the city-manager plan of government. 
It remains essential that the citizen understand the government of his city, its functions and services, since democracy will be preserved only to the extent that the lag between public opinion and technical administrative advances is shortened. Political education of the masses must bring about the public's willingness to employ scientific administrative techniques and make impossible government by a "contractor-controlled political party." The author outlines six generally accepted standards for the efficient conduct of urban government.

6211. Jones, Victor. Metropolitan government. Chicago, University of Chicago Press, 1942. xxiv, 364 p. (Chicago. University. Studies in social science, no. 39 [i.e. 40])

"List of bibliographies": p. 343-344.

$$
42-12520 \quad J S_{33} 1 . J 6 \quad \text { I942a }
$$

A general examination of some of the problems of integrating local government in the larger metropolitan areas of the United States. Dr. Jones regards the government of metropolitan areas as part of the larger question of the economic, social, and political organization of the nation, which calls for the periodic realignment of boundaries and the reallocation of functions among all levels of government. He considers the present government of metropolitan communities ineffective in the face of existing and emerging problems of urban life. This ineffectiveness he attributes to the formulation and administration of policies for these areas by "scores or hundreds of contiguous but independent, undernourished, and jealous units of local governments." Popular control and coordination of policy and budgeting are difficult if not impossible, the author argues, when power and responsibility are chopped up and the segments distributed among a large number of boards, commissions, or authorities within the same area. Politics are the primary ob. stacle in the way of organized efforts to integrate the multitude of units that govern metropolitan areas in the United States. Although statutes or charters can readily be drafted and given effect by technicians, legislative or electoral approval must first be secured. This situation, in Dr. Jones' opinion, calls for an active program of propaganda.

6212. Lancaster, Lane W. Government in rural America. 2d ed. New York, Van Nostrand, 1952. 375 p. illus. (Van Nostrand political $\begin{array}{llll}\text { science series) } & 52-9252 & \mathrm{JS}_{425} \cdot \mathrm{L}_{3} & \text { I } 952\end{array}$

A textbook, originally published in 1937 , about the operation of government in the towns, townships, counties, and school districts of American rural areas. It points out that the differences between political organizations in such units and those in populous areas are principally in scale rather than in the types of problems met; in their actions, most of the same processes are involved, although legal and constitutional differences do exist. "Government everywhere involves the translation of public wishes into rules binding upon citizens, the purchase and use of materials, the employment and management of personnel, and the enforcement of rules of action and conduct upon all within the jurisdiction of the authorities." The fundamental problem of local government in the 2oth century, as Professor Lancaster views it, is the inadequacy for their work of its traditional units, which were laid out when economic and social conditions were very different. With respect to area, population, taxable resources, and internal organization, they are far removed from the economic realities of today. The author calls for the consolidation of areas, internal reorganization, and a reallocation of functions.

6213. The Municipal year book. [25th year]; 1958. Chicago, International City Manag. ers' Association. $59^{8} \mathrm{p}$.

$$
34^{-27121} \mathrm{JS}_{344 .} \mathrm{C}_{5} \mathrm{~A}_{24}, 25^{\text {th }}
$$

The chief purpose of this yearbook, which has appeared since 1934, "is to provide municipal officials with information on the current problems of cities throughout the country, with facts and statistics on individual city activities, and with analyses of trends by population groups." Many of its sections are brought up to date and repeated year after year; these include forms of city government, methods of selecting the mayor and council, utilities owned and operated, salaries of chief municipal officers, personnel organization, city financial data, fire and police departments, municipal parking lots, directories of city managers and other officials, and model municipal ordinances. Some new material is included in each annual, beginning with an introductory article on the "municipal highlights" of the year. Other new sections in the $195^{8}$ volume are "City Planning Data" ( $\$ 6$ billion to be spent in the next five years), "Municipal Debt for Cities over 10,000 [bond issues of 1957 by 550 cities]," "Housing Demolition Data," "Municipal Cemeteries," "Municipal Airport Data," and "Regulation of Curb Loading Zones." Sources of information are listed at the end of most sections and, for the obstinately bewildered, there are five pages on "How to Use the Year Book."

6214. Rankin, Rebecca B. Guide to the municipal government of the city of New York. $7^{\text {th }}$ ed. New York, Record Press, 1952. 209 p.

First published in 1936 .

$$
{ }^{2-1927} \mathrm{JS}_{1228 . R_{3}}{ }^{2} 95^{2}
$$

A guide to the more than 100 separate units of administration of the government of New York 
City as they were operating on January I, 1952. The purpose of the manual is to describe simply and concisely the governmental organization and administration of the city, the functions of its many boards, departments, bureaus, divisions, commissions, courts, and committees, and their relationships to one another under the revised charter of 1938. Arrangement is in sections classified by the main functions of the departments, so that allied units may be treated together. A short index is designed to bring out other and less known functions of the city agencies. As Miss Rankin observes, New York operates under the "Strong MayorCouncil form" of government, which places most responsibility upon the mayor who appoints his department heads, prepares the budget, and sees that the government is properly administered. The consent of the council, elected by districts, is necessary to validate most actions of the mayor; it also shares in the making of policy. Many administrative departments are empowered by the charter and administrative code to make regulations in order to carry out their departmental functions. Printed once a year, these regulations have the force of law.

6215. Schmeckebier, Laurence F. The District of Columbia, its government and administration. Baltimore, Johns Hopkins Press, 1928. $\mathrm{xx}, 943$ p. maps. ([Brookings Institution, Washington, D. C.] Institute for Government Research. Studies in administration)

\section{Bibliography: p. 863-923.}

$$
28-\mathrm{I}_{4} 676 \quad \mathrm{JK}_{2725} \mathrm{I}_{928 . \mathrm{S}_{4}}
$$

A survey of the unique government of the District of Columbia, which suffers complete denial of direct representation, performs the functions of both a State, or territorial, and a municipal organization, and is treated in many respects by Congress as a minor subdivision of the Federal government. Although Mr. Schmeckebier admitted that "the interests of the United States and the residents of the District frequently clash," he refrained from criticism of the defects in organization, operation, and municipal and civil law resulting from the unfortunate conditions under which the District government operated in the 1920's, and of Congress' inability or unwillingness to work out a consistent policy in its treatment of the District. His purpose was rather to describe all of the governmental activities of the District essentially local in character, and to indicate the agencies which were responsible for performance of the work. He set forth in elaborate detail the functions, and, in most instances, the organization, finances, and personnel of the Commissioners of the District of Columbia, the several boards, commissions, or units dealing with District affairs only, the Federal agencies which held plenary power in their fields, the Federal agencies which had merely contractual relations with the District government, and the judiciary, as of about June 30, 1926. A more up-to-date but less detailed view is the Government of the District of Columbia; Manual of Organization ([Washington] Management Office, Dept. of General Administration [1954] I v. (various pagings)). It contains brief descriptions of the Board of Commissioners, the Office of the Secretary, and the Citizens' Advisory Council, as well as of 22 agencies subject to the full control of the Commissioners, and of 10 special advisory groups.

62r6. Stone, Harold A., Don K. Price, and Kathryn $\mathrm{H}$. Stone. City manager government in the United States; a review after twenty-five years. Chicago, Published for the Committee on Public Administration of the Social Science Research Council by Public Administration Service, 1940. xv, 279 p. (Social Science Research Council. Committee on Public Administration. Studies in admin-

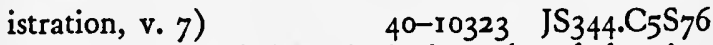

A summary of the principal results of the citymanager plan of government in 48 cities that were operating under it in 1938 , and in two cities that had abandoned it. Although these constituted only about one-tenth of all cities having city-manager government, they included nearly half of the manager cities with a population of 50,000 or more and a third of those with more than 25,000 inhabitants. Every section of the United States was represented, as was every State important to the city-manager movement. The selected cities had every kind of municipal history and background. The citymanager plan is here considered to involve two fundamental principles: unification of powers in a city council and concentration of administrative authority in a city manager appointed by and responsible to the council. In order to appraise the results of this new form of government, which was first introduced in 1908 , the authors compared politics and administration, and especially administrative methods, as practiced in each of the selected cities before and after adoption of the plan. They report general governmental improvements and abundant evidence that "graft and waste were reduced, that municipal personnel and methods were made more efficient, and that, therefore, unit costs necessarily were reduced."

6217. Wager, Paul W., ed. County government across the Nation. Chapel Hill, University of North Carolina Press, 1950. 817 p. illus.

Bibliography: p. [809]-816. 50-10780 JS 41 I. W3

A volume of case studies of sample counties, one 
in each of the 48 States. In the selection of counties for analysis, extremes such as metropolitan counties and sparsely settled desert counties have been excluded. The studies, ro of which were written by the editor and most of the others by his colleagues or former students, are presented in four regional groupings-New England, Eastern and NorthCentral, Southern, and Western States-each preceded by an introduction. These papers describe the structure of the county government, its functions, and the relationships between local and State officials, and tabulate the county revenues and expenditures. Each New England study consists principally of an analysis of a town in the sample county. A general introduction by the editor sets forth some facts, trends, and analyses concerning the primarily administrative, fiscal, and supervisory powers of the county. Professor Wager finds that the creation of collateral boards for the supervision of roads, welfare, elections, libraries, hospitals, and other matters is sapping the powers of the central governing body of the county. He recommends that the counties receive more legislative power, a substantial grant of police power, the grant of zoning authority, and the provision for each of a county executive or chief administrator.

6218. Zink, Harold. Government of cities in the United States. Rev. ed. New York, Macmillan, I948. 637 p. $49-7040$ JS331.Z5 1948
"Selected bibliography" at end of chapters.

This textbook, originally published in 1939, emphasizes a number of factors in American municipal government which came to the fore during the 1930's, among them the enlarged role of the Federal government in city affairs, the problem of large-scale public relief, a notable expansion of supervised recreation, changed goals in city planning, improvement in public personnel practices, progress in police administration, and increased concern for public housing. On the negative side are stressed the difficulties of obtaining adequate municipal revenues, the influence of pressure groups upon city government, and the very vigorous part played in it by political organizations and machines. Also discussed are the services rendered to their inhabitants by the cities, the elaborate and varied structures devised for the performance of these services, and the legal, administrative, and financial status of the cities in relation to the states and to the nation. In a concluding section Professor Zink considers the problems of improving the city through housing programs, zoning and other landuse controls, studies of trends in population and industry, and plans for thoroughfares, parks, recreation facilities, public buildings, sewage disposal, water supply, and public works programs. He considers, too, the problem of creating popular demand for better city government. 


\section{Law and Justice}

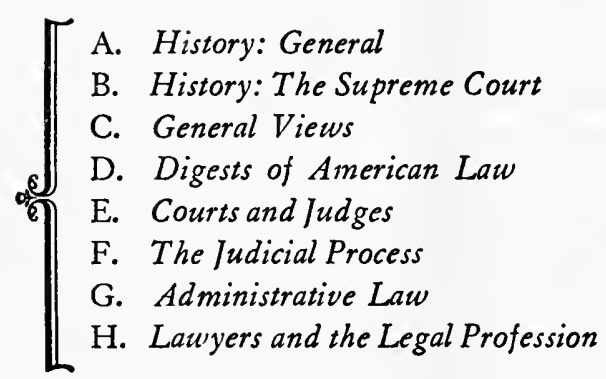

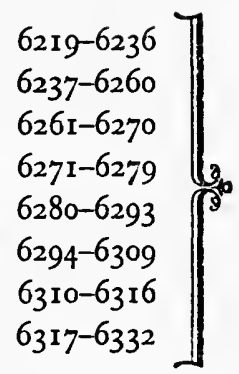

$\mathrm{T}$

HE PREVIOUS CHAPTER contains sections on constitutional law, on the civil liberties and rights which in America largely depend on constitutional guarantees, and on Congress, the national legislature. Various aspects of crime, police administration, and correction are included in the final section of Chapter XV on Society. The other major aspects of law and justice are dealt with here. Section B on the history of the Supreme Court is awkwardly separated from the previous chapter's Section C, on the constitutional law of which the Court is the supreme exponent, but it would be quite as awkwardly separated from Section E here, which is concerned with all the other American courts, of whose system the Supreme Court forms the apex.

Law is a discipline and a profession. The common law and the bar have descended in an unbroken line from medieval England, gradually adapting themselves to the changes of a society that keeps accelerating its rate of change. Lawyers have retained a strong sense of fraternity and a predominately conservative outlook. Legal education has settled into a vocational pattern, with the great object of getting the aspirant over the hurdle of the bar examinations. Legal literature is, for the most part, produced for the practical use of the profession and issued by specialized publishers. The more philosophical thinkers and writers of the legal profession have been conscious of the relative isolation of their sphere from the main stream of American thought, and have made valiant efforts to lessen it. A number of the works listed below deplore the ignorance and the distrust which even well-educated Americans may display concerning the sub-

stance and procedures of the law. The movement of legal reform, which has some noteworthy achievements to its credit but remains an unfinished task, has chiefly aimed at simpler, more lucid, and more easily discoverable laws, streamlined and humanized procedures, and greater social responsibility throughout the legal profession. There are few realms in which the interdisciplinary approach characteristic of American Studies has more to offer, to insiders and outsiders alike. The lay American needs to have a better knowledge of the history, the forms, and the processes of the law, and the American lawyer needs to relate his specialty to the adjacent fields of life and learning, to the mutual benefit of both.

American legal history offers peculiar difficulties because of the Federal structure of our government; each of the sovereign states has its own system of courts and body of statute law, with peculiarities developed at various times and for various reasons, and in Louisiana and the Southwest there are elements quite outside the common law tradition. It is the more regrettable that neither schools of law 
nor graduate schools of history have taken up the writing of American legal history in any systematic or intensive manner. The lack of large-scale and definitive work, as well as of the many local studies upon which it must be based, is often deplored, but some smaller studies of real value have been done; a substantial sample occupies Section A. The history of the Supreme Court has been best advanced on the biographical side; the larger narratives of Warren and Haines (nos. 6260, 6240) will eventually be overshadowed by the multivolumed work now in preparation through the Oliver Wendell Holmes Devise. The remaining six sections are largely attempts to select from the literature written by and for the profession those volumes which will be most intelligible and most rewarding to the general reader. A few, to be sure, have been written by lawyers for the general public; and another few are by laymen of various descriptions, audaciously invading the legal preserve with results peculiarly favorable to the lay reader-such is Covering the Courts (no. 6288), by a professor of journalism. The digests in Section D represent an older form of legal textbook, which in most classes has been replaced by the ubiquitous casebook, of value only to the trainee. These expositions aim at a logical arrangement of concepts and principles, and while they are abstract and difficult énough, a selection has been included in order to direct lay inquirers to statements of American substantive law in several important fields. This, in general, is the law, with variations from State to State. It goes without saying that they will not enable anyone to set up as his own attorney. Sections $E$ and $F$ are not mutually exclusive, and both include critical, diagnostic, and reformative titles as well as descriptive ones. The judges' own stories in E (nos. 6284, 6291), like the lawyers' in Section H (nos. 6322, 6324 ), are a rare but rewarding form of literature. $G$ on administrative law deals with one of the newest fields, brought into being by the development of the regulatory commissions since 1887; their relationship to the courts of law remains its crucial question, about which there continues a wide range of opinion. The training, organization, practice, and obligations of lawyers, often discussed in a critical spirit, are the subjects of the final section.

\section{A. History: General}

6219. Aumann, Francis $R$. The changing American system: some selected phases. Columbus [Ohio State University Press] 1940. 28 I p. ([Ohio. State University. Contributions in history and political science, no. 16]) 40-34949 Law Bibliography: p. [237]-269.

Professor Aumann's survey of "the main-travelled roads" is not intended for specialists in American legal history, but for "members of the bar, students of political science, and members of the general public who are interested in the American legal system in a more general way." The preface thus summarizes its contents: "The plan of procedure followed involves a brief consideration of some of the problems of colonial justice, including the several views as to the nature and extent of common law reception in the seventeenth and eighteenth centuries; the effect of the War of Revolution and reconstruction upon the legal system; the interest in the civil law and its influence in the post-war period; the upthrust of the common law system in the formative period of American life and its expansion into the newly formed commonwealths of the nation, including a supplementary survey of early court organizations and procedures; the role of legal education, etc. Also involved is a brief analysis of the course of American legal development in the period of industrial growth which intervened between the Civil War and the turn of the century, including a consideration of some of the changing concepts and contents of American law brought about by the conversion of a simple, agricultural society into a complicated industrial order. Following this excursion into the period of legal maturity, attention is turned to the changing patterns that appear in the legal order during the first third of the twentieth century."

6220. Gard, Wayne. Frontier justice. Norman, University of Oklahoma Press, 1949. 324 p. illus. 49-10511 F591.G215

Bibliography: p. $291-308$.

"This book is an informal study of the rise of order and law west of the Mississippi, where order often came before law. With abundant use of illustrative incidents and a minimum of abstract discussion, it traces the progress made from the chaotic, almost anarchic relations between many pioneers and the Indians to a state of peaceful settlement." Most of the episodes covered fall within the three decades following the Civil War, but some incidents go back to the 1830 's, and the sheep raids of Colorado went on as late as 1921 . The presentation is neither chronological nor geographical, but 
loosely topical, with sections entitled "Vengeance" (feuding in Texas, Arizona, and elsewhere) "War on the Ranges," "Vigilantes" (in Montana and several prairie communities as well as in California), and "Arms of the Law" (frontier marshals, sheriffs, and judges-notably Judge Isaac C. Parker of Indian Territory, who sentenced 172 malefactors to be hanged, as 88 of them actually were).

6221. Goebel, Julius, Jr., and Thomas Raymond Naughton. Law enforcement in Colonial New York; a study in criminal procedure (16641776). New York, Commonwealth Fund, 1944. xxxix, 867 p. (Publications of the Foundation for Research in Legal History, Columbia University School of Law)

"Sources": p. [765]-77o.

Colonial legal history on a new and grand scale, based on the dispersed and incomplete records of the provincial courts general and local, as well as upon personal papers and all relevant printed sources. The authors are concerned to emphasize the early reception of English law in the conquered Dutch province, and divide it into two stages: the first, r664-83, when "the Duke of York's lieutenants with great skill promoted as the provincial law the little they knew of English local administra-

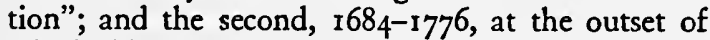
which "the practices and forms of the English central courts came into use." Thereafter the process became one of "selective reproduction of English legal institutions at large." Following the introduction the massive text is in two parts, the first (to p. 324) concerned with "Jurisdiction," the second with "Practice." The chapters of the latter are on "Prosecution," "Process," "Recognizances," "Trial" (two), and "Final Proceedings" such as punishments, fees, and pardon. Appendixes print typical commissions, bills of costs, and briefs. In concluding the authors reaffirm their rejection of the notion that "our American law begins in 1783 ."

6222. Holmes, Oliver Wendell. The common law. $3^{2 \mathrm{~d}}$ printing. Boston, Little, Brown, 1938. xvi, $422 \mathrm{p}$. 39-19139 Law

6223. The National law library. v. r. The history and system of the common law, by Roscoe Pound. New York, P. F. Collier, r939. 347 p.

Bibliography: p. 309-316. 39-8999 Law

Nearly 60 years separate these two expositions of the Anglo-American common law by two of the most eminent jurists that America has produced. Justice Holmes' classic originated in a series of lectures which he was invited to deliver at the Lowell Institute in Boston, and first appeared in $188 \mathrm{I}$. His point of departure was the dual nature of the law at any given time; some of it, especially its form and machinery, is an inheritance from the past, while the rest, especially the substance, depends upon current theories of legislation and corresponds with what is understood to be convenient. On this basis the author considered early forms of liability, the criminal law, torts, the bailee, possession and ownership, contract, and successions. Here we may regret that the author omitted from the book his I 2 th lecture, which summarized the foregoing II. Dean Pound's volume is wider in scope and more severely logical in outline. He points out how unfortunate it has been, in America where law and polity are inextricably joined, that Blackstone and Kent have had no successors in expounding the law for the citizen. His governing concept is that "law is experience developed by reason and reason tested by experience." He begins by discussing fundamental legal conceptions, and by sketching the history of the common law and of the institutions by which it lived. The source and forms of law are described, as are the reception and forms of the common law in America. A chapter on the organization and jurisdiction of courts is followed by descriptions of the common-law actions, and of procedure at law and in equity. Substantive law is digested under the headings of right, persons, acts, obligations, and property. "What is characteristic of the commonlaw system and gives it continuity in time and unity in space, is a taught tradition of ideas and doctrines and technique ... Above all, it is a tradition shaped in its beginnings as a quest for reconciling authority with reason, imposed rule with customs of human conduct, and so the abstract universal with the concrete particular."

6224. Horton, John Theodore. James Kent, a study in conservatism, $1763-1847$. New York, Appleton-Century, 1939. 354 p.

39-13988 Law

At head of title: The American Historical Association.

Bibliography: p. 327-34I.

There were able lawyers in America before Kent, but he was the first whose distinction and career derived from the superiority of his learning in the law. On graduating from Yale, he read law in the office of Egbert Benson, attorney general of New York, and practiced at Poughkeepsie and later in New York City, at first with indifferent success. But in 1793 he became the first professor of law at Columbia College, and the quality of his lectures led to his appointment to the Supreme Court of New York in 1798. He dominated the court even before his promotion to Chief Justice in 1804 and converted it to the practice of written opinions en- 
abling proper reporting. In 1814 he became the highest judicial officer of the State, the chancellor, and at once "the fabric of American equity began to rise" on the basis of a greater respect for precedents and written decisions properly reported. A State law required the retirement of judges (without pension) at the age of 6o; and the Democratic Party in the State was glad to see its most eminent jurist step down in the fullness of his powers. The indignity turned into a public and private benefit: Kent became a lawyer's lawyer and resumed his lectures at Columbia, published as the famous Commentaries on American Law (no. 6277), from which he derived $\$ 5,000$ every year until his death. Kent, "laying aside the robe of a local judge, became doctor of laws to the whole republic."

6225. Hurst, Willard. The growth of American law: the law makers. Boston, Little, Brown, I950. $502 \mathrm{p}$.

"Bibliographical notes": p. [45I]-472.

An introduction to the legal history of the United States whose form arises from the author's conviction that our legal institutions have been relatively tough and stable, while substantive law has been rather the creature of events, changing with rapid social and economic change. Mr. Hurst therefore discusses, with emphasis on their functions, five agencies of lawmaking in the order in which they emerged into leadership in successive periods of our history: the legislature, the courts, the constitution makers (in which the author includes legislative proposals and the initiative as well as constitutional conventions), the bar, and the executive. The burden of Mr. Hurst's clearly written essays is that our legal agencies have lost prestige to the degree that they have failed to keep the public interest in the forefront of their objectives. Urban courts have made dilatory and insufficient provision for the small claimant and the poor debtor, and for "the kind of mass social regulation that the traffic law exemplified." The bar, which gets the bulk of its business from the wealthiest I 3 percent of the population, has since 1870 largely abdicated its independence and its leadership. In an economy wherein special interests behave like billiard balls on a table, only the chief executive, in state and nation, is looked to for his independence and representation of the general interest.

6226. Langeluttig, Albert G. The Department of Justice of the United States. Baltimore, Johns Hopkins Press, 1927. xvi, 3 r 8 p. ([Brookings Institution] Institute for Government Research. Studies in administration. [no. 15])

Bibliography: p. 262-276.
6227. Cummings, Homer S., and Carl McFarland. Federal justice; chapters in the history of justice and the Federal executive. New York, Macmillan, 1937. 576 p. illus. $\quad 37-364$ JK873.C8

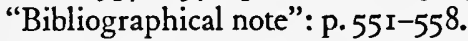

Dr. Langeluttig's dissertation traces the rise and development of the Department of Justice, the central agency belatedly created by the national government for the enforcement of the law for which it is responsible. One section of his study discusses the problems of the administration of the Federal law, and special attention is given to the very important matter of the Department's relations to the other law enforcement agencies of the Federal Government. Of broader scope is Cummings' (Attorney General, 1933-39) and McFarland's review of the administration of justice by the Federal Government. The development of the office of Attorney General as a policymaking, advisory, and supervisory governmental post is traced from its inception in 1789 . In 1870 , when the Department of Justice was finally established, these functions were greatly expanded, and this expansion to meet existing problems engendered new ones. Separate chapters of this work are devoted to the Department's role in various fields of activity, such as labor relations and the conduct of business, in which the Federal Government has exerted its regulatory capacity.

6228. Levy, Leonard W. The law of the Commonwealth and Chief Justice Shaw. Cambridge, Harvard University Press, 1957. $383 \mathrm{p}$.

Bibliography: p. [343]-357.

$57-6350$ Law

A critical study of the work of Lemuel Shaw ( $178 \mathrm{r}-186 \mathrm{r}$ ), chief justice of the Supreme Judicial Court of Massachusetts from 1830 to 1860 . The author estimates that no other State judge through his opinions alone had so great an influence on the course of American law, and he believes that Shaw's chief contribution was his domestication of the English common law. Shaw preserved its continuity with what was worthwhile in the past, and at the same time accommodated it to the ideals and necessities of Igth-century American life. Using some of Shaw's opinions, which numbered approximately 2,200, as points of departure and focus, the author has produced a series of chapters on American legal history. Some of these are concerned with the response of the law to great social issues, others with the accommodations in the law necessitated by changes in American industrial life, and still others with the growth of important doctrines of American law. 
6229. Morris, Richard B. Fair trial; fourteen who stood accused, from Anne Hutchinson to Alger Hiss. New York, Knopf, 1952. xv, 494 p. 52-6423 Law

"Bibliographical notes": p. 479-494.

A review of 14 notable American criminal trials which assesses their fairness. By later Anglo-American standards of fair trial, the author thinks, the accused in the Colonial cases, Anne Hutchinson, Peter Zenger, and Captain William Kidd, were not afforded fair trials; but trials conducted since 1789 have, in form if not in substance, conformed more closely to present notions of fair trial procedure. The three 2oth-century cases included (the Triangle Fire Case, the Hall-Mills Case, and the Hiss Case) expose, Professor Morris believes, glaring deficiencies in the conduct and procedure of American criminal trials, which persist despite the safeguards written into the Federal and State constitutions and the codes of criminal procedure. Among the deficiencies listed are: the character of sporting events or circus performances that trials too often assume; the failure of juries to be free from prejudice and possessed of the emotional and intellectual discipline essential for a critical examination of evidence; the perpetuation of archaic rules of evidence; the character of the bench itself; and the deterioration of the criminal bar.

6230. Morris, Richard B. Studies in the history of American law, with special reference to the seventeenth and eighteenth centuries. New York, Columbia University Press, 1930. 285 p. (Columbia University. Faculty of Political Science. Studies in history, economics and public law, no. $3^{16}$ )

$$
\text { 30-14173 } \mathrm{H}_{3} \mathrm{r} . \mathrm{C}_{7}, \text { no. 316; Law }
$$

"Bibliographical essay": p. 259-273.

In his first chapter Professor Morris undertakes "to synthesize and interpret the main characteristics of the development of American law in the seventeenth and eighteenth centuries." He notes the several influences which led during the 17 th century to widespread innovations, in particular procedural reforms making legal redress easier, faster, and less expensive; and the conservative reaction of the 18 th which brought in many common-law practices and made for the increasing importance of the professional lawyer. The three remaining chapters discuss "representative legal questions which are directly associated with early American social, economic, and intellectual conditions." "Colonial Laws Governing the Distribution and Alienation of Land" discusses, in part, the aristocratic practices of primogeniture and entailed estates as transplanted to America. "Women's Rights in Early American Law" shows that many of the common-law disabilities of married women were sloughed off in the
Colonies. "Responsibility for Tortious Acts" shows many small divergences from common-law doctrines emerging in American agrarian society, leading Dr. Morris to speak of "the refreshing originality which characterized our legal engineering," and to affirm that a later day's "ignorance of the trail which had been blazed by the seventeenth-century pioneers hampered the progress of American law."

6231. Pound, Roscoe. The formative era of American law. New York, P. Smith, $1950,{ }^{c} 1938$. $188 \mathrm{p}$. 50-50803 Law

"Four lectures ... delivered at the Law School of Tulane University on the occasion of the centennial of the death of Edward Livingston, October 27-30, 1936."

Dean Pound's formative era extended from independence to the Civil War, and since most of the spade work in local legal history remained to be done (as indeed it still does) he aimed only "to trace the working of the juristic theory which was chiefly operative, and to outline the development and achievements of the chief agencies of legal developments in that era." The task of this era, in the face of difficulties caused by the hostility to English law, a tendency to deprofessionalize the lawyer, and "a veritable cult of local law," he thus defined: "to work out from our inherited legal materials a general body of law for what was to be a politically and economically unified land." Within the era, he says, fell the work of six of the ten foremost judges in American judicial history: Marshall, Kent, Story, J. B. Gibson of Pennsylvania, Shaw, and Thomas Ruffin of North Carolina. Traditionalists or innovators, the lawyers, judges, and teachers of this era "found their creating and organizing idea in the theory of natural law." The succeeding three lectures trace the operation of this idea in legislation, in judicial decision, and in doctrinal writing. A taught tradition became established, and "the common-law technique of finding the grounds of decision in reported judicial experience became the decisive agency of law making." In the latter part of each lecture Dean Pound applied the ideas he had just discussed to the legal problems of his own day.

6232. Russell, Elmer Beecher. The review of American Colonial legislation by the King in Council. New York, Columbia University, 1915. 227 p. (Columbia University. Faculty of Political Science. Studies in history, economics and public law, v. 64 , no. 2; whole no. 155)

$$
\begin{array}{r}
\text { 15-151 } 8 \text { JK } 57 . P_{7} \mathrm{R} 8 \\
\mathrm{H}_{31} \text {.C } 7 \text {, v. } 64, \text { no. } 2
\end{array}
$$

"The power exercised by the English Privy Council, of annulling the enactments of the royal colonies, afforded the home government an important instru- 
ment of administrative control. It constituted a necessary check upon the only branch of the colonial governments which was responsive to popular sentiment, and gave the English executive a final word in regard to the minutest details of local administration in the dominions." The present dissertation, written under the guidance of Herbert L. Osgood (nos. 3220 and 3221 ), is confined to the 13 mainland Colonies, and largely to the period from 1696 to the Revolution, when the Board of Trade was charged with the examination of Colonial acts and made recommendations to the Privy Council. The author devotes one chapter to the period from 1660 to 1696 , when the Council's power of review was rather sporadically exercised; two to the details of the procedure employed after 1696; and four to the policies pursued in review, such as insistence upon conformity to English law and the repulse of encroachments upon the prerogative. From I6gi the royal and proprietary Colonies submitted some 8,563 acts, of which 469 , or 5.5 percent, were disallowed by the Privy Council. The process was unpopular with the colonists, but Dr. Russell observes that it "constituted at once a precedent and a preparation for the power of judicial annulment upon constitutional grounds now exercised by the state and federal courts in the United States."

6233. Sayre, Paul L. The life of Roscoe Pound. Iowa City, College of Law Committee, State University of Iowa, 1948. 412 p. illus.

$$
4^{8-1287} \text { Law }
$$

Botanist, practicing lawyer, judge, teacher, legal historian, and legal philosopher: Roscoe Pound is or has been all of these. The author, who was one of Dean Pound's graduate students, presents an admiring account of his life and work from his birth at Lincoln, Nebraska, in 1870 until his departure for Nanking, China, in 1947 to serve as adviser to the Ministry of Justice there. Particular attention is given to Dr. Pound's service to his native State, his life in Chicago, his service as dean of the Harvard Law School for 20 years, his work for the legal profession through the American Bar Association, his furtherance of particular projects of law reform, and his philosophy of the law.

6234. Smith, Joseph H. Appeals to the Privy Council from the American plantations. With an introductory essay by Julius Goebel, Jr. New York, Columbia University Press, 1950. lxi, 770 p. (A publication of the Foundation for Research in Legal History, Columbia University Law School)

"Sources": p. [687]-696.

50-7240 Law

"Table of cases": p. [699]-709.

A massive study which aims "to integrate the various records in the archives on this side of the Atlantic with the Privy Council records in London" in order "to describe and evaluate at length the Privy Council of England as a judicial body exercising appellate jurisdiction over the courts of the various American plantations" from I679, when the Lords Committee of Trade and Plantations undertook "a somewhat uneven regulation of the appellate process," to the Peace of Paris in 1783 . From 1696, when the appeals were entered in the Council Register, 795 appeals from the American plantations were heard; of these 157 were affirmed, 336 reversed or substantially altered, and 68 dismissed for nonprosecution. The cases of the West India Colonies are considered equally with those of the mainland Colonies, as their contemporary importance warrants. The origin of the Council's appellate jurisdiction is traced back to the Channel Islands of Guernsey and Jersey, and the precedents which they provide are treated at some length. The author finds it necessary to "employ technical language, much of it concerned with problems of procedural, rather than substantive, law." There are chapters on "The Settling of Jurisdiction," "The Regulation of Appeals," "Procedure at the Council Board," and "The Scope of Appellate Review." Dr. Smith goes into the elements of judicial and legislative review involved, but finds that the whole matter remained clouded and vague, since no clear doctrine was ever asserted or evolved concerning "the basic factors-the crown's powers of control over colonial legislation, and the status of this legislation in relation to the English law."

6235. Warren, Charles. Bankruptcy in United States history. Cambridge, Harvard University Press, 1935. I95 p. 36-424 $\mathrm{HG}_{3766 . \mathrm{W}_{35}}$

This book, which originated in lectures delivered on the Julius Rosenthal Foundation at the Law School of Northwestern University, discusses the legislative attempts to adjust the relation between debtor and creditor, which have been increasingly characteristic of the great economic depressions undergone by the United States. Congressional debates on bankruptcy are used by the author as the basis of his study of the expanding interpretation of the bankruptcy clause of the Constitution. Three chronological periods are distinguished: a period of the creditor, I789-1827, during which time relief was demanded only in the interest of the creditors; a period of the debter, $1827-6 \mathrm{I}$, in which relief was demanded only in the interest of the debtors; and a period of national interest, 186 I-1935, when bankruptcy laws came to be regarded as matters to be determined by the public interest and the restoration of national economic health. 
6236. Warren, Charles. A history of the American bar. Boston, Little, Brown, 1911. 586 p.

Contains bibliographies. I I-29086 Law

A general survey of law and lawyers down to I 860 , part one of which is concerned with legal conditions in each of the American Colonies during the 17 th and 18 th centuries. Among the aspects covered are the status of the common law as applied by the courts, methods of appointment and the composition of the courts, the leading lawyers, legislation regarding the legal profession, problems of legal education, and contemporaneous legal conditions in the mother country. The second part describes the growth of the American bar from the establishment of the U.S. Supreme Court to the opening of the Civil War. Following on discussions of the Court itself and of the legal profession, three chapters are concerned with what the author terms "the four great factors in the development of the Bar": the rise of corporation and of railroad law between 1830 and 1860 ; the expansion of the common law to meet changing economic and social conditions between 1815 and 1860 ; and the powerful movement for codification between 1820 and 1860 .

\section{B. History: The Supreme Court}

6237. Beveridge, Albert J. The life of John Marshall. Boston, Houghton Mifflin, 1919. 4 v.

illus. 33-29106 E302.6.M4B582; Law

"Works" cited at end of each volume.

Contents.-I. Frontiersman, soldier, lawmaker, 1755-1788.-2. Politician, diplomatist, statesman, 1789-1801.-3. Conflict and construction, 18001815. -4. The building of the nation, $1815-1835$.

6238. Jones, William Melville, ed. Chief Justice John Marshall; a reappraisal. Ithaca, N.Y., Published for College of William and Mary [by] Cornell University Press, 1956. xviii, 195 p. 56-3619 Law

Beveridge's Marshall is a detailed study of the world and life of the most noted of the early Chief Justices of the Supreme Court, who assumed that post in 1801 and held it until his death 34 years later. Perhaps the greatest contribution made by Marshall (1755-1835) to the constitutional development of the United States was the consolidation of an independent judiciary through an active use of the principle of judicial review, but this was only one of the many contributions which are here analyzed in great detail. It is with Marshall's work as Chief Justice that the author is chiefly concerned, but to contribute to the understanding of Marshall's greatest opinions much space has been allocated to discussions of the subject's experience as an inhabitant of frontier Virginia, soldier, legislator, lawyer, politician, diplomat, and statesman, and to the history of his period, the actions and opinions of those about him, the state of the nation, the condition of the people, and the tendency of the popular thought of the era. The partisanship of Senator Beveridge is self-evident: Marshall is glorified while others, such as Thomas Jefferson, are relegated to the ranks of the sinners. Chief Justice
John Marshall; a Reappraisal is largely composed of papers presented by various scholars at a conference held at the College of William and Mary (Williamsburg, Va.) in 1955 as one of the events of the Marshall Bicentennial Program. A foreword by Chief Justice Earl Warren and an introduction by Professor Carl B. Swisher are followed by discussions of Marshall in relation to the political and professional life of his times, the significance of his thought as measured by present-day standards, and his contributions to judicial review and to American law in general.

6239. Ewing, Cortez A. M. The Judges of the Supreme Court, 1789-1937; a study of their qualifications. Minneapolis, University of Minnesota Press, 1938. 124 p. 38-28601 Law

A statistical treatment of information concerning the 75 men who sat on the Supreme Court during the period covered. Graphs and statistical tables are used to aid in this analysis of the appointments, the geographical ties, the age at appointment, and the qualifications of education and prior public service of the Justices. Along with many interesting single facts, a few tendencies emerge. The average age of the Justices at appointment rose by a full ro years over the whole period. Once many Justices served without benefit of college degrees; all recent appointees have them. The percentage of Justices from the South has steadily decreased since $I 789$.

6240. Haines, Charles G. The role of the Supreme Court in American government and politics. Berkeley, University of California Press, 1944-57. 2 v.

57-10498 Law

Volume 2 by Charles Grove Haines and Foster H. Sherwood. 
Contents.- - [ I ] 1789-1835.-[2] 1835-1864.

Professor Haines of the University of California at Los Angeles died in 1948, leaving only three chapters of his second volume in completed form. It was finished by one who had been his student, research assistant, and colleague, but it only reaches 1864 instead of 1885 , as Haines had intended. Haines embarked on a new history of the Court because he thought that the extent to which it and its Judges "have participated in and have influenced the political and partisan activities of the time" was insufficiently explored; and because the conservative and nationalist viewpoints had been too frequently adopted, to be neglect of "the liberal and democratic approach," and the views of critics of the Court. The Court had been the object of persistent attacks for more than a decade when Jackson's election seemed to herald a new day. "But it was not until the end of his second administration that Jackson was able to appoint justices who could change the current of federal judicial decisions. And the change then inaugurated was far from as significant and far-reaching as Democratic leaders anticipated." Volume 2, in fact, is largely a demonstration of continuity between the Marshall Court and the Taney Court. On the whole, "the federal judicial power was more firmly established and far broader in extent at the end of the Taney period than at the beginning."

624I. Howe, Mark De Wolfe. Justice Oliver Wendell Holmes. v. I. The shaping years, 1841-1870. Cambridge, Belknap Press of Harvard University Press, 1957. 330 p. illus.

$$
57-634^{8} \text { Law }
$$

6242. Holmes, Oliver Wendell. The mind and faith of Justice Holmes; his speeches, essays, letters and judicial opinions, selected and edited with introduction and commentary by Max Lerner. Boston, Little, Brown, 1943. L, 474 p.

$$
43-677^{2} \text { Law }
$$

"Note on the Holmes literature": [452]-46o.

Following a decade and a half of writing, practicing, and teaching, Oliver Wendell Holmes (1841-1935), son of a Bostonian poet, essayist, and physician of the same name, was appointed a justice of the Supreme Court of Massachusetts in I882; 20, years later he went to the Supreme Court of the United States, from which he did not retire until 1932. During his 50 years on the State and Federal benches, Holmes was noted for writing opinions in a forceful and epigrammatic style. He was called a legal technician, a humanistic thinker, and a great human figure. All of these he was. Professor Howe's volume is the first of several in a projected biography. The years $184 \mathrm{I}-70$ were, in the author's opinion, the prologue to Holmes' life of achievement; in them he underwent the influences which molded his character and outlook whether found in the circle of his family and friends, on the battlefield of Antietam, or at midcentury Harvard. With Holmes opening his own law office, assuming the coeditorship of the American Law Review, becoming university lecturer on constitutional law in Harvard College, and beginning work on his edition of Kent's Commentaries (no. 6277), this volume ends. The Mind and Faith of Justice Holmes is an attempt, in the editor's words, "to give a rounded portrait of the mind and faith of one who was perhaps the most complete personality in the history of American thought." Each group of selections is prefaced by a note presenting background information.

6243. Hughes, Charles Evans. The Supreme Court of the United States, its foundation, methods and achievements; an interpretation. Garden City, N.Y., Garden City Pub. Co., 1936. 269 p. (Columbia University lectures. George Blumenthal Foundation) $37^{-1208}$ JK 156 r.H8 1936

Hughes' six lectures were delivered in $1927, \mathbf{I I}$ years after his resignation as Associate Justice and 3 years before his return to the Court as Chief Justice. They have, ever since their original publication by the Columbia University Press in 1928, been regarded as an admirable concise treatment of their subject. The eminent jurist disclaimed any intention of competing with Warren's history of the Court or with treatises on constitutional law; he aimed only "to assist those, who are not aiming to become legal scholars, to understand something of its origin, of the principles that govern it, of its methods and of the important results of its works." In an outstanding chapter on "The Court at Work," he says that the Judges bear "the heaviest burden of severe and continuous intellectual work that our country knows." "Liberty, Property and Social Justice" is the title borne by the two concluding lectures; at the end he finds the Court to be the indispensable guardian of all three. "The ends of social justice are achieved through a process by which every step is examined in the light of the principles which are our inheritance as a free people."

6244. King, Willard L. Melville Weston Fuller, Chief Justice of the United States, 188819ı. New York, Macmillan, 1950. 394 p. illus. 50-8032 Law

Bibliography: p. 343-347.

Born in Augusta, Maine, Fuller (1833-1910) removed to Chicago in 1856 , a year after being admitted to the Maine bar. The years preceding his appointment to the Chief Justiceship of the United 
States were occupied by his very active and general law practice, and by his conspicuous role in the affairs of the Democratic Party. Possessed of quiet humor, courage, a sense of nonpartisanship, and a wide range of scholarship, together with kindliness, human sympathy, and modesty, Fuller's most remarkable abilities lay in managing the business of the Supreme Court. The author of this finely drawn portrait concludes that it was Fuller's character rather than his intellect which captured for him the respect and confidence of the legal profession and of the public. He was an embodiment of the dignity of the Supreme Court.

6245. Klinkhamer, Marie Carolyn, Sister. Edward Douglas White, Chief Justice of the United States. Washington, Catholic University of America Press, 1943. 308 p. A 44-427 Law Bibliography: p. 296-306.

The second Southern Roman Catholic appointed to preside over the Supreme Court, and the first Associate Justice to be elevated to the Chief Justiceship, White (1845-1921) was early active on the bench and in the politics of his native Louisiana. (His middle name is usually spelled Douglass.) In I89I he took his seat in the United States Senate, and three years later was appointed to the Supreme Court by President Cleveland. He remained upon that bench for 27 years, after 16 of which he was raised to the Chief Justiceship by President Taft, in IgIo. The author declares that White's greatest contributions while on the High Court were made in the field of administrative law, but his opinions in the fields of procedure, contracts, interstate commerce, taxation, and due process are also subjected to analysis. The study of his decisions is preceded by a biographical essay. The appendixes contain tables of cases in the Louisiana and United States reports in which White's opinions are recorded; also given are the names of the Justices who concurred with him or dissented.

6246. Mason, Alpheus Thomas. Brandeis, a free man's life. New York, Viking Press, 1946. 713 p. illus. $\quad 46-25268 \mathrm{JK}_{15}$ I9.B $_{7} \mathrm{M}_{3}$ Law

6247. Brandeis, Louis Dembitz. The social and economic views of Mr. Justice Brandeis, collected with introductory notes by Alfred Lief. With a foreword by Charles A. Beard." New York, Vanguard Press, 1930. xxi, 4I9 p.

$$
\text { 30-30043 Law }
$$

6248. Brandeis, Louis Dembitz. The unpublished opinions of Mr. Justice Brandeis; the Supreme Court at work, by Alexander M. Bickel. With an introd. by Paul A. Freund. Cambridge,
Belknap Press of Harvard University Press, 1957. $\mathrm{xxi}, 278$ p. illus. 57-9069 Law

Brandeis (1856-1941), the son of Bohemian Jewish parents who came to the United States in the ranks of the "Forty-eighters," studied with distinction at Harvard Law School, and was soon engaged in a varied and lucrative law practice in Boston. His legal interests were as wide in scope as his extra-legal ones. Labor, trusts, railroads, insurance, finance, and even conservation all occupied him in his role as counsel and investigator. He achieved fame as a reformer bent on ameliorating the evils and injustices which had developed with industrial capitalism. President Wilson's nomination of Brandeis for the Supreme Court in 1916 precipitated a long and bitter wrangle, but eventually, with no little aid from Wilson himself, the Senate's confirmation was forthcoming. From then until his retirement in 1939 Brandeis' opinions regularly expressed his belief in the value of free institutions and democratic processes, which provided the best means of enhancing the dignity and potentialities of the individual. The greater portion of Mr. Mason's biography is concerned with Brandeis' pre-Court career and portrays a great advocate engaged in argument on behalf of what he conceived to be the basic principles of human freedom. The Social and Economic Views of Mr. Iustice Brandeis is a collection of his opinions, together with a few of his briefs, speeches, and articles, arranged under the categories of labor problems, regulation of business, public utility economics, guarantees of freedom, prohibition and taxation, and State and nation. Derived from Brandeis' private papers relating to his service on the Supreme Court, The Unpublished Opinions of Mr. Iustice Brandeis, I I in all, comprise, with Mr. Bickel's essays constructed from information found in the papers, an exposition of the working of Brandeis' mind, and of the processes by which judicial judgments are arrived at.

6249. Mason, Alpheus Thomas. Harlan Fiske Stone: pillar of the law. New York, Viking Press, 1956. 914 p. illus. 56-10404 Law "Note on Stone's legal writings": p. 888-891.

6250. Konefsky, Samuel Joseph. Chief Justice Stone and the Supreme Court. With a prefatory note by Charles A. Beard. New York, Macmillan, 1945. xxvi, $290 \mathrm{p}$.

A 46-501 JKI519.S8K6 r945; Law

Professor Mason's book is a detailed and scholarly account of the life and character of the only man who occupied consecutively every seat on the bench of the U. S. Supreme Court. Appointed to the Court in 1925, Stone (1872-1946) was pro- 
moted to Chief Justice in 1941. Emphasis is placed upon Stone's career on the Court, and upon the inner workings of that tribunal. Born in the New Hampshire hills, the late Chief Justice throughout his life took each task as it came to him, whether as teacher, attorney, government official, or judge, and performed it thoroughly and capably. This quality, together with his balance and dignity, brought him advancement despite his lack of a spectacular personality. "Respect for facts, unremitting intellectual effort in the face of social perplexities, gave him an understanding that on occasion led to what observers identified as the liberal position. The accolade was unwanted and not wholly deserved .... By tempering predilection with restraint and craftsmanship, he made the personal preference for social policy but one factor in his quest for judgment ... He became the statesman without ceasing to be the lawyer." Dr. Konefsky's Columbia University dissertation concentrates upon Stone's contributions to constitutional doctrine and his conception of the judicial function, against a background of the larger trends of constitutional development and the conditions which gave rise to the controversies brought before the Supreme Court from I 925 to I943. Not having, as did Mason, Stone's papers as a source, the author relied principally upon judicial opinions as a basis for his discussion. Characterized as "a leader of that liberal jurisprudence of which Holmes and Brandeis were the trail-blazers," Stone is judged in the concluding chapter to have been a great advocate of "an enlightened view of the judicial function."

625I. Pollard, Joseph P. Mr. Justice Cardozo; a liberal mind in action. With a foreword by

Roscoe Pound. New York, Yorktown Press, 1935. 327 p. 35-6010 Law

An admiring discussion on a lay level of the opinions of Benjamin Nathan Cardozo (1870-1938), who for 18 years served on the New York Court of Appeals (1914-1932) and for 6 on the U. S. Supreme Court (1932-1938). In no sense a biography, it studies a mind as revealed in judicial action in fields of litigation such as personal injury, crime, social welfare, labor, libel, and censorship, to name a few. It dwells for the most part on Cardozo's longer service on the State court, and concludes with a brief account of his first two years on the High Court during the launching of the New Deal.

6252. Pritchett, Charles $H$. Civil liberties and the Vinson Court. [Chicago] University of Chicago Press, 1954. 296 p. 54-8459 Law A sequel to the author's The Roosevelt Court be- low, which concentrates on the problem of civil liberties as encountered by the Supreme Court under the leadership of Chief Justice Fred M. Vinson (1890-1953; appointed in 1946) in such fields as free speech, denizenship, racial segregation, and criminal prosecution. It explores the motivations of the individual Justices in their opinions upon cases within these fields. The author concludes with a searching analysis of what the Court ought to do to improve its relationship to the free society of which it is the constitutional guardian.

6253. Pritchett, Charles $H$. The Roosevelt Court; a study in judicial politics and values, I937-1947. New York, Macmillan, 1948. xvi, 314 p. $\quad 4^{8-4203} \mathrm{JK}_{5} 56$ I.P7

The primary purpose of this work is to relate significant constitutional developments of the period to the ideological preference of the members of the Court. It is essentially a study of the politics and values of the Justices named to the Supreme Court by President Roosevelt. The author, a professor of political science at the University of Chicago, compiles 25 statistical tables in order to bolster his contention that in differences of opinion on questions of policy, given the same or similar conditions, there is a constant in the alignment of the members of the Court, derivable from their characters and backgrounds.

6254. Pusey, Merlo J. Charles Evans Hughes. New York, Macmillan, 195I. 2 v. (xvi, 829 p.) illus. 5 I-7851 Law

This authorized biography by a staff writer of the Washington Post is a narration and an interpretation of a career of service to State, nation, and mankind. Lawyer, investigator, teacher, governor, Presidential candidate, Secretary of State, Associated Justice and Chief Justice of the United States: Hughes (1862-1948) was all of these as well as a devoted husband, father, and grandfather. He was the only man to resign from the Court (in I9r6, after six years' service as Associate Justice) in order to campaign for the Presidency, and then to be reappointed, as Chief Justice, I4 years later. Fol. lowing his retirement from the bench in r94I until his death seven years later, his counsel was sought by those who remained in office, but Hughes by no means sought the role of a professional elder statesman. In his evaluation of Hughes' II-year performance as Chief Justice, the author notes at least four aspects of his work as outstanding: his enhancement of efficiency within the whole Federal court system; his mastery in presiding over the Court and the conferences of its Justices; his positive contributions to the law, notably the firm establishment of the four freedoms of the First 
Amendment as guarantees to the citizen against State actions; and last, but not least in importance, his stalwart and unemotional defense of the Court against efforts at executive domination. A much briefer, but exceedingly lucid and judicious appreciation of his great services in several realms, and especially on the Court, is Dexter Perkins' volume in The Library of American biography: Charles Evans Hughes and American Democratic Statesmanship (Boston, Little, Brown, 1956. xxiv, 200 p.).

6255. Ragan, Allen E. Chief Justice Taft. Columbus, Ohio, Ohio State Archaeological and Historical Society, 1938. 139 p. ([Ohio State Archaeological and Historical Society] Ohio historical collections, v. 8) $3^{8-28}$ I50 $^{8} \mathrm{E}_{7} 6_{2} . \mathrm{R}_{25}$

"Index of cases": p. 129-130.

Bibliography: p. 123-128.

This monograph, which originated as a dissertation at Ohio State University, attempts "to determine what contribution Chief Justice William Howard Taft made to the constitutional history of the country" from I921 to 1930. Some background for his Supreme Court decisions has been provided from his earlier judicial and administrative career. Separate chapters are concerned with Taft's judgments in cases involving labor, the Federal power over commerce, the limits of State power, restraint of trade, and the 18 th Amendment. The author concludes that despite Taft's industry, legal learning, and impartiality, his decisions lacked color, and "he failed to establish any new lines of constitutional interpretation" which could make his term outstanding. Apart from maintaining the inviolability of property rights against labor, his decisions were sufficiently nationalistic and liberal. Even though his success, under the circumstances, could only be partial, "his prolonged interest in and his tireless labors for judicial reform were his crowning achievements."

\section{Rodell, Fred. Nine men; a political history} of the Supreme Court from I790 to 1955 . New York, Random House, 1955. 338 p.

The author is a professor of law at Yale University who practices journalism on the side, and his book, which, he says, is not written down to lawyers, is robustly journalistic in manner. Professor Rodell says that he is a liberal and admires liberals, but that his "almost fanatical devotion to that kind of personal integrity that combines intellectual honesty with courage" is more important. The title is meant to imply that the Supreme Court is indistinguishable from the nine men who at any one time are its Justices, that they bring their characters and careers onto the bench with them, and that the Court is therefore "powerful, irresponsible, and human." The book is a vigorous summary of the Court's history from an advanced liberal point of view, in personal terms, and with most space given to the recent past. The Vinson Court is castigated as inimical to human dignity and democratic decency. Well-informed, never dull, obscure, or difficult, and transparent in its partisanship, Nine Men is well suited to those who dread the technicalities of the subject.

6257. Schwartz, Bernard. The Supreme Court, constitutional revolution in retrospect. New York, Ronald Press Co., 1957. 429 p.

57-9302 Law

In 1937 the President proposed to vitiate the independence of the judiciary by his Court-packing plan, Justices Roberts and Hughes ceased their objections to Federal intervention aimed at resuscitating a prostrated economy, and the Supreme Court handed down a whole group of decisions constituting a decisive break with its previous jurisprudence grounded on laissez-faire. This was the constitutional revolution; Professor Schwartz of the New York University School of Law atternpts to trace its consequences through the ensuing 20 years, during which, he thinks, "despite aberrations, notably by certain Justices, the Court's decisions have followed logical patterns, consistent with the bases" of 1937. As the Federal Government entered a whole new sphere of positive economic activity, the Supreme Court adopted an entirely new attitude toward statutes, refusing to void them so long as rational legislators could have regarded them as reasonable methods of promoting the public welfare. Therefore in 20 years "the Court's authority vis-à-vis the Congress has all but atrophied," and a drastic shift in the balance of governmental powers has taken place. Professor Schwartz reviews in turn the consequences in the Court's relation to Congress, the President, the administrative agencies, the inferior courts, the States, and the individual. He also discusses the manner in which the Court's work has been affected by war and cold war. A concluding chapter, "Anatomy and Pathology of the Court," says that while during the first to years the Court overruled too many precedents, it has since let stare decisis provide an essential element of continuity in the law; that the prestige of Justice Holmes has led too many of his successors to deliver dissenting opinions; and that judicial review is basically an undemocratic institution, which in a democratic system should be exercised with rigorous selfrestraint. 
6258. Swisher, Carl Brent. Roger B. Taney. New York, Macmillan, 1935. 608 p. illus. 35-19101 E340.T2S9; Law

Bibliography: p. 591-598.

Taney ( $1777-1864$ ) is best remembered for his role in Andrew Jackson's struggle against the Bank of the United States and for his decision, as Chief Justice of the United States, in the Dred Scott Case. Born into the Roman Catholic gentry of Calvert County, Maryland, Taney had a long and distinguished career- which included service as a Maryland legislator and attorney general, Attorney General and Secretary of the Treasury in President Jackson's Cabinet, and Chief Justice of the United States for almost three decades $(1836-64)$. Taney led the judicial forces seeking a modification of the assumption underlying so many decisions of the Marshall Court: that unchecked and centralized Federal power together with judicial benevolence toward private economic interests would invariably work for the good of the country. Although he received an exceptional amount of denigration or abuse from his contemporaries and from writers of the next two generations, the author feels that Taney well earned the accolade of Charles Evans Hughes: "he was a great Chief Justice."

6259. Trimble, Bruce R. Chief Justice Waite, defender of the public interest. Princeton, Princeton University Press, 1938.320 p. illus.

"Table of cases": p. [307]-310. 38-3414 Law

Bibliography: p. [301] -306 .

Waite (1816-88) was an Ohio lawyer of specialized practice and excellent political connections, but had no judicial experience when President Grant put him at the head of the Supreme Court. He was Chief Justice of the United States for I4 years ( $1874-88)$ and through careful planning and painstaking toil became, this biographer believes, a great administrator and a judge of recognized ability. Drawn largely from information found in Waite's letters, public papers, and judicial utterances, this study aims at showing something of Waite's influence in the solution of the constitutional problems which came to the fore during the Reconstruction period. The opinions which he rendered covered a multitude of those problems: radical Reconstruction legislation, the war amendments, western de- velopment, transcontinental railroads, agrarian movements, the control of public utilities and rates, and the relation of the States to the liquor traffic. In all these matters Waite made substantial contributions, the greatest of which, in Mr. Trimble's estimation, was probably his interpretation of the contract clause of the Constitution, in which he enunciated his doctrine of the "public interest."

6260. Warren, Charles. The Supreme Court in United States history. Rev. ed. Boston, Little, Brown, 1937. 2 v. $\left(8 \mathrm{r}_{4}, 8 \mathrm{r}_{2} \mathrm{p}\right.$. $)$

First published in 1922.

$$
3^{8-33016} \mathrm{JK}_{1561 . W_{3}} 1937
$$

Contents.-v. I. I789-1835.-v. 2. 1836-1918. A leisurely history of the first century of the Supreme Court, to the death of Chief Justice Waite in 1888; the succeeding 30 years, to the end of World War I, are more briefly summarized in two final chapters (v. 2, p. 690-756). The large-scale portion aims to narrate "a section of our National history connected with the Supreme Court" for laymen and lawyers alike, and "to revivify the important cases decided by the Court and to picture the Court from year to year in its contemporary setting." The background of social, political, and economic controversy out of which the Court's most famous cases arose is carefully described. Each appointment of a Chief or Associate Justice, including those which were declined, withdrawn, or disapproved by the Senate, is investigated and contemporary reactions sampled at some length. A chronological list of all such appointments appears at the close of volume 2 (p. 757-763). Warren also drew upon the papers of important contemporaries, legal and lay, and the newspaper and magazine press for the reception of important decisions; this is one of the most valuable features of his book. The service of the three first Chief Justices (John Rutledge took his seat and presided over one whole term of the Court before the Senate rejected him) is covered in the first 168 pages, and the remainder of volume $I$ is concerned with John Marshall's 35 epoch-making years. Useful material not easily found elsewhere is contained in Chapter 10, "The Judges and the Court-Rooms." The illustrations include photographs of the Court's first two (quite small) rooms in the Capitol, and group photographs of the Justices taken in 1865, 1882, and 1899 .

\section{General Views}

626r. Cahn, Edmond N. The moral decision; right and wrong in the light of American law. Bloomington, Indiana University Press, 1955. 342 p.

55-8739 Law 
Acting on the suggestion of a distinguished United States circuit judge and acknowledging the inspiration of Jerome Frank, Professor Cahn has written this book "to draw upon the supply of moral insight and experience that American courts have gradually developed and accumulated," and so answer the question, "What moral guides can be found in American law?" After a theoretical section which considers the extent to which morals is a legal order and law is a moral order, the author considers a series of "prismatic" cases which bring moral issues into sharp focus and encourage the reader to judge for himself. These are arranged in six chapters intended to sample human concerns in a natural progression from birth to death, of which only three ("Sexual Relationships," "The Conduct of Business," and "Business with Government") are homogeneous and self-explanatory. Further "prismatic" cases are used in the concluding chapters, which consider various moral aspects of trial, compromise, and judicial decision. This deeply felt and thought and warmly written work places American law in a more attractive light than it frequently enjoys.

6262. Cardozo, Benjamin Nathan. Selected writings. Edited by Margaret E. Hall. New York, Fallon Publications, I947. xxiv, 456 p. $47^{-11282}$ Law

A collection of Cardozo's extrajudicial utterances: addresses, lectures, essays, and the texts of his brilliant works on jurisprudence: Nature of the Judicial Process (1921), Growth of the Law (1924), Paradoxes of Legal Science (1928), and Law and Literature (193I). Most of these reflect his contributions to the literature and philosophy of American law: his insight and eloquence in defining and stating the moral values of the law; his craftmanship in bending, or not bending, a rule to meet the demands of ethical principle, or to uphold a legal or political value; and his aesthetic convictions expressed in his fondness for beauty of literary style and his belief in the close relationship of beauty and morals. Except for some works of his student days at Columbia which are included, these writings are by-products and reflections of Cardozo's work as a judge of the Supreme Court of New York (191432 ), before his appointment to the United States Supreme Court.

6263. Frank, Jerome. Law and the modern mind. New York, Coward-McCann, 1949. xxxi, 368 p. $\quad 49-2082$ Law An influential study in the theory of law by a well-known American jurist, which went through six printings between 1930 and I949; to the last the author adds a lengthy preface (p. vi-xxviii) out- lining the interim progress of his opinions. Recent logic, philosophy of science, and especially psychology are drawn upon to scotch "the basic legal myth," "the notion that law either is or can be made approximately and certain." The acceptance of this myth by lawyers, who should know better, as well as by the public is blamed by Frank for the widespread cynical disdain of lawyers as tricksters and quibblers. The trouble is that "the desire persists in grown men to recapture, through a rediscovery of a father, a childish, completely controllable universe, and that desire seeks satisfaction in a partial, unconscious, anthropomorphizing of Law, in ascribing to the Law some of the characteristics of the child's Father-Judge." Until we have followed the way pointed out by Justice O. W. Holmes, "the completely adult jurist," and put away this childish image and the childish emotions attached to it, "we shall not reach that first step in the civilized administration of justice, the recognition that man is not made for the law, but that law is made by and for men."

6264. Hand, Learned. The spirit of liberty; papers and addresses, collected, and with an introd. and notes, by Irving Dilliard. New York, Knopf, 1952. xxx, 262 p. 5I-13215 Law

In 1951 Learned Hand (b. 1872 ) retired from active service as Chief Justice of the U.S. Court of Appeals for the Second Circuit, thus completing a judicial career of more than four decades. Long before his retirement Hand had become a legend, first to the members of his profession and later to the general public. The vagaries of the American political system deprived him of a place on the U.S. Supreme Court, but he has been called its "tenth justice," and with some reason, for the High Court has been influenced by Hand's lower court decisions, and has on occasion given Hand's very words a place in its own. In 1939, when Harvard bestowed the degree of Doctor of Laws upon this distinguished son, the citation called him: "A judge worthy of his name, judicial in his temper, pro found in his knowledge, a philosopher whose decisions affect a nation." Irving Dilliard's appreciative essay prefaces this collection of Hand's nonjudicial pieces, which commences with his Harvard Class Day oration (1893) and concludes with an address he delivered at a celebration of his 8 oth birthday. Many of the judge's words in praise of others are included: of Holmes, Brandeis, and Cardozo, to name but three. He is one of the same breed, and must be praised in ideas and language of the same stamp.

6265. Jackson, Percival E. Look at the law; the law is what the layman makes it. Foreword 
by Arthur Garfield Hays. New York, Dutton, 1940. $377 \mathrm{p}$. 40-2727I Law

A rapid review of the chronic lay complaints that there is too much law; that the law is uncertain, rigid, technical, hypocritical, slow, and expensive; and that lawyers are dishonest, judges corrupt, and witnesses liars. The author, formerly counsel of the United States Senate Committee for the Investigation of the Administration of Justice in the United States Courts (1936) provides an abundance of illustration in his efforts to arouse public opinion to the point of doing something about a legal system as fallible as the society which it is meant to serve. Once the complaint is made, the bar should, the author asserts, suggest remedies from which laymen may choose the one they desire and insist on its application. The author's recommendations, aside from the need for stimulating the public to action and obtaining leadership, call for reduction of bulk and technicalities in the law, for a continuous digest of judge-made law by a public agency, for a court administration more conducive to the ends of justice; and for a general raising of standards for all actively concerned in the practice and administration of the law. There is no index.

6266. Konefsky, Samuel J. The legacy of Holmes and Brandeis; a study. in the influence of ideas. New York, Macmillan, 1956.316 p.

Drawing upon the writings of Justices Holmes and Brandeis (nos. 624I-6242, 6246-6248) and upon the recollections of the law clerks who served them, the author presents a comparative study of the constitutional and legal philosophy of these two men, who so often found themselves companions in dissent. Each of them, in his own way, "has come to symbolize the never-ending struggle to infuse law and balance into the processes by which the people of the United States are governed. They differed greatly in intellectual taste, social perception, political ideals, and juristic method. Yet they were able to achieve almost complete accord in their exposition of the Constitution. The harmony between Justices Holmes and Brandeis is as illuminating a commentary upon the essentially flexible nature of America's fundamental charter as one can expect to find in the whole field of judicial biography."

6267. Mortenson, Ernest. You be the judge. Illustrations by Alain. New York, Longmans, Green, 1940. 45I p. 40-6720 Law "Collaborator, Miss Sarah Paulding Ray."-p. x. "Suggestions for further reading": p. $44 \mathrm{I}-445$.

A New York lawyer seeks to make the law and its processes intelligible and reasonable to those without legal training, to which end he purposely omits qualifying phrases and legal terminology. Throughout he employs actual cases, simplifying them considerably by the omission of technicalities but supplying the fundamental legal principles which are usually presupposed in the judges' opinions. After two introductory chapters on the nature of legal actions and judicial processes, the author devotes successive chapters to the most common fields of substantive law: torts, property, crime, international law, domestic relations, equity, contracts (including bills and notes and insurance), wills, and Federal cases. Chapter 12, "Problems of Proof," discusses cross-examination as well as the varieties and values of evidence. The concluding chapter presents issues in the philosophy of the law and in its reform. Mr. Mortenson's cases are usually quite interesting in themselves, and his expositions uncommonly clear and crisp; the whole may be termed an attractive layman's casebook. He warns, of course, that it does not qualify the reader to conduct his own litigation.

6268. My philosophy of law; credos of sixteen American scholars, published under the direction of the Julius Rosenthal Foundation, Northwestern University. Boston, Boston Law Book Co., 194 I. 321 p. illus. 4I-19742 Law

A symposium of American legal philosophy contributed by such legal scholars as John Dickinson, Roscoe Pound, Max Radin, and John H. Wigmore, and by two scholars not primarily of the law: John Dewey and Morris R. Cohen. The remaining Io were all professors in the law schools of major universities; 3 of them, naturally enough, were of the faculty of Northwestern University, A photograph of each precedes his essay. The essays are untitled, since the subject of each is understood to be "My Credo about the Law": "the editorial committee feared that if the author were left free to select his own subject, the symposium would turn out to be a mere collection of papers lacking in definite unity." Since the print is large and the margins generous, these 15- to 20-page statements are even briefer than might be supposed. The views expressed by the contributors as to the ultimate ideas of the origin, nature, and ends of the law are varied in approach and conclusion, although nearly every one of the essays stresses the inadequacy of viewing the law as merely a body of precedents and rules.

6269. Shartel, Burke. Our legal system and how it operates; five lectures, delivered at the University of Michigan, February 23, 24, 25, 26, and 27,1948 , on the Thomas M. Cooley lectureship, enlarged and revised. Ann Arbor, University of 
Michigan Law School, I951. 629 p. (Michigan legal studies) 5I-61902 Law

Professor Shartel of the University of Michigan Law School has written for beginning law students, upper-level undergraduates, and general readers curious about the legal system an introductory book intended to supply the place once held by Sir William Blackstone's Commentaries on the Laws of England, now completely obsolete for general teaching purposes. He begins on a semantic note, with a discussion of the use of language in relation to law, and goes on to analyze the legal system in terms of two basic ideas: acts of individuals and officials, and standards intended to control these acts. Having spelled out his distinctions in these spheres, the author can proceed to chapters on "Legislation," the "Interpretation of Legislation," "The Common Law," and "Legal Policies and Policy Making," policies being defined as the ends for which standards are framed by lawmakers. However useful as a preliminary to more specialized law courses, it is unlikely to enjoy the long repute of Blackstone, for if most of it is plain enough, some of it is obvious, and all is quite prosaic.

6270. Vanderbilt, Arthur T. Men and measures in the law; five lectures delivered .... at the University of Michigan, Apr. I948. New York, Knopf, 1949. xxi, 156, x p. (William W. Cook Foundation lectures, v. 4) 49-8738 Law

The late and greatly regretted A. T. Vanderbilt, who taught at the New York University Law School for over $3^{\circ}$ years until his appointment as chief justice of the Supreme Court of New Jersey in 1947 , was an indefatigable leader in the cause of legal reform. In these lectures he took a critical look at the entire field of American law in the light of a time of world crisis. "Law in the Books," he found, was crushing in its volume and too little accessible; the great need was "for critical research apparatus to make it more available to us." The legal profession suffered from the lack of a sense of individual responsibility; its members turned away from politics and public office. The law schools spent far too much of their time on commercial law and the law of property; they were nevertheless the best hope of the future. In every jurisdiction substantive law cried out for continuous revision and continuous codification, as well as for public agencies charged with searching it for provisions deserving repeal. However, "the stumbling-block," in which improvements "come with far greater difficulty than progress in the substantive law," was procedure, for here both bench and bar had a vested interest in technicalities where they are at home and everyone else quite at sea. Vanderbilt concisely outlined the movements for procedural reform, the concrete gains that had been achieved, and the wide field for improvement that remained-including arrogance and bad temper on the bench. Here again the best hope was the law schools, as the best means "to mobilize, co-ordinate and direct the activities of the many bar associations, the judicial councils, and other organizations devoted to the improvement of the administration of justice."

\section{Digests of American Law}

6271. Brown, Ray A. The law of personal property. 2d ed. Chicago, Callaghan, 1955. 853 p. (National textbook series) 55-14547 Law

First published in 1936 under title: $A$ Treatise on the Law of Personal Property.

Table of cases: p. xv-xcvii.

Professor Brown of the University of Wisconsin Law School has drawn upon his own experience as teacher and practitioner, and has cited over 5500 cases in this comprehensive treatise on the American law of chattel property. An introductory chapter informs us that ownership is "not a single indivisible concept but a collection or bundle of rights, of legally protected interests," and that certain limited rights in land are regarded as chattels. Chapters 2-9 consider various ways of acquiring and transferring rights in personal property: original acquisition; finding lost articles; adverse possession; judgment and satisfaction of judgment; accession and confusion ("such an intermixture of goods owned by different persons, that the property of each can no longer be distinguished"); gifts of chattels and of "choses in action" (claims by one person against another for the performance of valuable acts, such as bonds or shares of stock); and sales. Six longer chapters deal with bailments ("the rightful possession of goods by one who is not the owner"), liens, and pledges, all situations wherein one person has a limited interest in the personal property of another. The two concluding chapters deal with fixtures and crops, both in the borderland between personal and real property. 
6272. Clark, George Luther. Summary of American law. With introd. by Roscoe Pound. Rochester, N.Y., Lawyers Co-operative Pub. Co., 1947. xxxv, 69I p. $47-8287 \quad$ Law

6273. Griffith, Virgil A. Outlines of the law, a comprehensive summary of the major subjects of American law. Indianapolis, BobbsMerrill, I950. $75^{2} \mathrm{p}$.

50-3721 Law

6274. Gavit, Bernard C. Introduction to the study of law. Brooklyn, Foundation Press, $195 \mathrm{I}$. xvi, 388 p. (University textbook series)

$5^{\mathrm{I}-4853 \text { Law }}$

Mr. Clark's Summary of American Law, covering practically the entire legal field, is designed, through its summations of 30 legal subjects, to aid the law student, armed with the appropriate case books, to obtain an effective general view of the law. Of its four sections, the first is concerned with the rudimentary aspects of the law, such as forms of action, torts, contracts, agency, and property; the second with equity and the law of commerce; and the third with public law, encompassing public utilities, municipal corporations, taxation, and constitutional, administrative and labor law. The con'cluding section is devoted to the principles of procedure in common law and code pleading, and in the presentation of evidence. Another survey of the law is Mr. Griffith's; of a more general nature with a minimum of case citations, and without the discussion of procedure included in Clark's Summary, this outline of major legal subjects is directed noi only to those of, or about to be of, the legal profession, but also to others seeking a comprehensive statement of the principles of American law. Mr. Gavit's contribution to this group of summary and introductory manuals "is not a law book; it is a book about the law." The most elementary of the three, it is intended for pre-law and law students as well as for the layman who desires to become acquainted with such fundamentals of the American legal system as legal education, the sources and forms of the law, the judicial process, legal ethics, procedure, the common law forms, and equity. The definition and explanation of basic concepts has resulted in an exposition extremely general in nature, but this should increase the work's usefulness to those for whom it is designed.

6275. Clark, William L. Handbook of the law of contracts. 4th ed., by Archibald $\mathrm{H}$. Throckmorton and Alvin C. Brightman. St. Louis, West Pub. Co., 1931. xv, 858 p. (Hornbook series)

Clark (1863-1918) won "the distinction of being one of the most prolific of American law writers, and it is probably true that during the past generation law students have used his books more extensively than those of any other author," say the editors of this volume. Clark's original edition appeared in 1894, and it and its successors had the widest circulation of all his works. The original analysis followed that of standard English works on contracts by Sir William Anson and S. M. Leake. In chapter I a contract is defined as "an agreement enforceable at law, made between two or more persons, by which rights are acquired by one or more to acts or forbearances on the part of the other or others." Successive chapters deal with "Offer and Acceptance," "Classification of Contracts [contracts of record, contracts under seal, and simple or parol contracts]," "Contracts Required to be in Writing," "Consideration ['A valuable consideration is essential to the validity of every simple contract']," "Capacity of Parties," "Reality of Consent," "Legality of Object [an agreement with an illegal object is no contract]," "Operation," "Interpretation," and "Discharge of Contract," and "Quasi Contract [obligations clothed by the law with the semblance of contract for the purpose of remedy]."

\section{Clark, William L., and William L. Marshall.}

A treatise on the law of crimes. 6th ed., rev. by Melvin F. Wingersky. Chicago, Callaghan, 1958. xix, 959 p. (National textbook series)

58-3192 Law

A standard digest of American criminal law since I 895 , into the latest edition of which a quantity of sociological matter has been written. Part I on "Legal Concepts of Crime" has chapters on the sources and characteristics of criminal law and on "Jurisdiction and Locality." Part 2 is labelled "Criteria of Accountability, Responsibility, Exemption, and Vindication"; it includes a chapter of ro4 pages on "The Mental Element." Part 3 classifies punishable behavior in six chapters: "Proscribed Coalitions," "Offenses against the Persons of Individuals," "Offenses Involving Sexual Behavior, Morality, and Family Relations," "Offenses against Property," "Burglary and Arson," and "Offenses against Government." Many persons will prefer the considerably simpler and more straightforward $5^{\text {th }}$ edition, prepared by James J. Kearney in $195^{2}$ (794 p.).

6277. Kent, James. Commentaries on American law. I2th ed., edited by O. W. Holmes, Jr. Boston, Little, Brown, 1873, ${ }^{c}$ Igor. 4 v. I-277II Law

A landmark in American legal literature, Chancellor Kent's Commentaries, the great American institutional legal treatise intended to instruct students of American jurisprudence in the fundamentals of 
that system, and based on Kent's lectures given at Columbia College in 1823 and 1824 , was first published between 1826 and 1830 . As early as 1832 a second edition was printed to meet the enthusiastic response to the work. Its six sections are devoted respectively to the law of nations, to the government and constitutional jurisprudence of the United States, to the sources of the municipal law of the several States, to the rights of persons, to personal property, and to real property. No separate treatment is given to the law of crimes or to equity. Justice Holmes' edition of the Commentaries, published a quarter of a century after Kent's death, not only brought the work up to date by means of Holmes' supplementary essays, but also sought to restore something of Kent himself by eliminating almost entirely the notes by other hands that had been added to previous editions later than the sixth ( 1848 ), which contained Kent's last corrections.

6278. Tiffany, Herbert Thorndike. A treatise on the modern law of real property and other interests in land. New abridged ed., by Carl Zollmann. Chicago, Callaghan, 1940. xxxvi, 1219 p.

\section{References: p. v-vi.} $40-14787$ Law

Tiffany's original edition was published in 1903; after its plates were worn out, two successive photostatic reproductions were used as teaching manuals in many law schools. It aimed "to present, in moderate compass, the principles which govern the various branches of the law of the land, adopting for the purpose a method of analysis and order calculated to make plain the relations of these various branches to one another and to the whole." Mr. Zollmann retained the original framework, but checked I 4 casebooks to add new cases, expanded some of the sections, and added some new ones. Part I contains "Preliminary Considerations" on the nature of real property, tenure and seisin, and the theory of estates. Laymen will be surprised to learn that the all-important legal distinction between real and personal property is no older than the middle of the 17 th century, when it arose out of the differing forms of action used to recover rights in land as against rights in chattels. Part 2 on "The Ownership of Land" is much the longest; it has chapters on "The Quantum of Estates," "Equitable Ownership," "Future Estates and Interests," "Concurrent Ownership," "Estates and Interests Arising from Marriage," and "Rights of Enjoyment Incident to Ownership." The four remaining parts are "Rights to Dispose of Land Not Based on Ownership," "Rights as to the Use and Profits of Another's Land," "The Transfer of Rights in Land," and "Liens."

6279. Walsh, William F. A treatise on equity. Chicago, Callaghan, 1930. xli, 603 p. (National textbook series) 30-25486 Law

"We think of equity as that system of remedial law administered by Chancery in England and by courts in the United States which exercised like powers and administered a like system of law"; its content and nature can be further understood only by studying its principles and practices. The basic sense, of course, is that the judicial power may do justice in cases where the letter of the law would work a clear injustice or hardship upon one of the parties. Modern codes and statutes have effected a merger of law and equity, and "modern equity has emerged as a coordinated part of the single system of law under which we live." A major purpose of Professor Walsh's book is to restate the rules and principles of equity from the point of view of this merger. The four parts deal with the "History, Nature, and Characteristics of Equity," "Equitable Relief in Tort Cases," "Equitable Relief in Contract Cases," and "Equitable Relief against Fraud and Mistake and in Miscellaneous Cases."

\section{E. Courts and Judges}

6280. American Law Institute. A study of the business of the Federal courts. Philadelphia, Executive Office, American Law Institute, 1934. 2 v. tables, diagrs.

35-8524 Law Contents.-1. Criminal cases.-2. Civil cases.

Inaugurated by President Hoover's National Commission on Law Observance and Enforcement, and carried out by a committee aided by several law schools and the Rockefeller Foundation, this study of cases, criminal and civil, made in 13 judicial districts has resulted in a detailed statistical account of the operation of the Federal courts-an operation found by this study to be in the main quite efficient. On the criminal side, this analysis pointed to the need for emphasis upon questions of substantive policy in Federal law administration as distinguished from attempts to refurbish procedure; a case in point cited was the need for the regulation, not the abolition, of the technique of pleading guilty. The interpreters of the statistics 
gathered from the study of the civil cases felt it desirable that devices be created for rapidly and efficiently sorting the cases and allotting each to the procedure best adapted to it. As a pilot project in the employment of statistical methods in studying courts of law, these reports, aside from the purely mechanical experience gained, are of value in that, admittedly, they point to the necessity of trained observation to supplement statistical tables.

6281. Bunn, Charles Wilson. A brief survey of the jurisdiction and practice of the courts of the United States. $5^{\text {th }}$ ed., by Charles Bunn. St. Paul, West Pub. Co., 1949. 408 p. 49-3344 Law

A short study dealing primarily with the jurisdiction of the Federal courts and only incidentally with practice before them. Three groups of cases confront a lawyer considering the problem of jurisdiction: cases in which only the State courts possess competence, those in which Federal jurisdiction is exclusive, and a third group in which Federal and State jurisdictions are concurrent, and where he and his opponent have a choice of forum depending upon such factors as the condition of trial calendars, the competence of judges, or the attitudes of juries. While these latter considerations are of importance, it is not the purpose of the author to treat them; what he does do is to set forth the areas of compelled selection and of choice in their main aspects and indicate the place to go for further information. Of value to law students, this work is complemented by an appendix containing the principal provisions of the Constitution, statutes, and rules bearing on the jurisdiction of the Federal courts.

6282. Callender, Clarence N. American courts; their organization and procedure. New York, McGraw-Hill, 1927. 284 p. 27-3682. Law

"References" at end of most of the chapters.

A description of the State and Federal courts together with an explanation of the procedures employed in handling various types of litigation. Intended for the general student, this work is concerned not with minutiae, but with the broader aspects of the administration of justice in the courts. In discussing the relationship between attorney and client, the State and Federal court systems, justices of the peace, pleadings and forms of action, the phases of trial procedure, courts of equity, probate and criminal courts, commercial arbitration, and the problem of improving legal procedure, the author has employed language comprehensible to the layman. A useful list of the jurisdictions of the several courts in each State concludes the book. While much of the book's information is now out of date, no survey of the same scope and on the same level has appeared to replace it.
6283. Carpenter, William S. Judicial tenure in the United States, with especial reference to the tenure of Federal judges. New Haven, Yale University Press, r9r 8.234 p.

$18-12485 \mathrm{JK} \mathrm{I}_{533} \cdot \mathrm{C}_{3}$; Law

In the United States judges, Federal and State alike, have a double function: they not only administer justice but act as the guardians of the Constitution, and can declare and enforce the nullity of any legisiation conflicting with its provisions (state judges, of course, guard the constitution of each State). The independence of the judiciary is essential to both functions, but it is only the second, the function of judicial review, that has brought such independence under political attack, invariably directed at the security of tenure of the judicial office. This concise volume reviews the history of such assaults since 1789 , and finds that the courts have usually been able to withstand them, "and in the end popular sentiment has usually supported the courts." The courts must be free, it argues, not only from executive and legislative control, but "from the political vagaries of the people themselves." It does not find that appointment necessarily produces a better bench than election; the local state of public opinion is a more important determinant. It stands out for impeachment as the only sound mode of removing incompetent or corrupt judges, conceding only that its procedural simplification is desirable. Four decades of additional experience have, for the most part, confirmed the solidity and soundness of Professor Carpenter's exposition.

6284. Chesnut, William C. A Federal judge sums up. [Baltimore] 1947. 274 p. illus. 47-5573 Law

An account of the conditions under which lawyers practiced in Baltimore at the close of the last and the beginning of the present century is presented in the first half-dozen chapters of this volume. Discussions and reminiscences of legal education, Baltimore judges and lawyers in the 189o's, the Maryland Court of Appeals and the Baltimore State's Attorney's Office at the.turn of the century, and general law practice from 1889 to 193 I fill these pages. In 193 I the author (b. 1873) was appointed United States District Judge for Maryland, and the latter half of his book is devoted almost wholly to a treatment of the day-to-day work of a Federal trial court. Directed to both laymen and those attorneys who do not practice in the Federal courts, these untechnical, easily digested chapters also include comments on the jury system and on improvements in judicial functions, while the final portion of the book sets forth a program of collateral reading for younger members of the legal profession seeking 
a larger perspective of the law and its practice. Very few American judges have thus summarized their personal experience for the benefit of a larger public.

6285. Frank, Jerome. Courts on trial; myth and reality in American justice. Princeton, Princeton University Press, I949. $44 \mathrm{I}$ p.

49-I I39I Law

A provocative book by a member of the Federal bench and self-confessed reformer which seeks to explode before the lay public the myth of judicial infallibility. Trials, trial courts, and judicial factfinding are the concern of the author, whose theme is that the process of factfinding by the trial courts is inadequately accomplished, and, as a consequence, the outcome of litigation is uncertain and injustice is too easily done. It is in the factfinding function that reform is held to be most needed. The reforms suggested to alleviate the situation are drastic, extending from a complete revamping of the system of legal education to the discarding of the judicial robe. Judges, juries (when employed at all), witnesses, and trial procedure itself would cease to contribute to the uncertainty with beclouds the judicial scene. The courts of law would become stages upon which would be enacted the drama of the ascertainment of truth; no longer would they be the arenas in which adversaries lock themselves in judicial combat. The arguments of the late Judge Frank (1889-1957) won much praise from laymen, but have hitherto had small effect upon the judicial process.

6286. Frankfurter, Felix, and James M. Landis. The business of the Supreme Court; a study in the Federal judicial system. New York, Macmillan, 1927. $349 \mathrm{p}$.

27-24024 Law

The title of this book, which first appeared serially in the Harvard Law Review, is far from self-explanatory. Its authors, whose distinguished careers were only begun when it was published, meant that the Supreme Court was the apex of the Federal court system, and that the work which devolved upon it was "largely predetermined by the jurisdictional ambit of the lower courts," which has been determined, in its turn, by successive acts of Congress. "It will be our purpose, therefore, to sketch rapidly the system of 'inferior courts' which Congress from time to time established, the authority which was vested in them, and the scope of review over them and the State courts by which Congress conferred 'appellate jurisdiction' upon the Supreme Court." It is largely a story of the increasing pressure of business arising from the growth of the country in size, population, and economic complexity, of the measures sought to relieve the higher courts from congestion, and the "lively issues of politics and policy" which entered into the ensuing legislation. The volume retains its value as an outline history of the structure of the Federal judicial system during its first 135 years; as a practical commentary on the Judiciary Act of 1925 it is of course quite obsolete. The authors divide their narrative into three broad periods, the dividing points of which are the Civil War and the establishment of intermediate courts of appeals in I89I.

6287. Lummus, Henry T. The trial judge; being a series of three lectures provided by the Julius Rosenthal Foundation for General Law, and delivered at the Law School of Northwestern University at Chicago in March 1937. Chicago, Foundation Press, 1937. I48 p. 37-9340 Law

A veteran of three decades on the Massachusetts bench when he delivered these lectures, Judge Lummus set forth in them canons of judicial conduct which should keep the bench beyond reproach. He points out that the lower courts are the keystone of the judicial system, for they are the most familiar to the multitude, and by them the whole system is judged. There are discussions of substance upon the qualities and duties of trial judges, judicial administration, and the trial judge in criminal cases. The weight of the lectures is to be found, however, in the concluding sections dealing with the appointment and tenure of judges in relation to the independence of the judiciary. Of the elective and appointive methods of selecting judges, the author prefers the latter and views the former as the natural enemy of judicial independence. In fact, he would prefer the appointive power within each State to be vested in some sort of a minister of justice, who would be elected and advised by a council. This would compensate for what is termed the "outstanding blunder" and the "most tragic failure" of American democracy: the usual method of selecting judges and of regulating their tenure.

6288. MacDougall, Curtis D. Covering the courts. New York, Prentice-Hall, 1946. xvi, 7 I3 p. (Prentice-Hall journalism series) 47-1042 Law

Written by a professor of journalism at Northwestern University, this handbook represents an attempt to aid newsmen in the writing of intelligent interpretive news accounts involving the administration of justice. Employing examples of legal forms and excerpts from pertinent news stories, the author presents summaries and explanations of legal history, theory, and procedure, civil and criminal, as well as expositions of the mechanics 
of appellate law, including a brief resumé of the history and functioning of the United States Supreme Court. With a warning that legal terminology may vary from jurisdiction to jurisdiction, Professor MacDougall points out certain differences between Federal and State laws, and between the practices of the States. An attempt to mediate between the disciplines of journalism and the law, the book is exceptionally well adapted to inform the general reader.

6289. Mayers, Lewis. The American legal system, the administration of justice in the United States by judicial, administrative, military, and arbitral tribunals. New York, Harper, 1955. $589 \mathrm{p}$.

Bibliography: p. 559-566.

A textbook developed in Professor Mayers' classes at the City College of New York to supply the lack of a single systematic account of American legal institutions-as distinguished from American law-in all their varied aspects. The chief institutions are traced to their historical roots, and current proposals for reform, including some made by the author, are indicated. Over two-thirds of the text is concerned with the courts; discussions of the Federal judicial power and that of the States precede a description of the court structure, State and Federal. Criminal proceedings are divided into investigation and prosecution, with a briefer discussion of "Summary Proceedings of a Criminal Nature," such as those against youthful offenders. Civil proceedings are discussed under objectives and procedure. The courts are considered as a check on the executive and on legislation, and as molders of the law. Their personnel is reviewed; after discussing judges and lawyers, Mr. Mayers notes the increasing difficulty of obtaining jurors of intelligence and probity and, in the criminal realm, the immense powers for good or evil wielded by prosecutors. Part 2 on "Administrative Tribunals and Their Supervision by the Courts" is primarily concerned with enforcement proceedings. Part 3, "Military Tribunals and Their Control by the Courts," includes those which we have maintained in occupied territory. Part 4 on "Voluntary Arbitration Tribunals" is much the briefest (p. 543557). Any layman in search of understanding can profit from this survey, well organized, lucid, and never more technical than the subject matter demands.

6290. Pound, Roscoe. Organization of courts. Boston, Little, Brown, s940. 322 p. (The Judicial administration series, published under the auspices of the National Conference of Judicial Councils) 40-10936 Law
Bibliography: p. [295]-304.

A comprehensive treatment of the growth of the courts in various American jurisdictions from the r 7 th century to the present era. Dean Pound emphasizes the common elements present in this growth, which have led to an American type of judicial organization despite diversities among the various components of the American judicial machinery. The book was written not as a part of a general history of American law, but in preparation for a reorganization of the American courts, which the author felt to be inevitable. The study points up the need for a thorough reorganization of the courts based upon the principles of unification, conservation of judicial energy, and responsibility. Stressed is the necessity of abolishing legislative regulation of the administrative details of the courts, and of establishing within the various jurisdictions an administrative hierarchy with a responsible head and responsible subordinates. "Only by some such centralized system," Dean Pound declares, "can the courts handle with a maximum of efficiency and expedition, and minimum of expense to litigants and public, the volume of litigation that comes to them under the social and economic order of today."

629r. Ulman, Joseph N. A judge takes the stand. New York, Knopf, 1936. 289 p.

$$
\text { 39-33779 Law }
$$

"Suggestions for further reading": p. 287-289.

"For the last eight years I have been one of the eleven judges comprising the court of first resort for all but minor cases in a city of eight hundred thousand people," says Judge Ulman of the supreme bench of Baltimore city. In this time he accumulated 22 notebooks, each of 500 closely written pages, covering the cases heard before him. He draws upon them for a series of topical chapters, in which comments and reflections arise out of selected facts, intended to let the average citizen know "what actually happens when cases are tried in court." He notes that juries, merely by the amount of damages they assess, have remade the law of contributory negligence as laid down by a judge in 1809 , and he reflects at length on the relationship of judge and jury, concluding that the judge is in danger of using his powers of interference more than the situation warrants. In a chapter entitled "I Object," he discusses the courtroom relationship of judge and lawyers, with respect to the rules of evidence and the treatment of witnesses. "It Is Unconstitutional" contains some unusual and most interesting comments on a decision of his which was reversed by the Maryland Court of Appeals but reaffirmed by the United State Supreme Court. "Murder" goes into the case of Herman Duker; Judge Ulman sentenced him to hang, but Governor Ritchie com- 
muted the sentence to life imprisonment. The book is instructive enough, but one wishes that its wise and humane author had the literary skill which could have made it quite outstanding.

6292. Warner, Sam Bass, and Henry B. Cabot. Judges and law reform. Cambridge, Harvard University Press, 1936. 246 p. diagr. (Survey of crime and criminal justice in Boston, conducted by the Harvard Law School, v. 4)

$$
\text { 36-15542 HV6795.B7S8, v. 4; Law }
$$

Of particular interest to students of the criminal law, this study, centered on the Boston and Massachusetts courts, is concerned with the administration of criminal justice in the courts, and with its improvement. The authors point out that it is to the judges that we should look for leadership in such reform, for if judges would assume such responsibility, reforms in legal procedure, they hope, would be brought about much more skillfully and expeditiously than if entrusted to a legislature; judges would take greater pains to see that justice is administered; and judgeships would be made more attractive to the highest caliber of lawyer. Not only are the organization of the courts and the mechanics of dispensing justice scrutinized but such tribulations of the public as discourteous attorneys, lack of proper courtroom facilities for visitors, and cumbrous procedure, and delays in the conduct of trials are also given deserved space here. It is not only on the bench and at the bar, but also in the attitude of the public toward the judicial function that a change must be wrought, if continuous reform of legal procedure is to become a reality.

6293. Wendell, Mitchell. Relations between the Federal and State courts. New York, Co- lumbia University Press, 1949. 298 p. (Columbia University. Faculty of Political Science. Studies in history, economics and public law, no. 555)

"Selected bibliography": p. 29I-292.

$$
\text { 49-11705 H31.C7, no. } 555
$$

If the primary contribution of the judiciary to the Federal structure of the United States has been made by the Supreme Court through its interpretation of the Constitution, the lower Federal courts and the State courts have nevertheless made significant contributions to the operation of the Federal system. These courts are responsible for the daily adjustment of the judicial relationship between the Federal and State governments. With this in mind, the author launches his discussion of the division of jurisdiction between the Federal and State courts. The first section of the book traces the development of the power of the Federal judiciary and is followed by an examination of the circumstances under which a litigant may be heard in a Federal court; this involves the knotty problem of diversity of citizenship. Thereafter much of this study is concerned with the background and aftermath of the cases Swift v. Tyson (1842) and Eire Railroad Co. v. Tompkins (1938). In the latter, the Supreme Court after 96 years reversed its doctrine in the former, that the Federal courts were free to disregard State precedents and apply their own interpretation of State law. The work closes with a brief survey of the problems of concurrent jurisdiction and with the author's conclusions in favor of continuing the dual judiciary, because of the need for efficient judicial administration and for State courts which have authority to make final determinations in matters of local law. The operations of the Federal judiciary, he thinks, should be restricted to areas of general national concern.

\section{F. The Judicial Process}

6294. Borchard, Edwin M. Convicting the innocent; errors of criminal justice. With the collaboration of E. Russell Lutz. New Haven, Yale University Press, I932. xxix, 42I p. (A publication of the Institute of Human Relations)

Bibliography at end of each case.

32-13534 Law

A Massachusetts district attorney having declared that "innocent men are never convicted," Professor Borchard of Yale University made this now famous collection of 65 cases, 50 of which are narrated at some length. They are drawn from 26 States of the Union, the District of Columbia, and England; 29 of them had to do with murder, 23 with robbery or swindling, 5 with forgery, and 4 with criminal assault. In each the innocence of the convicted person was subsequently established beyond reasonable doubt: in six cases the person supposed to have been murdered turned up alive, while in others the real culprit was caught and convicted, or new and exculpating evidence was discovered. In several instances the convicted person escaped execution by a hair's breadth, and in many the exculpating evidence came to light by sheer luck. The main causes of the erroneous convictions are found to be mistaken identification, erroneous inferences from circumstantial evidence, perjury, or several of these in combination; and Professor Borchard notes 
faults on the part of the police, the prosecution, and the state of community opinion. He offers, in an introductory chapter, some needed reforms in criminal procedure, and in a final one, a draft statute for indemnifying wrongfully convicted and arrested persons, based on a survey of European legislation for the purpose. He observes that, while there are nine cases of unjust acquittal for one of unjust conviction, this does not lessen the obligation to remedy the latter. And he makes the further observation: "In the majority of these cases the accused were poor persons, and in many of the cases their defense was for that reason inadequate."

6295. Brewster, Stanley F. Twelve men in a box. Chicago, Callaghan, I934. I75 p.

35-222 Law

Written primarily for the citizen who may someday be called for jury duty, this manual intends to familiarize him with the duties and functioning of both the grand and petit juries. The machinery of the jury system itself, as well as something of the background of trial by jury as an institution, and the organization of the courts are touched upon. However, the greatest emphasis is given to procedure in trials civil and criminal, and the role of the juror from the time of his selection to the rendering of the verdict. The author tells what every juror ought to know about the opening addresses; witnesses, including experts, and their examination and cross-examination; the weighing of evidence and the detection of perjury; the seven most important rules of evidence; summations, their purpose and importance; the judge's charge to the jury; and what goes on in the jury room while a verdict is being agreed on or disagreed about. This instructive little volume concludes by describing the different considerations that apply to juries in criminal cases, the principal one of course being that while civil juries may be satisfied with the preponderance of evidence, criminal juries must agree that the evidence establishes the guilt of the accused beyond any reasonable doubt.

6296. Busch, Francis X. Law and tactics in jury trials; the art of jury persuasion, tested court procedures. Indianapolis, Bobbs-Merrill, 1949. xxvii, II47 p. 49-4312 Law

This well-documented treatise, employing throughout specimens of trial proceedings, sets forth for attorneys and law students the general requirements of trial procedure, and is, in fact, a handbook on the art of advocacy. Its aim is "to present all of the contacts which the trial lawyer has with the jury in the course of a contested trial, and to indicate how every such contact may be utilized to induce the desired persuasion." Opening with brief statements concerning the origin and development of the jury and the constitutional bases of the right to trial by jury in the Federal and State courts, the author proceeds step by step, with occasional digressions on the respective functions of the court and the jury and on the methods of case preparation, through all of the considerations a trial lawyer must take into account during the course of a litigation. Volume I of a new "encyclopedic edition" to be complete in 4 volumes, and containing additional chapters as well as elaborate references to cases, appeared at the beginning of 1959 .

6297. Cockrell, Ewing. Successful justice. Charlottesville, Va., Michie Co., 1939. xxxix,

$1305 \mathrm{p}$. 39-1444I Law

"For twelve years I was an ignorant judge," says the author in opening his big book, explaining that the best legal education is usually a defective guide to practice and that most other judges were and are as ignorant as himself. Nearly all the troubles of the law come from its administration, but there are great successes in every part of the law, behind which lie definite practices grounded on facts and principles. "The science of successful justice is easily learned." Mr. Cockrell then proceeds through the whole panorama of the law in action offering concrete instances of contrasted "ignorance" and "success." Ignorant policemen are set against successful policemen, and so for prosecutors, criminal trial judges, children's judges, probation officers, jailers, parole officers, civil trial judges, juries, legislators, court experts, newspapers, etc., etc. When the author comes to declare "the principles and practices of successful justice," he offers only four: "General law of keeping agreements," "General law of punishment for law violations," "Practice of providing a reserve of punishment," and "Practice of adequate investigation." He has in the meanwhile produced an immense scrapbook on better and worse methods of the administration of justice in the United States.

6298. Frank, Jerome, and Barbara Frank. Not guilty, by Jerome Frank and Barbara Frank in association with Harold M. Hoffman. Garden City, N.Y., Doubleday, 1957. 26I p.

Sources: p. [253]-26r. 57-8299 Law

Judge Frank died of a heart attack less than two days after completing the manuscript of this book, written in collaboration with his daughter. It is made up of résumés of 35 criminal cases which resulted in wrongful convictions, 17 of them narrated at some length and 18 concisely. The cases are all later in date than Professor Borchard's volume (no. 6294 ) and show that the hazard has continued for a 
quarter of a century since he demonstrated its existence. The cases are followed by a concluding chapter of commentary ( $p$. 199-249) in which the authors illustrate the fallibility of witnesses, and criticize the concept of a trial as a duel between lawyers who use their knowledge of technicalities and their psychological insight as weapons; the victimizing of witnesses, too often treated as public enemies in the courtroom; and the concentration of prosecutors upon winning their cases rather than doing justice to the accused. By and large our system achieves fair results, but, the authors conclude, it will require major reforms in the administration of justice to make innocent men safe from imprisonment or execution. One which they urge is the extension to criminal cases of "discovery" procedure, by which either side before the trial is enabled to scrutinize the evidence in possession of the other, and so to avoid tactical surprises in the conduct of the trial.

6299. Kellor, Frances A. Arbitration in action; a code for civil, commercial and industrial arbitrations. New York, Harper, 1941. 412 p.

$$
4 \mathrm{I}-23598 \text { Law }
$$

The purpose of voluntary arbitration is "to determine a difference or dispute amicably, privately and finally and, in so doing, to exclude a court of law from such determination." The then executive vice president of the American Arbitration Association wrote this book on the basis of its records of 25,000 satisfactorily determined arbitrations, and in response to a mass of inquiries "by men, organizations, companies and unions who want to know how, when and where to arbitrate disputes." Essentially a practical guide to the technique, facilities, and equipment essential to end disputes, it takes account of legal principles and literature only so far as germane to this purpose, and refers the reader to Wesley A. Sturges' $A$ Treatise on Commercial Arbitrations and Awards (Kansas City, Mo., Vernon Law Book Co., 1930. ro82 p.) for a more strictly legal treatment. The largest section describes "General Procedure" and includes chapters on the arbitrator, arbitration agreements, the submission, the proceeding, evidence, the award, costs, and contesting an award. Part 2 describes three particular systems of arbitration: that set up under the authority of the Seventh International Conference of American States (Montevideo, 1933) to handle interAmerican commercial disputes; the Accident Claims Tribunal established in New York City by the American Arbitration Association in 1933; and the motion picture arbitration system set up by the industry, under pressure from the U. S. Department of Justice, in r940. The lengthly annexes (p. 217396) summarize existing statutes and print the rules of procedure administered by the American Arbitration Association and by the three systems just mentioned.

6300. Millar, Robert W. Civil procedure of the trial court in historical perspective. [New

York] Published by the Law Center of New York University for the National Conference of Judicial Councils, 1952. 534 p. (The Judicial administration series) 52-11758 Law

A compact but detailed survey of "the major procedural rules employed in the courts of the first instance in the United States and England, viewed especially from the standpoint of their historical progression." Implicit in this, of course, is its following of the course of contemporary procedural reform. The introductory section of this study is devoted to a general account of the problems of procedural evolution and reform within the AngloAmerican system. The second section, comprising the main body of the work, opens by considering the conjunctive administration of law and equity, and goes on to discuss specific phases of civil pro cedure arranged in practical order, from the commencement of a suit to the execution of a judgment. Because of its content and the language employed, Professor Millar's book will appeal most readily to those of the legal and political science professions.

6301. Orfield, Lester Bernhardt. Criminal procedure from arrest to appeal. New York, New York University Press, 1947. xxxi, 6ra p. (Judicial administration series, 6) 47-30727 Law

6302. Orfield, Lester Bernhardt. Criminal appeals in America. With an introd. by Roscoe

Pound. Boston, Little, Brown, 1939. 321 p. (The Judicial administration series, published under the National Conference of Judicial Councils)

"Bibliography on appeal statistics": $\begin{gathered}39-31420 \text { Law } \\ \text { [12 }]-214 .\end{gathered}$

6303. Puttkammer, Ernest W. Administration of criminal law. [Chicago] University of Chicago Press, r953. 249 p. 53-8736 Law

In Criminal Procedure from Arrest to Appeal each stage of a criminal proceeding is analyzed from the standpoints of its historical development, its current use, and the need, if any, for its reform. Admittedly, some topics such as evidence, jurisdiction, habeas corpus, and coroner's inquests are not considered because of limitations of time and space; their peculiarity to other branches of the law, their obsolescence, or the fact that they are well expounded elsewhere justifies this. Throughout, American procedure is compared with that of English courts, and occasionally with criminal procedure employed 
on the Continent. In his critiques of suggested reforms, the author endeavors to present fairly the ideas of both major groups who advocate the overhauling of criminal procedure: those, thinking of the professional criminal, who speak in terms of expediting a more rigorous prosecution, and those, concerned with innocent parties and the casual criminal, who talk of the preservation and strengthening of civil liberties. Criminal Appeals in America commences with a short history of criminal appeals in England, and then Professor Orfield, surveying the literature of his subject, synthesizes what has been written, thought, and enacted in America; reports on the functioning of criminal appellate procedure and on proposals for its reformation; and makes some suggestions of his own. These two works together comprise a guide to the task of improving the administration of criminal justice. A brief nontechnical description of the operation of the legal machinery in the realm of the criminal law is found in Professor Puttkammer's book. Written primarily for the law student and the layman seeking general information on the subject, it deals only with the conventional areas of criminal prosecution and avoids detailed discussions of controversial points. While the lack of ponderous footnotes should be welcome to the reader, the lack of a more extensive bibliography than the references included in the notes may not be so.

6304. Pound, Roscoe. Appellate procedure in civil cases. Boston, Little, Brown, 194 I. 431 p. (The Judicial administration series, published under the auspices of the National Conference of Judicial Councils)

Bibliography: p. [395]-4I I.

An historically grounded exposition of the development of civil appellate procedure. After a short statement of the scope and purpose of review in civil cases, there follows a historical survey of such review, which is traced here from the Roman law to the I7th century, and of civil appellate procedures in I 8th-century England, in the American Colonies, and in the United States to the end of the rgth century. Finally the condition of such proceedings in the present century, with special note of improvements made, is considered. The final chapter, "Toward an Effective System of Review," for which all before seems prologue, is an essay in which the way is pointed, and a program for the revision of the review of civil cases in the United States is marked out.

6305. Pound, Roscoe. Criminal justice in America. New York, Holt, 1930. xiv, 226 p. ([Brown University. The Colver lectures, 1924]) 30-22093 Law
In this series of five lectures Dean Pound analyzes the problems and difficulties of criminal justice and explores the English and American backgrounds of its 2oth-century administration. He discusses at some length the machinery of criminal justice, the obstacles to and agencies of its improvement, and asserts that the ultimate aim of any program for its reform must be a body of laws adequate to secure social interests, and capable of a high average of observance and enforcement. "The juristic thinking of today," he writes, "must transcend both nineteenth-century individualism and nineteenthcentury socialism . . . Instead of valuing all things in terms of politically organized society, we are valuing them in terms of civilization, of raising human powers to their highest possible unfolding-toward which spontaneous free individual action and collective organized effort both contribute. As this mode of thinking becomes general, the paths of criminal justice will be made straight." In I945 Criminal /ustice in America was republished, with the same pagination, by the Harvard University Press.

6306. Train, Arthur C. From the district attorney's office; a popular account of criminal justice. New York, Scribner, 1939. xiv, 431 p. illus. 39-27830 HV9468.T7; Law

Arthur Train (1875-1945), best known as a writer of popular fiction and creator of Ephraim Tutt, "the best known of American lawyers," served two terms as assistant district attorney of New York County. This is a revision of his The Prisoner at the Bar, first published in 1906, containing new material and including much of the relevant contents of three of his other books: On the Trail of the Bad Men (1925), Courts, Criminals and the Camorra (I912), and True Stories of Crime (1908). It is a description of the operation of metropolitan criminal justice done in an entertaining manner and laced with illustrations and anecdotes. Observations concerning the nature of crime, the rights of citizens charged with law violations, and the character of the police, prosecutors, and judges, together with numerous suggestions for the betterment of the administration of criminal justice, are to be found here. All would seem to point to the idea expressed in the final sentence: "We do not need new laws so much as better citizens." Any improvement in the laws themselves and in procedures will only come about, Train thought, when more persons have acquired a firsthand knowledge of the operational conditions of those agencies charged with the responsibility of seeing justice done.

6307. Vanderbilt, Arthur T., ed. Minimum standards of judicial administration; a survey of 
the extent to which the standards of the American Bar Association for improving the administration of justice have been accepted throughout the country. [New York] Published by the Law Center of New York Unversity for the National Conference of Judicial Councils, 1949. xxxii, $75^{2} \mathrm{p}$. (The Judicial administration series)

50-1655 Law

A study, the text of which is supplemented by 62 maps, making clear to lawyers and laymen the extent to which each state was measuring up to the minimum practical standards of judicial administration formulated during the years $193^{8}-40$ by the American Bar Association. The reasoning behind those recommendations is to be found in the various reports comprising the appendixes to this volume, while the main portion of it confines itself to the presentation of facts and leads to a detailed knowledge of what should be done in each state to give it a reasonably effective system of legal procedure. Not purporting to be all-inclusive, the recommendations of the Bar Association were meant to correct the fundamental problems, such as those arising in the selection of judges and juries, in rulemaking, in pretrial and trial practices, and in the state administrative agencies and tribunals, in the belief that once these were overcome other desirable advances would follow.

6308. Waite, John Barker. Criminal law in action. New York, Holston House, Sears Pub. Co., 1934. 32I p. 34-15268 Law An inquiry into the functioning of criminal justice in the United States. The law is viewed as a thing inert and its effectiveness as depending upon the activity of its agents. These agents-policemen, lawyers, commissioners, clerks, jurors, and judges as well as the public, newspapers, and the Federal government in its role as an enforcer of the laware the subject of this book. Some of the spectacular failures and the less glaring inefficiencies of the criminal law in action are recounted to bolster the author's contentions. In summing up he asserts that the public must shed the illusion that tinkering with the criminal law will improve its administration, and must turn its energies to improving the attitude of the law's administrators. But this, the author says, will only be brought about when the general attitude toward criminals is transformed into one which does not consider them as subjects for punishment or retribution, but as menaces to society who must be dealt with by isolation, segregation, rehabilitation, or even death.

6309. Willoughby, William F. Principles of judicial administration. Washington, Brookings Institution, 1929. xxii, 662 p. ([Brookings Institution] Institute for Government Research. Principles of administration [6])

Bibliography: p. $607-652$. 29-13834 JKi521. W5; Law

Intended for students of political science as well as for members of the legal profession, this inclusive survey seeks to determine the organizational and procedural principles to be followed if efficiency in the administration of justice is to be attained. Considered in a systematic manner is the entire subject of the organization and conduct of the judicial branch of government: the prevention of crime; the enforcement of the law; judicial organization, personnel, and procedure; and legal aid. Applying to the judicial branch of government the same criteria by which the efficiency of other governmental departments is evaluated, the author's method of attack is to resolve the great problem of judicial administration into its constituent elements; to determine the fundamental principles that should govern in handling the conditions to be met; to describe the action which has been taken; to point out wherein this action has failed to conform to the principles that should be observed and therefore has given unsatisfactory results; and, finally, to indicate the steps that should be taken to correct these mistakes, and the extent to which they have been taken in various jurisdictions.

\section{G. Administrative Law}

6310. Cooper, Frank E. Administrative agencies and the courts. Ann Arbor, University of Michigan Law School, 195I. xxv, 470 p. (Michigan legal studies)

Bibliography: p. $409-416$.

A systematic description of the standards which the courts impose upon administrative agencies, controlling and limiting their actions. Leading cases illustrating principles governing frequently- litigated questions in contests between agencies and those with whom they deal are brought together, and the techniques of administrative adjudication are discussed. In examining the relationship between administrative agencies and the courts, particular attention is given to judicial doctrines concerning constitutional limitations on the delegation of powers to administrative agencies, procedural requirements in cases where agencies 
exercise judicial powers, procedural and substantive requirements imposed in connection with the rulemaking activities of agencies, and methods and scope of judicial review.

6311. Heady, Ferrel. Administrative procedure legislation in the States. Ann Arbor, University of Michigan Press, 1952. I 37 p. (Michigan. University. Michigan governmental studies, no. 24)

52-62288 Law

An evaluation of the actual working of general administrative procedural laws in representative States: North Dakota, Wisconsin, California, and Missouri, all of which had had such statutes for at least five years, long enough to provide an accumulation of experience. Attention also is given to Michigan, which possesses such a law, but of limited scope, and to Oklahoma, which at the time of writing had not enacted any general procedural legislation. The object of this report is to determine whether such laws have improved the procedural practices of State regulatory agencies. Dr. Heady concludes that the general statutes reviewed "have had in the balance a beneficial effect in each state," and have not sabotaged the administrative process. But he issues a warning that there is pressure for more drastic regulation, which "threatens unless resisted to over judicialize the procedures of State regulative agencies."

6312. Landis, James M. The administrative process. New Haven, Yale University Press, 1938. 160 p. (Storrs lectures on jurisprudence, Yale School of Law, 1938)

$$
\text { 38-29177 JK 421.L33; Law }
$$

At the time Dean Landis delivered these lectures the administrative agencies had been the target of alarmist critics, who painted them as an incipient tyranny on the way to depriving the citizen of his inherited liberties and privileges under the rule of law. Such views are effectively contested here, by one who believed that the administrative process had come to stay, and was in fact "our generation's answer to the inadequacy of the judicial and the legislative processes." Agencies have been entrusted with rulemaking, enforcement, and the disposition of competing claims because the triadic compartmentalization of government breaks down in dealing with modern problems. They have come into being whenever government assumes "responsibility not merely to maintain ethical levels in the economic relations of the members of society, but to provide for the efficient functioning of the economic processes of the state." They represent an advance in the application of expertness to government, and the more agencies the greater efficiency of regulation-provided that the relationships of the agencies to each other and to the other branches of government are properly solved. The greater part of the lectures is devoted to these right relationships. Judicial review of the agencies' results remains desirable, but only if the judges will respect their expertness, and decline to review findings of fact made by "men bred to the facts."

6313. Parker, Reginald. Administrative law, a text. Indianapolis, Bobbs-Merrill, 1952.

344 p. $52-95^{1}$ Law

"List of books and articles used": p. 313-322.

Professor Parker of the University of Arkansas presents administrative law as a part of modern public law, which protects the government as well as its citizens, and ensures that the executive branch will function, in an adequate fashion, on behalf of the people and through law. He does not attempt to enter into the law pertaining to particular agencies, since each important subdivision would require a separate volume, but confines his treatise to general administrative law. Part I discusses the foundations of administrative law in the historic separation of powers and in the constitutional guarantee of due process, and analyzes the Administrative Procedure Act of 1946 , the text of which is given as Appendix 1. Part 2 is concerned with the establishment of agencies, the hierarchy within the executive branch, the internal organization of agencies, and the nature of administrative jurisdiction, which is not, as /a rule, geographically limited. Part 3 describes "Administrative Functions and Processes," with emphasis on regulations, interpretations, and administrative decisions. Part 4 deals with "Judicial Remedies," the sphere of which has been contracting in recent years, and for which there is no uniform procedure. The concluding parts discuss "Execution of Administrative Decisions" and "Damage Claims for Wrongful Administrative Acts," and the second appendix reprints most of the Federal Tort Claims Act of 1948.

6314. Pennock, James Roland. Administration and the rule of law. New York, Farrar \& Rinehart, I941. 259 p. (American government in action)

"Selected bibliography"; p. 250-254. $41-11629 \mathrm{JK}_{421} \cdot \mathrm{P}_{35}$; Law

This volume describes for the general reader "the fundamental safeguards which have developed around administrative action to insure the preservation of private rights and interests." They fall into two great classes. The author declares that many of the most effective checks against abuses of administrative rulemaking are themselves administrative, internal checks as against the external check of judicial review. The formulation and publica- 
tion of its policies by each administrative tribunal, adequate notice, full hearing, reasoned and written decisions, and provision for administrative review are all essential safeguards of the internal kind. Beyond them, and ultimately indispensable if the rule of law is to be maintained, lies the power of the courts to review administrative acts and decisions. The four chapters on the courts discuss their attempts to set limits to the legislature's delegation of lawmaking powers-an important but at best a crude safeguard; the methods by which judicial control is effected notwithstanding the state's general immunity from suit; the courts' own views of the basis and extent of their powers of reviewing administrative decisions; review of actions under the general police power, which is more extensive; and review of agencies' decisions, which is less so. As of I94 I, the author thought that the continuous struggle to keep administrative power in the service of the general interest had been reasonably successful, but warned that overrapid growth or the triumph of special pressures might make necessary "at least temporary retrenchment, until the forces of constitutionalism can catch up with the growth of power which has outdistanced them."

6315. Swenson, Rinehart J. Federal administrative law; a study of the growth, nature, and control of administrative action. New York, Ronald Press, $195^{2} .376 \mathrm{p}$. 52-9466 Law

This study is intended not only for administrators, judges, and lawyers, but also for those concerned with the present-day functions of the Federal government. It rests on the thesis that administrative action must continue to be developed into a coherent body of law, supervised by special courts of limited jurisdiction presided over by judges of such training and knowledge that they can cope with the highly technical points which are often involved in grievances resulting from such action. Dr. Swenson "traces the evolution of American thinking and practice in a changing economy and society from a philosophy of 'rugged individualism' to that of the modern 'service state' with its 'big government' and bureaucracy. The forms of administrative action and the means of their enforcement are examined. The relations of the constitutional separation of powers and of the Anglo-American rule of law to the development of administrative law in the United
States are explored at some length, and a detailed and extensive consideration is given to the review of administrative action by the regular courts. Finally, attention is called to the role of the Congress in supervising administration." Dr. Swenson thinks that we have not set up a satisfactory system for the control of administration, for control by the judicial courts is "a not-too-happy solution."

\section{U. S. Attorney General's Committee on} Administrative Procedure. Administrative procedure in government agencies. Report of the Committee on Administrative Procedure, appointed by the Attorney General, at the request of the President, to investigate the need for procedural reform in various administrative tribunals and to suggest improvements therein. Washington, U.S. Govt. Print. Off., I94I. 474 p. (77th Cong., Ist sess. Senate. Document 8)

$$
\text { 4I-50129 JK 4I6.A5 r94I; Law }
$$

Homer S. Cummings suggested it, Frank Murphy in I939 appointed the Attorney General's Committee on Administrative Procedure, and Robert $\mathrm{H}$. Jackson transmitted its final report. Dean Acheson was its chairman, Walter Gellhorn its director, and Francis Biddle, Lloyd K. Garrison, D. Lawrence Groner, Henry M. Hart, Jr., Carl McFarland, and Arthur T. Vanderbilt among the distinguished jurists who served upon it. The Committee assigned a staff of lawyer-investigators to study rulemaking and adjudicating procedures in 9 departments and 19 independent commissions or boards. The final report opens with a general view of the administrative process, and then surveys administrative information, informal and formal methods of adjudication, judicial review of such adjudication, and procedure in rulemaking. Four members of the Committee presented additional views and recommendations, and there are over 200 pages of appendixes. The Committee recommended the establishment of an office of Federal administrative procedure, and detailed changes in many of the agencies and departmental offices. It drafted a bill for the general control of Federal administrative procedure which, delayed by the war, revised after congressional hearings, and amended in the process of enactment, finally became the Administrative Procedure Act of 1946 .

\section{H. Lawyers and the Legal Profession}

6317. Brown, Esther Lucile. Lawyers and the promotion of justice. New York, Russell Sage Foundation, 1938. 302 p. $3^{8-39583}$ Law
The fifth in a series of monographs sponsored by the Russell Sage Foundation and concerned with various established or emerging professions in the 
United States, this study considers the legal profession primarily from the standpoint of its effectiveness in meeting public needs. The author finds that the bench and bar have fallen short of accepting certain social responsibilities, but notes trends that indicate a growing desire within the profession to promote justice more effectively. Among these particular attention is directed to improvements in the laws themselves, developments in the courts and in new tribunals, legal service both to the poor and to those of moderate means, and the movement to institute an integrated bar. Preceding this discussion are chapters dealing with the evolution of the legal profession in the United States, legal education, rules and procedures governing admission to the bar, the more important national professional associations, and the number of, demand for, and income. of lawyers. The following weaknesses in the administration of justice are diagnosed; delay and uncertainty in the courts, excessive expense of litigation, unprofessional conduct of attorneys sometimes resulting in their disbarment, lack of interest in the promotion of justice, and the failure of the profession to accept social responsibilities.

6318. Brown, Esther Lucile. Lawyers, law schools and the public service. New York, Russell Sage Foundation, I948. $25^{8}$ p. $4^{8-1216}$ Law Since 1933 the United States has been transformed into "a highly centralized, bureaucratic state of behemoth proportions," in which the men who make and carry out decisions are and will continue to be lawyers. Therefore, says Professor George E. Osborne, "it seems obvious that one basic function of any law school in the future must be the conscious and systematic training of leaders in policy-making and policy-administration for the achievement of those values" sought in a free society. During 1939-4I the author visited 23 law schools in all parts of the country in order to find out "to what degree and with what efficiency legal education was preparing men and women to serve the interests of government." The first two parts of her report are comparatively brief. Part I estimates the number of Federal attorneys and describes their recruitment. Part 2 describes the nature of their work, and especially their participation in policymaking through drafting, interpretation, review, litigation, and counseling-in consequence of which they readily move on into administration. Part 3, from page 93, is on the "Implications for Legal Education"; it discusses the use of social science materials, the introduction of new courses and teaching materials, and the reorientation of selected portions of the curriculum. The author feared that her report would seem a very pessimistic one; in spite of introductory efforts, "the wrench from traditionalism" was a slow and hazardous undertaking, and more money, larger staffs, and careful plans were needed for further progress.

6319. Drinker, Henry S. Legal ethics. New York, Columbia University Press, 1953. xxii, 448 p. (Legal studies of the William

Nelson Cromwell Foundation) 53-11928 Law Index of works cited: p. $[367]-436$.

6320. Phillips, Orie L., and Philbrick McCoy. Conduct of judges and lawyers; a study of professional ethics, discipline, and disbarment. Los Angeles, Published for the Survey of the Legal Profession by Parker, 1952, i.e. 1953. xiii, 247, xiv p.

Bibliography: p. v-xiv at end.

$53-834$ Law

Brief accounts of the origins and history of the bars of England and the United States, of the bar associations, and the development of standards of professional conduct and the disciplinary proceedings used to enforce them constitute part one of Legal Ethics, by the long-term chairman of the American Bar Association's. Standing Committee on Professional Ethics and Grievances. The aim of his study is to make available a summary of the decisions interpreting the canons of ethics made in the past three decades by the ethics committees of the various bar associations, as well as a few of the pertinent statutory provisions and court decisions. In essence, this is a handbook for the use of those seeking to ascertain the duties and obligations of lawyers. These duties and obligations of lawyers to the public, the courts, clients and professional colleagues, and the question of advertising and solicitation of professional employment are discussed at length in the second portion of this study. The final chapter is a summation of the canons of judicial ethics, supplemented by appendixes including decisions by the American Bar Association's Ethics Committee, a digest of representative court decisions specifying grounds for disbarment, suspension, or censure, the canons of professional and judicial ethics, and other useful materials. The report by Messrs. Phillips and McCoy resulted from the Survey of the Legal Profession under the auspices of the American Bar Association. Following a short treatment of the history of the codes of professional and judicial ethics, such matters are examined as the inculcation of professional standards and their observance, the determination of character requirements for admission to the bar, disciplinary procedures, the selection and conduct of judges, the views held by laymen, and the perennial problem of "trial by newspaper." While fundamental concepts of honesty and integrity must be adhered to by lawyers, the authors conclude, standards of con- 
duct must be reviewed constantly with regard to the impact of the activities of the legal profession upon the welfare of society as a whole. These fundamental concepts and standards must be inculcated in students at the outset of their law school careers, they must be made familiar to the public, and adherence to them must be demanded of those to whom the community has given the privilege of practicing law.

6321. Harno, Albert J. Legal education in the United States; a report prepared for the survey of the Legal Profession. San Francisco, Bancroft-Whitney, 1953. 2 I I p. 53-9063 Law

As an introduction to a critical appraisal of his subject, Dean Harno traces the evolution of American legal education from its English heritage in the institution of the Inns of Court and the person of William Blackstone, through its formative and laissez faire periods, and into the present era opened by Christopher Langdell's introduction of the case method of instruction in the latter half of the igth century. A discussion of the impact of professional groups, principally the American Bar Association and the Association of American Law Schools, upon legal education finds that they have been and are powerful forces for the advancement of legal instruction. Criticisms of modern legal education are surveyed and evaluated, and in his concluding chapter the author declares that its worst features have resulted from too little thinking about the objectives of legal education on the part of law school faculties. While the virtues implicit in the good lawyer are qualitative, admission standards for the law schools and the bar are quantitative. The lack of a quality criterion, inadequate financing of the schools, large classes, the lack of concern for prelegal education, overcrowded curricula, the excessive reliance upon the case method, and the serious cultural lag indicated by the great overemphasis on private law in the curriculum at the expense of public law are among the important topics surveyed. However, it is pointed out that there is now a ferment in the law schools which should produce changes for the better.

6322. Hays, Arthur Garfield. City lawyer; the autobiography of a law practice. New York, Simon \& Schuster, 1942. xvi, 482 p. illus.

$$
\text { 42-17237 Law }
$$

Hays (188I-1954) was a graduate of Columbia University Law School who began practice in New York City, with such successful and lucrative results that he was able to devote much of his time to the causes near his heart: the defense of civil liberties and the support of progressive politics. In his chapter on "Getting Started" he modestly de- clares that "sheer, downright luck" is essential for success at the bar: "Assuming that you know your business and are reasonably diligent, the gods of luck will make or break you." He became a favorite attorney with people in show business, and narrates his services to Billy Rose, Sigmund Romberg, and other members of the Song Writers Protective Association. His first law partnership had offices on Wall Street, and one chapter describes his business on behalf of brokerage firms; he thinks that their honestly was unjustly impugned, and that the Securities and Exchange Commission instituted a reign of terror on Wall Street. Another chapter generalizes from his practice in marriage and divorce cases; in them, he says, it is almost always impossible to fix the blame on either party. One chapter is devoted to his work for the American Civil Liberties Union, which he narrated at greater length elsewhere (no. 6127). In part 4 he describes at length several well-publicized trials in which he participated, including those of the Wendell will and heirs (1931) and the Reichstag Fire (in which he served on an international commission of inquiry which had no legal authority).

6323. Miller, Claude R. Practice of Law. Chicago, Callaghan, r946. xvi, 300 p.

$$
\text { 46-6524 Law }
$$

The legal profession, says Attorney Miller of Chicago, is usually about 90 percent practice to 10 percent law-in spite of which "most legal libraries have thousands of books on law for every one on practice." He therefore aims to set out, with much condensation and generalization, "a comprehensive picture of the kind of professional life that lawyers lead," with some suggestions, warnings, and advice. There are chapters on "The Study of Law," "Choosing a Place to Practice," "Starting Out in the Practice," "Securing Business," "Trying Cases" (including a section on "The Art of Losing" without incurring insomnia, indigestion, or alcoholism)," "Appellate Procedure," "General Office Practice," "Administrative Practice," "Corporation Practice," "Office Management," etc. In conclusion Mr. Miller sets before every new lawyer the desirability of doing his part to improve the profession, and suggests that politeness in the courtroom, even toward witnesses and spectators, would do much to advance the law's repute.

6324. Partridge, Bellamy. Country lawyer. Illustrated by Stephen J. Voorhies. New York, Whittlesey House, McGraw-Hill, 1939. $3^{17}$ p. 40-1181 Law

An engaging portrait of lawyer Samuel Selden Partridge, his practice, and his family, written by his son. The locale is an upstate New York village 
(Phelps, in Ontario County) and the period is that extending from Appomattox to Sarajevo, the golden age of the country town and the country lawyer, in which a more isolated and slow-paced and less regimented life than that of today existed. Then the local lawyer was often father confessor to the community in which he lived. Not intended to be merely regional, this account is held by the author to be typical of the legal practices carried on in small towns across the country during that era.

6325. Pound, Roscoe. The lawyer from antiquity to modern times, with particular reference to the development of bar associations in the United States. A study prepared for and published by the Survey of the Legal Profession under the auspices of American Bar Association. St. Paul, West Pub. Co., 1953. xxxii, 404 p.

Bibliography: p. $363-379$.

53-1859 Law

Basically a history of bar organization in the United States with an emphasis upon state and local groups, this is also a biography of a profession. Dean Pound, following an introductory discussion of the characteristics of a profession and a bar association, begins his narrative with an account of the earliest lawyers in ancient Greece, and brings it down through the medieval period, in which he finds the English origins of the legal profession of the English-speaking world. It was from the mother country that the Colonial lawyers brought to America that fraternalism characteristic of the English bar and which has remained a trademark of American lawyers. Most of this work is devoted to developments in the United States. It traces the histories of bar organization and the legal profession during the Colonial period, and during the middle years of the igth century when the law, under the stress of a movement for deprofessionalization, suffered from a breakdown of organization and education. Both were revived with the commencement of the era of modern bar associations in 1870 . From there the development of various state and local legal groups is traced, and in an epilogue the author enters a plea for an integrated bar as a means of preserving the profession from disintegrating tendencies.

6326. Reed, Alfred Zantzinger. Training for the public profession of the law; historical development and principal contemporary problems of legal education in the United States, with some account of conditions in England and Canada. New York, I921. xviii, 498 p. (The Carnegie Foundation for the Advancement of Teaching. Bulletin no. 15)

Bibliography: p. $460-469$.
6327. Reed, Alfred Zantzinger. Present-day law schools in the United States and Canada. New York, 1928. xv, 598 p. (The Carnegie Foundation for the Advancement of Teaching. Bulletin no. 21) 28-22195 LC II 4 I.R LB2334.C4, no. 21; Law "Bibliography and acknowledgments of assistance rendered": p. 561-573.

These two titles comprise a scholarly study of the development of American legal education and of the relationship between the law schools and the practice of the law. Education for the bar in the United States, the author points out, has been complicated by the intimate connection between politics and the legal profession; it is this connection upon which the American system of legal education rests. The major portion of Training for the Public Profession of the Law is concerned with the history of American legal education before 1890 , with a brief resumé of it from that year to the outbreak of World War I; with the relationship of the bar and bar examinations to legal education; and with the historical ties between a trained and educated bar and the administration of justice. The concluding section discusses briefly and affirmatively the premise that lawyers and law schools cannot be made to conform to a single standardized type; this involves a consideration of the various types of law schools and a plea for the strengthening of the legitimate schools if legal education and its products are to render adequate public service. Mr. Reed's second work deals with the function and work of the law schools in the United States and Canada at the time of writing, in the light of their curricula, conditions of administration, and methods of teaching, and of the relationship between the schools and the professional practitioners. The movement toward standardization of legal education is discussed at length, and the author calls for the maintenance of diversity among law schools and a graded bar, in order that the schools may not produce legal jacks of all trades.

6328. Roalfe, William R. The libraries of the legal profession; a study prepared for the Survey of the Legal Profession under the auspices of American Bar Association. St. Paul, West Pub. Co., 1953. xviii, 471 p. 53-12556 Law

"Survey of the Legal Profession; bibliography of I50 reports, by Reginald Heber Smith": p. 429-443.

The collections, personnel, and physical plants of law libraries of nearly all types-office, association, court, state and Federal-are treated in this comprehensive survey. Cooperation among libraries and library groups and through professional associations is also discussed. Law school libraries are not extensively examined, as they have been pre- 
viously considered in a survey of legal education. The task of advancing law librarianship, it is felt, rests not solely upon the shoulders of the librarians, but also upon those of the practitioners, who may reasonably be expected to have a general understanding and appreciation of the place of the law library in the profession's functioning, to make library staff appointments with care, and to assume a greater responsibility for the financial support of service rendered to them by the law libraries. It is maintained that this support, together with intelligent leadership among the librarians, can do much to raise the effectiveness of law library service.

6329. Smith, Reginald Heber. Justice and the poor, a study of the present denial of justice to the poor and of the agencies making more equal their position before the law, with particular reference to legal aid work in the United States. New York, Published for the Carnegie Foundation for the Advancement of Teaching by Scribner, I9I9. xiv, 271 p. 45-32508 HV682. $\mathrm{A}_{5} \mathrm{~S}_{5} 6$ 1919; Law

6330. Brownell, Emery A. Legal aid in the United States; a study of the availability of lawyers' services for persons unable to pay fees. Rochester, N. Y., Lawyers Co-operative Pub. Co., I95I. xxiv, 333 p. diagr.

5I-8125 Law

Iustice and the Poor is a study of the unavailability of justice to those unable to pay for legal counsel, and of the agencies endeavoring to give them assistance in the handling of their cases. Such remedial agencies as courts of small claims, conciliation, and domestic relations and administrative tribunals and their officials, as well as the work of assigned counsels and public defenders are considered. Lastly and most exhaustively, the development and operation of the legal aid societies since their origin in 1876 is discussed. Legal Aid in the United States is an authoritative compilation of facts concerning the subject, surveying its past and present and hopefully prognosticating its future. Between 1876 and 1948 the number of cases in which legal aid was given, as reported by the organizations concerned, steadily rose from 212 to 344,616 with a total of $8,043,990$ cases for the 73-year period. These operations rose in cost from \$ 1,060 to $\$ 1,519,076$, with a total of $\$ 19,855,024$ for the period. Sixty percent of the financial burden of legal aid was being borne by the community chests, and the next largest share came from private philanthropy. As a cause, it has gained little popularity with the man in the street but civic leaders have readily perceived that it is essential to democratic equality before the law. The volume was produced for the Survey of the Legal Profession conducted under the auspices of the American Bar Association. Both of these studies contain appendixes of illustrative statistics, and Mr. Brownell adds ro pages of legal aid offices operating in $195^{\circ}$.

6331. Sunderland, Edson R. History of the American Bar Association and its work. With a concluding chapter on the Committee on Scope and Correlation of Work and its program by William J. Jameson. [Ann Arbor?] 1953. 251 p.

53-4035 Law

6332. Rutherford, Mary Louise (Schuman). The influence of the American Bar Association on public opinion and legislation. Philadelphia, 1937. $393 \mathrm{p}$.

Thesis (Ph. D.) - University of Pennsylvania, 1936.

Bibliography: $p \cdot 3^{81-383}$.

With the objects of providing opportunities for social intercourse among lawyers, improving American jurisprudence, raising professional standards, and improving the administration of justice, the American Bar Association was formed in 1878 . Three eras in the history and development of the Association are defined by the author: the Saratoga era (1878-1902) during which, in a conservative and leisurely manner, the Association was establishing itself as a national organization, accumulating distinguished and influential members, and formulating policies looking toward the assumption of leadership in the American legal profession; the era of national expansion (1902-1936) in which the membership and variety of activities of the Association grew tremendously; and the era of federation, which began in 1936 when the Association ceased to be an organization of individuals and assumed, in the name of authority, efficiency, and professional solidarity and responsibility, the character of a federation of the organized units of the American bar. Mrs. Rutherford's is a specialized and penetrating study of the significance, possibilities, and effectiveness of the policies of the American Bar Association; she calls it suggestive rather than exhaustive. It classifies and organizes evidence of the organized bar's influence as reflected in the activities of certain sections and committees of the Association. Within the scope of this survey are analyses of the Association's structure, its influence on its own members, its public relations policies, and its influence on public opinion in regard to the Constitution, improving judicial procedure, controlling administrative agencies, and standardizing legislation. She concludes that the Association has done its best work in the field of judicial procedure, where it 
has put through some noteworthy reforms, and has rendered a distinct service in the drafting of legislation. It has done far too little in determining the curriculum of schools of law and in promoting legal aid, but on the whole it has pointed the way for voluntary organizations of experts to come to the aid of "a democracy enfeebled because of the paucity of trained leaders and workers in its service." 


\section{Politics, Parties, Elections}

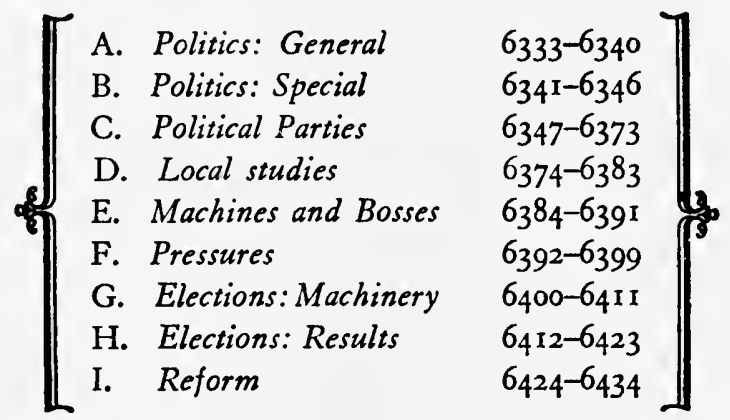

CHAPTER XXIX deals with American government in theory, in constitutional framework, and in concrete operation. The present chapter deals with the political processes which determine who shall be the governors and by what policies they shall be guided. Elections by the enfranchised portion of the people have been a feature of American life since 1619, when the "first-born child of the Mother of Parliaments," as F. W. Maitiand happily termed it, met at Jamestown; but neither then nor in 1776 or 1787 were the proportion of the electors to the whole population, or the offices thought proper to be filled by their ballots, the same as today. The tendency throughout has been toward an expansion of the franchise, with only one serious setback when the Southern Negro was disfranchised after 1877 . There has also been an increase in the number of offices filled by election, but here there has been in the recent past a considerable reaction, evident in such cases as judges and city managers. However, in America the persons who fill appointive offices are chosen by persons who have themselves been elected to office.

The national elections held every other year, and the State and local ones held at varying times, have never been left to the determination of an unguided, uninfluenced electorate. Party divisions began to emerge within a few years of the establishment of government under the Constitution in 1789 , and clearly determined the outcome of the third Presidential election, in 1796 . Although parties were organized in response to the national situation, they lost no time in taking State and local offices into their scope, with the result that each major party

normally offers a candidate for every office that is to be filled. Parties have regularly come into being in order to give effect to a particular policy or to ward off a particular menace, but those that survive have changed policies often and taken ambiguous lines even more often. Parties developed their characteristic organ, the national nominating convention, as early as the $1830^{\circ}$ 's, and the national committee, which maintains the organization between elections, not much later.

Along with the urban metropolis, there appeared about 1860 the new phenomenon of the party machine, usually dominated by an individual of exceptional qualities, the boss. These machines drew their power from the masses of the laboringmen and the foreign-born, to whom their precinct agents served as a kind of special providence in time of need or disaster. They drew their money by delivering the vote in favor of candidates who could and would act or enact to favor the men of enterprise who were supplying the city with gas mains, trolley lines, or whatever. The only persons un- 
benefited were the middling sort, who found themselves overtaxed and overcharged for inferior services, and turned mugwumps or progressives or reformers of various kinds. It is only in our own day that various factors, such as the increasing importance of mass communications, have caused a perceptible waning of the machine's importance. Long before this development, businessmen as well as other groups desiring political services had found another method of seeking them, by laying siege to legislators. The greatest pressure exerted by pressure groups is simply their refusal to take no for an answer: they have a single objective and their agents unlimited time to give to it, while the legislator has dozens of subjects and persons claiming his attention. Pressures, unlike machines, have been growing, and their regulation is still new and tentative. Political scientists made some admirable studies in both realms in the 1930's, most of which appear in Sections $E$ and F. The progressive movement early in the present century believed that political abuses could be eliminated by ingenious improvements in the machinery of elections. These have practically all been adopted or at least tried for a time, but seldom if ever produced the anticipated reformation. This need not imply that the changes were not desirable in themselves. These and related matters are treated in Section G. Recent students of elections have sought to predict future results from existing vote statistics or samples of opinion gathered by interviewers. The electorate continues to surprise them from time to time. Perhaps the most interesting titles in Section $\mathrm{H}$ are those which seek to trace, by repeated interviews in the course of a campaign, the formation and change of voting intention; this comes very near to the heart of democracy itself. A variety of things are grouped together in Section $I$, their common denominator being the aim of raising the political process onto a higher plane. Much of what seems failure might look very different if we could know what things would be like if the effort had never been made. Few but politicians express or have expressed any glowing satisfaction with American politics, but no one can deny that it keeps the future open, or that the voters can have what they want if they will keep their minds on it.

\section{A. Politics: General}

6333. Kent, Frank R. The great game of politics; an effort to present the elementary human facts about politics, politicians and political machines, candidates and their ways, for the benefit of the average citizen. Garden City, N.Y., Doubleday, Doran, 1935. xiv, $354 \mathrm{p}$.

First published in 1923 .

$$
35-8662 \quad \mathrm{JK}_{22} 26 . \mathrm{K}_{4} \quad 1935
$$

"A plain reporter's story of the political game," by an editor and political commentator of the Baltimore Sunpapers. The author has endeavored to show both the practical and the human side of the political machine, "the good as well as the bad in it, to tell who the men are, how they work, what they get out of it, whence it comes and how much," how political power is acquired, and how and why it is held. Mr. Kent emphasizes the "overwhelming proportion of insincerity, buncombe, and fakery that characterizes almost every campaign and nearly all candidates" and, in the latter chapters, sets forth his views of political issues, finances, and the formulation of newspaper political policies. In the author's opinion, the country was [as of 1935] really run by the political machines, and the bosses had become the most influential members of their communities because of the voters' inertia and ig- norance. Voters would not participate in the primaries, yet " 99 per cent of all candidates for all offices are nominated as a result of primaries," and control of them means control of the political situation in a given community. Mr. Kent offers neither panacea nor preachment, but pleads for "regular, intelligent, and informed voting by all those qualified to vote."

6334. Kent, Frank R. Political behavior; the heretofore unwritten laws, customs and principles of politics as practiced in the United States. New York, Morrow, r928. $342 \mathrm{p}$.

28-20042 JKI726.K 4

A disillusioned analysis of political processes and the behavior of politicians and voters in the United States by the redoubtable liberal Democrat. Mr. Kent sought to formulate the ground rules for political success and to clarify the facts of political life. He found "a legion of seasoned, tested axioms and a few broad general laws, a real study and understanding of which are just as necessary to the successful practicing politican as a thorough knowledge of legal procedure to a successful lawyer or biology to a doctor." The candidate who, consciously or unconsciously, applies the proved political 
rules and obeys the laws of politics has a tremendous advantage over the candidate who fails to do so, regardless of character and intelligence. Mr. Kent terms party regularity and organization support the two great essentials, and explains how to achieve the latter. He then takes up the more complex and flexible rules whereby candidates for elective office make successful appeals to the voters. Among the things to avoid are unnecessary antagonisms, controversial issues, overestimation of voter intelligence, showing up the opponent, high-hatting the voters, appearing ridiculous, and fixed principles. The candidate must be sure to put on a good show, and to have adequate finances and ample publicity.

6335. Key, Valdimer O. Politics, parties, and pressure groups. $3 \mathrm{~d}$ ed. New York, Crowell, 1952. xvi, $799 \mathrm{p}$.

First published in 1942 .

$$
5^{2-785 I} \quad \mathrm{JF}_{205 \mathrm{I} . \mathrm{K}_{4} \quad \mathrm{I} 952}
$$

A college textbook on politics which makes the central question "the relation of those with power to those who respond to, resist, or acquiesce in its exercise." Power is considered here as an indispensable means to the other ends which find expression in public policy, especially in legislation. In a democracy the mass of citizens choose from among competing inner circles of leaders, but initiative and leadership rest with the chosen leaders rather than with the mass. A leader in American politics, however, must make his decisions not only on the merits of the case but on their probable effects upon his supporters, and he may attempt to control by persuasion rather than by imposing his will. The problem of the politician or statesman in a democracy, Professor Key believes, is to maintain a balance among the demands of competing interests or values; it is not necessarily to express the "popular will," although every regime seeks to attract popular support. On these principles he analyzes the composition, objectives, and techniques of the competing interests, and the changes, maladjustments, and readjustments that have occurred in the American political equilibrium.

6336. Logan, Edward B., ed. The American political scene. Rev, ed. New York, Harper, 1938. 3 II $\mathrm{p}$.

First published in 1936 .

$3^{8-31039} \mathrm{JK}$ I726.L6 I938

Contents.-Present-day characteristics of American political parties, by A. N. Holcombe.-Party organization in the United States, by E. B. Logan.The politician and the voter, by J. T. Salter.Presidential campaigns, by H. R. Bruce.-The use of money in elections, by J. K. Pollock.-Pressure groups and propaganda, by H. L. Childs.-Nomina- tions, by Louise Overacker.-Appendix I. The changing outlook for a realignment of parties, by A. N. Holcombe-Appendix 2. The platforms of the two major parties.

Analyses by seven political scientists of the most important determinants in American politics. The authors attempt to explain some of the influences and controls which operate in the selection of our public officials and govern their activities after they have been selected. These writers find among the forces to be reckoned with: the relatively even division of the bulk of the voters between the Democratic and Republican Parties; a growing volatility of the electorate; the power of the political party over public policy and officials; the politician's practice of the art of politics; the management and techniques of caucuses, conventions, nominations, and campaigns; the necessity of party and candidate financial expenditure; and the influence of pressure groups, especially from business, labor, and agriculture.

6337. McKean, Dayton D. Party and pressure politics. Boston, Houghton Mifflin, I949.

7I2 p. 49-rorio JK2265.M27

A college textbook on practical politics and the relationship of propaganda to party and pressure politics. Professor McKean believes in the workability of the two-party system and in its value to popular democratic government. Representative government on a large scale, he thinks, can function only through parties. However, many of its difficulties arise from the inadequacies of parties, their inability to muster effective majorities, their lack of general and authoritative party voices and councils, and their indifference at the local and State level to national issues and public policy. Beset by these difficulties, by sectional differences, and by diverse interests, the major parties find the formulation and execution of broad policies difficult or impossible; but the organized minorities, not responsible to the electorate, know what they want and concentrate upon policy. The pressure groups can and do discipline legislatures and executives, engage in propaganda for or against them, get out the vote, and, in some instances, nominate officials. The problem, in Professor McKean's opinion, is to strengthen the national or Presidential party as against the pressure groups and local bosses. He considers several means of improving the national leadership and party responsibility. He shows less concern for the bosses since he considers them nowhere indispensable.

6338. Odegard, Peter H., and Elva Allen Helms. American politics; a study in political dynamics. 2d ed. New York, Harper, 1947. 896 p. illus. 
First published in 1938 .

A college textbook "combining structural description with functional analysis" of the American political system. Politics is defined as "the quest for power," involving "a struggle for the right to manage public affairs in a manner favorable to those who succeed in the quest and those whom they represent." This quest is pursued within the frame of the Constitution by persons organized in political parties or pressure groups or in both. The authors endeavor to show the operations of parties, pressure groups, bosses, and machines, as well as the effect of civil rights, election laws, and corrupt practices acts. American political history is discussed in terms not only of party leaders and organizations but also of fundamental economic and social cleavages. Since both major parties represent a cross section of the total political, economic, and social interests, "differences within the parties are greater than differences between them, and in the determination of policy pressure politics are usually more important than party politics." They cautiously suggest "some form of proportional or functional representation," supplementary to the existing system, in order to remedy the helplessness of legislatures before the organized pressure groups and their lobbyists.

6339. Stimpson, George W. A book about American politics. New York, Harper, 1952.

\section{4 p.

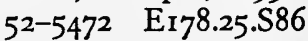

A collection of "the odd, the unusual and the interesting" facts about American political life arranged in question and answer form. The author's purpose has been to put together "the greatest number of answers to questions that are most often asked in this field." The answers consist of compact short articles "based on careful and prolonged research." Mr. Stimpson, an experienced Washington newspaper correspondent, deals with such matters as campaigns, committees, conventions, legislation, parties, platforms, politicians, and slo- gans. He traces the origin of many political terms, catchwords, phrases, and nicknames; notices splinter parties; and throws light on obscure or curious events, movements, and individuals. Unfortunately he does not refer to the sources of his information. A fairly full index compensates somewhat for the lack of any discernible organization in the book.

6340. Tourtellot, Arthur B. An anatomy of American politics; innovation versus conservatism. Indianapolis, Bobbs-Merrill, 1950. 349 p. $\quad 50-6590 \quad \mathrm{JK}_{34}$.T6 A general interpretation of American politics by a journalist who has endeavored to rethink the whole subject for himself, with results well suited to attract and inform the general reader. The first part, on political institutions, considers the evolution and relative positions of the Presidency, Congress, and the Supreme Court. There is no object more important to the voter than to secure a strong President capable of using for the public good the enormous power now attached to the office. Part 2 defines "The Basic Conflict" in American political experience as "conservatism versus progressivism, caution versus experimentalism." It has been expressed though the political parties, which have kept the continuity of their labels despite "a total absence of any continuity in party principles"-at times which party has been on the progressive side and which on the conservative has been completely confusing. Since the major parties are inclusive and tolerant and not exclusive or given to purges, thirdparty movements have lost impetus and nothing constructive is to be expected from them. Part 3, on political methods, discusses conventions, campaigns, and elections. The author dwells on the necessity, if the present system is to continue, for the party out of power to deal in live issues rather than ancient fears and compulsions, so as to present an effective challenge and alternative to the incumbents. The bibliographical essay (p. 319-336) is designed "for those who want to go deeper."

\section{B. Politics: Special}

6341. Carlson, Oliver, and Aldrich Blake. How to get into politics; the art of winning elections. New York, Duell, Sloan \& Pearce, 1946. 2 Io p. 46-8047 $\mathrm{JF}_{205} \mathrm{I}_{3} \mathrm{C}_{3}$

Mr. Carlson describes himself as a "public and industrial relations counsellor," and Mr. Blake himself as a "political research and organization advisor"; they have joined forces in order to inform the ordinary American citizen who may find himself catapulted into the political arena what it will involve and what he must and must not do. The task of winning and holding an electorate is one of the most complex, difficult, and problematic in human affairs. The ambitious politician, they note, must join a party, faithfully preach its gospel, and attend its precinct caucus. At this point, however, 
he must come to terms with "powerful and grasping factions." "With few exceptions, he simply gives way to that combination of special group interests which he believes has the money and the power to re-elect him, seeking some compromise where possible but submitting to the terms of unconditional surrender when necessary to his own self preservation." The authors offer much concrete and practical advice to the budding politician concerning the public relations of politics, notably, the campaign budget, the party workshop which lies behind campaign headquarters, precinct work, publicity and propaganda, and platforms and speechmaking.

6342. Douglas, Paul H. Ethics in government. Cambridge, Harvard University Press, 1952. II4 p. (The Godkin lectures at Harvard University, 195I) 52-9386 JK $468 . E_{7} \mathrm{D} 68$

In these four lectures Senator Douglas argues that although government ethics in the United States have generally improved during the last century, they are by no means good enough and require further melioration. He locates the areas wherein ethical difficulties and failures are most likely to occur, pointing out that in most instances the pressure comes from private sources which are seeking to obtain favors from government. Senator Douglas suggests rules and criteria for the regulation of economic controls, loans, and subsidies, warns against indirect influences, such as the acceptance of favors or gifts and the sale of government prestige or experience, and offers a code of ethical behavior for public officials. In a discussion of the ethical problems of legislators, he considers how far legislators and administrators may properly influence each other, and urges improvement in the procedures and attitudes of investigating committees. Some of the moral indignation aroused over the delinquencies of government officials should, in his opinion, properly be applied to the interests that entice and corrupt them.

6343. Garrigues, Charles Harris. You're paying for it! A guide to graft. New York, Funk \& Wagnalls, 1936. 254 p. $\quad 36-27398 \quad$ JKI994.G3

A cynical report on American politics by a disillusioned California crusader. The author holds that "graft is not a parasite sapping the tree of democracy, but the very fruit of the tree itself." Competition among special interests compels each to seek "special privileges" and to pay the representatives of government for such privileges; the system "compels every man to be as corrupt as his most corrupt competitor." The government official who refused a bribe would have neither campaign funds nor votes and would be replaced by one more com- pliant. The law is ineffectual, and the occasional grafter who goes to jail is either very stupid, very greedy, or the victim of a feud between politicians. The bosses the author regards as merely the "managers of the marketplace to which officials and special interests can come to buy or sell their commodities-special privilege." In mock earnest, he spells out the various means whereby the young politician may enjoy the fruits of graft, and very convincingly describes typical circumstances of the bribe, the fix, and the graft investigation.

6344. Graham, George A. Morality in American politics. New York, Random House, 1952. $337 \mathrm{p}$. ${ }^{22-7 I_{4}} \quad \mathrm{JK}_{4} 68 . \mathrm{E}_{7} \mathrm{G}_{7}$

A study of the problem of morality in American politics which maintains that the profession of politics, although differing importantly from the other professions, must be subject to at least equivalent standards of integrity and competence. Moral problems, moral standards, moral failures, and moral achievements are involved in the structure of political institutions: the legislature, the executive, the courts, public administration, parties, pressure groups, and even the public. Professor Graham explores certain public characteristics and attitudes: "complaisance over early and substantial American success in securing human rights and promoting individual welfare; subconscious confidence in the automatic qualities of the economic and political order; legalism"; philosophical naiveté; and a pattern of life dominated by specialization, organization, loyalties, and pressures. In his opinion, if this typical pluralistic organization of American life is to be preserved, it behooves each organization to avoid jurisdictional expansion and to strive constantly for moderation in its demands upon its members and society. A legalistic balance of rights and duties is not enough, however, nor is the mere avoidance of corruption. Leaders must keep their loyalties in balance, their special zeals in check, and they must recognize a public responsibility. The author appeals for renewed idealism in all Americans.

6345. Kelley, Stanley, Jr. Professional public relations and political power. Baltimore, Johns Hopkins Press, 1956. 247 p.

$$
\text { 56-8492 JF } \mathrm{JF}_{212 . \mathrm{P} 8 \mathrm{~K}_{4}}
$$

The first serious study of a new technique of politics which has already come near to revolutionizing the whole field, and is far from having disclosed all its possibilities. The author, who originated the study at Johns Hopkins and completed it at the Brookings Institution, has used "highly fugitive" materials-letters, interviews, and documents from private files-to supplement 
periodical articles and a few books of relevance. "The public relations man, more assiduously than others, has studied the problems of using the resources that a complex modern communication system offers for organizing and directing public opinion." First employed by business organizations, he has now become a permanent staff employee of State and national party organizations. Dr. Kelley seeks to determine his importance for democratic processes by means of "the description and analysis of the actions of particular public relations men at work in particular campaigns." He successively deals with "Campaigns, Inc." the California public relations firm otherwise known as Whitaker and Baxter, which has been operating since 1933; the American Medical Association's campaign of 1948-52 against President Truman's proposal of national health insurance, which included interventions in local elections intended to defeat legislators in favor of the plan; the part played by Jon M. Jonkel of Chicago in the Maryland campaign of 1950, whereby J. M. Butler displaced Millard Tydings as U. S. Senator; and the public relations activities, on a new and enlarged scale, in the 1952 campaign for the Presidency, when Robert Humphreys, heading the public relations division of the Republican National Committee, employed the Kudner and the Batten, Barton, Durstine and Osborn agencies. The chapter of conclusions notes that the decline of the boss is one reason for the rise of the public relations man, and that the latter is now called upon to take part in the planning sessions where the selection of issues takes place.

6346. Lubell, Samuel. The future of American politics. New York, Harper, 1952. 285 p. 52-5462 E743.L85

A comprehensive analysis of American political trends as observed by an eminent journalist in $195 \mathrm{I}$. Mr. Lubell finds that eight primary forces are remaking the politics of our time: the simultaneous coming of age of our various urban minorities, which has transformed machine politics and thrown political bosses on the defensive; the rise of a new middle class, conservative yet with political attitudes "rooted in memories of discrimination, poverty and the Great Depression"; the Negro, restless because of migration and discrimination; the economic revolution in the South which threatens to destroy Southern sectionalism; the upheaval in the international power situation; the fundamental change in the farmer's relation to the city; the advance of organized labor to unprecedented financial and membership strength and the recession of its political vitality; and, finally, the impact of the cold war upon the so-called welfare state. In the author's opinion, these revolutionary forces have produced a larger political revolution-the transformation of the United States from a nation with a traditional Republican majority to one with a normal Democratic majority, although, in $195 \mathrm{I}$, he found a governmental deadlock rather than an effective majority.

\section{Political Parties}

6347. Binkley, Wilfred E. American political parties, their natural history. $3 \mathrm{~d}$ ed., rev. and enl. New York, Knopf, 1958. 470 p.

$$
\text { 58-2201 JK 2261.B5 } 195^{8}
$$

Professor Binkley's book is a very readable history of parties and elections from the adoption of the Constitution to the reelection of Eisenhower; the "natural history" of the title is somewhat puzzling, but is evidently related to his conviction that all American parties have been made up of groups of varying economic interest or ideological persuasion, which are combined by national political leaders adept at group diplomacy and able to discover the formulas and focal points upon which all may agree. The pattern of party leadership was set by Thomas Jefferson, who was able to unite all the elements disadvantaged by the Hamiltonian policies. The Federalists did not want to be a party, but had to become one in sheer self-defense. American party leaders, however, can lead the people only where they are willing to follow, and must be astute opportunists governed by expediency and free from petrified ideas. Dr. Binkley concentrates upon the major parties and gives small attention to the minor ones. His chapters, which are not rigidly chronological, include treatments of "One-Party Government," I 816-28, and of "The Breakup of the Major Parties" during the 1850 's. The Democratic Party in 1860 entered upon a period of confusion which culminated in 1872 ; its revival began in 1876 . The Republican Party, born in 1856 , was reborn in 1868 when the forces of economic exploitation lined up behind Ulysses S. Grant. The book was originally published in 1943; the new edition adds an account of the 1948 election and a chapter on "The Recovery of the Republican Party." There is a supplementary index, but the bibliography contains no titles later than 194 I. 
6348. Black, Theodore Milton. Democratic Party publicity in the $194^{\circ}$ campaign. New York, Plymouth Pub. Co., 194I. 169 p. 42-8075 JK2317.1940.B5

An analysis of Democratic political propaganda during the bitterly contested Presidential campaign of 1940. Here is the "story of men in an organization; it describes their efforts to convince the American people that Franklin D. Roosevelt should be elected for a third term." The author writes from firsthand information, having been employed by the publicity division of the Democratic National Committee during part of the campaign. He illustrates the "techniques of political propaganda, in their modern setting, and the structure of a present-day political publicity bureau in its most active form." In his opinion, Charles Michelson and the publicity division's corps of veteran journalists, all skilled in the art of political warfare, were significant factors in the third-term success. Their chief tactics, as here reported, were to attack Willkie and the Republicans, to pin the tags of Big Business, Appeasement, and Inexperience upon them, and to caricature the Republican candidate. Blaming the frenzy and "personalization" of the campaign upon a lack of really controversial issues, the author acquits both sides of using "smear" strategy.

6349. Bone, Hugh A. "Smear" politics; an analysis of $194^{\circ}$ campaign literature. Washington, American Council on Public Affairs, 1941. $49 \mathrm{p}$. ([Studies in political science])

42-456I JK228I.B65

A study based largely upon unpublished data assembled by the Special Senate Committee to Investigate Campaign Expenditures in 1940. It aims to make available exhibits of the literature used in the 1940 campaign; to indicate the major psychological appeals employed; to call attention to some of the problems of determining responsibility for the issuance of campaign propaganda, and to those raised by anonymous political journalism; and "to offer suggestions for reducing the scope and volume of that campaign literature which does violence to the spirit and process of democracy." The examples of campaign literature included here were selected to display a fair cross section as to form, substance, and distribution; comment has been kept to a minimum. In the 1940 campaign "literature ostensibly printed and authorized by non-party groups greatly exceeded that of political parties," and proWillkie materials greatly exceeded those supporting Roosevelt. The majority of "smear" leaflets came from other than party sources. Not only did scurrilous personal attacks upon nominees and their families appear in these, but objectionable appeals were made to religion, race, and nationality. The author thought that legislation should require the name and address of the sponsor to appear on all campaign literature, and that the parties should maintain a much tighter control over their local agents in matters of publicity.

6350. Bryan, William Jennings. A tale of two conventions. New York, Funk \& Wagnalls, 1912. xviii, 307 p. ${ }_{12-22646} \quad \mathrm{JK}_{22} 6_{3} \quad$ 1912. 37 This rare example of political journalism by a leading politician is a collection of daily reports made by Bryan, acting as a special newspaper correspondent, at the Republican and Democratic National Conventions of 1912 in Chicago and Baltimore, respectively, together with a summary of the events and other matter bearing on the Progressive Party Convention in Chicago. It reprints the three platforms, selected contemporary cartoons, and the speeches of such notables as Theodore Roosevelt, Byran himself, Elihu Root, and Alton B. Parker. Bryan found that two evils stood out prominently at the Republican Convention: "the organization of a new convention by an old, outgrown committee"; and "the employment, for the purpose of overriding a majority of committeemen, of delegations representing mythical constituencies in the South." Of the 75 contested seats there, all were given to the Taft rather than the Roosevelt delegates, he notes, and with them went control of the convention. Bryan praised the constructive Democratic platform, and claimed that the responsiveness of the convention to the more than one hundred thousand telegrams sent to them by "the Democrats at home" showed the power of public opinion and the soundness of the party. Bryan's reports have immediacy and pace; his style is marked by rhetorical flourishes and pious apothegms; and he understood well what was going on.

6351. Carroll, Eber Malcolm. Origins of the Whig Party. Durham, N. C., Duke University Press, 1925. 260 p. 25-231.23 JK2331.C 1922 Thesis (Ph. D.)-University of Michigan, 1922. Bibliography: p. [228]-238.

A review of the complex origins and the history to 1840 of the Whig Party, which was united only in a general conservatism and in opposition to Jacksonian Democracy. Its difficulties, the author believes, inhered in its necessities as an opposition, requiring the aid of all dissidents, and in the failure of the National Republican Party to which it was heir. Its weaknesses Dr. Carroll attributes partly to John Quincy Adams' lack of skill as a politician and partly to the rising tide of frontier democracy in favor of Jackson. Adams' crushing defeat for reelection to the Presidency in 1828 eliminated him as leader of the National Republican Party, and 
Clay's thorough defeat in 1832 discredited the party itself. The Whig Party was organized in 1834 , but, the author notes, recognized leaders who could sap Democratic strength only after it had lost the election of 1836 . By nominating William Henry Harrison in 1840 , the Whigs demonstrated their cenviction "that the Democrats should be fought with their own weapons." "The reward was a brief tenure of power in $184 \mathrm{I}$; the penalty was the disruption of the party when, under Tyler, dissension became active again."

6352. Croly, Herbert D. Marcus Alonzo Hanna; his life and work. New York, Macmillan, 1912. 495 p. illus. I2-9163 $_{3}$ E664. $\mathrm{H}_{24} \mathrm{C}_{9}$

A sympathetic biography of the great Republican organizer based not only upon Hanna's very scanty papers but also upon statements solicited from his business and political associates. Although he does not underemphasize the difficulties of giving a fair account of Hanna's career or of passing objective judgments upon a man who was involved in bitter contention, Croly begs the "unprejudiced attention" of his readers. Mark Hanna (1837-1904), he maintains, was formed under the same influences as hundreds of other Middle Westerners who combined a business with a political career, but he lived "more energetically, more sincerely, and more successfully" than the others. His pioneering and prosperous coal and iron business and other enterprises at Cleveland were begun after the Civil War, when economic opportunities were abundant, and continued until 1894. As early as 1888, Croly asserts, this industrial pioneer "had made up his mind to nominate, if possible, a political leader from Ohio as the Republican candidate for the presidency." William McKinley became both the intimate friend with a bright political future and the available candidate. The author concludes that the interdependence of business and politics, in the era of McKinley and protectionism, gave to a man like Hanna, who embodied the alliance, an opportunity for effective influence.

6353. Davenport, Walter. Power and glory, the life of Boies Penrose. New York, Putnam, I931. 240 p. illus. 3I-31210 E664.P4 ID 3 A lively and anecdotal biography of Boies Penrose (1860-1921), one of the last and greatest of the political bosses, based mainly upon a series of articles published under the same title in Collier's Weekly. Of no political party in his youth, Penrose "was to become a Republican of Republicans." He came of Republican stock and tradition, and was "baptised in its most conservative pool-Philadelphiaand dedicated to its tightest fundamentals." Penrose is characterized here as an intellectual by inheritance and equipment, with no tolerance for the less gifted. He was drafted and elected in 1884 by the powerful Philadelphia Republican machine to the Pennsylvania legislature, where he represented a constituency composed of his city's highest and lowest social strata. After one term in the lower house, he was advanced to the State senate, serving there continuously from 1887 to 1897 . In 1897 , with the support of Matthew S. Quay, Republican State boss, he was elected to the United States Senate and served until his death. Once there, Penrose fought to stay; "his commitments, his pride, his love of power held him to that." He succeeded to control of the State party machinery upon Quay's death in 1904. In Mr. Davenport's opinion, it is highly probable that some of the Penrose victories were purchased, and certain that he jumped to do the bidding of the Pittsburgh steel magnate, Henry C. Frick.

6354. Farley, James A. Behind the ballots; the personal history of a politician. New York, Harcourt, Brace, 1938. $392 \mathrm{p}$.

$$
\text { 38-28947 E748. } \mathrm{F}_{24} \mathrm{~F}_{3}
$$

A candid political memoir by James A. Farley (b. 1888), a Democrat who began his political career at the age of 22 by winning the town clerkship of Stony Point, N. Y., a normally Republican community. After touching lightly upon his own earlier years, the author presents a behind-the-scenes account of the aggressive campaign for Franklin D. Roosevelt which he and Louis McHenry Howe conducted during the year and a half preceding the 1932 national convention. Mr. Farley, a strong believer in organization politics and in the mastery of detail, reports with particularity the grass-roots organizing, trial balloons, political drumming, and delegatepledging which helped him "sell a presidential candidate to the nation." His description of the bargaining done at the 1932 Democratic National Convention is both amiable and forthright. In Mr. Farley's opinion, the successful cultivation of the women's vote was a large factor in the Presidential election. The 1936 landslide had deep significance, he believes, because it occurred in the face of strenuous opposition from the big business interests. The author tends to discuss the New Deal and his own part in it in terms of men rather than issues, inasmuch as his forte was political management and backstage strategy rather than administration or legislation.

6355. Farley, James A. Jim Farley's story; the Roosevelt years. New York, Whittlesey House, 1948. $3^{88}$ p. illus. $4^{8-946}$ E806.F255 The continuation of Mr. Farley's political memoir is devoted mainly to a detailed history of the "slow, 
almost imperceptible drifting apart on political principles" of himself and President Roosevelt. Mr. Farley, placing the start of the estrangement at the 1936 campaign, believes that the President was jealous of possible successors, and never forgave him "for putting party welfare above the personal allegiance he considered his due." Mr. Farley may have regarded Roosevelt's suggestion that he run in New York either for Governor or for Senator as an attempt to sidetrack him from the election of 1940 . The attempted purge of 1938 , which violated the author's creed of party regularity, caused him to lose faith in the President. "The attempt to establish a personal party," Mr. Farley observes sorrowfully, "the neglect of party leaders, the assumption of control over the judiciary and Congress, and the gratification of personal ambition in the third and fourth terms-all were the evil fruit of his breaking the rules of the game." He does not consider that absorption in a course of policy may render personal ambition and playing a game equally irrelevant. Mr. Farley quotes many revealing conversations and anecdotes.

6356. Fine, Nathan. Labor and farmer parties in the United States, 1828-1928. New York City, Rand School of Social Science, 1928. 445 p. 28-24182 HD8o 6 . F5

The author, who was an associate of the Rand School of Social Science, was concerned to trace the attempts of "the American workers," on the land or in industry, to advance their interests through political organization. The earliest labor party was launched by the Mechanics' Union of Trade Associations of Philadelphia in 1828, and was promptly imitated in New York; neither group survived the presidential election of 1832 . After noting other early and sporadic movements, the author devotes a chapter to the united front of 1886, when Henry George ran for mayor of New York, and one to the Grangers, Greenbackers, and Populists. He then enters upon the history of the Socialist Labor Party, and pursues the fortunes of the socialist movement through the next eight chapters, the bulk of the book (p. 88-362). Concluding this with the Communist-Socialist split, he takes the measure of the former: "No matter how decent, progressive or militant a trade union leader or rank and filer is, the communist will try to destroy him if he does not take orders-whatever they are at the momentfrom the Workers' Party leadership in America and Moscow." The concluding chapters deal with the Nonpartisan League, the Farmer-Labor Party, and the Conference for Progressive Political Action. While his story could be regarded, he said, as one failure after another, "the most striking fact about the labor and farmer parties in America over the past century was that they never stopped springing up."

6357. Herring, Edward Pendleton. The politics of democracy; American parties in action [by] Pendleton Herring. New York, Norton, $194^{\circ}$. $\mathrm{xx}, 468 \mathrm{p}$. illus. $\quad 40-27328 \quad \mathrm{JK}_{22} 25 \cdot \mathrm{H}_{47}$

An attempt to show the nature of the American party system and its relations to other social processes through an analysis of the politics of democracy. The author examines such factors as machine control, pressure politics, propaganda, monied interests, patronage, and bureaucracy. These Dr. Herring considers merely the reverse sides of elements integral to the democratic process. This American political process, he believes, through its toleration of various attitudes and programs, provides the milieu within which a science of society may be developed and intelligence may be applied to our common problems. He maintains that we cannot greatly change the nature of American politics so long as the democratic order prevails, but that with patience and skill we should be able to achieve the desirable life. In his view, adjustment is the essence of the politics of democracy, in that political parties hold power only through popular support and in that the political machinery is able to keep power responsive to change and experimentation. The function of the American party system should be to keep the majority and minority viewpoints from diverging to the point where they can no longer be reconciled under constitutional procedure. Compromise and tolerance must be maintained.

6358. Hicks, John D. The Populist revolt; a history of the Farmers' Alliance and the People's Party. Minneapolis, University of Minnesota Press, 193I. 473 p. illus. 3I-30954 JK2372. $\mathrm{H}_{5}$

Bibliography: p. [445]-464.

A scholarly history of the Populist movement, the conditions that produced it, the supporters of the cause, and its contributions to political and economic reform. Professor Hicks thinks that, beginning in the late 1870 's, the American West was peopled too rapidly, and that the successive agrarian movements, particularly the Farmers' Alliance and the Populist Party, were merely the "inevitable attempts of a bewildered people to find relief from a state of economic distress made certain by the unprecedented size and suddenness of their assault upon the West and by the finality with which they had conquered it." Among the farmers' grievances were drought conditions in the decade $1887-97$, high shipping costs, the political influence of the railroads, the disappearance of free land, price-fixing by the trusts, the protective tariff, and especially a growing burden of debt. Among their demands were cheap money, 
free land, honest transportation, and the abolition of foreclosure. By 1890 it had become clear, the author notes, that neither the Northwestern formula of establishing state political parties nor the Southern formula of working through the Democratic Party was adequate for reform. Demand shifted "from free land to legislation, from the ideal of individualism to the ideal of social control through regulation by law." Most of the demands first formulated by the Populists were given effect by other parties in later decades.

6359. Kent, Frank R. The Democratic Party, a history. New York, Century, 1928. 568 p. illus. 28-8482 JK2316. $\mathrm{K}_{4}$

A chronicle of the Democratic Party from its birth in 1792 to early 1928 . The author's purpose was to tell the truth about his party rather than to glorify it. Mr. Kent admired the "genuine and indisputable greatness of the basic Democratic principles," but deplored the "almost incredible record of stupidity and failure, the frequency and violence with which its performances have clashed with its professions; the wreck it has time and again made of its own prospects." The story of the Democratic Party is, in the author's opinion, the story of five men outstanding in its history who gave the party its principles, shaped its policies and destiny, led it in the critical conflicts, were responsible alike for its greatest achievements and its monumental failures, and lent it color, character, and vitality. The first was Thomas Jefferson, enunciator of the basic democratic doctrine of government for and by the people. He was followed by Andrew Jackson, who originated the spoils system and modern party methods, Grover Cleveland, who acted upon the precept that "public office is a public trust," William Jennings Bryan, the financial heretic who changed the party principles, and Woodrow Wilson, whose record of domestic reforms was in 1928 unparalleled.

6360. Kipnis, Ira. The American socialist movement, 1897-1912. New York, Columbia University Press, 1952. $496 \mathrm{p}$.

$$
\text { 52-13945 JK2391.S6K5 }
$$

A history of the American socialist movement which centers in its years of peak activity, 1897-1912. The first six chapters deal with the background of the movement from the introduction of Marxian socialism into the United States by German immigrants of the I85o's down to the formation of the Socialist Party in Igor by American Marxists convinced that capitalism was destroying the nation's economic equality and corrupting its democratic heritage. The remainder of the book studies the Socialist Party both as a political organization and a social movement. Dr. Kipnis points out the impressive if ephemeral achievements of the party to 1912: its growth from less than 10,000 to 150,000 members, the increase of its voting strength from 95,000 to 900,000 , the election of more than 1,000 members to public office, the passage of hundreds of reform bills, the winning of position and influence in the American Federation of Labor, and its instrumentality in organizing the Industrial Workers of the World. The shortcomings of the revolutionary left-wing Socialists were serious enough, the author believes, but major responsibility for the decline of the movement rests upon members of the right wing who controlled the party and determined its policy and activities. Elated by electoral success, they turned the party into "an opportunist political organization devoted to winning public office for its leaders."

6361. Kleeberg, Gordon S. P. The formation of the Republican Party as a national political organization. New York, Moods Pub. Co., IgII. 244 p.

Bibliography: p. 235-244. I I-29805 JK2356.K6

This Columbia University dissertation traces the formation and the development to IgI I of the naParty. The Kansas-Nebraska Act of 1854 demonstrated that the West could be preserved as free territory only by a powerful political party committed to keeping slavery out, and those opposed to the extension of slave territory began to draw together in local political organizations. In parts of the West, New England, and the Middle States, Republican groups had reached a high degree of local organization by the Presidential year I 856 , and were ready to be built into a national machine. The national organization was substantially complete by adjournment of the second Republican $\mathrm{Na}$ tional Convention in 1860 , and the precedents it established were still operating more than half a century later-the national committee's call for the national convention, the convention itself, its temporary and permanent officers, its rules of procedure, the four great committees, the platform and nominations, the principle of majority nomination, the fixed number of delegates, and the national committee with its officers and powers. Dr. Kleeberg traces in detail the minor changes in the composition and procedure of the national conventions, and in the development of the Republican National Committee, during these 50 years.

6362. MacKay, Kenneth Campbell. The Progressive movement of 1924. New York, Columbia University Press, 1947. 298 p. illus. (Columbia University. Faculty of Political Science. 
Studies in history, economics and public law, no. 527)

$$
47-3855
$$

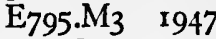

$\mathrm{H}_{3}$ I. $\mathrm{C}_{7}$, no. 527

Bibliography: p. 279-291.

An evaluation of the Progressive Party of 1924 in relation to the whole American progressive movement of the 2oth century, together with a detailed analysis of the campaign problems of the Progressives of 1924. Dr. MacKay sees in the 1924 movement a bond of common purpose with other progressive movements, reaching back to the policies of such early insurgents as the Greenbackers of 1876 , and extending forward to many of the reforms and experiments of the New Deal. In his opinion, three tendencies are common to American progressive movements: insistence upon the removal of exploitation and corruption, desire to change the structure of the government and to place control of it in the hands of the many, and belief in the necessity of extending government functions to relieve economic distress. The 1924 movement had its own distinctive features, however: it polled more votes than had any other minor party, it represented the first formal alliance of American organized labor with Socialists, farmers, and intellectuals, and it aimed to unite its diverse elements into a permanent party dedicated to political reform and economic democracy. The movement was doomed, the author believes, because it was hampered by state election laws, had too little campaign money, and lacked cohesiveness and organization.

6363. Merriam, Charles Edward, and Harold Foote Gosnell. The American party system; an introduction to the study of political parties in the United States. 4th ed. New York, Macmillan, 1949. 530 p. $49-3967 \quad \mathrm{JK}_{2265} \cdot \mathrm{M}_{4} \quad 1949$

First published in 1922.

An analysis of the American two-party political system. Professors Merriam and Gosnell discuss such general considerations as the relation of democracy to the party system, theories of suffrage, the functioning of parties in the formulation of social, economic, and political policy, and the motiveseconomic, sectional, racial, or religious-which govern political action. Among the other factors in American political life considered here are party leaders, bosses, and reformers; party organization; spoils politics; nominations and election machinery; modern techniques of winning elections; statistical sampling devices and their uses; election laws; and proposed methods of putting the party system upon a higher intellectual and administrative level. The party process is slowly being changed, the authors conclude, and party activities are being fundamentally modified. The decline of patronage as a principal element in the party, through the gradual substitution of the merit system for the spoils system in public administration, has weakened the machine and led to a professionally and technically based public service. Responsible government in turn tends to give broader scope to the party leader and less to the party boss. Professors Merriam and Gosnell detect a developing sense of civic responsibility in the United States, but regard many of the problems of democratic society as remaining to be solved.

6364. Michelson, Charles. The ghost talks. New York, Putnam, 1944. xvi, 245 p. illus. 44-3334 E806.M54

Chatty reminiscences and knowing political commentary by a former Washington newspaper correspondent who served as publicity director of the Democratic National Committee from 1929 to 1940. Mr. Michelson offers no startling new revelations but does clarify the record at certain points. Although Franklin D. Roosevelt listened to his advisers, the author believes, he pursued his own plans. The President dictated his own final versions of his speeches, generally culling the best ideas submitted in drafts. He was, in Mr. Michelson's opinion, "a better phrase maker than anybody he ever had around him." Denying the existence of a "smear Hoover" conspiracy in the 1930 or 1932 campaign, the author asserts bluntly: "There was no occasion for billingsgate, no necessity for misrepresentation, no excuse for slander. A man sat in the President's chair who did not fit." He discusses the members of President Roosevelt's entourage, their contributions to his success, their relative independence, their influence, and their rivalries. $\mathrm{He}$ describes the methods, issues, and financing of three Presidential campaigns. Prior to the European crisis, the author states positively, nothing was further from Roosevelt's mind than a third-term candidacy.

6365. Myers, William Starr. The Republican Party, a history. Rev. ed. New York, Century, 193r. 517 p. illus.

First published in 1928 .

$$
32-1529 \quad J K 2356 . M 85 \quad 193 \mathrm{I}
$$

6366. Moos, Malcolm C. The Republicans; a history of their party. New York, Random House, 1956. 564 p. 56-5195 JK 2356.M6

Professor Myers' long-standard history of the Republican Party from its inception in the "AntiNebraska Conventions" of 1854 through the elections of 1930, was written in "the conviction that parties are the natural and necessary organs of government and administration." In his opinion, the Republican platform of 1860 forecast much of 
the Republican policy of succeeding years, even to 1930, furnishing unity of purpose during the whole period of the party's domination of the Federal government. The first principle dealt with the tariff, and began the process of uniting in Republican ranks "the business and industrial interests without which, as not only American history but that of other self-governing countries shows, it is impossible to continue political domination." Built not merely for the year's campaign but looking toward a well-established and permanent national political party, the platform as a whole prepared an economic basis for the cooperation of the agrarian, commercial, and industrial interests of the country. The author credits the Lincoln administration with laying firmly the foundations upon which the later successes of the Republican Party were erected, Hayes with rehabilitating the party after the Grant administrations, McKinley and Theodore Roosevelt with reorganizing and activating it into an aggressive party, and Coolidge for saving it after Harding's errors. Dr. Moos' The Republicans has the obvious advantages of carrying the story through six further elections, of using some results of recent historical scholarship, and of employing up-to-date techniques of analyzing election returns. He provides a crowded narrative, filled with colorful and lively incidents, and accompanied by pungent comments, his own as well as those made by contemporaries. He is able to draw upon his own thorough knowledge of recent politics to illuminate situations in the remoter past. He narrates the party's origins and developments through the disputed election of 1876 in considerable detail, then rather skimps the four succeeding "fifty-fifty" elections, but amplifies his narrative from 1896 on until he requires two whole chapters to chronicle the great Republican comeback of 1952. His attitude is that of a moderate critic, to whom the "liberal capitalism" advocated by the party founders and by its "amateur" wing in our day is a valid doctrine. He does not like the "monopoly capitalism" which in I 868 captured and exploited for its own purposes a party that had become "hallowed in consequence of its fight to free the slaves and save the Union." The party so oriented would have succumbed to the revolts of the I89o's save for the timely emergence of the organizing genius of Mark Hanna, one of the few businessmen who have had a profound instinct for politics.

6367. Porter, Kirk H., and Donald Bruce Johnson, comps. National party platforms, $1840-$ 1956. Urbana, University of Illinois Press, 1956. 573 p. 56-10916 JK2255.P6 ${ }_{1956}$

First published in 1924 .

Unabridged texts of the national platforms of all the major and of the principal minor parties drawn from official proceedings of the conventions or from campaign literature, beginning with the campaign of 1840 and the Democratic platform of that year, and extending through the campaign of 1956, with the platforms of the Democratic, Prohibition, Republican, Socialist, Socialist Labor, and Socialist Workers Parties. The compilers have taken some account of the size of the group which professed to be a national party, the relative permanence of the organization, and its historical importance. Platforms of defecting segments of major parties have been included if of significance. An explanatory paragraph or two prefaces the chapter devoted to each campaign. The compilers consider platforms to be the primary statements of party principles and policies, and, as evidence of what party leaders believe to be the important current issues, reflections of major political trends. As such, they often foreshadow new economic, social, and political developments.

6368. Quint, Howard H. The forging of American socialism; origins of the modern movement. Columbia, University of South Carolina Press, 1953. 409 p. 53-9397 HX83.Q5 "Bibliographical essay": p. 389-394.

A study of the formative and hopeful phase of American socialism. An introductory chapter, "Marxism Comes to America," sets forth concisely the events of the earlier years, I870-86. The remainder of the book deals with the evolution of formal socialism and the development of socialist parties in the United States between 1886 and I90I. Indicating both the European influences and the distinctively American elements, Professor Quint shows that the upsurge of American socialism was only partly inspired by classical Marxist doctrine, and came primarily as a protest against the social inequities resulting from rapid industrialization and economic concentration. He explores the many and various ideas and movements which were with difficulty united in r9or to form the Socialist Party of America, among them Bellamyinspired Nationalism, Christian Socialism, DeLeonism, Non-Partisan Socialism, and Fabianism. It was Edward Bellamy's Looking Backward, published in 1887 , that first won a hearing for socialist ideas outside the laboring class and made socialism respectable. The emergence of the Populist wave in the early I8go's posed a problem to all socialist groups, and evoked every response from hostility to cooperation. After its collapse, Eugene V. Debs' adherence to the Social Democracy gave utopian socialism a brief revival, but the schism of 1898 left the way clear for a party on lines already worked out in Germany and Britain. 
6369. Ross, Earle Dudley. The Liberal Republican movement. New York, Holt, Igrg. $267 \mathrm{p}$. 19-12223 JK2356.R 5 E67I.R82

Bibliography: p. 240-254.

This Cornell University dissertation is a history of the group which split from the main Republican body as a new national party in 1872 . The author calls Senator Carl Schurz of Missouri its spearhead, and gives as its motives dissatisfaction with the corruption, blunders, and partisanship of Grant's administration, and belief in the necessity for reform measures. Dr. Ross is concerned particularly with the influence of the movement upon the reorganization of national parties. $\mathrm{He}$ notes the discredited condition of the Democrats, their inability to profit from the mistakes and dissensions of the Republicans, and their failure to show any real change of heart in 1868 . He indicates, also, their attempts in 1871 to rid themselves of the odium of disloyalty, and their willingness to enter into coalitions with the Liberal Republicans. He shows that many liberal Democrats were willing to merge with the new reform organization in order to defeat Grant. Greeley's nomination at the 1872 convention he terms a triumph of experienced political intriguers over inexperienced and over-confident reformers. The impossibility of reconciling large numbers of Democratic voters to Greeley as a candidate was, he believes, the principal reason for the overwhelming defeat of the coalition by Grant and the Republicans.

6370. Schattschneider, Elmer E. Party government. New York, Farrar \& Rinehart, 1942. $\mathrm{xv}, 219$ p. (American government in action series)

"Selected bibliography": p. 2 II-2I4. 42-2229 JK2265.S 35

An analysis of the American political party system which posits that the political parties created democracy, that modern democracy is unthinkable save in terms of them, and that they are not mere appendages of modern government but are in the center of it and play a determinative and original part in it. The Democratic and Republican Parties are here commended not only for their long duration and the stability of their "partnership" but for their accomplishments. Among these are the transformation of the American Constitution, the virtual abolition of the electoral college, the creation of a "plebiscitary presidency" and powerful contributions to the extraconstitutional growth of that office, and, most important, the remaking of the government of the United States from a small experiment in republicanism into the world's most powerful regime, vastly more liberal and democratic than it was in 1789 . Professor Schattschnei- der sees the Presidency as the focus and rallying point of the great public interests of the nation and, as such, an office of expanding influence. He views Congress as the no man's land of American politics where the national parties, local party bosses, and pressure groups are engaged in a war for supremacy, and where, he hopes, for the public interest the national parties will emerge triumphant.

6371. Shannon, David A. The Socialist Party of America; a history. New York, Macmillan, 1955. 320 p. 55-13545 JK2391.S6S 1955 "Bibliographical essay": p. 269-273.

A history of the Socialist Party of America from its formation in I 901 to its disintegration in the late I930's. Professor Shannon traces the party origins to revolt in the I89o's against the social and economic conditions created by the mushrooming industrialism of America, and its components to the membership of such protest movements as the Bellamy Nationalist clubs, the Populist Party, Eugene V. Debs' Social Democratic Party, and dissidents from the Socialist Labor Party. During nearly two decades of growth and promise, the author points out, the Socialist Party was a broad political organization representing all shades of leftist conviction and all regions except the eastern and central South. The party's decline is the story of its transformation from a widely based political party into a monolithic sect of a few thousand members. The author discusses the regional organizations of the party and their variety of social philosophies, as well as the membership in it of recent immigrants and Mayflower descendants, tenement dwellers and prairie farmers, intellectuals and sharecroppers, ministers and agnostics, syndicalists and trade unionists, and revolutionaries and gradualists. He attributes the decline of "the big tent of American radicalism" in the 1920's, and its insignificance thereafter, to a variety of causes. Some of these, such as its failure to develop strong local organizations, were internal; the more important ones, such as the high degree of class mobility in America, were external.

6372. Stedman, Murray S., Jr., and Susan W. Stedman. Discontent at the polls; a study of farmer and labor parties, 1827-1948. New York, Columbia University Press, 1950. I90 p.

$$
\text { 49-50349 JK226r.S84 }
$$

An analysis of the functions performed by the American farmer and labor parties which have competed seriously for control of state and nation. The authors examine the extent of such parties' success at the polls, the degree to which measures formulated by protest parties have become law, the factors 
making for farmer-labor success and failure, the relation of the protest vote to general economic conditions, the regional characteristics of this vote, the political strategy and tactics employed by the parties, and the legal and psychological barriers encountered by them. Farmer-labor parties act as vehicles for discontent, but have been most successful, the authors believe, as popularizers of ideas and issues neglected by the major parties. They have excited local and national interest in important problems and reform measures, but tend to die as soon as their principal issues are adopted by a major party. Their recurrent challenge to the major parties, however, strengthens the democratic process.

6373. Thomas, Harrison Cook. The return of the Democratic Party to power in 1884 . New York, Columbia University, Igrg. 26r p. (Columbia University. Faculty of Political Science. Studies in history, economics and public law, v. 89, no. 2; whole no. 203) 19-26013 E695. $\mathrm{T}_{452}$ $\mathrm{H}_{3}$ I.C 7, v. 89 , no. 2

A study of the election of 1884 , in which the chief issues were civil service and tariff reform. After four preliminary chapters, the book takes up its proper subjects: the Republican nomination of James G. Blaine (1830-1893), the Democratic nomination of Grover Cleveland, the campaign, the election, and the achievements of the Democratic administration. The Democrats were returned to power, the author believes, because of the lack of major issues between them and the Republicans, and because the characters of the candidates thereby became of determining importance. Blaine was an unsatisfactory candidate to the Independent Republicans; their defection and the defeat of the party ensued. He had always been a spoilsman and no civil service reformer; he had associated himself with many politicians of the lowest type; his popularity was based upon appeals to the emotions and not upon his identification with policies; and, perhaps most important, he had never convinced a large enough number of voters of his complete honesty. Although Dr. Thomas credits Cleveland with progress in reform and with forward-looking legislation, he thinks that the reestablishment of the Democratic Party in real rivalry of the Republicans was the main result of their victory.

\section{Local Studies}

6374. Fox, Dixon Ryan. The decline of aristocracy in the politics of New York. New York, Columbia University, 1919. 460 p. (Columbia University. Faculty of Political Science. Studies in history, economics and public law, v. 86; whole no. 198)

I9-18663 FI23.F792 $\mathrm{H}_{3}$ I.C7, v. 86

This is a history of the decline of the Federalists in the State of New York, from the defeat in 1800 of the Federalist gubernatorial candidate, Stephen Van Rensselaer, to the I 840 's. Starting with a tradition of government by an aristocracy of birth and station, the Federalists were ultimately transformed into Whigs, with a doctrine of government by capital and business enterprise. The story is told largely in terms of the programs and ideas of the opposing parties, Federalist and Democratic, and the careers and influences of such party leaders as DeWitt Clinton and Martin Van Buren. Dr. Fox contrasts the Federalists, led mainly by distinguished lawyers and supported chiefly by the landed gentry, wealthy merchants, bankers, and the Episcopal Church, with the Democrats, made up for the most part of farmers, workers, and immigrants. As the author observes, the bitter strife between the organizations had certain elements of a class war- but one in which the outcome was foredoomed. He narrates at some length the debates and proceedings in the decisive state constitutional convention of 1821 , which adopted manhood suffrage and largely abolished property qualifications for office. But no sooner had political equality triumphed than manufacturing acquired a new importance and prestige, and its interests were sedulously cultivated by the organizing genius of the new Whig Party, Thurlow Weed.

6375. Gosnell, Harold F. Negro politicians; the rise of Negro politics in Chicago. Chicago, University of Chicago Press, 1935. xxxi, 404 p. (Social science studies, directed by the Social Science Research Committee of the University of Chicago, no. 32) $35-15258$ F $548.9 . \mathrm{N}_{3} \mathrm{G}_{67}$ "Select bibliography": p. $380-387$.

A description of the struggle of a minority group to advance its status by political methods, interpreted to include voting, campaigning, bargaining for jobs and special favors, and office-holding. Much of the information presented has been collected by direct observation, interviews, and casual conversations. Republican, Democratic, and Communist meetings in Chicago's Black Belt have been 
observed, as have the work of party headquarters and the conduct of elections, legislative bodies, courts, and churches. In searching for economic opportunity, in trying to learn business practices, in seeking to run for city-wide elective offices, and in attempting to secure key positions in the party organizations, Negroes have met the obstacle of prejudice. In retaliation they have developed the doctrine and practice of race solidarity. The author mentions County Commissioner Edward Wright, a lawyer, and Congressman Oscar DePriest, a successful contractor and real estate dealer, among the new, aggressive leaders. Ministers as well as leaders of the colored underworld are powerful influences, and patronage is an important cementing agent. However inadequate the benefits secured by Chicago Negroes from their government as of 1935, the author believed their gains to be greater than those of unorganized minorities.

\section{Heard, Alexander. A two-party South?} Chapel Hill, University of North Carolina Press, 1952. xviii, 334 p. illus.

$$
\text { 52-850I } \mathrm{F}_{215} \cdot \mathrm{H}_{43}
$$

An analysis of Southern politics based upon a research project carried out with the aid of the Rockefeller Foundation, the Bureau of Public Administration of the University of Alabama, and the Institute for Research in Social Science of the University of North Carolina, in which the author was the principal associate of Professor V. O. Key, Jr. The project resulted in the preparation of Dr. Key's book, Southern Politics in State and Nation (no. 6378 ), of which this volume is, in a sense, an extension. Much of the information derives from $53^{8}$ interviews conducted between November 1946 and February 1948 with politicians, public officials, and observers of politics in I I Southern States. Professor Heard regards the Negro as the key factor in Southern politics and finds that two sets of influences are affecting Southerners-the forces of change that encourage the growth of a second party, and the forces of stability that retard it. In his opinion, however, much of the South, a changing section in a changing nation, is moving closer to competitive politics.

6377. Kane, Harnett T. Louisiana hayride; the American rehearsal for dictatorship, r 928

1940. New York, Morrow, 194I. 47I p. illus.

$$
4^{I}-7 \text { I } 43 \text { F } 375 . K_{1} 6
$$

A New Orleans newspaperman's vividly written report of the Huey Long regime in Louisiana, "the most complete despotism in the nation's history." Mr. Kane places the beginning in a poor-white upsurge, carefully nurtured by Long with his pleas for free books, good roads, free bridges, and lower utility rates, and his damaging charges against the administration, which put him in the governor's chair in 1928. Although Long (1893-1935), in the author's opinion, did not plan the full extent of his autocracy in advance, he dearly loved power. He differed from other Southern demagogues and spokesmen for the have-nots in his daring, his skills in manipulation, and his ability to snatch what he wanted regardless of the cost. After his impeachment and acquittal, Long began grooming himself for a national audience as a kind of Southern Will Rogers, the author observes, and in $193 \mathrm{I}$, after being elected United States Senator, he ventured upon his first national program, the "drop a crop" plan, which was less extravagant than his later "share the wealth" program, guaranteed to make every man a king. Over half the book is devoted to the regime of the Kingfish's political heirs, who were able to hold onto his powers and his opportunities for plunder for four and a half years after his assassination, and were dislodged only after an investigation by the U.S. Department of Justice had disclosed where the tax money was going.

6378. Key, Valdimer O. Southern politics in state and nation [by] V. O. Key, Jr., with the assistance of Alexander Heard. New York, Knopf, 1949. xxvi, 675 , xiv p. illus.

$$
\text { 49-10825 } \mathrm{F}_{215 . \mathrm{K}_{45} \quad 1949}
$$

An elaborate study of the electoral process in the South, based not only upon election statistics, statutes and constitutions, party rules, court decisions, newspapers, and other standard sources, but also upon interviews with $53^{8}$ Southerners active in public life, including Congressmen, governors and other state officials, state legislators, Democratic and Republican Party officials, campaign managers, precinct leaders, and persons charged with administration of the poll tax, registration, and elections. Many other participants in or observers of the political scene were consulted, among them publishers, editors, and reporters; labor, industrial, and farm organization leaders; plantation owners; small farmers; prominent Negroes; reform leaders; and students of government and politics. The first 12 chapters describe the factional competitions within the Democratic Party in each State. The remainder of the book consists of topical analyses of the oneparty system in operation, the size and composition of the electorate, and the restrictions on voting. Professor Key attributes Southern political regionalism and the special character of Southern political institutions to the Negro, and more particularly to the high-density black belts. The predominant consideration in Southern politics has been to assure 
a local subordination of the Negro population, and to block threatened interferences with the local arrangements from the outside.

6379. Lewinson, Paul. R̉ace, class, \& party; a history of Negro suffrage and white politics in the South. London, New York, Oxford University Press, 1932. $302 \mathrm{p}$.

Bibliography: p. 283-292.

32-10400 JKI929.A2L4

An explanation of the interaction between the racial question on the one hand, and the white class and party struggle on the other, in the South. The author notes the impossibility of telling the story of Negro suffrage in the South without taking account of the political division among the whites into the Bourbons-once planters, later industrialists, financiers, and landlords-and into a class of small farmers and city workingmen; he notes the equal impossibility of understanding white cleavages and issues without reference to the Negro as the common enemy, causing the formation of a solid white front. Part I shows the South as late as 1849 bipartisan in local politics, which were normal in outline but embittered by the social and economic divisions arising from slavery; in 1860 , effectively united to uphold the status quo; from 1867 to 1876 , again bipartisan; from 1876 to the 1890 's, discordant because of the agrarian revolt, with the Negro holding a balance of power between factions; and by $x 900$, reunited once more in a white man's party, with the Negro thrust outside the pale of political activity. Part 2 describes the working of Negro disfranchisement from Igoo to 1930, either by provisions of the state constitution, by the "white primary" rules of the local Democratic parties, or by complicated technical requirements for registration, enforced only against Negroes.

6380. Merriam, Charles Edward. Chicago; a more intimate view of urban politics. New York, Macmillan, 1929. $305 \mathrm{p}$.

29-12608 $\mathrm{F}_{548.5} \cdot \mathrm{M}_{56}$

An optimistic description, in part reminiscence, of some of the more important aspects of the political life of a great metropolitan community, by a University of Chicago professor who served as alderman for six years, and made a good race for mayor in IgIr. The author noted the presence of many interests in the political behavior of the city: those of the great agricultural clearing house, the rail and waterways, manufacturers, bankers, and the Chicago Federation of Labor. Also important to an understanding of Chicago's political attitudes and dispositions, he believed, were its three structural phases: the destruction by fire in $187 \mathrm{I}$ and the "magic rebuilding"; the expansion of the city and creation of the World's Fair in 1893; and the era ushered in by the City Plan of 1907. He pointed out certain forces, notably the reluctance of Illinois to grant Chicago sufficient power to deal with its kaleidoscopic local situation, which made difficult the problem of government organization and standards, and he stressed the importance of the three successive waves of immigration which gave Chicago its ethnological composition. The battle for home rule and the struggle for honesty and competence as against graft and spoils characterized the political history of Chicago to I929. The author analyzed "The Big Fix"-the inner organization designed to control the political situation and to be able to give immunity from the law-and illustrated the operation of actual government by the City Council.

6381. Peel, Roy V. The political clubs of New York City. New York, Putnam, 1935. 360 p. illus. $\quad 35^{-24274}$ JK2295.N74 $\mathrm{P}_{4}$ Bibliography: p. 336-347.

An analysis, which leans heavily on the vocabulary and methods of sociology, of the organization and activities of the political clubs of New York. Its thesis is that the club is the fundamental unit of political organization, provided for neither by state law nor by party rule, nevertheless universally acknowledged as the unit-cell of the major political parties. Clubs are formed, the author maintains, for the purpose of recruiting a stable personnel in the interests of the party organization, but the determination and satisfaction of those interests are left to the party leaders. The clubs and bosses of the metropolitan area have attempted without success to dictate to the state legislature, but in 1935 they did dominate city administration and the local bench. The clubs serve as political forums, stages for political talents, and headquarters for campaigns; they are the "spokes for the wheels of patronage, perquisites and graft"; and, as Professor Peel shows, they have civic, social, charitable, educational, and individual objectives as well, which, so far as the ordinary member is concerned, frequently outweigh the political ones. The author thinks that such clubs, in their present state, are of limited and sometimes dubious value; but that they reflect a true need of men in society and could become the basis of a new territorial reorganization of government.

6382. Riordon, William L. Plunkitt of Tammany Hall; a series of very plain talks on very practical politics, delivered by ex-Senator George Washington Plunkitt, the Tammany philosopher, from his rostrum, the New York County Court- 
House bootblack stand, and recorded by William L. Riordon. Introd. by Roy V. Peel. New York, Knopf, 1948. Ivi, r3I p.

48-8750 JK2319.N57 $\mathrm{R}_{5} \quad 1948$

The political ideals, attitudes, and mores of George Washington Plunkitt (1842-1924), a Tammany ward boss, as recorded by William L. Riordon and originally published in 1905. Plunkitt's techniques are here regarded as eminently practical and his political philosophy is considered typical of the thinking of the machine boss. He secured a few followers who would vote as directed, exchanged their votes with the regular leader in return for influence, specifically jobs and favors, saw that his successes were advertised and drew additional loyal adherents, repeating the process until he was the strongest man in the district. Careful to follow the organizational line, he managed to move quietly to the side of each successive Tammany boss: Tweed, Kelly, Croker, and Murphy. Soon after he entered politics, Plunkitt became wellto-do by using his official position and political contacts to buy land which he could sell at a large profit, to buy surplus public property for a song, and to accept gifts and other tokens of gratitude. A distruster of thinkers, orators, and the merit system in the civil service, he believed firmly in personal loyalty, patronage, human corruptibility, and the philosophy of "every man looking out for himself."

6383. Wooddy, Carroll Hill. The case of Frank L. Smith; a study in representative govern- ment. Chicago, University of Chicago Press, I931. 393 p. illus. 31-9949 F546. W91 A case history of an Illinois election leading to a major scandal, based upon interviews and correspondence with persons affected, as well as published sources and newspaper reports. The author finds "something impressive in the triumph and tragedy" of the career of Frank L. Smith (18671950), who in 1926 was chairman of the Republican State Committee of Illinois and chairman of the Illinois Commerce Commission. Had circumstances decreed that Smith contest for his real ambition, the governorship, rather than for Federal office, or had his senatorial ambitions fallen into a year other than 1926, Dr. Wooddy believes, his case might never have come to light. Because of the scandalous Vare-Pepper-Pinchot primary in Pennsylvania, however, the attention of a Senate investigating committee had been drawn to primary election expenses. Smith's fund was discovered to be not merely excessive (he spent $\$ 253,500$ ), but to have been contributed mainly by the very utility interests over which he held official jurisdiction, and especially by the electric power tycoon, Samuel Insull, who put $\$ 125,000$ in Smith's fund. The Smith case the author views as "merely a reflection of a maladjustment which has resulted from the perpetuation of the mechanisms of frontier democracy in a highly complicated industrialized and urbanized civilization," but he notes that the electorate reacted energetically as soon as information was put before it.

\section{E. Machines and Bosses}

6384. Flynn, Edward J. You're the boss. [Autobiography] New York, Viking Press, 1947. 244 p. 47-30772 Fi28.5.F6 An analysis and defense of machine politics, as well as a report of his own career, by "a reluctant politician" who argues that the "good" machine is both modern and indispensable to American political life. Boss Flynn of the Bronx (1891-1953) described in illuminating detail the organization and operation of the political machine, as well as his rise in public office as a machine stalwart, and in the Democratic Party itself. He served as an assemblyman from Bronx County, N.Y., 1918-21; as sheriff of Bronx County, 1922-25; chamberlain of New York City, 1926-28; and as secretary of state of New York, 1929-39. These public offices were clearly minor phases of his career. Mr. Flynn took far greater pleasure and wielded far more power in his positions as leader of the Bronx County Democratic Committee, 1922-53; national committeeman from the state of New York, 1930-53; and as chairman, Democratic National Committee, 1940-42. The book is a sincere justification of organization politics, marked by a calm acceptance of the use of patronage to obtain and maintain party fealty, of the absolute power of the county boss, the spoils system, rigidity of organization, and severely disciplined party regularity. To the author, the primary purpose of the party is to win elections; he therefore tends to equate party success with good government. It is hardly necessary to say that Flynn was an unusual sort of boss.

6385. Gosnell, Harold F. Boss Platt and his New York machine; a study of the political leadership of Thomas C. Platt, Theodore Roosevelt, 
and others. Chicago, University of Chicago Press, 1924. xxiv, $370 \mathrm{p}$. illus. 24-2633 FI24.G68

A description of the social, economic, and political background, the personal qualities, training, achievements, and techniques of Thomas Collier Platt (1833-1910), a typical State political boss who reached a position of leadership in the New York Republican Party in 1889 , and gained control of it in the middle 189o's when Theodore Roosevelt was coming into national attention. Professor Gosnell sho ws how Platt lost control of important elements of the organization step by step from $190 \mathrm{or}$ to 1904 , and retired, a broken old man, from the United States Senate in 1909, the year Roosevelt also ended his official career. In the author's opinion, Platt was primarily the keeper and guardian of a set of political traditions and devices to which he had fallen heir and which he had seen tested and exploited, whereas Roosevelt, with whom he maintained political relations for more than 20 years, was the popularizer of a new order. By Igoo, Platt, who "had had his difficulties with Governor Roosevelt," imagined him safely shelved in the Vice Presidency, but the latter, as Professor Gosnell shows, set out to capture the organization and succeeded when he became President. Until he did so, however, "the Easy Boss was able to cling to his place as an agent of the propertied classes, a retailer of franchises, government contracts, and special legislation."

6386. Gosnell, Harold F. Machine politics: Chicago model. Chicago, University of Chicago Press, 1937. xx, 229 p. illus. (Social science studies, directed by the Social Science Research Committee of the University of Chicago, no. 33 [i.e. 34])

37-20974 JS708.G6

Bibliography: p. 214-219.

A study of political behavior patterns in Chicago, particularly as exemplified in the workings of the party machines, the characteristics of party workers, voting behavior, and the political effectiveness of newspapers. It is based upon personal interviews, files of Chicago newspapers, observation of political meetings and election-day activities, participation in court trials, and upon the author's experience as an active party worker. The book aims to find the reasons why Chicago politics underwent so few fundamental changes during the profound economic crisis and changes of the years $1928-36$. As Dr. Gosnell points out, at the beginning of 1928 the two major parties were fairly evenly, if delicately, balanced, with the Republicans in possession of the city hall, yet by 1936 the Democrats were in complete control of all government agencies elected or represented in the Chicago area. The national policies of the Democratic Party made its local leaders supreme in Chicago, but did not effect any great change of individuals, or disturb their concentration upon jobs and spoils to the exclusion of genuine municipal issues. The author attributes the persistence of boss rule to a variety of factors including an unfavorable press situation, a dearth of civic leadership, and the impartial beneficences of Samuel Insull to both parties.

6387. Lynch, Denis Tilden. "Boss" Tweed; the story of a grim generation. New York, Boni \& Liveright, 1927. 433 p. illus.

Bibliography: p. 419-423.

$27-20559 \quad F_{128.47} \cdot T_{96}$

A breezy history of the political life and times of William Marcy Tweed (1823-1878), the "monumental" rogue who became boss of Tammany Hall, and master of the entire machinery of the New York state government-executive, legislative, and judicial-and who, in the author's opinion, "wanted to control the Nation as he did the State." Knowing the corruption of contemporary politics and determined to succeed, he entered it in 1852 as a Tammany alderman on the Common Council of New York City which was later known as "The Forty Thieves." Mr. Lynch describes Tweed's success, in this and other offices, at manipulating city purchases and sales, offering and accepting bribes, and making himself powerful by placing his friends in key positions. He shows Tweed's methods of operation, from the use of strong-arm thugs, repeaters, and newly naturalized immigrants at the polls to the employment of Republican leaders upon his own or the city's payrolls. The Tweed Ring proper did not begin its operations until Jan. I, 1869 , and lasted less than three years, but during this time it helped itself to some $\$ 45$ million, and cost the city of New York as much as $\$ 200$ million. Mr. Lynch credits the unbought part of the metropolitan press, and especially the New York Times under the editorship of George Jones, with arousing the public against the Ring, and so destroying it in 1871 .

6388. McKean, Dayton David. The Boss; the Hague machine in action. Boston, Houghton Mifflin, 1940. xvii, $284 \mathrm{p}$.

$$
\text { 40-32284 } \mathrm{Fr}_{44} \cdot \mathrm{J}_{5} \mathrm{H}_{3}
$$

An effort to explain how "a ruthless, two-fisted, unscrupulous, unlettered Irishman," Frank Hague (1876-1956), mayor of Jersey City, N.J., 1917-47, and his associates came to power in their municipality and Hudson County, and how their machine operated. Elected constable in 1897, and commissioner and director of public safety in $19 \mathrm{r} 3$, Hague "made his way upward through the armed forces of his community," especially through manipulating 
the Police Department. In Professor McKean's opinion, no other American political machine has approached the Hague organization in the completeness of its control over its territory. This Democratic organization controlled newspapers, taming an opposition journal by advertising boycotts and increased property assessments, and bought off or intimidated opposition leaders. Alone among American city machines, it "systematically and successfully utilized the methods of terrorism, the infiltration of groups and associations, the suppression of criticism, and the hierarchical principle of leadership that have characterized the fascist régimes in Europe." The author charges the machine with wiretapping, tampering with the mails, spying, false arrests, and beatings. The Hague regime survived the publication of Professor McKean's book, by seven years in the city, and by nine in the state.

6389. Salter, John T. Boss rule; portraits in city politics. New York, Whittlesey House, McGraw-Hill, I935. 270 p. 35-8152 JS I $268 . S_{3}$

A survey of the workings of the Republican organization of Philadelphia drawn from the oral narratives of the ward leaders themselves. The author has attempted a scientific study of the politician, first in general terms, then through a group of nine individual sketches from life, selected as being typical of widely differing kinds of division or precinct leaders. The defeat of the party in the election of November 7,1933 , is described, and the book concludes with predictions about the probable future of the Republican organization in Philadelphia as of 1935, together with suggestions of devices for better government. Professor Salter says that, however diverse in training, character, and ability urban politicians may be, they have in common the one function of service to their neighbors. To this personal service powerful metropolitan party organizations owe much of their strength. This strength is greatest where needs are most compelling, where there is most poverty, most unemployment, most conflict with the law, in districts more often than not inhabited by a majority of the foreign-born or of Negroes. The work of the party organization centers in the simplest creature wants-jobs, food, justice (or mercy or favoritism), and taxes-and in it, as in elections, the most vital factor is the division leader, who acts as "the personal sales agent of the party." Another study of the same machine, David Harold Kurtzman's Methods of Controlling Votes in Philadelphia (Philadelphia, 1935. 173 p.), originated as a University of Pennsylvania dissertation. It surveys the methods whereby the Philadelphia Republican organization has controlled votes, among them use of the public payrolls, magistrates' courts, and police; the personal contacts of the division leader; favors extended through real estate assessment, mercantile appraisal, and inspection of weights and measures; and control of the election mechanism.

6390. Van Devander, Charles W. The big bosses. [New York] Howell, Soskin, 1944. 318 p. 44-3308 JK2249. V3

A journalist's candid report on the operations of the major American political machines and their leaders, down to 1944. In some detail, Mr. Van Devander discusses the workings of: New York's Democratic Tammany Hall, the Republican state machine, and the O'Connell ring which preserved Albany and Albany County for the Democrats; the Democratic Hague machine of Jersey City, which, in 25 years "had become a way of life"; the highly organized Massachusetts Republican machine; the Republican Grundy machine of Pennsylvania; the Democratic Kelly-Nash machine of Chicago; and the Democratic organizations of the South-the absolute and arbitrary Crump machine of Tennessee, the Long dictatorship of Louisiana, the Lister Hill organization of Alabama, the Pendergast machine of Missouri. The record is full of patronage, favors, graft, deals, exposure and counterexposure, padded registrations and stuffed ballot boxes, manipulations of tax assessments, frameups, and salary assessments. Connections are found to such profitable sidelines as numbers lotteries, gambling rackets, and racing syndicates. The author notes the absence of machine politics in California, and comments upon the relation between the organizations and the realistic Franklin D. Roosevelt, who exchanged mutual aid with the machines that supported him and fought those that opposed.

6391. Zink, Harold. City bosses in the United States; a study of twenty municipal bosses. Durham, N.C., Duke University Press, I930. 371 p. illus. 30-31996 JS309.Z5

An analysis of the characteristics and careers of twenty municipal bosses of the 19th and 2oth centuries, selected on a basis of geographical distribution and party affiliation. Included are Democratic and Republican bosses, the boss who veers from party to party, the boss who begins as a reformer or who becomes one, the "political hermaphrodite," the lone boss, and the boss who heads a long-established, efficient machine, together with a few who, though influential, have never entirely controlled a city. Although Professor Zink has made some use of books and documents, he has drawn most of his information from newspapers and from interviews with "relatives, associates, and enemies." 
An introductory section considers the personal characteristics of city bosses, their domestic, social, business, and political relations, as well as their several methods of reaching the top. The remainder of the book is devoted to vignettes of the selected bosses, among them "Czar" Martin Lomasney of Boston, "Big Tim" Sullivan of the Bowery, Martin Behrman of New Orleans, "The Genial Doctor"
Albert A. Ames of Minneapolis, and Abraham Ruef of San Francisco. Professor Zink finds no typical boss but does observe a frequent occurrence of certain circumstances and traits, such as early residence in the city dominated, American birth of foreignborn parents, a poverty-stricken urban background, generosity to the poor, loyalty to faithful henchmen, persistence, and courage.

\section{F. Pressures}

6392. Chase, Stuart. Democracy under pressure; special interests vs the public welfare; guide lines to America's future as reported to the Twentieth Century Fund. New York, Twentieth Century Fund, 1945. I42 p. (His When the war ends [4])

45-922 JK I I 18. 4

A brief and lucid popular analysis of the pressures exerted upon Congress in 1944 by the lobbyists of big business, big agriculture, and big labor. Mr. Chase locates the heart of these big business pressures in the National Association of Manufacturers, the heart of small business pressures in the U.S. Chamber of Commerce, and of particular industries in their own organizations such as the American Iron and Steel Institute. He finds these business pressure groups oblivious to the interest of the public, their own consumers, and their own workers. Corporate financial interest has been their major concern, leading them to seek monopolistic advantages, subsidies, or both. Mr. Chase does not find much greater concern for the public interest among the best organized labor unions or "the farm bloc folks." He fears for free enterprise and free markets, but believes that the fundamental trouble with monopoly is neither greed nor arbitrary power but restriction of output. In his opinion, if output needs to be restricted, the state is the legitimate agent rather than big business, big union, or the Farm Bureau Federation. Considering the great changes of the postwar period, it is remarkable how much of Mr. Chase's analysis is still pertinent.

6393. Crawford, Kenneth G. The pressure boys; the inside story of lobbying in America. New York, Messner, 1939. $308 \mathrm{p}$.

\section{$39^{-27853} \mathrm{JK}$ II $8 . \mathrm{C}_{7}$}

A Washington newspaperman's prewar view of lobbyists, "who may be peddlers of personal influence, paid propagandists or amateurs promoting causes in which they sincerely believe," and who, collectively, "constitute a sort of phantom fourth branch of the government." Employed by private property interests, the majority devote "enormous energies and considerable talents" primarily to the protection of property, "sometimes by fair means and sometimes not." Private property is overprotected by the lobbies, the author contends; it has not hesitated to corrupt government in order to preserve or extend its advantages; and it exercises more influence upon Congress than its voting strength justifies in a representative democracy. Although Mr. Crawford does not attribute all of the ills of democracy to the property lobby, particularly business interests, he accuses it of swinging congressional votes in return for campaign contributions, promises, or threats; of possessing an influential system of propaganda, organized deceit, and skillful perversion of democratic processes; and of ruthlessly exercising economic power to achieve political ends. The property lobby's singleness of purpose-the protection or advancement of profits-and its uncomplicated selfishness give it enormous drive. The author provides illustrative case histories, but, unfortunately, no index.

6394. Gaer, Joseph. The first round; the story of the CIO Political Action Committee. New York, Duell, Sloan \& Pearce, 1944. xv, 478 p. illus. $44-51287 \quad$ E8 $12 . G_{3}$

Intended to preserve the credos and early propaganda tools of the CIO Political Action Committee, this is a reprinting of most of the pamphlets and manuals issued by the committee during its first year. Joseph Gaer, who has been a staff member, sets forth the events leading to the formation of the PAC at the beginning of 1944, the motivations of its activities, and the sources of its strength. Sidney Hillman is credited here with being the moving force, and Philip Murray with being the founder and establisher of basic policy. The organization was created "to protect the political rights of the working man, as well as the rights of the returning soldier, the farmer, the small business man, and the so-called 'common man'." Planning for full 
postwar employment at fair wages became the committee's primary policy. Full participation in the I944 elections was regarded as the first step toward this objective, and the PAC set as its primary task getting out the vote for its approved candidates throughout the nation. The pamphlets consist of campaign literature, illustrated largely with pictographs. The guides for its own workers include such titles as: "The Radio Handbook," "The Speakers Manual," and "A Woman's Guide to Political Action." A record registration was in fact achieved.

6395. McKean, Dayton David. Pressures on the Legislature of New Jersey. New York, Columbia University Press, 1938. 251 p. (Columbia University. Faculty of Political Science. Studies in history, economics and public law, no. 440) $3^{8-2393^{8}} \mathrm{JK}_{2498 . \mathrm{N}_{5} \mathrm{M}_{2}}$ I938a $\mathrm{H}_{3} \mathrm{I}_{7}$, no. 440

A realistic study of New Jersey politics and the force that makes the State government functionthe lobby. The author, a former New Jersey assemblyman, views a State legislature as a kind of battleground for the various interests of the State. The first three chapters show what these interests are: business-especially the Public Service Corporation of New Jersey and its gadfly, the Utility Users' Protective League of New Jersey-labor, agriculture, professional groups, religious groups, public employees, veterans, women's organizations, motorists, public education groups, and reform groups. Next analyzed in some detail are the internal affairs, membership, structure, financing, and goals of seven important and representative organizations, such as the New Jersey State Federation of Labor. The author then examines pressures from other branches of the State government, and group and party politics as they were fought out on the sales tax of 1935. Later chapters explore the methods and effectiveness of pressure groups which seek the nomination of friendly candidates and endeavor to have them bound by platform planks, personal pledges, and campaign contributions. The groups attempt to draw out the vote for men of approved pledges or records, and to influence legislation by providing information, drafting and guiding bills, and communicating arguments, promises, and threats to the legislators. Dr. McKean thinks that 90 percent of the legislature's acts are accounted for by pressures, but finds no way of measuring their effectiveness.

6396. Schattschneider, Elmer E. Politics, pressures, and the tariff; a study of free private enterprise in pressure politics, as shown in the 1929-1930 revision of the tariff. New York, Pren-
tice-Hall, 1935. 301 p. (Prentice-Hall political science series) 35-29634 HF $\mathrm{HF}_{1756 . \mathrm{S}_{3} 8} 1935$

Thesis (Ph. D.)-Columbia University, 1935.

A study of the political behavior of economic groups in making the Smoot-Hawley protective tariff of 1929-30, based upon the nearly 20,000 pages of testimony taken by the Senate Committee on Finance and the House Committee on Ways and Means. So as to observe the relation between economic interest and political activity on a broad scale, Dr. Schattschneider has analyzed the elementary and immediate interests affected by a large number of individual duties established in the law. He attempts to characterize the activity of pressure groups in the case of one major public policy, and to measure its strength, its direction, and variability, as well as to note the manner in which it is deflected and controlled. He finds that immediate active interests bring an intense pressure to obtain a protective duty; the indirect adverse interests remain inert and sluggish, and make no effective opposition. A few can exert great influence on the process of government because they are organized, are alert, have access to information, and know what they want; the mass remains apathetic. The protective tariff was made high by combining a multitude of interests in an omnibus piece of legislation.

6397. Schriftgiesser, Karl. The lobbyists; the art and business of influencing lawmakers. Boston, Little, Brown, r95 r. xiv, 297 p.

Bibliography: p. [273]-28r.

$$
\text { 5I-I2266 JKIII8.S }
$$

A history of lobbying as it has developed from the days of the Boston Tea Party and even simpler forms of persuasion down to I951. Mr. Schriftgiesser, who considers that lobbying may be either good or evil, attempts to show how it has become an integral part of the democratic legislative process. Much of his story is concerned with the Regulation of Lobbying Act, passed by Congress as part of the Legislative Reorganization Act in 1946. He goes into the passage of this act, the subsequent adherence to or evasion of its principles, and what can be learned from the information filed with Congress by those who come under its provisions. His object is to show the extent of lobbying both in Washington and elsewhere in the country, and to bring together the detailed information gathered by the House Select Committee on Lobbying Activities in 1950. His summary of the latter is probably his chief contribution. The danger remains that a quite small interest group may, by sheer vociferousness and persistence, have an effect on legislation far in excess of its own importance. Mr. Schriftgiesser believes in the unhindered right of petition, but believes also that anyone who petitions the gov- 
ernment for redress of grievance "should stand up and say who he is, and what he wants, why he wants it, and who paid his way."

6398. Turner, Julius. Party and constituency: pressures on Congress. Baltimore, Johns Hopkins Press, 1951 [i. e. I952] I90 p. (The Johns Hopkins University studies in historical and political science, ser. 69 , no. I)

$$
\begin{gathered}
\text { 52-839 JK 2265.T87 } \\
\text { H3I.J6, ser. 69, no. I }
\end{gathered}
$$

An attempt to measure, by quantitative methods, the effectiveness of pressures upon Congressmen from their political parties and constituencies. Dr. Turner has chosen four sessions for roll call analysis: I921, when the Republicans held a strong majority in the House and had captured the Presidency after eight years of Democratic rule; 1930-31, when the Republicans held a slight majority and were "faltering under President Hoover"; 1937, when the Democrats held three-quarters of the House after the Roosevelt landslide but were beginning to divide on the New Deal; and 1944, when the Democrats organized Congress but were so closely followed by the Republicans that the number of absentees determined the majority at any given time. In his opinion, the roll call record is "an accurate summation of the effectiveness of the pressure of various groups on each congressman, on those issues which are important enough or controversial enough so that a part of the membership wants a record kept of the vote for an ensuing election campaign." The great majority of Representatives, he concludes, yield to the pressures from their constituencies and especially to party pressures in casting their votes. Those who do not, especially if they are Republicans, are unlikely to achieve longevity in office.
"The American Congress is . . . a mirror of political pressure."

6399. Zeller, Belle. Pressure politics in New York; a study of group representation before the legislature. New York, Prentice-Hall, r937. 3 Io p. (Prentice-Hall political science series)

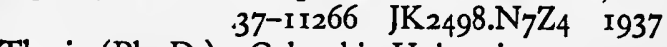

Thesis (Ph. D.) - Columbia University, 1937.

An analysis of the activities of the more important statewide pressure groups in New York and of their influence upon legislative policy, together with suggestions for solutions to some of the more pressing problems thereby created. Group pressures stem from three major sources, Miss Zeller foundlabor, business, and agriculture-as well as from a host of minor sources. The most vigorous pressure exerted at Albany was on behalf of labor legislation, particularly by the New York State Federation of Labor, the Women's Trade Union League of New York, and the Consumers' League of New York. Also engaged in a continuing battle for legislative influence were a score or more lobby groups representing money interests, industry, and agriculture, notably the Real Estate Association of the State of New York, the New York State Bankers Association, the Association of Life Insurance Presidents, Associated Industries, Inc., the Empire State Gas and Electric Association, and the New York State Conference Board of Farm Organizations. Labor groups have always secured greater assistance from Democratic administrations, industrial groups from Republican. To Miss Zeller, the outstanding feature of pressure-group technique is the use of mass propaganda channels for building support both within and outside the interest group itself long before the direct attack on the legislature begins.

\section{G. Elections: Machinery}

6400. Albright, Spencer D. The American ballot. Washington, American Council on Public Affairs, 1942. I53 p. 42-25091 JK2215.A6 Bibliography: p. 146-148.

A minute analysis and comparison of ballot forms which were in use in the United States, particularly during the I930's, both in general and in primary elections. As Dr. Albright points out, by the middle of the igth century ballot papers had become subject to legislation as to color, number, size, uniformity, and methods of marking and depositing. The majority of American states had, by the turn of the century, adopted the Australian ballot system in a modified form. Under the new system, here regarded as a fundamental advance, voting was elaborately regulated by the State. The ballots were printed and distributed by designated authorities, marked and deposited on election day within a polling place under the supervision of the proper officials, and canvassed according to law. In the 2oth century, almost continuous amendment of the ballot laws has been the rule, in many instances for the better. The author thinks that a general improvement has resulted from the voting-machine laws of the decade 1930-40; the machines are reliable and meet the needs of all elections including 
primaries. The voting public, he believed in 1942, was becoming aware of the advantages of the machine: the ease and speed with which the vote is recorded, as well as the economies made possible by the reduction in printing costs, personnel, supplies, and rental of polling places (through consolidation of precincts), and the elimination of recounts.

6401. Bishop, Cortlandt F. History of elections in the American Colonies. New York, Columbia College, 1893. 297 p. (Columbia University. Faculty of Political Science. Studies in history, economics and public law, v. 3, no. I)

$$
\text { 4-184I JK97.A3B6I }
$$$$
\mathrm{H}_{3} \mathrm{I} \cdot \mathrm{C}_{7}, \mathrm{v} \cdot 3
$$

"Authorities quoted": p. [289]-295.

This pioneer study, based upon a thorough examination of the statutes of the Thirteen Colonies, was so solidly done that it has been relied upon ever since. Dr. Bishop dealt first with general elections, and noted that they were in use in every colony, at least for constituting a legislative assembly, beginning with Virginia's choice of a House of Burgesses in I6rg. New York had to wait the longest, for neither the Dutch West India Company nor the Duke of York (the future King James II) cared for popular elections, and notwithstanding several anticipations there was no regular assembly until 1691 . Dr. Bishop next analyzed the qualifications for the suffrage in use throughout the period, noting the moral and religious ones which did not survive the Revolution. The chapter on "The Management of Elections" is full of concrete detail on such matters as the publication of the election writ, the hours of election, the method of taking the vote, and provisions against fraud; there is no such convenient accumulation of precise information for post-colonial elections. A briefer section deals with town, parish, and municipal elections, and the suffrage and management regulations which governed them. Appendixes print specimen writs, returns, and oaths, and some unpublished election statutes turned up in the author's researches.

6402. De Grazia, Alfred. Public and republic; political representation in America. New York, Knopf, 1951. xiii, 262, ix p.

Bibliography: p. 259-262.

$$
5 \mathrm{I}-954^{\circ} \quad \mathrm{JK}_{1} 846 . \mathrm{D}_{4} \quad \mathrm{I} 95 \mathrm{I}
$$

A description and a closely reasoned analysis of the major currents of political belief and practice during the last three centuries, each with its own interpretation of man and society and each with its own scheme of political representation. Dr. De Grazia cites the majority principle, universal suffrage, a real-property qualification for holding office, instruction of representatives by constituents, and proportional representation as among proposed means of obtaining a governmént to fulfill men's desires and to realize their values. He attempts to show how and why rich and poor, religious and political sects, and urban and rural populations have held differing views of representation. He isolates clusters of ideas about representation, traces their ancestry and history, and points out where some weakened and others grew strong, where some elements were incorporated into other groups, and where some died out. Beginning with English ideas of representation in the two centuries after Elizabeth I, the author traces the development of the American representative principle through three main forms: the ideas of direct representation, enlightened individualism, and pluralism, with power-clusters in a corporation-dominated society.

6403. Harris, Joseph P. Registration of voters in the United States. Washington, Brookings Institution, 1929. xviii, 390 p. ([Brookings Institution, Washington, D. C.] Institute for Government Research. Studies in administration [no. 23]) 29-17775 $\mathrm{JK}_{21} 6_{4} \cdot \mathrm{A}_{2} \mathrm{H}_{3}$ "Select bibliography": p. 383-385.

6404. Harris, Joseph P. Election administration in the United States. Washington, Brookings Institution, 1934. 453 p. ([Brookings Institution, Washington, D. C.] Institute for Government Research. Studies in administration, no. 27) 34-5509 $\mathrm{JK}_{1976 . \mathrm{H}_{3}}$

Registration of Voters in the United States is an analytical survey of American registration systems, based upon a 15-month field study of the legal provisions governing the several registration systems of the States and the practical workings of those systems, which included interviews with persons both in and outside registration offices who were acquainted with local political situations, organizations, and methods. Effort was made to secure information not only upon all phases of administration but also upon the general problems of registration. The author found no system absolutely satisfactory, nor did he expect to, since he considered no single system ideal for every State. He commended California for the most satisfactory system of records, Milwaukee and Minneapolis for the best transfer system, Omaha for the best canvass system, Boston for the best census of adults, and Detroit and St. Louis for the best method of selecting precinct officers. Dr. Harris regarded voter registration as essential to prevent frauds and therefore "the very foundation upon which an honest election system must rest." If properly adminis- 
tered, it may be an economical operation of no inconvenience to the mass of voters. He recommended permanent registration, whereby the voter remains registered so long as he remains at the same address, with the provision of certain safeguards. Based on a field study undertaken during 1929 and 1930, Election Administration in the United States continues Professor Harris' survey of the electoral process and describes the system then in operation in America for the casting and counting of ballots, and the canvassing and declaration of the result. Emphasis is placed upon the practical operation of election laws rather than upon the provisions of the statutes, although the latter were studied. Interviews were held with chief election officers and with politically informed persons outside the election office. The author undertook the study because in his opinion no other phase of public administration in the United States had been so badly managed as the conduct of elections, in which have regularly occurred "glaring irregularities, errors, misconduct on the part of precinct officers, disregard of election laws and instructions, slipshod practices, and downright frauds." Yet democratic government is completely dependent upon honestly and efficiently conducted elections. Dr. Harris called for a general revision of State election laws, a reorganization of election machinery, and improvements in election management-especially in the practice of the party machines in staffing election boards with their hacks. He offered "a model election administration code" ( $p$. 77-94). Voting machines are expensive but desirable "if properly used, and the limitations of the machines recognized."

6405. McGovney, Dudley O. The American suffrage medley; the need for a national uniform suffrage. Chicago, University of Chicago Press, 1949. $201 \mathrm{p}$. 49-9160 JKI853.M25 McGovney, a California professor of law, died in r 947 leaving the manuscript of this plea for the establishment of a uniform national suffrage. The control of suffrage requirements by the states, he believed, was a survival from the Colonial period, when the British settlers were "accustomed to the idea of restricting the suffrage to the upper economic levels" and to a medley of voting qualifications in electing members of the House of Commons. Since the framers of the Constitution made no alteration here, the adoption of universal suffrage has been piecemeal and incomplete. At the time of writing 5 States had rudiments of the old property qualifications; 7 had a poll-tax requirement; I 8 had educational requirements of a great variety, adopted for a variety of reasons; and 36 imposed a permanent disfranchisement upon persons sentenced to prison. Politicians, McGovney thought, have been able to use these survivals so as to interfere seriously with the democratic process. He proposed a constitutional amendment limiting suffrage requirements, for primaries as well as final elections, to adulthood, citizenship, and residence in a State for six months and in the precinct for three; and disfranchising only for insanity and for the duration of imprisonment.

\section{Merriam, Charles Edward, and Louise} Overacker. Primary elections. Chicago, University of Chicago Press, I928. 448 p.

First published in 1908.

$$
\text { 28-I49II JK2074.M5 } 1928
$$

"Bibliography and Sources of statistical material for primary and general election returns": p. 405427.

The development of legal regulation of the nominating process in the United States forms the subject of this history and analysis. The authors trace the expansion of regulation from the establishment of the representative party system, the general adoption of the delegate convention system, and the victory of universal male suffrage in the 1830's to the introduction of the mandatory, legally protected, direct primary during the first two decades of the 2oth century, with a noticeable reaction against it in the I920's. Inquiring into the attitude of the judiciary toward primary legislation, the authors find a recognition of the right of the legislature to regulate in some detail the method of voting, and an unwillingness to sustain the claims of the party, as a voluntary political organization, to regulate its own internal affairs. They consider the direct primary a weapon for the voter, a means to challenge or overthrow a corrupt or unrepresentative organization, and of especial significance to the one-party States where nominations are tantamount to elections. Among the improvements in nominating methods suggested by the authors are a reduction in the number of elective officers (why elect a coroner or a surveyor?), and limiting the popular choice to major executive officers concerned with the formulation of public policies. A long appendix (p. 359-404) summarizes the primary laws of each State (as of 1928).

6407. Overacker, Louise. Money in elections. Largely from material collected by Victor J. West. New York, Macmillan, 1932. 476 p. ([Parties and practical politics series])

$$
\text { 32-29858 JKig91.O7 }
$$

"Selected bibliography": p. 419-459.

"The present study is primarily concerned with the use of money in elections in the United States, the attempts to regulate such use, the operation of these regulations, and the possibility of more effec- 
tive control." Professor Overacker, who took over the research materials left by Professor V. J. West of Stanford University at his death in 1927 , defines elections to include primaries as well as general elections, and defines money to include the things money will buy and actual bribes. She is concerned with the raising, spending, and regulating of the money which influences voters in casting their ballots for or against certain candidates. Among expenditures, she lists general overhead of the headquarters offices, salaries and transportation for field activities, funds for publicity, and grants to subsidiary organizations by the national committees. Election-day expenditures, she observes, can smack unpleasantly of bribery. These she would eliminate by legal prohibitions or have them shouldered by the State or by nonparty groups. Since she finds a correlation between votes received and even "legitimate" funds spent, she would limit the size as well as the purpose of the latter, and throw pre-election publicity upon the amount and character of expenditures by all candidates, parties, and organizations involved. As of 1932, attempts to limit contributions and expenditures had been "nothing short of farcical."

6408. Overacker, Louise. The Presidential primary. New York, Macmillan, 1926. 308 p. ([Parties and practical politics series])

Bibliography: p. 277-294.

$$
\text { 26-6444 JK } 522.08
$$

An analysis, a comparison, and an evaluation of the 26 [as of 1926] State laws enacted to provide direct popular control of Presidential nominations through the election of delegates to national conventions, or a preference vote for President, or both. The functionings of the various types of Presidential primary were compared, and the author attempted to determine whether the combined effect of these laws upon the Presidential nominating process weakened or strengthened it. Although emphasis was placed upon the operation of existing State laws, consideration was given to various proposals for a national primary law, and suggestions were made for drafting an effective one. The author regarded the Presidential primary as part of the general movement for more democratic control of the American government and, in its concrete aspect, as an attempt to give the people some say in the election of their President, and to secure party responsibility. She found the effectiveness of the Presidential primary laws limited by faulty construction, lack of uniformity, and especially by the fact that they existed in so few States. She suggested extension of the system to all or most States, either through State or national action. Since 1926 the system has declined, however, until at present only 14 States have mandatory Presidential primaries, and in only a minority of these are the delegates pledged by the result.

6409. Porter, Kirk H. A history of suffrage in the United States. Chicago, University of Chicago Press, 1918. $260 \mathrm{p}$.

Issued also as thesis (Ph. D.) University of Chicago.

A history of the right to vote since 1776 , emphasizing the expansion of the suffrage by the gradual inclusion of groups to whom it was originally denied, presenting the general picture and the motivating ideals rather than the technicalities and local variations, and based primarily upon the debates in state constitutional conventions. For all its proclamation of natural rights, the American Revolution did not greatly alter the franchise restrictions prevailing in the later Colonial period, and when the Constitution was adopted voting was still confined to a small group of property owners and taxpayers. Dr. Porter traces the weakening and practically complete elimination of property tests; North Carolina did not abandon hers until 1856 , while two states, at the time of writing, had never given up a small taxpaying requirement. After the enfranchisement of the unpropertied, controversy in the realm became concerned with votes for free $\mathrm{Ne}$ groes and eventually for all Negroes, for aliens, and for women. While the general movement has been, however jerkily, in the direction of universal suffrage, the years from 1877 to 1904 saw a complete disfranchisement of Negroes in all the Southern states. Dr. Porter wrote shortly before the adoption of the Igth Amendment, when only 12 states had enacted full woman suffrage, and he anticipated a much longer and harder struggle for its passage than was about to take place.

6410. Sikes, Earl R. State and Federal corruptpractices legislation. Durham, N.C., Duke University Press, I928. $321 \mathrm{p}$.

Bibliography: p. 292-314.

$$
\text { 28-16725 JKI994.S6 }
$$

This Cornell University dissertation is a survey of the corrupt-practices legislation enacted in the United States to 1928 by both State and Federal governments, and an examination of the construction placed upon the statutes by judicial interpretation. Chapters $\mathrm{I}-3$ consider statutory prohibitions against corrupt inducements to voters, against their intimidation, and against fraudulent practices by voters on the one hand and by election officials on the other. Chapter 4 deals with State regula. tion of various forms of campaign literature. Chapter 5 reports on State legislation requiring publicity 
for campaign contributions and expenditures, prohibiting or restricting certain types of contributions, and regulating expenditures in campaigns. Chapters 6 and 7 are concerned with the regulation of elections by the Federal Government; 6 defines the division of power between the Federal and State governments over the control of elections, and 7 surveys Federal corrupt-practices legislation. Despite the stringent legislation enacted against abuses of the elective franchise from the I89o's, the worst evils did not appear, in 1928, to have been corrected. In the author's opinion, the increasing complexity of the electoral machinery, the rapid industrial and commercial development of the country, and the indifference of the public all contributed to domination by great political machines.

64ri. Wilmerding, Lucius. The electoral college. New Brunswick, N. J., Rutgers University Press, 1958. 224 p. 58-6290 JK529.W64 An explanation of proposals for reform as well as an historical outline and a critique of the system provided by the Constitution for electing the President through the agency of intermediate electors, or, in certain contingencies, through the votes of the House of Representatives. Dr. Wilmerding regards the former process as an "artificial and delusive system," because each candidate is given the unanimous and undivided electoral vote of every State where he has a plurality of the popular votes, receiving nothing from the remaining States. In each State, therefore, "a large minority of the people is made precisely equal to no minority at all and a bare plurality is made equal to the whole." An election by the House of Representatives he considers still further removed from an election by the people at large, since the representation of each State, regardless of its size, is given one vote which it casts according to the sense of its own majority. Yet the purpose of the Constitution, he believes, is "to elevate to the executive chair the man who is the choice of the majority of the people in the nation as a whole"; that intention having been defeated, the Presidency has been put on a federative rather than a national basis. The author, in arguing for electoral reform, expresses his preference for a system which would put the Presidential election upon a sound popular basis and a practical footing.

\section{H. Elections: Results}

6412. Bean, Louis H. Ballot behavior; a study of presidential elections. Washington, American Council on Public Affairs, 1940. 102 p. illus. 40-3449I JKIg67.B4

64r3. Bean, Louis $H$. How to predict elections. New York, Knopf, 1948. ig6 p. illus.

48-3I7I JK2007.B4

Ballot Behavior is a survey of 40 years (18961936) of Presidential election history for each of the 48 States, based upon political statistics from States, counties, and cities. Among the author's results are: the discovery of a number of States which go as the nation goes; a method of measuring political trends; the effect of business conditions on these trends; and a schedule of relationship between the national popular vote and the state electoral votes, by which national polls may be translated into a probable electoral lineup of the 48 States. Mr. Bean presents not a method of forecasting elections but basic facts so organized as to serve as a foundation for judgment. He offers analyses and data, leaving the reader to judge for himself. He does discern a fairly systematic pattern of behavior in the United States. A given national political shift has its reflection, he believes, to varying degrees, in each of the States and in a great many counties. Upon this theory, the behavior of one State may be translated into the corresponding behavior of the nation as a whole and then into the corresponding behavior of the other 47 States. Mr. Bean offers many tables and diagrams to indicate political patterns and tides. A companion volume, How to Predict Elections, reports the results of further research into voting statistics. Although less attention is given to theory and procedure, the method of analysis remains the same, and the findings and forecasts are again offered with reserve. The author continues to believe that "voting behavior, portrayed statistically, offers valuable keys to an explanation of the marked swings in American politics and helps to form a basis for judging political trends in the immediate future." Political tides over a period of years are represented here by the changing percentage of the Presidential vote cast in successive elections by the Democratic Party, or the proportion of the House or Senate seats won by either party. Most of the factors which have dominated elections from 1928 to 1946, years of "the New Deal tide," are treated separately, first historically, and later in relation to the 1946 and future elections. 
6414. Berelson, Bernard R., Paul F. Lazarsfeld, and William N. McPhee. Voting; a study of opinion formation in a Presidential campaign. [Chicago] University of Chicago Press, 1954. xix, 395 p. illus. $\quad 54-I_{1205} J_{52}$ I948. $_{4}$ An intensive study of the voting behavior of an American town, Elmira, N.Y., in the Presidential contest of 1948 between President Truman and Governor Dewey. The authors employed the socalled panel method of interviewing a representative sample of respondents before the political campaign began, during it, and after it. The main purpose was to analyze a developing process through repeated interviews with the respondentsin this case, approximately 1,000 . Both the social and the political aspects of the process are emphasized, the formation of preferences on the one hand, and, on the other, the relation between democratic theory and democratic practice. By statistical analysis, the authors have attempted to discover how, why, and by how much opinions and attitudes changed during the period under examination. Vote intentions supported by one's social environment, they find, are more predictably adhered to than are "deviant" intentions. Under the stress of a campaign, people develop an increased tendency toward conformity. Voters do have some of the classically required virtues of the citizen but not in the elaborate or comprehensive form demanded by political philosophers. In the authors' opinion, the political theory of democracy, formulated in the 18 th century, stands in need of revision, but not replacement, through empirical sociology.

6415. Ewing, Cortz A. M. Congressional elections, 1896-1944; the sectional basis of political democracy in the House of Representatives. Norman, University of Oklahoma Press, 1947. I I p. illus.

47-31040 JKI316.E9

6416. Ewing, Cortez A. M. Presidential elections from Abraham Lincoln to Franklin D. Roosevelt. Norman, University of Oklahoma Press, 1940. 226 p. illus. 40-33395 JK524.E94

The first of these works is a statistical analysis of elections to the House of Representatives, limited, because of the lack of detailed official figures for earlier ones, to those of $1896-1944$. Professor Ewing's evaluation of the last 50 years convinced him that success in the Presidential election will go to the party already in control of the House. He points out that the Republicans must win a majority of seats in the East, Middle West, and West to secure a majority in the House. If the border section goes Republican, that majority becomes overwhelming. The Democrats, sure of the South and at an advantage in the border, need add only 88 seats outside these sections to have a majority in the House. Professor Ewing expressed some doubt as to whether the sectional pattern normal in 1944 would continue, calling particular attention to the division in the Democratic Party between Southern conservatives and liberals in the other sections. In Presidential Elections the author applied the same kind of analysis to the presidential elections of the years $1864-1936$. He divided them into four major voting periods: $1864-1876$, when the Republicans won four straight triumphs; $1880-$ I 892, when the Democrats fought back to split the four elections equally; $1896-1916$, when landslides began to occur and the Republicans won all but the 1912 and 1916 elections, and lost those because of their own disunity; and 1920-36, when the Republicans won the first three, and the Democrats the last two elections. He thought that before World War I there was crystallization of party allegiance, and after it a decline of party regularity, a failure of tradition as a determinant of political behavior, and the emergence of economic security as a dominant motivation. He discussed, among other matters, sectional interests, minority parties, the electoral college, and the respective influences of these on the outcome of national elections.

6417. Gallup, George H. A guide to public opinion polls. [ $2 \mathrm{~d}$ ed.] Princeton, Princeton University Press, 1948. xxiv, I I 7 p.

First published in 1944 . $4^{8-3517} \mathrm{HM}_{26} \mathrm{I}_{27} \quad \mathrm{I}_{948}$

An elucidation of the "science of opinion measurement" set forth in question and answer form. The author attempted to furnish readers with a better conception of the methods employed in public opinion research and a fuller understanding of its value. Public opinion polls had been thoroughly tested since 1935, he contended, and the reliability of the methods practiced had been "demonstrated time and again." Although Dr. Gallup did not claim perfection for his system, he noted its "many contributions to our democratic process," especially through its accurate and prompt reports of public opinion and its focus of attention upon major national issues. Answers are provided here to all the questions most frequently put to polling organizations. Among the subjects covered are the functions of the poll, the size of sample necessary to reliability, the types of sampling, the selection of the interviewers, election predictions, and the interpretation and reporting of results. "Just as it can be said with certainty that polls will be highly accurate in the vast majority of elections, so with the same certainty it can be said that on occasion they will go wrong." Notwithstanding which dis- 
claimer, Dr. Gallup's poll lost heavily in prestige by picking Dewey rather than Truman in 1948 .

6418. Gosnell, Harold F. Grass roots politics; national voting behavior of typical States. Washington, American Council on Public Affairs, 1942. I95 p. illus. 42-25395 JK I967.G6

A quantitative analysis of political behavior chiefly of the 1920's and 1930's in six StatesPennsylvania, Wisconsin, Iowa, California, Illinois, and Louisiana-which aims to trace from this sample the main outlines of the pattern of national politics. Developments in Pennsylvania, the author believes, clearly demonstrate the extent of the national political upheaval of the 1930's, when the Democratic Party attracted to its ranks not only dissatisfied Republicans but a host of new voters. The depression worked toward a political realignment of socioeconomic groups both in California and in Wisconsin, where the New Deal gained strength among poor, foreign-born, and progressive farmers as well as among skilled and unskilled laborers of the cities. Dr. Gosnell finds that Herbert Hoover was made a scapegoat for the personal insecurity of many Iowa farmers. He considers that the even spread of the revolt against the Republican Party was a remarkable aspect of Illinois politics of the 1930's, and that the emergence of Louisiana's Huey Long indicates the precarious foundation of American democracy and the two-party system.

6419. Lazarsfeld, Paul F., Bernard Berelson, and Hazel Gaudet. The people's choice; how the voter makes up his mind in a presidential campaign. [2d ed.] New York, Columbia University Press, I948. xxxiii, I 78 p. illus.

First published in 1944 .

$$
\text { 48-8605 } \mathrm{JK}_{524 . \mathrm{L}_{3} 8} \quad 1948
$$

An analysis of the voting behavior of Erie County, Ohio, in the Presidential election of 1940 (President F. D. Roosevelt versus Wendell Willkie), based on interviews obtained from a panel of 600 respondents who were questioned once a month from May to November 1940. Interest centered in persons whose political opinions were changed in the interval, whether by a shift in party allegiance, by indecision until the end of the campaign, or by _abstention after declaration of a defnite vote intention, because in them the processes of attitude formation and change could be observed. They were compared with those who did not change political opinions; their personal characteristics, their contacts with other people, and their exposure to mass communications were examined. The opinions successively held by the shifters were also compared, and a I 3 percent turnover, stimulated chiefly by face-to-face contacts, was found to have occurred within the few weeks before the election. The authors state that they have found only preliminary answers to the questions of who changes opinion, in what direction, and in response to what influences.

6420. Litchfield, Edward H. Voting behavior in a metropolitan area. Ann Arbor, University of Michigan Press, 1941. 93 p. illus. (Michigan. University. Michigan governmental studies, no. 7) $4 \mathrm{I}-52812 \quad \mathrm{JS} 847 . \mathrm{A}_{3} \mathrm{~L}_{55}$

Covering five elections held during the years 1930-38, this dissertation studies the voting behavior of the principal social groups in Detroit, based upon assessment and census data in various city offices. There were three behavior indexeselectoral participation, third-party voting, and major party affiliation-for which material could be gathered. The participation data revealed a direct relationship between income and amount of participation: the higher the income, the greater degree of participation. The Polish middle class was the most Democratic in a predominantly Democratic city; the wealthy native white group was the most Republican. These two groups, Dr. Litchfield reports, were also the two most active participants. In general, "Democratic party affliation in the period after 1930 has varied inversely with economic status." His analysis of third-party voting habits shows that middle-class Russians were most attracted to third parties and the wealthy native whites were the least so. Important group concerns do exist, the author concludes, but group opinion remains flexible and classes are not highly self-conscious. Detroit as of 1938 was still concerned with the general interest.

6421. Mencken, Henry L. A carnival of buncombe. Edited by Malcolm Moos. Baltimore, Johns Hopkins Press, 1956. xviii, 370 p.

$$
\text { 56-1 1658 } \mathrm{E}_{742 . \mathrm{M}_{4}}
$$

A selection of 69 articles written during the 1920's and I930's for Mencken's weekly political column in The Evening Sun, Baltimore. The book's five s e c t i o n s-"Normalcy"; "Calvinism"; "Onward, Christian Soldiers: Hoover \& Al"; "Roosevelt Minor"; and "The Burden of OmnipotenceRoosevelt \& Alf"-are each introduced by appropriate commentary from the editor, who notices that Mencken's predictions were sometimes dead wrong. Couched in Mencken's characteristic irreverent and jocund style, these pieces offer acerb portrayals and interpretations of the behavior and motivations of politicians and public-office holders. The author, who starts from the premises that American government "must be a great deal more competent than it looks" and that honor has no place in poli- 
tics, writes of such matters as prohibition, the solid South, political fraud and corruption, convention and campaign tactics, and the depression. Particularly noteworthy was his article of July 14, 1924, on the disastrous Democratic National Convention of that year. In Mencken's very candidly expressed opinions, Harding was, intellectually, "a benign blank," Coolidge an "obscure and unimportant man," Alfred E. Smith "as provincial as a Kansas farmer" although honest and worthy, Hoover "careful and cautious," an adept politician if an incompetent President, and Franklin D. Roosevelt a dealer in "quackery."

6422. Moos, Malcolm C. Politics, presidents, and coattails. Baltimore, Johns Hopkins Press, 1952. xxi, 237 p. illus.

$$
5^{2-1} 3^{6}{ }_{3} \quad \text { JKI976.M6 }
$$

An analysis of the relationships between voting behavior in congressional and presidential elections. The primary concern of the inquiry is with congressional elections, but, in the author's opinion, "the selection of a congressman is often not unaffected by the choice of a President." After sketching briefly the so-called coattail theory-the belief that in years of presidential elections Congressmen are often elected or defeated according to the political appeal of their party's Presidential candidate (and so are said to ride upon his coattails)-Professor Moos compares Presidential and congressional voting records for the period $1896-1950$ as to their relative influence upon electoral victory, and then attempts to evaluate the discovered relationships. He concludes that, although the coattail influence is of minor significance, successful Presidential candidates normally run ahead of their congressional tickets. The steady rise of the Presidency in public policy and party leadership is one of the manifest political truths of the 2oth century, has occurred as an adaptation in response to a national need, and is a by-product of our haphazard and clumsy party system.

6423. Rogers, Lindsay. The pollsters; public opinion, politics, and democratic leadership. New York, Knopf, r949. 239 p.

$49-7842 \quad \mathrm{HM}_{2} 6_{3} \cdot \mathrm{R}_{57}$

An admittedly indignant denunciation of the commercial polling agencies, particularly the Roper, Gallup, and Time polls, and their claims of scientific accuracy in the measurement of public opinion. Professor Rogers demonstrates that a mere counting of yeas and noes, without considering the knowledge on which the opinion is based, the intensity with which it is held, and the willingness to act upon it, is of small consequence. He scouts the pollsters' assumption "that what they claim they have discovered public opinion to be should rule," and finds them guilty of two great sins of omission: they have never attempted to define what they are measuring, nor have they outlined the nature of the political society in which public opinion should be the ruler. The United States is not, and ought not to be, a town meeting. The author believes, moreover, that public opinion is not a measurable concept, and that polling is not a scientific method. Documented by examples from polls of wrong premises about our political society, imperfect samplings, ambiguous framing of questions, interviewer bias, and exaggerated claims based upon the results, his examination of sources of error in polling points to serious limitations in the method.

\section{Reform}

6424. Aaron, Daniel. Men of good hope; a story of American progressives. New York, Oxford University Press, 1951. xiv, 329 p.

$$
51-1402 \quad \mathrm{E}_{176 . \mathrm{A}_{2}}
$$

Contents.-Emerson and the progressive tradition.-Theodore Parker: 'the battle of the nineteenth century.'-Henry George: the great paradox.-Edward Bellamy: village utopian.-Henry Demarest Lloyd: the middle-class conscience.-William Dean Howells: the gentleman from $\mathrm{Al}$ truria.-Thorstein Veblen: moralist and rhetorician.-Theodore Roosevelt and Brooks Adams: pseudo-progressives.-In retrospect: I912-1950.Notes on sources (p. 309-32I).

A study of the American progressive tradition, beginning with the social philosophy of Ralph Waldo Emerson (1803-1882), its prophet, whose simultaneous acceptance and rejection of American civilization was shared by the progressives who followed him. In the author's opinion, progressivism was conceived when a moral-minded minority began to observe the social effects of the industrial age, and to protest against what they considered the betrayal of the republican ideal. Although they ranged from moderate to radical in attitudes and policies, the progressives agreed that whatever be the form of society, the proper concern of government is "the care and culture of men." The rgthcentury reformers here discussed appealed effectively to those of their contemporaries who sensed 
the inadequacies of American life and desired a serene and humane society based upon virtue and justice. Professor Aaron regards their 2oth-century successors as more efficient, more impersonal, and less eloquent. He believes that the old progressive vision provides a humanist philosophy, indisputably idealistic and ethical, which is essential to any truly liberal movement.

6425. Childs, Richard S. Civic victories; the story of an unfinished revolution. New York, Harper, 1952. xvii, 350 p. illus.

A study of and a program for State and local government election procedures by the originator of the short-form ballot and the council-manager plan of municipal administration. Mr. Childs is concerned with organizing elections to public office on lines that will best assure a practical working of the democratic process. Particularly is he anxious to eliminate the possibility of oligarchy and permit the people to put into public office the men they really want there. To prevent oligarchy, he contends, the ballot must be short enough and the number of offices to be filled small enough to permit individual candidates to receive the fullest and most public scrutiny. He would separate from the elective list all offices not high enough, or which determine no policies large enough, to stir the people to take sides, and so remove a cause of "blind voting." $\mathrm{He}$ would hold the constituency to a size feasible for canvass by the ordinary independent candidate, and he would integrate the powers of government so as to make popular control effective. In addition to the argument for his program, Mr. Childs provides a history of the crusade he undertook for it in 1909, together with a report of progress made.

6426. Greer, Thomas H. American social reform movements; their pattern since 1865 . New York, Prentice-Hall, 1949. 313 p. (Prentice-Hall sociology series)

Bibliography: p. 293-299.

The purpose of this book is to determine, through analysis of the basic elements-demand, organization, objectives, techniques, and accomplishmentsthe pattern of the major American reform movements initiated by labor, farmers, progressives, and radicals in the years 1865-1949. Economic distress, the author concludes, has given rise to most of the reform movements, which have gradually shifted from humanitarian purposes and utopian thinking to the more restricted, practical, and selfish aims of a group or class. Professor Greer finds this change reflected in the leadership of the movements. Idealists have given way to realistic advocates of self-interest in the fields of labor and agriculture, and radical extremists have been succeeded by more practical and respectable men. Although earlier reform movements sought to embrace many diverse forces, later groups have followed a trend toward limited and integrated membership, an exception being such a radical group as the Marxists whose numerical weakness forces them to accept a diverse membership in order to have any following. In the author's opinion, reform movements tend to be short-lived because the public loses its zeal, because the goals set are out of reach, or because one of the major parties has borrowed the reform programs; he credits them, however, with substantial achievements.

6427. Haynes, Frederick E. Third party movements since the Civil War, with special reference to Iowa; a study in social politics. Iowa City, State Historical Society of Iowa, 1916. 564 p. 16-6948 JK2261. 35

A study of the Liberal Republican, Farmers', Greenback, Populist, and Progressive movements, which regards all of them as growing out of the economic and social conditions arising from the settlement of the West. In Dr. Haynes' opinion, these successive third-party movements have, from the 1870 's to the second decade of the 2oth century, impelled the major political parties to take action against economic and social ills. These third parties he sees as means of agitation and education, and as expressions of objection to contemporary economic conditions. The Farmers', Greenback, and Populist movements, for example, represented repeated efforts of the democratic and enterprising citizens of the West to assert themselves against the oppressive predominance of industrial wealth which prevailed from the 1870 's to the 1890 's. The 1912 platform of the Progressive Party the author considers to have been the culmination of the service performed by these parties in the conversion of American politics from almost exclusive concern with constitutional and governmental matters to recognition of the vital needs of the people.

6428. Howe, Frederic C. The confessions of a reformer. New York, Scribner, 1925. $352 \mathrm{p}$. 25-23619 H59. H6A3

At the outset of his autobiography, Frederic Clemson Howe (1867-1940) remarks that his life really began not in the 1860's but in the early 1890 's at Johns Hopkins University where he came under the influence of Richard T. Ely, Woodrow Wilson, Albert Shaw, and James Bryce, and acquired a pressing sense of responsibility to the world as well as the ideal of the scholar in politics. He writes candidly of these and many other personages, among them Tom L. Johnson-with whom he was 
associated in a ten-year (1901-10) struggle to make Cleveland a free, orderly, and beautiful city-Mark Hanna, Lincoln Steffens, Brand Whitlock, Max Eastman, and Inez Milholland. He tells of his disillusioning experiences on the Cleveland city council, 1901-03, and in the Ohio State Senate, 1906-09, and of his humanitarian efforts as director of the People's Institute, New York, I9II-I4, and as United States Commissioner of Immigration at the port of New York, 1914-19. Freely he offers opinions, and indicates the processes whereby he reached them, upon such matters as political sovereignty, the single tax, the tariff, land speculation, special privileges, women's suffrage, World War I, and the League of Nations. Perhaps the most rewarding chapters are the several devoted to Tom Johnson and Woodrow Wilson.

6429. Johnson, Tom L. My story. Edited by Elizabeth J. Hauser. New York, B. W. Huebsch, 19ı . xli, 326 p. illus.

$$
\text { I I-35975 F496.J69 }
$$

The posthumously published memoir of Tom Loftin Johnson (1854-1911), who was an office boy in 1869 , a successful industrialist by 1879 , and a convert to the teachings of Henry George by $188_{3}$. Although Mr. Johnson writes very candidly and fully of his original determination to make money, he devotes most of his book to a history of his political career which began in 1888 with his unsuccessful Democratic candidacy for Congress, continued with his election as Representative from Ohio in 1890 and 1892 , and reached its climax with his election as mayor of Cleveland in $190 \mathrm{I}$ and his re-election for three successive terms. His chronicle of his years as a fighting reform mayor forms the heart of this volume. The reader is told of Johnson's famous tent-meeting campaigns, of his battle for home rule, for a three-cent street railway fare, and for just taxation, and of his continuous education of the electorate concerning local political questions and the rights of the people as opposed to the special privileges of corporations. Johnson expresses his conviction that involuntary poverty is the result of law-made privilege whereby some men get more than they earn while most earn more than they get. Finally, he shows how he fought to end such privilege; in doing so he not only transformed the city but also, although he does not say so, became the outstanding municipal administrator of his time.

6430. Regier, Cornelius C. The era of the muckrakers. Chapel Hill, University of North Carolina Press, 1932. 254 p. illus.

$$
\text { Thesis (Ph. D.)-University of Iowa, } 1922 .
$$

Bibliography: p. [217]-241.

An analysis of the crusade against corruption in American politics that was initiated by the popular magazines during the first decade of the 2oth century, and that got its name from Theodore Roosevelt talking like a party stalwart. The author places the beginning of the muckraking era at the publication of the October 1902 issue of McClure's Magazine, which printed an article by Claude $\mathrm{H}$. Wetmore and Lincoln Steffens, "Tweed Days in St. Louis," and announced the serial publication of Ida M. Tarbell's "History of the Standard Oil Company." S. S. McClure stumbled upon his highly successful policy of muckraking without premeditation, Dr. Regier believes, but the public response to the articles demonstrated that the American people were less indifferent to the illegalities and abuses attendant upon the industrialization of the country and upon government favors to business than had been supposed. After 1902, he notes, McClure's Magazine took first rank among the journals of exposure and reform. In 1903 muckraking became aggressive; by 1904 it had become sensational, and continued profitable and popular for nearly a decade. Among the matters investigated by the muckraking journalists were municipal, State, and national corruptions and the great corporations behind them, conservation, and labor problems. The author attaches a good deal of credit to the efforts of the muckrakers for the reform legislation of the years 1904-15.

6431. Schlesinger, Arthur M. The American as reformer. Cambridge, Harvard University Press, 1950. 127 p. ([John Randolph Haynes and Dora Haynes Foundation, Los Angeles. Contemporary American problems, I950])

$$
\text { 50-14677 } \mathrm{HN}_{57} \cdot \mathrm{S}_{35}
$$

Three lectures delivered at Pomona College, in which Professor Schlesinger seeks to interpret one aspect of the American spirit. The United States has stood in the forefront of such social innovations as manhood suffrage, freedom of the press, the separation of church and state, public education, and prison reform, he believes, because of two conditions: the lack of tradition to be torn down, and the nature of the original settlers and their successors, rebels against privilege and oppression in their homelands, who carried their rebellion to the point of departure for a strange and distant land. Such folk quickened the tempo of change and reform in America, the author contends, but because they wished to protect their new liberties, including those of speech and print, they quickly developed "a middle-class attitude toward reform," and threw their weight on the side of the pragmatic approach and piecemeal progress. This attitude 
has continued to dominate the American mind. In his opinion, the reform impulse itself has been susstained and refreshed by two basic sets of ideals, the one stemming from the Christian religion, the other from the Declaration of Independence.

6432. Steffens, Joseph Lincoln. The autobiography of Lincoln Steffens. New York, Harcourt, Brace, I93I. 884 p. illus.

$$
\text { 3I-2825 I PN4874.S68A } 3 \text { r93Id }
$$

The vivid and candid life story of Lincoln Steffens (1866-1936), eminent journalist, first and foremost of the muckrakers, student of ethics and politics. The author tells most engagingly of his boyhood when he enjoyed open country in California, his horses, dogs, and the sort of people who could share a child's dream world; this part of the book has been separately published. Steffens describes in generous detail his reportorial methods and his unorthodox principles of journalism. He provides vignettes of such notable or notorious figures as Richard Croker, the Tammany boss; Ray Stannard Baker and S. S. McClure, journalists; Joseph W. Folk, Seth Low, Robert M. La Follette, and other reformers; Theodore Roosevelt; and Woodrow Wilson. The core of the book, however, is its account of Steffens' discovery of the systematic corruption of city and state governments, through bribery of officials by certain businessmen, and of his conviction that bribery is not a mere felony but a treasonable and revolutionary process which transforms the ostensibly democratic representative government of State and city into a plutocratic system that serves only the seekers of privilege. "You cannot build or operate a railroad," says Mr. Steffens, "or a street railway, gas, water, or power company, develop and operate a mine, or get forests and cut timber on a large scale, or run any privileged business, without corrupting or joining in the corruption of the government." This theme was more fully developed in his once famous book, The Shame of the Cities (New York, P. Smith, I948 [ ${ }^{\mathrm{C}}$ 1904] 306 p.), first published as a series of articles in McClure's Magazine. A number of the author's conclusions, particularly those upon international affairs and world problems, have little cogency for today.

\section{Thomas, Norman M. A socialist's faith. New York, Norton, 195r. 326 p.}

$$
\text { 5 }{ }^{1-9725} \mathrm{HX} 86 . \mathrm{T}_{377}
$$

A re-examination of the nature and status of socialism, as well as an analysis of recent world affairs, by the longtime leader of the American Socialist Party, who still found in 195 I "abundant reason for faith in democratic socialism as the best basis for ordering the good society." "Fortunately for me," writes Mr. Thomas, "socialism and Marxism are not identical." In a very fair survey and analysis he discusses, among other matters, the course pursued and the program evolved by socialism since 1900, the function of religion in the social order, the development of the state and statism, the rise of equalitarianism, the problems of democracy, the chances for peace, and his own attitude toward the wars of his active lifetime. He seeks, "on the basis of simple affirmations of fraternity," to unite the social behavior of men of varying beliefs through the common denominator of a conviction that by cooperation they can win plenty, peace, and freedom. Democratic socialism, the author has come to believe, cannot today present itself as a complete, universal philosophy; rather it must be experimental; it must find a way to transform conflict and mass destruction into fellowship and the destruction of poverty.

6434. Whitlock, Brand. Forty years of it. New
York, Appleton, 1914. 373 p.

The warmly written and anecdotal autobiography of Brand Whitlock (1869-1934), who was elected reform mayor of Toledo in 1905, 1907, 1909, and IgII, is also a history of democracy's progress in the Middle West during the period 1879-1914. Mr. Whitlock's thesis was that the city has, in all ages, been the outpost of civilization, and that if the problem of democracy is to be solved at all, it must first be solved there. Finding in the city only one issue, the conflict between the democratic and the plutocratic spirit, he thought that the people had lost their voice in their own affairs. Representative government had disappeared, he believed, and had been replaced by machine rule operating for the benefit of public utility corporations through laws enacted precisely in their interests by state legislatures. He advocated such remedial measures as nonpartisan city elections, municipal ownership, home rule for cities, and the initiative, referendum, and recall. He recommended the selection of public officers for their honesty and efficiency rather than for their party affliation; he urged the people to be more active in selecting their officials and in preventing mere office-seekers from bringing about their own nominations. Finally, he stressed the need for regulation and control of public service corporations. When this book was published, Whitlock had already begun his distinguished service as our envoy to Belgium (1913-22). 


\section{Books and Libraries}

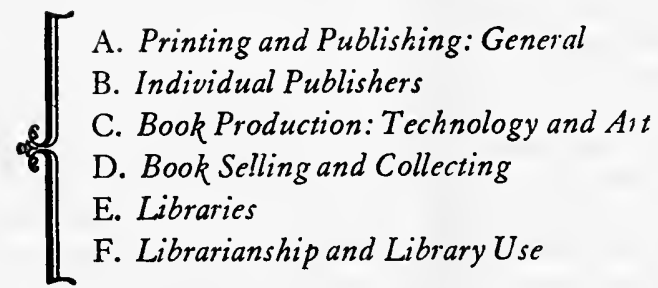

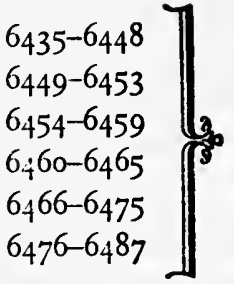

THIS CHAPTER represents, first of all, a selection of books depicting the introduction, 1 production, and diffusion of books in America. Because in these matters individual publishing firms have played a large part, some studies of prominent firms have been included. Since technical matters have been important in bringing about the large volume of books produced, several works on the tech nical aspects of production have been selected; some reflect increasing concern to produce books of distinctive format as well as content. Another phase of American culture centering about the book is provided by libraries of all types: public, private, school, college, university, regional, private research, town, city, State, and Federal. The existence of such a variety of institutions devoted to the accumulation, preservation, organization, and mobilization of books for use in the United States has led to the creation of a large descriptive and expository literature. From this wealth of material, the present chapter brings together only a few representative books that identify some of the many book collectors who have served to enrich the intellectual life of the Nation, that illustrate the social role of libraries, and that set forth the philosophy and practice of librarianship in this country. In this field, as perhaps in most fields today, a large part not only of recent fact and theory, but also of history, is to be found in periodicals. Among those published for librarians are Library Trends, College and Research Libraries, Library Journal, Special Libraries, and The Library Quarterly. While these are professional and technical journals not addressed to the layman, they nevertheless provide the serious student with information not otherwise obtainable. For the humanistic and literary interests in which many

great libraries abound, the reader is referred to proceedings of societies, such as The Papers of the Bibliographical Society of America, and the publications of libraries rich in rare books, of which the Henry E. Huntington Library, and the libraries of Harvard, Princeton, and Yale Universities are examples. A dominant note of all the stories of books and book-collecting is the Horatio Alger-like rise from poverty to riches, as America moved from its colonial situation, when books were a highly prized rarity, to its present-day position. Books now abound, the country boasts a number of the most distinguished libraries in the world, and the rise of the paperback book has meant not only wide distribution of many titles to a mass audience but also that books are no longer luxury items but are well within the purchasing power of the great majority of citizens.

Other chapters of this bibliography are, of course, closely related to subjects of the present one. The influence of the ideas presented by the books, and often giving the books their excuse for being, may be traced through Chapter XI, Intellectual History. The closely allied fields of newspapers and magazines are discussed in Chapter V, Periodicals and 
Journalism. Other pertinent works, including histories and discussions of various categories of books, may be found in Chapter III, Literary

History and Criticism.

\section{A. Printing and Publishing: General}

6435. Bowker lectures on book publishing. [Collected ed.] New York, Bowker, 1957.

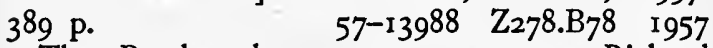

The Bowker lectures commemorate Richard Rogers Bowker (1 848-1933). This brings together the first 17 , delivered between 1935 and 1956 . The sponsors of the lectures wished them to be "an aid and stimulus to the study of book publishing in the United States and the mutual problems of authors, publishers, librarians, readers, all makers and users of books." The lectures cover such topics as textbooks, subscription books, the economics of authorship, mapmaking, children's books, book clubs, copyright, and paperbound books. Upon their delivery the lectures were published by the New York Public Library in its Bulletin and as separates; some have also appeared in whole or part in other periodicals; and the first 12 have been reprinted by the Typophiles in their Chapbooks series. Brought together here, the lectures are made available to the general public, and constitute a valuable survey of many of the problems and methods affecting the writing, producing, and distributing of books in America today.

6436. Boynton, Henry Walcott. Annals of American bookselling, I638-1850. New York, Wiley, I932. 209 p. illus. $\quad 32-34820 \quad Z_{473} \cdot B_{79}$ "Source books": p. 196-198.

This book opens with a brief sketch of the English background of book writing, publishing, and distribution. It goes on to show parallels in the American scene, and to trace the developing bookselling system of America, first in Boston, and later in Philadelphia, New York, and other centers. Since bookselling was seldom an independent vocation before 1850 , the author of necessity devotes much space to the printing and publishing of the period. The book is written for the general reader, and therefore has limited scholarly apparatus or detail, and does not present the results of original research. However, in brief compass it does present a fairly clear picture of the bookselling business as it developed in the thirteen colonies and the new republic. Bookselling developed first and most extensively in the Boston area, where it long remained largely on a printer-publisher-bookseller basis. This development is studied at length in George E. Little- field's Early Boston Booksellers, 1642-1711 (Boston, Club of Odd Volumes, I900. 256 p.), which gives a separate chapter to each individual included.

6437. Grannis, Chandler B., ed. What happens in book publishing. New York, Columbia University Press, 1957. 414 p.

$$
\text { 56-12739 } \mathrm{Z}_{47 \text { ז. }} 7
$$

6438. Schick, Frank L., ed. Trends in American book publishing. [Urbana, University of Illinois Library School] 1958. 233 p. (Library trends, v. 7, July 1958)

54-62638 Z67I.L6173, v. 7

Mr. Grannis' preface states that this book "is intended to give . . . a broad picture of what happens in publishing a book, particularly a book for trade (general retail) sale .... It is an outline of the procedures, a broad sketch to provide a context for the details; it is not a 'how-to' book." Part I describes the structure of the publishing industry. Part 2, "Steps in Trade Book Publishing," contains nine chapters which progress from securing and editing a manuscript, through manufacture, to advertising and selling the book. Part 3, "Some Underlying Problems," has four chapters on such topics as subsidiary rights, the business and legal aspects of publishing, and the foreign distribution of American books. Part 4 is made up of seven chapters on "Other Areas of Publishing"; they cover such aspects of nongeneral trade publishing as juveniles, textbooks, religious books, university press books, paperbacks, and book clubs. The volume concludes with an appendix, "Some Statistics Frequently Quoted," and an index. Each chapter of the book is by some individual with considerable experience in the field he discusses. There are brief lists for additional reading at the end of each chapter. Mr. Schick's symposium, which fills an issue of Library Trends, consists of 20 papers in addition to his introduction. Only two of them are concerned with generalities-the economic development of publishing and the physical development of bookmaking in the last decade-and trade-book publishing is disposed of in a 9-page statement by Mr. Grannis. Mr. Schick's main object is to "probe into the complexities of the heterogeneous topic of American book publishing," and the issue is partic- 
ularly valuable for its papers on a variety of specialties concerning which information is not easily found elsewhere. Besides treatments of most of the specialties dealt with in Mr. Grannis' volume, there are papers on private presses and collectors' editions; vanity press (its houses now refer to themselves as "subsidy" or "cooperative" publishers), foundation, and association publishing; and the publishing of hardcover reprints, reference and subscription books, art and architecture books, music books, law books, and medical books.

6439. Kerr, Chester. A report on American university presses. [Washington] Association of American University Presses, I949. 302 p. 49-4375 Z231.5.U6K 4

"Based on a survey sponsored by the American Council of Learned Societies with a grant from the Rockefeller Foundation."

Bibliography: p. 297-302.

American university presses, generally speaking, had a slow start in the roth century. In recent years they have developed rapidly, and they now hold an important position in American publishing. While some of this progress has occurred since Mr. Kerr's report was prepared, his study does show the emergence of the presses into public prominence. It is limited to the one Canadian and 34 American presses which at that time were members of the Association of American University Presses. The survey presents in some detail the organization, operational procedures, general policies, staffing, distribution, financing, selection policies, edition sizes, and other aspects of this branch of American publishing.

6440. Lehmann-Haupt, Hellmut. The book in America; a history of the making and selling of books in the United States, by Hellmut LehmannHaupt in collaboration with Lawrence C. Wroth and Rollo G. Silver. 2d [rev. and enl. American] ed. New York, Bowker, 195I. xiv, 493 p.

$$
\text { 5 I-II308 Z473.L522 I95I }
$$

Contents.-Book production and distribution from the beginning to the American Revolution, by L. C. Wroth.-Book production and distribution from the American Revolution to the War between the States, by L. C. Wroth and R. G. Silver.-Book production and distribution from 1860 to the present day, by $H$. Lehmann-Haupt.-Bibliography ( $p$. 422-466).

This historical study of book production and commercial distribution in America first appeared as Das Amerikanische Buchwesen, Buchdruck und Buchhandel, Bibliophile und Bibliothekswesen in den Vereinigten Staaten von den Anfängen bis zur Gegenwart (Leipzig, Hiersemann, 1937. 385 p.).
The subsequent revised and enlarged edition appeared in English as The Book in America; a History of the Making, the Selling, and the Collecting of Books in the United States (New York, Bowker, I939. 453 p.). Both of these editions contained a section by Ruth Granniss on book collecting and the development of public libraries in the United States; unfortunately, the increased size of the 195I edition required the omission of this material. The work as it presently stands is a comprehensive, concise survey of the field of book production and distribution. The authors trace the spread of printing, technological innovations, style changes, and other technical matters, and discuss the nature and range of the books published. Subsidiary problems such as book clubs, copyright, and private press work are also gone into. The extensive, though now slightly dated, bibliography is divided into subject categories.

6441. Miller, William. The book industry, a report of the Public Library Inquiry. New York, Columbia University Press, 1949. xvi, 156 p. 49-10422 Z471.M65 1949

"A note on method and sources": p. [133]-140.

Mr. Miller's work concentrates on "trade" books, new books published for general sale through retail bookstores. It does not extensively investigate reprints, book club editions, textbooks, university press books, government publications, or other nontrade publications. However, these aspects are touched upon at various points in the book, usually in their effect upon trade books. After a general survey of trade publishing, Mr. Miller devotes a chapter to the effect of various factors (popular taste, movies, book clubs, etc.) on the editorial decisions of publishers. Chapter 3 is on the nontechnical aspects of book manufacture and the costs incurred by the publication of a work. Chapter 4 surveys "The Book Markets"; in its course attention is directed to the effects of book clubs and advertising on the general markets book sales. The concluding chapter discusses the relationship between "Trade Publishing and the Public Libraries," concluding that libraries have but small effect on the publishers, though the latter are of major influence on the libraries. An appendix presents in tabular form "Some Book Industry Statistics." An earlier and more extensive study in the same field is Orion H. Cheney's Economic Survey of the Book Industry, 1930-1931, as Prepared for the National Association of Book Publishers, with 1947-1948 Statistical Report [of the American Book Publishers Council] (New York, Bowker, 1949. ' 1931.368 p.). The I $947-48$ report is little more than a brief statistical survey, and the volume is now of largely historical interest. Neither Cheney nor Miller covers the 
publishing "revolution" effected by paperbacks during the past decade.

6442. Oswald, John Clyde. Printing in the Americas. New York, Gregg Pub. Co., 1937. xii, 565, xvii-xli p. illus.

37-15130 Z205.O86

This history of printing in the Americas supplements but does not quite supplant Thomas' History of Printing in America (no. 6447). It opens with descriptions of the kinds of literature most commonly or strikingly produced by the printers of the Thirteen Colonies: newspapers (the product of nearly every pioneer printshop), Bibles (Eliot's Indian Bible of 1663 and Sower's German Bible of 1743 preceded Aitken's English Bible of ${ }_{1782}$ ), almanacs, pamphlet sermons, broadside ballads, etc. After describing the equipment of colonial printshops the author embarks upon a chronologicogeographical survey in the manner of Thomas. Each colony or State is introduced according to the priority of its printing, and for some of the older States there are chapters on individual printers, such as Matthew Day, the teen-ager who inaugurated American printing at Cambridge, Mass., in 1638 , or on printing families, such as the Greens, the Franklins, and the Sowers. After concluding with Wyoming (1867), Alaska, and Hawaii, the author devotes four topical chapters to "Fine Bookmaking," "Typography," "Machines and Methods," and "Printing Organizations." He then gives brief surveys of printing origins and history for the provinces of British North America, for Greenland, for the West Indies, and for the nations of Latin America. The book lacks a bibliography, but it has a 25 page index and numerous facsimiles (some in black and red) of early imprints.

6443. Rosenberg, Bernard, and David Manning White, eds. Mass culture; the popular arts in America. Glencoe, Ill., Free Press, 1957. 56r p. 57-6749 E169.1.R7755

As its title indicates, this "reader" is by no means concerned exclusively with books; however, it does devote considerable space to popular books (paperbacks, bestsellers, commercial fiction, etc.) and allied fields such as magazines and comic books, as well as the more distantly allied "literature" of radio, television, motion pictures, popular songs, and advertising. The 49 essays presented attempt to probe the relationships between cultural works produced for mass consumption, and the society that consumes them. An attempt also has been made to achieve a balance in the distribution of the contributors between those who look with favor upon the phenomenon covered, and those who view it with alarm. A few of the essays are here published for the first time; others are extracted from books; but the greater number are reprinted from learned journals or reviews. "Further Reading" is suggested at the end of each of the book's sections. Popular books are also covered at some length in other titles elsewhere in this bibliography, most notably under Literary History and Criticism; other aspects of mass culture are treated in other sections: Periodicals and Journalism, Music, Sports and Recreation, Entertainment, etc.

6444. Schick, Frank L. The paperbound book in America; the history of paperbacks and their European background. New York, Bowker, 1958. xviii, 262 p. illus. $\quad 5^{8-10097} \mathrm{Z}_{1033} \cdot \mathrm{P}_{3} \mathrm{~S}_{35}$

While this book devotes several chapters to the development of paperbound book publishing, it is mainly concerned with the mass market aspects that emerged with the appearance of Pocket Books in 1939 and have now revolutionized American publishing. The author traces the development of this mass market, the formats used, prices, distribution systems, and quantities. Little or no attention is given to literary evaluation. Individual sections sketch the history and present status of many of the leading present-day paperback publishers. The selective bibliography (p. 245-250) directs the reader to many other studies and articles on the subject.

6445. Sheehan, Donald H. This was publishing; a chronicle of the book trade in the Gilded Age. Bloomington, Indiana University Press, 1952. $288 \mathrm{p}$. $\quad$ 52-14582 $_{4} \quad \mathrm{Z}_{43}$.S47

In this study of the book industry from the end of the Civil War to the outbreak of World War I the author draws much of his information from the private records of Henry Holt and Co., Harper and Brothers, Dodd, Mead and Co., and Charles Scribners' Sons, as well as from the chronicling of the trade in Publishers' Weekly. Although the emphasis on four firms, because their records were the ones available, does place some limits on the study, the fact that these four were leaders in the field makes them reasonably representative of the whole. In this period the book industry grew, through many uncertainties and constantly recurring crises, into the giant of the present, evolving special methods which have continued in use. These the author traces in their manifold aspects of publishing policies, author-publisher relationships, contractual relationships, wholesaling, copyright problems, trade regulation, advertising, etc. The book is written in a lively manner for the layman, yet it includes a fairly extensive index and a bibliography ( $\mathrm{p}$. $273-278)$. 
6446. Stern, Madeleine B. Imprints on history, book publishers and American frontiers. Bloomington, Indiana University Press, 1956. $492 \mathrm{p}$. 56-1 $1995 \quad Z_{473 . S 857}$

This book presents for the general reader a large part of the story of printing and publishing in Igthcentury America regarded as an expansion into frontiers of space and frontiers of the mind. The approach is biographical, with each chapter presenting the story of an individual who pioneered in some aspect of this field. Typical figures studied include James Bemis, who brought printing to the frontier communities of upstate New York; William Hilliard, printer and bookseller, who supplied many of the needs of Harvard University, assembled the core collection of the newly established University of Virginia, and otherwise "helped to expand the awakening intellectual forces of the East"; Robert Fergus, pioneer printer of mushrooming Chicago; Jacob W. Cruger of Houston, Texas; Ernst Steiger, German-American publisher of New York City who played a significant role in the Americanization of the German immigrants; and John W. Lovell, who published outspoken works on social problems and did much to advance labor and woman's rights. The book concludes with a long supplement ( $p$. 329-338), arranged alphabetically, of short notes on the 191 publishing firms which were founded before 1900 and are still operating; it concludes with a chronological list, 1769-1899. The biographical sketches obviously do not cover more than a fraction of the field; nevertheless they give representative specimens of the kinds of innovation and change in printing and publishing that were going on throughout the century. Though not scholarly in tone, the book is thoroughly researched, with extensive notes (p. 389-464) indicating the sources, and an index.

6447. Thomas, Isaiah. The history of printing in America, with a biography of printers, and an account of newspapers. $2 \mathrm{~d}$ ed. Published under the supervision of a special committee of the American Antiquarian Society. Albany, N.Y., Munsell, I874. 2 v. (Archaeologia americana. Transactions and collections of the American Antiquarian Society, v. 5-6) 2-6034 Z208.E45I

Committee of publication: Samuel F. Haven, Nathaniel Paine, and Joel Munsell.

Contents.-I. Preface. Memoir of Isaiah Thomas by his grandson Benjamin Franklin Thomas. History of printing in America. Appendix A: History of printing in [Spanish] America. Communicated by John R. Bartlett [with lists of books printed in Mexico and Peru before 1600$]$.2. History of printing (cont.): History of newspapers. Booksellers in the Colonies, from the first settlement of the country to the commencement of the Revolutionary War, in 1775. Catalogue of publications in what is now the United States, prior to the Revolution of ${ }^{1775-6}$ [compiled by Samuel F. Haven, Jr.]. Index.

Isaiah Thomas (1749-1831) first published this work himself in two volumes in 18 ro. He made numerous manuscript notes for corrections and additions; these were incorporated in the second edition, but his lengthy survey of the origin of printing in Europe was omitted. Despite its age, this history remains a standard survey of colonial American printing. Some additional notes to the text were supplied by the editors, and bear their initials. In the later years covered by the book, Isaiah Thomas himself was a leading figure. He was probably the foremost American printer and publisher of his day, and he issued more titles than any of his contemporaries or predecessors. His interesting career is studied in Annie Russell Marble's From 'Prentice to Patron (New York, AppletonCentury, 1935. 326 p.). A shorter study, Clifford Kenyon Shipton's Isaiah Thomas, Printer, Patriot, and Philanthropist, 1749-1831 (Rochester, N.Y., Leo Hart, I948. 94 p.), is aimed at a more specialized audience of bibliophiles and typophiles, and includes more information on Thomas' activities in founding and promoting the American Antiquarian Society (1812). In our own day Clarence S. Brigham (b. 1877) has remade the Society's library at Worcester, Mass., into the greatest collection in the world of early American imprints of every description. His modest account of this achievement, including concise characterizations of the collections and their importance, is Fifty Years of Collecting Americana for the Library of the American Antiquarian Society, 1908-1958 (Worcester, Mass., 1958. I 85 p.).

6448. Wroth, Lawrence C. The colonial printer. [2d ed., rev. \& enl.] Portland, Me., Southworth-Anthoensen Press, 1938. xxiv, 368 p. illus. 38-14676 Z208. W95 $193^{8}$

"Works referred to in notes": p. [331]-347.

This book is a study not primarily of the books and other printed materials produced in America during the colonial period, but rather of the practical problems involved in their production. Attention is therefore focused on such matters as the nature of colonial presses, the typefaces used, the nature and production methods of ink and paper, working conditions, and bookbinding. A somewhat more bibliophilic study of the field for one colony was produced by Dr. Wroth in his $A$ History of Printing in Colonial. Maryland, 1686-1776 (Baltimore, Typothetae of Baltimore, 1922. 275 p.); this work was continued by Joseph Towne 
Wheeler in The Maryland Press, 1777-1790 (Baltimore, Maryland Historical Society, I938. 226 p.). A broader study is Douglas C. McMurtrie's $A$ History of Printing in the United States; the Story of the Introduction of the Press and of Its History and Influence During the Pioneer Period in Each State of the Union, of which only the second volume, Middle \& South Atlantic States (New York, Bowker, 1936. 462 p.), was completed at the time of the author's death; however, publication of additional material from his papers has been promised. A study of an area more influential in printing matters in its period is George E. Littlefield's The Early Massachusetts Press, 1638-171I (Boston, Club of Odd Volumes, 1907. 2 v.). A largely bibli- ophilic study of the first printing press in English America is Robert F. Roden's The Cambridge Press, 1638-1692 (New York, Dodd, Mead, 1905. I93 p.), considerable of which is made up of "A Bibliographical List of the Issues of the Press"; the text traces the press' history as much in terms of publications as in terms of changing ownership, methods, and working conditions. George Parker Winship's The Cambridge Press, 1638-1692 (Philadelphia, University of Pennsylvania Press, 1945. 385 p.) does not attempt to redo the systematic part of Roden's book, but brings a quantity of fresh I thcentury evidence to bear upon the circumstances in which the Bay Psalm Book, the Eliot Indian Bible, and many other issues of this press were produced.

\section{B. Individual Publishers}

6449. Burlingame, Roger. Of making many books; a hundred years of reading, writing and publishing. New York, Scribner, 1946. $347 \mathrm{p}$. ${ }_{46-8389} \quad \mathrm{Z}_{473} \cdot \mathrm{Bg}$

This volume was prepared to mark the centenary of Charles Scribner's Sons, which was founded in 1846 and grew to be one of America's largest general publishers. The book is not a formal history of the firm, but each chapter pursues, in generally chronological form, some aspect of the firm's history. These are developed mainly through extensive quotations from the communications of the publishers and their authors. This lends the book much variety, but its anecdotal manner does not permit the presentation of many statistics, facts of chronology, or other details of the organization's structural history. The book does convey an impression of author-publisher relations over a century, and of some publishing problems. The topics treated include bestsellers, plagiarism, acceptances, rejections, war, poetry, editing, and printing. Considerable space is also devoted to the magazines which the firm has issued. In preparing the book Mr. Burlingame had access to Scribner's complete files. "Since this was to be a picture of the past, it was agreed that the use of letters should be limited to those of authors who were no longer living." A few exceptions to this were made in order to complete certain stories, and no such restrictions were imposed upon the writings of the publishers and editors. Mr. Burlingame is also the author of a newly published history of the McGraw-Hill Book Company entitled Endless Frontiers (New York, McGraw-Hill, 1959. 506 p.).
6450. Harper, Joseph Henry. The house of Harper; a century of publishing in Franklin Square, by J. Henry Harper. New York, Harper, 1912. $689 \mathrm{p}$. illus. 12-3620 Z473. $\mathrm{H}_{29 H}$ I912

The house of Harper and Brothers was founded in 1817 as a printing establishment, which over the years was built up by the original four brothers and their descendants into one of the major American publishing firms of the igth and 20 th centuries. In this study one of the descendants presents an anecdotal history of the varied activities of the firm, including an extensive recounting of their ventures in the field of periodical publishing. This long book owes much of its length to its extensive quotations from the company's correspondence files. It affords considerable insight into the work and principles of I 1 th-century publishing, especially in the second half of the century. This is partly because of the author's tendency to use personal reminiscence as framework and subject. A later volume of reminiscences by the author, with less emphasis on the activities of the firm, is his I Remember (New York, Harper, 1934. 28I p.). It is written in a more discursive manner, and is largely made up of incidents concerning persons he had known in his long career as a publisher. It does, however, throw some further light upon the firm's activities, and it does something to bring the 1912 volume up to date.

6451. Kaser, David. Messrs. Carey \& Lea of Philadelphia; a study in the history of the booktrade. Philadelphia, University of Pennsylvania Press, 1957. $182 \mathrm{p}$.

$$
\text { 57-1177I } \mathrm{Z}_{473 \cdot \mathrm{L}_{45} \mathrm{~K}_{3}}
$$


Carey \& Lea was for some years probably the largest and best-known publishing firm in America. This history, which originated in a University of Michigan dissertation, traces the house from its inception in 1822 until the retirement of Henry Carey in 1838 , after which it rapidly declined. Since the firm was in its period a trade leader, the book offers much insight into the conditions prevalent throughout the trade during much of the Igth century. The first part of the book is a general history of Carey \& Lea, while the second part, larger than the first, consists of chapters analyzing the several types of its publications (literary, scientific, reprints, American originals, etc.), with a concluding chapter on the firm's relationship with the rest of the trade. The present-day publishing house descended from Carey \& Lea is Lea \& Febiger, dealing predominantly in scientific and medical works; a brief history of it and its antecedents is presented in its booklet, One Hundred and Fifty Years of Publishing, 1785-1935 (Philadelphia, Lea \& Febiger, 1935. 42 p.).

6452. Merritt, LeRoy Charles. The United States Government as publisher. Chicago, University of Chicago Press, I943. I79 p. incl. tables, diagrs. (The University of Chicago studies in library science) A $43-1562 \quad Z_{1223} . Z_{7} M_{35}$

Bibliography: p. $175^{-176 .}$

The United States Government has often been called the nation's leading publisher. Its annual production includes many thousands of titles totaling many million of copies. The numerous books, pamphlets, serials, and other materials reflect the extensive and highly complex activities of the Government itself. They include reports on the activities of the many branches of the Government, publications intended to facilitate administration, informational works for the benefit of specialists or the general public, etc. Mr. Merritt's study analyzes these publications with respect to issuing office, function, and subject, and discusses their distribution and general development in the 2 oth century. He noted, as of 1939, that the sale of Federal publications was increasing, and their free distribution diminishing. Some of the background of Government publishing may be obtained from Laurence F. Schmeckebier's The Government Printing Office; Its History, Activitics and Organization (Baltimore, Johns Hopkins Press, I925. I 43 p. Institute for Government Research of the Brookings Institution. Service monographs of the United States Government, no. 36), a study of the agency which designs, prints, and distributes most of the publications of the Government. While the Federal Government may be the most prolific American publisher, much publishing is also done by State and local governments and by the United Nations Organization, whose headquarters is in New York City; the scope, quantity, and general problems of these are outlined in James L. McCamy's Government Publications for the Citizen; a Report of the Public Library Inquiry (New York, Columbia University Press, 1949. I39 p.), written with the assistance of Julia B. McCamy. It is chiefly concerned with library problems in the acquisition, cataloging, and use of such materials. The guides to Federal publications by Schmeckebier and Boyd are entered in Chapter XXIX (no. 6138). William Philip Leidy's A Popular Guide to Government Publications (New York, Columbia University Press, 1953. xxii, 296 p.) lists, with brief annotations in most cases, some 2,500 items selected for their potential interest to the average citizen, and classified under nearly a hundred headings from "Agriculture" to "World War II."

6453. Wiley (John) and Sons, inc. The first one hundred and fifty years; a history of John Wiley and Sons, incorporated, 1807-1957. New York, 1957. 242 p. illus. $\quad 57-7626 \quad Z_{473 . W 63}$

This publishing house goes back to 1807 , when Charles Wiley opened in New York a printing shop and bookstore, two things which usually went to gether at that time. The firm published many distinguished literary works in its early decades. By the latter part of the Igth century it had given up general publishing for specialization in scientific and technical books. This later period receives the greatest attention here, partly because of its importance, but also because few of the old records have been preserved. The result is that after three opening chapters on the early period and the firm's literary books, there follow 25 chapters on its scientific and technical publications. Each of these chapters is devoted to books in a particular category, such as agriculture, metallurgy; geography, statistics, civil engineering, industrial engineering, architecture, chemical engineering, and psychology. In each some of the more important works are mentioned and related to both the development of the firm and of knowledge in the field. The treatment also gives some idea of the general development of scientific and technical publishing in America. A book of related interest is Edward M. Crane's $A$ Century of Book Publishing, 1848-1948 (New York, Van Nostrand, 1948. 73 p.). It traces the history of the D. Van Nostrand Company, another leading publisher of scientific works, which in its early days also cultivated naval and military history. Mr. Crane's arrangement is mainly chronological, emphasizing the development of the company rather than the subject matter of books published. 


\section{Book Production: Technology and Art}

6454. Asheim, Lester, ed. The future of the book; implications of the newer developments in communication. Chicago, University of Chicago, Graduate Library School, r955. 105 p. (Papers presented before the Twentieth Annual Conference of the Graduate Library School of the University of Chicago, June 20-24, 1955)

$$
5^{6-582} \mathrm{Z6}_{74 . C_{4}} \text { 2oth }
$$

"Published originally in the Library quarterly, October 1955."

Society has traditionally relied primarily upon books for the transmission of knowledge and culture. This has been challenged in modern times by the advent of mass communications (radio, television, etc.), nonprinted records (microfilms, motion pictures, phonorecords, etc.), and other technological innovations. At the same time the flood of materials has been such as to lead to the devising of mechanical controls through codification (via "mechanical brains," etc.), and large-scale problems in the storage as well as use of such materials. Further, some have feared that the demise of the book is imminent as a result both of the ascendancy of audiovisual mass media and of increasing costs of book production, rendering difficult the distribution in printed form of all but such works as have a presumable mass market. These problems are discussed in this symposium, which probably reveals less about the future of the book than about presentday trends and the problems and potentialities before us in the field of books and other records of man's experience.

6455. Baker, Elizabeth (Faulkner). Printers and technology; a history of the International Printing Pressmen and Assistants' Union. New York, Columbia University Press, 1957. 545 p.

Bibliography: p. [523]-528. 57-I $144^{8} \mathrm{Z}_{120 . B 16}$

A history of the union from its founding in 1889 through the activities of 1956 ; it is international in name, but most of its locals are in the United States. Such problems as technological changes over the years are treated from the point of view not of their effect on the design and distribution of printed matter, but of their effect on employment, pay, job skills, and like matters. In her introduction Mrs. Baker writes: "This book is more than a case study of the International Printing Pressmen and Assistants' Union, however, although it presents many expressed feelings of members and their leaders in an attempt to reveal the motives which led to their official action. In the process of tracing the course of policies and acts, we follow two closely allied issues: effect of technology upon printing and printing trades unionism, and the changing role of foremen and of union-management relations." A so ciological study of the structure and leadership of another union in the printers' trade is Union $D e$ mocracy; the Internal Politics of the International Typographical Union (Glencoe, Ill., Free Press, 1956. xxviii, 455 p.), by Seymour Martin Lipset, Martin A. Trow, and James S. Coleman.

6456. Gress, Edmund G. Fashions in American typography, 1780 to 1930, with brief illustrated stories of the life and environment of the American people in seven periods, and demonstrations of E. G. G.'s fresh note American period typography. New York, Harper, 1931. xxviii, 201 p. 3 I-3453I Z250.G83

Much of this book is devoted to the author's own ideas of how the types of seven periods of American history could be modernized (or "fresh noted") so as to be useful in modern press work designed to reflect a given period. The book mainly discusses the leading American type designs of the past. Most of its space is occupied by illustrations and facsimile reproductions, making clear the changes in typographical styles since the Republic was founded. As part of his attempt to convey the atmosphere of successive periods, the author has included a number of pictures illustrating the life of each period, and has briefly mentioned them in the text. An important book for modern type design is $A$ Half-Century of Type Design and Typography, 1895-1945 (New York, The Typophiles, 1946. 2 v.), a major work by one of this country's leading type designers, Frederic William Goudy (1865-1947).

6457. Hunter, Dard. Papermaking in pioneer America. Philadelphia, University of Pennsylvania Press, 1952. xiv, 178 p. illus.

$$
\text { 52-12473 TS } 1095 . U 6 \mathrm{H} 81952
$$

6458. Weeks, Lyman Horace. A history of papermanufacturing in the United States, 16901916. New York, Lockwood Trade Journal Co., 1916. xv, 352 p. illus. $17-12277$ TSio95.U6W 4 Mr. Dard Hunter (b. 1883) of Chillicothe, Ohio, has had his own private press since 1915 and has made his own paper by hand since 1929; as early as 
I9I5 and 1917 he produced what are thought to be the first books in the history of printing in which every element was the handiwork of a single man! Incidentally to the practice of his crafts he has become a world authority on the history and techniques of papermaking, and has established the Dard Hunter Paper Museum at the Massachusetts Institute of Technology. Papermaking in Pioneer America, printed on paper made by hand especially for the purpose at his small Connecticut mill, is based on lectures he delivered in 1948 when appointed to the University of Pennsylvania Rosenbach Fellowship in Bibliography. The art of papermaking, invented in China in ro5 A. D., reached America in 1575, at Culhuacán, Mexico, and the Thirteen Colonies about I690, when William Rittenhouse (born Rittinghuysen) and his son Nicholas set up a small water-powered papermill at Roxborough, near Germantown, Pennsylvania. Mr. Hunter describes "The Equipment and the Operation of the Early Mills," and then traces the pioneer mill of each colony and State from New Jersey (1726) to Tennessee ( $18 \mathrm{II}$ ). A final chapter describes the career of Nathan Sellers (1751-1830), whose skill at wirework enabled him to become the first American maker of paper moulds on a commercial scale, supplying hundreds of American papermakers. There is also much of American interest in $\mathrm{Mr}$. Hunter's magisterial Papermaking; the History and Technique of an Ancient Craft, $2 \mathrm{~d}$ ed. rev. and enl. (New York, Knopf, r947. xxiv, 6ri, xxxvii p.), which, with its 317 illustrations, describes materials, processes, and machines in every land from the most primitive to the most technologically advanced, and pays special attention to watermarks. Weeks' History contains much information for the earlier period that is not in Mr. Hunter's specialized lectures, and then describes a further hundred years of a constantly expanding industry, transformed in 1817 by Thomas Gilpin, who introduced in his mill near Wilmington, Del., a power-driven "revolving cylinder making paper continuous and endless in length instead of in single sheets." Chapter I I describes the search for new and cheaper raw materials, a great economic success gained at the expense of the quality and the permanence of the product. Present-day methods of mass production are succinctly described for the layman in Edwin Suter- meister's The Story of Papermaking (Boston, S. D. Warren Co., 1954. 209 p.).

6459. Winship, George Parker. Daniel Berkeley Updike and the Merrymount Press of Boston, Massachusetts, I860, I894, I 94 I. Rochester, N.Y., Leo Hart, 1947. I4I p. facsims. (The Printers' Valhalla) $\quad 48-1487 \quad Z_{232 . M 57} W_{5}$

Updike (I860-I94I) has been regarded by many as the greatest craftsman of fine printing that America has produced. In 1893 he set up his own business, the Merrymount Press, at Boston. His early work was florid in the manner of William Morris, the English prime mover of the "printing renaissance." Updike, however, soon moved to a greater simplicity and originality of book design. Throughout his career he endeavored to match the world's best printing designs with the particular work to be printed, so as to produce a work of clarity and beauty. He designed some books for other large presses, but most of his work was in the field of limited editions of works of limited interest. His work had a wide influence on the work of others, and was in itself a major factor in the modern interest in the typographical design of trade books. Winship's book traces Updike's career but gives most of its space to discussing and illustrating the work of the Merrymount Press. Updike himself wrote about his press and its aims in his Notes on the Merrymount Press \& Its Work (Cambridge, Harvard University Press, 1934. 279 p.), most of which ( $p$. 59-268) consists of a bibliography of the productions of the press. Updike: American Printer and His Merrymount Press (New York, American Institute of Graphic Arts, 1947. 156, [44] p.) is a group of nine essays issued in memory of Updike, whose own "Notes on the Press and Its Work," is reprinted at the beginning of the volume. Updike published three papers on fine typography as In the Day's Work (Cambridge, Harvard University Press, 1924. 69 p.). His major work was Printing Types; Their History, Forms, and Use; a Study in Survivals, $2 \mathrm{~d}$ ed. (Cambridge, Harvard University Press, 1937. 2 v.), which discussed and illustrated at length the major typographical advances of the Western world; while its main use is as a history of typography in the West, it also reveals Updike's own views on type design and printing.

\section{Book Selling and Collecting}

6460. Adams, Randolph G. Three Americanists: Henry Harrisse, bibliographer; George Brinley, book collector; Thomas Jefferson, librarian.
Philadelphia, University of Pennsylvania Press, 1939. I01 p. 39-6767 $\mathrm{Z}_{1206 . \mathrm{A}_{2} \mathrm{A2}}$ Three essays which originated as lectures at the 
University of Pennsylvania in 1938 . Here they appear with footnotes and an index. The first is on Henry Harrisse (1829-I910), a Franco-American bibliographer who specialized in the earliest Americana. Probably his best-known work is the Bibliotheca Americana Vetustissima (New York, G. P. Philes, 1866. 519 p.) and its supplementary volume subtitled Additions (Paris, Tross, 1872. 199 p.), the two combined being "A Description of Works Relating to America, Published between the Years I 492 and 155I," as the first volume was subtitled. Harrisse wrote other works on the period, and was also a book collector of considerable note. The second essay is on George Brinley ( $1817-1875)$, in the opinion of some the foremost collector of Americana as well as the first Americanist bibliophile of importance. The third essay describes Thomas Jefferson's book collecting activities. Jefferson appears at numerous other points in this Guide; here he is discussed in his relatively little known role as book collector, as "father" of the Library of Congress, whose collections were rebuilt about the nucleus of Jefferson's library, and as a figure of the first importance in the library classification of books. Since Jefferson probably had the foremost private library in America in 1815 , it would deserve considerable attention even without its subsequent history. Much about the collection itself, about Jefferson's other books, and about book collecting in America in his day will be found in the Catalogue of the Library of Thomas Jefferson (Washington, Library of Congress, 1952-59. 5 v.), compiled with annotations by E. Millicent Sowerby. In the foreword to volume I the compiler says that she undertook a study "which would reveal not only what volumes Mr. Jefferson had acquired but, when possible, where and why he had acquired them and, most important, how he had made use of them."

6461. Cannon, Carl L. American book collectors and collecting from Colonial times to the present. New York, Wilson, 194I. 391 p.

$$
4^{1-51592} \mathrm{Z}_{987} \cdot \mathrm{C}_{3}
$$

This study traces the main outlines of private book collecting in America from colonial times to about 1930. About half the book consists of chapters on individual collectors, and the rest of the chapters on the subjects and fields of collection. However, the subject chapters are usually subdivided into sections on individual collectors. The author attempts to show the motivations behind the collecting of rare and valuable books. He also indicates what later happened to each collection, and thereby reveals the great extent to which these collections became parts of larger libraries, or were themselves established as libraries available to scholars and the public. These collectors, the author points out, have added much to America's cultural resources.

6462. Goodspeed, Charles E. Yankee bookseller; being the reminiscences of Charles E. Goodspeed. Boston, Houghton Mifflin, 1937. 325 p. illus. $\quad 37-28796 \quad Z_{473 . G 57}$

Private book collecting on any considerable scale necessitates access to rare and other noncurrent books and related materials. For this purpose the mainstay of the private collector is the rare- and used-book dealer. One of the outstanding 2othcentury businessmen in this field was Charles Eliot Goodspeed ( $1867-195^{\circ}$ ), who established his Boston store in 1898 . His reminiscences, which are largely anecdotal in nature, do not present a concisely detailed or chronological account of his business, but they are almost exclusively concerned with it in one way or another. They illustrate many features of rare-book and used-book selling, as well as of private bcok collecting, in this country during the first three decades of this century. Goodspeed also narrates incidents concerning the closely allied fields of print and autograph selling, as well as forgeries of both printed and manuscript items.

6463. Lee, Charles. The hidden public; the story of the Book-of-the-Month Club. Garden City, N.Y., Doubleday, I958. 236 p.

$$
\text { 58-1 } 3908 \quad \mathrm{Z}_{549 \cdot \mathrm{B}_{6} \mathrm{~L}_{4}}
$$

Book clubs sprang up in Germany immediately after World War I; the first American one, the Book-of-the-Month Club, was inaugurated by Harry Scherman in April 1926, and its immense success has led to numerous imitations. Mr. Scherman (b. r887), founder, president, and chairman of the board, is still the guiding spirit of the enterprise. The essential idea is the guaranteed market provided by the members, who have contracted to take what will be chosen for them by a panel of superior literary intelligences, and can therefore buy for significantly less than the established retail prices (their benefits accrue only partially in reduced prices, for they receive "dividend" or "bonus" books as well). National advertising and the parcel post take the place of the local bookstore, which has in recent years been a declining institution. An original BOMC membership of $4,75^{\circ}$ grew to 889,305 in 1946 , and during $1947-50$ the Club paid an annual dividend of over a million dollars to its shareholders. Since 1948 the membership has remained at approximately half a million. The Club's literary record may be studied in Mr. Lee's "List of Selections, Dividends, and Alternates, 1926-57" (p. 161194). Mr. Lee has collected judgments from a num- 
ber of critics, which vary over a wide range of approval or disapproval. Max Lerner makes the shrewd comment that "the effect of the book club on American reading taste has been to make the almost-good much more popular than it would have been, and every now and then to get an audience for the really-good."

6464. Lewis, Wilmarth S. Collector's progress. New York, Knopf, 195I. 253 p. illus. 51-I I290 Z989.L5

Mr. Lewis urbanely discusses the history of his famous Horace Walpole collection. He opens with a brief account of his early collecting efforts, rapidly passes over his period as an amateur book collector, and then concentrates for the bulk of the volume on his activities as one of America's foremost private collectors, specializing in an individual whose life and letters mirror so much of 18 th-century culture. Indirectly the book reveals much about book collecting in 2oth-century America, and the rare-book dealers involved in projects such as that of $\mathrm{Mr}$. Lewis. He is also the principal editor of the multivolume edition of Walpole's correspondence being published by the Yale University Press. A book which discusses the goals, means, and problems of book collectors is A Primer of Book-Collecting, rev. and enl. ed. (New York, Greenberg, I946. 226 p.), by John $\mathrm{T}$. Winterich in collaboration with David A. Randall, who was mainly responsible for the revision. Mr. Winterich is also the author of a very pleasant survey of Early American Books \& Printing (Boston, Houghton Mifflin, 1935. 256 p.), written primarily from the collector's point of view and offering information likely to be serviceable to him.

6465. Stevens, Henry. Recollections of James Lenox and the formation of his library; revised and elucidated by Victor Hugo Paltsits. New York, New York Public Library, 1951. xxxvi, 187 p. illus. 5 5 I-1204I Z989.L45S8 r95I

One of the prime sources of rare and expensive books, as well as of important general and specialized collections, that public and college libraries rely on because of their frequent financial constriction, is the donation of the accumulations of private collectors. The collectors thereby insure that what they have put together with enthusiasm, skill, and loving care will not be broken up by indifferent heirs. One of the notable examples of a private library that became a public collection, and one of the earliest, is the Lenox Library. James Lenox (1800-1880) was a New York bibliophile with inherited financial resources to back his expensive tastes. His large library, which had overflowed his house, was incorporated in 1870 , and in 1895 it was merged into the New York Public Library. The study of Lenox by Henry Stevens (1819-1886) reveals much of Lenox's bibliophilic activities, but it also reveals at least as much about Stevens, an American antiquarian and rare-book dealer established in London, whose major customer was Lenox. The work was first edited into book form by the author's son, Henry N. Stevens, and published under the same title (London, Stevens, I886. 2 I I p.). The present edition is especially notable for the late Dr. Paltsits' many "Elucidations" appended to each chapter.

\section{E. Libraries}

6466. Clemons, Harry. The University of Virginia Library, 1825-1950; story of a Jeffersonian foundation. Foreword by Dumas Malone. Charlottesville, University of Virginia Library, r954. 229 p. illus.

Bibliography: p. 2x 1-2I3.

The University of Virginia was chartered in $18 \mathrm{r} 6$, and began instruction in 1825 . The library, like the rest of the University, received its main conception and impetus from Thomas Jefferson. His last visit was made in 1826 , but his concept of the library lingered long after, and has some effect today, as Mr. Clemons, librarian there from 1927 to 1950 , is at some pains to show in his story of the library's development. The book opens with an account of the founding of the library (1816-1826), and goes on to trace its history to the time of the Civil War. Chapter 3 carries the story to 1895 , when a fire destroyed the library building and most of the collection. Chapter 4 traces the library's resurgence after the fire to the year 1925, when the centennial of its founding was observed. Chapter 5 is a series of biographical sketches of the nine librarians who preceded Mr. Clemons in the office. The sixth and final chapter carries the story of the library from 1925 to mid-century. The book itself is one of the few relatively thorough studies of the development of a major university research library, and as such is representative of the development of libraries as instruments of American education.

6467. Compton, Charles H. Twenty-five crucial years of the St. Louis Public Library, 1927- 
1952. With a supplement, The Library's readers, by Charles $\mathrm{H}$. Compton [and others] St. Louis, 1953. 204 p. 53-11009 Z733.Si41C6

St. Louis, eighth in population among American cities in $195^{\circ}$, has one of the outstanding city public libraries. This study tells the story of its modern growth and the expansion of its role in society. Mr. Compton, who has served as assistant librarian, librarian, and librarian emeritus for almost $4^{\circ}$ years, writes in his foreword: "It shall be the endeavor of the writer to interpret the St. Louis Public Library as a living, pulsating, changing, and growing reality in the community and to indicate its importance in a free society." His report indicates not only the role of the library and the nature of its collections, but also the financial and administrative problems that have had to be faced. The library was founded in 1865 , and some account of its history through 1926 may be found in Compton's earlier Fifty Years of Progress of the St. Louis Public Library, 18761926 (St. Louis, St. Louis Public Library, I926. 84 p.), which was also issued as a supplement to the Annual Report of the Library for 1925-26. This sketch passes rapidly over the early years, and becomes detailed only with the founding of the American Library Association in 1876 . It was not meant to be a full history of the institution, but rather "an attempt to trace some of the ideas which have gone into the making of the library and to indicate significant and outstanding points in its development," and "to create in the reader's mind the atmosphere of the library in its earlier years in order that the library of today may be seen to be a natural growth from its infancy and youth."

6468. Keep, Austin Baxter. History of the New York Society Library, with an introductory chapter on libraries in Colonial New York, $1698-$ 1776. New York, Printed for the Trustees by the De Vinne Press, 1908. xvi, 607 p. illus.

\section{8-34672 Z $733 . \mathrm{N}_{74} \mathrm{~K}$}

In the early years of this country attempts to create a general library service usually took the form of a group of individuals agreeing to pool their resources for the establishment of a library, so that each might have access to more. Most of these were "society libraries," normally limited to the use of subscribers, with occasional courtesy extension of privileges to relatives and distinguished friends. As free public libraries grew in numbers and strength, the society libraries declined in importance, and often went out of existence or were incorporated into the public library. New York City had one of the larger society libraries, and generous endowments have enabled it to continue, albeit with a limited clientele, to the present day. Mr. Keep's history opens with an account of early New York libraries, and goes on to present a roughly chronological study of the Society Library from its founding in 1754 through its 150th anniversary in 1904. The work not only shows in detail the evolution, problems, and services of such a library, but also reveals much about the reading of New York's social and intellectual leaders throughout the period. The story is brought up to date in Mrs. Marion M. King's less formal Books and People; Five Decades of New York's Oldest Library (New York, Macmillan, I954. 372 p.). Mrs. King joined the staff in 1907, and her book not only describes the 2oth-century activities of the library, but in its year-by-year approach to its subject matter it gives a good picture of the more popular aspects of reading throughout the first half of the century. The anecdotal nature of much of the book also gives it value as a picture of life inside a library.

6469. Mearns, David C. The story up to now; the Library of Congress, 1800-1946. Washington, U.S. Govt. Print. Off., 1947. 226 p. $4^{8}-45515 \quad Z_{733 . U 6 M_{45}}$

"Reprinted from the Annual report of the $\mathrm{Li}$ brarian of Congress for the fiscal year ending June 30 , 1946, with the addition of illustrations and a slight revision of text."

The Library of Congress was founded in 1800 . It was subsequently destroyed when the British burned the Capitol during the War of 1812. In 1815 the Library made a fresh start when Congress purchased the library of Thomas Jefferson (see Adams, no. 6460). Since then the Library has steadily grown, save for a second setback by fire in 1851, until it is probably the world's largest, with a collection of more than $11,700,000$ books and pamphlets, over 16,100,000 manuscripts, 2,000,000 items of music, $2,400,000$ maps and views, etc., for a total collection of more than $38,100,000$ items in 1959. It serves not only Congress, but also, through many services, other government agencies, libraries throughout the world, and the general public. Since the Library is not only the largest in the country, but also the center of a number of the nation's library activities, an understanding of the Library of Congress is essential to an understanding of the role of libraries in the 2oth century. Mr. Mearns' history narrates the development of the Library's collections and services from the first proposals for a Government library up to 1946 . It emphasizes the work of two great Librarians of Congress, Ainsworth R. Spofford (1825-1908) and Herbert Putnam (186I-1955), whose nearly successive terms ran from 1864 to 1939 , in making theirs a truly national library. The early part of the story is 
related at greater length and without much art in the first and only volume published of William Dawson Johnston's History of the Library of Congress (Washington, Govt. Print. Off., rg04. 535 p.); it reaches 1864 . A brief and up-to-date account of the Library is Paul M. Angle's The Library of Congress: an Account, Historical and Descriptive (Kingsport, Tenn., Kingsport Press, 1958. 77 p.); it is based on The Story Up to Now and the subsequent annual reports of the Librarian.

6470. Potter, Alfred Claghorn. The library of Harvard University; descriptive and historical notes. $4^{\text {th }}$ ed. Cambridge, Harvard University Press, 1934. 186 p. (Library of Harvard University. Special publications, 6)

$$
\text { 34-20604 } \mathrm{Z}_{733} \cdot \mathrm{H}_{34} \mathrm{P} \quad 1934
$$

The Harvard Library is both the oldest and the largest university library in this country. The collection numbers over six million volumes, and is exceeded in size in America only by the Library of Congress and the New York Public Library. This publication, the first edition of which appeared as early as 1903 , therefore provides not only a history and analysis of a leading academic and research library, but also an example of the aims and problems of such libraries. A study of the problems currently faced in maintaining and furthering such a library, as well as in making it function to best advantage, is Keyes D. Metcalf's Report on the Harvard University Library; a Study of Present and Prospective Problems (Cambridge, Harvard University Library, 1955. I 31 p.); this not only gives a fairly clear picture of the Library's present scope and functions, but devotes considerable attention to the place of the Library, along with other leading research libraries, in the "American library" that is developing as a result of cooperation among libraries through interlibrary loan, microfilming, division of labor in collecting, accessibility to visiting scholars, etc. Second to the Harvard Library in size and age is the Yale University Library. Its main building is described in detail in a well-illustrated article, "The Sterling Memorial Library," which appeared on pages $57-\mathrm{r}_{23}$ of volume 5 (April 193I) of The Yale University Library Gazette. This is a thorough presentation of the physical plant of a leading research library. An interesting series of articles derived from various aspects of the library's collections, especially unusual items and special collections, is Papers in Honor of Andrew Keogh, Librarian of Yale University (New Haven, Priv. Print., 1938. 492 p.). They give an idea not only of some of the more esoteric material that may be found in a general research library, but also of the potential scholarly use and significance of such uncommon items and collections.
6471. Schenk, Gretchen (Knief). County and regional library development. Chicago, American Library Association, I954. 263 p.

Bibliography: p. [258]-26o. $53-7488 \mathrm{Z}^{2} 75 . \mathrm{C}^{8} \mathrm{~S}_{4}$

Since most early public libraries were established on a city or other local basis, many thinly populated areas found themselves without any public library service, while many small towns struggled to support inferior libraries on inadequate taxes. In recent years improved transportation and communication have made possible an alternative to this in the form of county and regional libraries. These usually involve plans for a shared budget and bookstock over a large area, and by raising the total bookstock, make more books available in each community. At the same time, pooled budgets have in some areas produced better services, such as reference and readers' advisory work, at a comparatively low cost. However, initial costs delayed many such projects. Mrs. Schenk's book was written in anticipation of Federal aid to libraries. Such aid was enacted soon afterwards, giving a great impetus to county and regional libraries. The author does not give a history of the movement, nor does she examine existing libraries in detail. She has rather attempted to synthesize procedures and programs as a guide to what is done for and by such libraries.

6472. Shera, Jesse H. Foundations of the public library; the origins of the public library movement in New England, 1629-1855. Chicago, University of Chicago Press, 1949. xv, 308 p. illus. (The University of Chicago studies in library science)

"Selected bibliography": p. 291-295.

Dr. Shera. writes in his introduction: "We are here concerned with those elements in American life which contributed directly or indirectly to the growth of the public library as a social agency and the character of the environment from which it emerged. Though attention is restricted to but one section of the United States, much of what is said here with reference to New England is equally applicable elsewhere as economic and social conditions began to approximate those of the northeastern Atlantic seaboard. But New England, because it is the cradle of American librarianship and because its cultural records have been so assiduously preserved, was the logical, if indeed not inevitable, place to begin." Much the same period and subject matter is covered by Charles Seymour Thompson's somewhat shorter Evolution of the American Public Library, 1653-1876 (Washington, Scarecrow Press, 1952. 287 p.). Sidney Ditzion's Arsenals of $a$ Democratic Culture; a Social History of the American Public Library Movement in New England and 
the Middle States from 1850 to 1900 (Chicago, American Library Association, 1947. 263 p.) brings the story to a later date. Samuel Swett Green's The Public Library Movement in the United States 1853-1893 (Boston, Boston Book Co., 1913. 336 p.) actually is mainly concerned with the period after 1876 , and in large part consists of the author's reminiscences of his participation in the free library movement. Librarian of the Worcester Public Library from 1871 to 1909 , he also served, from 1890 , on the Massachusetts Free Public Library Commission.

6473. Spencer, Gwladys. The Chicago Public Library; origins and backgrounds. Chicago, University of Chicago Press, 1943. xvii, 473 p. illus. (The University of Chicago studies in library science)

Bibliography: p. 423-435.

The author sums up the scope and purpose of this book in her introduction: "This study endeavors first ... to present with as high a degree of accuracy and clarity as is permitted by records often incomplete the scenes of library history in Chicago from the beginning through 1872 and, in addition, but more briefly, those in the surrounding state of Illinois as they formed unfolding backgrounds for the establishment in a great metropolitan center of its free public library of today. . . . Secondly, the study attempts to analyze such available data with the purpose of discovering the chief factors that contributed to the inception of this library. Lastly, the study suggests what may be the significance of the factors found to be influential in the origin of the Chicago Public Library as a representative institution in its relation to the history of the American library movement as a whole." The importance of this as a representative work is underscored by the author's thesis "that certain great decisive forces that had previously been and were still at work in Chicago, in the state at large, and even throughout the entire country bore a share of major importance as fundamental cofactors in the creation of the new institution." This investigation of other than immediate and obvious causes has been neglected in most library histories.

6474. U. S. Office of Education. Public libraries in the United States of America; their history, condition, and management. Special report, Department of the Interior, Bureau of Education. Part I. Washington, Govt. Print. Off., 1876. xxxv, I 87 p. illus.

I-9328 Z731.U 57

Part II consists of Cutter's Rules for a Printed Dictionary Catalogue, 1876 (2d edition, 1889; $3 \mathrm{~d}$ edition, I891).
This landmark in the writing of library history is probably the most thorough work of the kind that has yet been published. Despite its age, it remains of value for its impressive detail on the library situation in America about I875. It opens with a study of "Public Libraries a Hundred Years Ago." There follow chapters on the many types of public libraries, such as school, law, government, theoretical, historical society, medical, and scientific libraries. A number of chapters are also devoted to various aspects of free town libraries, and town organization libraries. The more technical aspects of librarianship are discussed in the later chapters, concerned with matters such as library buildings, catalogs, cataloging and classification, indexing, binding, reports and statistics, etc. The final chapter (p. 1010-1 174) consists of tables of general library statistics and a listing of librarians.

6475. Whitehill, Walter Muir. Boston Public Library; a centennial history. Cambridge, Harvard University Press, 1956. 274 p.

\section{${ }_{56-6528} \quad \mathrm{Z}_{733} \cdot \mathrm{B}_{752} \mathrm{~W}_{5}$}

In 1848 the Massachusetts legislature authorized the city of Boston "to establish and maintain a public library," thereby making the Boston Public Library the first tax-supported city library to be authorized by statute. The book collection grew rapidly, although the formal opening of the library was delayed for a few years. Mr. Whitehill's history presents in chronological form the story of the initial struggles to establish a public library; the early very rapid growth by which the library soon became one of the largest in the nation; the decline that set in during the late 1870's and continued for nearly a decade; the subsequent resurgence; a second decline resulting from financial stringency; and a new improvement brought about by the bettered financial situation after World War II. Because of its priority, the history of the Boston Public Library reflects much of the public library movement from its inception. Mr. Whitehill gives much detail on the books supplied to the community which was for many years the nation's cultural center. The story of the society library which supplied much of Boston's reading matter before the founding of the public library, and which itself came close to functioning as a public library, may be found in Josiah Quincy's detailed work, The History of the Boston Athenaeum (Cambridge, Metcalf, 1851. 263, 104 p.), which has also been distinguished as the "first formal history of an American library." The story is carried forward in the society's own publication, The Athenaeum Centenary: the Influence and History of the Boston Athenaeum from 1807 to 1907 
(Boston, Boston Athenaeum, r907. 236 p.), the greater part of which is, unfortunately for the gen- eral reader, devoted to "a record of its officers and benefactors and a complete list of proprietors."

\section{F. Librarianship and Library Use}

6476. American library pioneers. [v.] $\mathrm{I}-8$. Chicago, American Library Association, 1924-r953. $8 \mathrm{v}$.

I. Lydenberg, Harry Miller. John Shaw Billings, creator of the National Medical Library and its catalogue, first director of the New York Public Library. I924. 94 p. 24-20388 Z720.B6L9

2. Shaw, Robert Kendall. Samuel Swett Green. I926. 92 p. 26-10763 Z720.G8S5

3. Cutter, William Parker. Charles Ammi Cutter. I931. 66 p. $\quad 3$ I-28434 Z720.C99C9

4. Eastman, Linda A. Portrait of a librarian, William Howard Brett. 1940. 104 p.

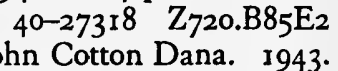
I05 p. $\quad 43^{-11446} \mathrm{Z}_{720} . \mathrm{D}_{2} \mathrm{H}_{2}$

6. Rider, Fremont. Melvil Dewey. 1944. $15 \mathrm{I} \mathrm{p.}$ 44-4322 Z720.D5R5

7. Borome, Joseph Alfred. Charles Coffin Jewett. 1951. $188 \mathrm{p}$. 51-10999 Z720.J59B6

8. Pioneering leaders in librarianship. First series. Edited by Emily Miller Danton. I 953 . 202 p. 53-10258 Z720.A4U47

The slender volumes in this series have appeared at widely spaced intervals. They describe the lives, with heavy emphasis on their professional librarian and bibliographical aspects, of persons who have attained prominence in American librarianship. As a group they afford considerable insight into advances in librarianship, particularly during the late rgth and early 2oth centuries. These studies have been written largely by librarians for librarians, and as a result suffer somewhat from a limited outlook. They all present very favorable portraits, but few of their subjects emerge as recognizable human beings. This results in part from the emphasis on the professional aspects of their lives; but this same emphasis enables one to obtain a clear idea of their professional advancements. Volume 8 , which treats "a wide assortment of distinguished persons who played a strong role in developing American libraries," is the first of a new "omnibus" subseries. Mrs. Danton, who edited the latest volume, took over editorship of the series after the death of Dr. Arthur E. Bostwick in 1942.

6477. Berelson, Bernard. The library's public; a report of the Public Library Inquiry. With the assistance of Lester Asheim. New York, Columbia University Press, 1949. xx, 174 p.

$$
\text { 49-10661 Z73r.B } 1949
$$

This report is actually a synthesis of two originally separate reports: one based on the results of a personal interview survey conducted in the autumn of r.947, and one based on an analysis of reports published since 1930 on library book use and users. It opens with a discussion of the position of library usage in the context of public usage of the mass media such as newspapers, films, and magazines. Chapter 2 analyzes the various groups who use public libraries and the intensity of their usage. Chapters 3 and 4 take up the questions of why and when people use public library facilities. Chapter 5 discusses the concentration of usage among a relatively small group. The concluding chapters consider what further research is needed to shed more light on this subject, and implications the studies already made have for library policy. The report concludes that the library actually has a number of publics with diverse purposes and fields, and that "it must decide what things it will be to whom." It suggests, without actually concluding, that the library should do less competing with the mass media in the field of entertainment, and more in books and services for "serious-minded people concerned with serious-minded materials."

6478. Brough, Kenneth J. Scholar's workshop; evolving conceptions of library service. Urbana, University of Illinois Press, 1953. xv, $197 \mathrm{p}$. (Illinois contributions to librarianship, no. 5)

Bibliography: p. $178-187$. $52-10462$ Z675. U $\mathrm{U}_{5} \mathrm{~B} 85$

Mr. Brough's study is "ostensibly limited to developments in the university libraries of Chicago, Columbia, Harvard, and Yale," but, he says, "the story would have varied little if the four institutions selected for investigation had been, say, California, Michigan, Pennsylvania, and Princeton." The author takes 1876 as the starting point for modern librarianship, and from that date he traces such problems of research libraries as services to readers, the nature of the collections, and their accessibility. Throughout the work he compares evolving policy to earlier practices. In the early years of this country the concept governing college libraries had been 
one of service to advanced scholars. Gradually students were allowed a limited use of the collections, and in time there arose the idea of actually trying to provide specifically for the needs even of undergraduates, as a result of which the libraries became increasingly an essential factor in the teaching program. The story of the early years of these libraries is told in considerable detail in Louis Shores' Origins of the American College Library, 1638-1800 (New York, Barnes \& Noble, 1935. 290 p.). A volume edited by Herman $\mathrm{H}$. Fussler, which discusses many of the areas in which the modern college library is concerned, from library architecture and student programing through personal policies and acquisitioning, is The Function of the Library in the Modern College (Chicago, University of Chicago, Graduate Library School, 1954. 117 p.); it consists of "Papers - presented before the nineteenth annual conference of the Graduate Library School of the University of Chicago." A parallel work, more concerned with technical problems such as cataloging, cost of maintenance, specialization, etc., is Problems and Prospects of the Research Library (New Brunswick, N.J., Scarecrow Press, 1955. 18r p.), edited by Edwin E. Williams for the Association of Research Libraries; it consists of a group of papers presented at the Monticello [Illinois] Conference of the Association in 1954.

6479. Bryan, Alice I. The public librarian; a report of the Public Library Inquiry, by Alice I. Bryan, with a section on the education of librarians by Robert D. Leigh. New York, Columbia University Press, 1952. xxvii, 474 p. diagrs. 52-8829 Z682.B7

This report concerns itself with the people who work in public libraries, with an emphasis on those on the professional level, secondary interest in those on a subprofessional level, and no attention at all to those on a nonprofessional level. Nearly two thirds of the volume is devoted to a study, based on questionnaires and tests, of the public librarians. The author attempts to determine factors such as personal characteristics (distribution by sex, marital status, recreational activities, personality, etc.), educational status, economic status (salaries, savings, insurance, etc.), and library career activities and attitudes. Also analyzed are the several aspects of personnel administration: management, employee selection, in-service training, promotion and pay systems, labor relations, unions, associations, morale, etc. About a third of the book is occupied by Mr. Leigh's section, "The Education of Librarians." The first chapter of this section gives a brief survey of the "Evolution of Library Schools"; the second studies library school programs; the fourth analyzes the student body (sex, geographical distribution, admission requirements, etc.), and the final chapter surveys "The Faculty and Instructional Resources."

6480. Leigh, Robert D. The public library in the United States; the general report of the Public Library Inquiry. New York, Columbia University Press, 1950. 272 p. 50-9138 Z731.L45

"Methods and sources": p. [247]-263.

Dr. Leigh was the director of the Public Library Inquiry, a project proposed by the American Library Association, carried out by the Social Science Research Council, and financed by the Carnegie Foundation of New York. His general report opens with an account of the purpose, nature, and limitations of the inquiry. There follow chapters which summarize findings and discuss prospective developments in various fields; their scope is indicated by their titles: "The Library Faith and Library Objectives," "The Business of Communication," "Library Units and Structure," "Library Materials," "Library Services," "Library Government and Politics," "Library Financial Support," "Library Operations," "Library Personnel and Training," and "The Direction of Development." Dr. Leigh's report is a balanced presentation of the position and problems of the public library in present-day America. Greater detail on special aspects of the subject is contained in other reports of the Public Library Inquiry by Miller (no. 6441), McCamy (no. 6452 note), Berelson (no. 6477), and Bryan (no. 6479). These studies are all limited by the definition of a public library as a free, tax-supported library available to the community in general, thus excluding, most notably, the free school libraries. However, related aspects of other types of libraries are considered throughout the series of reports. Dr. Leigh, who later became dean of the Columbia School of Library Service, also contributed the first paper, "Changing Concepts of the Public Library's Role," to New Directions in Public Library Development (Chicago, University of Chicago, Graduate Library School, 1957. 104 p.). These eight papers presented before the $22 \mathrm{~d}$ Annual Conference of the Graduate Library School (1957) were edited by Lester Asheim, and include discussions of the Federal Library Services Act and of community developments. In 1954 the Public Libraries Division of the American Library Association appointed a Coordinating Committee on Revision of Public Library Standards, which, after two conferences and the circulation of a first draft, was able to formulate a new statement of standards for public libraries, revised from the earlier codes of 1933 and 1943: Public Library Service; a Guide to Evaluation, with Minimum Standards (Chicago, American Library Association, 1956. xxi, 74 p.). This offers a numbered series of concise formulations in the realms 
of structure and government, service, books and nonbook materials, organization and control of materials, and physical facilities. For example, no. 73: "Films, recordings, and pictures should be available for use off the premises."

648r. Marshall, John David, comp. Books, libraries, librarians; contributions to library literature, selected by John David Marshall, Wayne Shirley [and] Louis Shores. Hamden, Conn., Shoe String Press, 1955. xv, 432 p.

Includes bibliographies. 55-3034 Z665.M66

Mr. Marshall opens his introduction thus: "Much of the literature of librarianship cannot be described truthfully as particularly enjoyable reading, for it lacks that intangible and elusive quality known as readability." The literature of librarianship is not the only field that has been plagued by this stylistic problem, and it might be contended that some other fields have a larger percentage of unreadable writings than does librarianship. At any rate, this volume is an attempt to present a selection of interesting and readable contributions from the profession's literature. The volume is therefore not only more readable than many others on libraries and librarianship, but it is also highly informative in its presentation of many aspects of the library world and its problems. The articles are presented in four sections: "Books and Reading," "Libraries," "Librarians and Librarianship," and "Notable Statements of the Librarian's Profession." The topics range widely from children's libraries to research libraries, and from library acquisition policies to the problem of theft of library books.

6482. Phinney, Eleanor." Library adult education in action; five case studies. Chicago, American Library Association, 1956. 182 p.

$$
\text { 56-9496 Z7 } Z_{7} \text { I.2.P5 }
$$

A modern development in the activities of public libraries is that of adult education-education beyond that of having a book stock available for loan. Eleanor Phinney's.study is mainly a report on what five libraries of moderate resources have been doing. She selected ones in Mount Vernon, N.Y., St. Mary's County, Md., Carrollton, Ga. (the West Georgia Regional Library), La Crosse, Wis., and Andover, Mass. The kinds of educational activity engaged in included displays and exhibits, reader-interest files and notification service, local radio programs, educational film programs, discussion groups, etc. A chapter on common elements in the programs has been included, emphasizing the importance of a zeal for adult education on the part of the chief librarian, the staff, and the board. The conclusions of a sur- vey of the subject will be found in Helen Lyman Smith's Adult Education Activities in Public Libraries; a Report of the ALA Survey of Adult Education Activities in Public Libraries and State Library Extension Agencies of the United States (Chicago, American Library Association, 1954. 96 p.).

6483. Rothstein, Samuel. The development of reference services through academic traditions, public library practice, and special librarianship. Chicago, Association of College and Reference Libraries, 1955. 124 p. (ACRL monographs, no. I4) 55-9938 Z674.A75, no. 14

Issued also in microfilm form, as thesis, University of Illinois, under title: The Development of Reference Services in American Research Libraries.

Bibliography: P. I I I-I 24 .

The author begins his final chapter thus: "To trace the development of reference services in American research libraries is to record the transformation of occasional and casual courtesy into a complex and highly specialized service of steadily increasing scope and importance. In most institutions, it is now taken for granted that one of the Library's primary functions is to make available personal assistance for readers seeking information." The development of this function, central to much of modern librarianship, is presented as "the result of a collocation of particular historical factors distinctive to the American library scene." The story is traced in some detail from 1850, from which year the author dates "The Rise of Research and Research Libraries" (chapter I). He then studies the growth of reference services in libraries, the development of special libraries, the problems of legislative and municipal reference work, and the recent development of reference service in industrial libraries for professional researchers. After carrying the story to the beginning of World War II, Dr. Rothstein concludes with a chapter on general trends. A detailed picture of. reference service as librarians conceive and practice it is presented in a volume edited by the late Pierce Butler: The Reference Function of the Library (Chicago, University of Chicago Press, 1943. 366 p.), consisting of papers read at the Library Institute of the University of Chicago in 1942. The topics dealt with include personnel and training for reference work, its administrative problems, book selection and supplementary reference materials, and reference service in special fields such as art, music, and rare books.

6484. Tauber, Maurice F., ed. Technical services in libraries: acquisitions, cataloging, classification, binding, photographic reproduction, and 
circulation operations. New York, Columbia University Press, 1954. xvi, 487 p. diagrs. (Columbia University studies in library service, no. 7)

$$
\text { 54-10328 Z665.T28 I954 }
$$

This volume, the work of Mr. Tauber and seven associates, is a study, aimed primarily at library school students, of the more or less technical operations that take place in a library, with a special emphasis on the point of view of a general research library. Since most of this activity goes on behind the scenes in most libraries, it is an aspect of library work that is largely unknown to the general public. While this volume is not aimed at that public, it will enable the layman to gain a just idea of many little-known problems that face the librarian, as well as a conception of the complexities involved in maintaining a modern research, college, or large public library. To a less extent it also reflects the tribulations of smaller public and school libraries. The final chapter concisely discusses the possibilities of applying cost analysis and management analysis to library operations, and of introducing various types of machines as savers of labor and time. A group of lectures which sum up a number of the problems and possibilities of modern librarianship is Challenges to Librarianship (Tallahassee, Florida State University, 1953. I56 p. Florida State University studies, no. 12), edited by Louis Shores; the lectures were originally delivered by distinguished visitors to the university, and cover such topics as censorship, microphotography, the sciences, audio-visual material, and international understanding.

6485. Trautman, Ray. A history of the School of Library Service, Columbia University. New York, Columbia University Press, 1954. 85 p. illus. (The Bicentennial history of Columbia University)

54-5197 Z669.T7

The rith ceritury witnessed a tremendous growth in the number of American libraries and in the total number of volumes held by most of them. This led to unanticipated complexities in the acquiring, cataloging, and servicing of books. Added difficulties arose out of rapidly expanding conceptions of desirable services to readers. The result was that the idea of professional librarianship began to emerge as an attempt to obtain competent librarians with more complex and skilled functions than merely guarding relatively small book collections. This situation led Melvil Dewey to establish a library school at Columbia University in 1883 . A few years later the school moved to Albany, and did not return to Columbia until 1926 . Thus, notwithstanding its long residence elsewhere, the Columbia University School of Library Service may claim to be the oldest as well as an outstanding li- brary school. Mr. Trautman's book traces the complicated history of the school, and also offers insight into the evolving concepts of librarianship. Difficulties currently being faced in developing curricula in library schools are brought together in a volume edited by Robert D. Leigh: Major Problems in the Education of Librarians (New York, Columbia University Press, I954. II6 p.), which resulted from a seminar on education for librarianship held in the Columbia School of Library Service in 195253. A work of somewhat wider range is Education for Librarianship (Chicago, American Library Association, 1949. 307 p.), edited by Bernard Berelson and consisting of papers presented at a library conference held at the University of Chicago in August 1948. It covers not only current professional problems, but also a history of the library school movement and a survey of the problems involved in the training of nonprofessional or subprofessional library employees.

6486. Utley, George Burwell. The librarians' conference of 1853 , a chapter in American library history; edited by Gilbert $\mathrm{H}$. Doane. Chicago, American Library Association, I951. I89 p.

$$
\text { 5I-11154 Z673.A49U7 }
$$

"Proceedings of the Librarians' Convention, held in New York City, September 15, 16, and 17, 1853. (Reprinted . . . from Norton's Literary and educational register, for 1854)": p. [129]-176.

The librarians' conference of September $15-17$, 1853, in New York City was the first general conference of American librarians, and its participants may be regarded as the forefathers of the modern library movement in general and of the American Library Association in particular. To this first conference came leading librarians throughout the nation, although the Northeast, where most libraries of any size were then located, was naturally the most strongly represented. The conference had relatively little direct influence of importance, but indirectly it set off a significant train of events. It initiated greater cooperation among libraries, and in turn this led to a greater attention to and understanding of library problems. It also established a precedent for the 1876 conference, when the American Library Association was founded and modern professional librarianism was firmly set on its way. The proceedings of the meeting are reprinted in offset at the end of this volume (p. 129-176). The final draft of Mr. Utley's book was nearly finished at the time of his death in 1946; the work of completion and editing was carried out by his nephew.

6487. Wilson, Louis Round, and Maurice F. Tauber. The university library; the organization, administration, and functions of academic 
libraries. 2d ed. New York, Columbia University Press, 1956. 641 p. diagrs. (Columbia University studies in library service, no. 8)

$$
\text { 55-I I } 184 \quad \text { Z675.U5W745 } 1956
$$

Bibliographies at end of chapters.

The first edition of this work was published by the University of Chicago Press in 1945. The authors state that their purpose "is to review the changes which have taken place in the university library in response to the demands made upon it by university growth; to consider systematically the principles and methods of university and library administration; and to formulate generalizations concerning the organization, administration, and functions of the university library to the end that it may serve its clientele more adequately and effciently than it has in the past." Though much of it sounds like a statement of what should be done, most of it is a statement, frequently in abstract form, of what has been done. Relatively little theory is advanced. This, combined with the emphasis of the study on the research collections and their administration, means that the volume actually offers a fairly thorough prospect of the nature, organization, and administration of large research libraries at the present day. There is relatively little historical material, although some is included in order to illustrate the development and changes in the problems that university librarians have had to face. The whole field is thoroughly covered in College and Research Libraries, the organ of the Association of College and Reference Libraries, a division of the American Library Association. This quarterly, which began publication in December 1939, is currently published at Fulton, Mo., by the American Library Association. An important recent development of great interest to research libraries was the establishment in $195^{6}$ of The Council of Library Resources, Inc., which has as its principal objective "to aid in the solution of library problems; to conduct research in, develop and demonstrate new techniques and methods and to disseminate through any means the results thereof." The Council was established at the instance of the Ford Foundation, which has made it a grant of $\$ 5$ million to be expended over a five-year period. The Council's endeavors are outlined in its Annual Report, 1956/57- (Washington, I957-). 


\section{Appendix: Selected Readings in American Studies}

AS EXPLAINED in the Introduction, in June 1954 the Council of the American Studies Association recommended that this Guide should include a separate section containing those titles which have a synthetic approach, bridge the various academic and scholarly disciplines, and are therefore of special significance to teachers or students pursuing courses in American studies. A tentative selection of 100 such titles was submitted to the Council and other prominent members in October of the same year, together with a request for specific suggestions. In consequence of the replies some titles were promptly deleted, and considerably more added. Since then further deletions have been made for various reasons, and a much larger number of additional titles accumulated, many but by no means all of which are publications later than 1954. The result, a list of Igo titles, is below. The Igo may be thus briefly accounted for: 83 are from the original list; 35 were recommended by A.S.A. members in 1954; and 72 are subsequent additions. Of the last 72 , nine do not appear in the main Guide; published since work upon the pertinent chapters was concluded, they have been thought too important to omit here.

To facilitate rapid finding, the 190 titles appear in a single alphabetical order. Most entries are limited to author, title, imprint, and pagination, plus a bracketed serial number which directs one to the fuller entry in the main body of the Guide, where the annotation will normally supply a justification for the work's inclusion here. Under authors, titles are also alphabetically ordered save in the case of sequels, which are placed directly after the primary work. For the nine recent works not in the Guide proper, the Library of Congress call and card numbers, and series note when there is one, have been added. In a very few cases the edition entered here is a later one than that in the body of the Guide; in this case also call and card numbers have been included.

Finally, it should be stated that this Appendix does not attempt to incorporate the classics of Ameri- can thought and expression, of the stamp of Emerson, Thoreau, Whitman, or William James; and that anthologies, save in a very few instances with special reasons for each, have been excluded. It must, of course, be regarded as suggestive rather than exhaustive; anyone can readily make his own amplifications from the chapters that precede it. Important guides to the present state of American studies, which appeared too late to be included in the main body of this book, are Sigmund Skard's American Studies in Europe; Their History and Present Organization (Philadelphia, University of Pennsylvania Press, 1958. 2 v.) and Robert $\mathrm{H}$. Walker's American Studies in the United States, a Survey of College Programs (Baton Rouge, Louisiana State University Press, 1958. 210 p.).

Aaron, Daniel. Men of good hope; a story of American progressives. New York, Oxford University Press, I95I. xiv, 329 p.

[6424]

Aaron, Daniel, ed. America in crisis; fourteen crucial episodes in American history. New York, Knopf, 1952. $363 \mathrm{p}$.

[3070]

Allen, Frederick Lewis. The big change: America transforms itself, 1900-1950. New York, Harper, 1952. $308 \mathrm{p}$.

[4514]

Allen, Frederick Lewis. Only yesterday; an informal history of the nineteen-twenties. New York, Harper, 1931. $37^{\circ} \mathrm{p}$.

[3477]

Almond, Gabriel A. The American people and foreign policy. New York, Harcourt, Brace, 1950. $269 \mathrm{p}$.

[3609]

Andrews, Wayne. Architecture, ambition and Americans; a history of American architecture, from the beginning to the present. New York, Harper, 1955. 315 p.

[5698] 
Barker, Virgil. American painting, history and interpretation. New York, Macmillan, 1950. xxvii, $717 \mathrm{p}$.

[5742]

Barzun, Jacques. Music in American life. Garden City, N.Y., Doubleday, 1956. 126 p. [5615]

Basler, Roy P. The Lincoln legend; a study in changing conceptions. Boston, Houghton Mifflin, 1935. $335 \mathrm{p}$.

[3395]

Bates, Ralph Samuel. Scientific societies in the United States. 2d ed. New York, Columbia University Press, 1958. 297 p.

$$
\text { 57-ror43 Qir.A1B3 1958 [4713] }
$$

Beard, Charles A., and Mary R. Beard. The rise of American civilization. New York, Macmillan, 1927-42. $4 \mathrm{v}$.

Contents.-v. I. The agricultural era.-v. 2. The industrial era.-v. 3. America in midpassage. - v. 4. The American spirit, a study of the idea of civilization in the United States.

$\left[3073,3479,375^{\circ}\right]$

Berelson, Bernard R., Paul F. Lazarsfeld, and William N. McPhee. Voting; a study of opinion formation in a presidential campaign. [Chicago] University of Chicago Press, 1954. xix, 395 p.

[64I 14$]$

Billington, Ray Allen. The Protestant Crusade, 1800-1860; a study of the origins of American nativism. New York, Rinehart, 1952, " 1938. 5I4 p.

[45'5]

Billington, Ray Allen. Westward expansion, a history of the American frontier, by Ray Allen Billington with the collaboration of James Blaine Hedges. New York, Macmillan, I949. 873 p.

[3074]

Blegen, Theodore C. Norwegian migration to America. Northfield, Minn., Norwegian-American Historical Association, 193 I-40. 2 v. [4484]

Boas, George, ed. Romanticism in America; papers contributed to a symposium held at the Baltimore Museum of Art, May 13, 14, 15, 1940. Baltimore, Johns Hopkins Press, 1940. 202 p. [375I]

Bowers, David F., ed. Foreign influences in American life; essays and critical bibliographies. Edited for the Princeton Program of Study in American Civilization. Princeton, Princeton University Press, 1944. 254 p. [3768]
Brebner, John B. North Atlantic triangle; the in terplay of Canada, the United States and Great Britain. New Haven, Yale University Press for the Carnegie Endowment for International Peace, Division of Economics and History, 1945. xxii, $3^{85} \mathrm{p}$.

[3552]

Bridenbaugh, Carl. Cities in the wilderness; the first century of urban life in America, 1625-1742. [2d ed.] New York, Knopf, 1955. 500 p.

[460I]

Bridenbaugh, Carl. Cities in revolt; urban life in America, 1743-1776. New York, Knopf, 1955. xiii, 433, xxi p.

Brooks, Van Wyck. Makers and finders; a history of the writer in America, 1800-1915. New York, Dutton, 1936-52 [v. I, 1944] 5 v.

[238I ]

Brown, Ralph H. Historical geography of the United States. New York, Harcourt, Brace, I948. $596 \mathrm{p}$.

[2969]

Bryce, James Bryce, viscount. The American commonwealth. London and New York, Macmillan, 1888. 2 v.

[4499]

Burlingame, Roger. March of the iron men, a social history of union through invention. New York, Scribner, 1938. xvi, $500 \mathrm{p}$.

$\left[47^{83}\right]$

Burlingame, Roger. Engines of democracy; inventions and society in mature America. New York, Scribner, 1940. xviii, $606 \mathrm{p}$.

$$
40-276_{37} \text { T.1. }_{27} \quad\left[478_{3} \mathrm{n}\right]
$$

Burns, Edward McNall. The American idea of mission; concepts of national purpose and destiny. New Brunswick, N.J., Rutgers University Press, 1957. $385 \mathrm{p}$.

$$
\text { 57-1096r Ei6g.r.B943 }
$$

Burns, James MacGregor, and Jack Walter Peltason. Government by the people; the dynamics of American national, state, and local government. 3d ed. Englewood Cliffs, N.J., Prentice-Hall, 1957. $990 \mathrm{p}$.

[6134]

Butts, R. Freeman, and Lawrence A. Cremin. A history of education in American culture. New York, Holt, 1953. 628 p.

[5I04]

Cady, Edwin $H$. The gentleman in America; a literary study in American culture. Syracuse, N.Y., Syracuse University Press, 1949. 232 p. 
Cahn, Edmond N. The moral decision; right and wrong in the light of American law. Bloomington, Indiana University Press, r955. $34^{2}$ p.

[626I $]$

Cash, Wilbur J. The mind of the South. New York, Knopf, 1941. 429 p.

[4066]

Chase, Gilbert. America's music, from the Pilgrims to the present. New York, McGraw-Hill, 1955. xxiii, $733 \mathrm{p}$.

[5608]

Cochran, Thomas C. The American business system; a historical perspective, 1900-1955. Cambridge, Harvard University Press, 1957. $227 \mathrm{p}$.

[6005]

Cochran, Thomas C., and William Miller. The age of enterprise, a social history of industrial America. New York, Macmillan, 1942. 394 p.

$\left[5^{8} 75\right]$

Cohen, Morris R. American thought; a critical sketch. Edited and with a foreword by Felix S. Cohen. Glencoe, Ill., Free Press, 1954. 360 p.

[3728]

Coleman, Laurence Vail. The museum in America; a critical study. Washington, American Association of Museums, 1939. 3 v. [3049]

Commager, Henry Steele. The American mind; an interpretation of American thought and character since the r880's. New Haven, Yale University Press, 1950. $476 \mathrm{p}$.

[3738]

Commager, Henry Steele, ed. America in perspective; the United States through foreign eyes. New York, Random House, 1947. xxiv, 389 p.

[423I]

Couch, William T., ed. Culture in the South. Chapel Hill, University of North Carolina Press, 1934. 7II p.

[4068]

Craven, Wesley Frank. The legend of the Founding Fathers. New York, New York University Press, 1956. I9I p.

[3051]

Crèvecoeur, Michel Guillaume St. Jean de, called Saint John de Crèvecoeur. Letters from an American farmer. London, T. Davies, 1782. $318 \mathrm{p}$.

[4500]

A paperback reprint is currently available:

Dutton Everyman Paperbacks, D8.

Croly, Herbert D. The promise of American life. New York, Macmillan, 1909. 468 p. [4502]
Curti, Merle E. The growth of American thought. 2d ed. New York, Harper, 195r. xviii, 910 p.

[3729]

Curti, Merle E. The roots of American loyalty. New York, Columbia University Press, 1946. $267 \mathrm{p}$.

[4526]

Curti, Merle E. The social ideas of American educators. New York, Scribner, 1935. xxii, 613 p.

[5116]

Curti, Merle E., ed. American scholarship in the twentieth century. Cambridge, Harvard University Press, 1953. $252 \mathrm{p}$.

[3739]

Cushman, Robert E. Civil liberties in the United States; a guide to current problems and experience. Ithaca, N.Y., Cornell University Press, 1956. $24^{8} \mathrm{p}$.

[6117]

Davidson, Donald. The attack on leviathan; regionalism and nationalism in the United States. Chapel Hill, University of North Carolina Press, 1938. $368 \mathrm{p}$.

[3781 ]

Davidson, Marshall. Life in America. Boston, Houghton Mifflin, 1951. 2 v.

[5801]

Degler, Carl N. Out of our past; the forces that shaped modern America. New York, Harper, 1959. 484 p. $\quad 5^{8-8824} \quad E_{17} 8 . D_{37}$

De Grazia, Alfred. Public and republic; political representation in America. New York, Knopf, 1951. xiii, 262, ix p.

[6402]

Denny, Margaret, and William H. Gilman, eds. The American writer and the European tradition. Minneapolis, Published for the University of Rochester by the University of Minnesota Press, 1950. $192 \mathrm{p}$.

[2412]

De Voto, Bernard A. The course of empire; with maps by Erwin Raisz. Boston, Houghton Mifflin, 1952. xvii, 647 p.

[316r]

De Voto, Bernard A. The year of decision, 1846 . Boston, Little, Brown, I943. xv, $53^{8}$ p. [3331]

Dorfman, Joseph. The economic mind in American civilization. New York, Viking Press, 194649. 3 v.

$\left[5^{876]}\right.$ Contents. -v. 1-2. 1606-1865.-v. 3. 1865I918. 
Dupree, A. Hunter. Science in the Federal Government, a history of policies and activities to 1940. Cambridge, Belknap Press of Harvard University Press, 1957. $460 \mathrm{p}$.

$$
57-5484 \text { Qr27.U6D78 }
$$

Edwards, Newton, and Herman G. Richey. The school in the American social order. Boston, Houghton Mifflin, 1947. 880 p.

[5140]

Egbert, Donald Drew, and Stow Persons, eds. Socialism and American life. Princeton, Princeton University Press, 1952. 2 v.

[3753]

Ekirch, Arthur A. The idea of progress in America, 1815-1860. New York, Columbia University Press, 1944. 305 p.

[3754]

Fainsod, Merle, Lincoln Gordon, and Joseph C. Palamountain. Government and the American economy. 3d ed. New York, Norton, 1959. 996 p. $\quad 59-6084$

$$
\mathrm{HD}_{3} 6 \mathrm{I}_{6} \mathrm{U}_{47} \mathrm{~F}_{3} \text { I959 [5885] }
$$

Fortune. U.S.A., the permanent revolution, by the editors of Fortune in collaboration with Russell W. Davenport. New York, Prentice-Hall, 195 I. xvii, $267 \mathrm{p}$.

[4503]

Frank, Jerome. Courts on trial; myth and reality in American justice. Princeton, Princeton University Press, 1949. 44I p.

[6285]

Frazier, Edward Franklin. The Negro in the United States. Rev. ed. New York, Macmillan, 1957. xxxiii, $769 \mathrm{p}$.

[4442]

Gabriel, Ralph Henry. The course of American democratic thought. 2d ed. New York, Ronald Press, 1956. xiv, $508 \mathrm{p}$.

[374r ]

Glazer, Nathan. American Judaism. [Chicago] University of Chicago Press, 1957. 175 P.

Goldman, Eric F. Rendezvous with destiny; a history of modern American reform. New York, Knopf, 1952. xiii, 503, xxxvii p.

[3455]

Greer, Thomas H. American social reform movements; their pattern since 1865. New York, Prentice-Hall, 1949. 313 p.

[6426]

Hacker, Louis M. The triumph of American capitalism; the development of forces in American history to the end of the nineteenth century. New York, Columbia University Press, I946. $460 \mathrm{p}$.
Hall, Thomas Cuming. The religious background of American culture. Boston, Little, Brown, 1930. xiv, $34^{8} \mathrm{p}$.

[5394]

Hammond, Bray. Banks and politics in America, from the Revolution to the Civil War. Princeton, Princeton University Press, 1957. 77I p. [60oo]

Handlin, Oscar. The uprooted; the epic story of the great migrations that made the American people. Boston, Little, Brown, 195 I. 3I0 p.

[44II]

Hansen, Marcus Lee. The immigrant in American history; edited with a foreword by Arthur M. Schlesinger. Cambridge, Harvard University Press, 1940. $230 \mathrm{p}$.

[4413]

Hays, Samuel P. The response to industrialism, 1885-19r4. [Chicago] University of Chicago Press, 1957. $210 \mathrm{p}$.

$57-698 \mathrm{r} \mathrm{HC}_{105} \mathrm{H}_{35}$

Herberg, Will. Protestant, Catholic, Jew; an essay in American religious sociology. Garden City, N.Y., Doubleday, 1955. $320 \mathrm{p}$.

[5488]

Higham, John. Strangers in the land; patterns of American nativism, I860-1925. New Brunswick, N.J., Rutgers University Press, 1955. xiv, 43I p.

[4422]

A History of American life, edited by Arthur M. Schlesinger and Dixon Ryan Fox. New York, Macmillan, $1927-48$. I3 v.

[3085]

Hofstadter, Richard. The American political tradition and the men who made it. New York, Knopf, 1948. xi, 378, xviii p.

[3099]

Hofstadter, Richard. Social Darwinism in American thought, 1860-1915. Philadelphia, University of Pennsylvania Press, 1944. I9I p. [3755]

Hopkins, Charles Howard. The rise of the social gospel in American Protestantism, 1865-1915. New Haven, Yale University Press, 1940. 352 p.

[5489]

Hubbell, Jay Broadus. The South in American literature, 1607-1900. [Durham, N.C.] Duke University Press, 1954. xix, 987 p.

[2442]

Huth, Hans. Nature and the American; three centuries of changing attitudes. Berkeley, University of California Press, 1957. xvii, $250 \mathrm{p}$.

57-12393 QH $77 . \mathrm{U6H8} \quad\left[5^{884 n}\right]$ 
Kazin, Alfred. On native grounds, an interpretation of modern American prose literature. New York, Reynal \& Hitchcock, 1942. 541 p. [2449]

Key, Valdimer O. Politics, parties, and pressure groups. 4th ed. New York, Crowell, 1958.

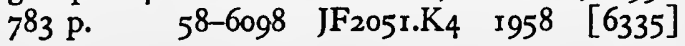

Knight, Grant C. The critical period in American literature. Chapel Hill, University of North Carolina Press, 1951. 208 p.

[2450]

Knight, Grant C. The strenuous age in American literature. Chapel Hill, University of North Carolina Press, 1954. $270 \mathrm{p}$.

[245I]

Koht, Halvdan. The American spirit in Europe, a survey of transatlantic influences. Philadelphia, University of Pennsylvania Press, 1949. 289 p.

[3769]

Kouwenhoven, John A. Made in America; the arts in modern civilization. Garden City, N.Y., Doubleday, 1948. xv, $303 \mathrm{p}$.

[569r]

Kraus, Michael. The Atlantic civilization: eighteenth-century origins. Ithaca, N.Y., Cornell University Press, r949. 334 p.

[3770]

Landis, James M. The administrative process. New Haven, Yale University Press, 1938. I60 p.

[6312]

Larkin, Oliver W. Art and life in America. New York, Rinehart, 1949. xviii, 547 p. [5693]

Lehmann-Haupt, Hellmut. The book in America; a history of the making and selling of books in the United States, by Hellmut Lehmann-Haupt in collaboration with Lawrence C. Wroth and Rollo G. Silver. 2d [rev. and enl. American] ed. New York, Bowker, 1951. xiv, 493 p. [6440]

Leigh, Robert D. The public library in the United States; the general report of the Public Library Inquiry. New York, Columbia University Press, 1950. $272 \mathrm{p}$.

[6480]

Lerner, Max. America as a civilization; life and thought in the United States today. New York, Simon \& Schuster, 1957. 1036 p.

57-10979 Er69.r.L532

Leuchtenburg, William E. The perils of prosperity, 1914-32. [Chicago] University of Chicago Press, 1958.313 p. ${ }^{8-5680}$ HCro6.3.L 3957
Literary history of the United States. Editors: Robert E. Spiller, Willard Thorp, Thomas H. Johnson [and] Henry Seidel Canby; associates: Howard Mumford Jones, Dixon Wecter [and] Stanley T. Williams. New York, Macmillan, 1948. $3 \mathrm{v}$.

[2460]

Lynd, Robert S., and Helen Merrell Lynd. Middletown, a study in contemporary American culture. New York, Harcourt, Brace, 1929. 550 p.

Lynd, Robert S., and Helen Merrell Lynd. Middletown in transition; a study in cultural conflicts. New York, Harcourt, Brace, 1937. xviii, 604 p.

[4593]

Lynes, Russell. The tastemakers. New York, Harper, 1954. $362 \mathrm{p}$.

[5694]

Macleod, William Christie. The American Indian frontier. New York, Knopf, 1928. xxiii, 598 p.

[3030]

Mann, Arthur. Yankee reformers in the urban age. Cambridge, Belknap Press of Harvard University Press, 1954. 314 p.

[4530]

Matthiessen, Francis O. American renaissance; art and expression in the age of Emerson and Whitman. New York, Oxford University Press, 194I. xxiv, $678 \mathrm{p}$.

[2476]

Maurer, Herrymon. Great enterprise; growth and behavior of the big corporation. New York, Macmillan, 1955. $303 \mathrm{p}$.

[6022]

May, Henry Farnham. Protestant churches and industrial America. New York, Harper, I949. $297 \mathrm{p}$.

[5492]

Mencken, Henry L. The American language; an inquiry into the development of English in the United States. 4th ed., cor., enl., and rewritten. New York, Knopf, 1936. xi, 769 , xxix p. - Supplement I-II. New York, Knopf, 1945-48. 2 v.

[2248]

Miller, Perry. The New England mind; the seventeenth century. New York, Macmillan, 1939. $528 \mathrm{p}$.

[3742]

Miller, Perry. The New England mind: from colony to province. Cambridge, Harvard University Press, 1953. 513 p.

[3743] 
Miller, William. The book industry, a report of the Public Library Inquiry. New York, Columbia University Press, 1949. xvi, 156 p. [644I]

Mills, Charles Wright. White collar; the American middle classes. New York, Oxford University Press, 1951. xx, $378 \mathrm{p}$.

[4553]

Milton, George Fort. The use of presidential power, 1789-1943. Boston, Little, Brown, 1944. 349 p.

[6146]

Morison, Samuel Eliot. The intellectual life of colonial New England. [2d ed.] New York, New York University Press, 1956. 288 p.

[3745]

Morison, Samuel Eliot, and Henry Steele Commager. The growth of the American Republic. [4th ed., rev. and enl.] New York, Oxford University Press, 1950. 2 v.

[3103]

Morris, Lloyd R. Not so long ago. New York, Random House, 1949. xviii, 504 p. [4519]

Morris, Lloyd R. Postscript to yesterday; America: the last fifty years. New York, Random House, 1947. xxvi, 475 p.

[3746]

Mott, Frank Luther. American journalism; a history of newspapers in the United States through 260 years: 1690 to 1950 . Rev. ed. New York, Macmillan, 1950. xiv, $835 \mathrm{p}$.

[2847]

Mott, Frank Luther. A history of American magazines. Cambridge, Harvard University Press, 1938-57. $4 \mathrm{v}$.

[2915]

Mumford, Lewis. The brown decades; a study of the arts in America, r865-1895. [2d ed.] New York, Dover, 1955. 266 p.

[5695]

Mumford, Lewis. The golden day; a study in American literature and culture. New York, Norton [1934?] $283 \mathrm{p}$.

[373I]

Mumford, Lewis. Sticks and stones; a study of American architecture and civilization. [2d ed.] New York, Dover, 1955. $23^{8}$ p.

[570r]

Murrell, William. A history of American graphic humor. New York, Whitney Museum of American Art, 1933-38. 2 v.

[5803]

Nef, John U. The United States and civilization. Chicago, University of Chicago Press, 1942. xviii, $421 \mathrm{p}$.
Nevins, Allan, ed. America through British eyes. [New ed. rev. and enl.] New York, Oxford University Press, 1948. $53^{\circ} \mathrm{p}$.

[4234]

Oliver, John W. History of American technology. New York, Ronald Press, 1956. 676 p. [4727]

Parkes, Henry Bamford. The United States of America, a history. 2d ed., rev. New York, Knopf, 1959. xviii, 783, xxiv p. 59-6I18 $\quad$ EI78.P25 1959 [3104]

Parrington, Vernon Louis. Main currents in American thought; an interpretation of American literature from the beginnings to 1920. New York, Harcourt, Brace, 1927-30. 3 v. [2485]

Pearce, Roy Harvey. The savages of America, a study of the Indian and the idea of civilization. Baltimore, Johns Hopkins Press, 1953. xv, 252 p.

[303I]

Perry, Ralph Barton. Puritanism and democracy. New York, Vanguard Press, 1944. xvi, 688 p.

[3733]

Persons, Stow. American minds; a history of ideas. New York, Holt, $1958.467 \mathrm{P}$.

$58-6318 \quad$ B851.P 4

Persons, Stow, ed. Evolutionary thought in America. [Edited for the special Program in American Civilization at Princeton University] New Haven, Yale University Press, I950. 462 p.

[3758]

Pickering, Ernest. The homes of America, as they have expressed the lives of our people for three centuries. New York, Crowell, 1951. 284 p.

[5702]

Pochmann, Henry A. German culture in America; philosophical and literary influences, 1600-1900. With the assistance of Arthur R. Schultz and others. Madison, University of Wisconsin Press, 1957. xv, 865 P. 55-679 I Er69.r.P596

Potter, David M. People of plenty; economic abundance and the American character. [Chicago] University of Chicago Press, 1954. xxvii, 219 P.

[3734]

Pressly, Thomas J. Americans interpret their Civil War. Princeton, Princeton University Press, 1954. xvi, $347 \mathrm{p}$. 
Purcell, Theodore V. The worker speaks his mind on company and union. Cambridge, Harvard University Press, 1953. xix, 344 p.

[6055]

Read, Conyers, ed. The Constitution reconsidered. New York, Columbia University Press, 1938. xviii, $424 \mathrm{p}$.

[6082]

Riesman, David. The lonely crowd; a study of the changing American character, by David Riesman in collaboration with Reuel Denney and Nathan Glazer. New Haven, Yale University Press, 1950. xvii, $386 \mathrm{p}$.

[4555]

Riesman, David. Faces in the crowd; individual studies in character and politics, by David Riesman in collaboration with Nathan Glazer. New Haven, Yale University Press, I952. 75I p.

Robert, Joseph C. The story of tobacco in America. New York, Knopf, 1949. xii, 296, xxiv p.

Rosenberg, Bernard, and David Manning White, eds. Mass culture; the popular arts in America. Glencoe, Ill., Free Press, 1957. 561 p. [6443]

Rossiter, Clinton L. Conservatism in America. New York, Knopf, 1955. 326 p.

[6067]

Rossiter, Clinton L. Seedtime of the Republic; the origin of the American tradition of political liberty. New York, Harcourt, Brace, 1953. xiv, $55^{8} \mathrm{p}$.

[6068]

Rourke, Constance M. American humor; a study of the national character. New York, Harcourt, Brace, 1931. $324 \mathrm{p}$.

[2501]

Rourke, Constance M. The roots of American culture and other essays. Edited, with a preface, by Van Wyck Brooks. New York, Harcourt, Brace, 1942. $305 \mathrm{p}$.

[3736]

Rural life in the United States, by Carl C. Taylor [and others] New York, Knopf, 1949. xviii, 549, xii p.

[4583]

Santayana, George. Character \& opinion in the United States. New York, Scribner, 1920. 233 p. $\quad 20-26993 \quad B_{945} \cdot S_{3} C_{5} \quad$ [5369] A paperback reprint is currently available: Doubleday, Anchor Books, A73.

Savelle, Max. Seeds of liberty; the genesis of the American mind. New York, Knopf, 1948. xix, 587 , xxxi p.

[3747]
Schafer, Joseph. The social history of American agriculture. New York, Macmillan, 1936. 302 p.

[5832]

Schlesinger, Arthur M. Paths to the present. New York, Macmillan, 1949. 317 p.

[3140]

Schlesinger, Arthur M., Jr. The age of Jackson. Boston, Little, Brown, 1945. xiv, 577 p. [3352]

Schneider, Herbert W. A history of American philosophy. New York, Columbia University Press, 1946. xiv, 646 p.

[526I]

Schneider, Herbert W. Religion in 2oth century America. Cambridge, Harvard University Press, 1952. $244 \mathrm{p}$.

[5409]

Seldes, Gilbert V. The great audience. New York, Viking Press, 1950. 299 p.

[4895]

Siegfried, André. America comes of age, a French analysis. Translated from the French by Henry H. Hemming and Doris Hemming. New York, Harcourt, Brace, 1927. $35^{8} \mathrm{p}$.

[4506]

Siegfried, André. America at mid-century. Translated by Margaret Ledésert. New York, Harcourt, Brace, 1955. 357 P.

[4508]

Siepmann, Charles A. Radio, television and society. New York, Oxford University Press, 1950. 410 p.

[4703]

Sirjamaki, John. The American family in the twentieth century. Cambridge, Harvard University Press, 1953. $227 \mathrm{p}$.

[457r]

Smith, Cecil Michener. Worlds of music. Philadelphia, Lippincott, 1952.328 p.

[5623]

Smith, Henry Nash. Virgin land; the American West as symbol and myth. Cambridge, Harvard University Press, 1950. xiv, 305 p.

[3759]

Stewart, George R. American ways of life. Garden City, N.Y., Doubleday, 1954. 310 p.

[452I]

Struik, Dirk Jan. Yankee science in the making. Boston, Little, Brown, 1948. $43^{\circ} \mathrm{p}$.

[4730]

Sutton, Francis $\mathrm{X}_{\text {., }}$ and others. The American business creed. Cambridge, Harvard University Press, 1956. $414 \mathrm{p}$.

[6oro]

Sweet, William Warren. Religion in the development of American culture, 1765-1840. New York, Scribner, 1952. xiv, $33^{8} \mathrm{p}$.

[54II] 
Taeuber, Conrad, and Irene B. Taeuber. The changing population of the United States. For the Social Science Research Council in cooperation with the U.S. Dept. of Commerce, Bureau of the Census. New York, Wiley, 1958. 357 p. (Census monograph series) $\quad 57^{-1345 I} \mathrm{HB}_{3505 . \mathrm{T}_{3}}$

Taft, Robert. Photography and the American scene, a social history, I839-1889. New York, Macmillan, 1938. $546 \mathrm{p}$.

[5781]

Tannenbaum, Frank. Crime and the community. Boston, Ginn, 1938. xiv, 487 p.

[4656]

Thistlethwaite, Frank. The great experiment; an introduction to the history of the American people. Cambridge [Eng.] University Press, 1955. 335 p.

[3146]

Tocqueville, Alexis C. H. M. C. de. Democracy in America. The Henry Reeve text as rev. by Francis Bowen, now further corr. and edited, with introd., editorial notes, and bibliographies, by Phillips Bradley. New York, Knopf, 1945. 2 v.

[4512]

Tunnard, Christopher, and Henry Hope Reed. American skyline; the growth and form of our cities and towns. Boston, Houghton Mifflin, 1955. $302 \mathrm{p}$.

[4609]

Turner, Frederick Jackson. The frontier in American history. New York, Holt, 1950, ${ }^{\mathrm{c}} 1947$. 375 p.

[3147]

Turpie, Mary C. A selected list of paintings for the study of American civilization. Minneapolis, Program in American Studies, University of Minnesota, 1953. 1091.

[5757]

Turpie, Mary C., comp. American music for the study of American civilization. [v. I] Formal compositions. Folk and popular songs. Minneapolis, Program in American Studies, University of Minnesota, 1955. 901.

$[5613]$

Tyler, Alice (Felt). Freedom's ferment; phases of American social history to 1860 . Minneapolis, University of Minnesota Press, 1944. 608 p.

Ulman, Lloyd. The rise of the national trade union; the development and significance of its structure, governing institutions, and economic policies. Cambridge, Harvard University Press, 1955. xix, $639 \mathrm{p}$.

[604 I ]
Vanderbilt, Arthur T. Men and measures in the law; five lectures delivered at the University of Michigan, Apr. 1948. New York, Knopf, 1949. xxi, I56, x p.

[6270]

Ward, Alfred Dudley, ed. Goals of economic life. New York, Harper, 1953. 470 p.

[5899]

Webb, Walter Prescott. The Great Plains. [Boston] Ginn, r93r. xv, 525 p.

[4164]

Wecter, Dixon. The hero in America, a chronicle of hero-worship. New York, Scribner, I941. $53^{\circ}$ p.

[4533]

Wecter, Dixon. The saga of American society; a record of social aspiration, 1607-1937. New York, Scribner, 1937. 504 p.

[4534]

Welker, Robert Henry. Birds and men; American birds in science, art, literature, and conservation, 1800-1900. Cambridge, Belknap Press of Harvard University Press, 1955. 230 p.

[474I ]

White, Edward A. Science and religion in American thought; the impact of naturalism. Stanford, Stanford University Press, 1952. I17 p. [3761]

White, Morton G. Social thought in America, the revolt against formalism. New York, Viking Press, 1949. $260 \mathrm{p}$.

[4545]

Wiener, Philip P. Evolution and the founders of pragmatism. Cambridge, Harvard University Press, 1949. xiv, $288 \mathrm{p}$.

$[5264]$

Williams, Robin M. American society; a sociological interpretation. New York, Knopf, 1951. xiii, $545 \mathrm{p}$.

[4558]

Wilson, Francis Graham. - The American political mind; a textbook in political theory. New York, McGraw-Hill, 1949. 506 p.

[6o70]

Wisconsin. University. Regionalism in America. Edited by Merrill Jensen. Madison, University of Wisconsin Press, 195I. xvi, 425 p.

[3785]

Wish, Harvey. Society and thought in America. New York, Longmans, Green, 1950-52. 2 v.

[3150]

Wittke, Carl F. The Irish in America. Baton Rouge, Louisiana State University Press, 1956. $319 \mathrm{p}$. 
Wood, James Playsted. Magazines in the United States. 2d ed. New York, Ronald Press, 1956. $390 \mathrm{p}$. [2919]

Wright, Louis B. The first gentlemen of Virginia; intellectual qualities of the early colonial ruling class. San Marino, Calif., Huntington Library, 1940. $373 \mathrm{P}$.
Wright, Thomas Goddard. Literary culture in early New England, 1620-1730. Edited by his wife. New Haven, Yale University Press, 1920. $322 \mathrm{p}$.

[2549]

Years of the modern; an American appraisal. John W. Chase, ed. New York, Longmans, Green, 1949. $354 \mathrm{P}$. 



\section{Index}

A

AEF. See American Expeditionary Force

AFL. See American Federation of Labor

AFL-CIO. See American Federation of Labor and Congress of Industrial Organizations

ASCAP. See American Society of Composers, Authors, and Publishers

Al'abri, 675

Aandahl, Fredrick, ed., 3292

Aaron, Daniel, 6424

ed., 3070

Abbot, Charles Grecly, about, 4722, 4775

Abbot, Waldo, 4682

Abbott, Charles C., 5976

Abbott, Edith, 4404-5, 4632

Abbott, Francis, ed., 5435

Abbott, George, 2332-33

Abbott, Lyman, about, 5396

Abdy, Edward Strutt, 43 I I

about, 4310

Abe Lincoln in Illinois, 1752, 2334

Abegglen, James C., 6029

Abel, John Jacob, about, 4722

Abell, A. S., about, 2876

Abell, Aaron I., 5489

Aberdeen, S. Dak., 3897

Abernathy, Cecil, 1046

Abernethy, Thomas Perkins, 3237, 3273 , 4072, 4103

Abilene, Kans., 4157-58

Abolitionism, 56, 178, 216, 239-40, 449, $562,662,2279,3305,3366,3370$, $3375,3380-8 \mathrm{r}, 340 \mathrm{I}, 3404,34 \mathrm{I} 3$, 3431

See also Antislavery movement; Slavery

Abrams, Charles, 4600

Abrams, Ray H., ed., 5409

Absalom, Absaloml, 1388

Academic freedom. See Teachers and teaching-academic freedom

Academies (schools), 5155, 5212

New York (State), 5159

Philadelphia, 5130

Acadians

fiction, 745

poetry, 429

See also Cajuns

Accent, 255I

Accident Claims Tribunal, 6299
Acculturation, 304 I, 4410-II, 4435, $4447,4456,4463$

Acheson, Dean, 3543, 6316

Acheson, Sam Hanna, 2866

Ackerman, Edward A., 5900

Across Spoon River, 1599

Across the Board on Tomorrow Morning, 2113

Across the Continent, 2301

Across the River and into the Trees, I 499

Across the Wide Missouri, 3330

Act of Darkness, 1225

Active, and Other Poems, 1586

Actors and actresses, I214, I22 I, 2475, 4927-39

biog. (collected), 4931, 4933-34, 4938

motion picture, 4946

Negro, 4921

Adam \& Eve \& the City, 1871

Adamic, Louis, 2578-79 about, 2579

Adams, Abigail, 96-100, 3277 about, 99, 2615

Adams, Adeline, ed., $574^{\circ}$

Adams, Agatha B., I 479, I895

Adams, Andy, $683-87$ about, 687

Adams, Brooks, 2601 about, 2601,6424

Adams, Charles Francis (1 807-1886) 2580

ed., $97-99$

about, $688,258 \mathrm{I}$

Adams, Charles Francis (1835-1915), $52,2580-82,3276-77,4036$

ed., 3279,3312

about, 2582

Adams, Ephraim Douglass, $355^{\circ}$

Adams, Franklin P., 865

Adams, George P., ed., 5250

Adams, Henry, 688-700, 2580, 327475,3311

about, 688, 94I, 123 I, 2407, 2480, $2544,2616,3055,3058$

Adams, Herbert B., 3044 about, 4540

Adams, James Truslow, 698, 3088 ed., 2967, 3071

Adams, John, 96, 99, 3276-77, 3279 about, 2608, 3276, 3278-79, 3285 , 4034

Adams, John Luther, about, 5433

Adams, John Quincy, 3312

about, 3313, 3360, 3529

Adams, Léonie, I153-54
Adams, Marian, about, 1231

Adams, Nehemiah, ed., 63-64

Adams, Ramon F., 2253

Adams, Randolph G., 6460

Adams, Samuel Hopkins, I I55-6o, 2688,3475

Adams, W. B., 4295

Adams, Walter, ed., 590 I

Adams family, 2503

Adamson, W. M., 5909

Addams, Jane, 46I 4

The Adding Machine, 1689, 2348

Addison, Agnes, 3751

Addison, James T., 5457

Addison, Joseph, about, 38 r

Addresses. See Lectures and lecturing

Ade, George, 70I-5

Adirondack Mountains, 3966, 5064 5765

Adirondack State Park, 3966

Adkins, Nelson F., 134

ed., 160

Adler, Felix, 5289

about, 5435

Adler, John H., 597 I

Administrative courts, 6316

Administrative law, 6090, 6r8 8 , 6201, $6310-16$

Administrative procedure, 63II-12, 6316

Administrative reform, 6316

Admiral of the Ocean Sea, $3 \times 64$

Adolescents. See Youth

Adult education, 5105, 5209, 5219, 6482

Adventurers, outlaws, etc., 51, 66, 5523 , $5525,5531,5556,5559,5562$

Adventures of a Novelist, 721

Adventures of a Young Man, 1332

The Adventures of Augie March, 192122

The Adventures of Huckleberry Finn, $782-83,787-93,81$ I

The Adventures of Tom Sawyer, 778$83,8 \mathrm{II}$

The Adventures of Wesley Jackson, 2 II

Advertising, 5962

fiction, 2188

hist., 5958

radio, 4696

television, 4696

Advice to the Privileged Orders, 103

Aeronautics, $472 \mathrm{I}$

flights, 2714-1 5, 2977, 4788

hist., 5938 
Aeronautics, commercial, 5943

finance, 5943

govt. regulation, 5941

hist., 594I

Aeronautics, military, $3643 a, 3647$, $3676,3711,3717,3727$

Aesthetic Papers, 586

The Affuent Society, 5886

Africa

descr., 2282

fiction, 1927, 2096

technical assistance to, 3641

travel \& travelers, 2282

After Holbein, 1855

After 1903-What?, 1218

After the Genteel Tradition, 2406

After the Lost Generation, 2371

Agard, Walter R., 3739

Agassiz, Elizabeth (Cary), 4742

Agassiz, Louis, 4742, 4744 about, 4721, 4724, 4742, 5222

The Age of Innocence, 1852,1855

The Age of Reason, 155

Age of Thunder, 2093

Agee, James, I907-8

Ager, Trygue M., tr., 1723

Agrarian policy, 3285

Agrarianism, 2421, 3420-21, 5833, $5859,6358,6372,6426-27$

Middle West, 3446

Southern States, 3286, 3361, 345I

The West, 3361,3427

The Agrarians (literary movement), $1464,1809,2559$

Agribusiness. See Agriculture-econ. aspects

Agricultural colleges, 2790

Agricultural credit, 5848

Agricultural economics. See Agriculture-econ. aspects

Agricultural education, 5191, 5836

Agricultural extension work, 5836, 5851

Agricultural fairs, 5827

Agricultural labor, 5846

Agricultural machinery, 5830

Agricultural organizations, 342 I

Agricultural products, 581 8-19, 5847

hist., 5820

marketing, 5845

Middle Atlantic States, 4329

New England, 4329

New York (State), 4237-38

Northwest, Old, 4329

Ohio, 4 I I9

Pa., 4237-38

Southern States, 4239

Agricultural research, 2790, 5836, 5857

Agriculture, 2943, 2947, 295I-53, 5819-6i

cooperatives, 5842

dictionary, 5849

econ. aspects, 4579, 4581-82, 5819, $5832-34,5838,584 \mathrm{I}, 5843-44$, $5847,5850,5861,5877,6358$ govt. regulation, $5831,5838,5853-$ 56,5860

handbooks, manuals, etc., 5849

hist., 5819-38

Colonial period, 5821

to $1860,5820,5823$
Agriculture-Continued

price supports, 5855,5860

soc. aspects, 5899

stat., 4329

yearbooks, 2947, 295 I

Calif., 4372

Fla., 4248-50

Ga., 4248-50

Great Plains, 4164

Ky., 4276

Middle West, 5831

Mo., 4108

New England, 4031, 4266, 5840

N.J., 4053

New York (State), 42 42-46, 4266

N.C., $4090,4248-50,4276$

N. Dak., 4 I 65

Northwest, Pacific, 4214

Northwestern States, 4147, 4212

Ohio, 4276

Pa., 4054, 4242-46, 4266

S.C., $4248-50,4276$

Southern States, 4079, 4083, 4266

Tenn., 4276

Tex., 4 I 94

The West, 4156, 4160

Agriculture and state, $5831,5833-34$, $5837-38,585$ I-61

Agwani, Mohammed Shafi, 3588

Ah, Wilderness!, I648, 2327

Ahlstrom, Sydney E., 5424

Ahnebrink, Lars, 2365

Ahrens, Maurice R., 5224

Aiken, Conrad Potter, 844, I 161-66, 1364

ed., 2344

about, 1165

Aiken, George L., 2347

Aikin, Wilford M., 5131

Aikman, Duncan, 4176

The Air-Conditioned Nightmare, I61 3

Air Force, about, 3643a

Air Materiel Command, about, $3643 a$

Air Transport Command, hist., 1551

Air University, about, 3643 a

Airlines, 5920, 5941, 5943

Akers, Dwight, 5054

Al Aaraaf, Tamerlane, and Minor Poems, 523-27

Al Que Quierel, 1881

Alabama, 3953, 4079, 4099

editorial, sketches, etc., I 94-97, 37980,1907

fiction, $1792-95,1836-38$

folksongs \& ballads, 5565

guidebook, 3848

hist., 4099, 4104

Alabama claims, 3444

Alaska, 2719-20, 275 r, 3554, 3968, 4218-19

climate, 2953

fiction, 2162

guidebook, 3940

hist., 3968, 4219

Indian art, 3016

place names, bibl., 2976

purchase, 3429

short stories, $1048-52,1058$

Albany, N.Y., 3807

Albemarle County, Va., guidebook, 3828
Albertson, Frederick W., 2966

Alberty, Harold B., 5158

Albion, Robert Greenhalgh, 5937, 595 I

Albree, John, ed., 672

Albright, Spencer D., 6400

Albright, William Foxwell, 5426 about, 5426

Albro, John A., 59, 65

Albuquerque, N. Mex., 4176, 4187

Alcoa, about, 5908

Alcott, Amos Bronson, r 86-87

about, I86, 2280, 5220, 5265-66, 5305

Alcott, Louisa May, 188-89

about, 188,2615

Alden, John Richard, 3238, 4072 ed., 3683

Alderfer, Evan B., 5902

Alderfer, Harold F., 3475

Alderman, S. S., 3562

Aldrich, Richard, 5626

Aldrich, Thomas Bailey, 706-15 about, 2277, 2922

Aldridge, Alfred Owen, 3187

Aldridge, John W., 2371, 2373 ed., 2372

Aleck Maury, 1466

Alexander, Carter, 5098

Alexander, De Alva Stanwood, 6150

Alexander, Hartley Burr, 3015

Alexander's Bridge, 1277

Alexandria, Va., guidebook, 3829

Alfred Venison's Poems, 1666

Alfriend, Edward M., 2305

The Algerian Captive, 168

The Alhambra, 381

Alias Simon Suggs, 379

Alice Adams, 1802 , 1805

Alien and Sedition Acts, 3308

Aliens, 4404-5, 4468, 6117, 6120, 6122

All God's Chillun Got Wings, 1648

All My Sons, 2043, 2046, 2335-36

All the King's Men, 2 197

All the Young Men, 1553

The Allegash and East Branch, 594

Allegheny, $\mathrm{Pa}$., hist., 381 7

Allegheny County, Pa., 459 I

Allegheny Mountains, travel \& travelers, 4350

Allegheny River, 3992

Allegiance, $3129,4526,4773,6107$, 6115,6118

See also Loyalty oaths

Allen, Arthur A., 2962

Allen, C. R., 5211

Allen, Charles, 2914

Allen, Edward L., 5903

Allen, Elizabeth L., 4443

Allen, Ethan, 5251, 5408

fiction, $580-82$

Allen, Francis H., comp., 599

Allen, Fred, 4964

about, 4964

Allen, Frederick Lewis, 3476-78, 3782, 4514,5978

Allen, Gardner W., 3678, 3685-86

Allen, Gay Wilson, $620,647,660$

ed., $645,648,2349$

Allen, Harry C., 3551

Allen, Harry K., 5164 
Allen, Hervey, I $167-71$, 1512 ed., 3969, 3977, 3996-4017

Allen, Hollis P., 5099

Allen, James Lane, 7 I 6-20, 2296 about, 716

Allen, Jerry, 813

Allen, John Edward, 2900

Allen, Jules Verne, 5503

Allen, Paul, Iog

Allen, Raymond B., 4855

Allen, Robert S., 6195 ed., 6195,6207

Allen, Shirley W., 5862

Allen County, Ohio, guidebook, 3869

Allred, B. W., 2966

Allston, Washington, about, 5760

Almanacs, I 22, 131-32, 2493

Almond, Gabriel A., 3609

Almy, Millie, 5148

Alnwick Castle, 324-25

Along This Way, 1539

Alsberg, Henry G., ed., 3822, 3924-25

The Altar of the Dead, 1012

Alterton, Margaret, 534

Altgeld, John Peter

about, 3446

fiction, 1978

Altitudes, 2970

Aluminum Company of America, about, 5908

Alvord, Clarence Walworth, 4I 28 ed., 41 26-32 about, 3058

Always the Land, 1969

Always the Young Strangers, 1732

Amacher, Richard E., ed., I30

Amaranth, 1714

Amargosa Desert, 3947

The Ambassadors, 998-99 about, 1009

Amberg, George, 4967

Ambler, Charles Henry, 3271, 4089

Amdur, Leon $\mathrm{H}$., 4780

America (song), about, 5616

America in literature

European, 3771-72

French, 3773 bibl., 3773

America Was Promises, 1586

The American, 987-88

The American, a Middle Western Legend, 1978

American Academy of Pediatrics. Committee for the Study of Child Health Services, 4841

American Academy of Political and Social Science, Philadelphia, 6 106

The American Adam, 2459

American Antiquarian Society, Worcester, Mass., about, 6447

American Anti-Slavery Society, about, 336o, $337^{\circ}$

American Arbitration Association, about, 6299

American Association for Gifted Children, 5205

American Association of School Administrators, 5106,5240

American Automobile Association, 2952 about, 5005
American Bar Association, about, 6307, $6331-32$

American Chemical Society, about, 4731

American Child, 1972

American Civil Liberties Union, about, $6106,6127,6322$

American Colonization Society, about, $3370,3375,4310$

The American Commonwealth, 4499

American Council of Learned Societies, 5100

American Council of Learned Societies. Committee on Linguistic and $\mathrm{Na}$ tional Stocks in the Population of the United States, 4390

American Council on Education. Cooperative Study of Evaluation in General Education, 5160

The American Crisis, 155

The American Democrat, 265-67

American Dialect Society, 2254-62

American Education Fellowship, 513I

American Educational Research Association, 5247

American English, 2237, 2243, 2245 5127

Sec also Language

American Estimates, 2396

American Expeditionary Force, about, 3710

American Expeditionary Force. Division of Urology, about, 4832

American Farm Bureau Federation, about, 5831,5859

American Federation of Labor, 5906 about, 6034-36, 6050, 6052, 6360

American Federation of Labor and Congress of Industrial Organizations, about, 6034,6049

American Federation of Musicians, about, 5619

American Folklore Society, 5518 about, 5518

American Foundation for Political Edu. cation, 36I7

American Foundation for the Blind, about, 4636

American Fur Company, about, 4148, 6024

American Geographical Society of New York, hist., 294I

American Guide Series, 3786-3941

American Harvest, 2354

American Heritage, 2339

American Historical Association, 3050 , 6224

American Historical Association. Commission on the Social Studies, 5 I 16

An American Hunter, 1724

American Ideas for English Readers, $46 \mathrm{I}$

An American in Paris (music), 5678

American Indians. See Indians, American

American Institute of Chemical Engineers, 4793

American Issues, 2355

American Jewish Congress, about, 6106

American Law Institute, 6280

American Legion, about, 3645
American Library Association, 6482 about, 6486

American Library Association. Coordinating Committee on Revision of Public Library Standards, 6480

American Life in Literature, $234^{\circ}$

American Literature and the Dream, 2400

American Medical Association, about, $4806-7,4882,4885$

American Men of Letters [Ist ser.], 2277-82

about, 1136

American Men of Letters [2d. ser.] 2283-89

The American Mercury, 1602

The American Mind, 2491

American Newspaper Publishers Association, about, 2855

The American Notebooks, 349

The American of the Future, 2469

American Outpost, 1757

American Party, about, 4515

American Philosophical Society, Philadelphia, 4059

about, 4718

American Psychiatric Association, 4833

about, 4837

hist., 4833,4863

American Quarterly, 2553

American Railway Express Company, about, 4667

American Renaissance, 585, 2476

American Revolution, 3089, 3139, 3157, 3237-72, 3678-84, 4038

campaigns \& battles, $3238-39,3680$, $3682-83,4251$

sources, 3239

causes, $3128,3176,3188,3231,3237$ $38,3241,3243,3246,3255,3257^{-}$ $58,3261-62,3265,3272,3304$

commerce, 5948

diplomatic hist., 3519, 3528, 3569

econ. aspects, 6016

European opinion, 3769

foreign participation, $3238,3248-50$, 3269,3773

for. rel., $3187,3239,3272$

hist., 2608, 2673, 3179, 3189-90, $3266,3277,3279$ sources, $3183-84,3260,3277$

in art, 5775

labor condit., 6057

military hist., 3238-39, 3255, 326I, $3269,3271-72$ sources, 3239

mutinies, 3264

naval operations, 3678

personal narratives, $3244,425 \mathrm{I}$

politics, 2740

religious aspects, 5406, $541 \mathrm{I}, 5477$ treason, 3264

American Revolution in literature

drama, I 05, 1477

fiction, 239, 252-57, 405, 409-I I, $546-47,552-53,579-82,766-67$, I 222, I 239-40, 1355, I 442, I695, I 707-11, 1730, 1916, 1974, 197677

letters, 96-100 
American Revolution in literatureContinued

pamphleteering works, 138, I 47, 154-60

poetry, 134-39, I46, 148, I65, I67, 323

satire, $147,165,167$

The American Rhythm, 1196

The American Scene, 1002-3

The American Scholar, 283 about, 230

American Society of Composers, Authors, and Publishers (ASCAP), about, 5621, $568 \mathrm{r}$

American Society of Equity, about, $583 \mathrm{I}$

American Song, 1968

The American Spirit in Letters, 2532

The American Spirit in Literature, 2491

American studies programs, 2553, 5184

American Telephone and Telegraph Company, about, 4673, 4710

American Theatre Wing War Service, Inc., about, 4919

The American Tradition in Literature, 2324

An American Tragedy, 1338

American Unitarian Association, about, 5472

The American Way, 1548

The American Way of Poctry, 2530

The American Weekly Mercury, about, 2854, 2880

The American Writer and the European Tradition, 2412

American Writers Series, 2290-96

Americanisms (language), 2236-4I, 2243-48, 2250, 2252, 2269, 2272, 2466,5127

See also Language

Americans in Great Britain (Colonial period), 3227

America's Coming-of-Age, 2380

America's Lost Plays, 2297-2317

Ames, E. S., 5289

Amberst, Mass., in literature, 984

Amherst College, 2674

curriculum, 5199

hist., 5200

Amish in Pennsylvania, 4058, 4480

Ammen, Daniel, 3700

Amnesty (1 86I-98), 3388

Among the Corn-Rows, 893

Among the Hills, 669

Amory, Cleveland, 4035

Ampère, Jean Jacques Antoine, 4358-59 about, 4358

Amphibious warfare, 3668

The Anatomy of Nonsense, 2544

Ancestors' Brocades, 851

\&, 1313

And Gladly Teach, 2491

And in the Human Heart, 1166

And Still the Waters Run, 3025

Anderson, Charles A., ed., 5466

Anderson, Charles R., ed., 1046

Anderson, Gordon V., 5229

Anderson, Hobson Dewey, 6043

Anderson, John, 4905

Anderson, Lee, 2350

Anderson, Marian, 5673

about, 5673
Anderson, Mary, 2584 about, 2584

Anderson, Maxwell, i 17 1-77, 2332-33, $2335-37,2348$

Anderson, Nels, 5465

Anderson, Odin W., 4886

Anderson, Oscar E., 4794

Anderson, Paul Russell, 525 I

Anderson, Sherwood, 832, $1178-87$ about, 959, I 182, I 186 , I $188-89$, $2372,2406,2419,2429$

Anderson, William, 6131, 6196

Andersonville, 1544

Andover House, Boston, about, 5438

Andover Review, 5438

Andover Theological Seminary, about, 5438

André, 2337, 2347

Andrews, Charles M., 3176-77, 3202 about, 3046

Andrews, E. A., 4724

Andrews, Frank Emerson, 4615-16. 4623

Andrews, J. B., 6033

Andrews, J. Cutler, 2851

Andrews, Kenneth R., 81 4

Andrews, Wayne, 5698

Andria, 1864

Anesthesia, hist., 4816

The Angel that Troubled the Waters. 1864

Angell, J. R., about, 5389

Angell, James Burrill, about, 5223

Angels and Earthly Creatures, 1903

Anghiera, Pietro Martire d', 3153

Angle, Paul M., 3395, 6469

ed., 3143, 3391

Anglo-American folklore

Ky., 5529, 5546

Mississippi River, 5523

N.C., 5529

Ozark Mountains, 5543

Southwestern States, 5518

Tex., 5518

Va., 5529

The West, 5526

Anglo-American folksongs and ballads, $5504,5550,5566$

bibl., 5550

hist., 5566

theories, methods, etc., 5550, 5566

Appalachian Mountains, 5583

Blue Ridge Mountains, 5582

Buchanan County, Va., 5582

Ind., 5571

Maine, 5566

N.C., 5582

Southern States, 5583

Tex., $552 \mathrm{r}$

Anglo-American legends

Southwestern States, 5518

Tex., 55 I 8, 5521

Anglo-French War. See French and Indian War $(1755-63)$

Anglo-Israel movement, 5439

Angoff, Charles, $445^{8}$

The Animal Kingdom, 1201, 2333

Animal lore and mythology, 551 3

Ga., 910-16, 922, 924-25

Ky., 5546

Mich., 5535
Animal lore and mythology-Continued Mo., 5528

N. Mex., 5537

Ozark Mountains, 5544

Animal, Vegetable, Mineral, 2413

Animals, 2954-56, 2960

domestic, 4276

editorials, sketches, etc., 1 724-25

hist., 2955

in art, 5806

in folksongs, 5559, 5563-64

prairies, 4188

short stories, I786, I 790

Death Valley, Calif., 4205

New World, 3155

New York (Colony), 4237-38, 4241

Pa., 4237-38, 4241

S.C., 5087

Ann Vickers, 1565

Anna Christie, 1648

Annand, George, maps, 4001, 4017

Annapolis, Md., 3825

Anne Boleyn, 207-8

Anne of the Thousand Days, 2335

Anni Mirabiles, 1235

Annie Allen, 1938

Anniversary, 1579

Another Animal, 2350

Another Part of the Forest, 1990

Antarctic expeditions, 2977-78

Antheil, George, 4968

Anthony Adverse, 1169

Anthropology, 2986-87, 2989, 2993, 2998, 3006, 3010, 4192, 4722, 535 J See also Ethnology

Antin, Mary, about, 2585

Antioch College, 5125, 5196

The Antioch Review, 2554

Antipathies, 517

Antiques

collectors \& collecting, 5596, 5598

dictionary, 5596

Antiquities. See Archaeology and prehistory

Anti-Semitism, 4457, 4462

Antislavery movement, 2689, 336o, 3370, 3375

See also Abolitionism; American AntiSlavery Society; Slavery

Anti-Slavery Papers, 463

Antler (Omaha) Reservation, 3042

Apache Indians, 3004, 3010, 3035

Apartment in Athens, 1839

Aphorisms, 3152

Apologetics, 5338

The Apostle, 1190

Appalachian Mountain region, 2933, 3958,3963

folksongs \& ballads, 5583

Appellate procedure, 6302,6304

Appellate review, 6234

The Apple of the Eye, 1839

Apples by Ocean, 1296

Appleseed, Johnny. See Chapman, John

Appleton, LeRoy H., 2967

Appointment in Samarra, 2070

Appomattox Court House, 2580

Apportionment (election law), 6163

Apprenticeship, 5210

April Twilights, 1277 
Aptitude tests, 5229

Arab States, relations with, 3588

Arapaho Indians, 304 I, 4 I 60

Arber, Edward, ed., 7 I

Arbitration, industrial, 6058, 6299

Arbitration and award (law), 6282, 6289,6299

Arbolino, J. N., 5197

Archaeology and prehistory, 2989-97 mounds \& moundbuilders, 2996, 4323 Calif., 3002

The East, 2990

Southwestern States, 2992

Archer, Gleason L., 4683

Architecture, 3969, 3751, 3758, 56985725

bibl., 5709

Colonial, 3747-48, 5706, 5713-14, $5721-23,5725,5796$

Creole, 5703

domestic, 5698, 5702, 5707, 5711 13, 57 I 7-1 8, 5721-22, 5725, 5732 , 5794,5796

exhibitions, 57 1 7-1 8

Georgian, 5714

Greek, 5708-9, 5719

hist., 5689, 5695, 5698, 5703, 5710, 5714

Indian, 5723

library, 6474,6478

modern, 5705, 5711-12, 5717-18

Spanish, 5703, 5723

Conn., 5707

Nashville, 3765

Northwest, Old, 5719

Ohio, 4I2I

Southern States, 5706

Southwest, New, 5723

Archives, 3066-67

management \& functions, 3063

Arciniegas, Germán, 3172

Arctic expeditions, 2979-81

Ardennes, Battle of the, 3720

Argentina, relations with, 3514

Aria da Capo, 1608, 2332

Ariel Poems, 1359

Aristocracy. See Upper class

Arizona, 2737, 4199

archaeology, 2992

architecture, Spanish, 5723

descr., 5073

deserts, 3947

guidebooks, 3925-26

hist., 3956, 396r, 41 89, 4199

Indians, 3023

Navajo Indians, 3013

music, 5630

short stories, 1762

travel \& travelers, 4378

writers \& writings, 4199

Arkansas, 3960, 4079, 4102

econ. condit., 4102

folklore, 5542

folksongs \& ballads, 5569

frontier life, 4097-98

guidebooks, $3853-54$

hist., 4102

poetry, 1434

Arkansas River and valley, 3984

The Arkansas Traveler, about, 5507, 5542
Armaments, 3525,3674

Armed Forces. See specific branches, e.g., Navy

Armed Neutrality, 3528

The Armed Vision, 2443

Armenians, 4435

Arminians, 5472

Armistice (1918), 3470

Armitage, Merle, ed., 4968, 5678

Arms, George W., 969, 976, 2374

Arms, John Taylor, about, 5783

Armstrong, Henry, about, 5025

Armstrong, Maurice W., ed., 5466

Army, 3643, 3653-65, 3709

hist., $2710-11,3648,3651-52,3657$ $3659,3661-64,4040$

American Revolution, 2673, $368 \mathrm{I}$

Civil War, 3693, 3697, 3702, 3705

World War I, 3709-10

World War II, 3726

mobilizations, $366 \mathrm{I}$

organization, 3648,3681

recruiting, enlistment, etc., 366r, $3665,3702,3709$

Army. American Expeditionary Force, about, 3710

Army. Armored Force, about, 3658

Army. Cavalry, hist., 3659

Army. General Staff Corps, about, 3653,3712

Army. Information and Education Division. Research Branch, about, 3724

Army. Medical Dept., hist., 4809

Army Air Forces, about, 3717, 3727

Army Ground Forces, about, 3726

Army Life in a Black Regiment, 2280

Army of Northern Virginia, 3695

Army of the Potomac, 3690-92, 3701, 3706

Army Service Forces, about, 3726

Army technical services, 3726

Arnold, Benedict, about, 2617, 2804, 3149,3264

Arnold, Byron, comp., 5565

Arnold, Henry H., 3717

Arnold, Matthew, about, 2545

Arnold, Willard B., 1812

Arny, William F. N., about, 3035

Arp. Bill, pseud. See Smith, Charles Henry

An Arrant Knave or Other Plays, 2308

Arrowood, Charles F., 5122

Arrowsmith, 1562

Arsenic and Old Lace, 2334

Art, 4741, 4743, 5351, 5688-97, 5726 32,5807

foreign influences, 3768,3774

hist., 5689-93, 5695

Indian, 2991, 3016-1 7, 5785

Navajo, 3013

Northwest coast, 2998

Penobscot, 30 I I

Plains, 3006, 3018

industries. See Arts and crafts

Italian, 4497

museums. See Museums.

Pennsylvania German, 4480

philosophy of. See Esthetics

Charleston, S.C., 3763
Art-Continued

Newport, R.I., 4040

Ohio, 4I 2 I

Philadelphia, 3764

See also Artists; Cartoons; Comic strips; Decorative arts; History and art; Painting; Prints; Sculpture

Art and state, 5697,6130

The Art of Fiction, 986, I010, I014

The Art of the Novel, 1004

The Art of Worldly Wisdom, 2098

Arthur, Chester A., about, 3437

Arthur, Timothy Shay, I90-91

Arthur Mervyn, 116-17

Arthur's Home Magazine, 190

Articles of Confederation, 3253, 3302, 6077

Articles on American Literature, 2457, 2552

Articulation (education), 5107, 5131, 5217

Artisans, Colonial, 6044

Artists, 3757, 4198, 5690, 5695, 5760$76,5779-80,5783,5797,5802$, 5806-7

See also Painters; Sculptors

Arts and crafts, 3748, 3969, 5593-5604, $5787,5919,6044$

design, 5594,5600

hist., 5594, 5602-3

Indian, 2993

Pennsylvania German, 5594, 55995600

Shakers, 5594

themes, motives, 5594, 5600

Mo., 4108

Southern States, 4083

See also Decorative arts

Arundel, 1708

Arvin, Newton, 443, 481, 2284, 2406 ed., 348,700

As I Lay Dying, 1384

As I Remember It, 1269

As If, 1953

Asbury, Francis, 5475

about, 2586, 5463, 5474-75

Asbury, Herbert, 2586-88, 4523, 5474 about, 2587

Asch, Shalom, I 190-94 about, 1195

Asgis, Alfred J., 4842

Ash Wednesday, 1357,1359 about, 1367

Ashburn, Percy M., 4809

Asheim, Lester, 6477 ed., 6454,6480

Asheville, N.C., fiction, I887-88

Ashley, William H., about, 4175

Ashmore, Harry S., 5206

Ashton, Wendell J., 2867

Ashworth, Mary Wells, 327 I

Asia

fiction, 2088, 2097

relations with, 3591 , 3596

technical assistance to, $364 \mathrm{r}$

travel \& travelers, 2282

Asia Minor

fiction, 1979

travel \& travelers, $677-78$

The Asiatics, 2088

Asirvatham, Eddy, 5496 
Askov, Minn., 4406

Aspects of Fiction and Other Ventures in Criticism, 2466

The Aspern Papers, 1007,1014

Asseff, Emmett, 4100

Assembly-line methods, 6055

Associated Press, about, 2860

Association for Education by RadioTelevision, 5230

Association for Higher Education, 5228

Association of American Law Schools, 6090

Association of American Universities, 5163

Association of American University Presses, about, 6439

Association of Land-Grant Colleges, $5 \mathrm{r} 86$

The Assyrian, 2118

Aston, Tony, about, 566r

Astor, John Jacob, about, 5882, 6024

Astoria, Oreg., 39r, 41 48, 6024

Astrology, 5541

Astrophysics, 4722

Aswell, E. C., 1892

Asylums, 19th cent., 4310

At Heaven's Gate, 2195

At Home and Abroad, 414

Athearn, Robert G., 4223

Atherton, Gertrude Franklin (Horn), $72 \mathrm{x}-25,3943$

about, 721

Atherton, Lewis Eldon, 4rog

Athletics, 4989

college, 4993, 4999

high school, 5000

Atkins, Gaius Glenn, 5454

Atkins, John A., 1501

Atkinson, Brooks, 1548,4907 ed., $300,59 \mathrm{r}$

Atlanta, Ga., 3838,4704

Atlantic cable, 4677

Atlantic coastal plain, 2933

The Atlantic Monthly, 368, 449, 706, $964,2555,2922$

Atlantic seaboard. See Eastern seaboard

Atlases and maps, 3786,4486

climate, 2952

historical geography, 2967, 2972. 2974

language, 2268-69

Atomic energy

hist., 4747

in literature, 1992, 2682

Atomic physics, 4722

A tomic warfare, 3621,3629

The Attack on Leviathan, $378 \mathrm{I}$

Attitudes Toward History, 2387

Attorney General's Committee on Administrative Procedure, $6_{3} 16$

Atwood, E. Bagby, 2263

Atwood, Wallace W., 2933, 4172

Auchincloss, Louis, 1909-1 3

Auden, W. H., 25 12

ed., 537,1003

about, 2378, 2426

Audiences

motion picture, 4895,4959

radio, $4700-3,4895$

television, 4699, 4702-4, 4895
Audio-visual methods in education, $523 \mathrm{I}, 5246$

Audubon, John James, 4743-44

about, 2210, 2624, 4724, 4734, 474r, 4743

Augur, Helen, 3154

August, John, pseud. See De Voto, Bernard $A$.

Augusta, Ga., 3839

Augusta, Maine, 3793-94

Augustana College, Rock Island, Ill., about, 4483

Aumann, Francis R., 6219

Aurora, 14I

Aurora Dawn, 2229

The Auroras of Autumn, 1784

Austin, Mary (Hunter), $1196-98$ about, I 196

Austin, Moses, 33I 4 about, 3314

Austin, Samuel, ed., 28

Austin, Stephen Fuller, 331 4 about, $33 \times 4$

Australia, relations with, 3556

Australian ballot, 6400

Austria in literature, 1245

Austrians, 4414

Ausübel, Nathan, tr., I 19 r

The Author of Beltraffio, 1007

Author-publisher relations, 6449-50

Authors and authorship, 2371, 2373, $2391,2405,3746,3757$

biog. (collected), 2433, 2454-55, 2526

dictionaries, 2433, 2454-55

radio \& television, 4697

Calif., 2536

Southwest, 2525

Authors as journalists

(r764-r8r9), rog, r34, r 41, r 54-60

$(1820-70), 190,192,209,216,280$, $313,319,365,422,445,449,463$, $520,546,556,558-59,585,612$, $619,655,657,662,674,677$, 2278-79, 2294

(1871-1914), 701, 704, 732, 768, $836,862,878-80,887,910,926$, $942,959,964,1048,1107,1126$, I $36,2479,2923$

(1915-39), 1214, 1409, I602-5, $1809,1859,2398,2503$

$(1940-55), 1992,2017,2029,2057$, $2133,2139,2149$

Authors Today and Yesterday, 2455

Authorship in the South before the War, $\mathrm{rro3}^{-4}$

Autobiography. See Biography and autobiography; Biography, collected

The Autobiography of Alice B. Toklas, $177 \mathrm{I}$

The Autobiography of an Idea, 5715

The Autocrat of the Breakfast-Table, $371-74$

Automation, 6003

Automobile industry, 4138,5940

finance, 5963

workers, 6055

Automobile motoring, 5002, 5005

Automobile racing, 5001, 5003-7
Automobile Workers' Union, about, 6039

Automobiles, 4519, 5005

Automotive transportation, 5942

Autres Temps, 1851,1855

Autumn, 1635

The Autumn Garden, 1991, 2335

Averill, Gerald, 2590

about, 2590

Avery, Clara Louise, 5784

Aviation. See Aeronautics

Avon's Harvest, $17 \times 4$

Awake and Singl, 2064, 2348

Award (law). See Arbitration and award (law)

Axel's Castle, 2535

Axt, Richard G., 5165

Ayars, Christine Merrick, 5628

Aydelotte, Frank, 5178

Ayer (N. W.) \& Son, Inc., about, 5958

Ayers, Lucille, 2258

Ayres, C. E., 2407

Azalia, 920

Aztec culture, 2997

The B. O.W.S., 4919

B.P.O.E. See Elks, Benevolent and Protective Order of

Babbitt, Irving, 2375, 241 1 , 2425, 5115 , 5259

about, 2375, 2479

Babbitt, $156 \mathrm{r}$

Babcock, Kendric Charles, 4482

Babes in Toyland (operetta), about, 5681

Baby Doll, 2220

Bach, George Leland, 5983

Bach Choir, Bethlehem, Pa., about, 2667

Bachman, George W., 4862

Back Home, 2736

Back-trailers from the Middle Border, $898-99$

Background to Glory, 3239

Background in Tennessee, 1743

Backgrounds of American Literary Thought, 244I

Backlund. Jonah Oscar, 2895

A Backward Glance O'er Travel'd Roads, 626-27

Backwoods to Border, 5507

Bacon, Eugene H., 3643

Bacon's Rebellion, fiction, 226

Bacteriology, 4722, 4831

Bad Lands, 2683

The Bad Seed, 1177

Badè, William F., ed., 1079, 1081-82

Badger, Kingsbury M., 2319

Baehr, Harry W., 2868

Baer, Julius B., 5952

Bagby, Ellen M., ed., 193

Bagby, George Williams, r92-93

Bailey, James O., 2377

Bailey, Joseph Cannon, $585 \mathrm{I}$

Bailey, Liberty Hyde, about, 2790

Bailey, Robeson, ed., $507 \mathrm{r}$

Bailey, Thomas A., 347 I, 351 7, 3560

Bainbridge, John, 2920, 4952

Bainton, Roland H., 5423 
Baird, Lucy Hunter, 4744

Baird, Spencer Fullerton, about, 4724, 4744,4775

Bakeless, John E., 3155, 3239-40, 3299

Baker, Carlos H., I 502

ed., 2355

Baker, Elizabeth (Faulkner), 6455

Baker, Franklin T., ed., 373

Baker, George Pierce, about, $494^{\circ}$

Baker, Gladys, 5852

Baker, Harry J., 5207

Baker, Melvin C., 5120

Baker, Newton D., about, 3713

Baker, Oliver E., 4579, 5816

Baker, Ray Stannard, 259I-96, 347071

ed., 3469

about, 2592-96, 6432

Baker, Richard Terrill, 2910

Bakewell, C. M., 5252, 5332

Balboa, Vasco Núñez de, about, 3167

Balboa Park (San Diego, Calif.), guidebook, 3932

Balcony Stories, 1034-35

Bald, Frederick Clever, 4137

Balderston, J. L., 2332

Baldwin, Hanson W., 36I5, 3618, 3646

Baldwin, James, I $914-15$

Baldwin, James Mark, about, 5262

Baldwin, Joseph Glover, 194-97, 2296

Baldwin, Leland D., 3103, 3280, 4061, 4 I 10

Balfour, Walter, 5428

Balkans, relations with, 3516

The Ballad of the Sad Café, 2024

Ballads. See Folksongs and ballads; Songs

Ballads for Sale, 1584

Ballads of Square-Toed Americans, 1295

Ballanta, Nicholas, $554^{\circ}$

Ballantine, Joseph W., 3589

Ballet, 4967, 4969-71, 5656-57

Ballot, 6400

Ballou, Hosea, 5428, 5473

about, 5473

Baltimore, Lord, about, 5396, 5419

Baltimore

editorials, sketches, etc., 1602

hist., 4062

law, 6284,629 I

public health, 4867

soc. life \& cust., 4062,4263

Balz, A. G. A., 5289

Bamberger, B. J., 4458

Bancroft, Frederic, 3359

Bancroft, George, about, 2462, 3057$58,3060,3776$

Bancroft, Hubert Howe, about, 3048

Band of Angels, 2201

Bandler, Bernard, II, 2425

Bands (music), 5653

Bank of the U.S.

first, 4059,6000

second, 31 26, 5999-6000

Bank Street Schools, New York (City), 5234

The Banker's Daughter, 2307

Bankhead, Tallulah, 4928 about, 4928

The Bankrupt, 2300
Banks and banking, 5972, 5974-75, $5983,5986,6002$

hist., $5979,5988,6000$

Boston, 5984

Chicago, 5985

New York (City), 5993

Banner by the Wayside, 1158

Banners, 2413

Banning, George Hugh, 593 I

Banning, William, 593 I

Banta, Richard E., 4003

Baptists, 5404, 5442

hist., 5413 , 5443

Bar associations, hist., 6325

Barba, Preston A., 2266

The Barbary Coast, 2586

Barbary Shore, 2027

Barbary States, relations with, 3686

Barbash, Jack, 4672, 6031

Barbella, Rocco. See Graziano, Rocky

Barber, Hollis W., 3619

Barber, Rowland, 5028

Barber, Samuel, about, 5674

Barck, Oscar Theodore, 3452

Bardèche, Maurice, 4944

Barefoot in Athens, 176

Barger, Harold, 581 9, 5907, 5920, 5944

Barghoorn, Frederick Charles, 356r

Baring Brothers and Company, hist., 5980

Barker, Charles A., 4535

Barker, Eugene C., 3314 ed., 3314

Barker, Howard F., 4390

Barker, James Nelson, 66, I 98-200, 2337,2347

about, 198

Barker, Shirley Frances, 1916-20

Barker, Virgil, 5742

Barkley, Alben W., 2597-98, 2892 about, 2598

Barlow, Joel, ror-4 about, IOI

The Barly Fields, 1637

Barnard, Charles, 23 I 4

Barnard, Ellsworth, 1717

Barnard, Harry, 3418-19

Barnard, Henry, about, 5116,5128

Barnes, A. C., 5290

Barnes, Al G., about, 4982

Barnes, Eric W., 4927

Barnes, Gilbert Hobbs, 3360

Barnes, Harry Elmer, 4540, 461 7, 4639

Barnes, Walter, ed., 765

Barnett, James H., 4546

Barnouw, Erik, 4684

Barns, 5724

Barnum, Phineas T., 4977

about, 261 7, 2797, 4977

Baron, Salo W., ed., 5267

Baron Rudolph, 2307

Barr, Alfred H., ed., 5689, 5797

Barrell, Joseph, 4715

Barren Ground, $1460-61$

Barrett, Clifford, 5252 ed., 5252

Barrett, Edward L., Jr., 6110-I I

Barrett, J. Lee, 5016

Barrett, James Wyman, 2889

The Barretts of Wimpole Street, 4919
Barrow, Edward G., 5008

about, 5008

Barrow, Joseph Louis. See Louis, Joe

Barrus, Clara, 2624

Barry, David W., 4702

Barry, Philip, Irg9-1 203, 2332-34, 2337,2348

Barry, Phillips, 5566-67

Barrymore, Ethel, 4929 about, 4929

Barrymore, John, about, 4933

Barrymore, Lionel, 4933 about, 4933

Barrymore-Drew family, about, 4929

Barth, A., 4513

Bartlett, Arthur C., 5009

Bartlett, John R., 6447 ed., 89

Bartlett, Ruhl J., ed., 3518

Barton, R. C., 2364

Barton, William, $475^{8}$

Bartram, John, 4237-38 about, 4236, 4247, 4745

Bartram, William, 4247-50 about, 4247, 4745

Barzun, Jacques, 5213, 5615

Baseball, 4987, 4990, 4993, 5008-15 short stories, $1554-55$

Basler, Roy P., 3395 ed., 420, 3390, 3395

Bassett, John Spencer, 3057, 3315, 3318 ed., 14,3318

Bassett, T. D. Seymour, 3753

Basso, Hamilton, 2406

Bataan in literature, 1992

Bateman, Mrs. Sidney F., 2347

Bates, Ernest Sutherland, 2884, 615I

Bates, Ralph S., 4713

Bates, Sanford, 4640

Bathe, Dorothy, 4795

Bathe, Greville, 4795

Battistini, Lawrence H., 3590-91

Battle, John J., 5278

The Battle Ground, 1461

The Battle of Bunker-Hill, 105, 2347

The Battle of Stillwater, 231 I

Battle of the Bulge, 3720

The Battle of the Kegs, 148

Battle-Pieces and Aspects of the War, 488

Battles. See Campaigns and battles under names of wars, e.g., Ameri. can Revolution-campaigns and battles; Civil War-campaigns and battles

Battles in art, 5807

Baudelaire, Charles, about, 520

Bauer, G. Philip, 5763

Bauer, Louis Hopewell, 4882

Baum, P. F., ed., 1046

Baumgarten, Eduard, 5254

Baumhoff, Richard G., 4 I 45

Baur, John I. H., 5688, 5745, 5762

Bawden, Henry Heath, 5254

Baxter, James Phinney, 4761, 61 30

Bay Psalm Book, 6448

Bayley, Frank W., ed., 5690

Bayou Folk, 760

Bayou l'Ombre, 1033

Beach, Joseph Warren, 988, п о 6, 2376

Beach, Lewis, 2332 
Beach, Moses S., about, 2874

Beach, William D., 3651

Beachheads in Space, 1959

Beacon of Freedom, 3778

Beadle and Adams (firm), 2444

Beale, Howard K., 3065, 3361, 3527, 5132-33

ed., 3046

Beall, Otho T., 40,4826

Bean, Louis H., 5837, 641 2-13

Bear, Donald, 5748

Beard, Charles A., 3046, 3065, 3073, $3479,3750,4499,5106,6082$, 6247,6250

about, 2407, 3046, 4545

Beard, Mary R., 3073, 3479, 3750

Beasley, Norman, 5452-53

The Beast in the lungle, 1007, 1012, I0I 4

The Beast in View, 2106

Beatty, E. C. O., 3058

Beatty, Richmond Croom, ed., 2320, 2324

Beauchamp murder case, 365,550

Beaufort, S.C., 3835

Beaumont, William, about, 48 I 8,4822

Beaumont, Tex., 3918

Beaumont de La Bonninière, Gustave Auguste de, about, 4512

Beauregard, P. G. T., about, 2613

The Beautiful and Damned, 1427

The Beautiful Changes, 2216

The Beautiful People, 2 II 3

Beaver, Joseph, 649

Beavers, 296I

Beck, Earl Clifton, 5567

Becker, Carl L., 4540, 5 191, 5222

Beckhart, Benjamin Haggott, 5993

Beckman, Theodore N., 5945, 5949

Beckwith, Martha Warren, 5504

Becky Sharp, 2313

$A$ Bed of Boughs, 74I

Bedford Springs, Pa., 4312

Beebe, Lucius M., 4153

Beech Mountain, N.C., folklore, 5529

See also North Carolina-folklore

Beecher, Henry Ward, I 137 about, 2797, 3413, 5428, 5476

Beecher, Lyman, about, 2797, 5395. 5403

Beer, George Louis, about, 3058

Beers, Clifford Whittingham, 4834 about, 4834

Beers, Henry A., 682

Before Barbed Wire, 41 52-53

Before Breakfast, I 648

Before the Gringo Came, 725

Beggar on Horseback, 2332

The Beginning of a Mortal, 2748

The Beginning of Wisdom, 1222

Behaviorism, 4545, 5389, 5393

Behold Our Green Mansions, 5863

Behrman, Samuel Nathaniel, I 204-13. $2327,2332-33,2348$

about, 1213

Beiman, Irving, 6207

Being a Boy, $1139-41$

Beirne, Francis F., 3687,4062

Belasco, David, 2314-15, 2337, 234748

about, 4943
Belden, Henry Marvin, ed., 5568

Belfrage, Gustaf Wilhelm, about, 4734

Belgium, travel \& travelers, 426

Belief and doubt (philosophy), 5323, 5370

Belknap, Jeremy, about, 3057

Bell, Alexander Graham, about, 4675 , $4678-79$

Bell, Bernard I., 5232

Bell, Herbert C. F., 3470

Bell, Whitfield J., 471 4

Bell, Book, and Candle, 2335

A Bell for Adano, 1994

Bell-founding, 5628

Bell Telephone System, 4673

Bellamy, Edward, 726-31

about, 726, 2517,6424

Bellamy, Gladys C., 81 5

Bellamy, Joseph, about, 5428

La Belle Russe, 2315

La Belle Sauvage, 199

Belles Demoiselles Plantation, 748

Bellevue, Nebr., 3902

Bellevue Hospital Medical College, New York, about, 4831

Bellow, Saul, 1921-22

The Belovéd Adventure, 1858

Bemis, James, about, 6446

Bemis, Samuel Flagg, 3313, 3520-2I, 3528-29, 3574

ed., 3519

Benchley, Nathaniel, I 221

Benchley, Robert Charles, 121 4-20 about, 1221

Benedict, Clare, ed., I 152

Benedict, Murray R., 5853-55

Benét, Rosemary Carr, ed., I 222

Benét, Stephen Vincent, 1222-24, 1904 ed., 3969, 3975, 3978-95 about, 1908

Benét, William Rose, 1904 ed., 1903, 2321

Benford, Robert T., music arr. by, 5590

Benham, Mrs. Miles, 5647

Benians, E. A., ed., 3 I 79

Benjamin, Florence O., 4057

Benjamin, Judah P., about, 2613, 3396

Benjamin, Marcus, 4049, 4724

Benjamin, Park, 2295

Bennett, Clarence, 2305

Bennett, Hugh H., 2947, 5808

Bennett, James Gordon (1 795-1872), 2848

about, 2877

Bennett, James Gordon (184r-rgr8), about, 2848, 2872, 2877

Bennett, John C., 5899 about, 5433

Bennett, Mildred R., 1279

Bennington College, hist., 5198

Benson, Adolph B., 4246, 4357, 4483

Benson, Egbert, about, 6224

Benson, Louis F., 5633

Benson, Mary Sumner, 4524

Bent, Newell, 5058

The Bent Twig, 1412

Bentley, Arthur F., 5286

Bentley, Eric R., 4908

Bentley, Harold W., 2264, 4999

Bentley, William, 2599-2600

about, 2600
Benton, Elbert J., 3530

Benton, Thomas Hart, 3322

about, 2793, 3321-22, 5783

Berding, Andrew H., 3546

Berelson, Bernard, 6414,6419, 6477 ed., 6485

Berger, Arthur V., 5675

Berger, Josef, 380 r

Berger, Max, 4224

Berger, Meyer, 2869

Bergmann, Leola M. (Nelson), 5664

Bergson, Henri, about, 5326,5368

Beringause, Arthur F., 2601

Berkeley Square, 2332

Berkshire Hills, Mass., 3799

Beowulf, translation, 1556

Berenike, 2 ror

Berkhof, Louis, about, 5433

Berkson, I. B., 4457

Berlandier, Jean Louis, about, 4734

Berle, Adolf A., 601 1-1 2

Berle, Alf K., $478 \mathrm{I}$

Berlin, Irving, about, 5639

Bernard, Francis, about, 3257

Bernard, Jessie, 4536

Bernard, Luther L., 4536

Bernard, William B., 518

Bernard, William S., ed., 4418

Bernard Clare, 1376

Bernardo, C. Joseph, 3643

Bernhard Karl, duke of Saxe-Weimar. Eisenach, 4297-99

about, 4297

Bernstein, Mel, illus., 308 I

Berrey, Lester V., 2272

Berry, Robert Elton, 4746

Berry, W. E., 5442

Berryman, John, 82 I, 1923-24, 2285

Berson, Robert C., 4861

Berthoff, Rowland Tappan, 4488

Bertsch, Carl W., illus., 3170

Best, Harry, 4628-29

Best, Katharine, 5059

The Best of Two Worlds, 2453

Beston, Henry, 3979

Bestor, Arthur E., 4525, 5233

Bestsellers, 2402, 2482, 6443, 6449

See also Popular books

Bethlehem, Pa., Bach Choir, 5667

Bethlehem Steel, 5918

Bethune, Mary McLeod, 5426 about, 5426

The Betrothal, 207-8

Bettmann, Otto, 4986

Between the Thunder and the Sun, 2807

Between Two Worlds, 1758

Beulah Land, 1314

Reveridge, Albert J., 6237

about, 3058, 3453

Beverley-Giddings, Arthur R., ed., 5079

Beyond Dark Hills, 2166

Beyond Life, 1262

Beyond the Horizon, ' 648,2337

Beyond the Hundredth Meridian, 2161

Beyond the Mountains, 2098-2101

Bianca Visconti, 2337

Bianchi, Martha (Dickinson), ed., 842

Bible (English)

fiction, 1190

influence on literature, 1 I 8, 505, 619 
Bibliography, $3773,6447,6460$

See also Books-and reading; Rare books; and also under specific - subjects, e.g., Education-bibl.

Bickel, Alexander M., 6248

The Bicycle Rider in Beverly Hills, 2121

Biddle, George, about, 5783

Biddle, Nicholas, about, 3126

Bidwell, Percy Wells, 5820

Bierce, Ambrose (Gwinnett), 732-39 about, 520, 732, 738, 926, 2380

Bierring, Walter L., 4807

The Big Bear of Arkansas, 61 3

The Big Bonanza, 2317

Big Bone Lick, 4336

Big Boy Leaves Home, 2234

The Big Cage, 2014

Big Fiddle, 1246

The Big Knife, 2067

The Big Money, 1325,1328

The Big Rock Candy Mountain, 2 I 62

The Big Sea, 1522

The Big Sky, I 489

Bigelow, John, ed., I 25, 132

Bigelow, Melville M., ed., 6roo

Biggar, Henry P., 3169

ed., 3156

Biggs, Hermann M., about, 4868

The Biglow Papers, 456-57

Bikle, Lucy Leffingwell (Cable), 747, 751

Bilingualism, 2267

Bill Arp: From the Uncivil War to Date, 556

Bill Arp, So Called, 557

Bill of Rights, 6106, 6108, 6121, 6127

Billings, John Shaw, about, 4403, 48 r9, 4845,6476

Billings, Josh, pseud. See Shaw, Henry Wheeler

Billington, Ray Allen, 3074, 4146, 4515

Billy Budd , 487, 496, 2335

Billy the Kid, 2305

Bingham, George Caleb, about, 576r

Bingham, Millicent (Todd), 851-53 ed., 843

Binkley, Wilfred E., 6132-33, 6140, 6347

Binns, Archie, 4930

Biography, a Comedy, 1205

Biography (collected), 2682, 2774, $3072,3080,3099,3145,3198$

bibl., $3080,3101-2$

dictionaries, 3080, 4049

See also under particular subjects, e.g., Civil War-biog. (collected)

Biography and autobiography, 25782844

Biracial education, 5206

Bird, George L., ed., 2927

Bird, Robert Montgomery, 201-5, 2309, 2337

about, 205

Birds, 2956, 2960, 2962, 4247, 474I, 4743

game, $5077,509 \mathrm{I}$

in literature, $474 \mathrm{I}, 5535$

protection, 474I

Birge, Edward Bailey, 5668

Birmingham, Ala., politics, 6207
Birney, James Gillespie, 3360

about, 3375,3413

Birth, 1454

Birth of a World, 1445

Birthright, I 792

Bishop, Cortlandt F., 6401

Bishop, Elizabeth, I925-26 about, 2426

Bishop, Farnham, 4796

Bishop, John Peale, I 225-27, 2406 ed., 2354

about, 1227

Bishop, Joseph Bucklin, 4796

Bishop, Morris, 3156

The Bishop's Wife, 1637

Bisland, Elizabeth. See Wetmore, Elizabeth (Bisland)

Bison, 2799

Bissell, Richard P., 4019

Bitter Creek, 1239

Bittinger, D. W., 5442

Bixler, J. S., 5335-36

Bixler, Paul, ed., 2554

Bjorka, Knute, 5869

Black, C. E., 3562

Black, John Donald, 5839-40

Black, Theodore Milton, 6348

Black April, 1654

Black Armour, 1903

Black Boy, 2232

The Black Cat, 529

Black Hawk (Sauk chief), about, 2645

Black Hills, S.D.

Custer State Park, 3898

Mount Rushmore National Memorial, 5737

Black Is My Truelove's Hair, 1705

Black Jews, 5498

The Black Man, 2303

The Black Panther, 1858

The Black Riders, 835

The Black Rock, I 433

Black Spring, I 6I I

Blackfeet Indians, tales, 3000

Blackford, Launcelot Minor, 2602-3

Blackford, Mary, about, 2603

Blackmur, Richard Palmer, I001, 1004, 1 228-35, 2443, 3768

Blackwell, Elizabeth, about, 4820

Blaine, Janıes Gillespie, about, 2616, 3442,6373

Blair, Francis Preston, about, 3410

Blair, Frank P., about, 34 ro

Blair, James, about, 5396

Blair, Montgomery, about, 3382, 3410

Blair, Walter, 5505-6

ed., 2323

Blair family, $34 \mathrm{IO}$

Blake, Aldrich, 634 I

Blake, Florence G., about, 4854

Blake, Forrester, ed., 5530

Blake, Harrison G. O., ed., 599

Blake, Nelson Manfred, 3452, 4797

Blake, William, about, 2128

Blakeslee, G. H., 3562

Blakey, Roy G., 5970

Blanchard, Dorothy C. A., 4038

Blanchard, Ralph H., 5990

Blanchard, Thomas, about, 4786

Bland, Richard, about, 6068
Blanshard, Brand, ed., 5335

Blanshard, Paul, 5444

Blau, Joseph L., 5253 ed., 3319, 5261, 5418

Bledsoe, Thomas A., ed., 895

Blegen, Theodore C., 4I 4I-42, 4484 ed., 4I 43, 4485

Blesh, Rudi, 5641

Blind

education of, 4628

law \& legislation, 4628

libraries for, 4636

rehabilitation, etc., 4628,4636

Blind, 1656

The Blind Bow-Boy, 1829

The Blithedale Romance, 333

Bloch, Bernard, ed., 2268

Bloch, Julia, 2268

Blodgett, Harold W., 648

ed., 644,2276

Blondel de Nesle, about, 2186

Blood Lines, 5066

Bloodstoppers \& Bearwalkers, 5533

The Bloody Tenent Yet More Bloody, 89

Bloom, Leonard, 4469

The Bloudy Tenent, of Persecution, for Cause of Conscience, 20, 86, 89

The Bloudy Tenent Washed and Made White in the Bloud of the Lambe, 20, 86

Blough, Roy, 5965

Blue books (society), 4534

The Blue-Grass Region of Kentucky, 717

The Blue Hotel, 824

Blue Ridge Mountains

descr., 3963

folksongs \& ballads, 5582

Blue Voyage, 1162

Blum, Daniel C., 4899, 4931, 4946 ed., 4906

Blum, John Morton, 3466 ed., 3465

The Boarding Schools, 2302

Boardman, F. W., Jr., 5197

Boas, Franz, ed., 3042 about, 2407

Boas, George, 5291 ed., 3751

Boas, Louise S., 3178

Boas, Ralph P., 3178,3751

Boatmen, French-Canadian, 3170

Boatright, Mody C., 5520 ed., 5507-9, 5518, 5521

Boats and boating, 4110 , 5016-22

Bode, Boyd H., 5234, 5254, 5336

Bode, Carl, ed., 598, 607, 2339

Bodmer, Charles

paintings by, 3330

about, 4307

Body, Boots \& Britches, 5548

The Body of Liberties, 75, 78

Body of This Death, 1237

Boerker, Richard H. D., 5863

Bogan, Louise, I 236-38, 2357

Bogart, Ernest Ludlow, 4 I 3 1 -32

Bogart, Leo, 4699

Bogue, Donald J., 4393

Bogue, Jesse P., $5 \mathrm{I}_{62}$ 
Bohemianism

hist., 3757

in literature, 732,1828

Bok, Curtis, 61 30

Bok, Edward William, 2604-5 about, 2605

Boker, George Henry, 206-8, 2300, 2337,2347

Bolívar, Simón, about, 1445

Boll, Jacob, about, 4734

Bolton, Charles Knowles, 3679 ed., 6149

Bolton, Ethel (Stanwood), 5593

Bolton, Herbert E., 3075, 31 57-58 ed., 3203, 4202

Bolton, Isabel, pseud. See Miller, Mary Britton

Bolton, Theodore, 5759

Bolts of Melody, 843,846

The Bomb that Fell on America, 2682

The Bombardment of Algiers, 2310

The Bonanza Trail, 4177

Bonaparte, Napoleon. See Napoleon I

Bonaventure, 745

Bonbright, James C., 6013

Bond, Beverly W., Jr., 4I II , 4 I 2 I

Bond, Horace M., 4443, 5206

Bond, Thomas, about, 4850

Bone, Hugh A., 6349

Bonfils, Frederick Gilmer, about, 2878

Bonifacius, 45

Bonner, S., 2296

The Bonney Family, 1798

Bontecou, Eleanor, 6110, 6112

Boodin, J. E., 5252

Book, F., 2364

Book of Moments, 2387

Book of Mormon, 5465

Book-of-the-Month Club, 6463

Book of Uncles, 1294

Book reviews (literary). See Criticism, literary-essays; Literature-

Books periodicals

and reading, i 4, 40, $171,177,2407$, $2418,2482,2549,3751,6443$, $6454,6477,6481-82$

teaching methods, 5127,5226

Ariz., 4199

Boston, 6475

Charleston, 3763

New York (City), 6468

Southwest, New, 4 I 90

banned, 1932

clubs, $6435,6437-38,6440-41,646_{3}$

collectors \& collecting, $6440,6460-$ $62,6464-65$

illustration, 2391

industries \& trade, $6435-36,644 x$, 6445,6448

popular. See Popular books

Books That Changed Our Minds, 2407

Booksellers and bookselling, 2391, $6435-38,6440-41,6444,6447$, $6462-64$

New England, 3745

Boom towns, 772-74

Boon Island, 1712

Boone, Daniel, about, $310,1873,3240$

Booth, Bradford Allen, ed., 4377

Booth, Catherine, about, 5497
Booth, Edwin, about, 4938

Booth, William ("General")

about, 5497

poctry, $158 \mathrm{I}$

Booth family, 4938

Boothe, Clare, 2327, 2333

Borchard, Edwin M., 6294

Borglum, Gutzon, about, 5737

Boring, E. G., $375^{8}$

Born, Wolfgang, 5743-44

Born Yesterday, 2334

Borome, Joseph Alfred, 6476

Borsodi, Ralph, 4579

The Boss, 2337

Bossard, James H. S., 4559

Bossing, Nelson L., 5225

Boston

booksellers, Colonial, 6436

concerts, 5649

culture, 4518

descr., I $437,4258,4315,4334$

econ. condit., Colonial period, 4602

essays, 979, I002-3

fiction, $726,967-70,982,992-95$, 1004,1008

foreign population, 4410

govt., 6207

guidebook, 3800

harbor, 3800

hist., $3800,4036,548$ I

law, 6292

libraries, 6475

music, 5648-49, 5672

industries, 5628

photographs, 1437

siege (1775-76), 3245

soc. condit. (I $880-1900), 4530$

soc. life \& cust., 4035, 4239, 426I, 4602

Boston, First National Bank, hist., 5984

Boston. Museum of Fine Arts, 5745

Boston. Public Library, hist., 6475

Boston Academy of Music, about, 5684

Boston Adventure, 2157

Boston Athenaeum, 6475

about, 6475

Boston Psychopathic Hospital, about, ${ }_{4} 838$

Boston Symphony Orchestra, hist., 5648-49

The Boston Transcript, about, 2870

The Bostonians, 992-95

Bostwick, Arthur E., ed., 6476

Boswell, Peyton, 5748

Botany, 2788, 2957, 4219, 4236, 4715, 4760

Both Your Houses, 1172

Botkin, Benjamin A., 4068, 5570, ed., 5510-12, 5515, 5522-26,

Boucher, Chauncey S., 5178

Boucicault, Dion, 2298, 2337

Boulding, Kenneth E., 5899

Bound East for Cardiff, 1648

Boundaries, 2970, 2974, 3351, 3540, $3553-55,3569$

Bourget, Paul Charles Joseph, 4387-89 about, 4387

Bourjaily, Vance, about, 237 I

Bourke-White, Margaret, photographs, 5447
Bourne, Edward Gaylord, ed., 3215

Bourne, Randolph

about, 2380

fiction, 2413

Bowditch, Nathaniel, about, 4746

Bowen, Catherine (Drinker), 2606-8

Bowen, Francis, tr., 45 I I-I 2

Bowen, Howard, 5899

Bowen, Trevor, 5500

Bowers, Claude G., 3281, 3320, 3362

Bowers, David F., ed., 3768

The Bowery in literature, $1002-3$

Bowes, Frederick P., 3763

Bowker, Richard Rogers, 6435

Bowles, Ella (Shannon), 4032

Bowles, Paul Frederic, 1 927-31 about, 237I

Bowles, Samuel, 4384 about, 261 4, 2879, 4383

Bowman, Isaiah, 2934 about, 294 I

Boxing, 4987, 5023-33

biog. (collected), 5025

heavyweight, 4991,5026

Negroes, 5025

television, 5033

Boy Meets Girl, 2327, 2333

Boyd, Anne Morris, 6138

Boyd, Ernest, 241 I

Boyd, James, $1239-41$

Boyd, Julian P., 6073 ed., 3292

Boyle, Kay, 1242-5I

Boynton, Henry Walcott, 6436

Boynton, Percy, 780

The Boys in the Back Room, 2536

$A$ Boy's Town, 982

A Boy's Will, 1452

Bracebridge Hall, 388-89

Bracke, William B., 3944

Brackenridge, Henry Marie, 2609-10

Brackenridge, Hugh Henry, I05-8, 2347

Bradbrook, M. C., 1367

Bradbury, Ray, 1 932-36

Braddy, Haldeen, 539

Braden, Charles S., 5439

Bradfield, H. J. S., tr. \& ed., 4296

Bradford, Andrew, about, 2880

Bradford, Cornelia, about, 2880

Bradford, Gamaliel, 2611-19

Bradford, Thomas Gamaliel, tr., 4314

Bradford, William, $\mathrm{x}-6,3204$

Bradley, A. G., ed., 7I

Bradley, Francis W., 2258, 2260

Bradley, Omar N., 3718

Bradley, Phillips, ed., 4512

Bradley, Sculley, 630 ed., 206, 628, 2324

Bradstreet, Anne (Dudley), 7-I I about, 79, 368, 3198

Brady, Mathew B. illus., 829

about, 821

Brain surgery, 4821

Branch, Edgar M., 816

Branch, Edward Douglas, 4516

Brandeis, Elizabeth, 6033

Brandeis, Louis Dembitz, 6247-48 about, $6246-48,6266$ 
Branden, Paul Maerker, 489 I

Brandt, Lilian, 4623

Brandwein, Peter, ed., 4984

Brandywine Creek, 2394, 398 I

Brant, Irving, 3282

Brasillach, Robert, 4944

Brassware, antique, 5787

Braun, F. X., 448 I

Brave Men, 2745

A Bravery of Earth, 135

Brawley, Benjamin, ed., 860

Brazer, Esther (Stevens), $\mathbf{5 7 2 6}$

Brazil, relations with, 3582

Brazos River, Tex., folklore, 5527

Bread out of Stone, I 53 I

The Bread-Winners, 94

Break the Heart's Anger, r968

Breakers and Granite, 1433

Breathe upon These Slain, 1743

Brebner, John B., 3159, 3552, 4473

Bredemeier, Harry C., 4550

Bremer, Fredrika, 4355-57 about, 4354

Brent, Charles H., about, 5457

Bretall, Robert W., ed., 5432-33

Bretnor, Reginald, ed., 2377

Brett, G. S., 5335

Brett, William Howard, about, 6476

Bretz, Rudy, 4697

Brevoort, Henry, about, 392

Brewer, Daniel Chauncey, 4026

Brewer, John Mason, 5527

Brewsie and Willie, $177^{\circ}$

Brewster, Paul G., 5585 ed., 5571

Brewster, Stanley F., 6295

Brickell, Herschel, ed., 235 I

Brickman, William W., ed., 5248

The Bride Comes to Yellow Sky, 835

The Bride of the Innisfallen, 2209

The Bridegroom Cometh, 1448

The Bridegroom's Body, 1246

Bridenbaugh, Carl, 3764, 45I7, 460I-2, 5704,6044

ed., 4240

Bridenbaugh, Jessica, 3764

The Bridge (Crane), 1303-4

The Bridge (Poole), 1656

The Bridge of San Luis Rey, 1867

The Bridge of Years, 2123

Bridger, Jim, about, 2831

Briggs, Arthur E., 650

Briggs, Harold E., 4147

Brigham, Clarence S., 2852, 6447

Bright, James R., 6003

Bright and Morning Star, 2234

Bright Center of Heaven, 2030

The Bright Doom, I 858

Bright Journey, 1962

Brightman, Alvin C., ed., 6275

Brightman, Edgar S., 5252 about, 5259,5433

The Brimming Cup, I $^{1} 4^{-1} 5$

Brimming Tide, I724, 5087

Brink, Wellington, 5808

Brinley, George, about, 6460

Brinton, Clarence Crane, 3502

Brinton, Howard H., 5468

Brisco, Norris B., 5949

Brissenden, Paul F., 6045
Brissot de Warville, Jacques Pierre, 4258-60

about, 4258

British ballads. See Anglo-American folksongs and ballads

British English, 2237, 2243, 2245

British immigrants, 4046,4488

British relations with Illinois, 4133

Britishisms (language), 2272

Britt, George, 2913

Britten, Benjamin, 487

A Brittle Heaven, $24 \mathrm{I} 3$

Broadax and Bayonet, 3663

Broadcasting. See Radio broadcasting; Television broadcasting

Brockunier, Samuel Hugh, 3197

Brodbeck, May, 2358

Broder, Nathan, 5674

Broderick, Edwin B., 4688

Brodie, Fawn (McKay), 5464

The Broken Span, 1878

The Broker of Bogota, 205, 2337

Brokmeyer, Henry C., about, 5305

Bromfield, Louis, 3782, 4594

Bronx County, N. Y., Democratic Committee, 6384

Brook, Alexander, 5800

Brook Farm, 280, 585, 2278-79, 288 I, 5256

Brookings, Robert S., about, 2685

Brookings Institution, Washington, D.C., 3634

Brookings Institution, Washington, D.C. Institute for Government Research, 3038,4762

Brookings Institution, Washington, D.C. International Studies Group, 3598

Brooklyn, 2703-4

foreign population, 4046

hist., 4046

soc. life \& cust., $42 \sigma_{3}$

Brooklyn Bridge, 4801

Brooklyn College, 632

Brooks, Charles F., 2953

Brooks, Cleanth, $1367,2378-79$ about, I 809

Brooks, Gwendolyn, 1 937-39

Brooks, John Graham, 4225

Brooks, Philiips, about, 5457

Brooks, Robert C., 4499

Brooks, Stella B., 910

Brooks, Van Wyck, ror6, 2380-82, 24 I I, 5773

ed., 26r 8-19,3736

about, 2394, 2406, 24I 7, 2443, 5508

Brooks, William Keith, about, 4724

Broom, Leonard, 4469

Brophy, Arnold, $3643 a$

Brother to Dragons, 2200

Brough, Kenneth J., 6478

Brougham, John, 23 I I

Broun, Heywood, 729

Broussard, James F., 2265

Brown, C. E., 5442

Brown, Charles Brockden, ro9-1 I7 about, I09, II 7, 2294, 2465, 2509

Brown, Charles H., 2901 ed., 657

Brown, Clarence A., comp., 2383

Brown, David Paul, 2347
Brown, Dee, 4158

Brown, Edward Killoran, 1280

Brown, Elmer E., 5152

Brown, Emily Clark, 6053

Brown, Ernest Francis, 2869

Brown, Esther L., 4800, 631 7-1 8

Brown, Francis J., ed., 4426

Brown, George Rothwell, 4063

Brown, Gerald S., 3555

Brown, H., 4513

Brown, H. C., 5254, 5289

Brown, Herbert R., 2384 ed., 2352

Brown, J. Hammond, ed., 5065

Brown, John, about, 261 7, 3 I 49, 34 I 4 poetry, 1222, I 224

Brown, John Crosby, 5979

Brown, John Mason, 4909

Brown, Josephine Chapin, 4630

Brown, Mark H., 4151-52

Brown, Milton W., 5746

Brown, Ralph H., 2968-69

Brown, Ralph Sharp, 6ro7

Brown, Ray A., 627x

Brown, Richard Lindley, 2425

Brown, Robert Eldon, 3046, $324 \mathrm{I}$

Brown, Spenser, 2350

Brown, Stuart Gerry, ed., 5360-6r

Brown, William Adams, 3636, 5953, 5993

Brown, William Norman, 3503

Brown Brothers and Company, 5979

The Brown Decades, 5695

Browne, Charles Albert, 4731, 4753, 5616

Browne, Charles Farrar, 209-15, 5524

about, 21 2, 557, 862, 2857

Browne, Sir Thomas, about, 248 r

Brownell, Baker, ed., 4579

Brownell, Emery A., 6330

Brownell, Gertrude Hall, 2386

Brownell, William Crary, 2385-86, 24 I $x$ about, 25I3, 2504

Browning, Robert, about, 2545

Brownlow, Louis, 6141

Brownstone Eclogues, I 166

Bruce, Alfred W., 5926

Bruce, B. G., 5078

Bruce, H. R., 6336

Bruce, S. D., 5078

Bruce, William Cabell, 2620-21, 3187

Brucker, Herbert, 2928

Brummé, Carl Ludwig, 5733

Brunner, Edmund de S., 4406, 4581, 5485

Bruno, Frank J., 4618

Brutus, 2347

Bryan, Alice I., 6479

Bryan, George S., 4782 ed., 4977

Bryan, James E., 4817

Bryan, Leslie A., 5943

Bryan, Mina R., ed., 3292

Bryan, Patrick W., 2939

Bryan, Wilhelmus Bogart, 4064

Bryan, William A., 4835

Bryan, William Jennings, 6350 about, 3135, 3446-47, 3457, 5430, 6359

Bryan, Ohio, 3863 
Bryant, Billy, 4978

about, 4978

Bryant, William Cullen, 216-25, 2858 about, 223-24, 323, 2277, 2290, $2295,2374,2422,2486,2513$, 2534,2873

bibl., 224

Bryce, James Bryce, viscount, 3554, 4499

about, 4225

Bryson, Lyman, 5426

about, 5426

Buccaneers, 3168

Buchanan, Annabel (Morris), ed., 5549

Buchanan, James, about, 3399

Buchanan, Lamont, 5034

Buchanan County, Va., folksongs, 5582

Buchler, J., 5 I 97,5350

ed., 5348

Buck, Elizabeth Hawthorn, 4054

Buck, Paul Herman, 3083, 3363

Buck, Pearl (Sydenstricker), i 252-60 about, 1260

Buck, Solon J., 3420-21, 4054, 4127 , 4132

The Buck in the Snow, 1609

Bucke, Richard M., ed., 627, 637

Buckham, John Wright, ed., 53 I 8

Buckingham, James Silk, 4329-33

Buckingham, Nash, 5066-69

The Bucktails, 517, 2337

Budget, Federal. See Governmentappropriations \& expenditures

Buechner, Frederick, about, 2371

Buchler, Alfred G., 5969

Buehrer, E. T., 5442

Buel, Elizabeth C. Barney, ed., 5793

Buffalo, N.Y., in art, 5762

Buffalo Bill's Wild West Show, 4979

Buffaloes, 2965, 4I 47, 4I5I, 4153

Buffington, A. G., 4479

Buffington, Albert F., 2266

Bugbee, Harold D., drawings: 4195, 5874

The Build-Up, I874, 1882

Building materials, 5700, $5711-12$, 5718

Buley, Roscoe Carlyle, 4112,4810

Bulfinch, Charles, about, 5720

Bull Run, ist Battle (186I), 4378-8I

The Bulwark, 1343

Bunce, Oliver Bell, 2347

A Bunch of Keys, 2306

Bunche, Ralph J., 4446

Bundy, McGeorge, 3547 ed., 3543

Bunker-Hill, Battle of, drama, 105

Bunn, Charles, ed., 628 I

Bunn, Charles Wilson, 6281

Bunner, H. C., 2467

Bunner Sisters, 1851,1855

Buntline, Ned, pseud. See Judson, Edward Zane Carroll

Bunyan, Paul, about, 5506, 5516,5567

Burchfield, Charles, about, 5762

Burchfield, Laverne, 4580

Bureau of Chemistry and Soils, about, 4772

Bureau of Indian Affairs, about, 303839
Bureau of Plant Industry, Soils, and Agricultural Engineering, about. 2947

Bureau of Soils, about, 2943, 2947

Bureau of the Budget, 3725 about, 6144

Bureau of the Census, 4400

Burgess, Ernest W., ed., 444 I

Burgess, John William, about, 4540

Burgoyne's invasion (1777), 3682 fiction, 1709

$A$ Buried Treasure, 1702

Burk, John N., 5648

Burke, Arvid J., 5098, 5144

Burke, Charles, 2347

Burke, Kenneth, 656, 2387-90 about, 2443

Burke, William J., 2391

Burke, Idaho, 4176

Burks, Arthur W., ed., 5346

Burlesque, 4976

Burlingame, Roger, $4783,5939,6449$

Burlington, Iowa, guidebook, 3890

Burma, John H., 4470

Burma, World War II, 3726

Burnett, Edmund Cody, 3242 ed., 3242

Burnham, James, 3620

Burning City, 1224

The Burning Mountain, 1435

The Burning of Fairfield, 121

Burns, Edward McNall, 2622-23, 3283

Burns, Eveline M., 463I

Burns, James A., 5 I OI-2

Burns, James MacGregor, 3496, 6134, 6 I 52

Burns, John Horne, 1940-43

about, 237 I

Burns, Robert, about, 2I 6, 662

Buros, Oscar K., 5229

Burr, Aaron, about, 1873, 2617, 277r, 3149,3273

Burr, George Lincoln, ed., 4I, 3205

Burr, William H., ed., 82

Burr Conspiracy (1 805-7), 3273

Burr Oaks, 135 I

Burrage, Henry S., ed., 3206

Burrage, Walter L., 4804

Burrell, John Angus, ed., 2325

Burroughs, Alan, 5747

Burroughs, John, 740-44, 2624-28

about, 2422, 2492, 2624, 2628

Burroughs, Julian, 744, 2628

Burstein, Abraham, tr., I 195

Burt, Alfred L., 3553

Burt, Maxwell Struthers, 397

Burt, Struthers, $I_{1} 8$

Burtis, Mary Elizabeth, 2646

Burton, Hal, 4603

Burtt, Edwin, 5289

Bury the Dead, 21 45, 2333

Bus lines, 5942

Bus Stop, 1998

Busch, Francis X., 6296

Bush, Vannevar, 4778

about, 4803

Bushnell, Horace, about, 5428, 5436, 5476

Business, 3094, 6003-30

control, 6004

govt. regulation, $5885,6006,6099$
Business-Continued

hist., 6005, 6007, 601 6

small, 6021

statistics, 6025

New York (City), 4047

Ohio, 412 I

Southern States, 4083

Tex., 4194

Business and education, 5116,5168 , $518 \mathrm{r}, 5190$

Business cycles, 5922, 5968, 6015, 6025

Business education, 6017

Business ethics. See Social and business ethics

Business management, 6009

Business research, 4777

Businessmen, 4387, 6010, 6023, 602729

See also Capitalists and financiers

But Gently Day, 1635

But Look, the Morn, 1543

But Not Forgotten, 4920

Butcher, Devereux, 5866

Butler, Benjamin Franklin, about, 26I 7

Butler, George D., 4997

Butler, Nicholas Murray, 2629-30, 3554

Butler, Pierce, 6483

Butler, Richard, 5375

Butler, Samuel, about, I 65, 2480, 2504

Butler County, Pa., 38 I 9

Butte, Mont.

hist., 4 I 76

politics, 6207

Butterfield, Lyman H., ed., 3292, 33 13, 4830

Butterfield 8, 2074

Butterworth, Julian E., 5208

Butts, R. Freeman, 5103-4

By These Words, 3 I 43

Byerly, Carl L., 5307

Byrd, Richard Evelyn, 2977-78 about, 2980

Byrd, William, 1 2-16, 2296 about, I 6

Byrnes, James Francis, 3544

Byron, George Gordon Noel Byron, 6th baron, about, $216,323,458,520$, 2545

\section{C}

CIO. See Congress of Industrial Organizations

The Cabala, 1864

Cabbages and Kings, I I I 2-I 3

Cabell, James Branch, I 26I-69, 3980

about, $1268-69,2406$

Cabeza de Vaca, about, 3158

Cabinet officers, $3382-84,61_{45}, 61_{4} 8$

See also specific offices, e.g., Secretaries of State; also names of incumbents, e.g., Dulles, John Foster

Cable, George Washington, 745-52, 2296

about, 748, 751-52, 2366

Cabot, Henry B., 6292

Cabot, John, about, 31 74, 3215

Cabot, Richard Clarke, about, 4805

Cabot, Sebastian, about, 3 I 74 
Cady, Edwin Harrison, 2392 ed., 2326

Caesar, Julius about, 5325

fiction, 1869

Caesars of the Wilderness, 3170

Café des Exilés, 748

Cahalane, Victor H., 2954

Cahill, Holger, 5594, 5602 ed., 5689

Cahn, Edmond N., 626r

Cain, James Mallahan, about, 2427, 2536

The Caine Mutiny, 2230

Cairo, Ill., guidebook, 3876

Cajuns

fiction, 745

language (dialects, etc.), 759-61

New Orleans, 4 I 01

short stories, 759-6I

Calamity Jane, 4 I 47

Calavar, 202

Calaynos, 207-8

Caldwell, Erskine, I 271-75, 2333, 2376, 2427

ed., $3942-68$

about, 2508

Caldwell, June, 4176

Caldwell, Lynton K., 61 70

Caldwell, S. L., ed., 89

$A$ Calendar of Sin, 1746

Calhoun, Arthur W., 4560

Calhoun, John Caldwell, 2296, 3328 about, 3327-28

Calhoun, Robert, about, 5433

California, 3955, 3957, 4200-1 1

architecture, 5723

descr., 1073-74, 1077, 5082

drama, 2110

fiction, 985, 1089-93, I1 96, 1775 , $1777,2110,2213$

fishing, 5083

folklore, 5518

frontier \& pioneer life, $364 \mathrm{I}, 3737$

gold discoveries, 2659, 4201-2, 4351

govt., 6I 95

guidebooks, 3927-34

hist., 2658-59, 3943, 3959, 3974 $3998,4189,4200-4,5354$

Indians, $985,3002,3022-23$

language (dialects, etc.), 2260

literature, 4202, 4204

music, 5630

natural hist., $1073-74,1077$

Orientals, 4468

pictorial works, 4202

poetry, 1064, 1066-67, 1532

short stories, 725, 733-34, 739, 926 , 2110

theater, hist., 4923

travel \& travelers, I073, 2753, 4345 $4351,4372,4378$

California. Senate. Fact-Finding Committee on Un-American Activities in California, 6I I I

California Folklore Quarterly, 5518

California Youth Authority, 4644

The Call of the Wild, 1051-52

Callahan, Jennie (Waugh), 4685

Callahan, North, 3945

Callender, Clarence N., 6282
Calvinism, 5299, $54 \mathrm{II}, 5428$

in literature, $17,26,40,562$ essays, $230-31$

fiction, 333

poetry, $79-83$

sermons, 24, 32, 59

Cambridge, Mass.

in literature, 979

printing, Colonial, 6448

Cameron, Norman, 5336

Camino Real, 2226

Camp, Charles L., 4202

Camp, William Martin, 4208

Camp-meetings, 5407

Campaigns, political. See Political Campaigns

Campaigns and battles. See under names of wars, e.g., American Revolution-campaigns \& battles

Campbell, Bartley, 2316

Campbell, Harry M., 1397

Campbell, John C., comp., 3634

Campbell, John W., Jr., 2377

Campbell, Killis, 526

ed., 527

Campbell, Laurence R., 2912

Campbell, Marjorie E., 4004

Campbell, Olive Dame, music by, 5583

Campbell, Persia C., 5954

Campbell, Roy, I3 66

Campbell, Thomas (clergyman), about, 5455

Campbell, Thomas (poet), about, 323

Campbell, Walter Stanley. See Vestal, Stanley, pseud.

Campbell, William Edward March, 1177

Campbell, William V., comp., 5166

Camping on My Trail, I 553

Can Grande's Castle, 1584

Can Such Things Be?, 733-34, 739

Canada

econ. relations with, 3638,4052

fiction, 2162

relations with, $3272,3552-55,4473-$ 74

Canal Town, 1157

Canal Zone, 4218

Canals, 4312, 5928

See also Waterways, inland

Canals, interoceanic, 4221

See also Panama Canal

Canary, Martha Jane, about, 4147

Canby, Henry Seidel, 444, 817, 1017 , 2394-98, 3981

ed., $605,2398,2460-61,2557$

Cancer research, 4722

The Candle in the Cabin, 1581

Canfield, Dorothy. See Fisher, Dorothea Frances (Canfield)

Canfield, William M., maps, 4053

Canham, Erwin D., 4513, 5427

about, 5427

Cannery Row, 1780

Cannon, Carl L., 646 1

Cannon, Ida M., 4805

Canton Island, 4218

The Cantos, 1665

about, 1672,1674

Cantwell, Robert, 2406

Canvassing for a Vote (painting), 5761
Canwell Committee. See Washington (State) Legislature. Joint FactFinding Committee on Un-American Activities

Canzoni, 1666

Cape Cod

fiction, I 640

fishing, 5083

Cape Cod, 596-97, 606

Cape Cod Pilot, 3801

Capers, Gerald M., Jr., 4105, 6207

Capital, U.S.

at Philadelphia, 4059

See also Washington, D.C.

Capital punishment, 239

Capitalism, 5882, 5887, 6007, 6357

fiction, 1334-37

hist., $3443,3476,5878$

Capitalism and labor, 3439,6094

Capitalism and state, $3352,336 \mathrm{I}, 342 \mathrm{I}$, $3424-25,3438-39,3446,6066$, 6101, 6195, 6207, 6352, 6366, $6374,6430,6434$

Capitalists and financiers, 5880,5882 , 6023,6027

Capitol Building, Washington, D.C. architecture, 5708, 5720 paintings, 5775

Caplow, Theodore, 4547

Capote, Truman, 1944-47 about, $237 \mathrm{I}$

Captain Abby and Captain John, 1290

Captain Caution, $1708-9$

Captain Craig, 1714

Cardozo, Benjamin Nathan, 6262 about, 625I

Cardwell, Guy A., 745

A Careful and Strict Enquiry into the Modern Prevailing Notions of ... Freedom of Will, 26

Carey, Jane (Clark), 6r 98

Carey, Mathew, I 7 I, 177

Carey \& Lea (firm), about, 645 I

Cargill, Oscar, 629, 2399 ed., $608,1898,2276$

Caribbean region, relations with, 3509 , $3577,3584,3587$

Caricatures. See Cartoons

Caridorf, 2309

Carlborg, Edith M. L., tr., 4246

Carleton, Will, 753-55

Carlson, Oliver, 2877, 2884, 6341

Carlyle, Thomas, about, 280, 633

Carman, Harry J., 3103,5426 ed., $5426,5827,6054$

Carmel, Calif., 3930

Carmer, Carl, 3972, 4020, 4047 ed., 3969, 3975, 3978-95, 4002-25

Carnegie, Andrew, 3434 about, 2503, 3434, 5880

Carnegie, Mrs. Andrew, about, 3434

Carnegie Corporation of New York, about, 5 I 63

Carnegie Institution of Washington. Geophysical Laboratory, 4715

Carnera, Primo, about, 4987

Carnes, Cecil, 2908

A Carnival of Buncombe, 6421

Carnivals, 4980

Carolina, hist., 3216, 4073

Carolina Chansons, I 168,1512 
Caroline Islands, 4218

Carpenter, Frederic Ives, 302, 2400 ed., 299

Carpenter, Jesse T., 6059

Carpenter, Niles, 4395

Carpenter, Paul S., 5623

Carpenter, Ralph E., 5794

Carpenter, William S., 6283

Carr, Charles C., 5908

Carr, Harry, 4207

Carr, Harvey, about, 5389

Carr, Lowell Juilliard, 4586

Carr, Malcolm Wallace, 4842

Carr, Robert K., 6r10, 6r13-14, 6r28, 6130

ed., 6106

Carr, William G., 5106

Carrier, Lyman, 5821

Carrière, Joseph Médard, ed., 5528

Carrington, Walter, 6ogr

Carroll, Eber Malcolm, 635I

Carroll, John, Abp., about, 5449, 545I, 5477

Carroll, John Alexander, 327 I

Carroll, William, about, 4103

Carruth, Gorton, ed., 3076

Carry Me Back, 2842

Carson, Gerald, 5955

Carson, Joseph, 4856

Carson, Kit, about, 2831

Carson, William G., 4913

Carstensen, Vernon R., 5194

Cartels. See Trusts, industrial

Carter, Clarence E., 3047

Carter, Everett, 977

Carter, Hodding, 2631-32, 3488, 3946, 3982

about, 2632

Carter, William G. Harding, 3653-54 about, 3653

Cartmell, Van H., I 124 ed., 2327

Cartoons motion picture, 4957 politics, 2859, 2917, 5803

Cartwright, Peter, 2633-34 about, 2633-34

Caruthers, William Alexander, 226-29 about, 226

Carver, George Washington, about, 2690,5825

Cary, Edward, 2278

Case, Robert Ormond, 4893

Case, Shirley Jackson, 5413

Case, Victoria, 4893

The Case of Mr. Crump, 1573

Cash, Wilbur J., 4066

Cass, Lewis, about, 3358, 6078

Cass Timberlane, 1568

Cassidy, Frederic G., 2251

Cast a Cold Eye, 2020

Castaigne, A., illus., 1 ror

Castañeda, Pedro de, 3217

Caste. See Class distinction

Castell, Alburey, ed., 5333

Castellón, Federico, about, 5783

Castilian Days, 94I

Castle Hayne, N. C., 4406

Castle Nowhere, I 150

Casualty, 2012

Caswell, Hollis L., 5 I 47
Cat on a Hot Tin Roof, 2228, 2336

Catalogues and Counters, 5956

The Catcher in the Rye, 2108

Cate, James Lea, ed., 3727

Cate, Wirt Armistead, 3364

Cater, Douglass, 5899

Cathay, 1666

Cather, Willa Sibert, 832, 1029, 1031, I $276-78$

about, 821, 1279-83, 2406, 2429

The Catherine Wheel, 2159

Catholic Church, 5404-5, 5444-47

bibl., 5449

doctrine, 2034, 2036, 2038, 2040-42

hist., 5448, 5450-5 r, 5477

schools, 5 I 0 I -2

soc. thought, 5484,5488

sources, 5449

Catholic (Uniate) Church, Ukrainian, 4492

Catholics, 3040, 4428, 4515, 5450, 5495

Catlin, George

paintings by, 3330

about, 5802

Catlin, Russ, $500 \mathrm{I}$

Caton, John Dean, about, 4680

Cats in literature

folklore \& hist., 1828

poetry, 1359

Catskill Mountains, 5064

in literature, 740

Cattell, J. McKeen, ed., 5212

Cattell, Jacques, ed., 4712

Cattle and cattle trade, 4r53-54, 4r57$58,4163,4165,4190,4196,4214$, $5868-69,5873$

brands \& branding, 687, 5503, 5507, 5509,5526

fiction, $1686-87$

ranges, $4153,5858,5873$

Cattle trails

fiction, $684-86$

short stories, 687

Catton, Bruce, 3690-92, 3696

Catullus, translation, 1482

Caughey, John W., 3048, 4200-1 ed., 4202

Causality (philosophy), 5289

Cauthen, Charles Edward, ed., 2635

The Cavaliers of Virginia, 227

Cavalry, hist., 3659

Cavan, Ruth (Shonle), 456I

Cavanaugh, John, Father, $504 \mathrm{I}$

Cavender's House, I 714

Caves, 2946

Cavins, Harold M., 4863

Cawdor, 1534

Cawley, Elizabeth Hoon, ed., 432 r

Cayton, Horace R., 4439

Cedar Mountain to Chancellorsville. 3695

Cedar Rapids, Iowa, guidebook, $389 \mathrm{r}$

Ceiling Unlimited, 5938

Cenci family, fiction, 2087

Censorship, 6r o6

in 1917,3462

motion pictures, 4947

Census, 2972, 4390, 4400, 4403 See also Population

Central Medical Group of Brooklyn, 4889
Central Pacific Railroad, about, 5927

Century Magazine, 992, 2923

Century of Conflict, 3226

$A$ Century of Dishonor, 985

Ceramic industries, 5792

Ceremony, 2217

Cerf, Bennett A., ed., I $124,2325,2327$, 2370

The Certain Hour, 1262

Chadwick, French Ensor, 3569, 3707

Chafee, Zechariah, 6108-9, 6r28, 6r30

Chaffee, Adna R. (1842-rgr4), about, 3654

Chaffee, Adna R. (1884-194I), about, 3658

Chagres River and valley, 4014

Chaikin, Joseph, 2898

Chaim Lederer's Return, I 192

Chain stores, 596r

The Chainbearer, 268-69

$X A I P E$ (Chaire), 1313

The Chambered Nautilus, 368

Chamberlain, D. E., 6r95

Chamberlain, John, 2406-7

Chamberlain, Joseph P., 6 I 53

Chamberlain, Lawrence H., 6r1o, 6115, $6 \mathrm{r} 42$

Chamberlain, Neil W., 6046-47

Chamberlin, Joseph Edgar, 2870

Chambers, Whittaker, about, 6r14

Chambers, William Nisbet, 332 I

Champaign County, Ohio, $387 \mathrm{I}$

Champlain, Samuel de, 3156, 3207

about, I873, $3156,317 \mathrm{r}$

Chance, Love, and Logic, 5347

Chandler, Lester V., 5975

Channel Islands, Calif., 3957

Channing, Edward, 3083

about, 3058

Channing, William Ellery, 230-38, 5428,5472

ed., 594,596

about, 230

Channing, William Henry, about, 2279

Chanute, Octave, 4788

Chapelle, Howard I., 3666

Chapin, Francis Stuart, 4548

Chapin, Howard M., 85

Chaplin, Charlie, about, 4953

Chapman, Arthur, 466r

Chapman, Herman H., 5909

Chapman, John, about, 4533, 5506, 5519

Chapman, John A., ed., 4897

Chapman, John Jay, 2697

about, 2539, 2697

Chapman, Robert, 487, 2335

Chappell, Louis W., 5517

Chappell, Matthew N., 4700

Character (psychology), 4556

Charavay, Etienne, 3250

The Chariot of Fire, 2415

Charities, 4615-16, 4618, 4621, 4626, $4628-30,4634,6209$

Jewish, $446 \mathrm{r}$

Allegheny County, Pa., 459r

New England, 434I

Pittsburgh, 459 I

See also Medicine-charities

The Charity Ball, 23 I 4

The Charity Patient (sculpture), 5739 
Charlemont, 550

Charles River, Mass., 3991

Charles the Second, 2337

Charleston, S.C.

descr., 1002-3, 4093

econ. condit. (Colonial period), 4602

fiction, I I 45, I $512-13$

hist., 4093

intellectual life (Colonial period), 3763

soc. life \& cust., 4602,4288

Charlotte, N.C., guidebook, 3832

Charlotte; a Tale of Truth, 162

Charlotte Temple; a Tale of Truth, I 63

Charlottesville, Va., guidebook, 3828

A Charmed Life, 2022

Charteris, Evan, 5771

Charters, Colonial, 6086, 6100

Charvat, William, 233 I

ed., 2294

Chase, Gilbert, 5608

Chase, Harold B., 5002

about, 5002

Chase, John W., ed., 4513

Chase, Mary Ellen, I284-89, 3782, 5214

Chase, Philander, about, 5457

Chase, Richard

comp., 5586

ed., 925, 5529

Chase, Richard V., 494, 497, 651, 656, 854

Chase, Salmon Portland, about, 3382

Chase, Stanley P., 2425

Chase, Stuart, 6392

Chastellux, François Jean, marquis de, 4252-54

about, $425 \mathrm{I}, 4254,4258$

Chattanooga, hist., 4104

Chatters, Carl H., 6r 35

Chauncy, Charles, about, 5472

Chautauquas, 4893

Cheever, Daniel S., 3610

Chelsea Rooming House, 1483

Chemical engineering, 4793

Chemical industry, 4735

Chemistry, 47I 5, 4731, 4740

Chemistry, physiological, 4732

Chemists, $4735,474^{\circ}$

Cheney, Orion H., $644 \mathrm{I}$

Cheney, Sheldon, ed., 4972

Chêng, Tê-ch'ao, 4463

Cherokee Indians, 4104, 4233, 4248-50

See also Five Civilized Tribes

Chesney, Alan M., 4845

Chesnut, Mary Boykin (Miller), 263637

Chesnutt, William C., 6284

Chesnutt, Charles Waddel, 756-58

about, 756

Chesnutt, Helen M., 756

Chester, Giraud, 4686

Chesterfield, Philip Stanhope, Earl of, about, 248

Chesterton, G. K., 4343

Chesuncook, 594

Chevalier, Michel, 43I3-14

about, 43 I 2

The Chevalier of Pensieri-Vani, 887

Cheyenne, Wyo., 4176
Cheyenne Indians, 2799, 2999-3000, 4160

soc. life \& cust., 2999-3000

Cheyney, Edward P., 5192

Chicago

banks \& banking, 5985

descr., 4134, 4136

econ. condit., 3425

fiction, 887-89, 956-58, I $094-95$, I333-34, I337, I339, 1372-74, 1376, I $921-22,1939,2054,2232-$ 33,2235

frontier life, 4136

govt., 6208

hist., $3987,4135-36$

land values, 5812

libraries, 6473

music, 5644, 565I-52, 5660

Negroes, 4439, $445 \mathrm{I}$

poetry, $1727,1731,1937-38$

politics, $6207,6375,6380,6386$

public health, 4864

soc. condit., $2836,4599,46 \mathrm{r}_{4}, 4658$, 6380

soc. life \& cust., 4134

Swedes, 4486

underworld, 2586

Chicago. Home Rule Commission, 6208

Chicago. Public Library, about, 6473

Chicago. University, 5201

Chicago. University. College, 5182

Chicago. University. Dept. of Edu. cation, 5249

Chicago. University. Laboratory School, 5 II 7

Chicago Bears, 5040

Chicago-Cook County Health Survey, 4864

Chicago fire (I 871 ) , 4136

Chicago Poems, 1731

The Chicago Renaissance in American Letters, 2419

Chicago Review, 2556

Chicago River, 3987

"Chicago school" of architecture, 5705

"Chicago school" of criticism, 24 IO

Chicago strike (1894). See Pullman strike

Chicago Symphony Orchestra, 5651-52

Chicago Tribune, about, 2862

Chickasaw Indians, 3027

Chickering, Geraldine Jencks, ed., 5575

Chidsey, Donald Barr, 5027

Child, Francis James, 5550

Child, John L., 5254, 529 I

Child, Lydia Maria (Francis), 239-44

about, 239, 244, 2280

Child, Robert, about, 3198

Child study, 5 I 49

Childhood and youth in literature drama, 2023

fiction, $188,778-83,787-93,8$ I 1 $878-80$, I $126-27$, I I 32 , I I 84 , $1372-74,1376, \quad 1412, \quad 1415-17$, 1635, 1683, 1 802-4, 1839, 1888, $1944-45,1964,2023,2032,2107-$ $8,2213,2229$

personal narratives, 706-10, 906-7, r $078,1204,1213,1284,1292$, 1543,2394
Childhood and youth in literatureContinued

poetry, 878 , I 126

short stories, I 786, I 790

Children, 4315, 4559

behavior, 4559

books, 17, 188-89, 239, 580-82, $906-7,984$, I I32, 2500, 4190

development, 5 I $49-50,5247$

education, 5105, 5148-50

employment, 4569

exceptional, 5 I I 4, 5205, 5207, 5246

folklore, 5588,5592

guidance, 5149

institutional care, 4644

periodicals, 190, 239

protection, 4618

songs, $5510,5559,5563,5588$

Children and Older People, 1796

Children Are Bored on Sunday, 2160

Children of God, 1424

Children of Swamp and Wood, I724, 5087

The Children of the Night, I 714

The Children's Hour (drama), I989, 2333

The Children's Hour (periodical), 190

Childs, H. L., 6336

Childs, James Rives, 3599

Childs, Marquis W., 5899

Childs, Richard S., 6425

Chile, relations with, 3580

Chillicothe, Ohio, 3864

Chills and Fever, I 676

A Chilmark Miscellany, 2380

China

econ. relations with, 3638

fiction, 1252-56, 1259

influences on literature, 1583

relations with, $3506,3589,3591-96$, 3619

World War II, 3726

Chinard, Gilbert, 3278

Chinaware, $5791-92$

Chinese, $3437,4463-64,4467-68$

The Chinese Nightingale, 1581

Chinese poetry, translations, 1664,1667

Chipman, Nathaniel, about, 5121

Chiricahua Apache Indians, 30 ro

Chiropractic, 48 I I

Chisholm, Jesse, about, 4158

Chisholm, Leslie L., 5I53, 5228

Chisholm Trail, 4157

Chita, 946-48, 951-52, 955

Chittenden, Hiram Martin, 4I 48, 4182 ed., 2663

Chittenden, Russell H., 4732

Chittick, Victor L. O., 709

Chitwood, Oliver Perry, 3323

Chivalry, 1262

Chivers, Thomas Holley, 540

Choate, Julian Ernest, 41 62-63

Choate, Rufus, about, 2676

Choctaw Indians, hist., 3024-25, 3027, 4233, 4248-50

The Choice, i $85 \mathrm{I}$

Choirs (music), 5632, 5664-67, 5672

Chopin, Kate (O'Flaherty), 759-76r about, 759

Chorus for Survival, 1483

Chosen Country, 1331 
Chotzinoff, Samuel, 2638-39 about, 2639

Chouart, Médard, sieur des Groseilliers, about, 3170

Christ-Janer, Albert, $576 \mathrm{I}$

Christchurch, 1295

Christensen, Erwin O., 5594

The Christian Disciple, 231

The Christian Examiner, 230-31

The Christian Philosopher, 46

Christian Science, 5404, 5439

hist., 5452-53

Christianity, 5338, 5351, 5358, 5899

Christiansen, F. Melius, about, 5664

Christmas

hist., 4546

songs, 5563

Christmas-Night in the Quarters, 1135

The Christmas Tree, I6I 6

Chronicler of the Cavaliers, 226

Chu, Pao Hsun, 4662

Chugerman, Samuel, 4537

Chujoy, Anatole, 4969

Church and education, 5419, 5491, 5494

Church and society, 5482, 5484-97

Catholic Church, 5484, 5488

Judaism, 5488

Protestant churches, 5485-86, 548889

Church and state, 4550, 5395, 5400, $5406,5409,5418-22,5444-45$, $6 \times 17$

educational aspects, $5103,5236,5238$

in literature, 17, 19, 84, 92-95

Mass., Colonial period, 3178,3182 , 3199, 3235

New England, Colonial period, 3197. 3743

Church history, 5394-96, 5399-540I, 5405-6, 5409, 54I1, 544I-42

Colonial period, 43, 5408, 5410 , 5417

Church music

hist., 5632-34

Mormons, 5630

Protestants, 5631

New England, 5633

Philadelphia, 5629

Church, of Christ, Scientist. See Christian Science

Church of God, Anderson, Ind., 5442

Church of Jesus Christ of Latter Day Saints. See Mormons and Mormonism

Church of the Brethren, 5442

Churches of Christ, 5442 hist., 5455

The Churches Quarrel Espoused, 93, 95

Churchill, Henry S., 4604

Churchill, Winston (1871-1947), 76267

Ciardi, John, I948-53

Cimarron, 1406

Cincinnati

descr., 4303, 4310, 4312

guidebook, 3865

intellectual life, 3767

soc. life \& cust., 4I 22, 4303

Cincinnati Symphony Orchestra, 5647

The Circuit Rider, 872-73

Circus, $4894,4977,4982$
The Circus in the Attic, 2198

Cistercians, 2040

Cities and towns, 3095, 4360, 4576, $4587,4594-95,4598,4601-2$ $5510,6207,6213,6218$

climate, 2952

frontier, 4 I 5 I, 4 I 53

growth, 460I-2, 4609

guidebooks, 3786

hist., 4609

in art, $580 \mathrm{r}$

place-names, 2976

planning, $4575,4587,4603-7,4612-$ 13,5707

population, 4393

recreation, $4997-98$

soc. condit., 4395

water supply, 4797

Colo., 3913

Conn., 404 I

Eastern seaboard, 4358

Middle Atlantic States, 4263

Middle West, 4109

Mo., 4108,4281

Nev., 3955,4184

New England, 3965, 4239, 4261, 4279

N.J., 4053

N.Y., 4239

Northwest, Old, 4358

Rocky Mountains, 4176

Southern States, 4083, 4288, 4595

Southwest, New, 4187

Southwest, Old, 4098

Va., 4086

The West, 4150, 4176-77

See also Communities, urban

Cities and towns in literature

drama, I 688-89, 2049, 2063, 2 I 45

editorials, sketches, etc., $701-5$

essays, I791, I 859

fiction, $887-89$, 956-58, 1 $090-95$, II $90,1300,1327,1332,1372-74$, $1561,1656-58, \quad 1828-29, \quad 1831$, 1845, 1908, I9I1-12, 1914-15, 1921-22, I 939, I940, I 943, I 966$67,2054,2069,2074,2182,2184$, 2229, 24I 5, 2431

poetry, 1727, I731, I 870, I 937-38, 2060, 2133

short stories, IIII, I I I4-I9, I 510 , $1851,1855,1910,1913,2057$, 2071-75, 2145

Citizen Tom Paine, 1977

Citizenship, 4424, 61 22, 6133, 6139

Negroes, 4443

Orientals, 6r 20

The City and the Pillar, 2180, 2183

City Ballads, 753

The City Boy, 2229

City government. See Local government

The City in the Dawn, II 7

City-manager plan, 6210, 6213, 6216, 6425

City of Discontent, 1582

The City of Trembling Leaves, 1956

Civil Aeronautics Act (1938), 5943

Civil arbitration, 6299

Civil cases (law), 6280

Civil control of the military, 3646,3650
Civil disobedience, $585-86,593,604-5$, $607-8$

Civil liberties and rights, 3308, 340 I, $6075,6106-30,6134,6338$

hist., 6 II 7

minorities, 6r 29

Negroes, 4445

Calif., 6II

N.Y. (State), 5115

Civil procedure (law), 6289, 6295, 6300,6304

Civil service, 6172, 6178-81, 6183, $6186,6188,6192-93$

hist., 6174

Civil Service Commission, 6I 74 about, 6174, 6186, 6190

Civil service reform, 3422-23, 343\%, $3437,6174,6178,6186-87,6363$, 6373,6382

Civil War, 2580, 2710-11, 2757, 3073 , $3092,3141,3373,3387-88,3554$, $3690-3706,448 \mathrm{I}$

art, 5765

biog. (collected), 2613-14, 3695

campaigns \& battles, $2828-30,3450$, $3690-93,3695-99,3701,3703$, 3706,4378

bibl., 3365

causes, 3065, 3122, 3366, 3370, 3398, 3400,3409

foreign opinion, $3536,3550,3769$

foreign rel., 3359

hist., $1729,3374,3382,3393,3408$, $34 \mathrm{I} 6,3450,4076,608 \mathrm{r}$ sources, 2416,3395

interpretations of, $3073,3106,3407$

naval operations, 3700

personal narratives, 277, 2280, 2637, $2823,2828-30,3693,3696,3704-$ $5,4378-8 \mathrm{r}$ bibl., 3365,3378

photographs, 829

regimental histories, 3690-92, 3695 bibl., 3365

reporters \& reporting, 285 I

songs \& music, 5569

sources, 3697,3700

Civil War in literature

editorials, sketches, etc., 556-57, 633, 1099, I I 03-4, I 106

fiction, I $88-89,245,247-50,278$ $79,745,763-65,821,825-29,836$, $1241,1382,1389,1449,1468$, 1541-42, I 544, I618-19, I730, I 745, 2201, 49 I 2

poetry, $206,456-57,459,486,488$, $614,616-17,623,666,1222,1224$, I 811,1824

propaganda, 422

short stories, 556-57, 733-37, 739, 1099-1 102, I 106, I 225, I 790

Civilian Conservation Corps, 5884

Civilian Public Service Camps, 3649

Clancy, William P., 5447

Clapesattle, Helen B., 4827

Clapp, Margaret, 4047

Clappe, Louise Amelia Knapp (Smith), 2640-41

Clare, Thomas H., 5309

Clark, Dan Elbert, 3078

Clark, David L., 109, 115 
Clark, E. H., 2240

Clark, Elmer Talmage, 5440, 5442, 5463

Clark, George Luther, 6272

Clark, George Rogers, 3239 about, 3239

Clark, Harry Hayden, 970, 2424-25, 2515

ed., 139, 142, $158,468,2290,2330$, 2337, 2401

Clark, Jane Perry. See Carey, Jane (Clark)

Clark, John Maurice, 3454, 5898, 6004 about, 5888

Clark, John Spencer, 5304

Clark, Lawrence E., 5983

Clark, Leadie M., 652

Clark, Lewis Gaylord, 2295

Clark, Thomas D., 2853, 3983, 4097, 4106

Clark, Victor S., 5904

Clark, Walter Van Tilburg, 1954-58, 4176

Clark, William, 3298

about, 3167, 3299

Clark, William L., 6275-76

Clark, William Smith, II, ed., 469

Clark County, Ohio, 3870

Clarke, Eric, 5617

Clarke, James F., ed., 313

Clarke, William N., about, 5428

Clark's Field, 958

Clash by Night, 2066

Class distinction, 4524, 4534, 4542, $4547,4549-51,4556-58,4561$, $4564,4566,4585,5146$

Classic Americans, 2397

Classical influences on authors, 201, 205, $611,1532,1556,1864,2098,2101$, 2479, 2493

Classics and Commercials, 2540

Clavers, Mary, pseud. See Kirkland, Caroline Matilda (Stansbury)

Clavière, Étienne, 4259

Clawson, Marion, 5809, 5839

Clay, Henry, 3344

about, 3342-44

Clay, Lucius D., 3570

Clayton-Bulwer Treaty, 3559

The Clear Sun-Shine of the Gospel Breaking Forth upon the Indians in New England, 62

Clearing in the $S k y, 2171$

Cleaveland, Moses, about, 4I 18

Cleaves, Freeman, 3325

Clegg, Charles, 4153

Cleland, Robert Glass, 4186, 4203-4, 4353

Clemens, Olivia (Langdon), 801

Clemens, Samuel Langhorne. See Twain, Mark

Clemmer, Donald, $464 \mathrm{I}$

Clemons, Harry, 6466

The Clergyman's Advice to the Villagers, 121

Cleveland, Grover, 3422

about, 26 I $6,3423,6359,6373$

Cleveland, Ohio

concerts, 5630

politics, 6207, 6428-29
The Cliff-Dwellers, 888

Clifford, Cornelius, 5289

Climate, 2937, 2951-53, 2959, 2966, 5816

maps, 2951-52

Nev., 4184

New York (State), 4237-38

Pa., 4237-38

Southern States, 4084

Southwest, Far, 4189

Utah, 4 I 83

The Climate of Eden, 1493

Clinch, C. B., 23 I I

Cline, Howard F., 3504

Clinical medicine, $4827,4829,483 \mathrm{I}$, 4885

Clinical Sonnets, 1625

Clipper ships, 5937

The Clod, 2332

The Clouds, Aigeltinger, Russia, \&c., 1878

Clough, Benjamin C., ed., 5513

Clubs, social, 4574,4578

Clugston, W. G., 6207

Clurman, Harold, 49 I 4

Clymer, Joseph Floyd, 5003

Coad, Oral Sumner, 4899

Coalfields, 4336

Coan, Otis W., 2402

Coast and Geodetic Survey, about, 4766

Coastwise navigation, 3787

Coats, Robert H., 4474

Cobb, Irvin Shrewsbury, 2642-43

about, 2643

Cobbett, William, 2647

Cobden, Richard, 432 I

about, 4320

Coblentz, Edmond D., comp., 2884

Coblenz, Constance G., 3630

Cochise, about, 3004

Cochran, Negley D., 2890

Cochran, Thomas C., 3103, 4047, $5875,5927,6005$

Cochrane, Alexander, about, 4735

Cochrane, Willard W., 5850

Cockerell, Theodore D. A., about, 4734

Cockrell, Ewing, 6297

Cocks Must Crow, 1684

The Cocktail Party, 1359

Coe, Eva (Johnston), 5593

Coe, Wesley R., 4715

Coeur d'Alene Valley, 4176

Coeur de Lion, Richard, about, 2186

Coffin, Charles Carleton, about, 2851

Coffin, Robert Peter Tristram, 129097,3973

about, 1292

Coffin, Tristram P., 5518, 5550, 5556

Coffman, Stanley K., 2403

Cogswell, Joseph Green, about, 2462, 3776

Cohane, Tim, 5035

Cohen, Elliot E., ed., 4452

Cohen, Felix S., ed., 3728, 5267

Cohen, Haskell, 5030

Cohen, I. Bernard, 47 I 9

ed., 122,4750

Cohen, Morris R., 3728, 5267-70, 6268 ed., 5347

about, 5267
Cohn, Alfred E., 4865

Cohn, David L., 3782, 5822

Cohn, Sarah W., 4407

Cohon, S. S., 4458

Coit, Margaret L., 3327-28

Coker, Francis W., ed., 6o6o

Colby, Merle, 3940

Colby, Vineta, ed., 2455

Cold Morning Sky, 1905-6

A Cold Spring, 1926

Colden, Cadwallader, 3194, 5251 about, 3194

Cole, Arthur Charles, 3092, 4130, 5193

Cole, Arthur Harrison, 5910

Cole, Cyrenus, 2644-45, 4144

Cole, Fay-Cooper, about, 2990

Cole, Stewart G., 5430

Cole, Thomas, about, 3751

Colean, Miles L., 4605, 4610

Coleman, James S., 6455

Coleman, Laurence Vail, 3049, 4716, 5794

Coleman, Roy V., ed., 2967, 3071

Coleman, William, 2858

Coleridge, Samuel Taylor, about, 520

Colfax, Schuyler, about, 4383-84

Collect, 633,638

Collective bargaining, $3132,6038,6046$, 6053

The College Widow, 701

Colleges and universities, 3113, 4719, 5160,5204

administration, 5135, 5194, 5201, 5244

criticisms, 5179, 5190, 5232, 5235

curricula, $5100,5178,5180,5182$, $5184,5187,5196,5199$

development and innovations, 5169 , $5178,5180,5182,5184,5187$, $5195-99,5215,5246$

directories, 5112,5161

England, 5167, 5179

enrollment, $3786,5163,5170$

faculties, 5181,5201

fiction, $200 \mathrm{I}, 202 \mathrm{I}$

finances, $5135,5163-68,5172,5175$, 5189,5194

geographical distribution, 5 I 71

govt. relations, $5094,5165,5167$

graduate instruction, 5099, 5105 , 5195

hist., 5101-2, 5113, 5122, 5125 , $5134,5143,5169,5176-77,5183$, $5186,5188,5191-5204$

libraries, 5201, 6478,6487

museums, 3049, 5201

needs \& objectives, $5173,5178,5180$, $5182,5187,5189,5194$

organization, $5135,5174,5189$

periodicals, 5244

personal narrative, 2394

poetry, I $65-67$

religious foundations, $541 \mathrm{I}$

scientific education, 4723,4725

soc. aspects, 5177,5183 , 5191, 519394

stat., 5 I I 4, 5 I 74

students, $5170,5175,5194$

surveys, $5114,5186,5201-2,5206$

Germany, 5179

Gt. Brit., 5167,5179 
Colleges and universities-Continued Southern States, 4723, 5176

See also Agricultural colleges; Athletics-college; Catholic colleges; Community colleges; Dental schools; Football-college; Junior colleges; Land-grant colleges; Music-education; State colleges and universities; and names of individual colleges and universities, e.g., Bennington College.

Collier, Donald, 2993

Collier, John, 4428

Collier, T., 6r 95

Collinge, Patricia, 4919

Collins, Carvel, ed., 1092

The Colloquy of Monos and Una, 529

Colm, Gerhard, 5898

Colombia, relations with, 3585

Colombo, Cristoforo. See Columbus, Christopher

Colonial life in literature, $1-6,12-16$, $43-44,66-71$

diaries, journals, etc., 15-16, 36-39, $49,53-58,90-91$

fiction, 226, 239, 25I-52, 258, 333, $405,511,546,548-49,665,1439$, I $441,1707,1916-18,1920$

legal documents, 32,78

poetry, $7-11,72-73,79-83,427,433$, 1222

religious writings, $17-35,40,43-48$, $59-62,84,86-89,90,92-95$

satire, $51-52,75-76$

See also Social life and customs

Colonial Williamsburg, Inc., 5595

Colorado, 3964, 3967, 4180-82

descr., 4174

fiction, 1249

guidebooks, 39 1 2-1 3

hist., 3913, 3956, 3961, 4147, 4174, 4180,4189

poetry, 1 409-10

theater, hist., 4925

travel \& travelers, 4378

Ute Indians, 304 I

Colorado Desert, 3947

Colorado River, 4017,4757

Colorado Springs, hist., 4150

Colton, Calvin, ed., 3344

Columbia, I 18

Columbia Plateau, Nez Percé Indians, 3001

Columbia River, 4022

Columbia River Valley, fiction, 1314

Columbia University, about, 5136,5181 , 5185

Columbia University. Bureau of Ap. plied Social Research, 4701

Columbia University. Columbia College, hist., 5197

Columbia University. Graduate School of Journalism, 2889, 2910

Columbia University. New York State Hospital Study, 4846

Columbia University. School of Library Service, hist., 6485

The Columbiad, 104

Columbus, Christopher, $3163-64$ about, $381,1873,3163-65$

poetry, 104
Columnists, 732, 878, 2017

Coman, Katharine, 4149

Comanche Indians, 301 4, 4160

Come Back, Little Sheba, 1996, 2335

Come into My Parlor, 2836

Comedy

farcical, 701

frontier \& pioncer, $5 \mathrm{I} 8$

lyrical, 1647

marital, 1518

musical, 701, 705

periods

( 1 764-18 19), 168-70

(1820-70), $198,517-18,676$

(1871-1914), 701, 705

(1915-39), I 199-1212, I 49193, $1518,1545-50,1647-48$, I 749

romantic, 676

satiric, 517, 1491-93, 1545-50, 1749

social, I 68-70, I199-1 212, I 317

theory, 5351

See also Drama

Comfort, William Wistar, 3222

Comic strips, 2865

The Coming Forth by Day of Osiris Jones, I 66

Coming Home, 1851

Coming to the Parson (sculpture), 5739

Commager, Henry Steele, 982, 3058, $3103,3274,3348,3738,4513$, $548 \mathrm{r}, 6082,6130$

ed., 3079,4231

Contmand Decision, 2337

Commentary, 4452-53

Commerce, $4069,5944-64$

foreign, 5946-48, 5950, 5953, 6002

govt. regulation, $5946-48,5950$ cases, 6095, 6104

hist., 5944, 5948, 5955, 5960, 6016 maritime, 3524

reporting, 2869, 2902, 2918, 2924

New England, 4266

New York (City), 595 I

New York (State), 4242-46, 4266

Pacific Northwest, 421 2, 4214

Pa., 4242-46, 4266

Southern States, 4266

The Thirteen Colonies, 3193, 3243, 3262,3289

See also Trade

Commercial arbitration, 6299

Commercial policy, $3285,3340,3638-$ 39, 5953

See also General Agreements on Tariffs and Trade; Tariff

Commins, Saxe, ed., 400, 3268, 327I

Commission on Financing Higher Edu. cation, 5163-75

Commission on Freedom of the Press, 4687,4947

Commission on Graduate Medical Education, 4857

Commission on Hospital Care, 4847

Commission on Life Adjustment Edu. cation for Youth, 5224

Commission on Medical Education, 4858

Commission on Organization of the Executive Branch of the Government, 4671, 5099, 6184, 6199
Committee for Economic Development, about, 5983

Committee for the Study of Recnt Im. migration from Europe, 4407

Committee on American History in Schools and Colleges, 3050

Committee on Public Information, 3462

Committee on the Costs of Medical Care, 4883-84

Commodity exchanges, 5952

The Common Glory, 1477

Common law, 6222-23, 6230-31, 6236

Common Sense, 155, 160

Commons, John R., 6033, 6038 about, 5888

The Commonweal, 5446

Communication Workers of America, about, 4672

Communications, $3724,466 \mathrm{r}-47 \mathrm{II}$, $4787,5246,5899,6454,6480$

See also individual means of communication, e.g., Books and reading; Language; Newspapers

Communism, 3620, 5351, 5445, 6128, $6130,6134,6356$

guilt by association, 6111,6117

Calif., 6111, 6114

Washington (State), 6116

Communists and the Communist Party, 3r 49,3490

Communitarian experiments. See Utopias (settlements)

Communities, 4551, 4656

Jewish, $4454,4457-58$

Negro, 4442,4446

Norwegian, 2267

Calif., 264I

Communities, rural, 2764, 4 I09, 4576 bibl., 4580

econ. condit., 4585

See also Farm and rural life

Communities, urban, 4548, 4550, 456r, 4576,4609

See also Cities and towns

Community centers, Jewish, 4454

Community colleges, $5 \mathrm{I} 62$

Community life, Japanese, 4466

Community music, 5625

Community organization, 4575

Compacts, New England (Colonial period), 6079

The Company She Keeps, 2018

Compensation, 285

Compensation for judicial error, 6294

Composers, 146, 1927, 5605, 5609-1 1, $561_{4}, 5620,5639,5656,5672$

See also Musicians

Composition, literary. See Literary composition

Comprehensive high schools, 5156

Compromise of $1850,3118,3344$

Compton, Arthur H., 4722, 4747, 5187 , 5434

about, 4747

Compton, Charles H., 6467

Compton, Frances Snow, pseud. See Adams, Henry

Compton, Karl' T., 4693

Comptroller General, 5996 
Comstock Lode, Nev., 4185 fiction, 1420

Comte, Auguste, about, 4536

Conant, James Bryant, 5134, 5180

Conceived in Liberty, 1974

Concerning the lews, 798-99

Concerts

hist., 561 2, 5679

Boston, 5649

Calif., 5630

Cleveland, 5630

New York (City), 5626-27

Concord, Mass.

essays, 1002-3

hist., 4037

Concord Circle, $186,230,280,333$, 585,6 rg, 2278

Concord School of Philosophy, 5220

Concord Sonata, 5682

Condit, Carl W., 5705

The Conduct of Life, 292-93

Conductors (orchestra), 5620

Confederate States, 2637, 2828-30, 3694-95, 3698

biog. (collected), 26r 3, 3384, 3695

for. rel., 3539

govt., $608 \mathrm{r}$

hist., 3373, 3383-84, 3396, 3698, 4076

bibl., 3365,3378

sources, 3697,3700

origins, 3404

soc. condit., 3373

Confederate States Army, 3369

cavalry, 3703

military life, 3704-5

sources, 3697

Confederate States Navy, sources, 3700

The Confederation (1781-89), 3190, $3245,3256,330 \mathrm{x} \rightarrow 2$

Conference for Progressive Political Action, 6356

Confessions of a Congressman, 6165

The Confessions of a Reformer, 6428

Confessions of an Actor, 4933

The Confidence-Man, 485, 49 I

The Confident Years, $238 \mathrm{I}$

The Confidential Clerk, 1360

Conformity, 6130

The Congo, 1581

Congregational-Christian $\mathrm{C} \mathrm{h}$ u r c h es, 5442

Congregational churches, Colonial, $17,19,32,40,43-44,59,92-95$

Congregationalists, 5404

hist., 5415, 5454

Congress, 6084, 6089, 6150-69, 6340

committees, 6159

foreign affairs, 3604, 3610-11, 361516

functions, $61_{51-52}, 61_{54-55}, 6167$, 6169,6191

hist., 3450, 6r 40, 61 42, 6I $50-51$

investigating committees, $61_{54}, 6160$, 6164

organization, $61_{50}, 61_{52}, 61_{55}, 61_{62}$, $6 \mathrm{r} 67,6 \mathrm{r} 69$

rules \& practice, $6150,6162,6167$, 6169

See also Legislative branch
Congress. House, 6150, 6163, 6165, 6415

committees, 6 I 56

election districts, $6 \mathrm{I}_{63}$

rules \& practice, 6150,6165

Congress. House. Committee Investigating Un-American Activities, 6112

Congress. House. Committee on Interior and Insular Affairs, 3039

Congress. House. Committee on UnAmerican Activities, hist., $6 \mathrm{I}_{4} 4$

Congress. House. Select Committee on Lobbying Activities, 6397

Congress. Joint Committee on the Economic Report, 5970

Congress. Senate

functions, 6158,6161

hist., 6158

rules \& practice, $6157-58,616 \mathrm{r}$

Congress. Senate. Committee on the Judiciary, 4424

Congress of Industrial Organizations, $6034-36$

Congress of Industrial Organiztaions. Political Action Committee, 6394

Congressional elections. See Elections

Congressional investigations, $6 \mathrm{I}_{2} 8$, $6 \mathrm{r}_{54}, 6 \mathrm{r} 60,6 \mathrm{r} 64$

The Conjure Woman, 757

The Conjurer's Revenge, 757

Conkle, E. P., 2332

Conklin, Edwin Grant, 5427 about, 5427

Connecticut, $3965,4041-42$

architecture, Colonial, 5707

early settlers, 32

guidebook, 3805

hist., $404 \mathrm{I}$

pol. \& govt., 2652

Connecticut Courant (Hartford), 2875

Connecticut Fundamental Orders of r639, 32

Connecticut in literature, $32,34,118$, 562

essays, 165

fiction, 1299,1301

poetry, 121,1782

Connecticut River and valley, hist., 4009

Connecticut Wits, I01, I I 8, I65, 2465

A Connecticut Yankee in King Arthur's Court, 794-97, 8I I

Connelly, Marc, 1545-46, 2327, 233233,2348

Conner, Frederick W., 2404

Connor, A. J., 2953

Conover, Merrill B., 462 I

Conover, Milton, 4768

Conquering the Wilderness, 4044

The Conqueror, 723-24

The Conquest of Canaan (novel), 1802

The Conquest of Canaan (poem), IIg

The Conquest of Mexico, History of, 2294

The Conquest of Peru, History of, 2294

Conquistador, 1585

Conrad, Robert T., 2347

Conscientious objectors

Civil War, 3702

World War II, 3649, 6124
Conservation of natural resources, 1072 , $1075-76,2790,2956,2960,4099$, $5810,5884,5900$

Conservatism, 3139,6340

hist., 6067,6070

Colonial period, 3195, 3255, 3262 American Revolution, 3253, 3267 I gth cent., 3303, 3336

Conservatism Revisited, 2189

Conservative Judaism, 5460

Considine, Robert B., 5012

The Conspiracy of Kings, 103

The Conspiracy of Pontiac, 3171

The Conspirators, 2092

Constable, William G., 5426 about, 5426

Constitution, 3046, $3116,3304,4266$, $4334,6075-78,6080-82,6084-89$, $6091-93,6100,6121,6129,6133-$ 34,6 I37 $_{37}$ I $_{43}, 6$ I57 $_{5}, 6$ I99 $_{9}, 64 \mathrm{II}$

amendments, 6098, 6102-3

Civil War, 6064, 612 I

Ist, $6107,6109,6123$

5 th, 6097, 6ro8

$I_{4}$ th, $6078,6094-95,6097$

article 5, 6098

commerce clause, 6096

compact clause, 6206

contract clause, 6 ros

econ. aspects, 3139

See also Bill of Rights

The Constitution of the United States (Annotated), 6102

Constitutional Convention (1787), $6082,6087-88$

Constitutional history, 3I4I, 3195 , $3253-54,3256,3282,6059,6073-$ $89,6094,6100$

Constitutional law, 6072, 6085, 6090$6105,6166,6255,6257,6259$ 6266,6277

cases, 6084, 6089-92, 6095, 6099$6100,6102-5,6121,6127,6129$

Civil War, 608I

Constitutions, state, 6080, 6086, 6195

Construction industry, 4600,4610

Consular service. See Diplomatic and consular service

Consumption (economics), 5954

Contemplations, 7

Contemporaries, 2280

Contemporary Trends, 2276

Continental Army Medical Dept., 4830

Continental Congress, 3242

church influence in, 5406

Ist (1774), 3262

2d (1775-89), 3304

Executive branch, 6083

Presidency (1774-89). See Presidency-Con $\mathrm{t}$ in en $\mathrm{t}$ a 1 Congress ( $1774-89$ )

See also The Confederation ( $1781-$ 89)

The Continuing Spirit, 5453

Contracts, 6ror, 6105

cases, 6279

laws, 6275

The Contrast, 168-70, 2337, 2347

Convention of 1818 with Gt. Brit., 3542 
Conventions, political. See Political conventions

Conversation at Midnight, 1609

Conversations, 313

Converse, Paul D., 5945

Conway, H. J., 23 I I

Conway, Moncure, 2646-48, 4049 ed., 155

about, 2646, 2648

Cook, Beatrice G., 5070

Cook, Elizabeth Christine, 2854

Cook, Frederick A., about, 2979

Cook, George A., 92

Cook, Reginald L., 609

Cook, Sherburne F., 3002, 3022

Cooke, Bob, ed., 4984

Cooke, George Willis, 5470 ed., 2328

Cooke, Jay, about, 5988

Cooke, John Esten, 66, 245-5 r, 2296

Cooley, Charles Horton, about, 4542

Cooley, Thomas W., 6og I

Cooley, W. F., 5289

Coolidge, Archibald C., ed., 924

Coolidge, Calvin, $348 \mathrm{I}$ about, 348o-8r

Coolidge, Dane, 3013

Coolidge, Mary Elizabeth Burroughs (Roberts) Smith, 3013, 4464

Cooper, Frank E., 6310

Cooper, James Fenimore, (r789-185r), 252-73, 2290, 2295

about, 252, 546, 579, 674, 2277, 2286, $2364,2385,2397,2456,247$ r, 2509, 2544

Cooper, James Fenimore (b. 1 858 ), ed., 270

Cooper, Peter, about, 3443

Cooper, Thomas, 5251 about, 3303, 4721

Cooperative societies, $5842,5964,6008$

Cope, Alfred Haines, ed., 3 ro8

Cope, Edward Drinker, about, 4724 . 4748

Copland, Aaron, about, 5675

Copley, Frank Barkley, 4798

Copley, John Singleton, about, 5749, 5763

Coppée, François, about, 2466

Copper, antique, 5787

"Copperheads," 901

Copyright law, music, 562I, 568I

Cora, Anna. See Mowatt, Anna Cora

Coral Gables, Fla., 3846

Coram, Robert, about, 5121

Cordier, Ralph W., 4057

The Cords of Vanity, 1262

Core courses in schools, 5158, 5225, 5237

Coriolanus and His Mother, 2134

Cork, J., 5291

Corle, Edwin, 3947, 4005

Corliss, Carlton J., 5927

Corn, 3948

Corn (Engle), 1968

Corn (Lanier), 1038

Corn Country, 3948

Cornelius, Charles Over, 5727-28, 5796

Cornell, William Bouck, ed., 5906

Cornell University, 61 10-25

hist., 5 I9I
Cornhuskers, I73I

Corning, Howard McKinley, 3937, 3939

Cornish folklore, Mich., 5533

Coronado, Francisco Vásquez de, about, 3158,3217

Corporation law, 6008, 6011, 6236

Corporations, 4616, 6011-12, 6018 , 6020,6022

finance, 4616,5967

hist., 6or 4-1 5

Corpus Christi, Tex., 3919, 4476

Corrupt practices acts, 6338

Corruption (in politics), 6195, 6207, $6333,6342-44,6377,6380,6383$, $6385,6387-93,6404,6407,6410$, $6425,6430,6432,6434$

See also Spoils system

Cortesi, Arnaldo, 3615

Cortissoz, Royal, 5735

Corwin, Edward H., 4848, 4851

Corwin, Edward S., 3758, 6092.-94, 6143

ed., 6102

Cory, Daniel, 5367

ed., I 741

Cosby, William, about, 293 I

Cosgrave, John O'Hara, II, illus., 748, $3974,4012,4019$

Cosmic Optimism, 2404

Cosmogony of the Universe, 53 I

Cosmology, 5252, 5303

Coss, John J., 5178,5289

Cost and standard of living, 4567,4593 , $4595,5883,6048$

Cotes, Peter, 4953

Cotterill, Robert S., 4067

The Cotter's Saturday Night, 662

Cotton, James Harry, 5362

Cotton, John, I 7-20, 89 about, 5396

Cotton and cotton production, 3539, $4084,4367-68,4476,4789,5822$

editorials, sketches, etc., 1907

fiction, I I 59, 1786

Couch, William T., ed., 4068

Coughlan, Robert, 1398

Coulson, Thomas, 4752

Coulter, Edith M., 4202

Coulter, Ellis Merton, 3365, 4076-77, 4094,5176

ed., 3404,4072

Coulter, John Merle, 4724

about, 2789

Council-manager plan. See Citymanager plan

Council of Economic Advisers, 6144

Council of State Governments, 5135, 6r97, 6r99

Council of State Governments. Committee on State-Local Relations, 6200

Council on Foreign Relations, 3634, 3637

Council on Library Resources, Inc., 6487

about, 6487

Counseling in education, 5228

Counsellor-at-Law, 1689

Counter-Statement, 2387

Country Cured, 2654

The Country Girl, 2068
Country Growth, 1963

Country life. See Farm and rural life

The Country of the Pointed Firs, 102729, $103 \mathrm{I}$

Country People, 1796

Country stores, 4086,5955

Country theater, 4902

Countryman, Vern, 6rio, 61 16

Counts, George S., 5106, 5136

County agricultural agent, 5852

County fairs, 5827

County government. See Local government

County libraries, $647 \mathrm{I}$

Courier (Louisville, Ky.), about, 2892

The Course of Empire, 3161, 3299

The Court of Fancy, I 44

Courtney, Marguerite (Taylor), 4932

Courts, 6078, 6097, 6280-93, 6306. 6309-10

decisions \& opinions, 3756, 6090-9r $6100,6103,6126$

hist., 6290

reform, 6307

Mass., 6292

Mo., 4108

See also Supreme Court

Courts, administrative (state), 63 I I

Courts, federal, 6280-82, 6286, 6293

Courts, military, 6289

Courts, state, 628I-82, 6293

Courts, traffic, 6307

Courts, trial, 6285

Courts-martial and courts of inquiry, 6289

Courtship, 4572

The Courtship of Miles Standish, 433

Cousins, N., 4513

Covarrubias, Miguel, 3016

illus., 474,566

The Covenant of Grace Opened, 35

Covenants, New England (Colonial period), 6079

Covered bridges, 5724

Covey, Cyclone, 3747

Cowboys, 2657, 2700, 4152-54, 4158, $4 \mathrm{I} 6 \mathrm{I}-63$

bibl., 4190

dances, $559 \mathrm{I}$

fiction, 683-86, I I $45-48,1484-86$, 1686-87

folklore, 5503

in art, 5770,5802

in literature, $41^{162-63}$

language (dialects, etc.), 2253, 5503

short stories, 687, 1 I 45, I686-87

songs \& music, 5503, 5556, 5558-60

Cowdrey, Mary Bartlett, 5768

Cowell, Henry, 5682

Cowell, Sidney (Robertson), 5682

Cowie, Alexander, 2405

ed., 549

The Cowled Lover, 2309

Cowley, Malcolm, 642, 955, 2406, 2408-9, 3758

ed., 357, 2406-7

Cox, John Harrington, ed., 5572

Cox, Reavis, 5963

Cox, William, 2295

Coxe, Louis O., 487, 2335

Coxey, Jacob S., about, 3440 
Coyle, David Cushman, 5884

Cozens, Frederick W., 4983

Cozzens, James Gould, I 298-1302

Crabtree, Arthur B., 5299

Crabtree, Lotta, about, 2798

"Cracker" dialect in literature, 556, I038

Craddock, Charles Egbert, pseud. See Murfree, Mary Noailles

Crafts. See Arts and crafts

Craig, Gordon, 4972

Craig, Hardin, 534

Craigie, Sir William A., ed., 2236

Craig's Wife, 2332

Cram, Ralph Adams, 694

Cramer, Clarence H., 5476

Cranch, Mary (Smith), 100

Crane, Edward M., 6453

Crane, Hart, $1303-6,2544$

about, 520, 1306, 1480, 2497, 2499, 2527

Crane, Milton, ed., 3494

Crane, Ronald S., ed., 2410

Crane, Stephen, 82 I- 37

about, 821, 1278, 1923, 2285, 2365, 2372,2430

Crane, Verner W., I 22, 31 80, 3186-87 ed., 3184

Crapy Cornelia, 1008

Craven, Avery O., 3058, 3366-67, 4075 comp., 3079

ed., 3357,3784

Craven, Wesley Frank, 3051, 4073 ed., 3727

Crawford, Bartholow V., 604

Crawford, Kenneth G., 6393

Crayon, Geoffrey, gent., pseud. See Irving, Washington

The Crayon Miscellany, $38 \mathrm{r}$

Crazy Horse (Oglala Sioux chief), about, 2801,3036

The Crazy Hunter, 1246

The Cream of the Jest, $1261-62$

Creative Intelligence, 5254

Credit, 5963, 5974

agricultural, 5848

public, $3289,329 \mathrm{I}$

Chicago, 5985

Creech, Margaret, 4632

Creeds, comparative studies, 5397

Creek Indians, 4233, 4248-50 See also Five Civilized Tribes

Creel, George, about, 3462

Creighton, James E., about, 5259

Cremin, Lawrence A., 5104, 5137

Creole dialect, 2265

in literature, 745, 759-61, I032

Creole Sketches, 95 I-52, 954

Creoles in literature, 759-61, 946-52, 954-55

fiction, 745-50

Cress, Eleanor Chittenden, 4182

Cress Delahanty, 2213

Cresson, Margaret (French), 5736

Cresson, William P., 3284

The Cretan Woman, 1532, 1536

Crèvecoeur, Michel Guillaume St. Jean de, $4232,4500-1$

about, 2456

Cricket, 5063
Crime and criminals, 2888, 4405, 46r 7 , $4619,4639,4641,4645-48,4655-$ $56,4659,6306,6308$

biog. (collected), 4652

Colonial period, 6056

identification, 6294

labor, 6056

language (dialects, etc.), 2274

rehabilitation, etc., 4639-40, 4643, 4648,4652

The West, 6220

See also Women-delinquents

Crime prevention, 6309

Crimea Conference, Yalta, Russia, 3109 , 3544,3567

Criminal cases, 6280

Criminal justice, $6294,6303,6306$

Criminal law, $4645,6292,6308$

administration, 6303

digests, 6276

Criminal procedure (law), 4645, 6282, 6289, 6294-95, 6298, 6301-3, $6305-6,6308$

Mass., 6292

New York (Colony), 6221

Criminal psychology, 2716-1 7, 4641

Criminal trials, hist., 6229

Criminology, 4639

Cripple Creek, Colo., 4 I 74

hist., $418 \mathrm{I}$

The Crisis, 763-65

The Crisis of the Old Order, 3500

Crissey, M. H., ed., 3357

A Critical Fable, 1584

The Critical Period in American Literature, 2450

Critical realism, 5255

Critical Woodcuts, 2505

Criticism, literary

and art, 5688

anthologies, 2372, 2383, 2410-I I, 2531,2538

bibl., 2550

Chicago school, 24 Io

drama, 2466, 2468

essays, $2425,2472,2477,2479-8 \mathrm{r}$, 2498, 2503-5, 25II, 2519-20, $2535-48,255^{\circ}$

fiction, 2373, 2466, 249 I, 2495

hist., $2507,2510,2515$

Marxist, 2439

methods, 2443, $255^{\circ}$

"New Criticism," 2378, 2421, 2559

periodicals, 2492, 255 I-77

periods when written

(1764-1819), 109

$(1820-70), 230,313,345,449$, $458,465-67,520,533,536$, $538,551,614,618$

(1871-1914), 896-97, 964, 977, 979,986 , 1004, 1010, 1016, I022, I044, I I 36

(1915-39), 1225-26, 1228-29, I $231,1233-36$, 1238 , $1278-$ $83,1304,1306,1312,1347-$ 49, 1357-58, 136r, 1363-71, 1375 , I 377, 1397-1 402, I $501-$ 5, 1622, 1675, 1678-79, 1809, 1823,2423
Criticism, literary-Continued

periods when written-Continued

(1940-55), 1923, 1999-2000, 2 r25, 2128, 2356-63, 2373, $2388-90$

poetry, 520, 6r 4, I 044, 2378-79, 2452, 249 I

principles, 2494

short stories, 2495

techniques, 2494

theory, 242 I, 2512

Criticism and art, 5688

Criticism and Fiction, 977

The Crock of Gold, 23 I I

"Crocker poems," about, 323

Crockett, David, 2296, 2649-50

about, 2649-50, 2796, 3353, 5506 drama, $230 \mathrm{I}$

Crofut, Florence S. M., 4041

Croker, Richard, about, 6432

Croly, Herbert D., 3424, 4502, 6352

Cronin, John F., 5484

Cronkhite, Bernice (Brown), ed., 5215

Cronon, Edmund David, 3046

The Crooked Mile, 2415

Cross, Barbara M., 5476

Cross, Wilbur Lucius, 265 I-52 about, 2652

The Cross and the Crown, 5452

Cross Creek, 1685

The Crossing, 766-67

Crotchets and Quavers, 5659

Crothers, Rachel, 2337, 2348

Crouse, Nellis M., 3 I60, 3170

Crouse, Russel, I31 7, 2327, 2334-35

Croushore, James H., ed., 3693

Crow Indians, 3005

Crowder, Walter F., 6030

Crowell, Paul, 6207

Crowell, Pers, 5867

Crowl, Philip A., 3668

Croy, Homer, 2653-57, 3948 about, 2654-55

The Crucial Decade, 3484

The Crucible, 2048

Cruger, Jacob W., about, 6446

The Cruise of the Cow, 2746

Crum, Mason, 4436

Crumbling Idols, 896-97

Crusade in Europe, 3719

Crutchfield, Richard S., 5390

A Cry of Children, 1940, 1943

Cuba, 3569

fiction, 1500

independence, 3575

relations with, 358 r

Cubberley, Ellwood P., 5138

Cuber, John F., 4549, 46 I 9

Cullen, Countee, $1307-8$

Cults, $5397-98,5404-5,5439-40,5498$

Culture, 3 I I $5,3736,3738,3741$, 3750, $3771,3779,3786,4502-4,4546$, 4586,5351

and education, 5099, 5104, 5126-27, $5136,5200,5203,5243$

European criticism \& interpretation, $3771-72,3779,4223,4225,4230$, $4234,4271,4300,4303,4336$, 4506 
Culture-Continued

foreign influence, $3146,3227,3474$, $3737,3740,3758,3768-70,3774$, $4187,4189,4197-98$

bibl., 3768

hist., 3737

Colonial period, $3740,3747-48$

Igth cent., 3399, 3436, 3744, 3754, 4293,4312

2oth cent., $3474,3479,3746$

urban, 4530,4590

See also Indians, American-culture; Intellectual life; Jews-culture; also under place names, e.g., Massachusetts-culture

Culture, 292

Cumberland Mountains, short stories, 1084

Cumberland Road, 5931

Cumming, William K., 4688

Cummings, Edward Estlin, 1309-13 about, I 3 IO , I 312,2426

Cummings, Homer S., 6227

Cummins, R., 5442

Cunningham, G. W., 5252

Cunningham, John T., 4053

Cunz, Dieter, 4480

A Cure of Flesh, 1299

Curme, George O., 2242-43

Curoe, Philip R. V., 5210

Currency question. See Monetary policy

Current, Richard N., 3336, 3368, 3395

Currier, Thomas F., comp., 377

Currier \& Ives

about, 5778-79

bibl., $5778-79$

A Curtain of Green, 2203

Curti, Merle E., 3065, 3103, 3729, 3785, 4526,5 I 16,5194

ed., 2355,3739

Curtis, George William, 2278 about, 2278

Cushing, Caleb, about, 2675

Cushing, Harvey W., 4829 about, 482 I

Cushing, Marshall H., 4663

Cushman, Harvey B., drawings, 4 I 10

Cushman, Robert E., 6II7, 6r 8I ed., 6IIO-25

Custer, George Armstrong, about, 3036

Custer State Park, S. Dak., guidebook, 3898

Custis, George Washington Parke, 2337

The Custom of the Country, 1850

Cutter, Charles Ammi, about, 6476

Cutter, William Parker, 6476

The Cynic's Word Book, 732

\section{D}

D., H. See Doolittle, Hilda

D. A. R. See Daughters of the American Revolution

Dabney, Thomas Ewing, 287 I

Daddy Grace, about, 5498

Dade County, Fla., 3846

Dahl, Robert A., 36 I I

Daiches, David, 656, 660, I 28 I, 2407

Daily Journal (Louisville, Ky.), about, 2892
Daily News (New York), about, 2862

Daily newspapers, 2847, 2849, 2903

The Daily Picayune (New Orleans), about, 287 I

Daisy Miller, 1007, 1014

Dakota Indians, 4 I 47

Dakotas

frontier life, 2683

Norwegians, 4487

Dale, Edgar, 523 I

Dale, Edward Everett, 3023, 4154, 4744,5868

The Dallas Morning News, about, 2866

The Dallas News, about, 2866

D'Alonzo, Constance A., ed., 4873

Dalton, A. P., 2257

Daly, Augustin, 231 7, 2337

Damaged Souls, 2617

Damrosch, Walter, 5676,5678

Dana, Charles A., about, 2848, 2874 , 288I

Dana, Henry Wadsworth Longfellow, 5760

Dana, James Dwight, 4744, 4749

about, 4721, 4724, 4749

Dana, John Cotton, about, 6476

Dana, Julian, 2658-60, 3974

Dana, Richard Henry (I8I5-1882), $274-76$

about, 276, 479, 2492, 2580

Dana, Richard Henry (I 85 I-I93I), about, 249 I

Dancing, 4967-72

hist., 4971

See also Ballet; Games and dances; Folk dances; Square dances

Danckaerts, Jasper, 3208

Danes, 4482

Danforth, Samuel, about, 2493

Dangerfield, George, 3329

Dangerfield, Royden J., 3612

The Daniel Jazz, $158 \mathrm{I}$

Danielian, Noobar R., 4673

Daniels, Jonathan, 3488, 4449

Danilevsky, Nadia, 440 I

Danilov, Victor J., 2905

Danish West Indies purchase, 357 I

The Danites in the Sierras, 2337

Dankers, Jasper, 3208

Dankert, Clyde E., 6036

Danner, Edwin R., 2266

Dante Alighieri, 437 about, 1303, 2281

Danton, Emily Miller, ed., 6476

Danz, Louis, 4968

Danzig, Allison, 5036, 5046 ed., 4984

Dargan, Marion, 3058, 3080

The Daring Young Man on the Flying Trapeze, 2110

The Daring Young Men, 5755

The Dark Bifocals, 5351

Dark Bridwell, 1422

Dark Carnival, 1933

Dark Glory, 5501

Dark Green, Bright Red, 2185

The Dark Hills Under, 1916

Dark Laughter, I I 83

Dark of the Moon, 18I 4

Dark Summer, 1237

Darkness at Noon, 2335-36
Darley, F., illus., 27 I, 555, I I 38

Darling, Arthur Burr, 3531

Darrah, William C., 4757

Darrow, Clarence, 2816 about, 2816,5430

D'Arusmont, Frances (Wright), 429I92

about, 4290

Darwin, Charles Robert, about, 695, 716,5274

Darwinism, 3755, 3768, 4721, 51 81

See also Evolution

Dauer, Manning J., 3285

The Daughter of Bugle Ann, 154 I

$A$ Daughter of the Middle Border, 898

Daughters of the American Revolution, about, 3644,4574

Davenport, Basil, 347

Davenport, Eugene, 266r about, 266I

Davenport, Francis Garvin, 3765, 4107

Davenport, Russell W., 4503

Davenport, Walter, 6353

David, Henry, 3425 ed., 6054

Davidson, Donald, 554, 378 r, 4006, 4068

Davidson, Edward H., 360

Davidson, J. Brownlee, about, 4803

Davidson, Levette J., 5514 ed., 5530

Davidson, Marshall, $580 \mathrm{or}$

Davidson, P. G., 3058

Davidson, Percy E., 6043

Davidson, Thomas, about, 5267

Davidson, William R., 5945

Davie, Maurice R., 4407, 4437

Davies, John D., 3752

Davies, Wallace Evan, 3079, 3644

Davis, Allison, 4438

Davis, Charles T., ed., 645

Davis, Clyde Brion, 3984

Davis, Curtis C., 226

Davis, Elmer Holmes, 3621

Davis, Hallie (Ferguson) F., 4915

Davis, Harold Lenoir, I 31 4-1 6

Davis, Jefferson, about, 1809,3369 , $3383-84,3388$

Davis, Joe Lee, ed., 2329

Davis, John, 4274-75 about, 4273

Davis, John H., 584 I

Davis, Joseph S., 4391, 60I4

Davis, Julia, 3997

Davis, Kenneth S., 3482

Davis, Kingsley, ed., $455^{\circ}$

Davis, Merrell R., 478

Davis, Michael M., 4885

Davis, Nathan Smith, about, 4807

Davis, Owen, 2337, 2348

Davis, Pearce, 59 II

Davis, R. S., 6207

Davis, Richard B., ed., 540, 4280

Davis, Theodore R., about, 5806

Davis, William T., ed., 4, 3204

Davison, Archibald, 563 I, 5669 about, 5672

Davison, Henry P., about, 5987

Davison, W. P., 3615

Davy Crockett, 2301

Dawes Severalty Act, 3034 
Dawn, 1344

Dawn in Lyonesse, 1287

Dawson, Howard A., 5208

Day, Arthur Grove, 4220

Day, Benjamin H., about, 2874

Day, Clarence, $1317-18$

Day, Donald, 2657, 3949

ed., 545, 2794, 5507

Day, Matthew, about, 6442

The Day of Doom, 79-83

The Day of the Locust, 1844

The Days Before, 1659

The Days of Armageddon, 3465

Days Off, 5096

Days Off in Dixie, 5087

A Day's Pleasure, 893

Days to Come, 1989

Days without End, 1648

De Orbe Novo, 3153

De Rebus Oceanis et Orbe Novo Decades Tres, 3153

De Rerum Natura, translation, 1556

The Deacon's Masterpiece, 368

Dead End, 2327, 2333

Deaf, 4629

Dealey, J. Q., 4540

The Dealings of God, Man, and the Devil, 2805

Dean, John W., ed., 82

Dean, Vera (Micheles), 3505

Deane, Charles, ed., 2

Deane, J. R., 3562

Dear Judas, 1534

Dearborn, Henry, about, 3660

Dearing, Charles L., 5921

De Armond, Anna Janney, 2880

Dearstyne, Howard, 4086

The Death and Birth of David Markand, 1447

Death Comes for the Archbishop, 1276 77

about, 1278

Death in the Woods, 1185

Death of a Man, 1245

Death of a Salesman, 2047, 2335-36

The Death of General Montgomery, 105

Death of the God in Mexico, $535 \mathrm{I}$

Death Valley, Calif., 4205 guidebook, 3928

Debo, Angie, 4170-71

Debs, Eugene Victor, about, 2819, 6045

Debts, public, 3125, 5976-77

De Camp, Lyon Sprague, 478I

$A$ Decent Birth, a Happy Funeral, 2117

Decentralization in government. See Government-centralization

Declaration of Independence, 3116 , $3255,6073-74$

Declaration of Independence (painting), 5775

Decorative arts, 5594, 5600, 5602-3, 5784-93

See also Arts and crafts

Decorative design, 5726, 5728, 5732, 5796

Dedmon, Emmet, 4134

Deems, M. M., 5442

The Deep Sleep, 2055

The Deepening Stream, 1416

Deephaven, 1024-26
The Deer Park, 2028

Deering, Ferdie, 5856

The Deerslayer, 258

The Deerstalkers, 5080

Defenses, $3525,3618,3639,3646,3725$

Definitions, 2394-96

Defoe, Daniel, about, 1278

De Forest, John William, 277-79, 3963 about, 277

De Forest, Lee, 4689 about, 4689

De Gogorza, Maitland, illus., 3973

De Grazia, Alfred, 6402

De Grey, 1012

De Groot, Alfred T., 5455

Deism, 5408

Deitrick, John E., 486 I

De Kruif, Paul Henry, I 520

Delaware

guidebooks, 3822-23

hist., 32 I 4,4043

Delaware Indians, 3020

Delaware infantry (Revolutionary War), 3683

Delaware River and valley, hist., 3993

DeLeon, Daniel, about, 6045

$A$ Delicate Affair, 1035

The Delicate Prey, 1929

The Deliverance, $146 \mathrm{I}$

Delo, David M., 2973

Delta Wedding, 2206

The Deluge, 1107

The Demagogue, 422

Demagoguery, fiction, 2197

De Mille, Agnes, 4970

about, 4970

De Mille, Henry C., 2314

De Mille, William C., 2313

Demobilization, 3652

Democracy, 3 I I 2-1 3, 31 42, 31 97, 324 I, $3252,3254,3281,3283,3368$, $3434,3463,3733,3741,3778$, 4069, 4I03, 4II 5, 4499, 4509-1 2, 4522, 4542, 4550, 4557, 5279, 5284, 5445, 6060, 6066, 6069$6071,6078-79,6$ г 34,6 г37, 6г 39 , $6178,6357,6362-63,6370,6414$, 6424,6434

sources, 3143,3319

See also Liberty; Politics

Democracy, an American Novel, 689-90

Democracy and education, 5100, 5106, $5115,5118,5125,5134,5136$, $5146,5186,5189,5209,5211$, 5224-25, 5243

Democracy and Leadership, 2375

Democracy and Other Addresses, 460

Democratic ideals in literature, 740 , 2514

documents, 32

fiction, 794-97

poetry, 459, 619-30, 636-37, 639, 642,1580

prose, $84,92-95$, 101, 103, 178-85, $26_{5}-67,631,635,638,642,652$

speeches, addresses, etc., $460-6 \mathrm{r}$

Democratic National Committee, 6364 , 6384

Democratic newspapers, 2851, 2863, 2866
Democratic Party, 3I4I, 3400, 3438, $3443,3500 a$

hist., 6359, 6369, 6373-74

National Convention (1912), 635051

National Convention (1924), 6421

National Convention (1932), 6354

platforms, 6367

publicity, 6348

Chicago, 6386

New York (State), 6384

Southern States, 6378-79

Democratic-Republican Party. See Republican Party (Jeffersonian)

Democratic-Republican societies. See Political clubs

Democratic Vistas, $631-32$

Demography, 4391, 4403, 4459

Dempsey, William Harrison (Jack), 5023

about, $3488,4987,5023$

Demuth, Charles, about, 5744

Denervaud, Marie V., 672

Denison, Tex., guidebook, 3920

Denmark, relations with, 3571

Dennett, Raymond, ed., 3562

Dennett, Tyler, 3426

Denney, Reuel, 4555

Dennie, Joseph, about, 2465

Dennis, A. P., 5222

Dennis, Martin, about, 4735

Denny, Margaret, ed., 2412

Denominations. See Cults; Religion; Sects

Dental health services, 487 I

Dentistry, 4842-43

Denver, 4176

hist., 2878,4150

politics, 6207

The Denver Post, about, 2878

De Paolo, Peter, 5006

about, 5006

Dept. of Agriculture, 2947, 295 1, 5816I 7,5837

about, $5836,5856-57$

Dept. of Justice, about, 6226-27

Dept. of Justice. Civil Rights Division, 6106,6113

Dept. of Labor, about, 6051

Dept. of State

about, 3599, 3604

hist., $3601-2,3606$

functions, 3601,3606

Dept. of State. Secretary of State's Public Committee on Personnel, 3600

Dept. of the Army. Office of Military History, 3665,3726

Department stores, 5956-57, 5959

Dependency, $4618,4632,4634$

Depression (1929), 3098, 3485, 5877 fiction, I 775, I777, I887, 1891

Derber, Milton, ed., 4635

Derleth, August William, 1959-65, 3985

A Descent into the Maelström, 529

A Description of New England, 69

Deseret News (Salt Lake City), about. 2867

Desert Island Decameron, 2370

The Desert Music, $188_{3}$ 
The Desert Year, 2453

Deserts, 3947

soils, 2944

Calif., 2753

Designed for Reading, 2569

The Desire of the Moth, 1687

Desire under the Elms, 1648, 2332

De Smet, Pierre Jean, 2662-63 about, 2663

DeSoto, Clinton B., 4690

De Soto, Hernando, about, 3158, 3217

Destler, Chester McArthur, 3427

Destruction and Reconstruction, 282930

The Destruction of the Pequods, 121

Detective and mystery fiction, 1959, $2415,2435-36$

Detective Story, 2335

Determinism, 5323

The Detour, 2348

Detroit

hist., 4138

politics, 6207

Deutsch, Albert, $4642,4836-37$

Deutsch, Babette, 2413-14

Deutsch, Helen, 4916

Deutsch, Leonhard, music arr. by, 558 .

The Devil and Daniel Webster, 1222

The Devil's Dictionary, 732, 739

The Devil's Pretty Daughter, 5545

Devotional books, 45, 87-89

De Voto, Bernard A., 818, 2415-18, $3161,3299,3330-31,5526$

ed., $781,790,812,3298$

about, 2498

Dew and Bronze, 1295

Dewey, Davis Rich, 5966

Dewey, Jane M., ed., 5294

Dewey, John, 5117-20, 5123, 5254, 5272-88, 5290-91, 5335-36, 5347, 5494,6268

about, $2407,3761,4545,5116,5222$, $5239,5254,5262,5271,5278$, $5283,5287-96,5494$

Dewey, Melvil, about, 6476

"Dewey School," 5117

Dewhurst, J. Frederic, 5647, 5896

Dewitt, David Miller, 3412

Dexter, Henry M., 4036

The Dial (1840-44), 280, 313, 315, 585,2279

Dialects. See Language-dialects \& regionalisms

Dialects in literature

Cajun, 759-6r

Cracker, 556, 745, 1038

Creole, 745, 759-6r, 1032-35

French, 1032-35

Hoosier, 867, I 126

humorous, 542-45

Irish, 862

Negro, I92-93, 756-59, 856-60, 910$16,922,924-25,1032,1038,1099$ I 1 02, I 1 06, 1 1 33-35, $1526-29$, 1653

Pike, 933-34, 937, 94I-44, I I 26

poor white (South), 910, 917-2I

Yankee, $456-57,558$

Ala. (north) 1836

Fla. (backwoods), 1680

Ga. (backwoods), 445-48, 556
Dialects in literature-Continued

Ky. (rural), 1697

Middle West, 701, 753-55, 768, 941 , II 6

New England (rural), 209, 558, 562, $88 \mathrm{I}-86$

Tenn. (east), 330-32

Tenn. (mountain), 1084-88

Va. (rural), 192-93

The West, $684-87,878$

Dialogues in Limbo, 1738

Diaries, journals, personal records, etc. (Chap. I, Literature)

(Colonial), 12, 15-16, 36-39, 49, 56$57,90-91$

(1764-1819), 109, 178-85

(1820-70), 186-87, 276, 294-95, $393,414,438,489,577,585,600-$ or, 603

(1871-1914), 1009, 1080

(I915-39), I I 70, 1310

(1940-55), 1965

Dibble, Roy F., 5027

Dice, Charles Amos, 5981

Dichter, Harry, 561 I

Dick, Everett N., 4098, 4155-56

Dick Boyle's Business Card, 937

Dickason, David Howard, 5755

Dickens, Charles, 4342-43 about, 4341

Dickerson, Oliver Morton, 3243

Dickinson, Edward, 853

Dickinson, Emily, 838-50, 2363, 2544 about, $851-55,984,2615$

Dickinson, Henry W., 4784

Dickinson, John, 3709, 6268

Dickinson, Thomas H., I070

Dictionaries (language). See Language-dictionaries

Dictionary of American Biography, 3080

Dictionary of American History, $307 \mathrm{I}$

Diedrich Knickerbocker's History of New York, 383, 2295

Dies Committee. See Congress. House. Committee Investigating UnAmerican Activities

Diff'rent, 1648

Digges, Jeremiah, pseud. See Berger, Josef

Dilliard, Irving, ed., 6264

Dillon, William A., 4973 about, 4973

Dilts, Marion May, 4674

Diman, J. L., ed., 89

Dime novels, bibl., 2444

The Diminished Mind, 5237

Dimock, Marshall E., 6006, 6154

Dinks, pseud., 5076

Dinosaurs, 4754

Dionysus in Doubt, 1714

Diphtheria, control, 488 I

Diplomatic history (to 1945), 2580, $3141,3144,3237,3313,3426$, $3444,3448,3452,3473,3486$, $3498-99,3501-97,3669,4114$ 4259-60, 6075

American Revolution, 3187, 3239 , $3272,3519,3528,3569$

bibl., 3519, 3521,4229

Civil War, 2757, 3359, 3536, 3539, 3550
Diplomatic history-Continued

See also Foreign relations

Diplomatic and consular service, 3598$3600,3602,3606$

Diplomatic privileges and immunities, 3606

Dirks, Rudolph, about, 2865

Disabled, rehabilitation, etc., 4628-29, $4636-37$

Disarmament, 3525

Disciples of Christ, 5442

hist., 5455

Discordant Encounters, 2535

Discovery and exploration, 4736, 4749, 4757

Minn., 4142

Utah, 4183

Washington (State), 4215

The West, 2971, 3335, 4149

See also under New France; The New World; Spanish North America

Discovery of Europe, 2498

Diseases, 4870

control, $4867,4874,4877,488$ I

etiology, $4829-30,4867,4881$

stat., 4864,4867

The Disenchanted, 1425

The Disinherited of Art, 2421

Dismal Swamp, 4336

Disney, Walt, about, 4957

Disobedience, civil. See Civil disobedience

The Dispossessed, 1924

Disston, Hamilton, about, 4096

Distribution (economics). See Marketing

District of Columbia. See Washington, D.C.

District of Columbia, 1332

Ditzion, Sidney, 6472

Divine, Robert A., 44I9

The Divine Comedy of Dante Alighieri, translation, 437

The Divine Pilgrim, I 166

The Divinity School Address, 284

Divinity schools. See Theologystudy \& teaching

Divorce, 3022, 456I

Divorce, 2317

Dix, Dorothea, about, $4834,4837,4839$

Dixon, George, about, 5025

Dixon, Roland B., 3002

Do I Wake or Sleep, I6I5

Doane, Gilbert H., ed., 6486

Dobert, E. W., $448 \mathrm{I}$

Dobie, James Frank, 687, 4190, 5509, $5520,5527,5531$

ed., $5507,5518,5532$

Dobzhansky, T., 3758

Dr. Bergen's Belief, 2134

Dr. Heidenhoff's Process, 727

Dr. Sevier, 745

Doctors. See Physicians and surgeons

The Doctor's Son, 207 I

Documentary films, $495^{8}$

Dodd, William E., 3286, 3369, 4069

ed., 3469

about, 3057

Dodd, Mead and Co., about, 6445

Dodds, Harold W., 5167

Dodge, Roger Pryor, 5644 
Dodsworth, 1564

Doerflinger, William Main, comp., 5551

Dog on the Sun, 1478

Dogs in fiction, $1051,1541,1635$

Doherty, Robert Ernest, about, 4803

Dollar, Melvin L., 4886

A Dome of Many-Coloured Glass, 1584

Domesday Book, 1601

Domestic animals, 4276

A Domestic Dilemma, 2024

Dominations and Powers, 1739

Dominican Republic, relations with, $3575,3584,3587$

Domnei, 1262

Don, the Story of a Lion Dog, 1486

Donahey, William, 783

Donnan, Elizabeth, ed., 3045

Donne, John, about, 1902

Donner party, 3331

fiction, 1420

Donovan, Leo, 6207

Donovan, Robert J., 3482

Don't Go Away Mad, 2117

Dooley, Mr., pseud. See Dunne, Finley Peter

Doolittle, Hilda, $1319-24$

The Doomed City, 526

Dorati, Antal, about, 5654

Dorfman, Joseph, 4538, 5876

Dorr, Thomas W., about, 3149

Dorris, Jonathan Truman, 3388

Dorson, Richard M., 5533-34 ed., 2345, 3244, 5535

Dos Passos, John, 1325-32 about, 2371, 2376, 2406, 2427-28, 2508-9

Dot, 2298

The Double Agent, 1228-29

Dougall, Herbert E., 5967

Douglas, Dorothy (Wolff), 4569

Douglas, Edward M., 2970

Douglas, Frederic H., 3017

Douglas, Marjory (Stoneman), .4007

Douglas, Paul H., 6048, 6182, 6342

Douglas, Stephen A., about, 3397, 3399

Douglas, William Orville, 2664-65 about, 2665

Douglass, Aubrey A., 5105

Douglass, Elisha P., $324 \mathrm{I}$

Douglass, Harl R., 51 54, 5224 ed., 5224

Douglass, Harlan Paul, 5485-87

Doull, James A., 4877

Dow, George Francis, 3181

Dow, Lorenzo, about, 2805

Dow, Peggy, 2805

Dowell, Austin Allyn, 5869

Down an Unknown Iungle River, 1486

Down by the Riverside, 2234

Down in the Holler, 2270

Downer, Alan S., 2359

Downes, Irene, ed., 5627

Downes, Olin, 5627,5678

Downing, Major Jack, pseud. Sec Smith, Seba

Downs, Joseph, 5796

Doyle, John A., 3

The Dragon and the Unicorn, 2102

Dragon Harvest, 1758

Dragon Seed, I 259
Dragon's Teeth, 1754,1758

Drake, Daniel, 2666-67

about, 2667,4822

Drake, Durant, 5255

Drake, Sir Francis, about, 3173

Drake, Francis S., 4036

Drake, Joseph Rodman, 328, 2295

about, 323

Drake, St. Clair, 4439

Drake, Samuel G., comp., 4 I

Drama

anthologies, $2327,2332-37,2347-48$, $4892-98,4924$

classical themes, 201, 205, 1532, I 535-36, I 556, 2101

collections, 2297-2317

experimental, $1357,1359-60,1647-$ $48,1864,2226$

folk. See Folk drama

historical themes, 198, 200, 206-8, $365,1477,1491,1520,1752,2048$

hist. \& crit., $1175,1571,2378,2466$, $2468-70,2472-73,2475,2506$, $4900,4904-5,4907,4924$

bibl., 4905

Negro themes, 1821

periods

(1764-1819), 1 05, 144-45, 16870, 2297-2317

(1820-70), 198-201, 205-8, $365,511,517-18,674,676$, 2297-2317

(1871-1914), 701, 705, 1013, 1069-70, 2297-2317

(1915-39), 1172-74, $1176-77$, 1199-1 212, $1271,1317,1357$, $1359-60,1403,1473,1475$, 1477, 1491-93, 1518-20, $1532,1536,1545-50,1556$, $1587,1608,1688-90,1740$, $1749-53,1762,1821,1864-$ $65,1868,1877$

(1940-55), 1988-91, 1995-98, $2023,2043,2046-49,2063-$ 68 , 2098, 2101, $2110,2112-$ 14, 2117, 2133-35, 2145 , $2218-21,2223,2225-26,2228$

psychological, 2218, 2221, 2223, 2228

radio, 4966

realistic, I $518-20,1647-48$, I 688 , 1995-98, 2023, 2043, 2046-47, 2049, 2063

regional, $1475,1477,4926$

social themes, 1069-70, I 199-1 204, $1271,1519-20,1647-48$, I 68891, 1 996-98, 2045-47, 2049, 2063, 2145

symbolism in, 221 8-19, 2226

verse. See Verse drama

See also Comedy; Theater

Draper, John W., about, 3761

Draper, Lyman Copeland, about, 3053

Drayton, John, 4262 about, 426I

Dream Girl, 1689, 2334

A Dream of Love, I 877

The Dream of Success, 2464

A Dreamer's Journey, 5270

The Dreamy Kid, 1648

Dred Scott case, 6258
Dreiser, Helen (Patges), 1346

Dreiser, Theodore, $1334-45$

about, 821, 887, 957, 1089, 1344, $1346-49,2372,2406,2430,2464$, 2476, 2509

Drepperd, Carl W., 5596

Dressel, Paul L., 5160

Dressler, David, 4643

Drew, Elizabeth A., 1361

Drexler, Arthur, ed., 5718

Drifting Apart, 2304

Drinker, Henry S., 6319

Driver, Carl S., 3287

Drucker, Peter F., 6012

Drucker, Philip, 2998

Drude, Oscar, ed., 2957

Drug traffic, vocabulary, 2274

Drum-Taps, 623-24

Drummond, Andrew L., 5441

Drummond, Thomas, about, 4734

Drums, 1 240-41

Drums along the Mohawk, 1355

Drury, Betty, 4407

Drury, C. M., 5442

Drury, John, 5794

Drury, Newton B., 4211, 5866

Dubinsky, David, about, 6049

Du Bois, Guy Pène, 5800

Dubuque, Iowa, guidebook, 3892

Ducange, Victor, 2299

Du Courteil, Lafitte, about, 5 I 2 I

Due, John F., 5971

Due process of law, 6094-95, 6097, 6106

Duer, William, about, 6014

Duffey, Bernard I., 2419

Duffy', John, 4877

Duke University, 643

Duker, A. G., $4457-58$

Duker, Sam, 5226

The Duke's Motto, 23 I I

Dulany, Daniel, about, 3257

Dulcy, $234^{8}$

Dulles, Foster Rhea, 3428, 3532-33, $3563,3592,4620,4985,6034$

Dulles, John Foster, 3622

Dulles, Joseph H., 5344

Dumbauld, Edward, 6074

Dumond, Dwight Lowell, 3370-71

Dunaway, Wayland F., 4055, 4490

Dunbar, Paul Laurence, 856-6I about, 859

Dunbar, Seymour, 4226

Duncan, Delbert J., 5945 ed., 6019

Duncan, Harry, 2350

Duncan, Isadora, 4972 about, 4972

Duncan, Otis Dudley, 4395

Dunellen, N. J., 3812

Duniway, Clyde Augustus, 2929

Dunkards, 4480

Dunlap, Leslie W., 3052

Dunlap, Lloyd A., ed., 3390

Dunlap, William, 109, 2299, 2337, $2347,4905,5690$

about, 5690

Dunn, D., 5442

Dunn, Esther C., 4917

Dunn, Frederick Roger, comp., 3079

Dunn, Waldo Hilary, 327 I 
Dunne, Finley Peter, 862-66 about, 558

Dunning, Philip, 2332

Dunning, Wilbald, about, 4540

Dunning, William Archibald, 3372, 3554

Du Noüy, Lecomte, about, 5434

Dunster, Henry, about, 3198

Dupee, Frederick W., 1018-1 9 ed., ror 5

Du Pont, Eleuthère Irénée, 5912

Du Pont, Henry A., about, 5912

Du Pont, Lammot, about, 5912

Du Pont Company, about, 5912

Du Pont de Nemours, Pierre Samuel, about, 5121

Dupuy, Richard Ernest, $3644 a$

Dupuy, Trevor N., 3644a

Durand, John D., 4392

Durant, John, 4986, 5024

Duren, William Larkin, 5475

Durham, Frank, 1514

Duron, Jacques, 1742

D'Usseau, Arnaud, 2334

Dust and Light, 1858

Dust Bowl, fiction, 1775,1777

Dutch

in Brooklyn, 4046

in New York

fiction, $5 \mathrm{II}, 5 \mathrm{I} 4^{-15}$

humor, $382-83$

in the Middle West, 4493

Dutch, Pennsylvania. See Pennsylvania Germans

The Dutchman's Fireside, 514-15

Dutton, William Sherman, 5912

Duveen, Joseph Duveen, baron, about, 1204

The Dwelling Place of Light, 762

Dwight, Sereno E., ed., 29, 31

Dwight, Timothy, I I 8-2 I, 4271 -72 about, 427 I

Dwight, Timothy, Jr., 4271

Dwight, William T., 4271

Dyer, Brainerd, 3332-33

Dyer, Frank L., 4782

Dyer, W. A., 5222

Dykeman, Wilma, 4021

Dykstra, C. A., 5336

Dynamo, 1648

\section{E}

Eagle in the Egg, $155 \mathrm{I}$

The Eagle, the Jaguar, and the Serpent, 3016

Eagles, 2958

The Eagle's Shadow, 1262

Eakins, Thomas, about, 5764

Eardley, Armand J., 2942

Earle, Alice (Morse), 4227

Earle, Edward Mead, 6075

Early Americana, 1692

An Early Martyr, 1881

The Early Worm, 1214

Earnest, Ernest P., 4745, 4828, 5177

Earth Horizon, 1196

Earth Song, 4202

The Easiest Way, 2347

East, Robert A., 6016
The East (general)

archacology, 2990

geology, 2936

guidebooks, 3788,3790

historic houses, 5722, 5794

language (dialects, etc.), 2263, 2269

physiography, 2936

travel \& travelers, 4235-36. 425I, 4262

trees, 2963

See also Eastern seaboard; Middle Atlantic States; New England

East Church, Salem, Mass., 2600

East of Eden, 1779

East River, a Novel, I193

East Wind, 1584

Eastern seaboard

geography, 2968-69

in literature, 2459

language (dialects, etc.), 2263

travel \& travelers, I7I, 1002, 4239, $4273,4279,4334,4336,4358$

Eastern shore, Md., 3999

Eastern Star, Order of the, about, 4574

Eastman, George, about, $567 \mathrm{r}$

Eastman, Joseph B., about, 2678

Eastman, Linda A., 6476

Eastman School of Music, Rochester, N.Y., University, about, $567 \mathrm{r}$

The Easy Chair, 2415

Eaton, Amos, about, 4737

Eaton, Clement, 3344, 3373, 3766, 4070

Eaton, Margaret L. (O'Neale) Timberlake, 2668-69

about, 2668-69

Eaves, T. C. Duncan, ed., 554

Ebaugh, Franklin G., 4859

Eberhart, Richard, I 350-52

Eberman, Edwin, 2908

Ebersole, Luke E., 4551

Eby, Edwin H., 653

The Ecclesiastical History of New Eng. land, 43-44

Ecclesiastical law, 5420-22

Eckelberry, R. H., ed., 5244

Eckenrode, Hamilton J., 3419

Eckert, Ruth E., ed., 5202

Eckman, Jeannette, 3822

Eckstorm, Fannie Hardy, 5566

Ecological Society of America, 2956

Ecology, 3022, 5810

Economic assistance to foreign nations, $3598,3636-37,3639-40$

Economic conditions, 3440, 3734, 3786, $4505-8,4550,4567,4634,4777$, $4783,5883,5894-99,6005,6136$, 6372

atlases, 2972, 2974

hist., 3073. 3085-98, 5877, 5881, 5883,6016

Civil War, 3374, 3539

I 9 th cent., 3352, 3399, 3421, $3436,3447,4315-17,5875$ 2oth cent., $3436,3474,3478-79$, 3500,5875

rural communities, 4585

See also Geography-economic; also subdivisions History and Economic conditions under names of places and regions, e.g., Montana-hist.; Southern States-econ. condit.
Economic Cooperation Administration, about, 3640

Etonomic influences on literature, 2485

Economic themes in literature

editorials, sketches, etc., 1907

fiction, 726, 728-3 r, 775-77, 887-89, 941, 956-58, 973-76, 978, 109095, $1107-10,1270-75,1333-37$, 1339, 1372-74, 1376, 1 754-56, $1758,1775,1777,1792,1887$ 2079, 2088, 2194, 2229, 2517

poetry, 1038, 1061-63, 1069, 1664, 2079

short stories, 887

tracts, 1754

Economics, 4513, 5254, 5875-6058

hist., 3106, $3139,3497,3500,3747$, $375^{8}, 453^{8}, 5876,5886,6082$

social \& ethical aspects, 5899

sources, 3319

See also Commercial policy; Foreign economic relations

Economists, 5888

Ecumenical movement, 540r, 5405, 5487

Eddy, Mary Baker, about, 5439, 5453

Eddy, Mary O., comp., 5573

Eddy, Richard, 5473

Edel, Leon, 1020, 1280

ed., 990, 1006, 1012-1 4

about, ror 6

Edelman, Jacob M., 4706

Edgar Huntley, II4-15, II7

Edge, Mary E., comp., 398

Edgell, David P., 230

Edgewater People, 885

Edidin, Ben M., 4454

Edison, Thomas Alva, about, 4782

Editing, 2901, 2906-7, 3047, 6438, 6449

See also Journalism

Editorials, sketches, etc.

(1764-1819), 140-43

$(1820-70)$, 192, 194-97, 332, 379$80,422-26,445-48,463,546,556$, $558-6 \mathrm{r}, 6 \mathrm{r}_{2}-\mathrm{r}_{3}, 674$

(187r-1914), 701-5, 732, 739, 86266, 923, 1064-65, 1068, 1099, I $103-4$, I 106

(I915-39), 1214-20, I238, 1263, 1 267-69, 1 294, 13 1 2, 1 31 7-1 8, 1375, 1378, I 409, I602, I622, 1659, 1724-26, 1815-20, 1 859-63

(1940-55), 1907, 2149-52, 2155, 2 I 89, 2 I9r

See also Essays; Journalism; Short stories

Edman, Irwin, 287, 5197, 5222, 5289, 5291

ed., 5120, 5288, 5374

Edmunds, Walter Dumaux, $1353-56$

Education, 3469, 3740, 4387, 4513, 4550-51, 5098-5249, 5254, 5285, 5289-9I

administration, 5139,5247

articulation, $5107,5131,5217$

associations \& societies, 5106, 5112 , $5116,5131,5150,5157,5162-63$, $5181,5186,5205,5228,5230$, $5242-43,5246-47$ 
Education-Continued

bibl., 5108, 5110-II, 5241, 5244, 5247-49

developments \& innovations, $5117-20$, 5134; 5137, 5157-58, 5224-25, $5227,5230-31,5237,5246-47$

direct., 5 II 2

editorials, sketches, etc., 655, 2425

fiction, 583-84, 1417,1792

finances, 5105, 5135, 51 4I, 5247

foreign countries, 5242

foreign population, $442 \mathrm{I}, 4483,4493$

German immigrant influence, 4477

hist., 5101-2, 5104-5, 5108-10, $5113,5116,5121-22,5125,5127-$ 28,5130

index, $524 \mathrm{I}$

Jews, 4457-58, 446I

library manual, 5098

methods \& techniques, 2767, 5224-3I

Negroes, 4443, 4450, 5 I I 6, 5206

periodicals, $5128,5230,5242,5244-$ $45,5247-49$

philosophy, 5115-30, 5236, 5246, 5307

poetry, 165-67

problems \& controversies, $5226,5232-$ 39

reference books, 5098, 5110-12, 5161

research, 5098, 5 I I I, 5246-47

rural, $5105,5208,5246$

sectional, 5 I 13

secular, 5103

segregated, 5206, 5236

soc. aspects, $5109,5116-18,5126$, $5128,5134,5136-38,5140,5142$, $5146,5150,5155,5158,5177$, 5183, 5206, 5208-9, 5211, 5215, 5224,5240

sources, 5108, 5121-22, 5125, 512728, 5130, 5138, 5143, 5191-92, 5201, $5212,5240-49$

stat., 5 II 4

surveys, 5 I I 4, 5 I 86, 5201, 5205-6

theories, 460, $5115-30,5220,5237$

women, 165, I67, $5116,5193,5198$ bibl., 5212

yearbooks, 5240, 5243, 5246

Ala., 4099

British Commonwealth, 5134

Charleston, S. C., 3763

England, 5129

Germany, 5310

Ky., 4107

Mass., 5125

Nashville, 3765

New England, 3745, 426r, 4271

N.C., 4090

Northwest, Old, 4 I 12

Ohio Valley, 5 I2I

Pa., 4055

Philadelphia, 3764

S.C., $409 \mathrm{I}$

Southern States, 4083, 5108, 5116 , 51 45, 5206

Tex., 4 I 94

Va., hist., 5122

W. Va., 4089

See also Television in education; also types of education, e.g., Adult cducation; under school subjects, e.g.,
Education-Continued

Music-education; and subdivision Study and teaching under special subjects, e.g., Law-study \& teaching

Education and business, 5116, 5168, 5181,5190

Education and church, 5419, 5491, 5494

Education and civilization, 5136,5140 , 5153

Education and political ideas, 5138

Education and state, 5099, $514 \mathrm{I}, 5164-$ $65,5167,5189,5211,6135$

The Education Index, 5241

The Education of an American, 289I

The Education of Henry Adams, 69598

about, 2407

Educational law and legislation, 5139

Educational measurements and testing, 5229,5247

Educational plans (early), 5121-23

Educational Policies Commission, 5ro6, 5205

Educational psychology, 5307

Educational reform, 165-67, 186-87, 5117

Educational research, 5098, 5 I12, 5247

Educational trends, 5 I00, 5 I04

Edwards, Alba M., 6043

Edwards, Everett E., comp., 3147

Edwards, Herbert W., 244 I

Edwards, John H., I 660

Edwards, Jonathan, 2I-31, 2290, 529798

about, 21, 29-30, 2288, 2480-81, $5297,5299,5396,5428,5436$, 5472

Edwards, Newton, 5139-40

Egan, John, about, 3439

Egbert, Donald Drew, 3758, 3768 ed., 3753

Eggan, Fred R., 2990

Eggleston, Edward, 867-77, 3740 about, 3058

The Ego and the Centaur, 1982

Ehlers, Henry, ed., 5236

Eidesheim, Julie, ed., I I 7 I

Eight-year study (education), 5I 3 I

Eimi, 13 I I

Einstein, Alfred, about, 5434

Einstein, Lewis, 3267

Einstein, 1586

Eire Railroad Co. v. Tompkins case (1938), 6293

Eisenhart, Luther P., about, 4059

Eisenhower, Dwight D., 3633, 36.37, 3719

about, 3482

Eisenstadt, Abraham S., 3046

Eisner, Simon, 4606

Eitel, Edmund H., ed., I 128

Eiteman, Wilford John, 5981

Eitt, Mrs. G. Embry, 5503

Ekirch, Arthur A., 3754, 606r

Ekström, Kjell, 2366

Ekwall, E., 2364

El Paso, Tex., 4I 76, 4187

Elder, George W., 5017

Eldorado, 2282
Eldorado, or, Adventures in the Path of Empire, 4352-53

Election law, 6338, 6400, 6403, 6406-8, 6410

Elections, 6r49, 6336, 6340, 6404, 6407-8, 64II-12, 6416, 6418, 6422

hist., $6347,640 \mathrm{I}$

of 1824,3313

of 1840,3326

of 1866,3361

of $1876,3417-18,3430,3432$

of 1884,6373

of 1896,3135

of 1912,3473

of 1924,6362

of 1940,6419

of $1948,64 \mathrm{I} 4$

stat., $6413-15$

Detroit, 6420

III., 6383

Wis., 4139

Electoral college, $64 \mathrm{II}$

Electricity, 4750

Elementary education, 5243

administration, 5135,5151

curricula, 5142, 5158,5226

developments \& innovations, 5147

European influences, 5142

finances, 5135

hist., 5142, 5147, 5151

methods, 5142

organization, 5135,5 I 5 I

philosophy, 5117

soc. aspects, 5 I 42

See also Primary education

Elements of Critical Theory, $242 \mathrm{I}$

Elfenbein, Julien, 2902

Elfving, Fredrik, ed., 4243-44

Elias, Robert H., 1347

Eliot, Charles William, 2670-7I about, 4034, 5203

Eliot, John, about, 3 I 98

Eliot, Thomas Stearns, 1357-6o, $24 \mathrm{I}$ I, 2425

ed., 1668

about, 1225, 136r-71, 2426, 2443, $2476,2497,2499,2527,2535$, 2544

bibl., 1362,1367

Eliot Indian Bible, 6448

Elizabeth the Queen, I 172,1174

Elkin, Henry, $304 \mathrm{I}$

Elks, Benevolent and Protective Order of, about, 4574

Eller, P. H., $544^{2}$

Ellingston, John R., 4644

Ellington, Duke, 5642

Ellinwood, Leonard Webster, 5606, 5632

Elliott, Charles Winslow, 3655

Elliott, George R., 2375, 2425

Elliott, John Lovejoy, about, 5435

Elliott, Maud (Howe), 4040

Elliott, William Y., 3608,3642

Ellis, Elmer, ed., 865

Ellis, George C., 4036

Ellis, George E., 3182

Ellis, Harold Milton, ed., 2330

Ellis, Howard S., 3637

Ellis, John Howard, ed., 9-1o 
Ellis, John Tracy, 5448, 5478 ed., 5449

Ellis, Lewis Ethan, 3058, 3100,3517

Ellison, Ralph, 1966-67

Ellison, William Henry, 4202

Elmer Gantry, 1563

Elmtown's Youth, 4564

Elovson, H., 2364

Elsbree, Willard S., 5216

Elsie Venner, 375

Elsworth, Ralph H., 5842

Ely, Mary L., ed., 5209

Ely, R. T., ed., 581 I

Emberson, Frances G., ed., 5569

Embroidery, 5593, 5785

The Emergence of Modern America, 3093

Emerson, Edward Waldo, 297 ed., 294

Emerson, Ralph Waldo, 280-301, 2290, 2544

ed., 313

about, 21, 186, 230, 302-6, 470, 585, $606,610,621,633,740$, I о г $2277,2280,2375,2380,2385$, $2397,2404,2422-23,2476,2479-$ $80,2492,2502-3,2513,2545$, $5222,5254,5265,5300-1,5472$, 6424

Emerson, Thomas I., ed., 6126

Emery, Edwin, 2845, 2855

Émigrés. See Refugees, political

Emmet, Boris, 5956

Emmet County, lowa, guidebook, 3893

Emmons, Nathanael, about, 5428

The Emotional Discovery of America, 2503

Emotions, 5339

Empedocles. Fragments, translation, 1556

The Emperor Jones, 1648,2348

Emrich, Duncan, 5526

The Encantadas, 484

Encounter in April, 2 I 23

Encyclopadia Britannica, 5748

End of Summer, 1 208, 2333

Enderbury Island, 4218

Endocrinology, 4722

The Enemy, 1684

The Enemy Gods, 1551

Engel, Edwin A., 1650

Engineers and engineering, 4793-4803

England, travel \& travelers, 96-98, 249, $252,263-64,280,333,350,426$, $449,460-61,489,674,677-78$, $688,986,1357,1968$

Englander, R., 2364

Engle, Paul Hamilton, I 968-72

Engler, Adolf, ed., 2957

English, Van H., maps, 3255

English Bards and Scotch Reviewers, 458

English influences

culture, $3227,3737,3740$

education, 5191

literature

drama, I68-70, 206-8, 517

poetry, 7, 72-74, I $18-19$, 1 44$45,323,61_{4}-17,1303,1902$, 2098,2530
English influences-Continued literature-Continued

prose, 1 2, 43-44, 75-77, 122 , $165,333,350,585,2854$

Southern colonies, 4073

English language. See Language

English national characteristics, 96,263 , 28a, 291, 350

The English Notebooks, 350

English Traits, 291, 298

Engravings, 5595, 5763, 5780, 5782

See also Prints

The Enlightenment, 24I 2, 2503

The Enormous Room, 1310

Entertainment, 2808, 4098, 4121, $4162-63,4281,4497,4520,4550$, $4577,4593,4892-4982,5801$

See also specific types, e.g., Opera; Sports

Entomology, 4722

Entrepreneurship, 6023

Epic poetry. See Poetry-epic \& ex. tended narrative

Epics, translations, 1556

Epidemics, 4874

Colonial period, $4809,4830,4877$

hist., 4877

See also Smallpox-epidemic (r72r); Yellow fever-epidemic, Philadelphia (I 793)

Episcopal Church, 5404, 5442

hist., 5456-57

Epistle to Prometheus, 2413

Epitaphs, collections, 4527

Epstein, Lenore A., 4448

Equality, 728

Equality before the law, 6060, 6063, $6094,6106,6126,6374$

Equitable remedies, 6279

Equity, $6279,6282,6300$

Erickson, Charlotte, 4408

Ericsson, John, about, 4786

Erie, guidebook, 3818

Erie, Lake, 3868

Erie Canal, fiction, $1155,1157-58$, 1160 , 1353-54, 1356

Erie County, $\mathrm{Pa}$., guidebook, $38 \mathrm{r} 8$

Erie Water, 1356

Ernst, James E., 3197

Ernst, Morris L., 6127

Ernst, Robert, 4409

Erosion, 5808, 581 8

Erskine, John, ed., 2393

Ervenberg, Louis Cachand, about, 4734

Esarey, Logan, 4123

Escapade, I743

Eskimos, Alaskan, 2719-20

Espey, John J., 1670

Espinosa, José Manuel, 5537

The Esquimau Maiden's Romance, 79899

Essay on Rime, 2142

An Essay on the Use and Advantages of the Fine Arts, 165-66

Essays

(1764-1819), 146-48, 179, 184-85

(1820-70), 230, 280-83, 285-87, $291-93,298-301,381,465,467$, $469,520,533,618$
Essays-Continued

(r87r-1914), 701, 705, 740-44, 896$97,900,945,951-52,955,964$, $977,979,1038,1046,1096$

(1915-39), 1226, 1229, 1233-34, $1267,1357-58,1378,1445,1585$, $1602,1664,1668,1673,1735$, 1738-39, 1783, 1791, 1810, 1828, I $873, \mathrm{I} 884$

(1940-55), 2017

(20th cent.), 2372, 2375-80, 2383 $2388,2394-98,2401,2406-7$, 2410-12, 2415, 242 I, 2424-25, 2435, 2449, 2466-72, 2474-75, 2477, 2479-81, 2492, 2497-98, $2503,2505,2511-13,2515,2519$ 20, 2530-31, 2535-42, 2544-48, 2550

See also Editorials, sketches, etc.

Essays, familiar

(1820-70), 192, 368, 406-8, 4 I4, $449,465,467,506-10,674$, I I 36 38

(1915-39), I 3 17, 1859-63

Essays To Do Good, 45

Essert, Paul L., 5209

Estavan, Lawrence, ed., 4918

Esther, 691-92

Esther Wynn's Love-Letters, 984

Estherville, Iowa, guidebook, 3893

Esthetics, 5254, 5282, 5289-91, 535 I, 5366,5694

literary, 2387, 2453, 251 2, 2529

Ethan Frome, 1848

Ethical Culture movement, 5435

Ethics, 3758, 5252, 5254, 5257, 5273, 5289, 5291, 5312, 5319, 5323 $5346,5354,5357-58,5375$

legal, 6319-20

political, 376o, 6342-44

See also Social and business ethics

Ethics and law, 626r-62

The Ethics of Living Jim Crow, 2234

Ethnology, 2982-83, 2985, 3004, 3007, $3010,3012,3030$

See also Anthropology; Archaeology and prehistory

Ethridge, M., 3562

Etiquette, 4532

Eureka, 531, 533

Euripides. Medea, translation and adaption, 1535

Europe

economic relations, $3539,3619,3637$, 3639

relations with, $3138,3528,3536$, $3617,3769-71$

travel \& travelers

( $1764-18$ r9), 96-98, ror, 122

(1820-70), 222, 252, 263-64, $280,313,323,38 \mathrm{r}, 414,426-$ $27,449,489,506,674,677-$ $78,2282,2462$

(1871-1914), 713, 768-71, 887, $941,964,984,986,1136$

(1915-39), 1242, I 432, 1659, I 766, I 839, I845, 1887, I 88990

anthologies, 2498

fictional, 986-91, 996-roor, I004, 1007, I $845,209 \mathrm{r}, 2187$ 
Europe-Continued

World War I, 354 I

World War II, 3718-r9, 3722, 372627

Europe in literature

descr., 2282

diaries, journals, etc., $350,414,489$, 1079

editorials, sketches, etc., 313, 426, $674,677-78,941,964,984$

essays, 4I 4, 506

fiction, 333, 971-72, 987-91, 996$1001,1004,1008,1242-45,1247$, I251, 1396, 1495, I656, I887, I 889-90, 209 I-93, 2 I 23, 2146

hist., 693-94

letters, 96

poetry, 323

satire, 769-71

short stories, 1004, 1007, 1242, 1250. 1659

soc. life \& cust., $96,252,263-64,426$

Europe without Baedeker, 2535

European immigrants, 4407-8, 44121 4, 4419, 4422, 4460

European influences

culture, $3146,3474,3758,3769-70$

education, 5128 , $5142-43$

literature, 2365, 2399

Colonial, 17

(1764-1819), 104-8, I 18,120

(1820-70), 201, 205-8, 323, $333,38 \mathrm{r}, 393,427,430$, $449,506,674,676-78$

(1871-1914), 887, 941, 964, 986, 1048, 1089

(1915-39), I303, I 4 I I

(1940-55), 2123

essays, 2412, 2424

hist. \& crit., 2534

poetry, 2530

European literature, hist. \& crit., I 235

European Recovery Program, 3638 , 3640

European War, 1914-18. See World War I

The Europeans, 1008

Eustis, William, about, 3660

Eutaw, 552

Eva Gay, 1747

Evangelical and Reformed Church, about, 5442

Evangelical Mission Covenant Church, about, 5442

Evangelical United Brethren Church, about, 5442

Evangeline, 429

about, 745

Evangelists, 5403, 5480

Evans, George Heberton, 6015

Evans, Henry Clay, 3580

Evans, Herbert McLean, about, 4721

Evans, Nathaniel, 145

Evans, Oliver, about, 4795

Evans, Walker, photographs by, 1907

Evening in Spring, 1964

The Evening Post (New York), 2873 about, $\mathbf{2 8 8 2}$

The Evening Sun (Baltimore), about, 2876

Everett, C. W., 5197
Everett, Edward, about, 2462, 3776

Everglades, Fla., 4007

Everleigh sisters, 2836

Every Man His Own Boswell, 371-74

Every Soul Is a Circus, 1581

Everyday Is Saturday, 1860

Evjue, W. T., 6r95

Evolution, 4537

and philosophy, 3758, 5259, 5274, $5289,5303,5317$

and pragmatism, 5264

and religion, $3758,5337,5428-30$

See also Darwinism

Evolution (theories) in literature, 69598,7 r $6,2404,2480$

Ewan, Joseph A., 4734

Ewbank, Henry L., 469 r

Ewen, David, 5678, 5685 comp., 5605

Ewers, John Canfield, 3018

Ewin, Cortez A. M., 6239, 6415-16

Excavations: $A$ Book of Advocacies, 1828

Executive branch, 6075, 6084, 6r33, $6140,6146,6184,6191,6193$, $6310,6312-13$

Continental Congress, 6083

functions, $3725,6137,6172-73$, $6178,6180-81,6311-12,6316$

hist., 6194

interdepartmental committees, 6189

laws. See Administrative law

local. See Local executive branch

organization, $6173-74,6178,6180-$ $8 \mathrm{r}, 6 \mathrm{r} 85,6 \mathrm{r} 87$

See also States-executive branch

Executive-legislative relations, $36 \mathrm{IO}-1 \mathrm{I}$, $61_{40}, 61_{42-43}, 61_{56} 67,61_{78}$, 6191,6342

Executive Office of the President, about, 6 I 44

Executive power, $6093,6140,6 r_{42}-43$, $6 \mathrm{r}_{4} 6-48,6 \mathrm{I}_{7} 8,6 \mathrm{r} 80-8 \mathrm{r}, 6340$, $6355,6370,6422$

Civil War, 6081, 6r91

The Exile, $1257-58$

Exile's Return, 2408

Exotics and Retrospectives, 951-52

Expansionism, 3154, 3167, 3180, 3306, $3312,3322,3335,3428,3448-49$. $3533,3586-87,3760$

in literature, $244 \mathrm{I}$

See also Territorial expansion

Expatriate authors, 986, 1242, 1357, 1432, 1494, 161 1, 1766, 1839, $2087,2408,3768$

Expatriated Americans, 986 fiction, 989-91, 1004, 161 1, 2376

The Expense of Greatness, 1231

Experience and Art, 2453

Experimental writing. See Literatureexperimental writing

Experimentalism, 5271

Experiments of Spiritual Life and Health, 87

Exploration. See Discovery and exploration; Polar exploration

Explorers, 4114, 4211, 4213

See also Names of individual explorers, e.g., Columbus, Christopher

Expression in America, I57 I
Exultations, 1666

Ezekiel, Mordecai, 5898

F

A Fable, 1379, 1396

A Fable for Critics, 402,458

Fables in Slang, 702

Fabricant, Solomon, 5905, 61 36

The Face of Time, 1374

Faces in the Crowd, 4556

Faculty psychology, 5307

Fadiman, Clifton, 739, I I 8

comp., 3152

ed., 10 II

Fagin, Nathan B., $54 \mathrm{I}$

Fagley, Frederick L., 5454

Fahrenheit 451, 1932

Fahrney, R. R., 3058

Fainsod, Merle, 5885

Faint Clews \& Indirections, 643

Faint Perfume, 1456

Fairbank, John King, 3506

Fairchild, Henry Pratt, 4427

Fairchild, Herman Le Roy, 4717, 4733

Fairfax, 2316

Fairs, 4100, 41 24, 5827

Fairyland, 526

The Faith Healer, 1069-70, 2337

Faith bealing, 481 I

Faithful Are the Wounds, 2127

A Faithful Narrative of the Surprising Work of God, 22-23

Falconer, John I., 5820

Falk, Isidore S., 4883

Falk, Robert, 240 I

Falkner, William. See Faulkner, William

The Fall of British Tyranny, 2347

The Fall of the City, 2333

The Fall of the House of Usher, 529

False Dawn (The 'Forties), 1845

False Shame and Thirty Years, 2299

Family, 444I, 4466, 4469, 4550-5I, $4558,4560-62,4567,4571-72$. 5070

A Family Matter, 1553

The Family Reunion, 1359

The Famous Mrs. Fair, 2348

Faner, Robert D., 654

Fantastic Fables, 739

Fantastics and Other Fancies, 951-52

Far East

policy, 3594, 3596

question, 3568

relations with, $3426,3591,3596$, 3617,3632

World War II. 3723

The Far Side of Paradise, 143 I

Farber, Norma, 2350

A Farewell to Arms, 1496

Fargo, Lucile F., 4217

Faris, R. E. L., 3758

Farley, James A., 6354-55

about, 6354-55

Farm and rural life, 2891, 4395, 4397. $4466,4500-\mathrm{I}, 456 \mathrm{r}, 4579,458 \mathrm{I}-$ $85,4594,5832$

art, 5765

bibl., 4580

drama, 1475 
Farm and rural life-Continued editorials, sketches, etc., 556, 558-6r, 1724,1907

essays, 506, 509, I I 37-38, I 859, 259 I

fiction, 402, 716, 718, 1290 , 1299 , $1301,1355,1379,1388,1403-4$, $1420-22,1474,1476,1541,1653$, $1681-83,1698,1702,1704,1720-$ $23,1775,1777,1786,1792,1796$, 1839, 2005-6, 2030, 2052, 2161, $2166,2210,2212-13,2282$

poetry, 662, 753-55, 1 1 26-31, 1290, 1 295, I 451-52, 1727, I 731, I 823, 1968, 2166,2172

short stories, $563,61_{2}-13,881-86$, 890-95, 1023-31, 1379, 1476, $1724,1796-97,2166-68,2170-71$

Conn., $404 \mathrm{I}$

Middle West, 2655

Vt., 2742

See also Communities, rural; Farmers; Plantation life

The Farm and the Fireside, 556

Farm Ballads, 754-55

Farm Legends, 753

Farm management, 5839

Farm mechanization, 5822, 5830

Farm produce. See Agricultural products

Farmer-Labor Party, about 6356

Farmers, 5837

editorials, sketches, etc., 1907

fiction, $1474,1775,1777$

folklore, 5523

German, 4479

immigrant, 4406

Irish, 4498

songs \& music, 5559,5576

Rocky Mountains, 4172

Southern States, $408 x$

The West, 4149

See also Farm and rural life; Sociology, rural

The Farmer's Advice to the Villagers, I2I

Farmers' Alliance, about, 6358

The Farmer's Almanack, 5524, 554 I about, 5524, 554I

The Farmers Hotel, 2077

Farmers' movement. See Agrarianism

Farmers Union, about, 5831

Farming. See Agriculture

Farquhar, Francis P., ed., 4210

Farra, Kathryn, 4624

Farragut, David (sculpture), $574^{\circ}$

Farrand, Max, ed., 1 26, 3357, 3784, 6087

Farrar, Victor J., 3429

Farrell, James Thomas, I132, 1372-73, 5291

about, 2372, 2376, 2427, 2509

Fascism, 3149

Fashion, 2337, 2347

Fashionable Follies, 2347

Fashions in Literature, 1136

Fast, Howard Melvin, 1973-80 ed., I 59, I 345

Fatal Interview, 1609

Fate, 292

Father and Son, 1374

Father Divine, about, 5439, 5498
Fatout, Paul, 732

Faulkner, Harold U., 3081, 3096, 5877, 6034

Faulkner, William, 1 379-96, 2406 about, 1397-1 402, 1 809, 2372, 2376, $2427-28,2508$

Fauna. See Animals

Faunce, Roland C., 5225

Fauset, Arthur Huff, 5498

Faust, Albert Bernhardt, 4477

Faust, Clarence H., $240 \mathrm{I}$ ed., 30

Faust, translation, 2282

Fay, Albert H., 4177

Fay, Bernard, 3773

Fay, Jay Wharton, 5388

Fay, Theodore Sedgwick, 2295

Faye, Harold, maps, 4057

The Feast of Ortolans, 1174

Feather, Leonard G., 5642

Fechner, Gustav Theodor, about, 5326

Fechter, Charles, 2313

Federal Communications Commission, 4710

Federal Council of the Churches of Christ, 5487

about, 5405

Federal courts, 6280

Federal Emergency Relief Administration, about, 4630

Federal government. See Government

Federal Housing Administration, about. 4600

Federal Library Services Act, 6480

Federal-local relations, 6218

The Federal Radio Commission, about, 4706

Federal Reserve Bank of New York, about, 5983

Federal Reserve System, about, 5983, 5986,5993

Federal Reserve System. Board of Governors, 5986

Federal-state relations, 6076,6078 , $6090,6096,6099,6103,6198-99$, 6206,6293

Federal Theater Project, hist., 4915

Federal Writers' Project, 3786, 5515

Federal Writers' Project. New York (City), 4497

Federalism

Colonial period, 3245

I 8 th cent., 3141, 3245-46

New England, 3275

The Federalist, 229I, 6075

Federalist newspapers, 2873, 2875

Federalist Party, 3279-81, 3285, 3305, 3308,6374

The Federalists, 6175

Feibleman, James, 535I about, $535 \mathrm{I}$

Feidelson, Charles N., 2420

Feild, Robert D., 4957

Feinberg, Charles E., 659

Feis, Herbert, 3483,3593

Feldman, William Taft, 5278

Feller, John Henry, 4975

Felton, William R., 4 I 5 I-53

The Feminine Fifties, 2489

Fenn, Percy Thomas, 6095

Fenneman, Nevin M., 2935-36
Fenno, Richard F., ed., 3109

Fenton, Charles A., I 503

Ferber, Edna, I 403-8, I 545, I 547, 2333 about, 1403

Ferdinand and Isabella, History of, 2294

Fergus, Robert, about, 6446

Ferguson, Charles W., 4574

Fergusson, Erna, 4176, 4187,4198

Ferm, Vergilius T. A., ed., 31, 5425, 5442

Fernandina, Fla., guidebook, 3844

Fernow, Bernhard Eduard, about, 2791

Fernow, Berthold, 4049

Ferré, Nels F. S., about, 5433

Ferril, Thomas Hornsby, $1409-10$

Fertility, 4396, 4402

Fesler, James W., 6201

The Festival of the Dead, 1033

Festivals

music, 5667

La., 4100

Fetching the Doctor (sculpture), 5739

Fetrow, Ward W., 5842

Fetter, Frank W., 5971

The Feud of Oakfield Creek, 5354

A Few Figs from Thistles, 1609

Fiction

bibl., 2402

detective. See Detective fiction

dictionaries, handbooks, etc., 2526, 2528

didactic, I61-64, I 90-91, 239

economic, 726, 728-31, 775-77, 956$58,964,973-76,978$, 1089-98, $1107-10,1270-75,1333-37,1372-$ 74, 1376, 1664, 1 754-56, 1758, I775, 1777, 1907, 2079, 2194 2229

ethical themes, 986, 1907-8, 1914, 1940, 1944, 2156

experimental, 1242-47, I249, I 25I, I $379,1450,1842,2082$

historical. See Historical themes in literature-fiction

hist. \& crit., $345,896-97,977,986$, 1004 , 1010, 2365, 2371-73, 2376, $2378,2384,2402,2405,2418$, 2425, 2427-31, 2458, 2508-9, $2517,2523,2526,2528,2530$, 2536

humanitarian, 2084

humorous, $768,775-83,787-97$, I $802,2149,2202$

in periodicals, $2864,2874,2913$, 2916,2926

See also Literary periodicals

industrial, 941, 1159, 1178,1183 , $1507,1754-56$

"international," 971-72, 986-9r, 996-1001, 1004, 1007, I014, 1242$47,1249,1251,1754,1758,1839$, 2187

naturalistic, 821-29, 835-37, 1048, 1051-52, 1054-57, 1059, 108998, 1333-39, 1372, 1621, 1743, I 775

picaresque, 105-8, I 169, 1921, 2052

political, 277, 422, 689-90, 722, 762, 775-77, I107, I 155-56, 1 566, 1792, 2025, 2027, 2148 , 2197 
Fiction-Continued

popular, 2384

See also Bestsellers

production, 2418

psychological, $368,375,727,986-$ I001, I 004, I149, II 63, I379, $1470,1927,1944-45,1954,2017-$ $18,2021,2023,2052,2107-8$, $2156,2174-75,2178,2184,2224$ realistic, $277-79,562,721,821-29$, $835-37,867-77,887-89,956-76$, $978,980,982-1004,1007-8,1014$, 1089, I107-10, 1333-39, I343, $1372,1379,1445-50,1453$, I 46062, I 494, 1559, I 57 I, I 6I I, I680, 1 720-23, $1743-48,1754-56,1758$, 1775, 1792, I 796, I932, 1940, 1954, 1992-94, 2003-4, 2011, $2025-28,2045,2052-56$, 2069$70,2074,2076-78,2128,2210$, 2229-31

romantic, 20I-4, 226-29, 245-60, 268-69, 3II, 333, 34I-47, 356, $405,471-78,546-50,552-53,555$, $716,745,749-50,762-67,1048$, 1054, 1089-95, 1099, $1105-6$, I $45-48$

satiric, 105-8, 689-90, 775-77, 79497, 1261, 1381, 1508, 1 559, 1589 , 1635, I643, I688, 1792, 1842, $1845,2001,2017,2053,2082$, 21 54, 2180, 2229

science. See Science fiction

sentimental, 161-64, 239, 241, 716, 867,2384

social questions, $689-92,616,718-$ 20, 726, 728-31, 756, 821-24, $835-37,887-89,956-70,973-76$, $978,980,982,986-88,992-95$, 1008, 1048, 1055, 1089-95, 1 107$10,1136,1142-43,1155-56,1190$, 1 270-75, 1 333-39, 1 372-74, 1376, $1414,1417,1445-50,1453,1460-$ $62,1467,1559$, I57I, I $589,1656-$ 57, 1754-56, 1758, 1775, 1777, 1907, 1932, 2045, 2050-51, 2059, 2079, 2081, 2084, 2090, 2148, $2180,2182-84$

stream of consciousness writing, I 161-62, I 183, 1379, I 579, I 887, 2055, 2174-75

surrealistic, 1987, 2079, 2081, 2084

symbolism in, $333,470,48 \mathrm{I}-83,49 \mathrm{I}$, I379, 1494, 1500, 1947, 1954, I992, 2023, 2081, 2212

techniques, 2372

theories, 333, 345, 867, 896, 964, 977,986 , 1004, 1010, 1014, 1096, I 136

Utopian, 726, 728-31, 956, 978

Fiction, periods

(1764-1819), 105-17, 161-64, 168

$(1820-70)$, I 88-91, 20I-4, 226-29, 239, 24I, 245-60, 268-69, 277$79,312,333-47,356,365,368$, $375,402-13,415-18,422,470-$ $83,485,487,491,511,514-16$, $546-53,555,562-76,578-84,674$
Fiction, periods-Continued

(1871-1914), 683-86, 689-92, 70610, $716-20,722-24,726-31,745$, $749-50,756,762-68,775-83,787-$ $97,821-30,835-37,856,867-77$, $887-90,900,941,945-52,955-$ $76,978,980,982,984-1001$, 1004, 1007-8, 1014, 1032, 1048, 1051, 1053-57, 1059, 1089-99, I $105-10$, I I 36, I I 42-43, I $145-48$ (I9I5-39), I I 55-59, I 161-63, I 16869, I I 1 I, I I 77-78, I I 80, I I 83, I 1 90-94, I 222-25, I 239-47, I 249, I 25I-57, I 259, I 261-62, I $264-$ 66 , 1 $270-74,1276-77,1284-90$, 1298-1302, 1314-18, $1325-28$, I33I-39, I343, I353-56, I372-74, I376, I379-92, I395-96, I 403-7, $1412,1414-17$, I 420-29, $1437-$ $50,1453-62,1465-72,1474,1489-$ $90,1493,1495-1500,1511-13$, I 515, 1527-29, I541-42, 1544 , 1551-52, 1559-69, 1571, 1573-74, 1 576-79, $1589-97,1611-12,1614-$ $19,1635-44,1646,1653-58,1661$, $1680-83$, 1686-88, I691, 16931702, 1704-5, 1707-12, 1720-23, $1727,1730,1733,1736,1743-48$, $1754-56$, 1758-60, 1 762-63, 1771, 1775, 1777-81, 1786-89, I 796, $1798-1800,1802-6,1823$, I 82833 , I $836-40,1842-50$, I $852-54$, $1864,1866-67,1872,1874-75$, I 882, I887-91, I902, I904, 2371

(1940-55), 1907, 1909, I911-12, 1914-18, I921-22, 1927-28, 193032 , 1934, 1940-45, 1947, 1954-57, $1959-62,1964,1966-67,1973-80$, 1984-85, 1987, 2001, 2003-6, 2011-1 4, 2017-19, 2021-23, 202528, 2045, 2050-56, 2059, 2069-70, 2074, 2076-78, 2081-82, 2084-85, 2087-94, 2096-97, 2107-8, $2110-$ I I, 2I I 5, 21 I 9-20, 21 22-23, 2125 , $2127-30,2132,2146,2148-49$, $2153-59,2161-64,2166,2169$, 2173-75, 2180-88, 2193-95, 2197 , 2199, 2201-2, 2204, 2206, 2208, 2210, 2212-13, 2224, 2229-31, 2371, 2373

The Fiddler in Barly, 1637

Fiedler, Leslie, 656

Field, Cyrus W., about, 4677, 5882

Field, Eugene, $878-80$

Field, Joseph M., 231 I

Field, Roswell M., 1880

Field and Stream, 5071

The Field God, 1475, 2337

The Field of the Grounded Arms, 323

Field sports, 2665, 2794, 5065-97

Fielding, Henry, about, 2651

Fields, Annie, ed., 577

Fields, Harry H., 470 I

Fields, James Thomas, about, 2922

Fields, W. C., about, 4956

The Fields, I694

The Fields Were Green, 2374

Fife, Alta (Stephens), 5538

Fife, Austin, 5538

The Fifth Column, 1498

The Fifty-Minute Hour, 2718
Figh, Margaret Gillis, 2257

Fighting Angel, 1258

"Fighting Furies," 5025

Figureheads, 5603

Figures for an Apocalypse, 2037

Figures of Earth, 1262

Files on Parade, 2072

Filipinos, 4470

Fill'Er Up, 5005

Filler, Louis, ed., 866

Finance, 5965-6002 agricultural, 5848 bibl., 5966

hist., 3476, 5966, 5973, 5999-6000

municipal, 5973

public, 3126, 3289, 3291, 3310, 3322, $3431,3448,5969,5971,5983$

state, 5973

Chicago, 5985

The Financier, 1336-37

Financiers. See Capitalists and financiers

Find $M e$ in Fire, 2013

Findlay, Ohio, 3866

Fine, Nathan, 6356

Fine Clothing to the Jew, 1521

Fink, Arthur E., 4621

Fink, Mike, about, 5506

Finkelstein, Louis, ed., 5426-27

Finkelstein, Simon J., 5426 about, 5426

Finletter, Thomas K., 3623

Finney, Charles Grandison, about, 3360, $5395,5403,5428,5490$

Finnish folklore, Mich., 5533

Finnish-language newspaper, 2896

Fir-Flower Tablets, 1584

Fire, Chicago (1871), 4136

Fire and Cloud, 2234

Fire and the Hammer, 1916

The Fire-Bringer, 1069

Fire for the Night, 2413

Firecrackers, 1831

Fireside Travels, 467

Firman, Sidney G., ed., 1068

First Flowers of Our Wilderness, 5750

The First Gentlemen of Virginia, 16, 3749

The First Man, 1648

The First Morning, 2192

The First Thousand Days, 3498

First Will \& Testament, 2080

Firth, Margaret A., ed., 4729

Fiscal policy. See Finance-public

Fisch, Max Harold, 5251

Fischer, Carlos, 5654

Fischer, John, 3624

Fish, Carl Russell, 3091, 61 83

Fish, Hamilton, about, 3444

Fish, John Charles Lounsbury, 4800

Fish, Lounsbury S., 6018

Fishbein, Morris, 4806-7

Fisher, Anne (Benson), 3998

Fisher, Dorothea Frances (Canfield), I 41 2-19, 4033

Fisher, Galen M., 5495

Fisher, Vardis Alvero, 1420-24

Fisheries, 4744, 5948

New England, 5872

Fishing. See Hunting and fishing

Fishman, Solomon, 2421 
Fisk, Ethel F., ed., 5304

Fisk, James, about, 5880

Fiske, John, 5302-4

ed., 3080 about, 3058, 3761, 5264, 5302, 5304

Fiske, Minnie Davey, about, 4930

Fitch, Clyde, 2337, 2347-48

Fitch, James Marston, 5699

Fitch, John, about, 4784

Fitch, John A., 5899, 6037

Fite, Emerson David, 3374

Fite, Gilbert C., $5737,5843,5860$

Fithian, Philip Vickers, $2672-73$

Fitzgerald, F. Scott, I 425-29

about, 821 , I 222, I 425, I 430-31, $2371-72,2429$

Fitzgibbon, Russell H., $358 \mathrm{r}$

Fitzpatrick, John C., ed., 327 I

The Five Books of Youth, 1516

Five Civilized Tribes, 3025-27

Five Generations, 1152

Fladeland, Betty L., 3375

Flagg, Edmund, 4322-23 about, 4322

Flagler, Henry M., about, 4096

Flaherty, Robert, about, $495^{8}$

Flame and Shadow, 1814

Flanagan, Hallie. See Davis, Hallie (Ferguson) $\mathrm{F}$.

Flanders, Helen (Hartness), comp., 5574

Flanders, Ralph Edwards, about, ${ }_{4} \mathrm{SO}_{3}$

Flanner, Hildegarde, 2406

Flaubert, Gustave, about, 2504

Fleischer, Nathaniel S., 5025-27, 5031 , 5060

Fleming, Allan J., ed., 4873

Fleming, Denna Frank, 3534

Fleming, Donald H., 4831

Fleming, Roscoe, 6207

Fleming, Walter L., 3377

ed., 3376

about, 3057

Flesch, Rudolf F., 5226

Fletcher, John Gould, I 432-35, 4102 about, I 432, I 436, I 809

Flexner, Abraham, 5179, 5195

Flexner, Atherton, 6052

Flexner, James T., $4784,4822,483 \mathrm{I}$, 5749-51

Flexner, Simon, 4831

Flick, Alexander Clarence, $343^{\circ}$ ed., 4044

Flint, Emily, ed., 2922

Flint, Timothy, 307-1 2 about, 307

The Floating World and Other Poems, 2350

Flood, Jessie B., musical arr. by, 5589

Floods and flood control, 2949, 295 I, 4147

Flora, Snowden D., 2948

Flora. See Plants

Florey, Robert, 4944

Florida, 3953, 4007, 4079, 4096

architecture (Spanish-Colonial), 5723 descr., 1685

essays, 1002-3

fiction, 1222, 1302, 1526-29, I68083,2051

fishing, $508_{3}$
Florida-Continued

folksongs \& ballads, 558 I

guidebooks, $3843-47$

hist., 3158, 3980, 4096

language (dialects, etc.), 2258

short stories, I 680, I 684

travel \& travelers, 4248-50, 425657,4293

Flour milling, Minn., 41 41-42

The Flourishing Village, 121

Flower, Milton Embick, 2776

Flowering Judas, 1660

The Flowering of New England, 238r

The Flowering of the Rod, 1324

Flowers in art, 5768

Floyd, Theodora A., about, 4854

Flush of Gold, 1058

The Flush Times of Alabama and Mississippi, 195-97

Flying Scud, 2298

Flynn, Edward J., 6384 about, 6384

Focus, 2045

Foerster, Norman, 2422-24, 2512 ed., 468, 2331, 2424-25

Fogdall, Soren J. M. P., 3571

Fogle, Richard H., 36I

The Folded Leaf, 2032

Foley, Martha, ed., 2322

Folk, Joseph W., about, 6432

Folk art and crafts. See Arts and crafts

Folk dances, 5587, 5589-90

analysis, $559 \mathrm{I}$

hist., 559 I

Appalachian Mountains, 5583

New England, 5580

Southern States, 5583

The West, 5591

Folk drama, 1473, 1475

Folk heroes, 2649, 3353, 4533, 550506, 5511-13, 5516-17, 5519-20, $5522-25,5529-30,5532,5538$, 5544,5548

Folk humor. See Humor-frontier

Folk literature. See Folklore; Legends and tales; Tales, folk; Tall tales

Folk magic, 5509, 5528-29, 5537

Fok medicine, Mich., 5533

Folk pottery, 579I

Folk religion. See Religion, folk

Folk rhyme. See Rhyme, folk

Folk sermons, Negro. See Preacher tales

Folk singers, 5557, 5561, 5565, 5572 , 5578,5580

Folk speech (Colonial period), 3740

Folk tales, See Tales, folk

Folke, Leander, 5293

Folklore, 3740, 3969

analysis, 5528-29, 5534, 5536, 5579

bibl., $5536-37,5542,5544$

cowboy, $4162-63$

Creole, 2265

definitions, 5504,5514

hist., $5534,5536,5581$

Indian, 3021

literary influence, 5534,5548

migration, 5509

Negro. See Negroes-folklore

railroad, 5512
Folklore-Continued

rural, 4579

sources, 551 4, 5524, 5529, 5534, $5536,5546,554^{8}$

themes, motives, etc., 5509, 5528 , $5535,5545-46$

theory, methods, etc., 5504, 5514

urban. See Urban folklore

Northwestern States, 4147

Southwest, New, bibl., 4190

See also Folkways

Folklore in literature

drama, 1473

fiction, 1526

poetry, 1532, 1580

Calif., 1532

Fla., 1526

Ky., 2166

N.H., 1222

Va., 1267

The Folks, I799

Folks from Dixie, 860

Folksongs and ballads, $79-83,146$, 1 48, 427-28, 753-55, 910,922 , 933-34, 941-44, I I 26-3 I, I 222 , I 224, I 295, 1 $580,4025,5509-12$, $5517,5549-84$

analysis, 5555-57, 5559, 556r, 5564, $5570,5577,5579$

bibl., $5556,5569,5613$

definitions, 5556

hist., $5556,5564,5570,5577,5580$

influence on poetry, 1697

sources, $5504,5555,5580$

themes, motives, etc., $5555-56,5560$, $5564,5576-77,558$ I

theories, methods, etc., 5569-70

Ala., 5565

Ark., 5569

Fla., 5581

Ky., 5584

Maine, 5567

Mich., 5567, 5575

Miss., 5576

Mississippi River, 5523

Mo., 5568-69

New England, 5524, 5554, 5574, 5580

New York (State), 5548

N.C., 5536

Ohio, 5573

Okla., 5570

Ozark Mountains, 5569

Pa., 5578-79

St. Helena Island, S.C., $554^{\circ}$

Schoharie County, N.Y., 5539

Southern States, 5525, 5561, 5572. 5577

Tex., 5518

Vt., 5574

The West, $5518,5526,5560,5569$

W. Va., 5572

See also Anglo-American folksongs and ballads; Cowboys-songs \& music; Religious folksongs

Folkways, 2407, 5504, 5506, $551 \mathrm{I}$, 5513-14, 5516, $5538,5553,5555-$ $56,5558,5585,5588$

Ala., 5565

Ark., 5542

Beech Mountain, N.C., 5529 
Folkways-Continued

Kans., 4 I 68

Mich., 5533, 5535

Miss., 5547, 5576

Mississippi River, 5505, 5523

Missouri River, 5505

New England, 5524, 5534, 5574

N. Mex., 5537

N.C., 5536

Ohio River, 5505

Ozark Mountains, 5543

Pa., 4480, 5579

St. Helena Island, S.C., 5540

Southern States, 4079, 5525, 5577

Tex., 5521

Vt., 5574

The West, 5526

See also Folklore

Follett, Wilson, ed., 832-33

Folmer, Henry, 3162

Folwell, William Watts, 4142

Fombombo, 1792

Foner, Philip S., ed., I 56

The Fool of Five Forks, 930

Football, 4990, 4993, 5034-45

Foote, Harry W., 4715

Foote, Henry Wilder, 5633

Footner, Hulbert, 3999

For the Sake of Shadows, 2752

For Whom the Bell Tolls, I 497

The Forayers, 552-53

Forays and Rebuttals, 2415

Forbes, Esther, I 437-44

Forbes, James, 2348

Forbes, Waldo Emerson, ed., 294

Forbidden Fruit, 2298

Force, Juliana, about, 5800

Force, Peter, about, 3057

Ford, Alice E., 5597

Ford, Edward, 4758

Ford, Guy Stanton, 3064

Ford, Henry, about, 5939

Ford, Henry Jones, 4489

Ford, Paul Leicester, comp., 123, 125, 177

$$
\text { ed., I 52, } 3293
$$

Ford, William E., 4715

Ford, Worthington Chauncey, 2580 ed., 5, 699, 3313

Ford Foundation, about, 5206

Ford Motor Company, about, 5939

Foreign correspondents, 2872

Foreign economic relations, 3546 , $3636-42$

Foreign exchange, 6002

Foreign influences on culture, 3146 , $3227,3474,3737,3740,3758$, $3768-70,3774,4096$

bibl., 3768

Foreign language periodicals, 2895-99

Foreign population, 2897, 2899, 4297, 4390, 4395, 4406-7, 44II-I7, $4421-22,4426,4515$

education, 4421, 4483, 4493

in literature

fiction, I190, 1720-22, 1796, 2578

reporting, $216 \mathrm{r}$

suffrage, 6409

Brooklyn, 4046

Milwaukee, 4 I 40
Foreign population-Continued

New England, 4026, 4435

New Haven, 4042

Sunderland, Minn., 4406

Wis., 4139

See also Refugees; and names of national groups, e.g., Chinese; Norwegians

Foreign relations (since 1945), 3482, $350 \mathrm{r}, 3523,3526,3529,3570$, $3598-3642,4503$

See also Diplomatic history; and names of countries, e.g., France, relations with

Foreign reputation of authors

(1764-1819), 109

(1820-70), 209, 230, 252, 280, 313 , $38 \mathrm{r}, 427,449,520,562,585,619$, 674

I gth cent., 24 I 2, 2432

(1871-1914), 768, 964, 1048, 1061

(1915-39), 1252, 1357, I379, 1445, I 484, I 494, I 559, I754, I 759, 24I 2, 2508

Foreign service. See Diplomatic and consular service

Foreign trade. See Commerce-foreign

Forensic psychiatry. See Psychiatry, forensic

The Forest and the Fort, II I I

Forest Life, $4 \mathrm{r} 8$

The Forest of the South, $147 \mathrm{I}$

Forester, Frank, pseud. See Herbert, Henry William

Forestry as a profession, 5865

Forests and forestry, 1072, 1079, 2791, $5816,5862-63,5865$

fossil, 4 I 82

soils, 2934, 2944

Mass., 3803

S.C., 5087

Southern States, 4084

Va., 4085

The Forge, 1793

Forked Lightning, 1548

Form, William H., 4552

Forman, Henry Chandlee, 5706

Forman, Jonathan, 4594

Forman, Sidney, 3656

Formosan policy, 3589

Forrest, Edwin, about, 201, 4937

Forrest, Nathan, fiction, 1468

Forster, John, 434I

Forster, John Reinhold, tr., 4245-46

Fort Laramie, Wyo., 4179

Fort Worth, Tex., 4187

The Fortunate Mistress, about, 1278

Fortune, 4503

XLI Poems, 1313

42nd Parallel, 1325,1328

Forty-eighters, 4481

Foscue, Edwin J., $294^{\circ}$

Fosdick, Harry Emerson, 5426 about, 5426

Fosdick, Raymond B., 4622

Foshay, A. Wellesley, 5147

Foster, Sir Augustus John, bart., 4280 about, 4279

Foster, Charles H., 562

Foster, Elizabeth S., ed., 49 I
Foster, Frank Hugh, 5428

Foster, Frank K., about, 4530

Foster, Maximilian, I 20

Foster, Ruel E., 1397

Foster, Stephen, about, 5677 bibl., 5677

Fothergill, John, about, 4247

The Foundling (sculpture), 5739

The Fountain, 1648

A Fountain in Kentucky, 2062

Four Faces West, 1686

The Four Million, I I $14-15$

Four Quartets, 1359

about, $1366-67$

Four Saints in Three Acts, 1771

Four-Square, 1418

Foust, Clement E., 205

Fowler, Dorothy (Ganfield), 4664

Fowler, Gene, 2878, 4933 about, 2878

Fowler, Lorenzo, about, 3752

Fowler, Orson, about, 3752

Fox, Dixon Ryan, 3090, 3221, 3730, 4027,6374

ed., 3085-98, 3200

Fox, George, about, 5468

Fox Indians, 304I

The Fox of Peapack, 1859

Foxeman, Grant, 3026-27

Frampton, Merle E., ed., 5207

France, Anatole, about, 2471

France

economic relations with, 4259-6o

fiction, 1242-44, 1247, 125 I, I 4 I I, I 4 I 6, I 495, 1578, I 61 I, 2093

personal narratives, 1310, 1766, I $769-7$ I

relations (general) with, 3508,3528 , $3531,3685-86,3773-75$

American Revolution, 3187, 3250, 3307

bibl., 4229

Civil War, 3536

World War I, 3710

short stories, I 242, I 413

soc. life \& cust., 96,264

travel \& travelers, $96,130,264,426$, I 4 I I, I 766, I 839 fiction, $987,998,2376$

France and Great Britain in the New World, 3171, 3188-89, 3191, 3226

France and Illinois, 4133

France and Spain in the New World, 3162,3171

France and Texas, 3577

Francesca da Rimini, 206-8, 2337, 2347

Francis, John F., about, 5744

Francis Berrian, 311

Frank, Barbara, 6298

Frank, Jerome, 6263, 6285, 6298

Frank, L. K., 529 I

Frank, Ruth, photographs by, 4187

Frank, Waldo David, 1445-50

ed., 1304

about, 1743

Frankenberg, Lloyd, 2426

Frankenstein, Alfred V., 5744

Frankfort, Ky., guidebook, 3857

Frankfurter, Felix, 3785, 5418, 6096, 6286

Franking, Mae, 1659 
Franklin, Benjamin, 122-33, 2290, 3 I $83-84,4750$

about, $36,45-46,122,171,1873$, $2277,2412,2456,2465,2503$, $2523,2620,2773,3123,3183$, $3185-87,4533,4721,4750,4850$, $5130,5803,6068$

bibl., 123

Franklin, John Hope, $444^{\circ}$

Franklin, William Temple, ed., 124, 126

Frantz, Joe B., 4162-63

Fraser, Chelsea C., 4799

Fraser River, 4013

Fraud and mistake cases, 6279

Frazier, Edward Franklin, 4441-42

Frederick, John H., 5943

Frederick, John T., ed., 2329

Free, 1341

Free enterprise, $3424,4538,5875,5877$, $5885,5901,6026,6060,6063$, $6067,6094,6101,6392$

Free Joe, 920-21

The Free Man, 1695

Free Religions Association, Boston, about, 5435

Free soil controversy, 3 r 4I, 3339

Free verse, 619, 821, $1583,1599,1727$, I731, I813

See also Experimental writing

Free will, 5297, 5472

Freedman, Florence B., ed., 655

Freedom. See also Liberty

Freedom and education, 5103, 5124, $5132-33,5181,5187,5236$

Freedom and Fate, 306

Freedom of accommodation, 6106, 6129

Freedom of assembly, 6117, 6121, 6123

Freedom of association, 6107

Freedom of belief, 6107

Freedom of labor, 6ro6, 6121, 6126, 6129

Freedom of opinion, 6060, 6065, 6108, 6164

Freedom of petition, 6117,6121

Freedom of religion, 4069, 5395, 5418$21,6106,6117,6123,6126$

Freedom of speech, 3462,3766 , 6106$09,6117,6121,6123,6126,6128$

Freedom of teaching. See Teachersacademic freedom

Freedom of the franchise, 6106,6126

Freedom of the person, 6117, 6121, 6126

Freedom of the press, $2846,2867,2880$, 2889, 2906, 2928-29, 2931-32, $3462,5307,6106,6108,6117$, $6121,6123,6127-28$

Freedom of the seas, 3558,357 I

Freedom of the will, 26

Freedom of thought, 3766

Freehof, S.B., 4458

Freeman, Douglas Southall, 3269, 3378, $3694-95,5525$

Freeman, Frank S., 5229

Freeman, Frederic Barron, ed., 487

Freeman, Mary E. (Wilkins), 881-86 about, 2486

Freeman, Otis W., ed., 4212

Freemasons. See Masons (Freemasons)

Freidel, Frank B., 3495
Frémont, Jessie Benton, about, 2818

Frémont, John Charles, 3334, 3535

about, 3335, 3345, 4734

Fremont, Ohio, 3867

French, Daniel Chester, about, 5736

French and Indian War (1755-63), 3171, 327I

French Broad River Valley, 4021

Frencb Canadians, 4413, 4435

folklore, Mich., 5533

French influences

culture, 3774

folklore, 5523,5528

in literature, $1032-35$

language, 2265

Philadelphia, 4263

French population, New Orleans, 4101

Freneau, Philip Morin, 134-43 about, $134,2465,2486$

Freud, Sigmund, about, 2407, 5392

Freudian concepts in literature, I 16I, 2441

drama, 1647-48, 2506

fiction, 1571

hist., $244^{\circ}$

Freund, Paul A., 6248

Freund, Robert, ed., 5755

Friden, George, 2364

Friederici, Georg, 3169

Friedman, Albert B., 5550

Friedman, Lillian, 2258

Friedman, Philip, 4459

Friedman, Theodore, ed., 4458

Friedrich, C. J., 448I

The Friend of My Youth, 711

The Friendly Persuasion, 2211

Friendly societies, 4574

Friends, Society of, about, 5404, 5442, $5467-68,5479$

See also Quakers

The Friends of the Friends, 1012

Friendship, 285

Friendship Village, 1453

Fries, Charles C., 2244

Fries, John, about, 3149

Friess, H. L., 5289, 5291

Fritz, Percy Stanley, 4I80

Frohman, Daniel, 5637

Frohock, Wilbur M., 2427

From a Bench in Our Square, 1155

From Bed to Worse, 1214

From Here to Eternity, 2004

From Jordan's Delight, 1230

From Main Street to Stockholm, 1570

From Milo to Londos, 506o

From Ponkapog to Pesth, 713

From Rags to Riches, 2305

From the Easy Chair, 2278

From the Hidden Way, 1262

From the "London Times" of 1904, 798-99

From Time to Time, 1952

The Front Page, 2327, 2332

Frontenac, Louis de Buade, comte de, about, 317 I

Frontier and pioneer life, 2407, 2802, $3074,3078,3082,3105,3147$, $3151,3188,3737,4372,5508$

arts \& crafts, 5596,5604

dances, 5590
Frontier and pioneer life-Continued

folklore, 5505, 5513, 5516, 5519-20, 5526,5542

folksongs \& ballads, 5526, 5549, 5553-56, 5559-60, 5570

Indians, 2988-89, 3030, 3032, 3035

law, 6220

legends, 3353, 5505, 5507, 5519, 5530

religion, $5411-16$

Ariz., 4199

Dakota, 2683

Fla., 4293

Ill., 4129,4136

Ind., 3995, 41 23

Middle West, $4097-98,4136,4810$

Minn., 4143

Mississippi River Valley, 3975, 5505

Missouri River and valley, 4I 47, 5505

Nebr., 2799-2800

New York (State) $¥ 4269$

Northwest, Old, 4112,4307

Northwest, Pacific, 4213-14

Northwestern States, 3663, 4I 47

Ohio, 4 I 21

Ohio River and valley, 2610, 5505

Pa., 3280, 4269

S.C., 3180

Southern Plains, 4160

Southern States, 3180,4097

Southwest, Old, 4098

Tenn., 3287, 3353

Tex., 3353, 4365, 4734

Va., 4251, 4269

The West, 3331, 3348, 4097, 4146, $4151-56,4158,4160-63,4175$, $4177,4223,4235,4281,4320$, $466 \mathrm{r}, 4667$

Wis., 4347

Wyo., 3971

Frontier and pioneer life in literature

bibl., 2502

comedy, 518

descr., 307-10, 365-67, 38r, 399, $772-74,784-86,890,898-99$, 1078

drama, 1556

editorials, sketches, etc., 194-97, 37980, 1064-65, 1068, 2424

fiction, 105-8, I I 4-15, II7, 201-4, 252, 258-60, 312, 415-18, 511, $514-16,546,550,555,579-84$, $684-86,766-67,778-83,787-93$, 980, I 1 45-48, I I 71, 1 239, 13 14I5, I 420, I 422, I 44 I, I 488-90, I644, I646, I 694, I 696, I 701, $1707,1720-21,1786,1840,1960-$ $62,1969,2129,2415-16$

hist. \& crit., 2437, 2502

humor, 2501

poetry, 933-34, 941-44, 1064, 1066$67,1132,1644-45,1825$

short stories, 319, 322, 330-32, 612$13,687,733-34,739,926-32,935-$ 40, 1145

Ala., 194-97

Alaska, $1048-52,1058$

Calif., 733-34, 739, 926-40, 106468

Ga., $445-48$

Idaho, 1420 , 1422 
Frontier and pioneer life in literatureContinued

Ky., 366, 516, 766-67, 1469, 1 70 I

Maine, 1707

Mich., 4I 5-1 8

Middle West, $1644-46$

Miss., I 94-97

Mississippi River and valley, 307, $319-22,768,778-83,787-93$

Mo., 366

New England, I 44I

Northwest, Old, 366

Ohio, 980,1694

Ohio River Valley, 3 I 9-2 I

Okla., 1 403, 1406

Oreg., 39I, I314-15

Pacific Coast, $1064-68$

Pa., I 05-8, 366, I694

Rocky Mountains, 312

S. Dak., 1720-21

Southern States, I94-97, 379-80, $612-13,1786$

Tenn., 330-32, 366

Utah, I 420,1424

Vt., 579-84

Va., $12-16,366$

The West, $683-87,772-74,941-44$, I $064-68$, I 420, I 488-90, I 644-46

Wis., $1078,1556,1960-62,2129$

Wyo., I I 45-48

Frontier humor. See Humor-frontier

Frontier hypothesis, 3074, 3105, 3127 , $3137,3147,3357$

Frontier in art. See The West-frontier-pictorial works

Froom, L. E., 5442

Frooman, Jack, 3046

Frost, Arthur B., illus., 912-13, 922, 924-25, I IOI

Frost, Robert, I 451-52, 5574

about, 1515, 2378, 2527

Frothingham, Octavius Brooks, 2279, 5256

Frothingham, Richard, 3245

Frothingham, Thomas G., 3680

Fruitlands, 5265

Fryburger, Vernon, 5962

Frye, Richard N., 3513

Fuchs, Lawrence H., $445^{8}$

Fülöp-Miller, René, 4905

Fuess, Claude Moore, 2674-78, 3336, $3431,3480,5217$

The Fugitive, 1809

Fuld, James J., 5677

Full Cargo, 1765

Fuller, Arthur B., ed., 316

Fuller, George W., 4213

Fuller, Henry Blake, $887-89$

about, 2419

Fuller, Melville Weston, about, 6244

Fuller, Muriel, ed., 2351

Fuller, Richard C., about, 46r 9

Fuller, (Sarah) Margaret (Marchesa d'Ossoli), 313-18

ed., 280

about, 313, 2280, 2615

Fuller, Zelotes, 5418

Fulton, John F., 4759, 4821

Fulton, Maurice G., I 135

Fulton, Robert, about, 4784,4786

Functional psychology, 5389
Fund for the Advancement of Education, about, 5206

Fundamentalism, 3761, 5429-30

Funeral rites and ceremonies, 4527 , 5507

Funk \& Wagnalls New "Standard" Dictionary, 2236

Fur trade

fiction, 312,1962

Northwest, Pacific, 4213

Oregon, 391

Utah, 4183

The West, 3330, 41 48-49, 41 75, 4186

Furie, W. B., 4458

Furnas, Joseph C., 4562

The Furnished Room, I $14-15$

Furniss, Edgar S., 3605

Furniss, Norman F., 5429

Furniture, 5727-28, 5731-32, 5796 decoration, 5726

$A$ Further Range, 1452

Fusfeld, Daniel R., 3497

Fussell, Edwin S., I7 8

Fussler, Herman H., ed., 6478

Futures, 5952

Fyles, Franklin, 2315

\section{G}

GATT. See General Agreement on Tariffs and Trade

Gabriel, Ralph Henry, 3082, 3741, 5420

Gabrielson, Ira Noel, 5870

Gaer, Joseph, 6394

Gaffney, M. Mason, 5817

Gagey, Edmond M., 4900, 4918, 5659

Gagliardo, Domenico, 4633

Gal Young Un, 1684

Galbraith, John Kenneth, 45I3, 588687

Gale, Zona, 1453-59

Galena, Ill., guidebook, 3877

Galinsky, Hans, 2245

Gall, Elena D., ed., 5207

Gallantry, 1262

Gallatin, Albert, about, 33 I 0-I I

The Gallery, I 940-4I

The Galley Slave, 2316

Gallico, Paul, 4987

Gallie, Walter B., 5352

Gallion, Arthur B., 4606

Galloway, George B., 6155

Galloway, John Debo, 5927

Gallup, Donald C., 1362

Gallup, George H., 64I7

Gallup, N. Mex., 4I 87

Galveston News, about, 2866

Gama, Vasco da, about, 3 I 69

Gambling, 2586, 4639, 5059

Gambrill, John Montgomery, ed., 3151

Games and dances, 5563, 5585-92

Ind., 5571

Mo., 5569

N.C., 5536

Okla., 5570

Schoharie County, N.Y., 5539

See also Dancing; Recreation; Sing. ing games
Gamio, Manuel, 447 I comp., 4472

Gangs, 4598, 4658

Gannett, Henry, 2970

Ganoe, William Addleman, 3657

Gans, Joe, about, 5025

Gans, Roma, 5148

Gantenbein, James W., ed., 3575

Garbo, Greta, about, 4952

Gard, Robert E., 4926

Gard, Wayne, 4I 57, 6220

The Garden of Adonis, 1467

Gardening, 2790, 5824

Gardiner, Frederic M., 5018

Gardner, Albert Ten Eyck,.5738

Gardner, Burleigh B., 4438

Gardner, Emelyn Elizabeth, 5539 ed., 5575

Gardner, Gilson, 2890

Gardner, Helen L., 1363,1367

Gardner, Mary R., 4438

Garfield, James Abram, about, 3450

Garis, Roy L., 4420

Garland, Constance, illus., 894

Garland, Hamlin, 890-99 about, 2365, 2419, 2517

Garland, John H., ed., 4 I 13

Garman, Charles Edward, about, 5222

Garnsey, Morris E., 4173

Garrets and Pretenders, 3757

Garrigue, Jean, I981-83

Garrigues, Charles Harris, 6343

Garrison, Fielding H., 4819

Garrison, Francis Jackson, 3379

Garrison, Garnet R., 4686

Garrison, George Pierce, 3337

Garrison, W. E., 5496

Garrison, Wendell Phillips, 3379

Garrison, William Lloyd, about, 2280, $3379-80$

Garrison, Winfred Ernest, 5405, 5455

Garvan, Anthony N. B., 5707

Gary, Elbert H., about, 2825

Gass, Sherlock B., 2425

Gassner, John, ed., 2332-35

Gates, Frederick T., 4622

The Gates of the Compass, 1516

Gateway to a Nation, 4043

Gaudet, Hazel, 64 I 9

The Gauntlet, 1789

Gaus, John M., 3785

Gauthier, Eva, 5678

Gaver, Jack, 2327 ed., 2336

Gavit, Bernard C., 6274

Geare, R. I., 4726

Geddes, Virgil, 4665

Gehrig, Henry L. ("Lou"), about, 4987,5010

Geiger, George R., 4535

Geiger, R., ed., 2953

Geiger, Theodore, 5898

Geiser, Samuel W., 4734

Geismar, Maxwell D., 2428-30 ed., 646

Gelatt, Roland, 56 I 8

Gelfant, Blanche H., 2431

Gellhorn, Walter, 4773, 6110, 6118, 6 r 30,6316

ed., 6110,6119 
General Accounting Office, about, 5995-97

General Agreement on Tariffs and Trade (GATT), about, 5953

General education, 5107, 5134, 5160, $5180,5182,5184,5228,5246$

See also Liberal education

General Motors Corporation, about, 5940

General stores, 4086, 5955

General William Booth Enters into Heaven, $158 \mathrm{I}$

The Generall Historie of Virginia, New-England, and the Summer Isles, 70

Generals, Civil War, 3690-92, 3695, 3706

The General's Lady, 1442

Genesis, 2136

Genetics, 4722

The "Genius," 1339

The Genius of America, 2503

The Genteel Tradition at Bay, 1735, 5368

"Genteel tradition" in literature, 2278, $2385-86,2513$

poetry, 25I 3,2545

revolt, 926, 1089, 1333, 2406, 2507

The Gentle Lena, 1767

The Gentleman from Indiana, 1802

The Gentleman in America, 2392

$A$ Gentleman of Bayou Têche, 760

Gentleman's Progress, 4240

Gentlemen, I Address You Privately, 1242

Gentles, Ruth G., ed., 1486

The Geographical Review, 2937

Geography, 2933-8 I

atlases \& maps, 2967, 2972, 2974 economic, 2939-40

historical, 2939, 2943, 2967-76, 3139

physical, 1079, 2933-36, 2970, 2973 , 2975, 5816

regional, 2933-37, 2939-40, 4113

Great Plains, 4159

Middle West, 4 I I 3

Missouri Valley, 4145

N. Dak., 4 I 65

Okla., 4 1 70-71

Southern States, 4084

territories, 4218

Tex., 4192

The West, $4 \mathrm{r}_{4} 8$

See also Language-atlases \& maps

Geography and Plays, 1771

Geological Society of America, about, 4733

Geological Survey, about, $476_{3}$

Geologists, 4737

Geology, 2935-36, 2942, 2945-46, $2957,2973,4336-38$

bibl., 4736

hist., $47 \times 5,4733,4737$

maps, 2942

Nev., $418_{4}$

Rocky Mountains, 4172

Tex., 4192

Yellowstone National Park, 4182
Geophysical Laboratory, Washington, D.C. See Carnegie Institution of Washington, Geophysical Laboratory

George, Henry, about, 4535, 6424

George Fox Digg'd Out of His Burrowes, 89

George Washington Slept Here, 1548

George's Mother, 824, 836-37

Georgia, 3953, 4079, 4094-95

architecture, 5706

editorials, sketches, etc., 445-48, 556

fiction, 546, 1270-74, 1380 , I 544 , I 618-19

govt., 6195

guidebooks, $3837-42$

hist., 4094, 4104

journalism, 2856

language (dialects, etc.), 2271

newspapers, 2856

poetry, $1038-43,1046-47$

resources, 4095

short stories, 556, 910-22, 924-25, 1270, I 275

travel \& travelers, $4248-50$

Georgia. University, hist., 5176

Georgia Press Association, about, 2856

Georgia Scenes, 446-48

Gerber, John C., 344

Gericke, Wilbelm, about, 5649

German-American newspapers, 2899

Germans, 4046, 4062, 4360, 4414, $447 \mathrm{I}-8 \mathrm{I}$

folklore, 5523

immigrant influences, 4477

See also Pennsylvania Germans

Germantown, Pa., 4477

Germany

economic relations with, 3638

fiction, 1250 , I 890-9I

relations with, 3570,3776

travel \& travelers, $426,1890,2462$

Geronimo, about, 3004

Gerontion, about, 1367

Gershwin, George, 1512

about, 5639,5678

Gershwin, Ira, 5678

Gerson, Robert A., 5629

Gervasi, Frank H., 61 84

Gesell, Arnold L., 5149

Gestalt psychology, 5389, 5392

Gethsemani Monastery, about, 204I

Gettysburg, Battle of, 2613

fiction, 1542

Ghent, William J., 3338

Ghent, Treaty of, 3329, 3542

Ghost and Flesh, 1986

Ghost stories, 5515

Mich., 5535

Schoharie County, N. Y., 5539

Tex., 5521

The Ghost Talks, 6364

The Ghostly Rental, 101 2

Ghostly Tales, 1012

Giants and ogres in folklore, 5528-29, 5546

Giants in the Earth, 1721

Gibb, G. S., 5913

Gibbons, Herbert Adams, 5957

Gibbs, Josiah Willard, about, 2105, $4721,4724,4751$
Gibbs, Oliver Walcott, about, 4740

Gibson, John M., 4823

Gibson, Joseph Bannister, about, 6231

Gibson, William M., 972 ed., 835

Giddings, Franklin Henry, about, 4540, 4542

Giddings, J. R., 3360

Gideon Planish, 1567

Gideonse, Harry D., 3608

Gifford, E. W., 3002

Gift-books (annuals, etc.), 2518

The Gift of the Magi, I I $14-15$

Gila River and valley, 4005

Gilbert, Douglas, 4974

Gilbert, Edmund W:, 2971

Gilbert, Sir Humphrey, about, 3223

Gilbert, Josiah, about, 850

The Gilded Age, 775-77, 1136

Gilder, Rosamond, ed., 4896

Gilgamesh, translation, 1556

Gill, Herbert A., 4744

Gill, Norman N., 6209

Gillette, William, 2337

Gilley, John, about, $267 \mathrm{I}$

Gillie, Mildred H., 3658

Gillin, John Lewis, 4540,4634

Gillmore, Margalo, 4919

Gilman, Daniel Coit, 4724, 4749, 5195 about, 5195

Gilman, Lawrence, 5683

Gilman, Richard C., 5310

Gilman, Roger, 375I

Gilman, William H., 498 ed., 2412

Ginsburg, Jekuthiel, 4739

Gipson, Lawrence H., 3188,3246

The Girl I Left behind Me, 2315

The Girl of the Golden West, 2348

The Girl with the Green Eyes, 2337

Gissing, George, about, 248 I

Gist, Noel P., ed., 4108

Gittler, Joseph B., ed., 4428

Give Your Heart to the Hawks, 1534

The Gladiator, 205, 2337

Glasgow, Ellen, I 460-63

about, $1267,1463,2430$

Glaspell, Susan, 2332

Glass industry, 5911

The Glass Menagerie, 2219, 2334, 2336

Glass Mountain, 2376

Glassware and glassmaking, 5789, 5796

Glaucus, 2300

Glazer, Nathan, 4555-56, 5458

Glazer, Sidney, 4137

Gleanings in Europe, 263-64

Gleason, Sarell Everett, 3537-38

Glenmary, N.Y., 674

Glenn, Bess, 3967

Glenn, John M., 4623

Glick, Carl, 490 I

Glicksberg, Charles I., 2383

Glimpses of Life in Colonial Virginia, I $103-4$

Glimpses of Unfamiliar Japan, 951-52

Globe (Atchison, Kans.), about, 2885

Glorious Incense, 539

Glory Never Guesses, 2079

The Glory of the Nightingales, I7 44

Glory Road, 369 I

Glover, John George, ed., 5906 
Glueck, Eleanor T., 4646-5I

Glueck, Steldon, 4645-5I

Go Down Moses, 1379

Go Tell It on the Mountain, 1915

Goblins and Pagodas, 1433

God and My Country, I 541

God and My Father, 1318

The Goddess Was Mortal, 1553

Godfrey, Thomas, 144-45, 2337, 2347

Godkin, Edwin Lawrence, 2858, 2882 about, 2882, 2921

The Gods Arrive, 1854

God's Controversy with New-England, 79

God's Little Acre, 1272

Gods of the Lightning, 1173,2332

God's Promise to His Plantation, 18

God's Trombones, 1538

Godwin, Parke, ed., 223

Goebel, Dorothy Burne, 3326

Goebel, Julius, Jr., 6221, 6234

Goethals, George Washington, about, 4221,4796

Goethe, Johann Wolfgang von, about, 2282

Gogh, Vincent van, about, 28 I 5

Gohdes, Clarence, 2412, 2432, 2496 ed., $643,1046,2338$

Going, Charles Buxton, 3339

Going to Pieces, $491 \mathrm{I}$

Going-to-the-Stars, 1581

Going-to-the-Sun, 1581

Gold, 1648

The Gold-Bug, 529

Gold mines and mining Calif., 2641, 2659, 4201-2

Cripple Creek, Colo., 4 I 8 I

Rocky Mountains, 4172

Gold rushes

Alaska, 27I9-20

Calif., 926, 94I, 3737, 420I-2, 435I

Rocky Mountains, 4174

Goldberg, Arthur J., 6049

Goldberg, Isaac, 5635

Goldberg, Ray A., $584 \mathrm{I}$

Golden Apples (Rawlings), 1682

The Golden Apples (Welty), 2207

The Golden Apples of the Sun, 1936

The Golden Bowl, 1000-I about, 998

Golden Boy, 2064, 2333

The Golden Darkness, 1871

Golden Falcon, 1295

The Golden House, I 42

The Golden Mirror, 1906

Golden Multitudes, 2482

The Golden Vase, 1577

Goldenweiser, Emanuel A., 5983

Goldfield, Nev., 4184

Goldin, Hyman E., ed., 2274

Goldman, Eric F., 3046, 3455, 3484 , 3751

ed., 3058

Goldman, Irving, 304 I

Goldmann, Franz, 4886

Goldsen, Rose Kohn, 4470

Goldsmith, Alfred F., comp., 633

Goldthwait, James W., 2937

Goldwin, Robert A., ed., 361 7

Golf, 4987, 4990, 5048, 5051, 5053

Gomme, Alice, Lady, 5588
Gompers, Samuel, 6050

about, 6050

Gone Tomorrow, 1592

Gone With the Wind, 1619

Good and evil, 5354

The Good Anna, 767

Good-Bye, My Fancy, 626, 638

Good-Bye Wisconsin, $184 \mathrm{I}$

The Good Earth, 1253

Good Intentions, 1631

Good Men and True, 1687

Good Morning America, 1731

Good neighbor policy, 3491, 3574, 3576,3578

Good News of Death, 2350

Good Night, Sweet Prince, 4933

The Good Spirit of Laurel Ridge, 2173

Goodale, George L., 4715

Goode, George Brown, 4726 about, 4724,4726

Goodloe, Daniel R., 4363

$A$ Goodly Fellowship, 1284, 5214

$A$ Goodly Heritage, 1284,5214

Goodman, Henry, ed., 955

Goodman, Nathan G., 4830 ed., 132

Goodrich, Annie M., about, 4854

Goodrich, Hubert B., 4725

Goodrich, Lloyd, 5764-65, 5773

Goodspeed, Charles Eliot, 5072, 6462 ed., 5690

Goodwyn, Frank, 4 I 92

Goodyear, Charles, about, 4786

The Goophered Grapevine, 757

Gordis, Robert, ed., 4458

Gordon, Albert I., 4456

Gordon, Caroline, $1464-72$

Gordon, George A., about, 5428

Gordon, John E., 4877

Gordon, Kate, 5289

Gordon, Lincoln, 5885

Gorgas, William Crawford, about, 4221, 4823

The Gorgeous Hussy, 2668

Gorlin, Selma, illus., 5587

Gosnell, Harold Foote, 6363, 6375, $6385-86,6418$

Goss, Madeleine B., 5609

Gottmann, Jean, 4085

Gottschalk, Clara. See Peterson, Clara Gottschalk

Gottschalk, Louis Moreau, 5679

Gottschalk, Louis R., 3247-50

about, 5679

Goubaux, Prosper, 2299

Goudy, Frederic William, 6456

Gould, George M., 2513

Gould, Jay, about, 5880,5882

Gould, Laurence M., 2977

Gould, Mary Earle, 5598

Govan, Gilbert E., 4104

Government, 2970, 3106, 4065, 4499, $455 \mathrm{I}, 6059-60,6077-78,613 \mathrm{I}-$ 39, 6147, 6167, 61 $70-71,6179$, 6202,6312

appropriations \& expenditures, 6001 , $61_{36}, 61_{39}, 6168,6180,6182,6191$ centralization, $606 \mathrm{r}, 6066,6085,6093$ expansion, 6093, 6099, 6103-4 functions, $2905,6133,6139,6178$, 6315
Government-Continued

history

I 7 th-1 8th cent., 3195, 322r, $3245,6068,6232$

I 8th cent., $3187,3192,6075$

American Revolution, 3242, 6083

Confederation, 3190

I9th cent., 3320, 3324, 3329, $3333,335 \mathrm{I}, 3357,3419,4288$, 4512,6373

2oth cent., $3416,3455,3485-87$, 349 1, 3498, 3500b

sources, $3349,3422,6065$

labor policy, 6r92

limitations, 609o, 6ro r

organization, $6173-74,6178$

regulations. See under special subjects, e.g., Commerce-govt. regulations

World War II program, 3725

See also Executive branch; Indians, American-govt. relations; Judicial branch; Legislative branch; Separation of powers

Government, democratic. See Democracy

Government, local. See Local government

Government, state. See State government

Government and art. See Art and state

Government and education, 5099, 5165 , 5189

See also State and education

Government and science. See Science and state

Government and the press, 286r, 292728, 2932

Government officials and employees, $4065,642 I$

appointment, qualifications, etc., $6083,6112,6136,6157,6159$, $6183,6186,6188,6193$

biog. (collected), 6187

Government ownership, 5885

Government Printing Office, about, 6452

Government publications, 6452 bibl., 6 13 $_{3} 8,6452$

Governors, powers and duties, 6203

Governors' Conference, about, 5 I 35

Gow, James, 2334

Gowan, Olina, Sister, about, 4854

Goyen, William, $1984-87$

Grady, Henry W., about, 2856, 3445

Graebner, Norman A., 3340, 36r 3

Graeff, Arthur D., 3230, 4479

Graf, Herbert, 5655

Graham, C. A., 4176

Graham, Edward H., 5810

Grabam, Frank, 5010

Graham, George A., 6344

Graham, Gerald S., 3189

Graham, Ian Charles Cargill, 449 I

Graham, J., pseud. See Phillips, David Graham

Graham, Lloyd, 3950

Graham, Martha, 4968

about, 4968 
Graham, Philip, 4978 ed., 1046

Grambs, Jean D., 5227

A Grammar of Motives, 2389

Grammars. See Language-grammars

Grand Army of the Republic, about, 3644

Grand Canyon, 4182

The Grand Design, 1332

Grand Inquest, $6 \mathrm{I}_{4}$

La Grande demoiselle, 1035

Grandfather Stories, I 160

The Grandissimes, 749-50

Grandmamma, 1035

The Grandmothers, 1840

Grandmother's Grandmother, 1035

Grandsons, 2578

Grange, Harold E. ("Red"), 5037 about, 5037

Granger movement, 3420-2 I, 6356

Grannis, Chandler B., ed., 6437

Granniss, Ruth, 6440

Grant, Bruce, 2253

Grant, Helen Hardie, 2633

Grant, Margaret, 5647

Grant, Ulysses S., 3696 about, 2280, 3435, 3444, 3696, 3706

Grant, William L., ed., 3156, 3207

Grapes of Wrath, 1775, 1777

Gras, Norman S. B., 5984, 6007

The Grass Harp, I 947

Grasselli, Eugene R., about, 4735

Grattan, C. Hartley, ed., 309, 2375

Grattan, Thomas Colley, 4334-35 about, 4334

Graves, William Brooke, 617 1, 6202 comp., 6I 85

Gray, Asa, 4036, 4760 about, 4724,4760

Gray, Henry David, 530I

Gray, J. W., about, 2857

Gray, James, 2358, 3986

Gray, Lewis Cecil, 5823

Gray, Wood, 3058

The Gray Wolf's Ha'nt, 757

Grayson, David, pseud. See Baker, Ray Stannard

The Graysons, 876-77

Graziano, "Rocky", 5028 about, 5028

The Great American Fraud, I 155

The Great Awakening, 22-23, 5401-2, 54II, 54 I9

Great Awakening, 5402

Great Basin, 297 I

Great Britain

Colonial policy, 3176-77, 3179, 3188 $89,3191-92,3195,3221,3225$, $324 \mathrm{I}, 3243$

commerce, 3 I 93

economic relations with, 3638

relations with, $3187-88,3221,3243$, $3246,3307,3340,3426,3444$, $3502,3531,3551-54,3557-59$, $3777-78$

Civil War, 3536, 3550

War of 1812,3542

Great Britain. Privy Council, about, 6232,6234

Great Britain and France in the New World, 3171, 3188-89, 3191,3226
Great Britain and Massachusetts, 324 I

Great Britain and Pennsylvania, 3225

Great Britain and Texas, 3554,3577

Great Circle, 1163

Great Depression (1929). See Depression (1929)

The Great Diamond Robbery, 2305

Great Dismal Swamp, 4336

The Great Divide, 1069-70

The Great Gatsby, $1428-29$ about, 1425

The Great God Brown, 1648, 2337

The Great God Pan, 4953

The Great God Success, 1108

The Great Good Place, I0 2

Great Lakes, 2803, 3170, 4 II3-14, $4140,4315,4329,4349$

short stories, I I 49-50

travels \& travelers, 3 I 4

See also Waterways, inland

The Great Lawsuit, 315

The Great Meadow, I70 I

Great Plains, 2933, 4 I 5 I-7 I

geography, 2969

grasslands, 2966

guidebooks, 3895-3909

hist., 3784,3964

Indians. See Plains Indians

Great Revival, 5402

Great Smoky Mountains, short stories, I084, I087-88

The Great Tradition, 2439

The Great Valley, I60 I

Greece, fiction, I 839

Greek Anthology, 1599, 248 I

Greeks, 4435

Greeley, Horace, 2883, 4373 about, 3I $3,2770,2797,2848,2858$, 2868, 2883, 4372

Greely, Adolphus W., 298 I about, 2980-8I

Green, Abel, 4892

Green, Constance McLaughlin, 478

Green, James A., 3326

Green, Nicholas St. John, about, 5264

Green, Paul, I 473-78, 2332-33, 2337 about, I 479

Green, Samuel Swett, 6472 about, 6476

Green, William, 5906

Green Bay Packers, about, 5045

A Green Bough, 1379

Green Centuries, 1469

Green Fruit, 1227

The Green Leaf, 1635

The Green Mountain Boys, 580-82

Green Mountains, Vermont, 2742

The Green Pastures, 2327, 2333, 2348

Green River, 217

The Green Town, 2350

The Green Wave, 2106

Greenbackers, 3421, 6356, 6362, 6427

Greenberg, Samuel Bernard, I 480-81 about, $148 \mathrm{I}$

Greenblatt, Milton, 4838

Greene, Bertram, drawings, 3164

Greene, Edward L., about, 4734

Greene, Evarts Boutell, 3089, 3190-92, 5419

Greene, Theodore M., 5100

Greene, Theodore P., ed., 3 1 I 0-I I
Greener Fields, 2725

Greenfield, Kent Roberts, ed., 3726

Greenfield Hill, 121

Greenough, Horatio, about, 5738

Greenslet, Ferris, 951, 2679-81 about, 2680

Greenway, John, 5552

Greenwich Village

Bohemianism, 3757

theater, 4916

Greer, Thomas H., 6426

Greever, Garland, ed., 1046

Gregg, Josiah, 4I 88 about, 4 I 88

Gregory, Herbert E., 4715

Gregory, Horace Victor, II32, I48283,1905 ed., I 185

Gregory, Mrs. Horace Victor. See Zaturenska, Marya

Gregory, Raymond W., 5224

Gregory, Winifred, 2915

Gress, Edmund G., 6456

Grew, Joseph C., 3545, 3599

Grey, Hugh, ed., 5071

Grey, Zane, 1484-86, 5073-74 about, $1486-87,5073$

Greyslaer, 365, 550

Grieve, George, tr., 4253

Griffes, Charles T., about, 5605, 5680

Griffin, Grace Gardner, 352 I

Griffin, James B., ed., 2990

Griffin, Marcus, 506I

Griffis, William Elliot, 285 I

Griffith, Louis Turner, 2856

Griffith, Richard, 4958

Griffith, Virgil A., 6273

Grimes, Alan Pendleton, 2921, 6062

Grimm brothers, about, 5504

Grinnell, George Bird, 2999-3000, 4724

Grinnell expeditions, 2980

Griswold, Alexancer Viets, Bp., about, 5457

Griswold, Alfred Whitney, 3594

Grodzins, Morton, 4469

Grogan, John M., 4695

Groost, Gerard, about, 3765

Gross, A. H., tr., I I 93

Gross, Ben, 4965 about, 4965

Gross, Gerald C., 4707

Gross, Mason W., ed., 5384

Gross, Samuel D., 4824 about, 4824

The Gross Clinic (painting), 5764

Grossman, James, 252, 2286

Grosvenor, Gilbert, ed., 2962

Grosz, George, illus., 1 I 18

The Ground We Stand On, 1329

The Group, 2347

Group dances, 5590

Group theatre, 4914

Grover, Leonard, 2301

Groves, Ernest R., 4563

Groves, Harold M., 5970

The Groves of Academe, 2021

Growth, 1806

Gruchy, Allan G., 5888

Grunder, Garel A., 3595

Gruskin, Alan D., 5752

Guard of Honor, 1302 
The Guardian Angel, 375

Guerrant, Edward O., 3576

Guest, Robert H., 6055

Guidance in education, 5149,5228

Guidebooks. See under names of places and regions, e.g., Alaskaguidebook

Guild, R. A., ed., 89

Guilday, Peter K., 5477

Gulf coastal plain, 2933

Gulf States, 3946

Gullah dialect, 227 I, 4436, 5540

Gulliksen, Harold, 5229

Gummere, Amelia Mott, ed., I 85

Gummere, Francis Barton, about, 5222

Gun Factory, Naval, hist., 3670

Gunderson, Robert Gray, 3326

Gunn, Selskar M., 4863

Gunther, John, 3499

Gustafson, Axel F., 5884

Guthe, Carl E., 2990

Gutheim, Frederick A., 4008

Guthmann, Harry G., 5967, 5971

Guthrie, Alfred Bertram, I 488-90

Guthrie, Paul N., ed., 6054

Guthrie, Ramon, tr., 3773

Gymnasiums, 4990

H

H. M. Pulham, Esquire, 1592

Haas, Theodore H., 4428

Haas, William H., 4218

Habenstein, Robert W., 4527

Haber, David, ed., 61 26

Haberle, John, about, 5744

Hacienda, 1660

Hacker, Louis M., 5878

Hackett, Alice Payne, 2482

Hackett, James H., about, 518

Hackett, Walter, 2348

Hadley, Chalmers, 6476

Haefner, George E., 5220

Hafen, Le Roy R., 4I 79, 4666

Hagedorn, Hermann, 2682-86

Hague, Frank, about, 6388

Hague. Permanent Court of International Justice, about, 3534

Hahn, Milton E., 5228

Haigh, Robert W., 5914

Haight, Gordon S., 279

Hail Columbia (song), about, 5616

Haiman, Miecislaus, 3250

Haines, Charles G., 6240

Haines, Francis, 300 I

Haines, George, IV, 3065

Haines, William Wister, 2337

The Hairy Ape, I647-48, 2332

Haiti, relations with, $3575,3584,3587$

Hakluyt, Richard, about, 3198

The Halcyon in Canada, $74 \mathrm{I}$

Hale, Bryant, 4946

Hale, Carolyn L., comp., 6205

Hale, Edward Everett, 880, 900-9, 4036

Hale, George Ellery, about, 4722

Hale, Robert Beverly, 5754

Hale, William Harlan, 2883

Hales, Dawson W., 5099, 5 I $4 \mathrm{I}$

Haley, James Evetts, 4I 53, 4 I 96

Halford, Francis John, 2687-88
Halich, Wasyl, 4492

Halkin, A. S., 4457

Hall, Basil, 4300-2

Hall, Clayton Colman, ed., 3209

Hall, Clifton L., ed., 5108

Hall, Dorothy, 5196

Hall, Francis, 4286-87 about, 4285

Hall, G. Stanley, about, 5116,5392

Hall, Gertrude, about, 1278

Hall, James, 319-22

Hall, Margaret E., ed., 6262

Hall, Margaret Hunter, 4300

Hall, Thomas Cuming, 5394

Halleck, Fitz-Greene, 323-29, 2295 about, 329

Hall-marks, pewterers', 5788

Hallenbeck, Wilbur C., 4587

Halline, Allan G., ed., 170, 200, 208, 2337

Hallowed Years, 5066

Hallowell, Maine, guidebook, 3793

Halpert, Herbert, 5545

ed., 5566,5576

Halsey, Francis W., I 63

Halsey, Richard T. H., 5796

Halsted, William S., about, 4821,4845

The Halt in the Garden, 1516

Hambridge, Gove, ed., 5837

Hamburger, Ernest, 521 I

Hamburger, Philip P., 1598

Hamer, Philip M., 3068

Hamilton, Alexander, 229r, 3288-89, 4240,6075

about, 723-24, 2873, 3125, 3281, 3288-91, 4239, 6015, 6170

Hamilton, Allan McLane, 3291

Hamilton, Andrew, about, 293 I

Hamilton, Charles, ed., 4652

Hamilton, Holman, 3333

Hamilton, R. S., about, 4536

Hamilton, Walton, 4513, 5290

Hamilton, William Baskerville, ed., 2571

Hamilton, William J., 2955

The Hamlet, 1391

The Hamlet of A. MacLeish, 1586

Hamlin, Sarah H. (Simpson), 5709

Hamlin, Talbot Faulkner, 5700, 5708-9

Hammarstrand, Nils, tr., 4486

Hammerstein, Oscar, 2337, 5659, 5685

Hammond, Bray, 6000

Hammond, Charles, about, 2857

Hampson, Alfred Leete, ed., 842

Hampton, Wade, 2635

Hampton, S. C., plantation life, 5087

Hampton Institute, about, 2982

Hanau, Stella, 49 r 6

Hanchett, David S., 5948

Hancock County, Ohio, 3866

Hand, Learned, 6264

Handel, Leo A., $495^{\circ}$

Handicrafts. See Arts and crafts

Handkerchiefs from Paul, 2483

Handlin, Mary F., 3083

Handlin, Oscar, 3083, 4410-1 I, 4428$30,4455,4481$

ed., $3079,4323,5483$

Hands Off, 3577

Hanford, A. Chester, 5178

Hanford, James Holly, 5573
Hanley, Louise, ed., 2240

Hanley, Miles L., 2268

Hanna, Alfred J., 3980, 4293

Hanna, Kathryn T. (Abbey), 4096

Hanna, Marcus Alonzo ("Mark"), about, 3424,6352

Hannah Thurston, 2282

Hansen, Allen O., 5121

Hansen, Alvin H., 5898, 5968

Hansen, Harry, 387 , I I 22, 3488, 3987 ed., I 125,2351

Hansen, Marcus L., 2268, 4390, 441 213, 4473

Hanson, Earl Parker, 4222

Hanson, Howard, about, $567 \mathrm{I}$

Happiness, pursuit of (law), 3756

Happy Days, 1604

The Happy Marriage, 1586

Happy New Year, Kamerades!, 2016

Haraszti, Zoltán, 3279

Harbeson, Georgiana (Brown), 5785

Harbison, Winfred A., 6077

The Harbor, 1657

Harbor of the Sun, 2746

Harbord, James G., 3710

Hard, Walter R., 4009

Hard Candy, 2227

Hard Winter, 1553

Hardee, Melvene D., ed., 5228

Harding, Thomas Swann, 5857

Harding, Walter $\mathbf{R}$.

comp., 589

ed., 610

Harding, Warren Gamaliel

about, 3475

fiction, 1756

Hardman, Jacob B. S., ed., 6032

Hardy, C. De Witt, 5169

Hardy, John, about, $55 \mathrm{I} 7$

Hare, James H., about, 2908

Hare, Robert, about, 4740

Hare, William H., Bp., about, 5457

Hargrave, Roy, 4968

Harlem (N.Y.)

fiction, 1832, 1914-15

short stories, I 521 , 1523-25

Harlow, Alvin F., 4122, 4667, 4675, 5928 ed., 5512

Harlow, Ralph Volney, 2689, 6156

Harman, R. Joyce, 4693

Harmon, Frances B., 5305

Harmon, George Dewey, 3028

Harmon, Nolan Bailey, 5463

Harmon, "Old Council," about, 5529

Harmonium, 1782, 1784

Harmony Society, hist., 38 I 9

Harned, Thomas B., ed., 627,637

Harnett, William M., about, 5744

Harno, Albert J., $632 \mathrm{I}$

Harnoncourt, René d', 3017

Harp of Columbia, 5577

Harper, Joseph Henry, 6450

Harper, Lawrence A., 3 I 93

Harper, Robert A., 46r9

Harper, Wilhelmina, comp., 937

Harper and Brothers, about, 6445,6450

Harper's Magazine, 2557

The Harpe's Head, 322

Harrigan, Edward, about, 4935

Harriman, Edward Henry, about, 5932 
Harriman, Margaret Case, 4931

Harrington, Fred Harvey, 3103

Harriot, Thomas, about, 4721

Harris, Charles K., about, 5635

Harris, George Washington, 330-32

Harris, J. S., 304 I

Harris, Joel Chandler, 880, 9ro-25, I $134-35,2296$

about, 910, 226r

Harris, Joseph P., 6157, 6403-4

Harris, Julia C., ed., 923

Harris, Mark, 1582

Harris, R. E. G., 6207

Harris, Seymour E., 5889-90, 6010 ed., 3638

Harris, Thaddeus W., about, 2280

Harris, William Torrey, 5266, 5306-8 about, 5259, 5305, 5307, 5309

Harrison, James A., ed., 533, 538

Harrison, Joseph B., ed., 938

Harrison, Peter, about, 5704

Harrison, Shelby Millard, 4588

Harrison, William Henry, 2996 about, 3325-26

Harrisse, Henry, 6460 about, 6460

Harrod, James, about, 2726-27

Harshberger, John W., 2957

Hart, Albert Bushnell, 3079, 3083, 3381 ed., 3177, 330r, 3337, 3356, 4034

Hart, Clyde, 4701

Hart, James D., 2433-34, 2482 ed., 2338

Hart, Lorenz, about, 5685

Hart, Moss, I 49 I-93, I 545, I 548, 2327. 2333-34

Hart, Tony, about, 4935

Harte, Francis Bret, 926-40, 2290 about, 732, 94I, I I 49, 2534

Hartford, Conn., 32

Hartford Convention, 3305

Hartford Courant, about, 2875

Hartford Wits. See Connecticut Wits

Hartmann, Edward George, 442I

Hartshorne, Charles, ed., 5346

Hartshorne, Richard, 2937

Hartung, Maurice L., ed., 5249

Hartz, Louis, 6063

Harvard Anniversary Address, 460

Harvard College, 3745

Harvard Guide to American History, 3083

Harvard University

about, $2767,5221,5670,5672$

curriculum, 5 I 80

hist., 5203

Harvard University. Committee on the Objectives of a General Education in a Free Society, 5180

Harvard University. Divinity School, about, 5424

Harvard University. Library, about, 6470

Harvard University. Philosophy Dept., about, 5369

Harvesting machinery, 5826

Harvey, Alexander, 975

Harvey, Fred, about, 4187

Harvey, William Brinton, 5468

Harwell, Richard B., ed., 2830
Hasse, Adelaide R., 4819, 5834

Hasslacher, Jacob, about, 4735

Hastings, George E., I 46

Hastings, Thomas, 5665

The Hasty Heart, 2334

Hasty Pudding, 102

Hatch, Louis Clinton, 368I

The Hatch, 2350

Hatcher, Harlan H., 4I I 4, 4 I I 8

Hathorn, Guy B., 6139

Haugen, Einar, 2267

Haunted Ground, 1553

The Haunted Mirror, 1703

Hauser, Elizabeth J., ed., 6429

Haven, Samuel F., 6447

Havighurst, Robert J., 4589, 51 46, 5205

Havighurst, Walter, 3975, 4979

Haviland, Henry Field, 3610

Having Wonderful Time, 2327

Hawaii, 2688, 3449, 42 I8, 4220, 4470 fiction, 2003-4

Hawes, G. R., 5197

Hawgood, John A., 4478

Hawkes, Herbert E., 5178

Hawley, Amos H., 4393

Haworth, Paul Leland, 3432

Hawthorne, Nathaniel, 333-59, 2290. 2406

about, 21, 280, 360-64, 381, 470, $487,538,2368,2385,2397,2420$, 2456, 2476, 2479, 2503, 2545

Hawthorne, Sophia (Peabody), 349-50

Hay, Clarence L., 944

Hay, John, 941-44, 3395, 3426

ed., 421

about, 689, I1 26, 3426

Hay-Pauncefote Treaty, 3559

Hayakawa, S. I., 378

Haycraft, Howard, 2436

ed., 2435, 2454-55

Hayes, Carlton J. H., 3572

Hayes, E. C., 4540

Hayes, Rutherford B., about, 341 8-19

Haymarket Riot, 3425

Hayne, Paul $\mathrm{H}$.

ed., 6 I 6

about, 6 I 4

Hayner, Norman S., 4590

Haynes, Benjamin R., 6017

Haynes, Frederick Emory, 3433, 6427

Haynes, George H., 61 58

Haynes, Williams, 4735

Hays, Arthur Garfield, 61 27, 6265, 6322

Hays, William Jacob, about, 5806

Haystead, Ladd, 4594, 5843

Hayward, Arthur H., 5786

Haywood, William Dudley ("Big Bill"), about, 6045

Hazard, J. N., 3562

Hazard, Lucy Lockwood, 2437

A Hazard of New Fortunes, 973-76

Hazel Kirke, 2337

Hazelton, George C., 2313

Hazlitt, Henry, 824

He and She, 2337

He Hanged Them High, 2656

He Sent Forth a Raven, I 704

He Went Away for a While, 2749

Head o' W-Hollow, 2167

Heady, Ferrel, 63 I I
Health

education, 4863

insurance, $4635,4808,4882,4885-90$

resorts, etc., 2278

services, $4805,48 \mathrm{r} 4,4864,4866$, $4868,4870-71,4874,4876,4878$, $4880-8 \mathrm{I}, 4885$

hist., 4875,4877

pediatric, $484 \mathrm{I}$

rural, $4869-70,4874$

Mass., 4879

Heard, Alexander, 6376,6378

Hearn, Lafcadio, 748, 945-55 about, 953, 955, 248 I

Hearst, William Randolph, $288_{4}$ about, 2848,2884

The Heart Is a Lonely Hunter, 2024

The Heart of Happy Hollow, 860

Heart of Man, 2546

The Heart of Maryland, 2315

The Heathen, 1052

The Heathen Chinee, 933

Heathen Days, 1604

Heavens and Earth, 1224

Heaven's My Destination, I 866

Heavy machinery, 4I 40

Hébert, Marcel, about, 5325

Hechler, Kenneth W., 3456

Hecht, Ben, 2327, 2332

Heck, Arch O., 5207

Heck, Harold J., 5946

Heckscher, August, 5855

Hedge, Frederic Henry, about, 5263

Hedges, James Blaine, 3074

Hedin, Naboth, 4483

Hedrick, Ulysses P., 5824

The Heel of Elohim, 2527

Heely, Allan V., 5 I 55

Heerwagen, Arnold, 2966

Heffelfinger, W. W. ("Pudge"), 5038

Heffen, Thomas, 2335

Heffner, Richard D., 3079

Hegel, Georg W. F., about, 3768, $5305-$ 6,5326

Heidbreder, Edna, 5389

Heilman, Robert B., 2378

Heilner, Van Campen, 5075

Heindel, Richard Heathcote, 3777

Heinzen, Karl, about, 448I

Heiser, M. F., 240 I

Heizer, Robert F., ed., 3002

Heldt, Henning, 6207

Helen of Troy, 1814

Heliodora, 1320

Hellbox, 2075

Heller (Robert) and Associates, 4671

Hellman, George S., ed., 392-93

Hellman, Lillian, 1988-91, 2327, 2333 36

Helm, MacKinley, 5767

Helms, Elva Allen, 6338

Helzner, Manuel, 5898

Hemingway, Ernest, I 494-1500, 2406 about, $821,1501-5,2371-72,2376$, 2406, 2427-28, 2508-9, 2537, 2542

Hemmen $i$ den Nya Verlden, 4355

Hemming, Doris, tr., 4506

Hemming, Henry H., tr., 4506

Hendel, C. W., Jr., 5252

Henderson, Algo D., 5196

Henderson, Archibald, ed., I 45 
Henderson, Daniel M., 3434

Henderson, George F., 3697

Henderson, Ky., guidebook, 3858

Hendrick, Burton J., 325I, 3382-84, 3434,37 I 6

Hennessey, Joseph, comp., 49 I I

The Henrietta, 2337

Henry, Andrew, about, 4175

Henry, Caleb Sprague, about, 5263

Henry, John, about, 5506, 5517

Henry, Joseph, about, 472 I, 4724, 4752, 4775

Henry, Merton G., 366I

Henry, Nelson B., ed., 5 I 50

Henry, O., pseud. See Porter, William Sydney

Henry, Patrick, about, 3263

Henry, Ralph Chester, 3951

Henry, Robert Selph, 3385, 3689, 3698, 5926

Henry, Stuart C., 5480

Henry of Navarre, 2281

Herald (Paris), about, 2872

Heraldic eagle, 2958

Heralds of American Literature, 2465

Herberg, Will, 5447, 5488

Herbert, F. Hugh, 2335

Herbert, Henry William, 5076-80

about, 5076-77, 5080

Herbert, Victor, about, 5605, 568 $\mathrm{I}$

Here Is New York, 1859

Here Lies, I 651

Hereditary organizations, 3644,4574

Here's O'Hara, 2074

Hergesheimer, Joseph, 1506-I 1

Hering, Doris, ed., 497 I

The Heritage of Hatcher Ide, 1802

Herlihy, Elizabeth M., ed., 4036

Hermaios, 2 Ior

The Hermit Place, 2130

Herne, James A., 2304, 2337

Heroes, legendary. See Folk heroes

Heroism, 285

Herr, John K., 3659

Herrick, Francis Hobart, 2958 about, 4743

Herrick, Robert, 956-58 about, $24 \mathrm{I} 9,2464$

Herrick, Virgil E., 5142

Herring, Edward Pendleton, 6357

Herring, James M., 4707

Herron, Ima Honaker, 2438

Hersey, John Richard, 1992-94

Herskovits, Melville J., 4446

Hertzler, Arthur E., 4825 about, 4825

Hervey, John, 5055

Herzberg, Joseph G., 2903

Herzog, George, ed., 5566, 5576

Hesperides, 1821

Hesperothen, 4382

Hesseltine, William B., 3053, 3435, 3785,4071

Hettinger, Herman S., 5647

Hewitt, Abram S., about 3443

Heyer, William, drawings, 5940

Heyward, Dorothy, 2332

Heyward, Du Bose, I 168, I 512-13, 2332,5678

about, 1514
Hiawatha, The Song of, 432

Hibbard, Benjamin Horace, $581 \mathrm{I}$

Hibben, Paxton, 3457,5476

Hickerson, Harold, 2332

Hicks, Granville, 2439

Hicks, John D., 3084, 3436, 5831, 6358

Hicks, Wilson, 2908

The Hidden Public, 6463

Hidy, M. E., 5913

Hidy, Ralph W., 5913, 5980

Higby, Chester Penn, ed., 2293

Higginson, Francis, $3 \mathrm{IO}_{2}$

Higginson, Henry Lee, about, 5649

Higginson, Thomas Wentworth, 2280, 4036

ed., 839-40

High Border Country, 395I

High Calling, I 789

High Falcon, II 54

High Passage, 1410

The High Place, 1262

High Plains, 4159, 4164

High schools. See Secondary education

High Tor, I I 74, 2333, 2336

Higham, John, 4422

Highet, Gilbert, 5218

Highwater Mark, 937

Highwaymen, Colonial, 4227

Highways, 3786, 3788, 4085, 5934

La., 4100

Wyo., 3911

Hiking, 5064

Hildeburn, Charles R., 4049

Hildreth, G. H., 5205

Hildreth, Richard, about, 3058

Hill, Charles E., 3522

Hill, Clyde M., ed., 5236

Hill, Frank Ernest, 5939

Hill, Helen, 3254

Hill, James J., about, 5880,5882

Hill, Lawrence F., 3582

Hill, Ralph Nading, 4010

Hill, W. H., 5335

Hilliard, William, about, 6446

Hillman, Arthur, 4575

Hillman, Sidney, about, 6049, 6394

The Hills Beyond, 1892

The Hills Give Promise, 1516

Hillsboro, Ill., guidebook, 3878

Hillstrom, Joseph, about, 2164

Hillway, Tyrus, ed., 499

Hillyer, Katharine, 5059

Hillyer, Robert, I515-17

Hilsman, Roger, 3603

Hindle, Brooke, 4718

Hindus, Milton, ed., 656

Hinkel, Lydia I., ed., 5572

Hinsdale, Burke A., 5125

Hinshaw, David, 3485, 5479

Hinshaw, Kenneth, $584 \mathrm{I}$

Hippolytus, 2313

Hipsher, Edward Ellsworth, 5656

The Hired Man on Horseback, 1686

Hiroshima, 1992

Hirschfeld, Charles, 3058

His Family, 1658

His Human Majesty, 1249

Hiscock, Ira V., 4866

Hislop, Codman, 40 I I

Hiss, Alger, about, 611 4, 6229
Historic houses, 5702, 5713, 5721-22, 5794

guidebook, 3786

Charleston, S.C., 4093

Conn., 3805, 404I

Mount Vernon, Va., 3271

Ohio, 4 II 9

Philadelphia, 4059

Washington, D.C., 4063

Historical Atlas of the United States, 2972

Historical Records Survey. District of Columbia, 5606

Historical research methods, 3054, 306 I

Historical societies, 3052

Historical themes in literature

annals, journals, etc., $1-6$, I $2-16$, $36-39,43-44,49,53-58,66-7$ I, 90-9I

drama, $198,200,206-8,365,1477$, I 49I, I 520, 2048

essays, I I $03-4,1267,1873$

fiction, $164,201-4,226-29,239,241$, 245-60, 268-69, 277-79, 307, 31 I I 2, 405-I3, 5I I, 5I4-I6, 546-50, $552-53,555,579-82,665,721$, $723-24,745,762-67,821,825-$ 29,835 , I I05, I 222-24, 1239-4I, I 325-28, I 331-32, I 353-56, I 379, I $382,1388-89,1403,1406,1420$, I 424, I 437-39, I 44I-44, I 468-69, I 488-90, I506, I 508, I 5 I I, I 54I42, I544, 1578, I618-19, 1644, I646, I656, I 691, I 693-96, I 70 I, I 707-1 2, I727, I730, I786, I842, 1916-18, 1920, 1959-62, 197380, 2005-6, 2194, 2199, 2201, 2799 hist. \& crit., 2458

poetry, I34-39, 323, 368-69, 42729, 432-34, 486, 488, 61 4, 61 6-I7, $623,662,664,666,1069,1222$, 1224, 1585, I644-45, I 824-25, 2200

short stories, 725, I 100-2, 1222 , I 224 , I379, I389, 1510

Historiography, 3044-69, 3730

bibl., 3064, 3066-67, 3074

local hist., $306 \mathrm{I}$

sources, 3083

theories, methods, etc., 3054-55, $3057,3062,3065,3075,3083$, 3174,3407

World War II, 3726

Southern States, 3057

History, general American, 2601, 3044$3500 \mathrm{~b}, 3740,3746,3754,3779$, 3784

bibl., 3083

chronology, 3072, 3076 -77, 3083, 3465

dictionaries, $3071-72$

humor, caricatures, etc., 5803

in music, bibl., 5613

philosophy, 693-98, 3628, 3632, $3735,5269,5313$

pictorial works, $308 \mathrm{I}-82,580 \mathrm{I}, 5804$ bibl., 5757, 5775, 5807

popular works, I 222

sources, $3068,3079,3100,3106-36$, $3143,3151,3183-84,3195,3201-$ 19, 3617 
History, general American-Continued study \& teaching, 3050, 3055, 3059, 3083

History, local, 2943, 306r, 378I-4222 See also History under names of places and regions, e.g., California-hist.

History and art, $5801-7$

See also History, general Americanpictorial works

History of Plymouth Plantation, 2-6, 3204

Hit the Line Hard, 1687

Hitchcock, Henry Russell, 5710-1 I ed., 57 I 8

The Hive of "The Bee-Hunter," 61 3

Hoagland, H. E., 6033

Hobart, John Henry, Bp., about, 5457

Hobbs, Edward H., 6I 44

Hobbs, William Herbert, 2979

Hobomok, a Tale of Early Times, $24 \mathrm{I}$

Hobson, Wilder, 5644

Hockett, Homer C., 3054

Hocking, William Ernest, 5252, 5310I 6

about, 5310

Hodder, Jessie S., Mrs., about, 4649

Hodge, Frederick W., ed., 2982, 3217

Hodges, Henry G., 6210

Hoebel, Edward Adamson, 3014

Hoeltie, Hubert H., 5265

Hoernlé, R. F. A., 5252

Hoffman, Charles Fenno, 365-67, 550, 2295

Hoffman, Daniel G., 5516

Hoffman, Edward Fenno, ed., 365

Hoffman, Frederick John, 2914, 2360, 2440

ed., I 399, 2326, 2330

Hoffman, Harold M., 6298

Hoffman, M. J., 5442

Hofstadter, A., 529 I

Hofstadter, Richard, 3099, 3458, 3755, $5169,518 \mathrm{I}$

Hogan, William Ransom, 4193

Hohman, Elmo Paul, 5871

Holbrook, Stewart H., 4022, 4028, 4394

Holcombe, Arthur N., 6076, 6336

Holden, Harold, ed., I $48 \mathrm{I}$

Holden, Paul E., 6 o 8

Holder, Charles Frederick, 4724, 508184

Holding companies, 60o8, 6013

Holiday, a Comedy in Three Acts, 1200, 2348

Holism in economics, 5888

Holland, Elizabeth Luna (Chapin), 850

Holland, Josiah Gilbert, 850

Holland, Maurice, 4785

Holland. See Netherlands

Holley, Irving B., 37 I I

Holliman, Jennie, 4992

Hollingshead, August de B., 4564

Hollinshead, Byron S., 5170

The Hollow Men, 1359

Holloway, Emory, 871 ed., 627,639

Hollywood, Calif., 2752, 4204, 4948

fiction, I 425, I833, I842, 2025, 2028, 2069, 2074, 2154

Holm, John Cecil, 2333
Holmer, N. M., 2364

Holmes, G. F., about, 4536

Holmes, John, about, 2280

Holmes, Oliver Wendell, Sr., 368-78, 2290

about, 375, 377, 449, 2277, 2374, 2513,2693

bibl., 377

Holmes, Oliver Wendell, Jr., 2607, $6222,6242,6277$

about, 2542, 2607, 4545, 5264, 624142,6266

Holmes, Thomas J., ed., 48

Holmes, William H., 2991

Holst, Hermann Eduard von, about, 3058

Holt, E. B., 5260, 5335

Holt, Henry, 689

Holt (Henry) and Co., about, 6445

Holt, Rackham, 2690, 5825

Holt, W. Stull, 3739

ed., 3044

about, 3058

Holy Land, travel and travelers, 769-7I

Homage to Sextus Propertius, 1666

Homan, P. T., $454^{\circ}$

Home by the River, I726, 5087

Home Country, 2745

Home Fires in France, 1413

Home manufactures, 5919

Home of the Brave, 2334

The Home Place, 2052

Home rule, Chicago, 6208,6380

Homer, Winslow, about, 5765

Homestead Act (1862), 5811

Homeward to America, 1949

Hone, Philip, 2691-92

Honest John Vane, 277

Honey in the Horn, 1315

Honey out of the Rock, 2413

Honeywell, Roy J., 5122

An Honorable Titan, 2869

Hook, Sidney, 3065, 5254, 5289, 529192

ed., 5257-58, 5291

about, 5259

Hooker, Joseph, about, 2614

Hooker, Nancy Harvison, 3545

Hooker, Thomas, 32-35

about, 6068

Hoole, William S., 379

Hooper, Claude E., 4700

Hooper, Johnson Jones, 379-80 about, 379

Hooper, Osman Castle, 2857

A Hoosier Holiday, $134^{\circ}$

The Hoosier Schoolmaster, 868-71

Hoover, Calvin B., 5891, 5947

Hoover, Herbert Clark, 3485 about, $3485-87$

Hoover, Margorie Leonard, 6135

Hoover, Theodore Jesse, 4800

Hoover Commission. See Commission on Organization of the Executive Branch of the Government

Hope of Heaven, 2074

Hopkins, Charles Howard, 5489-90

Hopkins, Frank E., ed., I I

Hopkins, Harry Lloyd, about, I749, 3499

Hopkins, James F., ed., 3344
Hopkins, Johns, about 4845

Hopkins, Louis B., 5 I 78

Hopkins, Mark, about, 5222

Hopkins, Samuel, about, 5428

Hopkins, Vivian C., 303

The Hopkins Review, 2442

Hopkinson, Francis, $146-48$

about, I 44, I 46, 2465

Hopper, Ida T., comp., 3292

Horace, 2281

Horace Mann-Lincoln Institute.

School of Experimentation, 5136

Horgan, Paul, 3782, 4197

Horine, Emmet Field, ed., 2667

Horizon, 2337

Horn, Stanley F., 3386,5864

Horn, Ted, about, 5001

Horn, Tom, about, 2758

Hornberger, Theodore, 2412, 47I 9 ed., 2323

Horne, A. R., 2266

Horner, Harlan H., 4843

The Horse and Buggy Doctor, 4825

Horse-raeing, 5054-57

dictionary, 2259

Ky., 5057

Horse-Shoe Robinson, 409-I I, 2347

Horse-Shoe Trail, Pa., 3820

Horsemanship, 5078

Horses, 2984, 5058, 5078, 5867 in art, 5770

Horticulture, 2790, 5824

Horton, John Theodore, 6224

Horton, Rod W., 244I

Horton, Walter M., about, 5433

Horwill, Herbert W., 2237

Hosmer, James K., ed., 91, 3219

Hospitals, $4310,4808-9,4839,484 \mathrm{I}$, $4862,4870,4885$

administration, 4847,4849

finance, $4847-49$

services, 4847-49

New York (City), 485 I, 4857

New York (State), 4846

See also Psychiatric hospitals

Hot-Foot Hannibal, 757

The Hot Iron, 1475

Hotel Universe, 1199

Hotels, taverns, etc., 4590

Colonial period, $4227,425 \mathrm{I}$

furniture, equipment, etc., 5526

Va., 4086

Yosemite, 4211

Houghton, Norris, 4901, 4920

The Hour, 2415

Housatonic River and valley, 4000

The House behind the Cedars, 756

House decoration, 5726, 5729-30, 5732, 5796

A House Divided, 1256

The House of Beadle and Adams, 2444

The House of Breath, 1985

The House of Connelly, 1475

The House of Mirth, 1847

The House of Sun-Goes-Down, 2415

The House of the Seven Gables, 345-47

A House Too Old, 2129

Housing, 4395, 4600, 4608, 46ro-r 2 , 4617

finance, 461 
Housing-Continued

Negroes, $444^{8}$

Willow Run, Mich., 4586

Houston, Sam, about, $334 \mathrm{I}$

Houston, Tex., guidebook, 392 I

The Hovering Fly, I 810

Hovland, C. I., 3724

How Santa Claus Came to Simpson's Bar, 930, 937, 939

How To Tell a Story, 798-99

How To Write Short Stories, 1554

Howard, Bronson Crocker, 2307, 2337, 2347

about, 2307, 2471

Yoward, Charles P., about, 6049

Koward, Delton T., 5283

Howard, John Tasker, 5607, 5677

Howard, Joseph Kinsey, 4I76, 4178 , 6207

ed., 4178

Howard, Leland O., about, 4722

Howard, Leon, 449, 482, 500, 2401 , 2412

ed., 2339

Howard, Sidney Coe, 1518-20, 2327, 2332, 2337, 2348

Howard, William 'Travis, 4867

Howe, Edgar W., 959-63, 2885

about, 959, 2885

Howe, Elias, about, 4786

Howe, Frederic C., 6428 about, 6428

Howe, George Frederick, 3437

Howe, Henry F., 4012

Howe, Irving, 995, I I 88, I 400

Howe, Julia Ward, 2313 about, 4040

Howe, Mark Antony De Wolfe, 2693$98,2922,5648,6241$

ed., 462,2607

about, 2698

Howe, Will D., 239 I

Howe, Winifred E., 5795

Howells, Mildred, ed., 98 I

Howells, William Dean, 21 4, 857, 859 , $86 \mathrm{r}, 893,96 \mathrm{r}, 964-83,2290$

about, 277, 279, 706, 887, 890, 97I, $977,983,986,1089,2517,2520$, 2534, 2922, 6424

Hower, Ralph M., 5958-59

Howes, Cecil, 4 I 68

Howes, Charles G., 4 I 68

Howgate, George W., 5376

Howison, George Holmes, 531 7-1 8

about, 53 I 7-I 8

Howitt, Mary, tr., 4356

Hoyt, Charles H., 2306, 2348

Hoyt, Charles Sherman, 5019

Hoyt, Elizabeth E., 5899

Hoyt, Harlowe R., 4902

Hoyt, Homer, 58 I 2

Hoyt, William G., 2949

Hrdlička, Aless, about, 4722

$\mathrm{Hu}$, Shih, 5290

Hubbart, Henry Clyde, 4115

Hubbell, Alvin A., 4844

Hubbell, Jay B., 4068 ed., 408, 2340, 2424, 2442

Hubble, Edwin Powell, about, 4721

Huckleberry Finn, The Adventures of, $782-83,787-93,8$ I I
Hudgins, Bert, 2940

Hudson, Arthur Palmer, 5576

Hudson, Wilson M., ed., 5509, 552 I

Hudson, Winthrop S., 5395 ed., 88

The Hudson Keview, 1664,2558

Hudson River and valley, hist., 3972

Hudson River Bracketed, 1854

Hudson River, essays, 1002-3

Huebner, Grover G., 5948

Huegy, Harvey W., 5945

Huff, Theodore, 4953

Huffman, Laton A., about, 4I 5I-53

Huffman, Roy E., 5858

The Huge Season, 2056

Hugh Selwyn Mauberley, I 666 about, I670

Hughes, Adella Prentiss, 5630

Hughes, Charles Evans, 6243 about, 6254

Hughes, Glenn, 4905

Hughes, Henry Stuart, 3507

Hughes, John, about, 3257

Hughes, Langston, 567, I 521-25, $444^{\circ}$ about, 1522

Hulbert, Archer Butler, 2943

Hulbert, James Root, 2239 ed., 2236

Hull, Cordell, 3546 about, 3549

Hull, John, about, 3198

Hull, William I., 3222

Hull House, Chicago, 46 I 4

Hultgren, Thor, 5922

The Human Comedy, 2115

The Human Fantasy, 1858

Humanism, New, I735, 2375, 2385-86, 2422, 2425, 2479, 2503, 25II, 5 II 5

Humanitarianism, 6071

essays, 2479

fiction, 2084

poetry, 1061, 1069, I872, 2079

Humanities, 2375, 2422, 3739, 5100, 5 II 5

A Humble Romance, 882

Humboldt River, Nev., 3989

Hume, Robert A., 688

Humidity, 5816

See also Climate

Humor, 192, 368, 456-57, 542-43, 768, $862-66,878$, I 629-34, I 65I-52, I 8 I 5-20, I 859-63, 2597-98, 2642$43,2657,2735-36,2796,2808$, $3732,3735,4097,4964,4991$, $4995,5506-7,5511,5513$

anthologies, 2370

essays, I 21 4-20, I3 I 7-1 8, 2469

frontier, I94-97, 379-80, 445-48, 6I2-I3, 94I, 250I, 3353, 4097, 5508,5542

hist. \& crit., 2501

periods

Colonial, 52-53

(I764-I8I9), I 22, I 28, I $30, I_{32}$

(1820-70), 192-97, 209-15, $330-32,368,379-81,422-26$, $445-48,456-58,511,542-$ $46,556-61,612-13$
Humor-Continued

periods-Continued

(1871-1914), 70I-5, 768-812, $856-66,878-80$, 910-16, 922 , 924-25, 94I, II 26-3I, 2469

(1915-39), I $214-20$, I $317-18$, $1523,1525,1554-55,1629-$ $35,1651-52,1802,1815-20$, $1828,1833,1842,1859-63$

( $1940-55), 2052,2149-55,2202$

Ark., 5542

Ga., $445-48,556-57$

Ky., 5546

Mich., 5533, 5575

Middle West, 70I-5, I I26-31

Mo., 5528

Ozark Mountains, 5544-45

Southwest, New, 4190

Tex., 552I, 5527

See also Cartoons; Comic strips; Tall tales

Humphrey, Don D., 5947

Humphrey, Edward F., 5406

Hungarians, 4360

Hungerfield, and Other Poems, 1536

Hungry Gulliver, 1896

Hunt, Gaillard, 3283, 360r ed., 3283

Hunt, George T., 3009

Hunter, Beatrice Jones, 5929

Hunter, Dard, 6457

Hunter, Louis C., 5929

Hunter, Milton R., 4I 83

Hunter College Elementary School, about, 5205

Hunting and fishing, 2665, 2794, 499o, 5065-97

essays, sketches, etc., 1724

fiction, I 466, I 500, I681, 1954, 1957

Huntington, Archer M., about, 294I

Huntsman, What Quarry?, 1609

Hurd, C. F., 6207

Hurlbut, Jesse Lyman, 4893

Hurricanes, 2307

Hurst, Willard, 6225

Hurston, Zora Neale, I 526-29

Hurt, Huber William, 5041

Hutchins, John G., 5930

Hutchins, Robert M., 5235, 61 26

Hutchinson, Anne, about, 6229

Hutchinson, Edward P., 4395

Hutchinson, Thomas, about, 3257

Hutchinson, Thomas H., 4692

Hutchinson, William T., 3058,5826 ed., 3058

Hutchison, Bruce, 4013

Hutchison, John A., 5487 ed., 5496

Huth, Hans, 5884

Hutson, Charles W., ed., 3292

Hutter, Elizabeth L., ed., 3292

Hutton, David Graham, 4 I I6, 4234

Hutton, Joseph, 2347

Huxley, Thomas Henry, about, 248 I

Hyde, Arthur Mastick, 3487

Hyde, George E., 3003

Hydroelectric power projects, 4214

Hydrographic Office, about, 4771

Hydrography, 4721

Hydrotherapy, 4840

Hyer, R. V., 6r95 
Hyman, Harold Melvin, 3387-88

Hyman, Stanley Edgar, 2443

Hymen, 1320

Hymn to the Rising Sun, 1475

Hymns, 662, 5633

See also Church music; Religious folksongs

Hyneman, Charles S., 3535, 6172

Hyslop, Francis E., ed. \& tr., 520

Hyslop, Lois, ed. \& tr., 520

ITO, about, 5953

I.W.W., about 6045,6360

I Am a Camera, 2336

I Am a Man, 2645

I Am movement, 5439

l Came out of the Eighteenth Century, 2783

I Cover the Waterfront, 2747

I De Dage, 1721

1 Hate Thursday, 1409

1 Remember, 6450

1 Remember Mamma, 2334

I; Six Nonlectures, 1312

I Thought of Daisy, 2535

I Wonder Why?, 4989

Ibsen, Henrik, about, $896-97$

Icebound, 2337

The Iceman Cometh, I647-48, 2335

Ichihashi, Yamato, 4465

Ickes, Harold L., 3498

Ida, 177 I

Idaho, 396r

guidebooks, $3935-36$

fiction, 1420-22

hist., 3959, 396r, 4147

natural resources, 4212

Idealism, 3732, 3769, 5252, 5259, 5262, $5305,5317,5334,5354-55$

Ideas of Order, 1784

The Ides of March, 1869

Idiot's Delight, I75 I, 2333

The Idols of the Cave, 2094

The Idyl of Red Gulch, 930

lle, 1648,2332

Iles, George, 4786

Ilg, Frances L., 5149

Ill Fares the Land, 5846

Illegitimate Sonnets, 1626

Illinois, 3948, 4 I 26-36

architecture, 5719

descr., 3988

econ. statistics, 4132

fiction, 867, 876-77, I 978, 2029, 2033

frontier life, $4097-98$

Germans, 4478

govt., 6r95

guidebooks, $3875-8 \mathrm{r}$

hist., $2757,3663,3875,3986,4$ I I I, 4 I 15,4 I 26-33

libraries, 6473

Norwegians, 4487

personal narratives, $225 \mathrm{I}$

poetry, I 825

politics, $638_{3}$

rural communities, 4109

travel \& travelers, 4322
Illinois. Centennial Commission, 412632

Illinois Central Railroad, about, 4320 , 5927

Illinois High School Association, about, 5000

Illinois River and valley

hist., 3986

travel \& travelers, 4322

Illusions, 292

The Illustrated Man, 1935

Illustration of books, 5782

Illustrators, 5806

$I^{\prime} m$ a Stranger Here Myself, 1630

I'm Sure We've Met Before, 2746

Image and Idea, 2498

Images or Shadows of Divine Things, $2 I$

Imagism, I319, I 432, I 583-84, I813, 1872,2403

Immigrants. See Foreign population

Immigrant's Return, 2777, 4494

Immigration, 3136, 3139, 4147, 4404I $7,4424,4551,4617$

Chinese, 3437,4464

English, 4488

Filipinos, 4470

Japanese, 4465

Jews, 4460

Mexicans, $4470-72$

Norwegians, 4484-85

Orientals, 4468

policy, 441 8-25, 61 22

Puerto Ricans, 4470

Scotch, 4488-449I

Welsh, 4488

The Immortal Storm, 2377

Immortal Wife, 281 8

Immunology, 4722

Impeachment, Presidential (1868), 3362,3412

Imperial City, 1688

Imperialism, 1069, 3110,3428

Implements, utensils, etc., 5596, 5598, 5787-88

The Importance and Means of a $\mathrm{Na}$. tional Literature, 230

Imports, 5947

Impressionism, 896-97

In a Farther Country, 1987

In a Yellow Wood, 2182

In Abraham's Bosom, I 473, 1475

In Defense of Reason, 2544

In Ghostly Japan, 951-52

In Mizzoura, 2347

In My Father's House, 1788

In Old Plantation Days, 860

In Ole Virginia, I 100-2

In Reckless Ecstasy, I73I

In Search of Heresy, 2373

In Spite of All, 2308

In Such a Night, 2413

In the American Grain, 1873

In the American Jungle, 1445

In the Days of Youth, 1614

In the Day's Work, 6459

In the Midst of Life, 735-37, 739

In the Money, $1874-75,1882$

In the Tennessee Mountains, 1085-86

In the Zone, 1648

In This Our Life, 1462
In Tragic Life, 1423

In War Time, 666

In What Hour, 2098

Income, 4395, 4448, 5899

national, 5893

$\operatorname{tax}, 5970$

Incredible Era, 3475

Indentured servants, 6056

Independence Hall, Philadelphia, 4059

Independent Christian Society, about, 5423

Independent Treasury Act ( 1846 ), 335I

Index Medicus, 4819

The Index of American Design, 5594

India

relations with, 3503

World War II, 3726

Indian agency, Red Cloud, Nebr., 3003

Indian agents, 3023,3035

Indian place names, 2364

The Indian Princess, 66, 199, 2347

Indian Reorganization Act (I934), 3039

Indian Summer, 971

Indian themes in opera, $568 \mathrm{I}$

Indiana, 3948, 41 23-25

architecture, 5719

fiction, 867, 1802, 1808, 2005-6, 2210-12

folksongs \& ballads, 557 I

frontier life, $4097-98$

guidebook, 3874

hist., 3995, 4 I I I , 4 I I 5, 4I 23-25 sources, 4125

poetry, 1126

rural communities, 4 I 99

travel \& travelers, 1340

writers \& writings, 4 I 24

Indiana State Teachers' Association. Historical Section, 41 25

Indiana University. Institute for Sex Research, 4566

Indianapolis Journal, I I 26

Indianapolis Speedway Race, 5003-4

Indians, American, 66-71, 319, 2663, 2802, 2982-3043, 4038, 4099, 4160, 4169, 4I7I, 4I79, 4188. 4308,4428

agriculture, $582 \mathrm{I}, 5824$

and white civilization. See White civilization-and the American Indians

art. See Art-Indians

captives of, 53-55, 3032, 4233

commerce, 3180

culture, 2319, 2983, 2986, 2988-89, 2998, 3002, 304I-42, 3348, 4054, 4197

econ. condit., 3039-40, 3043

education, $2982,3023,3040$

folklore, $3021,5518,5523,5526$

govt. relations, $2986,3023,3025-29$. $3034-35,3038-39,3043,3663$

in art, $5770,5802,5806$

language, $85,2982,2987,2989,3012$, 4198,4308

legends \& tales, 3000, 3005, 3021, $4273,5518,5533$

missions, 62, 3022, 3030, 3040, 4233 , $545 \mathrm{I}$

poetry, I I 96

religion, 3019-20, 3040 
Indian, American-Continued

reservations, 1613, 2986, 2989, 3040, 3043,4154

rites \& ceremonies, 3015

soc. life \& cust., $66,68,70,85,2722-$ 25, 2753, 2982, 2989, 2998, 3002, $3006,3025,3040,3042-43$, 4172, $4236,4248-50,4307$

tribes \& tribal groups, 2982, 298586, 2989, 2998-3014, 302 I, 3023, 3025-27, 3039-4I, 4I 48, 4213

wars \& warfare, $2645,2710-11,3307$, 3644a, 3660, 4I5I, 4I53, 4I79, 5505

See also names of tribes, e.g., Cheyenne Indians

Indians, American, in literature

annals, journals, etc., I-6, 53-55

drama, 198-99, 4926

editorials, sketches, etc., 62, 149 , 1065

fiction, $114,164,201-4,239,241$, $251-52,258-60,546,549,985$, I 196 , I 55 I-52, I 644, I646, I696, I $701,1710,1786,1960,1975,3000$

hist. \& crit., $3031-32$

poetry, $323,427,432,1644-45$

short stcries, 1553, 3000

The Indifferent Children, 1909

The Indigo Bunting, 1610

Indiscretions, 1666

Individualism, 3732-33, 6065, 6071, 6ror

Industrial arbitration, 6058, 6299

Industrial arts. See Arts and crafts; Decorative arts

Industrial chemistry, hist., 4793

Industrial education, $5210-11$

See also Workers' education

Industrial management, 4798, 6003, $6010,6018,6038$

Industrial medicine, 4873,4887

Industrial relations, 4552, 5894, 6037$38,6042,6053,6055$

Industrial Relations Research Association, 4635

Industrial research, $4720,4777,4785$

Industrial revolution, 6070

Industrial themes in literature

essays, I 445

fiction, $726,728-31,762,887,941$, 956-58, 973-78, $1053,1055,1107$, I $159,1178,1183,1507,1754-56$, 1758

philosophical writings, $695-98$

poetry, I 727, 1731

Industrial trusts, 3121

Industrial Workers of the World, about, 6045,6360

Industrialization, $3073,3440,4586$, 5695

opposition to, 1809

Industry, 2824, 2826, 3969, 4095, 4320, $4345,590 \mathrm{I}-6,6030$

agricultural, 5847

govt. regulation, 5885,6006

hist., 4531, 5878, 5904, 5906

in art, $5762,5772,5801$

labor, 4408,4488

museums, 3049,4716

organization, 6004
Industry-Continued

soc. aspects, 5899

Ariz., 4199

Fernandina, Fla., 3844

Ill., 4131

Mitchell, S. Dak., 3899

N.C., 4090

N. Dak., 4165

Pacific Northwest, 421 2, 4214

Southern States, 4079, 4083-84

Tex., 4194

Tulsa, Okla., 4I 7 I

W. Va., 4089

Industry and state, 5885,6006

Inflation (finance), 5889

Information service, overseas, 3607

Inge, William, 1995-98, 2335-36

An Ingenue of the Sierras, 937

Ingersoll, Jared, about, 3257

Ingersoll, Robert G., about, 5476

Inglis, Ruth A., 4947

The Injustice Collectors, 1910

The Inmost Leaf, 2449

Inner Landscape, 2123

Inness, George, about, 5766

The Innocent Eve, 1642

The In nocents Abroad, 769-7 I

Inns. See Hotels, taverns, etc.

Inoculation (smallpox), 4826

Inquiries and Opinions, 2468

Inscription for the Entrance into a Wood, 217-19

The Inside of the Cup, 762

Installment plan, 5963

Instinct vs Reason-a Black Cat, 538

Institute for Education by Radio and Television, about, 5230

Institute for Religious and Social Studies, Jewish Theological Seminary of America, 5491

Instrumentalism, 5271, 5275, 5290, 5291,5295

Insular possessions. See Overseas possessions

Insurance, 5990, 5992

Intellect, 285

Intellectual America, 2399

Intellectual freedom, 5181, 5190

Intellectual life, 695-98, 6443

bibl., 3729

Colonial, 2549

colleges \& universities, 5190, 5213 foreign influence, $3737,3740,375^{8}$, 3768-80, 4536

hist., 2445, 2459, 2491, 2601, 3073, $3085-98,3150,3236,3297,3303$, $3313,3352,3728-80,4518,4520$, $5104,5261,6443,6446$

refugees, 4414

See also Culture; also subdivisions Intellectual life and History under names of places and regions, e.g., New England-intellectual life; Pennsylvania-hist.

Intelligence in the Modern World, 5287

Intelligence service, 3603

The Intent of the Critic, 2512

Inter-American commercial arbitration, about, 6299
International City Managers' Association, 6213

An International Episode, 1007

International law, 3526, 3530, 6277

International News Service, about, 2860

International organizations, 3548,3631 , 5946

International Printing Pressmen and Assistants' Union, about, 6455

International relations. See Foreign relations

International themes in literature

fiction, 971-72, 986-91, 996-100r, $1004,1007,1014,1242-47$, 1 249, I $251,1754,1758,1839,2187$

poetry, 1585

short stories, 986, 1004, 1011, 1242, 1248,1250

speeches, addresses, etc., 1585

International Trade Organization (proposed), 5953

International Typographical Union, about, 6455

The Interpretation of Dreams, 2407

Interstate Commerce Commission, about, 2678,5942

Interstate compacts, 6206

Into the Main Stream, 4443

Into the Valley, 1993

Intonation (language), 2275

Intruder in the Dust, 1392

Inventions, $4780-92$

hist., $4783,4787,4792$

protection \& management, $4780-8 \mathrm{I}$

Inventors, $4783,4785-87,4792$

Investments, 3639, 3641, 5993-94

in foreign countries, 5989, 6002

Investments, British, in U.S., 5980

Invisible Empire, 3386

Invisible Man, 1967

Involuntary Witness, 2376

Iowa, 2644, 3948, 4I 44

Fox Indians, 3041

guidebooks, 3889-94

hist., 3663,4144

Norwegians, 4487

politics, 6427

rural communities, 4109

Iowa in literature

fiction, 1 796, I 798-1 800, 1 830, 1969, 2161

personal narrative, 1543

poetry, 1968

short stories, $1796-97$, I 801

lowa Interiors, 1797

Iphigenia, 2101

Iran, relations with, 3513

Irene, 526

Iris, Federico Scharmel, 1530-31

Irish, 4435,4498

in Boston, 4410

in Brooklyn, 4046

in New England, 4413

Irish dialect in literature, 862

Iron, 406I , 4I I 3, 4I 4I-42, 5909, 59I 8

The Iron Chain, 2057

The Iron Heel, 1055

The Iron Pastoral, 2061

Ironwork, 5790

The Irony of Joy, 2350 
Iroquois Indians

hist., $3008,3230,4236$

language, 2364

wars, 3009

Irradiations, Sand and Spray, 1433

Irrigation, $4214,4383,5858$

Irvine, Rosalind, 5762

Irving, Washington, $38 \mathrm{I}, 2290,2295$, 2337

ed., 219

about, 405, 511,674, I 136,2277 , 2397, 2532, 2534

Irving, William, 5 I I

Irwin, Mary, ed., 5I6I

Irwin, Ray W., 3686

Irwin, Robert B., 4636

Irwin, William H., 4963

Is 5,1313

Is He Living or Is He Dead?, 798-99

Is It Going to Rain?, 74 I

Is Sex Necessary?, 1816

Isaacs, Edith (Rich), 4921, 4968 ed., 4910

Isaacs, Raphael, 5426 about, 5426

Isely, Jeter A., 3668

Island in the Atlantic, 1449

The Island of Barrataria, 2312

The Island of the Innocent, 1420

The Island Within, 1574

Isolationism, 3534, 3537, 3613

Israel, fiction, 1979

Israfel, 526, x 167

It Beats Working, 4991

It Can't Happen Here, 1566

It Pays to Advertise, 2348

Italian-American literature, 4497

The Italian Bride, 2303

The Italian Notebooks, 350

Italians, 4046, 4435, 4494, 4496-97, Italy 4598

fiction, 333, 971-72, 1000, 1496, 1499, 1940-41, 2087

relations with, 3507

travel \& travelers, $333,887,964,97$ I72,1149

It's an Old Wild West Custom, 5526

Iverson, William J., 5227

Ives, Burl, 5506

comp., 5553

about, 5553

Ives, Charles, about, 5682

Ives, James Merritt. See Currier \& Ives

Ives, Sumner, 226I

The Ivory Tower, 1004, 1008

Ivy, Andrew C., 48 r 8

\section{J}

Jablonski, Edward, 5678

Jack, P. M., 2406

Jack Cade, 2347

Jack tales, 5529, 5546

Jackson, Andrew, about, 2772, 2820, $3126,3315-18,3320,3352,4533$, $6177,6258,6359$

Jackson, C. D., 3615

Jackson, C. S., about, 2863

Jackson, Clarence S., 5777
Jackson, George Pullen, 5555, 5577 ed., 5554

Jackson, Harry P., 60I7

Jackson, Helen Maria (Fiske) Hunt, 984-85

Jackson, Joseph Henry, 1780, 3782

Jackson, Percival E., 6265

Jackson, Rachel, fiction, $\mathbf{2 8 2 0}$

Jackson, Thomas Jonathan ("Stonewall"), about, 245, I 809, 3697

Jackson, William, 6087

Jackson, William H., 5777 about, 5777

Jacksonian democracy, 3139, 3318-19, $3322,3351-52,6177,6351$

See also Democracy

Jacob, Philip E., 3649, 6124

Jacobs, Helen Hull, 5047 about, 5047

Jacobs, James Ripley, 3660

Jacobs, Lewis, 4944

Jacobs, Philip P., 4868

Jacobs, Robert D., ed., 2442

Jacob's Ladder, 1684

Jaffe, Bernard, 472I-22

James, Alice, 5319

about, 2476, 5319

James, Bartlett Burleigh, ed., 3208

James, Edwin, about, 4734

James, Frank Cyril, 5985

James, Henry (1811-1882), 2476, 5319 about, 2529, 5319-20

James, Henry (1843-1916), 986-I015, $1152,2290,5319$

ed., 5328

about, 817, 1015-22, II 49, 2376, $2385,2405,2476,2498,2539$, 2616,5319

bibl., 5328

James, Henry (1879-1947), 5335 ed., 5330

James, James Alton, ed., 3239

James, Macgill, 5758

James, Marquis, 331 6-1 8, 3341, 5992

James, Preston E., ed., 2938

James, Reese D., 5659

James, Will, 2699-2700 about, 2700

James, William, 5123, 5319, 5321-33, 5362,5431

ed., 5319

about, 2476, 3733, 3761, 5116,5222 , $5254,5264,5319,5321,5333-35$, $5354,5369,5389$

James, Sir William M., 3678

James family, 2476, 5319

James River, Va., hist., 3977

James Shore's Daughter, 1223

Jameson, John Franklin, 3045, 3057, 3064,3208

ed., 3201, 3210-11, 3252

about, 2974

Jameson, William J., 633I

Jamestown, Va., poetry, 1222

Jandy, Edward C., 4539

Jane, Lionel Cecil, ed., 3 163

Jane, 1212

lane Talbot, 117

Janeway, Eliot, 5879

Janis, Harriet (Grossman), 564I

Janis, Sidney, 5696
Janowsky, Oscar I., ed., 4457

Japan

economic relations with, $36_{3} 8$

in literature, $945,951-53,955$

relations with, $3483,3510,3538$, $3545,3590-91,3594,3619,3780$

Japanese, $2811-12,4204,4428$, 4465$66,4468-69,6$ 1 20

Jarratt, Devereux, about, 5463

Jarrell, Randall, 1999-2002, 2363 about, 2497

lava Head, 1508

Jay, John, 6075 about, 3304,3519

Jay, John C., 5062

Jay's Treaty, 3304

Jazz music, 564I-46

analysis, 5645

bibl., $564 \mathrm{r}$.

discography, 564I-42

influence on art, $569 \mathrm{I}$

See also Popular music and songs

Jean Huguenot, 1222

Jean-ah Poquelin, 748

Jeanie with the Light Brown Hair (song), 5677

Jeffers, Edmund V., 5670

Jeffers, Robinson, I 532-36, 2335 about, 2406, 2527

Jefferson, Joseph, 4934 about, 26I6, 4934

Jefferson, Thomas, I49-53, 2291, 2296, $2337,3292-94,5418,6073$

about, 46, 2775, 2996, 3281, 3294$97,4533,4753,5122,5291,5408$, 54I8, 6170,6359,6460, 6466, 6469

drama, 1477

sculpture, 5737

Jeffersonian democracy, 607 1, 6176 See also Democracy

Jeffords, Thomas J., about, 3035

Jehovah's Witnesses, about, 5404, 5439

Jenkins, William Sumner, 3389

Jennie Gerhardt, 1335

Jennifer Lorn, 1904

Jensen, Merrill, 3253, 3302 ed., 3785

Jersey City, politics, 6388

Jessop, G., 2301

Jessup, Philip C., 3459

Jesuits, $3075,3158,3171,5447$

Jeuck, John E., 5956

The lewel Merchants, 1262

Jewett, Charles Coffin, about, 6476

Jewett, Clarence F., 4036

Jewett, Sarah Orne, 1023-31

about, 881, 1278, 2476

bibl., 1023

Jewish-American literature, 4457-58

Jews, $1445,2585,4407,4428,4435$, $4452-62,5270,5459,5495$

biog. (collected), 4453

culture, 4452-53, 4456-59

econ. condit., 4457,4459

fiction, $\mathrm{I} 190,1571,1574,1578,1635$, I 92I-22, I979, I992, 2045, 2231

Polish, 1992

Baltimore, 4062

Brooklyn, 4046

Jim Bludso, 942-44 
lingling in the Wind, 1700

Joan of Arc

drama, I 172

fiction, 768

Joan of Lorraine, 1172

Job and His Children, 23 I I

The Jockey, 2024

loe, 1035

Joerg, Wolfgang L. G., 2937

Joffe, Natalie F., 304I

Johannsen, Albert, 2444

John, Walton C., ed., 5309

John Brown's Body, I 222, 1224

John Dawn, 1290

John Deth, a Metaphysical Legend, II 66

John Dewey Society, 5243

John Godfrey's Fortunes, 2282

John Marr and Other Sailors, 488

John of the Mountains, 1080

Johnny Appleseed. See Chapman, John

Johnny Johnson, I 475, 2333

Johns, Ethel, 4845

Johns Hopkins Hospital, about, 4819, $4829,4831,4845$

Johns Hopkins University, about, $483 \mathrm{I}$, 4845,5195

Johns Hopkins University. School of Medicine, about, 4819, 4821, 4829 , 4831,4845

Johns Hopkins University. School of Nursing, hist., 4845

Johnson, Allen, ed., 3080, 3158, 4792, 5 II 3

Johnson, Alvin S., 2701-2, 4513, 5219 , 5426

about, 2702, 5426

Johnson, Andrew, 3376

about, 336r-62, 341 I-1 2, 3447, 4103

Johnson, Burges, I I 15

Johnson, Charles A., 5407

Johnson, Charles S., 443-44, 5426 about, 5426

Johnson, Clifton, 214,2627

Johnson, Donald Bruce, comp., 6367

Johnson, Edward, 32 I I ed., 73-74

Johnson, Emory R., 5948

Johnson, Frederick Ernest, ed., 549 I

Johnson, G. Orville, 5207

Johnson, Gerald W., 2869, 2876, 3782

Johnson, Guy Benton, 5517, 5540, 556I

Johnson, H. B., 448 I

Johnson, Harold Earle, 5649 ed., 5626

Johnson, Icie F., 2887

Johnson, Jack, about, 5025

Johnson, James Weldon, 1537-40 about, 1539

Johnson, Joseph E., ed., 3562

Johnson, Mary Louise, 5021

Johnson, Orlin, about, 5016

Johnson, Pamela H., I 896

Johnson, Robert, 303 I

Johnson, Robert Underwood, 2923 about, 2923

Johnson, Samuel, 5251

Johnson, Thomas Cary, 4723

Johnson, Thomas H., 855 ed., $30,846,2345,2460-6$ r
Johnson, Tom L., 6429

about, 6428-29

Johnson, Walter, 2893

comp., 3079

ed., 3545,3567

Johnston, Alexander, 5029

Johnston, Henry Phelps, 4049

Johnston, James, about, 2856

Johnston, Joseph E., about, 26I3

Johnston, William Dawson, 6469

Johnswood, 1436

Joint-stock companies, 6008

The Jolly Corner, I008, I01 2, I01 4

Jolly Flatboatmen (painting), $576 \mathrm{I}$

Jonah's Gourd Vine, 1527

Jonas, Klaus W., I 834

Jonathan Draws the Long Bow, 5534

Jonathan Gentry, I 824

Jones, Barbara (Slatter), 5198

Jones, Bobby, about, 5048

Jones, Clarence F., 2975 ed., 2938

Jones, E. E. Duncan, 1367

Jones, Fred Mitchell, 5960

Jones, George, about, 2869

Jones, Howard Mumford, 2424, 2445$47,2521,3756,3774$

ed., 378, I 1 87, 234I, 2460-6I

Jones, James, 2003-4

Jones, John Paul, about, I 873

Jones, Joseph Cranston, silhouettes by, 5547

Jones, Joseph Stevens, 2347

Jones, Llewellyn Rodwell, 2939

Jones, Marcus E., about, 4734

Jones, Richard Seelye, 3645

Jones, Robert C., tr., 4472

Jones, Robert W., 2846

Jones, Rufus M., 5426

about, 5426, 5479

Jones, Victor, 62 I I

Jones, William Melville, ed., 6238

Joplin, Scott, about, 564 I

Jordan, David Starr, ed., 4724 about, $2623,376 \mathrm{I}, 5434$

Jordan, Donaldson, 3536

Jordan, Philip D., 4 I 21, 593 I ed., 4I 43

Jordy, William H., 3055

Jorgenson, Chester E., ed., I 3 I

Joseph, Samuel, 4460

Joseph and His Brethren, 2312

Joseph and His Friend, 2282

Josephson, Bertha E., ed., 3061

Josephson, Matthew, $3438,3460,5880$

Josh Billing's Farmer's Allminax, 542

Joslyn, Carl S., 6027

Journal-Courier (Louisville, Ky.), about, 2892

Journal for Josephine, 1640

Journal of a Visit to Europe and the Levant, 489

Journal of a Visit to London and the Continent, 489

The lournal of Albion Moonlight, 2081

Journal of American Folklore, 5518

Journal of Experimental Medicine, 4831

The Journal of Higher Education, 5244

The Journal of Madam Knight, 38-39

The Journal of Medical Education, 4855

Journal of Speculative Philosophy, 5305
The Journal of the AERT, 5230

A Journal of the Transactions and OCcurrences in the Settlement of Massachusetts, 91

Journal up the Straits, 489

Journalism, 4479, 6432

bibl., 2850

business, 2902

education, 2910

hist., $2845-48,2857,2930$

legal reporting, 6288

photography, 2908

policies \& practices, 2900-I 2

schools, 2889, 2910

Ga., 2856

Ohio, 2857

Oreg., $286_{3}$

See also Magazines; Newspapers

Journalists. See Authors as journalists; Newspapermen; Reporters and reporting; and names of individual journalists

The Journey, 1761

A Journey in the Back Country, 4366

A Journey in the Seaboard Slave States, 4364

lourney into Fame, 5736

lourney of Tapiola, 1635

A Journey to Greatness, 5678

Journey to Love, 1885

lourney to the Coastal Marsh, 535I

$A$ lourney to the Land of Eden, I3

Joyce, James, about, 1887

Judaism, $4457-58,5267,5404,5458$

Conservative, 5460

Reform, 5459

social thought, 5488

Judd, Sylvester, 402-4

Judge Not - 1192

Judges, 6roI, 6224, 6231, 6237-39, $6241-60,6264,6280-93,6320$

See also Lawyers

ludgment Day (Farrell), 1373

ludgment Day (Rice), 1689

The Iudgment of Paris, 2187

The Judgment of Solomon, 2312

Judicial administration, 6287,6309

Judicial branch, 6075, 6084, 61 $33,61_{37}$

Judicial decisions. See subdivision Decisions and opinions under Courts and under Supreme Court

Judicial error, cases, 6294,6298

Judicial-legislative relations, 6089

Judicial power, 6257

Judicial review, 6089, 6092, 6094-95, 6 IoI-2, 6164, 6238

Judicial statistics, 6280

Judiciary, state, 6293

Judson, Edward Zane Carroll, about, 2759

Judson, Isabella Field, ed., 4677

Julia Bride, 1008

Julian, John, 5633

Juneau, Solomon, about, 4140

The Iungle, 1754-55

Junior colleges, 5162

Junior high schools, 5157

Junius Redivivus, pseud., 4295

Jurgen, $126 \mathrm{I}-62$

Juries, 6295-96

Jurisdiction, 6281, 6290, 6293 
Jurisprudence, Colonial period, 6100

Jurists. See Judges; Lawyers

The Just and the Unjust, $130 \mathrm{r}$

Justice, 6219-6332

administration of, $4645,4656,6265$, $6280,6289-92,6297-98,6300$, $6305-9$

See also Law

Justice and Expediency, $66_{3}$

Justices of the peace, 6282,6307

Juvenile delinquency, $4639,4650,5028$ case studies, $465 \mathrm{I}$

causes, 4657

control, $4644,4651,4657$

hist., 4657

Juvenile literature. See Childrenbooks

\section{K}

Kabakoff, Jacob, 4458

Kadelpian Review, 5242

Kähler, Alfred, 52 I I

Kaempffert, Waldemar B., ed., 4787

Kahn, Ely J., Jr., 4935, 5636

Kahn, James M., 5008

Kalbfleish, Martin, about, 4735

Kalijarvi, Thorsten V., ed., 3635

Kallen, Horace M., 4457, 5124, 5254, 5290-91, 5331, 5335

ed., 5258, 5331

Kallir, Otto, ed., 2763

Kalm, Pehr, 4241-46

about, $424 \mathrm{I}$

Kalorama, Ior

Kammerer, Gladys M., 6159, 61 86

Kamphoefner, H. H., 4594

Kane, Elisha Kent, 2980 about, 2980

Kane, Harnett T., 3952, 6377

Kane, Henry B., illus., 1083

Kanin, Garson, 2334

Kansas, 2730, 3944, 3948, 3964, 4167-68

frontier life, 4156

guidebooks, $3904-7$

hist., $3990,4167-68,4189$

in literature, 1997

rural communities, 4109

soc. life \& cust., 4168

Kansas City

culture, 2887

politics, 6207

Kansas City Star, about, 2887

Kansas-Nebraska Act (1854), 3397

Kansas River, 3990

Kant, Immanuel, about, 5289

Kantor, J. R., 5335

Kantor, Mackinlay, I 54 I-44

Kaplan, Abraham D. H., 6020-2I

Kaplan, Morton A., 3630

Kappa Delta Pi, about, 5242

Karolik, Mr. \& Mrs. Maxim, 5745

Karpel, Bernard, 5696

Karpeles, Maud, ed., 5583

Karr, Jean, 1487

Kaser, David, 645 I

Katharine Walton, 547

Kauffman, Henry, 5787
Kaufman, George Simon, I 403, 149 I, I545-50, 2327, 2332-34, 2348

Kaufman, Paul, 2424

Kaufmann, Edgar, ed., 5712

Kaufmann, F., 529 I

Kavanagh, 430

Kaw River, 3990

Kaysen, Carl, 6oro

Kayser, S. S., 4458

Kazeck, Melvin E., 4165

Kazin, Alfred, 6ro, 2412, 2448-49, 2703-4

ed., 1348,1430

about, 2704

Kearney, James J., ed., 6276

Keefer, Elizabeth E., illus., 5520

Keefer, Lubov, 3751

Keelboats, 41 10, 428I

Keeler, Oscar B., 5048

Keeley, James, 2862

Keenleyside, Hugh Llewellyn, 3555

Keep, Austin Baxter, 6468

Kegley, Charles W., ed., 5432

Keim, Sarah, about, 4818

Keith, E. Gordon, 5971

Keller, Franklin J., 5156

Keller, Helen Adams, 2705-9 about, 2706-8

Keller, Robert J., ed., 5202

Kelley, Pearce C., 5949

Kelley, Robert F., 5020

Kelley, Stanley, Jr., 6345

Kellog, Ansel Nash, about, 2864

Kellogg, Charles E., 2944

Kellogg, Louise Phelps, ed., 3212

Kellogg, Remington, 2955

Kellogg, Idaho, $41_{7} 6$

Kellor, Frances A., 6299

Kelly, Alfred H., 3058, 6077, 6128 ed., $6 \mathrm{I}_{2} 8$

Kelly, Clyde, 4668

Kelly, Fanny, about, 3032

Kelly, Fred C., 4788 ed., 705

Kelly, George, 2332, 2348

Kelly, Howard A., 4872

Kelly, Melville Clyde, 4668

Kelly, Robert L., 5183

Kemler, Edgar, 1606

Kemmerer, Donald L., 5986

Kemmerer, Edwin Walter, 5986

Kempfer, Homer, 5209

Kendall, George Wilkins, about, 287 I

Kendall, John S., 4922

Kendall, Patricia L., 4701

Kendrick, Myron Slade, 5969

Kenkel, William F., 4549, 4619

Kennan, George, 3625,5932

Kennebec River and valley, 1290, 3793 , 3973

Kennedy, Albert J., 4624

Kennedy, Gail, 5189 ed., 3112-15, 5199

Kennedy, John Pendleton, 405-14, 2296

Kennedy, Richard, ed., 3145

Kennedy, Stetson, 3953

Kenner, Hugh, 1671

Kent, Donald Peterson, $44 \mathrm{I} 4$

Kent, Frank R., 2876, 6333-34, 6359

Kent, James, 6277

about, 6223,6231
Kent, Rockwell, 5021

about, 5783

Kent, Sherman, 3603

The Kentuckian, 518

The Kentuckian in New York, 226

Kentucky, 3963, 4079, 4ro6-7

caves, 2946

culture, 3737

folklore, 5529,5546

folksongs \& ballads, 5584

frontier \& pioneer life, $2667,2726-$ 27,4098

guidebooks, $3856-60$

hist., 3240, 3983, 4106-7

language (dialects, etc.), I697, 2257

legends, 5529, 5546

soc. life \& cust., 5584

travel \& travelers, $366,4276,4283$, 4310,4322

Kentucky Derby, 5057

Kentucky in literature

editorials, sketches, etc., 7I 6-17

fiction, 202-4, 322, 516, 546, 550, $716,718,766-67,1464-65,1468-$ $69,1511,1697-99$, 1701, I 705, $2166,2169,2173,2193-94,2199$, 2201

personal narratives, 2166

poetry, 21 66, 2I 72, 2193, 2196, 2200 short stories, $716,1697,1703,1706$, 2166-68, 2 1 70-71

Kentucky River, 3983

Kentucky Tragedy (1825)

drama, 365

fiction, 365, 550, 2199

Kenyon, John Samuel, 2273 ed., 2238

The Kenyon Critics, 2559

The Kenyon Review, 2559

Keogh, Andrew, about, 6470

Kepler, Thomas S., ed., I 83

Keppel, Frederick Paul, about, 5197

Kerfol, I 851

Kern, Alexander, $240 \mathrm{I}$

Kern, Jerome, about, 5639

Kerr, Chester, 6439

Kerrison, Irvine L. H., 5210

Kertzer, M. N., $445^{8}$

Kerwin, Jerome G., ed., 3646

Kesselring, Joseph, 2334

Kessler, Henry H., 4637

Ketchum, Marshall D., 5994

Kettell, Russell Hawes, ed., 5729

Key, Valdimer O., 6335, 6378

$A$ Key into the Language of America, 85,89

Key Largo, 1174

Key West, guidebook, 3845

Key West, 1304

Keyes, Erasmus Darwin, 2710-I I about, 27 I I

Keys, Alice Mapelsden, 3194

The Keys of the Kingdom of Heaven, 19

The Kid, 1166

Kidd, William, Captain, about, 6229

Kienitz, John F., 3785

Kieran, John, 4988

Kies, Marietta, ed., 5308

Kiewiet, Cornelis W. de, 4428

Kikuchi, C., 4469 
Kilpatrick, William H., 51 23, 5289

Kimball, Fiske, 5713

Kimball, J. Golden, about, 5538

Kimball, Sidney Fiske, 5713

Kimble, George H. T., 2950

Kimbrough, Emily, 2809

Kimmel, Stanley P., 4938

Kin, David, pseud., 3152

Kincer, Joseph B., 5816

Kindergartens, 5105,5148

King, Clarence, 42 I0

King, E. J., 5577

King, Grace Elizabeth, 1032-37, 2296 about, 1136

King, Henry C., about, 5428

King, Mrs. Marion M., 6468

King, Willard L., 6244

King Cotton Diplomacy, 3539

King George's War (1744-48), 317 I

King Jasper, 1714

King of the Delawares, 2835

King of the Fur Traders, 2831

King Philip's War (1675-76), 3213 fiction, I 44I

King William's War (1689-97), 3171, 3213

The Kingdom of God in America, 5399

Kingdom of the Saints, 5465

The King's Henchman, 1608

Kingsblood Royal, 1569

Kingsley, J. Donald, 6188

Kingsley, Sidney, 2327, 2333-36

Kinne, Wisner Payne, 4940

Kinneman, John A., 4576

Kinney, Jay P., 3029

Kino, Eusebio Francisco, about, 3158

Kinsey, Alfred C., 4565-66

Kintner, William R., 3629

Kiowa Indians, 3007, 3035, 4160

Kiplinger, Willard M., 4065

Kipnis, Ira, 6360

Kirby, Gustavus T., 4989 about, 4989

Kirk, Clara M., ed., 983

Kirk, Grayson L., 361 4, 4045

Kirk, Rudolf, ed., 983

Kirk, Russell, 2621

Kirk, Samuel A., 5207

Kirkland, Caroline Matilda (Stansbury), 415-1 8

Kirkland, Edward C., 5881, 5933

Kirkland, Jack, 1271, 2333

Kirkland, Joseph, about, 2419

Kirkpatrick, Frederick A., 3165

Kirkpatrick, Sidney D., ed., 4793

Kirstein, Lincoln, 4968

Kiser, Clyde V., 4396

Kitsuse, John I., 4469

Kittredge, George Lyman, 5541, $555^{8}$ about, 5222

Kleeberg, Gordon S. P., 636r

Klees, Frederic, 4480

Klein, Arthur J., 5186

Klein, David, 5021

Klein, Philip, $459 \mathrm{I}$

Klem, Margaret C., 4887

Klineberg, Otto, ed., 4446

Klinkhamer, Marie Carolyn, Sister, 6245

Klipstein, August, about 4735

Klipstein, Ernest C., about, 4735
Klondike, short stories, $1048-52,1058$

Klondike gold rush, 2719-20

Kluckhohn, Clyde, 3015

Knapp, Robert H., 4725

Knapp, Seaman A., about, 5851, 5859

Knave and Queen, 2307

Knickerbocker, Diedrich, pseud. See Irving, Washington

Knickerbocker Group, 2295

The Knife of the Times, 1872

Knight, Edgar W., 5108

Knight, Grant C., 716, 2450-51

Knight, Henry Cogswell, 4284 about, 4283

Knight, Sarah (Kemble), 36-39

A Knight-Errant of the Foothills, 937

Knight's Gambit, 1393

Knights of Labor, about, 6034, 6054

Knights of Pythias, 4574

The Knights of the Horseshoe, 228-29

Knorr, Frederick, tunes arr. by, 559 I

Knott, Thomas Albert, ed., 2238

Know-Nothings, 4515

Knowing and the Known, 5286

Knowlton, E. H., 5913

Knox, Dudley W., 3667

Knox, Israel, 5483

Knox, Samuel, about, 5121

Kob, Walter, music arr. by, 5584

Kober, Arthur, 2327

Koch, Adrienne, ed., 3279

Koch, Robert, about, 4868

Koch, Vivienne, 1886

Kocher, Alfred Lawrence, 4086

Koenig, Samuel, 4407

Köppen, N., ed., 2953

Koht, Halvdan, 3769

Kolb, John H., 458I

Kolehmainen, John I., 2896

Kollmorgen, N. M., 4479

Kolodin, Irving, 5657

Komarovsky, Mirra, 4577

Konefsky, Samuel Joseph, 6250, 6266

Konvitz, Milton R., 5291, 6120-23, 6129

Kooken, Olive, 4930

Koos, Leonard V., 5157

Koppman, Lionel, 446r

Kora in Hell, $188 \mathrm{r}$

Korean War, 2746, 3597, 3738

Korn, Bertram Wallace, 446r

Korson, George G., ed., 5578-79

Korzybski, Alfred, about, 5392

Kosciuszko, T., about, 3250

Kossuth, Louis, about, 4360-6I

Kotto, 951-52

Kotzebue, August von, 2299

Koury, Phil A., 496I

Koussevitzky, Serge, 5678 about, 5648-49

Kouwenhoven, John Atlee, 4045, 569 I

Kraenzel, Carl Frederick, 4159

Kramer, Dale, 4963 ed., 2565

Krapp, George P., 2246

Krauch, Elsa, tr., I I9I -92

Kraus, Michael, 3056-57, 3770, 45 I 8 ed., 2294

Krech, David, 5390

Krehbiel, Henry Edward, 5564, 565859
Kreidberg, Marvin A., 366r

Kreymborg, Alfred, ed., 2342

Krieger, Murray, 2452

Kriesberg, Martin, 3615

Krinsky, Fred, ed., 3108

Kroeber, Alfred L., 2983, 3002

Kronenberger, Louis, 2406-7 ed., 4897

Krooss, Herman E., 5973

Krout, John Allen, 3090, 4528, 4990 ed., 4047

Krutch, Joseph Wood, 590, 2287, 2348, 2453, 4900

$\operatorname{Ktaadn}, 594$

$\mathrm{Ku}$ Klux Klan, hist., 3386

Kull, Irving S., 3077

Kull, Nell M., 3077

Kunitz, Stanley J., ed., 2454-55

Kuniyoshi, Yasuo, about, 5783

Kurath, Hans, 2243, 2269 ed., 2268

Kurtz, Stephen, 3279

Kurtzman, David Harold, 6389

Kuykendall, Ralph S., 4220

Kwaidan, 951-52, 955

Kyrk, Hazel, 4567

\section{L}

La, La Lucille (music), 5678

Labaree, Leonard Woods, 3195

Labatut, Jean, ed., 5934

Labor and capitalism, 3439, 6094

Labor and laboring classes, 3440, 4408, $5905,6031-58$

addresses, essays, lectures, etc., 235, 239

agriculture, 5846

British immigrants, 4488

Colonial period, 3740

education, 5210,5243 See also Vocational education

fiction, 941, 973-76, 1656-57, 1754$56,1775,1777,2578$

folklore, 5523

hist., 3425, 6033-34, 6057

Irish immigrants, 4498

laws \& legislation, 6033,6053

Mexican immigrants, 4476

poetry, $106 \mathrm{r}-63$

radicalism, 6039

Cripple Creek, Colo., 4I 74

Nueces County, Tex., 4476

The West, 4 I 49

Labor disputes, 6058

See also Industrial relations; Strikes

Labor-management education, 5210

Labor-Management Relations Act (1947), 6053

Labor movement, 3425, 3427, 3439, $3446,4216,4458-59,6356,6372$, 6426

Labor relations. See Industrial relations

Labor supply, 4392, 4401, 6037, 6040

Labor turnover, 6038

Laboratories, directory, 4720

Lace and lacemakers, 5793

Ladies and Gentlemen, 1263

Lady Baltimore, I 145 
Lady Barberina, 1007

Lady Franklin Bay expedition, 298 I

The Lady Is Cold, 1859

The Lady of Fashion, 4927

The Lady's Maid's Bell, 1855

Laemmar, Jack W., 4696

LaFarge, John, 4428, 5447

La Farge, Oliver, $1551-53,3039$

Lafayette, Marquis de, about, 3247-50 portrait, 5769

La Follette, Belle (Case), 3461

La Follette, Fola, 346r

La Follette, Robert M., about, 3446, $346 \mathrm{r}, 6432$

La Follette, Suzanne, 5692

La Fontaine, Jean de. Fables, translation (Creole), 2265

La Guard, Theodore de, pseud. See Ward, Nathaniel

La Jolla, Calif., 2746

Laissez-faire. See Free enterprise

Lamar, Lucius Q. C., about, 3364

Lamb, Charles, about, $38 \mathrm{I}$

Lambert, B., tr., $427^{8}$

Lamberton, Bernice (Grieves), 239

Lamers, William M., 4527

Lamke, Tom A., ed., 5247

Lamont, Thomas W., 5987

The Lamp and the Bell, 1608

Lamprecht, S. P., 5289

Lamps, 5786

Lancaster, Lane W., 6212

Lancaster County, $\mathrm{Pa} ., 4058$

Lancelot, I 7 I 4

Land, 5808-18

Colonial period, 3740

law. See Land tenure

monopoly, 4535

utilization, $5810,5817-18$

Calif., 4202

Chicago, 5812

New England, 5840

Texas, 4193

The West, 4149

$A$ Land and a People, ror 9

Land-Grant College Act, 5113,5186 , 5191

Land-grant colleges, 5186,5191

The Land Lies Open, 4142

The Land of Little Rain, 1197

The Land of Silence, 2126

Land of Their Choice, 4485

Land of Unlikeness, 2008

Land tenure, 4266, $5811,6120,6230$, 6278

Indian, 3029, 3043

New York (Colony), 3200

The West, 3237

Land Where Time Stands Still, 2753

Landis, James M., 6286, 6312

Landis, Kenesaw Mountain, about, 5015

Landis, Paul H., 4568

Landon, Melville D., 212

Landor, Walter S., about, 2545

Landsberg, Hans H., 5819

Landscape West of Eden, I 166

Lane, Wheaton J., 5935 ed., 5934

Laney, Al, 2872

Langbein, Walter B., 2949

Langdon, William Chauncy, 4529
Langeluttig, Albert G., 6226

Langer, William L., 3537-38

Langford, Sam, about, 5025

Langland, John, 2350

Langley, Samuel Pierpont, 4726

about, 4721, 4775

Langner, Lawrence, 4941

Language, $2236-75,2466,3737,3740$, 5291

atlases \& maps, 2268-69

dialects \& regionalisms, 2240-4I, 2244-46, 2248, 2253-71, 4093, $4098,4198,4271,4436,5516$, $5526,5531,5533,5536,5540$ See also Dialects in literature

dictionaries, 2236-41, 2246, 2253, 2259, 2264, 2266, 2272, 2274, 5127

essays \& studies, $2364-68,2466$ grammars, 2242-44, 2249, 2265-66 slang, 2248, 2253, 2272, 2274, 5503, 5507,5578

Language As Gesture, 1228, 1233

Lanham, C. T., 4513

Lanier, Henry W., ed., 886

Lanier, Mary (Day), ed., 1040-43

Lanier, Sidney, $1038-47,2296$

about, 2277, 2280, 2422, 261 6 bibl., 1046

Lanny Budd Series, 1758

Lansing, John, 6087

Lanterns on the Levee, 2779

Lapham, Jesse E., 2947

Lapham, Macy H., 2947

Lardner, John, 4991

Lardner, Ring, 1545, 1554-55 about, 2428

Larkin, Oliver W., 4676, 5693

Larks in the Popcorn, 2152

Larned, Kans., guidebook, 3905

La Rochefoucauld-Liancourt, François Alexandre Frédéric duc de, 426768

about, 4266

Larsen, Roy E., 5145

Larson, Adlowe L., 5845

Larson, Cedric, 3462

Larson, Henrietta M., 5988, 6007

Las Vegas, Nev., 4184, 5059

Laserson, Max M., 3564

Lasker, Bruno, 4470

Laski, Harold J., 2542, 4512

Lasswell, Harold D., 6130

The Last Adam, 1299

Last Chapter, 2745

The Last Circle, 1222

The Last Duel in Spain, 2303

The Last Frontier, 1975

The Last Look, I 827

The Last Man, 2310

Last of the Bad Men, 2758

The Last of the Mohicans, 258

The Last of the Provincials, 2429

The Last of the Valerii, 1012

The Last Puritan, 1736

The Last Trek of the Indians, 3027

The Lasting Elements of Individualism, 5313

Late City Edition, 2903

The Late George Apley, 1549, 1590

Latham, Earl, ed., 3107-36
Lathrop, George P., 35 I

ed., $34^{\circ}$

Latin America

documents, 3575

economic relations with, 3546,3638

in literature

fiction, 2185

short stories, 1 I 11 - 13

independence, 3569

relations with, $3442,3515,3549$, $3554,3574,3676,3578-80,3617$, $3619,3632,3635$

technical assistance to, $364 \mathrm{I}$

travel \& travelers, 1445

Latourette, Kenneth S., 3596, 5466

Latrobe, Benjamin Henry, abot1t, 5708

Laughing Boy, 1551-52

Laughing in the lungle, 2579

The Laughing Matter, 2122

Laughing to Keep from Crying, 1524

Laughlin, James, ed., 2560

Laughlin, Ledlie Irwin, 5788

The Launching of a University and Other Papers, 5195

Laurents, Arthur, 2334

Laurie, Joseph, 4892, 4974

Lavender, David, 4I 74

La Verendrye, Sieur de, about, 3170

La Violette, Forrest E., 4466

Law, 6219-6332

anecdotes, facetiac, satire, etc., 194-97, 556-57

codification, 6236

Colonial period, $75,78,6230,6232$, 6234

digests, $6271-79$

hist., 6166, 6219, 6225, 6230-31, 6236

Baltimore, 6284,6291

Boston, 6292

La., 6245

Md., 6284

Mass., 6228, 6242, 6292

Nebr., 6233

New York (Colony), 6221

The West, 6220

philosophy, 3728, 5269, 5290, 529I study \& teaching, 6270, 6289, $6317-18,6321,6326-27$

theory, 6263

Law, administrative, 6090, 6181, 6201, $6310-16$

Law, constitutional. See Constitutional law

Law, corporation, 6008, 601 1, 6236

Law, criminal. See Criminal law

Law, ecclesiastical, 5420-22

Law, election, 6338, 6400, 6403, $6406-8,6410$

Law, immigration, 4404-5, 4420, 4425, 4468

Law, international, $3526,3530,6277$

Law, land. See Land tenure

Law, libel, 2906, 293 1-32

Law, municipal. See Municipal law

Law, public health, 4876

Law and ethics, $6261-62$

Law enforcement, 6309

A Law for the Lion, 1912

Law libraries, 6328 
The Law of Civilization and Decay, 2601

Law reform, 6285, 6302-3

Mass., 6292

Lawrence, David Herbert, 2456

Lawrence, Ernest Orlando, about, 4721

Lawrence, J. E., 6195

Lawrence, William, Bp., about, 5457

Lawrenceville School, about, 5155

Laws, George Malcolm, 5556

Lawton, Sherman P., 4691

Lawyers, 3746, 6ror, 6224-25, 6231, $6236,6311-32$

See also Judges

Lay My Burden Down, 5515

Lazarsfeld, Paul F., 4701, 6414, 6419 ed., 3724

Lazarus Laughed, $1647-48$

Lazzaro, Ralph, 5424 comp., 5400

Lea, M. Carey, about, 4740

Lea and Febiger, about, $645 \mathrm{I}$

Leach, H. S., ed., 3469

Leach, MacEdward, 5550

Leach, Maria, 5506

Leacoc', John, 2347

Leader of the Revolution, 3260

The League of Frightened Philistines, 1375

League of Nations, 3534, 3541, 3632

Leander, Folke, 2375

The Leaning Tower, 1662

Lear, Walter J., 4887

Learned, Henry Barrett, 35 I9, 61 45

Learning and scholarship, 3739, 4458-59

Leary, Lewis G., 2457, 2552 ed., 1672

Leatherstocking Tales, 258

The Leatherwood God, c8o

Leavenworth, Kans., guidebook, 3906

Leaves from the Diary of an Impressionist, $951-52$

Leaves of Grass, 619-30, 636-37, 639, 642

about, 656

concordance, 653

Leaves of Grass One Hundred Years After, 656

Lebhar, Godfrey M., 596I

Leckie, George G., 3837

Le Clair, Robert C., I021

Lecture at Amory Hall, 286

Lectures and lecturing

(1820-70), 186, 192, 209, 230, $233-35,280,283-84,286,313$, $531,538,542$

(1871-1914), 745,768, 900, I I 26

(1915-39), 1235, 1445, 1585, 1783, 1823

Lectures on Modern Idealism, 5354

Ledésert, Margaret, tr., 4508

Le Duc, Thomas H., 5200

Ledyard, John, about, 3154

Lee, Alfred McClung, 2847

Lee, Charles, $6_{4} 6_{3}$

Lee, Charles, General, about, 3149

Lee, Gordon C., 5109

Lee, "Mother Ann," about, 5469

Lee, Richard, about, 325 I
Lee, Robert E., about, 245, 1099, 1267 , 2580, 26r $2,3388,3694-95,4533$

Lee family, about, 3251

Lee's Lieutenants, 3695

Leffler, George L., 5982

Lefler, Hugh Talmage, 4090

Legal aid, 6309, 6317, 6329-30

Legal education. See Law-study \& teaching

Legal ethics, 6319-20

Legal institutions, 6289

Legal philosophy, 5269, 5290-91, 6266, 6268

Legal profession, 631 7-32

Le Gallienne, Eva, 4936

about, 4936

Legaré, H. S., 2296

The Legend of Sleepy Hollow, 381

Legends and tales, 5503-5548

See also Folk heroes; and under regions, ethnic groups, etc., e.g., Indians, American-legends \& tales

Legends of the Old Plantation, 9 I I

Legends of the West, 322

Leggett, William, 2295

Legislation, 6142, 6153, 6165-67, 6198

Legislative branch, $6075,6 \mathrm{I}_{33}, 6 \mathrm{I}_{40} 0$

functions, 6 I 37

Legislative investigating committees, 6342

Legislatures, 6153, 6195, 6203, 6338, 6434

Colonial period, $640 \mathrm{r}$

committees, 6156

functions, $6166-67$

organization, $6166-67$

rules \& practice, $6166-67$

Le Goullon, Lamartine, illus., 5553

Lehmann-Haupt, Hellmut, 6440

Leidecker, Kurt E., 5309

Leidy, William Philip, 6452

Leigh, Robert D., 6479-80 ed., 6485

Leighton, Isabel, ed., 3488

Leighton, J. A., 5252

Leisure. See Recreation

Leisure class. See Upper class

Leisy, Ernest E., 2424, $245^{8}$ ed., 411,234 I

Leiter, Robert David, 5619

Leites, Nathan, $495 \mathrm{I}$

Lenin, Nikolai, about, 2407

Lenox, James, about, 6465

Leonard, John P., 5158

Leonard, William Ellery Channing, 1556-58

Leone, Lucile Petry, about, 4854

Leong, Gor Yun, 4467

Leonor de Guzman, 207-8

Leopold, Richard William, 2712-13 ed., 3100

Lerner, Max, 2407 ed., 6242

Leroux, Emmanuel, 5254

Lerwill, Leonard L., 3665

Lescohier, D. D., 6033

Lester, John A., ed., 5063

Lestschinsky, Jacob, 4459

Le Sueur, Meridel, 3954

Let Freedom Ring, 6127
Let It Come Down, 1930

Let Me Lie, 1267

Let Us Now Praise Famous Men, 1907

Let Your Mind Alonel, 1817

$A$ Letter Addressed to the People of Piedmont, 103

$A$ Letter on White-Washing, 148

$A$ Letter to His Countrymen, 262

$A$ Letter to Robert Frost and Others, 1515

$A$ Letter to the National Convention of France, 103

Letters

Colonial period, $x 4,58,89-91$

(1764-1819), 96-101, 109, 122, 129, 132-33, 17 1, 177

$(1820-70), 244,270,296,329,377$, $392,438,449,462,466-67,469$, $502,532-33,554,577,599-601$, $639,643,672$

(1871-1914), 699-700, 738, 745, $75 \mathrm{I}, 800-2,847-50,951-53,981$, $1005-6,1046,1152$

(1915-39), I I 87, 1 305, 1570, 1608, 1664, 1713, 1715-16, 1741, 189394

Letters and Leadership, 2380

Letters from an American Farmer, 4500-I

Letters from the West, 320

Letters from under a Bridge, 675

Letters of a Traveller, 222

Leuchs, Fritz A. H., ed., 608

Levant in literature, 489

Le Veillard, Louis Guillaume, tr., 126

LeVene, Clara Mae, 4754

Levenson, Jacob C., 3055

Levenson, William B., 5230

Levi, Werner, 3556

Levin, Harry, 2412

Levine, Isaac Don, 3647

Levinger, Lee J., $446 \mathrm{I}$

Levy, Beryl Harold, 5459

Levy, Leonard W., 6228

Levy, Marion J., Jr., 4550

Lewinson, Paul, 6379

Lewis, Benjamin M., 2915

Lewis, Cleona, 5989

Lewis, Edith, I 282

Lewis, Edward R., 6064

Lewis, Edwin, about, 5433

Lewis, George T., about, 4735

Lewis, Harold MacLean, 4607

Lewis, John L., about, 6049

Lewis, Lloyd, 3696, 3699, 41 35

Lewis, Meriwether, 3298 about, 3167,3299

Lewis, Nelson P., 4607

Lewis, Orlando F., 4653

Lewis, Oscar, 3955

Lewis, Richard W. B., 2459

Lewis, Sinclair, 1559-70 about, 2406, 2429, 2504

Lewis, Theodore H., ed., 3217

Lewis, Wilmarth S., 6464

Lewis and Clark Expedition, 3298

Lewisohn, Ludwig, 1571-79, 4501

Lexington, $\mathrm{Ky}$. guidebook, 3859

intellectual life, 3767

Leyda, Jay, ed., 493, 495, 501 
Leys, Wayne A. R., 4428

Libel law, 2906, 2931-32

Liberal Catholic Church, about, 5439

Liberal education, 5100, 5187, 5190, 5196-97, 5199, 5246

See also General education

The Liberal Imagination, 2519

Liberal Republican Party (1872), 6369, 6427

The Liberal Tradition in America, 6063

Liberalism, 3766, 4530, 5270, 5284, $5425,6061,6063,6065,6070-71$, 6164

Liberator, about, 3380

The Liberties of the Massachusetts Collonie in New England, 78

Liberty, 1 329, 3143, 3250, 3256, 3279, $3308,3313,3381,3747,4258$, $4370-71,4502-3,4513,4543$, $6060-61,6063,6068,6071,6079$, 6094, 6099, 6108, 6127-28, 6130, 6134

See also Democracy; Politics

Liberty against Government, 6094

Liberty of the press. See Freedom of the press

Librarians, 6466, 6474, 6476, 6479, 6481,6485

The Librarians' Conference of 1853. 6486

Libraries, 6452, 6466-75, 6477-84, 6486-87

Colonial, 14, 40, 73

reference dept., $648_{3}$

stat., 6474

Ariz., 4199

Charleston, S.C., 3763

Chicago, 6473

III., 6473

Middle States, 6472

Mo., 4108

Nashville, 3765

New England, 2549, 3745, 6472

New York (City), 4049

New York (State), 6468

See also special types of library, e.g. Law libraries; Public libraries

Library of Congress, 5807 about, 6460

hist., 6469

Library of Congress. Aeronautics Division, 4788

Library of Congress. Jefferson Collection, 6460

Library of Congress. Legislative Reference Service, 6102

Library of Congress. Prints and Photographs Division, 5807

Library of Congress. Reference Dept., 659-60

Library of the World's Best Literature, 1136

Library schools, 6479,6485

Library science, $6452,6454,6460,6474$," $6478,6481,6484$

research, 6487

study \& teaching, 6479,6485

Library surveys, $6477,6480,6482$

Lichten, Frances, 5599

Liddell Hart, Basil H., 3699

Lidice, Czechoslovakia, poetry, 1608
Lie Down in Darkness, 2175

Lieb, Frederick G., 5014

Lieberman, Herman, I 195

Lieberman, Judith Berlin, 5427 about, 5427

Liebling, Abbott J., 2904

Lief, Alfred, ed., 6247

Life adjustment education, 5224, 5235 . 5237,5240

Life along the Passaic River, 1872

Life among the Modocs, 1065

Life and Death of an Oilman, 2731

Life and Gabriella, $1_{4} 61$

Life and Liberty in America, 4370-71

The Life and Times of King Cotton, 5822

Life Doubles in Brass, 4973

Life in a Putty Knife Factory, 2150

Life in America, 5801,5804

Life insurance, 5991-92

Life Is My Song, 1432

Life (magazine), about, 2908

The Life of Billy Yank, 3705

The Life of Johnny Reb, 3704-5

The Life of Poetry, 2105

The Life of Reason, 5367, 5375

Life on the Mississippi, 784-86, 811

Life on the Texas Range, 4153

Life with Father, 131 7-18, 2327, 2334

Life with Mother, 1318

Light in August, 1386

The Light in the Forest, 1696

The Light of Distant Skies, 5751

Light up the Sky, 1492

The Lightning-Rod Man, 484

Lighting, Colonial, 5786

Lilienthal, David E., 5892

Liljeblad, S., 2364

Liljegren, Sten B., 2364, 2367

Lillard, Richard G., 2402, 3101, 4184

Lillibridge, George D., 3778

Lima, Ohio, guidebook, 3869

The Limestone Tree, 1511

The Limits of Evolution, 5317

Limners and Likenesses, 5747

Lin McLean, I 45

Linblad, K. E., 2364

Lincecum, Gideon, about, 4734

Lincoln, Abraham, 419-21, 3390, 3395 about, 557, 941, 1 727-29, 1873, 2542, $2757,2824,3382,3391-95,3416$, $3426,3706,4533,5186,6081$

bibl., 2757, 3395

drama, 1752

fiction, $332,763-65,876-77,2821$

poetry, 206, 459, 623, 1061 sculpture, 5736-37

Lincoln, Charles H., ed., 55, 3213

Lincoln, Mary Todd, fiction, 2821

Lincoln, Nebr., guidebook, 3903

Lincoln Finds a General, 3706

Lincoln Memorial (Washington, D.C.), 5736

Lind, John, 4143

Linda Condon, 1509

Lindbergh, Charles Augustus, $2714^{-15}$ about, 271 5, 4533, 5938

Lindeman, Eduard C., ed., 301

Lindheimer, Ferdinand Jakob, about, 4734

Lindholm, Richard W., 5943
Lindley, Harlow, $4 \mathrm{I} 2 \mathrm{I}$

Lindner, Robert Mitchell, 2716-1 8

Lindquist, Everet F., ed., 5229

Lindquist, Gustavus E. E., 3040

Lindsay, Howard, 1 31 7, 2327, 2334-35

Lindsay, Nicholas Vachel, 1580-81 about, 1582, 2419

Lindsey, Almont, 3439

Lindsley, Philip, about, 3765

Line, Ralph Marlowe, 5715

The Line of Love, 1262

The Lineage of Lichfield, 1262

Linford, Dee, 4176

Linford, E., 6195

Lingelbach, William E., about, 4059

Lingg, Claire, 4865

Linguistic Atlas of New England, 2268

Link, Arthur S., 3472-73, 3489 ed., 3100

Link, Eugene Perry, 3300

Linscott, Eloise Hubbard, ed., 5580

Linscott, Robert N., ed., 940

Linton, Ralph, ed., $304 \mathrm{I}$

The Lion and the Honeycomb, 1234

The Lion and the Rose, 2124

The Lion of the West, 518

Lionizing, 529

Lipman, Jean (Herzberg), 5601

Lippmann, Walter, comp., 3634

Lipset, Seymour Martin, 6455

Lipsius, Morris, ed., 2274

Lipson, Leslie, 6203

Lisbon, Portugal, fiction, 2092

The Listening Landscape, 1906

Litchfield, Edward H., 6420

Literary annuals, 2518

The Literary Apprenticeship of Mark Twain, 816

Literary Centres, 896-97

Literary composition, theories, $40,47-$ 48,618

Literary Culture in Early New England, 2549

Literary Encounters, 1277

The Literary Fallacy, 2417

Literary form, 2388

Literary Friends and Acquaintances, 979

The Literary History of the American Revolution, 2522

Literary History of the United States, $601,670,2460-61$

Literary Importations, 134

The Literary Life in America, 2380

Literary Opinion in America, 2550

Literary Pioneers, 2462, 3776

Literary Prophecy, 896-97

The Literary Record, 2355

Literary research, essays \& studies, 236468

Literary Review, 689

The Literary Situation, 2409

Literary Values, 740

The Literati, 520, 533

The Literati of New York City, 415

Literature, 1-2235

and land, 6262

anthologies, collections, \& series, 2276-2370, 2383, 2551, 2554, $2557,2559-60,2563,2565-66$, 2569, 2571, 3142 
Literature-Continued

bibl., 2393, 2402, 2448, 2460, 255253,6467

biographical series, 2276-89

dictionaries, handbooks, etc., 2433 , 244 I , 2447, 2454-55

esthetics, 2387, 2512, 2529

experimental writing

drama, 1357, 1359-60, I647-48, 1864,2226

fiction, 1242-47, 1249, I 251, I 379, I 450, 1771,1842

periodicals, 2560

personal narratives, $1768-70$

poetry, 1303-4, 1306, 1309, 1313 , $1357,1359,1432,1583-84$, $1620-21,1766,1782,1784$, $1872,2034,2079,2098,2134$

short stories, I 242, I 771

hist. \& crit., 1235, 1571, 2356-2550, $3731-32,3747-48,3751$

bibl., 2457

influence on art, $569 \mathrm{I}$

periodicals, 2551-77, 2854, 2895, 2914, 2922, 2925

philosophy, 2453, 2529

popular, 2384, 2402, 2434, 6443

See also Bestsellers

post World War II, 2373

techniques, 1664

theory, I 664, 2423, 2529

See also Folklore; Legends and tales; also forms of literature, e.g., Fiction; and names of individual authors

Literature and Morality, 1377

Literature and science, 21, 40, 46, 2493 essays, 2425

poetry, 649,2412

Literature and the American College, 2375

Literature \& Theology in Colonial New England, 2483

Lithic industries (Indian), 2991

Lithographers, $5611,5778-79$

Little, Nina Fletcher, 5730

Little, Shelby (Melton), 3270

Little Big Horn Battle, 3036

A Little Book of Profitable Tales, 878

$A$ Little Book of Western Verse, 878

Little Breeches, 942-44

Little Compton, 920

The Little Convent Girl, 1035

Little Dies Committee. See California Senate. Fact-Finding Committee on Un-American Activities in California

The Little Fellow, 4953

The Little Foxes, 1989, 2327

Little Friend, Little Friend, 1999

A Little Journey in the World, 1142-43

"Little magazines," 2563, 2914, 2925 bibl., 29 I 4

Little Orphant Annie, 1126

A Little Rebellion, 3309

Little Rivers, 5095

Little theaters. See Theater-little theater movement

The Little White Girl (painting), 5776

Little Women, I89

Littlefield, George E., 6436, 6448
Littleton, Mark, pseud. See Kennedy, John Pendleton

Live Another Day, 1951

Lively, Charles E., 4397

Livestock, Southern States, 4084

Livezey, William E., 3595

Living Authors, 2455

Livingood, James W., 4104

Livingston, Burton E., 2959

Livingston, Robert R., about, 3519

Livingston, N. J., hist., 3813

Llano Estacado, Tex., 4196

Lloyd, Elizabeth, 672

Lloyd, Hannibal Evans, tr., 4309

Lloyd, Henry Demarest, about, 6424

Lloyd, Margaret, 4968

Lo, the Former Egyptianl, 2151

Loans, 5848, 5993

Lobbying, 6338, 6392-93, 6395-97, 6399

Lobrano, Gustav S., 3430

Local civil service, 6192

Local Color in Art, 896-97

Local color in literature. See Regionalism and local color in literature

Local government, 3195, 3221, 3224, 3229-30, 3443, 6131, 6133-35, $61_{37}, 61_{39}, 6207-18,6391,6425$, 6432

budget, 5973, 6195, 6208-10, 6212$15,6217-18$

executive branch, 6r93

functions, 2905, 6195, 6211-15, 6217

labor policy, 6192

officials \& employees, 6209-10, 621215,6218

organization, 6195, 6208, 6213-15, 6217

publications, 6452

See also subdivisions Government and History under names of places and regions, e.g., New York (City)-govt.

Local history, 2943, 3061, 3781-4222 See also History under names of places and regions, e.g., California-hist.

The Local Novel, 896-97

Locke, David Ross (Petroleum V. Nasby), 422-26, 2857

Locke, John, about, 5289

Locke Amsden, 583-84

Lockridge, Ross Franklin, 2005-6

Lockwood, Francis Cummins, 3004 , 4199

The Locomotive-God, I 557

Locomotives, 5926

Locust and Wild Honey, 74I-42

Lodge, Henry Cabot, 2582, 4036 ed., 696

Loeb, Martin B., 5146

Locher, Rodney, 306 I

Loescher, Frank S., 5499

Loesser, Arthur, 5622

Loetscher, Lefferts A., ed., 5466

The Log of a Cowboy, 684-85

Logan, Edward B., 6336 ed., 6336

Logan, James, about, 3229

Logan, Joshua, 2335, 2337
Logan, Rayford W., 4440, 4445

Loggins, Vernon, 5582, 5679

Logic, 5254, 5257, 5267, 5275, 5283, $5286,5290,5306,5346,5359$

Lomax, Alan, 5643 comp., 5558-60

Lomax, John A., 5557 comp., 5558-60 about, 5557

Lombardi, John, 6051

Lomen, Carl J., 2719-20

London, Jack, 1048-60, 5021 about, 2430, 2464, 2486, 2815

Lone Cowboy, 2700

The Lonely Crowd, 4555

Long, Crawford W., about, 4822

Long, David F., 3103

Long, E. B., ed., 3696

Long, E. Hudson, I I I I ed., 2324

Long, Edward Le Roy, 5434

Long, Haniel, 3956, 4176

Long, Huey, about, 3488,6377

Long, John Davis, 4036

Long, John Luther, 2337

Long, Orie William, 2462, 3776

Long Black Son, 2234

Long Branch, N.J., hist., 3814

$A$ Long Fourth, 2177

The Long Habit, 5351

Long Hunt, 1239

Long Island

fiction, 1425

in art, 5768

travel \& travelers, 4279

Long Remember, 1542

The Long Run, 1851

The Long Stay Cut Short, 2220

The Long Valley, 1776

The Long Voyage Home, 1648

Longfellow, Ernest W., illus., 439

Longfellow, Henry Wadsworth, 427-44, 2290

tr., 437

about, $427,438,441,449,633,706$, $745,979,2277,2280,2374,2462$, $2486,2513,2534,3776$

Longfellow, Samuel, ed., 438

Longstreet, Augustus Baldwin, 445-48, 2296

Longstreet, James, about, 2613

Longstreth, Thomas Morris, 5064

Longworth, Nicholas, about, 4369

Lonn, E., 448I

Look at the U.S.A., 3782

Look Homeward, Angel, , 888-89

Look (magazine), 2161,3782 about, 2908

Looking Backward, 728-31 about, 726

Loomis, Alfred F., 5022

Lopez, M., 200

Lord, Clifford L., 2972, 3676

Lord, Elizabeth H., 2972

Lord, Otis Phillips, about, 852

Lord Chumley, 2314

Lord Weary's Castle, 2007, 2009

The Lords of Creation, 3476

Lorimer, George Horace, about, 2925

Lorwin, Lewis L., 6052 
Los Angeles

descr., 4207

guidebooks, 3929

hist., 4150, 4206-7

music, 5630

politics, 6207

Los Angeles County, Calif., 3957

Loshe, Lillie Deming, 2463

Losses, 1999

Lossing, Benson J., 3687

The Lost Colony, 1475

Lost Face, 1058

"Lost generation," 2371, 2406, 2408, 2417

Lost in the Horse Latitudes, 2150

A Lost Lady, 1 276-77

Lost Springtime, 2658

Lotus Eating, 2278

Louis XI, 2298

Louis, Joe, 5030 about, 5025, 5030

Louisiana, 3952, 4079, 4100-I

fiction, 745, 749-50, 1032, I 945

govt., 6195

guidebooks, $3851-52$

hist., 4100-1

language (dialects, etc.), 2265

law, 6245

politics, 6245,6377

short stories, 746-48, 759-6I, 1032-35

Louisiana. Legislative Council, 4100

Louisiana Hayride, 6377

Louisiana Purchase, 353I, 3660

Louisville, Ky., guidebook, 3860

Lounsbury, Thomas R., ed., I 44

Louttit, William Easton, Jr., 3426

Love, 285

Love and Liberation, 1858

Love Charm, 1553

Love Conquers All, 1214

Love, Death, and the Ladies' Drill Team, 2214

Love in ' 76,2347

Love Is Eternal, 2821

The Love Nest, 1554

Lovejoy, Arthur O., 5255, 5259

Lovell, John W., about, 6446

Love's Old Sweet Song, 2112

Lovett, Robert Morss, 2406 ed., 107 I

Lovingood, Sut, pseud. See Harris, George Washington

Low, Samuel, 2347

Low, Seth, about, 6432

Low Man on a Totem Pole, 2150,2155

Lowe, H. A., 6r95

Lowe, Victor, 5335, 5385

Lowell, Amy, 832, $1583-84$ about, 268I

Lowell, James Russell, 449-69, 6ro, 2290, 5222 about, 402, 449, 466, 585, 2277, $2374,2385,2422-23,2492,2513$, $2534,2545,268 \mathrm{r}, 2922$

Lowell, Robert, 2007-10, 2363

about, 2426

Lowell family, 268r

The Lowering Clouds, 3498

Lowes, John Livingston, 4250

Lowie, Robert H., 3005-6
Lowman, Guy S., Jr., 2268

Lowry, Robert, 201 I-1 6

Loyalty oaths, $3387-88,6107-8,6110$ See also Allegiance

Loyalty-Security Program (1947), 6107, 6 I $10,6 \mathrm{II}_{2}$

Loyola, Ignatius, 228I

Lozier, Herbert, 5004

Lubbock, Percy, ed., I004-5

Lubell, Samuel, 5947, 6346

Lucas, Henry S., 4493

Luce, Clare (Boothe), 2327, 2333

Lucifer with a Book, I940, 1942

The Luck of Roaring Camp, 927-32, 937,939

Luckman, Sid, 5039

about, 5039

Lucky Sam McCarver, 2348

Lucretius. De Rerum Natura, translation, 1556

Lucy Church Amiably, 1771

Lucy Gayheart, 1277

Luden, Heinrich, ed., 4298

Ludwig, Richard M., ed., 234I

Lueders, Edward G., I 835

Lull, Richard Swann, 4715

Lumber industry, 5864

Minn., 41 4I-42

Mississippi Valley, 3975

Lumbermen

folklore, 5523,5533

language (slang, etc.), 5516

songs \& music, $5551,5556,555^{8-59,}$ $5562,5567,5575$

Lummus, Henry T., 6287

Lumpkin, Katharine Du Pre, 2721, 4569

about, 2721

Lumsdaine, A. A., 3724

Lundberg, Ferdinand, $288_{4}$

Lundberg, George A., 4577

Lundblad, Jane, 2368

The Lure of the Frontier, 3082

Lustra, 1666

Lutherans, 323 I, 4479-80, 5404, 5442, $546 \mathrm{r}-62$

Lutz, E. Russell, 6294

Luxon, Norval Neil, 2924

Lydenberg, Harry Miller, 6476

Lyell, Sir Charles, 4337-40 about, 4336

Lyman, George D., 4185

Lyman, E. W., 5335

Lynch, Denis Tilden, 6387

Lynchburg, Va., 2842

Lynd, Helen Merrell, 4592-93

Lynd, Robert S., 4592-93

Lynes, Russell, 5694

Lynn, Kenneth S., 2464

Lyon, John H. H., 5582

Lyon, Mary, 5193 about, 2615

Lyons, Eugene, 3490

Lyons, James, 5607

Lyons, L. M., 6207

Lyric America, 2342

Lyrics of a Lad, 1530

Lyrics of Lowly Life, 857, 859, 861

Lyrics of the Hearthside, 858-59, 86I

Lytle, John Horace, 5085 about, 5085
$\mathbf{M}$

M; One Thousand Autobiographical Sonnets, 1624

Mabbott, Thomas O., 522, 524 ed., 538

Mabec, Carleton, 4676

MacArthur, Charles, 2327, 2332

MacArthur, Douglas, about, 1992

McCabe, Charles R., ed., 2890

McCaffery, John K. M., ed., 1504

McCain, William D., 3583

McCallum, John, 5038

McCamy, James L., 3604, 6452

McCamy, Julia B., 6452

McCann, Franklin T., 3166

McCarran, Patrick, 4424

McCarran Act (1950). See Subversive Activities Control Act

McCarthy, John A., 5211

McCarthy, Joseph R., about, 3482

McCarthy, Mary, 2017-22

McCarty, John L., 4195

McCausland, Elizabeth, 5766

McCleery, Albert, 4901

McClellan, George Brinton, about, 261 4, 3382

McClelland, Nancy V., 5728

MacClintock, Lander, 5679

McCloskey, J. J., 230 I

McClure, M. T., 5289

McClure, S. S., about, 6432

McCluskey, Ross; ed., 507 I

McCollum, Elmer V., about, 4722

McConahey, S. C., 4594

McConnell, Grant, 5859

McCormac, Eugene Irving, 3350-5I

McCormick, Cyrus, 5826

McCormick, Cyrus Hall, about, 4786, 5826

McCormick, Medill, about, 2862

McCormick, Robert, about, 5826

McCormick, Robert Rutherford, about, 2862

McCormick family, 2862

McCosh, James, 5337-44 about, 5337,5344

McCoy, Joseph G., about, 4158

McCoy, Philbrick, 6320

McCoy, Whitley P., 6058

McCracken, Harold, 5770, 5802

McCullers, Carson, 2023-24, 2335-36

McCulloch, Margaret, 4443

McCulloch, W. E., 5442

McCuskey, Dorothy, 5220

McDevitt, Josephine A., 561 1

McDonagh, Edward C., 4431

McDonald, Philip B., 4677

MacDonald, William, comp., 3079

Macdougall, A. R., 4972

MacDougall, Curtis D., 2905, 6288

McDougall, William, about, 5392

MacDowell, Edward, about, 2364, 5683

McDowell, Ephraim, about, 4822

McDowell, Tremaine, 255, 300, 5184 ed., $383,2276,2343$

McFarland, Carl, 6227

McFarland, Marvin W., ed., 4788

McFarland, Raymond, 5872

M'Fingal, 165, 167

McGeary, Martin Nelson, 6160 
McGibony, John R., 4849

MacGill, Caroline E., 5923

McGillicuddy, Cornelius, 501 I

about, $501 \mathrm{I}$

McGovern, John T., 4999

McGovney, Dudley O., 6405

Macgowan, Kenneth, 4901

McGraw-Hill Book Company, about, 6449

McGregor, John C., 2992

McGregor, Iowa, guidebook, 3894

McGuffey readers, 5126

Machinal, 2332

Machine politics, $3437-38,6218,6333$, $6338,6346,6353,6357,6363$, $6382,6384-91,6410,6434$

Mclnerny, Mary Alice, 4577

MacIver, Robert M., 5181, 5185, 6082

Mack, Connic. See McGillicuddy, Cornelius

Mack, Gerstle, 422 I

Mackay, Alexander, $4344-46$ about, 4344

Mackay, Charles, 4370-71 about, 4369

McKay, Donald C., 3508 ed., 3501,3516

Mackay, John A., about, 5433

MacKay, Kenneth Campbell, 6362

MacKaye, Percy, 2337, 2348

MacKaye, Steele, 2308, 2337, 2347

McKean, Dayton D., 6337, 6388, 6395

McKearin, George S., 5789

McKearin, Helen, 5789

McKee, Samuel, Jr., ed., 3289, 3291

McKelvey, Blake, 4050-52, 4654

McKelway, St. Clair, 2894

Mackenzie, Alexander, about, 3167

Mackenzie, Catherine D., 4678

Mackenzie River, 4015

McKeon, Richard, 5289, 5427 about, 5427

Mackey, David R., 4966

McKibbin, David, 5771

McKiever, Margaret F., 4887

McKinley, William, about, 3424, $3447-48$

McLaughlin, Andrew Cunningham, 3301, 3349, 6078-79

McLaughlin, George D., about, 4785

Maclaurin, William Rupert, 4693

McLean, John G., 5914

MacLean, Malcolm S., 5228

McLean, Murdoch C., 4474

MacLeish, Archibald, I585-88, 1908. 2333

about, 2378, 2499, 2527

MacLennan, S. F., 5289

Macleod, William Christie, 3030

McLoughlin, William G., 5480

Maclure, William, about, 4737

Macmahon, Arthur W., 6I87

McManis, Jack, ed., 148 I

McMaster, John Bach, 3046 about, 3046, 3058

Macmillan's Magazine, 989

MacMinn, George R., 4923

McMurry, Donald L., $344^{\circ}$

McMurtrie, Douglas C., 6448

MacNeil, Neil, 2906

MacNutt, Francis Augustus, tr., 3153
Macon, Nathaniel, about, 3286

Macon, Ga., guidebook, 3840

McPharlin, Paul, 4981 comp., 128

McPhee, William N., 6414

McRae, Milton A., 2886

about, 2886, 2890

McReynolds, Edwin C., 4169, 4171

McSorley's Wonderful Saloon, 2755

McTeague, 1090-92

McWilliams, Carey, 3957, 4176, 4462, 4475,5846

Macy, Anne Sullivan, 2706 about, 2705

Macy, John Albert, ed., 2706

Macy (Rowland H.) and Co., about, 5959

Madame Butterfly, 2337

Madame Célestin's Divorce, 760

Madame Délicieuse, 748

Madame Delphine, 747-48

Madame de Mauves, 1007

Madame De Traymes, 1855

Madame Zilensky and the King of Finland, 2024

Made in America, 5691

Madeleine (opera), 5681

Mademoiselle Olympe Zabriski, 7 I I

Madison, James, 3283, 5418, 6075, 6087 about, 2622, 3282-83

Madmen All, 517

Madrilène, 1033

Madsen, Borge, tr., 4485

Magazines, 2913-26

bibl., 2914-15, 2919

directory, 5958

folklore, 5518

hist., 2914-16, 2918-19

medical, 4809

photography, 2908

publishing, 6449-50

Maggie, a Girl of the Streets, 822-24, 835-37

Maggs, Douglas B., ed., 6090

Magic, folk, 5509, 5528-29, 5537

The Magic Curtain, $494 \mathrm{I}$

Magnalia Christi Americana, 43-44

The Magnificent Ambersons, 1802,1806

Magnificent Missourian, 3322

The Magpie and the Maid, 2302

Magriel, Paul D., ed., 4971-72

Mahan, Alfred Thayer, 3672, 3688, 3700

about, 3058,3672

Maher, R. L., 6\$95, 6207

Mailer, Norman, 2025-28

about, 237I

Main Currents in American Thought, 2485

about, 2407

The Main Line, 2314

Main Line of Mid-America, 5927

The Main Stream, 2503

Main Street, 1560

Main Street on the Middle Border, 4109

Main-Travelled Roads, 891-95

Maine, 2590

econ. condit., 4031

folksongs \& ballads, 5566-67

guidebooks, 3792-95

hist., 3473
Maine-Continued

in art, 5767

language (dialects, etc.), 2256

Penobscot Indians, 3011

soc. condit., 4031

Maine, U.S.S., 3530

Maine in literature

essays, 594-95, 606, 1859

fiction, $402-4,562,570-71,1284-85$, I 288, 1290,1707

poetry, 1 290, I 295, 1 713-1 4

short stories, 1023-3I

Maisel, Edward M., 5680

Major, R. H., 3163

Make Bright the Arrows, 1609

Make Light of lt, 1879

Makemie, Francis, about, 5396, 5466

Makers and Finders, 2381

Makers of Literature, 2545

The Making of Americans, 1768

The Making of a Southerner, 2721

The Making of an American, 2785

Making the American Mind, 5126

The Male Animal, 2334

Mall, Franklin B., about, 4845

Mallery, Richard D., 2250

Mallinckrodt, Edward, about, 4735

Malmin, Gunnar J., tr. \& ed., 4348

Malone, Dumas, 3295, 3303 ed., 3080

Malone, Kemp, ed., 1046

Malott, Deane W., 5847

Mamba's Daughters, 1512

Mammonart, 1754

Mammoth Cave, Ky., 2946

Mamoulian, Rouben, 5678

Man, prehistoric, 2995-96, 4202

The Man against the $S k y, 1714$

$A$ Man against Time, 1556

$M$ an and Boy, 2053

Man and Shadow, 2342

$M a n$ and Wife, 2317

The Man Coming toward You, 1871

The Man in the Crowd, 529

$A$ Man in the Divided Sea, 2035

A Man Must Fight, 5031

The Man That Corrupted Hadleyburg, 798-99

The Man Who Came to Dinner, I491, I 548, 2327, 2334

The Man Who Died at Twelve O'Clock, 1475

The Man Who Died Twice, I714

The Man Who Was There, 2052

Man With a Bull-Tongue Plow, 2166

The Man with the Blue Guitar, 1784

The Man with the Hoe, 1062

The Man without a Country, 901-5, 909

The Managed Casualty, 4469

Manassas to Malvern Hill, 3695

Manchester, Frederick, ed., 2375

Manchester, Herbert, 4992

Manchester, William R., I607

Manhattan

art, 5767,5773

fiction, I 449

See also New York (City)

Manhattan Project, 4747

Manhattan Transfer, 1327

Manifest Destiny, 3306, 3340, 3398, 3760 


\section{II46 / A GUIDE TO THE UNITED STATES}

Mankowitz, Wolf, 1367

Manly, John M., I070

Mann, Arthur, 4530

Mann, Horace, 5125,5418 about, 5116,5125

Manners, 286

Manning, Thomas G., ed., 3 I 06

Mannix, Daniel P., 4980

Manpower. See Labor supply

Manross, William W., 5456

Mansfield, Harvey C., 5996

Mansfield, Katherine, about, 1278

Mansfield, Luther S., ed., 49 I, 499

Mansfield, Richard, about, 4939

Mantle, Robert Burns, ed., 4897

Manuductio ad Ministerium, 47-48

Manufactures, 3291, 5902-6, 6030

hist., 5904, 5906

Ohio, 4 I I 9

Many Are Called, $205^{8}$

Many Long Years Ago, 1632

Many Mansions, 16 7

Many Minds, 2523

Many Thousands Gone, $1225-26$

A Map of Virginia, 68

Mapes, James Jay, about, 4735

Mapleson, James Henry, 5659

Maps. See Atlases and maps

Marberry, M. Marion, 1064

Marble, Alice, 5049 about, 5049

Marble, Annie (Russell), 2465,6447 ed., 595, 597

The Marble Faun (Faulkner), 1379

The Marble Faun (Hawthorne), 333

Marbut, Curtis F., 2947, 581 6 about, 2947

Marcel, Gabriel, 5363

March, Peyton C., 3712

March, Richard, ed., 1364

March, William. See Campbell, William Edward March

Marchand, Ernest, ed., I I 3

Marches Now the War Is Over, 624

Marching On, 1241

Marco Bozzaris, 323

Marco Millions, 1648

Marcosson, Isaac F., 2892

Marcou, Jules, 4742

Marcus Aurelius, 228 I

Marden, Charles F., 4432, 4578

Mardi, 478

Maretzek, Max, 5659

Margaret, 402-4

Margaret Fleming, 2337

Marginalia, 533

Maria, the Potter of San lldefonso, 2723

Marianas Islands, 4218

Marietta, Ohio, 3767,4030

Marin, John, 5767

about, 5767,5783

Marine Corps, hist., 3668

Marion, Francis, I 7 I

Maritime commerce, 3524

Maritime rights. See Freedom of the seas

Marjoric Daw, 71 1-12

Marjorie Morningstar, 2231

Markel, Lester, 3615
Marketing, 5944-45

See also Agricultural productsmarketing; Retail trade; Wholesale trade

Markham, Edwin, 1061-63

Marland, Ernest Whitworth, about, 2731

The Marmot Drive, 1992

Marquand, John Phillips, I549, I $589-97$

about, 1598,2376

Marquesas Islands, fiction, 47I-75

Marriage, $4550,4561,457 \mathrm{I}-72,4617$ counseling, 4570

Indian, 3022, 3043

The Marriage of Venus, 1740

The Married Look, 164

Marriott, Alice Lee, 2722-25, 3007

The Marrow of Tradition, 756

Marryat, Frederick, 4324-28 about, 4324

Mars Jeems's Nightmare, 757

Marse Chan, x 100-2

Marse Covington, 705

"Marse Henry," 2892

Marsh, James, about, 5263

Marsh, Othniel Charles, about, 472I, 4724,4754

Marsh, Philip M., ed., 143

Marshall, Helen E., 4839

Marshall, John, about, 6096, 6231, $6237-38,6240,6258,6260$

Marshall, John David, comp., 648r

Marshall, Thomas F., comp., 2552

Marshall, Thomas M., 3157

Marshall, William L., 6276

Marshall, Okla., 4 I 7 I

Marshall Islands, 4218

Marshall Mission to China, 3593

Marshall Plan, 3637, 3639-40

The Marshes of Glynn, 1038

Marston, William Moulton, 4975

Martens, Elise H., 5205

The Martian Chronicles, 1934

Martin, Alexander C., 2960

Martin, Asa Earl, ed., 4056

Martin, Boyce F., 5847

Martin, Clyde E., 4565

Martin, Edwin T., 4753

Martin, Eveline C., 3179

Martin, Harry B., 5053

Martin, Howard H., ed., 4212

Martin, John, 4968, 4972

Martin, John Bartlow, 4124

Martin, Paul S., 2993

Martin, Robert F., 5893

Martin, Thomas C., 4782

Martin Eden, $1056-57$

Martineau, Harriet, 4315-19

Martínez, María Montoya, about, 2723

Marvel, Ik, pseud., 506-10

Marvin, W. T., 5260

Marx, Herbert L., Jr., ed., 4703

Marx, Karl, about, I 743, 529r

Marxist influence in literature, 1048 , I 754, 242I, 244I, 2507, 2539

Marxist interpretation of literature, 2439

Mary, I 190

Mary of Scotland, I I 72, II74

Mary Peters, 1285
Mary Stuart, Queen of Scotland, drama, I I 72, II 74

Maryland architecture, 5706

culture, 3233

fiction, $405,412-13$

Germans, 4480

guidebooks, 3824-25

hist., 3209, 3233, 4073

legal hist., 6284

plantation life, 4517

printing, Colonial, 6448

rivers, 3999

The Maryland Gazette, about, 2854

A Mask for Privilege, 4462

Mask of Silenus, 2413

Mason, Alpheus Thomas, 6246, 6249 ed., 6065

Mason, Daniel Gregory, 5625

Mason, George, about, 3254

Mason, Kathryn Harrod, 2726-27

Mason, Lowell, about, 5684

Masons (Freemasons), 4574

The Masque of Judgment, 1069

The Masque of Kings, I I 74, 2348

A Masque of Mercy, 1452

The Masque of Pandora, 435

A Masque of Reason, 1452

The Masque of the Gods, 2282

Mass Communications. See Communications

Mass Culture, 6443

Massachusettensis de conditoribus, 3198

Massachusetts, $3965,4034-38$

courts, 6292

culture, $3178,3199,3235,3241$

early settlers, $7,17-18,32$

education, 5125

govt., 6195

guidebooks, 3798-3803

hist., 2580, 399 I, 401 2, 4034

Colonial period, 90-9I, 3178, 3181-82, 3198-99, 3211, 3235, 3241

in literature, $40-44,49-58,62-64$, $75-77,276,587-93,596-97,606$ fiction, $562,665,1438-39,1443$, 1589,2293

poetry, 7-I $I, 79-83,662$

sermons, 18,33

short stories, $88 \mathrm{I}-86$

legal hist., $6228,6242,6292$

maritime hist., 5936

printing, Colonial, 6448

relations with Gt. Brit., 324 I

rivers, 3991, 4012

Massachusetts General Hospital, Boston, hist., 4853

Massachusetts General Hospital, Boston. Social Service Dept., hist., 4805

Massachusetts Historical Society, 696

Massachusetts Medical Society, hist., 4804

Massachusetts Reformatory, Concord, about, 4648

Massachusetts Reformatory for Women, Framingham, about, 4649

Massachusetts State Board of Health, hist., 4879

Master Plan U.S.A., 3624 
Masters, Edgar Lee, 1599-1601, 3988 about, 1599, 2419

Masterson, James R., 5542

Materialism, 3134, 6067

Maternal and infant welfare, 4870 New York (City), 485 I

Mathematics, 5254

foundations, 5346

hist., 4739

Mather, Cotton, 40-50, 82, 3178, 3199 about, 40, 92, 1873, 2493, 3178, $4034,4826,5417$

Mather, Frank Jewett, Jr., 2425

Mather, Increase, about, 92, 2483, 3199

Mather, Stephen Tyng, about, 5866

Mathews, John A., about, 4785

Mathews, John Joseph, 2728-31

Mathews, John Mabry, 4I 32

Mathews, Lois Kimball. See Rosenberry, Lois (Kimball) Mathews

Matschat, Cecile (Hulse), 3976

Matter (philosophy), 5371

Mattfeld, Julius, 5639

Matthews, Basil J., 4450

Matthews, Brander, 770, 791, 2466-75 about, 2504

Matthews, Cornelius, 2295

Matthews, William, 3662

comp., 3102

Matthias at the Door, 1714

Matthiessen, Francis O., I349, 247677,5319

ed., 1008-9, 2344

about, 2127

Mauberley (Hugh Selwyn), about, I670

Maud-Evelyn, Ior 2

Maud Martha, 1939

Maudslay, Robert, 2732-33

Maugham, W. Somerset, 1652

Mauk, James F., comp., 4720

Mauldin, William Henry, 2734-38

about, 2737

Maule's Curse, 2544

Maurer, David W., 2259, 2262

Maurer, Herrymon, 6022

Maury, Matthew Fontaine, about, 472 r

Maverick, Maury, 6207

Maverick Town, 4195

Maxims. See Quotations

Maxwell, Allen, ed., 5509, 5521

Maxwell, Desmond E. S., 1365

Maxwell, William, 2029-33

May, Henry Farnham, 5492

May-Day, 289

The May-Pole of Merrymount, 51

Maya culture, 2994

Mayer, Arthur, 4959

about, 4959

Mayer, Frederick E., 5397

Mayers, Lewis, 6289

The Mayfield Deer, 1825

Mayhew, Jonathan, about, 5472, 6068

Mayhew, Lewis B., 5160

Maynard, Harold Bright, about, 4803

Maynard, Harold H., 5945

Maynard, Theodore, 5400,5450

Mayo, Bernard, 3342, 3344

ed., 3294, 3297

Mayo, Margot, 5587

Mayo, Morrow, 4206-7

Mayo, William W., about, 4827
Mayo Clinic, Rochester, Minn., about, 4827

Mayorga, M., ed., 4898

Mays, Arthur B., 5210

Mays, Benjamin Elijah, 5500

Mays, David John, 2739-40

Mazeppa, 2302

$M e$ and Juliet (music), about, 5685

Mead, Ben Carlton, illus., 5531

Mead, Edwin D., 907

Mead, Frank Spencer, 5398

Mead, G. H., 5254, 5289

Mead, Margaret, 3042

Meade, George Gordon, about, 2614

Meade, Robert Douthat, 3263, 3396

Meadows, John C., 4095

Meadows, Paul, 4757

Meaning, theories of, 5289, 5291, 5346

Means, Gardiner C., 5898, 601 I, 6013 about, 5888

Means, James H., 4888

Meany, Edmond S., 42 I 5

Mearns, David C., 3395, 6469

Mears, Eliot Grinnell, 4468

The Measure of Man, 2453

Measurement (education), 5229

Measurement and Prediction, 3724

Meat industry, 5869

fiction, I 754-55

Meat out of the Eater, 79

Mécanique céleste, 4746

Mechanic arts, study \& teaching, sigr

Mecom, Jane (Franklin), I 29

Medea, translation and adaptation, I 535, 2335

Medical missionaries, Hawaii, 2688

Medical societies, $48 \mathrm{I} 2$

Middle West (to 1850 ), 4810

Medical Society of the State of Pennsylvania, hist., 4804

Medicine, 2844, 472I, 4804-9I

care \& treatment, $4808,4825,4885$, 4889

case studies, 48 I 5

cost, $4808,4870,4882-91$

charities, $4820,4842,4862-64,4866$, 4868

education, $4813,4825,4831,4855-$ 61

post-graduate, $4857-59,486 \mathrm{r}$, 4873 premedical, $486 \mathrm{r}$

ethics, 4812,4817

group practice, $4862,4886,4888-89$

hist., 4049, 4809, 48 I 4

Colonial period, 4826

I 8 th-I 9 th cent., 4812

I9th cent., 3765,4112 2oth cent., 4805,4862

in literature

Colonial, 40

fiction, 375

See also Physicians and surgeons

laws \& legislation, 4809-10, 4882

personnel, $4809,4835-36,4838$, $4862,4870,4885$

practice, 409I, 4809, 48II, 48I3-I5, $4817,4825,4827,4829-30,4841$, 4891

research, $4779,48 \mathrm{Ig}, 484 \mathrm{r}, 4870$

hist., 48 I $3,483 \mathrm{I}^{2}$
Medicine-Continued

schools, 4809-10, 4812, 4831, 4860$6 \mathrm{I}$

social work, 4835,4839 hist., 4805

stat., 48 I 5, 4865

See also Clinical medicine; Industrial medicine; Magazines-medical; Preventive medicine; Quacks and quackery

Medill, Joseph, about, 2862

Medill family, 2862

Medina, José Toribio, 3174

Mediterranean area, relations with, 3573

Meek, Joe, about, 2833

Meetinghouse Hill, 1630-1783, 5417

Megrue, Roi Cooper, 2348

Meh Lady, 1 100-2

Meine, Franklin J., 5505 ed., 704

Meisel, Max, 4736

Melanctha, i767

Meland, Bernard Eugene, 5437

Melcher, Marguerite (Fellows), 5469

Meliboeus-Hipponax, 456-57

Mellichampe, 547

Meltzer, Milton, 4440

Melville, Annabelle McConnell, 5477

Melville, Herman, 470-96, 2290

about, 21, 274, 333, 478, 48r, 497$505,1231,2284,2380-81,2397$, $2420,2456,2476,2478,2544$

Melville Goodwin, USA, 1595

Melville Society, 499

The Member of the Wedding, 2023-24, 2335-36

The Memoirs of a Shy Pornographer, 2082

The Memoirs of an American Citizen, 957

Memoirs of an Epicurean, 228I

Memoirs of Carwin the Biloquist, I I I

Memoranda, 638

A Memory of Two Mondays, 2049

Memphis, Tenn.

hist., 4105

politics, 6207

Men and Brethren, 1300

Men and Women, 2314

Men at Work, 1548

Men of the Mountains, 2168

Men on Bataan, 1992

Men, Women, and Ghosts, $1583-84$

Men, Women, and Pianos, 5622

Mencken, Henry L., 832, I602-5, 2248, 24 I I, 2876, 6421

cd., 266-67

about, 1606-7, 2406, 2429, 2486, 2503

Meneely, Alexander Howard, 3702

Menes, Abraham, 4458-59

Menjou, Adolphe, 4954

about, 4954

Menke, Frank G., 5057

Mennonites, $4058,4480,5442$

Mental hygiene, 4619, 4833-36, 5246

Mentally ill, 46r 7

care \& treatment, $4828,4830,4833-$ $34,4836-40$ 
Mercantilism, Colonial period, 3193 $3242,3262,5878$

Mercer, Morgan. See Dana, Julian

Merchant marine, 5930

Mercier, Louis J. A., 2375

Mercy Dodd, 2298

Mercy Philbrick's Choice, 984

Merely Colossal, 4959

Mereness, Newton D., ed., 4233

Mergenthaler, Ottmar, about, 4786

Meriam, Lewis, 3038

Merit system. See Civil service reform

Merk, Frederick, 3083

Merlin, 1714

Merriam, Charles Edward, 3646, 4540, $6066,6363,6380,6406$

Merriam, George S., 2879

Merriam, Robert E., 3720

Merrick, Elliott Tucker, 2741-42

Merrill, Francis E., 4572, 4625

Merrill, George P., 4737

Merrily We Roll Along, 1548

Merritt, LeRoy Charles, 6452

Merry Mount, 5 I

Merry-Mount: A Rornance of the Massachusetts Colony, 2293

The Merry Partners, 4935

Merrymount Press, Boston, about, 6459 bibl., 6459

Merton, Robert K., ed., 3724

Merton, Thomas, 2034-42

Merton of the Movies, 1546

Merwin, Frederic E., ed., 2927

Mesick, Jane Louise, 4224, 4228

Mesmeric Revelation, 529

Messiah, 2188

Messiter, Arthur H., 5666

Metalwork, 5596

Metamora, $23 \mathrm{II}$

The Metamorphic Tradition in Modern Poetry, 2497

The Metaphysical Passion, 2499

Metaphysics, 5257, 5260, 5278, 5289, $5291,5310,5343,5346,5352$, $5355-56,5363$

The Metaphysics of Pragmatism, 5254

Metcalf, Clyde H., 3668

Metcalf, Eleanor M., ed., 489, 502

Metcalf, Frank J., 5634

Metcalf, Keyes D., 6470

Meteor, 1206

Meteorology, 2950-51, 4722

The Method of Divine Government, 5337

A Methodist Saint, 2586, 5474

Methodists, 2586-87, 5404, 5442

hist., 5416,5463

Willamette valley, 4213

Metropolitan government. See Local government

Metropolitan Life Insurance Company, about, 5992

Metropolitan State Hospital, Waltham, Mass., about, 4838

The Mettle of the Pasture, 719-20

Metzdorf, Robert F., ed., 276

Metzger, Arnold, 5335

Metzger, Walter P., 2358, 518 I

Mexican War. See War with Mexico

Mexicans, 4197, 4204, 4470-72, 447576
Mexico

cession of the Southwest, 3355

fiction, 3 I I

hist., 2294

poetry, 1585

relations with, $3504,3575,3586$

short stories, 1659

travel \& travelers, $1659,4352-53$

Meyer, Adolf, about, 4722

Meyer, Balthasar Henry, ed., 5923

Meyers, Marvin, 3319

Miami, Fla.

descr., 3846

politics, 6207

Mich, Daniel D., 2908

Michaux, François André, 4277-78 about, 4276

Michelson, Albert Abraham, about, 4721

Michelson, Charles, 6364

Michigan, 4137-38

architecture, 5719

Dutch, 4493

folklore, 5533,5535

folksongs \& ballads, 5567,5575

guidebook, 3882

historical geography, 2969

hist., 4I I I, 4137

Norwegians, 4487

rural communities, 4109

short stories, 415-1 8, I 149-50

soc. life \& cust., $266 \mathbf{r}$

Michigan. University, 520 I

Michigan State Medical Society, 4818

Michl, Herman E., 5902

Microbe Hunters, 1520

Mid-Century, 4453

Mid-Century American Poets, 1948

Mid-Channel, 1572, 1575

The Middle-Aged Man on the Flying Trapeze, 1817

Middle Atlantic States, 4043-65

guidebooks, 3806-26

hist., $378_{3}-84,4043$

printing, Colonial, 6448

public libraries (1850-1900), 6472

travel \& travelers, $4256-57,4263$, 4329

Middle Border in literature, 898-99

Middle classes, 2893, 3774, 4516, 4542, $4553,6063,6346$

Middle East, World War II, 3726

The Middle of the Journey, 2519

Middle West

agriculture, 5831

descr., 4113,4116

Dutch, 4493

econ. condit., 4109,4115

folklore, 5518

geography, 4I I 3

historic houses, etc., 5794

hist., $3053,3147,3427,3446,3784$, 4115

hunting, 2794

newspapers, 2862, 2887, 2893

Norwegians, 4487

pictorial guide, 3782

play-party songs, 5586

politics, 4115,6434

rural communities, 2655

singing games, 5586

soc. hist., $4810,4827,4860,5194$
Middle West-Continued

soc. life \& cust., 2893, 4097-98, 4ro9, $4115-16,4136,4564$

Middle West in literature

bibl., 2502

fiction, $867-77,959-63,1178,1183$, $1412,1416,1541,1543,1559-61$, $1564,1568,1644,1646,1786$, $1789,1802,1840,1845,2052$

hist. \& crit., 2502

poetry, 753-55, I I 26-31, 1580 , I644$45,1727,1731$

short stories, 701-5, 890-95

travels \& travelers, 314

The Middle Years, 1015

Middlemen, commercial, 5960

Middleton, George, 2743-44

about, 2744

Middletown, 4592

Middletown in Transition, 4593

A Midnight Bell, 2306

Midstream, 2708

Midway Island, 4218

Midwest at Noon, 4116

Miggles, 930, 937

Mighell, Ronald L., 5844

Migrant labor, 1775,5846

Migration, internal, 2943, 4028, 4030, $4098,4226,4394,4397,456 \mathrm{I}$

Mormons, 4183

Negroes, 4446

The West, 4149

Mikesell, Raymond F., 3562, 3639

Miles, Laban J., 2729

Miles City, Mont., pictorial hist., 4I5I, 4153

Military Academy, West Point, about, 3656

Military Air Transport Service, about, $3643 a$

Military assistance to foreign nations, 3598,3636

Military courts, 6289

Military history, 2580, 3141, 3643, $3644 a, 365^{\circ}$

American Revolution, 3238-39, 3255, $326 \mathrm{r}, 3269,327 \mathrm{r}-72$

French and Indian War $(1755-63)$, 3271

Civil War, 3408

World War I, 3715

World War II, 3499

See also specific branches of the Armed Forces, e.g., Army-bist.

Military life

civil relations, 3646,3650

Civil War, 3704-5

in art, 5765,5807

Revolutionary War, 3679

World War II, 3724

Military life in literature

drama, 1491, 21 45-46

fiction, 821, 825-29, 835-36, 1240$41,1249,1326,1380,1396,1496-$ 99, 154 I, 1544, I 708-11, 1745 , 1940-4I, 1992-94, 2003-4, 201 1, $2023,2025-26,2181,2229-30$

historical writings, 1551

personal narratives, $277,1170,1310$ poetry, 1599-1601, 1948, 1999, 2139 , 2141 
Military life in literature-Continued reporting, 1170, 1769-70, 1992-4, 2044

short stories, 732-37, 2011,2057

Military music, 5653

Military policy, $3623,3629,3634,3643$, 3651

Military psychiatry. See Psychiatry, military

Milk for Babes, 17

A Milk White Flag, 2306

Mill, J. S., 5337

about, 5337

Millar, Robert W., 6300

Millay, Edna St. Vincent, I 608-9. 2332 about, I6ro, 2406

Miller, Alfred Jacob, paintings by, 3330

Miller, Arthur, 2043-49, 2335-36

Miller, Claude R., 6323

Miller, D. S., 5222, 5335-36

Miller, Delbert C., 4552

Miller, Edgar G., 573 I

Miller, George F., 5 I 59

Miller, George J., 2940

Miller, Gerrit S., 2955

Miller, Helen Day (Hill), 3254

Miller, Henry, ed., 4418

Miller, Henry (b. 1891), 610, I61 1-13 about, 2498

Miller, Hẹrman P., 4395

Miller, James M., 3767

Miller, Joaquin, 1064-68, 2337

about, 1064, 1068, 2503

Miller, John C., 3255

Miller, Joseph, 3924-25

Miller, Lee Graham, 2745

Miller, Margaret, 5696

Miller, Mary Britton ("Isabel Bolton"), I614-17

Miller, Max Carlton, 2746-54

about, 2746-54

Miller, Merle, about, 237 I

Miller, Paul W., ed., 3838

Miller, Perry, 84, 2288, 2478, 3196, $3742-43,4513,5299$

ed., 2 I , 2345 -46, 3744

Miller, R. C., 3058

Miller, Robert Moats, 5493

Miller, William, $5875,644 \mathrm{I}$ ed., 6023

Miller, William H., about, 4785

Miller, William J., 2945

The Miller of Old Church, $146 \mathrm{I}$

Millet, Jean François, about, 1061

Millett, Fred B., 991

Millett, John D., 5171, 6187 ed., 5172

Millikan, Robert A., 4755 about, 4722, 4755, 5434

A Million and One Nights, 4944

Millis, Harry A., 6053

Mills, Charles Wright, 4470,4553

The Mills of the Kavanaughs, 2010

Milne, Gordon, 2278

Milton, George Fort, 3397, 4068, 6I 46

Milton, John, about, 231

Milwaukee, Wis., 3885, 41 40, 6207

Mimi's Marriage, 1035

Mims, Edwin, Jr., 4899

Mims, Stewart L., 4265 ed., 4264
Mind and Spirit, 4044

The Mind of Primitive Man, about, 2407

The Mind of the South, 4066

A Mind That Found Itself, 4834

Mine Eyes Have Seen the Glory, 2603

Mine the Harvest, 1609

Miner, Ward L., I 40I, 2508

Mineral resources. See Mines and mineral resources

Mineralogical Society of America, about, 4733

Mineralogy, 4715

Miners

folklore, 5533,5578

folksongs \& ballads, 5558,5578

language (dialects, etc.), 5578

Mines and mineral resources, 4I74, 5907,5917

folklore, 5531-32

Calif., 4372

Colo., 39r 3

Middle Atlantic States, 4255, 4336

Middle West, 4 I 13

Mo., 4108

Nev., 4 I $84-85$

N. Mex., 4188

Southern States, 4255,4336

The West, 4177,4383

Mingo, 917-19

Minhag America, 5483

The Minister's Wooing , 568-69

Mink and Red Herring, 2904

Minkoff, N. B., 4458

Minneapolis

Jews, 4456

music, 5654

Swedes, 4486

Minnesota, 3663, 3948, 3954, 4I 4 I-43

architecture, 5719

fiction, 1560,1568

guidebooks, 3886-88

historical geography, 2969

Norwegians, 4487

rural communities, 4109

Swedes, 4486

Minnesota. University, about, 5184 , 5202

Minnesota. University. Bureau of Institutional Research, 5202

Minnesota. University. Program of American Studies, 2553

The Minnesota Arrowhead Country, 3887

Minnie Field, 2332

Minorcan dialect, 2258

Minorities, 4426-35, $455^{1}$ bibl., 4426

civil liberties \& rights, 6129

magazines, 291 8

Great Plains, 4159

Washington, D.C., 4065

Minority Report, 2415

Minstrels, 2472, 4894, 5637, 5640

Minstrels of the Mine Patch, 5578

Minter, John Easter, 4014

The Minute Man (sculpture), 5736

The Minute Men of 1774-1775, 2304

Minute Particulars, 1227

The Miracle Chapel, 1035

Mirror for Gotham, 4048
$A$ Mirror for the Sky, 2210

A Mirror for Witches, 1439

Mirsky, Jeanette, 2980, 3I67, 4789

Miscally, Mildred Lois, 2856

Miss Lonelyhearts, 1843

Miss Lulu Bett, 1455

Miss Marvel, 1440

Miss Mehetabel's Son, 7 I I

Miss Ravenel's Conversion from Seces. sion to Loyalty, 278-79

Missionaries in China, fiction, 1252

Missions, 541 1, 5489, 5723

Baptist, 5443

Catholic, 545 I

Jesuit, 3075, 3158, 317 I

Negro, 5500

overseas, 5405

Hawaii, 2688

Missions, Indian. See Indians, American-missions

Mississippi, 4079

folklore, 5547

folksongs \& ballads, 5576

guidebooks, 3849-50

hist., 3850,4024

Mississippi in literature

drama, 221 8, 2223, 2225, 2228

editorials, essays, etc., 194-97

fiction, 546-1379, I 786, 2202, 2204 , 2206, 2208

short stories, 1379, 2202-3, 2205, 2207, 2209

Mississippi River, 2803, 3975, 3982, 4110

descr., $784-86$

folklore, 5523

in art, 5805

legends, 5523

showboats, 4978

travel \& travelers, $3170,4281,4300$, $4324,4336,4344,4369$

Mississippi River Delta, 2779, 3952

Mississippi Valley, 3954, 3960, 3975 fiction, $778-83,787-93,1403,1405$ geography, 4 I 13

hist., 3147, 3531, 3982, 4I64

short stories, $891-95$

travel \& travelers, 307, 319-21

Mississippi Valley Historical Association, 3050

Missouri, 2764, 3346, 3948, 3960, 4108

caves, 2946

fiction, $763-65$

folklore, 5528

folksongs \& ballads, 5568-69

frontier life, 4097-98

Germans, 4478

guidebook, 386 I

resources, $4 \mathrm{I} 08$

rural communities, 4109

travel \& travelers, 366,4322

Missouri Compromise, 3346

Missouri Fur Co., 4148

Missouri River and valley, 4001, 4145, 4147

fur trade, 4148

geography, 4113

in art, 5805

travel \& travelers, 4307

Mr. Dooley at His Best, 865

Mr. Dooley in Peace and War, 863 
Mr. Dooley in the Hearts of His Countrymen, 864

Mr. Dooley: Now and Forever, 866

Mr. Dooley Says, 866

Mr. Dooley's Opinions, 866

Mr. Dooley's Philosophy, 866

Mr. Hodge and Mr. Hazard, 1904

Mr. Pope, i 8x I

Mister Roberts, 2335

Mister Zip, 2154

Mrs. Bumpstead-Leigh, 2348

Mistress Nell, 2313

Mrs. Ripley's Trip, 893

Mitchell, Broadus, 329I, 4068, 5877

Mitchell, Donald Grant, 506-10

Mitchell, Donald W., 3669

Mitchell, Edward Page, about, 2874

Mitchell, John M., 5007

Mitchell, Langdon, 23I 3, 2337, 2347

Mitchell, Lucy Sprague, 5234

Mitchell, Margaret, I 61 8-19

Mitchell, Robert V., 5945

Mitchell, Silas Weir, about, 4828

Mitchell, Stewart, 344I ed., I oo

Mitchell, Wesley C., about, 5888

Mitchell, William, general, 298 I about, 3647,5938

Mitchell, S. Dak., guidebook, 3899

Mitropoulos, Dimitri, about, 5654

Mittelholzer, Edgar, I 493

Mittelman, E. B., 6033

Mixed Company, 2147

Mizener, Arthur, 1431

Mliss, 930, 937, 939

Mobilizations, military, 366I

Moby-Dick, 333, 48I-83, 49 I

Mock, Elizabeth, ed., 5717

Mock, James R., 3462

$A$ Model of Christian Charity, 90

Modern Chivalry, 1 06-8

A Modern Instance, 965-66, 982

Modern Language Association of America, 2457, 2552

Modern Poetry and the Tradition, 2378

Modern Rhetoric, 2378

The Modern Temper, 2453

Modernist-fundamentalist controversy, 5429-30

Modes of Being, 5382

Modoc Indians, editorials, sketches, etc., 1065

Moeller, Philip, 2337

Moffett, Harold Y., 765

Mohawk River and valley, 40 I I

fiction, 1355

Mohr, Charles E., ed., 2946

Mohun, 249-50

Mojave Desert, 3947

Molière, Jean Baptiste Pocquelin, about, 2466,2474

Mollhausen, Heinrich Balduin, about, 5806

Molloy, Robert, 4093

Monaghan, Frank, 3304, 4229

Monaghan, James (Jay), 2757-59, 3345

Monday Night, I 242

Monetary policy. See Finance-public

Money, 5974-75, 5983, 5993

Money Writes, 1754
The Monk and the Hangman's Daughter, 739

Monongahela River, 4019

Monopolies, 6026, 6030, 6392 radio, 4709

telephone, 4673, 4710

See also Oligopoly

Monro, Isabel Stevenson, 5753

Monro, Kate M., 5753

Monroe, Harriet, 2760-6I ed., 2567 about, 2760-6I

Monroe, James, about, 3284

Monroe, Paul, 5 I 43 ed., 5 IIO

Monroe, Walter S., 5247 ed., 5 I I I

Monroe County, N.Y., 3810

Monroe Doctrine, 3138, 3284, 3575, 3577,3579

Monroe Township, N.J., 3815

The Monster, 835

Mont Saint Michel and Chartres, 69394

Montague, Ludwell Lee, 3584

Montague, William Pepperell, 5260, 5289

ed., 5250

Montaigne, Michel Eyquem de, about, 280

Montana, 395I, 41 47, 4178

guidebook, 3910

in literature, 4179

resources, $42 \mathrm{I} 2$

Montcalm, Louis Joseph de, about, 3 I 7 I

Monte Cristo and Other Plays, 2313

Monteleone, Vincent J., 2274

Monterey, Calif., soc. life \& cust., 435253

Monterey peninsula, Calif., 3930

Monteux, Pierre, about, 5649

Montez, Lola, about, 4923

Montgomery, D. E., 5898

Montgomery, Richard, drama, 105

Montlezun, baron de, 4289

about, 4288

The Monument Rose, 1983

Monuments, public, 4049, 5735

See also specific monuments, e.g., Lincoln Memorial; Mount Rushmore National Memorial

Moody, Dwight L., about, 5395, 5403, 5405,5480

Moody, Helen Wills, about, 4987

Moody, William R., 5480

Moody, William Vaughn, Io69-7I, 2337

Moon, Bucklin, 2050-5I

$A$ Moon for the Misbegotten, 1649

The Moon Is Blue, 2335

The Moon Is Down, 1780

The Moon of the Caribbees, 1648

Moore, Addison Webster, 5254

Moore, Albert Burton, 4099

Moore, Douglas, 1222

Moore, Edward C., 5660

Moore, Ernest C., 5289

Moore, Glover, 3346

Moore, Harry Estill, 3783

Moore, Marianne, I 620-22

about, 2426
Moore, Merrill, I623-27

about, 1628,1809

Moore, R. C., about, 5457

Moorhead, Max L., ed., 4188

Moorish Science Temple of America, about, 5498

Moos, Malcolm C., 6132-33, 6366, 6422

ed., $642 \mathrm{I}$

Morais, Herbert M., 5408

The Moral Argument Against Calvinism, 23 I

The Moral Decision, 626I

Moral philosophy. See Ethics

Morals, 4315, 4519, 4566

Moravian Church, 4480,5442

More, Louis Trenchard, 2425

More, Paul Elmer, 2425, 2479-8 I

about, 2375, 2479, 2503, 2593

More Clinical Sonnets, 1627

More Fables, 703

More Fish to Fry, 5070

More Stories in the Modern Manner, 2566

Moreau de Saint-Méry, Médéric Louis Elie, 4263-65

about, 4263

Morehouse, Ward, 4900

Morgan, Arthur Ernest, about, 4803

Morgan, Barbara B., 4968

Morgan, Bayard Quincy, 448 I

Morgan, Dale L., 3989, 4176

Morgan, Edmund S., 3100, 3256-57

Morgan, Helen M., 3257

Morgan, Hugh Gerthon, 4589

Morgan, J. Pierpont, about, 5880, 5882, 5978

Morgan, John, about, 4822, 4856

Morgan, Lewis H., 2961, 3008

about, 3009

Morgan, Murray C., 4216

Morgan, Robert J., 3324

Morgan, Thomas Hunt, about, 4721-22

Morgenstern, Julian, 5427

about, 5427

Morgenthau, Hans J., 3626

Morison, Elting E., ed., 3465

Morison, Samuel Eliot, 3083, 3103 , $3164,3198,3271,3305,3536$, $3721,3745,5203,5936$

ed., 6, 31 71, 5203

Morley, Christopher, 5222

Morley, Sylvanus Griswold, 2994 about, 2994

Morley of Blackburn, John Morley, viscount, about, 2480-8 I

Mormons and Mormonism, 2867, 3879 , $3961,4183,5404,541 \mathrm{I}, 5439$

fiction, 1424

folklore, 5538

folksongs \& ballads, 5538

hist., $216 \mathrm{x}, 4384,5464-65,5538$

legends, 5538

music, 5630

The Morning after the First Night, 4906

The Morning Watch, 1907

Morrill, Justin Smith, about, 2768

Morrill Act, 5 I I 3, 5 I 86, 5 I 9 I

Morris, Alton Chester, ed., 558I

Morris, Charles, 5335

Morris, George Pope, 2295 
Morris, Joe Alex, 2860 ed., 3548

Morris, Lloyd R., 3746, 4048, 4519, $4903,5333,5938$

Morris, Richard B., 6057, 6229-30 ed., 3072, 3288

Morris, Robert, about, 6016

Morris, Wright, 2052-56

Morris, Ill., soc. condit., 4557

Morrison, Alfred J., tr. \& ed., 4257

Morrison, Hugh S., 571 4-15

Morrow, Dwight W., about, 3586

Morse, John T., Jr., 377, 3416, 4036 ed., 3263

Morse, Samuel F. B., about, 4675-76, $4680,4752,4786$

Mort, Paul R., 5 I 44

A Mortal Antipathy, 375

Mortal Summer, i 826

Mortenson, Ernest, 6267

Mortimer, Lillian, 2305

Morton, Ferdinand Joseph ("Jelly Roll"), about, 5643

Morton, Ira, 5037

Morton, Thomas, 51-52 about, I 873,3198

Morton, Thomas G., 4850

Morton, William T. G., about, 472I, 4822

Morton's Hope, 2293

Mosely, P. E., 3562

Moses, Anna Mary R. ("Grandma"), 2762-63

about, 2763

Moses, Montrose J., 4937 ed., I 45, I99, 2347-48

Mosher, William E., 6r 88

Mosier, Richard D., 5126

Moskowitz, Sam, 2377

Mosquitoes, 138 I

Mosses from an Old Manse, 338-40

The Moth and the Flame, 2347

The Mother (Asch), II9I

The Mother (Buck), 1255

A Mother in Mannville, 1684

The Mother's Recompense, 1853

Motion pictures, 4905, 4944-63

actors \& actresses, 4946

arbitration, 6299

audiences, 4895,4950

censorship, 4947

essays, 1226

hist., 4519, 4944-46, 4954-55, 4959 . $4962-63,5689$

in education, $523 \mathrm{I}$

psychological aspects, 4951

satire, I 688

Motley, John Lothrop, 2293 about, 2462,3376

Motorboat racing, 50r 6

Mott, Frank Luther, 1052, 2482

ed., 131, 2329, 2847, 2907, 2915

Mott, Frederick D., 4869

Mott, Rodney Loomer, 6097

Mounds and mound-builders, 2996, 4323

Mount, Charles Merrill, 577 I

Mount, William Sidney, about, 5768

Mount Holyoke College, hist., 5193

Mount Hood, guidebook, 3938
Mount Rushmore National Memorial, 5737

Mount Savage, 2302

Mount Shasta, 4210

Mt. Sinai Holy Church of America, Inc., about, 5498

Mount Tyndall, 42 ro

Mount Vernon, Va. (George Washington's residence), 327 I

Mount Whitney, 4210

Mountain Interval, 1452

Mountain life, 4174,5064 short stories, 910, 917-21, 1084-88

The Mountain Lion, 2158

Mountain men, 3330 fiction, 312

The Mountain on the Desert, 1691

Mountain States, 3784

Mountain Time, 2415

Mountaineering, 2665, 3938, 4174, 4210-II

Mourning Becomes Electra, $1647-48$

The Moving Finger, 1855

Mowatt, Anna Cora, 2337, 2347, 4927 about, 4927

Mowbray, Albert H., 5990

Mowrer, Edgar A., 3627

Mowry, George E., 3084, 3467, 4202

Muck, Karl, about, 5649

Muckrakers, 1107, I155, I 754, 6430, 6432

See also Reform and reform movements

Mudd, Emily (Hartshorne), 4570

Muclder, Hermann R., 2973

Muelder, Walter G., ed., 5259

Mueller, John H., 5650

Mueller, Kate (Hevner), 5212

Münsterberg, Hugo, about, 4225, 5392

Muhlenberg, Frederick Augustus, about, 3231

Muhlenberg, Henry Melchior, about, $3231,5396,5462$

Muhlenberg, William A., about, 5457

Muhlenberg family, 3231

Muir, John, I $072-83$ about, $1081-82,2422$

Muldoon, William, about, 5032

Mulford, Roland J., 5155

Muller, Herbert J., I 897

Mullet, Charles F., $325^{8}$

Mumford, Lewis, 2407, 3731, 5695, 5701

ed., 5716

about, 5508

Muncie, Ind., soc. condit., 4593

Municipal government. See Local government

Municipal law, 6277 radio \& television, 4708

The Municipal Year Book, 6213

Munitions problem, 3669

Munitz, Milton Karl, 5375

Munsell, Joel, 6447

Munsey, Frank A., about, 291 3

Munsey's Magazine, about, 29 I 3

Munson, Gorham B., 2425

Murat, Prince Achille, 4293-96

Murchison, Carl A., ed., 5393

Murder for Pleasure, 2436

Murder in the Cathedral, 1359
The Murder of Lidice, 1608

The Murders in the Rue Morgue, 529

Murdock, Frank, 230 r

Murdock, Kenneth B., 2424, 2483, 2496, 3199

ed., 48, 50, 83, 1009

Murfree, Mary Noailles, I 084-88, 2296

Murphy, Arthur E., 3739, 5290

Murphy, Henry C., 597I, 5977 tr., 3208

Murphy, Robert Cushman, 2962

Murray, Henry A., ed., 44 I

Murray, John, about, 5473

Murray, Philip, about, 6394

Murray, William G., 5848

Murrell, William, 5803

Murry, J. Middleton, 656

Museums, 3049, 4726, 5721, 5794-5800 directory, 4716

industrial, 4716

Ohio, 4119

Music, 3736, 3747-48, 3751, 4025, $5605-87$

and poetry, 1038, 1044-46, 1580

and the State, 5647

bibl., 5606, 56ro-1 I

criticism, 1828

discography, $56 \mathrm{r}_{3}$

econ. aspects, 5615,5623

education, $5617,5625,5629,5668$ 72,5684

hist., $5607-8,5612-14,5628,5635$, $5638-39,5650$

Jewish, 4458

Bethlehem, Pa., 5667

Boston, $5628,5648-49,5672$

Calif., 5630

Chicago, 565I-52

Cleveland, 5630

Minneapolis, 5654

Nashville, 3765

New England, 5633

New York (City), 4049, 5626-27

Philadelphia, 5629

Southwest, 5630

Toledo, 4894

See also Opera

The Music from behind the Moon, 1262

Musical comedy, 4935,5638

Musical Courier, about, $568 \mathrm{I}$

Musical instrument makers, 5628

Musicians, I 46, 2638, $5644,5673-87$

bibl., 5606

biog. (collected), 5622, 5632, 5634, 5642

unions, 5619

See also Composers

Muskingum, Ohio, 3873

Musselman, G. P., 4479

Musselman, Morris M., 4954

Musser, Paul H., 198

Mussey, June Barrows, ed., 4029

Mutiny in January, 3264

Muzzey, David Saville, 3442

My Ántonia, 1276-77

My Boyhood Dreams, 798-99

My Chinese Marriage, 1659

My Days of Anger, 1374

My Début as a Literary Person, 798-99

My Diary North and South, 4379-81 
My Ears Are Bent, 2756

My Farm of Edgewood, 509

My Father's Business, 2350

My First Lie, 798-99

My Glorious Brothers, 1979

My Heart and My Flesh, 1699

My Heart for Hostage, 1515

My Heart's in the Highlands, 2110,2112

My Lady Pokahontas, 66, 251

My Life among the Indians, 1065

My Life and Hard Times, 1817

My Lord, What a Morning, 5673

My Mortal Enemy, 1277

My Name ls Aram, 2 I I

My Partner, 2316

My Several Worlds, 1260

My Study Windows, 467

My Summer in a Garden, I I 37-38

My Ten Years in a Quandary, 1217

My Uncle Dudley, 2052

Myer, Jesse S., comp., 48 I 8

Myers, Albert Cook, ed., 3214

Myers, Gustavus, 5882

Myers, Louis M., 2249

Myers, Margaret G., 5993

Myers, William Starr, 3486,6385

Myrdal, Gunnar, 4446

Mystery novels. See Detective and mystery fiction

The Mystery of Marie Roget, 529

Mysticism, 5355

Mythology, Indian, 3013, 3021

Myths. See Legends and tales

Myths and Legends of the Old Plantation, 914

Myths and Myth-Makers, 5302

Myths and Realities, $45 \mathrm{I} 7$

\section{N}

NEA Journal, 5245

Nagel, Ernest, 5267, 5290, 5291, 5350 ed., 5267

Nagel, Hildegard, tr., 48 I 4

The Naked and the Dead, 2026

Nally, Thomas P., 5226

Names, 2238, 2246, 2248, 2264, 4390 See also Place-names

Names on the Land, 2976

The Nancy Flyer, a Stagecoach Epic, 1656

Nantucket, Mass., 4038

Napoleon I, about, 23 I

Narrative of the Captivity and Restoration of Mrs. Mary Rowlandson, 55

Narrative poetry. See Poetry-epic and extended narrative

Narratives of Early Virginia, 7 I

Narratives of the Indian Wars, 55

Narratives of the Witchcraft Cases, $4 \mathrm{I}$

The Narrow House, 1744

Nasby, Petroleum V., pseud. See Locke, David Ross

Nash, Ogden, I 629-34

about, 2426

Nashville, intellectual life, 3765

Nason, Arthur H., ed., I 67

Nason, Thomas W., about, 5783
Nast, Thomas, 5803

illus., 424-25, 544

about, 422, 2917

Nathan, George Jean, 4906

Nathan, Robert Gruntal, I635-43

Nathan, W. L., 3751

Nathanson, Jerome, 5296

Nation, Carry, about, 2588

The Nation, 2503, 2882, 2921

National Academy of Sciences, Washington, D.C., 4774

about, 4774

National Archives, 3066-67 about, 3066-67

National Association for the Advancement of Colored People, about, 6 ro6

National Association of Nurse Anesthetists, hist., 4816

National Avenue, 1806

National banks, 5993, 5999

National Bureau of Standards, about, 4769

National characteristics, 2380, 2464, 2469, 250I, 3I 23, 31 40, 3146-47, $3609,3732-35,3738,3762,4119$, 4223-24, 4229, 4234, 4513-14, $4555-56$

National Commission on Life Adjustment for American Youth, about, 5224

National Committee on General Education, 5228

National Conference of Social Work, 4618

National Council for the Social Studies, 3050, 3059

National Council of the Churches of Christ in the United States of America, about, 5487

National defense, 4761, 4773 econ. aspects, 5879, 5889

National Education Association, 5106, 5228, 5240, 5245, 5247

National Funeral Directors Association of the United States, 4527

National Gallery of Art, 5594

National Geographic Society, Washington, D.C., 2962

National Health Assembly, Washington, D.C., 4870

National Historical Publications Commission, 3068

National Industrial Conference Board, 5893

National Institute for Commercial and Trade Organization Executives, 6019

National Labor Union, about, 6034

The National Law Library, 6223

National Medical Library, about, 6476

National Museum, about, 4726, 4744

National Orchestral Survey, 5647

National parks and reserves, 1072, I075-77, 2956, 5813, 5866

National Planning Association. Committee of New England, 5890

National Research Council, 4777 about, 4774

National Resources Board. Land Planning Committee, 3043
National Resources Committee, 5898

National Resources Committee. Science Committee, 4777

National Resources Planning Board, 5898

about, 6r 44

National Resources Planning Board. Science Committee, 4777

National Science Foundation, about, 4776,4778

National Security Council, about, 6144

National Security Resources Board, about, 6144

National Society for the Study of Education, 5246

National Society for the Study of Education. Committee on Early Childhood Education, 5150

National songs, hist., 5616

National Tuberculosis Association, 4868 hist., 4863

National university, proposed, I or

Nationalism

I 8 th cent., 3246, 3282, 3328, 5406

I 8 th-1 9 th cent., 3106,4526

I 9 th cent., $3305,3313,3328,3347$, $3363-64,3397,3399,3412,3419$ $3431,3445,378 \mathbf{1}$

Nationalism in literature

essays, $242 \mathrm{I}$

(1 764-1819), 101, 105, 109-17, 134, 1 46-48, 165-70, 2412, 2530

$(1820-70), 198,230,252,280,283$, $3 \mathrm{I} 7,323,368,38 \mathrm{I}, 427,430,487$, $5 \mathrm{II}, 546,769-71,2295,2478$

(1871-1914), 890, I I 36

Nationality, $4417,4427,4430$

See also Foreign population

Native Son, 2233

Nativism, 4515,6164

Natoma (opera), $568 \mathrm{I}$

Natural history, 2956, 4726,4738

bibl., 4736

S.C., 5087

Tex., 4734

See also Animals; Plants

Natural history societies. See Scientific societies

Natural law, 3258, 6072, 6094

Natural resources, $2940,5810,5884$, 5898,5900

Ga., 4095

Middle West, 4113

Mo., 4108

N. Dak., 4165

Northwest, Pacific, 4212

Ohio, 41 I9

Southern States, 4079,4084

Vt., 4033

Va., 4085

See also Conservation of natural resources

Naturalism in literature, 3758

fiction, 768, 821, 959, 1048, 1089, I 333, 1743, 1 775, 2365, 2498

See also Realism in literature

Naturalists, 4307

bibl., 4736

biog. (collected), 4734

See also names of individual naturalists 
Naturalization, 4424

Nature, 281-82, 286, 293

Nature and Man, 5380

Nature in art, 5762

Nature in literature

anthologies, 2453

editorials, sketches, etc., 280-2, 286 , 293, 506, 509-10, 633, 716-17, $740-44$, I I 36-38, I I 44, т $724-26$, 2453

fiction, 716

hist. \& crit., 2422

poetry, 7-1 1, 134, 138, $216-21$, 223$25,455,61_{4-17}, 61_{9}-30,636-37$, $639,642,662,667-71,673,838-$ 46, I I $26-31$, I 823

prose, $21,36,46,585,587-97,599-$ $602,605-6,608-9,633-35,638$, I $072-83$

short stories, 612-13, 716, 1724

Naturopathy, 48 I I

Naughton, Thomas Raymond, 6221

Naughty Anthony, 2315

Naughty Marietta (operetta), 568I

Nauvoo, Ill., guidebook, 3879

Navajo Indians, 3013

fiction, I $55 \mathrm{I}-52$

Naval Academy, Annapolis, Md., about, 3825

Naval Gun Factory, Washington, D.C., hist., 3670

Naval Observatory, about, 4770

Naval policy, $3643,3666,3674$

Naval Research Laboratory, about, 3675

Naval warfare, law of, 3524

Navigation, 3164, $4110,4114,4746$

Navigation Acts ( $649-96), 3193,3243$

Naville, Pierre, 5393

Navy, 3666-77

biog. (collected), 3825

hist., 252, 3666-69, 3671-74, 3676, 4040

American Revolution, 3678

War with France (1798-1800), $3685-86$

War of 1812,3688

War with Mexico, 3689

Civil War, 3416,3700

Spanish-American War, 3708

in literature, 2746

personnel policies, 3669

Navy Dept., 3700

scientific research, 3675

Navy Yard, Washington, D.C., hist., 3670

The Nazarene, I 190

Near East, relations with, 3512,3588

travel \& travelers, 2278

Nebraska, 3944, 3948, 4 I 66

fiction, 1276,2052

frontier life, 2799-2800, 4 I 56

govt., 6 I 95

guidebooks, $390 \mathrm{I}-3$

hist., 3901,4166

law, 6233

rural communities, 4 I 09

The Necessary Angel, 1783

Ned Myers, 271

Needles and Pins, 2317

Needlework, 5593, 5595, 5604, 5785
Neely, Wayne Caldwell, 5827

Nef, John U., 4504

Neff, Emery Edward, I 7 19, 2289

Negligible Tales, 739

Negroes, 2690, 2839-40, 4310, 4428, 4435-5I

actors, $492 \mathrm{I}$

biog. (collected), 5515

boxers, 5025

colonization, Africa, 4258

econ. condit., $4446,4448,6375$

education, $4443,4450,5$ I 6,5206

folklore, 5515, 5517-18,5523, 5527 , 5535,5547

in literature, $910-16,922,924-$ 25

in art, 5765

language (dialect, etc.), 2271

in literature, 192-93, 756-59, 856-60, 910-16, 922, 924-25, 1032, 1038, 1099-1102, I 106, I $133-35,1526,1653$

legends, 551 7-1 8, 5521

musicians, 5644

politics \& suffrage, $3106,6375,6378$ 79,6409

religion, 5401, 5498-5502, 5527, 5547

soldiers (Civil War), 2280

songs, 5517-18, 5521, 5540, 5556, $5564,5569,5582$

spirituals, 5540, 5555, 5558-59

Baltimore, 4062

Brooklyn, 4046

Chicago, 4439, 445I, 6375

Northern States, 4310,4451

Philadelphia, 4258

Southern States, 4083, 4438, $44436376,6378-79$

See also Slavery

Negroes in literature

editorials, essays, sketches, etc., r9293, I099, I103-4, I 106, 2364

drama, I 821

fiction, 562-67, 722, 756, 949-52, 1099, I 106, 1390, 1 392, I 51 2-13, 1 526-29, 1 569, 1653-55, 1 759-60, $1832,1914-15,1937,1939,1966-$ $67,2011,2050-51,2232-33,2235$, 2631

humor, 250 I

poetry, 856-59, 861, 11 33-35, 1521, 1 $537-38$, I $540,1937-38$

reporting, 1653

short stories, 192-93, 756-61, 856, 859-6o, 910-16, 920-22, 924-25, 1032, 1099-1102, I106, I 523-25, 2234

Neighborhood houses, New York (City), 4624

Neihardt, John Gneisenau, I 644-46

Nelson, Arnold L., 2960

Nelson, Bruce C., 4147

Nelson, Helge, 4486

Nelson, John H., ed., 2276

Nelson, Joseph, 2764

Nelson, Lowry, 4582

Nelson, William Rockhill, about, 2887

Nerber, John, ed., 4 I 7

Netherlanders. See Dutch
Netherlands, 2293

relations with, 3528

Nets to Catch the Wind, 1903

Neuberger, R. L., 6207

Neufeld, Maurice F., ed., 6032

Neuman, H., tr., 4268

Neumann, Henry, 5435

Neumeyer, Esther S., 4998

Neumeyer, Martin H., 4998

Neurology, 4828 study \& teaching, 4840

Neurosurgery, $482 \mathrm{I}$

Neutrality, 3535,3582

World War I, 3470, 354 I

World War II, 3537-38

Nevada, 4 I $84-85$

descr., 4184

fiction, I 420,1954

guidebook, 3916

hist., 3959, 396r, 3989, 4 I 84, 4 I 89

Indians, 3019, 3023, 304I

music, 5630

Nevertheless, 1621

Nevins, Allan, 421, 2858-59, 2873, $3093,3259,3335,3398-99,3423$, $3443-44,3534,4033,4676,4789$, 5915-16, 5939

ed., 2691, 2823, 3313, 3334, 335I, $3422,4047,4234$

Nevius, Blake, 1856

The New Apologists for Poetry, 2452

New Castle, Del., 3823

"New Criticism," 2378, 242 I, 2559

New Deal, 3ir9, 3458, 3491-92, 3497 , $5877,6095,6354-55,6364$

New Directions in Prose \& Poetry, 2560

New England, 4026-42, 4423

agriculture, 5820,5840

biog. (collected), 2693, 4029, $427 \mathrm{I}$

church hist., 5417

descr., 5086

econ. condit., $403 \mathrm{I}, 5890$

fisheries, 5872

folklore, 5524, 5534, 554I

folksongs \& ballads, 5554, 5574, 5580

foreign population, 4026,4413

govt., Colonial period, 6079

guidebooks, 3782, 3791-3805

hist., 2268, 2681, 3279, 3281, 3783$84,3965,4030$

Colonial period, 313r, 318r, $3213,3219,3743$

intellectual life, 2549, 3742-43, 3745

language (dialects, etc.), 2268

in literature, $209,558,88 \mathrm{I}-86$

music, 5633

postal service, 4665

public libraries, 6472

schools, 2674

science \& technology, 4730

soc. condit., 4031

soc. life \& cust., 2600, 265I-52, 4029

theology, 2483,5428

transportation, 5933

travel \& travelers, $36-39,69-7 \mathrm{r}$, $3069,4227,426 \mathrm{I}, 4266,427 \mathrm{r}$, 4279, 4324, 4329

A New England Boyhood, 906-7

The New England Courant, about, 2854 

A New England Group and Others,

New England in literature, 2459

diaries, journals, etc., $36-39,49,53$, 58 , 90-91, 187, 294-95, 600-1, $603,706-10,900,906-7$

drama, $168-70,198,200,1647-48$

essays, 286-87, 291-93, 298-301, $368,371-74,465-67,469,979$, $1002-3,2486$

fiction, $188,333-47,356,402-4$, $470,481-83,491,562,568-73$, $576,579-84,665,706-10,1284$, $1286,1437-44,1589,1619,1736$, I $845,1916,1992,2156$

hist. \& crit., $1-6,43-44,69-71,91$, $2381,2483,2549$

humor, 209, 558-6r

poetry, 7-I1, 72-74, 79-83, 288-90, 368-70, 455-59, 662, 667-71, 673, $1451-52,1583-84,1713-14,2007$, 2374

prose, $585,587-97,599-606$

satire, $51-52,75-77$

short stories, $5 \mathrm{I}, 333-40,356,359$, $562,574-75,706,711-12,881-$ 86, 1023-31, 1 762, 2 1 60

theology, 17, 19-22, 33-35, 40, 43$44,59-62,65,86-89,93-95,2483$

New England: Indian Summer, 2381

A New England Nun, 883-84

The New England Quarterly, 2561

New England Reformers, 286

The New England Weekly Journal, about, 2854

A New England Winter, 1008

New Englander and Yale Review, 2577

New Englanders, 3965, 4027-30, 4394, 4423

drama, 4926

Northwest, Old, 41 1 7-1 8

See also Yankees

New English Canaan, 52

New Found Land, 1586 New France, 3156, $3171,3175,3207$,

New Hampshire, 4032

fiction, 706-10, 1656, 1916, 1918, $2 \mathrm{I}_{3}$

folklore, 1222

guidebook, 3796

hist., $403 \mathrm{I}$

poetry, I $451-52,1916$

short stories, 1222

New Haven, Conn., 4042, 4261

A New Home-Who'll Follow?, 416I 7

New Hope, 1800

New Humanism. See Humanism, New

New Jersey

culture, 3232

govt., 3470

guidebooks, $3811-15$

hist., 321 4, 3232, 3811 , 3994, 4053

politics, 6395

New Jersey in literature

fiction, 1872,1916

poetry, 1872,1876

short stories, 1879

New Jersey Legislature, about, 6395
The New Laokoon, 2375

New Mexico, 2737

archaeology, 2992

architecture, 5723

descr., 4198

fiction, 1196, 1686-87

folklore, 5537

guidebook, 3924

hist., 3956, 3961, 4I 74, 41 89, 4198

Indians, 2723-24, 3013, 3023, 304 I

language (dialects, etc.), $4 \mathrm{I} 98$ resources, $4 \mathrm{I} 88$

The New Mexico Quarterly Review, 2562

The New Nation, 726

New Netherland. See New York (Colony)

New Orleans, 2586, $287 \mathrm{r}$

guidebook, 3852

hist., 1 036, 4101

jazz music, 5644

soc. life \& cust., 4 I O I, 4283,4288

theater, 4922

New Orleans in literature

drama, 2221

fiction, 745, 749-50, 945, 1032, I381, 1390

short stories, 746-48, 945, 951-52, 954-55, 1032-35

The New Partisan Reader, 2566

New Plymouth Colony. See Plymouth Colony

The New Realism, 5260

The New Republic, 1821

New School for Social Research, about, 5219

The New South, 1038

The New Spoon River, I60I

New Thought, 5439

The New World, 3153-75

colonization, 3086, 3156-58, 3162 , $3169,3171,3173,3175,3223$

disc. \& explor., 3153-62, 3164-69, $3171-75,3203,3206-7,3212$, $3215,3217,3223,4230$ sources, 3163

geography, 3 1 55, 3 161, 3174

hist., 3075, 3086, 3153, 3157, 3165 , 3189,3223 sources, 3223

New World Writing, 2563

New Year's Day (The 'Seventies), 1845

New York (City)

art collections, 5795-5800

Bohemianism, 3757

Chinese, 4467

commerce, 5951

concerts, 5626-27

culture, Colonial period, 4518

econ. condit., 4602,4638

folklore, 5522

foreign population, 4409

geography, 2939

govt., 62 I 4

guidebooks, 3808-9

harbor, $595 \mathrm{I}$

hist., 2478, 3443, 4045-49

hospitals, 4851,4857

Italians, 4497

music, 5626-27, 5644
New York (City)-Continued

Negroes, 4447

pictorial works, 3782, 4045

politics, $4535,6207,6381-82$

press, 2904

Puerto Ricans, 4470

soc. condit., $4597,4624,4638$

soc. life \& cust., 2586, 2691-92, 2755, 2822-23, 4048, 4261, 4263, $4290,4602,5522$

theater, $2017,4897,4907-9,4916$, $4924,4926,4935,4942-43,5638$, $5657-59,5662$

Yiddish press, 2898

See also Brooklyn; Harlem (N.Y.); Manhattan

New York (City) in literature

descr., 242-43, 1859

drama, I 68-70, I 688-89, 2063, 2535

editorials, sketches, etc., 2466,4048

essays, 979, 1002-3, I 859, 2017

fiction, 691-92, $1190,1193,1300$, $1327,1333-35,1339,1372,1376$ $1446-47,1449,1612,1614,1636$, $1642,1656-58,1680,1688$, I 82829, $1831,1842,1845,1889-90$, 1909, 191 1-1 2, 191 4-15, 1966-67, 2025, 2027, 2069, 2074, 2094, $2107-8,2110,2132,2229,2231$, 2278

humor, 2152

personal narratives, 2473

poetry, $1857-58,2133$

short stories, IIII, I I I4-20, II 55, 1851,1855 , 1910, 1913, 2057, 2110,2145

New York (City) Health Dept., about, $488 \mathrm{I}$

New York (City) Metropolitan M!useum of Art, 5754, 5804

American Wing, 5796

hist., 5795

New York (City) Metropolitan Opera, about, $5657,5659,5662$

New York (City) Museum of Modern Art, 5602, 5697, 5717-18, 5797

New York (City) Public Library, about, 48 I $9,6465,6476$

New York (Colony)

govt., 3224

hist., 3194, 3200, 3210, 3224, 3232

law, $622 \mathrm{I}$

travel \& travelers, 3208

New York (State), 4044-52

biog. (collected), 427 I

boundaries, 4027

culture, 3224, 3232, 4027

folklore, 5518,5548

govt., 6 I 95

guidebooks, 3806-10

hist., 3304, 344I, 3966, 4027, 404344,4049

hospitals, 4846

libraries, 6468

politics, $6374,6384-85,6387,6399$

prisons, 4653

travel \& travelers, 3069, 424I, 426I, $4266,4269,4271,4285$ 
New York (State) in literature essays, 675,740

fiction, 268-69, $511,514-15,1155$, I 158, I I $60,1338,1353-56,2132$, 2282

humor, $382-83$

short stories, $384-87$, I 160

New York (State) Constitutional Convention (1821), about, 6374

New York (State) Constitutional Convention Committee, 6080

New York (State) Legislature, about, 6II5

New York (State) Republican Party, about, 6385

New York Academy of Medicine. Committee on Medicine and the Changing Order, 4808

New York Academy of Medicine. Committee on Public Health Relations, 4851

New York Academy of Sciences, about, 4717

New York City Ballet, about, 4969

New York Committee on the Study of Hospital Internships and Residencies, 4857

New York Daily News, about, 2862

The New York Evening Post, about, 2858, 2873

New York Folklore Quarterly, 5518

The New York Gazette, about, 2854

New York Herald, about, 285 I, 2868, 2877

New York Herald-Tribune, about, 2868 2903,4984

European ed., about, 2872

New York Hospital, about, 4838

The New York Idea, 2337, 2347

New York Society Library, about, 6468

New York State Historical Association, 4044

New York Stock Exchange, about, 5982

New York stock market, $3477-78$

The New York Times, 2564, 4984

The New York Times Book Review, 2564

The New York Weekly lournal, about, 2854,2931

New York Tribune, about, 2851, 2868, 2883

The New Yorker, 2565, 2567, 2919

Newcomb, Rexford, 5719, 5723

Newcomb, Simon, 4724, 4756

about, 4724,4756

Newcomer, Mabel, 6028

Newell, William Wells, 5588

Newfoundland fisheries controversy, $3542,3554-55$

Newhouse, Edward, 2057-59

Newlin, Claude M., ed., 108

Newman, Albert H., 5443

Newport, R.I.

econ. condit., 4602

essays, 1002-3

soc. life \& cust., 4040, 4387, 4602

News agencies, $2860,2864,2890$

News of the Night, 2309

Newsome, Albert Ray, 4090

Newspaper court reporting, 6288

Newspaper Days (Dreiser), I344
Newspaper Days (Mencken), I 604

Newspaper Enterprise Association, about, 2890

Newspapermen, $2847,2849,2853,2857$, 2877-94

bibl., 2850

biog. (collected), 2848

See also Reporters and reporting; and names of individuals

Newspapers, 2845-76, 2924, 2927

bibl., 2852

chain ownership, 2848, 2866, 2886, 2890,2927

Civil War, $285 \mathrm{I}$

Colonial, 2854,2880

directory, 5958

foreign language, 2895-99

hist., $2846-48,2852,6447$

policies \& practices, 2846,2851 , 2900-9, 29I I

Ariz., 4 I 99

Ga., 2856

New York (City), 2904, 4049

Northwest, Pacific, 4214

Obio, 2857

Oreg., 2863

Southern States, 2853

Washington, D.C., 4063

See also Newspapermen; Syndication (newspaper)

Newton, Arthur P., 3168

ed., 3169,3179

Newton, Earle W., 4033

Newton, Walter H., 3486

The Next Voice You Hear (motion picture), about, 4949

Nez Percé Indians, 3001

Niagara

essays, 1003

hist., 3950

travel \& travelers, 4336

Nicaragua, relations with, 3575

Nicaraguan Canal, 3437, 4221

Nice People, 2348

Nichols, Alice, $4 \mathrm{I} 67$

Nichols, Dudley, ed., 2332

Nichols, Roy Franklin, 3347, 3400

Nicholson, Joseph William, 5500

Nick of the Woods, 201-4

Nickerson, Hoffman, 3682

Nicodemus, I 714

Nicolay, John G., 421, 941, 3395, 3426

Niebuhr, Helmut Richard, 5399 about, 5433

Niebuhr, Reinhold, 5399, 5447, 5496 about, 5432-33, 5436

Niger, Samuel, 4459

Nigeria, 5989

Nigger Heaven, 1832

A Night in Acadie, 761

Night Music, 2065

Night of the Poor, 2090

Night over Taos, 1174

Night Rider, 2194

Nightingale, Florence, about, 4852 , 4854

The Nightmare Has Triplets, 1 264-66

Nights with Uncle Remus, 91 4-16

Nikisch, Arthur, about, 5649

Niklaus, Thelma, 4953
Niles, Blair, 3977

Niles, Hezekiah, about, 2924, 3260

Niles, Samuel V., 3260

Niles' Weekly Register, 2924, 3260

Nims, John Frederick, 2060-62

Nine Days to Mukalla, 2097

1919, 1325,1328

Nisei, 2812,4466

Nishimoto, Richard S., 4469

Nissenson, Samuel G., 3200

Nixon, Edgar B., ed., 5884

Nixon, Herman Clarence, 3958, 4068, 4594

Nixon, Phyllis J., 2255-56

Nixon, Raymond B., 3445

The No 'Count Boy, 1475

No Friendly Voice, 5235

"No Haid Pawn," I 100-2

No Man Is an Island, 2042

No Man Knows My History, 5464

No Matter What Happens, 2754

No More Bohemia, I 553

No More War, 2342

No Mother to Guide Her, 2305

No People Like Show People, 4931

No Poems; or Around the World Backwards and Sideways, 1216

No Retreat, 1483

No Star Is Lost, 1374

No Thanks, 1313

No Time for Comedy, 1209

No Villain Need Be, 1423

No, Yong-Park, 4232

Noah, Mordecai Manuel, 2347

Noble, Peter, 4960

The Noble Exile, 517

Noble savage, 239, 24I

Nock, Albert Jay, 3297, 4535 ed., 215

Noel, Mary, 2916

Noetzel, Gregor, maps, 3082

Nolan, Jeannette (Covert), I 132

Noland, Charles F. M., 5542

Nominalist and Realist, 286

Nomini Hall, Va., 2673

Nona Vincent, I0I 2

None Shall Look Back, 1468

Nonpartisan League, about, 5831, 6356

Nook Farm, 81 4

Noon Wine, $166 \mathrm{r}$

Norborg, Sverre, 5363

Nordstiernan, about, 2895

Norfolk, Va., 4088, 4263

Norris, Benjamin Franklin, 1089-98 about, 2365, 2430, 2464, 2517

Norris, George W., about, 3446, 61 95

North American Review, 2294

North \& South, 1925-26

North Carolina, $3833,3945,3963,4023$, 4079,4090

architecture, 5706

counties, 4090

culture, 3233

drama, 1473,1475

fiction, 405, 1 473-74, $1887-88$

folklore, 5529, 5536

folksongs \& ballads, 5582

governors, 4090

guidebooks, 383 I-33

hist., $3216,3223,3233,4021,4023$, 4090,4104 
North Carolina-Continued language (dialects, etc.), 2256

legends, 5536

short stories, 1239, 1476

travel \& travelers, $4248-50,4277-78$

North Dakota, 3951, 4165

econ. geography, 4165

frontier life, 4156

guidebook, 3895

hist., 4147

rural communities, 4109

North Is Black, I 553

North Little Rock, Ark., guidebook, 3854

North of Boston, 1452

North Pole expeditions. See Arctic expeditions

North Star Country, 3954

Northern Plains, frontier life, 41 55-56

The Northern Shoshoni Indians, 2364

North=op, F.S.C., 3758 ed., 5384

Northwest, Old, 4 I $09-44$

architecture, 5719

culture, $3737,4 \mathrm{I} 17$

descr. \& trav., $280_{3}$

econ. condit., 4 I I I

guidebooks, 3862-94

historical geography, 2969

hist., 3239, 4109-44, 5931

Indian fighting, 3660

soc. life \& cust., 4 I I I , 4 I I5

travel \& travelers, $366,4307,4322$, $4324,4329,4349,4358,4374$

writers \& writings, 4 I I 2

Northwest, Pacific

econ. condit., 4212

fiction, $216 \mathrm{I}$

governors, $42 \mathrm{I} 3$

guidebooks, 3935-39

hist., 4213-1 4, 4022

Russian claims, 3560

travel \& travelers, 39I

Northwest Passage, I710, 3160, 3167. 3169

Northwestern States, 395 I

boundaries, $395 \mathrm{I}$

descr. \& trav., 2663

hist., $366_{3}, 3783,4$ I 47

Indians, 2998

pictorial guidebook, 3782

Northwestern University, Evanston, Ill., about, 4993

Norton, Andrews, about, 5436

Norton, Charles Eliot, 5387

ed., I I, 462, 465-67

about, 2480

Norwegians

fiction, $1720-23$

immigration, 2267, 4482, 4484-85, 4487

language (dialects, etc.), 2267

Wis., 4347

Norwood, William Frederick, 4860

Noss, Murray, 2350

Not by Strange Gods, 1706

Not Guilty, 6298

Not Heaven, 1450

Not So Deep as a Well, 1651

Not So Long Ago, 4519
Notes of $a$ Son and Brother, 1015

Notes on the State of Virginia, 4753

Notions of the Americans, 261

Notre Dame, Ind. University, about, 5041,5044

Nourse, Henry S., ed., 55

Nova Britannia, $303 \mathrm{I}$

The Novel of Violence in America, 2427

Novels. See Fiction

November Boughs, 627,638

Now the Sky, 1827

Now with His Love, 1227

Nowell, Elizabeth, ed., 1894

Nueces County, Tex., 4476

Nugent, Elliott, 2334

Nullification (1820-1839), 3303, 3328

Number One, 1332

Nuñez Cabeça de Vaca, Alvar, 3217

Nursery Schools, 5148

Nurses and nursing, $4808,4816,4820$, 4835,4864

biog. (collected), 4854

hist., 4852

Nute, Grace L., 3170

Nutrition, 4722, 5819

Nutting, M. Adelaide, about, 4854

Nye, Edgar Wilson ("Bill"), about, I 126

Nye, Russel B., 306o, 3380, 3401, 3446

\section{$\mathrm{O}$}

O Captain! My Captainl, 623

$O$ Genteel Lady!, 1438

O Pioneersl, 1 276-77

O Shepherd, Speakl, 1758

Oakes, J. B., 6128

Oakley, Annie, about, 4979

The Oasis, 2019

Oats, 5835

Oberfirst, Robert, ed., 2318

Oberhoffer, Emil, about, 5654

Oberholtzer, Ellis Paxson, 3447

Oberlin College, about, 5670

Oberndorf, Clarence P., 375

O'Brien, E. J., ed., 2322

O'Brien, Frank M., 2874

O'Brien, Robert, 4209

Obscure Destinies, 1277

Observations by Mr. Dooley, 866

Occupational therapy, 4840

Occupations, 6043

immigrants, 4395

Italians, 4497

Jews, 4459

Negroes, 4439

Nisei, 4466

Ocean City, N.J., 4596

The Ocean Highway, 3788

Ochs, Adolf S., about, 2869

Ocmulgee National Monument, 3840

O'Connor, Basil, 5427

about, 5427

O'Connor, Richard, 370 I

O'Connor, William Van, I 402, I 785 , $2361,2484,3376$

The Octopus, 1093

The Octoroon, 2337

Ocular surgery, 4844

O'Daniel, W. Lee, about, 4192
An Ode in Time of Hesitation, 1069

Ode Recited at the Commemoration of the Living and Dead Soldiers of Harvard University, 459

Ode to the Confederate Dead, I 8 I I

Odegard, Peter H., 4554, 6338

Odell, Alfred T., ed., 554

Odell, George C. D., 4924

Odets, Clifford, 2063-68, 2327, 2333 , 2348

O'Donnell, James, about, 4536

Odum, Howard W., 3783, 3785, 4079, $4541,556 \mathrm{I}$

ed., 4540

Oehser, Paul H., 4775

Of All Things, 1214

Of Making Many Books, 6449

Of Men and Mountains, 2665

Of Mice and Men, $1780,2333,2336$

Of the Earth Earthy, 4531

of Time and the River, 1889-90

of Broadway, II 75

Offenbach, Jacques, 5679

Office of Air Force History, 3727

Office of Education, 5206, 6474

Office of Experiment Stations, about, 4768

Office of Indian Affairs, 3043

Office of Naval Records and Library, 3686

Office of Scientific Research and Development, 4778

about, $476 \mathrm{I}$

Office of the Comptroller of the Navy, 3677

Office of War Information, about, 3607

Official Records of the Rebellion, 3378 , 3697

Ogden, Rollo, 2858 ed., 2882

Ogg, Frederic A., 61 37

Oglala Sioux Indians, $280 \mathrm{I}$

hist., 3003

Ogres and giants in folklore, 5528-29, 5546

Oh, Promised Land, I 787

Oh Susanna (song), 5677

O'Hara, John, I 429, 2069-78 about, 2536

Ohio, 3948, 41 1 8-22

architecture, 5719

folksongs \& ballads, 5573

frontier life, 4097-98, 41 21

govt., 6r95

guidebooks, 3862-73

hist., 4030, 4109, 4III, 4115, 41 2021

journalism, 2857

politics, 6428-29

rural communities, 4109

travel \& travelers, $4277-78$

Western Reserve, 4030, 4118

Ohio in literature

editorials, sketches, etc., 422-26

fiction, 867,980 , I I 78 , I $69 \mathrm{I}, \mathrm{I} 694$

personal narratives, 964,982

poetry, 2788

short stories, I I 49-50, I I 79, 169 I

Ohio River and valley

descr., 2610

geography, 4113 
Ohio River and valley-Continued hist., 3147,4110 intellectual life, 3767 mounds, 2996

travel \& travelers, $319,321,4276$, $428 \mathrm{I}, 4300,4324,4336,4344$

Ohio State Senate, about, 6428

Oil! A Novel, 1756

Oil industry. See Petrolcum resources and industry

"Okie" minorities in Calif., 4204

Oklahoma, 3960, 3964, 4169-7 I

cities \& towns, 4I 7I

Delaware Indians, 3020

descr., 4I 70

fiction, 1403,1406

Five Civilized Tribes, 3025-27

folksongs \& ballads, 5570

guidebooks, 3908-9

hist., 4I 69, 4I 7 I , 4 I 89

Olcott, Charles S., 3448

Old age

employment, 4635

insurance, 4633

Old Black Joe (song), 5677

Old Bullion Benton, $332 \mathrm{I}$

Old Cambridge, 2280

Old Creole Days, 746-48

The Old English Dramatists, 465,467

The Old Farm and the New Farm, 147

The Old House in the Country, 2780

Old Ironsides, 368

Old Jules, 2800

The Old Lady's Restoration, 1035

Old Love Letters, 2307

The Old Maid, 1845, 1855

Old Man, 1390

The Old Man and Jim, I 126

The Old Man and the Sea, I 500

Old Mr. Flood, 2755

old Morality, 166r

An Old New England School, 2674

Old New York, 1845

Old Pines, 1239

Old Plantation Days, 1724, 5087

Old Possum's Book of Practical Cats, 1359

The Old South, I $103-4$

The Old Swimmin'-Hole and 'Leven More Poems, I 126

The Old Virginia Gentleman, 193

The Old Virginia Lawyer, I103-4

The Old World and the New, $377 \mathrm{I}$

Older, Fremont, 2888 about, 2888

Oider, Mrs. Fremont, 2884

Oldtown Folks, 572-73

Ole Miss', 5066

Ole 'Stracted, r 100-2

O'Leary, Frank, ed., 2274

O'Leary, R. S., 6r 95

Oligopoly, 5887

Oliphant, Mary C. Simms, ed., 554

Oliver, Egbert S., ed., 49 I

Oliver, Henry M., 597 I

Oliver, John W., 4727

Oliver, Robert T., 3597

Oliver Wiswell, 17 I 1

Olmsted, Frederick Law, 4363-68

Olney, Marguerite, comp., 5574
Olson, James C., 4 I 66

Olson, Julius E., ed., 3215

Olsson, K. A., 5442

Omaha Indian reservation, 3042

O'Meara, Carroll, 4694

Omoo, 476-77

On a Soldier Fallen in the Philippines, ro69

On Being Creative, 2375

On Native Grounds, 2448

On the Limits of Poetry, 1810

On These I Stand, 1308

On Trial, 1689

On Witchcraft, 42

Once in a Lifetime, 1548

One Arm, 2222

One Basket, 1408

One Clear Call, 1758

One Man's Meat, 1862

One More Spring, 1636

One Nation, 2161

One of Our Girls, 2307

One of Ours, 1277

"One of Us," 1035

One Part Love, 2413

One-Smoke Stories, 1198

I $x$ 1, I3 I 3

O'Neil, T.P., 6207

O'Neill, Edward H., 536

O'Neill, Eugene, r647-49, 2327, 2332, $2335,2337,2348$

about, 1650,2406

O'Neill, James, 2313

O'Neill, James M., 5445

Only Yesterday, 3477

The Open Boat, 830

The Open Heart, 2838

The Open Sea, I60 I

Opera, 487, 654, 1 222, 1512, 177 1, $2210,2472,5655-63$

comic, 701,705

hist., 5656, 566r, 5663

Chicago, 5660

New York (City), 4924, 5657-59, 5962

See also Theater

Operationism (psychology), 5392

Ophthalmology, hist., 4844

Opie, Redvers, 3636

Opinions of Oliver Allston, 2380

Opler, Marvin K., $304 \mathrm{I}$

Opler, Morris Edward, 30 ro

The Opposing Self, 2520

Optimism in literature, 280,619

Options, $111 \mathrm{I} 9-20$

Oralloossa, 205

Orange County, Calif., 3957

Orators, 420

Orchestras

jazz, 5644

students, 5672

symphony, $5647,5650,5652$

See also Bands (music)

The Orchid, 1637

The Ordeal, 3495

Ordeal by Hunger, 3331

The Ordeal of Mark Twain, 2380

Oregon

boundaries, 335 I

fiction, $1314^{-15}$
Oregon-Continued

guidebooks, 3937-38

hist., 3959, 4214

newspapers, 2863

Orientals, 4468

resources, 4212

short stories, 1316

travel \& travelers, 391

Oregon Trail, 3789

disc. \& explor., 3335, 3338, 3345

travel \& travelers, 3348

O'Reilly, John Boyle, about, 4530

Orfield, Lester Bernhardt, 6098, 6301-2

The Organizational Revolution, 5899

Orians, George H., 240 I ed., 2352,2369

O'Rielly; Henry, about, 4675,4680

Orient

in literature, 280

travel \& travelers, 1136

Orientals, 2811-12, 44ז6,4420, 446369

citizenship, 6 r 20

econ. condit., 4468

The Origin of the Feast of Purim, 2312

Original Narrative of Early American History, 3201-19

Ormandy, Eugene, about, 5654

Ormond, I I 2-13, II 7

Ornithological Biography, 4743

The Orphan Angel, 1904

Orphanages, 4310

Orpheus in America, 5679

Osage Indians, 2720

Osborn, F., 3562

Osborn, Henry Fairfield, 4748 about, 5434

Osborn, R. E., 5442

Osborne, Estelle Massey, about, 4854

Osgood, Ernest Staples, 5873

Osgood, Herbert L., 3220-2I

about, 3058, 3221

Osgood, Robert Endicott, 3628

Osler, Sir William, 4818 about, 482 r, 4829,4845

Ossian, about, 2364

Ossoli, Sarah Margaret (Fuller) marchesa d'. See Fuller, Sarah Margaret (Marchesa d'Ossoli)

Osteopathy, 48 I I

Osterweis, Rollin G., 4042, 4080

Ostheimer, Richard H., 51 74-75

Ostrom, John W., ed., 532

Oswald, John Clyde, 6442

Other Skies, 1950

The Other Two, 1855

Other Voices, Other Rooms, 1945

Otis, Harrison Gray, about, 3305

Otis, Philo Adams, 565 I

Ottawa Indian war, 3033

Otto, Henry J., 5151

Otto, M. C., 5336

Our America, 1445

Our American Weather, 2950

Our Boarding House, 2301

Our Fair City, 6207

Our Hearts Were Young and Gay, 2809

Our Heroic Themes, 206

Our Landed Heritage, 58 I 4 
Our More Perfect Union, 6076

Our New Home in the West, 41 6-1 7

Our Rising Empire, 3531

Our Singing Strength, 2342

Our Soldiers Speak, 3662

Our Times, 3468

Our Town, 1865, 2327

Out of the Red, 4995

Out of the South, 1475

The Outcasts of Poker Flat, 930, 937. 939

Outcault, Richard Felton, about, 2865

Outlaws. See Adventurers, outlaws, etc.

The Outlet, 686

Outlines of Cosmic Philosophy, 5303

Outre mer, 4388-89

The Outsider, 2232, 2235

The Over-Soul, 280,285

Over the Alleghenies and Across the Prairies, 4350

Over the Hills to the Poor House, 753

Overacker, Louise, 6336, 6406-8

Overland in a Covered Wagon, 1066, Io68

Overland journeys to the Pacific, 39I, I $068,3338,3345,3348,4373$

Overland mail and stagecoaches, 4666

Overland Monthly, 757, 933

Overland Trail. See Oregon Trail

Overseas possessions, 2970, 421 8-22

econ. condit., 4218

guidebooks, 3940-4I

Owen, Robert Dale, about, 27 I 3, 4525

Owen, Wilfred, 5921

Owen Wingrave, 1012

Owens, Hamilton, 2876

Owens, Richard N., 6008

The Owl in the Attic, 1817

Owsley, Frank Lawrence, 3539, 4081

The Ox-Bow Incident, 1955

The Oxford Anthology of American literature, $232 \mathrm{I}$

The Oxford Book of American Verse, 2344

The Oxford Companion to American Literature, 2433

Oxford Group movement, 5439

The Oxford History of the United States, 3103

Ozark Mountain region, 3960

folklore, 5543-45

folksongs \& ballads, 5569

geography, 4 I I 3

language (dialects, etc.), 2270

population, 4102

rural community, 2764

\section{$\mathrm{P}$}

\section{PMLA, 2457}

Pacific Coast States, 3137 editorials, sketches, etc., I064-65, 1068

hist., $3048,3340,3784$

historical geography, 2969

hunting \& fishing, 5084, 5091

Orientals, 4468-69

poetry, 933-34, 1064, 1066-67

short stories, 926-32, 937
Pacific Coast States-Continued travel \& travelers, 391, 1068, 4384, 4386

Pacific Fur Company, about, 391, 6024

Pacific Grove, Calif., 3930

Pacific Islands (Trust Territory), 4218

Pacific Northwest. See Northwest, Pacific

Pacific Ocean region

relations with, 359 I

World War II, 3668, 3722, 3726-27

Pacific railroads, hist., 4150

Pack, Robert, 2350

Packard, Francis R., 4809

Packet boats, 4283, 5937

A Paean, 526

Pagano, Grace, ed., 5748

Page, Charles Hunt, 4542

Page, Leigh, 4715

Page, Thomas Nelson, I099-1 106, 2296

about, 910

Page, Walter Hines, 2296, 5 I 45

about, 2922

Pageant of America, 3082

Paige, D. C., ed., 1664

Paine, Albert Bigelow, 77 1, 2917 ed., 800,808

Paine, Gregory, 2424 ed., 2296

Paine, Nathaniel, 6447

Paine, Thomas, 154-60, 2290

about, $2617,2647,5408$

fiction, 1977

Painters, 61 2, 1226, 5742, 5744, 575354,5756

biog. (collected), 5730, 5745, 574849, 5759

See also Artists

Painting, 375I, 5595, 5597, 5601, $5741-76,5797$

abstract, 5696

Colonial period, 3747

exhibitions, 5696, 577 1, 5804-5

hist., 5689, 5742, 5745, 5747, $5750-51,5755-56,575^{8}$

indexes, 5753,5757

landscape, 5743, 5745, 5766, 5768, 5804

miniature, 5759, 5763

Plains Indians, 3018

still-life, 5744

surrealist, 5696

Paiute Indians, religion, 3019

Pakistan, relations with, 3503

Pal Joey, 2074

Pale Horse, Pale Rider, I66I

Paleontological Society, about, 4733

Paleontology, 4721

hist., 4715,4748

Calif., 4202

Paley, William S., about, 4683

Palmer, Alice Freeman, about, 2766

Palmer, Charles, 4949

Palmer, Elihu, about, 5408

Palmer, Frederick, 3713-14

Palmer, George Herbert, 2765-67, 5250, 5252

about, 2767

Palmer, John McAuley, 3648
Palmer, William J., about, 4I 50

Palmer, Winthrop B., 4971

Palmetto Country, 3953

Palmyra, N.Y., fiction, I 157

Paltsits, Victor Hugo, ed., 6465

Palyi, Melchior, 5985

Pamphleteers, 75, 134, 138, $147,154-$ $60,662,727,1048,1053$

Pan American Airways, about, 5941

Pan American conferences, 3575

Panama, relations with, 3583

Panama Canal, 3559, 3575, 3577, 4014, $4218,4221,4796$

Pancoast, Harry S., I $09 \mathrm{I}$

Pandora, 1008

Pannill, H. Burnell, 5302

Papa La Fleur, 1459

Paperbound books, 6435, 6438, 644344

Papermaking and trade, hist., 6448, $6457-58$

Paquita, the Indian Heroine, 1065

The Parable of the Ten Virgins, 59

Paradise, I 44I

Paradise Lost, 2064

Pardon ( $186 \mathrm{I}-98), 3388$

The Pardon, 1684

Parentator, 3199

The Parenticide Club, 739

Paris. Peace Conference (rgIg), 3 III, 347 I

Paris, Americans in, 2872

Paris Bound, 2332, 2337

Paris Embassy, about, 3600,3606

Park, Edwards A., about, 5428

Park, Robert E., 2897

Park, Willard Z., 3019

Park-Street Papers, 2491

Parker, Barbara Neville, 5763

Parker, Donald Dean, 306r

Parker, Dorothy (Rothschild), 1651-52 comp., I 429

Parker, Everett C., 4702

Parker, Florence E., 5964

Parker, Isaac Charles, about, 2656, 6220

Parker, Reginald, 6313

Parker, Theodore, about, 2279-80, 5472, 5481,6424

Parker, William Belmont, 2768-69

ed., 463, 2769

Parkes, Henry Bamford, 3104

Parkhurst, Helen H., 5289

Parkins, Almon E., 2940

Parkman, Francis, 228I, 2290, 3069, 3171,3348

about, 2281, 3058, 3069, 3175

Parks, E. Taylor, 3585

Parks, Edd Winfield, ed., 618, 2292, 4068

Parks

Mass., 3803

Rocky Mountains, 4172

S. C., 3836

See also National parks and reserves; and names of parks, e.g., Adirondack State Park

Parmer, Charles B., 5056

Parole, 4643

Mass., $4648-49$ 
Parran, Thomas, 4869 about, 4864

Parrington, Vernon Louis, $2424,248_{5}$ about, 2407, 3058

Parrish, Lydia, 5540

Parry, Albert, 3757

Parry, Charles C., about, 4734

Parsons, Edward, ed., 27

Parsons, Elsie Clews, 5540

Parsons, Frank, about, 4530

Parsons, Geoffrey, 2903

Parsons, Robert P., 4809

Part of a Man's Life, 2280

Parties, I 828

The Partisan, 547

The Partisan Review, $2017,2133,2498$, 2566

Parton, James, 2770-76, 2883 about, 2776

Partridge, Bellamy, 5005, 6324

Partridge, Eric, 2272, 2274

Partridge, Samuel Selden, about, 6324

Parts of a World, 1784

Paskman, Dailey, 5637

Pasó por Aqui, 1686-87

A Passage in the Night, 194

Passage to Glory, 3154

Passage to Walden, 609

Passaic River, 3994

The Passing of Marcus O'Brien, 1058

The Passing of the Frontier, 4121

The Passion of Sacco and Vanzetti, 1980

Passions Spin the Plot, 1423

Pastor, A., 3 I69

The Pastoral Bees, 741

Pastoral manuals, $47-48$

Pastures, 2780

Patchen, Kenneth, 2079-86

Patent laws and legislation, 4780-8I

Patent medicines, 5955

Patent Office, about, 4767

Patents, 4780-8I

Paterson, Isabel, 1904

Paterson, N.J., poetry, 1876

The Path I Trod, 6054

The Path finder, 258

Pathological psychiatry, 4833

Pathology, 4831

Paths to the Present, 3140

The Patient's Dilemma, 489

Patrician and Plebeian in Virginia, 3234

Patrick, John, 2334, 2336

Patrick, Rembert W., 3384

Patriot and President, 3269

Patriotic societies, 3644

Patriotism, 4526

Patriotism in literature, $511-12,2465$

fiction, $579-82,1730$

poetry, 1 34-39, $146-48,206,368-70$

short stories, $901-5,909$

Patriots (American Revolution), 3244, 3282,3304

The Patriots, 2334, 2336

Patronage. See Spoils system

Patrons of Husbandry, 342 I

Patroon system, 3200

Pattee, Fred Lewis, 810, 884, 2424 , 2486-90

ed., 1 I I, 138

Pattern of a Day, 1515

The Pattern of Responsibility, 3543
Patterns of Anti-Democratic Thought, 6069

Patterson, Caleb Perry, 6r 47

Patterson, E. W., 5290-91

Patterson, Eleanor ("Cissy"), about, 2862

Patterson, Harry N., about, 4734

Patterson, Joseph, about, 2862

Patterson, Robert L., 230

Patterson, Robert W., 2862

Patterson family, 2862

Pauck, Wilhelm, about, 5433

Paul, Randolph E., $597^{\circ}$

Paul, Rodman W., 774

Paul, Sherman, 304, 483

Paul Kauvar; or Anarchy, 2347

Paulding, James Kirke, 51 1-19, 2295. 2337

Paulding, William Irving, 517

Paulison, Walter M., 4993

Paullin, Charles O., 2974, 3678

The Pavilion, 4912

Paviotso shamanism, 3019

Pawnee Indian tales, 3000

Paxson, Frederic L., 3105, 3463

Paxton, Harry, 4996

Payne, John Howard, 2295, 2302-3, 2337,2347

Payne, Pierre S. R., 4953

Peabody, Elizabeth P., ed., 586

Peabody, Josephine Preston, 2348

Peace in the Heart, 1724, 5087

Peace Mission movement, 5439, 5489

Peace, My Daughters, I 917

Peach, Arthur W., ed., 157

Peake, Ora B., 3028

Peale, Charles Willson, about, 2804, 5749,5769

Peale (Charles Willson) family, 5744

Peanuts, 2690

Pearce, Roy Harvey, 3031, 3102 ed., 2326

Peare, Catherine O., 3222

The Pearl, 1780

Pearl Harbor, 3130

The Pearl of Orr's Island, 570-71

Pearson, Norman Holmes, 276, 593 , 2412

ed., $350,356,2321$

Pearson, T. Gilbert, 2962

Peary, Robert E., 2979 about, 2979-80

Pease, Theodore Calvin, 4129, 4133

Pease, Mrs. Theodore Calvin, 4133

Peattie, Donald Culross, $1130,2963-64$

Peattie, Roderick, ed., 4172

Peck, Taylor, 3670

Peckham, Howard H., 3032-33

Pecos Bill, about, 5506

The Peculiar Institution, 3403

A Peculiar Treasure, 1403

Peden, William, ed., 153, 3279

Peder Victorious, 1722

Pediatrics, 4841

Pedlar's Progress, 186, 5266

Peek, George A., ed., 3279

Peek, George N., about, 5860

Peel, Roy V., 6381-82

Peffer, E. Louise, 5813
Peirce, Charles Sanders, 5346-49

about, 5264, 5345, 5350-53

Pellegrini, Angelo M., 2777, 4494 about, 2777

Pelopidas, 205

Peltason, J. W., 61 28, 6134

Pelton, Walter J., ed., $487 \mathrm{I}$

Penal colonies, Colonial period, 6056

Penard, Eugene, about, 4734

Pencillings by the Way, 677-78

Pendleton, Edmund, about, 2740

Penhally, 1465

Penn, William, 5418

about, I 7 I, 3222, 5396, 5419

drama, 2310

Penn State Yankee, 2490

Pennell, Elizabeth (Robins), 4060, 5776

Pennell, Joseph, 406o, 5776

Penniman, Howard R., 6139

Pennock, James Roland, 6314

Pennsylvania, 4054-6I

bibl., 4054

culture, 3229, 3231-32, 4054

farm life, 2891

fiction, 105-8, 1239, 1507, 1691, $1694-95,1916,2055,2069,2076-$ 78,2282

folklore, 5579

folksongs \& ballads, $5578-79$

geography, 4057

govt., 3229-30, 4057, 6195

guidebooks, 38 I 6-2 I

hist., 3280, 3962, 3993, 4043, 405457

Colonial period, 2880, 3214,3222 , $3225,3229-32,4490$

legends, 5579

relations with Gt. Brit., 3225

Scotch-Irish, 4490

travel \& travelers, $366,4241,4255$, 4266, 4269, 4279, 4285

Pennsylvania. University, hist., 5130, 5192

Pennsylvania. University. Dept. of Medicine, hist., 4856

Pennsylvania Dutch. See Pennsylvania Germans.

The Pennsylvania Gazette, about, 2854

Pennsylvania Germans, 4479-80

arts \& crafts, 5594, 5599-5600

culture, 3230-31

language (dialects, etc.), 2266, 4479

literature, 2266, 4479

religion, $3230-31$

Pennsylvania Hospital, Philadelphia, hist., 4850

Pennsylvania-Virginia frontier, 2673

Penobscot Indians, 301 I

Penology, 4639, 4654, 5028

Penrod, 1803

Penrod and Sam, 1802

Penrose, Boies, about, 6353

Penrose, E. F., 3562

Penson, Lilian M., 3179

Pconage laws. See Freedom of labor

People Behave Like Ballads, 1295

People of Plenty, 3734

The People of the Abyss, 1053

The People, Yes, 1731

The People's Choice, 6419 
The People's Lawyer, 2347

Pepinsky, Harold B., 5228

Pepinsky, Pauline N., 5228

Pepper, George Wharton, 616r

Percival, Milton O., $48 x$

Percy, William Alexander, 2778-79 about, 2779

Père Antoine's Date-Palm, 7I I

Père Raphaël, 748

Pereida, Ralph J., illus., 5503

Performing rights (music), $562 \mathrm{x}$

Periodicals. See Literature-periodicals; Magazines; Newspapers

Perkin, Robert, 4176

Perkins, Dexter, 3491, 3509, 3523, 3577,6254

Perkins, Eli, pseud., 212

Perkins, Frances, 3498

Perlman, Philip B., 4425

Perlman, Selig, 6033

Permanence and Change, 2387

The Permanent Horizon, $157 \mathrm{I}$

Permit Me Voyage, 1908

Perry, Bliss, 2491-92, 3732, 5221

ed., 295

about, 2922, 5221

Perry, Ralph Barton, 3733, 526o, 533435

ed., $5327,5329,5334$

Perry, Thomas Sergeant, 5304

Pershing, John J., $37 \times 5$

about, 3714

Pershing Expedition (in Mexico), 3586

Persichetti, Vincent, 5687

Person, Place and Thing, 2140

Personae, 1666

Personal property law, 627 I

Personalism, 631, 5265, 5317

Personality, 4568, 4572, 5289, 529 I

Personnel administration, library, $647^{8-}$ 80,6483

Personnel management in industry, 6038,6042

Persons, Stow, 5435 ed., 3753, 3758

Persons and Places, 1737

Peru, History of the Conquest of, 2294

Pessimism in literature, 695-98, 732$39,768,798-99,1532,1927$

Peter Martyr, 3153

Peter Whiffle, 1828

Peterkin, Julia Mood, 1653-55

Peters, Aimée M., comp., 937

Peters, Harry T., 5778-79

Petersburg, Va., 4406

Petersen, Elmore, 6009

Peterson, Clara Gottschalk, ed., 5679

Peterson, Elmer T., ed., 4594

Peterson, Florence, 6035

Peterson, Houston, ed., 5222

Peterson, Marcelene, 4946

Peterson, Robert E., tr., 5679

Peterson, Theodore, 2918, 2932

Peto, John Frederick, about, 5744

The Petrified Forest, 1749-50, 2327, $234^{8}$

Petrillo, James Caesar, about, 56 i 9

Petroleum resources and industry, $2586,2731,2746,5914$
Petrology, hist., 47 1 5

Petrullo, Vincenzo, 3020

Petry, Howard K., ed., 4804

Pewter, 5788

Peyotism, 3020

Peyton, Green, pseud. See Werten. baker, Green Peyton

Peyton, John Lewis, 4350

about, 4349

Pfeffer, Leo, $5 \mathrm{I} 03$

Pfefferkorn, Blanche, 4845

Phaedra, 21 or

Phelps, N. Y., in literature, 6324

Philadelphia

Chinese, 4463

culture, 4518

drama, 198,1202

econ. condit., 4602

epidemic (1793), 4872

essays, $1002-3$

fiction, I16-17, 1333, 1336, 1345

guidebooks, 3821

historic houses, etc., 4059

hist., 3764

music \& music industries, 5629

Negro religious cults, 5498

politics, $6207,6353,6389$

soc. life \& customs, $3764,4059-60$, $4251,4258,4263,4283,4602$ theater, 5659

The Philadelphia Story, 1 202, 2334

Philanthropy, 2689

fiction, 1568

See also Charities

Philip II of Spain, 2294

Philippine Islands,

annexation, 3594

Japanese conquest, 1992

relations with, 3595,4218

Phillips, Cabell, 3615

Phillips, Charles F., 5945

Phillips, David C., 4695

Phillips, David Graham, I I 07 - то about, 2464

Phillips, Duncan, 5767

Phillips, Merton Ogden, 2940

Phillips, Orie L., 6320

Phillips, Ulrich Bonnell, 3402-5, 5828 about, 3057-58

Phillips, Wendell, 244 about, 2280, 2546, 3099

Phillips, William, ed., 2566

Phillips Academy, Andover, Mass., about, 2674

Philo, an Evangeliad, 402

The Philosopher of the Common Man, 5290

Philosophers, 3746, 5250, 5253, 5257$58,5265-5387$

Philosophers at Court, $174^{\circ}$

Philosophers Lead Sheltered Lives, $535 \mathrm{I}$

Philosophy, 3728, 3747, 3751, 3758, $5250-5387$

and religion, 5259,5289, 5311, 5319, $5338,5354,5358,5361,5431$, 5437

as literature, $21,186,280,585,1733$

European influences, 5262

hist., $3741,5261-62,5334$

Indian, American, 3015
Philosophy-Continued

Scottish, 5337

study \& teaching, 2767

The Philosophy of Composition, 520 , 538

Phinney, Eleanor, 6482

Phipps, Henry, about, 4834

Phoenix, Ariz., 4187

The Phoenix and the Tortoise, 2099

Phonographs and records, 5618, 5629

Photography

hist., 5689, $578 \mathrm{r}$

journalistic, 2908

Phrenology, 3752, 4516

Phyfe, Duncan, about, 5728

Physicians and surgeons, 48I 7-32 biog. (collected), $4804,4807,4822$, 4844,4856

drama, 1520

fiction, 1 299, 1562, 1 872

Physics, 4721

hist., 4715

Physiological chemistry, 4732

Physiology, 48 I 8

Piano industry, 5622

The Piazza Tales, 484, 491, 493

Pickard, Karl, 4889

Pickard, Madge E., 48 ro

Pickard, Samuel T., 672

Pickering, Ernest, 5702

Pickett, Clarence E., 5427 about, 5427

Pickett, Ralph R., 5994

Pickford, Mary, 4955 about, 4955

Pickpockets, language (slang, etc.), 2262

Picnic, 1997, 2336

Pico, Rafael, 4222

Pictorial Americana (catalog), 5807

Pictures from an Institution, $200 \mathrm{x}$

Pictures of the Floating World, 1584

A Piece of Land, 917

A Piece of My Mind, 2543

Pierce, Bessie Louise, 4136

Pierce, Edward L., 3406

Pierce, Franklin, about, 3347

Pierce, Truman M., ed., 5206

Pierce, W. H., 6207

Piercy, Josephine K., 2493

Pierre, S. D., guidebook, 3900

Pierson, George W., 4512

Pike, Kenneth L., 2275

Pike County Ballads, 942-43, 3426

Pike dialect in literature, 933, 937, 94 I-44, I I 26

Pike's Peak theater, 4925

The Pilgrim Hawk, 1839

The Pilgrims

hist., $\mathrm{I}-6,3204$

satire, $5 \mathrm{I}-52$

Pilgrims through Space and Time, 2377

The Pilot, 256-57

Pinckney, Josephine, 4068

Pinckney, Pauline A., 5603

Pinckney, Mich., in literature, 415

The Pink Church, 1878

Piñon Country, 3956

Pinson, Koppel S., ed., 5267

Pioneer America, 5596 
Pioneers, 4I 86, 4I 99, 42I I, 42I3 architecture, 5719

See also Frontier and pioneer life

The Pioneers, 258-60

Pioneer's Mission, 3053

Pioneer's Progress, an Autobiography, 2702, 5219

Pious and Secular America, 5399

Pipe lines (industry), 5920

Pipe Night, 2073

Piper, C. V., ed., 5821

The Piper, 2348

Pique, 2317

The Pirate, 1211

Pirsson, Louis V., 4715

The Pisan Cantos, 1665

The Pit, 1094-95

Pitkin, W. B., 5260

about, 5327

Pittenger, W. Norman, about, 5433

Pittsburgh, 4312

econ. condit., $459 \mathrm{I}$

hist., 3962, 4061

intellectual life, 3767

soc. condit., 4591

Place, Charles A., 5720

Place names, 2967

bibl., 2976

Indian, American, 2364

New York (State), 5548

Place of Hawks, 1959

Plagued by the Nightingale, 1243

Plain Folk of the Old South, 408I

Plain Language from Truthful James, 933, 937

Plain People, 959, 2885

"Plain" style, Puritan, 1 8, 33, 45, 75

Plains. See Great Plains; High Plains; Northern Plains

Plains Indians, 2799, 3006, 4164 painting, 3018

Plainville, U.S.A., 4585

Plant, Henry B., about, 4096

Plant lore, Ozark Mountains, 5544

Plant pathology, 2792

Plantation life, 4242-46, 4436, 4442

songs \& music, 5677

Fla., 4293

Md., 4517

Miss., 5576

S.C., 4517,5087

Southern States, 3402-3, 4283, 4363

Va., 327I, 4086, 3279, 4517

See also Farm and rural life

Plantation life in literature

descr., I 724

editorials, sketches, etc., I92-93, 1 099, I $103-4$, I 106

essays, familiar, 406-8

fiction, 245, 405-8, 1099, $1105-6$, I 467, I618-19, I653

poetry, 856-59, 861; I I $33-35$

short stories, 192-93, 856, 859-60, $911-16,922,1032-35,1099-1102$, I 106, I 724

Ga., 9 I I-16, 922

La., 1032

Va., 15-16, 192-93, 245, 405-8, 1099-1 106

See also Farm and rural life
Plantation Proverbs, 911

Planter and Patriot, 3260

Plants, 2956-57, 2959-60, 2966, 2969, $4241,4247,4276$

prairies, 4188

Fla., 4247

Ga., 4247

Ky., 4276

New York (State), 4237-38, 424I

New World, 3155

N.C., 4247,4276

Ohio, 4276

Pa., 4237-38, 424I

S.C., 4247,4276

Tenn., 4276

Plaskitt, Harold, 3146

Platonism, 280, 5368

Platt, Philip S., 4863

Platt (Thomas C.) political machine, 6385

Play-party songs

Appalachian Mountains, 5583

Middle West, 5586

Oklahoma, $557^{\circ}$

Ozark Mountains, 5569

Southern States, 5583

Playing Doctor (sculpture), 5739

Playing the Mischief, 277

Pleading, legal, 6282

Pleasure Dome: On Reading Modern Poetry, 2426

Plotkin, David George, ed., 3152

Plowman, Edward Grosvenor, 6009

Pluck and Luck, 1214

The Plum Tree (Chase), 1289

The Plum Tree (Phillips), 1107

A Plumb Clare Conscience, 1684

Plunder, 1155

Plunkitt, George Washington, about, 6382

A Pluralistic Universe, 5326

Plymouth, Mass., poetry, I 222

Plymouth Colony

hist., $1-6,3204$

satire, $51-52$

Po' Sandy, 757

Poage, George Rawlings, 3344

Pocahontas, 2337

Pocahontas legend, 4273

See also Indians, American-legends \& tales

Pocahontas legend in literature, 66, 70 drama, 198-99

fiction, 25 I

Pochmann, Henry A., 5305 ed., 399, 2349

Poe, Edgar Allan, 520-38, 2290 about, 216, 333, 365, 381, 405, 41 5, $520,533,539-41,614,633,732$, 856 , 1016, I 167, I $303,1873,2277$, $2385,2397,2420,2423,2436$, 2453, 2456, 2468, 2471, 2478-79, $2486,2513,2545$

Poems about God, 1675

Poems for a Son with Wings, 1295

Poems for Music, 1516

Poems Here at Home, I 127

Poems of the War, 206

Poet of the People, II 32

The Poetic Principle, 216, 520, 538
Poetry

and science, 2412

anthologies, 1870, 1948, 2292, 2328, $2331,2342,2344,2350,2363$, 2483,2513

elegiac, 623

epic \& extended narrative, IOI, 104 , $118-21,165,167,427,429,432-$ 33, I 222, I 224, I 434, I 532-34, I 585, I644-45, I 713-1 4, I 824-25, $1876,2134,2200$

ethical themes in, $1872,2007,2189$

experimental, 1303-4, 1306, 1309, $1313,1357,1359,1432,1583-84$, $1620-21,1664-66,1766,1782$, $1784,1872,2034,2079,2098$

hist. \& crit., 2544

"gentecl tradition," 2513, 2545

hist. \& crit., 520, 61 4, 1044, 1226 , $1236,1238,1304,1306,1482$, $1668,1670-75,1678-79,1717-19$, 1809-10, 1905, 2105, 2128, 2191, $2357,2374,2378-79,2403-4$, 2413-14, 2426, 2452, 2484, 249I, $2513,2527,2533$

humanitarian, 1061, 1069, 1872, 2079

humorous, $368,456-58,680,878$ $80,933,941-44$, I I 26-32, I 629$34,1651-52$

See also Verse, light; Verse, vernacular

metaphysical, 2497, 2499

music in relation to, $1038,1044-46$, 1580

neo-classical, 2215,2544

pastoral, 1 451-52

periodicals, 2567

periods

Colonial, 7-1 1, 72-74, 79-83, 2483

(1764-1819), I O I-4, I I 8-21, 134$43,146-48,165-67$

$(1820-70), 206-8,216-21,223-$ $25,280,288-90,323-29,365$, $368-70,427-29,431-44,449-$ $59,464-67,469,486,488,491$, $494,520-27,530,533,536-38$, $546,585,598,61_{4}-17,619-30$, $636-37,639-42,644-46,662$, $664,666-71,673,675,679-81$

(1871-1914), 706, 714,821, 831, $833,835-36,838-46,852,856-$ $59,861,878-80,926,933-34$ $941-44,984,1038-43,1946-47$, 1061-64, 1066-67, 1069, 1071, I $126-35$

(1915-39), 1153-54, I161, 1166, I 1 196, I 222, I 224, 1227,1230 , 1232, 1 236-37, I 290, I 295-97, 1 303-4, 1306-9, I313-1 4, 131924, 1350-52, 1357, I359, 1379, 1 409-10, I 432-35, 1451-52, $1480-83,1512,1515-17,1521$, $1530-38,1540,1556,1558$, 1580-86, 1588, 1599-1601, I 608-9, I 61 4, I 620-21, I62327, 1629-35, 1644-45, 165152, 1664-66, I 675-77, I679, 1697, 1699, 1713-14, 1724, 1727, 1731, 1733-34, 1740, 
Poetry-Continued

periods-Continued

(1915-39)-Continued

$1766,1782,1784,1809,1811$, I $813-14,1821-27,18507-59$, I863, 1870-72, I876, I878, I881, I883, I885, 1902-3, $1905-6$

$(1940-55), 1907-8,1916$, 1919, $1923-26,1948-53$, 1959, 1968, 1970-72, 1981-83, 1999, 2002, 2007-10, 2034-35, 2037, 2039, 2060-62, 2095, 2098-2100, $2102-6,2123-24,2126,2133-$ $34,2138-44,2166,2172,2189-$ $93,2196,2200,2215-17$

political verse, 134-39, 456-57, 662, 664,1069

psychological, 1357

realistic, 612, 1290, 1295-97, 1727 , I 731

religious, $72-73,79-83,662,680$, $1357,1359,1369,1537-381540$, 2034-35, 2037, 2039

satiric, $120,134-38,148,165,167$, $323,456-57,2189$ essays, 2465,2467

sentimental, I $126-31$

sonnets, 206, 427, I608, I623-27, 1972

structure, 2379

surrealist, 2034

theories, $216,280,520,538,61_{4}$, $618,620,1038$, 1044-46, I196, $1783,2142,2476,2484$

vernacular, $753-55,933-34,941-44$, I 1 26-31

See also Ballads; Folk ballads; Verse drama

Poetry: a Magazine of Verse, 2139,2760

Poetry and the Age, 2000

Poetry in Our Time, 2414

Poetry in the Theater, 1175

$A$ Poet's Life, 276r

The Poet's Testament, 1740

Poganuc People, 576

Pohl, Frederick J., 3172

Point four program. See Technical assistance

Point of No Return, 1596

The Point of View, 1008

Points of View, 2504

Poland, fiction, 1992

Polar exploration, 2977-81, 3669

Poles (Polanders), 4435, 4495

Poletti, Charles, 6080

Police, 3644a, 4498, 4642, 4655, 465960

Political bosses, 3438, 6207, 6333, 6337$38,6346,6382,6384-91$

Political campaigns, $6 \mathbf{1} 49,6333,6336$, $6340-4 \mathrm{I}, 6362$

(1884), 6373

(1 $932-40), 6364$

(1948), 6414

funds, $634 \mathrm{r}, 6407,64 \mathrm{ro}$

literature, $6348-49,6394,6410$

Political candidates, $6333-34$

Political clubs, 3300

New York (City), 638I
Political conventions, $3400,6149,6340$, 6361

Political economy. See Economics

Political ethics, 376o, 6342-44

Political influences on literature, 2485

Political leaders and leadership, 3416 , $3460,3494,3496$

Political machines. See Machine politics

Political parties, $3139,3320,4499,6078$, $61_{34}, 61_{47}, 6335-38,6340,6347-$ $73,6398,6416,6419,6427$

discipline, $6341,6354-55,6381-82$, 6384,6389

hist., 6076, 6149, 6347

platforms, 634I, 6366-67

New York (State), 4044

Southern states, 6376

Political psychology, $6345,6349, \sigma_{354}$

Political science, 5279

hist., 3760

Political themes in literature

drama, I I72, I I 76

editorials, sketches, etc., 422, 465 , $467,512,546,663,862,1048$, $1103-4,1107,1739,1859,2278$

fiction, $277,422,689-90,722,762$, 775-77, 1 107, 1155-56, 1566, $1792,2025,2027,2148,2197$, 2278

periods

Colonial, 75-78, 84, 92-95

(1764-1819), 101, 103-4, I 5460

$(1820-70), 252,261-62,265-$ $67,585-86,593,604-5,607-8$, 619,631

poetry, $134-39,456-57,662,66_{4}$, 1069

satire, $147-48,422-25,558,862$, I 792

Political thought, 3073, 3099, 3758, $4556,6059-72,6074,6170,6382$, 6402

hist., 6062,6070

Colonial period, 3182, 3199, 3747

I 8th cent., 3187, 3256-59, 326r, $3279,3283,3300,6075,6085$

rgth cent., 3319, 6064, 6066, 6roI

2oth cent., 3487,3492 , 34993500,6101

Southern States, 6059

The Politician Out-Witted, 2347

The Politicos, 3438

Politics, $3616,4499,4502,6133-34$, $61_{37}, 6139,6333-46,6357,6389-$ $92,6396,6418,6421,6426$

Corruption. See Corruption (in politics)

Dutch, 4493

hist., 2677

American Revolution, 3187, $3252,3277,3279$

Civil War, 3382, 3400, 3416, 3435,3441

Colonial period, 3187, 3194, 3256, 3261
Politics-Continued

hist. - Continued

I 8 th cent., 3141, 3279, 3281, $3285-86,3303$

19th cent., $3141,3275,3286$, 3303 , 3313, 3319, 3322$26,3333,3337,3339,3352-$ $53,3356-58,3397,3408-10$, $3412,3417,3421,3423,3431$, $3436,3438,3442,3444,3447$, $3450,4312,4315-17,4334$, 4515,4664

2oth cent., $3453,3456,3458$, $3460,3463,3465-67,2469-$ $70,3472-75,3478-79,3496$, 3498 , 3500a, 3548, 3613, $4405-8,4515,6076,6$ I 65

public relations. See Public relations-politics

See also subdivisions History and Politics under names of places and re g i o ns, e.g., Illinois-hist.; Maine-politics

Politics and the press, $2846,2884,2888$, 2919, 2924, 2931

cartoons, 2859, 2917

Baltimore, Md., 2876

Hartford, Conn., 2875

New York (City), 2868-69, 2921

Ohio, 2857

Oreg., 2863

Tex., 2866

See also Presidents and the press

Polk, Alma Forrest, 4443

Polk, James Knox, 3349, 335 I

about, 3350-5I, 3540

Pollack, Queena, 2668

Pollak, Gustav, 292 I

Pollard, James E., 291 1, 2930

Pollard, John A., 662

Pollard, Joseph P., 625 I

Pollock, Sir Frederick, 2607

Pollock, J. K., 6336

Pollock, Thomas C., ed., 1898

Polls. See Public opinion-research

Polly, 1 100-2

Polo, 5058

Polynesian life, fiction, $470-78$

"Polyphonic prose," I 432, I 583

Pomeroy, Wardell B., 4565

Ponce de Léon, about, 3158

Pond, Frederick E., ed., 5077

The Ponder Heart, 2208

Ponteach, 2347

Pontiac (Ottawa chief), about, 3030, 3033, 317 I

Pony Express, 466I

Pool, David de Sola, 4457, 5427 about, 5427

Poole, Ernest, r656-58

Poole, Kenyon E., ed., 597 I

Poor Aubrey, 2332

Poor laws, R.I., 4632

Poor Richard Improved, I 31

Poor Richard's Almanack, 122, 131

Poor White, 1180

Poor whites (South) in literature

fiction, I $80,1270,1391,1775,1777$, 2090

short stories, 9I0, 9I7-2I, I270, 1275 
Poorhouses, 4310

Pope, Bertha, ed., 738

Pope, Jennie Barnes, 5951

Pope, Liston, 4702

Pope-Hennessy, Una, ed., 4300

Popular books, 2384, 2434, 2482, 5126 See also Bestsellers

Popular music and songs, 4935, 4973 , 5635-40, 6443

bibl., 561 3,5639

hist., 5635,5639

Population, 4390-4403, 4551, 4617

cities \& towns, 4393

Colonial period, 4398

Indian, 2985, 301 2, 3022, 3043

maps, 2937, 2972, 2974, 2985

stat., 3786, 4403

Ga., 4095

Milwaukee, 4140

Mo., 4108

Ohio, 4119

S.C., 4092

Wis., 4139

See also Foreign population; Migration, internal

Populism, 3421, 3427, 3458, 6356, $6358,6368,6427$

Populist Party, about, 6358

Porgy, 151 2-13, 2332

Porgy and Bess (opera), 1512, 5678

Port Arthur, Tex., 3922

Portage, Wis., 3884

fiction, 1453

Portals of Tomorrow, 1959

Porter, Cole, about, 5639

Porter, Katherine Anne, I659-63, 2372 about, $166_{3}$

Porter, Kenneth Wiggins, 6024

Porter, Keyes, 5606

Porter, Kirk H., 6204, 6409 comp., 6367

Porter, Mae Reed, 3330

Porter, Thomas C., about, 4734

Porter, William Sydney (O. Henry), I I I I-25, 2296

about, 926, I I I I , 2486

Porter, William T., 5542 ed., 4097

Portland, Maine, guidebook, 3795

Portland, Oreg., 4150

Portrait for Posterity, 3395

Portrait of a Gentleman Skating (painting), 5774

The Portrait of a Lady, 989-91

Portrait of an American, 1291

Portrait of lennie, 1639

Portraits, 5735, 5759, 5763, 5769, 5771 , $5774-76,5804$

Portraits of Places, 1093

Portsmouth, N.H., 426 I

Portsmouth, Va., 4263

"Posson Jone," 748

Post Office Dept. and postal service, $466 \mathrm{I}-7 \mathrm{I}$

Postal, Bernard, 446I

Postscript to Yesterday, 3746

The Pot of Earth, 1586

Potiphar Papers, 2278

Potofsky, Jacob S., 5426 about, 5426
Potomac River, 4008

Potsdam Conference, 3544

Potter, Alfred Claghorn, 6470

Potter, Alonzo, about, 5457

Potter, David M., 3734 ed., 3106

Potter, Elmer B., ed., 3671

Potter, William J., 5435

Potter's Field, 1475

Pottery, 5596, 5791-92, 5796 Indian, 2723

Pound, Arthur, 41 38, 5940

Pound, Ezra, 1664-68 about, 1670-74, 2426, 2497 bibl., 1669

Pound, Louise, ed., 635, 2330

Pound, Roscoe, 4649, 6223, 6231, 6233, $6251,6268,6272,6290,6302$, $6304-5,6325$

Pounds, Norman J. G., 2939

Poverty, 46r 7, 4626, 4630 prevention, 4634

relief, 4634

New York (City), 4638

R.I., 4632

Powder River, 397

Powderly, Terence V., 6054 about, 6054

Powdermaker, Hortense, 4948

Powell, John H., 4872

Powell, John Wesley, 4757 about, 2161, 4757

Power, Richard Lyle, 4 II 7

Power and Glory, 6353

Power and Policy, 3623

Powers, Alfred, 3959

Pragmaticism, 5345

Pragmatism, 3115, 4545, 5254-55, 5259, 5291, 5324-25, 5327, 5332$34,5345-50,5352$

and evolution, 5264

and science, 5254

hist., 5254, 528I

Prahl, A. J., $448 \mathrm{r}$

The Prairie, 258

Prairie City, 4171

The Prairie Schooner, about, 2925

The Prairie Years, I 728, 3395

Prairies

travel \& travelers, 4350

Ill., 4322

Southwest, 4188

The Praise of Folly, and Other Papers, 2492

Pratt, Dorothy, 5721-22

Pratt, Edwin J., 3536

Pratt, Fletcher, 3722 ed., $438 \mathrm{I}$

Pratt, J.B., 5255 about, 5325

Pratt, Julius W., 3058, 3306, 3449, 4218

Pratt, Marion Dolores, ed., 3390

Pratt, Richard, 5721-22

Pratt, Richard N., about, 3035

Prayers of the Social Awakening, 5482

The Preacher and the Slave, 2164

Preacher tales

Brazos River, Tex., 5527

Mich., 5535
Precipitation (meteorology), 5816

Predilections, 1622

Preface to Life, 1457

A Preface to Logic, 5267

Prehistoric man, 2995-96, 4202

Prehistory. See Archaeology and prehistory

Preludes and Symphonies, 1433

Preludes for Memnon, 1166

Premedical education, 486r

Presbyterians, 5404, 5442

biog. (collected), 5466

hist., 5414, 5466

Preschool education, 5148

See also Kindergartens

Prescott, Frederick G., ed., 229I

Prescott, Samuel C., about, 4785

Prescott, William Hickling, 2294, 2534 about, 2277

Prescription for Rebellion, 2716

Presidency, 3399, 61 40-49, 6184, 6340, 6370,6422

and the press, 2861,2930

candidates for, 2817,2819

Continental Congress (I 774-89), 6083

foreign affairs, $3604,3610-11$

functions, 61 40-4I, 615I.

powers of, 3472

See also Executive branch

The President Makers, 3460

Presidential Agent, 1758

Presidential elections. See Elections

Presidential Mission, 1758

Presidential primaries, 6408

Presidents, U.S. See names of Presidents, e.g., Adams, John Quincy

President's Advisory Committee on Government Housing Policies and Programs, 46I I

The President's Cabinet, 6145

President's Commission on Higher Education, 3 I I3, 5189

President's Commission on Immigration and Naturalization, 4425

President's Commission on the Health Needs of the Nation, 4862

President's Communications Policy Board, 471 I

The President's Lady, 2820

President's Research Committee on Social Trends, 6r94

President's Scientific Research Board, 4779

Press, 2847, 2858, 2904-5, 2907

associations, $2849,2860,2864,2890$

bibl., 2931

business, 2902

Dutch, 4493

foreign language, 2895-99

law, 2932

Ukrainian, 4492

Southern States, 2853

Washington, D.C., 2861, 4065

See also Freedom of the press; Government and the press; Magazines; Newspapers; Politics and the press; Society and the press

Presses, printing. See Printing

Pressly, Thomas J., 3407 
Pressure groups, 6139, 6201, 6218, $6335-38,6343,6357,6392-99$

Prestage, E., 3169

Preston, Captain, about, 3279

A Pretty Story, 147

Preventive medicine, $4815,4826,4864$, 4873-74

Price, Don K., 4776, 6216

Price, Harry Bayard, 3640

Price, Robert, 5519

Priest, Loring Benson, 3034

Priestley, Herbert Ingram, 3086

Primaries, 6406 presidential, 6408

Primary education, 51 48, 5150 See also Elementary education

Prime, William C., 5086

Primer for America, 1295

Primer for Combat, 1247

Primitivism and Decadence, 2544

Primitivism in art, 5595, 5597, 560 r

Prince, Morton, about, 5392

Prince Ananias (operetta), 5681

Prince Deukalion, 2282

A Prince in Their Midst, 4293

The Prince of Parthia, 144-45, 2337, 2347

Prince of Players, 4938

The Princess Bob and Her Friends, 930

Princeton, Ill., guidebook, 3880

Princeton College, 2673

Princeton University, about, 3470, 3472 , 5204, 5221

The Principles of Literary Criticism, about, 2407

The Principles of Psychology, 5322

Pringle, Henry F., 3464, 3467, 4785

Printers

biog. (collected), 6446-47

early, 1 22, 130,6442

Printing, $6446,6448,6455,6459$

hist., $6436,6440,6442,6447,6456$, 6459,6464

public, 6452

trade unions, 6455

university presses, 6437-39

New England, 3745

Philadelphia, 3764

Prints, $5778-80$, $5782-83$

See also Engravings

Prisons, 4310, 4639-4r, 4652

hist., 4653-54

Mass., 4648

New York, 4653

Prisons (military)

fiction, 1544

personal narratives, 1310

Pritchard, John Paul, 2494

Pritchett, Charles H., 6252-53

Pritchett, Henry S., 4999

The Private Dining Room, 1634

Private enterprise. See Free enterprise

The Private Life, ror 2

Private schools, 5155, 5217

fiction, 1940, 1944

See also Academies (schools); Seminaries (schools)

Probability, theory of, 5346

Probation. See Parole

Prochazka, Anne, about, 4854

Prochnow, Herbert V., ed., 5972
Proctor, Frederick Freeman, about, 4975

The Professor's House, 1277

about, 1278

The Professor's Story, 375

Profiles from the New Yorker, 2565

The Profits of Religion, 1754

Progress, idea of, 3754

Progress and Poverty, 4535

The Progress of Dullness, 165,167

$A$ Progress to the Mines, 13

Progressive education, 5104, 5131, 5198 , $5217,5234,5236,5239$

Progressive Education Association. Commission on the Relation of School and College, 5131

Progressive Party, 6350, 6362, 6427

Progressivism and the Progressive movement, 1048, 3433, 3446, $3453,3458,3467,3473,3489$, $4202,6340,6362,6424,6426-27$

Prohibition, 4523

Prohibition Party, platforms, 6367

Prokosch, Frederic, 2087-97

The Promised Land, 2585

Pronunciation, 2238, 2246, 2273, 2364

Propaganda, 3462, 3561, 3607, 6336$37,6341,6348-49,6357,6393-$ 94

Property rights, 601 1, 6060, 6094, 6101, 6105

The Prophet (Asch), 1190

The Prophet (Taylor), 2282

Prophet in the Wilderness, 2682

The Prophet of the Great Smoky Mountains, 1087-88

Proportional representation, 6059, 6134, 6402

Prospect of the Future Happiness of America, 121

Prosperity, economic, 4502

Prosser, Charles A., 5211

Prostitution

Chicago, 2836

New York (City), 4597

Protective tariff. See Tariff

Protestant churches, 5404-5, 5441-42

hist., 5492-93

music, 5631

segregation, 5499

soc. problems, $5485-89,5492-93$

Protestant Episcopal Church. See Episcopal Church

Protestants and Protestantism, 3040, $4515,5394,5404,5425,5438$, $544 \mathrm{I}, 5495$

Proud Riders, 1314

Prout, Henry G., 4790

Provençal poetry, translations, $166_{4}$ 1667

Proverbs, 5511

Miss., 5547

New York (State), 5548

N.C., 5536

Providence, R.I., soc. life \& cust., I8th cent., 4261

Provincetown Playhouse, I647, 1762, 4916

Provincialism, 896-97

Provo, Utah, 3915
Prucha, Francis Paul, 3663

Prue and 1,2278

Prufrock, 1359

Psychiana, 5439

Psychiatric hospitals, $4833-38$

Psychiatry, 4722, 5409

forensic, 4840

military, 4833

nursing, 4835

research, $4833,4835-36,4838$

study \& teaching, $4835-36,4838$, 4840,4859

Psychical research, 5323

Psychoanalysis, 2716-18, 5389

Psychological influences and themes in literature

drama, $1519,1647-48$ hist. \& crit., 2506

fiction, $365,375,727,986-1001$, 1004, 1149, 1163, 1379, 1470, 1927, I944-45, 1954, 2017-18, $2021,2023,2052,2107-8,2128$, 2130, $2156,2174-76,2178,2184$, 2224,2415

personal narrative, 1557

poetry, $1357,1623-27$

short stories, 1929, 1944, 1946, 2128 , $2176-77,2179$

Psychology, 5272, 5322-23, 5340-41, 5388-93

and pragmatism, 5254

educational, 51 23, 5229, 5307

experimental, 539r

faculty, 5307

functional, 5389

Gestalt, 5389, 5392

hist., 5388, 5392-93

pathological, 4833

physiological, 539 I

political. See Political psychology

religious, 25

social, 3724

testing, 5229, 5247

therapy, 4840

Public administration, $61_{34-35} 61_{39}$, $6170-72,6174,6178,6179-81$, $6184,6188,6198,6204$

Public assistance, Negroes, 4448

Public debts. See Debts, public

Public defenders, 6329-30

Public domain. See Public lands

Public education, 4095, 5106

administration, 5135, 5139, 5240, 5307

buildings, 5240

criticism, 5226, 5232-33, 5235-39

curricula, $5136,5158,5224-25$, $5235,5237,5240$

directory, 5I I 2

experiments \& innovations, 5158, $5224,5235,5237,5240$

finances, 5135,5144

function, 5134

govt. relations, 5141,5144

hist., 5122, 5125, 5137-38, 5140 , 5143

laws \& legislation, $5143,613^{8}-39$

local control, 5099, $514 \mathrm{I}$

methods, 5236

objectives, $5124,5136,5146$ 
Public education-Continued

organization, 5135

problems, 5240

programs, 5136

school buildings, 5240

soc. aspects, $5136-38,5140,5146$

sources, 5I 25, 5138-39

state control, 5 I 4 I

stat., 5 II 4

surveys, 5 I I 4

teachers, 5105, 5132-34, 5216

theories, 5237

Concord, Mass., 5220

Mass., 5125

Va., 5122

Public finance. See Finance, public

Public health, 461 7, 4808, 4823, 4829 , $4831,4841-42,4858,4862-81$

Indians, 3023

laws, 4876

stat., 4862

Ala., 4099

Baltimore, 4867

Chicago, 4864

Ga., 4095

See also Health services; Medicinecharities

Public Health Service, $4847,4864,4878$ about, 4765,4880

The Public Is Never Wrong, 4963

Public lands, 2970, 3237, 5809, 58I I, $5813-14,5817$

Public libraries, 6440-41, 6472, 6474, $6480,6{ }_{4} 82-83$

hist., 6474

personnel, 6479

Public Library Inquiry, 6441, 6452, $6477,6479-80$

Public opinion, 3462, 3609, 3615, 4405, 4499, 4550, 4554

and the press, $2858,2868,2884$, 2927

research, $4700,6417,6423$

France, 3775

Russia, 356r

Public opinion polls. See Public opinion-research

Public records, 3079

bibl., 3067

preservation \& management, 3063

Public relations, politics, 6341,6345 , 6348

Public Speech, I 586

Public utilities, 6004, 6013

Public welfare, $4618,4621,4630-31$, 4634

services, 4095

R.I., 4632

Publishers and publishing, 2391, 6435$38,6440-41,6444-46,6449-53$

Colonial, 122

directory (before 1889 ), 5611

music, 5635

periodicals, $2852,2855,2915$

See also Newspapers-policies \& practices

Boston, 5628

Nashville, 3765

Philadelphia, 5629

Publishers' Weekly, about, 6445
Puckett, Newbell Niles, 5561

Pueblo Indians

architecture, 5723

govt. relations, 3035

Puerto Ricans, 4428,4470

in Brooklyn, 4046

Puerto Rico, 4222

guidebook, 3941

Puerto Rico Reconstruction Administration, 394I

Puleston, William D., 3672

Pulitzer, Joseph, about, 2848,2889

Pulitzer prizes, 2869, 2889

Pullman strike (1894), 3133, 3439

Pulszky, Ferencz Aurelius, 4360-62 about, 4360

Pulszky, Terezia (Walder), 436o-62 about, 4360

Punch, 209

Punch: The Immortal Liar, I 66

Pupasse, 1035

The Pupil, 1007, 1014

Pupin, Michael I., 479I

about, 4791

The Puppet Master, 1635

Puppets and puppeteers, 2472, 498I

Purcell, Ralph, 5697

Purcell, Theodore V., 6055

A Puritan in Babylon, 3481

The Puritan Pronaos, 3745

Puritan Sage, 31

The Puritan Way of Life, 2345

Puritans and Puritanism, 43, 2345 $3131,3733,3742-43,3745,5394$, 5428

music, 5633

Mass., $3178,3182,3197,3235$

Puritans and Puritanism in literature, $7-11,17-35,40-50,53-55,59-65$, 72-95, 244I

anthologies, 2345

controversial writings, $17,20,86,89$

drama, 198, 200, 1069-70

essays, 2401, 2424, 2486, 2503

fiction, 333, 562, I 730, 2293

poetry, 7-I1, 72-74, 79-83, 2483

sermons, 18, 21, 24, 33, 35, 59-62, 65

short stories, 333, 562

See also The Pilgrims; Separatists

The Puritans as Literary Artists, 2345

The Purloined Letter, 529

Pusey, Merlo J., 6254

Putnam, Carleton, 3467

Putnam, George Palmer, 4205

Putnam, Herbert, about, 6469

Putney, Cornelia F., 5589

Puttkammer, Ernst W., 6303

Putz, Louis J., ed., 5447

Puyallup Indians, $304 \mathrm{I}$

Pyle, Ernie, 2745

about, 2745

Pyles, Thomas, 2250

Pylon, 1387

Q

Quacks and quackery, I I55, 4806, 48 I $0-1$ I , 4860

Quadrille (dance), 5587, 5590
Quaife, Milo Milton, 4I 37

ed., 3349

Quaker Oats Co., about, 5835

Quakers and Quakerism, 3222, 4038 , 4258

in literature, I 78-85, 662, I343, 22 I I

See also Friends, Society of

Qualey, Carlton C., 4487

Quare Medicine, 1475

Quarries and quarrying, 2991

Quarterly Review of Literature, 2568

Queen, Ellery, pseud., 2436

Queen Anne's War (I 702-13), 3 I7I

Queeny, John F., about, 4735

Queries, of Highest Consideration, 89

The Quest for Certainty, 5280

Quia Pauper Amavi, 1666

Quiet Cities, 1510

Quiet, Please, I 268

Quiett, Glenn Chesney, 4150

Quigley, Thomas H., 5211

Quillian, W. F., Jr., 3758

Quilts, 5604

Quimby, George I., 2993

Quincy, Josiah, 6475

Quinn, Arthur Hobson, 2337, 2495-96, $3735,4904-5$

ed., 1 45, I 70, 200, 205, 208, 536, $1070,1855,2496$

Quinn, Bernetta, 2497

Quinn, David B., 3223

ed., 3223

Quinn, Kerker, ed., 255

Quint, Howard H., 6368

Quite So, 7 I I

Quo Vadimus, I 86r

The Quorndon Hounds, 5080

Quotations, 3152

\section{$\mathbf{R}$}

Rabbi in America, $548_{3}$

Rabbis, 4458

Rabble in Arms, I 708-9

Race question, 28I I-1 2, 2839-40, 3399, $3404,4426-27,4430-34,4443$, 4447, 4550, 4617, 4619, 6106, $6117,6121,6129,6379$

Race question in literature, 1653

essays \& studies, $1103-4,2364$

fiction, 722, 756, 789-93, 1099, I 105, 1569, 1653, 1759-60, 1914I 5, I 939, 20I I, 2045, 2050-5I

personal narratives, 1522 , 1539

poetry, 856-58, I 133-35, I 537-38, 1540

short stories, 756-58, 856, 910, 1099I 102, 1523-25

See also Slavery in literature

Racing. See Automobile racing; Horseracing; Motorboat racing; Yacht racing

Racketeering, 2274, 4652

Rackman, Emanuel, 4458

The Racquet Game, 5046

Radar, 3675

Radiation, 4722

Radical empiricism, 5327

Radical Republicans, 3361, 3377, 341 2 
Radicalism, 3139, 3253, 3255, 3262, $3303,3425,3427,6039,6130$, 6426

Radin, Max, 6268

Radin, Paul, 2407

Radio and radio broadcasting, 4682, $4684,4686,4691,4695,4697-98$, 4700-1, 4703, 4965

advertising, 4696

audiences, $4700-1,4703,4895$

drama, 4966

hist., 45 I 9, 4690,4693

in education, 5230-31

in religion, 4702

industry, 4683,4687

journalists, 2848

law \& regulations, 4706-9

Radisson, Pierre Esprit, about, 283I, 3170

Raeder, Ole Munch, 4348 about, 4347

Rael, Juan Bautista, 5537

Raesly, Ellis Lawrence, 3224

Rafinesque, Constantine Samuel, about, $472 \mathrm{I}$

Ragan, Allen E., 6255

Rage for Order, 2529

Rage of the Soul, 2806

A Rage to Live, 2076

Ragusin, Anthony, 3946

$R a h a b$, I 446

Rahv, Philip, 994, 2498

ed., 1007,2566

Railroadmen, songs \& music, 5512, 5559,5562

Railroads, 2580, 2937, 43 I 2, 5920, 5922, 5924-27

biog. (collected), 5927

fiction, ro93

folklore, 5512

frontier, 4156

hist., 5923, 5927

law, 6236

mountain, 4174

New England, 5933

Northwest, Pacific, 4214

The West, 4 I 39

Wis., 4I 39

Railton, G. S., about, 5497

Rain from Heaven, 1207

Rainbow on the Road, 1444

Raintree County, 2006

Raisz, Erwin, 4172

maps, 3 I 6I, 3 I 64, 3298

Raivaaja Publishing Company, about, 2896

Raiziss, Sona, 2499

Rajan, Balachandra, ed., 1367

Raleigh, Walter, Sir, about, 3223

Raleigh, N.C., 3833

Rall, Harris Franklin, about, 5433

Ralston, William Chapman, about, 2660

Ramona, 985

The Rampaging Frontier, 4097

Ramsaye, Terry, 4944

Ramsdell, Charles W., 4068

Ramsey, Frederic, ed., 5644

Ranch life, 2794, 4I52-54, 4I6x-63, $4174,4196,5503$
Randall, David A., 6464

Randall, James G., 608 I

Randall, Henry S., 3296-97

Randall, J. H., Jr., 3065, 5289-90

Randall, James G., 3388, 3394-95, 3408

Randolph, John, about, 26 1 7, 2621

Randolph, Vance, 2270, 5543-45 ed., 5569

Raney, William Francis, 4139

Rankin, Daniel S., 759

Rankin, Hugh F., 3244

Rankin, Rebecca B., 6214

Ransom, John Crowe, I675-79, 2512 about, 2499, 2544, 2559

Rare books, 6462, 6464

Raritan River, 3994

Raskin, A. H., 6207

Ratchford, Benjamin U., 5891

Rathbone, Perry T., 5805

The Rational Study of the Classics, 5115

The Rationale of Verse, 520

Ratner, Joseph, ed., 5120,5287

Ratner, Sidney, 5290-91, 5970

Rats, Lice and History, 2843

Rauch, Basil, 3492 ed., 3494

Raudebaugh, Charles, 6207

Rauschenbusch, Walter, 5482 about, 5396, 5436, 5443, 5482

The Raven and Other Poems, 530

The Raven and the Whale, 2478

Raw Material, I55 I

Rawlings, Marjorie (Kinnan), 1680-85 about, 1685

Rawson, Marion (Nicholl), 4531

Ray, Sarah Paulding, 6267

Rayburn, Otto Ernest, 3960

Raymond, Henry Jarvis, about, 2848, 2869

Razzle Dazzle, 2114

Reactionary Essays on Poetry and Ideas, $18 \mathrm{ro}$

Read, Conyers, ed., 6082

The Reader's Digest, about, 2919-20

Reading Modern Poetry, 1968

Reading the Spirit, 1351

Real estate business, 5812,5815

Real property law, 6278

The Real Right Thing, ror 2

Realism in literature

drama, I 518, I647, 1688, 1995, 2043, 2063

fiction, $277,821,867,887,956,959$, $964,986,1372,1379,1445,1453$, $1460,1494,1559,157 \mathrm{I}, 1611$, $1647,1720,1743,1754,1775$, $1792,1940,1954,1992,2003$, $2011,2025,2069,2128,2229$

hist. \& crit., 2276, 2364, 2401, 2424, 2485

poetry, 1290,1727

short stories, $821,881,890,986$, I 1 49, 1379, 1453, 1494, 1796, 2011, 2071-73, 2128,2210

theories, $890,964,977$

See also Naturalism in literaturefiction

Reality, 5379
Realms of Being, 5371

about, 5375

Realms of Value, 5334

Reason and Law, 5269

Reason and Nature, 5268

Reason in Madness, 1810

Reason the Only Oracle of Man, 5408

Rebel without a Cause, 2717

Rebels and Ancestors, 2430

Rebels and Democrats 3241

Rebels and Gentlemen, 3764

Rebels and Redcoats, 3244

The Rebuilding of Old Commonwealths, 5145

Récamier, Marie, 228r

Recollections and Impressions, 2279

Recollections of Europe, 263

Recollections of the Last Ten Years, 308-9

Reconstruction, 3093, 3120, 3 I 4 I, 336I$63,3372,3377,3385,3387-88$, $3408,3412,3416-17,4077$ editorials, sketches, etc., 556

fiction, $1105,1382,1618-19$ reminiscences, $277,2828-30$ short stories, 1151,1389 sources, 3376

Reconstruction in Philosophy, 5276

Recreation, 4983-5097 areas, 3786

See also Parks

community, $4997-98$

Plains Indians, 3006

social aspects, 4998

Mass., 3803

Mitchell, S. Dak., 3899

Northwest, Pacific, 4214

San Diego, Calif., 3932

See also Games and dances

Recreations of an Anthologist, 2467

The Red Badge of Courage (motion picture), about, 4949

The Red Badge of Courage (novel), $821,825-29,835-36$

Red Bird, 1556

Red, Black, Blond, and Olive, 2535

Red Cloud (Sioux chief), about, 3003

Red Cross, American, hist., 4620

The Red Decade, 3490

Red Jacket, 323

The Red Mill (operetta), $568 \mathrm{I}$

Red: Papers on Musical Subjects, 1828

The Red Pony, 1780

Red River valley, 3954

Red Rock, I 105

Red Roses for Bronze, 1321

Red Sand, 1792

Red Sky in the Morning, 1290

Red Wine \& Yellow Hair, 2086

Redburn, about, 498

Redfield, Robert, 4472

The Re-discovery of America, 1445

The Redskins, 268

Redwood, 3959

Reebel, Dan, 5918

Reed, Alfred Zantzinger, 6326-27

Reed, David W., 2260

Reed, Henry Hope, 4609

Reed, Louis S., $48 \mathrm{I} \mathrm{r}$

Reed, Mark, 2333 
Reed, Walter about, 4872 drama, 1520

Reed, William Gardner, 5816

The Reef, 1849

Reese, Albert, 5780

Reese, Lizette Woodworth, 2780-8I about, 278 I

Reese, M. Lisle, 3896

Reeve, Henry, tr., 4510-12

Reeves, Jesse S., 3540

Reflections at Fifty, 1378

Reflections in a Golden Eye, 2023-24

Reform and reform movements, 4614, 6424-34

I9th cent., 3430-3I, 3446, 3769, $4522,4530,4535,4537,6360$

2oth cent., $3446,3455,3458,6360$, 6362

See also Muckrakers

Reform Judaism, 5459

Reformatories. See Prisons

The Reformed Church, about, 5442

The Reformed Presbyterian Church, about, 5466

Refrigerators and refrigerating machinery, 4794

Refugees, political, 4263, 4289, 448I

since $1933,4407,4414,4419$

Regier, Cornelius C., 6430

Regional characteristics, 4230,4283 See also Culture

Regional libraries, 6471

Regionalism, $1809,378 \mathrm{r}, 3783,3785$, 3942,4079

in art, 5748

Regionalism and local color in literature

editorials, sketches, etc., 192-93, 445$48,542-45,556-61,612-13,701-$ 5, 716-17, 1064-65, 1068, 1072, 1090, I 1 03-4, I 724-26, I 791

fiction, 402-4, 562, 683-86, 716, $718-20,745,749-50,768,867-$ 73, 945-52, 955, 959-63, 980, 1032, 1 099, I 1 05, I I 45-8, $1270-$ 74, 1276-77, 1314-15, 1379, 1453 , $1460-62,1653-55,1680-83,1686-$ $87,169 x, 1693-4,1696,1697-99$, 1701, 1705, 1786-89, I 792-96, 1798-1800, I836-40, I845, 1959$62,1964-65,2023-24,2166,2193-$ 94, 2197,2199

poetry, 662, 753-55, 926; 933-34, $941-44,1038-43,1046-47,1064$, 1 066-67, I I 26-3 I, I 1 33-35, 1290 , $1295-97,1314,1809,1959,2166$, $2172,2193,2196,2202$

short stories, 556-62, 574-75, 612$13,687,701,704-5,716,745-48$, 759-60, 881-86, 890-95, 910-22, 924-32, 935-40, 945, 951-52, 95455, 1032-35, 1084-88, 1099-1102, $1149-51,1270,1275,1379,1453$, $1680,1684,1686-87,1697,1724$, $1796,1839,1841,1845,2110$, 2166-68, 2170-71, 2202, 2205, 2207,2209

anthologies, 2322, 2369
Regionalism and local color in literature-Continued

See also names of regions, states, and places in literature, e.g., New Eng. land in literature

Regionalisms (language). See Language-dialects \& regionalisms

Regulation of Lobbying Act, 6397

Regulatory agencies. See Executive branch

Rehabilitation centers, 4637

Reich, Nathan, 4457

Reichard, H. H., 4479

Reid, Ira De A., 4428, 4447, 5500

Reid, Ogden Mills, about, 2868

Reid, Whitelaw, about, 2868

The Reign of Law, 718

The Reign of Philip the Second, History of, 2294

Rein, David M., 4828

Reindeer industry, Alaska, 2719-20

Reinemann, John Otto, 4657

Reinhardt, George C., 3629

Reinhart, C. S., illus., 1 1 01

The Reinterpretation of American Literature, 2424

Reis, Claire (Raphael), 5609, 5620

Reischauer, Edwin O., 3510

Reisner, Edward H., 5 I 2 I

Reiss, Albert J., Jr., 4395

Reissman, Norman, 5039

Reitzel, William, 3573,3630

Reizenstein, Elmer. See Rice, Elmer L.

Religion, 3469, 3969, 4551, 5254, 5311 , 5394-5502

biog. (collected), 5396, 5426-27

Colonial period, 3747,3763

Dutch communities, 4493

frontier \& pioncer, $5411-16$

hist., 4224, 4315, 5394-5417

Jews, 4458

law \& legislation, 5420-22

Negroes, 5498-5502, 5527, 5547

Pennsylvania Germans, 4480

Baltimore, 4062

Mass., 4034

Nashville, 3765

New England, 5417

N.C., 4090

Northwes:, Old, 4 II 2

Ohio, 4121

Pa., 4054-55

S.C., 4091

Southern States, 3766, 4069, 4083

See also Indians-religion; Radio in religion; Sects; Cults; Television in religion; and names of individual religious bodies

Religion, folk

Brazos River, Tex., 5527

Mo., 5528

N. Mex., 5537

Religion and public education, 5103 , $5181,5236,5419,5491,5494$

Religion and science, $3114,3761,5315$, 5337,5434

Religious folksongs, 5549, 5553-54, 5564

hist., 5549

Appalachian Mountains, 5583

Ky., 5584
Religious folksongs-Continued Mich., 5575

Ozark Mountains, 5569

Southern States, 5583

Religious institutions, Jewish, 4461

Religious leaders, $5474-83$

Religious life

Italians, 4497

Swedish, $448_{3}$

Religious literature, Colonial period, $3742-43,3745$

Religious movements, 4522,4525

Jewish, 4459

Religious music. See Choirs (music); Church music

Religious themes in literature

Christian life, I7, 45, 90

church govt., 19, 34, 93-95

church hist., $43-44$

controversial writings, $17,20,86,89$ conversion, 60-6I

devotional books, $45,87-89$

diaries, journals, etc., $178-85$

doctrinal, 26, 230-3I

essays, 230-31, 2479

fiction, 402-4, 716, 762, 1252,1343 , 1396, I 446, 1563,1578, 2415

hist. \& crit., 2483,2493

manual for pastors, $47-48$

meditations, 2034, 2038, 2041-42

missions, 62

natural theology, 46

personal narratives, 2024, 2036

poetry, 7-11, 72-73, 79-83, 662, 670-

$71,680,1357,1359,1369$, $1537-$

38, I 540, 2034-35, 2037, 2039

prose, 2279

psychological, 25

revivals, 22-23

sermons, 17-18, 24, 33, 35, 230, 900

See also Theology-in literature

Religious thought. See Theology; Religion; Philosophy; etc.

Relocation centers, Japanese, 4469

Remedial law, 6279

Remember to Remember, 1613

Remembered Yesterdays, 2923

Remembering Laughter, $216 \mathrm{I}$

Remembrance Rock, 1727, 1730

Remington, Frederic

drawings, 5034

illus., 1147

about, 5770,5802

bibl., 5770

Removal and Return, 4469

Remsen, Ira, 4724

Renascence, 1609

Rendezvous with Destiny, 3455

Renegade, 1578

Reno, Nev., 2746, 4176, 4184 in literature, 1954,2746

Repent in Haste, 1594

Reporters and reporting, 2903, 2905-7, 2928

Civil War, 285 I

Oreg., 2863

Washington, D.C., 2861, 2930

See also Newspapermen

Representative American Dramas, 2348

Representative American .Plays, 145, $170,200,205,208,1070,2337$ 
Representative Men; 298

Representative Plays by American Dramatists, I45, 170, 199, 2347 Republic Steel, 5918

The Republican Era, 1869-1901, 6178

Republican newspapers, 2851, 2862-63, 2868-70, 2875

Republican Party, 3424, 6347-48, 6352$53,6361,6365-66,6370$

hist., $2879,3438,3442,3456,3466$, $3500 a, 6361,6365-66$

National Committee, $636 \mathrm{r}$

National Convention (1912), 6350

platforms, 6367

Philadelphia, 6353,6389

Republican Party (Jeffersonian), 3141 , 3286,33 I0-1 1 , 6347

Republicanism, 31 44, 3308

Requiem for a Nun, 1395

Research. See specific subjects, e.g., Business research

Research libraries, 6470, 6478, 6483, 6487

Reserves, national. See Forests and forestry; National parks and reserves

Resorts. See Health-resorts, etc.; Skiing and ski resorts

The Responsibilities of the Critic, 2477

The Responsibilities of the Novelist, 1096

Restless Is the River, 1961

Reston, James, 3615

The Restoration of Learning, 5233

The Resurgent Years, 5913

Retail trade, 5949

The Return of a Private, 893

The Return of Lanny Budd, 1758

The Return of Peter Grimm, 2347

Return to the Fountains, 2494

Reuben and Rachel, 164

Reunion and Reaction, 3417

Reunion in Vienna, 1749

Reusser, Walter C., 5 I 44

Reutter, E. E., Jr., 5216

Revelry, 1156

Reverchon, Julien, about, 4734

Revere, Paul, about, 1437

The Reverend Griffith Davenport, 2304

Reveries of a Bachelor, 507-8

Revett, Marion S., 4894

The Revival of Realism, 5351

Revivals and revivalism, 22-23, 5401-3, $5407,5411,5480$

See also Great Awakening; Great Revival

Revolution, right of, 6073

Revolution and Other Essays, 1048

The Revolutionary Generation, 3089

Revolutionary War. See American Revolution

Revolutionists. See Patriots (American Revolution)

Rexroth, Kenneth, 2098-21 02

Reynolds, Levering, Jr., 5424

Reynolds, Lloyd G., 6037

Reynolds, Mary (Trackett), 6189

Rhapsody in Blue (music), 5678

Rhees, Rush, about, 5671

$A$ Rhetoric of Matives, 2390

Rhode Island, 3965, 4039-40

econ. condit., 4632
Rhode Island-Continued

founding, 84

guidebooks, 3804

hist., 3197, 4039

soc. condit., 4632

Rhodes, Charles D., 3651

Rhodes, Eugene Manlove, I686-87 about, 1686

Rhodes, Frederick Leland, 4679

Rhodes, James Ford, about, 2695, 3058

Rhodes, May Davison, 1686

Rhyme, folk, 5510-1 1, 5592

N.C., 5536

Schoharie County, N.Y., 5539

Southwest, 5507

Rhymes of Childhood, 1127

Rhymes to Be Traded for Bread, 1581

Rhyne, Charles S., 4708

Rhyne, J. J., 4594

Rhys, Ernest, ed., 4343

Rian, Edwin H., 5494

Ribalow, Harold U., ed., 4453

Ribalow, Menachem, 4453

Rice, Charles S., 4058

Rice, Edward, 5024

Rice, Elmer L., 1688-90, 2332, 2334, 2348

Rice, Grantland, 4994, 5048 about, 4994

Rice, John Andrew, 2782-83 about, 2783

Rice, Philip Blair, 5366

Rice, William North, 4724

Rich, Arthur Lowndes, 5684

Rich, Wesley E., 4669

Richard Edney, 402

Richards, Eugene S., 443 I

Richards, Ivor Armstrong, about, 2407

Richards, Laura E., 4040

Richardson, Alfred Talbot, ed., 2663

Richardson, Edgar P., 5755-56, 5760

Richardson, Harry V., 5501

Richardson, Henry Hobson, about, 5710

Richardson, Lyon N., 2915 ed., 2352

Richardson, Rupert Norval, 4189, 4194

Richert, Gottlieb Henry, 5949

Richey, Herman G., 5140

Richman, Irving Berdine, 4039

Richmond, Va., essays, $1002-3$

Richter, Conrad Michael, 1691-96

Rickaby, Franz L., 5567

Rickard, Tex, about, 4987

Rickard, Thomas Arthur, 5917

Riddick, Floyd M,. 6 I 62

Riddles, $551 \mathrm{I}$

N.C., 5536

Schoharie County, N.Y., 5539

Rideout, Walter B., ed., I 187

Rider, Fremont, 6476

Rider, Richard L., 4682

Riders of the Purple Sage, 1485

Ridge Runner, 2590

Ridler, Anne, ${ }_{3} 67$

Riegel, Robert E., 3 103, 31 37, 4520

Riegger, Wallingford, 4968

Riemer, Ruth, 4469

Riesman, David, 4452, 4513, 4555-56, 5190

Riggs, Robert L., 5050 about, 5050
Right of revolution, 6073

Right of search, 3554,3558

Right to vote. See Freedom of the franchise

Rights of man, 6068, 6071-73, 6085, 6094

The Rights of Man, 155

Riis, Jacob August, $2784-85,4638$ about, 2785

Riker, Charles Cook, 567 I

Riker, Dorothy, comp., 4125

Riley, I. Woodbridge, 5262

Riley, James Whitcomb, 1 I 26-31 about, 941, I I32, 4124

Rimmer, William, about, 5738

Rinehart, Mary (Roberts), 2786-87 about, 2787

Ring, Martha D., 4883

Ringer, Gordon, tr., 5363

Ringer, Virginia, tr., 5363

The Ringer, 1486

Ringwalt, Ralph Curtis, ed., 4464

Rio Grande River and valley, 4197, 5083

Riordon, William L., 6382

Rip Van Winkle

autobiography of Joseph Jefferson, 4934

play by Charles Burke, 2347

play by Joseph Jefferson, 2337

short story by Washington Irving, $38 \mathrm{I}, 384-87$

Rip Van Winkle Goes to the Play, 2475

Ripley, George, about, 2279

Ripley, Sarah Alden, about, 2615

Ripostes, 1666

Rippy, James Fred, 3138, 3586

Rips, Rea Elizabeth, $6{ }_{13} 8$

The Rise of a New Federalism, 6198

The Rise of American Civilization, $3073,3479,3750$

The Rise of Realism, 2276

The Rise of Silas Lapham, 967-70, 982

The Rise of the Common Man, 3091

The Rise of the Dutch Republic, 2293

Rise of the New West, 3356-57

Rister, Carl Coke, 4160, 4189

Ritchie, Andrew Carnduff, 5696

Ritchie, Anna Cora (Ogden) Mowatt. See Mowatt, Anna Cora

Ritchie, Thomas, about, 1267

Rittenhouse, David, about, 4758

River boat life

Mississippi River, 784-86, 4281, 5505

Ohio River, 5505

A River Goes with Heaven, 1837

River navigation, 5929

River travel. See Travel and travelersriver

Riverhead, 1515

A Rivermouth Romance, 7 I I

Rivers, 3969-4025

Canada, 4237-38

Fla., 4247

Ga., 4247

Ill., 4322

Ind., 4282

Ky., 4282, 4322

La., 428 2

Md., 3999

Mass., 4012 
Rivers-Continued

Miss., 4282

Mo., 4322

New York (State), 4237-38, 4282

Ohio, 4282

Pa., 4237-38, 4282

Southern States, 4083

Tenn., 4282

Va., 4282

See also Waterways, inland; and also specific rivers, e.g., Hudson River

Rivers Parting, 1918

Rivers to the Sea, 1814

The Riverside Bookshelf, 685

Riverside County, Calif., 3957

Rives, William Cabell, 3283

The Rivet in Grandfather's Neck, 1262

The Road Between, 1376

Road of Ages, 1635

The Road to Disappearance, 3025

The Road to Rome, 1749, 2332

Roads, 5934

guides, 3786, 3805

See also Highways

Roalfe, William R., 6328

Roan Stallion, 1534

Rob of the Bowl, 41 2-13

Roback, Abraham A., 5392

Robacker, Earl F., 2266

The Robber Barons, 5880

The Robber Bridegroom, 2204

Robbins, Ira S., 4612

Robbins, Rossell H., 1368

Robbins, Roy M., 58I 4

Robbins, Thomas, 44

Robert, Joseph C., 5829

Robert Emmet, 2298

Roberts, Anna M., tr. \& ed., 4265

Roberts, Elizabeth Madox, 1697-1 706

Roberts, Henry L., 3557

Roberts, Howard, 5040

Roberts, John S., 5307

Roberts, Kenneth, 1707-12 tr. \& ed., 4265

Roberts, Leonard W., ed., 5546

Roberts, Leslie, 4015

Roberts, Mary M., 4852

Roberts, Morris, ro10

Robertson, Elizabeth Wells, 5604

Robertson, Stuart, 225 I

Robertson, William, 3031

Robeson, Dave, 4982

Robinson, Blackwell P., ed., $383 \mathrm{I}$

Robinson, Daniel S., ed., 5359

Robinson, Edwin Arlington, 1713-16 about, 1717-19, 2289, 2404, 2527, 2544,2682

Robinson, George O., 4747

Robinson, James Harvey, about, 4540, 4545

Robinson, John, about, 3257

Robinson, Roland I., 5971

Robinson, Thomas Porter, 4709

Robinson, William W., 4202

Robson, Eric, 326r

Rochester, N.Y.

guidebook, 3810

hist., 3810, 4050-52

Rockefeller, Abby (Aldrich), Folk Art Collection, 5595
Rockefeller, John D., about 3117, 5915-16

Rockefeller, John D., Jr., about, 4622

Rockefeller Foundation, 4622

about, 5 I63, 5198

A Rocket in My Pocket, 5592

Rocket to the Moon, 2064

Rockford, Ill., 3881

Rockne, Bonnie Skiles, ed., 5041

Rockne, Knute, 5041 about, 5041, 5044

Rocks before the Mansion, 2788

Rocky Mountain Fur Co., 4148

Rocky Mountain Herald, 1409

Rocky Mountain region, 2933, 3967, $4172-85$

cities \& towns, 4I 76-77

fiction. 312,1239

folklore, 5530

frontier life, $4155-56$

fur trade, 4148

geology, 4172

guidebooks, 3910-16

travel \& travelers, 391, 4384

Rocky Mountain Review, 2576

Rodabaugh, James H., ed. \& illus., 4I 20

Rodall, Marie F., 2436

Rodell, Fred, 6256

Roden, Robert F., 6448

Rodgers, Andrew Denny, 2788-92, 4760

Rodgers, Richard, about, 5639, 5685

Rodgers, Robert R., 5170

Rodman the Keeper, $115 \mathrm{I}$

Roe, Frank G., 2965, 2984

Roebling, John August, about, 480 I

Roebling, Washington Augustus, about, $480 \mathrm{r}$

Roebuck, A. D., about, 5956

Rølvaag, Ole Edvart, 1720-23

Roemer, Ferdinand, about, 4734

Roemer, Milton I., 4869

Roethke, Theodore, $2 \mathrm{I} \mathrm{O3}_{-4}$

Rogers, A. K., 5255, 5289

Rogers, Bruce, illus., 4123

Rogers, John, about, 5739

Rogers, Lindsay, 6423

Rogers, Meyric R., 5732

Rogers, Richard, 2337

Rogers, Robert, 2347

about, I 710

Rogers, Samuel, about, 219

Rogers, Walter P., 5191

Rogers, Will, about, 556, 558, 862 , 2657

Rogers, William Garland, 1773

Rogers groups, 5739

Rogers' Rangers, fiction, I 710

Rogin, Leo, $5^{830}$

Rogue's Legacy, 2413

Roll, Jordan, Roll, 1653

Roll River, 1239

Rollins, Philip Ashton, 4I6I, 4163

Roman Bartholow, I 7 I 4

Roman Catholic Church. See Catholic Church

Roman Fever, 1855

The Roman Spring of Mrs. Stone, 2224

Romance of a Plain Man, I46I

The Romance of Certain Old Clothes, 1012
The Romance of Madroño Hollow, 930

The Romantic Comedians, 1460-6I

The Romantic Egoists, 1913

The Romantic Triumph, 2276

Romanticism, 3751, 4080, 6065

Romanticism in literature, 2364,2367 , 2375, 2401, 2424, 2485, 2507, 2510

anthology, 2276

editorials, sketches, etc., 192, 674, 716

essays, 280

fiction, 201, 226, 245, 252, 333, 345, $405,471-78,546,716,762,768$, 1048, 1089, 1099, I 445

poetry, $134,216,323,427,520,586$, $61_{4}, 619,662,941$

short stories, 381, 520, 716, 745, 1099

Romberg, Sigmund, 6322

Rome Haul, 1354

Romines, Stephen, 5158

Romulus, the Shepherd King, 2302

Roosevelt, Eleanor, 3493

Roosevelt, Elliott, ed., 3493

Roosevelt, Franklin D., 3493-94

about, 1749, 3108, 31 30, 3489, 3491, $3494-3500,3567,5884,6354-$ 55,6364

Roosevelt, Theodore, 2793-95, 3307, 3465

about, $2474,2503,2542,2625,2682-$ $83,2686,2795,3058,3121$, $3466-67,3489,3527,4533$, $6385,6424,6432$

sculpture, 5737

Root, Elihu, about, 271 2, 3459, 3653

Root, Winfred Trexler, 3225

The Roots of American Culture, 3736

The Roots of National Culture, 2276

The Rope, 1648

Roper, Daniel C., 4670

Rorem, C. Rufus, $488_{3}$

Rose, Arnold M., 4433, 4446

ed., 4434

Rose, Billy, about, 6322

Rose, Caroline, 4433

Rose, J. Holland, ed., 3179

Rose Bowl football game, 5042

Rose Michel, 2308

The Rose Tattoo, 2225

Roseboom, Eugene H., 4120-21, 6149

Rosedale, 2301

Rosen, Carl George Arthur, about, 4803

Rosen, George, 4844

Rosenau, James N., ed., 3494

Rosenbach, Abraham S., 2500

Rosenberg, Bernard, ed., 6443

Rosenberry, Edward H., 503

Rosenberry, Lois (Kimball) Mathews, 4028,4030

Rosenfield, Harry N., 4425

Rosengarten, George D., about, 4735

Rosenman, Samuel I., 3499

Rosenthal, Herbert, 308 I

Rosenthal, Morris S., 5950

Rosenwald, Julius, about, 5956

Rosewater, Victor, 2860

Ross, Charles D., 5186

Ross, Clay C., 5229

Ross, Earle Dudley, 6369 
Ross, Edward Alsworth, 4543 about, 4542

Ross, Harold W., about, 2565

Ross, Ishbel, 4820

Ross, Leonard Q., 286r

Ross, Lillian, 4949

Ross and the New Yorker, 2565

Ross County, Ohio, 3864

Rossetti, Christina Georgina, about, 1905, 2481

Rossiter, Clinton, L., 6067-68

Rossiter, William S., 4400

Rosskam, Edwin, ed., 3039

Rosten, Leo C., 286r, $494^{8}$

Rotary International, about, 4578

Rotha, Paul, 4944

Rothberg, Abraham, ed., 2322

Rothenberg, Robert E., 4889

Rothenberg, Stanley, 562I

Rothery, Agnes Edwards, 4087

Rothstein, Arthur, 2908

Rothstein, Samuel, 6483

Rottschaefer, Henry, 6099

Roucek, Joseph S., ed., 4426

Rough-Hewn, 1415

Roughing It, 772-74

Round by Round, 5023

Round dances, 5587

$A$ Round of Visits, 1008

Round-Shot to Rockets, 3670

Rourke, Constance M., 2443, 2501, 2796-98, 3736, 5772

Rousseau and Romanticism, 2375

Rovere, Richard H., 3482

Rowing, 4990, 5020

Rowland, Henry Augustus, about, 4724

Rowland, Stanley J., drawings, 5728

Rowlandson, Mary (White), 53-55, about, 3032

Rowlingson, Donald T., 5496

Rowson, Susanna (Haswell), I6I-64 about, I 6r

Roxy, 874-75

Royal Government in America, 3195

A Royal Slave, 2305

Royce, Josiah, 5303, 5354-61 about, 5252, 5354, 5362-64, 5369

Rozwenc, Edwin C., ed., 3118-22

Rubin, Joseph J., ed., 657

Rubin, Louis D., 1899 ed., 2442

Rucker, Frank W., 2909

Ruffin, Edmund, about, 3367 ed., 13

Ruffin, Thomas, about, 6231

Rugg, Harold O., 5104

Ruggles, Eleanor, 4938

Rukeyser, Muriel, 2105-6

Rumford, Count. See Thompson, Benjamin

Rumsey, James, about, 4784

Runaway Star, 688

The Rungless Ladder, 562

The Running of the Tide, 1443

Rural communities. See Country life

Rural folklore, 4579

Rural government. See Local government

Rural life. See Communities, rural;

Farm and rural life

Rural press, Southern, 2853
Rush, Benjamin, $525 \mathrm{I}$ about, $4822,4830,4872,5121$

Rush, Nixon Orwin, 5479

Rusk, Howard A., 4637

Rusk, Ralph Leslie, 2502 ed., 295, 305

Rusling, James Fowler, 4386 about, 4385

Russell, Bertrand, about, 5368

Russell, Carl Parcher, 42 I I

Russell, Charles Edward, 5652

Russell, Charles M., about, 5802

Russell, Elmer Beecher, 6232

Russell, Henry Norris, 5427 about, 5427

Russell, Irwin, I 133-35 about, 1135

Russell, Peter, ed., 1673

Russell, William, 5644

Russell, William Henry, about, 466r

Russell, Sir William Howard, 4379-82, about, 4378

Russell, William L., 4838

Russell Sage Foundation, 4623

Russia

econ. relations with, 3619,3638

fiction, I 190

relations with, $3505,3523,3557$, $3563-64,3619$

I9th cent., 3429

2oth cent., $3546,3560-65,3567-$ $68,3570,3620,3622,3624-25$, $3627,3629-30$

reporting, 2535

travel \& travelers, 131 I

Russian Revolution, fiction, 1656

Russo, Dorothy Ritter, 1807

Ruth, George H. ("Babe"), 4987, 5012 about, 5012

Rutherford, Mary Louise (Schuman), 6332

Rutherfurd, Livingston, 293 I

Rutledge, Archibald, I 724-26, 5087-90, about, $5087-90$

Rutledge, John, about, 6260

Rutledge, Joseph L., 3226

Ryan, Earl H., 4695

Ryan, Grace L., comp., 5590

Ryan, Margery W., ed., 5206

Rymer, Charles A., 4859

Rynning, Ole, 4485

Ryskind, Morris, I545

S

S.U.M., about, 6015

Sac Prairie Saga, 1960

Sacco, Nicola

drama, I I 73

fiction, 1980

Sachs, Leon, 6104

Sachse, William L., 3227

Sacramento River, 3974

Sacred and Profane Memories, 1828

Sacred Books of the East, 280

The Sacred Harp, 5577

The Saga of the Roaring Road, 5007

Sagamore Hill, 2686

Sage, Margaret Olivia, about, 4623 .

Sahagún, Bernardino de, 2997

Sailing, $5017,5019,5021$
Sailor on Horseback, 2815

Sailors

folklore, 5533

songs, 555I, 5553, 5556, 5558-59, 5562,5580

St. Augustine, Fla.

guidebook, 3847

language (dialects, etc.), 2258

St. Cloud, Minn., guidebook, 3888

Saint Elizabeths Hospital, Washington, D.C., about, 4840

Saint-Gaudens, Augustus, about, 5735

St. Helena Island, S. C., Negro folklore, 5540

St. John, J. Hector. See Crèvecoeur, Michel Guillaume St. Jean de

St. John, Vincent, about, 6045

St. John's River, Fla., 3980

St. Lawrence River, 3979

St. Louis, Mo.

drama, 2219

fiction, $763-65$

Hegelians, 5305

politics, 6207

theater, 4913

St. Louis. City Art Museum, 5805

St. Louis. Public Library, 6467

St. Martin, Alexis, about, 4818,4822

St. Olaf College, Northfield, Minn. Choir, 5664

St. Paul, Minn., Swedes in, 4486

Saint Peter Relates an Incident, 1540

Saints of Sage \& Saddle, 5538

Sakoda, J., 4469

Sakolski, Aaron M., 58I 5

Sale, John B., 5547

Salem, Mass., 2600

drama, $198,200,2048$

essays, 1002-3

fiction, $1439,1443,1508,1917$

witchcraft trials, $41-42,56,198,200$, 2048

See also Witchcraft

Salesmen, 5955

Salina, Kans., guidebook, 3907

Salinas River, Calif., 3998

Salinger, Jerome David, $2107-9$

Salley, Alexander S., 554 ed., 3216

Salmagundi, 51 I

Saloons. See Hotels, taverns, etc.

Saloutos, Theodore, 5831

Salt Lake City, 4176

Salter, J. T., 6336, 6389

Saltwater Farm, 1295

The Salvage, 4469

Salvation Army, about, 5497 poetry, 1581

Salvation on a String, 1476

Sam Ego's House, 2117

Sam Lawson's Oldtown Fireside Stories, $574-75$

Samaroff Stokowski, Olga, 5686 about, 5686

Sam'l of Posen, $230 x$

Samoa, American, 4218

Samplers (needlework), 5593

Sampling (radio program rating), 4700

Sampson, Martin W., 999

Samuelsen, Rube, 5042

Samurai and Serpent Poems, 2350 
San Antonio, 4187 guidebook, 3923

San Bernardino County, Calif., 3957

San Diego, Calif., 2746-47, 2750, 4150 guidebooks, 3931-32

San Diego County, Calif., 3957

San Francisco

Bohemianism, 3757

fiction, r $090-92$

guidebook, 3933

hist., $2560,3943,4150,4208-9$

politics, 2888,6207

port, 4208-9

soc. life \& cust., 4352-53

theater, 4918,4943

underworld, 2586

San Francisco Bay, 3933, 4208

San Francisco Federal Theatre, Research Dept., 4918

San Ildefonso Indians, 3041

San Xavier del Bac (Ariz.) mission, guidebook, 3926

Sanborn, Franklin B., 5266

ed., 599-60I

Sanctuary, 1385, 1395

Sand, George

about, 2504

drama, 2337

Sandage, Charles H., 5962

Sandburg, Carl, 1727-32, 3393, 3395, $4483,551 \mathrm{x}$

ed., 5562

about, 2406, 2419,2503

Sanders, Jennings B., 3058, 6083

Sanders, Rufus, pseud., 2257

Sando at Seventy, 626

Sandoz, Jules Ami, about, 2800

Sandoz, Mari Susette, 2799-2801

Sands, Robert Charles, 2295

Sandusky Bay (Ohio) region, guidebook, 3868

Sandusky County, Ohio, 3867

Sandys, Edwyn, 509r

Sanford, Charles L., ed., $3 \times 23$

Sanford, Trent Elwood, 5723

Sangamon River, 3988

Sanger, Joseph P., ed., 3651

Sanitary engineering, $4823,4831,4864$, 4874,4878

Mass., 4879

Sankey, Ira D., about, 5405, 5480

Santa Barbara, Calif., guidebook, 3934

Santa Barbara County, Calif., 3957

Santa Fe, 41 48, 4176,4187

Santa Fe Trail, 4188

Santayana, George, I733-41, 5255, 5366-74

about, 1678, 1742, 5259, 5262, 5365, 5375-77

Santee River, 4023

Saposs, D. J., 6033

Sapphira and the Slave Girl, 1277

Sappington, Clarence O., 4873

Saratoga, N.Y.

essays, 1003

fiction, 1407

Saratoga campaign, 3682

poetry, 323

Saratoga Trunk, 1407

Sarazen, Gene, 5051 about, 505I
Sargeant, Winthrop, 5622, 5645

Sargent, John Singer

illus., 439

about, 577 I

Sarnoff, David, about, 4683

Saroyan, William, 2 I 10-22, 2327, 2334, 2336

about, 2119, 2121,2536

Sarton, May, $2123-27$

Sartoris, 1382

Saskatchewan River, 4004

Satanstoe, 268-69

Satire, 3732

drama, I317, I 548-49

editorials, sketches, etc., 209-1 5, 381$83,422-26,542-45,556-61,732$, $862-66,1214,1815-20$

essays, 147-48, 165, 1317-18, 1602, r604-5

fiction, ro5-8, 689-90, 775-77, 79497, 1261-62, 1 267, 1381, I 559$64,1567,1589-90,1635,1643$, $1682,1792,1842-45,2001,2017-$ 19, $2021-22,2053,2154,2180$, 2229

periods

Colonial, 51-52, 75-77, 92-93, 2493

(1764-1819), 105-8, 118,120 , 1 34-39, 1 47-48, 165-68

(1820-70), 209-15, 323, 381-83, $422-26,456-58,542-45,556-6 \mathrm{I}$

(1871-rgr4), 689-90, 732, 775$77,794-97,862-66$

(1915-39), 126r-62, 1267, 131718, 138r, 1545, 1548-49, 1589$90,1635,1643,1651-52,1688$, 1792, I815-20, 1842-44, 1845

(1940-55), 2017-22, 2053, 2082, $2154,2180,2189-92,2229$

poetry, 120, 134-39, 148, 165, 167, $323,456-58$, 1651-52, $2189-92$, 2467

short stories, $1651-52$

Satires \& Bagatelles, 128

Satterlee, Herbert I., 5978

The .Saturday Evening Post, about, 2919, 2926

Saturday Night, 1475

The Saturday Review of Literature, 2398, 2415, 2569

Saturday's Children, 2332

Savage, Carlton, 3524

Savage, Henry, 4023

Savage, Howard J., 4599

Savage, James, ed., 9 I

Savannah, Ga., guidebook, $384 \mathrm{r}$

Savannah River, 4016

Savelle, Max, 3747

Saveth, Edward N., ed., 3062

Saxe Holm's Stories, 984

Saxon, Olin Glenn, 5952

Say, Thomas, about, $472 \mathrm{I}$

Sayre, Charles R., 5839

Sayre, Paul L., 6233

Scandinavia, relations with, $351 \mathrm{I}$

Scandinavians, 4482-87

in Brooklyn, 4046

in the Mississippi Valley, 3975

folklore, 5523
Scarborough, Dorothy, 5582

The Scarecrow, 2337, 2348

The Scarlet Letter, 34 I-44

Scarlet Sister Mary, I 655

Scarlett, William, Bp., 5499

Scenes and Portraits, 2380

Scepticism and Animal Faith, 5370 about, 5375

Schachner, Nathan, 3290-9r

Schafer, Joseph, 5832

Schaldach, William J., 5092-93

Schantz, B. T., ed., 2293

Schary, Dore, 4949

Schattschneider, Elmer E., 6370, 6396

Schaub, Edward L., ed., 5309

Schauman, Georg, ed., 4243-44

Scheer, George F., 3244

Schele de Vere, Maximilian, 2252

Schellenberg, Theodore R., 3063

Schenk, Gretchen (Knief), 647 I

Scherman, Harry, about, 6463

Schevill, James Erwin, I 89

Schick, Frank L., 6444 ed., 6438

Schickele, Rainer, 5860

Schilling, Jane Metzger, 6047

Schilpp, Paul A., ed., 5294, 5377, 5385

Schlesinger, Arthur Meier, Jr., 3083 , 3352,3500

Schlesinger, Arthur Meier, Sr., 2424 $3083,3095,3139-40,3262,4532$, 6431

ed., 3085-98, 4368, 4412-I3

Schlesinger, Eugene R., 597 I

Schlosberg, Harold, 5391

Schmeckebier, Laurence F., 4706, 4765, $6 r_{3} 8,6163,6215,6452$

Schmitt, Martin F., 4158

Schneider, Herbert W., 5261, 5289, 5291, 5335, 5409, 6082 ed., 5335

Schnier, Jacques P., 5734

Schoberlin, Melvin, 4925

Schönberg, Arnold, 6678

Schöpf, Johann David, 4256-57 about, 4255

Schoharie County, N.Y., 5539

Scholar's Workshop, 6478

Scholarship and learning, 3739, 445859

Scholes, Percy A., 5633

The School for Scandal, 168

The School Review, 5249

The School that Built a Town, 5145

Schoolcraft, Henry Rowe, 2802-3 about, 2802

Schools

art, 5690

frontier, 4214

in fiction, $583-84$

Indian, 3040

Jewish, 4454

music, 5668

public, 4320

Cincinnati, 4310

Ga., 4095

Ky., 4310

Pennsylvania Germans, 4479

New England, 2674

Va., 4310 
Schools-Continued

See also Education; and specific types of schools, e.g., Journalismschools

Schools and business enterprise, 5116

Schools in Transition, 5206

Schorer, Mark, $2128-32$

Schouler, James, 3141 about, 3058

Schramm, Wilbur L., 2932, 5899

Schreiber, Flora Rheta, 5687

Schreyvogel, Charles, about, 5802

Schriftgiesser, Karl, 3500a, 6397

Schroeder, Gertrude G., 5918

Schuchert, Charles, 47 I 5, 4754

Schulberg, Budd, I 425

Schuller, Charles F., 5231

Schultz, Christian, 4282 about, 428 I

Schulweis, H. M., 4458

Schuman, William, about, 5687

Schurr, Sam H., 5907

Schurz, Carl, 2858 about, 2677, 2882, 3431, 448I

Schwantes, Robert S., 3780

Schwartz, Bernard, 6257

Schwartz, Delmore, 21 33-38

Schwartz, Edward, 1663

Schwartz, Harry Wayne, 5653

Schwartz, Morris S., 4838

Schwartz, Sulamith, 4457

Schweitzer, Albert, about, 2682

Science, 45I3, 4537

awards, 4729

bibl., 471 4, 6453

Colonial period

Charleston, S.C., 3763

New England, $3745,3747-48$

Pbiladelphia, 3764

hist., 4714-15, 47 I 8-1 9, 4721-24, $4726,4730,4753,4761,5289$

museums, 3049

periodicals, 4715,4736

philosophy of, 5267-68, 5280, 5291, 5349

study \& teaching, 4719

New York (City), 4049

Northwest, Old, 4 I 12

Southern States, 4723

Science, 4678

Science and pragmatism. See Pragmatism-and science

Science and religion. See Religion and science

Science and state, 4761-4779, 6II8, 6130

Science and the Idea of God, 5315

Science as a profession, 4725

Science fiction, 520, 1932, 1934, 1959 anthologies, 1959

essays \& studies, 2377

Scientific apparatus and instruments, 4719,4721

Scientific management, 4798

Scientific method, 5254, 5257, 5267-68, 5289,5346

Scientific personnel, 4725, 4779

Scientific research, $3675,4777-79$

hist., 4722

wartime, 4761
Scientific societies

directory, 4728

hist., 4713,4726

Scientists, 4725, 4742-60, 4765, 4773, 5434

bibl., 4729

biog. (collected), 471 2, 4717, 4721, $4724,4730,4774,4785$

directory, 4712

Scientists against Time, $476 \mathrm{I}$

Scoon, R., $375^{8}$

Scopes trial, 5429

Scotch immigrants, 4488, 449 I

Scotch-Irish, 4489-90

Scott, A. P., 3058

Scott, Arthur L., ed., 819

Scott, Cecil W., ed., 5236

Scott, Clinton Lee, about, 5473

Scott, Evelyn, 1 743-48

Scott, Franklin D., 351 I ed., 3064

Scott, Harvey Whitefield, about, 2863

Scott, Hugh L., about, 3025

Scott, James Brown, 3519

Scott, Marian, 4893

Scott, Robert L., Jr., 3643 a

Scott, Sir Walter, bart. (I771-1832), about, 216, 252, 323

Scott, Walter (I796-186I), about, 5455

Scott, Wilbur S., ed., 2353

Scott, Winfield, 3655

about, 2710,3655

Scribner's (Charles) Sons, about, 6445, 6449

Scripps, Edward W., 2890 about, 2857,2890

Scripps, George, about, 2890

Scripps, James, about, 2890

Scripps-McRae League, 2886

Scroggs, William O., comp., 3634

The Scrolls from the Dead Sea, 2535

Scudder, Horace E., 466, 599, 4036 ed., 370, 441, 453, 671, 2922

Scudder, Townsend, 4037

Scudder, Vida D., I 81

about, 4530

Sculptors, 5734, 5738, 5740

Sculpture, 5595, 5601, 5733-40

abstract, 5696

collection, 5797

exhibition, 5696

hist., 5689, 5696, 5733-34, 5738, 5740,5797

Sea Garden, 1320

The Sea-Hunters, $587 \mathrm{I}$

Sea in art, 5765,5767

Sea Islands, S.C., 3835

folklore, 5540

Negroes, 4436

The Sea of Grass, 1693

The Sea-Wolf, 1054

Seafaring life

diaries, journals, etc., 274-75

drama, I 647-48

fiction, $252,256-57,470,479-83$, $487,562,1054$

The Seagull on the Step, 1251

Sealock, Richard B., 2976

Seamen, cruelty to, 274-75

fiction, $479-80$

Seapower, $3671,3673-74,3688$
Search, right of, 3554,3558

$A$ Search for the King, 2186

Sears, Clara E., 5265

Sears, Laurence, ed., 5259

Sears, Louis M., 3058

Sears, P. B., 4594

Sears, Richard W., about, 5956

Sears, Roebuck and Company, about, 5956

The Seaside and the Fireside, 431

The Season of Comfort, 2184

Seasoned Timber, I 417

Seattle, 4150, 4216, 6207

Seaver, Edwin, 2370

Secession movement, 3328, 3364, 3367, $3370-71,3404,5828$

Second April, 1609

The Second Generation, I I09-Io

Second Growth, 2163

The Second House from the Corner, 2750

The Second Man, 1206, 2332, 2348

Second Overture, 1174

Second Threshold, 1203

The Second Tree from the Corner, 1863

The Second World, 1232

Secondary education, 5131

administration, 5135, 5154

athletics, 5000

comprehensive high schools, 5156

criticism, 5236

curricula, 5100, 5153, 5158, 5224

finances, 5135

hist., 5152

junior high schools, 5157

methods \& techniques, 5227

objectives, 5217

organization, 5135

periodical, 5249

private, 5155

sources, 5158

vocational, 5156

See also Academies (schools); Catholic schools; Public education; Seminaries (schools)

Secret History of the American Revolu. tion, 3264

Secret Service, 2337

Secret societies, 4574

Secretaries of state, 3519

See also Diplomatic history; names of individual Secretaries, e.g., Hull, Cordell

Sectionalism, 3106, 3305, 3323, 3328, $3337,3354,3356-57,3363,3781$, $3784,4067,4074-75$

economic causes, 3346

political aspects, 3346, 3361, 3397, 3399-3401, 3409, 3451

See also Regionalism; Secession movement

Sects, 5397-98, 5400-1, 5404-5, 5409, 5439-4I, 5495

Secularism, 5395, 5399, 5401, 5409, 5488

Securities and Exchange Commission, about, 6322

Security investigations and programs, 3149

Security risks, $6112,6117-18,6130$ 
Security tests, 6ro7, 6rio

See also Loyalty-Security Program

Sedgwick, Ellery, about, 2922

Sedgwick, Henry Dwight, 228 I about, 2281

See You in the Morning, 2085

Seeds of Contemplation, 2038, 2042

Seeds of Liberty, 3747

Seedtime of the Republic, 6068

Seeger, Charles, music arr. by, 5559

Seeger, Ruth (Crawford), 5563

music arr. by, 5559

Seehafer, Eugene F., 4696

Seeing More Things, 4909

Seeing Things, 4909

Seely, Pauline A., 2976

Segregation, 4437, 4444, 445 I, 5447, 5499-5500, 61 20

in cducation, 5206,5236

See also Minorities; Race question

Seilhamer, George O., 4905

Seillière, Ernest, about, 2375

Seitz, Don C., 2877

Selden, Elizabeth S., 4971

Seldes, Gilbert, 4895, 4945 ed., 1555

Selective Service Acts of 1917, 3709

Self, 2347

Self-Culture, 233

The Self, Its Body and Freedom, 5313

The Self-Made Man in America, 3762

Self-Reliance, 285

Seligman, Edwin R., 5963

Sellards, Elias H., 2995

Sellars, R. W., 5255

Sellars, Wilfrid, 529 r

Sellers, Charles Coleman, 2804-5, 5769

Sellers, Charles Grier, 3351

Sellers, N. W., 5849

Sellers, Nathan, about, $6457-58$

Sellery, G. C., 5336

The Selling of Joseph, 56-57

Semantics, 3756

in literature, 2388-90

Seminaries (schools), 5212

Seminole Indians, 3025-27

Semiotic, 5346

Semmes, Raphael, about, 2613

Semple, Ellen Churchill, 2975

Senate, U.S. See Congress. Senate

Senator North, 722

Seneca, Ill., 4589

Senior, Clarence, 4428,4470

Sense and Sensibility in Modern Poetry, 2484

The Sense of Beauty, 5366

The Sense of the Past, 1004 about, roog

The Sentimental Novel in America, 2384

The Sentimental Years, 4516

The Sentinels, 2310

Separation of powers, 3608,3610 , $6075-76,6199,6257,6312,6315$

Separatists, I, 84

The Sequel of Appomattox, 3377

Sequoya (Cherokee Indian), about, 3027

Seraph on the Suwanee, I 529

Serbein, Oscar N., 4890

Serena Blandish, 1206
The Serenade (operetta), 568I

Serenade to the Big Bird, 2814

The Serene Cincinnatians, 4122

Sergeant, Elizabeth Shepley, 1283

Sermons

Colonial, 17-1 8, 21, 24, 32-33, 35, 59-6I

hist. \& crit., 2493

in verse, $1537-38$

See also Preacher tales

Sertorius, 2347

Servants, indentured, 6056

Sessions, Archibald, 1117

Sessions, Roger, 5615

Settlement houses, New York (City), 4624

Seven Decisions that Shaped History, 3549

The Seven-League Crutches, 1999

7 P.M., 1827

The Seven Sleepers, 1827

The Seven Storey Mountain, 2034, 2036

The Seven Who Fled, 2089

Seven Years' Harvest, 2398

Seven Years' War in America. See French and Indian War (1755-63)

Seventeen, 1804

Seventh-Day Adventists, 5404, 5442

The Seventh Hill, 1516

Seventy Years of $I t, 4543$

Seventy Years of Life and Labor, 6050

Severinghaus, Aura E., 486I

Sevier, John, about 3287

Sewall, Harriot Winslow, ed., 244

Sewall, Samuel, 56-58

about, 2493

The Sewanee Review, 1809, 2570

Seward, William Henry, about, 2614 , $3359,3382,3416$

Sexual behavior (human), 4560-6r, 4565-66

Seybold, Ethel, 6 1 I

Seymour, Charles, 3541

Seymour, Flora Warren (Smith), 3035

Seymour, Horatio, about, 3441

Shackford, James Atkins, 2649, 3353

Shackford, John B., ed., 3353

Shadow of a Man, 2123

Shadow of Night, 1959

The Shadow of the Hawk, 1748

Shadows in Silver, 4086

Shadows Move Among Them, 1493

Shadows on the Rock, $1277-78$

Shafer, Henry Burnell, 4812

Shafer, Robert, 2425, 2479

Shakers, 3736, 541 I, 5469, 5594

Shakespeare, William, about, 280, 49r 7

Shakspeare in Love, 2310

Shaler, Nathaniel S., 4036, 5222

Shamanism, 3010, 3019

Shame and Glory of the Intellectuals, 2189

The Shame of the Cities, 6207,6432

The Shame of the States, 4837

Shankland, Robert, 5866

Shannon, David A., 6371

Shannon, Fred Albert, 3702, 4I 64, 5877

Shannon, W. V., 6rig5

Shantymen and Shantyboys, $555 \mathrm{I}$

Shantz, Homer L., 5816

The Shapers of American Fiction, 2509
The Shaping Spirit, 1785

Shapiro, Charles, ed., 1348

Shapiro, Elliott, 56 I I

Shapiro, Karl, 2139-44 ed., 2363

Shapiro, Theresa R., 4712

Sharp, Cecil J., comp., 5583

Sharp Eyes, 74I

Sharpe, Dores Robinson, 5482

Sharps and Flats, 878

Shartel, Burke, 6269

Shattuck, Charles, ed., 2551

Shattuck, Lemuel, about, 4403, 4879

Shaw, Henry Wheeler, 542-45 about, 5524

Shaw, Irwin, 21 45-48, 2333 about, 2371

Shaw, Lemuel, about, 6228, 6231

Shaw, Lloyd, 5591

Shaw, Robert Kendall, 6476

Shaw, Wilbur, 5006 about, 5006

Shaw, Wilfred B., ed., 5201

Shawnee Indians, 3037

Shay's Rebellion, 3309

She Would Be a Soldier, 2347

Shea, John D. Gilmary, 545 I

Sheean, Vincent, 1610, 2806-7

Sheehan, Donald H., 6445 ed., 3062

Sheeler, Charles, 5772 about, 5772

Sheep industry, 5874

Tex., 2733

Sheffield, F. D., 3724

Shelburne Essays, 2479-81

Sheldon, Edward, 2337

Shelford, Victor E., ed., 2956

Shelley, Percy Bysshe, about, 520, 2481, 2545

The Sheltered Life, $146 \mathrm{I}$

The Sheltering $S k y, 1928$

Sheltering Tree, 5265

Shenandoah (Howard), 2337, 2347

Shenandoah (Schwartz), 2135

Shenandoah River and valley, 3997 fiction, 226, 228-29

Shenk, Hiram Herr, ed., 4056

Shepard, Odell, 186, 442, 404I, 5266 ed., $187,588,603,2375$

Shepard, Thomas, 59-65 about, 63, 65, 3198

Shepardson, Whitney H., 3634

Shepherd, W. R., 4540

Shepherd's Empire, 5874

Shepperson, Wilbur S., 4488

Shera, Jesse H., 6472

Sheridan, Philip H., about, 3701

Sheridan, Richard, 168

Sherman, C. B., $445^{8}$

Sherman, John K., 5654

Sherman, Stuart Pratt, 2503-5, 5222 ed., 1067,2393

Sherman, William Tecumseh, about, 2614,3699

Sherwood, Elizabeth J., comp., 3292

Sherwood, Foster H., 6240

Sherwood, Garrison P., ed., 4897

Sherwood, Robert Emmet, 1203, 1749$53,2327,2332-34,2348,3499$

Shetrone, Henry Clyde, 2996 
Shilling, Ned, 4395

Shipbuilding, 5930

Shippen, William, about, 4856

Shipping industry, 5930

Mass., 5936

New York (City), 5937

Ships

in art, $580 \mathrm{r}$

See also Warships

Shipton, Clifford Kenyon, 6447

Shipwrecks, fiction, 1712

Shirley, Dame, pseud. See Clappe, Louise Amelia Knapp (Smith)

Shirley, Hardy L., 5865

Shirley, Wayne, 6481

Shiskin, Julius, 5905

The Shock of Recognition, 2538

Shoemaker, Ervin C., 5127

Shoemaker, Floyd Calvin, 3346 ed., 5569

Sholes, Christopher Latham, about, 4786

De Shootinest Gent'man, 5066

Shores, J. Harlan, 5 I 58

Shores, Louis, 6478,6481 ed., 6484

The Shores of Light, 2541

Shorewood, Wis., 3885

Short, Lloyd Milton, 61 73

Short, Raymond W., ed., 2353

Short ballot, 6203,6425

Short Grass Country, 3964

Short stories

anthologies, 2318, 2322, 2325, 2351, 2369

experimental writing, 1242, 1379, I $766-67,177$ I

hist. \& crit., 2362, 2487, 2489, 2495

periodicals, 2916, 2922, 2925

See also Fiction in periodicals periods

(1 $820-70), 319,322,330-40$, $356,359,381,384-90,405-8$, $484,491,493-94,496,520$, $528-29,533,536,556-62$, $574-75,612-13,674$

(1871-1914), 683, 687, 701, $704-6,711-12,716,725,732-$ $37,739,745-48,756-61$, $798-99,821,830,834,836-$ $37,856,859-60,878,881-$ $87,890-95,900-5,909-22$, 924-32, 935-40, 945, 951-52, $954-55,984,986,1004$, $1007-8$, 1011-12, $1014,1023-$ $35,1048-52,1058-60,1084-$ 88, 1099-1 102, I 106, I I I I25, I 145 , I $149-52$

(1915-39), II55, $1160-61$, I $64,1178-79,1181$, I I 85 , $1197-98$, I 222, 1224,1239 , $1242,1248,1250$, I 270 , I 275 , $1277,1316,1341-42,1345$, 1372, 1379, 1389, 1393-94, 1403, I 408, I 411,1413 , I 418 , $1429,1453,1464,1471,1476$, 1478 , 1494, 1498, 1510 , 152325, 1541, 1553-55, 1651-52, $1659-60,1662,1680,1684$, $1686-87, \quad 1691-92, \quad 1697$, 1703, 1706, 1724, 1762,
Short stories-Continued periods-Continued

(1915-39)-Continued 1 764-67, I $771,1776,1786$, $1790,1796-97,1801,1839$, $1841,1851,1855,1872,1879$, 1892

(1940-55), 1910, 1913, 1927, 1929, 1932-33, 1935-36, 1944, 1946, 1958-59, 1963, 1986, 2011, 2015-16, 2020, 2024, 2057-58, 207I-75, 2109-10, $2116,2118,2128$, 2131, 2133-34, 2137, 2145, $2147, \quad 2160-61,2165-68$, 2170-71, 2176-77, 2179, $2198,2202-3,2205,2207$, 2209-11, 2214, 2222, 2227, 2234

techniques, 520,538 , I I I I

The Shoshonee Valley, 312

Shoshoni Indians, 2364, 304 I

Shouts and Murmurs, 49 I I

Show Biz, from Vaude to Video, 4892

The Show Must Go On, 1688

The Show-Off, 2348

Showboats, 4978

fiction, I 405

A Shower of Summer Days, 2125

Shreve, Forrest, 2959

Shryock, Richard H., 40, 3061, 3103, $4479,4813,4826,4845$

Shumaker, Wayne, 2421

Shurter, Robert L., 731

Shuster, George N., 4457, 5426, 5447 about, 5426

Sibley, Mulford Q., 3649, 6124

Sicily, fiction, 1994

Sidelights on American Literature, 2486

Sidewalks of America, 5510

Siebert, Frederick Seaton, 2932

Siege, I 155

The Siege of London, 1007

Siegfried, André, 4505-8

Siepmann, Charles A., 4685, 4703, 5230

Sierra Nevada, 3955, 4210-I I

disc. \& explor., 2971

Sierras, Songs of the, 1066

'Sieur George, 748

Sievers, Wieder David, 2506

Sigerist, Henry E., 4814

Sights and Spectacles, 2017

The Sign of Jonas, $204 \mathrm{I}$

The Signature of All Things, 2100

Den Signede Dag, 1723

The Significance of the Frontier in American History, 2437

about, 2407

Signor Marc, 2311

Signs, Theory of (philosophy), 5346

Sikes, Earl R., 6410

Silas Crockett, 1286

Silas Timberman, 1973

Silberling, Norman J., 6025

Silcox, Clarice Edwin, 5495

Sill, Edward Rowland, 2769 about, 2769

Silliman, Benjamin, about, 4724,4740 , 4759

Silver, Rollo G., 6440 ed., 643
Silver and silversmithing, 5784

The Silver Cord, 1519, 2337

Silver rushes, 772-74

The Silver Stallion, 1262

Simkhovitch, Mary K., 5426 about, 5426

Simkins, Francis Butler, 4082

Simmons, E. J., 3562

Simms, Henry H., 3409

Simms, William Gilmore, 546-55, 2296

about, 554, 2277

Simon, Charlie May (Hogue), 1436

Simon Suggs' Adventures, 380

The Simple Cobler of Aggawam, 76

Simple Speaks His Mind, 1523

Simple Takes a Wite, 1525

Simplification (doctrine), 585

Simpson, Louis, 2350

Sims, William Sowden, 3716

Sinai, Nathan, 4886

Sinatra, Frank, about, 5636

Since Yesterday, 3478

The Sincere Convert, 60

Sincerely, Willis Wayde, 1597

Sinclair, Upton, I 754-58

about, 2380, 2406

Singers, operatic, $566_{2}$

biog. (collected), $566_{3}$

Singing games, 5588

Middle West, 5586

New England, 5580

The Single Hound, 2123

Single tax doctrine, 4535

Singleton, Arthur, pseud. See Knight, Henry Cogswell

Singstad, Ole, about, 4803

Sinners in the Hands of an Angry God, 24

Sioux Indians, 2831, 3003

fiction, 1646

Sir Dominick Ferrand, 1012

Sir Edmund Orme, 1012

Sir Henry, 1643

Sirjamaki, John, 4571

Sirmay, Albert, 4025

Sis' Becky's Pickaninny, 757

Sister Carrie, 1334

about, 1089

Sitterson, Joseph Carlyle, 5822

Sitting Bull, about, 2832, 3036

Situation Normal, 2044

Six Horses, 5931

Six Nations. See Iroquois Indians

Sizer, Theodore, ed., 5775

Skandinaven, about, 2895

Skeel, Emily E. F., ed., 177

The Sketch Book, 384-87

Sketches. See Editorials, sketches, etc.

Sketches in Criticism, 2380

Skid Road, 4216

The Skies of Europe, 2091

Skiing and ski resorts, 5062

Rocky Mountains, 4 I 74

The Skin of Our Teeth, 1868

Skinner, Constance Lindsay, ed., 3969-77

Skinner, Cornelia Otis, 2808-10

about, 28 ro

Sklare, Marshall, 5460

Skyscrapers, 5703, 5705 
Slabs of the Sunburnt West, I731

Slang

in literature, $619,701-5,878-80$, 1111 , $1554-55$

See also Language-slang

The Slave Auction (sculpture), 5739

Slave patrol, 3554,3558

Slave trade, $3558,4224,4258,4293$, $4333,4336,4341,4440$

Slavery, 2603, 3122, 3398-99, 3414, $3766,4258,4364,4367-68,4440$, 4442,5828

defense, $3286,3303,3366,3370$, $3381,3389,3404$

econ. aspects, $3234,337 \mathrm{I}, 338 \mathrm{r}, 338 \mathrm{~g}$, 3402-3, 3409

extension to the territories, 3339 , $3346,3371,3397$

folklore, 5515,5521

political aspects, 3370-71, 3389, 3409

public opinion, 3346,3409

social aspects, $337 \mathrm{I}, 338 \mathrm{I}, 3389$

See also Abolitionism

Slavery in literature, 1 49, 192, 216, 239, 449, 51 1 , 556, 1 099

antislavery pamphlets, tracts, etc., 56 , $178-85,232,240,463,662-63$ 2493

fiction, 562-67, 749-50, 949-52, 1277,2201

poetry, $456-57,664,856-59,86 \mathrm{I}$, I 222, I 224, 2200

short stories, $757-58,856,859-60$, I I 00-2

See also Civil War in literature; Plantation life in literature; and Race question in literature

Sleepers Awake, 2084

The Sleeping Fury, 1237

Slender, Robert, pseud. See Freneau, Philip Morin

Slichter, Sumner H., 5894, 6038-39

Sloan, John, 5800

about, 2380, 5773

Sloane, Eric, 5724

Sloane, Howard N., ed., 2946

Sloane, William Milligan, ed., 5344

Slocum, Joshua, 5021

Slogans, 3152

Slogum House, 2799

Slosser, Gaius J., ed., 5466

Slosson, Edwin E., 4724, 5113

Slosson, Preston William, 3097

Slovenian folklore, Mich., 5533

Slums, $2784,4598,4612$

New York (City), 4638

Sluyter, Peter, 3208

Slye, Maud, about, 4722

Small, Albion Woodbury, about, 4540 , 4542

A Small Boy and Others, I015

Small business, 6021

The Small Town in American Literature, 2438

Smalley, Donald, ed., 4377

Smallpox

epidemic (1721), 4826

treatment, 40, 2493

Smallwood, Mabel Sarah Coon, 4738

Smallwood, William Martin, 4738

The Smart Set, 1602
Smet, Pierre Jean de, 2663 about, 2662-63

Smidt, Kristian, 1369

Smiley, Dean F., 4999 ed., 4855

Smillie, Wilson G., 4874-75, 4877

Smire; an Acceptance in the Third Person, 1266

Smirt; an Urbane Nightmare, 1264

Smith, A. Merriman, 6r 48

Smith, Abbot Emerson, 6056

Smith, Al, about, 5450, 5493

Smith, Albert E., 496r about, 496r

Smith, B. Othanel, 5158

Smith, Bernard, 2406-7 ed., 2407, 3142

Smith, Bradford, 66

Smith, Bruce, 4655

Smith, Cecil Michener, 5623,5638

Smith, Chard Powers, 4000

Smith, Charles Alphonso, ed., I 123

Smith, Charles Edward, ed., 5644

Smith, Charles Henry, 556-57, 2257

Smith, Chetwood, 5739

Smith, Chris, about, 5016

Smith, Darrell Hevenor, 5995, 6rgo

Smith, David Eugene, 4739

Smith, Edgar F., 4740

Smith, Elbert B., 3322

Smith, Erwin E., photographs by, 4153 about, 4 I 53

Smith, Erwin Frink, about, 2792

Smith, Frank E., 4024

Smith, Frank L., about, 6383

Smith, George Otis, 4715

Smith, Gerrit, about, 2279, 2689

Smith, Guy-Harold, ed., 4 I I 9

Smith, H. Allen, 21 49-55, 2370, 5013

Smith, Harold D., 6roI

Smith, Harry de Forest, about, I 7 I 6

Smith, Harry James, 2348

Smith, Harry Worcester, 5080

Smith, Helen Lyman, 6482

Smith, Henry Justin, 4135

Smith, Henry Ladd, 2845, 594I

Smith, Henry Nash, 2412, 3759

Smith, Hilrie S., 5436

Smith, Hubert L., 6018

Smith, Huston, 5187

Smith, Ira L., 5013

Smith, J. Lawrence, about, 4740

Smith, J. P., 3058

Smith, James Eugene, 2875

Smith, James G., 5993, 5998

Smith, James Morton, 3308, 6I 25

Smith, Jay, about, 5016

Smith, John, captain, 66-7I about, 66, 3198

Smith, John Edwin, 5364

Smith, Johnston, pseud. See Crane, Stephen

Smith, Joseph, about, 4I 83, 5464-65

Smith, Joseph H., 6234

Smith, Joseph Russell, $294^{\circ}$

Smith, Julia, 5675

Smith, Justin H., 3354, 3689

Smith, Kendall, 5938

Smith, Lillian, I 759-6I

Smith, Louis, 3650

Smith, Marian W., 304 I
Smith, Mary, 5739

Smith, Mortimer B., 5237

Smith, Onnie Warren, 5094

Smith, R. L., 4594

Smith, "Red." See Smith, Walter W.

Smith, Reginald Heber, 6328-29

Smith, Richard Penn, 2310,2650

Smith, Robert Miller, 5014

Smith, Samuel H., about, 5 I 2 I

Smith, Samuel Stanhope, 5251

Smith, Seba, 558-6I

Smith, Shirley W., 5223

Smith, Stephen W., 5644

Smith, T. V., 3646, 5289, 6r28

Smith, Thelma M., 2508 ed., 464

Smith, Theodore Clarke, 3 I 44, 3450

Smith, Thomas Lynn, 4584

Smith, Thomas P., 4740

Smith, Walter Bedell, 3565

Smith, Walter Buckingham, 5999

Smith, Walter W., 4995

Smith, William, I 45

Smith, William Carlson, 44 I 5

Smith, William Ernest, 34 I 0

Smith, a Sylvan Interlude, 1265

Smithies, Arthur, 6001

Smith's London Journal, 2155

Smithson, James, about, 4775

Smithsonian Institution

about, 4775

See also names of administrative divisions, e.g., National Museum

Smoke and Steel, I73I

The Smoking Mountain, 1250

Smoky Mountains, 3945

Smyth, Albert H., 2282 ed., $31_{3}$

Smyth, Mary Winslow, 5566

Smythe, Dallas W., 4702

Snell, George D., 2509

Snow-Bound, 662, 667

Snyder, Richard C., 3605

So-Big, 1404

So Little Time, 1593

So Red the Rose, 4912

Sobel, Bernard, 4942, 4976

Social and business ethics, 5273, 5899, 6010

Social clubs, 4574,4578

Social conditions, 2824, 4225, 4415, $4551,4554,4557-58,4562,4581$, $4595,4617,4619,4627,4634$ $5405,6346,6426,6431$

cities, 4395

country life, 4395

hist., 3073, 3085-98, 3150, 4514$4534,4560,4654,5875,6005$, 6082

American Revolution, 3252-53

Civil War, 3374

Colonial period, 31 41, 3747

I 9 th cent., $3091,3275,3281$, $3313,3421,3425,3447,3754$, $4313,4345,4499,5781$

2oth cent., $3096,3474,3477-78$, $3494,3746,4505-8,4514$, $4571-72,4625$

maps, 2972

Negroes, 4437, 4439, 4441-42, 4446, 4448 
Social conditions-Continued

Orientals, 4468

Poles, 4495

See also Church and society; also subdivisions History and Social conditions under names of places and regions, e.g., Chicago-soc. condit; Southern States-hist.

Social influences on literature

hist. \& crit., 2448, 2450-5I, 2485, 2489,2507

Social insurance. See Social security

Social life and customs, 4232, 4234, $4531-32,4534,4562,5510,5596$, 5598,6456

bibl., 4229

hist., 4235, 4519-21 , 4529, 5729

Colonial period, 3748,4227 , 4263,4518

I 8 th cent., $4228,4500-1$

I 9 th cent., $4224,4228,4303-5$, 4314-1 7, 4354-57, 4370-71, $4516,4927,4937$

See also subdivisions History and Social life and customs under names of places and regions, e.g., Indiana-hist.; Virginia-soc. life \& cust.

Social life and customs in literature, 319-22, 512

diaries, journals, etc., 36-39, 56-57 drama, 168-70, 198, I 199-1 204

essays, 1002, 2469

fiction, $16 \mathrm{I}-64,689-92,964-76,978$, $980,982,986-88,992-95,1007-8$, ro1 4, I 589, I 828-29, I831-33, $1845,1874,1909,1911-12,2078$, 2149,2278

letters, $96-100$

satire, 381

short stories, 415-18, 986, 1004, 1008, 1011, 101 4

Social medicine (plans), 4882,4888

Social psychology, 3724, 4539, 4556, $4561,4635,5277$

Social questions in literature

anthology, 2355

drama, I I 99-1204, I 51 8-20, I64748, 1688-90, 1988-91, 2043-49, $2063-68,2145,2218-21,2223$, 2228

essays \& studies, 546, 695-98, 732, 862-66, 1155, 1 $357-58$, 1372, 1375, 1445, 1602, 1907, 2189, $2278,2412,2519,2532$

fiction, 689-92, 716, 718-20, 722, $726,728-31,756,821-24,835-37$, $867-75,887-89,941,956-70,973-$ $76,978,982,986-1001$, 1004, 1048, 1056, 1089-95, $1107-10$, I $136,1142-43,1155-56$, I I 78 , 1180,1183 , I 1 90-94, 1 270-74, $1333-39,1343,1372-74,1376$, $1379-84,1386,1388,1390-92$, I $414,1417,1425-29$, I 445-50, $1453-59,1460-62,1467,1472$, $1474,1494-97,1499-1500,1559-$ $69,1571,1573-74,1576,1579$, 1589-97, 1656-58, 1743-44, 1746-48, $1754-56,1758-60,1775$, $1777-81,1792-95,1845-50,1852-$
Social questions in literature-Continued fiction-Continued

55, 1887-91, 1907, 1914-15, 1932, 1940-43, 2045, 2050-51, 2059, 2079, 2081, 2084, 2090, 21 45-46, $2156-59,2180,2182-84,2229$, 223I, 2235

poetry, 1038-43, 1046, 1061-63, 1069-70, 1225, I 227, I357, 158586 , 1588, 1599-1600, 1608-9, $1727,1731,1872,1878,1881$, I 885, 1907, 1968, 2079, 2105-6

tracts \& propaganda, $178,184-85$, 235, 239, 313, 726, 862, 1048, 1053, $1107,1559,1571,1754$, $1759,1775,1907,1932,1973$, 2180,2183

The Social Record, 2355

Social Register (Boston), 4035

Social Science Research Council, 4777

Social Science Research Council. Committee on Historiography, 3065

Social Science Research Council Public Library Inquiry. See Public Library Inquiry

Social sciences, $3739,4536,4544-45$

biog. (collected), 4540, 4712

research, 4777

study \& teaching, 4540

Social security, $4621,4631,4633,4635$

Tex., 4194

Social Security Act, 4631

Social settlements, New York (City), 4624

Social status, 4549,4557

children, 4559

occupation, 4547

women, $3073,4524,4563$

Social work, $4618,4621,4624$ medical. See Medicine-social work

Socialism, 3753,6356

bibl., 3753

fiction, $726,728-31,964,973-76$, 978 , 1048, 1055, 1656, 1754-56, 1758

hist., $3753,6360,6368,6433$

propaganda, 2896

Socialist Party

about, $6356,6360,6367,6371,6433$ platforms, 6367

A Socialist's Faith, 6433

Society and the press, $2845,2847,2912$, 2915, 2919-20, 2927-32

Society and Thought in America, 3150

Society for Establishing Useful Manu. factures (SUM), about, 6015

Society for the Advancement of Edu. cation, 5248

Society in America, 4315-17

Society in Transition, 4617

Society Islands, fiction, $476-77$

Society, Manners and Politics in the United States, 4314

Society of Economic Geologists, about, 4733

Society of the Cincinnati, about, 3644

Society of the United Believers, about, 5469

Society; the Redeemed Form of Man, 5319

Socinianism, 5471
Sociology, 2717-18, 3758, 4536-37, $454 \mathrm{I}-43,4547-48,455 \mathrm{I}, 4558-59$, 4599,5351

Christian, 5484-97

hist., 3755,4539

industrial, 4552

motion picture industry, 4948, $495 \mathrm{I}$

rural, $45^{8} \mathrm{r}, 4583-84,5832$ bibl., 4580

urban, 4587

Nev., 4184

Socrates

drama, $1 \geq 76$

fiction, 2413

The Sod-House Frontier, 4156

Soil conservation, 5808

Soil Conservation Service, about, 5884

Soil Survey, about, 2947

Soils, 2934, 2943-44, 2947, 58I6

bibl., 2947

maps, 2943-44, 2947

Fla., 4248-50

Ga., 4248-50

Middle West, 4 1 13

New York (State), 4237-38

N.C., 4248-50

Pa., 4237-38

S.C., $4248-50$

Southern States, 4084

The Sojourner, 1680, 2024

The Soldier, I 166

Soldier in the White House, 3333

Soldier of Democracy, 3482

Soldier of the Republic, 3333

Soldiers, 3652, 3662, 3679, 3690-92, 3704-5, 3724

Pennsylvania German, 4479

songs, $5556,5559,5562$

World War II, 2734

Soldiers' Pay, 1380

A Soldier's Story, 3718

Soldiers without Swords, 5497

Soley, James Russell, 3700

The Solid Gold Cadillac, 1550

The Solitary Singer, 647

A Solo in Tom-Toms, 2878

Solomon, Barbara Miller, 4423

Solstice, 1534

Soltes, Mordecai, 2898

Solum, Nora O., tr., 1722

Some Chinese Ghosts, 951-52, 955

Some Creole Melodies, 951-52

Some Enchanted Evenings, 5685

Some Laggards Yet, 638

Some Old Puritan Love Letters, 90

Some Others and Myself, $180 \mathrm{r}$

Somebody up There Likes Me, 5028

Something about Eve, 1261-62

Sometimes, 956

$A$ Son of Earth, 1558

$A$ Son of the Middle Border, 898-99

The Son of the Wolf, 1049-50

Sone, Monica (Itoi), 281 I-1 2

about, 2812

Song and Idea, $135 \mathrm{r}$

A Song Catcher in Southern Mountains, 5582

Song in the Meadow, 1697

The Song of Hiawatha, 432

The Song of Hugh Glass, 1645

Song of the Chattahoochee, 1038 
The Song of the Indian Wars, 1645

The Song of the Lark, 1276-77

The Song of the Messiah, 1645

The Song of Three Friends, 1645

Song Writers Protective Association, about, 6322

Songs, $4025,5614,5677$

bibl., 561 I

in literature, $911-13,922$

Mexican, 4472

national, 5616

See also Folksongs and ballads; Play-party songs; Popular music and songs; Work songs

Songs and Satires, $160 \mathrm{r}$

Songs before Parting, 623

Songs for Eve, 1588

Songs of Italy and Others, 1066

Songs of Parting, 624

Songs of the American Seas, 1066

Songs of the Sierras, 1066 about, 1064

Songs of the Sunlands, 1066

Sonn, Albert H., 5790

Sonneck, Oscar George Theodore, 56ro, $5612,5616,5661,5677$

Sonnets to Duse, 1814

Sonnichsen, Charles L., 4163

Sons, 1254

Sons and Soldiers, 2145

Sons of Science, 4775

Soper, David Wesley, 5433

Sophocles. Women of Trachis, translation, 1664

Sorokin, Pitirim A., 3566

A Sort of a Saga, 2737

Sosman, R. B., 4715

Soth, Lauren, $586 \mathrm{I}$

The Soul of America, 3735

Soule, George, 2407, 5877

The Soules Preparation for Christ, 33

Soulsby, Hugh G., $355^{8}$

The Sound and the Fury, 1383

The Sound Believer, 61

The Sound Wagon, 1792

Sour Grapes, 188 I

The Sources of Religious Insight, 5354

The South. See Southern states

South America. See Latin America

The South as a Conscious Minority, 6059

The South Atlantic Quarterly, 2571

South Carolina, 3963, 4023, 4079, 4091-93

architecture, 5706

counties, 4092

culture, 3233

governors, 4092

guidebooks, $3834-36$

Gullah dialect, 2271

hist., 3180, 3216, 3233, 4023, 409 s-93

language (dialects, etc.), 2258, 2260 natural hist., 5087

parks, 3836

plantation life, 4517,5087

population, 4092

soc. life \& cust., 4091, 45 I 7

travel \& travelers, $4248-50,4277-78$

The South Carolina Gazette, about, 2854
South Carolina in literature

descr., $1724-26$

fiction, 405, 546-49, 552-53, $1512-$ $13,1653,1720-23$

poetry, $614-17,1168,1512$

short stories, I I 49, 1762

South Dakota, 3948,3951

frontier life, 4156

guidebooks, 3896-3900

hist., 4147

rural communities, 4109

South from Hell-fer-Sartin, 5546

South Moon Under, 1681

South Pacific, 2337

South Pacific Islands in literature, $470-78$

South Pole expeditions. See Antarctic expeditions

South Star, 1434

South Today, 1759

Southeast Asia, relations with, 3591

Southern Folklore Quarterly, 5518

Southern Renaissance, 2442

Southern Review, 1809,2572

Southern States, 2635, 3958, 4066-96

agriculture, 5823

architecture, 5706

culture, $4067-70,408_{3}-84$

econ. condit., 3402-3, 4067-68, $4079,4084,4401,4438,5828$, 5891

folklore, 55 I 8,5525

folksongs \& ballads, $5572,5582-83$

guidebooks, 3827-47

historiography, 3057

hist., 3286, 3361, 3367, 3404, 3415, $3417,3445,3451,3754,4067$, $4070-72,4074,4077-78,4080-82$, 5828,6059

industry, 4084,5909

intellectual life, 3766,4723

Ku Klux Klan, 3386

nationalism, $4067,4075,4080$

Negro songs, $556 \mathrm{r}, 5582$

Negroes, 4443

pictorial guide, 3782

pol. \& govt., $4067,4075,6376$, $6378-79$

rural press, 2853

science, 4723

soc. condit., $2721,4066-68,4078-79$, 4084,4438

soc. life \& cust., 4081,4097

travel \& travelers, $3365,4233,4235$, 4256-57, 4266, 4285, 4297, 4329, $4336,4344,4367,4387$

white spirituals, 5577

See also Confederate States

Southern States in literature, 1036-37, $1724-26,1761,1791,1907,2296$ anthologies, 2292, 2296, 2320

drama, 1473, 1475-77, 2218-21, $2223,2225,2228$

editorials, sketches, etc., r92-97, $330-32,379-80,405-8,445-48$, $556-57,6$ 1 2-13, 1809

essays, 618, 945, 951-52, 954-55, I 103-4, 1679, I791, I 809-10, 2442,2466
Southern States in literature-Continued fiction, 226-29, 245-51, 277-79, 409-13, 546-50, 552-53, 555, 745, 749-50, 756, 946-52, 955, 1032, 1099, I 105-6, 1239-41, $1270-7,1379-95,1460-62,1464-$ $70,1472-74,1512-13,1526-29$, I 61 8-19, 1653-55, 1680-83, 16971 702, 1704-5, 1759-60, I 786-89, 1792-95, 1 836-38, 1887-91, 1944$45,2023-24,2050-51,2090,2174-$ $76,2178,2193,2199,2201-2$, 2204, 2206, 2208, 2232

folklore, $910-16,922-25$

hist., 1 2-16, 66-68, 70-71, 1 49-53, 2442

humor, 192-97, 379-80, 445-48, $556-57,856-61,910-16,922$, 924-25

poetry, 520-30, 533, 536, 61 4-1 7, $856-58,861, \quad 1038-43$, 1046, I $33-35,1512,1623-24,1675-79$, $1809,1811,2172,2193,2196$, 2200, 2292

short stories, 612-13, 745-48, 7566I, 856, 859-60, 910-22, 924-25, 951-52, 954-55, 1032-35, 1099I $102,1106,1149$, I 151 , I 225, 1 240, 1 275, 1379, 1389, 1 393-94, $1471,1476,1478,1684,1703$, 1790, 1892, 1944, 1946, 2024, $2176-77,2179,2202-3,2205$, 2207, 2209, 2222, 2227

travel \& travelers, I 2-1 4, 66-68, 7071, 61 2-13

Southwest

archacology, 2992

architecture, 5723

biog. (collected), 4190

cession by Mexico, 3355

colonization, 3158

culture, 4I 9 I

disc. \& explor., 3158

folklore, 5503, 5507, 5509, 5518, 5520,5531

guidebooks, 3917-26

hist., 3158, 3783-84, 3947, 3956, $4005,4017,4186-99,5874$

Indians, 3023,3027

Apache, 3004

Comanche, 3014

customs, 2722

Navajo, 3013

shaminism, 3019

language (dialects, etc.), 2264

legends, 5531

Mexicans, 4475

music, 5630

Southwest, Old, 4097-4108

descr. \& trav., 4I9I

guidebooks, $3848-6$ r

hist., 3287,4098

soc. life \& cust., 4098

See also Southern States

Southwest in literature

bibl., 2525

fiction, $1276,1551-52,1691$

periodicals, 2562,2572

poetry, I 984 
Southwest in literature-Continued short stories, I196-98, 1553, 1659, 1691,1762

writers \& writings, 4187

Southwest Review, 2572

The Soveraignty \& Goodness of God, 54

Soviet Union. See Russia

Sow the Golden Seed, 2896

Sowerby, Emily Millicent, comp., 6460

Spaeth, Sigmund G., 5637, 5639

Spain

Civil War, 3536

culture, I 445

fiction, I 495, 1497

hist., 2294

legends \& sketches, 381

relations with, $3307,3444,3449$,

$3528,3530-31,3569,3572,3707$

travel \& travelers, 381,449

Spain in the New World, 3162,3171

Spalding, Albert G., about, 5009

Spalding, Walter Raymond, 5672

Spanish-American War, 3448, 3554, 3707-8

diplomatic hist., 3530

fiction, 2682

naval operations, 3708

songs, 5616

Spanish Bayonet, 1222, 1224

The Spanish Borderlands, 3158

The Spanish Husband, 2302

Spanish influence

arts \& crafts, 5594

culture, $985,4187,4189,4197-98$

folklore, $5518,5526,5537$

folksongs \& ballads, 5521

language (dialects, etc.), 2264, 4198

legends, 5518,5521

on literature, 201, 205, 2534

Spanish missions. See Missions, Indian

Spanish North America

colonization, $3075,3156-58$

disc. \& explor., 3153, 3157-58, 3165, 3203,3217

hist., 3075, 3158, 3165

Spann, John R., ed., 5496

Spargo, John, 5791

The Spark (The 'Sixties), I845

Sparks, Jared, about, 3057

Sparrow, Stanwood Willston, about, 4803

Spaude, Paul W., 5462

Spaulding, E. G., 5260

Spaulding, Oliver Lyman, 3664

Speak to the Earth, 2746

Speaking Frankly, 3544

Specimen Days, 633-35

Speck, Frank G., 3009, 301 I

Speckled Trout, 741

Speculation (stocks), 5952, 5981, 5993

Speeches, addresses, etc., 230-31, 233, $276,420-21,460-61,465,467$, 900

See also Lectures and Lecturing

Speiser, Ephraim A., 3512

Spelling, simplified, 2469

Spelling books, 5127

Spencer, Eleanor P., 3751

Spencer, Gwladys, 6473

Spencer, Samuel R., 4450

Spengler, J. J., 3758
Spengler, Oswald, about, 2407

Sper, Felix, 4926

Spero, Sterling D., 6192

Sperry, Willard L., 5400, 5424, 5427 about, 5427

Spewack, Bella, 2327, 2333

Spewack, Samuel, 2327, 2333

Spider Boy, 1833

The Spider's House, I93 I

Spiller, Robert E., 230, 252, 267, 30x, $692,897,2412,2510$ ed., $264,269,273,2276,2460-6$ I

Spingarn, Joel Elias, 241 I, 251 I

Spink, J. G. Taylor, 5015

Spires of Form, 303

The Spirit and the Flesh, 1258

The Spirit of St. Louis, 2715

Spirit of the Times, 379, 613,4097, 5542

Spiritual Laws, 285

Spiritualism, 4516, 5439

Spirituals. See Negroes-spirituals; White spirituals

Spitz, David, 6069

Spivack, R. G., 6 195

The Splendid Idle Forties, 725

Splendid Poseur, 1064

Spoerri, William T., 377 I

Spofford, Ainsworth R., about, 6469

Spohn, George Weida, ed., 2330

The Spoilage, 4469

Spoils system, 3424-25, 3437-38, 4664, $6183,6357,6363,6382,6384$, $6386,6389-90$

See also Corruption (in politics)

Spokane, Wash., 4I50, 4217

Spoon River Anthology, 1599-1601

The Sport of Gods, 856

Sporting goods business, 5009

Sports, 2794, 4387, 4983-84, 4986-88, 4990-92, 4994-96, 5065-97

fiction, 5080

hist., 4990

soc. aspects, $498_{3}$

Baltimore, 4062

Berkshire Hills, Mass., 3799

Rocky Mountains, 4174

Southern States, 4083

See also Athletics; Recreation; and particular sports, e.g., Baseball

Spotswood, Alexander, fiction, 226, 228-29

Sprague, Marshall, 4 I $8 \mathrm{I}$

Spring, Leverett Wilson, 4I 68, 5222

Spring and All, 188 .

Spring Birth, 1827

Spring Thunder, 1827

Springfield, Ill., I 582, 4588

Springfield, Mass., guidebook, 3802

Springfield [Mass.] Republican, about, 2879

Springfield, Ohio, guidebook, $3^{870}$

Sprout, Harold H., 3673-74

Sprout, Margaret, 3673-74

The Spy, 253-55, 23II

Square dances, $4 \mathrm{I} 60,5587,5589-9 \mathrm{r}$

Srole, Leo, 4435

Stackpole, Edouard A., 5871

Stafford, Jean, $2156-60$

Stage. See Theater
Stage-Coach and Tavern Days, 4227

Stagecoaches, 4666,5931

drivers, 4227

See also Travel and travelers-stagecoach

Stage Door, 1547, 2333

Stagg, Amos Alonzo, 5043 about, 5043

Stahl, O. Glenn, 61 88

Stahlberg, John, 4176

Stalin, Joseoh, 3622

Stallings, Laurence, 2332

Stallman, Robert W., 828, 2383 ed., 836-37

Stalson, J. Owen, 599 I

Stamp Act, 3257

Stampp, Kenneth M., 3403

Standard of living. See Cost and standard of living

Standard Oil Company, about, 2824, 5913,5916

Stanley, John M., about, 5806

Stanley, Julian C., 5229

Stanley, William O., 5158

Stanton, Alfred H., 4838

Stanton, Edwin McMasters, about, 2614

Stanwood, Edward, 6149

The Star Spangled Banner (song), 5616 about, 56I6

Stark, John Stilwell, about, 564 I

Starke, Aubrey H., ed., 1046

Starkey, Marion L., 3228, 3309

Starr, Harris E., 4544 ed., 3080

Starr, Mark, 529 r, 6034

Stars To-Night, 1814

Starved Rock, I601

Stasheff, Edward, 4697, 5230

The State, 5279, 5310,6073

See also specific subjects "and state," e.g., Church and state; Industry and state

The State of Mind, 2131

State of the Nation, 1330

State of the Union, 2335

State rights, $3139,3303,3367,3369$, 3397,6101

States

and local relations, $6200,6217-18$

civil service, 6192

colleges \& universities, $5163-68,5176$, $5194,5201-2$

constitutions, 6080, 6086, 6rig5

courts, 6281-82, 6293

executive branch, 6193, 6197, 6201, 6203-4, 631 I

executive-legislative relations, 6203

finance, 5973

govt., 4266, 6133-35, 6137, 6167,

$6195-6206,6425,6432$ functions, $6139,6180,6196-97$ hist., 3259

labor policy, 6r.92, 6r95

organization, 6r37, 6r8o, 6rg697

govt. officials \& employees, 6r96-97

govt. publications, 6452

bibl., 6205

judicial branch, 6197

legislative branch, 6 I97 
States-Continued

legislative power, 6098, 6154-56, $6158,6160,6164,6168,6178$, 6rgi, cases, 6ogr

library extension agencies, 6482

See also names of individual states, e.g., Alabama

Statesmen of the Lost Cause, 3383

Statistics, 2970

See also specific subjects, e.g., Agriculture-stat.; Census; Vital statistics

Statues. See Monuments

The Statues, 2137

Stauffer, Donald A., ed., 2512

Steamships and steamboats

hist., 4784,5929

in literature, $784-86$

Stearns, Marshall W., 5646

Stearns, Myron M., 5023

Stebbins, Richard P., 3634

Stedman, Edmund Clarence, $25 \times 3$

Stedman, Laura, 2513

Stedman, Murray S., Jr., 6372

Stedman, Susan W., 6372

Steeg, Clarence Ver, 4072

Steel industry, 2825, 4061, 5909, 5918

Steel Workers' Union, about, 6039

Steele, Sir Richard, about, $38 \mathrm{I}$

Steele, S.S., 23 I I

Steele, Wilbur Daniel, I 762-65

Steelman, John R., 4779

Steeple Bush, 1452

Steere, Douglas V., about, 5433

Steffens, Joseph Lincoln, 6207,6432 about, 6430,6432

Stefferud, Alfred, ed., 5817

Stegner, Wallace, $216 \mathrm{I}-65,3782,396 \mathrm{r}$, 4757

Steiger, Ernst, about, 6446

Stein, Gertrude, $1766-72$ about, I 773-74, 2504, 2535

Stein, William B., 362

Steinbeck, John, 1775-81, 2333, 2336 about, 2376, 2427-28, 2508, 2536

Steinberg, Milton, 4457

Steinman, David B., $480 \mathrm{I}$

Steinmetz, Rollin C., 4058

Stendler, Celia B., 5148

Step Right Upl, 4980

Stephen Escott, 1576

Stephens, Alexander H., about, 2613, 3415

Stephens, John L., 2994

Stephenson, George M., 4416

Stephenson, Nathaniel Wright, 327I, 3355

Stephenson, Wendell Holmes, 3057 ed., 4072

Sterling, George, 737-38

Sterling Memorial Library, 6470

Stermer, James Edson, 4586

Stern, Bernhard J., 3009, 4815

Stern, Madeleine B., 188,6446

Stern, Philip Van D., ed., 421, 535

Stern, Siegfried, 6002

Sterner, Richard, $4446,444^{8}$

Stettinius, Edward R., 3567

Stevens, Henry, 6465 about, 6465
Stevens, Henry N., ed., 6465

Stevens, John, about, 4786,4802

Stevens, John Austin, 4049

Stevens, Robert Livingston, about, 4786

Stevens, Sylvester K., 4057

Stevens, Thaddeus, about, 3362, 3368

Stevens, Wallace, 1782-84

about, $1785,1923,2426,2497,2544$

Stevenson, Adlai, 3646

Stevenson, Elizabeth, 688, 1022

Stevenson, Robert Louis, 6ro about, 520

Steward, Julian H., ed., 4222

Stewart, Edgar I., 3036

Stewart, George B., Jr., ed., 931

Stewart, George R., 2976, 333 I, 452 I

Stewart, Irvin, $476 \mathrm{I}$

Stewart, Isabel M., about, 4854

Stewart, Kenneth, 2848

Stewart, Lawrence D., 5678

Stewart, Lowell O., 4800

Stewart, Paul R., 2925

Stewart, Randall, ed., 349-50, 2320, 2323

Stewart, Raymond F., 4704

Stewart, Watt, $305^{8}$

Stewart, William Drummond, about, 3330

Sticks and Stones, 5701

Stieglitz, Alfred, about, 5783

Stiles, Bert, 281 3-1 4 about, 28I 4

Stiles, Helen E., 5792

Still, Bayrd, 4048, 4I 40

Still Seeing Things, 4909

A Stillness at Appomattox, 3692

Stilwell, H., 6r95

Stilwell, Joseph W., 3723

Stimpson, George W., 6339

Stimson, Henry L., about, 3547, 3595

Stine, C. S., 4479

Stine, Oscar C., 5855

Stirring Them in Austria, 798-99

Stock, Frederick, about, 5652

Stock, Leo F., ed., 3045

Stock companies, 6008

Stocking, Geórge W., 6026

Stocks and stock-exchange, 5981-82

Stoddard, Richard Henry, 224

The Stoic, 1337

Stokes, Anson Phelps, 5103, 5420

Stokes, Thomas L., 4016

Stokowski, Evangeline, 4968

Stone, Barton W., about, 5455

Stone, Candace, 288 I

Stone, Geoffrey, 504

Stone, Harlan Fiske, about, 6249-50

Stone, Harold A., 6216

Stone, Henry, 461

Stone, Irving, 2815-2 I ed., 3145

Stone, John Augustus, 518, 2311

Stone, Kathryn H., 6216

Stone, Shepard, 3615

Stone, William L., 4049

Stone, Witmer, 4724

Stone quarrying and mining, 299r

Stone Walls and Men, 2716

Stonecutters, 5738

Storck, John, 5289

The Store, 1794
Stores. See Department stores; Chain stores; etc.

Storey, Moorfield, 2696 about, 2696

Stories in the Modern Manner, 2566

Stories of the Streets and of the Town, 704

Stories on Stone, 4527

Storm, Hans Otto, about, 2536

Storm and Echo, 2096

Story, Isabelle F., 41 82

Story, Joseph, 6roo about, 623I

The Story of a Bad Boy, 707-10 about, 706

The Story of a Country Town, 960-63

The Story of a Day, 1035

The Story of a Poker Steer, 687

The Story of a Year, 1008

The Story of Bras-Coupé, 749-50

The Story of Kennett, 2282

$A$ Story of the War, 91 I

The Story of Toby, 475

A Story Teller's Story, I 182

The Story up to Now, 6469

Stoudt, John J., 5600

Stouffer, S. A., 3724, 6130

Stourzh, Gerald, 3187

Stout, Wesley Winans, 5043

Stovall, Floyd, 640, 2401, 25I4 ed., 2515

Stowe, Harriet (Beecher), 562-78 about, 562, 577-78, 881, 1023, 2615, 2797,3413

Stowe, W. H., 5442

The Strange Career of Jim Crow, 4444

The Strange Children, 1472

Strange Fruit, $1759-60$

Strange Holiness, I 290

Strange Interlude, 1647-48

Strange Ports of Call, 1959

Strange Victory, I8I 4

A Stranger Came to Port, 2746

Strangers in the Land, 4422

The Stranglers of Paris, 2315

Strategic Air Command, about, 3643a

Stratemeyer, Florence B., 5158

Stratton, George Malcolm, ed., 5318

Stratton, Winfield Scott, about, $418 \mathrm{I}$

Straumann, Heinrich, 2516

Straus, Isidor, about, 5959

Straus, Nathan, 4608,5959

Straus, Oscar S., about, 2504

The Straw, 1648

Strawberries, 741

Straws and Prayer-Books, 1262

Stray Leaves from Strange Literature, 95I-52

Strayer, Joseph Reese, ed., 6087

Stream of consciousness writing, fiction, I I 61 -62, I I 83, I 379, I 579, $1887,2055,2174-75$

Street, James, Jr., ed., I 791

Street, James Howell, I786-91, 5822

Street Corner Society, 4598

A Street in Bronzeville, 1937

Street Scene, 1688-89, 2332

A Streetcar Named Desire, 2221, 2335-36

Streeter, Floyd Benjamin, 3990

Streets in the Moon, 1586 
The Strength of Gideon, 860

The Strength of the Strong, 1052

The Strenuous Age in American Literature, $245 \mathrm{I}$

The Strenuous Life, 2793

Strevey, T. E., 3058

Stribling, Thomas Sigismund, 1792-95

Strickland, W. P., ed., 2634

Strictly Dishonorable, 2332

Strike through the Mask!, 2191

Strikes, 3439, 4I 47, 4I8I, 4310, 6047

Strode, Hudson, 3369

Strong, Charles Augustus, 5255

Strong, George Templeton, 2822-23 about, $\mathbf{2 8 2 3}$

Strong Cigars and Lovely Women, 4991

Structural geology, 2942

Structural psychology, 5389

A Struggle for Life, 7 I I

The Struggle for Survival, 5879

Struggles and Triumphs, 4977

The Struggies (Social, Financial and Political) of Petroleum V. Nasby, 425

Struik, Dirk Jan, 4730

Strunsky, Simeon, 2858

Stryker, Lloyd Paul, 34 I I-I 2

Stuart, Charles, about, 3360

Stuart, Gilbert, about, 5749, 5774

Stuart, H. W., 5254

Stuart, J. E. B., about, 2613, 3703

Stuart, Jesse, 21 66-73

Stuart, Lyle, 2894

Studenski, Paul, 5973

Studies in Classic American Literature, 2456

Studies in Literary Types, 2493

Studies in Logical Theory, about, 2407

Studies of a Litterateur, 2547

Studies of Good and Evil, 5354

Studs Lonigan, 1373

Stumpf, Florence Scovil, 4983

Sturges, Henry C., 224

Sturges, Preston, 2332

Sturges, Wesley A., 6299

Styron, William, 21 74-75

Substance and Shadow, 5319

The Suburb by the Sea, I 517

Subversive Activities Control Act, 6108

Subversives and subversive activities, $4424,6112,6119,6130$

New York (State), 6 I 15

Success, 3762, 6029

as a theme in literature, 2464

Such Counsels You Gave to Me, 1534

Sucker's Progress, 2586

Suckow, Ruth, I 796-1 801 about, I 809

Suffolk County, Mass., 4036

Suffrage, $6401-2,6405,6409$

Southern States, 6378-79

Sugar industry, 5822

Suggs, Simon, pseud. See Hooper, Johnson Jones

Sullivan, Anne Mansfield, 2706

See also Macy, Anne Sullivan

Sullivan, E. C., about, 4785

Sullivan, James, about, 5121

Sullivan, John Florence. See Allen, Fred
Sullivan, John Lawrence, about, 5027

Sullivan, Louis Henry, 57 I 5 about, 5703, 5715

Sullivan, Mark, 2891, 3468 about, 289I

Sullivan, Paul H., ed., 6019

Sullivan, Thelma L., I 807

Sullivant, William Starling, about, 4760

The Sultan of Sulu, 701, 705

Sulzberger, Arthur Hays, about, 2869

Suman, John Robert, about, ${ }_{4803}$

Summer and Smoke, 2223, 2335

Summer on the Lakes, in 1843, 314

Summer Resort, 4596

Summers, Robert E., ed., 3631

Sumner, Charles, 425, 3406

about, 2280, 26r 4, 3406

Sumner, Helen L., 6033

Sumner, William Graham, about, 2407, 4542, 4544

The Sun (Baltimore), about, I602, 2876

The Sun (New York), about, 2874, 288 I

The Sun also Rises, 1495

Sun-Up, 2337

Sunday, Billy, about, 5403, 5480

Sunderland, Edson R., 6331

Sunrise to Sunset, 1159

Sunshine and Shadow, 4955

Supernatural stories

Mich., 5535

New England, 5534

See also Ghost stories

Supernaturalism, Indian, 3006, 3019

Superstition

Mich., 5533

Miss., 5547

New England, 5541

N.C., 5536

Ozark Mountains, 5543

Pa., 5578

Schoharie County, N.Y., 5539

Superstition, 200, 2337

Supper for the Dead, 1475

Supreme Court, 3108, 3304, 6078, 6093-94, 6096, 6098, 6101, 6120, $6147,6151,6236-60,6286,6340$ decisions \& opinions, 6084,6089 , $6092,6095,6099-6100,6102$, $6104-6,6121,6128-29$

influence in pol. \& govt., 6240

Surgeon General's Library, Washington, D.C., about, 48 I 9

Surgeons. See Physicians and surgeons

Surgery, $482 \mathrm{I}, 4824,4827,483 \mathrm{I}$

Surgery of the eye. See Ocular surgery

Surgery of the nervous system. See Neurosurgery

Surrealism in literature

drama, 2226

fiction, $1987,2079,208 \mathrm{r}, 2084$

poetry, 2034

Surry of Eagle's Nest, 247-48

A Survey of the Summe of Church Discipline, 34

Susan Lennox, 1107

Susquehanna River and valley, 4020 in literature, 675

Sut Lovingood, 331-32

Sutcliffe, Denham, ed., 1716
Sutermeister, Edwin, 6458

Sutherland, Donald, I 774

Sutherland, Stella H., 4398

Sutter, John, about, 2659

Sutton, Albert Alton, 2910

Sutton, Francis X., 6010

Suwannee River, 3976

Suenska Amerikanaren about, 2895

Swallow Barn, 405-8

Swan, Howard, 5630

Swan, M. L., 5577

Swan, W. H., 5577

Swanee (song), 5678

Swanton, John R., 2985, 3012

Swedes, $4482,4483,4486$

Swedish-American journalism, 2895

Sweeney, James Johnson, 4968

Sweeney in the Trees, 2113

Sweet, William Warren, 5396, 5401-2, $5410 \rightarrow 16,5466$

ed., $5412-16,5463$

Sweet Thursday, $178 \mathrm{I}$

Swenson, May, $235^{\circ}$

Swenson, Rinehart J., 6315

Swetnam, George, 3962

Swift, Jonathan, about, 165

Swift \& Co., about, 6055

Swift v. Tyson case, 6293

'Swingin Round the Cirkle', 424

Swinnerton, James, about, 2865

Swisher, Carl Brent, 6084-85, 6238, 6258

Switzerland, travel \& travelers, 426

Sword Blades and Poppy Seed, 1583-84

Sybil, I91 I

Sydnor, Charles S., 4074

A Symbolic of Motives, 2390

Symbolism in literature

drama, 1069-70, 2218-1 9, 2226

essays, 2388,2535

fiction, $333,470,478,481-83,491$, $128 \mathrm{r}, 1379,1388,1494,1500$, 1947, 1954, 1992, 2023, 2081, 2212

hist. \& crit., 2420

poetry, I 823,1948 crit., 2378

The Symphony, 1038

Symphony Hall (Boston), 5649

Synagogues, 4454, 4457

Syndicalism, 6045

Syndication (newspaper), 2864, 2881, 2890, 2894

Syntax, 2243

Syrett, Harold C., 3 I03, 3318

Syrkin, Marie, 4457

System of Logic, 5337

Systematic Theology, 5433

Szarkowski, John, 57 I 5

\section{$\mathrm{T}$}

TVA. See Tennessee Valley Authority

Tableau des Etats-Unis, 4507

Tacoma, Wash., 4150

Taeuber, Conrad, 4397

Taff, Charles A., $59: 2$

Taft, Kendall B.; ed., 2295

Taft, Lorado, $574^{\circ}$ 
Taft, Philip, 6033, 6039

Taft, Robert, 5781, 5806

Taft, William Howard, about, 3464, 6255

Taft-Hartley Act, 6053

Take Them, Stranger, 2413

Take Them Up Tenderly, 4931

Taking the Census, 380

A Tale for Midnight, 2087

$A$ Tale of Two Conventions, 6350

Tales. See Legends \& tales; Short stories; Tales, folk; Tall tales

Tales, folk, 910-16, 922-25, 5506, $5508,5510-13,5516$

Mormon, 5538

Beech Mountain, N.C., 5529

Brazos River, Tex., 5527

Ky., 5529, 5546

Mich., 5533, 5535

Middle West, 55 ig

Miss., 5547

Mississippi River, 5523

Mo., 5528

New England, 5524, 5534

N. Mex., 5537

New York (City), 5522

New York (State), 5548

N.C., 5529,5536

Ozark Mountains, 5545

Pa., 5578-79

Rocky Mountains, 5530

Schoharie County, N.Y., 5539

Southern States, 5525

Southwest, 5507, 5509, 5518, 5520, 5531

Tex., 55 I 8, 5520-21, 5532

Va., 5529

West, 5526

Wise County, Va., 5529

Tales before Midnight, 1224

Tales from the Plum Grove Hills, 2170

Tales of a Time and Place, 1033

Tales of a Wayside Inn, 434

Tales of Fishes, 1486

Tales of Lonely Trails, 5073

Tales of Soldiers and Civilians, 735

Tales of the Grotesque and Arabesque, 528

Talifer, 1714

Talking books, 4636

Talking to the Moon, 2730

The Talking Turtle, 5545

Tall tales, 330-32, 379-80, 511, 5506, $5508,5511-13$

Ark., 5542

Mich., 5535

New England, 5534

New York (City), 5522

New York (State), 5548

Ozark Mountains, 5544

Rocky Mountains, 5530

Southern States, 5515

Southwest, 5503, 5509, 5520

Tenn., 330-32

Tex., 5520, 5532

Tallant, Robert, 3852

The Talley Method, 1210

Tallmadge, Thomas E., 5703

Talmadge, John Erwin, 2856

Tamar and Other Poems, 1534

Tambimuttu, M. J., ed., 1364
Tambo and Bones, 5640

Tamerlane, $521-27$

Tammany Hall, $6382,6387,6390$

Tammen, Harry Heye, about, 2878

Tancred, King of Sicily, 23 I I

Taney, Roger B., about, 6096, 6240, 6258

Tanks (military science), 3658

Tannenbaum, Frank, 3632, 4656

Tannenbaum, Samuel A., 4891

Tansill, Charles Callen, 3587

Taos, N. Mex., 4187,4198 drama, 1174

Tapp, Jesse W., $5^{855}$

Tappan, Arthur, about, 3360

Tappan, Lewis, 3360

Taps for Private Tussie, 2169

Tar, a Midwest Childhood, 1184

Tarbell, Ida M., 2824-27, 3094, 5916, 6430

about, 2827

Tariff, 3124, 3303, 3351, 3422-23, $3448,3638,5947,6352,6366$, 6373,6396

See also General Agreement on Tariffs and Trade

Tarkington, Booth, 968, 1802-6 about, I 808, 2504, 41 24 bibl., 1807

Tascosa, Tex., hist., 4195

The Tastemakers, 5694

Tate, Allen, I 48I, I 809-1 I, 2008 ed., $1227,1809,2354$ about, 1812, 2499

Tate, Mrs. Allen. See Gordon, Caroline

Tate, Merze, 3525

Tattered Coat, 5068

The Tattooed Countess, 1830

Tatum, Laurie, about, 3035

Tauber, Maurice F., 6487 ed., 6484

Taubman, Hyman Howard, 5624, 5627, 5662

Taussig, Frank W., 6027

Taverns. See Hotels, taverns, etc.

Taxation, 5965, 5970-71, 5973, 6090, 6095,6105

cases, 6090, 6095

gift deductions, $46 \mathrm{I}_{5}$

radio \& television, 4708

Tayleure, Clifton W., 2347

Taylor, Albert H., 3675

Taylor, Anne (Dewees), 5834

Taylor, Bayard, 2282, 4351-53 tr., 2282

about, 2282, 2513, 435I

Taylor, Carl C., 4583, 5833

Taylor, Charles A., 2305

Taylor, Deems, r6o8, 4946, 5685

Taylor, E. G. R., 3169

Taylor, Edward, 72-74 about, 73-74

Taylor, Eugene J., 4637

Taylor, Frederick W, about, 4798

Taylor, George Rogers, ed., 3107-36, 5877

Taylor, Henry C., 5834

Taylor, Horace, 5895

Taylor, John, 2296

Taylor, Laurette, about, 4932

Taylor, Nathaniel W., about, 5428, 5436
Taylor, Paul Schuster, 4476

Taylor, Peter Hillsman, 21 76-79

Taylor, Richard, 2828-30

Taylor, Robert J., 3079

Taylor, Robert Lewis, 4956

Taylor, Rosser H., 4091

Taylor, Telford, 6164

Taylor, Walter Fuller, 2517

Taylor, Zachary, about, 3332-33

Teachers and teaching, $118,2767,5105$, $5213-23,5239,5243$

academic freedom, 5132-33, 5181, $5185,5238-39,5243,6115-17$, 6123,6126

colleges \& universities, 5213-15, $5219,5221-23$

education \& training, 5233, 5236, 5239

hist., 3050, 3055, 3059, 3083

laws \& legislation, 5139

methods \& techniques, 5218, 522527,5239

private schools, 5217

profession, 5128,5216

public schools, 5134, 5216, 5239

Tead, Ordway, 5427

about, 5427

The Teahouse of the August Moon, 2336

Teale, Edwin W., ed., 1083

Team Bells Woke Me, 1316

'Teamsters' Union, about, 6039

Teapot Dome scandal, fiction, 1756

Tears and Smiles, 198

The Tears of the Blind Lions, 2039

Teasdale, Sara, 18 $13-14$

Tebbel, John, 2848, 2862, 2884, 2926 ed., $317 \mathrm{I}$

Technical assistance, $3624,3636,3641$

Technical societies, directory, 4728

Technology, 6440, 6454-55, 6458

awards, 4729

bibl.; 4729,6453

development, 3670-7I, 37I r, 3722, 4079

hist., 4312, 4320, 4727

Tecumseh (Shawnee chief), about, 3030,3037

Teedyuscung (Delaware chief), about, 2835

Teeters, Negley K., 4639, 4657

Teichmann, Howard, 1550

Teigler, Elaine, ed., 3064

Telecommunication, 47 I I

hist., 4675

laws \& regulations, 4707

Telegraph, 4675, 4680-81, 4707 unions, $468 \mathrm{r}$

Telephone, 4674

hist., 4675,4679

industry, 4672,4710

Television, 4692

advertising, 4696

audiences, 4699, 4703-4, 4895

boxing, 5033

broadcasting, $4682,4686,4691-92$, $4694-95,4697,4699,4703-5$, 4965

in education, 4685, 4688, 4705, 5230-3I

in religion, 4702 
Television-Continued journalists, 2848,2894 laws \& regulations, 4708

Teller, James D., 4742

Temperance movement, 4516,4528 fiction, I $90-9$ I

A Temperance Town, 2306

The Tempers, $188 \mathrm{I}$

Temple School, Boston, about, 5220

The Temptation of Roger Heriott, 2059

The Ten Grandmothers, 3007

Ten Nights in a Bar-Room, 191

Ten North Frederick, 2078

Ten Years in Japan, 3545

Tender Buttons, I 771

Tender Is the Night, 1429

Tenement life, 2703-4

New York (City), 4638

Tennessee, 3945, 3963, 4079, 4103-5 caves, 2946

frontier life, 4097

guidebook, 3855

hist., 3287, 3353, 4021, 4103

pol. \& govt., 4103

travel \& travelers, $366,4277-78$

Tennessee in literature

fiction, $1464,1468,1470,1472,1792$ humor, 330-32

language (dialects, etc.), 330-32

short stories, 1684-88

Tennessee River and valley, 4006

Tennessee Valley Authority, 4006, 4794, 5892

Tennessee's Partner, 930, 937, 939

Tenney Committee. See California. Senate. Fact-Finding Committee on Un-American Activities in California

Tennis, 4987, 4993, 5046-47, 5049-50, 5052

The Tent on the Beach, 668

The Tenth Muse Lately Sprung up in America, 8

Terence. Andria, about, 1864

Terrible Woman, 1762

Territorial expansion

overseas, $3428,3527,353 \mathrm{I}, 3540$

The West, $3075,3138,3161,3307$, 3314, 3330, 3337, 3340, 3354, $3663,3760,4146,4218$

Terror and Decorum, 2190

Terry, John Skally, 1893

The Testament of Man, 1420

Texas, 3964, 41 88, 4192-97

architecture, 5723

bibl., 4190

boundaries, 3355

descr. \& trav., 3949

econ. condit., 4193

fiction, 1985,1987

folklore, $5507,5509,5518,5520-21$, 5532

frontier life, 2733

German immigrants, 4478

govt., 6rg5

governors, 4194

guidebooks, 391 7-23

hist., 2650, 2866, 331 4, 3353-55, 3949, 3956, 4189, 4193-94, 4196

Mexican labor, 4476

naturalists, 4734
Texas-Continued

pictorial work, 4 I 53

relations with France, 3577

relations with Gr. Brit., 3554, 3577

short stories, 1659

soc. condit., $4 \mathrm{I} 93$

travel \& travelers, 4365

U.S. Senators, 4194

Texas Folklore Society, about, 5518

Texas Sheepman, 2733

The Texas Review, 2572

$A T$ exas Steer, 2348

Textile arts, 5595, 5600, 5604

Thacher, Thomas, 2493

Thanatopsis, 217

Thane, Eric. See Henry, Ralph Chester

Tharp, Louise Hall, 5125

That Fortune, I I 42

That Girl from Memphis, 1763

That Reminds Me, 2598

That Spot, 1058

Thatcher ,Virginia S., 4816

That's All that Matters, I87I

Thayer, Frank, 29 I I

Thayer, Horace S., 5283

Thayer, James Bradley, 5387

Thayer, John E., ed., 55

Thayer, Sylvanus, about, 3656

Thayer, Vivian T., 5103, 5238, $549 \mathrm{r}$

Thayer, William R., 689

Theater, 2743, 4897-4943, 4929, 4932 , $498 \mathrm{I}$

anthology, 4896

Colonial period, 3748

criticism, 4906-12

design, 5689

experimental plays, 2535

fiction, 1688

hist., 4899-4900, 4902-3, 4905, 4909, 4912, 4929-30, 4932, 494I

little theater movement, 1647,1762 , 4901

yearbooks, 4897,4906

Calif., 2798, 4923

Colo., 4925

Nashville, 3765

New Orleans, 4922

New York (City), 2017, 4907-9, $4916,4924,4935,4942-43$

Ohio, 4 I 2 I

Philadelphia, 5659

St. Louis, 4913

San Francisco, 491 8, 4943

Toledo, Ohio, 4894

See also Drama; Musical comedy; Opera

Theatre Arts, 4896

Theatre Guild, about, 4941

Theatrical dancing, 2472, 4971

Theatricals, 3736

Their Eyes Were Watching God, 1528

Their Fathers' God, 1723

Theologians, 5425-27, 5433

Theology, 3758, 5409, 5433

hist., $5436,5438,5489$

in literature, $17,21,26,32,40,59$, $84,230,2483$

See also Religious themes in literature
Theology-Continued

natural, 5338

study \& teaching, 5423-24

New Englánd, 5428

See also Philosophy - and religion

$A$ Theology for the Social Gospel, 5482

The Theory of American Literature, 2446

The Theory of Business Enterprise, about, 2407

Theory of Flight, 2106

The Theory of Human Culture, 5351

Theory of Literature, 2529

The Theory of the Leisure Class, 4538

Theosophy, 5439

There Is Another Heaven, 1637

There Shall Be No Night, 1753

There Will Be Bread and Love, I 295

These Also Believe, 5439

These Bars of Flesh, 1792

These Many Years, 2473

These Things Are Mine, 2744

These 13,1379

They Also Ran, 28I7

They Built the West, 4150

They Came Like Swallows, 2031

They Gathered at the River, 5403

They Knew What They Wanted, 1518, 2327, 2332

They Seek a Country, 5466

They Stooped to Folly, 146I

They Took to the Sea, 5021

Thies, Frieda C., comp., I046

Third party movements. See Political parties

The Third Person, 1012

Thirteen Americans, 5427

The Thirteen Colonies

census, 4398,4400

commerce, $3193,3243,3262$

culture, 3088,3236

elections, $640 \mathrm{I}$

German immigrants, 4477

govt., 3195, 3221, 6088

hist., 3087-88, 314I, 3157, 317I, $3176-77,3179,3188,3190,3202$, 3221,3236

Scotch immigrants, 4491

Scotch-Irish immigrants, 4490

trade, 4398

Thirteen O'Clock, 1224

35,000 Days in Texas, 2866

This Body the Earth, 1474

This Green Thicket World, 1838

This House against This House, 2807

This Life I've Led, 4996

This Modern Poetry, 2413

This Music Crept by Me upon the Waters, 1587

This Reckless Breed of Men, 4186

This Side of Paradise, 1426

This Simian World, $1317-18$

This Was Normalcy, 3500a

Thistlethwaite, Frank, 3146

Thomas, Allen C., 5467

Thomas, Augustus, 2337, 2347-48

Thomas, Benjamin Franklin, 6447

Thomas, Benjamin P., 3392, 3395, 3413

Thomas, Dorothy S., 4428, 4446, 4469

Thomas, Elbert D., 5427

about, 5427 
Thomas, George Henry, about, 2614

Thomas, Harrison Cook, 6373

Thomas, Isaiah, 6447

about, 6447

Thomas, Jeannette (Bell), 3963, 5584

Thomas, Lewis V., 3513

Thomas, Milton Halsey, ed., 2823

Thomas, Norman M., 6433

Thomas, Robert B., $554 \mathrm{I}$

Thomas, Theodore, about, 5652

Thomas, William I., 4495

Thomas Aquinas, about, 5289

Thomas-Thomas-Ancil-Thomas, 1293

Thomason, John W., 3703

Thompson, Alan Reynolds, 2425.

Thompson, Benjamin, about, 4721,4724

Thompson, Charles Manfred, 4131

Thompson, Charles Seymour, 6472

Thompson, Daniel G. Brinton, 4043

Thompson, Daniel Pierce, 579-84

Thompson, Esther Katherine, 5823

Thompson, Harold W., 5548

Thompson, Holland, 4792

Thompson, John Eric S., 2994, 2997

Thompson, L. S., 448I

Thompson, Manley H., 5350

Thompson, Oscar, 5663

Thompson, Ralph, 2518

Thompson, Randall, 5670

Thompson, Robert L., 4680

Thompson, Ronald, 3065

Thompson, Stith, ed., 3021, 5518

Thompson, Warren S., 4399, 4594

Thompson, William Boyce, about, 2682

Thomson, Charles A. H., 3607

Thomson, Elizabeth H., 4759, 482 I

Thomson, Virgil, I 77I

Thoreau, Henry David, 585-608, 2290 about, $186,280,470,606,609-11$, 619, 740, 2277, 2287, 2364, 2394, $2397,2422,2453,2476,2479,248$ I bibl., 589, 599

Thoreau, Sophia, ed., 594, 596

Thornbrough, Gayle, comp., 4I 25

Thorndike, Edward L., 4595 about, 5 I 6

Thorne, Florence Calvert, 6050

Thornthwaite, Charles Warren, 2937

Thornton, Harrison John, 3058, 5835

Thornton, Richard H., 2240 about, 2240

Thorp, Margaret (Farrand), 4950

Thorp, Willard, 2412 ed., $481,492,2355,2460-61,4083$

Thorp, Willard Long, 6030

Thorpe, Francis Newton comp., 6086 ed., 5130

Thorpe, Thomas Bangs, 612-13, 5542

Those Not Elect, 1154

Those Were the Days, 5090

Thoughts on Death and Life, 5316

Thoughts without Words, 1318

A Thousand-Mile Walk to the Gulf, 1079

Thrasher, Frederic M., 4658

The Thread That Runs So True, 2166

The Three Black Pennys, I 507

Three Cities, I 190

"The Three Colored Aces," 5025

Three Essays on America, 2380
Three Lives, $7_{7} 67$

Three Men on a Horse, 2333

Three Men on Third, 5013

3 Smiths in the Wind, 2150

Three Soldiers, 1326

The Three Taverns, I7I 4

Three Worlds, 2523

Threshold and Hearth, 1906

Throckmorton, Archibald H., ed., 6275

Through the Brazilian Wilderness, 2794

Through the Eye of the Needle, 978

Thurber, James Grover, I815-20, 2334 drawings, I 8 I 5

Thursfield, Richard E., 5128 ed., 3059

Thurso's Landing, 1534

Thwaites, Reuben Gold, ed., 3299

Thwing, Charles F., 5188

Ticknor, George, about, 2462, 2534, 3776

Ticonderoga, Fort, fiction, 580-82

Tidwell, James Nathan, 2257

ed., 518

Tiffany, Herbert Thorndike, 6278

Tiger in the House, 1828

Tiger Joy, 1224

Tiger-Lilies, 1046

Tilden, Freeman, 5866

Tilden, Samuel Jones, about, $343^{\circ}$

Tilden, William T., 5052 about, 5052

Tilghman, Benjamin Chew, about, 4786

Till Fish Us Do Part, 5070

Till the Day I Die, 2064

Tillich, Paul, about, 5433, 5436

Tilquin, André, 5393

Tilton, Eleanor M., ed., 377

Tilton, Theodore, about, 5476

Timber Line, 2878

Timberlake, Craig, 4943

Timberland Times, 2661

Time in the Rock, I 166

The Time of Man, 1698

The Time of Your Life, 2110, 2112 , $2327,2334,2336$

A Time to Act, 1585

Time to Come, 1959

Time Will Darken It, 2033

Times-Herald (Washington, D.C.), about, 2862

The Times-Picayune (New Orleans), about, 287 I

Timoleon, 488

Timrod, Henry, 61 4-1 8

Tindall, George, 4072

Tinker, Edward Larocque, 748, 4 I 01

Tinling, Marion, ed., Is tr., I 6

Tinware, 5726, 5787

The Titan, 1337

Titchener, Edward B., about, 5389

'Tite Poulette, $74^{8}$

To a Waterfowl, 217

To Build a Fire, 1052, 1058

To Helen, 526

To the Finland Station, 2535

Tobacco industry, 5823,5829

fiction, 2194

Tobacco Road, I 271, 2333
Tobey, James A., 4876

Tobias, Channing H., 5427 about, 5427

Tobin, James, 6oro

Tocqueville, Alexis de, 4509-12 about, 4512

The Tocsin of Revolt, 2474

Todd, Charles B., I OI

Todd, Mable (Loomis), ed., 839-41, $843,847-49$

Together, 956

Toilers of the Hills, I 421

Toledo, Ohio entertainment, 4894 politics, 6434

Tolles, Frederick B., 3229

Tolley, Howard R., 5837

Tolman, Richard C., about, 4722

Tom Owen the Bee-Hunter, pseud. See Thorpe, Thomas Bangs

Tom Sawyer, The Adventures of, 77883,811

Tomas, Vincent, ed., 5349

Tomorrow the New Moon, 1920

Tomorrow the World, 2334

Tompkins, Pauline, 3568

Toombs, Robert, about, 2613, 3405

Top, Franklin H., ed., 4877

Topical songs, $5552,5556,5564,5575$, $55^{8} 4$

Torbet, R. G., 5442-43

Tories, 3262, 3267, 3272, 4044

Tornadoes, 2948

Torpey, William G., 5421, 6r93

Torrence, Frederic Ridgely, 1821-22

Torrey, Bradford, ed., 600

Torrey, John, about, 4760

Torrielli, Andrew J., 3779

Tort Claims Act of 1948 (Federal), 6313

Tortesa, the Usurer, 676, 2337, 2347

Tortilla Flat, 1780

Torts, 6230,6279

Toscanini, Arturo, about, 2638, 5622 $A$ Tour of the Prairies, 381

Tourtellot, Arthur Bernon, 3991, 6340

Toward a Better Life, 2387

Toward the Flame, 1170

Toward the Gulf, 1601

The Town, 1694

The Town down the River, 1714

Town Hall Tonight, 4902

Town Meeting Country, 3965

The Town with the Funny Name, 2746

Towne, Charles Wayland, 5874

Towns. See Cities and towns

Towns and villages in literature

drama, 1865,2223

editorials, sketches, etc., 701

essays, 4 I 8

fiction, 562, 572-73, 576, 959-63, I 178, I 225, I 299, I 301, I 453, $1560,1568,1694,1705$, 1786, 1789, 1830, 1964, 1997, 2005 , 2033, 2070, 2129, 2163, 2208 hist. \& crit., 2438

personal narrative, 1543

poetry, 1 599-1601, 1727, 1731

short stories, 415-17, $562,574-75$, 1023-31, I I 78-79, 1476, 1797 
Townsend, Harvey Gates, 5262 ed., 5298

Townsend of Lichfield, 1262

Trachtenberg, Joshua, 4459

The Track of the Cat, 1957

Tracy's Tiger, 2120

Trade

Colonial period, 4069,4398

Indian, 2993, 3009

Santa Fe, 4148

See also Commerce

Trade associations, 6008, 6019

Trade book publishing, 6437-38, 6441

Trade-marks, $478 \mathrm{I}$

Trade regulation. See Commercegovt. regulation

Trade schools, 5210

Trade unions, 5899, 6032-42, 6049, 6054,6192

See also names of individual organizations, e.g., National Telegraph Union

Trading posts, Indian, 3028

Traffic courts, 6307

Traffic regulation, $4655,4659-60$

Tragedy. See Drama

The Tragedy of "Superstition," 200

The Tragic Era, 3362

Tragic Ground, 1274

Trail Driving Days, 4158

The Trail-Makers of the Middle Border, 898

Train, Arthur C., 6306

The Traitor, 2229

The Trampling Herd, 4158

Transatlantic Migration, 2508

Transcendentalism, 186-87, 230, 239, $280-82,313,585,2279-80,3134$, $5256,5259,5263,5301,5305$

anthology, 2346

essay, 2401

fiction, 333, 402-4

poetry, 6 I9

anthology, 2328

Transcontinental routes, 297 I

Transitions in American Literary History, 2401

Transport to Summer, 1784

Transportation, $4113,4221,5920-43$

automotive, 5942

govt. regulation, 5921,5924

hist., 4227, 4281, 5877, 5920, 5923-24

in art, 5801

inventions, 4787

Mississippi Valley, 4 I 10

New England, 5933

N.C., 4090

Northwest, Old, 4 i 12

Northwest, Pacific, 4214

Ohio, 4 I 19

Rocky Mountains, 4174

Tex., 4 I94

The West, 4349

See also Travel \& travelers

Trappers, folklore, 5523

Trappists, 2034

Traubel, Horace L., 658 ed., 627,637

Traumatic surgery, 4873

Trautman, Ray, 6485
Travel and travelers, 4223-4389

bibl., 4229

fiction, 1656

horseback, 36-39

river, $4247,428 \mathrm{I}$

See also names of individual rivers

stagecoach, 4227

See also subdivisions Guidebooks and

Travel \& travelers under names of places and regions, e.g., New England - Guidebooks; Indianatravel \& travelers

A Traveler from Altruria, 978

The Traveling Anecdote, 5509

Travelling with a Reformer, 798-99

Travels in Two Democracies, 2535

Treadmill to Oblivion, 4964

Treadwell, Sophie, 2332

Treason, 3148, 3273

American Revolution, 3264

Treasure-trove, folklore, 5531-32

The Treasurer's Report, and Other Aspects of Community Singing, I 214

Treaties, 3522, 3526, 3540, 361 2

Treatise on the Atonement, 5428, 5473

Treaty-making power, 3612

Treaty of Ghent, 3329, 3542

A Tree, a Rock, a Cloud, 2024

A Tree Is a Tree, 4962

The Tree Named John, 5547

The Tree of Life, 1433

A Tree of Night, 1946

Trees, 2960, 2963-64

The Trees, 1694

Trembling Prairie, 5351

Trent, William Peterfield, 393, 2393, $450 \mathrm{I}$

ed., 2345, 2393, 4724, 4786

Trent Collection, Duke University, 643

Trente ans, ou La vie d'un joueur, 2299

Trial by Time, 1410

Trial courts, 6285

See also Courts

Trial of a Poet, 2143

Trial practice, 6295-96

Trial procedure, 6282

Trial without Jury, 2302

Trials, 6292, 6298, 6322 criminal, 6229

Triangle Fire case, 6229

Tribute to the Angels, 1323

Trifles, 2332

Trigg, Oscar L., 620 comp., 637

Trilling, Lionel, 792, 2406, 2412, 2519-20, 5197

A Trilogy of Desire, 1337

Trimble, Bruce R., 6259

Trinity Church, New York (City) Choir, about, 5666

A Trip to Chinatown, 2306

The Triple Thinkers, 2539

"Trippe, Juan, about, $594 \mathrm{I}$

Tristram, I7 4

The Triumph, 3495

Triumph of Freedom, 3255

The Triumph of Infidelity, 120

The Triumph of Night, $185 \mathrm{I}$

The Triumph of the Egg, 1181

Triumphant Democracy, 3434
Trivial Breath, 1903

Trollope, Anthony, 4375-76 about, 4374

Trollope, Frances (Milton), 4304-06 about, 4303

Tropic of Cancer, $16 \mathbf{1} \mathbf{I}$

Tropic of Capricorn, 1612

Trouble in July, 1273

Trouble on Lost Mountain, 920

The Trouble with Cops, 4642

The Troubled Air, 2158

Troupers of the Gold Coast, 2798

Trow, Martin A., 6455

Troy, N.Y., fiction, 1159

Trucking industry, 5942

Trudeau, Livingston, about, 4868

True, Alfred Charles, 5836

True, Frederick W., ed., 4774

True Account of America for the Information and Help of Peasant and Commoner, 4485

Truesdell, Leon E., 4474

Truman, Harry S., 3500b, 5189 about, 3489

Truman, Stanley R., 48 I7

Trumbull, J. H., ed., 89

Trumbull, John (1750-1 831), I 65-67 about, 167,2365

Trumbull, John (1756-1843), 5775 about, 5775

Trumbull County, Ohio, 3872

Trumpets of Jubilee, 2797

Trumps, 2278

Trust, 1058

Trust companies, 5998, 6006

Trusts, industrial, $3121,6008,6026$ govt. control, 6004

The Trusty Knaves, 1687

Truxal, Andrew G., 4572

Tryon, Rolla Milton, 5919

Tryon, Warren S., ed., 4235

Tsanoff, R. A., 5252

Tuberculosis, control, $4868,488 \mathrm{I}$

Tucker, Glenn, 3037

Tucker, Samuel M., ed., 909

Tuckerman, Bayard, ed., $269 \mathrm{r}$

Tuckerman, Henry T., 4230

Tucson, Ariz., 4176, 4187

Tufts, James H., 5254, 5273, 5289

Tufts, Matilde C., 5289

Tugwell, Rexford Guy, 2407, 3498 ed., 5827 about, 5888

Tulips and Chimneys, 1309, 13 33

Tulloch, Avis, sculptures, 2994

Tulsa, Okla.

guidebook, 3909

hist., 4 I 7 I

The Tumult and the Shouting, 4994

Tuna industry, fiction, 2746

Tunnard, Christopher, 4609

Tunney, Gene, 3488, 503 I about, $4987,503 \mathrm{I}$

Turbulent Era, 3545

Turkey, relations with, 3513, 3545

The Turmoil, , 806

The Turn of the Screw, 1007, 1012

Turn West, Turn East, 817, 1017

Turnbull, Archibald D., 3676, 4802

Turnbull, George S., 2863

Turner, Arlin, 752 
Turner, Frederick Jackson, 3083, 3147 , $3356-57,3784$

about, 2407, 3058, 3137, 3147, 4540, 5222

Turner, Julius, 6398

Turner, Lorenzo Dow, 227 I

Turner, Nat, about, 5502

Turner, Scott, about, 4803

The Turning Wheel, 5940

A Turning Wind, 2106

Turns and Movies, 1166

Turpie, Mary C., 5757 comp., 5613

Tuskegee Institute, Tuskegee, Ala., 4450

Tutt, Ephraim, about, 6306

Twain, Mark, 768-81 2, 2290, 2367

about, 445, 542, 745, 813-20, 926, 982, I 017 , I I $26,2380,24$ I6-17, $2468,2474,25$ I 7, 26r 6

'Twas All for the Best, 2309

Tweed (William Marcy) Ring, 6387

Twelve Men, 1342

Twelve Men in a Box, 6295

The Twenties, 2440

Twentieth Century Authors, 2455

Twentieth Century Fund. Committee on Cartels and Monopoly, 6026

Twentieth Century Fund. Housing Committee, $4610,5896-97,6040$

Twentieth-Century Literature in America, 2356-62

XXIV Elegies, 1433

27 Wagons Full of Cotton, 2220

20,000 Leagues under the Sea; or, David Copperfield, 1215

Twice-Told Tales, 334-37 about, 333,538

Twichell, Joseph H., ed., 90

The Twin Adventures, 2119

Twins of Genius, 745

Twiss, Benjamin R., 61 61

Two Blades of Grass, 5857

Two Gentlemen in Bonds, 1677

Two Lives, 1556

Two Minutes Till Midnight, $362 \mathrm{I}$

Two Old Colonial Places, $1103-4$

Two on an Island, 1689

Two on the Aisle, 4909

Two Reels and a Crank, 4961

Two Slatterns and a King, 1608

The Two Sons-in-Law, 2302

Two-thirds of a Nation, 4608

Two Years before the Mast, 275, 479

Tyler, Alice (Felt), 4522

Tyler, John, about, 3323-24, $354^{\circ}$

Tyler, Lyon Gardiner, ed., 71, 3218

Tyler, Moses Coit, 2521-22, 3263 about, 252 I

Tyler, Royall, 168-70, 2312, 2337, 2347 Type and type-founding, 6442,6448 , 6456,6459

Typee, $47 \mathrm{I}-75$

Types of Philosophy, 5310

Typhus, 2843

The Tyranny of Sex, 1573

\section{U}

U.S.A., 1325,1328

U.S.A., the Permanent Revolution, 4503
U.S. 1,2106

U.S. One, Maine to Florida, 3790

U.S.S.R. See Russia

Ukrainians, 4492

Ullman, Edward L., 2937

Ulman, Joseph N., 6291

Ulman, Lloyd, $604 \mathrm{I}$

Ulrich, Carolyn F., 2914

Ulriksson, Vidkunn, $468 \mathrm{I}$

Umbra, 1666

Unc' Edinburg's Drowndin', I 100-2

Uncle Ethan Ripley, 893

Uncle Moses, I 192

Uncle Remus. See Harris, Joel Chandler

Uncle Sam's Acres, 5809

Uncle Sam's Stepchildren, 3034

Uncle Sam's Uncle Josh, 545

Uncle Tom's Cabin, 563-67, 749-50, about, 562

2347

Uncle Tom's Children, 2234

The Undeclared War, 3538

Under Duke and King, 4044

Under the Bridge, 2680

Under the Lion's Paw, 893

Undercliff, 1352

Underground River, 2123

Underhill, Ruth Murray, 2986, 3013

Understanding the American past, 3062

Undertakers and undertaking, 4527

Underworld, 2586, 4652

language (slang, etc.), 2274

Unemployment, 3440,6048

Unemployment insurance. See Social security

Unfinished Cathedral, I 795

Unger, Leonard, ed., 1370

Union List of Serials, 2915

A Union Officer in the Reconstruction, 277

Union Pacific Railroad, about, 5927, 5932

Union Portraits, 261 4

Union reporters, $285 \mathrm{I}$

Unions, labor. See Trade unions

Unit instruction in education, 5158

Unitarianism, 230, 239, 280, 402, 900, $2279,5404,5428,5442,5470$

hist., $5435,547 \mathrm{I}-72$

Salem, Mass., 2600

United Brethren, 4480

United House of Prayer of All People, about, 5498

United Nations, 3557,3635

special agencies, 3633

U.S. particiaption, 3619, 3633

The United Netherlands, History of, 2293

United Packinghouse Workers of America, about, 6055

United Presbyterian Church, 5442, 5466

United Press, about, 2860, 2890

United Service Organizations for $\mathrm{Na}$ tional Defense, theater production, 4919

United States. For official agencies of the U.S. government, see the name of the agency, e.g., Congress; Dept. of State
United States Commission on Organization of the Executive Branch of the Government, 5099

United States Exploring Expedition (I 838-42), about, 4749

United States Steel, 5918

Unity School of Christianity, 5439

Universalism, 5428 bibl., 5473

Universalist Church of America, 5442, 5473

Universities. See Colleges and universities

The University of Kansas City Review. 2573

University Players, 4920

University presses. See Printing-uniersity presses

Unknown Soldier (World War I), about, 4533

Unpartisan Review, 689

Untermeyer, Louis, 1584

ed., 221, 290, 443, 673, 845, 2363

Unto Such Glory, 1475

Untriangulated Stars, 1716

The Untried Years, 1020

The Unvanquished (Fast), 1976

The Unvanquished (Faulkner), 1389

Up from Methodism, 2587

Up from Slavery, 4449

Up Front, 2735

Up Stream, 1572, 1575

Up the Coolly, 893

Updegraff, Clarence M., 6058

Updike, Daniel Berkeley, about, 6459

Updyke, Frank A., 3542

Upper class, 3139, 3434, 4524, 4538, 6063,6070

New England, 3279

New York (State), 6374

Southern States, 3766

The Thirteen Colonies, 3236

Va., 3234, 3749

Uppsala. Universitet. Amerikanska Seminariet, $2364-68$

The Uprooted, 441 I

Upstage, 4909

Upton, Emory, 3651

Upton, William Treat, 5614

ed., 5610

Urban, W.M., 5252

Urban blight, redevelopment, etc. See Cities and towns-planning; Housing

Urban communities. See Cities and towns; Communities, urban

Urban folklore, 5510-1 1, 5514

New York (City), 5522

Urban government. See Local government

Urban Land Institute. Central Business District Council, 4603

Urbana, Ohio, 387 I

Urology, 4832

Useful arts. See Decorative arts; Arts and crafts

Ushant, 1165

The Usurper, 2311

Utah, 4 I 83

fiction, I 420, 1424

govt., 6195 
Utah-Continued

guidebooks, 391 4-15

hist., 2161, 3956, 3961, 4174, 4183, 4189

Indians, 3023

Mormons, 5465

Utah Humanities Review, 2575

Ute Indians, 3041, 4174

Utley, George Burwell, 6486

Utopian themes, fiction, 726, 728-31, 956, 978, 2019

Utopias (settlements), 4525

See also Brook Farm; Fruitlands; Harmony Society

Utter, William T., 3058, 4121

\section{V}

$V$-Letter, 2141

Vail, R. W. G., I6I

Vaillant, George C., 2997

Valente, John, 632

Valien, Bonita, 444I

Vallandigham, Clement, 3 I 49

The Valley Below, 2724

Valley Forge, drama, I 174

The Valley Nis, 526

The Valley of Decision, 1846

Value, theory of, 5252, 5334

Van Amringe, John Howard, abour, 5197

Vance, Rupert B., 3785, 4068, 4084 4401

Van den Bark, Melvin, 2272

Vandenberg, Arthur H., 3548

Vanderbilt, Arthur T., 6270 ed., 6307

Vanderbilt, Cornelius, about, 5054, $5880,5882,5935$

Vanderpoel, Emily (Noyes), 5793

Van Dersal, William R., 5818

Van Deusen, Glyndon G., 2883, 334344

Van Devander, Charles W., 6390

Van Doren, Carl, 127, 133, 480, 796, $827,834,905,1904,2523-24$, $3185,3187,3264,6088$

ed., 129,2393

Van Doren, Charles, comp., 3152

Van Doren, Mark, 363, 641, 660, 849, 1823-27

ed., $13,57,176,358,4249-50$

Van Druten, John, 2334-36

Van Dyke, Henry, 5095-96

Van Dyke, T. S., 5091

Van Every, Edward, 5032

Van Gogh. See Gogh, Vincent van

Vanguards of the Frontier, 4155-56

The Vanishing Virginian, 8241

Van Kirk, Walter M., 5496

Van Metre, Thurman W., 5924, 5948

Van Nostrand (D.) Company, about, 6453

Van Nostrand, Jeanne Skinner, 4202

Van Riper, Paul P., 6r74

Van Santvoord, George, ed., 924

Van Tyne, Claude H., 3265-67 about, 3058

Van Vechten, Carl, 1828-33, 1904, 4972,5678
Van Vechten, Carl-Continued

ed., 1771

about, I 835

bibl., I 834

Vanzetti, Bartolomeo

drama, 1173

fiction, 1980

The Varieties of Religious Experience, 5431

Varmints, 1684

Vassar College, about, 5670

Vaudeville, 4892, 4973-76

hist., 4974

Vaudeville for a Princess, 2138

Vaughan, Floyd L., 478I

Veblen, Thorstein, 5190

about, $2407,4538,4540,4545,5888$, 6424

Vegetation, 2956-57, 2959, 2956, 2969, 5816

Vein of Iron, 1460-61

The Venetian Glass Nephew, 1904

Venezuela, fiction, 1792

Ventura County, Calif., 3957

$A$ Venture in Remembrance, 2698

Verbrugghen, Henri, about, 5654

Veritism, 890

Vermilion, Ohio, 2958

Vermont, 4010,4033

boundary, 4027

econ. condit., 4031

farm life, 2742

fiction, 579-84, 1411, $1414-15,1417$, 1635

folksongs \& ballads, 5574

guidebook, 3797

hist., 1419,4033

poetry, $1451-52$

soc. life \& cust., 4031

travel \& travelers, 4290

Vermont. University, 5223

Versailles Treaty, 3 I I I , 347 I, 3541

Verse, light, $368,878-80,1629-34$, $1651-52,1859,1863$

Verse, vernacular, 753-55, 856-59, 861, $878-80,933,941-44,1038,1126-$ $31,1133-35$

See also Poetry-humorous

Verse drama, 144-45, 1 98, 200-1, 205, 1069-70, I172, II 74, 1357, 1359$60,1535,1585,1587,1608,1664$, 2098, $2101,2134-35$

criticism, 1175

Versification, theory, $216,520,538$, $61_{4}, 618,1038,1044-46$

Versus, 1633

Very, Jones, 280, 2544

Vespucci, Amerigo, about, 3172

Vestal, Stanley, pseud., 2525, 2831-33, $3964,4001,4175,4190$

Veterans, 3652

organizations, $3644-45$

World War II, 2736

Vicissitudes Exemplified, 2805

Vickery, Olga W., ed., 1399

Victor Talking Machine Company, about, 56 I 8

Victorian Knight-Errant, 449

$A$ Victorian Village, $278 \mathrm{I}$

The Victory at Sea, 3716

Victory at Sea (music), about, 5685
Vidal, Gore, $2180-88$

about, $237 \mathrm{I}$

Vidor, King W., 4962 about, 4962

Viereck, Peter, 21 89-92, 2363

$A$ View from the Bridge, 2049

Vigilance Committees, 6220

Vignettes of Manhattan, 2466

Village Daybook, 1965

Village Year, 1959

Villages

immigrant, 4406

Middle West, 4109,4197

Villains Galore, 2916

Villard, Oswald Garrison, 2849, 34 I 4

Villon, François, fiction, 2413

Vincent, Howard P., 48 I ed., 491

Vincent, J. M., 4540

Vinde, Victor, 4232

A Vindication of the Government of New England Churches, 94-95

Vines, Howell Hubert, $1836-38$

Vineyard, Catherine Marshall, 5507

Viniculture, Calif., 4494

Vinson, Fred M., about, 6262, 6256

Vinton, Stallo, 4148

The Violent Wedding, $201 \mathrm{I}$

Virgin Islands, 4218

Virgin Land, 3759

Virgin Spain, 1445

Virginia, $3963,4079,4085-88$

architecture, 5706

biog. (collected), 3749

caves, 2946

culture, 3233-34

descr., 149-53

econ. condit., 4085

education, 5122

folklore, 5529

guidebooks, 3827-29

hist., $12-16,66-68,70-71,149-53$, $245,3218,3233-34,3271,3295$. 3977,4073

pictorial works, 4086

in literature

drama, 1477

editorials, sketches, etc., 192-93, 1099, I 103-4, I 1 06, 1267

fiction, 226-29, 245-51, 405-8, 516, 1099, 1 1 05-6, I 261, $1460-62,1466,1469$

short stories, 405-8, 1099-1102, I 106

intellectual life, 3749

language (dialects, etc.), 2255-56

mounds, 2996

plantation life, 4517

politics, 2740

soc. life \& cust., $2603,2841,3749$, 4086-87, 4517

travel \& travelers, $12-13,66-68,70-$

$71,366,4269,4279,4283,4310$

Virginia University, 5122,6466

Virginia City, Nev., $4184-85,5630$

The Virginia Comedians, 246

The Virginia Gazette, about, 2854

The Virginia Quarterly Revicw, 2574

The Virginian, 11 45-48, 2316

The Virginians, 405

Visher, Stephen S., 2952, 4725 
The Vision, 121

The Vision of Columbus, 104

The Vision of Sir Launfal, 455

Visson, André, 3772

Vistas of New York, 2466

Vitagraph, 4961

Vital statistics, 4402 See also Census

Vocational education, 5105, 5211, 5246 colleges \& universities, 5179

Federal participation, 5211

foreign countries, 5211

secondary, 5156,5211

Vogt, P. L., 4594

Voice in the West, 2867

The Voice of Bugle Ann, 1541

The Voice of the City, I I $6-18$

The Voice of the Desert, 2453

The Voice of the People, 1461

The Voice of the Street, 1656

The Voice of the Turtle, 2334

Voices of Freedom, 664

Vollmer, August, 4659

Vollmer, Lula, 2337

Voltaire, about, $277^{\circ}$

A Volunteer's Adventures, 277, 3693

Von Abele, Rudolph R., 3415

Von Stroheim, Erich, about, 4960

Voorhies, Stephen J., illus., 6324

Voorhis, Horace Jeremiah ("Jerry"), 6165

Vosburgh, Walter S., 5055

Voss, Joseph Ellis, 4596

Voters and voting, $6334,6336,6414$, $6418-20,6422$

registration, $6403-4$

Voting maps, congressional, 2974

$A$ Voyage to Pagany, 1872

$A$ Voyage to Purilia, I 688

Voyages, small-boat, 5021

Voyageurs. See Boatmen, FrenchCanadian

W

$W, 1313$

Wabash River and valley, 3995

Wade, John Donald, 4068

Wade, Mason, 3069

Wadswortb, Jeremiah, about, 6016

Wagenknecht, Edward Charles, 427, 2526

Wager, Paul W., ed., 6217

Wages, $4310,6040,6048$

Waggoner, Hyatt H., 359, 364, 2527

Wagner, Fred J., 5007

Wagner Act, 6053

The Wagnerian Romances, about, 1278

Wah'kon-tah, 2729

Wahlke, John C., ed., 3 I 28-29

Waite, John Barker, 6308

Waite, Morrison R., about, 6096, 6259

Waiting for Lefty, 2064, 2327

Wake Island, 4218

Wake Island (poetry), 2106

Wake Up the Echoes, 4984

The Waking, 2103-4

Walcott, Charles Doolittle, about, 4775

Walcott, Joe, about, 5025
Wald, Lillian D., 4614 about, 4854

Walden, 589-93, 606

Walden Pond, 585

Walker, Charles R., 6055

Walker, Franklin D., 4202

Walker, Harvey, 6 r 66

Walker, John, 5758

Walker, Mabel L., 4612

Walker, "Singin' Billy," 5577

$A$ Walker in the City, 2704

Wall, Joseph Frazier, 2892

Wall, Norman J., 5834

The Wall, 1992

Wall decoration, 5726, 5730

Wall Smacker, 5006

Wallace, Anthony F. C., 2834-35

Wallace, Bigfoot, about, 283 I

Wallace, David Duncan, 4092

Wallace, DeWitt, about, 2920

Wallace, Edward S., 3659

Wallace, Ernest, 3014

Wallace, Francis, 5044

Wallace, Paul A. W., 3230-31

Wallace, Willard M., 3683

Wallace, Idaho, 4 I 76

Wallack, Lester, $230 \mathrm{r}$

Waller, George M., ed., 3 130-31

Waller, Judith C., 4698

The Wallet of Time, 4931

Wallin, John E. Wallace, 5207

Wallis, Charles L., 1063, 4527

The Walls Do Not Fall, 1322

Walpole, Horace, 6464

Walser, Richard G., ed., 1479, 1900

Walsh, William F., 6279

Walter, Eugene, 2347

Walters, Raymond, 3310, 5667

Wanamaker, John, about, 5957

Wann, Louis, ed., 2276

Wansey, Henry, 4234

The Want of a History of the Southern People, 1103-4

War, 3140,3524

econ. aspects, 5879,5889

in art, 5807

moral aspects, 234

satire, 1608

See also Indians, American-wars; Military history; and specific wars, e.g., Civil War

War correspondents. See Reporters and reporting

War Dept., 3697 about, $3376,3702,3726$

War Dept. General Staff, about, 3653

War Is Kind, 831,835

War of $1812,3687-88,4038$

causes, 3306, 3553

diplomatic hist., $3189,3306,3542$

naval operations, 3688

public opinion, 3305-6

War of the Classes, 1048

The War of the Rebellion: A Compilation of the Official Records, 3697

War with France (r798-r800), 368586

War with Mexico, 3331, 3333, 3340, $3351,3355,3554,3689$

diplomatic hist., 3586
War with Mexico-Continued personal narratives, 3696 sources, 3349

The War Years, 3393, 3395

Warbasse, James P., 5964

Ward, Alfred Dudley, 5899 ed., 5899

Ward, Archie, 5045

Ward, Artemus, pseud. See Browne, Charles Farrar

Ward, Christopher, 3683

Ward, Lester F., about, 4537, 4540, 4542

Ward, Nathaniel, 75-78

about, 3198

Ward, R. M., 5529

Ward, Robert DeCourcy, 2953

Ward, Theodora (Van Wagenen), ed., 850

$A$ Ward of Colonel Starbottle's, 937

Ware, Henry, about, 5472

Ware, Norman J., 6054

Warfel, Harry R., 2528, 5127 ed., 2369

Warne, Colston Estey, ed., 3132-33

Warner, Charles Dudley, 775-77, 1 1 3644

ed., 2277

about, 2466

Warner, Lucien C., about, 4735

Warner, Sam Bass, 6292

Warner, William Lloyd, 4435, 4438, $4557,5146,6029$

Warpath, 2831

Warren, Austin, 342, 355, 2529, 5319

Warren, Charles, 6089, 6235-36, 6260

Warren, Earl, 6238

Warren, Helen Ann, 4748

Warren, Joseph, about, 3245

Warren, Mercy (Otis), 2347

Warren, Robert Penn, 2193-2201, 2372, 2378

about, r 809, 2499

Warren, Sidney, 4214

Warren, Stanley, 5208

Warren, Ohio, 3872

The Warrens of Virginia, 2313

Wars 1 Have Seen, 1769

The Wars of Love, 2132

Warships, 3666, 3708, 3716

The Warwick Woodlands, 5076, 5080

Washburn, Carleton W., 5234

Washburn, Charles, 2836

Washburn, Frank S., about, 4735

Washburn, Frederic A., 4853

Washington, Booker T., 4449

about, 4449-50, 5 I 16

Washington, Chester L., 5030

Washington, George, 3268, 327r, 4254 about, $171-76,38 \mathrm{r}, 1873,3269-71$, 3680,4533

fiction, 1976

port., 5769

sculpture, 5737

Washington (State), 4215-17

descr., 5070

guidebook, 3939

officials (State), 4215

Orientals, 4468

Puyallup Indians, 304I

resources, 4212 
Washington (State) Legislature. Joint Fact-Finding Committee on UnAmerican Activities, about, 6 I 6

Washington (State) University. Committee on Tenure and Academic Freedom, about, 6 I 16

Washington, D.C., 4063-65, 6215

essays, 1002-3

fiction, 689-90, 722, I I56, I332, 2278

guidebook, 3826

historic houses, etc., 4063

hist., $3826,4063-64,4344$

pol. \& govt., 4065,6215

public life, 286I

reporters \& reporting, 2861, 2930

soc. life \& cust., 2668-69, 3320, 3362, $3395,4065,4279,4283$

Washington, D.C., Navy Yard, hist., 3670

Washington, Ga., 3842

The Washington Correspondents, 286 I

Washington Herald, about, 2862

Washington Post, about, 2862

Washington Square, 1008, 10 4

Washington Times-Herald, about, 2862

Washington University (St. Louis), 5187

The Waste Land, 1357,1359

about, 1367

The Watch Diggers, 2212

Watch on the Rhine, 1989, 2334, 2336

Water conservation, 5808,5858

Water power, Rochester, N.Y., 4050 , 4052

Water resources

Great Plains, $4 \mathrm{I} 6_{4}$

Middle West, 4 I I 3

Mo., 4108

N. Mex., 4198

Water-supply problem (city), 4797

Waterman, Thomas Tileston, 5725

Waterman, Willoughby Cyrus, 4597

Waters, Edward N., 5615, 568I ed., 5560

Waters, Frank, 4017

The Waters of Siloe, 2040

Waterways, inland, $3786,4312,5018$, 5920, 5923

See also Canals; Great Lakes; Rivers

Watkins, Floyd C., I 90 I ed., 2320

Watkins, Myron W., 6026

Watson, Elmo Scott, 2864

Watson, Forbes, 574I

Watson, Frank Dekker, 4626

Watson, John Broadus, 5393 about, 5389

Watson, Thomas E., about, 345 I

Wattenberg, William W., 4573

Watterson, Henry, 2892 about, 2892

Watts, Harold H., 1674

Waud, Alfred R., about, 5806

Waugh, Coulton, 2865

The Wave, 1745

Waverly, Md., 278I

Way, Frederick, 3992

Way Down East, $56 \mathrm{I}$

The Way of the Churches of Christ in New England, 19
The Way of the South, 4079

The Way West, 1490

Wayfaring Stranger, 5553

Wayne, Anthony, about, 3684

The Wayward Bus, 1778

The Wayward Press, 2904

The Wayward Pressman, 2904

We Accept with Pleasture, 24I 5

We Always Lie to Strangers, 5544

We Are Betrayed, 1423

We Are Not Divided, 5487

We Called It Culture, 4893

We Speak for Ourselves, 3145

We Went Thataway, 2153

We Were New England, 4029

We Who Built America, 4417

Wealth, 292

Wealth and Commonwealth, 4044

Weapons, 3664, 37 II

The Weary Blues, $152 \mathrm{I}$

Weather, 2950

See also Climate

Weather Bureau, 2953

about, 2951-52, 4764

Weather lore

Ozark Mountains, 5544

Southwest, 5509

Weaver, James Baird, about, 3433

Weaver, John E., 2966

Weaver, Raymond M., 474, 566 ed., 487,489

Weaver, Robert C., 445 I

Weaver, Samuel P., 6ro3

Weaver, William Wallace, 4627

The Web and the Rock, I890-9 I

Webb, Walter Prescott, 4 I 64

Weber, Brom, 1306 ed., 332, 1305

Weber, Carl J., comp., 1023

Weber, Clara C., comp., I 023

Weber, Gustavus A., $4764,4766-67$, 4769-72

Webster, Clarence M., 3965

Webster, Daniel, 3336

about, $2674,3336,4034$

fiction, 1222

Webster, Noah, 2236, 5127 about, 2277, 2364, 5121, 5127

Webster's New International Dictionary of the English Language, 2236,2238

Wecter, Dixon, 786, 791, 820, 3098, $3652,3662,4533-34$

ed., $80 \mathrm{I}-2,2460-6 \mathrm{I}$

The Wedge, 1878

$A$ Week on the Concord and Merrimack Rivers, 587-88, 606

Weeks, Edward A., 2837-38

about, 2838, 2922

Weeks, Lyman Horace, 6458

Weeks, Mary Elvira, 4731

Weems, Mason Locke, I 7 -77

bibl., I77

Wehle, Harry B., 5759, 5804

Weidner, Edward W., 6r 96

Weinberg, Albert K., 3760

Weiner, Edward, 2894

Weingarten, Joseph A., 2272

Weinlick, J. R., 5442

Weinstein, J. J., 4457

Weisberger, Bernard A., 285I, 5403
Weisenburger, Francis P., 41 20-2I

Weiser, Conrad, about, 3230

Weisgall, H. D., $445^{8}$

Weiss, Paul, 5379-82

ed., 5346

about, 5378

Weitenkampf, Frank, 2859, 5782

Weitling, Wilhelm, about, $448 \mathrm{r}$

Welch, William Henry, about, 4722, $4813,4821,4823,4829,4831$, 4834,4845

Weld, Isaac, 4269-70 about, 4269

Weld, Ralph Foster, 4046

Weld, Theodore Dwight, 3360 about, 3360, 341 3

Welded, 1648

Welker, Robert Henry, 4741

The Well Wrought Urn, 2379

Wellek, René, 2529, 3739

Welles, Edgar T., ed., 3416

Welles, Gideon, 341 6 about, 3416

Welles, Sumner, 3549, $45 \mathrm{I} 3$ ed., 3501

Wellesley College, 2766

Wellman, Paul I., 4158

Wells, Benjamin W., ed., 2345

Wells, Carolyn, comp., 633

Wells, Frederic L., comp., 4838

Wells, H. G., about, 4225

Wells, Henry W., I 628, 2530

Wells, Horace L., 47 I 5

Wells, Ronald Vale, 5263

Welty, Eudora, 2202-9 about, 1809,2372

Wendell, Barrett, about, 2694

Wendell, Mitchell, 6206, 6293

Wenger, J. C., 5442

Went, Stanley, ed., 3040

Wentworth, Edward Norris, 5874

Wentworth, Harold, 224I

Wentz, Abdel R., 546r

Werner, Morris R., 4977

Wertenbaker, Green Peyton, 4 9 I

Wertenbaker, Thomas Jefferson, 3087 , $3232-35,3748,4088,5204$

Wescott, Glenway, 1839-4I

Wesley, Charles, about, 5463

Wesley, Edgar B., 3050, 4142

Wesley, John, about, 5463

West, Benjamin, 144 about, 5749

West, E., 5442

West, James, pseud. See Withers, Carl

West, Jessamyn, 2210-1 4

West, Nathanael, i 842-44

West, Ray Benedict, 2362, 5465 ed., 253I, 4 I 76

West, Richard S., Jr., 3416

West, Victor J., 6407

The West, 2610, 3759, 3783, 3948, $3964,4145-50,4860$

biog. (collected), 4175

descr. \& trav., 4148

disc. \& explor., 297 I, 3335, 3345

econ. condit., $4 \mathrm{I} 49$

folklore, $5518,5526,5591$

folksongs \& ballads, 5560,5569

geology, 2935 
The West-Continued

guidebook, 3789

hist., $2867,3048,3074,3078,3105$, $3137,3147,3151,3964,3967$, 4001, 4017, 4146, 41 48-58, 4160, $4164,4174,4176-77,4179,4186$ pictorial works, $415 \mathrm{I}-53,4158$, $5770,5777,5802,5806$

I 8 th cent., $3170,3237,327 \mathrm{I}$, 3307

I9th cent., 3331, 3342-44, 3356

language (dialects, etc.), 2253

law, 6220

physiography, 2935

soc. life \& cust., 4097

theater, 4943

travel \& travelers

I 8 th cent., 3170, 4235

I gth cent., $365-67,39 \mathrm{r}, 984$, $3069,3298,3348,4223,4235$, $4277-78,4281,4315,4320$, $4344,4372,4382-83,4386-$ 87

The West in literature, $768,772-74$, $1064-65,1068,2831,3759$

descr., $365-67,1072-77,1079-83$, 2153

drama, 1069-70

fiction, $312,683-86,984-85$, $1145-$ 48 , 1239, 1420-24, $1484-90,1644$, $1646,1763,1954-57,2161-62$, 2415

poetry, 926, 933-34, 94I-44, 1064, $1066-67,1644-45$

short stories, 687, 926-32, 937, 93940, I 145

West Indies, 3168

in literature, $945-52$

The West in American History, 3078

West of Midnight, 1970

West Point, 3656

West-Running Brook, 1452

West Virginia, 4089

fiction, 1225

folksongs \& ballads, 5572

guidebook, 3830

hist., 4089

legislators, 4089

Westchester County, N.Y., soc. condit., 4577

Westcott, Minita, ed., 6019

Westerfield, Bradford, 3616

Westerfield, Ray Bert, 5974

Westering, 1410

Western dialect in literature, 683-87, 933-34, $941-44$

Western Federation of Miners, about, 6045

The Western Humanities Review, 2575

Western Lands and the American Revolution, 3237

Western Literary Institute and College of Professional Teachers, about, 5121

Western Reserve, hist., 4030, 4118

The Western Review, 2576

Western Star, 1222

Westerns (novels), 1314, I484-86, I 686-87

Westin, A. F., 6128

Westinghouse, George, about, 4790
Westmeyer, Russell E., 5925

The Westover Manuscripts, 13

Westward Ho!, 516

Wetmore, Alexander ed., 2962

about, 4775

Wetmore, Claude H., 6430

Wetmore, Elizabeth (Bisland), 951-53

Weyl, Nathaniel, 31 48-49

Whaling, 5871

fiction, 470, $481-83$, $49 \mathrm{I}$

Wharton, Charles, about, 5477

Wharton, Edith, I 845-55 about, i 856, 2537

Wharton School of Finance and Commerce, about, 6017

What Are Years, 1621

What Dooley Says, 866

What Is American Literature?, 2523

What Is Humanism?, 5115

What Man Can Make of Man, 5314

What Price Glory?, 2332

What's O'Clock, $1583-84$

Wheat, Carl I., 264I

Wheat, $3944,4141-42,4165,5830$

fiction, I 093-95

Wheeler, A. C., 2305

Wheeler, Anne Bolling, 5763

Wheeler, Harold Alden, about, 4803

Wheeler, Joseph Towne, 6448

Wheeler, Lynde Phelps, $475 \mathrm{I}$

Wheelock, John Hall, I $857-58$ ed., 2350

Wheelwright, Philip, 1367

Whelpton, Pascal K., 4399, 4402

When Johnny Comes Marching Home, 3652

When Lilacs Last in the Door-Yard Bloom'd, 623

When the Frost Is on the Punkin', I 126

When the Tree Flowered, 1646

When the War Ends, 6392

When the Whippoorwill, 1684

When This You See Remember Me, 1773

Where Main Street Meets the River, 2632

Where the Cross Is Made, 1648

Where the Word Ends, 5679

Whetstone, Pete, 5542

Whicher, George F., 592, 2496 ed., $3107-36$

Whicher, Stephen E., 306

A Whig Embattled, 3324

Whig Party, 3141, 3255, 3324, 3326, $3333,3344,6075,6351$

New York (State), 2691, 6374

Whigs (Revolution), 2691

poetry, 165, 167

New York (State), 4044

Whipple, George Chandler, 4879

Whipple, Mary Anne, ed., 3002

Whiskey rebellion (I 794), 3280

Whistler, James McNeill, about, 2616, 5776

Whitaker, Arthur P., 351 4-15, 3579

Whitaker, Joe Russell, 5900

White, Andred D., about, 5191

White, Andrew S., about, 376I

White, B. F., 5577

White, Charles Langdon, 2940
White, David Manning, ed., 6443

White, Donald J., 5872

White, Edward A., 376I

White, Edward Douglas, about, 6245

White, Elizabeth Brett, 3775

White, Elwyn Brooks, I 816, 1859-63 ed., 2370

White, Frederic R., 730

White, John, about, 3198

White, John M., 5849

White, Katherine S., ed., 2370

White, Leonard D., 61 75-79

White, Llewellyn, 4687

White, Morton G., 4545, 5291, 5295

White, Newman I., 5564

White, Theodore H., ed., 3723

White, Walter Francis, 2839-40 about, 2840

White, William, Bp., 5457

White, William Alanson, 4840 about, 4840

White, William Allen, 2887, 2893, 348 about, 2893

White, William Carter, 5653

White, William Chapman, 3966

White April, 2780

White Buildings, 1304

White Bull (Sioux chief), about, 283 I

White civilization

and Negroes in literature, 2631

and the American Indians, 2729, $2835,3082,3156,3161,3171$, 3180, 3229-30

White Collar, 4553

White Dresses, 1475, 2332

The White Gate, 1284

White Hopes and Other Tigers, 4991

White House Office, about, 6144

White-lacket, 274, 479-80

White Knife Shoshoni Indians, 3041

White Mule, 1874-75, 1882

The White Oxen, 2387

The White Slave \& Other Plays, 2316

White spirituals, 5554-55, 5558

Southern States, 5577

Whitefield, George, about, 5396, 5480

Whitehead, Alfred N., 5129,5384

about, $5378,5383,5385$

Whitehill, Walter Muir, 6475

Whiteman, Paul, 5678

Whiting, B. J., 2256

Whitley, William T., 5774

Whitlock, Brand, 6434

about, 6434

Whitman; Walt, 619-46, 2290, 2363, 2406

about, 280, 470, 647-52, 654-61, $740,1303,1727,2277,2280$, $2394,2397,2413,2420,2422-$ 23, 2456, 2476, 2491, 2503, 2513, 2624

bibl., 633,637

catalog, 659

concordance, 653

Whitman, William, $304 \mathrm{I}$

Whitney, Eli, about, 4786,4789

Whitney, Gertrude Vanderbilt, about, 5800

Whitney, Janet, ed., 182

Whitney, Willis R., about, 4785

Whitney Foundation, 5198 
Whitney Museum of American Art, New York, 5798-5800

about, 5798-5800

Whittall, Gertrude Clarke. Gertrude Clarke Whittall Poetry and Literature Fund, 660

Whitten, Charles W., 5000

Whittier, John Greenleaf, I 79, I81, 244, $662-73,4036$

about, 662,672

Whittlesey, Walter, 5677

Whiz Mob, 2262

Who Blowed Up the Church House?. 5545

Wholesale trade, 5949

Whom We Shall Welcome, 4425

Why Johnny Can't Read, 5226

Whyte, William F., 4598

Wickford Point, 1591

Wide Is the Gate, 1758

The Wide Net, 2205

Wider Horizons of American History, 3075

The Widow's Marriage, 207-8

The Widows of Thornton, 2179

Wicd-Neuwied, Maximilian Alexander Philipp, Prinz von, 4308-09 about, 4307

Wieland, I 10-1 I, I I 7

Wieman, Henry Nelson, 5437 about, 5433

Wiener, Philip P., 5264 ed., 5353

Wienpahl, P. D., 529 I

Wieting, Charles Maurice, 5964

The Wife, 2314

$A$ Wife at a Venture, 2310

The Wife of His Youth, 758

Wiggins, Lida Keck, 859

Wigglesworth, Michael, 79-83

Wight, Frederick S., 5767

Wigmore, John H., 6268

Wigwam and Bouwerie, 4044

Wilbur, Earl Morse, 5471

Wilbur, Homer A. M., pseud. See Lowell, James Russell

Wilbur, James H., Father, about, 3035

Wilbur, Ray Lyman, $3487,4840,4884$

Wilbur, Richard, $2215^{-17}$ ed., 2363

Wilcox, Francis O., ed., 3635

Wilcox, Jerome K., ed., 6205

Wilcox, Walter W., $5838-39,5850$, 5899,6133

The Wild Flag, 1859

Wild Horse Mesa, 1486

Wild Life of the South, 1725

The Wild Palms, 1390

Wild Scenes in the Forest and Prairie, 367

Wildcats (football team), about, 4993

Wilder, Burt G., 4724

Wilder, Thornton, $1864-69,2327$

The Wilderness Hunter, 2794

Wildes, Harry Emerson, 3684, 3993-94

Wildlife

birds, 2960,2962

conservation, 5870

Yellowstone National Park, 4182

Wildwood, Will, psoud. See Pond, Frederick E.
Wiley, Bell Irvin, 3704-5

Wiley, Farida A., ed., 744

Wiley (John) and Sons, about, 6453

Wiley, Lulu R., 109

Wilkes County, Ga., 3842

Wilkins, J. H., 23 I I

Wilkins, Mary E. See Freeman, Mary E. (Wilkins)

Wilkinson, James, about, 3273, 3660

The Will to Believe, 5323

Willard, Charles B., 66I

Willard, Frances Elizabeth, about, 2615

Willcox, Walter F., 4390, 4403

Williams, Albert N., 3967

Williams, B. C., ed., 235 I

Williams, Ben Ames, ed., 2637

Williams, Cecil B., ed., 204

Williams, D. C., 5335

Williams, Daniel Day, 5438

Williams, Edward, ed., 27

Williams, Edward I. F., 5125 ed., 5242

Williams, Edwin E., ed., 6478

Williams, George, about, 5490

Williams, George Huntston, ed., 5424

Williams, Gluyas, illus.; 1214

Williams, Herbert Lee, 2909

Williams, Hermann Warner, 5768

Williams, John P., 5404

Williams, Joseph P., 5033

Williams, Kenneth P., 3706

Williams, Leewin B., 2370

Williams, Mary Wilhelmine, 3559

Williams, Oscar, 1870-7I ed., 2344

Williams, Phyllis H., 4496

Williams, Ralph C., 4880

Williams, Rebecca (Yancey), 284I-42 about, 2842

Williams, Robin M., 4558 ed., 5206

Williams, Roger, 20, 84-89, 5418 about, 84, 89, 3196-97, 5396, 5443, 6068

Williams, Stanley T., 383, 398, 793, $2412,2532-34,3693$

ed., 393, 401, 2460-61

Williams, Tennessee, $2218-28,2334-36$

Williams, William Appleman, ed., 3518

Williams, William Carlos, $656,1872-85$ about, $1880,1886,2426,2497-98$

Williams College, 5221

Williams County, Ohio, 3863

Williamson, George, 1371

Williamson, James A., 3169, 31 73-74

Williamson, Thames R., 3968

Willis, Edgar E., 4682

Willis, Nathaniel Parker, 674-82, 2295 , 2337,2347

about, 2277

Williwaw, 218 I

Willoughby, Westel Woodbury, 6ro4

Willoughby, William F., 6167, 6180, 6309

Willow Run, Mich., 4586

Wilmer, James Jones, 123

Wilmerding, Lucius, $6 \mathrm{I} 68,64 \mathrm{I}$

Wilmot, David, about, 3339

Wilmot, Walter S., Jr., 6134

Wilmot Proviso, 3339
Wilson, Alexander, 474 I

about, 4724, 474I

Wilson, Arthur Herman, 5659

Wilson, C. R., 3058

Wilson, Edmund, 251 2, 2535-37, 253943

ed., I 226, 2538

a'vout, I01 6, 2443

Wilson, Everett E., 4621

Wilson, Francis Graham, 6070

Wilson, George Lloyd, 5943

Wilson, George P., 2270

Wilson, Harold Fisher, 4031

Wilson, Harry Leon, 1546

Wilson, Herbert W., 3708

Wilson, James Grant, 329

ed., 328, 3080, 4049

Wilson, James Harrison, 288 r

Wilson, John, 3020

Wilson, Louis Round, 6487

Wilson, Milburn L., 4579, 5426 about, 5426

Wilson, Orlando W., 4660

Wilson, Paul A., 3557

Wilson, Robert Renbert, 3526

Wilson, William B., about, 605 I

Wilson, William E., 3995

Wilson, Woodrow, 2296, 3469

about, 2492, 2591, 3058, 3 I I I, 3121, $3470-73,3489,3541,5222,6359$, 6428,6432

Wilstach, Paul, 327 I

Wiltse, Charles M., 3328, 607 I

Winchell, Walter, about, 2894

Wind, Herbert Warren, 5051, 5053

Wind over Wisconsin, 1960

Windless Cabins, 1823

Winds of Doctrine, 5368

The Winds of Fear, 2631

Winds of Morning, 1314

Windswept, 1288

Wine from These Grapes, 1609

Winesburg, Ohio, I 179

Winged Victory, 1491

Wingersky, Melvin F., ed., 6276

The Wingless Victory, 1174

The Wings of the Dove, 996-97 about, 998

Winkler, John K., 2884

Winn, Matt J., 5057

about, 5057

The Winner, 1690

Winnick, Louis, 4395

The Winning of the West, 3307

Winooski River, 4010

Winship, George Parker, 38, 6448, 6459

Winslow, Charles E. A., 4877, 4881

Winslow, Mary N., 2584

Winslow, Ola Elizabeth, 3197, $375 \mathrm{r}$. 5299, 5417

Winsor, Justin, ed., 4036

Winston, Ellen, 4448

Winston, Robert W., 3412

Winter, Jefferson, 4943

Winter, William, 4931, 4934, 4938-39

A Winter Diary, 1827

Winter in April, 1638

A Winter in the West, 366

The Winter Sea, I81 I

Winterich, John T., 6464

ed., 829 
Winters, Robert K., ed., 5865

Winters, Yvor, 2544

about, I 23 I, 2443

Winterset, I $173-74,2333,2336-37$

Winther, Oscar Osburn, 4214

Winthrop, John, Jr., about, 3198, 4735

Winthrop, John, Sr., 90-91, 3219

about, 90, 3 198, 4034

Winthrop, Margaret (Tyndal), 90

Winthrop, Robert C., 4036

Wirt, W., 2296

Wirth, Louis, 3739

Wisan, Jacob M., ed., 487 I

Wisbey, Herbert A., 5497

Wischnitzer, Mark, 4459

Wisconsin, 3948, 41 39-40

architecture, 57 I 9

Germans, 4478

govt., 6195

governors, 4139

guidebooks, 3883-85

historical geography, 2969

hist., 3663, 4I 39

Norwegians, 4487

towns, $4 \mathrm{I} 09$

travel \& travelers, 4324,4347

Wisconsin. University, 5194

Wisconsin Earth, 1959

Wisconsin in literature

drama, 1556

fiction, I 453-59, 1839-40, 1959-62, $1964,2030,2129$

personal narrative, $1078,1959,1965$ poetry, 1959

short stories, I 453, I $839,1841,1963$

Wisconsin River, 3985

Wise, Isaac M., about, 5483

Wise, John, 92-95

about, 92, 6068

Wise, Stephen S., 5483 about, 5483

Wise County, Va., 5529

See also Virginia - folklore

Wish, Harvey, 31 50, 3474

Wissler, Clark,2987-89, 4592

Wister, Owen, I I $45-48$

Wiszniewski, Wladek, about, 4495

The Wit of Porportuk, 1058

The Witch Diggers, 2212

Witchcraft, 3205,5513

Mich., 5535

New England, 554I

Salem, Mass., drama, $198,200,2048$

fiction, 1439,1917

trials, 40-42, 56

Schoharie County, N.Y., 5539

The Witching Hour, 2337, 2348

With a Quiet Heart, 4936

With Lust for Life, 2815

With the Procession, 889

With Various Voices, 4143

With Western Eyes, 1656

Withers, Carl, 4585

comp., 5592

Within an Inch of His Life, 2304

Without Fear or Favor, 2906

Without Magnolias, 2051

A Witness'Tree, 1452

Wittich, Walter A., 5231
Wittke, Carl F., 2899, 441 7, 4498, 5640 ed., 4089, 4I06, 4I 20-2I, 4I39. 4180,4194

Witty, Paul, ed., 5205

Wobblies. See Industrial Workers of the World

Woestemeyer, Ina Faye, ed., 3151

The Wolf, 1094

The Wolf That Fed Us, 2015

Wolfe, James, about, 3171

Wolfe, Julia Elizabeth, 1893

Wolfe, Linnie Marsh, ed., ro8o

Wolfe, Thomas, $1887-94$

about, I 892, I 895-1901, 2372, 2376, $2406,2427-28$

Wolfenstein, Martha, 4951

Wolff, Robert L., 3516

Wolle, Muriel V. (Sibell), 4177

Wolseley, Roland E., 2850, 29 I 2, 2919

Wolseley, Garnet J., viscount, 3697

Womack, Bob, about, 4 I 8I

Woman in the Nineteenth Century, 315

The Woman of Andros, 1864

$A$ Woman of Means, 2178

The Woman Within, 1463

Woman's Revenge, 2303

Women, 4315, 4387, 5212

biog. (collected), 26 I 5

delinquents, 4649

education, 165, 167, 5116, 5193, 5198

bibl., 5212

employment, 4312, 434I

fertility, 4402

in history, 3139,4563

in industry, 2583

in literature, 4524

in society, 2583

Indian, 3042

legal status, 2588, 4290, 45 I 6, 6409

physicians \& surgeons, 4820,4860

publishers, 2588

status. See Social status-women

S.C., 4091

New York (City), 4047

Washington, D.C., 4065

The West, 4098

The Women, 2327, 2333

The Women at Point Sur, 1533

Women at Yellow Wells, 1553

Women of Trachis, 1664

The Women on the Porch, 1470

The Women on the Wall, 2165

Women's rights in literature, 31 3, 315-6

fiction, 992-95, 1008, 1565

Won at Last, 2308

Wonder-Working Providence, 16281651,3211

Wonderful Neighbor, 2655

The Wonders of the Invisible World, $41-42$

Wood, Gar, about, 5016

Wood, H. J., 3169

Wood, Helen, 47 I 2

Wood, James Playsted, 2919

Wood, Leonard, about, 2684, 3595

Wood, Ralph, ed., 4479

Wood-carving, 5603

Woodard, Clement M., 2256

Woodberry, George E., 24 I I, 2545-48 about, 2385,2513
Woodbridge, F. J. E., 5289

Woodbridge, Homer, 2503

Woodburn, James A., 3368

Woodbury, Coleman, ed., 4613

The Woodcutter's House, 1637

Wooddy, Carroll H., 6r 94,6383

Woodfin, Maude H., ed., 16

Woodford, Frank B., 3358

Woodling, George V., 4780

Woodress, James L., 971, 1808

Woodring, Paul, 5239

Woodrow Wilson Foundation, 3642

Woodrow Wilson Foundation. Study Group, 1950-51, 3608

Woodruff, George P., 5952

Woods, Henry F., 3152

Woods, Walter, 2305

Woods and woodworking, 5598, 5724

Woodson, Carter G., 5502

Woodward, Comer Vann, 34I7, 345I, 4078,4444

Woodworth, Robert S., $539 \mathrm{I}$

about, 5389, 5391

Woodworth, Samuel, 2295

Woody, Thomas, 5212 ed., 5130

Woofter, Thomas J., $554^{\circ}$

Wool industry, 5910

Woollcott, Alexander, $49 \mathrm{II}$

Woolley, Mary E., 5193

Woolman, John, I 78-85

Woolson, Constance Fenimore, I I 4952

about, II 52

Worcester, Mass.

Jews, I 213

Swedes, 4486

The Worcester Account, 1213

The Word of Love, I971

$A$ Word of Remembrance and Caution to the Rich, 180

Words That Won the War, 3462

Work, Hubert, 3038

Work songs, $5510,5517,555^{8}, 556 \mathrm{r}$, 5564

See also Cowboys-songs \& music; Railroadmen

Workers. See Labor and laboring classes

The Works of Love, 2054

Works Projects Administration, 3786, 4630

The World (New York), about, 2889

The World a Mask, 2300

The World and the Individual, 5355-56

World Court, 3534

World Enough and Time, 2199

The World I Live In, 2707

$A$ World I Never Made, I374

The World in a Man-of-War, 479

The World in the Attic, 2052

The World Is a Wedding, 2137

The World of Fiction, 2418

The World of Washington Irving, 238

World politics, 3557, 3618, 3621-22, $3625,3629,3634,5310$

World power, U.S. as a, 3520, 3527 , 3532,3769

See also Foreign relations

The World, the Flesh, and $H$. Allen Smith, 2155 
A World to Win, 1758

World War I, 3097, 3462-63, 3468-71, $3473,3709-16$

aerial operations, $37 \mathrm{II}$

costs, 3454

diplomatic hist., 354 I

in foreign-language newspapers, 2897

military operations, 3715

naval operations, $37 \mathrm{r} 6$

songs, 56 i 6

sources, 3524

World War I in literature

diaries, journals, etc., 1167,1310

fiction, $1326,1380,1396,1496$

reporting, 1170

short stories, 1413

World War II, 3482-83, 3499, 350ob, $3668,3717-27$

aerial operations, 2813-14, 3717, 3727

agriculture, 5838

campaigns, 3718-20, 3722

causes, $3130,3563,3590$

conscientious objectors. See Conscientious objectors

diplomatic hist., 3537-38, 3544, $3546-47,3549,3562,3576,3591$

econ. aspects, $4586,4589,5879,5977$

evacuation of Japanese, 2811-12, 4469,6120

historiography, 3726

naval operations, 3721

personal narratives, $2813-14,3718$ 1 9, 3723

pictorial works, 3726

relations with Spain, 3572

science, 4761,4778

social aspects, 4625

Mediterranean Sea, 3573

World War II in literature, 2746,2807

drama, r 49r, 2046

fiction, 1247, 1249, 1302, 1499, 1640, 1 839, 1940-41, 1992-94, 2003-4, $2011,2025-26,2053,2092-94$, $2146,2169,2181,2229-30$

personal narratives, $1769-70$

poetry, 1608, 1948, 1999, 2139, 21 41

reporting, 1992, 2011,2044

short stories, 2057

The World's Body, 1678

World's Christian Fundamentals Association, about, 5430

World's End, 1758

World's Fair (1 893), Chicago, 4r34-36

The World's Rim, 3015

Worn Earth, 1968

Worship, 292

Wouk, Herman, 2229-3r

The Wound and the Bow, 2537

Wounds in the Rain and Other $1 \mathrm{~m}$ pressions of War, about, 1278

Woytinsky, Wladimir S., 6040

Wrensch, Frank A., 5054

Wrestling, 5060-6i

Wright, Alfred J., 2940

Wright, Benjamin Fletcher, 6072, 6105

Wright, Charles, about, 4734

Wright, Chauncey, 5386-87

about, 5264, 5386-87

Wright, Chester W., 5883

Wright, Conrad, 5424, 5472
Wright, Edith A., 56 I I

Wright, Fanny. See D'Arusmont, Francis (Wright)

Wright, Frank Lloyd, 5712

about, 57 I I-I 2

Wright, Henry, 4612

Wright, John K., 2941 ed., 2938, 2974

Wright, Louis B., 2412, 3236, 3737, 3749

ed., $15-16,2339$

Wright, Nathalia, 505

Wright, Orville, about, 4788, 5938

Wright, Richard, 2232-35, 4439

Wright, Robert Joseph, about, 4536

Wright, Thomas Goddard, 2549

Wright, Wilbur, about, 4788,5938

Wriston, Henry M., 3600

The Writer in America, 2382

Writers in Crisis, 2428

Writers' Program, 3786

The Writing of American History, 3057

Wrong, George M., 3175, 3272

Wroth, Lawrence C., 6440,6448 ed., 77

Wunderkind, 2024

Wylie, Elinor (Hoyt), 1902-4 about, 1904, 2499

Wylie, Max, 4697, 5705

Wylie, Philip, 5097

Wyllie, Irvin G., 3762

Wyman, Jeffries, about, 4724

Wyoming, 395 r, 3967, 3971, 4179

Arapaho Indians, 3041

fiction, 1 I 45-48

hist., 391 1, 3961, 41 47, 4174

\section{$\mathrm{X}$}

XIT Ranch, Tex., 4196

Xingu, 1851,1855

$\mathbf{Y}$

Yachting, 4990, 50 19, 5022

Yakima Indians, 3035

Yale Review, 2577

Yale University, 2652 about, 5035

Yale University. Divinity School, about, 5423

Yale University. Library, about, 6470

Yalta Conference, 3109, 3544, 3567

Yankee Coast, 1290

Yankee Doodle (song), about, 5616

The Yankee Exodus, 4028, 4394

Yankee from Olympus, 2607

Yankee in London, 168

Yankee Life by Those Who Lived It, 4029

Yankee Reformers in the Urban Age, 4530

Yankee Science in the Making, 4730

Yankee Stargazer, 4746

Yankee Stonecutters, 5738

Yankee Teacher, 5309

Yankees, 4435

drama, i 68-70

humor, $456-57,558-61,250$ I
Yankees-Continued

language (dialects, etc.), 456-57, 558

See also New Englanders

Yankees and Yorkers, 4027

Yarmolinsky, Avrahm, tr., 2413

Yates, Brock W., 5003

Yates, Robert, 608 ?

Yazoo River, 4024

Year before Last, 1244

The Year of Decision, 3331

Year of Decisions, $3500 \mathrm{~b}$

Yearbook of Agriculture, 2947, 2951, 5817,5837

The Yearling, 1683

Years of Adventure, 3485

The Years of Preparation, 3465

Years of the Modern, 4513

Years of This Land, 2973

Years of Trial and Hope, $3500 \mathrm{~b}$

Yeats, William Butler, about, 1225 , 2497

Yellow fever, $4105,4221,4823$

control, 4872

drama, 1520

epidemic, Philadelphia (1793), 4872 fiction, I $16-17$

etiology, 5872

Yellow Gentians and Blue, $145^{8}$

Yellow Jack, 1520

The Yellow Violet, 217

Yellowstone National Park, 2625, 4182

The Yemassee, 548-49

Yes, My Darling Daughter, 2333

Yet Other Waters, 1376

Yiddish culture, 4459

Yiddish newspapers, 2898

Yoder, Dale, 6042

The Yoke of Thunder, 1295

Yosemite National Park, 1077, 421 I

Yost, Edna, 4803,4854

You and I, 2337

You Be the ludge, 6267

You Can't Go Home Again, 1891

You Can't Take It With You, 149I, 1548,2333

Youma, 949-52

Young, Brigham, about, 4183,5465

Young, Eugene ("Scrapiron"), 504I about, $504 \mathrm{I}$

Young, Francis Marion, 4179

Young, Frederic Harold, 5320 ed., 5353

Young, Hugh H., 4832 about, 4832

Young, Owen D., about, 2826

Young, Philip, 1505

Young, Roland, 6169

Young, Stark, 1 047, 4912, 4968 about, 49r2

Young, Thomas Daniel, ed., 2320

Young, William H., 6137

Young Adventure, 1224

Young America, 4520

A Young Desperado, 7 I 1

The Young Lions, 2146

Young Lonigan, 1373

Young Men's Christian Associations, 5490

Young People's Pride, 1222

Your City, 4595 
You're Paying for It, 6343

You're the Boss, 6384

Youth, 4564, 4568, 4573, 4619

See also Children and youth in literature

Youth and the Bright Medusa, 1277

\section{Z}

Zabel, Morton D., ed., $255^{\circ}$

Zaharias, Mildred (Didrikson), "Babe," 4996 about, 4996

Zanesville, Ohio, 3873
Zanzig, Augustus Delafield, 5625

Zaturenska, Marya, I 482, I905-6

Zeitlin, Jacob, 2503

Zeleny, Carolyn, ed., 44 I 8

Zeller, Belle, 6399

Zenger, John Peter, 293 I

about, 2931, 6229

bibl., 2931

Ziegler, Benjamin Munn, ed., 3136

Zigrosser, Carl, 5783

Zilboorg, Gregory, 4833

Zim, Herbert S., 2960

Zimmermann, Frederick L., 6206

Zink, Harold, 6r39, 6218, 6391

Zinsser, Hans, 2843-44
Zionism, 4457-59

Znaniecki, Florian, 4495

Zola, Émile, about, 1089

Zollinger, James, 2659

Zollmann, Carl F. G., 5422 ed., 6278

Zolotow, Maurice, 493 r

Zon, Raphael, 58 r 6

Zook, George F., 5189

Zoology, 47I 5

Zorach, William, 5734

Zorbaugh, Harvey Warren, 4599

Zucker, Adolf E., ed., 448 r

Zukor, Adolph, 4963 about, 4963 





